3.

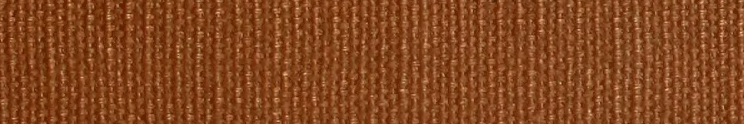
WW WW H.W W. H1W6HWW 1 W 131) How 6s HWh HWH: (1) 3.6. Muพm) 10. 3 3. Ho How

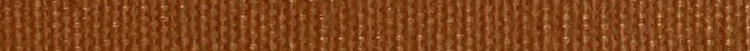
Wh3 2ง -7. H. 3 (3)

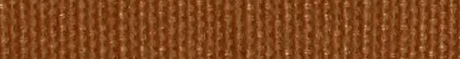
15.

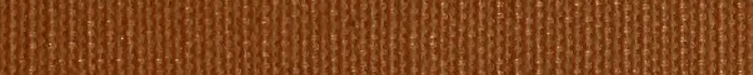
H. 3.73

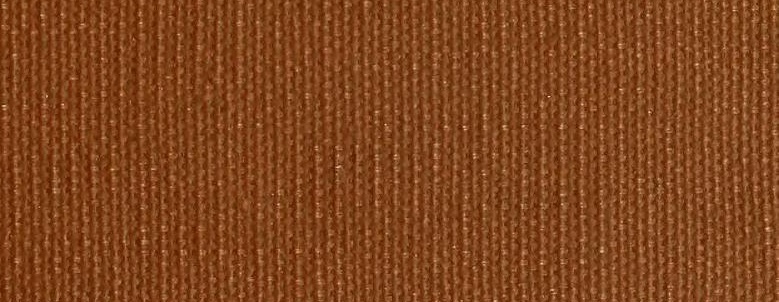

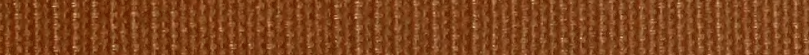
W. WW

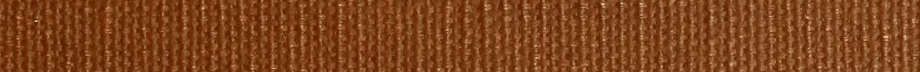

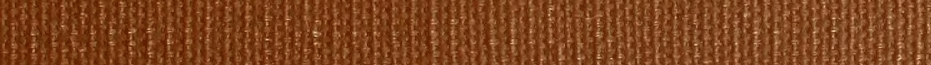
How H.M.

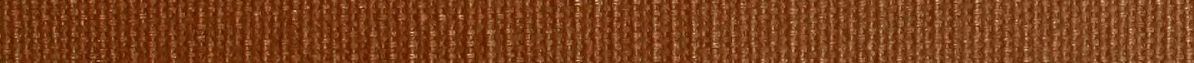

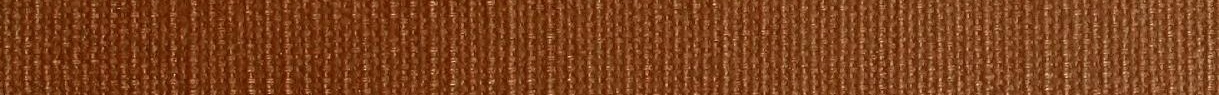








\title{
NATURGESCHICHTE
}

\author{
DER
}

\section{INSECTEN DEUTSCHLANDS.}

ERSTE ABTHEILUNG.

SECHSTER BAND. 



\section{NATURGESCHICHTE}

DER

\section{INSECTEN DEUTSCHLANDS}

BEGONNEN VON

DR. W. F. ERICHSON,

FORTGESETZT VON

Prof. Dr. H. SCHAUM, Dr. G. KRAATZ,

H. von KIESENWETTER, J. WEISE uNd E. REITTER.

ERSTE ABTHEILUNG

COLIOPTIRA.

SECHSTER BAND.

BEARBEITET VON

JULIUS WEISE.

\section{BERLIN 1893.}




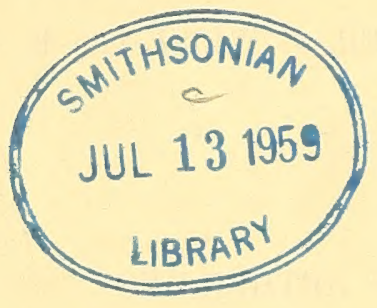




\section{VORREDE.}

Im vorliegenden sechsten Bande sind Thiere behandelt, welche bereits in Monographieen oder kleineren Aufsätzen eingehend bearbeitet wurden und verhältnissmässig gut gekannt sind. Meine Aufgabe konnte also nur darin bestehen, die Arten genau zu begrenzen, auf die erste Beschreibung zurück zu führen und, nebst den Gattungen, in eine möglichst natürliche Reihenfolge zu bringen.

Das Erkennen einer Art bietet-bei. ausreichendem Materiale geringe Schwierigkeit, ist aber nąch einzelnen Stücken oft sehr misslich; daher dürften sich, viele meiner Aurgaben als ungenau herausstellen, weil eine Anzahl von Arten nur in whenigen Exemplaren, einige überhaupt nich zu erlangen wàren. Hierin vermag der zunehmende Sammeleifer in der Folge gewiss Wandel zu schaffen, wenn die Lebensweise der "Thiere mehr als seither berücksichtigt, der Sammler kleinerer Chryssomeliden also darüber klar wird, dass er ein Thier in Menge zu fangen vermag, sobald er die Futterpflanze kennt.

Grössere Mühe als das Erkennen einer Art macht oft das Aufsuchen ihrer richtigen Benennung aus mangelhaften Beschreibungen. Nicht auf alle neueren Schriftsteller trifft das Lob zu, welches Creutzer (Ent. Versuche 13) dem Autor der Käfer Preussens zollt: „Wer ein von Illigern beschriebenes Insekt nicht aufs erstemal erkennt, dem ist zu rathen, dass er das entomologische Studium aufgebe." Man sucht sich in nenester Zeit mehr als nöthig dadurch zu helfen, dass man sich typische Stücke zur Ansicht schicken lässt.

In der Erwägung, dass die Type sehr vergänglich, leicht zu verwechseln, die Beschreibung danernd und unveränderlich ist. und. in der Meinung, das die Beschreibung doch einzig zu dem Zwecke geliefert wurde, die Art zu erkennen, halte ich die Ansicht von Original-Exemplaren nur in den dringendsten Fällen für gerechtfertigt. Das blosse Arbeiten nach Typen dürfte auf der einen Seite zu flïchtigen Beschreibungen anspornen, auf der andern die 
Bequemlichkeit des Nacharbeiters bestärken, welcher der Mühe überhoben wird, die Beschreibungen gehörig zu prüfen und zu erfassen. Selbst aus schlechten Beschreibungen lässt sich zuweilen noch durch eine nebensächliche Angabe auf das in Rede stehende Thier schliessen, andernfalls habe ich die Art eingezogen und es mögen nun die Rechte derselben nachgewiesen werden.

Bei der Eintheilung, die der Hauptsache nach von Chapuis herrührt, habe ich die Gruppen, Gattungen und Arten möglichst nach ihrer Verwandtschaft aneinander zu reihen versucht, aber es ist selbstverständlich, dass diese Anordnung nicht die Zustimmung aller Leser finden wird.

Einigen Gattungen sind Tabellen beigefuigt, welche das schnelle Bestimmen der Arten bezwecken. Für sich allein benutzt, dürften sie durch Förderung der Oberflächlichkeit mehr Schaden als Nutzen stiften, da eine wirkliche Artkenntniss nicht aus ihnen, sondern nur ausvollständigen Beschreibungen gewonnen werden kann.

Dem Plane nach muss dieser Band noch die Bearbeitung der Coccinelliden enthalten, würde aber ohne eine Theilung zu umfangreich werden; letztere schien auch aus dem Grunde geboten, weil die genannten Thiere einen in sich abgeschlossenen Stamm der Coleopteren darstellen, welcher durch verschiedene Merkmale, unter Anderem auch durch die Einrichtung des Penis von den übrigen Familien abweicht.

Das langsame Erscheinen der Lieferungen ist durch die geringe Zeit veranlasst, die mir zu entomologischen Arbeiten uibrig bleibt, die Verzögerung in der Ausgabe des letzten Heftes ausserdem durch meine Theilnahme an der Bearbeitung des neuesten Cataloges und längere Krankheit. Von den Lieferungen sind erschienen:

$$
\begin{array}{rrr}
\text { I. S. } 1-192 \text { am } & \text { 1. October } & 1881 . \\
\text { II. S. } 193-368, & \text { 1. Decemb. } 1882 . \\
\text { III. S. } 369-568 & \text { 15. October } & 1884 . \\
\text { IV. S. } 569-768 ~ & \text { 15. Juni } & 1886 . \\
\text { V. S. } 769-960, & \text { 10. Mai } & 1888 .
\end{array}
$$

Möge dieser Band mit seinen mannigfaltigen Schwächen und Fehlern der Nachsicht meiner Kollegen empfohlen sein, von denen ich allen, die mich bei der Arbeit durch Rath und That unterstïtzten, hiermit meinen verbindlichsten Dank ausspreche.

Berlin, Lichtmess 1893. 


\section{CHR YSOMEIIDAE.}

Phytophaga Chapuis, Genera X. 1.

Corpus plerumque ovatum et superne glabrum, saepe colore laeto aut metallico ornatum.

Mandibulae saepissime breves, sat crassae, apice multifidae.

Labrum distinctum, transversum, clypeus immobilis.

Antennae plerumque 11-articulatae fronti in fossulis depressis insertae, mobiles.

Oculi rotundi, ovales vel oblongi, interdum margine interiore sinuati.

Prothorax lateribus saepe marginatus.

Elytra plerumque seriatim punctata, epipleuris distinctis.

Abdomen segmentis 5 ventralibus compositum.

Tarsi pseudo-4-meri, articulis 3 primis pulvillatis.

Penis tubulosus.

Die Chrysomeliden übertreffen an Umfang alle übrigen Familien der Coleopteren, von denen die Curculioniden an Artenzahl nur unbedeutend, die iibrigen ganz erheblich zurückstehen. Betrachtet man die unendliche Fülle der Pflanzenwelt und die Mannigfaltigkeit der Stoffe, welche die Gewächse hervorbringen, so wird die grosse Zahl der Thiere erklärlich, die sich von ihnen leicht und beständig ernähren können. Durch die Lebensweise liess sich Chapuis bestimmen, die vorliegende Familie mit dem Namen der Phytophages zu versehen. Abgesehen davon, dass diese Bezeichnung doch nur dann am Platze wäre, wenn sie alle Käfer umfasste, welehe auf die Pflanzenkost angewiesen sind (z. B. auch den Stamm der Coccinelliden), so müsste sie besonders aus dem Grunde zurïckgewiesen werden, weil sie inconsequent ist. Die Familien sind gleichmässig zu benennen, man darf also nicht die eine als Phytophages, die anderen als Erotyliens, Endomychides und Coccinellides bezeichnen.

Zur Trennung von den übrigen nahe verwandten Familien giebt es natürlich kein sicheres Merkmal, welches nicht durch Ausnahmen abgeschwächt würde; bei den Mylabriden ist der Kopf rüsselförmig verlängert, bei den Cerambyeiden der Körper gestreckt, mehr oder weniger dicht anliegend behaart, meist mit langen, nach 
der Spitze verschmälerten, ziemlich starren Fühlern, die in einer Ausrandung der Augen stehen, und das Kopfschild ist fiei beweglich.

Der Körper der Chrysomeliden ist im Allgemeinen klein his mässig gross, wenigstens sind Riesenformen, wie bei den Böcken und Scarabaeiden nicht vorhanden, und die grössten, z. B. die tropischen Sagra-, die südamerikanischen Alurnus- und CassidaArten, gehen nicht iiber das Mass unserer einheimischen Carabus hinaus. Vorherrschend ist die ovale mässig gewölbte Form; diesolbe geht zuweilen in eine cylindrische (Cryrtocephalus), oder schlanke und flache (verschiedene Hispinen), selbst runde (Cassida) oder halbkugelförmige (Sphaeroderma) über. Bei dem grössten Theile ist die Oberseite mehr oder weniger lebhaft metallisch gefärbt und glänzend wie bei den Buprestiden, zuweilen auch mit Zeichnungen (Binden, Flecken, Linien oder Strichen) versehen, die aber entweder verwaschen begrenzt, oder sehr derb sind und niemals so zierlich ausfallen wie bei zahlreichen Cerambyciden; die prächtigsten, leider allzu vergänglichen Gold- und Silberfarben, sowie auffällige Zusammenstellungen, z. B. grosse grellrothe Flecke auf mattgriunem, blauem oder schwarzem Grunde, findet man bei den Cassiden. Weniger vertreten sind gelbe, grüne, rothe oder schwarze nicht metallische Farben.

Der Kopf ist vorgestreckt und hinten mehr oder weniger halsförmig verengt (Donacia, Galeruca) oder tief in das Halsschild eingezogen, mit senkrechter Stirn und nach unten gerichtetem Munde (Clytra), oder unter dem erweiterten Vorderrande des Halsschildes verborgen und der Mund nach hinten gerichtet (Cassida).

Die Fühler sind meist sehr beweglich, am vorderen Innenrande der Augen, auf der Stirn zwischen den Augen, auch auf dem Scheitel in Gruben eingefüigt, faden- oder schnurförmig, oft in den letzten Gliedern verbreitert, selten so lang als der Körper, oder kurz, mit zahnförmig erweiterten Gliedern; zuweilen sind auch einzelne Glieder bei exotischen Galerucinen auffällig geformt, oder bei dem Männchen einiger Haltiken erweitert. Es sind fast immer elf Glieder vorhanden, Psylliodes hat zehn, Nonarthra aus Ostasien neun Glieder, bei mehreren Hispinen-Gattungen sinkt die Anzahl durch inniges Verschmelzen der Glieder bis auf drei.

Die A ugen sitzen an den Seiten des Kopfes und sind rund oder länglich, zuweilen mit einer Ausbuchtung an der Innenseite, fein oder nicht besonders grob facettirt (z. B. bei mehreren Chrysomelen, Cyrtonus etc.), mit wenigen Ausnahmen (Megistops) weit getrennt.

Kopfschild unbeweglich, von der Stirn häufig durch einen Eindruck oder eine Furche abgesetzt, am Vorderrande gerade, oder 
in schwachem Bogen ausgerandet und tief der Quere nach niedergedriickt, so dass es in einem hornigen, glatten Querstreifen endet, der vielen Donacien und den Eumolpiden fehlt. Unter demselben ist die Oberlippe befestigt, welche stets vorgestreckt, hornig, in der Mitte des Vorderrandes gewöhnlich ausgebuchtet ist.

Die Mandibeln sind kräftig, gleichmässig oder winkelig gebogen, mitunter iiber die Oberlippe hinausragend (Chrysochares, Chrysochus etc.) oder stark verlängert (bei den Männchen vieler Clytra), einfach zugespitzt bei den Sagrinen, sonst in Zähne endigend, die entweder nur an der Spitze, oder noch zu beiden Seiten derselben, bei den Hispinen allein am oberen Rande stehen. Maxillen klein, grösstentheils hornig, die innere Lade einfach, innen am Grunde glatt, oben bewimpert, die äussere selten einfach, meist zweitheilig. Maxillartaster viergliedrig, das Endglied konisch, oval, selten fast beilförmig. Kinn meist klein, quer, vorn abgestutzt oder ausgerandet. Zunge in der Regel quer und hornig, vorn gerade abgeschnitten, aber bei den Sagrinen oft sehr gross, häutig, dreieckig ausgeschnitten oder tief gespalten; Lippentaster dreigliedrig.

Das Halsschild umfasst zuweilen die Basis der Flïgeldecken, oder ist viel schmaler als dieselbe und hängt dann mit ihr loser zusammen; es besitzt, wie bei den meisten Käfern, vier Ecken, jede nicht selten mit einer Borstenpore versehen, nur bei den Cassiden sind die Vorderecken fast immer geschwunden, und das Halssch. hat die Form eines Kreissegmentes, vielfach fehlen auch noch die wirklichen Hinterecken, denn das, was Boheman in mehreren Gattungen als solche bezeichnet, ist nichts weiter als eine winkelige Verengung des Seitenrandes.

Das Schildchen bleibt nur bei den Stylosomus-Arten völlig verborgen, bei den übrigen ist es sichtbar, gewöhnlich dreieckig, hinten zugespitzt (vorn spitz, hinten breit bei vielen Chlamyden) oder abgerundet, in der Gattung Pseudocolaspis viereckig, hinten abgestutzt oder dreispitzig. Die Oberfläche ist eben, oder steigt nach hinten zu einer Querleiste vor der Spitze auf (Pachybrachys).

Die Flügeldecken sind selten viel kürzer als der Hinterleib (Marseulia, Arima, sowie bei vielen Weibchen der Galeruciden vor der Eiablage), oder lassen nur das Pygidium frei (Clytra); hinten sind sie einzeln oder gemeinschaftlich abgerundet, in wenigen Fällen abgestutzt, und greifen oft mit dem Ende der Nahtkante in eine Rinne der Afterdecke ein. Zur festeren Verbindung mit den Seiten der Brust und des Hinterleibes besitzen sie mehr oder weniger lange und breite Epipleuren, welche in der Nähe des Seitenrandes, seltener weit von demselben entfernt liegen, wie in der Gattung Oides und 
bei den meisten Cassiden, deren Seiten dachartig verlängert sincl. Bei einem Theile ist die Scheibe durchaus verworren punktirt, bei einem anderen sind die Punkte theilweise oder unregelmässig gereiht, bei einem dritten in regelmässige Reihen oder Streifen gestellt, einzelne Zwischenstreifen zuweilen kielartig erhöht.

Wenn die Fliigeldecken in den Schultern winkelig heraustreten und deutliche Schulterbeulen besitzen, ist die Art rollkommen geflügelt. Die Flügel sind gross, weisslich bräunlich, oder roth gefärbt (Orina intricata) mit dunkleren Adern. Die Randarler ist am Grunde ziemlich stark, hinten feiner, die Schulterader und die innere Mittelader sind kräftig, fast ron gleicher Länge, nach aussen stark divergirend und am Ende hakenförmig zurückgebogen. Die äussere Mittelader läuft an der Basis nahe der inneren hin, wendet sich dann gegen die Analader und verbindet sich mit dieser. Von der Mitte der inneren Mittelader geht ein Ast aus. welcher der Analader parallel nach hinten zieht. Die Flïgel falten sich vorn der Länge nach, legen sich aber am Haken der Schulterader in mehrere grosse Falten zusammen, so dass sie unter den Decken geborgen werden können. Uebrigens findet man in der Stärke und im Verlaufe der Adern bei den einzelnen Chrysomeliden-Gruppen mannigfaltige Unterschiede, deren Aufzählung hier zu weit fuihren würde. In mehreren Gattungen tritt neben der oben bezeichneten Form noch eine zweite mit verkümmerten Flügeln auf(Longitarsus), endlich fehlen dieselben gänzlich (Colaspidea, Timarcha, die kleinere Hälfte der Gattung Chrysomela, Sclerophaedon etc.).

Die geflügelten Arten haben theils einen schnellen und ungestiimen (Clytra), theils einen langsamen, sehr ruhigen Flug (Cassida), welcher z. B. bei unseren Haltica-Arten zuweilen durch einen Sprung eingeleitet wird.

Von besonderer Wichtigkeit fuir die Trennung der Gruppen und Gattungen muss der Bau der Vorderbrust angesehen werden. Dieselbe ist vorn flach, ausgeschnitten, oder zur Aufnahme des Mundes erhöht und vorgezogen (Apteropeda) selten mit vollständigen Fühlerfurchen (Lamprosoma), häufiger mit einem aufstehenden Vorderrande der Seitenstücke versehen, an den sich die Fühler anlegen (viele Eumolpiden). Das Prosternum ist zwischen den Hüften entweder verdeckt, sehr schmal, sogar abgekürzt, oder in zahlreichen Gattungen breit, deutlich wahrnehmbar, hinten in einen Fortsatz erweitert, der manchmal in eine Vertiefung der Mittelbrust eingreift, um den Vorder- und Hinterkörper fester zu verbinden. Berühren die Seitenstïcke hinter den Hüften das Prosternum, so werden die Gelenkhöhlen der Vorderbeine geschlossen, im anderen Falle bleiben sie offen. 
Die Mittelbrust ist kurz, mit deutlich begrenzten Seitenstïcken, das Mesosternum, nur bei Orsodacna zwischen den Hüften sebr verengt, wird in einzelnen Fällen durch die übermässige Ausdehnung des Metasternum völlig verdeckt, oder es bildet baid eine Querleiste, bald eine längliche oder quere, seltener quadratische Fläche, und steigt bisweilen in zwei Spitzen (Timarcha) oder einen dicken, langen Dorn auf (Doryphora).

Die Hinterbrust ist bedeutend grösser und fällt nach den Seiten mehr oder weniger ab, wo die Seitenstiicke durch eine starke Naht vom Metasternum getrennt werden (eine Ausnahme bilden z. B. die Gattungen Mniophila und Cardax). Die langen Episternen verschmälern sich gewöhnlich nach hinten, die Epimeren nach vorn, letztere sind klein und liegen grösstentheils unter den Epipleuren der Flügeldecken.

Die Beine sind meist unter dem Körper verborgen, verhältnissmässig kurz, am längsten wohl noch bei den Eupoden, die Vorderbeine gewöhnlich kürzer als die hinteren, bei den Männchen mancher Clytra-Arten aber länger. Die Hüftpfannen der Vorderbeine sind rund, seltener quer (Chrysomelini), die des hintersten Beinpaares gross, stark quer, weit, wenigstens deutlich getrennt; die Vorderhüften ragen häufig hervor, während die Hinterhüften kaum oder wenig über die Brustfläche hinaustreten. Die Schenkel haben meist eine normale Form, sind bisweilen mit einem oder mehreren Zähnchen bewehrt, oder auf der Unterseite zur Aufnahme der Schienen ausgerinnt, die Hinterschenkel der Eupoden und Haltiken sind verdickt. Die Schienen verbreitern sich in der Regel etwas nach der Spitze hin, oder sind vor derselben ausgerandet, am Ende bald einfach, bald mit einem Enddorne versehen, höchst selten mit zwei Dornen. Die Tarsen sind an der Spitze, bei Psylliodes auf dem Rücken der Schienen eingefügt und bestehen aus vier Gliedern, von denen die drei ersten bei den Haemonien schmal, in den übrigen Gattungen nach der Spitze verbreitert und unten mit einer verschieden dichten Filzsohle versehen sind, welche zuweilen halbirt, bei den Leptosonyx-Arten durch Dörnchen ersetzt ist.

Die Halticiden zeichnen sich oft durch ein sehr verlängertes erstes Glied der Hintertarsen aus.

Das Klauenglied sitzt auf dem dritten, herzförmigen oder zweilappigen Tarsengliede, wird von den Lappen desselben eingeschlossen (Cassiden), oder ist frei. An der Basis bemerkt man zuweilen eine deutliche Verdickung, den Rest des verkümmerten vierten Gliedes; die Spitze ist bei einem Theile der Halticiden blasenförmig aufgetrieben, oder bei einigen Chrysomelen auf der 
Unterseite jederseits zahınförmig erweitert. Die Klanen der Chrysomeliden sind der Form nach einfach (Cryptocephalus), am Grunde (Lema) oder bis zur Spitze verwachsen (Monochirus), gezähnt, oder mit einem zahnförmigen Anhängsel an der Basis (Haltica), gespalten (Pseudocolaspis), endlich kammförmig gezähnt (Aspidomorpha); ihrer Lage nach bald genähert (Crioceris) bald gespreizt (Cassida).

Der Hinterleib besteht aus fün Segmenten, ron denen das erste und letzte bei vielen Arten länger als einer der eingeschlossenen drei Ringe ist; zuweilen sind die beiden ersten Segmente (Hispiden) oder die beiden letzten (Camptosomata) verwachsen und unbewreglich, oder die drei mittleren Ringe durch eine auffällige Ausdehnung des ersten oder letzten Ringes bis auf einen kleinen, dreieckigen Zipfel am Seitenrande des Bauches rerkleinert (bei rerschiedenen Cryptocephalus-Männchen). Die Zahl der Rückensegmente ist meistens sechs, bei Cryptocephalus sieben, bei C'assida acht; sie sind gewöhnlich glatt, häutig, seltener hornig und jederseits mit einem queren Tomentflecke versehen (Cryptocephalus). Das letzte ist fast bei allen Arten hornig, punktirt, behaart, oft mit einer Mittelrinne besetzt; neben der bei den Crioceris-Arten eine Zirpleiste liegt, oder es ist sehr vergrössert, nach unten gebogen und von den Flügeldecken nicht bedeckt (Clytrini).

Das Geschlecht der Chrysomeliden lässt sich äusserlich meist sicher erkennen. Im Allgemeinen ist das Männchen durch einen kleinen, namentlich schlanken Körper, im Besonderen durch erweiterte Taster, Fühler- und Tarsenglieder, oder verlängerte, gebogene oder erweiterte Schienen, stärkeren Schenkelzahn und durch abweichende Bildung des Bauches, mindestens des Analringes ausgezeichnet. Der Penis besteht aus einer mehr oder weviger gebogenen Röhre, durch welche der ductus läuft. Diese Röhre ist bei vielen Eumolpiden ziemlich weich, in den iibrigen Gruppen hornig, einfach, am Ende nur abgestutzt, abgerundet, zugespitzt oder ausgerandet (Cassiden, Galeruken, und die Mehrzahl der Chrysomelen), oder vorn in Zähne, Dornen oder gezähnte Lappen endigend, oft mit Bartbüscheln versehen, bei den Clytrinen. In der Ruhe wird die Röhre von einer weichen Haut umgeben, welche vorn, sowohl auf der Ober-, wie auf der Unterseite in einen feinen, hornigen, klammerförmigen Rand übergeht, der den Penis umfasst. Vielleicht um den Austritt desselben zu regeln, befindet sich bei den mit Chrysomela verwandten Thieren im Innern, in der Mitte des Hinterrandes am Analringe, eine aufstehende grosse Hornplatte, welche, der Penisform angemessen, im oberen Rande sanft ausgeschweift, oder verschieden tief ausgerandet ist, Die Oeffnung 
für den ductus wird häufig in der Ruhe durch eine Klappe geschlossen, und in der davor liegenden Verlängerung des unteren Randes der Penisröhre bemerkt man nicht selten eine offene oder bedeckte Rinne (z. B. bei mebreren Phytodecta-Arten), in welche sich der ductus einlagert. Letzterer ist bei vielen Chrysomelen hart, pergamenthäutig oder hornig, am Ende grade oder schräg abgeschnitten, gerundet, spitz, oder verdickt.

Das Weibchen erkennt man bei den Camptosomaten an einer Eigrube auf dem Analringe, sonst an dem stärker gewölbten, oder am Hinterrande abgerundeten letzten Bauchsegmente.

Die Entwicklung der Chrysomeliden ist in den Gruppen, deren Larven sich leicht aufziehen oder beobachten lassen, genau bekannt, aber bei den übrigen Gruppen, den Hispinen, Halticinen und vor allem den Camptosomaten sind noch manche Zweifel zu lösen. Die Eier sind elliptisch, glatt und glänzend, oder mit Runzeln oder sehr kleinen und fiachen Grübchen versehen, ziemlich matt, und werden an die Nährpflanze einzeln oder in Gruppen geklebt, bei den Camptosomaten, nachdem sie einige Zeit in der Eigrube gelegen haben, bei den Orinen in dem Augenblicke, wo die Larve entwickelt ist und ausschlüpfen will (Deutsch. Z. 1885. 403). Die Larve bohrt sich in den Stengel (Sagra, Longitarsus), oder minirt die Blätter (Hispa, Dibolia), oder lebt endlich frei, indem sie sich von der Blattsubstanz oder der weichen Oberhaut des Stengels nährt, bis sie, nach einigen Wochen, bei den Camptosomaten erst im dritten Jahre, ausgewachsen ist. Nun verfertigt sie sich einen Cocon (Eupoden) oder verwandelt sich ohne einen solchen, bald in oder an der Nährptlanze, bald in der Erde zur Puppe, aus welcher nach kürzerer oder längerer Zeit der Käfer schliipft. Die hauptsächlichsten Unterschiede sind aus folgender Zusammenstellung zu erkennen:

A. Die Larve verfertigt sich aus ihrem Kothe:

a. einen hartschaligen Sack, den sie mit sich herumträgt und in dem sie ihre Verwandlung durchmacht: Camptosomata;

b. ein Dach anf dem Rücken. Dasselbe liegt unmittelbar auf dem feuchten, oben gewölbten Körper: Criocerini, oder ist an einer Gabel des Afters befestigt und kann über dem ziemlich flachen, an den Seiten bedornten Körper auf und ab bewegt, ja ganz zurückgeschlagen werden: Cassidini.

B. Die Larve ist unbedeckt und lebt:

a. gesellschaftlich in Anschwellungen des Stengels und verfertigt sich hier zur Verpuppung einen Cocon (Sagra); oder einzeln in Blattminen (Dibolia, Hispa) auch in Gängen 
unter der Wurzeloberhaut. Verwandlung meist in der Erde. Longitarsus;

b. frei an der Nährpflanze, entweder an den Blättern derselben: Eumolpini, Chrysomelini, Galerucini, oder am Stengel unterhalb des Wasserspiegels: Donaciini. Die Larven der letztgenannten Abtheilung sind sebr gestreckt und von allen übrigen durch zwei lange Afterdornen ausgezeichnet. Diese bohren sie völlig in einen unter Wasser befindlichen Pflanzentheil ein und entnehmen den Lufträumen desselben die Luft zum Athmen mit Hilfe eines grossen Stigma, welches sich an der Basis jedes Dornes befindet (Dewitz, Berlin. Zeitschr. 1888. 5).

Linné fasste die Blattkäfer (Syst. Nat. ed. X. 1758) in zwei grosse Gattungen, Chrysomela und Cassida, zusammen, hieran fügte 1762 Geoffroy (Hist. Ins. 1.) Crioceris, Cryptocephalus, Luperus, Galeruea und Haltica, sodann 1767 Linnè (ed. XII) die Gattung Hispa, Fabricius 1775 (Syst. Ent.) Donacia, endlich Laicharting: (Verz. Tyrol. Ins. 1. 1781) die Gattung Clytra.

Die Eintheilung der Chrysomeliden ist theilweise ron Latreille, Duméril, Illiger und Spinola versucht, aber erst von Lacordaire gegeben und von Chapuis (Genera X und XI) näher begründet worden. Danach gliedert sich die Familie in vier grosse Abtheilungen:

1. Kopf vorgestreckt, hinter den Augen halsförmig verengt, Halssch. viel schmaler als die Fld. und ohne Seitenrandleiste, Mandibeln einfach, zugespitzt . . . . . . . . Eupoda.

1 $^{1}$. Kopf bis zu den Augen in das Halssch. eingezogen, dieses so breit, oder wenig schmaler als die Fld., an den Seiten meist gerandet, Mandibeln mit mehreren Zähnen oder Spitzen versehen

2. Körper cylindrisch, vorn und hinten abgestutzt, die beiden letzten Abdominalringe verwachsen, Pygidium gross, nach unten gebogen, meist unbedeckt . . . . Camptosomata.

$2^{1}$. Körper xund, oval oder gestreckt, zuweilen die beiden ersten Abdominalringe verwachsen, Pygidium klein, nach hinten gerichtet und unter den Fld, verborgen . . . . . . . 3.

3. Stirn geneigt oder senkrecht, der Mund nach unten gerichtet. Die Zähne der Mandibeln stehen an der Spitze und zu beiden Seiten derselben . . . . . . . . . Cyclica.

$3^{1}$. Stirn unterhalb der Fühler und Mund nach unten und hinten gerichtet, niemals ron oben sichtbar, Mandibeln nur am oberen - Rande gezähnt 


\section{Erste Abtheilung: $\mathbf{E P O M A}$}

Chapuis, Genera des Coleopt. X. 25 .

Caput pone oculos constrictum.

Prothorax lateribus immarginatus.

Fühler faden-oder schnurförmig, nur bei Haemonia schwach borstenförmig, elfgliederig, dicht am Vorderrande der Augen durch die ganze Stirubreite von einander getrennt oder etwas vor demselben und einander genähert eingefügt, selten so lang als der Körper, häufiger länger oder wenig kürzer als die Hälfte, dicht und fein, meist leicht abstehend behaart. Kop f mässig vorgestreckt, dreieckig, mit stark heraustretend-gewölbten ganzen oder ausgerandeten Augen, hinter diesen nit gewölbten, selten fehlenden Schläfen, aber immer eingeschnürt und halsförmig verlängert, so dass der Vorderrand des Halsschildes mehr oder weniger weit von den Augen entfernt bleibt. Die Mandibeln verhältnissmässig kurz, stark, ganzrandig oder ari der Spitze gezähnt oder gespalten, meistens fast ganz unter der Oberlippe verborgen. Halsschild so lang als breit oder länger, an den Seiten ohne Kante oder Rand, verschieden weit vor den Hinterecken eingeschnürt oder rerengt und am Hinterrande meist nur halb so breit als die Flügeldecken. Schildchen dreieckig oder hinten abgestutzt. Flügeldecken mit stumpf vorragenden Schultern, doppelt so lang als zusammen breit oder länger, die Seiten mehr oder weniger parallel, oft nach hinten erweitert, oft verengt, den Hinterleib ganz bedeckend. Von den fünf Ringen des Abdomens ist der erste fast durchgängig der längste. Beine lang, nicht selten alle Schenkel oder nur die hinteres keulenförmig verdickt und mit Zähnen bewaffinet, oft weit über den Rand der Flügeldecken reichend. Die Vorderhüften ragen kegelförmig, die mittleren kugelförmig aus den Gelenkpfannen hervor, die hinteren sind quer.

Die hierher gebörigen Insekten sind durch den vorgestreckten und binter den Augen halsförmig abgeschnürten Kopf, welcher mit dem in die Länge gezogenen, an den Seiten ungerandeten Halsschilde beträchtlich schmäler als die gestreckten Flügeldecken ist, von den übrigen Chrysomeliden stets sicher zu trennen; sie besitzen

VI. 
weder zusammengewachsene Abdominalsegmente, norh ein Pygidium und ihre Fühler sind tiefer am Kopfe und weiter von einander eingefügt wie bei einigen im Körperbau ähnlichen Eumolpiden und Galeruciden.

Die Abtheilung enthält, nachdem die im Règn. animal. von Latreille dazugerechneten Gruppen der Megasceliden und Megalopiden von $\mathrm{Chapuis}$ ausgeschieden und $z u$ den Camptosomen gestellt wurden, folgende drei Gruppen:

A. Die Vorderbüften durch einen schmalen Fortsatz des Prosternum getrennt: Sagrini.

B. Vorderhüften frei, fast aneinander stehend:

a. Erster Hinterleibsring wenigstens so lang als die folgenden zusammen, Fühler an der Basis einander genähert: Donaciini.

b. Erster Hinterleibsring wenig länger als einer der übrigen; Füblerbasis durch die ganze Breite der Stirn getrennt: Criocerini.

Diese Gruppen fanden ihre erste gründliche uvd noch heute mustergiltige Bearbeitung 1845 durch Lacordaire in der Monographie des Coléoptères subpentamères, famille des Phytophages, welche von Suffrian in der Stettiner entomol. Zeitung 1846 und 1847 in Bezug auf die deutschen Arten eingehend besprochen wurde.

\section{Erste Gruppe: SAGRINI.}

Lacordaire, Monogr. des Phytophages 1.

Prosternum inter coxas anticas processu distincto.

Die Mitglieder dieser Abtheilung, grösstentheils den heissesten Erdstrichen angehörend, bilden ein Gemisch von Formen, deren $\mathrm{Zu}$ gehörigkeit zu den Chrysomeliden auf den ersten Blick oft zweifelhaft ist. So sind Megamerus und Verwandte von den Cerambyciden, Carpophagus etc. von den Bruchiden schwer zu trennen, und selbst die einzige europäische Gattung, die seit Latreille hierhergerechnet worden ist, Orsodacna, passt wenig zu den typischen Formen, welche die Gattungen Necynodera und Sagra enthalten. Bei allen ist die Vorderbrust zwischen den Vorderhüften in einen schmalen, hohen Kiel verlängert, welcher die herausstehenden Hüften in ihrer ganzen Länge trennt. Die übrigen Unterschiede sind variabel und zur Trennung von den beiden folgenden Abtheilungen ungeeignet.

Die Larven leben im Innern von Pflanzen und zeigen dadurch die nahe Verwandtschaft mit den Cerambyciden an, während sie durch Lebensweise und Körperbau von den Donaciinen- und Crio- 
cerinen-Larven ausserordentlich abweichen. Mit letzteren, welche vorzugsweise Pflanzen aus der Familie der Asparageen bewohnen, haben sie insofern einen geringen Verwandtschaftsgrad, als sie sich in den kletternden Dioscoreen aufzuhalten pflegen, die in den Tropengegenden unsere Asparageen vertreten.

Die Eier werden nach Lucas (Annales d. Fr. 1873 p. 231 Sagra splendida) an die Stengel der Dioscorea-Arten geklebt. Die Larven durchbohren die Oberhaut der Pflanze und es bilden sich dadurch an den durchfressenen Stellen gemeinschaftliche grosse und hohe Längsauswüchse, in denen die Larven familienweise leben. Letztere sind sehr langsam, dick und breit, fleischig, vorn und hinten abgerundet, halbkreisförmig gebogen und den Lamellicornien-Larven nicht unähnlich, glänzend gelblich braun, glatt. Ihr Kopf ist klein, hart, ohne Ocellen, mit sehr kurzen viergliederigen Fühlern und dreigliederigen Maxillartastern. Jede verfertigt sich dicht unter der Oberhaut des Auswuchses einen länglichen, cylindrischen, beiderseits abgerundeten Cocon, dessen Wände dünn und zerbrechlich sind, wahrscheinlich aus den Excrementen und bildet sich in etwa zwei Monaten, April und Mai, zum vollkommenen Insekte aus.

Jedenfalls würde die bis jetzt unbekannte Lebensweise und Entwicklung von Orsodacna eine ähnliche sein müssen, wenn diese Gattung künftig bei den Sagrinen bleiben sollte.

Rhaebus Fisch dagegen, der sich in den Früchten von Nitraria Schoberi ähnlich wie alle Bruchiden entwickelt, ist nach den Ausführungen von Dr. Kratz (Deutsch. ent. Z. 1879. 277) ganz von den Chrysomeliden zu entfernen und bei den Bruchiden unterzubringen, zu denen die Gattung bereits von Seidlitz (Fauna balt. 130) gestellt worden ist. Die Bildung des Kopfes, der Augen und der Füsse, die Einlenkung der Fühler in der tiefen Ausrandung der Augen, und die verkürzten Flügeldecken, welche das grosse Pygidium nicht bedecken, lassen diese Stellung durchaus natürlich erscheinen.

\section{Drsodacha.}

L atreille, Hist. nat. Crust. et Ins. III. 223.

Mandibulae apice acutiusculae.

Oculi rotundi, integri.

Acetabula antica occlusa.

Unguiculi tarsorum denie acuto armati.

Fühler elfgliederig, fadenförmig, mit Ausnahme des ersten Gliedes dünn, Glied zwei bis vier cylindrisch, fünf bis zehn nach der Spitze deutlich verbreitert, elf elliptisch, beiderseits zugespitzt. Kopf dreieckig, mit breiter Stirn, zwischen den Fühlerwurzeln meist 
quer eingedrückt, mit grossen, mässig heraustretend gewöllten Augen. hinter denen der kurze Hals nur schwach abgeschnürt ist. Die Oberlippe ziemlich gross, vorn gerundet abgestutzt und dicht bewimpert; Nandibeln schlank, vorn einfach zugespitzt. An den Maxillartastern ist das dritte Glied kaum halb so lang, das rierte dagegen so lang oder länger als das zweite, bald schmal, cylindrisch, vorn schief abgestutzt, bald breiter, eiförmig. Die Zunge ist sehr gross, häutig, rorn stark erweitert und herzförmig ausgerandet, ihre Lappen sind divergiretid, aussen stark gerundet. Halssehild so lang als breit oder länger, hinter den Vorderecken lejcht gerundet erweitert, von der Mitte an allmählich bis zur Breite des Vorderrandes ocer mehr verengt, dicht ror dem Hinterrande wieder etwas verbreitert und etwa halb so breit als der Grund der Flügeldecken. Schildchen klein, dreieckig oder hinten abgerundet. Flügeldecken mehr als doppelt so lang als zusammen breit, verworren punktirt, an der Spitze gemeinschaftlich abgerundet. Beine mässig stark und lang, die Schenkel etwas zusammengedrückt, die Schienen fein abstehend behaart, nach der Spitze allmählich erweitert und hier mit zwei kleinen Enddomen versehen, Glied eins und zwei der Tarsen lang dreieckig, drei kurz, herzförnig-zweilappig, das Klauenglied ungefähr so lang als die zwei vorhergehenden zusammen, nur an der Basis in die Lappen des dritten Gliedes eingelegt. Die Klauen haben einen langen, spitzen Zalın in der Mitte. Geschlechtsunterschiede treten äusserlich nicht herror. Die Männchen sind kleiner und schlanker als die Weibchen, durch die Form des letzten Kiefertastergliedes, wie Thomson (Skand. Col. VIII. 132) angiebt aber kaum zu unterscheiden.

Die Arten leben in Amerika, Europa und Asien auf Blüthen: über ihre früheren Stände ist nichts bekannt.

Latreille stellte die Gattung zuerst zwischen Donacia und Crioceris. später zu Sayru und hierin sind ihm alle Schriftsteller grefolgt. Nur Thomson rereinigte sie in seinen ,Skandinaviens Coleoptera" mit symetn und Kengophora zu der Abtheilung der Orsidacmidae, eine Stellung, die sehr natürlich erscheint, wenn man den Habitus ins Auge fasst, die Zungen- und Hüftbildung aber als nebensächlich ansieht.

1. D. cerossi: Elongata, supna subylubru, subhus dense pubescens: prothorace subcordalo cupiteque info-ieslaceis, parce punctatis, scutello lacri, elygris mims mebre punclatis pedibusyue testaccis, pectose, abdomineque ferrugineis vel vigris. - Long. $4,5-8 \mathrm{~mm}$.

Linn. Syst. Nat. X. 376 (Crioceris). - Lac. Mon. 76. 6. Redtb. Faun. A. II. 438. - Seidl. F. balt. 502.

Crioceris chlorotica Oliv. Enc. mèth. VI. 203.

Lema fulvicollis Panz. Faun. Germ. 83. 8. 
Var. a. Subtus tesiacea.

O. chlorotica Latr. Hist. nat. XI. 350.

Var. b. Vertice, corpore subtus, elytrortm sulura margineque laterali basi nigro-fuscis.

O. lineola Lac. Mon. 76.

Var. c. Covpore subtus, vertice elytrorumque apice nigro-fuscis.

Galleruca melanura Fabr. Ent. Syst. II. 22, 45.

$\mathrm{Var}$ d. Corpore sublus verticeque nigris, prothorace iufo-piceo vel sigro, elytris margine laterali fusco wel suha margineque laterali nigrofuscis.

O. limbata Oliv. Entom. VI. 754. t. 1. f. 5. - Daftsehm. Faun.

A. III. 246.

Var. e. Nigra, abdomine. fronte elytromungue disco mestentibus.

Var. f. Nigra, abdomine, capile antice thoraceque rufis.

Crioceris glabrata Panz. Ent. Germ. 170. 16; Faun. Germ. 34.6.

Var. g. Obscure coerulea, capite thoraceque rufis.

Crioceris cantharoides Fabr. Syst. Ent. 120.

Var. h. Nigra, antennis pedibusque fuscis.

Crioceris glabrata Fabr. Supplem. Ent. Syst. 89.

Orsod. glabrata Duft. Faun. A. III. 249.

Eine in Grösse, Körperform und Farbe sehr veränderliche Art.

Langgestreckt, mit fast kahler Ober- und dicht behaarter Unterseite, hellgelb, Fühler, Kopf und Halssch. röthlicher; die Brust und der Bauch rothbraun bis schwarz. Kopf sparsam fein punktirt und behaart, die Mitte der Stirn und des Scheitels meist ohne Punkte. Halssch. ziemlich herzförmig, kaum oder wenig länger als in der Mitte breit, weitläufig und fein punktirt, kahl. Schildchen glatt. Fld. etwas dichter als das Halssch. punktirt, die Zwischenräume der Punkte grösser als diese, jeder Punkt, wenigstens die am Seitenrande und vor der Spitze befindlichen, mit einem sebr kurzen Härchen besetzt, welches oft abgerieben ist.

Die Färbung der Art ändert vielfach $a b$ :

a. (chlorotica Latr.) der Bauch oder die ganze Unterseite einfarbig hellgelb.

b. (lineola Lac.) Unterseite, Scheitel, Naht und der Aussenrand der Fld. an der Basis schwärzlich.

c. (melanura Fabr.) Unterseite, Scheitel und die Spitze der Fld. mehr oder weniger breit schwärzlich.

d. (limbata O1.) Unterseite und Scheitel schwarz, Halssch. rothbraun bis schwarz, Seitenrand der Fld., oder Naht und Seitenrand breit schwärzlich gefärbt.

e. Schwarz, Bauch, Stirn, Halssch. und Scheibe jeder Fld. röthlich. 
f. (glabratu Panz.) Schwarz, Bauch, Vorderkopf und Halssch. roth.

g. (cantharoides F abr.) Schwarzblau, Kopf und Halssch. roth.

h. (glabrata Fabr. Dft.) Einfarbig schwarz, Fühler und Beine braun.

In gebirgigen Gegenden auf Dolden, Prunus-, Sorbus- und Crataegus-Blüthen nicht selten.

3. D. Timeola: Elongala, lestacea, supra dense pubescens ciebrerue punctata, sublus parce pubescens; prothorace elonjato, subcordato, lineola dorsali, suturt elytrorum intesdum, capite pectoreque nigris. Long. $4-7 \mathrm{~mm}$.

Panz. Ent. Germ. 170. 15; Faun. Germ. 34. 5. (Crioceris). Fabr. Ent. Syst. Suppl. 89.

Var. a. Tota testacea vel rufo testacea.

Var. b. Testacea, capite pectoreque brunneis vel nigris.

Ors. nigriceps Latr. Gen. Crust. et. Ins. III. 44. - Lac. Mon. 80. 7. - Redtb. Faun. A. II. 438.

o. mespili Lacord. Mon. 73. 4.

Var. c. Nigra, elytris aut testaceis, margine laterali interdun wiynicante, aut piceis.

O. nigricollis Oliv. Ent. VI. 753, t. 1. f. 3. - Redtb. 1. c. 438 .

O. marginella Duft. Faun. A. III. 248, 6 .

Var. d. Nigra vel nigro-cyanea, thorace maculis duabus buseos elytioque singulo macula humerali rufis.

O. humeralis Latr. Hist. nat. Crust. et Ins. XI. 350. - Lac. Mon. 82. 8. - Redtb. 1. c. 438 .

Var. e. Eadem, elytris immaculatis.

Var. f. Omnino ut var. $d$, sed prothorax immaculatus.

Var. g. Eadem, elytris immaculatis.

O. coerulescens Duft. 1. c. 248, 5.

\%. nematoides Lac. Mon. 84. 9.

Von der Vorigen durch dickere Maxillartaster, dicht und ziemlich lang behaarte und dichter punktirte Oberseite, das längere Halssch. und die glänzendere Unterseite, die weitläufiger punktirt und behaart ist, leicht zu unterscheiden; ebenso veränderlich wie jene.

Kopf rerschieden dicht und stark punktirt, die Stirn gewöhnlich mit glatter Mittellinie. Halssch. deutlich länger als breit, nach vorn und hinten oft weniger stark gerundet-verengt wie bei cerasi, aber wohl doppelt so dicht punktirt, zuweilen mit einer schmalen, leicht erhabenen glatten Längslinie über die Mitte der Scheibe. Fld. bald breit und wenig gewölbt, bald schmal und hochgewölbt, verschieden stark, ziemlich dicht punktirt, die Zwischenräume kaum so gross als die Punkte. 
Der Färbung nach lassen sich folgende Hauptformen unterscheiden:

a. Körper nebst Fühlern und Beinen blassgelb oder röthlichgelb. Fld. oft heller als das Halssch. und wie der Kopf mit leichtem grünen Metallschimmer. Selten zeigt sich auf den Fld. am Schildchen eine gemeinschaftliche dreieckige dunkle Makel.

b. Kopf dunkler, rothbraun bis schwarz, nicht selten mit grünlichem Glanze, die Brust schwarz, Bauch und Fühler zuweilen bräunlich. Die helleren Stücke sind mespili Lac., die dunkleren nigriceps Latr.; Exemplare mit schmaler dunkler Naht und kurzer schwarzer Mittellinie des Halsschildes lineola $\mathrm{P}$ an $\mathrm{z}$

c. Kopf, Halssch. und Brust, seltener die ganze Unterseite schwarz, Fühler dunkel, am Grunde heller; Fld. einfarbig gelblich (nigricollis Ol.) oder mit dunklem Seitenrande (marginella Duft.), oder pechbraun, an der Naht dunkler (picipennis $\mathrm{Duft}$.).

d. (humeralis Latr.) schwarz, die Oberseite oft blau oder grünlich schimmernd, zwei längliche Makeln am Grunde des Halssch. und eine Makel auf der Schulter der Fld. roth. Fühler entweder ganz rothgelb oder in der Mitte dunkler oder schwärzlich mit drei röthlichen Basalgliedern.

Bei weiterer Zunahme der schwarzen Färbung verschwinden die Makeln:

e. der Fld., f. des Halssch., g. der Fld. und des Halssch. (coerulescens Duft.).

In Mittel- und Süddeutschland seltener, häufig in Südeuropa.

\section{Zweite Gruppe: DONACIINI.}

Lacord. Monogr, des Phytophages 91.

Antennae basi subapproximatae.

Oculi rotundi, integri. Elytra punctato-siriata.

Coxae anticae apice fere contiguae, e prosterno hand sejunctae. Abdomen segmento primo reliquis simul sumtis longiore vel longitudine aequali.

Unguiculi tarsorum simplices, validi.

Das Hauptmerkmal dieser Abtheilung ist die Länge des ersten Hinterleibsringes, welche die der andern Segmente zusammengenommen erreicht oder übertrifft. Nur die eigentlichen Sagrinen besitzen eine ähnliche Bildung, sind aber unschwer dadurch zu unterscheiden, 
dass bei ilnen die Vorderbrust zwischen den Vorderliüften kielartig erhaben ist.

Fühler ror den Augen einander etwas genähert ringefügt, faden- oder schwach borstenförmig, länger oder wenig kürzer als der halbe Körper, dicht und fein bchaart, das erste G'lied stärker, cylindrisch oder nach der Spitze hin verdickt, meist schwach gebogen, das zweite Glied kürzer als eins der übrigen. Kopt buhart, mit den Augen höchstens so breit als das Halsschild am Vorderrande, Oberlippe quer, vorn leicht gerundet oder ausgerandet, Scheitel gewölbt, Stirn mit einer mehr oder weniger langen Vittelrine. Augen rundlich, ganzrandig, gewölbt. Halsschild vicreckig, im vorderen Drittel des Seitenrandes jederseits mit einem melir oder weniger starken Höcker, so dass sich die grösste Breite bald hinter den Vorderecken befindet; die Basis schwach gerundet, deutlich oder nicht gerandet, vor dem Schildchen meist schwach ausgeschweift, der Rücken ziemlich flach, mit einer verschieden tiefen Längsfurche über die Mitte, welche weder den Vorder- noch Hinterrand erreicht. Schildchen mässig gross, dreieckig, dicht seidenhaarig. Flüg-ldecken mit zelın regelmässigen ganzen Punktstreifen und einem abgekürzten an der Naht am Schildehen. Vorderhüften ziemlich dicht, frei neben einander stehend, an der Spitze fast zusammenstossend, die Mittelhüften weiter auseinander gerückt, die Hinterhüften sehr breit getrennt. Klauen einfach, gekrümmt, lang und stark. Die ganze Unterseite mit einer grauen, weiss- oder goldig-schimmernden Behaarung versehen, entweder einer doppelten, aus anliegenden, kurzen, dicht aneinandergedrängten Härchen bestehend, zwischen denen sich längere, dickere und abstehende Haare befinden (Donacia, Plateumaris), oder einer filzigen, bei der die einzelnen Härchen nicht mehr zu unterscheiden sind (Haemonia).

Der Penis bildet eine winkelig nach unten gebogene Röhre mit schiefer Oeffinung und besitzt auf der Oberseite einen eigenthümlicheu Anhang. Derselbe entsteht dadurch, dass sich die pergamentartige Haut, welche den Penis am Grunde umgiebt, oberseits in eine schmale Spitze verlängert, welche ebenso fest wie der Penis, hornig und am Ende lang bewimpert ist und sich, leicht gekrümmt, bis dicht vor die Penisspitze hinzieht oder in die Penisöffnung hineinragt. Zur bequemen Lagerung dieses Anhanges besitat der Penis oberseits meistens eine Längsrinne.

Die Donaciinen leben an Wasserpflanzen, theils über, theils unter dem Wasser; ihre Eier kleben sie einzeln im Wasser an die Wurzeln, den Stengel oder die Blätter ihrer Näbrphauzen. Die Larven sind kurzbeinig, sehr träge, kommen nie an die Oberfläche 
des Wassers und befincen sich in der Mitte eines gallurtartigen Schleimes, welcher dem Froschlaich sehr ähnlich ist. Ob sie von diesem Schleime leben, welcher vielleicht durch ihre Verletzungen der Pflanzenhaut entsteht, wie Perris (Ann. d. Fr. 1848. 33) vermuthet, ob sie wirklich bis zur dritten Häutung die zarten Wurzelfasern, nachher aber nur die äussere Haut abnagen, wie Heeger ${ }^{3}$ ) (Sitzungsber. Ac. Wien 1854. 38) beobachtet haben will, oder ob endlich die Ernährung der einzelnen Arten ganz verschieden ist, so dass von einer Art nicht auf die übrigen geschlossen werden dürfte, ist noch unaufgeklärt. Der Körper der Larven ist langgestreckt, nach vorn mehr als nach hinten verengt, mit elf Segmenten, von denen das letzte fast im vorletzten steckt und mit zwei langen Afterdornen bewaffnet ist, welche zur Befestigung der Larve an den Pflanzenstengeln dienen ${ }^{2}$ ). Die Dornen sind etwas gekrümmt, dicht unter dem oberen Rande des Segmentes angeheftet und vorn stark zugespitzt. Der ganze Körper ist behaart, matt, die einzelnen Segmente haben eine oder mehrere Querfurchen, vor und hinter diesen dagegen Querreihen von röthlichen Punkten oder Börstchen, im ganzen acht bis neun Paar Stigmen ${ }^{3}$ ). Zur Verpuppung verfertigt sich die Larve ein lang-ovales, pergamentartiges Gehäuse aus ihrem Speichel an, welches an der Nahrungspflanze befestigt ist und aus dem der Käfer auskriecht, nachdem er am oberen Ende einen förmlichen Deckel abgenagt hat.

Im Habitus erinnern die Arten dieser Abtheilung an die Cerambyciden; sie wurden deshalb von den älteren Autoren Linné, Marsham, Paykull etc. bei Leptura und Rhagium untergebracht und der von Fabricius 1775 aufgestellte Gattungsname Donacia gelangte erst spät zu allgemeiner Annahme. 1829 trennte Latreille die Gattung Haemonia davon ab und seitdem ist eine weitere Spaltung in Gattungen nicht versucht worden. Nur Thomson brachte die mit Don. sericea verwandten Arten in eine besondere Abtheilung,

1) Seine Angaben über die Dauer der Entwicklung sind unzuverlässig; rechnet man nämlich die einzelnen zusammen, so ergiebt sich, dass $D$. clavipes statt Ende September, wie behauptet wird, bereits Anfang Februar fertig entwickelt ist. Verdächtig ist auch die Beobachtung, dass die Larve keine Ocellen besitzen soll.

2) Nach Heeger 1. c. sitzen diese Dornen bei D. clavipes unten am vorletzten (?) Segmente, sind nach aussen gebogen, in der Ruhe nach vorn geschlagen und dienen beim Kriechen als Nachschieber!

3) Perris 1. c. fand an der Larve von D. bicolora nur acht Paare, eins auf dem Mesothorax, die übrigen auf den ersten sieben AbdominalSegmenten; ebenso Bellevoye an den Larven von Haemonia Mosellae. 
Plateumaris. Die hierher gehörigen Thiere unterscheiden sich durch Körperbildung und Lebensweise aber so bedeuterd ron Donacia, dass mir die Aufstellung einer eigenen Gattung für sie durctrau. gerechtfertigt erscheint.

\section{Haemonia.}

Latreille, Cuv. Règn. anim. ed. 2. V. 136.

Compus hand metallicmm, subius cum caprite antemisque tommento flavo-cinerascente obtectum.

Elytra apice exierne spinoso-producta, sutura elevala.

Abdomen seymento primo reliquis simul sumlis lompirudine aeguali. Tarsi elongati, parce ciliati, articulo tertio minutissimo, ultimo maximo.

Mandibeln lang, ziemlich kräftig, vorn fast rechtwinkelig gegen einander gebogen, die schwach ausgerandete Oberlippe etwas überragend. Kopf mässig breit, mit grossen, kreisrunden, stark gewöllten Augen, die Stirn hat in der Mitte eine tiefe Längsgrube, welche beiderseits von einer hohen Leiste begrenzt wird, die rorn, wo sie am höchsten ist, steil abfällt. Der Hals ist hinter den Augen nur leicht abgeschnürt. Fühler vor den Augen, einander gelühtert eingefügt, wie der Kopf und die ganze Unterseite mit einer dichten, seidenglänzenden Filzkruste bedeckt, leicht borstenförmig, indem die letzten Glieder schlanker als die ersten sind. Sie erreichen etwa " der Körperlänge. Halsschild viereckig, hinter den Vorderecken mit einem niedrigen, seitwärts gerundet heraustretenden Seitenhöcker. auf der Scheibe mit einer breiten, flachen Mittelrinne, in welcher sich ein oft scharfer Längskiel hinzieht. Flügeldecken fein behaart. mehr als doppelt so lang als breit, die Seiten fast parallel, hinter der Mitte etwas verbreitert, nach der Spitze hin wenig verengt, diese selbst einzeln ausgerandet-abgestutzt, die Aussenecken in einen Dorn ausgezogen; jede mit 10 zu je zweien einander genäherten Punktstreifen und einem abgekürzten an der Naht am Schildchen. Die Naht ist bald hinter dem Schildchen bis ror die Spitze dachförmig erhaben, mit schmalem Filzsaume, der dritte, fünfte und neunte Zwischenraum breiter und stärker gewölbt als die übriger. Die Flügeldecken sind weisslich gelb, die Punkte der Streifen stehen jedoch auf schwarzem Grunde oder die Streifen sind ganz schwarz, zuweilen so ausgedehnt, dass nur noch die drei gewölbteren Zwischenräume die Grundfarbe behalten.

Die Beine sind schlank, dit hinteren bedeutend länger als die übrigen, wenigstens die vier Vorderschenkel leicht keulig-verdickt, 
die Schienen meist schwach gebogen, nach der Spitze hin wenig verbreitert, die Innenseite der hinteren zweimal geschweift, Tarsen zusammen länger als die Schienen, cylindrisch, sparsam bewimpert, obne Filzsohle, ihr drittes Glied das kleinste, das vierte länger als die übrigen zusammen, mit zwei langen, kräftigen, stark gekrümmten, einfachen Klauen. Dieser eigenthümliche Bau der Füsse findet sich in der ganzen Familie nicht wieder, wohl aber bei den ähnlich lebenden Dryopiden-Gattungen Potaminus und Potamophilus.

Die Männchen sind an den schwächer gebogenen Hinterschienen und an einer weiten Grube auf der Mitte des ersten Abdominalsegmentes kenntlich, welches bei den ㅇ gewölbt ist. Der Penis ist ein auffällig kleiner, gerader und ziemlich dicker Cylinder mit einer schiefen, grossen Oeffnung, über welche der bandförmige Anhang hinaus ragt.

Die Käfer leben unter Wasser an Potamogeton-, Myriophyllumund Ruppia-Arten, deren Stengel sie so fest umklammern, dass sie nur mit Mühe abgelöst werden können. Sie sind jedenfalls weit verbreitet, aber bisher übersehen worden und treten in grossen Massen auf, wie die Donacien.

Die ersten Stände von $H$. equiseti sind seit Germar') bekannt, später von Heeger ${ }^{2}$ ) beobachtet und besonders von Bellevoye ${ }^{3}$ ) ausführlich beschrieben worden. Die Larven werden $10 \mathrm{~mm}$ lang und $3 \mathrm{~mm}$ breit, sind weiss, matt, einzeln fein behaart, der Kopf, die Beine und Afterdornen röthlich. Der Kopf ist klein, kaum ein Drittheil so breit als das Thoraxsegment, mit 4 gliedrigen Fühlern und 5 Ocellen jederseits. Die Beine sind dreigliederig. Lacordaire fand $^{4}$ ) an den Larven von $H$. Gyllenhali Lac., die er lebend aus Putzig erhielt, keine Ocellen und nur zweigliederige Fühler. Herr Bellevoye (l. c. p. 94) glaubt nun, dass diese Larve gar nicht zu Haemonia gehört haben könne, allein ohne rechten Grund; denn Lacordaire's ausführliche Beschreibung weist mit Sicherheit auf eine Haemonia-Larve hin.

1. Hilnem. appendiculata: Nigra, prothorace, elytris pedibusque flavo-testaceis, femorum tarsorumque articulis apice nigris, thorace elongato-quadrato, nigro-bilineato, callo laterali obsoleto, elytris pro-

1) Neue Schrift. Ges. Halle I. 6. 34.

2) Sitzungsber. Ac. Wien XI. 940.

3) Bull. Soc. Hist. Nat. Moselle 1870. 91. f. 1-16.

4) Stettin. Zeit. 1S51. 263. 
funde punctato-striatis, striis punctis nigris impressis, elytris dente externo lonyo, acuto armatis, femoribus posticis evidenter claratis. Long. $5,5-8,5 \mathrm{~mm}$.

Mas: abdominis segmento primo medio longinudinaliter impresso, tibiis posticis subrectis, interne leniler bisinuatis.

Panz. Faun. Germ. 24. 17 (Donacia).

H. equiseti Fabr. Supplem. Ent. Syst. 128 (Don). - Lac. Mon. 212. - Suffr. Stett. Z. 1846. 90. - Thoms. Skand. Col. VIII. 126. Redtb. Faun. A. II. 443. - Seidl. F. balt. 504.

H. mosellae Bellevoye Bull. Soc. Hist. Nat, Mosell. 1870. 91. Bedel Ann. Fr. 1872. Bull. 51.

Var. a. Thorace immaculato.

H. mosellae var. flavicollis Bellev. 1. c. 93.

Var. b. Striis elytrorum punctis haud nigris.

H. Chevrolati Lac. Mon. 215.

Var. c. Elytris nigro-lineatis.

H. lineata Chevr. Guer. Ic. regn. anim. Ins, 258. 1.

Schwarz, der Mund, das Halsseh., die Fld, die Beine mit Ausnahme eines feinen Ringes am äussersten Ende der Schenkel und der Spitze der Tarsenglieder, sowie der mittlere Theil der vier letzten Abdominalsegmente gelbbraun. Halssch. länger als hinter den Vorderecken breit, vor den Hinterecken etwas verengt, sodann gleichbreit bis etwa zur Mitte, wo der schwache Seitenhöcker eine allmähliche Verbreiterung hervorruft. Die Scheibe mit zwei nach vorn convergirenden schwarzen Linien. Fld. tief punktirt-gestreift, die Punkte in den Streifen, zuweilen mit Ausnahme der im achten und neunten stehenden, schwarz, der dritte, fünfte und neunte Zwischenraum breiter und meist gewölbter als die übrigen, die Spitze ausgerandet-abgestutzt, der Nahtwinkel in eine sehr kurze und wenig: scharfe Spitze vorgezogen, der A ussenwinkel in einen langen, schmalen und sehr spitzen, dornartigen Zahn verlängert. Alle Schenkel keulenförmig verdickt, die hinteren gekrümmt, das erste Tarsenglied gewöhnlich kürzer als das zweite.

Das kleinere Männchen besitzt auf der Mitte des ersten Bauchsegmentes eine längliche Grube, die Hinterschienen sind fast grade, innen unmerklich ausgeschweift (beim $q$ gekrümmt, innen deutlich zweimal gebuchtet), seine Fld. sind tiefer gestreift, die Zwischenräume der Streifen schmaler und gewölbter als beim $^{\text {. Die Oeff- }}$ nung des Penis ist am Vorderrande breit abgerundet, mit einer kurzen, deutlich abgesetzten Spitze.

Die Färbung der Art ändert ab:

a. Das Halssch. ist ungefleckt. 
b. Die Fld. sind einfarbig, die Punkte derselben stehen nicht auf schwarzem Grunde. (Wohl nur ganz frische Stücke.)

c. Je zwei der schwarzen Punktstreifen fliessen fast oder ganz zusammen, so dass die Fld. der folgenden Art ähnlich gefärbt sind.

In Flüssen und Seen an Potamogeton lucens, pectinatus und Myriophyllum spicatum im Mai und Juni.

2. Hatem. sosterre $\left.{ }^{1}\right)$ : Nigra, prothorace, elytris pedibusque flavotestaceis, thorace subiransverso, nigro-bilineato, callo laterali distincto, elytris dente externo breniore armatis, subtilius punctato-strialis, striis plus minusve nigro-punctalis, femoribus posticis vix clavatis, tarsis articulis apice fuscis. - Long. 4, 5-6 $\mathrm{mm}$.

Mas: Abdominis segmento primo late impresso.

Fabr. Syst. El. II. 127. - Gyllh. Ins. Suec. 4. 683 (Donac.) Kraatz Deutsch. Z. 1876. 182.

H. Gyllenhali Lac. Mon. 218. - Redtb. Faun. A. II. 443.

H. Sahlbergi Lac. Mon. 220. - Seidl. F. balt. 504.

Var. a. Thorace immaculaio

Var. b. Eytris nigro-lineatis, thorace bimaculato.

H. Curtisi Lac. Mon. 214. - Thoms. Skand. Col. VIII. 128. Redtb. 1. c. 443 .

H. Sahlbergi var. baltica Seidl. F. balt. 504.

Var. c. Elytris nigris, limbo externo cum interstiiiis alternis plus minusve testaceis. - Long. $6-7 \mathrm{~mm}$.

H. ruppiae Germ. Faun. Ins. Eur. 14. 9 (Don.) - Kraatz 1. c. 181.

H. Schioedtei Guér. Ic. regn. anim. Ins. 259. 4.

H. zosterce Thoms. 1. c. 129.

Im Allgemeinen kleiner als die Vorige und besonders durch folgende Punkte verschieden: das Halssch. ist kürzer, hinter den Vorderecken meist breiter als lang, der Seitenböcker ist stärker und tritt ziemlich schnell aus dem Seitenrande heraus. Die Fld. sind flacher gestreift, die Punkte in den Streifen feiner und dichter, die Zwischenräume deutlicher quer gerunzelt, der Zahn am Aussenwinkel der Spitze ist kurz, dreieckig. An den Beinen fehlt der dunkle Ring an der Spitze der Schenkel, zuweilen sind sogar die Tarsen ganz gelbbraun, die Hinterschenkel sind allmählich hinter der Mitte verdickt, aber kaum keulenförmig, das erste Tarsenglied ist länger,

1) Die nur nach einzeInen Stücken beschriebenen $H$. incis $S a h l b$. und rugipennis Sahlb. (Öfers. Fin. Soc. 1870. 65) bedürfen wohl noch der weiteren Aufmerksamkeit der nordischen Entomologen, um als Arten festgehalten werden zu können. 
etwa so lang als das zweite; die Grube auf dem ersten Bauchsegmente des $\hat{\sigma}$ breiter. Die Oeffinung des Penis ist länglich. am Vorderrande allmählich in eine Spitze verlängert.

Die Färbung der Oberseite ist veränderlich. Bei der hellsten Form, die der appendiculata sehr ähnlich ist, sind die Punkte der Fld. im Grunde der Streifen mit Ausnahme des achten und zuweilen auch neunten schwarz; der Thorax hat zwei schiefe, schwarze Längslinien, die in seltenen Fällen ganz fehlen (Var. a). Die Spitze der Fld. ist bald einzeln ausgerandet-abgestutzt, mit deutlichem Nahtzähnchen (zosterae Lac.), bald grade abgestutzt, ohne N̦ahtzähnchen (Sahlbergi und Gyllenhali Lac.).

Bei den dunkleren Stücken fliesst die schwarze Farbe der Punkte zu mehr oder weniger breiten Längslinien zusammen, der dritte, fünfte und neunte $Z$ wischenraum sind meist breit, der zweite, vierte, achte und zehnte schmal, gelbbraun, während der sechste ganz verschwindet; das Halssch. hat zwei grosse schwarze Makeln oder ist bis auf die Ränder schwarz (Curtisi Lac.).

Die dunkelste Form, die sich zugleich durch ihre Grösse und das gestrecktere Halssch. auszeichnet, hat nur den neunten $\mathrm{Z}$ wischenraum und den an der Spitze verbreiterten Aussenrand der Flügeldecken gelbbraun, öfter ist jedoch auch der dritte, fünfte und siebente Zwischenraum bräunlich; das Halssch. mit zwei grossen schwarzen Makeln, oder bis auf die Ründer schwarz.

Im Brackwasser am Strande der Nord-und Ostsee an Ruppia maritima. Bei Krasnowodsk am Caspischen Meere ( $F$ a ust). Die Var. b. ist in den Sammlungen am meisten verbreitet, die Var. c. kommt nur an der Küste des Sundes (Insel Amager bei Kopenhagen, Lomma, Malmö) und bei Trelleborg vor.

\section{Donacia.}

Fabricius, Syst. Entom. p. 195.

Mandibulae apice lubrum parum superantes. Oculi magni.

Elytra metallica, apice truncata vel rotundato-. haud spinoso-producta, margo suturalis subrectus.

Abdomen segmento primo reliquis simul sumtis longiore.

Tibiae apice externe haud dentato-productae.

Tarsi articulis 2 primis sublus holnsericeis, articulo tritio bifido, subtes hirsuto.

Körper gestreckt, metallglänzend, die Oberseite flach oder wenig gewölbt, die Unterseite mit starker, hoher Brust und mässig gewölbtem oder flachem Bauche, ist nebst den Beinen sehr dicht und 
fein anliegend, dazwischen einzeln abstehend behaart. Kopf mit drei Längsfurcben auf der Stirn, eine in der Mitte und je eine an der Seite vor dem Innenrande der Augen bis zur Fühlerwurzel, die Fortsetzung der Halseinschnürung nach vorn vorstellend. Mandibeln fast ganz unter der Oberlippe verborgen, kurz und breit, vorn in zwei meist scharfe Spitzen ausgezogen, von denen die innere länger als die äussere ist. Augen gross, wenig länger als breit, nach unten leicht divergirend, stark gewölbt und vorspringend. Fühler fadenförmig. Halsschild viereckig, quadratisch oder länger als breit. Flügeldecken doppelt bis dreifach länger als zusammen breit, der Rücken ziemlich flach mit mehr oder weniger deutlichen Vertiefungen, vor der Spitze allmählich, an den Seiten dagegen stärker abwärts gewölbt, die Spitze scharf oder gerundet-abgestutzt, nie in einen Zahn ausgezogen. Beine schlank, ihre oft keulig verdickten Schenkel überragen die Seiten der Flügeldecken bedeutend. Gewöhnlich sind die Hinterschenkel länger und dicker als die vorderen, auf der Unterseite entweder einfach abgerundet oder in eine wenig scharfe Längskante verschmälert, welche vor der Spitze in einen Zahn ausläuft, hinter dem in seltenen Fällen noch ein oder mehrere kleine Zähnchen hervortreten. Einige Arten haben ausserdem in der Nähe der Mitte an der Innenseite der Hinterschenkel ein nach innen gerichtetes Zähnchen, so dass sie ihre gebogenen Hinterschienen fest zwischen dieses und den grösseren Zabn einlegen können. Schienen schmal, nach der Spitze wenig verdickt, die hinteren schwach auswärts gekrümmt. Tarsen zusammen kürzer als die Schienen, nur bei clavipes an den Vorderbeinen so lang als dieselben, Glied eins und zwei dreieckig, unten dicht und fein kurzseidenhaarig, drei zuweilen so lang als die beiden ersten zusammen, bis zum Grunde gespalten, unten mässig stark, dicht und lang behaart. Das Klauenglied ist fast ganz in die Lappen des dritten Gliedes eingeschlossen.

$\mathrm{Zu}$ den Geschlechtsunterschieden sind die schlankere Gestalt, längere Fühler und Beine und die merklich schwächere Punktirung der Männchen zu rechnen. Bei einer Art zeigen sich auf dem ersten Bauchringe zwei kleine Höckerchen, bei den meisten ist der Hinterrand des letzten Segmentes abgestutzt, in der Mitte mit einem Eindrucke versehen, beim Weibchen dagegen in eine dreieckige oder abgerundete Spitze vorgezogen, endlich sind die Hinterschenkel stärker gezähnt, die Hinterschienen zuweilen am Innenrande erweitert und mit spitzen Höckerchen bewaffnet. Diese Auszeichnungen sind jedoch sehr variabel; bei kräftigen Männchen scharf ausgeprägt, verschwinden sie vollständig bei den schwachen, 
so dass sich diese nur noch an der Bilukng des fünften Sugmentes sicher erkennen lassen.

Der Penis ist länger, aber viel düuner und flacher als der von Haemonia, vor der Oeffnung meist leicht eingeschnürt, der Anhang ist liuicntörnig, nach vorn wenig oder kaum verschmälert (appendiculata, limbata, thalassina, impressa, semicuprea, simplex), oder im vorderen Drittel leicht erweitert (sparganii) und vor der Spitze schnell vereugt (obscura, fennica), oder nach vorn ziemlich stark erweitert, oft mit scharfer Mittelriunc (crassipes, versicol,rea, dentata, aquatica), endlich schmal bandfömig, vorn mit zwei dreieckigen Spitzen (bicolora, tomentosa).

Beim Tode strecken die Weibchen oft die Legeröhre hervor. Diese ist ebenfalls winkelig gebogen und endigt vorn in zwei bald abgerundete, bald zugespitzte, mit Wimpern versehene weiche Läppehen. Da der Penis im Ganzen nur geringe Abweichungen zeigt und in der Länge und Stärke bei den verschiedenen drter fast vollständig übereinstimmit, so ist es nicht zu verwundern, dass man schon die verschiedensten Species in copula beobachtet hát. Lacordaire zählt folgende auf: simplex und impressa $\hat{\jmath}$ mit sericea , dentata ô mit limbata o und limbata ô nit versicolorea $q$.

Die Donacien leben auf den Blättern oder Stengeln direkt im Wasser stehender Pflanzen, welche sie benagen ${ }^{1}$ ). Zwei Arten (crassipes, versicolorea) sitzen auf schwimmendeu Blättern ju wagerechter Stellung, die übrigen klettern und sitzen bald mit uach oben, bald nach unten gerichtetem Kopfe, bei rauher Luft verkriechen sie sich in die Blattwinkel oder auf die Unterseite der Blätter. Jede Art ist auf bestimmte Pflanzen angewiesen und es ist unnütz, andere anzugeben als die, von denen sie wirklich frist. Leider finden sich, besonders in Suffrian's Bemerkungen zu Lacord. Monogr. eine Reihe der widersinuigsten Angaben, welche theilweise anch in Kaltenbachs Pfanzenfeinde Autnahme gefunden haben; so soll crassipes auf Typha latifolia (Rosenhauer), versicolorea auf Typha (Rosh.) und Sagittaria (Suffr.), dentutu auf Riedgräsern (Rosh.), aquatica auf jungen Fichten- und Kieferschlägen (Rosh.), clavipes auf Iris pseudacorus (Gyllh.), vulgaris auf Trapa natans und Scirpus maritimus (Alir.), semicuprea auf Sparganium und Carex-Arten (Suffr.), tomentosa auf einem Equisetum etc. leben.

1) Ahrens (Mon. p. 10) bezweifelt dies mit Unrecht. Ich habe das Abnagen grosser Blattlächen bei $I$ ). dentitı, semicupren und tumentusa beobachtet. 


\section{Erste Gruppe.}

Halssch. und Fld. kahl. Hinterschenkel gezähnt, die Spitze der Fld. erreichend oder überragend.

1. DD. crossipes: Supra depressa, viridi-aenea, subtus argenteosericea; prothorace transverso, fere laeviyato, elytris profunde striatopunclatis, apice emarginalo-truncatis, dorso cupreo-vel violacev-micans; pedibus ferrujineis, femorum clava supra aenea. - Long. 9-11 $\mathrm{mm}$. Mas: segmento $5: 0$ ventrali apice truncato, femoribus posticis bidentatis, tibiis posticis infra medium fortiler vel vix dilatatis, denticulatis. Fem: segmento 5: o ventr. acuminato, femoribus posticis dente acuto armatis.

Fabr. Syst. Entom. 195. 1. - Lac. Mon. 102. 3. - Redtb. Faun. A. II. 439. - Seidl. F. balt. 505.

D. striata Panz. Ent. Germ. 215. 4; Faun. Germ. 29. 1.

D. spinosa Thoms. Skand. Col. VIII. 110. 5.

Var. b. Supra tota rufo-aenea.

Var. c. Supra tola violacea, subopaca.

Suffr. Stett. ent. Zeit. 1845. p. 330.

Breit, plump und eckig gebaut, oben flach gedrückt, metallisch grïn oder goldgrün, die Scheibe des Halssch. und der Fld. ron der Naht bis zum 8. Punktstreifen kupferig, violett oder schwarzgrün angelaufen, die Unterseite silberweiss behaart. Fühler beim ô länger, beim q so lang als der halbe Körper, schwarzgrün, einfarbig oder die einzelnen Glieder am Grunde röthlich, Glied 3 reichlich doppelt so lang als 2, 4 und 5 länger als 3, 6 und die folgenden allmählich etwas kürzer werdend. Kopf fein weisslich behaart, fein und dicht punktirt, die drei Stirnfurchen tief. Halsscb. breiter als lang, nach hinten schwach verengt, der Seitenhöcker, aussen nur leicht angedeutet, wird innen durch eine tiefe Grube begrenzt. Die Längsrinne über der Scheibe beginnt hinter dem in der Mitte stark erhabenen Vorderrande, ist schmal und tief, hinten grübchenartig und verliert sich in einem weiten, flachen Quereindrucke vor dem Hinterrande. Die Oberfläche ist ausserordentlich dicht und fein, nach den Seiten hin etwas stärker gerunzelt, kaum punktirt, schwach seidenschimmernd. Fld. tief gestreilt-punktirt, die inneren $Z$ wischenräume der Streifen glatt, die äusseren fein quer gerunzelt. Die Spitze ist scharf abgestutzt, oft schwach bogenförmig ausgeschnitten. Beine röthlich braun, die Oberseite der Schenkelkenle, oft auch die Schienen schwach metallgrün.

Beim Männchen ist das letzte Bauchsegment an der Spitze breit abgestutzt, der Hinterrand in der Mitte leicht gerundet vorgezogen und mit einer schwachen Vertiefung versehen; HinterVI. 
schenkel stark verdickt, mit zwei Zähnen, der vordere spitz, an der Innenseite, der hintere grösser und breiter, auf der Unterkante der Schenkel, dahinter oft noch $2-3$ kleinere Zähnchen. Die Hinterschienen sind unter der Mitte bei starken $\hat{o}$ breit, bei schwachen kaum erweitert und an der Innenkante gezähnelt. Beim Weibchen ist das letzte Bauchsegment in eine mässig scharfe Spitze ausgezogen und die Hinterschenkel haben nur einen Zahn.

Die Scheibe der Fld. ist bei den Männchen häufiger kupfrig oder bräunlich, bei den Weibchen dagegen spangrün oder violett; selten sind Stücke mit einfarbiger, goldigroth glänzender (meist ô) oder tief violetter Oberseite (meist 오). Bei letzteren sind die Zwischenräume der Punktstreifen auf den Fld. oft dicht und fein gerunzelt, matt.

Auf den Blättern von Nymphaea alba und Nuphar-Arten besonders im Juni nicht selten.

2. D. dentata: Supra subconvexa, aenea, cupreo-vel viridi-micans subius argenteo-sericea; prothorace quadrato, rugoso-punctato, femoribus posticis dentibus 2 armatis, segmento 5:0 ventrali ferrugineo. Long. $7-9,5 \mathrm{~mm}$.

Mas: segmento 1:o ventrali depresso, biluberculato, tibiis posticis infra medium dilatatis, denticulatis.

Hoppe Enum. Ins. Erlang. 40. f. 2. - Ahr. Mon. 17. 3. Kunze Mon. 7. 3. - Lac. Mon. 121. 15. - Redtb. Faun. A. II. 440. - Seidl. F. balt. 505. - Thoms. Skand. Col. VIII. 111. 7.

Var. a. Supra viridis, aureo-vel coeruleo-viridis, saturate viridi-cuprea vel violacea.

Var. b. (feminae.) Femoribus posticis unidentatis.

D. phellandrii Sahlb. Ins. Fenn. II. 271. 5.

D. dentata Thoms. Skand. Col. VIII. 111. 7. q

Var. c. Minor; segmento 1:0 ventrali maris subtiliter vel haud tuberculato. - Long. 5-8 $\mathrm{mm}$.

D. angustata Kunze Mon. 4. 8. - Lac. Mon. 124. 16. - Suffr. Stett. Zeit. 1845. 331。

Der vorigen Art nahe verwandt aber schmaler, gewölbter und durch die Form und Skulptur des Halssch, die Punktirung der Fld. und die Geschlechtsauszeichnungen leicht zu unterscheiden. Ziemlich langgestreckt, oben wenig gewölbt, erzfarbig mit kupferigem oder grünem Schimmer, die Unterseite silberweiss behaart, am Kopfe und an den Seiten mit einem Stich ins gelbliche. Fühler halb so lang als der Körper, schwarz, die einzelnen Glieder am Grunde breit, beim $\hat{\sigma}$ oft bis über die Hälfte roth gefärbt, während die der 
우 dunkler, zuweilen einfarbig schwarz erscheinen; sie sind im Allgemeinen ähnlich gebaut wie bei der vorhergebenden, nur ist Glied 3 etwas kürzer, schwach doppelt so lang als 2, Glied 11 dagegen eine Spur länger. Kopf mit gelben Härchen besetzt, dicht und mässig stark punktirt, die Zwischenräume der Punkte fein genetzt, die 3 Stirnfurchen tief. Halssch. so breit als lang; an den Seiten vor der Mitte schnell aber schwach verengt, sodann gradlinig bis zum stumpf vortretenden Hinterrande, der Seitenhöcker schwach, innen durch eine halbkreisförmig gebogene Linie abgesetzt, die abgekürzte Längsrinne auf der Scheibe breit und tief, ein Quereindruck vor dem Hinterrande nur angedeutet, die Oberfläche ungleichmässig stark punktirt und quer gerunzelt. Die Fld, zeigen 4 leichte Eindrücke jederseits an der Naht und sind von den Schultern nach hinten allmählicher verengt als bei crassipes, an der Spitze ausgeschnittenabgestutzt und tief gestreift punktirt; die Punkte sind gross, etwas quer, durch eine schmale scharfe Kante von einander getrennt, und greifen die Zwischenräume jederseits an, so dass diese, besonders beim 오, nur schmal und stark quer gerunzelt erscheinen. Letztes Bauchsegment ganz oder theilweise rothbraun. Beine röthlich, die Oberseite der Schenkel, theilweise auch die Schienen, metallgrün oder violett, die Hinterschenkel mit 2 starken Zähnen, von denen der vordere gewöhnlich etwas kleiner ist. Letztere sind näher an einander gerückt, als bei der Vorigen und es zeigen sich, wie bei dieser, hinter dem grossen Zahne oft noch einige kleinere. Während der Bauch beim $\rho$ dick und stark gewölbt erscheint, ist er beim $\hat{O}$, zumal das erste Segment, flach; auf letzterem bemerkt man in der Mitte, näher dem Vorder- als dem Hinterrande 2 Höckerchen, zwischen diesen eine leichte Längsvertiefung, das letzte Segment zeigt in der Mitte vor dem Hinterraude eine weite, flache Vertiefung; die Hinterschienen sind unter der Mitte zusammengedrückt, erweitert und am Innenrande gezähneit.

Die Farbe der Oberseite ändert vielfach ab. Man findet lebhaft grüne, gold- oder blangrüne, tiefviolette und gesättigt kupferrothe Stücke, welche einen eigenthümlichen dunkelgrünen, die Hauptfarbe kaum beeinflussenden Anflug haben (Var. a.); seltener pflegen bei uns die Weibchen zu sein, denen der vordere Zahn der Hinterschenkel ganz fehlt (Var. b.).

Im südlichsten Theile des Gebietes und in ganz Südeuropa tritt diese Art ausschliesslich in einer kleineren, schlankeren, weniger stark sculptirten Form auf, welche bisher als angustata $\mathrm{Kunze}$ für eine eigene Art angesehen wurde. Da die Männchen mitunter fast so blank wie polita werden und $\mathrm{Kunze}$ wahrscheinlich, Lacordaire 
sicher nur of zur Beschreibung vor sich hatte, so ist es bei dem Mangel an Material ticht zu verwundern, dass Beide von der Güte der Art überzeugt waren, die sie hauptsächlich durch das Fehlen der Höckerchen auf dem 1. Segmente des $\hat{\sigma}$ begründeten. Durch die Güte meines Freundes Stussiner in Laibach liegen mir von dieser Form eine Reihe Männchen vor, am 13. Juli auf Froschlöffel (Alisma?) in den Gräben am Eisenbahndamme bei Laibach gesammelt, von denen $1 / 3$ mit den normalen Höckerchen des 1 . Segmentes versehen, $2 / 3$ höckerlos sind.

Die bisher wohl unbekannten Weibchen haben nur einen schwachen vorderen Schenkelzahn oder gehören ganz zur Var, b.

Auf Sagittaria sagittaefolia im Juli und Anfang August häufig.

3. Densicolorea 1): Mudice convexa, supra viridi-aenea violaceomicans, nilida, subtus argenteo-sericea: prothorace subquadrato, disco disperse punctato, transversin strigoso; elytris profunde panctato-

1) Den südlichsten Theilen des Gebietes dürfte kaum fehlen:

D. polita: Modice elongata, subconvexa, supra aureo-viridis vel aureocuprea, subtus argenteo-holosericea; prothorace subelungato, crebre sat fortiter punctato parceque strigoso, callo laterali magno, canalicula dorsali obsoleta; elytris apice truneatis, minus profunde punctato-striatis, interstitiis transversim strigosis; pedibus valiclis, rufescentibus, femorum clava supra aenea. - Long. 7-9 mm.

Mas: femoribus posticis bidentatis, segmento ultimo ventrali apice truncato. Fem: femoribus posticis unidentatis, segmento ultimo ventrali apice rntrindat..

Kunze Mon. Neu. Schrift. Ges. Halle II. 4. 29. - Lacord. Mon. 12S. 18.

Durch starke Fühler und Beine, das gestreckte Halsseh. und die verhältnissmässig lange Behaarung der Unterseite recht ausgezeichnet; einer kurzen clavipes nicht unähnlich. Körper länglich, etwas gewölbt, goldgrün oder kupferig, unten mit silberweissen Härchen dicht, jedoch viel weitläufiger und rauher als bei den verwandten Arten bekleidet. Fühler kräftig, schwärzlich, Glied 3 bis 7 gewöhnlich am Grunde roth, 3̉ wenig länger als 2. Kopf weisslich behaart, dicht und fein punktirt, die 3 Stirnfurchen mässig breit und tief. Halssch. deutlich länger uls breit, die Seitenhöcker gross, länglich, innen scharf begrenzt, die Längsrinne auf der Scheibe fein oder nur als Anfangs- und Endpunkt angedeutet, die Scheibe schwach gewölbt, dicht und stark punktirt, bei den Exemplaren aus Dalmatien nur an den Seiten, bei südlicheren oft ganz querrunzelig. Fld. hinten grade abgestutzt, wenig tief punktirt-gestreift, die inneren Streifen feiner und flacher,

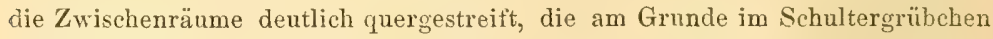
befindlichen dicht unregelmässig punktirt. Mittelhüften nur mässig breit ge trennt. Beine stark, dunkelröthlich, die Oberseite der Schenkel dunkel- 
striatis, interstitiis tenuiter strigosis, apice recte truncatis; perlibus ferrugineis, femorum clava coeruleo-aenea. - Long. 6-9 mm.

Mas: Femoribus posticis dentibus 2 transversim positis; tibiis posticis interne crenulatis.

Fem: Femoribus posticis dente parvo armatis, tibiis posicis rarissimo crenulatis.

Brahm. In. Kalender I. 135 (Chrysomela).

D. bidens Oliv. Encycl. méth. VI. 291. 2. - Lac. Mon. 118. 14. Thoms. Skand. Col. VIII. 111. 6. - Seidl. F. balt. 505.

D. cincta Germ. Neue Schrift. Ges. Halle I. 3 15. - Kunze Mon. 5. Redtb. Faun. A. II. 439.

D. clavipes Ahr. Mon. 15. 2.

Kürzer, gerundeter, und stärker (schwach lackartig) glänzend als die vorigen, metallgrün, der Rücken des Halssch. und der Fld. stets dunkler, braunviolett, violett oder dunkelgrün gefärbt. Unterseite silberweiss behaart. Fühler beim $\hat{o}$ so lang, beim $q$ kürzer als der halbe Körper, dunkel, die einzelnen Glieder am Grunde mehr oder weniger ausgedehnt röthlich, Glied 3 nur wenig länger als 2, 4 bis 11 mit Ausnahme des etwas längeren Gliedes 5 unter sich ungefähr gleich lang. Kopf fein weisslich behaart, dicht und fein punktirt, die drei Stirnfurchen mässig tief und fein. Halssch. besonders beim $\hat{\sigma}$ ein wenig länger als breit, an den Seiten nach der Mitte hin schwach verengt, der Höcker hinter den Vorderecken länglich, innen durch eine tiefe, gebogene Linie scharf begrenzt, die Längsrinne über die Mitte, besonders aber der Quereindruck vor dem Hinterrande fein; die Oberfläche ziemlich weitläufig punktirt, nach den Seiten hin quergerunzelt, besonders glatt erscheint die Querwulst, die sich vor den Hinterrand legt. Fld. mit zwei sehr schwachen Eindrücken an der Naht, im letzten Drittel gerundet verengt, hinten grade abgestutzt mit gerundeten Aussenecken; tief gestreift-punktirt, die Zwischenräume mässig breit, leicht quergerunzelt, indem sich die Kanten, welche die Punkte in den Streifen trennen, noch auf die Zwischenräume der Streifen fortsetzen. Beine röthlich, die Schenkelkeulen metallisch-violett.

An den Hinterschenkeln besitzt das Männchen zwei quergestellte Zähne, an der Innenseite der Hinterschienen einige kleine, stumpfe

metallisch, schwach bläulich schimmernd; Klauen gross. Das Männchen besitzt an den Hinterschienen 2 Zähnchen, der vordere klein und wenig spitz, leicht nach innen gerichtet, bald hinter der Mitte, der hintere stark, sehr spitz in der Mitte zwischen dem ersten Zahne und der Schenkelspitze. Den Weibchen fehlt der vordere Zahn.

Croatien, Dalmatien und ganz Südeuropa bis Nordafrika. 
Höckerchen; das Weibchen hat nur einen Zahn an den Hinterschenkeln, der mitunter undeutlich wird, höchst selten ganz verschwindet (dann von der sehr ähnlichen Malinovskyi durch die doppelt so starken Punktstreifen der Fld. zu unterscheiden); Hinterschienen meist einfach; selten fast eben so stark als beim Männchen gezähnelt.

Auf den schwimmenden Blättern von Potamogeton natans im Juni häufig im ganzen Gebiete.

Obgleich die IJeschreibung Brahm's nicht ganz auf die vorliegende Art angewandt werden kann, denn der Vergleich: „der Brustschild ist mehr zugerundet" (als bei aquatica) trifft nicht $\mathrm{zu}$, wie auch die Worte: "die Frankfurter Exemplare haben unbewaffnete Schenkel", so halte ich es doch für nützlicb, bei diesem Namen zu bleiben, einmal, weil die übrigen Angaben Brahm's nur auf diese Art passen, zweitens, um nicht wieder vor die Frage gestellt zu werden, ob Olivier's oder Germar's Benennung Geltung haben soll.

3. aquatica: Subdepressa, viridi-aurea, subius auro-sericea; prothorace subquadrato, crebre punctato, lateribus ruguloso; elytris vitia lata media purpurea, apice summo valde attenuatis, truncatis, ad suiuram fortiter impressis, haud profunde punctato-striatis, intersitiis subtiliter creberrimeque rugosis, basi punctatis; perlibus aeneis, femoribus posticis unidentatis. - Long. $6-9,5 \mathrm{~mm}$.

Mas: segmento $5: 0$ ventrali apice truncato, late impresso.

$\mathrm{F}$ em: segmento $5: 0$ ventrali apice rotundato.

Linn. Syst. nat. ed. X. 397 (Leptura). - Suffr. Stett. Zeit. 1869. 50. - Thoms. Skand. Col. VIII. 116.

D. dentipes Fabr. Ent. Syst. I. 2. 116. - Lac. Mon. 130. 20. Panz. Fn. Germ. 29. 5. - Redtb. Faun. A. II. 440. - Seidl. F. balt. 505 .

Durch einfarbige Fühler und Beine, die am Grunde verworren punktirten Flügeldecken und die goldig-seidenhaarige Unterseite von den verwandten Arten sehr verschieden. Länglich, oben etwas niedergedrückt, goldgrün, Halsschild oft messingglänzend, violett oder blau angelaufen, Flügeldecken mit einer mehr oder weniger breiten purpur- oder braunrothen Längsbinde. Fühler so lang als der halbe Körper, die ersten drei oder vier Glieder metallisch, gelblich behaart, die übrigen schwarz mit weisslicher Behaarung, Glied 3 doppelt so lang als 2, 4 bis 11 unter sich von fast gleicher Länge. Kopf dicht und mässig stark punktirt, goldig behaart, mit schmaler aber tiefer Mittelrinne, die Seitenrinnen flach, undeutlich. Halssch. wenig länger als breit, die Seiten fast gradlinig, in der Mitte deutlich eingeschnürt, der Höcker länglich, innen meist nur 
flach begrenzt, die Mittelfurche wenig tief, in der Mitte am flachsten; die Oberfäche dicht und mässig stark punktirt, an den Seiten quer gerunzelt. Fld. hinter den Schultern leicht eingeschnürt, im letzten Drittel stark verengt, hinten gradlinig abgestutzt, an der Naht mit einer oft starken Längsvertiefung. Diese beginnt am Grunde an der Innenseite des Schulterhöckers, zieht sich schräg einwärts zur Naht, welche sie in $1 / 3$ der Länge der Fld. in Gestalt einer tiefen Grube erreicht und setzt sich, den 1. und 2. Punktstreifen einnehmend, fast bis zur Spitze fort. Die Punktstreifen sind wenig tief und verflachen sich vor der Spitze, ihre Zwischenräume sind sehr dicht und fein gerunzelt, am Grunde verworren punktirt. Die rothe Längsbinde lässt den ersten und die 3 äusseren Zwischenräume grün, sie ist an den Seiten, auf dem 2. und 7. Zwischenraume, von einem Goldsaume begrenzt und wird nach innen dunkler, violett oder schwärzlich. Seltener kommen Stücke mit rerschmälerter Binde, höchst selten ganz einfarbige vor.

Mittelhüften mässig breit getrennt. Beine grün erzfarbig, die Schenkel bei beiden Geschlechtern wenig verdickt, die hinteren mit einem starken spitzen Zahne bewaffnet.

Beim Männchen ist der Hinterrand des letzten Bauchringes abgestutzt und mit einem Eindrucke versehen, beim Weibchen einfach gerundet.

Im ganzen Gebiete auf Carex-, Glyceria- und Sparganium-Arten im Mai nicht selten.

\section{Zweite Gruppe.}

Halssch. und Fld. kahl. Hinterschenkel gezähnt, die Spitze der Fld. nicht erreichend.

5. D. sparganio: Hodice elongata, subdepressa, virescenti-cuprea, subtus cinereo-sericea, prothorace quadrato, subtiliter confertim punctatostrigoso, subopaco; elytris vage impressis, minus fortiter punctatostriatis, interstitiis transversim-rugosis, apice truncatis; pedibus aeneis, fem ribus posticis tidentatis. - Long. $7-9 \mathrm{~mm}$.

Mas: segmento 5:0 apice impresso.

Ahrens Mon. 20. 5. - Lac. Mon. 126. 17. - Redtb. Faun.

A. II. 442. - Seidl. F. balt. 506 .

Var. a. Supra viridis, auro-cuprea vel violacea.

Von der Gestalt der $D$. dentata, indessen meist schmaler und flacher, mit einfarbigen Fühlern und Beinen, kürzeren Schenkeln und merklich feinerer Skulptur der Oberseite, deren Farbe gewöhnlich ein dunkeles, kupferiges Grün ist. Fühler schlank, so lang als 
der halbe Körper, schwarz, am Grunde grünlich schimmernd, Glied 3 doppelt so lang als 2. Die 3 Stirnfurchen tief, die mittlere besonders breit, die zwei dazwischen liegenden Längserhöhungen schwach gekielt. Halssch. quadratisch, die Seitenhöcker und die Längsfurche sehr schwach, oben dicht und fein punktirt und quergerunzelt, meist matt. Fld. an den Seiten ziemlich parallel, hinten allmählich verengt, die Spitze grade abgestutzt; mit 4 flachen Eindrücken an der Naht; ihre Punktstreifen flach, nur am Schildchen, dem Aussenrande und der Spitze tiefer, die Punkte in denselben klein, ziemlich weit von einander entfernt; Zwischenräume öfter fast glatt oder nur fein gerunzelt, öfter, besonders beim $\hat{\delta}$, stark querrunzelig. Beine mässig lang, einfarbig metallgrün, Hinterschenkel mit 2 Zähnchen, die ziemlich nahe bei einander stehen. Unterseite dicht gelblichgrau, seidenschimmernd behaart, wodurch die Art von der ihr sehr ähnlichen dentata, mit der sie zusammen lebt, leicht zu unterscheiden ist.

Der letzte Bauchring beim $\hat{\sigma}$ unter den Flügeldecken verborgen, hinten grade abgestutzt, mit einer weiten Grube in der Mitte des Hinterrandes, beim Weibchen gerundet-abgestutzt, eben und etwas über die Flügeldecken hinaus vorgezogen. Ebenso sind die Hinterschenkel des ô dicker, ihre Zähnchen, besonders das innere, deutlich grösser als beim o.

Die Färbung der Oberseite ist ziemlich constant, an den Seiten grün oder goldgrün, auf dem Rücken kupferig oder violett; selten sind einfarbig grüne, goldgrüne oder veilchenblaue Stücke.

Besonders im Juli auf Sparganium simplex und Butomus umbellatus im nördlicheren und mittleren Theile des Gebietes nicht selten anzutreffen, wiewohl vielfach übersehen.

6. Himbata: Subdepressa, aenea, subtus cinereo-sericea; prothorace quadrato, postice minus attenuato, callo laterali obsolelo, rugosopunctato, lateribus strigoso; elytris quarlri-impressis, vitta submarginali cuprea, purpurea vel chalybaea, minus profunde panctalo-striatis, striis postice vix discretis; femoribus posticis dente parvo armatis. Long. $8-11 \mathrm{~mm}$.

Mas: segmento ultimo ventrali apice iruncato, latius impresso.

Fem: ventre segmento $5: 0$ apice subproducto.

Panz. Faun. Germ. 29. 12.

D. lemnae Fabr. Syst. EI. II. 128. 10. - Red tb. Faun. A. II. 440. Seidl. F. balt. 506 .

D. lemnae var. $C$. Lac. Mon. 133 .

D. lateralis Bonell. Act. Soc. agr. Taurin. 1812. fasc. V. 171. 
Var. a. Elytris praeterea playa basali mediu purpurea.

D. vittata Panz. Faun. Germ. 29. 11.

D. lemnae Lac. Mon. 132. 21.

Var. b. Elytris unicoloribus, aeneis vel cupreis.

D. lemnae var. D. Lac. Mon. 133.

In der Körperform der $D$. crassipes ähnlich, besonders die Weibchen plump gebaut, durch die deutlichen Vertiefungen der Flügeldecken jedoch von den vorigen Arten hinlänglich verschieden.

Kopf nebst der Unterseite und den Beinen weisslich- oder gelblich-grau seidenschimmernd behaart. Fühler schwarz, die ersten fünf Glieder metallisch glänzend, beim $\hat{\jmath}$ so lang, beim $q$ viel kürzer als der halbe Körper, Glied 3 wenig länger als 2. Stirn flach, die Mittelfurche schmal, tief, die Seitenfurchen weit und flach; dicht aber fein punktirt. Halssch. quadratisch, nach hinten schwach verengt, die Seiten fast grade nur in der Mitte und vor dem Hinterrande zuweilen mit der Spur einer Einschnürung, der Seitenhöcker kaum angedeutet, die Scheibe mit sehr schwacher, vorn und hinten vertiefter Mittelrinne, grob aber wenig dicht punktirt, die Zwischenräume der Punkte glatt, glänzend, runzelartig erhaben, die Seiten dichter punktirt mit zahlreichen Querrunzeln. Fld. mit 4 mässig tiefen Eindrücken; der erste am Schildchen ist beiden Decken gemeinsam, der zweite zieht sich vom Schulterhöcker schräg nach innen zur Naht, die er etwa da erreicht, wo der abgekürzte Nahtstreif endet, unmittelbar hinter diesem liegt der dritte, wenig hinter der Mitte der Flügeldecken, zwischen diesem und der Spitze der vierte, zugleich der schwächste. Die Punktstreifen sind am Grunde der Fld. durch eingemengte Punkte verworren, treten sodann, aus starken und tiefen Punkten gebildet, kräftig hervor, nehmen an Stärke nach der Spitze hin mehr und mehr ab und sind vor derselben undeutlich oder ganz geschwunden. Zwischenräume doppelt so breit als die Streifen, sehr fein und dicht darmartig gerunzelt, ihr Glanz dadurch abgeschwächt. Die Farbe der Oberseite ist sehr veränderlich, dunkelerzfarbig mit grün- oder gelblichem Schimmer und hellerzfarbig mit gelb- oder kupferrothem, selbst violettem Anfluge; seltener einfarbig, meist aber mit einer goldgrün, roth oder bläulich gefärbten Längsbinde auf dem 8. und 9. Zwischenraume, zu der sich mitunter noch ein gleichfarbiger Fleck am Grunde zwischen dem 1. und 2. Eindrucke gesellt. Beine dunkelmetallisch, die Hinterschenkel mit einem kleinen, stumpfen Zähnchen, welches beim Weibchen nicht selten undeutlich wird. Bei letzterem ist der Hinterrand des 5 . Segmentes in der Mitte in eine 
kurze dreieckige Spitze ausgezogen, wäbrend er beim Männchen daselbst abgestutzt und tief eingedrückt ist.

Auf Sparganium - und Carex-Arten rom Mai bis Juli durch ganz Europa bis Nordafrika und Sibirien verbreitet.

- ED. bicolora: Elongata, subdepressa, aurato-viridis sericeo micans, subtus aureo-sericea; prothorace quadrato, creberrime punctato, elytris 6 -impressis, minus profunde punctato-striatis, striis postice vix discretis, ventre segmento primo medio linea subelevata; femoribus posticis dente acuto armalis. - Long. 8,5-10 $\mathrm{mm}$.

Mas: segmento uliimo ventrali apice truncato, late impresso.

Fem: ventre segmento 5:0 apice subproducto.

Zschach Mus. Lesk. 1788. 27. 589.

D. sagittariae Fabr. Ent. Syst. I. 2. 117. 5. - Panz. Faun. Germ. 29. 7. - Lac. Mon. 137. 23. - Redtb. Faun. A. II. 440. - Seidl. F. balt. 506 .

D. aurea Hoppe Enum. Ins. Erlang. 43. f. 5.

Var. a. Capite prothoraceque coeruleis.

D. collaris Panz. Ent. Germ. I. 216. 11; Faun. Germ. 29. 8. Var. b. Supra tota coerulea.

D. sagittariae var. c. Thoms. Skand. Col. VIII. 115.

Durch stärkere Stirnhöcker, dickere Fühler, dichter punktirtes, nach hinten nicht verengtes Halsschild, dichter quer gerunzelte und mit tiefen Eindrücken versehene Flügeldecken, spitzen und stärkeren Zahn der Hinterschenkel, sowie die dichtere goldige Behaarung der Unterseite und die Bildung des ersten Bauchsegmentes mit Sicherheit von der vorigen Art zu trennen.

Einfarbig goldgrün mit mattem, seidenartigen Glanze, die Unterseite lebhaft goldig seidenschimmernd behaart. Fühler schwarz, grau behaart, Glied 1 bis 5 metallisch, 3 fast doppelt länger als 2. Kopf dicht und fein punktirt, die Zwischenräume fein genetzt, die drei Furchen tief, ibre Längshöcker mässig hervorstehend. Halss ch. quadratisch, mit fast geraden Seiten, der Seitenhöcker schmal, innen nur undeutlich abgesetzt, die Mittelrinne fein und seicht; oben mässig stark und tief, sehr dicht punktirt, die Zwischenräume der Punkte werden von äusserst schmalen, glänzenden Kanten gebildet, die sich besonders an den Seiten zu feinen Querrunzeln vereinigen. Fld. jede mit 6 deutlichen Eindrücken, 4 an der Naht wie bei der vorigen Art und 2 schräg nach aussen vom dritten und vierten Eindrucke (zuweilen auch bei limbata angedeutet). Die Punktstreifen haben am Grunde eingemengte Punkte und sind in den Eindrücken aus starken, auf den Erhöhungen aus schwächeren Punkten gebildet, nach der grade abgestutzten Spitze hin sind sie besonders fein aber 
deutlicher und stärker als bei limbata. Zwischenräume äusserst dicht und fein ziemlich regelmässig quer gerunzelt, matt. Erstes Hinterleibssegment in der Mitte mit einer schwach erhabenen Längslinie, die beim $q$ viel länger und deutlicher als beim $\hat{\sigma}$ ist und über welcher die nach innen gerichteten aufstehenden Härchen des Segmentes zusammenstossen. Dadurch erscheint der Hinterrand des Segmentes in der Mitte unmerklich nach hinten vorgezogen. Beine metallisch, goldgrün, Tarsen stahlblau, Hinterschenkel mit einem auch beim Weibchen deutlichen spitzen Zähnchen. Geschlechtsunterschiede wie bei der Vorigen.

Nur selten wird die grüne Färbung auf Kopf und Halssch. (Var. a.) oder auf der ganzen Oberseite durch eine himmelblaue ersetzt (Var. b.).

Die Larve lebt nach Letzner, Verzeichn. Käf. Schles. p. 282 zwischen den Blattscheiden von Sparganium, auf dessen Blättern, sowie auf Sagittaria, Glyceria und Carices stellenweise häufig vom Mai bis August auch das vollkommene Insekt.

8. H. obscura: Elongata. subconvexa, supra obscure aenea, subopaca, subtus obscure aureo-tomentosa; prothorace quadrato, basi leniter angustato, angulis anticis prominulis, subrugoso-punctato, canalicula obsoleta; elytris punctulato-striatis, striis apice subtruncato discretis, interstitiis basi punctatis, femoribus posticis dente valido acuto armatis. - Long. $8,5-10 \mathrm{~mm}$.

Mas: segmento 5:o ventrali apice iruncato, late impresso.

$\mathrm{Fem}$ : segmento 5:0 apice rotundato.

Gyllenhal Ins. Suec. III. 654. 6. - Lac. Mon. 138. 24. Redtb. Faun. A. II. 440. - Seidl. F. balt. 506 .

D. impressa A hr. Mon. 23.

Gestrecktere Körperform, dunkle Färbung der mässig gewölbten, matten Oberseite, bis zur Spitze deutliche Punktstreifen und die zu zwei leichten Längsvertiefungen verbundenen Eindrücke der Flügeldecken sowie die Farbe der Unterseite zeichnen diese Art von den vorhergehenden wesentlich aus. Der Körper ist dunkel metallbraun, die Unterseite trüb goldig behaart. Fühler mässig dick, schwarz, Glied 1 dunkel metallisch, röthlich angeflogen, Glied 3 fast doppelt so lang als 2. Stirn wenig gewölbt, die Mittelfurche schmal, tief, die Seitenfurchen flach. Halssch. quadratisch, nach dem Grunde hin leicht verengt mit fast graden Seiten, kaum sichtbarem Seitenhöcker und fast erloschener Mittelrinne, dicht und mässig stark punktirt, hie und da schwach querrunzelig. Die Vorderecken, die bei limbata kaum, bei bicolora schwach hervortreten, sind hier deutlich zahnförmig nach aussen gebogen. Fld. verhältniss- 
mässig fein punktirt-gestreift mit gedrängt stehenden Punkten in den Streifen, die Zwischenräume äusserst fein darmartig gerunzelt, matt; am Grunde zwischen dem Schulterhöcker und dem Schildchen dicht unregelmässig punktirt. Die 6 Eindrücke, welche bei der vorigen Art scharf hervortreten, sind hier zu zwei leichten Längsvertiefungen verbunden, die eine längs der Naht, die andre nach aussen zwischen dem 5. und 8. Punktstreifen. Beine von der Farbe des ersten Fühlergliedes, die Hinterschenkel mit einem starken, spitzen, etwas nach hinten gerichteten Zahne, welcher meist stärker als beim $\hat{\sigma}$ von bicolora ist.

Diese Art gilt im Allgemeinen als selten; sie kommt jedoch im Nai auf blühenden Scirpus- und Carex-Büschen stellenweise zahlreich im ganzen Gebiete vor. Herr Simon sammelte sie mit Plateumaris sericea zusammen auf dem Schwarzwalde am Kniebis und bei Buhlbach. In der Umgebung Berlin's findet sie sich auf Carex ampullacea nur bei Eberswalde.

9. Dobalassina: Elongato-linearis, subconvexa, supra virescentiaurea sericeo micans, subtus flavo-aureo-tomentosa; prothorace crebre et profunde rugoso-punctato, callo laterali disctincto, angulis anticis prominulis; elytris vage impressis, punctato-striatis, femoribus posticis dente sat valido, acuto armatis. - Long. $7-9 \mathrm{~mm}$.

Mas: segmento 5 : o ventrali apice subtruncato, impresso.

Fem: segmento 5:0 ventrali subacuminato-producto.

Germar Neue Schrift. Ges. Halle I. 6. 29. - Lac. Mon. 143. 26. - Redtb. Faun. A. 441. - Seidl. F. balt. 506. Var. b. Supra aene-cuprea, rubra, purpurea vel cyaneo-viridis.

Langgestreckt, ziemlich gewölbt, goldgrün oder grün, messingfarbig, matt seidenglänzend, Kopf und Unterseite mit heller goldglänzender Behaarung. Fühler beim Männchen länger, beim Weibchen kürzer als der halbe Körper, schwarz, die ersten 6 Glieder metallgrün; Glied 3 länger als 2, 4 fast so lang als 5. Kopf dicht runzelig-punktirt, die 3 Stirnfurehen tief, die Längswulst jederseits zwischen ihnen hinten höckerartig erhaben. Halssch. etwas länger als breit mit schwachem, innen deutlich begrenzten Seitenhöcker jederseits, dadurch vorn breiter als hinter der Mitte, die grösste Breite zwischen den zahnförmig nach aussen gerichteten Vorderecken; dicht und tief runzelig-punktirt, die schmalen $Z$ wischenräume der Punkte glänzend, die Mittelrinne flach, oft recht undeutlich. Fld. bis hinter die Mitte gleich breit, dann nach der Spitze hin allmählich verengt, die letztere scharf abgestutzt; mit zwei schwachen Eindrücken jederseits an der Naht, von denen der vordere deutlicher ist, stark punktirt-gestreift, die Zwischenräume sehr dicht 
querrunzelig, die Runzeln verbinden fast strahlenförmig die runden Punkte der nebeneinander liegenden Reihen. Der erste Punktstreifen wird innen, hinter der Mitte der Fld. bis zur Spitze von einer schmalen, scharf erhabenen Randleiste begrenzt, die sich auch bei den verwandten Arten ähnlich findet; der Raum zwischen dieser Leiste und der Naht ist deutlich querrunzelig, bei impressa niemals. Beine gestreckt, die Hinterschenkel mit einem starken, sehr spitzen, nach hinten gerichteten Zähnchen.

Die angeführten Farbenabänderungen, Stücke mit kupferigerzfarbiger, rother, purpurrother oder tief blaugrüner Oberseite, gehören, mit Ausnahme der letzten, nicht zu den Seltenheiten.

Beim Männchen ist der erste Bauchring in der Mitte der Länge nach flach gedrückt, der Hinterrand des letzten Segmentes gerundetabgestutzt und mit einem Eindrucke versehen, beim Weibchen dagegen in eine dreieckige Spitze vorgezogen. Der Penis ist gleich breit, nur vor der Spitze leicht verengt, diese ist schwach verbreitert, vorn fast halbkreisfömig, mit dreieckig vorgezogener Spitze in der Mitte.

Anfang Juni auf den Blüthen von Scirpus (Heleocharis) palustris und Carex-Arten am Rande von Teichen und Seen im ganzen Gebiete häufig.

10. Dovercornis: Minus elongata, subrlepressa, supra obscure cuprea, sat micans, subtus flavescenti-aureo-tomentosa; mothorace subopaco, parcius creberrime punctato, angulis anticis vix prominulis; elytris sat distincle impressis, punctalo-striatis, femoribus posticis obsoletissime dentalis. - Long. $8-9,5 \mathrm{~mm}$.

Mas: segmento ultimo ventrali apice subtruncato, leviter impresso.

Fem: segmento ultimo apice rotundato.

Ahrens Mon. 26. 10. - Lac. Mon. 140. 25. - Suffr. Stett. ent. Zeit. 1845. 362.

D. platysterna Thoms. Skand. Col. VIII. 118. 15. - Seidl. F. balt. 506 .

D. thalassina var. A. Lac. Mon. 143 .

D. impressa var. Kraatz Berl. Ent. Zeit. 1869. 266. - Czwalina Dentsch. Ent. Zeit. 1878. 203.

Var. Supra acneo-vel aureo-viridis.

Grösser, breiter und flacher als die vorhergehende Art, die Weibchen den einfarbigen Stücken der $D$. limbata nicht unähnlich; dunkel erzfarbig, jedoch heller als obscura und dunkler als impressa, die Unterseite goldglänzend, etwas weisslich schimmernd behaart. Fühler kaum halb so lang als der Körper, schwarz, die ersten 5, selten 6 Glieder metallisch, ganz oder an der Spitze kupferig-violett, 
Glied 3 wenig oder kaum länger als 2,4 oft so lang als 5 . Kopf dicht runzelig-punktirt, die Stirnfurchen tiefer und die 2 Höckerchen fast höher als bei thalassina. Halssch. quadratisch, gleichbreit, die Seiten, besonders beim Weibchen in der Mitte und vor dem Hinterrande tief eingeschnürt, so dass jede aus 2 nach aussen gebogenen Halbkreisen zu bestehen scheint. Die grösste Breite liegt nicht zwischen den stumpfen, kaum zahnförmig heraustretenden Vorderecken, sondern dahinter, in der Mitte des wenig deutlichen Seitenhöckers; die Scheibe mit flacher, oft undeutlicher Mittelrinne, sehr dicht und viel feiner als bei thalassina punktirt, die schmalen Zwischenräume der Punkte durch Runzeln und feine Pünktchen matt. Mitunter zeigen sich in der Nähe der Mittelrinne zwei weitläufig-punktirte, nur dicht gerunzelte Stellen; solche Stücke beschreibt Thomson. Fld, zumal beim Weibchen, bis zur Mitte leicht verbreitert, im letzten Viertel stark verengt, die Spitze schmal, abgestutzt; der Rücken mit 4 jedoch schwächeren Eindrücken jederseits an der Naht wie bei limbata, stark punktirtgestreift, die Zwischenräume, auch der erste, dicht verworren gerunzelt, die Runzeln kürzer als bei der Vorigen. Beine gestreckt, metallisch, die Kniee violett, Hinterschenkel mit einem ausserordentlich kleinen, dreieckigen Zähnchen.

Geschlechtsunterschiede wie bei thalassina, nur ist beim Weibchen der Hinterrand des 5. Segmentes in der Mitte nicht dreieckig vorgezogen, sondern einfach gerundet. Der Penis ist vor der Spitze stark gerundet-erweitert, die Spitze selbst kurz dreieckig.

Jedenfalls über ganz Deutschland rerbreitet, bisher aber nur von folgenden Punkten bekannt: Magdeburg, Aschersleben, Dortmund (Suffrian), Königsberg (Czwalina), aus Hessen und Schlesien (Kraatz).

Eine der am meisten verkannten und übersehenen Arten. Die Männchen, welche etwas an impressa erinnern, wurden bei dieser Art, die Weibchen, welche grossen thalassina ähnlich sehen, hier untergebracht. Allein mit Unrecht. Die mir vorliegenden 11 Stücke, darunter 3 Typen ron Thomson (Sammlung Dr. Kratz) und 5 ron Herrn Czwalina am Dammteiche bei Königsberg gesammelte, sind vollkommen übereinstimmend, nur finden sich unter den kräftigen Königsberger Stücken auch einige mit metall- und schwach goldgrüner Oberseite. Wahrscheinlich besass Lacordaire vorwiegend solche Exemplare und er nannte die Art daher, ,laete aenea" (worüber sich Suffrian l. c. 364 wundert), während er die dunklen, von Thomson als die normalen beschriebenen Stücke zur Var. A. bringt und jedenfalls, wie auch Suffr. vermuthet, noch einmal als thalassina var. A. beschreibt. Merkwürdig ist es, dass Suffr. seine brevicornis ,im Allgemeinen kleiner als thalassina findet", er muss wohl nur Männchen besessen 
haben. Kraatz kannte im Jahre 1869, als er seine Bemerkungen über deutsche Donacien schrieb, die Art noch nicht; er hat später mehrere Exemplare seiner Sammlung richtig bei platysterna untergebracht. Herr Czwalina zieht a. a. O. die Art zu impressa; sie ist jedoch durch Körperform und Skulptur nur mit thalassina verwandt und unterscheidet sich wie diese stets sicher von impressa durch die Runzelung des ersten $\mathrm{Z}$ wischenraumes.

12. D. impressa: Modice elongata, depressa, supra aeneo-cuprea subnitida, subius aureo-tomentosa; prothorace haud rugoso-punctato, callo laterali vix discreto, angulis anticis prominulis; elytris evidentius impressis, profunde punctulato-striatis; femoribus posticis dente obsoleto armatis. - Long. 6,5-9 $\mathrm{mm}$.

Paykull Faun. Suec. II. 193. 6. - Lac. Mon. 145. 27. Redtb. Faun. A. 440. - Seidl. F. balt. 506.

오 D. brevicornis Kunze Mon. 16.

Var. b. Supra rufo-cuprea, nigro-cuprea, aeneo-viridis vel viridi-coerulea. Lacord. 1. c. var. $D$.

Kürzer als die beiden vorhergehenden Arten, viel glänzender; die Punktstreifen der Fld. regelmässiger und schärfer begrenzt; broncefarbig mit lejehtem Kupferschimmer, der Kopf zart-, die Unterseite dichter goldig behaart. Fühler so lang ( $\hat{f}$ ) oder etwas kürzer (q) als der halbe Körper, schwarz, die ersten 5 Glieder grün-metallisch, Glied 3 unmerklich länger als 2, 4 deutlich kürzer als 5. Die Mittelrinne der Stirn tief, die Seitenfurchen weit und flach, die Höcker niedrig. Halssch. so lang als breit, nach binten kaum verengt, mit fast graden Seiten und undeutlichem Seitenhöcker, die Vorderecken zahnförmig heraustretend; auf der Scheibe fein und dicht punktirt, kaum gerunzelt, ziemlich glänzend. Die Mittelrinne beginnt schwach am Vorderrande und endet in einer starken Vertiefung weit vor dem Hinterrande. Fld. mit den gewöhnlichen vier Eindrücken jederseits an der Naht, wovon die 3 vorderen klar hervortreten; tief aber verhältnissmässig fein punktirtgestreift, der erste Punktstreifen im dritten Viertel seiner Länge stark vertieft, die Punkte länglich, scharf begrenzt; Zwischenräume dicht und fein, jedoch schwächer quergerunzelt als bei den vorhergehenden Arten, so dass der Glanz lebhafter ist. Der erste Zwischenraum mit einer im schiefen Schultereindrucke beginnenden äusseren Längsleiste, gewöhnlich grünlich oder goldig gefärbt, mit einigen groben und zahlreichen feineren Längsrunzeln versehen. Der Zahn an den Hinterschenkeln ist sehr klein, dreieckig, spitz, und fehlt zuweilen gänzlich ${ }^{1}$ ).

1) Südeuropäische Stücke sind oft sehr klein und fast immer ungezähnt. Diesen ist nahe verwandt D. andalusiaca Kraatz (Berl. Zeit. 1869. 271) 
Die Farbe der Art ändert höchst selten ab. Mir sind nur Stücke mit schwärzlich-kupferfarbiger und blaugrüner Oberseite bekannt. Lacord. führt noch eine roth-kupfrige und erzgrüne Form auf.

Geschlechtsunterschiede wie bei thalassina, der Längseindruck auf der Mitte des ersten Bauchringes beim Männchen deutlicher. Der Penis ist bis zur Spitze allmählich leicht verschmälert, diese selbst stumpf-dreieckig.

Im Mai auf Carex acuta und paludosa an See- und Teichufern häufig.

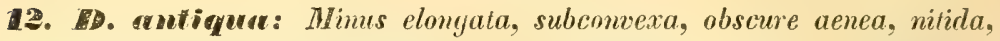
subtus flaveseenti-aureo-sericea; fronte subplana haud bituberculato. prothorace subelonyato, transversim rugoso parceque punctato, elytris 4-impressis, pedibus crassis, femoribus posticis dente sat magno acuto armatis. - Long. $7-9 \mathrm{~mm}$.

Mas: ventre segmento ultimo apice leviter impresso.

Fem: ventre segmento ultimo apice subacuminato-producto.

Kunze Mon. 21. - Suffr. Stett. Zeit. 1845. 365. - Kraatz Berl. Zeit. 1S69. 264. - Redtb. Faun. A. II. 442.

D. simplicifrons Lac. Mon. 135. 22. - Suffr. 1. c. 361.

D. brevicornis Gyllh. Ins. Suec. IV. 674. - Thoms. Skand. Col. VIII. 119. 16. - Seidl. F. balt. 506.

() D. gracilis Suffr. 1. c. 366 . - Kraatz 1. c. 264. - Redtb. Faun. A. II. 442 .

Der Käfer hat mit impressa grosse Aehnlichkeit, ist aber durch die auffallend dicken Beine, die flache Stirn und das quergerunzelte Halssch. sofort zu unterscheiden; von Plat. sericea und Verwandten trennt ihn der grade Nahtrand. Er ist nicht ganz so dunkel gefärbt wie obscura, doch dunkler als impressa und eben so stark glänzend wie diese.

Die Fühler sind kräftig, schwarz, so lang als der halbe Körper, Glied 3 doppelt so lang als 2; Stirn eben, nur mit einer schmalen aber tiefen Mittelrinne, ohne Höcker zwischen den Augen. Halssch. besonders beim schlanken Männchen deutlich länger als

aus Andalusien. Glänzender, die Punktstreifen der Flügeldecken weniger scharf begrenzt, ihre $Z$ wischenräume sehr dicht quergerunzelt, am Grunde von der Schulterbenle bis zur Naht dicht verworren punktirt; die Eindrücke flach wie bei thalassina, Schienen und Tarsen verhältnissmässig breit. Dass mit dieser Art D. apricans Lacord. (Mon. 158. 37) aus Sicilien, welche länger aber schmaler und gewölbter als impressa sein soll, identisch wäre, scheint mir sehr zweifelhaft. 
breit, mit wenig scharfer Mittelrinne, die Seiten fast grade, der Seitenhöcker sehr flach, innen von einem starken Eindrucke begrenzt, quer gerunzelt und nur in der nächsten Nähe der Mittelrinne punktirt.

Fld. mässig tief punktirt-gestreift, die Zwischenräume fein, wenig dicht quer gerunzelt und fein punktirt, die Skulptur derselben sieht daher etwas verschwommen oder abgenutzt aus; jede mit 4 deutlichen Eindrücken, einer am Schildchen, 2 an der Naht und einer an der Seite. Unterseite hell goldgelb oder weisslichgelb seidenglänzend behaart. Beine stark mit dicken Schenkeln, die hinteren mit einem grossen, dreieckigen, spitzen Zahne versehen.

Die Farbe der Oberseite wird bei Thomson, ,aureo-cuprea"6 genannt und Lacordaire führt eine Varietät, fusco-cenea vel obscure cuprea" auf, beides Abänderungen, welche mir nicht bekannt sind.

Das Mäunchen hat einen leichten Eindruck am Hinterrande des gerundet-abgestutzten 5. Bauchsegmentes, beim Weibchen ist letzteres eben, der Hinterrand in der Mitte in eine kurze Spitze vorgezogen.

Die Art ist von den Entomologen wenig beachtet worden und deshalb selten geblieben; sie kommt wohl überall im Gebiete, nach Letzner auf Carex-Arten, wie es scheint mit impressa zusammen vor und steckt in den meisten Sammlungen unerkannt unter diesem Namen. Küster versandte sie als limbata. (2 Expl. im Cabinet des Herrn Micklitz).

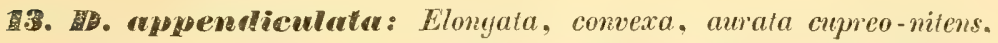
subtus cinereo-sericea, antennis tenuibus, nigris, articulis basi apiceque rufescentibus, prolhorace 4 -tuberculato, angulis anticis fortiter prominulis; elytris vage punctato-striatis, rude transversim-strigosis, reticulatis, apice producto-attenuatis, singulatim rotundatis; femoribus posticis dente acuto armatis. - Long. 7,5-10 $\mathrm{mm}$.

Mas: segmento 5:o ventrali apice subtruncato, medio inciso, pilis lomgissimis ciliato.

Fem: segmento 5:o ventrali acuminato-producto.

Ahrens Mon. 34. 16. - Lac. Mon. 129. 19.

D. reticulata Gyllh. Schönh. Ins. App. III. 37. - Redtb. Faun.

A. II. 442 .

Var. a. Supra viridi-aurata vel violacea.

Länglich, mässig gewölbt, grün goldglänzend, an den Seiten gewöhnlich mit kupferigem Anfluge, unten grau seidenschimmernd behaart. Der Kopf matt, äusserst dicht punktirt, fein greis behaart, die Stirn flach, ihre drei Furchen schmal aber die mittlere besonders VI. 
tief. Fühler schwarz, die einzelnen Glieder am Grunde und an der Spitze röthlich gesäumt, beim Männchen so lang als der Körper, beim Weibchen $1 / 4$ kürzer, sehr schlank, nur Glied 1 doppelt so stark als die übrigen. Glied 2 ist kurz, halb so lang und 3 so lang als 1,4 bis 11 beim $\hat{o}$ unter sich von gleicher Länge, jedes länger als 3 und viermal so lang als breit, beim of sind Glied 6 bis 11 nur so lang als 3. Halssch. mit der grössten Breite am Vorderrande, bis zur Mitte schwach, in derselben schnell verengt und gleichschmal bis zum zahnartig heraustretenden Hinterrande. Der Vorderrand ist grade, vor den Ecken jederseits tief niedergedrückt, so dass diese stark nach vorn und aussen gezogen erscheinen; die Seitenhöcker hoch, zugespitzt, hinter ihnen erheben sich auf der Scheibe, nur durch die kurze Mittelrinne getrennt, 2 glatte Querhöcker, welche aussen steil abfallen; die Oberfläche ist wenig dicht und stark punktirt, sparsam gerunzelt. Fld. gleichmässig gewölbt oder mit schwachen Spuren zweier Eindrücke an der Naht, jede einzelne hinten in eine abgerundete, mehr oder weniger lang ausgezogene Spitze verschmälert, flach punktirt-gestreift, die Punkte durch grobe Runzeln netzförmig verbunden, der 9. und 10. Zwischenraum am Grunde fast glatt. Beine lang, mit ziemlich starken keuligen Schenkeln, dunkel metallisch, Schenkelbasis zuweilen, die Schienen und Tarsen öfter rostroth, die Hinterschenkel mit einem schmalen, spitzen Zahne bewehrt, hinter diesem nicht selten fein gekerbt. Klauen am Grunde gerundet-erweitert.

Während der Hinterrand des 5. Bauchsegmentes beim Männchen abgestutzt, niedergedrückt, mit langen Haaren bewimpert und in der Mitte mit einem Ausschnitte versehen ist, läuft derselbe beim Weibchen in eine mässig scharfe Spitze aus.

Die Farbe der Oberseite ist zuweilen goldgrün oder violett.

Die Art lebt in den südlichsten Theilen des Gebietes z. B. bei Salcano bei Görz und Veldes bei Radmannsdorf in Krain (Micklitz) und ist dort im August auf Sparganium ramosum nicht selten.

\section{Dritte Gruppe.}

Halssch. und Fld. kahl. Hinterschenkel ungezähnt, die Spitze der Fld. nicht erreichend. Beine wenigstens theilweise roth.

14. D. clavipes: Elongato-linearis, supra aureo-viridis, subtus aryenteo-sericea; antennis pedibusque ferrugineis; prothorace parce punctato, bis-vel 4 -tuberculato; elytris crenato-striatis, interstitiis fortius strigosis. - Long. 7-12 mm.

Mas: segmento $5: 0$ ventrali apice rotundato-truncato. 
Fem: segmento 5:o ventrali apice acuminato.

Fabricius Ent. Syst. I. 2. 117. - Panz. Ent. Germ. 216;

Faun. Germ. 29. 13.

D. menyanthidis Gyllh. Ins. Suec. III. 662. - Lac. Mon. 156. 36. Red tb. Faun. A. II. 441. - Seidl. F. balt. 507.

D. mutica Thoms. Skand. Col. VIII. 109.

Var. a. Antennis, femoribus tibiisque plus minusve nigricantibus.

Var. b. Supra aureo-cuprea.

Var. c. Supra viridi-coerulea, subopaca.

Langgestreckt, ziemlich gewölbt, Fühler und Beine rothbraun, Halssch. und Fld. grünlich goldglänzend, die Unterseite und der Kopf silberweiss behaart. Stirn schwach gewölbt mit sehr breiter kurzer Mittelrinne und weiten und flachen Seitenfurchen. Die Fühler reichen weit ( $(\hat{)})$ oder wenig (ㅇ) über die Hälfte des Körpers hinaus, an ihnen ist Glied 2 das kürzeste, 4 und 5 sind die längsten, die übrigen ungefähr gleichlang. Das Halssch., sehr ähnlich dem der vorigen Art, hat abgerundete Vorderecken, zwei deutliche Seitenhöcker und 2 hinten jederseits durch eine Grube begrenzte, zuweilen schwache, selten ganz fehlende Querhöcker in der Mitte der Scheibe und eine vorn kaum bemerkbare, hinten tiefere Längsrinne über die Mitte der schwach und zerstreut punktirten, stark glänzenden Scheibe. Fld. besonders beim Männchen ziemlich gleichbreit, hinten allmählich verengt und gerundet-abgestutzt, ohne deutliche Eindrücke, mehr oder weniger tief punktirt gestreift, die Zwischenräume durch die ron den Punkten strahlig auslaufenden Runzeln gekerbt. Beine lang und dünn, Hinterschenkel und Schienen am Grunde merklich gekrümmt und fast sehwächer, als die der Vorderbeine; die Tarsen erreichen fast oder ganz die Länge der Schienen. Klauen am Grunde zahnartig erweitert.

Die Färbung der Art ist nicht so constant wie Lacordaire angiebt. Die gewöhnliche grüngoldene Farbe geht zuweilen in kupferroth, tief grün, oder blau mit schwach grünlichem Schimmer über. Einige Stücke der letzteren Varietät, (Ilmenau, Ludy), zeichnen sich durch ausserordentlich starke Skulptur der fast matten Oberseite aus. Auch die Fühler und Beine sind nicht selten dunkel, erstere zuweilen am Grunde oder auch ganz schwarz gefärbt.

Man trifft diese Art vorzüglich im Mai auf Arundo phragmites, auf welcher sie sich nach Suffrian zwischen den zusammengerollten Blattscheiden, den Kopf nach unten gerichtet, zu verkriechen pflegt, und Phalaris arundinacea im ganzen Gebiete stellenweise häufig an. ${ }^{1}$ )

1) D. glabrata Solsky Hor. Soc. ent. Ross. VIII. 245 aus Ost-Sibirien ist kleiner, flacher und glänzender als clavipes, die Stirnfurche länger aber 
15. D. femmica: Subelongata, modice convexa, supra rufo-testacea. sublus argenteo-sericea; capite niyro-aeneo, fronte violacea; prothorace subquadrato, callo laterali vix discreto, punctato parceque subtiliter transversim-rugoso; elytris apice rotundato-truncato punclato-striatis, interstitiis subtilissime rugulosis, nitidis; pedibus rufescentibus, femoribus superne aeneis. - Long. $6-8,5 \mathrm{~mm}$.

Mas: segmento 5:o ventrali apice truncato, subimpresso.

Fem: segmento 5:o apice roiundato-producto.

Payk. Faun. Suec. III. 70. 5. (Rhagium). - Gyllh. Ins. Suec. III. 668. - Lae. Mon. 166. 43. - Suffr. Stett. Zeit. 1846. 55. - Redtb. Faun. A. II. 443. - Seidl. F. balt. 508. Czwalina Deutsch. Ent. Zeitsch. 1878. 203.

D. arundinis Ahr. Mon. 41. 22.

Var. a. Prothoracis disco maculis 2 cupreis vel disco fere toto aeneocupreo.

Var. b. Prothorax ut in a; elytris vitta submarginali cuprea apicem versus abbreviata.

Var. c. Supra nigro-viridis vel-violacea; maryinibus prothoracis elytrorumque laete viridibus vel aureis.

D. Malinovskyi Ahr. Mon. 29. 31. - Lac. Mon. 165. 42. Redtb. 1. c. 443 . - Seidl. 1. c. 508.

Länglich, mässig gewölbt, die Oberseite mit Ausnahme des Kopfes und Schildchens röthlichgelb, Unterseite und Kopf weisslichseidenschimmernd behaart. Letzterer ist schwarz- oder grün-metallisch, die Stirn violett, dicht und fein punktirt, die Mittelfurche der Stirn tief, die seitlichen breit und flach, die Längswulst jederseits deutlich. Fühler zart, schwarz, Glied 1 metallgrün, die übrigen am Grunde und auf der Unterseite mehr oder weniger weit geröthet; beim Männchen so lang als der Lalbe Körper, Glied 3 doppelt so lang als 2, 4-6 gleichlang, jedes doppelt so lang als 3, 7 - 11 etwas kürzer und stärker; beim Weibchen kürzer als der halbe Körper, Glied 3 etwa $1 \frac{1}{2} \mathrm{mal}$ so lang als 2, 4 und 5 doppelt so lang als 3, 6-11 kürzer als 4, 7-11 deutlich stärker. Halssch. quadratisch, nach hinten leicht verengt, der Seitenhöcker nur angedeutet, die Seiten hinter demselben schwach eingeschnürt, die Vorderecken scharf aber kaum vorgezogen; auf der Scheibe mit kurzer, hinten grübchenartiger Mittelrinne, wenig dicht und stark punktirt, die Zwischenräume der Punkte besonders vorn und an den Seiten fein

schwächer, das Halssch. kürzer, mit stumpfen Vordereeken und stärkerem Seitenhöcker, die Fld. mit Punktreihen, welche in sehr flachen Streifen stehen, ihre $Z$ wischenräume sind einzeln und schwach quer-gestrichelt. Long. 9,5 mm. Die angegebenen Unterschiede sind so unbedeutend, dass die Aufstellung einer eigenen Art nicht gerechtfertigt erscheint. 
quergerunzelt, ziemlich matt. Schildchen schwarz, fein behaart. Fld. bis hinter die Mitte unbedeutend erweitert, nach der Spitze zu allmählich verengt, letztere fast einzeln gerundet-abgestutzt, der Nahtrand in den hinteren zwei Dritteln metallgrün gefärbt; oben mässig stark punktirt-gestreift, die $Z$ wischenräume wenig dicht, äusserst fein gerunzelt, stark glänzend. Beine röthlich, die Oberseite der Schenkel, oft auch die Aussenseite der Schienen erzfarbig grün oder violett; die Hinterschenkel erreichen die Spitze der Flügeldecken nicht, wie Lacordaire behauptet.

Beim Männchen ist der Hinterrand des 5. Bauchringes abgestutzt und in der Mitte schwach eingedrückt, beim Weibchen gerundet vorgezogen.

Uebergänge zu der auffälligen Var. Malinovskyi sind ausserordentlich selten; Germar kannte 1810 Neue Schrift. Ges. Halle I. 34. schon die Var. b., Suffrian 1846 a. und b., seitdem sind weitergehende Beobachtungen nicht mehr gemacht worden.

Bei Var. a. zeigt die Scheibe des Halssch. zwei kleine kupferrothe, violett schimmernde Makeln, die sich mitunter zu einer grösseren vereinigen; bei b. tritt noch eine gleichfarbige Längsbinde auf den Fld. hinzu, welche am Grunde den 5. und 6. Zwischenraum, in der Mitte den fünften bis achten einnimmt und in $2 / 3$ der Länge der Fld. endet. Sie giebt genau den Aussenrand der dunklen Färbung an, welche sich bei Malinovskyi über die ganze Scheibe ausbreitet. Letztgenannte Varietät sieht der $D$. versicolorea am ähnlichsten, ist aber viel schlanker, durch längere Fühler, breiteren Vorderkörper und bedeutend schwächere Punktirung der Fld. leicht zu unterscheiden. Ihr $\mathrm{Halssch}$. ist entweder einfarbig-metallgrün oder in der Mitte der Scheibe kupferig-violett; die Fld. sind schwarzgrün oder dunkelviolett, ihre Naht bis zum ersten Punktstreifen, ihr Aussenrand vom 8. Punktstreifen an und die Punkte in den Streifen grün oder goldig gefärbt.

Ausser dieser Färbung giebt es keinen Unterschied, welcher uns berechtigte, die $D$. Malinovskyi als Art anzusehen. Seidlitz täuscht sich, wenn er a. a. O. der fennica an der Spitze kaum abgestntzte Fld. und eine nicht metallisch-glänzende Oberseite zuschreibt im. Gegensatze zu den deutlich abgestutzten Fld. und der metallglänzenden Oberseite der Malinovskyi. Bei Var. b., welche ich durch die Güte des $\mathrm{H}$. Czwalina von Königsberg erhielt, ist die Oberseite auch noch neben der Längsbinde metallglänzend; die Abstutzung der Flügeldeckenspitze ist bei beiden Formen dieselbe und eine kleine Abweichung in der Breite der Spitze nur individuell. Lacordaire scheint die Abstutzung der fennica sogar für stärker zu halten, denn er nennt ihre Flügeldecken: „singulatim oblique rotundatis" und ,singulatim rotundatis" bei Malinovskyi. 
Die Art lebt im Juni meist unter dem Wasser an den Stengeln von Arundo phragmites, Glyceria aquatica etc., ist aber auch ron Malinovsky auf Hydrocharis morsus ranae gefangen worden. Beide Hauptformen wurden zusammen beobachtet bei Magdeburg, Leipzig, Breslau, Danzig und Königsberg, fennica allein bei Wriezen, in Schlesien von Glogau bis Ratibor, in Oesterreich bis Wien. Nach Norden reicht ihr Verbreitungsbezirk bis nach Finnland.

16. D. semicuprea ${ }^{1}$ ): Oblonga, convexiuscula, aurea vel aureoviridis, sublus cuprea, argenteo-sericea; prothorace subelongato, basi leniter angustato, callo laterali vix discreto, confertim punctato; elytris vitta lata cuprea suturali crenato-striatis, interstitiis transversim strigosis; femoribus basi libiisque apicem versus obscure rufis. - Long. 5-9 $\mathrm{mm}$. Mas: ventre segmento 1: o medio longitudinaliter late impresso, $5: 0$ apice subtruncato.

$\mathrm{Fem}$ : ventre segmento ultimo apice subrotundato - producto.

Panzer Faun. Germ. 29. 14. - Redtb. Faun. A. II. 442. Seidl. F. balt. $50 \%$.

D. simplex Fabr. Syst. El. II. 129. - Lac. Mon. 163. 41. Gyll h. Ins. Suec. III. 664 .

ㅇ D. moerens Kunze Mon. 47.

Var. a. Antennis pedibusque rufescentibus.

Var. b. Supra saturate viridlis, vitta elytrorum purpurea vel nigro-aenea. Var. c. Supra tota nigro-aenea.

Die in Grösse, Körperform, Skulptur und Farbe veränderlichste und in Nord - und Mitteldeutschland zugleich gemeinste Art der ganzen Gattung. Der Körper der Männchen, welche meist nur halb so gross als die Weibchen werden, ist gestreckt, schmal, fast gleichbreit, derjenige der Weiber breit und plump gebaut. Fühler beim $\hat{o}$ länger, beim $q$ kürzer als der halbe Körper, Glied 2 und 3

1) Dieser Art am nächsten stehend ist:

D. Kraatzi: Elongatula, subdepressa, aureo-viridis, subtus cuprea, argenteo. sericea, capite prothoraceque supra dense subtilissime pubescens, hoc elongato-parallela, basi leviter dilatato, callo laterali nullo, dense subtiliter punctato, canalicula dorsali fortiter abbreviata, elytris apice singulatim rotundatis, subtiliter subseriatim punctatis, interstitiis transversim strigosis, femoribus posticis muticis. - Long. 9,5 mm. Amasia.

Var. a. Corpore obscure nigro-aeneo.

Von dieser Art, die durch das behaarte, parallele, vor den Hinterecken erweiterte Halssch. von allen Donacien abweicht, liegen mir $2 \subsetneq$ aus der Sammlung des Herrn Dr. Kraatz vor und ich vermuthe nur, dass auch das $\hat{\odot}$ wie bei semicuprea ungezähnte Hinterschenkel besitzt. 
gleichlang, 4 etwas kürzer und 5-11 so lang als Glied 1; dunkelbraun oder schwärzlich, die einzelnen Glieder zuweilen am Grunde heller. Kopf meist dunkler als das Halssch., oft violett schimmernd, mit ziemlich kleinen Augen und breiter gewölbter Stirn, die Mittelrinne schmal und flach, die Seitenrinnen wenig oder kaum bemerkbar, fein und dicht punktirt und hehaart. Halssch. in beiden Geschlechtern länger als breit, nach hinten leicht verschmälert, die Seiten ziemlich grade, nur in der Mitte und vor dem Hinterrande leicht verengt, oben gleichmässig schwach gewölbt, dicht, stark punktirt, die kurze Mittelrinne oft breit und tief, oft kaum bemerkbar. Fld. ziemlich gewölbt, gekerbt-gestreift, die Zwischenräume mit mehr oder weniger dichten und starken, von den Punkten ausgehenden Querrunzeln, daher bald glänzend, bald matt, vor der gerundet-abgestutzten Spitze verworren punktirt, goldig oder grüngolden mit einer die inneren 5 , höchstens 6 Zwischenräume einnehmenden Längsbinde von gelbbrauner bis kupferrother Farbe. In dem Maasse, in welchem die Seiten der Fld. gesättigt grün oder blaugrün werden, färbt sich die Binde purpurn oder schwarzgrün; seltener sind Stücke mit einfarbig metallschwarzen Flügeldecken. (Var. c.) Beine mässig lang, die Hinterschenkel und Schienen am Grunde gebogen, dunkelmetallisch, Basis der Schenkel und Spitze der Schienen dunkel rostroth, zuweilen die ganzen Beine und die Fühler rothgelb gefärbt. (Var. a.) Unterseite kupferroth oder hell violett, silberweiss behaart.

Beim Männchen findet sich an den Hinterschenkeln noch die Andeutung eines Zahnes, indem sich dieselben vor der Spitze plötzlich verengen; das erste Hinterleibssegment ist in der Mitte sehr flach und weit der Länge nach niedergedrückt, das fünfte an der Spitze gerundet-abgestutzt. Beim Weibchen sind die Segmente gleichmässig: gewölbt, der Hinterrand des letzten ist in der Mitte stumpf vorgezogen.

Im Mai und Juni auf den Blättern von Glyceria spectabilis gemein. Die Käfer nagen die Blattunterseite so weit ab, dass nur noch ein dünnes, weisses Gewebe von den feinen Längsrippen und die Oberhaut übrig bleibt.

18. D. vulgaris: Elongato-linearis, depressa, viridi-aurata sericeomicans, subtus argenteo-sericea; prothorace crebre subrugoso-punctato; elytris fortiter punctato-striatis, apice emarginato-truncatis, vitta suiurali aurichalcea saepe purpurea -vel chalybaea-variegata; antennis pedibusque testaceo-variegatis. - Long. $6-9 \mathrm{~mm}$.

Mas: segmento 5:o ventrali apice impresso.

Zschach Mus. Lesk. 27. 594. 
D. typhae Ahr. Mon. 37. 19. - Lac. Mon. 162. "40. - Redtb. Faun. A. II. 442. - Seidl. F. balt. 507.

Var. a. Elytris unicoloribus.

Von der ähnlichen D. thalassina durch die flachen, hinten stärker abgestutzten Flügeldecken und die theilweise gelben Beine leicht zu unterscheiden.

Sehr gestreckt und flach, goldgrün, die Unterseite silberweiss seidenschimmernd behaart. Stirn mit den gewöhnlichen drei tiefen Längsfurchen, zwischen diesen wulstig erhöht, dicht aber feiner als der deutlich abgesetzte Hals punktirt. Fühler kräftig, beim Männchen länger als der halbe Körper, beim Weibchen viel kürzer, Glied 3 etwas länger als 2; einfarbig schwarz oder Glied 2-11 am Grunde röthlich. Halssch. wenig länger als breit, die Seiten in der Mitte und vor dem Hinterrande meist stark zusammengezogen, die Seitenhöcker deutlich; oben dicht und stark punktirt, leicht gerunzelt mit der Spur einer Mittelrinne auf der vorderen Hälfte der Scheibe. Fld. ziemlich gleichbreit, im letzten Drittel schnell gerundet-verengt, die Spitze scharf abgestutzt und einzeln schwach bogenförmig ausgeschnitten, die Ecken beinahe rechtwinkelig; mit 2 schwachen Vertiefungen jederseits an der Naht, grob und tief gestreift-punktirt, die Zwischenräume fein, nicht ganz regelmässig querrunzelig und dadurch seidenglänzend. Sie sind häufig einfarbig goldgrün, kupferroth, purpurn oder blaugrün, häufig mit einer messinggelben Längsbinde versehen, welche den 2. bis 5. Zwischenraum einnimmt und in grösserer oder geringerer Ausdehnung einen purpurrothen oder stahlblauen Kern besitzt, welcher durch den ersten Eindruck an der Naht ganz oder theilweise unterbrochen wird. Beine metallgrün, die Basis der Schenkel und die Schienen mehr oder weniger rothgelb, die Schenkelspitze oben veilchenblau angelaufen.

Das Männchen besitzt am Hinterrande des letzten Bauchsegmentes, welches schwach abgestutzt ist, einen tiefen Eindruck; derselbe fehlt dem in eine kurze Spitze vorgezogenen Segmente des Weibchens.

A uf verschiedenen Wasserpflanzen, besonders Typha-, Sparganiumund Carex-Arten im Juni und Juli im ganzen Gebiete anzutreffen, aber vielfach übersehen.

18. D. simplex: Elongato-linearis, subdepressa, supra obscure aeneoviridis, subopaca, subtus cinerascenti-argenteo-sericea; prothorace subilius subrugoso-punctato, elytris apice late truncatis, minus fortiter subregulariter crenato-striatis; antennis pedibusque ferrugineo-variegatis. - Long 7-9 mm.

Fabr. Syst. Ent. 195. - Panz. Faun. Germ. 29. 15. 
D. linearis Hoppe Ins. Erlang. 46. 10. - Lac. Mon. 160. 39. Redtb. Faun. A. II. 441. - Seidl. F. balt. 507.

Var. a. Supra obscure, cuprea, purpurea vel coeruleo-viridis.

Der Vorigen ausserordentlich nahe stehend, aber bestimmt verschieden; gewölbter, durchgehends feiner punktirt und dichter gerunzelt, daher matter, die Punktstreifen der Flügeldecken unregelmässiger, letztere hinten allmählicher in eine längere, grade abgestutzte Spitze verschmälert, stets einfarbig, die Fühler dünner, der Hals viel breiter, die Behaarung der Unterseite endlich dunkler, mehr in's Graue fallend. Eine Verwechselung mit $D$. thalassina, welche täuschend ähnlich aussieht, dürfte wegen der ungezähnten Hinterschenkel und theilweise rothen Beine nicht leicht sein.

Kopf gleichmässig dicht und fein runzelig punktirt, die Stirnfurchen, besonders die seitlichen flach; der Hals breit, hoch gewölbt, vom Kopfe kaum abgesetzt, die Augen dadurch kleiner und weniger vortretend. Fühler ähnlich gebaut als bei vulgaris, nur schlanker. Halssch. sehr dicht runzelig-punktirt, die Runzeln selbst fein gestrichelt; matt, mit kurzer, oft undeutlicher Mittelrinne auf der hinteren Hälfte der Scheibe. Auf den Fld. zeigt sich ein deutlicher, bis zur Naht reichender schiefer Schultereindruck, ihre Punktstreifen, die aus mässig grossen, sehr gedrängt aber unregelmässig, oft doppelt stehenden Punkten gebildet werden, sind im Eindrucke besonders tief, deutlich der Naht zugebogen, die Zwischenräume sehr dicht verworren gerunzelt. Die Spitze erscheint länger als die der vorigen Art, weil die Verschmälerung der Flügeldecken allmählich erfolgt; sie ist grade abgestutzt, mit stumpfen oder abgerundeten Aussenecken und mehr oder weniger weit über den Hinterleib hinaus vorgezogen. Die Beine sind metallgrün, die Basis der Schenkel und die Schienen theilweise oder ganz rothbraun.

Bisweilen ist die Oberseite dunkel kupferfarbig, purpurroth oder blaugrün.

Geschlechtsunterschiede wie bei der vorigen Art.

Häufig auf Glyceria und Carex-Arten im Juni.

\section{Vierte Gruppe.}

Oberseite dicht behaart. Hinterschenkel ungezähnt, die Spitze der Fld. nicht erreichend.

19. D. cinerea: Elongato-linearis, subdepressa, aenea, dense argenteo cinereo-tomentosa, pedibus rufo-variis, tibiis apice denticulalo-producto. antennis articulo 3:0 2:0 sublongiore; elytris punctato-striatis interstitiis planis. - Long. 7-10 mm. 
Mas: segmento ultimo ventrali apice subtruncalo, impresso.

Fem: segmento ultimo ventrali apice rotundato.

Herbst Füessl. Arch. V. 100. - Hoppe Enum. Ins. Erlang. 46. f. 11.

D. hydrocharis Fabr. Ent. Syst. I. 2. 118. - Panz. Faun. Germ. 29. 17.

D. hydrochaeridis Fabr. Syst. El. II. 129. - Ahr. Mon. 1. 43.

D. hydrocharidis Kunze Mon. I. 50. - Lac. Mon. 168. 44. Red tb. Faun. A. II. 442.

D. hydrochoeridis Seidl. F. balt. 508.

D. tersata Panz. Faun. Germ. 29. 16.

Langgestreckt, wenig gewölbt, grün- oder röthlich-metallglänzend; diese Farbe durch die kurze und dichte silbergrau schimmernde Behaarung verdeckt, so dass der Körper matt erscheint. Kopf undeutlich runzelig punktirt, die Stirnfurchen, besonders die mittlere tief, die Längswulst jederseits zwischen ihnen mässig erhaben; der Hals breit, sehr schwach abgeschnürt, der Quere nach gewölbt. Fühler ziemlich kräftig, schwarz, Glied 2-11 am Grunde mehr oder weniger roth, Glied 3 etwas länger als 2. Halssch. nach hinten leicht verengt, wenig länger als breit, vor dem Hinterrande und in der Mitte schwach ausgeschnitten, die Seitenhöcker mehr oder weniger stark gerundet hervortretend und bis zu den stumpfen Vorderecken eher verengt als verbreitert. Fld. vorn gleichbreit, im zweiten Drittel leicht erweitert, hinten schnell gerundet-rerengt, die Spitze selbst einzeln abgerundet oder sehr schwach abgestutzt; oben mit zwei undeutlichen Längseindrücken, del eine auf dem 2 . bis 4 . Zwischenraume an der Naht, der andere auf dem 6. bis $\delta$. an der Seite, mässig stark punktirt-gestreift mit ebenen, dicht verworren gerunzelten Zwischenräumen. An den rothen Beinen sind die Schenkelkeulen ganz, die Schienen am Aussenrande und die Tarsen oben dunkel-metallgrün gefärbt, die Spitze der Schienen, insbesondere der vorderen, ist schwach erweitert, scharf abgeschnitten und in einen kleinen Zahn an der Aussenseite verlängert.

Beim Männchen ist der Hinterrand des letzten Bauchsegmentes schwach abgestutzt und in der Mitte eingedrückt, beim Weibchen einfach gerundet.

Auf Sparganium, Typha latifolia und Arundo phragmites im nördlichen und mittleren Theile Deutschlands stellenweise nicht selten, sparsam im südlichen. Ende Mai und Juni.

Lacordaire führt eine Varietät mit einfarbigen, dunklen Fühlern auf, unter welcher er tersata Panz. citirt. Er hat hierbei nur auf die Abbildung $P$ anzers gesehen, die Beschreibung: 
"Antennae fuscae, articulis basi rufis" ganz ausser Acht gelassen. Bei starker Vergrösserung zeigen sich die einfarbig schwarz aussehenden Fühlerglieder an der Basis doch noch schmal roth gefärbt.

20. ID. tomentoset: Elongato-linearis, subdepressa, aenea, supra dense flavescenti-tomentosa, subtus cinerascenti-argenteo-sericea, pedibus ferrugineo-variis; antennis articulo 3:0 2:0 duplo longiore, elytris profundius punctato-striatis, interstitiis convexiusculis. - Long. 7-10 $\mathrm{mm}$.

Ahrens Mon. 42. 23. - Lac. Mon. 169. 45. - Redtb. Faun.

A. II. 442. - Seidl. F. balt. 508.

Var. a. Elytris viridibus, cupreis, purpureis vel cyaneis.

Langgestreckt, schwach gewölbt, heller oder dunkler metallgrün schimmernd, oben mit dichtem grünlich- oder graugelben, unten mit hellerem silbergrauen Tomente bedeckt. Stirn ziemlich flach, ihre Furchen mässig tief, der Hals deutlich abgeschnürt, schmal und wenig gewölbt. Fühler sehr schlank, schwarz, Glied 2 bis 11 am Grunde mehr oder weniger roth, Glied 3 reichlich doppelt so lang als 2. Halssch. kaum oder nur beim Männchen unmerklich länger als breit, die Seiten vor dem Hinterrande und besonders in der Mitte tief ausgeschnitten, von hier bis zu den heraustretenden Vorderecken allmählich und fast gradlinig verbreitert. Fld. gleichbreit, im letzten Drittel allmählich verschmälert, an der Spitze einzeln abgerundet oder abgestutzt; ihre Oberfläche tief punktirt-gestreift, die Zwischenräume etwas gewölbt, dicht mit kurzen, feinen Querrunzeln besetzt. Der zweite und dritte Punktstreifen krümmt sich vor der Spitze nach aussen und vereinigt sich mit dem achten und neunten; die Zwischenräume der genannten Streifen sind besonders beim 우 auffallend breit, erhaben und dichter behaart als die übrigen. Die Farbe der Beine variirt von metallgrün, mit rother Schenkelbasis und Schienenspitze, bis ganz roth, nur die Schenkel oben und der Aussenrand der Schienen schmal grün. Letztere sind an der Spitze kaum erweitert und stumpf abgeschnitten. Die Fld. mitunter grün, kupferig, purpurn oder kornblumenblau gefärbt, ohne Rücksicht auf das Geschlecht.

Von der vorigen Art durch eine mehr gleichbreite Gestalt, flachere Oberseite, schlankere Fühler, deren 3. Glied sehr gestreckt ist, schmalen Hals, die Bildung des Halssch. und der Beine, sowie eine anders gefärbte Behaarung hinreichend verschieden.

Geschlechtsunterschiede wie bei der vorigen Art.

An sumpfigen Gräben, Teich- und Flussufern auf den Blättern von Butomus umbellatus, häufiger im nördlichen als im südlichen Theile des Gebietes. Ende Juli bei Berlin zahlreich.

Wenn das Thier ruhig sitzt, streckt es gern seine langen Fühler nach vorn, wie Uliota (Brontes) planata. 


\section{Plateumaris.}

Thomson, Skandinav. Col. VIII. p. 121.

Mandibulae validae, labrum multo superantes.

Oculi parvuli.

Elyira metallica, apice integra vel obtuse truncata, hand spinoso. producta; margo suturalis ante apicem replicato.

Abdomen segmento prino reliquis simul sumtis longitudine aequali. Tibiae anticae apice externe dentato-productae.

Körper länglich, gewölbt, metallisch gefärbt, Unterseite, Kopf und zuweilen auch das Halsschild fein und dicht behaart. Mandibeln stark und breit, vorn in zwei Zähne gespalten, von deven der innere breit, an der Spitze abgerundet, der äussere kürzer aber dünn und spitz ist, sie überragen die vorn gerundet-abgestutzte Oberlippe bedeutend. Kopf breit, die Stirn flach, mit einer Mittelrinne; Augen klein, etwas länger als breit, mässig gewölbt. Flügeldecken hinten abschüssig gewölbt, an der Spitze entweder zusammen oder einzeln abgerundet oder leicht abgestutzt, die obere Randlinie der Naht ist vor der Spitze auf die Flügeldecken heraufgebogen, so dass dadurch der erste Zwischenraum hinten ganz oder fast ganz verschwindet und nur der untere Nahtrand als längliche glatte Fläche sichtbar bleibt. Der erste Hinterleibsring so lang als die vier übrigen zusammen oder kürzer. Die Beine stark, ihre vier Vorderschenkel wenig zusammengedrückt, fast keulig, die hinteren stärker zusammengedrückt; Vorderschienen am Aussenrande an der Spitze in einen deutlichen Zahn ausgezogen, die einzelnen Tarsenglieder meist so lang als breit, die Klauen einfach, ziemlich klein. Penis kräftig, gleichbreit, vorn ganz allmählich in eine grade Spitze ausgezogen; der Anhang entweder lang und fast gleichbreit oder kurz, am Grunde dünn, hierauf schnell verbreitert und verdickt und gleichbreit bis zur Spitze (sericea und discolor). Die Legeröhre der Weibchen ist rorn hornig, die obere Klappe abgerundet, die untere in der Mitte in eine kurze dreieckige Spitze ausgezogen. Bei zwei Arten (braccata und consimilis) ist die Unterklappe auffallend breit (bei consimilis am Rande fein gezähnt), bei den übrigen schmal, ganzrandig.

Die Arten, von denen 6 in Europa und Asien, 14 in Nordamerika vorkommen, leben auf Gräsern in Sümpfen. Es sind träge Thiere, welche sich durch ihren gewölbten, hinten abschüssigen Körper, lange Mandibeln, kleine Augen, flache Stirn, vor der Spitze aufgeschlagenen Nahtrand der Flügeldecken, kürzeres erstes Bauchsegment und starke, plumpe Beine deutlich von den Donacien absondern. Während sich diese nur auf Pflanzen aufhalten, welche im freien Wasser stehen, findet man die Mehrzahl der Plateumaren 
in zugewachsenen Sümpfen, die freie Wasserflächen oft gar nicht haben, und hieraus darf schon auf eine ganz andere Lebensweise der Larven geschlossen werden, von der bisher nichts bekannt geworden ist. Die Puppen von $P l$. consimilis fand Dr. Bach bei Boppard an den Wurzeln von Caltha palustris. $\left.{ }^{1}\right)$

Halssch. kahl.

\section{Erste Gruppe.}

1. PI. sericen: Convexiuscula, supra viridi-coerulea, subtus argenteovel aureo-tomentosa; antennis pedibusque aeneis; prothorace elongatulo, sericeo-micans, angulis anticis discrete prominenibus, elytris apice rotundato-truncatis, punctato-striatis, interstitiis transversim-strigosis, femoribus posticis dente valido armatis; antennis longiusculis, articulo 3: o 2: o plus quam sesqui lonyiore. - Long. 7-9,5 mm.

Mas: segmento 1:0 basi late, $5: 0$ apice impresso, hoc apice subtruncato. Fem: segmento 5:0 apice rotundato.

Lin né Faun. Suec. 196. 683. (Leptura). - F a br. Syst. Ent. 198. Suffr. Stett. Zeit. 1846. 84. - Redtb. Faun. A. II. 441. Seidl. F. balt. 507. - Letzner Arb. Schles. Ges. 1876. 19. D. sericea (pars) Gyllh. Ins. Suec. III. 657. - Lac. Mon. 180. 49.

D. micans Ahr. Mon. 28. 11.

D. laevicollis Thoms. Skand. Col. VIII. 125. 23.

D. sibirica Solsky. Horae Soc. ent. Ross. VIII. 245.

Var. a. Supra cyanea, violacea vel rubro-violacea.

D. festucae Fabr. Ent. Syst. II. 116. - Panz. Faun. Germ. 29. 2. D. violacea Hoppe Enum. Ins. Erlang. 44. f. 7.

Var. b. Supra viridi-aenea vel vinidi-aurea, elytris plus minusve nitidis. D. micans Panz. Faun. Germ. 29. 9.

Var. c. Supra aurichalcea, obscure-aenea vel-cuprea.

D. armata Payk. Faun. Suec. II. 194.

D. discolor Panz. Faun. Germ. 29. 4.

Var. d. Supra aureo-vel rubro- cuprea.

D. nymphaeae Fabr. Ent. Syst. II. 116. - Panz. Ent. Germ. 215; Faun. Germ. 29. 6.

D. a enea Hoppe Enum. Ins. Erlang. 44. f. 6. Var. e. Supra nigra, aeneo-micans.

D. sericea var. a Suff r. Stett. Zeit. 1846. 89.

Var. f. Intersiitiis elytrorum vix transversim strigosis.

D. viola cea Gyllh. Ins. Suec. III. 660. 9. Var. g. Antennis articulis ultimis basi ferrugineis.

Durch Glanz und Farbenpracht, sowie die grosse Neigung Farbenvarietäten zu bilden, ist diese und die folgende Art von den schmucklosen Verwandten sehr ausgezeichnet.

1) Kaltenbach, Pflanzenfeinde p. 10 u. 762. 
Körper gewölbt, mässig gestreckt, metallglänzend, Unterseite dicht weisslich- oder goldig-seidenhaarig. Kopf dicht punktirt, die Mittelfurche der Stirn schmal und tief. Fühler einfarbig schwarz, die ersten 5 Glieder deutlicher erzglänzend als die letzten, länger als der halbe Körper, Glied 1 dick, die übrigen schlank, unter sich kaum an Stärke verschieden; Glied 3 fast doppelt so lang als 2, 4 bedeutend länger als 3 und beinahe so lang als 5,6 bis 11 unter sich und mit 4 ungefähr von gleicher Länge. Halssch. länger als breit, die Seiten ziemlich parallel, nur vorn durch den jederseits gerundet-heraustretenden Seitenhöcker stark verbreitert. Letzterer ist am Vorder- und Hinterrande scharf begrenzt; innen zwar deutlich, aber schwächer abgesetzt. Die Vorderecken sind als kleine, scharfe Spitze nach aussen gezogen und wie bei den Verwandten mit einem abstehenden Borstenhärchen versehen, welches im Grunde eines breiten, tiefen Punktes steht. Die Scheibe mit einer bald tieferen, bald flacheren, vor dem Grunde in einen starken Quereindruck übergehenden Mittelrinne, sehr fein und dicht punktirt und ausserordentlich fein und dicht quergerunzelt, matt-seidenschimmernd, nur vom Quereindrucke bis zum Hinterrande stärker punktirt und glänzend. Fld. in den Schultern am breitesten, bis $2 / 3$ ibrer Länge leicht verschmälert, dahinter bis zur gerundet-abgestutzten Spitze schneller verengt, mit zwei schwachen Eindrücken jederseits an der Naht, mässig stark punktirt-gestreift, die Punkte durch mehr oder weniger tiefe, oft über die ganze Scheibe reichende Quervertiefungen verbunden, in diesen kurz aber wenig dicht quer-gestrichelt. Je ebener die Zwischenräume wérden, desto stärker wird ihr Glanz. Beine erzfarbig, mässig lang, dick, die Männchen mit besonders starken Hinterschenkeln, welche mit einem grossen und sehr spitzen Zahne bewaffnet sind.

Beim $\hat{o}$ ist der erste Bauchring in der Mitte der Basis breit und tief niedergedrückt, der fünfte an der Spitze schwach abgestutzt, mit leichtem Eindrucke in der Mitte; das of hat ein gleichmässig flachgewölbtes erstes und an der Spitze abgerundetes fünftes Segment.

Farbe der Oberseite sehr veränderlich. Es lassen sich fünf Hauptvarietäten unterscheiden, die durch Zwischenstufen eng mit einander verbunden sind. Bei der ersten ist blau rorherrschend, welches oft durch Hinzutritt von roth in violett übergeht; b ist blaugrün (von Linné beschrieben), metall- oder goldgrün; c messinggelb, broncefarben oder kupferig, braun; d hell kupferroth oder stark goldig; e schwarz, mit Metallschimmer. Nicht selten besitzt auch das Halssch. eine andere Färbung als die Fld.; es sind besonders 3 Formen erwähnenswerth: Fld. grün und Halssch. blau, 
oder erstere messingfarbig, letzteres grün; endlich Fld. kupferroth, Thorax violett. Selten tritt die unter g aufgeführte Form auf, deren letzte Fühlerglieder am Grunde roth geringelt sind.

Der Verbreitungsbezirk der Art ist fast noch unbekannt. Suffrian nennt sie zwar l. c. p. 86 ,eine der in Deutschland allergemeinsten und in den grössten Massen vorhandenen Arten, die überall zu finden ist," allein mit Unrecht. Sie fehlt bei Berlin, Frankfurt a. O., auf dem schlesischen Gebirgszuge vom Isergebirge bis zum Altvater und auf dem Schwarzwalde. Sichere Fundorte sind nur Magdeburg oder Braunschweig ( A h rens) und Bonn (Dr.Kratz).

Stücke ron Irkutsk beschrieb Solsky als sibirica.

Die Synonymie ist schwer festzustellen und es dürften viele der unter den Varietäten aufgeführten Benennungen der folgenden Art zuzuweisen sein. Ob Herr Letzner, welcher die Zusammengehörigkeit dieser und der folg. Art befürwortet, richtige Stücke der vorliegenden besessen hat, glaube ich bezweifeln zu müssen.

Panzer bildet in der Faun. Germ. 29 unter N. 4 als discolor Fem. (mit langen Fühlern! und scharfen Vorderecken des Thorax) ein Männchen der vorliegenden, unter No. 3 discolor Mas. (mit kurzen, gelbgeringelten Fühlern und stumpfen Vorderecken des Halsschildes) unzweifelhaft ein Weibchen der folgenden Art ab, die er auch nnverkennbar beschreibt. Da nun die discolor Hoppe (1795) den älteren Namen consimilis Schrank (1781) annehmen muss, so bleibt für comari als älteste Bezeichnung nur discolor Panz. übrig.

2. Pl. discolor: Convexiuscula, supra obscure aenea, subtus argenteovel aureo - sericea; antennis pedibusque ferrugineo - variegatis; prothorace subquadrato, strigoso-punctato, angulis anticis haud prominulis, antennis breviusculis, articulo 3:0 2:0 parum longiore. - Long. 6,5-9 $\mathrm{mm}$.

Panzer Faun. Germ. 29. 3. - Brüggemann Abhandl. Ver. Bremen III. 1873. 514. - Kraatz Berl. Zeit. 1874. 125.

D. sericea Ahr. Mon. 29. 12.

D. sericea (pars) Gyllh. Ins. Suec. III. 657. - Lac. Mon. 180. 49.

D. proteus Kunze Mon. 29. - Kraatz Berl. Zeit. 1869. 267.

D. palustris Schilling Uebers. Arb. Schles. Kult. 1837. 104. Letzn. Arb. Schles. Ges. 1876. 20.

D. comari Suffr. Stett. Zeit。 1846. 84. - Redtb. Faun. A. II. 443. - Seidl. F. balt. 507. - Letzn. l. c. 19.

D. geniculata Thoms. Skand. Col. VIII. 123.

Var. a. Supra cyanea, violacea vel rubro-violacea.

Var. b. Supra viridi-aenea vel-aurea.

D. Lacordairei Perris Ann. Fr. 1864. 300.

Var. c. Supra aurichalcea. 
Var. d. Supra auro-vel rubro-cuprea.

Var. e. Pedibus aeneis.

Var. f. Antennis pedibusque aeneis, haud variegatis.

Der Vorigen täuschend ähulich, jedoch durch folgende Punkte schwer aber wohl sicher zu unterscheiden:

Der Körper ist kürzer (Stücke von 8--9 mm sind sehr selten) und plumper gebaut. Die Fühler (beim Männchen halb so lang als der Körper, beim Weibchen nerklich kürzer und stärker) sind ziemlich dick, Glied 2 und 3 birnförmig, das uritte besonders beim $f$ wenig länger als 2, Glied 4 etwas länger als 3, die einzelnen Glieder, vom zweiten angefangen, am Grunde mehr oder weniger breit roth geringelt, die letzten zuweilen ganz roth. Halssch. fast quadratisch, stärker punktirt und gerunzelt, mässig glänzend aber nie matt seidenschimmernd; der Seitenhöcker ist merklich schwächer als bei sericea und geht vorn und hinten allmählich in den Seitenrand über, so dass die Vorderecken zwar grade, aber nicht zahnförmig nach aussen vorspringend erscheinen, der Vorderrand ist deshalb auch bedeutend schmaler. Die Fld. sind bis $3^{\prime} / 4$ ihrer Länge parallel oder in $2 / 3$ am breitesten und vor der Spitze kürzer und stärker verschmälert als bei sericea; ihre Skulptur ist ebenso reränderlich aber kaum, gröber"6, wie Suffrian behauptet. Beine meist deutlich kürzer, mit stärkeren Schenkeln, die Schienen und Tarsen am Grunde röthlich gefärbt. Die Unterseite ist feiner und sparsamer weiss- oder gelblich seidenschimmernd behaart, so dass jlire Erzfarbe stärker hervortritt.

Exemplare mit einfarbigen Beinen (var. e) sind nicht selten, dagegen scheinen, nach dem mir vorliegenden bedeutenden Materiale, solche mit einfarbigen Fühlern (bei starker Vergrösserung!) nur sparsam vorzukommen.

D. Lacordairei Perr. aus der Sierra Guadarrama stimmt ganz mit discoior überein; sie wird oft stark glänzend und das Halssch. ist zuweilen weitläufig feiu punktirt, kaum gerunzelt.

Die Art findet sich in Sümpfen, in denen Eriophorum alpinum wächst, entweder an dieser Pflanze oder auf Carex-Arten; ihr Vorkommen auf Comarum war ein rein zutälliges. Sic ist im Mai bei Bremen (Brügyem.), Berlin, Eberswalde, Wriezen, Frankfurt a. O., Ende Mai auf dem Schwarzwalde (Buhlbach, Simon) und im Juli auf dem Iser-, Riesen- und Glatzer-Gebirge sowie an der Brünnelhaide und dem kleinen See auf dem Altvater gemein. Dah 1, Ahrens, Suffrian, Fuchs und in neuester Zeit Degenhardt in Clausthal sammelten sie auf dem Harze, H. r. Heyden im Ober - Engadin. 


\section{Zweite Gruppe.}

Halssch. dicht und fein behaart.

3. P1. braccata: Elongata, convexiuscula, supra violaceo-nigra, subtus griseo-vel aureo-sericea; abdomine basi exepta, pedibus antennisque rufo-ferrugineis; prothorace subcordato, viridescens, canalicula media obsoleta, angulis anlicis vix prominulis; elytris apice conjunctim-rotundatis, striato-punctatis, interstitiis transversim rugosis. Long. 9-11 $\mathrm{mm}$.

Mas.: prothorace parce punciato, nitido, metasterno et segmento primo merlio late impresso, 5:o apice emarginato; femoribus posticis dente valido armatis.

Fem.: prothorace crebre punctato, segmento $5: 0$ apice subtruncato, femoribus posticis obsolete dentatis vel muticis.

Scopoli Annus V. Hist. nat. 100.

Donacia nigra Fabr. Ent. Syst. I. 2. 117. - Germ. Neue Schrift. Ges. Halle VI. 31. - Lac. Mon. 171. 46. - Redtb. Faun. A. II. 441. - Seidl. F. balt. 508 .

D. palusiris Herbst. Füessl. Arch. V. 100. - Panz. Ent. Germ. 217. 13; Faun. Germ. 29. 10.

Var. a. Antennis, pedibus abdomineque nigris.

Var. b. (femina). Supra aenea, thorace chalybaeo-micans.

Suffr. Stett. Zeit. 1846. 56.

Körper schwarz mit violettem Schimmer, das Halssch. grünlich glänzend, die Unterseite grau oder goldgelb seidenschimmernd behaart. Fühler, Beine und die vier letzten Hinterleibsringe rostroth. Kopf fein und dicht punktirt, die Stirnfurchen lang und tief. Fühler länger als der halbe Körper, Glied 3 doppelt so lang als 2 und kaum kürzer als eins der folgenden, welche unter sich ungefähr gleichlang und öfter an der Spítze angedunkelt sind. Halssch. schwach herzförmig, nach hinten stark verengt, der Seitenhöcker gross, innen scharf begrenzt, vorn und hinten allmählich in den Seitenrand übergehend, die Vorderecken klein, stumpf, kaum zahnförmig heraustretend; die Scheibe gewölbt, ihre Mittelrinne schwach, oft nur der Anfangs- und Endpunkt grübchenartig, beim Männchen weitläufig, beim Weibchen dicht aber fein punktirt, kurz und mässig dicht behaart. Fld. ziemlich parallel, im letzten Viertel gerundet-verengt, jede an der Spitze einzeln abgerundet, mässig stark gestreift-punktirt, die Zwischenräume leicht gewölbt und mehr oder weniger dicht quergerunzelt.

Zuweilen erhält das Halssch. einen bläulichen oder PurpurSchimmer, selten sind Fühler, Beine und Hinterleib einfarbig schwärzlich. 
Die Fld. der Weibchen sind öfter am Seitenrande, bis zum neunten Punktstreifen erzfarbig; Suffrian erwähnt sogar zwei von Hornung bei Stassfurt gesammelte Stücke, deren Oberseite die matte Erzfarbe der Weibchen von consimilis zeigt, mit schwach stahlblauem Halssch.

Beim Männchen ist die Hinterbrust und der erste Bauchring in der Mitte der Länge nach eingedrückt, der Hinterrand des letzten Segmentes gerundet-ausgeschnitten und die Hinterschenkel sind stark gezähnt; beim Weibchen ist der Hinterrand des fünften Segmentes schwach abgestutzt, der Zahn an den Hinterschenkeln stumpf oder ganz undeutlich.

Im Juni auf Phragmites communis stellenweise zahlreich in Nordund Mitteldeutschland.

4. PI. consimilis: Oblonga, convexiuscula, supra metallica subtus dense cinereo-pubescens; prothorace subovato-quadrato, dense punctato, canalicula media temi, angulis anticis minimis, acutis. Long. $6-8 \mathrm{~mm}$.

Mas: supra niger plus minusve violaceo micans, antennis pedibusque rufo ferruyineis; elytris inierstitiis subcoriaceis, femoribus posticis dente valido armatis.

Fem: brevior, supra aenea, antennis pedibusque mfo-fermyineis, femoribus viridi-aeneis posticis dente parvo vel obsoleto armatis; elytris interstitiis transversim strigosis.

Schrank. Enum. Ins. Austr. 155. 292. $\hat{\wp}$ (Leptura).

Leptura assimilis Schrank. 1. c. 156.

Donacia discolor Hoppe Enum. Ins. Erlang. 45. f. 8. 9. - Lac. Mon. 173. 47. - Redtb. Faun. A. II. 441. - Seidl. F. balt. 508.

- Thoms. Skand. Col. VIII. 123. 21.

Var. a. Angulis anticis prothoracis obsoletis.

D. variabilis Kunze Mon. 39.

Var. b. (mas.). Supra purpurea, viridis, aureo-viridis vel aenea: pedibus saepe aeneo-variis.

Var. c. (fem.). Supra aureo-viridis, aeruyinosa, nigro-purpurea rel - violacea.

Kürzer und verhältnissmässig breiter als braccata, das Halssch. nach hinten weniger verengt. Männchen mit schwarzer, an der Naht oder ganz violett schimmernder, das Weibchen mit erzfarbiger Oberseite, unten dicht grauschimmernd, oben auf dem Kopfe und Halssch. weitläufiger und undeutlicher behaart. Fühler ziemlich kräftig, heller oder dunkler rostroth, die einzelnen Glieder zuweilen an der Spitze oder fast ganz schwärzlich, das zweite Glied sehr kurz, etwa $1 / 3$ so lang als eins der übrigen, welche unter sich von gleicher Länge sind. $\mathrm{Halssch}$. so lang als breit, die grösste Breite 
in der Mitte der undeutlichen Seitenhöcker, von hier nach hinten allmählich schwach gerundet-, nach vorn wenig verengt, die Vorderecken als sehr kleine, spitze Zähnchen vorgezogen, die Scheibe schwach kissenartig gewölbt, mit feiner, selbst ganz verwischter Mittelrinne und leichtem Quereindrucke vor dem Hinterrande, dicht und mässig stark punktirt und äusserst fein gerunzelt. Fld. tief gestreift-punktirt, die Zwischenräume am Grunde mit eingemengten Punkten, beim Männchen schwach lederartig gerunzelt, beim Weibchen fein und dicht quer gestreift, hinten einzeln abgerundet. Unterseite dunkel erzfarbig, der Hinterrand der Segmente oder die vier letzten ganz (rorzugsweise $\hat{\jmath}$ ) hell rostroth gefärbt. Beine röthlich, die des $\hat{\sigma}$ einfarbig, mit grossem dreieckigen Zahne an den Hinterschenkeln, die des ㅇ․ mit theilweise oder ganz erzfarbigen Schenkeln, von denen die hinteren nur schwach oder undeutlich gezähnt sind.

Die meist kleineren süddeutschen Stücke (variabilis $\mathrm{K}$ unz.) verlieren nicht selten die vortretenden Zähnchen an den Vorderecken des Halsschildes, doch kommen, wie schon Suffrian erwähnt, ähnliche auch bei uns vor.

In der Färbung der Oberseite lassen sich folgende Abänderungen, vorzugsweise zu variabilis gehörig, unterscheiden:

b. Die $\widehat{A}$ sind schwarz mit Purpurschimmer, grün, goldgrün oder, wie die normalen Weibchen, erzfarbig.

c. Die $q$ sind goldgrün, spangrün, dunkelpurpurn oder violett gefärbt.

Selten kommen $\hat{\sigma}$ mit schwarzmetallischen und $q$ mit einfarbig rostrothen Schenkeln vor.

Auf Carex-Arten vom Mai bis Juli überall häufig.

5. Fil. mustica: Oblonga, convexiuscula, melallica, subtus dense flavescenti-argenteo-pubescens; antennarum basi pedibusque ferrugineis; prothorace quadrato, sat plano, crebre subtiliter punctato, angulis anticis haud calloso-prominulis. - Long. $6-8 \mathrm{~mm}$.

Mas: supra niger, parum viridi-vel coeruleo-micans, metasterno et segmento 1:o late impressis, femoribus posicis incrassatis, dente magno, valido parum acuto armatis, elytris subtiliter punctato-striatis, intersiitiis transversim-rugosis, subcoriaceis.

Fem: supra aenea, femoribus posticis gracilioribus, obtuse vel obsolete dentatis, elytris punctato-strialis, interstitiis transversim-strigosis.

Kunze Mon. 31. - Suffr. Stett. Zeit. 1846. 80. - Seidl. F. balt. 508. - Czwal. Deutsch. Zeit. 1878. 204 (Don.).

Don. affinis (ex parte) Lac. Mon. 176. 48.

Var. a. (mas.). Prothorace elytrisque plus minusve coeruleis.

D. planicollis Kunze Mon. 34 .

$\mathrm{V}$ ar b. Antennis testaceis.

Var. c. (fem.). Sizpra coeruleo-nigra. 
Durch die bei beiden Geschlechtern verschiedene Färbung der Oberseite ist diese und die folgende Art zwar mit der vorhergebenden verwandt, aber an dem flachen, viereckigen Halssch. leicht zu unterscheiden.

đ̂ mässig gewölbt, mit schwarzer, schwach grün oder blau schinmernder und fettglänzender Oberseite, unten dicht silberweiss behaart mit gelblichem Anfluge. Fühler gestreckt, länger als der halbe Körper, das erste, oft auch das zweite Glied hell rostroth, die übrigen schwarz, am Grunde wenig lebhaft roth geringelt, alle von gleicher Länge, nur das zweite kaum halb so lang als eins der übrigen. Halssch. quadratisch, nach hinten deutlich verengt, der Vorderrand ziemlich grade, die Vorderecken stumpf-abgerundet und undeutlich in die Höhe gebogen, der Seitentöcker nur durch einen flachen Längseindruck innen angedeutet; die Seiten fast grade, vor den Hinterecken mit einem kleinen, dreieckigen Ausschnitte, die Scheibe ziemlich flach gedrückt, dicht und sehr fein punktirt, mit einer seichten Quervertiefung vor dem Hinterrande, in welcher die Mittelrinne schmal aber deutlich hervortritt. Fld. an der Spitze fast zusammen abgerundet, fein punktirt-gestreift, die $\mathbf{Z}$ wischenräume mit deutlichen Querrunzeln, ausserordentlich dicht und fein lederartig skulptirt. Beine rostroth, mässig lang, stark, mit dicken, keuligen Vorderschenkeln und sehr breiten, zusammengedrückten Hinterschenkeln, welche mit einem grossen, etwas nach hinten gerichteten, wenig spitzen Zahne versehen sind. Unterseite dunkel, stellenweise violett gefärbt, bei frischen Stücken die vier letzten Bauchringe theilweise oder ganz dunkelroth.

In den südlichen Theilen des Gebietes sind Exemplare mit lebhaft blau schimmernder Oberseite vorherrschend, ihr Halssch. erscheint etwas flacher und die Punktirung der Fld. stärker. Da sie in den übrigen Merkmalen jedoch mit der Stammform ganz übereinstimmen und Uebergänge, besonders im Schwarzwalde (Simon) gefunden worden sind, können sie nicht als Art angesehen werden.

q stärker gewölbt, bräunlich oder grünlich erzfarben, das Halssch. etwas dichter, die Fld. tiefer punktirt, die Zwischenräume der Streifen stark querrissig und mit einzelnen kurzen Querrunzeln versehen, je nach der Stärke dieser Skulptur mehr oder weniger glänzend. Ihre Fühler sind kürzer, die Hinterschenkel schlank mit einem sehr stumpfen, oft undeutlichen Zahne.

Die Var. b. mit einfarbig röthlichgelben oder an der Spitze schmal schwarz geringelten Fühlergliedern scheint selten zu sein, denn mir liegen nur zwei Berliner Exemplare vor. Dieselben sind nicht frisch und unausgefärbt und bilden, wie man leicht zu 
glauben versucht sein könnte, keineswegs einen Uebergang zur folgenden Art.

Weibchen mit bläulichschwarzer Oberseite (Var. c.), wovon Suffrian eins aus der Schweiz erwähnt, sind mir unbekannt.

Vom Juni bis August an Carex-Arten häufig. Scheint dem nordwestlichen Deutschland zu fehlen.

6. PI. affinis: Oblonga, convexiuscula, metallica, subtus dense argenteo-pubescens, antemis abdomineque busi exepta fermgineis, pedibus pallide testaceis; prothorace quadrato, ante basin fortiter sinuato, subtiliter punctato, angulis anticis calloso-prominulis. - Long. $5-8 \mathrm{~mm}$. Mas: supra niyro-purpureus, prothorace parce punctato, metasterno et segmento 1:o late impressis, femoribus posticis incrassatis, dente magno, valido, acuto armatis, elytris puncfato-striatis, interstitiis subcoriaceis.

Fem: supra aenea, prothorace crebre punctato, femoribus posticis gracilioribus, dente parvo, subacuto armatis, elytris punctato-striatis, interstitiis transversim strigosis.

Kunze Mon. 37. - Suffr. Stett. Zeit. 1846. 80. - Redtb. Faun. A. II. 441. - Seidl. F. balt. 508 (Don.). - Thoms. Skand. Col. VIII. 122. 20.

D. affinis (ex p.) Lac. Mon. 176. 48.

D. discolor Gyllh. Ins. Suec. III. 660.

$\checkmark$ ar. a. (mas.). Elytris fortiter punctato-striatis.

D. pallipes Kunze Mon. 35.

Var. b. $(\hat{\oplus})$ Supra viridis vel coerulea.

Var. e. (fem.) Supra nigro-cyanea vel aeruginosa.

Var. d. Antennarum articulis apice obscuris.

ô schwarz mit deutlichem Purpurschimmer, Fühler kurz, die Hälfte des Körpers nicht erreichend, röthlichgelb, die 2 ersten Glieder blassgelb. Halssch. quadratisch, bis vor den Hinterrand unmerklich verengt, hier tief dreieckig ausgeschnitten, der Vorderrand ziemlich grade, die Vorderecken stumpf, schräg abgeschnitten, schwielig-aufgeworfen, der Seitenhöcker noch schwächer als bei der vorigen angedeutet; Scheibe flach mit einer feinen, in der Mitte und vor dem Hinterrande meist tieferen ganzen Längsrinne, weitläufig fein punktirt, die $Z$ wischenräume mit einigen äusserst feinen Punkten. Fld. an der Spitze einzeln abgerundet, ziemlich stark punktirtgestreift, die $Z$ wischenräume äusserst fein lederartig gerunzelt, der zweite und vierte oft schwach erhaben. Beine kurz, blassgelb, die Schenkel stark, die hinteren sehr breit, zusammengedrückt und mit einem grossen, dreieckigen Zahne bewehrt, der in eine nach hinten lang ausgezogene scharfe Spitze endet. Unterseite dunkel, der Bauch mit Ausnahme des ersten Ringes rostroth. 
Stücke aus der Úmgebung Nürnbergs sind merklich stärker punktirt (Var. a), sonst aber ohne durchgreifenden Lnterschied.

ㅇ braun oder grünlich erzfarbig, Halssch. dicht und fein punktirt, die Zwischenräume der Punktstreifen auf den Fld. mit tiefen Querstrichen versehen, zwischen diesen quergerunzelt; die Hinterschenkel schlank, mit einem zwar kleinen, aber mässig spitzen Zahne, der nur selten stumpfer als beim $\hat{\sigma}$ der vorigen Art wird.

Die Farbe der Oberseite ändert, wiewohl selten, so ab, dass beim $\widehat{\jmath}$ (oft nur auf dem Halssch.) dunkelblau, blaugrün oder grün (Var. b), beim \& schwarzblau oder schwarzgrün vorherrschend wird (Var. c). Zuweilen sind die einzelnen Fühlerglieder mit Ausnahme der beiden ersten an der Spitze dunkel, bei einem Exemplare ron Eberswalde sogar total schwarz (Var. d).

Die Art ist im Allgemeinen schlanker als rustica und von ihr leicht durch die helle Farbe der Beine und Fühler, stärkere Skulptur der Fld., die Form des Halssch. und durch den spitzen Zahn der Hinterschenkel zu trennen.

Sie erscheint früher als rustica, im Mai und Anfang Juni und ist auf Carex-Arten, vorzüglich im nordwestlichen Deutschland anzutreffen, doch auch bei Berlin, in Schlesien (Altvater im Juli), Mähren und bei Wien zuweilen häufig.

\section{Dritte Gruppe: CRIOCERINI.}

La cord. Monogr. des Phytophag. 222.

Antennae basi late distantes.

Abdomen segmento primo brevi.

Fühler kürzer und am Vorderrande der Angen weiter ron einander eingefügt, als bei der vorhergehenden Abtheilung, durch die ganze Breite der Stirn getrennt, fast perlschnurförmig, das zweite bis vierte Glied schmaler und nebst dem ersten weniger dicht behaart und glänzender als die übrigen. Kopf bald quer, mit den Augen breiter als lang, bald dreieckig, nach vorn verlängert, so lang als breit oder länger. Augen mehr oder weniger tief ausgerandet, von den europäischen Gattungen nur bei $S_{\left.y n e t \alpha^{1}\right)}$ ganz. Halsschild

1) Symeta Lac. (Mon. 226.). Oculi parvi, rotundi integri. Prothurax lateribus medio dilatatus, parce denticulatus. Elytris punctutis, lineis paucis dorsalibus subelevatis. Acetabula antuca aperta. Unguiculi tarsorum dente acuto armati.

Im nördlichsten Europa (Norwegen, Lappland, Finnland) eine Art:

S. betulae Fabr. (Ent. Syst. I. 2. 5). Elongata, unlique tenwiter 
entweder in der Mitte oder dicht hinter dem Vorderrande am breitesten, der Grund stets schmaler als die Flügeldecken. Letztere sind ungefähr doppelt so lang als breit, hinten fast gemeinschaftlich abgerundet, verworren oder reihig punktirt. Das erste Hinterleibssegment ist höchstens so lang als die zwei folgenden zusammen. Beine mässig lang, Klauen einfach, oft bis zur Mitte verwachsen, oder gezähnt.

Von unseren Gattungen ist Syneta durch den Körperbau mit Galeruca nahe verwandt und die Zeugophora-Arten weichen in ihrer Lebensweise und durch ihre fusslosen, Blätter minirenden Larven recht bedeutend von den wirklichen Criocerinen ab, deren Larven stets mit ihren Excrementen bedeckt sind.

\section{Zeugophora.}

Kunze, Neue Scchriften der naturf. Gesellschaft zu Halle II. 4. 71.

Corpus parce pubescens.

Oculi leviter emarginati.

Prothorax tuberculo laterali magno; elytra punctata.

Acetabula antica occlusa.

Unguiculi tarsorum dente obtuiso armati.

Körper gestreckt, weitläufig fein behaart, die Behaarung auf dem letzten Bauchsegmente und den Seitenstücken der Brust, besonders auf dem vorderen Drittel derselben, dichter. Kopf viel breiter als lang, die Oberlippe stark quer, vorn in einem sehr flachen Bogen ausgerandet, fast grade abgestutzt. Mandibeln kurz, beinahe gleichbreit, an der Spitze leicht gespalten. Fühler so lang als der halbe Körper, kräftig, die ersten fünf Glieder gestreckt und mit Ausnahme des Basalgliedes merklich schmaler als die folgenden, welche nur so lang als breit und stärker behaart sind. Augen gross, stark gewölbt, wenig länger als breit, am Innenrande hinter der Fühlerwurzel schwach bogenförmig ausgerandet, mit deutlichen Schläfen. Halsschild viereckig, jederseits mit einem grossen, dreieckigen Seitenhöcker. Schildchen klein, lang dreieckig, hinten schmal abgestutzt. Flügeldecken gewölbt, fast parallel, der Grund jederseits am Innenrande der Schulterbeule eingedrückt, unregelmässig punktirt. Beine ziemlich stark, kurz, das erste Tarsenglied lang,

pubescens, parum nitida, nigro-fusca, ore, untennis, pedibus elytrisque limbo laterali flavo-testaceis, thorace dense subtlliter elytrisque profundius punctatis.

- Long. 5,5-6,5 mm.

Femina: segmento ultimo impressione triangulari, profunda. 
das zweite kurz, dreieckig, das Klatuenglied ist zur Hälfte in die Lappen des breiten dritten Gliedes eingelegt; Klauen kurz, fein, jede mit einem breiten Zahne am Grunde.

Männchen kleiner als das Weibchen, der Hinterrand des fünften Bauchsegmentes in der Mitte leicht vorgezogen, während derselbe beim Weibchen abgestutat ist. Penis schwach gebogen, oben rinnenförmig ausgehöhlt und vorn allmählich in eine scharfe, nach oben zurückgebogene Spitze ausgezogen (flavicollis).

Die Arten leben auf Pappelgebüschen und sitzen oft auf der Unterseite der Blätter, von denen sie sich nähren. Die abgefressenen Stellen sehen schwarz aus, vertiefen sich nicht selten oder rollen sich zusammen. Die Larve ron flavicollis') minirt die Oberseite der Schwarz- und Zitterpappelblätter vom Juni bis September. Sie ist 2 Lin. lang, fusslos, gelb mit braunem Kopfe und etwas plattem Leibe, der zu beiden Seiten sägeartig gekerbt ist. Die Verwandlung geht in der Erde, die Entwicklung der Sommerbruten im Mai des folgenden Jahres vor sich.

1. Z. scutellaris: Oblonga, convexa, nitida, temiler pubescens. nigra. antennis articulis tribus primis, mesosterno pedibusque flaris, capite, prothorace, scutelloque mifo-flavis; thorace tuberculo laterali magno, obtuso elytrisque parce profinde punctatis; temporilues magnis. Long. $3-4 \mathrm{~mm}$.

Mas: segmento ultimo ventrali apice subacuto.

Fem: segmento ultimo apice subtruncato.

Suffr. Stett. Zeit. 1840. 99. 2. - Lac. Mon. 236. 1. - Redtb.

Faun. A. II. 444. - Seidl. Faun. b. 503.

Var. a. Elytris sub humeris rufo-flacis.

Var. b. Scutello nigro.

Var. c. Fronte, vertice scutelloque nigris.

Z. frontalis Suffr. 1. c. 100.3. - Lacord. Mon. 23\%. 2. - Redtb. I. c. 445 .

Die grösste Art der Gattung, von der folgenden durch Bildung und Skulptur des Kopfes und Halssch. verschieden. Schwarz, die ersten drei, bisweilen vier Fühlerglieder, die Vorder- und Mittelbrust und die Beine hellgelb, Kopf, Halssch. und Schildchen rothgelb oder das letztere röthlichbraun. Kopf zwischen den Augen weitläufig, hinten dichter aber fein punktirt, kaum mit der Spur einer glatten Längslinie auf der Stirn, hinter den mässig grossen und schwach gewölbteu Augen mit breiten, wulstartigen Schläfen. Halssch.

1) KaItenbach, Pflanzenfeinde p. 544 . 
wenig dicht aber ziemlich grob punktirt, vom Seitenhöcker nach den stumpfwinkeligen V orderecken stark verengt: der Seitenhöcker gross, stumpf, mit kleiner, leicht abgerundeter Spitze. Fld. stark und tief punktirt, der umgeschlagene Rand mit einer unregelmässigen, sehr feinen Punktreihe.

Die Färbung der Art ändert ab:

a. Seitenrand der Fld. an den Schultern gelbroth.

b. Schildchen schwarz.

c. Wie b, aber auch der Kopf ist vom Vorderrande der Augen an nach hinten schwarz gefärbt wie bei flavicollis. Ein Uebergangsstück zu dieser Var. frontalis S u ffr. erwälnt H. K ellner Berl. Zeitschr. 1873. 211; bei ihm ist nur die Mitte des Scheitels schwarz.

Nach Suffrian auf Populus nigra. Selten, aber wohl vielfach übersehen.

2. Z. subspimosa: Nigra, antennis articulis quatuor primis, capite, thorace pedibusque rufis; prothorace tuberculo laterali obtusiusculo elytrisque fortiter crebre punctalis; temporibus parvis. - Long. $3 \mathrm{~mm}$.

Fabr. Spec. Ins. 55. 33. (Crioceris). - Kunze Neue Schrift. Ges. Halle II. 4. 75. 1. - Suffr. Stett. Zeit. 1840. 98. 1. - Lac. Mon. 238. 3. - Redtb. Faun. A. II. 444. - Seidl. F. balt. 502 .

Var. a. Mesosterno rufo.

Var. b. Elytris sub humeris rufo-flavis.

Schwarz, die vier ersten Fühlerglieder, Kopf, Halssch., Vorderbrust und Beine roth. Kopf wenig dicht, ziemlich stark punktirt, mit deutlicher glatter Längslinie auf der Stirn, hinter den grossen, stark vorspringend-gewölbten Augen schnell verengt, mit sehr schmalen oder undeutlichen Schläfen. Halssch. dicht punktirt, vom Seitenhöcker nach den stumpfwinkeligen Vorderecken stark, gradlinig verengt, der Seitenhöcker sehr stumpf, seine Spitze breit, abgerundet. Fld. dicht und stark punktirt, ihr umgeschlagener Rand mit einer dichten, starken Punktreihe.

Zuweilen (Var. a.) ist auch die Mittelbrust oder (Var. b.) der Seitenrand der Fld. an den Schultern roth oder rothgelb, in letzterem Falle sind die Fühler oft einfarbig gelblich.

Auf Weiden-, Haselnuss-, besonders aber Pappelgebüschen bäufig im ganzen Gebiete.

3. W. Tumneri: Subelongata, rufo-testacea, meso-et metasterno ab domineque nigris; prothorace tuberculo laterali obtuso crebre minus 
fortiler punctato, angulis anticis subrectis, elytris fortiter crebie punctatis, temporibus magnis. - Long. $3,5 \mathrm{~mm}$.

Power Zoologist 1863. 8735. - Rye Ent. Annual. 1864. 70. t. 1. f. 8 .

Z. rufotestacea Kraatz Berl. Zeit. 1571. 162; 1. c. 1873. 214: 1. c. 1874. 446. - Redtb. Faun. A. II. 445.

Von gestreckterer Gestalt als die übrigen Arten, röthlichgelbbraun, Kopf und Halssch. meist stärker roth gefärbt; die Mittelund Hinterbrust, sowie der Bauch schwarz. Kopf breit, vorn zerstreut, hinten dichter punktirt, hinter den stark gewölbten Augen zuerst schwächer, dann plötzlich verengt, die Schläfen gross aber weniger wulstig wie bei scutellaris. Halssch. dicht und tief punktirt mit sehr schmaler, vor dem Hinterrande meist deutlich erhabener glatter Längslinie und einem leichten Quereindrucke, der sich ungefähr von der Mitte des Hinterrandes jederseits schief nach dem Seitenhöcker hinzieht. Letzterer tritt vorn und hinten scharf, winkelig aus dem Seitenrande heraus und wird innen durch einen Eindruck begrenzt; seine Spitze ist breit, abgerundet. Die Seiten des Halssch. sind nach den Vorderecken hin wenig verengt, diese selbst erscheinen deshalb fast rechtwinkelig. Fld. dicht und stark punktirt, ihr umgeschlagener Seitenrand mit einer feinen, oft undeutlichen Punktreihe.

Bei Gilgenburg in Ostpreussen von H. Kramer entdeckt; Thüringer Wald (Kellner). Zahlreich in England und Schottland (Sharp).

Die Art ist von Paykull, Faun. Suec. II. 79, - Suffrian Stett. Zeit. 1846. 153, - Seidl. F. balt. 502 für eine Varietät von subspinosa angesehen worden, jedoch durch die Bildung des Kopfes und Halsschildes sehr verschieden.

4. Z. favicollis: Nigra, antemis articulis quatuor primis, capite antice, prothorace pedibusque flavis vel rufo-flavis, femoribus posticis nigricantibus; prothorace tuberculo laterali spiniformi parce jrofunde punctato, elytris parce fortiter punctatis, temporibus magnis. - Long. $2,5-3,5 \mathrm{~mm}$.

Marsh. Ent. Brit. I. 217. 8 (Auchenia). - Kunze Neue Schrift. Ges. Halle II. 4. 75. - Lac. Mon. 239. 4. - Seidl. F, balt. 503 .

Var. a. australis. Femoribus posticis rufo-flavis.

Z. flavicollis Redtb. Faun. A. II. 444.

$\mathrm{V}$ ar. b. Elytris sub humeris rufo-flavis.

Eine durch den spitzen Seitenhöcker des Halsschildes leicht kenntliche, gedrungene Art; schwarz, die ersten vier Fühlerglieder, der Kopf vor den Augen, das Halsseh, und die Beine, mit Ausnahme 
der schwärzlichen Hinterschenkel, gelb oder rothgelb. Kopf mässig stark und dicht punktirt mit breiter, glatter Mittellinie über Stirn und Scheitel, hinter den Augen zuerst schwach, dann plötzlich verengt, die Schläfen gross, wenig stärker als bei der Vorigen. Halssch. zerstreut, tief punktirt, eine meist deutliche Längslinie über die Mitte glatt. Der Seitenhöcker tritt hinten gerundet-rechtwinkelig, vorn stumpfwinkelig heraus und hat eine gewöhnlich scharfe, feine Spitze; vor demselben ist der Seitenrand bis zu den rechtwinkeligen Vorderecken grade, kaum verschmälert. Fld. zerstreut, stark punktirt, ihr umgeschlagener Seitenrand mit einer Reihe sehr feiner, weit von einander entfernter Punkte.

Farbenabänderungen sind:

a. Alle Beine einfarbig rothgelb.

b. Seitenrand der Fld. an den Schultern oder ganz rothgelb, in letzterem Falle sind auch die Fühler einfarbig, mehr oder weniger hell röthlich.

Auf Pappeln, zumal Populus tremula im ganzen Gebiete, in Gebirgsgegenden bis $4000^{\prime}$ hoch bäufig; im Süden scheint nur die Var, australis vorzukommen, welche bei uns äusserst selten ist. (Meissen, Moritz).

\section{Lema.}

Fabricius, Supplement. Ent. Syst. 90.

Oculi emarginati.

Elytra punctato-striata.

Scutellum apice truncatum.

Unguiculi tarsorum mutici, connati.

Kopf so lang als breit oder länger, mit einem kurzen, tiefen Eindrucke zwischen den Augen, welcher etwas höher als die Fühlerwurzel liegt und sich nach vorn und hinten in je zwei divergirende Furchen verlängert. Die vorderen begrenzen das fast dreieckige Kopfschild, die hinteren theilen sich; der eine Zweig läuft quer zum Vorderrande der Augen, der andere setzt sich bis zur Einschnürung hinter den Augen fort. Meist ist der Scheitel durch eine vorn und hinten abgekürzte Längsfurche halbirt. Oberlippe ziemlich gross, quer, vorn leicht ausgerandet und abgestutzt, von den starken, an der Spitze gespaltenen Mandibeln etwas überragt. Augen gross, am Innenrande mehr oder weniger tief ausgerandet. Fühler nach der Spitze allmählich, aber schwach verdickt, Glied zwei das kürzeste und, wie das erste, sparsam, die übrigen dichter behaart, Glied fünf bis elf gestreckt, das achte etwas kleiner, als die einschliessenden. 
Halsschild hinter der Mitte eingeschnürt, sparsam punktirt, mit ein bis drei Längsreihen von Punkten über die Scheibe. Schildchen hinten abgestutzt oder schwach ausgerandet. Flügeldecken mässig gewölbt, mit zehn regelmässigen Punktstreifen, welche sich vor der Spitze vertiefen, und einem abgekürzten an der Naht am Schildchen; sie sind am Innenrande der Schulterbeule und am Aussenrande hinter derselben eingedrückt und besitzen eine verschieden starke Quervertiefung jederseits hinter dem Schildchen. Unterseite sparsam kurz behaart, der erste Bauchring länger als einer der folgenden. Beine ziemlich schlank; das erste Tarsenglied lang dreieckig, das zweite kürzer, das vierte ist bis zur Hälfte in die Lappen des dritten eingelegt; die Klauen stehen enge aneinander und sind bis zur Mitte verwachsen.

Der Körper der europäischen Arten ist glänzend, blau oder grünlichblau gefärbt, zuweilen mit rothem Halsschilde. Die schwarzen Varietäten sind dadurch auffällig, dass sie den Glanz theilweise oder ganz verlieren.

Die Larven haben sechs mässig lange Beine, sind plump, gewölbt, hinter der Mitte am höchsten und breitesten, mit zwölf Segmenten und neun Stigmenpaaren. Ihre Fühler sehr kurz, dreigliederig wie die Maxillartaster; die Lippentaster zweigliederig. Der Körper ist feucht, und dadurch sehr ausgezeichnet, dass sich der After auf der Oberseite des letzten Segmentes befindet und nach vorn öffnet, so dass der reicbliche Koth auf dem Rücken allmählich vorwärts gestossen wird und zuletzt den ganzen Körper bis zum Kopfe bedeckt. Zur Verpuppung kriecht die Larve in die Erde, wobei sie den Kothüberzug verliert, und klebt sich einen festen Cocon aus Erdpartikelchen zusammen, in welchem ihre Verwandlung vor sich geht. Aus demselben kommt nach 14 Tagen bis drei Wochen der vollständig ausgefärbte Käfer.

Ueber die Larve von $L$. cyanella berichten Cornelius (Stett. Zeit. 1859. 44) und Rupertsberger (Verhandl. zool. bot. Ver. Wien 1872. 20). Sie lebt auf Cirsium arvense und ist unter der schwarzen Kothdecke fast rein weiss, der Kopf klein, rundlich, nach vorn zugespitzt, pechschwarz, glänzend; das Maul braun, die Taster weiss mit schwärzlicher Spitze. Nacken, Stirn und der mit tiefer Mittellinie versehene Scheitel wenig dicht, flach punktirt; die drei Thoraxringe mit feinen zerstreuten Punkthöckerchen besetzt. Abdominalringe glatt und glänzend, Tracheenkegelchen bräunlich. Die Puppe ist 2 Lin. lang, an der breitesten Stelle halb so breit, gelblichweiss, kahl, hinten mit zwei sehr kurzen, am Ende braun gefärbten Spitzen. 
Die Larven von L. lichenis und melanopa, die nach Cornelius (Stett. Zeit. 1850 p. 20) einander sehr ähnlich sein sollen, bewohnen Gräser und benagen deren Blätter in graden Längsstreifen. Kaltenbach fand sie auf dem Hafer (Pflanzenfeinde p. 755), der Gerste (1. c. 733) und dem Weizen (738). Sie sind 1/1/2 Lin. lang, gelblich, mit schwarzem, glänzendem Kopfe, welcher im Nacken einen gelben, mit schwarzen Pünktchen bestreuten Saum besitzt. Prothorax schwärzlich mit breiter gelber Mittellinie und einem flachen Quereindrucke an den Vorderecken, in dem sich schwache Erhöhungen befinden. Bauchrand mit schwarzen Punkten besetzt, Beine gelb, Klauen und Gelenke schwarz. - Puppe goldgelb, glänzend, Augen und Mandibeln dunkelbraun, die Stirn mit wulstigen Erhöhungen und tiefen Eindrücken; Hinterrücken mit breiter Mittelrinne, die Ränder der einzelnen Ringe in stumpfe Spitzen ausgezogen.

1. L. cyanellax: Brevior, virirli-coerulea, antennis tarsisque nigris; prothorace pone medium constricto, mims crebre punctato, linea dorsali subelevata laevi, elytris subtiliter punctato-striatis. - Long. $4-5,5 \mathrm{~mm}$.

Linn. Syst. Nat. ed. X. 376 (Chrysomela). - Fabr. Syst. El. I. 475. - Panz. Ent. Germ. I. 168; Faun. Germ. 71. 1 (Lema). Waterh. Trans. ent. Soc. 1861. 26.

Lema cyanella femina Gyllh. Ins. Suee. III. 639.

L. puncticollis Curt. Brit. Ent. VII. t. 323. - Redtb. Faun. A. II. 445. - Seidl. F. balt. 503.

L. rugicollis Suffr. Stett. Zeit. 1841. 97. - Lac. Mon. 362. Var. a. Supra coerulea, violacea, nigro-violacea vel nigra.

Weit grösser und breiter als die übrigen Arten, besonders die Fld. stark glänzend, grünlichblau, die Fühler, mit Ausnahme des ersten Gliedes, die Tarsen und zuweilen auch die Spitze der Schienen schwarz. Kopf mässig dicht und stark punktirt mit grossen, hochgewölbten Augen, hinter diesen sehr tief eingeschnürt, die Stirn in der Mitte leicht beulenartig gewölbt mit einer feinen Längsfurche. Halssch. so lang als die grösste Breite an den Vorderecken, etwas hinter dem Vorderrande, beträgt, von hier bis zur schmalsten Stelle in der Mitte stark, fast gradlinig verengt, hinterwärts wieder etwas verbreitert; die Oberfläche nur mässig gewölbt, vor dem Hinterrande mit einer feinen, erhabenen Querlinie, welche an den Seiten stark der Mitte des Halsschildes zugebogen ist. Der Raum zwischen dieser Linie und dem doppelt gerandeten Grunde ist glatt; vor der Querlinie zeigt sich eine breite, im Grunde stark punktirte Quervertiefung, die sich nach den Seiten hin erweitert und vertieft, in der Mitte des Seitenrandes endlich grubenförmig wird und die 
starke Einschnürung desselben veranlasst. Die Scheibe ist wenig dicht, stark aber unregelmässig punktirt, die Punkte drängen sich auf der Mitte derselben in zwei vorn divergirende Längseindrücke zusammen, zwischen denen sich eine fast glatte, kielartige Längslinie emporhebt. Fld. fein punktirt-gestreift, die Streifen am Grunde und besonders vor der Spitze stärker vertieft, ihre Zwischenräume breit und flach, äusserst fein quergerunzelt.

Die Farbe der Oberseite ist zuweilen himmelblau, violett, schwarzviolett oder schwarz.

Auf Wiesen und Aeckern nicht selten an Cirsium-Arten; besonders an $C$. arvensé.

Dass Panzer die vorliegende Art und nicht lichenis abbildet, geht aus der Grössenangabe $(5,5 \mathrm{~mm})$ und der charakteristischen Form des Halsschildes seiner Abbildung hervor.

2. I. Erichsomi: Oblonga, viridi-coerulea, antennis, tibiis tarsisque nigris; prothorace convexo, ante basin minus fortiter constricto, striciura dense subtiliter punctato, disco creberrime subtilissimeque punctulalo punctis majoribus triseriatis; elytris subtiliter punctato-striatis. Long. $4-4,5 \mathrm{~mm}$.

Suffr. Stett. Zeit. 1841. 104. 13. - Lac. Mon. 366. - Redtb. Faun. A. II. 445. - Seidl. F, balt. 503.

Var. a. Supra virescenti-nigra.

V a r. b Nigra, thoracis elyirorunque punctis subtilioribus, illis vix seriatis.

L. Erichsoni var. Lipperti Gredl. Käf. Tirol. 405.

Der Vorigen am ähnlichsten, aber von ihr wie auch von lichenis durch die auffälig kurze Stirn, deren Furchen sich zwischen den Augen nicht winkelig treffen, sondern eine nach vorn gerundete Querlinie bilden und die Form des Halssch. sehr verschieden. Mässig breit, stark glänzend, grünlich blau, Fühler mit Ausnahme der vier ersten Glieder, Schienen und Tarsen schwarz. Kopf dicht und fein punktirt, die Stirn quer, durchaus eben, mit meist ganzer Mittelrinne, die sich über den Scheitel fortsetzt. Halssch. länger als breit, hochgewölbt, die Seiten leicht gerundet, vor dem Hinterrande mit einem breiten, tiefen Quereindrucke, welcher sich nach den Seiten hin merklich erweitert und verflacht und gleichmässig dicht und fein, schwach runzelig punktirt ist. Die Oberfläche äusserst dicht und fein, hinter den Vorderecken gröber und zerstreut punktirt, über den Rücken laufen drei ziemlich regelmässige Iängsreihen mässig starker Punkte. Fld. fein punktirt-gestreift, Zwischenräume der flachen Streifen gleichbreit, eben, scharf begrenzt, der zweite mit einer weitläufigen, sehr feinen Punktreihe, die übrigen vereinzelt punktulirt. Penis vorn scharf zugespitzt. 
Nicht selten ist die Oberseite grünlich-schwarz oder tiefschwarz mit grünlichem Seitenrande. Die Var. Lipperti Gredl. dürfte, da sie kaum gereihte Punkte auf den Fld. besitzen soll, als Missbildung aufzufassen sein.

Auf Wiesen im ganzen Gebiete, aber nicht häufig.

3. C. septentrionis: Elongata, satwate coerulea, prothorace atrocoeruleo, convexo, ante basin minus fortifer constricto, strictura parce punctato, disco subtilissime punctulato punctis majoribus triseriatis, elytris fortiter punctato-striatis. - Long. 3,5-4 mm.

Weis e Deutsch. Zeit. 1880. III. 158.

L. Erichsoni Thoms. Skand. Col. VIII. 141.

Var. a. Supra viridi-vel nigro-coerulea.

Bedeutend schlanker als die vorige und die folgende Art, beinahe so gestreckt als melanopa, himmelblau, das Halsschild dunkler, fast schwarz, der Kopf gewöhnlich grünlich. Letzterer hat dieselbe Form wie bei Erichsoni, ist aber etwas weitläufiger, stärker und tiefer punktirt. Das Halssch., sehr ähnlich dem der vorigen Art, ist vor dem Hinterrande deutlich schmaler und tiefer eingeschnürt, die Einschnürung ist wenig dicht mit tiefen, verschieden grossen Punkten besetzt, an den Seiten, wo sie sich erweitert und verflacht, feiner, dichter und gleichmässiger punktirt. Die Oberfläche wenig dicht, kaum sichtbar punktirt, stark glänzend, mit einigen fast in kurzen Längsreiben stebenden grösseren Punkten hinter den Vorderecken und eben solchen über die Mitte der Scheibe, welche in drei Längsreihen geordnet sind. Fld. nur mässig glänzend, grob punktirt-gestreift, die Streifen tief, ihre Zwischenräume sehr schmal, von den Punkten der Streifen angegriffen und schlecht begrenzt, deutlich gewölbt, mit einzelnen sehr feinen Pünktchen. Penis vorn abgerundet.

Die tief himmelblaue Farbe der Fld,, die bei keiner der übrigen Arten sich findet und meist schon allein genügt, die vorliegende sicher zu erkennen, erhält höchst selten einen grünlichen oder schwarzen Schimmer.

Bei Berlin, besonders am Müggelsee auf Nasturtium-Arten nicht selten und jedenfalls in Norddeutschland weiter verbreitet, da sie anch nach Thomson im südlichen und mittleren Schweden vorkommt.

4. L. Vichemis: Oblonga, obscure viridi-coerulea, antennis, tibiis phus minusve tarsisque nigris; prothorace convexo, ante basin fortiter constricto, strichura sublaevi lateribus striolata, disco punctis biseriatis, elytris fortiter punctato-striatis. - Long. 3-4 $\mathrm{mm}$. 
Griateris eyanella-Voet. Cat. Syst. II. 42. t. 3\%. f. 27.

Lema cyanella $\hat{\odot}$ Gyllh. Ins. Suec. III. 639.

J. cyanella Suffr. Stett. Zeit. 1841. 102. 1\%. - Lacord. Mon. 363.

- Redtb. Faun. A. II. 445. - Seidl. F. balt. 503.

L. gallaeciana Heyd. Ent. Reis. Span. 164.

Var. a. Supra coerulea vel violacea.

Var. b. Supra nigro-cuprea vel nigra.

Crioceris obscura Steph. III. Brit. IV. 281.

V a r. c. Elongatula, elytris subtiliter punctato-striatis.

Kleiner und etwas schlanker als Erichsoni, mässig glänzend, dunkel grünlichblau, die Fühler mit Ausnahme des ersten Gliedes, die Schienen theilweise oder ganz und die Tarsen schwarz. Kopf sehr fein punktirt mit einigen eingemengten grösseren Punkten. hinter den gewölbten Augen tief eingeschnürt, die Stirn gleichmässig gewölbt, mit einem tiefen, länglichen Grübchen in der Mitte. Halssch. länger als breit, hoch gewölbt, vor dem Hinterrande mit einer breiten, tiefen Einschnürung, welche rerloschen runzelig punktirt ist und fast glatt erscheint, an den Seiten sich grubenförmig verbreitert und vertieft und hier stark punktirt und mit kurzen Längsstricheln versehen ist. Die Oberfläche hinter den Vorderecken zerstreut punktirt, auf der Mitte treten zwei parallele Längsreihen von Punkten hervor. Fld. stark punktirt-gestreift, der zweite und dritte, sowie der vierte und fünfte Streifen einander genähert, der zweite und vierte Zwischenraum dadurch breiter als die übrigen, oft leicht gewölbt. Die Zwischenräume sind glatt, mit wenigen feinen Pünktchen besetzt, die zwischen der abgekürzten Punktreihe und der Naht, auf dem zweiten, vierten und achten Zwischenraume zahlreicher und $z u$ weitläufigen Reihen geordnet sind.

Stücke mit himmelblauer oder violetter Oberseite und oft grünlichem Thorax scheinen seltener, solche mit kupferig-schwarzer oder schwarzer Oberseite zahlreich vorzukommen.

Die gestreckte Form (Var. c.) sondert sich wenig scharf ron der gewöhnlichen ab; sie ist etwas schmaler, feiner punktirt und glänzender als diese.

Auf Wiesen häufig.

Die Beschreibung der L. yallaeciana Heyd. passt vollkommen auf dunkle, auch bei uns vorkommende Stücke dieser Art, deren 2. und 4. Zwischenraum erhabener als die anderen sind. Die Angabe: "der erste Punktstreifen scheint an der Basis eine Doppelreihe zu bilden" ist wohl dadurch entstanden, dass H. v. Heyden die abgekürzte Punktreihe zum ersten Streifen zählte. 
5. L. flwvipes: Oblonga, viridi-coerulea, antennis nigris, pedibus rufo-flavis, prothorace elongatulo, convexo, ante basin fortiter constricto, lateribus postice stricturaque crebre punctatis, dorso sublaevi punctis uniseriatis, elytris sat fortiter punctato-striatis. - Long. $3,5 \mathrm{~mm}$.

Suffr. Stett. Zeit. 1841. 100. - Lac. Mon. 367. - Redtb. Faun. A. II. 446.

Kürzer und in den Fld. paralleler als lichenis, grünlichblau, stark glänzend, die Fühler einfarbig schwarz, die Beine röthlichgelb, ihre Tarsen angedunkelt. Kopf nicht dicht aber fein punktirt, mit ebener Stirn und einem kurzen Längsgrübchen auf der Mitte des Scheitels, um welches einige stärkere Punkte unregelmässig gestellt sind. Halssch. länger als breit, vor dem Hinterrande quer eingeschnürt, die Seiten von den Vorderecken bis zur Einschnürung allmählich verengt. Letztere ist mit einer dichten und feinen Punktirung versehen, welche sich an den Seiten weit über die Mitte nach vorn ausdehnt und auf dem gewölbten Rücken einen länglichen Mittelfleck frei lässt, der mit einer Längsreihe von Punkten besetzt ist. Ebenso bleibt am Vorderrande ein breiter Querstreifen glatt, auf welchem sich einige zerstreute grössere Punkte befinden. Fld. stark punktirt-gestreift, der zweite Zwischenraum breit, mit einer weitläufigen feinen Punktreihe; die übrigen schmal, glatt, nur der siebente bis neunte in der Mitte etwas erweitert und mit je drei feinen Pünktchen besetzt.

Auf trockenen Grasplätzen, selten.

6. I. melanopax ${ }^{1}$ : Elongata, viridi-cyanea, prothorace pedibusque rufis, antennis, apice tibiarm tarsisque nigris, prothorace convexo, ante basin leviter constricto, strictura dense subtiliter punctato, disco antice parce punctato medio punctis triseriatis, elytris punctato-striatis. Long. 4-4,5 $\mathrm{mm}$.

Linn. Syst. Nat. ed. X. 376 (Chrysomela). - Fabr. Syst. EI. I. 476. - Suffr. Stett. Zeit. 1841. 101. - Lac. Mon. 393. Redtb. Faun. A. II. 446. - Seidl. F. balt. 503.

Var. a. Elytris coeruleis.

Var. b. Elytris aeneis.

Var. c. Elytris nigris, subtiliter punctato-striatis.

L. cyanella var. atrata Waltl. Reis. Span. 81.

L. Duftschmidi Redtb. Faun. A. II. 446.

Langgestreckt, grünlichblau, Halssch. und Beine roth, letztere etwas gelblicher, die Fühler, Spitzen der Schienen und die Tarsen

1) L. Hoffmannseggi L ac. Mon. 396. 97 aus Portugal, durch ganz schwarze Beine verschieden, ist wahrscheinlich eine blosse Varietät dieser Art.

VI. 
schwarz. Kopf oft schwarzblau mit kurzer, flacher Stirn und vorn bogenförmigen Stirnfurchen wie bei Erichsoni. Fühler gestreckt, Glied 2 so lang als breit, 3 und 4 fast, 5 reichlich doppelt so lang als breit, jedes einzelne am Grunde schmal und bis zur Spitze ganz. allmählich verbreitert. Halssch. am Vorder- und Hinterrande meist schwarz gesäumt, länger als breit, hoch gewïlbt, die Seiten bald schwächer, bald stärker gerundet; vor dem Hinterrande mit einer breiten, tiefen Einschnürung, die sich natch den Seiten hin erweitert und verflacht und gleichmässig dicht und fein punktirt ist. Die Oberfäche hinter den Vorderecken zerstreut punktirt mit drei Längsreihen mässig starker Punkte über die Mitte. Fld. ziemlich stark punktirt-gestreift, die Zwischenräume beim Männchen schnal, oft leicht erhaben, beim Weibchen breiter, flach, der zweite nit einer ganzen, der vierte und sechste mit einer hinten algekürzten feinen Punktreihe.

Die Farbe der Flügeldecken ändert $a b$ :

a. Rein blau.

b. Grün erzfarbig.

c. Schwarz, zuweilen grün oder kupferig angeflogen, der umgeschlagene Seitenrand normal gefärbt. Der Kopf ist entweder dunkelgrün oder schwarz und die Fld. pflegen fein punktirt-gestreift, oft matt zu sein. Hierher gehört sicber atrata Waltl, und Duftschmidi Redtb.

Ueberall häufig.

๑. L. mfocyanea: Ublonga, cyaner, prothorace predibusque rufis. antemis brevioribus tarsisque niyris, elytris fortiter punclato-striatis. Long. $4 \mathrm{~mm}$.

L. rufocyanea Suffr. Stett. Zeit. 1847. 99.

L. cyanipennis Duft. Faun. A. III. 243. 8. - Küst. Käf. Eur. V. 98.

L. melanopa var. Lac. Mon. 394.

Var. a. Supra viridi- vel nitgro-coerulen.

Der rorigen Art tänschend ähnlich, indessen durch kürzere, gedrungene Gestalt und die Fühlerbildung verschieden. Die Fld. sind bei gleicher Breite stets dentlich kürzer als bei kleinen süddeutschen Stücken der melanopa, durchgängig stärker und tiefer punktirtgestreift, die Zwischenräume schärfer begrenzt und dentlich herrorgehoben. Fühler verhältnissmässig kurz und dick, Glied 2 fast doppelt so breit als lang, 3 und 4 wenig, 5 um die Hälfte länger als breit, die Glieder, vom dritten angefangen, am Grunde schneller rerbreitert und daher stärker wie bei dwerwandten Art. Kopf 
und Halssch. bieten weder durch Bildung noch Punktirung den geringsten Unterschied dar.

Sehr selten. Wien (Duftschmid), Erlangen (Küster), Schweiz, Tyrol (Kratz).

Wenn Suffrian 1. c. von seinem Stücke sagt: „es hat mit melanopa ausser der Färbung gar nichts gemein" und: „es scheint von cyanella (lichenis) kanm anders als dureh die rothe Farbe von Halsschild, Schenkeln und Schienen abzuweichen", so sind diese Angaben nur geeignet, jeden in der Erkennung der Art irre zu leiten, der lichenis durch die grubenförmige Einschnürung des Halsschildes von den übrigen Arten sicher unterseheiden gelernt hat. Küster's Beschreibung verdient schon durch die Angabe, dass das Schildchen abgerundet, dreieckig sein soll, wenig Vertranen.

\section{Crioceris.}

Ge of froy, Hist. Ins. Par. I. 237.

\section{Oculi emarginati.}

Scutellum apice leviler vel haud truncatum.

Unguiculi tarsorum mutici, haud connati.

Von der Gattung Lema hauptsächlich durch die nicht verwachsenen und deshalb weiter von einander abstehenden Klauen, weniger durch die Form des Schildchens zu unterscheiden. Letzteres ist bei den Arten der ersten Rotte schmal, bedeutend länger als breit und an der Spitze mehr oder weniger deutlich, wenn auch selten so stark wie bei Lema abgestutzt; bei denen der zweiten Rotte etwa so lang als breit, hinten abgerundet oder leicht zugespitzt.

Die Käfer leben gesellig auf Liliaceen und Asparageen und richten im Verein mit ihren gefrässigen Larven zuweilen grosse Verheerungen an den Blättern und jungen Trieben der Pflanzen an. Die Larven sind im Körperbau denen der vorigen Gattung sehr ähnlich und schon vor Linné bekannt und abgebildet worden. Die von asparagi sind nach Letzner (Arbeit. Schles. Ges. Breslau 1857 p. 133 - 136) olivenfarben, äusserst fein und kurz zerstreut bräunlich behaart, 4 Lin. lang; Kopf mit 6 Ocellen, wie die Beine schwarz. Auf der Mitte der Bauchsegmente stehen dicht neben einander zwei kleine Tuberkeln und nach aussen jederseits eine böhere. Sie dienen der Larve zunächst beim Gehen wie die Afterfüsse der Raupe (nur die des ersten Segmentes sind kürzer und berühren beim Kriechen den Boden nicht); aber auch zum Festhalten, indem das Thier die dünnen Spargelblättchen zwischen dieselben einklemmt und, wenn es zu fallen fürchtet, den Anus um das Blatt herumbeu- 
gend, gegen eins dieser Tuberkelpaare andrückt. Der Anus wird ausserdem als Nachschieber gebraucht und beim Kriechen bald rechts, bald links son der eingeschlagenen Richtung nach auswärts geschleudert. In der Erregung bringt die Larve einen grünlichen Saft aus den Munde, der schnell erhärtet. - Puppe $2-2 !$ Lin. lang, blassgelb, Abdomen dunkler. Die Eier sind ', Lin. lang, grau, gelblich durchschimmernd, und werden einzeln durch einen schwarzen Kitt zu 4 bis 5 an einem Blatte in einer Reihe so angeklebt, dass sie senkrecht darauf stehen.

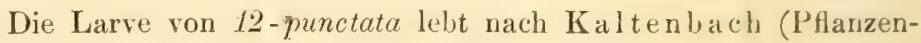
feinde 721) bis zu ihrer Verpuppung stets einzeln in den frühreifen Beeren des Spargels, die von tibialis nach H. v. Heyden (Jahresbericht. naturf. Ges. Graubündten 1863. 44.) auf der Lnterseite der Blätter von Lilium martayon. Sie wird beinahe $4 \mathrm{Lin}$. lang und ist glänzend, hellgrau, mit schwarzem Kopfe. Die verhältnissmässig kleine Puppe hat eine schmutzig blassgelbe Farbe, der Hinterleib ist röthlich.

Nimmt man die Käfer in die Hand, so bringen sie einen Zirpton hervor, welcher bei $C r$. lilii ziemlich stark ist und ihr den Namen Lilienhähnchen eingetragen hat. Sie besitzen zur Tonbildung auf dem Rücken des Aftersegmentes in der Mitte des Vorderrandes eine, bei den verschiedenen Arten verschieden geformte Zirpleiste, welche aus zwei, stets durch eine Mittelrinne geschiedenen, aussen oft von einem Rande dichter, seidenglänzender Härchen umgebenen länglichen oder queren Erhöhungen besteht und äusserst dicht mit sehr feinen Querrippen besetzt ist, zwischen denen bei einzelnen Arten einige stärker hervortreten. Von der Grösse dieser Zirpleiste und der Stärke der Rippen ist die Kraft des Tones abhängig, der dadurch entsteht, dass die Leiste an der Unterseite der Flügeldecken reibt, welche an der Naht vor der Spitze äusserst dicht und fein gerunzelt oder gestrichelt sind. Bei $C r$. lilii, merdigera (und alpina?) nimmt die Zirpleiste die Hälfte, bei den übrigen und den LemaArten etwa ein Viertel von der Länge des Segmentes ein, nur bei macilenta kaum ein Fünftel. Die stärksten Rippen besitzen lilii und 5-punctata.

\section{Erste Rotte.}

Halssch. in der Mitte tief eingeschnürt, fast herzfömig, sein Vorderrand wulstig. Stirn rom Halse deutlich abgeschnürt. Seitenstücke der Hinterbrust kahl, glatt oder mit zerstreuten Punkten. Hinterbrust glatt. Auf Liliaceen. 
1. Cr. lilii $^{1}$ ): Oblongo-parallela, nigra, prothorace elytrisque miniatis; capite breviusculo, elytris subtiliter punctato-striatis. - Long. 6-8 mm. Attelabus lilii Sicop. Entom. Carn. 36. 112.

Chrysomela merdigera var. Linn. Faun. Suec. 171. 563.

Crioceris merdigera Fabr. Syst. Ent. 120; Ent. Syst. II. 6. n. 19; Syst. El. I. 472. - Panz. Faun. Germ. 45. 2. — Lac. Mon. 575. 31. - Suffr. Stett. Zeit. 1846. 155. - Redtb. Faun. A. II. 446. - Seidl. F. balt. 503. - Suffr. Stett. Zeit. 1841. 24. (Lema.)

Crioc. liliorum Thoms. Skand. Col. VIII. 138.

Mässig langgestreckt, die Fld. hinter den Schultern wenig erweitert, ihre Seiten ziemlich parallel. Schwarz, Halssch. und Fld. zinnoberroth, nach dem Tode gelbroth. Kopf mit den Augen breiter als lang, die beiden äusseren Stirnfurchen bilden mit der Halsabschnürung ein gleichschenkliges Dreieck, dessen Grundlinie am Halse liegt, die zwei Stirnhöcker sehr wenig gewölbt. Halssch. vor dem Hinterrande mit einem weiten und flachen Quereindrucke, welcher sich an den Seiten etwas vertieft, nach vorn krümmt und in der Mitte mit der tiefen Einschnürung verbindet; die Scheibe gewölbt, hinter dem Vorderrande jederseits schwach quer vertieft, einzeln punktirt, mit einer ziemlich regelmässigen Punktreihe auf der Mittellinie. Fld. fein punktirt-gestreift, die Punktstreifen von der Mitte nach hinten sehr fein, vor der Spitze, wie der ganze zehnte Streifen, stark vertieft und grob punktirt. Zwischenräume eben, der erste und der Aussenrand mit einer sehr feinen Punktreihe.

Auf Lilium-Arten im ganzen Gebiete häufig, im nördlichen Theile besonders auf Lil. candidum in Gärten. Mai, Juni.

1) Dieser Art nahe verwandt; jedoch weit grösser und stärker punktirt ist:

Cr. stercoraria. Linn. (Syst. Nat. ed. XII. 600.) Oblongo-parallela, prothorace fortiter constricto elytrisque rubris, illis fovealato-punctatis, lateribus parce fortiter rugosis. - Long. $\mathrm{S}-9 \mathrm{~mm}$.

Var. laeviuseula: Elytris subtiliter punctato-striatis, punctis remotis.

Auf den Fld. sind die normalen zehn Punktreihen durch schwarze Punkte bezeichnet, von denen einige, ohne bestimmte Ordnung, vertieft sind und in weiten, zuweilen gemeinschaftlichen Gruben stehen, so dass die Fld. unregelmässig punktirt erscheinen. Nach den Seiten hin verbinden sich die Gruben oft zu Quervertiefungen, ihre Ränder zu breiten, darmartigen Runzeln. Sehr auffällig ist die Var. laeviuscula. Bei ihr treten die Reihen schwarzer Pünktchen auf den Fld. deutlich und regelmässig hervor, etwa der dritte bis achte Punkt ist eingestochen, Gruben und Runzeln fehlen fast ganz oder ganz. - Süditalien, Südspanien, die Var. in Andalusien. 
2. Cr. meraligera $\left.{ }^{1}\right):$ Oblonga, subtus nigra, supra, abdominis apice pedibusque miniatis, femorum basi, gemubus tarsisque vigris, capite longiusculo, fronte bituberculato, elytris punctato-striatis. - Long. $6-7,5 \mathrm{~mm}$.

Linn. Syst. Nat. ed. X. 375; Faun. Suec. 171. 563 (Chrysom.). F abr. Syst. Eleuth. I. 472. 9 (Lema).

Crioceris brunnea Fabr. Ent. Syst. I. 2. 6. 17. - Panz. Ent. Germ. I. 2. 167; Faun. Germ. 45. 1. - Lac. Mon. 576. - Suffr. Stett. Zeit. 1841. 38 (Lema); 1846.155. - Redtb. Faun. A. II. 446. Seidl. F. balt. 503 .

Var. a. Antennarum basi plus minusve rubra.

Crioceris rufipes Herbst Fïessl. Arch. IV. 67.

Chrysomela similis Brahm Ins. Kal. I. 79.

Var. b. Antennis rubris, articulis 2 primis subtus nigits.

Lema Suffriani Schmidt. Stett. Zeit. 1842. 27.

Var. c. Pedibus miniatis.

var. d. Capite nigro, fronte medio miniato.

Var. e. Eadem, prothorace basi nigro.

Etwas kleiner, in den Fld. hinten breiter und durchweg stärker punktirt als die vorige Art, an den grossentheils rothen Beinen leicht zu erkennen. Unterseite und Fühler schwarz, Glied 5 bis 7 zuweilen an der Spitze röthlich, die Oberseite, die Beine, mit Ausnahme der schwarzen Schenkelbasis, der Kniee und Tarsen, sowie die Spitze des Hinterleibes zinnoberroth, wenig dunkler wie bei lilii, nach dem Tode braunroth. Kopf mit den Augen so breit als lang

1) Nahe verwandt ist:

Cr. Faldermanni Guèr. (Icon. regn. anim. Ins. 264. L. cornuta Falderm. Nouv. Mém. Mose. V. 323. t. 12. f. 2). Oblonga, nigra, capite omnino, prothorace, elytris pedibusque miniatis, femorum basi tarsisque nigris; capite longiusculo, fronte fortiter bituberculata, elytris obsolete striatopunctatis. - Long. $7 \mathrm{~mm}$.

Kopf auch unterseits roth, Bauch schwarz, Stirnböcker schmaler und höher als bei merdigera, Halssch. sehr tief eingeschnürt (von allen Verwandten am tiefsten), seine rothe Färbung erreicht an den Seiten fast die Vorderhüften; Beine roth, Grund der Schenkel, mehr als ein Drittel ihrer Länge und die Tarsen schwarz. Fld. verloschen punktirt, die Punkte stehen nirgends in Streifen, mit Ausnahme der 10. Reihe, welche einen groben und tiefen Punktstreifen bildet.

Lacordaire lässt Falderm. Beschreibung unbeachtet und schreibt der Art einen rothen letzten Hinterleibsring zu. Sie ist dem hohen Kaukasus eigenthümlich; 2 Stücke, angeblich von Konstantinopel stammend, sah ich auch bei Dr. Kratz. 
oder etwas schmaler, die beiden äusseren Stirnfurchen bilden mit der Halsabschnürung ein gleichseitiges Dreieck, die Stirnhöcker sind länger und merklich höher als bei der Vorigen, ebenso ist die Mittellinie des Halssch. hier häufiger furchenartig vertieft.

Während von $C$. lilii Varietäten nicht bekannt sind, bietet die vorliegende Art nicht unbedeutende Farbenabänderungen einzelner Körpertheile dar:

a. (rufipes Hbst.). Fühler an der Wurzel roth, entweder einzelne der ersten vier Glieder oder alle an der Unterseite, oder Glied 1, seltener auch 2 und 3 ganz roth.

b. (Suffriani Schmidt). Fühler roth, die ersten zwei Glieder unterseits schwarz. Hierher gehört auch das von H. Strübing erwähnte Exemplar mit fast ganz rothen Fühlern (Stett. Zeit. 1846. 155).

c. Beine mit den Tarsen einfarbig roth.

d. Die Oberlippe oder der ganze Vorderkopf, oder der Kopf mit Ausnahme der Stirnhöcker und der Oberseite des Halses, oder endlich der ganze Kopf mit Ausnabme der Stirnhöcker schwarz.

e. (collaris Lac.). Kopf sehwarz, nur die Stirnhöcker roth, die hintere Hälfte des Halssch. schwarz gefärbt.

Das Roth der Hinterleibsspitze ist in seiner Ausdehnung sehr veränderlich. Bald nimmt esadas letzte Segment allein, theilweise oder ganz ein, bald die zwei oder drei letzten Ringe und auch die übrigen sind oft an den Seiten roth; zuletzt wird der Hinterleib und die Brust an den Seiten roth gefärbt, wenn L. abdominalis Villa Col. alt. Suppl. 63, welche zugleich theilweise rothe Fühler und Tarsen besitzen soll, wirklich hierher gerechnet werden darf.

Der Penis dieser Art ist auffällig dick, vorn allmählich in eine lange, scharfe Spitze ausgezogen, während der von lilii bei gleicher Länge kaum halb so breit ist und eine sehr kurze, drejeckige, kaum scharfe Spitze besitzt.

Auf Convallaria-Arten und Allium cepa, in den Gebirgen auf Lilium martagon häufig. Die Larve zerstörte nach Schilling Arb. Schles. Ges. 1833. 78. eine Zwiebelpflanzung.

Wenn Gredler Käf. Tirols 406 diese Art mit der vorigen vereinigt, nur aus Consequenz, weil dodecastigma mit 12 -punctata verbunden worden ist, so sind hier darüber weiter keine Worte zu verlieren. 


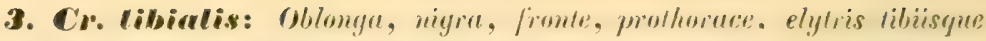

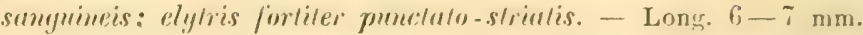

Lema tibialis Villa. Col. alt. Suppl. 69. - Weis. Deutsch. Z. 1880. III. 158.

L. alpina Redt. Faun. A. ed. 1. 517. 3; Faun. A. II. 447. (Crine.).

Von der Gestalt der vorigen Art, durch sehr grob punktirte Fld. und rothe Schienen aufällig verschieden. Schwarz, der Scheitel, das Halssch., die Fld. und Schienen hell blutroth, nach dem Tode röthlichbraun. Kopf und Halssch. wie bei merdigera, nur die Stirn etwas kürzer, die Fld. grob und tief punktirt gestreift, ihre Zwischenräume schmal, die der Naht am nächsten liegenden flach, die übrigen kielig-gewölbt, vor der Spitze verworren. Oefter sind je zwei Punktstreifen am Grunde der Fld. einander genähert. Unterseite stärker und dichter punktirt als bei den Verwandten, weniger glänzend, Schienen und Fühler merklich dicker, der aufgeworfene Seitenrand der Fld, bei merdigera hinter den Schultern stark verbreitert, ist hier fast gleichbreit.

Auf Lilium martagon im ganzen Alpenzuge.

\section{Zweite Rotte.}

Halssch. vor dem Hinterrande leicht eingeschnürt, cylindriscb, sein Vorderrand flach, Stirn und Hals gleichmässig gewölbt; Seitenstïcke der Hinterbrust äusserst dicht punktirt und behaart, Hinterbrust an den Seiten dicht punktirt. Auf Spargel-Arten.

4. Cr. duodecimpunctata: Oblongo-parallela. mufa, antemis, scutello, elytrorum puncis duodecim, pectore, abdominis basi, gemüus, libianm apice tarsisque nigris, prothorace sublilissime punclato lateribus minus rotundato; elytris punctuto-striatis. - Long. 5-6,5 mm.

Linn. Syst. Nat. ed. X. 376. (Chrysomela.) - Suffr. Stett. Zeit. 1841. 42. (Lema). - Fabr. Syst. Ent. 120. - Panz. Faun. Germ. 45. 3. - Lac. Mon. 581. - Redtb. Faun. A. II. 447. - Seidl. F. balt. 504.

Var. a. Antennarum articulo ultimo fermigineo.

Var. b. Elytris punctis octo vel decem nigris.

Var. c. Scutello, pectore abdomineque rufis.

Var. d. Metasterno plus minusve abdomineque mis.

Var. e. Capite antice, pectore pedibus abdomineque nigris, femoribus medio abdomisque lateribus obscure rufis.

V ar. f. Pedibus abdomineque nigris.

Lema dodecastigma Suffr. Stett. Zeit. 1S41. 40; 1846. 156. Lac. Mon. 582. - Redtb. Faun. A. II. 447. (Crioc.)

Wenig kürzer, aber in den Fld. fast nur halb so breit als merdigera, ziegelroth, Fühler, Schildchen, sechs Punkte auf jeder 
Fld. (1, 2, 1, 1, 1), die Kehle, Brust und Mitte des ersten Hinterleibsringes, die Kniee, Spitze der Schienen und Tarsen schwarz Kopf mit den Augen so lang als breit, einfarbig roth, oder der Raum zwischen dem Auge und der äusseren Stirnfurche, sowie die Spitze der Mandibeln und die Oberlippe schwarz; die Stirnhöcker sehr niedrig, hinten ganz allmählich in den Hals übergehend. An den Füblern ist das dritte Glied deutlich länger als das vierte, beinahe so lang als das fünfte. Halssch. länger als breit, die Seiten fast parallel oder wenig gerundet, die Scheibe gewölbt, äusserst fein und dicht, dazwischen, besonders nach den Seiten hin, zerstreut stärker punktirt; vor dem Hinterrande mit einer leichten Quereinschnürung, welche sich an den Seiten allmählich erweitert und vertieft und in der Mitte von einer Querfalte getheilt wird, die sich bis zu den Vorderhüften hinziebt. Fld. mässig stark punktirt gestreift, in der Nähe der abschüssigen Wölbung feiner; von den sechs schwarzen Punkten ist der vierte stets, der sechste meistens quer, die übrigen sind rund. Punkt 1 steht auf der Innenseite des Schulterhöckers, 2 und 3 in ein Viertel der Länge, ersterer am Aussenrande, letzterer an der Naht; Punkt 4 in der Mitte, dem Aussenrande genähert, 5 dahinter, dicht an der Naht, 6 in drei Viertel der Länge, näher dem Seitenrande als der Naht.

Die Färbung ändert vielfach ab:

a. Endglied der Fühler rothbraun.

b. Einer oder mehrere Punte der Fld. fehlen. Am häufigsten verschwindet der fünfte, seltener der dritte oder beide zusammen, zuweilen auch 5 und 6 .

c. Die ganze Unterseite, oft auch das Schildchen roth, oder nur hinten schwarz gerandet; Punkte der Fld. klein.

d. Die Hinterbrust, wenigstens in der Mitte, und der Hinterleib roth.

e. Kopf mit Ausnahme der Stirnhöcker und des Halses, sowie die ganze Unterseite schwarz; an den Beinen ist nur die Mitte der Schenkel düster rothbraun, am Hinterleibe sind die Seiten und die Spitze schmal roth. Einige Stücke dieser Uebergaugsform wurden von Herrn Oberförster Micklitz bei Montona in Istrien am 3. Oktober gesammelt und mir als intermedia übersandt.

f. (dodecastigma Suffr.) Wie vorige, aber die Beine und die Unterseite einfarbig schwarz; die 12 Punkte der Fld. oft sehr gross.

Ausserdem erwähnt Suffrian Stett. Zeit. 1841. 43. eine Abänderung, bei welcher der vierte und sechste Fleck der Fld. durch eine schmale Längslinie zusammenhängen. 
Auf Asparagns officinalis gemein. Die Varietïter c. und d. scheinen dem Hochgebirge anzugehören (Alpen, Suffr. Karpathen, Sajo, Kaukasus, Leder), e. und f. kommen nur in Süddeutschland und Südeuropa vor.

5. Cr. quatonondecimpunetata: Oblomyn-parallela, inja. subines nigro-variegata, antemis, fiontis lateribus, verticis maculn, prothoracis punctis quinque, scutello, elytronum maculis qualuordecim jedibusque nigris, femoribus medio rufis, prothorace lateribus rotumdalo. - Long. $5-6,5 \mathrm{~mm}$.

Scop. Ent. Carn. 37. 116. (Attelabus.) - F abr. Gen. Ins. 222.

- Panz. Ent. Germ. I. 168; Faun. Germ. 45. 4. - L a c. Mon. 584. - Suffr. Stett. Zejt. 1S41. 45. (Lema); 1846. 156.

Var. a. Prothorace punclis qualuor nigris.

Var. b. Elytris maculis sedecim.

Var. c. Capite antice nigro, punctis prothoracis maculisque elytrorum plus minusve confluentibus.

Der Vorhergehenden nahe verwaud, merklich schlanker, die Stirn flacher, das Halsschild hinten tiefer eingeschnürt, rorn stärker verengt, an den Seiten gerundeter, durch die schwarze Zeichnung des Körpers leicht zu unterscheiden.

Ziegelroth, Fühler, Seiten der Stirn an den Augen, ein Fleck auf dem Scheitel, oft auch der Mund, fünf Flecke auf dem Halssch., von denen vier in einer nach vorn gebogeneu Querrcihe, der fünfte vor dem Schildchen stehen, letzteres, sowie sieben Makeln auf jeder Fld. (1, 2, 2, 1, 1) schwarz. Auf der Unterseite sind ein Querfleck jederseits an den Vorderhüften, die Aussenränder der Mittel- und Hinterbrust, eine Makel an der Seite der ersten drei Segmente und die Beine schwarz, ihre Schenkel in der Mitte roth. Kopf stärker punktirt als bei der Vorigen, der Hals breiter, die Schläfen dicht vor der Einschnürung hinter den Augen höher; Halssch. wenig länger als breit, die Seiten stark gerundet, vor dem Hinterrande mit einem schmalen, tiefen Quereindrucke, welcher sich an den Seiten erweitert und vertieft und vorn von einer erhabenen Querfalte begrenzt wird, die oft schon ror dem Schildchen beginnt (so dass die Basis doppelt gerandet ist) und, seitwärts stark nach vorn gebogen, in der Mitte der Vorderbrust endet. Die Oberfläche mässig dicht und fein, dazwischen äusserst zart punktirt, vor der Mitte der Einschnürung mit der Spur einer kurzen Mittelrinne, in welcher der füfte schwarze Punkt steht, auf der vorderen Hälfte mit zwei oft recht deutlichen Längsreilien ron Punkten, zwischen denen die Mittellinie mehr oder weniger emporgehoben ist. Fld. mässig stark punktirt-gestreift, nach aussen und auf der hinteren 
Hälfte feiner; die Makeln sind meist rund, 4 und 6 stets quer; die erste steht auf der Innenseite der Schulterbeule, 2 dahinter am Aussenrande, 3 an der Naht, dem Grunde viel mehr genähert als bei 12 -punctata, 4 und 5 in einer Querreihe in der Mitte, 6 in drei Viertel der Länge, gleichweit von der Naht, wie vom Seitenrande, 7 in der Spitze, öfter so, dass der erste $Z$ wischenraum roth bleibt.

Als Varietäten sind zu betrachten die Exemplare:

a. denen der fünfte Punkt auf dem Halssch. fehlt;

b. bei denen sich die breite, hinten ausgerandete Makel 6 in zwei Flecke auflöst;

c. mit schwarzem Vorderkopfe und mehr oder weniger zusammengeflossenen Flecken des Halssch. und der Fld.

Nach Charpentier (Horae Ent. 231) kommen auch Stücke vor, denen einzelne Makeln der Fld. fehlen.

Im nordöstlichen Theile Deutschlands von Berlin bis Königsberg und Breslau selten, im südöstlichen und in Ungarn stellenweise häufig.

6. Cr. quinquepunctate $\left.{ }^{1}\right):$ Oblongo-parallela, nigra, prolhorace rubro, lateribus rotundato, elytris rufo-testaceis, subliliter punctatostriatis, plaga oblonga commumi maculisque quatuor nigris. - Long. $5-6 \mathrm{~mm}$.

S cop. Ent. Carn. 36. 114 (Attelabus). - F a br. Mant. Ins. I. 88. Suffr. Stett. Zeit. 1841. 66. - Lac. Mon. 586. - Redtb. Faun. A. II. 447.

Wenig schmaler als die beiden Vorigen mit dickeren, einfarbigen Beinen; schwarz, Halssch. roth, Fld. rothgelb, nach dem Tode hell gelbbraun. Kopf mit leicht gewölbter Stirn, welche von einer tiefen Mittelfurche durchzogen wird, fein punktirt, der hinterste Theil des Halses (oft vom Thorax bedeckt) ist roth gefärbt mit schwarzer Mittellinie. Halssch. vor dem Hinterrande leicht quer eingedrückt, der Eindruck erweitert sich an den Seiten, wird vorn

1) Zwischen 6 und 7 ist einzureihen:

Cr. bicruciata Sahlb. (Pericul. ent. 54. t. 3. f. 3. Cr. distincta Lac.

Mon. 5S7). Oblongo-parallela, nigra, prothorace rufo, nigro-bilineato, latiribus minus rotundato, elytris rufo-testaceis, sat jortiter punctatostriatis, sutura, fasciis duabus, singulo maculis binis humeralibus apiceque nigris. - Long. 4-5,5 $\mathrm{mm}$.

Stirn eben, dicht behaart und punktirt, Halssch. hinten unmerklich eingeschnürt.

Griechenland, Kleinasien (Kr üper), Kaukasus (L eder). 
von einer erhabenen Querfalte begrenzt und endigt in einer tiefen Quergrube dicht hinter der Mitte des Seitenrandes, welche das Halsschild mehr oder weniger einschnürt. Die Seiten vor der Einschnürung gerundet-erweitert, an den Vorderecken verengt, Oberfläche dicht unregelmässig, wenig tief punktirt und etwas matt, hinten mit der Spur einer Mittelrinne, in der nicht selten ein schwarzer Punkt steht, vorn zuweilen mit angedeuteter erhabener Mittellinie. Fld. gleichstark, fein punktirt-gestreift, die Zwischenräume eben, glatt, mässig glänzend, die Naht bis zum ersten Punktstreifen jederseits schwarz gesäumt. Dieser Saum erweitert sich ein Stück hinter dem Schildchen allmählich so weit, dass er den dritten, vierten oder fünften Punktstreifen erreicht, in oder hinter der Mitte verengt er sich schnell bis zur Naht. Ausserdem ist jede Fld. mit zwei schwarzen Flecken geziert, der eine länglich, auf der Schulterbeule zwischen dem fünften und neunten Punktstreifen, der andere meist grösser, rund oder quer, manchmal in zwei Flecke aufgelöst, in drei Viertel der Länge, zwischen dem dritten oder vierten und neunten Streifen.

Auf Spargel in Baiern und Oesterreich stellenweise häufig.

7. Cr. paracenthesis: Oblongo-parallela, nigra, prothorace rufo, saepissime vittis duabus nigris, elytris testaceis, sutura, fascia ante apicem, singulo maculis tribus apiceque nigris, pedibus testaceis, nigrovariegatis. - Long. $4-4,5 \mathrm{~mm}$.

Linn. Syst. Nat. ed. XII. 1066. (Chrysomela). - Charp. Hor. ent. 230. t. 7. f. 2. - Lac. Mon. 587.

Var. a Elytrorum macula teria deest.

Cr. suturalis Gravh. Vergleich. Uebers. zool. Syst. 139.

Var. b. Elytrorum fascia interrupta.

Var. c. Prothorace nigro, rufo limbato.

Die kleinste und am hellsten gefärbte Art der Gattung, schwarz, Mandibeln und Mund oft mehr oder weniger gelblich, Halssch. roth, einfarbig oder mit zwei schwarzen Längsstreifen über die Scheibe, welche bald linien- bald makelförmig sind. Fld. hell bräunlichgelb oder weissgelb, die Naht, eine Querbinde ror der Spitze und diese selbst, sowie drei Flecke auf jeder einzelnen schwarz. Beine gelbbraun, die äussere Hälfte der Schenkel, die Spitze der Schienen und der einzelnen Tarsenglieder schwarz. Kopf mit ebener Stirn, welche bis dicht an die feine Mittelrinne behart und ziemlich grob aber weitläufig und flach punktirt ist. Halssch. an den Seiten wenig oder kaum gerundet, länger als breit, dicht und mässig fein punktirt, vor dem Hinterrande schmal aber tief, nach den Seiten hin sich verflachend eingeschnürt. Fld. fein gestreift-punktirt, die 
Streifen nur am Aussenrande und vor der Spitze stark vertieft; ihre Zwischenräume mit je einer feinen Punktreihe. Der schwarze Nahtsaum reicht im ersten Viertel bis zum ersten Punktstreifen, dahinter bis zum zweiten; er verbindet sich in etwa drei Viertel der Länge jederseits mit einer breiten, mondförmigen Querbinde, welche nicht ganz den Seitenrand erreicht, und ist sodann bis zur Spitze wieder auf den ersten Zwischenraum beschränkt. Die drei Makeln liegen in der Nähe des Seitenrandes, die erste ist länglich, auf der Schulterbeule und nicht selten mit der zweiten, kleineren, welche etwas dahinter, mehr nach aussen liegt, verbunden, die dritte, in der Hälfte der Fld. ist gross, rundlich oder wenig quer.

Zuweilen verschwindet die Makel 3 (v. suturalis Gravh.), oder die Querbinde der Fld. ist jederseits an der Naht unterbrochen (var. b.) oder die beiden Striemen auf der Scheibe des Halssch. vereinigen sich $\mathrm{zu}$ einem grossen viereckigen schwarzen Flecke, der nur die Ränder roth lässt (var. c.).

Auf Asparagus acutifolius bei Görz (Schreiber) und Montona (Micklitz) häufig.

Sehr ähnlich ist die in Sicilien vorkommende Lokal-Varietät Dahli Lac. (Mon. 589.) mit dunkelbraunen Fühlern und verschwommener schwarzer Zeichnung der Fld. und Beine. Die extremsten Stücke haben gelbbraune Fld. mit dunkler Naht, hellbraunen Mund und einfarbig röthliche Fühler und Füsse. Ebenso ist $\mathrm{C} r$. decorata Moraw. (Bull. Mosc. 1860. I. 299.) von Sarepta mit einfarbig schwarzen Beinen so lange als Varietät zu betrachten, bis andere Unterschiede nachgewiesen worden sind.

8. Cr. asparagi: Elongata, viridi-coerulea, prothorace rubro, viridi bi-vel tripunctato, tibiis basi elytrisque limbo laterali apice dilatato ferrugineis, his minus profunde punctato-striatis, singulo maculis tribus albidis, duabús anticis connexis duabus posticis cum limbo confluentibus; capite thorace pectoreque sat fortiter punctatis. - Long. $5-6,5 \mathrm{~mm}$.

Linn. Syst. Nat. ed. X. 376 (Chrysomela), - Fabr. Syst. Ent. 121; Ent. Syst. Supplem. 93. 24. - Panz. Faun. Germ. 71. 2. - Suffr. Stett. Zeit. 1841. 67 (Lema). - Lac. Mon. 590. - Suffr. 1. c. 1846. 156. - Redtb. Faun. A. II. 447. - Seidl. F. balt. 504 (Crioc.).

Lema pupillata Ahr. Neue Schrift. Ges. Halle II. 2. 30. t. 1. f. 16. Var. a. Elytrorum macula basali libera.

Var. b. Prothorace rubro.

Var. c. Prothorace virido-nigro, rufo-limbato.

Helodes campestris Fabr. Syst. El. I. 470. 
Var. d. Eutem, sed femoribus basi tibiisque fernutineis.

Chrysomela campestris Linn. Syst. Nat. ed. XII. 602

Lema maculipes Geb l. T3ull. Hose. 1834. 171. - Küst. Käf. Eur. I. 57.

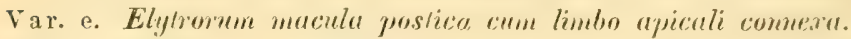
Var. f. Elyformen maculis duabus postecis plus mimesce compluemtibus. Var. . Maculis elytromun fascia lomginulinali bismuala commexis.

Gestreckter und flacher als die Verwandten, grünlichblau, die Fühler schwarz, ihre ersten vier Glieder blänlich; Halssch, roth mit zwei schlecht begrenzten dunkelgrünen Flecken auf der Scheibe und einem kleineren vor dem Schildchen. Fld. am Aussenrande bis zum neunten Punktstreifen nach innen rothbraun gesäumt; der Saum erweitert sich vor der Spitze, lässt aber den ersten Zwischenraum an der Naht frei. Ausserdem befinden sich auf jeder einzelnen drei unregelmässig-rechteckige weissliche Makeln, welche genau am dritten Punktstreifen beginnen, die erste länglich, am Grunde, die beiden anderen quer, mit dem Seitensaume verbundev, die zweite vor, die dritte hinter der Mitte. Makel 1 und 2 sind zusammengeflossen und umschliessen eine blaugrüne Strieme auf und hinter der Schulterbeule. Unterseite einfarbig oder (bei süddeutschen Exemplaren) mit einem rothen Flecke jederseits auf dem letzten Segmente. An den Beinen sind die Schenkel dunkelgrün, bei Stücken aus dem Norden einfarbig, aus dem Süden mit röthlicher Basis; Schienen und Tarsen schwarz, erstere am Grunde rothbraun. Kopf vor den Fühlern und am Augenrande dicht runzelig, Stirn und Hals weitläufig, ziemlich stark punktirt, die Schläfen wulstig. Halssch. länger als breit, die Seiten leicht gerundet, vor dem Hinterrande schwach eingeschnürt und doppelt gerandet, die Scheibe hinter dem Vorderrande sanft quer eingedrückt, weitläufig, ziemlich stark punktirt. Die drei ersten Punktstreifen der Fld. sind wenig, die beiden letzten stärker vertieft und wie die Seiten der Hinterbrust stark aber nur mässig tief punktirt.

Der auf Asparagus officinalis im ganzen Gebiete häufige Käfer ist zahlreichen Veränderungen unterworfen, welche zum Theil rom Aufenthaltsorte abhängig sind. In Allgemeinen sind die dem Süden angehörigen Formen kleiner, mit vorherrschend einfarbig rothem Halssch, und sehr kleinen Makeln der Fld, bei den im Norden vorkommenden grösseren Stücken zeigen die Makeln nicht selten das Bestreben, sich zu vereinigen. Es sind folgende Abänderungen zu unferscheiden: 1)

1) Lema pupillata Ahr., bei der die hintere Makel der Fld. ein unregelmässiges dunkles Fleckchen zeigt, jst als Missfürbung, aber nicht als Varietät aufzufassen. 
a. Die Makel 1 ist hinten nicht mit der zweiten verbunden. Von dieser in Deutschland häufigsten Form muss als Normalfärbung ausgegangen werden, wenn auch Linné und die älteren Autoren sie nicht als solche angeseben haben.

b. Halssch, einfarbig roth.

c. Die Makeln des Halssch. fliessen zusammen, anfänglich in einen Querfleck otler eine Vförmige Zeichnung, zuletzt so, dass nur noch die Ränder roth bleiben (campestris $\mathrm{Fabr}$.).

d. (campestris Linn.) Wie vorige, die Wurzel der Schenkel, oft bis über die Hälfte und die Schienen, mit Ausnahme der Spitze, roth.

e. Die hintere Makel ist mit dem Seitensaume und an der Naht mit dem Spitzensaume verbunden und umschliesst einen viereckigen oder runden Fleck von der Grundfarbe der Fld.

f. Die beiden hinteren Makeln der Fld. verbinden sich, entweder theilweise mit einander oder die vordere mit der Makel am Grunde, die hintere mit dem Spitzensaume.

g. Die Makeln der Fld. sind nieht mit dem Seitensaume verbunden, sondern bilden eine aussen zweimal gebuchtete Längsbinde.

Da die Makel am Grunde der Fld. nicht selten punkt- oder strichförmig wird, erscheint es nicht unwahrscheinlich, dass sie auch ganz verschwindet.

D. Cr. macilenta: Elongata, sublepressa, nigro-aenea, pedibus testaceo-variegatis, prothorace fermaineo-limbato, elytris profunde punctalo-strialis, margine teni testaceo singuloque fascia longitudinali albida; capite, prothorace pectoreque crebre sat fortiter punctatis. Long. $4,5-5 \mathrm{~mm}$.

Weise Deutsch. Zeitschr. 1880. III. $15 \mathrm{~S}$.

Cr. campestris Rossi Faun. Etruse. I. 10\% - Panz. Faun. Germ. 3. f. 12. - Lac. Mon. 594.

Lema campestris Suffr. Stett. Zeit. 1841. 72. Var. b. Var: a. Coleoptera maculis quatuor vel sex albidis.

Var. b. Elytrorum fasciis apice cum limbo laterali confluentibus; pedibus testaceis, femoribus aeneo-maculatis.

Var. c. Prothorace nigro-aenea; tibiis tarsisque apice nigris.

Kleiner und noch flacher als die vorige Art, schwarz-erzfarbig, das erste Fühlerglied heller grün, die drei folgenden dunkler, die übrigen schwarz; alle Ränder des Halssch. rothbraun, der Seitenrand der Fld. bis zur Spitze dagegen gelbbraun gesäumt. Jede Decke mit einer aus drei Längsmakeln zusammengeflossenen weisslichen Längsbinde, welche am Grunde beginnt und sich ziemlich gleichbreit 
zwischen dem dritten und sechsten Punktstreifen bis drei Viertel der Länge hinzieht. Beine hell gelbbraun, die äussere Hălfte der Schenkel erzgrün, die Spitze der Schienen und die Tarsen angedunkelt. Kopf vorn und am Augenrande dicht runzelig, Stirn und Hals ziemlich dicht und stark punktirt, die Schläfen nur mässig gewölbt. Halssch. kaum länger als breit, die Seiten fast parallel, vor dem Hinterrande unmerklich eingeschnürt und doppelt gerandet, die Scheibe gleichmässig, wenig gewölbt und dicht, ziemlich stark punktirt. Die Punktstreifen der Fld. sind regelmässiger, weit enger punktirt und stärker vertieft als bei asparagi, der helle Saum nimmt den Seitenrand vom neunten, auch oft nur vom zehnten Streifen ein und verbreitert sich etwas ror der Spitze. An den Beinen sind die Hinterschenkel kaum schmaler, aber ihre Keule erscheint nur halb so lang als bei der verwandten Art.

Die Hauptabänderungen sind:

a. Die Längsbinde jeder Fld. ist in ihre einzelnen Makeln aufgelöst; seltener in drei, dann stehen die beiden hinteren weiter von einander entfernt, als die vorderen, häufiger in zwei, dann sind Makel 1 und 2 zusammengeflossen.

b. Die Längsbinde der Fld, verbindet sich vor der Spitze mit dem Seitensaume; Beine gelbbraun mit einem mehr oder weniger grossen Punkte auf der Oberseite der Schenkel.

c. Halssch. nur am Vorder- und Hinterrande äusserst schmal röthlich gesäumt oder einfarbig erzgrün, die Schienen oft bis über die Hälfte und die Spitze der einzelnen Tarsenglieder schwarz.

In Istrien selten, in Dalmatien und Italien, nach Rossi auf wildem Spargel (Asparagus tenuifolius?), häufig.

Während die Makeln 2 und 3 von asparagi fast immer quer und mit dem Seitensaume verbunden sind, haben die langgezogenen Normalmakeln der vorliegenden Art nicht die geringste Neigung, sich seitwärts auszubreiten oder gar mit dem Saume an den Seiten zu vereinigen. Die ausserordentlich seltene Var. g. ron asparagi ist nicht als Uebergangsform anzusehen, da sie in Körperform, Farbe und Punktirung mit der Stammform übereinstimmt. Panzer, Suffrian und Redtenbacher vermengen beide Arten, Ersterer bildet aber unsere Art ab. Da mir ein giltiger Name für die bisher fälschlich auf campestris Linn. Fabr. bezogene Art nicht bekannt ist, musste eine Neubenennung eintreten. 


\section{Zweite Abtheilung: CAMPTOSOMA.}

Chapuis, Genera d. Coleopt. X. 78.

Corpus cylindricum.

Caput collo mullo.

Thorax lateribus saepissime marginatus.

Abdomen segmentis 2 ultimis connatis.

Die Fühler sind am Vorderrande der Augen, durch die ganze Stirnbreite von einander getrennt, eingefügt, gesägt oder fadenförmig. Der Kopf ist bis zu den Augen in das Halsschild eingezogen und besitzt keinen Hals; er hat eine senkrechte Stirn, meist grosse, ausgerandete Augen und kräftige, oft sehr verlängerte und unter der Oberlippe weit vorragende Mandibeln. Das Halsschild ist quer, gewölbt, an den Seiten zusammengedrückt und scharf gerandet, am Grunde so breit als die Flügeldecken daselbst (nur bei den exotischen Megascelini schmaler), an die es sich theilweise (Clytrini) oder ganz (Cryptocephalini) fest anschliesst. Das Schildchen ist mehr oder weniger geneigt, hinten meist über die Naht der Flügeldecken emporgehoben. Letztere sind gewölbt, fast gleichbreit, an der Spitze gemeinschaftlich oder einzeln abgerundet, länger oder wenig kürzer als der Hinterleib. Dieser besteht aus fünf Ringen, von denen der erste meist länger als einer der übrigen ist, die beiden letzten sind miteinander verwachsen. Der After wird von einem grossen Pygidium bedeckt, welches entweder von den Flügeldecken überragt wird (Clytrini) oder unbedeckt ist (Cryptocephalini). Die Beine sind im Allgemeinen kurz und kräftig, öfter jedoch einzelne Paare, besonders das vordere, stark verlängert, die Klauen einfach.

Die Larven weichen von den übrigen darin ab, dass sie $\mathbf{z u -}$ sammengekrümmt in einem Sacke stecken, welchen sie mit sich herumtragen, weil sie nur die vordere Körperhälfte aus demselben herausstrecken können.

Die Abtheilung gliedert sich in zwei ${ }^{1}$ ) sehr natürliche Gruppen:

1) Ueberhaupt in 6 Gruppen, von denen aber 4 in Europa nicht vertreten sind. Nach Chapuis (Genera d. Col. 82) würden dieselben so zu unterscheiden sein :

VI. 
a. Vorderhüften nahe an einander stehend, Fühler gesägt, Stirn der Larve gewölbt, Larvensack dünn, zerbrechlich Clytrini.

b. Vorderhüften weit getrennt, Fühler fadenförmig, Stirn der Larve flach gedrückt, Larvensack dick, fest . . . . . . . Cryptocephalini.

\section{Erste Gruppe: CLYTRINI.}

Chapuis, Genera d. Col. X. 95.

Caput verticale, magnum.

Antennae serratae.

Thorax transversus.

Abdomen elytris brevius, pygidio verlicali.

Coxae fere contiguae.

Oberlippe lederartig, breit, mit gerundeten Vorderecken, mehr oder weniger tief ausgerandet und behaart. Die Mandibeln ragen besonders bei den Männchen hervor und sind kräftig, stark gekrümmt, an der Spitze oft in drei Zähne verlängert, seltener einfach zugespitzt, die linke ist zuweilen stärker und bedeckt dann theilweise die rechte, die Innenseite ist der Länge nach zur Aufnahme der Oberlippe vertieft. Maxillartaster viergliederig, das erste Glied sehr klein, das zweite das längste, das Endglied kürzer oder so lang als das dritte, ausnahmsweise (Saulopalpa) länger. Fühler dicht vor dem Vorderrande der Augen, zwischen diesen und dem Grunde der Mandibeln eingefügt, elfgliederig, vom vierten oder fünften Gliede an gesägt, das Endglied mit deutlich abgesetzter, dreieckiger Spitze, welche zuweilen gross und so tief abgeschnürt ist, dass sie ein zwölftes Glied bildet. (Teinocera und einige Lophobasis-Arten.) Augen schief gestellt und wenig (Clytra) oder bedeutend nach unten divergirend, der Vorderrand ist in der Mitte

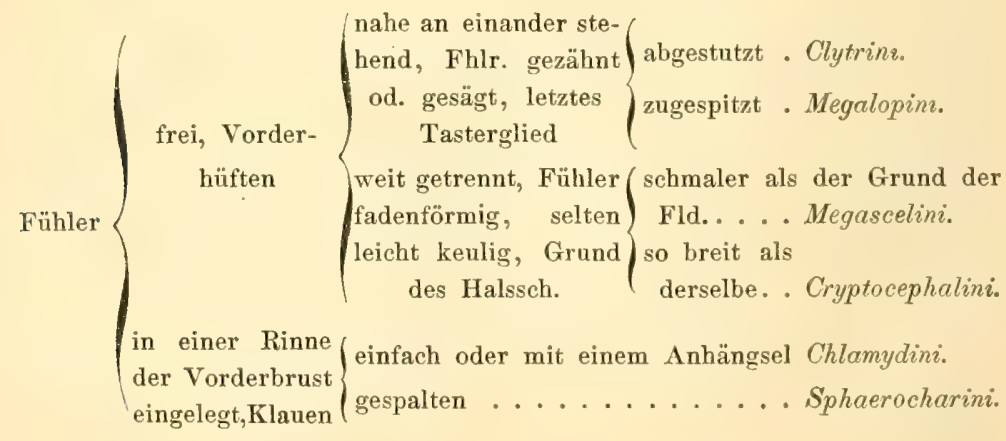


über der Fühlerwurzel ausgerandet, die Oberfläche gewölbt; sie werden innen von einer feinen, leistenartigen Kante begrenzt, die sich am Hinterrande merklich, schläfenartig erweitert, so dass das Halsschild die Augen nicht direkt berührt. Kopf geneigt, an den Seiten hinter der Wurzel der Mandibeln in einen ohrförmigen Lappen verlängert, Kopfschild vorn ausgerandet, die senkrechte Stirn ausgehöhlt oder eingedrückt, selten fast eben, mit einem Eindrucke längs des oberen Augenrandes, der an den Seiten des Scheitels bei vielen Arten mit einer wenig deutlichen rothen Makel versehen ist. Halsschild quer, an den Seiten zusammengedrückt, so breit oder wenig schmaler als die Flügeldecken am Grunde. Schildehen dreieckig oder an der Spitze abgestutzt und grubenförmig vertieft. Flügeldecken cylindrisch, hinten gemeinschaftlich, am Nahtwinkel meist einzeln abgerundet; sie bedecken vollständig den Hinterleib; der Seitenrand ist schmal abgesetzt, der umgeschlagene Rand ist an den Schultern breit und endet gewöhnlich am ersten Hinterleibsringe. Der Hinterleib besteht aus fünf Ringen, von denen die zwei hinteren verwachsen sind, und einer grossen, abwärts geneigten Afterdecke; das erste Segment ist an den Seiten lappenförmig nach vorn verlängert und schiebt sich zwischen den Rücken und die Seitenstücke der Hinterbrust. Die Vorderbeine haben kegelförmige, vortretende Hüften, die wie die hinteren nahe beisammenstehen oder (Clytra) durch einen schmalen Fortsatz der Vorderbrust bis zur Spitze getrennt sind.

Aeussere Geschlechtsmerkmale sind auf der Unterseite des letzten Hinterleibssegmentes bei allen Gattungen wahrnehmbar, ebenso sind bei den meisten die Männchen an dem dicken Kopfe und den verlängerten Vorderbeinen zu erkennen. Das männliche Geschlechtsorgan bildet eine Röhre, welche vorn eine Oeffnung hat, die in der Rube von einer Klappe verschlossen ist, während ihre Seiten sich unten nach vorn verlängern und meist in einer Spitze endigen. Es lässt sich nicht nur die Form der Oeffnung sondern auch, besonders bei den grösseren Arten, die sehr verschiedene Gestalt der Klappe mit Erfolg zur sicheren Scheidung der Arten anwenden.

Ueber die ersten Stände sind uns besonders dureh Rosenhauer ${ }^{1}$ ) wichtige Mittheilungen gemacht worden; die Larven von

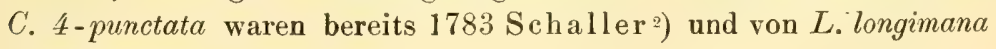
$\left.1785^{3}\right)$ Hübner bekannt.

1) Entwicklung und Fortpflanzung der Clytr. 1852.

2) Abhandlungen d. Hall. Ges. I. 328.

3) Füessl. Arch. VI. 1-6. 
Die Eier sind elliptisch, hellgelb, glänzend, werden einzeln in grösseren Zwischenräumen gelegt, vom Weibchen mit einer Kothrinde überzogen und direkt oder mittels eines borstenartigen Stieles (Coptocephala) an die Pflanzen geklebt. Die Kothrinde erhärtet sich und dient der Larve als Anfang eines Sackes, den sie nach Bedürfniss aus ihren Excrementen grösser baut und bis zu ihrer Verpuppung mit sich herumträgt. Die zerbrechlichen Säcke sind fast cylindrische, braune oder schwarze Röhren, hinten geschlossen, nach vorn verengt und mit einer schiefen Oeffnung versehen. Die Aussenseite ist kahl, glatt oder fein runzelig-gestreift (Lachnaea), oder mit haarähnlichen Auswüchsen besetzt (Labidostomis), oder mit Rippen belegt, die vom Rücken grade oder schräg, ähnlich den Dachsparren eines Hauses, herablaufen (Clytra, Tituboea). Die Larve kann sich aus dieser Hülle, obgleich nirgends an derselben befestigt, nur etwa bis zur Hälfte des Körpers herausbegeben, da ihr Hinterleib verdickt und vom vierten Segmente ab nach rorn gekrümmt ist. Vor der Verwandlung kriecht sie in einen Ameisenhaufen (Clytra, Tituboea) oder unter einen Stein in der Nähe solcher Haufen, verschliesst die Oeffnung mit einem Deckel, der zu gleicher Zeit zum Festkleben an Holzstückchen, Zweige, Steine oder andere Larvensäcke dient, und kehrt sich vollständig um, so dass vorn in der schmaleren Hälfte, wo sich bisher der Vordertheil der Larve befand, nun der Hinterleib der Puppe zu finden ist.

Die gelbliche Larve hat einen gewölbten, braunen Kopf mit dreigliederigen konischen Fühlern und 6 Ocellen auf jeder Seite; der erste Brustring besitzt oberseits eine halbmondförmige Hornplatte, die Beine sind lang, die 9 Abdominalsegmente oben stark gewölbt und von Querfurchen durchzogen. Sie kriecht ziemlich schnell.

Die Lebensweise ist bei den Clytren eine ziemlich gleichförmige. Man findet sie hauptsächlich an den jungen Trieben der Laubbäume, vorzüglich der Eichen, an Weiden-, Schlehen- und Weissdornbüschen, in Blüthen oder am Grase.

Die Classification der Abtheilung bietet insofern grosse Schwierigkeiten dar, als die zuerst von Lacordaire als Subgenera aufgestellten Gattungen oft Formen enthalten, welche in einzelnen Merkmalen zu anderen Gattungen hinüber leiten. Indessen dürfte sich bei besserer Kenntniss der ersten Stände die Berechtigung der Gattungen immer mehr herausstellen, wie sie schon jetzt bei Labidostomis, Clytra und Coptocephala keinem Zweifel mehr unterworfen ist.

Die Gattungen, welche bei uns Repräsentanten aufzuweisen Laben, lassen sich in folgender Weise überblicken: 
1. Vorderecken des (zahnartig vorgezogen . . . . 2. Kopfschildes r rechtwinkelig oder abgerundet . 3.

2. Halsschild \{ einfarbig metallisch grün oder blau Labidostomis. an den Seiten roth . . . Chilotoma.

3. Vorderhüften

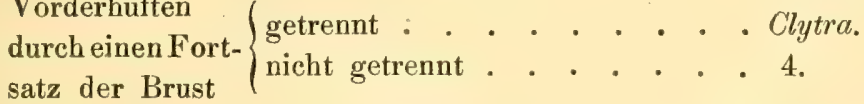

4. Körper

$$
\text { fzottig behaart...... Lachnaea. }
$$

(kurz behaart . . . . . 5. kaum ausgerandet; Lappen des 3.

5. Oberlippe $\left\{\begin{array}{c}\text { Tarsengliedes fast spitz . . . Coptocephala. } \\ \text { deutlich ausgerandet; Lappen des } \\ \text { 3. Tarsengl. vorn abgerundet. } 6 .\end{array}\right.$

6. Zweites und 3. (so breit als das erste ( $\delta$ ) . Macrolenes. Fühlerglied viel schmaler als das erste . . 7.

7. Vorderschienen fstark gekrümmt . . . . . Tituboea. des $\widehat{o}$ meist gerade . . . Gynandrophthalma.

\section{Labidostomis.}

Lacord. Mon. d. Phytophag. II. 30.

Clypeus bi- vel tridentatus.

Mandibulae apice forcipatae, supra profunde canaliculatae, maris maximae, valde prominentes.

Antennae articulo tertio secundo angustiore.

Prothorax apice compresso, basi lobo medio producto, angulis posticis acutis, elevatis.

Pedes antici, praesertim maris, quam intermedii longiores.

Körper blau, blau- oder erzgrün, Flügeldecken entweder rothoder gelbbraun, bald einfarbig, bald mit ein bis zwei Punkten auf jeder, oder (Subgen. Chlorostola) grossentheils oder ganz wie der Körper gefärbt. Die Unterseite, der Kopf und zuweilen auch das Halsschild behaart. Fühler, mit Ausnahme des zweiten und dritten Gliedes oder der vier ersten Glieder, zusammengedrückt, vom vierten oder fünften Gliede an gesägt, Glied 3 stets schmaler, aber oft länger als 2. Kopfschild im Bogen oder viereckig ausgerandet, jederseits in eine scharfe Spitze ausgezogen, die Mitte der Ausrandung beim $\hat{o}$ nicht selten mit einem Zähnchen. Mandibeln stark, an der Spitze zwei- bis dreizähnig, am Innenrande der Oberseite der Länge nach vertieft, der Aussenrand als mehr oder weniger hohe Längskante aufgebogen. Augen mässig gross, breit-oval, schief gestellt, nach unten gegen einander stark divergirend, leicht 
lausgerandet. Stirn breit, ausgehöhlt oder eingedrückt. Halsschild quer, die Vorderecken stark herabgebogen und von oben nicht sichtbar, die Hinterecken scharf, oft nach hinten ausgezogen, deutlich über den Grund der Flügeldecken emporragend; die Oberfläche mit einem Quereindrucke vor dem Hinterrande und einem schwächeren am Vorderrande. In der Mitte des Grundes ist ein kurzer, gerundeter Lappen gegen das Schildchen vorgezogen. Beine wie der Körper gefärbt, lang, mit mässig starken Schenkeln und schwachen Schienen, von denen die vorderen meist gekrümmt sind.

Körper des Männchens cylindrisch, Kopf und Halssch. gross und breit, die Mandibeln stark verlängert, Fühler kräftig, die Vorderbeine mit wenigen Ausnahmen bedeutend länger als die hinteren. Letztes Bauchsegment eben, sein Hinterrand grade. Penis eine sehr kurze, dicke Röhre, mit grosser Oeffnung, welche durch eine dreieckige, vorn in eine Spitze verlängerte Klappe im Ruhezustande geschlossen wird.

Weibchen oval, vorherrschend kleiner als das Männchen, Kopf und Halssch. schmaler, Fühler schwächer und kürzer, Mandibeln kaum oder wenig vorragend, Vorder- und Mittelbeine fast gleichlang. Letztes Bauchsegment in der Mitte vertieft oder mit einem Grübchen am Hinterrande, welcher mehr oder weniger tief ausgeschnitten ist.

A. Fühler vom vierten Gliede an gesägt. Oberlippe pechschwarz. ${ }^{1}$ )

1. Lab. taxicornis: Cyanea, viridi-micans, subopaca, subtus temuiter albido pubescens; labro piceo, antennis latissimis, prothoracis basin superantibus, nigro-cyaneis, capite prothoraceque rude punctatorugosis, hoc lateribus eroso-crenulato; elytris dense punctulatis, flavovel rufo-testaceis. - Long. 7-12 $\mathrm{mm}$.

1) Hierher gehören noch folgende Arten:

a. Ohne Schultermakel:

1. L. maroccana Lefèvre (Ann. Fr. 1872. 380). Long. 11-15 mm. Kopfschild tief bogenförmig ansgerandet $(\hat{\odot})$, Kopf und Halssch. ziemlich stark silberweiss behaart. - Marocco.

2. L. lucaniformis Lefèvre (1. c. 382). Long. 7-13 mm. Die ersten drei Fühlerglieder unterseits röthlich, Halssch. stark quer gewölbt mit spitzen Hinterecken, Quereindruck des Kopfes zwischen den Fühlerwurzeln fehlend. - Marocco. - Beide der taxicornis ausserordentlich ähnlich.

3. L. rubripennis Luc. (Rev. Zool. 1845. 120). Long. 6-10 mm. Die ersten drei Fühlerglieder unterseits röthlich, der lang behaarte 
Mas: Capite magno, quadrato, fronte late excavata, clypeo profunde subquadratim emarginato, mandibulis validis, exsertis, pedibus anticis longissimis, femoribus subtus subcrenulatis, ante apicem abrupte angustatis, tibiis anticis fortiter arcuatis.

Fabr. Ent. Syst. I. 2. 56 (Cryptoceph.). - Gyllh. Ins. Suec. III. 586. 2 (Clythra). - Lacord. Mon. II. 32. - Suffr. Stett. Zeit. 1851. 198. - Kraatz. Berlin. Zeit. 1872. 194. Lefèvr. Ann. Fr. 1872. 69. - Redtb. Faun. A. II. 449.

of Cylindrisch, dunkel kornblumenblau, die Unterseite, Kopf und Halssch. meist grünlich schimmernd, Fld. hell gelb- oder rothbraun. Fühler kräftig, stark zusammengedrückt, den Hinterrand des Halssch. bedeutend überragend, einfarbig schwarzblau oder Glied 2 und 3 am Grunde undeutlich trübroth, Glied 1 flach gedrückt, wenig breiter und länger als 4, Glied 2 und 3 dagegen halb so breit und zusammen so lang als 4 , dieses dreieckig, etwa halb so breit als 5 ,

Kopf und das Halssch. glänzend, Stirn tief eingedrückt, Scheitel stark gewölbt, mässig dicht und fein punktirt, Scheibe des Halssch. weitläufig mit sehr groben und tiefen, dazwischen mit feinen Punkten besetzt, kaum gerunzelt, die Seitenränder ganz oder nur mit der Spur einiger Einschnitte. - Algier.

b. Mit Schultermakel :

4. L. lusitanica Germ. (Ins. Spec. nov. 549) = tibialis Lac. Mon. II. 36. Long. 51/2 $-10 \mathrm{~mm}$. Viertes Fühlerglied innen sehr scharf zugespitzt und nur wenig schmaler als das fünfte. Gestreckt, Kopf und Halssch. deutlich behaart und wie die Fld. fein punktirt. Letztere beim $\hat{\odot}$ matt. Kopfschild bogenförmig ausgeschnitten. - Südfrankreich, Spanien, Portugal.

5. L. meridionalis Lac. (Mon. II. 38). Long. 5-71/2 mm. Kleiner aber gedrungener als vorige, Kopf sparsam, Halssch. selten fein behaart, beide wie die Fld. kräftig punktirt, letztere beim $\hat{\odot}$ glänzend. (pyrenaea Kraatz Berl. Zeit. 1872. 197). - Südfrankreich, Spanien.

6. L. quadrinotata Fabr. (Mant. I. 79) = hybrida Luc. Rev. Zool. 1845. 121. Long. 7-9 mm. Unterseite, Kopf und Halssch. lang und dicht silberweiss behaart. Fühlerglied 1 unten, 2 und 3 ganz rothgelb. Fld. ausser der Schultermakel noch mit einer eckigen, meist grösseren queren Makel hinter der Mitte. Kopfschild beim $\hat{\odot}$ bogenförmig ausgerandet, Kopf und Mandibeln wenig stärker als beim 오. - Algier.

7. L. bigemina Suffr. (Stett. Zeit. 1851. 200). - Long. $6 \mathrm{~mm}$. Kleiner aber gestreckter als die vorige, Kopf und Halssch. feiner behaart, Stirn tiefer eingedrückt, Scheitel gewölbter, glatter, glänzender; hintere Makel der Fld. länglich, blau- oder grünlichschwarz. Kopf des $\hat{\odot}$ gross, Kopfschild viereckig ausgerandet. - Spanien, Sardinien. 
welches wie die folgenden quer viereckig nach innen ausgezogen und schief abgeschnitten ist. $\mathrm{K} \cap \mathrm{pf}$ breit, viereckig, fein und kurz behaart, die Stirn weit und flach ausgehöhlt. Die Aushöhlung wird hinten von einer queren Bogenlinie begrenzt, welche an der Ausrandung der Augen beginnt; vorn von einer erhabenen Querfalte, vor welcher ein breiter und tiefer Quereindruck sich ron einer Fühlerwurzel zur andern hinzieht. Scheitel quer gewölbt, wenig feiner als die Stirn punktirt, Kopfschild tief, schwach-viereckig ausgeschnitten, die Mitte des Ausschnittes meist grade, selten leicht gerundet-vorgezogen. Mandibeln stark, wenig kürzer als der Kopf, ziemlich grade, erst an der Spitze nach innen gebngen, der Aussenrand oberseits dicht am Grunde in eine kleine zahnartige Längskante aufgebogen. Halssch. dicht hinter der Mitte am breitesten, von hier nach vorn und hinten gleichmässig rerengt, die Hinterecken stumpf, abgerundet, der Hinterrand grade oder in der Mitte leicht erweitert, die Oberseite unregelmässig, dicht runzelig punktirt, matt oder mit einer sparsamer punktirten und glänzenderen Längslinie über die Mitte und einer ähnlichen mehr oder weniger grossen Fläche dicht vor dem Abfalle nach dem Seitenrande. Letzterer ist ausgenagt-gezähnt. Fld. dicht und fein punktirt, matt. Unterseite und Beine dünn und kurz weisslich behaart; Vorderbeine so lang als der Körper, ihre Schenkel unterseits in eine fein gekerbte Längskante verschmälert, die ror der Spitze plötzlich bogenförmig ausgeschnitten, fast stumpf gezähnt ist. Vorderschienen stark gekrümmt, die mittleren schwächer, Hinterschienen grade. Penis an der Oeffnung leicht erweitert, die Seitenränder unten allmählich in eine vorn abgerundete Spitze vorgezogen.

ㅇ Kürzer und breiter als das Männchen, der Lab. tridentata täuschend ähnlich, aber durch die doppelt so breiten und viel längeren Fühler von ihr unterschieden. Kopf fast dreieckig, die Stirn sehr flach eingedrückt, Fühler wenig kürzer aber deutlich schwächer als beim Männchen, die erweiterten Glieder innen oft noch stumpfer, zuweilen abgerundet, Halssch. nach rorn stark rerengt, Vorderschienen schwach gebogen, die vier hinteren grade.

Auf Pumex-Arten in ganz Italien, Nordafrika, Spanien und Südfrankreich.

Ob die Stücke in Cherrolat's Sammlung (Ann. Fr. 1872, 70) wirklich aus Tirol stammen, ist sehr zweifelhaft. Immerhin wäre ein Hinaufgehen der Art von der Lombardei bis Südtirol weniger unwahrscheinlich als das Vorkommen von tibialis $\mathrm{Lac}$. (nach $\mathrm{Bach}$ ) bei Boppard. - Redtenbacher nennt mit Unrecht die ersten drei Füblerglieder gelb. 
B. Fühler vom fünften Gliede an gesägt. Oberlippe pechschwarz.

2. Lab. tridentata: Cyanea, cyaneo-virescens aut viridi-aenea, nitidula, subtus breviter albido-pubescens, capite subtriangulare, rugosopunctato, vertice fere plano, antennis gracilioribus, nigro-coeruleis, ante basin ferrugineis, prothorace brevi, confertim punctato, basi fortiter bisinuato, elytris testaceis, sat crebre punctatis. - Long. $6-8,5 \mathrm{~mm}$. Mas: fronte late depressa, clypeo tridentato, mandibulis parum exsertis, thorace ante apicem transversim impressa.

Linn. Syst. Nat. ed. X. 374. (Chrysomel). - Lacord. Mon. II. 58. - Suffr. Stett. Zeit. 1851. 202. - Lefèvr. Ann. Fr. 1872. 100. - Kraatz Berl. Zeit. 1872. 203. - Seidl. Faun. balt. 472 .

Lab. Leithneri Redtb. Faun. A. II. 448. Var. a. Elytris puncto humerali piceo.

$\hat{\sigma}$. Selten rein cyanenblau, must mit grünem Schimmer oder ganz metallgrün, die Fld. gelbbraun. Fühler kurz und auffällig dünn, die erweiterten Glieder scharf dreieckig, schwach oder kaum quer, schwarzblau, das erste Glied unten, das zweite und dritte ganz, das vierte am Grunde rothbraun, letzteres breiter aber unmerklich länger als das dritte. Kopf fast dreieckig mit mässig gewölbten Augen, äusserst sparsaı, und kurz behaart, mit einem weiten, flachen Eindrucke auf der Stirn, welcher dicht und grob runzelig punktirt ist, seitwärts bis an die Augen reicht, vorn kaum scharf begrenzt ist und hinten allmählich in den $\mathrm{fl}$ achen, dicht punktirten Scheitel übergeht. Kopfschild vorn dreizähnig, der mittlere Zahn stumpfer und kürzer als die seitlichen. Mandibeln breit und kurz, wenig vorragend, schwach gekrümmt, der Seitenrand oberseits leicht aufgebogen. Oberlippe pechschwarz, die Ränder fein braun oder gelbbraun gesäumt. Halssch. am Hinterrande am breitesten, von hier gleichmässig nach vorn verengt, der Hinterrand beiderseits ausgerandet, in der Mitte in einen breiten, gerundeten Lappen gegen das Schildchen vorgezogen, welcher kaum so weit nach rückwärts reicht als die zurückgebogenen Hinterecken. Die Oberfäche dicht, ziemlich stark punktirt, die Punkte rund, vor der gewöhnlichen vertieften Querlinie am Hinterrande noch mit einem oft tiefen, bogenförmigen Quereindrucke. Fld. dicht, mässig stark punktirt. Vorderbeine schwach verlängert, ihre Schienen vor der Spitze leicht gekrümmt. Penis dick, oberseits vor der Oeffnung mit einem Grübchen.

․ Kräftiger als das Männchen, jedoch demselben ähnlicher wie bei den übrigen Arten. Mandibeln und Vorderbeine kürzer, Stirn flacher, Hinterecken des Halssch. kaum zurückgebogen, die Ver- 
tiefungen auf demselben undeutlich oder fehlend, letztes Bauchsegment in der Mitte tief eingedrückt mit bogig ausgeschnittenem Hinterrande, Ausrandung des Kopfschildes ohne Zahn in der Mitte.

Die Art ist nur mit der folgenden nahe verwandt und die Unterscheidung der Weibchen oft schwierig; die kurze, gedrungene Form und die schwachen, kürzeren Fühler der tridentata $q$ sind besonders zu beachten.

Var, a., aus den südlichen Provinzen Oesterreichs und rom Rheine, besitzt einen deutlichen, aber an den Rändern verwaschenen pechbraunen Schulterpunkt.

Auf Birken und Eichen im Mai und Juni durch das ganze Gebiet verbreitet, aber nirgends häufig.

3. Lab. Humeralis'1): Virirli-aenea interdum viridi-cyanea, nitidula subtus breviter capiteque parce albido-pubescens. fronte impressa, rugoso-punctata, vertice crebre punctato anticeque subtiliter transversim

1) Nahe verwandt sind:

a. Oberlippe sehwarz, Halssch. kahl. Fld. rothbraun.

1. L. armeniaca Lac. (Mon. II. 5\%). L. 7,5-9 mm. Armenien, Persien.

2 L. hebraea Lac. (1. c. 55). L. 7-10 mm. Naht dunkel, jede Fld. nit sehr grosser, schwarzer Schultermakel und einer Längsmakel dahinter, die sich zuweilen zu einer breiten Längsbinde vereinigen (Var. limbata Lac.). Syrien.

3. L. bipunetata Mannh. (Humm. Essais IV. 40). L. $8-9 \mathrm{~mm}$. Blaugrün, Fld. hell gelbbraun. Gestreckter als humeralis. - Sibirien.

b. Oberlippe schwarz, Kopf und Halssch. dicht behaart.

4. L. asiatica Fald. (Nouv. Mém. Mosc. V. 370. t. 13. f. 8. 9). L. 9-13 mm. Blau- oder erzgrün, mässig glänzend, Fld. gelbbraun mit grosser Schultermakel, Halssch. wenig dicht, fein punktirt. Kopfschild beim $\hat{\odot}$ viereckig ausgeschnitten. - Kaukasus, Armenien.

5. L. proquinqua Fald. (1. c. 372. t. 13. f. 10. 11). L. 6,5-10 mm. Halssch. dichter und tiefer punktirt als bei Voriger, seine Hinterecken höher. Kopfschild des $\hat{\odot}$ dreizähnig, die Vorderschenkel vor der Spitze mit grossem, stumpfen Zahne. - Griechenland, Türkei, L'mgebung des schwarzen Meeres, Kaukasus. - Steveni Lac. (Mon. II. 4S) certe, sulcicollis Lac. (1. c. 49)?

6. L. rufa Waltl. (Isis VI. 472). L. 6-10 $\mathrm{mm}$. Schwarzblau, matt, Fld. rothbraun mit mässig grossem Schulterpunkte. Halssch. äusserst

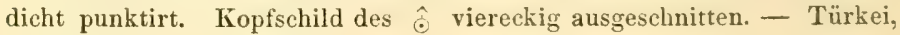
Griechenland, Kleinasien.

7. L. cavifrons Lefèvr. (Ann. Fr. 1872. 80). L. 9 mm. Wie vorige, aber blaugrün, etwas matt, Stiru weit und auftällig tief ausgehöhlt. Kopfschild des $\hat{\odot}$ schwach dreizähnig. - Tanger. 
rugoso, antennis sat validis, nigro-coeruleis, articulis tribus vel quatuor baseos inferne ferrugineis, prothorace creberrime punctato, basi haud bisinuato, medio evidenter lobato, elytris testaceis, puncto humerali nigro signatis. - Long. $7,5-10 \mathrm{~mm}$.

Mas: Cylindricus, capite magno, quadrato, fronte sat profunde impressa, vertice convexo; clypeo subquadratim emarginato, mandibulis validis, exsertis, lamina laterali fortiter elevata instructis.

Schneider Neu. Magaz. I. 2. 192 (Clythra). - Lac. Mon. II. 64. - Suffr. Stett. Zeit. 1851. 202. - Lefèvr. Ann. Fr. 1872. 101. - Kraatz Berl. Zeit. 1872. 203. - Seidl. Faun. b. 472. - Redtb. F. Austr. II. 448.

In der Regel grösser und gestreckter als die Vorhergehende, dunkel metallgrün, seltener blaugrün.

$\hat{o}$. Cylindrisch, Fld. blass gelbbraun, zuweilen mit dunklen Tüpfeln oder Längsstrichen versehen oder angedunkelt, mit mässig grossem, scharf begrenzten schwarzen Punkte auf der Schulterbeule. Fühler den Hinterrand des Halssch. überragend, schwarzblau, die ersten drei oder vier Glieder oberseits blaugrün, unterseits röthlich. Glied 3 und 4 gestreckt, letzteres doppelt so lang als breit und fast so lang als das erste oder Glied 2 und 3 zusammen; Glied 5 bis 10 dreieckig, 5 länger als breit, die folgenden quer, bis zum siebenten allmählich verbreitert, von hier bis zum zehnten leicht verschmälert. Kopf breit, viereckig, mit grossen, stark gewölbten Augen, sparsam und sebr kurz behaart, die Stirn tief quer eingedrückt. Die Vertiefung ist grob runzelig punktirt und wird vorn zwischen den Fühlerwurzeln von einer gebogenen, hohen Querkante

c. Oberlippe gelb. Kopf und Halssch. dicht behaart.

S. L. maculipennis Lefèvr. (Ann. Fr. 1872. 87. t. 1. f. 3, Kindermanni Kraatz Berl. Zeit. 1872, 201). L. 8-11 mm. Fld. ausser dem grossen Schulterpunkte mit einer runden Makel vor der Mitte, nahe der Naht. - Astrachan, Armenien.

9. L. diversifrons Lefèvr. (1. c. 90. t. 1. f. 5, speculifrons Kr. 1. c. 200). L. $8-11 \mathrm{~mm}$. Kopf und Halssch. äusserst dicht kurz behaart, seidenschimmernd, Scheitel stark gewölbt mit feiner Mittelfurche. $\hat{\odot}$. Kopfschild schwach dreizähnig, Vorderschenkel mit grossem stumpfen Zahme vor der Spitze. Fld. meist ohne Schulterpunkt, beim + mit Schultermakel. - Sarepta, Syrien.

10. L. decipiens Fald. (Faun. Transc. II. 373. t. 14. f. 1. 2). L. 7,5 bis $9,5 \mathrm{~mm}$. Scheitel durch eine breite Mittelfurche in zwei stark gewölbte Hälften getheilt, $\hat{\odot}$ mit fast viereckigem Ausschnitte des Kopfsch., Schulterpunkt leicht angedeutet, beim $q$ deutlich, zuweilen in einen Längswisch verlängert (Var. lineola Redtb.). - Südrussland, Armenien, Persien. 
begrenzt, vom Scheitel durch eine Bogenlinie und von den Augen durch eine von der Fühlerwurzel aufwärts ziehende Èrhöhung getrennt. Scheitel gewölbt, fein punktirt oder längsrunzelig, mit seichter Mittelfurche und feinen Querrunzeln am Vorderrande. Kopfschild tief, fast viereckig ausgeschnitten, die Mitte des Ausschnittes grade oder in einen kurzen, stumpfen Zahn verlängert. Mandibeln breit und stark, gekrümmt, mässig vorgestreckt, der Seitenrand oberseits in eine hohe Kante aufgebogen. Halssch. hinter der Mitte am breitesten, von hier nach vorn gerundet-, nach hinten gradlinig verengt, Hinterrand beiderseits kaum ausgerandet, aber in der Mitte in einen breiten, gerundeten Lappen gegen das Schildchen vorgezogen, welcher weiter nach rückwärts reicht als die graden Hinterecken. Oberfläche sehr dicht, wenig stark punktirt, die Punkte länglich. Fld. weitläufiger, flacher und wenig gröber punktirt als das Halssch. Vorderbeine sehr lang, Unterseite der Schenkel vor der Spitze leicht ausgeschnitten, die vier Vorderschienen stark gekrümmt. Hinterrand des gleichmässig gewölbten letzten Bauchsegmentes in der Mitte grade.

Penis oben mit einer starken Längsvertiefung, die Seiten vor der Oeffnung gerundet erweitert und unten in eine scharfe Spitze vorgezogen.

․ Wenig kleiner als das Männchen, vorn und hinten schmaler, Kopf dreieckig, Kopfschild bogenförmig ausgeschnitten, Stirn mit flachem Eindrucke, von dem fast ebenen Scheitel nur durch zahlreiche Querrunzeln getrennt; Halssch. von den Hinterecken allmählich nach vorn verengt, Fld. stärker punktirt und meist dunkler gelbbraun gefärbt. Mandibeln und Beine kurz. Letztes Bauchsegment vor der Mitte des bogenförmig ausgeschnittenen Hinterrandes mit einer Grube.

Vom westlichen Frankreich durch die Schweiz, Oesterreich und Ungarn bis Sarepta verbreitet, nördlich einzeln bis Stockholm.

4. Lab. Iucida' ${ }^{1}$ : Viridi-cyanea aut-aenea, nitida, subtus temuiter pubescens; fronte plus minusve impressa, rugoso-punctata, rertice convexo, punctato-ruguloso, antennis validis, nigro-coeruleis, basi

1) Hierher folgende habituell sehr ähnliche Arten der europ. Fauna: (Oberlippe pechschwarz, Kopf und Halssch. fein behaart.)

1. L. brevipennis Fald. (Faun. Transe. II. 375. t. 14. f. 3. 4.) L. $6-8,5 \mathrm{~mm}$. Die ersten vier Fühlerglieder fast so lang als die folgenden zusammen. Stirn weit ausgehöhlt, vorn fein und dicht gerunzelt, hinten fast glatt, mit einem tiefen Grübchen in der Mitte 
inferne rufescentibus; prothorace punctulato, basi haud bisinuato, elytris pallide testaceis, crebre punctulatis, puncto humerali nigro. Long. 5-9 mm.

Mas: cylindricus, capite magno, quadrato, clypeo subquadratim emarginato, sinu obsolete dentato, mandibulis validis.

Germar Ins. Spec. nov. 548 (Clythra). - Lacord. Mon. II. 67. - Suffr. Stett. Zeit. 1851. 203. - Lefèvr. Ann. Fr. 1872. 102. - Kraatz Berl. Zeit. 1872. 204. - Redtb. Faun. A. II. 448 .

zwischen den Augen. Kopfschild des $\hat{\odot}$ scharf viereckig ausgeschnitten. - Von Sarepta durch Caucasien und Armenien bis Persien.

2. L. Beckeri: Brevis, viridi-aenea, subtus tenuiter capite thoraceque tenuissime pubescens; antennis nigro-coeruleis, articulis quatuor baseos gracilioribus, inferne rufescentibus, articulis $5^{0}-11^{0}$ latissimis; labro piceo; fronte fere plana, foveolis tribus instructa, sparsim punctata, vertice punctulato, prothorace minute basique fortiter punctato, angulis posticis obtusiusculis, parun elevatis; elytris testaceis confertim sat grosse profundeque punctatis. Mas: capite quadrato thoraceque magno, clypeo tridentato, mandibulis validis, exsertis, margine laterali basi fortiter elevato instructis. - Long. 6,5-8 mm. Sarepta (B ecker).

Eine durch die fast ebene, in der Mitte einzeln, stark punktirte Stirn und die kräftig punktirten Fld. leicht kenntliche Art.

3. L. metallica Lefèvr. (Ann. Fr. 1872. 83). L. $6-7 \mathrm{~mm}$. Von voriger durch gerunzelte, leicht vertiefte Stirn, hohe Hinterecken des Halssch. und die feine Punktur der Fld. verschieden. Sarepta. Orenburg.

4. L. senicula Kraatz (Horae ent, Ross. VIII. 29). L. 5-7 mm. Gestreckt, lebhaft metallgrün, oft goldglänzend, Kopf und Halssch. lang weisslich behaart, Stirn tief quer eingedrückt, matt, dicht und wenig stark gerunzelt, Scheitel und Halsschild fein, nicht dicht punktirt; Hinterecken des Halsschildes hoch aufgebogen, spitzwinkelig, mit abgerundeter Spitze. Fld. blass gelbbraun, sehr fein verloschen punktirt mit kleinem Schulterpunkte. Kopfschild des $\hat{\odot}$ schwach dreizähnig. Der Körperbau erinnert an pallidipennis. L. nitida Ball. Bull. Mose. 1878. II. 371. aus Kuldsha seheint nahe verwandt zu sein. - Sarepta. Astrachan.

5. L. uralensis Lacord. (Mon. II. 73.) L. 5-6 mm. Blaugrün. Körperform und Punktirung des Halssch. der $C l$. longimana ähnlich. Scheitel gewölbt, mit einer Mittelfurche. Kopfschild des $\hat{\odot}$ schwach dreizähnig. - Klein-Asien.

6. L. rugicollis Lefèvr. (Ann. Fr. 1872. 86). L. 5-7 mm. Kopf und Scheitel eben, dicht und fein runzelig punktirt. Das Halssch. dicht mit feinen Punkten besetzt. Kopfschild glatt, das des $\hat{\odot}$ tief viereckig ausgeschnitten. - Südrussland. Astrachan (Faust). Eine ähnliche Kopfbildung findet sich nur beim 오 von tridentata. 
Var. a. Brevior, thorace minus convexo. creberrime punctulato.

Lab. axillaris Lacord. Mon. II. 69. - Redtb. l. e. 448.

Jab. laticollis Lacord. 1. e. 69.

Var. b. Humeris immaculatis.

§. Cylindrisch, blau- oder erzgrün, besonders das Halssch. glänzend, Fld. weisslich gelbbraun mit mässig grossem schwarzen Schulterpunkte. Fühler mindestens den Hinterrand des Halssch. erreichend, schwarzblau, die ersten drei bis vier Glieder unterseits oder fast ganz trüb röthlich, Glied 3 und 4 dünn, gestreckt, letzteres so lang als die beiden vorhergehenden zusammen, die folgenden stark nach innen erweitert. Kopf breit, viereckig, mit grossen, hoch gewölbten Augen; Stirn kaum sichtbar behaart, wenig tief quer eingedrückt, oft fast eben, stark runzelig punktirt; der Scheitel gewölbt, bald sparsamer, bald dichter fein punktirt, die Punkte länglich, ihre Zwischenräume meist mit äusserst feinen, in Längsrunzeln stehenden Punkten besetzt. Kopfschild gleichmässig rertieft, fast immer schwach messingglänzend, tief fast viereckig ausgerandet, in der Mitte in einen sehr stumpfen, kurzen Zahn vorgezogen, selten gerade. Mandibeln stark, vorn plötzlich nach innen gebogen, die Aussenseite mit hoher Kante, die Spitze roth gesäumt. Halssch. wenig vor den Hinterecken am breitesten, nach vorn stark gerundet-verengt, die Oberfläche mässig gewölbt, weitläufig und fein punktirt, mit einem oft tiefen Grübchen jederseits hinter der Mitte. Fld. dicht, etwas stärker als das Halsschild punktirt. Schenkel der langen Vorderbeine unterseits vor der Spitze leicht ausgeschnitten, die vier Vorderschienen etwas gekrümmt.

Penis dem der vorigen Art ähnlich, oben vor der Oeffnung mit einer tiefen, kurzen Grube, die Oeffnung lang, die Seiten kaum erweitert.

‥ Kleiner; Kopf nach vorn verschmälert, Kopfschild bogenförmig ausgeschnitten, Stirn unmerklich eingedrückt oder eben, mit zwei Grübchen zwischen den Augen und einem dritten darüber am Vorderrande des Scheitels. Halssch. von den Hinterecken nach rorn allmählich verengt, Fühler kürzer, besonders Glied 3 und 4, vom fünften Gliede an weniger breit erweitert; Fld. kräftiger punktirt.

Es sind zwei merklich verschiedene Formen zu unterscheiden, die vielleicht gute Arten sind:

a. Lab. lucida der Autoren, zu der die Var. sareptana $\mathrm{Kr}$. (Horae VIII. 29) gehört, ist gestreckt, Stirn in beiden Geschlechtern eben, Halssch. mässig gewölbt und weitläufig punktirt, Kopf beim $\hat{\jmath}$ nur etwas breiter als beim $ᄋ$, Fld. mehr als doppelt so lang als breit, weisslich, mit sehr kleinem Schulterpunkte. In Südeuropa 
von Spanien bis Sarepta verbreitet, einzeln im mittleren und südlichen Deutschland. Das Weibchen ist leicht mit lusitanica zu verwechseln.

b. Lab. axillaris Lac., in Oesterreich, Ungarn und den Donaufürstenthümern am Grase auf trockenen Bergabhängen nicht selten, ist kurz und plump, Stirn deutlich, oft tief eingedrückt, Kopf und Halssch. dichter und stärker punktirt (letzteres flacher) und beim Männchen bedeutend breiter als beim Weibchen. Fld. nur doppelt so lang als breit, mit grösserem Schulterpunkte.

Von beiden Formen finden sich Stücke, besonders Männchen, denen der Schulterpunkt fehlt.

5. Lab. Longimane $\left.{ }^{1}\right):$ Aenea, nitidula, subtus tenuiter pubescens; fronte impressa, rugoso-punctata, vertice subconvexo, punctulato, longi-

1) L. h.spanica Lac. (Mon. II. 74) aus Spanien unterscheidet sich nur durch die bläuliche Körperfarbe, die in beiden Geschlechtern kaum verschiedene Kopfbildung, die flache Stirn und den in der Mitte graden Ausschnitt des Kopfschildes beim $\hat{\odot}$.

Hierher gehören ferner:

1. L. eentromaculata Géné (Mem. Ac. Torin 1839. 31. t. 1. f. 24). L. 4-5,5 mm. Kopf dicht behaart. Körper rein blau, blau- oder bronzegrün, Fld. rothgelb, ein Schulterpunkt, eine gemeinschaftliche ovale Makel auf der Naht, vom Schildchen bis zur hinteren Wölbung reichend, und eine Längsmakel am Seitenrande, von der Mitte bis zur Krümmung entsprechend gefärbt wie das Halssch. - Auf Erica scoparia in Corsica und Sardinien.

Es lassen sich drei Varietäten unterscheiden:

a. syriaca Lac. (Mon. II. 75). Das Roth nimmt überhand und verkürzt die gemeinschaftliche Makel der Fld., so dass sie znletzt klein, queroval, die Seitenmakel halbkreisförmig wird.

b. 4-notata O1. (Enc. méth. VI. 33). Das Roth breitet sich so aus, dass es die Makeln verschmälert und bei der extremsten Form nur noch ein schmaler Naht- und Seitensaum dunkel bleibt.

c. Damryi: Die Makeln dehnen sich ans. Zunächst fliesst Schulterpunkt und Seitenmakel in eine breite Längsbinde zusammen, später vereinigt sich diese mit der Nahtmakel, endlich sind die Fld. blan oder blaugrün, ein schmaler Saum am Grunde und eine grosse ovale Makel vor der Spitze jeder einzelnen rothgelb. - Sardinien (Dam ry).

L. Lejeuni Fairm. ist täuschend ähnlich gefärbt, aber durch feine Skulptur der Thorax und der Fld. verschieden.

2. L. Ghilianii Lac. (Mon. II. 77). L. 6 mm. Schwarz, Kopf und Halssch. kahl, Fld. hellgelb, ausser dem Schulterpunkte mit einem grösseren Punkte hinter der Mitte. - Spanien. 
tudinaliter sulcato, antennis nigro-coeruleis, basi inferne rufescentibus, prothorace fortiter minus crebre punctato, elytris testaceis, crebre punctatis, puncto humerali nigro-fusco. - Long. $3,5-7,5 \mathrm{~mm}$.

Mas: capite magno, quadrato, clypeo subquadratim emarginato, sinu medio rotundato-producto, mandibulis validis.

Linn. Faun. Suec. 170 (Chrysom.). - Lac. Mon. II. 70. Suffr. Stett. Zeit. 1851. 204. - Lefèvr. Ann. Fr. 1872. 103. Seidl. F. balt. 472. - Redtb. Faun. A. II. 448 (Lab.).

Var. a. Viridi-cyanea, thorace crebre punctato.

Lab. dalmatina Lac. 1. e. 71.

Var. b. Humeris immaculatis.

§. Metallgrün, Fld. hell gelbbraun, auf der Schulterbeule ein schlecht begrenzter schwärzlicher Schulterpunkt; Unterseite dicht, fein und kurz weisslich behaart. Fühler kaum den Hinterrand des Halsschildes erreichend, schwarzblau, die vier ersten Glieder unterseits oder fast ganz trübroth, Glied 2 bis 4 wenig schmaler als das erste, 4 gestreckt, etwas länger als 3, die folgenden mässig erweitert. Kopf breit, viereckig, mit einzelnen schlecht bemerkbaren Härchen, Stirn tief eingedrückt und dicht runzelig, aber nicht tief punktirt, matt, der Eindruck setzt sich, allmählich verschmälert, in der Mitte des dicht und fein punktirten Scheitels bis zum Vorderrande des Halssch. fort. Kopfschild tief viereckig ausgerandet, in der Mitte in einen kurzen, gerundeten Lappen rorgezogen. Mandibeln mässig lang, stark gekrümmt, oberseits ausgehöhlt. Halsschild wenig vor den Hinterecken am breitesten, nach vorn und hinten fast gradlinig verengt, die Oberseite mässig gewölbt, uneben, mit tiefer Querlinie vor dem Hinterrande, unregelmässig, wenig dicht aber grob punktirt. Fld. dicht und fein punktirt. Vorderbeine verlängert, die vier vorderen Schienen leicht gekrümmt.

Penis oberseits mit zwei tiefen Längsfurchen, die durcb einen scharfen Kiel getrennt werden, die Oeffnung kurz, oben grade abgeschnitten, die Seiten vor derselben gradlinig verengt und in eine breite, gerundete Spitze vorgezogen.

오. Wenig kleiner, ovaler, durchgängig stärker punktirt, die Fld. dunkel gelbbraun, mit grösserem Schulterpunkte versehen. Kopf, Mandibeln und Vorderbeine kleiner, Kopfschild bogenförmig ausgeschnitten.

Zuweilen ist der Körper grünlichblau, das Halssch. dicht punktirt (Var. dalmatina), häufiger noch fehlt der Schulterpunkt.

Ueberall; die Var. a. mehr im Süden. 
C. Fühler vom fünften Gliede an gesägt. Oberlippe gelb. Flügeldecken ohne Schulterpunkt.

6. Lab. pallidipennis: Viridi-aenea, corpore subtus, capite prothoraceque supra dense albido-pubescens, antennis cyaneis, articulis tribus vel quatuor baseos, rufo-flavis, primo macula aenea superne notato, capite subquadrato, fronte profunde transversim impressa, vertice convexo, prolhorace parum profunde puncialo, nitido, elytris pallide testaceis. - Long. $7-10 \mathrm{~mm}$.

Mas: capite mediocri, clypeo sat profunde arcuatim emarginato, mandibulis validiusculis, modice exsertis, perlibus anticis elongatis, tibiis arcuatis.

Gebl. Ledeb. Reis. II. 3. 199 (Clythra). - Lac. Mon. II. 50. -

Suffr. Stett. Zeit. 1851. 202. -- Lefèvr. 1. c. 91. - Kraatz

Berl. Zeit. 1872. 202. - Redtb. Faun. A. 449.

Cl. longipennis Gebl. Bull. Mose. 1848. I. 366.

Cl. chalybeicornis Brull. Exped. Mor. III. 268.

Var. a. Robustior, prothorace minus subtititer menctato, subopaco, elyiris, praesertim feminae, fortiter punctatis.

Cl. distinguenda Rosenh. Beitr. Ins. F. Eur. 63. - Lefèvr. l. c.

78. - Kraatz 1. c. 202. - Gredler Käf. Tir. 407. - Redtb. 1. c. 449 .

Var. b. Fronte obsolete impressa, prothorace subtilissime punctato, nitido. Lab. pilicollis Lac. 1. c. 52. - Suffr. 1. c. 202. - Lefèrr. 1. e. 92. Kraatz 1. c. 202 . Redtb. l. c. 447.

§. Erz- oder blaugrün, Fld. blass gelbbraun, die Unterseite sowie Kopf und Halssch. dicht behaart. Fühler den Hinterrand des Halssch. kaum überragend, dunkel kornblumenblau, die ersten drei oder vier Glieder hell rothgelb, das erste oberseits mit grüner Makel. Glied 1 dick, gestreckt, 2 sehr kurz, nach innen merklich erweitert und kaum schmaler als das erste, Glied 3 gleichbreit, 4 wenig länger, am Grunde so breit als 3, nach der Spitze deutlich erweitert und oft in einen scharfen Zahn ausgezogen, 5 bis 10 ziemlich gleichbreit, nur mässig erweitert, das Endglied mit langer und schmaler Spitze. Kopf viereckig, die Stirn breit, mehr oder weniger tief quer eingedrückt oder ausgehöhlt, dicht und tief, mässig stark punktirt; der Scheitel gewölbt. Kopfschild vorn tief ausgerandet, die Ausrandung fast halbkreisförmig oder viereckig, die Mitte grade oder in einen kleinen gerundeten Lappen, selbst einen schwachen Zahn vorgezogen. Mandibeln mässig lang und stark, leicht gebogen, der Seitenrand oberseits nur undeutlich erhöht. Halssch. quer, etwas gewölbt, von den Hinterecken nach vorn gerundet-verengt, vor dem Hinter- und am Vorderrande quer vertieft, mit einem breiten Grübchen jederseits auf der Scheibe hinter 
der Mitte, wenig dicht, seitwärts und vor dem Hinterrande dichter und stärker punktirt, mehr oder weniger glänzend. Fld. matt, dicht mit wenig tiefen, feinen Punkten besetzt. Vorderbeine stark verlängert, ihre Schenkel dick, vor der Spitze unterseits ausgeschnitten, ihre Schienen stark-, die mittleren wenig-gekrümmt.

Penis kurz, fast so breit als lang, die Seiten an der Oeffnung wenig erweitert und in einen breiten Lappen so nach innen umgeschlagen, dass vor der Spitze eine schmale, rinnenförmige Oeffnung frei bleibt.

ㅇ. Etwas breiter als das Männchen, mit glänzenden, stärker punktirten Fld., wenig kleinerem Kopfe, kurzen Mandibeln und Beinen und flacherer Stirn. Kopfschild leicht bogenförmig ausgeschnitten, Halssch. nach vorn stärker und gradliniger verengt, seine Eindrücke nur angedeutet. Hinterrand des letzten, in der Mitte schwach vertieften Bauchsegmentes bogenförmig ausgeschnitten.

In Oesterreich auf Weiden stellenweise häufig, in Südeuropa weit verbreitet.

Die Art kommt in drei Formen vor:

1. pallidipennis Gebl. - Häufigste Form. Stirn sehr tief eingedrückt, Halssch. kurz, quer, fein punktirt, glänzend.

2. distinguenda Rosh. - Tirol. Kärnthen. Breiter als pallidipennis, Stirn mässig tief eingedrückt, Halssch, kurz, quer, seicht aber wenig fein punktirt, zwischen den Punkten äusserst dicht und zart nadelrissig, ziemlich matt. Fld. besonders beim Weibchen stark punktirt.

3. pilicollis Lac. - Von Ungarn bis zum Caspischen Meere verbreitet. Stirn fast eben, Scheitel weniger gewölbt als bei den vorigen, Halssch. länger, schwach viereckig, sehr fein punktirt, stark glänzend.

Obwohl Lefèvre diese Formen als Arten festhalten will und distinguenda sogar in eine unnatürliche Verbindung zur ersten Gruppe bringt, scheint mir ihre Zusammengehörigkeit kaum zweifelhaft. Die Fühlerbildung ist bei allen dieselbe und die Ausrandung des Kopfschildes sowie die Vertiefung der Stirn sehr variabel. Unter Stücken von pallidipennis, bei Prag ron H. Stussiner gesammelt, ist die Ausrandung bald halbkreisförmig, bald viereckig oder leicht dreizähnig. Lacordaire und Lefèvre nennen mit Recht pilicollis breiter, weniger gestreckt als pallidipennis, während Suffrian dieselbe (Stett. Zeit. 1851. 202) als ,schmäler und schlanker" angiebt. 
7. Lab. cymicormis ${ }^{1}$ ): Viridi-aenea, niiidula, sublus dense, capite prothoraceque supra subtilissime albido-pubescens, antennis cyaneis, articulis tribus vel quaiuor baseos rufo-flavis, primo macula coerulea vel aenea superne signato; capite subquadrato, fronte late impressa, clypeo tridentato; prothorace minus dense profundeque punctato, elytris testaceis. - Long. 5-8 $\mathrm{mm}$.

Mas: capite thoraceque magno, mandibulis validis, thorace basi fortiter transversim impresso, pedibus anticis elongatis, tibiis arcuatis.

Germ. Faun. Ins. Eur. VII. 7. - Lacord. Mon. II. 53. Suffr. Stett. Zeit. 1851. 202. - Lefèvr. Ann. Fr. 1872. 93. - Redtb. Faun. A. II. 448.

Lab. tridentata Redtb. 1. c. 448 .

Kleiner, zumal kürzer als die Vorige, sparsamer und schwächer behaart, die Fld. tiefer gelb, das Kopfschild in beiden Geschlechtern dreizähnig.

§ै. Cylindrisch, erzgrün, selten bläulich, die Unterseite kurz und dicht, Kopf und Halssch. weitläufiger fein weisslich behaart, letz-

1) Hierher L. lepida Lefèvr. (Ann. Fr. 1872. 94) L. 6-7,5 mm. Kürzer, Halssch. bläulichgrün, sparsam punktirt, kahl; Kopf sehr breit, feinhaarig, Kopfschild beim $q$ in der Mitte ohne Zahn. - Südöstliches Russland. (Orenburg, Faust.)

Die Abtheilung der Gattung mit dreizähnigem Kopfschilde des $\hat{\odot}$ und grösstentheils oder ganz blau- oder erzgrün gefärbten Fld. (Chlorostola m.) ist in Deutschland nicht vertreten. Zu ihr gehören:

a. Oberlippe röthlich oder gelbbraun. Erstes Fühlerglied normal.

1. L. sibirica Germ. (Ins. spec. nov. 545). L. 4,5-6,5 mm. Fld. dicht und grob punktirt. Mittelzahn des Kopfschildes kurz. - Sibirien.

b. Oberlippe schwarz. Erstes Fühlerglied sehr schlank, so lang als die drei folgenden zusammen.

aa. Flügeldecken mit rothgelber Spitzenmakel.

2. L. Guerini Bassi (Ann. Fr. 1834. 472.) L. 4,2-5 mm. Stirn mit drei im Dreieck stehenden tiefen Grübchen. Mittelzahn des Kopfschildes kurz. - Sicilien.

3. L. Lejeuni Fairm. (Ann. Fr. 1866. 70. - Pelissieri Bucq. Kraatz Berl. Zeit. 1872. 205.) L. 4,5-6 mm. Wie die vorige, doch ausser der Spitze auch die Basis der Fld. rothgelb. Mittelzahn des Kopfschildes so lang als die seitlichen. - Algier.

bb. Flügeldecken einfarbig grün.

4. L. trifoveolata Desbr. (Bull. Ac. Hippon. 1866. 42.) L. 4,5-6,5 mm. Ganz wie Guerini, nur ohne Spitzenmakel. - Algier.

5. L. hordei Fabr. (Mant. I. 83.) L. $3-5 \mathrm{~mm}$. Stirn ohne die drei Grübchen, besonders beim $\hat{\odot}$ stark rothgoldig. Mittelzahn des Kopfschildes breiter und fast so lang als die seitlichen. -- Spanien, Portugal, Nordafrika. 
teres oft fast ganz abgerieben. Fühler ähnlich gefärbt und gebildet wie bei pallidipennis, die Spitze des letzten Gliedes kürzer und breiter. Kopf viereckig, die Stirn weit und flach eingedrückt, die grösste Vertiefung in der Mitte, als Aufang der Längsfurche über den wenig gewöllten Sclieitel; dicht runzelig punktirt, die Punkte des Scheitels schwächer und zu Längsrunzeln vereint. Kopfschild tief ansgerandet, in der Mitte mit einem stumpfen Zahne, welcher bedeutend kürzer als die beiden seitlichen ist. $M$ andibeln mässig lang, stark gekrümmt, der Seitenrand oberseits in eine hohe Kante aufgebogen. Halssch. hinter der Mitte am breitesten, beiderseits leicht gerundet-verengt, quer gewölbt, am Hinterrande stärker als am Vorderrande quer vertieft, mit einem sehiefen Längseindrucke jederseits auf der Scheibe hinter der Mitte. Die Oberfläche wenig dicht und fein, tief punktirt, ähnlich, alver bedeutend schwächer als bei longimana, die Punkte in der Nähe des Hinterrandes stärker und dichter; zuweilen sind die Zwischenräume äusserst fein nadelrissig. matt. Fld. glanzlos, dicht und fein punktirt. Vorderbeine stark verlängert, die vier Vorderschienen vor der Spitze gekrümmt. Hinterrand des letzten Bauchsegmentes in der Mitte grade.

Penis dem der vorigen Art ähnlich, die Seiten aber vor der Oeffnung nicht erweitert.

․ Selten so lang als das Männchen, aber breiter, glänzender, die Zähne des Kopfschildes bedeutend kürzer, Mandibeln klein, Vertiefungen auf Kopf und Halssch. schwächer. Vorderbeine nicht verlängert, die Schienen gerade. Hinterrand des letzten, in der Mitte längsgerinnten Bauchsegmentes bogenförmig ausgeschnitten.

In den südlichen Provinzen Oesterreichs, wie in Südfrankreich. Norditalien, Ungarn und Südrussland häufig. Tiroler Stücke (Bozen, Ludy) sind sehr kräftig, mit auffallend breitem Halssch.

\section{Macrolenes.}

Lacord. Monogr. d. Phytophag. II. 100.

Clypeus angulis anticis rotundatis.

Alandibulae parum exsertes, crassae, apice hand forcipatae. Antennae articulo tertio secundo vix angustiore.

Prothorax busi lobo medio elecalo. angulis posticis acutis, elevatis. Pedes antici maris longiores.

Körper schmächtig, schwarz, der Mund, das Halsschild, die Flügeldecken und zum grossen Theil die Beine röthlichgelb; Unterseite dicht, der Kopf fein behaart. Fühler kräftig, die ersten drei Glieder gleichbreit und nur mässig schmaler als die folgenden ge- 
sägten. Kopfschild im Bogen ausgerandet, die Vorderecken gerundet. Mandibeln stark, gleichbreit, grade vorgestreckt, gelblich, die Spitze schwarz. Halsschild quer, mit deutlichen, aufgebogenen Hinterecken und einer graden Querfurche am Hinterrande von einer Ecke zur andern; der Mittellappen des Hinterrandes aufgebogen, aber kaum gegen das Schildchen vorgezogen. Beine schlank.

Das Männchen ist schmal, ähnlich gebaut wie Lab. cyanicornis, aber das Halsschild fast breiter als die Flügeldecken, mit stark gerundeten Seiten. Die Vorderbeine sehr lang, ihre Schenkel unterseits vor der Spitze rinnenförmig vertieft, das erste Tarsenglied meist so lang als die zwei oder drei folgenden zusammen. Penis kurz, ziemlich schmal, die Oeffnung durch eine vorn grade abgestutzte Klappe geschlossen. Das Weibchen ist kurz, oval, einer Coptoceph. floralis auch in der Färbung nicht unähnlich.

Als Untergattungen sind aufzufassen: Barybaena, Plecomera und Nosognatha Lac., während die Vereinigung mit Miopristis, Atelechira, Smeia etc., wie sie der Münchener Catalog angiebt, nicht natürlich ist.

1. Tuecr. muficollis ${ }^{1}$ ): Nigra, capite antice, prothorace, elytris pedibusque rufo-lestaceis, his dorso tarsisque nigris; antennis nigris, articulis quatuor baseos plus mimusve testaceis. Fronte late profunde depressa, prothorace fere laevi, elytris subtiliter punctatis, puncto humerali nigro. - Long. $4-7 \mathrm{~mm}$.

Mas: parallelus, femoribus anticis subtus ante apicem bidendatis.

Fabr. Syst. ent. 109 (Cryptoc.). - Suffr. Stett. Zeit. 1851. 205. - Kraatz Berl. Zeit. 1872. 206.

Var. a. Elytris immaculatis.

Var. b. Elytro singulo maculis duabus nigris.

M. (Cryptoc.) bimaculata Rossi Faun. Etruse. I. 91.

Var. c. Elytro singulo maculis tribus nigris, pedibus saepe omnino fuscis.

Cl. salicariae Ménétr. Bull. Ac. Petr. I. 151. - Küst. Käf. Eur. 7.99. $\mathrm{V}$ ar. d. Elytro singulo maculis qualuor nigris, pedibus fuscis.

M. ruficollis Lac. Mon. II. 100. - Lefèvr. Ann. Fr. 1872. 113.

Kopf schwarz, Kopfsehild und Mund rothgelb. Stirn weit und tief eingedrückt, flach gerunzelt, Scheitel gewölbt, fast glatt. Fühler schwarz, die vier ersten Glieder rothgelb, oberseits mit schwarzer

1) Sehr ähnlich ist M. Bellieri Reiche (Ann. Fr. 1869. 735) aus Sicilien und Algier (Leder.). L. 4,5-9 mm. Beine einfarbig rothgelb, Tarsen schwarz; Vorderschenkel des $\hat{3}$ unbewehrt, Vorderschienen äusserst fein gezähnelt, Mittelschenkel nach der Spitze gradlinig verengt. Fld. ansser dem Schulterpunkte mit einem schwarzen Flecken hinter der Mitte an der Naht, oder einfarbig. 
Makel. Halssch. röthlich, fein und undeutlich punktirt, fast glatt, Fld. wenig stārker punktirt, aber beller und gelblicher als das Halssch., mit einem grossen, länglichen schwarzen Schulterpunkte Schildchen schwarz. Beine gelblich-roth, eine Längslinie auf dem Rücken der Schenkel (zuweilen fehlend) und Schienen, sowie die Tarsen schwarz. Oft sind Mittel- und Hinterschienen ganz dunkel gefärbt.

Bei dem schlanken of ist die Rinne der Vorderschenkel jederseits vor der Spitze mit einem starken Zahne besetzt, von denen der innere sebr spitz ist, die Mittelschenkel sind unterseits vor der Spitze bogenförmig ausgeschnitten, fast stumpf gezähnt. Das \& besitzt auf der Mitte des letzten Bauchsegmentes einen breiten, glatten Längseindruck.

Die Zeichnung der Fld. ändert vielfach ab. Sie sind:

a. Einfarbig.

b. Jede mit zwei Makeln, eine auf der Schulter, die andere hinter der Mitte unweit der Naht.

c. Jede mit drei Makeln; ausser den rorigen noch mit einer meist dreieckigen am Seitenrande hinter der Mitte. Beine oft ganz dunkel.

d. Jede mit vier Makeln; zwei auf der Schulter und zwei hinter der Mitte, von denen die vorderen gewöhnlich zu einer grossen, eckigen Makel, die hinteren zu einer breiten Querbinde vereinigt sind.

Auf jungen Eichen in der Umgebung des mittelländischen Meeres häufig. Der mir bekannte nördlichste Fundort ist Fiume, dagegen erscheint Lacordaire's Angabe über das Vorkommen in Tirol zweifelhaft, zumal auch Gredler die Art nicht erwähnt.

\section{Tituboea.}

L a cord. Monogr. d. Phytophag. II. 141.

Clypens angulis anticis rotundatis vel subrectis.

Mlandibulae parum exsertes. sinistra longiore apice acuia.

Antennae articulo tertio secundo parum angustiore.

Prothorax basi biimpressus, anyulis posticis subrotundatis, haud elevatis.

Pedes antici mavis lompiores, tarsi articulo primo longissinu.

Körper kräftig, schwarz, Halsschild und Flügeldecken oder nur letztere rothgelb; Unterseite dicht, Kopf sparsamer fein behaart. Fühler ziemlich kurz, das erste Glied sehr breit, 2 und 3 kurz und schmal, 4 länglich dreieckig, 5 bis 10 stark quer, innen breit zuge- 
spitzt. Kopfschild im Bogen oder leicht dreieckig ausgerandet mit abgerundeten oder fast rechtwinkeligen Vorderecken. Mandibeln stark, wenig vorstehend, die linke länger als die rechte, vorn zugespitzt. Halsschild mit abgerundeten, kaum aufgebogenen Hinterecken und einem Eindrucke jederseits am Hinterrande. Flügeldecken gewöhnlich heller als das Halsschild, jede mit einem selten fehlenden Schulterpunkte und zwei bis vier punktförmigen schwarzen Makeln. Beine mässig schlank.

đิ Cylindrisch, die Vorderbeine stark verlängert, ihre Schienen gekrümmt; das 우 meistens länglich-oval, stärker gewölbt, der Kopf kleiner, Mandibeln und Vorderbeine kürzer, das letzte Bauchsegment vor dem Hinterrande grubenförmig vertieft. Penis (von macropus) an der Oeffnung allmählich erweitert, die Seiten derselben parallel, vorn in eine scharfe, dreieckige Spitze verschmälert, unten jederseits mit einer Längsreihe steifer, gelblicher Borstenhärchen. Die Oeffnung ist durch eine vorn dreizähnige Klappe geschlossen.

1. T. meacropous: Nigra, subtus capiteque albido-pubescens, fronte late impressa parceque ruyuloso-punctata, vertice convexo, obsolete punctulato; antennis nigris, articulis quatuor primis fulvis; prothorace fulvo, nitido, sublaevi, elytris pallide fulvis, inordinate lineatim punctatis, maculis tribus (una humerali, duabus infra medium saepe confluentibus) nigris. - Long. 6-10 $\mathrm{mm}$.

Mas: pedibus fulvis, genubus tarsisque nigricantibus; pedibus anticis longissimis, tibiis ejusdem subarcuatis.

F em: pedibus brevioribus, femoribus tarsisque nigris, tibiis fulvis.

Illiger Wiegm. Arch. I. 2. 128 (Clytra). - Lacord. Mon. II. 146. - Lefèvr. Ann. Fr. 1872. 124. - Redtb. Faun. A. II. 450 .

Var. a. Elytris maculis duabus (altera humerali, altera ad suturam infra medium) piceis.

Var. b. Elytris puncto humerali piceo.

Var. e. Elytris immaculatis.

Schwarz, Halssch. und Fld. (letztere blasser) rothgelb. Kopf länglich, sparsamer als die Unterseite weisslich behaart, Stirn breit eingedrückt, weitläufig, flach runzelig-punktirt, an den Augen sparsam gekörnt, zwischen den Augen mit einem tieferen Grübchen, zwischen den Fühlerwurzeln mit einem leichten Längskiele. Scheitel gewölbt, verloschen punktulirt. Fühler schwarz, die ersten vier Glieder rothgelb. Halssch. kaum doppelt so breit als lang, glänzend, fast glatt, die Hinterecken abgerundet. Schildchen breit-dreieckig, schwarz. Fld. fein, unregelmässig gereiht-punktirt mit je 3 schwarzen Makeln, die eine auf der Schulterbeule, die bejden 
andern in einer Querreihe hinter der Mitte (oft zusammengeflossers). die äussere stets kleiner.

Beim $\hat{\jmath}$ ist das Halssch. so breit als die Fld. in den Schultern, Beine rothgell, mit Ausnahme der dunklen Knime und Tarsen, die vorderen sehr lang, ihre Schienen gekrümmt. Das $f$ ist gewölbter, das Halssch. deutlich schmaler als die Fld., nur die Schienen rothgell,

Die Art ist in Grösse und Körperform sehr variabel. Von den Makeln der Fld. verschwindet nicht selten die äussere des hinteren Paares (Var. a.), oft fehlen die lieiden hinteren (Var. b.), selten alle drei (Var. c.).

Bei Wien. Häufiger in Ungarn und ganz Südeurnpa.

Tabelle der Tituboea-Arten:

1. Seitenrand der Fld. wenig gekrümmt, innere Randlinie des Umschlages dicht hinter der Schulter stark auf die Unterseite der Fld. gebogen. Letztere mit je drei schwarzen Makeln: 1, 2 .

- Seitenrand stark gekrümmt, innere Randlinie des Umschlages bis zur Mitte der Fld. sichtbar; diese gewöhnlich mit vier schwarzen Makeln: 1, 1,2 oder 2, 2 schief gestellt . .

2. Hinterecken des Halssch. vollkommen abgerundet

- Dieselben fast stumpfwinkelig. Halssch. schwarz, schmal rothgelb gerandet, selten roth, mit fünf schwarzen Makeln: 4, 1. - L. $10-13 \mathrm{~mm}$. Algier. (Lac. Mon. II. 142. Lefèvr. Ann. Fr. 1872. 119. t. 2. f. 1.) . . . . . . .

3. Beine einfarbig schwarz . . . . . .

- Schenkel und Schienen (̧), oder Schienen (f) rothgelb

Illigeri.

macropus.

4. Halssch. einfarbig rothgelb. - L. $8,5-13 \mathrm{~mm}$. Südeuropa, Nordafrika, Kleinasien, Persien. (Fabr. Spec. Ins. I. 138) . . . . •

- Halssch. mit drei oder fün schwarzen Makeln: 2, 1 oder 4, 1. - Andalusien (Kraatz), Malaga (Wehncke), Algier. (Lac. Mon. II. 148) . . . . . . . . sexm var parviceps.

5. Erstes Tarsenglied höchstens so lang als die zwei folgenden zusammen

- Dasselbe fast doppelt so lang. Mitte der Tarsensohle kahl. Halssch. rothgelb, Fld. blasser, sexmaculata. 
ihre Makeln: 2, 2 schief. - L. $5-8 \mathrm{~mm}$. Portugal. Algier. (Fabr. Mant. I. 79. Cryptoc.) octopunctata.

6. Vorderschenkel einfach. Kopfschild bogig ausgeschnitten

- Vorderschenkel unterseits am Grunde tief ausgeschnitten. Schildchen schwarz mit rother Spitze. Makeln der Fld. schief: 2, 2, 1 oder 2, 2. ô Kopfschild schwach lappenförmig vorgezogen, in der Mitte eingekerbt; linke Mandibel in einer langen, aufwärtsgebogenen Spitze endigend. - L. $6,5-9 \mathrm{~mm}$. - Algier. (Lac. 1. c. 161) . . . . . . . . Paykulli.

Var. Beine und Kopf rothgelb, zwischen den Augen mit schwarzer Querbinde. - (Lefèvr. Ann. Fr. 1872. 129) . . . . . . . v. fasciata.

7. Halssch. sparsam grob punktirt, schwarz. Makeln der Fld. schief: 2, 2. - L. 8-9 mm.Algier. (Fabr. Syst. Eleuth. II. 36) . . octosignata.

- Halssch. fein punktirt.

8. Beine und Kopf (meistens) schwarz . . . . 9.

- Beine ganz, der Kopf grösstentheils rothgelb . 12.

9. Halssch. an den Seiten stark gerundet, breiter als der Grund der Fld. . . . . . . . 10.

- Halssch. an den Seiten wenig gerundet, stark gerandet, so breit als die Basis der Fld. Diese mit ein bis vier schwarzen Makeln: 1, 1, 2 . Zwei Formen:

a. ô Halssch. schwarz, am Vorderrande zwei eckige Makeln oder eine hinten gezackte Querbinde gelblich; \& Halssch. rothgelb, mit ein bis drei schwarzen Makeln. L. 6-9 mm. - Südeuropa. (Oliv. Encycl. méth. VI. 34) ... . . . . . . क

biguttata.

ㅇ sexpunctata.

b. Fld. kirschroth. $\hat{\jmath}$ Halssch. einfarbig schwarz oder (q) roth mit $1-5$ schwarzen Punkten. (Lue. Rev. Zool. 1845. 123) var. dispar.

10. Schildchen roth. - L. $8,5-10 \mathrm{~mm}$. - Algier. (Oliv. Eutom. VI. 846). . . . . laticollis.

- Schildehen schwarz. . . . . . . . 11. 
11. Halssch, roth mit 5 schwarzen Punkten. Makeln der Fld. schief: 2, 2. - L. $7,5-8,5 \mathrm{~mm}$. Algier. (Desbr. Abeille VII. 128) . . . 13-punctata.

- Halssch. schwarz, roth gerändert. Die beiden hinteren Makeln der Fld. bilden eine gemeinschaftl. Querbinde. - L. $9 \mathrm{~mm}$. - Aegypten. (Lac. Mon. II. 159) . . . . . . . . Olivieri.

12. Fld. kaum sichtbar punktirt. - L. $6 \mathrm{~mm}$. Algier. (Desbr. Mém. Ac. Hippon. 1870. 79) Perrisi.

- Fld. deutlich punktirt . . . . . . . 13.

13. Schildehen schwarz. - L. $7 \mathrm{~mm}$. - Arabien. (Lac. 1. c. 160) . . . . . . . . filitarsis.

- Schildchen ganz oder wenigstens die Spitze roth 14.

14. Die vier Makeln der Fld. schief gestellt. L. 7-8 mm. - Aegypten. Arabien. (Oliv. Eutom. VI. 860) arabica.

- Die zwei vorderen in grader Querreihe, die hinteren bindenförmig. - L. 4,5-5,3 mm. Südrussland. (Lefèvr. Ann. Fr. 1872. 136). nigričentris.

\section{Lachnaea, 1)}

Lacord. Monogr. d. Phytophag. II. 168.

Clypeus angulis anticis rotundatis.

Mandibulae apice subforcipatae, maris prominentes.

Antennae articulo tertio secundo angustiore.

Prothorax angulis posticis rotundatis.

Corpus plus minusve villosum.

Pedes elongati, tarsi plerumque longiores.

Körper kräftig, oft plump gebaut, selten metallisch-blau oder grün, meist schwarz mit grünem, blauem oder violettem Schimmer;

1) Nahe verwandt ist die Gattung Barathraea Lac. 1. c. 164. Beim $\hat{\leftarrow}$ ist der Kopf vorn bis zwischen die Fühlerwurzeln ausgeschnitten und jederseits in einen sehr langen, spitzen Zahn ausgezogen, beim $\{$ halbkreisförmig ausgeschnitten, die Vorderecken spitz, etwas aufstehend. 2 Arten:

Körper blau, matt, Fld. (wie bei Lachnaea rothgelb mit 3 schwarzen Makeln) kahl. Long. $8-11 \mathrm{~mm}$. Audalusien. Nordafrika. (Oliv. Ent. VI. 844) . . . . . . . . . cerealis.

Körper metallisch-grün, ziemlich glänzend. Fld. kurz längsreihig behaart, wie bei der vorigen gefärbt. Long. 6,5-9 mm. Sicilien? (Suffr.). Nordafrika. (straminipennis Luc. Rev. Zool. 1S45. 122. - Schneid.

Neu. Mag. I. 2. 191) . . . . . . . tripunctata. 
die Flügeldecken roth, rothgelb oder blassgelb, jede (paradoxa und variolosa ausgenommen) mit drei schwarzen Makeln, eine an der Schulter, die beiden andern in einer Querreihe hinter der Mitte. Die Unterseite nebst den Beinen, der Kopf und (mit Ausnahme ron puncticollis) das Halsschild zottig behaart.

Fühler ziemlich kurz, schwarz, Glied 2 und 3 röthlich, das erste Glied sehr breit, gerundet-viereckig, die beiden folgenden höchstens zusammen so lang als das erste, Glied 3 etwas schmaler als 2, das vierte bald dreieckig, so lang als breit und kaum schmaler als das fünfte, bald langgestreckt, zur Spitze hin mässig erweitert; die folgenden quer, innen zugespitzt. Kopfschild bogenförmig oder leicht dreieckig ausgerandet. Mandibeln stark, gerundet, mehr oder weniger vorgestreckt, an der Spitze mehrzähnig. Stirn zwischen den Augen stets längsrunzelig; Augen breit-oval. Schildchen dreieckig, hinten abgestutzt. Beine ziemlich schlank. Der Körper des $\hat{\sigma}$ ist wenig von dem des $q$ verschieden. Oft sind die Flügeldecken und die hinteren Makeln derselben matt; Kopf und Halsschild sind grösser und breiter als beim $q$, die Vorderbeine meist stark verlängert, ihre Tarsen so lang oder länger als die Schienen. Die Penisröhre ist gekrümmt, nach der Spitze stark erweitert, die Oeffnung durch eine mannigfach gestaltete Klappe verschlossen, welche durch die Verlängerung des Oberrandes gebildet wird und mit den Seitenrändern durch eine dehnbare Haut verbunden ist.

1. Lachm. sexpenmetata: Subelongata, postice latior, nigra, obscure coeruleo-aut virescenti - micans, subtus cum capite thoraceque albidovillosa; capite inter oculos transversim impresso denseque longitudinaliter rugoso, prothorace transverso, apice fortiter compresso, lateribus late marginato, angulis posticis fere distinctis, supra parum comvexo, ante medium leviter transversim impresso, antice parce posticeque dense punctato, subopaco; elytris pallide testaceis aut luteis. - Long. 9-13 mm. Mas: clypeo depresso, leniter arcuatim emarginato; pedibus anticis valde elongatis, tarsis latissimis.

Buprestis sexpunctata Scopol. Ent. Carn. 67.

L. longipes Fabr. Syst. ent. 105 (Cryptoc.). - Lac. Mon. 178. Lefèvr. Ann. Fr. 1872. 162. - Redtb. Faun. A. II. 450.

L. glabricollis Suffr. Stett. Zeit. 1851. 210.

L. brachialis Küst. Käf. Eur. III. 81 .

§. Mässig gestreckt, die Fld. hinter den Schultern erweitert, schwarz, schwach blau oder grünlich schimmernd, die Unterseite und Beine, Kopf und Halssch. weisslich, zottig behaart. Stirn zwischen den Augen quer eingedrückt und dicht längsgerunzelt, zwischen den Fühlerwurzeln mit einer schmalen, erhabenen, stark punktirten Quer- 
fläche, welche vorn das Kopfschild ziemlich gradlinig begrenzt. Dieses ist quer vertieft und leicht bogenförmig ausgeschnitten. Mandibeln mässig vorgestreckt, gleichbreit, regelmässig gekrümmt, die Spitze zweizähnig. Scheitel gewölbt, dicht und fein punktirt, mit schwacher, vorn stärker als hinten vertiefter Mittelfurche. Halssch. quer, von der Mitte nach vorn allmälılich stark zusammengedrückt, die Hinterecken gerundet-stumpfwinkelig, deutlicher wie bei den verwandten Arten, der abgesetzte Seitenrand verbreitert sich nach dem Grunde zu. Die Oberfläche vor der Mitte mit einer Quervertiefung, davor weitläufig und fein, dahinter dichter punktirt und mehr oder weniger glanzlos. Fld. blass-oder gesättigt-gelbbraun oder tief lehmfarbig, matt, nur die Schultermakel glänzend. Vordertarsen zusammen so lang aber deutlich breiter als die Schienen, das dritte Glied rerkehrt herzförmig.

Der untere Vorderrand des Penis oval, in der Mitte mit einer kurzen, graden Spitze; die Klappe ist in drei Theile gespalten, die beiden äusseren sind pechbraun, dick, dornartig, der mittlere ist bedeutend länger, gelbbraun, bandförmig, nach der gerundeten Spitze hin stark verbreitert, diese selbst hakenförmig zurückgebogen.

Beim $\rho$ ist der Kopf und das Halssch, nach vorn stärker verschmälert, die Fld, sind glänzend, die Vorderbeine nicht verlängert.

In Oesterreich und Südeuropa auf Weiden im Mai und Juni oft häufig. Die nördlichsten Fundorte scheinen Prag (Stussiner) und Brünn zu sein.

L. glabricollis Suffr., nach einem völlig abgeriebenen und missfarbenen Weibchen beschrieben, ist ebensowenig wie brachialis $\mathrm{K} u ̈$ st. als Art oder Varietät anzusehen.

2. Lach. italica: Brevior, postice lation, nigro-coerulea. subius cun capite prothoraceque aldido-villosa; capite inter oculos dense lomgitudinaliter rugoso, prothorace fortiter transverso, apice subcompresso, lateribus valde rotundato lateque marginato, angulis posticis rolundatis, supra parum convexo, punctulato. nitido. elytris pallide-testaceis rufo-testaceis aut huteis. - Long. 7,5-10 $\mathrm{mm}$.

Mas: clypeo declini, mimus profunde arcuatim emaryinato, pedibus anticis valde elongatis, articulis tarsorum tibiis haud latioribus.

L. dalmalina Dej., florentina Dahl., ochripes $\mathrm{Ziegl.} \mathrm{i.} \mathrm{litt.}$ K raatz Berl. Zeitschr. 1872. 210.

L. tripunctata Lac. Lefèvr. (pars.).

$\hat{\jmath}$. Ziemlich kurz, hinter den Schultern leicht erweitert, schwarzblau. Stirn fast eben, dicht längsrunzelig, das Kopfschild abschüssig, schwach bogenförmig ausgeschnitten. Scheitel gewölbt, von der Stirn durch eine vertiefte Bogenlinie geschieden, kaun gefurcbt. 
Halsch. stark quer, nur dicht an den Vorderecken etwas zusammengedrückt, die Seiten gerundet, gleichmässig breit gerandet, die Hinterecken vollkommen abgerundet. Seine Oberfläche gleichmässig wenig dicht, fein punktirt, glänzend, oft mit einem kurzen Quereindrucke vor der Mitte. Fld. blassgelbbraun, rothbraun oder schmutziggelb, nicht ganz so stark glänzend wie beim ㅇ. Vordertarsen zusammen so lang aber nur so breit als die Schienen, schlank.

Unterer Vorderrand des Penis breit dreieckig, die Klappe fünftheilig, die vier äusseren Theile pfriemenförmig, gekrümmt, zu je zwei übereinander gestellt, die oberen zwei pechbraun, die unteren heller; der mittlere Theil bandförmig, gleichbreit, die Spitze hakenförmig zurückgekrümmt.

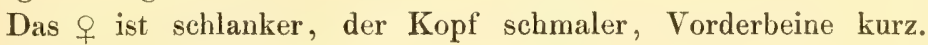
Halssch. wie beim $\hat{\jmath}$.

Der vorigen Art äusserst ähnlich und seither für eine kleine Form derselben gehalten, von Lacordaire und Lefèvre mit tripunctata vereinigt. Charakteristisch ist das Halsschild, dessen gleichbreite abgesetzte Seitenränder von oben bis zu den Vorderecken sichtbar bleiben, die lichter blaue Färbung des Körpers und die Tarsenbildung.

In Südtirol, Italien, Corsica und Sardinien häufig.

Uebersichtstabelle der Lachnaea-Arten.

1. Kopf und Halssch. lebhaft metallisch blau oder blaugrün

- Kopf und Halssch. schwarz, oft mit leichtem grünen, blauen oder violetten Schimmer . .

2. Halssch. kahl. Cylindrisch, beide Geschlechter glänzend, Halssch. am Grunde stärker als auf der Vorderhälfte punktirt, Fld. stark punktirt. Vorderbeine des $\hat{\sigma}$ kaum verlängert, Augen auffallend gewölbt. Penis flach, die Spitze gerade, scharf dreieckig, die Oeffnung nimmt die Hälfte der ganzen Länge ein, und wird durch eine Klappe geschlossen, welche aus zwei vorn buckelig aufgetriebenen, bandförmigen Lappen besteht. - L. $5-7,5 \mathrm{~mm}$. Südfrankreich, Spanien, Algier ${ }^{1}$ ). (Chevrol. Revue Zool. 1840. 17.) puncticollis.

- Halssch. dicht behaart. Kopf (Scheitel ausgenommen) längsrunzelig, matt. Fld. des $\delta$ 
matt, Vorderbeine stark verlängert. Viertes Fühlerglied dreieckig, so breit als 5. Penis kräftig, die feine Spitze nach unten gekrümmt, Klappe dreitheilig, die Seitentheile fast eylindrisch, der mittlere bandförmig, zur Hälfte hakenförmig, nach oben gebogen. - L. 6,5 bis $9,5 \mathrm{~mm}$. Südfrankreich, Spanien, Algier, Italien. (L a c. Mon. II. 183.)

tristigma.

3. Fld. punktirt

4.

- Fld. mit grossen und tiefen schwarzvioletten Blatternarben, die im Grunde runzelig punktirt sind. Unterseite dunkelblau, Kopf, Halssch. und Schildchen schwarzviolett, Fld. blutroth. L. $7-9,5 \mathrm{~mm}$. Südspanien, Algier. (Lin n. Syst. Nat. XII. 591)

variolosa.

4. Erstes Tarsenglied des $\hat{\jmath}$ bedeutend länger als die folgenden zusammen, fast cylindrisch, gekrümmt, nur am Grunde mit kurzer Filzsohle. Fühler vom 5. Gliede an spitz gesägt . .

- Erstes Tarsenglied kaum so lang als die folgenden zusammen, breit gedrückt, mit dichter Filzsohle. Fühler vom 4. Gliede an gesägt .

5. Fld. einfarbig rothgelb. Penis oberseits rinnenförmig vertieft, die Klappe mit zwei aufgerichteten kurzen Hörnchen am Vorderrande. L. $8,5-10 \mathrm{~mm}$. Sicilien. Algier. (Oliv. Ent. VI. 844)

paradoxa.

- Fld. blutroth, jede mit drei schwarzen Makeln. Penisklappe in der Mitte des Seitenrandes jederseits mit kleinem Querhöcker, am Vorderrande leicht dreieckig ausgeschnitten. - L. 5 bis $13,5 \mathrm{~mm}$. Südspanien, Nordafrika. (L a c. Mon. II. 173) . . . . . . . • . .

6. Die vordere Makel der Fld. steht auf dem Schulterhöcker

vicina.

7.

- Dieselbe steht hin ter der Schulterbeule. Langgestreckt, Kopf und Halssch. bläulich. Scheitel mit breiter, tiefer Längsfurche. Beine robust, bei beiden Geschlechtern gleichlang. - L. 8 bis $11 \mathrm{~mm}$. Südfrankreich, Spanien, Algier, Italien. (Lac. l. c. 186) - . . . . cylindrica. 
7. Viertes Fühlerglied bedeutend länger als breit, Körper mässig lang behaart . . . . .

- Viertes Fühlerglied fast so breit als lang, Körper auffallend lang behaart. Gestreckt, walzenförmig, Halsseh. kaum doppelt so breit als lang, cylindrisch, Mitte schwarzblau, Seiten, Kopf und Unterseite heller blau. Augen stark gewölbt. Penis stark, unterseits bärtig, mit langer, grader Spitze; die Klappe besteht aus zwei dreieckigen Hälften, welche dem vorderen Theile einer Lichtscheere nicht unähnlich sind. L. 7,5-11 mm. Südfrankreich, Spanien, Nordafrika. (hirtipes All. Ann. Fr. 1864. 383. tripunctata Lac. (pars) Mon. II. 180. - Suffriani $\mathrm{Kr}$. Berl. Zeit. 1872. 210. - Fabr. Syst. El. II. 30) - . . . . . . . . hirta. ${ }^{1}$ )

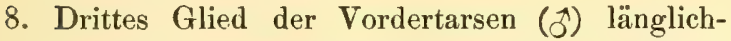
herzförmig, das zweite kaum doppelt so lang als breit

- Drittes Glied gestreckt, Seiten fast parallel; zweites fast dreimal so lang als breit. Kopf und Halssch. schwarz-violett oder grünlich. Abgesetzter Seitenrand des Halssch. gleichbreit. Penis nach der Spitze stark verdickt, die Klappe in drei breite Spitzen verlängert, von denen die mittlere halbkreisförmig nach oben gebogen ist. - L. 9-13 mm. Südfrankreich, Spanien, Nordafrika. (palmata Lac. 175; macrodactyla Lac. 177. - Du four Ann. Sc. phys. Bruxelles VI. 307) .. . . . . . . . . . pubescens.

9. Vorderrand des Kopfschildes leicht ausgeschnitten

- Derselbe tief halbkreisförmig ausgesehnitten. Körper schwarz. - L. 8-10 mm. Griechenland. Creta . . . . . . . orientalis n. sp. ${ }^{3}$ )

1) hirta Lac. ist nach einem kleinen $\hat{\odot}$ aus Marocco mit blutrothen Fld, und verloschener Punktirung des Halssch. beschrieben. Lefèvre kennt nur dieses Stück im Mus. Chevrolat. Kraatz erwähnt (l. c.) Exempl. von Cordoba und Jaen; ähnliche finden sich auch bei Barcelona (D. Muller).

2) Lachn. orientalis: Elongata, nigra, subtus interdum obscure cyane-viridis, subtus cum capite, prothoraceque griseo-villosa; capite inter oculos longitudinaliter rugoso, clypeo profunde semicirculariter emarginato, 
10. Hinterecken des vorn stark zusammeigedrückten Halssch. gerundet-stumpfwinkelig. - L. 9 bis $13 \mathrm{~mm}$. Süddeutschland. Südeuropa . . sexpunctata.

- Hinterecken des vorn wenig zusammengedrückten Halssch. vollkommen abgerundet. - L. 7,5 bis $10 \mathrm{~mm}$. Tirol. Italien . . . . . italica.

\section{Clytra, ${ }^{1)}$}

Laicharting. Verz. Tyrol. Ins. I. 165.

Clypeus angulis anticis subacutis; mandibulae brerissimae.

Oculi maximi, oblongi.

Antennae ab articulo quarto serratae.

Prothorax angulis posticis rolundatis.

Pedes validi, tibiae ayicem versus incrussatae, tarsi lati; coxae aniicae mimus conicae, lamina anqusta prosterni separatae.

Durch die in beiden Geschlechtern übereinstimmende Körperform, die grossen, mit dem Innenrande fast parallel gestellten Augen

prothorace transverso, subcylindrico, lateribus marginato, angulis posticis subrotundatis, supra subtiliter minus dense punctulato, nitido; elytris testaceis vel luteis, singulo punctis tribus nigris. - Long. 8-10 mm.

Griechenland (K r üper), Creta ( $Z$ ebe).

Durch gestrecktere Gestalt, schwarze Färbung des Körpers, die wenigstens auf Kopf und Halssch. kaum einen blauen oder grünen Schimmer annimmt, das fast cylindrische Halssch. und den tiefen, halbkreisförmigen Ausschnitt des Kopfschildes von sexpunctate und italica verschieden. Der untere Vorderrand des Penis ist abgerundet, die dreieckige Kilappe besitzt jederseits in der Mitte des Seitenrandes eine erhabene Querfalte.

1) Wenig rersehieden ist die afrikanische Gattung Melitonoma Lac. Bei ihr sind die Augen verhältnissmässig noch grösser, die Schienen schlanker, die vorderen beim $\hat{\hat{S}}$ länger als die übrigen, die Fld. wenig glänzend, rerloschen punktirt, wenigstens mit 5 schwarzen Makeln: 1, 2, ?. Eine noch unbeschriebene Art ist:

Melit. Simomi: Elongatuln, nigra, subtus densissime griseo-pubescens, cupite sublacri, nitidn, fronte purce obsoleteque transversim rugulosa, prothorace elytrisque rufo-flavis, illo parce minutissime punctulato, nitido, maculis binis triquetris, lateribus sinuatis, lasi contuentibus, nigris; his subtilissime obsnlete punctatis, subnititis, singulo maculis sex funa humerali, duabus ante, duabus infra medium, una apicali) nigris. - Long. $6,5-7,5 \mathrm{~mm}$.

Var. a. Maculis infra nedium elytrorum contuentibus, interdum etiam cum macula apicali in lunulam latam conjunctis.

Von Herrn Simon in Stuttgart aus dem Ashante-Lande erhalten und ihm zu Ehren benannt. 
und die dicken, kurzen Beine, deren wenig vorstehende Vorderhüften durch einen schmalen Fortsatz der Vorderbrust bis zur Spitze getrennt sind, scharf von den verwandten Gattungen zu unterscheiden.

Körper cylindrisch, schwarz, Kopf und Unterseite mässig lang, dicht behaart. Mandibeln kräftig, sehr kurz, vorn fast rechtwinkelig gegen einander gebogen. Kopfschild schwach ausgerandet, die kurzen Seiten zur Aufnahme der Mandibelkante winkelig ausgeschnitten, die Vorderecken dadurch mehr oder weniger scharf. Fühler kurz, das erste Glied dick, zottig behaart, die zwei folgenden klein, die übrigen breit dreieckig. Halsschild entweder schwarz oder roth mit schwarzen Makeln. Flügeldecken fein punktirt, roth oder gelblich mit einem schwarzen Flecken auf der Schulter und zwei anderen, meist zu einer Querbinde vereinten, hinter der Mitte, zu denen sich bei einigen Arten noch ein vierter in $1 / 3$ der Länge an der Naht gesellt. Beine stark, gleichlang, die Schienen grade, an der Spitze schief abgestutzt, Tarsen kurz und breit.

1. Cl. quadripuacterta: Elongala, nigra, vitidula, subius eren capile griseo-pubescens, prothorace brevissimo, parum convexo, lateribus late marginato, vix reflexo, limbo crebre et fortius, disco parce subtiliter punctato, angulis posticis subrotundatis, elytris rufis, singulo macula oblonga humerali maculaque majore pone medium migris, angulis suturalibus obtusinsculis. - Long. 7-11 mm.

Mas: segmento ultimo ventrali medio impressione lata, vitida. minus profunda.

Linné Syst. Nat. X. 374 (Chrysomela). - Schmidt Stett. Zeit. 1841. 152. - Lac. Mon. II. 202. - Lefèvr. Ann. Fr. 1872. 142. - Redtb. Faun. A. II. 451. - Seidl. Faun. balt. 473 . Cl. quadrisignata Maerk. Germ. Zeitschr. Ent. III. 223. - Schmidt 1. c. 154 . - Suffr. Stett. Zeit. 1851. 211. - Redtb. 1. c. 451 . Kraatz Berl. Zeit. 1872. 213.

Var. a. Elytris macula posteriori minuta.

Var. b. Macula postica elyirorum deficiente.

Var. c. Elytris immaculatis.

Var. d. Elytris macula posteriori magna. subfasciata.

Gestreckt, cylindrisch, beiderseits schnell verengt, mässig glänzend, schwarz, die Unterseite, Beine und Kopf dicht grauweiss behaart. Fühler schwarz, das erste Glied mässig lang hehaart, Glied 2 und 3 ganz, die zwei folgenden theilweise röthlich. Augen gross, stark gewölbt, mässig vorstehend. Halss ch. quer viereckig, nach vorn stark verengt, die Ecken leicht abgerundet, der breit abgesetzte, dicht runzelig-punktirte und flach ausgebreitete Seitenrand von oben bis dicht an die Vorderecken sichtbar, die Oberfläche 
wenig gewölbt, uneben, oft mit einer tiefen Grube jederseits linter der Mitte, an den Ründern dicht und stark, die Scheibe weitläufiger fein punktirt. Fld. gelblichroth, eine längliche, selten runde Makel auf der Schulterbeule und eine Quermakel hinter der Mitte, der Naht näher als dem Seitenrande, nach aussen gewöhnlich verschmälert, schwarz. Nahtwinkel der Fld. scharf stumpfwinkelig, die innere Randlinie des umgeschlagenen Seitenrandes bleibt bis zum letzten Hinterleibssegmente sichtbar. Bauch dicht querrunzelig, matt, letztes Segment des ô mit einem, die ganze Mitte einnehmenden, fast glatten, wenig tiefen Eindrucke und gleichmässig gerundetem Hinterrande; beim o mit einer kleinen, flachen Grube vor dem in der Mitte bogig ausgeschnittenen Hinterrande.

Das $q$ ist meist kräftiger, stärker punktirt, der Seitenrand des Halssch. weniger breit abgesetzt.

Penis schmal, oberseits mit zwei feinen Längsrinnen, an der Spitze schnell um das Doppelte erweitert, rorn jäh verengt und in eine scharfe, ein gleichseitiges Dreieck bildende Spitze vorgezogen.

Die hintere Makel der Fld. erseheint meist aus zwei Flecken zusammengesetzt, von denen der äussere nur selten so gross oder grösser als der innere ist. Bei der Abänderung a ist die Quermakel klein, so gross oder kleiner als die der Schulter, bei b verschwindet sie ganz, bei c (nach Lacord. v. D.) auch die Schultermakel; bei $d$ endich bilden beide Quermakeln fast eine breite, gemeinschaftliche, nur an der Naht schmal unterbrochene Querbinde.

Nord- und mitteldeutsche Stücke, deren breiteste als 4 -signata von Märkel beschrieben wurden, sind auf der Scheibe des Halssch. sehr deutlich, die süddeutschen viel feiner punktirt, fast glatt.

Im Juni am Grase und auf Gebüschen ziemlich häufig, die Varietäten selten.

2. Cu. appenedicind: Elongata, nigra, nilidula, sublus cum capite griseo-pubescens, prothorace brevissimo, sat comero, lateribus minus late marginato et subreflexo, disco subtitissime punctaio. angulis posticis rotundatis, elylris stramineis, singulo maculis duabus migris. anculis suturalibus obtusiusculis; pedibus minus validis. - Long. i-11 nm.

Lacord. Mon. II. 208. - Lefèvr. Ann. Fr. 1872. 144. Kraatz Berl. Z. 1872. 211.

Var. a. Elytris macula posteriori minuta.

Var. b. Macula postica elytrorum deficiente.

Es verbindet diese Art die Körperform und Zeichnung der vorigen mit der Halsschildbildung der folgenden Art, ist aber nur mit ersterer verwandt. Sie unterscheidet sich von ihr hauptsächlich in folgenden Punkten: 
Das Halssch. ist vorn deutlich zusammengedrückt, gewölbter, sein abgesetzter Seitenrand dadurch nicht nur schmaler, sondern auch, bei der Ansicht von oben, viel mehr verdeckt und kaum bis zur Hälfte nach vorn sichtbar. Der Rand ist zerstreut punktirt, kaum gerunzelt, an den Seiten schwach aufgebogen; die Scheibs feiner punktirt, glänzender, die Hinterecken sind stärker abgerundet. Fld. strohgelb, ihre Makeln durchschnittlich etwas kleiner, aber von derselben Form, wie bei 4 -punctata. Die Beine, besonders die Schienen, merklich länger und schlanker.

Von Abänderungen sind nur bekannt: a. die hintere Makel wird klein, punktförmig, b. dieselbe fehlt ganz. Die Fld. haben bei der letzten Form, die dem $\hat{\sigma}$ der Titub. dispar sehr ähnlich ist, wie bei 4 -punctata Var. b. eine röthlichbraune Farbe.

Geschlechtsauszeichnung und Gestalt des Penis genau wie bei der Vorigen; da jedoch unter einem reichen Materiale wirkliche Uebergangsstücke fehlen, scheint es mir noch nicht räthlich, beide zu vereinigen.

In Südfrankreich, Italien, dem ganzen Alpenzuge, den Donaustaaten, Südrussland und Sibirien bis zum Amur (Faust) verbreitet; in Krain (Micklitz) ebenso zahlreich, wie 4 -punctata.

3. Cl. Uacviuscula: Elongatula, nigra, nitida, subtus cum capite griseo-pubescens, prothorace breve, convexo, lateribus anguste marginato-reflexo, margine antico et postico punctis minutis transversin adsperso, disco obsolete subtilissimeque punctalo, fere luevi, angulis posticis rotundalis, elytris rufo-flavis, puncto humerali majore maculaque subfasciata pone medium nigris, angulis suturalibus rotundatis. - Long. 7-11 mm.

Mas: segmento ultimo ventrali apice emarginato, medio impressione lata, nitida, antice profunda.

Ratzeb. Forstins. I. 201. - Schmidt Stett. Z. 1841. 148. Lac. Mon. II. 206. - Lefèvr. I. c. 143. - Redtb. Faun. A. II. 450. - Seidl. F. balt. 473.

Var. a. Elytris macula posteriori e punctis duobus coalitis formata. Var. b. Macula posteriori elyirorum humerali vix vel haud majore. Var. c. Elytris fascia lata communi infra medium nigra.

Lang-oval, stark glänzend, schwarz, die Unterseite und Beine wie der Kopf dicht grauweiss behaart. Fühler schwarz, Glied 2 und 3 röthlich, Glied 1 mit einem Büschel sehr langer, an der Spitze zusammengekrümmter, rein weisser Haare. Augen sehr gross, schwach gewölbt. Halssch. cylindrisch, nach vorn stark rerengt, zusammengedrückt, die Seiten von oben unsichtbar, Vorderecken leicht, Hinterecken vollkommen abgerundet. Die Seiten schmal 
erhaben-gerandet, der Rand glatt; die Oberfläcle gewölbt, äusserst fein punktirt, fast glatt, mit einigen deutlichen Punkten längs des Vorder- und Hinterrandes. Fld. rothgelb, ein grosser Schulterpunkt und eine breite, bindenförmige Quermakel hinter der Mitte, der Naht näher als dem Seitenrande, schwarz. Nahtwinkel meist rollständig abgerundet, die innere Randlinie des umgeschlagenen Seitenrandes ist schon an den Hinterbüften auf die Unterseite gebogen und unsichtbar. Bauch wenig dicht, ron hinten eingestochen fein punktirt, glänzend, das letzte Segment beim $\hat{\jmath}$ mit einem die ganze Mitte einnehmenden, fast glatten, vorn sehr tiefen hufeisenförmigen Eindrucke, der Hinterrand in der Mitte bogig ausgeschnitten; beim $q$ ist der Eindruck eben so lang, aber schmaler und flacher, der Hinterrand breiter ausgerandet.

Penis breit, nach vorn auffällig verdickt, oberseits mit zwei tiefen Längsrinnen, die durch einen schmalen Kiel getrennt werden, vor der Spitze plötzlich verengt, die Spitze selbst quer viereckig und in ein breites Dreieck verlängert.

Die Zeichnung der Fld, variirt nur in der Ausdehnung der hinteren Makel. Dieselbe erscheint a wie bei 4 -punctata aus zwei Makeln zusammengesetzt, b höchst selten so klein als der Schulterpunkt oder e zu einer gemeinschaftlichen breiten, an der Naht kaum unterbrochenen Querbinde vereint. Die Punktirung des Halsschildes wird mitunter recht deutlich.

Im Juli auf Weiden und Schlehenbüschen häufig.

\section{Uebersicht der Clytra-Arten.}

1. Langgestreckt. Jede Fld. mit 3 schwarzen Makeln, eine auf der Schulter, die andern hinter der Mitte und meist verbunden.

2.

- Kurz-oral.

2. Halssch. ganz oder theilweise roth . . . 3

- Halssch, einfarbig schwarz . . . . . . . 4

3. Erstes Tarsenglied gross und breit. Halssch. mit 2 oder 4 schwarzen Makeln in einer Querreihe. Dieselben vergrössern sich zu 2 grossen, eckigen Makeln, durch eine schmale Mittellinie getrennt, oder das Halssch. schwarz, die Ränder roth gesäumt. (Var. tetrastigma Schmidt, dissimilithorax Desbr.). - L. $8-12 \mathrm{~mm}$. Südrussland. Kleinasien. Ungarn? Griechenland? (Ménétr. Cat. rais. 237) . . . valerianae. 
3. Erstes Tarsenglied langgestreckt. Halssch. mit 3 oder 5 schwarzen Makeln, eine vor dem Schildchen, die andern in einer Querreihe. Oberseite gelblichroth oder (Var, aleppensis Redtb. Russegg. Reise II. 989, globulosa Lefèvr. 1. c. 147) lebhaft kirschroth. - L. 6 bis 9 mm. Südeuropa, Kleinasien, Nordafrika. (novempunctata Oliv. - F abr. Syst. El. II. 41) elata.

4. Halssch. wenig gewölbt, deutlich punktirt, der breit abgesetzte, flache Seitenrand gerunzelt quadripunctata.

- Halssch. gewölbt, fein punktirt, der schmal abgesetzte, wenig aufgebogene Seitenrand punktirt appendicina.

- Halssch. cylindrisch, fast glatt, die Seiten sehr schmal, rinnenförmig gerandet

laeviuscula.

5. Halssch. schwarz, Fld. mit (odèr ohne) Schulterpunkt und breiter gemeinschaftlicher Querbinde hinter der Mitte. Letztere schmaler, an der Naht unterbrochen $=$ Var. ovata Lac. Mon. 200. - L. 7-9 mm. Kleinasien. Konstantinopel? (Lac. 1. c. 200)

- Halssch. rothgelb, wie die Fld.

6. Kopf schwarz. Halssch. einfarbig oder mit 3 oder 5 oft zusammenfliessenden schwarzen Makeln, selten schwarz, vorn breiter als an den übrigen Rändern roth gesäumt oder die vier Ecken roth. Jede Fld. mit Schulterpunkt, Quermakel hinter der Mitte und einer Makel in $1 / 3$ an der Naht. - L. 6,5-10 $\mathrm{mm}$. Südeuropa. Kleinasien. (P all. Reis. II. 725) . atraphaxidis.

- Kopf rothgelb, meist mit schwarzem Stirnpunkt. Halssch. mit 4 zuweilen fehlenden Makelu in einer Querreihe. Fühler und Beine rothgelb. Fld. mit 4 Punkten $(1,1,2)$. - L. $5,5-7,5 \mathrm{~mm}$. Südrussland (Astrachan Faust), Kleinasien, Persien. (Zubk. Bull. Mosc. 1833. 338) . . maculifrons.

\section{Gynandrophthalma.}

Lacord. Monogr. des Phytoph. II. 256.

Clypeus haud vel evidenter emarginatus, angulis articis aut rotundatis aut subaculis.

Antennae articulo primo valido.

Oculi subrotundati, subintegri. 
Prothorax angulis posticis rotundalis, rarissime elevatis.

Pedes antici quam intermedii parum vel haud longiores, coxae anticae lamina prosterni haud separatae, lobi articuli tertii tar. sorum apice rotundati.

Körper ziemlich klein, bald langgestreckt, bald kurz-oval, verschieden gefärbt, nur selten in beiden Geschlechtern abweichend gebaut, Kopf und Bauch sparsam, die Brust dichter kurz und fein behaart. Augen klein oder mässig gross, breit eiförmig, oft fast rund, hinter der Fühlerwurzel kaum merklich ausgerandet. Fühler kurz, das dritte Glied sehr schmal, die gesägten Glieder so breit als das erste. Hinterecken des Halsschildes abgerundet, nur bei wenigen Arten über den Grund der Flügeldecken emporgehoben wie bei Labidostomis. Beine entweder schlank, besonders die Vorderbeine des $\hat{\sigma}$, oder kurz und verhältnissmässig dick, mit länglicken Tarsengliedern; Vorderhüften zapfenförmig vorragend und von einander abstehend oder kurz, fest aneinander gefügt, nie durch einen Fortsatz der Vorderbrust bis zur Spitze getrennt. Das Männchen ist gewöhnlich kleiner als das 오, parallel, das letzte Hinterleibssegment in der Mitte flach gedrückt, glänzend; das $q$ nach hinten erweitert, mit einer an den Rändern bewimperten Grube auf dem etzten Segmente, dessen Hinterrand in der Mitte mehr oder weniger tief ausgeschnitten ist.

In der hier angenommenen Umgrenzung enthält die Gattung mehrere durch Form und Farbe ausserordentlich verschiedene Artengruppen, die jedoch durch die seitherige Absonderung von chloris und Reyi nicht an Einheitlichkeit gewinnen. Denn die erstere Art, durch das vorn grade Kopfschild und das lange erste Tarsenglied des $\hat{o}$ ausgezeichnet, ist durch viridana (Kopfschild grade, 1. Tarsenglied des $\hat{o}$ mässig lang) mit concolor, limbata und ihren dünnbeinigen Verwandten aufs Innigste verbunden, andererseits durch die Bildung des Kopfschildes mit baetica und djebelina nahe verwandt, welche sich wieder von nigritarsis, thoracica etc. kaum trennen lassen; Reyi, deren Stirnbildung Chil. musciformis nicht unähnlich erscheint, besitzt, da die Ausrandung des Kopfschildes merklich flacher und vollständig gerundet, das erste Fühlerglied dick und das erste Tarsenglied langgestreckt ist, nicht die Hauptmerkmale der Gattung Chilotoma; sie leitet vielmehr, ans Ende zu den Arten mit dunklem Mittelfleck des Halsschildes gestellt, sehr natürlich zu Chilotoma hinüber.

Bei den Coptocephala-ähnlichen Arten findet wohl auch Cl. japonica Baly nebst der ähnlichen chinesischen Art ihre richtige Stelle. 
1. Cymandr. solicina: Ovalis, convexa, nigro-cyanea, plerumque virescens, capite inter oculos transversim impresso, antennis nigricantibus, basi fulvis, prothorace rufo, laevi, elytris cyaneis, virescenticoeruleis vel nigris, confertim fortier punctatis, pedibus fulvis, femoribus basi plus minusve nigris. - Long. 4,5-6,5 $\mathrm{mm}$.

Scopoli Ent. Carn. 65 f. 199 (Buprestis). - Lefèvr. Ann. Fr. 1872.349.

Gyn. cyanea F abr. Syst. Ent. 109 (Cryptoc.). - Lac. Mon. II. 300. Suffr. Stett. Z. 1851. 213. - Redtb. Faun. A. II. 451. - SeidI. F. balt. 473. - Kraatz Berl. Z. 1872. 214.

Kurz-oval, schwarzblau mit grünem Schimmer; Kopf klein, bronzegrün, Mund pechschwarz, Stirn mit einer kurzen Schrägrinne jederseits zwischen der Fühlerwurzel, die sich mit einem deutlichen Quereindrucke zwischen den Augen verbindet, fein punktirt, der Scheitel fast glatt. F ̈̈hler dünn und kurz, schwärzlich, die ersten vier Glieder ganz, die folgenden drei theilweise rothgelb, Glied 5-7 so breit als das erste, innen mit scharfer Ecke, die folgenden drei schmaler, ihre Innenecke stumpf. Halssch. am Grunde fast doppelt so breit als lang, nach vorn stark verschmälert, zusammengedrückt, gewölbt, glatt, vor dem breit dreieckigen Schildchen quer eingedrückt und mit einigen feinen Punkten besetzt. Fld. kornblumenblau, dicht und stark, vor der Spitze sparsamer punktirt, mit Spuren unregelmässiger Punktreihen. Beine kräftig, rothgelb, heller als das Halssch., nur selten fast einfarbig, indem nur der Grund der Schenkel, besonders der hinteren, gebräunt ist; meist sind die Hinterschenkel zu zwei Drittheilen, die Mittelschenkel zur Hälfte schwarz oder erzgrün.

Die Fld. sind häufig blaugrün, selten dunkel-violett oder schwarz.

Vom Mai bis Juli auf Blüthen (Rumex, Letzner) nicht selten.

2. Hymandr. favicollis: Oblongo-elongata, modice convexa, nigroaenea, capite inter oculos vix impresso, antennis nigricantibus, basi fulvis, prothorace rufo-flavo, disco obsolete punctato, elytris cyaneis, profinde minus crebre subseriatim punclatis, pedibus rufo-flavis, femoribus posticis basi plus minusve infuscatis. - Long. 3,5-4,5 mm.

Charpent. Horae Ent. 236 (Clytra). - Lac. Mon. II. 301. Suffr. Stett. Z. 1851. 214. - Lefèvr. Ann. Fr. 1872. 345. Redtb. Faun. A. II. 451. - Seidl. F. balt. 473 .

Gestreckt, mässig gewölbt, dunkel erzgrün, der Kopf heller, die Stirn eben oder zwischen den Augen punktförmig eingedrückt, weitläufig fein punktirt, der Scheitel fast glatt. Fühler schwärzlich, die ersten vier Glieder und die Unterseite der drei folgenden rothgelb. Halsseh. hell röthlichgelb, nach vorn verschmälert und 
zusammengedrückt, am Hinterrande fast grade, schwach gewölbt, die Scheibe sparsam, wenig deutlich punktirt. Schildchen schmal, dreirekig. Fld. glänzend, kornblumenblau, selten mit schwachen grünen Schimmer oder schwarzviolett, mässig dicht und stark in unregelmässigen Reihen punktirt, $z$ wischen denen einzelne unmerklich gewölbte Längsstreifen hervortreten. Beine schlank, röthlichgelb, die Hinterschenkel wenigstens an der Basis gebräunt, oft bis zu drei Viertheilen schwarz.

Durch schmalen Körper, das weniger gewölbte, mehr viereckige Halssch., die unregelmässig reihig punktirten Fld. und schlanke Beine von der Vorigen sehr verschieden.

Im Juni und Juli einzeln im nördlichen, häufiger im mittleren und südlichen Theile des Gebietes.

3. Cynumaln. diversipes: Aene-viridis, mothorace pedibusque rufis plerumque infuscatis, his femoribus anticis basi, posticis $2 \mathrm{rel}$ 1 ommino nigro aeneis, tibiis posticis rigyis; elytris crebre subtiliter punctatis. - Long. $3,5-5 \mathrm{~mm}$.

Letzner Arb. Schles. Ges. 1S39. 8 (Clytra). - Suffr. 1. c. 214. Kraatz Berl. Z. 1872. 215.

G. flavicollis Var. b. Lac. 1. c. 302 . - Lefèvr. 1. c. 345 .

Der Vorhergehenden äusserst nahe verwandt, jedoch in Folgendem unterschieden: Stirn zwisehen den Augen tiefer punktförmig eingedrückt, Kopf durchweg kräftiger, runzelig punktirt. Halssch. dunkler roth gefärbt, oft mit unbestimmten schwärzlichen Makeln besetzt, zuweilen ganz dunkelbraun oder schwarzviolett, dichter punktirt. Fld. erzgrün oder metallisch blaugrün, nie rein blau, sehr dicht, fein und flach verworren punktirt, ohne Spuren von Punktreihen auf dem Rücken. Die Farbe der Beine ist variabel. Bei den hellsten Stücken ist die Basis der Vorderschenkel und die Grundhälfte der Mittelschenkel schwarz, die Hinterschenkel sind bis zur rothbraunen Spitze bronzegrün, ebenso ist der Rücken der vier Vorderschienen theilweise oder ganz gebräunt, die Hinterschienen sind schwarz. Diese dunkle Färbung nimmt so zu, dass zuletzt nur die Unterseite der Vorderschenkel und -Schienen und die Basis der Vordertarsen düster roth bleibt.

Die $q$ sind meist doppelt so gros̄̄ als die j̧.

In Blüthen ron Polygonum bistorta im Juli auf den höheren Stellen des Altvater-Gebirges. Stets zahlreich am Wurpis-Steine, der ersten Einsattelung auf dem Wege rom rothen Berge nach der Schweizerei. 
4. Fymandr. ampita: Oblongo-ovalis, nigra, nitida, ore piceo, fronte obsolete angulatim sulcato, antennis nigricantibus, basi prothoraceque rufo-teslaceis, hoc sublaevi, vitta media lata subparallela nigra; elytris nigro-coeruleis, minus crebre punctatis, pedibus rufo-testaceis. femoribus basi plus minusve nigris. - Long. 4,5-6 $\mathrm{mm}$.

Linn. Syst. Nat. XII. 596 (Chrysomel.). - Panz Faun. Germ. 25. 20. - Lac. Mon. II. 308. — Suffr. Stett. Z. 1851. 214. Redtb. 1. c. 451 . - Seidl. 1. c. 473 .

Schwarz, oberseits stark glänzend, der Kopf sparsam behaart, weitläufig, fein punktirt, zwischen den Füblerwurzeln mit zwei Schrägfurchen, die sich mit dem Quereindrucke zwischen den Augen zu einem fast hufeisenförmigen Eindrucke verbinden. Fühler schlank, vom fünften Gliede an wenig verbreitert, keins dieser Glieder breiter als lang; schwärzlich, die ersten vier Glieder ganz, die folgenden zwei oder drei theilweise röthlich. Halssch. gewölbt, röthlich gelbbraun, ein rechteckiger, nach dem Grunde leicht verbreiterter Längsstreifen über die Mitte der Scheibe schwarz; letztere einzeln, kaum sichtbar punktirt, am Hinterrande jederseits mit einigen deutlichen Punkten. Fld. schwarzblau, wenig dicht und stark, ziemlich tief punktirt. Beine röthlich gelbbraun, selten fast einfarbig mit leicht gebräunter Schenkelbasis, meist die Vorder-und Mittelschenkel bis zur Hälfte, die Hinterschenkel fast bis zur Spitze schwarz.

Im Mai und Juni auf Haselnussbäschen, Birken und Weiden ziemlich selten.

Bei Stücken vom Kaukasus (Abastuman und Liryk, Leder) sind die vier Hinterbeine fast einfarbig schwarzbraun.

Die von Lacordaire als Var. a. aufgeführte, nach einem + aus Steiermark beschriebene Form, welcher Lefèvre (1. c. 339) den Namen dissimilis ertheilt, hat mit thoracica $\mathrm{K} \ddot{\mathrm{u}} \mathrm{st}$. nichts zu thun, sondern gehört zu affinis.

5. Aymandr. affinis: Oblongo-parallela, nigro-cyanea, nitidula, pedibus omnino, ore, antennis apice infuscata excepta prothoraceque rufo-testaceis, hoc evidenter punctato, vitta media lata subparallela nigro-cyanea, elytris cyaneis, confertim punctatis. - Long. 2,5-4 mm.

Hellw. Ed. Rossi I. 97 (Cryptoceph.). - Panz. Faun. Germ. 25. 21. - Lac. Mon. II. 303. - L e fèvr. Ann. Fr. 1872. 340. Kraatz Berl. Z. 1872. 216. - Redtb. Faun. A. II. 451. Seidl. F. balt. 473 .

Gestreckt, schwarzblau, mässig glänzend, der ganze Mund, die an der Spitze gebräunten kurzen Fühler, deren 5.--10. Glied breiter als lang ist, und die Beine röthlich gelbbraun. Kopf bronzegrün, 
fast eben, dicht und fein, vorn leicht runzelig punktirt. Halssch. rothgelb, ein breiter, nach dem Grunde schwach erweiterter Längsstreifen über die Scheibe schwarzblau oder schwarzgrün, letztere fein aber deutlich punktirt. Fld. kornblumenblau oder blaugrün, dicht und mässig stark punktirt. Vorderhüften gelblich, die Basis der vier Hinterschenkel zuweilen leicht gebräunt.

Vom Mai bis Juli auf Eichentrieben und in Blüthen im mittleren und südlichen Deutschland häufiger, im nördlichen selten.

Tiroler Exemplare von 2 "' Grösse haben nach Gredler (Käf. Tir. 408) bis über die Mitte geschwärzte Hinterschenkel.

6. Cynandr. xamthaspis: Oblongo-elongata, subcylindrica, nigroaenea, capite rugoso-punctato, inter oculos impresso, prothorace rufoflavo, vitta media antice angustata nigro-cyanea, disco parce punctulato, elytris cyaneis vel viridi-coeruleis, confertim fortiter juxta suturam subseriatim punctatis, pedibus rufo-flavis, femoribus basi plus minusve nigro-aeneis. - Long. 4,5-6 $\mathrm{mm}$.

Germ. Ins. Spec. nov. 547 (Clytra). - Küst. Käf. Eur. 16.93. Lac. Mon. II. 306. - Suffr. Stett. Z. 185̃1. 214. - Lefèvr. Ann. Fr. 1872. 337. - Redtb. Faun. A. II. 451.

Cyaniris thoracica Küst. Käf. Eur. 5.99. — Kraatz Berl.Z.1871.218.

Gestreckt, cylindrisch, bronzegrün, der Kopf fein runzeligpunktirt, zwischen den Augen quer eingedrückt. Mund pechschwarz. Fühler kräftig, schwarz, die ersten vier Glieder mit Ausnahme einer bräunlichen Makel auf der Oberseite und die folgenden drei am Aussenrande röthlich; Glied 3 sehr schmal, Glied 5-10 breiter als lang. Halssch. rothgelb, mit einem nach vorn stark verschmälerten, oft fast dreieckigen schwarzblauen Längsstreifen über die Mitte der einzeln punktirten, fast glatten Scheibe. Fld. blau oder blaugrün, dicht und stark, zuweilen runzelig punktirt. Die Punkte bilden an der Naht auf der hinteren Hälfte unregelmässige, vertiefte Doppelstreifen, deren Zwischenräume schwach gewölbt sind. Füsse ziemlich stark, röthlichgelb, die Basis der Vorderschenkel, die Mittel- und Hinterschenkel fast bis zur Spitze bronzegrün. Selten ist der Grund der Schenkel nur gebräunt.

In Süddeutschland und Oesterreich, nördlich bis Erlangen und Prag. Ebenso auf der griechischen Halbinsel, in Südrussland und Kleinasien (Olymp. Merkl.).

Unter Cyaniris thoracica beschroibt $\mathrm{K}$ üster die vorliegende Art, die er 1846 noch nicht kannte, da er sie nicht zum Vergleiche heranzieht, sehr genau, bis auf die falsche Angabe, dass die Punkte der Fld. feiner wie bei aurita wären. 
Uebersichtstabelle der Gynandrophthalma-Arten:

1. Kopfschild des $\hat{o}$ breit, vorn gerade abge-

schnitten, beim o leicht ausgerandet . . . . 2.

- Kopfschild bei beiden Geschlechtern schmal,

deutlich ausgerandet . . . . . . . . 5.

2. Körper einfarbig grün, Hinterecken des Halssch. nicht emporgehoben

ว..

- Körper mehrfarbig, Halssch. vor dem Hinterrande tief quer eingedrückt, die Hinterecken über den Grund der Flügeld, anfgebogen . .

3. Letztes Glied der Maxillartaster schlank, doppelt so lang als das vorletzte (Saulopalpa m). Lebhaft metallgrün, selten kupferig oder bläulich, stark glänzend, Kopf eben und wie das Halssch. weitläufig fein, Flügeld. dichter und stärker punktirt. ô Halssch. sehr gross, breiter als die Fld., Glied 1 der Vordertarsen kaum so lang als 2 und 3 zusammen. L. $4-5 \mathrm{~mm}$. Syrien. (L a c. Mon. II. 291.) . . . . . .

- Letztes Tasterglied normal, wenig länger als das vorletzte. Metall- oder blaugrün, schwach glänzend, Kopf zwischen den Augen vertieft und einzeln, Halssch. dichter stark punktirt; Flügeld. stark runzelig punktirt. $\hat{\jmath}$ Mandibeln lang, vorgestreckt, Glied 1 der Vordertarsen so lang als 2-4 zusammen. - L. 4-5 $\mathrm{mm}$. Süd-Ungarn ${ }^{1}$ ). (Calyptorrhina Lac. 1. c. 83) . chloris.

Körper dunkel metallgrün oder pechschwarz, die Beine dunkel rothbraun: . .... Var, banatica.

4. Düster metall - oder blaugrün, Wurzel der schwarzen Fühler, Halssch. und Beine mit Ausnahme der schwärzlichen Tarsen gelblichroth. Mund pechschwarz. Stirn dicht längsrunzelig, Halsschild mässig dicht, grob, Flügeld. dicht runzelig punktirt. Mandibeln des of stark, verlängert . . . . . . . . baetica $n . s p .{ }^{2}$ )

1) Wohl nicht in Süddeutschland, wie Redtenbacher l. c. 449 angiebt.

$\left.{ }^{2}\right)$ Gyn. baetica: Oblongo-parallela, obscure viridi-aenea vel-coerulea, subopaca, subtus capiteque tenuiter griseo-pubescens, capite dense longitudilaniter ruguloso, vertice punctulato, prothorace rufo, irregulariter sat fortiter 
4. Blau oder grünlich blau. Kopf dicht, Halssch. weitläufiger stark punktirt, Flügeld. grob runzelig-punktirt. Mund, Fühler (die Oberseite der Spitzenhälfte dunkel), Halssch. und Beine röthlichgelb. L. $3-3,5 \mathrm{~mm}$. Syrien. (L efèv r. Ann. Fr. 1872. 349.) . . . . . . . djebelina.

5. Oberseite einfarbig blau oder grün . . . . 6.

- Oberseite mehrfarbig . . . . . . . . 8.

6. Beine wie der Körper gefärbt . . . . . . 7.

- Beine ganz oder theilweise rothgelb. Schwarzblau, selten grünlich, mässig glänzend; Kopf und Halssch. weitläufig und fein, die Fld, dicht und stark punktirt. Beine einfarbig rothgelb,

punctato, angulis posticis elevatis: elytris confertim. minus fortiter rugosopunctatis, pedibus rufis, femoribus posticis busi infuscatis, tarsis nigro-piceis. L. 5-6,5 mm. - Andalusien.

Mas: cylindricus, capite maximo, mandibulis validis, valde exstrtis, basi fortiter gibbosis; clypeo haud emarginato; elytris opacis.

Cyaniris virens Ramb. Dej. Cat. ed. 3. 444.

Von der kleineren, besonders kürzeren nigritarsis durch das grob punktirte, sehr unebene Halssch, die (vorzüglich beim $\hat{.}$ ) matten, grünlichen Fld., welche feiner aber viel dichter punktirt sind, den bis zum Vorderrande gerunzelten Kopf und das Kopfschild des $\hat{\sigma}$ verschieden, welches vorn grade abgeschnitten, nicht ausgerandet ist. Die Hinterschenkel sind nur an den Hüften angedunkelt, bei nigritarsis bis über die Hälfte schwarz. Uebergänge, von denen Lacordaire und Lefèvre im Allgemeinen sprechen, sind mir nicht bekannt.

Mit dieser Art verwandt, an dem unregelmässig, grob-runzelig punktirten Halssch. kenntlich, sind die von Lefèvre (Ann. Fr. 1S72. 317) als Otiocephala abgesonderten Arten, deren Kopf, Halssch., Schildchen, Unterseite und Beine tiefblau, die Fld. gelbbraun sind, mit:

a. zwei blauen Querbinden, eine an der Basis, weder Naht noch Seitenrand berührend, die andere, gemeinschaftliche, hinter der Mitte. - L. 4,5-5 mm. Algier. (Lucas Rev. Zool. 1845. 122) . . - forcipifera.

b. zwei blauen Makeln am Grunde (die Schultermakel länglich, die andere nahe dem Schildchen rund) und gemeinschaftlicher Querbinde hinter der Mitte. L. $5 \mathrm{~mm}$. Algier. (Lef. Ann. Fr. 1873. Bull. 210) Warioni.

c. einem grossen blauen Schulterpunkte und einer ebensolchen Makel hinter der Mitte. - L. 5 bis $5,7 \mathrm{~mm}$. Andalusien, Nordafrika. (Rosenh. Thiere Andal. 308). 
(Var. hellenica Mars. Abeille V. 205. Syrien) oder Grund der Mittel- und Hinterschenkel schwarzblau. - L. $3-5 \mathrm{~mm}$. Auf jungen Eichen in Griechenland und Kleinasien. (Brull. Exped. Mor. III. 268. t. 44. f. 6) • . . . tibialis.

7. Dunkelblau, oft nur Kopf und Halssch. grünlich. Kopf fein, runzelig punktirt, Halssch. einzeln, verloschen, Fld. äusserst dicht punktirt. L. 2,5-3,5 mm. Serbien, Bulgarien, nördl. Türkei. (Lac. 1. c. 288)

hypocrita.

- Lebhaft metall- oder blaugrün, selten himmelblau, stark glänzend. Stirn quer eingedrückt, stark punktirt, Halssch, fein, die Fld. dicht punktirt. L. 3,5-5 mm. Auf Cerealien. Südfrankreich, Spanien, Italien. $\left.{ }^{1}\right)$ (F a b r. Ent. Syst, I. 2. 69)

concolor.

8. Halssch. metallisch blau- oder goldgrün, wie der grösste Theil des Körpers . . . . . .

- Halssch. ganz oder theilweise roth . . . . 12.

9. Fld. wie der Körper gefärbt;

a. mit gelblicher Spitzenmakel . . . . 10.

b. mit gelblichem Seitensaume . . . . . 11.

- Fld. rothgelb, jede mit schwärzlichem Schulterpunkte und grosser, viereckiger, blauer oder blaugrüner Makel. Grundhälfte der Fühler, die Schienen und Tarsen gelbbraun. Oberseite gleichmässig dicht punktirt, Punkte des Halssch. feiner. - L. 4-5 mm. Daghestan bis Bagdad. Anfang Mai auf Tamarix. (Ménétr. Cat.

rais. 236) • . * * * * • • • . wird klein: Var. venusta Lefèvr. l. c. 337 ; oder die Fld. einfarbig rothgelb: Var. aegyptiaca Lef èvr. 1. e.

10. Beine grün mit schwarzen Tarsen. - L. 4,5 bis $5 \mathrm{~mm}$. Spanien. (Lac. l. c. 292) . . . Menetriesi.

- Beine und Fühler gelbbraun, letztere an der Spitze und die Tarsen angedunkelt. - L. 3,5 bis $4 \mathrm{~mm}$. Algier. (Lucas Rev. Zool. 1845. 124) gratiosa.

1) Stücke aus Deutschland (Redtenb. 451) sind mir nicht bekannt. 
11. Beine metallgrün. Halssch. ziemlich stark punktirt. - L. 3,5-6 mm. Türkei, Griechenland, Kleinasien bis zum Caucasus. (Stev. Mém. Mosc. I. 157. t. 10. f. 1) • • • • • • • limbata.

- Schenkel metallgrün, Schienen und Tarsen gelbbraun. Halssch. fein punktirt. Von der grünen Farbe der Fld. bleibt nur eine gemeinschaftliche Längsmakel bis zur Mitte der Naht übrig. L. $4,5-5,5 \mathrm{~mm}$. Syrien. (Lefèvr. 1. c. 335) scutellaris.

12. Halssch. einfarbig rothgelb . . . . . 13.

- Nur die Seiten des Halssch. oder eine Makel in den Vorderecken rothgelb . . . . . 21.

13. Fld. rothgelb, jede mit zwei dunklen Makeln. 14.

- Fld. himmelblau, Naht, Seiten- und Spitzenrand (letzterer breiter) hellroth, Unterseite und Beine schwarzblau. Halssch. fast glatt, Fld. dicht punktirt. - L. $4 \mathrm{~mm}$. Corsica. (Desbr. Abeille VII. 130.) . . . . . . . . Raffrayi.

- Fld. blau oder grünblau . . . . . . . 15.

14. Schwarz, die zwei ersten Fühlerglieder unterseits, Halssch. und Fld, rothgelb, auf jeder der letzteren eine hinten gebuchtete Quermakel am Grunde und eine schiefe, viereckige, hinter der Mitte schwarzblau. Fld. dicht und stark in unregelmässigen Streifen punktirt. - L. 4,5 mm. Syrien, Mesopotamien. Coptoc. scopolina sehr ähnlich. (Lac. 1. c. 310) . . . coptocephaloides.

- Wie vorige; Fld. fein, verloschen punktirt, ein Schulterpunkt und eine Makel hinter der Mitte schwarz; Fühlerglied 1-3 roth. - L. 4,5 bis $5 \mathrm{~mm}$. Portugal, Algier. Coptoc. rubicunda ähnlich. (Lefèvr. 1. c. 351.) . . . . . brevicornis.

15. Halssch. am Hinterrande leicht eingedrückt, Hinterecken nicht aufgebogen . . . . 16.

- Halssch. am Hinterrande stark eingedrückt, Hinterecken über den Grund der Fld. emporgehoben. Gesättigt blau, Halssch. glänzend, sparsam und fein punktirt, die Fld. dicht, stark und tief punktirt, Beine rothgelb, die Grundhälfte der Hinterschenkel schwarz, Tarsen schwärzlich. - L. 3-5 mm. Südfrankreich, Spanien. (Lac. Mon. 297) . . . . . nigritarsis. 
16. Halssch. deutlich, stark punktirt

- Halssch. kaum sichtbar oder nur stellenweise fein punktirt .

17. Hinterrand des mässig gewölbten Halssch. fast grade abgeschnitten. Beine kurz, stark, rothgelb, Grundhälfte der vier Hinterschenkel schwärzlich. - L. $4 \mathrm{~mm}$. Spanien, Portngal. (Lacord. 1. c. 299)

thoracica.

- Hinterrand des stark gewölbten Halssch. deutlich zweibuchtig. Beine schlank, wie bei der Vorigen gefärbt. Der Körper länglicher. L. 3,5-5 mm. Griechenland. (Kraatz Berl. Zeitschr. 1872. 217)

18. Maxillartaster schwarz 18.

- Taster gelbbraun, letztes Glied wenig dunkler, Mund und Beine gelb. Fld. metallisch, hell blaugrün, äusserst dicht, tief punktirt. L. $3-5 \mathrm{~mm}$. Corsica, Sardinien. (Géné Mém. Ac. Torin 1839. 82) . . . . . . ferulae.

19. Stirn mit breitem und tiefem Quereindruck. Körper plump. Beine stark. L. 4,5-6,5 mm. Europa .

- Stirn flach, fast punktförmig eingedrückt, Körper gestreckt. Beine dünn . . . . . 20.

20. Die vier Hinterbeine metallgrün wie die Fld., die vorderen rothgelb mit schwarzer Rückenlinie; Fld. stark runzelig punktirt. - L. 3,5 bis 4,5 mm. Algier. (L a c. 299) . . . . . . graeca 우 19. salicina. rufimana.

- Beine rothgelb, Hinterschenkel meist bis zur Mitte angedunkelt oder schwärzlich. Fld. tiefblau, selten leicht grünlich, mässig dicht punktirt. - L. 3,5-4,5 mm. Mitteleuropa . flavicollis.

- Beine düster rothgelb wie das Halssch., wenigstens die Hinterschenkel, oft die Hinterbeine schwarzgrün, Fld. erzgrün, dicht und flach punktirt. - L. $3,5-5 \mathrm{~mm}$. Schlesien . diversipes.

21. Halssch. schwarzblau (wie die Fld.) mit gelblichem Augenflecke jederseits in den Vorderecken, der weder Vorder- noch Seitenrand berührt. (Lac. 289) . . . . . tibialis v. bioculata.

Vorderecken des Halssch. bis zum Innenrande der Augen mit einer hinten schlecht 
begrenzten rothen Quermakel, die sich auch auf der Unterseite als schmale gelbe Querbinde bis in die Nähe der Vorderhüften hinzieht:

tibialis var. liturata.

21. Halssch. mit schwarzem oder blauem Mittelstreifen, Seiten breit roth gesäumt

22. Fld. einfarbig 23.

- Fld. mit gemeinschaftlicher gelbbrauner Spitzenmakel. Oberseite gesättigt blau, Kopf grünlich, Seiten des zerstreut punktirten Halssch. breit roth. Beine roth, die Rückenlinie schwarz. L. 4-5 mm. Sibirien. (Fabr. Spec. Ins. I. 143 )

collaris.

23. Scheibe des IIalssch. kaum, Fld. fein und tief punktirt

- Scheibe des Halssch. deutlich, Fld, ziemlich stark punktirt . . . . . . . . . . 24

24. Beine und Vorderhüften rothgelb . . . affinis.

- Hüften schwarz . . . . . . . . . . . 25.

25. Fld. an der Naht vor der Spitze mit ziemlich regelmässigen Punktreihen, deren $\mathrm{Z}$ wischenräume deutlich erhöht sind .

- Fld. ohne erhabene Zwischenräume an der Naht . . . . . . . . . 27

26. Mandibeln des ô stark, vorstehend, am Innenrande gezähnt. - L. $4-5 \mathrm{~mm}$. Syrien. (Lefèvr. 1. c. 342)

- Mandibeln sehr kurz. L. 4,5-6 mm . judaica.

27. Beine rothgelb, die äusserste Basis der Vorderschenkel, die Mittel- und Hinterschenkel fast bis zum Knie schwärzlich. - L. $3-4 \mathrm{~mm}$. Griechenland. (Kraatz Berl. Zeit. 1872.217) graeca $\hat{o}$.

- Vorderbeine rothgelb, zuweilen mit dunkler Rückenlinie, die übrigen Beine schwarzgrün . 28.

28. Kopf des ô grösser als beim 우. Kopfschild tief ausgerandet. - L. 4-4,5 mm. Spanien. (Bris. Ann. Fr. 1866. 422. Chilotoma) . . Reyi.

- Kopf des ô kaum grösser, Kopfschild weniger tief ausgerandet. - L. 4-4,5 mm. Spanien. (Lefèvr. 1. c. 341) 


\section{Chilotoma.}

L a cord. Monogr. d. Phyt. II. 341.

\section{Clypeus bidentalus.}

Antennae articulo primo longissimo.

Oculi parvi, subrotundati.

Prothorax angulis posticis rotundatis, elevatis.

Tarsi articulo primo crassiusculo, tertio lobis apice rotundatis.

Durch die Farbe mit Gynandrophthalma, durch die Körperform der Männchen mit Coptocephala verwandt, während die Bildung des Kopfschildes, des ersten Fühlergliedes und der Hinterecken des Halsschildes lebhaft an die Chlorostola-Arten erinnert.

Körper cylindrisch, fast gleichbreit, unterseits sparsam und fein behaart. Fühler kurz und schlank, vom fünften Gliede an gesägt, das erste Glied dünn und etwa so lang als die drei folgenden zusammen. Halsschild quer, die gerundeten Hinterecken über den Grund der Flügeldecken emporgehoben. Beine mässig dick, das erste Tarsenglied fast so lang und etwas breiter als die zwei folgenden zusammen.

3. Kopfschild breit, tief ausgerandet, jederseits in einen breiten Zahn verlängert. Mandibeln weit rorgestreckt, regelmässig gebogen, an der Spitze zweizähnig. Letztes Hinterleibssegment in der Mitte leicht eingedrückt.

․ Kopfschild schmal, wenig tief bogenförmig ausgerandet, seine Vorderecken kurz, zahnartig. Mandibeln schwach vorstehend. Letztes Hinterleibssegment in der Mitte grubenförmig vertieft, der Hinterrand leicht ausgeschnitten.

1. Chil. mase iformis ${ }^{1}$ ): Viridi-coerulea, nitida. ore, antemunm basi, prolhorace pedibusque rufo-flavis, illo macula magna, rotundala viridi-coerulea in medio rtisci ornato, his femoribus basi tarsisque superne nigro-vividis vel nigricantibus. - Long. $3-5 \mathrm{~mm}$.

Mas: Cupite valido. clypeo profunde quadratim emarginato, mandibulis crassis, prominulis.

Goeze Ent. Beitr. I. 319 (Chrysomela). - Lefèvr. Ann. Fr. 1872. 355.

Chil. bucephala Schall. Abh. Ges. Halle I. 276 bis (Chrysomela). F abr. Mant. I. 82 (Cryptoc.). - Panz. Faun. Germ. 45.6 (Clytra). -

1) Kräftiger gebaut, aber ebenso gefärbt ist:

Ch. erythrostoma Fald. (Nouv. Mèm. Mosc. V. 376. t. 14. f. 5-7). Ausschnit des Kopfschildes beim $\hat{\odot}$ gerundet-viereckig, mit nicht parallelerı Innenseiten. Halssch. nur auf der Scheibenmakel deutlich punktirt. L. $5-7 \mathrm{~mm}$. Kaukasus. 
Lac. Mon. II. 343. - Suffr. Stett. Z. 1851. 215. - Redtb. Faun.

A. II. 452. - Seidl. Faun. balt. 473.

$\mathrm{V}$ ar, a. Prothorace nigro-aeneo, lateribus anguste rufo.

Unterseite dunkelblau oder grün, der Kopf metallgrün, glänzend, undeutlich behaart, wenig dicht, fein punktirt, mit leichtem Quereindrucke zwischen den Augen. Der ganze Mund, mit Ausnahme der gebräunten Mandibelspitze, röthlich gelb, ebenso die Fühler, deren fünf oder sechs letzte Glieder schwärzlich sind, und das Halssch. Dieses ist doppelt so breit als lang, mässig dicht, fein punktirt, mit einer gerundeten blau - oder erzgrünen Makel in der Mitte der Scheibe, welche einen äusserst schmalen Saum am Vorderund Hinterrande frei lässt. Fld. blau, blaugrün oder erzfarbig, dicht und mässig stark punktirt, mit schwachen Spuren von vertieften Punktreihen an der Naht hinter der Mitte. Beine rothgelb, die Vorderschenkel am Grunde, die mittleren etwa bis zur Hälfte, die hinteren bis nahe an die Spitze schwarz oder grünlich, die Tarsen oberseits schwarz. Bei südlichen Stücken ist die Basis der Schenkel bisweilen nur leicht gebräunt.

๙. Kopf breit, viereckig, Halssch. vorn so breit als am Hinterrande, die Seiten leicht gerundet. Penis schlank, ganz allmählich in eine sehr lange Spitze ausgezogen.

오. Kopfschild quer-vertieft, Halsseh. nach vorn deutlich verschmälert.

Die Grösse der Halsschildmakel ist nicht ganz constant. Sie nimmt in seltenen Fällen soweit zu, dass nur noch ein dreieckiger, vorn breiterer Seitensaum des Halssch, roth bleibt. Var. a.

Auf Rumex acetosella (L ef èv re) und Anthyllis vulneraria ( $\mathrm{Suffr}$.) stellenweise im ganzen Gebiete.

\section{Coptocephain.}

Lacord. Mon. des Phytophag. II. 345.

Clypeus plus minusve profunde enarginatus, angulis anticis rotundatis, labium maris latissimum, apice parum emarginalum.

Oculi parvi, subrotundati.

Prothorax angulis posticis rotundatis.

Pedes anici maris longiores: tarsi articulo primo elongatulo, tertio lobis apice subacutis.

Cylindrisch, unterseits dicht und fein, der Kopf sparsamer behaart. Fühler kurz, vom füntten Gliede an wenig scharf gesägt, erstes Glied dick, kaum so lang als die zwei folgenden zusammen, das zweite etwas schmaler, so lang als breit, das dritte kürzer, 
halb so breit als das zweite, Glied vier gestreckt, nach der Spitze erweitert, die ersten vier Glieder fast ganz, die zwei folgenden oft unterseits rothgelb, die übrigen schwarz. Halsschild quer, vor dem Schildchen leicht niedergedrückt, die Hinterecken abgerundet. Flügeldecken fein punktirt mit äusserst fein gerunzelten oder punktirten Zwischenräumen. Beine ziemlich dünn, das erste Tarsenglied schmal, gestreckt, etwa so lang als die zwei folgenden zusammen, die Lappen des dritten Gliedes fast gradlinig nach vorn in cine ziemlich scharfe Spitze verschmälert.

J. Kopf sehr breit, viereckig, die Oberlippe gross und breit, vorn unmerklich oder kaum ausgerandet. Mandibeln mässig vorgestreckt, dicht vor dem Grunde stark gekrümmt, am Ende dreizähnig. Kopfschild breit, der Vorderrand mehr oder weniger tief bogenförmig ausgerandet, mit abgerundeten Vorderecken. Halsschild vorn so breit oder wenig schmaler als am Grunde, die Seiten gerundet. Vorderbeine verlängert, die Schienen gekrümmt, fast gleichbreit.

․ Kopf nach vorn verschmälert, Mandibeln wenig vorstehend; Halsschild nach vorn stark verengt, Flügeldecken merklich stärker punktirt als beim $\hat{\partial}$, letztes Hinterleibssegment mit wenig tiefer Längsgrube in der Mitte.

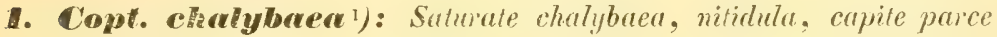
thoraceque dense subtitissimeque punctuluto, elytris obsolete munctatis, alutaceis. - Long. 3-4 mm.

Mas: clypeo leniter emarginato.

Germ. Ins. Spec. nov. 546 (Clytra). - Lac. Mon. II. 359. Kraatz Berl. Z. 1872. 231.

ふ. Cylindrisch, einfarbig tief stablblau, zuweilen Kopf und Halssch., selten auch die Fld. grünlich schimmernd, schwach glänzend. Kopf zwischen den Augen quer eingedrückt, davor oft mit zwei Grübchen, einzeln undeutlich punktirt oder gerunzelt. Kopfschild sehr breit und flach ausgerandet. Fühler schwarz, die ersten vier Glieder rothgelb, oberseits das erste metallgrün, das zweite und vierte schwärzlich. Halssch. nach vorn wenig verschmälert, dicht, kaum sichtbar punktirt, Fld. mit mässig grossen, flachen Punkten, deren Zwischenräume äussert dicht und fein lederartig gerunzelt sind.

1) Von Lefèvre (Ann. Fr. 1872. 374) mit dieser Art vereint, jedoch sicher verschieden ist:

C. unicolor Luc. (Rev.'Zool. 1845. 125): Viridi-aenea interdum cyaneo-virescens, nitida, elytris obsolete punctatis, interstitiis crebre subtilissimeque punctulatis. Mas: clypeo profunde emarginato, - Long. 3-4 m. Sicilien. Algier. 
ㅇ. Länglich oval, nach hinten leicht verbreitert, Stirn kaum deutlich eingedrückt, Halssch. nach vorn stark verengt, Fld. etwas glänzender als beim $\hat{\jmath}$.

Auf trockenen Grasplätzen im nördlichen Karste bei Triest (Schreiber) häufig. Ausserdem vom südlichen Ungarn bis zum Kaukasus.

2. Copt. mighaciatar: Nigro-aenea aut cyanea, nitirla, prothorace fortiter bansverso, rufo-testaceo, elytris obsolete punctatis, pallidioribus, singulo fasciis duabus latis (altera basi, scutellum attingente, altera pone medium) nigro-aeneis aut cyaneis, labro pedibusque plus minusve testaceis. Mandibulis maris medio fortiter angustatis. Long. $4-7 \mathrm{~mm}$.

Scopoli Ent. Carn. 66. 205 (Buprestis).

C. quadrimaculata Linn. Syst. Nat ed. XII. 596 (Chrysomel.). Suffr. Stett. Z. 1851. 218. - Kratz Berl. Z. 1872. 219. Lefèvr. Ann. Fr. 1872. 370. - Seidl. F. balt. 473 .

C. femoralis Küst. Käf. Eur. 2. 91.

Var. a. Elytris infra medium fascia communi.

C. quadrimaculata Lac. Mon. II. 354. - Redtb. Faun. A. II. 452. Var. b. Elytrorum fasciis extus coeuntibus.

Var. c. Elytrorum fascia antica sculellum haud atingente.

Var. d. Fronte inter antennas maculis duabus rufis.

C. 4 -maculata var. maculiceps Kratz 1. c. 223 .

Var. e. Pedibus rufo-testaceis.

C. femoralis $\mathrm{Kr}$. 1. c. 222 .

Var. f. Labro nigro, antice ferrugine-maryinaio.

o. Dunkel-erzgrün, selten schwarzblau, glänzend. Kopf fast glatt, Stirn mit mehr oder weniger tiefem, oft aus zwei Gruben bestehendem Quereindrucke, Oberlippe rothgelb, Kopfschild quer vertieft, weit und flach bogenfömig ausgerandet; viertes Füblerglied etwas länger als das dritte. Halssch. gesättigt rothgelb, kurz, stark quer, äusserst fein, kaum sichtbar punktirt, der Hinterrand an den Seiten grade, in der Mitte in einen breiten Lappen gegen das Schildchen vorgezogen, überall scharf gerandet. Fld. fein und flach punktirt, blass rothgelb, jede mit zwei schwarzgrünen Querbinden; die erste am Grunde, den Seitenrand nicht, wohl aber, nach innen allmählich verengt, das Schildchen ganz oder theilweise berührend; die zweite hinter der Mitte, einen sehr schmalen Nahtsaum und etwas breiteren Seitensaum freilassend, nach der Naht zu etwas verengt, thinten oft ausgerandet. Beine ziemlich schlank, die vorderen länger als die übrigen, mit gekrümmten Schienen, gelbbraun, die Tarsen theilweise oder ganz dunkel, oft schwarz und: 
a. die Mittelschenkel am Grunde gebräunt, die Hinterschenkel bis über die Hälfte schwarzgrün;

b. die vier Hinterschenkel bis zum Knie schwarzgrün;

c. die Wurzel der vier Vorderschenkel mehr oder weniger weit dunkel, die hinteren über die Hälfte schwarzgrün (femoralis Küster);

d. alle Schenkel, mit Ausnahme der Spitze, oder ganz schwarzgrün;

e. Schenkel schwarzgrün, die Schienen, mit Ausnahme der Aussenseite am Grunde, und die Tarsen schwarz.

Penis an der elliptischen Oeffnung allmählich schwach erweitert, von der Mitte derselben nach vorn gradlinig rerengt und in eine kurze, etwas nach unten gebogene Spitze rerlängert.

Die Zeichnung der Fld. ändert ab:

a. Die Hinterbinden beider Fld. bilden eine gemeinschaftliche, an der Naht nicht unterbrochene Querbinde.

b. Die Binden sind stark vergrössert und fliessen aussen zusammen. Zuletzt bleibt von der Grundfarbe nur ein gemeinschaftlicher rhombischer Fleck auf der Mitte der Naht, ein schmaler, vor der Mitte leicht dreieckig erweiterter Seitensaum und eine grosse Spitzenmakel übrig. Meist 우.

c. Die Binden sind verkleinert; die vordere erreicht innen nicht mehr die Seiten des Schildehens, vorn nur in geringer Ausdehnung die Basis der Fld. und ist hinten tief ausgerandet, so dass sie wie aus zwei Makeln zusammengesetzt erscheint. Auch die hintere ist weiter von der Naht entfernt.

Als auffällige Varietäten verdienen noch hervorgehoben zu werden:

d. Kopf zwischen der Einlenkungsstelle der Fühler mit zwei grossen, fast dreieckigen, rothgelben Flecken.

e. Beine bis auf die dunkleren Tarsen einfarbig rothgelb.

f. Oberlippe schwarz, vorn fein röthlich gesäumt.

Auf Dolden häufig; die Var. b, d, e, f jedoch selten.

Lacordaire betrachtet die bei uns nicht vorherrschende Var. a als Grundform.

C. femoralis Küst. hat nur nach der Diagnose rothgelbe Beine, nach der Beschreibung theilweise schwarze Schenkel; sie ist eine häufige, unbedeutende $\mathbf{A b a ̈ n d e r u n g . ~}$

3. Copt. scopolina: Nigro-cyanea, interdum-aenea, nitidula, prothorace modice transverso, rufo-testaceo, elytris pallidioribus, subseriatim punctatis, singuln fasciis duabus (altera basi, scutellum attingente, 
altera pone medium) nigro-cyaneis. Mundibulis maris sensim anguslatis. - Long. $5-7 \mathrm{~mm}$.

Linn. Syst. Nat. XII. 597 (Chrysomela). - Suffr. Stett. Z. 1851. 218. - Kraatz Berl. Z. 1872. 219. - Lefèvr. Ann. Fr. 1872. 365. - Redtb. Faun. A. II. 452. - Seidl. F. balt. 473.

V ar. a. Major.

C. Küsteri Kraatz 1. c. 230.

C. melanocephala Küst. Käf. Eur. 9. 100.

Var. b. Elytris pone medium fascia communi.

C. scopolina Lac. Mon. II. 349 (pars).

Var. c. Elytrorum fasciis anticis scutellum haud attingentibus.

Var. d. Elytro singulo maculis duabus baseos fasciaque angusta infia medium.

Var. e. Elytro puncto medio basi lineolaque transversa infia medium.

Var. f. Elytro punctis tribus (uno basi, duobus infra medium).

Var. g. Elytro pumotis duobus (ultero basi, altero pone medium).

Var. h. Elytris puncto basali.

C. plagiocephala Fabr. Ent. Syst. I. 2. 60.

Var. i. Elytris macula pone medium.

Var. k. Elytris immaculatis.

Durchschnittlich etwas grösser, meist länger als die vorige Art, mit einfarbig schwarzen Beinen, in folgenden Punkten von ihr abweichend: Unterseite, Beine, Kopf und die Binden der Fld. sind schwarzblau, selten grün; die Oberlippe ist schwarz, das vierte Fühlerglied reichlich so lang als die zwei vorhergehenden zusammen und mehr als doppelt so lang wie das dritte. Das Halssch. erscheint deutlich länger, weniger quer, stark zusammengedrückt, cylindrisch, gewölbt, der Hinterrand, vor dem Schildchen jederseits leicht ausgebuchtet, ist an den Ecken weniger deutlich gerandet, die Fld. sind stärker, leicht gereiht punktirt und lederartig gerunzelt, daher matter als bei der vorigen Art. Die Binden der Fld. zeigen das Bestreben, sicb erheblich zu verschmälern, in einzelne Flecke aufzulösen oder zu verschwinden. Die Aussenseite der Mandibeln ist nach der Spitze hin allmählich und sehr mässig verschmälert, bei unifasciata dagegen in der Mitte schnell und stark verengt (beim $\hat{\sigma}$ besonders leicht $z u$ bemerken), hierauf bis zur Spitze gleichbreit.

Der Penis endlich ist an der breit-gerundeten Oeffnung stark erweitert, vorn schnell verengt und in eine kurze, scharfe Spitze ausgezogen.

Auffällig grosse Stücke aus Dalmatien, Corsica (Kratz) und Sicilien (Lefèvre) sind von Küster als melanocephala beschrieben worden, welcher Name von Kraatz in Küsteri umgeändert wurde. Sie sind jedoch ebensowenig specifisch von der vorliegenden Art 
zu trennen als die Riesenexemplare der unifasciata (L. $7 \mathrm{~mm}$ lat $4 \mathrm{~mm}$ ) aus Syrien ( $\mathrm{Simon}$ ) von der letzteren.

Bei der Grundform hat jede Fld. zwei Querbinden, die vordere, an der Basis, ist fast gleichbreit, hinten ausgerandet, am Schildchen plötzlich verengt und berührt letzteres, aber aussen nicht den Seitenrand; die andere, linter der Mitte, ist ebenfalls fast gleichbreit, schief gestellt, und erreicht weder den Seiten-noch Nahtrand. Diese Zeichnung ändert ab:

b. Die Hinterbinde beider Fld. ist zu. einer gemeinschaftlichen Querbinde ausgedehnt.

c. Die Basalbinde erreicht das Schildchen nicht.

d. Dieselbe ist in zwei Flecke aufgelöst, der eine auf der Schulter, der andere, meist grössere, nahe dem Schildchen.

e. Von diesen verschwindet einer (gewöhnlich der Schulterfleck); die Hinterbinde ist schmal, oder

f. in zwei Flecke geschieden, von denen bei

g. einer verschwindet (meist der äussere).

h. Die Hinterbinde fehlt, die vordere ist punktförmig.

i. Die Vorderbinde fehlt, die hintere ist eine kleine Quermakel nahe der Naht.

k. Flügeldecken einfarbig.

Die Var. b der unifasciata ist bei der vorliegenden Art noch nicht beobachtet worden, wogegen jener wieder die oben angeführten Var. d bis $\mathbf{k}$ zu fehlen scheinen.

Der Verbreitungsbezirk der Art in Deutschland ist, da dieselbe erst in neuerer Zeit durch die vorzügliche Arbeit Dr. Kraatz's scharf von rubicunda geschieden wurde, noch wenig bekannt. Es liegen mir Exemplare von Augsburg, Wien und aus Oberkrain (Micklitz) vor. Sie scheint in Süddeutschland und Oesterreich selten, häufig in Dalmatien und Südeuropa zu sein.

4. Copt. mbicumala ${ }^{1}$ ): Nigro-aenea, nitidula, fronte transversim impressa, antenis articulo quarto tertio sesqui longiore, thorace brevi mo-testaceo, elytris subiliter punctatis, pallidioribus, singulo maculis duabus (una oblonga humerali, altera majori transversa infra medium) nigro-aeneis. - Long. 4,5-6 $\mathrm{mm}$.

Lai ch. Verz. Tyrol.Ins. I.169(Clytra). - Kraatz Berl.Z.1872.226.

1) Sehr ähnlich, aber in Folge der abweichenden Penisbildung bestimmt verschieden ist :

C. floralis Oliv. (Encycl. méth. VI. 37): Nigro-cyanea, nitidula, fronte late impressa, antennis articulo quarto tertio plus quam duplo longiore, prothorace minus brevi, rufo-testaceo, elytris pallidioribus, singulo puncto 
C. tetradyma Küst. Käf. Eur. 2. \$9, - Lefèvr. Ann. Fr. 1872.367.386.

C. scopolina var. G. Lac. Mon. II. 350 .

Var. a. Elytris pone medium fascia communi.

Var. b. Macula posteriori in puncta duo divisa.

Var. c. Macula posteriori mimuta.

Var. d. Elytris macula humerali.

Var. e. Tibiis basi evidenter fermugineis.

Durch die Farbe der Oberlippe und Beine mit der Vorhergehenden verwandt, indessen durch die nie quere Schultermakel leicht zu unterscheiden.

ふ. Dunkel erzgrün, selten blau. Kopf mit schmalem, leicht gerunzeltem Quereindrucke zwischen den Augen, sonst einzeln, verloschen punktirt. Kopfschild jederseits quer vertieft, sehr schwach in einem breiten Bogen ausgerandet. Viertes Fühlerglied kürzer als die zwei vorhergehenden zusammen, aber etwa $1 \frac{1}{2}$ mal so lang als das dritte. Halssch. über doppelt so breit als lang, an den Seiten leicht gerundet, gewölbt, kaum sichtbar punktirt. Fld, röthlich gelbbraun, fein punktirt, eine Längsmakel auf der Schulter, welche einen schmalen Grund - und breiteren Seitensaum frei lässt, sowie eine breite, meist nach aussen verschmälerte Quermakel, der Naht näher als dem Seitenrande, schwarzgrün oder schwarz. Beine ziemlich scblank, schwarz, die Vorderschienen mässig gekrümmt.

Penis kräftig, die Seiten der Oeffnung in der Mitte bogenförmig ausgeschnitten.

q. Kopf und Halssch. schmaler, letzteres nach vorn stark rerengt, die Fld. nach hinten wenig erweitert, glänzender und häufig mit grösseren Makeln versehen als beim $\hat{\jmath}$.

Die wichtigsten Abänderungen sind folgende:

a. Die hintere Makel beider Fld. bildet eine gemeinschaftliche Querbinde.

humerali maculaque angusta, transversa infira medum mgro-cyaneis, femoribus nigro-cyaneis aut virescentibus, tibiis rufo-testaceis, tarsis nigricantibus. - L. 4,5-6 mm. Balearen. Spanien.

Variat a. elytris macula posteriori in puncta duo divisa (bistrimaculata Kïst. Käf. Eur. 15. 100), b. macula posteriori minuta, c. elytris immaculatis et d. pedibus nigris.

Die besonders beim $\hat{6}$ breit eingedrückte Stirn, das sehr lange vierte Fühlerglied, das längere Halssch, die meist schwachen Makeln der Fld. und die rothgelben (nur selten schwarzen) Schienen zeichnen die Art von rubicunda aus. Der Penis ist auffallend schlank, an der lang-elliptischen Oeffnung leicht erweitert, die Seiten allwählich nach rorn verengt und in eine kurze, nach unten gebogene Spitze verlängert. 
b. Die hintere Makel ist in zwei Fleeke aufgelöst.

c. Sie ist punktförmig oder

d. fehlt ganz.

e. Schienen an der Basis rothbraun. Diese Varietät lildet einen scheinbaren Uebergang zur rothschienigen floralis.

In Deutschland und Oesterreich weit verbreitet, nördlich bis Schlesien und Thüringen, an Blüthen auf trockenen Hügeln nicht selten.

\section{Uebersicht der Coptocephala-Arten.}

1. Halssch. wic der ganze Körper blau oder grün 2.

- Halssch. rothgelb einfarbig oder mit 5 Makeln 3.

- Halssch, rothgelb, ein breiter, viereckiger Längsstreifen über die Scheibe blaugrün, wie der Körper mit Ausnahme der rothgelben Spitze der Fld. - L. 3-4 mm. Südrussland. Kaukasus. (Lac. Mon. 361)

2. Blau, mässig glänzend. Fld. zwischen den Punkten sehr fein lederartig gerunzelt .

apicalis.

- Grün oder blaugrün, glänzend. Fld. zwischen den Punkten dicht und sehr fein punktulirt. unicolor.

3. Halssch. einfarbig

- Halssch. mit 5 schwarzgrünen Makeln, 4, 1. Fld. rothgelb, jede mit 2 bindenförmigen schwarzgrünen Quermakeln, eine am Grunde, die andere hinter der Mitte. Oberlippe und Beine schwarz. - L. 5,5 mm. Corsica. (Lefèvre Ann. Fr. 1872. 364) . . . . . quinquenotata.

4. Kopf schwarz, blau oder grün schimmernd . 5 .

- Vorderkopf rothgelb. - L. 3,5-7 mm. Südrussland. (L a c. 356)

5. Oberlippe roth . . . . . . . . 6 .

- Oberlippe pechbraun oder schwarz . . . . 7.

6. Füsse schwarz, Stirngrube eiförmig, jede Fld. mit 2 schwarzen Punkten. - L. 4,5-7 mm. Sicilien. (Lefèvr. 1. c. 372) . . . . fossulata.

- Wenigstens die Schienen am Grunde rothgelb unifasciata.

7. Fld, rothgelb, am Grunde und hinter der Mitte dunkel gezeichnet . . . . . . . 8 .

- Fld. mit schmalem, schief über die Schulter ziehenden Saum am Grunde. - L. 5-6 mm. Sardinien. (Lac. J. c. 348) . . . . . cyanocephala.

8. Beine schwarz . . . . . . . . . . 9. 
8. Schenkel meist gelbbraun. Fld. mit Schulterpunkt und schmaler Quermakel hinter der Mitte. - Spanien . . . . . . . floralis.

9. Fld. mit 2 Querbinden . . . . . scopolina.

- Fld. mit länglicher Schultermakel und einer Querbinde hinter der Mitte... . . rubicunda.

- Fld. mit 2 Längsmakeln am Grunde (auf der Schulter und am Schildchen) und einer Quermakel hinter der Mitte. - L. 5-7 $\mathrm{mm}$. Algier. (Fabr. Illig. Mag. II. 293) . . bistrinotata.

\section{Zweite Gruppe: CR YPTOCEPHALINI.}

Chapuis, Genera d. Col. X. 153.

Caput verticale, retractum.

Antennae tenues, filiformes.

Pygidium nudum.

Coxae distantes.

Kopf mässig gross, ganz oder wenigstens bis zum Hinterrande der Augen in das Halsschild eingesenkt, die Stirn senkrecht, flach oder wenig gewölbt, ohne abgesetztes Kopfschild. Oberlippe deutlich, quer, vorn meist ausgerandet, die Ecken gerundet. Mandibeln kurz, regelmässig gebogen, die Aussenseite gewölbt, die Innenseite ausgehöhlt, das Ende breit, gezähnt. Maxillartaster viergliederig, das Endglied gewöhnlich das längste, nach vorn verschmälert. F ühler in der Mitte des unteren Innenrandes der Augen oder unter derselben eingefügt, dünn, fadenförmig, ausnahmsweise (bei den $\hat{\sigma}$ von $\mathrm{Cr}$. lobatus und cganipes in der Mitte verdickt) borstenförmig oder leicht keulenförmig ${ }^{1}$ ), elfgliederig, länger als der halbe, oft so lang als der ganze Körper. A ugen an den Seiten des Kopfes herablaufend, gross, wenig gewölbt, an der Imnenseite tief ausgerandet, nierenförmig, oder klein, gewölbt, unmerklich ausgerandet. Hals schild meist quer, seitlich zusammengedrückt, fest an die Flügeldecken geschlossen und dieselben oft mit den etwas verlängerten Hinterecken an den Schultern umfassend. Schildchen mässig gross (nur bei Stylosomus unsichtbar), hinten meist abgestutzt und ïber die Ebene der Flügeldecken emporstehend. Letztere sind fast walzenförmig, gleichbreit oder nach hinten schwach erweitert, selten verengt, an der Basis niedergedrückt, hinten stark abwärts gewölbt und

1) Bei Achaenops dorsalis Suffr. Mon. XI. 234. aus Südafrika. 
meist einzeln gerundet-abgestutzt, die Oberfläche verworren oder gereiht-punktirt. Vorder- und Mittelbrust kurz, zusammen kaum so lang als die Hinterbrust. Beine mässig lang und stark, die Hüften der vier vorderen Fusspaare fast kugelig, die hinteren quer, alle gewöhnlich gleichbreit durch die Brust getrennt. Hinterleib ausser der grossen, freien Afterdecke mit 5 Segmenten, das erste und letzte grösser als die mittleren, welche auf dem Bauche nach der Mitte hin verschmälert und von denen wenigstens das vierte, selten auch (bei einigen $o^{1}$ ) das dritte und zweite mit dem letzten verwachsen sind.

Die $q$ sind ausser an der plumperen Körperform, stärkeren Punktirung und den kürzeren Fühlern besonders an einer tiefen Grube auf der Mitte des letzten Bauchsegmentes zu erkennen, in welcher sie jedes Ei, ehe sie es an der Nährpflanze befestigen, stundenlang herumtragen, um es mit Koth zu überziehen. Diese Grube fehlt beim $\hat{\sigma}$ entweder ganz oder ist schwach angedeutet, nur in einzelnen Fällen in gleicher Tiefe vorhanden, aber dann bedeutend breiter und mit Zähnchen, Querleisten etc. versehen.

In den ersten Ständen, die von Gyllenhal, Dufour, Rosenhauer ${ }^{1}$, Letzner, Perris und Rupertsberger beobachtet wurden, zeigen die Cryptocephalinen die grösste Verwandtschaft mit den Clytrinen. Die Larven stecken ebenfalls, den Hinterleib gegen die Brust gekrümmt, in einem cylindrischen, nach vorn verengten, aber festen Sacke, den sie an der schmalen Oeffnung nur bis zum ersten Hinterleibsringe verlassen können und bei ihrem ruckweisen Fortkriechen schräg aufgerichtet mit sich herum tragen. Sie unterscheiden sich von den Clytra-Larven nur durch den flachen, plattgedrückten Kopf; leben (bei der Zucht im Zimmer) nach Rosenhauer in den ersten 2 Jahren von trocknen Blättern, im dritten von frischem Laube und kleben sich zur Verpuppung fest an dürres Reisig, trockne Blätter und Grashalme, so dass sie nicht wie die Clytra-Arten auf einen Aufenthalt bei Ameisen angewiesen zu sein scheinen. Das vollkommene Insekt ist Anfang des Sommers entwickelt und auf Gebüschen oder Wiesenblumen anzutreffen.

Die von Linné in der dritten Abtheilung seiner Gattung Chrysomela untergebrachten europäischen Arten sind von Suffrian in der Linnaea entomologica Band II. und III. 1847-1848 vorzüg-

1) Entwicklung der Clytren und Cryptocephalen. Erlangen 1852. Eine Nachbildung einzelner Larven und ihrer Säcke gab Tappes Ann. Fr. 1S69. T. 1. f. $1-6,9.11$; die Fig. 7, 8 und 10 sind Original-Abbildungen. 
lich bearbeitet, Band VIII. 1853 mit Zusätzen versehen und neu geordnet worden. Sie bilden 3 Gattungen:

Schildchen

$\left\{\begin{array}{l}\text { unsichtbar, Augen gewölbt, kaum aus- } \\ \text { gerandet, Hinterrand des Halsseh. mit } \\ \text { breiter Riefenleiste . . . . . Stylosomus. } \\ \begin{array}{l}\text { deutlich, Augen flach, } \\ \text { tief ausgerandet, Hin- } \\ \text { terrand des Halssch. }\end{array}\end{array}\right.$

\section{Cryptocephalus.}

Ge offroy Ins. Par. I. 231.

Oculi reniformes.

Prothorax basi immarginatus confertissimeque denticulalus, utrinque sinuatus.

Scutellum distinctum, apice plus minusve assurgens.

Elytra basi haud marginata.

Augen gross, nierenförmig, der untere Lappen gewöhnlich grösser als der obere, kaum oder wenig gewölbt, an den Seiten des Kopfes bis zu den Vorderecken des Halsschildes oder weiter hinablaufend, ihre tief, leicht winkelig ausgerandeten Innenseiten sind fast parallel oder divergiren stark nach unten. Kopfschild zwischen den Fühlerwurzeln kaum deutlich von der Stirn getrennt, nach unten verbreitert, die Seiten grade und oft scharf gerandet, zwischen ihnen und dem Unterrande der Augen befindet sich eine kurze Rinne zum Einlegen des ersten Fühlergliedes, welche oft anders als der Kopf gefärbt ist. Halsschild meist quer, vorn und an den Seiten stark abwärts gewölbt, der Vorderrand ist ein Halbkreis, die Seiten sind werig breit, scharf gerandet, die Basis, welche vor dem Schildchen grade, dann jederseits bis zu den spitzen Hinterecken ausgeschweift ist, besitzt keine Randleiste, sondern ist rinnenförmig niedergedrückt (zur Aufnahme des scharfen, vorgezogenen Grundrandes der Flügeldecken) und dicht mit gleichlangen, schwarzen, nach hinten gerichteten, sehr regelmässigen Zähnen besetzt, welche unter den Vorderrand der Flügeldecken greifen und nur bei vorgebogenem Halsschilde sichtbar sind. Von diesen Zähnen stehen etwa 7 bis 10 am mittleren graden Theile und 20 bis 25 jederseits davon bis vor die Hinterecken. Schildchen selten in einer Ebene mit den Flügeldecken (pini), sondern schräg aufsteigend, der Hinterrand grade oder gerundet-abgestutzt, so dass eine kleine, breit dreieckige Fläche, zur Naht abfallend, von hinten sichtbar wird. Flügeldecken cylin- 
drisch, gewölbt, an der Basis ohne erhabenen Rand, allmählich und gleichmässig zum Grunde des Halsschildes abfallend oder mit zwei deutlichen Eindrücken jederseits, der eine innen an der hohen Schulterbeule, der andere am Schildchen, wodurch die Umgebung des letzteren stark in die Höhe gehoben erscheint (sericeus). Seitenrand an den Schultern erweitert, selten fast grade, die Epipleuren, welche von der Seite, seltener nur von unten sichtbar sind und durch einen scharfen Rand von den Decken getrennt werden, beginnen breit am Schulterwinkel, verschmälern sich allmählich oder plötzlich am Ende der Hinterbrust und enden etwa am Hinterrande des ersten Abdominalsegmentes, nur ausnahmsweise an der Spitze der Flügeldecken. Diese ist breit, gerundet-abgestutzt und bedeckt nur den obersten Theil des Pygidium; die Oberfläche ist unregelmässig punktirt oder punktirt-gestreift, die Punkte sind am Vorderrande und auf dem hinteren Abfalle feiner, oft verloschen. Vorderbrust in der Mitte sehr kurz, der Vorderrand halbkreisförmig oder in der Mitte nach unten verlängert, zwischen den Vorderhüften eben, gewölbt oder längsrinnig, die Mitte des Hinterrandes grade, oder ausgerandet und in zwei Zähne ausgezogen oder dreieckig verlängert; zur Aufnahme der Vorderschenkel zieht sich vor dem Hinterrande jederseits ein breiter und tiefer Quereindruck nach den Seiten hin.

Mittelbrust schmal, die Seitenstücke lang dreieckig, ihre Spitze etwas nach hinten gerichtet. Hinterbrust quer-viereckig, mit mehr oder weniger tiefer Mittelrinne, die Seitenstücke lang, grade nach hinten gerichtet und nach hinten etwas verscbmälert.

Die ganze Unterseite ist kurz und dicht behaart, verschieden stark punktirt, weniger glänzend als die Oberseite, der Bauch oft fein quer gestrichelt.

Von den Cryptocephalen wurden zuerst 12 Arten von Linné als Chrysomela beschrieben, Ge offroy, der Begründer der Gattung, kannte 10; jetzt ist die Anzahl der beschriebenen Arten auf etwa 750 angewachsen. Dieselben gliedern sich in eine Reihe von Abtheilungen, die jedoch nach den verschiedensten Richtungen hin in einander übergehen, so dass eine scharfe Eintheilung unüberwindliche Schwierigkeiten darbietet und wohl immer ein frommer Wunsch bleiben wird. Suffrian, welcher die erste Monographie der Gattung lieferte, stellte die europäischen Arten Linnaea II. und III. in 13, zuletzt, Linnaea VIII, in 18 Rotten nach einer Summe von Merkmalen zusammen, die der Körperform, Farbe, Fühlerbildung und besonders der Punktirung entnommen sind. Viele dieser Rotten sind natürlich, einige dagegen, wenigstens in ihrem Ǔm- 
fange 1), kaum haltbar. Marseul braucht für 197 Species aus Europa, Nordafrika und Nordasien, die er in der Abeille XIII. 1875 (Monographie des Cryptocéphales du nord de l'ancien-monde) beschreibt oder zusammenstellt, 23 Gruppen, ron denen mehrere nur eine Art enthalten. Seine Eintheilung ist im Wesentlichen die Suffrian's geblieben.

Im Folgenden ist der Versuch gemacht, ohne weitläufige und trotzdem doch nicht stichhaltige Beschreibung der Gruppen, die verwandten Arten um einen Typus zu ordnen, zu dem, so weit als möglich, die bekannteste und häufigste Art gewählt wurde.

\section{Reihe. Verwandte von Cr. coryli.}

A. Fld. verworren oder unregelmässig gestreift-punktirt. Vorderhüften des oinander genähert.

a. Vorderhüften ( $\hat{\jmath})$ stark genähert. Basis der Vorderbrust in der Mitte abgestutzt oder leicht ausgerandet und dann mit einem kurzen Zähnchen jederseits. Homalopus Chevr.

1. Cr. Doreyi: Subnitidus, subtus capiteque parce pubescens, niger, mandibulis, antennis basi ferrugineis, prothorace subtiliter minus dense punctato, margine laterali late reflexo, elytris laete rufis, fortiter subrugoso-punctatis, lineis nonnullis subelevatis. - Long. 8-9 mm.

Mas: Elytris maculis 3 nigris (duabus basi oblique positis, tertia pone medium); tibiis anticis leviter biflexuosis, posticis incurvis apiceque interno lamella rotundata dilatatis, tarsis anticis fortius oblique dilatatis.

Fem: Elytris sutura, fasciis 2 maculaque iransversa apicali nigris.

Sol. Ann. Fr. 1832. 687 t. 20. A. (). - Rouget l. c. 1833. 207. t. 6. (宅). - Suffr. Mon. II. 62, VIII. 93.

Var. a. ( $\hat{\odot})$ Elytris maculis 4 nigris (4 angusta ante apicem).

Var. b. ( $\hat{\wp})$ Elytris maculis 2 nigris.

Var. c. (ㅇ) Elytris macula libera externe a fascia antica separata.

Cr. major Comoll. De. Col. Norocom. 51.

Die grösste europäische Art. Schwarz, Mandibeln, Fühlerglied 2-4 wenigstens unterseits, die obere Innenrandlinie der Augen und die Sohlen der Füsse rothbraun, Fld. rothgelb. Kopf dicht und mässig stark punktirt, Stirn leicht längsvertieft. Fühler dünn, beim $\hat{\sigma}$ so lang als der Körper. Halss ch. nur im vorderen Drittel stark abwärts gewölbt und seitlich zusammengedrückt, der gerundete, breit

In Suffrian`s Rotte 1 z. B., welche nur Cr. cynarae und curvilinea enthält, müssten nothwendig crassus, amoenus, sulphureus, vielleicht auch trimaculatus, dem Körperbau nach, gebracht werden. 
abgesetzte, aufgebogene und runzelig punktirte Seitenrand in der hinteren Hälfte von oben sichtbar; alle Ecken stumpf, die Oberfä̈che ziemlich fein und wenig dicht punktirt, glänzend. Schildchen länglich, hinten stumpf abgerundet, schwarz. Fld. stärker und dichter als das Halsschild punktirt, leicht runzelig, die Punkte, welche an der Basis und vor der Spitze feiner sind, bilden nahe der Naht und dem Seitenrande einige unregelmässige Reihen, zwischen denen einzelne schwach gewölbte Zwischenräume hervortreten.

ڤ. Fld. mit drei schwarzen Makeln, die erste länglich, auf dem Schulterhöcker, dic zweite kleiner, rundlich, in der Mitte zwischen der ersten und der Naht, aber von der Basis weiter entfernt; die dritte hinter der Mitte, dem Aussenrande näher als der Naht, länglich. Brust zwischen den Vorderhüften schmal, nach hinten breit dreieckig erweitert (die Mitte vertieft) und in zwei lange Spitzen ausgezogen. Beine lang, besonders die vorderen, die Schenkel unterseits abgeflacht, mit zwei feinen Längsrinnen, Schienen zusammengedrückt, der Innenrand der vorderen am Grunde und vor der Spitze leicht ausgeschweift; die Mittelschienen gekrümmt, auf der Innenseite mit tiefer Rinne, deren Hinterrand vor der Spitze scharfkantig erhaben ist; Hinterschienen am unteren Ende mit einer gerundeten lappenförmigen Erweiterung, welche in der Mitte einer kleinen, scheibenförmigen Fläche endet, die sich nach unten in einen kräftigen, graden Zahn verlängert. Vordertarsen stark erweitert, die äussere Hälfte der einzelnen Glieder grösser als die innere. Klauen am Grunde fast zahnartig erweitert.

Penis kräftig, an den Seiten der Länge nach vertieft, über der Oeffnung jederseits in ein breites, an der Spitze nach oben gebogenes Horn verlängert, unter der Oeffnung jederseits mit einem langen, graden, vorwärts gerichteten Zahne.

ㅇ․ Fld. mit zwei gemeinschaftlichen, aussen und an der Naht erweiterten schwarzen Querbinden und einer Quermakel in der Spitze, die den Aussenrand frei lässt. Naht bis zur hinteren Wölbung schwarz gesäumt. Brust zwischen den Vorderhüften breit rechteckig; Beine einfach.

Zuweilen wird auch beim $\hat{\sigma}$ die Spitzenmakel des $q$ sichtbar (Var, a.), oder von den drei schwarzen Flecken verschwindet der zweite (Var. b.); beim of löst sich von der Vorderbinde jederseits die Schultermakel los (Var. c), wobei die Hinterbinde entweder normal bleibt oder an der Naht unterbrochen wird.

Im Mai auf Hainbuchen und Eichen an Südabhängen der Alpenkette. Kärnthen, Tirol. Schweiz (Pilatus), Norditalien, Südfrankreich. 
In Tirol dürften noch aufzufinden sein:

a) Cr. informis Suffr. (Mon. II. 66; VIII. 9t). Niger, antennis basi ferrugineis, fronte lineolis 2 ocularibus flavis, thorace subtilissime punctato, elytris rubris, punctis duobus infra basin transversim digestis (primo posthumerali, secundo interdum deficiente), maculaque transversa pone medium nigris. $\hat{j}$. Tibiis incurvis, tarsis anterioribus dilatatis, femoribus posticis basi tenuibus, medio abrupte clavato-dilatatis. ㅇ. Thorace margine laterali macula elongata punctisque 2 medio basi albidis. L. $7-8 \mathrm{~mm}$. West-Alpen (Mt. Genèvre), Piemont.

b) Cr. tricolor Rossi (Faun. Etr. Mant. I. 33; florentinus Oliv. Ent. VI. 792. Suffr. Mon. II. 68). Niger, mandibulis, antennis basi ferrugineis, fronte lineolis 2 ocularibus, thorace maculis 6 (duabus utrinque margine laterali, duabus margine basali) albidis; elytris rubris, punctis duobus infra basin, transversim digestis (primo posthumerali), maculaque transversa pone medium nigris. 今. Segmento 5:o ventrali medio late impresso. - L. 6-7 $\mathrm{mm}$.

Var. a Thorace maculis 8 albidis, adjectis margine antico.

Von Genf (Stierlin) durch ganz Italien verbreitet.

b. Vorderhüften des $\widehat{o}$ mässig genähert. Vorderbrust in der Mitte des Hinterrandes mit zwei fast senkrecht gestellten Zähnen. (Schildchen weiss, die Ränder schwarz.)

2. Co. corinthincus'): Niger, nitidus, antennis basi obscure ferrugineis. fronte lineolis duabus ocularibus, proihoratis angutis anticis et margine laterali postice scutelloque ulbidis, episternis mesothoracis apice ferrugineis; elytris crebre subruyoso-pnenctatis, fascia obliqua, plus mimusve. intermpta, ante merlium maculaque transcersa apicis rufo-testaceis. Long. $5-6 \mathrm{~mm}$.

Mas: coxis anticis inierne denticulo obtuso armatis, segmento 5:o forea vage impressa.

Suffr. Mon. III. 1; VIII. 99. - Redtb. Faun. A. II. 464.

Var. a. Fascia elyirorum in maculas 2 parvas divisa.

Schwarz, stark glänzend, die vier ersten Fühlerglieder theilweise dunkel röthlich, zwei Stirnflecke am oberen Innenrande der

1) Sehr ähnlich ist Cr. excisus Seidl. (Col. Heft. X. 254; crosus Seidl. Berl. Zeit. 1S67. 189). Die rothe Binde der Fld. aussen nicht nach hinten, sondern nach vorn bis zur Basis verlängert; das Halssch. sehr dicht, an den Hinterecken runzelig punktirt. Hinterschienen des ror der Spitze des Innerrandes ausgeschnitten. - L. 4-5 mm. Escurial. Sierra de Bejar. Pena de Francia. 
Augen, ein Punkt in den Vorderecken des Halssch. und ein schmaler, kurzer Saum an den Seiten, dicht vor den Hinterecken, sowie das Schildchen, mit Ausnahme der Ränder, weiss. Auf den Fld. ist eine schiefe, unregelmässige Querbinde und eine Quermakel in der Spitze, welche die Ränder frei lässt, rothgelb. Die Binde besteht aus einem eckigen Flecke dicht vor der Mitte der Fld, nahe der Naht, welcher sich hinter der Schulterbeule schmal, oft leicht unterbrochen, zum scbwarzen Aussenrande hinzieht und hier meist in einen nach binten (nie nach vorn, wie bei simuatus) gerichteten spitzen Zipfel ausgedehnt ist, der sich zuweilen, aber wenig deutlich, mit der Makel in der Spitze verbindet. Halssch. nur mässig gewölbt, in der vorderen Hälfte zusammengedrückt, der schmale, vor den Hinterecken erweiterte Seitenrand ist von oben kaum bis zur Mitte nach vorn sichtbar; die Scheibe ist wenig dicht, fein, doch deutlich punktirt, die Punkte rund, mit äusserst feinen Pünktchen in den Zwischenräumen. Fld. mehr oder weniger uneben, dicht und ziemlich stark unregelmässig punktirt, schwach gerunzelt, mit Spuren kurzer, erhabener Längslinien. Unterseite schwarz, Seitenstücke der Mittelbrust an der Spitze meist roth, selten weisslich gefleckt. Beine stark, mit dicken Vorderschenkeln; Vorderhüften hinten an der Innenseite mit einem, beim $\hat{\sigma}$ kräftigeren, kleinen, stumpfen Zähnchen. Das letzte Segment des $\hat{\sigma}$ hat in der Mitte eine wenig tiefe, dreieckige, glänzende Grube. - Penis pechschwarz, nach vorn verdickt und seitlich zusammengedrückt, unten jederseits mit einer dichten Reihe langer, gelber Borstenhärchen, die Vorderseiten in eine kurze, dicke Hornplatte nach aussen vorgezogen, der Unterrand der Oeffnung in der Mitte mit einem schmalen, schräg nach vorn gerichteten gelben Zahne.

Ohne Zweifel ist die Binde und Spitzenmakel ein Rest der ursprünglichen rothen Farbe der Fld., welche bei der Ausdehnung von 4 schwarzen Normalpunkten (zu je zwei schief gestellt, wie bei 4-punctatus) übrig geblieben ist, nachdem die Punkte sich zu zwei breiten Querbinden vereinigt hatten. Solche Anfangsformen mit rothen Fld. sind bis jetzt nicht nachgewiesen, dürften aber noch aufgefunden werden. Dagegen sammelte H. Micklitz bei Ratschach in Oberkrain Stücke, bei denen die schwarze Farbe soweit überhand nimmt, dass die rothe Binde in 2 Makeln aufgelöst ist, von denen die äussere fast punktförmig wird (Var. a).

Im Juli und August in den Kärnthener und Krainer Alpen. Wallis (Stierlin).

Möglicherweise könnte in den österreichischen Gebirgen noch aufgefunden werden:

VI. 
Cr. sinuatus: Niger, nitidus, antennis basi ferrugineis, fronte lineolis duabus ocularibus scutelloque albidis; prothorace minus dense sub. tilissime punctato, coieopteris minus crebre punctatis, rufo-testaceis, fasciis duabus, utrinque abbreviatis (altera basi, altera pone medium) nigris. - Long. $3,5-5 \mathrm{~mm}$. - Von den Pyrenäen durch Südfrankreich bis in den Jura bei Neuchatel verbreitet, häufig im Wallis.

H a rold Col. Heft. X. 254; Berl. Zeit. 1873. 173.

Cr. fasciatus H. Schäff. Faun. Germ. 127. 13. - Suffr. Mon. II. 95 .

Var. a. Elytris nigris, epipleuris, fascia obliqua ante medium maculaque transversa apicis rufo-testaceis.

$\mathrm{V}$ ar. b. Ut in a, sed elytrorum fascia in maculas 2 parvas divisa.

Cr. abietinus Gaut. Ann. Fr. 1861. 194. - Suffr. Stett. Zeit. 1866. 205.

Durch das einfarbig schwarze Halssch., rothen Umschlag der Fld. und einfache Vorderhüften von der vorigen Art zu trennen. Die Var. abietinus, welche auf Abies excelsa in den Bergen von Savoyen lebt, kann nur zu dieser Art gehören, obwohl die Fld. etwas stärker punktirt sind. Suffrian vereinigte sie a. a. O. mit carinthiacus.

Ohne sichere Bürgschaft wurde der dentschen Fauna wohl bisher zugezählt:

Cr.quadripunctatus O1. ${ }^{1}$ ) (Ent. VI. 800. t. 5. f. 65. - Suffr. II. 93. - Redtb. Faun. A. II. 464.) Niger, antennis basi ferrugineis, fronte lineolis duabus ocularibus, prothoracis margine laterali postice scutelloque albidis; elytris crebre punctatis, rufis, maculis 4

1) Verwandt sind:

1. Cr. lusitanicus Suffr. (Mon. II. 98): Elongatus, niger, antennis basi obscure ferrugineis, fronte lineolis duabus ocularibus, prothorace margine laterali scutelloque albidis; prothorace magno, minus fortiter concexo, crebre punctato, elytris dense subrugoso-punctatis, rufis, punctis 3 (1 humerali, 2 pone medium oblique positis) nigris, pedibus elongatis. Mas: rentre seg. mento ultimo transversim impresso. Long. $5-6 \mathrm{~mm}$. Spanien. Portugal.

Variat a. tarsis anticis testaceis, prothorace nigro, marginibus antico et lateralibus maculaque basali divisa albidis = lividimanus $\mathbf{S u f f} \mathrm{r}$. Mon. VIII. 100 ; b. elytris nigris, fuscia ante medium (plerumque interrupta) maculaque apicis rufo-testaceis; c. elytris nigris, macula transversa ante apicem rujotestacea; d. elytris nigris.

2. Cr. floribundus Suffr. (Stett. Zeit. 1866. 207): Niger, maculis duabus frontalibus, thoraris angulis posticis scutelloque albidis, thorace limbo antico (in medio dilatato) et laterali (puneto nigro notato) maculaque subcordata antescutellari rufs; elytris fascic (interne abbreviata, extrorsum dilatata) apiceque rufis. Long. 5,3 mm. Ein einzelnes of von Pau. 
(2, 2 oblique digestis) nigris; thorace convexo, dense punctato. - Long. $4,5-5 \mathrm{~mm}$. Wallis, Südfrankreich, Spanien.

Variat a. macula una alterave elytrorum deficiente; b. Stierlini: elytris puncto humerali nigro; c. maculis 4 interioribus in crucem conjunctis; d. maculis posterioribus connatis et (e) cum oppositis fasciam latam formantibus; f. maculis in fascias 2 confluentibus.

Die von H. Stierlin (Faun. col. helv. 318) erwähnte Var. von Siders im Wallis, welche mir der Entdecker derselben in einem Stücke freundlichst überliess, ist in den Hinterecken des Halssch. fein weisslich gerandet und besitzt auf den kaum rothen, sondern gelbbraunen Fld. nur einen schwarzen Schulterpunkt. Die Naht und der Seitenrand (in der hinteren Hälfte) schwarz gesäumt, wie bei der Stammform. Ich halte es nicht für überflüssig, auf diese ausgezeichnete Abänderung durch einen eigenen Namen aufmerksam zu machen. - Das Vorkommen der Art in Oberschlesien (Letzner Verz. Käf. Schles. 487) und bei Glatz nach Zebe ist unwahrscheinlich, besonders da H. Letzner selbst, nach einer freundlichen Mittheilung, schlesiche Stücke nicht gesehen hat.

c. Vorderhüften des $\widehat{O}$ mässig genähert. Vorderbrust in der Mitte der Basis schwach halbkreisförmig ausgerandet.

3. Cr. conyli: Niger, antemis basi ferrugineis, fronte lineolis duabus ocularibus flavis, prothorace maris nigro, feminae rufo subtiliter punctulato, elytris rufis, punctis fere seriatis. - Long. $6-7 \mathrm{~mm}$.

Mas: segmento 5:0 ventrali fovea media vage impressa.

Linn. Syst. nat. ed. X. 375 (Chrysomela). - Panz. Faun. Germ. 68. 6. - Küst. Käf. Eur. III. 85. - Suffr. Mon. II. 100. - Redtb. Faun. A. II. 457. - Seidl. F. balt. 474.

Cr.vitis Panz. Faun. Germ. 68. 5. $\hat{\circ}$.

Var. a. Elytris puncto humerali nigro.

Var. b. Ut in a, sed elytris macula transversa nigra pone medium.

Var. temesiensis Suffr. Mon. II. 101. - Marseul Mon. 59.

Var. c. (f) Elytris maculis tribus nigris (2, 1); thorace plus minusve nigro - variegato.

Vẩr. d. ( + ) Ut in c, sed maculis anterioribus connexis.

Mässig gestreckt, schwarz, die unteren 4 bis 5 Fühlerglieder mit Ausnahme der Oberseite des ersten rothbraun, ein Längsfleck am oberen Innenrande jedes Auges weissgelb, die Fld. ( $\hat{b})$ und das Halssch. (q) roth. Kopf dicht und fein punktirt, längs der Mitte niedergedrückt. Halssch. stark gewölbt, glänzend, sehr fein und nicht dicht punktirt, der hinten breiter abgesetzte, aufgebogene und runzelig punktirte Seitenrand von oben kaum bis zur Hälfte nach vorn sichtbar. Schildchen schwarz. Fld. mässig glänzend, ziemlich dicht und fein punktirt, mit äusserst fein gerunzelten $\mathbf{Z}$ wischenräumen, 
die Punkte besonders auf der hinteren Hälfte zu wenig regelmässigen Reihen geordnet, die Naht bis vor die Spitze fein schwarz gesäumt.

๙. Letztes Bauchsegment mit einem breiten kreisförmigen Eindrucke. - Penisseiten vorn plötzlich gerundet-verengt und in der Mitte in eine nach unten gerichtete dreieckige Spitze ausgezogen.

An dem schwarzen Halssch. des $\delta$ ist die feine Leiste des Vorderrandes rothbraun, zuweilen zeigt sich auch ein heller Fleck in den Hinterecken; das Halssch. des $q$ ist gewöhnlich nicht einfarbig roth, sondern am Seitenrande schwärzlich, die Seitenkante hinter der Mitte, die Hinterecken und ein verloschener Saum längs des Vorder- und Hinterrandes weisslichgelb.

Die bei uns häufigste Form hat einen schwarzen Schulterpunkt (Var. a), selten sind Stücke, die ausserdem eine grosse, meist quere Makel hinter der Mitte (Var. b) und eine dritte, zwischen Schultermakel und Naht haben (Var. c). Durch das Zusammenfliessen der beiden Vordermakeln entsteht ein Querfleck (Var. d). Von den Abänderungen $\mathrm{c}$ und $\mathrm{d}$ sind bis jetzt nur einzelne $q$ bekannt, bei welchen zugleich das Halssch. mehr oder weniger schwarz gezeichnet ist, zuletzt so weit, dass ein schmaler, in der Mitte dreieckig erweiterter Vordersaum, ein breiter, zweimal gebuchteter Seitensaum, welcher hinter der Mitte eine Makel einschliesst, und eine Linie am Hinterrande roth bleiben.

Auf Haseln, Birken, Erlen und Weiden in ganz Europa, aber nirgends häufig.

B. Fld. verworren oder unregelmässig gestreift-punktirt. Vorderhüften beider Geschlechter weit getrennt.

a. Körperschwarz. Halssch. roth mit schwarzen Flecken bis schwarz mit rother oder gelblicher Zeichnung.

4. Cr. cordiger: Niger, antennis basi, tibiis tarsisque fermgineis, epistomate, coxis anticis, femoribus et pygidio apice macula flavoalbida notatis; prothorace parcius subtiliter punctato, macula cordata antescutellari, linea merlia antica lateribusque late albidis, his puncto nigro; elytris rubris minus crebre punctatis, singulo punctis duobus majoribus (primo posthumerali, altero infra medium) nigris. - Long. $5,5-6,5 \mathrm{~mm}$.

Mas: prothorace puncto laterali cum nigredine disci confluente, segmento 5:o ventrali maximo, medio longitudinaliter impresso, basi carina parva instructo.

Linn. Syst. nat. ed. X. 375 (Chrysomela). - Panz. Faun. Germ. 13. 6. - Schneider Magaz. II. 209. - Gyllh. Ins. Suec. III. 593. - Küst. Käf. Eur. III. 84. - Suffr. Mon. II. 71; VIII. 98. - Redtb. Faun. A. II. 458. - Seidl. Faun. b. 475. 
V ar. a. Elytro singulo punctis 3 nigris.

Var. b. Antennis articulo primo tibiisque 4 posterioribus basi vel omnino nigris.

Kurz, plump, schwarz, die ersten 5 bis 6 Fühlerglieder, die Schienen und zwei ersten Tarsenglieder rotbbraun; Kopfschild, Seiten des Halssch. und eine unterbrochene Mittelstrieme desselben, die Vorderhüften, eine Makel vor der Spitze der Schenkel und eine quere, zuweilen getheilte Makel an der Spitze der Afterdecke gelblich-weiss. Stirn vertieft, ziemlich dicht und fein punktirt, der Scheitel mit kurzer Mittelrinne. Halssch. stark gewölbt, der Seitenrand schmal abgesetzt und von oben nur an den Hinterecken sichtbar; die Oberfläche weitläufig fein punktirt, die Punkte schwach-länglich; der weisse, auch auf die Unterseite übergreifende breite Seitensaum ist fast rechteckig, in der Mitte leicht verbreitert, mit einem eingestochenen schwarzen Punkte, der sich, vorzüglich beim $\hat{o}$, mit dem Schwarz der Scheibe verbindet. Die Mittelstrieme besteht aus einer bis hinter die Mitte reichenden Linie, die sich am Vorderrande nicht selten mit dem Seitensaume verbindet, und einer breiten, fast herzförmigen Makel vor dem Schildchen. Fld. mässig dicht und stark punktirt, roth, ein schmaler Nahtsaum and zwei grössere Punkte schwarz, der eine rund, hinter der Schulterbeule, der andere, leicht quer, hinter der Mitte, dem Aussenrande näher als der Naht.

o. Segment 2 und 3 des Hinterleibes in der Mitte sehr schmal, leistenförmig, das letzte gross, mit einem breiten Längseindrucke, der am Vorderrande einen kurzen, scharfen Längskiel trägt. Penis oben quer eingedrückt, an der Oeffnung gerundet erweitert, die Spitze dreieckig.

Als Abänderungen verdienen Beachtung:

a. Jede Fld. mit einem dritten schwarzen Punkte zwischen dem ersten und der Naht.

b. Erstes Fühlerglied und die vier Hinterschienen theilweise oder ganz schwarz.

Auf Gebüschen nicht häufig.

5. Cr. octopmetatus: Niger, antennis basi tibiisque anticis interne ferrugineis, facie inferne maculis 3 prothoraceque vittis 3 (media postice dilatata et lineola longitudinali nigra signata) flavo-albidis, coxis anticis femoribusque apice macula alba notatis; elytris rubris, epipleuris, margine omni anguste punctisque $4.2,2)$ nigris, thorace elytrisque minus crebre punctatis. - Long. 5-6 $\mathrm{mm}$.

Mas: ventre segmentis 3 ultimis connatis, segmento $5: 0$ maximo, medio late excavato, excavatione medio basi bituberculato utrinque spina valida, hamata instructo. 
Fem: pyyidio sulco medio longitudinali foreaque profunda utrinque impressa.

Scopoli Ent. Carn. 67. f. 209 (Buprestis). - Harold Berl. Zeit. 1873. 171. - Seidl. F. balt. 475.

Cr. variabilis Schneid. Mag. I. 1. 95; 2. 207. - Panz. Faun. Germ. 13. 7. - Suffr. Mon. II. 80. - Redtb. Faun. A. II. 458.

Var. a. Thorace linea media angusta postice abbreviata.

Var. b. Elytrorum punctis secundi paris comatis.

$\mathrm{V}$ ar. c. Elytris punctis 3 nigris.

$\mathrm{V}$ ar. d. Elytris punctis 2 nigris.

Var. e. Elytris puncto posthumerali vel puncto pone medium nigro.

Var. f. Elytris immaculatis.

Var. g. Epipleuris plus mimusve rubris.

Var. h. Scutello albicero picto.

Wenig schlanker als die vorige Art, schwarz, die Innenseite der Vorderschienen und die ersten 4 bis 5 Fühlerglieder, mit Ausnahme der Oberseite des ersten, rothbraun; drei Makeln des Unterkopfes, drei Längsbinden des Halssch. und eine Makel auf den Vorderhüften und vor der Schenkelspitze weiss oder weissgelb. Stirn fast eben, wenig dicht und sehr fein punktirt, Scheitel mit grübchenartiger Mittelrinne. Halssch. stark gewölbt, der Seitenrand breit abgesetzt, von oben bis zu den Vorderecken sichtbar; die Oberfläche etwas weitläufig, mässig fein und tief punktirt, die Punkte länglich; der weisse Seitensaum ist in der Mitte leicht verbreitert, selten mit einem dunklen Punkte versehen, aussen fein schwarz gerandet und verbindet sich mehr oder weniger breit am Vorderrande mit der Mittelbinde. Letztere ist vorn fast dreieckig, hierauf schmal bis hinter die Mitte, wo sie sich beim $\hat{o}$ wenig, beim $q$ bedeutend erweitert und ein schwarzes Längsstrichelchen einschliesst. Schildchen schwarz. Fld. mässig dicht und stark punktirt, roth, der Seitenlappen und alle Ränder, sowie 4 Punkte auf jeder, das erste Paar unterhalb der Schulterbeule, das andere hinter der Mitte (die inneren Punkte kleiner als die äusseren) schwarz.

3. Bauchsegment 3 und 4 mit dem letzten verwachsen und nur an den Seiten sichtbar, Segment 2 in der Mitte schmal, leistenförmig, 5 gross, bauchig aufgetrieben, in der Mitte grubenförmig ausgehöhlt, die Grube fast glatt, glänzend, bald hinter dem Vorderrande mit zwei Höckerchen und jederseits von diesen mit einem langen, nach hinten gebogenen, nach der Spitze allmählich verschmälerten Dorne. - Penis breit, die Seiten an der Oeffnung in je einen grossen, abstehenden Lappen erweitert, vorn in einen Zahn ausgezogen; der Unterrand der Oeffnung ist eine fast rechteckige, vorn dreieckig zugespitzte Platte. 
‥ Pygidium quer, beinahe viereckig, mit breiter Mittelrinne, einer Grube jederseits in den unteren Ecken und einem Längswulste zwischen der Mittelrinne und jeder Grube, der am Ende selten röthlich gefärbt ist.

Zuweilen dehnt sich die schwarze Farbe des Halssch. aus und verschmälert oder unterbricht die Mittelbinde so, dass die Erweiterung derselben vor dem Schildchen makelförmig abgesondert wird. Letztere verkleinert sich zuletzt zu einem Punkte in der Mitte des Hinterrandes oder verschwindet ganz (Var. a). Bei dieser Form hat der Seitensaum gewöhnlich einen schwarzen Mittelpunkt.

Auf den Fld. vereinigen sich die beiden hinteren Punkte mitunter zu einer abgekürzten Querbinde (Var. b), oder es verschwinden: einer der beiden inneren Punkte (Var. c), beide innere Punkte (d) und einer der äusseren (e), endlich alle Punkte (Var. f). Bei den letzten Abänderungen ist der umgeschlagene Seitenrand der Fld. oft theilweise oder ganz roth gefärbt und dem entsprechend auch der eigentliche Seitenrand im vorderen Drittel der Fld. (Var. g).

Das Schildchen besitzt hinten nicht selten eine wachsgelbe Makel (Var. h).

Auf Weiden häufig, nur in der norddeutschen Tiefebene seltener.

6. Cr. sexpametatus: Niger, antennis basi tibiisque anticis interne ferrugineis, facie inferne maculis 3 albidis, coxis anticis femoribusque apice albo-notatis, prothorace rufo-testaceo-variegato, crebre punctato, elytris fortiter subrugoso-punctatis, rujo-testaceis, limbo omni maculisque tribus magnis (2, 1, primo humerali) nigris. - Long. $4,5-6,5 \mathrm{~mm}$.

Mas: prothorace medio lineola abbreviata rufo-testacea; segmentis $3 \mathrm{ul}$. timis ventralibus comatis, segmento $5: 0$ maximo, late excavato, excavatione medio ruga transversa bipartita utrinque spina hamata instructo.

Fem: prothorace medio vitta ancoraeformi rufo-testacea; pygidio bituberculato.

Linn. Syst. nat. ed. X. 375 (Chrysom.). - Panz. Faun. Germ. 68. 7. - Suffr. Mon. II. 83. - Redtb. Faun. A. II. 458. Seidl. F. balt. 475 .

Var. a. thoracicus: Thorace rufo-testaceo, maculis 5 (2 ante medium, 3 basi) nigris.

Var. b. Ut in a, sed maculis posterioribus in fasciam tricuspidatam connatis.

Var. c. Thorace nigro, margine antico et lateralibus rufo-testaceis, his plerumque puncto nigro notatis. 
Var. d. Elytris maculis 1 nigris, posteriore nempe in 2 riviso.

Var. e. Coleopterorum maculis posterioribus in fasciam communem confluentibus.

Var. f. Macula secunda cum opposita in maculam sutaralem conjuncta. Cr. picıus Suffr. Mon. II. 87.

Var. g. Maculis secunda et tertia sutura connexis.

Var. h. Elytris niyris, macula basali trigona, fascia media undulata maculaque apicis rufo-teslaceis.

Cr. separandus Suffr. Mon. II. 87.

Var. i. Gyllenhali: Elytris nigris, lunula basali, macula obsoleta in medio maryinis aliaque magna vel parva intra apicem rubris.

Gyllh. Ins. Suec. UI. 600. var. e.

Dem Vorhergehenden ähnlich, indessen durch dichtere und stärkere Punktirung, die Zeichnung des Halssch. und der Fld., sowie die Geschlechtsmerkmale leicht und sicher zu unterscheiden. Kopf, Fühler, Unterseite und Beine wie bei 8 -punctatus, $\mathrm{Halssch}$. ähnlich gebaut aber dichter, an den Seiten fast runzelig punktirt und nach einem andern Systeme gezeichnet. Bei den hellsten Stücken ist es röthlich-gelbbraun, mit schwarz gesäumten Seiten und fünf schwarzen Makeln, von denen zwei halbmondförmige auf der Mitte der Vorderhälfte, drei an der Basis stehen, die beiden äusseren dreieckig, die mittlere strichförmig (Var. thoracicus). Nimmt die schwarze Färbung zu, so vereinigen sich die 3 Basalmakeln zu einer Binde am Hinterrande, welche 3 Spitzen nach vorn sendet (Var. b); ron diesen fliessen später die beiden äusseren mit den Vordermakeln zusammen und es entsteht die Normalzeichnung der $q$ : ein rothgelber ankerförmiger Mittelfleck, der am Vorderrande des Halssch. durch einen feinen gelblichen Saum mit einem rothgelben, entweder in der Mitte winkelig nach innen erweiterten oder gleichbreiten Seitensaume zusammenhängt. Die $\widehat{\jmath}$ haben nur eine schmale rothgelbe Mittellinie auf der vorderen Hälfte, die höchst selten ganz verschwindet (Var. c), und oft einen schwarzen Punkt im Seitensaume. Schildchen stets schwarz. Fld. dicht, leicht runzelig punktirt, röthlich gelbbraun, die Seitenlappen, alle Ränder und 3 grosse Makeln auf jeder schwarz; die erste länglich, a uf der Schulterbeule, etwas schräg nach hinten und innen gerichtet, die zweite kleiner, rund, nahe der Naht hinter dem Schildchen, die dritte quer, grösser als die erste, hinter der Mitte, gleichweit von der Naht wie vom Seitenrande, zuweilen (Var. d) ein Theil der inneren Hälfte als punkt- oder strichförmige Makel abgesondert. Vorderschenkel häufig einfarbig.

3. Bauchsegment 3 und 4 mit dem letzten verwachsen und wie das zweite, in der Mitte stark verengte Segment nur an den 
Seiten sichtbar; 5 gross, bauchig aufgetrieben, in der Mitte grubenförmig ausgehöhlt, die Grube in der Mitte durch eine fein gekörnte zweitheilige, hohe Querrunzel getheilt, die vordere Hälfte glatt, die bintere längsrunzelig; die Seitenränder der Grube sind in der Mitte mit einem schmalen, langen, nach hinten gekrümmten Zahne besetzt, hinten in eine breit dreieckige Spitze nach unten vorgezogen und erscheinen zwischen dem Zahne und der Spitze halbkreisförmig ausgeschnitten. - Penis breit, die Seiten vor der Oeffnung ausgerandet und in je zwei breite Zähne erweitert, der Unterrand der Oeffnung ist eine viereckige Platte, die in der Mitte des Vorderrandes in ein kleines Dreieck verlängert ist.

†. Pygidium gerundet-viereckig, mit 3 Eindrücken, die sich unten zu einer tiefen, den Rand umziehenden Rinne vereinigen und zwei mehr oder weniger hohe Höcker trennen.

Die Abänderungen in der Zeichnung der Fld. bestehen nur in einer allmählichen Vergrösserung der Makeln. Die hintere dehnt sich bis zur Naht zu einer gemeinschaftlichen Querbinde aus (Var. e), oder die innere Vordermakel bildet mit der der andern Decke einen grossen Nahtfleck (Var. f), oder die Fld, besitzen die Querbinde und den Nahtfleck (Var. g), mit welchem sich endlich auch die Schultermakel vereinigt (Var. h). Bei der Form i endlich sind die Fld. schwarz, ein unscheinbarer Fleck an der Basis, ein ähnlicher in der Mitte des Seitenrandes und ein verschieden grosser, aber meist scharf begrenzter Querfleck vor der Spitze rothgelb.

Stücke mit ganzer Mittellinie des Halssch., wie bei 8-punctatus, die Suffrian (1. e. 85) als normal gezeichnete ansieht, sind mir unbekannt.

An Eichen-, Weiden- und Haselgebüschen nicht selten.

7. Cr. signatus ${ }^{1}$ ): Niger, antennis basi tibiisque anticis interne ferrugineis; facie inferne maculis 3 albidis, coxis anticis femoribusque apice saepissime albo-notatis, prothorace vittis 3 , intermedia postice abbreviata, elytrisque rufo-testaceis, crebre punctatis, his epipleuris concoloribus, maculis tribus $(2,1)$ nigris, pygidio subconvexo. - Long. $4,5-7 \mathrm{~mm}$.

1) Sehr ähnlich ist Cr. cribratus Suffr. Mon. II. 90. Kopfschild und Beine schwarz. $\hat{b}$ Pygidium in der Mitte grubig vertieft (beim $q$ schwächer), letztes Abdominalsegment mit flachem, breit dreieckigem Eindrucke, dessen Vorderrand scharf erhaben, die Seitenränder in der Mitte zahnartig erhöht sind, - L. 6-7 mm. Constantinopel, Kleinasien, Kaukasus. 
Mas: segmento 5:o ventrali medio depresso.

Laicharting Verz. Tyrol. Ins. I. 174. - Harold Berl. Zeit. 1873. 173.

Cr. interruptus Suffr. Mon. II. 88. - Redtb. Faun. A. II. 458. Var. a. rubellus: Thorace rufo-testaceo, maculis 4 plus mimusve confluentibus lineolaque antesculellari nigris.

Var. b. Thorace nigro, vittis 3 rufo-testaceis, intermedia postice dilatata lineolam nigram includente.

Var. c. Elytrorum macula secunda deficiente.

Var. d. Macula secunda cum opposita in maculam suturalem conjuncta. $\mathrm{V}$ ar. e. Ut in $d$, sed maculis prima et tertia etiam confluentibus.

Var. f. Ut in d, sed macula tertia cum opposita in fasciam latam comera.

Gestreckter, paralleler und gewölbter als die vorige Art, das Halssch. mit länglicheren Punkten, weniger gerundeten, undeutlich schwarz gesäumten Seiten und längeren Vorderecken, die Fld. feiner, kaum runzelig punktirt, ihr Seitenrand in der vorderen Hälfte und der ganze Seitenlappen rothgelb; Afterdecke gleichmässig schwach gewölbt mit aufgebogenen Rändern, aber ohne Vertiefungen. Durch letzteres Merkmal sind die $q$ von sexpunctatus und octopunctatus var. a, deren Halssch. wie bei der vorliegenden Art gezeichnet ist, stets sicher zu trennen; die $\hat{\sigma}$ dürften sich kaum mit einander verwechseln lassen.

Halssch. schwarz, ein schmaler Vorderrandsaum, mit dem eine kurze, bis zur Mitte reichende Mittellinie und ein Seitensaum zusammenhängt, rothgelb. Letzterer ist mit starken, fast gereihten und im Grunde oft dunklen Punkten besetzt, mässig breit, parallel oder in der Mitte erweitert, häufiger verengt. Scheibe des Halssch. dicht, an den Seiten, besonders vorn, leicht längsrunzelig punktirt. Schildchen schwarz. Makel 1 der Fld. länglich-viereckig, in der Regel auf und hinter der Schulterbeule, aber vom Vorder- und Seitenrande weiter entfernt als bei sexpunctatus; Makel 2 klein, rund, nahe der Naht, 3 quer. Beine schwarz, die Schenkel vor der Spitze mit einer weisslichen Makel, die jedoch an den Vorderschenkeln oft, seltener auch an den Mittelschenkeln fehlt.

o. Die 3 inneren Bauchsegmente in der Mitte verengt, das letzte leicht quer eingedrückt. - Penis flach, breit, an der Oeffnung mässig gerundet-erweitert, vorn breit zugespitzt.

Die gewöhnliche Zeichnung des Halssch. bildet sich ähnlich wie bei der vorigen Art. Zuerst ist das Halssch. rothgelb, zwei grosse Makeln auf der vorderen Hälfte, zwei dreieckige an der Basis, hinten leicht mit einander verbunden, und ein Längsstrichelchen vor dem Schildchen, welches aber nicht wie bei sexpunctatus den Grundrand 
berührt, schwarz. Sobald die Spitze der Hintermakeln sich verlängert und die Vordermakeln berührt, entsteht eine sehr breite, rothgelbe, ankerförmige Figur (Var. a), von der allmählich die Seiten des gebogenen Theiles (Var. b; Mittelbinde genau wie bei 8-punctatus), zuletzt die ganze hintere Hälfte verschwinden. Zuweilen zeigt sich ein rother Punkt vor dem Schildchen oder ein ähnlicher jederseits am Ende der Mittellinie; diese selbst kann bis auf eine dreieckige Erweiterung des Vorderrandsaumes zusammenschrumpfen. Von den Var. a und $b$ sind mir nur $q$ bekannt.

Auf den Fld. fehlt höchst selten die Makel 2 ganz (Var. c), gewöhnlich dagegen bildet sie mit der entgegengesetzten einen breiten Nahtfleck (Var. d). Ausserdem vereinigt sich mitunter die Schultermakel mit der hinteren (Var. e), oder endlich diese mit der entgegengesetzten zu einer gemeinschaftlichen Querbinde, welche durch einen breiten Nahtsaum mit dem Nahtflecke in Verbindung steht (Var. f).

Auf Weiden in den Gebirgsgegenden Mittel- und Süddeutschlands, selten.

8. Cr. variegratus: Subelongatus, niger, antennis basi tibiisque anticis interne ferrugineis, facie inferne maculis 3 albidis, coxis anticis femoribusque apice albo-notatis, prothorace subopaco, vittis 3 elytrisque testaceis, his puncto humerali nigro. - Long. 5,5-6 mm.

Mas: thorace vitta media saepissime interrupta, segmento ultimo ventrali medio depresso.

F abr. Spec. Ins. II. App. 497. - Suffr. Mon. II. 77. - Redtb. Faun. A. II. 458.

Cr. axillaris Charp. Hor. ent. 239. t. 7. f. 9. ( $(\hat{\odot})$.

Var. a. Elytris bipunctatis.

Stierlin Faun. col. helv. 317.

Durch das verhältnissmässig lange, matte Halssch. und die gelb braune Farbe der Fld. sehr ausgezeichnet.

Kopf nebst Fühlern, die Unterseite und Beine wie bei den vorigen Arten gefärbt, die Fühler jedoch merklich kürzer, die einzelnen Glieder dicker. Halssch. hinter der Mitte jederseits leicht quer eingedrückt, dicht mit länglichen Punkten besetzt, deren Zwischenräume äusserst fein und dicht längsrunzelig, matt sind. Es ist schwarz, der Vorderrand, eine hinten verbreiterte und ein schwarzes Strichelchen einschliessende Längsbinde, sowie die Seiten, mit Ausnahme des äussersten Saumes hell gelbbraun. In der Regel ist die Seitenbinde des $q$ breit, in der Mitte nach innen erweitert, beim $\hat{\sigma}$ schmal, in der Mitte ausgerandet und die Mittelbinde unterbrochen, zuletzt so stark, dass von dem hinteren breiten Theile nur 
ein schmaler Saum vor dem Schildchen gelb bleibt, wie bei distinguendus. Fld. nebst Epipleuren etwas dunkler als die Zeichnung des Halssch., mässig fein und dicht punktirt, fettglänzend, der Nahtund Seitenrand, letzterer nur in der hinteren Hälfte, sehr schmal schwarz gesäumt, ein länglich-viereckiger Fleck auf der Schulterbeule schwarz.

ठ․ Letztes Bauchsegment gross, vor der Mitte des Hinterrandes quer eingedrückt, vor dem Eindrucke zuweilen mit der Spur zweier Höckerchen. - Penis dem der vorigen Art sehr ähnlich, wenig dicker, die Spitze kürzer.

Die unbedeutenden Abänderungen betreffen theils das Schildchen, welches nicht selten einen kleinen gelblichen Punkt vor der Spitze hat, theils die Beine, bei denen öfter die Makel am Ende der Vorderschenkel fehlt. Ausserdem findet sich nach Stierlin bei Schaff hausen eine Form, die auf jeder Fld. zwei schwarze Punkte besitzt.

An Erlen und Weiden im ganzen Alpenzuge.

9. Cr. distinguendus: Niger, mandibulis et antennis basi ferrugineis, facie puncto infra antennas, prothorace margine antico et laterali maculaque basali didyma flavescentibus, elytris rufo-testaceis, sutura maculisque duabus (prima humerali, secunda pone medium) nigris. - Long. 5-6 $\mathrm{mm}$.

Mas: segmento 5:o ventrali late, longitudinaliter impresso.

Schneider Neu. Mag. I. 2. 209. - Panz. Faun. Germ. 13. 8. Suffr. Mon. II. 74. - Redtb. Faun. A. II. 464. - Seidl. F. balt. 474 .

Cr. variegatus Gyllh. Ins. Suec. III. 597.

Var. a. Prothoracis macula basali aut parva lineari, saepe divisa, aut deficiente.

Var. b. Thorace margine antico lineolam lativrem abbreviatam in medio emittente.

Var. c. Elytris maculis 3 nigris (plerumque 1, 2).

Var. d. Elytris maculis 4 nigris (2, 2).

Var. e. Elytris puncto tantum humerali nigro.

Cr. humeralis Sturm Cat.

Var. f. Tibiis anticis interne ferrugineis.

Thoms. Skand. Col. VIII. 298 var. g.

Von den Verwandten durch das schwarze Kopfschild und einfarbig schwarze Beine leicht zu unterscheiden; cribratus, der ihm in dieser Hinsicht gleicht, hat mehr rothe Fld, einen Eindruck auf der Afterdecke und andere Geschlechtsmerkmale.

Kürzer als der Vorige, schwarz, Mandibeln und Fühlerbasis bis zum vierten Gliede rothbraun, Glied 1 oberseits schwarz; ein Fleck 
vor jedem Auge, Vorder- und Seitenrand des Halssch., sowie eine Quermakel vor dem Schildchen gelb. Fld. nebst den Seitenlappen röthlich gelbbraun, ein schmaler Nahtsaum und zwei Makeln auf jeder $(1,1)$ schwarz. Kopf längs der Mitte vertieft, mässig dicht und fein punktirt. Halssch. breit, die wenig gerundeten Seiten schmal abgesetzt; auf dem Rücken mässig, an den Seiten sehr dicht punktirt; der gelbe Saum am Vorderrande schmal, in der Mitte dreieckig erweitert, der Seitensaum, bis auf die Unters eite reichend, wenig breit, innen meist tief ausgerandet, die Makel vor dem Schildchen zweilappig. Fld. besonders beim $\hat{\sigma}$ dicht und stark punktirt, Makel 1 gross, länglich-viereckig, auf und hinter der Schulterbeule, 2 kleiner, grade hinter der ersten, unter der Mitte.

§. Segment 5 der ganzen Länge nach in der Mitte breit, aber wenig tief eingedrückt, der Eindruck glänzend, vorn fast glatt, hinten punktirt.

Das Halssch. variirt so, dass entweder bei der Zunahme der schwarzen Färbung zuletzt die dreieckige Erweiterung des Vordersaumes und die Makel vor dem Schildchen verschwindet (Var. a), oder bei Abnabme derselben sich der Vordersaum zu einer Mittellinie bis zur Hälfte und die Quermakel zu einem herzförmigen Flecke, wie bei cordiger, vergrössert (Var. b).

Auf den Fld. zeigt sich mitunter ein strichförmiger oder runder Fleck zwischen der vorderen oder hinteren Makel und der Naht (Var. c), selten sind beide vorhanden (Var. d), oder von den Makeln bleibt nur ein Schulterpunkt übrig (Var. e). Die von Thomson angeführte Var. f, mit rother Innenseite der Schienen, ist mir unbekannt.

Auf Birken in Nord- und Mitteldeutschland. Nordeuropa. Sibirien.

10. Cr. alboliseatews: Niger, antennis basi facieque puncto infra antennas ferrugineis, prothorace dense subaciculato-punctato, linea media postice abbreviata vittaque marginali utrinque flavescentibus, elytris opacis, minus dense punctatis, interstitiis alutaceis, lineis nonnullis subelevatis instructis, maryine laterali, apice plus minusve dilatata, vittaque angusta media flavescentibus. - Long. 5-6,3 $\mathrm{mm}$.

Mas: segmento 5:o ventrali late impresso (impressione canaliculata), basi crista transversa armato.

Suffr. Mon. II. 55; VIII. 98. - Redtb. Faun. A. II. 459. Mars. Mon. 75.

Var. a. Linea media prothoracis postice dilatata.

Var. b. Vitta elytrorum nulla.

Cr. Suffriani Suffr. Stett. Zeit. 1849. 18.

Cr. Perrieri Fairm. Ann. Fr. 1861. 649. 
Var. c. Ut in b, sed epipleuris plus minusve rufescentibus.

Var. d. Linea media prothoracis nulla, elytris totis nigris.

Cr. Bischoffi Tappes Ann. Fr. 1869. 8. t. 1. f. 17.

Etwas breiter und plumper als der Vorhergehende, im Körperbau cordiger am ähnlichsten, glänzend schwarz, die Fld. matt; ein kleiner Fleck unterhalb jedes Auges und die Fühlerbasis rostroth, eine Mittellinie und ein Seitensaum des Halssch., sowie zwei schmale Längslinien, die eine am Seitenrande, die andere über die Mitte der Fld. weisslich- oder röthlichgelb. Kopf dicht, oft runzelig punktirt. Fühler sehr kräftig, ziemlich lang, die mittleren Glieder $(5-7)$ merklich verdickt. Halssch. stark gewölbt und seitlich zusammengedrückt, besonders auf der hinteren Hälfte dicht und mehr oder weniger deutlich nadelrissig-punktirt; der abgesetzte Seitenrand mässig breit, die helle Mittellinie schmal, hinten abgekürzt, am Vorderrande dreieckig erweitert, der gelbe Saum an den Seiten lässt den äussersten Rand schwarz, ist hinten sehr schmal, verbreitert sich allmählich nach vorn und ist am Vorderrande zuweilen fein mit der Mittellinie verbunden. Schildchen fast glatt, glänzend. Fld. nur mässig dicht und wenig tief punktirt, dazwischen fein und äusserst dicht lederartig gerunzelt, matt, mit einigen, verschieden stark angedeuteten erhabenen Längslinien auf der vorderen Hälfte. Der gelbe, feine Seitensaum erweitert sich vor der Spitze und sendet von hier nach vorn eine schmale gelbe Längslinie über die Mitte, die sich im ersten Drittel der Fld. dem Schulterhöcker zubiegt und den Torderrand nicht erreicht.

ऽ. Segment 3 in der Mitte unter dem zweiten verborgen, Segment 5 gross, sehr weit aber flach eingedrückt, da Eindruck von einer nach vorn verbreiterten und vertieften Mittelfurche durchzogen, am Vorderrande mit einer nach hinten gerichteten, wenig oder kaum aufstehenden queren Hornplatte, deren Hinterrand in der Mitte ausgeschnitten, an den Ecken abgerundet ist.

Die mir bekannten Abänderungen in der Färbung des Halssch. bestehen einestheils darin, dass vor dem Schildchen ein rerschieden grosser, röthlicher Fleck auftritt oder die gelbe Mittellinie ror dem Schildchen, ähnlich der von octopunctatus, in eine breite Makel erweitert ist, welche ein schwarzes Längsstrichelchen einschliesst (Var. a); anderntheils darin, dass die Mittellinie ganz verschwindet. Das Schildchen besitzt mitunter einen rothen Mittelpunkt; die Fld. verlieren allmählich die Längslinie über den Rücken (Var. b) und die Seitenrandlinie erlischt auf der hinteren Hälfte (die Epipleuren verwaschen rothgelb: Var. c) oder gänzlich (Var. d). Zuweilen sind die Vorderhüften an der Spitze röthlichgelb; bei dunklen 
Exemplaren endlich verschwindet auch der rothe Fleck unterhalb der Augen.

In den Hochalpen Ende Juli und im August äusserst selten. Tirol (Kahr), am Schlern (Gredler), Gross-Glockner (Mann), Strela Pass in Bündten ( $\mathrm{m}$ hoff), Fluela Pass (Bischoff). Auch bei Mödling in der Nähe von Wien (Schiner). Von letzterem Fundorte übersandte mir H. Reitter ein $\delta$ aus Redtenbacher's Sammlung, welches zur zweiten Form der Var. a gehört und bei der Beschreibung in der Faun. Austr. 459 benutzt worden ist. Die unklare Angabe daselbst: "Die Mittellinie ist dann hinten gabelförmig gespalten" ist wie oben angegeben zu verstehen. Herr Dr. Thieme fand ein $q$ der Var. c unter einem Steine auf dem Esel des Pilatus.

Helle Formen dieser merkwürdigen Art, die bisher allerdings noch nicht beobachtet worden sind, müssen der Var. d von distinguendus überaus ähnlich sein, denn nur aus dieser Var. lässt sich die Entstehung der beiden Längsbinden auf den Fld. ungezwungen ableiten. Denkt man sich nämlich die beiden äusseren langgezogenen, schwarzen Makeln (disting. var. d) zu einer Längsbinde vereint, die beiden inneren, strichförmigen, unter sich und mit der Naht verbunden, so ergiebt sich genan die Färbung von albolineatus. Aehnlich gezeichnete distinguendus dürften im Norden wahrscheinlich noch aufgefunden werden, aber an den glänzenden Fld. and der Geschlechtsauszeichnung zu unterscheiden sein.

Mit dieser Art scheint mir Cr. Bischoffi Tappes mit Bestimmtheit vereinigt werden zu müssen.

11. Cr. laevicollis: Niger, nitidus, coxis anticis interne lamina elevata instructis femoribusque apice albo-notatis, antennis articulis 5 primis, tibiis anticis interne rufescentibus, prothorace subtilissime punctato, rufo, maculis $6(4,2)$ lineolaque antescutellari nigris, elytris fortiter punctatis, laete rufis, maculis 3 (2, 1) magnis nigris. Long. 4-5 $\mathrm{mm}$.

Mas: pedibus anticis intermediis longioribus, tibiis incurvis, apice hamatis, segmento 5:0 ventrali longitudinaliter, basin versus fortius, impresso dente acuto verticali armato.

Gebler Ledeb. Reis. II. 3. 205. - Suffr. Mon. II. 91; VIII. 99. Redtb. Faun. A. II. 457.

$\mathrm{Var}$ a. Maculis prothoracis plus minusve confluentibus.

Var. b. Viennensis: Thorace nigro, marginibus antico (vittam angustam in medio emittente) et lateralibus rufis, coxis anticis pedibusque haud maculatis, elytris maculis anterioribus fere contiguis, macula tertia cum opposita in fasciam transversam connata.

In der Zeichnung der Oberseite den hellsten Formen von sexpunctatus und signatus ähnlich, auch in derselben Art variirend wie 
diese, jedoch glänzender, lebhafter roth und von den schwarzköpfigen Verwandten leicht dadurch zu unterscheiden, dass sich die rothe Färbung unterseits noch auf die Vorderbrust ausdehnt.

Die ersten fünf Fühlerglieder einfarbig rothbraun; Halssch. seitlich bis zum feinen und sehr schmalen, von oben kaum sichtbaren Seitenrande gewölbt, weitläufig und fein, nach den Seiten zu dichter punktirt, hellroth mit 6 schwarzen Makeln, 4 derselben in einer Querreihe wenig vor der Mitte, die inneren $(2+3)$ gross, die äusseren $(1+4)$ punktförmig, zuweilen selbst fehlend, die übrigen $2(5+6)$ an der Basis, fast halbkreisförmig und viel weiter von einander entfernt als 2 von 3 . Vor dem Schildchen eine, die Basis nicht berührende, kurze schwarze Längslinie. Von diesen Makeln vergrössern sich allmählich 5 und 6 , indem sie eine breite Spitze nach vorn senden, die sich zuletzt mit dem Aussenrande der Makeln 2 und 3 vereinigt und eine breite, rothe, ankerförmige Figur einschliesst (Var. a). Sobald die Seiten des Ankers verschwinden, bleibt eine, vor dem Schildchen verbreiterte Mittelbinde übrig, ähnlich, nur feiner als die des 8-punctatus und nicht selten vor der Erweiterung unterbrochen (Var. b). Fld. mässig dicht und stark punktirt, lebhaft roth, ein feiner Nahtsaum und 3 grosse Makeln auf jeder schwarz; die erste länglich, auf und hinter dem Schulterhöcker, die zweite rund, nahe der Naht, die dritte quer, hinter der Mitte. Vorderhüften am Innenrande in eine, besonders beim $\hat{\sigma}$ hohe, lange und gebogene Hornplatte verlängert. Beine schwarz, Vorderhüften und Spitze der Schenkel mit einer weissen Makel, Innenseite und Spitze der Vorderschienen röthlich.

ơ Vorderbeine verlängert, ibre Schienen gekrümmt, die Spitze an der Innenseite in einen breiten, starken Haken zurückgebogen, mit welchem das Thier die Schienen an der aufstehenden Platte der Vorderhüften so befestigen kaṇ, dass sie sich nur mit einiger Mühe trennen lassen. Letztes Bauchsegment mit einem vorn verengten und stärker vertieften Längseindrucke, an dessen Vorderrande ein kleiner, spitzer Zahn grade aufsteigt.

Bei der Var. b sind Beine und Vorderhüften ungefleckt, die Seiten der Fld. in der hinteren Hälfte schwarz gesäumt, die Vordermakeln unter sich und mit der Naht fast oder leicht verbunden und die Makeln 3 beider Fld. zu einer gemeinschaftlichen Querbinde ausgedehnt. Dieser Form ist Cr. Mniszechi Tappes (Ann. Fr. 1869. 11) vom Altai sehr ähnlich, doch hat das $\hat{\sigma}$ eine tiefe, durch einen Längskiel getheilte Grube.

Bei Wien von H. Sartorius aufgefunden. Von der Türkei durch Südrussland bis Sibirien verbreitet. 
b. Körper schwarz. Halssch. einfarbig roth.

12. Cr. bimaculatos' $\left.{ }^{1}\right):$ Niger, nitidus, prothorace subtilissime punctato elytrisque rufo-testaceis, his minus subtiliter, interdum subseriatim punctatis, punctis $2(1,1)$ nigris; ventre segmento $1: 0$ medio nitidulo. Long. 5-6,5 mm.

Mas: abdominis segmento 5:0 medio fovea lata vaye impressa.

Fabr. Spec. Ins. I. 141. - Ol. Ent. VI. 790. t. 2. f. 18; t. 4. f. 52. - Suffr. Mon. II. 58. - Redtb. Faun. A. II. 463.

Var. a. Elytris puncto pone medium nullo.

Var. b. Elytromum punctis 2 valde dilatatis.

Var. bisbipustulatus Suffr. Mon. VIII. 92.

Etwas schmaler, feiner punktirt und mit kürzeren Fühlern versehen als der sehr ähnliche bipunctatus. Schwarz, Halssch. und Fld. röthlichgelbbraun, letztere heller, gelblicher, mit zwei mässig grossen, schwarzen Punkten: der eine auf der Schulterbeule, der andere hinter der Mitte, gleichweit vom Seitenrande wie von der theilweise oder ganz dunkel gesäumten Naht. Fübler schwarz, die Basis nicht selten rothbraun, Glied 2 bis 4 schmal, von den folgenden jedes einzelne nach dem Ende hin merklich erweitert. Halssch. stark gewölbt, die fein gerandeten Seiten von oben nicht sichtbar; wenig dicht und sehr fein, dazwischen äusserst fein punktirt. Fld. bald sehr fein, bald stärker, aber flach punktirt, die Punkte in Reihen geordnet, von denen die an der Naht und dem Seitenrande ziemlich regelmässig sind. Bauch dicht und kräftig punktirt, das letzte Segment beim $\widehat{\delta}$ mit einer grossen dreieckigen, flachen Grube.

Von Varietäten sind bisher nur Stücke bekannt, a, denen der hintere Punkt der Fld. fehlt, b, deren Normalpunkte sich zu grossen Makeln ausgedehnt haben.

Ende Juni auf Blüthen von Lavandula spica und Genista tinctoria in Steiermark (nach Brancsik sehr häufig), Kärnthen und Tirol. Italien, Südfrankreich, Spanien, Nordafrika.

1) Dieser Art steht sehr nahe:

Cr. infirmior Kraatz (Deutsch. Zeit. 1876. 138). Niger, prothorace nitido, laevissimo, vix perspicue punctulato elytrisque laete rufo-testaceis, his nitidulis, crebre fortiterque punctatis, punctis $2(1,1)$ minutis nigris, segmento 1:o ventrali subopaco, maris segmento 5:o medio deplanato. Long. 4,8 mm. Pyrenäen, Hyères (Stierlin), Italien.

Kleinere Gestalt, weit hellere Färbung, kleinere schwarze Flecke auf den unregelmässig gröber punktirten Fld. und ein fast glattes Halssch. zeichnen die Art aus. Kraatz's Exemplare stammen aus den Pyrenäen, ich besitze eins aus Toskana. - In den beiden Diagnosen von Kraatz (1. c. 138) müssen die Worte von "his" an umgewechselt werden.

VI. 
c. Körper schwarz mit blauem oder grünem Schimmer. Halssch. kahl. ${ }^{\text {) }}$

13. Cr. primearius $\left.{ }^{2}\right)$ : Niger, leviter coeruleo-micans, antemis basi ferrugineis, capite prothoraceque dense subtiliter punctatis. elytris

1) Halssch. deutlich behaart bei :

1. Cr. cicatricosus Luc. (Rev. Zool. 1845. 125. Expl. Alg. 528. t. 47. f. 7; Suffr. Mon. VIII. 90). Dunkelblau, Fld. glatt, blutroth, mit unregelmässigen Reihen blauer, innen narbig punktirter Grübchen. - L. 5,5 bis $7,5 \mathrm{~mm}$. Algier. Sicilien?

2. Cr. sexmaculatus Ol. (Encycl. méth. VI. 611; Suffr. II. 32). Mässig gewölbt, schwarzblau oder grünlich. Fld. lebhaft roth, sehr seicht unregelmässig punktirt-gestreift, deutlich quer gerunzelt, mit 3 schwarzen, zuweilen einzeln oder insgesammt fehlenden Punkten (1, 2). Penisspitze dreilappig, die beiden äusseren Lappen gerundet, mit nach innen gebogener Spitze, der mittlere dreieckig. - L. 5,5-7 mm. Wallis. Südfrankreich. Algier

3. Cr. tristigma Charp. (Hor. ent. 236. t. 4. f. 7; Suffr. II. 34). Wie voriger, länger und gewölbter, FId. rothbraun oder rothgelb, tief unregelmässig punktirt-gestreift, mit 3 schwarzen Punkten (1, 2). Penisspitze dreilappig, die äusseren Lappen spitz, dreieckig, der mittlere rhombisch. L. $6,5-9 \mathrm{~mm}$. Spanien. Portugal.

4. Cr. hirticollis Suffr. (Mon. II. 35). Schlanker und kleiner als der vorige, fast rein schwarz; Halssch. feiner, Fld. stärker punktirt, letztere röthlich gelbbraun, mit 3 schwarzen Punkten (1, 2 schief). - L. 5 mm. Calabrien. Sicilien.

5. Cr. ilicis 01. (Ent. VI. 801. t. 2. f. 21; Suffr. II. 36). Lebhaft metallisch blau oder grünlich, Halssch. sehr dicht, Fld. mässig stark und dicht punktirt, letztere röthlich gelbbraun, ein Punkt auf der Schulter und ein zweiter hinter der Mitte an der Naht schwarz. - L. 4-6,5 mm. Umgebung des Mittelmeeres auf Quercus ilex.

Aendert ab: Fld. a. mit 4 Punkten $(2,2$ schief $)=$ etruscus Dej.; 4-notatus Sturm; b. mit 3 Punkten (1, 2); c. nur mit Schulterpunkt; d. ohne Punkte.

Penis gleichbreit, vorn scharf dreieckig zugespitzt, an den Ecken, an welchen das vordere Dreieck beginnt, mit einem nach aussen gerichteten, gleichbreiten, halbkreisförmig nach oben gebogenen Hornhaken.

2) Sehr ähnlich sind:

1. Cr. pexicollis Suffr. (Mon. II. 51). Halssch. breiter, dicht längsrunzelig punktirt, oft matt seidenschimmernd. Makeln der Fld. kleiner, die vierte schmal, quer, Fortsatz der Vorderbrust kürzer und breiter, nach hinten verengt, an der Spitze dreieckig ausgekerbt. Penis dick, die Seiten unten in eine breit dreieckige, jederseits unmerklich zweimal gebuchtete Spitze ausgezogen. - L. 6-8 mm. Südfrankreich. Spanien. Algier.

2. Cr. Perrisi Tappes (Ann. Fr. 1869. 9. t. 1. f. 18). Wie der vorige punktirt und gefärbt, aber kürzer und flacher, die 5 Makeln der Fld. 
rubris, punctis 5 (2, 2, oblique digestis, 1) nigris, prosterno processu subparallelo apice inciso. - Long. 4,5-7 $\mathrm{mm}$.

$\mathrm{Mas}$ : segmento 5 : o ventrali late impresso.

Harold Col. Heft X. 254; Berl. Zeit. 1873. 169.

Cr. imperialis Fabr. Suppl. Ent. Syst. 106. - Suffr. Mon. II. 49. Redtb. Faun. A. II. 463. - Küst. Käf. Eur. I. 100.

Var. a. Punctis elytrorum plus minusve deficientibus.

Var. b. Elytrorurn punctis plerisque connatis.

Var. c. Elytris nigris, margine omni rufis.

Var. rufolimbatus Suffr. Mon. II. 51.

Schwarz mit blauem Schimmer, Fühler schwarz, ihre fünf ersten Glieder wenigstens unten, oft fast ganz rothbraun, Fld. roth, mit 5 schwarzen Punkten: 1 und 2 hinter der Basis und 3 und 4 hinter der Mitte rund, die inneren weiter nach hinten gerückt als die äusseren, 1 auf der Schulterbeule, 4 von allen der grösste, der fünfte in der Mitte des Abfalles vor der Spitze, leicht quer. Kopf meist dicht punktirt, Halssch. stark gewölbt, der feine Seitenrand nach den Hinterecken verbreitert und nur an denselben von oben sichtbar; vorn und an den Seiten dichter als auf der Scheibe, leicht runzelig punktirt und weniger glänzend. Fld. etwas weitläufiger und stärker als das Halssch. punktirt, selten mit Spuren unregelmässiger Streifen.

§. Letztes Bauchsegment in der Mitte mit einem flachen, fast dreieckigen Grübchen, welches stärker und sparsamer als das Segment punktirt ist. - Penisseiten vorn plötzlich gerundet-verengt, hierauf in eine gemeinschaftliche, jederseits leicht ausgebuchtete Spitze verschmälert.

Die Makeln der Fld. sind theils einer Verkleinerung und allmählichem Verschwinden, theils einer Vergrösserung und fortschreitendem Zusammenfliessen unterworfen. Im ersten Falle beginnt gewöhnlich das Verlöschen der Flecke mit dem dritten, es folgt

verbunden $(1+3+5+4+2)$, so dass jede Fld. schwarz erscheint, ringsum roth gesäumt, ein breiter, vom Vordersaume an der Innenseite des Schulterhöckers ausgehender und sich bis zur Mitte erstreckender Streifen, der leicht nach aussen gekrümmt ist, sowie eine längliche Makel hinter demselben und eine kleinere zwischen seiner Spitze und der Mitte der Naht, roth. - L. $6 \mathrm{~mm}$. Der Fortsatz der Vorderbrust nach hinten soll an dem einzigen, (platt gedrückten?) schlecht erhaltenen Exemplare, an welchem Kopf und Hinterbeine fehlten (nach Marseul, Mon. 42) dick sein, vorn eingeschnitten, die Spitzen (, les bords de l'entaille larges, verticaux") breit, vertical. Jedenfalls eine Varietät von pexicollis, deren Punkte ähnlich wie bei primarius v. rufolimbatus zusammengeflossen sind. 
hierauf 5 und 2, endlich auch 3, so dass nur ein Schulterpunkt übrig bleibt (Var. a). Im andern Falle verbinden sich die Flecke meist der Länge nach theilweise oder ganz mit einander (Var. b) oder fliessen vollständig zu einem länglichen schwarzen Scheibenflecke zusammen, welcher nur einen schmalen Grund- und Seirensaum, sowie einen breiteren Naht- und Spitzensaum roth lässt (Var. ${ }^{1}$ ).

Auf Weiden und Haselnussbüschen. Vom Harze (Saxesen) und von Thüringen (Kellner) durch den westlichen Theil Süddeutschlands bis Bozen verbreitet. Häufiger in Oberitalien und Frankreich.

C. Fld. ziemlich regelmässig gestreift-punktirt.

a. Epipleuren roth.

14. Cr. imperialis: Niger, antennis basi ferrugineis, elytris subparallelis, apice singulatim truncato-rotundatis, minus subtiliter striatopunctatis, pallide testaceis, sutura et margine laterali postice punctisque 3 (1, 2) nigris. - Long. 4,5-8 $\mathrm{mm}$.

Mas: ventre segmento $5: 0$ foveolato-impresso.

Laich. Verz. Tyr. Ins. I. 179. - Gredl. Käf. Tir. 416. Seidl. F. balt. 477.

Cr. bistripunctatus Germ. Ins. spec. nov. 557. - Charp. Hor. ent. 237. t. 7. f. 6. - Küst. Käf. Eur. II. 92. - Suffr. Mon. III. 32. Redtb. Faun. A. II. 462.

Schwarz, das Halssch. stark glänzend; die Fld. matter, blass gelbbraun, wenig oder kaum röthlich, mit schmalem ganzen Nahtund breiterem Seitensaume auf der hinteren Hälfte und drei schwarzen Punkten: der erste auf der Schulterbeule, der zweite und dritte hinter der Mitte, schief gestellt, indem der innere weit nach hinten gerückt ist. Fühler schwarz, die ersten 4 bis 5 Glieder, mit Ausnahme der Oberseite des ersten, röthlich; Halssch. kurz, mässig

1) Vom Autor selbst fraglich für eine Varietät von coryli gehalten ist der nach einem Stücke ( $q$ ), dem die vier letzten Fühlerglieder fehlen, beschriebene, in einem Spinnengewebe zu Moutiers in Savoyen vom Grafen Manuel gefundene Cr. Manueli Tappes (Ann. Fr. 1874. Bull. 250). Untersetzter als coryli, schwarz, der runzelig punktirte Kopf und das stark glänzende, sehr fein und dicht punktirte Halssch. grün oder erzfarbig schimmernd. Fld. glänzend, sehr fein runzelig punktirt, schwarzbraun mit violettem Anfluge, eine verwaschene Makel an der Naht in der Spitze roth. Die Lappen des dritten Tarsengliedes schmal. L. $71 / 2 \mathrm{~mm}$.

Nach Diagnose und Beschreibung unzweifelhaft ein sehr dunkles und glänzendes $q$ von primarius, bei dem sich vielleicht durch eine kräftige Behandlung mit Benzin die verdunkelten Normalflecke wieder zeigen dürften. 
zusammengedrückt, gewölbt, wenig dicht und äusserst fein punktirt, der ziemlich breit abgesetzte, dicht runzelig punktirte und matte, gleichbreite Seitenrand ist von oben bis vor die Mitte sichtbar. Fld. hinter den Schultern leicht eingeschnürt, sonst fast gleichbreit, jede einzelne an der Spitze breit abgestutzt, mit gerundeten Ecken; stark und tief, theilweise gereiht-punktirt, die Reihen 4 bis 7 und die abgekürzte unregelmässig, die übrigen fast regelmässig, mit mehr oder weniger gewölbten Zwischenräumen.

$\widehat{0}$. Letztes Bauchsegment in der Mitte mit einem mässig tiefen, grubenförmigen Eindrucke vor dem Hinterrande. - Penis breit, vorn stark gerundet-erweitert und in drei Zipfel ausgezogen; die beiden seitlichen breit, vorn zugespitzt, die Spitze leicht nach innen gerichtet, der mittlere quadratisch, vorn in ein Dreieck verlängert, seine 4 Seiten gerundet-ausgeschweift.

Zuweilen sind die Fld. hinter Punkt 3 angedunkelt oder mit einem schwarzen, oft scharf begrenzten Flecke besetzt, welcher das Bestreben zeigt, sich mit Punkt 3 zu verbinden. Weitere, gewiss nicht fehlende Abänderungen sind bis jetzt unbekannt.

Böhmen (Stussiner), Glatz, Wien, Steiermark, Kärnthen, Krain, Tirol selten auf Birken und Haseln.

15. Cr. trimerculatus: Niger, supra nitidissimus, antennis basi ferrugineis, elytris postice leviter angustatis, apice singulatim rotundatis, subtilissime punctato-striatis, rufis, sutura punctisque 3 (1, 2) nigris. - Long. 5,5-8 $\mathrm{mm}$.

Mas: ventre segmento 5 : o vage foveolato-impresso.

Rossi Faun. Etrusc. I. 96. t. 4. f. 12. - Charp. Hor. ent. 237. t. 7. f. 5 .

Cr. salicis Fabr. Ent. syst. I. 2. 53. - Suffr. Mon. III. 29. Redtb. Faun. A. II. 462 .

Cr. sexmaculatus OI. Ent. VI. 791. - Küst. Käf. Eur. II. 93. Var. a. Elytris paulo fortius punctatis, margine laterali postice nigro. Var. b. Punctis posterioribus elytrorum confluentibus vel in fasciam contiguam connatis.

Schwarz, oben sehr stark glänzend, die Fld. rothgelb oder rothbraun, mit schmalem dunklen Naht- oder Spitzensaume und drei schwarzen Punkten: der erste, etwas länglich, auf der Schulterbeule, der zweite, rund, dicht hinter der Mitte, näher dem Aussenrande als der erste, vom 8. und 9. Punktstreifen durchsetzt; der dritte und grösste, zwischen der Naht und dem zweiten Punkte, doch etwas mehr nach hinten gerückt als dieser, genau vom 2. und 5. Punktstreifen begrenzt. Fühler schwarz, die ersten 4 bis 5 Glieder, mit Ausnahme der Oberseite des ersten, dunkel röthlich. 
Halssch. stark zusammengedrückt, kugelig-gewölbt, weitläufig und äusserst fein, oft kaum sichtbar punktirt, der schmal aufgebogene, einzeln punktirte, glänzende Seitenrand an den Hinterecken erweitert und nur hier von oben sichtbar. Fld, von den Schultern nach hinten leicht verschmälert, jede einzelne an der Spitze volikommen abgerundet, sehr fein und seicht, in meist ganz regelmässigen Reiben punktirt, die Zwischenräume eben.

Das $\hat{\sigma}$ hat in der Mitte des letzten Bauchsegmentes einen breiten, flachen und schwach glänzenden Eindruck. - Penis schmal, vorn leicht verbreitert und in drei Zipfel ausgezogen; die beiden seitlichen fast grade, schmal und sehr spitz, der mittlere rechteckig, die schmale Vorderseite in ein Dreieck verlängert, seine 4 Seiten fast grade.

In der Türkei, Griechenland und Kleinasien findet sich eine Form, deren Fld. merklich stärker punktirt und nicht nur an der Naht und Spitze, sondern auch auf der hinteren Hälfte des Seitenrandes schwarz gesäumt sind. Diese Varietät (a) ist nicht immer leicht von der ähnlich gefärbten und punktirten vorigen Art zu trennen, doch würde die dunklere Farbe, der stärkere Glanz und die regelmässige Punktirung der Fld. einer Verwechselung mit derselben vorbeugen. - Mitunter sind Punkt 2 und 3 mehr oder weniger vollständig verbunden oder mit den entsprechenden Punkten der andern Fld. zu einer breiten, gemeinschaftlichen Querbinde vereint (Var. b).

Die Art steht zu imperialis genau in demselben Verhältnisse, wie sexmaculatus zu tristigma; überraschend ist besonders die wenig abweichende Penisbildung bei allen 4 Arten. Eine Trennung derselben, wie sie durch die bisher befolgte Eintheilung Suffrian's nöthig wurde, ist durchaus widernatürlich und unzulässig.

Nach Brisont auf der Steineiche. In Steiermark, Kärnthen, Krain und Tirol zuweilen zahlreich. Südeuropa.

\section{b. Epipleuren schwarz.}

16. Cr. bipunctatus: Niger, nitidus, antemis basi fervugineis, thorace laevissimo, elytris (striato-punctatis, interstitiis planis) rufis, margine ommi, epipleuris punctisque duobus $(1,1)$ nigris. - Long. 4-6 mm. Mas: segmento 5 : o ventrali fovea media sublaevi vage impressa. Fem: segmento 5: o fovea lata profunde impressa.

Linn. Syst. Nat. ed. X. 374 (Chrysom), - Sehneid. Mag. I. 205. Panz. Faun. Germ. 68. 2. - Suffr. Mon. III. 33; VIII. 136. Red tb. Faun. A. I. 462. - S eidl. F. balt.477. - Mars. Mon. 196. Cr. dispar Payk. Faun. Suec. II. 142. - Gyllh. Ins. Suec. III. 614. V ar. a. Elytris immaculatis.

Var. b. Elytris puncto humerali nigro. 
Var. c. Elytris puncto secundo valde dilatato.

Var. d. Elytris vitta lata longitudinali nigra.

Cr. sanguinolentus Scop. Ent. Carn. 66 (Buprest).

Cr. lineola F abr. Ent. Syst. I. 2. 59.

Var. e. Elytris nigris, maculis duabus (prima basuli, secunda apicali) rubris. Var. f. Thomsoni: Elytris nigris, macula transversa, angusta apicis mfa. Var. g. Elytris nigris.

Schwarz, glänzend, die langen Fühler bis zum fünften Gliede rothbraun oder röthlichgelb, die Fld. lebhaft roth, mit 2 schwarzen Punkten: der eine auf dem Schulterhöcker, der andere, etwas grössere, hinter der Mitte, der Naht näher als dem Seitenrande. Ausserdem sind alle Ränder schwarz gesäumt und der Umschlag ist einfarbig schwarz. Kopf ziemlich dicht und fein punktirt, Halsseh. fast spiegelglatt, die sparsamen Punkte sehr flach und nur bei starker Vergrösserung sichtbar. Fld. fast regelmässig gestreiftpunktirt, die Punkte in den Reihen mässig stark, oft dunkel gefärbt, die abgekürzte und die erste, sowie die fünfte bis siebente Punktreihe nicht selten etwas verworren; die $\mathbf{Z}$ wischenräume meist eben. Vierter Bauchring in der Mitte mässig verschmälert und, wie bei der folgenden Art, weniger fest mit dem fünften verbunden als bei den Verwandten.

§. Die Grube in der Mitte des fünften Bauchringes breit und flach, glänzend, mit feinen, verloschenen Punkten besetzt. - Penis hellbraun, verhältnissmässig schlank, an der Oeffnung leicht gerundeterweitert, vorn schnell verengt und in eine wenig scharf abgesetzte, breit dreieckige Spitze verlängert. Die Grube des 우 breit und tief, fein chagrinirt, matt.

Von den zahlreichen Abänderungen in der Färbung der Fld. verdienen besonders hervorgehoben zu werden: a. Fld. einfarbig roth, oder b. nur mit einem Schulterpunkte; c. der hintere Punkt vergrössert sich $\mathrm{zu}$ einer meist schiefen Makel und sendet von seiner vorderen Aussenseite eine Spitze nach dem Schulterpunkte hin. Sobald diese den Punkt erreicht, entsteht eine mehr oder weniger breite, vorn nach aussen gekrümmte Längsbinde auf der Scheibe jeder Fld. (Var. d), welche sich allmählich seitwärts bis zum Seitenrande und später bis zur Naht ausdehnt, so dass nur eine Quermakel vor der Spitze und eine meist verwaschene Makel an der Basis, entweder am Schildchen, oder aussen am Schulterhöcker, roth bleibt (Var. e). Endlich verschwindet die Basalmakel (Var. f) und zuletzt auch die schmale, bandförmige Spitzenmakel (Var. g). Bei den vier letzten Abänderungen sind die Fld. oft quer gerunzelt oder fein gestrichelt, mehr oder weniger matt. 
Durch ganz Europa verbreitet; auch in Sibirien, Kleinasien und Algier. Auf Gebüschen und in Blüthen an Waldrändern bergiger Gegenden häufig. Die Varietäten $a, f$ und $g$ sind äusserst selten.

18. Cr. bigattatus: Niger, nitidus, antennis basi ferrugineis, thorace laevissimo, elytris fortiter striato-punctatis, intersitiis subconvexis, macula magna, rotundata apicis rufo-testacea. - Long. 4,5-6 mm.

Mas: segmento 5 : o ventrali fovea media pu.ctata minus vage impressa. Fem: segmento 5 : o fovea longitudinali profunde impressa.

Scop. Ent. Carn. 65. f. 201 (Buprestis). - Herbst Füessl. Arch. VII. 163. t. 44. f. 6. - Harold Berl. Zeit. 1873.165. Cr. bipusiulatus Fabr. Syst. Ent. App. 821. - Panz. Faun. Germ. 68. 15. - Redtb. Faun. A. II. 461. - Mars. Mon. 197.

Cr. bipunctatus var. Sehneid. Mag. I. 205. - Gyllh. Ins. Suec. III. 615. - Suffr. Mon. III. 35. - Thoms. Skand. Col. VIII. 304. Seidl. F. balt. 477 .

Glänzend schwarz, die vier oder fünf ersten Fühlerglieder wenigstens unterseits röthlichgelb, eine grosse, gerundete Makel in der Spitze der Fld., welche nirgends die Seiten berührt, rothgelb, nach dem Tode hell gelbbraun. Halssch. weitläufig, kaum sichtbar punktirt, Fld. mit starken und tiefen, zu ziemlich regelmässigen Reihen geordneten Punkten; die Reihen vertieft, ibre Zwischenräume daher leicht gewölbt. Vierter Bauchring in der Mitte stark verschmälert.

ふ. Fünftes Segment mit einer deutlichen, dreieckigen, weitläufig aber kräftig und tief punktirten, glänzenden Grube. - Penis pechschwarz, fast doppelt so stark als bei der vorigen Art, an der Oeffnung breit erweitert, vorn in drei Lappen ausgezogen: die beiden seitlichen breit, kurz, stumpf zugespitzt, der mittlere dreieckig. Grube des $q$ tief, länglich, zuweilen mit fast parallelen Seiten.

Auf Wiesen in ebenen Gegenden häufig. Nach Gredler in Tirol bis an den Krummholzgürtel verbreitet.

Diese Art ist zuerst von Schneider a. a. O. mit der vorigen verbunden und später von den bedeutendsten Schriftstellern bei derselben belassen worden, obwohl z. B. Suffrian (Mon. III. 36) selbst die Unmöglickeit einsieht, dass sich aus bipunctatus var. sanguinolentus (lineola) die grosse, runde Spitzenmakel der vorliegenden entwickeln könne. In neuester Zeit trennt sie Marseul durch die Form und Punktirung von bipunctatus, allein diese Unterschiede, die sich bei der ausserordentlichen Wandelbarkeit der CryptocephalusSkulptur verwischen, gewähren keine absolute Sicherheit, und es wäre daher nicht unwahrscheinlich, dass sich aufs Neue Stimmen für eine Vereinigung beider Arten, vielleicht sogar in einer Form, 
wie sie Gredler (Käf. Tir. 416 Anmerkung) liebt, erheben möchten. In diesem Falle ist die von $\mathrm{Kraatz}$ so oft, besonders Deutsch. Zeitschr. 1881. 113, warm empfohlene Untersuchung des männlichen Begattungsgliedes wohl geeignet, jeder Unsicherheit ein Ende zu machen. Sie zeigt uns, dass der seitherige $C r$. bipustulatus eine Mischart war, die aus der vorliegenden Art und der seltenen Var. f. des bipunctatus bestand, die ich, um die Aufmerksamkeit der Entomologen besonders auf sie hinzulenken, nach dem Begründer der Penis-Theorie benannte. Diese Varietät ist von biguttatus leicht dadurch zu unterscheiden, dass bei ihr die Spitzenmakel roth, schmal und bandformig, also am Vorderrande nicht gerundet-erweitert, sondern gerundet ausgeschnitten ist. $\mathrm{Ob}$ von $\mathrm{Cr}$. biguttatus auch Formen existiren, die der Stammform des bipunctatus ähnlich sind, ist mir unbekannt, jedoch glaube ich dies nach meinem nicht unbedeutenden Materiale bezweifeln zu müssen.

Cr. anticus Suffr., vom Kaukasus, bildet eine täuschend ähnliche Var., die aber an den gelben Vorderbeinen erkannt werden kann.

\section{Reihe. Verwandte von Cr. 14-maculatus.}

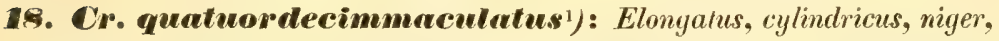
nitidus, episternis mesothoracis, facie inferne maculis 3 , antennis basi

1) Dieser Art nahe verwandt sind:

1. Cr. Tappesi Mars. (Abeille V. 206; bidens Suffr. Stett. Zeit. 1871. 22). Elongatus, cylindricus, niger, thorace elytrisque late rufis, nitidis, coxis anticis macula ferruginea, antennis basi facieque injerne maculis 3 nfo-ferrugineis; prothorace fortiter convexo, minus crebre punctato, maculis 6 subrotundis (4 in medio transversin positis, 2 basi) nigris, elytris paulo fortius punctatis, parce pubescentibus, maculis 4 nigris. - Mas: ventre segmentis 3 ultimis connatis, segmento 5: o late profundeque excavato, mar. give antico excavationis dentibus 2 crassis terminato, pygidio maximo, bicalloso, femoribus anticis basi latissimis. - Fem: pygidio tricarinato. L. 5,5-7 mm. Taurus. Libanon.

Variat maculis nigris prothoracis confluentibus, vittam mediam includentibus, coleopteris rufis, fasciis 2 latis, nigris.

Die 8 Makeln beider Fld. sind kreisförmig gestellt, da sich die Schultermakel weit hinter dem Schulterhöcker befindet. Zunächst verbinden sich die inneren mit der Naht, später mit den äusseren zu zwei, aussen abgekürzten, breiten Querbinden.

2. Cr. coronatus Suffr. (Mon. II. 53). Gestreckt, schwarz, ein Fleck des Kopfsehildes, der sich auf der Stirn in 2 Aeste spaltet, Fühler, äussere Hälfte der 4 Vorderschenkel, Schienen und Tarsen, sowie Seiten. und Vorderrand des auffällig grossen Halssch., nebst 3 hinten abgekürzten Längsbinden desselben und die Fld. roth, letztere mit 4 schwarzen Punkten 
thoraceque rufo-testaceis, hoc maculis $8(6,2)$ nigris, subtiliter punctato, scutello nigro, elytris crebre punctatis, parce pubescentibus, flavotestaceis, macula elongata humerali punctisque $3(1,2)$ nigris, pygidio

(2, 2), der erste hinter dem Schulterhöcker. ¿ Eindruck des 5. Segmentes flach, halbkreisförmig, davor eine zweihöckerige Querfalte. - L. 6 mm. Sarepta.

3. Cr. Stschukini Fald. (Mem. Ac. Petr. II. 447. t. 5. f. 9. Suffr. IX. 106). Breiteste Art, wie 14-maculatus gefärbt und gezeichnet, die Makeln des Halssch. und der Fld. gross und mehr oder weniger zusammenfliessend, oft das Halssch., bis auf einen Vordersaum (Var. dauricus Suffr.) und die Fld., bis auf einen Seitensaum schwarz (Var. ramosus Suffr.). Der Unterrand der Augen gelb gesäumt, Beine schwarz. - L. 5-6 mm. Daurien. Mongolei.

4. Cr. floralis Krynicki (Bull. Mose. 1834. 173. t. 5. f. 6. halophilus Suffr. II. 105). Ganz wie 14 -maculatus, 2 linienförmige Stirnflecke gelb. Beine schwarz, Vorderschienen oft ganz oder nur innen bräunlich. $\hat{\oplus}$ Segment 1 und 2 längsgekielt, 5 einfach, seicht quer eingedrückt. - L. 5,5 mm. Südrussland.

* 5. Cr. flavicallis Fabr. (Spec. Ins. I. 140; nigritarsis Suffr. II. 170). Wie 14-maculatus und ähnlich variirend, aber ohne schwarze Makeln am Hinterrande des Halssch. Beine rothbraun, eine Makel vor der Spitze der Schenkel gelb, ein schmaler Ring am Knie und die Tarsen schwarz (zuweilen der Rücken der Schenkel und die Spitze der Schienen schwarz). 2 Stirnlinien, Seitenstücke der Mittelbrust und der Afterrand gelblich. (.) mit einer einfachen, elliptischen, wenig tiefen Längsgrube auf dem letzten Segmente. - Penis breit, flach, vorn gerundet-abgestutzt, die Mitte des Vorderrandes in ein kleines Dreieck verlängert. - L. 5-6 mm. Südrussland. Sibirien.

6. Cr. Suffriani Dohrn (Stett. Zeit. 1859. 426; Beckeri Moraw. Bull. Mosc. 1860. I. 299). Klein und sehr schlank, schwarz, Unterkopf und 2 quer-dreieckige Stirnflecke (oft ein ganzer Saum am Innenrande der Augen), erstes Fühlerglied, Seitenstücke der Mittelbrust, Hüften und Beine (Tarsen und eine Rückenlinie der Schenkel, welche vor der Spitze meist eine gelbe Makel haben, schwärzlich) sowie das Halssch. röthlichgelb, letzteres mit 8 schwarzen Punkten (2, 4, 2), mässig dicht, kräftig punktirt. Fld. schwärzlich-gelb, Seitenrand, Spitze und eine in der Mitte meist unterbrochene Längslinie über den Rücken weissgelb, 4 Makeln schwarz ( 2 an der Basis, 2 vor der hinteren Wölbung). Schildchen mit weissem Mittelflecke. (ิ) 2 fast senkrechte, spitze Zähne vor der weiten und tiefen Längsgrube des letzten Segmentes. - Penis flach, sehr breit, Vorderrand in der Mitte mit einem gerundet-dreieckigen Zipfel und jederseits einem längeren, stark gekrümmten Zahne. - L. 3-4,5 mm. Sarepta.

Das Halssch. variirt a. Punkt $1+4,2+5$ verbunden, b. die Punkte $3,6,7$ und 8 fehlen. Fld. mit verwaschenen oder ganz fehlenden Makeln. Bauch zuweilen, oder die ganze Unterseite hellgelb. 
apice tibiisque plus minusve testaceis, femoribus apice interdum macula alba notatis. - Long. 4,5-6 mm.

Mas: segmento 5:o ventrali longitudinaliter la te impresso, basi dente acuto subverticali armato.

Schneid. Neu. Mag. I. 2. 195.

Cr. coloratus Suffr. Mon II. 102. - Redtb. Faun. A. II. 45\%. Mars. Mon. 100.

Var. a. Maculis prothoracis plus minusve dilatatis et confluentibus, medio vittam ancoraeformem includentibus.

Var. b. Puncto ultimo elytrorum cum opposito in maculam suturalem conjunctum, sutura interdum late nigra.

Var. c. Maculis prothoracis plus minusve deficientibus.

Var. d. Elytrorum punctum interius paris posterioris deest.

Cr. Pilleri Schrank. Faun. boic. 555. - Kraatz Deutsch. Z. 1879. 263.

Var. e. Puncta posteriora elytrorum desunt.

Var. f. Elytris punctis 2 suturalibus deficientibus.

Cr. coloratus Fabr. Supplem. Ent. Syst. 108.

Var. g. Elytris macula humerali nigra.

Schwarz, eine Quermakel auf dem Kopfschilde und ein Fleck jederseits unterhalb der Augen, die Basis der Fühler und das Halssch. rothgelb, Fld. weisslich-, seltener röthlich-gelb. K $\mathrm{K}$ p in der Mitte leicht vertieft, weitläufig und fein punktirt. Fühler mässig schlank, oft bis zur Basis des sechsten Gliedes hell gefärbt, die Grundhälfte des ersten Gliedes oberseits schwarz. Halsch. stark gewölbt, der fast gerade, schmal abgesetzte und von oben nur an den Hinterecken sichtbare Seitenrand hinter den Vorderecken eingeschnürt, so dass diese zahnfömig nach vorn und aussen vortreten; die Oberfläche fein, wenig dicht punktirt, vor dem Schildchen mit einem oft kaum bemerkbaren Eindrucke jederseits. Von den 8 Makeln desselben stehen 6 in einer Querreihe über die Mitte, die zwei inneren $(3+4)$ gross, fast bis zum Vorderrande ausgedehnt, durch eine verschieden breite, rothgelbe Mittellinie getrennt, zu beiden Seiten von ihnen je zwei kleinere, meist mit einander verbunden; die Makeln 7 und 8 befinden sich dicht vor der Basis und sind klein, punktformig oder quer. Fld. wie bei den übrigen schlanken und cylindrischen Arten der zweiten Reihe, mit einzelnen kurzen und sehr feinen, meist zu Längsreihen geordneten greisen Härchen besetzt, die sich sehr leicht abreiben und deshalb meist nur noch an den Seiten oder vor der Spitze zu bemerken sind; die Oberfläche unregelmässig dicht, aber wenig stark punktirt (die Punkte zuweilen leicht angedunkelt), mit einer langgestreckten, die Basis berührenden schwarzen Makel über den Schulterhöcker und 3 schwarzen Punkten: der erste, klein, dicht am Vorderrande in einer Vertiefung am Schildchen, der 
zweite grösser, hinter der Mitte, wenig näher dem Seitenrande als der Naht, der dritte klein, zwischen Naht und Punkt 2, aber etwas mehr nach hinten gerückt, als dieser. Afterdecke am Unterrande mit einem breiten, oft in der Mitte unterbrochenen gelblichen Saume. Unterseite schwarz, Seiten der Vorderbrust, Seitenstücke der Mittelbrust ganz oder theilweise und oft auch die Spitze der Seitenstücke der Hinterbrust röthlich-gelb. Beine schwarz, die Schenkel nicht selten mit einer weisslichen Makel vor der Spitze, die Schienen ganz, oder am Hinterrande, oder wenigstens in der oberen Hälfte düster gelbbraun. Tarsen fast so lang als die Schienen.

ふै. 5. Bauchsegment gross, mit einem breiten, nach vorn verflachten Längseindrucke, am Vorderrande ein aufstehender, wenig nach binten gerichteter, spitzer Zahn. - Penis breit und flach, zur Oeffnung hin allmählich erweitert, der Vorderrand fast grade abgeschnitten und in der Mitte in zwei kurze, gerundete, unterseits gerinnte hornige Lappén ausgezogen.

Zuweilen wird die Quermakel des Kopfschildes undeutlich, oder fehlt ganz; auf dem Halssch. versehwinden entweder die Makeln 2 und 5, 7 und 8 (Var. c), oder die Makeln dehnen sich aus und fliessen zusammen, bis zuletzt in der Mitte eine breite ankerförmige Figur, wie bei signatus var. a, entsteht, die öfter ein schwarzes Längsstrichelchen vor dem Schildchen einschliesst (Var. a). Die Fld. verlieren oft den Punkt 3 an der Naht (Var. d), oder die beiden hinteren Punkte (Var. e), selten die beiden inneren (Var. f; Suffr. nicht bekannt); zuletzt alle drei Punkte, so dass nur die Schultermakel übrig bleibt (Var. g). Bei der Abänderung b fliesst der hinterste Punkt mit der Naht zusammen; diese ist fast bis zum Schildchen breit schwarz gesäumt und theilweise oder ganz auch mit dem Punkte 1 verbunden.

Auf trocknen Hügeln bei Wien, und von Ungarn bis Sibirien verbreitet.

19. Cr. Heitter $\left.{ }^{-1}\right)$ : Niger, nitidus, antennis articulis 2 primis inferne, tibiisque interne obscure ferrugineis, thorace subtilissime punctato, rufo,

1) Aehnlich ist:

1. Cr. halophilus Gebl. (Ledeb. Reis. II. 3. 204; Suffr. VIII. 105.) Das stark punktirte Halssch. und die flachen Fld. lehmgelb; von den 4 Makeln des ersteren die 2 inneren hinten vereint, die 2 äusseren mit einem breiten, schwarzen Hinterrandsaume verbunden. Auf den Fld. 4 grosse, schwarze Flecke $(2,2)$. Kopf mit 2 dreieckigen, gelben Stirnflecken; Unterseite und Beine einfarbig schwarz. $\hat{\odot}$. Grube des 5 . Segmentes kreisförmig, mit scharfen Rändern, durch eine Kiellinie der Länge nach getheilt, 
maculis 4 transversim digestis, nigris, elytris creberrime subtiliter punctatis, flavo-testaceis, punctis $3(2,1)$ nigris. - Long. $5 \mathrm{~mm}$.

Mas: segmento 5:o ventrali late transversim impresso, basi crista magna transversa, subbidentata armato.

Der vorigen Art, besonders deren Var. d, täuschend ähnlich, aber durch Punktirung, Färbung der Fühler, des Kopfes und der Unterseite, sowie die Geschlechtsmerkmale leicht von ihr zu unterscheiden.

Kopf, mit Ausnahme der bräunlichen Mandibeln, schwarz, die Stirn schwach vertieft, dicht und fein punktirt. Fühler schlank, schwarz, die ersten zwei Glieder unten verwaschen rothbraun. Halssch. ähnlich gebaut wie beim Vorigen, aber vorn etwas breiter, durchgängig feiner punktirt und tiefer roth, mit 4 gerundeten, schwarzen Makeln quer über die Mitte der Scheibe, von denen die zwei inneren nur wenig grösser als die äusseren und leicht quer sind. Fld. sehr dicht und ziemlich fein punktirt, bräunlichgelb, zwei Punkte am Vorderrande, der eine länglich, kaum halb so lang als bei 14-maculatus, auf der Schulter, der andere, etwas kleiner, rund, nahe dem Schildchen und ein dritter kleiner Punkt, dicht vor der hinteren Wölbung, gleichweit vom Seitenrande wie von der Naht, schwarz. Afterdecke, Unterseite und Beine schwarz, die Innenseite der Schienen, wenigstens an den Vorderbeinen, rothbraun.

đ. Letztes Bauchsegment in der Mitte der hinteren Hälfte weit und mässig tief quer eingedrückt, vor dem Eindrucke eine aufstehende dicke und breite Hornplatte, die hinten quer vertieft, nach vorn von einer kurzen Mittelrinne durchzogen ist, so dass die Ränder in Gestalt zweier, weit getrennter Zähnchen aufstehen. - Penis gleichbreit, flach, der Vorderrand mit zwei tiefen, hinten gerundeten Aus-

am Vorderrande 2 breite, schräg nach hinten gerichtete Zähne. - L. 4 mm. Kirgisen-Steppe. West-Sibirien.

2. Cr. rubi Ménétr. (Cat. rais. 1832. 238; Suffr. II. 114). Halssch. grob runzelig-punktirt, schwarz, Vorder- und Seitenrand, eine schmale, hinten verkürzte Mittellinie und ein verwaschener Querfleck vor dem Schildchen düster gelb. Fld. strohgelb, schwächer als das Halssch., in ziemlich regelmässigen, oft dunklen Reihen punktirt, mit 4 schlecht begrenzten schwarzen Makeln $(2,2)$ und einer fünften vor der Spitze, aus mehreren Strichelchen zusammengesetzt. - L. $4 \mathrm{~mm}$. Caucasus.

3. Cr. astracanicus Suffr. (Stett. Zeit. 1867. 309; tamaricis Solsky Hor. Ross. IV. 183). Braungelb, Beine gelb. Halssch. äusserst dicht, grob punktirt, ein dunkles $\mathbf{M}$ oft nur angedeutet, Fld. grob punktstreifig, mit 4 bräunlichen Nebelflecken (2, 2). - L. 4 mm. An der unteren Wolga. 
schnitten, wodurch drei Zipfel gebildet werden, von denen der mittlere schmal, an der Spitze leicht gerundet-erweitert und nach unten gebogen ist.

Die mir vorliegenden 6 Exemplare variiren wenig. Bei einem derselben sind die Makeln des Halssch. klein und verloschen, bei einem andern tritt zwischen Punkt 3 der Fld. und der Naht noch ein kaum bemerkbares Pünktchen hervor. Jedenfalls werden sich also auch Stücke finden, deren Fld. denen des $\mathrm{Cr}$. 14-maculatus ähnlich gezeichnet sind.

In Croatien von H. Reitter entdeckt und ihm zu Ehren benannt. Der nach Brancsik in Steiermark (Käf. Steierm. 105) auf Blüthen lebende $C r$. coloratus dürfte zur vorliegenden Art gehören, die sicher auch im östlichen Krain nicht fehlen wird. $\left.{ }^{1}\right)$

1) Einen Uebergang zu den folgenden Arten, deren Fld. eine Längsbinde besitzen, bilden:

1. Cr. gamma Herrich-Schäff. (Faun. Germ. 130. 1; sesquistriatus Krynick. Bull. Mosc. V. 174; VII. t. 5. f. 7; ypsilon Suffr. II. 111). Halsseh. grob und dicht punktirt, schwarz, eine abgekürzte, glatte Mittellinie, ein schmaler Vorder- und breiter Seitensaum, gelb, in letzterem ein schwarzer Punkt, der oft mit dem Schwarz der Scheibe verbunden ist. Vor dem Schildchen 2 grosse, nach vorn divergirende, gelbe Makeln. Am Grunde der gelblichen Fld. 2 strichförmige, schwarze Makeln, von denen die auf der Schulter gewöhnlich mit der inneren von zwei feinen, schwarzen Längslinien über die Scheibe zusammenhängt. Diese Zeichnung ist nicht selten bis auf die Schultermakel verschwunden. Letztes Segment des $\hat{\oplus}$ einfach eingedrückt. - Penis schmal, oberhalb der Oeffnung vertieft, vorn zugespitzt. - L. 4-5 mm. Südrussland. Sibirien.

2. Cr. ergenensis Moraw. (Hor. Ross. II. 174; Beckeri Suffr. Stett. Zeit. 1864. 265). Wie voriger, aber blaugrün, Halssch. sparsam, sehr fein punktirt, lebhaft glänzend, der Vorderrand, ein breiter Saum an den Seiten, mit einem schwarzen Punkte besetzt, und zwei stark divergirende, oft in 2 Makeln getheilte Längsflecke vor dem Schildchen gelb. Fld. blassgelb, mit strichförmiger Schultermakel, selten noch mit einer dunklen Längslinie nahe der Naht, hinter der Mitte. - L. $5 \mathrm{~mm}$. Sarepta.

Näher noch sind mit bohemius verwandt:

a. Cr. limbellus Suffr. (Mon. II. 119; IX. 113). Längsbinde der Fld. nur durch eine schmale gelbe Linie vom Nahtsaum getrennt; Seitenstücke der Mittelbrust und Pygidium schwarz, Beine gelb. - L. 3,5 mm. Baikal-See. Jedenfalls mit Unrecht bisher der europäischen Fauna zugezählt.

b. Cr. sareptanus Moraw. (Hor. Ross. II. 173). Schwarzgrün (auch die fast gleichbreite, schlecht begrenzte Längsbinde der Fld.), 3 Makeln des Untergesichtes und 2 Stirnpunkte gelb. Halssch. fein punktirt, der in der Mitte fast unterbrochene Seitensaum, die beiderseits abgekürzte Mittellinie, 
20. Cr. bohemius: Niger, antennis brunneis, basi pedibusque rufotestaceis, femoribus apice albidis, facie, lineis 2 ocularibus, margine antico (lineolam abbreviatam in medio emittente) et laterali maculisque 2 posticis prothoracis rufo-flavis, elytris flavis, sutura vittaque media nigra; epipleuris mesothoracis, segmento 1 : o medio pygidioque apice albidis. Thorace crebre elytrisque minus dense fortiter punctatis. Long. $4 \mathrm{~mm}$.

Mas: ventre segmentis 4 ultimis connatis, segmento 5:0 maximo, vage longitudinaliter impresso, impressione antice canaliculata, basi tuberculo parvo instructa, segmento $1: 0$ carinato.

Drap. Ann. Se. phys. Brux. I. 1819. 296. t. 11. f. 7. - Harold Berl. Zeit. 1873. 165.

Cr. $\boldsymbol{B} \ddot{o} h m i$ Germ. Ins. spec. nov. 1824. 558. - Suffr. Mon. II. 117.

- Redtb. Faun. A. II. 463.

Die Art ist durch die schwarze Längsbinde jeder Fld. leicht kenntlich. Kopf dicht und fein punktirt, schwarz, der Theil vor den Fühlern, mit welchem eine Linie längs des Innenrandes der Augen bis auf die Stirn verbunden ist, und ein kleiner, oft getheilter Fleck zwischen den Fühlerwurzeln, doch etwas höher als diese, röthlich-gelb. Fühler schlank, braun, nach der Basis hin allmählich heller, gelblich. Halssch. sehr dicht, vor dem Hinterrande leicht längsrunzelig punktirt, schwarz, ein Vorder- und ein am Grunde dreieckig erweiterter Seitensaum, welcher als schmale Linie auf die Unterseite reicht, rothgelb. Vom Vorderrande zieht sich eine ähnlich gefärbte glatte Mittellinie bis zur Mitte, hinter dieser stehen parallel zwei ovale, rothgelbe Makeln, die nicht selten die Basis berühren. Fld. viel stärker aber weniger dicht als das Halssch. punktirt, die Punkte auf der hinteren Hälfte an der Naht und am Seitenrande gereiht; hell strohgelb, ein gegen die Wölbung hin verschmälerter Nahtsaum und eine Längsbinde schwarz. Letztere beginnt schmal

und vor dem Schildchen ein schmaler, zuweilen getheilter Saum gelb. Beine gelb, Schenkel mit grosser, schwarzgrüner Rückenmakel. - L. 3,5-4 mm. Sarepta.

c. Cr. flexuosus Kryn. (Bull. Mosc. 1834. 173. t. 5. f. 6; Suffr. II. 109). Die ganze Oberseite dicht und fein behaart. Halssch. schwarz, mit schmalem Vorder- und in der Mitte verengtem gelben Seitensaume. Fld. gelbbraun, ein breiter Nahtsaum, der hinter dem Schildchen jederseits gerundet erweitert ist, und eine, hinter der Mitte eckig nach innen verbreiterte Längsbinde, näher dem Seitenrande als der Naht, schwarz. Beine röthlich gelbbraun, der Rücken der Schenkel nicht selten schwarz, die Spitze weiss gefleckt. Hinterleib des $\hat{\odot}$ einfach. - Penis über der Oeffnung mit stark erhabener Querleiste, sonst dem von bohemius sehr ähnlich. - L. 4 mm. Krim, Sarepta. 
an der Wurzel, erweitert sich schnell makelförmig, indem sie den Schulterhöcker mit umfasst, und setzt sich, wieder verengt, fast gleichbreit bis zur hinteren Wölbung fort, wo sie, parallel dem Hinterrande, der Nabt zugekrümmt ist. Auf der Unterseite sind die Seitenstücke der Mittelbrust und das erste Segment zwischen den Hinterhüften (beim $q$ nur punktformig) weiss oder gelb, ebenso die Spitze der Afterdecke und ein undeutlicher Saum der Vorderbrust zwischen den Hüften. Beine braunroth, Hüften und Spitze der Schenkel weiss.

§. 5. Bauchsegment sehr lang, mit dem ersten zusammenstossend (die Zwischen-Segmente nur an der Seite sichtbar), der Länge nach leicht eingedrückt, mit einer Mittelfurche, die nach vorn tiefer und jederseits von einer erhabenen Randlinie eingefasst wird. An der Basis erhebt sich ein stumpfer Höcker zu gleicher Höhe mit dem gelben Längskiele des ersten Segmentes. - Penis oberhalb der Oeffnung buckelig aufgetrieben, an derselben schwach gerundeterweitert, hierauf in eine dreieckige, rorn breit abgerundete Spitze vorgezogen; die Seiten da, wo sie sich zu verengen beginnen, mit einem Büschel langer Borstenhärchen, welche bei schwacher Vergrösserung einem Zahne ähnlich sehen.

An der Donau in Nieder-Baiern und Oesterreich selten; häufiger in Ungarn und Südrussland bis Sarepta. Die Angabe Brancsik's (Käf. Steierm. 105), dass H. Spitzy bei Marburg den Cr. flexuosus gefangen habe, beruht gewiss auf einer Verwechselung mit der vorliegenden Art.

21. Cr. "picalis: Saturate coeruleus, vel nigro-viridis, nitidus, facie inferne maculis 4 , antennis basi tibiisque anticis rufo-testaceis, maculis 2 ocularibus frontis, angulis posticis prothoracis, maculis 2 marginalibus elytrorum flavo-albidis; femoribus anticis interne, posticis apice albidis; prothorace subtiliter elytrisque sut fortiter punctatis, his parce pubescentibus. - Long. 4-6,5 $\mathrm{mm}$.

Mas: thorace linea transversa flavo-albida pone marginem anticum, ventre segmentis 3 ultimis connatis.

Gebl. Ledeb. Reis. II. 3. 201. - Harold Berl. Zeit. 1873. 163. Cr. flavoguttatus Suffr. Mon. II. 180; VIII. 120. - Redtb. Faun.

A. II. 464 .

V ar. a. Fronte immaculata.

Var. b. Maculis elytrorum conjunctis.

Var. c. eburatus: Elytris flavescentibus, fascia lata transversa ante medium maculaque pone medium nigro-coeruleis.

Der Käfer, welcher durch die Färbung etwas an marginellus erinnert und von Suffrian in eine Gruppe mit demselben gestellt wurde, ist den Arten der zweiten Reihe durch die schmale Körper- 
form und die leicht behaarten Fld. eben so nahe verwandt, als lateralis $^{1}$ ) und deshalb hier anzuschliessen.

Dunkelblau bis schwarzgrün, oberseits glänzend, 4 Flecke auf dem Unterkopfe, je einer in der Grube unter dem Auge und einer dicht daneben an den Seiten des Kopfschildes (beim ô öfter zu einer Makel vereint, die das ganze Kopfschild einnimmt), die Basis der schwarzen Fühler und die Vorderschienen nebst allen Tarsen (wenigstens unterseits) röthlichgelb; 2 Stirnmakeln an den Augen, ein längliches Fleckchen in den Hinterecken des Halssch., zwei Randmakeln jeder Fld., die eine längs der weisslichen Epipleuren, die andere quer in der Spitze, sowie die Unterseite der Vorderschenkel und eine Makel vor der Spitze der Mittel- und Hinterschenkel weissgelb. Halssch. wenig breiter als lang, stark gewölbt, fast cylindrisch, wenig dicht und sehr fein punktirt. Schildehen länglich-viereckig, fast glatt. Fld. dicht und mässig stark, leicht runzelig-punktirt, die feine Behaarung meist nur vor der Spitze deutlich.

Das ô hat eine schmale gelbe Linie dicht hinter dem Vorderrande des Halssch., welche mitunter noch ein Stück am Seitenrande nach hinten läuft, ohne die Makel in den Hinterecken zu erreichen. Segment 2 des Bauches in der Mitte unter dem ersten verborgen, 3 und 4 mit dem letzten, fast gleichmässig gewölbten, verwachsen. Penis gleichbreit, vorn einfach abgestutzt.

Nicht selten verlöschen die Stirnflecke ganz (Var. a), oder die Makeln der Fld. verbinden sich durch einen schmalen Saum am Seitenrande (Var. b), oder sie dehnen sich so aus, dass die Fld. weisslichgelb werden und nur eine breite, gemeinschaftliche, schlecht begrenzte Querbinde dicht hinter der Basis und eine Makel hinter der Mitte schwarzblau bleiben. Die Makel hängt oft durch einige dunkle Linien mit der Querbinde zusammen und berührt zuweilen die Naht, kann sich jedoch auch (nach Suffrian 1. c. 120) in unregelmässige Längslinien aufösen (Var. c).

Das Vorkommen der Art in Oesterreich, nach Olivier, Suf. frian etc., ist nicht verbürgt; sie könnte sich an der Donau zwischen Wien und Pressburg finden, da sie H. v. Hopffgarten bei Komorn sanmmelte. Von hier aus zieht sich ihr Verbreitungsbezirk östlich durch die Donaustaaten und Südrussland bis Sibirien.

1) Cr. lateralis Suffr. (Mon. VIII. 108). Cylindriseh, metallisch schwarzgrün, Fühlerwurzeln, Schenkelspitzen, Schienen und Tarsen nebst einem breiten Aussenrandsaume der Fld. rothgelb. L. 2,5-3,3 mm. Krim. Sarepta.

Variirt a. Hinterecken des Halssch. fein rothgelb, b. Seitensaum der Fld. hinter der Mitte breit unterbrochen.

VI. 


\section{Reihe. Verwandte von $\mathrm{Cr}$. laetus.}

22. Cr. Ineths 1 : Nigro-viridis, supia subtilissime, subtus dense pubescens, capite thoraceque auro-viridibus, hoc crebre punctato. margine laterali testaceo, antennis basi, tibiis elytrisque testaceis, his minus crebre punctatis, interstitiis alutaceis, maculis $3(2$, i) nigris aut nigro-aeneis. - Long. 4-5 $\mathrm{mm}$.

Mas: segmento 5:o ventrali longitudinaliter deplanato.

Fabr. Ent. Syst. I. 2. 54. - Suffr. Mon. II. 46. - Seidl. F. balt. 474 . - Redtb. Faun. A. II. 457.

Var. a. Maculis 2 anterioribus elytrorum connatis.

Var. b. Elytris puncto libero interne a macula postica separato.

? Chrysomela salisburgensis Moll. Füessl. Neu. Mag. II. 1. 43. Var. c. Macula secunda elytrorum deficiente.

Var. d. Elytris puncto humerali nigro.

Dunkelgrün, Kopf, Halssch., Schildchen und Afterdecke lebhaft goldgrün, die Basalhälfte der kurzen, schwarzen Fühler, der Seitenrand des Halssch. und die Fld. bräunlich-gelb, letztere mit drei

1) Hierher noch folgende Arten:

1. Cr. regalis Gebl. (Ledeb. Reis. II. 3. 206; pilosus Baly Trans. ent. Soc. 1873. 90). Das sparsamer punktirte Halssch. und die Beine einfarbig grün; die 3 Makeln der Fld. lebhaft grün, oft der Länge nach verbunden, selten die ganzen Fld. einnehmend $=\mathrm{v}$. mutatus $\mathrm{Kra}$ atz (Deut. Zeit. 1879. 262). Körper (hypochoevidis ähnlich) dunkelblau, Fld. violett: v. dauricus (Daurien, Faust). - L. $5 \mathrm{~mm}$. Ostsibirien. Japan.

2. Cr. rugicollis Ol. (Enc. méth. VI. 611; Suffr. II. 41). Stärker als laetus behaart, schwarz, leicht blau oder grün schimmernd, Fld. rothoder gelbbraun, mit 3 schwarzen Flecken $(2,1$, der hintere länglich, nie quer). Halssch. sehr dicht nadelrissig punktirt. Die dreieckige Spitze des Penis kürzer und breiter, als bei laetus. - L. $4 \mathrm{~mm}$. Umgebung des Mittelmeeres.

Die Zeichnung der Fld. sehr variabel. Dieselben sind a. einfarbig gelbbraun, oder besitzen b. einen Schulterpunkt (= humeralis O1. Fabr.) ausserdem c. eine Makel näher dem Schildchen oder d. hinter der Mitte; e. 3 Makeln. Von diesen fliesst f. Schulterpunkt und Hintermakel in eine Längsbinde zusammen, mit welcher sich g. auch die Vordermakel vereinigt. Zuletzt sind h. die Fld. schwarz, Epipleuren, Spitze und ein Fleckchen an der Basis gelb, (二 vermeosus Suffr. Mon. II. 43) oder i, einfarbig schwarz. Stücke mit feiner punktirtem, glänzendem Halssch. bilden die Var. sexnotutus Fabr. (Ent. Syst. I. 2. 53) mit der virgatus Suffr. (II. 43) identisch ist, während W'agneriKüst. (II. 95) die Abänderung bezeichnet, welche anf den Fld. nur den Schulterpunkt besitzt.

3. Cr. baeticus Suffr. (Mon. II. 38). Wie der vorige, Fld. kirschroth, ausser den 3 schwarzen Makeln noch mit einem vorn und hinten erweiterten schwarzen Nahtsaume. - L. 4,5. Andalusien. Algier. 
schwarzen Makeln: die erste auf der Schulterbeule, die Basis nicht berührend, die zweite, kleinere, näher dem Schildchen, die dritte, meist grün schimmernde, gross, quer viereckig, hinter der Mitte. Kopf fein punktirt, Kopfschild manchmal messingglänzend. Halss ch. gewölbt, stark zusammengedrückt, die Seiten sehr schmal gerandet, oben sparsam, weiss, anliegend behaart, dicht und kräftig punktirt, glänzend, oder äusserst dicht punktirt, fast matt. Der gelbe Seitensaum ist an den Hinterecken etwas erweitert und zieht sich vorn noch ein Stück am Vorderrande herauf. Fld. weniger dicht als das Halssch. punktirt, deutlicher behaart, die $Z$ wischenräume der Punkte verschieden stark lederartig gerunzelt und dem entsprechend meist mit geringem Glanze. Beine ziemlich kräftig, Schienen und Tarsen theilweise oder ganz trüb gelbbraun.

§. Letztes Bauchsegment in der Mitte der Länge nach niedergedrückt, fein punktirt und glänzend. - Penis gekrümmt, vorn einfach scharf zugespitzt.

Auf den Fld. bilden die beiden Vordermakeln zuweilen eine abgekürzte Querbinde (Var. a), oder von der verkleinerten Hintermakel ist innen ein Fleck abgelöst (Var. b. Die Fld. besitzen entweder $3(1,2)$ oder $4(2,2)$ Makeln), oder es verschwindet der innere Vorderfleck (Var. c), endlich auch die Hintermakel, so dass nur der Schulterpunkt übrig bleibt (Var. d).

Auf gelbblühenden Pflanzen (Leontodon, Helichrysum, Hieracium etc.) in der östlichen Hälfte des Gebietes ziemlich selten. Ostwärts bis Sibirien.

Cr. salisburgensis Moll. liesse sich mit Sicherheit auf diese Art beziehen, wenn nicht die Schlussbemerkung, dass die 4 Makeln der Fld. eine ähnliche Zeichnung wie bei Saperda scalaris (? 1, 1, 1, 1) bilden sollen, dagegen zu sprechen schiene.

\section{Reihe. Verwandte von Cr. Schäfferi.}

Proctophysus Redtb. Faun. Austr. 1849. 564.

23. Cr. Schäferi ${ }^{1}$ ): Pilosus, coeruleo-violaceus, supra interdum viridiaeneus, antennis nigris, basi rufo-testaceis, facie, macula alba infra antennas notata, tuberculis 2 instructa, fronte subconvexa, vage canaliculata, thorace parce elytrisque crebre punctatis. - Long. 5-6,5 mm.

1) Hierher gehört:

Cr. Wehnchei: $\hat{6}$. Pilosus, coeruleo-violaceus, viridr-micans, antennis compressis, apicem versus fortiter attenuatis, nigris, basi rufo-flavis, facie macula alba infra antennas notata, tuberculis 2 instructa, thorace minus dense, elytrisque crebre punctatis, his macula parva rufa laterali ante apicem. Tibiis posticis interne apicem versus in lobum subquadratum pro- 
Mas: Antennis compressis, apicem versus fortiter attenuatis, pedibus viridi-coeruleis, tibiis posticis interne ante apicem lobo rhomboidali producto, ventre seymentis 3 ulimis connatis, segmento primo in lonyum apicem subacutum protracto, carinato, carina simplici et ad ultimum fere finem apicis pertinente.

Fem: Elytris apice pedibusque rufo-testaceis, pygidio canaliculato, emarginatura apicali lata, profunda.

Schrank Naturf. XXIV. 69, - Schneider Neu. Mag. I. 2. 212.

仓ิ Cr. lobatus Fabr. Ent. Syst. I. 2. 63. - Panz. Faun. Germ. 13. 9. - Suffr. Mon. II. 143; VIII. 114. - Redtb. Faun. A. II. 456 (Proct.).

Cr. unicolor OI. Enc. méth. VI. 608.

오 Cr. haemorrhoidalis 01. 1. c. 608. - Panz. 1. c. 68. 14.

Var. a: (q) Femoribus intermediis infuscatis, posterioribus nigro-aeneis apice rufis.

๙. Ziemlich breit, dunkelblau, der Kopf stets, öfter das Halssch., selten auch die Fld. metallisch grün, der ganze Körper mit langen, abstehenden grauen Haaren besetzt. Kopf mit pechbraunen oder röthlichen Mundtheilen und einer grossen weissen Makel unterhalb der Augen, die Stirn deutlich gewölbt und durch eine breite, kurze, aber wenig tiefe Mittelfurche getheilt; dicht über der Fühlerwurzel befindet sich ein Quereindruck, vor welchem sich, zwischen den Fühlern, zwei scharf begrenzte, glänzende Höcker erheben. Fühler länger als der halbe Körper, schwarz, die ersten 5 Glieder rothgelb, das 3. bis 5. oberseits meist gebräunt, Glied 1 lang, gekrümmt, dick, 2 schmal, in der vorderen Hälfte plötzlich dreieckig erweitert, die folgenden stark zusammengedrückt, Glied 3 fast so lang als das erste, am Grunde schmal, nach der Spitze gradlinig verbreitert, 4 bis 6 breit, das 5 . etwas länger als die einschliessenden, die übrigen, vom siebenten an, unter sich gleichlang, allmählich

ductis, ventre segmentis :3 ultimis connatis, segmento 5:0 late excavato, 1:0 in longum apicem subacutum protracto, carinato, carina ad ultimum finem apicis pertinente, in fine bifariam divisa. - Long. 5,5 mm. Taurus.

Von Schäfferi durch etwas dichtere und stärkere Punktirung des Halssch, einen rothen Fleck in den hinteren Aussenecken der Fld, dicht am Seitenrande derselben, den fast quadratischen, nach unten nicht in eine Spitze ausgezogenen Schienen-Anhang, besonders aber durch den Längskiel des 1. Hinterleibssegmentes ausgezeichnet. Dieser ist vorn sehr scharf und schmal, allmählich verbreitert und gabelt sich zuletzt in 2 dicke, fast wagerecht abstehende, nach unten gekrümmte Zähne.

Ein $\hat{.}$, von Lederer gesammelt, von Suffrian als lobatus bestimmt, erhielt ich von H. Wehncke in Harburg, nach dem ich die Art mir zu benennen erlaube. 
wieder schmaler. Halssch. kurz, mässig gewölbt, nur vorn zusammengedrückt, der schmal abgesetzte Seitenrand bis zur Hälfte nach vorn von oben sichtbar; die Oberfläche ziemlich weitläufig und nicht fein punktirt, glänzend. Fld. dicht und stark querrunzeligpunktirt. Beine einfarbig blau oder blaugrün, Tarsen schwarz, unterseits oft bräunlich, oder die Vorder- und Mittelschienen auf der Innenseite, zuweilen auch die Spitze der Hinterschienen röthlich. Die letztere ist nach innen in eine grosse, rhombische Schaufel erweitert.

Von den Bauchringen sind die drei letzten mit einander verwachsen, der zweite ist in der Mitte sehr schmal und unter dem ersten verborgen; dieser selbst verlängert sich nach hinten in einen zahnartigen, blauen Mittelzipfel, welcher ein Stück vor dem Hinterrande des letzten Segmentes in einer kleinen, leicht nach unten gebogenen Spitze endet und, wie das ganze Segment, mit einem hohen, schwarzen, in der hinteren Hälfte quer-gerieften Längskiele belegt ist. Derselbe beginnt schmal und scharf zwischen den Hinterhüften, erweitert sich allmählich fast bis zur Breite des Mittelzipfels und läuft ebenfalls in eine kurze Spitze aus. Das letzte Segment besitzt eine weite und tiefe, aber nicht scharf gerandete Grube, in welche vom Vorderrande her his zur Mitte eine schwarze, matte, mit einer Mittelrinne versehene Längswulst hineinzieht, auf der sich die sie verdeckende Verlängerung des ersten Segmentes bequem einlagern kann.

Penis dick, oben schwach abgeplattet, die Seiten der Oeffnung plötzlich in einen grossen ohrförmigen, unten gerundet-zugespitzten Lappen verbreitert, dessen dreieckiger Innenzipfel in die Oeffnung gebogen ist. Auf der Unterseite des Penis befindet sich ein sehr hoher Längskiel, der weit über den graden Vorderrand als ein langer und dicker Zahn hinausreicht.

ㅇ grösser und breiter als das $\hat{\sigma}$, glänzender, die Höcker zwischen den Fühlerwurzeln weiter getrennt, die Fühler fast fadenförmig, Glied 2 bis 5 sehr scbmal, die folgenden etwas breiter; die ganze Spitze der Fld., mit Ausnahme eines feinen Naht- und Seitensaumes, sowie die einfachen Beine röthlichgelb. Pygidium mit tiefer Mittelrinne und einem breiten Ausschnitte an der Spitze; erstes Hinterleibssegment längs der Mitte kielartig erhöht.

Von Abänderungen ist nur eine Form des $q$ bekannt, bei der die Mittelschenkel angedunkelt und mit schwarzer Rückenlinie versehen, die Hinterschenkel bis kurz vor die Spitze schwarzgrün sind.

In Mittel- und Süddeutschland oft zahlreich auf Gebüschen, besonders blühendem Crataegus. 
24. Cr. cyamipes: Pilosus, coeruleo-violaceus, antennis nigris, basi ferrugineis, facie, macula alba infra antennas notata, tuberculis 2 vix discretis instrucla, fronte subconvexa, haud canaliculata, thorace parce elytrisque crebre punctatis, pedibus viridi-coeruleis. - Long. 5,5-7 mm. Mas: omnino ut in Cr. Schäfferi, sed antennis compressis longioribus, apicem versus minus attenuatis.

Fem: elytris apice macula transversa rufo-testacea, pygidio canaliculato, emarginatura apicali angusia profunda.

Suffr. Mon. II. 146; VIII. 115. - Mars. Mon. 133.

Sehr ähnlich der vorigen Art, aber durch folgende Punkte zu unterscheiden: $\hat{o}$ oft grösser als das 우 Stirnfurche kaum angedeutet, Höcker zwischen den Fühlerwurzeln durch eine Querwulst ersetzt, welche in der Mitte leicht eingeschnitten ist, Fühler bedeutend länger und schlanker, Glied 3 bis 6 kaum halb so breit, aber länger als bei Schäfferi, unter sich gleichbreit, jedes einzelne von der Basis zur Spitze allmählich erweitert, die folgenden schlank, nach und nach verdünnt. Die zahnförmige Verlängerung des ersten Segmentes schmaler, der Längskiel bis hinten scharf, glatt, nicht quer gestrichelt. In die Grube des letzten Segmentes zieht sich eine breite und tiefe Längsrinne hinein, deren Ränder leistenförmig erhaben sind; der Kiel auf der Unterseite des Penis ist weniger hoch, nicht halb so breit und über den Vorderrand mindestens doppelt so weit verlängert als beim vorigen.

Die $q$ sind leichter an den blauen oder grünlichen Beinen, deren Schienen und Tarsen, wie beim $\hat{\jmath}$, auf der Innenseite meist verwaschen gelbbraun gefärbt sind, und an der gelben Makel der Fld. zu erkennen, die am Hinterrande einen blauen Saum frei lässt. Der Ausschnitt der Afterdecke ist schmal.

Am Ortler in Tirol. Ausserdem bei Ardetz im Engadin, im Tessin und bei Siders selten (Stierlin); häufiger am Aufstiege auf den Mt. Cenis, an der italienischen Seite.

Die Farbe der Fühler, durch welche Marseul a. a. O. beide Arten trennt $(\hat{\odot}$, die ersten 4 Glieder rothbraun, + Glied 2 und 3 etwas röthlich"), bietet bei meinen Exemplaren keine Verschiedenheit dar.

25. Cr. villosulus: Pilosus, coeruleus, anternis lomgis, filiformibus, vigris, basi tibiisque anticis interne rufo-testaceis, prothorace minus dense elytrisque crebre punctatis. - Long. $4 \mathrm{~mm}$.

Mas: segmento 5:o medio deplanato.

Fem: elytris apice macula rufo-testacea transversa.

Suffr. Mon. II. 148. - Redtb. Faun. A. II. 459.

§. Dunkelblau, deutlich lichter als Schäfferi, mit sehr langen, aufstehenden, bräunlich-grauen Haaren besetzt. Auf dem Kopfe 
eine kleine, weisse Makel unter jedem Auge, die Stirn flach, über der Fühlerwurzel jederseits ein schiefes Höckerchen. Fühler fast von der Länge des Körpers, dünn, gleichbreit, ihre 5 oder 6 ersten Glieder rothgelb, die folgenden schwarz. Halssch. vor dem Hinterrande deutlich quer-vertieft, mässig dicht, die Fld. dichter und weit stärker punktirt. Beine blau, Schienen und Tarsen schwärzlich, letztere unterseits verwaschen gelbbraun, wie die Innenseite der Vorder - und die Spitze der Mittelschienen. Bauch normal, Segment 5 breit, in der Mitte flach gedrückt. - Penis schmal, flach, gekrümmt, mit scharf dreieckiger Spitze, deren Seiten leicht gerundetausgeschnitten sind.

Das of hat kürzere Fühler und vor der Spitze der Fld. einen kleinen rothgelben Querfleck, welcher von einem blauen Hintersaume umzogen wird. Pygidium ohne Ausrandung.

Der Käfer ist durch Kleinheit, hellere Färbung, schlanke Fübler des $\hat{o}$ und den einfachen Hinterleib desselben, sowie die normal gebaute Afterdecke des 우 von den verwandten Arten leicht zu trennen.

In Steiermark (Gatterer), bei Wien (nach Redtenbacher auf jungen Eichen) und in Ungarn selten.

5. Reihe. Verwandte von $C r$. sericeus.

26. Cr. sericeus: Viridi-sericeus, prothorace confertim punctato, angulis posticis acutis, elytris confertissime subrugoso-punctatis, prosterni processu postice bidentato. - Long. $6-7,5 \mathrm{~mm}$.

Mas: segmento ultimo ventrali ante apicem trunctatum impresso vel deplanalo, basi crista transversa bidentata armato.

Fem: segmento ultimo apice subtruncato.

Linn. Syst. Nat. ed. X. 374 (Chrysom.). - Suffr. Mon. II. 129;

III. 106. - Redtb. Faun. A. II. 459. - Thoms. Skand.

Col. VIII. 292. - We is e Entom. Monatsblätter II. 75.

Cr. bidens Thoms. 1. c. X. 274.

Cr. aureolus Seidl. Faun. balt. 475 .

Var. a. $(\hat{\odot})$ Crista segmentis quinto haud bidentala.

Var. b. Aureus.

Cr. pratorum Suffr. Mon. II. 131.

Var. c. Viridi-coeruleus vel coeruleus.

Cr. coeruleus Ziegl. i. coll.

Var. d. Cyaneus vel violaceus, interdum subopacus.

Var. e. Nigro-viridis, cupreo-micans.

Var. f. Purpurascens.

Var. g. intrusus: Robustior, laete viridis, subopacus, prothorace dense subtilissime elytrisque crebre subtiliter punctalis, his vix rugosis, basi 
foveis 2 latis, profundis, pedibus validis: maris segmento ullimo rentrali postice fovea transversa insiructo. - Long. $7-8 \mathrm{~mm}$.

Cr. intrusus Meg. i. litt. - Suffr. Mon. II. 137 pars.

? Cr. zambanellus Mars. Mon. 130.

Var. h. Ut in I/, sed viridi-coeruleus, nigro-coeruleus, cupreus vel purpurascens.

Kurz, plump, metallisch-grün mit Seidenschimmer; Fühler kurz, schwarz, das erste Glied lebhaft, die folgenden drei schwächer wie der Körper gefärbt, Glied 1 gekrümmt, 2 fast kugelig, 3 um die Hälfte länger als 2, aber etwas kürzer als 4, die folgenden gestreckt, unter sich ziemlich gleichlang oder das 5. wenig länger als eins der übrigen. Halssch. nach vorn und an den Seiten stark gewölbt, am Hinterrande jederseits vor dem Schildchen mit einem mehr oder weniger tiefen, selten ganz fehlenden Eindrucke, einem Grübchen in der Nähe der Mitte und einer leichten Schrägvertiefung auf der seitlichen Wölbung; Seitenrand (von der Seite betrachtet) deutlich, wenn auch schwach verkehrt $\mathrm{S}$-förmig gekrümmt, die Hinterecken in eine scharfe Spitze nach unten ausgezogen; die Oberfläche mit Ausnahme der schmalen Mittellinie gleichmässig, wenig fein und sehr dicht punktirt, mit einzelnen äusserst feinen Pünktchen in den Zwischenräumen. Schildchen länger als breit, stark punktirt, die Mittellinie fast glatt. Fld. am Grunde mit den gewöhnlichen zwei Vertiefungen (die schwächere am Schildchen, die tiefere an der Innenseite der Schulterbeule) nach hinten leicht verschmälert, sebr dicht und ziemlich stark punktirt. Die Punkte bilden meist undeutliche, doppelte Längsreihen, ihre Zwischenräume theils feine Querrunzeln, theils unregelmässige, erhabene Längslinien, besonders in der Nähe der Naht und des Seitenrandes. Vorderbrust zwischen den Hüften breit, am Hinterrande eingedrückt und gerundet oder dreieckig ausgeschnitten, die Seiten der Ausrandung als 2 kurze, stumpfe Zähnchen auf die Mittelbrust gezogen.

§. Letzter Bauchring quer eingedrückt, der Eindruck, welcher bald mässig tief, an den Seiten deutlich begrenzt, bald ganz flach und kaum bemerkbar ist, wird vorn von einer scharf erhabenen Querleiste geschlossen, welche eine Mittelrinne in zwei zahnartige Höcker theilt. Der Hinterrand des Segmentes ist in der Mitte abgestutzt und durchaus grade. - Penis kräftig, der Unterrand der Oeffnung winkelig in ein Dreieck verschmälert, dessen breite Spitze leicht nach unten umgebogen ist.

Bei den merklich grösseren $\rho$ ist der Hinterrand des letzten Segmentes ähnlich gebildet als beim $\hat{\jmath}$, in der Mitte fast grade, oder nur schwach in einem weiten Bogen ausgerandet. 
Eine bedeutende Abänderung (a) findet sich beim $\hat{\sigma}$, dessen Querleiste an der Basis des letzten Bauchringes zuweilen keine Spur einer theilenden Mittelrinne zeigt; sonst variirt nur das Colorit des Halssch., der Fld. oder des ganzen Körpers. Im letzteren Falle dürften vielleicht noch 5 Farbenreihen zu beachten sein: das normale, leicht goldige Grün wird b. brennend goldgelb, c. blaugrün oder licht himmelblau, d. kornblumen- oder veilchenblau, e. dunkelgrün, mit lebhaftem Kupfersehimmer und f. purpurroth. Die Fld. sind bei d. fast ohne Glanz, bei e. tritt die tief-kupferrothe Farbe nur in gewisser Richtung und oft nur in getrennten Flecken deutlich hervor.

Besondere Wichtigkeit für die Abgrenzung der Art muss der Var. g. beigemessen werden. Dieselbe ist im Allgemeinen kräftiger als unsere norddeutsche Form gebaut, das Halssch. wenig weitläufiger, aber sehr fein punktirt, die Zwischenräume sind dicht mit äusserst feinen Pünktchen besetzt, ziemlich matt, die Eindrücke vor dem Schildchen, wie die an der Basis der Fld, weit und tief. Auf den Fld. stehen die Punkte sehr dicht, oft in deutlichen Reihen beisammen, ihre Zwischenräume sind punktulirt, wenig glänzend und kaum oder höchst selten zu wenigen feinen Querrunzeln verbunden. Schenkel und Schienen breit und kräftig. Einen ganz abweichenden Bau zeigt der letzte Bauchring des $\widehat{\sigma}$. Derselbe besitzt eine tiefe, scharf markirte Quergrube, deren Vorderrand von der Basis des Segmentes viel weiter als bei sericeus entfernt bleibt, in einer Ebene mit der gewölbten Fläche des Bauchringes liegt und weder eine Querleiste, noch Höckerchen, höchstens die Andeutung einer Rinne in der Mitte besitzt. Die Farbe ist grün, blau, kupfer-oder purpurroth; goldgrüne oder veilchenblaue Stücke scheinen ganz zu fehlen.

Auf Compositen im ganzen Gebiete; in der norddeutschen Tiefebene gemein. Die Varietäten $a, b, c$, e und $f$ sind seltener, $g$ und $\mathrm{h}$ sind mir nur von Triest (Wehneke), aus Croatien und Dalmatien (Reitter) bekannt, möchten sich aber auch bei Wien, wie überhaupt in Süddeutschland und Südeuropa finden, da die von Redtenbacher (l. c. 458) in der Anmerkung erwähnte rzweite Form" wohl sicher hier untergebracht werden muss.

Wie schon von Suffrian (l. c. 140) hervorgehoben wurde, darf Linné's Chrysomela sericea nur auf einen Käfer bezogen werden, der, wie der vorliegende, ebenso oft blau als grün vorkommt. Da nun blaue Cr. hypochoeridis zu den grössten Seltenheiten gehören, die Chrys. hypochoeridis Linn. vielleicht gar kein Cryptocephalus ist (der Nachweis dürfte schwer zu führen sein, da in Linné's Sammlung nach Schaum (Suffr. Mon. III. 106) eine Chrys. hypochoeridis nicht existirt), scheint es bedenklich, Herrn v. Ha rold 
zu folgen, der in Münchener Cataloge die vorliegende Art als hypochneritis Linn. aufführt.

Der mir unbekannte Cr. robustus Suffr. (Mon. VIII. 113) vom Kaukasus, dessen Halssch. und Fld. fein punktirt und glänzend sind, während die Grube des letzten Bauchringes beim $\hat{\epsilon}$ schwächer, durch eine Längserhöhung in 2 Grübchen getheilt und vorn von 2 weniger höckerig hervortretenden Zähnchen begrenzt ist, lässt sich nicht von sericers trennen.

28. Cr. ameolus ${ }^{y}$ : Brevior, viridi-sericeus, prothorace confertim plerumque subtiliter punctato, anyulis posticis fere rectis. elytris fortius rugoso-punclatis, prostermi processu postice truncato. - Long. $5,5-7,5 \mathrm{~mm}$.

Mas: segmento ultimo ventrali ante apicem emaryinatum varge transversim impresso.

Fem: segmento ultimo apice profunde emarginato.

Suffr. Mon. II. 132. - Thoms. Skand. Col. X. 275.

Cr. sericeus Küst. Käf. Eur. III. 86. - Seidl. F. balt. 475.

Var. a. Aureus.

Var. b. Viridi-coeruleus vel violaceus.

Var. c. Nigro-viridis, cupreo-micans vel purpurascens.

Var. d. Prothorace sublaevi.

Dem vorhergehenden täuschend ähnlich, jedoch merklich kürzer und breiter, daher plumper gebaut, durch folgende Punkte zu unterscheiden: das Halssch. ist kürzer, nach vorn (von oben und hinten betrachtet) stark verschmälert, die Wölbung nach den Seiten hin viel geringer und mit tieferen Schrägeindrücken versehen, die Vertiefungen vor dem Schildchen gewöhnlich flacher, der Seitenrand (bei der Seitenansicht) fast grade, nur dicht ror den beinahe rechtwinkeligen, kuræen Hinterecken leicht gekrümmt, die Punktirung der Oberfläche oft etwas weitläufiger und feiner. Die Fld. sind gleich-

1) Vor diese Art ist zu stellen:

Cr. globicollis Suffr. (Mon. II. 141; VIII. 112). Farbe, Bildung der Vorderbrust und des Hinterrandes vom letzten Bauchringe wie bei sericeus; indessen viel feiner punktirt, glänzender, mit einem auffällig grossen, breiten und kugelig-gewölbten Halssch. (der Rücken desselben ist fast so breit als die nach hinten verschmälerten Fld. an der Schulter). $\hat{\theta}$ Eindruck auf Segment 5 und Penis ähnlich dem von aureolus. - L. $6,5-8 \mathrm{~mm}$. Bei Nizza und Marseille häufig; seltener in Italien, Spanien und Algier.

Hiervon sondert Marseul seinen Cr. zambanellus, vom Mt. Zambano, ab. Da die Beschreibung ohne Zwang auf sericens var. g. angewandt werden kann, der Autor auch einen sericeus $\hat{\oplus}$ ohne Querhöcker oder Zähnchen nicht anführt, habe ich zambanellus fraglich unter genannter Var. citirt. Mit Sicherheit lässt sich dies insofern nicht thun, als Marseul die ,fovéole dans sa moitié postérieure", beim $\hat{e}$, nur légère nennt. 
breit oder nach hinten schwach verbreitert, nie verengt, durchgängig tiefer und stärker punktirt und kräftiger quer gerunzelt, meist mit höheren gewölbten Längslinien, besonders vor der Spitze, besetzt. Vorderbrust in der Mitte des Hinterrandes grade oder mit einem äusserst flachen Ausschnitte, dessen Seiten vollständig abgerundet sind.

Beim $\delta$ ist der Hinterrand des letzten Bauchringes schwach, doch deutlich dreieckig ausgerandet, vor demselben befindet sich ein schmaler, flacher Quereindruck, welcher vorn allmählich in die Ebene des Segmentes übergeht, oft wie aus 2 Quergrübchen zusammengesetzt erscheint, oft aber auch kaum wahrnehmbar ist. - Penis weniger gewölbt, der Unterrand der Oeffnung gerundet in ein längeres Dreieck verschmälert, dessen schmale Spitze sich leicht nach unten umbiegt.

Hinterrand des letzten Bauchsegmentes beim $q$ in der Mitte tief dreieckig ausgeschnitten.

Die Färbung ist im Ganzen der vorigen Art ähnlich und ändert eben so ab als diese, nur scheint die goldrothe Var. a noch seltener zu sein; die blaugrünen oder violetten Stücke (Var. b), deren Fld. nicht so matt als bei sericeus werden, sowie die dunkelgrünen, kupferschimmernden oder purpurfarbenen Exemplare sind vorzugsweise in Süddeutschland und Südeuropa gefunden worden.

Die Skulptur des Halssch. ist weit veränderlicher als die der Fld. Auf diesen verschwinden zuletzt die Querrunzeln, aber die Punkte bleiben stark und tief; dagegen ist das Halssch. der am feinsten punktirten süddeutschen Stücke, die oft für globicollis bestimmt werden, fast spiegelglatt und nur weitläufig mit kaum sichtbaren Pünktchen versehen (Var. d).

Auf Compositen in ganz Deutschland; bei Berlin einige Wochen früher als sericeus.

Die Aehnlichkeit der zwei vorstehenden Arten ist so gross, dass die Berechtigung beider bisher manchem Zweifel begegnete. Ich selbst war geneigt (Kratz Entom. Monatsbl. II. 75) den aureolus für eine Form von sericeus zu halten, bei deren $\hat{\odot}$ die zweizähnige Querleiste des letzten Bauchringes rerschwunden ist. Allein eine durch die zwei letzten Sommer fortgesetzte Beobachtung der Thiere gab mir die Gewissheit, dass die Vereinigung beider Arten ebenso unzulässig, wie die sichere Unterscheidung, auch der $f$, möglich ist. Normal gebaute $\hat{\odot}$ sind ohne Mühe durch die Bildung des letzten Bauchsegmentes zu trennen. Bei der Bestimmung von sericeus var. intrusus (ohne Höckerchen oder Querleiste) ist besonders zu beachten, dass der Eindruck des letzten Segmentes grösser, deutlicher begrenzt und vorn viel tiefer als bei aureolus $\hat{\epsilon}$ ist, während der Hinterrand des Segmentes in der Mitte durchaus grade verläuft. Schwieriger sind die $f$ aus- 
einander zu halten. Die schwache seitliche Wölbung des kurzen Halssch., grob punktirte Fld., die hinten abgestutzte Vorderbrust und der tiefe, dreieckige Ausschnitt des Hinterrandes am letzten Bauchringe kennzeichnen aureolus, die starke seitliche Wölbung des längeren Halssch., mässig grob punktirte Fld., die hinten zweizähnige Vorderbrust und der grade oder in einem weiten, flachen Bogen ausgeschnittene Hinterrand des letaten Bauchringes sericeus. Zwischenstufen in der eben erwähnten Bildung des Hinterrandes sind seltener als ich (1. c. Anmerkung, wo die Namen sericeus und aureolus zu vertauschen sind) vermuthete, und würden mit Hülfe der übrigen Merkmale immer sicher unterzubringen sein.

28. Cr. Hypochoeridlis $\left.{ }^{1}\right):$ Supra viridi-sericeus, subtus virescens, prothorace confertim punctato, elytris fortiter subrugoso-punctatis, prosterni processu postice subtruncato, pygidio apice emarginalo plerumque carina media instructo, scutello subtransverso. - Long. 4-5,5 mm. Mas: segmento ultimo ventrali ante apicem subemarginatum late et minus profunde impresso, linea elevata nigra marginis postici medio dilatata. Hem: fovea segmentis 5 : o parum nitida.

Linn. Syst. Nat. ed. X. 370 (Chrysomela). ? - Suffr. Mon. II. 137. - Thoms. Skand. Col. VIII. 292. - Redtb. Faun. A. II. 459 . - Seidl. F. balt. 475 .

Cr. sericeus F abr. Syst. Ent. 109; Ent. Syst. I. 2. 63. - Thoms. 1. c. X. 275 .

Var. a. Pygidio apice truncato.

Var. b. ( $\hat{\odot})$ Ventre segmento ultimo late longitudinaliter, basin versus paulo fortius impresso, impressione basi transversim elevato-terninato. Cr. cristatus Duf. Excurs. Vall. d'Ossau 112. - Suffr. Stett. Zeit. 1849. 19; Mon. VIII. 112.

1) Hierher 1. Cr. asturiensis Heyd. (Reis. Span. 166). Schwarz, Oberseite mit grünem oder bläulichem Bronzeschimmer. Halssch. fein punktirt, stark glänzend, länger und gewölbter als bei hypochoeridis. Fld. grob und dicht, meist runzelig-punktirt. $\hat{\odot}$. Letates Bauchsegment körnig-punktirt, mit einer allseitig sanft ansteigendeu breiten Querwulst in der Mitte, dahinter ein einfach punktirter, glänzenderer Quereindruck. - L. 4,5-5,5 mm. Asturien. (v. Heyden. Getschmann.)

2. Cr. concolor Suffr. (Mon. II. 127). Schwarz, kaum merklich blau oder grün schimmernd. Halssch. wie beim vorigen gebaut, nicht stärker, aber dichter und leicht nadelrissig punktirt. Punkte der Fld. feiner. $\hat{\hat{~}}$ Letztes Segment auf der hinteren Hälfte mit halbkreisförmiger Grube, deren Vorderrand von einer eben so gebogenen hohen und scharfen Leiste umsäumt wird. Vor dieser Leiste ist eine grade Querrinne und vor dieser eine hohe Querfalte: der Hinterrand des 4. Segmentes. Stücke mit sehr fein punktirtem Halssch. und grob punktirten Fld. sind duplicatus Suffr. (II. 126). L. 5-6 mm. Im Kaukasus weit verbreitet. Klein-Asien (Merkl), Südrussland. 
Cr. cristula Duf. 1. c. 113.

Cr. rugulipennis Suffr. Mon. VIII. 111.

Var. c. Violaceo-vel cupreo-coeruleus.

Thoms. 1. e. VIII. 293. var. b. et e.

Var. d. Nigro-viridis, cupreo-micans.

Mit sericeus weniger, desto näher dem vorigen verwandt, meist breit und plump wie dieser, seltener gestreckt, wie jener, die $q$ von der Grösse der kleinsten $\hat{\sigma}$ des aureolus, die $\hat{\jmath}$ bedeutend kleiner. Oberseite der norddeutschen Stücke goldgrün, der süddeutschen tief bläulichgrün, glänzend, Unterseite, insbesondere die Brust, violettoder schwarzgrün, ziemlich matt. Kopf zwischen den Fühlerwurzeln mit einem breiten und tiefen, bis auf den Scheitel allmählich verengten Eindrucke, Halssch. an den Seiten verschieden stark abwärts gewölbt und meist ohne Schrägeindruck, der Seitenrand fast grade oder kurz vor den Hinterecken leicht nach unten gekrümmt, die Oberfläche dicht, doch weitläufiger, flacher und feiner als bei der nördlichen Form des aureolus punktirt, zuweilen fast spiegelglatt, mit oder ohne zwei Grübchen vor dem Schildchen. Dieses kurz, kaum so lang als an der Basis breit. Fld. stark und dicht punktirt, mit wenigen leichten Querrunzeln und mebr oder weniger (besonders beim $\hat{\jmath})$ deutlich und zahlreich hervortretenden erhabenen Längslinien, zwischen welche die Punkte dann in Reihen gestellt sind. Vorderbrust in der Mitte des Hinterrandes fast grade abgestuzt, mit stumpfwinkeligen Ecken. Pygidium stark quer gewölbt, weitläufig punktirt, glänzend, vor dem Unterrande, der einen verschieden tiefen Ausschnitt besitzt, kaum oder wenig eingedrückt und dicht runzeligpunktirt, auf der unteren Hälfte mit einem feinen, scharfen, oft metallisch gefärbten Mittelkiele, welcher nur selten undeutlich wird. Eine ähnliche Kiellinie haben öfter auch die $q$ der beiden vorigen Arten, sie ist jedoch sehr schwach angedeutet, beginnt meist näher dem Oberrande der Afterdecke und verschwindet vor dem Eindrucke, der sich längs des Unterrandes hinzieht.

3. Letztes Bauchsegment in der Mitte mit einem breiten, wenig tiefen Eindrucke, welcher zuweilen nur vor dem Hinterrande als eine Quervertiefung sichtbar wird, häufiger aber, allmählich verschmälert, bis dicht an die Basis des Bauchringes hinzieht und sich entweder nach und nach verflacht und unmerklich in die Ebene des Segmentes übergeht, oder sich vertieft und von einer scharfen, glatten Querkante oder -Falte (der Naht des vierten Ringes) begrenzt wird (Var. b). Die schwarze, erhabene Linie, welche den Hinterrand des 5. Segmentes bildet und bei aureolus einfach ist, erweitert sich in der Mitte zu einem kurzen und sehr breiten, glänzenden Dreiecke, 
dessen Spitze nach vorn gerichtet ist. - Penis (ron der Seite betrachtet) in der vorderen, winkelig nach unten gebogenen Hälfte flach, allmählich nach der Spitze verschmälert; von hinten gesehen, an der Oeffnung plötzlich gerundet-verengt und in ein deutlich abgesetztes Dreieck ausgezogen.

Das $q$ hat eine einfache, grade oder ausgerandete Hinterrandlinie des letzten Segmentes, die Grube desselben ist zwischen der Punktirung dicht lederartig gerunzelt und daher fast matt.

Farbenabänderungen sind selten. Die Oberseite wird blau und schimmert bei gewissem Lichte grünlich, kupferroth oder violett (Var. c), oder sie ist schwarzgrün, kupferroth angelaufen (Var. d). Weniger als Varietät, wie als die am schwächsten ausgeprägte Form müssen die unter a angeführten Stücke betrachtet werden, bei denen der Unterrand der Afterdecke in der Mitte grade abgeschnitten ist.

Ebenfalls auf Compositen im ganzen Gebiete, aber bei uns noch zeitiger als aureolus.

29. Cr. violaceus ${ }^{1}$ ): Obsure coeruleo-violaceus, prothorace, interdum viridi-micans, subtiliter punctato, scutello subtransverso, elytris ruyosopunctatis, anyulis apicalibus omnino rotundatis. - Long. 4-7 mm.

Mas: segmento 5:o ventrali longitudinaliter deplanato, basi muga elevata, transversa instructo, apice leviter rotundato-producto.

L a i ch. Verz. Tyrol. Ins. 172. - F a br. Ent. Syst. I. 2.62. - Gyllh.

Ins. Suec. III. 607. - S u ffr. Mon. II. 121. - Se idl. F. balt. 475.

Cr. virens Redtb. Faun. A. II. 459.

Var. a. Elytris parum nitidis, obsolete substriato-punctatis, interstitiis creberrime subtilissimeque rugulosis.

Cr. violaceus Redtb. l. c. 458.

Var. b. Violaceus, plus minusve aeneo-micans, vel niger.

Var. c. Viridis, obscure aeneus vel auro-viridis.

Cr. smaragdinus Suffr. 1. e. 124.

1) Mit dieser Art ist vielfach verwechselt worden:

Cr. virens Suffr. (Mon. II. 125). Laete coeruleo-violaceus, capite prothoraceque aeneo micans, hoc parce subtilissime punctato, scutello laevi, elytris minus dense punctatis apice subtruncatis; maris segmento 5:0 ventrali transversin fere semicirculariter depresso, apice truncato. - L. $4,5-5,5 \mathrm{~mm}$. Krim. Sarepta. Sibirien.

Lebhaft himmelblau, selten mit einem Stich in's Grüne, Kopf u. Halssch. grün metallschimmernd, hinterer Aussenwinkel der Fld., die beim $\hat{\odot}$ grob, beim fast verloschen punktirt sind, abgerundet aber deutlich sichtbar. Letztes Segment des $\hat{\odot}$ mit einem schwachen Quereindrucke, welcher vor der abgestutzten Mitte des Hinterrandes eine quere, vorn gerundete Erhöhung unberührt lässt. Alle von mir untersuchten Stücke aus Deutschland, der Schweiz und Ungarn sind grünliche violaceus. 
Schwarzblau, Unterseite und Kopf dunkler, oft fast schwarz und ziemlich matt, das meist grünliche Halssch. und die Fld. glänzend. Ersteres bis zum sehr schmal aufgebogenen, fast graden Seitenrande kugelig gewölbt, sehr fein punktirt, die Punkte rund oder länglich, weitläufig oder dicht gestellt, beim $\widehat{\sigma}$ auf der Vorderhälfte nicht selten zu leichten Längsrunzeln verbunden. Schildchen fast breiter als lang, mit wenigen undeutlichen Punkten. Fld. nach der vollkommen abgerundeten Spitze hin etwas verengt, oben unregelmässig, wenig tief und stark punktirt, Zwischenräume einzeln punktulirt, glänzend, hie und da zu Querrunzeln geordnet; oder die Punkte bilden unordentliche Doppelreihen, zwischen denen schwach erhabene Längslinien hervortreten. Pygidium ziemlich dicht punktirt, wenig glänzend, oft mit einem feinen Längskiele vor dem breit abgerundeten oder abgestutzten Unterrande.

§. Letzter Bauchring längs der Mitte geebnet, nach der Basis hin etwas stärker zu einem Grübchen vertieft, dessen Seiten sich nach vorn allmählich erheben und zu einer kräftigen Querleiste vereinigen. - Penis an der Oeffnung nach und nach in eine breite, sehr schwach nach vorn umgebogene Spitze verschmälert.

Der Käfer variirt in der Skulptur und Farbe. Auffällig ist besonders die Var. a (vorzugsweise $\nmid$ ), bei welcher die Fld. fast matt die Punkte derselben in Reihen gestellt, aber durch die äusserst dichte nadelrissige Runzelung der Zwischenräume undeutlich oder ziemlich verdrängt sind. Die Farbe wird nur selten violett oder schwarz (Var. b), öfter grün, erzfarbig, zuweilen sogar goldgrün (Var. c).

Auf Laubholz in den Gebirgsgegenden ganz Deutschlands.

\section{Reihe. Verwandte von $C r$. nitidus.}

30. Cr. elongatus'1): Subcylindricus, nigro-coeruleus leviter aeneomicans, antennis nigris, basi et tibiis anticis inferne testaceis, thorace parum dense, subtiliter, elytrisque fortiter punctatis. - Long. $3,5-4 \mathrm{~mm}$. Mas: segmento 5:0 postice transversim subdepresso.

Germ.Ins.sp. nov. 557. - S u ff r. Mon. II. 120.—Red tb. F. A. II. 459.

Gestreckt, fast cylindrisch, schwarzblau, oft sehr schwach grün metallschimmernd, mässig glänzend. Fühler lang, doch kräftig, schwarz,

1) Cr. tibialis Bris (Ann. Fr. 1866. 421; poeciloceras Heyd. Reis. Span. 168) ist grösser, tiefer blau gefärbt, nur die ersten drei Fühlerglieder unterseits röthlich, sonst ähnlich gebaut und punktirt. Das $\hat{\odot}$ hat nach der Spitze um das 3- bis 4-fache erweiterte Mittel- und Hinterschienen, einen hinten zweitheiligen Längskiel des 1. Segmentes und eine längliche, glänzende Grube auf dem letzten Ringe, die vorn von einem zahnförmigen Höcker begrenzt wird. - L. 4,2-5 mm. Pyrenäen. Spanien südlich bis Madrid. 
die ersten 4 Glieder röthlich gelbbraun, das Basalglied oberseits dunkel. Halssch. wenig breiter als lang, stark zusammen gedrückt, an den Seiten fast gerade, mit schmal aufgebogenem Rande; Oberseite fein punktirt, die Punkte länglich und tief. Schildchen schmal, glatt. Fld, ziemlich dicht, mässig stark punktirt, selten mit Spuren kurzer Doppelreihen, aber oft mit einer dem Seitenrande parallelen, erhabenen Längslinie, die am glatten Schulterhöcker beginnt und besonders vor der Spitze deutlich wird. Beine schwarzblau, Innenseite der Vorderschienen röthlich-gelb. Letzter Bauchring des $\hat{\sigma}$ vor dem Hinterrande schwach quer niedergedrückt.

Von Abänderungen ist mir nur eine wenig in die Augen fallende bekannt, bei welcher der Seitenrand der Fld. (von unten betrachtet) im mittleren Theile roth gesäumt ist.

Bei Wien und in Steiermark (Branes.). Ungarn. Südrussland.

31. Cr. manginelless: Nigro-eocruleus inlerdum viridi-micans, facie infra antemas maculis 2 frontalibus, prothoracis et elytronum margine laterali albidis, antemis piceis, basi, pedibnsque phus mimusve testaceis; thorace transverso, subliliter punctato, elytris fortiter punctatis. macula iransversa apicali rufo-flava. Long. $3-4,5 \mathrm{~mm}$.

OI. Enc. méth. VI. 616. - Suffr. Mon. II. 168. - Red tb. 1. c. 459. Var. a. Elytris rufo-testaceis, callo humerali nigro.

Cr. inexpectus Fairm. Ann. Fr. 1861. XI.; Sffr. Stett. Z. 1866. 20 ว.

Schwarzblau, nicht selten mit grünem Schimmer; der Kopf unterhalb der Fühler (beim $q$ oft nur an den Seiten), ein kleiner Stirnfleck an jedem Auge und der feine, aufgebogene Seitenrand des Halssch. nebst dem der Fld. bis hinter die Mitte gelblich-weiss; eine Quermakel in der Spitze der Fld., welche meist den Hinterrand frei lässt, rothgelb. Fühler schlank, beim $\hat{\jmath}$ fast so lang als der Körper, schwarzbraun, Glied 1-5 gelbbraun. Halsseh. viel breiter als lang, mässig zusammengedrückt und gewölbt, ziemlich dicht, fein punktirt. Fld. auf dem Rücken wenig gewölbt, weit stärker punktirt als das Halssch., die Epipleuren innen schwarz gesäumt. Beine gelbbraun, die Schenkel mit dunkler Rückenlinie oder die letzteren theilweise oder ganz, oft auch die 4 hinteren Schienen nebst Tarsen schwärzlich.

Das fünfte Segment des $\hat{o}$ längs der Mitte etwas niedergedrückt.

Da die Zeichnung der Art nur in der Grösse der Spitzenmakel leicht variirt, bleibt es sehr zweifelhaft, ob die mir unbekannte $A b a ̈ n d e r u n g ~ a$, mit röthlich gelbbraunen Fld., auf denen nur die Schulterbeule und Naht schwarz ist, wirklich hierher gerechnet werden darf.

Von den Pyrenäen längs der Alpenkette dureh Ungarn bis Sarepta verbreitet. 
32. Cr. nitidulas $\left.{ }^{1}\right)$ : Supra aureo-vel coeruleo-viridis, nitidus, subtus niger; antennis piceis, basi, facie cum ore maculaque frontali cordata flavo-testaceis, prothorace subtilissime punctato, angulis et margine antico plerumque anguste flavis, elytris fortius punctatis, pedibus testaceis, femoribus superne plus minusve, posticis plerumque totis nigris. - Long. 3,5-5 $\mathrm{mm}$.

Fabr. Mant. I. 84. - Gyllh. Ins. Suec. III. 610. - Suffr. Mon. II. 165. - Redtb. Faun. A. II. 460.

C'r. ochrostoma Harold Col. Heft. X. 254.; Berl. Zeit. 1873. 170.

- Kiesenw. Berl. Zeit. 1874. 75. 28. - Seidl. F. balt. 476.

Var. a. Supra smaragdinus vel cupreo et cyaneo-virescens.

Lebhafter gefärbt und auf den Fld. stärker punktirt als der Vorige, durch das gewölbtere Halssch., die rothgelbe Oberlippe und Stirn und die ungezeichneten Fld. leicht zu unterscheiden.

Oben gold- oder blaugrün, glänzend, der ganze Mund und der Unterkopf bis zur Fühlerwurzel, sowie ein breit herzförmiger Stirnfleck hell rothgelb. Stirn mit feiner Mittelrinne. Fühler schlank, pechbraun, die ersten vier, fünf oder sechs Glieder röthlich gelbbraun. Halssch. stark zusammengedrückt und gewölbt, schmal gerandet, weitläufig und äusserst fein punktirt, fast spiegelglatt, selten ganz einfarbig, gewöhnlich mit einer feinen gelben Seitenlinie in den Vorder- und Hinterecken (meist of) und einer schmalen gelben Querlinie dicht hinter dem schwärzlichen Vorderrande (meist $\left.\hat{\jmath}^{2}\right)^{2}$ ). Fld. nicht dicht, aber grob und etwas ungleichmässig, oder auf der Scheibe runzelig punktirt, die Punkte zuweilen zu unregelmässigen Reihen vereinigt. Unterseite schwarz, ziemlich matt, Beine und Hüften gelbbraun, nur der Rücken der vier vorderen Schenkel und

1) Hierher, besser noch vor marginellus zu stellen sind: 1. Cr. tetraspilus Suffr. (VIII. 121). Gestreckter als elongatus, schwarzblau oder schwarzgrün, Fühlerbasis röthlich, Halssch. so lang als breit, stark zusammengedrückt und gewölbt, dicht und fein, die Fld. dicht und mässig stark punktirt, auf letzteren die Epipleuren, ein länglicher Randfleck über diesen und ein Querfleck in der Spitze rothgelb. Letzter Bauchring des $\hat{\epsilon}$ gross, unmerklich der Länge nach niedergedrückt. - L. 4-5 $\mathrm{mm}$. Gebirge Südfrankreichs. Catalonien. 2. Cr. Ramburi Suffr. (II. 183). Parallel, wenig gewölbt, blau bis goldgrün, der schmale Seitenrand des fein und sehr dicht punktirten Halssch., sowie ein breiter Saum am Aussen- und Hinterrande der Fld., die Spitze der Schenkel und die Episternen der Mittelbrust gelbbraun. Fld. sehr dicht und grob gekerbt-gestreift, Zwischenräume der Punkte zu langen Querrunzeln vereint. - L. 3,5-5 mm. Spanien.

2) Der ähnliche C'r. Kulibini Gebl. (Nonv. Mém. Mose. II. 1832. i1) aus Daurien hat einen ganzen, weissgelben Seitensaum des Halssch. und einen ebenso gefärbten über den gelben Epipleuren der Fld.

VI. 2 . 
die Hinterschenkel, oder bei dunklen ja die vier Hinterbeine fast ganz schwarz. Prosternum am Hinterrande fast gerade abgeschnitten. Letztes Segment des j kaum merklich quer niedergedrückt.

Die Farbe der Fld. oder der Oberseite geht ron smaragdgrün durch gold- und blaugrün in ein kupferig-riolettes, fast purpurnes Grün über (Var. a.).

Auf Betula und Corylus im ganzen Gebiete, aber nur in den Gebirgsgegenden zahlreicher, besonders in Schlesien (Letzner, Klette).

Der Käfer ist von Fabricius a. a. O. unverkennbar nach einem \& Stücke mit einfarbigem Halssch, und bläulichen Fld, beschrieben und Gyllenhal hat mit Fug und Recht seine Art aut nitidulus $\mathrm{F}$ abr. bezogen. Suffrian hielt nach Ansicht des OriginalExemplares, welches jedoch so schlecht erhalten war, dass er sich darnach nicht getraute die Gattung mit Sicherheit festzustellen (Mon. II. 167), den nitidulus Fabr. und Gyllh. für zwei verschiedene Thiere, ohne die deutliche Beschreibung bei Fabricius (elytra cyanea, pedes flavi, femoribus linea nigra) zu beachten. Es fällt somit der Grund weg, der Herrn v. Harold bestimmte, den Namen der Art in ochrostoma zu ändern.

33. Cr. nitidus' 2 ): Nigro-coeruleus, nitidus, facie infra antennas flava, labro et antennis piceis, his basi testaceis; thorace sublaeri, elytris mimus fortiter punctatis; prosterni processu postice bimucru. nato. - Long. $3,5-5 \mathrm{~mm}$.

Mas: fronte lineolis 2 ocularibus flavis, pedibus anticis testaceis, femoribus superne cum pedibus 4 posterioribus nigris; segmento ultimo ventrali late impresso.

Fem: pedibus totis testaceis.

Linn. Syst. Nat. ed X. 374 (Chrysom.). - Harold Berl. Zeit. 1873. 170. - Seidl. Faun. b. 476.

Cr. nitens Linn. Faun. Suec. 169 (Chrys.) - Fabr. Syst. ent. 110. ㅇ․ - Gyllh. Ins. Suec. III. 608. - Panz. Faun. Germ. 68. 8. 우.Küst. Käf. Eur. III. 88. - Suffr. Mon. II. 162; III. 108. Redtb. Faun. A. II. 460.

Cr. flavifrons F abr. Ent. Syst. I. 2. 65. $\hat{\odot}$.

Var. a. Supra obscure viridi-micans.

1) Für Camptosoma ist richtiger Camptosomata zu setzen.

2) Hierher noch $\mathrm{Cr}$. modestus $\mathrm{Suffr}$. (Mon. III. 107). Gestreckt, schwarzblau, glänzend, nur die Fühler bis zum fünften Gliede rothbraun. Kopf and $\mathrm{Halssch}$. spiegelglatt, Fld. besonders beim $\hat{\odot}$ ziemlich stark und in fast regelmässigen Reihen punktirt. - L. 2,8-4 mm. Südöstliches Russland. 
j. Schwarzblau, glänzend, der Kopf über dem pechschwarzen Munde bis an die Fühlerwurzel und eine kurze, erhabene Linie am oberen Innenrande der Augen hellgelb. Fühler schlank, pechschwarz, bis zum fünften oder sechsten Gliede rothgelb, Glied 1 oberseits oft dunkel, Glied 3 reichlich doppelt so lang als 2. Halssch. dicht aber kaum sichtbar punktirt. Fld. mässig dicht und wenig stark punktirt, die Punkte zu unregelmässigen Doppelreihen geordnet, deren Zwischenräume besonders an der Basis leicht gewölbt hervortreten. Unterseite schwarzblau, ziemlich matt, die Vorderbeine nebst Hüften gelbbraun, der Rücken der Vorderschenkel wie die vier Hinterbeine schwarz, oder auch Mittelhüften und Unterseite der Mittelschenkel, zuweilen selbst die Hinterhüften röthlich. Hinterrand der Vorderbrust in der Mitte in zwei schräg nach unten gerichtete kurze, oft rothgelb gefärbte Spitzen verlängert. Letzter Bauchring mit einem weiten, glänzenden Quereindrucke. - Penisöffnung sehr lang, die Seiten vorn schnell gerundet-verengt und in eine scharf abgesetzte breite Spitze verlängert.

Dem kräftigeren $q$ fehlen, wenn auch nicht immer, die beiden gelben Stirnlinien, die Fld. sind feiner punktirt und alle Beine und Hüften röthlich gelbbraun. Auf der Stirn zeigen sich drei Grübchen, eins in der Mitte, die andern am Augenrande. Die Grube des letzten Bauchringes ist auffällig gross und breit.

Zuweilen erhält die Oberseite einen schwachen grünen Schinmer (Var. a.), auch finden sich Stücke, bei denen die Mundtheile mit Ausnahme der Mitte der Oberlippe rothbraun gefärbt sind.

In ganz Deutschland auf Salix, Betula und Corylus nicht selten.

34. Cr. punctiger $\left.{ }^{1}\right)$ : Subelongatus, coeruleo-niger, nitidus, prosterno plus minusve, antennarum basi, facie cum ore, macula bifida fronlali pedibusque anterioribus flavis, his femoribus superne infuscatis; vertice prothoraceque nigris, hoc margine antico et angulis posticis flavis, supra sat profunde punctato; elytris coeruleis, interdum viridiinicantibus, profunde punctalo-striatis. - Long. 2,5-3,5 $\mathrm{mm}$.

Mas: macula frontali magna.

Payk. Faun. Suec. II. 146. - Gyllh. Ins. Suec. III. 624. Suffr. Mon. III. 11; VIII. 127. - Thoms. Skand. Col. VIII. 305. - Seidl. F. balt. 477. - Redtb. Faun. A. II. 464.

1) Aehnlich sind Cr. pumilio Suffr. (Mon. XX. 140) und confusus Suffr. (1. c. 140) aus Daurien. Ersterer, 2,3 mm lang, glänzend blaugrün, mit stark aber wenig dicht punktirtem Halssch., letzterer, $2 \mathrm{~mm}$ lang, tief schwarzblau, mit äusserst dicht und fein punktirtem Halssch. Stirn und Halssch. bei beiden ohne gelbe Zeichnung. 
ふ. Langgestreckt, blauschwarz, glänzend, Kopf gelb, die Taster dunkel, der Scheitel und eine von diesem ausgehende, breit-dreieckige Stirnmakel, sowie ein Strich am oberen Innenrande jedes Auges und ein Punkt über der Fühlerwurzel jederseits schwarz. Halssch. nach vorn mässig verengt, mit fast gradem, schmal abgesetztem Seitenrande; schwarz, ein breiter Vorderrandsaum, der sich in den Vorderecken erweitert, und die Hinterecken, selten der ganze Seitenrand blassgelb; die Oberseite in der Mitte sparsamer, an den Seiten dichter, nicht stark, aber ziemlich tief punktirt, die Dichtigkeit und Stärke der Punktirung jedoch sehr variabel. Fld. blau oder grünblau, tief und stark gestreift-punktirt. Prosternum am ganzen Vorderrande und zwischen den Hüften gelb, diese selbst und die vier Vorderbeine gelbbraun, oder die letzteren mit dunklem Rücken der Schenkel. Hinterbeine pechbraun, ihre Schenkel oft blauschwarz.

Das $q$ ist merklich breiter, mit schwarzer Stirn, auf welcher vom rothgelben Unterkopfe aus zwei divergirende und leicht nach aussen gebogene rothgelbe Linien aufwärts bis etwa zur Mitte der oberen Augenlappen ziehen. Der Vordersaum des Halssch. ist weniger hell gefärbt und bedeutend schmaler als beim $\hat{\jmath}$.

Auf Betula alba und Salix caprea nördlich rom deutschen Mittelgebirge ziemlich selten. Nördliches Europa, ausser England.

Für diese Art wurde zuerst durch Gozis im Cat. Col. Fr. 86. der ältere Name chrysocephalus Deg. eingeführt, der aber in Folge der irrthümlichen Beziehung auf die Linné'sche Chrysomele gleichen Namens (Psylliodes chrysocephalus) hinfällig geworden ist. Ausserdem lässt sich de Geer's Beschreibung mit demselben Rechte auf die folgende Art anwenden, da von einem hellen Vordersaume des Thorax keine Rede ist.

35. Cr. pallifions: Subelongatus, nigro-coeruleus, nilidus, prosterno parce, antennarum basi, facie cum ore. macula bifida /rontali pedibusque flavo-testaceis, femoribus posticis medio nigris: prothorace laevissimo, elytris coeruleis, punctato-striatis. - Long. 2,5-3,5 mm. Mas: fronte fere tota flava, prothorace angulis anticis testaceis.

Gyllh. Ins. Suec. III. 625. - Suffr. Mon. III. 26; VIII. 135. - Thoms. Skand. Col. VIII. 306. - Seidl. Faun. b. $47 \%$. - Redtb. Faun. A. II. 460.

Cr. insignis $\mathrm{Payk}$. Act. Holm. 1799. 116. spec. montros.

Dem Vorigen sehr ähnlich, indessen durch das glatte, deutlich blau schimmernde und nach vorn stärker verengte Halssch., welches beim $q$ einfarbig, beim $\hat{j}$ nur in den Vorderecken röthlich gelbbraun ist, sowie die fast ganz rothgelben Hinterbeine leicht zu unterscheiden. Ausserdem ist die helle Zeichnung der Stirn breiter, da in dieselbe 
nur eine kurze, dunkle Linie vom schwarzen Scheitel her ( $\hat{j})$, oder noch ein schwarzer Fleck in der Ausrandung der Augen (f) hineintritt. Das Halssch. besitzt oft einen Schrägeindruck in der Mitte der seitlichen Wölbung; die Vorderbrust ist nur zwischen den Hüften () und längs des Vorderrandes (j) gelb. - Der Penis läuft vorn in zwei lange, gabelig gestellte, stumpfe Spitzen aus, zwischen welche von oben her eine gleichlange, schmale, zungenförmige Spitze eingelagert ist.

Auf Betula und Salix-Arten selten. Schlesien. Norddeutschland. Nordeuropa. Sibirien.

\section{Reihe. Verwandte von $C r$. parvulus.}

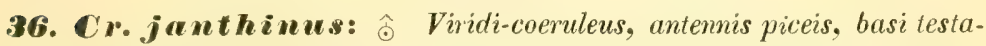
ceis, articulo primo supra infuscato, facie infra antennas, macula bificla frontali, margine antico prothoracis coxisque anticis flavo-albidis, prothorace margine laterali anguste reflexo, disco convexo, sat fortiter punctato, latera versus inaequaliter subrugoso-punctato, interstitiis crebre punctulatis, elytris profunde punctato-striatis, interstitiis obsoletius ruyulosis, subnitidis. - Long. $3-3,5 \mathrm{~mm}$.

Fem: robustior, prothorace unicolori elytrisque minus fortiter punctatis, clypeo medio fronteque viridi-coeruleis, hac lineolis 2 ocularibus testaceis. - Long. 3,5-4,5 $\mathrm{mm}$.

Germ. Ins. Spec. nov. 555. - Suffr. Mon. III. 12; VIII. 127.

- Redtb. Faun. A. II. 460. - Seidl. F. balt. 476. Mars. Mon. 178.

Var. a. Coeruleus vel violaceus.

Var. b. Coxis anticis concoloribus.

$\mathrm{V}$ ar. c. $\hat{\jmath}$ Linea flava pone marginem anticum prothoracis in medio interiupta.

Var. d. $\hat{\odot}$ Prothorace ut in $c$, aut unicolori, fronte viridi-coerulea maculis 2 ocularibus testaceis.

var.e. \& Fronte omnino viridi-coerulea.

In den Schultern am breitesten, von hier nach hinten wenig, nach vorn stark verengt, dunkelblau, meist mit leichtem grünem Schimmer, der bald auf dem Halssch., bald auf den Fld. deutlicher hervortritt. Fühler pechschwarz, die ersten fünf Glieder gelbbraun, oberseits (wenigstens das Wurzelglied) angedunkelt.

$\hat{\jmath}$ Kopf unterbalb der Fühler, eine zweilappige Stirnmakel, eine Linie dicht hinter dem Vorderrande des Halssch. und die Vorderhüften weisslich gelb. Die Stirnmakel besteht aus zwei dreieckigen, an die oberen Augenränder gelehnten Flecken, die unten mit einander verbunden sind und mit dem gelben Kopfschilde schmal zusammenhängen. Halssch. nach vorn stark zusammengedrückt und rerengt, der sehr schmale, fast gerade Seitenrand von oben 
nicht sichtbar; gewöllot, ohne deutliche Eindrücke, dicht und stark punktirt, die Punkte auf dem Vordertheile der Scheibe feiner. ar den Seiten sehr stark und stellenweise runzelig, ihre $\mathrm{Z}$ wischenräume überall dicht und äusserst fein punktulirt, so dass der Glanz merklich abgeschwächt ist; die gelbe Linie am Vorderrande ist in den Vorderecken etwas verbreitert und sendet lier bisweilen eine feine Spitze nach hinten. Fld. stark und tief punktirt-gestreift, Zwischenräume mit mehr oder weniger deutlichen, sehr feinen Querrunzeln und äusserst feinen Pünktchen, die auf dem Alffalle zur Spitze au zahlreichsten sind. Beine schwarzgrün, Füsse pechbraun mit braunen Haarsohlen, Vorderhüften gelb, hintere Hüften wie alle Trochanteren braun oder pechschwarz. Letzter Bauchring in der Mitte leicht eingedrückt und stärker als an den Seiten punktirt; Hinterrand des vorletzten Ringes hoch und scharf. - Penis rorn am breitesten und fast grade abgeschnitten, nur die Mitte leicht rorgezogen.

Das $q$ ist bedeutend grösser und breiter, sein Kopfschild nur an den Vorderecken gelb, auf der Stirn ist jederseits am oberen Innenrande der Augen nur eine schmale und kurze gelbbraune Linie: Halssch. einfarbig, auf der Scheibe fein punktirt, die Punkte der Fld. feiner und seichter als beim $\hat{\jmath}$.

Zuweilen ist die Oberseite, wenigstens auf den Fld., gesättigt himmelblau oder violett (Var. a.), oder die Vorderhüften sind ron der Körperfarbe (Var. b). Beim j wird die gelbe Querlinie des Halssch. in der Mitte unterbrochen (Var. c.) oder sie verschwindet ganz; im ersteren Falle pflegt der obere Theil des Kopfschildes grün zu sein, im zweiten ist die Stirnmakel in zwei Flecken aufgelöst. Beim fohlen die beiden gelblichen Stirnstriche oft ${ }^{*}$ ganz (Var. e.).

Der Larrensack wurde ron Letzner (Zeitschr. Ent. Breslau 1855 p. 80) beschrieben.

Auf Birkengebüschen in der Ebene und den Vorgebirgen im ganzen Gebiete. Mitteleuropa, Sardinien (D amry), Sibirien. Besonders in den Sümpfen der norddeutschen Tiefebene im Juli nicht selten.

3\%. Cr.prowas: Viridi-coeruleus, antemis piceis, basi teslaceis superne infirscatis, facie inferne flaco-albirla, trochanteribus teslaceis: prothonace margine laterali late reflexo, disco evidenter biimpressu sat fortiler minus dense, latera versus crebrius punctato, interstitiis parce punculatis, elytris profunde punctato-strintis. interstitiis laevibus. nitidis. - Long. 3-4,5 $\mathrm{mm}$.

Müll. Zool. Dan. Prodr. $5 \mathrm{~S}$. 
Cr. nigrocoeruleus Goeze Ent. Beitr. I. 320. - Harold Berl. Zeit. 1S73. 171.

Cr. violaceus Fouror. Ent. Par. 92.

Cr. coeruleus Oliv. Encycl. méth. VI. 616.

Cr. livens Gmel. Ed. Linn. I. 4. 1711.

Cr. flavilabris Fabr. Mant. I. 84. - Oliv. Ent. VI. S31. -

H. Schäff. Faun. Germ. 116. 5. - Seidl. Faun. balt. 476.

Cr. fulcratus Germ. Ins. Spec. nov. 556. - Suffr. Mon. III. 15;

VIII. 128. 129. - Redtb. Faun. A. II. 460. - Mars. Mon. 179.

Cr. nitens Rossi Faun. Etr. I. 94. - Suffr. 1. c. III. 1S.

Var. a. Supra viridis, coeruleus vel saturate violaceus.

Ebenso gefärbt als der vorige, aber durch die einfarbige Stirn, das in beiden Geschlechtern weissgelbe Kopfschild, den breit abgesetzten und leicht gerundeten, von oben noch ein Stück vor den Hinterecken sichtbaren Seitenrand des einfarbigen Halssch., welches an den Seiten zwar stärker als auf der Mitte, aber nie runzelig punktirt ist und stets zwei, oft sehr tiefe Schrägeindrücke besitzt, ferner durch die stärker punktirten, in den Zwischenräumen glatten und glänzenden Fld., sowie die mit dem Körper gleichfarbigen Hüften, deren Trochanteren aber hell gelbbraun sind, sicher $z u$ unterscheiden.

Die beiden Eindrücke des Halssch. beginnen am Hinterrande jederseits vor dem Schildchen und ziehen von hier aus schräg nach den Seiten hin, wo sie etwa in der Mitte der Wölbung enden. Bei grossen Stücken ist die Mitte des Halssch. oft fast glatt; dieselben finden sich daher in vielen Sammlungen als flavilabris Suffr. bestimmt, von dem sie durch das nach vorn rerengte Halssch. und die dunklere Fühlerbasis abweichen. Die Fld. sind hinten ebenso breit oder breiter als an den Schultern, die Zwischenräume der Punktreihen schmal, vorn meist leicht gewölbt.

Wie bei der vorigen Art sind die $\hat{\jmath}$ kleiner, auf dem Halssch. dichter und stäker, auf den Fld, tiefer punktirt als die 오. Den Larvensack beschrieb Dufour Ann. Fr. 1852, 450.

Die Oberseite ist nur selten rein grün, himmelblau oder violett gefärbt (Var. a.).

Auf Birken (Betula alba) in ganz Europa und Sibirien.

Die Synonymie dieser Art ist nicht so verwirt, wie es nach Suffrian's Ausführung (Mon. III. 18) den Anschein hat, sondern ganz einfach, wenn die alten Autoren wirklich verglichen werden. Das Thier ist zuerst von Geoffroy 1762 (Hist. abr. d. Ins. I. 235) als le gribouri blen strie beschrieben und an den oben angegebenen Orten ron $M$ üller $17 \% 6$ parvulus, Goeze 1777 nigrocoeruleus, Fourcroy 1755 violaceus und ron Fabricius 17si favilabris genannt worden. Goeze druckt Müllers Beschreibung 
wörtlich ab, giebt aber trotzdem einen anderen Namen, und auch Fabricius nennt ausdrücklich den Müller'schen Käfer flavilabris, dem er eine für die Artunterscheidung werthlose eigene Diagnose beisetzt. Der letztere Name ist deshalb ein Synonym von parvulus, gleichgiltig, ob Fabricius wirklich das Thier von Müller und Geoffroy ror sich gehaht hat, oder nicht. Da bei Paris bisher nur die vorliegende Art gefunden ist, so kann Geoffroy nur ein grosses $f$ derselben mit feiner Punktirung des Halssch. (er nennt das ,corcelet poli et luisant") beschrieben haben.

38. Cr. coerulescens: Viridi-coeruleus, antennis piceis. basi plerumque omnino testaceis, facie inferne flavo-albida; prothorace margine laterali sat late reflexo, supra parce subtiliter punctato, elytris haud profunde punctato-striatis. stivis apice obsoletis, interstitiis laevissimis, pedibus sat validis. - Long. 4-5,5 mm.

Sahlb. Diss. ent. Ins. Fenn. II. 261. - Seidl. F. balt. 476. Cr. flavilabris Suffr. Mon. III. 16. - Redtb. Faun. A. II. $₫ 60$. - Gyllh. Ins. Suec. III. 623.

Cr. androgyne Mars. Mon. 184. spec, monstros.

Cr. Pelleti Mars. Mon. 185.

Var. a. Prothorace sat fortiter punctato.

Var. b. Trochanteribus brunneis vel testaceis.

Cr. flavilabris Thoms. Skand. Col. VIII. 304.

Var. c. Supra nigro-violaceus.

Var. d. ‥ Elytris puncto posthumerali testaceo.

Var. e. ㅇ. Elytris apice macula transversa testacea.

Var. f. 9 . Elytris puncto posthumerali maculaque ante apicem teslaceis.

Durch das vorn breitere und fast halbkugelige Halssch. noch etwas paralleler als der Vorige, aber (in den gleichen Geschlechtern) bedeutend grösser, etwas lichter grünlichblau gefärbt und glänzender, die Basis der Fühler viel heller gelb und gewöhnlich ohne dunkle Oberseite des ersten Gliedes; das $\mathrm{Halssch}$. ist vorn stärker gewölbt, mit ganz fehlenden oder seichteren Schrägeindrücken und meist zerstreut und sehr fein, höchst selten so stark als bei grossen parvulus punktirt. Die Punkte desselben sind nur nahe dem Vorderrande etwas dichter gestellt, an den Seiten dagegen weder dichter noch stärker. Fld. beim $\hat{\jmath}$ höchstens so stark punktirtgestreift als die des + von parvulus (die Punktreiben auf dem Abfalle zur Spitze fast erloschen), mit ziemlich breiten, glatten und ebenen Zwischenräumen, die des grösseren $q$ bedeutend feiner. Beine merklich länger und stärker als beim vorigen, mit breiten Schienen und Tarsen und pechschwarzen Trochanteren. Die gelbe Färbung des Kopfes unterhalb der Fühlerwurzel ist gewőnlich schmäler, da die Spitze des Kopfschildes schwarzgrün ist. 
Bisweilen sind die Trochanteren braun oder gelbbraun (Var. b.), oder die Oberseite ist dunkel veilchenblau (Var. c.); beim 우 zeigt sich ein gelbbrauner Punkt hinter dem Schulterhöcker (Var. d.) oder eine gelbliche Quermakel vor der Spitze (Var. e.), endlich, die Verbindung von $d$ und e, ein Punkt hinter der Schulter und eine Spitzenmakel (Var. f.). Exemplare, bei denen sich diese Zeichnung zu einer gelben Längsbinde erweitert, würden von concinnus ') schwer zu trennen sein.

1) Cr. concinnus Suffr. (Mon. VIII. 129 und 132). Die lebhaft himmelblauen $\hat{\odot}$ sind nur an den tieferen, stärker und dichter punktirten Streifen der Fld, die $q$ dadurch zu unterscheiden, dass ihre Fld. weissgelb sind, die Epipleuren und ein sehr feiner Seitensaum schwarzgrün, eine breite, parallele Nahtbinde, die auf der hinteren Wölbung plötzlich verengt ist, blau, selten nit grünem Schimmer. Schulterbeule gelb, selten leicht gebräunt, dann aber nicht mit dem Seitensaume verbunden. - L. 4-5,5 mm. Ungarn, Siebenbürgen und längs der Donau bis zum schwarzen Meere.

Von dieser Art ist der mir unbekannte $C r$. biguttulus Suffr. (III. 24; VIII. 129 u. 135) aus der Krim durch schlankere Form, das stärker punktirte Halssch. und die fein quer-gerunzelten Zwischenräume der Fld. unterschieden. Das $\hat{\odot}$ hat einen grossen, hellgelben Schrägfleck ror der Spitze.

Hieran schliesst sich der, nach einem $q$ mit blauen Fld. und gelbem Querfleck vor der Spitze beschriebene Cr. rufilabris Suffr. (VIII. 128) aus der Krim. Die Fld. sind in den $\mathbf{Z}$ wischenräumen ebenfalls fein quer-runzelig, das Halssch. ist aber sehr dicht und grob punktirt. Es ist nicht zu entschuldigen, dass Suffrian diese, in der Punktirung variirenden Arten nach einzelnen Stücken beschrieben und dadurch die Wiedererkennung fast unmöglich gemacht hat. Auf ruflabris möchte ich eine Reihe, von H. Retowski bei Theodosia gesammelter Exemplare beziehen, nach denen die Diagnose etwa so lauten würde: C. rufilabris: Nigro-coeruleus, viridi-micans, facie inferne flava, antennis gracilioribus nigris, articulis 5 primis testaceis, prothorace minus transverso modice convexo, antice sat angustato, margine laterali late reflexo, supra crebrius fortiterque punctato, elytris fortiter purctatostriatis.

Mas: elytris unicoloribus vel macula parva transversa ante apicem.

Fem: elytris a. macula transversa flavo-testacea ante apicem, b. praeterea vitta angusta humerali. c. limbo lato intramarginali flavo-testaceo. Long. 3,5-5 mm. Russia mer. Crimea.

Von marginatus durch die schwarzblaue, dentlich grüne Farbe, die feinen und langen Fühler und das dichter und stärker punktirte, viel längere, an den Seiten breiter abgesetzte, sonst jedoch ähnlich gebaute Halssch. leicht zu trennen. (Bei coerulescens und concinnus ist das Halssch. fast halbkugelig.) Die $q$ haben einen röthlich gelbbraunen, aussen breiteren Querfleck vor der Spitze oder noch eine ähnlich gefärbte schmale Längsstrieme auf und hinter dem Schulterhöcker, die sich zuletzt mit dem Spitzenflecke zu einer Längsbinde vereint. Diese wird innen etwa von der fünften 
$\mathrm{Zu}$ dieser Art muss C'r. androgyne Mars. gezogen werden, weleher nach einem frischen, unvollständig ausgefärbten Stücke beschrieben wurde, das auf der linken Fld. zwei gelbe Makeln hat. Auch $\mathrm{Cr}$. Pelleti Mars. gehört hierher.

Auf Birken- und Haselnussgebüschen besonders in Norddeutschland, selten. Wien (Redtenbacher), Piemont (Baudi), Pyrenäen (Marseul).

39. Cr. manginatas: $\hat{e}$ Nigno-coemleus, antemis nigris busi inferne rufescentibus, facie infra antemas flaza, proihoruce bieri modice comexo, antice angustato, lateribus parum rotundatis. disco postice biimpresso, punctato, elytris fortiter punctato-striatis, segmento 5 : o ventrali leviter impresso. - Long. $3,5-5 \mathrm{~mm}$.

F em: sublus nigro-coerulea, capite prothoraceque viridi-coevuleis rel viridinigris, elytris flavo-testaccis, epipleuris. macula humerali, limbo laterali vittaque suturali nigro-coeruleis.

Fabr. Spec. Ins. I. 140 ․ - Panz. Faun. Germ. 68. 1 ․․ - Suffr. Mon. III. 19. - Redtb. Faun. A. II. 462.

Var. a. $\hat{\odot}$. Elytris macula obliqua rufa vel testacea ante apicem.

Cr. terminatus Germ. Ins. Spec. nov. 555. - Suffr. 1. c. 21.

Bei der vorliegenden Art (und ihren nächsten Verwandten ${ }^{1}$ ) sind die Fld. des $\hat{j}$ ganz oder grösstentheils blau, die des $f$ gelbbraun, und es ist deshalb eigentlich nur die Unterscheidung ihrer Männchen von der vorigen Art schwierig. Hierbəi würde besonders

Punktreihe, aussen von einem, bis zwei Drittel der Länge allmählich schwach erweiterten schwarzblauen Saume begrenzt.

1) Cr. palliatus Suffr. (Stett. Zeit. 1861, 91). $\hat{\oplus}$ etwas kleiner, heller blau gefärbt und glänzender als marginatus, Halssch. feiner, Fld. regelmässiger und tiefer punktirt-gestreift. Das f hat gesättigt gelbbraune Fld., deren Epipleuren und ein äusserst schmaler, überall gleich breiter Saum an der Naht, dem Seiten- und Hinterrande schwarzblau sind. Toskana. Bei Rom in Mehrzahl von H. Dr. Thieme auf Rubus-Blättern gefunden.

Ein von H. Royer in Langres eingesandtes aus Toskana besitzt ein grob und dîtht (stärker als bei Grohmanni) punktirtes Halssch. und erweckt dadurch gerechten $\mathbf{Z}_{\text {weifel }}$ über die Güte der Art.

Cr. Grohmanni Suffr. (III. 22; VIII. 129 u. 133). Kopfschild granz schwarz, Punktirung des Halssch. etwas dichter und stärker als bei marginatus. Fld. beim $\hat{\odot}$ blau, mit einer grossen, die Spitze ohne die Ränder einnehmenden, rothgelben Quermakel, selten noch mit einem bleinen röthlichen Querfleck zwischen Schulter und Naht und einem rerwaschenen Flecke hinter der Schulterbeule. Fld. des wie bei der Form ron marginatus, bei welcher Seitensaum und Nahtbinde hinter der Mitte stark erweitert sind. - Sicilien. 
die dunkle Farbe der Fühlerbasis, stärkere Punktirung der Fld, schwarzblaue Oberseite und die Bildung des Halssch. zu beachten sein.

$\hat{j}$ Schwarzblau, Kopf unterhalb der Fühler mit Ausnahme des Mundes und eines schmalen Vordersaumes am Kopfschilde gelb. Fühler schwarz, Glied eins bis fünf unterseits röthlich braun. Halssch. sehr kurz, nur mässig gewölbt, nach rorn stark verschmälert, der Seitenrand wenig gerundet und rorn schmäler als linten abgesetzt, der $\mathrm{R} \ddot{u} \mathrm{cken}$ mit einem Schrägeindrucke jederseits ror dem Schildchen, mässig dicht und meist fein, nach den Seiten und dem Hinterrande hin dichter und stärker punktirt. Fld. stark und tief punktirt-gestreift, mit flachen, ziemlich glatten und glänzenden Zwischenräumen. Letzter Hinterleibsring in der Mitte weit und flach eingedrückt.

千 Breiter und plumper, durchweg feiner punktirt als das $\hat{j}$, Unterseite schwarz-blau, Kopf und Halssch. grünlich-blau oder schwarzgrün, ersterer unter der Fühlerwurzel gelb, wie beim j̧, oder die Mitte des Kopfschildes schwarz. Fld. bräunlich-gelb, die Epipleuren, ein Saum am Seitenrande, ein Schulterfleck und eine Längsbinde auf der Naht dunkelblau, blau- oder schwarzgrün. Der Seitensaum steht mit dem Schulterpunkte in Verbindung und ist verschieden breit, bald nur auf den äusseren Zwischenranm beschränkt, ziemlich gleich breit, bald ein Stück hinter der Schulter nach innen bis zur siebenten oder sechsten Punktreihe zu einer halb ovalen Makel erweitert. Die Nahtbinde varïrt meist dementsprechend. Sie ist entweder fast gleich breit und erreicht vorn etwa die erste, von der Mitte $a b$ die zweite Punktreihe, oder sie erweitert sich hinter der Mitte zu einer grossen gemeinschaftlichen Makel, die zuweilen bis zur fünften Punktreihe reicht und dann den erweiterten Seitensaum beinahe berührt.

Nicht selten sind die $\hat{j}$ dicht über der äusseren Hinterecke jeder Fld. mit einer kleinen, schräg nach der Nahtecke gerichteten rothen bis gelbbraunen Makel versehen (Var. a).

In Gebirgsgegenden auf Birken, Eichen und Weiden in Mai und Juni.

8. Reihe. Verwandte von Cr. quinquepunctatus.

10. Cr. quinquepmsetatus $\left.{ }^{1}\right)$ : Teslaceus, subopacus, cupile. prothorace yedibusque ferrugineis, antemis piceis, basi testaceis: wothorace

1) Vor diese Art sind zu stellen:

1. Cr. cynarae Suffr. (Mon. II. 27). Niger nitidus, ore, puncto infra antennas, punctis 2 frontalibus, antennarum basi, prothorace, segmenti 
confertissime sat fortiter punctuto, punctis duobus nigris, elytris minus dense punctatis, lineis nomullis subelevatis, punctis 5 (2, 2, 1) nigris.

- Long. 5-6 $\mathrm{mm}$.

Mas: segmento 5 : o ventrali late impresso.

Harrer Beschr. Ins. Schäff. I. 55. - Harold Berl. Zeit. 1873. 172.

Cr. duodecimpunctatus Fabr. Ent. Syst. I. 2. 67. - Suffr. Mon.

II. 150. - Redtb. Faun. A. II. 457.

Var. a. Elytris punctis 4 nigris (puncto postico nullo).

Cr. octomaculatus Rossi Faun. Etr. I. 96.

Var. b. Puncta elytrorum 2 et 5 vel 4 et 5 desunt.

Cr. octonotatus Schneid. Neu. Mag. I. 2. 210.

Var. e. Elytris punctis 2 nigris.

Var. d. Elytris immaculatis.

Cr. testaceus Villa Col. Eur. dupl. 36.

Var. e. ut in c, sed thorace immaculato.

Cr. stramineus Suffr. Mon. II. 153; VIII. 117.

Durch die verschossene Farbe, starke und dichte Punktirung und eigenthümlich stumpfe Oberseite des Halssch. recht ausgezeichnet; schmutzig-gelbbraun, der Kopf leicht, Halssch. und Beine tiefer rostroth, Stirn breit und fast eben (q), oder schmal, mit feiner dunkler Mittelrinne ( 3 ); Fühler sehr schlank und dünn, pechbraun, die ersten 5 Glieder rothbraun. Halssch. nur mässig zusammengedrückt, äusserst dicht, ziemlich stark punktirt, fast matt, ein grosser Punkt

ultimi ventralis apice pedibusque rufo-testaceis, tarsis nigricantibus: prothorace antice fortiter compresso-angustato, parce subtilussimeque punctulato, punctis 2 nigris, elytris flavo-testaceis, minus dense punctatis, lineis nonnullis subelevatis, punctis 4 (2, 2, oblique digestis) nigris. - L. 5,5-7 mm. Andalusien.

Var. 12-plagiatus Fairm. (Ann. Fr. 1859. Bull. 151.) Punctis 2 ocularibus confuentibus, elytris punctis 5 nigris, adjecto nempe ante apicem.

2. Cr. curvilinea O1. (Ins. VI. 812. t. 5. f. 82; Suffr. II. 29.) Niger, nitidulus, antennis capiteque testaceis, fronte punctis 2 piceis supra antennas maculayue centrali sanguinea; prothorace confertim sat fortiter punctato, sanguineo, margine antico, lineolam ablreviatam (postice latiorem) in medio emittente, vitta marginali medio excisa anteque scutellum vittis 2 antice abbreviatis, curvatis, flavis; elytris flavo-testaceis, substriato-punctatis, maculis $4(2,2)$ parvis, nigris, umbra longitudinali medio disci; pedibus brunneis, femoribus apice interdum flavo-notatis, prosterno mesosternoque parce flavis, pygidio segmentoque ultimo omnino testaceis. - Long. $4-6 \mathrm{~mm}$. Sicilia, Sardinia, Hispania, Africa septentrionalis.

Variat a. abdomen testaceum, b. witta marginali prothoracis lata, in medio striola obliqua rubra notata, c. lineola medic prothoracis utrinque ablweviata; elytris: (Var. inops), d. punctis $3(2,1)$, e. $2(1,1)$ nigris, $f$. puncto humerali nigro vel $g$. immaculatis. 
jederseits in der Mitte schwarz. Schildchen schwarz, oft mit braunem oder selbst weisslichem Mittelflecke. Fld. weniger dicht, aber stärker als das Halssch. punktirt, glänzender, die Punkte besonders an der Naht und dem Aussenrande zu wenig regelmässigen Reihen geordnet, zwischen denen einige leichte Längsrippen hervortreten. Von den fünf schwarzen Punkten steht der erste auf der Schulterbeule, 2 zwischen 1 und der Naht, 3 hinter 1 und dicht hinter der Mitte der Fld., 4 hinter 2, etwas näher der Naht als der letztere, 5 auf dem Abfalle der Fld. zur Spitze, näher dem Seitenrande als der Naht; die inneren Punkte der zwei Paare sind weiter nach hinten gerückt, als die äusseren. Hinterseite der vorderen Schenkel oft angedunkelt, Tarsen beim $\hat{o}$ meist schwarz. Letzteres hat eine wenig tiefe, länglich-dreieckige Grube auf dem letzten Bauchringe. - Penis dünn, an der Spitze stark erweitert und in drei Lappen ausgezogen, von denen die beiden äusseren gerundet und mit ihrer stumpfen Spitze nach innen gebogen sind, der mittlere ist kurz dreieckig; die Oeffnung wird von oben durch eine breite, zungenförmige Hornplatte verdeckt, welche dem sehr ähnlichen Penis des 6-maculatus Ol. fehlt.

Die Neigung der schwarzen Punkte, sich auszudehnen, ist gering (bei einem meiner Stücke ist Punkt 4 quer, makelförmig und erreicht fast die Naht), grösser die, zu verlöschen. Es verschwindet a) Punkt 5 , b) 2 und 5 oder 4 und 5, c) 2,4 und 5 ; später sind 1 und 3 nur noch durch einen Schatten angedeutet oder fehlen bei d) ganz; bei e) sogar die beiden Punkte des Halssch.

Im Spätsommer auf Eichengebüschen nirgends zahlreich; die Var. a. vorherrsehend. Nördlich nur bis Berlin. Ausserdem im östlichen Frankreich, der Schweiz, Italien, Ungarn, Russland und Sibirien.

Cr. stramineus Suffr. aus dem östlichen Russland, mit gelben Stirn- und Halsschildrändern, ist wahrscheinlich von der vorliegenden Art nicht zu trennen; wenigstens ergeben sich aus Suffrian's längerer Beschreibung keine positiven Unterschiede.

\section{Reihe. Verwandte von Cr. pini.}

11. Cr. pimi ${ }^{1}$ : Luteus, antennis sat brevibus, articulis 6 ultimis paulo crassioribus et piceis, capite prothoraceque fuscescentibus, confertim

1) Cr. Simoni: Flavo-testaceus, nitidissimus, antennis longis, fliformibus, articulis 6 ultimis brunneis, prothorace fortiter compresso, parce subtilissimeque punctato, scutello elytrisgue saturate sulphureis, his minus dense punctatis. - Long. $4 \mathrm{~mm}$. 
elylrisque puzulo fortius punclatis, prosterno processu postice triangulariter producto, pedibus crassis, tibiis margine exteriore carinatis larsisque latis. - Long. $3,5-5 \mathrm{~mm}$.

Mas: segmento 5 : o ventrali depresso, tibiis tarsisque fortiler dilatatis.

Linn. Syst. Nat. ed. X. 375 (Chrysom.). - Panz. Faun. Germ. 39. 17. - Suffr. Mon. II. 157. - Redtb. Faun. A. II. 465 (Disopus). - Seidl. F. balt. 474.

Disopus abietis Redtb. 1. c. 165.

Var. a. Capite prothoraceque (elytris interdum) saturatius fuscis. maiginbus flavis, pectore abdomineque plus minusve infiscatis.

Cr. abietis Suffr. Mon. II. 160.

Var. b. Elytris piceo-plagiatis. - Stierlin. Faun. col. helv. 319.

Durch die kurzen und dicken Beine vor allen Verwandten sehr ausgezeichnet, hell lehmgelb, glänzend, Fühler ziemlich kurz, röthlich gelbbraun, nach der Spitze hin allmählich dunkler braun oder selbst schwarz; Kopf fast eben, rothbraun, Stirn- und Mundränder, zuweilen auch zwei ziemlich deutliche Makeln am oberen Innenrande der Augen gelb. Halssch. mässig zusammengedrückt, dicht punktirt, rothbraun, Seiten- und Vorderrand breit, Hinterrand oft schmal verwaschen gelb gesäumt, nicht selten ist auch eine bis hinter die Mitte reichende gelbe Mittellinie angedeutet. Fld. viel weitläufiger,

Mas: segmento ultimo ventrali fovea parva impresso, tarsorum articuln primo latitudine plus quam duplo longiore.

Die Art ist pini täuschend ähnlich, gestreckter, heller und lebhafter gefärbt, stark glänzend, die Fühler beim $\hat{\odot}$ so lang als der Körper, Vorderbrust hinten breit, grade abgeschnitten; Schienen und Tarsen sehr schlank. Von Herrn Simon im December bei Algesiras gefangen.

Aehnlich ist auch Cr. podager Seidl. (Berl. Zeit. 1S67. 190) aus der Sierra Guadarrama. Gelbbraun, Schildchen und Schulterpunkt, der grössere Theil der Mittelbrust und der Bauch schwarz. Halssch. sehr fein, Fld. stark punktirt. Beim $\hat{\odot}$ sind die hinteren Schienen stark erweitert, das letzte Bauchsegment ist gross, der Länge nach eingedrückt, bis zum ersten Segmente ausgedehnt, dieses in der Mitte des Hinterrandes mit zwei Spitzen. L. $6 \mathrm{~mm}$. Da ich vergeblich versucht habe, die Art zur Ansicht zu erhalten, so lässt sich nicht angeben, ob sie hierher oder in die zweite Reihe gehört. Dagegen schliessen sich hier an:

1. Cr. laevigatus Suffr. (II. 156), nach einem Stück aus Südrussland beschrieben, seither nicht wieder gefunden. Flach, braungelb, Halssch. dicht punktirt, Punkte länglich, Fld. regelmässig gestreift, in den Streifen punktirt. - L. $3 \mathrm{~mm}$.

2. Cr. sulphureus OI. (Ent. VI. 806. t. 5. f. 72.) Cylindrisch, gewölbt, blassröthlich oder strohgelb, Halssch. besonders am Vorder- und Seitenrande ziemlich stark, aber flach punktirt, Punkte rund, Fld. stark in regelmässigen Reihen punktirt. - L. 4-5 mm. Italien. Südfrankreich. Spanien. 
doch stärker als das Halssch. punktirt, das Innere der Punkte dunkel; lehmgelb, die Schulterbeule und eine nur selten bedeutend erweiterte verwaschene Längsbinde rothbraun, eine unbestimmte Längsnakel unter der Schulter am Seitenrande weisslich gelb. Unterseite gelbbraun, Seitenstücke der Mittelbrust ganz, die der Hinterbrust an der Spitze, sowie das Pygidium und letzte Bauchsegment heller. Vorderbrust zwischen den Hüften schmal, grob punktirt, hinten in eine dreieckige, gerade oder leicht nach unten gekrümmte Spitze verlängert. Beine sehr kräftig, die Schenkel dick, die Schienen zusammengedrückt, nach der Spitze erweitert, am Aussenrande mit deutlicher Rinne, die Tarsen breit.

Beim $\hat{j}$ sind die Schienen noch breiter als beim $q$, die zwei vorderen mit einfacher, scharfer Aussenkante, erstes Tarsenglied fast breiter als lang.

Letztes Bauchsegment in der Mitte schwach eingedrückt. Penis schlank, vorn wenig scharf zugespitzt.

Dunkel gefärbte Stücke, bei denen die Unterseite mehr oder weniger schwärzlich ist, nannte Suffrian abietis (Var. a.); bei der von Stierlin im Engadin gefundenen Var. b haben die Fld. einen wischartigen, pechschwarzen Scheibenfleck, der sich schmal bis auf die Schulterbeule nach vorn zieht.

Auf Pinus silvestris und Abies excelsa nicht selten.

Auf diese Art gründete Redtenbacher wegen des abweichenden Baues der Beine die Gattung Disopus. Dieselbe wird jedoch durch den spanischen Cr. Simoni so enge mit den übrigen Arten verbunden, dass sie kaum als Untergattung brauchbar ist, die dann durch die Form der Vorderbrust abgezWeigt werden müsste.

\section{Reihe. Verwandte von $\mathrm{Cr}$. decemmaculatus.}

42. Cr. decemmaculatus: Niger, pedibus (femoribus posticis exceptis), antennarum basi, facie infra antennas, macula cordata frontali prothoraceque testaceis, hoc maculis 1, plerumque in vittas 2 flexuosas connexis, nigris; elytris sat fortiter punctato-striatis, flavis, pustulis 5 (2, 2, 1) nigris, epipleuris angulum apicalem externum haud attingentibus. - Long. 3,5-4,5 $\mathrm{mm}$.

Linn. Syst Nat. ed. X. 375 (Chrysom.). - Seidl. F. balt. 478. Cr. decempunctatus Linn. Faun. Suec. 170 No. 560 (Chrys.). Panz. Faun. Germ. 68. 12. - Suffr. Mon. III. 3; 109. - Redtb. Faun. A. II. 464.

Var. a. solutus: Prothorace maculis 2 vel 4 nigris; elytrorum pustulis nonnullis deficientibus.

Var. b. scenicus: Pustulis elytrorum plus minusec confluentibus. 
Var. c. moestus: Elylris nigris, aut uncoloribus aut striolis 2 flavis pone sculellum, interdum etiam busin versus punctis nommellis mbris.

C'r. 10-punctulus var. b. Schneid. Mag. I. 197. 4. - Suffr. Mon. III. 10 .

V ar. d. Elytris prothoraceque nigris, hoc margine anticn rillaque media postice dilatata testaceis.

Cr. bothnicus Linn. Syst. Nat. ed. X. 375 (Chrys.). - Fabr. Ent. Syst. II. 59. - Panz., 1. c. 68. 3.

Cr. betulae nanae Schill. Uebers. Arb. Schles. Ges. 1837. 99. Letzner Zeitschr. f. Entomol. Breslau 1854. 1S.

Var. e. $U t$ in $d$, sed prothorace nigro, linea media abbreviata punctisque? duobus oblongis ante scutellum testaceis.

Cr. ornatus Herbst Fuessl. Arch. IV. 63. t. 23. f. 24.

Var. f. Prothorace linea media abbreviata testacea.

Var. g. Prolhorace nigro.

Chrys. barbareae Linn. Faun. Suec. 169. - Suffr. Stett. Zeit. 1866. 161 .

Ziemlich kurz, schwarz, Fühler schwarzbraun, bis zum 5. oder 6. Gliede gelbbraun, Mund, Gesicht unterhalb der Fühler, eine breit herzförmige Stirnmakel und das Halssch. gelbbraun. Letzteres nach vorn stark verengt und zusammengedrückt, auf der Scheibe fein und zerstreut, nach den Seiten hin dichter und stärker punktirt, mit €inem tiefen Quereindrucke jederseits hinter der Mitte und rier schwarzen Makeln, die eine, fast viereckig, jederseits vor, die andere länglich, schief, hinter dem Quereindrucke, an welchem beide schmal zu einer buchtigen Längsbinde vereint sind. Ausserdem ist der äusserste Seitenrand gebräunt oder schwarz. Schildchen schwarz. Fld. ziemlich stark punktirt-gestreift, weisslich-gelb, mit fünf grossen schwarzen Punkten: 1 auf dem Schulterhöcker, 3 und 5 nahe dem Seitenrande, 2 und 4 nahe der Naht; die vorderen vier bilden mit den entsprechenden der andern Fld. zwei nach hinten gebogene Querreihen. Epipleuren innen braun oder schwarz gesäumt, meist schon hinter dem ersten Bauchsegmente undeutlich. Unterseite schwarz, Beine gelbbraun, die vorderen einfarbig oder mit schwärzlicher Rückenlinie der Schenkel, an den Hinterbeinen die Mitte der Schenkel schwarz. Das schlanke $\hat{o}$ hat eine schwache Quervertiefung auf dem letzten Bauchringe.

Die Zeichnung der Oberseite ist sehr reränderlich: a. Bei der hellsten Form hat das Halssch. entweder zwei oder vier getrennte schwarze Flecke, die Fld. besitzen nur den Schulterpunkt oder noch Punkt 5 ror der Spitze; b. die vier Makeln des Halssch. zu zwei breiten, buchtigen Längsbinden vereint, Fld. mit vergrösserten schwarzen Flecken, welche theilweise zusammenfliessen, bald 3 und 4 
oder 1 und 2, bald 3, 4 und 5; c. Halssch. mit zwei fast gleich breiten schwarzen Längsbinden, Fld. schwarz, einfarbig oder zwei Strichelchen hinter dem Schildchen gelblich, oft auch der Seitenrand in der vorderen Hälfte und einige Punkte an der Basis rothbraun (diese Form, welche Schneider zuerst beobachtete, ist dem $\mathrm{Cr}$. frenatus täuschend ähnlich und von Suffrian aus Unkenntniss bei dieser Art untergebracht worden); d. Halssch. und Fld. schwarz, der Vorderrand der ersteren nebst einer vor dem Schildchen verbreiterten Längsbinde, welche zuweilen ein dunkles Längsstrichelchen einschliesst, rothgelb; die Längsbinde ist bei e. schmal und hinter der Mitte unterbrochen, so dass sich vor dem Schildchen zwei längliche rothgelbe Flecke befinden; bei f. reicht sie nur bis zur Mitte und fehlt endlich bei $\mathrm{g}$. ganz. Die letzten drei Varietäten haben meist einfarbig schwarze Fld. Das unter d. erwähnte Strichelchen vor dem Schildchen ist auch bei den Var. a. bis c. gewöhnlich angedeutet.

Im Juli auf Weidengebüschen in der nördlichen Hälfte Deutschlands zuweilen zahlreich (die Var. d., e. und besonders f, vorherrschend), sehr selten in der südlichen.

43. Cr. frenatus: Niger, capite (macula transversa verticis excepta). prothorace (vittis 2 nigris ornato) pedibusque testaceis, femoribus superne niyris; elytris minus fortiter punctato-striatis, epipleuris angulum apicalem fere attingentibus externe punctisque 2 pone scutellum testaceis. - Long. 3,5-5 $\mathrm{mm}$.

Laich. Verz. Tyrol. Ins. I. 183. - Panz. Faun. Germ. 68. 4. - Harold Berl. Zeit. 1873. 168.

Cr. trilineatus Fabr. Supplem. Ent. Syst. 105.

Var. a. Thorace testaceo, immaculato vel maculis 2 vel 1 parvis nigris; elytris flavis, macula humerali nigra; episternis mesothoracis testaceis.

Cr. callifer Suffr. Mon. III. 9.

Var. b. Ut in a, sed elytris maculis 2 usque ad 5 nigris.

Cr. flavescens Schneid. Neu. Mag. I. 196. - Suffr. Mon. III. F

- Redtb. Faun. II. 462. - Seid1. F. balt. $47 \%$.

Var. c. seminiger: Ut praecedens, sed differt maculis elytrorum magis minusve confluentibus.

Var. d. Fabricii: Prothorace postice maculis 2 elytrisque fere ommino nigris.

Cr. frenatus Fabr. Ent. Syst. I. 2. 60.

Viel schlanker als die vorige Art, die Fühler länger, der ganze Kopf mit Ausnahme des Scheitels gelbbraun, die Fld. feiner und seichter punktirt-gestreift, ihre Epipleuren bis kurz ror die Spitze deutlich. Die helleren Formen sind ausserdem durch die gelben

VI. 2 . 
Seitenstücke der Mittelbrust leicht zu unterscheiden; bei dunkleren Stücken jedoch verwischt sich dieses Merkmal immer mehr, und der typische frenatus kommt nicht selten mit einfarbig schwarzen Seiten der Mittelbrust vor.

Die Reihe der Abänderungen ist der des 10-maculatus ähnlich, unterscheidet sich aber dadurch, dass sie mit hell ren Individuen beginnt und mit weniger dunklen endet. Den Anfang derselben bildet die Var. a. mit einfarbig rothgelbem Halssch. und blassgelben Fld., welche nur einen länglichen schwarzen Schulterfleck haben. Hierher sind auch die Stücke mit zwei oder rier kleinen schwarzen Makeln auf dem Halssch. (zwei am Hinterrande und zwei in der Mitte) zu rechnen.

Bei weiterer Zunahme der schwarzen Färbang entsteht die seltene, dem 10-maculatus ähnliche Var. b.: Halssch. einfarbig oder mit zwei oder vier schwarzen Flecken, Fld. mit zwei bis fünf schwarzen Makeln in folgenden mir bekannten Zusammenstellungen:

aa. 2 Makeln: 1, 5. 1, 2. 1, 4 .

bb. 3 Makeln: 1, 2, 4. 1, 4, 5. 1, 3, 5.

ce. 4 Makeln: 1, 2, 4, 5. 1, 3, 4, 5.

dd. 5 Makeln: 1 auf der Schulterbeule, 3 und 5 dahinter am Seitenrande, 2 und 4 an der Naht; 2 bis 5 meist schlechter begrenzt und weniger tief gefärbt als die Schultermakel.

Von diesen Makeln fliessen (Var.c) einige zusammen, z. B. $2+4,3+5,4+5,2+2$ (der andern Fld.), $4+4$ (der andern Fld.), $3+4+5,2+4+5,2+3+4+5$; in den letzten drei Fällen entweder nur unter sich oder mit den entsprechenden Makeln der andern Fld. Das Zusammenfliessen geht also nicht immer rom Hinterflecke aus, wie Suffrian (l. e. 9) meint und erfolgt oft schon, wenn auf jeder Fld. zwei Makeln vorhanden sind.

Zuletzt vereinigen sich alle Flecke und es bleibt ron der ursprünglichen gelben Farbe der Fld. nur ein Saum a. an der Basis, b. unter der Schulter am Seitenrande und auf der Aussenseite der Epipleuren, sowie c. an der Spitze und ein Längsfleckchen jederseits auf der Naht hinter dem Schildchen übrig. Hierron rerschwindet der Basal- und Spitzensaum, während bei den dunkelsten Stücken der Seitensaum und die zwei gelben Striche hinter dem Schildchen punktförmig werden. Alle diese Abänderungen mit fast schwarzen Fld. gehören zur Var. d., wenn das rothgelbe Halssch. zwei schwarze Basalmakeln besitzt oder zum frenatus Laich., wenn sich auf demselben zwei schwarze Längsbinden befinden.

Auf Weiden im mittleren und südlichen Deutschland häufig. 


\section{Reihe. Verwandte von Cr. flavipes.}

4. Cr. quadriguttatus 1): Niger, nitidus, antennis basi teslaceis, prothorace dense sublititer elytrisque sat fortiter punctatis, his maculis 2 rufis, altera sublunala marginali sub humeris, altera lransversa in apice. - Long. 4-5,5 $\mathrm{mm}$.

Germ. Ins. spec nov. 555. - Suffr. Mon. II. 177; III. 108;

VIII. 123. - Redtb. Faun. A. II. 464.

Cr. nigribuccis Gebl. Ledeb. Reis. II. 3. 208.

Var. a. Macula subhumerali postice in fasciam, medium disci fere attingentem, dilatata.

Var. b. Elytris apice immaculatis.

V ar. c. Elytris omnino nigris.

Cr. 4-guttatus var. maurus Suffr. Mon. III. 108.

Cr. flavipes var. Kowarzi Gradl. Entom. Nachr. 1881. $30 \%$.

Mässig gestreckt, schwarz, glänzend, Fühler bis zum fünften Gliede gelbbraun mit dunkler Oberseite des Basalgliedes; Oberlippe heller oder dunkler pechbraun. Jede Fld. mit zwei lebhaft rothen Makeln, die erste, auf den Epipleuren und am Seitenrande, beginnt schmal an der schwarzen Schulterecke, zieht sich gradlinig über das äussere Drittel der Schulterbeule nach hinten, erweitert sich hinter derselben leicht gerundet nach innen und endet dicht vor der Mitte. der Fld. Die zweite ist gross, quer, in der Spitze, von welcher sie einen schmalen Saum am Hinterrande und der Naht frei lässt. Kopf dicht und fein punktirt, die Stirn in der Mitte und an den Augen leicht vertieft. Halssch. gewölbt, nach vorn stark zusammengedrückt, dicht und sehr fein punktirt, mit äusserst dichten und feinen Punkten in den Zwischenräumen. Fld. dicht, mässig stark punktirt, an der Naht und am Seitenrande auf der hinteren Hälfte mit einigen vertieften, unregelmässigen Punktreihen. Beine schwarz, schlank, erstes Tarsenglied fast so lang als die folgenden zusammen. Hinterrand der Vorderbrust in der Mitte ausgerandet und in zwei stumpfe Höckerchen verlängert. Letztes Bauchsegment des $\hat{3}$ schwach niedergedrückt.

Die Zeichnung der Fld. ändert ab: a. die Schultermakel ist

1) Hierher noch: Cr. creticus Suffr. (Mon. II. 178) Breviter-cylindricus, niger, nitidissimus, capite (vertice excepta), antennamm basi, epipleuris, macula sublunata marginali sub humeris elytrorum (vix medium disci attingente) a'iaque transversa in apice laete rufo-flar is; prothorace laevi, elytris fere regulariter punctato-striatis; coxis pedibusque anterioribus plus minusce testaceis.

- L. 3,5-4,5 mm. Creta. Dalmatia.

Durch geringe Grösse und den fast ganz rothen Kopf von 1 -guttutus, durch das stets einfarbige Halssch, ron flavipes leicht zu trennen. 
linten zu einer bis zur Mitte der Fld. reichenden Querbinde erweitert; b. die Spitzenmakel verschwindet, auch der Schulterfteck ist merklich verschmälert; c. letzerer verschwindet endlich ganz, die Fld. sind einfarbig schwarz.

In den Gebirgsgegenden Mitteleuropas selten, rorherrschend die Var. c. Altvater im Oppakessel und bei Winkelsdorf auf Blüthen. Mähren: Steinau und Freistadt (Reitter, Letzner), sächsische Scbweiz, Bayern (Marseul). Verbreiteter in Ungarn, Siebenbürgen und Südrussland bis nach Barnaul in Sibirien.

45. Cr. quadripustulates' 1): Niger, nitidus, prosterni margine antico, antennarum basi, ore, facie infia antennas, prothoracis maigine laterali et angulis anticis pedibusque anterioribus rufo-flavis, prothorace laevissimo, elytris irregulariter punctato-striatis, macula marginali sub humeris apiceque rufo-testaceis. - Long. 3,5-4,5 mm.

Gyllh. Ins. Suec. III. 613. - Suffr. Mon. II. 174; VIII. 122.

- Thoms. Skand. Col. VIII. 301. - Seidl. F. balt. 4i6.

- Redtb. Faun. A. II. 460

Var. a. Macula apicali elytrorum minima, macula subhumerali interdum lituraeformi vel angustissima.

Cr. 4-pustulatus var. similis Suffr. Mon. VIII. 123.

Cr. 4-pustulatus var. apicalis Mars. Mon. 161.

var. b. Prothorace angulis anticis testaceis; macula apicali elytrorum deficiente.

Cr. rhaeticus Stierl. Mittheil. Schweiz. Ges. 1863. 64.

Cr. 4 pustulatus var. bisignatus Suffr. Mon. II. 175. 177.

Var. c. Elytris nigris, epipleuris plus minusve rufo-testaceis.

Var. d. aethiops: Elytris omnino nigris.

Kleiner und schmaler als die rorige Art, durchgängig feiner und weitläufiger punktirt, an der einfarbig schwarzen Stirn in Verbindung mit dem rothgelben Unterkopfe von allen Verwandten leicht zu unterscheiden.

Gestreckt, glänzend schwarz, die ersten vier oder fünf Fühlerglieder gelbbraun, Mund und Unterkopf bis dicht über die Fühlerwurzel rothgelb, die Seiten unterhalb der Augen oft heller. Stirn in der Mitte leicht vertieft, weitläufig und sehr fein punktirt. Halssch. nach vorn stark zusammengedrückt und verengt, neben dem scharf aufgebogenen Seitenrande mit einer breiten Rinne, die

1) Noch schlanker, aber ähnlich punktirt als diese Art ist:

Cr. princeps Rottenb. (Berl. Z. 1571. 24S) Kopf und Halssch. scheinen nach der Diagnose schwarz zu sein; die Schultermakel ist hinten nach innen gerundet erweitert, die Spitzenmakel aussen halbmondförmig nach vorn gebogen, beide sind schwefelgelb. - L. $6 \mathrm{~mm}$. Auf Eichen. Cava bei Neapel. 
eine grobe Punktreihe besitzt; die Oberfläche weitläufig und äusserst fein punktirt, fast glatt, schwarz, der Seitenrand ganz oder in der Milte unterbrochen röthlich gesäumt. Dieser Saum erweitert sich in den Vorderecken und setzt sich, nirgends scharf begrenzt, nach oben noch ein Stück am Vorderrande, nach unten auf der Vorderbrust bis zu den Hüften fort. Fld. weitläulig und fein in unregelmässigen Reihen punktirt, mit je zwei rothgelben Makeln: die eine ist gleich breit, dicht unter der Schulterbeule, innen von der vorletzten Pnnktreibe begrenzt, und nimmt aussen auch die Epipleuren ein (diese selbst sind am scharfen Fld.- und Aussenrande oft schwarz gesäunt); die andere ist quer-oval, in der Spitze, von der ein breit abgesetzter Saum frei bleibt. Hinterrand der Vorderbrust fast gerade. Hüften und vordere Beine rothgelb, Vorderschenkel meist mit dunkler Rückenlinie, welche an den Mittelschenkeln breiter und dunkler wird und sich oft auch über die Mittelschienen und -Tarsen fortsetzt. Hinterbeine ganz schwarz, oder die Innenseite der Schienen und Tarsen röthlich. Erstes Tarsenglied kaum so lang als die zwei folgenden zusammen. Beim $\hat{o}$ ist die Mitte des letzten Bauchringes kaum merklich eingedrückt.

Von Abänderungen in der Zeichnung finden sich: a. Beide Makeln der Fld. verkleinern sich so, dass die hintere quer strichförmig, die vordere schmal, am Innenrande verwaschen, oder linienförmig wird und nur den äussersten Seitenrand (nebst Epipleuren) einnimmt; b. die Spitzenmakel fehlt; c. auch der Schulterfleck verlöscht, aber die Epipleuren bleiben roth; d. Fld. und umgeschlagener Seitenrand schwarz.

In Gebirgsgegenden auf Abies excelsa (Strübing) und SalixArten (Letzner) häufiger als 4-guttatus; die Var. b. ;vorherrschend.

Suffrian stellt ohne jeden Grund den Cr. Wydleri Fald. zu dieser Art (Mon. VIIY, 122). Faldermann's Thier hat nach der Beschreibung einen "caput totum testaceum" und ist einfach so lange unter flavipes zu citiren, bis eine, dem flavipes äusserst ähnliche blauschwarze Art aus dem Kaukasus nachgewiesen ist.

Da Gyllenhal endlich seinen Käfer nur fraglich auf den 4-pustulatus Fabr. (Tritoma 4-pustulata L.) bezieht, kann sein Name, entgegen der Ansicht des H. v. Harold (Berl. Zeit. 1873. 175), nicht für verfallen erachtet werden.

\#6. Cr. frovipes: Niger, nitidus, capite (vertice excepla;, anlemarum basi pedibusque rufo-testaceis, femoribus posticis plus minusie nigris, anterioribus superne lineola niyricante notalis; prothorace sat conexo. laevi, elytris subseriatim punclatis, epipleuris subcomexis, cxleme flavis. - Long. $3-5,5 \mathrm{~mm}$. 
Mas: minor, prosterni maryine antico plerumque prollowacisque margine. antico et laterali flavis.

$\mathrm{Fem}$ : prothoracis angulis testaceis.

Fabr. Spec. Ins. I. 146. - Panz. Faun. Germ. 68. 10. - Küst.

Käf. Eur. III. 89. - Suffr. Mon. II. 170; VIII. 124. Seidl. F. balt. 476. - Redtb. Faun. A. II. 459.

Cr. Wydleri Fald., Nouv. Mém. Mosc. V. 388.

Var. a. femina. Prothorace omnino nigro.

Var. b. femina. Prothoracis pictura ut in mare.

Var. c. mas. Linea flava pone marginem anticum prolhoracis deficienle.

Cr. /lavipes var. nigrescens Gradl. Entom. Nachr. 1851. 307.

var. d. mas. Linea trunsversa flava prothoracis cun linea lalerali canfluente.

Var. e. Fronte nigra, macula cordata rufo-testacea.

Var. f. Ut in e, sed clypeo nigro.

Var. g. dispar: Clypeo fronteque nigris, hac lineis duabus lestaceis.

Var. h. Plerumque ut in e, sed elytris omnino nigris.

Cr. flavipes var. signatifrons Suffr. Mon. II. 172.

Cr. furcatus et alpinus Dahl i. litt.

$\hat{\jmath}$ Mässig gestreckt, glänzend schwarz, Fühler bis zum vierten oder füuften Gliede gelbbraun, der Kopf mit Ausnahme des schwarzen Scheitels hell gelbbraun. Die dunkle Farbe des letzteren wird ron der hellen Farbe der weitläufig punktirten Stim gradlinig und scharf begrenzt, sendet aber oft eine kurze schwarze Mittelrinne in diesellue hinein. Halssch. gewölbt, vorn stark zusammengedrückt, fast glatt, schwarz, der ganze Seitenrand und eine, dicht hinter der schwarzen Rinne am Vorderrande hinziehende Querlinie gelb. Letztere biegt nahe den Vorderecken nach hinten und endet, ohne sich mit dem hellen Seitemrande zu verbinden, in der Mitte des Halssch. Fld. mässig stark in nicht ganz regelmässigen Reihen punktirt, schwarz, der Seitenrand bis zur Mitte und die Aussenseite der Epipleuren gelb. Letztere sind gewölbt und gehen allmählich in den wulstigen Seitenrand der Fld. über. Vorderbrust vorn gelb gesäumt oder mit einem dreieckigen gelben Flecke unter den Vorderecken des Halssch. Beine röthlich gelbbraun, selten einfarbig, die vorderen Schenkel gewöhnlich mit dunkler Rückenlinie, Hinterschenkel in der Mitte oder ganz schwarz. Letzter Bauchring in der Mitte wenig deutlich eingedrückt.

Das $q$ ist oft mehr als doppelt grösser, die Kopfzeichnung röthlich gelbbraun, das Halssch. nur an den Ecken fein gelb gesäumt, die Vorderbrust schwarz, Punktirung der Fld. weitläufiger und feiner.

Die Art ist wje in der Grösse so auch in der Zeichnung sehr veränderlich. Besondere Beachtung verdienen zunäcbst solche Weib- 
chen, bei denen a. das Halssch. einfarbig schwarz oder b. wie beim $\hat{\jmath}$ gezeichnet ist. Die letztgenannte Form ist sehr selten, häufiger finden sich aber Uebergänge, die eine rothgelbe Linie am Seitenrande des Halssch, und eine kürzere in der Mitte des Vorderrandes besitzen. c. Zuweilen verschwindet die gelbe Querlinie des Halssch. beim $\hat{\jmath}$, oder $d$. dieselbe verlängert sich bis zu den Hinterecken des Halssch. und fliesst mit dem Seitensaume zusammen. Die letzteren Stücke sind durch ganz gelbe Stirn und innen schwarze Epipleuren von turcicus zu trennen. e. Auf dem Kopfe ist eine Makel jederseits in der Ausrandung der Augen und fo auch das Kopfschild schwarz; dadurch entsteht auf der Stirn ein herzförmiger rothgelber Fleck, oder es bleiben zuletzt nur noch zwei, parallel nach unten laufende röthliche Strichelchen (ähnlich ocellatus) übrig (Var. g.). Bei den drei letzten Abänderungen sind die Fld. normal gezeichnet, bei h. dagegen einfarbig schwarz (die Stirn wie bei e. oder f.).

Auf Salix, Populus, Betula und Corylus nicht selten. Ganz Europa, nur in England (Rye, Abeille 14. 74) noch nicht aufgefunden.

1\%. Cr. turcicus: Niger, nitidus, antennarum basi, facie cum ore maculaque frontali cordala, prothoracis margine laterali, macula marginali sub humeris elytrorum, epipleuris pedibusque flavo-testaceis, femoribus posticis nigris; prothorace minus convexo, subtilissime punctulato, elytris subseriatim punctatis. - Long. 3-4 $\mathrm{mm}$.

Mas: prothoracis margine antico flavo.

Cr. flavipes var. turcicus Suffr. Mon. II. 173.

Cr. pistaciae Suffr. Mon. VIII. 124. - Mars. Mon. 169.

Der vorigen Art täuschend ähnlich, aber in folgenden Punkten sicher verschieden: In der Grösse weniger veränderlich, die $q$ höchstens so gross als mittle flavipes $\hat{\jmath}$; Kopf wie bei deren Var. e, mit einer rothgelben, herzförmigen Stirnmakel, die nur sehmal mit dem röthlichen Unterkopfe zusammenhängt. Halssch. mässig gewölbt, vorn weniger zusammengedrückt und verengt, der Seitenrand daher bei der Ansicht von oben fast bis zu den Vorderecken sichtbar (bei flavipes nur an der Basis) und breiter rothgelb gesäumt. Der Saum beginnt schmal in den Hinterecken und verbreitert sich allmählich nach vorn, wo er am Innenrande, kurz vor dem Vorderrande des Halssch, gewöhnlich eine gerundete Ausbuchtung besitzt. Beim $\hat{j}$ ist ausserdem der Vorderrand selbst von einer gelben Linie umzogen. Vordertheil des Prosternum bei beiden Geschlechtern rothgelb. Fld. merklich feiner punktirt, die gelbe Seitenrandmakel nimmt oft einen schmalen Streifen der Fld. selbst und die ganzen 
Epipleuren ein. Letztere sind eben und reichen weiter nach linten. als bei flavipes. Die vorderen Beine meist einfarbig gelbbraun, selten mit dunkler Rückenlinie der Schenkel, an den Hinterbeinen die Schenkel fast ganz schwarz.

Auf Pistacia terebinthus und lentisci im südlichen Tyrol. In Italien (Kahr), Dalmatien (Reitter) und Griechenland nicht selten. Aus Steiermark erhielt ich durch H. Wehncke zwei Exemplare unter flavipes und sah andere, ron $\mathrm{Kahr}$ ebenda gefangene, in E ppelsheim's Sammlung; doch scheint mir dies Vorkommen zweifelhaft, weil die Futterplanze in der Steiermark fehlt.

Die Art musste, da sie Suffrian zuerst unter dem Namen turcicus erwähnt und (als Varietät von flavipes) beschreibt, unter ihrem ursprünglichen Namen hier aufgeführt werden.

\section{Reihe. Verwandte von Cr. labiatus.}

18. Cr. chrysopes: Cylindricus, niger, nitidus, antemanm basi, epipleuris, limbo apicali elytrorum pedibusque rufo-testaceis, prothorace laevissimo, elytris sat fortiter punctato-striatis, striis postice fere evanescentibus, prosterno postice subtrancato, processu labiali brevi.

- Long. 2-3,5 mm.

Mas: capite, prothoracis et prosterni margine antico et laterali antice flavis.

Femina: capite infra antennas maculisque 2 frontalibus testaceis.

Gmel. Ed. Linn. I. 4. 1713. - Seidl. F. balt. 479.

Cr. Hübneri Fabr. Ent. Syst. I. 2. 65. - Panz. Faun. Germ. 39. 16. - Suffr. III. 84. - Redtb. Faun. A. II. 461.

C'r. biguttatus Schall. Abh. Hall. Ges. I. 27S. - Harold. Berl. Zeit. 1873. 164.

V ar. a. ․ Capite flavo.

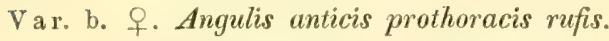

Merklich gestreckter als labiatus und von den Verwandten, zwei südliche Arten ${ }^{1}$ ) ausgenommen, durch die rothgelbe Spitze der Fld. verschieden. Schwarz, Fühlerbasis und Beine röthlich gelbbraun.

1) 1. Cr. limbifer Seidl. (Berl. Zeit. 1S67.190) aus der Sierra Nevada hat in beiden Geschlechtern einen gelben Kopf und einen gelben Saum am Vorder- und Seitenrande des Halssch. und am Seitenrande der Fld., deren Spitze breit roth gezeichnet ist.

2. Cr. C'zwalinae: Breviusculus, niger, nitidus, capite (linea media frontis excepta), antennarum basi pedibusque faicis, prothorace parce subtilissimeque punctulato, margine laterali flavo, elytris subtiliter punctato-striatis interstitiis parce fere seriatim punctulatis, macula transversa angusta in apice epipleurisgue flavis; prosterno antice et inter coxas flavescenti, processu 
Kopf eben, nur über dem Kopfschilde fein punktirt, Stirn mit ganzer Mittelrinne. Halsseh. ziemlich kurz, nach vorn mässig verengt, kaum sichtbar punktirt. Fld. schwarz, an der Spitze breit rothgelb gesäumt, die Epipleuren mit Ausnahme der feinen Seitenränder weisslich gelb bis trüb-gelbbraun; regelmässig punktirtgestreift, die Punktreihen ziemlich stark, etwas vertieft, vor der Spitze feiner und flacher. Vorderbrust zwischen den Hüften mässig breit, der Länge nach vertieft, der Vorderrand leistenförmig aufstehend, der Hinterrand beinahe grade abgestutzt.

$\hat{\jmath}$. Kopf gelb oder rotbgelb, die Stirnrinne 'zuweilen dunkel; Halssch. mit einem schmalen, gelben Saume am Vorderrande, der sich in den Vorderecken erweitert und bis zur Mitte des Seitenrandes fortsetzt, selten von hier aus noch äusserst schmal bis $z u$ den Hinterecken hinzieht. Auch die Vorderbrust ist am Vorderrande und zwischen den Hüften gelblich. Das erste Tarsenglied der vorderen Füsse ist nicht, wie bei den Verwandten, erweitert, sondern so schlank als beim ㅇ. - Penis dick und kurz, zangenförmig, der Unterrand ist gekrümmt und läuft in zwei lange, durch einen tiefen Schlitz getrennte Lappen aus, auf die sich eine gleichlange, aber entgegengesetzt-gekrümmte pfriemenförmige Verlängerung des Oberrandes legt. Eine ähnliche Penisbildung findet sich bei allen Angehörigen dieser Reihe.

ㅇ. Unterkopf und zwei Stirnmakeln, ähnlich dem ô von ocellatus, röthlich gelbbraun, zuweilen jedoch der ganze Kopf mit Ausnahme der dunklen Stirnlinie rothgelb (Var. a.); Halssch. einfarbig schwarz, oder der Vorderrand äusserst schmal, die Vorderecken dentlicher roth (Var. b.).

Auf Gebüschen häufig. Stücke aus Dalmatien sind, wie schon Suffrian erwähnt, erheblich grösser als die deutschen.

19. Cr.front al is $\left.{ }^{1}\right)$ : Niger, nitidus, antennarum basi pedibusque rufotestaceis, femoribus posticis nigris, anterioribus superne leviter infus-

labiali sat magno, deflexo $(\hat{\odot})$ vel brevi $(\uparrow)$. Tarsis anterioribus articulo primo maris dilatato. - Long. 2-2,5 $\mathrm{mm}$.

Von Herrn $\mathrm{Czw}$ alina aus Königsberg in Italien bei Vallombrosa wahrscheinlich auf Quercus cerris gefangen.

1) Hierher: 1. Cr. scapularis Suffr. (III. 99) aus Italien, von Toskana (Bellier) bis Sicilien, ist etwas grösser, Fühlerwurzel, Kopf, Vorderrand des Halssch. (beim $f$ in der Mitte meist unterbrochen) und die Beine einfarbig rothgelb, Epipleuren (nur beim $\hat{\sigma}$ ) und Vorderbrust 2wischen den Hüften gelb. Letztere ist von einem sehr hohen, scharfen und dachförmigen Mittelkiele durchzogen, der Vorderrand ist niedrig, gerundet. 
calis; facie infra antennas, prothoracis margine antico et anyulis anticis, scutelli apice elytrorumque epipleuris flavis, prothorace laevissimo. elytris fortiter punctato-striatis, prosterno postice subemarginato. Long. $2-3 \mathrm{~mm}$.

Mas: fronte flava, tarsis anterioribus articulo primo dilatuto.

Femina: fronte macula cordata mufo-testacea.

Marsh. Ent. Brit. I. 211. - Gyllh. Ins. Suec. III. 626. Suffr. Mon. III. 100. - Redtb. Faun. A. II. 464. Seidl. F. balt. 479. - Schwarz Ber. Schles. Ges. 1870. 26. Var. a. ㅇ․ Scutello nigro.

Die Art verbindet ungefähr die Gestalt des labiatus mit der Zeichnung des flavipes und lässt sich von unseren ähnlichen kleinen Arten mit schwarzen Fld. durch das meist helle Schildchen und die gelben Epipleuren ohne Mübe unterscheiden.

Schwarz, Fühlerwurzel und Beine röthlich gelbbraun, Hinterschenkel fast ganz schwarz, die vorderen Schenkel auf dem Rücken gebräunt. Kopf fast glatt, gelb, höchstens die Mittelrinne der Stirn dunkel ( $\hat{o})$, oder ein Punkt in der Ausrandung der Augen und eine breite, nach unten verengte Mittellinie der Stirn schwarz, so dass von der gelben Färbung nur eine tief-herzförmige Makel zwischen den Augen übrig bleibt. Halssch. sebr kurz, binten doppelt so breit als lang, wenig gewölbt, spiegelglatt, der Vorderrand und die Vorderhälfte des Seitenrandes gelb. Schildchen mit einem gelben Punkte vor der Spitze, der, wie die übrige helle Zeichnung, in der Regel beim Weibchen dunkler, weniger bemerkbar ist, selten ganz fehlt (Var. a.). Fld. schwarz, Epipleuren und beim $\hat{\jmath}$ gewöhnlich noch die Kante des Seitenrandes über denselben gelb; die Punktreihen regelmässig, kräftig, vor der Spitze nur wenig feiner als vorn. Vorderbrust am Mundrande, oft auch zwischen den Hüften gelblich, hier ziemlich eben, hinten in einem schwachen Bogen ausgerandet.

Auf Birken und Weiden in Gebirgsgegenden. Ausserdem im nördlichen Europa, mit Ausschluss Englands.

2. Cr. mystacatus Suffr. (III. 94) aus Spanien und Portugal, hat schwarzblaue, fein punktirt-gestreifte Fld. mit schwarzen Epipleuren, rothgelbe Fühlerbasis und einfarbig rothgelbe Beine. Beim $\hat{\odot}$ (Cr. larlatus Suffr. 1. c. 9S) ist der Kopf mit Ausnahme der Mittellinie der Stirn und einer Querlinie über der Fühlerwurzel, sowie das Halssch. am Vorderrande und in den Vorderecken gelb; beim $q$ Unterkopf und Saum in der Ausrandung der Augen gelb, Vorderrand des Halssch, bräunlich. Vorderbrust zwischen den Hüften gelb, mit feinem, niedrigem Mittelkiele, der Mundrand in der Mitte stumpfwinkelig vorgezogen. 
50. Cr. suliceti: Niger, nitidus, antennarum basi perlibusque rufotestaceis, femoribus posticis nigris, anterioribus superne infuscatis, facie infra antemas, maculis 2 frontis, prothoracis margine antico et laterali (medio interrupla) flavo-testaceis, prolhorace laevissino, elylits mimus fortiter punctalo-striatis, striis apice deletis, epipleuris interdum piccis, prosterno antice et inter coxas flavescenti, postice bimcronato. - Long. $2,5-3,5 \mathrm{~mm}$.

Zebe Stett. Zeit. 1855. 28. - Redtb. Faun. A. II. 464 . Seidl. Faun. balt. 479. - Schwar z Ber. Schles. Ges. 1870. 26.

In Grösse und Körperform dem folgenden am ähnlichsten, aber sofort an der Vorderbrust, die, wie bei Moraei, linten in zwei lange, wach unten gerichtete gelbe Dornen ausläuft, zu erkennen.

Schwarz, stark glänzend, Fühlerwurzel und Beine röthlich gelbbraun, Hinterschenkel mehr oder weniger weit schwarz, die vorderen Schenkel auf dem Rücken gebräunt. Kopf einzeln punktirt, mit kurzer Stirnfurche, schwarz, Unterkopf und zwei wenig scharf begrenzte Makeln auf der Stirn, zwischen der Mittelfurche und dem oberen Innenrande der Augen, länglich (meist $\hat{\jmath}$ ) oder rund (meist gelb. Halssch. kurz, mässig gewölbt, kaum sichtbar punktirt, der Torder- und Seitenrand gelb gesäumt. Der Seitensaum ist beim $\tilde{\jmath}$, breiter als der vordere, lässt den abgesetzten schwarzen Rand selbst frei, biegt aber dicht vor den Hinterecken auf denselben über und ist in der Mitte gewöhnlich punktförmig unterbrochen; beim q, dessen belle Zeichnung röthlich und weniger deutlich ist, wird der Vorderrandsaum in der Mitte undeutlich, vom Seitensaume bleibt nur eine Längsmakel in den Vorderecken und der kurze, nach aussen gebogene Theil vor den Hinterecken übrig. Schildchen schwarz. Fld. mit pechbraunen Epipleuren, ziemlich fein punktirt-gestreift, die Punktreihen erlöschen auf der hinteren Wölbung ( $\hat{\jmath})$ oder vor derselben (q). Vorderbrust am Mundrande und zwischen den Hüften gelb, hinten in zwei lange Dornen endigend, die beim Weibchen kürzer und weiter von einander gerückt sind als beim Männchen.

Auf Weiden (Salix caprea) in Gebirgsgegenden (Thüringen, Harz, Schlesien, Alpen) selten.

51. Cr. ocellatas $\left.{ }^{1}\right)$ : Breviusculus, niger, nitidus, antennarum basi pedibusque rufo-lestaceis, capile infira antennas maculisque 2 fromtalibus flavis, fronte canaliculata, prothorace sublaevi, elytris junclalo-

i) Cr. ochropezus Suffr. (VIII. 144) aus Sicilien, ist schmaler, Halssch. länger, vorn weniger verengt. Fld. gleichbreit, matter, merklich feiner punktirt. Beim $\hat{\epsilon}$ Unterkopf und zwei kleine Stimmakeln gelb, beim ํ. nur die Seiten des Kopfes unterhalb der Augen rothgelb. 
striatis, striis pone medium evanescentibus; rentre subopaco; prosterno Irto, longitudinaliter deplanato, postice bidentato. - Long. 3-4 mm. Mas: maculis frontis sat magnis, emaryinatura oculorum evidenter tesfoceolimbata.

Femina: maculis frontis parvis, emarginatura oculorum obsolete rel parum flavo-limbata.

Drap. Ann. gén. Sc. phys. Brux. I. 201. t. 25. f. 5. - H a rold Berl. Zeit. 1873. 168. - Seidl. Faun. balt. 479.

Cr. geminus Gyllh. Ins. Suec. IV. App. 670. - Küst. Käf. Eur. III. 91. - Suffr. Mon. III. 92. - ? Redtb. Faun. A. II. 461.

Var. a. 9 . Fronte omnino nigra.

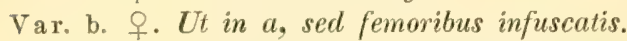

Von der Grösse des flavipes $\hat{\jmath}$, aber vorn schmaler, hinten mehr gerundet verengt, die grösste Breite hinter der Mitte der Fld. schwarz, Fühlerwurzel und Beine röthlich gelbbraun, Kopf unterhalb der Fühler, ein damit zusammenhängender Saum, der nach oben hinter der Fühlerwurzel bis in die Ausrandung der Augen reicht und zwei Stirnmakeln gelb, gelbbraun oder rothbraun. Auf der flachen Stirn befindet sich eine Mittelrinne und ein tiefer Schrägeindruck am oberen Innenrande der Augen. Halsseh. gewölbt, nach vorn stark verengt, sehr fein punktirt, fast glatt. Schildchen ziemlich breit, hinten abgestutzt. Fld. besonders beim Weibchen von der Basis allmählich nach hinten erweitert, regelmässig punktirt-gestreift, die Punktreihen vorn ziemlich stark, hinter der Mitte meist sehr fein $(\hat{\jmath})$ oder fast erloschen (q), nur die am Seitenrande tief; Zwischenräume auf der vorderen Hälfte der Fld. beim $\hat{\jmath}$ etwas gewölbt, ihr Glanz durch eine, selbst bei scharfer Vergrösserung kaum sichtbare Netzelung abgeschwächt und in einen leichten Fettschimmer verwandelt. Bauch zwischen der Punktirung dicht und fein quer gerunzelt, ziemlich matt. Vorderbrust zwischen den Hüften breit, an den Seiten mit hoher Randlinie, die Mitte deshalb längsvertieft, der Vorderrand flach, einfach gerundet, der Hinterrand jederseits in eine scharfe Spitze ausgezogen.

Das $\hat{j}$ ist an den grösseren, oft helleren Stirnmakeln, dem längeren und breiteren hellen Saume in der Ausrandung der Augen und dem flachgewölbten letzten Bauchringe zu erkennen.

Bei der seltenen Var. a. ist die Stirn einfarbig schwarz; von der Var. b. fand ich ein Exemplar in der Marmarosch bei Sziget in Ungarn, welches sich durch stärkere Punktirung des Halssch. auszeichnet und bei dem die vier hinteren Schenkel mit Ausnahme der Basis und Spitze schwarz, die Vorderschenkel nur auf dem Rücken leicht gebräunt sind. 
Auf Weiden häufig. Fehlt in Schweden und England.

Es ist fraglich, ob $C r$. geminus Redtb., welcher schwärzliche Hinterschenkel besitzen soll, wirklich hierher gerechnet werden darf. Die mir vorliegenden österreichischen Exemplare stimmen mit den norddeutschen genau in den einfarbigen, lebhaft rothgelben Beinen überein.

52. Cr. queneti: Elongalulus, nitjer, nitidissimus, antemis piceis, basi, capite infra antennas pedibusque ru/o-testaceis, femoribus posticis infiscatis, fronte plana, prothorace laevissimo, elytris leviter coeruleomicantibus, punctato-striatis, striis pone medium evanescentibus; ventre niticlo, prosterno postice truncalo, processu labiali brevi. - Long. $3 \mathrm{~mm}$. Suffr. Mon. III. 96. - Redtb. Faun. A. II. 464. - Seidl. Faun. balt. 478. - Schwarz Ber. Schles. Ges. 1870. 25.

Cr. labiatus Fabr. Syst. Ent. 112. - Panz. Faun. Germ. 68. 9.

Bedeutend gestreckter, paralleler und viel glänzender als der rorige, die schwarze Farbe der Oberseite oder wenigstens der Fld. mit einem Stich ins Stahlblaue; Kopf einzeln, sehr fein punktirt, in beiden Geschlechtern nur unterhalb der Fühlerwurzeln röthlichgelb, beim $q$ jedoch das Kopfschild in der oberen Hälfte schwarzbraun. Stirn eben, Fühler dunkelbraun, nach der Basis hin heller. Halssch. spiegelglatt. Schildchen schmal, dreieckig, hinten meist scharf zugespitzt. Fld. punktirt-gestreift, die inneren Punktreihen hinter der Mitte sehr fein und undeutlich; die Punkte der Reihen sind flacher als bei ocellatus, und greifen nie auf die ebenen und stark glänzenden Zwischenräume über. Unterseite schwarz, Bauch weitläufig punktirt und gerunzelt, glänzend. Beine lebhaft röthlich gelbbraun, Hinterschenkel auf der Oberseite gebräunt. Vorderbrust zwischen den Hüften nach hinten verbreitert, mit einem schwachen, feinen Mittelkiele, der Vorderrand in einen stumpfen Winkel nach unten vorgezogen, der Hinterrand ziemlich grade abgestutzt.

Auf Eichen und Birken selten.

Gredler hält diese Art (Käf. Tir. 415) ohne Grund für eine Form des ocellatus mit fehlendem Stirnflecke: eine Verwechselung kann nur mit labiatus stattfinden, ist aber $\mathrm{zu}$ vermeiden, wenn die bedeutendere Grösse, Schlankheit, hellere und lebhaftere Färbung der Beine und die Bildung der Vorderbrust beachtet werden.

53. Cr. Iabiatos: Minus elongatus, niger, nitidus, antemarum basi. facie infra antemas omnino ( $\hat{\jmath}$ ) vel latera versus (f) et perlibus anterioribus rufo-testaceis, femoribus anticis supra lineola nigra notatis, intermediis superne infuscatis; prothorace laevissimo, elytris fortiler. 
punctato-striutis, striis apice deletis, prosterno carina media antice fortiter elevata instructo, processu apice subemarginato. - Long. $2-2,8 \mathrm{~mm}$.

Mas: tarsis anterioribus articulo primo dilatato et quam lertius longiore. Fem: tarsis anterioribus articulo $1: 03: 0$ aequali.

Linn. Faun. Suec. 169 (Chrysom). - Küst. Käf. Eur. III. 90.

- Suffr. Mon. III. 86. - Redtb. Faun. A. II. 461. -

Seidl. Faun. balt. 479. - Schwarz Ber. Schles. Ges. 1870. 25.

Var. a. Pedibus intermediis infuscatis.

Cr. exilis Steph. Ill. Brit. IV. 361. - Suffr. 1. c. 88.

Var. b. $\hat{\sigma}$. Emarginaiura oculorum frontali plus minusve testaceo-limbata.

Cr. digrammus Suffr. 1. c. S8. - Redtb. 1. c. 464.

Var. c. $\hat{\circ}$. Fronte nigra punctis 2 testaceis.

C'r. labiatus var. ocularis Heyd. Jahresber. Ges. Graubündt. 1863. 46 .

Länglicher und nur halb so gross als ocellatus, schwarz, der Unterkopf ganz hellgelb $(\hat{\jmath})$ oder mit Ausnahme des pechschwarzen Kopfschildes (ㅇ) gelbbraun. Stirn leicht gewölbt; Fühler etwa so lang als zwei Drittel des Körpers ${ }^{1}$ ), bis zum fünften Gliede röthlich gelb, Glied 6 bis 11 braun oder schwarz, jedes ron diesen, das Endglied ausgenommen, nach der Spitze zu etwas erweitert. Halssch. kurz, kaum sichtbar punktirt; Schildchen hinten mit leicht abgerundeter Spitze. Fld. weniger glänzend als das Halssch., stark punktirt-gestreift, die inneren Punktreihen auf dem Abfalle zur Spitze oder dicht vor demselben erlöschend, die Zwischenräume auf der vorderen Hälfte und an den Seiten schwach gewölbt. Unterseite schwarz, Bauch wenig dicht punktirt und äusserst fein gerunzelt, fettig glänzend. Beine röthlich gelbbraun, Vorderschenkel mit schwarzer Rückenlinie, Mittelschenkel oberseits gebräunt, Hinterschenkel fast ganz oder ganz schwarzbraun. Diese dunkle Färbung nimmt jedoch zuweilen so zu, dass die Mittel- und Hinterbeine schwarz sind, mit bräunlichen Schienenspitzen und Tarsen, und auch die Vorderschenkel oben angedunkelt werden (Var. a.). Vorderbrust zwischen den Hüften sehr breit, mit einem starken, rorn hohen und dachförmigen Längskiele; der Vorderrand in einen spitzen Winkel nach unten vorgezogen, der Hinterrand leicht ausgeschnitten. Das erste Tarsenglied ist an den Vorder- und Mittelbeinen beim $\hat{j}$

1) Bei Cr. longicornis Thoms. (Skand. Col. VIII. 311) aus Schweden, sollen die Fühler etwas länger $(\hat{\odot})$ oder wenig kürzer ( $\hat{f}$ ) als der Förper und rom sechsten Gliede an beim Männchen dreieckig erweitert sein. Im Uebrigen ist das Thier von einem kleinen labiatus nicht zu unterscheiden und wohl keine Art. 
erweitert und so lang als die zwei folgenden zusammen, beim $f$ breit dreieckig, innen mit scharfer Spitze und nur so lang als das dritte.

Bei den Männchen zieht oft vom Unterkopfe aus hinter der Fühlerwurzel ein schmaler gelber Saum in die Ausrandung der Augen verschieden weit hinein, doch niemals bis an den obcren Innenrand der Augen am Scheitel, wie bei der folgenden Art. Diese Stücke bilden den Cr. digrammus Suffr., sind aber von labiatus nicht zu trennen, da die Länge des Augensaumes sehr variabel ist und sonstige Unterschiede, besonders bei den $q$ ganz fehlen. Die Var. c. hat nur einen kleinen gelben Punkt jederseits in der Ausrandung der Augen.

Auf Weiden- und Birkengebüschen häufig.

5.4. Cr. exigums: Elongatulus, niger, nitidus, supra plemumque leviter coeruleo-micans, antennarum basi pedibusque rufo-testaceis, femoribus posticis piceis, prothorace subilissime punctato-strigoso, elytris punctato-striatis. - Long. 2-2,5 $\mathrm{mm}$.

Mas: capite flavo, fronte linea media antice interdum plus minusve dilatata nigra, tarsis anterioribus articulo 1 : o fortiter dilatato.

Femina: capite nigro, epistomate labroque rufis.

Schneid. Neu. Mag. I. 2. 204. - Suffr. Mon. III. 109.

Cr. Wasastjernae Gyllh. Ins. Suec. IV. 669. - Suffr. 1. c. 90.

- Redtb. Faun. A. II. 464. - Seidl. Faun. balt. 478.

Vom vorigen durch das längere, längsrunzelige Halssch. und die bis zur Spitze der Fld. fast gleichstarken Punktreihen leicht $z u$ unterscheiden.

Gestreckt, schwarz, die Oberseite meist mit einem schwachen blauen Schimmer, Fühlerwurzel und Beine mit Ausnahme der Hinterschenkel röthlich gelbbraun. Kopf fast eben, die Stirn mit einer seichten Mittelrinne. Halssch. mässig lang, stark gewölbt und zusammengedrückt, nach vorn wenig verengt, dicht und sehr fein der Länge nach, doch nicht ganz regelmässig gestrichelt und in den Strichen punktirt. Fld. mässig stark punktirt-gestreift, die Punktreihen auf dem Abfalle zur Spitze nur wenig feiner.

Das $\hat{o}$ hat einen gelben Kopf, auf der Stirn eine kurze und schmale schwarze Mittellinie. Letztere verbreitert sich zuweilen zu einem breiten Dreiecke über der Fühlerwurzel, so dass dann nur ein gelber, bis an den Scheitel reichender Saum am Innenrande der Augen übrig bleibt. Von diesem ist bei den dunkelsten Stücken der oberste Theil in Form einer runden Makel abgetrennt. Das 우 hat einen schwarzen Kopt, von welchem nur die Oberlippe und cin schmaler Saum über dem Munde, seltener das ganze Kopfschild roth ist. 
Auf Weiden, auch auf Blüthen am Rande feuchter Waldwiesen, in Nord- und Mitteldeutschland stellenweise nicht selten. Tirol.

Die Skulptur des Halssch. ist nicht ganz constant; bisweilen verschwinden die Längsstriche auf der hinteren Hälfte, so dass diest nur mit grösseren und feineren Punkten ziemlich dicht verworren besetzt ist. Solche Stücke, die auch bei uns vorkommen, sammelte H. Gredlex bei Leifers in Tirol (Käf. Tir. 417).

\section{Reihe. Verwandte von Cr. Moraei.}

55. CN. Vonei: Niger, nitidus, antennarum basi obscue leslacea: prothorace parce, subtilissime punctato, anyulis posticis elevatis flavoalbidis; elytris profunde punctato-striatis, interstitiis exterioribus convexis, epipleuris, macula marginali sub humeris apiceque flavo-albidis. pedibus anticis plus minusve flavis, prostemi processu postice testacenbimucronato. - Long. $3-5 \mathrm{~mm}$.

Mas: capite signatura flava litteram $\boldsymbol{X}$ formante, thoracis margine antico flavo.

Femina: Fronte lineolis 2 ocularibus flavis.

Linn. Syst. Nat. ed. X. 374 (Chrysom.). - Panz. Faun. Germ. 68. 11. - Suffr. Mon. II. 185̆. - Redtb. Faun. A. II. 461. - Seidl. Faun. balt. 478.

Var. a. Tibïs tarsisque testaceis, femoribus posterioribus macula albu nolatis.

Var. b. $\hat{.}$. Capitis, interdum etiam thoracis pictura ut in lemina.

Var. c. $\hat{\odot}$. Capite flavo striola verticis nigra, prothorace plerumque vittu laterali, medio angustata, flava.

Var. d. 오. Lineolis ocularibus antice connexis.

Var. e. ㅇ. Capitis et prothoracis pictura ut in mare.

Var, f. Prothorace maculis 2 antescutellaribus obscure-rubris.

Var. g. Capite ut in $c(\hat{\odot}+f)$, prothoracis margine antico (lineolam abbreviatam in medio emittente) et laterali fasciaque pone medium (saepe divisa) rufo-flavis ${ }^{1}$.

1) Dieser Var. ähnlich, aber gestreckt, gleich breit, cylindrisch ist $\mathrm{Cr}$. Mariae Muls. (Mém. Ac. Lyon 1851 p. 145 - signatus Ol. Suffr.). Kopt und Halssch. wie bei vittiger gefärbt, letzteres fein aber dicht punktirt, nach vorn wenig verengt; Fld. in etwas unregelmässigen Reihen punktirt, bräunlich gelb, die Naht und zwei verwaschene Querbinden, eine hinter der Basis, die andere hinter der Mitte schwarz. Diese Binden oft in vier Makeln $(2,2)$ aufgelöst, von denen 2,3 und 4 verwaschen sind oder (Var. pyre naeus) theilweise, selbst ganz fehlen, 1, auf der Schulter, länglich und scharf begrenzt ist. Beine gelbbraun mit weisslichem Flecke ror der Schenkelspitze. Unterseite schwarz, Seitenstïcke der Mittelbrust, oft auch der Hinterbrust und eine Makel an der Seite jedes Bauchringes gelb. Vorderbrust hinten nur leicht ausgeschnitten. - L. 3,5-4,5 mm. Südfrankreich. Spanien, Algier. 
Cr. Moraei var. vittiger Mars. Mon. 165.

Var. h. Elytris striolis 2 flavis pone scutellum.

Var. i. Elytrorum macula subhumerali in fasciam utringue dentatam rarissime interruptam dilatata.

Cr. bivittatus Gyllh. Ins. Snec. III. 619.

Cr. interrupto-fasciatus Suffr. Mon. II. 188.

Cr. Moraei var. cruciatus Mars. Mon. 165.

Var. k. arquatus: Elytris flavescentibus, sutura fasciisque 2 angustis

(interdum etiam intermuptis), altera basi, altera pone medium, nigris.

Eine der bäufigsten Arten; durch die zwei langen, gelben Spitzen, in welche der Hinterrand der Vorderbrust verlängert ist, von den übrigen, ausser nitidus, sofort zu unterscheiden.

Mässig gedrungen, in den Schultern am breitesten, schwarz, glänzend, Füblerbasis ganz oder unterseits dunkel gelbbraun, Hinterecken des Halssch. und zwei Makeln auf jeder Fld., die eine länglich, unter der Schulterbeule über den gelben Epipleuren, die andere quer, in der Spitze, gelb. Halssch. auf der Scheibe zerstreut und sehr fein, nach den Seiten hin dichter und stärker punktirt. Fld. stark punktirt-gestreift, die inneren $\mathbf{Z}$ wischenräume ziemlich eben, die äusseren gewölbt. Beine schwarz, die Unterseite der Vorderschenkel, die Vorderschienen und Tarsen gelb. Diese helle Färbung nimmt jedoch, ohne Rücksicht auf die Zeichnung der Fld., oft so zu, dass auch die hinteren Schienen und Tarsen gelb, und die hinteren Schenkel mit einer weissen Makel vor der Spitze versehen sind: Var. a.

j. Klein, Kopf mit x-förmiger gelber Zeichnung, deren untere Schenkel schmaler als die oberen sind; Halssch. mit schmalem gelben Vordersaume, der sich in den Vorderecken zuweilen erweitert und ein Stück am Seiteurande fortsetzt. - Penis schlank, auf der Oberseite der vorderen Hälfte vertieft, die gerundet-rerengte Spitze winkelig nach unten gebogen. ․ Gross, plump, Kopf schwarz, zwei kurze Längslinien auf der Stirn am inneren Augenrande gelb.

Die Zeichnung ist sehr veränderlich. Bei südlichen, besonders griechischen Exemplaren zeigt der Kopf des $\hat{\sigma}$ nur zwei gelbe Stirnlinien und das Halssch. zuweilen nur gelbe Hinterecken, wie das + (Var. b.), oder der Kopf ist im entgegengesetzten Falle ganz gelb, mit feiner, schwarzer Mittellinie unterhalb des Scheitels, während der gelbe Vordersaum des Halssch. nicht selten seitwärts bis zu der Makel in den Hinterecken verlängert ist (Var. c.). Die f haben oft vorn verbundene Stirnlinien (Var. d.), oder die vollständige Kopfzeichnung des $\hat{j}$ und auf dem Halssch, eine gelbe Linie a. in der Mitte, b. jederseits oder c. längs des ganzen Vorder-

vT. 2. 
randes (Var. e.). Nur selten treten vor dem Hinterrande des Halssch. zwei dunkelrothe, wenig deutliche Makeln ror dem Schildchen hervor (Var.f.), die sich später zu einer beiderseits zugespitzten, in der Mitte durch eine feine schwarze Längslinie getrennten, rotbgelben Querbinde vergrössern (Var. g.). Auf den Fld. befinden sich zwei kurze, gelbe Längsstriche an der Naht hinter dem Schildchen (Var. h.), oder es dehnt sich (Var. i.) hinter dem Schulterhöcker die vordere Makel zu einer meist zackigen Querbinde aus, von welcher auch der innere Theil in Form einer runden, gelben Makel abgetrennt sein kann; die Binde verbreitert sich zuletzt so, dass bei der glejchzeitigen Vergrösserung des Spitzenfleckes die Fld. gelb sind, mit schwarzer Naht und zwei oft sehr schmalen, gemeinschaftlichen Querbinden, die eine an der Basis, die andere hinter der Mitte (Var. k). Von diesen Binden ist mitunter aussen eine schwarze Makel abgesondert, die eine auf der Schulter, die andere am Seitenrande hinter der Mitte. Bei frischen Stücken ist die helle Zeichnung der Oberseite oft feuerroth.

Auf Blüthen an sonnigen Abhängen häufig.

56. Cr. sexpustulatus $\left.{ }^{1}\right)$ : Niger, nitidus, antennis basi et perlibus anticis testaceis, tarsis posterioribus subtus obscure testaceis, pro-

1) Vor diese Art sind zu stellen:

a. Beine gelbbraun, Hinterschenkel theilweise schwarz.

1. C'r. crassus Ol. (Encycl. VI. 620. - gravidus H. Schäff. Faun. Germ. 143. 23; Suffr. III. 43). Kopf und ein breiter Vordersaum des Halssch. ( $\hat{\odot}$ ), oder nur die Stirn ( $q$ ) gelb. Halssch. fast glatt, Fld. fein in Reihen, dazwischen zerstreut äusserst fein punktirt, mit vier rothgelben Flecken $(1,2,1)$. - L. 3-4,5 mm. Norditalien, Südfrankreich, Spanien.

Var. tenebricosus: Eine oder mehrere Makeln der Fld. fehlen; zuletzt sind die Fld. mit Ausschluss der Epipleuren schwarz.

b. Beine gelbbraun, Schenkel dunkler.

2. Cr. maculicollis Suffr. (XI. 222). Wie voriger: Halssch. bei $\hat{\jmath}$ und $q$ mit breitem gelben Vordersaume, der sich in der Mitte dreieckig erweitert, und mit drei gelben Makeln vor der Basis. - L. 4,5 mm. Aegypten.

c. Beine schwarz, Vorderschienen und -Tarsen gelbbraun, Hintertarsen braun.

3. Cr. stragula Rossi (Mant. Ins. II. 90). Schmaler als crassus, ebenso fein, aber auf den Fld. unregelmässiger punktirt. Kopí und Halssch, bei $\hat{\oplus}$ und $q$ schwarz. Fld. schwarz, mit breitem strohgelben Seitensaume, der in der Mitte stark verengt ist. Diese Zeichnung entsteht, wenn Makel 1 und 3 des $C r$. sexpustulatus rer- 
thorace lacei, elytris punctalo-striatis, maculis $1(1,2,1)$ flavis. Long. 3,5-5 $\mathrm{mm}$.

Mas: facie infra antennas, macula cordala frontis, margine antico et angulis posticis prothoracis flavis; segmento ultimo ventrali lonyiludinaliter deplanato.

Fem: facie inferne flavo-maculata.

Rossi Faun. Etr. I. 97. t. 2. f. 7. - Suffr. Mon. III. 38. Seidl. Faun. balt. 477.

Cr. octoguttalus Schneid. Neu. Mag. I. 2. 200. - Oliv. Ent. VI. 816. - Redtb. Faun. A. II. 461.

Var. a. P. Prothorace aut margine antico aut angulis posticis flavosignato.

Yar. b. oneratus: Elytrom signaturis flavis dilatatis et magis minusve confluentibus.

Var. c. omissus: Maculis nonnullis elytrorum deficientibus.

Etwas grösser und gewölbter als Moraei, schwarz, Fühler pechbraun, an der Basis oft bis zum siebenten Gliede und die Vorderbeine hell gelbbraun, die hinteren Tarsen unterseits dunkelbraun. Halssch. fast spiegelglatt, Fld. ziemlich stark punktirt-gestreift, mit je vier gelben Flecken; der erste quer, bindenförmig, an der Basis zwischen Schildchen und Schulter, der zweite über den gelben Epipleuren am Seitenrande, vorn schmal, hinter der Schulterbeule halbkreisförmig erweitert, der dritte länglich oder rund, in der Mitte, nahe der Naht, der vierte quer, dicht vor der Spitze.

3. Kopf unterhalb der Fühler, eine schmal-herzförmige Stirn-

schwunden und 2 und 4 (am Seitenrande) schmal verbunden gedacht werden. - L. 5-6 mm. Toskana. Südfrankreich.

d. Beine schwarz, Vorderbeine und bisweilen die Unterseite der Mittelschenkel rothgelb.

4. Cr. anticus Suffr. (III. 37; VIII. 137). Von 6-pustulatus durch schmaleren Körper, feiner punktirte Fld. und kleinere rothgelbe Flecke der Fld., von welchen oft nur die Spitzenmakel vorhanden ist, verschieden. Beim $\hat{\odot}$ ist die Mitte des Kopfschildes, beim der ganze Kopf schwarz. - L. 4,5-6,5 mm. Kaukasus.

5. Cr. Koy r Suffr. (III. 46). Kopf mit Ausnahme des vorn gerade begrenzten schwarzen Scheitels und ein breiter, in den Ecken erweiterter Vordersaum des Halssch. ( $\hat{\jmath}$ ), oder Kopf mit Ausnahme des Scheitels und der Mitte des Kopfschildes (q) rothgelb. Sonst wie 6-pustulatus. - L. 3,5-5 mm. Frankreich. Spanien.

Zuweilen ist Makel 2 und 3 der Fld. zu einer Querbinde, oder Makel 1, 3 und 2 zu einem grossen, rothgelben Flecke vereint, welcher auf der Vorderhälfte der Fld. nur einen Schulterpunkt schwarz. lässt: Var. Martinezi. 
makel, der Vorderrand und eine strichfömige Makel in den Hinterecken des Halssch, gelb. Letzter Bauchring in der Mitte fast spiegelglatt, der Länge nach niedergedrückt. - Penis kurz, breit, rorn allmählich in eine abgerundete Spitze vorgezogen.

․ Kopf und Halssch. schwarz, ersterer mit einem gelben Fleckchen unter jedem Auge.

Auf dem Halssch. rerschwindet beim $\hat{j}$ zuweilen die Makel in den Hinterecken fast ganz, beim $\Varangle$ stellt sich dagegen die Zeichnung des $\hat{j}$ wenigstens theilweise in den Hinterecken oder in der Mitte des Vorderrandes ein (Var. a.). Die Makeln der Fld. können sich vergrössern und rerbinden sich dann zum Theil mit einander (Var. b.), oder sie verkleinern sich und verlöschen (Var. c). Bei b. ist zuletzt Makel 2 mit 3 zu einer in der Mitte verschmälerten Querbinde und mit 4 schmal am Seitenrande rerbunden; bei c. erlischt eine der drei rorderen Makeln. Wenn sich Makel 2 bedeutend rerkleinert oder ganz verschwindet, so sind auch die Epipleuren schwarz.

Auf feuchten Wiesen im Juli nicht selten. Fehlt nur in Nordeuropa.

5. Cr. vittatas $\left.{ }^{1}\right)$ : Niger, antemis basi miescentibus. prothorace parce subtilissime, juxta angulos anticos crebrius punctuto. clytris substriato-punctatis, flavis, sutura vittaque media nirira. - Long. 3-4,5 nu. Mas: prothorace juxta angulos anticos parce temissime muscenti. ciltu media elytrorum ante apicem cum sutura late connexa.

Fem: Elytris vilta media postice cum sutura anyuste vel hund comexa. Fabr. Syst. Ent. 110. - Suffr. Mon. III. 51. - Redtb. Faun. II. 462. - Seidl. Faun. balt. 477.

1) Vor diese Art gehört:

Cr. Rossii Suffr. (III. 48; VIII. 139). Schwarz, Fühlerwurzel röthlich, vier Flecke der Fld. (wie bei 6 -pustulatus) rothgelb. Halssch. in den Vorderecken dichter punktirt und (beim $\hat{\epsilon}$ ) deutlich behart. - L. 3 bis $5 \mathrm{~mm}$. Südfrankreich. Spanien.

Aendert ab. a. Makel 1 fehIt: centrimaculatus Suffr. (Stett. Zeit. 1849. 20; Kïst. 17. 99); b. wie a, aber Makel 2 und 3 zu einer Querbinde vereint: Graëllsi; c. die inneren Makeln 1 und 3 telslea (Moraci ähnlich): hirtifrons Graëlls (Mém. Map. 1858. 98): d. alle 4 Makeln der Fld. rergrössert und mehr oder weniger zusammen geflossen: zunächst 2 und 3 : dann 2 und 3 mit 1 ; endlich 2 innen mit 3 und 1 , am Seitenrande mit 4 . Bei der letzten Form sind die Fld. roth, mit schwarzew Schulterpunkte und schwarzer Naht, die hinter dem Schildchen makeliörnig und hinter der Mitte zn einer aussen verbreiterten, abgekürten Querbinde erweitert ist (t $t$-punctatus ähnlich): gaditanus Mars. Mon. 206. 
Var. a. negligens: Villa media elytrontm postice et pone sculellum com sutura comnexa.

Eine bäufige, durch die schwarze Längsbinde auf den gelben FId. dem Cr. bohemins und tlewnosus ähnliche Art, die durch die Skulptur des Halssch. vor allen Verwandten recht ausgezeichnet ist.

Schwarz, glänzend, Fühlerwurzel röthlich, Fld. auf der Scheibe nicbt ganz regelmässig punktirt-gestreift, gelb oder gelbbraun, die Naht und eine Längsbinde, welche an der Basis beginnt und vor der Spitze endet, schwarz. Diese Binde ist beim 우 hinten gar nicht oder nur schmal, beim $\hat{j}$ breit mit dem schwarzen Nahtsaume verbunden, welcher bald fast gleich breit, bald hinter dem Schildchen gerundet-erweitert ist. Kopf und Halssch. einfarbig schwarz, letzteres rorn stark zusammengedrückt, weitläufig und sehr fein, gegen die Vorderecken hin dichter und stärker punktirt und hier, beim $\hat{\sigma}$ mit kurzen, weissen, anliegenden Härchen besetzt. Die behaarte Stelle ist ziemlich dreieckig und wird innen von einer Linie begrenzt, die ungefähr von der Mitte des Seitenrandes nach dem oberen Innenrande jedes Auges gezogen gedacht wird. Beim $q$ ist die Behaarung theilweise oder ganz abgerieben.

Penis schmal, vorn allmählich in eine scharfe Spitze verengt, am Anfange der Verschmälerung jederseits mit einigen abstebenden, nach vorn gerichteten Haaren. Sehr ähnlich ist der Penis von $\mathrm{Cr}$. Rossii.

Die einzige bemerkenswerthe Abänderung bildet sich vorzugsweise, doch nicht ausschliesslich beim $\hat{\jmath}$, durch die Erweiterung des Nahtsaumes hinter dem Schildchen bis zur Längsbinde nach aussen (Var. a.). Die Fld. sind hier schwarz, ein schmaler Saum am Seitenund Spitzenrande, eine kurze Quermakel an der Basis und eine Längsmakel an der Naht gelb.

Auf sonnigen Grasplätzen in Mitteleuropa häufig; selten in den Alpenländern.

58. Cr.bilineatus $\left.{ }^{1}\right):$ Niger, antennis basi pedibusque rufo-testaceis, femoribus apice flavescentibus, prothorace confertim lineato-strigoso,

1) Vor diese Art gehört Cr. celtibericus Suffr. (III. 53). Kopf ( $\hat{\odot}$ und f) nur mit zwei gelben Stimpunkten. Halssch. dicht und stark punktirt, sein Seiten- und Vorderrand, sowie eine ron diesem ausgehende glatte Mittellinie, die in der Mitte erlischt, gelb. Fld. gelb, eine gleich breite Nahtbinde, bis zur 2. Punktreihe jederseits, und eine Längsbinde zwischen Reihe 4 und 9, vor der Spitze mit der Naht rereint, schwarz. Die 9. und 10. Punktreihe we it getrennt. - L. $3-3,5 \mathrm{~mm}$. Andalusien. Sardinien (Marseul). 
sericeo-micans, flavo-marginalo, elytris punclato-striatis flaris, sulura villaque media nigra. - Long. 2-3 mm.

Mas: larsis articulo primo dilatato; capile flavo. linea merlin fromtis nigra. $\mathrm{F}$ em: labro clypeoque testaceis, maculis 2 frontulibus flavis.

Linn. Syst. nat. ed. 12. 597 (Chrys). - Germ. Faun. Ins. Eur.

7. 8. - Küst. Käf. Eur. II. 97. - Suffr. Mon. III. 58. -

Redtb. Faun. A. II. 462. - Seidl. F. balt. 478.

Var. a. $\hat{\circ}$. Capitis pictura ut in femina.

Var. b. Elytrorum vitta media ante apicem vel pone sculellum rum sulura connexa.

V a r. c. Elytrormm vilta media anle et pone medium cum sutura comexa. Var. d. mo estus: Elytris nigris, macula transversa basi limboque laterali et apicali flavo-testaceis.

Var. e. armeniacus: Prothorace maculis 2 flavis ante scule:lum.

Fald. Nouv. Mém. Mosc. V. 382. t. 14. f. 11 (Pachybrach). Suffr. Mon. VIII. 141. - Kraatz Deutsch. Zeit. 1879. 265. Cr. Spitzyi Suffr. Mon. III. 59.

Durch das nicht punktirte, sondern dicht und fein längsgestrichelte, matt seidenschimmernde Halssch. ausgezeichnet; schwarz, Basis der Fühler und die Beine röthlich-gelbbraun, die Schenkel nach der Spitze hin heller gelb; Vorder- und Seitenrand des Halssch. und die Fld. blassgelb, Naht der letzteren, eine hinten abgekürzte Längsbinde und der Grund der Punkte in den Streifen schwarz. Kopf zerstreut-punktirt, entweder gelb, eine kurze Mittelrinne der Stirn, öfter auch ein Punkt jederseits über der Fühlerwurzel schwarz $(\hat{3})$, oder schwarz, Oberlippe und Kopfschild (ganz, oder nur an den Seiten) gelbbraun, zwei kleine Stirnflecke gelb (f). Halssch. wenig gewölbt, mit einem Punktstreifen am Seitenrande, die Scheibe, mit Ausnahme der glatten, gelben Ränder, nicht ganz regelmässig, aber sehr dicht mit feinen Längsrunzeln besetzt. Fld. bis zur Spitze gleichmässig stark punktirt-gestreift, der schwarze Nahtsaum gleichbreit, oder hinter dem Schildchen und vor der Spitze erweitert; die Längsbinde ist an der Schulter schmal und breitet sich dahinter etwa zwischen der 4. und 8. Punktreihe aus.

Bei dunklen $\hat{o}$ ist die Kopfzeichnung ähnlich der des fo (Tar.a); zuweilen rereinigt sich die Längsbinde der Fld. vor der Spitze oder hinter dem Schildchen mit der Naht (Var, b), oder gleichzeitig an beiden Stellen (Var. c.); zuletzt ist die Scheibe schwarz, eine schmale, hinten schlecht begrenzte Quermakel an der Basis und ein Saum längs des Seitenrandes und der Spitze, auf dem rorletzten und letzten, oder nur auf dem letzten Zwischenraume, gelb (Tar. d). Zur Var. e. gehören die Stücke, bei welchen, ganz unabbängig von der 
Zeichnung der Fld., zwei gelbe, oft ziemlich grosse Makeln vor dem Schildchen, am Hinterrande des Halssch., auftreten.

Auf trocknen Wiesen häufig, die Abänderung d. selten.

59. Cr. elegantulns: Niger, antemarum basi pedibusque rufo-teslaceis, femoribus apice flarescentibus, prothorace crebre punctato, nitido, flano-marginato. elytris punclato-striatis. epipleuris, limbo laterali maculisque duabus (prima transwersa basi, secunda medio) flaris. Long. $1,5-2,5 \mathrm{~mm}$.

Mas: capite flavo. linea media fironlali punctisque 2 supra antennas migris. Fem: capite nigro, labro brumeo.

Gravenh. Vergl. Uebers. zool. Syst. 152. - Harold Berl. Zeit. 1873. 167.

Cr. tesselatus Germ. Mag. Ent. I. 128. - Suffr. Mon. III. 55;

VUI. 140, - Redtb. Faun. A. II. 460.

Var. a. Elytrorum pictura nigra marginem lateralem attingente.

Var. b. Elytris macula media nulla.

Tar. c. Elytris nigris, epipleuris maculisque 2 transversis (altera basali, altera apicali) flavis.

Tar. d. Elytris nigris, plerumque basi macula transversa flava notatis, mothorace omino nigro vel margine antico flavo-limbato. femoribus posticis maxima parte nigris.

Cr. jucundus Fald. Nouv. Mém. Mosc. V. 396. - Suffr. Mon. VIII. 140.

Dem vorigen nahe verwandt und der Var. c. desselben sehr ähnlich, jedoch kleiner und hauptsächlich in folgenden Stücken verschieden: Der Kopf ist mit Ausnahme der braunen Oberlippe beim f ganz schwarz, das Halssch. ist länger, nach vorn stärker zusammengedrückt und rerengt, dicht und fein punktirt, die Punkte länglich, mit glänzenden Zwischenräumen. Fld. schwarz, Epipleuren, eine schmale Quermakel an der Basis, ein schmaler Saum am Seitenrande, der sich vor der Spitze etwas verbreitert, und ein Fleck nahe der Naht, dessen grössere Hälfte hinter der Mitte liegt, gelb. Beine etwas dunkler als bei bilineatus, die Spitze der Schenkel daher deutlicher makelförmig gelb gefärbt; Hinterschenkel zuweilen angedunkelt.

Aendert ab: a. die schwarze Farbe der Fld. dehnt sich bis zum Seitenrande aus, so dass von dem Saume nur ein Querfleck an der Spitze übrig bleibt; oder b. der Saum ist ganz, aber die Makel an der Nabt verschwindet. Bei c. erlischt der Seitensaum und die Nahtmakel und der Querfleck an der Spitze wird gewöhnlich unscheinbar. Diese Stücke bilden den Cebergang zu der auffälligen, in Südrussland von der Krim bis in den Kaukasus verbreiteten Var. d. mit einfarbig schwarzer Oberseite oder einem gelben Saum am Vorderrande des Halssch. und einer schmalen gelben 
Basalmakel auf den Fld. Selten sind die Epipleuren bräunlich, die Hinterschenkel dagegen sind mit Ausnahme der gelben Spitzenmakel schwarz.

Auf Artemisia campestris and Jasione montana in Mittel- und Süddeutschland nicht häufig.

60. Custrggosus: Niger, nitidus, antemasum basi pedibusque rufolestaceis, prothorace sublaevi, elytris, punctalo-sticatis. epipleuris maculisque duabus angustis (altera basali, altera marginali sub humeris) flavis. -- Long. $2-3 \mathrm{~mm}$.

Mas: capite flavo, linea media frontali punctisque duobus supia antemas nigris, margine antico prothoracis linea flava notato.

Fem: capile nigro, facie inferne testaceo-bimaculato, fronte punctis 2 flavis.

Germ. Ins. Spec. nov. 560. - Suffr. Mon. III. 102. - Redtb. Faun. A. II. 461.

Var. a. Elylris maculis 3 flavis, adjecta transversu une apicem.

Grösser und glänzender als der vorige und von ihm leicht durch das fast glatte Halssch. zu unterscheiden; schwarz, Fühlerwurzel und Beine röthlich-gelbbraun, eine schmale Quermakel an der Basis der Fld., die Epipleuren, mit Ausnahme der dunklen Aussenkante, und eine kaum bis zur Mitte nach hinten reichende Längsmakel über denselben, auf den äusseren $Z$ wischenraum beschränkt, gelb. Halssch. fast spiegelglatt, Fld. regelmässig fein punktirt-gestreift, die Punktreihen bis zur Spitze deutlich, die äusseren Zwischenräume durchgängig, die inneren nur vor der Spitze schwach gewölbt.

Beim $\hat{\jmath}$ ist der Kopf gelb, eine kurze Mittelrinne der Stirn und ein Punkt jederseits über der Fühlerwurzel schwarz; am Vorderrande des Halssch. befindet sich eine feine, gelbe Linie, die sich oft noch ein Stück am Seitenrande nach hinten zieht, oft aber auch seitwärts so verkürzt ist, dass sie nur noch in der Mitte des Vorderrandes durchscheint. Beim $q$ ist der Kopf schwarz, mit einer gelbhraunen Makel jederseits unter den Augen und zwei gelben Stirnpunkten.

Eine seltenere Form (Var. a) hat auf den Fld, noch eine dritte, gelbe oder braune Makel quer vor der Spitze.

Süd-Baiern, Oesterreich, mit Ausschluss von Böhmen und Mähren. Ungarn. Nord-Italien.

Es bleibt gewiss merkwürdig, dass Suffrian die nahe Verwandtschaft der beiden letzten Arten so wenig erkannte, dass er sie weit von einander trennte und die Zeichnung der vorliegenden , ,on allen einheimischen Arten gänzlich abweichend" nennen konnte. 


\section{Reihe. Verwandte von Cr. fulvus.}

61. Cr. pygma eus: Niger, antennum basi perdibusque testaceis. prothorace mimus crebre subtitissime punctato, nitidissimo. murgine. antico et laterali flavo-limbato, elytris flavis vel fluvo-testaceis. sumra maculaque humerali nigris. - Long. 2-3,5 $\mathrm{mm}$.

Mas: capite maxima parte flaro, larsis anterioribus articulo mimo fontiter dilatato.

Fem: facie infra antennas maculisque 2 frontis flavis.

Fabr. Ent. Syst. I. 2. 70. - Suffr. Mon. III. 66. - Redtb. Faun. A. II. 463. - Seidl. F. balt. 478. - Mars. Mon. 220.

Var. a. Macula humerali elytrorum deficiente.

Var. b. Elytris maculis 2 nigris, adjecta pone medium.

Var. c. Prothorace plemimque evidenter minus profunde punctato. nilidulo elytronum sutura viltaque media nigris.

Cr. amoenus Drap. Ann. gén. Sc. phys. Brux. II. 48. - Harold Berl. Zeit. 1873. 163.

Cr. vittula Suffr. Mon. III. 63. - Redtb. 1. c. 462. - Seidl. l. c. 478. - Mars. Mon. 216.

Var. d. orientalis: Vitta elytrorum postice, interdum eliam antire crm sutura connexa.

Kürzer und gewölbter als vittatus, schwarz, Fühlerwurzel und Beine röthlich gelbbraun, Kopf gelb, beim $\hat{\sigma}$ der Scheitel und eine kurze schwarze Mittellinie der Stirn, beim $f$ ausserdem noch ein Querstreifen über der Fühlerwurzel, welcher mit der Mittellinie zusammenhängt, schwarz. Halssch. wenig dicht mit sehr feinen, wenig tiefen Punkten besetzt, dazwischen einzeln, äusserst f'ein (nur bei starker Vergrösserung sichtbar) punktirt, längs des Seitenrandes bis auf eine starke Punktreihe glatt; mit scharf begrenztem, schmalem Vorder- und breiterem gelben Seitensaume. Letzterer erreicht nur aussen, nicht innen, den Hinterrand, ist in der Mitte meist leicht ausgerandet und davor bis zum Vordersaume gerundet-erweitert, selten gleich breit. Fld. regelmässig punktirt-gestreift, gelb oder gelbbraun, ein, wie bei vittatus gebildeter, gleichbreiter oder vor der Spitze, seltener auch hinter dem Schildchen erweiterter Nahtsaum und eine Schultermakel schwarz; ausserdem ist die hintere Hälfte des Seitenrandes und der Hinterrand fein schwärzlich gesäumt. Unterseite schwarz, der Unterrand des Pygidium öfter, häufiger noch die Vorderbrust an der Seite oder zwischen den Hüften rothgelb.

ふै. Erstes Tarsenglied stark erweitert; letzter Hinterleibsring einfach, flach gewölbt (beim \& mit einem schmalen, flachen Längsgrübchen). Penis schlank, fast gleich breit, vorn in zwei dicke, 
gerundete Lappen ausgezogen, zwischen die eine pfriemenförmige Verlängerung des Oberrandes eingelagert ist.

Die Zeichnung der Fld. variirt nicht unbedeutend: Es rerschwindet der Schulterfleck öfter ganz (Var. a), oder es zeigt sich ausser der Schultermakel noch eine weniger scharf begrenzte Makel hinter der Mitte (Var. b), die sich mit ersterer nach und nach zu einer verschieden breiten Längsbinde zwischen der fünften und achten Punktreihe vereinigt. Im Allgemeinen ist die Längsbinde beim $\hat{j}$ nur selten vorhanden und dann schmaler und weniger scharf begrenzt als beim $f$; sie verbindet sich zuweilen mit der Naht ror der Spitze (dem vittatus täuschend ähnlich) oder ausserdem noch hinter dem Schildchen (Var, d).

Auf trocknen Grasplätzen auf Blüthen z. B. ron Achillea millefolium im Juli nicht selten. Der typische pygmaeus scheint nur in Südfrankreich und Spanien vorzukommen, da alle meine Stücke aus Griechenland und Italien zu vittula gehören.

Suffrian erblickte in den auf dem Halssch. sehr fein punktirten Individuen den eigentlichen pygmaeus und sonderte die bei uns rorherrschenden, etwas stärker punktirten, kräftigeren Stücke als eigene Art ab. Die eigenthümliche Punktirung des Halssch. ist aber bei beiden Formen dieselbe, nur in der Breite der Punkte verschieden (aber so, dass sich eine sichere Grenze überhaupt nicht ziehen lässt), daher ist das Halssch. des meist kleineren $p y g$ maeus, der grösseren Zwischenräume wegen, merklich glänzender als das unseres vittula, bei dem die breiten Punkte näher an einander rücken. Die Angaben über die Verschiedenheit der Form des Halssch. und der Fld. sind individuell, dagegen ist richtig, dass die $f$ von pygmaeus nur selten eine schwarze Längsbinde auf den Fld. haben, was bei dem $q$ des vittula Regrel ist; dass die Binde jedoch bei den $\hat{f}$ beider Formen fast gleich selten rorkommt, ist Suffrian entgangen.

62. Cr. connexus 1): Niger, antennarum basi, facie infra antemas, prothoracis margine antico et laterali pedibusque rufo-teslaceis, prothorace parce subtilissime punctato elytris punctato-striatis, flaris, postice

1) Cr. signaticollis Suffr. (III. 6S) aus den Ǩ̈üstenländern des adriatischen Meeres steht dieser Art am nächsten und zeichnet sich durch kleineren, besonders schlankeren Körper und den fehlenden dunklen Randsaum der Fld. aus. Kopf der hellen Stücke wie beim $\hat{\odot}$, der dunklen wie beim $f$ von connexu gefärbt. Halssch. und Fld. gelbbraun, ersteres am Grunde mit einem feinen schwarzen Saume, der sich ror den Schultern in eine dreieckige Makel erweitert und mit zwei verschieden grossen und deutlichen schwarzen Flecken auf der Mitte der Scheibe. Fld. mit schwarzer Naht und dunkler Längshinde. Zwei Hauptabänderungen: a. succinctus: Halssch. durch Vereinigung der vier Makeln schwarz, Yorder- unb Seitenrand, sowie eine schmale, vor 
subliliter nigro-marginatis, sutura anguste (pone medium triangulariler dilatata) viltaque media postice latiora et ante apicem cum sulura connexa nigris - Long. 2,5-4 $\mathrm{mm}$.

Mas: fronte maxima parte flare, tarsis anterioribus articulo mino sot fortiler dilatato.

Fem: fronte medio nigra.

Oliv. Ent. VI. 836. t. \%. f. 11\% - Suffr. Mon. III. 61. Redtb. Faun. A. II. 463.

Var. a. $\hat{\odot}$. Frontis pictura ut in femina.

V'ar. b. subconnexus; Villu elytrovum anyusta cum sulura haud connexu. Var. c. arenarius: Prothorace rufo-tectaceo, basi maculis 2 magnis nigricantibus.

Tom vorigen durch den meist breiteren, innen kaum scharf begrenzten hellen Saum des Halssch. und die Form der Naht- und Rückenbinde verschieden.

Kopf gelb, eine kurze Mittellinie der Stirn, oft noch ein rerwaschener Fleck über jeder Fühlerwurzel schwärzlich $(\hat{\jmath})$ oder beim o die Stirn schwarz, eine längliche Makel jederseits in der Ausrandung der Augen und zwei Punkte vor dem Scheitel gelb. Gewöhnlich tritt vom Kopfschilde her noch ein kurzer gelber Zipfel in die schwarze Farbe der Stirn hinein. Halssch. nach vorn wenig rerengt, sehr fein und sparsam punktirt, fast glatt, der Seitenrand wenig gerundet, und durch eine tiefe, kräftig punktirte Linie abgesetzt; die Scheibe schwarz, am Vorder- und Seitenrande hell gesäumt. Der Saum ist in den Vorderecken etwas verbreitert, blass gelbbraun, innen dunkler, rothbraun, und meist schlecht begrenzt. Fld. regelmässig punktirt gestreift, weissgelb bis bräunlich gelb, die Naht und eine vor der Spitze mit ihr verbundene Längsbinde, sowie ein feiner Saum am Seitenrande, der nur über den Epipleuren fehlt, schwarz. Der Nahtsaum ist bis zur Mitte schmal, hinter derselben

dem Schildchen erweiterte Mittellinie gelb, (oft verschwindet die Mittellinie vorn, selten auch noch ihre hintere Erweiterung). Längsbinde der Fld. meist vor der Spitze mit der Naht vereint; b. apricus: Halssch. nur mit den zwei schwarzen MakeIn am Grunde oder einfarbig rothgelb, Längsbinde der FId. deutlich, oder in zwei Makeln aufgelöst, selbst bis auf einen feinen Schulterpunkt verkleinert. (Wie fulvus, aber eine Mittellinie der Stirn und zwei Punkte über der Fühlerwurzel schwarz.)

Hierher ferner: Cr. blandulus Harold (Col. Hft. X. 254; pulchellus Suffr. III. 71). Kaum halb so gross als connexus, Kopf und Halssch. lebhaft bräunlich-roth, letzteres am Vorder- und Seitenrande schmal gelblich. Die schwarze Längsbinde der Fld. gewöhnlich hinten mit der Naht verbunden und zuweilen hinter der Mitte bis zum Seitenrande verbreitert, selten verkürzt and frei. - L. 1,5-2 mm. Südfrankreich, Spanien, Algier. 
schnell dreieckig erweitert; die Längsbinde nimmt an der Basis den fünften oder sechsten bis achten Punktstreifen ein, verbreitert sich innen allmählich bis zur vierten Punktreihe und stösst hinter der Nitte mit dem dort am meisten ausgedehnten Nahtsaume zusammen. Es bleibt deshalb von der Grundfarle an der Naht jeder Fld. nur eine hinten scharf zugespitzte Längslinde und an den Seiten tin Saum übrig, welcher vor der Spitze merklich breiter wird. Unterseite pechschwarz, Vorderbrust beim $\hat{j}$ ganz oder mit Ausnahme eines dunklen Schattens an den Seiten, beim $q$ nur zwischen den Vorderhüften rothgelb. Beine röthlich gelbbraun mit dunkleren Tarsen.

$\mathrm{Zu}$ der unbedeutenden Abänderung a. gehören Männchen mit der Stirnzeichnung der Weibchen; bei Var. b. ist die Längsbinde der Fld. schmal, verwaschen, und erlischt in oder hinter der Mitte. ohne sich mit der Naht zu vereinigen; bei c. ist das Halssch. röthlich gelbbraun, mit einer vorn gerundeten, verwaschenen schwarzen Makel am Grunde jederseits ror dem Schildehen. Die Fld. dieser Varietät können normal oder wie bei b. gezeichnet sein.

Bei Wien, Steiermark (Kahr). Häufiger in Ungarn, Rumänien und Südrussland.

63. Cr. fulvus: Ninus elongatus, m/o-testacens, elytris pallide flaris. sutura calloque humerali infuscato, antennis apice, pectore abdomineque piceis, collo nigro, prosterno et episternis mesothoracis testareis. ano brunneo limbato; fronte subplana, subtiliter canaliculata, sulcis 2 ocularibus evidenter impressa, supra antennas subrugoso-punctata: prothorace convero, fere laen, angulis anticis obtusis, haud promimelis; elytris sat fortiter punctato-striatis, interstitiis epiplewisque luevibus. prosterno plano, postice subemarginata, processu labiali mullo: tibiis anticis rectis, articulo tertio tarsorum tenui. - Long. 2-3 $\mathrm{mm}$.

Goeze Ent. Beitr. I. 321. - Harold Berl. Zeit 1873. 168.

Vor diese Art ist zu stellen:

Cr. Fausti: Elongatulus, antennis mgris, basi pelibusque rufo-testaceis, elpite prothoraceque rufis, hoc parce subtilissime junctato, angulis anticis subacutis, parum prominulis, elytris flavo-albides, ritta media lata nigra, fortiter punctato-striatis, interstutus leviter alutnceis. - L. 2-3 mm. Derbent (Faust).

Vorn schmaler, hinten breiter als fulcus, die Punktreihen der Fld. weniger regelmässig aber stärker vertieft, alle $Z$ Wischenräume leicht gewölbt, die schwarze Längsbinde zwischen der zweiten und siebenten Punktreihe ist in ein Drittel ihrer Länge etwas verschmälert, dahinter schwach erweitert und erreicht hinter der Mitte die Naht, an welcher daror eine gemeinschaftliche schmale Längsbinde weisslich bleibt. 
Cr. minutus Fabr. Ent. Syst. I. 2. 70. - Panz. Faun. Germ. 39. 18. - Küst. Käf. Eur. II. 98. - Suffr. Mon. III. 73. - Redtb. Faun. A. II. 463. - Seidl. F. balt. 479.

Var. a. Elytris flavis.

Cr. fulvus var. fulvicollis Suffr. 1. c. 74.

Var. b. Pygidio flavo.

Var. c. Prothorace fusco, elytris sordide testaceis, callo humerali vel limat media nigricantibus, femoribus posterioribus interdum infuscatis.

Wenig gestreckt, breit-cylindrisch, glänzend, Kopf (mit Ausnahme der pechbraunen Taster, Mandibeln und Oberlippe), Halssch. und Beine röthlich gelbbraun; Fld. blassgelb, mit gebräunter Schulterbeule und Naht; Hinterbrust und Bauch grösstentheils pechschwarz.

Kopf flach, mit einer Grube jederseits über der Fühlerwurzel, einem ziemlich tiefen Schrägeindrucke am oberen Innenrande jedes Auges und einer kurzen, feinen Mittelrinne auf der Stirn; zwischen den Augen uneben, in den fast runzelartigen Vertiefungen punktirt; einfarbig, oder Kopfschild, Saum in der Ausrandung der Augen und oberer Theil der Stirn weisslich, der Hals stets schwarz. Halssch. ziemlich kurz, so breit als die Fld., stark gewölbt und seitlich zusammengedrückt, nach vorn gerundet-verengt, mit stumpfen, nicht rortretenden Vorderecken, mässig dicht, aber kaum sichtbar punktirt, einfarbig, oder der Seiten- und Vorderrand, sowie eine Mittellinie etwas heller, gelblich, aber mit verwaschener Begrenzung. Schildchen braun- oder weisslich gelb, an den Rändern schwarz. Fld. ziemlich stark punktirt-gestreift, die Punkte, im Innern gebräunt, sind hinten zwar etwas feiner als vorn, aber bis zur Spitze deutlich, die Zwischenräume, besonders die äusseren, leicht gewölbt, glänzend; Epipleuren vor dem Ende der Hinterbrust schnell verengt, nicht punktirt. Vorderbrust zwischen den Hüften flach, mit kaum erhöhtem Vorder- und schwach ausgeschnittenem Hinterrande, nebst der Mittelbrust gelb, eine Makel neben der Aussenseite der Vorderhüften und die Umgebung der Mittelhüften schwarz. Hinterrand des letzten Bauchringes und der Unterrand des Pygidium heller oder dunkler braun gesäumt. Beine kurz, mit dicken Schenkeln und graden Schienen; Lappen des dritten Tarsengliedes schmal und kaum so lang als das erste Glied. Dieses ist beim $\hat{\jmath}$ an den vorderen Beinen etwas breiter als beim ․ - Penis vorn mit drei Lappen, der obere fast so breit als die Röhre, abgerundet, die unteren etwas länger, ihr Vorderrand gerade abgeschnitten und in eine Randleiste aufgebogen.

Bei hellen Stücken sind die Fld. gelb, nur die Naht schwarz gesäumt, auch das Halssch. ist lebhafter roth gefärbt (Var. a); oder 
das Pygidium ist gelb, oft noch die Hälfte des letzten Bauchringes (Var. b.); dagegen haben die dunkelsten Stücke auf der Scheibe des Halssch. jederseits eine grosse, verwaschene, braunrothe Makel, schmutzig gelbbraune Fld., deren Schulterbeule oder eine wischartige Längsbinde, die fast bis zur hinteren Wölbung reicht, schwärzlich ist und zuweilen dunkle Hinterschenkel.

Auf trocknen Grasplätzen häufig.

61. Cr. macellus: Elongatulus ( $\hat{\odot}$ ) vel breviusculus ( $\{$ ), lestaceus, capite, prothorace pedibusque rufescentibus, antennamin apice, inetasterno, abdomineque nigris, episternis metathoracis et segmentis ultimi apice pygidioque testaceis; prothorace brevissimo, minus convexo, sublaevi, angulis anticis rectis, leviter prominulis, elytris striis punctatis pone medium obsoletis, interstitiis laevibus. - Long. $2-3,3 \mathrm{~mm}$.

Suffr. Mon. XIV. 53. - Mars. Mon. 226.

Cr. ochroleucus Suffr. Stett. Zeit. 1868. 171.

Var. a. Subtus omnino brunneus vel testaceus ${ }^{1}$.

Gestreckter $(\hat{\jmath})$ oder breiter $(q)$ als der vorige und ron diesem in folgenden Punkten verschieden: der Kopf ist einschliesslich des Mundes und Halses röthlich-gelbbraun, das Halssch, ist reichlich ein Drittel kürzer, weniger gewölbt, mit scharf rechtwinkeligen, etwas vorgezogenen Vorderecken. Die Fld. sind etwa so lang wie bei fulvus, deshalb mehr als dreimal so lang als das Halssch., bei jenem kaum zweieinhalb Mal, hell bräunlich-gelb, weder die Naht noch die Schulterbeule dunkler, fein punktirt-gestreift, die Punkte nicht gebräunt, die der inneren Reihen meist hinter der Mitte, die der äusseren ror der Spitze sehr fein, fast erloschen. Auf der schwarzen Unterseite ist nicht nur die ganze Vorder- und Mittelbrust, sondern auch die Spitze des Seitenstückes der Hinterbrust, oder deren ganzer Hinterrand, sowie ein Saum des letzten Bauchringes und das Pygidium hell gelbbraun. Zuweilen ist die ganze Unterseite braun oder rötblich-gelb (Var, a).

Wahrscheinlich im ganzen Gebiete, aber rielfach rerkannt und übersehen. Berlin (auf Eichen), Ahrweiler (Fuss), München(W eidenbach).

1) Dieser Varietät sehr ähnlich sind:

1. Cr. politus Suffr. (Mon. VIII. 143), Halssch. wenig länger und gewölbter, Punktreihen der Fld. etwas feiner. Ober- und Lnterseite blassgelb. - Südfrankreich, Spanien, Italien.

2. C'r. Mayeti Mars. (Nouv. et faits 1878. No. 21. S2). Viel grösser, dabei breiter, weniger cylindrisch als politus, sonst ähnlich gefärbt und punktirt; aber Schildchen und Schulterhöcker schwarz, Naht und eine breite rerwaschene Längsbinde der Fld, braun. - Long, 4,5 mm.

Nur 3 우 auf Pinus bei Montpellier. 
Diese Art wurde von Suffria n 1860 nach Stücken aus Griechenland, 1868 als ochroleucus nach Stücken aus Südfrankreich beschricben, in die deutschen Sammlungen hauptsächlich durch Herrn Javet gebracht, welcher das Thier bei Dieppe zahlreich gefangen hatte.

Die französischen und deutschen Stücke sind merklich grösser als die griechischen und kleinasiatischen, unsere zugleich auf den Fld. stärker punktirt, doch lässt sich sonst kein wesentlicber Unterschied auffinden. Alle stimmen im Baue des Halssch., woran dic Art bei einiger Uebung sicher von den Verwandten getrennt werden kann, aufs Genaueste überein 1).

65. Cr. planifroms: Elongatus, capite cum ore et collo, prothorace pedibusque fulvis, elytris flavis, antennis piceis, basi testaceis, meso-et metasternm, abdomine pygidioque saturate nigris, fronte leviter concexa, plana, pnetata, prothorace convexo, subtilissime punchulato, angulis anticis obtusis, haud prominulis, elytris sat fortiter punctatostriatis, striis apice obsoletioribus, interstitiis fere laevibus, epipleuris uniseriatim punctatis, postice sensim angustatis. - Long. 2-3,3 mm.

1) Hier findet seine natürlichste Stellung auch $\mathrm{Cr}$. alboscutellatus Suffr. (VIII. 118.) aus Corsica, Sardinien, Sicilien, Algier und Südspanien, an dem weissen Schildchen kenntlich. $\hat{\sigma}$ schmal, schwarz, Unterkopf und eine zweilappige Stirnmakel, Fühlerwurzel, Vorderrand, die Seiten- und eine Mittellinie des Halssch. sowie die Beine röthlich-gelbbraun, Fld. mässig stark punktirt-gestreift, dunkelblau, ein breiter, bis zur fünften Punktreihe nach innen reichender Saum an den Seiten gelbbraun. Letzter Ring des Hinterleibes mit grosser und tiefer Grube. \& plump, röthlich-gelbbraun, Spitze der Fühler und Mitte der Brust angedunkelt, Fld. mit feinen, regelmässigen, vor der Spitze tiefen Punktreihen. - L. 2,5-3,5 mm.

Aeusserst veränderlich. Beim $\hat{\odot}$ wird die Stirn schwarz, nit $z$ wei gelben Augenpunkten, oder einfarbig; anf dem Halssch. erlischt die gelbe Mittellinie, oder es wird ganz schwarz; auf den FId. tritt die schwarzblaue Farbe des Rückens hinter der Mitte in Form einer Quermakel in den breiten gelben Saum hinein und verlängert sich in demselben, parallel dem Seitenrande, strichförmig bis zur Schulterbeule, so dass dadurch eine gelbe Längsbinde, nach innen vom Schulterhöcker, ron der Basis bis zur Mitte der Fld, reichend, abgetrennt wird. Später verschwindet diese Binde, hierauf auch der noch übrige schmale, gelbe Saum am Seitenrande und vor der Spitze; Fld. einfarbig blau. Beine bei den dunkleren Formen oft schwarz.

Beim 우 zeigt sich eine schmale, schwarzgrüne Nahtbinde, die sich allmählich verbreitert (Var. nigridorsum Chevr. Rev. 1960. 453) und zuletzt die ganzen Fld., mit Ausnabme eines feinen Seitensaumes über den hellen Epipleuren und einer verwaschenen Quermakel in der Spitze, einnimmt. Der Kopf färbt sich nach und nach schwarz, das Halssch. hat nicht selten zwei schwarze Makeln am Grunde und zwei Nebelflecke nale dem Vorderrande, die Unterseite und das Pygidium zuletzt schwarz. 
Die Art ist der seltenen Var. a. des $C^{\prime}$. fulvus sehr ähnlich, aber gestreckter, oberseits heller, unterseits dunkler gefärbt, an den hellen Mundtheilen, der elenen Stirn, dem rothen Halse, der schwarzen Mittelbrust und dem schwarzen Pygidium, sowie an den längeren, punktirten Epipleuren leicht zu unterscheiden.

Der ganze Kopf nebst dem Halse, Halssch. und Beine heil rothbraun, oder die Stirn, Oberlippe, Taster und Beine heller, gelb; Fld. gelb, böchstens die Naht gebräunt, Nittel- und Hinterbrust, Bauch und Pygidium einfarbig tief schwarz. Fühler schwarz, die ersten fünf Glieder gelbbraun. Stirn mit angedeuteter Mittelrinne, sonst gleichmässig bis zum Augenrande gewölbt, über der Fühlerwurzel jederseits nit einem weiten, flachen Grübchen, mehr oder weniger dicht, fein punktirt. Halsseh. unmerklich länger, aber ganz ähnlich gebaut als bei fulvus, etwas deutlicher punktirt, einfarbig, selten mit helleren Rändern. Schildchen rothgelb, dunkel gesäumt. Fld. ziemlich stark punktirt-gestreift, die Punkte zuweilen innen bräunlich, die der inneren Reihen werden beim $\hat{\jmath}$ auf dem Abfalle zur Spitze, beim of schon hinter der Mitte sehr fein. Epipleuren am Ende der Hinterbrust allmählich verengt, mit einer mehr oder weniger zahlreichen Reihe von starken Punkten nahe dem Innenrande.

In Kärnthen, Krain und Steiermark; besonders kräftige Exemplare in Südungarn (Merkl), Theodosia (Retowski).

66. Cr. ochroleucus ${ }^{1}$ ): Elongatus, pallide flaus, subius rufotestaceus, mandibulis nigris, fronte plana, prothorace subcomero, subtiliter, minus dense punctato, angulis anticis acutis, prominulis, elytris fortiter punctato-striatis, interstitiis vix sibiliter punctulatis exterioribus subconvexis, tibiis anticis rectis. - Long. $2-3 \mathrm{~mm}$.

1) Hierher:

1. Cr. luridicollis Suffr. (Stett. Z. 1S68. 174 und 175), Unterseite hell wie bei ochroleucus, Grösse, Körperform und Farbe der Oberseite wie bei fulvus, aber das Halssch. deutlich dicht und fein punktirt, mit einer kleinen, schiet nach aussen gerichteten braunen Makel jederseits vor der Schulter, die sich voru mit einer ebenfalls braunen Quermakel über die Scheibe verbindet. Von dieser Art ist plantaris Suffr. (1. c. 174) wahrscheinlich nicht specifisch verschieden. - Südfrankreich, Sicilien?

2. Cr. lineellus Suffr. (Stett. Z. 1849. 290). Schlanker als popul, Kopf, Halssch. und Lnterseite rothbraun, Seiten- und Vorderrand, sowie eine Mittellinie des ziemlich stark längsrunzelig punktirten Halssch. gelb. Fld. stark punktirt-gestreift, gelb, die Streifen und zwei wenig scharfe Längsbinden, die sich auf dem hinteren Abfalle vereinigen, braun. - Sūdspanien, Marocco. 
Fairm. Ann. Fr. 1859. 63. - Redtenb. Faun. A. Il. 465. Seidl. F. balt. 480. - Mars. Mon. 230.

Cr. fallax Suffr. Stett. Zeit, 1868, 173. 174.

Bedeutend schlanker, besonders vorn schmaler als fulus, weniger glänzend, heller gefärbt und von ilım hauptsächlich in folgenden Stücken abweichend: Am Kopfe sind nur die Mandibeln und Augen schwarz, die Stirn ist leicht gewölbt, nur mit einem seichten Grübchen über jeder Fühlerwurzel, sonst eben, einzeln punktirt. Das II alssch. ist wenig gewölbt und zusammengedrückt, an den Seiten fast gradlinig nach rorn verengt, mit spitzen, deutlich vorgezogenen Vorderecken, auf der Scheibe mässig dicht punktirt, gewöhnlich mit einem Quergrübchen jederseits hinter der Mitte. Die Punktirung besteht aus grösseren und kleineren unter einander gemischten Punkten und ist in der Stärke sehr veränderlich, bisweilen fast so fein wie bei fulvus. Fld. stark punktirt-gestreift, die Punkte in den Reihen nicht gebräunt, tiefer als bei fulvus und näher an einander gerückt; Zwischenräume schmaler, die inneren flach, die äusseren gewölbt, ihr Glanz durch eine äusserst feine, nur bei scharfer Vergrösserung sichtbare Punktirung abgeschwächt. Farbe der Oberseite blassgelb, Halssch. und gewöhnlich noch ein schmaler Längswisch über die Fld. röthlich-gelb, Unterseite und Beine gelbbraun, Hinterbrust und Witte des Bauches meist dunkler, rothbraun. - Die drei Lappen des Penis gleich lang, der obere löffelförmig.

Auf Pappel-Schösslingen im August selten, aber gewiss vielfach übersehen. Bei Berlin ron H. Strübing einmal in grosser Menge gefangen.

Suffrian beschrieb die Art noch einmal als fallax, in Folge einer Verwechselung der Typen mit macellus.

67. Cr. populi: Sat elongatus, rufo-iestaceus, pectore abdomineque nigris, prosterno, episternis mesothoracis pygidioque testaceis; fronte canaliculata, prothorace subconvexo, medio utringue transversim impresso, subtilissime punctato, angulis anticis subacutis, parum prominulis. elytris punctato-striatis, striis apice obsoletioribus, interstitiis leviter alutaceis, nitidulis, tibiis anticis subcurvatis, articulo tertio tarsorum sat lato; prosterno carina media parva instructo, postice emarginato, processu labiali fere nullo. - Long. $2,5-3 \mathrm{~mm}$.

$\mathrm{M}$ as: tarsis anterioribus articulo primo dilatato.

Suffr. Mon. III. 76. - Redtb. Faun. A. II. 463. - Seidl. F. balt. 479 .

Cr. brachialis Muls. Ann. Soc. Linn. Lyon VII. 343.

Var. a. Sutura et callo humerali elytrorum nigris, dorso interdum levitor infuscato.

VI. 2 . 
Eine cylindrische, in der Färbung der folgenden selir ähnliche Art, mit noch schwächer glänzenden Fld. als die rorige, an den gebogenen Vorderschienen leicht kenntlich; röthlich-gelbbraun, Mittelbrust, mit Ausvahme des Seitenstückes, IIinterbrust und Bauch schwarz, Hinterrand des letzten Segmentes und die Afterdecke gellylich. Kopf einzeln punktirt, mit breiter, bis zwischen die Fühlerwurzel reichender Mittelrinne. An den Füllern die oljeren Glieder leicht verbreitert, schwarz. Halssch. kurz, wenig gewölbt und zusammengedrückt, an den Seiten fast gradlinig nach vorn verengt, sehr fein, weniger deutlich als bei ochroleucus punktirt, hinter der Mitte jederseits mit einem Quereindrucke, die ziemlich spitzen Vorderecken nicht rorstehend. Schildchen gelbbraun, schwarz gesäunit. Fld. mässig stark punktirt-gestreift, die Punkte gebräunt, hintın feiner und seichter als vorn, Zwischenräume äusserst zart und dicht gerunzelt, fettig glänzend. Vorderschienen gekrümmt, ror der Spitze verbreitert und hier schnell und stark nach innen gebogen. Der Innenrand ist verschieden geformt, bald bildet er ein Stück ron der Spitze entfernt einen hakenförmigen Zahn, bald eine stumpfe, selbst abgerundete Ecke. Lappen des dritten Tarsengliedes länger und breiter als bei den Verwandten, wenigstens so lang als das erste Glied. Dieses ist beim $\hat{j}$ an den rorderen Beinen erweitert. Vorderbrust zwischen den Hüften breit, mit feinem Mittelkiele, der Vorderrand ziemlich niedrig, der Hinterrand mehr oder weniger tief ausgeschnitten, mit einem verschieden langen Zähnchen jederseits.

Bei dunklen Exemplaren ist die Naht und die Schulterbeule schwarz, ausserdem zeigt sich nicht selten noch eine gemeinschaftliche braune, sebr verschwommene Querbinde hinter der Mitte oder eine ähnliche Längsbinde, die sich hinter der Nitte mit der Naht vereint (Var. a).

Auf Pappel-Schösslingen selten.

68. Cr. pusilles: Minus elongalus, rufo-testacens, metasterno abdomineque nigris; prothorace antice fortiler angustato, laeri, scutello piceo, elytris sat fortiter punctalo-striatis, striis apice obsoletioribus, sutura, callo humerali maculaque transversa pone medium nigris, presterno plano, processu labiali magno, acuto. - Long. 2,5-3 mm. Mas: tarsis anterioribus articulo primo dilatato tertio sesqui longiore. Fem: tarsis articulo primo tertio fere aequali.

Fabr. Gen. Ins. Mant. 221. - Suffr. Mon. III. 78. - Redtb. Faun. A. II. 463. - Seidl. F. balt. 480.

Cr. verticalis Boh. Acta Holm. 1851. 97.

Cr. minutus Herbst. Füessl. Arch. IV. 57. t. 23. f. 19 b. 
Far. a. Sculello brumeo, elytrontm sulura calloque humerali nigris.

Cr. pusillus var. immaculalus Westhof lïäf. Westph. (1892) 266. Var. b. Elytris fasciis 2 transwersis nigris, antica angusta, postica lata, communi. Episternis mesothoracis plerumque nigris.

Var. c. Marshami: Episternis mesothoracis elytrisque nigris, his epijuleuris, linea marginali apiceque testaceis ${ }^{1}$ ).

Cr. marginellus Marsh. Ent. Brit. I. 211.

Cr. gracilis Redtb. 1. c. 461 .

Durch ein verhäitnissmässig kleines, nach vorn auffällig verschmälertes Halssch. ausgezeichnet und deshalb nur bei oberflächlicher Betrachtung in den hellsten Formen mit dem vorigen oder fulvus, in den dunkelsten mit dem folgenden zu verwechseln. Bemerkenswerth ist die Neigung der Makeln auf den Fld., sich in die Quere auszudehnen.

Kopf klein, röthlich gelbbraun, Stirn mit breiter, aber flacher Mittelrinne und einem punktförmigen Grübchen jederseits am oberen Innenrande der Augen. Fühler lang und dünn, die uisteren Glieder gelbbraun, die oberen schwärzlich. Halssch. röthlich-gelbbraun, die Seiten ein Stück bis vor die Hinterecken gleichbreit, hierauf nach rorn stark verengt, die Verengerung fast gradlinig oder leicht ausgebuchtet, der Rücken äusserst fein punktirt, nahezu glatt, glänzend, gewölbt, die Wölbung nach vorn ebenfalls verengt. Hierdurch erschejnt das Halssch., bei der Ansicht von oben, nicht halbkreisförmig, wie bei den nahestehenden Arten, sondern ziemlich dreieckig. Schildchen pechbraun, die Mitte wenig heller. Fld. gelbbraun, Nahtrand, Schulterbeule und eine verwaschene Makel hinter der Mitte schwarz; ziemlich stark punktirt-gestreift, die Punkte sind im Innern gebräunt und werden ror der Spitze, die inneren schon früher, fein oder erlöschen beinahe. Unterseite schwarz, Vorder- und Mittelbrust gelb, mit einer schwarzen Makel an der Aussenseite der Vorder- und Mittelhüften, nur bei frischen Stücken ist auch der After rothbraun gesäumt. Vorderbrust zwischen den Hüften flach, Vorderrand hoch, in der Mitte in eine lange, dreieckige Spitze vorgezogen. Beine ziemlich kräftig, rothgelb, mit graden Schienen, das erste Tarsenglied beim $\hat{o}$ um die Hälfte länger als das dritte und an den vorderen Füssen stark erweitert, beim o kaum länger als das dritte.

Die Zeichnung ist veränderlich. Bei den bellsten Stücken (Tar. a) ist nur der Nahtrand und Schulterhöcker der Fld. schwärz-

1) Der ähnliche $C r$. discicollis Fairm. (Ann. Fr. 1867.413) ans Algier ist nur $2 \mathrm{~mm}$. lang und unterscheidet sich durch eine schwarze Makel vor dem Schildchen. 
lich; sodann zeigt sich eine verschieden grosse, innen schlecht begrenzte dunkle Makel hinter der Mitte (Stammform), später noch ein Fleck zwischen Schulter und Schildchen. Allmählich rerbinden sich: die Scheibenmakel mit der der andern Fld. zu einer gemeinschaftlichen breiten, die beiden vorderen Flecke zu einer schmalen Querbinde (Var. b), so dass ron der Grundfarbe ein Saum am Vorder-, Seiten- und Spitzenrande, nebst einer, durch die dunklen Punktreihen vielfach unterbrochenen Querbinde hinter der Schulter übrig bleibt. Zuletzt dehnt sich die rordere schwarze Binde bis zur Naht und Basis der Fld. aus und vereinigt sich nach rückwärts nit der hinteren Binde: die Fld. sind schwarz, ein schmaler Saum am Seitenrande, der sich über den gelbbraunen Epipleuren und vor der Spitze etwas erweitert, gelbbraun. Das Schildchen und die Seitenstücke der Mittelbrust sind bei der Hauptform öfter, bei der Var. b. und c. immer schwarz. Zuweilen besitzt noch das Halssch. einen breiten schwärzlichen Querwisch, dessen grösserer Theil sich vor der Mitte befindet.

Auf Eichen-, Birken-, Weiden- und Haselgebüschen im Juni nicht häufig, die Var. a. selten.

Redtenbacher's Cr. gracilis gehört jedenfalls zur Var. c. der vorliegenden Art, da er tief punktirt-gestreifte, am Seiten- und Spitzenrande rothgelbe Fld. besitzen soll.

69. Cr. rupipes $\left.{ }^{1}\right)$ : Elongatus, niger, pro-et mesosterni maxima parte item capite pedibusque totis testaceis, prothorace antice angustato, laci. fulvo, scutello elytrisque nigris, his epipleuris maculaque elongata marginali, postice abbreviata, flavo-albidis, apice interdum brunneo-pellucidis, punctato-striatis, striis pone medium obsoletis, prosterno carina merlia instructo, processu labiali brevi, obtuso vel nullo. - Long. 2,5 bis $3 \mathrm{~mm}$.

Goeze Ent. Beytr. I. 321. - Geoffr. Hist. Ins. Par. I. 236. Harold Berl. Zeit. 1873. 172. - Seidl. F. balt. 480 .

Cr. gracilis Fabr. Ent. Syst. I. 2. 70. - Küst. Küf. Eur. II. 99. Suffr. Mon. III. S2. - Mars. Mon. 237.

1) Hierher noch $\mathrm{Cr}$. oranensis: Nims elongatus, capite prothoraceyue fulcis, hoc dense subtilissime punctato. Elytris sultiliter punctato-striatis, striis pone medium obsoletis, interstitiis parce punctulatis: nigris, epipleuris, limbo basali (ante humeros anyustato) et laterali (pone medium jere interrupto) litura parre media subsuturali Havis. Subtus niger, prosterno pedibusyue testaceis, ano ferrugineo-limbato. - Long. $2 \mathrm{~mm}$. Oran (Leder).

Die Zeichnung der Fld. ist Cr. elegantulus ähnlich. 
Tar. a. Prothorace maculis 2 parvis nigris ante scutellum

Cr. gracilis var. Sturm Catal. 1796. 43. t. 1. f. 11.

Der Var. c. des rorigen sebr ähnlich, aber gestreckter, eylindrisch, auf den Fld. feiner punktirt, Seitenstücke der Mittelbrust stets gelb, Halssch. und Vorderbrust verscbieden gebildet.

Tief schwarz, glänzend, Fühlerwurzel, Kopf, Vorder- und Mittelbrust und die Beine röthlich-gelbbraun, Halssch. lebhaft rothbraun, Epipleuren und eine Längsmakel über denselben weisslich-gelb. Halssch. allmählich ron den Hinterwinkeln nach vorn verengt, gewölbt, kaum punktirt. Schildchen schwarz. Fld. fein und flach punktirt-gestreift, die Punkte schon von der Mitte ab merklich schwächer; die Seitenmakel nimmt den äusseren $Z$ wischenraum bis linter die Mitte ein, wo sie sich nach und nach verengt, aber sie greift gewöhnlich rorn hinter dem Schulterhöcker makelförmig auf den rorletzten Zwischenraum über. Vor der Spitze ist oft ein bräunlich durchschimmernder Querfleck bemerkbar, der nur selten beinahe so klar wie bei pusillus herrortritt ${ }^{1}$ ). Die Vorder- und Mittelbrust hat zwar auch eine schwarze Makel an der Aussenseite der Hüften, aber die Seitenstücke der Mittelbrust bleiben gelb. Die Vorderbrust besitzt einen hohen Mittelkiel, welcher zu dem bald stumpf rorgezogenen, bald rollständig abgerundeten Vorderrande abfällt. Am Hinterrande des Halssch. befindet sich bisweilen eine kleine, längliche, vorn gerundete schwarze Makel jederseits ror dem Schildchen (Var. a). Seidlitz erwähnt (l. c.) eine sehr auffällige Abänderung, bei der das Halssch. bis auf den Vorder- und Seitenrand schwarz sein soll. Auf Weiden rom Mai bis Juli ziemlich selten.

\section{Pachybrachys.}

Suffrian Linn. ent. III. 111.

Oculi reniformes.

Prothorax basi marginatus, utrinque simuatus.

Scutellum assurgens, pone medium truncato-depressum

Elytra basi marginata.

Augen gross, nierenförmig, der obere Lappen etwas breiter und länger als der untere, die Stirn daher vor dem Scheitel meist schmaler, über den Fühlern breiter als bei Cryptocephalus. Kopfschild breit und kurz, ron der Stirn nicht getrennt. Fühler fadenförmig,

1) Solche Stücke erwähnt schon Sturm 1. c. 43. Suffrian bringt sie obne Grund zu pusillus. 
Glied 1 lang oval, 2 kurz, kugelig, die folgenden sehr schmal, dreibis fünfmal länger als breit, rom 6. Gliede an sehr schwach zusammengedrückt. Halsschild stark quer, nur an den Seiten vorn abwärts gewölbt, der Vorderrand bildet die breite Hälfte eines Ovales, die Seiten sind durch eine feine Rinne alggesetzt, wenig gebogen, dicht vor den Vorderecken eingeschnürt, letztere daher kurz zahnförmig und, wie die stumpfwinkeligen oder abgerundeten Hinterecken, mit je einem längeren Borstenhärchen versehen; die Basis, welche jederseits leicht ausgeschnitten ist, besitzt eine hohe und scharfe Randleiste, die vor dem Schildchen am höchsten ist, daror eine stark punktirte tiefe Querlinie, deren Vorderrand durch einen noch weiter nach vorn liegenden Quereindruck jederseits leistenförmig emporgehoben wird. Sehildehen in zwei Theile getheilt, der vordere viereckig, nach hinten etwas rerschmälert, schräg aufsteigend und oben gradlinig abgestutzt, der hintere dreieckig, vertieft. Flügeldecken cylindrisch, hinten gemeinschaftlich gerundetabgestutzt, nur schwach gewölbt, an der Basis und um das Schildchen stark aufgeworfen, der Seitenrand unter den Schultern etwas erweitert, die Epipleuren sind nur von unten sichtbar, schmal, durch einen scharfen Rand von den Decken getrennt ${ }^{1}$, verschmälern sich allmählich nach hinten, wo sie etwa am Ende des letzten Hinterleibsringes endigen. Die Oberfläche ist entweder ziemlich unregelmässig punktirt-gestreift oder stellenweise, besonders vorn rerworren punktirt, doch tritt bei den meisten Arten ein schwach gewölbter, von zwei Punktreihen begrenzter Zwischenraum deutlicher hervor, welcher am Vorderrande, innen vom Schulterböcker beginnt, sich über die Scheibe, hinten der Naht etwas genähert, hinzieht und auf dem Abfalle zur Spitze verschwindet. Dieser Mittelkiel (costa dorsalis) theilt jede Fld. in eine innere und äussere Hälfte und behält bei den gefleckten Arten seine gelbe Farbe noch lange, nachdem die Flügeldecken grösstentheils schwarz gefärbt sind. Unterseite fein weisslich behaart. Vorderbrust in der Mitte kurz, der Vorderrand bildet ein Halboval, ist nicht aufstehend und schliesst die Mund-

1) Eine unbeschriebene Gattung ohne Epipleuren ist: Thelyterotarsus Caput verticale, mandibuls sat validis. Antennae 11-articulatae, filiformes. Oculi subconvexi leviter reniformes. Prothorax transversus, basi marginatus utrinque sinuatus, angulis rotundatis. Scutellum magnum, haud assurgens, triangulare, apice rotundato. Elytra bast margmata, epipleuris nullis. Pedes elongati, tibiis angustis, tarsis elongatis, articulo tertio angustato, bifido, ultimo longissimo. Unguiculi mutici. Prosternum inter coxas elevatum. Corpus villosum. 
theile nicht wie bei Cryptocephalus ein; die Fläche zwischen den kugeligen, stark herausstehenden Vorderhüften ist der Länge nach vertieft, binter den Hüften abfallend, aber in der Mitte des IHinterrandes in einen breit dreieckigen dachförmig erhabenen Zipfel ausgezogen, welcher sich über den dreieckig nach unten wweiterten Vorderrand der Mittelbrust legt. Beine mässig lang, die cinzelnen Paare nach hinten an Länge zu-, an Stärke abnehmend, das erste Tarsenglied, besonders an den Hinterbeinen, oft länger als die zwei folgenden zusammen.

Beim Männchen, welches stets kleiner und schlanker gebaut ist, als das f, ist das erste Tarsenglied an den vier Vorderbeinen erweitert, das letzte Bauchsegment in der Mitte quer eingedrückt, der Eindruck zu beiden Seiten meist mit Büscheln oder Reilen langer, aufstehender Wimperhaare besetzt. Der Penis ist eine Röhre, deren Unterseite etwa von der Mitte ab merklich nach hinten erweitert und vorn in einen Zipfel ausgezogen ist, der unten jederseits einen Haarbüschel trägt, oder in mehrere Spitzen endet.

Die Gattung Pachybrachys hat in allen Weltheilen Repräsentanten (die meisten, über 100, in Nord- und Südamerika), welche unter einander grosse Aehnlichkeit haben, aber von Cryptocephalus leicht an der ungezähnten, erhaben gerandeten Basis des vorn nicht gewölbten Halsschildes, dem Schildchen, der stark aufgeworfenen Wurzel der Flügeldecken und der Bildung der Vorderbrust zu unterscheiden sind.

Die meist gelb und schwarz gezeichneten, in grosser Menge auftretenden Arten sind hauptsächlich ron Suffrian beschrieben, aber oft nur in verschwommenen Lmrissen begrenzt worden, was nicht nur die vielen falschen Bestimmungen, die noch heute in den Sammlungen vorkommen, verschuldet, sondern von der Beschäftigung mit der Gattung überhaupt abgeschreckt hat. Wenn auch die Zeichnung der Oberseite erheblich abändert, so geschieht dies nicht regellos, wie Suffrian (Linn. III. 1.33) angiebt, sondern bei jeder Art in ganz bestimmten Grenzen und in leicht erkennbaren Reihen. Erst das vernachlässigte Studium der Varietäten führt auch hier, wie in anderen Gattungen, zur sicheren Kenntniss der Arten.

Th. Fausti: Subcylindricus, niger, parum nitidus, subtus, capite, prothorace scutelloque densc albido-rillosis, mandibulis, marginihus prothoracis, elytris perlibusque stramineis, ano flavo-limbato, capite prothoraceque crebre punctato, hoc subconvexo, lateribus minus rotundato; elytris creberrime, postice subseriatim punctatis, dense breviterfue fere seriatim pubescentibus, callo humerali punctisque 4 pone medium (2, 2) nigris. - Long. 3 - 3,5 mm. Scharud (Christof, Faust).

Variat macula humerali vel punctis nigris elytrorum nullis. 
* Episternen der Mittelbrust ganz oder theilweise gell).

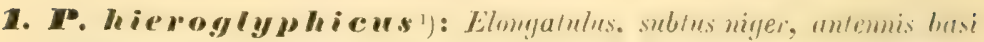

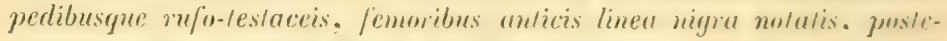
romibus exleme apicem eresus nigris macula albu armalis. Iarsis plus mimusre infuscutis; supra flaro-teslaceus, rerlice. linen media firmala

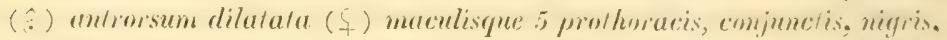

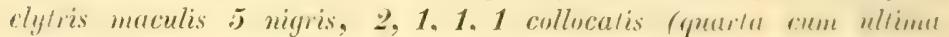
distincte, cum secunda haud rel inondinate conjunc/a). amtice inorequer-

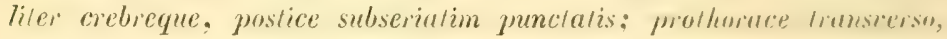

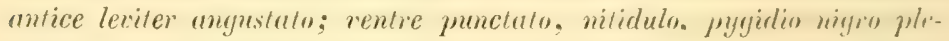
rumque flavo-bimaculato. - Long. $3-4,5 \mathrm{~mm}$.

Laich. Verz. Tyrol. Ins. I. 182. - F abr. Ent. Syst. I. 2. 66. - Panz. Faun. Germ. 68. 13 (Cryptocephalus). - Suffr. Mon. IU. 131 (pars). — Redtb. Faun. A. II. 466. - Seidl. F. balt. 480 .

1) Nahe verwandt sind:

1. P. scriptidorsum Mars. (Mon. 261. - P. scripticollis Suffr. Mon. III. 129). Elongatus, subtus niger, antennarum basi pedibusque omnino dilute rufo-testaceis, femoribus apicem versus albicantibus: supra laete trivus, vertice, linea media frontali maculisque is prothoracis (2, 3; internis 3 parvis, externis trigue basali magnis anticeque punctum flavum includentibus) nigris; elytris minus crebre cxterne et postice subseriatim punctatis, maculis 5 nigris $(2,1,1,1)$, ventre punctulato, nitidulo, marginibus posticis ultimi segmenti maculaque magna transversa dilym a pygidii flaco-albidis. - Long. $3-4 \mathrm{~mm}$. Sarepta.

Iar. lugubris: Prothoracis et elytrorum maculis dilatats magis minusve confluentibus, ad ultimum: prothorace nigro margine antico et laterali anguste favo, plerumque etiam lineis 2 brevibus divergentibus in basi favis. elytris nigris,. margine basali et humerali anguste flavo-limbatis.

Gestreckter als hieroglyphicus, gleichmässiger und feiner punktirt, oberseits gesättigter gelb gefärbt, und an den einfarbigen Beinen leicht zu unterscheiden. Der Seiten- und Spitzenrand der Fld. ist bei den hellen Formen gelb. Der Penis ist rorn in eine sehr lange und scharfe Spitze allmäblich ausgezogen.

2. P. albicans: Elongatulus, subtus niger, antennarum hast pedibusque dilute rufo-testaceis, femoribus apicem versus albicantibus; supra Havo-albidus, vertice, linea media frontali maculisque i prothoracis (2, 3 ; internis : litteram $Y$ formantibus, externis magnis anticeque punctum allidum includentibus) niyris, elytris maculis ju niyris (2, 1, 1, 1, internis duabus lineis nonnullis nigris conjunctis), subtiliter striato-punctalis, ventre creberrime junctulato, subopaco, marginibus posticis ultimi segmenti maculisque 2 divergentibus pygidii flavo-albidis. - Long. 4-4,5 mm. Kasumkent (F a ust).

Dem vorigen nahe verwandt, kräftiger, mehr gleich breit gebaut, oberseits weisslich, Fld. fein gestreift-punktirt. 
Var. a. ictoricus: Maculis elytomm liberis, una allowe eamm interdum deficiente.

var. b. Marulis elytionum dilatatis. prima cam tertia, quarla cun quinta et secunda connexis.

var. c. Elylits nigris, punclis lineolisque flavis sporsis rel disco ommeno nigro. margine basali limboque lalo apicali antrorsum ramulum lahm cxserente flaris; capite prolhoraceque interdum nighis. tibies posterionibus infuscatis.

Cryptocephalus tristis Laich. 1. c. 184.

Cr. histrio Fabr. Spec. Ins. I. 145. - Gyllh. Ins. Suec. IV. 667 . Buprestis lunata Scop. Ent. Carn. 66. f. 204.

Var. d. Elytris nignis.

Var. e. itulicus: Lt in e, sed pectibus rufo-testaceis, femoribus superne linea obscura signalis.

Cylindrisch, mit wenig gewölbter Oberseite, unten schwarz, Vorderhüften und Episternen der Mittelbrust weisslich oder rothgelb, Beine röthlich gelbbraun, Vorderschenkel mit dunkler Rückenlinie, Mittel- und Hinterschenkel nach der Spitze hin (besonders aussen) schwärzlich und mit einer weissen Makel besetzt. Tarsen, oft auch Mittel- und Hinterschienen in der unteren Hälfte, gebräunt. Oberseite hellgelb, dunkler und immer mehr zum Roth neigend, je mehr die schwarze Zeichnung auf derselben vorherrschend wird. Am Kopfe ist der Vorderrand des Kopfschildes, ein Punkt jederseits über der Fühlerwurzel, die Mittelrinne der Stirn und der Scheitel schwarz. Das Halssch. hat fünf schwarze Makeln, die in Form eines auf der Basis stehenden $M$ zusammengeflossen, und von welchem die beiden äusseren Schenkel breiter als die inneren (ebenfalls die Basis berührenden) sind und hinter dem gerundeten Vorderrande zuweilen einen wenig deutlichen gelben Punkt einschliessen. Fld. mit je fünf schwarzen Makeln, 1, 3, 5 am Seitenrande, 2 und 4 zwischen dem Mittelkiele und der Naht: 1 länglich, auf dem Schulterhöcker, den gelben Basalrand meist unterbrechend; 2 breiter und länger, ziemlich viereckig, in der Mitte zwischen Schulterfleck und Naht und fast parallel der letzteren, im vorderen Theile meist mit einer kurzen, vom gelben Basalrande ausgehenden erhabenen gelben Längslinie; 3 klein, quer, auf der Hälfte der Fld., genau hinter .1; 4 hinter der Mitte, die grösste, aussen vom Mittelkiele, innen ron der ersten regelmässigen Punktreihe an der Naht begrenzt, vorn in eine schiefe, nach a ussen gerichtete Spitze verlängert, welche die Makel 3े beinahe oder ganz erreicht. Etwas vor dem Hinterrande rerbindet sie sich noch bald schmaler, bald breiter, jedoch 
scharf mit Makel j. Diese ist rundlich, liegt über der gerundeten Aussenecke der Fld. und weiter nach hinten, als t. Dadurch, dass sich die letztere vor ilırem Hinterrande mit der fünften Makel vereint, erscheint der breite gelbe Spitzensaum der Fld. in der Vitte in eine kurze, dreieckige Spitze nach vorn ausgezogen, welehe auf dem hinteren Ende des Mittelkieles liegt und durch ilıre verschiedene Form zur Unterscheidung ron einigen verwandten Arten gebraucht werden kann. Der Naht-, Spitzen- und Seitenrand ist bis zur daran fortlaufenden Punktreibe, wie bei den meisten Arten, schwarz gefürbt. Pygidium mit einer länglichen, selten scharf hervortretenden hellen Makel jederseits vor der Spitze, bei den wenig schwarzfleckigen Individuen zeigt sich auch ein gelber Punkt an der Seite des letzten Bauchringes.

Kopf sparsam, nur in der leicht rertieften Mittelrinne der Stirn dichter punktirt. Halssch. etwa doppelt so breit als lang, die grösste Breite hinter der Mitte, ron hier nach rorn etwas mebr als nach hinten verengt, der schmale, scharf abgesetzte, gewöhnlich schwarze Seitenrand ist gerundet, die Oberfäche verschieden stark und dicht punktirt, oft mit glatter Mittellinie, glänzend. Fld. stark punktirt, die Punkte auf den hellen Stellen der vorderen Hälfte dunkel, hinter der Nitte zu einigen, auf dem Abfalle zur Spitze verbundenen oder erloschenen Reihen geordnet, zwei bis vier an der Naht, zwei am Seitenrande. Unterseite mässig dicht punktirt, Bauch mit leichten Querrunzeln, etwas glänzend.

Der Quereindruck auf dem letzten Bauchringe des $\hat{j}$ ist ziemlich tief, ror dem Hinterrande ron einer leichten erhabenen Querfalte durchsetzt, an den Rändern schwach und kurz behart. Penis vorn breit-abgerundet und in der Mitte in eine sehr kurze, wenig scharfe Spitze verlängert.

Die Zeichnung der Oberseite variirt in folgender Weise: die hellsten Stücke (Var. a) haben auf den Fld. fünf freie Makeln, von denen nur selten die dritte oder die zweite ganz fehlt. Es verbindet sich Makel 4 hinten mit 5 , vorn oft mit 3 oder auch undeutlich mit 2 (Stammform). Sodann dehnen sich Makel 1 und 3 bis zum Seitenrande aus und vereinigen sich theilweise oder ganz, hinten auch durch eine feine Linie über dem Seitenrande mit 5; 2 erreicht hinter dem Schildcben die Naht (Var. b). Bei dieser ist also die Makel 1 ron 2 stets durch den gelben Mittelkiel, von 3 durch ein oder zwei kurze gelbe Längsstrichelchen, oder nicht getrennt; 2 wird ron 4 durch einen schiefen, gelben, mit schwarzen Punkten durchsetzten Querfleck an der Naht, und 3 ron 5 durch einen breiten, dreieckigen gelben Fleck geschicden, welcher innen auf dem Mittelkiele 
liegt 1). Diese Trennungsstellen verkleinern sich oder (rlöschien \%nerst einzeln, dann insgesammit (Var. c): Fld. schwarz, Basalrand, oft auch ein Fleck hinter der Mitte, oder auch nur ein Spitzensaum rothgelb, endlich, Var. d, einfarbig schwarz. Aut dem Halsseh. ver-

1) Täuschend ähnlich ist P. Suffriani Schanf. (Ann. Fr. 1S62. 312): Elongutulus, niger, antennis basi ohscure, episternis mesnthwracis peditusque late testaceis, femoribus apice macula albu it superne macnlu nigma notritis, tibiis posterioribus apicem versus tarsisque totis infuscatis, capite aut clypen umnino $(\hat{S})$ aut maculu clypei $(\underset{\gamma}{)}$ ) lineistue 2 uculurilus flavis, prothorace transverso, margine antico (utrinque triangulariter dilutato, lineolam abbreriatam in medio et vittam angustam intramarginalem utrinque emittente) maculisque 2 elungatis (antice divergentibus) in basiftrtis; elytris sat fortiter punctatu-substriatis, limbo in margine omni (ante apicem lineolam flaram antrorsum exserente) a medio suturae ad scutellum deficierte, maculis 2 elongatis, eleva'is (prima postscutellari, secunda medio sutrrae), costa dorsali intra humerum, macula elongata (punctis nonnullis nigris perturbata) extra costam dorsalem lineisque 2 brevibus interstitii penultimi flaris. - Long. $4 \mathrm{~mm}$. St. Albas, Brañnelas (v. Heyden Reis. Span. $47=P$. julvipes). Burgos. In Erica arborea.

\section{Variat episternis mesothoracis nigris.}

Fld. mit grossen, in ziemlich deutlichen Reihen stehenden Punkten, schwarz, der feine Basalrand, welcher sich auf der Aussenhälfte der Epipleuren bis zum Ende der Hinterbrust fortsetzt, aber an der Schulter unterbrochen ist, gelb; die übrigen Ränder fein schwarz gesäumt. Innerhalb dieses schwarzen Saumes läuft ein gelber Sanm von der schulter genau auf dem letzten Z wischenraume bis zur spitze der Fld., wo er sich etwas erweitert, eine kurze, gelbe Linie auf dem Mittelkiele nach rorn sendet und sich dann auf dem ersten Zwischenraume an der Naht bis zu deren Mitte fortsetzt. Von hier bis zum Schildchen liegen zwei Reliefmakeln, die vordere gerade, linienförmig, die hintere schmal dreieckig, schief. Ausserdem ist der Mittelkiel an der Schulter, ein langgestreckter, mit einigen schwarzen Punkten durchsetzter Fleck dicht an demselben (nach aussen) von der Schulter bis zwei Drittel der Fld, und ein Strich hinter der Schulter, sowie ein ähnlicher, zuweilen fehlender, in zwei Drittel der Fld, beide auf dem regelmässigen vorletzten $\mathbf{Z}$ wischenraume, gelb. - Penis vor der Oeffnung leicht gerundetverengt, hierauf in einen breiten, parallelen Zipfel rorgezogen, der am Ende in ein spitzes Dreieck mit gerundeten Seiten ausläuft.

Von der gelben Zeichuung der Fld. bleibt oft nur der Saum, die Reliefmakeln an der Naht und die Basis des Mittelkieles übrig, und die Episternen werden schwarz. Bei P. terminalis Suffr. (Stett. Zeit. 1S49. 291) aus Portugal, der vielleicht nur die dunkle Varietät des vorliegenden ist, hat das Halssch. einen schmalen gelben Saum am Vorder- und Sieitenrande, auf den Fld. ist der Basalrand, ein Spitzensaum und ein Längsfleck hinter der Schulter gelb. 
breitert sich die schwarze Zcichnung elsenfalls allmählich und nimmt dasselbe bis auf einen schmalen Saum am Vorder-und Scitenrande und eine längliche Nakel jederseits vor dem Schildehen, oder zuletzt ganz ein, doch geht die Ausdehnung der dunklen Färlong nicht immer mit der der Fld. Hand in Hand. Der Kórpf wird zuweilen bis auf einen Saum am Innenrande der Augen und einen Fleck auf dem Kopfochilde, seltener ganz schwarz. Beine ziemlich constant gefärbt, nur bei Stücken aus Toskana (Fuchs). Welche rorwiegend zur Var, c. gehören, einfarbig rothgelb, bis auf tine feine dunkle Linie längs des Rückens der Schenkel. Da das Gell, dèr Episternen der Mittelbrust aber bei einigen Stücken auf einen schmalen Streifen am Hinterrande zusammenschrumptt, so ist es wahrscheinlich, dass auch, wie bei piceus'), Exemplare mit ganz schwarzen Episternen vorkommen werden.

Auf Weiden in Norddeutschland stellenweise, in Mittel-und Süddeutschland häufig.

Die Diagnose von $\mathrm{Cr}$. hiernglyphicus $\mathrm{L}$ a ich., welche nach $\mathrm{H}$. r. Harold (Berl. Z. 1873. 176) und H. v. Kiesenwetter (1. c. 1874. 75) zur Unterscheidung ron den rerwandten Arten unbrauchbar sein soll, kennzeichnet die vorliegende Art genau und lässt sich weder auf hippophä̈s noch tesselutus anwenden. Cr. tristis $\mathrm{Laich}$. ist die Var. c, und zwar die Form derselben, bei welcher der dreieckige Trennungsfleck zwischen Makel 3 und 5 oder der Spitzensaum allein übrig geblieben ist; die Beziehung auf fimhriolatus Suffr. ist nach Laichartings Beschreibung unzulässig.

2. P. suturalis: Elmgatus, subtus miger. maculis 2 abliquis pyyidii (interdum comexis) marginibusque segmenti ultimi albidis. perlibus lacle mfo-testaceis, femmibus superne minus infuscatis apice albesrentibus; supra pallide flarus. vertice lineaque mediu fromtali nigris. prothomace lateribus mims rotundato, parm crebre punctato. marulis 5 niyris, 2. 3. exiernis marmis, punctum flarum inchulentibus plemumque cum internis 3 conjunctis, litteram $\boldsymbol{M}$ formantibus; clytris irregulariter

1) P. piceus Suffr. (Mon. III. 116). Schwarz, Kopf beim $\hat{\odot}$ in grösserer Ausdehnung als beim $c$ gelb gefärbt, Vorderrand und Vorderund Hinterecken des Halssch. oft mit schmaler gelber Linie, ebenso der Vorderrand der Fld. am Schildchen und der Seitenrand unter der schulter. Beine rothgelb, Schenkel oberseits rerschieden stark angedunkelt. - Long. $3-5 \mathrm{~mm}$. Kiew. Ton den fast schwarzen Stücken des hiernglyplicus und scriptilorsum durch einen tieferen Quereindruck ror dem Hinterrande des Halssch. und die auf der vorderen Hälfte der Fld. starke, hinten fast erloschene Punktirung zu unterscheiden; jedenfalls aber nur die dunkelste Form einer oberseits vorwiegend gelb gefärbten Art. Ich habe bisher nur $C$ daron gesehen. 


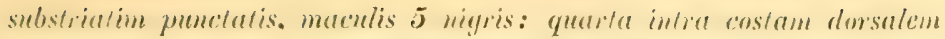
cum serenda conjunete: rentre punctulato, nilidulo. - Long. 3,5-4 mm. Var. a. Iallicus: Maculis prothoris liberis, elytris stramimes, interne striis 3 nigro-punctatis, sutura calloque homerali nigris.

Dem vorigen äusserst ähnlich und seither zu ihm gerechnet, aber etwas schlanker, oberseits heller gefärbt und hauptsächlich in folgenden Stücken verschieden: das II alssch. ist merklich schmaler, der gelbe Seitenrand weniger gerundet, bei den meisten Exemplaren fast gerade, der gelbe Punkt nahe dem hellen Seitensaume gross und deutlich. Von den fünf Makeln der Fld. sind die äusseren drei $(1,3,5)$ ziemlich klein, 3 und 5 oft in einzelne schwarze Striche aufgelöst und schlecht begrenzt; die inneren (2 und 4) bilden eine gleichbreite Längsbinde parallel der Naht, aussen rom Mittelkiele, innen von einem schmalen gelben Nahtsaume eingeschlossen, welcher in der vorderen Hälfte von zahlreichen schwarzen Punkten durchsetzt, auf der hinteren Hälfte dagegen scharf begrenzt ist. Die Trennung der beiden zur Längsbinde vereinigten Makeln wird durch ein oder mehrere verschwommene gelbe Längsfleckchen in der Mitte angedeutet. Hiernach ist bei der Unterscheidung von hieroglyphicus besonders darauf zu achten, dass Makel 4 des vorliegenden nur selten, und dann nur schwach mit 5 oder 3 verbunden ist und dass die letztere sich nie bis zum Seitenrande ausdehnt oder sich mit 1 (die den gelben Basalrand nicht unterbricht) vereinigt. Vorderbüften, Episternen der Mittelbrust, Seiten- und Hinterrand des letzten Bauchringes, sowie zwei schräge, oft in einen Querfleck vereinte Makeln am Unterrande des Pygidium weisslich. Beine bell rothgelb, Schenkel an der Spitze weisslich, ihr Rücken dicht über dem Knie mit einem kurzen, linienförmigen Schatten, welcher sich an den Hinterschenkeln zu einem Ringe um die weisse Makel ausdehnt.

Letzter Bauchring des ô mit einer glatten, sehr flachen Quergrube, welche vor dem Hinterrande eine vertiefte Querlinie besitzt und an den Seiten mit langen, weisslichen Haaren bewimpert ist. Die Seiten des jederseits lang bebarteten Penis vor der Oeffnung allmählich schwach gerundet-verengt, hierauf gradlinig, vorn mit breit-dreieckiger Spitze, deren beide Seiten leicht gerundet ausgeschnitten sind.

Die hellsten Stücke (Var. a) haben freie Makeln des Halssch. und strohgelbe Fld, auf denen die Naht und der Schulterhöcker schwarz sind und deren innere Hälfte von drei schwarz punktirten Längslinien durchzogen wird.

In Baiern und dem Elsass. Häufiger in Mittel- und Südfrankreich. 


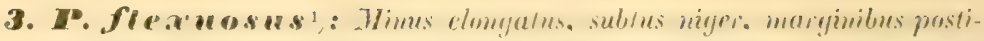

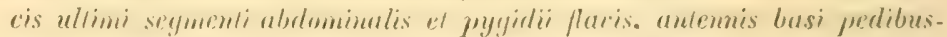

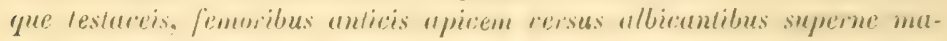

1) Nahe rerwandt sind:

1. P. pallid"lus Kiesw. (Ann. Fr. 1551. 652. Siulfr. Mon. VIII. 14i). Parallelux, cylimlicus, suljounerus, sul,tus niger, maryinilus prosticis ultimi segmenti abdominelis maculatyue transversa dilyma pygidii flacis, peditus rujo-testacei., femoribus apice albicantibus, linea slsscura superne signutis; supre prollide flarus, vertice lineayue media frontali nigris, prothorace mims transverso, luterilus fortiter compresso, antice leviter angustati, cylindrico, rrebre sat fortiter punctate, maculis 5 litteram $M$ latam confluchtilus nigris, elytris punctati-sulstriatis, maculis 5 minus discretis nigris: 1 et 3 connatis et cum i lineis nonnullis nigris contiguis, 2 parca, 4 magna et a 5 separata; ventre punctsto, nitido. - Long. 3-4 mm. Pyrenaei.

Durch die gुleich breite Gestalt, das längere, stark gewölbte, an den Seiten zusammengedrückte und deshalb cylindrische Halssch. von allen Verwandten ausgezeichnet.

2. P. scriptus H. Schäff. (Faun. Germ. 164. 4. - Suffr. III. 119). Breviter-cylindriens, niger, parum nitidus, antennis busi pedibusque pallidetestaceis, femoribus posterioribus apicem versus albidis, capite flavo, rertice lineaque media frontali cum puncto nigro supra antennas haud $(\hat{\widehat{S}}$ ) vel late conjuncta nigris; scutello nigro, saepe macula pallida notato; prothorace crebre minus fortiter punctato, nigro, margine antico (utrinque triangulariter dilatato et lineam abbreriatam in medio emittente) et laterali, puncto parro utrinule maculisque 2 baseos testaceis; elytris flavo-pallidis, "-striato-punctatis, macula parva humerali striisque nigris, interstitiis (50, $67^{\circ}$ et $7^{\circ}$ irreyularibus) sut convexis; marginilus. posticis ultimi segmenti rentrali maculaque mayna, transversa pygilii apice pallidis. - Long. $3-4 \mathrm{~mm}$. Italia. Corsica. Sardinia.

Tariut a. (erycinus Géné i. litt.) prothoracé testaceo, medio macula nigra, litteram $Y$ formante plerumque cum macula magna nigra, punctum testaceum includente, lateraliter conjuncta; b. (Hellwigi Dahl i. litt.) striis nigris elytrorum latissimis, interstitiis angustissimis crebrius subinterruptis.

Penis rorn breit abgerundet und in der Mitte in eine abgesetzte, kurze Spitze verlängert.

3. P. lineolatus Suffr. (III. 122). Praecedenti simillimus, sed prothorace mimus crebre fortius punctato margine retlexo laterali nigro, signaturis favis capitis, prothoracis et elytrorum pallidioribus, scutello et pygidio semper nigris bene distinctus. - Andalusia.

Der Seitenrand des Halssch, beim rorigen auch noch auf der Lnterseite gelb, ist hier schwarz, der Penis vorn wenig und allmählich rerengt, jederseits in eine fast wagerecht abstehende, sehr scharfe Spitze ausgezogen, davor ganz gradlinig abgeschnitten, in der Mitte dieses graden Vorderrandes mit einer kurzen, breiten, abgerundeten Spitze.

4. Der mir unbekannte, nach der guten Beschreibung sehr ähnliche 
rula niyga motalise posterionibus fore mmino albirlis; supra flarus,

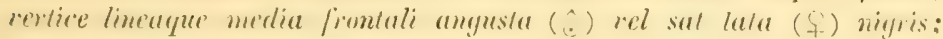
orulis purum distantibus, problhorace lianswerso fortiter, mimus arebre

P. pteromeles Grä̈ls (Mem. Map. geol. Zool. 1S5S. 99) hat die Zwischenräume 6 und 7 zu einer sehwarzen Längsbinde, parallel dem Seitenrande, vereint, dunkel gefleckte Schenkel, den IIinterrand des letzten Bauchringes und die Spitze des Pygidium weisslich. - L. $4 \mathrm{~mm}$. Escorial.

5. P. Kraatzi (fulvipes Mars. Mon. 269): Breviter-(ylindricus, niyer, nitidulus, antemnis basi pedibusyue fulvis, femoritus superne linea nbscuru signatis, posterioribus apice pallielis, tarsis plerumque infuscatis; capite ant flaro, rertice lineayne mediu nigris $(\hat{\hat{O}})$, aut nigro, clypeo lineisque 2 oculavibus thavis (子), prothorace crebre punctato, maryine antion (utringue dilatutu et lineam intramaryinalem, in medio etiam lineam abbreviatam, eleratam, cmittente, lineisyue 2 baseos flacu-pallidis; elytris pallide facis, internecrebre, inndinate, externe et postice irregulariter striato-punctatis, striis nigris, interstitiis angustis minus converis, punctos nigros perturbatis, maculis 3 nigris: prima humerali, secunda ct tertia sat determinatis, conjunctis, ante apicem: pygidio maculis 2 parvis, obsoletis, pallidis. - Long. 2,5-4,5 mm. Hispania.

Iariat corpore omnino nigro, antennarum basi pedibusque obscure fulvis.

Penis an der Oeffinung allmählich schwach verengt, am Vorderrande mit 3 Zipfeln, die beiden äusseren gerundet, der mittlere schmal, fast gleichbreit, leicht aufwärts gekrümmt.

Die Art, die mit Unrecht bisher für fulripes Suffr. gehalten wurde, erlaube ich mir nach Herrn Dr. Kraatz zu benennen, der mich durch das reiche Material seirer Sammlung stets auf das Freundlichste unterstützte.

6. P. testaceus Perris (Ann. Fr. 1865. 510). Elongatus, flavotestaceus, antennis apice, vertice, linea media frontali piceis; prothorace sat crebre incerualiter punctato, disco aut subrubicundo aut maculis 5 brunneis rel piceis $(2,3)$, anticis saepe obsoletissimis, cxternis trigae magnis punctum rufescentem ubsolete includentibus; elytris sulphureis, margine luterali, apicali et humerali angustissime nigro-limbatis, callo humerali interdum piceo, seriatim punctatis, punctis nigris, sterno ventreque fere omnino pallide flaris ( $q$ ) vel plus minusve nigricantibus ( $\hat{)})$; pygidio dimidia parte posteriore plerumque pallido. - Long. 3-3,5 mm. Corsica. Sardinia.

Variat a. (P. riguus Mars. Mon. 2S7) elytris margine laterali concoloribus, tarsis infuscatis; $b$. maculis 3 internis prothoracis litteram $I^{r} b$ soletam formantibus.

Die gelbe Makel, welche oft die ganze untere Hälfte des Pygidium einnimmt, ist beim $\hat{\odot}$ in der Regel rorn gerade, beim $f$ bogig begrenzt oder fast in zwei Schrägflecke zertheilt. Nach einem ähnlichen $q$, bei dem zugleich der Seitenrand der Fld. gelb und die Tarsen schwärzlich sind, ist riguus Mars. beschrieben. Dagegen bildet $P$. anoguttatus Suffr. (Stett. Z. 1S66. 208) von Mallorca wohl eine gute Art, die sich durch einfarbig röthlich gelbes Halssch. und schwarze Unterseite auszeichnet, auf der die Episternen der Mittelbrust, der Hinterrand des letzten Banchringes und eine 


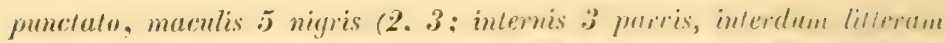

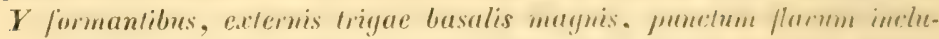

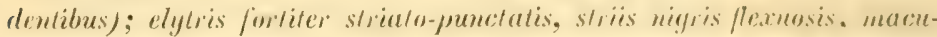
lis 5 nigris: externis (1. 3, 5) subrlistrelis, intermis lineis numbllis

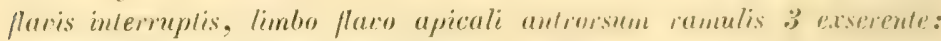
intermedio bifido. - Long. 3-4 $\mathrm{mm}$.

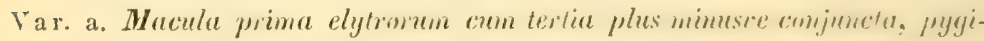
dio segmentoque ultimo ventrali fere totis nigris.

Var. b. viennensis: Oculis sat late distantibus, pedibus info-lestuceis, femoribus apicem versus albidis, muculis 1 et ij elyformen dislincle commatis, limbo flavo apicali antrorsum ramulum anyushm exsigente.

Bedeutend kürzer als die rorigen, besonders die $f$ hinter den Schultern erweitert, durch die groben Punktstreifen der Fld. und die unregelmässigen schwarzen Makeln derselben, sowie durch die stark genäherten Augen leicht zu unterscheiden.

Unterseite schwarz, ein gleich breiter Saum am unteren Rande des Pygidium und ein ähnlicher an den Rändern des letzten Bauchringes gelb. Beine gelbbraun, Vorderschenkel nach der Spitze zu weisslich, mit einer breiten schwarzen Makel längs des Rückens, die vier Hinterschenkel fast ganz weisslich, mit einem braunen oder schwärzlichen Schatten in der Mitte und auf dem Rücken. Fühler-

Makel jederseits auf dem Pygidium gelb sind. Von diesen beiden Arten dürften sich $P$. laetificus Mars. (Mon. 2S2), scheinbar aus Südrussland, und $P$. simius Mars. (283) ans Algier nur schwierig unterscheiden lassen.

7. P. scrupticollis Fald. Nouv. Mém. Mosc. V. 3S1; is raelita Tappes Ann. Fr. 1871. 267). P. testaceo similis, sed brevior, pedibus prallide testaceis, femoribus albidis, crpite prothoraceque flavo-pallidis, vertice, linea medir frontali antice bipartita maculisque 5 prothoracis (internis 3 litteram $I^{r}$ furmantibus, exterioribus 2 magnis punctum tcstaceum includentibus) nigris; elytris flavo-vel cinereo-albidis, sutura calloque humerali (interdum) nigris, seriatim punctatis, punctis nigris; subtus niger, segmentis ultimi apice pygidioque flavo-albidis, hoc angustissime nigro maiginato mox distinguendus. Long. $3 \mathrm{~mm}$. Armenia. Persia. Syria.

8. P. glycirrhizae Ol. (Ent. VI. Sə3S) aus Armenien und Mesopotamien, ist grösser als der vorige, mit einfarbig gelbbraunem Halssch., und an der dicht silberweiss behaarten Unterseite sofort zu erkennen.

9. P. vermicularis Suffr. (IX. 56). Breviter-cylindracus, supra sordide stramineus, ubique sat dense punctatus, punctis brunneis et apicem versus elytrorum subseriatis; capite magno macula verticali et fiontali prothoracisque maculis 3 vel 5 brunneo-pellucidis; subtus niger, laterihus prosterni, marginibus posticis meso-et metathoracis (plerumque etiam segmentorum ventralium) maculaque transversa pygidio stramineis, pedibus testaceis. Long. 3-3,5 mm. Sarepta. 
wurzel rothbraun. Oberseite gelb. Kopf fein punktirt, Scheitel und eine schmale $(\hat{\jmath})$ oder breite $(\phi)$ Mittelrinne der Stirn schwarz. Diese ist in beiden Geschlechtern vor dem Scheitel sehr schmal, da die oberen Hälften der Augen einander noch mehr als beim $\hat{j}$ von tesselatus genähert sind. Halssch. wie bei hieroglyphicus gebaut, grob, aber weniger dicht, schwarz punktirt, mit fünf schwarzen, meist sehr unregelmässig begrenzten Makeln $(2,3)$; die inneren, in ein Dreieck gestellten, klein, die äusseren der Basalreihe gross, mit einem ziemlich grossen, gelben Punkte fast in der Mitte. Fld. grob und tief punktirt-gestreift, die Streifen schwarz, ihre gelben Zwischenräume gewölbt, die erste und zweite vordere Punktreihe ist stark der Naht zugebogen und erreicht dieselbe etwa in der Mitte. Hier erlischt die erste, die zweite setzt sich, indem sie schief nach. aussen biegt, als erste hintere Punktreihe bis vor die Spitze fort. Dadurch wird der dritte, in der Mitte zu einer dreieckigen, glatten Makel erweiterte Zwischenraum hinter der Mitte zum zweiten, der rierte, in der Mitte weniger verbreiterte, zum dritten, der fünfte (die Mittelrippe) endet in zwei Drittel der Länge, ist hinten schmal, ron der Mitte nach vorn etwa über drei $Z$ wischenräume verbreitert und an der Basis von zwei unregelmässigen Punktreihen durchsetzt. Die 5 Makeln der Fld. sind wenig deutlich, die erste und regelmässigste liegt auf dem Schulterhöcker, vom gelben Wurzel- und Seitenrande umschlossen, die zweite auf dem 2., 3. und 4. vorderen Z $\mathbf{Z}$ wischenraume, deren Basis meist gelb bleibt, 3 ist klein, hinter 1, 4 ist durch den hinteren dritten Zwischenraum halbirt, 5 liegt auf den drei vorletzten Zwischenräumen über der gerundeten Aussenecke der Fld. Diese sind aussen ron einem gewölbten gelben Saume umgeben, welcher hinter der Schulterbeule beginnt und sich bis zur Mitte an der Naht herumzieht. Vor der Spitze sendet er drei Aeste nach vorn, der innere, nahe der Naht, ist kurz, schmal und läuft in die Makel 4 hinein, der mittlere ist breiter, am Anfange der hinteren Wölbung in zwei gelbe Linien gegabelt, von denen die innere auf dem dritten hinteren Zwischenraume fast bis zur Basis läuft, die äussere sich mit dem gelben Trennungsraume zwischen Makel :3 und 5 rerbindet. Der dritte Ast ist kurz und breit. Unterseite zerstreut, der Bauch dichter und runzelig punktirt, weniger glänzend als die Brust.

Bisweilen erweitert sich Makel 3 der Fld. bis zum Seitenrande und rerbindet sich auch theilweise mit 1. Von der gelben Zeichnung des Hinterleibes bleibt dann oft nur ein Punkt an der Seite des letzten Bauchringes übrig (Var. a). Die Var. b. könnte, da sic einfarbig rothbraune Beine (mit weisslichem Schenkelflecke) und eine

VI. 2 . 
breite Stirn besitzt, vielleicht eine eigene Art bilden. Bei ihr ist Makel 2 der Fld. durch die gelben $Z$ wischenräume verdeckt, welche nur hie und da durch eintretende schwarze Punkte leicht unterbrochen werden, 3 reicht bis zum Seitenrande und verbindet sich mit 5, welche gross, scharf begrenzt ist und vorn mit 4 in Verbindung steht. Der gelbe Spitzensaum hat hier ungefähr dieselbe Form, wie bei tesselatus.

Tirol (Kahr), Sicilien(Frei-Gressner), Griechenland (Kra a tz). Var. b. auf dem Bisamberge bei Wien von H. Ganglbauer in einem Pärchen gesammelt, welches sich im Wiener Museum befindet ${ }^{1}$ ).

* Episternen der Mittelbrust schwarz.

4. F. Haliciensis: Elongatulus, niger, antennis basi. tibiis anticis fere ommino intermediisque basi testaceis, femoribus anticis inferne flarotestaceis, posterioribus macula alba notatis; capite flavo-albido, vertice lineaque media frontali nigris $(\hat{\odot})$, aut nigro, clypeo lineisque 2 ocularibus flavo-albidis ( $($ )); prothorace nigro, margine antico (utrinque dilatato, lineolam abbreviatam in medio et vittam angustam intramarginalem utrinque emittente) maculisque 2 elongatis in basi flavoalbidis; elytris subtiliter, externe et postice subseriatim-punctatis, flavoalbidis, maculis 5 nigris: secunda et quarta in vittam subsuturalem, medio maculam flavam, elevatam includente, connatis, tertia et quinta etiam cum ritta confluentibus, ventre ruguloso-punctato, subopaco, Long. $3-4 \mathrm{~mm}$.

Mill. Verh. zool. bot. Ver. Wien 1868, 29.

P. hieroglyphicus var. $\beta$ Suffr. Mon. III. 134.

Var. a. rufimanus: Maculis elytrorum liberis, femoribus anterioribus inferne rufo-testaceis.

Von der Gestalt des hieroglyphicus und dessen Var. b. ähnlich gezeichnet, indessen durch schwarze Episternen der Mittelbrust, schwarzes Pygidium, dunkle Beine mit schwarzen Tarsen, scharf begrenzte, in anderer Weise zusammenfliessende Makeln der Fld. und die äusserst dicht punktirte, matte Unterseite auf den ersten Blick zu unterscheiden.

Unten schwarz, Vorderhüften, Torderschienen und Basis der Mittelschienen rothgelb bis rothbraun, die untere Hälfte an der Vorderseite der beiden Vorder- und eine Makel an der Spitze der vier Hinterschenkel gelblich-weiss. Oberseite gelb, etwas blasser als bei den vorigen, bei Stücken aus den Karpathen selbst weisslich, Scheitel, Mittelrinne der Stirn, ein unscheinbarer Punkt jederseits

1) Ein drittes Stück $(\hat{S})$ von demselben Fundorte gehört zu einer neuen Art, die sich durch ein auffällig grosses Halssch. auszeichnet und die grösstc europäische Pachybr.-Art bilden dürfte, da das $\hat{\odot}$ schon fast $5 \mathrm{~mm}$. lang ist. 
über der Fühlerwurzel und der Vorderrand des Kopfschildes schmal schwarz (j). Das $f$ behält nur ein oder mehrere Punkte auf dem Kopfschilde und einen schmalen Saum am Innenrande der Augen gelb. Halssch. durch die Ausdehnung der fünf Normalmakeln schwarz, ein sehr schmaler Saum am Vorderrande, welcher eine abgekürzte gelbe Mittellinie aussendet, sich vor der Vorderecke jederseits in eine scharfe Spitze erweitert, hierauf wieder leicht verengt und schmal am schwarzen Seitenrande bis zu den Hinterecken, oft auch noch ein Stück am Hinterrande fortzieht, gelb. Ausserdem zeigt sich eine gerade, linienförmige gelbe Längsmakel jederseits vor dem Schildchen, die etwa bis zur Mitte nach vorn reicht. Die fünf schwarzen Makeln der Fld. haben ungefähr dieselbe Form und Stellung, wie bei hieroglyphicus, nur ist 1 kürzer, ziemlich rund, und 4 länger. Letztere liegt mit der vorderen Hälfte auf dem Mittelkiele und rerbindet sich breit und ganz scharf mit 2 zu einer breiten Längsbinde. Diese nimmt vorn die innere Hälfte der Fld. bis zur Naht ein, mit Ausnahme einer kurzen, gelben, mit wenigen schwarzen Punkten rersehenen Längsmakel hinter dem Schildchen, biegt in der Mitte, wo sie mit Makel 3 zusammenstösst, etwas nach aussen um einen ovalen, gelben, glatten, reliefartig erhabenen Fleck an der Naht herum und läuft parallel der letzteren, durch den ersten Zwischenraum getrennt, bis auf den Abfall zur Spitze, wo sich vor ihrem Hinterende auch Makel 5 mit ihr vereint. Die wesentlichsten Unterschiede von hierogl. var. $b$ bestehen also darin, dass Makel 1 stets frei bleibt und dass von der scharfen, durch Makel 2 und 4 gebildeten Längsbinde ein gelber Relieffleck an der Naht umschlossen ist.

Die Punktirung des Halssch. ist veränderlich, bald dicht und ziemlich stark, bald weitläufig und fein, die Fld. sind nur auf der vorderen Hälfte zwischen Mittelkiel und Naht verworren, sonst in Reihen punktirt, die Punkte feiner als bei hieroglyphicus, und hinter der Mitte fast erloschen.

Grube des letzten Bauchringes beim ô hinter der Mitte tiefer als vorn. Penis vor der breit dreieckigen, am äussersten Ende nach unten gekrümmten Spitze jederseits mit einem kleinen Ausschnitte und einer kurz behaarten Längsrinne über demselben.

Die Art variirt nur in der Richtung, dass die gelbe Grundfarbe der Fld. sich ausbreitet und die Verbindung der schwarzen Makeln unter einander aufhebt. Es trennt sich die dritte, seltener auch die fünfte Makel von der Längsbinde; bei den hellsten Stücken ist die letztere durch eine, vom Reliefflecke ausgehende, schief nach vorn und aussen gerichtete, gelbe, schwarz punktirte Binde unter- 
brochen. Die vier vorderen Schenkel sind rotligelb, wach der Spitze hin weisslich, mit schmaler, schwarzer Makel längs des Rückens, auch die Hinterschienen an der Basis zuweilen röthlich (Var. a).

In Gebirgsbächen auf Myricaria germanica und Weiden liäufig in einem Streifen von Arnsberg an der Rulir ( $\mathrm{Suffr}$.) nach dem Harze (Degenhardt) und Thüringen (Kellner, Ludy) durch Schlesien (Liegnitz? Ratibor, Ustron; Letzner Bericht. Arl, Schles. Ges. 1872. 18) und den ganzen Karpathenzug bis Siebenbürgen und in den Banat (Mehadia); an den nördlichen Fundort+rn rorherrschend die Var. a.

Da Suffrian die vorliegende Art nicht erkannte, also auch von hippophaes nicht zu unterscheiden rermochte, gehören seine Stücke ,aus der Schweiz (Hornung)" wohl zur folgenden.

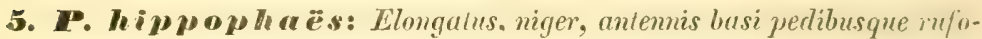
testaceis, femoribus superne macula nigra notalis, apicem versus ullicantibus, tarsis obscuris; capite albido, vertice lineaque media frontuli

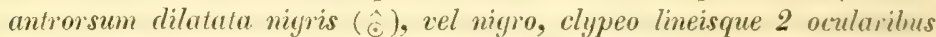
flavis; prothorace nigro, margine antico (lineolam abbrevialam in mediu et maculam trigonam utrinque emittente) et laterali maculisque 2 el(ungatis in basi albidis, elylris punctato-substriatis, albidis, marulis , nigris: secunda el quarta in vittam subsuturalem flineam flavam elerutam includente) connatis, quinta etiam cam ritta confluente. limbo flure "picali antrorsum ramulum difformen vel suber zatum exserente: rentit ruguloso-punctato, subopaco. - Long. $3,5-4 \mathrm{~mm}$.

Suffr. Mon. III. 125. - Redtb. Faun. A. II. 466.

Var. a. Maculis elytrorum parvis obsoletis, striis nigris malyis minusie? subconjunctis, tarsis interdum testaceis.

Crypt. lignosus Dahl i. litt.

Var. b. Episternis mesothoracis puncto flavo notatis.

Etwas gestreckter als die vorhergehenden, dem hieroglyphicus nur in der Färbung der Beine, dem vorigen in der Zeichnung der Fld. ähnlich, aber an dem gelbgerandeten Halssch. und den in (oft schwarzen) Reihen punktirten, nit gewölbten Zwischenräumen rersehenen weisslichen Fld, deren Makel 4 weiter nach hinten reicht, zu unterscheiden.

Unterseite schwarz, Beine röthlich-gelbbraun, Vorderhüften und Schenkel nach der Spitze hin weisslich, Rücken der Schenkel mit einer schwarzen Längsmakel, Hinterschienen an der Spitze und alle Tarsen schwärzlich. Oberseite weisslich, schwach gelblich, Scheitel, Mittelrinne der Stirn und ein unscheinbarer Punkt jederseits über der Fühlerwurzel schwarz (j) oder der Kopf schwarz, ein schmaler Saum am inneren Augenrande und ein Punkt auf dem Kopfschilde 
weissgelb (). Halssch. durch Vereinigung der fünf Makeln schwarz, ein sehr schmaler Saum am Vorderrande, welcher eine abgekürzte Mittellinie und jedereits eine dreieckige Spitze aussendet, und sich, rorn breiter, hinten allmählich verschmälert, am Seitenrande und ein Stïck am Hinterrande hinzieht, weisslich gelb. Der Seitenrand selbst ist nicht, wie beim rorigen, scliwarz, sondern anch noch auf der Unterseite gelb. Ausserdem besitzt das Halssch. zwei abgekürzte, rorn leicht dirergirende gelbe Längsmakeln ror dem Schildchen und pinen gelben Punkt in der Vitte jederseits, nahe dem Seitensaume, der zuweilen bei dem jo der Var, a. mit der Seitenspitze des Vorderrandsaumes zu einer riereckigen Makel zusammenfliesst. Von den fünf schwarzen Makeln der Fld. sind 1 und $\partial$ klein, durch einen kurzen, verschieden breiten, gewölbten Zwischenraum, der von zwei regelmässigen Punktreihen begrenzt wird, getrennt; $\dot{4}$ richt so weit nach hinten wie 5 und ist ein Stück vor dem Hinterende mit dieser schmal verbunden, so dass dadurch ein langer, vom Spitzensaume rorwärts gerichteter, entweder vorn erweiterter, oder linienförmiger dann aber leicht nach aussen gekrümmter weisslicher Ast umschlossen wird. Mit dem rorderen Ende liegt die Makel 4 aussen auf dem Mittelkiele, ist höchst selten mit 3 , aber stets mit 2 zu einer breiten Längsbinde zusammen geflossen, welche von der Naht in der hin-

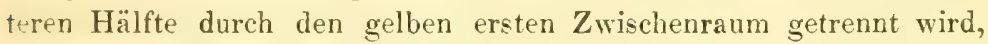
auf der vorderen Hälfte dieselbe erreicht, aber eine, wenig schräg nach aussen gerichtete, fast linienförmige gelbe Reliefmakel in der Nitte und eine ähnliche, aber am Rande durch schwarze Punkte unregelnässig begrenzte hinter dem Schildchen einschliesst.

Halssch, verworren, meist grob und ziemlich dicht, Fld. in veränderlicher Stärke in Reihen punktirt. Bei kräftig und regelmässig punktirten Exemplaren ist die zweite und dritte Punktreihe ror der Mitte an die Naht gebogen, wo die zweite Reihe aufhört, die dritte aler die Reliefmakel vom gelben Nahtsaume trennt und sich, am Aussenrande desselben, als erste Punktreihe bis vor die Spitze fortsetzt. Unterseite äusserst dicht, fein runzelig-punktirt, fast matt. Penis rorn schnell in eine breite, stumpfe Spitze verschmälert, mit einem auffällig langen, gelben Haarbüschel jederseits.

Bei sehr hellfarbigen Stücken (Var, a) sind die Punktreihen gebräunt oder schwarz, Makel 1 ist normal, 3 und 5 werden nur durch breiter schwarz gefärbte Punktreihen angedeutet, die durch verschmälerte weissliche $\mathrm{Z}$ wischenräume getrennt werden, oder fehlen ganz, der Mittelkiel ist fast durchgehend hell gefärbt und Makel 4 wird ron einem weissen $\mathrm{Z}$ wischenraume (dem dritten von der Naht) durchsetzt, der anfangs neben dem mittleren Reliefflecke sichtbar 
wird. Bisweilen ist auch das Schildchen in der Mitte weisslich, die Tarsen gelbbraun. Von der Var. b., mit einem kleinen gelben Flecke auf den Episternen der Mittelbrust, sandte mir H. Gredler ein tiroler Exemplar zur Ansicht. Aehnliche Stücke sind von flexuosus sogleich durch den Relieffleck an der Naht und den gestreckten Körper zu unterscheiden.

In Baiern (Weidenbach) und den Alpenländeru, nach Kunze auf Hippophae rhamnoides, weit verbreitet.

6. P. tesselatos: Brevis, niger, nitidus, anlennis basi. libiis lunsisque anticis testaceis, posterioribus infuscatis, femoribus anticis interne fere omnino albidis, posterioribus basi parum testaceis. apicem versus macula alba notatis; capite flavn-albido, vertice lineagne medin frontali cum puncto nigro supra antennas utrinque haud ( $\vec{\xi})$ rel lort: $\left(\begin{array}{c}+ \\ )\end{array}\right.$ conjuncta, nigris; prothorace sat fortiter punctato, nigno, margine antico (maculas 3 trigonas emittente) et laterali maculisque 2 basens flavo-albidis; elytris crebre inordinate, extus et pone medium parce substriato-punctatis, nigris, margine basali, limbo intramarginali pone medium, costa dorsali (in medio et ante apicem intermpta) maculisque 4 favo-albidis, politis, elevatis : prima transversa pone callum humeralem et plerumque cum flavedine costae dorsalis comjuncta, secunda anousta postscutellari, tertia obliqua, in medio, subsuturali, quarta transversa pone medium, prima et quarta striis punctatis subinterrupta; rentre crebre punctato, subnitido, pygidio maculis 2 flaris. - Long. $3-4,5 \mathrm{~mm}$.

$\mathrm{Mas}$ : oculis minus late distantibus.

Oliv. Encyclop. méth. VI. 618 (Cryptoc.). - Harold Berl. Zeit. 1873. 176.

Cr. histrio Oliv. 1. c. - Suffr. Mon. III. 135 (Pach.) pars. Mars. Mon. 265.

P. bisignatus Redtb. Faun. A. ed. 1. 563; ed. 3. II. 465.

P. tauricus Suffr. 1. c. 137.

Var. a. aethiops: Corpore toto nigro, maculis albidis femmum parris, tibiis tarsisque testaceis, posterioribus infuscatis.

Eine der breitesten und plumpsten europäischen Arten, an den wenigen, scharf begrenzten und stark erhabenen gelben Makeln der Fld. ohne Mühe zu erkennen. Schwarz, eine Schrägmakel jederseits auf dem Pygidium, Vorderhüften, die grössere untere Hältte an der Vorderseite der Vorderschenkel, sowie eine scharf begrenzte Makel an der Spitze der vier hinteren Schenkel gelblich-weiss, Vorderscbienen und -Tarsen meist einfarbig gelbbraun, die hinteren Schienen am Knie oder an der Spitze röthlich, die hinteren Tarsen wenigstens oberseits dunkel. Kopf weisslich-gelb, Scheitel und Mittelrinne der Stirn, welche beim $\hat{\jmath}$ kaum, beim $q$ gewöhnlicb mit einem schwarzen Flecke über der Fühlerwurzel jederseits verbunden ist, 
schwarz. Halssch. quer, mit gerundeten Seiten, die grösste Breite wenig hinter der Mitte, mässig dicht und ziemlich kräftig punktirt, glänzend, schwarz, ein schmaler Vorderrandsaum, welcher drei breite Spitzen nach hinten aussendet (die mittlere derselben die längste) und sich, vor der Mitte etwas verengt, als Seitensaum innen vom schwarzen, abgesetzten Seitenrande bis vor die Hinterecken zieht, sowie eine Längsmakel an der Basis jederseits weissgelb; ein kleiner Punkt nahe dem Seitensaume röthlich-gelb. Fld. kräftig punktirt (auf dem vorderen Innenviertel dicht verworren, sonst in unregelmässigen Reihen), schwarz, eine Linie auf dem Basalrande, welche sich, vor der Schulter nicht unterbrochen, am Aussenrande der Epipleuren fortsetzt und bald hinter der Schulterbeule endet, weissgelb. Ebenso gefärbt ist ein Saum, der auf dem stark gewölbten letzten Zwischenraume unter der Schulter beginnt und um die Spitze herum bis zur Mitte der Naht fortläuft. Derselbe ist gewöhnlich in der Mitte des Seitenrandes durch den Eintritt der Normalmakel 3 unterbrochen und sendet vor der Spitze, wo er etwas verbreitert ist, eine kurze gelbe Linie auf dem Mittelkiele nach vorn. An den Saum lehnen sich zwei schmale, gelbe, durch tiefe Längslinien in Reliefstriche getheilte Quermakeln, die innen bis a uf den Mittelkiel reichen, die erste in ein Drittel, die andere in zwei Drittel der Fld. Der Mittelkiel ist an drei Stellen gelb gefärbt: von der Basis bis zur ersten gelben Quermakel, am Innenrande der zweiten und vor der Spitze. Auf der inneren Hälfte der Fld. befinden sich zwei Reliefmakeln nahe der Naht, eine linienförmige hinter dem Schildchen, die andere schief, fast quer, dreieckig, in der Mitte.

Beim ô sind die oberen Augenlappen sehr nahe zusammengerückt, die ziemlich tiefe Quergrube des letzten Bauchringes ist an den Seiten lang bewimpert. Penis vor der Spitze leicht eingeschnürt, hierauf wieder ein wenig erweitert und, ohne scharfe Aussenecken, gradlinig zu einer schwach bogenförmig ausgerandeten, mässig breiten Spitze verschmälert. In die grosse Oeffinung selbst ragt vom Oberrande her ein langer, gleichbreiter Hornhaken hinein.

Nach und nach verkleinern sich die gelben Zeichnungen der Fld. und des Halssch. und verschwinden theilweise oder ganz; selbst der Kopf wird zuletzt bis auf die gelbe Oberlippe schwarz (Var. a). Diese Form ist von den sehr äbnlichen schwarzen Stücken anderer Arten nur noch an der Farbe der Beine zu erkennen.

Schlecht gehaltene Exemplare haben statt der weissgelben Zeichnung der Oberseite eine gelbbraune. Nach solchen, zugleich kräftig punktirten Stücken ist wahrscheinlich $P$. tauricus Suffr. beschrieben, dessen Unterscheidung um so mehr befremden muss, als Suffrian, 
bei seiner geringen $\mathbf{K}$ tnntniss der Pachybrachen, nicht einmal die vorliegende von der folgenden Art zu trennen in Stande war.

Auf jungen Eichen in Baiern und Oesterreich weit verbreitet. Häufig im südlichen Europa.

- P. picus 1): Breriusculus, niger, nitidulus, antennis basi pedibusgue testaceis, femoribus superne nigsis, posterioribus aprice macula alba ornatis; capite flavo, vertice lineaque media fronlali anu puncto nigrn supia antemas haud $(\hat{\hat{S}})$ rel late comjuncta $(\hat{x})$ miyris; prolhoracte erebie subtilius punctalo, nigro. margine antico (interdum utrinque dilutato, lineolam abbreviatam in medio emittente) et laterali muculisque? elongatis baseos flaris. Elytris minus fortiter et parnm ponfinde exius et pone medium substriation punctatis, nigris, margine basuli, limbo intramarginali pone medium (plerumque interrupto rel antice abbreviato). costa dorsali basi et ante apicem maculisque 1 flacis, his ut in P. tesselato positis, sed macula prina a flacedine costae dorsulis separata. Long. $3-3,8 \mathrm{~mm}$.

P. histrio Redtb. Faun. A. II. 466.

P. histrio Suffr. Mon. III. 135 (pars.). - Mars. Mon. 265.

1) Durch Körperform, Punktirung und die Bildung des Penis steht dieser Art äusserst nahe: P. limbatus Ménètr. (Bull. Ac. Petr. I. 151; Cat. Ins. Balk. 1 S3S p. 48. t. 2. f. 9.) Bieviusculus, niger, nitidulus, antennis basi, tibiis tarsisque anticis testaceis, femoribus macula alba notutis: capite aut Anvo, vertice lineaque media fiontali cum puncto nigro supra antennas utrinque conjuncta $(\hat{\odot})$ nigris, aut nigro, puncto clypei lineisque 2 irmatis rufis $(\doteqdot)$; prothorace confertim punctato, interstitiis fere laevibus, nitidulis, margine antico (interdum lineam mediam et lineam intramarginalem emittente) furo; elytris cum costa dorsali nigris, margine basali, limbo anyusto subapicali punctisque 3 politis, elevatis, flavo-albidis: 1:0 pone callum humeralcm, 2: o medio, subsuturali, 3: o bipartito infra medium. - Long. 3-4 mm. Turcia, Graecia, Asia minor.

Variat a (maculatus Suffr. Mon. III. 139). Prothuracis intersitius punctorum evidentius punctulatis, minus nitidis, b. femoribus anticis marima parte, intermediis basi et inferne testaceis; c. (P. ater Dahl i. litt.) corpore omnino nigro, antennarum basi, tibiis et tarsis anticis testaceis.

Der Penis (der Var. maculatus) ist vorn ganz allmählich verengt und in eine lange Spitze ausgezogen.

Obwohl mir von dem typischen limbatus Suffr. aus Kleinasien nur wenige weibliche Stücke vorliegen, so bin ich kaum zweifelhaft, dass sie mit dem griechischen maculatus Suffr, dessen Halssch. zwischen der Punktirung etwas deutlicher mit feinen Pünktchen besetzt und deshalb matter ist, eine Art bilden. Die von Suffrian angegebenen Unterschiede in der Färbung der Fühler, der Bildung des Halssch. und der äusseren Streifen der Fld. sind nicht stichhaltig. 
Var. a. Prothorace flaro, maculis 5 nigris, lilleram $\boldsymbol{M}$ formantibus postice ornato.

Durchschnittlich kleiner und etwas schlanker als der rorige, von demselben in folgenden Punkten zwar unbedeutend aber sehr bestimmt verschieden: das Pygidium ist schwarz und, wie die ganze Unterseite, dichter punktirt und weniger glänzend; die Beine sind gelbbraun, Vorderschenkel längs des Rückens mit einer schmalen schwarzen (aber ohne weisse) Makel, bei den vier oder oft nur zwei hinteren Schenkeln ist die schwarze Makel breiter und umschliesst zuweilen ihren weissen Spitzenfleck deutlich. Ebenso ist das Ende der Hinterschienen und der einzelnen Tarsenglieder öfter gebräunt. Halssch. dichter, doch meist feiner punktirt, der Seitenrand auch noch auf der Unterseite gelb, Vorderrandsaum einfach, nur mit schmaler, kurzer Mittellinie, oder, wie beim vorigen, noch jederseits in eine dreieckige Spitze erweitert, selten (Var. a) nebst dem Seitensaume sehr breit, so dass das Halssch. gelb ist, mit M-förmiger schwarzer Zeichnung. Auf den Fld. ist der Mittelkiel an der Basis kürzer gelb gefärbt und nie mit der ersten gelben Quermakel vereint (ähnliche tesselatus haben dunkle Beine!), der gelbe Aussensaum reicht selten von der Schulter, um die Spitze herum, bis zur Mitte an der Naht, gewöhnlich ist er nur vor der Spitze deutlich, oder das vordere Stück an der Naht ist makelförmig abgetrennt. Alle hellen Zeichnungen sind gesättigt gelb, die der Fld. etwas weniger erhaben, als bei tesselatus. - Penis an den Seiten der Oeffnung leicht verschmälert, vorn schnell verengt und in eine kurze Spitze vorgezogen.

Viel seltener als der vorige, auf Haseln (Suffr.) und wilden Rosen (Redtb.). Am Rheine: Alrweiler (Kratz), Brohl (Habelmann), Thüringen, Schlesien, Kärnthen (Kahr), Wien (Redtb.).

8. F. fimbriolatus'j): Cylindricus, niger, subnitidus, femoribus nigris, apice macula alba notatis, tibiis tarsisque testaceis, posterioribus plus minusve infuscatis; capite flavo, vertice lineaque media frontali

1) Sehr ähnlich ist $P$. cinctus Suffr. (III. 123) Cylindricus, parum nitidus, niger, antennis basi obscure rufo-testaceis, clypeo, taeniis duabus oculos semicircumdantibus (interdum interruptis), marginibus prothoracis et muculis duabus brevibus, latis, in basi, pallide-testaceis, elytris limbo lato, favo circumcinctis, sat fortiter et parum profunde substriato-punctatis; prothorace confertissime punctulatus; pedibus testaceis, femoribus superne linea obscura signatis, marginibus segmenti ultimi maculaque transversa didyma pygidii favis. - Long. 2-3 mm. Corsica, Sardinia.

Variat costa dorsali basi flaro rel elytris puncts nonnullis parris fluris.

Von den ähnlichen kleinen Arten durch den sehr breiten, glatten 
cum puncto nigro supra anlennas haud, anguste $\left(\hat{\epsilon}_{0}\right)$ vel late $\left({ }_{f}\right)$ conjuncla, nigris; prothorace conferlim punctato, nigro, margine antico, lineola media abbreviata, linea intramarginali lineisque 2 baseos flaris; elytris basi sat crebre confuse, externe et postice porte obsoleteyue substriato-punctatis, nigris, margine basali, limbo intramaryinali ad medium suturae pertinente, lineis 2 elevatis, subsuturalibus (prima pone scutellum, secunda in medio), costa dorsuli basi lineisque 2 interstitii penultimi pallide flavis. - Long. 2,5-3 mm.

Suffr. Mon. III. 142. - Redtb. Faun. A. II. 466.

Cr. tristis Oliv. Ent. VI. 810. t. 5. f. 79.

Var. a. Femoribus anticis interne testaceis apicem versus albidis, posterioribus basi testaceis.

? P. fimbriolatus Mars. Mon. 278.

Var. b. Signaturis flavis prothoracis et elytrorum plus mimusve deficientibus.

P. pteromelas Mars. Mon, 274 .

Var. c. Prothorace elytrisque omnino nigris.

Die kleinste und zugleich am dunkelsten gefärbte deutsche Art, cylindrisch, schwarz, oberseits gewöhnlich nur mit einem schwachen Fettglanze; Schenkel schwarz, an der Spitze mit weisser Makel, Schienen und Tarsen röthlich-braun, die der vier hinteren Beine theilweise oder ganz dunkel. Kopf gelb, der Scheitel und eine breite Mittellinie der Stirn, welche beim $\hat{j}$ häufiger als bei den vorigen Arten (beim $ᄋ$ stets breit) mit dem schwarzen Punkte jederseits über der Fühlerwurzel verbunden ist, schwarz. Halssch. kurz, dicht punktirt, schwarz, ein schmaler Saum am Vorderrande, der gewöhnlich eine kurze Mittellinie nach hinten sendet und nur ausnahmsweise an den Seiten etwas verbreitert ist, ein schmaler Saum dicht über dem schwarzen Seitenrande und zwei linienförmige Makeln jederseits vor dem Schildchen gelb bis rothbraun. Fld. auf der vorderen, inneren Hälfte ziemlich dicht und verworren, sonst weitläufiger und wenig tief, unregelmässig gestreift-punktirt; doch variirt diese Punktirung oft so, dass nur zwei Punktreihen am Aussenrande deutlicher hervortreten. Der erhabene Basalrand und die Aussenseite der Epipleuren, ein Saum über der äussersten Punktreihe ron der Schulter um die Spitze bis zur Mitte der Naht ziehend, zwei Reliefmakeln parallel der letzteren (die grössere in der Mitte, die kleinere hinter dem Schildchen), der Mittelkiel an der Basis und

äusseren Zwischenraum der Fld. zu unterscheiden. Auf demselben läuft der gelbe Saum gleich breit von der Basis bis zur Spitze und setzt sich hier an der Naht auf dem ersten $\mathbf{Z}$ wischenraume, vorn mit einigen Punkten bestreut und zuweilen leicht verbreitert, bis zum Schildchen fort, wo er sich mit dem erhabenen gelben Basalrande verbindet. - Penis vorn einfach abgerundet. 
zwei kurze Längsstriche auf dem vorletzten $Z$ wischenraume, der eine hinter der Schulter, der andere hinter der Mitte, gelblich-weiss.

Der Penis ist sehr schlank und (Seitenansicht) nicht wie der der übrigen Arten in der Mitte gekniet, sondern ziemlich gerade, an der Oeffnung (Vorderansicht) jederseits bogenförmig ausgerandet, hierauf gradlinig in ein breites Dreieck verschmälert, dessen beide Vorderseiten in der Mitte mit einem kurzen, nach hinten gerichteten Haarbüschel besetzt sind.

Zuweilen (Var. a) sind die Vorderschenkel nur aussen schwarz, die ganze Innenseite ist gelbbraun, nach der Spitze hin allmählich weiss, auch die Basis der hinteren Schenkel in geringer Ausdehnung röthlich ${ }^{1}$. Auf den Fld. ist nur selten die schmale Reliefmakel

1) Diesen Stücken ist ähnlich: P. probus (二 fimbriolatus Suffr. VIII. 149. pars.): Breviusculus, niger, subnitidus, pedibus testaceis, femoribus anticis superne linea et posterioribus macula nigra notatis, his apicem versus albidis; capite flavo, praecedenti $(\hat{\odot} f)$ similiter nigro-signato; prothorace sat dense fortiterque punctato, nigro, margine antico (lineolam abbreviatam in medio et maculam trigonam utrinque emittente), limbo intramarginali maculisque 2 elongatis baseos flavis vel rufescentibus; elytris sat fortiter et irregulariter punctato-striatis, nigris, limbo toto, ante medium suturae punctos nonnullus nigros perturhato et a macula oblonga, elevata parum separato, flavo-albido circumcinctis, costa dorsali intra humerum (interdum etiam in apice), lineola infra callum humeralem maculaque transversa pone medium (saepissime cum limbo laterali conjuncta) pallide-flavo signatis. - Long. 2,5-3,5 mm. Rossia mer. Crimea (Parreyss), Sarepta (Becker), Derbent (Faust), Kaukasus (Schneider, Leder).

Variat signaturis flavis elytrorum prothoracisque magis minusue deficientibus, femoribus posterioribus interdum nigris, apice macula alba.

Wenig grosser, aber breiter als fimbriolatus, durchweg stärker punktirt, die Fld. etwas glänzender, die drei Spitzen des Vordersaumes und die beiden Basalmakeln des Halssch. breit, der gelbe Seitensaum der Fld. zieht sich gleichbreit rom Schulterhöcker um die Spitze und an der Naht bis zum Schildchen hin, ist aber vor der schlecht abgetrennten Reliefmakel (in der Mitte der Naht) durch schwarze Punkte mehr oder weniger getrübt und weniger scharf begrenzt, als hinten. Hinter dem Schulterhöcker befinden sich ein oder mehrere gelbe Striche auf den vorletzten $\mathbf{Z}$ wischenräumen und unter der Mitte ein gelber Querfleck, so dass hierdurch die schwarzen Grundmakeln 1, 3, 5 getrennt sind. Beine gelbbraun, Schenkel mit schwarzer Rückenmakel, die sich an den Vorderbeinen nur bei ganz dunklen Stücken, an den hinteren Schenkeln öfter zu einem Ringe um die Mitte ausdehnt und dann die weisse Makel an der Spitze einschliesst. - Penis an der Oeffinung jederseits zweimal halbkreisförmig ausgerandet, hierauf schnell, jederseits leicht bogig ausgeschnitten, in eine kurze, mässig breite Spitze verschmälert. Der 
hinter dem Schildchen so verlängert, dass sie den gelben Nahtsaum in der Mitte fast oder undentlich berührt, häufiger verschwindet sie ganz; ebenso erlöschen bei dunklen Exemplaren allmällich: die Striche des vorletzten Zwischenraumes, der Saum an der hinteren Hälfte der Naht (oder der ganze Saum), auch die grössere Reliefmakel und die kurze Basallinie des Mittelkieles, so dass nur der Grundrand gelblich bleilbt (Var. b). Zuletzt sind Halssch. und Fld. einfarbig schwarz, der Kopf hat zwei helle Stirnlinien oder ist ebenfalls schwarz (Var.c).

vordere Theil hat sonach fünf Spitzen, zwei an jeder Seite 'die obere sehr scharf), und eine vorn.

Diese Art begreift die gelbbeinigen südrussischen fimbriolatus in sich die Suffrian (Mon. III. 144 und VIII. 150) erwähnt. Sollte sich die Angabe in meiner Sammlung (Gallia, Wehncke) bestätigen, so wäre das Thier jedenfalls auch in Deutschland einheimisch. P. mendar suffr. (XIV. 60), der im Kaukasus, der Kirgisensteppe, in Persien, aber auch bei sarepta (Faust) vorkommt, verbindet die Zeichnung heller probus mit der Körperform und Grösse eines kräftigen tesselatıs, und becteht wahrseheinlich noch aus zwei verschiedenen Arten.

$P$. fulcipes Suffr. (III. 145) ron Cadix, ebenso gross, aber besonders vorn breiter als fimbriulatus, ist an den rothgelben Beinen, deren Schienen und Tarsen unmerklich gebräunt sind, zu erkennen. Der einzige Typ. in Dr. Iraatz's Sammlung befindlich, hat Kopfschild, einen Strich in der Ausrandung und einen andern am oberen Innenrande der Augen jederseits gelb. Vordersaum nebst Mittellinie des Halssch. schmal, Seitensaum breit, gelb, zwei schmale Basalmakeln angedentet. Wurzelrand der Fld., ein breiter Saum der Epipleuren, von der Schulterecke bis zum Ende des ersten Bauchringes, ein schmaler Saum auf dem äusseren Zwischenraume, hinter der Schulter beginnend und, um die Spitze herum erweitert, etwas for dem Nahtwinkel endigend, sowie vier punktförmige Makeln gelb: eine derselben auf der Basis des Mittelkieles, zwei an der Vorderhälfte der Naht, die vierte hinter der Mitte, der Seite genähert. - Der Penis besitzt jedenfalls zwei sehr lange, gelbe Haarbüschel (wie hippophaes), ron denen der eine bei dem vorliegenden Exemplare sichtbar ist. Hieran schliessen sich:

1. P. pradensis Mars. (Mon. 270) Cyliudricus, niger, antennis busi pedibusque testaceis, femoribus anticis superne linea et posterioribus macula nigiu notatis, clypeo lineisque 2 frontalibus favis; prothorace minus transverso, cylindrico, antice angustnto, convexo, confertissime unnctuluto, fere opaco, nigro, limbo angusto flaro circumcincto (limbo antico utrinque parum dilatato medin lineam abbreviatam emittente), maculis duabus baseos faris; elytris sat fortiter punctato-substriatis, faro-pallidis (margine laterali etiam faro), punctis striarum maculisque 5 nigris: 1 humerali, 2 et 4 in rittam subsuturalem confluentibus, 3 minime, scope nullu, 5 subrotunder et cum 4 auguste conjuncta: luterilus segmenti ultimi et yygidii apice manula furr signutis. - Long. 2 bis $3 \mathrm{~mm}$. Pyrenaei. 
In der Rheiuplalz, Baiern und den südlichen P'rovinzen Oesterreichs nicht häufig; im südlichen Europa von Mittelspanien bis in die Krim verbreitet.

Spanische, mir von J. Martinez-y-Saez ebenfalls als pteromelas übersandte Stücke beschrieb Narseul unter diesem Namen, ohne die Diagnose des wirklichen pteromelas Graells zu kennen.

An der gelben Seitenkante der Fld. leicht kenntlich, von pallidulus Kïesw., der ein ähnliches langes und cylindrisches Halssch. besitzt, durch die viel feinere und dichtere Punktirung desselben, schwarze Episternen ete. sehr verschieden.

2. P. baeticus: Praecedenti simillimus, pedibus obscurioribus, femoribus maxima parte nigris, apice macula alba, tiliis apice tarsisque infuscatis, prothorace fortius punctato, elytris minus regulariter sed crebrus punctato-substriati, nigris, margine basali limboque angusto a humero ad melium suturat pertinente et ante apicem ramuium trifidum exserente flavis, costc clorsali et interstitiis internis (bas? vigris ante medium favis crelurius subinterruptis, pygidio apice utrinque puncto flavo, mox distinguendus. - Long. $3 \mathrm{~mm}$. Andalusia (Staudinger, Kratz).

Form des Kiörpers und Halssch. wie beim vorigen, letzteres ebenso dicht aber etwas stärker punktirt, Fld. mit wenig tiefen, breiten (beim o unregelmässig doppelreihigen) Punktstreifen und sehr schmalen erhabenen Zwischenräumen, ron denen die inneren im zweiten Viertel der Länge, durch eintretende schwarze Punkte oft unterbrochen, gelb gefärbt sind. Ebenso ist der Mittelkiel in der vorderen Hälfte und eine verschwommene Makel hinter der Mitte, dicht ausserhalb desselben, gelb.

3. $P$. viridissimus Suffr. (III. 115): Supra laete viridis, aeneo micans, subtus obscure riridis, antennis basi pedibusque testaceis, femoribus superne haud rel apicem rersus infuscatis; capite favo, vertice, canalicula frontali sat profunda punctoque supre antennas utrinque viridibus, prothorace unicolori rel flavo-marginato, crebre fortaterque punctato; elytris fortius rugosopunctatis, margine basali et laterali sub humeris favis. - Long. 3-3,5 mm. Hispania, Algier.

Variat elytris limbo angusto $a$. subaprcal vel $b$. ( $P$. regus $\mathrm{Schauf}$. Ann. Fr. 1862. 312) intramarginali ab humero ad angulum apicalem pertinente et ante apicem dilatato, flavo.

4. $P$. azureus Suffr. (III. 113) Praedenti simillimus, supra aut omnino coerulens, violaceus vel obscure viridis (suhtus obscurior), aut clypeo, taeniis dualus nculos semicircumdantibus, marginilus prothoracio magis minusve margineque lasali et laterali sub humeris elytrorum flavis, prothorace elytrisque crebre fortiterque punctatis, antennis basi pedibusqus testaceis, femoribus superne nigris bene distinctus. - Long. 3-3,5 $\mathrm{mm}$. Gallia merid., Hispania.

Der Penis ist an der Oeffnung allmählich schwach rerengt, am Vorderrande zweimal halbkreisförmig ausgeschnitten und deshalb in drei nach vor $u$ gerichtete Spitzen ausgezogen, die äusseren beiden breit, die mittlere ziemlich schmal. 


\section{Stylosomus.}

Suffr. Linn. ent. III. 146.

Corpus pubescens.

Oculi ovales, subintegri.

Prothorax basi leviter rotundalus, subreflexo-marginatus. limbo postico confertissime striolato.

Scutellum occultum.

Elytra basi marginata.

Augen nur mässig gross, gewölbt, oval, die Mitte des Innenrandes kaum merklich ausgeschweift, die Stirn zwischen ihnen breit, schwach gewölbt, oft mit leicht vertiefter Mittellinie, rorn rom Kopfschilde nicht getrennt. Fühler höchstens halb so lang als der Körper, die 5 oder 6 letzten Glieder etwas breiter als die rorhergehenden. Halssch. an den Seiten stark abwärts gewölbt und zusammengedrückt, fast cylindrisch, gleichbreit oder nach rorn verschmälert, der Vorderrand von den Ecken nach der Mitte allmäblich schwach gerundet-erweitert und etwas über die Stirn vorgezogen, der Hinterrand gleichfalls nach der Naht hin leicht gerundet-erweitert, so dass die Länge über die Mitte die der Seiten bedeutend übertrifft. Der Hinterrand schliesst sich, mit Ausnahme einer kleinen Stelle über dem Schildchen, dicht an den Grundrand der Flügeldecken an und verlängert sich unter diesem in Gestalt einer schmalen, schwarzen Querleiste, welche, wie der Rand selbst, äusserst dicht mit feinen Längsrippen besetzt ist $\left.{ }^{1}\right)$. Die Verbindung der Hinterecken mit dem schmalen und flachen, aber scharfen Seitenrande wird durch eine Grube in den stumpfen, fast abgerundeten Hinterecken unterbrochen, so dass an den letzteren meist ein Ausschnitt bemerkbar ist. Schildchen gross, dreieckig, aber unter dem Halsschilde vollständig verborgen. Flügeldecken cylindrisch, oder nach hinten etwas verbreitert und zuletzt schwach einzeln abgerundet oder fast gemeinschaftlich abgestutzt, an der Basis mit hoher und scbarfer Leiste; Epipleuren mässig breit, vor der Spitze allmählich erlöschend. Vorderbrust zwischen den Hüften breit, bald eben, bald leicht gewölbt, der $\nabla$ orderrand wenig aufstehend, der Hinterrand fast gerade abgestutzt. Beine schlank, ziemlich gleich lang, die Tarsen entweder so lang als die Schienen, schmal, Glied 1 und 2 fast gleich lang, $3 \mathrm{kurz}$, in zwei schmale Lappen gespalten, welche das vierte und längste Glied kaum bis zur Hälfte einschliessen (St. tamaricis);

1) Diese Leiste wird von Morawitz (Bull. Mosc. 1S60. 301) fälschlich zu den Flügeldecken gerechnet. 
oder Tarsen kürzer als die Schienen, mässig breit, die drei ersten Glieder allmählich kürzer werdend, Klauenglied ziemlich dick und über die Hälfte in die oft breiten Lappen des dritten Gliedes eingelagert (St. minutissimus). Der ganze Körper fein, mässig dicht behaart; die Haare sind anliegend, nur auf den Fld. schräg aufgerichtet und $\mathrm{zu}$ mehr oder weniger regelmässigen Reihen geordnet.

Beim Männchen ist der letzte Bauchring einfach, die Tarsen sind ein wenig breiter als beim grösseren Weibchen.

Die Arten, welche habituell den Cis-Arten ähnlich sind, bewohnen die Küstenländer des Mittelmeeres und verbreiten sich östlich bis zum Caspischen Meere und Mesopotamien, westlich bis auf die Canarischen Inseln. Sie sind an dem scheinbar fehlenden Schildchen sofort zu erkennen.

* Tarsen schlank. Seiten des Halssch. fast gerade.

1. St. tamaricis ${ }^{1)}$ : Elongatulus, testaceus, elytris pallidioribus, antennarum apice, vertice, sutura elytrorum, meso-et metasterno tarsisque

1) In diese Abtheilung gehören noch:

1. St.flavus Mars. (Mon. 295). Elongatulus, testaceus, antennis apice tarsisque infuscatis, fronte subconvexa, subtilissime punctata, prothorace subtransverso, creberrime punctulato, opaco, elytris profunde fortiterque punctatostriatis, interstitis angustis, subnitidis. - Long. $2-2,5 \mathrm{~mm}$. Graecia. Sarepta (Becker). Kaukasus (Leder).

Variat vertice infuscato.

Durch die gewōlbte, in der Mitte kaum vertiefte Stirn, fast einfarbigen Körper, feinere Punktirung des Kopfes und Halssch., sowie die tieferen und breiteren Punktreihen der Fld, von denen die abgekürzte an der Naht bis hinter die Mitte deutlich ist, von tamaricis verschieden. Griechische und südrussische Exemplare stecken in vielen Sammlungen unter cylindricus.

2. St. niloticus Suffr. (XI. 251) vom unteren Nil, blassgelb, glänzend, Halssch. wenig dicht, grob punktirt, dazwischen mit unregelmässigen glatten, erhabenen Stellen. Fld. stark punktirt-gestreift.

3. St. erythrocephalus Suffr. (Mon. VIII. 151) aus Mesopotamien, ist nach der Beschreibung etwas kleiner und flacher als tamaricis, Kopf und Halssch. einfarbig roth, Fld. gelblich, mit breiter, scharf begrenzter, tief schwarzer Nahtbinde, fein punktirt-gestreift.

4. St. macer: Elongatus, subtus niger, supra testaceus, elytris pallidioribus, antennis apice, fronte, disco prothoracis tarsisque nigris; prothorace subquadrato, ruguloso-punctato, opaco, elytris fortiter punctato-striatis, interstitibs angustis, subnitidis. - Long. 1,5 mm. Flumen Rubus (Faust). Algeria (M a rs.).

St. erythrocephalus Mars. Mon. 294.

Variat sutura leviter infuscato. 
plus minusve nirgis; fromte obsolete comaliculatn, cobbre subliliter rue punctata. prothorace transierso, munloso-pnoctato: opaco, elytris junctato-strialis, interstiliis sat angustis, subuilidis. - Long. 1,5-2,5 mm.

H. Schäff. Faun. Germ. 143. 24 (Cryptoc.). - Suffr. Mon. III. 148. - Redtb. Faun. A. II. 466.

Var. crucialus: Prothorace antice maculis 2 (interdum confluentilus) nigris, elytris vitta lata suturali maculaque infira medium Cplernumpe cum opposita in fasciam communem abbrecialam conjuncta, crucem (ormante) nigris, ventre magis minusve nigro.

Mässig gestreckt, röthlich gelbbraun, mit blasseren Fld., die sechs letzten Fühlerglieder, ein schmaler Quersaum auf dem Scheitel und ein gleichbreiter oder nach der Basis allmählich breiterer Nahtsaum der Fld. schwarz, die Tarsen an der Spitze gebräunt oder einfarbig schwarz, wie der grösste Theil der Mittel- und Hinterbrust. Stirn sehr schwach gewölbt, in der Mitte der Länge nach leicht eingedrückt, dicht und fein punktirt. Halssch. breiter als lang, mit fast geradem und glattem Seitenrande und stumpfen Ecken, äusserst dicht, etwas stärker als der Kopf querrunzelig-punktirt. Fld. etwa $2 \frac{1}{2}$ Mal so lang und nur beim ${ }_{0}$ merklich breiter als das Halssch., mässig stark punktirt-gestreift, die Streifen auf dem Abfalle zur Spitze verworren, mit ziemlich schmalen, gewölbten Zwischenräumen, von denen jeder mit einer dichten Reihe weisslicher Borstenhärchen besetzt ist. Unterseite fein punktirt.

Die Färbung veränderlich. Auf dem Kopfe wird zuerst die

Schlanker, besonders Kopf und Halssch. schmaler als bei tamericis, Punktreihen der Fld. sehr regelmässig und viel schärfer begrenzt. Scutellarreihe kurz.

5. St. biplagiatus Woll. (Cat. Can. 399) von den canarischen Inseln, etwas grösser als tamaricis, einfarbig röthlich gelb, nur die Fld. mit zwei schwärzlichen, oft in einzelne Makeln aufgelösten, schlecht begrenzten Querbinden, die vordere, hinter dem Schildchen, schmal.

6. St. bipartitus Fairm. (Ann. Fr. 1867. 414) aus Algier, soll Kopf, Halssch. und Beine roth und schwarze Fld. haben, deren Spitze bräunlich durchschimmert. Hinterleib schwarz, kaum punktirt.

7. St. cylindricus Moraw. (Bull. Mosc. 1860. I. 301). Elongatus, opacus, ferrugineus, elytris pallidioribus, antennis apice tarsisque (interdum) infuscatis; fronte confertim punctulata, obsolete canaliculata, prothorace elongato, confertissime punctulato, elytris crebre, postice et externe substriato-punctatis. - Long. 2-2,8 mm. Sarepta. Kaukasus (Schneider).

Durch grösstentheils rostrothe Farbe, bedeutend längeres als breites Halssch., die dicht, aber unregelmässig, nur auf der hinteren Hälfte und aussen schwach reihig punktirten Fld. und etwas kürzere Tarsen von tamaricis sehr verschieden. 
schwache Mittelrinne, später fast die ganze obere Stirn schwarz; hinter dem Vorderrande des Halssch. zeigen sich zwei wenig scharf begrenzte schwarze Makeln, die of zusammenfliessen und einen grösseren Theil der Scheibe bedecken; die Fld. erhalten einen breiten Nahtsaum bis zwei Drittel der Länge und eine dunkle Makel hinter der Mitte, die sich mit der entgegengesetzten (auf der andern Fld.) $z u$ einer aussen abgekürzten, gemeinschaftlichen Querbinde vereint. Unterseite, mit Ausnahme der Vorderbrust, schwarz.

Auf Tamarix-Gebüschen bei Triest und Monfalcone. Sonst an der Küste des Mittelländischen Meeres, östlich bis Dalmatien, häufig.

* Tarsen breit und kurz. Seiten des Halssch. gerundet.

2. St. ilicicole $\left.{ }^{1}\right)$ : Minus elongatus, niger, antennis basi pedibusque testaceis, capite prothoraceque sat dense punctatis, hoc medio evidenter transversim impresso, lateribus antice sensim rotundato-angustato, elytris crebre substriato-punctatis. - Long. 1,5-2,2 mm.

Suffr. Mon. III. 151; VIII. 153. - Redtb. Faun. A. II. 466. Var. a. Pedibus magis minusve nigricantibus.

Kürzer und breiter, etwas glänzender als der vorige, vorn schmaler, mit kleineren, weniger gewölbten und deshalb nicht so weit über die Seiten des Halssch. hinaustretenden Augen, schwarz, die fünf ersten Fühlerglieder und die Beine röthlich gelb, letztere mit dunkleren oder schwarzen Tarsen. Stirn in der Mitte mit einem seichten Längsgrübchen, ziemlich dicht, fein aber flach punktirt. $\mathrm{Halssch}$. in der Mitte fast so lang als breit, nach vorn verschmälert; der ziemlich breit abgesetzte, flache Seitenrand ist in den Hinterecken durch einen tiefen Ausschnitt rom Hinterrande getrennt, mässig gerundet und vorn allmählich verengt, seitlich mit äusserst feinen Höckerchen besetzt; auf dem ansteigenden Hinterrande treten jederseits einige scharfe Querrunzeln deutlich hervor. Die Oberfläche ist ziemlich dicht, stärker als der Kopf punktirt und wird duich einen Quereindruck in der Mitte, der dem normalen vor dem Hinterrande ähnlich ist, aber an den Seiten sich verbreitert und nach den Vorderecken hin krümmt, in zwei Querwülste geschieden,

1) Vor diese Art gehört: St. ericeti Kiesenw. (Ann. Fr. 1851. 653. Suffr. VIII. 151. - St. bituberculatus Desbr. Heyd. Reis. Span. 169. St. constrictus Schauf. Isis 1861. 92). Subtus niger, supra obscure ferrugineus, fronte nigra prothoraceque (maris disco nigro) medio transversim inpresso crebre punctatis, elytris fortiter punctato-striatis, interstitiis angustis, disco piceo, macula obsoleta juxta scutellum fasciaque angusta semicirculari favis. - Long. 2-2,5 mm. Hispania.

VI. 2 . 
von denen der rordere der höchste und in der Mitte zuweilen ron einem leichten Längseindrucke durchsetzt wird. Fld. dicht punktirt, die Punkte besonders an den Seiten zu unregelmässigen Längsreihen geordnet, zwischen denen die leicht gewölbten und mit sehr feinen weissen Härchen reihig besetzten $\mathrm{Z}$ wischenräume hervortreten. Unterseite wenig dicht, fein punktirt, glänzend.

Nur selten sind die Beine theilweise oder ganz schwärzlich (Var. a.); die, nach Suffrian, eigenthümlich geformte Grube auf dem letzten Bauchringe des + ist oval und einfach, wit bei den übrigen Arten.

Auf Quercus ilex (im Winter unter der Rinde) im südlichen Tirol. Südfrankreich, Spanien, Portugal.

3. St. minutissimus: Himus elongatus, niger, antennis basi perlibusque testaceis, capite prothoraceque confertim punctatis, hoc comexo, lateribus antice valde rotundato-anyustato, elytris crebre punctatis, lineis nonnullis subelevatis. - Long. 1,5 mm.

Germ. Ins. spec. nov. 561 (Cryptoc.). - Suffr. Mon. III. 150. - Redtb. Faun. A. П. 466.

Merklich kleiner als der vorige, dichter punktirt, schwarz, Basis der Fühler und die Beine dunkel rothgelb, Tarsen oft bräunlich oder schwarz. Stirn dicht und fein, Halssch. dichter und stärker punktirt, letzteres breiter als lang, der breit abgesetzte, flache Seitenrand vorn stark gerundet-rerengt, so dass die Vorderecken, die bei der vorigen Art deutlich sichtbar bleiben, ganz undeutlich und hinter den Augen versteckt sind. Die Oberfläche gleichmässig gewölbt oder nur mit der Spur einer Vertiefung jederseits ror der Mitte nahe den Seiten. Fld. dicht punktirt, bald ganz unregelmässig, bald in wenig regelmässigen Reihen, deren Zwischenräume leicht gewölbt und mit feinen, weisslichen Haaren reihig besetzt sind.

Im südlichen Tirol, Görz, Istrien. Wien? Häufig in Dalmatien, Italien, Südfrankreich und Spanien; vielfach unter dem Namen St. depitis versandt. 


\section{Dritte Abtheilung: CYCLIC.}

Chapuis, Genera des Coleopt. X. 209.

Caput collo mullo vel brevissimo.

Prothorax lateribus sacpissime marginatus.

Abdomen segmentis liberis.

Tarsi articulo ultimo penultimum longe superante.

Fühler über der Basis der Mandibeln, am Unterrande der Augen, weit von einander getrennt, oder zwischen den Augen, verschieden hoch auf der Stirn, einander genähert eingefügt (Galerucini), in der Bildung sehr variabel. Kopf bis zu den Augen in das Halssch. eingezogen, seltener frei, der Mund nach unten oder schräg rorwärts gerichtet. Halsschild meist breiter als lang, gewöhnlich so breit als die Basis der Flügeldecken, an den Seiten gerandet (der Rand fehlt z. B. bei Adoxus und den mit Leprotes verwandten exotischen Gattungen, oder ist undeutlich bei einigen Pachnephorusund Timarcha-Arten). Das Schildchen liegt in der Ebene der Flügeldecken. Diese sind oval oder länglich, gewölbt, hinten meist gemeinschaftlich-abgerundet, selten abgestutzt, und bedecken gewöhnlich len Hinterleib. Letzterer besteht in den meisten Fällen aus fünf Ringen, ist flach oder der Quere nach etwas gewölbt. Beine im Allgemeinen mässig lang und stark, ihre Schenkel überragen nur in wenigen Gattungen den Rand der Flügeldecken bedeutend. Das dritte Tarsenglied ist bis zum Grunde gespalten und in zwei Lappen getheilt (Eumolpini) oder nur an der Spitze eingeschnitten oder ganz; es ist meist nur halb so lang, als das Klauenglied.

Die Larven leben frei an Pflanzenblättern, seltener im Innern der Stengel, sind weder in einen Sack eingeschlossen, wie die der vorigen Abtheilung, noch von ihren Excrementen bedeckt, wie die Lema-Larven.

Die Abtheilung enthält den eigentlichen Kern der Chrysomeliden und ist ausserordentlich reich an Grattungen und Arten. Sie gliedert sich in drei grosse Gruppen, von denen die erste der vorbergehenden Gruppe, die dritte den Cryptostomen verwandt ist. Dieselben lassen sich folgendermassen unterscheiden: 
A. Fübler an der Basis weit getrennt, auf der Stirn über der Wurzel der Mandibeln eingefügt.

a. Gelenkhöhlen der Vorderhüften rund. Drittes Tarsenglied zweilappig . . . . . Eumolpini.

b. Gelenkböhlen der Vorderhüften quer. Drittes Tarsenglied ganz oder an der Spitze ausgerandet . . . . . . . . . Chrysomelini.

B. Fühler an der Basis genähert, meist auf der Stirn zwischen den Augen eingelenkt . . Galerncini.

\section{Erste Gruppe: EUMOLPINI.}

Chapuis, Genera des Col. X. 220.

Clypeus emarginatus.

Antennae basi late distantes fronti pone mandibularum basin insertae.

Acetabula antica rotunda.

Tarsi articulo penultimo bifido.

Kör per länglich, fest, vorherrschend glatt, glänzend, lebhaft gefärbt, seltener behaart oder mit Schuppen bedeckt. Kopf nicht oft frei, meist in das Halssch. eingezogen, mit nach unten oder schräg nach hinten gerichtetem Munde. Stirn eben oder schwach gewölbt, Kopfschild selten deutlich von ihr getrennt, aber vorn stets einfach und ausgerandet. Oberlippe quer, vorn meist bogenförmig ausgerandet und mit einer Querreibe von Grübchen besetzt, von denen jedes ein Haar trägt. Mandibeln kurz, gleichmässig oder winkelig gebogen, an der Spitze zweizähnig. Maxillartaster viergliederig, das erste Glied das kürzeste, das zweite das längste. Fühler mit fünf bis sechs mehr oder weniger erweiterten Endgliedern, häufig in eine Rinne an der Seite des Prosternum einlegbar und dann nach dem Tode des Thieres beständig zwischen die Vorderhüften untergeschlagen. Augen länglich, innen gewöhnlich schwach bogenförmig ausgerandet. Halssch, in seiner grössten Breite in oder hinter der Mitte schmaler als die Flügeldecken. Schildchen dreieckig, oder gerundet-viereckig, selbst fünfeckig, die drei hinteren Ecken sehr spitz ${ }^{1}$ ). Flügeldecken bald cylindrisch, bald länglich oder breit-eiförmig, selten ohne stark entwickelte Schultern, meist mit einem schiefen Quereindrucke hinter denselben. Prosternum deutlich, quer oder

1) Bei einigen Pseudocolaspis-Arten und den afrikanischen Gattungen Pallena, Himera, Maceles und Enipeus Chap. 
lïnglich, in seltenen Fällen schmal. Vorderrand der Vorderbrust entweder ganz (dann ist der Innenrand des Episternum nicht aufgebogen), oder durch eine Rinne zwischen dem Prosternum und dem hohen Innenrande des Episternum unterbrochen. Zur ersteren dieser beiden Abtheilungen gehören zahlreiche Gattungen, von denen in Europa nur zwei, Pales und Pseudocolaspis, vertreten sind; die zweite hat auch in Deutschland einige Repräsentanten. Die Gelenkhöhlen der Vorderhüften sind rund (Pales ausgenommen), die Hüften selbst kugelig, die Episternen, zwischen dem Vorderwinkel des Halsschildes, den Hüften und dem Prosternum, ziemlich dreieckig, bei den Chrysomelinen quer viereckig. Die Mittelbrust ist nur bei Lamprosoma unsichtbar, die Hinterbrust hat deutliche Parapleuren, deren Hinterecke zuweilen sehr spitz ist. An den Tarsen ist das erste Glied gewöhnlich das längste, oft länger als die beiden folgenden zusammen; die Klaven sind gezähnt oder gespalten, nur bei Chloropterus, Pales und der australischen Gattung Spilopyra Baly einfach.

Geschlechtsunterschiede sind äusserlich nur selten zu erkennen; sie zeigen sich dann gewöhnlich in dem erweiterten ersten Tarsengliede der $\hat{\jmath}$. Der Penis ist meist weich, häutig, seine Form daher zur Unterscheidung der Arten nicht zu benutzen. Ueber die ersten Stände liegen bis jetzt nur dürftige und sich theilweise widersprechende Mittheilungen ron einer Art, Adoxus vitis, vor.

Die hierher gehörigen Thiere wurden von Linné und in den ersten Werken des Fabricius zur Gattung Chrysomela gerechnet, später rom letzteren Autor in zwei Gattungen, Eumolpus und Colaspis, gestellt, oder bei Cryptocephalus untergebracht. Die exotischen Formen sind zwar in den grossen Sammlungen reich vertreten, aber erst zum kleinsten Theile, hauptsächlich von Baly, bearbeitet worden, so dass sich die ungeheure Anzahl derselben bis jetzt nicht annähernd bestimmen lässt. Eine Grundlage zu der schwierigen Feststellung und Begrenzung der hervorragendsten Gattungen rerdanken wir Chapuis, dessen vorzügliche Arbeit, Genera des Col. X., bei der Beschäftigung mit der vorliegenden Gruppe unentbehrlich ist.

Die wenigen europäischen Gattungen dürften sich nach der folgenden Tabelle leicht bestimmen lassen:

1. Mesosternum occultum. Antennae in sulcis sternalibus totae receptae. Elytra epipleuris foreolatis .

Lamprosoma.

1. Mesosternum conspicuum. Antennae in sulcis sternalibus antice vel haud receptae. Elytra epipleuris planis vel nullis. 
2. Episternum prothoracis margine antico $2 n$ terno elevato et a margine antico prosterni evidenter separato.

21. Episternum prothoracis margine antico interno plano et a margine antico prosterni haud separato .

3. Sulci antennales distincti, longi. Corpus squamosum

Pachnephorus.

$3^{1}$. Sulci antennales brevissimi, obsoleti. Corpus haud squamosum

4. Prothorax lateribus $\left\{\begin{array}{l}\text { immarginatus . . . Adoxus. } \\ \text { marginatus . . } 5 .\end{array}\right.$

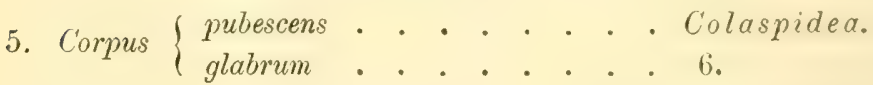

6. Tibiae posteriores $\left\{\begin{array}{l}\text { emarginatae . . . } 7 . \\ \text { haud emarginatae . }\end{array}\right.$

7. Unguiculi $\left\{\begin{array}{l}\left.\text { simplici(Moraw.Horae. I.162.) Chloropterus }{ }^{3}\right) \text {. } \\ \text { bifidi.... Bedelia }{ }^{2} \text {. }\end{array}\right.$

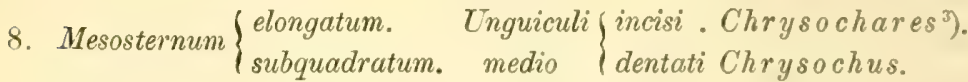

1) Chlor. versicolor Moraw. (Bull. Mosc. 1860. I. 302). Eiförmig, schwarz, glänzend, Kopf, Halssch., Schildchen, Vorder- und Mittelbrust rothbraun, Fühlerwurzel, Fld. und Beine gelbbraun; nicht selten eine Scheitelmakel auf dem fein punktirten Kopfe, zwei grosse, schiefe, vorn convergirende Makeln des Halssch., welches dicht und ziemlich stark punktirt ist, sowie die Naht der fast regelmässig punktirt-gestreiften Fld. schwarz. Halssch. an den Seiten stark gerundet, die Vorderecken in ein Läppchen gegen die Augen vorgezogen. - Long. 3,5-5 mm. Sarepta.

Von dieser Art ist Chl. stigmaticollis Fairm. (Ann. Mus. Cir. Genov. VII. 65) aus Tunis, nach der allgemein gehaltenen Diagnose nicht zu trennen; Chl. bimaculatus Raffr. (Rev. zool. 1873. 355) ans Algier, wie versicolor gefärbt, aber mit einer verwaschenen, schwarzen Makel auf der Mitte jeder Fld, gestreckt, mit grossen, sehr genäherten Augen und stumpfen Vorderecken des Halssch., gehört wohl sicher einer neuen Gattung an.

2) Hiervon beschreibt Lefèvre zwei Arten: angustatc (Ann. Fr. 1875. Bull. 43. 10) und insignis, wahrscheinlich rom Urumia-See in Persien, ron denen als Vaterland der ersteren in der synops. d. Eum. p. 19. Caucase. p. 30 Ourmiah u. p. 32 Caire angegeben wird.

3) Moraw. Horae I. 160. Chr. asiaticus Pallas (Reis. I. 2. 463). Metallisch blaugrün, stark glänzend, die fünf letzten Fühlerglieder matt schwarzblau, Fld. mit schwachem Purpurschimmer oder purpurroth mit gold- oder 
9. Unguiculi $\left\{\begin{array}{l}\text { simplici. Prothorax } \\ \text { fissi. lateribus }\end{array}\right.$ muticuso-dilatatus Pales $\left.{ }^{1}\right)$. Redtb.

10. Unguiculi bifidi. Scutellum apice subtruncatum. Elytra apice subtruncata callo humeraliepipleurisquedistinctis (L.up. Silb. Rev.23.) Pseudocolasp) is ${ }^{2}$ ).

10. Unguiculi medio incisi. Scutellum triangulare. Elytra apice communiter-rotundata callo humerali epipleurisque nullis . . . Calliope n.g. ${ }^{3}$ ).

\section{Lamprosoma.}

Kirby Trans. Linn. Soc. XII. 445.

Domorphus Curtis Brit. Ent. VIII. 34\%.

Antennae in sulcis sternalibus totae receptae.

Elytra epipleuris latis, foveis, femorum posteriorum apicem excipientibus, instructa.

Iesostermum occulium.

Körper eiförmig, Halssch. und Fld. gemeinschaftlich in einer Fläche gewölbt. Kopf klein, stark geneigt, unten nach rückwärts gerichtet und fast ganz eingezogen. Mandibeln kurz und stark, an der Spitze leicht eingeschnitten; Oberlippe quer, ganzrandig oder fein

messingfarbenem Metallglanze. Kopf und Fld. mässig dicht, Halssch. einzeln fein punktirt. - Long. $15 \mathrm{~mm}$. Sarepta, Umgebung des Caspischen Meeres, Altai.

1) P. ulema Germ. (Mag. Ent. I. 1. 125). Gestreckt, schwärzlichmetallgrün, oberseits goldgrün, mässig glänzend, fein (unten weisslich, oben gelblich) behaart, Mund, Fühler, Beine und After hell gelbbraun; sehr dicht und mässig stark, auf den Fld. stärker und etwas runzelig punktirt. Das f hat auf den Fld. eine schwach S-förmig gekrümmte hohe Längsleiste von der Schulterbeule bis vor die Spitze. - Long. 4-6 mm. Banat, Serbien, Dalmatien, Griechenland.

2) Die hauptsächlich in Nordafrika zablreich vertretenen Arten haben einen ovalen, metallgrünen, braunen oder kupferig-messingfarbenen, selten schwarz@n Körper, welcher kurz und mässig dicht behaart ist. Die Haare der Fld. sind aufgerichtet und stehen entweder unregelmässig (bei Heydeni Lef., carbonaria Lef. und der syrischen, bis $7 \mathrm{~mm}$. langen brunnipes Oliv.) oder in Reihen. Von diesen sind alle einfach bei cylindrica Küst., oder nur die ungraden, während die graden aus zwei- bis dreifachen Haarreihen bestehen (bei Leprieuri Lef., die wohl mit aeneonigra Fairm. identisch ist, und der griechischen graeca Schauf.).

3) Calliope: Corpus oblongo-ovatum, parce pubescens. Antennae dimidio corporis breviores, articulo secundo tertio fere aequali, articulis 5 ultimis: crassioribus. Prothorax sulielongatus, lateribus rotundatis immarginatus. S.ntellum triangulare. Elytra elliptica, apice communiter rotundata, callo 
gekerbt. Kopfschild vorn sehr schwach bogenförmig ausgerandet. Stirn wenig gewölbt, nach den Augen schnell abfallend, mit einer Mittelrinne. Fühler den Hinterrand des Halssch. erreichend, rom dritten Gliede an zusammengedrückt, glänzend, hart und spröde, sparsam behaart; Glied 1 dick, 2 halb so lang und dick, an der Basis sehr verschmälert, 3 bis 6 schmal und kurz, 4 und fi etwas kürzer als 3 und 5,7 bis 10 nach innen dreieckig erweitert, gleich gross, nur Glied 8 schmaler und kürzer als die übrigen, selten fast cylindrisch, das Endglied länglich-eiförmig. Augen gross, ziemlich flach, gekörnt, in der Mitte des Innenrandes ausgesclinitten. Hals schild quer, an der Basis enge an die Fld. angeschlossen und fast so breit als diese, nach rorn gleichmässig, stark rerengt, die Seiten fast gerade, fein gerandet. Schildchen klein, schmal dreieckig. Flügeldecken breit, an den Schultern etwas erweitert, nach hinten allmählich leicht verengt, gemeinschaftlich abgerundet, den Hinterleib ganz bedeckend; ihre Epipleuren rorn breit, an der Seite des ersten Bauchringes schnell verschmälert, mit drei Gruben zur Aufnahme der Schenkelspitzen. Die vordere Grube sehr flach, die mittlere tiefer, beide durch eine schwache Querkante getrennt, die hintere Grube sehr tief, rorn ron einer hohen Querleiste begrenzt. Vorderbrust kurz, der Vorderrand und der Innenrand der Episternen aufgebogen, zwischen letzterem und dem Prosternum, welches eine nach hinten leicht verschmälerte, über die Hüften emporgehobene Querplatte bildet, befindet sich die Rinne zum Einlegen der Fühler, von denen nur das erste und letzte Glied sichtbar bleibt. Die Hinterbrust reicht über das Mesosternum weg bis zur Vorderbrust und ist jederseits zur Aufnahme der Hinterschenkel quer rinnenförmig ausgehöhlt. Diese Rinne setzt sich, schräg ron aussen nach innen ziebend, auf dem ersten Bauchringe fort, wo die Hinterschienen und -Tarsen eingelagert sind. Beine kurz, die Seiten des Körpers kaum überragend, Schenkel mässig dick, mit einer Rinne für die Schienen, diese etwas zusammengedrückt, an der Spitze behaart und mit einem Ausschnitt für die Tarsen. Letztere sind breit, die drei ersten Glieder quer, das dritte bis zur Mitte in zwei Lappen gespalten, ans denen das

humerali nullo, epipleuris haul distinctis. Pro-et mesostermum fortiter transversum. Pedes sat elongati, femoribus subclavatis dente paro armatis, tarsis sat angustis. Unguiculi tenues, medio incisi.

C. Fausti: Nigro-aenea, viridi-cel aurichalcen-micans, nitida, parce subtilissimeque pubescens, antenmis testaceis, pedibus ferrugineis, crpite prothuraceque dense minus fortiter punctatis, elytris parum dense concinne, externe irregulariter, interne subseriatim punctatis, setulis albidis subseriatis instructis. - Long. 4-5 mm. Schah Dagh, Kaukasus (Faust). 
vierte Glied etwa zur Hälfte herausragt. Klauen dünn, mit einem verschieden grossen Zahne an der Basis.

Die Heimath dieser Gattung ist Mittel- und Südamerika, ron wo gegen 80 Arten bekannt sind, ausserdem wurden bis jetzt nur noch zwei Arten in Japan und je eine auf Formosa, in Afrika') und Europa aufgefunden. Ihre Farbe ist meist lebhaft metallisch und rariirt ron schwarzgrün durch grün, messingfarbig, gold- und kupferroth bis blau; sie leben auf Gesträuch, unsere deutsche Art auch auf niederen Pfianzen (nach Redtenbacher auf Astrantia major) und im Grase trockener Wiesen. Beunruhigt, zieben sie die Beine ein, lassen sich fallen und stellen sich todt, wie die Byrrhen. Ueber ihre ersten Stände ist nur das Wenige bekannt, was Westwood") von den Larrensäcken einer brasilianischen Art berichtet, die denen der Chlamyden ähnlich sein sollen. Diese Mittheilungen sind jedoch so lange mit Vorsicht aufzunehmen, bis die Entwicklung einer Lamprosoma aus dem Larvensacke mit Sicherheit nachgewiesen worden ist. Viele Arten haben entwickelte Schulterbeulen und verrathen dann schon durch die Körperform ihre Zugehörigkeit zu den Eumolpiden, einige dagegen, denen der Schulterhöcker fehlt, sehen einer Simplocaria oder einem Olibrus ähnlicher, und es ist erklärlich, dass Sturm unsere einheimische Art zuerst als Byrrhus concolor beschrieb, wozu ihn die Uebereinstimmung im Bau der Unterseite und Beine mit verleitet haben mag, während Stephens das Thier unter Phalacrus einreihte.

Die schwierig zu unterscheidenden Arten wurden in eingehender Weise von Lacordaire ${ }^{3}$ ) bearbeitet, von ihm aber als abweichende Gruppe zwischen die Megalostomiden und Chlamyden bei den heutigen Camptosomaten eingeschoben, wodurch das Hauptmerkmal dieser Abtheilung, das grosse, freie Pygidium, hinfällig ward. Erst Chapuis wies ihnen ${ }^{4}$ ) ihre natürliche Stelle am Anfange der 3. Hauptabtheilung an, wo sie bei ihm eine Gruppe ron den Eumolpiden bilden, die hauptsächlich durch das Vorhandensein einer Fühlerrinne gekennzeichnet ist. Da eine ähnliche, wenn auch meist kürzere Rinne bei sämmtlichen Eumolpiden rorkommt, deren Episternen der

1) L. africanum: Subhemisphaticum, sultus nigro-viridi-ceneum, supra cupren-aurichalceum, capite obsolete canaliculato, parce subtiliter punctato, interstitiis alutrceis, subopacis; prothorace obsolete crebre punctulato, alutureo, nitidulo: elytris subtiliter et obsolete punctato-strintis, interstitiis creberrime subtilissimeque punctulatis. - Long. $2 \mathrm{~mm}$. Südafrika.

2) Annals and Mag. of nat. hist. VIII. 297.

3) Monogr. Mém. Liége V. 559.

4) Genera Col. X. 212. 
Vorderbrust einen erhabenen Innenrand besitzen, so ist die Trennung ron ihnen nicht gerechtfertigt. Ebensowenig ist die Gattung (mmorphus Curt. von Lamprosoma verschieden. Das kleinere achte Fühlerglied findet sich nicht nur bei onmorplus, wie Chapuis angiebt, sondern auch bei Lamprosoma und den Lychnophä̈s-Arten.

1. C. concolor: Oblongo-oratum, nigro-acneum, nitidum, antrmis articulo secundo mfo-testacen, capile sublaevi, prollumace sat dense subliliter punciato, elytris punclato-stratis, interstitiis paree punchulatis. - Long. 2-3 $\mathrm{mm}$.

Sturm Ins. II. 109. t. 35. f. a. A. (Bymhus). - Curtis Brit. Ent. VIII. 347 (Oomorphus). - L a cord. Mon. 631. - Küst. Käf. Eur. 18. 100. - F airm. Gen. Col. Eur. IV. 216. t. 64. f. 304. - Redtb. Faun. A. II. 453, - Seidl. F. balt. 480. Phalacrus maritimus Steph. Ill. Brit. II. 159. t. 15. f. 1. Uomorphus unicolor Brull. Hist. nat. Ins. V. 355.

Länglich-eiförmig, glänzend schwarz, mit gelbem Metallschimmer, Tarsen und Fühler mit Ausnahme des zweiten, rothgelben Gliedes schwarz. Kopf fast glatt, äusserst zart lederartig gerunzelt, mit zwei rertieften Linien, die beide in der Regel aus zwei länglichen Eindrücken bestehen, die eine quer, über der Fühlerwurzel, die andere längs der Mitte der Stirn. Halssch. ziemlich dicht, fein punktirt. Fld. mässig fein gereiht-punktirt, die breiten $\mathrm{Z}$ wischenrãume sparsam punktulirt, die Pünktchen zuweilen zu unordentlichen Längsreihen zusammengestellt. Bauch sparsam und sehr feiu punktirt und behaart, der Hinterrand des letzten (fünften) Segmentes gekörntgekerbt. Klauen sehr klein. Flügel ziemlich kurz und schmal.

Die grösseren Stücke (Weibchen?) sind oberseits merklich stärker punktirt als die kleineren und haben gewöhnlich ein Grübchen vor dem Hinterrande des letzten Segmentes.

In Mittel- und Süddeutschland nicht selten, aber vielfach übersehen.

\section{Pachnephorus.}

Red tenbacher Faun. Austr. ed. I. 569.

Corpus squamosum.

Tibiae posteriores externe ante apicem emarginatre.

Unguiculi appendiculati vel mutici.

Prosternum sulcis antemalibus longis.

Mesosternum conspicum.

Abdomen margine apicali segmentis ultimi crenulato.

Körper länglich, oft fast cylindrisch, sparsam oder dicht beschuppt. Kopf stark geneigt, bis zu den Augen in das Halssch. 
eingesenkt; Mandibeln kurz, stark, gleichbreit, an der Spitze zweizähnig, der obere Zahn länger und spitzer als der untere; Oberlippe klein, schwächer als das mit der Stirn verbundene Kopfschild ausgerandet. Stirn zwischen den kleinen, wenig gewölbten Augen eben oder leicht gewölbt. Fühler etwa halb so lang als der Körper, Glied 1 fast kugelig, 2 gleich lang, aber viel schmaler, ziemlich stark gekrümmt, 3, 4 und 6 kürzer, 5 fast so lang als 2, die fünf Endglieder merklich verbreitert und an der Spitze fast so breit als lang. Halsschild zusammengedrückt, ziemlich cylindrisch, die Wölbung nach vorn schwächer als nach hinten verengt, die gerandeten Seiten fast gradlinig, rorn stark nach unten laufend. Schildchen klein, länglich, hinten zugespitzt. Flügeldecken länglich, eiförmig oder cylindrisch, an der Basis so breit als das Halssch., bis zu den Schultern etwas erweitert, hierauf ziemlich gleichbreit bis zwei Drittel der Länge, wo sie allmählich verschmälert und gemeinschaftlich abgerundet sind; die Oberfläche gereiht- oder gestreift-punktirt, mit verworren (erste $\mathrm{Abth}$.) oder einreibig punktulirten $\mathrm{Z}_{\text {wischenräumen }}$ (zweite Abth.). Epipleuren fast gleichbreit, am Ende des vorletzten Bauchringes schnell verengt, der Länge nach leicht vertieft. Vorderbrust mit deutlichen Fühlerrinnen, welche vorn von dem aufgebogenen Innenrande des Episternum begrenzt werden, sich an den Vorderhüften herumziehen ${ }^{1}$ ) und etwas erweitern, aber den Hinterrand nicht erreichen. Mittelbrust kurz, quer. Abdomen mit fünf Segmenten, das erste so lang als die übrigen zusammen, das letzte am ganzen Rande fein gekerbt. Beine mässig lang und dick, Schenkel deutlich punktirt und beschuppt, in der Mitte kaum verdickt, die vier hinteren Schienen am Aussenrande vor der Spitze in ein Zähnchen erweitert, wodurch zwischen diesem und der Spitze ein Ausschnitt entsteht. Tarsen ziemlich breit; Klauen einfach (bei pilosus, ruficornis und canus) oder mit einem Einschnitte in der Mitte (cylindricus) oder nahe der Basis (bei den übrigen Arten), durch den ein spitzes, wenig abstehendes Zähnchen abgetrennt wird.

Die kleinen Arten, welche nur in Australien zu fehlen scheinen, kriechen im Sande oder am Grase an Ufern; ihre sonstige Lebensweise und ihre Entwicklung ist unbekannt. Die Schuppen, mit denen der Körper bedeckt ist, sind bei einigen Arten breit, fast viereckig und ganzrandig, bei andern oval oder selbst haarförmig, an der Spitze verschieden tief eingeschnitten und stehen bald einzeln, in Reiben (Verwandte von cylindricus), bald so dicht, dass die Körperfarbe ganz verdeckt wird.

1) Dieselbe Bildung findet sich bei den zahlreichen Arten der afrikanischen Gattung Syagrus Chap. 
* Elytra interstitiis haud seriatim punchulatis et syuamosis.

1. P. pilosws: Oblongus, nigro-aenens, squamulis angustis, bifirlis supra parrem dense sublus densissime tectus, antennarum basi, inlerdun ctiam pedibus rufescentibus. prothorace minus elongato, lateribus maryimatis angulato, crebre punctalo, elytris apice communiter late rolundatis, striis punctatis pone medium eranescentibus, stria prima subrecta, interstitiis subtiliter punctatis. - Long. 2,5-3,5 mm.

Rossi Faun. Etrusc. I. 100. - Lefèvr. Synops. d. Eumolp. 12. Cryptoceph. aeneus Schneid. Nen. Mag. I. 2. 220.

P. arenarius Panz. Faun. Germ. 39. 19. - Fabr. Ent. Syst. Suppl. 109 (Cryptoc.). - Redtb. Faun. A. II. 45t. - sieidl. F. balt. $\dot{t}>0$. - Fairm. Ann. Fr. 1861. 587.

P. lepidopterus Küst. Käf. Eur. 4. 94.

Var. a. Supra aeneus vel cupreus.

Die kürzeste und breiteste Art der Gattung, schwarz, mit braunem Metallschimmer, Fühler pechschwarz, die ersten fünf oder sechs Glieder röthlich, Beine schwärzlich oder dunkelroth und wie die Fühler schwach metallschimmernd. Kopf ziemlich dicht einfarbig grau beschuppt, oder vor dem Scheitel mit zwei grossen, runden braunen Schuppenmakeln. Halssch. wenig länger als breit, an den Seiten vor der Mitte deutlich gerundet-erweitert, mit schmalem aber scharf abgesetztem Seitenrande, der Rücken sehr dicht, fein punktirt (die Punkte nach dem Hinter- und Seitenrande hin etwas grösser und tiefer) und mässig dicht hellbraun beschuppt, dazwischen mit weissgrauen Schuppen bezetzt, die besonders an jeder Seite zu einer undeutlichen Längsbinde vereinigt sind. Fld. bedeutend breiter als das Halssch., an den Seiten unmerklich gerundet-erweitert, hinten gemeinschaftlich breit abgerundet, auf dem Rücken wenig; an den Seiten stark gewölbt, mit einer sehr schwachen Quervertiefung hinter dem Schulterhöcker. Die Punkte in den Reihen sind rorn stark, aber sie werden schon vor der Mitte fein und treten erst ror der Spitze wieder deutlicher hervor. Die erste Reilse ziemlich gerade die beiden äusseren Reihen vertieft und fast bis zum Ende kräftig punktirt. Zwischenräume dicht und fein unregelmässig punktirt, mässig dicht mit bräunlichen und weissen Schuppen besetzt, ron denen die letzteren kleine, deutlicher hervortretende Längsfleckchen auf der Schulterbeule und dem dritten, fünften und siebenten Zwischenraume bilden. Auf der Unterseite sind die Seitenstücke der Hinterbrust und der Bauch äusserst dicht, die übrigen Theile und die Beine sparsamer weisslich beschuppt. Alle Schuppen sind fast bis zum Grunde gespalten; die schmalsten, beinahe harfömigen, befinden sich an den Beinen, den Pleuren der Hinterbrust und dem Bauche, 
wenig kürzer und breiter sind die auf dem Halsseh,, den Fld. und der Hinterbrust.

Die Farbe der Oberseite, die durch die Beschuppung deutlich erkenubar bleibt, ist bisweilen dunkel mettallisch-grün, gelblich oder kupferig (Var. a), selten sind fast alle Schuppen der Fld. weissgrau.

An trockenen Grasplätzen und in Grasbüscheln an sandigen Flussufern häufig; seltener in Norddeutschland.

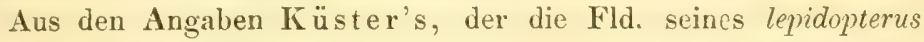
„kurz, mit mässig grossen, hinten kleiner werdenden Punkten“" in den Streifen, die Fld. seines arenarius dagegen ,an den Seiten gleich breit bis hinter die Mitte, mit ziemlich starken Punktstreifen, die beiden ersten jederseits abgekürzt, schief gegen die Naht gerichtet" angiebt, geht mit Bestimmtheit hervor, dass er unter der erstgenannten Art die vorliegende, unter der zweiten die folgende beschrieben hat.

2. P. tesselntus $\left.{ }^{1}\right)$ : Sat elongatus, cupreo-aeneus, squamulis sat latis, apice incisis, supra luteis vel fuscis et albis, subtus albis densissime tectus, antennis basi interdum etiam pedibus rufescentibus, pro-

1) Hieran schliessen sich 2 Artcn, die oberseits sehr dicht, unterseits einzeln beschuppt sind: 1. P. ruficornis Lefèrr. (Synops. d. Eumolp. 10) Elongatus, supra aurichalceus, squamulis luteis et cinereis latis, apice parum vel haud incisis densissime tectus, subtus nigro-aeneus, parce cinereo-squamosus, squamulis angustis, bifidis; antennis pedibusque magis minusve fuscis, prothorace sat dense, lateribus haud angulatis fortiter punctato, elytris suhparallelis punctato-striatis stria prima subrecta, interstitiis latis, planis, minutissime punctulatis. - Long. 2,5-3 mm. Bagdad (v. Heyden).

2. P. canus: Elongatus, piceus, haud aeneo-micans, antennis pedibusque fuscis; supra tesselato-squamosus, squamulis adpressis integris, striolatis, cinereis, subtus squamulis piliformibus, bifidis parce tectus; prothorace lateribus subangulato, margine laterali haud reflexo, crebre fortius subrugoso-punctato, elytris postice parum laterioribus, punctato-striatis, interstitiis magis minusve punctulatis. - Long. 2-3 mm. Sicilia, Russia mer.

Durch den pechschwarzen Körper ohne Metallschimmer, die breiten, fast viereckigen, nicht eingeschnittenen, aber mit zarten Längslinien versehenen grauen Schuppen der Oberseite, die stärker als bei den übrigen Arten angedrückt sind, das in der Mitte breitere Halssch. und die vorn schmaleren Fld. vom vorigen leicht zu unterscheiden. Gestreckt, pechschwarz, Fühler und Beine dunkel rothbraun, erstere an der Basis heller. Halssch. länger als breit, an den Seiten gerundet-erweitert, ohne deutlich abgesetzten Seitenrand, die grösste Breite ziemlich in der Mitte, unter den Schuppen sehr dicht und ziemlich grob, fast runzelig-punktirt. Fld. am Grunde kaum breiter als das Halssch. in der Mitte, nach hinten leicht erweitert, hierauf allmählich verengt und schmal gemeinschaftlich abgerundet, unter den Schuppen mit 
Thorace clongato, lateribus parum marginatis leviler anyulato. rrebs? punctalo, elytris subparallelis, ayice communiter haud late voludalus. fortiter punctato-strialis, stria prima ante medinm cridentor an rata. interstitis antice angustissimis crebre punctalis. - Long. 2,i-3 mm.

Duftschm. Faun. Austr. III. 217 (Eumolp.). - Küst. Küf. Lur. 6. 96. - Redtb. Faun. A. II. 454. - Fairm. Ann. Fr. $1 S 61$. 587. - Lefèvr. Synops. d. Eumolp. 11. - Seidl. Faun. balt. 480 .

V a r. a. Major, interstitiis elytron latis, plerumque mimus dense. subtiliter punctatis. - Long. $3-4 \mathrm{~mm}$.

P. sabulosus Gebl. Ledeb. Reise II. 3. 210; Bull. Mosc. 1S4S. III. 39. P. arenarius Küst. Käf. Eur. 4. 94.

Var. b. Corpore obscure aeneo vel aurichalceo.

P. villosus Fairm. Ann. Fr. 1861. 587. - Lefèvr. Synops.d. Eumolp. 11.

Var. c. Corpore supra squumulis albis tecto.

P. villosus Redtb. Faun. A. II. 454 .

Dem vorigen ähnlich, aber gestreckter, oberseits dichter beschuppt und durch folgende Punkte leicht zu unterscheideu: H alss ch. bedeutend länger, fast cylindrisch, vor der Mitte unmerklich erweitert, der Seitenrand schmal abgesetzt. Fld. länger, ziemlich parallel, hinten allmählicher verengt und schmal gemeinschaftlich abgerundet, punktirt-gestreift, mit leicht gewölbten, dicht punktirten Zwischenräumen. Die Punkte in den vertieften Reiben sind hinter der Mitte wenig feiner, als vor derselben; die abgekürzte Punktreihe an der Naht ist länger als bei pilosus, die erste Punktreihe da, wo die abgekürzte endet, meist plötzlich der Naht zugebogen, so dass sie scheinbar die Verlängerung der kurzen Reihe bildet. Endlich sind alle Schuppen breiter, ziemlich oval, vorn weniger tief eingeschnitten, aber auch hier sind die auf den Beinen, den Pleuren der Hinterbrust und dem Bauche befindlichen merklich schmaler als die der übrigen Körpertheile.

Bei wohlerhaltenen, frischen Stücken ist die Oberseite so dicht

starken, hinter der Mitte wenig feineren Punktreihen, deren Zwischenräume dicht, verschieden stark punktulirt sind. Unterseite und Beine weitläufig punktirt, mit einem schmalen, graureissen, haarförmigen, gespaltenen Schüppchen in jedem Punkte.

Obgleich mir von dieser Art ein Stück als rarenarius Austria“ aus der Wehncke'schen Sammlung vorliegt, scheint ihr Vorkommen in Deutschland zweifelhaft. Sie findet sich nicht selten in Sicilien (Rottenberg Berl. Zeit. 1871. 242 als villosus) und in Südrussland (Theodosia, Retowski; Sarepta, Becker; Derbent, Faust; Kaukasus, Leder Deiträg. Kauk. Faun. 331 als sabulosus angeführt). 
beschuppt, dass die Punktirung und die schwarz-metallische, kupferig oder bläulich schimmernde Grundfarbe nur schwach durchscheint. Die Schuppen der Unterseite sind stets, die der Oberseite selten einfarbig weissgrau (Var. c.), gewöhnlich bilden gelbliche oder bräunliche, weniger in die Angen fallende Schüppchen zwei runde Makeln For dem Scheitel, eine breite, oft scharf begrenzte Längsbinde über die Vitte des Halssch. und verschiedene grosse, meist unbestimmte Flecke auf den Fld., die einige längliche, weissere Makeln auf dem dritten, fünften und siebenten Zwischenraume herrortreten lassen.

Die Art ist in Grösse, Skulptur und Farbe sehr veränderlich. Bei der kleineren Form, dem eigentlichen tesselatus Duft., sind die Reihen der Fld. vor der Mitte ziemlich weitlänfig grob punktirt, ihre Zwischenräume sehr schmal; hinter der Mitte werden die Punkte etwas feiner und die Zwischenräume breiter. Letztere sind dicht, rorn weniger, hinten jedoch oft fast eben so stark als die Reihen punktirt, zuweilen noch gerunzelt. Die grössere Form, sabulosus Gebl., hat etwas feiner aber viel enger punktirte Reihen, deren Stärke nach hinten nur in geringem Grade abnimnt, die Zwischenräume sind (auch rorn) breiter, meist etwas feiner und weitläufiger punktirt, zuweilen fast glatt.

Dunkelgrüne oder messingfarbene Exemplare (Var. b.) scheinen bei der kleineren Form zahlreicher aufzutreten, als bei der grossen. Hit dem rorigen an gleichen Orten und eben so häufig; die Var, b. liegt mir aus Tirol, Ungarn, Südrussland (Sarepta und Derbent, F aust) und Sibirien (Indrskoë, v. Heyden) vor.

* Elytra interstitiis uniseriatim punctulatis et piloso-squamosis.

3. Tillosus $\left.{ }^{1}\right)$ : Oblongus, aenens, subtus parce pilosus, metasterno albido-squamoso, pleuris submudis, antennis piceis basi perlibusque magis minusve rufescentibus. fronte convcra canalicula media obsoleta,

l) Hierher: 1. P. baeticus: Oblongus, nigro-aeneus, omnino parce griseo-syuamosus, squamulis piliformibus, apice incisis, antennis pedibusque rufescentilus, fronte convexa, canalicula media obsoleta brevi, prothorace laterihus vix angulato sat dense minus fortiter profunde punctato, punctis rotundis, elytris apice communiter late rotundatis, striis punctatis postice obsoletis. - Long. $3,5 \mathrm{~mm}$. Andalusia (Staudinger, $\mathrm{Kra}$ atz).

Durch das schmale, einfach punktirte Halssch., die etwas breiteren und kürzeren gewölbten Fld, sowie die schmalen, langen, haarförmigen, an der Spitze gespaltenen Schuppen, womit der ganze Körper wie mit einem grauen Hauche (ähnlich dem laevicollis) belegt ist, unterschieden.

2. P. impressus Rosenh. (Thier. And. 310). Modice elongatus, nigrovirili-ueneus, elytris aeneo-lirunneis, antennis pedibusque plerumque rufescen- 
antice (supra antemas) transmersim dipresso: prothorace disco subtiliter punclato, postice ot lateribus rude rugoso-punctato et pare squamoso, elytris striis punctatis pestice obsoletis, interstitiis uniseriatim

tibus, subtus parce albidr-piloso-squamoso; fronte convexu inter antenus transversim elevato, prothorace confertissime fortius punctato, sat derse squamoso, squamulis fere bifulis, intermediis angustis, testaceis, laterulibus snt latis albicantibus; elytris prme humeros evidenter oblique impressis jurtiter et profunde punctato-striatis, striis uniseriatim pils,sis, interstitiis angustis uniseriatim testaceo-et albidu-, minus adpresso-squamosis. - Long. 3-4 mm. Hispania, Gallia mer., Corsica, Sicilia, Graecia (Habelmann), Ashante (Simon).

3. P. cylindricus Luc. (Expl. Alg. Ent. 519. t. 46. f. i). Cylindricus, nigro-aeneus, nitidus, parce subtilissimeque pilosus, pilis squamiformibus, antennis piceis vel fuscis, basi rufescentibus, tibiis tarsisque abscure ruris, prothorace interdum aurichalceo vel cupreo-micans, sat dense subtiliter punctato, lateribus ante basin leviter sinuatis, elytris striis punctatis pone medium deletis, interstitiis uniseriatim albido-pilosis. - Long. 2,5-4 mm. Gall. mer., Hispania, Algeria.

Variat a. (corinthius Fairm. Ann. Fr. 1861. 590) prothurace subtilissime punctulato; b. (hipponensis Desbr. Mittheil. Schweiz. Ges. III. 358 ) elytris obscure coeruleis, prothorace aurichalceo vel cupreo.

Cylindrisch, wenig gewölbt, braun oder dunkelgrün erzfarbig, glänzend, dünn mit weissen haarförmigen Schuppen bekleidet. Fühler und Beine pechschwarz, Basis der ersteren, sowie Schienen und Tarsen in der Regel röthlich braun. Halssch. etwas länger als breit, mit gerundeten Seiten, ror der Basis quer linienförmig eingedrückt, mässig dicht und sehr fein punktirt, die Punkte am Grunde und an der Seite dichter und stärker. Fld. mit feinen, hinter der Mitte fast erlöschenden Punktreihen, ihre Zwischenräume mit einer, nur bei starker Vergrösserung sichtbaren Reihe von Punkten, von denen jeder ein weisses, kurzes Schuppenhärchen trägt. Auf der fein punktirten Lnterseite und den stärker punktirten Beinen ist jeder Punkt mit einem ähnlichen Härchen besetzt. - Die Fundortsangaben Istrien und Dalmatien einiger Sammlungen sind bis jetzt nicht verbürgt.

4. P. Bruchi Fairm. (Ann. Fr. 1S61. 590). Praecedenti simillimbs, sed aeneus, clytris plerumque nigro-coeruleis vel nigris, prothorace angustion minus dense jortins punctato, lateribus ante basin profunde sinuatis, striis elytrorum fortiter et parcius punctatis, punctis interstitimum minutissimis bene distinctus. - Long. 2,5-3,5 mm. Gallia mer., Sicilia Melly, Mus. v. Heyden), Palermo, Catania, Syracus (Rottenberg Berl. Zeit. 1871. 24: sub cylindricus).

5. P. robustus Desbr. (Abeille VII. 18;0. 132). P. cylindrico afitnis, sed piceus vel niyro-viridis aeneo micans, antennis pelibusque rupis, prothorace dense fortiterque-, lateribus subruguloso-punctato, elytris interstiriis striarum evidentius punctatis mox distinetus. - Long. 3,5-4 mm. Sarepta (Becker), Theodosia (Retowski). 
squanusis (squnmulis bifidis, linearibus, lestuceis), muculis nomullis obsoletis albido-squamosis. - Long. 3-4 $\mathrm{mm}$.

Duftschm. Faun. Aust. III. 217 (Eumolp). - Küst. Käf. Eur. 4. 95 .

P. aspericollis Fairm. Ann. Fr. 1S61. 588. - Lefèvr. Synops. d. Eumolp. 13.

$\boldsymbol{P}$. rugaticollis Mill. Wien ent. Mon. 1872. 281.

Var. a. chalybaeus: Elytris saturate chalybaeis.

Eine durch die Punktirung des Halssch. recht ausgezeichnete, iu der Bildung des Körpers an tesselatus erinnernde Art, dunkelmessingfarbig, ziemlich glänzend, die sechs ersten Fühlerglieder und die Beine theilweise oder ganz rothbraun. Kopf mässig dicht punktirt und beschuppt, Stirn mit feiner Mittelrinne, über der Fühlerwurzel quer vertieft. Halssch. etwas länger als breit, die Seiten vor der Mitte gerundet-erweitert, der deutlich aufgebogene Seitenrand, bei der Ansicht ron oben, bis vor die Mitte sichtbar, hier plötzlich nach innen den Vorderecken zugebogen und von der Wölbung des Halssch. verdeckt. Die Scheibe längs der Mitte mässig dicht und fein punktirt, die Punkte am Vorderrande sehr fein, länglich, in der Richtung der Mittellinie stehend, nach hinten und besonders nach den Seiten hin immer grösser und tiefer, nach aussen gerichtet, zuletzt quer, grübchenartig, mit schmalen und hohen, die Oberfläche gitterförmig durchschneidenden Zwischenräumen. In jedem Grübchen befindet sich ein weissliches, auf dem Aussenrande des Grübchens befestigtes und an der Spitze eingeschnittenes Schüppchen. so dass dadurch eine weisse Längsstrieme am Seitenrande gebildet wird. Fld. bis zur Mitte leicht erweitert, hinten allmählich verengt und mässig breit gemeinschaftlich abgerundet, oben mit einem, zuweilen recht deutlichen Quereindrucke hinter der Schulter und wenig starken, hinter der Mitte schwachen Punktreihen, deren Zwischenräume mit einer regelmässigen Reihe von feinen Pünktchen besetzt sind, von denen jedes eine haarförmige, bräunliche, gespaltene Schuppe trägt. Ausserdem werden durch etwas breitere weisse Schuppen einige unbestimmte Makeln gebildet, eine innen rom Schulterhöcker, von der Basis der Fld. bis in den Quereindruck reichend, eine punktförmige hinter der Mitte und eine halbkreisförmige, nach der Naht offene, vor der Spitze. Diese Schuppen

P. laevicollis Fairm. (Ann. Fr. 1861. 590) und P. hispidulus Fairm. (1. c. 1866. 72) beide nur aus Algier, sind von cylindricus schwer zu unterscheiden. Der erstere ist oberseits glänzender, wie polirt, der zweite besitzt sowohl in derı Punktreihen als in den sehr deutlichen $Z$ wischenraumsreihen weissliche Schuppenhärchen.

VI. 2 . 
beeinträchtigen kaum den Glanz der Oleerseite. Unten ist nur die Hinterbrust ziemlich dicht weiss beschuppt, die Pleuren derselben kahl oder mit einer feinen Schuppenreihe, der übrige Theil der Brust und der Bauch baben einzelne weissliche, schuppenförmige Haare.

Wie bei den übrigen Arten ist die Punktirung variabel, bald sind die Punkte der Reihen auf den Fld. kaum, bald viel stärker als die der Zwischenrüume; letztere verlieren öfter, besonders bei syrischen Stücken, durch eine sehr feine und dichte Runzelung allen Glanz. Zuweilen (Var. a.) sind die Fld. gesättigt stăllblau.

In den südlichen Provinzen Oesterreichs und in Südeuropa, mit Ausnahme der Pyrenäen-Habinsel, häufig; östlich bis Syrien (Simon) und Persien.

Die Beschreibung Duftschmid's, noch mebr die von Küster. lässt keinen $Z$ weifel, dass der später aufgestellte aspericollis $\mathrm{F}$ a irm. mit dem vorliegenden zu vereinigen ist.

\section{Colaspidea.}

Laporte de Castelnau Silb. Rev. I. 21.

Dia Redtb. Faun. Austr. ed. II. 894.

\section{Corpus pubescens.}

Tibiae haud emarginatae.

Unguiculi bifidi.

Prosternum sulcis antennalibus brevissimis.

Körper ungeflügelt ${ }^{1}$ ), oval oder ziemlich rund, metallfarbig, verschieden dicht, mit weichen, ziemlich langen, meist anliegenden Haaren besetzt. Kopf geneigt, bis zum Hinterrande der mässig gewölbten, schwach nierenförmigen Augen in das Halssch. eingezogen; Stirn leicht gewölbt, mit vertiefter Mittellinie. Fühler wenig länger als die Hälfte des Körpers, Glied 1 länglich, 2 oft nur halb so lang und dick, 3 bis 6 dünn, 4 und 6 gewöhnlich eben so lang und 3 und 5 länger als 2,7 bis 11 deutlich erweitert, aber länger als an der Spitze breit. Halsschild quer, gewölbt, an den Vorderecken zusammengedrückt, die Seiten schmal gerandet, gerundeterweitert, die grösste Breite in oder kurz hinter der Mitte, Hinterecken stumpfwinkelig, fast abgerundet, Vorderecken ziemlich spitz und leicht vorgezogen. Flügeldecken am Grunde so breit als das Halssch., länglich oder sehr breit-oval, verworren punktirt, die Schulterbeule nur bei einer Art (Saportze) stark entwickelt, Epipleuren vorn breit, ziemlich schnell verengt und schmal bis zum

1) Eine Ausnahme bildet C. Saportae, mit vollständigen Flügeln und freien Fld. 
Ende, kurz ror der Spitze der Fld. Prosternum zwischen den Hüften verengt, wenig länger als breit, dis Fühlerrinne nur am Vorderrande, vor den Müften angedeutet. Erster Bauchring viel kürzer als die übrigen zusammen. Beine mit stark rerdickten Schenkeln, cinfachen, an der Spitze rrweiterten Schienen, ziemlich breiten Tarsen und gespaltenen Klau(n ), bei denen der innere Theil merklich kürzer als der äussere ist.

Das $\hat{\jmath}$ hat einen kleineren, schmaleren, stärker punktirten und meist glänzenderen Körper als das f, und ist an dem erweiterten ersten Tarsengliede zu erkennen.

Die kleinen Arten leben, ähnlich den Pachnephoren, an niederen Pflanzen, haben aber nur kleine, scharf begrenzte Verbreitungsbezirke, Von den 4 europäischen Arten bewohnt die gemeinste, oblonga Blanch., einen Streiten ron Creta, an den Küsten des Adriatischen und Tyrrhenischen Meeres aufwärts bis Südfrankreich ?), metallica Rossi ist Mittelitalien (Pisa, Dahl), Saportae Gren. der Provence (Aix) ausschliesslich eigen, die vierte, globosa Küst., gehört Spanien an, von wo sie sich sowohl nach dem südlichsten Frankreich, als auch nach Algier ausbreitet. Dieselben lassen sich in folgender Weise übersehen:

1. Metathorax pleuris dense albido-villosis. Elytra subparallela callo humerali distincto, magno. Saportae Gren.

1. Metathorax pleuris parce pubescentibus vel glabris . . . . . . . . . . . 2 .

2. Elytra oblongo-ovata, intra marginem lateralem late reflexum profunde impressa, callo humerali, praesertim maris, obsoleto . . . oblonga Blanch.

2. Elytra intra marginem lateralem anguste reflexum haud impressa, callo humerali nullo . 3.

3. Corpus subhemisphaericum, supra parce subtilissimeque pilosum, prothorace et elytris fere communiter convexis . . . . . . metallica Rossi.

3'. Corpus breviter-ovatum, sat dense pilosum, prothorace et elytris haud communiter convexis globosa $\mathrm{Küst.}$

1) Redtenbacher's Angabe, Faun. Austr. II. 455, die Klaten seien einfach, ist unrichtig.

2) Die Art geht nicht bis nach Spanien. Lefèvre, der dies, Synopsis des Eumolpides p. 16, behauptet, hat, wie ich aus seinen Bestimmungen in der v. Heyden'schen Sammlung ersehe, die italienische und spanische Art nicht richtig unterschieden. 
1. C. obomga: Oblongo-mata, sujna cuprea-eterea, mims dense albidn-pubescens, subus viridi-aenca. juire pulsestens: antemis basi perlibusque mo-teslaceis, femoribus superne aprectu versus viridi. acneis; prolhonace subtranswerso, antice posticeque anyuslatu. dense concime punclalo, interstiliis alulaceis. plytris lateribus parum 1 - 1 rel haud (..) rlilalalis, subparallelis, postice sensim atienuatis, apjice ungusle communiter-rohudatis, intra marginem lateralem late ieflexum profunde impressis, tuberculo humerali parum ( ) rel minus ( 1 ) rliscrelo, minus dense punctatis. - Long. 1,5-3 $\mathrm{mm}$.

Mas: tursis articulo primo dilalalo, elyhis nitidis, fortiler punclutis.

Fem: elylris minus fortiter punclatis, interstitiis magis mimusie ululaceis. minus nitidis.

Dia oblonga Blanch. Ann. Fr. 1855. Bull. 4. - Fairm. Ann. Fr. 1861. 591.

Dia nilida Redtb. Faun. A. ed 2. 895 ; ed. 3. II. 455 (Colresp.). - Desbroch. Mittheil. Schweiz. Ent. Ges. III. 358. - Lefèr re Synops. Eumolp. 16 (Colasp.).

Dia proxima Fairm. Ann. Fr. 1861. 591.

Die schmalste Art der Gattung, länglich-eiförmig, oben kupferröthlich-erzfarben, nicht dicht mit langen, weisslichen, auf Kopf und Halssch. fast anliegenden, auf den Fld. halb aufgerichteten Haaren besetzt, unterseits dunkelgrün-erzfarbig, einzeln bebaart. Fühler an der Basis hell röthlich gelb, nach der Spitze dunkler, Beine röthlich gelbbraun, Schenkel auf dem Rücken mit einem rerschiedeu grossen, dunklen, metallfarbigen Flecke vor der Spitze. Kopf zwischen den Augen grübchenartig (beim f neist stärker und länger als beim j) eingedrückt, ziemlich dicht punktirt. Halsseh. in der Mitte am breitesten, nach rom wenig melır als nach hinten verengt, dicht, aber feiner als der Kopf punktirt, die Zwischenräume äusserst dicht und fein lederartig gerunzelt. Fld. mehr als doppelt so lang und an der Basis wenig breiter als das Halssch, die Seiten bis unter die Schultern schnell verbreitert, hierauf fast parallel oder sehr schwach gerundet bis zur Mitte, von wo sich die Fld. allmählich verengen und hinten schmal gemeinschaltlich abgerundet sind. Vom Schildchen aus läuft dicbt hinter der Basis ein leichter Quereindruck bis zur Schulter, wo er sich verbreitert und rertieft und innerhalb des breit abgesetzten Seitenrandes bis zu zwei Drittel der Längu nach hinten zieht. Dieser Eindruck sowohl als der längliche, innen schwach begrenzte, wenig deutliche Schulterhöcker sind beim $\Varangle$ bedeutend stärker als beim $\hat{\jmath}$. Der Rücken ist weitläufiger und stärker als das Halssch. punktirt.

Das $\hat{j}$, an dem durchschnittlich kleineren und schmaleren Körper kenutlich, hat meist kräftig punktirte, glänzende Fld. und ein 
zienlich grosses erstes Tarsenglied. Die Fld. des f haben zwischen der feineren Punktirung gewöhnlich verschieden starke Runzeln, die den Glanz an den Seiten, seltener auf der ganzen Fläche in verschiedenem Grade abschwächen.

Die Art int zwar in der Grösse und Skulptur sehr veränderlich, aber an dem länglichen Körper ${ }^{1}$ ), dessen Fld. nicht bis zum Seitenrande hinab gleichmässig gewölbt sind, ron den verwandten zu trennen. Besonders kräftige Stücke von den Hyèren beschrieb F airm. a. a. O. als proxima.

Wenn auch das Vorkommen des Thieres in Istrien, bei Triest ete. kaum bezweifelt werden darf', so ist es doch bis jetzt nicht verbürgt, obwohl mir von den verschiedensten Seiten her Exemplare aus Kärnthen und Krain (Kahr) vorliegen. Sie scheinen alle aus Dalmation zu stammen, wo sie $\mathrm{Kahr}$ und in neuester Zeit Reitter bei Ragusa in Menge gefangen hat.

Bei der Klarlegung der verworrenen Synonymie ist hauptsächlich zu entscheiden, ob die Chrysomela metallica Rossi (1790) auf die vorliegende Art, oder auf sphceroides Fairm. bezogen werden muss. Für letzteres sprechen nicht nur die Grössenangabe $\left(1 \frac{1}{s}\right.$ lin.), sondern auch die Worte der Beschreibung: C. „subrotunda, laevis, thorcex antice angustatus, postice transversus", sowie die Tradition; das erstere könnte aus der schlechten Abbildung, die ein längliches Thier zeigt, welehes, ,nicht selten" genannt wird und auf den Fld. "für ein bewaffnetes Auge kaum sichtbar punktirt" sein soll, gefolgert werden. Da die ersten Gründe entschieden überwiegen, ist die grosse und breite italienische Art als metallica Rossi aufuführen. Diese benennt Fabricius (1792), sogar unter Bezug auf Rossi, reruginect, Fairmaire (1S61) sphaerides. Für die kleine Art tritt als frïhester Name chlonga Blanch. ein; der V'ersuch Desbrocher's und Lefèvre's, die spanisch-algerische C. nitide Lucas (Explor. Alg. Ent. (1849) $515=$ Pachnephorus glubosus Küst. Käf. Eur. 13.92 (1848) darauf zu beziehen, ist nach Lucas Worten: ,enfin elle ne puurra être confondue avec la C. oblonga Blanch. is couse de sce forme, leaucoup plus conrte et surtout plus spliérique unzulässig.

\section{Adoxus.}

Kirby Faun. bor. Am. IV. 209.

Eumolpus Redtb. Faun. Austr. ed. 2. 893; ed. 3. II. 453.

Bromius Chap. Gen. Col. X. 364.

Corpus haud metallicum, undique pubescens.

Prothorax subglobosus lateribus immarginatus.

1) Die hierin ähnliche C. grossa Fairm. (Ann. Fr. 1866. 73) ans Marocco, ist mindestens $3 \mathrm{~mm}$ lang, stark punktirt und an dem nach hinten wenig, nach vorn auffällig verengten Halssch., dessen Seiten stark gerundet sind, leicht zu unterscheiden. 
Piostermuni transversum.

Pygidium apice mudum.

Unguiculi bifidi.

Körper ohne Mctallarbe, fein behaart. Kopf stark geneigt, bis zom Hiuterrande der ovalen, mässig gewölbten Augen in das Halssch. eingezogen, Mandibeln winkelig-gebogen, Oberlippe und Koptschild selır schwach bogenförmig ausgerandet. Stirn breit, fast eben, wit einer Mittelrinne. Fühler länger als der halbe Körper, die sechs letzten Glieder fein und dicht anliegend behaart, etwas erweitert, das Endglied mit deutlich abgeschnürter, ein zwölftess Glied rorstellender, schmaler Spitze. Halsschild fest an die Fld. geschlossen, kugelig, etwas breiter als lang, an den ungerandeten Seiten fast gleichmässig abwärts gewölbt, die Ecken nur als sebr kleine Höcker angedeutet, wovon der die Vorderecken bildende den Hinterrand der Augen bedeckt. Schildehen länglich, parallel, mit breit dreieckiger Spitze. Flügeldecken am Grunde so breit als das Halssch., in den vorragenden Schultern viel breiter, wenig länger als zusammen breit, hinten gemeinschaftlich abgerundet, die kleine Afterdecke frei lassend, hinter der Schulterbeule quer niedergedrückt, verworren punktirt, mit Spuren ron breiteu Streifen, in welchen grösserte Punkte stehen. Epipleuren schmal bis zur Spitze. Vorderrand der Vorderbrust mit fast unmerklichem Ausschnitte am schwach aufgebogenen Innenrande der Episternen; Prosternum quer viereckig, fast eben, so breit als das Mesosternum, Parapleuren der Hinterbrust schmal und sehr spitz. Beine gestreckt, mit leicht verdickten Schenkeln, nach der Spitze zu schwach erweiterten Schienen und mässig breiten Tarsen. Klauen etwas über der Wurzel gespalten, der innere Theil weniger spitz und kürzer als der äussere.

Die einzige Art lebt ron Weinblättern, die sie streifenweise abschabt und durchlöchert, oder an Epilobium angustifolium, ohne bei uns je einen nennenswerthen Schaden verursacht zu haben. Dagegen soll die Larve (von A. vitis) in Südfrankreich zuweilen die jungen Triebe des Weinstockes zerstören $\left.{ }^{1}\right)$.

Ueber dieselbe berichten Horvath ${ }^{2}$ ) und Lichtenstein ${ }^{3}$ ) Ausführliches. Nach dem erstgenaunten ist sie $8 \mathrm{~mm}$ lang, 2,5 $2 \mathrm{~mm}^{\mathrm{m}}$ breit, weiss, mit einzelnen gelblichen Härchen besetzt und hat 13 Ringe. Kopf gelb, flach gewölbt, schwach verworren runzelig. Nitte der Scheibe des ersten Brustringes gelb. Beine hell, besonders an der

1) Latreille Hist. nat. XI. 331; Guérin Ann. Fr. 1866. Bull. 35.

$\left.{ }^{2}\right)$ Verhandl. zool. bot. Ver. Wien 1873. 37.

3) Ann. Fr. 18:5. Bull. 105 u. Etudes sur le Gribouri. Montpell. 1879 p. 12. 
Innenseite ziemlich stark borstenartig behaart, mit einer einfachen, wenig gebogenen, dunkel gefärbten Kralle. Statt der fehlenden Augen befindet sich an der Seite des Kopfes hinter den Fühlern je ein heller Quertleck. Fühler kurz, kegelförmig, zweispitzig. Oberlippe halbrund, bräunlich wie der ziemlich breite Clypeus. Oberkiefer pechbraun, aussen an der Spitze schwach eingekerbt, an Innenrande schwach ausgebuchtet und mit mehreren unregelmässigen, f'ust unmerklichen Kerbzähnen besetzt. Unterkiefer einfach, länglich, hornig, an der Spitze beborstet. Kiefertaster 4 gliederig, die zwei ersten Glieder dick, breiter als lang, gleichlang, Glied 3 so lang als breit, das stumpf spindelförmige Endglied so lang als das dritte. Am Ende des wulstigen Kinnes und der Unterlippe sitzen die aus je einem cylindrischen Gliede bestehenden Lippentaster, welche so laug als das Eudglied der Kiefertaster sind und an ihrer Spitze ein starkes Borstenhaar tragen.

Die Larve frisst in die Rinde der Wurzeln Rinnen, in denen sie sich halbversteckt aufhält; da sie überwintert, so empfiehlt Horvath zu ihrer Vertilgung ein fleissiges Umgraben der Erde im Spätherbste. Das rollkommene Insekt lässt sich, sobald man es anfassen will, fallen; es ist systematisch insoferu interessant, als es durch den nur wenig aufgebogenen Innenrand der Episternen des Prothorax den Lebergang zu den Eumolpiden-Gattungen bildet, bei denen dieser Rand ganz flach ist.

1. obscums: Niger, subopacus, tenuiter albido-pubescens, antennis basi ferrugineis, elytris sat crebre subtiliter punctatis striis punctorum majorum. - Long. 5-6 $\mathrm{mm}$.

Linn. Syst. nat. ed. X. 375 (Chrysomela). - Fabr. Ent. Syst. II. 60. - Panz. Faun. Germ. 5. 12 (Cryptocephal.). - Oliv. Ent. VI. 910. t. 2. f. 22. - Gyllh. Ins. Suec. III. 583. Thoms. Skand. Col. VIII. 314. - Redtb. Faun. A. II. 453. - Seidl. F. balt. 480 (Eumolpus). - Küst. Käf. Eur. 1. 94 (Bromius).

Var. a. epilobii: Elytris fuscis, tibiis (interdum pedibus) obscure ferrugineis.

Var. b. Ut in a, sed pilis corporis flavescentibus, striis elytrorum evanescentibus.

Cryptocephalus vitis Fabr. Syst. Ent. 108. - Oliv. Ent. VI. 911.

t. 1. f. 9. - Redtb. 1. c. 453 . - Taschenberg Prakt. Insektenk.

274 (Eumolp.). - Küst. Käf. Eur. 1. 95. - F a irm. Gen. Col. Eur. IV.

t. 65. f. 307 (Bromius).

Tar. c. $L^{\top}$ in $b$, sed niger, antennarum basi tibiisque ferrugineis.

Schwarz, wenig glänzend, kurz und fein weisslich behaart, die ersten vier Fühlerglieder roth. Kopf wie das Halssch. dicht und 
fein punktirt. Fld. etwas weniger tief, aber eben so dicht punktirt, als das IIalssch, mit zehn breiten, schwach vertieften Streifen, in denen an der Basis und im Quereindrucke hinter der Schulter, ss,wie am Seitenrande grössere Punkte stehen, welche hinter der Schulterbeule oft durch feine Querrunzeln verbunden sind.

Die Art kommt in zwei, durch Farbe und Lebensweise sehr verschiedenen Formen vor, die bisher als zwei Arten betrachtet wurden. Die eine, oben beschriebene, lebt an Epilobium angustifolium, ist bis auf die vier ersten Fühlerglieder schwarz, fein weiselich behaart; die andere, nur am Weine lebende (Var. b.) ist gewönlich kleiner, hat hell chocoladenbraune Fld und ausser den vier ersten Fühlergliedern noch rothe Schienen, dazu eine dichtere und längere deutlich gelbe Behaarung des Körpers und meist feiner punktirte Fld., auf denen die grösseren Punkte in den undeutlichen Reihen kaum durch Querrunzeln (besonders hinter dem Schulterhöcker) verbunden sind. Zwischen beiden stehen die Abänderungen: a. ganz wie vitis gefärbt und die Fld. zuweilen eben so fein punktirt, aber mit weisser Behaarung (auf Epilobium; in vielen Sammlungen als vitis bestimmt), und b. wie obscurus gefärbt, mit rothen Schienen und gelber Behaarung, ebenfalls auf Epilobium. Zur vollständigen Uebergangsreihe fehlen mir nur weiss behaarte, an Weinreben gefangene Stücke, deren Existenz jedoch kaum einem $\mathrm{Z}$ weifel unterliegt.

Einzeln im ganzen Gebiete, doch nur im mitteldeutschen Gebirgslande häufiger (auch die Var, a.) an geschützten Südlehnen oder Bachufern im Juni und Juli. Die Var. b. scheint bei Sommerfeld, wo sie nur in wenigen windfreien Weingärten lebt, ihre nördlichste Grenze zu erreichen.

\section{Chrysochus.}

Redtenb acher Faun. Austr. ed. 1. 558.

Corpus metallicum, subcylindricum, glabrum.

Prothorax lateribus marginatus.

Unguiculi medio dentati.

Pygidium occultum.

Körper kurz, oder länglich-eiförmig, fast cylindrisch, blau oder grün, mit Metallschimmer, kahl. Kopf länglich, Mandibeln kurz und stark, winkelig gebogen, die Oberlippe und das ron der Stirn undeutlich getrennte Kopfschild rorn leicht bogenförmig ausgerandet. Stirn mit seichter Mittelrinne und einer feinen und schmalen, gebogenen Furche am Innen- und Oberrande der schwach nieren- 
förmigen Augen '). Fülıler. fast so lang als der halbe Körper, Glied 2 kurz, die fünf letzten Glieder etwas erweitert, das Endglied mit kurzer, abgesetzter, ein zwölftes Glied bildender Spitze. H alsschild gewölbt, fast so breit als die Fld, an den Vorderecken etwas zusammengedrückt, am Vorderrande jederseits über den Augen schwach ausgeschnitten, an den Seiten schmal, doch scharf gerandet, zerstreut punktirt. Schildchen breit dreieckig oder gerundet viereckig. Flügeldecken länglich, mit fast parallelen Seiten, hinter den wenig vorragenden Schultern niedergedrückt, unregelmässig punktirt, hinten gemeinschaftlich abgerundet, den Hinterleib ganz bedeckend. Die Epipleuren sind vorn mässig breit, verschmälern sich allmählich und erreichen die Spitze der Fld. Füblerrinnen kurz, aber durch den hoch aufgebogenen Innenrand der Episternen tief und deutlich. Prosternum länger als breit, zwischen den Hüften etwas verengt. Mesosternum viereckig, fast so breit als lang. Beine kräftig, Schenkel in der Mitte nur leicht verdickt, Schienen vor der am Aussenrande in einen breiten Zahn erweiterten Spitze nicht ausgeschnitten, Tarsen ziemlich breit, Klauen in der Mitte mit einem gleichbreiten, abgestutzten oder abgerundeten Zahne, der die Spitze nicht erreicht.

Bei den $\hat{\jmath}$ ist das erste Tarsenglied der vier vorderen Beine merklich erweitert.

Die einander sehr ähnlichen Arten verbreiten sich von Europa durch Asien bis zur Westküste von Nordamerika; unsere einheimische Art schwitzt, nach $\left.\mathbf{A} u \mathrm{bé}^{2}\right)$, einen farblosen, stinkenden Saft aus.

1. Chr.pretiosws: Oblongo-ovatus, violaceus, nitidus, capite elytrisque minus fortiter punctatis, prothorace parum transverso, subtilissime punctato. - Long. 8-10 $\mathrm{mm}$.

Mas: tarsis anterioribus articulo primo dilatato.

Fabr. Ent Syst. I. 1. 324. - Panz. Faun. Germ. 44.13 (Chrysomela). - Schneid. Neu. Mag. I. 2. 218 (Cryptoc.). - Oliv. Ent. VI. 904. t. 2. f. 20 (Eumolp.). - Küв t. Käf. Eur. 1. 96. - Redtb. Faun. A. II. 453.

Var. a. Corpore supra vel omnino viridi-aeneo.

Länglich-eiförmig, dunkel-veilchenblau, glänzend, Fühler und Tarsen fast schwarz. Kopf wenig dicht und stark punktirt, äussert

1) Diese Furche ist bei den zahlreichen Arten der Gattung Corynodes Hope, ans Asien und Afrika, sehr breit und tief.

$\left.{ }^{2}\right)$ Ann. Fr. 1866. Bull. 58. 
fein, sparsam behaart. Ifalssch. bein $\hat{j}$ fast hallokugelig ${ }^{1}$ ), beim f länger und wach rorn stärker verengt, wejtläufig und viel feiner als Kopf und Fld. punktirt. Schildchen glatt. Fld. mit wenig starken, oft zu unregelmässigen Doppelreiben geordneten Punkten, von welchen auf der hinteren Hälfte an der Naht ungefähr drei leicht vertiefte Reihen deutlicher hervortreten.

Das $\hat{j}$, welches stärker punktirt und etwas kürzer ist, als das f, lässt sich ausser an dem breiteren Halssch. noch an dem erweiterten ersten Tarsengliede der vier Vorderbeine leicht erkennen.

Zuweilen ist die Oberseite oder der ganze Körper metall- bis schwach goldgrün.

Auf Vincetoxicum officinale Moench. im Elsass, dem südlichen Tirol, Steiermark und Krain oft in zahlloser Nenge. Ausserdem vom südlichen Frankreich bis Syrien, Armenien nnd Sibirien verbreitet.

\section{Zweite Gruppe: CHRYSOMELINI.}

Chapuis Gen. des Col. X. 351 .

Clypens subtrunclatus. maryine antico transzersim depresso.

Aulenna basi late distantes fronti pone mandibulan um basin insertae. Acetabula antica transversa.

Tarsi articulo tertio haud bifido, rarissime bilobo.

Körper halbkugelig, elliptisch, oval oder gestreckt, fest, gewölbt, unterseits nur selten sparsam, oberseits kaum behaart. Kopf gerundet, bis zu den Augen in das Halssch. eingezogen, von oben wenig oder nicht sichtbar, mit senkrechter oder schräg rorgestreckter, wenig gewölbter Stirn. Diese besitzt gewöhnlich eine schwache Mittelfurche, die sich vorn, zwischen der Fühlerwurzel, theilt und dadurch das Kopfschild mehr oder weniger deutlich abtrennt. Letzteres ist am Vorderrande fast gerade abgestutzt und tief der Qutre nach niedergedrückt, so dass es in einem, rom eigentlichen Kopfschilde deutlich abgesetzten, tiefer liegenden, hornigen, glatten Querstreifen endet. Mandibeln klein, kurz, aber stark, an der oft wenig verengten Spitze ausgeschnitten und in mehrere Zähne verlängert. Oberlippe quer, ausgerandet; Kinn deutlich, oft sehr gross und beinahe so weit vorgestreckt, als die Mandibeln (Timarcha). Augen

1) Chr. chinensis Baly (Ann. nat. Hist. 3. Ser. IV. 1859. 125) aus China uud Japan, der in den Sammlungen sich als exquisitus Esch. befindet, kommt auch am Amur (Faust) ror und ist durch den dunkler gefärbten, bedentend kürzeren Körper mit breitem Halssch. von pretiosus verschieden. 
länglich, meist schmal, am Innenrande leicht ausgeschnitten, an den Seiten des Kopfes, nach unten divergirend herablaufend. Fühler utwas unter der Mitte des Innenrandes der Augen, weit ron cinander entfernt eingefügt, halb bis drei Viertel so lang als der Körper, die fünf letzten Glieder erweitert und oft leicht zusammengedrückt. Halsschild fast so breit als die Fld, selten quadratisch (Prasocuris), meist quer, an den Seiten oft wulstartig aufgeworfen. Schildchen dreieckig. Flügeldecken im Allgemeinen nit wenig entwickelten Schultern und an diesen wenig breiter als das Halssch.; ibre Epipleuren breit, oft bis zur Spitze deutlich, und am Innenrande bei verschiedenen Gattungen ganz ${ }^{1}$, oder nur auf der hinteren Hälfte (Chrysomela) bewimpert. Die Bildung der Brust ist höchst mannigfaltig und bei der Eintheilung dieser Gruppe allein massgebend. Der mittlere Theil der Vorderbrust, das Prosternum, ist bald breit (Sclerophaedon), bald so schmal, dass die Vorderhüften fast zusammenstossen (Colaspidema), oder der Länge nach gewölbt und zu den Hüften ohne Randleiste abfallend, oder längsvertieft; in diesen Fällen endet er in einem Zapfen, der sich in eine Grube des Mesosternum fest einlagert (Chrysomela), oder fällt steil zur Mittelbrust ab (Timarcha). Das Episternum ist vom Prosternum durch keine Naht getrennt, quer viereckig, und schliesst die Gelenkhöhlen von vorn; das Epimerum ist undeutlich, verlängert sich hinter den Vorderhüften entweder in ein spitzes Dreieck, ohne das Prosternum zu erreichen, dann sind die Gelenkhöhlen offen und die Hüften liegen zum Theil in zwei Gruben unter dem Vorderrande der Mittelbrust, oder es erreicht hinter den Hüften in einem schmalen Streifen das Prosternum, so dass die Gelenkhöhlen geschlossen werden. Letztere sind quer, wie die Hüften, welche aus ihnen verschieden hoch herausragen. Die Mittelbrust ist nur bei zwei exotischen Gattungen ${ }^{2}$ ) unsichtbar, weil bei ihnen das Metasternum die Vorderbrust berührt, sonst erscheint sie meist als schmale Querleiste, oder ist quer-viereckig, selten quadratisch, eben oder gewölbt, mitunter in zwei aufstebende, divergirende Spitzen verlängert (bei einigen Timarchen), oder in einen dicken, langen, zuweilen bis zum Munde reichenden Stachel ausgezogen $^{3}$ ). Hinterbrust bald schmal, so dass die Hinterhüften wenig hinter den Mittelhüften liegen, wie bei Timarcha, oder länger als die Vorderbrust; das Metasternum tritt vorn in einem Bogen mehr oder weniger weit zwischen die Mittelhüften und hat meist

1) Bei der afrikanischen Gattung Ceralces Gerst.

2) Gavirga Stål aus Südamerika und Paralina indica Hope.

3) Doryphora Illiger aus Nord- und Südamerika. 
eineu erhabenen Vorderrand; es ist nur bei der Gattung Metastyle Chap. alus Rio in einen dornartigen Fortsatz bis zwischen die Vorderhüften verlängert. Drr ITinterlejl, besteht aus fünf Ringen. Die Beine sind kurz und stark, die Schenkel kräftie, mehr oder wroniger keulenförmig, ungezähnt') und überragen nur in wenigen (rattungen den Rand der Fld. bedeutend. Schienen an der Spitze abgerandet oder zahnartig erweitert. Tarsen mit drei ziemlich breiten, unten flzigen Gliedern, ron denen das zweite meist das kürzestr ist, und einem langen Klanengliede. Das dritte Glied ist an der Spit\% entweder ganzrandig, oder verschieden tief ausgeschnitten, aber nie $s 0$ tief gespalten, wie bei den Eumolpiden²). Die Tarsen unserer teinheimischen Arten sind rorwiegend einfach, bei Phytrdecta und Plugllodecta mit einem Zahne am Grunde.

Aeusserliche Geschlechtsunterschiede sind an versehiedenen Theilen des Körpers deutlich ausgeprägt; sie zeigen sich bei den Männchen in den viel längeren Fühlern oder der Erweiterung cines Gliedes derselben (Prasncuris phellandrii), an den erweiterten Tarsen, oder in einem Eindrucke am Hinterrande des letzten Bauchringes. Die Weibchen sind meist kräftiger gebaut, oft auch weniger glänzend, als die Männchen. - Der Penis ist eine hornige Röhre, und durch seine Bildung bei der Unterscheidung nahe rerwandter Arten ron der grössten Wichtigkeit.

Die Kenntniss der ersten Stände der Chrysomelinen ist, soweit sie die europäische Fauna betrifft, eine recht erfreuliche, was wohl zum grössten Theile in der leichten Beobachtung der frei lebenden Larven seinen Grund baben mag. Dieselben halten sich entweder an der Oberfläche der Blätter auf und fressen dann gewöhnlich nur den oberen Theil des Blattgewebes, oder sie sitzen auf der Unterseite und durchlöchern das Blatt siebartig. Ihr Körper ist kurz eiförmig, nach hinten verbreitert, oder länglich, beiderseits verschmälert (Melasoma), gewölbt, verschieden gefürbt, kahl, behaart oder mit Tuberkelreihen besetzt. Kopf mit vier (Timarcha) oder sechs Ocellen jederseits, vier in einem Rhombus über den Fühlern und zwei nach aussen, seitlich neben den Fühlern, Fühler konisch, dreigliederig ${ }^{3}$ );

3) Bei den Männchen ron Labidomera Chap. aus Mittel-Amerika mit 2wei Zähnen.

2) Die Gattung Stenomela Gr. ans Peru und Chile, die ron Chapuis (Genera X. 421) trotz ihres ganz gespaltenen dritten Tarsengliedes und des ausgerandeten, einfachen Kopfschildes zu den Chrysomelinen gerechnet wird, ist ein Eumolpide.

3) Auch bei Chrysomela, wo sie Chapuis (Gen. X. 357) viergliederig angiebt. 
das Abdomen besteht ans acht Ringen und dem Analsegmente, an Stigmen sind bei Timarcha acht, sonst neun Pare vorhanden. Die Verwandung zur Puppe geschieht theils in der Erde (Timarcha), theils an der Nährpflanze, indem sich die Larve mit dem Anus so festklebt, dass dex Kopf nach unten hängt. Sie zieht sich hierauf etwas zusammen, streift die Larrenhaut ab und umbüllt mit derselben die Spitze der Puppe. Wird diese berührt, so bewegt sie den Vorderleib auf und nieder, nach Art der Coccinellen-Puppen. Das vollkommene lnsekt schlüpft nach verhältnissmässig kurzer Zeit aus.

Die Chrysomelinen sind über dic ganze Erde verbreitet, in Ganzen träge, durch einen starken Geschlechtstrieb ausgezeichnete Thiere und treten massenweise auf; die einzelnen Gattungen leben zum Theil auf ganz bestimmten Pflanzenfamilien. Um sie in schwierigen Fällen von deu Eumolpiden sicher unterscheiden zu können, verdienen folgende Punkte besondere Beachtung. Das Kopfschild ist vorn ziemlich gerade, selten scharf abgeschnitten (wie bei Colaphus), sondern am eigentlichen Vorderrande quer vertieft, hautartig; es reicht weniger weit vor die Fühlerwurzel, als bei den meisten Eumolpiden, deren Kopf daher länglicher, das Kopfschild selust schmaler und stets mit einem ausgerandeten, einfachen Vorderrande versehen ist. Dieses Merkmal, welches meines Wissens bisher noch nicht zur Trennung benutzt wurde, halte ich für das Wichtigste, weil es am leichtesten zu sehen ist und bei den mir bekannten exotischen Gattungen nicht variirt. Nach demselben ist z. B. die Zugehörigkeit ron Ceralces Gerst. zu den Chrysomelinen zweifellos. Etwas schwieriger gestaltet sich die Unterscheidung durch die Form der vorderen Gelenkhöhlen, der Vorderhüften und der Episternen an der Vorderbrust. Die genannten Theile sind bei den Chrysomelinen quer, bei den Eumolpinen nicht, aber es fehlt nicht an Ausnahmen, zu denen z. B. die europäische Gattung Pales, mit queren Gelenkhöhlen etc. zu rechnen wäre.

Ein dritter wesentlicher Unterschied beruht in der Bildung des vorletzten Tarsengliedes. Dasselbe ist bei allen Eumolpiden gespalten, bei den Arten der vorliegenden Gruppe ganz, oder am Vorderrande verschieden tief ausgeschnitten, so dass es dann in zwei breite Lappen endigt.

Die schwierige Classification der Chrysomelinen hat durch die gründliche Bearbeitung von Chapuis ${ }^{1}$ ) ihre erste sichere Grundlage gewonnen, wenn auch im Einzelnen noch Manches daran wird geändert werden müssen. So ist vielleicht die Zerlegung der Gruppe

1) Genera X. 351 . 
in zwei Theile, von denen der erste, kleinore, alle Arten umfasst, bei denen das Metasternum kürzer, drr zwritr die, bei denen es länger ist, als das Prosternum, nicht ganz glücklich gewählt, weil das Längsverhältniss der hetreffenden Körpertheile oft in einer Gattung variirt, wozu beispielsweise das kurze Vetasternum der C'hrysnmela lichenis einen Beleg liefert. Ich halte eine Scheidung danach, ob das Prosternum, zur festeren Verbindung des Vorderkïrpers mit dem Hinterkörper, durch einen Fortsatz auf die Mittelbrust ülergreift, oder nicht, für wichtiger und zutreffender.

Suffrian, welcher die europäischen Arten, mit Ausnahme der Gattungen Colaphus, Cyrtonus und Timarcha, zuerst in ausführlicher Weise zusammenhängend beschrieb (Linnaea entom. V. 1-281), vereinigte dieselben noch unter der Gattung Chrysomela, obgleich R cdtenbacher schon in der Fauna Austriaca ed. 1. die Mehrzahl der Gattungen durch eine Summe ron Merkmalen characterisirt hatte. Jetzt wäre ein Zurückgehen auf den einseitigen Suffrian'schen Standpunkt wohl unmöglich, a durch schärfere Beobachtung der wesentlichen Unterschiede die Absonderung der einzelnen Gattungen mehr und mebr gerechtfertigt worden ist. Dieselben lassen sich in folgender Weise übersehen:

1. Prosternum processu postico $\begin{cases}\text { nullo } & . \\ \text { evidenter instructum } & 5 .\end{cases}$

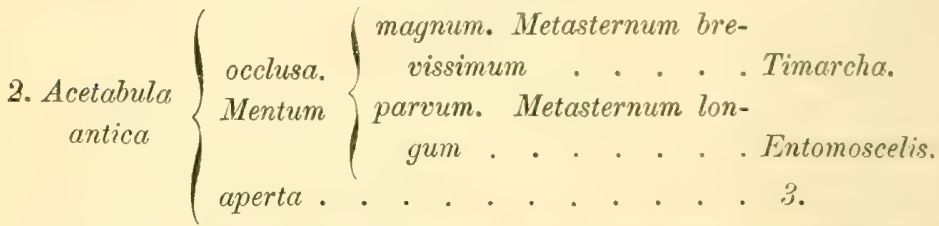

3. Prothorax fovea angulis anticis seta 1 praedita. Colaspidema.

(angulis anticis sine seta et fovea. . 4.

4. Prothorax basi $\left\{\begin{array}{l}\text { marginatus . . . . . . . Gastroidea. } \\ \text { immarginatus . . . . . . . Colaphus. }\end{array}\right.$

5. Prothorax margine $\left\{\begin{array}{l}\text { profunde sinuato, depresso et } \\ \text { dentibusmagnis obtusis instructo Cyrtonus. } \\ \text { peviter vel haud sinuato, mutico } 6 .\end{array}\right.$

6. Elytra margine interno postico $\left\{\begin{array}{l}\text { subtilissime ciliata } \\ \text { haud ciliata . . } \\ 8 .\end{array}\right.$

ovatum vel breviter-ovatum, humeris parum vel vix prominulis. Abdomen 7. Corpus $\left\{\begin{array}{c}\text { segmento 1:0 metasterno longiore. Chrysomela. } \\ \text { sat elongatum, humeris prominulis. } A b \text { - }\end{array}\right.$ domen segm. primo metasterni longitudine alquali . . . . . Orina. 
8. Unguiculi

$$
\int\left\{\begin{array}{l}
\text { saltim posteriores, ex- } \\
\text { terne ante apicem }
\end{array}\right.
$$

dentati. Tibiae<smiles>[Li][Mg][Mg]</smiles>

9. Tarsi articul

10. Corpus

11. Prothorax fovale, convexum (elongatum . transversus, postice immarginatus. $\mathrm{Fe}$ mora postica marginem elytrorum vix quperantia . . . . . . . . . postic. marg. elytr. longe superantia Prasocuris.

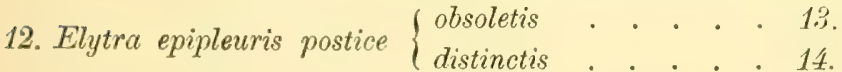
13. Prosternum $\left\{\begin{array}{l}\text { latum. Tibiae posteriores mutici. . Sclerophaedon }{ }^{1} \text { ) } \\ \text { angustum. Tib. post. externe ante }\end{array}\right.$ apicem dentato-productae . . Acanthodon.

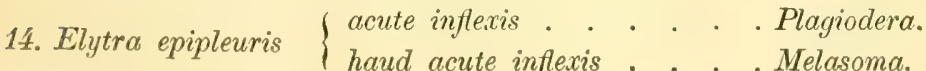
haud acute inflexis . . . Melasoma.

\section{Colnphus ${ }^{2}$.}

Redtenbacher Faun. Austr. ed 1. 556.

Corpus viridi-metallicum vel cyaneum.

Piothorax basi immarginatus, angulis anticis rotundatis sine fovea et seta.

Elytra postice attenuata apice acuminata.

Prosternum perspicuum processu postico nullo.

Coxae anticae sat late distantes apice haud conico-prominulae.

Mesosternum transversum, planum.

K örper geflügelt, oval, beiderseits verengt, stark gewölbt, grün oder blaugrün mit Metallschimmer. Kopf ziemlich breit, mit zwei

1) Die Gattung musste für Phaedon carniolicus gegründet werden.

2) Verwandt, aber in Deutschland noch nicht aufgefunden, ist die Gattung Colaspidema Lap.: Corpus magis minusve nigrum, haud metallicum. Prothorax angulis anticis obtusiusculis, fovea seta 1 praedita instructis. Prosternum haud perspicuum, angustissimum, processu postico mullo. Coxae anticae apice conico-prominulue et fere contiguce. Mesosternum haud transversum. 
Grübchen zwischen der Fühlerwurzel, die oft durch einen feinen Quereindruck verbunden sind, welcher das Kopfischild undeutlich abtrennt. Dieses ist am Vorderande zienlich gerade und ohne hatutartige Verlängerung. Oberlippe gross, breit, leicht ausgerandet; Mandibeln stark, lang, winkelig-gebogeı, an der bpitze zweizähnig. Augen klein, oval, ziemlich stark gewölbt. Fühler kaum hall so lang als der Körper, ihre fünf letzten Glieder verdickt. II alsschild kurz, stark quer, nach rorn etwas verengt, mit gerundetem, ungerandetem Hinterrande, die Hinterecken stumpl, die Vorderecken vollkommen algerundet, ohne ein, mit einer aufstehenden Borste versehenes Grübchen. Schildchen breit dreieckig, die Spitze abgerundet. Flügeldecken wenig breiter als das Halssch. und etwas länger als zusammen breit, gewölbt, ron der Mitte an allmählich verschmälert, der Nahtwinkel in eine breite, abgerundete Spitze ausgezogen. Prosternum deutlich, wenn auch nur mässig breit, hinten ohne Fortsatz, die Vorderhüften wenig höher als dasselbe, ihre Geler khöhlen nicht geschlossen. Mesosternum breiter als lang, doppelt so breit als das Prosternum, eben. Beine kräftig; Schenkel schwach keulenförmig, Schienen nach der Spitze verbreitert und gerinnt, Tarsen kurz, ziemlich breit, ihr drittes Glied rorn leicht ausgerandet, Klauenglied lang, mit zwei einfachen Klawen.

Das Weibchen ist bedeutend breiter und weniger glänzend als das Männchen, scheint aber nie einen so unförnlich aufgetriebenen Hinterleib zu bekommen, wie die Colaspidema- und CrastroideaWeibchen.

Die ersten Stände sind noch unbekannt.

Trotzdem Redtenbacher selbst die vorliegende, in der ersten

Dazu gehören: 1. C. atrum Ol., von England durch Belgien, Frankreich und Spanien bis Algier verbreitet und auf der Luzerne häufig, ist schwarz, mit röthlicher Fühlerbasis, oder die Seiten und die Spitze der Fld. röthlich (Var. barbarum Fabr.), unausgefärbt rothgelb, eine rerwaschene Scheibenmakel des Halssch. dunkler (Var. maculicolle Lef.). 2. C. Dufouri Perez, aus Spanien, schwarz, dicht, stark punktirt, die ersten $\&$ bis 6 Fühlerglieder und die Beine rothbraun, jede Fld, ringsum rothyelb gesäumt. 3. C. rugifrons Ol., ans Algier, schwarz, dicht, fein punktirt, die zwei ersten Fühlerglieder, Kopf, Saum jeder Fld., Schenkel und Spitze der Schienen rothgelb. 4. C. signatipenne Guér., von Algier und Tunis, schwarz, Fld. hell rothgelb, jede mit schwarzem Naht- und seitensaume und zwei schiefen, schwarzen Makeln, die sich zuletzt (Var. plagiatum) zu einem breiten LängsHecke auf der scheibe vereinigen, so dass von der gelben Grundfarbe nur cin schmaler, von den Rändern weit entfernter, oft unterbrochener Saum nibrig bleibt. 
Ausgabe seiner Fauna aufgestellte Gattung in der edit. 3 derselben mit Colaspidema Lap. vereinigte, so muss doch eine Wiederherstellung derselben erfolgen, da die Unterschiede in der Bildung der Brust zu bedeutend sind, als dass sie unberücksichtigt bleiben könnten. Lefèvre schrieb $187+$ eine Monographie ${ }^{1}$ ) der europäischen Arten, in welcher merkwürdiger Weise C. apicalis Mén. aus Yersien aufgeführt, $C$. tibialis Redtb., mit demselben Fundorte, unerwähnt gelassen wurde; eben so sind darin die grünen Colaphus- und die schwarzen, melhr oder weniger gelb gefärbten Colaspidema-Arten unter einander gemischt, die Verschiedenheiten der Gattungen überhaupt nicht angedeutet.

1. C. sophice: Cyaneus, antennis nigris, basi rufescentibus, articulo primo superne cyaneo, tibiis tarsisque testaceis; capite prothoraceque subtiliter, elytris fortius punctatis, interstitiis subtilissime alutaceis. Long. 4-5,3 $\mathrm{nm}$.

Mas: angustior, sat nitidus.

Femina: latior, subopaca, elytris evidenter subruguloso-punctatis.

Schaller Act. Hal. I. 272. - Panz. Faun. Germ. 25. 10. Fabr. Syst. El. I. 445. - Oliv. Ent. V. 537. t. 7. f. 97. Illig. Mag. I. 416. - Gyllh. Ins. Suec. III. 475 (Chrysomela). - Lefèvr. Ann. Fr. 1874. 345. - Redtb. Faun. A. II. 484 (Colaspidema). - Küst. Käf. Eur. 9. 99. - Redtb. 1. c. ed. 1. 556. - Seidl. F. balt. 485 .

Chrysomela rufipes Herbst Füessl. Arch. V. 59. erythropus Gmel. Ed. Linn. I. 4. 1690.

Var. a. Corpore viridi-cyaneo vel viridi-aeneo.

Kornblumen- oder stahlblau, Fühler schwarz, die sechs ersten Glieder rothgelb, das erste jedoch oberseits wie der Körper gefärbt ²), Schienen, mit Ausnahme der Basis, und Tarsen hell rothgelb, nur das Klauenglied pechbraun. Kopf auf dem Kopfschilde dicht und stark runzelig-, sonst wie das Halssch., wenig dicht, fein punktirt, die Fld. mit etwas stärkeren, hie und da Reihen bildenden Punkten besetzt, die durch Risse mehr oder weniger deutlich verbunden

l) Ann. Fr. 1874. p. 329-350.

2) Bei dem sehr ähnlichen C. Höfti Mén. (Cat. rais. 235) von Sarepta, dem Kankasus und Armenien sind die ersten Fühlerglieder und die Beine, mit Ausnahme der Schenkelwurzel, einfarbig rothgelb.

Ausserdem gehören wahrscheinlich noch hierher C. apicalis Mén. (Mem. Ac. Petr. VI. 270) und C. tibialis Redtb. (Denkschr. Wien. etc. I. 50) aus l'ersien, sowie C. pulchellus Luc. (Expl. Alg. Ent. 517. t. 46. f. 4) aus Algier.

VI. 2 . 
werden und nach der schwärzlichen Spitze hin sich immer mehr zusanmendrängen. Die ganze Oberseite ist zwischen der Punktirung äusserst dicht und fein lederartig gerunzelt.

Bei dem schmaleren, gewölnlich stärker glänzenden und feiner punktirten Männchen sind die Risse der Fld. zuweilen undeutlich.

Häufiger als die ron Schaller und Panzer beschriebenen blanen sind bei uns die blaugrünen oder grün-erzfarbigen Stücke drr Var. a.

Auf Sisymbrizm Sophia L. und Raphanus Paphanistrum L. stellenweise nicht selten; bis Schweden, Norditalien und in die Krim verbreitet.

\section{Gatroider.}

Hope The Col. Man. III. 164.

Ciastrophysa Redtenb. Faun. Austr. ed. 1. 553.

Prothorax basi marginalus.

Elytra apice communiter rotundata.

Tibiae apice externe dentato-productae.

Antennae articulis 6 ultimis crassioribus.

K ör per geflügelt, länglich, schmal elliptisch, mässig gewölbt, blau oder blaugrün, oft mit starkem Metallschimmer. Kopf klein, ziemlich breit, das Kopfschild vorn hautartig rerlängert und von der Stirn deutlich durch einen bogenförmigen oder winkeligen Eindruck geschieden. Augen mässig gross, lang-oval, etwas gewölbt. Fühler kaum halb so lang als der Körper, ihre sechs letzten Glieder rerdickt und dicht behaart, Glied 3 länger als die umgebenden. Hals schild stark quer, wenig gewölbt und nach vorn verengt, an der Basis deutlich gerandet, alle Ecken stumpf, mehr oder weniger abgerundet, ohne Borstenhare. Flügeldecken breiter als das Halsschild und wenigstens um die Hälfte länger als zusammen breit, hinten gemeinschaftlich abgerundet, an den Seiten scharf gerandet, die Schulterbeule angedeutet, die Naht dicht binter dem Schildchen und ron der Mitte bis zur Spitze erhaben. Prosternum schmal, hinten ohne Fortsatz, von den Vorderhüften wenig überragt, das Nesosternum wohl dreimal breiter, nach rorn schnell erweitert, die Seitenstücke der Hinterbrust hinten etwas breiter als vorn. Vordere Gelenkhöhlen nicht geschlossen. Beine ziemlich kräftig, Schenkel nur mässig dick, Schienen nach der Spitze etwas verbreitert, mit seichter oder nur rorn angedeuteter Rinne, deren Aussenrand, besonders an den hinteren Beinen, in einen dreieckigen Zahn erhöht ist. Von den Tarsen ist Glied 1 länglich-, 2 kurz-dreieckig, letz- 
teres zugleich das schmalste, Glied :3 am Vorderrande leicht ausgeschnitten; das Tarsenglied lang, mit zwei cinfachen Klauen.

Das Männchen ist schlanker als das Weibehen und hat etwas breitere Tarsen. Den trächtigen Weibchen schwillt der Hinterleib so an, dass sie ihn nur mit Mühe nachschleppen, aber nicht mehr unter den Fld. bergen können. Die Larren unserer beiden Arten wurden von Letzner'), die der viridula noch einmal von Kawall²) ausführlich beschrieben. In Allgemeinen ähneln sie den Lina-Larven, sind gelblich weiss, lang grau behaart, Beine, Kopf und zwei Längslinien an den Seiten des Körpers dunkelbraun.

Die Gattung Gastroidea ist von der vorigen und Colaspidema durch den länglichen Körper, das an der Basis gerandete Halssch. und besonders durch den hautartigen Vorderrand des Kopfschildes, ron den beiden folgenden Gattungen durch die offenen Gelenkhöhlen der Vorderhüften verschieden.

Von den 14 beschriebenen Arten leben 3 in Europa, die übrigen in Asien und Nordamerika. Zweifelhaft erscheint nur die Zugehörigkeit von G. amphibia Motsch. (Schrenk Reis. II. 222), welche springen soll, weshalb Motschulsky in seiner flüchtigen Chrysomelen-Arbeit ${ }^{3}$ ) die ganze Gattung in eine völlig unnatürliche Verbindung mit Podagrica gebracht wissen wollte.

1. virialula: Supra viridi-aurea, subtus migro-coemelea, antennis longis nigro-aeneis, apice nigris, fronte evidenter canaliculata, scutello Iransierso, postice rotundato: capite et prothorace mims dense subtititer elytrisque crebre fortiterque punctatis. - Long. 4-6 $\mathrm{mm}$.

Mas: tarsis articulo primo dilatato.

Degeer Mém. Ins. V. 311. - Oliv. Ent. V. 575. t. 9. f. 133 (Chrysomela). - Thoms. Skand. Col. VIII. 269. - Seidl. Fann. balt. 486 (Gastrophysa).

Chrysomela raphani Herbst Füessl. Arch. V. 59. t. 23. f. 21. Fabr. Ent. Syst. I. 2. 19 (Galleruca); Syst. El. I. 400. - Gyllh. Ins. Suec. III. 472. - Duft. Faun. A. III. 208. - Suffr. Linn. ent. V. 239. - Küst. Käf. Eur. 7. 88. - Redtb. Faun. A. II. 481 (Gastrophysa).

Chrysom. polygoni var. b. Linn. Faun. Suec. 163.

Var. a. Supra coernlea, cupreo-virilis vel cupreo-brumea, subtus nigroaenea.

Var. b. pennina: Prothorace erebre sat fortiter punctato.

G. alpina Kiesw. Berl. Zeit. 1861. 392.

I) Arbeit. Schles. Ges. 1859 p. 48 und 1. c. 1855 p. 106.

2) Stett. Zeit. 1861 p. 123.

3) Schrenks Reis. im Amur-Lande II. 179. 
Oberseite goldig grün, Unterseite schwarzblau oder schwarzgrün wie die Fühler und Beine, oder letztere, besonders deren Schienen, hell metallgrün. Fühler verhältnissmässig lang und stark, Glied :" um die Hälfte länger als 2 oder 4, die sechs oberen Glieder schwarz. Stirn mit deutlicher und tiefer Mittelfurche, welche sich auf dem Scheitel zu einer glatten, erhabenen Längsleiste umbildet. Halssch. nach vorn stark verschmälert, an den Vorderecken zusammengedrückt, um die Hälfte breiter als lang; Schildchen quer, ziemlich halbkreisförmig. Hinterrand der Schienen in seiner ganzen Länge gerinnt. Die Punktirung ist im Allgemeinen auf Kopf und Halssch. fein und mässig dicht, auf den Fld. dicht und stark, mit Spuren einzelner Reihen; die Unterseite ist zerstreut punktirt.

Beim Männchen ist besonders das erste Tarsenglied erweitert und fast breiter als das dritte.

Bisweilen wird die Oberseite rein blau, oder grün- und kupferroth-schillernd, selbst matt kupferig-braun (Var. a.). Die Abänderung b. kommt hauptsächlich am Gr. St. Bernhard und Mte. Rosa (Macugnaga) vor und ist durch sehr dichte und ziemlich starke Punktirung des Halssch. ausgezeichnet. Kiesenwetter hielt sie für die echte G. alpina Gebl., die zwar täuschend ähnlicb, aber durch den grossen Zahn an der Spitze der Vorderschienen, der bei unserer Art nur angedeutet ist, sowie durch das scharf dreieckige, sehr spitze Schildchen sofort zu unterscheiden ist und bisher nur im AltaiGebirge und am Baikalsee gefunden wurde.

Auf Rumex-Arten, vorzüglich in der Nähe der Gebirgsbauden und Sennhütten gemein, in der Ebene selten.

2. Holygoni: Coerulea, nitida, antemis brevioribus nigris, basi. prothorace, ano pedibusque rufis, tarsis plus minusie infuscatis: fronte vix canaliculata, scutello subtriangulari, postice interdum rolundato. haud transverso. - Long. 4-5 mm.

Mas: tarsis modice dilatatis.

Linn. Syst. nat. ed. X. 370. - Oliv. Ent. V. 576. t. 3. f. 36. - Fabr. Ent. Syst. I. 322; Syst. El. I. 439. - Gyllh. Ins. Suec. III. 474. - Duftschm. Faun. A. III. 208 (Chrysomela).

- Küst. Käf. Eur. 7. 87. - Redtb. Faun. A. II. 481. Seidl. Faun. balt. 486 (Gastrophysa).

Var. a. Capite elytrisque viridi-coeruleis vel viridi-aureis.

Chrysom. ruficollis Fabr. Mant. I. 71. - Olir. 1. c. 577. t. 3. t. 35. Var. b. Antennis nigris.

Var. c. Prothorace medio infuscato.

Dunkelblau, unterseits schwarzblau; Fühler ziemlich kurz, schwarz, ihre ersten fünf Glieder, sowie das Halssch., die Beine und 
der After roth, Tarsen meist angedunkelt, selbst schwärzlich. Stirn mit undeutlicher Mittelrinne, die auf dem Scheitel in eine glatte Mittellinie übergeht. Halssch. reichlich doppelt so breit als lang, nach vorn wenig verschmälert, an den Vorderecken kaum zusammengedrückt; Schildchen wenigstens so lang als breit, meist länger, an den Seiten fast parallel, hinten in eine stumpf-dreieckige, selten verrundete Spitze ausgezogen. Hinterrand der Schienen leicht gewölbt, ohne Rinne. Die Punktirung ist auf dem Kopfe und Halssch. fein, stellenweise dicht, aber durch unregelmässige grössere glatte Zwischenräume unterbrochen, auf den Fld. dicht und ziemlich stark, mit Spuren einzelner Reihen.

Beim Männchen sind die Tarsen etwas breiter als beim Weibchen.

Von den unbedeutenden Abänderungen sind zu erwähnen: die Var. a. mit grünlich blauen oder rein grünen, verschieden stark goldglänzenden Fld., ferner Var. b. mit einfarbig schwarzen Fühlern und c. mit ein oder mehreren verwaschenen dunklen Flecken auf der Scheibe des Halssch. Die rothe Farbe des Afters erstreckt sich zuweilen auf das ganze letzte Segment, oder sie verschwindet bis auf einen unscheinbaren Saum am Hinterrande desselben.

Auf Polygonum aviculare L. und Rumex-Arten gemein; wie die rorige Species durch Sibirien bis Nordamerika (coeruleipennis Say) verbreitet.

\section{Entomoscelis.}

Chevrolat D Orbign. Dict. univ. Hist. nat. III. 656. - Redtb. Faun. A. ed. 1. 552 .

Acetabula antica occlusa.

Mentuin parvum.

Metasternum longum.

Femora postica marginem elytrorum vix superantia.

Prothorax basi utrinque leviter simuatus, immarginatus.

Körper geflügelt, länglich-eiförmig, mässig gewölbt, unten schwarz, oben roth, mit schwarzer Zeichnung. Kinn sehr schmal, Kopf etwas länger als breit, zwischen der Fühlerwurzel mit einer leicht gebogenen, vertieften Querlinie, welche das am Vorderrande hautartige Kopfschild deutlich von der Stirn trennt, ausserdem mit einem tiefen, schrägen Eindrucke jederseits am Innenrande der Augen. Diese sind länglich, nach unten merklich verschmälert, wenig gewölbt. Fühler etwa halb so lang als der Körper, ihre sechs letzten Glieder breiter als die vorhergehenden. Halsschild doppelt so breit als lang, gleichmässig leicht gewölbt, der Vorder- 
rand schwach gebogen, dicht und fein bewimpert. der Hinterrand jederseits fast unmerklich geschwunger. Schildchen eine halbe Ellipse. Flügeldecken oval, etwas lreiter als das Halsoch., linten allmählich verschmälert und gemeinschaftlich abgerundet oder in eine sethr kurze Spitze ausguzogen, mit,schmalen, kurz vor der Spitze undeutlichen Epipleuren. Kinn kurz, quer. Prostrroum schmal, fast fulu: behaart, Gelenkhöhlen der Vorderbrust hinten geschlosscn, Nesosternum vertieft, fast viereckig; Hinterbrust in der Mitte länger als das Prosternum, mit schmalen, liuten allmählich leicht verengten Scitenstücken. Beine zienulich kräftig, Schienen an der Spitze twas urweitert, mit einer beinahe bis zur Basis reichenden Rückenrinne, deren Aussenrand an der Spitze in einen stumpfen Zahn erlöht ist.

Beim Männchen, welches kleiner und schlanker als das Weibchen ist, sind die Tarsen leicht erweitert und das letzte Bauchsegment hat vor dem in der Mitte gerundet-vorgezogenen Hinterrande eine Längsvertiefung. - Der Penis ist eine einfarche, nach der Spitze hin abgeplattete Röhre.

Die Gattung wurde seither in die Nähe von Phytodecta gestellt. weil sie im Allgemeinen eine ähnliche Färbung l,esitzt, sie gehört aber nach dem übereinstimmenden Baue der Brust in die allernächste Terwandtschaft von Timarcha; von ibren neun Arten, die nicht leicht zu unterscheiden sind, ist die bekannteste ron den Rheingegenden durch Oesterreich, Ungarn, Russland und Sihirien bis Nordamerik: rerbreitet, eine ist auf Südspanien und das gegenüberliegende Nordatrika, zwei andere sind auf das südöstliche Europa beschränkt, dic übrigen kommen in Sibirien (zwei), Syrien (eine) und in Mittel- und Südafrika (zwei) vor.

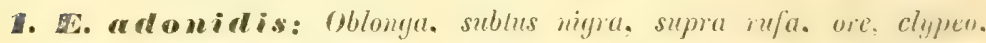
genis, antemis maculaque frontali nigris. prothorace disen subtilite unctato, vitta media lata postice dilatala punctoque nirinque nigris: scutello nigro: elytris sal fortiter crobreque punclutis, pamm nitiris. limbo sumali viltaque media utringue abbreciata migris. - Lons. : bis $10 \mathrm{~mm}$.

Pallas Reis. I. 2. 463. - Fabr. Spec. Ins. I. 117. - Suffr. Linn. ent. V. 207 (Chrysom.). - Redtb. Faun. A. II. 479. Seidl. F. balt. 485 .

Var. a. Vitta media elyirorum parva.

Die grösste Art der Gattung, lünglich, die Fld. des j fast gleichbreit, die des $q$ hinter der Mitte am breitesten, Unterseite, Beine und Fühler schwarz, Oberseite dunkel feuerroth, nach dem Tode gewöhnlich hell gelbroth oder gelbbraun, der ganze Mund, 
Kopfschild, Wangen, eine Scheitelmakel, eine breite, ganze Lüngsbinde über die Mitte des Halssch. und ein Punkt jederseits derselben, ein Nalıtsaum, sowie eine abgekürzte Längsbinde über die Scheibe jeder Fld. schwarz. Kopf wenig gewölbt, nur auf dem Kopfschilde deutlich punktirt, namentlich an dessen Vorderrande; die Scheitelmakel ziemlich gross und breit, viereckig oder dreieckig, im letzteren Falle rorn am breitesten. Fühler mässig schlank, Glied 2 bis 5 leicht zusammengedrückt, 3 doppelt so lang als 2, 1 und 2 bisweilen unten oder an der Spitze bräunlich. Halssch. etwá doppelt so breit als lang, mässig gewölbt, am Vorderrande wenig tief ausgeschnitten und jederseits leicht ausgebuchtet, an den Seiten ron den Hinterecken bis zur Mitte sehr wenig, vor derselben etwas mehr und leicht gerundet-verengt, die Scheibe bald fein, bald mässig stark punktirt, nach den Seiten und besonders nach der Basis hin etwas stärker. Die schwarze Mittelbinde nimmt am Vorderrande etwa ein Drittel der Breite ein, ist bis zur Mitte ziemlich gleich breit, hinter derselben allmählich gerundet-erweitert und bedeckt linten ungefähr zwei Drittel der Basis; jede Seite bildet einen flach-convexen Bogen, der sich um den dicht ror der Mitte und nahe dem Seitenrande des Halssch. stehenden schwarzen Punkt (den scheinbaren Mittelpunkt) herum krümmt. Schildchen schwarz. Fld. zwei ein halb mal so lang als breit, hinten allmählich in eine geneinschaftliche sehr stumpfe Spitze rerengt, aber der Nahtwinkel jeder einzelnen schwach abgerundet; auf dem Rücken weniger stark als an den Seiten gewölbt, die Naht ron der Mitte bis zur Spitze von einem hinten allmählich tieferen Nahtstreifen begleitet. Die Punktirung mässig dicht und stark, unregelmässig oder hie und da zu undeutlichen Doppelreihen geordnet, die Punkte der hinteren Hälfte oft durch feine Linien verbunden, der Glanz der Zwischenräume durch eine äusserst zarte, nur bei scharfer Vergrösserung sichtbare lederartige Runzelung abgeschwächt. Der schwarze Nahtsaum ist fast gleich breit, aussen scharf begrenzt, oder nach vorn merklich verbreitert und hier schlecht begrenzt, er reicht hinten genau bis zum Nahtstreif; vorn bleibt er vom Schildchen, mehr als die Länge desselben beträgt, entfernt. Die Längsbinde beginnt schmal auf der undeutlichen Schulterbeule, erweitert sich innen geradlinig schräg nach hinten ungefähr bis zu derselben Höhe, wo an der Naht der Saum beginnt, und setzt sich dann parallel der Naht und dem Seitenrande bis in die Mitte des hinteren Abfalles fort. Auf der wenig glänzenden, zerstreut und fein punktirten Cnterseite sind nur die Seiten des Halses und der Vorderbrust roth, Hüftand Kniegelenke bisweilen röthlich.

Das Männchen, dessen Merkmale schon bei der Besprechung der 
Gattung angegeben sind, hat einen langen und schmalen, gleich breiten, vor der Basis schwach gebogenen Penis, welcher vorn allmählich in eine stumpfe Spitze rerschmälert ist.

Die leichten Abänderungen in der Zeichnung erstrecken sich entweder auf die Längsbinde des Halssch., die zuweilen am Hinterrande jederseits etwas verengt ist, oder auf die Binde der Fld., welche erheblich verschmälert und verkürzt ist.

Auf Adonis-Arten im mittleren und südlichen Deutschland und in Oesterreich stellenweise häufig; nördlich bis Oberschlesien und Thüringen. Nach Redtenbacher soll die Larve in Ungarn den Raps (Brassica napus) verwüstet haben, und der Käfer wurde auf Cochlearia draba gefunden; Gerhardt beobachtete ihn Ende Mai an Blättern von Petasites officinalis, Sajo auch auf Disteln und Korn.

2. E. sacr $\left.\boldsymbol{a}^{\mathrm{I}}\right)$ : Oblongo-ovalis, subtus nigra, supra rufa, ore. clypeo, yenis, antennis (basi excepta) maculaque frontali nigris; prothorace disco subtilissime punctato, vitta media lata, postice dilatata, punctoque

1) Mit dieser Art sind nahe verwandt:

1. E. suturalis: Breviter-ovata (q) aut oblonginscula $(\hat{\odot})$, subtus nigra, supra rufa, capite parce clypeoque densius punctato, ore, antennis (basi interdum excepta) punctoque frontali nigris, prothorace disco subtilissime punctato, vitta media oblonga, antice abbreviata, ante basin utrinque sinuata, punctoque utrinque nigris; scutello nigro; elytris postice parum dilatatis, sat fortiter punctatis, minus nitidis, limbo suturali nigro. - Long. 6-7,5 mm. Graecia, Salonichi (Wehncke), Theodosia (Retowski).

Die kürzeste und breiteste Art, die Weibchen besonders breit; Fld. kaum doppelt so lang als breit, Nahtsaum derselben schmal, überall scharf begrenzt, nach vorn nicht verbreitert; Längsbinde des Halssch. oval, vorn in eine Spitze verschmälert, welche den Vorderrand nicht erreicht, mit concargerundeten Seiten, die vor dem Hinterrande leicht und schmal ausgebuchtet sind. Der Hals und der ganze Kopf, mit Ausnahme des Mundes und eines Scheitelpunktes roth oder rothgelb.

Diese Art ist von sacra, die folgende von kleinen adonidis ausser durch den helleren Kopf leicht durch die Form der schwarzen Binde des Halssch. zu unterscheiden, welche concave, dem Seitenpunkte zugebogene Seiten hat, die bei den verwandten Arten convex, dem Seitenpunlite abgebogen sind.

2. E. berytensis Reiche (Ann. Fr. 185\$. 36): Oblunga, subtus nigra, supre rufa, nitida, capite parce punctulato, ore, antennis punctoque frontali nigris; prothorace disco subtilissime punctato, vitta media antice sensim minus fortiter basi interdum abrupte angustata punctoque utrinque nigris; elytris limbo suturali vittaque media abbreviata nigris. - Long. 6-7,5 mm. Syria, Palästina.

Durch die kaum hervortretende Runzelung der Fld. glänzender, als die übrigen, Längsbinde des Halssch. schmal, mit leicht concaven Seiten, nach 
ulringue nigris: sculello nigro: elybis postice dilatatis, mims fontiter

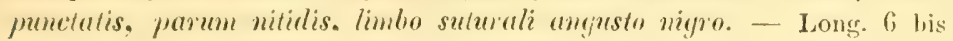
$9 \mathrm{~mm}$.

Linn. Syst. Nat. ed. X. 372. - Towns Travel. Hung. App. 460 (Chrysom.).

Chrysomela dorsulis Fabr. Gen. Ins. Mant. 220. - Suffr. Linn. ent. V. 208. - Redtb. Faun. A. II. 479 (Entom.).

Chrysom. adonidis var. Schrank Naturf. 24.66. - Fabr. Ent. Syst. I. 1. 312. - Duft. Faun. A. III. 199. - Redtb. I. c. ed I. 552. Var. a. Punctis 2 nigris prothoracis deficientibus.

Var. b. Elytris vitta media parva nigra.

Der vorigen sehr ähnlich, in der Form der Mittelbinde des Halssch. sogar mit ihr übereinstimmend, aber durchschnittlich kleiner, flacher, weniger parallel, in den Schultern schmaler, nach hinten merklicher verbreitert, lebhafter roth gefärbt, diese Farbe dauerhafter, verblichen dunkler gelbroth oder gelbbraun. Die Fühler sind kürzer und verhältnissmässig dicker, besonders bis zum fünften Gliede, die beiden Basalglieder gewöhnlich unterseits, oder an der Spitze, zuweilen ganz roth. Punktirung des Halssch. und der Fld. gewöhnlich feiner. Auf den Fld. fehlt die schwarze Längsbinde, der dunkle Nabtsaum ist hinten vom Nahtstreifen scharf begrenzt, vorn etwas rerbreitert, mit verwaschenen Rändern. Der Penis ist kürzer und breiter, stark gebogen, rorn schnell in eine abgerundete Spitze verschmälert.

Bei einigen Stücken fehlt der schwarze Seitenpunkt des Halssch., der bei normalen Stücken kleiner als bei adonidis ist, ganz (Var. a); selten zeigt sich auf der Scheibe jeder Fld. eine schmale schwarze Längsbinde (Var. b).

Wenn von $E$. adonidis ausnahmsweise Exemplare mit schmaler und kurzer (selbst fehlender?), von der vorliegenden solche mit schmaler Längsbinde der Fid. rorkommen, so ist dadurch die Zusammengehörigkeit beider Arten, die sich bei einiger Aufmerksamkeit mit blossem Auge sicher trennen lassen, nicht erwiesen.

Auf Adonis vernalis bei Wien. Häufiger in Ungarn (Sajo, Statist. Zool. 37) östlich bis Sarepta und Baku (Schneider).

vorn etwas verschmälert, kaum ein Viertel der Breite des Vorderrandes einnehmend, vor dem Schildchen nicht oder schnell und stark gerundet-verengt.

3. E. rumicis Fabr. (Mant. I. 70). Wie adonidis gefärbt, Kopf (nur Oberlippe, Maxillartaster und Scheitelpunkt schwarz), Fühlerwurzel und Beine mit Ausnahme der Tarsen roth. Halssch, ohne Mittelbinde, mit vier in einer Querreihe stehenden schwarzen Punkten. - Long. 5-S mn. Südspanien, Algier. 


\section{Timarcha.}

Latreille Cuv. Régn. anim. ed. 2. Y. 150.

Acelabula antica occlusa.

Mentum magnum emarginatum.

Mietasternum brevissimum.

Femora postica marginem elytrorum longe superantia.

Prothorax basi truncatus.

Tarsi articulo tertio angustissimo.

Körper hart, ungeflügelt, hoch gewölbt. Kopf etwas breiter als lang, Stirn ziemlich eben, mit zwei schiefen Eindrücken zwischen der Fühlerwurzel, welche sich zuweilen winkelig oder bngenförmig vereinigen und mit einer kurzen, punktförnigen, selten scharf ausgeprägten Mittelrinne verbinden, wodurch das Kopfschild mehr oder weniger deutlich von der Stirn getrennt wird. Oberlippe mässig gross, tief bogig ausgerandet. Mandibeln rerhältnissmässig klein, kurz und breit, nach der Spitze kaum verschmälert, diese selbst mit zwei bis drei sehr kurzen, breiten und stumpfen Zähnen. Endglied der Maxillartaster breit abgestutzt; Kinn gross, quer, vorn bogenförmig ausgerandet. Fühler stark, faden- oder fast perlschnurförmig. kürzer als die Hälfte des Körpers, Glied 1 verdickt, 2 kurz, 3 bisweilen das längste, die folgenden ziemlich gleichlang, oder die drei vorletzten merklich kürzer, Glied 7 stets grösser und etwas dicker als die beiden umgebenden. Augen schmal, wenig gewölbt. der Innenrand leicht gebogen. Halsschild quer, in der grössten Breite. die gewöhnlich vor der Mitte liegt, fast doppelt so breit als lang oder noch breiter, vorn ziemlich tief ausgeschnitten, hinten gerade algestutzt oder vor dem Schildchen in einem weiten, fast unmerklichen Bogen ausgerandet, an den Seiten dicht vor der Basis rerengt, ringsum oder theilweise, bisweilen nur am Grunde, gerandet. Schildchen klein, dreieckig, meist breiter als lang. Flügeldecken kugelig oder kugelig-eiförmig, breiter als das Halssch,, an der Naht verwachsen oder frei'), mit breiten, sehrohoch an den Seiten hinauf-

1) Fairmaire, Chapuis, Seidlitz etc. nennen überhaupt die Fld. verwachsen (soudées), ohne der vielen Arten mit freien Fld. zu gedenken. Bei diesen stösst der obere Nahtrand der einen Fld. nicht dicht an den der andern, sondern beide sind dadurch lose zusammenhängend, dass die ziemlich breiten unteren Nahtränder über einander greifen und dass sich die Spitze der rechten Fld. in eine kurze, meist gekrümmte linne der linken einlagert. Beim ungeschickten Aufspiessen werden die Fld. dieser Arten aus ihrer normalen Lage gebracht und klaffen. -- Die spitze eines feinen Messers in die Mitte der Nahtfuge gut aufgesteckter Stücke gesetzt, zeigt sofort, ob die Fld. verwachsen oder frei sind. 
geruckten, wenig nach unten umgebogenen Epipleuren, die erst dicht vor der Spitze durch einen leichten bogenfömigen Ausschnitt des Seitenrandes schnell verengt werden. Die Spitze sellost tritt jederseits als kleines, of sehr scharfes Zähnchen nach hinten vor und legt sich fest auf das nicht vollständig bedeckte Pygidium. Dieses besitzt, wie bei vielen ähnlich gebauten Gattungen, eine tiefe und breite Mittelrinne, damit es sich, durch die angedrückte Spitze der Fld. nicht gehindert, bewegen kann. Prosternum schmal, nur bej den Verwandten von T. metallica mässig breit, zwischen den Hüften etwas verengt, nach hinten mehr als nach vorn abfallend, in der Mitte der Länge nach vertieft, hinter den Hüften durch eine schmale Leiste mit den Seitenstücken der Vorderbrust verbunden, die vorderen Gelenklı̈hlen dadurch geschlossen. Mesosternum viereckig, quer oder länglich, nach hinten stark, oft bis zur Höhe der Mittelhüften ansteigend; es bildet $z$ wischen letzteren eine einfache gerade, oder in der Mitte verschieden tief ausgebuchtete Leiste, die bei mehreren andalusischen Arten durch einen Ausschnitt von den Hüften getrennt und in zwei aufstehende, nach aussen gekrümmte Zähnchen verwandelt ist. Hinterbrust kurz, über die Mitte kürzer als das Prosternum, die beiden hinteren Hüftenpaare daher einander mehr genähert, als bei den meisten Chrysomeliden, und wenig weiter von einander entfernt, als die Mittelhüften von den Vorderhüften. Abdomen mässig gewölbt. Beine kräftig, die beiden hinteren verlängert und mit den Schenkeln weit über den Rand der Fld. hinausragend, da sie wenig von den Seiten der Brust entfernt eingefügt siud. Schenkel leicht keulenförmig verdickt; Schienen fast cylindrisch oder schwach dreiseitig mit stumpfen Kanten, ohne Rinnen, aber mit einem kurzen Ausschnitte an der Spitze zum theilweisen Einlegen des ersten Tarsengliedes. Tarsen in beiden Geschlechtern sehr verschieden; im Allgemeinen breit mit dicker Filzsohle, das erste oder zweite Glied breiter als das dritte, das erste an den Hinterbeinen zugleich das längste, das Klauenglied kräftig, unterseits dicht behaart, mit zwei einfachen, leicht gekrümmten Klauen.

Beim Männchen sind die drei ersten Tarsenglieder, hauptsächlich an den vorderen Beinen, stark erweitert und zu einer eiförmigen oder breit elliptischen Scheibe dicht aneinander gefüt, die der $\mathrm{Pa}$ lette eines Malers ähnlich ist. Der Penis ist verhälnissmässig klein und bildet eine gleichmässig gebogene, stark zusammengedrückte Röhre, die oben eine sehr lange, von zwei neben einander liegenden nvalen Häutchen bedeckte Oeffrung hat und rorn zugespitzt oder abgestutzt ist.

Beim grösseren, oberseits weniger glänzenden Weibchen sind die 
Tarsen nicht nur bedeutend schmaler, sondern besitzen auch bei einer ganzen Reihe ron Arten eine glatte Mittellinie auf der Lnterseite, welche die Filzsohle halbirt.

Die Arten leben an der Erde im Grase und an niederen Pflanzen, besonders Galium-Arten, und halten sich bei Tage meist unter Moos und Steinen auf; ihre eigentliche Heimath ist die PyrenïenHalbinsel. Von den dicken, nach hinten verbreiterten Larven sind bisher nur wenige, und auch diese nur unvollkommen bekannt. Sie? besitzen eine ziemlich feste, pergamentartige, dunkel-metallisch gefärbte Oberseite, welche unbehaart, aber meist fein lederartig gerunzelt ist, und eine helle, weichere Unterseite. Der Rücken ist stark gewölbt, der Kopf und die letzten sehr kurzen und schmalen Hinterleibsringe sind in der Ruhe so nach unten umgeschlagen, dass der Mund und der After fast die Beine berühren. Der Kopf ist ziemlich gross, flach, die Stirn beiderseits schräg und tief eingedrückt. Fühler schlank, konisch, dreigliederig, Glied 2 das längste. Ceber den Fühlern liegen die vier grossen, im Rhombus stehenden Ocellen, während die zwei, bei den Verwandten vorhandenen seitlichen fehlen (metallica). Der Prothorax ist ziemlich gross, quer, und berührt mit den Vorderecken fast die Fühlerwurzel. Das letzte Segment ist einfach, nach $\mathrm{Cb}$ apuis jedoch (bei $T$. tenebricosa?, Genera X. 411) in ein gespaltenes, zur Fortbewegung dienendes Anhängsel ausgezogen.

Die Larve von tenebricosa ${ }^{1}$ ) ist metallisch blaugrün, von rugosula Rosh. ${ }^{2}$ ) auf Kopf und Halssch. dunkel metallgrün-schillernd, der übrige Körper broncefarben mit hellerer Unterseite und schwarzen Beinen; die von violaceonigra Deg. ${ }^{3}$ ) ist matt grünblau, metallisch glänzend, Unterseite und Beine fleischroth, die von metallica endlich schwarz, mit lebhaftem Bronceschimmer.

Da die Beschreibung Rosenhauer's von der letztgenannten Larve ${ }^{4}$ ) unrichtig ist, gebe ich hier kurz die Hauptkennzeichen nach Exemplaren an, die sich auf dem Glatzer Schneeberge unter Steinen fanden: Larve $6 \mathrm{~mm}$. lang, $3 \mathrm{~mm}$. breit, schwarz, etwas schwächer broncegelb schimmernd als das vollkommene Insekt, Kopf und Halsschild ausserdem noch bläulich angelaufen. Kopfschild und Mund nebst Tastern und Fühlern hell, gelblich; ein Ring am Grunde aller vier Maxillartasterglieder braun, das erste Fühlerglied schwarz.

1) Westwood Introd. 1839. I. 388. f. 48. - Chapuis Genera X. 411 .

2) Rosenhaner Stett. Zeit. 1882. 162; hier mit Unrecht als aprimrin Waltl, aufgeführt.

3) Rosh. 1. c. 163 .

4) 1. c. 163 . 
Stirn mit feiner Mittelrinne, die sich schwächer über die Thoraxringe fortsetzt. Prothorax gewölbt, sehr fein lederartig gerunzelt, jederseits mit einer weiten aber seichten Vertiefung, welche grol, und flach punktirt ist, die Vorderecken schräg abgestutzt. Die beiden folgenden Brustringe, sowie die Hinterleibsringe stärker gerunzelt, von letzteren nur die vier ersten oben sichtbar, die folgenden auf die Bauchseite umgeschlagen. Beine weisslich, Schiene und Fuss auf der Aussenseite, sowie die Stigmen schwarz.

Die beiden zuerst bekannten Arten wurden von Linné 1767 als Tenebrio laevigatus und rugosus in der ed. XII. der Systema Nat. beschrieben, die späteren Autoren stellten sie meist zu Chrysomela. Den Gattungsnamen Timarcha (Timorcha) erwähnt zuerst $1825 \mathrm{D}$ u ftschmid (Fauna Austr. III. 164), wo er zugleich die Unterschiede von seinen übrigen, unter Chrysomela aufgefübrten „Familien" austinandersetzt, allein erst Latreille wandte 1829 den Namen mit Bestimmtheit auf die heute darunter begriffenen Arten an. Dieselben sind im Ganzen so übereinstimmend gebaut, dass die Zerlegung in mehrere Gattungen, wie sie Motschulsky (Schrenk. Reis. Amur. II. 187) vorgenommen hat, unzulässig ist. Seine Gattung Metallotimarcha, auf metallica begründet und durch die metallische Farbe und ungerandete Halsschildseiten von den übrigen abweichend, würde einerseits nicht die schwarzen Arten chloropus, Gougeleti und trapezicollis umfassen, obwohl sie der Halsschildbildung nach hinein gehören müssten, andererseits durch asturiensis und chloropus, welche eine, vor den Hinterecken des Halssch. oft ziemlich deutliche Randlinie haben, ungezwungen mit der Gruppe der gerandeten Arten verbunden werden. Sie lässt sich daher nicht einmal als Untergattung halten, noch viel weniger Timarchostoma, die durch einige allgemeine, unzutreffende Angaben (Type: coriaria F abr.) unterschieden wird.

Die Arten sind zuerst ron Herrich-Schäffer, Synopsis, Fauna Ins. Germ. 156 (1838) zusammengestellt, später in eingehender Weise von Fairmaire in einer Rérision du genre Timarcha, Annales de France 1873 p. $143-202$ nebst Notes rectificatives et complémentaires 1. c. 525-528 beschrieben, aber in einzelnen Fällen wohl nicht so scharf von einander geschieden, wie es für diese schwierigste unserer Chrysomeliden-Gattungen, bei welcher die Punktirung, Form des Halssch. und des Mesosternum oft erheblich variurt, nöthig erscheint. Daher sind die Bestimmungen der mit parvicollis, tenebricosa und violaceonigra verwandten Species bisher nicht besser geworden. In der letzten Zeit beschrieb Dr. Kratz (Deutsch. Zeitsch. 1879 p. 380-384) noch vier und Fairmaire (Naturaliste 1880 p. 332) sechs neue spanische Arten. 
Ich wollte nicht unterlassen, äber die einzelnen Gruppen eine Ueborsicht zu geben, die zwar viele Irrthümer enthalten wird, da mein Material ungenügend ist, aber doch einge bisher übersehene sichers Unterschiede in der Zusammentügnng der Fld., der Hal-schildrandung und der Bildung des dritten Tarsengliedes beranzicht, welche sich vielleicht bei einer späteren, gründlichen Bearbeiturg verwenden lassen.

Die folgende Reihe vor Arten, hei denen die Mittelbrust in zwri anfstehende, divergirende Spitzen verlängert ist (die nur bei lugens Ros. und calceatr Perez (f) zuweilen undeutlich werden oder fehlen), ist bei uns nicht vertreten.

1. Seiten des Halssch. ungerandet: T. melitensis: Brevis, conrexu. nigro-subriolacea, opaca, capile, antemarum basi, scutello. pribusque violaceis, his nitidis, cajute sparsim pumelulato, mothorace transverso, dense subtilissime punchulato, alulaceo, laleribus rotundalis haud perspicue muryinatis, basi abrupte rectis, elytris globosis, tenuiler purum dense punctatis, interstitiis inaequaliter subconeris. - Long. $12 \mathrm{~mm}$. Malta (Koltze).

11. Seiten des Halssch. gerandet . . . . . . 2.

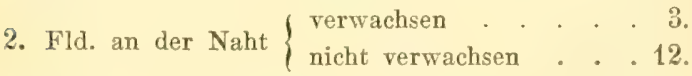

3. Halssch. vor den Hinterecken eingeschnürt, Randlinie daselbst erloschen. Oval, grün oder blau, selten schwarz, mit blauem, violettem oder bronzefarbenem Anfluge, matt seidenglänzend, ohne deutliche Punktirung. - L. 11-15 mm. Balearen. (Ic. règn. anim. 300).

balearica Gory.

31. Halssch. vor den Hinterecken nicht eingeschnürt, gradlinig oder leicht ausgebuchtet-verengt, Randlinie ganz.

4. Hinterecken des Halssch. stark nach unten gebogen. Grösse, Körperform u. Randlinie des Halssch. wie bei sericea; tief schwarz, leicht bläulich, matt. Kopf und Halssch. ziemlich stark, Fld. weitläufig fein punktirt. Jaen.

(Deutsch. Zeit. 1879. 382)

Kiesenvetteri Kratz

41. Hinterecken des Halssch. gerade oder unmerklich nach unten gebogen . . . . . . . כ.

5. Halsseh. $\left\{\begin{array}{l}\text { und Fld. weitläufig sehr fein punktirt } \\ \text { mässig oderstark, Fld. }\left\{\begin{array}{c}\text { starkpunktirt } \\ \text { grobrunzelig- } \\ \text { punktirt }\end{array} .\right.\end{array}\right.$ 5.

6. Abgesetzter Seitenrand des Halssch. breiter als bei den übrigen Arten, Randlinie breit und tief. Hinterecken stumpfwinkelig. Sehr plump, 
schwarz, mitmässigemFettglanze.-L.12-17mm.

Murcia. Cartagena. (Rév. 153) . . . sericea Fairm.

Var. Ehlersi. Halssch. ausser den feinen mit zerstrenten gröberen Punkten besetzt.

6!. Abgesetzter Seitenrand des Halsseh. schmal, Hinterecken rechtwinkelig. Schwarz, $\hat{\odot}$ klein, schlank, mässig glänzend, der insparsa Rosh. ähnlich; f gross, breit, die Fld. matt, mit zwei schwachen Längsrippen. - L. 10 bis 13 mm. Sierra Nevada. (Thier. Andalus. 317) lugens Rosh.

7. Breit-eiförmig glänzend schwarz, schwach bläulich, Halssch. einfach dicht und fein punktirt. L. 9-11 mm. Barcelona (Brulerii Fairm. Rév. 154; Ann. Fr. 1873. 525) . . . Piochardi Fairm.

i! Breit-eiförmig Unterseite und Beine schwarz oder schwarzblau, Oberseite messingfarbig. Halssch. doppelt punktirt. - L. 10-13 mm. Reynosa. Madrid. Alicante. (Ins. nuev. Esp. 1S65. 20) fallax Perez.

S. Ha]ssch, deutlich herzförmig, Körperform der insparsa ähnlich. Schwarzblau, Beine lebhaft roth, Knie, Spitze der Schienen und die Tarsen schwarz-blau. Kopf und Halssch. glänzend, stark punktirt (letzteres doppelt), Fld. matter, dicht und grob runzelig-punktirt. - L. 10-12 mm. Portugal (Hoffmannsegg). Reynosa. Madrid. Andalusien. (1. c. 18) . . . . . . calceata Perez ${ }^{1}$ ).

\$1. Halssch. quer-viereckig . . . . . . . 9.

9. Körper sehr breit, schwarz, Fühler und Beine

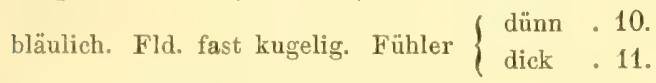

10. Halssch. an der Basis gradlinig verengt, stark gewölbt. - L. 10-14 mm. Mittel- und Südspanien. (Synops. 156. 22. b.) . . . . hispanica H. Schäff.

Hinter diese Art stellt Fairmaire (Naturaliste 1880. 332) noch T. vermiculata aus Portugal, laevisterna aus Cuenca und tenuicor. $n$ is von Valencia.

101. Halssch, an der Basis leicht, aber deutlich ausgebuchtet, schwach gewölbt. - L. 10-14 mm. Madrid. Aragonien. (1. c. 1866. 54) . . . . rugipennis Perez.

11. Glänzend, Halssch. kräftig punktirt. - L. $10 \mathrm{~mm}$. Portalegre. (Rév. 157) erosa $\mathrm{Fairm}$.

1) Zu dieser Art, bei der die Mittelbrust des $q$ oft nur tief ausgerandet ist, gehören blos die rothbeinigen Stücke; die schwarzbeinigen, die oft als culceate versandt werden, bilden eine nahe verwandte Art, deren Halssch. weniger herzförmig ist. 
11'. Ziemlich matt. Halssch. dicht und ziemlich fein punktirt. - L. $10 \mathrm{~mm}$. Tanger (1. c. 159) .tingitena Fairm.

12. Randlinie des ( ganz. . . . . . . 13.

Halsscb. vor den Hinterecken fehlend 14.

13. Zwischenräume der Punkte auf den Fld. eben. Schwarz, wenig glänzend, Fühlerwurzel, Beine, Kopf und oft das Halssch. violett. Letzteres dicht und ziemlich stark, meist doppelt punktirt. - L. $12-16 \mathrm{~mm}$. Andalusien. (Thier. And. 317)

13. Zwischenräume der Punkte auf den Fld. uneben. Schwarz, mässig glänzend, Beine meist bläulich. Halssch. wenig dicht und tief, doppelt punktirt. - L. 10-12 mm. Andalusien (1. c. 318)

marginicollis Rosh.

14. Halssch. matt (wie die Fld.), äusserst dicht und fein lederartig gerunzelt, dazwischen zerstreut sehr flach und deshalb nur bei starker Vergrösserung sichtbar punktirt . . . . 15.

14. Halssch. glänzend . . . . . . . 17.

15. Fld. fettig glänzend, mässig dicht, fein punktirt, die $\mathbf{Z}$ wischenräume eben. Schwarz, Fühlerwuxzel und Beine violett oder blau. Halssch. hinten stark eingeschnürt. - L. $9-13 \mathrm{~mm}$. Junquera? (Fairm.) Sierra Nevada (1. e. 320) parvicollis Rosh.

151. Fld. matt, wenig dicht, fein punktirt, die Zwischenräume uneben

16. Schwarz, Fühlerwurzel, Beine, Kopf und zuweilen das Halssch. violett; letzteres dicht vor den Hinterecken tief eingeschnürt. - L. 9-11 mm. Murcia. Andalusien. (Rév. 147) coarcticollis Fairm.

Dieser Artsehr ähnlich, grösser, tiefer schwarz, etwas glänzender ist $T$. apricaria Waltl. (Reis. Span. 1853. 83) aus Andalusien. (2 Typen auf dem berliner Museum.) - L. $15 \mathrm{~mm}$.

16. Schwarzblau. Halssch, viel weiter vor den Hinterecken eingeschnürt, als bei der vorigen, von der sie vielleicht nur eine Varietät ist. L. 10-12 mm. Portugal. (Deutsch. Zeit. 1879. 3S3)

Paulinoi Kraatz.

17. Halssch. fast glatt, oder sehr fein punktirt, dicht vor den Hinterecken stark eingeschnürt. Schwarz, Fühlerwurzel und Beine zuweilen bläulich, Fld. sehr fein und nicht dicht punktirt, glänzend.-L, 7,5-10 mm. Sierra Nevada(1.c.384) Seidlitzi Kraatz. 
171. Halssch. mässig stark, gleichmässig punktirt, oder mit zerstreuten starken Punkten zwischen der Punktirung

19. Grün oder purpurfarbig (unterseits schwächer). - L. 13-17 mm. St. Juan de Alcaras. Valencia. (Ann. Soc. Espan. I. 2. 121) . . . . . . splendida Perez ${ }^{1}$ )

1S 1. Schwarz, Unterseite und Beine zuweilen bläulich.

- L. 9-11 mm. Alpujarras . . . . . Heydeni $\left.{ }^{2}\right)$

† Seiten des Halsschildes gerandet.

3. Tenebricosa: Breviter ovata, nigra, subopaca, subtus violacea. capite sat fortiter jnmotalo, antennis crassis, moniliformibus, apricem rprsus haud dilatalis, articulis primis violaceis fortiter punctatis. arlimlo secundo subtransverso, prothorace minus convexo, brevi, subcordato, crebre subtititerque punctato, angulis posticis rectis, etytris mimus crebre et profunde sed paullo fortiter punclatis, interstitïs sparsim subtilissime punctatis, interdum tenuissime reticulatis, mesosterno angusto, elongato, triangulariter emarginato. - Long. 11-18 mm.

\section{Mas: tarsis articulis 3 primis valde dilatatis.}

Femina: tarsis articulo primo subtus linea media glabra.

Fabr. Syst. Ent. 94; Spec. Ins. I. 1. 116; Syst. El. I. 423. Rossi Faun. Etr. I. 74. - Panz. Faun. Germ. 44. 1. Schäffer Jcon. t. 126. f. 1 (Chrysomela). - H. Schäff. Synops. 156. 21. b. - Fairm. Révis. 169. - Redtb. Faun. A. II. 468 .

1) Wenn das Halssch. dieser mir unbekannten Art an den Seiten ganz gerandet ist, was aus der Beschrejbung nicht hervorgeht, so gehört sie in die Verwandtschaft der marginicollis.

") T. Heydeni: Ovata, convexa, nigra, subtis cum pedibus coerulescens, crupite plus minusve fortiter parum dense punctato, antennis sat validis, basi plerumque coeruleis aut violaceis, articulis 5 ultimis haud crassioribus, prothorace nitidulo lateribus fortiter (interdum fere angulatim) rotundato, linea marginali basi deficiente, disco minus convexo subtiliter punctato, punctis majoribus sparsim impresso; elytris subopacis, parce subtiliter punctatis; mesosterno porrecto, bifdo. Femina: tarsis articulis 3 primis subtus linea media glabra. - Long. 10-13 $\mathrm{mm}$.

In der Sierra Lanjaron der Alpujarras von H. v. Heyden gesammelt und als purvicollis versandt. Von letzterer Art ist sie durch das glänzende, an den Seiten stärker gerundete, oberseits verhältnissmässig kräftig punktirte Halssch., von der ähnlicheren insparsa Rosh. durch die vor den Hinterecken fehlende Seitenrandlinie nicht schwer zu unterscheiden. Bei zwei mir vorliegenden Exemplaren ist die Punktirung des Halssch. einfach, mässig dicht und stark.

VI. 2. 
Chrysomela laevigala Duft. Faun. A. III. 161. - Küst. Iït. Eur. 9. 91 (Tim.) - Redtb. 1. c. 463.

T. angusticollis Fairm. Révis. 170.

T. angulicollis Motsch. Bull. Mosc. 1849. III. 151.

T. subcyanea Motsch. 1. c. 152 .

T. iberica Motsch. 1. c. 152.

T. semipolita Chevr. Cat. Gren. 1S63. 120.

T. validicornis Fairm. Réris. 172.

? T. gravis Rosh. Thier. Andal. 316.

? T. Camoensi Fairm. Réris. 171.

? T. chalcosoma. Fairm. Gen. Col.Eur. IV. Cat. 261: Ann. Fr. 1873.525.

$\mathrm{Var}$ a. Corpore omnino nigro.

V ar. b. Nigro-violacea, -coerulea vel-viridis.

Var. c Nigro-violacea, cupreo-vel aurichalseo-micans.

Var. d. Angulis posticis prothoratis oblusiusculis.

Var. e. Angulis posticis prothoracis acutis.

Var. f. Mas: Elytris opacis.

Die grösste einheimische und vor allen Verwandten durch sehr dicke Fühler ausgezeichnete Art; breit eifönisg, oben schwarz, gewöhnlich mit blauem oder grünem Anfluge, ziemlich matt, seidenartig schimmernd, namentlich die Weibchen, unten blau oder violett, glänzend. Kopf ziemlich dicht und stark punktirt, besonders das Kopfschild, welches von der Stirn darch zwei kräftige Schrägeindrücke abgesetzt wird, die sich meist zu einer, bis auf den Scheitcl reichenden feinen Mittelrinne vereinigen. Fühler kurz, stark, die ersten sechs Glieder, oder noch die Basis des siebenten blau, glänzend, sparsam schwarz behaart und kräftig punktirt, die übrigen schwarz, matt, dicht behaart; Glied 1 breit-oval, die folgenden unter sich gleich dick, etwa halb so breit, als das erste, 2 fast breiter als lang, 3 oval, 4 bis 6 kugelig. Halssch. sehr flach gewölbt, doppelt so breit als lang, die grösste Breite etwas for der Mitte, ron hier beiderseits gleichmässig gerundet-verengt, doch so, dass der Bogen ein Stück vor dem Hinterrande sich gradlinig bis zu den Hinterecken fortsetzt. Dadurch erscheinen die Seiten bauchig-gerundet, hinten stark eingeschnürt, und das Halssch. ist leicht herzförmig, mit abgerundeten Vorder- und rechtwinkcligen Hinterecken, die dadurch noch spitzer erscheinen, dass der Hinterrand der Vorderbrust seitlich ron ihnen als kleine Ecke sichtbar wird. Die Oberfläche ist dicht mit feiner, tiefen, nach den Seiten hin stärkeren aber weitläufigeren Punkten besetzt, ringsum von einer tiefen Randlinie umzogen und oft mit einer glatten Mittellinie versehen. Fld. verwachsen, ziemlich weitläufig mit grösseren aber flacheren Punkten besetzt als das Halssch.; die Punkte, besonders beim $\hat{\jmath}$, oft durch 
feine Linien netzartig verbunden, ihre Zwischenräume wenig dicht und sehr fein punktirt. Prosternum zwischen den Hüften stark verengt, schmal, runzelig-punktirt, mit leichter Mittelrinne. Mesosternum schmal, länger als breit und nicht vicl breiter als das Prosternum, hinten tief dreieckig ausgerandet, so dass es in zwei stumpfe, kurze Spitzen endet, welche sich kaum über den Vorderrand des Metasternum erheben. Hinterleib in der Mitte fein, die Seiten und das ganze letzte Segment dichter und stärker punktirt.

Das Männchen ist etwas glänzender, stärker punktirt und besonders in den Fld. schmaler als das Weibchen, weshalb sein Halssch. verhältnissmässig breiter erscheint. Die Tarsen der Vorderbeine sind zu einer breiten Scheibe, die der Mittelbeine weniger, die der Hinterbeine am schwächsten erweitert. Der Penis ist stark gebogen, flach, die etwas verengte, breit abgerundete Spitze leicht nach hinten gebogen.

An den Tarsen der Weibchen wird die gelbe Filzsohle des ersten Gliedes, wenigstens in den vorderen zwei Dritteln, durch eine breite, glatte Mittellinie unterbrochen.

Die oben angegebene Färbung des Käfers ist die gewöhnlich vorkommende; nur selten ist der Körper ganz einfarbig tief schwarz, häufiger die Oberseite ziemlich lebhaft violett, blau oder grün gefärbt, wozu sich bei Stücken von Frankfurt a. M. noch ein Kupferoder Bronceschimmer gesellt.

Die Punktirung variirt wenig in der Anordnung, desto mehr in der Stärke. Es finden sich Individuen, die theils auf dem Halssch., theils auf den Fld. oder auf beiden zugleich entweder fast glatt oder weit stärker als die typische Form punktirt sind. Selten treten zwischen den dichten, feinen Punkten des Halssch. noch zerstreute grössere Punkte deutlich hervor.

Wichtige Veränderungen, dic viel zur Aufstellung schlechter Arten beitrugen, erleidet die Form des Halssch. Dasselbe verengt sich nach vorn und hinten oft nicht in einem regelmässigen Bogen, sondern fast gradlinig; dann sind die Seiten in der Mitte winkeligerweitert, wie bei der Herrich-Schäffer'schen Abbildung; es fehlt die deutliche Einschnürung ror dem Hinterrande und die Hinterecken werden stumpfwinkelig. Aelnliche Ecken entstehen auch, wenn die Verengung nur nach hinten gradlinig ist (Var. d.). Bei einem hierher gebörigen Stücke von Kreuznach (Strübing) ist das fast runzelig punktirte Halssch. in seiner grössten Breite, weit vor der Nitte, bedeutend breiter als die Fld. Stücke mit sehr starker Einschnürung ror den fast spitzwinkeligen Hinterecken bilden die Var. e; zu f endlich gehören die Männchen mit matten Fld. 
Das Mesosternum ist bisweilen grade aljgestutzt, kaum ausgerandet oder gefurcht.

Nur südlich der Donau und in einem schmalen Streifen am Rheine herab nördlich bis Coblenz, stellenweise nicht selten. Im Süden von Malaga bis Theodosia (Retowski) verbreitet.

$\mathrm{Zu}$ dieser Art ist ohne Zweifel $T$. validicornis $\mathbf{F}$ airm., wahrscheinlich auch gravis Rosh., Camoensi und chalcosroma Fairm. zu ziehen, da sie sich nur in unwesentlichen Punkten unterscheiden. $T$. intermedic H. Schäff. angeblich aus Spanien, stelle ich nach der Form der Fühler und des Halssch. zur folgenden.

2. T. mickeensis: Ovata, nigra, subnitida, sublus violacea. capite mimes fortiter punctato, antennis sat validis, apicem versus crassioribus, articulis primis violaceis sparsim subtiliter punctalis, artirulo secundo et tertio elongatis; prothorace transverso-quadrato, convero, sat crebre subtiliterque punctato, lateribus rotundatis, angulis anticis rolundalo-oblusiusculis, angulis posticis subobtusis, elytris minus crebre et profunde sed paullo fortiter punctatis, interstitiis sparsim subtiliter punctulatis, mesosterno subtransverso magis minusve emarginato. Long. 10-14 $\mathrm{mm}$.

Mas: tarsis articulis 3 primis valde clilatatis.

Femina: tarsis articulo primo subhus linea mediu glabra.

Villa Supplem. Col. Eur. Dupl. 49. - Fairm. Révis. 165.

T. italica H. Schäff. Synops. 156. 22. $\mathfrak{f}$.

? T. intermedia H. Schäff. 1. c. 21. c.

Var. a. Corpore omnino nigro.

V ar. b. Prothorace viridi-vel coeruleo-nigro.

Var. c. Supra violacea aut viridis, interdum cupreo-micans.

Den kleinen Stücken der rorigen sehr ähnlich, indessen durch folgende Punkte meist sicher zu unterscheiden: Körperbau im Allgemeinen mehr gleichbreit; Kopf feiner und weitläufiger punktirt mit schwächeren Eindrücken; Fübler merklich schlanker, ihre ersten Glieder feiner und sparsamer punktirt. Glied 2 ist etwas länger als breit, 3 doppelt so lang als breit, auch die folgenden sind länger und schlanker wie bei tenebricosa, so dass die fünf breiteren Endglieder sich deutlich von ihnen abheben. Halssch.kaum herzförmig, sondern quer-viereckig, mit gerundeten Seiten, die dicht vor den stumpfwinkeligen Hinterecken nur leicht, oft fast unmerklich ausgeschweift sind. Die Vorderecken sind spitzer, stumpfwinkelig; weniger verrundet; die Oberfläche ist namentlich über dem Seitenrande deutlich abwärts gewölbt, die schwächere Seitenrandlinie daher von oben schlechter sichtbar, als bei der rorigen. Halssch. 
und Fld. sind zwar sehr ähnlich, jedoch meist weitläufiger punktirt und ein wenig glänzender. Mesosternum bei der Mehrzahl der Stücke breiter, quer, und weniger tief ausgerandet.

Die Farbe ist veränderlich; a. Körper, einschliesslich der Fühler und Beine, einfarbig schwarz; b. Halsschild grün- oder blauschwarz; c. die ganze Oberseite dunkel violett oder grün, bisweilen mit Kupferschimmer.

Bei Areo (Reitter) und im Karst bei Triest (Schreiber) zahlreich; hauptsächlich aber im nördlichen Italien und von Nizza bis Toulon (Coquerel) verbreitet. Ein Stück mit der Bezeichnung Türkei (Abresch) in Reitter's, früher Haag's Sammlung.

Obgleich es zuweilen schwierig werden dürfte, kleine, in der Halsschildund Fühlerbildung ähnliche tenebricosı von der vorliegenden Art mit Sicherheit zu trennen, so kann ich mich vorläufig zu einer Zusammenziehung beider, die nur aus einem reichen italienischen Materiale ihre Begründung finden könnte, nicht entschliessen.

3. T. venosul( $\left.{ }^{1}\right)$ : Ovata, nigra, subnitida, antennis basi pedibusque violaceis, capite antice crebre rugoso-punctato, postice minus crebre fortiter punctato; antennis parum validis, prothorace modice convexo,

1) Mit dieser Art verwandt und in der breiten, schwach ausgerandeten oder abgestutzten Mittelbrust übereinstimmend sind: , nicht verwachsen, Filzsohle an den Tarsen

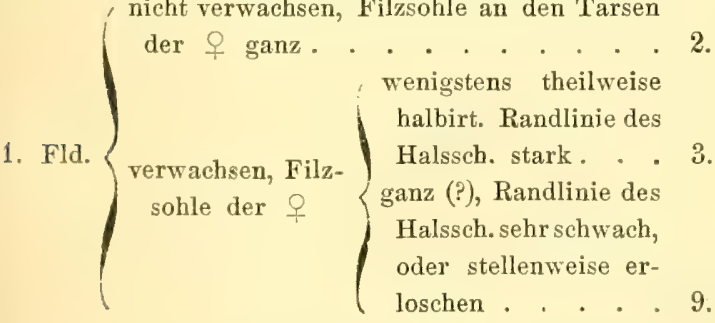

2. Matt, schwarz, Fühlerbasis und Vorderkörper leicht, Beine stark violett, oft mit grünlichen Schenkeln. Halssch. fein, dazwischen grob aber sehr seicht punktirt, Fld. weitläufig grob punktirt, mit breiten, wenig scharfen Runzeln. - L. 12 bis $15 \mathrm{~mm}$. Algier. Marocco (scabripennis F a irm. Gen. Col. Eur. 261. - Ent. V.91.507). . scabra O1.

21. Matt seidenschimmernd, tief schwarz, sehr fein punktirt. - L. $12-15 \mathrm{~mm}$. . . . . maroecana ${ }^{1}$ )

1) T. maroccana: Breviter-ovata, atro-sericea, antennis sat validis, capite subtilissime exidenter punctato, prothorace transverso, lateribus minus fortiter fere angulatim-rotundato, concexo, crebre subtilissimeque punctato, elytris liheris subglobosis, parce subliliter punctatis, mesosterno transverso, leviter emarginato. Mas: tarsis articulis 3 primis valde ditatatis. Long. 12-15 mm. Marocco. Casablanca (Reitter). 
lateribus ralde rolundatis ante basin vix simalis, angulis posticis ob. lusis, sal dense fortiter incequaliterque punclatn, parce punctis grossis. profundis impresso. saepissime plagis munerosis parzis subelevatis in-

3. Drittes Tarsenglied

$$
\left\{\begin{array}{l}
\text { in beiden Geschlechtern } \\
\text { kaum merklich ausge- } \\
\text { randet } . \\
\text { beim } \hat{f} \text { wenigstens an den } \\
\text { Hinterbeinen, beim }- \text { an } \\
\text { allen Beinen deutlich, } \\
\text { selbst sehr tief ausge- } \\
\text { randet . . . . }
\end{array}\right.
$$

4. Fühler, Schenkel und Schienen schlank. Schwarz, matt seidenglänzend, die $\hat{\sigma}$ zuweilen stark fettglänzend. Halssch. sehr dicht nnd fein doppelt punktirt, Fld. weitläufig fein punktirt, beim $\hat{e}$ eben, beim $f$ mit weiten und sehr flachen, undeutlichen Vertiefungen. Beine selten grünlich oder bläulich, häufiger (Var. amethystipes Chevr. Ann. Fr. 1873. 206) nebst Fühlern, Kopf und Halssch. lebhaft violett. - L. 13-17 mm. Sar dinien. Sicilien. (Synops. 156. 21. a.) - pimelioides H. Schäff.

Hierher gehören, nach dem einzigen männlichen Exemplare zu urtheilen, welches ich von jeder Art besitze, noch $T$. crassaticollis $\mathrm{E}$ a irm. Révis. 166 und Henoni F airm. 1. c. 167; vielleicht auch die mir unbekannte $T$. brachydera Fairm. 1. c. 165 ; alle drei aus dem östlichen Algier.

5. Drittes Tarsenglied des $\hat{\text { an den Hinterbeinen }}\left\{\begin{array}{c}\text { schmal, tief dreieckig } \\ \text { ausgerandet, die Zip- } \\ \text { fel schmal, spitz } \\ \text { ziemlich breit, wenig } \\ \text { tief dreieckig ausge- } \\ \text { randet. . . . . . }\end{array}\right.$

6. Filzsohle des $\hat{\odot}$ an den Hintertarsen ganz fehlend oder halbirt. Schwarz, mässig glänzend, Halssch. nicht dicht, fein, Fld. weitläufig, wenig stark punktirt. - L. 12-20 mm. Algier. (Syst. Nat. ed. XII. 678)

61. Filzsohlen des $\hat{\odot}$ ganz. Schwarz, wenig glänzend, Halssch. einfach, mässig dicht und fein, Fld. sehr grob grubig-punktirt und gerunzelt. Zuweilen (Var. rufipes) sind Schenkel und Schienen rothbraun. - L. $12-20 \mathrm{~mm}$. Südspanien ? Algier (1. c. 678) . . . . . . . rugosa L. 
structo; elytris sul remote fortius punctalis, mujs haud ( $)$ rel sul profundis vermiculatis, interstitiis paree punctulatis. Mesostemo transverso, leviter emarginato. - Long. 10-14 mm.

7. Halssch. $\left\{\begin{array}{l}\text { halb so breit als die kugeligen, fast } \\ \text { kreisrunden Fld. . . . . ventricos } a^{1} \text { ) } \\ \text { etwas schmaler als die breit-eiförmigen } \\ \text { Fld. . . . . . . . . S. }\end{array}\right.$

8. Schwarz, mässig glänzend, Fühler und ganze Unterseite blau oder violett. Halssch. sehr dicht und fein, Fld. weitläufig, etwas stärker punktirt, uneben, mit weiten, aber flachen Vertiefungen. Fühler und Beine stärker als bei der ähnlichen pimelioides. - L. 13-18 mm. Algier. (Wagn. Reis. III. 189. t. 8) . . . . . . . . . turbida Er.

Hierzu stellt Fairmaire seine Var. punctatella (Rév. 163), die etwas weniger gewölbt, auf den Fld. dichter punktirt und wenig uneben ist.

S?. Schwarz, meist erz- oder broncefarbig, unten violett, Halssch. dicht und fein doppelt punktirt, Fld. sehr grob darmartig gerunzelt, nur selten mit deutlichen Punkten. - L. 12-15 mm. In der Tarsenbildung des $\hat{\odot}$ und der Punktirung der Fld. von rugosa sicher verschieden (1. c.) - generosa Er.

9. Beine roth, Knie, Spitze der Schienen und die Tarsen schwarz (wie bei calceata). Kopf glatt oder, wie das Halssch. dicht und fein punktirt. Mittelbrust quer, abgestutat, nur bei insignis ausgerandet.

a. Oberseite $z$ wischen der Punktirung äusserst dicht und fein lederartig gerunzelt, matt-seidenglänzend, Fld. oval, wenig breiter als das Halssch. und weitläufig fein punktirt.

aa. Halssch. einfarbig schwarz wie der Körper, an den Seiten leicht gerundet. - L. 11 bis $13 \mathrm{~mm}$. Algier. (Expl. Alg. 532) . . punica Luc.

1) T. ventricosa: Subglobosa, nigra, interdum obscure aurichalcea, nitidula, pedibus plerumque viridi-vel tiolaceo-micans, capite sat crebre punctato, antennis parum validis, brevissimis, prothorace parto, lateribus modice rotundato, minus convexo, crebre subtilissimeque punciato, elytris globosis, fortius sat $(\hat{\odot})$ vel minus profunde $(\hat{f})$ punctatis, interstitiis conrexis $(\hat{\odot})$ vel subrugosis $(f)$, mesosterno transterso, subtruncato; $\mathrm{M}$ a s: tarsis anterioribus articulis 3 primis calde, posticis sat fortiter dilatatis. F em: tarsis articulo tertio profunde emarginato. - Long. 14-20 mm. Marocco: Casablancn (Qu edenfeld).

Das Halssch. ist vor der Mitte am breitesten, wach vorn schnell gerundet-, nach hinten allmählich gradlinig verengt, ohne die leichte Ausbuchtung der rugosa vor den Hinterecken, die Fld. sind kaum halb so stark wie bei rugosa punktirt, die Zwischenräume der Punkte beim $\hat{f}$ nur gewölbt, beim $ᄋ$ zu grossen, flachen Runzeln verbunden. 
Mas: tarsis anticis articulis \# primis ralde, posterioribus mimes fortiler rilatatis.

Fem: larsis articulis 3 primis subtus linea merlia lala glabra.

Var. a. Antennis pedibusque nigris.

In der Gestalt am meisten mit sardea übereinstimmend, jedoch viel matter, das auffälig sculptirte Halssch. breiter, nach hinten stärker verengt, die Fld. bauchiger und gerundeter. Schwarz, wenig glänzend, Beine und die ersten Fühlerglieder violett. Kopf mit den gewöhnlichen zwei Schrägeindrücken, welche das dicht runzelig punktirte Kopfschild von der Stirn mehr oder weniger deutlich trennen. Diese hat eine meist tiefe, schmale Mittelrinne und ist weitläufiger als der Vorderkopf, grob punktirt. Fühler des Männchens fast ron halber Körperlänge, wenig stark, ihre ersten Glieder kräftig punktirt, das zweite kurz, so lang als breit, das dritte doppelt so lang als breit, die fünf Endglieder wenig verdickt. Halssch. schwach herzförmig, dicht hinter der Mitte am breitesten, von hier nach rorn allmählich gerundet-, nach hinten schneller, fast gradlinig verengt, oft noch vor den Hinterecken unmerklich ausgebuchtet, die Hinterund Vorderecken stumpfwinkelig, letztere schwach abgerundet. Die Oberfläche nur mässig, aber bis an die feine, tiefe Randlinie gleichmässig gewölbt, ziemlich dicht, stark punktirt, mit zahlreichen, unregelmässig eingestreuten tiefen, grubenartigen Punkten; alle Zwischenräume merklich emporgehoben und hie und da zu unregelmässigen grösseren, glatten Flecken vereinigt, ron denen besonders

bb. Halsschildseiten stark, fast winkelig erweitert, roth. - L. $15 \mathrm{~mm}$. Constantine. (Ann. Fr. 1859. Bull. 190) . . . . . . . insignis Guer.

b. Kopf und Fld. glänzend, Halsschild matt, wenig quer, seitlich schwach gerundet; Fld. fast kugelig, weitläufig gross, tief punktirt, mit leicht gewölbten, zu unordentlichen Erhabenheiten verbundenen Zwischenräumen.

Körper schwarz, leicht grün schimmernd. L. 9-11 mm. Bona. (Rev. zool. 1840. 243) . endora Buquet.

c. Oberseite glänzend; schwarz, metallschimmernd.

Halssch. seitlich stark gerundet und gewölbt; Fld. fast kugelig, ziemlich stark punktirt, Punkte netzartig verbunden, ihre $Z$ wischenräume gewölbt.

- L. 11-13 mm. Atlas. (Rév. 191).. corallipes Fairm.

Von diesen 4 Arten kenne ich nur das + der punica, welches eine ganze Filzsohle hat, und es bleibt deshalb fraglich, ob die anderen Arten ähnlich gebildet sind. 
einer jederseits in der vorderen Hälfte an der Mittellinie gross und deutlich zu sein pflegt. Eine entfernt ähnliche Sculptur findet sich nur noch bei den am stärksten punktirten Stücken der parnassia. Fld. verwachsen, ziemlich kugelig, weitläufig grob punktirt; die Punkte stehen in kurzen feinen ( $(+)$ oder ziemlich tiefen $(\hat{j})$ Runzeln, ihre Zw ischenräume sind leicht gewölbt und sparsam, beim f kaum sichtbar, bein $\hat{j}$ f'ein punktirt. Mesosternum quer-viereckig, leicht ausgerandet.

An den Vorderbeinen sind die drei ersten Tarsenglieder des Männchens bedeutend, die der hinteren Beine schwächer erweitert; beim Weibchen besitzen sie insgesammt unten nur eine schmale, linientörmige Filzsohle beiderseits, die Mitte ist glatt.

Von Abänderungen sind mir nur einfarbig schwarze Stücke (Var. a.) bekannt. Zuweilen sind die Seiten des Halssch. nicht gerundet-, sondern fast winkelig erweitert, wie bei der Var. d. der tenebricosa.

In Krain ( $\mathrm{K}$ ah r) und bei Triest.

1. T. pretemsis "): Ovata, nigra, subnitida, antennis basi pedibusque violaceis, capite minus crebre punctato, clypeo apice laevi, anlennis parum validis, articulis ullimis crassioribus, prothorace comexiusculo, transverso-quadrato, lateribus rotundatis basi leviter simatis, angulis

1) In Grösse, Färbung und dem Körperbau ähnlich, aber weniger stark punktirt und gerunzelt, deshalb glänzender sind folgende, unter sich äusserst nahe verwandte Arten:

1. T. sardea Villa (Suppl. Col. Eur. 50). Tief schwarz, glänzend, Fühlerwurzel weniger lebhaft als die Beine grünlich, blau oder violett gefärbt; Halssch. nach vorn und hinten gleichmässig gerundet-verengt; FId. mässig dicht, ziemlich gross und tief punktirt, mit sparsam, kaum sichtbar punktulirten, beim $\&$ stärker als beim $\hat{\odot}$ runzelartig gewölbten $\mathrm{Z}$ wischenräumen. - L. 11-14 mm. Sardinien.

2. T. sicelidis Reiche (Ann. Fr. 1860. 736). Wie die vorige, aber die Punkte der Fld. durch feine Runzeln verbunden, ihre Zwischenräume kaum gewölbt. Sicilien.

3. sublaevis Fairm. (Kév. 174). Meist etwas kleiner als sardea und auf dem Halssch. gleichmässig, einfach punktirt. Punkte der Fld. kleiner, weniger tief. - L. $9-13 \mathrm{~mm}$. Corsica.

4. T. montana F airm. (l. c.). Soll von sardea durch den stärker punktirten Kopf, kürzere, an der Basis metallische Fühler, etwas breiteres, seitlich weniger gerundetes Halssch., mit einfacher, dichter und feiner Punktirung und die längeren, an den Seiten weniger gerundeten Fld, deren ziemlich grosse Punkte kaum durch Runzeln verbunden sind, verschieden sein. - L. 9 mm. Macedonien. 
posticis subrecits, sul rlense punclato, plerumgue junctis majoribus im. presso; elytris ruyosis, mejis arosse junclatis, inlerslitiis jumm convexis parce subtiliterque punctatis: mesostemo subquadralo ( . I aul elomgato ( $\hat{\odot})$, fere truncaio, sulcato. - Long. 10-13 mm.

Mas: tarsis articulis 3 primis valde dilatatis.

Fem: tarsis articulis 3 primis subtus linea media glabra.

Duftschm. Faun. Austr. III. 162 (Chrys.). - H. Schäff. Synops. 156. 22. d. - Fairm. Réris. 178. - Iiedtb. Faun. A. II. 468 .

Var. a. Capite prothoraceque violaceis.

Var. b. Elytris vix ruyosis.

Von der vorigen durch das kürzere, nach hinten weniger, nach vorn mehr rerengte Halssch. leicht, schwieriger zuweilen ron der folgenden zu unterscheiden, da die Ausbuchtung ror den Hinterecken des Halssch. bei vielen Männchen fast unmerklich, die Form des Mesosternum durchaus ähnlich wird. Hier bleibt die rein schwarze Färbung der Fld, bedeutendere Grösse und die durchgängig weitläufigere und stärkere Punktirung der vorliegenden allein zur Trennung übrig.

Eiförmig, Weibchen breit-eiförmig, schwarz, wenig glänzend (die $\hat{\jmath}$ oft stark), Beine und die ersten Fühlerglieder violett, bisweilen grün schimmernd. Kopf beim $\hat{o}$ fein, beim + stärker, wenig dicht punktirt, die Spitze des Kopfschildes, welche an der Vereinigung der beiden Schrägeindrücke liegt, meist glatt. Fühler wenig stark, ihre fünf Endglieder merklich verdickt und, mit Ausnahme des achten, einzeln länger als das dritte. Halssch. quer-viereckig, nach vorn etwas mehr als nach hinten verengt, beim $\hat{o}$, wie der Kopf, glänzend, mässig dicht punktirt, die Seiten wenig gerundet-erweitert, vor den Hinterecken sehr schwach ausgebuchtet, beim of matter, stärker und dichter punktirt, deutlicher ausgebuchtet, in beiden Geschlechtera von einer scharfen Randlinie umzogen und gewöhnlich mit verschieden zahlreichen, etwas grösseren Punkten besetzt. Fld. verwachsen, breit-eiförmig, mässig dicht, aber nicht tief gerunzelt (beim $\hat{\jmath}$ kräftiger), in den Runzeln mit starken, grossen Punkten; ihre Zwischenräume wenig gewölbt, zerstreut und fein punktirt. Mesosternum des $q$ ziemlich viereckig, des $\hat{j}$ schmaler, länglich; abgestutzt mit mehr oder weniger ausgeprägter Mittelrinne.

Das mehr gleichbreite, glänzendere Männchen hat stark erweiterte Tarsen, das Weibchen auf der Unterseite derselben eine glatte Mittellinie.

Selten sind Kopf und Halssch. deutlich violett (Var. a); zuweileu verschwinden die Runzeln der Fld. fast ganz, wenn die Zwischenräume der groben Punkte eben werden (Var, b). 
In südlichen Tirol, Krain, Görz und Istrien lsäufig. Auch im nördlichen Italien, Kroatien (Reitter) und Dalmatien.

5. T. violaceomigra'): Ovala, nigra, leviter violaceo-, coevuleomul rividi-micans, subopaca, antemis basi pedibusque interdum enpreis; capile punctato, antemis mims validis, articulis ultimis crassionibus,

1) Verwandt sind:

1. Seiten des Halssch, stark gerundet, vor der Basis tief eingeschnürt, wie bei coarcticollis. Schwarz, Beine blänlich, Kopf und Halssch. ziemlich stark punktirt, letzteres mit eingemengten groben Punkten; Fld. stark punktirt, Punkte netzartig verbunden, Zwischenräume sparsam fein punktirt. - L. S-12 nm. Pyrenäen. (Ann. Fr. 1861. 594) . strangulata Fairm.

2. Seiten des Halssch. hinten in einem langen und leichten Bogen ausgerandet, vorn schnell gerundetrerengt, die grösste Breite etwas vor der Mitte.

* Mittelbrust mässig breit, fast immer ausgerandet.

a) Schwarz, Beine einfarbig schwarz, blau oder violett, Kopf und das breite, an den Seiten etwas winkelige Halssch. dicht und kräftig-, Fld. etwas stärker, dicht punktirt (oft runzelig, besonders beim 우), die Zwischenräume mit mässig feinen, tiefen Punkten. An der nicht besonders starken, aber dichten und tiefen Punktirung leicht zu erkennen. - L. 8-10 mm. Oestliche Pyrenäen: Le Vernet. (Ann. Fr. 1861. 595) . . . sinuatocollis Fairm.

b) Schwarz, Mitte der Schenkel lebhaft roth bis dunkel rothbraun; Kopf und das schmale Halssch. (dasselbe ist nicht, wie Fairmaire beschreibt, "plus de deux fois et demie aussi large que long", sondern kaum doppelt so breit als lang), kräftig punktirt, letzteres etwas unregelmässig; Fld. ähnlich der pratensis, nur etwas schwächer punktirt-gerunzelt. - L. 7-12 mm. Asturien (Getschmann) Galicien (Ins. spec. nov. 582) . geniculata Germ.

** Mittelbrust sehr breit, abgestutzt. Schwarz, Fühlerwurzel und Beine schwarz, grün, blan oder violett; Kopf und das breite Halssch. dicht und kräftig punktirt, Fld. darmartig-gerunzelt, in den Runzeln ohne deutliche Punktirung, die Zwischenräume gestrichclt oder einzeln punktirt. - L. 6-11 mm. Südfrankreich (Ann. Fr. 1855. 79) 
prothorace transverso-quadrato, convexiusculo, lateribus leniler rotun. datis. basi hand sinuatis. confertim punctato; elytris sal dense fortiterque punctatis. intersleties parce punctulatis, mesosterno andpesto. profunde emarginato. - Long. 8-13 $\mathrm{mm}$.

3. Halssch. nach vorn und hinten ziemlich gleichmässig gerundet-verengt, wie bei violaceonigra.

a) Oberseite sehwarz, selten Kopf und Halssch. blau oder violett, letzteres etwas stärker als bei violaceonigra, doppelt punktirt. - L. 10 bis $12 \mathrm{~mm}$. Griechenland: Helikon, Parnass (Gen. Col. Eur. IV. Cat. 261) . . parnassia Fairm.

T. parnassia Ramb. (Dej. Cat. ed. 3. 423) ist eine Art mit zweizinkigem Mesosternum. Im berliner Museum stecken unter dieser Bezeichnung zwei unausgefärbte Stücke, mit braunen Fld, von denen das kleinere wohl zu Seidlitzi Kr. gehört.

b) Schwarz, mit Ausnahme der bläulichen Fühlerwnrzel und Beine, bedeutend glänzender und durchweg feiner punktirt als violaceonigra. L. 9-13 mm. Pyrenäen, Sevennen. (Ann. Fr. 1861. 594). . . . . . . interstitialis Fairm.

4. Halssch. nach vorn mehr als nach hinten verschmälert, oder ron der Basis bis zur Mitte gleichbreit, davor leicht gerundet-verengt. Schwarze glänzende Arten (Gougeleti sehr ähnlich), bei denen wenigstens Fühlerwurzel und Beine, oder die ganze Unterseite blau, grünlich oder violett ist. Sie sind $9-12 \mathrm{~mm}$. lang.

a) Körper fast elliptisch; Seitenrandlinie des Halssch. kräftig. Nach einem $q$ von den Balearen beschrieben. (Rév, 180) . . elliptica Fairm.

b) Seitenrandlinie des Halssch. schwach, oft undeutlich oder von der Mitte nach vorn fehlend.

aa) Kopf und Halssch. mässig dicht und stark, etwas ungleich punktirt, Fld. an der Basis breiter als das Halssch., mit vorstehenden Schulterecken, stark punktirt, mit einzeln fein punktirten $\mathrm{Z}$ wischenräumen. Von interstitialis schwer zu trennen. Pyrenäen. (Act. Soc. Linn. Bordeaux 1851. 53) . . . . monticola Duf.

Als Var. gehören hierher: cyanescens Fairm. (Ann. Fr. 1861. 593) dunkelblau, Halssch. dicht punktirt, Fld. zu- 
Mas: tarsis articulis is primis valde dilatatis.

Fem: larsis articulis :3 mimis sublus linea media glabra.

De Geer Mém. Ins. V. 298 (Chrysom.).

Chrysomela coriaria Laich. Verz. Tyrol. Ins. I. 143. - Fabr. Ent. Syst. I. 1. 309; Syst. EI. I. 424. - Panz. Ent. Germ. 1. 2. 156; Faun. Germ. 44. 2. - Duftschm. Faun. Austr. III. 163. - Gyllh. Ins. Snec. III. 451. - H. Schäff. Synops. 156. 22. a (Tim.) - Küst. Käf. Eur. 9. 92. - Thoms. Skand. Col. VIII. 243. - Fairm. Réris. 1S4. - Seidl. F. balt. 481. - Redtb. F. Austr. II. 468.

Chrysom. angusticollis Duftseh. 1. c. 163.

Chrysom. crassipes Grimm. Steierm. Col. 47.

Chrysom. goetlingensis Fabr. Mant. I. 67. - Payk. Faun. Suec. II. 51.

Var. a. Capite mothoraceque saturale violaceis aut viridi-coeruleis.

Var. b. Elytris salurate violaccis, cocruleis nel viridibus, interdum cuprenaut aurichalceo-micans.

T. coriaria var. aerea Fairm. Révis. 185.

Var. c. Elytris intricato-rugosis.

Chrysom. rugosa Duft. 1. c. 162.

Die am weitesten nach Norden, bis Schweden und Livland hinaufsteigende, in Deutschland häufigste Art, welche an dem fast gleichmässig dicht und tief punktirten viereckigen Halssch. und ihrer Färbung leicht $\mathrm{zu}$ erkennen ist.

Eiförmig, schwarz, oben stets mit violettem, blauem oder grünem Anfluge, fast matt, unten lebhaft violett oder grün, glänzend, namentlich die Beine. Kopf verschieden stark, mässig dicht punktirt, selten fast glatt. Fühler nicht besonders stark, beim $\hat{\jmath}$ etwas, beim $q$ viel kürzer als der halbe Körper, ihre fünf matten Endglieder merklich verdickt. Halssch. quer-viereckig, etwas gewölbt, doppelt so breit

weilen äusserst dicht, gleichmässig stark punktirt; und recticollis Fairm. (1. c. 592) Halssch. fast gleichbreit, Seiten fast gerade, Fld. an der Basis nicht breiter als das Halsseh.

bb) Fld. kugelig, an der Basis, besonders beim $\hat{\odot}$, mit vollständig verrundeten

Schulterecken. Madrid. (Rév. 186) . globipennis Fairm.

Hierher scheint nach der Diagnose, in welcher der Thorax ,tenue marginatus, postice parum angustior" genannt wird, auch T. rugonula Rosh. (Thier. Andal. 321) von Malaga zu gehören.

T. gallica Fairm. (Rév. 182) = laevigata H. Schäff. ist mir unbekannt. Alle meine südfranzösischen Exemplare sind schwarze viulaceonigra, mit matten, meist feiner als bei deutschen stücken punktirten Fld. 
als lang, oder breiter, nach vorn wenig mehr als nach hiuten schwach verengt, mit sanft gerunleten Seiten, die vor den stumpliwinkeligen Hinterecken kaum ausgebuchtet sind. Die ()berfäche ist dicht und tief punktirt, in Allgemeinen längs der Mitte ünd aller Ränder am dichtesten und feinsten, ein Eindruck jederseits zwischen Mittellinie und Seitemrand, der fast allen Timarchen eigen ist, gewöhnlich deut. lich, die Randlinie überall scharf. Fld. verwachsen, etwas weitläufiger aber stärker als das Ialssch. punktirt, mit ebenen, einzeln und fein punktirten Zwischenräumen. Mesosternum wenig breiter als das Prosternum, meist tief ausgerandet und in zwei stumpfen Spitzen über den Vorderrand des Metasternum emporstehend; selten flach, abgestutzt.

Das kleinere, kräftiger punktirte Männchen hat sehr stark crweiterte Tarsen; die Filzsohle der letzteren ist bei den Weibchen durch eine breite, glatte Mittellinie getheilt.

Die Art variirt bedeutend in Form und Farbe. Zur Veränderung der ersten trägt besonders die Gestalt des Halssch. bei, welches bald so breit als die Fld, bald beträchtlich schmaler ist und verschieden stark gerundete Seiten hat. Die Extreme beider Formen hielt D uft schmid für Arten und beschrieb sie als coriaria und angusticollis.

Auffällige Farbenabänderungen entstehen: a) wenn die Fld. schwärzlich, Kopf und Halssch. dagegen gesättigt violett oder blaugrün sind; oder b) wenn wenigstens die Fld., oft die ganze Oberseite oder der Körper, lebhaft violett, blau oder grün, zuweilen kupferig- oder metallgelb schimmernd werden. Auf ähnliche Stücke bezieht Fairmaire die T. aerea H. Schäff, die nach der Abbildung auf keinen Fall hierher, sondern in die nächste Verwandtschaft der $T$. laevigata L. gestellt werden muss, wenn nicht, was kaum anzunehmen, das Schäffer'sche Exemplar aus dem Vorderleibe einer sericea und dem Hinterleibe der dalmatinischen corinthia zusammengeklebt war.

Duftschmidt's rugosa lisst sich ungezwungen auf die Var. c. anwenden, bei der die Fld. dicht und tief darmartig gerunzelt sind, die Runzeln dichter, schärfer begrenzt als bei pratensis, ihre Zwischenräume sparsam, ziemlich stark punktirt.

Nicht selten. Fehlt in der norddeutschen Tiefebene und in Schlesien (nur bei Karlsbrunn und Ustron, Letzner) fast ganz.

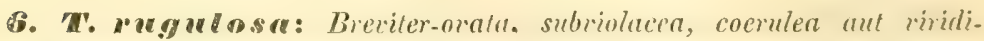
coemlea, nilida; capite subtiliter punclato, antemis parum validis. ariiculis ultimis crassionibus; prothorace transierso-quadruto. sai comero, lateribus rolundatis busi loniler simalis. linea marginali ante angulis 
poslicis rectis inlerrupla, disco lenuiter punclalo punelis grossis impresso: elylris minus dense fortiler punctatis, lalera versus ylus minusve ruyulosis. interstiiis lacrissimis aut sparsim punctulatis. Mesosterno laevi transzerso, plerumque truncalo. - Long. $S-13 \mathrm{~mm}$.

Mas: tarsis articulis 3 primis dilatatis, articulo tertio lato.

Femina: tarsis articulo primo sublus linea media brevi glabra.

Herr. Schäff. Synops. 156. 22. c. - Fairm. Révis. 1S9; 1. c. $52 \%$.

Var. a. Prolhorace basi subito coarctato.

T. Lomricli Millex Verh. zool. bot. Ver. Wien 1567.503 et 551 .

T. ylobata Fairm. Révis. (1873) 177.

Var. b. Prothorace subtitissime vix inaequaliter punctato.

Breiter, in den Fld. bedeuterd gerundeter als die vorige, lebbafter gefärbt und glänzender, durch die doppelte Punktirung des Halssch, breite Mittelbrust, rollständige Filzsoblen an den Tarsen der Weibchen etc. leicht zu erkennen. Breit-eiförmig, hochgewölbt, dunkel violett, blau oder blaugrün, zuweilen mit Metallschinmer, glänzend, das Halssch. oft spiegelnd. Kopf zerstreut fein punktirt, glänzend, die gewöhnlichen Eindrücke meist weit und flach. Fühler nicht besonders stark, auch die letzten dickeren Glieder matt dunkelblau; Glied 1 kurz, kugelig, 2 so lang als breit, 3 gestreckt, fast länger als 1 und nebst dem elften Gliede das längste. Halssch. ziemlich gewölbt, quer-viereckig, mit gerundeten Seiten, die vor den beinahe rechtwinkeligen Hinterecken sanft ausgebuchtet sind. In dieser Ausbuchtung exlischt die Randlinie. Die Oberfläche ist mässig dicht, fein punktirt, mit zahlreichen grossen und tiefen Punkten bestreut. Fld. rerwachsen, mehr oder weniger kugelig, ziemlich weitläufig grob, nach den Seiten hin etwas dichter punktirt, die Zwischenräume leicht gewölbt, über dem Seitenrande und der Spitze zu kurzen, erhabenen Runzeln vereint, glatt oder sparsam punktirt. Mittelbrust breit, glatt, meist eben und hinten gerade abgestutzt, seltener längsrertieft und hinten schwach ausgebuchtet. Die drei ersten Tarsenglieder sind beim Männchen weniger stark erweitert, als bei den vorigen Arten, das dritte Glied ist fast so breit als das zweite, namentlich an den hinteren Beinen. Die Filzsohle des Weibchens wird nur in der vorderen Hälfte des ersten Gliedes durch eine schmale glatte Mittellinie unterbrochen.

Ton dieser Art lassen sich die zuerst ron Miller als Lomnichi beschriebenen galizischen Stücke, obwohl sie durch das ror den Hinterecken plötzlich stark eingeschnürte Halssch. sehr auffallen, specifisch nicht trennen, weil $Z$ wischenstufen existiren; aber sie rerdienen gewiss ihren eigenen Namen. B $i$ ihnen wird zuweilen 
die Punktirung des Halssch. äusserst fein, mit kaum angedeuteter grösseren Punkten (Var. b).

In Mähren (Plason, Fleischer) bisher nur die Var. a.; Galizien (Miller), Siebenbürgen, Banat (Nerkl), Czernetz (Schmidt), die Var, a. vorherrschend.

Es ist njeht zu billigen, dass Fairmaire die $T$. Lomnichi Nill. einfach als Synonym zu rugulosa zieht (Ann. Fr. 1873, 527). ohne zu erwähnen, dass seine globata mit der Miller'schen Form identisch, also erst recht einzuziehen ist.

Hieran schliesst sich die nur in einem Stücke bekannte $T$. Olicieri Fairm. (Rér. 177) aus Konstantinopel; oben schwarz, glänzend, Unterseite, Beine und Fühler etwas violett; Halssch, wie bei strangulata gebildet und punktirt, Fld, mit einer der rugosa ähnlichen Skulptur. - L. $13 \mathrm{~mm}$. Ausserdem noch T. oblongula Fairm. (Naturaliste 1880. 334) aus Spanien.

\section{†t Seiten des Halssch. ungerandet. ${ }^{1}$ )}

E. T. metallicat Breviter ovata, fusco-aurichalcea, witida, antemnis pedibusque fuscis aut piceis, capite punctato, antemis mims validlis,

1) Diese Gruppe lässt sich so übersehen:

1. Mittelbrust breit, abgestutzt. Tarsen des of nit ganzer Filzsohle . . 1'. Mittelbrust mässig breit, ausgerandet. Filzsohle des $\Varangle$ unterbrochen $j$.

2. Halssch. von der Basis nach vorn stark, fast gradlinig verengt

globosa H. Schäff.

$2^{1}$. Halssch. nach rorn wenig mehr als nach hinten verengt, die Seiten gerundet oder fast parallel . . . . . . . . . . . . . 3.

3. Taster schwarz, Beine und Fühler violett, Endglieder der letzteren schwarz, matt, gelblich behaart. Messingfarbig, Halssch. ziemlich dicht und stark doppelt punktirt, fast runzelig, Fld. grob punktirt, Punkte zuweilen durch Runzeln verbunden. - L. 10-13 mm. Dalmatien. (Rév. 197) . . . . . . . . . corinthia Fairm.

31. Taster, Fühler und Beine mehr oder weniger rothbraun . . . . . 4.

4. Halssch. klein . . . . . . . metallica Laich.

4 ${ }^{1}$ Halssch. gross, weitläufig oder dicht, ziemlich stark doppelt punktirt. Braun, violett oder grünlich, mit Kupferschimmer. Fld. punktirt (oder mässig dicht gerunzelt $=$ armeniaca Fald.). - L. S- 13 mm. Kraukasus. (Nouv. Mém. Mosc. V. 381. t. 12. f. 7.) . . . Hummeli Fald.

5. Halssch. fast gradlinig ron der Basis nach vorn verengt. Länglich-oral, dunkel messingfarbig, $\hat{\odot}$ ziemlich, $q$ wenig glänzend, Lnterseite, Fühler und Beine violett oder grünlich, Halssch. fein und dicht, Fld. wenigg stärker, dicht, doppelt punktirt, beim f noch gerunzelt. Endglieder der Fühler schwarz, schwarz behaart. - L. 9-12 mm. Portugal. (Ins. spec. nov. 5S3) scortea Germ. 
articulis $\tilde{5}$ ultimis testaceo-pilosis parum crassioribus; prothorace trunsverso-quadrato, sat convevo, parnm dense pumctato, interdum pmetis majoribus impresso, lateribus subparallelis postice lenissime simuatis, prope angulos amticos rotunduto-angustatis; elytris liberis, parum dense punchatis, interstitis laevissimis aut parce punclatis. Prosterno sat lato, mesosterno transverso, truncato. - Long. 5-10 mm.

Mas: tarsis articulis 3 primis modice dilatalis.

L a ichart. Verz. Tyrol. Ins. 144. - Fabr. Ent. Syst. I. 1. 311. - Herbst Arch. IV. 55. t. 23. f. 14. - Panz. Faun. Germ. 44. 4. - Duftschm. Faun. Austr. III. 164 (Chrysom.). H. Schäff. Synops. 156. 23. b. - Fairm. Révis. 198. Redtb. Faun. A. II. 468 .

Var. a. Prothorace minus transverso.

$\mathrm{V}$ ar. b. Laete picea, leviter violaceo-micans.

Var. e. Elytris fusco aut piceo-aeneis.

Var. d. Elytris alutaceis, subopacis, tenuiter reticulatis.

Breit-eiförmig, braun, mit starkem Messingglanze, Taster, Fühler und Beine rothbraun bis pechschwarz. Kopf mässig gross, zerstreut verschieden stark punktirt, die beiden Schrägeindrücke meist kurz und seicht. Fühler wenig stark, die fünf letzten Glieder gewöhnlich heller als die übrigen, und nicht schwarz behaart, wie bei den vorigen Arten, sondern gelbbraun. Halssch. quer-viereekig, reichlich doppelt so breit als lang, mässig gewölbt, die Seiten nur selten ganz parallel,

Die mir unbekannte T. trapezicollis Fairm. (Rév. 196) aus Portugal ist hiervon vielleicht nur eine schwarze Varietät.

$5{ }^{1}$. Halssch. beiderseits leicht gerundet verengt . . . . . . . 6 .

6. Fld. kugelig. Schwarz, wenig glänzend, Fühler und Beine violett. Halssch. mässig stark, sehr dicht runzelig punktirt. Fld. stark gerunzelt und punktirt. - L. $11 \mathrm{~mm}$. Spanien. (ex Fairm. Rév. 192) sphaeroptera Fairm.

$6{ }^{1}$. Fld. eiförmig . . . . . . . . . . . . . . . 7.

7. Halssch. und Fld. stark gewölbt. Schwarz, glänzend, Fühler und Beine violett oder grünlich, Mitte der Schenkel roth. - L. 9-13 mm. Bilbao, Asturien, Galizien. (geniculata H. Schäff. Synops. 156. 24. b. - Ann. Fr. 1859. Bull. 216) . . . . . . . Gougeleti Fairm.

7?. Halssch. und Fld. flach gewölbt . . . . . . . . . . . 8.

S. Beine violett oder grünlich, einfarbig. - L. 9-11 mm. Portugal. (1. c. 5S3) chloropus Germ.

81. Beine violett oder grünlich, Schenkel in der Mitte roth oder rothbraun. L. 8-11 mm. Asturien. (Deutsch. Zeitschr. 1879. 384)

asturiensis Kraatz.

T. immarginata H. Schäff. ist eine räthselhafte, vaterlandslose ganz. schwarze Art, die nach der Abbildung genau die Form der Chrysomela grossa Fabr., aber nicht die einer Timarcha hat.

VI. 2 . 
sondern hinter der Mitte sehr leicht, an den Vorderecken schneller und stärker verengt, so dass eine schwache Rundung der Seiten bemerkbar ist und die grösste Breite des Malssch. ror die Mitte fällt. Die Oberfätche wenig dicht punktirt, die Punkte zuweilen sehr fiein, häufiger mässig stark, zwischen ihnen einzelne grobe, unregelmässig vertheilte Punkte. Eine Randlinie ist nur an der Basis angedeutet. Fld. an der Naht nicht rerwachsen, beim $\hat{j}$ kugelig, beim $f$ breiteiförnig, über dem Seitenrande vertieft; dieser, besonders hinter der Mitte, wulstig-rerdickt. Die Scheibe mässig dicht, mehr oder weniger stark punktirt, mit glatten oder sparsam punktirten Zwischenräumen. Prosternum breit, fein gerunzelt, eben oder längsvertieft; Mesosternum kurz, quer, fast glatt, gerade abgestutzt.

Bei dem Männchen sind die drei ersten Tarsenglieder etwas breiter als beim Weibchen, Glied 3 kaum schmaler als 2, die Filzsohle ist in beiden Geschlechtern ganz.

Die Veränderungen, denen die Form des Halssch, unterworfen ist, entstehen aus der verschiedenen Stärke der Verscbmälerung an den Vorderecken und vor der Basis. Die Vorderwinkel sind abgerundet, wenn die Verengerung stark ist, andernfalls treten sie spitz vor. Letztere Form, mit fast gleichbreitem Halssch., steckt in vielen Sammlungen als globosa und macht besonders dann einen eigenen Eindruck, wenn das Halssch, verhältnissmässig lang, nicht ganz doppelt so breit als lang wird (Var, a). Frische, unausgefärbte Individuen sind rothgelb, vollkommen harte zuweilen röthlich pechbraun, statt des Bronceschimmers violett glänzend (Var. b); oder die Fld. lebhaft spangrün (Var. c). Bisweilen wird der Glanz der Oberseite durch eine scharf hervortretende sehr feine Chagrinirung bedeutend abgeschwächt und die Punkte der Fld. sind durch feine Linien netzartig verbunden (Var. d).

Es liess sich nicht sicher feststellen, ob die Art an V'accinium myrtillus lebt; sie ist jedoch nur in Menge unter solchen Steinen zu finden, die zwischen dem Blaubeergesträuch liegen und die Stengel theilweise bedecken. Bei der Berührung bringt sie eine blutrothe Flüssigkeit aus dem Munde.

Auf den deutschen und ungarischen Gebirgen im Juni and Juli häufig, mit den Bächen in das Vorland hinabsteigend; hier unter Moos und Geniste im Frühlinge.

8. Tibba: Subglobosa, fusco-aurichalcea, nitida, antennis pedibusque fuscis aut piceis: capite parvo, punctaio, antennis sat gracilibus, articulis 5 ultimis testaceo-pilosis parum crassioribus; prothorace transverso apicem versus sensim angustalo, minus comexo, dense subtiliter 
punctato, elytris liberis, sat crebre punclatis. interstitis punctulatis. Long. $8-11 \mathrm{~mm}$.

Hoppe Nov. Act. Leop. Carol. XII. (1825) 48\%. t. 45. f. 11.

Chr. ylobosa H. Schäff. Synops. 156. 23. c. -- Redtb. Faun. A. II. 468 (Tim.). - Fairm. Révis. 198.

Var. a. Elytris piceis, interdum violaceo micuntibus.

Ebenso gefärbt, aber in gleichgrossen Stücken viel breiter als die rorige, sebr plump gebaut, durchgängig dichter und feiner punktirt, mit dünneren Fühlern, hauptsächlich aber an dem Bave des Halssch, zu erkennen. Letzteres hat seine gröste Breite an der Basis und verengt sich vou hier aus allmählich nach vorn, entweder ganz gleichmässig, geradlinig, oder mit leicht gebogenen Seitenrändern, indem die Verengerung zuerst sehr schwach, nach den Vorderecken hin stärker vor sich geht. Daher ist es hinten breiter, vorn bedeutend schmaler, als das der metallica, und der Körperumriss erscheint zwischen Halssch. und Fld. weit schwächer eingeschnürt. Ebenso ist die Scheibe dichter fein punktirt, weniger gewölbt. Die Fld. haben stumpfwinkelige, weniger abgerundete Schulterecken und sind fast doppelt so dicht punktirt; die Bildung der Brust und Beine ist nicht wesentlich verschieden.

Bei manchen Stücken ist die Farbe der Oberseite oder wenigstens der Fld. dunkelbraun mit bläulichem Schimmer.

Nur in Krain, selten.

Nach der Beschreibung und Abbildung unterliegt es keinem Zweifel, dass die Chrysom. gibba Hoppe, die bisher fälschlich auf die dunkelbeinige corinthia Fairm. bezogen worden ist, die nicht auf den Bergen bei Triest vorkommt, auf die vorliegende Art gedeutet werden muss.

\section{Chrysomela.}

Linné Syst. Nat. ed. X. 368 .

Corgus onatum vel breviter-ovatum, humeris parum vel vix prominulis.

Elytra margine interno postico sublilissime ciliata.

Mentum magnum.

Acetabula antica aperta.

Episterna metathoracis apicem versus angustata.

Abdomen segmento primo metasterno longiore.

Tarsi articulo secundo angustissimo.

Körper ziemlich hart, ungeflügelt oder mit kurzen Flügelstummeln versehen, die zum Fliegen ungeeignet sind, oder geflügelt, gewölbt, 
breit-eiförmig, eiförmig oder fast parallel. Kopf etwas breiter als lang, bis zum Hinterrande der Augen in das Hahsschild eingesenkt, das Kopfschild gewöhnlich von der Stirn durch zwei zwischen der Fühlerbasis schräg aufwärts laufende vertiefte Linien geschieden, die sich bogenförmig oder winkelig vereinigen und meist als Mittelrinne bis auf den Scheitel fortsetzen. Oberlippe ziemlich gross, quer, abgestutzt oder ausgerandet. Mandibeln kurz und mässig breit, fast winkelig gebogen, nach der Spitze wenig verschmälert, diese selbst einfach zugespitzt, oder in mehrere verschieden scharfe Zähne ausgezogen. Kinnladentaster viergliederig, Glied 1 kurz, 2 das längste, 4 gewöhnlich länger und breiter als das vorhergehende, abgestutzt. Lippentaster dreigliederig, Glied 2 sehr breit, oft kugelig, 3 schmal. Kinn deutlich, ziemlich gross, quer. Augen schmal, mehr als doppelt so lang als breit, wenig gewölbt, der Längsdurchmesser fast senkrecht. Fühler ziemlich schlank, mit den letzten vier oder fünf Gliedern die Hinterecken des Halsschildes überragend, selten fast fadenförmig, ihre sechs Endglieder vielmehr nach und nach leicht rerdickt und zusammengedrückt, Glied 1 länglich, breit, 2 kurz, höchstens halb so lang aber schmaler als 1,3 bis 5 etwa so breit als 2 , unter sich fast gleichbreit, das dritte wenigstens so lang als 1, die letzten Glieder meist gestreckt, länger als breit. Halsschild ungefähr so breit als die Basis der Flügeldecken, quer, doppelt so breit als lang, oder breiter, mit gerundeten, oder fast parallelen, selbst nach rorn stark convergirenden Seiten; der Vorderrand in einem ziemlich tiefen, in der Mitte fast geraden Bogen ausgeschnitten, der Hinterrand in einem flachen Bogen gegen das Schildchen rorgezogen und beiderseits noch leicht ausgebuchtet, so dass die Hinterecken mehr nder weniger scharf werden. Die Oberfläche. ist vorn und an den Seiten meist von einer kräftigen Randlinie umzogen, an der Basis oft ungerandet, nur bei wenigen Arten (Verwandte ron graminis, guttata, salviae etc.) sehr fein gerandet, über den Seiten häufig mit einem Längswulste, der von der Scheibe durch eine punktirte Längsvertiefung oder einen scharfen, faltenartigen Eindruck geschieden wird. Der Vorderrand des Halsschildes ist nur an der Innenseite, die nicht sichtbare, an die Mittelbrust gedrückte Hinterwand desselben gewöhnlich ganz behaart. Schildchen dreieckig, die Seiten geradlinig oder schwach gerundet. Flügeldecken länglich, ziemlich gleichbreit, hinter der Mitte am breitesten, oder fast kugelig, hinten mehr oder weniger breit gemeinschaftlich abgerundet, der Nahtwinkel ziemlich scharf, aber in keine Spitze endigend, wie bei Timarcha. Sie sind an der Naht rerschieden fest in einander gefügt, indem der untere Nahtrand der rechten Flügeldecke in eine tiefe Rinne der 
linken eingreift, sehr selten verwachsen. Die Schultern sind abgerundet, Schulterhöcker nicht oder schwach angedentet, Epipleuren ganz auf die Unterseite gerückt, fast wagerecht, ziemlich breit, hinten stark verschmälert, aber fast bis zur Spitze deutlich, ihre innere Randlinie im letzten Drittel mit einer dichten Reihe von kurzen Haaren besetzt. Ihre Oberfläche ist selten ganz unregelmässig punktirt, wie bei lichenis, häufiger mit ein oder mehreren regelmässigen Punktreihen, welche einen meist breiten, weniger punktirten Streifen über dem Aussenrande, den Seitensaum, begrenzen; oder es sind 9 regelmässige Punktreihen (und eine abgekürzte am Schildchen) vorhanden, die gleichweit von einander entfernt oder so zu zweien genähert stehen können, dass die erste an der Naht stets von den übrigen entfernt bleibt. Prosternum gewöhnlich mit einer Längsfurche, zwischen den Hüften schmal, hinter denselben verbreitert, der Hinterrand leicht gerundet, in eine Vertiefung des Mesosternum eingreifend; die vorderen Gelenkhöhlen hinten offen. Mesosternum quer, so breit als die Verlängerung des Prosternum, vorn grubig vertieft, die Vertiefung durch eine winkelige oder gerade, erhabene Randlinie begrenzt, hinter derselben selten eben, meist quer eingedrückt. Metasternum zwischen den Hüften abgestutzt, vorn und an den Seiten gerandet, mit einer hinten breiteren Mittelrinne und schmalen, nach der Spitze verengten Episternen. Erstes Abdominalsegment gewöhnlich so lang als die drei folgenden zusammen, über die Nitte länger als das Metasternum. Füsse mässig stark, Schenkel ror der Spitze etwas verdickt, bei der Bewegung und nach dem Tode nicht über den Rand der Flügeldecken hinausragend; Schienen ziemlich gerade, nach der dicht gelblich behaarten Spitze hin leicht verbreitert, schwach dreiseitig, mit abgerundeten Kanten und einer kurzen, seichten Rinne zum Einlegen des ersten Tarsengliedes. Letzteres ist doppelt so lang als das zweite Tarsenglied, aber kaum länger als die beiden folgenden zusammen, und so breit als Glied 3; das $z$ weite ist bedeutend schmaler. Klauenglied lang, sparsam behaart, mit zwei einfachen, leicht gekrümmten Klauen.

Die Männchen sind kleiner, namentlich schmaler als die Weibchen, ibre drei ersten Tarsenglieder sind merklich erweitert, der Hinterrand des letzten, in der Regel mit einem Längseindrucke rersehenen Bauchringes ist entweder gerade abgestutat oder beiderseits ausgebuchtet, beim $q$ gerundet. Der Penis ist kräftig entwickelt, eine stark gebogene Röbre, deren Spitze auf die mannigfachste Art zugespitzt, gerundet, abgestutzt oder wellig gebogen ist.

Die Larven sind länger- oder breiter-eiförmig, mit schmalem Kopf und Prothorax und stark verbreitertem Hinterleibe, oben ge- 
wölbt, glatt oder nur theilweise sparsam behaart, verschieden gefärbt, mit neun Stigmenpaaren und am Kopfe jederseits sechs Ocellen $(4,2)$. Sie fressen grosse Löcher in die Blätter ihrer Nährpflanzen. Bis jetzt wurden beschrieben die Larven von ( $h r$. americana L.'),

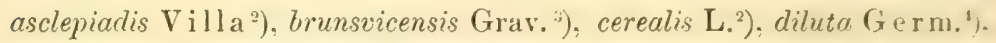
fastuosa L. ${ }^{2}$ ), goettingensis L. ${ }^{2}$ ), graminis L. ${ }^{5}$ ), haemoptera L. ${ }^{2}$ ), hyperiri Forst. ${ }^{2}$ ), limbata Fabr. ${ }^{2}$ ), menthastri $\left.\mathrm{Suffr} .{ }^{2}\right)$, polita L. ${ }^{2}$, sanguinolenta L. ${ }^{6}$ ), staphylea L. ${ }^{2}$ ), varians $\mathrm{S}\left(\mathrm{chall}^{7}\right.$ ) uud violacen Fabr. ${ }^{1}$ ).

Die vollkommenen Thiere leben, wenn sie geflügelt sind, auf Pflanzen, oder werden auf Wegen oder im Grase kriechend gefunder. die unvollkommen geflügelten sind fast durchgängig Gebirgsbewohner und halten sich vorzugsweise unter Steinen, oft in Gesellschaft der Timarcha metallica, auf.

Die Gattung ist über die ganze Erde verbreitet und auch in Deutschland zahlreich rertreten; sie bildet mit Cyrtomus Latr. ${ }^{5}$ ) und Orina Cherr., sowie zahlreichen exotischen Gattungen eine scharf begrenzte Gruppe, die durch bewimperte Epipleuren der Flügeldecken ausgezeichnet und deshalb leicht von den mit Melasoma und Phytodecta verwandten Gattungen zu unterscheiden ist. Aus Europa sind wenig über 100 Arten bekannt, welche grösstentheils schon ron Suffrian in der Linnaea entomologica V. 1851 (Mon.) bearbeitet und in zwölf Gruppen untergebracht worden sind. Obgleich die ron Suffrian beobachtete Reihenfolge der einzelnen Arten allgemeine Annahme gefunden hat, konnte sie doch hier nicht ganz inne gehalten werden, da die Zusammenstellung der Gruppen nicht natürlich ist. Wenn z. B. Chrysomela staphylea (No. 12) mit marcasitica

1) Chapuis Mém. Liége 1853, 609-611.

2) Rosenhauer Stett. Zeit. 1882. 148-160.

3) Cornelius Stett. Zeit. 1858. 217.

4) Mulsant Ann. Soc. Lyon 1852. 52.

5) Letzner Arb. Schles. Ges. Breslau 1841. 105.

6) Letzner 1. c. 1859. 95.

7) Letzner 1. c. 1852. 92 und Rupertsberger Verh. zool, bot. Ges. Wien. 1870. 840.

8) Cyrtonus Latr., ungeflügelt, Fld. rerwachsen, Halssch, an der Basis jederseits ausgebuchtet und mit einigen grossen Kerbzähnen rersehen, die Hinterecken nach rückwärts ausgezogen und den Schulterrand der Fld. theilweise umfassend, ist eine, nur auf das südlichste Frankreich und die I'rrenäen-Halbinsel beschränkte Gattung, mit einigen 20, blau-, grün- oder braunmetallischen, ziemlich glatten, glänzenden Arten. Sie findet ror Chrysonize'n ihre natïrliche Stellung. 
und ihren nächsten Verwandten $(14-20)$ zusammengeworfen ist, letztere aber wieder von hemisphaerica (27), globosa (37) und olivacea, ron denen sie schwer zu unterscheiden sind, durch abweichend gebaute Arten wie coerulea (21), varians (22) und goettingensis (23) getrennt werden konnten, oder Chr. islandica (122) hinter die Orinen gestellt wird, so dürfte wohl von einer natürlichen Anordnung nicht die Rede sein.

Auch diese Gattung hat Motschulsky ${ }^{1}$ ) versucht, nach dem Habitus, der Fühlerbildung und Punktirung in einzelne Gattungen (etwa 30) aufzulösen, aber es ist hier, wie bei Timarcha, unmöglich, seine Namen als Gruppenbenennungen zu verwerthen, da die umfangreichen und sehr unbestimmten Unterscheidungsmerkmale, so sicher sie auch die als Typen angegebenen einzelnen Arten vielleicht trennen mögen, sich verändern und schon auf die nächstverwandten Arten nicht mehr zutreffen. Von der Flüchtigkeit der genannten Arbeit. welche Chapuis eine élucubration und einen erreur entomologique nennt ${ }^{2}$, in der aber doch der bekannte Scharfblick Motschulsky's stellenweise nicht zu verkennen ist, liefert die Gattung Orina, in drei Gattungen: Orina, Alpaeixena und Dlochrysa zerlegt, den besten Beweis. Als Type zur ersten ist Chr. tristis F. angegeben und allen begründeten Ansichten entgegen auf eine, der speciosa Panz. nahe stehende Art bezogen; zur zweiten wird senecionis F. genannt, die Fabricius nie beschrieben hat, zur dritten speciosa L., welche bald auf fastuosa, bald auf speciosissima gedentet worden ist. Unter den wenigen guten Gattungen ist Crosita $^{3}$ ), mit dem Typ. altaica Gebl., eine der ausgezeichnetsten, durch die offenen Gelenkhöhlen der Vorderhüften, das in eine Verlängerung ausgezogene und auf die Mittelbrust übergreifende Prosternum, sowie die fein bewimperten Epipleuren der Fld. Chrysomela (aber nicht Timarcha) nahe verwandt, indessen durch verwachsene Fld. und die Form des zweiten Tarsengliedes, welches etwas breiter als das erste Glied ist, sicher unterschieden. Beim Weibchen sind alle Tarsenglieder schmal und nur am Rande behart, das dritte sehr tief dreieckig ausgerandet, mit spitzen Zipfeln; das Männchen hat ähnliche Hintertarsen, die vorderen sind sehr breit, mit ganzer Filzsohle, das dritte Glied ist kaum ausgerandet.

A. Körper ungeflügelt. Flügeldecken an der Naht verwachsen.

1. Chr. otra: Aptera, atra, alutacea, minus (c) vel sat nitida ( ), prothorace subtilissime punctato, callo laterali impressione lata, fortiter

1) Schrenk Amur-Reis. II. 201.

2) Genera X. 362.

3) Schrenk 1. c. 190. 
punctala, subruyosa terminato; olytris disperse pundalis, interstilies sparsim obsoletissime punctulatis. - Long. 10-13 $\mathrm{mm}$.

Herr. Schäff. Faun. Germ. 157. 8. c. - Suffr. Mon. 6. Redtb. Faun. A. II. 476.

Die einzige europäische Art mit verwachsenen Fld.; sehr breit und plump, tief schwarz, äusserst fein lederartig gerunzelt, daher die $\hat{j}$ etwas, die $q$ ziemlich matt, fettig glänzend. Kopf mässig dicht, s ehr fein punktirt, Fühler kurz, schwarz, nur die Spitze des ersten Gliedes geröthet. Halssch. dicht vor den Hinterecken am breitesten, von hier nach rückwärts unbedeutend, nach vorn etwas stärker, aber allmählich gerundet-verengt, der Vorderrand wenig tief, in einem fast regelmässigen Bogen ausgeschnitten, die Vorderecken scharf, beinahe rechtwinkelig, die Scheibe wenig gewölbt, ziemlich dicht und sehr fein punktirt, beiderseits von einem, dem Seitenrande parallel-gebogenen sehr breiten und ziemlich tiefen Eindrucke begrenzt, welcher stärker punktirt als die Scheibe und an den Seiten mit einigen Runzeln und groben Punkten besetzt ist, die in den Seitenwulst theilweise hineinreichen, so dass derselbe innen nicht scharf begrenzt wird. Fld. beim $q$ etwas bauchiger als beim $\hat{j}$, an der Wurzel breiter als das Halssch, hoch gewölbt, auf dem Abfalle zur Spitze leicht aber deutlich flach gedrückt, zerstreut und mässig fein punktirt, die Zwischenräume ausser der Netzelung noch mit einigen sehr feinen, kaum bemerkbaren flachen Punkten. Beine mässig dicht, ziemlich stark punktirt, oft blau schimmernd. Unterseite zerstreut und fein, nur die Mitte der Hinterbrust und der zwischen den Hinterhüften befindliche Lappen des ersten Bauchringes stärker punktirt.

Das Männchen hat an den vorderen Beinen merklich erweiterte Tarsen und einen fast ausgerandet-abgestutzten Hinterrand am letzten Bauchsegmente.

Hauptsächlich auf Sicilien, aber auch schon bei Fiume (Scriba) gefangen, so dass die Verbreitung bis Istrien wahrscheinlich ist.

B. Körper mit kurzen, schmalen Flügelstummeln, welche höchstens halb so lang als die Fld. und zum Fliegen unbrauchbar sind.

a. Halssch. hinten fast parallel, vorn gerundet-rerengt.

* Beine und untere Hälfte der Fühler schwarzblau, selten schwarz.

2. Chr. fimbrialis $\left.{ }^{1}\right)$ : Subaptera, breviter-ovalis, nigro-coerulea, nitidula, antennis articulis duobus primis inferne vel apicem versus

1) Vor diese Art gehört Chr. helopioides Suffr. (Mon. 12) aus Andalusien, welche in Farbe, Glanz und Punktirung ganz mit atra übereinstimmt, 
rufis; prothorace dense subliliter latera versus fortiter pronctalo, linea media abbieviala laevi, callo laterali impressione lata, grosse junctala terminalo. elytris limbo laterali lacte rujo, forlins punctatis, interstitiis parce punctulatis. - Long. $8-12 \mathrm{~mm}$.

Mas: segmento ultimo ventrali tumidulo.

K üst. Käf. Eur. 2. 74.

Chr. fimbrialis var. $\gamma$ Suffr. Mon. S.

Var. a. Supra nigra. nitida, nothomace elytrisque minus fortiter punctatis, his limbo laterali laete mo.

Chr. molluginis Redtb. Faun. A. ed. 1. 544.

Chr. fimbrialis Fuss Verhandl. Siebenb. Verein. 1861. 1. - Suffr. Stett. Zeit. 1869. 266. - Redtb. 1. c. ed. 3. II. 469.

Var. b. Nigro-coerulea, supra interdum violaceo-vel viridi-micans; prothorace elytrisque fortiter punclatis, his limbo laterali rufo brunneo, piceo aut nigro.

Chr. hungarica Fuss 1. c. 1. - Suffr. Stett. Zeit. 1869. 265.

Chr. fimbrialis Suffr. Mon. 7. - Fuss 1. c. 1856. Siebenbürg. Chrys. No. 2.

Sehr breit und plump, schwarzblau, ein breiter Saum am Seitenrande der Fld. und die Epipleuren hellroth, wie bei sanguinolenta, die beiden ersten Fühlerglieder unten oder an der Spitze roth, die stärker behaarten und breiteren Endglieder fast schwarz Halssch. nach hinten wenig, nach vorn stärker gerundet-verengt, dicht und ziemlich fein, ungleichmässig und nach den Seiten hin stärker punktirt, dazwischen mehr oder weniger deutlich lederartig gerunzelt, mit einer vorn und hinten meist abgekürzten ziemlich glatten Mittellinie. Der Seitenwulst ist wenig gewölbt, parallel, bald schmal, bald breit, innen durch einen grob punktirten tiefen Eindruck, dessen Punkte theilweise auf den Wulst übergreifen, seiner ganzen Länge nach abgesetzt, ausser der weitläufigen stärkeren Punktreibe über der Seitenrandlinie äusserst fein punktirt, fast glatt. Fld. in den abgerundeten Schultern etwas breiter als die Basis des Halssch, nach hinten beim $\hat{\jmath}$ wenig, beim \& stärker erweitert, mässig dicht, grob, aber nicht tief punktirt, Zwischenräume glatt oder sehr fein lederartig gerunzelt und sparsam, verloschen punktulirt, nach den Seiten und der Spitze hin oft wulstartig erhaben, die Punktirung deshalb runzelartig. Von Punktreihen treten gewöhnlich nur einige über dem ziemlich glatten, breiten Seitensaume deutlicher hervor. - Penis gleichbreit, ror der Spitze jederseits tief gerundet-ausgeschnitten, so dass

aber einen riel schlankeren Körper hat. Bei ihr ist der Seitenwulst des Halssch. nur an der Basis bemerkbar, wo ex durch einen grubenförmigen, tiefen Eindruck emporgehoben erscheint. - L. $11 \mathrm{~mm}$. 
die Vorderecken spitz nach aussen vortreten; der Vorderrand sellyst breit, flach abgerundet.

Die Art ist in der Punktirung und Farbe veränderlich. Zuweilen werden die Punkte des Halssch. kräftig, seltener die der F'ld. fein. Stücke mit rein schwarzer (Var. a) oder schwarzblauer O),rscite und hellrothem Saume der Fld. bilden die Ausnalime, in der Regel ist die Farbe schwarz, mit blanem, violettem oder grünlichem Influge, der Saum der Fld. und die Epipleuren sind dunkel rothbraun. pechbraun (violett angehaucht) oder tief' schwarz (Var. b). Ebeuso finden sich Exemplare, bei denen Kopf und Thorax violett, die Fld. bläulich gefärbt sind, oder umgekehrt,

Bei Wien (Redtenb.) und in Krain (Micklitz). Häufiger in Ungarn, dem Banat und Siebenbürgen. Dalmatien?

Von Küster wurden zuerst schwarzblaue, roth gesäumte Individuen beschrieben und Suffrian vereinigte damit 1851, ebenso Fuss 1856, auch die nicht roth gesäumten. Später (1861) gelangte Fuss zu der Ansicht, dass nur die oberseits schwarzen, verhältnissmässig fein punktirten Stücke einen hellrothen Saum der Fld. besässen, die schwarzblauen nicht; er nannte die ersteren fimbrialis Küst., wozu nach Küsters Beschreibung gar kein Grund rorlag, die anderen hungarica, und betrachtete beide als Arten. Dieser ungerechtfertigtun Ansicht schloss sich 1869 auch Suffian an, indem er das Vorkommen von schwarzblauen, rothgesäumten Exemplaren, die ihm bei seiner ersten Beschreibung (Mon. 8) sicher vorgelegen haben, mit Stillschweigen überging.

3. Chr. cribrosa: Subuptera, breviter-ovalis, nigra, subtilissime alutacea, nitidula, subtus nigro-coerulea, antemis basi (articulis 2 primis apice rufescentibus) pedibusque nigro-chalybaeis, prothorace crebre punctato, callo laterali postice plica profunda subcurvata terminalo: elytris fortius subrugoso punctatis, interstitiis punclulalis. - Long. 10 - $12 \mathrm{~mm}$.

A hr. Faun. Ins. Eur. 1. 10. - Germ. Reis. Dalm. 203. - Küst. Käf. Eur. 1. 70. - Suffr. Mon. 10. - Redtb. Faun. A. II. 477 .

Es verbindet diese Art ungefähr die Körperform von Chr. atra mit der Skulptur ron Tim. pratensis, mit welcher sie denselben Verbreitungsbezirk hat. Sehr breit eiförmig, schwarz, wenig glänzend; die fünf ersten Fühlerglieder und die Unterseite schwächer, die Beine lebhafter schwarzblau, Glied 1 und 2 der Fühler an der Lnterseite oder Spitze röthlich. Kopf und $\mathrm{Halssch}$. ziemlich kräftig punktirt, die Punkte stehen gewöhnlich sehr dicht, etwas ungleichmässig 
und lassen nur selten eine schmale, glatte, leicht erlabene Mittellinie auf dem Halssch. frei, zuweilen sind sie wenig dicht und dann auch feiner als bei normalen Stücken. Seiten des Halssch. ron der Basis nach vorn zuerst sehr wenig, im vorderen Drittel etwas stärker gerundet-verengt, der fein punktirte Seitenwulst nur hinter der Mitte deutlich gewölbt und hier auf der Innenseite von einem leicht gebogenen tiefen und (aussen) scharfen, runzelig-punktirten Eindrucke begrenzt, der in der Mitte verschwindet, bisweilen aber, nahe den Vorderecken, als eine leichte, weite Vertiefung, die mit einzelnen groben Punkten besetzt ist, wieder zum Vorschein kommt. Der Vorderrand ist ziemlich tief ausgeschnitten, in der Mitte gerade, jederseits daron in einem sebr flachen Winkel gerundet nach vorn und aussen gebogen, die Vorderecken abgerundet-rechtwinkelig. Fld. mässig dicht, grob und tief punktirt, die Punkte, besonders nach aussen und hinten hin durch Runzeln verbunder, Zwischenräume unmerklich gewölbt und zerstreut, fein punktirt. Epipleuren glänzend, hinterwärts querfaltig. Brust und erster Bauchring ziemlich dicht und stark, die übrigen Ringe und die Beine sparsamer punktirt. Bei dem Männchen sind die Tarsen und das Endglied des Maxillartaster deutlich breiter als beim Weibchen.

In Istrien. Häufiger in Croatien und Dalmatien.

4. Chr. coermber $\left.{ }^{1}\right)$ : Subaplera, breviter-ovalis, satwale coeruleoviolacea. subnitida, antennis articulis 2 primis subtus vel apicem versus rufis, prothorace fortiter transverso, sat crebre subtiliter punctato, callo laterali postice impressione profunda, rugoso-punctata interne terminato; elytris subparallelis crebre sat fortiter punctatis, inlerdum lineis nommullis subelevatis subtiliter punctatis instructis. - Long. S$13 \mathrm{~mm}$.

Oliv. Ent. V. 515. t. 5. f. 73. - Germ. Reis. Dalm. 203. Duft. Faun. Austr. III. 165. - Küst. Käf. Eur. 1. 71. Suffr. Mon. 32. - Redtenb. Faun. A. II. 471.

1) Vor diese Art gehören: 1. Chr. obscurella Suffr. (Mon. 11; pelagiéa. Cherr. Cat. Gren. 1863. 120) aus Südfrankreich und dem nördlichen Italien (Nizza), mit tief schwarzem, mattem, dicht und fein punktirtem Körper, dessen Beine und Fühler dunkelblau sind. Seitenwulst des Halssch. nur dicht vor der Basis durch einen tiefen, grob punktirten Eindruck emporgehoben. L. $9-13 \mathrm{~mm}$.

2. Chr. tagana Suffr. (Mon. 9) aus Portugal. Kürzer und gewölbter als coerulen, dunkel-olivengrün, mit leichtem Messingglanze, Fühler und Beine metallisch-violett. Halssch. in der Mitte zerstreut und fein, längs des niedrigen Seitenwulstes stark punktirt, letzterer hinten durch einen weiten, sehr flachen Eindruck undeutlich abgesetzt. Fld. dicht, mässig fein, dazwischen zahlreich fein punktirt. - L. $9-12 \mathrm{~mm}$. 
Var. a. Supra nigro-coerulea vel violacea.

Var. b. Prothorace (callo laterali intesdume excepros) elylisyne nigris.

Ebenso breit, aber weniger gewölbt und viel allmählicher, länger und flacher zur Spitze der Fld. abfallend, als die vorigen Arten, vorn fast abgestutzt; tief bläulich-violett, Kopf und Halssch. äusserst fein lederartig-gerunzelt, tettig glänzend, Fld. etwas glänzender. Kopf wenig dicht, sehr fein punktirt, Fühler einfarbig blau, die ersten sieben Glieder sparsam, die letzten dicht hell gelburaun behaart. Halssch. breit und kurz, hinten ziemlich gleichloreit, vor der Mitte stark gerundet-verengt, Basis in einem kräftigen Bogen gegen das Schildchen vorgezogen, Vorderrand tief ausgeschnitten, in der Mitte gerade, hierauf jederseits in einem stumpfen Winkel gerundet nach vorn und aussen gebogen, mit breiten, abgerundeten Vorderecken. Die Scheibe mässig dicht, fein punktirt, Seitenwulst hinten schmal, gleichbreit, hoch, innen von einem tiefen, geraden, runzelig punktirten Eindrucke begrenzt, welcher in der Mitte endet, davor nur durch einige stärkere Punkte angedeutet oder durch einen, weiter nach innen gerückten, wenig bemerkbaren Eindruck ersetzt wird. Fld, von den Schultern bis hinter die Mitte schwach erweitert und fast parallel, hierauf gerundet-verengt, ihre dichte, doppelte Punktirung, die bei oberflächlicher Betrachtung einfach erscheint, besteht aus mässig starken und tiefen Punkten, zwischen denen etwas feinere eingestreut sind. Die Zwischenräume sehr schmal, an den Seiten und vor der Spitze zu kurzen, schwach erhabenen Runzeln vereint; der schmale Seitensaum feiner punktirt, innen ron einer wenig regelmässigen Punktreihe begrenzt. Unterseite fein gerunzelt, das erste Bauchsegment längs der Mitte, das letzte ganz, stärker und dichter als die übrigen punktirt. Flügelstummel kurz.

Das Männchen hat sowohl das Endglied der dicken Maxillartaster, als auch die drei ersten Tarsenglieder erweitert. Penis lang, schwach gebogen, gleichbreit, nur an der abgestutzten Spitze leicht erweitert, die Seiten derselben in Gestalt kleiner, breit-dreieckiger Läppchen nach hinten umgebogen.

Die Oberseite wird bisweilen schwarz, mit blauem oder violettem Anfluge (Var, a), oder tief schwarz, nur der Kopt und die verdickten Seiten des Halssch. bleiben violett (Var. b). Nicht immer ist die Punktirung der Fld. durchaus unregelmässig, sondern es können vier bis sechs wenig regelmässige Reihen der stärkeren Punkte hervortreten, welche zu je zwei, drei undeutliche, zuweilen leicht erhabene, feiner punktirte Längslinien einschliessen. Von diesen läuft die innere von der Mitte der Basis schräg nach innen und hinten, und ist in der vorderen Hälfte meist deutlich; die zweite zieht sich 
von der Innenseite des Schulterhöckers, die dritte von der Mitte desselben nach hinten. Beide sind gewöhnlich kaum zu bemerken, indessen erheben sich alle drei bei monströsen Stücken, wovon Herr Prof. Schreiber bei Görz ein sehr auffälliges sammelte, zu regelmässigen, starken Rippen, welche dem Thiere ganz das Aussehen eines Erodius verleihen.

Auf Alpenwiesen unter Steinen in den südlichen Provinzen Oesterreichs, sowie im Banat, in Serbien, Rumänien und Galizien.

Mit coemulea sehr nahe verwandt, aber kürzer, durchgängig feiner punktirt (auf den Fld. deutlich doppelt) und an dem Halssch., welches im Verhältniss zu den breiten, bauchigen Fld, nur schnal erscheint, leicht zu erkennen, ist: Chr. globipennis (Suffr. Mon. 36): Subaptera, breviter ovalis, laete violaceo-purpurea, nitidula, antennis articulis 2 primis subtus rufis, prothorace transverso minus crebre subtilissime punctato, callo laterali postice impressione haud profunda terminato; elytris globosis, sat fortıter punctatis, interstitiis punctulatis.

- Long. 8-10 mm. Moldau, Bessarabien.

5. ChN. Lichenis '): Subaplera, obovala, convexiuscula, supra niyroviriclis, aurichalceo-micans, subtus nigro-coerulea; antennis nigris, basi subcoeruleis, articulis 2 primis subtus vel apicem versus rufis; prothorace transverso lateribus postice subparallelis, antice rolundato-anguslatis, callo laterali incrassato impressione lata postice profundiore lerminato, disco sat crebre subtiliter punctato, elytris parum fortiter mimus dense aequaliter punctatis. punctis interdum in series nommullas obsoletissimas dispositis. - Long. $5,5-7,5 \mathrm{~mm}$.

Richter Suppl. Faun. Ins. Eur. I. t. 6. - Matzek Bericht.

1) Dieser Art schliesst sich am natürlichsten an: Chr. Schneideri: Subuptera, oblongo-obovata, minus convexa, nigro-coerulea vel-violacca, minus nitida, antennis longis, articulis 2 primis subtus rufescentibus, capite parvo, parce subtiliter punclato, lineis epistomatis et canalicula abbreviata frontali profundis, prothorace minus transverso, lateribus postice subparallelis, apicem versus leniter angustatis, callo laterali valde incrassato impressione lata profunda terminato, disco haud crebre punctato, linea media laeni, elytris sat dense purum fortiter punctatis, punctis confuse subseriatim dispositis. - Long. $5,5-7 \mathrm{~mm}$.

Durch das verhältnissmässig Iange, uquer-viereckige, in vorderen Drittel geradlinig schwach verengte Halssch, lange Fühler und an den sichultern deutlich heraustretende Fld. sehr ausgezeichnet und eine der interessantesten europäischen Arten, da sie im Umrisse ganz einer Orina, am meisten der O. monticola Duft. ähnlich ist; in der Färbung gleicht sie der Agelrsticu alni. Sie wurde von Herrn Dr. O. Schneider in Dresden auf einer kleinen Stelle in der hohen Tatra in Mehrzahl gesammelt. 
Schles. Ges. 1842. 7. - Letzne r Verzeichn. Käf. Schles. 1871. 292.

Thr. ahena Germ. Ins. spec. nov. 5s6. - Suffr. Mon. 1S4. (pars.). Letzn. Arb. Schles. Ges. 1850. 74.

Var. a. Prothorace linea media laevi interdum subelevala.

Var. b. Prothorace canaliculato.

$\mathrm{V}$ ar. c. Supra viridi-aenea, nigro-cuprea aut nigro-coemulea.

Var. d. nigerrima: C'onpore (antennis basi excepla) omeino nigro, haud metallico.

Var. e. quadricollis: Prothoracis lateribus rectis, antice hand anyustatis.

Var. f. moraviaca: Corpore plerumpue nigro, leriler aurichalce-micuns, prolhorace sublilissine elylrisque parum fortiter confertim punctatis, interstitiis alutaceis.

Var. g. Piothorace lateribus sut obsolele calloso-incrassalis, interne inpressione basali brevi terminatis, prothorace elylrisque dense punctalis, interstitiis plus minusve alutaceis.

Chr. islandica Germ. Ins. spec. nov. 585. - Falderm. Nouv. Mém. Mosc. V. 362. t. 13. f. 3. - Suffr. Mon. 186 (pars.). - Kratz Berl. Zeit. 1859. 293. - Motsch. Schrenk. Reis. II. 190 (Heliostula). - Redtenb. Fann. A. II. 470.

Chr. lichenis Duft. Faun. Austr. III. 177.

Var. h. Nigro-violacea, elyiris virescentibus, prothorace sublitisime jumclato, aluaceo, lateribus obsolete calloso-incrassulis, inleme impressione obsolelissima terminatis.

Chr. carpathica Fuss Verh. u. Mitth. Siebenb. Ver. 1856. 25 et 31.

Bedeutend kleiner und nach vorn stärker verengt als die vorigen Arten, oben schwarzgrün mit Bronzeglanz, unten mehr schwarzblau, oft, wie die Beine, theilweise grün schimmernd. Fühler schwarz, oder in der unteren Hälfte bläulich, Glied 1 und 2 unterseits oder an der Spitze roth. Kopf zerstreut sehr fein punktirt, Halssch. mindestens doppelt so breit als lang, schwach gewölbt, die Seiten in der hinteren Hälfte fast parallel oder nach der Basis unmerklich verengt, in der vorderen Hälfte, namentlich binter den Vorderecken deutlich verschmälert, der Vorderrand flach ausgeschnitten, mit ziemlich scharfen, leicht abgerundeten Vorderecken. Scheibe mässig dicht, fein punktirt, Seitenwulst gewölbt, innen durch einen breiten, kräftigen Eindruck begrenzt, welcher hinter der Mitte tiefer als vor derselben, aber hier durch eine weite, nicht scharf begrenzte grubenartige Vertiefung verbreitert ist. Fld. an den Schultern leicht gerundet-erweitert, gegen das Halssch, wenig abgesetzt, von den Schultern nach hinten ganz allmählich verbreitert, die grösste Breite hinter der Mitte, dahinter schnell gerundet-verengt, der Rücken in einer regelmässigen Wölbung schnell zur Spitze abfallend, so dass 
die Hinterecken ron oben kaum sichtbar sind. Die Scheibe etwas weitläufiger und stärker als das Halsseh, punktirt, Punkte gleichmässig verworren, selten treten vier bis sechs undeutliche Reihen hervor, deren Zwischenräume dann, wie bei den Germar'schen Typ. drei verloschene Längsrippen bilden.

In Form, Farbe und Skulptur so veränderlich, dass einige der local geschiedenen Varietäten schon als Arten betrachtet worden sind. Den verhältnissmässig breitesten und flachsten Körper haben die siebenbürgischen Stücke ron carparthica, den schmalsten und sewölbtesten lichenis und quadricollis rom Riesengebirge; zwischen beide reihen sich die islandica der Alpen und moraviaca vom Altvater ein. - Die Farbe der Oberseite wird dunkelgrün (ohne Bronzeglanz), schwarzblau oder schwarz violett (Var. c), selbst tief schwarz (Var. d). Bei Exemplaren von der Czerna hora, die noch zur carpathica gehören, sind Kopf und Halssch. dunkelviolett, mitunter in blau übergehend, und die Fld. dunkelgrün. Im Allgemeinen sind lichenis nebst den Var. a bis d weitläufiger und stärker punktirt, besonders glänzender als die Var. $\mathrm{f}$ bis $\mathrm{h}$, bei denen die lederartige Runzelung der Oberseite stärker hervortritt. Auf dem Halssch. befindet sich zuweilen eine glatte, selbst leicht erhabene Mittellinie (Var. a), oder eine Mittelrinne (Var. b); der Seitenwulst wird zuletzt flach und ist innen entweder nur ror der Basis durch einen kurzen Eindruck deutlich (Var. g) oder durchweg undeutlich begrenzt (Var. h). Selten sind die Seiten vorn nicht verengt, gerade (Var. e).

Unter isländischem Moose und Steinen, sowie am Grase auf den höchsten Kämmen der Sudeten (Iser- und Riesengebirge, Glatzer Schneeberg, Altvater und Karpathen nicht selten, spärlicher in den Ostalpen, Transsylranischen Alpen und dem Kaukasus.

Schon Kraatz hat a. a. O. mit Recht hervorgehoben, dass er die von suffrian angegebenen Unterscheidungsmerkmale zwischen ahena und islandica Suffr, bei grösseren Reihen von Individuen nicht vereinigt findet und dass erstere deshalb nicht einmal als gute Abart ron der letzteren zu betrachten sei; beide konnten daher nur thcilweise citirt werden und zwar so, dass auf die Form des Seiteneindruckes am Halssch. geachtet, Farbe, Punktirung und Vaterland ganz übergangen wurden. In Schlesien, der eigentlichen Heimath unserer Art, kommen vorherrschend Stücke mit ganzem, oder wenigstens über die Mitte nach rorn reichendem Seiteneindrucke vor und wurden 1820 von Richter als lichenis beschrieben; zu ihr gehören ausschliesslich die Var. b, d und e. Die Alpenform (islandica Germ.) rom Wiener Schneeberge, aus Steiermark (Pipitz) etc, deren Halssch. merklich breiter und nur dicht an der Basis jederseits deutlich eingedrückt ist, fehlt in Schlesien wohl ganz; sie nähert sich auch in Hinsicht der dichten, feinen 
Punktirung sehr der Form ans Galizien und Siblentüirn.n. mit undentlichem Seiteneindrucke.

\section{* Fühler und Beine rothbraun bis schwarzbraun.}

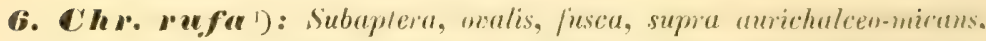
nitida, antennis perlibustque juscis aut jeceis, articulo ullimo jalponum maxillarinem sat lalo, prothorace subtiliter pumelulo, litansrerso. lateribus postice subparalletis, anlice sut (:) bel mimes forliter (†) rolumdalo-angustatis, callo laterali obsoleto, sublaevi, interne leviter deplunalo basique sacpissime subimpresso, elylitis sat dense punctutis, junclis interdum subseriatis, interstitiis phes mimusve punctulatis. - L. 5-9 mm. Mas: palporum maxillarium arliculo ultimo fortiter larsisque ameriorilus leviter dilatatis, segmento $5: 0$ ventralè tumidulo.

1) Sehr ähnlich ist Chr. porphyrea Fald. (Nouv. Mém. Mosc. 1S37. 354. t. 12.f. 9): Subaptera, obovata, convexa, rufa, supra cupreo-virilacen splendens, prothorace sat dense inaequaliter punctulato, lateribus jere rectis upicem versus leniter angustatis, callo laterali mullo; elytris parce punctrtis, interstitiis subtilissine parum punctatis, fere laevibus. - Long. $7 \mathrm{~mm}$. Kaukasus. Suram-Gebirge (L eder).

Durch den lebhaft rothen, oberseits stark kupferglänzenden und hier zugleich violett schimmernden Körper eine der schönsten Arten dieser Gruppe, an der Bildung des Halssch. leicht erkennbar. In Faldermanns Diagnose wird der Körper übermässig rund angegeben. Die von Fairmaire (Ann. Fr. 1S65. 76) versuchte Deutung auf eine mit biculor $\mathrm{F}$ abr. verwandte Art und ihre Vereinigung mit der vollkommen geflügelten cupreopunctata $R$ eiche entbehrt jeden Grundes.

Hieran schliesst sich, als Uebergang zu den folgenden Arten, Chr. caucasica: Subaptera, fere hemisphaerica, late rufa, supra leviter viridi-aurichalcea, nitida, antennis pedibusque testaceix, prothorace modice convexa: brevi, sat dense tenuiter punctato, laterihus postice subparallelis antice minus fortiter rotundato-angustatis, callo laterali sublacvi, obsoletissimo, hasi impressione brevi, profunda, terminato; elytris mimus dense sat fortiter punctatis, interstitiis parce punctulatis. - Long. 5-6 mm. Kaukasus: Tbatani (Le d e r).

Der Penis dieser kleinen, fast halbkugeligen Art ist an der Oeftinung jederseits leicht verengt, vorn gerade abgestutzt mit abgerundeten Ecken.

Ganz gleichmässig bis zur Seitenrandlinie verflacht ist das Halssch. von Chr, mfilabris Fald. (Mém. Ac. Petr. II. 1935. 443) aus Irkutzk. Luterseite rothbraun, Mund, Fühler und Beine hell bräunlichgelb, Kiopf und Halssch. pechbraun, letzteres zwischen der sehr feinen lederartigen Runzelung wenim dicht, ziemlich kräftig punktirt, jederseits mit einer gebogenen etwas unregelmässigen Reihe sehr grober Punkte. Fld. braun, messingglänzend, mit neun, zwischen der übrigen feinen Punktirung wenig hervortretenden Punktreihen, von denen die 5. bis 7. ganz verworren ist. - L. $6-7 \mathrm{~mm}$. 
Duft. Faun. Austr. III. 186. - Suffr. Mon. 26 ( $f$ ). - Kraatz Berl. Zeit. 1859. 292. - Redtb. Faun. A. II. 470.

Chr. melallica Küst. Käf. Eur. 9.93.

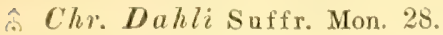

Chr. opulenta Suffr. Mon. 30.

Chr. squalida Suffr. Mon. 31.

Chr. menthae Duft. Faun. A. III. 187. - Redtb. I. c. 472.

Var. a. Immatura. mio-lestacea, aut unicolora aut suma leciter cupreo-, coeruleo- vel violaceo-micans.

Var. b. Supra saturate brunneo-cuprea.

Var. c. Picea, aurichalceo-micans.

Var. d. Piceo-violacea.

Die Art lebt mit Timarcha metallica zusammen, ist ähnlich gefärbt und in der Körperform eben so veränderlich wie diese. Breiteiförmig, rothbraun, oberseits messingglänzend, Fühler und Beine hell rothbraun bis schwarzbraun. Kopf zerstreut und fein, nur auf dem Kopfschilde dichter punktirt. Halssch. schwach gewölbt, die Seiten in der hinteren Hälfte fast parallel oder nach der Basis unmerklich, beim $\hat{\jmath}$ meist deutlich verschmälert, in der vorderen Hälfte besonders beim ô ziemlich stark gerundet-verengt, am Vorderrande mässig tief ausgeschnitten, mit stumpfwinkeligen, leicht abgerundeten Ecken; Scheibe ziemlich dicht und fein, selten sehr fein punktirt, nach den Seiten hin mit etwas grösseren und tieferen Punkten; Seitenwulst schwach, nur an der Seite steil abfallend, fast glatt, ausser der Längsreihe von einzelnen grösseren Punkten, welche bei den meisten Chrysomelen über der Randlinie vorhanden ist, nur sparsam und äusserst fein punktirt, innen von der Scheibe durch eine dem Seitenrande fast parallele, ziemlich regelmässige Punktreihe scharf geschieden und der Länge nach leicht niedergedrückt, vor dem Hinterrande oft mit einem flachen, dicht punktirten Grübchen. Fld. an der Basis etwas breiter als das Halssch. (die Schultern geradlinig heraustretend), mit dem Halssch. in einer Flucht gewölbt, zur Spitze steil, aber in nicht ganz regelmässiger Wölbung abfallend, sondern etwas flach gedrückt; die Seiten beim joj gleichmässig schwach gerundet, beim $q$ hinter der Mitte am breitesten. Die Scheibe ist ziemlich dicht, stärker als das Halssch. punktirt, entweder ganz verworren oder mit mehr oder weniger regelmässigen Punktreihen; di Zwischenräume bald fast glatt, bald sehr deutlich sparsam und fein punktirt.

Die kleineren Männchen erkennt man theils an dem stark erweiterten Endgliede der Maxillartaster, theils an den schwach verbreiterten rorderen Tarsen, sowie an dem ein wenig aufgeblasenen, mindestens gewölbten fünften Hinterleibssegmente. Ihr Körper ist

VI. 2. 
ausserden sctmaler, mehr gleichbreit, das IIalsech. vorn stärker verengt, auch vor der Basis merklicher verschmälert, als bej dem Weibchen, der Bauch bedentend stärker punktirt. - Penis schlank, gleichbreit, vorn abgerundet.

Die hauptsächlichsten Farbenabünderungen sind: a) der ganze Körper ist hell röthlich gelbbraun wie bei staplyglea, entweder einfarlig, oder mit kupferigem, blatem oder violettem Anfluge. Hirrzu gehören meist frische Stïcke. b) Unterseite leller oder dunkler gelbbraun, Oberseite gesättigt braun, mit starkem Kupferschimmer, welcher zuweilen cine unerhebliche violette Beimischung hat und dadurch in purpurroth übergeht. c) Pechbraun mit gelblichem Metallglauze (eine Färbung, die sich dem Olivengrün nähert), Fühler und Beine gewöhnlich heller. d) Pechbraun, wenigstens nberseits violett.

Auf den höheren Bergen der Sudeten und Karpathen unter Steinen ziemlich häufig, seltener in der sächsischen Schweiz, dem Harze (Wilken) und den Alpen, sowie in Siebenbürgen.

Bei der Begrenzung dieser Art darf weder auf die variirende Stärke des Eindruckes in den Hinterecken des Halssch.. noch aul die Körperform und Punktirung ein so grosses Gewicht gelegt werden, wie es Suffrian dafür in Anspruch nabm, sonst möchte die Zerlegung in vier Arten kaum ausreichen. Seine Chr. squalida umfasst die, an Männchen von staphylea (auch in der Farbe) crinuernden Stücke, bei welchen das Halssch. etwa so breit als die Flu. ist, bei den übrigen drei Arten ist es merklich schmaler. Chr. opulenta Suffr. sind hauptsächlich Männchen, deren Fld. in der Form ungefähr mit haemoptera übereinstimmen, Dahli Suffr. sehr kurze Männchen, mit fast gleichbreiten Fld., und rufa Suffr. endlich grosse, zugleich fein punktirte Weibchen. Da sich die rerschiedene Tiefe des Basaleindruckes auf dem Halssch. mit dem Körperbaue nicht in Einklang bringen lässt, wäre es nutzlos. die angeführten verschwommenen Arten als Varietäten zu halten. Massgebend bleibt im Grunde nur die Gestalt des Thorax und seines niedrigen, gleichbreiten und ziemlich glatten Seitenwulstes, welcher scharf ron der Scheibe geschieden ist, obwohl sein Innenrand nu. durch eine leichte Depression abgesetzt wird.

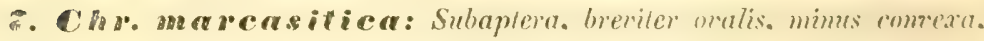
brumen-cuprea. nitida. antemis pedibusque obserne rufis rel piceis. ar.;culo ultimo palporum maxillarium angusto. mothorace brevi. parum comexo, evidenter marginato, aequaliter sat dense punchulalw. lateribus basi subparallelis. antice sensim sat forliter rotumdalo-angustatis. callo laterali postice plica profunda, recia. terminalo; elytris subparallelis. 


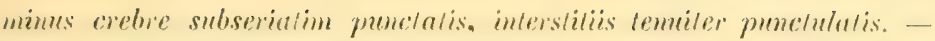
Long. $7-9 \mathrm{~mm}$.

Mis: larsis articulo primo forliler dilulato. segmenlo ultimo rentrali surconvexo.

Germ. Ins. spec. nov. 585 . - Suffr. Mon. 22. - Redtb. Faun. A. II. 471 .

Chr. subincrassata Duft. Faun. Austr. III. 179.

Var. a. Supra cupreo-violacea.

$\mathrm{V}$ ar. b. Supra piceo-aurichalcea.

Var. c. turyida: Breviter-elliplica, comexa. bromeo-cuprea, nitidula. antemis pedibusque piceis. proihonace sat breri, modice comexu. obsolele maryinalo, inatequaliter dense punctulato, interstiliis subeleralis. linen media laeri subelerata instruelo laterinus postice parallelis, antrorsum rolumblo-angustatis, callo laterali basi plica brevi. profunda. recta. terminato; elytris pone humeros evidenter dilatalis. minus crebre vix seriatim punctatis, interstitiis punctulatis.

Var. d. pannonica: Nigro-olivacea.

Var. e. Supra picea, leviter violaceo-micans.

Die flachste, zugleich mit den schlanksten Fühlern und Tastern versehene, unvollkommen gefügelte Art, sehr breit eiförmig, gesättigt braun, oberseits stark kupferig glänzend, unterseits matter, weniger lebhaft oder kaum kupferschimmernd, Prosternum und Seitenstücke der Mittel- und Hinterbrust meist metallisch grün. Fühler schlank, fast fadenförmig, wie die Beine einfarbig dunkel rothbraun bis pechbraun, oder die oberen Glieder dunkler als die unteren; Glied 3 und 11 von allen die längsten. Maxillartaster wenig breit, namentlich das Endglied. Kopf sparsam und sehr fein punktirt, Kopfschildlinien tief. Halssch. kurz, mehr als doppelt so breit wie lang, der Quere nach schwach gewölbt, aber auf der vorderen Hälfte in einem ziemlich starken Bogen nach abwärts gerichtct, ringsum fein, doch deutlich gerandet; die Scheibe gleichmässig, ziemlich dicht, fein punktirt, die Punkte des Seitenwulstes etwas feiner. Seiten nur dicht vor der Basis kaum merklich rerengt und fast parallel, in den vorderen zwei Dritteln allmählich in einom starken Bogen gerundet-rerengt; der Seitenwulst auf der rorderen Hälfte innen weit und flach, undentlich niedergedrückt und schlecht begrenzt, wie bei rufa, anf der hinteren Hälfte durch einen weraden, starken, hinterwärts tieferen faltenartigen Eindruck, welcher. dem Seitenrande parallel läuft, scharf begrenzt und hoch emporgehoben. Fld. an der Pasis etwas breiter als das IIalssch., mit weradlinig heraustretenden Schultern, nach hinten nur unbedrutend "rweitert, fast parallel, beim jo ungefähr ron der Vitte ab, wenig breit, beim $\{\mathrm{im}$ hinteren Drittel breit gemeinschaftlich abgerundet, 
der Rücken ziemlich flach, zur Spitze in kurzer, sur leicht verflachter Wölbung abfallend. Die Punktirung ist mässigs stark, zu etwa dreizehn, wenig scharf hervortretenden Reihen greordnet, wh denen meist sechs an der Naht und zwei über dem beitensaum ziemlich regelmässig und zu zweien einander genähert, die mittleren ganz unregelmässig sind; ihre Zwischenräume einzeln feein punktirt. Flügel kurz und schmal, bandförmig.

Das Männchen ist an dem stark erweiterten ersten Tarsengliede und dem gewölbten letzten Bauchsegmente zu erkennen. Der Penis bildet rorn eine mässig lange dreieckige Spitze, deren Seiten leicht ausgebuchtet sind und auf der Rückseite ein unscheinbares, nach oben gerichtetes breites Häkchen besitzen.

Die Farbe der Oberseite ist bisweilen kupferig-violett (Var. a) oder pechbraun, mit starkem Messingschimmer, ähnlich der Timarch. metallica (Var. b).

Sehr abweichend ist die Var. c. Ihr Körper ist nach vorn und hinten bedeutend verengt, breit-elliptisch, hoch gewölbt, durchgängig matter, besonders das Halssch. Fühler, Taster und Füsse ähnlich geformt aber dunkler, pechbraun, die ersten Fühlerglieder oft theilweise röthlich. Das Halssch. bedeutend länger und zagleich etwas schmaler, höher gewölbt, rorn weniger abschüssig, die Seiten bis zur Mitte parallel, davor allnählich mässig, fast gradlinig verengt, die Scheibe dicht und fein ungleichmässig punktirt, anf der hinteren Hälfte stärker und dichter, die Zwischemräume der Punkte hie und da deutlich gewölbt wie die glatte Mittellinie hinter der Mitte. Der tiefe, faltenartige Eindruck ist dicht punktirt und reicht nicht bis zur Mitte des Halssch., sondern nimmt nur das Basalviertel ein, in den übrigen drei Vierteln geht der Seitenwulst unmerklich in die Fläche der Scheibe über. Fld. an der Basis bedeutend breiter als das Halssch., hinter den gradlinig heraustretenden Schultern merklich erweitert, in der Mitte am breitesten, nach linten allmählich verengt, an der Spitze schnell gemeinschaftlich abgerundet; der Rücken gewölbt, sein Abfall zur Spitze findet in einem längeren und sehr flachen Bogen statt. Die Punktirung ist mässig stark, kaum gereiht, oder es treten nur zwei Reihen über dem Seitensaume dentlicher hervor. - Der Penis bildet vorn eine kurze, breit-dreieckige, abgerundete Spitze, deren Seiten gerade sind und auf der Rückseite ein grosses, breites, nach oben gerichtetes Häkchen besitzen.

Von Abänderungen in der Farbe kommen bei dieser Form vor: die Oberseite kupferig-violett wie bei marcasitica Var. a, oder pechbraun, veilchenblau angelaufen (Var. e). Sehr grosse Stücke von 
den Theissquellen in der Czerna hora sind olivengrün, etwas dunkler als bei ( $h r$. olvacea, Fühler, Taster und Beine pechbraun (Var.d).

In Steiermark (Kahr, Stussiner) nach Branesik (Käf. Steierm. 10(i) nicht selten. Wahrscheinlich auch in Tirol und den osterreichischen Alpen. Die Varietäten e bis e im Glatzer- und Altvater-Gebirge selten, zahlreicher in der hohen Tatra und dem ganzen Karpathenzuge bis Siebenbürgen und in den Banat.

Es ist wahrscheinlich, dass die unter c beschriebene schlesische Form eine gute Art ist, aber ich mochte es nicht als gewiss hinstellen, da ich von der steirischen Form zu wenige Stücke besitze, um daran die Variationsfähigkeit der Art mit Sicherheit zu erkennen. Suffrian hat beide unter marcasitica zusammengefasst und auch Germar hielt später Banater Exemplare (Museum Berlin) für die von ihm aus Steiermark beschriebene Art.

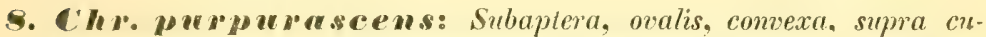
meo-purpurea, sat nitida. subtus picea. leviter aeneo micans subopaca; anlennis pedibusque rufo-testaceis nel piceis, prothorace, basi coleop)teris parum angustiore, modice convexo, sat dense muctulato, lateribus basi subparallelis, antice fortiter rotundato-angustatis, angulis posticis subrectis, callo laterali incrassato, in medio dilatato, subtilissime punclulato, postice plica profunda, subcurvata, antice impressione profunda lerminuto; elytris sat crebre subseriatim punctatis. interstitis parce punctulatis. - Long. 6-9 $\mathrm{mm}$.

Mas: segmento ultimo ventrali tumidulo.

Fem: segmento ultimo ventrali utrinque impresso.

Germ. Faun. Ins. Eur. 5. 6. - Suffr. Mon. 24. - Redtb. Faun. A. II. 471.

Chr. crassimargo Duft. Faun. Austr. IIl. 178. - H. Schäff. Faun. Germ. 15\%. 10. a.

Chr. Dahli Matzek Bericht. Schles. Ges. 1842. 155.

Var. a. Immatura, rufo brunnea, subaurichalcea.

Var. b. Picea, viridi-vel aurichalceo-micans.

Durch den hohen, in der Mitte merklich verbreiterten Seitenwulst des Halssch., welcher innen seiner ganzen Länge nach tief begrenzt ist, ausgezeichnet; eiformig, die Weibchen breiter und gerundeter, oben kupferig braun, oder durch Beimischung ron blau dunkel purpurn, ziemlich glänzend, unterseits metallisch-pechbraun, matt seidenschimmernd, Fühler, Taster und Beine hell gelbbraun bis pechschwarz, im letzteren Falle die ersten Fühlerglieder röthlich. Kopf mit stark abgesetztem Kopfschilde und leicht gewölbter Stirn, glänzend, sehr fein und sparsam punktirt. Letztes Glied der Maxillartaster besonders beim $\hat{j}$ breit; Fühler kurz, mit fünf deutlich 
verbreiterten Endgliedern, Glied :) un die Mälfte länger als 2 und bedeutend kürzer als 11. IIalssch. kurz, auf dem Seitenwulst: sehr fein, auf der Scheibe fein und ziemlich dicht punktirt, die Seiten nur dicht vor der Basis ziemlich parallel oder kaum merklich verschmälert, mit rechtwinkeligen Hinterecken, in den vorderen zwei Dritteln allmählich in einem starken Bogen gerundet-verengt; der Seitenwulst breit, gewölbt, auf der hinteren Hälfte durch einen tiefen, rinnenförmigen, leicht nach innen gebogenen Eindruck, worn durch einen etwas flacheren, kaum faltenartigen, schwach nach aussen gebogenen Eindruck begrenzt. Beide Eindrücke verbinden sich etwa in der Mitte des Halssch., wo sie am flachsten sind, zu einem nach innen gerichteten Bogen, so dass der Seitenwulst daselbst aru breitesten, um die Hälfte breiter als vorn ist. Fld. in den geruıdet heraustretenden Schultern nur wenig breiter als die Basis des Halssch., nach hinten kaum (3) oder leicht erweitert (†), hoch gewölbt, mässig dicht und ziemlich stark punktirt, die Punkte auf der vorderen Hälfte und über dem Seitensaume zu einigen, meist drei paarigen Reiben geordnet, (das äussere Paar derselben fast regelmässig) zwischen denen zuweilen drei leicht erhabene Längslinien, eine auf dem inneren Viertel, die andere in der Mitte, die dritte über dem breiten und fast glatten Seitensaume, hervortreten. Die Zwischenräume sind sparsam, fein punktirt. Auf der Unterseite ist nur die Mitte der Bauchringe glänzend und nebst der Mitte der Hinterbrust und den Seitenstücken derselben deutlich punktirt.

Das kleinere und schmalere Männchen hat ein etwas aufgetriebenes fünftes Bauchsegment, welches beim Weibchen flach und jederseits quer eingedrückt ist. - Der Penis ist an der Oeffinung schwach erweitert, am Vorderrande gerundet-abgestutzt, mit einem fast unmerklichen Ausschnitte in der Mitte, die Seitenränder der Oeffnung sind nach rückwärts in einen schmalen Lappen umgebogen, dessen oberes Ende als ein scharfes Zähnchen jederseits über die Seiten hinausragt.

Die Punktirung der Fld. ist bisweilen ganz verworren, ohne Spur von Streifen; die Farbe der Oberseite ist bei frischen Stücken hell rothbraun, mit Messingschimmer (Var. a), bei ausgehärteten selten schwärzlich, grün oder messinggelb glänzend (Var. b).

In Gebirgsgegendem unter Moos und Steinen; in der sächsischen Schweiz (von hier "prope Schandaviam" stammen Germars Typen) und den schlesischen Gebirgen ziemlich häufig, seltener in Thüringen, dem Harze und den östlichen Alpen; Karpathen, Kodscha Balkan (Merkl). 


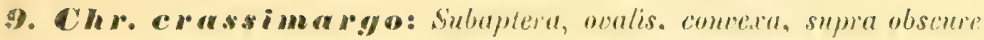

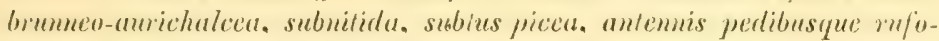
lestaceis rel piceis, prolhorace basi colcopleris haud angustione mimes conrexo, alutaceo, subopaco, dense punctululo, lateribus antice leviler rolundalo-angustatis, angulis posticis aculis, callo laterali incrassato. subtilissime pumctulato, postice plica profunda, antice impressione profunda terminalo, clytris crebre subscratim punctalis, interstitiis parce punctulatis. - Long. $6-9 \mathrm{~mm}$.

Germ.- Ins. spec. nov. 584. - Suffr. Mon. 23. - Redtb. Faun.

A. II. 470 .

Var. a. viridis: Supra saturate viridis.

Var. b. Supra picea.

Diese Art steht zur vorigen etwa in demselben Verhälnisse wie turgida zu marcasitica, und lässt sich nur bei grosser Aufmerksamkeit durch folgende Punkte unterscheiden: Sie ist im Allgemeinen schwächer glänzend (namentlich auf dem Halssch.), dichter punktirt und zeigt keine Neigung, oberseits eine kupferige oder purpurne Färbung anzunehmen; letztere bleibt vielmehr bei der gewöhnlichen Form dunkelbraun, stark in's Messinggelbe spielend, oder wird lebhaft grün (Var. a) oder pechschwarz, ohne merklichen Metallschimmer (Var. b). Der Kopf ist etwas dichter punktirt, matt seidenschimmernd, die Stirn kaum gewölbt. Das Halssch. ist in den spitzen, nach hinten leicht a usgezogenen und die Schultern etwas umfassenden Hintereken am breitesten und verengt sich von hier aus allmählich schwach gerundet nach vorn, wo es merklich breiter als bei purpurascens, und viel breiter als bei hemisphaerica ist, obwohl die Seiten selbst durch die schwache Rundung denen der letztgenannten Art ähnlich werden. Der Seitenwulst ist eben so hoch wie bei der vorigen Art, aber in der Mitte kaum verbreitert, da die beiden tiefen Eindrücke an der Innenseite sich in der Mitte, wo sie am flachsten sind, fast in grader Linie vereinigen. Die Scheibe endlich ist viel dichter punktirt und durch eine sehr dichte und feine lederartige Runzelung matt seidenschimmernd, besonders bei dem Weibchen. Die Fld, sind in den Schultern nur so breit als die Basis des Halssch. und erweitern sich allmählich nach hinten so, dass die grösste Breite etwa in der Mitte, selten hinter derselben liegt; ihre Punktirung ist etwas dichter, kaum schwächer, die drei, von ziemlich regelmässigen Punktreihen begrenzten Längslinien treten meist deutlich hervor.

In Steiermark (Brancsik, Pipitz), Kärnthen: Kötschach und Tirol: Niederdorf (Ludy), sowie in Krain nicht selten. Nack Suffrian auch in Ungarn. 
b. Halsschildsuiten gerade, nach vorn stark convercirund.

* Fühler und Beine rothbraun bis schwarzbraun.

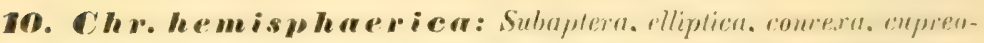
purpuren, nilidula. antennis pedibnesyne brmmeis. prothorace modice ranrexo, sat dense punctulato. basi coleopleris parnm angustione. apjirem rersus fortiter anguslato, trape:iformi. lateribus subrectis. angulis pustidis aculis. callo laterali incrassato, saepe in medio dilalato. sublilissime. prenctulato, posice plica profunda, interdum subcurvata, antice intpressione profunda terminato; elytris sat crebre subseriatiar punctatis. interstitiis punctulatis. - Long. $6-8 \mathrm{~mm}$.

Mas: segmento 5 : o ventrali tumidulo.

Germ. Reis. Dalmat. 204. - Duft. Faun. Austr. III. 178. Suffr. Mon. 40. - Motsch. Schrenk. Reis. II. 215 (Colaphoptera).

Var. a. Supra brunneo-aurichalcea.

Var. b. Supra viridi- vel violaceo-cuprea.

Var. c. laeta: Supra saturate viridis.

In der Farbe mit purpurascens, in der Gestalt der Halsschildseiten mehr mit der vorigen Art übereinstimmend, beiden durch den ähnlichen Seitenwulst des Halssch. nahe verwandt, aber von ihnen durch das nach vorn stark verengte Halssch. nicht schwierig zu trennen.

Ziemlich breit elliptisch, nach vorn und hinten fast gleichmässi@ verschmälert, oben kupfrig braun, durch Beimengung von blau fast purpurfarbig, mässig glänzend, die ziemlich matte Unterseite, Beine und Fübler dunkelbraun, Basalglieder der letzteren meist heller. Kopf mit schwach abgesetztem Kopfschilde und leicht gewölbter Stirn, glänzend, fein und sparsam punktirt, Endglied der Maxillartaster ziemlich breit, Fühler mit dickeren Endgliedern. Halssch. kurz, beiderseits von den Hinterecken nach rorn gradlinig rerschmälert, trapezförmig, mässig gewölbt, auf dem Seitenwulste sehr fein, auf der Scheibe fein und ziemlich dicht punktirt, die Hinterecken spitz-, die Vorderecken rechtwinkelig, der Seitenwulst breit und hoch, innen von einem Längseindruck abgesetzt, welcher aut der hinteren Hälfte sehr tief, rinnenförmig, vorn weniger tief, vor der Mitte oft leicht einwärts gebogen und flacher, zuweilen sogar fast unterbrochen ist. Fld. hoch gewölbt, in den gerundet heraustretenden Schultern wenig breiter als die Basis des Halssch., bis zur Mitte merklich erweitert, die Seiten gleichmässig gerundet, auf dem Rücken mässig dicht und ziemlich stark punktirt, die Punkte hie und da $z u$ einigen undeutlichen Reihen geordnet, ihre Zwischenräume dicht und fein punktirt. 
Bei den Mănnchen ist das erste und dritte Tarsengliod etwas rrweitert, der fünfte Bauchring wenig aufeblasen, mit einem Eindrucke in der Mitte des IFinterrancles; die Wribehen haben auf dem genannten Ringe eine Querrertiefung jederseits. Der Penis ist dem ron purpurascens täuschend ähnlich, aber die Seitenränder der Oeffnung sind nur im oberen Theile in ein dreicckiges, abstehendes Läppchen nach hinten umgebogen.

Es finden sich sowohl bräunlich-messingfarbene, in der Färbung an crassimargo erinnernde, als auch grünlich oder violett schimmernde kupferfarbene Stücke, beide Varjetäten aber sehr selten. Besonders auffallig ist die Var. c mit lebhaft grüner Oberseite.

Cnter Steinen in den östlichen Alpenländern, besonders in Steiermark ziemlich häufig. Das Vorkommen bei Glatz in Schlesien (Zebe), sowie in Sicilien (Museum Berlin, Helfer) ist nicht wahrscheinlich.

11. CIr. crassicollis: Subaptera. clliptica. convexa. nitida, supra cupren-purpurea, sublus brunneo-metallica, nitidula, antemis perlihusque brumeis, illis basi, ore, tibiamm apice tarsisque testaceis. articulo ultimo palporum maxillarium lato, subsecuriformi: prothorace minus convexo. sat dense teniter punctato, basi coleopteris anmstiore. trapesiformi, callo laterali obsoleto, angusto, subtilissime punctulato. postice impressione fortiter punctata terminato. elytris crebre subseriutim punctatis, interstitiis punctulatis. - Long. $7-9 \mathrm{~mm}$.

Suffr. Mon. 50. - Redtb. Faun. A. II. 476.

Var. a. Immatura, rufa, leviter cupreo-micans.

Var. b. Supra cupreo-aurichalcea.

Diese und die beiden folgenden Arten sind an dem wenig deutlichen, innen schwach abgesetzten oder ganz feblenden Seitenwulste des Halssch. zu erkennen und trotz ihrer ähnlichen Körperform und zum Theil übereinstimmenden Färbung kaum mit den vorigen drei Spezies zu verwechseln.

Die vorliegende ist ziemlich breit elliptisch, oben wie hemisphae. rica und purpurascens gefärbt, kupferroth mit bläulichem Schimmer, glänzend, unterseits nebst den Beinen metallisch-braun, ziemlich glänzend, Fühler, besonders ihre Basalglieder, Taster, Spitze der Schienen und die Tarsen hell gelbbraun (ähnlich goettingensis). Kopf zerstreut, sehr fein punktirt, Stirn wenig gewölbt, Kopf'schild tief abgesetzt, Endglied der Maxillartaster sehr stark verbreitert, last beilfömig, Fühler mässig lang, ihre fünf letzten Glieder deutlich rerdickt. Halssch. trapezförmig, die Seiten gerade oder ror der Basis bisweilen unmerklich ausgebuchtet, an den Vorderecken 
etwas nach innen gebogen, der Rücken schwach grwölt, nur mänsig dicht, weitlüufiger als bei hemisphaerica, fein purktirt. I) Sor Sit"ntwulst fast glatt, schmal, vorn kaum so deutlich als bei ruja, in der linteren Hälfte durch cinen breiten, flachen, stärker punktirten Eindruck, welcher in der Mitte verschwindet aber durch einige starke l'unkte bis zum Vorderrande angedeutet wird, etwas in die Höhe gehoben. Fld. an den Schultern kurz aber fast gerade heraustretend, dahinter wenig $(\hat{j})$ oder stark $(f)$ bauchig erweitert. hoch gewölbt, dicht punktirt, die stärkeren Punkte zu unordentlichen Längsreilen geordnet. Unterseite zerstreut und fein, Mitte des ersten Bauchringes und der Hinterbrust, sowie die Seitenstücke derselben stärker punktirt. Prosternum ziemlich breit. Das schlanke Männchen, welches Suffrian nicht kannte, hat breitere Tarsen als das und einen leicht gewölbten fünften Bauchring.

Zuweilen ist die Oberseite kupferbraun, messingglänzend (Var. b), frische Stücke sind roth, mit schwachem Kupferschimmer.

In Oesterreich (Germar), Krain (Kahr), dem Banat und Siebenbürgen (Merkl).

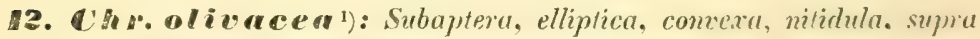
oliwaceu, subtus picea, perlibus antennisque piceis, his gracilibus. basi rufescentibus, articulo ultimo palporzm muxillarium anyusto, prothorace minus convexo, confertim punctulato, basi coleopleris parum angustione, trapeziformi, callo laterali obsoleto, fere nullo, subtilissime punclulato, elytris crebre, inaequaliter punctatis. - Long. i-10 mm. Mas: segmento 5: o ventrali antice tumidulo fortiterque punctato; tarsis articulo primo dilatato.

Suffr. Mon. 53. - Redtb. Faun. A. II. 477.

Chr. atra Matzek Bericht Schles. Ges. 1842. 154.

Var. a. Supra nigra, leviter aurichalceo micans.

Von den vorigen Arten durch die Farbe, Bildung des Halssch. und die dichte, auf den Fld. kaum gereihte Punktirung sehr verschieden, die schlanken Taster und Fühler, sowie die Erweiterung des ersten Tarsengliedes beim $\hat{o}$ erinnern mehr an turgida.

Breit elliptisch, hinten fast buckelig-gewölbt, nur mässig glänzend, oben dunkel olivengrün, selten schwarz, mit schwachem

1) In der Körperform sehr ähnlich ist C'hr. Blanchei Chevr. (Ann. Fr. 1865. 75): Subaptera, elliptica, castanea, nitidissima, prothorace parce punctulato, trapeziformi, basi coleopteris haud angustiore, callo laterali obsoleto, angusto, interne depressione sparsim punctata terminato, elytris vage seriatim punctatis, interstitris vix punctulatis, fere politis. - Long. 7-10 mm.

Diese in Syrien gemeine Art wird vielfach als subferruginea Küst., angeblich aus Frankreich stammend, versandt. 
Messingschimmer (Var. a), unten nebst Fühlern, Tast(rn und Beinen pechschwarz, Oberlippe, Vorderrand des Kopfschildes und die unteren Fühlerglieder mehr oder weniger röthlich. Kopf ziemlich dicht punktulirt, mit schwach abgesetztem Kopfschilde, Endglied der Maxillartaster schmal, Fühler nicht besonders lang, aber dünn, nach der Spitze hin wenig verbreitert. Halssch. trapeztörmig mit geradeu, an den Vorderecken etwas nach iunen gebogenen Seiten, wenig gewölbt, dicht und fein punktirt, der Seitenwulst sehr schwach, innen der Länge nach kaum merklich niedergedrückt und wenig stärker punktirt, aussen fast glatt. Fld. an den Schultern sehr kurz gradlinig heraustretend, dahinter stark bauchig erweitert, dicht unregelmässig punktirt, die Punkte verschieden gross, ihre Zwischenräume sehr fein punktirt. Mitte des ersten Bauchringes und der Hinterbrust stark runzelig-punktirt. Prosternum schmal, hinter den Hüften kaum erweitert.

Das Männchen ist an dem sehr breiten ersten Tarsengliede und dem fünften Bauchringe zu erkennen, der in der vorderen Hälfte etwas aufgeblasen und stark punktirt ist, während die hintere, vertiefte Hälfte nur einzelne Punkte besitzt. - Der Penis ist schlank, gleichbreit, vorn abgestutzt, mit gerundeten Aussenecken.

In Gebirgsgegenden unter Moos und Steinen, auch auf Wegen. Sächsisches Erzgebirge: Annaberg, Karlsbad; Waldenburger-, Glatzer- und Altvater-Gebirge oft zablreich. Theissquellen in der Czerna hora.

13. C7r. globosa: Subaptera, breviter elliptica, nilida, supra brunneo-cuprea, subtus brunnea, antennis pedibusque rufo-testaceis vel brunneis, articulo ultimo palporun maxillarium sat lato, prothorace modice comexo, crebre tenuiter gnuctato, trapeziformi, basi coleopleris parum vel vix angustiort, callo laterali nullo; elytris minus dense subseriatim punctatis, intersitiis parce punctulatis. - Long. 5-8 mm.

Mas: segmento 5 : o ventrali subconvexo.

Panz. Faun. Germ. 87. 16. - Suffr. Mon. 52. - Redtb. Faun. A. ed. 2. 911 ; ed. 3. II. 472.

Chr. aerea Redtb. 1. e. ed. 1. 547.

Var. a. Callo laterali prothoracis postice impressione obsoleta terminaio. Var. b. Supra bruneo- vel piceo-aurichalcea.

Var. c. Supra cupreo-purpurea.

? Var. d. Elytris viridi-aeneis.

Chr. aerea Duft. Faun. Austr. III. 187. - H. Schäff. Faun. Germ. 157. 5. a. - suffr. 1. c. et 274 .

Etwas kleiner und bedeutend breiter als die rorigen, einzelne Männchen wenig länger als breit und daher von fast kreisförmigem 
Utmrisse; oben kupferig l,raun. unten braun, Fühlu.r und Broine rö̈hlich-sulb, raun bis dunkel rothbraun. Im letzteren Falle dir. Fühlerbasis leeller. Kopf bald ziemlich glatt, glänzend, bald dicht. fast runzelig-punktirt und wenig gläszend, Kopfschild tief abgresetzt, Stirn sehwach gewölbt, durch einen Eindruck in der Mitte esewölınlich in zwei niedrige Beulen geschieden. Letztes Glied der Kinnladentaster ziemlich breit, Fühler fast halb so lang als der Kürrw.r, dir Endglieder merklich verdickt. Halssch. trapezförmig, schwach aher gleichmässig bis an die Seiten gewölbt. fein und dicht. der al,schüssige Seitenrand sparsamer und sehr fein punktirt, die Seiten durchaus gerade, oder vor der Mitte etwas stärker als hinter derselben convergirend, so dass sie sehr leicht gerundet erscheinen, der Wulst fehlend, bisweilen aber durch einen flachen Eindruck (in welchem die Punktirung oft etwas stärker ist) linter der Mitts in die Höhe gehoben (Var. a). Fld. an den Schultern in einem sehr flachen Bogen über die Basis des Halssch. heraustretend, mit stark gerundeten Seiten, hinten allmählich in eine gemeinschaftliche stumpfe Spitze verschmälert, hoch gewölbt, wenig dicht in unordentlichen Reihen punktirt, deren Zwischenräume nicht dicht, fein punktirt sind.

Bei dem kürzeren und breiteren Männchen ist besonders das dritte Tarsenglied etwas breiter als beim of und der fünfte Bauchring leicht gewölbt. - Der Penis ist kurz, an der Oeffnung mïssig rerengt, die Seiten der letzteren mit einem bogenförmigen Ausschnitte, der abgestutzte Vorderrand nach hinten umgeschlagen und in einen kurzen, häkchenartigen Zahn jederseits verlängert.

Oft wird die Oberseite braun oder pechschwarz mit Messingschimmer (Var. b), oder kupferig-purpurn, wie bei purpurascens (Var, c). Da ich Exemplare mit metallisch-grünen Fld, wie sie Duftschmid bei seiner aerea beschreibt, nicht gesehen habe. kann dieselbe nur fraglich hierhergezogen werden. Zu bedauern hleibt es allerdings, dass aus Mangel an Material aus der östlichen IIälfte der Alpen, wohin so wenige gute Sammler kommen, noch heute dasselbe Dunkel über einige alte Arten ausgebreitet ist. wie z.u Suffrian's Zeit.

In Steiermark (Stussiner), Kärnthen, Tirol und Krain, Augsburg? (Riehl).

* Fühler und Beine schwarzblau oder lebhaft metallisch grelürbt.

1. Chr. vernalis: Subaptera. oblomgo-nata. supra obscure riridiaurichalcea. alutacea. sublus crm perlibus et antennis nigro-riridis rel -coerulea. anlennarum apice piceo. articulis primis inferne mujescenti- 
bus: prolharace trape:i/armi. sublilissime punchalo, cullo laterali postice plicu pro/unda, subcurvalu, antice impressione houd profunda termimato: elytris punciatis, punctis plemenque cupneis, internis inergularibus, extermis majoribns, propundioribus et in series geminatas sal regulaves disprositis. Articulo secundo tarsomm lato. - Long. 7-11 mm. Mas: farsis dilutatis, segmento t:o ventrali deplanato, 5:0 fovea sul magna impresso.

Brullé Exped. Mor. III. 269. t. 44. f. 7. - Suffr. Mon. 41. Motsch. Sehrenk Reis. II. 214 (Ovosoma).

Chr. bicolor Germ. Mag. Ent. I. 2, 148. - Küst. Käf. Eur. 1. 78. - H. Schäff. Faun. Germ. $15 \%$.

Var. a. Minor. sujwa nigno-niridis nel-coerulea, mitidior; elytris plenumque crebrius el profundius punctatis, interstitiis evidenter punctulatis.

Chr. Heri H. Schäff. Faun. Germ. 164.2. b. - Küst. Käf. Eur. 2. 76. - Suffr. Mor. 43. - Redtb. Faun. A. II. 476. - Weise Kraatz Ent. Mon. 1S80. 102.

Var. b. Elytris (interdum etiam prothorace) nigro-violaceis aut niyris, vix. vel haud aurichalce-micans.

Chr. florea H. Schäff. Faun. Germ. 7. a.

? Chr. incerta H. Schäff. 1. c. 15\%. 7. b.

Var. c. Elytris brunneo-aurichalceis.

Var. d. Lateribus prothoracis haud rectis, leniter rotundatis.

Var. e. gallica: Callo laterali prothoracis nullo.

Var. f. Corpore subgloboso, supra nitida.

Chr. turca Fairm. Ann. Fr. 1865. 74.

Var. g. italica: Lt in f, sed corpore supru fere opaca, callo laterali prothoracis antice nullo.

Die Art zeichnet sich mit ihren nächsten Verwandten ${ }^{1}$ ), die in den Ungebungen des Mittelmeeres leben, durch einen eigenthümlichen Bau des Penis und die bei den Männchen auffällig breiten

1) Die unvollkommen geflügelten lassen sich so übersehen:

1. Fld. mit neun groben Punktreihen, je zwei einander genähert . . . ". 11. Fld. verworyen punktirt oder nit ungefähr 14 unregelmässigen Reihen 3. 2. Punktreihen der Fld. sehr grob und tief, gleichmässig; Wulst des Halssch. ganz, hinten durch eine Rinne, vorn durch einen tiefen, grob punktirten Eindruck abgesetzt. Oberseite bronzirt grün, oft kupferig angeflogen (dann die grubigen Punkte der Fld. hellgrün), Unterseite bronzirt schwarz. Var. Olivieri; Fld. (Kopf und Halssch. zuweilen weniger lebhaft) stark metallisch kupferroth oder durch Beimischung von blau fast purpurroth. - L. S-10 mm. Creta. (Ent. V. 51S. t. 6. f. 77. - Suffr. Mon. 14). cretice Oliv.

$\dot{z}^{1}$. Punktreihen der Fld. grob, mässig tief, oft unterbrochen. Wulst des Halssch. hinten durch eine Rinne abgesetzt, die sich mitunter bis zum Vorderrande flach hinzieht. Oben grünlich bronzefarben, unten schwarz- 
Tarsenglieder aus, welche dadurch, dass das zweite Cilied kaum schmaler als dats erste und wenigg schnaler als das dritte follind ist. einige Achnlichkeit mit dan Fussgljedern der Timarchrn brkommen. Die Flügelstummel sind schmal und reichen bei einigen Arten bis auf den zweiten Hinterleibsring. Trotzdem Suffrian att dir Beschatienheit der Unterflügel kein Gewicht legte und die Verschiedenheiten des Forceps noch nicht kannte, so durfte er kaum die hirerher gehörenden Arten, die an drei Orten zwischen grundverseliedene Thiere eingekeilt sind, so prinziplos anordnen, wie er es in der Mon. leider gethan hat.

Bedeutend länglicher, hinten breiter, als die vorhergthenden Arten, länglich-eiförmig, oberseits grünlich bronzefarben. äusesst dicht und fein lederartig gerunzelt, matt seidenglänzend idas ; glänzender), unterseits schwarzgrün oder schwarzblau. Taster mässig stark, das Endglied etwas verbreitert. Fühler sehr kurz, dünn, nach der Spitze hin wenig rerdickt, pechschwarz, gelblich behaart, die ersten Glieder unterseits meist röthlich, die mittleren leicht grün bder blau sehimmernd. Halssch. trapezförmig. brim

urrïn oder schtrarzblau. Punkte der FJd. oder norh ein K̈reis m disselben kupferroth oder messingfarbig -- L. $-10 \mathrm{~mm}$. Tionstantinopel, Griechenland, Smyrna (Koltze). (Ent. V. 512. t. 5. f. 70. - Suffr. 44.) orientalis Oliv.

3. Halssch. ohne Seitenwulst 4.

3'Halssch. mit Seitenwulst

4. Halssch. seidenglänzend, sehr dicht und fein punktirt.

vernalis var. gallica.

4'. Halssch. glänzend, dicht und fein ungleichmässig punktirt, Zwischenräume oft zu kleinen, erhabenen Runzeln vereint. - L. 5-8 mm. Pic de Bigorre (Ann. Fr. 1865. 77) . pyrenaica var. bigorrensis Fairm.

5. Seitenwulst hinten durch einen schwachen Eindruck begrenzt. Oben schwarz, unten schwarzblau, Halssch. dicht punktirt (oft runzelig). - L. 6-9 mm. Hochpyrenäen: Pic de Bigorre (carbonaria Suffr. 49. Excurs. Vall. d'Ossan 106) . . . . . pyrenaica Dufour.

51 Seitenwulst hinten rinnenförmig begrenzt 6.

6. Flıl. grob punktirt, mit breiten, ebenen, fast glatten Zwischenrüumen vernalis Brull.

6.Fld. dicht, ziemlich stark unregelmässig doppelt punktirt: die stärkeren Punkte aussen gereiht. Hierher wahrscheinlich a) die bronzefarbene coriacea Suffr. (Mon. 59) aus Spanien und Portugal und ihre schwarze, anf den Fld. stärker punktirte und gerunzelte Var. rugipennis Har. (Col. Heft. 14. 140) aus Andalusien, mit der sich foswlate Suffr. (Ann. Fr. $185 \%$ 101) identisch erweisen dürfte; b) cantubrien Heyd. (Reis. Span. 170), welche vernalis im asturischen Gebirge rertritt; c) subnenea Suffr. (Mon. 60) aus den Hochpyrenäen. 
viel kürzer als beim $\hat{j}$, zwischen der äusserst dichten lederartigen Runzelung mässig dicht und sehr fein punktirt, die Seiten ganz gerade oder leicht ansgeschweift, so dass die Hinterecken schwach nach hinten und aussen vorgezogen erscheinen, selten (Var. d) wio bei crassimargo nach vorn gerundet-verengt. Der Seitenwulst ist breit, aber nicht besonders hoch gewölbt, feiner als die Scheibe punktirt, seiner ganzen Läuge nach innen ron einem Eindrucke begrenzt, welcher hinter der Mitte tief, furchenartig wird und in der Mitte oft nach imnen gebogen ist. Fld. ziemlich stark punktirt, die Punkte, die im Innern und am Rande kupferroth, zuweilen etwas bläulich sind, werden nach aussen stärker, grübchenartig und bilden neun nicht ganz regelmässige Reihen, von denen je zwei einander genähert sind, die innere an der Naht aber einzeln steht. Ausserdem befinùet sich eine abgekürzte, aus ungefähr acht Punkten bestehende Reihe jederseits am Schildchen. Zwischen diese Reihen schieben sich hinter dem ersten Viertel der Fld. noch etwa fünf andere, noch weniger regelmässige Reihen (die meisten davon zwischen die an der Naht einzeln stehende und die nächstfolgende Reihe), so dass die Punktirung, namentlich innen, ziemlich verworren wird. Zwischenräume der Punkte sparsam und meist sehr verloschen punktulirt, stellenweise nadelrissig. Das schlanke Männchen hat sehr breite Tarsen, sein viertes Bauchsegment ist in der Mitte flach gedrückt und oft längsrunzelig, mit kielig aufgeworfenem, jederseits schwach erhöhtem Hinterrande, das fünfte Segment besitzt einen weiten, grubenförmigen Eindruck am Hinterrande. - Der Penis ist selır breit, seine Oberseite längsvertieft und vorn in zwei stumpfe, dicht neben einander liegende Spitzen ausgezogen, die in die Oeffnung hineinragen; der Unterrand biegt sich in einem grossen Halbovale nach vorn und oben und ist am Ende hakenförmig umgeschlagen. Von der Seite betrachtet sicht der Unterrand ziemlich S-förmig aus.

Das Thier ist sehr variabel. Die kleinere, oben und unten schwarzgrüne oder schwarzblaue, metallschimmernde Form IJeri ist glänzender, durchweg kräftiger punktirt, mit deutlich punktulirten (bei frischen Stücken dicht nadelrissigen) Zwischenräumen der Fld. Von ihr kommen auch Stücke mit schwarz-violetten, oder tief schwarzen Fld., selbst ähnlich gefärbter Oberseite vor (Var. b), die ron H. Schäffer als florea, vielleicht auch als incerta beschrieben wurden. Zur Var. e mit bräunlich-bronzefarbenen Fld. gehören vorzugswejse Männchen von vernalis, zu e solche Heri aus den Pyrenäen (Royer), bei denen das Halssch. gleichmässig bis zu den Seiten gewölbt ist und weder Eindruck noch Seitenwulst besitzt; f und g sind durch 
ihren kurzen und breiten Bau sthr auftällig. I) eretere (turca). ron Constantinopel und aus dem Kodscha Balkan (Merkl), ist glïnzeud, oberseits meist schwarz, mit ganzem, worn oft urob punktirtem Eindruck innerhalb des Seitenwulstes auf dem Halssch.; letztere (italica) ist fast matt, wie Ileri gefürbt, aber beinahe halbkugelig. der Seiteneindruck des Halssch. vorn fehlend.

Wahrscheinlich in Krain und Istrien, aber spezielle und rerbürgte Fundorte nicht bekannt. In südlichen Frankreich, Italien, Dalmatien, Griechenland und der Türkei nicht selten.

\section{Körper vollkommen geflügelt.}

* Halsschild trapezförmig.

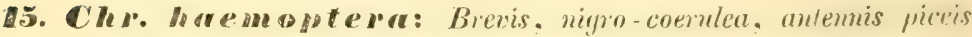
basi rufescentibus. pothorace trapesiformi, sat dense pumitulato, pumiti. nonnullis majoribus utrinque impresso, callo laterali mullo, elytris substriatim punctatis, seriebus punctorum plerumque per puriu approximatis. - Long. 5-9 $\mathrm{mm}$.

Mas: pulpis articulo ultimo tarsisque modice dilatatis.

Linn. Syst. Nat. ed. X. 369. - Gyllh. Ins. Suec. III. 452: Suffr. Mon. 54. - Redtb. Faun. A. II. 47\%. - Seidl. F. balt. 482 .

Chr. hottentotta Fabr. Ent. Syst. I. 1. 309. - Payk. Faun. Suec. II. 64. - Duft. Faur. A. III. 194. - Küst. Käf. Eur. 7. 85. Motsch. Schrenk Reis. II. 212 ('olaphodes).

Var. a. Supra nigro-violacea, -purpurea, -cuprea vel-viridis.

Var. b. Supra nigra.

Breit- (), oder länglich-oval $(\hat{j})$, gewölbt, glänzend-schwarzblau, unten dunkler als oben. Kopf zerstreut und sehr fein, nur auf dem Kopfschilde deutlich punktirt, Taster ziemlich schlank. Fühler pechschwarz, gelblich behaart, die Basalglieder unten röthlich. Halssch. trapezförmig, mässig dicht, fein punktirt, mit einigen stärkeren Punkten jederseits, welche den kaum angedeuteten Seitenwulst innen undeutlich begrenzen. Fld. in den Schultern kaum breiter als die Basis des Halssch., kräftig punktirt, die Punkte zu unordentlichen, gebogenen Doppelreihen zusammengestellt, zwischen denen oft einige Zwischenräume deutlich hervortreten.

Das Männchen hat das Endglied der Maxillartaster und die Tarsen mässig erweitert.

Die Farbe der Oberseite wird zuweilen schwarz - violett oder purpurn, selten kupferschimmernd oder grün; häufig sind auch oben tiefschwarze Stücke.

Ganz Europa. 
Da das Halssch. zuweilen nach vorn nicht gradlinig, sondern gerundet-verengt ist (eine Bildung, die man bei allen Chrysomelen mit trapezförmigem Halssch. ausnahmsweise findet), so wäre es möglich, dass Chr. Camerani Piolti aus Italien nur eine dunkel bronzefarbene (bronzato-scuro) Varietät ist.

Eine ausgezeichnete Lokalform (Chr. znicolor Suffr. Mon. 55) findet sich in Italien, scheint aber nicht bis zum südlichen Tirol herauf zu gehen. Sie ist durchschnittlich grösser, beiderseits etwas stärker verschmälert, oberseits tiefer bläulichschwarz gefärbt, lackartig glänzend und durchweg feiner punktirt. Dass sie nicht specifisch zu trennen ist ergiebt sich aus der Form des Penis, welcher mit dem der haemoptera übereinstimmt. Derselbe ist sehr kurz und breit, kaum doppelt so lang als breit, in der Mitte eingeschnürt, der ror der Einschnürung befindliche breitere Theil, welcher die Oeffnung enthält, ist fast quadratisch, vorn schwach gerundet-abgestutzt. ${ }^{\text {) }}$

Von dieser Form ist, trotz der grossen Aehnlichkeit, Chr. hyacinthina Suffr. (Mon. 45) aus Sicilien wohl sicher verschieden; denn ihr feiner punktirtes Halssch. besitzt vor dem Hinterrande jederseits einen kurzen, wenig tiefen aber aussen scharfen Eindruck, welcher den Seitenwulst deutlich emporhebt. Der Käfer ist schwarzblau oder schwarzviolett, oberseits mit mehr oder weniger starker Beimischung von Grün, und lackartig glänzend; die Fld. sind kaum sichtbar lederartig gerunzelt, dazwischen äusserst fein punktirt (wie bei haemoptera), jedoch mit 4 Reihenpaaren starker Punkte, von denen jedes einen leicht gewölbten Zwischenraum einschliesst. Die übrigen, breiteren Zwischenräume sind mässig dicbt, aber nur wenig feiner als die Doppelreiben punktirt, so dass letztere meist nicht recht deutlich herrortreten. Stücke, bei denen die Punkte der Fld. ungefähr gleichstark und so unregelmässig vertheilt sind, dass Punktreihen nicht mehr erkennbar sind, balte ich für die Var. cribellata Suffr. (Mon. 46) so lange die Beobachtung Suffrian's, die Fühler dieser Art seien

1) Vor haemoptera steht Chr. Sahlbergi Ménétr. (Cat. rais. 235. Fal derm. Nouv. Mém. Mose. V. 358. t. 12. f. 11. - cupreopunctata Reiche Ann. Fr. 1858. 30) aus Transkaukasien, Kkleinasien und Syrien. Dieselbe ist der Chr. orientalis in Form, Farbe und Skulptur sehr ähnlich, aber vollkommen geflügelt, und die groben, in kupferfarbigen Kreisen stehenden Punkte der Fld. sind meist weit von einander eingestochen, so dass die von ihnen gebildeten 9 paarig-genäherten Reihen wenig deutlich sind. Körper bald breit elliptisch, mässig gewölbt, bald kurz, fast halbkugelig. Punkte der bronzefarbenen Fld. zuweilen bläulich-metallgrün, oder Körper schwarzblau (Var. venefica), Punkte der Fld. kupferig bronzefarben. - L. $7-9,5 \mathrm{~mm}$. Der Lnterrand des Penis sehr schmal aber wie bei nernalis stark S-förmig gebogen.

VI. 3. 
kürzer und dicker, ,fast denen einer Timarcha gleich", nicht noch anderweitig bestätigt ist.

Nach der Beschreibung schien auch Chr. atrocirans Friv. (Adatrk 1876 p. 335) -prope Bazias, in Valle Ribis inventa - mit haemopterf verwandt; allein nach Ansicht von Original-Exemplaren, die Herr ron Frivaldszky freundlichst einsandte, ist die Art ungeflügelt und \%wischen Heeri und pyrenaica zu stellen. Von letzterer ist sie durch den nach vorn stärker verschmälerten Körper, die schwarzgrüne Farbe der Oberseite und die deutlicheren, obschon immer noch unregelmässigen Doppelreihen der starken Punkte auf den Fld., deren $\mathbf{Z}$ wischenräume dichter und deutlicher punktirt sind, zu unterscheiden.

Dagegen findet hinter hyacinthina wohl ihre natürlichste Stelle die einzige Vertreterin einer in Afrika verbreiteten, umfangreichen Gruppe: C' $h r$. diluta Germ. (Ins. Spec. nov. 591. - Küst. 1. 93): Subglobusa, nigroaenea vel -coerulea, antennarum basi inferne elytrisque testacen-brunneis, capite prothoraceque subtiliter punctatis, hor apice quam basi multo angustiore, lateribus fere rectis, callo laterali obsoleto parce fortiter punctato, postice impressione sat profunda brécissima, punctata, anticeque punctis majoribus terminato; elytris irregulariter seriatim punctatis, lineis nonnullis subelevatis, callo humerali, sutura et punctis elytrorum plerumque nigricantibus vel nigroaeneis aut disco fere toto infuscato. - Long. 6-S mm. In der Cmgebung des Mittelländischen Meeres von Portugal und Maroceo bis Syrien und Südrussland häufig.

Der Penis ist mehr als halb so lang wie der ganze Körper, sehr flach, oben rinnenförmig vertieft, zweimal sehr leicht gebogen, vorn ganz allmählich in eine breite, abgerundete Spitze verschmälert, die Oeffinung sehr lang, der ductus ejaculatorius breiter als bei den Verwandten, oben rinnenförmig.

16. Chr. Hossia: Breviter-elliptica, nigro-coerulea vel -violacea. antennis articulis duobus primis inferne rufescentibus, articulo ulimo palporum maxillarium lato, prothorace trapeziformi, subtiliter minus dense punctulato, callo laterali incrassato. impressione profunda sparsim punctata terminato, elytris limbo laterali laete rufo, sat fortiter parum dense punctatis. - Long. 7-10 $\mathrm{mm}$.

Illiger Mag. I. (1S02) 415. - Küst. Käf. Eur. II. 75. H. Schäff. Faun. Germ. 157. 1. g.

Chr. Rossii Suffr. Mon. 38. - Motsch. Schrenk Reis. II. 213. (Ovomorpha). - Redtb. Faun. A. II. 476.

Chr. sanguinolenta Rossi Faun. Etr. I. 77.

Breit oval, aber besonders das $\hat{j}$ hinten zugespitzt, stark gewölbt, glänzend $(\hat{j})$ oder matt seidenschimmernd $(f)$, oben tief schwarzblau oder schwarz-violett, unten lebhafter und heller blau oder violett; die beiden ersten Fühlerglieder unten röthlich, ein breiter Saum am Seitenrande der Fld. und die Epipleuren hellroth, wie bei sanguinolenta. Kopf zerstreut und fein punktirt, Maxillar 
taster kräftig, ihr letztes Glied breit. Halssch. trapezförmig, wenig dicht and sehr fein punktirt, mit einzelnen stärkeren Punkten am Innenrande des ziemlich breiten und hohen Seitenwulstes, welcher innen durch einen ziemlich geraden Eindruck in seiner ganzen Länge begrenzt wird. Dieser Eindruck ist auf der hinteren Hälfte schmal und tief, er verbreitert und verflacht sich in der Mitte oft so weit, dass er den Seitenwulst kaum mehr emporhebt, und wird nach dem Vorderrande hin wieder tiefer. Eckporen und Borsten fehlen. Fld. in den Schultern wenig breiter als die Basis des Halssch., ziemlich stark und weitläufig punktirt, die Punkte bilden nur über dem Aussenrande zwei fast regelmässige, deutliche Reihen, von denen die äussere auf dem rothen Randsaume stebt, während die innere denselben meist scharf begrenzt.

Bei dem grösseren und breiteren, dabei stärker punktirten Weibchen sind die Punkte der Fld. oft durch leichte Runzeln verbunden, beim Männchen ist das erste Tarsenglied mässig erweitert una' der letzte Bauchring quer aufgewulstet, sowie am Hinterrande sehr flach ausgeschnitten. Der Penis ist mässig stark, ein Stück über der Oeffunng leicht gerundet-erweitert und vorn allmählich in eine breite, stumpfe Spitze rerschmälert, übrigens dem der sanguinolenta sehr ähnlich. Auf der Rückseite der Spitze befindet sich jederseits eine ziemlich tiefe Rinne, ebenso ist die Mitte der Länge nach weit und flach vertieft.

In den Alpen Oesterreichs, besonders im südlichen Tirol nach Gredler nicht selten. Triest, Italien, Dalmatien, Ungarn.

Die Art findet ihre einzig richtige Stellung in der Gruppe der Chr. sanguinolenta, aber es ist bei der hier befolgten Anordnung der Gattung nicht möglich, sie näher an die verwandten Thiere heranzurücken.

In Portugal lebt ein habituell ähnliches Thier Chr. mactata Fairm. (Ann. Fr. 1859. Bull. 152; 1865. 75). Sie ist weniger breit gerundet, schwarz, stark glänzend, das Halssch. fast glatt, nach vorn weniger verschmälert, die Fld. haben einen sehr breiten gelbrothen Basal- und Seitensaum, welcher auf dem Rücken nur eine grosse, gemeinschaftliche, verwaschen begrenzte Makel schwarz lässt, und sind mässig stark, am Grunde und an den Seiten in Reihen punktirt.

17. Chr. femoralis: Ovalis, nitidula, supra nigra. plerumque leviter coeruleo-micans, subtus nigro-violacea. antennarum basi femoribusque in medio sanguineis; prothorace basi coleopleris angustime. subtrape:iformi, dense inaequaliter punctato, linea media laevi. lateribus subrectis, callo laterali obsoleto, postice plica profunda subcurvala. 
fortius punclato terininato; elyfris crebre punclatis. punclis majorilnus in series geminulas iregulares dispositis impressis. - Lon. $f ;-10 \mathrm{~mm}$. Mas: tarsomum articulo tertio dilatato. seqmento ultimo rentrali romexte. apice truncato.

Oliv. Encyclop. méth. V. 690 ; Ent. V. 514. t. 1. f. $72 .-$ Suffr. Mon. 56.

Var. a. Pedibus violaceis.

Var. b. Tagenii: Fortius punctata, prothoracis lateribus exidenter rutundatis.

Herr. Schäff. Faun. Germ. 1838. 157. 9. b.

Chr. confusa Suffr. Mon. 47.

Var. c. laeta: Supra saturate violacea aut coevulea, interdum rividimicans.

Ungefähr von der Gestalt der folgenden, vorn jedoch ein wenig schmaler, hinten etwas breiter, stärker punktirt und an den rothen Schenkeln sofort zu unterscheiden.

Oben tief schwarz oder schwarz mit bläulichem Schimmer. durch die feine lederartige Runzelung nur matt seidenartig glänzend, unten schwarzblau, Taster und Basis der Fühler röthlich, die Mitte der Schenkel blutroth. Kopf überall deutlich, aber nicht dicht punktirt. Halssch. mässig gewölbt, nach rorn geradlinig stark rerengt, mit spitzwinkeligen Hinterecken, der Seitenwulst wenig deutlich, nur im hinteren Drittel von einem breiten, grubenförmigen, aussen nicht besonders scharfen Eindrucke begrenzt, welcher sich rorn allmählich verflacht und meist etwas nach einwärts biegt. Die Scheibe etwas stärker, und besonders nach den Rändern hin viel dichter punktirt als der Kopf und Seitenwulst, die Zwischenräume der Punkte ungleich gross; die glatte, beiderseits abgekürte Mittellinie meist deutlich. Fld. bedeutend stärker und weitläufiger als das Halssch. punktirt, dazwischen mit etwas gröberen Punkten, die zu s, wenig in die Augen fallenden, einander paarig genäherten Reihen geordnet sind. Deren vier Zwischenstreifen sind, wie die Zwischenräume der übrigen Punkte, bald deutlich und tief, bald undeutlich fein punktirt und zuweilen gewölbt. An den rothen Schenkeln ist die Basis gewöhnlich, die Spitze stets blau gefärbt.

Das Männchen hat stark erweiterte Tarsen und einen gewölbten, an der Spitze abgestutzten letzten Bauchring. - Der Penis ist dem von goettingensis ähnlich, aber in den vorderen zwei Dritteln deutlich verbreitert, an der Spitze länger abgerundet und deshalb schmaler. die Klappe kurz, am Vorderrande ausgeschnitten, dachförmig.

Sehr variabel. Die Beine werden einfarbig blau (Var. a), die Oberseite wird gesättigt violett, blau, oder grünlichblau (Var. c); die Form des Halssch. verändert sich dadurch erheblich, dass die Seiten sich 
nach vorn in einern deutlichem Bogen verengen, wie bei goettingensis $\left(\right.$ Var. b) ${ }^{1}$ ). Bei dieser Form, die Suffrian noch für eine Art hielt, sind die Hinterecken des Halssch. weniger spitz, der Eindruck jederseits an der Basis des Halssch. ist tiefer und länger, ausserdem die ganze Oberseite stärker punktirt.

Sehr häufig im südlichen Frankreich, sparsamer in Italien bis Sicilien. Als deutschen Fundort giebt Brancsik Steiermark an, ich selbst besitze ein unzweifelhaft deutsches Stück aus den österreichischen Alpen, welches zur Varietät c. gehört, die vorzüglich im Departement Basses Alpes in der Umgegend von Digne zu Hause ist.

1) In derselben Weise variirt die nahe verwandte Chr. affinis Fabr. (Mant. I. 67; Ent. Syst. I. 310. - caliginosa Suffr. 48): Alata, breviter "valis, nitilula, supra brunneo-vel viridi-aurirhalcea, subtus vinlacea, antennarum basi jemorihusque sanguineis; prothorace basi coleopteris vix anyustiore, subtrapeiformi, plus minusve dense punctato, latgribus sulrectis, "allo laterali ubsoleto, postice impressione subplicaefor mi sat profunda, fortius punctata terminato; elytris minus crebre fortiter punctatis, punctis plerumque subseriatis, lineis nonnullis subelevatis, interstitiis plus minusve subtiliter punctatis. Mas: tarsis dilatatis, segmento ultimo ventrali convexo. - Long. $7-10 \mathrm{~mm}$.

Variat. a. varipes Suffr. (Mon. 17): Supra nigra, leviter aurichalceomicans, nitida; b. baetica Suffr. (Mon. 16): Supra brunneo-vel ciridiaurichulcea, sericeo-micans, prothoracis lateribus evidenter rotundatis.

Zahlreich im südlichen Spanien, gemein im nordwestlichen Afrika.

Der Penis ist wie bei femoralis gebaut, aber vorn breiter gerundet-abgestutzt.

Herr Brisout de Barneville, der die Freundlichkeit hatte, die Typen aus Olivier's und Chevrolat's Sammlungen zu untersuchen, hat vielleicht Recht, diese Art nur als eine oberseits bronzefarbene Lokalform der femoralis anzusehen; aber ich kann mich, abgesehen von der Farbe und der geringen Verschiedenheit des Penis, aus folgenden Gründen nur schwer zu einer Vereinigung verstehen: Bei affinis sind Kopf und Halssch. feiner, verloschener, die Fld. dagegen stärker und gewöhnlich viel sparsamer punktirt, ihre Doppel-

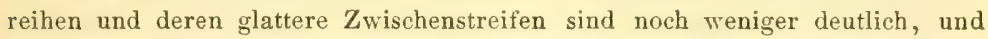
die Schultern der Fld. treten kaum je so stark wie bei femoralis heraus, wodurch das Thier eine wesentlich andere Körperform erhält.

Dahinter ist einzureihen:

Chr. rufofemorata Heyd. (Reis Span. 171): Alata, nigra, haud reneo-micans, subopaca, femoribus sanguineis, antennis (articulis 2 primis apice rufis), tibiis tarsisque nigro-coeruleis; prothorace crebre inaequaliter ingoso-punctato, apicem versus fortiter angustato, lateribus evidenter rotunlatis, callo laterali obsoleto, parce punctulato, postice depressione parum distincta terminato; elytris crelore fortiteryue rugoso-punctatis, interstitiis parce profundeque punctulatis. Mas: trersis dilutatis, segmento ultimn ientrali apice subtruncato. - Long. 7-8,5 mm. Asturia. 
** Halsschild quer viereckig, vorn gerundet verengt.

18. Chr. goettingensis: Ovalis, violaceu, antennamu basi. palpis tarsisque ferrugineis, prothorace subtiliter punctato, transrerso. lateribus postice subparallelis, antice sut $(\hat{\hat{j}})$ vel minus fortiter ( $\hat{\Sigma}_{\text {) }}$ rotundato-angustatis, callo laterali obsoleto, sublaevi, interne leviter deplunato, elytris dense punctatis, punctis majoribus in series irrequ. lares dispositis. - Long. 6-10 mm.

Mas.: palporum maxillarium articulo ultimo tarsisque fortiter dilatutis.

L inn. Syst. Nat. ed. X. 368. - Panz. Ent. Germ. I. 156; Fauu. Germ. 44. 3. - Duft. Faun. Austr. III. 186. - Küst. Käf. Eur. I. 72. - Matzek Bericht Schles. Ges. 1842. 155. Suffr. Mon. 35. - Thoms. Skand. Col. VII. 251. - Mots ch. Schrenk Reis. II. 216 (Colaphosoma). - Redtb. Faun. A. II. 472. - Seidl. F. balt. 483.

Chr. haemoptera Fabr. Ent. Syst. I. 315. - Payk. Faun. Suec.

II. 52. - Oliv. Ent. V. 520.

Var. a. Antennis ferrugineis.

$\mathrm{Var}$ b. Tarsis superne violaceis.

Var. c. Sturmi: Supra nigro-aenea.

Westh of Käf. Westphal. 268.

Var. d. polonica: Viridis, plus minuse coeruleo-micans, vel viridi-aured.

Weise Deutsch. Zeit. 1883. 253.

Diese häufige Art ist an den rostrothen Tarsen leicht zu erkennen; in der Farbe ähnelt sie dunklen Stücken der coerulea, in der Körperform und der Bildung des Halssch. steht sie rufo sehr nabe.

Dunkelviolett, Unterseite und Beine heller und lebhafter violett oder blau, die Basis der braunen, bläulich angelaufenen Fühler, die Taster und Tarsen rostroth. Kopf zerstreut und sehr fein, nur auf dem Kopfschilde deutlich und ziemlich dicht punktirt, Taster kräftig. Halssch. schwach gewölbt, die Seiten von der Basis nach der Mitte unmerklich gerundet-erweitert, fast parallel, vor der Mitte mässig $(+)$ oder stark $(\hat{J})$ gerundet-verengt, auf der Scheibe dicht und fein punktirt, die Punkte nach den Seiten hin etwas grösser. Seitenwulst undeutlich, fast glatt, innen uur auf der hinteren Hälfte durch einen seichten, aber deutlichen Längseindruck begrenzt, welcher mehr oder weniger dicht und stark punktirt ist. Fld. ziemlich dicht und ungefähr eben so stark als das Halssch. punktirt, dazwischen mit etwas stärkeren Punkten, von denen die grössten gewöhnlich zu unordentlichen, wenig in die Augen fallenden Reihen geordnet sind.

Das Männchen zeichnet sich durch den schwach aufgetriebenen letzten Bauchring, das erweiterte Endglied der Maxillartaster und besonders durch stark erweiterte Tarsen aus. Die Erweiterung derselben 
erstreckt sich an den vorderen Beinen auf die drei ersten Glieder, an den Hinterbeinen nur auf das Basalglied. - Der Penis ist ziemlich stark, gleichbreit, vorn sehr flach abgerundet, seine lange Klappe ist am Vorderrande fast gerade abgestutzt.

Farbenabānderungen sind: a. Fühler einfarbig rostroth; b. Tarsen oberseits eben so dunkel gefärbt, wie Schenkel und Schienen; c. Oberseite schwarz mit Metallschimmer, Unterseite violett oder bläulich; d. Oberseite oder der ganze Körper, mit Ausnahme der Fühlerbasis, der Taster und Tarsen, blaugrün bis lebhaft goldgrün.

Europa. Zahlreich unter Steinen auf trockenen Grasplätzen im Frühlinge. Kaukasus (Leder). Die Varietät d. besonders im westlichen Russland.

19. Chr. limbata: Ovalis, nigra, supra plus minusve aeneo-micans, articulo ultimo palporum maxillarium mayno, antennis articulis 2 primis inferne rufescentibus, prothorace transverso-quadrato, evidenter alutaceo subtiliterque punctato, callo laterali postice plica profinda punctata, antice impressione fortius punctata terminato, coleopteris dense subtiliter punctatis, punctis majoribus in series irregulares dispositis, limbo toto rufo vel sanguineo; tarsis parvis. - Long. 6-10 mm.

Mas: tarsis modice dilatatis, segmento ultimo ventrali apice truncato.

Fabr. Syst. Ent. 101. - Payk. Faun. Suec. II. 70. - Schrank Faun. boic. 534. - Panz. Faun. Germ. 16. 8. - Oliv. Ent. V. 562. t. 1. f. 7. - Gyllh. Ins. Suec. III. 461. - Duft Faun. Austr. III. 181. - S teph. Ill. Brit. IV. 343, - Küst. Käf. Eur. 1. 82. - Matzek Bericht Schles. Ges. 1842. 155. - Suffr. Mon. 69. - Motsch. Schrenk Reis. II. 206. (Zeugotaenia). - Thoms. Skand. Col. VIII. 250. - Redtb. Faun.

A. II. 469. - Seidl. F. balt. 482.

Var. a. Supra leviter viridi-vel coeruleo-micans.

V ar. b. Elytris rufis, macula communi magna nigra.

Var. c. limbifera: Subelonyata, nigro-coerulea aut -viridis.

Küst. Käf. Eur. IV. 91. - Suffr. Mon. 71.

Var. d. Hoch huthi: Saturate nigro-coerulea, interdum subtiliter punctato. elytris rufis, macula communi magna laete coerulea.

Suffr. Mon. 72 .

Chr. limbata var. Kryn. Bull. Mose. V. 1832. 168.

Var. e. Findeli: Nigra, haud aeneo-micans, prothorace crebre punctulato, callo laterali postice plica profunda, antice impressione obsoletissima fere uniseriatim punctata terminato, coleopteris plemumque for. tius punctatis, limbo toto rufo.

Suffr. Mon. 70. - Redtb. Faun. A. II. 476.

Eiförmig, vorn fast gleichbreit, schwarz, leicht seidenglänzend, oberseits mit mehr oder weniger deutlichem Metallschimmer, unter- 
seits bläulich, die zwei ersten Fühlerglieder unten und ein breiter Saum an der Wurzel und den Seiten der Fld. roth, im Lelen blutroth. Kopf fein und zerstreut punktirt, Endglied der Maxillartaster breit, doppelt so breit als das vorletzte, Fühler kräftig. Halssch. quer-viereckig, an den Seiten gewöhnlich rom Grunde bis vor die Mitte geradlinig-, oder schwach gerundet-erweitert (beim $\hat{j}$ in der Regel stärker als beim f), vorn schnell gerundet verengt, zuweilen aber in der hinteren Hälfte parallel, selten sogar schon von der Basis an leicht, kurz vor den Vorderecken stärker verschmälert, ohne Eckporen und Borsten. Die Oberfläche vorn stark abwärts gewölbt, dicht und deutlicher als die Fld. lederartig gerunzelt, dazwischen fein punktirt. Der Seitenwulst breit und dick, ebenso wie die Scheibe punktirt, aussen mit ein bis zwei unregelmässigen stärkeren Punktreihen dicht über der Randlinie, innen von einer breiten und tiefen, punktirten Rinne begrenzt, welche nicht ganz bis zur Mitte nach vorn reicht und hier plötzlich, indem sie wenig nach einwärts biegt, endet; davor ist die Trennung von der Scheibe nur durch einen sanften, dicht vor dem Vorderrande verbreiterten und vertieften Eindruck angedeutet, welcher mit sehr groben, oft noch auf den Wulst selbst gestellten Punkten besetzt ist. Fld. äusserst fein lederartig gerunzelt, dicht und fein punktirt, mit unregelmässigen, stärkeren Punktreihen. Von diesen sind in der Regel nur die beiden äusseren, auf dem rothen Seitensaume, und die inneren Reihen an der Basis der Fld. deutlich und fast regelmässig. Die Unterseite ist auf der vorderen Hälfte noch matter, als die Oberseite, die Beine sind glänzend, mit schlanken Tarsen.

Das Männchen hat mässig erweiterte Tarsen und einen schwachen Eindruck vor dem abgestutzten Hinterrande des letzten, leicht gewölbter Bauchringes; sein Körper ist kleiner als beim Weibchen, fast parallel, nach hinten kaum bauchig erweitert, das Halsschild vorn breiter und wie die Fld. glänzender. - Der Penis ist schlank, nur dicht an der Basis gebogen, ziemlich flach, nach der Oeffnung hin allmählich und gering verbreitert, vorn leicht verengt und abgerundet.

Die Art ist in jeder Hinsicht reränderlich, und es scheint mir angemessen, hier ihren wirklichen Umfang festzustellen, da ihre vers shiedenen Formen noch als Arten angesehen werden. Der leichte gelbliche Metallschimmer aller schwarzen Stellen der Oberseite wird nicht selten durch einen metallisch-grünen oder -blauen Glanz ersetzt (Var. a). Die hierher gehörigen Stücke zeichnen sich oft durch einen gestreckten Körperbau aus; sie bilden dann den Anfang zu der im südlichen Russland, der Krim und dem Kaukasus (auch noch 
auf dem Kuruseh, Faust) einheimischen, lebhaft gefärbten Varietät limbifera $\mathbf{K}$ üst. (Var. c), die sich durch keins der von Küster und Suffrian angegebenen Merkmale specifisch trennen lässt.

Eine zweite Reihe von Abänderungen entsteht dadurch, dass sich der rothe Saum der Fld. mehr und mehr verbreitert. Bei normaler Färbung ist der Basalsaum hinten nicht scharf begrenzt und etwas schmaler als der Seitensaum; dieser wird innen ziemlich scharf von der schwarzen Scheibe durch eine Linie geschieden, die dem Seitenrande parallel läuft und nur dicht vor der Spitze demselben bald zu-, bald etwas abgebogen ist. Sie fällt im mittleren Theile etwa mit den beiden Parallelen zusammen, die durch die Verlängerung der Hinterecken des Halssch. entstehen würden. Es kann sich nun der Grundsaum fast bis zur Hälfte der Länge, und der Seitensaum bis zur Mitte jeder Fld, regelmässig oder unregelmässig, einzeln oder gleichzeitig ausdehnen; im letzteren Falle würden die Fld. als roth, mit einem gemeinsamen schwarzen Mittelflecke zu bezeichnen sein (Var. b). Ist die Grundfarbe des Körpers, die gemeinschaftliche Makel auf den Fld, eingeschlossen, ein lebhaftes, gesättigtes Schwarzblau, so entsteht die Var. Hochhuthi, die in Sibirien weit verbreitet ist. Sie ist zuweilen etwas feiner punktirt als unsere limbata.

Sehr auffällig ist endlich eine grosse Lokalrasse vom Südfusse der Alpen (Monte Viso, Thieme; Kärnthen; Görz; Ternowaner Forst, Miller; Triest; Mostar, Reitter) die von Suffrian unter dem Namen Findeli beschrieben wurde. Ihr Körper ist rein und tief schwarz, oberseits glänzend $(\hat{O})$ oder meist sehr matt $(q)$, das Halssch. des $q$ ist von den Hinterecken nach vorn gleichmässig in einem schwachen Bogen verengt, der Seitenwulst des Halssch. ist rorn schmaler, niedriger, selten deutlich von der Scheibe und dann nur durch wenige starke Punkte und einen glatten Eindruck am Vorderrande geschieden; die Fld. des 오 sind feiner und gleichmässiger, die des $\hat{o}$ stärker punktirt als bei der Stammform, ibr rother Saum ist in der Breite ebenso veränderlich wie bei dieser.

In Mitteleuropa, dem Kaukasus und in Sibirien verbreitet.

Chr. discipennis Fald. (Mém. Ac. Petr. II. 1835. 268. t. 4. f. 14. Suffr. 72) aus Armenien, der Kirgisensteppe und Daurien, ist die einzige verwandte Form, die ich nicht mit Sicherheit als Varietät zu limbata stellen möchte. Bei gleicher Körperform und übereinstimmender Bildung des Halssch. ist die Farbe schwarzviolett, die Fld. besitzen einen breiten dunkelrothen Saum und sind viel stärker punktirt. Die Punkte bilden, ausser einer abgekürzten Reihe am Schildchen, 9 deutliche Reihen, von denen die innere einzeln steht, die übrigen sind paarweise genähert und schliessen so 4 sehr schwache, fein punktirte Längsrippen ein, während die breiten Längsstreifen zwischen den einzelnen Reihenpaaren sehr dicht, fast runzelig und eben so stark als 
die Reihen punktirt sind, mit feinen I'unkten in den schmalen Zwischenräumen. Jedoch zeugt das eine meiner Stücke, bei dem zwischen der starken Punktirung weder schwache Längsrippen noch Punktreihen hervortreten, auch hier von der Veränderlichkeit der Skulptur.

20. Ch\%. Iuriala: Oralis, atra, antennarum basi in/erne elytrisque testaceo-brunneis, capile prothoraceque aeneo-micantibus, fere laevibus. hoc transverso-quadrato, apice quam basi multo angustiore. lateribus leviter rotundatis, callo laterali mimus fortiter incrassato. postice plicu profunda anticeque punctis majoribus terminato; elytris striato-punctatis, interstitiis parce subtilissimeque punctulatis, sutura infuscata. Long. 5-6 $\mathrm{mm}$.

Mas: tarsis modice dilatatis, segmento ultimo ventrali subtumidulo.

Linn. Syst. Nat. ed. XII. 590. - Fabr. Ent. Syst. I. 318. Steph. Ill. Brit. IV. 342. - Küst. Käf. Eur. 1. 92. - Suffr. Mon. S6. - Motsch. Schrenk Reis. II. 207 (Taeniosticha). - Redtb. Faun. A. II. 473. - Seidl. F. balt. 481.

Der vorigen am nächsten verwandt (aber nicht Chr. diluta), indessen bedeutend kleiner und so abweichend gefärbt und punktirt, dass eine Verwechselung mit keiner europäischen Art, ausser Chr. Reitteri ${ }^{1}$ ), möglich ist.

Breit eiförmig, fast gerundet-viereckig, schwarz, die ersten Fühlerglieder unten und die Fld. gelblichbraun, Kopf und Halssch. zerstreut und sehr fein punktirt, fast glatt, mit metallisch gelblichen Anfluge, stark glänzend. Halssch. beinahe dreimal so breit als über die Mitte lang, nach vorn in einem sanften Bogen verengt. der Vorderrand gleichmässig ausgeschnitten, in der Mitte nicht rorgezogen, der Seitenwulst mässig dick, im Basaldrittel durch eine tiefe, grubenförmige Rinne, davor durch einen weiten und flachen Eindruck abgesetzt, der ziemlich stark punktirt und über dem Vorderrande merklich vertieft ist. Einzelne starke Punkte gehen auch auf den Wulst selbst über. Schildchen schwarz. Fld. mit 9 regelmåssigen, grob und dicht punktirten Streifen und etwas gewölbten, fein punktirten Zwischenräumen, die Naht und die innere Randlinie der Epi-

1) Chr. Reitteri W e is e (Deutsch. Z. 1SS3. 163) vom Kaukasus (Swanetien. Leder), ist etwas grösser, schlank, Kopf, Halssch. und Unterseite rein schwarz. Halssch. kaum doppelt so breit als lang, überall gleichmässig, ziemlich dicht, deutlich punktirt, der Vorderrand in der Mitte vorgezogen, der niedrige Seitenwulst hinten durch eine wenig tiefe, punktirte, nicht scharfe Rinne, davor durch einen flachen Eindruck abgesetz.t. Fld. in den Streifen dichter und tiefer punktirt als lurida, Zwischenräume dentlich lederartig gerunzelt und punktirt. Tarsen des $\hat{\odot}$ sehr breit. 
pleuren schwärzlich, ebenso, doch seltener, auch die Punkte in den Streifen. Die Unterseite ist glänzend, sehr sparsam punktirt.

Das Männchen wird durch eine geringe Erweiterung des letzten Tastergliedes und der Tarsen, sowie durch den etwas aufgetriebenen fünften Bauchring kenntlich gemacht. - Der Penis ist schmal, gleichbreit, schwach gebogen, oben rinnenförmig eingedrückt, an der Spitze in schwachem Bogen abgerundet und leicht nach hinten umgebogen, der ductus ejaculatorius röhrenförmig, schwarz.

Stellenweise in Mitteleuropa; südlich bis nach Dalmatien und in den Kaukasus (Leder) verbreitet. Bei Berlin zuweilen zahlreich im Mai und Juni in Käfergräben.

21. Chr. In aks: Breviter-ovalis, minus convexa, nitidiuscula, supra aeneo-olivacea, subtus, ore, antennis gracilibus pedibusque ferrugineis; prothorace subtilissime punctato, antrorsum rotundatoangusiato, callo laterali angusto, incrassato, impressione integra arcuata, latissima, rugoso-punctata terminato; elytris minus crebre grosse punctatis, punctis interdum subseriatis. Prosterno inter coxas angusto, longitudinaliter profunde impresso. - Long. 7-11 mm.

Mas: palpis articulo ultimo tarsisque modice dilatatis, segmento 5 : o ventrali apice truncato.

Fabr. Syst. Ent. 95; Ent. Syst. I. 310. - Oliv. Ent. V. 513. t. 1. f. 5. - Rossi Faun. Etr. I. 75. - Steph. Ill. Brit. IV. 343. - Küst. Käf. Eur. 1. 79. - Suffr. Mon. 15. Motsch. Schrenk Reis. II. 208 (Stichosoma). - Redtb. Faun. A. II. 476 .

Var. a. Supra aeneo-cuprea, vel -violacea.

Var. b. chlorizans Supra saturate viridis, plus minusve aeneo-micans. Chr. lepida Suffr. Mon. 16.

Die breiteste und zugleich flachste Art dieser Gruppe, oben schmutzig grün oder dunkelbraun mit starkem Messingschimmer, unten einfarbig-rostroth. Fühler kurz, dünn, wie der Mund oder der ganze Vorderkopf und die Taster rostroth. Halss ch. von den spitzen Hinterecken nach vorn stark verengt, die Seiten mehr oder weniger gerundet, seltener ziemlich gerade, auch die Vorderecken spitz. Die ganze Oberseite sehr fein punktirt, fast glatt, der Seitenwulst hoch, sehr schmal, innen plötzlich zu einem breiten und tiefen, grob runzeligpunktirten Eindracke abfallend, welcher sich, nach vorn wenig verflacht, bis zum Vorderrande hinzieht und nach innen allmählich in die schwach gewölbte Scheibe übergeht. Fld, aussen unregelmässig, grob, ziemlich dicht und tief punktirt, mit gewölbten, oft zu Querrunzeln verbundenen Zwischenräumen; nach der Naht zu werden die Punkte immer kleiner and flacher, zugleich deutlicher gereiht. 
Diese Punktirung ist sehr variabel, zuletzt so fein, dass die Fld. auf der inneren Hälfte fast glatt sind, mit wenigen flachen Punkten, nach aussen werden die Punkte etwas zahlreicker und tiefer und stehen dann weitläufig in einigen unregelmässigen Reihen. Bei diesen Stücken, die der verwandten C $/ h r$ obsoleta $\mathrm{Brull}$. von den Canarischen Inseln ähneln, ist auch der Eindruck auf beiden Seiten des Halssch. beinahe glatt. Die Vorderbrust ist zwischen den Hüften schmal, tief gerinnt.

Das ô unterscheidet sich vom $q$ nur unbedeutend, indem die drei ersten Tarsenglieder und das Endglied der Kinnladentaster erweitert sind, auch ist der 5. Bauchring gewölbter und in der Mitte des Hinterrandes abgestutzt. - Der Penis ist sehr klein, gleichbreit, über der Oeffnung etwas eingedrückt, die Seiten der letzteren wulstig verdickt, vorn schnell mit schwacher Ausbuchtung in eine ziemlich breite Spitze verschmälert, die gebuchtet-abgestutzt ist.

Bei der Var, a. ist die Oberseite metallisch kupferroth, selbst lebhaft violett, bei b. gesättigt grün, mit mehr oder weniger Metallschimmer.

In Istrien, sowie in der Umgebung des mittelländischen Meeres, besonders in Nordafrika gemein.

Suffrian hat die grüne Varietät auf lepida Brull. (Exped. Mor. III. Zool. 270) bezogen, aber die Abbildung und Beschreibung Brullés bestätigt diese Annahme nicht. Die Art soll $5 \mathrm{~mm}$. lang sein und punktirt-gestreifte Fld. besitzen.

22. Chr. staphylea: Ovalis, convexa, sat nitida, ferruginea, supra aeneo-micans; prothorace sat crebre subtiliter, inaequaliter punctato, lateribus subrotundato, callo laterali sat angusto, incrassato, impressione interga arcuata, profunda, lata, rugoso-punctata lerminato, elytris inaequaliter punctatis, lineis nonnullis subelevatis; prosterno inter coxas sat lato, longitudinaliter impresso. - Long. 6-9 mm.

Mas: palpis articulo ultimo valde tarsisque modice dilatatis, seymento 5:0 ventrali apice truncato.

Linné Syst. Nat. ed. X. 370. - Fabr. Ent. Syst. I. 317. Schrank Enum. 71. - Oliv. Ent. V. 544. t. 4. f. 40 . Gyllh. Ins. Suec. III. 455. - Steph. Ill. Brit. IV. 344. Duft. Faun. Austr. III. 172. - Matzek Ber. Schles. Ges. 1842. 157. - Küst. Käf. Eur. 1. 88. - Suffr. Mon. 20. Motsch. Sehrenk Reis. II. 210 (Chrysolina). - Thoms. Skand. Col. VIII. 250. - Redtb. Faun. A. II. 470. - Seidl. F. balt. 482 .

Chr. cuprea Deg. Mém. Ins. V. 294. t. 8. f. 24.

Chr. rubrocuprea Fourer. Ent. Par. I. 108. 
Var. a. Supra haud aeneo-micans.

Var. b. daurica: Elytris fortiter sed mims profunde subrugoso-punctatis.

Geb1. Nouv. Mém. Mosc. 1832. II. 73. - Motsch. 1. c. 229.

Var. c. Lederi: Subdepressa, mims nitida. supra olinacea, subtus brunnea, elytris subseriatim punctatis.

Weise Schneid. u. Leder Beitr. Kauk. Käf. f. 332.

Var. d. (I) subferruginea: Major. fermqinea, elytris nilidissimis.

Suffr. Mon. 21.

Oral, das Männchen mehr gerundet-riereckig, verschieden stark glänzend, rostroth, oben mit gelblichem oder grünlichem Metallschimmer. Halsscb. stark quer, mit gerundeten Seiten, nach hinten wenig, nach vorn stärker verengt, der fast glatte Seitenwulst schmal und boch, doch etwas breiter als bei der vorigen, innen plötzlich zu einem breiten und tiefen Eindrucke abfallend, welcher der Rundung der Seiten ungefähr parallel läuft, vor der Mitte mehr oder weniger sich verflacht und nach innen allmählich in die etwas gewölbte Scheibe übergeht. Letztere ist ziemlich dicht und fein ungleichmässig punktirt, während der Eindruck mit stärkeren, zuweilen grubenförmigen Punkten besetzt ist. Fld. nicht stark, verworren oder in unregelmässigen Doppelreihen punktirt, zwischen denen 3 bis 7 leicht gewölbte Längslinien mehr oder weniger deutlich hervortreten; nur die beiden äusseren Punktreihen sind fast regelmässig. Die Zwischenräume der Punkte sind fein punktulirt und noch feiner als das Halssch. lederartig gerunzelt, beim $\hat{\jmath}$ fast glatt. Die Vorderbrust ist zwischen den Hüften ziemlich breit, mit einer Mittelrinne.

Das $\hat{j}$ ist rom $f$ durch das breitere Endglied der Maxillartaster und etwas breitere Tarsen, sowie durch den an der Spitze abgestutzten, kürzeren letzten Bauchring zu unterscheiden. - Der Penis ist dem ron Banksi ähnlich, etwas schlanker, die Seiten der Oeffnung sind weniger verdickt und die fast trapezförmige kurze Spitze hat so abgerundete Ecken, dass sie fast wie ein flacher Bogen aussieht.

Die Oberseite ist bisweilen ohne Spur eines metallischen Schimmers (Var. a), oder dunkel mettallisch-olivengrün (Var. c); ebenso variirt die Stärke und Anordnung der Punktirung erheblich. Am feinsten sind die Fld. der Var. d. punktirt, die Suffrian nach einem f aus Südfrankreich beschrieb, am regelmässigsten bei Lederi; sehr stark, selbst runzelig punktirte Exemplare, haben oft scharfe Rippen auf den Fld. Zwischen den Formen, die mit unseren deutschen völlig übereinstimmen, finden sich in Sibirien auch etwas abweichende Stücke, mit grossen, aber ziemlich flachen, zu schwachen Runzeln vereinigten Punkten auf den Fld., und schmalen, dichter punktulirten gewölbten Zwischenräumen. Sie bilden die Var. b. 
Am Rande feuchter Wiesen gemein, auch im Winter im Anspülicht. Nord- und Mitteleuropa, Kaukasus, ganz Sibirien.

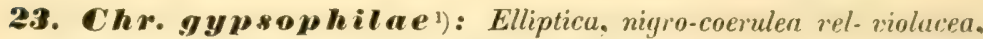
antennis sat tenuibus, articulis 2 primis subtus rufis, prothorace sat convexo, disco punctulato, lateribus antrorsum rotundato-angustato, callo laterali crasso, interne fortius punctato, postice impressione subarcuata. antice impressione minus profunda terminato; elytris minus crebre profunde subrugoso-punctatis, limbo laterali lato uni-vel biseriatim punctato, interne irregulariter terminato miniato. - Long. S-11 mm.

Mas: tarsis articulis 3 primis valde dilatatis, segmento ultimo ventrali subtumidulo, apice transversim impresso.

Küst. Käf. Eur. 2. 71. - Suffr. Mon. 64. - Redtb. Faun. A. II. 476 .

Chrys. sanguinolenta var. Seidl. F. balt. 482.

Var. a. Gaubili: Limbo laterali miniato elytrorum latissimo.

Luc. Expl. Alg. Ent. 535. t. 45. f. 10. - Fairm. Ann. Fr. 1865. 79.

Chrys. gypsophilae var. rufomarginata Suffr. Mon. 65. Var. b. lucidicollis: Prothoracis disco obsolete punctulato, polito.

Küst. 1. c. 73 . - Suffr. 1. c. 67 .

Var. c. Punctis seriei exterioris in fundo nigris.

1) Nahe verwandt und dicht vor diese Art zu stellen sind:

1. Chr. stachydis Gené (Mém. Ac. Torin. 1839, 79. - Suffr. 136). Länglich-oval, schwarzblau, die Oberseite zuweilen stahlblau oder grünblau, Unterseite der ersten Fühlerglieder röthlich, Halssch. fast glatt, nach rorn mässig verengt; Seiten schwach gerundet. Seitenwulst durch einen grob punktirten Eindruck abgesetzt, welcher im Basaldrittel tief und furchenartig ist und den Wulst stark emporhebt, davor bedeutend flacher wird, mit seinen groben Punkten auf den verbreiterten Wulst übergreift und denselben niederdrückt. Fld. mit groben und tiefen, ziemlich regelmässigen parigen Punktreihen. Penis dem von gypsophilae sehr ähnlich. - L. 7-S,5 mm.

2. Chr. variolosa Petagn. (Atti Ac. Napol. I. 1819: melanostigma H. Schäff. Faun. Germ. 1838. 157. - Sparshalli Curtis Ann. nat. Hist. V. 1840. 282. - Suffr. 62). Breit oval, schwarz, violett oder blau schimmernd, die zwei ersten Fühlerglieder unten röthlich. Halssch. fast glatt, vorn stark verengt, mit stark gerundeten Seiten. Wulst hoch und breit, mit ein oder mehreren groben Punkten auf der inneren Seite, durch einen breiten und tiefen, in der Mitte etwas flacheren, fast glatten Eindruck begrenzt. Fld. gelblichroth, ein schmaler Nahtsaum und vereinzelte grobe Punkte mit ihrer nächsten Umgebung schwarz. Diese Punkte bleiben übrig, wenn die 9 normalen Punktreihen durch weite Zwischenräume unterbrochen werden, und es sind gewöhnlich zwei bis vier Punkte zu kurzen, schwarzen, perlschnurförmigen, schief stehenden Querbinden vereint; die breiten $Z$ wischenräume glatt oder weitläufig, fein, sehwarz durchschimmernd punktirt. Penis dem von maryinalis am ähnlichsten. - L. 9-10 mm. Auf Sicilien gemein. England. 
Länglich elliptisch, nur einzelne Weibchen breiter und gerundeter, dunkel violett oder blau, die Fld. gewöhnlich nur mit schwachem blauem oder violettem Schimmer, selten rein schwarz, ihre Epipleuren und ein breiter Saum am Aussenrande zinnoberroth, nach dem Tode gelbroth. Fühler ziemlich schlank, das dritte bis fünfte Glied an der Spitze wenig dicker als am Grunde, die beiden ersten Glieder unterseits röthlich. Halssch. in der Regel mit der grössten Breite ror der Mitte, von hier nach hinten schwach, nach vorn stärker gerundet-verengt, der Seitenwulst breit, gewölbt, einzeln fein punktirt, mit zahlreichen groben Punkten auf der inneren Hälfte. Er wird von der Scheibe überall deutlich durch eine Vertiefung geschieden, welche am Grunde breit und sehr tief furchenartig ist, etwa in der Mitte nach innen biegt und sich hier allmählich verflacht, vor der Mitte wieder nach und nach vertieft und schwach nach aussen gebogen bis zum Vorderrande hinzieht. Die Scheibe selbst ist ziemlich gewölbt, bald fast glatt und stark glänzend (Var. b), bald deutlich und tief fein punktirt (namentlich längs des Grundes), schwächer glänzend. Eckporen und Borsten fehlen; als Ausnahme darf wohl ein märkisches Stück gelten, in dessen linker Hinterecke eine Borste steht. Fld. wenig dicht, grob punktirt, die Punkte umschliessen verschieden grosse, unregelmässige, leicht gewölbte Zwischenräume und sind im vorderen Drittel der Fld. sowie über dem Seitenrande deutlich gereiht, ausserdem beim Weibchen deutlicher als beim Männchen zu kurzen Querrunzeln zusammen geflossen. Oefter werden bei der Ansicht von der Seite zwei schwache Längsrippen auf jeder Fld. sichtbar. Der rothe Seitensaum reicht innen bis zur zweiten Punktreihe und ist hier nicht gerade und scharf, sondern zackig begrenzt, weil die schwarzen Punkte der entsprechenden Punktreihe in den Saum hineintreten, auf dem Saume befindet sich also eine Reihe tief eingestochener, grober Punkte in ungleichen Abständen von einander und dicht darüber eine zweite Reihe ähnlicher, aber schwarz gefärbter Punkte, die durch seichte Runzeln mit den Punkten der äusseren Reihe verbunden sind, während der breite Raum zwischen letzterer und dem Seitenrande glatt und deutlich gewölbt ist. Stücke mit sehr breitem, zuweilen bis in die Mitte der Fld, reichenden rothem Seitensaume bilden die Var. a.; Stücke, bei denen die Punkte der äusseren Reihe theilweise oder insgesamt schwarz sind, die Var. c.

Das kleine, fast gleichbreite und glänzendere Männchen ist an den breiten Tarsengliedern und dem leicht aufgeblasenen letzten Bauchringe zu erkennen, welcher vor dem Hinterrande einen kurzen Quereindruck, zuweilen auch eine vertiefte Mittellinie besitzt; sein 
Penis ist nach vorn bis zur Oeffinung allmählich verlbeitert, daror wieder gleichmässig gerundet-verengt, mit rollkommen abgerundeter Spitze. Letztere hat auf der Rückseite jederseits eine tiefe Rinne, mit aufgebogenem Aussenrande.

In sandigen Gegenden häufig und über ganz Mittel- und Südeuropa verbreitet. Sie ist, wie die Mehrzahl der Chrysomelen. ein nächtliches Thier, kriecht erst gegen Abend auf Gräser und andere Pflanzen und hält sich des Tages über unter Steinen und Pflanzen auf.

24. Chr. sanguinolemta: Oralis nigro-coerulea, antemis sat crassis, articulis 2 primis subtus rufis; prothorace minus convexo sat crebre punctulato, lateribus postice parallelo antice rotunduto-angustato. callo lalerali interne impressione lata fortiter rugoso-punctata deplanato; elytris niyris, crebre profundeque subrugoso-punctatis. limbo laterali sat lato, parallelo, sublaeri. interne exacte terminato miniato. - Long 7-9 $\mathrm{mm}$.

Mas: tarsis articulis 3 primis fortiter dilatatis, segmento ultimo ventrali subtumidulo.

Linn. Syst. Nat. ed. X. 3\%1. - Fabr. Ent. Syst. I. 325 . Payk. Faun. Snec. II. 52. - Oliv. Ent. V. 561. t. 1. f. 3. Gyllh. Ins. Suec. III. 460. - Panz. Faun. Germ. 16.10. Duft. Faun. A. III. 182. - Matzek Ber. Schles. Ges. 1842. 155. - Küst. Käf. Eur. 2. 69. - Suffr. Mon. 65. Motsch. Schrenk Reis. II. 209 (Stichoptera). - Thoms. Skand. Col. VIII. 250. - Redtb. Faun. A. II. 469. - Seid I. F. balt. 482 .

Var. a. Limbo miniato elytrorum uniseriatim punctato.

var. b. Elytris disco nigro-coeruleis.

Der vorigen Art ähnlich, aber in folgenden Punkten wesentlich verschieden: Der Körper ist im Allgemeinen kürzer, insbesondere beim $q$ gerundeter und nach hinten rerbreitert, auch die Fühler sind kürzer, ihre Glieder 3 bis 5, ebenso die Endglieder nach der Spitze zu stärker verdickt. Das Halssch. ist an den Seiten rom Grunde bis vor die Mitte ziemlich parallel, rorn schneller gerundetverengt, der Seitenwulst ist von der nur wenig gewölbten, ziemlich dicht unregelmässig punktirten und deutlich lederartig gerunzelten Scheibe, welche einen matten Seidenschimmer besitzt, durch einen breiten, grob runzelig-punktirten Eindruck abgesetzt, der auf den Wulst selbst übergeht und denselben so niederdrückt, dass nur eine schmale Stelle längs des Seitenrandes gewölbt und ron der groben Punktirung befreit bleibt. Allerdings ist der absetzende Eindruck an der Basis des Halssch. ähnlich wie bei gypsophilae stark vertieft, 
aber er erscheint hier nicht rinnenförmig, sondern wie eine kurze und breite, runzelig punktirte Grube. Die Fld. sind tief schwarz, in Ausnahmefällen bläulich (Var. b), ihre Punktirung ist bei ungefähr gleicher Stärke erheblich dichter, der rothe Randsaum scharf begrenzt und zwar so. dass er bei normaler Färbung in einer Linie dicht über der äusseren Punktreihe endet, manchmal jedoch bis zur zweiten Punktreihe ausgedehnt ist (Var. a).

In den äusseren Geschlechtsmerkmalen ist kam ein Unterschied zu finden, aber der Penis ist fast gleichbreit und der aufgebogene Aussenrand, welcher die Rinnen auf der Rückseite der Spitze begrenzt, ist oben verkürzt, schief abgeschnitten.

Auf trockenen Grasplätzen und sandigen Hügeln nicht häufig, noch seltener im nördlichen und südlichen Europa.

b. $\left.{ }^{1}\right)$ Halsschild in jeder Ecke mit einer Borstenpore.

* Flügeldecken in der Regel mit rothem Seitensaume.

25. Chr. mergingeris: Oblongo-ovalis, niyro-violacea, antemis crassiusculis, articutis 2 primis subtus rufis; prothorace sat convexo, subtilissime junctulato, fere laevi, lateribus posice subparallelo, antice rotundato-angustaio, callo laterali crasso, interne fortins punctato. postice intpressione subarcuata mofienda, antice impressione nimis profunda terminato: ely/ris sat crebre punctatis, limbo laierali lato, uniseriatim punctato, interne exacte ierminato miniaio. - Long. 6-8,5 mm. Mas: tarsis modice dilatatis, segmento ultimo ventrali subtumidulo.

Duft. Faun. A. III. 182. - Küst. Käf. Eur. 2. 70. - Suffr. Mon. 68. - Redtb. Faun. A. II. 469.

Chrys. sunguinolenta var. marginalis Matzek Ber. Schles. Ges. 1842. 155. - Seidl. F. balt. 482.

Chrys. carnifex Panz. Faun. Germ. 16. 9. ㅇ․

Etwas kleiner und schlanker als die vorige, aber verhältnissmässig breiter als gyppsophilae, schwarz-violett, seltener bläulich; die Fühler ziemlich kräftig, ihre beiden ersten Glieder unterseits roth. Halssch. im Bau der sanguinolenta ähnlich, nämlich hinten fast parallel, vorn stark gerundet-verengt, oder die Seiten gleichmässig und zuweilen noch stärker gerundet als bei gypsophilae. Mit letzterer stimmt die Skulptur des Halssch. überein: das Mittelfeld ist gewölbt (beim $\hat{\jmath}$ mehr als beim o), einzeln sehr fein punktirt, fast glatt, glänzend; es wird durch einen glatten, hinten tiefen und rinnenförmigen, in der Nitte flachen, daror wieder vertieften Eindruck von dem breiten, gewölbten Seitenwulste geschieden, welcher in der inneren Hälfte grob, in der äusseren feiner, aber stärker als die Scheibe, punktirt ist. Die den Vorder- und Seitenrand des Halssch.

1) Auf pag. 368 fehlt: a. Halsschild ohne Eckporen und Borsten. VI. 3 . 
umsäumende Randleiste lässt an den Vorder- und Hinterecken einen grösseren dreieckigen Raum frei, welcher mit je einem tiefen und starken Punkte besetzt ist, aus dem eine weissliche Borste herausragt. Die Vordereckborste ist nach hinten, die Hintereckborste nach rorn gekrümmt. Die Fld, sind ziemlich dicht punktirt, die Punkte nicht von gleicher Stärke. Die in der Mitte jeder Decke sind etwa so stark, wie bei den zwei vorigen, ihre Zwischenräume gewölbt, nach der Nabt und dem Seitenrande hin werden sie bedeutend feiner und ihre $Z_{\text {wischenräume flacher. Ueber dem Aussenrande befinden }}$ sich 2 regelmässige Punktreihen, von denen die innere und zugleich stärkere den rothen Seitensaum scharf begrenzt, während die äussere, feinere Reihe auf dem Saume steht, denselben aber nicht merklich emporhebt, weil ihre kleinen Punkte nicht so tief eingestochen sind wie bei sanguinolenta oder gypsophilae. Die beiden ron Küster erwähnten schwachen Längsrippen, welche bei der Ansicht von der Seite auf jeder Fld. sichtbar werden, sind viel undeutlicher als bei den vorhergehenden Arten.

Beim $\hat{j}$ sind die Tarsen an den Hinterbeinen kaum, an den vorderen mässig erweitert, namentlich das dritte Glied, ebenso ist der letzte Bauchring schwach aufgeblasen, beim $q$ dagegen flach. Der Penis ist fast grösser als der von gypsophilae, der aufgebogene Aussenrand, welcher die Rinnen auf der Rückseite der Spitze begrenzt, ist oben plötzlich tief ausgebuchtet und dadurch in eine scharfe Spitze ausgezogen.

Ueber ganz Deutschland und Mitteleuropa verbreitet und in sandigen Gegenden häufig.

Obgleich die richtige Deutung der Chr. carnifex Panz. für die Synonymie ohne Belang bleibt, möchte ich doch darauf hinweisen, dass die Panzer'sche Abbildung, welche einen dicken Seitenwulst des Halssch. zeigt, weder in der Punktirung noch Körperform mit carnifex F. übereinstimmt (in gleichem Sinne äussert sich Duftschmid 1. c. 184) und besten Falles auf ein breites $q$ der vorliegenden Art bezogen werden kann. Chr. coerulescens Suffr. vermag ich darin auf keinen Fall zu erkennen.

26. Chr. carnifex ${ }^{1}$ ): Oblongo-ovalis, supra nigra, parum aeneomicans, nitidula $(\hat{\odot})$ vel opaca $(+)$, subtus nigro-coerulea, antennarum

1) Ein natürliches Bindeglied zwischen marginalis und carnijex ist $C h r$. interstincta Suffr. (Mon. 79) aus Italien ron Genua bis Sicilien. Einfarbig lebhaft dunkelblau, oder blau, Unterseite, Kopf und Halssch. schwarzviolett, glänzend, ein breiter, innen meist scharf begrenzter Seitensaum der Fld. zinnoberroth oder gelbroth wie bei marginalis. Halssch. wie das von 
basi inferne limboque laterali elytrorum interne obsolete torminato lateritiis: capite sparsim subtilissimeque punctato; prothorace ahtaceo. sat crebre subtiliter punctato, lateribus antrorsim leniter rolundatoangustato, callo laterali postice impressione brevi profunda, rugosopunctata anticeque impressione obsoleta fortiter punctata terminato; elytris alutaceis crebre punctatis, punctis majoribus in series geminatas irregulares dispositis. - Long 5,5-9 $\mathrm{mm}$.

Mas: tarsis sat fortiter dilatatis, segmento ultimo ventrali subcomexo foveola aut linea media vage impressa.

Fabr. Ent. Syst. I. 1. 325. - Gyllh. Ins. Suec. III. 462. Obs.

- Duft. Faun. Austr. III. 184. - M atzek Ber. Schles. Ges. 1842. 155. - Suffr. Mon. 75. - Redtb. Faun. A. II. 473. - Seidl. F. balt. 482 .

Var. a. coerulescens: Supra niyro-coerulea aut-violacea, elytris plenumque fortius punctatis, limbo lateritio lato interdum nullo.

Suffr. Mon. 76. - Redtb. 1. c. 477. - Ch. Brisout Ann. Fr. 1873. Bull. 211.

Var. b. provincialis: Supra tota nigra; elytris rarissime limbo angusto rufescente.

Harold Col. Heft. XII. 1874. 152.

Chr. aethiops Oliv. Ent. V. 519. t. 6. f. 79. - Suffr. Mon. 18.

Länglich-eiförmig, wenig gewölbt, oben schwarz mit geringem Metallschimmer, das kleinere und mehr gleichbreite Männchen ziemlich glänzend, das grössere, nach hinten gewöhnlich deutlich verbreiterte Weibchen matt; unten schwarzblau; die Unterseite der ersten Fühlerglieder und ein Saum an der Seite der Fld. ziegelroth. Kopf mit deutlich abgesetztem Kopfschilde und flacher, durch eine Mittelrinne getheilter Stirn, sparsam und äusserst fein punktirt. Kinnladentaster mässig stark, das letzte Glied am Grunde kaum so breit als das vorhergehende und nach der Spitze etwas verschmälert. Fühler ziemlich kräftig, ihr siebentes Glied deutlicher als bei den

carnifex, aber nach vorn etwas stärker verschmälert und auf der Scheibe weitläufiger und flacher punktirt. Fld. mit sehr unregelmässigen Doppelreihen grober Punkte und wenig feiner punktirten $Z$ wischenräumen. Der rothe, fein und ziemlich dicht punktirte Seitensaum reicht nach innen entweder bis zur 7. Punktreihe, oder nur bis zur neunten (Var. depressa Fairm. Ann. Fr. 1854. 317, aus Südfrankreich), oder fehlt ganz, so dass die Fld. einfarbig dunkelblau sind: Var. subseriata Suffr. (Mon. 80). - Der Penis ist eine flache, vorn etwas nach unten gekrümmte und leicht verbreiterte Röhre, welche am Vorderrande mit gerundeten Aussenecken fast geradlinig abgestutzt und in der Mitte in eine lange Spitze verlängert ist. Diese Spitze besitzt eine tiefe Rinne, in welcher der fadenförmige, die Spitze selbst weit überragende ductus ejaculatorius liegt. Die Oeffnung ist sehr gross und wird in der Ruhe durch eine viereckige Klappe fast vollständig geschlossen. 
vorigen Arten oberseits in eine kleine Kante verlängrt, welele unbedeutend über den Grund des $r$. Gliedes lidausragt. II alssel. nur selten in der hinteren Ilälfte gleichbreit, gewrihulich vor den leicht eingezogenen Hinterecken am breitesten, von hier bis zur Mitte sehr wenig, davor etwas stärker und rerundet rerenent. Dir siviten wulst breit, aber nicht besonders looch, innen durch eine seichte. grob punktirte Verticfung begrenzt, welche hinter dur Mitte in einen tiefen, aussen mit scharfem Raude rersehenen, innen allmählich zur Scheibe ansteigenden Eindruck übergeht, welcher dicht runzelig punktirt ist. Die Scheibe (und der Wulst) ausser der lederartigen Runzelung ziemlich dicht, unregelmässig, fein punktirt, mit undeutlicher glatter Nittellinie. Beim Weibchen sind alle Zwischruräume der Punkte und die Mittellinie schwach erhöht. Fld. lederartig gerunzelt, dicht und nässig fein punktirt, nit 9, beim , selır undeutlichen, bein $q$ deutlichen und oft fast regelmässigen Reihen gröberer Punkte, ron denen die 8 äusseren zu je zweieu einander genähert sind. Der rothe Seitensaum reicht nach innen meist über die äussere Doppelreihe hinweg und geht hier allmählig in die schwarze Färbung der Scheibe über; selten ist die Innengrenze ziemlich scharf.

Der letzte Batuchring des $\hat{j}$ ist schwach gerölbt, mit vinem Grübchen oder einer Mittelrinne in der rorderen Hälfte, ausserden sind bei demselben die drei ersten Tarsenglieder zimlich stark erweitert. - Der Penis ist schlank, Aach, gleichbreit, rorn allmählich gerundet-rerengt, hierauf in eine lange, zum rollständigen Einlegen des ductus ej. mit einer tiefen Rinne rersehene, gleichbreite Spitze verlängert. Die Ouffnung nimmt mehr als die Hälfte des Penis ein und ist nur im oberen Theile durch eine fast durchsichtige, rorn dreieckige Klappe bedeckt.

Die Farbe der Oberseite ist rariabel. Tritt zum Schwarz derselben ein blauer, violetter oder blan-grüner Schimmer. so entsteht die Var. coemulescens. Bei derselben ist das Halssch. bäufig hinter der Mitte etwas verengt, die Punktirung der Fld. meist stärker. der rothe Seitensaum der Fld. entweder so breit, wie bei der Stammform, oder schmaler, oft fehlt er gänzlich. Letzteren Stücken ähnelt die Var. b. provincialis, mit einfarbig tief schwarzer Oberseite, oder in seltenen Fällen noch mit einem schmalen dunkelröthlichen Seitensaume. Weniger auffällig ist eine Abänderung der typischen carnifex. bei der auch die Umgebung des Schildchens roth gefärbt ist.

In sandigen Gegenden Mitteleuropas und Sibiriens nicht selten. Die Stammform gehört dem Osten an; erst am Rheine tritt (bei Darmstadt, Mainz und in der Pfalz) die Var. a. mit rothem Seitenrande der Fld. auf, weiter westlich kommt dieselbe Form obne rothen 
Rand, und im ganzen südichen Frankreich (besonders häufig auf den Hyèren) die Var. b. ror.

Auf die Giltigkeit des Artnamens bleibt die Erwägung ohne Einfluss, ob Fabricius, der die Flel. laevissima nennt, die vorliegende Art wirklich beschriehen hat, oder nicht; denn Oliviers aethiups darf wegen des grletchen, aber älteren Namens von Fabr. (für cine Var. der veriens śchall.) nicht eintreten, es folgt vielmehr carnifer Gyll., worunter myeifelhaft unsere Art zu verstehen ist.

2-. Chr. marginata $\left.{ }^{1}\right)$ : Oblongu, subconvext, supra piceo-antichalcea. sublus nigra, plus minuser rividi-coeruleo micans, antennarum

1) Hierher gehören noch folgende Arten aus dem curopäischen FaunenGebiete :

a. ohne rothen Saum der Fld.

1. Chr. armeniaca Fald. (Nouv. Mém. Mose. V. 355) aus Transkaukasien, Gebirge von Mangliss, westlich von Elisabethal (Leder). L. 9-10 mm. Gross, breit, plump gebaut, schwarz, mit schwachem Erzschimmer, überall dicht lederartig gerunzelt und in beiden Geschlechtern wenig glänzend, Halssch. dicht, mässig fein punktirt, der breite Seitenwulst vorn durch zahlreiche grobe Punkte, die in einer weiten, flachen Grube stehen, hinten durch einen kurzen, tiefen, wie aus mehreren neben einander liegenden Gruben gebildeten Eindruck von der Scheibe gesondert. Fld. dicht, stärker als das Halssch. punktirt, mit 9 noch stärkeren, aber wenig hervortretenden Punktreihen, von denen die 8 äusseren paarweise stark genähert sind; die schmalen $\mathrm{Z}$ wischenstreifen, sowie die Räume zwischen den Punkten in den breiten Zwischenstreifen noch mässig dicht und fein punktirt. Beim $\hat{\oplus}$ die drei ersten Tarsenglieder aller Beine sehr stark erweitert.

2. Chr. curvilinea Weise (Deutsch. Zeit. 1884. 164) von Aranjuez (Miller). L. 6-7 mm. Gerundeter und höher gewölbt als alle verwandten Arten, oben grün, unten schwärzlich metałlisch, glänzend; Halssch. fein und flach punktirt, der breite, aber niedrige Seitenwulst durch einen flachen, rorn und hinten etwas vertieften, grob punktirten Eindruck begrenzt; Fld. mit 9 regelmässigen, stark und sehr dicht punktirten Reihen, davon die $S$ äusseren parweise einander genähert, die beiden mittleren Reihenpaare im ersten Drittel der Naht bedeutend zugekrümmt, die äusseren ziemlich gerade, die schmalen $\mathrm{Zwischen-}$ streifen eines Paares einzeln, kaum bemerkbar punktirt, die breiteren zwisehen je zwei Paaren mässig dicht und etwa halb so stark punktirt als die Reihen.

b. Mit rothem Saum der Fld.

3. Chr. hyrcana: Oblonga, convexa, nitida, supra nigra, viridi-aurichalceo micans, subtus nigro-viridis, antennis gracilibus basi inferne mjesrentibus, articulo primo sut elungato, limbo laterali clytrurum rufotestaceo; crpite fere plan", lineis epistumatis frontisque vage inpressis, 
basi miescente, limbo laterali elytronum testaceo. Prothorace sat crebre subtiliter punctalo, lateribus postice subparallelo antice rotundato-angustato, callo laterali impressione obsoleta, fortiter punclata basi profundiore et triangulariter dilatata terminato; elytris minus crebre subtiliter punclatis, punctis majoribus in series geminatas dispositis. - Long. 5- $7 \mathrm{~mm}$.

Mas: elytris nitidis, tarsis anterioribus fortiter dilatalis, segmento ulimo, ventrali subconvexo.

Femina: elytris subopacis, sericeo- inicantibus, interstitiis serierum subelevatis, segmento ultimo ventrali plano.

oculis sat magnis, interne plica profunda haud curvata, fere recta terminatis; prothorace crebre subtiliter punctato, postice parum anticeque evidenter angustato, lateribus subrotundatis, callo laterali antice jovea obsoleta fortius punctata, postice plica profunda subarcunta interne terminato; elytris seriebus sat regularibus per paria approximatis punctorum minus profundorum et fortiorum, interstitiis angustioribus fere uniseriatim et latioribus parce subtilissimeque punctulatis. Mas: tarsis anterioribus fortiter dilatatis, segmento ultimo ventrali linea media vage impress. - Long. $7-8 \mathrm{~mm}$. Habitat in Russia meridionali: Derbend (Faust), Baku (Becker, Leder).

Chr. marginatae similis, sed paullo major, multo magis convexa, postice magis ampliata, antennae graciliores, thoracis disco crebre punctato calloque plica distincta terminato, elytrorum seriebus sat regularibus etc. forte distincta.

4. Chr. cinctipennis Harold (Catal. Col. 3416; circumducta Suffr. Mon. 77) von Ungarn (Frivaldszky) bis in das östliche Russland verbreitet (Orenburg, Faust; Sarepta, Becker). L. 6-8 mm. Durch das grosse, hinten stark zusammengezogene Halssch. und die aus schmaler Basis hinterwärts breit eiförmig erweiterten Fld. von marginata leicht zu unterscheiden. Dunkel grünlich bronzebraun, überall dieht lederartig gerunzelt, mässig glänzend, ein Saum an der Seite der Fld, der sich um die Schultern bis zur Spitze des Schildchens zieht, roth. Halssch. ziemlich flach ausgebreitet, fein, nach der Seite hin allmählich stärker punktirt, der Seitenwulst breit, niedrig, ron einem nach vorn flacheren Eindrucke begrenzt, der in der Mitte unterbrochen ist. Fld. ausser der dichten und feinen Punktirung noch mit 9 wenig regelmässigen, starken Punktreihen, von denen die äusseren parig genăhert sind; die Punkte derselben sind unregelmässig eingestochen, nicht gleich gross, und verlieren sich vor der Spitze in der übrigen Punktirung.

5. Chr. Graëllsi Perez (Ann. Soc. esp. Hist. nat. 872. 124. t. 2. f. 6) aus Spanien. L. $7-8,5 \mathrm{~mm}$. Körperform und Farbe der marginata, die Fld. aber in den wenig regelmässigen Reihen mit grossen, bald sebr tiefen, bald flacheren Grubeu besetzt. Da die Körperfarbe zuletzt einfarbig schwarz wird (Aragonien, Reitter; Murcia, v. Heyden) so ist es nicht unmöglich, dass Sufirian die p. 366 von mir zu rugipennis gestellte Chr. fossulato nach solchen Stücken beschrieben hat. 
Linn. Syst. Nat. ed. X. 371. - F abr. Ent. Syst. I. 325. Oliv. Ent. V. 563. t. 4. f. 54. - Panz. Faun. Germ. 16. t. 11. - Gyllh. Ins. Suec. III. 491. - Duft. Faun. Austr. III. 184. - Matzek Ber. Schles. Ges. 1842. 155. - Küst. Käf. Eur. 1. 83. - Suffr. Mon. 81. - Motsch. Schrenk Reis. II. 209 (Chalcoidea). - Thoms. Skand. Col. VIII. 246.

- Redtb. Faun. A. II. 473. - Seidl. F. balt. 482. - Baly Trans. ent. Soc. 1879. 189. t. 2. f. 13.

Var. a. $\hat{\varsigma}$ cinctella: Elytris brunneis, plus minusve aurichalceo- vel viridi-aeneo-micantibus, limbo laterali pallido.

Gyllh. 1. c. IV. Append. 650. Obs.

Var. c. solitaria: Nigra, supra parum aeneo-micans, limbo laterali elytrorum testaceo.

Chr. marginata var. d. Gyllh. 1. c. 650 .

Var. d. glacialis: Minor, elytris multo subtilius et obsoletior punctatis feminae interdum nitidis. - Long. 4-6 $\mathrm{mm}$.

Var. e. songorica: Major et angustior, elytris punctato-striatis, interstitiis convexis subcostulatis parce subtiliter punctatis.

Gebl. Bull. Ac. Petr. I. 1843. 39; Bull. Mosc. 1859. IV. 350.

Chr. sulcata Fisch. Cat. Col. Karelin. 1843. 25. - Suffr. Mon. 82.

Schmal elliptisch, noch weniger gewölbt als die vorige, oben pechbraun mit Messingschimmer (die Fld. stets etwas heller als Kopf und Halssch.), oder bei Hinzutritt von Grün schmutzig olivengrün; unten schwarz, mehr oder weniger grünlichblau glänzend, die Seiten des Bauches und der Hinterrand des letzten Segmentes manchmal röthlich. Kopf zerstreut und äusserst fein punktirt, glänzend, die Stirn wie gewöhnlich durch eine weite Vertiefung jederseits, die in einer halbkreisförmigen Rinne um den Ober- and Innenrand des Auges endet, etwas in die Höhe gehoben, die Linien des Kopfschildes und der Stirn schwach, undeutlich. Halssch. glänzend, mässig dicht und fein punktirt, die Form veränderlich, in der Regel vom Grunde bis zur Mitte nur wenig, davor stärker verschmälert, oder hinten fast gleichbreit, seltener mit der grössten Breite dicht vor der Mitte. Der Seitenwulst wird innen durch einen stark punktirten, aber sehr flachen Eindruck begrenzt, welcher sich an der Basis merklich vertieft und einwärts verbreitert, so dass er fast dreieckig erscheint. Fld. glänzend $(\hat{\jmath})$ oder matt seidenschimmernd (q), wenig dicht, fein punktirt, mit 9 nicht ganz regelmässigen gröberen Punktreihen, die paarweise einander etwas genähert sind. Die Punkte dieser Reihen sind auf der Scheibe grösser und tiefer als nach den Rändern hin, selbst grübchenartig, und stehen entweder in einfachen Reihen (vorzugsweise $\hat{\jmath}$ ), oder in schwachen Furchen (meist $q$ ). Im ersten Falle sind die Zwischenräume der Reihen flach, höchstens die schmalen durch eine leichte Wölbung markirt, im andern Falle 
treten sie als schmale Längsrippen deutlich hervor. Dr.r röthlichgelbe Seitensaum ist innen mässig scharf begrenzt und dehost sich in der Regel bis zur neunten Punktreihe, linter drr Mitte, bei schlechterer Begrenzung, auch noch weiter nach innen aus; jedoch krmumen auch Exemplare ror, bei denen er die Punkte der zweiten Doppelreihe (Fon aussen gerechnet) erreicht, andere, bei denen er nur noch dicht über den röthlichen Epipleuren angedeutet ist.

Das Männchen ist schlanker, zuweilou jedoch hinter der Mitte eben so stark erweitert als das Weibchen, und durch die glänzenden Fld., stark erweiterte Tarsen der vorderen Beine und den gewölbten letzten Bauchring sofort zu unterscheiden. - Der Penis ist dem der $C h r$. carnifex täuschend ähnlich, die gerinnte Spitze, in die der Vorderrand ausläuft, aber merklich breiter.

Bei ganz frisch entwickelten Stücken (Gyllh. var. c) sind Inopf, Halssch. und Unterseite röthlich pechbraun, die Fld., Fühler und Beine fast gelbbraun; reifere Männchen mit pechbraunem, gellich erzfarbigem Kopfe und Halssch., und rothbraunen Fld., welche bald wenig oder kaum, bald eben so stark messinggelb oder grünlichmetallisch glänzen, wie die Stammform und einen helleren Seitensaum besitzen, bilden die Var. a., solche Individuen, deren Oberseite mit Ausnahme des röthlichen Seitensaumes der Fld. tief schwarz ist, mit geringem Metallschimmer, die Var. b. Bei der Zwergform c.. aus den höheren Alpen, rom Grossglockner, St. Beruhard etc. (Rätzer; auch von H. Letzner auf dem Gletschereise gefangen) ist die Punktirung des Halssch, gewöhnlich stärker, die der Fld. feiner, flacher und in den Reihen unregelmässiger, der Glanz der Fld. bei beiden Geschlechtern gleichstark. Die in Sibirien bis zum Amur verbreitete Var. d. zeichnet sich durch bedeutende Grösse, schlanken Körper und die, auch beim Männchen als schmale Längsrippen hervortretenden Zwischenräume der Fld. aus.

In sandigen Gegenden, besonders in der Nähe von Flüssen nicht selten. Europa, nördliche Hälfte ron Asien, Nordafrika.

Chr. dierythra Rottb. (Berl. Zeit. 1371. 243) nach einem 우 von Sicilien beschrieben, lässt sich von der vorliegenden Art nicht trennen, bildet vielmehr eine der cinctella ähnliche Varietät, bei welcher das in der Mitte sehr fein punktirte, daher stark glänzende Halssch. rein schmarzgrün ist, ohne den ins gelbliche spielenden Erzglanz der Normalform, die Fld. sind rothbraun, nur noch am Nahtrande grünlich gefärbt. Dieser Ansicht stimmt auch H. Letzner in Breslau völlig bei, welcher so freundlich war, das in seinem Besitze befindliche Originalexemplar einer genauen Betrachtung zu unterziehen.

Auch Chr. luteocincta Fairm. (Ann. Fr. 1864. 647 u. 1865. 79 aus Algier: nigra, vix cenescens, nitidn, elytris castaneo-brunneis, aeneo- 


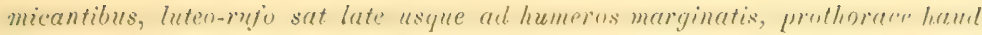
evidenter punctute, impressinnilus lateralitus punctrtis, sububsuletis, luteribus magis rectis etc. ist nur als eine Varietät aufzufassen.

28. Chr. amalis: Gblomga, subcomed, supra nigra, leviler aeneo-, cyaneo- vel riridi-coeruleo-mieans, subtus nigra vel nigro-coemelea, antennarum basi rujescenle: limbo laterali clytrorum rupo; capite polito, lincis epristomalis aul obsoletis anl nullis: prothmace antice transversim deplanuio, polito, basi paree subtilissime menctulato, callo laterali hand distincto punctis mumerosis inteme tesminato; clytris seriebus 9 per puria subapproximalis punctorum mims pofundorum, interstities latioribus subtiliter interdum subseratim punctatis. - Lons. 3,5-6,5 mm. Mas: tarsis anterioribus dilatulis, seymento 5:o ventruli subumidulo, apice truncato.

Linn. Syst. Nat. ed. XII. 592. - Fabr. Ent. Syst. I. 326. Panz. Faun. Germ. 16. 13. - Gyllh. Ins. Suec. III. 492. Duft. Faun. Austr. III. 197. - Matzek Bericht. Schles. Ges. 1842. 156. - Suffr. Mon. 83. - Thoms. Skand. Col. VILI. 247. - Redtb. Faun. A. II. 472. - Seidl. F. balt. 482.

Chr. schach Fabr. 1. c. 326 .

Var. a. lomata: Colore paymae suyerioris, praesertim clytromum saturate violaceo, nigro-coeruleo aut nigro-viridi-coevuleo; limbo laterali elytronum rubro.

Herbst Fuessl. Arch. IV. 54. t. 23. f. 8.

Chr. schach Oliv. Ent. V. 565. t. 8. f. 122. - Panz. 1. c. 16.12.

Duft. 1. c. 196 . - Redtb. 1. c. 473.

Chr. analis Schrank Enum. 80.

rar. b. prasina: Supra viridi-aenea, interdum aureo-micuns, limbo laterali elytrorum rubro.

Suffr. Mon. 85 .

Eine unserer kleinsten Arten, durch den Bau des Halssch, sehr ausgezeichnet. Schmal elliptisch, wenig gewölbt, oben schwarzmetallisch, die Fld. gewöhnlich mit violettem oder grünlichblauem Schimmer, unten schwarz bis schwarzblau, die Wurzel der Fühler und ein schmaler Seitensaum der Fld. gelblichroth. Kopf spiegelglatt, die Linie, welche das Kopfschild begrenzt, nur als ein tiefer Eindruck in der Nähe der Fühlerwurzel jederseits angedeutet, die Stirn deutlich gewölbt und allmählich von der leicht erhabenen Mittellinie nach den Augen zu abfallend. Halssch. kurz, mit schwach gerundeten Seiten nach hinten weniger als nach vorn rerengt, der Vorderrand tief ausgeschnitten, die vordere Hälite der Scheibe quer niedergedrückt, spiegelglatt, die hintere Hälfte sparsam und sehr fein punktirt; die Seiten nicht wulstig rerdickt, ihr steiler Abfall aber durch zahlreiche, wenig starke Punkte, die dicht an der Basis in einen unmerklichen Eindruck übergehen, seiner ganzen Länge 
nach von der Scheibe geschieden. Fld. ausser der äusserst feinen lederartigen Runzelung mit 9 wenig starken und selten deutlich bervortretenden Punktreihen, welche von aussen nach innen paarweise einander etwas genähert sind; ihre vier schmalen Zwischenräume schwach gewölbt, die breiteren eben, mässig dicht und nur wenig feiner als die Reihen selbst punktirt, die Punkte hier und da gereiht. Der rothe Seitensaum reicht bis zur neunten Punktreihe und wird hier ziemlich scharf begrenzt.

Beim Männchen ist der letzte Bauchring etwas aufgetrieben und am Hinterrande abgestutzt, die vorderen Tarsen sind verbreitert. Der Penis ist am Vorderrande stärker und plötzlicher verengt als bei den beiden vorigen Arten, hierauf in eine mässig lange, rinnenförmig ausgehöhlte Spitze verlängert.

Obgleich die oberseits fast schwarze Form überall nar selten vorkommt, so wird sie doch seit Linné als Grundform betrachtet; weit häufiger ist die Var. a., die insofern eine Reihe von Abänderungen umfasst, als ihre gesättigt dunkel-violetten, -blauen oder -grünlich-blauen Fld. sich mit einem schwarz-erzfarbigen, schwarzvioletten, schwarz-blauen oder grünlichblauen Halssch. verbinden können. Die oben lebhaft und rein grüne, selbst goldigglänzende Var. b. findet sich nicht nur in den Pyrenäen, von wo sie Suffrian zuerst beschrieb, sondern auch in der Mark und in Schlesien.

In Mittel- und Nordeuropa auf sandigen Feldern, an Ufern etc. nicht selten.

* Flügeldecken ohne rothen Seitensaum.

$\dagger$ Halsschild trapezförmig.

* Seitenwulst schmal, nur am Grunde schwach abgesetzt.

29. Chr. fuliginosa: Breviter-ovalis, valde convexa, nigra. alutacea, sericeo-micans fere opaca, antennis pedibusque plerumque coeruleis. interdum viridi-vel cupreo-micantibus; prothorace trapesiformi, parce subtilissimeque punctato, callo laterali angusto, obsoleto, antice punctis nonnullis posticeque impressione parum profunda terminato; elytris sat crebre inaequaliter punctatis, punctis majoribus in series haud distinctas, geminatas dispositis; tarsis latis. - Long. $7,5-9,5 \mathrm{~mm}$.

Mas: tarsis dilatatis, segmento $5: 0$ ventrali apice subtruncato.

Oliv. Ent. V. 514. t. 1. f. 2. - Suffr. Mon. 59.

Chr. op aca Suffr. Ann. Fr. 1853. 124.

Var. a. Subtus nigro-coerulea, interdum plus minusve cupreo-micans.

Var, b. Nigro-coerulea, elytris saturate nigro-viridibus.

Var. c. galii: Supra vel tota nigro-coerulea, pectore pedibusque interdum cupreis; elytris fortius punctatis.

Chr, molluginis Suffr. Mon. 57. - Redtb. Faun. A. ed. 3. II. 477. 
Grösser und gewölbter als die ähnlich gebaute Chr. haemoptera, schwarz, überall deutlich lederartig gerunzelt und dadurch mattseidenschimmernd, Fühler und Beine (wenigstens die Schienen) gewöbnlich blau, oft mit grünem oder kupferig-violettem Anfluge. Kopf zerstreut und sehr fein punktirt, Fühler mässig lang, das erste, dicke Glied und die folgenden vier sehr schlanken Glieder oft metallisch kupferroth, die letzten sechs, nach innen stark erweiterten Glieder mehr schwarzblau. Halssch. mit fast geraden, zuweilen merklich ausgebuchteten, seltener. sehr sanft gerundeten Seiten nach vorn stark verschmälert, trapezförmig, vorn nicht besonders tief ausgeschnitten, alle Ecken spitz und mit einer kleinen Borstenpore besetzt; die Scheibe wenig gewölbt, zerstreut und sehr fein punktirt, an den Seiten mit etwas stärkeren Punkten, welche rorn in einem undeutlichen Eindrucke, hinter der Mitte aber in und neben einer schmalen und ziemlich flachen rinnenförmigen Vertiefung stehen und so den sehr schmalen, flachen Seitenwulst begrenzen ${ }^{1}$ ). Fld. mit dreifacher Punktirung: die stärksten Punkte bilden 9, einander paarig genäherte Reihen, welche kaum deutlich hervortreten;

1) Genau dieselbe Bildung und Skulptur des Halssch. findet sich bei folgenden nahe verwandten Arten:

1. Chr. coriacea Stuffr. (Mon. 59) aus Spanien und Portugal. Geflügelt, Halssch. mit Eckborsten, Fld. bedeutend stärker als fuliginosa und deren Var. galii punktirt, Oberseite, zuweilen auch die Unterseite, bronzefarben; oder schwarz = Var. rugipennis Harold (Col. Heft. 14. 140). Diese Art steht zu fuliginosa in demselben Verhältnisse, wie affinis F. zur femoralis; meine p. 366 geäusserte Ansicht, sie gehöre wahrscheinlich in den Verwandtschaftskreis der ungeflügelten Chr. vernalis, hat sich, nachdem ich die Art gesehen, nicht bestätigt.

2. Chr. confossa Fairm. (Ann. Fr. 1865. 76) aus Algier. Dunkelblau, die Beine oft kupferig-violett, Fld. sehr gross aber sehr flach runzelig punktirt, sonst wie fuliginosa. Eine auffällige Varietät (dorsalis $m$.) hat rothgelbe Fld, gewöhnlich mit einem gemeinschaftlichen dreieckigen, schwarzblauen Flecke, der sich, allmählich verschmälert, von der Innenseite des Schulterhöckers bis zum Abfalle zur Spitze hinzieht und von hier aus auf den Nahtrand beschränkt ist.

3. Chr. lepida Oliv. (Ent. V. 522. t. 6. f. 73; Suffr. 132) aus Südfrankreich, Spanien und Algier. Bedeutend kleiner als fuliginosa, lebhaft dunkelblau, oder metallisch blaugrün, die ersten 4 bis 5 Glieder der schwarzen Fühler roth, Tarsen, oft die ganzen Beine bräunlich. Fld. mit 9 mehr oder weniger groben, parig genäherten Punktreihen, deren Zwischenstreifen zerstreut, sehr fein punktirt sind. Die Körperfarbe ändert ab: kupferig-violett, olivenfarbig, kupferig-bronzefarben. L. $5,5-8 \mathrm{~mm}$. 
wenig feiner sind die zalulreichen Punkte. Wrelse in dun breiteren Zwischenräumen, zwischen jo zwei Do[prelwihen stelen; di Räume zwischen diesen Punkten endlich, sowie dit sclunalen Zwischenräume jeder einzelnen Doppelreile sind sparsam sthr fein punktirt. Dir. Ijeine sind kräftig, ilıre drei ersten Tarsenglieder verhältnissmässive lرreit.

Das Männchen ist etwas kleiner, wenig schlanker und eine spur glänzender als das Weibchen, übrigens durch dic wenig breiteren Tarsen und den nur leicht abgestutzten Hinterrand des letzten Bauchringes schwer zu unterscheiden. - Der Penis ist klein uud schmal, gleichbreit, vorn durch eine leichte Ausbuchtung jederseits allnählich und schwach verengt, hierauf gerundet-abgestutzt.

Diese Art variirt nicht unbedeutend, indem die schwarze Körperfarbe durch eine gesättigt schwarzblaue oder stahlblaue verdrängt wird. Dies geschieht zunächst blos auf der Unterseite (Tar. a), später, aber nur in seltenen Fällen, auf der Oberseite allein, häufiger auf beiden Seiten zugleich (Var. c). Oft erhält diese blaue Farbe einen rioletten Schimmer, namentlich auf Kopf und Halssch., oder geht (Var. b) auf den Fld. oder der ganzen Oberfläche in ein gesättigtes Schwarzgrün über. Die Beine sind bald einfarbig schwarz, bald theilweise (Schenkel oder Schienen allein) oder gänzlich blaugrün, stahlblau, violett, purpurfarbig bis lebhaft metallisch-kupferroth; an letzterer Färbung nehmen zugleich'auch die Brust und die Aussenseite der ersten Bauchringe theil. Alle diese Abänderungen bilden zwei Hauptformen, die bisher als Arten angesehen wurden: 1. die eigentliche fuliginosa und ihre Varietäten a, und b., nit durchweg fein punktirten Fld., und 2, die Chr. molluginis Suffrian's: bei der die Fld. bedeutend stärker, in den Reihen oft grübchenartig punktirt sind.

Auf Kalkboden an Galium mollugo in der westlichen Hälfte Deutschlands vom Harze und Thüringen (Arnstadt, Ludy) bis Südbaiern, stellenweise häufig, aber nur die Var. c., ebenso in der Schweiz und ganz Frankreich; erst bei Genf (Manuel) und in Südfrankreich tritt neben dieser Form die typische fuliginosa aut:

* Seitenwulst breit, durch einen tiefen, rinnenförmigen Eindruck seiner ganzen Länge nach abgesetzt.

30. Chr. erythromera: Subhemishacrica. aurichalceo-olicacen. nitidissima, ore, antemis pedibusque fermumeis: prothorace trape:iformi ubique parce subtiliter punctalo, callo luterali sat lato et crasso, plica integra, leviter flexusa terminato: elytris seriebus $10-11$ per paria subapproximalis punctorum sat profundom, intersitiis parce subtilissimeque punctulatis. - Long. 7-9 $\mathrm{mm}$. 
Mas: Larsis panllo dilatatis. seymento ultimo ventrali apice subtruncalo.

Lucas Explor. Alg. Ent. 1849. 534, t. 45. f. 9.

Chr. Schotti Suffr. Mon. 39. - Redtb. Faun. A. II. 477.

? Chr. meridionalis Herr. Schäff. Faun. Germ. 15\%. 6. a.

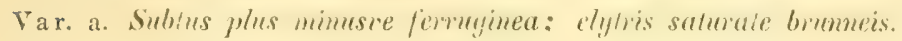
Var. b. peregrina: Supra viridi-aenea vel nigro-coerulea.

Herr. Schäff. l. c. 157 . 6. c.

Breit-eiförmig, hoch gewölbt, fast halbkugelig, bräunlich-olivengrün, mit starkem Messingglanze, der Mund, die Fühler und Beine rostroth. Kopf zersireut und fein punktirt, Linien des Kopfschildes und der Stirn fein, aber deutlich, der Eindruck am Innenrande jedes Auges ist tief, linienförmig und läuft gerade nach unten. Halssch. trapezförmig, vorn flach ausgeschnitten, alle Ecken spitz, ihre feine weissliche Borste steht in einer Pore unmittelbar in der Randlinie; die Seiten sind entweder ganz gerade oder in der Mitte sanft ausgebuchtet, der Seitenwulst breit, seiner ganzen Länge nach ron einem tiefen, in der Mitte schwach nach innen gebogenen furchenartigen Eindrucke begrenzt, welcher, wie die ganze Oberfläche des Halssch. nur zerstreut und fein punktirt ist. Fld. mit 10 bis 14 selten ganz regelmässigen Punktreihen, welche zu zweien einander etwas genähert sind; ibre Punkte sind mässig gross und stehen ziemlich dicht aneinander (gewöhnlich mehr als 30 in einer Reihe), aber sie sind in der Mitte der Scheibe, besonders hinter den Schultern grösser als nach den Rändern $z u$, die Zwischenräume sind sparsam, sehr fein punktirt.

Das $\hat{j}$ unterscheidet sich nur wenig rom 9 durch etwas breitere Tarsen und den in der Mitte des Hinterrandes schwach abgestutzten letzten Bauchring. -- Der Penis ist klein, flach, schmal, gleichbreit, vorn gerundet-abgestutzt, der Seitenrand beiderseits über der Spitze in einen schräg nach aussen und hinten aufstehenden sehr spitzen Zahn ausgezogen.

Bei sehr frischen Stücken ist die Unterseite einfarbig hell rostroth, häufiger sind jedoch die Hinterbrust und die ersten Bauchringe dunkelgrün, messinggelb glänzend, die Fld. gesättigt braun mit Metallschimmer, ähnlich wie bei staphylea. Auf peregrina Schäff. sind ohne Zweifel solche Stücke zu beziehen, deren Oberseite schwarzblau ist (wie bei laevicollis) auch stelle ich noch diejenigen dazu, die oben eine rein und lebhaft grün-metallische Farbe besitzen.

Bei Triest, nach Redtenbacher auch im südlichen Tirol. Verbreiteter in ganz Italien bis Sicilien, Corsica, Sardinien und Südfrankreich. 
31. Chr. oricalcia: Elliptica, sat convexa, supra aurichalcea. nitida, sublus nigro-viridis vel -coerulea, aeneo micans, antennis piceis, basi unguiculisque testaceis; prothorace subtrapeziformi, laevissimo, lateribus rectis vel leviter rotundatis, callo laterali lato plica integra terminato, elytris seriebus 9 punctorum profundorum, interstitiis parce subtilissimeque punctulatis. - Long. $6,5-8,5 \mathrm{~mm}$.

Mas: tarsis articulis 3 primis dilatatis.

Müller Zool. Dan. Prodr. 1776. 82.

Chr. lamina Matzek Ber. Schles. Ges. 1842. 156. - Küst. Käf. Eur. 1. 80. - Motsch. Schrenk Reis. II. 211 (Hoplosoma). - Redtt. Faun. A. II. 473.

Var. a. lamina: Supra nigro-aeneo-virescens.

Fabr. Ent. Syst. I. 1. 311. - Panz. Faun. Germ. 44. 5. Duft. Faun. Austr. III. 174. - S uffr. Mon. 120. - Seidl. F. balt. 481 .

Chr. Hobsoni Steph. IIl. Brit. IV. 343.

Var. b. laevicollis: Capite prothoraceque nigro-aeneo-virescens, elytris viridi-coeruleis, coeruleis vel cyaneis.

Oliv. Ent. V. 519. t. 6. f. 78.

Chr. lamina Steph. 1. c. 342. - Gyllh. Ins. Suec. III. 47S. -

Thoms. Skand. Col. VIII. 247.

Var. c. Ut in b, sed breviter-ovalis, elytris interstitiis serierum alutaceis haud punctulatis.

Chr. laevicollis Suffr. Mon. 120.

Kleiner, flacher und viel weniger gerundet als die vorige, auf den Fld. nur 9 stärker und weitläufiger punktirte Reihen; elliptisch, beiderseits stark verschmälert, oben bräunlich-messinggelb, glänzend, unten dunkler, schwarzgrün oder schwarzblau mit Metallschimmer, Fühler und Tarsen pechschwarz, die beiden Basalglieder der ersteren und die Klauen gelbbraun. Halssch. spiegelblank, trapezförmig, von den Hinterecken nach vorn seltener ganz geradlinig verengt, meist in der hinteren Hälfte schwächer als in der vorderen verschmälert, so dass die Seiten deutlich, wenn auch schwach gerundet sind; alle Ecken scharf rechtwinkelig, der Seitenwulst breit, innen plötzlich zu einem tief'en Eindrucke abfallend, welcher besonders tief am Grunde beginnt, bald davor sich allmählich, aber unbedeutend verflacht und in fast gleicher Tiefe, den Seiten parallel zum Vorderrande läuft, wo er sich mit der vertieften Linie desselben verbindet. Fld. mit neun regelmässigen Reihen starker und tiefer, nicht dicht gestellter Punkte, die am Grunde, an der Naht und vor der Spitze etwas schwächer werden, nur die beiden äusseren Reihen einander etwas genähert, die Zwischenräume fast glatt, undeutlich lederartig gerunzelt und meist deutlich, aber sehr fein punktirt.

Das kleine und schmale Männchen erkennt man mit Sicherheit 
an den mässig erweiterten Tarsen. - Der Penis ist stark gekrümmt, breit, vorn allmählich gerundet-erweitert, sodann in einem flachen Bogen abgestutzt, der ductus ragt weit heraus und ist auf die Rückseite umgebogen, auf dieser selbst bemerkt man bei Seitenansicht ein nach oben gerichtetes, wenig abstehendes und sehr scharfes Zähnchen jederseits, welches sich, bei der Ansicht von hinten, als eine halbkreisförmige Platte erweist. Die Oeffnung ist sehr lang und breit und wird fast vollständig von einer Klappe bedeckt, die in der Mitte von einer feinen, tief gerinnten Längsleiste durchzogen ist, am Vorderrande in zwei längliche Lappen endet.

Die messinggelbe Farbe der Oberseite verändert sich durch Hinzutritt ron Grün in eine schwärzlich metallisch-grüne (Var. a); häufiger zeigt sich die letzgenannte Färbung nur auf Kopf und Halssch., die Fld. sind grünlichblau, rein blau oder violett (Var. b). Einzelne so gefärbte Stücke aus Italien und Südrussland (Theodosia, Retowski), die sich durch einen sehr breiten Körper auszeichnen und zugleich zwischen den Punktreihen der Fld. kaum wahrnehmbar punktirt sind (Var. c), betrachtete Suffrian, jedoch ohne Recht, als Art.

In ganz Mitteleuropa stellenweise nicht selten. Südschweden. Oberitalien.

$\dagger \dagger$ Halssch. quer-viereckig, mit gerundeten Seiten nach vorn wenig verschmälert.

Seitenwulst der ganzen Länge nach rinnenförmig abgesetzt.

32. Chr. chalcites $\left.{ }^{1}\right)$ : Oblongo-ovalis, sat convexa, aurichalceoolivacea alutacea, nitidiuscula, tarsis antennisque rufo-piceis, his basi

1) Vor diese Art gehört Chr. morio Kryn. (Bull. Mosc. V. 1832. 171. - Suffr. 118): Ovata, sat convexa, nigra, alutacea, supra leviter aeneo-micans, subnitida, antennarum articulis primis apice rufescentibus; prothorace sat crebre subtiliter punctato, fortiter transverso, lateribus rotundatis antrorsum angustatis, callo laterali lato, plica integra terminato; elytris seribus 9 punctorum sat profundorum, interdum per paria subapproximatis, interstitiis evidenter punctulatis. Mas: tarsis articulis 3 primis dilatatis, segmento ultimo ventrali subtumidulo, apice truncato. - Long. 7-10 mm. Hungaria. Russia media et meridionalis: Podolia, Odessa, Theodosia (Retowski), Kasan, Sarepta, Kaukasus.

Durch das breite, an den Seiten stark gerundete und nach vorn weniger verschmälerte Halssch., welches wie die Zwischenräume der Fld. deutlich punktirt ist, von Chr. oricalcia sehr verschieden. - Der Penis ist breit, ziemlich gerade, flach, die fast kielförmig aufstehenden oberen Seitenränder sind über der kleinen, queren Oeffnung jederseits in ein nach innen laufendes 


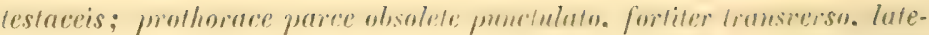

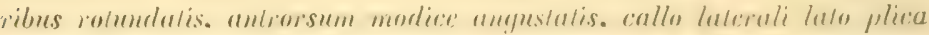

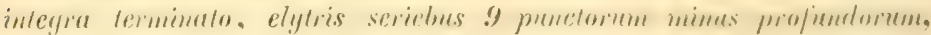

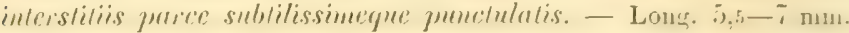

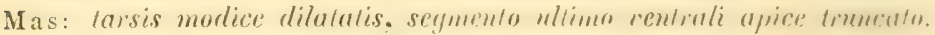

Germ. Ins. spec. nov. 587. - Redtb. Faun. A. II. 473.

Chr. chalcitis Suffr. Mon. 121.

Etwas kleiner als die rorhergelınde, mit breitem, nach rorn weniger verengten, an den Seiten stärker gerundeten Halssch. und feiner punktirten Fld., länglich-eiförnig, bräunlich-olivengrün mit Messingschimmer, äusserst fein lederartig gerunzelt und deshalb nur mässig gläuzend, Tarsen und Fühler röthlich pechbraun. letztere mit unterseits helleren Basalgliedern. Halssch. kurz, mehr wie doppelt so breit als lang, nach roln nur mässig verengt, mit gerundeten Seiten und stumpfwinkeligen, leicht abgerundeten Ecken, sparsam verloschen punktirt, der Seitenvulst breit, der denselben innen scharf begrenzende, rinnenförmige Eindruck, welcher dem Seitenrande parallel gebogen ist, noch tiefer als bei der rorigen. Fld. ebenso fein gerunzelt und punktirt als das Halssch., mit neun. weder starken und tiefen, noch dicht punktirten Reihen, welche anf dem Abfalle zur Spitze sehr fein werden. Unterseite dunkler als die Oberseite.

Beim $\hat{o}$ sind die Tarsen mässig erweitert, der Hinterrand des letzten, leicht gewölbten Bauchringes ist abgestutzt. - Penis ziemlich kurz, breit, nach vorn bedeutend erweitert und in einem flachen, in der Mitte ausgerandeten Bogen abgestutzt.

Wahrscheinlich kommt diese Art auch mit blaugrünen und blauen Fld. vor, aber es sind mir bisher nur Stücke mit schwarz metallgrüner Oberseite bekannt geworden.

Auf Salzboden im südöstlichen Europa. Istrien. Dalmatien (Pipitz). Neusiedler See. Ufer des Schwarzen (Krim) und Kaspischen Meeres (Derbend, Faust). Bei Tiflis (Leder). Syrische Küste (Simon).

33. Chr. ruforemea: Oblongo-ovalis, sat convexa, mo-brmmea. aurichalceo micans, nitidiuscula, capite. prothorace metasternoque plerumque piceo-aurichalceis nel nigro-aeneo-virescentibus; prothorace alutaceo, parce subtiliter punctato, transwerso. lateribus rotundatis antrorsum modice angustalis, callo laterali lato plica inlegia terminato, elytris

Schräghöckerchen erhöht, die breite, allmählich etwas verengte Spitze zuerst stark nach oben, dann wieder nach unten, zusammen fast S-förmig gebogen, ähnlich wie bei Chr. vernalis. 
punctato striatis (punctis striarum creberrimis), interstitiis subconvexis subtiliter punctulatis. - Long. 5,5-7 mm.

Mas: ventre convexo, tarsis dilatatis.

Suffr. Mon. 122.

Var. a. fallaciosa: Supra brunnea, coeruleo splendens.

Fast ganz von der Gestalt der vorigen, das Halssch. jedoch länger, die Reihen der Fld. viel dichter punktirt und in deutlich vertiefte Streifen gestellt; länglich eiförmig, mässig gewölbt, rothbraun mit Messingschimmer, ziemlich glänzend, Kopf, Halssch. und Hinterbrust gewöhnlich dunkler, pechschwarz mit gelblichem Metallschimmer oder schwärzlich metallgrün, auch bläulich. Halssch. etwas stärker lederartig gerunzelt und matter als Kopf und Fld., etwa doppelt so breit als lang, nach vorn mit gerundeten Seiten mässig verengt, die Ecken stumpfwinkelig, leicht abgerundet. Der Seitenwulst breit, innen der ganzen Länge nach von einem tiefen, rinnenfömigen, den Seiten parallelen Eindrucke scharf begrenzt. Fld. am Grunde so breit wie der Hinterrand des Halssch., dahinter beim $\hat{o}$ kaum, beim ㅇ deutlich verbreitert, mit neun Punktstreifen; die Punkte in denselben sehr dicht gestellt, mässig stark, tief, zahlreicher als bei allen übrigen Arten. Die Zwischenräume der Streifen gewölbt, mässig dicht, fein punktirt.

Das Männchen ist an den breiteren Tarsen, dem schmalen, höher als beim Weibchen gewölbten Bauche und einem wenig in die Augen fallenden Grübchen am Vorderrande des letzten Segmentes zu erkennen. - Der Penis ist dem der vorigen Art sehr ähnlich, stärker gebogen, der breite Vorderrand tiefer ausgebuchtet, sein linker Lappen etwas grösser als der rechte.

Die einzige bekannte Abänderung entsteht dadurch, dass die Oberseite stark und lebhaft blau schimmert.

Bis jetzt nur in einem vielleicht eingeschleppten Exemplare bei Nassau von Dr. Buddeberg gefangen. Sonst an der Westküste von Frankreich z. B. bei Rochefort (Pipitz), in Portugal und MittelSpanien zuweilen zahlreich.

$\bigcirc \bigcirc$ Seitenwulst nicht rinnenförmig begrenzt.

34. Chr.brunsvicensis: Oblongo-ovalis, sat convexa, supra aurichalceo-cuprea, nitidissima, capite, interdum etiam prothorace viridiaeneo, subtus coevuleo-nigra, plerumque aeneo micans, antennis rufopiceis, basi dilutioribus, prothorace convexiusculo, evidenter sat crebre subtiliterque punctato, callo laterali antice depressione punctata, postice sulca brevi profunda terminato; elytris crebre subtiliter punctatis, punctis majoribus in series 9 geminatas, parum discretas, apicem versus obsoletiores, dispositis. - Long. $6 \mathrm{~mm}$.

VI. 3. 
Mas: tarsis modice dilatatis, segmento ultimo ventrali subconvexo, apice truncato.

Gravenh. Vergl. Uebers. zool. Syst. (1807) 135. - " Duft. Faun. Austr. III. 175.

Chr. duplicata Zenker Germ. Mag. I. 2.148. - Suffr. Mon. 12\%.

- Redtb. Faun. A. II. 473.

Chr. subseriepunctata Dietr. Stett. Zeit. 1857. 135.

Durch den starken Glanz der Oberseite und die wenig hervortretenden Punktreihen der Fld. von den folgenden leicht zu unterscheiden; länglich eiförmig, mässig gewölbt, oben lebhaft kupferroth mit Messingschimmer, stark glänzend, der Kopf und ein schmaler Nahtsaum der Fld. meist, zuweilen auch das Halssch. und Schildchen metallisch grün, Fühler röthlich-pechbraun, die ersten drei bis vier Glieder rothgelb. Halssch. mehr als doppelt so breit wie lang, gewölbter als bei den folgenden, nach rorn mässsig verengt, die Seiten von der Basis aus zuerst schwach, vor der Mitte stärker convergirend, der Seitenwulst deutlicb, fast glatt, vorn von einem kräftig punktirten, flachen Eindrucke begrenzt, welcher in der Mitte verschwindet, an der Basis durch eine kurze und tiefe, glatte Rinne abgesetzt. Die Scheibe überall ziemlich dicht und deutlich, fein, aber nicht tief punktirt. Fld. kaum stärker, aber dichter und tiefer als das Halssch. punktirt, mit 9, einander paarig genäherten stärkeren Punktreihen, welche jedoch aus der übrigen Punktirung nur schwach hervortreten und besonders nach der Naht hin und auf dem Abfalle zur Spitze fast verschwinden. Die Punkte der Reihen stehen im Allgemeinen so dicht wie bei geminata, aber die Grösse der Z wischenräume varïrt selbst bei den Reihen jedes einzelnen Stückes erheblich.

Das Männchen ist am sichersten an den mässig erweiterten Tarsen, weniger durch den etwas gewölbten und am Hinterrande abgestutzten letzten Bauchring rom Weibchen zu unterscheiden, ausserdem gewöhnlich etwas schlanker gebaut. - Der Penis ist länger als der Hinterleib, schlank, wenig gebogen, gleichbreit, sur dicht vor der Spitze unmerklich erweitert; sodann beiderseits mit abgerundeter Ecke schnell und fast gradlinig rerengt und in eine mässig breite, abgerundete, wenig bemerkbare Spitze verlängert. Der ductus ist häutig und sehr dick.

Auf Hypericum hirsutum und perforatum (im Juni und dann wieder im September, Cornelius) zerstreut durch ganz Deutschland, aber wohl vielfach übersehen. Der nördlichste, mir bekannte Fundort ist Holstein. 
35. Chr. geminata $\left.{ }^{1}\right)$ : Elliptica, convexa, supra violacea, alutacea, sericco-micans, subtus nigro-violacea vel-coerulea subvirescens, antennis nigris; prothorace parum convexo crebre subtilissimeque punctato, callo laterali antice depressione punctaia posticeque plica profunda terminato; elytris crebre subtiliter, sed inaequaliter punclatis, seriebus 9 punctorum majorum ubique distinctis per paria approximatis, punctis serierum crebris. - Long. 6,5-7,5 mm.

Mas: tarsis sat fortiter dilatatis, segmento ultimo ventrali fovea magna impresso, margine apicali utrinque sinuato.

Payk. Faun. Suec. II. 65. - Oliv. Ent: V. 535. t. 7. f. 95. Gyllh. Ins. Suec. III. 477. - Zenker Germ. Mag. I. 2. 148. - Duft. Faun. Austr. III. 174. - Matzek Ber. Schles. Ges. 1842. 156. - Küst. Käf. Eur. 7. 86. - Suffr. Mon. 129. - Thoms. Skand. Col. VIII. 245. - Redtb. Faun. A. II. 474. - Seidl. F. balt. 481 .

Var. \&. Supra nigra aut nigro-coerulescens.

Var. b. Supra coerulea viridi-micans, aut obscure viridis.

Var. c. cuprina: Supra obscure cupreo-aurichalcea; prothorace plerumque crebre inaequaliter punctato, elytris fortius punctatis, punctis serierum magnis, mimus crebris, interstitiis latioribus subtiliter vugulosis; maris segmento ultimo subconvexo, haud foveolato.

Duft. 1. c. 177 .

Var. d. Supra violaceo-cuprea aut viridis violaceo-micans.

Grösser, breiter und viel matter als die vorige, elliptisch, gewölbt, oben dunkel violett, deutlich lederartig gerunzelt, matt seidenschimmernd, besonders das $f$, unten grünlich schwarz-violett oder schwarzblau, Fühler schwarz, die Spitze der ersten Glieder bisweilen rerwaschen röthlich. Halssch. an der Basis doppelt so breit als lang, wenig gewölbt, nach vorn mässig verengt, aber in der Form recht rariirend, weil die Seiten in der hinteren Hälfte entweder parallel, oder schwach nach vorn, seltener nach hinten rerengt sind, vor der Mitte convergiren sie in starker Rundung. Der Seitenwulst ist deutlich, etwas glatter als die Scheibe, rorn von einem stark punktirten flachen Eindrucke, der in der Mitte verschwindet, hinten von einem tiefen, rinnenförmigen Eindrucke begrenzt; die Scheibe dicht und fein, besonders flach punktirt. Fld. mit neun deutlich

1) Bedeutend grösser als diese Art, aber ihr am nächsten rerwandt, ist Chr. corcyrica Suffr. (Mon. 133) ron Corfu. Körperbau (auch an vernalis erinnernd), Gestalt und Punktirung des Halssch. und der Fld. wie bei geminata, nur der Eindruck, der den Seitenwulst in der hinteren Hälfte des Halssch. begrenzt, entsprechend tiefer und länger, die starken Punkte in den regelmässigen Reihen der Fld. bedeutend schärfer, tiefer und grösser. Oben dunkel metallisch grün, lebhaft glänzend, unten schwarzblau. - L. 9 mm. 
hervortretenden, paarig genäherten starken Punktreihen, in denen die Punkte so dicht stehen, dass sie (zumal in den 6 äusseren Reih(rı) eine ununterbrochene Vertiefung, einen seichten Streifen bilden. Die flachen breiteren $\mathrm{Z}$ wischenräume sind dicht mit feinen, aber doch rerschieden grossen Punkten bestreut und erscheinen durch die unmerkliche Wölbung zwischen den einzelnen Punkten, sowie einzelne Querrisse etwas uneben, fast rauh; glatter, feiner und sparsamer punktirt sind die kaum merklich gewölbten schmäleren Zwischenräume.

Beim Männchen sind die Tarsen ziemlich stark erweitert, der letzte Bauchring besitzt einen breit dreieckigen Eindruck, welcher sich in der Mitte zu einer Rinne vertieft, die gewöhnlich den Vorderrand erreicht; der Hinterrand ist abgestutzt und jederseits leicht ausgebuchtet. - Penis noch etwas länger und kräftiger als bei brunsvicensis, durchaus gleichbreit, rorn allmählich in eine leicht abgerundete Spitze verschmälert. Der häutige, weissliche, sehr grosse ductus besitzt oberseits zwei braune, rauhe Längsleisten.

Diese Art kommt in zwei sehr abweichenden Formen vor, die sich schon durch die Farbe der Oberseite auseinander balten lassen, wenn nicht mein ziemlich reiches Material zur vollständigen Beurtheilung der Art doch noch unzureichend sein sollte. Die erste. oben beschriebene, im Ganzen seltene Form ist oberseits dunkel violett, aber auch schwarzblau oder schwarz (Var. a), blaugrün oder dunkelgrün (Var. b), Halssch. und Fld. sind verhältnissmässig sehr fein punktirt und die Punkte in den Reihen der Fld. zwar stark. aber niclit grübchenartig, sehr zahlreich; bei der zweiten Form, Duftschmid's cuprina, ist die Punktirung durchweg stärker, daher erscheinen das Halssch. und die Fld. unebener, die Punkte in den Reihen der Fld. sind gross, tief, grübchenartig, aber weniger zahlreich, beim ô fehlt die Grube auf dem letzten Segmente gänzlich oder ist nur durch einen verschieden tiefen Eindruck am Hinterrande angedeutet. Die Oberseite ist düster kupferroth, gelblich metallschimmernd, oder violett angelaufen, zuweilen tritt die letztere Färbung auch in Verbindung mit einem wenig lebhaften Grün auf (Var. d).

Auf Hypericum perforatum im Vorgebirge zuweilen nicht selten: die eigentliche geminata vorwiegend im südlichen Scbweden und im norddeutschen Berglande, die kupferige Form in Schlesien, den Karpathen bis Siebenbürgen und den Alpen.

36. Chr. quadrigemina: Oblongo-ovalis, sat comexa, nitidu. subtus nigro-coerulea, antemis piceis basi dilutioribus, capite prothoraceque viridi-aeneis, hoc parum convexo, sat crebre subtilissimeque 
punctato, callo laterali antice impressione punctata, postice sulca profunda terminato; elytris viridi- aut brumeo-aurichalceis, sat crebre subtiliter et aequaliter punctatis, seriebus 9 punctorum majorum per paria approximatis, punctis serierum magnis, remotis, interdum infuscatis. - Long. 5-6,5 $\mathrm{mm}$.

Mas: tarsis modice dilatatis, segmento ultimo ventrali convexo plerumque in medio longitudinaliter impresso.

Suffr. Mon. 125. - Redtb. Faun. A. II. 477. - Kraatz Berl. Zeit. 1859. 294.

Chr. gemellata Rossi Faun. Etr. Mant. I. 30. - Duft. Faun. Austr. III. 176.

Var. a. Supra tota cupreo-brunneo-aenea.

Var. b. indigena: Supra laete coerulea aut nigro-chalybaea.

V a r. c. Antennis rufescentibus.

Var. d. alternata: Major, ovalis, convexa, supra laete viridi-metallica, nitidissima, intersitiis elytrorum evidenter punctatis. - Long. 6-7 mm.

Suffr. Mon. 127.

Var. e. Supra plus mimusve coeruleo-viridis, aeneo-micans.

Der Chr. hyperici sehr ähnlich und von ihr hauptsächlich durch folgende Punkte nur bei der grössten Aufmerksamkeit sicher zu unterscheiden: Unsere deutschen Stücke sind im Durchschnitt kleiner und etwas schlanker, das $\mathrm{Halssch}$. ist etwas gewölbter, überall deutlich, obgleich sehr fein punktirt, vor dem Hinterrande etwas stärker als in der Mitte, der Eindruck vor den Hinterecken jederseits ist breiter und tiefer, nach vorn nicht verflacht, sondern plötzlich abbrechend, die Punkte vor demselben stehen in einem deutlichen, wenn auch nicht besonders tiefen Eindrucke, der den Seitenwulst auch rorn in die Höhe hebt und begrenzt, und sind merklich stärker; das Schildchen ist schmaler. Die Fld. sind in beiden Geschlechtern glänzend, etwas stärker, dichter und tiefer punktirt, die Punkte scharf eingestochen und dicht durch Runzeln verbunden, ihre Doppelreihen gewöhnlich mit grösseren Punkten.

Das Männchen hat mässig erweiterte Tarsen und einen breiten, flachen Längseindruck auf dem gewölbten letzten Bauchringe. Der Penis ist dem der vorigen Art sehr ähnlich, ebenso gross, aber vorn einfach breit abgerundet.

Die Farbe der Unterseite ist einfarbig schwarzblau, oder die Brust schwächer, Schenkel und Schienen stärker metallisch grün, Fühler pechschwarz, an der Basis bräunlich, oder einfarbig rothbraun (Var. c); oberseits ist Kopf und Halssch. dunkel metallisch grün, die Fld. sind gewöhnlich etwas heller, bräunlich-kupferig oder olivengrün mit Messingschimmer. Diese Färbung ändert ab: die Oberseite einfarbig grünlich oder braun messingfarbig (Var. a), oder lebhaft 
blau bis schwärzlich-stahlblau (Var. b). In Südeuropa, besonders in Italien, Corsika, Sardinien und Sicilien, kommt die Art in einer kräftigen, breiter und höher gewölbten Form vor, welche mehr an geminata erinnert, aber bedeutend kürzer und breiter, hinten gleichmässiger abgerundet und weniger zugespitzt ist. Dieselbe ist oben entweder rein und lebhaft hellgrün, sehr stark metallisch glänzend (Var. d) oder bläulichgrün gefärbt (Var. e).

Auf Hypericum perforatum, im Frühlinge auch unter Steinen auf bergigen Triften, nicht selten in Mittel- und Süddeutschland. In der Mark bei Sommerfeld. Südeuropa. Nordafrika.

Durch die Untersuchung des Penis wird diese, zuerst von Suffrian richtig erkannte, aber vor und nach seiner Zeit mit hyperici vereinigte Art einerseits so sicher festgestellt, dass ein Zweifel an derselben in Zukunft absolut ausgeschlossen ist, andrerseits die nahe Verwandtschaft nicht mit der äusserlich täuschend ähnlichen hyperici, sondern mit geminata nachgewiesen. Der ursprüngliche Name gemellata Ross i ist nicht anwendbar, weil die noch ältere Benennung gemellata $\mathrm{F}$ o u r cr. zur vorliegenden oder wahrscheinlicher zur folgenden Art gehören kann. Weun oben die grosse Form als alternata Suffr. angeführt ist, obwohl meine Beschreibung in wesentlichen Punkten ron der Suffrian's abweicht, so geschieht dies, weil Suffrian sich an seine, nach einem abnormen Stücke aufgestellte Diagnose späterhin selbst nicht gekehrt, sondern die oben bezeichnete Form als alternatas. vielfach versandt und bestimmt hat.

37. Chr. hyperici: Oblongo-ovalis, sat convexa, submitida, sublus nigro-coerulea, antennis piceis, basi inferne ditutioribus, capite prothoraceque viridi-aeneis, hoc minus convexo, obsolete punctulato, fere laeri. callo lalerali antice depressione obsoletissima, subtiliter punctala, postice plica sal profunda antrorsum obsoletiore terminato; elytris virilliaurichalceis aut cupreo-brumeo-aeneis, subtiliter vageque punclatis subrugulosis, seriebus 9 punctornm majorum per paria approximalis. punctis serierum magnis, remotis, plerumque infuscatis. - Long. 5-7 mm.

Mas: tarsis modice dilatatis, segmento ultimo ventrali subconcexo, antice posticeque leviter transversim impresso.

Forster Nov. spec. Ins. I. 1771. p. 20. - Marsh. Ent. Brit. I. 173.

C'hr. fucata Fabr. Spec. Ins. I. 126. - Oliv. Ent. V. 535. t. 4.

f. 45. - Duft. Faun. Austr. III. 176. - Suffr. Mon. 124. Thoms. Skand. Col. VllI. 245. - Redtb. Faun. A. II. 473. Seidl. F. balt. 481 .

Chr. gemellata Fourcr. Ent. Par. I. 1755. p. 110. - Gyllh. Ins.

Suec. IV. 647. - Zenker Germ. Mag. I. 2. 147. - Matzek Ber.

Schles. Ges. 1842. 156. 
Var. a. Supra tota viridi-aurichalcea aut cupreo-brunneo-aenea.

Var. b. ambigua: Supra nigro-coerulea aut-violacea.

Var. c. privigna: Supra tota nigra.

Länglich-elliptisch, mässig gewölbt, wenig lebhaft glänzend (ぶ) oder matt seidenschimmernd (ㅇ), unten schwarzblau, Brust und Beine zuweilen grün metallisch, Fühler pechschwarz, an der Basis unterseits bräunlich, Kopf und Halssch. metallisch grün, Fld. grün mit Messingschimmer oder kupferig-braun, metallglänzend. Hals s c b. kurz, sehr wenig gewölbt, nach vorn mässig verengt, die Seiten von der Basis aus zuerst schwach, vor der Mitte stärker convergirend, der Seitenwulst ist vorn flach und geht allmählich mit einem kaum bemerkbaren, ziemlich fein punktirten Niederdrucke in die Scheibe über; hinten dagegen ist er gewölbter und durch einen ziemlich tiefen, bald rinnenförmigen und glatten, bald weniger scharfen und runzelig punktirten Eindruck begrenzt, welcher sich nach der Mitte zu allmählich verflacht. Die feine und seichte Punktirung der Scheibe ist nur am Grunde ziemlich deutlich, vor der Mitte aber zwischen der feinen Netzelung kaum noch bemerkbar. Fld. mit 9 einander paarig genäherten Reihen starker, grübchenartiger Punkte, die im Innern gebräunt und in unregelmässigen Abständen weitläufig so eingestochen sind, dass je zwei Punkte einer Doppelreihe als ein zusammengehöriges, in schräger Richtung gegenüberliegendes Punktpaar erscheinen, welches von dem nächsten weit geschieden ist. So kommt es, dass bei dieser und der vorigen Art weniger die Längsreihen als die schief gestellten Punktpaare in die Augen fallen. Zuweilen treten auch bei dem Ausfalle eines Punktes in einer der beiden nebeneinander liegenden Reiken drei Punkte zu einer abgesonderten Gruppe zusammen, welche Duftschmid mit einem Träubchen vergleicht. Die Zwischenräume sind sehr fein punktirt, die breiteren deutlicher als die schmaleren, und gewöhnlich sehr fein gerunzelt.

Beim Männchen sind die Tarsen mässig erweitert, der letzte Bauchring ist etwas gewölbt und in der Mitte am Vorder- und Hinterrande seicht eingedrückt. - Der Penis ist viel kürzer als der Hinterleib, mässig breit, stark gebogen, vorn schnabelförmig ausgezogen, indem er, allmählich gerundet-verengt, hierauf wieder etwas erweitert, in einem weiten flachen Bogen jederseits ausgerandet an der Spitze breit abgerundet ist.

Nehmen Kopf und Halssch. die Farbe der Fld. an, so entsteht die unbedeutende Var. a., mit messingglänzend grünlicher oder kupferbräunlicher Oberseite, bei welcher die Grübchen der Punktreihen meist immer gebräunt, bisweilen mit ihrer nächsten Umgebung brandschwarz, oder die schmalen $Z$ wischenräume gänzlich schwach 
gebräunt sind, wäbrend die breiteren grünlich bleiben; eine zweite, seltnere Abänderung ist einfarbig schwarzblau oder schwarzviolett, aber meist dunkler als bei 4-gemina; zur dritten, häufigen Varietät gehören die oberseits schwarzen Stücke. Ein Vergleich der Farbenreihen dieser und der vorigen Art ergiebt, dass eine messingfarbige und eine blaue Form bei beiden, eine rein und lebhaft grüne dagegen nur bei 4-gemina, und eine schwarze nur bei hyperici bisher beobachtet worden ist.

Auf Hypericum perforatum und quadrangulare ziemlich häufig.

38. Chr. didymatat $\left.{ }^{1}\right)$ : Ovalis, convexa, saturate coerulea, inter. dum virescens, evidenter alutacea, sericeo-micans, antennis piceis articulis primis superne subcoeruleis; prothorace parum convexo, subtiliter, subinaequaliter, latera versus fortius punctato, callo laterali fere mullo, postice plicatula punctata subtiliter terminato; elytris obsolcte subtiliter punclulatis, seriebus 9 punctorum majorum per paria approximatis, punctis serierum sat parvis, subremotis; tarsorum articulo tertio sat angusto. - Long. 6-7,5 $\mathrm{mm}$.

Mas: segmento ultimo ventrali subconvexo, postice transversim deplanato, apice truncato.

Scriba Journ. Liebh. Ent. I. 1791. p. 294. - Suffr. Mon. 131

Durch den breiten, höher gewölbten, fein punktirten Körper, die in beiden Geschlechtern deutlich lederartig gerunzelte, matt seidenschimmernde Oberseite und den schwachen Eindruck, welcher den Seitenwulst des Halssch. hinten nur leicht absetzt, ron den vorhergehenden Arten nicht schwer zu unterscheiden, in der Form der alternata am ähnlichsten. Breit eiförmig, gewölbt, gesättigt blau, zuweilen mit grünlichem oder violettem Anfluge, besonders auf der

1) Eine nahe verwandtc Art ist Chr. syriaca: Oblongo-ovalis, sat convexa supra sordide cupreo-olivacea, obsolete alutacea, sat nitida, subtus nigro-aenea, antennis piceis articulis primis superne aeneis; prothorace parce et obsolete, latera versus fortius punctato, callo laterali fere nullo, postice impressione punctata brevissima, interdum fere nulla subtiliter terminato; elytris subtiliter sed evidenter punctulatis, seriebus 9 punctorum majorum per paria approximatis, punctis serierum sat magnis, remotis; tursorum articulo tertio lato; maris segmento ultimo ventrali in medio vage impresso, apice truncato. - Long. 6-7 mm. Syria: Haifa (Simon, Reitter).

Körperform und Punktirung der hyperici, das Halssch. aber wie bei didymata, nur an den Seiten stärker gerundet, die Punktirung desselben durchgängig schwächer, ebenso der Eindruck an der Basis, letzterer sehr kurz, zuweilen kaum angedeutet. - Penis wie der von didymata, aber nach rorn allmählich verbreitert, an der Spitze breit abgerundet.

Die Farbe der Oberseite ändert wenig und nur insofern ab, als bald das trübe Kupferbraun, bald Olivengrün vorherrschend wird. 
Unterseite, wenigstens an den Beinen. Fühler pechschwarz, die Oberseite der ersten Glieder bläulich. Halssch. wenig gewölbt, ron den Hinterecken nach vorn mässig verengt (beim $q$ in grösserer Rundung als beim $\hat{\jmath}$ ), überall gleichmässig sehr fein punktirt, mit etwas unebenen $Z$ wischenräumen, der schwache Seitenwulst ist anf der inneren Hälfte mit zahlreichen, etwas stärkeren Punkten besetzt und von der Mitte an hinterwärts noch durch einen seichten faltenartigen Eindruck abgesetzt. Fld. mässig dicht, sehr fein und verloschen punktirt, mit 9 , einander paarig genäherten Reihen mässiger Punkte, die ungefähr eben so stark sind wie die von brunsvicensis, enger als bei hyperici an einander stehen, aber nicht, wie bei dieser und alternata, in den nebeneinander liegenden genäherten Reiben zu einzelnen Punktpaaren abgesondert sind. Die Tarsen sind schlank, das dritte Glied ist nur unmerklich breiter als das erste und schmaler, als bei den verwandten Arten.

§. Letzter Bauchring etwas gewölbt, vor dem abgestutzten Hinterrande quer niedergedrückt. - Penis so lang als der Hinterleib, stark gebogen, schmal, gleichbreit, erst über der Oeffnung ziemlich schnell gerundet-erweitert, vorn wieder in eine abgerundete Spitze verengt, die Form ungefähr mit einem Löffel zu vergleichen. Der ductus ist eine verhältnissmässig breite Röhre mit schief abgeschnittener Oeffnung.

Am Rheine bei Mainz. Frankreich. Ungarn. Amasia.

39. Chr. salviae: Ovata vel elongato-ovata, convexa, nigro-coerulea aut-violacea, supra evidenter alutacea, sericeo micans, antennis nigris, articulis 2 primis apice rufescentibus; prothorace crebre subtiliter punctato, apice emarginato, quam basi parum angustior, lateribus leviter rotundatis, callo laterali sat crasso, impressione integra, angusta, profunda, parce fortiterque punctata terminato; elytris sat crebre punctatis, seriebus 9 punctorum majorum per paria approximatis, punctis serierum magnis, remotis. - Long. $7-10,5 \mathrm{~mm}$.

Mas: segmento ultimo ventrali subconvexo, apice truncato, articulo tertio tarsorum dilatato, tarsis anterioribus articulo primo et posticis articulis 3 primis subtus linea media glabra.

Femina: segmento ullimo ventrali haud convexo, apice rotundato, tarsis articulis 3 primis gracilibus, subtus linea merlia glabra.

Germ. Ins. spec. nov. 1824. 586. - Sahlb. Thon. Arch. II. 1. 1829. 28. - Küst. Käf. Eur. 1. 81. - Suffr. Mon. 135. Motsch. Schrenk Reis. II. 206 (Bittotaenia). - Redtb. Faun. A. ed. 3. II. 473 .

Chr. sculptipennis Fald. Nouv. Mém. Mosc. V. 1837. 359. t. 13. f. 1.

Chr. cuprina Redtb. 1. c. ed. 1. 548.

$\mathrm{V}$ ar. a. Obscure coeruleo-viridis. 
Var. b. Supra obscure cuprea, leviler violaceo-micans, subtus plerumque nigra.

Var. c. Supra saturate olivacea, interdum aurichalcea.

V ar. d. Elytris sublititer punctatis, punctis serierum haud magnis.

Der Form cuprina von Chr. geminata am ähnlichsten, indessen bedeutend grösser und gestreckter, der Wulst des Halssch. seiner ganzen Länge nach abgesetzt, die starken Punkte der Reihen auf den Fld. weitläufiger; übrigens von allen einheimischen Arten durch die an Crosita erinnernde Beschaffenheit der Tarsen sehr abweichend. Sie ist die einzige europäische Vertreterin einer Gruppe, zu der mehrere sibirische Arten gehören.

Kurz- oder länglich-eiförmig, selbst lang elliptisch, gewölbt, schwärzlich blau oder violett, oben gleichmässig sehr fein lederartig gerunzelt, seidenschimmernd, unten glänzender. Fühler schwarz, die beiden ersten Glieder an der Spitze röthlich. Halssch. querviereckig, vorn wenig schmaler als hinten, die Seiten beim $\hat{\jmath}$ fast parallel, nur an den Vorderecken convergirend, beim $q$ mehr oder weniger stark gleichmässig gerundet, der Seitenwulst mässig breit und hoch, wie die Scheibe dicht und fein punktirt, innen ron einem schmalen und tiefen Eindrucke begrenzt, welcher dem Seitenrande parallel läuft und gewöhnlich mit einigen starken Punkten besetzt ist. Zuweilen ist die Mittellinie des Halssch. theilweise oder ganz vertieft. Fld, in den Schultern etwas breiter als der Hinterrand des Halssch., besonders beim $q$ bauchig erweitert, mässig dicht punktirt, mit 9 Reihen grober, entfernt stehender Punkte, von denen die 8 äusseren einander paarig genähert sind; die schmalen $\mathrm{Z}$ wischenstreifen sparsamer punktirt als die breiteren.

Beim Männchen ist der letzte Bauchring gewölbt, am Hinterrande abgestutzt, das dritte Tarsenglied stark erweitert, die Filzsoble der Tarsen an den vier Vorderbeinen nur beim ersten Gliede, an den Hinterbeinen bei allen drei Gliedern durch eine glatte Mittellinie unterbrochen. - Der Penis ist schlank, ungefähr so lang als der Bauch, an der Oeffnung leicht gerundet-verbreitert, vorn jederseits geradlinig bis zur halben Breite verschmälert, der Vorderrand abgestutzt. Da, wo die Verschmälerung beginnt, befindet sich auf der Rückseite ein breites, aber scharfes nach oben gerichtetes Zähnchen.

Beim Weibchen ist der Hinterrand des nicht gewölbten fünften Bauchsegmentes gerundet-vorgezogen, die drei ersten Tarsenglieder sind schmal, unten nur auf einem schmalen Streifen jederseits mit filzigen Haaren besetzt, in der Mitte glatt.

Die Färbung ist nie lebhaft, aber, wie die Körperform und Skulptur, sehr veränderlich. Es finden sich noch folgende Haupt- 
formen: a. dunkel bläulich metallgrün, namentlich Kopf und Halssch.; b. Oberseite dunkel kupferroth, mit schwachem violettem Schimmer, Unterseite (öfter auch Kopf und Halssch.) schwarz-violett oder schwarz; c. Oberseite dunkel olivengrün, seltener bronzefarbig.

Die Punktirung der Oberseite wird zuweilen auffällig fein, so dass die starken Punkte der Reihen auf den Fld. am Grunde, an der Naht und auf dem Abfalle zur Spitze fast erlöschen (Var. d).

In Oesterreich, Kärnthen und Istrien selten; häufiger in Dalmatien, Kleinasien, Syrien und dem Kaukasus.

40. Chr. americanat): Saturate cupreo-brunnea, aurichalcen micans, splendida, clypeo, vittis 3 obsoletis prothoracis, sutura et vittis 1 elytrorum aeneo-coeruleis; prothorace parce subtilissimeque punctulato, fere laevi, callo laterali fere nullo punctis grossis interne terminato; elytris sublaevibus, punctato-substriatis, striis per paria approximatis.

- Long. 6-8 $\mathrm{mm}$.

Mas: tarsis, praesertion articulo primo, modice dilatatis, segmento ultimo apice leviter truncato.

Linné Syst. Nat. ed. X. 372. - Fabr. Ent. Syst. I. 323. Rossi Faun. Etr. 86. - Oliv. Ent. V. 547. t. 7. f. 107. Duft. Faun. Austr. III. 195. - Küst. Käf. Eur. 1. 76. Suffr. Mon. 101. - Redtb. Faun. A. II. 472.

Var. a. lesinae: Supra cupreo-brunnea, plerumque virescens aut cyanescens, signaturis aurichalceis.

Reitter i. litt.

1) Vor diese Art gehört Chr. bicolor Fabr. (Syst. Ent. 95. - Suffr. 102; nigropunctata Reitt. Berl. Zeit. 1872. 175). Sehr breit, plump, in der Mitte gleichbreit, vorn und hinten fast gleichmässig gerundet-verengt, nicht stark gewölbt; Unterseite und Kopf, oft auch die Seiten des Halssch. blau oder violett, die übrigen Theile der Oberseite metallisch hellgrün, die Fld. oft mit messinggelbem oder kupferig-messingfarbenem Schimmer, stets mit 9 paarig genäherten Reihen sehr weitlāufig stehender, grosser Punkte, welche in einen violetten Kreis eingestochen sind, der sie noch ringförmig umgiebt. Halssch. fast glatt, mit einem breiten, hinten etwas tieferen, grob runzelig punktirten Eindrucke jederseits, der den Seitenwulst fast ganz niederdrückt. Penis flach, nur dicht an der Basis gebogen, gleichbreit, der Vorderrand regelmässig abgerundet, aber in der Mitte in eine sehr kurze, stumpf dreieckige Spitze vorgezogen; der Seitenrand der Oeffnung jederseits auf die Rückseite umgeschlagen und oben ausgerandet-abgestutzt, zahnförmig. L. 9-12 $\mathrm{mm}$. Umgebung des mittelländischen Meeres.

Abänderungen: a. consularis Er. (Wagn. Reis. III. 190. - Küst. 1. 77). Einfarbig goldgrün oder die Fld., zuletzt auch die ganze Oberseite kupferig-messingfarbig, die Punkte der Fld. stets violett oder kupferroth. b. dolorosa Reiche (Rev. et Mag. 1873. 359) einfarbig schwarzblau oder violett, ohne grünen Schimmer, Punkte der Fld. gleichfarbig oder schwach kupferig. 
Eine durch die scharf begrenzten Längsbinden und die regelmässige Punktirung der Fld. leicht kenntliche, hübsche Art, gesättigt kupferroth, bald zu braun, bald zu purpurroth hinneigend, stark glänzend, das Kopfschild, eine breite, ror der Mitte plötzlich stark verengte Längsbinde über die Mitte des Halssch. und eine schmalere Binde jederseits davon am Innenrande des Seitenhöckers, alle drei verwaschen. die Naht und vier scharf begrenzte Längsbinden auf jeder Fld. metallisch grünblau oder grün. Hiernach bleiben auf der Oberseite nur die Stirn, der Seitenwulst und zwei Längsbinden des Halssch., letztere im vorderen Drittel spitzwinkelig nach innen erweitert, und 5 Längsbinden der Fld, von der rothen, an den Rändern in Messinggelb übergehenden Grundfarbe bedeckt. Kopf und Halssch. sind fast glatt, letzteres ist mehr als doppelt so breit wie lang, vom Hinterrande nach vorn zuerst wenig, vor der Mitte stärker verengt, schwach gewölbt, mit zahlreichen groben Punkten jederseits, welche in und neben einem undeutlichen Eindrucke stehen, der den Seitenwulst nur unmerklich in die Höhe hebt. Fld. mit 9 regelmässigen, an der A ussenseite der grünlichen Längsbinden fast in Streifen stehenden Punktreihen, von denen die 8 äusseren einander paarig genähert sind. Das erste und vierte Paar rereinigen sich vor der Spitze, das zweite ist nur hinten, das dritte beiderseits abgekürzt. Die Zwischenräume sparsam, verloschen punktulirt, fast glatt. Auf der Unterseite sind die Mundtheile und Fühler, Vorderbrust, Epipleuren der Fld., Schenkel und Tarsen meist rothbraun, mit geringem Metallschimmer, die Mittel- und Hinterbrust und der Bauch sind lebhaft kupferig oder purpurfarbig, an den Rändern in messinggelb übergehend, die Seitenstücke der Brust, sowie Kniee und Scbienen (besonders an der Aussenseite) schimmern goldgrün.

Das Männchen ist durch die etwas breiteren ersten Tarsenglieder und den leicht abgestutzten Hinterrand des letzten Bauchringes schwer rom Weibchen zu unterscheiden. - Der Penis ist etwa halb so lang als der Hinterleib, schmal, gleichbreit, rorn stumpf-dreieckig abgeschnitten und besitzt auf der Rückseite in jeder Ecke, wo die plötzliche Verschmälerung beginnt, ein nach hinten gerichtetes, sehr spitzes Zähnchen.

Die einzige Farbenabänderung entsteht dadurch, dass die grünlich-blauen Zeichnungen der Oberseite durch rein messinggelbe ersetzt werden, während die Grundfarbe, kupferig-rothbraun, oft einen grünen oder blauen Schimmer annimmt.

In Istrien und an der ganzen Küste des mittelländischen Meeres auf Rosmarinus officinalis; die Var. a wurde von Reitter auf der Insel Lesina gefangen. 
41. Chr. cereatis $\left.{ }^{1}\right)$ : Ovalis convexa, sublus nigro-violacea, supra aureo-ignita, vittis 3 prothoracis, sutura vittisque 3 elytrorum violaceis. viridi-aureo limbatis; prothorace sat crebre inaequaliter punctato, callo laterali impressionibus 2 (posteriore profundiore) punctatis terminalo: elytris rebre fortius punctatis, interstitiis lineisque 2 aut 3 subelevatis parce subtilissimeque punctatis. - Long. 6-11 mm.

Mas: tarsis modice dilatatis, segmento ultimo ventrali subconvexo, apice simuato-truncato.

Linné Syst. Nat. ed. XII. 588. - Rossi Faun. Etr. I. 82. F abr. Ent. Syst. I. 323. - Sehrank Faun. boic. 531. Panz. Faun. Germ. 44. 11. - Oliv. Ent. V. 545. t. 7. f. 104. - Duft. Faun. Austr. III. 180. - Letzner Ber. Schles. Ges. 1841. 102. - Matzek 1. c. 1842. 156. - Küst. Käf. Eur. 1. 75. - Suffr. Mon. 107. - Motsch. Schrenk Reis. II. 204 (Chrysomorpha). - Redtb. Faun. A. II. 472. - Seidl. F. balt. 483 .

Var. a. Subtus viridi-aenea, signainis paginae superioris violaceis vel viridi-aeneis.

Var. b. fulgens: Elytris aureo-ignitis, lineis subelevatis parum infuscatis, sutura coeruleo-viridi limbata.

Dufour Act. Soc. Linn. Bordeaux 1851. 304.

Chr. Kiesenwetteri Motsch. 1. c. 227.

Var. c. alternans: Sordide cuprea, subtus obscuriore aut violacea, vittis prothoracis et elytrorum (interdum distinctis coeruleis) plerumque obsoletis obscure viridibus vel violaceis, interdum etiam nullis.

Panz. 1. c. 67. 16. (1799). - Küst. Käf. Eur. 2. 77. - Suffr. Mon. 110.

Chr. Mlegerlei Fabr. Syst. Eleuth. I. 439. (1801). - Oliv. Ent. V. 547. t. 7. f. 106. (1807). - Duft. 1. c. 180. - Redtb. 1. c. 472. Chr. mixta Suffr. Mon. 112. - Kraatz Berl. Zeit. 1859. 293.

1) Die nächste Verwandte ist die in der Mongolei häufige C'hr. quadriimpressa Motsch. (Bull. Mosc. 1845. I. 109; Suffr. Mon. 105). Unterseite goldgrün, Beine und Fühler violett, letztere an der Basis theilweise gelblich. Oberseite hell rothviolett, zwei von je einem tiefen Punkte zwischen den Augen ausgehende Linien, die sich auf dem Scheitel unter einem Winkel vereinigen, eine breite Mittellinie des Halssch., welche am Vorderrande jederseits bindenförmig ausgebreitet und hinter der Mitte makelförmig erweitert ist, die Naht und 3 wenig scharfe Längsbinden der Fld. grün, oft mit violettem Kerne. Halssch. breit, ziemlich fein punktirt, mit 2 weiten, grob und runzelig punktirten Eindrücken jederseits. Fld. dicht, nicht stark punktirt, Punkte theilweise gereiht, Zwischenräume dicht punktulirt; hinter der Schulter drei wrosse, stark punktirte, grüne Gruben in einer Querreihe. L. $10 \mathrm{~mm}$.

Da die Bildung der Hinterbrust mit der von cerealis übereinstimmt, so ist der Versuch Baly's, die für diese Art von Motscliulsky anfgestellte Gattung Ambro toma zu halten (Trans. ent. Soc. 1S79. 192) verfehlt. Suffrian's Vaterlandsangabe: südöstliches Russland, entbehrt der Bestätigung. 
Var. d. ornata: Supra viridi-aenea, viltis prothoracis et elytrorum violaceis.

A hr. Nov. Act. Hal. Ir. 2. 13. t. 1. f. 3 c. - Herr. Schäff.

Fann. Germ. 157. - Suffr. Mon. 109.

Chr. laminula Herr. Schäff. 1. c.

Ch. cyaneo-aurata Motsch. 1. c. 227.

Chr. ericae Motsch. 1. c. 227.

Var. e. Supra olivacea, vittis obsoletis nigro-violaceis.

Var. f. octovittata: Cupreo-violacea, subtus interdum viridi micans. vittis elytrorum nigro-violaceis.

Schrank Naturforscher 24. 66.

Chr. Megerlei Matzek 1. c. 157. - Küst. 1. c. 1. 74.

Var. g. livonica: Violacea, vittis elytrorum obsoletissimis nigris.

Motseh. 1. c. 227.

Var. h. mixta: Tota nigro-violacea, vel nigro-coerulea, impressione anteriore prothoracis et lineis subelevatis elytrorum interdum nullis.

Küst. I. c. 87 . $\hat{\odot}$.

Chr. violacea Schall. Abh. Hall. Ges. 1783. p. 270. - Fabr. Ent. Syst. I. 1. 315 .

Chr. haemoptera Küst. 1. c. 73. 오.

Chr. cuprina et ornata Motsch. 1. c. 227.

Chr. Megerlei Seidl. 1. c. 483 .

Var. i. melanaria: Ut in $h$, sed supra nigra.

Suffr. Mon. 115.

An der Form des hinteren Eindruckes auf dem Halssch. leicht kenntlich, oval, das Männchen mehr gleichbreit, länglich-riereckig, hinten abgerundet, vorn fast abgestutzt, das Weibchen in oder hinter der Mitte am breitesten, gewölbt, unten dunkel violett, oben lebhaft feuerroth, drei Längsbinden des Halssch., die Naht und drei Längsbinden auf jeder Fld. violett, am Rande allmäblich in Grün und hell Messinggelb übergehend. Halssch. quer viereckig, doppelt so breit wie lang, ziemlich dicht mit grösseren und kleineren Punkten besetzt und etwas uneben, eine verschieden breite, bald ebene, bald rinnenförmig vertiefte, selbst leicht erhabene Mittellinie glatt. Die Seiten entweder von den Hinterecken aus nach vorn fast geradlinig oder in einem deutlichen Bogen convergirend, der Seitenwulst mässig breit und gewölbt, hinten von einem grossen und tiefen, grubenfömigen Eindrucke begrenzt, welcher aussen scharf abgeschnitten ist, nach innen allmählich ansteigt und vorn ungefähr in der Mitte an einer, den Wulst mit der Scheibe rerbindenden Querleiste endet; vor dieser befindet sich ein schwächerer, nach vorn allmählich vertiefter, stark punktirter Eindruck, der gewöhnlich den Vorderrand nicht ganz erreicht, jedoch auch vollständig fehlen kann. Fld. ziemlich dicht und kräftig punktirt, mit 2 bis 4 deutlichen, leicht 
gewölbten Längslinien, von denen jede zu beiden Seiten von einer ziemlich regelmässigen Punktreihe eingefasst wird und eben so fein punktirt ist wie die Zwischenräume der stärkeren Punkte. In Wirklichkeit besteht diese Punktirung aus den normalen 9 Punktreihen, wovon die 8 äusseren einander paarig genähert sind; der Aussensaum und die 4 schmalen, als leicht gewölbte Längslinien hervortretenden Zwischenräume sind nur zerstreut und fein, die breiteren Zwischenräume ausserdem noch ziemlich dicht und eben so stark punktirt wie die Punktreihen selbst, so dass diese sich nur undeutlich von ihnen abheben. $\mathrm{Zu}$ beachten ist besonders, dass die erste, an der Naht einzeln stehende und die zweite Punktreihe gewöhnlich undeutlich sind, die dritte, vierte und fünfte, sechste und siebente, sowie die achte Reihe sind dagegen deutlich, weniger die neunte über dem Seitenrande. Ebenso stehen die sechste und siebente Reihe näher aneinander als die übrigen Paare; ihren schmalen Zwischenraum nannte Suffrian ,den Kernstreifen".

Beim Männchen sind die 3 ersten Tarsenglieder mässig erweitert, der letzte Bauchring ist viel schmaler als beim Weibchen gewölbt, mit einer mehr oder weniger deutlichen Mittelrinne hinter dem Vorderrande, der Hinterrand ist abgestutat und jederseits schwach ausgerandet, in der Mitte selbst aber wieder leicht nach hinten gerundetvorgezogen, vor dem Hinterrande befindet sich eine Reihe kurzer, aufgerichteter Härchen. - Der Penis ist kaum halb so lang als der Bauch, stark gekrümmt, nach rorn wenig verengt, an der Spitze gerundet-abgestutzt; die Oeffnung sehr gross, in der oberen Hälfte von einer durchscheinenden Haut bedeckt.

In der Skulptur und Farbe sehr veränderlich. Dass der vordere Eindruck des Halssch., welcher den Wulst von der Scheibe trennt, fast ganz verschwinden und nur durch wenige stärkere Punkte angedeutet sein kann, ist schon oben erwähnt, aber auch auf den Fld. werden zuweilen (besonders bei den violetten Varietäten) die erhabenen Längslinien und ihre sie einschliessenden Punktreihen so undeutlich, dass die Fld. gleichmässig, durchaus unregelmässig punktirt erscheinen, mit undeutlich bis ziemlich stark punktulirten Zwischenräumen.

Bei der Form cerealis L. ist die Unterseite nebst Beinen, Fühlern und dem Munde violett, nur die ersten Fühlerglieder sicd unterseits oder an der Spitze röthlich; die Oberseite ist lebhaft metallischfeuerroth, das Kopfschild, die ziemlich gerade Rinne am Innenrande jedes Auges und die Mitte des Scheitels violett. Dieselbe Farbe baben drei Längsbinden des Halssch, eine in der Mitte and eine jederseits in den Seiteneindrücken, sowie die Naht und drei hinten 
zusammenlaufende Längsbinden der Fld. Die erste derselben, zwischen der dritten und vierten, und die zweite, zwisehen der fünften und sechsten Punktreihe, beginnen fast unmittelbar an der Basis, die dritte, zugleich schmalste, zwischen der siebenten und achten Punktreihe, entspringt hinter dem Schulterböcker. Alle diese violetten Binden der Oberseite sind nicht scharf begrenzt, sondern gehen durch grün und messinggelb in die metallische Grundfarbe der Oberseite. feuerroth, über. Die zahlreichen Farbenvarietäten entstehen nun dadurch, dass die metallische Grundfarbe 1. sich weiter ausbreitet (a und b), 2. verändert (c bis f) oder durch schwarzviolett, schwarzblau oder schwarz ersetzt wird:

a. Unterseite metallisch grün oder grünlich messingfarbig, Binden der Oberseite violett, blaugrün oder erzfarbig grün.

b. fulyens. Fld, fast ganz feuerroth glänzend, die erhabenen Längslinien etwas dunkler, ein breiter Nahtsaum, der Seitenrand und meist auch die Epipleuren grün. Von den dunklen Längsbinden zeigen sich gewöhnlich Spuren der zweiten und dritten Binde hinter der Schulter in bellgrüner oder messinggelber Farbe. Die Binden des Halssch. sind einfarbig grün oder grün mit violettem Kern.

c. alternans. Unten schwärzlich oder violett, oben blass oder etwas verschossen kupferroth, Binden der Oberseite (höchst selten deutlich) verwaschen grün oder bläulich, zuweilen ganz fehlend.

d. ornata. Wie cerealis, die Hauptfarbe der Oberseite aber lebhaft grün, die beiden Mittelflecke des Halssch. und der Streifen an der Naht anfänglich noch mit goldigem Kerne. Von den violetten Längsbinden der Fld. fliesst die zweite und dritte zuletzt theilweise oder ganz zusammen.

e. Oberseite schmutzig olivengrün, Längsbinden undeutlich, rerwaschen, schwarz, meist mit bläulichem Schimmer.

f. octovittata. Violett mit lebhaftem Kupferschimmer, fast purpurroth, die Längsbinden schwarz-violett. Unterseite zuweilen mit grünlichem Schimmer.

g. Dunkel violett, mit ein oder mehreren wenig berrortretenden schwarzen Längsbinden auf den Fld.

h. mixta. Einfarbig dunkel-veilchenblau oder schwarzbau; Fld. mit oder (haemoptera $\mathbf{K}$ üst.) ohne erhabene Längslinien der Fld.

i. melanaria. Oberseite schwarz.

Ausserdem verdienen noch die unvollständig ausgefärbten Stücke einer Erwähnung, bei denen Kopf und Halssch. fast schwarz, die Fld. heller oder dunkler rothbraun und oft fast glanzlos sind. Da bei einigen von ihnen noch eine Binde am Aussenrande, bis zur 
8. Punktreibe nach innen, einen schwachen Metallschimmer besitzt, so kann ihre mangelhafte Färbung nicht durch Abreiben entstanden sein, wie Letzner (I. c. var. c.) annimmt, und ebenso ist es nicht richtig, diese Stücke als Varietät zu betrachten, worauf schon Suffrian aufmerksam macht.

In sandigen Gegenden Mittel- und Südeuropas häufig; die Varietäten b. und i. nur in den Pyrenäen, f. in den deutschen Gebirgen, g. und h. in den Alpen.

Bei einer Betrachtung der verschiedenen Färbung dieser Art, sind hauptsächlich die Scheibe des Halssch. und der innere Theil der Fld., bis zur zweiten erhabenen Längslinie nach aussen, massgebend, weil die übrigen Theile durch die Wölbung nach unten verdeckt werden und so keine besondere Einwirkung auf die Hauptfarbe des Thieres ausüben können. Daher ist hier auch die Färbung der dritten erhabenen Längslinie (Suffrian's Kernstreifen), die meist nicht so lebhaft ist, wie die der anderen Linien, nicht in Betracht gezogen worden. Die Synonymie liess sich, bei der Verwirrung, welche in der Farbenbezeichnung bei den Entomologen herrscht, nur annähernd angeben; Chr. bivittata Schrank (Naturf. 24. p. 66) nigro-violacea, thorace vittis tribus, elytris duabus viridibus etc. ist mir ein Räthsel geblieben, Chr. mixta Suffr,, die mit der gleichnamigen Varietät Küster's nichts zu thun hat, lăsst sich nur auf die grössten Exemplare von v. alternans $\mathrm{P}$ a nz. beziehen.

42. Chr. relucens: Ovalis, sat convexa, supra cuprea, plus minusve aurichalceo micans, splendida, subtus nigra, viridi- vel coeruleo micans, prolhorace fere laevi, callo laterali impressionibus 2 parce punctatis terminato; elytris fere laevibus, seriebus 9 sat regularibus punctorum per paria approximatis impressis, interstitiis latioribus parce punctatis. - Long. $7 \mathrm{~mm}$.

Rosenhauer Beitr. Ins. Eur. I. 62. - Suffr. Mon. 114. Redtb. Faun. A. II. 477.

Der vorigen sehr ähnlich und vielleicht doch nur eine lokale Form derselben. Die Unterschiede bestehen hauptsächlich in folgenden Punkten: Das Halssch. ist fast glatt, nur bei starker Vergrösserung fein lederartig gerunzelt und zerstreut punktulirt, der hintere, tiefere und der rordere schwache Eindruck am Innenrande des Seitenwulstes nur mit wenigen starken Punkten besetzt. Auf den Fld. sind die feinen Punkte des Grundes vereinzelt, äusserst fein und kaum bemerkbar, dagegen treten die normalen, ziemlich regelmässigen neun Punktreihen, von denen die acht äusseren einander paarig genähert sind, deutlich hervor. Die Punkte der Reihen haben ungefähr die Grösse wie die von brunsvicensis, stehen aber etwas enger aneinander, die breiteren Längsstreifen, zwischen je zwei Reihenpaaren, sind zerstreut und nur wenig feiner punktirt als die Reihen selbst, die schmaleren Längsstreifen erscheinen glatt.

VI. 3. 
In der Farbe ist diese Art den einfarbigen Stücken von cerealis var. alternans Panz. recht äbnlich; die Unterseite ist schwarz, mit grünlichem oder bläulichem Schimmer, die Oberseite ist stark glänzend, von der Seite betrachtet fast einfarbig messinggelb mit grünem Schimmer, von oben betrachtet mehr kupferig-violett, Kopf und Halssch. dunkler als die Fld.

Das Männchen soll nach Suffrian einen sebr seichten rundlichen Eindruck auf dem letzten Bauchringe haben; mir liegt nur ein ron Rosenhauer stammendes $f$ aus der v. Heyden'schen Sammlung ror.

Unter Steinen auf Bergen bei Lienz oder Brixen (3000` Höhe) in Tirol von Rosenhauer gefangen. Auch auf der Stamser Alpe (Gredler).

43. Chr. asclepiadis ${ }^{1}$ ): Elongato-subquadrato ( $\left.\hat{6}\right)$, vel ovalis, postice dilatata et gibboso-convexa (f), nigro-violacea, nitida, elytris plerumque laete cupreo-violaceis, antennis piccis, articulis 5 primis rufescentibus; prothorace brevi, subalutaceo, sublitissime punctato, callo laterali sat convexo, antice latiore, impressione postice profundiore sal fortiter punctata terminato; elytris crebre subtiliter vageque punctatis, lineis 4 obsoletissimis subelevatis, parce punctulatis. - Long. $6-8 \mathrm{~mm}$. Mas: prothorace transverso-quadrato, apice quam basi parum angustiore, lateribus in medio subparallelis antice posticeque subrotundalo-angustatis. elytris subparallelis, minus convexis, tarsis fortiter dilatatis, segmento ultimo ventrali apice truncato et leniter bisinuato.

Femina: corpore ante medium aequaliter et sat fortiter angustato, tarsis angustis, segmento ultimo ventrali apice rotundato et elevato.

Villa Col. Eur. dupl. 1833. 36. - Küst. Käf. Eur. 1. 84. Suffr. Mon. 187. - Motsch. Schrenk Reis. II. 202 (Anopachys). - Redtb. Faun. A. 476.

Var. a. Nigro-viridi-coerulea.

1) Aeusserst nahe verwandt ist Chr. aurichalcea Mannh. (Humm. Essais ent. IV. 1825. 39), von Kasan durch ganz Sibirien verbreitet und besonders in Japan häufig. Sie ist im Körperbau asclepiadis sehr ähnlich, in beiden Geschlechtern ebenso verschieden (die $\hat{\odot}$ sind selten), aber auf Halssch. und Fld. weitläufiger und viel stärker punktirt, glänzender, auf den Fld. mit rier deutlich hervortretenden Längslinien, welche von fast regelmässigen Punktreihen eingefasst sind. Die Farbe ist sehr veränderlich, einfarbig schwarzblau, schwarzviolett, kupferig-violett, dunkel olivengrün mit Metallschimmer, goldgrün, endlich oberseits lebhaft bronzefarbig, unten schwarzblau, schrarzgrün oder dunkel bronzefarbig.

Zu dieser Art stelle ich auch Chr. elevata Suffr. Mon. 189, da sich aus der Beschreibung durchaus kein Unterschied ergiebt. Der überraschende Fundort: „aus der Gegend von London" beruht wahrscheinlich auf einem Irrthume. 
Durchweg feiner und dichter punktirt als die einfarbigen Formen von cerealis, die $q$ denselben ganz unähnlich, weil der hinten buckeliggewölbte Körper nach vorn stark verengt ist, aber die $\hat{\jmath}$ leicht zu verwechseln, indessen durch die geringe Wölbung der Oberseite, die heller gefärbten, längeren Fühler, das fast um die Hälfte kürzere, breiter gewulstete Halssch. und breitere Tarsen sicher zu unterscheiden.

Schwarz-violett, die Fld. meist lebhaft kupferroth-violett, glänzend; Fühler des $\hat{o}$ fast halb so lang als der Körper, kräftig, beim $q$ viel kürzer und dünner, die ersten 5 Glieder röthlich, oberseits bläulich angelaufen, die letzten 6 Glieder dunkelbraun. Halssch. auffällig kurz, vorn tiet ausgeschnitten, mit weit vorragenden Vorderecken; wenig gewölbt, äusserst fein lederartig gerunzelt, sehr fein verloschen punktirt; der Seitenwulst gewölbt, nach vorn etwas verbreitert, innen ron einem breiten, ziemlich stark punktirten Eindrucke begrenzt, welcher hinten am tiefsten ist, sich in der Mitte verflacht und als sehr schwacher Niederdruck, etwas nach innen gebogen, bis zum Vorderrande hinzieht, wo er über dem Innenrande der Augen endet. Nur selten besteht der begrenzende Eindruck wie bei cerealis aus zwei, durch eine Querleiste in der Mitte gesonderten deutlichen Grübchen. Fld. dicht und fein, scheinbar ganz verworren punktirt, beim Hin- und Herwenden des Thieres werden 4 sehr schwach gewölbte Längslinien auf jeder Decke bemerkbar, welche sparsam und sehr fein punktirt und jederseits von einer Punktreihe begrenzt sind. Diese Reihen heben sich insofern wenig aus der Punktirung heraus, weil die Punkte kaum grösser sind als die der breiteren $Z_{w i s c h e n-}$ räume.

3. Schlank, fast gleichbreit, länglich-viereckig, vorn beinahe abgestutzt, hinten abgerundet, wenig gewölbt; das breite Halssch. vorn wenig schmaler als an der Basis, die Seiten in der Mitte parallel, an den Vorderecken etwas stärker als an den Hinterecken verengt, die Stelle, an welcher die Verengung jederseits beginnt, erscheint leicht winkelig. Fld. wenig breiter als das Halssch., die 4 Längslinien derselben deutlich, mitunter rippenförmig. Tarsen sehr breit, letzter Bauchring hinten abgestutzt und in der Mitte beiderseits sanft ausgerandet. - Penis so lang als der Hinterleib, schlank, röhrenförmig, oben nur mit schmaler Rinne, an der kleinen Oeffnung jederseits tief ausgebuchtet, so dass der vordere kurze, aber breite, sehr stumpf dreieckige Theil auf jeder Seite in eine haarscharfe Spitze ausgezogen ist und die Gestalt einer schmalen Sichel hat.

․ Einem Melasoma ähnlich gebaut, von den Vorderecken des Halssch. bis hinter die Mitte allmählich fast in grader Linie erweitert, 
hinten breit abgerundet; die Oberseite ist ungefähr in der Mitte am höchsten gewölbt und fällt nach vorn allmählich, nach linten schnell ab, sie erscheint daher etwas buckelig. Das Halssch. ist nach vorn bedeutend verengt aber an den Seiten fast ebenso gebaut wie beim 3; die 4 erhabenen Längslinien der Fld. sehr undeutlich. Tarsen schlank; letzter Bauchring am Hinterrande aufgebogen und abgerundet.

Die Farbe des Körpers ist bisweilen schwarzblau mit oder ohne deutlichen grünen Schimmer. (Var. a).

Auf Vicetoxicum officinale Mönch. Harz, Sächsische Schweiz (Maerkel), Baiern (Rosenhauer), Steiermark (Kahr). Häufiger am Südfusse der Alpen in Oberitalien.

Von dieser Art sind in den Sammlungen vorherrschend Weibchen vertreten und diese auch bisher nur beschrieben worden, ja Suffrian hat sogar die Merkmale seiner ganzen Gruppe 13 ausschliesslich von solchen entnommen.

14. Chr. coerulans: Oblongo-ovalis, convexa, viridi-coerulea. sat nitida; prothorace minus convexo, antrorsum sensim angustato, sal crebre, sed parum profunde, vage punctato, alutaceo, callo laterali vix vel haud distincto interne punctis numerosis profundis terminato, linea mediu laevi lituraque obsoleta marginis basalis et lateralis violaceis; elytris sat crebre punctatis, punctis antice subseriatis, postice intricatis, interstitiis parce punctulatis, sutura vittaque media lituraeformi, indistincta, violaceis. - Long 6-9 $\mathrm{mm}$.

Mas: palpis articulo ultimo tarsisque articulis 3 primis dilatatis, segmento ultimo ventrali apice fortiter truncato et leniter bisinuato.

Scrib. Journ. Liebh. Ent. III. (1791) 286. - Hoppe Ent. Taschenb. 177.

Chr. violacea Panz. Faun. Germ. 44. 8. - Oliv. Ent. V. 522. t. 6. f. 82. - Duft. Faun. Austr. III. 188. - Suffr. Mon. S8. - Redtb. Faun. A. II. 471. - Seidl. F. balt. 483.

Chr. oblonga Duft. 1. c. 188.

Var. a. Tota coeruleo-violacea, haud virescens.

$\mathrm{V}$ ar. b. Viridi-aenea, interdum linea media maculisque 2 basalibus, obsolctissimis prothoracis, sutura et litura obsoletissima pone humeros clytrorum subviolaceis.

Var. c. subfastuosa: Prothorace et elytris aureo-viridibus, signaturis obsoletissimis ut in b, sed magis virescentibus. Mas: minor, parum nitidus; femina major, nitidissima.

Motsch. Schrenk Reis. II. 226. ( $\hat{\odot})$.

Var. d. angelica: Aureo-ignita, prothoracis linea media et limbo basali. hoc utrinque dilatato, suturaque elytrorum vividi-aeneis, rarissime coerulescentibus, elytris vitta coerulea.

Reiche Ann. Fr. 1858. 33. t. 1. f. 8.

Chr. spendovifera Motsch. I. c. 226. 
Den violetten Stücken von cerealis ähnlich, aber stets heller blau und ohne einen deutlich abgesetzten Seitenwulst des Halssch., länglich-eiförmig, gewölbt, metallisch grünlich-blau, die Unterseite nebst Fühlern und Beinen mehr violett, die Mittellinie und der Hinterund Seitenrand des Halssch., die Naht und ein Längswisch auf der Scheibe jeder Fld. (alle diese Zeichnungen unbestimmt und sehr verwaschen) violett. Halssch. wenig gewölbt, von den Hinterecken nach vorn allmäblich, an den Vorderecken selbst stärker verengt, die Scheibe äusserst fein lederartig gerunzelt und mit Ausnahme der Mittellinie ziemlich dicht, aber flach und verloschen punktirt, die Seiten mit zahlreichen starken Punkten, welche in zwei unmerklichen Vertiefungen, vor der Mitte und am Hinterrande, besonders grob und nahe aneinander gerückt sind und so den schmalen, kaum gewölbten, einzeln fein punktirten Seitenwulst kaum merklich in die Höhe heben. Fld. nicht lederartig gerunzelt wie das Halssch., daher stärker glänzend, ziemlich dicht, mässig stark punktirt, die Punkte auf der rorderen Hälfte hie und da unregelmässig gereiht, theilweise durch Nadelrisse mit einander verbunden, auf dem Abfalle zur Spitze dagegen ohne Ordnung zusammen gestellt, deutlicher durch Runzeln rerbunden, alle $Z$ wischenräume sparsam und sehr fein punktirt.

Beim $\hat{o}$ sind die 3 ersten Tarsenglieder und das letzte Glied der Taster deutlich breiter als beim $q$, der Hinterrand des letzten Bauchringes ist abgestutzt und in der Mitte jederseits leicht ausgerandet. - Der Penis ist kaum so lang als die letzten 4 Segmente zusammen, stark gekrümmt, oben wenig zusammengedrückt, fast gleichbreit, vorn zuerst allmählich gerundet-verengt, dann in eine schmale und kurze, in der Mitte leicht eingeschnittene Spitze verlängert.

Die Farbe des Körpers ist veränderlich. Die seltenste Form a. ist einfarbig bläulich violett, ohne merklichen grünen Schimmer; bieran schliesst sich die Stammform, bei welcher ein grosser verwaschener Fleck auf jeder Seite der Mittellinie des Halssch. und ein Streifen an der Naht und am Aussenrande der Fld. mehr oder weniger deutlich zunächst grünblau, dann metallisch grün gefärbt ist. Zuletzt wird der Körper fast ganz metallisch grün (Var. b), jedoch nie so lebhaft wie bei menthastri, und es bleibt nur eine Spur der blauen Farbe zurück an den Tastern, den oberen Fühlergliedern, auf der Mittellinie und dem Hinterrande des Halssch., der Naht und dem Eindrucke hinter der Schulterbeule der Fld., auf der Vorderund Mittelbrust und den Seitenstücken der Hinterbrust.

Stücke aus dem hohen Kaukasus sind goldgrün, die normalen rerwaschenen Zeichnungen auf dem Halssch, und den Fld, rein grün, 
zuweilen mit bläulichem Anfluge. Die $\hat{\jmath}$ klein, wenig oder mässig glänzend, die + gross, fein punktirt und stark glänzend (Var. c). In Lenkoran (Leder), Armenien und weiter südlich bis Syrien und Arabien tritt die prächtige Form d. auf, mit lebhaft feuerrothen Körper, die Mittellinie und eine schmale, beiderseits makelförmig erweiterte Binde an der Basis des Halssch., sowie die Naht der Fld., scharf begrenzt, goldgrün, seltener bläulich grün, eine von der Schulter bis dicht vor die Spitze der Fld, reichende scharfe Längsbinde violett, am Rande in grün und messinggelb übergehend.

Auf Mentha-Arten und Weiden ${ }^{1}$ ) an Gebirgsbächen häufig; durch Hochwasser auch in's Flachland geführt, aber in der norddeutschen Tiefebene nicht heimisch.

Die C'hr. violacea Goeze (Ent. Beitr. I. 301), die bisher irrthümlich auf diese Art bezogen wurde, ist, wie die Chrysomela Nr. 6 Geoffroy's, gleich goettingensis.

45. Chr. fastuosa $\left.{ }^{2}\right)$ : Oblongo-ovalis, convexa, viridi-aurea, nitida, antennis piceis basi ferrugineis, prothoracis maculis 2 obsoletis ante basin, elytrorum sutura vittaque media abbreviata cyaneis; prothorace transverso-quadrato, sat convexo, basi plerumque transversim deplanato. lateribus subparallelo, minus crebre, versus latera fortius punctato. callo laterali vix vel haud distincto; elytris minus crebre sat fortiter. punctatis, punctis latera et suturam versus subseriatis; tarsis articulo ultimo apice utrinque dentato-producto. - Long. 5-7 mm.

Mas: tarsis parum dilatatis, segmento ultimo ventrali apice subtruncato. Scopoli Ent. Carn. (1763) 74. - Linné Syst. Nat. ed. XII. (1767) 588. - Fabr. Ent. Syst. I. 324. - Panz. Faun. Germ. 44. 12. - Oliv. Ent. V. 548. t. 2. f. 17. - Gyllh. Ins. Suec. III. 470. - Duft. Faun. Austr. III. 196. - Matzek Ber. Schles. Ges. 1842. 156. - Küst. Käf. Eur. 1. 86. Suffr. Mon. 99. - Thoms. Skand. Col. VIII. 249. - Redtb. Faun. A. II. 469. - Seidl. F. balt. 483.

Var. a. Salurate viridis, splendida, sutura vittaque elytrorum cyaneis.

Var. b. Viridi-aurea, sutura lituraque media obsoletissima elytrorum laete viridibus.

1) Panzers Angabe: Hab. in salicibus, von Suftrian p. 90 für einen Irrthum erklärt, ist richtig.

2) Chrys. ventricosa Suffr. (Ann. Fr. 1S5S. 539) ron Neapel ist nach der Beschreibung genau wie fastuosa gebaut und gefärbt, auf dem Halssch. aber nur an den Hinterwinkeln stark punktirt und die Punkte der Fld. sind zu unregelmässigen Doppelreihen geordnet. Wahrscheinlich eine Form ron fastuosa, was Herr Fairmaire, der die Type besitzt, leicht entscheiden kann, sobald er die Bildung des 4. Tarsengliedes untersucht. 
Var. c. speciosa: Capite prothoraceque maxima parte viridi-aureis vel ignitis, elytris ignilis sulura viltaque media laete virescentibus, interdum subcyaneis.

Linné 1. c. 588 .

Chr. galeopsidis Schrank Faun. boic. 53\%.

Durch die Bildung des vierten Tarsengliedes von allen europäischen Chrysomelen, durch die Form des Halssch. und die stärker heraustretenden Schultern von den verwandten Arten leicht zu unterscheiden. Länglich eiförmig, gewölbt, glänzend goldgrün, zwei verwaschene Flecke an der Basis des Halssch., die oft durch eine schmale Querbinde längs des Hinterrandes zusammenhängen, grün oder blau, die Naht und eine deutlich begrenzte Längsbinde hinter dem Schulterhöcker der Fld. violett, am Rande in Grün übergehend. Fühler pechschwarz, bläulich schimmernd, die ersten 4 bis 5 Glieder gänzlich rothgelb, oder oberseits metallisch grün überflogen, die letzten 6 Glieder breiter als bei den Verwandten. Halssch. querviereckig, mit ziemlich parallelen, nur an den Vorderecken gerundet nach innen gebogenen Seiten, die Scheibe gewölbt, längs der Basis gewöhnlich etwas niedergedrückt, wenig dicht, kräftig punktirt, die Punkte werden nach den Seiten hin grösser und tiefer und stehen hier gewöhnlich in zwei wenig bemerkbaren Vertiefungen, eine vor der Mitte, die andere an der Basis, welche den undeutlichen Seitenwulst kaum absetzen. Fld. am Grunde etwas breiter als das Halssch., weitläufiger und stärker punktirt wie die ron coerulans; die Punkte bilden in der Nähe der Naht und des Seitenrandes nicht ganz regelmässige Reihen und ihre $Z$ wischenräume sind mit einzelnen Pünktchen besetzt. Das vierte Tarsenglied besitzt an der Spitze der Unterseite einen tiefen Eindruck, dessen Seiten zahnförmig aufge= bogen und ungefähr bis in die Mitte der Klaue vorgezogen sind.

Das $\hat{o}$ ist kleiner und schlanker als das $q$, gewöhnlich auch stärker und dichter punktirt, an den schwach erweiterten Tarsen und dem abgestutzten letzten Bauchsegmente jedoch nicht leicht zu erkennen. - Der Penis ist mässig lang, oben etwas zusammengedrückt und leicht wellig gebogen, unten in einer stärkeren Wellenlinie gekrümmt, mässig breit, an der langen, durch eine zungenförmige Klappe bedeckten Oeffnung allmählich rerschmälert, hierauf wieder schnell gerundet-erweitert, vorn ein Stück jederseits fast geradlinig abgestutzt aber in der Mitte in einen halb ovalen queren Zipfel ausgezogen.

Von Farbenvarietäten sind zu erwähnen:

a. Gesättigt grün, stark glänzend, die verwaschene Zeichnung des Halssch. bläulich, die Naht und die Längsbinde jeder Fld. tief veilchenblau, zuweilen mit Kupferschimmer; 
b. Goldgrün, alle Zeichnungen der Oberseite verwaschen, lebhaft grün.

c. Kopf und Halssch. goldgrün oder feuerroth, letzteres mit verwaschener grüner Zeichnung oder ohne dieselbe, Fld. feuerroth, Naht und Längsbinde lebhaft grün, mit oder ohne violetten Kern, am Rande in messinggelb übergehend.

Auf Labiaten, namentlich Galeopsis tetrahit und ladanum L. gemein.

46. Chr.graminis: Oblonga, valde convexa, viridi-aurea, nitidula, antennis basi ferrugineis, prothorace, sutura lituraque obsoletissima elytrorum laete viridibus, interdum subcoerultis; prothorace convexo, ante medium plerumque latissimo, lateribus rolundato, supra parum dense punctalo (versus latera fortius), interstitiis tenue punclatis; elytris fortiter subrugoso-punctatis. - Long. $8-10,5 \mathrm{~mm}$.

Mas: Ano dense piloso, segmento ultimo ventrali subtumidulo, linea media impresso, apice truncato.

Linné Syst. Nat. ed. X. 369. - Fabr. Ent. Syst. I. 314. Oliv. Ent. V. 538. t. 1. f. 3. - Gyllh. Ins. Suec. III. 468. - Duft. Faun. Austr. III. 189 (pars). - Suffr. Mon. 97. Motsch. Sekrenk Reis. II. 226. - Thoms. Skand. Col. VIII. 248. - Redtb. Faun. A. II. 471. - Seidl. F. balt. 483.

Chr. fulgida Letzner Ber. Schles. Ges. 1841. 105. - Matzek 1. c. 1842. 156 .

Chr. artemisiae Motsch. 1. c. 225.

Var. a. Viridis, capite, prothorace, elytrorum sutura vittaque media lata coeruleo-violacea.

Var. b. fulgida: Cupreo-aurea, plerumque sutura et vitta media clytrorum laete virescentibus, interdum parce violaceis.

Fabr. Syst. El. I. 432. - Duft. 1. c. 191.

Var. c. Subtus aenea, supra nigra, capite prothoraceque vix cupreis.

Thoms. 1. c. 249. var. d.

Grösser, schlanker, aber höher gewölbt und durchweg stärker punktirt als die beiden vorigen Arten, daher mit diesen nicht leicht zu verwechseln, viel ähnlicher der folgenden Art, aber auch in den habituell übereinstimmendsten Stücken sofort an den mehrfarbigen Fld. zu erkennen. Gestreckt, ziemlich gleichbreit, nur die Weibchen hinter der Mitte etwas erweitert, hoch gewölbt, goldgrün, nicht stark glänzend, das Halssch., die Naht und ein unbestimmter Längswisch über die Scheibe jeder Fld. rein grün. Fühler lang und ziemlich stark, schwarzblau, die ersten 6 Glieder metallisch grün, Glied 1 und 2 stets, oft auch noch das dritte, unterseits oder wenigstens an der Spitze rostroth. Halssch. quer viereckig, mit der grössten Breite etwas vor der Mitte, von hier nach rorn schnell, nach hinten 
allmählich, leicht gerundet verengt, die Rundung der Seiten verschieden stark ausgeprägt, zuweilen so schwach, dass die Seiten hinten fast parallel erscheinen; die Scheibe gewölbt, zart lederartig gerunzelt, wenig dicht mit tiefen, aber nur mässig starken Punkten, dazwischen mit einzelnen Pünktchen besetzt; die Punkte nach den Seiten hin grösser und stärker, in zwei weiten und flachen, selten ganz fehlenden Eindrücken, der eine vor der Mitte, der andere an der Basis, grübchenartig. Der Seitenwulst schmal, kaum gewölbt. Fld. dicht und stark fast runzelig punktirt, mit zahlreichen, schon bei schwacher Vergrösserung sichtbaren Nadelrissen und einzelnen Pünktchen in den $Z$ wischenräumen.

Beim Männchen ist das letzte Bauchsegment leicht beulig erhöht, von einer Mittelrinne durchzogen, am Hinterrande gewimpert und abgestutzt; dahinter wird das ziemlich kleine, dicht und lang braun behaarte Aftersegment sichtbar. - Der Penis hat die meiste Aehnlichkeit mit dem von coerulans, er ist etwa so lang als der Hinterleib, fast röhrenförmig, aber nach rorn verdickt, sehr stark gebogen, an der kleinen und schmalen Oeffnung allmählich verengt und leicht gerundet-abgestutzt. Der ductus hat einen nach oben gerichteten, röhrenförmigen Theil, welcher gewöhnlich zur Oeffnung herausragt, und einen flachen, zungenformigen, nach unten gebogenen Theil, der sich vorn verbreitert und in 3 abgerundete Ecken endet, von denen eine weiter vorsteht als die beiden anderen.

Bisweilen ist der Körper dunkelgrün, ohne merklichen Goldschimmer, Kopf, Halssch., die Naht und der grösste Theil der Scheibe jeder Fld. bläulich bis blau-violett (Var. a); oder der Körper goldig kupferroth, fast feuerroth, die Naht und eine Längsbinde jeder Fld. grün, selbst mit riolettem Kerne (Var. b). Von dieser Form finden sich Stücke, bei denen die Mittellinie und ein jederseits verbreiterter Saum an der Basis des Halssch. bläulich gefärbt sind. Die von Thomson angeführte Var. c. ist mir unbekannt.

Auf Tanacetum vulgare L. häufig. Nord- und Mitteleuropa, Kaukasus, ganz Sibirien.

Die am Amur lebende Dlochrysa virgat, Motsch. (Schrenk Reis. II. 224) und ihre unbedeutende Abänderung auraria Motsch. (1. c.) ist wie fulgid $九$ oder wie die Var. a. gefärbt, etwas grösser und glänzender; auf den FId. etwas feiner und weniger runzelig punktirt, die Punkte deutlicher gereiht, sie besitzt auf dem Halsseh. einen breiten und sehr tiefen, grob punktirten Eindruck, welcher den gewölbten Seitenwulst bis zu den Vorderecken deutlich in die Höhe hebt. Trotzdem ist es nicht unwahrscheinlich, dass sie mit graminis zusammenfällt. 
47. Chr. menthestri $\left.{ }^{1}\right)$ : Oblongo-ovalis, sat convexa, viridi-aurea, nitidissima, antennarum articulis 2 primis plerunque parum mescentibus; prothorace minus convexo, parum dense et versus latera fortius punctato, interstitiis punctulatis, lateribus postice subparallelo, ante medium angustato, elytris sat fortiter subseriatim punclatis, lineis duabus subelevatis. - Long. 7-11 mm.

Mas: segmento ultimo ventrali linea vel foveola media impresso, apice truncato et leniter bisinuato, ciliato.

Suffr. Men. 90. - Kratz Berl. Zeit. 1859. 292. - Redtb. Faun. A. 471. - Seidl. F. balt. 483.

Chr. fulminans Suffr. Mon. 92 (pars.).

Chr. graminis Duft. Faun. Austr. III 189 (pars.). - Matzek Ber. Schles. Ges. 1842. 156.

Chr. blanda Motsch. Schrenk Reis. II. 226. - Weise Schneid. u. Leder Kauk. 333.

厄ै Chr. caucasica Motsch. 1. c. 225.

Var. a. herbacea: Subtiliter punctata, lineis subelevatis elytrorum nullis; punctis in medio prothoracis interdum obsoletis.

Duft. l. c. 192 . - Redtb. I. c. 471 .

Chr. recticollis Motsch. 1. c. 225.

$\mathrm{V}$ ar. b. Laete viridis, vix aureo-micans.

Var. c. rugicollis: Coeruleo-virens, capite prothoraceque violaceis aut tota cyanea vel violacea.

Weidenbach 12. Bericht Naturf. Versamml. Augsburg 1859. 84.

Var. d. croatica: Saturate brunneo-olivacea, parum aeneo micans.

Var. e. resplendens: Supra (aut omnino) viridi-auro-cuprea vel aureoignita.

Suffr. Stett. Zeit. 1855. 144.

Chr. ignita Suffr. Mon. 94.

Chr. fulminans Suffr. Mon. 92 (pars.).

Chr. fulgida Motsch. 1. c. 226 .

1) Aeusserst ähnlich ist Chr.viridana Küst. (K. Eur. 1. 85. Suffr. 95. - Kraatz 1. c. 392; palustris Suffr. 96. - Motsch. 1. c. 226): Breviter ovalis, sat conrexa, viridi-aurea, splendida, antennis articulis primis interdum parum rufescentibus; prothorace minus cunvexo, antrorsum angustato, subtiliter vageque punctato, callo laterali fere nullo puncis plurimis grossis, profundis, terminato, elytris minus fortiter subseriatim punctatis. Mas: segmento ultimo ventrali convexiusculo, linea metia impresso, apice truncato et leniter bisinuato, ciliato. Long. $6-8,5 \mathrm{~mm}$.

Variat a. (chloris Luc. Expl. Alg. 536. t. 45. f. 11). Viridi-coerulescens; b. (sardea) olivacea aut nigro-olivacea: c. (aurocuprea Fairm. Ann. Fr. 1859. 282; 1865. 80) auro-cuprea vel laete cuprea, aeneo-splendens. - Corsica, Sardinia, Hispan merid., Algeria.

Die Spitze des Penis ist kaum halb so lang als bei menthastri, nur unmerklich verschmälert und sanft ausgebuchtet. 
Chr. auraria Motsch. 1. c. 225.

Chr. cribellata Motsch. 1. c. 226.

Breiter und flacher als die vorige, nach hinten gewöhnlich mehr erweitert, das Halssch. vorn stïrker verengt, die Fld. auf der hinteren Hälfte nicht in regelmässiger Wölbung abfallend, sondern meist etwas Hach gedrückt, die Fühler an der Basis weniger weit oder nicht rostroth, ebenso auf der Scheibe der Fld. niemals eine Binde oder ein Wisch von erheblich anderer Farbe als auf den übrigen Theilen.

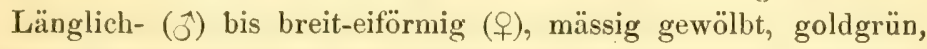
stark glänzend, das Halssch. gewöhnlich weniger goldig glänzend als die Fld. Fühler schlank, einfarbig, oder die Spitze des ersten und die Unterseite des zweiten Gliedes röthlich. Halssch. vorn bedeutend schmaler als an der Basis, von den Hinterecken bis zur Mitte (oder noch darüber hinaus) fast gleichbreit, bald unmerklich erweitert, bald verengt, vor der Mitte stärker verschmälert, entweder in gleichmässiger Rundung, oder mehr geradlinig. Im letzteren Falle tritt die breiteste Stelle, nahe der Mitte, jederseits stumpfwinkelig hervor. Scheibe wenig gewölbt, etwas uneben, wenig dicht aber ziemlich tief punktirt, am Hinterrande etwas dichter; die Punkte werden nach dem Seitenrande zu stärker, grübchenartig, dicht gedrängt, besonders in dem langen, aber gewöhnlich nur dicht vor dem Hinterrande deutlicher hervortretenden Eindrucke, welcher den kaum gewölbten undeutlichen Seitenwulst innen begrenzt. Fld. am Grunde wenig breiter als das Halssch., mit abgerundeten Schultern, dahinter nur beim $q$ bauchig erweitert, von der höchsten Stelle, in oder vor der Mitte, bis kurz vor die Spitze selten ganz gleichmässig abwärts gewölbt, sondern deutlich flach gedrückt; die Punktirung ron sehr veränderlicher Stärke, im Allgemeinen nur mässig stark, auf der inneren Hälfte zu wenig hervortretenden Längsreihen geordnet, zwischen denen gewöhnlich zwei leicht gewölbte Längsstreifen, der eine auf dem inneren Viertel, der andere ungefähr in der Hälfte der Breite, sich herausheben, welche nur sparsam und fein punktulirt sind, wie die Zwischenränme der theilweise durch Nadelrisse verbundenen Punkte. Unterseite einzeln fein punktirt und gerunzelt, die Ränder der Bruststücke oft bläulich gefärbt, die Seitenstücke der Hinterbrust kräftig punktirt.

Das kleine und fast gleichbreite Männchen besitzt auf dem letzten Bauchringe, dessen Hinterrand in der Mitte abgestutzt und jederseits sanft ausgerandet ist, eine Mittelrinne oder wenigstens ein längliches Grübchen am Vorderrande. - Der Penis stimmt in der Form mit dem von coerulans und graminis überein, erscheint aber rorn in eine lange Spitze ausgezogen, weil jede Seite der langen 
Oeffnung ziemlich tief bogenförmig ausgerandet ist; vor dieser Ausrandung ist er mit abgerundeten Ecken plötzlich abgestutzt.

Bei den fein punktirten Stücken treten die beiden Längsstreifen der Fld. kaum noch deutlich bervor, zuweilen ist selbst die Scheibe des Halssch. verloschen punktirt, fast glatt (Var. a). Diese Form, von Duftschmid als herbacea beschrieben ${ }^{1}$ ) lässt sich von viridana nur schwer unterscheiden; sie ist länger und schmaler, der Seitenwulst des nicht gleichmässig nach vorn verengten Halssch. weniger deutlich, die Fld. schwächer punktirt. Hierher stelle ich auch $\mathrm{Chr}$. recticollis Motsch. vom Kaukasus und aus Südrussland (Samara, Faust), bei welcher das deutlich punktirte Halssch. an den Seiten von der Mitte nach vorn zwar winkelig verengt ist, jedoch in geringerem Grade als bei der typischen menthastri, so dass es mehr viereckig erscheint.

Die Körperfarbe ändert $a b$ :

a. lebhaft grün, ohne merklichen Gold- oder Messingschimmer;

b. kornblumenblau oder violett, zunächst auf der Oberseite nur Kopf und Halssch., unterseits Brust und Beine (die eigentliche rugicollis Weidenb.), später der ganze Körper;

c. dunkelbraun, ungefähr wie nicht zu stark gebrannte Kaffeebohnen, durch den geringen Metallschimmer schwach olivenfarbig. d. oberseits oder total goldig kupferroth, mit grünem Schimmer, oder goldig feuerroth.

Auf Mentha aquatica L. an Bächen des niederen Gebirges und Hügellandes, besonders in Süddeutschland und Südeuropa häufig. Kirgisen-Steppe. Sibirien. Die Var. b. hauptsächlich in Ungarn, Serbien, und der Türkei, c. in Croatien (Reitter), d. auf Sicilien.

Die Art wurde vor Suffrian stets mit graminis L. verbunden, lăsst sich aber meist aus den alten Beschreibungen erkennen, besonders wenn als Nahrungspflanze Mentha-Arten angegeben sind, oder wenn die Fld. einfarbig genannt werden. So gehören z. B. bei Duftschmid die Var. $\alpha, \beta, \gamma$ und $\delta$, sowie $\beta$ und $\eta$ von graminis hierher, die übrigen (auch Chr. fulgida D uft., die nicht $=$ fulminans Suffr. ist) zur wirklichen graminis. Grössere Mühe macht es, die Beschreibungen Motschulsky's, wahre entomologische Preisräthsel, zu entziffern; ich hoffe, bei der Deutung derselben keinen groben Fehler gemacht zu haben, da ich alle Formen, mit Ausnahme der Chr. auraria Mot, von den Original-Fundstellen besitze.

48. Chr. varians: Breviter ovata, conexa, viridi-aenea, plus minusve coeruleo micans, prothorace crebre subtiliter punctato, callo

1) Ein typisches Exemplar befindet sich im Wiener ent. Museum und ist mir von Herrn Ganglbauer freundlichst zur Ansicht übersandt rorden. 
laterali obsoleto, depressione parum fortius punctata vage terminato. elytris crebre sat fortiter punctatis; tibiis anterioribus margine exteriore usque ad genua deplanatis. - Long. 4,5-6 $\mathrm{mm}$.

Mas: segmento ultimo ventrali apice truncato foveaque parva impresso.

Schaller Abh. Hall. Ges. I. 1783. 271. t. 9. f. 13. - Panz

Faun. Germ. 44. 9. - Fabr. Ent. Syst. I. 1. 315. - Oliv.

Ent. V. 536. t. 7. f. 96 . - Gyllh. Ins. Snec. III. 471. Matzek Ber. Schles. Ges. 1842. 156. - Küst. Käf. Eur. 9.

94. - Suffr. Mon. 33. - Redtb. Faun. A. II. 471.

Chr. hyperici Thoms. Skand. Col. VIII. 251. - Seidl. F. balt. 483 .

Var. a. Supra viridi-aut olivaceo-aurichalceo.

Var. b. centaura: Supra aurichalceo-cuprea, subtus viridi-aenea, femoribus cupreis.

Herbst Füessl. Arch. IV. 1783. 56. t. 23. f. 15.

Chr. centaurei Fabr. 1. c. 315. - Panz. 1. c. 44.10.

Var. c. pratensis: Tota nigro-coerulea vel cupreo-violacea.

Chr. hyperici Degeer Mém. Ins. V. 1775. 312. t. 9. f. 13-17.

Var.d. aethiops: Tota nigra.

Fabr. Ent. Syst. I. 1. 309.

Eine der kleinsten und häufigsten breiten Arten; sehr kurzeiförmig, oft nur etwas länger als halbkugelförmig, metallisch grün, mehr oder weniger bläulich, namentlich unterseits. Fühler schwarz, das erste Glied wie die Oberseite gefärbt. Halssch. kurz, flach gewölbt, dicht und sehr fein punktirt; vorn bedeutend schmaler als an der Basis, an den Hinterecken gewöhnlich unmerklich verengt, die Seiten nach vorn in einem schwachen Bogen convergirend, der sparsam punktirte Seitenwulst undeutlich, kaum gewölbt, innen durch etwas stärkere Punkte, die an der Basis in einem seichten Eindrucke meist zahlreicher und dichter beisammen stehen, unmerklich abgesetzt. Fld. dicht, mässig stark aber nicht tief punktirt, mit zerstreuten Pünktchen in den Zwischenräumen. Auf der Unterseite ist der Bauch glänzender als die Brust, sparsam fein punktirt. An den vier vorderen Schenkeln reicht die Rinne auf der Aussenseite ziemlich bis zur Basis.

Das Männchen besitzt am abgestutzten Hinterrande des letzten Bauchringes einen mehr oder weniger deutlichen dreieckigen Eindruck. - Der Penis ist kurz, gerade, gleichbreit, oben rinnenförmig vertieft, am Vorderrande gerundet-abgestutzt, aber die breit dreieckige Spitze selbst von oben nicht sichtbar, sondern in kurzer Biegung auf die Unterseite geschlagen, an die sie antreffen würde, wenn sich an der Stelle nicht ein breiter, tiefer, dreieckiger Eindruck befände. 
Die hauptsächlichsten Farbenabänderungen sind folgende:

a. Die Oberseite wird rein grün oder olivenfarbig, mit starken Messingschimmer, oder

b. lebhaft goldig-kupferroth; ein unbestimmter Saum am Hinterrande des Halssch, und das Schildchen bleiben nicht selten grün oder messinggelb, die Unterseite ist grünlich, Schenkel und die Aussenseite der Schienen kupferig;

e. der ganze Körper ist schwarzblau bis kupferig-violett, oder

d. einfarbig schwarz, mit metallisch gelblichem Anfluge.

Auf Hypericum-Arten, besonders H. perforatum und quadrangulare L. gemein; die Varietät d. hauptsächlich im höheren Gebirge.

49. Chr.polit $\left.{ }^{1}\right)$ : Ovalis, conrexa, auro-viridis, antemis piceis. basi rufescentibus, prothorace alutaceo, crebre subtiliter punctato, discon auro-cupreo, callo laterali impressionibus 2 profundis, fortiter punctatis. terminato; elytris rufo-brunneis, politis, punctis parvis sat crebre adspersis, interstitiis parce punctulatis - Long. 6,5-8,5 mm.

II s: segmento ultimo ventrali subconvexo, apice subtruncato.

Linné Syst. Nat. ed. X. 370. - Scopoli Ent. Carn. 73 (Coccinella). - Fabr. Ent. Syst. I. 1. 317. - Payk. Faun. Suec. 2. 54. - Oliv. Ent. V. 553. t. 3. f. 37. - Gyllh. Ins. Suec. III. 456. - Duft. Faun. Austr. III. 172. - Matzek Ber. Schles. Ges. 1842. 157. - Küst. Käf. Eur. 1. 90. - Suffr. Mon. 116. - Thoms. Skand. Col. VIII. 249. - Redtb. Faun.

A. II. 470. - Seidl. F. balt. $4 \mathrm{~S} 2$.

Var. a. Subtus coeruleo-viridis, prothorace viridi-aeneo, nitido, vix rel haud cupreo-micante.

Var. b. Puncta elytrorum suturam versus subseriata.

Eiförmig, gewölbt, goldgrün, Halssch. (wenigstens auf der Scheibe) und oft auch der Kopf kupferig schimmernd, Brust bläulich metallisch-grün, Fühler pechschwarz, die ersten Glieder unterseits röthlich. Fld. glänzend rothbraun, ihr Glanz bisweilen metallisch gelblich oder grünlich. Halssch. lederartig gerunzelt, seidenschimmernd, die Seiten hinten fast parallel oder nach der Mitte hin unmerklich erweitert,

1) Recht ähnlich, aber grösser und namentlich breiter ist Chr. Sufjrian! Fairm. (Ann. Fr. 1859. 282) aus Corsica und Sardinien: Unten schwarzgrün mit Kupferschimmer, nur die beiden ersten Fühlerglieder röthlich, oben stark kupferig-kastanienbraun, mitunter bläulich oder grünlich schillernd, sehr stark glänzend; Kopf sparsam, Halssch. sehr fein rerloschen punktirt und kaum bemerkbar chagrinirt, Seitenwulst deutlich gewölbt, der ganzen Länge nach ron einem breiten, grob punktirten, vorn und hinten stärker rertieften Eindrucke begrenzt; Fld. polirt, mit wenig starken, sehr weitläufig gestellten und zu unregelmässigen Reihen vereinten, innen metallisch grünen Punkten. L. $7-10 \mathrm{~mm}$. 
davor in mässiger Rundung convergirend, der Seitenwulst hoch aber wenig breit, von zwei tiefen, grubenförmigen, stark punktirten Eindrücken begrenzt, welche durch eine leicht gewölbte Querleiste geschieden werden. Fld, ziemlich dicht aber wenig stark, verworren punktirt, die Punkte nur an der Naht und über dem Seitenrande zu je zwei ziemlich deutlichen Reihen vereinigt, ihre nicht gewirkten, glänzenden Zwischenräume mit vereinzelten Pünktchen besetzt. Die Banchringe an den Seiten, die beiden letzten zuweilen fast ganz röthlich. Tarsen kräftig.

Beim Männchen ist der letzte Bauchring etwas gewölbt, an der Spitze leicht abgestutzt, und besitzt am Vorderrande oft einen seichten Eindruck. - Der Penis ist ungefähr so lang als die 4 letzten Segmente zusammen, schmal, mässig gebogen, an der Oeffnung sebr wenig und geradlinig verengt, vorn mit scharfen Ecken in einem unmerklichen Bogen fast geradlinig abgestutzt.

Die unbedeutende Varietät a., bei welcher die ganze Unterseite bläulich grün, der Kopf und das glänzende Halssch. metallisch grün, ohne Kupferschimmer sind, hat gewöhnlich auch dunkler braune, weniger rothe Fld. und kommt vorzugsweise, jedoch nicht ausschliesslich, in Südeuropa ror; zur Var. b. gehören die Exemplare mit 6 bis 8 deutlichen, wenn auch nicht ganz regelmässigen Punktreihen auf der inneren Hälfte der Fld. Sibirien.

Am Rande von Sümpfen und feuchten Wiesen gemein. Europa.

50. Chr. gross $\left.{ }^{1}\right)$ : Breviter elliptica, sat convexa, coeruleo-viridis, nitida, prothorace antrorsum valde angustato, subtiliter punctato, callo laterali lato, crasso, interne grosse punctato, impressione lata sat profunda,

1) Mit dieser Art wurde bisher fälschlich verbunden: Chr, chloromaura Oliv. (Ent. V. 553. t. 8. f. 113. - gallega Fairm. Ann. Fr. 1861. 595): Elliptica, subparallela, nigra, leviter cyanescens vel virescens, nitida, prothorace antrorsum parum $(\hat{\odot})$ aut valde angustato $(q)$ subtilissime vageque punctato, callo laterali angusto, crasso, impressione la!a ubique profundissima, grosse profundeque punctata terminato; scutello elongatulo, apice subacuto; elytris saturate brunneo-rufis, sat crebre fortius et subseriatim punctatis, lineis nonnullis subelevatis. Mas: ano piloso, segmento ultimo ventrali apice truncato. - Long. 7,5-11 mm. Gallaecia. Lusitania. Schwarz, oft leicht violett, bläulich oder grünlich schimmernd, Halssch. feiner, Fld. stärker und weitläufiger punktirt, Seitenwulst des Halssch. halb so breit als bei grossa, innen überall scharf, wenn auch nicht in regelmässiger Linie durch einen weit tieferen Eindruck begrenzt, Penis von der Mitte nach vorn allmählich verengt, die Spitze schmaler aber ähnlich gebaut wie die von grossa, die Oeffnung länger, die Klappe vorn aufstehend. 
pone angulos anticos extrorsum curvata el abbreviata terminato; scutello lato, apice rolundalo; elytris saturate brumeo-rufis, crebre sat fortiler, suturam versus subtiliter sublineatim punctatis, lineis nonnullis subelevatis. - Long. 9-11 mm.

Mas: ano piloso, segmento ultimo ventrali apice truncato, tarsis modice dilatatis.

Fabr. Ent. Syst. I. 1. 317. - Oliv. Ent. V. 551. t. 3. f. 33.

- Charpent. Hor. ent. 233. - Küst. Kăf. Eur. 1. 91. Suffr. Mon. 200. - Redtb. Faun. A. II. 476.

Var. a. Coeruleo-violacea, parum vel haud viridi micans, elytris rufis. Var. b. illita: Elytris nigris, lateribus plus minusve epipleurisque rufescentibus.

Ungefähr von der Gestalt der Chr. Banksi, etwas gestreckter und bedeutend gewölbter, in der Färbung an Melasoma populi erinnernd; breit elliptisch, bläulich metallgrün, stark glänzend, die schlanken Fühler mit Ausnahme des ersten Gliedes bläulich schwarz, die Spitze oder die Unterseite der ersten zwei bis vier Glieder röthlich, Fld. tief rothbraun, oder bei frischen Stücken gelblich rothbraun. Kopf und Halssch. mässig dicht, fein aber tief und deutlich punktirt, letzteres am Hinterrande doppelt so breit als lang, nach vorn stark verengt, die Seiten ein kleines Stück an der Basis ziemlich parallel, davor bald in gleichmässiger starker Rundung, bald mehr geradlinig convergirend, der Seitenwulst hoch und ziemlich breit, verloschen punktirt, durch einen breiten, aber nicht scharfen Eindruck abgesetzt. Dieser Eindruck ist mit sehr groben Punkten, die auf die innere Fläche des Wulstes übergreifen, nicht dicht besetzt; er läuft hinten dem Seitenrande parallel, ist an der Basis tief und verflacht sich gewöhnlich in der Mitte, vor derselben wird er wieder tiefer, biegt merklich nach aussen, so dass er den Wulst verengt, und endet, ohne den Vorderrand zu erreichen. Schildchen halb elliptisch, blaugrün, selten an der Spitze röthlich. Fld. dicht und ziemlich stark punktirt; die Punkte sind an der Naht fein und wenig tief, zu unregelmässigen Reihen geordnet, nach aussen werden sie immer stärker und tiefer, hinter der Schulter bilden sie mehr oder weniger deutliche Runzeln und ein Stück über dem Seitenrande eine ziemlich regelmässige Reihe; ihre $Z$ wischenräume sind glatt, einige von diesen treten oft als leicht erhabene Längslinien herror.

Das Männchen ist auf dem Rücken gewöhnlich stärker punktirt als das , der letzte Bauchring am Hinterrande gerundet-abgestutzt, wodurch der dicht behaarte After sehr breit erscheint, die Tarsen sind deutlich erweitert, namentlich das erste und dritte Glied an den vorderen Füssen. - Der Penis ist kurz und schmal, gleichbreit, an der Oeffnung jederseits schwach, fast geradlinig bis etwa auf die 
halbe Breite verengt, vorn abgestutzt, so dass also vier undeutliche, abgerundete Ecken entstehen, zwei am Beginn der Verengerung, zwei am Vorderrande.

Bei der unbedeutenden Abänderung a. wird die Farbe des Körpers (ohne die Fld.) zuletzt rein blau-violett, ohne Beimischung von grün; recht eigenthümlich sieht die Var. b. aus, bei welcher die Fld. tief schwarz sind, mit starkem Glanze, nur dicht an den Seitenräudern schimmern sie röthlich, die Epipleuren sind roth.

Nach Gredler (Käf. v. Tirol 423) auf Papilionaceen im südlichsten Tirol. Ausserdem in Dalmatien, und Italien sehr häufig, seltener in Spanien und Nordafrika.

Einige Aehnlichkeit in der Färbung (schwarz, bläulich oder violett schimmernd, Fld. bräunlich rothgelb) haben zwei verwandte südeuropäische Arten, die sich aber leicht durch das bedeutend schmalere, nach vorn weniger verengte Halssch. unterscheiden, dessen Seiten durch den breiten, grob punktirten, aber nur un merklich vertieften Eindruck kaum in die Höhe gehoben werden und nicht wulstig verdickt sind. Es sind:

1. Chr. laevipennis Suffr. (Mon. 202; lucida Charp. Horae ent. 233; Küst. Käf. Eur. 2. 79) aus Unteritalien und Sicilien. Halssch. auf der Scheibe sehr fein, aber deutlich, Fld. weniger stark und tief als bei grossa, doch ebenfalls deutlich punktirt. L. $8-11 \mathrm{~mm}$.

2. Chr. lucida Oliv. (Ent. V. 553. t. 8. f. 112; Suffr. 204; chloromaura Charp. 1. c. 233; Küst. 1. c. 2. 78; Suffr. 203) aus Südfrankreich und der Pyrenäen-Halbinsel. Halssch. auf der Scheibe spiegelglatt, mit einzelnen Pünktchen bestreut, Fld. spiegelglatt, nur unter der Loupe sichrbar punktirt. L. $8-10,5 \mathrm{~mm}$.

Die Synonymie dieser 4 Arten ist auf unverantwortliche Weise in Unordnung gebracht und durch Suffrian nicht berichtigt worden. Olivier kannte die typische laevipennis Suffr. nicht, hat aber die drei anderen Arten treffend beschrieben, insbesondere chloromaura (gallega $\mathrm{F}$ a ir m.): atro-cyanea, thor. lateribus incrassatis etc., Charpentier und Küster besassen dagegen die wirkliche chloromaura Oliv. von der Westseite der Pyrenäen-Halbinsel nicht, bezogen vielmehr darauf die lucida 01., während sie in der specifisch süditalienischen laevipennis die lucida zu erkennen glaubten. Suffrian endlich, der alle 4 Arten vor sich hatte, konnte chloromaura Oliv., die ihm in 3 Stücken aus dem Berliner Museum vorlag, ngar nicht von grossa unterscheiden" (Mon. 202) und trennte auf ein ganz untergeordnetes Merkmal hin von der lucida $\mathrm{Ol}$. noch eine lucida s. ab.

VI. 3. 


\section{Drina.}

Chevrolat Dej. Cat. 3. éd. p. 426.

Corpus sat elongatum, humeris prominulis.

Foveae setigerae prothoracis grossae, umbilicatae.

Elytra epipleuris angustis.

Abdomen segmento primo metasterni longitudine aequali.

Körper wenig hart, geflügelt, ziemlich gestreckt, länglich-elliptisch, entweder fast gleichbreit und verschieden stark gewölbt, oder hinterwärts erweitert und daselbst buckelig gewölbt. F ühler schlank, nach der Spitze kaum oder wenig verdickt, alle Glieder, mit Ausnahme des zweiten, länger als breit, das dritte Glied 3 bis 4 mal so lang als 2, das achte kürzer als 7. Halsschild quer viereckig, ringsum gerandet, die Randlinie spaltet sich in jeder Ecke und umschliesst einen grossen, eine lange, weissliche Borste tragenden Punkt, der deshalb genabelt erscheint. Die Flügeldecken treten an den Schultern ziemlich gerade heraus, der Schulterhöcker ist kräftig entwickelt, und die Ecke selbst ist schärfer als bei der Gattung Chrysomela, weil die Randlinie sich weiter ausbreitet und von oben deutlicher sichtbar wird. Sie sind gewöhnlich in zwei Dritteln der Länge am breitesten, an der Naht niemals fest in einander gefügt, hinten gemeinschaftlich abgerundet, mit einzeln abgerundetem Nahtwinkel; die Epipleuren sind an den Schultern breit, verengen sich ziemlich schnell und greifen daher mit dem Innenrande auch nur schwach auf die Brust und den Bauch über, ibre Wimperhaare, womit sie vom 2. Bauchringe bis zur Spitze gesäumt sind, meist bedeutend kürzer, als die von Chrysomela. Die einzige Ausnahme bilden $O$. tristis $F$. und rugulosa Suffr, deren breite Epipleuren erst kurz vor der Spitze bedeutend rerengt sind, und es ist deshalb unbedingt nothwendig, mit diesen Arten die Gattung zu beginnen. Die Oberfläche der Fld. ist gewöhnlich unregelmässig punktirt, selten treten die Punkte an einigen Stellen zu unregelmässigen paarigen Längslinien zusammen, deren Zwischenräume dann etwas gewölbt sind; aber niemals werden die bei den meisten Chrysomelen vorhandenen 9 Punktreihen deutlich zu erkennen sein. Das Prosternum ist vor den Hüften verhältnissmässig breit, zwischen den Hüften von einer mehr oder weniger tiefen Längsrinne durchzogen, hinter den Hüften verbreitert und meist abwärts gewölbt, in eine Grube des Mesosternum eingelegt. Diese Grube besitzt kaum die Spur einer, über die Verlängerung des Prosternum hinaus gehobenen Randlinie, die bei den Chrysomelen stets sichtbar ist. Metasternum länger als bei der vorigen Gattung, über die Mitte ge- 
messen nicht kürzer als der erste Abdominalring. Tarsen lang, besonders das erste Glied, welches an den hinteren Beinen etwas länger ist als die beiden folgenden Glieder zusammen, das dritte Glied beim $q$ breiter als das erste, seine Filzsohle heller als die der anderen Glieder.

Die beiden vorherrschenden, aber sehr veränderlichen Körperfarben der meisten Arten sind metallisch-grün oder dunkelblau, einerseits bis violett oder schwarz, andrerseits bis goldgrün oder metallisch feuerroth variirend; wenige Arten sind brennend rothgelb, mit der allmäblichen Verdunkelung zu schwarzbraun: Ludovicae, melanocephala, melancholica und plagiata. Die Flügeldecken sind entweder einfarbig, also ohne Binden, bei tristis rugulosa, intricata, viridis, Ludovicae, melanocephala, melancholica, elongata und frigida; oder sie besitzen 1. einen Längswisch, der hinter der Schulterbeule beginnt: alpestris, decora, basilea, pretiosa, cacaliae, splendidula, 2, eine gemeinschaftliche schwarze Nahtbinde: plagiata, 3. eine an der Basis der Fld. beginnende, dem Schildchen zugebogene Längsbinde: elegans, 4. eine in der Regel scharfe Längsbinde hinter dem Schulterhöcker: vittigera, gloriosa, speciosissima, 5. zwei Längsbinden: excellens liturata und virgulata.

Bei einigen Arten z. B. alpestris, gloriosa und speciosissima, scheint die Färbung zum Theil von der Höhe des Aufentbaltsortes abhängig zu sein, denn in den tieferen Regionen der Gebirge treten vorherrschend metallisch- oder goldgrüne und feuerrothe Formen auf, die in bedeutenderer Höhe von dunkleren, blauen, violetten und schwarzen ersetzt werden ${ }^{1}$ ); bei anderen Arten lebrt die Erfahrung das Gegentheil. So z. B. sind die lebhaft metallischen Stücke von luctuosa und bifrons bei Weitem höher gefangen worden als die blauen. Grössere Wichtigkeit besitzen die Färbungen, welche, wie Anderschi, polymorpha, decora, senecionis etc. ausschliesslich einem Gebirgszuge eigenthümlich und als Unterarten (S ubspecies) aufzufassen sind, weil mit der verschiedenen Farbe auch eine abweichende Körperbildung und Skulptur Hand in Hand geht. Hier dürfte auch der richtige Ort sein, mit einem Worte auf den eigenthümlichen Umstand hinzuweisen, dass in den Pyrenäen so viele Arten massenhaft in einer total schwarzen Form auftreten, wie in keinem anderen Gebirge.

Das Männchen ist kleiner und schlanker, dabei dichter und kräftiger punktirt als das Weibchen, hinter der Mitte wenig oder nicht erweitert, der letzte Bauchring in der Mitte oft der Länge nach eingedrückt, am

1, Diese Ansicht vertritt auch Letzner, Bericht Schles. Ges. 185:. 1-4. 
Hinterrande abgestutzt und ziemlich tief zweimal gebuchtet, das erste Tarsenglied stark erweitert und so breit als das dritte.

Die Larven sind breit eiförmig, hoch gewölbt, das Ende des Körpers nach unten und vorn gekrümmt, der Prothorax kaum halb so breit als der Hinterleib, die Segmente dicht und fein gerunzelt. Bis jetzt sind nur die Larven von $O$. cacaliae ) (schwarz, mit gelbem Thorax), alpestris ${ }^{2}$ ) (schmutzig weiss, Kopf und Thorax heller, gelblich weiss) und glorios $a^{3}$ ) bekannt. Sie treten in ungeheurer Menge auf und zerfressen die Blätter ihrer Nährpflanzen, Senecio-, Adenostyles-, Chaerophyllum- und Anthriscus-Arten, bis auf die Rippen.

Die vollkommenen Thiere leben im Gebirge auf den genannten Nährpflanzen der Larven an schattigen, mit Buchen bewachsenen Abhängen (intricata), oder in kleinen, blumenreichen Lichtungen, unmittelbar am Rande solcher Gebirgsbäche, welche von möglichst dichten, feuchten Wäldern eingesäumt werden (die meisten Arten). oder auf Alpenwiesen (an Doronicum austriacum Jacq. z. B. O. plagiata; an Hieracien $O$. viridis). Sie entwickeln sich frühestens Anfang Juli (nur cacaliae schon im Juni), überwintern aber in Menge unter Baumrinden und, auf den höchsten Alpenmatten, unter Steinen. Ihre eigentliche Heimath sind die Alpen, von hier aus verbreiten sie sich, jedoch in abnehmender Artenzahl, westlich durch das südfranzösische Bergland und die Pyrenäen bis in das Asturische Gebirge, östlich bis in den Balkan und nördlich durch die den Alpen vorgelagerten Gebirge von den Karpathen bis zu den Vogesen; ihr nördlichster Fundort ist der Harz. Ausserhalb Europas kommt nur noch eine Art auf dem Altai und den Gebirgen nördlich davon, von Kusnezk bis zum Baikalsee vor. In der Ebene ist bisher O. cacaliae bei Potsdam, Brüssel und im westlichen Frankreich ${ }^{\text {t) }}$ gefangen worden, aber es ist mit Sicherheit anzunehmen, dass die Thiere im Puppenzustande in Erdballen, mit welchen man die zum Anpflanzen bestimmten Farrenkräuter des Gebirges versendet, eingeschleppt worden sind, und dass sie sich nicht weiter entwickeln können, da ihnen ihre Futterpflanzen fehlen, die nur in den wallenden Nebeln der Berge gedeihen.

Von dieser Gattung beschrieb Scopoli 1763 speciosissima und liturata, Schrank 1785 cacaliae, mehrere andere Arten wurden durch

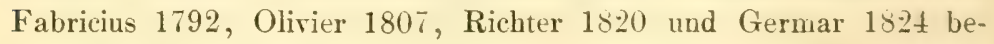
kannt, die in den Alpen einheinischen Arten bearbeitete 1825 Duft-

1) Letzner Bericht Schles. Ges. 1S56. 106.

2) Weise Deutsch. Zeitschr. 1883. 216.

3) Perroud Ann. Soc. Linn. Lyon 1855. 402.

4) Ann. Fr. 1879. Bull. 73. 
schmid, jedoch so wenig genau, dass sich die meisten aus den Beschreibungen nicht sicher erkennen lassen, die schlesischen Arten 1843 Schummel; aber den Grund zur Unterscheidung der überaus ähnlichen Formen legte erst 1851 Suffrian, welcher in seinem umfangreichen Aufsatze "Zur Kenntniss der europäischen Chrysomelen" (Mon.) im 5. Bande der Linnaea entomologica 30 Arten unterscheidet. Dieselben suchte Kraatz, mit Hilfe seines reichen Materials bis auf 9 Arten zu reduciren, 1 ) indem er die noch heute in der Entomologie bethätigte, auf den ersten Anblick zwar sehr bestechende, aber das Streben nach einer scharfen Unterscheidung gradezu untergrabende Ansicht theilte, dass zwei gut unterschiedene Arten vereinigt werden müssen, sobald sich sogenannte $Z$ wischenformen vorfinden, die in ein oder mehreren Merkmalen (jedoch nicht in der Summe derselben) beide Arten zu verbinden scheinen. Seine Meinung erwies sich nach den Untersuchungen des Penis, die für die vorliegende Gattung zuerst Baly anstellte2), bei mehreren Arten als zu weitgehend, und die von ihm selbst ${ }^{3}$ ) und $\mathrm{mir}^{4}$ ) fortgesetzte Beschäftigung mit diesem, die beschreibende Entomologie in neue und sichere Bahnen lenkenden Gegenstande, zeigte, dass die Orinen durchaus nicht in dem Grade variiren, wie früher angenommen wurde, und machte es möglich, heute die Arten mit absoluter Sicherheit festzustellen.

Synoptische Tabelle.

1. Endglied der dicken Maxillartaster breit, oft fast beilförmig, an oder dicht vor der Spitze am breitesten. Die zwei ersten Fühlerglieder unterseits oder an der Spitze roth, 1. Gruppe . 2.

- Endglied der wenig dicken M. mässig breit; Fühler einfarbig. 2. Gruppe . . . . . . . . . . . . . 15.

- Endglied der dünnen M. schmal, kegelförmig, nach rorn verschmälert; Fühler einfarbig. 3. Gruppe . . . . . . 19.

2. Umschlag der Fld. breit, Seitenwulst des Halssch. breit, hoch gewölbt; Fld. ohne Längsbinde . . . . . . . . . 3.

- Umschlag der Fld. schmal, Seitenwulst des Halssch. flach, oder wenig gewölbt. . . . . . . . . . . . . . 4.

3. Halssch. lang, an der Basis kaum eingeschnürt, die Seiten bis zur Mitte fast parallel, davor gerundet-convergirend. L. 9-12 mm. Jura. Alpen. Banat . . . . . . 1. tristis F.

1) Berliner ent. Zeitschr. 1859. 275-291.

2) Transactions entomological Society London 1879. 171-188.

3) Kraatz Monatsblätter 18:0. 33-38.

4) Kraatz 1. c. 1880. 97-102. 
- Halssch. mässig lang, an der Basis eingeschnürt, die Seiten in der Mitte parallel, nach vorn und hinten fast winklig convergirend. L. 9-12 mm. Lausitz. Banat. Siebenbürgen 2. rugulosa Suffr.

4. Fld. überall grob darmartig gerunzelt. Seitenwulst des Halssch. der ganzen Länge nach breit abgesetzt und sehr flach gedrückt. Fld. ohne Längsbinde, ihre Zwischenräume polirt. L. T-11 mm.

a) Oberseite schwarzblau, violett oder schwarz. Sudeten, Karpathen . . . . . 3. intricata Germ.

b) Oberseite blau- bis goldig grün. Alpen v. Anderschi Duft.

- Fld. wenigstens im innern Drittel punktirt, nach aussen zu oft gerunzelt. Der Längseindruck, welcher den Seitenwulst des Halssch. absetzt, besteht aus 2 Theilen, der hintere ist tiefer als der vordere, beide sind durch eine mehr oder weniger deutliche Erhebung dicht vor der Mitte getrennt . . . . . 5.

5. Zwischenräume der Punkte auf den Fld. $\left\{\begin{array}{l}\text { polirt } \\ \text { geschuppt . . . }\end{array}\right.$

6. Jede Fld. mit 2 schwarzblauen Längsbinden, die sich meist vor der Spitze vereinigen. L. 8,5-11 mm. Kärnthen. Krain.

7. liturata Scop.

- Jede Fld. höchstens mit einer rerwaschenen Längsbinde . 7.

7. Die den Seitenwulst des Halssch. absetzenden 4 Eindrücke sind sehr flach, der Seitenwulst ist kaum emporgehoben und die Scheibe fast gleichmässig bis zu den Seiten abwärts gewölbt. L. $7-11,5 \mathrm{~mm}$.

a) Fld. nach aussen $z u$ grob runzelig punktirt. Oberseite rorherrschend dunkel gefärbt, blau, violett, schwarz oder blaugrün, Fld. selten mit einer wischartigen Längsbinde. Glatzer und Altvater Gebirge. Karpathen

4. alpestris Schumm.

b) Fld. weitläufiger und stärker punktirt, weniger oder kaum gerunzelt. Oberseite vorherrschend lebhaft metallisch grün bis feuerroth, Fld. gewöhnlich mit einer Längsbinde. Riesengebirge. Thüringer Wald. Schwarzwald

v. polymorpha Kraatz.

- Von den Seiteneindrücken des Halssch. sind die hinteren tief und heben den Seitenwulst scharf und deutlich enpor . . 8.

8. Fld. fein, doppelt punktirt (die Punktirung besteht aus untereinander gemischten feineren und stärkeren Punkten), auf dem Abfalle zur Spitze flach gedrückt, Körper wenig gewölbt. L. 8-11 mm. Alpen . . . . . . 9. bifrons F.

- Fld. einfach, mässig stark punktirt, hinten fast buckelig gewölbt . 
9. Thorax vor dem Hinterrande quer niedergedrückt. Hinterrand des letzten Bauchringes beim 우 jederseits deutlich ausgerandet. Alpen. Kleiner Balkan . . . 6. variabilis Weise.

- Thorax vor dem Hinterrande kaum niedergedrückt. Hinterrand des letzten Bauchringes beim 우 fast gleichmässig gerundet.

gloriosae var.

10. Halssch. beinahe gleichmässig bis zum Seitenrande gewölbt, die 4 Eindrücke sehr flach. Fld. des $\hat{o}$ glänzend, des $q$ matt. L. $7-10 \mathrm{~mm}$.

a) Einfarbig. Seiten des Halssch. $\left\{\begin{array}{r}\text { schwach gerundet. Alpen } \\ 10 \text { viridis Duft. } \\ \text { stark gerundet. Trans- } \\ \text { sylvanischeAlpen. Banat } \\ v . \text { Merkli Weise. }\end{array}\right.$

b) 우 Fld. mit sehr breiter, matter Längsbinde. Ostalpen

v. mirabilis Weise.

- Seitenwulst des Halssch. hinten deutlich emporgehoben . 11.

11. Fld. beim ô glänzend, beim of matt. L. $7-10 \mathrm{~mm}$. Altai

9 a. basilea Gebl.

- Fld. in beiden Geschlechtern mit gleichem Glanze. . . 12.

12. Fld. fein und dicht doppelt punktirt, nach aussen gerunzelt, mit 3 deutlichen Doppelreihen von Punkten und einer gewöhnlich verwaschenen Längsbinde. Ein Saum am Hinterrande des Halssch. stets dunkler als die Scheibe bifrons $v$. decora Richt.

- Fld. einfach punktirt . . . . . . . . . . . 13.

13. Körper flach, einer Melasoma ähnlich. Eindrücke des flachen, fast viereckigen Halssch. zahlreich und grob punktirt, die vertiefte Mittellinie desselben, oder eine Längsmakel vor dem Schildchen oft blau. Fld. mit weitläufigen, starken, meist unregelmässig gereihten Punkten und gewöhnlich mit scharfer Naht- und Scheibenbinde. L. 8-10 mm. In der Nähe der Gletscher in den Centralalpen . . . 8. vittigera Suffr.

- Körper ziemlich flach, gestreckt, oder nach hinten erweitert und gewölbt. Punkte der Fld. zahlreicher, kaum gereiht . . 14.

14. Fld. ausser der dunklen Naht, höchstens noch mit einer Längsbinde. L. 9-13 mm. Alpen. Pyrenäen.

$$
\text { Körper }\} \begin{aligned}
& \text { schlank . . . . . . . . . . gloriosa F. } \\
& \text { breit . . . . . pretiosa Suffr. }
\end{aligned}
$$

- Fld. mit je 2 brennend rothen oder goldgelben Längsbinden, die sich meist vor der Spitze vereinigen $v$. excellens Weise.

15. Körper metallisch gefärbt. L. $7-8,5 \mathrm{~mm}$. Gebirge Mitteleuropas 11. virgulata Germ. 
-- Körper nicht metallisch gefärbt, schwarz, Halssch. und Fld. roth, rothbraun oder pechbraun . . . . . . 16.

16. Halssch. gleichmässig bis zum Seitenrande gewölbt, ohne merklichen Wulst. Körper sehr schlank. L. 8-10 mm. Centralalpen . . . . . 13. melancholica Heer.

- Halssch. mit deutlich abgesetztem Seitenwulste . . . . 17.

17. Oberseite glänzend. Halssch. schmal, mit schwach gerundeten Seiten. Körperform der O. alpestris. - L. $8-10 \mathrm{~mm}$.

a) Fld. mit mehr oder weniger breiter, gemeinschaftlicher schwarzer Nahtbinde. Karpathen 14. plagiata Suffr.

b) Fld. einfarbig roth. Kärnthen ? v. commutata Suffr.

- Oberseite ziemlich matt. Halssch. breit, mit stark gerundeten Seiten, Form des Seitenwulstes fast wie bei intricata . . 18.

18. Körper breit, plump. Fld. fein und sehr dicht runzelig-punktirt, schwärzlich bis pechschwarz, Naht, Seitenrand und Umschlag roth. L. 10-12 mm. . . . 11a. Ludovicae Muls.

- Körper schlanker, besonders beim $\hat{\jmath}$. Fld. roth, grob gerunzelt. L. 9-11 mm. Centralalpen - 12. melanocephala Duft.

19. Halssch. fast gleichmässig bis zum Seitenrande gewölbt. Fld. beim $\hat{f}$ glänzend, beim $\&$ matt. L. 7-9 mm. Pyrenäen

14 a. splendidula Fairm.

- Halssch. mit abgesetztem Seitenwulste . . . . . 20.

20. Fld. mit geschuppten Zwischenräumen, grün oder blau. L. 6-8,5 mm. Alpen . . . . . 17. elongata Suffr.

— Fld. mit polirten Zwischenräumen . . . . . . . . 21.

21. Fld. mit einer kupferig rothen Längsbinde, die sich an der Innenseite des Schulterhöckers nach innen dem Schildchen zubiegt und die Basis jeder Fld. ganz erreicht. L. 6,5-8 mm. Westalpen . . . . . . . 16a. elegans Arrag.

- Fld. höchstens mit einer beiderseits abgekürzten Längsbinde 22

22. Fühler kurz, von den Gliedern 5 bis 8 jedes nur wenig länger als breit. Halssch. und Fld. kräftig punktirt. Fld. ohne Binde. L. $5-6,5 \mathrm{~mm}$. Centralalpen .. . 18 frigida Weise.

- Fühler schlank, Glied 5 bis 8 einzeln fast doppelt so lang als breit . . . . . . . . . . . . 23.

23. Körper verhältnissmässig schlank. Seitenwulst des Halssch. ganz oder theilweise grob punktirt. Fld. weitläufig nadelrissig punktirt, oft mit breiter, matter Längsbinde. L. 8-11 mm. Gebirge Mitteleuropas . . . 15. cacaliae Schrank.

- Körper meist kurz, nach hinten verbreitert. Seitenwulst des Halssch. fast glatt. Fld. dicht, einfach punktirt, oft mit glänzender Längsbinde. L. 7-10 mm. Gebirge Nitteleuropas 
A. Endglied der Maxillartaster breit. Wenigstens die zwei ersten Fühlerglieder an der Spitze roth.

a. Umschlag der Fld. breit; Seitenwulst des Halssch. hoch.

1. Or. tristis: Convexa, nigro-violacea vel -coerulea, subtiliter alutacea, subopaca, antennis basi rufescentibus; prothorace subquadrato, leviter transverso, apice sat profunde emarginato, lateribus postice subparallelo, antice paullo rotundato-angustato, angulis posticis rectis, callo laterali crasso, antice interne fortiter punctato. impressione integra, profunda, fortiter punctata terminato, disco subtiliter punctato, linea media laeri; elytris sat dense punctatis, lateribus plus minusve calloso-incrassatis, epipleuris latis, segmento ultimo ventrali antice convexiusculo. postice late depresso et fortiter punctato (depressione antice linea obsoleta arcuata terminata), linea media profunda $(\hat{\odot})$ vel obsoletissima (q) impressa. - Long. 9-12 mm.

Fabr. Ent. Syst. I. 1. 315 (1792)。 - Küst. Käf. Eur. 13. 89. Baly Trans. ent. Soc. 1879. 183. t. 2. f. 7 (pars.).

Chr. luctuosa Oliv. Ent. V. (1807) 549. t. 3. f. 34 . - Duftsch. Faun. Austr. III. 166. - Suffr. Mon. 182. - Redtb. Faun. A. II. 475. - Kraatz Berl. Zeit. 1859. 290; Monatsbl. 1850.37. - Weise Monatsbl. 1850. 98; Deutsch. Zeit. 1883. 243. 248.

Chr. haemoptera Panz. Faun. Germ. 44. 7.

Var. a. smaragdina: Supra vel tota coeruleo-viridis, olivaceo-nigra, laete viridis, aurichalcea vel aurea.

Weise 1. c. 1883. 243.

Var. b. cuprina: Supra cupreo-brunnea, cuprea vel ignita, subtus plerumque obscurior.

Weise 1. c.

Var. c. tenebrosa: Supra saturate nigra.

Die breiten Epipleuren der Fld, der dicke und bis vorn abgesetzte Seitenwulst des Halssch. und der in der Regel wulstig verdickte Seitensaum der Fld, machen diese und die folgende Art so kenntlich, dass eine Verwechselung mit den anderen Arten der ersten Gruppe ausgeschlossen ist.

Hoch gewölbt, dunkel violett oder dunkelblau, sehr fein geschuppt, wenig glänzend; die beiden ersten Fühlerglieder unterseits oder an der Spitze röthlich, zuweilen auch noch die folgenden zwei bis drei Glieder. Halssch. nur ungefähr ein Drittel breiter als lang, vorn schmaler als am Grunde, die Seiten sebr leicht gerundet, nämlich ron den scharf rechtwinkeligen Hinterecken bis zur Mitte sanft erweitert, fast parallel, davor wieder verengt, der Vorderrand ziemlich tief ausgeschnitten. Die Scheibe mässig gewölbt, bald zerstreut und sehr fein, bald dichter und kräftiger, gewöhnlich doppelt punktirt, etwas glänzender als die Flu., mit nicht punktirter Mittellinie. Der Seitenwulst nüssig breit, hoch gewölbt, innen ron einem 
tiefen, grob punktirten Eindrucke abgesetzt, welcher in der Mitte schwach nach innen biegt, vor derselben etwas flacher wird und mit seiner groben Punktirung theilweise auf den Wulst übergreift, so dass dieser zwar nicht erheblich niedergedrückt, aber schlechter begrenzt wird wie auf der hinteren Hälfte. Fld, beim $\hat{j}$ kaum, beim ㅇ deutlich nach hinten erweitert, ziemlich dicht aber wenig stark, nach der Naht hin etwas weitläufiger und feiner punktirt, mit einer regelmässigen, tiefen Punktreihe in der Rinne des Seitenrandes; der Raum über letzterer wulstartig verdickt und durch den Eindruck, welcher hinter der Schulterbeule entspringt und sich bis zur Spitze der Fld. parallel den Seiten hinzieht, von der Scheibe geschieden. Epipleuren nach hinten zwar verengt, aber bis zum letzten Bauchringe noch deutlich flach ausgebreitet.

Das letzte Bauchsegment ist in beiden Geschlechtern verbältnissmässig lang, beim Männchen mit tiefer, beim Weibchen sehr feiner Mittelrinne, ein kleiner, hinten bogenförmig begrenzter Theil an der Basis gewölbt und fein punktirt, der grössere Raum dahinter niedergedrückt und stärker punktirt, der Hinterrand gerundet ( $q$ ) oder zweimal sanft ausgebuchtet $(\hat{\jmath})$.

Der Penis ist fast so lang als der Hinterleib, und seine Breite gleich der Länge des letzten Bauchringes (3,8 mm lang, 1,2 mm breit); vor der Spitze jederseits leicht eingeschnürt oder ausgerandet und mit je einem nach rückwärts gerichteten, sehr scharfen, querkantigen Zähnchen verseben, welches als Widerhaken dient; die Spitze selbst bildet ein gleichseitiges Dreieck und ist am Ende schwach abgerundet.

Die Färbung ändert ab:

a. Oberseite, oder der ganze Körper bläulich grün, schwärzlicholivenfarbig, lebhaft und hell metallisch grün, fast maigrün, selbst mit starkem Messing- oder Goldschimmer;

b. Oberseite kupferig braun, kupferroth oder metallisch feuerroth, Unterseite gewöhnlich dunkler, mit metallisch grüner Beimischung;

c. Oberseite rein und tief schwarz, auf der Unterseite wenigstens noch die Beine violett.

Auf Bergwiesen, besonders im niederen Gebirge häufig, ron den Pyrenäen durch Südfrankreich bis in den Jura, und durch die Alpen bis in den Banat und Siebenbürgen verbreitet; die Var. a. hauptsächlich in den Westalpen bis zum Simplon (Rätzer) und in Krain (Tolmein, Micklitz); b. Mte. Rosa (Thieme), St. Gotthardt (Rätzer); c. Pyrenäen (Royer).

Bei dieser Art muss leider die allgemein gebräuchliche Benennung Oliviers durch die ältere von Fabricius ersetzt werden, wenn man sich keiner wissentlichen Fälschung theilhaftig machen will. Da nicht anzunehmen ist, dass 
sich Suffrian in der Art geirrt hat, als er die in der Fabricii'schen Sammlung befindlichen 2 Exemplare für die blaue Varietät von cacaliae Schrank erklärte, so ist eine Verwechselung derselben gewiss vorgekommen.

2. Or. rugulosa: Comvexa, nigro-violacea vel-coerulea, subtiliter alutacea, subopaca, antennis basi rufescentibus; prothorace trans. verso, apice profunde emarginato, basi subconstricto, lateribus in medio parallelo, antice posticeque fere abrupte angustato, angulis posticis acutis, callo laterali crasso, lato, antice interne fortiter punctato, impressione integra, profunda, fortiter punctata terminaw, disco subtiliter punctato, linea media laevi; elytris sat dense punctatis, lateribus plus minusve calloso-incrassatis, epipleuris latis. Long. 9-12 mm.

Suffr. Mon. 181. - Redtb. Faun. A. II. 478.

Chr. tristis Baly Trans. ent. Soc. 1879. 183. (pars.).

Or. luctuosa Ol. var. Kraatz Berl. Zeit. 1859. 290. - Weise Monatsbl. 1880. 98.

Chr, nobilis Waltl. Isis 1839. 226. ?

Von der vorigen durch den Bau des Halssch. sehr abweichend. Dasselbe ist bedeutend kürzer, doppelt so breit als lang, am Vorderrande tiefer und winkeliger ausgeschnitten, vor dem Hinterrande jederseits eingeschnürt, so dass die Hinterecken sehr spitz zahnförmig nach aussen vortreten, die Seiten sind in starkem, aber aus zwei stumpfen Winkeln bestehendem Bogen gerundet, nämlich vor der Einschnürung im letzten Viertel stark divergirend, in der Mitte ziemlich parallel, gewöhnlich schwach convergirend, im vorderen Viertel wieder stark convergirend; der Seitenwulst ist breiter und höher, vorn tiefer abgesetzt.

Der Penis ist wenig kürzer aber fast nur halb so breit als der von tristis (3 mm lang, $2 / 3 \mathrm{~mm}$ breit), die Ausrandung vor der Spitze jederseits ist so schwach, dass sie kaum als besonderer Theil, sondern nur als der Anfangspunkt der allmählich und fast geradlinig verengten Spitze erscheint; letzterer fehlen die kantigen Widerhaken auf der Rückseite gänzlich.

Das Thier zeichnet sich durch seinen eckigen und plumpen Bau aus, ist aber mit tristis übereinstimmend punktirt und dunkel-violett oder dunkelblau gefärbt. Von beiden Arten giebt es Stücke (besonders frische), bei denen die Punkte der Fld. so, wie es Suffrian nur von der vorliegenden Art beschreibt, ,an der Wurzel, über dem wulstigen Seitensaume und vor der Spitze zu gekrümmten, durcheinander fahrenden Linien zusammen fliessen, wodurch die Zwischenräume als feine, unregelmässige Runzeln emporgehoben werden ${ }^{66}$.

Hauptsächlich im Banat, in Siebenbürgen und Ungarn, nach Rosenhauer auf Centaurea jacea L.; seltener auf den Phonolitkegeln 
der Oberlausitz. Die aus der Umgegend von Passau beschriebene nobilis $\mathrm{W}$ al tl., mit einem ,thorace dilatato, brevissimo" gehört wahrscheinlich hierher, aber Suffrian's späterer Name muss so lange Geltung behalten, bis das Vorkommen der rugulosa im östlichen Baiern sicher nachgewiesen ist.

b. Umschlag der Fld. schmal. Seitenwulst des Halssch. niedrig.

3. Or. intricata: Brevis, sat convexa, atro-coerulea. antemnis, articulis primis apice rufescentibus exceptis, pedibusque aenen-virescentibus, capite prothoraceque subtilissine alutaceis, hoc transverso, minus convexo, inaequaliter subrugoso-punctato, apice quam basi parum angustiore, lateribus ante basin leniter rotundato-sinuatis, apicen versus paullo convergentibus, callo laterali lato, depresso. impressione haud profunda, fortiler punctata terminato, elytris intricato-rugosis. interstitiis politis, sparsim punctulalis. - Long. 7-10 $\mathrm{mm}$.

Mas: segmento ultimo ventrali brevi, convexiusculo, basi lineola media vaga, apice truncato.

Germar Ins. spec. nov. 1824. 596. - Schummel Ber. Schles. Ges. 1843. 197. - Suffr. Mon. 180. - Redtb. Faun. A. II. 475. - Kraatz Berl. Zeit. 1859. 290. - Baly Trans. ent. Soc. 1879. t. 2. f. 5. - W eise Monatsbl. 1880. 98; Deutsch. Z. 1883. 211. 248.

Var. a. Corpore plus minusve coeruleo-viridis, aeneo micans.

Var. b. amethystina: Supra salurate violacea vel rubro-violacea.

Weise 1. c. 1883. 211.

Var. c. seminigra: Supra fere tota nigra.

Weise 1. c. 211.

Subsp. d. Anderschi: Laete viridi-aenea, vel viridi-aurea, nilens, callo laterali prothoracis plerumque paullo crassiore, interne impressione evidenter profundiore terminato, elytris subtiliter punctato-rugulosis. - Long. 7-11 $\mathrm{mm}$.

Duftschm. Faun. Austr. III. 1825. 166. - Redtb. Faun. A. ed. 2. 914 et ed. 3. II. 475 .

Chr. intricata Baly Trans. ent. Soc. 1879. 182.

Chr. aurulenta Suffr. Mon. 179.

Chr. cacaliae Duftschm. 1. c. 165 . - Redtb. 1. c. ed. 1. 549.

Var. e. Prothorace parce subtiliterque punctato.

Merklich breiter als die vorigen, wenig flacher, durch den breiten, niedergedrückten Seitenwulst des Halssch. und die darmartig gewundene Runzelung der Fld., in welcher die sie bildenden starken Punkte fast verschwinden, ron allen Verwandten leicht zu trennen.

Kurz oval, fast viereckig, oben tief schwarzblau (das Blau jedoch blass), wenig glänzend, die Unterseite lebhafter blau. oft grünlich, Beine, Mund und Fühler metallisch blaugrün, an letzteren die 
Spitze der ersten zwei oder drei Glieder röthlich. Kopf mässig punktirt und äusserst fein lederartig gerunzelt, wie das Halssch. Letzteres quer, über die Mitte fast nur halb so lang als an der Basis breit, wenig gewölbt, unregelmässig doppelt punktirt, mit gewölbten, zu leichten Runzeln vereinten Zwischenräumen; die Hinterecken treten in spitzem Winkel nach aussen, davor sind die Seiten zuerst in leichtem Bogen ausgeschweift, sodann etwas verbreitert, die grösste Breite hinter, in, oder vor der Mitte, zuletzt wieder so verengt, dass die verlängert gedachte tiefste Stelle des Seiteneindruckes ungefähr die ziemlich spitzen Vorderecken treffen würde. Der Seitenwulst ist breit, aber wenig gewölbt, da er von dem grob punktirten, hinter und vor der Mitte merklich vertieften Eindrucke niedergedrückt wird, welcher ihn von der Scheibe trennt.

Fld. hinterwärts etwas erweitert, stark und ziemlich dicht punktirt; die Punkte treten nur an der Basis deutlich, dabinter undeutlich hervor, denn sie stehen in kurzen, tiefen, bald der Länge, bald der Quere nach zusammenhängenden Runzeln, deren darmartig gewundene Zwischenräume polirt und mit sehr vereinzelten feinen Pünktchen besetzt sind.

Beim Männchen ist der letzte Bauchring kurz, leicht gewölbt, meist mit einer kurzen, seicht eingedrückten Mittellinie am Vorderrande, der Hinterrand grade abgestutzt. - Penis kurz, nach vorn allmählich und schwach verbreitert und verdickt $(2,3 \mathrm{~mm}$ lang, $1 \mathrm{~mm}$ breit), der Vorderrand abgerundet und in der Mitte in eine unscheinbare, stumpfe Spitze vorgezogen, die Oeffnung gross, in der oberen Hälfte von einer häutigen, gerade abgestutzten, nach unten jederseits in einen langen Zipfel verlängerten Klappe bedeckt.

Der Glanz der Fld. kann, trotz der polirten Zwischenräume, nicht zur Geltung kommen, weil er durch die starke Runzelung zu sehr beeinträchtigt wird. Die blaue Farbe der Oberseite ist nur in den Runzeln hell und klar, ihre darmartig erhabenen $\mathrm{Z}$ wischenräume sind stets schwärzlich, besonders von der Seite betrachtet. An Abänderungen treten auf:

a. die tiefen Runzeln sind metallisch bläulich grün, und an dieser Färbung nehmen auch der Kopf, das Halssch. (besonders an den Rändern), das Schildchen und die Unterseite mehr oder weniger Theil; oder die Oberseite ist

b. gesättigt veilchenblau oder roth-violett,

c. tief schwarz, nur die Runzeln dicht über dem Seiten- und Hinterrande gewöhnlich blau, blaugrün oder violett.

Sehr abweichend ist die Unterart d., mit lebhaft metallisch grüner bis goldgrüner Oberseite, welche aber, bei der Ansicht von 
der Seite, fast immer blau schimmert; Mundtheile, Fühler und Beine metallisch-grün, Brust und Bauch mehr grünlich blau. Der Seitenwulst des Halssch. ist innen durch einen tieferen, etwas schärferen Eindruck abgesetzt und stärker emporgehoben, die Fld. sind feiner punktirt, viel glänzender, ihre Punkte treten deutlich hervor und sind durch leichte Runzeln unter einander verbunden, die Zwischenräume nur unmerklich gewölbt. Bei e. ist das Halssch. auch in den Seiteneindrücken sparsam, fein punktirt.

Die typische Form auf Senecio nemorensis L. häufig, rom Iserbis zum Altvatergebirge, sparsamer im ganzen Karpathenzuge (die Var. a. b. und c. nicht häufig); auf den Alpen bis nach Siebenbürgen vorherrschend die Subsp. d. von welcher ich die prächtigsten Exemplare durch H. Stussiner in Laibach vom Ilovea-Walde in Oberkrain erbielt.

Duftschmid beschrieb die stärker gerunzelten Stücke aus den Alpen, die den besten Uebergang zur schlesischen Form bilden, als cacaliae, die feiner gerunzelten als Anderschi (in der Beschreibung der letzteren ist die dreimal wiederkehrende sinnlose Benennung der zum Vergleiche herangezogenen Art $C h r$. bifrons in cacaliae umzuändern); beide suchte Suffrian von O. intricata unter dem Namen inurulenta specifisch zu trennen, aber nicht allein die veränderlichen Merkmale, sondern auch die bei ausgehärteten Exemplaren gleiche Form des Penis beweisen, dass eine Trennung in der Natur nicht stattfindet.

4. Or. alpestris: Oblongo-ovalis, sat convexa, dilute cyanea, interdum viridi-micans, nitidula; antennis sat validis, articulis 6 ultimis evidenter crassioribus, articulis 2 primis apice rufescentibus; capite prothoraceque subtilissime alutaceis, hoc modice transverso, leviter convexo, subtiliter et inaequaliter subruguloso punctato, apice quam basi angustiore, lateribus postice subparallelo, callo laterali angusto, obsoleto, postice impressione haud pro/unda, fortiter punctata, antice impressione obsoletissima, transversa terminato, elytris sut fortiter punctutis. extrorsum ruyosis, interstitiis politis, sparsim punctulatis. - Long. i- $10 \mathrm{~mm}$.

Mas: segmento ultimo ventrali basi linea media abbreciata sat profunde impressa, postice transversim deplanato, apice utrinque vix simuto.

Schummel Bericht Schles. Ges. 1843. 197. - Weise Monatsbl. 1880. 99; Deutsch. Zeit. 1883. 212.

Chr. intricata immatura Suffr. Mon. 181.

$\mathrm{Vax}$ a. punctatissima: Concexa, minus profunde punctata, lateribus prothoracis interdum ante angulos posticos sinuatis. - Long. 9-11,5 mm.

Suffr. Mon. 181. - Kraatz Berl. Zeit. 1859. 278.

Var. b. Interstitiis elytrorum subtilissime alutaceis.

Var. c. rivularis: Salurale violacea aut cupren-riolacert. interdum viridi micans.

Weise 1. c. 1883. 212. 
Var. d. fontinalis: Tota coeruleo-viridis, aut supra laete viridis, aureomicans.

Weise 1. c. 212 .

Var. e. olivacea: Supra obscure olivacea, subtus viridis, chalybaea aut violacea.

We is e 1. c. 212.

Var. f. moesta: Supra nigra.

Weise 1. c. 212.

Var. g. bicolora: aa. Prothorace viridi-coeruleo, chalybaeo, cyaneo aut violaceo, elytris saturate nigris vel leviler viridi- aut cyaneomicantibus.

bb. Prothorace viridi-aeneo aut virescenti-aureo, elytris cyaneis, violaceis vel nigris, interdum leviter virescentibus aut cyanescentibus.

Var. h. bannatica: Elytris vitta media lituraeformi.

Chr. speciosa var. bannatica Suffr. Mon. 173.

Subsp. i. polymorpha: Breviter ovalis, convexa, nitida, viridi-aenea, -aurea, vel -ignita, disco prothoracis plerumque cyaneo, elytris minus crebre sat fortiter punctatis, vix rugulosis, sutura vittaque media obsoleta cyaneis, violaceis vel virescentibus. - Long. \$-10 mm.

Kraatz Monatsbl. 1880. 35. - Weise 1. c. 99.

Chr. speciosa Suffr. Mon. 172 (pars.). - Kraatz Berl. Zeit. 1859. 276.

Var. k. umbrosa: Ut in i, sed violacea, vel viridi-auricalcea tota, aut nigro-chalybaea, -violacea aut -viridis, elytris rarissime litura media angusta.

Schlanker, das Halssch, und die Schultern schmaler, daher vorn bedeutend enger erscheinend als die vorige, feiner punktirt und gerunzelt, glänzender, auch an dem seitlich gewölbteren Halssch., dessen schmaler Seitenwulst eigentlich nur hinten abgesetzt wird, sofort zu unterscheiden.

Länglich eiförmig, mit fast gleichbreiten $(\hat{\jmath})$, oder nach hinten stark erweiterten Fld. (), ziemlich glänzend kornblumenblau, Kopf und Halssch., Mundtheile, Fühler, Beine und Unterseite bisweilen grünlich angehaucht. Fühler kräftig, das erste Glied an der Spitze, das zweite ganz oder nur unterseits röthlich, die letzten 6 Glieder breiter als die vorhergehenden, und jedes einzelne von ihnen, das Endglied ausgenommen, wenig länger als breit. Kopf und $\mathrm{Halssch}$. äusserst fein geschuppt, letzteres nur etwas länger als breit, von den Hinterecken nach vorn in grader Linie unmerklich erweitert, die Seiten fast parallel, die grösste Breite ungefähr im ersten Drittel, davor gerundet-verengt, beim $q$ stärker als beim $\hat{\jmath}$; die Oberfläche leicht gewölbt, ungleichmässig mit feinen und dazwischen gemengten stärkeren Punkten besetzt, deren Zwischenräume sich zu mehr oder 
weniger ausgeprägten Schwielen emporheben. Der Seitenwulst ist schmal, niedrig, nur an der Basis deutlich, wo er von einem nicht tiefen, grob runzelig punktirten Eindrucke einigermassen scharf, jedoch kaum bis zur Mitte begrenzt wird, vor dieser gelıt er durch einen Saum grober Punkte oder eine quere Depression über jedem Auge in die Scheibe über. Fld, ziemlich dicht punktirt, die Punkte zwar tief, aber nirgends scharf eingestochen, längs der Naht etwas feiner, wenig deutlich durch Runzeln verbunden, mit mehr flachen Zwischenräumen, nach der Seite zu allmählich stärker, ihre Trennungsstellen zu unregelmässigen, kurzen, verworrenen Runzeln emporgehoben, welche polirt und mit einzelnen Pünktchen besetzt sind.

Beim Männchen ist der letzte Bauchring an der Spitze abgestutzt, der aufgebogene Hinterrand in der Mitte unmerklich rorgezogen, vor demselben befindet sich ein tiefer Quereindruck und eine, nach vorn tiefere Mittelrinne.

Penis sehr schlank ( $3,8 \mathrm{~mm}$ lang, $0,4 \mathrm{~mm}$ breit) mässig gekrümmt, fast gleichbreit, nur im Beginn des vorderen Drittels unmerklich eingeschnürt, und endigt vorn in eine länglich ovale, schwach nach unten gebogene Spitze. Die Oeffinung ist sehr klein, ihr oberer Rand läuft in keine Klappe aus, sondern besitzt eine kurze, aufgebogene Kante; der ductus ist cylindrisch.

Als Abänderungen sind zu betrachten:

a. Kräftig entwickelte, meist etwas weitläufiger und flacher punktirte, höher gewölbte Stücke aus dem Karpathenzuge von der Babia Gora (Stobiecki) bis Siebenbürgen, bilden die Var. punctatissima Suffr, bei welcher die Seiten des Halssch. vor den Hinterecken zuweilen sanft ausgeschweift sind.

b. Die Zwischenräume der Punkte auf den Fld. äusserst fein, doch bei scharfer Vergrösserung deutlich geschuppt.

c. Allmählich geht die Farbe der Oberseite oder des ganzen Körpers unter Zunahme von roth in ein gesättigtes Veilchenblau oder in metallisch kupferroth, mit violettem, zuweilen noch grünlichem Schimmer, oder

d. durch Zutritt von Grün in ein helles und lebhaftes Metallgrün bis Goldgrün über. Hierzu gehören auch die Stücke mit grünem Rücken und blauen Seiten der Fld.

e. Unterseite grün, blau oder violett, Oberseite dunkel olirengrün, oder $\mathrm{f}$. tief schwarz.

g. Halsschild grünlich blau, blau, violett, Fld. tief und rein schwarz, aber auch grün, blau oder violett angehaucht; oder Halssch. metallisch- bis goldgrün, Fld. rein schwarz oder mit grünem, blavem bis violettem Schimmer. In vielen Fällen stimmt mit 
der Farbe des Halssch. auch die des Schildchens, des Kopfes, der Fübler und der Unterseite überein. Nicht zu dieser Varietät, sondern besser zur Normalfärbung sind die Stücke zu rechnen, bei denen die Fld. nur einen geringen Ton dunkler gefärbt sind als das Halssch.

๖. Fld. mit einer Längsbinde über die Scheibe. Dieselbe ist gewöhnlich von einem gleichfarbigen schmalen Nahtsaume begleitet, nicht scharf begrenzt, beim $q$ deutlicher ausgeprägt als beim $\hat{\sigma}$, einfarbig schwarz bei violetten, blau oder violett, zuweilen mit schwarzem Kerne, bei grünen Fld.

Die zweite, mehr westlich lebende Hauptform dieser Art (Subsp. polymorpha $\mathrm{Kr}$.) ist ron der oben betrachteten östlichen nicht unwesentlich rerschieden; von kurz gedrungenem Baue (namentlich die Weibchen in den Schultern breiter und nach hinten weniger erweitert), höher gewölbt, lebhafter gefärbt, glänzender, selten ganz ohne Längsbinde über die Scheibe der Fld. Letztere sind gleichmässiger und bedeutend weitläufiger punktirt, die Punkte sind schärfer begrenzt, indem sich die verbindenden Runzeln weniger vertiefen und ibre Zwischenräume weniger wölben. Die vorherrschenden Farben sind bei i. 1. metallisch-grün, Halssch. mehr oder weniger, Naht und Binde der Fld., Mittelbrust, Seitenstücke und Nähte der Hinterbrust violett; 2. grünlich oder rein messingfarbig, goldgelb oder verschossen bis brennend goldig roth, Scheibe des Halssch. dunkelgrün, selten theilweise violett, Naht und Binde der Fld. grün, stellenweise mit Blau oder Violett belegt, Seiten der Mittelbrust und Nähte der Hinterbrust violett. Bei der Var. k. ist der Körper bald einfarbig violett oder grünlich messingfarbig, bald dunkel stahlblau, schwarzveilchenblau bis schwarzgrün, die Binde der Fld. undeutlich dunkelblau bis schwarz, oder fehlend.

Die Längsbinde der Fld. ist nicht scharf begrenzt, in dem Eindrucke hinter der Schulter am tiefsten gefärbt und am breitesten; wenn sie sich nach hinten nicht verschmälert, so tritt oft eine helle Linie von der Grundfarbe der Fld. in sie hinein und trennt einen schmalen Streifen nach der Naht zu ab.

Auf Anthriscus silvestris, Chaerophyllum aromaticum und hirsutum häufig, alpestris mit den Varietäten a. bis h. (darunter b., c., e., f. und h. selten) im Glatzer-Gebirge, dem Altvater und den Karpathen; polymorpha im Riesen- und Isergebirge, dem Böhmerwalde, Harze, in Thüringen und auf dem Schwarzwalde, die Var. k. Riesengebirge und Schwarzwald. Ob die Art überhaupt in den Alpen vorkommt, scheint mir zweifelhaft.

VI. 3. 
5. Or. gloriosa: Subelongata, postice paullo dilatata, plerumque minus convexa, viridi-aenea vel aurea, subtiliter alutacea, nitidula, meso- et metasterno latera versus, prothoracis disco interdum, vitta media elytrorum limboque suturali angustissimo violaceis; antennis sat validis, basi rufescentibus, articulis 6 ultimis crassioribus; prothorace transverso, sat convexo, subtiliter punctato, apice quam basi angustiore, lateribus leviter rotundatis, callo laterali angusto, impressione lata, fortiter rugoso-punctala, postice profundiore, in medio vix interrupta terminato; elytris minus fortiter subruguloso-punctatis, interstitiis parce punctulatis. - Long. 9-13 mm.

Mas: elytris plernmque seriebus 4 sat irregularibus punctorum per paria approximatis, segmento ultimo ventrali in medio longitudinaliter foveolato-impresso, apice truncato utrinque sat profunde sinuato.

Femina: elytris extrorsum evidenter rugulosis, segmento ultimo ventrali ante apicem rotundato-productum linea media obsolete impresso.

F a br. Spec. Insect. II. App. 497; Ent. Syst. I. 1. 324. - Panz.

Faun. Germ. 23. 14. - Oliv. Ent. V. 545. t. 7. 103. Duftschm. Faun. Austr. III. 168 (pars.). - Suffr. Mon. 165. Kraatz Berl. Zeit. 1859. 280; Monatsbl. 1880. 35. - Redtb. Faun. A. II. 477. - Weise Monatsbl. 1880. 99; Deutsch. Zeit. 1883. 244.

Chr. phalerata Redtb. 1. c. ed. 1. 549.

Chr. pretiosa Redtb. 1. c. II. 474.

Chr. speciosa Baly Trans. ent. Soc. 1879. 175. t. 2. f. 1. - Kraatz Monatsbl. 1880. 36 .

Var. a. virgo: Eadem, tota aeneo-viridis, haud vel evidenter coeruleo micans, aut elytris umbra longitudinali saturatius coerulescente.

Var. b. nubila: Saturate coerulea aut cyanea, interdum elytris nigricantibus, his rarissime vitta obscuriora distincta.

Var. c. pretiosa: Latior, plerumque fortiter convexa, postice magis ampliata, coeruleo-viridis aut viridi-aenea plus minusve aurichalceovel aureo-splendens, lateribus pectoris, disco prothoracis (interdum), sutura vittaque media elytromem nigro-violaceis, cyaneis aut coerulescentibus, hac aut distincte terminata aut lituraeformi; impressione laterali prothoracis interdum minus profunda, interstitiis elytrorum saepe subtilius sed evidenter punctatis.

Suffr. Mon. 167 .

Chr. speciosa Suffr. Mon. 172 (pars.). - Redtb. 1. c. II. 474.

Var.d. superba: Elytris rubro-cupreis, sutura vittaque media (rarius etiam limbo angusto laterali) viridi- inauratis.

Oliv. Ent. V. 544. t. 7. f. 102.

Var. e. venusta: Chalybaea, cyanea, violacea aut violaceo-nigra, rarius elytris vitta media obscura.

Suffr. Mon. 175 (pars.). - Kraatz 1. c. 1859. 279. - Baly l. c. 1879.176 (Var.). 
Var. f. nigrina: Saturate nigra, interdum sublus cyanescens aut viridicoerulescens.

Suffr. Mon. 176. - Kraatz 1. c. 1859. 282. - Baly 1. c.

Chr. venusta Suffr. 1. c. (pars.).

Var. g. discolor: a. Prothorace laete coeruleo aut cyaneo, elytris nigris, interdum leviter coeruleo-, violaceo- aut viridi- micantibus.

b. Prothorace laete viridi-aeneo, elytris coeruleis, violaceis aut nigricantibus.

Chr. venusta Redtb. 1. c. II. 474.

Subsp. h. excellens: Minus convexa, viridi-aenea vel -aurea, elytris vittis duabus antice posticeque confluentibus ignitis, fronte, callo laterali prothoracis, metasterno ventreque aureis, interdum cupreo micantibus, Chr. superba Suffr. Mon. 168. - Kraatz 1. c. 1859. 282. - Baly 1. c. 1879. 176. (Var.) - Weise 1. c. 1883.246.

Chr. speciosa Fabr. Syst. Ent. 101; Ent. Syst. I. 1. 324. - Panz.

Faun. Germ. 23. 15. - Oliv. Ent. V. 543. 63. t. 7. f. 101.

Var. i. Eadem, sordide aurichalcea, vittis elytrorum obsolete cupreis.

Var. k. Onnino ut var. $h$, sed vittis elytrorum aureis lituraeformibus, fere nullis.

Var. 1. Interstitiis elytrorum haud alutaceis.

Bei der Zusammenfassung der verschiedenen Formen dieser Art zu einem Gesammtbilde ${ }^{1}$ ) bleiben als Unterscheidungsmerkmale von der ähnlichen Var. polymorpha (die eigentliche alpestris besitzt nur geringe Aehnlichkeit) etwa die folgenden Punkte übrig: der Körper ron gloriosa ist bedeutend grösser, entweder nur gestreckter oder überhaupt plumper, und im letzteren Falle auch stärker gewölbt, das Halssch. ist auf der Scheibe feiner punktirt, der Seitenwulst breiter, dabei deutlicher und tiefer abgesetzt, die Punkte der Fld. sind feiner und etwas weitläufiger, aber tiefer eingestochen und noch deutlicher begrenzt, ihre Zwischenräume geschuppt, der Eindruck längs der Mitte des letzten Bauchringes ist beim Männchen grubenförmig, nicht nur tiefer, sondern auch länger; der Penis endlich ist fast $5 \mathrm{~mm}$ lang, vor der Spitze stärker erweitert, $0,5 \mathrm{~mm}$ breit, die Spitze selbst ist stärker verengt und viel mehr nach unten gekrümmt, der ductus immer eingezogen, unsichtbar. Die Oberseite der braunen Röhre wird vor der Mitte durch einen gelblichen Längsstreifen geschlossen, welcher aus einer durchscheinenden, pergament-

1) Eine befriedigende Kenntniss der Orinen lässt sich nur erreichen, wenn man möglichst viele Stücke von jedem Fundorte und jeder Färbung vor Augen hat; durch 4 bis $S$ Stücke, auf welche Zahl manche Sammlungen beschränkt sind, ist es kaum möglich, einen Eindruck von den wesentlichen Eigenschaften einer stark variirenden Art, noch weniger einen Einblick in die Veränderlichkeit derselben zu erhalten. 
artigen Haut besteht; er zieht sich, allmählich schwach erweitert, bis an die Oeffnung hin, wo er in einen halbovalen Lappen endet, der die Oeffnung zudecken würde, wenn er nicht stets in die Höhe gekrümmt wäre. Hierdurch wird die Spitze bei der Seitenansicht einem weit geöffneten Fischmaule ähnlich, dessen Unterlippe stärker verlängert ist $\left.^{1}\right)$.

Die Art kommt in drei habituell sebr verschiedenen Formen vor, die erste, gloriosa F., ist schlank, die zweite, pretiosa Suffr., breit und plump gebaut, meist hinten buckelig gewölbt, die dritte, excellens, hält in der Körperform etwa die Mitte, zeichnet sich aber durch zwei Längsbinden auf jeder Fld. aus.

1. gloriosa Fabr. Langgestreckt, auch die grösseren Weibchen schmal, hinterwärts wenig erweitert, seitlich stark zusammengedrückt, aber verhältnissmässig nicht hoch gewölbt, überall fein geschuppt, mässig glänzend metallisch grün oder goldgelb, die Seiten der Mittelund Hinterbrust, oder wenigstens ihre Nähte, Kopfschild und Scheibe des Halssch, zuweilen, eine abgekürzte schmale Längsbinde sowie ein sehr schmaler Nahtsaum und öfter auch der hintere Theil der Epipleuren der Fld. violett, am Rande in Blau und Grün übergehend. Fühler ziemlich kräftig, ihre 6 letzten Glieder breiter als die vorhergehenden, die 2 bis 4 ersten Glieder an der Spitze röthlich. Kopf fein punktirt. Halssch. fast doppelt so breit als lang, mässig gewölbt, fein und zerstreut punktirt, fast spiegelnd, oder stärker, doppelt punktirt ${ }^{2}$ ), mit der grössten Breite vor der Mitte, von hier nach hinten sanft, nach vorn stärker gerundet-verengt, der Seitenwulst mässig breit, durch einen breiten, grubig-runzelig punktirten tiefen Eindruck abgesetzt, welcher in der Mitte durch eine schmale Querleiste leicht oder undeutlich unterbrochen wird und sich vor dieser, weniger tief als hinten, aber immerhin deutlich bis zum Vorderrande hinzieht. Fld. wenig breiter als das Halssch., ziemlich dicht und stark, jedoch sehr veränderlich punktirt, die Punkte durch feine Runzeln rerbundeu, welche besonders auf der Längsbinde, oder überhaupt auf der äusseren Hälfte mehr hervortreten, die Zwischenräume zerstreut fein punktirt.

Beim Männchen ist der letzte Bauchring an der Spitze abgestutat und jederseits tief ausgebuchtet, so dass der aufgebogene Hinterrand in der Mitte deutlich vorgezogen erscheint, vor demselben

1) Kratz Monatsbl. 1880. 36.

2) Die von Suffrian erwähnte, hinten scharf eingeschnittene Mittellinie des Halssch. ist individuell und findet sich auch bei einzelnen Exemplaren der anderen Arten. 
befindet sich eine bis an den Vorderrand reichende, nach vorn verengte und etwas verflachte tiefe Längsgrube; auf der inneren Hälfte der Fld. sind die Punkte hie und da gereiht, (beim Weibchen weniger deutlich) besonders treten oft zwei paarige Punktreihen hervor, welche je einen unmerklich gewölbten $\mathrm{Z}$ wischenraum einschliessen. Der äussere von diesen begrenzt die Längsbinde der Fld. nach innen, wenigstens im hinteren Theile, der andere liegt in der Mitte zwischen dem äusseren und der Naht. Beim Weibchen ist der Hinterrand des letzten Bauchringes fast gleichmässig gerundet-vorgezogen.

Die Farbe des Körpers geht allmählich in ein dunkles Metallgrün, später in blaugrün über, dann bleibt von der Längsbinde der Fld. gewöhnlich nur ein breiter, violetter oder bläulicher Schatten, zuletzt keine Spur übrig ( $V$ ar. a); bei den rein blauen und violetten, oder auf den Fld. schwarzen Stücken, welche die der venusta ähnliche Var. b. bilden, ist nur selten eine dunklere Längsbinde der Fld. zu bemerken.

Häufiger als die eben besprochene, den Hochalpen eigenthümliche Form, ist die tiefer lebende, bis in die Thäler der niederen Gebirge, z. B. des Jura, übergehende Var. c., für welche der Name pretiosa Suffr. erhalten bleiben kann. Sie übertrifft gloriosa zwar kaum an Länge, wohl aber an Breite und Wölbung bedeutend, enthält überhaupt die grössten Stücke (dem Körperumfange nach), die in der Gattung vorkommen; die Fld. sind in den Schultern bedeutend breiter als das Halssch., nach hinten erweitert, am Abfalle zur Spitze fast buckelig gewölbt ${ }^{1}$ ), die Eindrücke, welche den Seitenwulst des Halssch. begrenzen, sind zuweilen weniger tief (diese Stücke zählte Suffrian zu seiner speciosa) und die feinen Punkte in den Zwischenräumen der Fld. treten mitunter schon bei schwacher Vergrösserung deutlich hervor. Die Farbe ist wie bei gloriosa lebhaft metallisch grün bis goldgelb, öfters die Scheibe des Halssch. und gewöhnlich die Seiten der Mittel- und Hinterbrust, selten die ganze Unterseite violett, ein gemeinschaftlicher Nahtsaum und eine Längsbinde über die Fld, beide ziemlich scharf begrenzt, schwarz oder violett, mit blauen Rändern. Hierher gehören auch die auffälligen Exemplare a. mit metallisch grünen oder goldigen Fld., und schwarz violettem Nahtsaume, bei denen die Längsbinde als bläulicher Hauch hinter der Schulterbeule sichtbar bleibt, oder ganz fehlt (aus der Umgegend von Porrentruy von H. Spiess eingesandt); b. mit hochfeuerrothen Fld., die Naht, eine breite, mehr oder weniger scharf begrenzte

1) Stücke aus den Alpen und Pyrenäen sind weniger gewölbt als die aus dem schweizer Jura. 
Längsbinde und zuweilen ein feiner Streifen über dem Aussenrande lebhaft metallisch grün oder blaugrün. Diese Exemplare, vom Reculet (Böschenstein-Fäsi), sind von excellens nur noch durch den hinten buckelig gewölbten Körper zu unterscheiden, und da die Skulptur der Fld. oft feiner ist, als bei der genannten Var., so beziehe ich darauf die superba Oliv., welche vom Mt. Pilat bei Lyon beschrieben ist.

Je mehr sich die Farbe des Körpers dem Blaugrün oder Grünlichblau nähert, desto undeutlicher und verwaschener wird in der Regel der Nahtsaum und die Längsbinde der Fld., zuletzt ist das Thier einfarbig stahlblau, kornblumenblau, violett oder schwarz, mit kupferig-violettem Schimmer (Var. e) oder tief schwarz, unterseits zuweilen violett oder grünlichblau (Var.f). Bei der Var. g. ist a. der Körper, besonders das Halssch., lebhaft blau oder violett, Fld. schwarz, bläulich, violett oder grünlich schimmernd; b. Körper metallisch grün, Fld. blau, violett oder fast schwarz.

2. excellens. Den flachsten Stücken von pretiosa ähnlich, metallisch grün oder goldgrün, von der Seite betrachtet oft bläulich schimmernd, zwei mässig breite Längsbinden über jede Fld., an der Basis und vor der Spitze mit einander verbunden, die eine nahe der Naht, die andere nahe dem Aussenrande, goldroth oder hochfeuerroth. Während also der Nahtsaum und die Längsbinde der Fld. bei gloriosa eine andere Farbe als der Körper besitzen, werden sie bei excellens (in Verbindung mit einem Seitensaume, welcher gloriosa fehlt) von der Körperfarbe gebildet und durch zwei anders gefärbte Binden getrennt. Zuweilen ist das Thier verschossen bräunlich messinggelb, fast bronzefarbig, die Binden der Fld. meist breit, schwärzlich kupferroth (Var. i); oder der Körper bläulich metallisch grün, die 'goldgelben Binden der Fld. wischartig, fast verloschen (Var. k). Der Penis hat ganz die Form wie der von gloriosa, aber der in die Höhe gekrümmte Lappen über der Oeffnung ist etwas länger, schmaler und am Grunde jederseits leicht ausgerandet.

Die Var. 1. mit polirten Zwischenräumen der Fld. findet sich äusserst selten bei der mit einer scharfen Binde rersehenen pretiosa und bei excellens.

Auf den Pyrenäen (vorherrschend die Var. f), in den Alpen und im schweizer Jura bäufig; excellens nur auf der Südseite der Centralalpen, am Mte. Rosa, Simplon und in Tirol.

In Bezug auf die von Suffrian total rerfahrene Synonymie muss auf folgende Punkte ausdrücklich hingewiesen werden: 1. Panzers speciosa, mit zwei rothen Längsbinden der Fld. ist gleich speciusa Fabr. (1792) und Oliv. (1S0i) aber dieser Name darf wegen des gleichen, von Linné 1767 
gebrauchten, nicht angewandt werden. 2. O. specios $a \mathrm{Suffr}$. ist ein Gemisch von Formen der polymorpha und gloriosa, 3. O. pretiosa Suffr. ist durch Uebergänge mit der schmaleren gloriosa so enge verbunden, dass eine Trennung beider Formen nur für die Weibchen sich immer durchführen lässt. Merkwürdig bleibt es, dass Suffrian die in den östlichen Alpen häufigen Exemplare mit scharfer Binde der Fld. nicht gekannt hat.

6. D. variabilis: Ovalis, convexa, nigro-cyanea, nitida, elytris sutura vittaque media nigris, antennis sat validis, articulis 2 primis apicem versus rufescentibus, prothorace transverso, antice posticeque angustato, lateribus subrotundatis, callo laterali incrassato, postice impressione profunda, grosse punctata terminato, disco convexo, minus dense subtiliter punctato, elytris sat crebre fortiterque punctatis, interstitiis politis, parce punctulatis. - Long. 9-11 mm.

Mas: segmento ultimo ventrali linea media vage impresso, apice utrinque leniter emarginato.

Fem.: segmento ultimo ventrali apice utrinque evidenter emarginato, in medio angulato-producto.

o. pretiosa var. variabilis We ise Deutsch. Zeit. 1883. 245.

Chr. gloriosa Baly Trans. ent. Soc. 1879. 178. t. 2. f. 2.

Var. a. Eadem, limbo suturali vittaque media elytrorum nullis.

$\mathrm{V}$ ar. b. Viridi-coerulea, sutura vittaque lituraeformi elytrorum violaceis.

Var. c. Tota nigra.

Var. d. Tota viridi-aenea vel -aurichalcea.

Var. e. balcanica: Nigro-cyanea vel -violacea, elytris viridi-coeruleis. viridi-aureis, cupreo-aureis vel ignitis, outura vittaque media interdum obscurioribus.

O. pretiosa var. balcanica We ise 1. c. 245 .

o. pretiosa Weise $\mathrm{I}$. c.

In der Körperform und Punktirung am meisten mit den hochgewölbten mittelgrossen Stücken der Var. pretiosa aus dem schweizer Jura, in den polirten Zwischenräumen der Fld. mit der Var. polymorpha von alpestris übereinstimmend, von beiden äusserst schwierig durch folgende Punkte zu unterscheiden:

Die Scheibe des Halssch. ist stärker gewölbt und fällt deshalb auch deutlicher zum Hinterrande ab, wo sich gewöhnlich ein querer Niederdruck vor der aufgebogenen Randlinie befindet, der Seitenwulst ist höher, schärfer begrenzt, glatter, hinten durch einen sehr tiefen, fast furchenartigen Eindruck begrenzt, der mit grossen und tiefen Punkten besetzt ist, nach vorn flacher wird und in der Mitte rollständig erlischt. Vor der Mitte ist der Wulst, ähnlich wie bei alpestris, nur durch eine weite, wenig deutliche, stark punktirte Vertiefung von der Scheibe geschieden. Die Punktirung der Fld. hält etwa die Mitte zwischen der sehr weitläufig und gross, aber ver- 
hältnissmässig flach punktirten Thüringer polymorpha and den am dichtesten, ziemlich fein punktirten Stücken von pretiosa. Das Männchen hat nur eine $\mathrm{schwach}$ eingedrückte Mittellinie auf dem letzten Bauchringe, dessen abgestutzter Hinterrand beiderseits auch weniger tief ausgerandet ist als bei pretiosa. Der Penis ähnelt dem von alpestris, ist aber bei ungefähr gleicher Länge doppelt so breit (4 mm lang, 0,8 mm breit), die Oeffnung doppelt so lang, ihr Oberrand nicht aufgebogen, die abgerundet-dreieckige Spitze ist gerade, nicht stark nach unten gekrümmt, der ductus vorgestreckt, ziemlich flach gedrückt, nach der Spitze verbreitert. Beim Weibchen ist der Hinterrand des letzten Bauchringes jederseits deutlich ausgebuchtet und in der Mitte fast winkelig in eine kurze, breit dreieckige Spitze ausgezogen.

Die Farbe des Körpers ist dunkel bis schwärzlich kornblumenblau, einfarbig (Var. a), oder ein schmaler Nahtsaum und eine scharf begrenzte, aber wenig abstechende Binde vom Schulterhöcker bis vor die Spitze jeder Fld. schwarz. Bei dunkleren Stücken nehmen zuerst die Fld., später alle Theile des Körpers eine tiefschwarze Farbe an (Var. c); bei helleren werden anfänglich der grösste Theil der Unterseite, der Kopf und das Halssch. (zuletzt auch die Fld.) grünlich blau, Naht und Längsbinde riolett, an den Rändern allmählich durch blau in die wenig abstechende Hauptfarbe übergehend (Var. b); oder der Körper ist (mit Ausnahme der Mittel- und Hinterbrustseiten) lebhaft metallisch grün, oder grün mit starkem Messingschimmer (Var. d). Eine dieser Art eigenthümliche Zusammenstellung von Farben ist unter der Var. e. zusammengefasst; der Körper ist schwärzlich kornblumenblau oder schwarz violett, die Fld. sind 1. metallisch grünlich blau, einfarbig, oder Naht und Binde violett; 2. Fld. grün, mit verschieden starkem Goldschimmer, Naht und Binde schwach violett, blan oder dunkelgrün, 3. Fld. kupferig goldgelb bis hoch feuerroth, einfarbig, oder die Längsbinde und oft auch die Naht grün.

Bis jetzt einzeln aus den Algauer Alpen bei Immenstadt, von Engelberg im Kanton Unterwalden, und aus Kärnchen und Krain bekannt, häufiger von Merkl im kleinen Balkan gesammelt.

Nachdem ich von Suffrian bestimmte pretiosa gesehen, ist meine Ansicht, die vorliegende Art unter diesem Namen weiter zu führen, hinfällig geworden; es scheint mir nun das Beste, den Namen meiner ersten Varietät (Deutsch. Zeit. 1883. 245) auf die Art selbst zu übertragen und die unter pretiosa m. (l. c.) beschriebene Form mit der Varietät balcanica zu verbinden. 
7. Ir. Iiturata: Breviter ovals, convexa, aurato-virens, nitidiuscula, prothorace disco minus convexo, plus minusve cyaneo, subtiliter, latera versus fortiter punctato, callo laterali parum crasso, impressione lata, fortius punctata, postice paullo profundiore terminato; elytris crebre punctatis, vittis duabus nigro-violaceis, coeruleo-vel viridi-cinctis, interstitiis punctorum politis. - Long. 8,5-11 mm.

Mas: segmento ultimo ventrali antice foveola media parva.

Scopoli Ent. Carn. 73 (Coccinella). - Suffr. Mon. 170.

Chr. phalerata Germ. Faun. Ins. Ent. 16. 13. - Kraatz Monatsbl. 1880. 36.

Chr. speciosa var. phalerata. Baly Trans. ent. Soc. 1879. 176.

Var. a. Nigro-cyanea aut violacea, elytris viridi-aeneis, aurichalceo-vel aureo-micantibus, vittis 2 nigro-violaceis.

Grösser als die in Habitus und Punktirung ähnliche speciosissima, an der Lage der beiden Längsbinden jeder Fld., die in der ganzen Gattung nicht wiederkehrt, mit Sicherheit zu erkennen.

Breit eiförmig, gewölbt, grün, in verschiedener Stärke messinggelb bis goldig glänzend; Fühler mässig stark, die sechs letzten Glieder deutlich verbreitert, die ersten Glieder unterseits oder an der Spitze röthlich. Halssch. kurz, quer, die Seiten hinten fast parallel, vor den Hinterwinkeln gewöhnlich sanft ausgebuchtet, so dass die spitzen Ecken etwas nach aussen gerichtet sind, im vorderen Drittel mehr oder weniger stark gerundet-verengt, die Scheibe meist violett gefärbt, wenig gewölbt, sehr fein geschuppt, zerstreut und fein punktirt (die Punkte von verschiedener Grösse, ihre Zwischenräume etwas uneben), mit glatter Mittellinie, an den Seiten allmählich zu einem weiten, flachen, stark punktirten Eindrucke übergehend, welcher nach der Basis zu etwas mehr vertieft und hier zugleich dichter, runzelig punktirt ist und den nicht breiten Seitenwulst schwach in die Höhe bebt. Bisweilen geht die starke Punktirung des Seiteneindruckes, namentlich vorn, auf den Wulst selbst über, drückt diesen herunter und reduzirt ihn auf eine schmale Kante am Rande. Fld. in den Schultern breiter als die Basis des Halssch., beim Weibchen stärker als beim Männchen nach hinten erweitert, zur Spitze in starker Wölbung abfallend, dicht, ziemlich tief, aber wenig stark punktirt, die Punkte hie und da gereiht, selten mit einigen deutlich bemerkbaren Längslinien, $Z$ wischenräume polirt, einzeln punktulirt. Jede Fld. hat zwei ziemlich scharf begrenzte, schwarz-violette, selbst schwarze Längsbinden, mit blauem oder grünem Hofe, die innere beginnt dicht binter der Basis an der Innenseite der Schulterbeule in dem Eindrucke, welcher letztere in die Höhe hebt, und läuft, schräg nach innen gerichtet, bis vor die Spitze, wo sie die Naht fast berührt und sich gewöhnlich mit der zweiten 
Längsbinde vereinigt. Diese entspringt dicht neben der höchsten Stelle des Schulterhöckers, etwas nach aussen und hinten von derselben, und zieht sich, dem Aussenrande vollkommen parallel, bis dicht an die Naht hin. Die meiste Aehnlichkeit in dieser Bindenzeichnung findet man bei excellens, allein es bleiben folgende wesentliche Unterschiede übrig: 1. bei liturata läuft die innere Binde weniger der Naht parallel, weil sie am Grunde bedeutenả weiter nach aussen zu beginnt als bei excellens, hinten aber sich der Naht eben so stark nähert, wie bei dieser; 2. die äussere Binde liegt mit ihrem Aussenrande ungefähr auf derselben Linie, welche den Innenrand der Binde bei excellens begrenzt, sie bleibt also durch einen breiten Zwischenraum rom Seitenrande getrennt.

Das Männchen besitzt ein punktförmiges Grübchen in der Mitte des Vorderrandes auf dem letzten Bauchringe. - Der Penis ist am Grunde stark gebogen, davor fast gerade, 3,5 mm lang, an der Oeffnung gerundet erweitert, der vordere Theil schwach löffelförmig, die obere Wölbung der Röhre wird fast in der ganzen Breite, und ron der Basis bis zur Oeffnung durch eine pergamentartige Haut bedeckt.

Die Art ist bis jetzt noch nicht gründlich gesammelt worden, und ich kann daher, nach meinem spärlichen Materiale, nur die ron Suffrian erwähnte unbedeutende Varietät a. anführen, welche durch Zunahme von Blau auf den Rändern des Halssch, , auf dem Kopfe und der Unterseite entsteht. Zuletzt sind die genannten Theile einfarbig dunkel kornblumenblau oder röthlich-riolett.

Findet sich in Krain und auf den Karawanken (Stussiner) im südlichen Kärnthen.

8. Dr. vittigera: Oblongo-ovalis, retrorsum sensim dilatata, minus convexa, viridi-aurichalcea vel -aurea, vitta media elytrom suturaque nigro-violaceis coeruleo cinctis, antennis sat validis. artirulis 2 primis apice rufescentibus, prothorace basi coleopteris paullo anqustiore. fortiter transverso, mimus convexo, lateribus postice subparallelo, antice parum rotundato-angustato, disco sat crebre subtiliter. latera versus fortius punctato, linea media laevi aut elerata aut antice posticeque vage impressa, saepius subcoerulea; callo laterali impressione lata, carioso-punctata, in medio rugulis nommullis eleratis subinternuta terminato, elytris sat crebre profundeque, extrorsum fortius punctatis, lineis nonmullis subelevatis. interstitiis punctorum subconiexis. alutaceis. sparsim punctulatis. - Long. $8-10 \mathrm{~mm}$.

Mas: segmento ultimo ventrali antice linea media vage impresso.

Suffr. Mon. 166. - Kraatz Berl. Zeit. 1859. 279; Monatsbl.

1S80. 36. - Weise l. c. 1S80. 100; Deutsch. Zeit. 1S83. 246.

Var. a. Sutura vittaque media elytrom viridi-coemleis aut rivescentibus. hac lituraeformi, interdum nulla. 
Var. b. Coeruleo-viridis, vitta media elytrorum (plerumque lituraeformi) suturaque violaceis, interdum concoloribus.

? Chr. bifrons Duft. Faun. Austr. III. 193.

Var. c. glacialis: Coerulea aut nigro-cyanea, elytris limbo angusto suturali vittaque media nigris aut saturate violaceis, rarius concoloribus.

Der Umriss des Körpers ist namentlich bei den Weibchen dem von Melasoma aenea recht ähnlich, da die Fld. an den Schultern, die mit hoher Beule versehen sind, nur wenig über die Basis des Halssch. seitwärts hinaustreten und sich von hier aus in einem schwachen Bogen allmählich nach hinten erweitern, so dass der Körper, wenn der geringe Ausschnitt hinter der Mitte des Halssch. bis zu den Schulterecken abgerechnet wird, in einer Flucht von den Vorderecken des Halssch. bis zum Anfange des letzten Drittels der Fld. verbreitert erscheint. Beachtet man ausserdem die eigenthümliche Skulptur, sowie die in der Regel vorhandene, scharf begrenzte Längsbinde der Fld., so ist eine Verwechselung mit den verwandten Arten nicht gut möglich. Von letzteren könnten nur alpestris, mit gleicher Grösse und ähnlichem Körperbau, nnd die meist grössere gloriosa, wegen der ähnlichen Färbung in Betracht gezogen werden. $O$. alpestris hat nun einen weit schwächer abgesetzten, schmaleren und niedrigeren Seitenwulst des Halssch., eine niedrige Schulterbeule, weniger scharf eingestochene, nirgends merklich gereihte, aber nach aussen durch stärkere Runzeln verbundene Punkte der Fld., deren Zwischenräume polirt sind, und nur ausnahmsweise eine Längsbinde; bei gloriosa hat der Körper nie eine Melasomaähnliche Form und die stärkeren Punkte an den Seiten der Scheibe des Halssch. reichen weniger weit nach innen.

Das Halssch. ist glänzender als die Fld., kaum oder sehr fein geschuppt, quer viereckig, die Seiten beinahe parallel oder bis zum vorderen Drittel unmerklich erweitert, davor in mebr oder weniger starker Rundung convergirend, die Oberfläche wenig gewölbt, ungleichmässig nicht dicht mit feinen und dazwischen gemengten grösseren Punkten besetzt, die glatte Mittellinie vorn und hinten schwach aber deutlich vertieft, seltener eben oder in der ganzen Länge sanft gewölbt. An den Seiten der Scheibe werden die Punkte schnell stärker und gehen unmerklich in die sehr grobe, tiefe und runzelige Punktirung des Seiteneindruckes über, welcher hinten tiefer als vorn, in der Mitte durch einige erhabene Runzeln fast unterbrochen ist und den Seitenwulst deutlich emporhebt. Fld. ziemlich dicht, sehr unregelmässig gereiht punktirt; die tief und scharf eingestochenen Punkte stehen in seichten, fast runzelartigen Vertiefungen, welche die deutlich geschuppten und einzelu fein punktirten Zwischen- 
räume etwas in die Höhe heben; sie werden, wie die Punkte, nach aussen zu stärker. Gewöhnlich treten auf jeder Fld. vier schwach erhöhte, von paarigen Punktreihen eingeschlossene Längslinien hervor, die innere liegt in der Mitte zwischen der Schulterbeule und Naht, die beiden folgenden, hinter der Schulter, begrenzen die Längsbinde so, dass der blaue Hof derselben auf ihnen liegt, die äussere endlich befindet sich ein Stück über dem Seitenrande. Der Raum zwischen der inneren und äusseren Längslinie ist hinter der Mitte der Fld. nicht so gewölbt als bei den verwandten Arten, vielmehr etwas flach gedrückt, daher sondert sich der breite Seitensaum auch meist deutlicher vom Rücken der Fld. ab.

Das Männchen hat eine schwach eingedrückte Längslinie auf der vorderen Hälfte des letzten Bauchringes, dessen Hinterrand abgestutzt und in der Mitte nur wenig vorgezogen ist. - Der Penis ist gleichmässig stark gebogen, 3,5 $\mathrm{mm}$ lang, $1 \mathrm{~mm}$ breit, die Spitze durch eine sanfte Ausbuchtung jederseits verschmälert, vorn breit abgerundet, die Oeffnung mässig gross, im oberen Theile von einer gerade vorgezogenen, am Vorderrande tief ausgeschnittenen pergamenthäutigen Klappe bedeckt, der ductus breit, dicht behaart.

Die gewöhnliche Form ist lebhaft metallisch grün, messinggelb oder goldgelb glänzend, ein schmaler Saum an der Naht und eine mässig breite, scharf begrenzte Längsbinde hinter der Schulter bis vor die Spitze der Fld. violett, mit hellblauem Hofe; ausserdem ist auf dem Halssch. der vordere vertiefte Theil der Mittellinie, häufiger noch der hintere Theil derselben blau oder violett angelaufen, oder es befindet sich eine, an den Rändern verwaschene, grosse, blaue bis violette längliche Makel vor dem Schildchen. Nimmt man nun Grün, mit messing- oder goldgelb überzogen, als die Grundfarbe an, so ist diese auf der Längsbinde, der Naht und einem Theile des Halssch. mit den Nebenfarben blau und darüber violett bedeckt, und die Veränderungen gehen ungefäbr in folgender Reihe vor sich:

1. Es verschwindet zunächst die obere Nebenfarbe violett (Naht und Binde blau), später auch die untere Nebenfarbe blau; dann kann der Nahtsaum und die Längsbinde a. noch deutlich, rein grün, am Rande verwaschen hervortreten, wenn die Fld. stark messinggelb bis goldgelb gefärbt sind, oder b. mit dem übrigen Theile der nur goldig angehauchten Fld. gleichfarbig, also unsichtbar sein (Var. a);

2. die Grundfarbe des Körpers wird durch Hinzutritt ron Blau bläulichgrün, Nahtsaum und Längsbinde der Fld. violett (scharf begrenzt oder verwaschen) oder gleichfarbig (Var. b); 
3. Grundfarbe entweder blau, Binde der Fld. violett oder fehlend, oder die Farbe schwärzlich kornblumenblau bis -violett, Längsbinde der Fld. schwarz, häufig fehlend (Var. c).

Es scheint mir hier der passendste Ort, darauf hinzuweisen, dass von allen Arten mit röthlicher Fühlerwurzel auch Stücke vorkommen, bei denen die ersten zwei Fühlerglieder an der Spitze nur noch undeutlich oder nicht mehr roth gefärbt sind, weil diese Ausnahme bei vittigera, namentlich bei ihrer Var. glacialis am häufigsten zu beobachten ist. Man kann die genannte Art und Var. dann leicht mit der habituell und in der Tasterbildung ähnlichen virgulata verwechseln, aber die geschuppten Zwischenräume der Fld. und die tieferen Eindrücke an den Seiten des Halssch. unterscheiden sie bestimmt von derselben; bei den übrigen Arten ist eine Vermengung nicht gut möglich.

In den Centrålalpen stellenweise häufig, z. B. am Simplon in der Nähe des Rossbodengletschers (Spiess), im Berner Oberlande, in Baiern und Tirol; seltener in Kärnthen und Steiermark.

Die Chr. bifrons Duftschm. lässt sich nicht mit Sicherheit auf die Var. b. beziehen, weil sie eine violette Unterseite besitzen soll, eine Färbung, die mir nicht bekannt ist, aber ich wüsste keine Art, auf welche die Beschreibung besser passen würde, als auf die vorliegende.

9. Or. bifrons: Oblonga $(\hat{\odot})$ vel brevius ovalis $(\hat{q})$, convexiuscula, nitida, supra viridi-aenea, interdum sordide aurichalceo-splendens, subtus nigro-chalybaea, aut virescens, antennis gracilibus, articulis (secundo excepto) fortiter elongatis, primis apicem versus rufescentibus : prothorace sat crebre subtiliter punctato, linea media laevi, callo laterali convexo, antrorsum latiore, impressione lata fortius punctata, postice profundiore, plicaeformi, in medio interrupta, terminato; elytris ante apicem depressiusculis, parum fortiter punctatis, interdum lineis nonnullis obsoletis, interstitiis politis punctis minoribus impressis. Long. 8-11 $\mathrm{mm}$.

Mas: segmento ultimo ventrali in medio late et profunde impressa.

Fabr. Ent. Syst. I. 1. 314. - Suffr. Mon. 160. - Kraatz Berl. Zeit. 1859. 279; Monatsbl. 1880. 36. - Baly Trans. ent. Soc. 1879. 179. t. 2. f. 3. - Weise 1. c. 1880. 99; Deutsch. Zeit. 1883. 244.

Chr. monticola Duftsehm. Faun. Austr. III. 167.

Var. a. Stussineri: Margine postico prothoracis, sutura vittaque elytrorum cyanescentibus.

Chr. bifrons var. vittigera Baly 1. c.

Var. b. aerosa: Supra sordide vel saturate cuprea.

Chr. bifrons var. luctuosa Baly l. c.

Var. c. Coeruleo-viridis vel coerulea. 
Subsp. d. decora: Angustior, obsolete coeruleo-viridis, subnitida, disco prothoracis subtilissime punctato, sublaevi, limbo angusto basali cyaneo; elytris crebrius et paullo fortius punctatis, parce longitudinaliter rugulosis, lineis subelevatis evidentioribus (praesertim in mari), interstitiis alutaceis, sutura vittaque media saepe obsoleta cyaneis aut violaceis.

Richter Supplementa Faun. Ins. Eur. 1820. I. p. 7. t. 7. Weise Deutsch. Zeit. 1883. 213 (inclus. Var. virescens Weise 1. c.).

Var. e. aenescens: Eadem, sed tota nigro-viridi-aenea vel fusco-aenea. Suffr. Mon. 161.

Var. f. aurata: Laete viridi-aurichalcea vel -aurea, interdum margine postico prothoracis vittaque media elytrorum viridibus aut cyanescentibus.

Weise 1. c. 213.

Var. g. cyanescens: Tota sordide nigro-chalybaea vel-cyanea, aut elytris vitta media indeterminata nigra.

Weise 1. c. 213.

Durch die Bildung des Körpers, schlankere Fühler, feiner punktirte Fld., sowie die eigenthümliche Vertheilung der Nebenfarbe von den vorigen Arten sehr abweichend; die einfarbige bifrons und die Var. b. und c. sind wegen ihrer stark glänzenden Oberseite, die unter dem blossen Auge wie polirt aussieht, nicht leicht mit einer andern Art zu verwechseln, aber die Varietäten a., d. und f., mit einer Längsbinde auf jeder Fld., werden $O$. gloriosa, und die blauen oder violetten Stücke, welche die Var. g. ausmachen, der alpestris so ähnlich, dass nur ein geübtes Auge die extremsten Formen richtig auseinander halten kann.

1. bifrons Fabr. Länglich $(\hat{\jmath})$, oder sehr breit eiförmig (우), vorn jedoch durch die wulstig aufgebogenen Seiten des Halssch. weniger verengt, mehr viereckig erscheinend, flach gewölbt, oben metallisch grün, bisweilen verschossen messinggelb glänzend, unten schwärzlich stahlblau, grünlich blau oder metallisch grün. Fühler schlank und dünn, beim Männchen bedeutend länger als der halbe Körper, die letzten sechs Glieder schwärzlich, kaum erweitert, jedes einzelne mehr als doppelt so lang wie breit, die ersten 2 bis 4 Glieder unterseits oder an der Spitze röthlich. Halssch. stark quer, ziemlich dicht und fein punktirt, mit unscheinbarer Mittellinie, die Scheibe leicht gewölbt, nach allen vier Ecken hin, aber nicht in der Mitte, abfallend. Hierdurch entstehen zwei Eindrücke jederseits, welche den Seitenwulst vorn und hinten deutlich emporheben, der hintere Eindruck ist (bei Ansicht von hinten) ziemlich breit dreieckig, aussen mässig scharf begrenzt, und auf den tiefsten Stellen mit etwas stärkeren Punkten besetzt; der vordere Eindruck ist sparsamer 
punktirt, sehr veränderlicb, bald den Seiten, bald dem Vorderrande parallel, oder läuft von der Scheibe schräg nach aussen bis über die Augen, er ist entweder gleichmässig schwach vertieft, oder mit einer oder mehreren seichten Gruben versehen. Fld. auf dem Abfalle zur Spitze mehr oder weniger deutlich flach gedrückt, überall mässig dicht und fein punktirt, in der Nähe der Naht wenig schwächer und weitläufiger, die Zwischenräume polirt, mit einzelnen etwas feineren Punkten. Bisweilen sind an verschiedenen Stellen die Punkte durch feine und kurze Längsrunzeln verbunden, dann werden zwischen ihnen meist zwei unordentliche Längslinien sichtbar.

Beim Männchen hat der letzte Bauchring eine grubig vertiefte Längslinie, welche den Hinterrand nicht erreicht; letzterer ist zwar jederseits etwas ausgebuchtet, aber kaum abgestutzt, da der grosse und breite Mittelzipfel weit nach hinten vorgezogen ist. - Penis in der Mitte schwach winkelig nach unten gebogen, $5 \mathrm{~mm}$ lang, $0,8 \mathrm{~mm}$ breit, die Spitze anfangs fast gradlinig verengt, dann mit parallelen Seiten noch ein Stück vorgezogen, so dass sie jederseits sanft ausgebuchtet erscheint. Da die Verschmälerung auf der linken Seite früher beginnt und viel stärker ist als auf der rechten Seite, so ist die unsymmetrische, am Ende schief-abgestutzte Spitze bedeutend nach der rechten Seite gebogen, während der breite, vorn lappig erweiterte ductus nach der linken Seite zu heraustritt.

Bisweilen tritt auf der Oberseite auch als Nebenfarbe ein violettes Blau auf, welches einen schmalen, fast gleichbreiten, vorn schlecht begrenzten Streifen längs des ganzen Hinterrandes (eine ähnliche Zeichnung besitzen oft cacaliae und speciosissima), einen sehr schmalen, wenig in die Augen fallenden Saum an der Naht und auf jeder Fld. eine Längsbinde einnimmt. Diese ist entweder verwaschen, nicht tief gefärbt, oder gut begrenzt, (Stücke vom Ilovca-Walde) schwarzviolett, blau oder grün umsäumt, beginnt mässig breit hinter dem Schulterhöcker und zieht sich, allmählich etwas verschmälert, nach hinten; sie wird an der Seite von der zweiten und dritten undeutlichen, wenig gewölbten Längslinie der Fld. begrenzt, aber auch der Raum zwischen der ersten und zweiten Längslinie ist mitunter dunkler grün, weniger messingglänzend gefärbt als der übrige Theil der Fld. (Var. a). In den Fällen, wo Blau oder Violett auf dem Halssch. der verwandten Arten auftritt, bildet es bei vittigera stets eine längliche Makel vor dem Schildchen, in deren Mitte sich die vertiefte Mittellinie befindet, oder bei gloriosa eine äusserst verwaschene Makel jederseits vor dem Schildchen, wenn es nicht die Scheibe grösstentheils oder ganz überzieht. Bei der nicht seltenen Var. b. ist die Oberseite einfarbig verschossen oder gesättigt kupfer- 
roth, die Unterseite meist schwärzlich blau; grünlich blaue oder blaue Stücke bilden die Var. c.

Im ganzen Alpenzuge, jedenfalls nicht selten, aber verkannt oder übersehen. Die Var. a. von Grintovac in den Karawanken, sowie aus dem Ilovea-Walde in Oberkrain (Stussiner), und in der Schweiz aus dem Val Ferrez (Rätzer), und dem Engadin (Stierlin).

2. decora Richter. Findet sich hauptsächlich in den Sudeten, einzeln auch in den Alpen und steht zu brifrons ungefähr in demselben Verhältnisse wie alpestris zu polymorpha. Sie ist durchgängig schmaler als bifrons, weniger glänzend, der Var. a. ähnlich aber trüber gefärbt, die Scheibe des Halssch. feiner, die Fld. dagegen etwas stärker punktirt, letztere zugleich eine Spur kräftiger gerunzelt, fein geschuppt, auf dem Abfalle zur Spitze, namentlich nahe der Naht, tiefer niedergedrückt, stets mit drei ziemlich regelmässigen paarigen Punktreihen, die je einen sanft gewölbten $\mathrm{Z}$ wischenraum einschliessen; Stücke mit einer Längsbinde, bei bifrons die Ausnahme, bilden hier die Regel. Der Penis ist im Grossen und Ganzen dem von bifrons ährlich, aber die schiefe Spitze ist allmählich, gradlinig und weniger stark verschmälert.

Die Farbe der in Schlesien häufigsten Form ist ein etwas trübes, blasses Schwarzblau, dessen Glanz nur auf dem meist grünlich schimmernden Halssch. stark ist, auf den Fld. aber durch die dichte Punktirung und schwache Runzelung, sowie die beschuppten $\mathrm{Zwischen-}$ räume erheblich abgeschwächt wird; es geht unter Zunahme von Roth in schwarz violett über (Var. g). Von Farbenabänderungen finden sich in Schlesien noch: verschossen-blau- bis schwarzgrüne (die eigentliche decora Richter), und lebhaft grüne, messing- oder goldglänzende Exemplare (Var. f), in den Alpen einfarbig schwarz metallisch grüne oder metallisch kaffeebraune Stücke (Var, e). Der Saum am Hinterrande des Halssch. und eine Längsbinde über die Mitte der Fld., welche fast immer sehr schmal und kurz, meist nur hinter der Schulterbeule sichtbar ist und innen von dem zweiten regelmässigen erhabenen $Z$ wischenraume scharf, aussen verwaschen begrenzt wird, sind bei blauen und violetten Stücken schwarz, bei grünen violett, bei goldglänzenden grün oder violett.

Auf Anthriscus silvestris und Chaeropbyllum aromaticum und hirsutum in der unmittelbaren Nähe der Gebirgsbäche in der zweiten Hälfte des Juli.

Ich habe in der Deutsch. Zeitschr. 1583. 213 die häufigste, blaue Form für decora angesprochen, aber da Richter die Beschreibung nach blaugrünen Stücken aufstellte, so fällt meine Var. virescens mit decor $\alpha$ Richt. zusammen und die blauen decora $\mathrm{m}$. sind am besten bei der Var. cyanescens unter zu bringen. 
10. Or. viridis ${ }^{1}$ ): Ovalis, convexa, alulacea, viridi-aenea, plerumque aurichalceo-vel coeruleo-micans, capite, pectore abdomineque interdum cyanescentibus, antemis parum elongatis, nigricantibus, articulis primis plus mimusve rufescentibus, prothorace postice subparallelo, angulis posticis leniter simutis, antice rotundato-angustato, supra usque ad latera convexiuscula, crebre evidenter punctato, callo laterali obsoleto, depressionibus binis fortiter punctatis vage terminato, elytris sat crebre minus fortiter interstitiisque parce subtilius punctatis. - Long. 7-10 mm. Mas: Minor, nitidiusculus, elytris haud vel vix longitudinaliter rugulosis, segmento ultimo ventrali brevi, linea media antice vage impressa.

Fem: Major, elytris in disco vel totis opacis, punctis aciculato-exculptis.

Duft. Faun. Austr. III. 167 (우). - Redtb. Faun. A. ed. 1. 549 (ㅇ). - Weise Monatsbl. 1880. 100; Deutsch. Zeit. 1883. 246.

Chr. nivalis Heer Mittheil. I. 46. - Suffr. Mon. 163. - Redtb. 1. c. ed. 3. II. 474 (q). - Baly Trans. ent. Soc. 1879. 177. t. 2. f. 4. Var. a. Heeri: Coerulea, lateribus prothoracis virescentibus, elytris smaragdinis.

Suffr. Mon. 164.

Var. b. lugubris: Tota violacea vel nigro-coerulea, elytris interdum suturate nigris, epipleuris saepissime viridi-aureis.

We ise Deutsch. Zeit. 1883. 246.

Var, c. ignita: Aut cuprea, viridi-aurichalceo micans aut ignita.

Comolli Col. nov. Novocom. 1837. 49. - Küster Käf. Eur. 13. 90 (우). - Suffr. Mon. 164. - Weise 1. c. 246.

Var. d. (ㅇ) Omnino ut in O. viridi, sed elytris viridi-aurichalceis, sutura margineque laterali coeruleis, umbra longitudinali lata coeruleo-viridis. Var. e. (ㅇ) mirifica: Elytris aurichalceis, vitta media latissima atra, nigro-coeruleo et viridi-cincta.

Weise 1. c. 244. (Or. decora var.).

1) Die einzige aussereuropäische Art, 9a. Or. basilea Geb1. (Mém. Mosc. 1823. 122; Germ. Ins. Spec. nov. 594) steht zwischen bifrons und viridis etwa in der Mitte; mit ersterer hat sie die langen Fühler, ähnliche, doch gewöhnlich tiefere Eindrücke des Halssch. und die etwas schiefe Penisspitze gemeinsam, die Farbe und die fast matten Fld. des Weibchens erinnern an viridis, von welcher sie sich durch das längere und bedeutend schmalere Halssch. mit tief abgesetztem Seitenwulste und in der Regel sehr gestreckte Fld. unterscheidet. Die F'arbe ist grün, mit messing- bis goldgelbem oder blauem Schimmer; sie geht allmählich in ein einfarbiges lebhaftes Blau oder in gesättigt violett über. Stücke mit 4 breiten, beim $q$ stets tieferen Längs furchen auf den Fld. (die erste am Seitenrande, die zweite hinter der Schulterbeule, die dritte und vierte zwischen dieser und der Naht, sowohl nach der Basis, als auch nach der Spitze hin sich verflachend) die durch drei gewölbte Längsstreifen getrennt werden, bilden die Var. sulcata Gebl. (l. c. 123; Baly Trans. ent. Soc. 1879. 150). L. $7-10 \mathrm{~mm}$. Altai. Daurische Gebirge.

VI. 3. 
Subsp. f. Merkli: Angustior, nigro-coerulea, -violacea aut -cuprea, subtus interdum virescens, lateribus prothoracis valde rotundatis.

Var. g. transsylvanica: Eadem, sed viridi-aenea, aurichalceo vel coeruleo micans.

Die Eigenthümlichkeit dieser Art besteht hauptsächlich darin, dass der Glanz und die Punktirung der Fld. in beiden Geschlechtern sehr verschieden ist, im Baue des Halssch. zeigt sich die meiste Aehnlichkeit mit alpestris, aber der Seitenwulst ist breiter, innen noch undeutlicher abgesetzt, wie bei dieser.

Länglich, die Männchen ziemlich gleichbreit, elliptisch, die Weibchen nach hinten etwas erweitert, mehr eiförmig, gewölbt, dunkel metallisch grün, meist messinggelb oder auch bläulich schimmernd, seltener der Kopf, häufiger Brust und Hinterleib violett angelaufen, die nicht besonders langen Fühler am Grunde schwach metallisch grün, mit röthlicher Unterseite oder Spitze der ersten Glieder, die sechs letzten, etwas verbreiterten Glieder schwärzlich. Halssch. kurz, hinten fast gleichbreit oder nach der Mitte zu sanft erweitert, daror ziemlich stark gerundet-verengt, in den Hinterecken jederseits mit einem leichten Ausschnitte, der durch die Eckpore gebildet wird. Diese ist gewöhnlich grösser, namentlich länger als bei den verwandten Arten, tiefer eingedrückt, meist mit zwei Borsten besetzt, und ihre untere, aufgebogene Randlinie tritt seitlich kaum heraus. Die Oberfläche ist äusserst fein geschuppt, glänzend, dicht und fein, ziemlich tief punktirt, mit schmaler glatter, bisweilen etwas erhabener Mittellinie, schwach aber fast gleichmässig bis zum Seitenrande gewölbt, die Wölbung wird nur ein Stück vor dem Seitenrande jederseits undeutlich durch zwei niedergedrückte, stärker punktirte Stellen unterbrochen, welche den breiten Seitenwulst schlecht begrenzen und wenig in die Höhe heben, am deutlichsten noch dicht an den Hinterecken. Zuweilen sind die den Wulst absetzenden beiden Eindrücke so tief wie bei 0. basilea. Fld. beim Männchen ziemlich glänzend, mässig dicht und stark punktirt, die Punkte stehen in unscheinbaren Runzeln, die sich bald der Quere, bald der Länge nach vereinigen, ohne dass merkliche Längslinien hervortreten, die $Z$ wischenräume etwas feiner aber deutlich punktirt; beim Weibchen sind die Punkte feiner, meist weitläufiger, durch scharfe Nadelrisse, oder auf der Mitte der Scheibe oft durch kräftige Runzeln verbunden, die Zwischenräume so stark mit runden Schüppchen belegt, dass der Glanz dadurch auf dem grössten Theile der Fld. verloren geht; glänzend bleibt gewöhnlich ein breiter Streifen über dem Aussenrande und ein gemeinschaftlicher, breit dreieckiger Raum an der Basis, welcher sich als schmaler Saum an der Naht bis zur Spitze fortsetzt. 
Das kleine Männchen zeichnet sich durch ein sehr kurzes letztes Hinterleibssegment aus, auf dessen vorderer Hälfte die Mittellinie schwach eingedrückt ist. - Der Penis ist stark gebogen, $3 \mathrm{~mm}$ lang, $0,7 \mathrm{~mm}$ breit, vorn schwach verengt und abgerundet, die Oeffnung klein.

Die grüne Farbe des Körpers wird auf der Unterseite, dem Kopfe und auf der Scheibe des Halssch. zuweilen durch Blau verdrängt (Var. a), oder gänzlich durch Violett oder Schwarzblau (Var. b), Kupferroth mit grünlichem Messingschimmer bis gesättigt Feuerroth, öfters mit einer schwachen Beimischung von Violett, ersetzt (Var. c). Von b. giebt es auch Stücke, deren Fld. schwarz sind, doch bleibt der Umschlag in den meisten Fällen grün oder goldig, und ein ähnlicher Schimmer tritt oft auf der Naht und an der Seite unter der Schulter hervor.

Zwei andere Abänderungen betreffen nur Weibchen. Bei diesen kann die Naht und der schmale, aufgebogene Seitenrand der goldiggrünen Fld. blau, ein breiter, wischartiger Längsschatten über die Mitte jeder Fld. bläulich grün sein (Var. d), oder der grösste Theil jeder Fld, ist von einer matten, tief schwarzen Längsbinde eingenommen, welche nach aussen in einen schwarzblauen oder -violetten, hierauf in einen gesättigt grünen schmalen Rand übergeht und nur einen mässig breiten, glänzenden messing- bis goldgelben Saum an allen Seiten frei lässt. Dieser ist über dem Aussenrande gleichbreit, erweitert sich aber vorn plötzlich, indem er den Schulterhöcker umfasst, an der Naht bedeckt er den ganzen Raum bis zum Eindrucke an der Schulter, verschmälert sich nach und nach bis zur Mitte und läuft von hier aus schmal zur Spitze ${ }^{1}$ ).

Eine den Transsylvanischen Alpen (Merkl) und dem Banat (Mehadia, Frivaldszky) eigenthümliche Unterart zeichnet sich durch geringere Grösse, Breite und Wölbung, sowie ein an den Seiten stark gerundetes Halssch. aus. Sie ist in den Siebenbürger Alpen vorherrschend schwärzlichblau, -violett oder -kupferig (f), im Banat metallisch grün, messinggelb oder bläulich glänzend wie viridis (g).

Auf niederen Pflanzen (Merkl) und unter Steinen auf Alpenmatten, nach Rätzer am Sustenpasse (jedenfalls zufällig) auch auf Alnus viridis; die Var. a. und b. selten, d. und e. bisher nur aus den Ostalpen bekannt. Da sich in den Sammlungen überwiegend Weibchen befinden, so ist die Art, die wahrscheinlich auch in die niederen Thäler herabsteigt, seither zu spät gesammelt worden.

1) Diese prächtige Var. wurde von mir a. a. O. irrthümlich zu decora gestellt, weil mir die Uebergangsform d. damals unbekannt war und ich deshalb das Auftreten einer Längsbinde bei viridis bezweifelte. 
B. Endglied der Maxillartaster mässig breit. Fühler einfarbig.

a. Körper metallisch blau oder grūn gefärbt, oder rein schwarz, ohne rothe Beimischung.

11. Or. virgulata: Oblonga, retrorsum vix vel evidenter dilutata. convexiuscula, nigro-cyanea aut-violacea, nitida, interdum linea media prothoracis, sulura umbraque longiludinali elytromum obscurioribus, articulo ultimo palporum maxillarium lato, antermis elongatis apicem versus infuscatis; prothorace transverso, subconvexo, subtiliter punctato, callo laterali fere nullo, depressione fortius punctata vage terminato: elytris sat crebre punctatis, extrorsum obsolete rugulosis. - Long. $7-8,5 \mathrm{~mm}$.

Mas: segmento ultimo ventrali brevi, subconvexo, apice sinuato-truncato. antice linea media vage impressa.

Germar Ins. spec. nov. 596. - Kraatz Monatsbl. 1880. 37.

Chr. alcyonea Suffr. Mon. 156. - Kratz Berl. Zeit. 1859. 283; Monatsbl. 1850. 37. - Baly Trans. ent. Soc. 1879. 182. t. 2. f. 6.

- Weise 1. c. 1880. 101; Deutsch. Zeit. 1883. 213.

V a r. a. Prothorace minus nitido, grosse sed parum profunde, fere variolosopunctato.

Var. b. serena: Coeruleo-viridis, saturate viridi-aenea vel aurichalcea, interdum vitta media obsoleta prothoracis, saepissime sutura umbraque longitudinali elytrorum obscurioribus: violaceis vel viridibus.

Var. c. candens: Sordide aut laete ignita, vitta media prothoracis (interdum), sutura vittaque media lata elytrorum viridi-aeneis, sutura plerumque violacea.

Var d. praefica: Nigro-viridis, violaceo-cupreo micans, vel saturate cuprea leviter cyanescens.

Der Or. speciosissima in jeder Beziehung ähnlich, aber etwas schlanker, weniger gewölbt und an dem Baue des Halssch. und der Form des Endgliedes der Kiefertaster sicher zu unterscheiden. Letzteres ist bei virgulata und den übrigen Arten der 2. Gruppe zwar etwas schmaler als das der meisten Arten aus der 1. Gruppe, tristis und rugulosa vielleicht ausgenommen, aber noch bedeutend breiter und verhältnissmässig kürzer als in der 3. Gruppe.

Lang eiförmig, die Fld. in beiden Geschlechtern bald wenig breiter als die Basis des Halssch. und nach hinten kaum erweitert, fast gleichbreit, bald in den Schultern bedeutend breiter als das Halssch. und nach hinten merklich erweitert, habituell mit Melasoma aenea übereinstimmend. Die Tasterglieder sind um die Hälfte breiter als die von speciosissima; die Fühler ziemlich schlank, mit dem Körper gleichfarbig, nur die letzten fünf stärker behaarten Glieder angedunkelt, mehr schwärzlich. Halssch. kurz, fast doppelt so breit als lang, am Grunde am breitesten, vor den etwas spitz nach aussen vortretenden Hinterecken zuerst sanft ausgebuchtet, hier- 
auf allmählich bis zum ersten Drittel nach vorn schwach und nicht ganz bis auf die Basalbreite erweitert, davor mässig gerundet-verengt, die Oberfläche wenig stark aber beinahe gleichmässig gewölbt, f'ein und zerstreut punktirt, über den kaum wulstig verdickten Seiten mit einem breiten, sanft niedergedrückten und stark punktirten Streifen, welcher die Wölbung in der Regel nicht unterbricht, zuweilen aber dicht am Hinter- und Vorderrande eine Spur tiefer wird. Nicht selten befinden sich auf der Scheibe zwei Grübchen; dieselben sind wenig mehr von einander entfernt, als jedes einzelne vom Seitenrande und stehen oft, aber nicht immer, viel weiter hinten als bei den Arten, bei denen eine ähnliche Bildung vorkommt, z. B. alpestris und decora. Fld, mässig, aber hinten nicht buckelig gewölbt, ziemlich dicht und fein, stärker als das Halssch. punktirt, die Punkte werden in der Mitte der Scheibe stärker und sind an einigen Stellen schwach gereiht, so dass häufiger eine oder mebrere Längslinien auf der inneren Hälfte angedeutet werden; die Zwischenräume sind polirt, mit einigen feinen Pünktchen besetzt und stellenweise von einzelnen feinen Nadelrissen durchschnitten, die von den Punkten ausgehen.

Das Männchen ist klein, aber in der Form nicht vom Weibchen verschieden und an dem sehr kurzen, leicht gewölbten, in der vorderen Hälfte mit einer schwachen Mittelrinne versehenen letzten Bauchringe zu erkennen, dessen Hinterrand in weitem Bogen ausgerandet-abgestutzt ist. - Der Penis ist kurz und breit, $3 \mathrm{~mm}$ lang, etwas über $1 \mathrm{~mm}$ breit, in der vorderen Hälfte flach gedrückt, an der Oeffnung unmerklich erweitert, vorn nicht verengt, sondern in breitem Bogen gerundet abgestutzt, mit einer kleinen Spitze in der Mitte. Die nicht grosse Oeffnung befindet sich ziemlich weit vom Vorderrande entfernt, ihre breiten Seiten sind in leichter Wölbung nach rückwärts gekrümmt, so dass sich unter ihnen, auf der Rückseite, zwei lang ovale Aushöhlungen bilden, die durch einen breiten Mittelkiel getrennt werden, auf dem oben der haarförmige ductus ruht.

Wie bei speciosissima ist nicht selten das ganze Halssch. mit wenig tiefen, aber grossen Punkten besetzt, fein pockennarbig, die Zwischenräume sind leicht gewölbt, stärker geschuppt und matter als bei den fein punktirten Stücken (Var.a).

Die Farbe der von Germar zuerst beschriebenen Form ist dunkelviolett bis dunkelblau; sie verändert sich in blaugrün, gesättigt metallisch grün oder messinggelb (Var. b), verschossen bis lebhaft metallisch feuerroth (Var. c), und bei d. in schwarzgrün, rermischt mit violettem Kupferroth, oder in dunkel und gesätligt kupferroth, in's Violette überspielend, ähnlich der gewöhnlichsten Färbung bei 
Melasoma cuprea. Ganz einfarbige Stücke kommen nur als Ausnahme bei der blauen oder violetten Form, in der Regel jedoch bei der Var. d. vor; sonst ist noch eine Nebenfarbe vorhanden, welche in eigenthümlicher Vertheilung auftritt. Sie nimmt auf dem Halssch. einen breiten, an den Rändern verwaschenen Längsstreifen über die Mitte der Scheibe (bisweilen unterbrochen), einen Saum an der Naht nebst einer Längsstrieme über jede Fld. ein. Der Streifen des Halssch. ist bei blauen, blaugrünen und grünen Exemplaren violett, bei messing- und feuerfarbenen grün, der Nahtsaum fast immer tief violett, selten grün (bei einzelnen Stücken mit messinggelber und feuerrother Oberseite), und die Längsstrieme der Fld. nur wenig dunkler als die Hauptfarbe; daher tritt sie, ausser bei der Var. c., nirgends recht deutlich hervor, sondern erscheint nur als ein leichter Schatten. Derselbe ist etwas schmaler, aber ganz ähnlich gebildet wie bei den 오 von viridis, insbesondere von deren Var. mirifica, denn er beginnt an der Basis jeder Fld. als schmaler Streifen, welcher sich in der Längsgrube an der Innenseite des Schulterhöckers hinzieht, erweitert sich dicht hinter diesem beiderseits und zieht, dem Aussenrande näher als der Naht, aber beiden durchaus parallel, bis kurz vor die Spitze hin. Wie schon erwähnt bildet sich dieser Längsschatten meist nur bei der Var. c. zu einer bestimmten, grünen Binde aus, welche am Rande durch messinggelb in die feuerrothe Grundfarbe übergeht; diese wird, da auch die Naht und der Seitenrand grün gefärbt sind, auf $z$ wei schmale Längsbinden, wie bei excellens, zusammengedrängt.

Von den Pyrenäen durch die Alpen, den Banat, die Transsylvanischen Alpen und Karpathen bis zum Altvater und in das Glatzer Gebirge verbreitet; jedenfalls eben so häufig, wie die anderen Arten, aber bis jetzt nur einzeln gefangen, weil sie mit speciosissima verwechselt wurde.

Da Germar's Beschreibung, nach einem Exemplare mit nicht ganz normaler Skulptur der Fld. entworfen, doch die rorliegende Art zweifellos kenntlich macht, das typische Stück ausserdem von Suffirian ausdrücklich als zu dieser Art gehörig bezeichnet worden ist, so ist die Neubenennung alcyonea entschieden zurück zu weisen.

b. Körper nicht metallisch gefärbt, schwarz, Halsschild und Flügeldecken roth, rothbraun oder pechschwarz.

12. Or. melanocepha (a $\left.{ }^{\mathrm{I}}\right)$ : Oblonga, comexiuscula, nigra, supra subopaca, subtus nilidula, abdominis segmento ultimo, prothorace ely-

1) Vor diese Art gehört Nr. 11 a. Or. Ludovicae Muls. Mém. Ac. Lyon 1854. 18. - nigriceps Fairm. Ann. Fr. 1856. 545; 1565. 69). 
trisque rufis; prothorace brevi, apice profunde sinuatim emarginato quam basi parum angustiore, laleribus rolundatis, angulis omnibus obtusiusculis, anticis haud declivibus, supra parum convexo, alutaceo, inaequaliter punctato, callo laterali lato, impressione haud profunda, fortiter punctata, evidenter terminato; elytris rugoso-punctatis, interstitiis convexis, politis, subtilissine punctulatis. - Long. 9-11 mm.

Mas: segmento ultimo ventrali brevi, apice truncato, utrinque leniter sinuato.

Duftschmid Faun. Austr. III. 170. - Redtb. Faun. A. ed. 1. 549; ed. 3. II. 474. - Kiesenwetter Berl. Zeit. 1861. 392. - Weise Monatsbl. 1880. 100; Deutsch. Zeitschr. 1883. 250.

Chr. nigriceps Suffr. Stett. Zeit. 1861. 432.

Chr. melanocephala Suffr. 1. c. 433 (pars.).

仓. Chr. Peirolerii Bassi Ann. Fr. 1834. 465. t. 11. f. 9. Var. a. Elytris piceis, margine basali et laterali rufescentibus.

Gestreckt, nach hinten allmählich und mässig erweitert, daher im Körperbau der 0 . gloriosa am ähnlichsten, kaum stärker gewölbt wie diese; Kopf, Fühler, Beine und die etwas glänzende Unterseite schwarz. Auf letzterer sind die Seiten der Vorderbrust, Epipleuren der Fld., der Aussenrand der ersten Bauchringe, die hintere Hälfte des vorletzten und der ganze letzte Ring roth. Dieselbe Farbe,

Breviter-ovalis, minus convexa, nigra, nitida; prothorace rufo, magno, apice profunde simuation emarginato quam basi multo angustiore, lateribus fortiter rotundatis, angulis omnibus obtusiusculis, supra minus convexo, subtiliter punctato, callo laterali latissimo impressione parum profunda evidenter terminato, elytris prothorace vix vel haud latioribus, oleo-micantibus, piceis, aut rufo-piceis, sutura, margine basali et laterali rufis, dorso crebre subtiliterque reticulato-punctatis, interstitiis alutaceis et rugulosis; limbo angusto margine apicali segmenti ultimi rufo. - Long. 10-12 mm. Pyrenaei.

Variat disco prothoracis elytrisque nigris, his epipleuris rufescentibus.

Grösser, flacher und bedeutend breiter als melanocephala, überall viel dichter und feiner punktirt, schwarz, das breite Halssch. und ein Saum am Hinterrande des letzten Bauchringes roth; Fld. schwärzlich roth bis pechschwarz, die Naht, ein schmaler, unbestimmter Saum am Vorderrande und ein breiterer, innen verwaschener Saum über dem Seitenrande roth. - Penis $3,5 \mathrm{~mm}$ lang, $1 \mathrm{~mm}$ breit, vor der fast halbkreisförmigen Spitze jederseits eingeschnürt, die Oberseite bis zum Grunde aufgeschlitzt, mit nach vorn immer mehr klaffenden Rändern; der ductus fast bandförmig, der Unterrand vorn plötzlich winkelig erweitert und gerundet abgestutzt, der Oberrand ist kürzer und endet in einem schräg nach hinten aufgerichteten, dreieckig-herzförmigen, unten in zwei grössere Lappen, oben in zwei kurze Spitzen ausgezogenen, hornigen Theile, welcher in der Ruhe die oben offene Höhlung der Penisröhre nach hinten abschliesst.

Bisweilen ist die Scheibe des Halssch. sowie der grösste Theil der Fld. schwarz, die Epipleuren und ein schmaler Raum über denselben röthlich. 
beim lebenden Thiere leuchtend korallenroth, nach dem Tode brüunlich ziegelroth, findet sich auf dem schwach glänzenden Halssch. und den noch weniger glänzenden Fld.

Das Halssch. ist fast doppelt so breit wie lang, der mittlere Theil der Basis in einem sehr flachen Bogen nach hinten vorgezogen, der Vorderrand tiefer als bei den vorigen Arten und über jedem Auge fast winkelig ausgeschnitten, die grösste Breite in oder vor der Mitte, nach vorn etwas stärker als nach hinten verengt, die Seiten gerundet, alle Ecken stumpfwinkelig; die Scheibe wenig gewölbt, äusserst fein geschuppt und mit grösseren und kleineren Punkten,

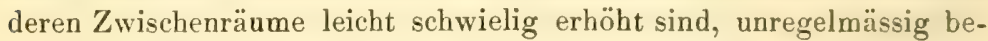
setzt. Die Punkte werden nach dem Hinterrande, namentlich aber nach den Seiten zu stärker, wo die Scheibe allmählich in einen breiten, wenig tiefen Längseindruck übergeht, welcher an der Basis am tiefsten, zugleich den Seiten am nächsten ist und den breiten, aber nicht besonders hohen Seitenwulst überall deutlich absetzt. Die grobe Punktirung dieses Eindruckes greift zuweilen noch ein Stück auf den Wulst über und drückt diesen dann theilweise herab, lässt aber die Hinterecken und die dicken Vorderecken meist frei. Fld. ziemlich dicht, stark und tief runzelig-punktirt, die Punkte stellenweise schwach gereiht, so dass ein oder zwei erhöhte Längslinien auf der inneren Hälfte undeutlich hervortreten; die $Z$ wischenräume gewölbt, fast darmartig gewunden, besonders in dem Raume hinter der Schulterbeule; äusserst fein, kaum sichtbar punktirt und von einzelnen feinen Nadelrissen durchsetzt.

Beim Männchen ist der Hinterrand des letzten, kurzen und gewölbten Bauchsegmentes abgestutzt und beiderseits ausgerandet. Der Penis ist etwas über $3 \mathrm{~mm}$ lang, ror der sehr grossen Oeffnung gerundet-erweitert und hier mehr als $1 \mathrm{~mm}$ breit, sodann ziemlich schnell in einer etwas ausgebuchteten Linie zu der kurzen und breiten Spitze gerundet-verengt. Die breit gedrückte, fast bandförmig scheinende Röhre des ductus liegt rorn stets frei, ihr Unterrand ist am Ende plötzlich breit sichelförmig erweitert, die conrexe Seite nach vorn gerichtet, der Oberrand ist riel kürzer, lippenförmig verdickt.

In der zweiten Hälfte des Juli und im August auf Aronicum glaciale Reichb. und in der Nähe der Scbneefelder unter Steinen im ganzen Alpenzuge.

13. Or. melancholica: Subelongala, comeriuscula, nigra, nitidula, abdominis segmento ultimo et epipleuris elytrom rufescentibus; prothorace sat parvo, apice mimus propunde emaiginato quam basi 
multo angustiore, lateribus postice parum, antice fortius rotundatis, angulis posticis obtusiusculis, anticis subacutis, subdeclivibus, supra sat comvexo, alutaceo, inaequaliter fortius punc/ato, callo laterali fere nullo, postice depressione obsoleta vage terminato, elytris crebre profundeque rugoso-punctatis, interstitiis convexis, politis. - Long. 8-10 mm.

Heer Neujahrbl. Nat. Ges. Zürich 1845. 17. f. 11. - Kraatz Berl. Zeit. 1859. 289. - We is e Deutsch. Zeit. 1883. 246.

? Var. a. Prothorace elytrisque rufis.

Chr. Peirolerii Suffr. Mon. 158. - ? Redtb. Faun. A. ed. 2. 914; ed. 3. II. 474.

Chr. melanocephala Suffr. Stett. Zeit. 1861. 433 (pars.)

+. Fast noch schmaler als die $\hat{\jmath}$ der vorigen, das Halssch. kleiner, rorn viel schmaler, auch weniger tief ausgeschnitten, die Seiten ebenfalls gerundet, aber nach vorn bedeutend stärker, nach hinten schwächer wie beî melanocephala, die Oberfläche sparsamer und kräftiger punktirt, höher gewölbt, gleichmässig bis zum Seitenrande abfallend, der Seitenwulst nur dicht vor den stumpfen Hinterecken angedeutet, wo er durch eine Depression undeutlich in die Höhe gehoben wird. Die Vorderecken sind ziemlich spitz, an die Seiten des Kopfes gedrückt, und der Raum über ihnen ist flach, abschüssig, nicht wulstig emporstehend. Die Fld. endlich sind glänzender und besitzen eine dichtere und viel tiefere Punktirung und Runzelung, zwischen welcher eine Anzahl rippenartiger Längslinien zum Vorschein kommen.

Das Thier ist schwarz, der letzte Bauchring ganz roth, oder mit einer breiten, schwarzen Makel auf jeder Seite am Vorderrande, der Umschlag der Fld. röthlich.

Obgleich ich von dieser Art bis jetzt nur 2 우 gesehen habe, welche Herr Pfarrer Rätzer aus Büren am Sustenpasse gesammelt und das eine für meine Sammlung freundlichst überlassen hat, so glaube ich doch, dass sich die hier angefübrten Unterschiede noch sicherer als specifische erweisen werden, sobald Männchen bekannt sind; denn von den vielen mir vorliegenden Stücken der melanocephalc zeigt auch nicht eins die Neigung zu einer ähnlichen Bildung des Halssch. Aus der guten Beschreibung ron Peirolerii Suffr. Mon. 158 schliesse ich, dass Suffrian dabei Stücke von melancholica aus den österreichischen Alpen, mit rothem Halssch. und rothen Fld. ror sich gehabt hat, die ich nicht kenne und deshalb oben nur fraglich als Var. a. anführen konnte; dieselben bringt er in seiner späteren schlechten Arbeit (Stett. Zeit. 1861. 429-437) als kleine, unvollkommen ausgebildete! Exemplare zu melanocephala.

14. Or. plegiata: Oblongo-ovalis, comexa, niyra, nitida, prolhorace, coleopteris, villa communi abbreviata excepta, anoque rufis; illo 
brevi, modice convexo, subtiliter et inaequaliter (interdum subruguloso) punctalo, apice quam basi angustiore, lateribus postice subparallelo, angulis posticis rectis, acutis, callo laterali obsoleto impressione haud profunda (in medio plerumque interrupta) vage terminatn. elytris sat fortiter punctatis, extrorsum rugosis, interstitiis politis, sparsin punctulatis. - Long. 8-10 mm.

Mas: abdominis segmento ultimo apice truncato.

Suffr. Stett. Zeit. 1S61. 436. - Kiesenwetter Berl. Zeit. 1869. 308. - Weise Monatsbl. 1880. 101; Deutsch. Zeit. 1883. 250.

- Fuss Verh. Siebenb. Verein. 1861. 161.

Chr. melanocephala (var.) Suffr. Mon. 179. - Fuss 1. c. 1852. 136. ? Var. a. commutata: Vitta communi nigra coleopterorum deficiente. Suffr. 1. c. 1861.435.

Chr. melanocephala Suffr. Mon. 178.

In der Grösse, Gestalt und Punktirung, sowie dem Glanze der Oberseite am meisten mit $O$. alpestris übereinstimmend; glänzender, hinten höher gewölbt und auf den Fld. in ganz anderer Art punktirt wie melanocephala und die beiden anderen, nicht metallisch gefärbten Arten der 2. Gruppe, von denen sie leicht zu trennen ist.

Länglich-eiförmig, mit wenig (3)), oder stark nach hinten erweiterten Fld., ziemlich glänzend, schwarz, der After röthlich, Halssch. und Fld. (letztere mit Ausnahme einer gemeinschaftlichen breiten, vorn und hinten verschmälerten und abgekürzten schwarzen Nahtbinde) im Leben leuchtend korallenroth, nach dem Tode bräunlich rothgelb, ungefähr wie Entomoscelis sacra. Kopf und Halssch. äusserst fein geschuppt, dieses fast doppelt so breit als lang, von den scharfen, rechtwinkeligen Hinterecken nach rorn in fast grader Linie unmerklich erweitert, die Seiten fast parallel, die grösste Breite etwa im ersten Drittel, davor stark gerundet verengt. Die Oberfäche mässig gewölbt, ziemlich dicht und fein ungleich punktirt, die $\mathrm{Z}$ wischenräume eben oder schwielig erböht. Der Seitenwulst ist breit, ron einem schmalen und nicht tiefen, in der Mitte beinahe unterbrochenen Eindrucke begrenzt, wenig gewölbt oder theilweise niedergedrückt. Fld. ziemlich dicht und tief, aber nirgends scharf punktirt, die Punkte in der Nähe der Naht feiner, durch schwache Runzeln verbunden, nach den Seiten zu allmählich stärker, in tieferen Runzeln stehend, ihre Zwischenräume leicht gewölbt, polirt und vereinzelt fein punktulirt.

Das Männchen hat eine schwach eingedrückte, bisweilen nur durch zwei Grübchen angedeutete Mittellinie auf dem letzten Bauchringe, welcher am Hinterrande fast gerade abgestutzt ist, lässt sich aber durch geringere Grösse und das sehr breite erste Tarsenglied stets sicher rom Weibchen trennen. - Der Penis ist dem ron 
Ludovicae ähnlich, etwas kürzer und breiter, sein ductus schmaler, mit regelmässig herzförmigem Oberrande der Oeffinung.

Die gemeinschaftliche schwarze Nahtbinde der Fld. variirt in der Länge und Breite, und es ist daher nicht unwahrscheinlich, dass sie ganz verschwinden kann; nach solchen Stücken dürte die mir unbekannte $O r$. commutata Suffr. von Tröpolach in Kärnthen beschrieben worden sein (? Var. a), wenigstens vermag ich aus den von Suffrian selbst als ,fein" bezeichneten Merkmalen einen positiven Unterschied von plagiata nicht heraus zu lesen.

Im Juli auf Doronicum austriacum Jacq. im ganzen Karpathenzuge von der Babia Gora (Kiesenwetter, Stobiecki) bis in die Transsylvanischen Alpen (Fuss) und, die Bestätigung meiner Ansicht über O. commutata rorausgesetzt, auch in Kärnthen; auf dem AltvaterGebirge, wo die Nährpflanze ganze Bergwände überzieht, z. B. den Peterstein und die Kessel, ist das Thier trotz des eifrigsten Nachsuchens noch nicht gefunden worden.

C. Endglied der Maxillartaster schmal, kegelförmig, Fühler einfarbig.

15. Or. cack $\boldsymbol{c}$ ia $\left.\boldsymbol{e}^{1}\right):$ Oblongo-ovalis, postice parum dilatata, convexiuscula, aurichalceo-viridis, nitens, limbo angusto basali prothoracis, sutura vittaque lata, opaca elytrorum, pro- et mesosterno lateribusque metasterni et abdominis cyaneis aut violaceis; prothorace minus crebre inaequaliter punctato, lateribus postice subparallelo (plerumque ante angulos posticos acutos sinuato), antice paulatim angustato, callo la-

1) Vor dieser Art ist einzureihen 14a. Or. splendidula Fairm. (Ann. Fr. 1865. S1) aus den Pyrenäen. Schlanker als speciosissima, die $\hat{\odot}$ sehr schmal, das Halssch. dicht und fein punktirt, fast gleichmässig bis zum Seitenrande gewölbt wie bei virgulata, der Wulst daher nur durch einen stärker punktirten unmerklichen Eindruck abgesetzt, aber kaum in die Höhe gehoben; Fld. deutlich geschuppt, ziemlich dicht, mässig stark und meist unordentlich gereiht punktirt, wenigstens mit ein bis zwei deutlich herrortretenden paarigen Punktreihen über dem Seitenrande, welcher der ganzen Länge nach aufgewulstet ist. Oberseite glänzend, ohne Erböhungen auf den Fld. ( $\hat{\odot})$, oder die Fld. von mehreren schwachen Längsrippen durchzogen und auf dem grössten Theile der Scheibe matt. L. $7-9 \mathrm{~mm}$.

Der Körper ist grün, mit Messingschimmer, die Scheibe des Halssch., die Naht der Fld. und die Seiten der Brust oft bläulich grün, oder blau bis violett, die Basis und der Seitenwulst der Fld. meist goldgelb. Die Farbe ändert ab: Var. Fairmairei: Schwarzblau bis einfarbig schwarz.

H. Gozis hat sich die unnütze Mühe gemacht, den Namen der Art in Fairmairiana umzuändern, wegen Chrys. splendidula F. aus Sumatra, die jedenfalls gar nicht zur Gattung Chrysomela gebört. 
terali sat crasso, interne fortiler punctulo impressione profundu terminato; elytris minus crebre aciculalo-megoso-punclatis. - Long. 8-11 mm.

Mas: abrlominis segmenio ultimo brevi, linea media vage impresso, apice truncalo utrinque leniter simuato; articulo primo tarsorum fortiter dilatuto.

Femina: segmento ultimo longiore apice evidenter bisinuato et in medio triangulariter producto, articulo primo tarsorum elongato.

Schrank Füessl. Neu. Mag. II. 4. 1785. 317: Faun. boic. 527. - Oliv. Ent. V. 545. t. 7. f. 109. - Suffr. Mon. 150. Kraatz Berl. Zeit. 1859. 283; Monatsbl. 1880. 37. - Baly Trans. ent. Soc. 1879. 184. t. 2. f. 8. - Redtb. Faun. A. ed. 3. II. 476. - Weise 1. c. 1880 101; Deutsch. Zeit. 1883. 250. Chr. gloriosa Germ. Ins. spec. nov. 595.

Var. a. coeruleolineata: Eadem, sed colore primario plus minusve cyaneo-micante; elytris interne minus nitidis.

Duftschm. Faun. Austr. III. 169. - Redtb. 1. c. ed. 1. 550.

Var. b. sumptuosa: Saturate coerulea, cyanea aut violacea, elytris tenuiter punctatis, plerisque subopacis, basin versus nitidiusculis, aut unicoloribus aut umbra longitudinali obscuriore.

Redtb. 1. c. ed. 1. 550.

Chr. tristis Duftschm. 1. c. III. 165. - Suffr. Mon. 154. - Kratz 1. c. $283 .-W$ eise 1. c. 101 .

Var. c. tussilaginis: Eadem, elytris parum sed evidenter nitidulis.

Suffr. Mon. 155. - Kraatz 1. c. 283.

Var. d. nubigena: $U$ t in b, sed elytris sordide viridibus aut oliraceis, subopacis, saepe umbra longitudinali cyanescente, vel elytris fere omnino nigricantibus.

Var. e. macera: Subelongata, obsolete aurichalceo-viridis, parum micans, prothorace interdum limbo tenui basali elytrisque sutura violaceis, his paullo fortius punctatis plerumque etiam umbra longitudinali coerules. cente aut virescente.

Subsp. f. senecionis: Minor, magis nitida, tota coerulea, elytris paullo profundius punctatis, obsoletius rugulosis.

Schummel Arb. Schles. Ges. 1S43. 198. - Suffr. Mon. 153.

- Kraatz l. c. 284. - Weise Monatsbl. 1880. 101; Deutsch. Zeit. 1883. 214.

Var. g. cyanipennis: Supra vel tota saturate rubro-cyanea.

Weise 1. c. 1883 . 215.

Var. h. tristicula: Supra olivaceo-nigra.

Weise 1. c. 215.

Var. i. fraudulenta: Supra aut ommino lacte viridis, plus minusie aurichalcea.

W eis e 1. c. 215 .

Die am weitesten verbreitete und an allen Fundorten gemeinste, daher bekannteste Art, in den breitesten Stücken an pretiosa, in den schmalen an gloriosa, in den kürzesten an speciosissima erinnernd 
von den beiden ersten durch die dünnen Taster und einfarbige Fühler, von der letztgenannten durch die Punktirung, sowie die Lage und Form der Längsbinde auf den Fld, verschieden.

Länglich oval, nach hinten etwas erweitert und gewölbt, glänzend grün, mehr oder weniger stark messinggelb, selten schwach und verschossen goldig roth; ein Saum am Hinterrande des Halssch., dessen Scheibe bei seitwärts einfallendem Lichte oft ganz bläulich erscheint, die Naht und eine breite matte Längsbinde der Fld., Vorder- und Mittelbrust, sowie die Seiten der Hinterbrust und des Bauches kornblumenblau bis schwärzlich violett.

Maxillartaster dünn, ihr vorletztes Glied aus sehr schmaler Basis nach der Spitze hin allerdings stark erweitert, aber doch viel weniger, als bei den Arten der ersten Gruppe, das letzte Glied erreicht an der breitesten Stelle, näher der Basis als der Spitze, nicht ganz die Breite des vorhergehenden, und ist nach vorn bedeutend verschmälert, nicht ganz doppelt so lang als breit. Halssch. etwa nur ein Drittel breiter als lang, hinten fast parallel, indem die sanft ausgeschweiften Seiten, welche in den spitzen Hinterecken nach aussen gerichtet sind, sich bis vor die Mitte unmerklich erweitern, im vorderen Drittel ziemlich schnell, aber nicht stark gerundet-verengt, mit scharfen Vorderecken. Scheibe wenig gewölbt, nicht dicht und in sehr verschiedener Stärke ungleichmässig punktirt, die Zwischenräume der Punkte bald wie polirt, eben, glänzend, bald deutlich geschuppt, schwielig gewölbt, ziemlich matt; der Seitenwulst dick, innen von einem kräftigen Eindrucke abgesetzt, der den Seiten beinahe parallel läuft und mit seiner starken Punktirung auf die innere Hälfte des Wulstes übergreift. Fld. hinter der Schulter leicht eingeschnürt, mässig stark aber nicht dicht punktirt, die Punkte durch feine, wie mit einer starken Nadel eingeritzte Runzeln mehr der Quere als der Länge nach verbunden; dazwischen treten auf der Nahthälfte zwei undeutliche, aber doch meist gut aufzufindende Doppelreihen von Punkten hervor, die vorherrschend durch Längsrisse vereinigt sind und je eine kaum gewölbte Längslinie einschliessen. Die äussere derselben, welche vom Eindrucke an der Innenseite des Schulterhöckers bis vor die Spitze läuft, bildet stets die innere Grenze der matten Längsbinde. Diese nimmt ungefähr ein Drittel von der Breite jeder Fld. ein, liegt aber dem Seitenrande näher als der Naht, und zieht sich von der Vertiefung hinter der Schulterbeule, allmählich heller gefärbt und verwaschener begrenzt bis zum Abfalle vor die Spitze. An den Tarsen ist das erste Glied länger als die beiden folgenden zusammen, das zweite sehr klein, das dritte breiter ( $($ ) oder deutlich schmaler $(\hat{\sigma})$ als das erste; die Art unterscheidet sich 
demnach von den vorhergehenden durch die bedeutendere Länge and Breite des ersten Gliedes in Verbindung mit dem verhältnissmässig kleinen dritten Gliede.

Beim Männchen ist der letzte Bauchring mässig lang, fast gerade abgestutzt, jederseits unmerklich ausgerandet, mit einer schwach eingedrückten Mittellinie, beim Weibchen gewöhnlich auf jeder Seite quer eingedrückt, am Hinterrande beiderseits deutlich ausgeschnitten und der mittlere Theil als dreieckige Spitze weit rorgezogen. Der Penis ist $3,3 \mathrm{~mm}$ lang, ziemlich flach, gleichmässig gebogen, bis zur Oeffnung allmählich gering verbreitert, hierauf mit stumpfen Ecken schnell verengt und endigt in einer langen, vorn abgerundeten Spitze.

Von dieser Art lassen sich 3 Hauptformen unterscheiden: die erste, cacaliae, ist gross, ziemlich breit, die Fld. entweder glänzend und dann stets mit einer Längsbinde, oder matt, die Längsbinde kaum oder nicht bemerkbar; die zweite ist eben so gross, aber sehr schlank, auf den Fld. weniger glänzend, mit rerwaschener, gleichsam von der Grundfarbe überdeckter Längsbinde; die dritte, senecionis, ist durchschnittlich kleiner, gleichmässig glänzend, nie mit einer Längsbinde auf den Fld.

1. cacaliae. Zuweilen sind die Seiten des Halssch. (in den hinteren zwei Dritteln) durchaus geradlinig und nicht ausgeschweift, in seltenen Fällen auch stark gerundet und nach hinten nur wenig schwächer als nach rorn verengt (einzelne Stücke aus den Seealpen); der den Wulst absetzende Eindruck ist oft vor der Mitte grubig vertieft.

Farbe und Glanz der Oberseite variiren an den verschiedenen Fundorten sehr, an der einzelnen Lokalität wenig. Die am lebhaftesten gefärbten, glänzendsten Exemplare finden sich vorherrschend in mässiger Höhe in den Ostalpen, Steiermark, Kärnthen, Krain, Görz und Tirol, sowie in den Bairischen Alpen, auf dem Schwarzwalde und den Vogesen; bei ihnen breitet sich allmählich die Farbe der Längsbinde über den grünen, messinggelb glänzenden Streifen an der Naht vom ersten Drittel bis zur Spitze der Fld. aus und überzieht ihn mit einem matten, bläulichen Hauche (Var. a); in der Folge wird auch der ganze Streifen über dem Seitenrande hinter der Schulter damit bedeckt, und es bleibt von der glänzend grünen, nach und nach immer stärker zu Blau hinneigenden Grundfarbe nur noch ein Raum an der Basis übrig. Das Halssch. ist auf der Scheibe gänzlich blau bis violett. Diese Form bildet den Uebergang zu der in den centralen Hochalpen, besonders in der Näbe der Gletscher bäufigen, meist einfarbig blauen (genau wie das bekannte Berliner 
Blau) bis schwärzlich violetten Var. b., welche seit Duftschmid ohne Grund auf tristis Fabr. bezogen worden ist und für die ich den ältesten Namen sumptuosa Redtb. wieder aufnehme. Bei ihr sind die Fld. mit Ausnahme der Basis oder wenigstens des Schulterhöckers matt, feiner nadelrissig punktirt wie die von cacaliae, auch scheint der duftartige blaue Ueberzug weniger fest $\mathrm{zu}$ sitzen, weil er oft, selbst bei lebenden Thieren, an einzelnen Stellen abgerieben ist und die stark glänzende Chitinschale der Fld. durchblicken lässt. Aehnliche matte, aber grüne, olivenfarbige bis schwarze Exemplare bilden die Var. d.; für die eine Spur glänzenderen blauen bis schwarz violetten Stücke, deren Flügeldeckenüberzug nicht reifartig erscheint (Var. c., aus den Pyrenäen, vereinzelt in den Alpen) beanspruchte Suffrian zwar Artrechte, aber seine Ansicht ist seit der Arbeit von Kraatz von allen einsichtigen Entomologen als irrig erkannt worden, da es nicht möglich ist, eine Grenze $z$ wischen ,mehr oder weniger matt" zu ziehen. Bei den Abänderungen b. bis d. zeichnet sich gewöhnlich der Raum hinter der Schulterbeule, auf dem bei cacaliae die Längsbinde liegt, durch etwas dunklere Färbung aus.

2. macera. Sehr schlank, wie gloriosa, die Fld. auch beim 우 wenig breiter als die Basis des Halssch. und durchschnittlich kräftiger punktirt als bei cacaliae; grün, mehr oder weniger (etwas verschossen) messinggelb, nicht lebhaft glänzend, der Hinterrand des Halssch. zuweilen, die Naht der Fld. in der Regel blau oder violett, ausserdem ein kurzer Längswisch hinter der Schulter dunkler: bläulich oder grünlich.

Auf der Choralpe von H. Baron ron Tiesenhausen in Bozen gesammelt.

3. senecionis. In den Sudeten und Karpathen zu Hause, im Allgemeinen kleiner wie die beiden rorstehenden Formen und durch die gleichmässig glänzenden bindenlosen Fld., deren schärfer begrenzte, tiefere Punkte weniger durch Nadelrisse als durch schwach eingedrückte Runzeln verbunden sind, von ihnen zu unterscheiden. Die verbreitetste Färbung ist auf der Oberseite ein blasses Blau, oft mit metallisch grünem Schimmer, auf der Unterseite, namentlich an den Beinen, blaugrün bis goldig grün, Kopf und Halssch, zuweilen wenig lebbaft grün, mit Messingglanze, ohne blaue Beimischung. Von bemerkenswerthen Abänderungen kommen häufig vor: Var. g. Oberseite oder der ganze Körper gesättigt roth-violett, Halssch. ab und zu blaugrün; Var. h. Oberseite sehr dunkel olivengrün bis fast schwarz, von der Seite betrachtet bläulich schimmernd, der Eindruck über dem Seitenrande an der Schulter nicht selten lebhaft grün; Var. i. Oberseite oder der ganze Körper grün, messing- 
gelb schimmernd, einfarbig, oder die Scheibe des Halssch, und die Naht mit violettem Anfluge.

Auf Senecio- und Adenostyles-Arten rom Juni bis in den August.

16. Or. speciosissima: Wvalis, retrorsum paullo dilatata, convexa, laete viridis, aurichalcea vel aurata, nitida, limbo basali prothoracis, sutura vittaque angusta elytrorum nigro-violaceis, coeruleis, vel virescentibus, subtus plus minusve coerulescens; prothorace brevi, disperse subtilissimeque punclato, lateribus postice subparallelo, antice rotundato-anyustato, callo laterali crasso, impressione profunda, fortiter punctata, ante medium plerumque extrorsum cumata terminato, elytris crebre sat subtiliter punctatis, interstitiis politis. - Long. 6,5-10 mm.

Mas: abdominis segmento ultimo linea media vage impresso, apice truncato, articulo primo tarsorum dilatato.

Scopoli Ent. Carn. 74. - Suffr. Mon. 142. - Letzner Arb.

Schles. Ges. 1852. 1. - Kraatz Berl. Zeit. 1859. 286. Baly Trans. ent. Soc. 1879. 186. t. 2. f. 9. - Redtb. Faun. A. ed. 3. II. 475. - Weise Monatsbl. 1880. 101; Deutsch. Zeit. 1883. 214.

Chr. gloriosa Duftschm. Faun. Austr. III. 168 (pars.). - Redtb. l. c. ed. 1. 550 .

Chr. speciosa Germ. Ins. spec. nor. 596. - Schummel Arb. Schles. Ges. 1843. 195.

Chr. speciosissima var. cupreoviridis, pretiosa et-viridis, Letz n. I.C Var. a. Let zeri: Eadem, sed supra ignita. splendida, rarius subopaca.

Weise 1. c. 1883. 214.

Chr. spesiosissima var. ignita Letzn. l. c.

Var. b. viridescens: Supra omnino saturate viridis, interdum aurichalceo-splendens.

Suffr. Mon. 143. - Letzn. 1. c.

Var. c. Schummeli: Supra coerulea interdum vividi-micans, sutura vittaque elytrorum violaceis.

We is e 1. c. 214.

Chr. tristis Oliv. Ent. V. 550. t. 1. f. 12. - Letzn. 1. c. et var. coerulescens et nigrocoerulea.

Var. d. violacea: Supra vel ommino nigro-violacea, plerumque disco prothoracis sulura vittaque elytrorum nigris.

Letzner 1. c.

Var. e. fuscoaenea: Supra fusco-aenea.

Schummel 1. c. 196.

Chr. speciosissima var. fuscocuprea et nigroaenea Letzn. 1. c.

Var. f. nigrescens: Supra vel omnino nigra.

Letzner 1. c. - Weise 1. c. 214.

Var. g. Prothorace sat fortiter et inaequaliter punctato, minus nitido, interstitiis punctorum plus minusve convexis.

Var. h. Supra leviter opaca. 
Var. i. Rufo-picea, elytris mfis, antennis pedibusque mfo-testaceis.

Subsp. k. silesiaca: Brevis, fortius comvexa, supra nigro-aut saturate viridis, interdum viridi-aurichalcea, elytris rarius villa obsoletissima obscurata, prothorace saepissime ut in $g$.

Chr. fusco-aenea Suffr. Mon. 141. - Letzn. 1. c. - Weise 1. c. 1880. 101.

Subsp. 1. juncorum: Statura fere O. speciosissimae, sed angustior, minus convexa, humeris magis promimulis, callo laterali prothoracis haud crasso, impressione fortiter punctata haud profunda terminato; supra salurate viridis, leviter aurichalcea, sat nitida, sublus viridis, subcoerulescens.

Suffr. Mon. 144. - Kraatz I. c. 1859. 287.

Subsp. m. carpathica: Supra tota coerulea, violacea aut nigro-cuprea, elytris crebrius et tenuiter punctatis.

Kra atz 1. c. 1859. 288.

Subsp. n. convergens: Praecedenti paullo longior, magis parallela, lateribus prothoracis antrorsum sensim convergentibus, callo laterali crasso, interne impressione profunda, parce punctata terminato; supra viridis, coerulea aut violacea, sutura vittaque obsoleta elytrorum obscuratis.

Suffr. Mon. 145 . - Kraatz 1. c. 294.

Var. o. pyrenaica: Eadem, sed tota nigra.

Subsp. p. troglodytes: Oblongo-ovalis, retrorsum plerumque fortiter dilatata, minus convexa, nitidiuscula, obsolete aurichalcea, fusco-aenea, viridis vel cyanescens, prothorace sat parvo, plerumque fortius inaequaliter punctato, elytris crebrius ruguloso-punctatis, sulura vittaque obsoletissima virescentibus aut cyanescentibus.

Kiesenwetter Berl. Zeit. 1861. 391.

Durchschnittlich kleiner, breiter und höher gewölbt als die vorige, der Wulst des vorn schmaleren Halssch. dicker, innen deutlicher begrenzt, die Fld. nach hinten mehr erweitert, viel dichter, aber nicht nadelrissig punktirt. Eiförmig, gewölbt, glänzend und lebhaft grün, nach messinggelb oder goldgelb übergehend, ein Saum am Hinterrande des Halssch., die Naht und eine schmale, scharf begrenzte Längsbinde der Fld. schwarzviolett, blau gesäumt, oder (bei weniger scharfer, oft sehr verwaschener Begrenzung) blau oder grünlich. Die Unterseite ist, mit Ausnahme der Beine, mehr bläulich metallgrün, bei Stücken mit scharfer, tief violetter Binde der Fld. in der Regel längs der Mitte grün, messingglänzend, an den Rändern der Brust und des Bauches violett.

Halssch. stark quer, in der Regel vom Grunde bis zum vorderen Drittel unbedeutend verengt, fast gleichbreit, davor stärker verschmälert, die Hinterecken fast rechtwinkelig, aber nie so scharf und weit heraustretend wie bei cacaliae, oft sogar etwas eingezogen.

VI. 3. 
Die Scheibe nur nach vorn stärker abwärts gewölbt, zerstreut und sehr fein punktirt, glänzend; an der Seite geht sie in einen tiefen, kräftig punktirten Eindruck über, welcher gewöhnlich bis zur Mitte gerade nach vorn läuft, hier etwas nach innen biegt und ron einer leicht erhabenen Falte undeutlich unterbrochen wird, daror sich zuerst grubenförmig vertieft, und dann flacher bis zum Vorderrande hinzieht. Der Seitenwulst ist breit und hoch, nur an der grubenförmigen Vertiefung des absetzenden Eindruckes verengt und mit einigen stärkeren Punkten versehen. Fld. hinter der Schulter eingeschnürt, dicht und ziemlich fein punktirt, mit polirten, einzeln fein punktulirten Zwischenräumen. Die Längsbinde ist der ron vittigera am ähnlichsten; sie beginnt schmal hinter der Schulterbeule, erweitert sich bald darauf etwas, ist aber schon von der Mitte der Fld. ab wieder allmählich verengt und endet ein Stück vor der Spitze. Ihre äussere Grenzlinie läuft dem Seitenrande ziemlich parallel, aber die innere ist schwach wellig gebogen und der Naht nicht parallel wie bei cacaliae, ebenso erreicht die Binde in den seltenen Fällen, wo auf den Fld. zwei schwach gewölbte Längslinien hervortreten, höchstens an der breitesten Stelle vor der Mitte die äussere dieser Linien, dahinter biegt sie sich stark nach aussen. Von den Tarsen ist das erste Glied, namentlich an den Hinterbeinen, merklich kürzer als bei cacaliae, beim 우 schlank, beim of breit.

Das Männchen erkennt man am abgestutzten letzten Bauchringe, auf dem die Mittellinie schwach eingedrückt ist. - Penis $3 \mathrm{~mm}$ lang, gleichbreit, vorn gleichmässig in eine kurze dreieckige Spitze verschmälert.

Diese Art ist unstreitig die veränderlichste in der ganzen Gattung und in den einzelnen Hauptformen mit Chrysomela lichenis, Or, virgulata, cacaliae und den beiden folgenden Arten ungemein leicht zu verwechseln; daher ist eine Untersuchung des Penis dringend zu empfehlen, wenn alle $Z$ weifel beseitigt werden sollen.

1. speciosissima. In den niederen Thälern der Alpen (besonders der östlichen Hälfte), im Schwarzwalde, in Thüringen, dem Böhmerwalde und den Sudeten. Die Grundfarbe des Saumes am Hinterrande des Halssch., der Naht und der Längsbinde der Fld. ist grün, darauf liegt in abnehmender Breite Blau und Violett, deshalb besteht die vollständig ausgeprägte Zeichnung aus einem violetten (zuweilen schwärzlichen) Kerne, welcher nach aussen zuerst in ein schmales blaues, dann in ein grünes Streifchen übergeht. Letzteres kann natürlich nicht zu sehen sein, wenn die Hauptfarbe der Flu. selbst ein reines Grün ist. Zuweilen fehlt nun der violette Keril, oder die darunter folgende Farbe Blau theilweise oder ganz. 
Die Grundfarbe der Oberseite ändert ab:

a. brennend roth, selten der Saum des Halssch., häufiger Naht und Längsbinde der Fld. allein mit blauem oder violettem Kerne (Thüringer Wald: Beerberg, Schneekopf und Kickelhahn, Sudeten. Einzelne Stücke aus den Alpen, die hierher gezogen werden könnten, sind durchschnittlich weniger glänzend und nicht so lebhaft gefärbt, etwas verschossen);

b. gesättigt grün, bisweilen messinggelb schimmernd, Längsbinde der Fld. kaum bemerkbar (Schlesien);

c. bläulich grün bis rein blau, Zeichnung violett;

d. dunkel violett, der Agelastica alni ähnlich, meist die ganze Scheibe des Halssch., die Naht und Längsbinde der Fld. schwarz;

e. dunkelbraun (wie gebrannter Kaffee) mit mehr oder weniger starkem Messingschimmer;

f. schwarz.

Die Stammform und ibre Varietäten a. und b. gehören beinahe ausschliesslich der niederen Region des Gebirges an und zeichnen sich durch ein vorwiegend fein punktirtes, glänzendes Halssch. aus; bei den folgenden Abänderungen, die höher leben, ist das Halssch. oft stärker und fast runzelig, aber sehr ungleichmässig punktirt, matter, die $Z$ wischenräume der Punkte sind schwielig gewölbt (Var.g). Während nun die Var. c. bis fo auf dem Altvater und Riesengebirge in der Grösse nicht unbeträchtlich hinter der Stammform und den lebhaft gefärbten Abänderungen zurück bleiben, sind dieselben in den Tiroler und Schweizer Alpen eher grösser, besonders länger, mit den Var, von cacaliae leicht zu verwechseln. Die grössten, mir bekannten Stücke, die bei oberfächlicher Betrachtung gar nicht mehr an speciosissima erinnern, wurden von $\mathrm{H}$. Gredler auf dem Schlern gesammelt.

Mitunter ist die Oberseite wie von einem Fettüberzuge becleckt (Var. h), wodurch nicht nur der Glanz abgeschwächt, sondern auch die Farbe getrübt wird, und es entstehen so die mannigfaltigsten, rerschossenen Färbungen, welche oft von einer Abänderung zur andern überleiten. Sehr auffällig ist ein auf dem Altvater gefangenes, vollständig ausgehärtetes Exemplar, bei dem Unterseite, Kopf und Halssch. röthlich pechbraun, die Fld. mehr bräunlich roth und die Fühler und Beine hell rothgelb sind (Var. i).

2. silesiaca. Die kürzeste und gewölbteste Form, der Chrysom. lichenis in Farbe und Habitus ungemein ähnlich, schwarzgrün, selbst fast schwarz, oben leicht messinggelb, unten bläulich glänzend, die Längsbinde der Fld. gewöhnlich binter der Schulter durch einen blauen Schimmer angedeutet, das Halssch. wie bei specinsissima ge- 
bildet, in den meisten Fällen wie bei der Var. g., also stärker als die Fld. und runzelig punktirt; letztere sind länglich, sonst aber beinahe halbkugelig gewölbt und hinter dem Schulterhöcker kaum merklich zusammengedrückt. Es kommen Exemplare mit gleichmässig und sehr stark gerundeten Seiten des Halssch. vor; die Farbe der Oberseite wird zuweilen kupferig glänzend, oder blaugrün bis goldig grün, einfarbig, seltener auf den Fld. mit der Spur einer dunkleren Längsbinde. - Nahe dem Kamme des Riesengebirges nicht selten.

3. juncorum. Eine Spur schlanker und flacher als speciosissima, das Halssch. in der Regel etwas schmaler, der Seitenwulst weniger tief abgesetzt, oft nur in der hinteren Hälfte deutlich, kaum halb so breit und hoch wie bei der Stammform, rorn durch starke Punkte theilweise niedergedrückt, die Fld. in den Schultern kräftig heraustretend, nach hinten zu schwach erweitert, dicht punktirt. Darch die Bildung des Halssch, die an Or. virgulata erinnert, sowie die einfarbige Oberseite recht ausgezeichnet. Letztere ist gesättigt grün mit schwachem Messingschimmer, höchst selten die Naht und eine verloschene Längsbinde der Fld. dunkler, unten sind die Brustseiten bläulich. - In den Transsylvanischen Alpen.

4. carpathica. Der vorigen sehr äbnlich, aber in der Farbe und in der Punktirung der Fld. abweichend. Erstere ist oberseits ein blasses Schwarzblau, dunkel Violett, oder ein kupferig schimmerndes Schwarz. Die Punktirung der Fid, erscheint in den meisten Fällen dadurch dichter, dass die feinen Pünktehen der Zwischenräume an Stärke zunehmen und den übrigen Punkten gleichen, welche merklich feiner sind, als bei speciosissima. In den Waldkarpathen, besonders in der Nähe der Theissquellen.

5. convergens. Etwas gestreckter und flacher als die Alpenform der speciosissima, nach hinten weniger erweitert, das Halssch. in der Regel an den Hinterecken am breitesten und ron hier aus allmählich, zuweilen fast gradlinig nach rorn rerengt, der Seitenwulst durch einen beinahe graden, aber tieferen und weniger zahlreich punktirten Eindruck schärfer abgesetzt. Die Oberseite ist grün, blau oder violett, die Naht und eine schlecht begrenzte Längsbinde der Fld. dunkler. Häufig ist das Thier einfarbig schwarz (Var, o). Pyrenäen.

6. troglodytes. Die gestreckteste und flachste Form, welche in den grösseren Stücken mit cacaliae, in den kleineren mit elongati sehr leicht zu verwechseln ist, aber ron beiden durch dis viel dichtere Punktirung der Fld., von grünen Stücken der elongata ausserdem durch die stets angedeutete Längsbinde der Fld. sich trennen lässt. Das verhältnissmässig kleine Halssch. ist gewöhnlich nur in 
der Mitte der Scheibe fein, nach den Rändern hin stark punktirt, seltener sind die Punkte überall gleich stark und tief, ihre Zwischenräume zuweilen schwielig erhöht. Die Fld. haben einen leichten Fettschimmer; sie verbreitern sich aus schmaler Basis meist bedeutend nach hinten und sind durchschnittlich etwas feiner und dichter wie die von speciosissima punktirt, oft mit eben so deutlichen Nadelrissen zwischen den einzelnen Punkten wie bei cacaliae. Die Oberseite, oder der ganze Körper ist verschossen messinggelb, dunkelbraun, mit Messingschimmer, goldgrün oder grün, zuletzt grünlich blau, die Naht und eine wischartige', jedoch der von speciosissima und nicht von cacaliae ähnlich geformte Längsbinde über die Fld. grünlich (bei messinggelben oder dunkelbraunen bis goldgrünen Exemplaren) oder bläulich. Oberhalb der Baumgrenze bis an die Schneeregion auf dem Aeggischhorn und am Monte Moro (Kiesenwetter), aber auch in Kärnthen und Krain (v. Tiesenhausen).

Auf Senecio nemorensis, im Hochgebirge auf Adenostyles albifrons, auch unter losen Baumrinden noch im Juli, häufig.

Wenn man von dem immerhin gewagten Schlusse absieht, die Worte "Elytra margine coeruleo" nur auf die Naht zu beziehen, so lässt sich Scopoli's Beschreibung recht gut auf die vorliegende Art anwenden; bei Duftschmid finden wir die Hauptfärbungen aus den Alpen unter gloriosa aufgezählt, aber beide Arten sind so vermengt, dass man die vorstehende nur unter der Var. $\beta$ sicher voraussetzen darf.

17. Or. elomgata: Oblongo-ovalis, retrorsum fortiter dilatata, parum convexa, viridis, interdum coeruleo vel aurichalceo micans, sat nitida, sutura plerumque violacea; prothorace subtransverso-quadrato, lateribus aut parallelo aut antice posticeque angustato, subrotundato, supra minus convexo, sat fortiter subruguloso-punctato, callo laterali crasso interne punctis fortibus depresso et impressione sat profunda terminato, elytris minus crebre fortius punctatis, interstitiis alutaceis. - Long. $6-8,5 \mathrm{~mm}$. Mas: Abdominis segmento anali linea media rage impressa.

Suffr. Mon. 146. - Kraatz 1859. 286; Monatsbl. 1880. 38. Redtb. Faun. A. II. 475. - Baly Trans. ent. Soc. 1879. 185. t. 2 f. 17. - Weise Monatsbl. 1880.102; Deutsch, Zeit. 1883. 250.

Var. a. Supra plus minusve sordide cuprea.

Var. b. cyanea: Supra aut tota saturate cyanea.

Suffr. Mon. 147.

Bei flüchtiger Betrachtung sind die blauen Stücke mit bindenInsen vittigera, die grünen noch leichter mit speciosissima var. troglodytes zu verwechseln, von der ersteren aber durch das schmale Endglied der Taster und einfarbige Fühler, von der letztgenannten durch weitläufig punktirte, in den Zwischenräumen geschuppte 
Fld., welche niemals die Spur einer Längsbinde besitzen, rerschieden.

Gestreckt, in beiden Geschlechtern nach hinten stark erweitert. wenig gewölbt, metallisch grün, entweder messinggelb oder bläulich schimmernd, mässig glänzend, die Naht violett. Fühler lang, wie der Körper gefärbt (das zweite Glied bei frischen Stücken manchmal bräunlich), die letzten Glieder etwas dunkler, schwärzlich, jedes einzelne von ihnen bedeutend länger als breit. II alss ch. fast viereckig, nicht ganz um die Hälfte breiter als lang, die Seiten beinabe parallel, oder bis zum vorderen Drittel unmerklich erweitert, davor schwach und fast gradlinig convergirend, mit spitzen Vorderecken, die Oberfläche wenig gewölbt, unregelmässig doppelt punktirt, die stärkeren Punkte zuweilen grübchenartig, und ihre Zwischenräume dann schwielig gewölbt. Der Seitenwulst breit und ziemlich dick, ron einem weiten und tiefen, im vorderen Drittel grubig erweiterten Eindrucke abgesetzt, welcher mit seiner groben Punktirung auf die innere Hälfte des Wulstes übergeht und dieselbe etwas niederdrückt. Fld. wenig dicht, stark und tief unregelmässig gereiht punktirt; die Punkte stehen in leichten runzelartigen Vertiefungen, welche die geschuppten und einzeln fein punktulirten Zwischenräume etwas in die Höhe heben. Oft treten drei leichte Längslinien, jede von zwei Punktreihen eingeschlossen, wenig deutlich herror, zwei auf der inneren Hälfte, die dritte in dem Längseindrucke ein Stück über dem Aussenrande.

Beim Männchen zeigt sich eine schwache Mittelrinne auf dem letzten Bauchringe, dessen Hinterrand in beiden Geschlechtern fast grade abgestutzt ist. - Der Penis ist etwa $2 \mathrm{~mm}$ lang, schwach wellig gebogen, oben ziemlich flach gedrückt, an der Oeffunng bein Beginn des letzten Drittels allmählich in eine gleichbreite vorn $a b$ gerundete lange Spitze verschmälert.

Bisweilen nimmt die Oberseite einen rerschossen rothgoldigen, selbst kupferigen Schimmer an, und die Naht ist dann gewöhnlich nicht blau, sondern grünlich oder schwärzlich gefärbt (Var. a). Bei der Zunahme ron Blau, welche allmählich so vor sich zu gehen pllegt, dass der mittlere Theil der Fld. tiefer blau, ein breiter Streifen an der Naht und ein schmaler Saum am Aussenrande am längsten grünlich bleiben, entsteht die häufige Var. b. mit gesättigt cyanenblauem, oft zu Violett hinneigendem Körper; die Naht meist tief violett.

In der höheren Region der Alpen weit verbreitet und nicht selten. Eine grüne Form, die stärker glänzt als die Stücke rom St. Bernhard, der Gemmi, dem Mte. Rosa ete. wurde ron H. Baron v. Tiesenhausen auf der Choralpe gesammelt. 
Fig. 1.

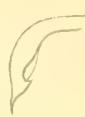

Fig. 8. (V)<smiles>C1CCC1</smiles>

Fig. 2.

Fig. 9

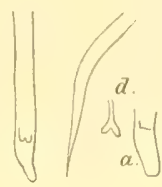

Fig. 1

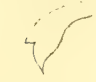

Fig. 4. $d$

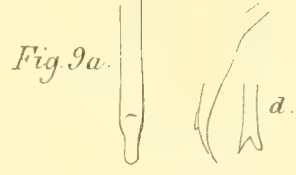

Frig.s.

Fig. 10.

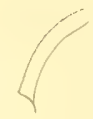

Fig. 6. $\|_{b} / \int_{i}$

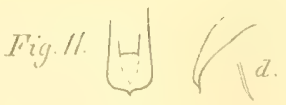

$\operatorname{lig} i$

i)

II cise dit
$F y .16$ i

Fig. 19)

Fig $\mu_{t}, H$

Fing 15

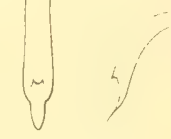

Fing lise<smiles>c1ccccc1</smiles>

Fing /i

Fing 18 . 

Suffrian's Var. $\beta$ aenea (Mon. 147) fällt mit elongata zusammen; Baly's Var. B. ,viridi-cyanea, linea suturali vittaque discoidali coeruleis". ist Or. vittigera.

18. Or. frigial a: Ovalis, retrorsum paullo dilatata, convexiuscula, viridis, interdum coeruleo vel aurichalceo micans, nitidula; antennis sat brevibus, articulis ultimis paullo elongatis, prothorace brevi, antice rotundato-angustato. crebre punctato, callo laterali haud crasso, impressione modice profunda, subrugoso-punctata terminato, elytris sat crebre et fortiter punctatis, interstitiis politis. - Long. 5-6,5 mm.

Mas: Ablominis segmento anali subconvexo, apice emarginato-truncato.

We is e Deutsch. Zeitschr. 1883. 247.

C'hr. monticola Suffr. Mon. 149. - Kraatz Berl. Zeit. 1859. 288.

- Kiesenwetter 1. c. 1861. 392. - Weise Monatsbl. 1880. 102. Var. a. rhaetica: Coerulea aut subviolacea.

Var. b. Kiesenwetteri: Tota nigra.

Die kleinste Art, in Farbe und Habitus der Gastroidea viridula am ähnlichsten, von kleinen Stücken der speciosissima durch die gedrungenen Fühler, weniger tief abgesetzten Seitenwulst des Halssch. and die einfarbigen, etwas weitläufiger und stärker punktirten Fld. leicht zu trennen.

Eiförmig, hinterwärts kaum (§̋) oder wenig erweitert (오), ziemlich gewölbt, grün, bläulich oder messingfarbig schimmernd, nur mässig glänzend. Fühler kaum halb so lang als der Körper, die einzelnen Glieder rom vierten angefangen (mit Ausnahme des letzten) wenig länger als breit. Halssch. kurz, reichlich um die Hälfte breiter wie lang, rorn stark abwärts gewölbt, nach hinten wenig, nach vorn mehr verengt, die Seiten leicht gerundet; mässig dicht und stark doppelt punktirt, bald in der Mitte fast glatt, bald schwach runzelig; der Seitenwulst mässig breit und nicht besonders hoch, durch einen grob punktirten Eindruck abgesetzt, welcher in der Regel riel schwächer ist als der von speciosissima. Die Punktirung der Fld. hält zwischen elongata und speciosissima ungefähr die Mitte, sie ist etwas schwächer und dichter als bei ersterer und weitläufiger und stärker wie bei letzterer. Die Punkte stehen in kurzen rissartigen Runzeln, sind aber durch dieselben nur an einzelnen Stellen rerbunden. Zwischenräume polirt, sparsam und feiner punktirt.

Beim Männchen ist der letzte Bauchring sehr kurz, gewölbt, hinten ausgerandet-abgestutzt und besitzt zuweilen ein Grübchen in der Mitte des Vorderrandes. - Der Penis ist sehr klein, etwas über $1 \mathrm{~mm}$ lang, breit, stark gebogen, vorn ziemlich schnell in eine kurze Spitze gerundet-rerengt, an der Hinterseite, ein Stïck über der Spitze, mit einem rechteckigen, nach hinten gerichteten $Z$ ähnchen jederseits. 
Die Farbe geht allmählich unter Zunahme ron Blau in ein einfarbiges lebhaftes oder in ein dunkles, fast violettes Blau über (Var. a); seltener ist sie einfarbig tief schwarz (Var. b).

Unter Steinen auf den höchsten Matten der Central- und Ostalpen.

\section{Phytodecta.}

Kirby Faun. bor. Am. IV. 1837. p. 213.

Gonioctena Redtenbacher Faun. Austr. ed. 1. 1849. 557.

Corpus ovale, haud metallicum.

Prothorax transversim subquadratus, angulis posticis vel omnibus fovea et seta 1.

Elytra punctato striata, margine interno postico haud ciliata.

Tibiae posteriores apice externe dentato-productae.

Tarsi articulo tertio apice leniter emarginato.

Unguiculi appendice dentiformi acuta armati.

Körper kurz- oder länglich-eiförmig, bei wenigen Arten etwas walzenförmig, gefügelt, mehr oder weniger gewölbt. Kopf geneigt, breit, Kopfschild durch eine feine, wenig deutliche Bogenlinie von der Stirn getrennt, Oberlippe kurz und breit, tief ausgerandet. Mandibeln gross, stumpf, wenig hervorstehend, fast winkelig gebogen, vor der Basis mit einem Grübchen zum theilweisen Einlegen des verbreiterten, etwas zusammengedrückten und breit abgestutzten vierten Tastergliedes. Augen quer, oval, wenig gewölbt, weit getrennt. Fühler kurz, gewöhnlich nur mit den letzten zwei oder drei Gliedern die Hinterecken des Halssch. überragend, rom sechsten Gliede an allmählich gegen die Spitze verdickt, und oft schwach zusammengedrückt, die vorletzten Glieder bald viereckig, so lang als breit oder breiter, bald gestreckt. Halsschild stark quer, an der Basis so breit oder fast so breit wie die Flügeldecken, nach vorn in leichter Rundung verengt, am Vorderrande schwach ausgeschnitten, oben gleichmässig gewölbt, nach dem Rande zu meist grob punktirt. Schildchen halb oval, oder stumpf-dreieckig. Flügeldecken an den Seiten ziemlich parallel oder nach rückwärts leicht divergirend, hinten gemeinschaftlich abgerundet, der Nahtwinkel scharf und öfters in eine kurze Spitze endigend, auf dem Rücken mit neun regelmässigen, einfachen Punktstreifen oder eben so vielen jedoch unregelmässigeren doppelten Punktreihen (variabilis). Prosternum zwischen den Hüften gewöhnlich eben oder etwas gewölbt, hinter denselben verbreitert, in eine Vertiefung des kurzen Mesosternum eingreifend. Metasternum vorn abgestutzt, kaum oder sehr deutlich gerandet. Beine kräftig und kurz, Schenkel in der Mitte rerdickt, Schienen stark, nach der Spitze rerbreitert, vierkantig; zwischen den beiden inneren Kanten, die sich an die Schenkel legen, eine Rinne oder ein 
ebener Streifen; von den beiden äusseren Kanten ist an den Vorderbeinen öfters die hintere, an den vier Hinterbeinen stets die äussere in einen Zahn ausgezogen, dessen unterer, den Tarsen zugekehrter Rand mit einer Reihe feiner, kurzer Dörnchen besetzt ist. Tarsen mässig breit, ihr erstes Glied länger, als die beiden folgenden zusammen, in den ausgerinnten vorderen Theil der Schienen eingelegt und mit der Spitze wenigstens das Ende des Schienenzahnes erreichend. Klauen dünn, gebogen, am Grunde mit einem breiten, scharfen, kaum die Mitte jeder Klaue überragenden Zahne.

Die Farbe ist roth, gelbroth oder bräunlich gelb, einfarbig oder die Oberseite mit schwarzen Makeln, welche entweder ganz verschwinden, oder sich zuletzt so ausdehnen können, dass die einzelnen Theile der Oberseite, oder der ganze Körper einfarbig schwarz werden; Form, Stellung und Zahl dieser Makeln, sowie die Art ihres Zusammenfliessens sind für die einzelnen Arten charakteristisch und erleichtern das Erkennen derselben.

Das Männchen ist kleiner und schmaler als das Weibchen und erscheint überhaupt mehr gleichbreit, weil das Halsschild vorn weniger stark verschmälert ist, während die Flügeldecken nach hinten kaum erweitert sind; ausserdem ist es an den breiten Tarsen, an denen namentlich die Erweiterung des ersten Gliedes in die Augen fällt, leicht zu erkennen. Der Penis ist eine oben ziemlich flache Röhre, deren Spitze auf verschiedene Art in überraschenden Formen zugespitzt, abgestutzt oder aufgebogen ist.

Die Larven sind bedeutend länger und schmaler als die Käfer, sehr gestreckt, nur hinten, oder beiderseits etwas verschmälert, unten fast flach oder wenig gerundet, oben mässig gewölbt, kaum glänzend, braunschwarz (viminatis), bräunlich oder gelblich; der Meso- und Metathorax, sowie jedes der acht Abdominalsegmente, welche am Seitenrande in eine grosse, behaarte Tuberkel ausgezogen sind, durch eine Querrinne halbirt; auf jeder Hälfte stehen in einer Querreihe sechs (bis acht) feine Querhöckerchen, welche meist mit je einem, nach rückwärts gerichteten Härchen besetzt sind. Bis jetzt wurden beschrieben die Larven von rufipes ${ }^{1}$ ), viminalis $\left.{ }^{2}\right)^{3}$ ), nivosa $\left.{ }^{4}\right)$, fornicata ${ }^{5}$, olivacea $\left.{ }^{1}{ }^{6}\right), 5-$ punctata $^{7}$ ) und ? pallida ${ }^{8}$ ); sie

1) Chapius Mém. Liége 1853. 613. 614.

2) Letzner Arb. Schles. Ges. Breslau 1855. 109. 111.

3) Cornelius Stett. Zeit. 185\%. 165-167.

4) Letzner 1. c. 1864. 143.

5) Heeger Isis 1848. 322, t. 3.

6) Letzner 1. c. 1857. 126. 127.

7 Cornelius 1. c. 1850. 19.

8) Frauenfeld Verh. zool, bot. Ges. Wien, 1872. 394. 
halten sich an der Unterseite der Blätter ihrer Nährpflanzen auf, die sie siebartig durchlöchern. Da es nicht ganz sicher ist, ob Cornelius die Ph.5-punctata und Frauenfeld pallida vor sich gehabt haben, gebe ich hier die Hauptkennzeichen der Larve von 5-punctata an. Dieselbe ist matt, grünlich gelbgrau, fast $9 \mathrm{~mm}$ lang und $2,5 \mathrm{~mm}$ breit, vorn wenig, hinten in den letzten 5 Ringen allmäblich stärker verengt; auf der vorderen Hälfte jedes Abdominalringes stehen 6 bis 8 kurze, auf der hinteren Hälfte 6 fast dreimal längere, nach hinten gekrümmte, weissliche Borstenhaare in einer Querreihe, die kurzen in ungefähr gleichen Abständen ron einander, die langen zu zweien einander etwas genähert. Bei der Betrachtung von oben machen sich nur die längeren Haare bemerklich; sie bilden 6 regelmässige Längsreihen, davon ein Paar in der Mitte und ein Paar an jeder Seite.

Die Gattung, von der bis jetzt etwa 30 Arten beschrieben worden sind, ist vorzugsweise in der kälteren Hälfte der nördlichen Hemisphäre verbreitet; ihre europäischen Arten behandelte Suffrian in der Linnaea entomologica V. 1851. 209-237 (Mon. - 17. Gruppe. Chrysomelae calcaratae) so vorzüglich, dass eine sichere Bestimmung durchaus keine Schwierigkeiten macht. Der spätere Versuch Redtenbacher's, die Phyt. flavicornis, triandrae, affinis und rufipes mit riminalis zu verbinden ${ }^{1}$ ), ,weil sie sich nicht mit einiger Sicherheit von den zahllosen Varietäten der letzteren Art unterscheiden" lassen, hat wohl nur in allzugrosser Bequemlichkeit seinen Grund und ist von Dr. Kraatz durch eine eingehende, sorgfältige Arbeit ${ }^{2}$ ), in der die Unterschiede scharf zusammengefasst werden, entschieden zurückgewiesen worden. Motschulsky brachte die Arten ${ }^{3}$ ), lediglich auf die Körperform, Bildung der Schienen und Punktirung der Flügeldecken hin, in vier Gattungen: Spartoxena (Ph. variabilis), Spartophila (olivacea), Gonioctena (viminalis) und Goniomena (pallida); ich theile dieselben in folgende 2 Gruppen:

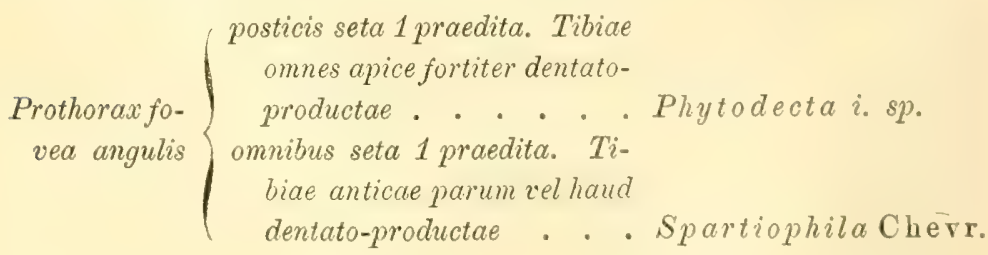

1) Fauna Austriaca ed. 3. II. 490. 481.

2) Zeitschrift für Entomologie. Nene Folge. Breslau 1579. 45-56.

3) Schrenck Reis. Amur II. 180. 
1. Gruppe. Halsschild nur in den Hinterecken mit einer borstentragenden Pore. Alle Schienen vor der Spitze stark zahnartig verbreitert. Phytodecta i. sp.

A. Drittes Fühlerglied nicht oder kaum länger als das fünfte, Glied 10 breiter als lang.

1. Fhytod. viminalis: Ovalis, nigra, antennarum basi abdomi. nisque seqmento anali apice rufo-testaceis, prothorace elytrisque rufis, illo lateribus sat fortiter rotundato, angulis anticis obluse productis, disco punctis 2 vel 3 subbasalibus nigris plerumque in maculam transversam baseos (interdum subreniformen) confluentibus; elytris immaculatis punctato-striatis, interstitiis fere politis, crebre evidenter punctatis, rarius apice sutura nigricante, scutello nigro. - Long. $5,5-7 \mathrm{~mm}$.

Linné Syst. Nat. ed. X. 371. - Oliv. Ent. V. 572. t. 9. f. 130. - Fabr. Ent. Syst. I. 319; Syst. Eleuth. I. 436. - Gyllh. Ins. Suec. III. 487. - Duft. Faun. Austr. III. 200. - Suffr. Mon. 211 (Chrysomela). - Thoms. Skand. Col. VIIr. 259. Redtb. Faun. A. II. 481 (pars.). - Seidl. F. balt. 484 (Gonioctena). - Kraatz Zeitschr. f. Ent. Breslau 1879. 46.

Coccinella signata Scop. Ent. Carn. 74.

Chrys. fridrichsdalensis Müll. Fn. Frid. 8.

Yar. a. munda: Prothorace elytrisque rufis, immaculatis, scutello nigro.

Chrys. viminalis Panz. Faun. Germ. 78. 3.

Var. b. bicolor: Prothorace nigro, elytris rufis, immaculatis.

Kraatz 1. c. 49.

Var. c. decempunctata:

1. Prothorace rufo, immaculato, elytris basi nigro-maculatis;

2. Pioth. vufo, punctis 2 vel 3 subbasalibus elytrisque maculis 1, 2 vel 3 nigris;

3. Proth. macula magna basali transversa elytrisque maculis 1, 2, 3 vel 4 nigris;

4. Pioth. macula magna basali transversa, elytrisque apice sutura maculisque 5 (quinta elongata ante apicem) nigris.

Linné 1. c. 371. - Fabr. 1. c. 320 ; 1. c. 436 . - Scopoli 1. c. 76 (Coccinella). - Suffr. Mon, 214. - Kraatz 1. c. 48.

Chrys. nigripes Deg. Mém. Ins. V. 296.

Var. d. Baaderi: Prothorace macula magna transersa rarissime apicem attingente nigra, elytrorum maculis plus minusve con/luentibus:

1. macula quarta et tertia inter se,

2. et cum prima,

3. et cum secunda,

4. et cum quinia (maculae omnes: Baaderi);

5. macula quinta cum opposita in lunulam apicalem

6. et cum quarta; 
7. maculae 2 submerliae (3 et 1) inter se et 2 basules inter se,

8. macula quarta et tertiu cum oppositis in maculum centralem.

Panz. Faun. Germ. 24. 14. 犬. - Duft. 1. c. 200, - Suffr. 1. c. 214 . Kraatz 1. c. 48 .

Var. e. cincta: Prothorace macula majore, apicem plerunque attingente nigra, elytris nigris, rufo-testaceo cinctis (proesertim in margine basali et laterali).

Chrys. Baaderi Panz. 1. c. 59. 2. 우. - Duft. 1. c. 201.

Var. f. calcarata: Nigra, antennarum basi testaceo, ano apice rufomarginato.

Fabr. Ent. Syst. I. 2. 19 (Galleruca); Syst. El. I. 431. Duft. 1. c. 201. - Suffr. Mon. 214 (Chrysom.).

Coccinella haemorrhoidalis Scop. 1. c. 72. - Fabr. Syst. Ent. 102. - Kratz 1. c. 49.

Var. g. Tibiis anterioribus rufescentibus.

Var. h. Fronte punctis 2 testaceis.

Oval, die $\hat{\jmath}$ mehr gleichbreit, die $f$ nach hinten meist stark erweitert, mässig gewölbt, schwarz, Fühlerwurzel und ein schmaler Saum an der Spitze des letzten Bauchringes rothgelb, Halssch. und Fld. lebhaft ziegelroth, glänzend. Kopf dicht punktirt. Maxillartaster röthlich, das letzte, breite Glied schwarz. Fühler kräftig, ihre ersten sechs oder sieben Glieder rothgelb, die übrigen schwarz; Glied 1 dick, etwas länger und breiter als das Endglied, 2 kaum balb so lang und dick, 3 und 4 schmal, das fünfte nur unmerklich, die folgenden immer stärker erweitert und nach unten in eine Ecke ausgezogen, zusammengedrückt, leicht gesägt, das siebente bis zehnte fast breiter als lang. Halssch. kurz, doppelt so breit wie lang, bis zur Mitte fast gleichbreit oder nur unmerklich verbreitert, daror in gleichmässiger Rundung stark verengt $(\hat{\jmath})$, oder von den Hinterecken an allmählich, im vorderen Drittel etwas stärker als hinten verschmälert (ㅇ), mit kaum rechtwinkeligen, eher etwas stumpfen Vorderecken und einer kurzen, weisslichen, nach rorn gekrümmten Borste in jeder Hinterecke. Die Scheibe mässig dicht und fein, ein breiter Streifen über dem Seitenrande grob punktirt, mit zahlreichen, äusserst feinen und nur bei starker Vergrösserung bemerkbaren Pünktchen in den Zwischenräumen. Schildchen halboval, schwarz. Fld. mit 9 regelmässigen ganzen und einem abgekürzten Punktstreifen am Schildchen, die Streifen sehr flach, ihre Punkte mässig stark, dicht aneinander gereiht und, nebst einem sie umgebenden Kreise, bräunlich durchschimmernd. Die breiten Zwischenstreifen dicht, fein aber deutlich punktirt, ausserdem noch von äbnlichen schwer sichtbaren Pünktchen bedeckt wie das Halssch. Unterseite etwas weniger glänzend als die Oberseite, dicht und ziemlich stark 
punktirt. Der Zahn an den Vorderschienen, gross, spitz, wenig oder kaum kleiner als der an den hinteren Schienen.

Der Penis ist fast grade, gleichbreit, vorn plötzlich und ticf halsförmig eingeschnürt, sodann in eine vorn grade abgeschnittene Spitze verbreitert, deren verdickte und umgeschlagene Ränder nacb oben in je einen langen, aufstehenden Zahn ausgezogen sind. Diese Spitze ist unten geschlossen, oben offen, ihr vorderer Umfang einem Hufeisen ähnlich; der röhrenförmige, am Ende kolbige ductus ragt ein Stück aus ihr hervor.

Die Veränderung der Farbe des Halssch. und der Fld. aus roth in schwarz geschieht ungefähr in folgender Weise:

Auf dem einfarbig rothen Halssch, zeigen sich anfänglich zwei grosse schwarze Punkte vor dem Hinterrande, die weiter von einander entfernt sind als jeder einzelne vom Seitenrande; zwischen beide tritt dann ein dritter, kleinerer und meist verwaschener Fleck auf die Mittellinie, ein Stück vor dem Schildchen. Die beiden äusseren Punkte dehnen sich mehr nach innen und hinten zu als nach vorn aus, fliessen zusammen und bilden eine ziemlich nierenförmige, auf der Mitte des Hinterrandes ruhende Quermakel, welche kaum oder wenig über die Mitte des Halssch. nach vorn hinausreicht, aber allmählich sich bis an den Vorderrand und in die Hinterecken des Halssch., zuletzt über das ganze Halssch. ausbreitet.

Auf den Fld. bilden sich aus anfangs verwaschenen dunklen Stellen fünf mässig scharfe, schwarze Makeln aus: drei (1, 3 und 5) in einer Längsreihe über dem Seitenrande zwischen dem 5. und 8. Punktstreifen (die erste länglich, auf dem Schulterhöcker, die dritte quer, vor der Mitte, die fünfte lang, oft strichförmig), und zwei (2 und 4) an der Naht, die zweite gross, rund, in der Mitte zwischen Naht und Schulter, etwas weiter von der Basis der Fld. entfernt als Makel 1, die vierte länglich, hinter der Mitte. In der Regel erscheinen diese Makeln in folgender Reihe: zuerst 2 oder 1, dann 3 , zuletzt 5 oder 4 , daraus folgt, dass die früher auftretenden schärfer begrenzt und weniger veränderlich sein werden als die übrigen, und dass ein Zusammenfliessen der Flecke vorherrschend vom vierten ausgehen muss. Derselbe verbindet sich breit mit Makel 3, durch diese schmal mit 1, später auch für sich mit 2, endlich mit 5, die Scheibe ist schwarz, aber es treten vom rothen Rande aus zwei lange, gebogene Streifen (der eine vom Basalrande her zwischen Makel 1 und 2, der andere von der Seite zwischen 3 und 5), sowie zwei kleinere Ausbuchtungen hinein (die eine an der Seite zwischen Makel 1 und 3, die andere an der Naht zwischen Makel 4 und 5). Später verschwinden dieselben, die Fld. sind schwarz, mit einem 
breiten rothen Saume, der nur auf der hinteren Hälfte an der Nalit schmal oder selbst undeutlich ist, zuletzt gänzlich von der schwarzen Farbe überschwemmt wird.

In seltenen Fällen verbinden sich Makel 4 mit 3 , und 2 mit 1 zu zwei Querbinden, oder 4 und 3 mit den beiden entsprechenden Makeln der andern Fld. zu einem gemeinschaftlichen grossen viereckigen Mittelflecke, welcher ungefähr die Form eines Sattels hat, an dessen vorderer Spitze jederseits ein Riemen befestigt ist. Für die Art ist die längliche, meist strichförmige Makel 5, sowie die, nur den hellsten Stücken gewöhnlich ganz fehlende schwarze Spitze der Naht, die bei keiner andern Art auftritt, sehr charakteristisch. Exemplare, bei denen die vorderen Makeln frei, dagegen 5 mit 5 der andern Fld. (oft auch noch 4) zu einer dicken, halb ovalen Linie um die Spitze der Fld. herum verbunden sind, finden sich häufiger.

Als Normalfärbung der Art ist in unserem Gebiete die zu betrachten, bei der das Halssch. einen queren Basalfleck, die Fld. drei bis fünf Makeln und eine schwarze Spitze besitzen, weil sie überall vorherrschend auftritt; aber da seit Gyllenhal für die Art der Name viminalis allgemein angenommen wurde, muss auch von der durch Linné dafür angegebenen Färbung ausgegangen werden: Halssch. roth, mit zwei feinen schwarzen Punkten, Fld, einfarbig roth. Aus der ganzen Reibe von Abänderungen heben sich nun, sowohl durch ihr häufiges Auftreten, als auch durch ihre ziemlich bestimmt abgeschlossene Färbung folgende Hauptvarietäten heraus, zwischen denen Uebergänge nur selten gefunden werden:

Var. a. munda. Halssch. und Fld. einfarbig roth.

Var. b. bicolor. Halssch. einfarbig schwarz, Fld. roth.

Var. c. 10 -punctata. Halssch, roth, mit einem nierenförmigen schwarzen Basalflecke, Fld. mit 10 freien schwarzen Makeln und schwarzer Spitze.

Var. d. Baaderi. Halssch. wie bei c., oder der Basalfleck bis zum Vorderrande ausgedehnt (ähnlich wie bei der Normalfärbung von linnaeana), alle fünf Makeln der Fld. verbunden, aber 1 und 2, sowie 3 und 5 nicht direkt mit einander, sondern die beiden erstgenannten nur durch 3 und 4 , die letztgenannten durch 4 .

Var. e. cincta. Halssch. wie bei der vorigen, Fld. schwarz, ein Saum um jede einzelne, welcher auf der hinteren Hälfte der Naht bis auf die Nahtleiste selbst beschränkt ist, roth.

Var. f. calcarata. Einfarbig schwarz, nur die Fühler am Grundeund ein Saum am After rothgelb. 
Ausserdem sind erwähnenswerth :

Var. g. die zwei oder vier vorderen Schienen röthlich, und Var. h. der Kopf mit zwei rothgelben Punkten auf der Stirn.

Auf Weiden, besonders Salix cinerea und aurita vom Mai an gemein, auch die angegebenen Varietäten, mit Ausnahme von g. und h., nicht selten.

2. Phytod. rufipes: Ovalis, supra rufa, nitida, capite postice, macula basali bi-aut triloba prothoracis, scutello maculisque 5 elytrorum (quinta transversa longius ab apice remota) nigris, subtus nigra, antennis (apice infuscato excepto), pedibus, epimeris prosterni, marginibus segmentorum ventralium anoque rufis; prothorace lateribus parum. rotundatis, angulis anticis acute productis, elytris tenuiter punctatostriatis, interstitiis punctulatis. - Long. 5,5-7,5 mm.

Degeer Mém. Ins. V. 1775. 295. t. 8. f. 25. - Payk. Faun. Suec. II. 69. - Gyllh. Ins. Suec. III. 486. - Suffr. Mon. 210. - Thoms. Skand. Col. VIII. 261. - Koltze Berl. Zeit. 1872. 161. - Kraatz Zeit. f. Ent. Breslau 1879. 45. Seidl. F. balt. 484 . - Redtb. Faun. A. II. 480.

Chrysom. fulvipes Duft. Faun. Austr. III. 199.

Var. a. Elytris maculis 4 nigris: maculis 2 posticis una alterave deest. Var. b. sexpunctata: Maculis duabus ultimis elytrorum deficientibus.

Fabr. Mant. I. 70. - Suffr. Mon. 211.

Grösse und Gestalt der vorhergehenden, in der Färbung deren Varietät decempunctata sehr ähnlich, aber durch folgende Punkte leicht und sicher von ihr zu unterscheiden: Die Fühler sind rothgelb, ihre letzten Glieder nicht schwarz, sondern nur angedunkelt, das Kopfschild, die Mundtheile, mit Ausnahme der Mandibelspitze, und die Beine einfarbig rothgelb. Das $\mathrm{Halssch}$. ist an den Seiten weniger gerundet, mit spitzeren Vorderecken; stets mit zwei schwarzen Makeln, welche an die Basis gelehnt und an derselben durch einen schmalen, vor dem Schildchen bisweilen fein unterbrochenen Saum verbunden sind. Die Fld. sind etwas glänzender, die Punkte in den Reihen meist nur unbedeutend, in den Zwischenstreifen bedeutend feiner; deshalb treten auch die Punktstreifen auf dem Abfalle nach hinten durchgehends deutlicher hervor. Die Spitze der Fld. ist nie $\mathrm{schwarz}$, von den fünf Makeln derselben sind die beiden hinteren (4 und 5), auch wenn sie sich verkleinern, schärfer begrenzt, niemals wischartig, die inneren beiden ( 2 und 4 ) haben ungefähr dieselbe Form und Lage, die äusseren drei (1, 3, 5) nicht; vielmehr zeigt Makel 1 und 3 das Bestreben, sich stets bis zur neunten, äussersten Punktreihe auszudehnen, was ähnlich nur bei der Varietät Baaderi vorkommt, und die hinterste Makel, 5, ist fast immer quer, höchst 
selten länglich aber nicht fast strichförmig, bleibt auch von der Spitze der Fld, viel weiter entfernt. Cnterseite feiner punktirt, glänzender.

Der Penis ist bedeutend länger, stark gebogen, rorn plötzlich verengt und in eine schmale Spitze ausgezogen, die ungeführ ein Viertel der ganzen Länge einnimmt, vorn etwas rerdickt und leicht wellig gekrümmt ist. Ihre Ränder sind oben so zusammen gebogen, dass sie zusammenstossen und eine feine Röhre bilden helfen, aus welcher der äusserst zarte, nadelförmige ductus, nach oben gekrümmt, weit heraus ragt.

Die Färbung ist wenig veränderlich. Die beiden Basalflecke des Thorax vergrössern sich nach innen und rorn zu grösseren, halb ovalen Makeln und sind durch einen breiten Saum längs der Basis rerbunden, welcher gewöhnlich in der Mitte eine kurze Spitze nach vorn sendet. Auf den Fld. rerkleinert sich bald der vierte, bald der fünfte Fleck allmählich, bis einer oder der andere (Var. a), oder beide zugleich verschwinden (Var. b). Stücke mit zusammengeflossenen Makeln sind mir eben so wenig, wie Suffrian oder Kraatz, bekannt geworden, trotzdem ist die Möglichkeit ihres Vorkommens kaum zu bezweifeln, weil bei einigen meiner Exemplare die innere Hinterecke der Makel 3 sich der äusseren Vorderecke ron Makel 4 so nähert, dass, durch eine geringe Ausdehnung beider, die Vereinigung stattfinden würde.

An Waldrändern auf den jungen Trieben der Espenbüsche (Populus tremula) und Weiden in Mittel- und Nordeuropa stellenweise vom Mai ab häufig.

3. Phytod. fiaviconnis: Breviter-ovalis, convexiuscula, nigra, sat nitida, antennis (apice infuscatis), tibiis, tarsis limboque anali testaceis, elytris rufis, semper immaculatis. Prothorace lateribus parum rotundatis, angulis anticis obtuse prorluctis, disco subtiliter sed evidenter, latera versus fortius punctato, linea media laevi, interstitiis alutaceis; elytris interne tenuiter, extrorsum fortius profunde punctato-striatis, interstitiis crebre evidenter punctatis. - Long. 4,5-6,5 $\mathrm{mm}$.

Suffr. Mon. 215.

Chrysomela tibialis var. luridla Duft. Faun. Austr. III. 202.

Var. a. Elytris nigricantibus.

Var. b. Kau/manni: Prothorace rufo, macula magna bidentata, apicem fere attingente, nigra.

Miller Verh. zool. bot. Ges. Wien. 18s0. 7.

Viel kürzer, flacher, jedoch verhältnissmässig wenig schmaler als die vorhergehenden, der Chrysomela lurida nicht unähnlich, in der Färbung an viminalis var. bicolor Kr. erinnernd und bei ober- 
flächlichster Betrachtung nur mit dieser zu verwechseln. Die Unterschiede sind folgende: Fühler gelbbraun, ihre fünf letzten, breiten Glieder nur angedunkelt. Halssch. überall fein gewirkt, auf dem Mittelfelde kaum stärker, aber etwas tiefer punktirt, gewöhnlich mit deutlicherer glatter Mittellinie, an den Seiten, ähnlich rufipes, weniger gerundet, die Vorderecken aber etwas stumpf, wie bei viminalis. Fld. schwächer glänzend, die inneren vier Punktstreifen nur auf dem Abfalle zur Spitze, die äusseren durchgängig stärker vertieft und kräftiger punktirt, die Zwischenstreifen, die an der Schulter entspringen, sind beim Männchen vorn schmal, fast kielartig gewölbt und nur mit einer feineren Punktreihe besetzt, hinten breiter und (wie die übrigen) dicht, mindestens so stark als bei viminalis punktirt. Schienen, oft mit Ausnahme der Wurzel, und Tarsen bräunlich gelb, oder pechbraun $=$ sorbi Motsch. (Schrenck Reis. Amur II. 223).

Der Penis stimmt in der Länge beinahe mit dem von viminalis überein, ist aber breiter und mehr gebogen, vorn jederseits ausgerandet- und fast abgestutzt-verengt, hierauf in eine schmal beginnende, allmählich etwas erweiterte, vorn mit gerundeten Ecken grade abgeschnittene Spitze ausgezogen, in deren Mittelrinne sich der ductus einlagert; die Rückseite besitzt einen hohen Mittelkiel.

Färbung ziemlich konstant. Bei der dunkelsten Form werden die Fld. zuletzt pechbraun, selbst schwärzlich, zuweilen bleibt die Schulter und der Aussenrand etwas lichter (Var. a); bei den hellsten Stücken ist das Halssch. roth, mit einer sehr grossen, schwarzen Makel, welche auf der Basis von einer Ecke bis zur andern ruht, und sich, stark verschmälert, bis in die Nähe des Vorderrandes hinzieht, wo sie durch einen tiefen, dreieckigen Ausschnitt in zwei breite Spitzen getheilt wird (Var, b). Der Uebergang zu der typischen flavicornis geschieht in der Regel so, dass die schwarze Makel sich vorn ausdehnt, mit den Spitzen den Vorderrand berührt, den dreieckigen Ausschnitt überschwemmt und nur einen schmalen, vorn breiteren Seitensaum frei lässt.

Ende Juni auf Weiden an der Grenze des Baumwuchses in den Alpen (Schweiz, Tirol, Steiermark (Eppelsheim) und Waldkarpathen, Galizien; im Schwarzwalde bei Buhlbach (Simon), Altvater (Letzner); Daurien (Eversmann, Faust). Die Varietät Kaufmanni fand Herr Miller bei Weissenfels in Krain unter den Felsenwänden des Mangert gesellschaftlich mit Phytod. 5-punctata, auch an der heiligen Wand in den Karawanken.

VI. 3. 
B. Drittes Fühlerglied fast doppelt so lang als das fünfte, Glied 10 mindestens so lang als breit.

4. Fhytod. limnaeama: Subelongata $(\hat{\hat{j}})$, aut ovalis $(\hat{q})$, sat nitida, nigra, antennis basi, tibiis (margine interno infuscato vel nigro excepto) limboque ani angusto tesiaceis; antennarum articulo $4: 05: 0$ evidenter longiore; prothorace rufo, vitta media lata, pone medium abrupte dilatata, nigra, lateribus fortiter rotundato, angulis antiris obluse productis, disco parce inaequaliter punctato; elytris rufis, immaculatis, interne tenuiter, extrorsum paullo fortiter punctato-striatis, interstitiis crebre vage quepunctulatis, parum dense aciculatis $(\hat{\hat{c}})$, aut exidenter creberrimeque alutaceis, sericeo-micantibus (†). - Long. 6-7 mm.

Mas: segmento ultimo ventrali subconvexo, apice late emarginato.

Femina: segmento ultimo haud convexo, apice anguste semicirculariter impresso-emarginato.

Schrank Enum. Ins. 69 (Chrysom.).

Chrysomela triandrae Suffr. Mon. 216. - Thoms. Skand. Col.

VIII. 261 (pars.). - Kraatz Zeitschr. f. Ent. Breslau 1979. 49. Seidl. F. balt. 484.

Chrys, tibialis Duft. Fann. Austr. III. 202 (pars.).

Var. a. decastigma: Eadern, sed elytris maculis 1, 2, 3, 4 vel 5 nigris.

Chrys. tibialis var. decostigma Duft. 1. c. 203. - Suffr. Mon. 221. - Kratz 1. c. 52.

Chrys. decempunctata Schrank. 1. c. 75 .

Chrys. affinis var. c. et d. Gyllh. Ins. Suec. III. 485.

Var. b. orientalis: Eadem, sed maculis elytrorum plus minusve confluentibus, ad ultimum elytris nigris, limbo basali et laterali rufis.

Var. c. Prothorace rufo, vitta antice angustata vel abbreviata.

Var. d. Kraatzi: Prothorace nigro, elytris rufis, immaculatis.

Westh of Käf. Westphal. 273.

Var. e. nigricollis: Eadem, sed elytris 1-5 maculatis, maculis liberis vel rarissime hinc inde confluentibus.

Westhof 1. c.

? Gonioctena salicis Motsch. Schrenck Reis. Am. II. 223.

Var. f. satanas: Tota nigra, antennis basi limboque ani testaceis.

Westhof 1. c.

Die drei Arten der zweiten Gruppe unterscheiden sich von denen der ersten durch die Fühlerbildung und Punktirung ganz bedeutend. Die Fühler sind hier im Allgemeinen länger, in den letzten Gliedern weniger erweitert und deshalb auch nicht schwach gesägt wie bei den Verwandten von viminalis, im Besonderen ist das dritte Glied verlängert, das fünfte verkürzt, jenes daher fast doppelt so lang als dieses, das vorletzte Glied ebenfalls gestreckt, ja bei dem $\hat{o}$ der affinis, welches von diesen Arten die längsten Fühler besitzt, doppelt so lang als breit. Unter einer guten Loupe bemerkt man, dass die 
äusserst feinen, gedrängt stehenden Pünktchen, welche bei den vorigen Arten die Zwischenräume der Punkte auf den Fld. und dem Hinterleibe bedecken, hier durch sehr zart eingeritzte Linien ersetzt sind, wodurch der Glanz der fein gewirkten Oberfläche etwas abgeschwächt wird.

Die rorliegende Art erinnert durch den ziemlich breit ovalen Körper des Weibchens an viminalis, die Männchen sind bedeutend schlanker, mehr zusammengedrückt und schwächer gewölbt. Die Fühler reichen mit den letzten drei Gliedern über die Hinterecken des Halssch. hinaus, Glied 1 bis 6 sind röthlichgelb, nur die Oberseite des ersten Gliedes und Glied 5 und 6 gebräunt, die folgenden schwarz. Kopf schwarz, kräftig und dicht, auf der Stirn sparsamer punktirt, die Spitze der Mandibeln meist röthlich. Halssch. halb so lang als breit, beim Weibchen zwischen den Hinterecken und der Mitte, beim Männchen im ersten Drittel am breitesten, vorn in sehr starkem Bogen verengt, die Seiten, namentlich bei vielen Männchen, stark gerundet, mit stumpfwinkeligen Vorderecken; oben zerstreut, ungleichmässig, nach den Seiten hin grob punktirt, roth, eine Längsbinde, welche das mittlere Drittel des Vorderrandes einnimmt, ziemlich in gleicher Breite bis kurz vor die Mitte zieht und sich hier plötzlich stark erweitert, so dass sie an der Basis fast die Hinterecken erreicht, schwarz. Von der rothen Farbe bleibt deshalb nur ein, am Grunde schmal beginnender, allmählich stark verbreiterter Seitensaum übrig, dessen innere Grenzlinie einen stumpfen Winkel von etwa 135 Grad bildet. Fld. einfarbig roth, mit ziemlich feinen, nach aussen etwas stärkeren Punktstreifen und verloschen punktirten Zwischenstreifen, die beim $\hat{\sigma}$ wenig dicht nadelrissig und mässig glänzend, beim ㅇ dicht gewirkt, matt seidig oder ölig schimmernd sind. Unterseite schwarz, die äussere Hälfte der Thoraxepimeren roth, ein feiner Saum am Hinterrande des letzten Bauchringes rothgelb. Schenkel und Knie schwarz, der übrige Theil der Schienen hell bräunlichgelb, aber die breite Spitze leicht gebräunt und die innere den Schenkeln zugekehrte Fläche angedunkelt, schwärzlich, selten schwarz. Tarsen oberseits pechbraun oder schwarz.

Beim Männchen ist das Analsegment schwach gewölbt und an der Spitze in leichtem Bogen ausgerandet, beim Weibchen flach ausgebreitet, der Hinterrand in der Mitte tief eingedrückt und zu gleicher Zeit halbkreisförmig ausgeschnitten. - Der Penis ist wenig gebogen, breit und flach, vorn jederseits ziemlich schnell gerundet verengt, und endigt in eine lange, allmählich verschmälerte scharfe Spitze.

Die Veränderung der Farbe auf Halssch. und Fld. aus roth in schwarz geschieht plötzlich, sprungweise, wenigstens gehören die 
eigentlichen Uebergangsformen, bei denen das rothseitige Halssch. schwarz wird, oder die schwarz gemakelten Fld. in einfarbig schwarze übergehen, bei uns zu den Seltenheiten, in Sibirien scheinen sie aber häufiger vorzukommen. Auf dem Halssch. zeigt sich ein schwarzer Punkt ziemlich in der Mitte des rothen Seitensaumes, oder es ist einfarbig schwarz; die rothen Fld. erhalten nach und nach fünf schwarze Makeln in folgender Reihe:

1. eine Makel, entweder 2 oder 3,

2. zwei Makeln: 2 und 3, seltener 2 und 1, oder 2 und 4,

3. drei Makeln: 1,2 und 3 (häufige Form),

4. vier Makeln: 1, 2, 3 und 4 (häufige Form), sehr selten 1, 2, 3 und 5,

5. alle fünf Makeln. Dieselben stimmen in der Lage und Form mit denen von rufipes überein, vergrössern sich, fliessen theilweise oder insgesammt zusammen (am längsten scheint sich Makel 1 gegen eine Vereinigung zu sträuben) und bedecken zuletzt die ganze Fld.

Unter Berücksichtigung der Wechselbeziehung zwischen der Färbung des Thorax und der Fld. ergeben sich folgende Hauptvarietäten:

1. Halssch. mit breit rothen Seiten, Fld. einfarbig roth (linnaeana) oder mit ein bis fünf schwarzen, freien (Var. decastigma), oder zusammengeflossenen Flecken (Var. b). Bei dieser Varietät, die im östlichen Russland z. B. bei Orenburg (Faust) und in Sibirien häufiger vorkommt, bleibt gewöhnlich nur ein Saum um jede Fld., welcher vom ersten Drittel an der Naht nach hinten plötzlich auf die Nahtkante selbst beschränkt ist, roth.

2. Halssch. einfarbig schwarz, Fld, roth (Var. Kraatzi), oder mit ein bis fünf freien, oder theilweise verbundenen Makeln (Var. nigricollis), endlich einfarbig schwarz (Var. satanas). Die letzte Abänderung hat fast immer schwarze Schienen.

Bisweilen ist die breite schwarze Mittelbinde des Halssch. makelförmig, beinahe gradlinig nach vorn verengt, öfter auch so verkürzt, dass sie den Vorderrand nicht mehr erreicht (Var. c).

In den gebirgigen Gegenden Mitteleuropa's, in Sibirien und Nordeuropa häufig auf Salix triaudra, viminalis, fragilis und purpurea.

Die Beschreibung von Schrank bezieht sich ohne $Z_{w e i f e l}$ auf die vorliegende Art, und aus der Längenangabe dürfte wohl geschlossen werden, dass sie die Ph. flavicornis nicht mit umfasst, wie Duftschmid's tibialis.

5. Phytod. mivos $\left.{ }^{2}\right)$ : Oblongo-ovalis, convexiuscula, ubique subtilissime alutacea, sat nitida, nigra, antennis piceo-brumeis basi, tibiis

1) Von dieser Art ist nur schwierig zu trennen: Phyt. affinis Schōnh. Syn. Ins. I. 3. 25\%. not. z.; Suffr. 218 (pars.). aus dem nördlichsten 
(margine interno infuscato excepto) tarsis, limboque angusto ani testaceis; antennarum articulis 1 et 5 aequalibus, prothorace rufo, macula magna basali antrorsum rotundato-angustata, apice plerumque emarginata, nigra, in disco crebre subtilissimeque punctato, lateribus paullo rotun. datis, angulis anticis acute productis; elytris rufis, maculis 5 nigris, sat fortiter punctato-striatis, interstitiis vage punctulatis. - Long. $4,5-5,5 \mathrm{~mm}$.

Mas: abdominis segmento anali subconvexo, apice subemarginato-truncato. Femina: segmento anali apice fere rotundato.

Suffr. Mon. 222. - Fairm. Gen. Col. Eur. IV. t. 67. f. 318. - Letzner Arb. Schles. Ges. 1864. 142. - Kraatz Zeitschr. f. Ent. Breslau 1879. 54 .

Chr. affinis Suffr. Mon. 218 (pars.).

Var. a. rufula: Prothorace rufo, maculis duabus pone medium transversim positis, plerumque basi conjunctis aut in maculam basalem magnam confluentibus, nigris, elytris rufis, immaculatis.

Kraatz 1. c. 55 .

Var. b. personata: Prothorace nigro, elytris rufis, maculis 1-5 nigris. Var. c. Prothorace ul in $a$. aut b., sed maculis elytrorum plus minusve conjunctis.

Var. d. Eppelsheimi: Eadem, elytris nigris, macula magna apicali rufescente.

Var. e. funesta: Prothorace elytrisque nigris, his epipleuris rufescentibus aut rufo-piceis.

Der vorigen nahe verwandt, indessen kleiner, weniger gewölbt, die Fühler kürzer, bis zum vierten oder sechsten Gliede rothgelb, die folgenden Glieder angedunkelt, röthlich pechbraun, aber nicht schwarz, Glied 4 bis 6 kurz, knotig, unter sich gleichlang. Kopf weniger uneben, sparsamer und feiner punktirt, die Stirn mit er-

Europa, besonders Lappland und den Finnmarken. Grösser, schmaler gebaut, die Fühler sehr schlank, Glied 3 mehr als doppelt so lang wie 5,4 bis 6 gestreckt, das vorletzte beim $\hat{\odot}$ dünn, doppelt so lang als breit. Kopf und Halssch. durchgängig sparsamer punktirt, die Punkte auf der Stirn und der Scheibe des Halssch., ebenso in den Zwischenstreifen der Fld. ziemlich erloschen. Schwarz, Fld. roth mit 5 schwarzen Makeln, von denen 2, 3 und 4 gross, eckig, immer schärfer begrenzt sind, wie bei nivosa, Basis der Fühler und ein schmaler Analsaum gelblich. Der Penis ist etwas schlanker, vom ersten Drittel an ziemlich gleichmässig bis zur Spitze verengt, so dass die stärkere Verschmälerung am Anfange des letzten Drittels weniger in die Augen fällt. - L. 5,5-6,5 mm.

Stücke mit rothen Seiten des Halssch. sind sehr selten, von hellschienigen hat Thomson (Skand. Col. VIII. 264) nur ein einziges gesehen. Die Makeln der Fld. können entweder bis auf eine (in der Regel Makel 2) verschwinden, oder sich über die ganzen Fld. ausdehnen. 
löschenden Punkten, fast glatt. Halssch. in der vorderen Hälfte schmaler, da es sich von der breitesten Stelle vor den Hinterecken zuerst ganz allmählich, später etwas stärker verengt, die Seiten deshalb weniger gerundet, die Vorderecken spitzer. Die vorherrschende Zeichnung besteht in einer grossen schwarzen Makel, fast ron der Form eines auf der Basis ruhenden Kreissegmentes, dessen bogenförmiger Vorderrand über die Mitte hinausreicht und in der Regel einen Ausschnitt besitzt. Fld. ziemlich flach, roth, mit grossen schwarzen Flecken, kräftig punktirt-gestreift, die Zwischenstreifen meist leicht gewölbt und mit zahlreichen verloschenen Pünktchen besetzt, die aber etwas deutlicher hervortreten als bei linnaeana. An den Beinen sind die röthlichen Schienen zwar auch am Knie und auf der inneren Fläche schwärzlich, aber sie werden bei der dunkelsten Form niemals einfarbig schwarz; die Tarsen sind oberseits heller, röthlich bis bräunlich.

Das Analsegment ist beim $\hat{j}$ an der Spitze nur unmerklich ausgerandet, beinahe grade abgestutzt, beim ㅇ fast gleichmässig abgerundet und ohne Eindruck. - Penis am Unterrande regelmässig gebogen, im ersten Drittel mässig dick, gleichbreit, im mittleren verflacht und allmählich auf die Hälfte der ursprünglichen Breite verengt, am Beginn des letzten Drittels dagegen schnell in eine gleichbreite, vorn mit gerundeten Ecken abgestutzte Spitze verschmälert.

Die Reibe der Farbenabänderungen bildet sich im Grossen und Ganzen ähnlich wie bei der vorigen Art, aber sie beginnt hier mit einem helleren Halssch., endet mit weniger dunklen Fld. und Schienen und bestätigt die Meinung von einem Zusammenhange zwischen der Färbung des Halssch. und der Fld. nicht, weil sie einige, bei den bisher betrachteten Arten noch nicht beobachtete Formen mit hellem Halssch. und dunklen Fld. entbält.

Auf dem rothen Halssch. treten anfangs zwei dunkle Flecke in einer Querreihe über die Mitte auf; dieselben sind höchst selten frei, gewöhnlich durch einen Saum längs der Basis verbunden, nehmen allmählich an Umfang zu, so dass sie zunächst die Zeichnung der rufipes, später die der flavicornis kopiren, und breiten sich zuletzt über das ganze Halssch. aus.

Die Fld. sind einfarbig roth, oder haben:

1. eine Makel, entweder 2, 4 oder 3 ,

2. zwei Makeln, 2, 4 oder 2, 3,

3. drei Makeln, 1, 2, 3 oder 1, 2, 4,

4. vier Makeln, 1, 2, 3, 4 oder 1, 2, 3, 5,

5. fünf Makeln, in Stellung und Form wie bei rufipes, jedoch ist die Schultermakel öfters in 2 Flecke getheilt und die drei 
hinteren stehen etwas dichter an einander. Bei der Vergrösserung derselben fliessen zuerst 3 und 4 oder 4 und 5 , dann $4,3,1$, oder 3, 4, 2, oder 3, 4, 5 zusammen, hierauf vier Makeln so, dass entweder Makel 2 oder 5 frei bleibt, zuletzt alle Makeln. Von der rothen Grundfarbe ist nur noch um die Basis und den Aussenrand ein schmaler Saum übrig, der vor der Spitze zu einem grossen gemeinschaftlichen, vorn durch eine etwas zackige Querlinie begrenzten Flecke ausgedehnt ist. Schliesslich erlöschen Spitzenfleck und Saum, und die Fld. sind oben einfarbig schwarz, mit röthlichem bis pechbraunem Umschlage.

Die Hauptabänderungen sind folgende:

Var. a. rujula. Halssch. roth, mit 2 schwarzen Makeln, die entweder frei oder an der Basis verbunden, meist zu einem Flecke von der Form eines Kreissegmentes ausgedehnt sind, dessen Bogen den Vorderrand nicht berührt und in der Mitte ausgerandet ist; Fld. roth, ausnahmsweise auch der Kopf.

Var. b. personata. Halssch. schwarz, Fld. mit 1-5 Makeln.

Var. c. Halssch, wie bei a. oder b., Makeln der Fld. mehr oder weniger verbunden.

Var. d. Eppelsheimi. Ebenso, aber die Fld. schwarz, mit grossem, rothem Spitzenflecke, anfänglich auch noch mit einem schmalen Saum an der Basis und dem Aussenrande von gleicher Farbe.

Var. e. Körper schwarz, Schienen und Basis der Fühler gelbbraun, Epipleuren der Fld., Tarsen und Saum am Hinterrande des Analsegmentes roth, rothbraun oder pechbraun.

Bei Stücken mit vollzähligen freien oder verbundenen Makeln der Fld. ist oft die Nahtkante vom Schildehen bis zur Spitze gebräunt oder schwarz.

An der Grenze des Baumwuchses auf Salix retusa im ganzen Alpenzuge. In letzter Zeit in prächtigen Varietätenreihen von Dr. Eppelsheim aus Grünstadt auf dem Stilfser Joche gesammelt.

2. Gruppe. Halsschild in allen vier Ecken mit einer borstentragenden Pore. Vorderschienen an der Spitze schwach oder kaum zahnartig erweitert. Spartiophila Chevr. Küst.

A. Thorax der Quere nach stark gewölbt, mit fein punktirter Scheibe. Vorderschienen schwach zahnartig erweitert.

6. Phytod. fornicata '): Ovalis, valde convexa, alutacea, nitidiuscula (仓) aut subopaca (†), nigra, labro, antennarum basi, palpis,

1) Etras länger und noch mehr cylindrisch gebaut ist Phytod. variabilis O1. (Enc. méth. V. 1790. 708; aegrota Suffr. 228) aus Südfrankreich, 
libiis (inargine interno infuscalo excepto) (arsisque (estaceis, prothorace transwersim convexo, crebre subtilius, lalera versus parum fortiter. punctoto, miniato, maculis duabus nigris; scutello nigro; coleopteris miniatis, maculis 7 nigris, subtiliter punclato-striatis, interstitiis crebre

Spanien und Portugal. Sie ist auf dem Halssch. dicht und fein punktirt, an den Seiten mit groben Punkten, auf den Fld. entweder ziemlich dicht und stark, ganz unregelmāssig, oder in 9 doppelten Reihen punktirt, zwischen denen die breiteren Streifen gewöhnlich als gewölbte Längslinien emporgehoben sind. $\hat{\odot}$ mit einer weiten Grube auf dem grossen letzten Bauchringe. L. $5-8,5 \mathrm{~mm}$.

Die Farbe sehr veränderlich: a. einfarbig bräunlich oder röthlich gelb; b. Kopf mit schwarzer Querlinie auf dem Scheitel, in der Mitte oft strichförmig nach vorn verlängert, Halssch. mit 2, Fld. mit 2 bis 3 schwarzen Punkten (1 auf dem Schulterhöcker, 2 am Seitenrande und 3 an der Naht), ziemlich in der Mitte (v. sexnotata Fabr. Suppl. ent. Syst. 1793. 86); c. Kopf schwarz, ein schräger Querfleck jederseits zwischen dem Oberrande der Augen gelb; Halssch. mit grosser, schwarzer, halbkreisförmiger Makel, die auf der Basis ruht, und eine Querlinie vor dem Schildchen, sowie eine, vom Vorderrande her eindringende Mittellinie frei lässt, oder schwarz, ein breiter, verschieden geformter Saum am Seitenrande und ein schmaler, oft fehlender Saum am Vorderrande rothgelb. Fld. meist mit 2 oder 3 grossen schwarzen Punkten wie bei b., einem ähnlichen Punkte vor der Spitze, mehreren unregelmässigen kleinen Makeln ( 2 bis 3 in einer Querreihe vor, 3 hinter der Mitte) und einer zweitheiligen Makel in $2 / 3$ der Länge an der schwarzen Naht (v. spartii Ol. Ent. V. t. 9. f. 128 a. b.); d. die Makeln der Fld. fliessen zu einem grossen, unregelmässigen, lappigen Flecke zusammen: der Kopf bisweilen ganz schwarz; e. Fld. mit 4 schwarzen, unregelmässig unterbrochenen Längslinien auf den abwechselnden Zwischenstreifen, Halssch. meist mit 2 schwarzen Punkten; nur 우 (v. aegrota Fab. l. c. 1798. 87).

Von dieser Art unterscheidet sich Phyt. Grandini Desbr. (Abeille VII. 18\%0. 132) von Amélie-les-Bains in Südfrankreich nach der Beschreibung kaum: Blass gelbbraun, eine bogenförmige Quermakel von einem Auge zum andern, eine unregelmässige Makel auf der Mitte des Halssch. und das Schildchen kastanienbraun, Naht und Seitensaum über den Epipleuren bräunlich. Punktirung der Oberseite wie bei variabilis. - L. $6 \mathrm{~mm}$.

Acanthodon lineatum Gené (Mém. Ac. Torin 1839. S0. t. 2. f. 18) ron Corsica und Sardinien stimmt in der Färbung mit der Var. aegrota F. überein, ist aber kürzer, die Fld. haben 9 regelmässige starke und tiefe Punktreihen, von denen die $S$ inneren parig genähert sind und 4 schmale, schwarz gesprenkelte Streifen einschliessen. Tarsen einfach. Letzter Bauchring sehr gross, beim $\hat{\odot}$ mit tiefer Mittelgrube, die nahe dem Vorderrande einen kleinen Längswulst einschliesst. Hinterschienen am Knie etwas winkelig vorspringend, mit scharfem Zabne, der beim $\nmid$ so gross als an den Mittelschienen, beim $\hat{\odot}$ dreimal länger und stark gekrümmt ist. - L. $6-7 \mathrm{~mm}$. 
punctulatis, abdomine parce, segmento ultimo crebre punctato, tibiis anticis supra apicem parum, posterioribus valde dentato-productis. Long. 5-7 mm.

Mas: abdominis segmento anali leviter transversim depresso.

Brüggemann Abhandl. Nat. Ver. Bremen 1873. 518.

Chrysom. sexpunctata Panz. Faun. Germ. 26. 2. - Oliv. Ent. V. 571. t. 9. f. 129. - Duft. Faun. Austr. III. 204. - Steph. Ill. Brit. IV. 339. - Suffr. Mon. 223. - Redtb. Faun. A. II. 480 (Gonioctena). - Seidl. F. balt. 483 .

Var. a. innotata: Rufo-testacea, antennis apice infuscatis.

Var. b. Prothorace plerumque maculis 2, elytrisque maculis 2 vel 3 nigris $\mathrm{V}$ ar. c. Ut in b., sed coleopteris maculis 5 nigris.

Spartiophila sexpunctata Küst. Käf. Eur. 13. 91.

Var. d. picea: Nigro-picea, labro, antennis, palpis, epipleuris elytrorum, tibiis tarsisque obscure rufo-brunneis.

Höher gewölbt und an den Seiten mehr zusammengedrückt als die vorigen, schwach walzenförmig, das Halssch. nach vorn und den Seiten hin stark abwärts gewölbt, über dem Seitenrande nur wenig kräftiger punktirt als auf der Scheibe, mit einer Pore und einem Borstenhärchen in jeder Ecke.

Kurz eiförmig, nach hinten wenig erweitert, beiderseits gleichmässig breit abgerundet, äusserst fein $(\hat{o})$ oder fein gewirkt $(q)$, schwarz, Oberlippe, Taster, Fühler, mit Ausnahme der angedunkelten oberen Hälfte, Tarsen und Schienen bräunlich gelb, letztere am Knie, am Vorderrande und auf der inneren Seite dunkel, selbst schwarz; Halssch. und Fld. lebhaft roth, fast zinnoberroth, nach dem Tode bräunlich, jenes mit zwei, diese zusammen mit sieben schwarzen Makeln. Halssch, von den Hinterecken an nach vorn in flacher Rundung verengt, dicht, etwas feiner als der Kopf punktirt, nach den Seiten zu untermischt mit etwas grösseren Punkten, die besonders in der Nähe der Hinterecken schärfer hervortreten; die beiden schwarzen Makeln stehen schief nach hinten und aussen, mit ibrem grösseren Theile hinter der Mitte in einer Querreihe, und sind unter sich beinahe doppelt so weit entfernt wie jeder einzelne vom Seitenrande. Schildchen fast balbkreisförmig, schwarz. Fld. fein punktirt-gestreift, in den Zwischenstreifen dicht, sehr fein aber deutlich punktirt, von den sieben Makeln, die sie zusammen besitzen, ist 1 klein, punktförmig, auf dem Schulterhöcker; 2 gross, länglich viereckig, zwischen dem 2. und 4. Punktstreifen schief nach hinten und innen ziehend und mit der korrespondirenden, sowie dem Schildchen und den beiden Makeln des Halssch. genau wie die fünf Augen eines Würfels gestellt; 3 gross, eckig, ziemlich in der Mitte der Fld. zwischen der 4. und 7. Punktreihe, ron letzterer fast immer scharf 
begrenzt; die gemeinschaftliche Makel endlich ist ebenfalls gross, länglich-viereckig und liegt mit den Makeln 3 in einer graden Querreihe, oft jedoch ist sie klein, vorn verkürzt, in zwei Flecke aufgelöst, die weiter nach hinten gerückt sind als Makel 3, wohl aber nie so weit, wie in der Panzerschen Zeichnung. Zahn an den Vorderschienen klein, an den vier hinteren Schienen sehr gross und spitz.

Das Männchen erkennt man an den breiteren Tarsen und an einem Quereindrucke vor dem aufgebogenen Hinterrande des letzten Bauchringes. - Der Penis ist schlank, gleichbreit, an der Oeffnung eingeschnürt, davor wieder erweitert, der Vorderrand grade abgestutzt, mit breiten, abgerundeten Aussenecken und einem tiefen, dreieckigen Ausschnitte in der Mitte; der ductus vorn leicht verbreitert, zweispitzig, die rechte Spitze eine Spur länger als die linke.

Die Farbe und Zeichnung ändert $a b$ :

Var. a. Der ganze Käfer einfarbig rothgelb, bei frischen Stücken blass bräunlich gelb, und die letzten Fühlerglieder oft angedunkelt;

Var. b. Halssch. einfarbig roth oder mit den zwei normalen Flecken, jede Fld. mit $2(2,3)$ bis $3(1,2,3)$ schwarzen Makeln, oder

Var. c. die Fld, zusammen mit fün Makeln, 1, 2 und der gemeinschaftlichen an der Naht;

Var. d. Körper pechschwarz, Oberlippe, Taster, Fühler, Epipleuren der Fld., Schienen und Tarsen rothbraun oder düster gelbbraun.

Auf Weiden und Sorbus aucuparia in Schlesien selten, in Oesterreich (Mähren, Fleischer), Baiern, Ungarn, Südrussland und Südeuropa stellenweise gemein. Syrien (Reitter).

- Phytod. olivacea: Ovalis, valde convexa, subtilissime alutacea, sat nitida, mufo-testacea, prothorace transversim convexo. basi subtruncato, subtilius inaequaliter, latera versus fortius punctato, elytris fortiter punctato-striatis, interstitiis parce obsoleteque punctulatis, sutura, pectore abdomineque infuscatis aut nigricantibus, hoc parum crebre punctato. - Long. $3,5-5 \mathrm{~mm}$.

Mas: articulo ultimo palporum maxillarium lato, securiformi.

Forster Nov. Spec. Ins. I. 1771. 23. - Ma r sh. Ent. Brit. I. 181.

Var. a. flavicans: Tota rufo-testacea aut pallide sulphurea.

F a br. Mant. I. 72; Ent. Syst. I. 32S. - Oli r. Ent. V. 604. t. 1. f. 15.

Var. b. litura: Rufo-lutea, maculis 2 frontalibus, sutura vittaque elytrorum, pectore abdomineque nigris.

F a b r. Syst. Ent. 102 ; Ent. Syst. I. 328. - Oliv. 1. c. V. 574.

t. 9. 132. - Panz. Faun. Germ. 78. 6. - Marsh. 1. c. 182. 
- Duft. Faun. Austr. III. 207. - Küst. Käf. Eur. 9.95 (Spartiophila). - Suffr. Mon. 225. - Thoms. Skand. Col. VIII. 267. - Redtb. Faun. A. II. 480. - Seidl. F. balt. 484. Var. c. nigricans: Nigra, capite antico, prothorace, limbo laterali elytrorum, antennarum basi tibiisque obscure testaceis, valde infuscatis.

Ganz ähnlicb gebaut, aber bedeutend kleiner als die vorhergehende, der Kopf, die Seiten des Halssch. und die Reihen der Fld. viel stärker punktirt. Kurz eiförmig, stark gewölbt, hinten fast buckelig, überall sehr fein gewirkt, ziemlich glänzend, bråunlich rothgelb, auf dem Halssch. lebhafter als auf den Fld, die Naht der letzteren, Brust und Bauch dunkel, oft schwärzlich. Kopf beinahe eben, dicht und ziemlich stark punktirt, die Linie des Kopfschildes nur an jeder Seite schwach eingedrückt. Halssch. in der Mitte dicht und mässig fein, an den Seiten grob punktirt, die Eckpore und Borste deutlich. Punktstreifen der Fld. stark und tief, die sechs inneren sind nach hinten etwas der Naht zugebogen, die drei inneren ganz, die drei folgenden abgekürzt, indem sie sich auf dem Abfalle zur Spitze mit der unregelmässigen siebenten Punktreihe verbinden, die beiden äusseren stehen dicht neben einander und laufen den inneren nicht, wohl aber dem Seitenrande parallel; sie vereinigen sich an der Spitze mit der 2. und 3. Reihe. Zwischenstreifen oft leicht gewölbt, sparsam und verloschen punktirt. An den Vorderschienen ist der Zahn sehr kurz und stumpf, an den vier hinteren dagegen gross, spitz. Bauch wenig dicht, stark punktirt.

Beim Männchen ist das letzte Palpenglied fast doppelt so breit als beim Weibchen, beilförmig, die Tarsen sind merklich erweitert. - Penis schlank, zuerst gleichbreit, im vorderen Drittel weit und schwach eingeschnürt, hierauf an der linken Seite nicht erweitert, fast gradlinig bis vorn verlaufend, an der rechten Seite stark verbreitert, in eine scharfe, nach aussen gerichtete Spitze vorgezogen, von der aus der vordere Theil in einem sehr schiefen Bogen abgerundet ist, welcher noch, etwas rechts von der Mitte, einen spitzenförmigen, leicht nach unten gekrümmten Fortsatz hat. Auch die Rinne für den nadelförmigen ductus liegt ganz auf der linken Seite, so dass das rordere Drittel ausserordentlich missgestaltet aussieht.

Die allmähliche Veränderung der Farbe geht ungefähr in folgender Weise vor sich: Die hellste Form, welche nicht etwa frische und unausgefärbte, sondern vollständig ausgehärtete Thiere umfasst, ist einfarbig gelbbraun, oder auf der Oberseite gesättigt gelblich weiss, fast hell schwefelgelb, nur die Fühler nach der Spitze zu gebräunt (Var. a). Hierauf färbt sich die Naht und die Unterseite schwärzlich; es entsteht ein scharf begrenzter schwarzer Nahtsaum, der 
hinter dem schwarzen Schildchen schmal beginnt, sich allmählich bis zur ersten Punktreihe ausdehnt und an dieser bis zur Spitze läuft. Auf dem Scheitel treten zwei kleine dunkle Flecke auf, ebenso zwei Längsstriche auf jeder Fld, der eine hinter der Schulter auf dem siebenten $\mathrm{Z}$ wischenraume, der andere hinter der Mitte auf dem fünften. Beide verbreitern und vereinigen sich zu einer gebogenen schwarzen Längsbinde (Var. b), welche nach Suffrian zuweilen makelförmig auf das Halssch. übergreifen soll, und die sich zuletzt so verbreitert, dass sie mit ibrer schwarzen Farbe fast die ganze Fld. überzieht (Var. c). Diese Abänderung scheint bei flüchtiger Betrachtung einfarbig schwarz zu sein, aber der Vorderkopf, der grösste Theil des Halssch., ein Saum an der Seite der Fld. bis zur vorletzten Punktreihe, die Basis der Fühler und der grösste Theil der Schienen sind dunkel gelbbraun, geschwärzt. Schon bei der Var. b. sind die Schenkel an der Spitze schwärzlich. Die Meinung von Fabricius, dass die röthlichen Stücke Weibchen seien, ist dahin zu berichtigen, dass bei den ㅇ die hellen Färbungen flavicans und olivacea, bei den $\hat{\sigma}$ die dunkleren b. und c. vorherrschen. Auf Spartium scoparium gemein, in Südeuropa auf Ginsterbüschen.

B. Thorax der Quere nach wenig gewölbt, überall grob punktirt. Vorderschienen nicht zahnartig erweitert.

8. Phytod. quinquepunctata: Sat elongata, convexiuscula, rufo-testacea, sat nitida, antennis articulo penultimo crassitie sua evidenter longiore; prothorace lateribus ante medium leviter rotundatodilatatis, grosse, latera versus crebrius punctato; elytris maculis pluribus nigris, fortiter punctato striatis, striis mumerose punctatis, anguln suturali haud mucronato, epipleuris margine interiore pone medium evanescente. - Long. 5-6,5 mm.

F a br. Mant. Ins. I. 72. - Suffr. Mon. 231. - Thoms. Skand. Col. VIII. 266. - Redtb. Faun. A. II. 481. - Seidl. F. balt. 484. - Weise Monatsbl. 1880. 76.

Chrysom. dispar Gyllh. Ins. Suec. III. $4 \mathrm{~S} 2$ (pars.), - Redtb. Faun. A. ed. 1. 557 (Gonioctena).

Paropis sorbi Grimmer Steierm. Col. 47.

Var. a. unicolor: Tota pallide aut saturate rufo-testacea.

Chrysom. dispar Duft. Faun. Austr. III. 204.

Var. b. flavicollis: Subtus plus minusve nigra, supra capite vel saltem fronte prothoraceque (interdum nigro-bimaculato) rufo testaceis, maculis elytrorum plerumque connatis vel confluentibus.

Duft. 1. c. 206. - Suffr. Mon. 233.

Var. c. sorbi: Subtus plus mimusve nigra, supra capite antice, prothorace maxima parte (linea media plerumque excepta) vel omnino nigris, maculis elytrorum connatis. 
Vаг. d. obscura: Nigra, ore, antennarum basi, fronte pedibusque rufescentibus, his interdum nigris.

Grimmer 1. e. 48 .

Schlanker und flacher als die beiden vorigen, ziemlich gleichbreit, beiderseits sehr kurz abgerundet, daher von mehr eckigem Ansehen, Halssch. und Fld. grob punktirt, Zahn der Mittel- und Hinterschienen schwächer.

Gestreckt, wenig gewölbt, röthlich gelbbraun, ziemlich glänzend. Fühler die Hinterecken des Halssch. wenig überragend, nach der Spitze hin oft gebräunt, oder angedunkelt, das vorletzte Glied länger als breit. Halssch. mehr wie doppelt so breit als lang, ziemlich flach, vor der Mitte am breitesten, mit gerundeten, hinten wenig, vorn stärker convergirenden Seiten, auf der Scheibe unregelmässig und nicht dicht, grob punktirt, die Punkte nach den Seiten hin etwas grösser und tiefer, mit einzelnen sehr feinen Punkten in den Zwischenräumen. Fld. mit starken, regelmässigen Punktreihen, von denen die siebente durch überzählige Punkte hinter der Mitte unregelmässig verdoppelt ist und sich mit der sechsten bis dritten nach und nach verbindet. Die fünfte Punktreihe beginnt sehr tief an der Basis, hebt den Schulterhöcker kräftig empor und tritt hinter diesem in eine leichte Quervertiefung, die sich nach der Naht zu zieht. Die Zwischenstreifen sind einzeln, sehr fein, beinahe einreihig punktirt. Epipleuren ziemlich schmal, bis zum Anfange des zweiten Bauchringes flach gedrückt, von hier aus bis zur Spitze gewölbt, so dass die innere, aufgebogene Randlinie anfangs verdeckt wird, und später ganz erlischt. Vorderschienen mit gerundeter, nicht zahnartig erweiterter Aussenkante; der Zahn an den Mittelschienen etwas grösser als an den Hinterschienen.

Das Männchen erkennt man an den mässig erweiterten Tarsen und den glatten Zwischenräumen der Punkte auf den Fld, die beim f äusserst fein gewirkt sind. - Der Penis ist nach vorn leicht verengt, an der grossen, unten von einer durchscheinenden Haut geschlossenen Oeffnung gerundet-erweitert, hierauf wieder stark gerundet-verengt und in eine wellig gebogene, dreieckige Spitze verschmälert, deren Ränder wulstig verdickt sind.

Die hellste Form ist einfarbig, entweder blass, oder gesättigt röthlich-gelbbraun (Var. a), hierauf bilden sich auf beiden Fld. zusammen 5 schwarze, selten recht scharf begrenzte Makeln: eine runde, dicht hinter der Basis, zwischen Schulter und Schildchen, eine quere, etwas schräg nach innen und hinten ziehende, vor der Mitte, zwischen der 4. und 8. Punktreihe, und eine gemeinschaftliche, in der Mitte auf der Naht (Stammform). Bei weiterer Zunahme der schwarzen Farbe wird: 
1. die Unterseite dunkel, auf den Fld. zeigen sich noch ein oder mehrere, in der Form sehr veränderliche schwarze Punkte oder Makeln auf der hinteren Hälfte, während sich die Quermakel vergrössert, nach vorn auf dem 8. Zwischenstreifen bis zur Schulterbeule verlängert und nach innen $z u$ mit der gemeinschaftlichen Nahtmakel zusammenfliesst; Kopf und Halssch. sind röthlich braun, oder ersterer vorn schwarz, letzteres mit 2 schwarzen Punkten (Var. b); oder

2. die Unterseite mit Ausnahme der Beine und Fühler, Vorderkopf und Halssch. schwarz, dieses meist mit rother Mittellinie oder noch einem schmalen Saume am Vorder- und Hinterrande, Makeln der Fld. mehr oder weniger verbunden (Var. c); endlich 3. der Körper schwarz, Mund, Fühlerwurzel, Stirn und Füsse röthlich, letztere bisweilen schwarz (Var. d).

Auf Sorbus aucuparia an feuchten, schattigen Orten in der norddeutschen Tiefebene sehr zerstreut, im Berglande und Gebirge gemein.

9. Phytod. pallida: Oblongo-ovalis, convexa, rufo-testacea, sat nitida, antennis articulo penultimo crassitie sua haud longiore, prothorace lateribus subparallelis, antice angustato, grosse, latera versus crebrius punctato, elytris fortius punctato-striatis, striis sat mumerose punctatis, angulo suturali plerumque mucronato-producto, epipleuris margine interiore usque ad apicem elevato. - Long. 5-7 mm.

Linné Syst. Nat. ed. X. 370. - Suffr. Mon. 234. - Thoms. Skand. Col. VIII. 264. - Redtb. Faun. A. II. 481. - Seidl. F. balt. 484. - We ise Monatsbl. 1880. 76.

Chrysom. dispar Gyllh. Ins. Suec. III. 482 (pars.).

Chrysom. padi Degeer Mém. Ins. V. 301. t. 9. f. 2.

Var. a. decipiens: Pectore abdomineque saepe piceis vel nigris, elytris maculis plurimis nigris.

Var. b. borealis: Ut in a, sed prothorace nigro-bimaculato vel in disco late nigro, maculis elytrorum confluentibus.

Var. c. frontalis: Nigra, plerumque capile vel sallem ore, antemis basi genubus tarsisque brunneo-testaceis.

Oliv. Ent. V. 591. 98. t. 8. f. 123. - Suffr. Mon. 235.

Der vorigen sehr ähnlich, aber kürzer und breiter, viel höher gewölbt, ausserdem durch folgende Punkte sicher zu unterscheiden: Die Fühler sind weniger lang, ihre letzten fünf Glieder breiter, deutlicher von den vorhergehenden abgesetzt, das vorletzte kaum so lang als breit. Halssch. nicht vor der Mitte, sondern kurz vor den etwas eingezogenen Hinterecken am breitesten, die Seiten weniger gerundet, fast parallel, oder zuerst sehr schwach, im rorderen Drittel etwas stärker convergirend. Fld. nach hinten zu etwas mehr erweitert und schwach buckelig gewölbt, noch kräftiger punktirt- 
gestreift, aber die Reihen, namentlich die 4. bis 7, bald hinter der Mitte in einander gewirt; der Nahtwinkel ist schärfer, fast immer in eine kurze Spitze vorgezogen, die Epipleuren endlich sind am Ende der Brust weniger verschmälert, mehr gleichbreit, überall flach gedrückt, ihre innere Randlinie ist bis zur Spitze deutlich aufgebogen. Auch der Sporn an den vier Hinterschienen ist gewöhnlich etwas grösser und spitzer als bei 5-punctata.

Der Penis ist breiter und fast um die Hälfte länger, an der Oeffnung nur unmerklich gerundet-erweitert, davor schwach und ziemlich geradlinig verengt, vorn abgestutzt und in der Mitte in eine stumpf-dreieckige, unten beinahe flach angedrückte Spitze umgeschlagen; die wulstig verdickten Ränder der Oeffnung stossen nicht zusammen, sondern lassen eine Rinne für den ductus frei. Auf der Unterseite läuft ein hoher Mittelkiel bis kurz vor die Spitze.

Die Farbe ist ein ziemlich helles, auf den Fld. noch blasseres Rothbraun, bei frischen Stücken einfarbig weisslich gelbbraun; $\mathbf{A b}$ änderungen, die im Allgemeinen denen der vorigen Art entsprechen, sind bei uns selten, nur in Finnland und der nördlichen Hälfte Schwedens, wo das Thier häufig ist, kommen sie öfter vor. Es färbt sich Brust und Bauch dunkel, pechbraun bis schwarz, die Fld. erhalten eine (gemeinschaftliche) schwarze Makel, oder viele schwarze Flecke, die noch unregelmässiger gestellt sind wie bei 5-punctata (Var. a); oder das Halssch. hat zwei schwarze Punkte, welche sich so ausdehnen, dass sie fast die ganze Scheibe einnehmen, während zu gleicher Zeit einzelne oder alle Makeln der Fld. zusammenfliessen (Var. b); zuletzt ist das Thier schwarz, der Kopf, wenigstens der Mund, die Basis der Fühler, Knie und Tarsen dunkel braungelb.

Auf Sorbus aucuparia in Nord- und Süddeutschland viel seltener als die vorige, im mitteldeutschen Berglande und Gebirge stellenweise sehr zahlreich. Karpathen. Sibirien.

\section{Phyllodecta.}

Kirby Faun. bor. Am. IV. 1837. 216.

Phratora Redtenbacher Faun. Austr. ed. 1. 1849. 554.

Corpus oblongun, coeruleo- aut viridi-metallicum.

Prothorax transversim subquadratus, angulis sine fovea et seta.

Elytra striato-punctata.

Tibiae apice haud dentato-productae.

Tarsi articulo tertio lato, bilobo, unguiculis appendice dentiformi acuta armatis.

Körper gestreckt, sehr lang eiförmig, geflügelt, mässig gewölbt, metallisch blau oder grün, selten bis messinggelb, kupferig violett 
oder schwarz variirend. Kopf geneigt, von oben nicht sichtbar, klein, so lang als breit, Kopfschild von der Stirn durch eine winkelige Linie getrennt, welche am Vereinigungspunkte ibrer Schenkel am tiefsten ist und von hier aus einen verschieden langen Eindruck zwischen die Augen sendet, der den gewölbten Raum über dem Kopfschilde in zwei Beulen theilt. Oberlippe kurz, quer, vorn gerundetabgestutzt. Mandibeln schwach gekrümmt, dreizähnig, Endglied der Palpen länglich, vorn leicht zugespitzt. Augen oval, stark gewölbt. Fühler ungefähr so lang als der halbe Körper, schwarz, die beiden Basalglieder unterseits röthlich, ${ }^{1}$ ) die fünf letzten Glieder schwach verdickt, Glied 1 ziemlich dick, die übrigen cylindrisch. $\mathrm{Hals}$ $\mathrm{schild}$ quer viereckig, etwas schmaler als die Flügeldecken, nach den Seiten hin schwach, nach vorn stärker abwärts gewölbt, Vorderecken niedergedrückt, Seiten fein, aber scharf gerandet, im vorderen Drittel convergirend, ohne eine Pore oder Borste in den Ecken. Schildchen halbelliptisch. Flügeldecken an den Schultern etwas gerundet heraustretend, dahinter ziemlich parallel, am Ende gemeinschaftlich breit abgerundet, mit einer abgekürzten und neun ganzen, über der Spitze verworrenen Punktreihen, von denen die erste hinter der Mitte furchenartig vertieft ist. Die 5. und 6. beginnen an der Basis in einem Eindrucke, der die Schulterbeule kräftig emporhebt. Die Zwischenstreifen dicht und sehr fein punktirt, nur der Streifen zwischen der 7. und 8. Punktreihe (bei einer Art der Raum zwischen der 6. und 9. Reihe) besitzt so starke Punkte wie die Reihen selbst, so dass diese nicht deutlich herrortreten können. Epipleuren breit, allmählich nach hinten verschmälert, vor der Spitze erlöschend. Vorderbrust zwischen den Hüften etwas verengt, in der Mitte der Länge nach fast kielförmig gewölbt, mit tiefer Randlinie, nach hinten wieder erweitert und gerundet-abgestutzt, in eine breite Grube des Mesosternum eingreifend. Letztes Abdominalsegment am ganzen Hinterrande röthlich, ${ }^{1}$ ) bewimpert, oder mit zwei feinen Haarbüscheln. Beine ziemlich lang, Schenkel mässig dick, Schienen nach der Spitze allmählich schwach erweitert, das zweite Tarsenglied klein, das dritte gross, breit, fast bis zum Grunde in 2 Lappen gespalten, zwischen denen das Klauenglied zur Hälfte, oder darüber hinaus eingelagert ist, Klauen gelbbraun, dünn, gebogen, an einem breiteren schwarzen Basaltheile befestigt, der jederseits scharf abgeschnitten ist und daher zahnförmig vorsteht.

Das Männchen zeichnet sich durch kleineren Körper, längere Fühler, namentlich aber durch die Erweiterung des ersten Tarsen-

1) Dies Merkmal ist in der Beschreibung der Arten nicht mehr erwähnt. 
gliedes aus. Der Penis bildet eine kurze, ziemlich dicke Röhre, mit grosser Oeffnung, deren unterer Rand an der Spitze abgerundet oder in eine Spitze verlängert ist; ductus bandförmig, zweispitzig, oft mit Anbängen rersehen. Beim Weibchen hat das Analsegment ror dem Hinterrande einen schwachen Quereindruck, welcher sich seitwärts etwas verbreitert und vertieft und bis zum Vorderrande jederseits hinzieht, wodurch der vordere Theil des Segmentes wulstig in die Höhe gehoben wird.

Die ersten Stände sind schon seit Rösel (Insect. Belust. 1749. 5-7. t. 1. f. 1-3) und Degeer (Mém. Ins. V. 401. t. 9. f. 27-33) bekannt, ausführlich wurde beschrieben die Larve und Puppe von vitellinae durch Westwood (Introd. 1839. 1. 389. f. 48. 18-19) und Letzner (Arb. Schles. Ges. Breslau 1855. 106); eine vollständige, zuverlässige Entwickelungsgeschichte unserer Arten verdanken wir aber Cornelius (Stett. Zeit. 1857. 392-399). Nach demselben sind die Eier länglich rund, stumpf zugespitzt, kornförmig, weiss, nur die von atrovirens zimmtbraun; sie werden auf die Unterseite der Blätter in Häufchen von 13 bis 18 Stück so in zwei Reihen nebeneinander gelegt, dass sich die Spitzen berühren und das ganze Häufchen einen länglich viereckigen Fleck bedeckt, hierauf mit einer Flüssigkeit überzogen, die zu einer blätterigen Haut zusammentrocknet. Die Larven schlüpfen nach ungefähr 8 Tagen aus und beginnen, neben einander nach aussen $\mathrm{zu}$ stetig fortschreitend, die Unterseite der Blätter, die an den angegangenen Stellen schwarz werden, zu skelettiren, bis sie sich nach ungefähr drei Wochen zur Verpuppung in die Erde verkriechen. Sie sind etwas länger als die Käfer, schmal, ziemlich flach, und baben auf dem Rücken vier ziemlich regelmässige Längsreihen von Warzenhöckerchen, die mit einigen aufstehenden Haaren besetzt sind.

Die Larve von vitellinae hat, nach Letzner, dreigliedrige Fühler (Glied 1 und 2 kurz, dick, 3 dünn, cylindrisch, etwas länger als 2), vier Augen in einem Viereck hinter den Fühlern, viergliederige Maxillartaster (Glied 3 so lang als 1 und 2 zusammen, 4 etwas länger als 3) und zweigliederige Lippentaster. Auf der Oberseite ist der Kopf schwarz, mit weisslicher Oberlippe, Brust schwärzlich, Bauchsegmente trüb weiss, die Mitte des 4. bis 6. Segmentes dunkel; auf der rein weissen Unterseite steht in der Mitte a. jedes Brustringes ein schwarzer, zuweilen doppelter Fleck, b. jedes Bauchringes ein Querstrich und jederseits von diesem ein Punkt von schwärzlicher Farbe.

Ganz ähnlich ist die Larve von viennensis, aber die Oberseite glanzlos, russfarbig, von einer gelblichen Mittellinie durchzogen;

VI. 3. 
weniger stimmt die von atrovirens überein, da sie oben eine trüb olivengrüne Grundfarbe hat und in den Gelenkrinnen der Hinterleibssegmente eine Querreihe von verloschenen russfarbigen Flecken besitzt (zwischen den nebeneinander liegenden Paaren der Warzenpunkte je einen Fleck), welche in Verbindung mit den Höckerchen dunkle Längsstreifen bilden. Die Unterseite ist weisslich, mit einer Reihe dunkler Punkte nahe dem Seitenrande.

Die Larven von vulgatissima und laticollis sind unterseits einfarbig gelblich weiss. Erstere ist die längste von allen, nach hinten sehr rerschmälert, in der Jugend und kurz vor der Verpuppung oben gelblich weiss, Kopf und Warzen schwarz, sonst fast schwarz, matt, mit olivengrünlicher Mittellinie. Von laticollis beobachtete Cornelius zwei Formen, die er aus den Eiern derselben Mutter erzog; die grössere hat die gewöhnliche Bildung, indem auf der geschwärzten Oberseite vier schwarze Längsstreifen von Tuberkeln stehen, bei der kleineren sind die Tuberkeln nicht vorhanden, und die weissgelbe Oberseite ist ron dem schwarzen Kopfe, den eben so gefärbten Tracheenkegeln und einem Flecke auf dem Analsegmente wie mit einem schwarzen Gürtel umzogen.

Von den bis jetzt beschriebenen 20 Arten, die auf Weiden oder Pappeln leben und über die nördliche gemässigte und kalte Zone verbreitet sind, bleiben nach Abzug der von Motschulsky in unglaublicher Flüchtigkeit beschriebenen, nur wenige, grösstentheils in Deutschland einheimische Arten übrig. Sie variiren in der Körperform, Farbe und Punktirung nicht unbedeutend, so dass ihre sichere Unterscheidung schwierig ist, und gliedern sich in 2 Abtheilungen:

a. Antennae articulis 4-6 longe pilosis, prothorax basi subtiliter marginatus . . . . Chaetocera Weis e.

b. Antennae haud longe pilosae, prothorax basi immarginatus

A. Fühlerglied 4 bis 6 lang abstehend behaart, Glied 2 fast so lang oder länger als 3. Halsschild überall gerandet.

\section{Fhyllod. (Chactocera) vulgatissimaํ): Oblonga,} aeneo-coerulea, nitida, metasterno segmentoque primo ventrali cupreoaurichalceis, capite tuberculis facialibus sat magnis, linea profunda postice divisa discretis, fronte subconcexa, vertice vage impresso; pro-

1) Ausserordentlich ähnlich ist $P h$. (Chaetocera) inhonesta: Oblonga, nigro-coerulea, interdum viridi micans, subnitida, capite tuberculis facialibus sat magnis, impressione profunda discretis, fronte medio evidenter excarato, prothorace leviter transverso, basi utrinque impressiune transiersa, elytris 
thorace leviter transverso, basi utrinque obsolete vel haud impresso, elytris sat regulariter striato-punctatis, striis $6-9$ confusis, interstitiis sat crebre subtilissimeque punctulatis, octavo subcostato. - Long. 4-5 mm.

Mas: tibiis posticis subincurvis, articulo mimo tarsorum valde dilatalo, tertio latiore et sequentibus 2 fere longiore.

Linn. Syst. Nat. ed. X. 370. - Scop. Ent. Carn. 71. - Duft.

Faun. Austr. III. 210. - Suffr. Mon. 258 (C'hrys.). -

Cornelius Stett. Zeit. 1857. 402. - Thoms. Skand. Col.

VIII. 276. - Redtb. Faun. A. II. 484. - Seidl. F. balt. 487.

Chrys. vitellinae Gyll, var. d. Ins. Suec. III. 497. - Küst. var. $\gamma$. Kăf. Eur. 7. 90.

Phratora coerulescens Küst. 1. c. 14. 100. - Weise Deutsch. Zeit. 1884. 156.

Phrat. longula et obtusicollis Motsch. Schrenck. Reis. II. 229. 230. Var. a. aestiva: Supra viridi-aenea, haud coeruleo-sed obscure aurichalceo-micans.

Var. b. obscura: Supra nigro-cyanea, laete cupreo-violacea, violaceonigra cupreo-micans aut nigra, margine laterali elytrorum plerumque virescens.

Lauggestreckt, wenig gewölbt, metallisch grünlich blau, glänzend, die Mitte der Hinterbrust und des ersten Bauchringes messinggelb, oft mit Kupferschimmer. Kopf ziemlich dicht und fein punktirt, Kopfschild sehr breit, dreieckig, eben, vorn durch einen schwachen Quereindruck fast allmählich in den schwarzen, häutigen Theil übergehend, so dass der Vorderrand nicht in Form einer Kante aufsteigt, die beiden oberen Grenzlinien durchschneiden sich $\mathrm{X}$-förmig und trennen so zwei quer eiförmige, meist kupferige Beulen zwischen der Fühlerwurzel; darüber ist die Stirn flach gewölbt, mit einer kurzen, schwachen Mittelrinne auf dem höchsten Theile des Scheitels.

minus regulariter striato-punctutis, striis 7 et 8 conjusis, interstitïs parce evidenter punctatis, octavo elevato. - Long. 4-5 mm.

Etwas schwächer glänzend als vulgatissima, Beulen des Unterkopfes breiter getrennt, Stirn der ganzen Länge nach dreieckig ausgehöhlt (weniger tief und breit wie bei laticollis), Basis des Halssch. durch einen tiefen und deutlichen Quereindruck, der in der Mitte unterbrochen ist, in die Höhe gehoben, Punktreihen der Fld. etwas stärker, aber unregelmässiger, nicht so scharf hervortretend, da die Zwischenstreifen zwar sparsamer, aber weit kräftiger punktirt sind. - Penis schlanker, in der Mitte melır verengt, vorn stärker verbreitert, die in einem weiten Bogen gerundet-abgestutzte Spitze gerade vorgestreckt.

Bei Kjachta (Eversmann, Faust). Sarepta?

Auf die vorliegende Art vermag ich keine der nichtssagenden Beschreibungen Motschulsky's anzuwenden. 
Fühler dünn, das zweite Glied "ntweder so lang als das dritte, nder eine Spur länger, zuweilen auch kürzer, aber nie so bedeutend, wie bei den folgenden Arten, das 4. bis 6. Glied mit einer Reihe langer. weisslicher Haare am Vorderrande. Halssch. etwas breiter als lang, viereckig, die Seiten hinten fast parallel, vorn leicht convergirend. die Hinterecken scharf rechtwinkelig, die Vorderecken stumpf, abgerundet; ringsum gerandet, die aufgebogene Kante am IIinterrande jedoch feiner als an den übrigen Rändern; die Oberfäche mässig gewölbt, vor der Basis jederseits nicht oder nur schwach quer eingedrückt, in der Mitte der Scheibe fein und zerstreut, nach den Seiten hin stärker punktirt. Fld, bedeutend breiter als das Halssch. fast gleichbreit, die inneren fünf Punktreihen fein, ziemlich regelmässig, etwas geschlängelt, ihre $\mathbf{Z}$ wischenstreifen glänzend, unter einer scharfen Loupe betrachtet ziemlich dicht, sehr fein punktulirt, dazwischen mit einzelnen grösseren Punkten. Die äusseren rier Punktreihen stärkes, durch überzählige Punkte verdoppelt und verworren, die siebente rertieft, so dass der nach aussen liegende Streifen als schwache Längsrippe mehr oder weniger deutlich emporgehoben wird. Der Zahn am Grunde der Klauen ist gross und überragt die Mitte derselben.

Beim Männchen sind die Hinterschienen sanft einwärts gekrümmt, das erste Tarsenglied ist sehr gross, breiter als das dritte und fast länger als die zwei folgenden zusammen. - Penis ron der Mitte nach vorn leicht verbreitert, der untere, vorstehende Theil der Oefinung etwas aufwärts gebogen, vorn mit schwacher Rundung abgestutzt und in der Mitte in eine kurze, breite, abgestutzte Spitze rerlängert. Die grosse Oeffnung wird ein Stück ron einer häutigen Klappe bedeckt, die jederseits in einen hornigen, senkrecht in die Oeffnung hinein gebogenen Zipfel ausläuft.

Die Farbe der Oberseite verändert sich durch Zunahme Var. a. con Grün in ein reines, nicht mit Blau gemischtes Grün, welches einen mehr oder weniger starken, ziemlich rerschossenen Messingschimmer besitzt, Halssch, und Schildchen oft kupferig; oder umgekehrt durch Zunahme

Var. b. von Blau in dunkel kornblumenblat, violett, kupferig violett oder schwarz, mit oder ohne Kupferschimmer. Im letzteren Falle bleibt meist ein Streifen am Seitenrande der Fld. grünlich.

Auf den grauhaarigen Weiden z. B. Sal, caprea, cinerea, riminalis und aurita häufig, im Frühlinge rorherrschend blaue bis blaugrüne, im Sommer, besonders Anfang August, metallisch grüne Stücke. 
B. Fühlerglieder 4 bis 6 ausser den organischen Borsten ohne abstehende Haare, Glied 2 viel kürzer als 3. Halsschild an der Basis nicht gerandet. Phyllodecta i. sp.

* Klauenzahn sehr klein.

2. Plyllod.viennensis: Oblonga, viridi-aenea, aurichalceo micans, nitida, tibiis tarsisque testaceis; capite tuberculis facialibus sat depressis, linea profunda discretis, fronte longitudinaliter obsolete impresso, prothorace leviter transverso, sat comexo, basi utrinque transzersim impresso, lateribus subvolundatis; elytris fere regulariter strialo-punctatis, interstitiis subtilissime punctulatis; articulo quarto tarsorum longissimo, unguiculis basi paullo crassis, subliliter dentatis. - Long. 5-6 mm.

Mas: segmento ultimo ventrali medio deplanato, articulo primo tarsorum dilatato, quam tertio parum latiore.

Schrank Enum. Ins. 72. - Weise Deutsch. Zeit. 1882. 157.

Chrysom. tibialis Suffr. Mon. 259. - Cornelius Stett. Zeit. 1857. 399. - Seidl. F. balt. 487.

Phratora vulgatissima var. Kellner Berl. Zeit. 1873. 217. Redtb. Faun. A. II. 484.

Var. a. Aurichalcea, plus minusve cupreo-micans.

Var. b. coerulea: Coeruleo-viridis aut nigro-coerulea parum vel haud viridescens.

Var. c. Cornelii: Tibiis coeruleo-aeneis, basi subcupreis, tarsis piceis. Weise 1. c. 1882.157.

An dem sehr langen Klauengliede, welches viel weiter über die Lappen des dritten Tarsengliedes hinaus ragt als bei den folgenden Arten, sowie an den Klauen, deren schwarze Basalhälfte nur schmal ist und an der Spitze in einen sehr kleinen scharfen Zahn endet, mit Sicherheit zu erkennen.

Langgestreckt oder länglich-oval, dunkel metallisch grün mit Messingschimmer, glänzend, Schienen und Tarsen röthlich gelbbraun. Kopfschild breit dreieckig, einzeln stark punktirt, vorn durch einen schwachen Quereindruck in den häutigen Theil übergehend, hinten tief begrenzt; die Linien vereinigen sich in der Mitte zu einer kurzen Rinne, welche die am Vorderrande wulstigen, hinten flach gedrückten Beulen zwischen der Fühlerwurzel trennt und sich in einem dicht punktirten Eindrucke verliert, der sich bis auf den Scheitel erstreckt, aber in der Mitte etwas verflacht ist. Fühler lang, besonders beim $\hat{j}$, Glied 2 fast nur halb so lang als das dritte, die folgenden bedeutend länger als breit. Halssch. schmal, etwas breiter als lang, die Seiten hinten ziemlich parallel, nur vor der Basis leicht ausgeschweift, mit spitzen Hinterecken, im vorderen Drittel stark convergirend, die Vorderecken scharf. Oberseite ziemlich gewölbt, ein 
rundlicher, breiter aber flacher Eindruck jederseits in der Mitte (zuweilen auch vier Grübchen in einer Querreihe) sowie eine tiefere Querlinie auf jeder Seite des Schildchens vor dem Hinterrande dicht und ziemlich kräftig punktirt, der übrige Theil der Scheibe viel feiner und weitläufiger punktirt. Fld. bedeutend breiter als das Halssch., die Punktreihen in der Regel ziemlich stark und fast gerade, unmerklich geschlängelt, die Zwischenstreifen sehr fein punktulirt, nur der zwischen der 7. und 8. Reihe unregelmässig mit eben so grossen Punkten besetzt wie die Reihen selbst.

Beim $\hat{\sigma}$ ist die Mitte des Analsegmentes flach gedrückt, das erste Tarsenglied stark erweitert und wenig oder kaum breiter als das dritte Glied. - Penis gleichbreit, an der Oeffnung schnell und beinahe in grader Linie verschmälert, hierauf in eine kurze, breite, scharf abgestutzte, etwas aufgebogene Spitze verlängert; die häutige Klappe vorn grade abgeschnitten.

Die Farbe verändert sich in:

a. messinggelb, ohne grünen Schimmer, mehr oder weniger in Kupferroth übergehend, namentlich auf Kopf und Halssch., b. dunkel blaugrün bis schwarzblau, wenig oder kaum mit Grün versetzt.

Bei diesen Färbungen sind die Schienen, mit Ausnahme der Kniegelenke, und die Tarsen röthlich gelbbraun, oder die Schienen werden allmählich einfarbig bläulich- oder rein metallgrün mit kupferigen Kniegelenken, die Tarsen pechschwarz (Var. c).

An Gebirgsbächen hauptsächlich auf Salix purpurea häufig, seltener in der norddeutschen Tiefebene. Der nördlichste bekannte Fundort ist Riga (Seidlitz).

Die Art hat mit vulgatissima, womit sie mehrfach rerbunden wurde, kaum die Gattung gemein, dunkelschienige Stücke könnten bei oberfächlicher Betrachtung eher mit vitellinae verwechselt werden.

* Klauenzahn gross.

3. Phyllod. vitellinde: Oblongo-oralis, viridi-aurichalcen, nilida, antennis sat brexibus, clypeo mayno, subplano. tuberculis facialibus parum conrexis, impressione modice jrofunda, superne lineam lomgiludinalem subeleratam includente, discretis, protharace transierso, lateribus postice subparallelis, antice convergentibus: elytris sat requlariter striato-punctatis, punctis striarum sat crcbre impressis, interstitiis parce punctulatis, unyuiculis fortius dentatis. - Long. $4-5 \mathrm{~mm}$.

Mas: tarsis articulo primo modice dilatato, quam tertio angustiore. Femina: tarsis articulis 2 primis sat parvis, articulo tertio lato.

Linné Syst. Nat. ed. X. 370. - Oliv. Ent. V. 575. t 4. f. 56. a. b. - Panz. Faun. Germ. 44. 16. - Gyllh. Ins. Suec. 
III. 497 (pars.). - Duft. Faun. A. III. 209. - Küst. Käf. Eur. 7. 90 (pars.). - Suffr. Mon. 261. - Thoms. Skand. Col. VIII. 276. - Redtb. Faun. A. II. 484. - Seidl. F. balt. 487. - Weise Deutsch. Zeit. 1882. 158.

Phratora angusticollis Motsch. Schrenck Reis. II. 230. Phratora latipennis Motsch. 1. c.

Var. a. Elytris cupreis.

Var. b. Obscure aenea, parum vel haud aurichalceo-micans.

Var. c. Nigro coemuleo-aenea, elytris interdum nigro-chalybaeis.

Phratora brevicollis Motsch. 1. c.

? Phrat. funesta Fald. Nouv. Mém. Mose. V. 363.

? Phrat. Fairmairei Bris. Ann. Fr. 1866. 423.

Var. d. nigrica: Supra vel omnino nigra.

Motsch. 1. c. 230 .

Var. e. major: Robustior, plerumque nigro-coeruleo-aenea, interdum obscure aenea, subaurichalcea, prothorace elytrisque fortiter punctatis.

Stierlin Mittheil. Schweiz. Ges. 1863. 65.

\section{Var. f. Brunneo-metallica.}

Von der vorigen durch den regelmässiger ovalen Körper, das kürzere, rerhältnissmässig breitere Halssch., kurze Fühler, dem Körper stets gleichfarbige Schienen, beim ô schmalere Tarsen und besonders durch die an der Basis breiten, einen grossen, scharfen Zahn bildenden Klauen verschieden.

Länglich-eiförmig, lebhaft grünlich messinggelb, glänzend. Fühler ziemlich kurz, das zweite Glied wenig oder viel kürzer als das dritte, das sechste bis zehnte Glied kaum länger als breit, die Keule vom siebenten Gliede an deutlich abgesetzt. Kopfschild gross, beinahe eben, vorn durch einen schwachen Quereindruck in den häutigen Theil übergehend, hinten tief begrenzt; die Linien verbinden sich in der Mitte zu einem Eindrucke, welcher die wenig gewölbten Beulen zwischen der Fühlerwurzel trennt and in zwei, mit je einer starken Punktreihe besetzte Eindrücke sich verlängert, die einen kleinen, schwachen Längskiel zwischen den Augen einschliessen. $\mathrm{Halssch}$. breit, die Seiten hinten parallel oder vor der Basis leicht ausgebuchtet, mit rechtwinkeligen oder spitzen Hinterecken, in der vorderen Hälfte stark convergirend. Oberseite mässig gewölbt, ein bis zwei Punkte jederseits hinter der Mitte und ein Quereindruck auf jeder Seite ror dem Schildchen sehr undeutlich, die Punktirung zerstreut und fein, in den Eindrücken etwas stärker. Fld. breiter als das Halssch., mit kräftigen, hie und da geschlängelten Punktreihen und sparsam punktulirten Zwischenräumen, von denen der achte wie gewöhnlich eben so starke Punkte besitzt, als die Reihen. Klauenglied lang, nur zur Hälfte von den Lappen des dritten Gliedes umschlossen. 
Beim $\hat{j}$ ist das erste Tarsenglied mässig erweitert, breiter als das zweite, aber etwas schmaler als das dritte Glied, beim sind die beiden ersten Glieder ziemlich gleichbreit und bedeutend schmaler als das dritte. - Penisröhre dick, nach der Oeffnung sanft verbreitert, daror in einem grossen Bogen abgerundet, mit einer unscheinbaren stumpfen Spitze in der Mitte des Vorderrandes, oder ohne eine solche.

Die Farbe verändert sich durch Wegfall der grünen Beimischung in ein reines, starkes Messinggelb, zu dem später ein leichter Kupferschimmer tritt, welcher sich auf den Fld. in blass bis gesättigt kupferroth verdichtet (Var. a); oder die Messingfarbe schwindet, der Körper wird einfarbig dunkel erzgrün (Var. b) oder bläulich dunkelgrün, metallglänzend, zuweilen mit schwärzlich blassblauen, fast dunkel stahlblauen Fld. (Var. c), oder oberseits, selbst gänzlich schwarz (Var. d). Häufig ist das Halssch. dunkler als die Fld.

Auch im Körperbau und der Punktirung ist die Art an bestimmten Fundorten ganz erheblichen Abweichungen unterworfen. Eine grosse Form (Var. e), die vorherrschend dunkel blaugrün gegefärbt ist, seltener dunkelgrün mit mässigem Messingschimmer, zuweilen auch kaffeebraun, metallglänzend (Var.f), findet sich in den Alpen, in Norwegen (Cornelius) und Lappland. Sie ist oben durchweg stärker punktirt als unsere kleine, gewöhnliche Form, und die Reihen der Fld. zeigen mebr Neigung, sich zu verwirren; von vitellinae ist sie wegen der gleichen Kopf-, Tarsen- und Klauenbildung nicht spezifisch zu trennen.

Stücke aus dem südlichen Europa (Spanien, Reitter), aus dem Libanon, Amasia und Armenien erreichen ebenfalls die Grösse der Var. e., sind aber oft noch feiner punktirt als die typische vitellinae; auf sie beziehe ich funesta Fald., die nach den bei uns seltener vorkommenden Exemplaren beschrieben wurde, welche zwei Eindrücke dicht vor dem Schildchen besitzen. Ton Phrat. Fairmairei ron Reynosa, die Brisout nur mit der nicht rerwandten vulyatissima vergleicht, müssen erst neue und stichhaltige Unterschiede erbracht werden, wenn sie als Art angesehen werden soll.

Auf Salix- und Populus-Arten gemein.

A. Phyllod. Iaticollis: Sat oblonga, obscure chalybaea. nitida, antemis longissimis sat validis, clypeo antice elevato et abrupte decliri, postice depresso, tuberculis facialibus convexis, linea profunda discretis, fronte late excavato; prothorace transverso, lateribus ante medium subrotundato-dilatatis, elytris regulariter punctato-striatis, punctis striarum creberrime impressis, interstitiis planis, crebre subtiliter punetulatis, unguiculis fortius dentatis. - Long. $4-5 \mathrm{~mm}$. 
Mas: tarsis arliculo primo modice dilatato, quam tertio mullo anyustiore. Femina: tarsis articulis 2 primis parvis, anyustis, articulo lertio latissimo. Suffr. Mon. 263. - Cornelius Stett. Zeit. 1857. 403. - Red tb.

Faun. A. II. 485. - Weise Deut. Zeit. 1882. 158.

Phyll. cavifrons Thoms. Skand. Col. VIII. 278. - Seidl. F. balt. 488 .

? Phrat. altaica Motsch. Schrenk Reis II. 230.

Var. a. Nigro-viridis, subaurichalcea.

Diese und die folgende Art unterseheiden sich von den vorhergehenden durch das Kopfschild, welches einen hohen, steil abfallenden Vorderrand und eine sehr vertiefte Spitze hat, durch das Halssch., welches vor der Mitte stärker erweitert ist, durch die sehr dicht stehenden Punkte in den durchaus regelmässigen Reihen auf den Fld. und die eigenthümlichen Grössenverhältnisse der Tarsenglieder; ebenso sind beide noch nie auf Weiden, sondern nur auf Pappeln gefunden worden.

Ziemlich langgestreckt, die ? mehr oval und der vitellinae ähnlich gebaut, die $\hat{\jmath}$ fast viereckig, beiderseits kurz abgerundet, dunkel stahlblau, glänzend. Fühler lang und kräftig, beim fo die längsten in der Gattung, länger als der halbe Körper, beim $f$ entsprechend kürzer, die fünf abgesetzten letzten Glieder gestreckt. Kopfschild mässig gross, einzeln punktirt, am Vorderrande verdickt, durch einen sehr tiefen Quereindruck steil abfallend, nach hinten stark vertieft, so dass die Beulen zwischen der Fühlerwurzel gewölbt hervortreten; die winkeligen Linien vereinigen sich zu einer breiten, tiefen Rinne, welche auf der Stirn in eine weite, oben verschmälerte Aushöhlung übergeht. Halssch. fast doppelt so breit als lang, die grösste Breite vor der Mitte, nach hinten in leichter Ausbuchtung allmählich, nach vorn schneller und stärker gerundet-verengt, die Oberfläche mässig gewölbt und zerstreut, nach den Seiten hin und vor dem Hinterrande etwas dichter punktirt. Fld. in den Schultern breiter als das Halssch., mit kräftigen Punktstreifen, von denen die sechs inneren ganz regelmässig, äusserst dicht punktirt sind und, mit Ausnahme der fünften Reihe hinter der Mitte, nirgends einen über-

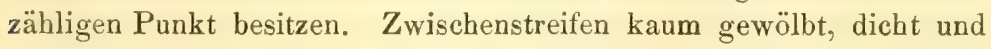
sehr fein punktulirt. Das dritte Tarsenglied gross und sehr breit, die beiden ersten Glieder erscheinen deshalb viel schmaler als bei den verwandten Arten; die schwarze Basalhälfte der Klauen ist breit und bildet an der Spitze einen grossen Zahn.

Beim $\hat{\jmath}$ ist das erste Tarsenglied mässig erweitert, doppelt so breit als das zweite, aber nur halb so breit als das dritte Glied, beim $q$ sind die beiden ersten Glieder klein, ziemlich gleichbreit 
und kaum halb so breit als das dritte. - Penis dick, an der sehr grossen Oeffnung jederseits leicht ausgebuchtet, vorn schnell gerundet-verengt und in eine kurze, breite, gerundet-abgestutzte Spitze ausgezogen. Auf der Rückseite befinden sich 3 Aushöhlungen, cine grosse, welche die obere Hälfte einnimmt, und zwei kleinere, längliche in der unteren Hälfte, durch eine hohe Längskante von einander, und durch eine noch höhere, an den Seiten zahnförmig vortretende Querkante von der oberen Vertiefung getrennt. Die Oeffnung ist vollständig durch eine Klappe geschlossen, die oberseits zwei hohe Beulen besitzt und am Ende in zwei abgerundete Lappen gespalten ist.

Durch Zunahme von Grün wird die Farbe des Thieres schwärzlich-grün, mehr oder weniger messingglänzend.

Auf Populus tremula und alba in ganz Europa häufig, aber vielfach übersehen.

5. Phyllod. atrovirens: Ovalis, nigro-aenea aut -cyaner, nitida, antennis brevibus, haud validae, clypeo parvo, antice elevato et abrupte declivi, postice depresso, tuberculis facialibus haud convexis, linea, postice plerumque divisa, discretis; prothorace brevi, fortiter transverso, lateribus ante medium subrotundato-dilatatis, elytris regulariter et sat fortiter punctato-striatis, punctis striarum creberrime impressis, interstitiis subconvexis, subtilissime punctulatis, unguiculis minus fortiter dentatis. - Long. 3,5-4,5 $\mathrm{mm}$.

Mas: tarsis articulo primo modice dilatato, quam tertio multo angustiore. Femina: tarsis articulis 2 primis parvis, angustis, articulo tertio latissimo. Cornelius Stett. Zeit. 1857. 400. - Redtb. Faun. A. II. 484.

Die kleinste Art, durch den verbältnissmässig kleinen Klauenzahn mit viennensis, durch die kurzen Fühler mit vitellinae, und durch die Form des Halssch. und der Tarsen, die dicht punktirten, regelmässigen Reihen der Fld. mit der vorigen verwandt. Von letzterer unterscheidet sie sich besonders in folgenden Punkten: Die Färbung ist immer dunkler, schwarz metallgrün oder schwarzblau, selten mit der Spur eines messinggelblichen Schimmers; Kopfschild kleiner, hinten eben so stark vertieft, aber die darüber liegenden Beulen flach, kaum gewölbt, durch eine tiefe Linie getrennt, welche sich gewöhnlich spaltet und in einem kleinen, flachen Eindrucke der Stirn endet. Fühler kurz, beim $\hat{o}$ nicht halb so lang als der Körper, die vier vorletzten Glieder wenig oder kaum länger als breit. Halssch. sehr kurz, nach hinten etwas mehr verengt. Fld. bedeutend flacher, beim 우 hinter den Scbultern weniger eingezogen, sondern an den Seiten gleichmässig ron der Schulter bis hinter die Mitte erweitert, die Punkte in den Reihen eine Spur weitläufiger 
gestellt, tiefer und stärker, auch die Reihen selbst vertieft (die fünfte durchaus regelmässig), so dass dic $\mathrm{Zwischenstreifen,} \mathrm{die} \mathrm{noch}$ feiner punktulirt sind als bei laticollis, deutlich gewölbt sind. Die Grösse des Klauenzahnes hält ungefähr die Mitte zwischen dem der vorigen und viennensis.

Penis klein, gleichbreit, oben tief gerinnt, vorn allmählich und fast gleichmässig in eine etwas aufgebogene stumpfe Spitze verschmälert, die Rückseite gewölbt, die Klappe kurz, mit vier Zipfeln in die mässig grosse Oeffnung heruntergeschlagen.

Auf Zitterpappeln (Populus tremula) in Mittel- und Norddeutschland weit verbreitet.

\section{IIydrothassa.}

Thoms on Skandinav. Coleopt. VIII. 279.

Corpus ovale vel oblongo-ovale, coeruleum aut viridi-aenum, subtus submudum.

Prothorax transversus, subquadratus, basi immarginatus.

Elytra 8 -punctato-striatis, serie accessoria irregulari sublaterali.

Prostermu ante coxas haud latum, processu marginato, mesosternum ante coxas haud latum, metasternum processu inter coxas intermedias marginato.

Femora marginem elytrorum parum vel vix superantia, tibiae apice haud dentato-productae, tarsi articulo tertio bilobo, praecedente vix latiore, unguiculis muticis.

Körper eiförmig oder länglich-eiförnig, rerschieden stark gewölbt, geflügelt, dunkelblau oder metallisch grün, meist die Flügeldecken oder auch noch das Halsschild roth gesäumt; die Unterseite fast kahl. Kopf entweder senkrecht, ziemlich bis zum Vorderrande der Augen in das Halsschild eingezogen, oder geneigt, die Augen beinahe ganz frei; Kopfschild von der Stirn durch eine bogenförmige oder winkelige Linie getrennt, Oberlippe kurz, vorn ausgerandet, Mandibeln mit zwei langen spitzen Zähnen, Endglied der Maxillarund Lippentaster schmal, rorn zugespitzt. Die Fühler überragen etwas den Hinterrand des Halsschildes, Glied 1 ist dick, 2 kurz, 3 so lang als 1,4 bis 6 kurz, die folgenden bilden eine abgesetzte, schwache Keule. Augen quer, mässig gewölbt. Halsschild ohne Poren oder Eckborsten, um die Hälfte oder doppelt breiter als lang, im ersten Falle wenig gewölbt, mit etwas vorgezogenen Vorderecken, im andern Falle stärker gewölbt, mit niedergedrückten und zusammengepressten Vorderecken, oben zerstreut, an den Seiten sparsamer punktirt, die Basis ungerandet, fast gerade oder gerundet. Schildchen länglich-oder kurz-oval. Flügeldecken in den gerundet-heraus- 
tretenden Schultern wenig oder kaum breiter als der Grund des Halsschildes, mit ziemlich parallelen, oder nach hinten schwach erweiterten Seiten und acht regelmässigen, dichten, in vertieften Linien stehenden Punktreiben und einer nicht streifigen, weitläufig eingestochenen, unregelmässigen Reihe über dem Aussenrande, die Epipleuren breit, bis dicht vor die Spitze verlängert. Vorderbrust schmal, vor den Hüften mit einer tiefen, nur bei marginella und hannoverana wenig deutlichen Rinne, welche auch den nach hinten erweiterten Fortsatz zwischen den Hüften überzieht und den Rand leistenförmig in die Höhe hebt. Mittelbrust ziemlich schmal, in der Mitte gewölbt und mit einer tiefen, meist umrandeten Grube versehen, welche die Verlängerung des Prosternum aufnimmt. Hinterbrust zwischen den Mittelhüften deutlich gerandet. Beine mässig stark, Schenkel die Seiten der Flügeldecken wenig oder kaum überragend, Schienen nach der Spitze etwas verdickt, weder mit einer Rinne auf dem Rücken, noch mit einer zahnartigen Erweiterung vor der Spitze; die drei ersten Tarsenglieder ziemlich gleichbreit, das dritte zweilappig, Klauenglied stark, fast so lang wie die vorhergehenden zusammen, mit einfachen Klauen.

Die Männchen sind kleiner und schmaler als die Weibchen und nur bei den Arten leicht zu erkennen, bei denen das Weibchen eine Längskante auf der Schulter besitzt. - Der Penis bildet eine am Grunde stark gebogene Röhre mit sehr langer, durch eine häutige Klappe geschlossener Oeffnung und breit abgerundeter Spitze.

Die Arten, deren Entwicklung besonders von Cornelius (Stett. Zeit. 1857. 167-170), ausserdem ron Chapuis Mém. Soc. Liége 1853. 612. aucta) und Kaltenbach (Pflanzenfeinde 7) beschrieben wurde, leben gesellig auf einigen Ranunculaceen und legen ibre kleinen, kornförmigen Eier in die Stengel dieser Pflanzen. Nach Cornelius sind die Eier von hannoverana dottergelb, ungefähr wie die Blüthe von Caltha palustris, nur matter, und sehen aus dem Loche, welches das Weibchen vor der Eiablage in die Blattstiele ron Caltha frisst, mit der Spitze heraus; die von marginella und aucta sind kleiner und heller und werden, perlschnurförmig neben einander gereiht, in die Stengel von Ranunculus-Arten, hauptsächlich R. acris, gelegt. Die Larven der genannten Arten sind überaus ähnlich, ziemlich gleichgross, wenig gewölbt, an beiden Enden etwas zugespitzt, anfangs fast ganz schwarz, ausgewachsen oberseits schwärzlich, die einzelnen Segmente schmutzig gelb gerandet, unten graugelb. Kopf mit tief eingedrückter, punktirter Stirn und glattem Scheitel, der von einer Mittelrinne durchzogen ist. Prothorax gewölbt, beiderseits ein narbiger Quereindruck, der am Aussenrande 3 bis 4 Borsten 
trägt. Jedes Segment hat oben 4 Höckerchen in einer Querreihe und ist an der Seite in eine spitze, 2 lange gelbe Borsten tragende Warze ausgezogen; unten befinden sich auf der Vorderbrust 2, auf jedem Bauchringe 4, in ein enges Viereck gestellte, schwärzliche Höckerchen. Beine schwarz, Fuss unten weisslich. Bei der Verpuppung leimt sich die Larve an den Stengel der Nährpflanze, die Puppe drängt sich aus der Larvenhaut, die am Schwanzende zurückbleibt.

Von den anfangs weisslichen, dann hellgelben Puppen unserer drei Arten ist die der hannoverana etwas bunt, weil ihre langen, braunen Borsten auf verdicktem, schwärzlichem Grunde stehen und die Tracheen dunkel sind, die der anderen beiden Arten sind einfarbig, mit kurzen (marginella) oder längeren (aucta), hell gelblichen Borstenhaaren, die weder eine dickere, noch dunklere Wurzel besitzen.

Die Thiere wurden zuerst zur Gattung Chrysomela, später zu Prasocuris gerechnet, von denen sie Thomson mit Recht trennte; Chapuis bringt die $H$. aucta (Genera des Col. X. 372), allen begründeten Ansichten entgegen, bei Phaedon unter.

A. Caput verticale, oculi semi-occulti, prothorax fortiter transverso, apice compresso.

1. Hyalroth. ancta: Ovalis, convexa, nigro-aenea vel-coerulea. nitida, capite prothoraceque confertim sat fortiter punctatis, elytris sat fortiter punctato-striatis, interstitiis subtilissime punctatis, limbo laterali flavescenti- rufo serie punctorum sat remotorum. - Long. 3-4 mm.

Fabr. Mant. Ins. (1787) 72. - Oliv. Ent. v. 567. t. 8. f. 126.

- Panz. Faun. Germ. 16. 14. - Gyll h. Ins. Suec. III. 494. -

Duft. Faun. A. III. 198. - Suffr. Mon. 264 (Chrysomela). Küst. Käf. Eur. 9. 98. - Redtb. Faun. A. II. 485. - Seidl.

F. balt. 487 (Prasocuris). - Thoms. Skand. Col. VIII. 280. Var. a. glabra: Limbo laterali elytrorum piceo-aenea.

Herbst Archiv IV. 60. - Gyllh. 1. c. 494. - Weise Monatsbl. 1880. 102.

Chrysom. egena Gyllh. 1. c. IV. 649.

Kurz eiförmig, hoch gewölbt, schwärzlich erzgrün oder blau, glänzend, Fld. mit hellrothem Aussenrande. Halssch. beinahe doppelt so breit wie lang, namentlich beim $\hat{\jmath}$, an der Basis gerundet, die herabgedrückten Seiten vor der Mitte leicht erweitert, mit stark convergirenden Vorderecken, oben gewölbt, wie der Kopf dicht, stark und tief punktirt; die Punkte sind in der Mitte, wo die Mittellinie oft ganz frei bleibt, etwas feiner als an den Seiten und werden auf dem steil abfallenden Streifen über dem Seitenrande plötzlich sparsam, aber gross und grubenförmig. Fld. in den abgerundeten 
Schultern unmerklich breiter als die Basis des Halssch, mit ziemlich parallelen $(\hat{\jmath})$ oder gerundeten Seiten $(q)$, ohne deutliche Schulterbeule, die acht regelmässigen Streifen dicht und ziemlich stark punktirt, ihre $Z$ wischenstreifen sehr fein punktulirt, der 8. Streifen ist stärker vertieft als die übrigen und hebt den breiten, rothen Saum über dem Seitenrande etwas wulstig empor. Auf diesem Saume befindet sich eine, dem Seitenrande genäherte Reihe weitläufig eingestochener Punkte, die durch daneben tretende Punkte unregelmässig verdoppelt wird. Die breiten, rothen Epipleuren sind dicht und kräftig, alle Theile der Unterseite stark punktirt. - Prosternalfortsatz stark gerandet.

Die Stärke der Punkte auf der Oberseite variirt bei unseren einheimischen Stücken nicht unerheblich, aber in der Regel so, dass ein feiner punktirtes Halssch. mit feiner punktirten Fld. verbunden ist; dagegen findet sich in Spanien eine grosse, gestrecktere Form (Hydr. hispanica Graells, Mém. Ac. Madrid 1851. 152. t. 8. f. 10. a. b.), bei welcher die Fld. sehr stark punktirt-gestreift, die Punkte in der Mitte des Halssch. verschwindend klein sind. Ob dieser Form Artrechte zukommen, lässt sich nur an der Hand eines reichlichen Materials feststellen.

Bei der einzigen bemerkenswerthen Farbenabänderung (Var. a) geht der Seitensaum nebst den Epipleuren der Fld. allmählich von hell gelbroth in metallisch dunkelroth bis pechschwarz, mit starkem grünen Schimmer über. Diese Färbung sticht bei blauen Stücken mehr wie bei grünen, aber bei diesen doch noch immer deutlich ron der Hauptfarbe der Fld. ab, so dass von einem ,einfarbig grünen Körper" (Suffr. 265) nicht die Rede sein kann. Wirklich einfarbig, aber lebhafter metallisch grün, oft mit kornblumenblauem Schimmer, ist die Oberseite der kleineren und bedeutend schlankeren $H y d r$. Suffriani Küst. (Käf. Eur. 25. 100; Phratorce pumila Reiche Ann. Fr. 1862. 298) von Corsica und Sardinien, welche sich von der Var. glabra ausserdem noch durch die weitläufiger gestellten Punkte in den Streifen der Fld. unterscheiden lässt ${ }^{1}$ ).

1) Den Uebergang zu den folgenden Arten vermittelt Hydroth. flarocincta Brull. (Exped. Mor. III. 271. t. 44. f. 9. - Suffr. 266) aus Dalmatien, den jonischen Inseln und Griechenland. Elliptisch, mässig gewölbt, dunkelblau oder schwarzgrün, Halssch. ziemlich flach, an der Basis gerundet, nach vorn stark verengt, mit spitzen Vorderecken, dicht und wenig stark punktirt, wie der Kopf fein chagrinirt, schwach glänzend. Fld. hinten weniger breit abgerundet als bei aucta, sehr fein punktirt und weitläufig gewirkt, etwas glänzender als das Halssch., die acht regelmässigen Punktstreifen mässig stark, die Reihe auf dem wulstigen, rothgelben Seitensaume vereinzelt punktirt, 
Auf feuchten Wiesen häufig. Europa. Sibirien.

Die Chr. egena Gyll. ist nach Thomson, der den Typ gesehen, und nach den Worten der Beschreibung "Thorax lateribus ante medium ampliatus ${ }^{c k}$ sicher mit glabra $\mathrm{Hbst}$. identisch, und kein Phaedon.

B. Caput subnutans, oculi subliberi, prothorax minus fortiter transverso, apice vix compresso.

2. Mydroth. marginella: Oblonga, leviter convexa, nigroaenea, nitida, elytris magis virescentibus, prothorace leviter transverso, lateribus rectis aut rotundatis antice angustato, limbo laterali, pone medium exciso, flavo-rufo; elytris sat fortiter punctato-striatis, limbo laterali flavo-rufo serie punctorum remotorum. - Long. $3,5-4,5 \mathrm{~mm}$. Femina: elytris costa humerali.

Linné Syst. Nat. ed. X. 371. - Panz. Faun. Germ. 16. 15. Oliv. Ent. V. 566. t. 3. f. 35. - Herbst Füessl. Arch. IV. 54. - Gyllh. Ins. Suec. III. 495 (pars.). - Duft. Faun. A. III. 197. - Küst. Käf. Eur. 7. 94. - Suffr. Mon. 266. Thoms. Skand. Col. VIII. 282. - Redtb. Faun. A. II. 485. Seidl. F. balt. 487 .

Var. a. Nigro-coerulea, haud virescens, prothorace elytrorumque limbo laterali flavo-rufo.

Langgestreckt, wenig gewölbt, glänzend schwarzgrün, die Fld. gewöhnlich heller grün, zuweilen mit messinggelblichem Anfluge. Halssch. nur etwas breiter als lang, an der Basis fast grade und wenig breiter als an der Spitze, die Seiten bald ziemlich gradlinig, bald gleichmässig gerundet, oben wenig gewölbt, weitläufig und ziemlich stark punktirt, mit einem breiten, rothgelben Seitensaume, dessen Innenrand hinter der Mitte halbkreisförmig ausgebuchtet ist. Fld. in den gerundet-heraustretenden Schultern breiter als die Basis des Halssch,, gleichbreit $(\hat{\jmath})$, oder nach hinten leicht erweitert (†), mit deutlicher Schulterbeule, ziemlich stark punktirt-gestreift, mit breitem, gelbrothem Seitensaume und einer weitläufigen Punktreibe auf demselben. Epipleuren glatt, nur die vertiefte innere Randlinie punktirt. Prosternalfortsatz undeutlich gerandet.

Beim Weibchen ist die fünfte und sechste Punktreihe nebst dem eingeschlossenen Streifen auf dem ersten Drittel der Fld. stark vertieft und hebt den siebenten Zwischenstreifen rippenartig empor.

Selten wird die Hauptfarbe des Körpers messinggelb, häufiger dagegen schwarzblau, die der Fld. entweder metallisch dunkelgrün oder ebenfalls schwarzblau (Var. a).

die Epipleuren glatt, nur mit einer Punktreihe dicht an der inneren Randlinie. Unterseite zwischen der groben Punktirung lederartig gerunzelt. Long. $3,5-4,3 \mathrm{~mm}$. 
An Gräben und auf feucliten Wiesen gemein. Europa. Sibirien.

Der rothe Seitensaum der Fld. hat bei der vorliegrenden Art dieselbre Form wie bei ancta und flavocincta, er wird von der 8 . Punktreihe scharf begrenzt und an der Spitze durch die eintretende dunkle Naht unbedentend rerkürt, ist hier aber nie in einen Zipfel verlängert, der auf dem dritten (zweiten) Zwischenraume liegt (Suffr. Mon. 26\%). Diese Form gehört vielmehr zur folgenden Art.

3. Hyaroth. hannoverand: Ovalis, sut convexa, nigro-coerulea, interdum nigro-aenea, nitida, antennis articulo $7: 0$ supra triangulariter producto, prothorace transverso, limbo laterali curvato flavo-mefo, elytris fortiter menctato-striatis, interstitiis subcomexis, vilfa merlia. basin versus extrorsum arcuata limboque laterali flaco-rufis, hoc serie punctorum sat remotorum. - Long. $4-5 \mathrm{~mm}$.

Femina: interstitiis $5: 0$ et $7: 0$ basi subcostatis.

Fabr. Syst. Ent. 102; Ent. Syst. I. 326. - Panz. Farn. Germ. 16. 16. - Oliv. Ent. V. 567. t. 8. f. 125. - Küst. Käf. Eur. 9. 97. - Suffr. Mon. 26\% - Letzner Ber. Schles. Ges. 1875. 177. - Redtb. Faun. A. II. 486. - Seidl. F. balt. 48\%. - Weise Deut. Zeit. 1883. 251.

Chrys. ranunculi Herbst Füessl. Arch. 4. 55, t. 23. f. 12.

Chrys. marginella var. d. Gyllh. Ins. Suec. III. 495.

Var. a. potentillae: Vitta elytrorum plus minusve interrupta.

Herbst 1. c. 55. t. 23. f. 11. - Weise 1. c. 252.

Var. b. calthae: Vitta elytrom abbreviata: a. antice, b. postice.

c. antice posticeque.

We is e 1. c. 252.

Chrys. hannoveriana Herbst 1. c. 54 . - Gyllh. 1. c. 495.

Var. c. germanica: Vitta elytrorum deficiente.

Weise 1. c. 252.

Hydr. hannoverana Thoms. VIII. 280.

Chrys. marginella var. Suffr. Mon. 267 (Zett. var. $\beta$ ).

Der vorigen sehr ähnlich, aber merklich breiter und gewölbter, eiförmig, schwarzblau, selten schwarzgrün; das siebente Fühlerglied oben in einen kurzen, dreieckigen Lappen rerlängert, welcher sich auf das achte Glied legt. Das Halssch. kürzer, nach rorn mehr verengt, der rothe Randsaum schmaler, fast gleichbreit; er zieht sich zuerst ein Stückchen an den Seiten des Vorderrandes nach aussen, biegt dann nach hinten und läuft dem Seitenrande parallel bis zur Basis, oder, wenn man sich den Saum breit und am Innenrande ausgebuchtet rorstellen will, würde die Ausbuchtung hier ror der Mitte liegen, und dahinter erreicht der Saum selbst seine ursprüngliche Breite, wie am Vorderrande, nicht mehr. Fld. in den stärker vertieften Streifen etwas sparsamer (nur die Reihe auf dem 
rothen Seitensaume dichter) aber kräftiger punktirt, die Zwischenstreifen deutlicher gewölbt, besonders die abwechselnden, oder wenigstens der sehr breite dritte, auf dem sich eine gelbrothe Längsbinde befindet. Dieselbe ist vor der Spitze mit dem rothen Randsaume verbunden und wendet sich rorn, ungefähr im ersten Viertel der Fld. schräg nach aussen bis zum fünften $\mathrm{Z}$ wischenstreifen, auf dem sie sich bis zur Basis fortsetzt.

Beim Weibchen ist der fünfte und siebente $Z$ wischenraum der Fld. an der Basis rippenförmig gewölbt.

Die Hauptvarietäten entstehen dadurch, dass die Längsbinde der Fld. unterbrochen, abgekürzt, oder fast vollständig erloschen sein kann. Var. a. Die Binde ist unterbrochen, entweder einmal, in der Mitte (Letzn. l. c. v. h), dann bleibt der Basaltheil auf dem fünften Zwischenstreifen und ein mit dem Aussenrande zusammen hängender Strich an der Spitze übrig, oder mehrmals (Letzn. v. e), dann wird die Binde durch ein Fleckchen an der Basis, einen Strich auf der Mitte, der sogar wieder unterbrochen sein kann (Letzn.v.d), und eine kleine Ecke an der Spitze bezeichnet. Var. b. Die Binde ist abgekürt: a. vorn (Letzn. v. i), b. hinten (Letzn. r. c.), c. beiderseits (Letzn. v. g). Der in der Mitte übrig bleibende Strich zuweilen unterbrochen (Letzn. ₹. f).

Var. c. Die Längsbinde fehlt (Letzn. v. k). Bei dieser Abänderung hat der Randsaum nur selten ganz dieselbe Form wie bei marginella, gewöhnlich ist der Innenrand an der Spitze, nahe der Naht, noch in eine kleine Ecke ausgezogen.

Im Winter auf dem Eise am Rande von Schilfsümpfen, im April und Mai an Caltha auf sumpfigen Wiesen häufig in der nördlichen Hälfte ron Deutschland, sehr zerstreut in der südlichen. Schweden. Reval.

\section{Prasocuris.}

L atreille Hist. nat. Crust. et Ins. III. 59.

Helodes Payk. Faun. Suec. II. (1799) 84.

Corpus elongatum, subtus parce pilosum.

Prothorax quadratus aut subelongatus basi marginatus.

Elytra 9-striato-punctata.

Prosternum ante coxas latum, processu immarginato, mesosternum ante coxas sat latum, metasternum processu inter coxas intermedias immarginato.

Femora marginem elytrorum longe superantia, tibiae apice haud dentato-productae, tarsi articulo tertio bilobo, praecedente haud latiore, unguiculis muticis.

Körper langgestreckt, schwach gewölbt, geflügelt, dunkelblau oder metallisch grün, bisweilen mit röthlichen Rändern oder LängsVI. 3. 
streifen, die Unterseite ziemlich dicht behaart, auf der Vorder- und Mittelbrust aufstehend, sonst anliegend. Kopf ziemlich lang, geneigt, bis zum Hinterrande der Augen in das Halsschild eingezogen, Kopfschild gross, durch eine schwach winkelige Linie von der Stirn getrennt, Oberlippe kurz, vorn ausgerandet, Mandibeln mit zwei breiten, scharfen Zähnen, Endglied der Taster gestreckt, vorn zugespitzt. Die Fühler erreichen den Hinterrand des Halsschildes, Glied 1 ist dick, 2 bis 6 sind viel dünner, unter sich gleich dick, 2 und (i kurz, die übrigen länger, Glied 7 bis 11 bilden eine abgesetzte, kräftige Keule, deren Glieder so breit als lang, oder erheblich breiter sind, Glied 7 ist oberseits in eine dreieckige Spitze verlängert, die sich auf das 8. Glied legt. Augen quer, gewölbt. Halsschild so lang oder länger als breit, quadratisch oder rechteckig, die Vorderecken etwas vorgezogen, die Seiten und die gerade abgestutzte, oder vor dem Schildchen sanft ausgebuchtete Basis deutlich gerandet, die Oberfläche sehr schwach gewölbt, zerstreut punktirt. Schildchen breit oval. Flügeldecken gestreckt, gleichbreit, in den ziemlich grade heraustretenden Schultern breiter als der Grund des Halsschildes, mit neun regelmässigen, dichten, in vertieften Linien stehenden Punktreihen und breiten, bis zur Spitze fortlaufenden Epipleuren. Vorderbrust breit, vor den Hüften sowie auf dem Fortsatze zwischen den Hüften ohne Randlinie und aufgebogenen Rand. Mittelbrust ziemlich breit, flach, in der Mitte mit einer ungerandeten, leichten Vertiefung, in die sich der Fortsatz des Prosternum legt. Hinterbrust $z$ wischen den Mittelhüften nicht oder undeutlich gerandet. Beine stark, Schenkel die Seiten der Flügeldecken weit überragend, die ersten drei Tarsenglieder ziemlich gleichbreit, das dritte zweilappig, die Lappen aber kurz, da der Einschnitt zwischen ibnen kaum die Mitte überragt, oder (bei phellandrii) dieselbe nicht erreicht, Klauenglied sehr kräftig, so lang als die vorhergehenden zusammen, mit einfachen Klauen.

Die Larve von Pras. phellandrii ist gleichzeitig von Letzner (Arb. Schles. Ges. 1857. 127) und Cornelius (Stett. Zeit. 1857. 404) bekannt gemacht. Sie erreicht ausgewachsen eine Länge von beinahe $9 \mathrm{~mm}$, bei einer Breite von nicht ganz $2 \mathrm{~mm}$. und ist grünlich schwarz, unten heller. Der Kopf schwarz, Kopfschild von der weit und tief ausgehöhlten Stirn durch einen Quereindruck geschieden. Prothorax von einer narbigen, etwas glänzenden Grube der Quere nach durchzogen, während die aufgebogenen Ränder glanzlos sind. Die beiden folgenden Brustringe besitzen einen nach vorn offenen, hufeisenförmigen Eindruck, der in den Vorderecken sehr tief ist, jedes Hinterleibssegment eine tiefe Querrinne und in den Ecken 
eine aus zwei Eindrücken bestehende Grube. Auf der Unterseite stehen auf jedem Ringe drei schwarze Punkte. Man findet die Larve gesellschattlich in den Stengeln von Cicuta virosa L., Sium latifolium L. und Oenanthe-Arten, worin sie sich auch verpuppt. Die Puppe ist schmal und lang, oben weisslich, ziemlich bunt gescheckt, unten rein weiss.

Von Pras. junci wurden die Larven durch Letzner (1. c. 1857. 130) und Cornelius (1. c. 1863.119) beschrieben; sie sind kleiner, doch eben so schlank als die von phellandrii, oben matt schwärzlich grün, Kopf, Prothorax und Rücken der beiden letzten Segmente glänzend schwarz, unten gelblich grün.

Die Gattung enthält wenige, im Habitus sehr ähnliche Arten, ron denen zwei bei uns vorkommen.

1. Pras. phellamariil): Elongata, sat convexa, nigro-aenea, supra nitida, subtus alutacea, sericeo-micans, limbo sinuato laterali prothoracis, limbo laterali vittaque subsuturali elytrorum, femoribus basi tibiisque flavis, antennarum articulo $7: 0$ supra triangulariter producto, articulis $\mathcal{S}-\mathbf{1 0}$ fortiter transversis; prothorace parce fortiterque punctato, elytris punctato-striatis, interstitiis subtilissime punctulatis. - Long. 5-6 $\mathrm{mm}$.

1) Hinter dieser Art ist einzureihen Pras. distincta Lucas (Explor. Alg. Ent. 539. t. 46. f. 1): Elongata, depressiuscula, viridi-aenea aut nigrochalybaea, antenmis rufo-piceis, basi, limbo laterali lato prothoracis (interne recte terminato), limbo laterali elytrorum pedibusyue rufo-testaceis; prothorace elongato, apice quam hasi vix angustiore, lateribus subrectis, supra subtiliter punctato, elytris punctato-striatis, interstitiis subtilissime transversim aciculatis. - Long. $4 \mathrm{~mm}$.

Variat a. suturella Reiche (Ann. Fr. 1858. 38. t. 1. f. 9): Elytris rufo-testaceis, limbo angusto suturali viridi-aeneo; b. marginicollis Suffr. (Mon. 270): Elytris omnino viridi-aeneis aut nigro-chalybaeis.

Die Zeichnung des Halssch., auf dem von der Grundfarbe des Körpers nur eine fast gleichbreite Längsbinde (kaum so breit als die Stirn) übrig bleibt, scheint sehr constant zu sein; dagegen sind die Fld. entweder einfarbig dunkel metallisch grün bis stahlblau (Var. b), oder besitzen einen röthlich gelben, innen häufiger verwaschenen als scharf begrenzten Seitensaum, der sich vor der Spitze gewöhnlich verbreitert, zuweilen auch so ausdehnt, dass die Fld. rothgelb sind, mit einer gemeinschaftlichen grünen oder blauen Nahtbinde. Diese ist entweder scharf vom 2. oder 3. Punktstreifen begrenzt, ungefähr so breit als die Binde des Halssch., oder verwaschen, hinten verschmälert, die Spitze nicht erreichend (Var, a). Stücke mit rothbraun gefleckten Schenkeln, wie sie Lucas beschreibt, sind mir nicht bekannt.

An der Küste des mittelländischen Meeres von Südspanien und Marocco bis Syrien. 
Mas: libiis apicem rersus larsisque modice dilalatis. segmenlo nltimo ventrali linea media subimpressa.

Linné Syst. Nat. ed. X. 376. - Suffr. Mon. 269 (Chrys.) Payk. Faun. Suec. II. 84. - Oliv. V. 594. t. 1. f. 1. Gyllh. Ins. Suec. III. 499. - Duft. Faun. A. III. 236 (HeIndes). - Latr. Gen. Crust. Ins. III. 59. - Küst. Kä́. Eur. 7. 92. - Thoms. Skand. Col. VIrI. 283. - Redtb. Faun. A. II. 485. - Seidl. F. balt. 48\%, - Weise Deutsch. Zeit. 1883. 252.

Var. a. sii: Vitta elytrorum interrupta aut abbreviata.

Weise 1. c. 252.

Var. b. cicutae: Vitta elytromm deficiente.

Weise 1. c. $25 \%$.

Schmal, fast gleichbreit, ziemlich gewölbt, schwarz metallischgrün, oben glänzend, unten zwischen der Punktirung fein gewirkt, seidenschimmernd. Kopf dicht und ziemlich stark punktirt, Fühler vom siebenten Gliede an schwarz, eine dicht behaarte, breite, zusammengedrängte Keule bildend, das siebente Glied oben stark erweitert, das achte bis zehnte quer. Halssch. ziemlich flacb. quadratisch, etwas länger als breit, auf der Scheibe mit einigen undeutlichen Vertiefungen, zerstreut und stark punktirt, an den Seiten mit einem blassgelben Saume, welcher in einem weiten und nicht tiefen Bogen ausgerandet ist. Fld. in den Schultern wenig breiter als die Basis des Halssch., nach hinten leicht erweitert, aber hinter der Schulter etwas eingezogen, tief punktirt-gestreift, ein Seitensaum, vom achten Punktstreifen scharf begrenzt, und eine Längsbinde auf dem dritten und vierten $\mathrm{Z}$ wischenstreifen blassgelb. Dieselbe Farbe besitzt die Basalbälfte der Schenkel und der grösste Theil der Schienen, ausser dem Knie. Drittes Tarsenglied kaum bis zur Mitte gespalten.

Das Männchen zeichnet sich durch kleineren Körper, erweiterte Schienen und Tarsen, sowie durch die leicht vertiefte Mittellinie des letzten Bauchringes aus. Die Ränder dieser Linie sind zuweilen an der Spitze des Segmentes beulenförmig.

Der Seitensaum der Fld. verändert sich nicht, desto mehr die Längsbinde. Dieselbe kann:

1. sich verbreitern, so dass sie a. hinten, b. rorn, c. beiderseits, d. in ihrer ganzen Länge auch den zweiten und fünften Zwischenraum bedeckt; oder

2. sich verschmälern: a. in der Mitte bis auf den dritten Zwischenraum, b. vorn, c. hinten;

3. in der Mitte unterbrochen oder hinten abgekürzt sein (Var. a); endlich 
4. vollständig verschwinden (Var. b). Der Randsaum ist bei dieser aufï̈lligen Form vor der Spitze meist noch in eine kurze Ecke über den 8. Punktstreifen hinaus verlängert.

Auf' Wasserpflanzen häufig. Europa. Sibirien. Nordamerika.

2. Pras. junci: Elongata, sat convexa, nigro-coerulea aut -chalybaea, vilidula, antennarum articulo $7: 0$ supra vix triangulariter producto, articulis $S-10$ subtransversis, prothorace apice quam basi vix angustiore, lateribus antice sat rotundatis, ante basin evidenter sinuatis, supra pone apicem et ante basin obsolete impresso, plus minusve crebre punctato, interstitiis subtiliter punctulatis, elytris lateribus fere parallelis, minus profunde punctuto-striatis, interstitiis subtiliter punctulatis et transversim aciculatis, ano flavo-limbato. - Long. 4-5 mm.

Brahm Ins. Kalend. I. (1790) 62.

Chrys. beceabungae Illig. Schneid. Neu. Mag. I. 5 (1794) 600. -Panz. Faun. Germ. 25. 11. - Suffr. Mon. 272. - Gyllh. Ins. Suec. III. 500 (Helodes). - Payk. Faun. Suec. III. App. 451. - Küst. Käf. Eur. 7. 93. — Thoms. Skand. Col. VIII. 283. - Seidl. F. balt. 487.

Crioceris violacea Fabr. Ent. Syst. I. 2. 11. - Oliv. Ent. V. 594. t. 1. f. 2 (Helodes). - Duft. Faun. A. III. 237. -- Redtb. Faun. A. II. 485. $\mathrm{V}$ ar. a. Nigro-coerulea, virescens.

Var. b. atra: Nigra, vix coerulescens.

Duft. l. c. 237.

Var. c. Ano haud flavo-limbato.

Langgestreckt, mässig gewölbt, schwarzblau oder stahlblau, ziemlich glänzend, oben mehr als unten, der After rothgelb gerandet. Kopf zerstreut und wenig stark punktirt, Fühler schwarz, die ersten secbs Glieder mit Metallschimmer, die übrigen dicht grau behaart, matt, eine breite, gegliederte Keule bildend, das siebente Glied oben kaum rorgezogen, das achte bis zehnte schwach breiter als lang. Halssch. seitlich mehr zusammen gedrückt und gewölbter als bei der vorigen, mit herabgedrückten Vorderecken, etwas länger als breit, vor der Mitte am breitesten, von hier aus nach vorn schnell, nach hinten allmählich gerundet-verengt, vor den Hinterecken wieder leicht erweitert, die Seiten daher vor der Basis ausgeschweift. Die Oberfläche mit mehreren deutlichen oder kaum bemerkbaren Querrertiefungen, eine jederseits ein Stück hinter dem Vorderrande, und eine vor dem Hinterrande, auf der Scheibe zerstreut oder ziemlich dicht, stärker oder schwächer punktirt, mit oder ohne glatte Mittellinie, die Zwischenräume der Punkte dicht, äusserst fein punktulirt, zuweilen gewirkt. Fld. in den Schultern breiter als die Basis des Halssch., dahinter gleichbreit, hinten gemeinschaftlich abgerundet, wenig tief und ziemlich fein punktirt-gestreift, die Zwischenräume 
äusserst fein punktulirt und quer nadelrissig. Ĺnterseite zwischen der Punktirung weniger deutlich gewirkt und etwas glänzender als bei phellandrii. Drittes Tarsenglied bis zur Mitte gespalten. Geschlechtsunterschiede treten äusserlich nicht hervor.

Die Körperfarbe wird zuweilen grünlich (a), oder schwarz, fast ohne blauen Schimmer (b), nicht selten ist der After ohne rothen Saum (c).

Auf Wasserpflanzen, besonders Veronica beccabunga und anagallis L. in ganz Europa, Spanien und Süditalien rielleicht ausgenommen ${ }^{1}$ ).

\section{Selerophaedon.}

Phaedon Motsch Schrenck Reis. II. 221.

Corpus apterum, breviter ovale, valde convexum.

Prothorax antrorsum fortiter angustalus, in medio apicis immarginatus.

Elytra 9-striato-punctala, apice subacuminata, epipleuris postice obsoletis.

Prosternum processu inter coxas latissimo; mesostermum foveu magna immarginata.

Tarsorum articulo tertio apice haud sinuato, praecedente latiore.

Körper hart, ungeflügelt, fast kreisförmig, an beiden Enden, besonders aber hinten etwas in die Länge gezogen, hoch gewölbr, dunkel messingfarbig, bis kupferroth, grün, blau und schwarz bin variirend, wenig dicht und ziemlich grob punktirt. Kopf bis zur Mitte der quer gestellten, mässig gewölbten, grob facettirten Augen in das Halsschild eingezogen, mit grossem, bogenförmig begrenzteu Kopfschilde und breiter Stirn, Mandibeln stark, winkelig gebogen,

I) Hier lebt eine schwer zu unterscheidende, bedeutend flachere Art: Pras. vicina Lucas (Explor. Alg. Ent. 539. t. 46. f. 2. - litigiosa Rosen h. Thier. Andal. 323). Elongata, depressa, virescenti-coerulea aut nigro-viridis, plus minusve aurichalceo-micans, prothorace apice yuam basi vix angustiore, luteribus antice sat rotundatis, postice sensin anyustatis, hand sinnatis, elytris lateribus fere parallelis, abdomine concolore, interdum ano tenuiter flavo-limbato. - Long. 4-5 $\mathrm{mm}$.

Variat. a. chalybaea Suffr. (Mon. 271). Tote nigro-chulybuen: b. hispanica: Nigro-chalybaea, interdum subrirescens, prothorace apice quam basi multo angustiore, lateribus vix rotundatis, supra subplano, tenuiter punctato, elytris in medio leviter ampliatis: laterihus paullo sed evidenter rotundatis.

Die Punktirung des Halssch. ist auf der Mitte der Scheibe gewöhnlich feiner, oft aber eben so stark und dicht wie bei junci, die Fld. sind ganz ähnlich punktirt. Die auttällige Var. b. erhielt ich durch Reitter von Algeciras. 
in zwei breite, spitze Zähne endigend, letztes Tasterglied lünglicheiförmig, vorn zugespitzt. Fühler mit den letzten drei oder vier Gliedern die Hinterecken des Halsschildes überragend, Glied 1 verdickt, 2 halb so lang und breit, 3 etwas länger, 4 bis 6 kurz, unter sich fast gleich lang und so breit als 3, die folgenden verdickt, wenig länger als breit. Halsschild quer, mit gerundeter Basis, nach vorn stark verengt, die Seiten gerundet, scharf gerandet, der Vorderrand mässig tief, bogenförmig ausgeschnitten und in der Mitte ohne Randlinie und aufgebogene Leiste; die Oberfläche gewölbt, weitläufig punktirt. Schildchen halboval. Flügeldecken an der Basis kaum, oder wenig breiter als der Grund des Halsschildes, hinter den beulenlosen Schultern unbedeutend erweitert (ㅇ) oder fast gleichbreit ( $\widehat{O})$, hinten allmählich in eine breit abgerundete Spitze verschmälert, mit 9 Reihen weitläufig eingestochener, grober Punkte, die Reihen regelmässig, nur die siebente öfter unregelmässig verdoppelt, oder der ganze Streifen zwischen der 7. und 6. Punktreihe mit zerstreuten groben Punkten bedeckt. Vorderbrust vor den Hüften mässig breit, zwischen denselben breit, in einen hinten bogenförmig abgeschnittenen Fortsatz verlängert, Mittelbrust sehr kurz, die Mitte fast ganz von der Verlängerung der Vorderbrust bedeckt, allmählich nach vorn abfallend, der Vorderrand hoch aufgebogen, Hinterbrust kurz. Der erste Bauchring über die Mitte länger als die Mittel- und Hinterbrust, oder auch die drei folgenden Ringe zusammen, das fünfte Segment breit dreieckig. Vorderhüften weit, Mittel- und Hinterhüften noch etwas weiter getrennt, Beine mässig lang, die Schenkelspitzen ragen wenig über die Seiten der Fld. hinaus, Schieneu nach der Spitze etwas verdickt, Tarsen klein, das dritte Glied breiter als das zweite und an der Spitze grade abgestutzt. Das Klauenglied ist kürzer und schmaler als bei den zwei vorhergehenden Gattungen, mit kleinen, einfachen Klauen.

Geschlechtsunterschiede sind äusserlich schwer zu sehen. Das Männchen ist kleiner und etwas glänzender als das Weibchen, Fühler und Tarsen sind eine Spur breiter, die Flügeldecken an den Seiten weniger gerundet. Penis klein, ziemlich flach, an beiden Enden leicht verschmälert, vorn breit abgerundet, mit aufstehender Klappe.

Die Entwickelungsgeschichte von Scl. carniolicus, die ich hier theilweise ergänzt wiedergebe, brachte zuerst Maerkel in der allgemeinen naturbistorischen Zeitung Isis 1857 p. 171. Die Larve, welche vorn ziemlich breit, nach hinten etwas erweitert und hoch gewölbt, am Ende stark zugespitzt, also einer Larve aus der Gattung Chrysomela ähnlich ist, lebt an Gebirgsbächen oder an feuchten, schattigen Stellen der Gebirgsthäler, wo sie die Blätter von Malachium 
aquaticum Fr. oder Stellaria nemorum L. zerfrisst. Sic ist $4-5 \mathrm{~mm}$ lang, 1,5-2 mm breit, weisslich gelb, unten etwas heller als oben und mit sehr kurzen, steifen Härchen sparsam besetzt. Kopf gross, quer, glänzend schwarzbraun, mit einem tiefen, aus zwei Grübchen bestehenden Eindrucke über dem Kopfschilde und deutlicher Längsrinne auf der Stirn. Fühler kurz, kegelförmig, hinter denselben 4 Ocellen. Prothorax etwas breiter als der Kopf, wenigstens so lang als die folgenden 2 Brustringe zusammen, braun, schwach metallisch glänzend, jn der Mitte mit leichtem Quereindrucke, der Meso- und Metathorax, sowie die Bauchringe, die beiden letzten ausgenommen, einzeln stark gewölbt und von einer tiefen Mittelrinne der Quere nach durchzogen, so dass jeder aus zwei erhabenen, dunkler gefärbten Querstreifen besteht, die sich an der Seite gerundet verbinden. Beine stark, gelblich, Knie und Klauenglied dunkler, die Klaue klein. Die Puppe, welche sich nicht anhängt, sondern liegend verwandelt, ist gelb. Man fängt den Käfer am häufigsten mit dem Käscher in der ersten Hälfte des Juli, wo er auf den Blättern ron Malachium sitzt, aber sich fallen lässt, sobald er Gefahr wittert.

Bis jetzt sind zwei Arten beschrieben, von denen nur die eine in Europa vorkommt.

1. Soleroph. carmiolicus $\left.{ }^{1}\right)$ : Breviter ovalis, fere hemisphaericus, brunne-aurichalceus, interdum virescens aut cupreo-micans, nitidulus, antennis pedibusque piceis, prothorace basi leviter votundato, antice angustato, lateribus evidenter rotundato, supra sat convexo, remote punctato, scutello plerumque violace-cupreo, elyiris fortiter striatopunctatis, punctis serierum sat remotis. - Long. 3,5-4 mm.

Germ. Ins. spec. nov. 588. - Duft. Faun. A. III. 211 (Chrysom.). - Küst. Käf. Eur. 9. 96. - Motsch. Schrenck Reis. II. 221. - Redtb. Faun. A. II. 482. - Weise Deutsch. Zeit. 1875. 365 (Phaedon).

Chrys. orbicularis Suffr. Mon. 243.

Var. a. Nigro-viridis.

Var. b. obscurus: Niger, supra plerumque leviter coeruleo-aut violaceomicans.

Var. c. Kenderesyi: Major, brunneo-aeneus, nitidus, antennis, tarsis, rarissime etiam scutello rufis, pedibus rufo-piceis. - Long. $5 \mathrm{~mm}$.

Kiesenwetter Deutsch. Zeit. 1879. 256 (Chrysomela).

1) Hierher gehört, der Punktirung nach, der mir unbekannte Scler. (Phaedun) foveolatus Gebl. (Bull. Mose. 1S48. III. 36). Violett oder fast kupferig-erzgrün, Fühlerglied 2 und 3 roth, die Fld. nicht in Reihen, sondern unregelmässig zerstreut punktirt, sonst wie carniolicus. In Westsibirien am Flusse Ters bei Kusnezk. 
Phaten carniolicus var. Fuss. Verh. Siebb. Ver. Hermannstadt 1S61. 169.

Var. d. Oealis, postice fortiter anyustulus, apice mayis acuminatus.

Chr. carniolica Suffr. Mon. 245.

Var. e. transsylvanicus: Ut in $a$, sed prothorace minus convexo antrorsum sensim angustato, lateribus subrectis, elytris apice sat fortiter acuminatis. - Long. $4 \mathrm{~mm}$.

Fuss 1. c. 1861. 169 .

Var. f. carpathicus: Eadem, sed major, bruneo-aeneus, antennis tarsisque rufis. - Long. $4,5 \mathrm{~mm}$.

Weise 1. c. 1875. 366.

Sehr breit eiförmig, fast halbkugelförmig, hinten stärker als vorn verschmälert, an den Seiten steil abfallend, die Mitte des Rückens aber etwas flach gedrückt; dunkelbraun mit starkem Messingschimmer, oder grün-messingfarbig, auch kupferig, äusserst dicht und fein chagrinirt, mässig glänzend, Fühler und Beine pechbraun, fast schwarz. Halssch. quer, an der leicht gerundeten Basis mehr als doppelt so breit wie lang, nach vorn stark verschmälert, die Seiten gerundet, oben etwas gewölbt, so dass der Abfall des Körpers, von der Seite betrachtet, nach vorn nicht in einem so regelmässigen Bogen stattfindet als nach hinten, sparsam mit ziemlich grossen, wenig tiefen Punkten besetzt. Schildchen gewöhnlich kupferig-violett, ohne Punkte. Fld, in eine sehr kurze, breite Spitze ausgezogen, die ziemlich weitläufigen Punkte der Reihen vorn stärker als hinten, doppeit so gross und tief als die des Halssch., jedoch sehr variabel; die Zwischenstreifen der Reihen, bei starker Vergrösserung, mit je einer leicht geschlängelten, eingeritzten Mittellinie versehen, von welcher ein Querriss zwischen je zwei Punkten einer Reihe hindurch zu den benachbarten Mittellinien läuft und die Oberfläche, ähnlich dem Panzer einer Schildkröte, in unregelmässige, querviereckige Felder theilt. Brust ziemlich grob, Bauch feiner punktirt.

Von dieser äusserst veränderlichen Art sind folgende Varietäten zu beachten:

a. Die Oberseite oder der ganze Körper schwarzgrün, ohne merklichen Messingschimmer,

b. schwarz, meist bläulich oder violett angelaufen.

c. Die grösste, zugleich stärker glänzende Form, die ron Fuss auf dem Götzenberge, in letzter Zeit von Merkl ebenfalls in Siebenbürgen gesammelt wurde, ist dunkelbraun, mit grünem Metallschimmer, und durch das an den Seiten stark gerundete, ror der Basis in der Regel verengte Halssch. recht ausgezeichnet. Die Beine sind röthlich pechbraun, Tarsen, Fühler und mitunter auch das Schildchen roth. 
d. Der Körper weniger breit, oval, hinten stärker verengt und in eine etwas längere Spitze ausgezogen.

e. Oval, schwarzgrün, Fühler und Beine pechschwarz, Halssch. an den Seiten fast gradlinig nach vorn verschmälert, oben weniger gewölbt, so dass der vordere Abfall des Körpers (bei der Seitenansicht) einen eben so regelmässigen Bogen bildet als der hintere; die Fld. in eine mässige Spitze verlängert.

f. Der vorigen im Baue des Halssch. ähnlich, aber grösser, dunkelbraun, mit gelblichem Metallschimmer, Fühler, Spitze der pechbraunen Schienen und die Tarsen roth.

An schattigen Gebirgsbächen häufig; die Var.c. und e. nur in den transsylvanischen Alpen und dem siebenbürgischen Erzgebirge, f. an den Theissquellen.

\section{Phaedon.}

Latreille Cuv. Rég. anim. ed. 2. V. (1829) 151.

Emmetrus Motsch. Schrenck Reis. II. 221.

Corpus alatum 1), breviter ovale, convexum.

Prothorax antrorsum fortiter angustatus, apice marginatus.

Elytra S-punctalo-striata, serie adjecta irregulari punctorum sat remotorum, apice leviter acuminata aut rotundata.

Prosternum processu inter coxas angusto; mesosternum fovea transversa evidenter marginata.

Tarsorum articulo tertio bilobo, praecedente latiore.

Im Habitus der vorigen Gattung am ähnlichsten, aber in folgenden Stücken wesentlich verschieden: der Körper ist geflügelt '), hinten mehr abgerundet und weniger zugespitzt, dicht punktirt. Das Halsschild am ganzen Vorderrande von einer deutlichen vertieften Linie umzogen, welche den Rand selbst mehr oder weniger breit in die Höhe hebt. Die Flügeldecken haben acht dicht punktirte Streifen und eine meist unregelmässige, mitunter doppelte Punktreibe am Seitenrande, deren Punkte gewöhnlich weitläufig eingestochen sind. Das Prosternum ist zwischen den Hüften verengt, und viel schmaler als bei Sclerophaedon, der Fortsatz greift auf der Mittelbrust in eine schmale und tiefe Quergrube ein, welche hinten deutlich gerandet ist und vom Mesosternum einen Querstreifen freilässt. Der letzte Bauchring ist nicht dreieckig, sondern ein querer Streifen, das dritte Tarsenglied ist zweilappig.

Die Larven, von denen bisher die der cochleariae (Letzner Bericht Arb. Schles. Ges. 1853. 209. t. 2. f. 25-30) und armoraciae

1) Ungeflügelt nur bei einer europäischen Art. 
(Cornelius Stett. Zeit. 1863. 122) beschrieben sind, nähern sich durch ihren bunten Körper denen von Plagiodera und Melasoma, aus welchem Grunde die genannten Gattungen nicht wie früher räumlich $\mathrm{zu}$ trennen, sondern dicht aneinander zu rücken sind. Bei cochleariae ist, nach Letzner, die auf Nasturtium amphibium lebende Larve ungefähr 5,5 mm lang, in der Mitte am breitesten, vorn wenig, hinten stärker verengt, fast durchscheinend schmutzig weiss, oben mit glänzend schwärzlichem Kopfe und 4 Längsreihen schwarzer Tuberkeln. Fühler dreigliederig, vor ihnen 2, dahinter 4 Ocellen. Erster Brustring glatt, mässig glänzend, am Vorder- und Hinterrande mit je 5 punktförmigen dunklen Höckerchen. Die beiden folgenden Brustringe und die Hinterleibssegmente matt, fein gewirkt, mit je einer Querreihe von 4 rundlichen, in die Quere gezogenen, hornigen und mit einem langen Borstenhaare besetzten Tuberkeln, sowie einer höheren, zugespitzten Tuberkel in der Mitte, nahe dem ausgezogenen Seitenrande. Aus den spitzen Seitenhöckern tritt bei der Berührung ein gelblicher Saft, der nach einer Zeit wieder aufgesaugt wird. Auf der Unterseite hat jeder Ring in der Mitte 3 sehr flache Erhebungen und an jeder Seite eine, mit einem Härchen besetzte Tuberkel.

Die Larve von armoraciae lebt nach Cornelius auf Veronica beccabunga L., ist etwa $6,5 \mathrm{~mm}$ lang, überall ziemlich gleichbreit, schmutzig gelblich, glanzlos, Kopf und Tuberkeln glänzend schwarz, Unterseite heller gelb. Das dritte Fühlerglied einfach zugespitzt, oder in 2 Sprossen getheilt, an deren Spitze kleine Börstchen stehen. Der Prothorax hat in jeder Ecke einen tiefen Quereindruck, mit gekörneltem Grunde, jedes Rückensegment am Vorderrande 4 kleinere, am Hinterrande 2 grössere, glänzende Tuberkeln. Die saftführenden Seitenhöcker gross. Die Mitte des Prosternum besitzt eine kleine, schwarze Makel, die Mittelbrust eine grosse, dahinter zwei sebr kleine, jeder Bauchring eine grosse und zu jeder Seite zwei kleinere Tuberkeln.

Wenn die Larven unter beständigem Abnagen der Blätter ihrer Nährpflanzen ausgewachsen sind, gehen sie zur Verpuppung in die Erde, wo sie sich inwendig geglättete Ballen anfertigen. Die Puppen sind grösstentheils citronengelb, der Vorderkörper glänzend, der Hinterleib fast ohne Glanz, auf dem Prothorax stehen ringsum 15 bis 16 gelbe oder braune Borsten.

Von den mehr als 40 beschriebenen Arten gehören die Hälfte Amerika, einige Australien, Nordafrika und Asien an, in Europa leben 7 Arten, die bis auf eine in Deutschland vorkommen, leicht zu unterscheiden, aber schlecht gekannt sind, weil sie in oberflächlichster Art, ohne Angabe der wesentlichen Unterschiede, am 
besten noch von Duftschmid beschrieben wurden. Die Bildung der Vorderbrust, auf welche Suffrian so grosses Gewicht legte, ist bei der Eintheilung nicht zu gebrauchen.

A. Ungeflügelt.

1. Phated. $\operatorname{segnis}$ ): Apterus, ovalis, postice leviter acuminatus, convexus, nigro-aeneus, supra modice, subtus fortiter aurichalceo-micans, nitidulus, antennis piceis basi, tibiis piceis apicem versus tarsisque rufescentibus; prothorace parum concexo, subtilissime alulaceo crebreque punctato, elytris callo hunerali nullo, sat fortiter punctato-striatis, striis crebre punctatis, prima pone medium haud sulciformi, interstitiis parce obsoleteque punctatis et aciculatis, serie adjecta tenuiler punctata, linea marginali elevatu ante apicem obsole' a vel deficiente. - Long. 3,5-4 mm. Chrys. pyritosa Duft. Faun. Austr. III. 211.

Phaedon hederae Kraatz Deutsch. ent. Zeit. 1876. 185.

Var. a. obscurus: Nigro-coeruleus, vix vel haud virescens, minus nitidus, interstitiis elytrorum disperse sed evidenter punctatis.

Durch den ungeflügelten Körper, stark punktirte und auf der Schulter beulenlose Fld, bei denen die erste Punktreihe an der Naht hinter der Mitte nicht furchenartig vertieft, die aufgebogene Seitenrandlinie vor der Spitze sehr schwach, gewöhnlich ganz erloschen ist, leicht von den übrigen Arten zu unterscheiden.

Nach Habitus und Farbe am meisten mit Scleroph. carniolicus var. transsylvanicus verwandt, oval, vorn etwas abgestutzt, hinten leicht und kurz zugespitzt, gewölbt, schwarzgrün, oben mässig, unten stark messinggelb schimmernd, hier oft noch etwas kupferig, ziemlich glänzend, Fühler pechbraun, die ersten fünf Glieder wenigstens unterseits oder an der Spitze, das zweite meist ganz röthlich. Kopf ungefähr so stark als das Halssch. punktirt, mit tief und deutlich, oder ganz undeutlich abgesetztem Kopfschilde. Halssch. beinahe doppelt so breit als lang, nach vorn fast gradlinig oder schwach gerundet-verengt, die Ecken stumpfwinkelig, die hinteren scharf, die vorderen abgerundet und nach unten gedrückt, die Scheibe wenig gewölbt, aber an den Seiten steil abfallend, so dass die Randlinie

1) Hierher noch: Phaed. Fausti: Apterus, onalis, postice vix acuminatus, convexus, nigro-aeneus, aurichalceo-micans, nitidulus, antennis piceis, lasi rufescentibus, pedibus flavis, trochanteribus niyris, genubus tarsisyue leviter infuscatis, capite prothoracegue sat fortiter et crelire punctatis, hoc antrorsum angustato, lateribus sat rotundatis, apice vit perspicue maryinato, ungulis anticis subacutis, elylris callo humerali nullo, sat fortiter punctatostriatis, striis sat crebre punctatis per paria subapproximatis, prima apicem cersus haud sulciformi, interstitiis parce vix sibiliter punctulatis, serie adjecta mulla. - Long. 3,5 mm. Ochotsk (Faust, Sahlberg). 
durch die Wölbung verdeckt wird und von oben nicht sichtbar ist, äusserst dicht und zart gewirkt, mässig dicht und fein, aber tief und deutlich punktirt, entweder überall gleichstark, oder in der Mitte merklich feiner als an den Seiten. Fld. ohne Spur einer Schulterbeule, die $S$ Punktstreifen rerhältnissmässig tief, mit starken Punkten dicht besetzt, der erste hinter der Mitte gewöhnlich zu einer blossen Punktreihe verflacht, nicht furchenartig rertieft, die $Z$ wischenstreifen einzeln verloschen punktirt und weitläufig, äusserst fein quer nadelrissig, der äusserste, zwischen dem achten Punktstreifen und der feinen, ror der Spitze undeutlichen oder ganz fehlenden Seitenrandlinie mit einer mässig dichten, unregelmässigen, stellenweise doppelten Punktreihe besetzt, deren Punkte lange nicht die Grösse der in den Streifen befindlichen erreichen. Brust kräftig und weitläufig, Bauch dichter punktirt, namentlich an den Seiten der einzelnen Segmente; After röthlich gerandet.

Die auffällige Var. a. ist schwarzblau, bisweilen etwas grünlich, weniger glänzend, die Punktstreifen der Fld. sind meist schwächer punktirt, oft etwas geschlängelt und treten aus den zahlreicher und viel deutlicher punktirten Zwischenstreifen nicht so scharf heraus.

Beim Männchen sind besonders die ersten zwei Tarsenglieder merklich erweitert.

In Gesellschaft von Scler.carniolicus, wahrscheinlich auf Malachium aquaticum, an schattigen Gebirgsbächen in den Alpen und dem ganzen Karpathenzuge von der Tatra bis Siebenbürgen. Ich habe das Thier bisher nur gesiebt.

Die Beziehung dieser ausgezeichneten Art auf ('hr. pyritosn I) uft. ist insofern nicht ganz zweifellos, als Duftschmid ausdrücklich, ,zwei Punktreihen auf dem glatten Aussenrande der Fld." erwähnt, welche nur bei pyritosus Rossi dentlich auftreten; Chr. hederae Suffr. kann nicht hierher gestellt werden, weil der Vergleich mit cochleariae zu fern liegt, insbesondere sind die Punktstreifen wohl vorn aber nicht ,vom rierten an besonders hinter der Mitte furchenartig eingedrückt", die äusserste Punktreihe ist nicht , ,aus sebr rereinzelten "und tief eingestochenen Punkten zusammengesetzt" und eine Längsgrube an der Schulter, die sogar deutlicher als bei cochleariae sein soll, nie rorhanden. Die rothe Färbung der Schienenspitze und der Tarsen findet sich bei verschiedenen Arten.

\section{B. Geflügelt.}

a. Erster Punktstreifen der Fld. hinter der Mitte nicht furchenartig vertieft.

2. Promed. pyritosus: Alatus, breviter-ellipticus, valde comexus, fusco-aeneus, plerumque cupreo-micans. nitidulus, antemis, tibüis tarsisque piceis aut rufo-piceis; capite prothoraceque alufaceis. hoc suh- 
convexo, crebre et concime punctato, elyiris callo humerali mullo, minus fortiter punctato-striatis. striis creberrime punctatis. prima pone medium haud sulciformi, interstitiis minus crebre sed evidenter punctulatis et Iransrersin aciculatis, 9:0 seriebus 2 sat crebre punctatis. linea marginali elevata pone humeros deficiente. - Long. 3-4 mm.

Rossi Mantissa I. 31. - Oliv. Ent. V. 580. t. 9. f. 138. -

Suffr. Mon. 246. - Kraatz Deutsch. ent. Zeit. 1876. 186.

Chrys.graminicola Drap. Ann. phys. Brux. I. 1819. p. 53.t. 4. f. 6.

- Duft. Faun. A. III. 214.

Phaedon orbicularis Redtb. Faun. A. II. 452.

Var. a. Aurichalceo-virens aut nigro-aeneus.

In der Körperform einem grossen Cercyon z. B. haemorrhoidalis ähnlich, an den sehr dicht punktirten Streifen der Fld., sowie an der fehlenden Seitenrandlinie derselben sogleich kermtlich; regelmässig elliptisch, vorn und hinten gleichmässig verengt und abgerundet, hoch gewölbt, braun-erzfarbig, ziemlich glänzend, Fühler, S'chienen und Tarsen pechschwarz bis rothbraun. Kopf mässig dicht und fein punktirt, die Punkte auf dem vertieften und durch eine Hache Bogenlinie begrenzten Kopfschilde dichter und stärker. Fühler kräftig, ihre vier vorletzten Glieder quer. Halssch. mehr wie doppelt so breit als lang, nach vorn nur mässig, gerundet oder fast uradlinig verengt, mit ziemlich scharfen, stumpfwinkeligen Hinterecken und abgerundeten, rechtwinkeligen Vorderecken, die Scheibe wenig gewölbt, an den Seiten steil abfallend, so dass alle Ecken herabgedrückt sind und die Seitenrandlinie von oben nicht sichtbar ist, wie der Kopf äusserst dicht, zart gewirkt, seidenschimmernd, licht und fein, nicht tief punktirt, in der Mitte noch schwächer als an den Seiten. Fld. ohne Spur einer Schulterbeule, die 8 Punktstreifen wenig tief, mit mässig starken, äusserst dicht an einander gedrängten Punkten, der erste hinter der Mitte nicht furchenartig vertieft, vor der Spitze fast erlöschend, die Zwischenstreifen wenig dicht, deutlich punktulirt und quer nadelrissig, der äusserste, zwischen dem achten Punktstreifen und der feinen, bald hinter der Schulter vollständig erlöschenden Seitenrandlinie, mit zwei ziemlich dichten, unregelmässigen Punktreihen versehen, deren Punkte etwa halb so gross sind als die der Streifen. Der aufstehende Hinterrand der Grube auf dem Mesosternum bildet einen regelmässigen Bogen. Brust kräftig und ziemlich weitläufig, Bauch feiner und an den Seiten etwas dichter punktirt.

Beim Männchen ist das erste Tarsenglied schwach erweitert.

Die Farbe des Körpers wird zuweilen dunkelgrün, mit Messingschimmer oder schwarz-erzfarbig (Var. a). 
Auf Ranunculus-Arten in Norddeutschland sehr zerstreut, besonders in Thüringen, häufiger in Süddeutschland und Südeuropa. Kaukasus. Taschkend (Faust).

b. Erster Punktstreifen der Fld. hinter der Mitte furchenartig.

3. Phaed. laevigatus: Ovalis, postice leviter acuminatus, subcomeexus, nigro-aeneus, nitidus, elytris plenumque nigro-cupreis, antennis pedibusque nigris, illis articulis primis apice interdum piceis; prothorace antrorsum fortiter angustato, parum convexo, subtiliter, latera versus paullo fortius punctato, punctis subelongatis, interstitiis crebre subtilissimeque punctulatis, elytris callo humerali obsoletissimo, tenuiter punctato-striatis, stria prima postice sulciformi, interstitiis subtilissime punctulatis punctis majoribus intermixtis, 9: o serie sublaterali obsoleta, remote punctata. - Long. 2,5-3 mm.

Duft. Faun. Austr. III. 214.

Chr. sabulicola Suffr. Mon. 248. - Redtb. Faun. A. ed. 3. II. 483.

Phaedon gramicus Redtb. 1. c. ed. 1. 555.

Phaedon galeopsis Seidl. Faun. balt. 486.

Var. a. violaceus: Elytris cupreo- aut nigro-violaceis vel -cyaneis.

Var. b. caucasicus: Viridi- vel brunneo-aurichalceus, elytris obsolcte punctato-striatis.

Die kleinste Art, einem Limnichus ähnlich gebaut, an der eigenthümlichen Farbe und an den feinen, aber scharfen Punktstreifen der Fld. kenntlich, in denen die Punkte so schwach und undeutlich hervortreten, wie bei keiner andern Art.

Eiförmig, vorn etwas abgestutzt, bald hinter den Schultern am breitesten, dahinter allmählich verengt und am Ende leicht und kurz zugespitzt, verhältnissmässig wenig gewölbt, schwarz erzgrün, oder schwarz, mit Bronceschimmer, glänzend, die Fld. gewöhnlich schwarz kupferfarbig, Fühler und Beine schwarz, die Spitze der Basalglieder der ersteren, sowie die Schienenspitzen und die Tarsen zuweilen etwas röthlich, dunkel pechbraun. Kopf wenig stärker als das Halssch. punktirt, mit deutlich abgesetztem Kopfschilde. Halssch. mehr wie doppelt so breit als lang, nach vorn stark verengt, die Seiten schwach gerundet, alle Ecken spitzwinkelig, die vorderen weniger herabgebogen, leicht abgerundet; oben wenig gewölbt, dicht an den Seiten steil abfallend, die Randlinie von oben kaum sichtbar, äusserst dicht und fein punktulirt und ziemlich dicht, fein punktirt, nach den Seiten zu wenig stärker. Die Punkte sind nicht rund, sondern länglich. Fld. dicht an das Halssch. angeschlossen und mit diesen in einer Flucht gewölbt, die höchste und breiteste Stelle liegt ungefähr im ersten Drittel; ihre 8 Punktstreifen sind sehr regelmässig, fein, aber ziemlich scharf und tief, dicht mit kleinen 
Punkten besetzt, die sich, bei schwacher Vergrïsserung. nur undeutlich aus den Streifen herausheben (bei den übrigen Arten sind dir Punkte stets deutlicher als die Streifen), die ersten vier Streifen auf der vorderen Hälfte der Fld. besonders fein, der fünfte und sechste an der Basis eine Spur stärker vertieft, so dass eine wenig in die Augen fallende Schulterbeule gebildet wird. Zwischenstreifen äusserst fein punktulirt, zuweilen kaum sichtbar quer nadelrissig, mit etwas grösseren, dazwischen gemengten deutlichen Punkten. Die Punktreihe auf dem breiten Seitenstreifen ist weitläufig und sehr fein, bald hinter der Basis dem Seitenrande mehr genähert als dem achten Punktstreifen.

Die Farbe der Fld, oder der ganzen Oberseite geht unter Zunahme von Blau in ein kupferröthliches, dunkles Violett oder Kornblumenblau, oder ein reines Schwarzviolett über (Var. a); Stücke, welche H. Leder bei Katharinenfeld im Kaukasus sammelte, sind einfarbig grün- oder bräunlich-messinggelb und durchgehends feiner punktirt als unsere, die Punktstreifen auf den Fld. schwer sichtbar (Var. b).

Auf Weiden am Ufer von Flüssen in der Nähe des Gebirges. vorzüglich in den Alpenländern bäufig, nördlich bis zur Ruhr, der oberen Weser und an die Katzbach (Gerhardt) verbreitet. Petersburg und Dorpat (Seidlitz), Ungarn, Pyrenäen, Kaukasus (Leder).

Es ist von mir wiederholt darauf hingewiesen worden, dass die von Suffrian angegebenen Citate aus Duftschmid mit der grössten Vorsicht aufzunehmen sind, da Suffrian bei seiner Arbeit die Fauna Austriaca nicht eingesehen hat. Wer diese vergleicht, findet sofort, dass die vorliegende Arr den Namen laevigatus führen muss, unter dem sie Duftschmid unrerkennbar beschreibt, ebenso, dass gramicus $\mathrm{Duft}$. eine ron gremmicus Suffr. total verschiedene Species ist.

4. Phat. gramicus: Breviter-ovalis, fere subrotundus, concerus, nigro-aeneus, nitidus, elytris nigro-cupreis, antemis piceis, tibiis apicem versus tarsisque rufescentibus; prothorace brevi, antrorsum fortiter angustato, sat convexo, apice subdeclivi, sat crebre punctato. punctis subelongatis, interstitiis disperse subtilissimeque punctulatis, elytris callo humerali fere mullo, parm fortiter punctalo-striatis, stria prima postice sulciformi, interstitiis subtilissime punctulatis et temiter transversim aciculatis, $9:$ o serie sublaterali obsoleta, remole punctata. - Long. $3 \mathrm{~mm}$.

Duft. Faun. Austr. III. 215.

Sehr breit eiförmig, fast halbkreisförmig, durchschnittlich grösser, etwas gewölbter und viel gedrungener als die rorige Art, ganz ähnlich gefärbt, das Halssch. jedoch kürzer, nicht so genau mit den Fld. in einer Flucht gewölbt, sondern nach der Basis leicht, 
nach vorn stark abwärts gewölbt, bedeutend kräftiger punktirt, weshalb auch die unpunktirte Mittellinie deutlicher sichtbar wird, die Fld. haben in den Punktstreifen stärkere und tiefere, ein wenig weitläufiger gestellte Punkte, welche mehr hervortreten als dic Streifen, die Zwischenräume sind feiner punktirt, ibr Grund ist nicht äusserst fein punktulirt, sondern mehr quer nadelrissig.

Nach Duftschmid in Oesterreich. Bei Sarepta (Becker) häufig.

Die Art steht zur rorigen ungefähr in demselben Verhälnisse, wie grammicus Suffr. zu cochlearize, und es ist nicht unmöglich, dass sie sich bei reichlichem Materiale als Varietät herausstellen dürfte.

5. Howed. cochleariare $\left.{ }^{1}\right)$ : Ovalis, convexus, subtus nigro-aeneus, supra obscure coeruleus, haud vel evidenter virescens, nitidus, antemis sat tenuibus, nigris, articulis 2 mimis phs minusve rufescentibus: capite impressione epistomatis obsoleta, prothorace antrorsum fortiter angustato, lateribus leviter rotundatis aut subrectis, disco parce, lateru versus paullo fortius et crebrius punctato, punctis rotundis, elytris callo humerali obsoleto, sat fortiter punctato-striatis, stria prima postice sulciformi, quinta el sexta basi sat profunde impressa, interstitiis sub. tilissime punctulatis, punctis majoribus parce intermixtis, 9:o serie remote punctala, pectore, abdomineque punctulatis, nitidis. - Long. $3,5-4 \mathrm{~mm}$.

Fabr. Ent. Syst. 1. 1. 330. - Oliv. Ent. V. 579. t. 9. f. 13 i. - Duft. Faun. A. III. 213. - Suffr. Mon. 252. - Thoms. Skand. Col. VIII. 272. - Seidl, F. balt. 487.

Phaed. omissus Sahlb. Ins. Fenn. II. 1834. 203. - Kratz Berl. Zeit. 1872, 272. - Seidl. 1. c. 486.

Phaed. galeopsis Letzn. Bericht Schles. Ges. 1848. 10.

Phaed. gramicus Redtb. Faun. A. II. 483.

Chrys. cochleariae var. c. Gyllh. Ins. Suec. III. 480.

Var. a. Immaturus, tibiis apicem versus tarsisque rufescentibus.

1) Hinter diese Art gehört Phred. tumidulus Germ. (Ins. spec. nov. 588; Suffr. 249) aus dem westlichsten Europa: im Nordenglischen und Schottischen Berglande nicht selten, Frankreich (Normandie, Manuel; Mt. Dor, Kraatz) und in den Pyrenäen. Den grössten Stücken von cochlearice ähnlich, dunkelblau bis metallisch grün, Fühlerglieder 1 und 2 und After oft röthlich. Kopf dicht und kräftig punktirt, mit tief abgesetztem Kopfschilde. Halssch. nur an den etwas wulstigen Seiten oder am Hinterrande fein punktirt, auf der Scheibe äusserst fein chagrinirt, breit niedergedrückt, über jedem Auge fast grubenförmig vertieft, so dass die breite (keine andere Art besitzt eine ähnliche) Leiste des Vorderrandes deutlich aufgebogen ist. Fld. fein, sehr regelmässig punktirt-gestreift, in den Zwischenrüumen nur gewirkt, der Streifen am Seitenrande mit einer verloschenen oder grösstentheils fehlenden weitläufigen Punktreihe. - L. $4 \mathrm{~mm}$.

VI. 3. 
Var. b. neglectus: Supra obscuie aut late viridi-aeneus.

Sahlb. 1. c. 204. - Kraatz Deutsch. Zeit. 1876. 187.

Var. c. Supra obscure aut laete violaceus.

Var. d. hederae: Supra niger.

Suffr. Mon. 253.

Var. e. obesus: Breviter-ovalis, striis elylorum pro/undioribus, interstitiis leviter convexis, parcius obsoleteque punctulatis, nitidioribus.

Chr. grammica Suffr. Mon. 254.

Die häufigste, in Körperform, Farbe und Punktirung sehr veränderliche Art, mit den vorhergehenden wenig verwandt und kaum zu verwechseln, aber der folgenden oft sehr ähnlich, so dass sie von den älteren Autoren meist nicht unterschieden worden ist.

Länglich-eiförmig, gewölbt, unten schwärzlich erzfarbig, oben glänzend dunkelblau, ohne grünen Schimmer oder stark grünlich, die ziemlich dünnen Fühler schwarz, ihre ersten zwei Glieder gänzlich, oder unterseits, wenigstens an der Spitze hellroth bis dunkel rothbraun, die vier vorletzten Glieder kaum, oder wenig breiter als lang, der After an den Seiten schmal und verwaschen röthlich gesäumt, oder schwarz. Kopf mässig dicht oder zerstreut, fein punktirt, das Kopfschild durch eine Bogenlinie begrenzt, welche in der Mitte meist vollständig unterbrochen ist, so dass nur die beiden tiefen Seitentheile übrig bleiben. Halssch. wenigstens doppelt so breit als lang, nach vorn stark verengt, die Seiten in der ganzen Länge, oder nur rorn leicht gerundet, die Seitenrandlinie überall ron oben sichtbar, die Scheibe wenig gewölbt, zerstreut und fein, nach den Seiten zu stärker und dichter punktirt, die Punkte rund, mit äusserst fein punktirten Zwischenräumen. Fld. fein bis ziemlich stark punktirtgestreift, die Streifen dicht punktirt, vor der Spitze mit einander verbunden; der erste hinter der Mitte furchenartig, der fünfte und sechste an der Basis vertieft, wodurch die Schulterbeule schwach oder undeutlich in die Höhe gehoben wird, die Zwischenstreiten eben, äusserst fein und dicht punktirt, mit dazwischen gemengten etwas grösseren, deutlichen Punkten, der neunte trägt eine weitläufige Reibe von Punkten, die gewöhnlich grösser und tiefer sind als die der Punktstreifen. Brust und Bauch zerstreut, fein punktirt, nicht chagrinirt, glänzend.

Bei frischen Exemplaren sind die Schienen an der Spitze, die Tarsen und oft auch die letzten Bauchringe am Hinterrande röthlich. Die Oberseite wird rein metallisch dunkelgrün bis lebhaft grün, mit schwachem Messingschimmer (Var. b), oder dunkel bis licht violett (Var. c), endlich schwarz (Var. d). Nach einem frischen Stücke der letzten Abänderung ist Suffrian's Chr. hederce beschrieben. 
Die hauptsächlich im Gebirge (Glatzer Schneeberg, Altvater, Karpathen, Alpen) lebende Var. e. ist grösser als die Form der Ebene und nähert sich durch ihren breiteren Bau der folgenden Art. Die Punktstreifen der Fld. sind nach den Seiten hin und hinter der Mitte fast ohne Ausnahme stärker punktirt und tiefer eingedrückt wie bei der typischen cochlearicae, so dass die sparsamer und verloschener punktirten, glänzenden Zwischenstreifen an den bezeichneten Stellen sich gewöhnlich scbwach wölben.

A uf Cruciferen, besonders Nasturtium amphibium R. Br. und palustre D.C. an Gräben und Flüssen häufig.

6. Howed. armoraciac: Breviter-ovalis, sat comexus, nigrocoeruleus plerumque virescens, nilidus, antennis sat crassis nigris; capite impressione epistomatis distincta, fere angulata, prothorace antrorsum angustato, lateribus rotundatis, disco sat crebre, latera versus parum fortiter punctato, punctis rotundis, elytris callo humerali magno, interne fovea terminato, minus fortiter punctato-striatis, striis apice confusis, prina postice sulciformi, quinta basi profunde impressa, interstitiis crebrius evidenter punctatis, punctis subtilissimis intermixtis, 9) o serie obsolela remote punctata, pectore abdomineque punctulatis, alutaceis, sericeo-micanlibus, ano plus minusve late rufo-limbato. Long. $3-4 \mathrm{~mm}$.

Linn. Syst. Nat. ed. X. 369. - Thoms. Skand. Col. VIII. 272. Chrys. parvula Duft. Faun. A. III. 213.

Phaelon betulae Küst. Käf. Eur. 7. 91. - Suffr. Mon. 250 (Chrys.). Seidl. Faun. b. 486 (Phaed.).

Chrys. cochleariae Panz. Faun. Germ.44.15. - Gyllh. Ins. Suec.

III. 479. - Sahlb. Ins. Fenn. II. 202. - Redtb. Faun. A. II. 483 .

Var. a. salicinus: Minor, ovalis, nigro-aeneus aut niger. interdum violaceo-vel coeruleo-micans.

Heer Neujahrsbl. Nat. Ges. Zürich 1845. 17. - Snffr. Mon. 254.

Var. b. concinnus: Nigro-aeneus aul -coeruleus, elytris viridi-aeneis, viridi-subauratis vel cupreis.

Steph. Ill. Brit. IV. 334. - Suffr. Mon. 256. - Thoms. 1. c. 274. - Seidl. 1. c. 486 . - Redtb. l. c. 483.

Die wesentlichen Unterschiede von der vorigen Art bestehen in folgenden Stücken: Das Kopfschild ist durch eine tiefe, zuweilen fast winkelige Bogenlinie scharf von der Stirn getrennt, die Fühler sind einfarbig schwarz, merklich dicker, ihre 4 vorletzten Glieder deutlich breiter als lang. Das Halssch. ist gewöhnlich dichter und gleichmässiger punktirt, nach vorn etwas weniger verengt, an den 
Seiten gerundeter. Auf den Fld. treten di: Punktstreifun aus der stärkeren Punktirung der Zwischenstreifen weniger deutlich herwor, besonders auf dem Alfalle zur Spitze, wo sie sich, mit Aunnalıme der beiden inneren und äusseren Streifen, rerwirren und in den übrigen Punkten verlieren; ausserdem ist nur der fünfte Punktstreifon an der Basis allmählich vertieft, er tritt dort in eine weite Grube, die den länglichen, gewölbten Schulterhöcker innen begrenzt. der sechste Punktstreifen läuft, verflacht und rerfeinert, auf der Wölbung der Schulterbeule hin und ist nur an der äussersten Spitze. wo er in die Schulterbeule einbiegt, tiefer. Der After hat in der Regel einen breiten, rothen Saum. Das beste Lnterscheidungsmerkmal bleibt jedoch die nicht glänzende, sondern durch eine deutliche. dichte Chagrinirung etwas matt seidenschimmernde Unterseite.

Der Körper ist breit eiförmig, nur mässig gewölbt, schwärzlich. blau, oft mit grünlicher Beimischung, besonders auf der Unterseite. Von den beiden angeführten Abänderungen findet sich die

Var. a. in der alpinen Region der Pyrenäen und Alpen zwischen niederen Pflanzen ,auf dem rom thauenden Schnee feuchten Boden kriechend". Sie ist kleiner und länglicher, im $\mathrm{C}_{\mathrm{m}}$ riss der cochleariae ähnlich, schwarz metallischgrün, auch rein schwarz, oder blau bis violett angelaufen, stark glänzend; die

Var. b. lebt auf Salzstellen im Binnenlande und an der Meeresküste ron Schottland (Sharp) bis Daurien (Faust) auf Triglochin maritimum L. und anderen Salzpflanzen. Ihre Farbe ist schwärzlich erzfarbig, dunkelblau oder dunkelriolett mit metallisch grünen, schwach goldgrünen oder lebhaft kupferrothen Fld. Auf diesen heben sich in vielen Fällen die etwas stärker punktirten äusseren Punktstreifen und die Punktreihe über dem Seitenrande etwas schärfer aus der Punktirung der Zwischenstreifen heraus wie bei der eigentlichen armoraciae.

Auf sumpfigen Wiesen, am Rande von Seen, Teicben und Gräben auf Cruciferen, besonders Nasturtium-Arten, auch an Cochlearia armoracia L, häufig.

Die angeführten Varietäten lassen sich auf keinen Fall als Arten halten, denn sie besitzen alle oben angegebenen Hauptmerkmale der urmoracice, dagegen kein einziges stichhaltiges Unterscheidungsmerkmal: überhaupt scheint sowohl sutririan wie Thomson die nahe Verwandtschaft zwischen crucimms und armoraciae entgangen zu sein, da sie die genannte Varietät melır an cochleariae rücken. 


\section{Plagiodera.}

Redtenbacher Fauna Austriaca ed. 1. 1849. p. 553.

Corpus subrotundum, supra modice conrexum, sublus planum.

Elytra haud punctato-striula, plerumque callo obsoleto juxta marginem, epipleuris latis acute inflexis, glabris.

IIndibulae latae, apice birlentatae; antennae prothoracis basin parum superantes, apice subcompressae.

Mesosternum sat longum, metasternum inter coxas intermedias marginatum, episterna parallela.

Tibiae margine externo usque ad genua canaliculatae, tarsi articulo ullimo apice intus lamina parva sinuata producto.

Kopf klein, fast bis zur Mitte der mässig grossen, gewölbten Augen in das Halssch, eingezogen, Kopfschild durch eine schwache Bogenlinie von der Stirn getrennt. Mandibeln kurz und breit, winkelig gebogen, mit einer oben hoch gerandeten Rinne zum Einlegen der Taster, der breite Vorderrand nach dem Munde zu tief dreieckig ausgeschnitten und deshalb zweizähnig. Fühler die Hinterecken des Halsschildes kaum überragend, vom sechsten Gliede an meist rerbreitert und schwach zusammengedrückt. Halsschild kurz, forn und an den Seiten mässig abwärts gewölbt, ringsum fein gerandet, am gerundeten Hinterrande fast so breit als die Basis der Flügeldecken, nach vorn gerundet und stark verengt, Schildchen dreieckig. Flügeldecken an den Seiten die Rundung des Halsschildes ziemlich genau fortsetzend, verworren oder in sehr undeutlichen Reihen punktirt, oft mit einem schwachen Wulste über dem Seitenrande, die Epipleuren breit, sehr scharf auf die Unterseite geschlagen and für die Bewegung der Schenkelspitzen vertieft. Mesosternum zwischen den Hüften länger als bei den verwandten Gattungen und, bei unserer einheimischen Art, leicht quer gewölbt; Metasternum rorn gerandet, seine Episternen nach hinten eher erweitert als verengt. Beine kurz und wenig stark, Schenkel mit einer Rinne zum Anlegen der Schienen, diese sind undeutlich vierkantig, die beiden Seitenflächen breiter als die innere und äussere Fläche, letztere bis zum Knie schwach gerinnt. Das erste Tarsenglied ist wenig, das dritte, bei einigen Arten zweilapppige, bei andern an der Spitze nur ausgerandete Glied etwas breiter als das zweite, Klauenglied lang, in der Mitte des vorderen Innenrandes in eine kurze, breite, an der Spitze ausgebuchtete Kante verlängert, mit einfachen Klauen. Letzter Bauchring mit einem kleinen Büschel abstehender Haare jederseits am Hinterrande.

Die Gattung, welche durch ibren runden, oben mässig gewölbten, unten flachen Körper, an verschiedene Coccinelliden-Gattungen er- 
innert, weicht von den verwandten hauptsächlich durch die nicht in Streifen punktirten Flügeldecken, und deren breite, tief eingedrückte und durch einen sehr scharfen Rand von der Oberseite getrennte Epipleuren ab, und enthält mehr als 70 , grösstentheils der südlichen Hemisphäre angehörende Arten, von denen nur eine auf Weiders und Pappeln bei uns vorkommt. Ihre Larve ist nach Letzner (Ber. Arb. Schles. Ges. Breslau 1852. (1 ') gestreckt, oben sehr wenig gewölbt, nach hinten von der Mitte ab allmählich verschmälert, Kopt mit sehr kurzen Fühlern und jederseits 4 Ocellen, nebst dem Prothorax tief schwarz, glatt, lackartig glänzend, der übrige Körper oben dunkelgrau, matt, unten weisslich. Ueber den Rücken laufen zu jeder Seite der sanft eingedrückten Mittellinie 4 Längsreihen schwarzer Erhabenheiten, ron denen die in der zweiten Reihe ron aussen, auf dem Meso- und Metathorax stehenden, die höchsten und wie kleine Hörner empor gerichtet sind. Dieselben lassen bei der Berührung eine gelbliche Flüssigkeit austreten. Auf der Unterseite bilden die schwarzen Stigmenöffnungen ebenfalls eine Längsreihe jederseits.

Die Larve nagt bald auf der Unter-, bald auf der Oberseite einen Theil der Blattsubstanz weg, so dass die angegangenen Stellen der Weidenblätter zuletzt wie ein feines, braunes Gewebe aussehen; will sie sich verpuppen, so setzt sie sich mit dem Aftersegmente fest auf die Unterseite des Blattes, krümmt den Körper schleifenförmig zusammen und streift in dieser Stellung die Haut ab, welche auf der Bauchseite der Puppe am Blatte hängen bleibt. Die Puppe ist kahl, weisslich, Kopf, Fld., Fühler und die bei der Larve vorhandenen Tuberkeln schimmern schwärzlich durch.

1. Plagiod. versicolora: Supra coeruleo-virescens, sat nitida, subtus nigro-aenea, antemis basi ferruyineis; prothorace parce subtiliter punctato, interstitiis subtilissime punchulatis, elytris confertim punctatis, callo humerali et laterali distinctis, hoc uniseriatim punctato. - Long. 2,5-4,5 mm.

Laichart. Verz. Tirol. Ins. I. 148. - Gredler Käf. Tir. 429. Chrys. armoraciae Fabr. Syst. Ent. 103. - Oliv. Ent. V. 578. t. 4. f. 55. - Panz. Faun. Germ. 44. 14. - Gyllh. Ins. Suec. III. 474. - Duft. Faun. A. III. 212. - Küst. Käf. Eur. 7. 89. Steph. Ill. Brit. IV. 332. - Suffr. Mon. 242. - Redtb. Faun. A. II. 482. - Seidl. F. balt. 485.

Plag. salicis Thoms. Skand. Col. VIII. 271.

Var. a. Elytris viridi-auratis. capile prothoraceque obscurioribus.

Var. b. Elytris coeruleis, haud virescentibus: cyaneis, violaceo-micantibus; violaceis aut cupreo-violaceis.

1) Auch Heeger (Sitzungsber. Wien. Akad. 1853. 930 t. 2) und Cornelius (Stett. Zeit. 1857. 170) beschrieben die Larve. 
Var. c. Elytris cupreo-aurichalceis.

Var. d. clavicornis: Nitirlior, mothorace parce, subtilissime elytrisque subtiliter punctatis.

Steph. 1. c. 332 .

Etwas länglicher als die meisten exotischen Arten, oben bläulichgrün, mässig glänzend, unten schwarzgrün oder schwarz, mit Metallschimmer, die ersten fünf oder sechs Fühlerglieder rothbraun, die Tarsen dunkelbraun oder röthlich. Halssch. zerstreut und fein punktirt, mit äusserst feinen Punkten in den Zwischenräumen. Fld. mit einer deutlichen, auf der Innenseite durch eine mehr oder wenigel tiefe Grube begrenzten Schulterbeule und einem Längswulste über dem Seitenrande; ziemlich dicht und bedeutend stärker als das Halssch. punktirt, in den Zwischenräumen kaum sichtbar punktulirt. Die Punkte sind grösstentheils verworren, aber sie treten nicht selten auf der vorderen, inneren Hälfte der Fld, in einige fast regelmässige Reihen zusammen, ebenso befindet sich auf dem Seitenwulste eine deutliche, daneben, in dem absetzenden Längseindrucke, eine weniger scharf herrortretende Punktreihe.

Die Farbe der Fld. wird a. goldiggrün, b. rein hellblau, kornblumenblau, oft nach violett hinneigend, rein dunkel-violett oder roth-violett mit Kupferschimmer, c. dunkel broncegelb mit kupferigem Anfluge. Halssch. und Kopf sind fast immer viel dunkler, oder mindestens nicht so lebhaft gefärbt als die Fld., grünlich oder bläulich schwarz.

Von der auffälligen, sehr fein punktirten und glänzenderen Form d. besitzt Reitter ein Exemplar von Coimbra, auf welches die Angaben über die Punktirung von clavicornis Steph. zutreffen. Aus Deutschland sind mir ähnliche Stücke nicht bekannt.

Auf den verschiedensten Weiden-Arten, auch an Büschen ron Populus alba in Mitteleuropa gemein, seltener in Süd- und besonders Nordeuropa. Sibirien (Kjachta, Faust).

Die Angaben über das Vorkommen des Thieres auf Meerrettig und Ranunculus - Arten rühren wohl nur aus einer Verwechselung mit Phaedon armoraciae $\mathrm{L}$. her und bedürfen sehr der Bestätigung.

\section{Melasoma.}

Stephens Illustrations of British Entomology IV. 1S31. p. 350.

Lina Redtb. Faun. Austr. ed. 1. 1849. p. 551.

Lina et Macrolina Motsch. Schrenck Reis. Amur 1S60. p. 19s.

C'orpus obovatum, minus convexum, plus mimsve metallicum.

Elytra haud punctato-striata, costa marginali, epipleuris latis haud acute inflexis, glabris. 
Mandibulae lalae, apice bidentatae; anlemne prothoracis basin parum superantes, apice subcompressae.

Mesosternum angustum, metastermun inter coxas intermedius suepius subelevatum et immarginatum.

Tibiae margine externo usque ad genua deplanato vel canalimlato, tarsi articulo ultimo apice intus utrinque evidenter iel huur dentato-producto.

K o $\mathrm{f}$ bis zur Mitte der lang oralen, an den Seiten herablaufenden Augen in das Halsschild eingesenkt, Maxillartaster kurz und dünn, das letzte Glied lang eifömig, mit schmaler Spitze, Mandibeln breit, vorn etwas verengt, in zwei breite Zähne endigend. Fühler kaum die Hinterecken des Halsschildes überragend, rom siebenten Gliede an zusammengedrückt und allmählich erweitert. Halsschild verhältnissmässig klein, quer viereckig, im Umrisse sehr variabel, ziemlich flach, ringsum fein gerandet, vorn tief ausgeschnitten, die breiten Vorderecken vorstehend, die Seiten ziemlich gerade oder mässig gerundet, vorn etwas convergirend; bei den meisten Arten befindet sich jederseits auf dem Rücken ein tiefer Längseindruck, welcher die Scheibe von den fast wulstartigen Seiten absondert. Schildchen dreieckig. Flügeldecken am Grunde breiter als die Basis des Halsschildes, an den Schultern stark gerundet-heraustretend, dahinter zuerst leicht eingeschnürt, später in verschiedenem Grade verbreitert, hinten breit abgerundet, mit scharfem oder in eine kurze Spitze verlängerten Nahtwinkel, auf der Schulter ist gewöhnlich eine Beule, über dem Seitenrande stets eine Längsrippe ziemlich glatt, der übrige Theil verworren punktirt. Epipleuren breit, kahl, eben, oder nur vor der Spitze rinnenförmig vertieft. Mesosternum schmal, Metasternum zwischen den Mittelhüften schwach erhöht, nicht gerandet (die einzige Ausnahme macht $\boldsymbol{M}$. aenea, mit scharfem Rande), seine Seitenstücke ziemlich parallel, nach hinten etwas erweitert, aber nicht verengt wie bei Chrysomela. Die Hinterbrust, ohne die punktirten Seitenstücke, und der Bauch sind fast glatt, wie polirt glänzend, oft weitläufig quer nadelrissig, jeder Bauchring hinter der Mitte mit einer sehr feinen Querreihe von haartragenden Punkten, welche bei collaris gewöhnlich am deutlichsten zu sehen sind. Beine mässig dick, Schienen sehr kräftig, mehr oder weniger vierkantig, am Vorderund Hinterrande gewöhnlich rinnenförmig. Zweites Tarsenglied schmaler als die einschliessenden, das dritte bei der einen Hälfte unserer Arten zweilappig, bei der andern an der Spitze ausgerandet, diese besitzen zugleich an der Spitze des Klauengliedes jederseits eju unter die Klauen verlängertes Zähnchen, bei jenen ist das Klauenglied in der Mitte des Innenrandes in eine kurze, breite, an der Spitze zuweilen ausgebuchtete Kante verlängert. 
Die Gattung ist mit der vorigen nahe verwandt, aber durch den gestreckteren und flacheren, nach hinten mehr oder weniger erweiterten Körper, das flache, mehr viereckige Halsschild und die an den Schultern stark heraustretenden Flügeldecken, deren Epipleuren nicht vertieft sind, durchaus verschieden; mit der Gattung Chrysomela ist die Verwandtschaft sehr gering, da kaum ein Körpertheil bei beiden übereinstimmend gebaut ist.

Es sind bis jetzt 27 Arten beschrieben, von denen 9 in Europa und Asien, 5 nur in Asien, 9 in Amerika und 4 in Afrika auf Erlen, Birken, Pappeln oder Weiden leben. Ihre röthlichen Eier legen sie bis zu 10 Stück nebeneinander in Häufchen an die Unterseite der Blätter. Die Larven sind ungefähr dreimal so lang als breit, ziemlich stark gewölbt, an beiden Enden etwas verschmälert, der Kopf nach unten geneigt, mit sechs sehr hohen, grossen Ocellen hinter den Fühlern, zwei an den Wangen, vier an der Seite der Stirn. Prothorax jederseits grubig vertieft, die beiden folgenden Brustringe und die Bauchringe (der letzte ausgenommen) mit zwei Längsreihen schwarzer Flecke über den Rücken und auf jeder Seite derselben mit 2 Reihen kegelförmiger, stark hervortretender Tuberkeln, von denen die innere Reihe viel höher als die äussere ist. Zugleich liegen die inneren Tuberkeln der beiden Thoraxstücke weiter nach aussen als auf den Bauchsegmenten, und geben bei der Berübrung einen weisslichen Saft von sich, der bei vielen Arten einen unangenehmen, scharfen Geruch besitzt. An der Puppe sind meist nur die ersten 4 Rückensegmente sichtbar, die übrigen Ringe bis zur Spitze haben eine äusserst zarte Haut und sind von der Larvenhaut fest umschlossen.

Beide Entwickelungsstufen wurden beschrieben von $M$. aenea (De geer Mém. V. 396. t. 9. f. 7-12), cuprea (Letzner Ber. Schles. Ges. Breslau 1857. 123, Cornelius Stett. Zeit. 1857. 162 und Rupertsberger Natur und Offenb. 1875. 569. f. 12 und 13), lapponica (Märkel Isis 1857. 174 und Letzner 1. c. 1875. 172), vigintipunctata (Letzner 1. c. 1857. 225), collaris (Heer Obs. ent. Turici 1836.31. t. 6. und L etzner 1. c. 1875. 176), populi (Degeer 1. c. 386. t. 8. f. 18-22) und ? tremulae (Ratzeb. Forstins. I. 200. t. 20. f. 3; Klingelhöffer Stett. Zeit. 1843. 86 .

Die ron Motschulsky (Schrenck Reis. II. 198-200) gegebene Eintheilung unserer Arten in 3 Gattungen: Macrolina (20-punctata), Lina (populi) und Linaeidea (aenea) lässt sich nicht verwerthen, da zwischen diesen Typen positive Unterschiede nicht existiren; nur Linaeidea kann als Untergattung angesehen werden, weil ihre Hinterbrust scharf gerandet ist. 
A. Metasternum processu inter coras intermedias evidenter marginato. Prothorar lateribus haud callosis: I inaeidea Motsch.

1. Telas. wemear: Oblongo-nalis, supra luete viridi-aenea, plus mimusve aurichalcea, subtus obscurior, antemis basi, segmentis 2 ultimis ventralibus margine laterali tarsisque fervugineis vel piceis: prolhorace subconvexo, inaequaliter, latera versus paullo fortius punciato. ante medium subimpresso, elytris callo humerali interne forea terminato. crebre sat fortiter punclatis, sacpius obsolete sulcatis; articulo tertin tarsorum apice emarginato, ultimo intus utringue dentato-producto. Long. 6,5-8,5 $\mathrm{mm}$.

Mas: prothorace parvo, lateribus ante medium leriter ampliato, articulo ultimo palporum maxillarium apice oblique truncato.

Linné Syst. Nat. ed. X. 369. - Fabr. Ent. Syst. I. 329; Syst. El. I. 444. - Oliv. Ent. V. 556. t. 8. f. 116. - Panz. Faun. Germ. 25. 9. - Rossi Faun. Etr. I. 78. - Gyllh. Ins. Snec. III. 467. - Duft. Faun. Austr. III. 192. - Steph. Ill. Brit. IV. 351. - Ratzeb. Forstins. I. 246. t. 20. f. 13. - Suffr. Mon. 191. - Thoms. Skand. Col. VIII. 253. - Redtb. Faun. A. II. 479 . - Seidl. F. balt. 484.

Chrys. fuscicornis Fabr. Spec. Ins. 126; Mantissa I. 73.

Var. a. vitellinae: Supra vel omnino auro-cuprea.

Scop. Ent. Carn. 72.

Var. b. Tota obscure olivacea vel nigro-viridi-metallica, interdum leviler coeruleo-micans.

Var. c. Viridi-coerulea, laete coerulea aut cyanea.

Var. d. haemorrhoidalis: Saturate violacea aut nigra, parum rubroviolaceo-micans.

Linné 1. c. 369. - Müller Zool. Dan. Prodr. 81. - Kraatz Deutsch. Zeit. 1882. 156.

Chr. betulae Scop. 1. c. 71.

Chr. coeruleoviolacea Deg. Mém. Ins. V. 316. - Gyllh. 1. c. 46:

Chr. violacea Oliv.

Chr. amethystina Gmel. Ed. Linn. I. 4. p. 1688.

Länglich - eiförmig, oben lebhaft metallisch grün, mehr oder weniger messinggelb glänzend, unten dunkler, schwärzlich grün, Fühler und Mundtheile schwarz, das erste Fühlerglied oben von der Farbe des Körpers, unterseits (wenigstens an der Spitze) wie die 3 bis 5 folgenden Glieder rötblich, die Seiten der letzten beiden Bauchringe und die Tarsen rothbraun oder pechschwarz. Halssch. wenigstens doppelt so breit als lang, nach vorn wenig und ganz allmählich verengt, mit ziemlich graden Seiten (f) oder schmaler, kaum doppelt so breit wie lang, vor der Mitte am breitesten und nach vorn schnell, hinterwärts nach und nach schwach verengt, die Seiten gerundet $(\hat{\jmath})$; oben etwas gewölbter als bei den übrigen 
Arten, in der Mitte feiner, nach den Seiten stärker punktirt und in den Zwischenräumen fein punktulirt, mit einigen seichten Vertiefungen: einer queren, hinter dem Vorderrande, und einer rundlichen jederseits in der Mitte über dem Seitenrande. Fld. ungefähr doppelt so stark als das Halssch. punktirt, mit länglichem, innen ron einer tiefen, furchenartigen Grube begrenzten Schulterhöcker und einer hohen, äusserst fein punktirten Seitenrippe, die von einzelnen Querrissen durchzogen ist. Der zwischen die Mittelhüften vorgezogent Lappen der Hinterbrust wird von einer tiefen Randlinie umzogen, welche die Randleiste stark und scharf in die Höhe hebt. Schienen breit und kräftig, die der vorderen Beine am Grunde und an der Spitze verschmälert, so dass der Aussenrand deutlich gebogen ist, drittes Tarsenglied nur ausgerandet, nicht zweilappig, das vierte an der Spitze der Unterseite jederseits in einen spitzen Zahn ausgezogen.

Beim $\hat{j}$ sind die Schienen und die Taster etwas breiter, das Endglied der letzteren vorn zugleich nicht so stark zugespitzt als beim Weibchen, sondern leicht schräg abgestutzt. Einzelne Stücke besitzen ein sehr fein punktirtes, in der Mitte fast glattes, und oft von einer feinen Mittelrinne durchzogenes Halssch., andere haben auf den Fld. eine grössere oder geringere Anzahl von breiten, sehr seichten Längsfurchen, und schwach gewölbte Längsrippen zwischen ihnen.

Die Farbe ist veränderlich: a. Oberseite, oder der ganze Körper goldgelb, kupferschimmernd, b. Oberseite eben so dunkelgrün wie bei der Normalfärbung die Unterseite, entweder dunkel olivengrün, wenn noch ein schwacher Messingschimmer vorhanden ist, oder rein schwarz metallisch grün, selten mit bläulichem Zusatze, c. grünlich blau, hell und lebhaft blau oder kornblumenblau, d. roth violett, dunkel riolett oder schwarz, zuletzt mit kaum bemerkbarem violetten Schimmer.

In der Ebene im Frühlinge auf Alnus glutinosa, im Gebirge auf A. incana Ende Juli gemein, die Var. b. nur in den Alpen.

B. Metasternum processu inter coxas intermedias immarginato. Prothorax callo laterali.

a. Elytra plus minusve aenea vel nigro-violacea.

* Callum humerale distinctum. Tarsi articulo tertio bilobo.

2. Melas. cuprea: Ovalis, nigro-metallica vel -aenea, nitida, antennis articulis primis plus minusve rufescentibus, abdominis margine rufo-testaceo; prothorace in disco obsolete punctato, sublaevi, canaticulato, callo laterali sat lato, fortiter punctato, impressione profunda terminato, elytris crebre sat fortiter punctatis. obscure cupreis. Long. $7-10 \mathrm{~mm}$. 
F abr. Syst. Ent. 1775. p. 96; Ent. Syst. I. 315. - Oliv. Ent. V. 555. t. 8. f. 115. - Panz. Faun. Germ. 25. 8. - Gyllh. Ins. Suec. III. 464. - Duft. Faun. A. III. 171. - Küst. Käf. Eur. 2. 82. - Suffr. Mon. 195. - Redtb. Faun. A. II. 479. - Fein. Zeitschr. Ent. Breslau 18S4. XXII.

Chrys. ruficaudis Deg. Mém. Ins. V. 1775. p. 305. - Thoms. Skand. Col. VIII. 254 (Lina). - Seid]. F. balt. 485.

Var. a. Elytris cupreo-virescentibus vel brunneo-furichalceis. $\mathrm{V}$ ar. b. Elytris coeruleo-violaceis.

Etwas grösser, hinter den Schultern stärker eingedrückt, dahinter mehr erweitert als die rorige, schwarz, mit Metallschimmer, oder schwarzgrün, Fld. gesättigt kupferroth, nach violett überspielend, die ersten Fühlerglieder an der Spitze oder fast ganz röthlich, die Seiten des Bauches rothgelb gesäumt. Halssch. kurz und breit, nach vorn in leichter Rundung verengt, die Scheibe ziemlich flach, zerstreut und verloschen punktirt, fast glatt, mit feiner, selten vollständiger Mittelrinne, an den Seiten der Länge nach tief eingedrückt, der Eindruck und die dadurch wulstartig emporgehobenen Seiten stark punktirt. Fld. mit hoher Schulterbeule und schmaler Seitenrippe, dicht punktirt, die Pankte an der Naht fein, nach aussen zu stärker und in dem Eindrucke über der Seitenrippe etwas gröber als auf den Seiten des Halssch. Drittes Tarsenglied zweilappig, Klauenglied in der Mitte des inneren Vorderrandes in eine sehr kleine Kante verlängert.

Bei der Betrachtung von der Seite verlieren die Fld. ihre rothriolett angehauchte Kupferfarbe und sehen messinggelb aus, mehr oder weniger stark mit Grün gemischt; eine ähnliche Farbe haben die Fld. zuweilen, wenn sie von oben betrachtet werden, nämlich kupferig-grün oder dunkel fast bräunlich bronzefarben (Var. a), oder die Fld. sind dunkel stahlblau, an der Basis und im Eindrucke hinter der Schulter und über der Seitenrippe gewöhnlich roth-riolett (Var. b).

Auf Salix-Arten, besonders S. fragilis in Mittel- und Nordeuropa, sowie in Sibirien weit rerbreitet und stellenweise, aber immer nur in kleinen Bezirken, häufig.

3. Melas. Iapponica: Oblonga, nigro-aeneu, nitidula, antennis basi, tibiis anoque maryine testaceis; prothorace in disco sublaeri, alutaceo, callo laterali sat lato, fortiter punctato. impressione profunda terminato, elytris sat crebre punctatis, mfo-testaceis, sulura, macula magna difformi basali, fascia media subunduta arcuque ante apicen viridi-aeneis, coeruleis vel cyaneis. - Long. 5-8 $\mathrm{mm}$.

Mas: segmento anali apice subimpiesso-truncato. 
Linn. Syst. Nat. ed. X. 371. - Fabr. Ent. Syst. I. 322. Oliv. Ent. V. 559. t. 1. f. 9. - Panz. Faun. Germ. 23. 13. - Gyllh. Ins. Suec. III. 463. - Gebler Mém. Mosc. 1823. 124; Ledeb. Reis. II. 2. 214; Bull. Mosc. 1848. III. 32. Küst. Käf. Eur. 2. 85. - Suffr. Mon. 196. - Thoms. Skand. Col. VIII. 254. - Letzner Ber. Schles. Ges. 1875. 168. - Redtb. Faun. A. II. 479. - Seidl. F. balt. 485.

Var, a. Tibiis nigro-aeneis.

Yar. b. Metastemi processu inter coxas intermedias evidenter muminato. Var. c. altaica: Nigro-aenea vel -cyanea, elytris rufo-testaceis, suhura angusta nigra.

Lina lapponica var. g. Gebl. 1. c. 1848. 32.

Var. d. curvilinea: Nigro-aenea vel-cyanea, elytris coeruleis vel nigro-cyaneis, margine laterali et lineis variis arcuatis aut punctis nonnullis disci rufescentibus.

Deg. Mém. Ins. V. 302. t. 9. f. 3. - Gyllh. 1. c. var. b. c. Küst. 1. c. var. $\alpha, \beta$.

Tar. e. bulgharensis: Virescenti-coerulea, coenulea rel nigro-cyaner. Fabr. Suppl. Ent. Syst. 1798. 88. - Gyllh. 1. c. 466. - Küst. 1. c. 2.84 .

Lina lapponica mas Redtb. 1. c. 479.

Lina lapponica var. Gebl. 1. c. 32. - Suffr. 1. c. 197. - Kraatz Deutsch. Zeitschr. 1882. 156.

Durchschnittlich kleiner und schmaler als die vorige, weniger glänzend, nach hinten nur gering erweitert, hinter den Schultern viel schwächer oder kaum eingedrückt, über der breiteren und höheren Seitenrippe schärfer vertieft.

Mässig gestreckt, metallisch dunkelgrün, etwas glänzend, unterseits zuweilen schwarzblau, auch rein schwarz, die ersten sechs Fühlerglieder, Schienen und Seitenränder des letzten Bauchringes mehr oder weniger gelbbraun, die Fld. röthlich gelbbraun, die Naht, eine grosse Makel auf der Schulter, die sich nach innen gewöhnlich rerschmälert, eine breite, etwas wellige Querbinde in der Mitte und ein nach hinten offener Bogen vor der Spitze, letztere beide mit dem Nahtsaume verbunden, metallisch grün, grünblau oder kornblumenblau. Kopf und Halssch. sehr fein gewirkt, dieses an den Hinterecken oder kurz vor denselben am breitesten, nach vorn fast gradlinig verengt, auf der Scheibe zerstreut und sehr verloschen, im tiefen Seiteneindrucke und auf dem Wulste stark punktirt. Fld. ziemlich dicht punktirt, bisweilen die Punkte an der Nabt gereiht, seltener zeigen sich auch einige leicht gewölbte Längslinien auf der Mitte der Scheibe. Fortsatz der Hinterbrust zwischen den Mittelhüften ungerandet, zuweilen aber fast eben so scharf gerandet wie bei aenea (Var. b). Drittes Tarsenglied zweilappig, der innere 
Vorderrand des Klauengliedes in eine kurze, ausgerandete Kante verlängert. Beim $\hat{j}$ ist der abgestutzte Hinterrand des kurzen Analsegmentes in der Mitte vertieft.

Von den drei Stücken, welche die Zeichnung der Fld. bilden, ist jedes aus 2 Theilen zusammengesetzt: Die grosse Basalmakel aus einer länglichen Makel auf der Schulterbeule und einer kleineren, runden, zwischen Schulter und Naht; die Mittelbinde aus einem eckigen Flecke über dem Seitenkiele und einem Querflecke, der an der Naht in eine allmählich verschmälerte Spitze bis zum Schildchen ausläuft; der Bogen vor der Spitze endlich aus einem kurzen, nach aussen leicht gerundeten Längsbande am Seitenkiele und einem freien Querflecke oder einem fast kommaförmigen, der Naht stark zugekrümmten und an dieser verschmälert bis zur Spitze laufenden Theile. Exemplare, bei denen alle diese 6 Makeln deutlich getrennt sind, gehören zu den Seltenheiten.

Es können nun die Makeln entweder gänzlich verschwinden, dann sind die Fld. gelbbraun, mit fein schwärzlich gesäumter Nałt (Var. c), oder sich allmäblich so ausdehnen, dass sie die Grundfarbe rollständig verdrängen. Diese Ausdehnung und theilweise Vereinigung geschieht so, dass zunächst Schultermakel und Mittelbinde, oder diese und der Spitzenbogen allein, endlich alle drei Theile der Länge nach zusammenfliessen. In diesem Falle bleiben von der Grundfarbe ein in der Mitte verschmälerter Längsstreifen auf dem ersten Drittel der Fld, ein dreieckiger Fleck im zweiten Drittel und eine verschieden geformte Makel vor der Spitze, alle drei nahe der Naht, sowie zwei kleine, nach innen gerichtetete Spitzen am gelben Seitenkiele übrig, die eine im ersten, die andre im zweiten Drittel (Var. d). Diese Reste der Grundfarbe schrumpfen zu Punkten zusammen, welche nach und nach versehwinden: die Fld. sind hellblau, zuweilen grün schimmernd, oder kornblumenblau (Var, e). Eine Uebersicht über die in Schlesien beobachteten Varietäten giebt Letzner a. a. O.

In Deutschland ist die Var. a. mit einfarbig schwarzgrünen Schienen vorherrschend.

Auf Weiden, Betula alba (Schmidt, Letzner), Alnus glutinosa und Populus tremula (Rosenhauer) im Nord- und Mitteldeutschen Berglande stellenweise nicht selten: Pommern, Harz, Erz-, Glatzerund Riesengebirge, Schwarzwald (Simon), Baiern, Böhmen, bei Wien. China (v. Kraatz). Die Var, c. in den sibirischen Gebirgen, in denen die Art weit verbreitet ist.

1. Melas. vigintipunctata: Subelongata, nigro-aenea, sat nitida, antennis nigris, articulis primis apice rufescentibus, femorun. 
basi, tibiis, marginibus segmentorum ventraliun, lateribus prothoracis elytrisque stramineis, his sulura maculisque decen $(1,2,1,2,1,2,1)$ nigro aeneis aut -violaceis; prothorace disco parce subtiliter punclato, callo laterali minus lato, impressione profinda, fortiter punctata, in medio plenumque extrorsum dilatala, terminato, elytris crebre punctatis.

- Long, 6,5-8,5 mm.

Mas: tibiis tarsisque dilatatis segmento anali apice transversim impresso.

Scopoli Entom. Carn. 1763. 78. - Oliv. Ent. V. 557. t. 8. f. 118. - Panz. Faun. Germ. 6. 10. - Duft. Faun. Austr. III. 171. - Steph. Ilı. Brit. IV. 351. - K üs t. Käf. Eur. 2. 86. Suffr. Mon. 194. - Motsch. Schrenck Reis. Amur II. 198 (Macrolina). - Redtb. Faun. A. II. 478. - Seidl. F. balt. 484.

Var. a. Tibiis nigro-aeneis.

Var. b. Macula postica elytrorum nulla.

Var. c. pustulata: Maculis elytrorum plus minusve connatis vel confluentibus.

Die schlankste unserer Arten, langgestreckt, nach hinten wenig erweitert, dunkel metallgrün, ziemlich glänzend, die ersten vier bis sechs Glieder der schwarzen Fühler unten oder an der Spitze röthlich, Basis der Schenkel, ein verschieden grosser Theil der Schienen, die Hinterränder der Bauchringe, Seiten des Thorax und die Fld. strohgelb bis gelblich braun, letztere mit einem metallisch grünen oder schwarzen, violett schimmernden Nahtsaume und 10 ebenso gefärbten länglichen Makeln in drei Längsreihen, die erste an der Naht mit vier, die zweite in der Mitte und die dritte am Seitenkiele mit je drei Makeln. Halssch. nach vorn in sehr schwacher Rundung fast gradlinig verengt, mit nach aussen gerichteten, spitzen Hinterecken, die Scheibe zerstreut und fein punktirt, oft fast glatt, nach aussen allmählich in den stärker punktirten Längseindruck übergehend, welcher fast immer in der Mitte grubig vertieft und nach aussen erweitert ist, so dass der wenig breite Seitenwulst hier merklich verengt wird. Auf die erweiterte Stelle erstreckt sich zugleich die dunkle Farbe der Scheibe, oder es ist daselbst eine schwärzliche Makel abgesondert. Fld. zuweilen (bei frischen Stücken?) mit einigen leicht erhabenen Kiellinien belegt, dicht punktirt, die Punkte hie und da in kurze Reihen geordnet. Fortsatz der Hinterbrust zwischen den Mittelhüften abgestutzt oder ausgerandet, ungerandet. Drittes Tarsenglied zweilappig, innerer Vorderrand des Klauengliedes in eine kurze, am Ende bogenförmig ausgeschnittene Kante verlängert.

Beim Männchen sind die Schienen und Tarsen deutlich erweitert und der letzte Bauchring besitzt am Hinterrande eine Quergrube.

Die hellsten Stücke sind die, denen die hintere, einem Apostroph ähnliche Makel der Fld, fehlt (Var. b), bei den dunkelsten vereinigen 
sich die Makeln zu grossen, unregelmässigen Flecken z. B. die Makeln 1, 2, 3 und 4 unter sich und mit der Naht, oder. Makel ; bis 10) ror der Spitze (Var. c). Wahrscheinlich werden aucl noch $_{\text {t }}$ Stücke mit einfarbig schwarzgrünen oder violetten Fld., die bei der nahe verwandten nordamerikanischen lineatopunctata Forst. häufig vorkommen, aufgefunden werden.

Die Var, a. besitzt einfarbig dunkelgrüne Schienen.

Auf Weidenarten in Mitteleuropa und Sibirien stellenweise häufig. Bei Berlin nur auf Salix fragilis.

" Callum humerale obsoletum. Tarsi articulo tertio aprice sinuat".

5. Melas. collaris $\left.{ }^{1}\right)$ : Breviter-ovalis, comexa, nigro-submelallica. -coevulea vel -aenea, nitidula, ore el antemis basi rufescentibus, limbu lato laterali prothoracis flavo-albido, luteo aut rufo, puncto nigro: prothorace lato, minus convexo, lateribus postice subrecto, antice rotumdato-angustato, apice profunde emarginato, disco parce subtiliter pumtato, callo laterali lato, sparsim grosse punctato, impressione panum vel vix profunda terminato, elytris violaceis, crebre punctatis, interstitiis subtilissime rugutosis. - Long. 5,5-7,5 mm.

Mas: prothorace latione, epiplewis linea externa apice rotundata, interma leviter dentato-producta, tibiis tarsisque dilatatis.

Femina: epipleuris linea externa apice fortiter dentato-producta.

Linné Syst. Nat. ed. X. 371. - Fabr. Ent. Syst. I. 319. Oliv. Ent. V. 564. t. 8. f. 121. - Gyllh. Ins. Suec. III. 459. - Duft. Faun. A. III. 185. - Küst. Käf. Eur. 2. 87. Letzn. Bericht Schles. Ges. Breslau 1844. 69; 1875. 175. Suffr. Mon. 192. — Thoms. Skand. Col. VIII. 256. Redtb. Faun. A. II. 478. - Seidl F. balt. 484.

Chr. Escheri Heer Obs. ent. p. 31. t. 6. f. 9.

Var. a. geniculata: Prosterno fere omnino pedibusque rufis, yembus tarsisque plerumque nigris.

Duft. 1. c. 185 .

Var. b. Major, - Long. 7,5-9 $\mathrm{mm}$.

Var. c. Prothoracis puncto nigro ulrinque nullo.

Var. d. thoracica: Prothorace margine antico lineague postica obliqua utrinque luteis.

1) Der rothbeinigen Form ron collaris ist sehr ähnlich Melas. alpina Zett. (Ins. Lapp. 226. - Thoms. VIII. 25i) ans Norwegen und Lappland. Durchschnittlich kleiner und schlanker, die Fühler an Grunde dünner, nach der Spitze zu breiter, ihr drittes Glied mehr als doppelt so lang als das vierte; Halssch, viel kleiner, der Qaere nach deutlich gewölbt, vorn weniger tief ausgeschnitten, an den Seiten stärker und fast gleichmässig gerundet, die Vorderecken weniger rorgezogen, Fld. etwas feiner und dichter punktirt. L. 5-6,5 $\mathrm{mm}$. 
Var. e. salicis: Elytris commleis. interdum viridi-micantibus.

Fabr. 1. c. 319 .

Var. f. daurica: Elytris nigro-aeneis, interdum plus mimusve cupreomicantibus, vel obscure aurichalceis, aut nigris.

Motsch. Schrenck Reis. Amur II. 224.

Die Art ist ausser der Fürbung besonders noch an ihrem eigenthümlichen Körperbau kenutlich, welcher dadurch bedingt wird, dass die Fld. an der Basis nur so breit als der Hinterrand des Halssch. sind und kaum die Spur einer, bei den vorigen Arten so deutlichen Schulterbeule besitzen. In dieser Hinsicht bildet sie den Uebergang zu den folgenden Arten, während das an der Spitze nur ausgerandete dritte Tarsenglied auf eine Verwandtschaft mit aenea, tremulae und longicollis hinweist.

Kurz eiförmig, nach hinten stark erweitert und gewölbt, schwarz, mit Metallglanz, schwarzblau oder schwärzlich erzgrün, Fld. lebhaft bis schwarz-violett, Oberlippe und Mandibeln, sowie die ersten sechs Fühlerglieder mehr oder weniger röthlich, der breite, mit einem schwarzen Punkte versehene Seitenwulst des Halssch., oft auch noch ein schmaler Saum an der Seite der beiden letzten Bauchringe weissgelb, bräunlich gelb bis dunkel gesättigt rothgelb. Fühlerglied 3 meist ein und ein halb mal so lang als das vierte. Halssch. doppelt so breit wie lang, von den Hinterecken nach vorn ziemlich gleichbreit oder sehr schwach verbreitert, im vorderen Drittel gerundet-verengt, der Vorderrand tief ausgeschnitten; oben schwach gewölbt, der breite, aber flache, sparsam grob punktirte Seitenwulst durch eine zerstreut und stark punktirte, leicht eingedrückte Vertiefung von der fein punktirten, zuweilen fast glatten Scheibe geschieden. Fld. hinter der Basis in starker Rundung heraustretend, mit schmaler, innen wenig tief begrenzter Rippe über dem Seitenrande, dicht punktirt, in den $Z$ wischenräumen sehr fein lederartig gerunzelt, beim $\hat{o}$ glänzender als beim $q$. Fortsatz des Metasternum zwischen den Mittelhüften abgerundet, ungerandet, drittes Tarsenglied ausgerandet, Klauenglied mit einer kaum sichtbaren Spitze jederseits unter der Wurzel der Klauen.

Das kleine Männchen hat ein verhältnissmässig grosses, breites Halssch., erweiterte Schienen und Tarsen, eine Quergrube an der Spitze des letzten Bauchringes und hinten ziemlich gleichmässig gemeinschaftlich abgerundete Fld., an denen die obere Nahtecke der Epipleuren gerundet, die untere (innere) dagegen leicht zahnförmig verlängert ist; beim Weibchen ragt die obere Nahtecke in Gestalt einer kurzen und breiten, nach hinten aufgebogenen Spitze weit über die untere vor.

VI. 3 . 
Diese veränderliche Art besteht aus zwei Formen, zwischen denen Uebergänge äusserst selten sind; die eine hat cinfarbig grünlich schwarze, die andere gelbrothe Beine, an denen stets die Tarsen oben schwarz, die Knie in den meisten Fällen schwarz oder schwarzgrün bleiben (Var, a). Die übrigen Abänderungen gehören gleichmässig beiden Formen an.

In Bezug auf die Grösse zeigen sich bei unseren deutschen Stücken kaum grössere Unterschiede als bei den übrigen Arten, aber in Ungarn tritt besonders an den Ufern der unteren Theiss eine Riesenform auf (Var. b) die den grössten Stücken der cuprea nur wenig nachsteht.

Die Farbenabänderungen, welche sehr eingehend von Letzner 1. c. behandelt wurden, betreffen theils das Halssch., theils die Fld. Auf dem Halssch. fällt die innere Grenze des rothen Seitensaumes gewöhnlich mit der leicht gebogenen Längsrertiefung zusammen, tritt aber auch im vorderen Drittel und am Grunde des Halssch. etwas über diese weg nach innen; bei der seltenen Var.d. ist der ganze Vorderrand roth umsäumt, ausserdem geht von der Basis jederseits eine schräg nach vorn laufende Linie aus, so dass die Grundfarbe des Halssch. auf eine querliegende, nit der convexen Seite nach vorn gerichtete halbmondförmige Makel beschränkt wird. mit der ein dreieckiger Fleck vor dem Schildchen schmal zusammenhängt. Weniger auffällig ist die Var. c., ohne dunklen Punkt aut dem Seitenwulste.

Die Fld. werden lebhaft und rein blau bis grünlich blau (Var. e ${ }^{1}$ ), schwarzgrün, bisweilen mehr oder weniger kupferig schimmernd, dunkel broncegelb, oder rein schwarz (Var.f). Bei einzelnen Weibchen bleibt auf den Fld. nur ein sehr matter Seidenglanz übrig, wenn die lederartige Runzelung in den Zwischenräumen der Punkte an Stärke zunimmt und sich zu deutlichen, von den Punkten beinahe sternförmig ausgehenden Runzeln ausbildet.

In sumpfigen Gegenden, besonders in Torfmooren auf Salix repens, rosmarinifolia etc. in Mitteleuropa und Sibirien häufig, in den Alpen auf Salix retusa.

Rothbeinige Exemplare scheinen in Schweden, wo die Art auch an Espen lebt, nicht vorzukommen, da weder Gyllenhal noch Thomson dieselben erwähnen, Küster und Heer haben jedenfalls solche ror sich gehabt, aber nit der nordischen alpina $\mathrm{Z}$ ett. verbunden. In unserer Gegend finden sich beide Hauptformen fast in gleicher Anzahl unter einander, in ersten Frühlinge auch im Anspülicht auf Torfwiesen, in Schlesien ist, nach Letzner, die rothbeinige Form häufiger.

1) Die eigentliche salicis $\mathbf{F}$ abr. umfasst zu gleicher Zeit auch die Var. a. 
b. Elytra mufa.

* Tarsi articulo tertio bilobo. Costa laterali elytrorum externe fere uniseriatim punctata.

6. Melas. poputi: Orata, nigro-coerulea aut viridi-aenea, nitida. canite prothonaceque plenumque rividi-aeneis, hoc disco sublaevi. callo laterali fortiter punctato impressione sat profunda, antice curvata, postice obsoleta, terminato, elytris miniatis, sat nitidis, apice sutura nigris. creberrime minus fortiter punctatis. - Long. 10-12 $\mathrm{mm}$.

Mas: tarsis modice dilatatis, segmento ultimo brevi.

Linné Syst. Nat. ed. X. 370. - Scop. Ent. Carn. 73. - Oliv.

Ent. V. 551. t. 7. f. 110. - Gyllh. Ins. Suec. III. 457. -

Duft. Faun. A. III. 170. - Küst. Käf. Eur. 2. 80. -

Ratzeb. Forstins. I. 245. t. 20. f. 4. - Suffr. Mon, 197. Redtb. Faun. A. II. 478. - Seidl. F. balt. 485 .

$\mathrm{V}$ ar. a. Capite prothoraceque nigro-coemuleis vel nigris.

Von den beiden folgenden Arten durch das zweilappige dritte Tarsenglied, die Bildung des Klauengliedes, die wenigen, fast in eine Reihe geordneten Punkte über der Seitenrandlinie der Fld. und deren schwarze Spitze stets sicher zu unterscheiden.

Breit eiförmig, plump gebaut, unten vorherrschend schwarzblau, seltener schwarzgrün, die Ränder der letzten Bauchringe röthlich, Kopf und Halssch. dunkelgrün, zuweilen schwach broncegelb schimmernd, Schildchen wie die Unterseite gefärbt, die Fld. lebhaft und gesättigt ziegelroth, nach dem Tode hell gelblich braun, mit schwarzer Nahtspitze. Fühler und Taster schwarz. Halssch. klein, vorn etwas schmaler als am Grunde, an den Seiten hinten fast parallel, im rorderen Drittel gerundet-verengt, oder die Seiten gleichmässig und stark gerundet, oben der Quere nach etwas gewölbt, die Scheibe zerstreut, sehr fein punktirt, fast glatt, dicht vor dem Hinterrande oft mit stärkeren Punkten, der wenig hohe, stark punktirte, nach vorn verbreiterte Seitenwulst von einem ziemlich tiefen Eindrucke abgesetzt, welcher ror dem Hinterrande fast erlischt, in der vorderen Hälfte stark nach innen gekrümmt ist. Fld. mit gewölbter, aber auf der Innenseite undeutlich begrenzter Schulterbeule, ziemlich glänzend, sehr dicht, wenig stark punktirt, die Punktreihe über der Kante des Seitenrandes ist entweder ganz regelmässig (meist $\hat{j}^{\text {) }}$ oder unter der Schulter verdoppelt, dahinter durch einige an der Aussenseite herantretende Pünktchen mehr oder weniger gestört. Der innere Rand an der Spitze des Klauengliedes ist in eine kleine, am Ende bogig ausgerandete Kante vorgezogen.

Das Männchen besitzt etwas erweiterte Tarsen und ein kurzes, breit abgestutztes Analsegment. - Der Penis ist vorn allmählich in eine breite, wenig aufgebogene Spitze rerschmälert. 
Bei der unbedeutenden Abänderung a. ist Kopf und Halssch. entweder schwarzblau oder rein schwarz; zuweilen wird der längliche schwarze Fleck am Ende der Naht so unscheinbar, dass nur die Nahtkante selbst in der Spitze der Fld. angedunkelt ist. Einzelne Exemplare zeichnen sich durch etwas stärker punktirte, ziemlich matte Fld. aus, auf denen einige breite und sehr seichte Längsfurchen auftreten, die von ungefähr vier schmalen, erhabenen Linien durchsetzt sind.

Auf Pappelgebüsch, weniger an Weiden, gemein.

** Tarsi articulo tertio apice emarginato. Costa laterali elytrorum externe numerose punctata.

F. Melas. tremulae: Ovata, nigro-coerulea, nitida, capite prothoraceque virescentibus, hoc vix transversim convexo, lateribus pone medium sinuatis, disco parce evidenter punctato. callo laterali valde incrassato, fortins punctato, impressione profundissima, integra, subplicaeformi, terminato, elytris miniatis, minus nitidis, creberrime fortiter et profunde punctatis, tarsis articulo ultimo apice intus utrinque exidenter dentatoproducto. - Long. 7,5-10 $\mathrm{mm}$.

Mas: segmento ultimo ventrali brevi.

Fabr. Mant. I. 69; Ent. Syst. I. 317. - Schrank. Enum. 68. - Oliv. Ent. V. 552. t. 7. f. 11. - Payk. Faun. Suec. II. 55. - Gyllh. Ins. Suec. III. 458. - Duft. Faun. Austr. III. 170. - Steph. Ill. Brit. IV. 350. - Zett. Ins. Lapp. 226. - Küst. Käf. Eur. 2. 81 (1845. Erster Druck). - Redtb. Faun. A. ed. 1. 551.

Chr. longicollis Suffr. Mon. 199. - Küst. 1. c. 25. 96. - Thoms. Skand. Col. VIII. 255. - Kirsch Berl. Zeit. 1870. 218. - Redtb. 1. c. ed. 3. II. 478. - Seidl. Faun. balt. 485.

Var. a. Elytris apice suturae puncto infuscato.

Der vorigen ganz ähnlich gebaut, breit eiförmig, glänzend schwarzblau, die Unterseite nur selten, Kopf und Halssch. gewöhnlich erzgrün schimmernd, die Seitenränder des letzten Bauchringes röthlich, Fld. gesättigt ziegelroth, obne schwarze Spitze; Taster pechschwarz, Fühler schwarz, zweites Glied an der Spitze düster roth. Halssch. mässig gross, vor den nach aussen vorspringenden Hinterecken zuerst eingezogen, hierauf allmählich, in der Nitte meist etwas stärker erweitert, die grösste Breite in, oder dicht ror dem ersten Drittel, davor in starker Rundung verengt, rnrn tief ausgeschnitten, mit dicken, breiten und stumpfen Vorderecken, oben kaum der Quere nach gewölbt, die Scheibe zerstreut aber deutlich punktirt, der sehr hohe, nach rorn etwas verbreiterte, einzeln und grob punktirte Seitenwulst 
ron einem sehr tiefen, fast rinnenförmigen Eindrucke begrenzt, welcher von der Basis bis zum Vorderrande gleichmässig gerundet und gleichtief hinläuft, und dicht und grob punktirt ist. Fld. wenig glänzend, sehr dicht, stark und tief punktirt, über dem Seitenrande mit zwei Punktreihen, welche durch dazwischen tretende feinere Punkte oft vervielfacht und theilweise gestört sind. Das Klauenglied ist an der Spitze der Unterseite jederseits in einen grossen Zahn ausgezogen, der kürzer, breiter und stumpfer als der von aenea ist.

Das kleinere, nach hinten weniger erweiterte Männchen hat ein kürzeres Analsegment als das Weibchen, und ist vor dem breit abgestutzten Hinterrande rertieft. - Penis an der grossen Oeffnung allmählich schwach verengt, hierauf beiderseits plötzlich in starkem Bogen erweitert, davor gradlinig und schnell verschmälert, so dass der vor der Oeffnung liegende, gleichsam abgeschnürte Theil ein sehr stumpfes Dreieck bildet, dessen stumpfer Winkel vorn liegt.

Bisweilen sind die Seiten des Halssch, vor der Basis nicht ausgeschweift sondern divergiren schwach in ziemlich grader Linie vou den rechtwinkeligen, nicht vorspringenden Hinterecken nach vorn; bei einzelnen Exemplaren tritt unmittelbar in der Spitze der Fld. ein, wenig in die Augen fallender dunkler, bläulicher Punkt auf. (Var. a).

An Pappelgebüsch, ausnahmsweise auch an Weiden, viel seltener als die vorige.

Alle Schriftsteller beziehen die vorliegende Art anf tremulae F., nur Suffrian nicht, weil er in den beiden Stücken der Fabricii'schen Sammlung die folgende, fast ausschliesslich auf Weiden lebende, anders gefärbte Art zu erkennen glaubte. Die Untersuchung der alten Typen berechtigte Suffrian nicht, mit der durch Gyllenhal vollständig sicher gestellten Tradition $z u$ brechen, da, wie schon wiederholt nachgewiesen, auch von mir p. 442 bei Chr. tristis F, erwähnt worden ist, die vorgefundenen Thiere oft gar nicht mehr zur Beschreibung passen. Wenn Suffr. Chr. tremulae Steph. zu seiner lungicollis bringt, weil "die Färbung als blaugrün bezeichnet ist", so musste er auch tremulae F. dazu rechnen, da sie ausdrücklicb "coerulescens" genannt wird.

\$. Nelas. saliceti: Oblonga, obscure viridi-aenea, nitida, mothorace transversim conexo, postice subparallelo, antice rolundatoangustato, aut lateribus fere aequaliter rotundato, disco parce subtiliter. punclato. sublaevi, callo laterali minus crasso, impressione sal profunda. antice posticeque obsolela, terminato; elytris minutis. sat nitidis. crebre mimus profunde muctatis, tarsis articulo ultimo apice intus utrinque -vix sibiliter dentato-producto. - Long. 7,5-9 $\mathrm{mm}$.

Mas: segmento ultimo ventrali brevi. 
Chrys. tremulne siuffr. Mon. 198. - Küster Käf. Eur. 2. 81 (1552. Nachdruck). - Thoms. VIII. 255. - Kirsch. Berl. Zeit. 1970. 218. - Redtb. Faun. A. ed. 3. I. 478. - Seidl. F. balt. 485. Var. a. Prothoracis lateribus pone medium sinuatis.

Var. b. Capite prothoraceque nigris.

Etwas kleiner, namentlich schmaler als die rorhergehende. und ron ihr durch folgende Punkte leicht zu unterscheiden: Die Farbe der Unterseite, des Kopfes and Halssch, enthält nur selten eine deutliche blaue Beimischung, sondern ist mehr broncegrün; das Halssch. ist merklich kürzer, der Quere nach deutlich gewölbt, vorn weniger tief ausgerandet, mit spitzeren Vorderecken, die Seiten sind in den hinteren zwei Dritteln bald gleichbreit, bald unmerklich nach vorn verengt, ziemlich parallel (q), oder nach hinten und vorn fast gleichmässig verengt, stärker gerundet $(\hat{\jmath})$, dicht vor den Hinterecken zuweilen schwach ausgebuchtet, die Scheibe ist feiner punktirt, der Seitenwulst viel niedriger, nach rorn weniger verbreitert und verdickt, von einem dicht punktirten, bedeutend flacheren, beiderseits erlöschenden Eindrucke begrenzt. Die Fld. sind weitläufiger, weniger tief punktirt, glänzender, so dass sich die Art, wenn man nur auf dieses Merkmal achtet, schon mit blossem Auge von tremulae trennen lässt. Das Klauenglied endlich besitzt auf jeder Seite des Unterrandes nur ein feines, spitzes, schwer sichtbares Zähnchen, ist überhaupt im vorderen Drittel bedeutend schlanker.

Da der Umriss des Halssch. wie bei den übrigen Arten sehr variirt, so finden sich einzeln auch Stücke der vorliegenden, bei denen die Seiten vor den stark heraustretenden Hinterecken ausgebuchtet, bis zum vorderen Drittel verbreitert, davor schnell, oft fast gradlinig verengt und deshalb ähnlich wie bei tremulae geformt sind (Var.a); zuweilen ist Kopf und Halssch. schwarz (Var. b).

Das Männchen ist kleiner als das Weibchen, hinterwärts kaum erweitert, Schienen und Tarsen sind unmerklich verdickt, der kurze letzte Bauchring ist am Hinterrande breit abgestutzt. - Der Penis ist dem der vorigen sehr ähnlich, vorn bedeutend breiter, an der Oeffnung etwas erweitert, davor schwach eingeschnürt, so dass ein stumpf-dreieckiger, vorn fast gerundeter Theil abgesetzt wird.

Auf Salix purpurea und amygdalina besonders am Ufer ron grösseren Flüssen, Strömen und Seen häufig.

Küster hat in den Käf. Eur. Heft 2, Blatt $\$ 1$ im Jahre $1 \$ 4$ unter Lina tremulae die vorige Art beschrieben, als er aber Suffrian's Chrysomelen-Arbeit kennen lernte, nahm er die darin gegebene Srnonrmie an und lieferte eine neue, auf die rorliegende Art passende Beschreibung von tremulae, die wahrscheinlich gleichzeitig mit Heft 25 im Jahre 155:2 ausgegeben wurde. Dieser Nachdruck ist ohne Recht wieder als Heft 2, Blatt 81 signirt. 


\section{Dritte Gruppe: GALERUCINI.}

Chapuis Genera des Coleoptères XI. 1.

Caput revticale. labro sat magno, clypeo postice sarpe retuso hand perspicue terminato, fronte angusto.

Antennae approximatae, aut in linea inferiore oculari aul in fronte: inter oculos insertae.

Oculi rotundi.

Unguiculi saepissime appendiculati vel dente armati.

Kopf mässig gross, gewöhnlich bis zum Hinterrande der Augen in das Halsschild eingesenkt, mit schmaler Stirn, der Mund nach unten, oder in seltenen Fällen etwas schräg vorwärts gerichtet. Oberlippe verhältnissnässig gross, deutlicb vorgestreckt, meist breiter als lang, vorn leicht ausgerandet oder abgestutzt; Mandibeln ziemlich lang und dick, in mässiger Rundung gegen einander gebogen, fast immer mit zwei Zähnen an der Spitze. Maxillartaster viergliederig, Glied 1 kurz, 2 und 3 verkehrt kegelförmig, nach der Spitze mehr oder weniger verdickt, 4 in der Regel scharf zugespitzt. Lippentaster dreigliederig. Fühler in einer Linie zwischen dem Unterrande der Augen oder weit höher auf der Stirn, einander genähert, in grossen, kreisrunden, umrandeten Gruben eingefügt, bei unsereu Arten fadenförmig, halb so lang als der Körper, oder länger. Augen entweder rund, oder schwach länglich, ganzrandig, gewölbt. Kopfschild ziemlich undeutlich, über der Oberlippe zunächst mit einem schmalen, niedergedrückten Querstreifen beginnend, sodann allmählich, häufiger jedoch stark und schnell zu einem stumpfwinkeligen oder geraden Rande ansteigend, der in den meisten Fällen eine darüber befindliche Quervertiefung jederseits, die zur veisen Einlagerung des ersten Fühlergliedes dient, leistenförmig rgehoben wird. Von diesem Rande geht oft eine schmale, mehr oder weniger hohe Längsleiste zwischen den Fühlerwurzeln hindurch bis auf die untere Stirn. Halsschild schmaler als die Flügeldecken, quer-viereckig, meist nach vorn verengt, mit scharfem Seitenrande und in den Ecken häufig mit grossen Borstenporen. Schildchen deutlich, mässig gross, breit oder lang elliptisch, auch dreieckig. Flügeldecken im Allgemeinen mit schwach entwickelten Schultern und nach hinten allmählich verschmälerten Epipleuren '), selten in Reihen punktirt. Prosternum zwischen die Vorderhüften entweder nur als schmale, kürzere oder längere, von den IIüften 
rollständig verdeckte Kante oder als länglich-viereckig̣ Platte eingeschoben, die aber kaum in einen auf die Mittelbrust reichenden Fortsatz verlängert ist. Gelenkhöhlen der beiden Vorderbeine gross, quer-eiförmig, hinten offen oder durch eine schmale Kante der Epimeren geschlossen, aus ihnen ragen die Hüften mehr oder weniger weit heraus. Mittelbrust kurz, allmählich nach dem geraden Vorderrande hin abfallend, Mittelhüften fast zusammenstossend oder mässig weit, die Hinterhüften weit getrennt. Beine meist schlank. Hinterschenkel normal oder sehr verdickt und zum Springen eingerichtet. Klauen mit einer zahnförmigen Erweiterung am Grunde versehen oder gezähnt, selbst gespalten, höchst selten einfach.

Das Hauptmerkmal dieser Gruppe besteht in den einander genäherten Fühlerbasen, welche vom inneren Rande der Augen weit abstehen 1) und nur durch einen schmalen Zwischenraum, aber nicht durch die ganze Stimbreite von einander getrennt werden, wie bei den vorhergehenden Gruppen. In dieser Hinsicht sind wohl die Donacien am nächsten verwandt, weshalb auch Thomson dieselben direkt voranstellt, jedoch durch den binter den Augen halsförmig abgeschnürten Kopf, ungerandete Seiten des Halsschildes, stark entwickelte Schultern, den langen ersten Bauchring u. s. w. mit Sicherheit ron den Galerucinen zu trennen. Ein anderes wichtiges, aber weniger in die Augen fallendes Unterscheidungsmerkmal zeigt sich auf dem über dem Munde befindlichen Theile des Kopfes, wo das bei den Chrysomelinen und Eumolpinen grosse und deutliche, meist durch eine scharfe Linie von der Stirn geschiedene Kopfschild sehr klein, undeutlich, kaum scharf begrenzt ist, vielmehr durch einen Quereindruck jederseits in die Stirn übergeht. Auf dieser rücken die beiden, in den meisten Fällen vorhandenen Beulen über den Fühlerbasen so dicht zusammen, dass sie nur noch durch eine feine Rinne getrennt werden.

Die fast unübersehbare Menge der hierhergehörigen Thiere, ron denen eine ziemliche Anzahl auch in Europa vorkommt, gliedert sich in zwei Theile:

a. Coxae anticae apice conico-prominulae, contiguae vel subcontiguae, e prosterno haud vel imperfecte separatae; coxae intermediae fere contiguae. Pedes postici haud saltatorii

Galerucae.

b. Coxae anticae saepissime haud conico-prominulae, e prosterno distincte separatae, intermediae plus minusve distantes. Pedes postici saltatorii . Halticae.

1) Getrenute, dicht am Augenrande stehende Basen besitzt Psylliodes. 


\section{Erste Unterabtheilung: Galerucae.}

Körper gefliigelt (nur bei wenigen Arten aus verschiedenen (rattungen ungeflügelt), mehr oder weniger eiförmig, ziemlich weich, wenigstens nie besonders hart, oben entweder kahl, oder sparsam, und dann gewöhnlich aufstehend, bis ziemlich dicht, kurz und fein niederliegend behaart, unten, mit Ausnahme der Vorderbrust, dichter und oft länger behaart. K opf verhältnissmässig klein, bedeutend schmaler, oder nur bei den Männchen einiger Luperus-Arten mit den Augen so breit als das Halsschild. Die Augen sind oval, fein facettirt, wenig orler mässig gewölbt (desto stärker, je mehr sich ihr Linfang einem Kreise nähert) und laufen an den Seiten der breiten stim gerade oder wenig nach vorn divergirend nach unten. 1)ie Fühlergrnben stehen jederseits in einer weiten Vertiefung, die nach der Mitte des Gesichtes allmåhlig zu einem gemeinschaftlichen schmalen, oder einem breiteren und dann gewöhnlich durch eine Mittelrime getheilten Längskiele ansteigt; über ihnen befindet sich fast ohne Ausnahme je eine Beule. Das Halsschild ist viereckig, fast immer breiter als lang, aber schmaler als die Flügeldecken, vorn und hinten bald ziemlich grade abgestutzt, bald an der Basis mehr oder weniger tief dreimal gebuchtet, an der spitze gerundeta usgeschnitten, die Seiten sind entweder gradlinig, ziemlich parallel, sder nach vorn (nur in der Gattung Intrsenlir nach hinten) convergirend, oder sie sind in oder vor der Mitte gerundet-, selbst winkelig erweitert, oft noch (bei vielen Gulevuca-Arten) mit einem Ausschnitte versehen. Die Oberfläche ist wenig oder mässig gewölbt, in der Regel mit Eindrücken, zuweilen auch mit einer Querrinne besetzt, ringsum, häufiger nur an zwei oder drei Seiten serandet, die aufgebogene Kante des Seitenrandes mit einigen Wimperhaaren versehen, die in feinen Punkten stehen, in jeder Ecke eine Borstenpore oder ein Borstenkegel. Schildchen halboval, hreieckig oder viereckig. Flügeldecken nach hinten erweitert, in oder hinter der Mitte am breitesten, seltener fast gleichbreit, an der Basis im mittleren Theile zum Schildchen schwach abfallend. in äusseren Theile höher und mit gerundeten Schultern heraustretend, hinten einzeln oder gemeinschaftlich abgerundet, ausnahms- 
weise verkürzt und alygestutzt, unregrelmässig bunktirt. buj wenigrn exntischen Gattungen \%. B. Cialemerida Mrotsch., grestreift- nde' wereiht-punktirt. Das I'rosternum bildet rine schunale. niedriege Kante, welche zwischen den zapfenfïmig vorragenden mul zusammun. stossemrlen Vorderhiiften versteckt ist und nur bei eines Art . 1/11-

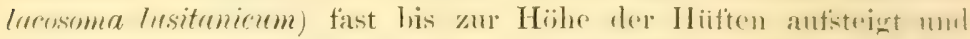
sichthar wird. Die Kante ist in einigen Fallen solh kit\% (rin kleine, dreeckige. selarte spitze, die nur vorn an die Itiiften stionst.

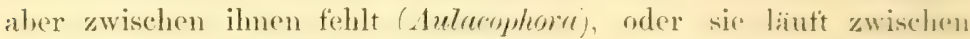
den Hiiften hindurch, dam endet sie hoch, aber sehr schmal mit einem plötzlichen Abfalle (fiulemella), oder erweitert sich hinter den Hüiften dreieckig und fällt hier allmählich oder in schwachem Bogen zur Mittelbrust hinah (Galenura). Das Epistermum ist schmal, quer viereckig, rom Prosternum nicht, wohl alver von Epimerum durch eine schräg nach aussen und vorn laufende Naht getrennt. Letzteres verlängert sich hinter den Vorderlitiften entweder in ein spitzes Dreieck, und erreicht das Prosternum nicht, so dass die Gelenkhöhlen hinten offen bleiben. oder es setzt wich hinter den Hüften in einem schmalen Streifen l,is zum I'rosternum fort und schliesst die Gelenkhöhlen hinten. Das Mesosternum ist schunal und meist undeutlich, da es die Vorderhüften mehr oder weniger bedecken und die Mittelhüften beinahe zusammenstonsen: es zieht sich als dreieckige spitze ziemlich weit zwischen die Mittehliifteu hinein und fällt nach vorn allmählich ab: die Hinterbrust ist gewöhnlich länger als die Vorderbrust, selten sehr kurz. sie ist der Quere nach gewölbt, mit einer Mittelrimne oder einem dreieckigen Eindrucke vor der Mitte des Hinterrandes. und sendet vorn einen kleinen tiefliegenden Zipfel zwischen die Mittelhüften. Zuweilen ist dieser jedoch ziemlich breit, gewölbt, etwas höher als die Hüften und reicht dann bis zum vorderen Theile derselben, wo die Mittelbrust abschiissig ist (Ageless, Grelemeida), oder der Zipfel reicht bei den mit Hylaspes rerwandten Gattungen bis an das Prosternum und bedeckt mit dem vorderen Theile, ler mit dem Brustdorn von Doryphor einige Aehnlichkeit hat. das Mesinsternum vollständig. Der Hinterleib besteht ans tünff Ringen von ziemlich gleicher Länge, selten ist der letzte Ring bei den Männchen einiger Arten viel länger, als einer der vorhergehenden. Die Beine sind mässig lang und stark; Schenkel einfach, etwas mehr spindelförmig als cylindrisch, mehr oder weniger zusammengedrückt, an allen Beinen ungetähr von gleicher stärke. Schienen zienlich gleichbreit oder an der Spitze verbreitert, hier zugleich mit einem Kranze kurzer Dörnchen versehen, in vielen Fällen noch mit einem längeren Enddorne; der Aussenrand ist einfach gewölbt oder gae- 
rimnt. 'T'arsen nit drei mässig breiten, auf' der Sohle filzigen wher (Jef)toseny.x) bedornten (Aliedem. von denen das erste meist dis lïngste, das zweite das kürzeste ist, namentlich an den Hinterbeinen; Klanenglied schlank, Klauen gerähnt, gespalten oder einfach.

Beide (ieschlechter sind an verschiedenen iusseren Merkmalen, über die Suffrian in der Stettiner ent. Zeit. 184\%. p. 91 austïhrlich berichtete, leicht zu unterscheiden; das Männchen ist durchschnittlich kleiner und schlanker, dabei feiner punktirt als das Weibehen, besitzt bald längere Fiuhler (Iteperns), oder eine Erweiterung des ersten (Aulacophora) oder siebenten Fühlergliedes (Galemera), bald gewölbtere Angen, oder erweiterte Tarsenglieder und stets eine andere Bildung der Bauchringe, besonders des letzten. Der Penis besteht aus einer hurnigen Rïhre, mit grosser, besonders langer ()effinung für den Ductus. Da das Weibchen verhältnissmässig viele und grosse Eier zu beherbergen hat, die lange Zeit zu ihrer vollstindigen Ausbildung brauchen, so schwillt ihm oft der Hinterleil, ausserordentlich an, die Nähte der ziemlich harten Bauchringe dehnen sich weit aus, während die weicheren Ruickenringe zu einer gleichmässig stark gewölbten Fläche aufgetrieben werden, an der die Nähte kaum noch deutlich zu sehen sind; daher tritt der Hinterleib seitwärts und hinten weit unter den Fld. vor. Die Legescheide hesitzt zwei weit getrennte lange und dicke hornige spitzen (Galenocu) oder endet in zwei fast aneinander liegende, verschieden lange und schmale weiche Zipfel, welche an der Spitze lang bewimpert sind.

Die Entwickelung ist nur von wenigen weit verbreiteten europaiischen Arten bekannt; das unvollkommene Resultat der Beobachtungen lässt sich etwa in Folgendem zusammenfassen: Die Eier der Galeruken sind verhältnissmässig gross, elliptisch ${ }^{1}$ ) bis kugelrund, weisslich, gelblich oder hellbraun, mit weiten und sehr flachen regelmässigen Eindrücken versehen, die durch leicht aufstehende feine Ränder getrennt sind; letztere durchziehen netzförmig die ganze Oberfläche. Im Mai oder Juni (bei Sermyla schon im Herbste) werden die Eier in Häufchen von 5 bis 20 und mehr stück an die Blätter deṛ Nährpflanzen gelegt und gewöhnlich mit dem einen Ende angeklebt. Die Larven sind gestreckt, an beiden Enden leicht rerjuingt, dunkel bis schwarz (Cideruca) oder scheckig (mehrere Gralerucellai), besitzen in der Regel nur eine Ucelle jederseits anf dem Kopfe. die ron einigen Borstenkegelchen

1) Am freien Ende zugespitzte Eier, wie sie Joannis (Mon. Tat. 2 Fig. 2) abbildtet, angeblich einer Gulleruque, also der hentigen Gattung ralerucella angehörend, kommen in der genamnten (rattung nicht vor. 
ungeben ist, und im granzen 1:3 Ringe, von denen die beiden hinteren Brust- und die 8 Rückenringe nit je zwei querreihen stacheliger oder sparsam behaarter 'Tuberkeln besetzt sind; las dreizehnte oder Analsegnent ist stets einfach; unter jeder Klane befindet sich ein Hautlappen. Sie zerfressen die Bläter, worlureh sie an jungen Strïuchern und Laubluäunen oft grossen scharlen anrichten, und rerwandeln sich meist in der Frrle zu der gelhen Puppe, aus der das vollkommene Thier in Hochsommer wler Herbste auskriecht, bei den meisten Arten aber nur langsam zu seiner vollständigen Aushärtung und Färbung gelangt.

Die Galeruken sind träge 'Thiere, die im südwestlichen Asien. namentlich auf den Sunda-Inseh, und in Amerika ihre grösste. in Anstralien die geringste Verbreitung besitzen; ilore Nahrung wird im Kïrper zu einem gelben, übelriechenden, scharfen, ölartigen Safte verwandelt, den sie zum Munde heraushefördern. sobald sie beunıuhigt werden. Derselbe legt zugleich den Grund zu der rorherrschend gelben Farbe des Körpers, die nur in wenigen Fällen gänzlich durch Schwarz, Blau oder Griin ersetzt wird Die europäischen Arten zeichnen sich weder durch angenehme Körperform noch Färbung aus und sind daher ron den Entomologen weder grem gesammelt noch eingehender untersucht worden, so dass ihre Kenntniss geringer als die in den iibrigen Gruppen ist: sie wurden zuerst von Limné 1758 in der Gattung Chrysomela, 1762 von Geoffroy, in seiner Histoire des Ins. des envixons de Paris, in zwei Gattungen, Galeruce und Luperus, endlich ron Fabricius 1775 hei Croceris und Ptims untergebracht, Laicharting brauchte 1 is1. (Verzeichn. Tyrol. Insekten j. 190) für Guleruca Geoffr. den Namen Adimonia, und bei den folgenden Autoren: Panzer, Gyllenhal und Duftschmid schwanken die Benennungen zwischen Galleruca und Crioceris. In Kataloge von Dejean führte Cherrolat eine Reihe neuer Gattungsnamen ein, ron denen später einige im Dictionnaire d'Hist. nat. de D'Orbigny 1846 durch ihn selbst kurz charakterisirt. andere erst rou Redtenbacher (Fauna Austriaca ed. 1. 1849) näher begrindet wurden, es fand jedoch hierbei eine ungerechtfertigte Begriffsverschiebung statt, indem fuir die Gattung Grelumen Geoffr. der congruente, bis dahin verschollene Name Adimonia Laich. gebraucht und Gialevuca auf die oberseits dicht behaarten Arten mymphaeae, calmariensis etc. reducirt wurde, obgleich Geoffroy diese nicht als Typus seiner Gattung beschrieben und abgebildet hatte. Aut diesen Fehler machte Crotch (Proc. Ac. Phil. 1873) aufmerksam, stellte Adimonia Laich. in Synonymie mit Galerucr Geoffr. und führte für die bis dahin als Galcrucı angesehene Gattung den Namen Gralemeclla ein. Inzwischen wurde von Erichson die 


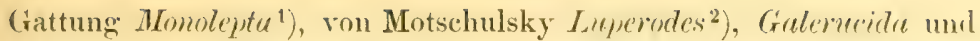
Agelasu ${ }^{3}$ ) ron Joannis, der die ganze (iruppe bearbeitete, ohne dabei irgend welche Gesichtspunkte für die Gruppirung der Gattungen und Arten zu bringen, M(arsenlice ${ }^{4}$, späterhin von Chapuis Arimer ${ }^{3}$ ) und von mir Lochmaea und Diorhabda ${ }^{6}$ ) errichtet, olne dass dadureh für alle in Europa und der nördlichen Hälfte ron Asien lebenden Thiere die generische Eintheilung zum Abschlusse gekonmen wäre. Es erübrigt vielmehr, wenn die von Chapuis zur Gruppirung der Gulerucae benutzten Merkmale ${ }^{7}$ ) consequent durchgefïhnt werden, noch einige neue Gattungen abzuzweigen, wonach sich eine Uebersicht derselben folgendermassen gewinnen lässt:

1. Gelenkhöhlen der Vorderbeine hinten offen, die Epimeren der Vorderbrust erreichen hinter den Hüften nicht das Prosternum 2.

$1^{1}$. Gelenkhöhlen der Vorderbeine hinten geschlossen, die Epimeren der Vorderbrust verbinden sich vollständig mit dem Fortsatze des Prosternum hinter den Hüften . . . . . . . . 11.

2. Körper ungeflügelt, Hinterbrust kürzer als die Vorderbrust. Fld. an der Naht verwachsen, sehr kurz, den Hinterleib weit frei lassend . . . . . . . . . . . . . 3.

$2^{2}$. Körper fast immer geflügelt, Hinterbrust länger als die Vorderbrust. Fld. den Hinterleib bedeckend . . . . . . . 4.

3. Tarsen schlank, Klauen zart, nicht gezähnt, am Grunde leicht verdickt. Fld. hinten gemeinschaftlich tief dreieckig ausgeschnitten, der Seitenrand kaum aufgebogen, die Epipleuren daher undeutlich begrenzt . . Marseulia Joannis. $\left.{ }^{\circ}\right)$

1) Wiechm. Archiv 1843. I. p. 265.

$\left.{ }^{2}\right)$ Etud. ent. VII. 1858 p. 102.

3) 1. c. IX, 1860 p. 24.

4) Abeille III. 1866 p. 160.

5) Genera XI. p. 217.

$\left.{ }^{6}\right)$ Deutsch. ent. Zeitschr. 1883 p. 31 .

$\left.{ }^{7}\right)$ Nur die relative Länge der Hinterbrust, nach der Chapuis seine Groupe 18 (Rupilites) von den iibrigen sondert, ist zur Eintheilung unbrauchbar, weil dann z. B. Galeruca monticola Kiesw. und sicana Reiche von ihren nächst verwandten Arten getrenut und in dieselbe Groupe 18, ungefähr zu Metaleyta Baly gestellt werden müssten.

8) Die bis jetzt bekannte einzige Art ist Marseulia dilativentris Reiche. Einer Melö ähnlich gebant, schwar', glänzend, Kopf, Halsch. und Fld. schwarzblau, äusserst fein punktirt (die Fld. etwas stärker). Halssch. viercekig, etwas länger als breit, wenig gewöll;t, nach hinten, die Fld, nach vorn verschmälert. L. $3-4 \mathrm{~mm}$. Syrien. 


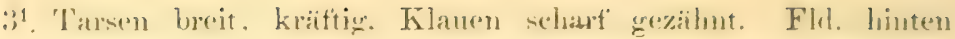
gemeinsehattlich tief dreieckirg germudet-anserechnitten, mit

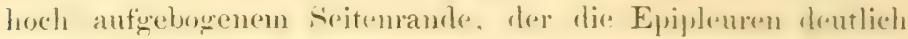
begrenzt . . . . . . . Arima (hapuis. $\left.{ }^{1}\right)$

4. Fld. an den Seiten senkrecht abfallend. fast zusamunengedriickt, Epripleuren fehlend oder gleichbreit. linienfömuig. Schimen ohne Enddorn . . . . . . Phyllobrotica Redtb.

$4^{1}$. Fld. an den seiten regelmässigr ahfallend. Epiplenren wenigstens unter der Schulter deutlich und breit . . . . . . . . 5.

5. Klauen gezähnt oder gespalten . . . . . . . . 6.

5². Klanen mit einer breiten, zahnartigen Erweiterung am Grunde 8.

6. Halssch. mit einer Querfurche, an der Basis zienlich grerade abgestutzt. schienen mit Enddorn Auluenphora ('herrolat.2)

1) Die einzige Art ist Arima maryinatu Fabr. (breripennis Illig.) Schwarz, wenig glänzend, die ersten Fïhlerglieder. Wenigstens unterseits, und eine mehr oder weniger deutliche Makel anf der Stirn (nicht selten in zwei getheilt) dunkel röthlich, die Seiten der Vorderbrust, ein Saum am Seitemrande des Halssch. und der grünlichen Fld. rothoells oder gelbbram. Halssch. quer, in der Mitte am breitesten und beiderseits gleichmässig schwach gerundet-rerschmälert, oben mäsig dicht, die

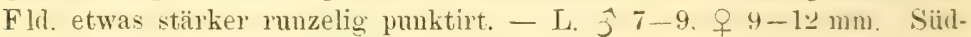
frankreich, südliche Hälfte von Italien.

Var, a. cincta. Stirnmakel hellroth, Halssch. auch am Vorder-, selbst noch am Hinterrande rothgelb gesäumt.

Var. b. brachyptera Kiist Punktirung der Oberseite durchgängig. teiner und dichter als bei der Stammform, Kopt und Halssch. schwarz, letzteres mit der grössten Breite hinter der Mitte. Die ersten Fühlerglieder unterseits gebräunt. Bisweilen sind die Fld. mit Ansnahme des hellen Seitensaumes tief schwarz. Umgebung von Neapel.

2) Von den in den Kïstenländern des indischen Oceans zahlreich vertretenen Arten rerbreiten sich bis nach Europa zwei: a) Aulucophora ubdominulis Fabr. (s foceicollis Küist., nigricentris Redtb.). (Hlänzend rüthlichgelb, Spitzenlälfte der Mandibeln und die Oberlippe pechbram, Augen, Hinterbrust und Banch mit Ansmahme des Afters schwarz. Halssch. quer-viereckig, hinten und an den Seiten gerandet, die rordere Borstenpore ein Stiick hinter den gerundeten Vorterecken, die hintere in den fast rechtwinkeligen Hinterecken. der Riicken ron einer tiefen, unpunktirten, in der Mitte etwas nach hinten gebogenen Querfurche halbirt. sparsam, die Fld. dichter fein punktirt, letztere mit kuzen. an der Hinterbrnst endigenden Epipleuren. Beim $\hat{j}$ ist das erste Fühlerglied verdickt, der mittlere Theil der Querfurche des Halssch. sehr rertieft und verbreitert, die Bauchringe sind in der Hitte stark verschmälert, der letzte daher sehr gross, mit 22 bis ror die Hitte reichenden Einschnitten, zwischen denen ein beweglicher breiter, zungentürmiger Zipfel, der bis 
6'. Malsseh. ohne Querfurehe, an der Basis nahe den Hinterecken

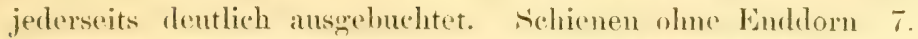

7. Oberseite dicht seidenbariog. . . Cialemuella ('rotseh.

71. Oherseite kahl ofler einzehn behatart . Jorkmere Weise.

8. Schicuen mit sehwachen oder undenthehem Enddorne, wenig stens an den vier vorderen Beinen, erstes und zweites l'arsenglied sehr schlank, merklich dümner als das dritte . . . 9.

8'. Schienen mit starkem und dentlichen linddorne, 'T'arsen wenig schlank, das erste Glied fast so breit als das dritte . . 10.

9. Erstes 'larsenglied bedentend länger' als das zweite

I,uperus Geoftr.

9^. Die beiden ersten Tarsenglieder gleich lang

Luperodes Motsch. ${ }^{1}$ )

zum Hinterrande des Segmentes reicht, sich einlagert. Vom Vorderrande des Segments läuft eine allmählich verbreiterte und vertiefte Mittelrime bis zur Spitze des Zipfels. - Penis schlank, mit langer und scharfer, etwas nach oben gebogener Spitze. -- L. 6,5-8 nm. Suidlichstes Europa, nördliche Hälfte von Afrika, siidliche Hälfte Asiens bis China. b) Aulacophora signata Kirsch. Ganz wie vorige, aber Oberlippe, Mandibeln und die Mitte der Hinterbrust rothgelb, Halssch. weniger quer, mit seichterer, deutlich punktirter, in der Mitte kaum gebogener Querfurche; Fld. nach hinten weniger verbreitert, mit längeren, bis zum 2. Bauchringe reichenden Epipleuren, jede mit 2 schwarzen Makeln, eine dicht vor der Mitte auf der Scheibe, die andere vor der Spitze, nahe dem Seitenrande. Die Klauen nur mit einem sehr kleinen Zähnchen an der Basis. - Sicilien.

Bestätigt sich die Angabe iiber die Bildung der Klanen, so gehürt diese mir unbekannte Art nicht zu Aulacophora.

1) Hir ist diese Gattung unbekannt; Motschulsky giebt keinen stichhaltigen Unterschied von Luperus an, Chapuis tremnt sie (Genera XI. 186 u. 188) hauptsächlich durch den Enddorn an allen Schienen, iibersieht aber dabei die ganz gleiche Bildung bei Luperus, so dass seine Tabelle der. Lupérites (p. 186) nicht zu brauchen ist. In Europa soll eine Art: L. dubius Motsch (Bull. Mosc. 1838. 179. t. 3. f. C.) an Gräsern bei Jekaterinograd am Terek in Ciskaukasien vorkommen, die nach der unvollkommenen Beschreibung und Abbildung ganz wie Monolepta erythrocephala Oliv. gebaut und gefärbt ist, so dass ich sie in diese Gattumg stelle. Vom Amur hat Motschulsky 3 Arten beschrieben: 1) L. nigripennis (Schrenck. Reis. Amur 232. t. 11. f. 18, die gelbe hintere Parthie der Abbildung ist nicht ein Saum der Fld., sondern die vorragende Spitze des Hinterleibes!) Schwarz, Stirn, Fühlerbasis, Halssch. und Hinterleib gelb. - L. 6,5 mm.; 2) L. praeustus (1. c. Fig. 19). Gelb, Jlund, die 8 letzten Fïhlerglieder, Schildchen, ein Saum der Fld, hinten stark rerbreitert, Brust und Beine schwarz (jedentalls das $\hat{\jmath}$ der vorigen); 3 ) $L$. quadriguttatus (1. c. 233. Fig. 20). Schwarz, Kopt, Fühlerbasis, Halsiseh., hnie 
10. Sieiten des Halsseh. ausser den Endborsten fast olune alsstrelende Härchen. die hreite Aussenkante der sichirourn fratt. mur an

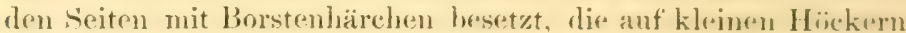
stehen Agelastica Redtb.

101. Seiten des Halssch. regelmässig bewimpert; die schmale Aussenkante der Schienen wenigstens in der unteren Hälfte dentlich behaart ......... Malacosoma Chevrol.

11. Erstes Glied der Hintertarsen so lang oder länger als dir drej folgenden zusammen, alle schienen, besonders die Hinterschienen mit langem Enddorne, Spitze des Hinterleibes unbedeckt

Monolepta Erichs.')

11'. Erstes Tarsenglied der Hinterbeine deutlich kürzer als die folgenden zusammen . . . . . . . . . . . 12.

12. Klauen einfach . . . . . . . . . . . 13.

$12^{1}$. Klauen gezähnt . . . . . . . . . . . . . . 14.

13. Sohle der Tarsen ohne Filz, wie die Schienen nur mit Dornen besetzt. Drittes Tarsenglied kaum halb so lang als das zweite. Mittelschienen mit Enddorn . . . T.eptosonye Weise."

und Schieneuspitzen gelb, ebenso auf den Fld. die Basis und spitze. sowie eine fünfeckige Makel auf jeder hinter der Schnlter. - L. 4 mm.

1) In Afrika und Sürlasien in zahlreichen Arten, in Europa nur durch zwei vertreten: 1) Mon. erythrocephala Oliv. Vom Ansehen einer Podagrica fuscicornis, schwarz, der Kopf mit Answahme der Augen und des MIundes, die ersten drei Fühlerglieder, Halsch, Vordex- und Mittelbrust, Schenkel und Schienen rothgelb, Fld. blau, kräftig punktirt. L. 3-3,5 mm. Südrankreich, Spanien. 2) Mon. (?) dubia Jotsch. Kornblumenblau, Stirn, die füuf ersten Fühlerglieder, Halssch., Schildchen und Beine roth. - L. $4 \mathrm{~mm}$. Am Terek.

$\left.{ }^{2}\right)$ Leptosonyx nov. gen. Corpus subdepressum. Acetabulu antica occlusa. Tibiae spinulosae, intermediae calcari parro instructae. Tursi articulis 3 primis subtus haul spongiosis, sed parce spinulosis, articulo tertio minutissimo. Unguiculi simplices, mayni. Elytra postice plus mimusie singulatim rotundata, linea epipleurali humeros haud ambiente.

Es sind bis jetzt 4 Arten bekannt: 1) Lept. silphoides Sahlb., ron Sarepta bis an den Fuss des Altai verbreitet, geflïgelt, tief schwarz, glänzend, Halssch. hellrothbraun, mässig glänzend; ersteres quer, etwas vor der Mitte am breitesten, nich vorn und hinten fast gleichmässig verengt, Vorderecken ziemlich abgerundet, auf der Scheibe eine schmale Mittelrimne und ein weiter, grubenförmiger Eindruck jederseits. Fld, fast. parallel, dicht punktirt, oft mit Spuren einiger Längsrippen, der Seiten-. Hinter- md Nathrand aufgebogen. - L. $8--9 \mathrm{~mm}$. - 2) Lept. contipennis Kirsch (Kraatz, Monatsbl. 1880. 164) ron Krasnowodsk. Wie rorige, 
13'. Schienen behtart, ohne Enddorn, 'Tarsen mit Filzsohle, ihr drittes Glied wenig kiirzer aber breiter als das zweite

Pallasia Weise. ${ }^{1}$ )

14. Vorletztes 'Tasterglied dick, melır oder weniger kugelig autgetrieben, letztes kur/z, konisch, Aussenrand der Schienen abgerundet, die vier Hintersehienen mit Endlorn . . . . 15.

14'. Vorletztes 'Tasterglied kaum aufyetrieben und nicht dicker als das zweite, letztes lang, allmählich nach vorn versehmälert 17 .

15. Fortsatz der Hinterbrust zwischen den Mittelhüften dreieckig, kurz, niedrig, stark gerandet . . . . . Sermyla Chap.

15'. Die Hinterbrust setzt sich nach rorn in einem ansteigenden, gewölbten, ungerandeten Streifen fort, der die Höhe der Mittelhiiften erreicht und fast bis zu deren Vorderrande hinzieht, wo er, schwach vornüber gewölbt in einem Ausschnitte der Mittelbrust endet . . . . . . . . . . . 16 . .

Halssch. und Fld. glänzender, ersteres fast quer viereckig; mit ziemlich parallelen Seiten und deutlichen Vorderecken, Fld. mit 3 Längsrippen, 1, 2, 4. - 3) Lept. nigrolineatus Mannh. im Altai und seiner Umgebung, schwarz, Fld. (oder auch der ganze Körper) dunkelbraun bis dunkel gelbbraun, die Naht and die 4 dicken Hauptrippen der Fld. schwarz. L. 8,5 mm. - 4) Lept. hirtus Weise (Deutsch. ent. Zeitschr. 1885. 315) aus der Umgegend von Ili. Im Körperbau der Avima marginata ähulich, ungeflïgelt, dunkel röthlichbraun, der Banch pechbraun; ïberall mit kurzen, aufstehenden gelblichweissen Haaren besetzt. Halssch. ziemlich flach, quer viereckig, mässig dicht und kräftig, Fld. dichter und feiner punktirt; letztere lassen die drei letzten Banchringe unbedeckt. Hinterbrust sehr kurz. - L. $8 \mathrm{~mm}$.

1) Pallasia nor. gen. Corpus subdepressum, pube argentea sat dense obtectum. Acetabula antica occlusa. Tibiac pubescentes, simplices. Tarsi articulis primis subtus spongiosis, articulo tertio sat lato. Unguiculi longi simplices. Hierher nur eine Art: Poll. absinthii Pallas, aus der östlichen Hälfte von Sibirien. Gestreckt, fast gleichbreit, unten etwas dichter weisslich seidenschimmernd behaart als oben, weissgelb oder blass röthlich gelbbraun, die Fühler und Taster, Seiten der Mittel- und Hinterbrust, Knie. Tarsen, der hintere Theil des Kopfes, eine Quermakel des Halssch.. Schildchen, die Naht und 3 erhabene Längslinien auf jeder Fld, pechschwarz. - L. 5,5-8 mm.

Nach der Abbildung der Tarsen kömnte in diese Gattung auch die mir unbekannte Galleruca violacea Luc. (Explor. Alg. 540. t. 44. f. 7) aus Algier gehören. Sie ist $3,5-5 \mathrm{~mm}$. lang, ziemlich gleichbreit, violett, stark punktirt, Fld. mit 4 Rippen, an der Spitze sehr stark einzeln abgerundet.

VI. 4. 
16. Halssch. mit einer fast unterbrochenen Querfurche in res Nitte und wie die Flel. gleichnässigr verworren punktirt Agelasa Motsch. ${ }^{1}$ )

161 Halssch. mit zweet weiten Gruben, groh, und nicht dicht punktirt. in der Mitte der Scheibe rereinzelt. Fld. dicht unil tein punktirt mit a groben ziemlich regelmässigen P’unktreihen

Galerucida Motsch. ${ }^{2}$ )

17. Klanenglied so lang als die iibrigen Tarsenglierler zusammen. Schienen ohne Enddorn, ihre Aussenkante einfach

Diorlabda Weise.

$17^{1}$ Klanenglied bedentend kuirzer als die vorhergehenden zusammen . . . . . . . . . 18.

18. Nur die Mittelschienen mit einem Enddorn, die Aussenkante der Schienen hat einen hohen Mittelkiel. Gralerucr Geofti.

$18^{1}$ Alle schienen mit einem Enddorn. Aussenseite der schienen abgerundet . . . . . . Euluperus Weise.

1) Ayelasa Motsch. Mit Sermylu viel weniger als mit Galeruride. verwandt, das dritte Fïhlerglied ist kürzer als das zweite, beim $\hat{o}$ sinı die Fithler vom vierten Gliede an stark verdickt, dagegen ist eine Erweiterung des ersten Tarsengliedes nicht rorhanden: die Hinterhuiften werden nur durch einen schmalen, aber gewölbten Ziptel des ersten Banchringes getrennt, die Klanen haben am Grunde eimen grossen, scharfen Zahn. (Hotsch. stellt sie als ungezähnt hin!) Die einzige Art A $\%$. nigriceps Motsch., kommt in Japan, China und am Amur vor und sieht wie Sermyla halensis aus: Kopf, Flügeldecken und Hinterbrust sind lebhaft metallisch grün bis goldgrïn, Thorax, Beine und Bauch rotb, Fühler, Mitte der Vorderbrust, Mittelbrust und Seitenstiicke der Hinterbrust, Hüften und eine Makel an der Spitze der Schenkel sowie die Tarsen schwarz. Halsschild über doppelt so breit als lang, dicht und fein punktirt, mit tiefer, dem Vorderrande parallel gebogener Querfurche in der Mitte, Flügeldecken stark, äusserst dicht punktirt. - L. 6-8 mm.

$\left.{ }^{2}\right)$ Hierher mehrere Arten ans dem istlichen Asien. Die behimnteste ist $G$. bifascirata Motsch., vom Amur bis nach Jajan rerbreitet; breit und plump gebant, schwarz, Flïgeldecken bräunlichgelb. Naht, eine Makel an der Basis zwischen Schildchen und Schulter, eine gemeinschaftliche breite, zackige Querbinde vor der Mitte, 3 Makeln in einer Querreihe hinter derselben (oft leicht rerbunden) und eine Makel in der Spitze schwarz. - L. $7-8 \mathrm{~mm}$. 


\section{Agelastica.}

Redtenbacher Faun. Austr. ed. 1. 1849 p. 525.

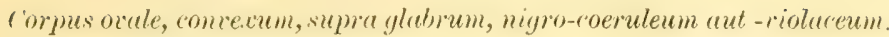
Acetabula antica aperta.

Flytra epipleuris sut latis, usque ad apicem brevissime el vix sibiliter ciliatum continuatis; scutellum triangulare.

Tilvice margine exteriore glabrae, apice calcari distincto; unguiculi appendiculati.

Körper verhältnissmässig breit und hoch, oben kahl, schwarzblau oder dunkel veilchenblau, mit leichtem Metalschimmer. Kopf mässig gross. Mandibeh kurz und kräftig, mit vier stumptèn Zähmen, von denen mu der dritte weit vortritt, Maxillartaster ziemlich schlank, die drei oberen Glieder fast gleich lang, das zweite und dritte verkehrt kegelförmign, das vierte schmaler, allmählich stumpf zngespitzt. Fühler länger als der halbe Körper, die hohen Ränder der Vertiefumgen um die Fiihlergruben vereinigen sich nicht in einem Längskiele auf' der Mitte der Stirn, sondern sind durch eine Rimme getrennt. Halsschild melır als doppelt so breit wie lang. lie aufgebogene Kante des Seitenrandes breit, die des Vorder- und Hinterrandes schmal abgesetzt, der Vorderrand hinter den Augen stark niedergedrückt. Schildchen dreieckig. Flügeldecken nach hinten etwas bauchig, ihre Epipleuren sind vorn mässig breit und im inneren Drittel rimnenförmig vertieft, verengen sich an der Hinterbrust allmählich und bleiben bis kurz vor die abgerundete Nahtecke sichtbar, wo sie äusserst kurz, fein und dicht, kaum sichtbar bewimpert sind. Das Prosternum bildet zwischen den Hiiften eine schmale, hinten bogenförmig abfallende Kante, von der die Epimeren weit entfernt bleiben und die Gelenkhöhlen offen lassen. Schienen mit starkem Enddorne ${ }^{1}$ ), an der Aussenseite kahl, mit einem Mittelkiele, sonst ziemlich dicht und fein borstenförmig behaart. Erstes 'Tarsenglied so lang als die folgenden beiden zusammen, Klauen am Grunde breit zahnartig erweitert.

Die Entwicklung unserer einheimischen Art ist seit Degeer (Mém. 5. p. 400. t. 9 f. 20-23) bekannt, später beschrieb Bouché (Nat. Ins. 1835 p. 205) die Larve und Ratzeburg (Forstins. I p. 199 u. 200) Larve und Puppe noch ausführlich. Erstere findet man im Mai und Juni häufig an den Blättern von Erlen; sie ist. ausgewachsen, 11-12 mm lang, im Mesothorax am breitesten, nach vorn ziemlich schnell, nach hinten allmählicher verengt, glänzend

1) Chapuis (Genera XI. p. 168) hat den Enddorn der Vorderschienen nicht bemerkt. 
griinlichschwarz, mit kleinem, ziemlich flachen, vor dem Scheipel vertieften Kopfe und einer Ocelle jerlerseits hinter den kur\%:n Fühlem. Meso- und Metathorax, sowie die folgenden Lorihesringe sind durch eine Querfurche halbirt, auf jerler Hälfte stehen zwei

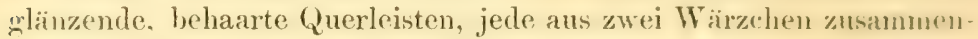
gesetzt. Ende Juli gehen die Larven, welche beinahe wir spannuraupen kriechen, in die Erde und verwandeln sich dicht unter de'r Oberfläche zu der weichen und zarten, hellgelben, oben lang und steif behaarten Puppe, yon 6-7 mm. Länge, aus der im August der Käfer schlüpft. Dieser frisst bis zum Eintritte des Frostes und überwintert unter Moos und Laub.

1. A. alni: ') Ovalis, convexiuscule, coeruleo-nigna, nitida, antennis artirulo tertio secundo evidenter longiore, tibiis tarsisque nigris, scutello polito, prothorace angulis anticis leviter promimulis elytrisque violuceis confertim punctatis. - Long. 6-7 mm.

Ias: Segmento 5: o ventrali apice semicirculariter impresso.

Linn. Syst. nat. ed. X. 369. - Scop. Ent. Carn. 68. - Ratzeb. Forstins. I. 244. t. 20. f. 6 (Chrysomela). - Oliv. Ent. VI. 638. t. 1. f. 8. - Payk. Faun. Suec. II. 87. - Gylth. Ins. Suec. III. 519 (Galleruca). - Küst. Käf. Eur. 2. 67. Joann. Mon. 108. - Thoms. Skand. Col. VIII, 108. Redtb. Faun. A. II. 491. - Seidl. F. balt. 492.

Adimonia violacea Laich. Verz. Tyr. Ins. 193.

Var. a. Elytris coeruleis vel cyaneis.

Var. b. Supra rubro-violacea vel obscure cupreo-violacea, interdum aeneomicans.

Var. c. Supra fere tota nigra.

Eiförmig, ziemlich gewölbt, glänzend bläulich-schwarz. die Fühler, mit Ausnahme der beiden ersten metallisch angelaufenen Glieder, Schienen und Fiisse matt schwarz. Kopt mit ganzer Mittelrinne, die sich zwischen den Augen zu einer Grube erweitert und die flachen Stirnhöcker hinten nur schwach und undeutlich begrenzt. Fühler ziemlich kräftig, Glied 3 merklich länger als 2. aber kuirzer als 4. Halsschild mässig gewölbt, hinter der Mitte am breitesten, mit leicht gerundeten seiten nach hinten wenig. nach rorn stärker rerschmälert, und hier etwas zusammengedrückt;

1) Die zweite Art, A. coerulea Baly (Trans. ent. Soc. 1874. 188) aus Japan und Nordamerika ist der rorliegenden täuschend ähnlich, etwas stärker punktirt, die Fühler bedeutend schlanker. Glied 3 nur so lang als 2, Stirnhöcker hinten scharf begrenzt, Halsschild stark gewöllht und rorn mehr zusammengedrickt, der Seitenrand tritt hinter der Borstenpore winkelig und spitz vor. 
die Ecken schwach abgerundet, die linteren stump,fwinkelig, die vorderen beinahe rechtwinkelig und durch die grosse Borstenpore nach aussen gedrückt, so dass der Seitenrand hinter ihnen sanft ansgeschweift ist; die Oberfliche dicht punktirt, öfter mit einem Hachen, grubenförmigen Eindrucke jederseits in oder vor der Mitte. Schildchen dreieckig", glatt. Fliigeldecken eben so dicht aber etwas stairker punktirt als das Malsschild. Auf' der Unterseite sind die Seiten der Hinterbrust und deren seitentheile dentlich punktirt, der unebene Bauch ist mit sehr feinen Querrissen weitläufig besetzt.

Beim Männchen hat der fïnfte Bauchring eine fast halbkreisförmige, lang behaarte Grube am Hinterrande. - Der Penis ist sehr einfach gebaut, ziemlich schlank, gleichmässig gebogen, nu die schwach abgesetzte, allmählich verschmälerte Spitze etwas mehr nach unten gedrüickt.

Die Farbe der Uberseite, insbesondere der Flïgeldecken, variirt nur in engen Grenzen; sie wird a) dunkel kornblumen- oder himmelblau, olme rothe Beimischnng; b) violett, stark mit roth gemischt, dunkel kupferigriolett, dam ist zuweilen bei schräg einfallendem Lichte ein mehr oder weniger starker gelber oder grimer Erzschimmer bemerkbar; c) schwarz, doch behält hier meistens ein schmaler Naht- und Seitensaum die Grundfarbe.

Ueberall auf Erlen häufig.

\section{Malacosoma.}

Chevrolat D'Orbign. Dict. univ. VII. p. 605.

Corpus elongatum, subcylindricum.

Acetabula antica aperta.

Antenme sut validue, subservato-filiformes, rpicem rersus leviter attenuatae.

Elytia pilis subtilissimis erectis parce instructa, epipleuris distinctis postice evanescentibus; scutellum apice rotundatum.

Titiae margine exteriore basin versus glabrae, apice calcari distincto, tarsi sat breves, articulo primo tertio haud angustiore; unguiculi appendiculati.

Der Körper erhält durch seinen gestreckten, mehr oder weniger cylindrischen Bau eine gewisse Aehnlichkeit mit verschiedenen Clytriden, welche bei mehreren Arten noch durch die bräunlichgelbe Färbung der Oberseite erhöht wird. Der Kopf ist mässig gross. die Oberlippe in weitem Bogen ansgerandet, Mandibeln kurz und kräftig, nit drei Zähnen, von denen der mittlere doppelt so breit und lang als die iibrigen ist, Maxillartaster ziemlich schlank, Glied 2 und 3 nach der Spitze verbreitert, verkehrt kegelförmig. das vierte nach vorn allmählich verschmälert. Fuihler kräftig, etwas läuger 
als der halle Krirper, nach der sjpitze zu leicht verdünt; schwach sägezähnig, indem sich besonders dic nittleren Glierter von der schmalen Basis nach der Spitze bedeutend verbreitern; das zweitr Glied ist hall, so lang als das dritte. Die Vertiefungen un dir. Fühlergrube setzen sich nach oben rinnentömnig fort und "nden in der Querfurche zwischen den Augen, wo heide zusammenstossen. Halsschild wenig breiter als lang, ringsum gerandet, doch an den Seiten breiter und tiefer als an der Basis und Spitze, alle Ränder. oder (bei M. lusitanica) nur die Seitenränder regelnä̈ssig weitläntig bewimpert, bei der genannten Art zugleich Vorder- und Hinterrand dicht behaart, die Scheibe mässig gewölbt, olne merkliche Eindriicke. Schildchen hinten abgerundet, meist hallıval. Flïgeldecken ziemlich gleichbreit, an der Spitze fast gemeinschaftlich alggerunlet. nicht stark gewölbt, wenig dicht mit teinen aufstehenden Härchen besetzt, die sich leicht abreiben und daher gewijhnlich nur in der hinteren Hälfte oder auf dem Abfalle der Fliugeldecken wahrzunehmen sind; Epipleuren schmal, bewimpert, won der Hinterlorust an verengt, im letzten Viertel fehlend. Das Prosternum bildet eine schmale, hinten ziemlich steil alffallende Kante, welche bei II. Insitanicu sichtbar, bei den übrigen Arten unter den zusammenstossenden Hüften rersteckt ist. Cnterseite fein, ziemlich lang, aut'stehend behaart. Schienen mit starkem Enddorne, an der Aussenseite in einen schmalen und undeutlichen Längskiel zusammengedruickt, welcher eben so dicht als der übrige 'Theil der Schienen hehaart. nur nahe dem Knie kahl ist. Erstes Tarsenglied so lang als die beiden folgenden zusammen, das Klauenglied eben so lang, mit zwei schwachen, am Grunde in einen breiten, spitzen Zahn erweiterten Klauen.

Beim Männchen sind die Fühler rerdickt, das erste Tarsenglied ist eine Spur erweitert und der Hinterrand des letzten Bauchringes winkelig gebogen. Derselbe läuft nämlich an den Seiten etwas schräg nach vorn und imen und biegt damn plïtzlich nach linten, so dass ein breiter, fast riereckiger Hittelzipfel entsteht. der an den steiten flach gerundet, hinten abgestutzt ist. jedoch wird seine Spitze durch die vor der Afterdecke weit herrorstehende Kante des Anus in der Regel bedeckt. Der Penis ist eine ziemlich gerade Röhre, die an der sehr grossen, von einer Haut vollständig bedeckten Oeffnung leicht erweitert und rorn, wenigstens bei M. lusitanica, in zwei parallel neben einander stehende dreicekige spit»en ausgezogen ist.

Die wenigen Arten sind in Afrika, Siideuropa, Kleinasien und sibirien verbreitet und treten oft in ungeheurer Menge auf; iiher ilire Entwicklung ist noch nichts bekannt. 
1. N. Iusitanica: ") Nigra, ablomine, mothorace sublilissime munctuluto elytrisque subtiliter punctatis ochuceis; prosterno plerumque ochrucen inter coxcs elevato et evidenter conspicuo. - Long. 6-8,5 $\mathrm{mm}$. II as.: segmento quinto rentrali profunde longitudinuliter impresso.

Linné Syst. Nat. ed. XII. App. 1066 (Chrysomela). - Oliv.

Ent. VI. 650. t. 4, f. 61 (Galleruca). - Küst. Käf. Eur. 2. 66. - Joann. Mon. 103, - Redtb. Faun. A. II. 491. Var. a. Rufo-testacen, fronte, meso-et metusterno plus minusve piceis.

Schwarz, Halssehild und Fliigeldecken gesättigt, Vorderbrust und Bauch blasser ockergelb, ziemlich glänzend. Fühler stark, nach der Spitze hin allmåhlich etwas dünner, das zweite Glied klein, das dritte mehx als doppelt so lang und wie die folgenden vier Glieder an der Spitze merklich verbreitert, entweder einfarbig schwarz, oder die Basis jedes Gliedes röthlich. Halsschild mässig gewölbt, f'ast quadratisch, an den Seiten sanft gerundet, äusserst fein, ziemlich dicht punktirt, mit einem Längsgrübchen vor dem Schildchen und zwei bis vier schwachen, grubenförmigen Eindricken in einer Querreihe in der Nähe der Mitte. Flügeldecken ziemlich flach und fein, doch deutlich punktirt, eben, oder mit einigen seichten Längsstreifen. Die Vorderbrust bildet zwischen den Hüften eine schmale Leiste. die rorn in starkem Bogen fast bis zur Höhe der Hüften ansteigt, zwischen ihnen also sichtbar bleibt, und hinten eben so schnell zu einem wenig verbreiterten, lang behaarten, äusserst kurzen Fortsatze abfällt.

1) Von dieser Art sind nicht generisch zu trennen zwei Arten aus der europäischen Fauna, bei denen die Vorderbrust zwischen den Hüften niedrig und verdeckt, das dritte Fühlerglied nur wenig länger als das zweite und die Punktirung der Flügeldecken etwas stärker ist. Es sind:

a. M. collaris Hummel (Essais IV. 1825 p. 69. Luperus. - luteicollis Gebl. Ledeb. Reis. 1830. II. 3. 219. - cyanoptera Kryn. - lepida Gebl. Küst - triumphans Fald.). Schwarz, Halsschild, Vorderbrust (in verschiedener Ausdehnung) und Bauch rothgelb, Flügeldecken metallisch blau oder grün; Pleuren der Hinterbrust lang behaart. - L. $6-7 \mathrm{~mm}$. Südliches Russland, Westsibirien, Kaukasus, Syrien; nach Gebler auf Hemerocallis flava $L$.

Aendert ab: Mund, Fïhler und Beine mehr oder weniger rothgelb bis hellgelb. - Var. flavipes Heyd. (Schneid. u. Led. Beitr. Cauc. Käf. 336) Lenkoran.

b. $M$. thoracica Redtb. (Russegg. Reis. I. (1843) p. 989. f. 28. Schwarz, Halsschild, Vorderbrust (in verschiedenem Grade) und Banch rothgelb bis röthlich gelbbraun. Pleuren der Hinterbrust kurz behaart. Länge $5-7 \mathrm{~mm}$. In Syrien häufig.

Aendert ab: Var. Gaudioni Reiche (Ann. Fr. 1862. 545.) Bauch schwarz. Salonichi, Syrien. 
Beim Männchen läuft eine tiefe Vittelrime vom Vorderrande des letzten Banchringes bis zur suitze des Mittelzipfols.

Zuwrilen ist die Vorderbrust mit Ausuahme der Sieiten schwarz. oder der Kärper ist (Var. a) ribthlich gell,bram, die Stirn üher den Sichwielen, die Mittel- und Hinterbrust wenigstens in der Mitte pechschwarz, die spitze der einzelnen Fiihlerglieder lejeht ze-hräint.

Auf' Asclepias cincetoximu $I$. in 'Tyrol stellenweise sehr häutig; im siidlichen Europa und Nordafrika gemein.

\section{Phyllobrotica.}

Redtenbacher, Faun. Austr. ed. 1 p. 525.

Acetabula antica aperta.

Elytra epipleuris nullis vel haud discretis.

Tibiue margine postico tereti, upice muticue, ununiculi uprendiculuti. Coxae anticae et intermediae perfecte contiguae.

Körper weich, nach hinten etwas erweitert, oder gleich hreit, schwach bis mässig gewölbt, oben rothgelb, mit schwarzer Zeichnumg, glänzend oder etwas stumpf, fein punktirt. Kopf' entweder klein, bis zu den grossen. gewiolbten Augen in das Halsschild einziehbar, mit kurzem Scheitel, oder gross, aus dem Halsschilde ziemlich weit herausstehend, Augen klein. wenig gewilbt, stirn und scheitel gross (Ph. adusta). Mandibeln kurz und breit, dreiziahnig. die Zähne beinahe gleich lang, das dritte Glied der Maxillartaster breiter als das zweite, Endglied kurz, konisch. Fïhler länger als der halbe Körper, ihr drittes Glied etwas länger als das zweite. das vierte beinahe so lang als das erste, die folgenden ungefähn mit dem vierten von gleicher Länge. Halsschild kaum orter wenig breiter als der Kopf, quer viereckig, an der Basis so breit als an der Spitze, die Seiten nur im ersten Drittel sanft gerundet erweitert, die Borstenporen in den vier Ecken gross, die Oberfläche wenig gewölbt, jederseits undentlich eingedruickt, mit einer Randleiste an den Seiten oder noch an der Basis. Schildchen dreieckig, mit abgerundeter Spitze. Fliigeldeck en etwas breiter als das Halsschild. schwach gewölbt, der breite seitenstreifen, welcher nach aussen von der Schulterbeule liegt, ist in den vorderen zwei Dritteln der Länge stark nach unten gebogen und an den Körper gedrückt, so dass die Randlinie daselbst, bei der Ansicht von oben, vollständig verdeckt ist; die Epipleuren fehlen ganz. Auf der Lnterseite stossen die Vorder- und Mittelhiiften vollständig zusammen, die Vorderbrust und die verhältnissmässig lange Mittelbrust senden in der Yitte je eine kurze und schmale dreieckige spitze nach hinten, die sich an 
die (ntsprechenden II iiften anlegt und ein kleines stiick einschiebt, jedoch nieht zwischen ihnen hindurch lïutt; daher stehen die Gelenkhöhlen der Vorderbeine schr weit offen und die der Mittelbeine bilden eine gemeinschattliche, in der Mitte verengte (Qnergrube, zu der die Hinterbrust steil abfällt. Schienen am Aussenrande abgerundet, an der Spitze mbewehrt, 'Tarsen schlank, zusammen fast ron der Länge der Schienen, ihr exstes Glied so lang als die folgenden heiden zusammen, Klanen kurz, am Gruncte in einen breiten Zahn erweitert.

Beim Männchen ist das Pygidium senkrecht, die Banchringe sind längs der Mitte vertieft, zuweilen auch zusammengeschoben und in diesem Falle der letzte sehr ausgedehnt; einige Segmente sind mit Spitzen oder Anhängseln versehen, der Hinterrand des letzten durch zwei ticte Einschnitte in drei Zipfel getheilt. - Der Penis bildet eine einfache, gekrümmte, vorn etwas zusammengedritickte Röhre.

Die Arten sind iiber Europa, Asien und Nordamerika verbreitet mul leben an schattigen oder feuchten Orten ungesellig, meist in einem Paare an den Blättern von einer Pflanze; es sind furchtsame 'Thicre, welche die Beine anziehen und sich fallen lassen, sobald man in ihre Nähe kommt. Ihre Entwicklung ist unbekannt.

A. Halsschild an der Basis ungerandet.

1. Ph. quadripunctata: Oblongo-elongata, subconexa, flara, orulis sat magnis, fronte supra sulcum transwersum, muculis a elytrorum $(1,1)$, metasterno abdomineque nigris, fronte plana longitudinaliter canaliculata, pothorace fere laevi, elytris sat crelre subtiliter punctatis. - Long. $5-7 \mathrm{~mm}$. II as: articulo primo tusorm dilutato, ventre segmentis 4 anterioribus brevibus, transcersim concexis, 3:0 et 4:0 impressione subtringulari profunda, is:o macimo late impresso fere dectivi, longitudinaliter canaliculato.

Linn. Syst. nat, ed. X. 376 (Chrysomela). - Payk. Faun. Suec. II. 91. - Gyllh. Ins. Suec. III. 516 (Galleruca). Duftsehm. Faun. A. III. 231 (Crioceris). - Redtb. Faun. A. ed. 1. 525. et ed. 3. II. 491. - Joann. Mon. 111. Thoms. Skand. Col. VIIT. 159. - Seidl. F. balt. 492.

(rioceri.s bimaculata Fabr. Ent. Syst. IV. 51. - Panz. Faun. Germ. 48. 16. Var. munda: Macula subbasali elytrorum nulla.

Ziemlich gestreckt, mit fast geraden seiten nach hinten etwas erweitert, mässig gewölbt, gelb, nach dem Tode mehr oder weniger rïthlich oder bräunlich, die Stiru iiber den Höckern. zwei Makeln auf jeder Fliigeldecke, Hinterbrust und Bauch schwarz. Kopf mässig gross, mit einer Mittelrinne. welche zwischen den Fühlern 


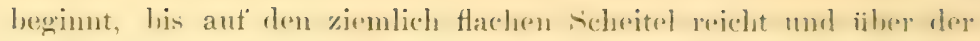

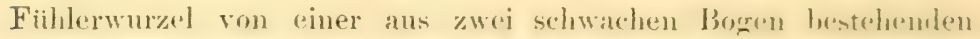
Querinme durchsetzt wird, wodurch die stirnhöcker olwen dentlich bererenzt sind; Augen geross, gewiilht, hreit oval: Fiihler riothlichgell). Maxillartaster diek, das Endglied kurz kegeltrimnig. Hals schild quer vierekign, hinter der Mitte und in den Vorderecken nubedeutend verschmälert. an den seiten breit. doch wenis tief arerandet, die Hinterecken stumpfiwinkelig, die Vorderecken leicht ahgerundet; oben wenig gewoilbt, bald ziemlich eloen, hald (besonders bei frischen Stioken) mit einer feinen Wittelrinne in der vorderen Hältte und einem Quereindrucke vor dem schildchen. der sich zu einer bogenföruigen, nach vorn offenen Vertiefung vergrössern kann: entweder ziemlich glatt, nur an den Seiten vor den Hinterecken mit einigen deutlichen Punkten, glänzend, oder gleichmäksig äusserst fein gewirkt, wonig glänzend. Schildchen gelb. Fliigeldecken hinten breit abgerundet, zuletzt ummerklich abgestntzt, mit a!)geschrägtem Nahtwinkel, ziemlich dicht und sehr fein punktirt. mehr oder weniger glänzend. Die rordere Makel ist rund und steht dicht hinter der Basis zwischen Naht und schulter, die andere. ein stück linter der Mitte, ist bedeutend grösser, quer. zuweilen bindenförnig; Naht- und Seitenrand fast erreichend.

Beim Männchen sind die drei mittleren Bauchringe in der Mitte zusammengeschoben. daher kurz. querüber stark gewiolbt, der finfte ist so lang als die ibrigen zusammen und fällt ziemlich steil nach hinten ab; über die Mitte des Bauches läut' ein Eindruck, welcher fein und schmal hinter einem warzenförmigen Höcker aut dem ersten Ringe beginnt und sich nach hinten immer mehr erweitert und vertieft, jedoch durch den aufgebogenen Hinterrand der beiden ersten und den exhöhten vorderen Theil des dritten segmentes in mehrere Abschnitte getrennt wird und nicht in einer Flucht verläuft. Daduch entsteht anf dem zweiten Segmente ein Grübchen. auf dem dritten eine abschüssige Grube, deren hohe kantige sciten in einen kurzen, dreieckigen Fortsatz rerlängert sind, aut dem vierten eine grosse, breit dreieckige Grube, ebentalls ahschüssig, in der Mitte gerinnt, auf dem fïnften endlich ein Eindruck, der fast die Breite des Segmentes eimnimmt und eine Mittelfurche besitzt. Der Penis ist so lang als die vier letzten Bauchringe zusammen, stark gebogen, gleichbreit, an der spitze fast gratlinig rerengt. so dass diese ungefähr ein gleichseitiges Dreieck bildet.

Die Zeichnumg der Flügeldecken kann a) abnehmen, indem die vordere Makel kleiner wird und zuletzt ganz rerschwindet, die hintere oft nur noch einen dicken Querstrich bildet, (Var.a), oder b) zumehmen, so dass die Basalmakel gross und länglich ist und 
mit ihrem zackigen Hinterrande sich der vergrösserten hinteren Makel nähert, doch sind mir Stücke mit vollständig verbundenen Makeln noch nicht vorgekommen.

An schattigen, feuchten Orten aut' Scutelluin galevionlata stellenweise häufig in ganz Europa.

\section{B. Halsschild an der Basis gerandet. ${ }^{1}$ )}

2. Ph. adusta: Elongata, depressiusculu, nigra, capite prothoracerpe subluevibus, rufo-testuceis, antemis basi, pedum anticomm femoribus.

1) In diese Abtheilung gehören noch:

a. Ph. signuta Mammh. (Humm. Essais IV. 38 (Galeruca). -- bisignuta Gebl. Ledeb. Reis, 219 et Bull Hosc. 1848. 15. - sibirica Joann. IIon. 113). Statur der 4-maculata, röthlichgelb, eine breite Längshinde nahe der Naht jeder Flügeldecke, von der Basis bis vor die Spitze, sowie die Seiten der Brust und des Bauches rothbraun; öfter eine runde oder zweilappige Makel auf dem Scheitel schwarz. L. 5-6 mm. Auf Artemisia-Arten bei Barnaul.

b. Ph. frontalis: Oblonyo-elongata, sat convexa, rufo-flava; antemis articulis 6 ultimis, fronte subcomera supra sulcum transversum, scutello trigono, maculis 4 elytronum (1:1 mima basali sat magna, a humero ısque ad scutellum continuata, secunda magna, pone medium), metasterno abdomineque nigris; femoribu, anterioribus nigro-maculatis, posticis nigris, tarsis suma obscuris, tibiis posticis subincurvatis; prothorace laeri, elytris sat crebre evidenter punctulatis. - I Long. 6-7 mm. Asia minon. Amasia.

Variat: macula prima elytrorum cum secunda prope suturam confluente.

Den grössten Exemplaren der 4-maculata ähnlich, aher Kopf und Halsschild bedentend breiter, die Vorderschenkel haben je eine schwarze Makel an der Basis der Hinterseite, an den Mittelschenkeln ist die ganze Hinterseite, oft auch noch eine Makel am Grunde der Vorderseite schwarz, zuweilen sind auch die gebogenen, sehr hellen Hinterschienen an der Spitze gebräunt.

c. Ph. elegans Kraatz (Berl. Zeit, 1866. 285) Statur der adusta, schwarz, die 4 bis 5 ersten Fühlerglieder, Halsschild, Flügeldecken (mit Ausnabme einer gemeinschaftlichen dreieckigen Makel am Grunde und einer länglichen oder queren Makel hinter der Mitte, beide oft dicht an der Naht verbunden), Seiten der Vorderbrust, Spitzen der vorderen Schenkel, Vorderschienen und die obere Hälfte der Mittelschienen bräunlich rothgelb. - $\$$ Erster Banchring in der Jitte weit und flach eingedrïukt, zweiter in zwei mässig lange. grangelb helaarte Zipfel verlängert, zwischen denen sich noch 2 kleine, umbehaarte, glänzende Spitzen nach hinten strecken, der dritte und vierte Ring in der Mitte stark zusammengeschoben und quer vertieft. - L. 5-6,5 mm. Konstantinopel, Amasia (Möhring), Kaukasus (Leder). 


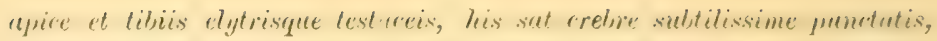

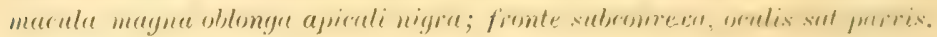
- Long. 5- $6,5 \mathrm{~mm}$.

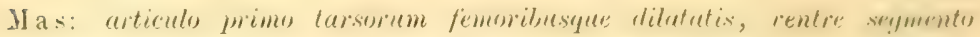

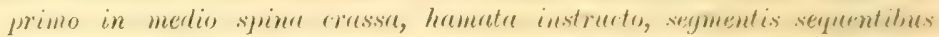

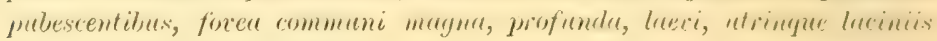
tribus pilosis ornata impressis.

Creutzer. Ent. Versuche (1.99) 121. t. 2. f. 24. - Fabr. Syst. El. I. 461 (1801). - Duft. Faun. A. III. 231 (Crioceris). Redtb. Faun. A. ed. 1. 525; ed. 3. II. 491. - Joann. Mon. 113. - Kraatz Berl, ent. Zeit. 1866. 286.

Gestreckt, fast gleich breit, wenig gewijlht. schwar\%, Konf und Halsschild bräunlich rothgelb, die vier oder füint ersten Fülıleregrieder, spitze der vorderen Schenkel und die Vorderschienen (hisweilen auch die Wittclschienen), sowie die Flügeldecken bräunlichselb, letztere ror der śpitze mit einer länglichen, ovalen schwarzen Makel, die dem șeiten- und Hinterande viel nälıer liegt als der Naht. Kopf gross, worgestreckt, lange nicht bis zmm Hinterande ter ziemlich kleinen, ovalen Angen in das Halsschild einziehbar, die Stim ibber den schart begrenzten Achwielen vleichmässig schwach gewölbt, äusserst fein gewirkt; Maxillartaster diinn. das letzte Giied lang kegelfömig. Halsschild quer-viereckig. hinten und an den Seiten gerandet, weit ror der Mitte am breitesten, nach hinten und in den Vorderecken verengt, oben wenig gewiilbt, kaum punktirt. chen oder mit drei schwachen Gruben. ron denen die mittlere mehr nach hinten gerückt ist als die seitlichen. Schildchen schwarz. Flïgeldecken wenig breiter als die Basis des Halsschildes, ziemlich dicht und fein punktulirt.

Das Männchen ist an den dickeren Sichenkehn und dem prweiterten ersten 'Tarsengliede zu erkennen; ausserdem ist bei ihm das erste Bauchsegment in der Mitte etwas zusammengedrückt und in einen langen, schwach gebogenen, nach hinten gerichteten dicken Dorn verlängert, welcher bis zum Ende des dritten siegmentes reicht, der zweite bis funfte Ring ist in der Mitte breit und tief eingedrickt, die Seiten der dadurch gebildeten riemlich wlatten Laingsgrube sind durch einen beharten. nach hinten gerichteten lanzettlichen I appen auf jedem segmente (mit Ansmahme des letzten) stark erhöht. Der Lappen des vierten Ringes ist der kiirzeste. er wird von dem breiteren des dritten fast vollständig bedeckt, auf diesem wieder liegt in leichter Krimmung der lïngste und zugleich schmalste Lappen des zweiten Ringes.

In Oesterreich, nördlich bis T'eschen (Letzner), Lnemam (Sajo), Athen. 


\section{Linperus.}

Geoffroy, Hist. Ins. I. 1762. p. 230. t. 4. f. 2.

Acetabula antica aperta.

Antennae tenues, filiformes, maris corpore plerumque longiores.

Tibiae subeylindricae, apice calcari temissimo, articulo primo tur-

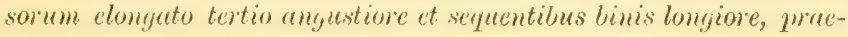
sertim in pedibus posticis.

Körper weich, mehr oder weniger gestreckt, mässig oder schwach gewölbt, gelb, stahlblau, dunkelgrün oder schwarz. Kopf klein, in den Augen zuweilen so breit, oder breiter als das Halsschild, init schmalem queren Kopfschilde, welches sich zwischen den Füblern als hoher Iäugskiel fortsetzt. Derselbe läuft oben in eine Spitze ans, welche zur tiefen Querrinne der Stirn abfällt, die die Schrägbeulen über jeder Fühlerwurel deutlich in die Höhe hebt. Mandibeln mit fỉuf Zähnen, der obere und die beiden unteren klein und spitz, die beiden dazwischen liegenden länger, breit, an der Spitze ziemlich abgestutzt; Maxillartaster klein, Glied 2 und 3 verkehnt kegelförmig, 3 etwas breiter als 2, das Endglied an der Basis so breit als die Spitze des vorhergehenden, kurz kegelförmíg. Augen gross, gewölbt, körnig facettirt. Fühler dünn, fadenförmig: beim $q$ fast so lang, beim ô länger als der Körper, Glied 1 kurz, verdickt, 2 sehr klein, 3 ebenso lang (Calomicrus Steph.) oder länger, zuweilen drei bis viermal so lang als 2, Glied 4 häufig länger als die beiden vorigen zusammen, die folgenden unter sich und mit dem vierten etwa gleichlang, zuweilen vier bis sechsmal so lang als breit. Halsschild in den meisten Fällen quer viereckig, rorn grade abgeschnitten. an den Seiten und der Basis etwas gerundet, ringsum gerandet, alle Ecken scharf, da die Borstenpore in denselben auf einer Beule oder einem kegelförmigen Höcker steht, die Oberfläche wenig gewölbt, eben oder mit zwei Vertiefungen, fein punktirt; Schildchen dreieckig, mit gerundeten Seiten. Flügeldecken breiter als das Halsschild, nach hinten schwach oder kaum erweitert, hinten gemeinschaftlich, doch am Nahtwinkel leicht einzeln abgerundet, unregelmässig; nach den Seiten und der Spitze zu feiner punktirt, kahl oder behaart. Epipleuren schmal, hinten allmählich verengt, im letzten Viertel fehlend, fein bewimpert. Das Prostermum ist eine sehr schmale, zwischen die Hüften geschobene und ron ihnen verdeckte Platte, die hinten fast senkrecht abfällt und sich, wenig verbreitert, mit dem etwas aufgebogenen Boden der Huiftptannen rerbindet; das Mesosternum ist mässig lang, die Mittelhüften stossen beinahe zusammen, es tritt zwischen sie eine breit dreieckige Spitze der Mittelbrust und eine ähnliche, aber viel niedrigere 


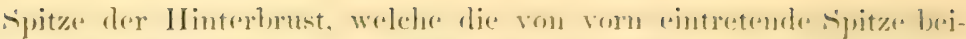

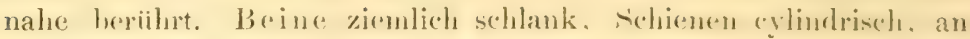
der sitze mit einen feinen und kur\%+n. schwer sichtharen Einddorne. Glied 1 und 2 der Tarsen schualer als das dritte, das erste linger als die beiden folgenden zusammen; Klanen ku\%, ann Grunde in einen spitzen Zahn verbreitert.

Bein Mrännchen sind die Fühler melir oder weniger verlängred. die Augen treten an den Seiten des Kopfes mehr heraus als heim Weibchen, da sie grïsser und gewöllster sind, zugleich wird durch zwei tiefe Einschnitte an Hinterrande des letzten Banchringes ein breiter Mittelzipfel abgesondert, welcher stets grulig ansqehöhlt ist. Einige Arten, z. B. pinicola und gularis haben die erwilinten Einschnitte nicht; bei ihnen geht der kure Vittelzipfel direct rom Hinterrande des Segmentes aus, und die auf ihm befindliche Grube ist klein, quer, und steigt jederseits zu einer höckerförmigen Kante auf. Der Penis bildet eine feine, wenig gebogene Rïhre, deren Spitze einfach oder mit ein bis zwei Häkchen versehen ist.

Die Luperus-Arten komnen hauptsächlich in Europa. sparsamer in Afrika. Asien und Nordamerika aut Gebüschen und Bäumen wr: sie haben sich bisher der Autmerksamkeit der Entomologen nicht zu erfreuen gehabt, woran wohl ihr weicher Körper, welcher weder durch Form noch Farbe ausgezeichnet ist und oft unregelmäisign zusammen trocknet. sowie die Zerbrechlichkeit der Fühler und Beine schuld sein mag. Die Verwandlung ist unbekamnt. denn die Angaben von Thiersch (Forstkunde p. 27) iber Lup. pinicollı, die Ratzeburg (Forstins. ed. 2. p. 245) unter berechtigtem Zweifel wiedergiebt, sind wohl nicht ernst zu nehmen, und die ron Geoffroy und nach diesem von Joannis mit wenigen Worten beschriebene Larve (les laries sont assez grosses, courtes, de forme orale; elles ont sic pattes et une petite téte érrillense) dürfte wegen ihrer Körpertorm kaum zu den Galeruciden-Larven zu rechmen sein.

Die Gattung wurde von Geoffroy auf den nachträylich durch Goeze benannten $L$. niger begründet; ein Jahr später heschrieb Scopoli seine Coccinella rufipes, die wohl zur vorliegenden Gattung gehören, aber weder auf longicornis $\mathrm{F}$, noch xanthopoda Schrank mit Sicherheit bezogen werden kann, damn folgten Linné, 1767. mit Chrysomela flacipes, 1781 Fabricius mit Ptimes longirornis und Schrank mit Chrysomela xanthopoda, endlich wieder Fabricius 1787 mit Crioceris mipes. Diese letztere Benennung wurde ron den folgenden Schriftstellern ohne Ausnahme auf Arten übertragen, die Fabricius nicht gemeint hat, und es entstand so eine Verwirrung in der Synonymie der weit verbreiteten schwarzen Arten, die nur schwierig zun sichten ist und den Gebrauch des Namens rufipes unmöglich 
macht. 18:31 zerlegte Sitephens (Illustr. Brit. IV. 294) die Grattumger mach der länge des zweiten und dritten Fiihlergliedes in C'alomirnts und Inperves; später gah) H. v. Kiesenwetter (Berl. ent. '/seit. 1861 p. 393) (eine Lebersicht der ihm bekamiten wenigen Arten, und 1866 liefierte Joamis eine Bearheitung der ganzen Gattume, die noch das beste stiick von seiner Monographie des (ialerucides ist. Sie enthält die Beschreibung von 40 Arten, zu denen Kiesenwetter (1. e. 1873 p. 2:3-31) ergänzende Bemerkuneren, Berichtigungen und Nachträge brachte.

Eine sichere und endgiltige Feststellung der emopäischen Arten ist mit dem jetzigen ungenügenden Materiale der Śammlungen unmöglich. besonders da ausgehärtete Männchen sehr sparsam rertreten sind.

\section{Uebersicht der Luperus-Arten.}

1. Zweites Fiihlerglied so lang, oder etwas (selten um die Hälfte) kïrzer als das dritte. Flügeldecken auf der hinteren Hälfte sparsam mit aufstehenden Härchen besetzt Calomicrus Steph. 2.

$1^{1}$. Zweites Fiihlerglied bedeutend kürzer als das dritte, $1 / 3$ bis $1 / 6$ so lang als dasselbe. Flügeldecken entweder durchaus kahl. ${ }^{1}$ ) oder nur bei wenigen metallisch blauen oder griinen Arten dicht vor der Spitze einzeln behaart. Luperus in spec. . 13.

2. Stirn kahl, nur mit einem Börstchen jederseits in der Nähe des Auges. Flügeldecken gelb, einfarbig, oder mit schwarzer Zeichnumg . . . . . . . . . . . . . . 3.

21. Stirn behaart. Flägeldecken schwarz oder blau . . . . 9.

3. Der Kopt, eine Querbinde an der Basis des Halsschildes (oft noch zwei Flecke davor) und ein breiter Nahtsaum der Fliigeldecken schwarz

$3^{1}$. Oberseite tast einfarbig blass bräuulichgelb. Flügeldecken olnne Nahtsaum

4. Fühler dunkel, an der Basis roth-oder gelbbraun. Der schwarze Nahtsaum der Flügeldecken setzt sich um die śpitze und am Seitenrande herum (hier etwas verblasst und schlecht begrenzt) bis dicht an die Schulter fort, wo er dann nur auf die Epipleuren beschränkt bleibt. - I. 3-4 nm. Mitteleuropa.

nigrofasciatus Goeze.

4. Fühler fast einfarbig rothgelb. Der Nahtsaum der Fliigeldecken verschmälert sich und verblasst, indem er sich um die spitze herumzieht, so, dass nur im hinteren Drittel der Flügeldecke

1) Jedoch ist der Aussenrand der Flïgeldecken bei Calomicrus wie bei Luperus sparsam bewimpert. 
ein feiner Schatten an Seitenrande sichthar hleibt, die Epipleuren sind einfarbig gell). - I. 2,i-3 unn. Yittel- nud Südspanien . . . . . . . suturalis Joannis.

5. Halsschild mit einem Quereindrucke in der Mitte, wolcher in der Regel aus einem weiten, flachen Quergriibchen jerterseitbesteht

51 . Scheibe des Halsschildes bei ausgehärteten Stücken glcichmilssig flach gewölbt, ohne Vertiefungen

6. Halsschild wenig breiter als lang, glanzend. zerstreut und tein punktirt, Flügeldecken äusserst dicht und f'ein, runzelig punktirt. etwas matt. Blass röthlich-gelbhraun, Fühler nach der spitze angedunkelt, Stirn und Schildchen röthlichłraun, Flïgeldecken weisslich, auch in der vorderen Hälfte mit einigen Reihen weitläufig stehender, aufrechter Härchen. - L. 3 mm. Oran

\section{setulosus $\mathrm{Ws}^{2}$ )}

6. Halsschild doppelt so breit als lang. Fliigeldecken mässig dicht, aber sehr deutlich punktirt . . . . . . . 7 .

7. Hinterbrust (q) und Bauch $(\hat{o})$, Augen und die Wurzel des ersten Tarsengliedes an den Hinterheinen schwarz, die übrigen Theile rothgelb, die Flügeldecken etwas blasser. Halsschild oft mit einigen veränderlichen braunen Fleckchen, an den seiten schwach gerundet. - L. 3-4 mm. Andalusien. Algier

fallax Joann. ${ }^{2}$ )

71. Unterseite und Beine wie die Oberseite weisslichgelb. Augen schwarz. Stirn roth. Fühler nach der Spitze leicht angedunkelt. Tarsen schwarz, oder die einzelnen Glieder an der Spitze schwärzlich. Halsschild mit scharfen Ecken, nach hinten fast gleichmässig und gradlinig verengt. - L. $3-3,5$ mm. Algier: Blidah, Biskra ........ nigritarsis Joann.

1) L. setulosus n. sp. Oblongus, suldepressus, flaro-testaceus, antemis apicem. versus infuscatis, fronte evidenter punctuta scutelloque rufo-brummeis, mothorace subtransverso, nitido, parce punctulato, trensersim impresio, elytris fluro-ulbidis, crebervime subtilissimeque ruguloso-punctutis, mimus nitidis, parce lineatim setulosis. - Long. $3 \mathrm{~mm}$. Oran (Reitter).

Die Stim ist wie bei fallax äusserst fein gewirkt. kahl, aber jederseist deutlich punktirt, das zweite Fühlerglied ungefähr so lang als das dritte.

$\left.{ }^{2}\right)$ Lup. sordidus Kiesenw. (Berl. Zeit. 1873. 24) ist nach der Beschreibung dieser Art sehr ähnlich, aber ,kleiner, mit schlankeren Fühleru. hreiterem und kürzerem Halsschilde, stärker punktirten Flïgeldecken." Kopf. Brust und Banch schwarz. - Länge 2,5 mm. Auf Gresträuchen 1 Jin Jaen. 
8. Fühler und der ganze Körper, mit Ausnalume der schwarzen oder dunklen Augen, der Mittel- und Hinterbrust, selten anch des Banches, blass röthlich-geelbhraum. Halsschild von der Mitte nach hinten etwas stärker als nach vorn verengt, alle Ecken schart'. '/weites Fiihlerglied nur halb so lang als das dritte. - L. 4,5-6 $\mathrm{mm}$. Algier. Mittel- mol viüdspanien (flaus Rosh. 1856). . . . flavipennis Lucas (184911).

81. Fiihler an der Basis hell rothgelb, vom dritten oder vierten Gliede an gebräunt bis tiefischwar\%. Halsschild von dex Mitte nach rom stirker als nach hinten verengt, die Ecken stumpf. Zweites Fühlerglied wenig kürzer als 3. I. 3,5-4,5 mm. Syrien: Haifa (Simon) . . . . . . . . . lividus Joann.

9. Fld. tief schwarz. Halsschild quer, rorn ungerandet . . 10.

91. Oberseite dumkel stahlblau oder bläulich-metallgrün. Halsschild viereckig, beinahe so lang als breit, wie der Kopf sparsam mond äusserst f'ein punktirt, stark glänzend, ringsum gerandet, Hinterecken scharf rechtwinkelig, Flügeldecken kräftig punktirt, mit äusserst fein gewirkten und punktulirten Zwischenräumen, weniger glänzend. Unterseite schwarz oder schwarzgrün, Fühler und Beine schwarz, die Basalglieder der ersteren, sowie die Kniee und der obere Theil der Schienen an letzteren röthlichgelb. Prosternum hinter den Hüften leicht dreieckig erweitert. Gelenkhöhlen breit geöffnet. - L. 5-6 mm. Altai

altaicus Mannh. ${ }^{2}$ )

Wahrscheinlich ist I. minutus Joann. aus Daurien nach einem kleinen, frischen, violettblauen Stücke dieser Art heschrieben worden.

10. Beine einfarbig gelb. Körper tief'schwarz, glänzend, Mund roth- oder pechbraun, die Basalhälfte der Fühler rothgelb, die obere Hälfte schwärzlich . . . . . . . . . . . 11.

101. Schenkel ganz oder wenigstens in der Basalhälfte schwarz. Halsschild meist roth

11. Beine bleichgelb, Halsschild glatt, ausserordentlich glänzend. auf jeder seite eine grosse, grubenartige Vertiefung. - I. $3 \mathrm{~mm}$. vierra Nerada

foreolatus Rosh. ${ }^{3}$ )

1) Spanische und Norlafrikanische Stïcke sind durch nichts resschieden.

${ }^{2}$ ) Exemplare vou Kultuk (Fanst) sind swischen den Punkten aut den Flïgeldecken sparsam punktulirt, aber kaum gewirkt. - Ob rlic Stirn bei dieser Art behaart ist, läsit sich an den mir vorliegenden Stiicken nicht mit Sicherheit erkennen, dit dieselben nicht gut erhalten simf.

3) Die Art fehlt in allen mir lekamnten Sammlungen, auch Joamis:

VI. 4. 


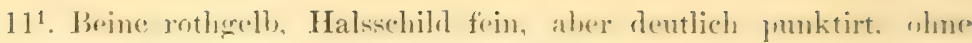
Vertiefungen. - J. 3,j-4 mm. Sicilien Jisttenlerefi Ragrusa.

12. Kopf schwar\%, Fühler schwarz oder loamn. (ilied 1-4 riithlich. - 1. 2,४-4,; mm. Mitteleuropa. Schweden pinicoln Duft.

121. Konf wenigstens unterhalb der Fühler motherelb. diese einfartig rothgell, oder nach der sjitze ummerklich geluräunt. - L. $3,-5-4, \hookrightarrow$ mm. Mittel- und Ostalpen . . gularis Gredler.

13. Flïgeldecken vor der spitze mit einzehn aufstehenden Härchen . . . . . . . . . . . . . . 14.

131. Flügeldecken kahl . . . . . . . . . . 17.

14. Stirn glatt . . . . . . . . . . . . 15.

$14^{1}$. Stirn fein und diclit gewirkt. Beine einfarbig gelh . . 16.

15. Halsschild etwa so lang als breit $(q)$, oder länger $(\hat{j})$, kaum sichtbar punktirt, nebst den Flügeldecken schwärzlich stahlhlau. stark glänzend, letztere ziemlich weitläufig und fein punktirt. die ersten Fühlerylieder und die Beine hell röthlichgelb, Schenkel an der Basis, die lintersten fast bis zur Spitze. schwärzlich. - L. 4-5 mm. Sarepta Kiesenuetteri Joann.

151. Halsschild stark quer, in der hinteren Hälfte rerhältnissmässig stark punktirt, Flügeldecken dunkel metallisch-griin oder blangriun, stark punktirt. die ïbrigen Körpertheile schwarz. selten (Var. geniculutus Joann.) die ersten Fuihlerglieder unterseits und die Knie röthlich. - L. 3,5-5 mm. Hochalpen.

nigripes Kiesw.

16. Der Mund bis über den Vorderrand des Kioptschildes bräunlichgelb. - L. 4-5 mm. Smyrna . . . . lydius Ws. ${ }^{1}$ )

hat sic nicht gesehen, da er die Beschreibung Rosenhaners nur übersetzte. Gegen eine Tereinigung mit sulphuripes (rraëls, der ron Rosh. (Thier. And. 329) als rufipes Fabr. aufgeführt ist. spricht die geringe Grörse und Wïlbung, das glatte, mit zwei (rruben rersehene Halsschild und die äusserst dichte, sehr feine Punktirung der Fliigeldecken.

1) L. lydius n. sp. Viridi-cueneus, vix coeruleo-micans, ubique subtiliter, sed eridenter alutacess, nitidulus, ore, lubro, clypei margine antiro,

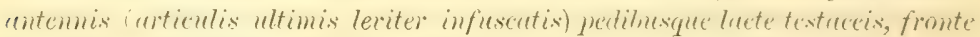

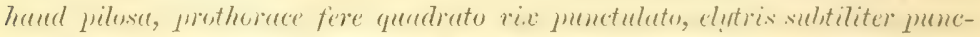
tatix, pectore parce pubescente. Mas: rentre segmentis :3 at 4 singelo lit-

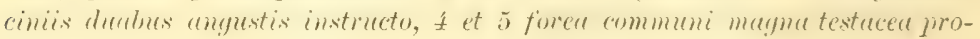
funde excavatis. - Long. 4-5 mm. Smyrna, Graecea? (Kriiper).

Die aussergew whimlich tiefe Grube des $\hat{o}$ nimmt den grössten Theil der beiden letzten grossen Segmente ein, in diesclbe ragen zwei kurze, schmale Lappen hinein, die von der Mitte am Hinterrande des dritten Segmentes ausgehen, zugleich ist die scharfe Scitenkante der Grube auf dem rierten Segmente jederseits in einen langen Zipfel ansgezogen. 


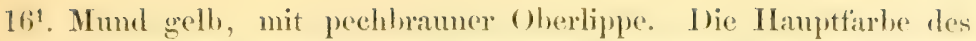
Körpers ist lehhaft metallisch-grünlichblau (Kopf und IIalsschild zuweilen griun eratarbig), oder gesittigt blau, auch mit violettem schimmer, die 4 ersten Fiihlerglieder und die Beine gelb. Stim gewirkt. Halsschild nur wenig breiter als lang, fein, die Flügeldecken dicht nud riemlich kräftig punktirt, schwach querrunzelig. Brust, besonders in den seitenstioken. dicht und lang behart. of Letzter Bauchring mit einer durchgehenden breiten und tiefen Längsgrube, die sich auch noch auf' die vorhergehenden Ringe abgeschwächt fortsetzt. - L. 4,5-6 mm. I. wryterus Fald. 오, amoenus Fald. ô, orientalis

Fald. $\left.{ }^{1}\right)$

17. K̈̈rper hell röthlich- oder bräunlichgelb. Kopf iber den Fïh]ern, Schildchen, Mittel- und Hinterbrust, sowie die Fühler. nach der Spitze hin dunkelbram bis schwarz. - L. 4-5 mm. Corsika . . . . . . . . . Revelierei Perris.

17'. Hauptfarbe des Körpers dunkel: schwarz, schwarzblau oder schwarzgrïin . . . . . . . . . . . . . . 18.

18. Stirn dicht über der Querrinne der Länge nach gestrichelt und einzeln fein behaart. Schwarz, Fühlerbasis und Beine gelb. L. 4-5 mm. Ungarn. Siebenbürgen . . rugifrons $\mathrm{Ws}_{\circ}^{2}$ )

1) Faldermann beschrieb ausgehärtete $ᄋ$ als orientalis, ein frisches , dessen Flïgeldecken am Ende klaffen und in eine Spitze endigen, als rexpterus, das $\hat{\sigma}$ endlich als amoenus. Für die Grössenangabe bei oxy pterus ron $1^{1}{ }_{2}$ lin. muss $2^{1}{ }_{2}$ lin. gelesen werden, denn derselbe wird nu schmaler, aber nicht kleiner als der $2 \frac{1}{2}$ lin. lange orientalis, amoenus aber (bei 2 lin. Länge) kleiner als oxypterus genannt. Der MLonograph Joannis hat die Beschreibungen Fald.'s und die falsche Grössenangabe kritiklos abgeschrieben.

$\left.{ }^{2}\right)$ L. rugifrons n. sp. Niger, nitidus, antennis infuscatis basi pedibusque totis facis, fronte supra sulcum transersum longitudinaliter strigosa et parce pilosa, prothorace transverso-quadrato, parum crebre rix sibiliter punctulato, lateribus paullo rotunduto, elytris subtiliter punctulatis, ectrorsum fere laevibus. Mas: elongatus, antennis corpore longioritus, capite cum oculis magnis prominulis prothorace evidenter latione; coleopteri. Tatitudine triplo longioribus. - Long. 4-5 mm.

Vom gelbbeinigen cunthoporla. Schrank durch das viel weitläntige prmktulirte, glänzendere Halsschild und die in beiden Geschlechtern sehr abweichende Körperbildung verschieden, in dieser Hinsicht am meisten an longicornis erimernd, aber durch die einfarbigen Beine, von beiden ansserdem durch die gestrichelte und beharte Stim leicht zu tremmen. E. liegen mir $\hat{\jmath}$ und $q$ aus dem Banat und ron Hermamnstadt (Reitter). sowie aus der Czerna hora vor. 
18'. Stirn uiber der Querrinne glatt und kahl . . . . 19.

19. Beine nebst den Hüften einfarbig gelb . . . . 20.

19'. Wenigstens die Basis der Schenkel schwarz . . . . 26.

20. Banch rothgelh, Schwarzhlau oder schwarzviolett, lieine stsuittigt. Bauch blasser rothgelb, Fühler wenig lebhatt rïtllich-

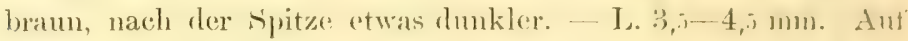
Gesträuch im Juli in der sierra Nevarta redominulis limb.

$2(1)^{\prime}$. Bauch schwarz. . . . . . . . . . . 21.

21. Halsschild und Vorderbrust rötlilichgelb . . . . . . 22.

21'. Halsschild und Vorderbrust schwarz . . . . . 23.

22. Kopf und Flügeldecken schwar, letztere ziemlicls ferin, in hinteren Drittel sehr fein punktirt. ô Kopf mit den vorstehenden Augen mindestens so breit als das Halsschild. - L. 3, 3,-4, 4, 1 mm. Italien. Lugano (Dr. Schneider) . . . pygmaeus Joam.

2:21. Lopt und Fliigeldecken lebhaft metallisch blau voler griin. letztere dicht und ziemlich stark punktirt; $\hat{o} \mathrm{~K} n$ pf in den mässigr vortretenden Augen nicht sn Ineit als das Halsschild. - I. 3-3,5 mm. Pyrenäen . . . . . pyrenaeus Germ. ${ }^{1}$ )

23. Körper rein und tiefsehwarz . . . . . . . . . . 24.

23․ Körper schwarz, oberseits orler wenigstens auf Halssehild und Flïgeldecken mit bläulichem oder grünlichem s'chinmer. Fliigeldecken rerhältnissmässig stark punktirt. - I. 3-3,.; $111 m$. Elbufer . . . . . . . saxonicus Gmel.

24. Beide Geschlechter sehr abweichend. Querfurche der stirn gradlinig, Mandibeln dunkel. Halssehild wenig dicht, aber in der hinteren Hälfte stets deutlich punktirt. Tief schwarz. glänzend, Beine einfarbig hell röthlichgell, die untere Hältte der Fühler mehr oder weniger gell,lich. Flügeldecken stärker. aber kaum dichter als das Halsschild punktirt, mit fast glatten Zwischenräumen. - L. $3,5-5 \mathrm{~mm}$. Ganz Spanien und Portugal. (Mem. Map. Geol. 1858 p. 95 . t. 5 f. 6.)

sulphuripes Graëlls.

$24^{1}$. Beide Geschlechter wenig verschieden. Querturche der stim klammerförmig. Mandibehn rothgelb. IIalsschilı zimulich glatt (nur bei starker Vergrösserung sind ülrerans feine Pïnktehen auf der Scheibe zu bemerken). Glïnzend schwarz. Beine und die 4 bis 5 ersten Fühlerglieder rothgelb . . . . . 25.

1) Sollte diese Art auf dem Abfalle zur Spitze behaarte Fliigeldecken besitzen, was ich nicht entscheiden kamm, da mir zwar eine JIenge. aber nicht gut erhaltene Stïcke rorliegen, so wäre sie unter No. 14 zu bringen und dort die einzige Art mit rothem Halsschilde. 
25. Halsschild an den seiten schwach gerundet, nach vorn kaum mehr als nach hinten verengt, die Vorderecken von oben sichtbar. Fliggeldecken deutlich punktirt. - I. 4-5,5 $\mathrm{mm}$. Oesterreich, Ungarn, Krim . . . innthopodu Schrank.

25'. Halsschild an den Seiten stark germulet, nach vorn viel mehr als nach hinten verengt, die Vorderecken von oben nicht sichtbar. Flïgeldecken äusserst fein punktirt. - L. 4,5-5 $\mathrm{mm}$. Derbent. Kaukasus. (Beitriig. Kauk. Käferfauna 1. 337)

armeniacus Kiesw.

26. Kopf und Halsschild schwarz, oder mit den Flügeldecken gleichfarbig . . . . . . . . . . . . . . 27.

26 ${ }^{1}$. Halsschild und Vorderbrust gauz oder grösstentheils roth. Kopt und Flïgeldecken schwarz, blau oder grün . . . . . 32.

27. Oberseite einfarbig tief schwarz, höchstens die Basalkante des Halsschildes röthlich . . . . . . . . . . . . 28.

$27^{1}$. Kopt und Halsschild schwarz, selten mit schwachem Metallschimmer, Flïgeldecken schwarzblau, stahlblau oder grün, oder schwarz, mit deutlichem griinen Anfluge. . . . . . . 30.

28. Halsschild an den Seiteu kaum gerundet, nach hinten unmerklich verengt, auf der Scheibe glatt, an den Seiten bei starker Vergrösserung mässig dicht punktulirt, Flïgeldecken ziemlich dicht erloschen punktirt und gerunzelt. Fühler, Schienen und Tarsen düster gelbbraun, grösstentheils geschwärt, und nu die Knie heller. Beim $\delta$ sind die Fïhler länger als der Körper, der Kopf ist mit den grossen, stark vorgequollenen Augen breiter als das Halsschild. - L. $3,5-4,5 \mathrm{~mm}$. Kaukasus. Lenkoran und Liryk (Leder)

floralis Fald.

281. Halsschild an den Seiten gerundet, nach hinten merklich verengt, Flügeldecken deutlich punktirt . . . . . . . 29.

29. Klein; Längskiel zwischen den Fühlern breit und flach, die denselben begrenzenden, oben zusammenlaufenden Rimnen nicht tief. Halsschild stets einfarbig schwarz. - L. 2,5-3,5 $\mathrm{mm}$. Dalmatien, besonders um Zara häufig; Herzegowina (Reitter), Griechenland . . . . . . . aetolicus Kiesw.

29:. Mittelgross. Längskiel der Stirn schmal und hoch, an den Seiten von je einer tiefen Rinne scharf begrenzt, die aufgebogene Kante am Hinterrande des Halsschildes oft röthlich, Flügeldecken mässig stark und dicht punktirt. - I. $4-5 \mathrm{~mm}$. Fast über ganz Europa verbreitet . . longicornis. Fabr. ${ }^{1}$ )

1) Stiicke aus Dalmatien (von Metkowich, Reitter) und Griechenland zeichnen sich durch dickere Fühler und eine sehr dichte und feine un- 
34. Halsschild queriber ziemlich stark gewijlht, hei schwacher lergrïsserung grlatt, bei starker ghleichmisig, aher weitliatig punktirt. Kopf und Ifalsschild schwarz, weniestens ersterer mit Bronceschimmer, Flügeldecken schwarzhlau orler dunkel metallischblaugriin, deutlich punktirt, Fiihler schwarz. an Girunde wenif heller, Beine schwarz. die obere spitzenhailfte der schenkel und die Schienen der Vorderbeine, nebst den Knieen an den vier hinteren Beinen röthlich. . cuucusicus Ws. var. mirtus.

301. Halsschild wenig gewölbt, hei starker Vergrösserung dicht, aloer sehr fein und undeutlich punktulirt, anf dem mittleren Theile der Scheibe fast glatt . . . . . . . . . . 31.

31. Flügeldecken schwar\% mit grünlichem Anfluge, mässig fein punktirt . . . . . . . . . niger Goeze $\hat{o}$.

$31^{1}$. Flügeldecken dunkel stahlblau, sebr fein punktirt. I)ie ersten 3 oder 4 Fühlerglieder und die Beine rothgelb, sichenkel an der Basis (die der Hinterbeine bis zur Mitte) schwarz. - L. $3,5-4,5 \mathrm{~mm}$. Kaukasus (Leder 25) . . discolor Fald. $\left.{ }^{1}\right)$

32. Flügeldecken schwarz, höchstens mit kaum bemerkharem, b] ]üulichen oder grünlichen Schimmer . . . . . . . . 33.

321. Flügeldecken deutlich dunkel metallisch-grïn oder griulichblau . . . . . . . . . . 36

33. Flügeldecken glatt, bei starker Vergrösserung iiberaus fein und erloschen punktirt und germuelt, die Zwischenräume mit einzehen noch feineren Pünktchen besetzt: sonst dem L. flacipes täuschend ähnlich. Zuweilen ist die Scheibe des Halsschildes gebräunt. - L. $4 \mathrm{~mm}$. Corsica (laevis Kiesw. Berl. ent. Zeit. 1873. 30) . . maculicorn is Desbr. (Ann. d. Fr. 1872. 131.) $33^{1}$. Flügeldecken deutlich punktirt . . . . . . . . 34.

34. Die Punktirung derselben fein, aus grösseren und kleineren Punkten zusammengesetzt. - L. $3,8-5 \mathrm{~mm}$. Europa, nördliches Asien . . . . . . . . . . . flavipes $L$.

$34^{1}$. Punktirung der Flügeldecken aus gleich grossen, mu mässig feinen Punkten gebildet .

gleichmässige Punktirung der Flügeldecken aus, welche iu der Stärke an die von xanthopoda erinnert. Sie besteht aus grösseren und kleineren unter einander gemischten Punkten, die in der Nithe der Naht in feinen Querrunzeln stehen. Da ich glaube, dass die angegebenen Unterschiede sich als constant erzeigen werden, lege ich der Art, die in der Körperform und Farbe mit longicornis übereinstimmt, den Namen L. araccu: bei.

1) Nach der Beschreibung lässt sich der mir unbekannte L. cyanipemis Küst. aus Montenegro ron discolor vielleicht nur dureh stärkere Pünktchen an der Basis und den Seiten des IIalsschildes unterscheiden. 
35. Halsschild an den Seiten merklich gerundet. - L. 4-1,5 mm. Mittel- und Südeuropa....... . niger Goeze 우 $35^{1}$. Halsschild mit fast gradlinigen feiten. - L. 3,5-4 mm. Alpen. . . . . . . . . .. carniolicus Kiesw.

36. Halsschild wenig breiter als lang, ungemein tein, ghleichmissigen und ziemlich weitläutig punktirt. L. 4,5-5,5 mm. Kaukasus. caucasicus $\mathrm{W}_{\mathrm{s}}{ }^{1}$ )

$36^{1}$. Halsschild bedentend breiter als lang, aut der hinteren Hälfte weitläufig mit flachen, aber ziemlich grossen Punkten besetzt, die wenigstens an den Seiten yor den Hinterecken bei mässiger Tergrösserung deutlich sind. - I. 3,5-5 mm. Mittel- und Sideuropa, Asien bis zum Amur . . viridipennis Germ. ${ }^{2}$ )

A. Zweites Fühlerglied ungefähr so lang als das dritte. Halsschild rorn ungerandet, seine Eckborsten stehen in tiefliegenden Poren, die vorderen ein Stiick hinter den Vorder-

$\left.{ }^{1}\right)$ Lup. cancasicus (L. viridipennis var. caucasicus Ws. Verh. zool. bot. Ges. Wien 1879. 486): Oblongus, niger, nitidus, antennis basi, mothorace, pedilus anticis plus minusve et posteriorum femoribus apice tibiisque basi rufo-testaceis, fronte polita, leviter metallica, prothorace subquadrato, minus transversus, convexo, apice quam basi parum angustiore, lateribus. sulrotundatis, supra minus crebre aequaliter et subtiliter punctulato; elytris jam nigro-cyaneis, jam viridi-aeneis, sat dense punctatis. - Long. 4,5-5,5 mm.

Var. a. mixtus: Prothorace aut piceo lateribus plus minusve rufis, aut nigro, antemis pedibusque plevumque nigricantibus, gemubus rufescentibus. Im hohen Caucasus weit verbreitet (Leder, Faust).

Das Halsschild färbt sich zuerst auf der Yitte der Scheibe, später bis zum Aussenrande dunkel und wird zuletzt total schwarz; die ersten vier Fühlerglieder sind rothgelb, meist mit einer dunklen Makel auf der Oberseite, oder wie die ibrigen Glieder schwarz, an der Basis mit röthlichem Schimmer; die Beine werden ziemlich schwarz, die obere Hälfte der SchenkeI und die Basalhälfte der Schienen an den Vorderbeinen, sowie die Knie in geringer Ausdehnung an den hinteren Beinem düster röthlich. Ich habe diese Form (Verh. zool. bot. Ges. Wien 1879. 486) mit Unrecht für den mir bis dahin unbekannten $L$. discolor Fald. angesehen.

${ }^{2}$ ) Bei dem sehr ähnlichen L. Biraghii Ragusa (Bull. Soc. Ital. II. 1871. 315; aetnensis Rottenberg Berl. ent. Z. 1871. 244) von Sicilien (Anfang Mai auf Eichen bei Nicolosi) ist der Stirnkiel breit, flach, punktirt, der Scheitel etwas stärker gewirkt, das Halsschild vorn weniger verschmälert, daher etwas breiter, die Punktirung der Fligellecken feiner als bei deutschen, aber stärker als bei südfranzösischen Stïcken des viridipennis. 
ecken. Fliggeldecken in der hinteren Hailfte mit rinzelnen aufstehenden Härchen. Calomicrus Steph.

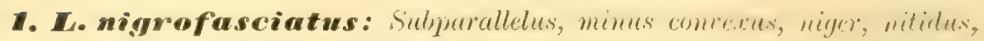

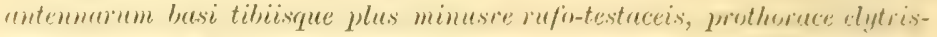
que sulphureis, illo transerso, subtilissime punctulato, leviter hiimpresser, maculis 3 vel is, saepe confluentilues nigris motratis; elytris crelne junclulutis, limbo suturali, apicali et laterali nigno; fronte glatron, tursis gracilibus. - Long. 3-4 mm.

Goeze Ent. Beiträge I (1777) 312.

('rioceris circumfusus Barsh. Ent. Brit. (1802) 227. - Siteph. IIl. Brit. IV. 294 (C'alomicrus). - Shuckard Brit. Col. 65. t. 75. f. 2. - Joann. Mon. 118 (Luperus). - Kiesw. Ber]. Zeit. 1873. 23. - Redtb. Faun. A. II. 492. - Bach Käferf. III. 135. Haltica spartii Koch Ent. Heft. II. (1803) 76. - Duftschm. Faum.

A. III. 235 (Crioceris).

Altica brassicae Panz. Faun. Germ. 21, 18.

Gestreckt, fast gleich breit, wenig gewölbt, schwarz, glänzend. Halsschild und Flügeldecken grösstentheils bräunlich schwefelgelb, die drei bis vier ersten Finhlerglieder, die Spitze der Schenkel, die Schienen und Tarsen an den vorderen Beinen, oft auch die Schienen der Hinterbeine röthlich gelbbraun. Kopf mit kahler Stirn. Halsschild um die Hälfte breiter als lang. hinten etwas schmaler als vorn, mit leicht gerundeten Seiten und abgerundeten Fcken. oben wenig gewölbt, äusserst fein und undeutlich, aber in der hinteren Hälfte etwas stärker als vor derselben punktirt, mit einer schwachen Grube jederseits hinter der Mitte und drei bis fünf schwarzen Makeln. Drei derselben stehen an der Basis frei, häufiger jedoch zu einem schmalen Basalsaume vereint, der sich zuletzt so ausdelmt, dass er die hintere Hälfte der Scheibe einnimmt und vier spitzen nach ror'n sendet, zwei in der. Mitte bis in's rordere Drittel und je eine am Seitenrande. Schildchen schwarz. Flügeldecken dicht. und fein punktirt, ein mehr oder weniger breiter, ziemlich schart begrenzter Saum an der Naht schwarz. Dieser Saum setzt sich um die Spitze und den Seitenrand herum, etwas verschmälert und imnen schlechter begrenzt, bis zur Schulter fort, wo er auf' die breiten. aber kurzen Epipleuren allein beschränkt ist. Dic Tarsen sind schlank, ihr erstes Glied an den Hinterbeinen ist länger als die folgenden zusammen.

Beim ô sind die Fühler reichlich so lang als der Körper, der Mittelzipfel des letzten Bauchringes ist viereckig, schwach vertieft. Penis von der Länge des Hinterleibes, fast gleich breit und ziemlich grade, der Oberrand (bei der Seitenansicht) in der Mitte schwach winkelig erhöht, der Unterrand daselbst leicht eingeknickt, die 
spitze serundet-verengt, an Ende wis ain kleiner Haken umgeschlagen.

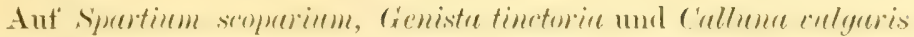
in Mittel- und Sïdleutschland häutig, wie in groissten Theile rom Mitteleuropa und in einigen Giegrenden Siideuropat's

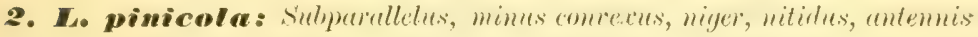

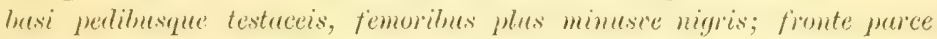

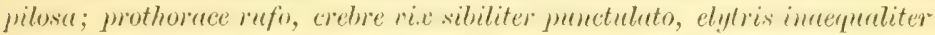

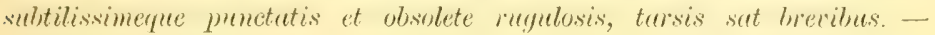
Long. 2,8-4,5 $\mathrm{mm}$.

Duftschm. Faun. A. IIr. 234 (Crioceris). - Ratzeb. Forstins I. 24.5. t. 20. f. 9. 10 (Galleruca). - Küist. Käf. Eur. 14. 99. - Joann. Mon. 126. - Kiesenw. Berl. ent. Zeit. 1873. 24. - Thoms. Skand. Col. VIII. 161. - Redtenb. Faun. A. II. 492. - Seidl. F. balt. 492.

Var. a. silvestris: Prothorace nigro-piceo.

Gestreckt, nach hinten leicht erweitert, wenig gewölbt, schwarz, glänzend, die Mandibeln und Wangen, die vier ersten Fiihlerglieder und die Beine röthlich gelb, die Schenkel bald nur an der Basis, mamentlich an den vorderen Beinen, bald fast bis zur Spitze schwarz, Haisschild gelblich roth. Stirn ïber der Querrinne fein und sparsam behaart. Halsschild etwa doppelt so breit wie lang, rorn und hinten ziemlich gleich breit, mit gerundeten Seiten und abgerm deten Ecken, oben mässig gewölbt, dicht, aber schwer sichtbar junktulirt. Flïgeldecken deutlicher punktirt als das Halsschild, die Punktirung besteht aus unter einander gemischten grösseren und kleineren flachen Punkten, welche hier und da durch äusserst schwache und kurze Runzeln verbunden sind. Tarsen kurz, ihre drei ersten Glieder an den Vorderbeinen ziemlich breit, das erste Glied der Hinterbeine so lang als die folgenden zusammen.

Beim Männchen hat der letzte Banchring fuir die beiden Einschnitte der meisten übrigen Arten zwei Beulen und zwischen diesen eine Quergrube, die grösstentheils anf dem kurzen Mittelzipfel liegt. - Der Penis ist rorn alluählich in eine scharfe. zuletzt gerade nach unten gebogene Spitze verschmälert.

Das Halsschild ist nicht immer einfarbig roth, häufig zeigen sich einige unbestimmte braune Flecke, oder eine Quermakel ror der Mitte, oder die Scheibe ist (Var. a) mit Ausschluss der Ränder, oder einfarbig pechschwarz.

An den jungen Trieben der Kiefern häufig in ganz Deutschland und Mitteleuropa, Schweden. 


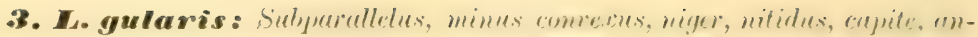

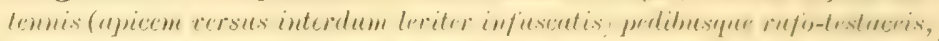

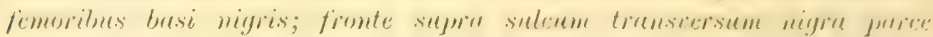

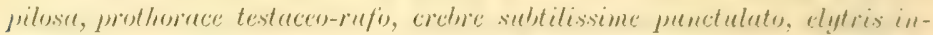

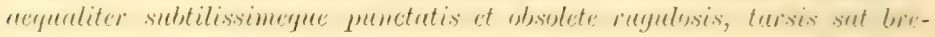
vibus. - Long. 3,5-4,8 mm.

Gredler Käf. v. Passeier II. 185.7, 73. - Kiesw. Berl. ent. Zeit. 1861. 394; 1. c.1873. 24. - Joann. Mon. 127.

Dem vorigen sehr nahe verwandt, in der Geschlechtsauszejchnung vollkommen iblereinstimmend, aber doch wohl mit Recht ron Gredler als eigene Art abgesondert, da Lelergange l,is jetzt noch nicht bekannt geworden sind. Er ist durchschnittlich grijsser als pirierlu, die Flügreldecken sind eine Spur glïnzender: die Fibler einfarlig röthlich gelbbraun, oder die oberen Glieder schwach gebräunt, indem die Spitze jedes einzelnen einen dunklen Anflug hesitzt. Der Koyt ist fast ganz roth, nur der Scheitel, oder die behaarte stim bis zur Querfurche, seltener noch die stimbeulen order die Oberlipue schwarz. Das Halsschild ist immer einfarbig roth, zuweilen wird, vielleicht bei frischen oder fettigen Stiicken, eine Stelle hinter dem Vorderrande dunkel, weil dort der Hals durchschimmert:

In den Alpen von Tirol lis Steiermark und Krain rerbreitet und stellenweise häufig; die ersten stïcke wurden ron H. Meister. auf Vaccinum myrtullus gefunden.

B. Zweites Fühlerglied bedeutend kiurzer als des dritte. Halsschild ringsum gerandet, seine Eckporen stehen auf kleinen Kegeln: Luperus in spec.

a. Flïgeldecken aut dem Abfalle zur Spitze mit einzelnen aufstehenden Härchen.

4. L. nigmipes: Subparallelus, concexiusculus, niger, nitidus, prothorace postice subtiliter sed exidenter elytrisque dense fortius punctutis, his nigro-coenuleis ant -rividibus, interdum etiam cum capite et prothorace aurichalceo micantibus. - Long. 3,5-5 $\mathrm{mm}$.

Kiesenw. Berl. ent. Zeit. 1861. 392. - Joann. MIon. 152.

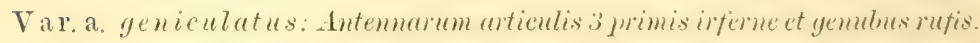
Joann. Mon. 151. - Kiesw. 1. c. 1873. 31.

An der starken Punktirung und den schwarzen Fïhlern und Beinen leicht kemnthch. Gestreckt, nach linten wenig erweitert, ziemlich gewölbt, schwarz, glänzend, nur die Flitgeldecken dunkelblau oder griin, zuweilen nebst Kopt und Halsschild mit Messingschimmer. Halsschild quer, rom und hinten etwa gleich breit. an den gerundeten Seiten hreit und hoch. an der Basis und spitze 
aber nur fein gerandet, oben etwas gewoilbt, über den seiten und in der hinteren Hälfte mässig dicht und tein, vorn vicel finere und verloschen punktirt. Schildchen schwar\%. Flügeldecken gleichmässig, dicht, und für die Gattung rerhiiltnissmïssig stark punktirt, am Aussemrande hinter der Mitte und vor dex Spitze otwas schwächer und weitläufiger. Tarsen schlank.

Das Jännchen ist dem Weibchen recht ähnlich, doch an den grö̈sseren und gewölbteren Augen, den längeren Fiihlern und der ziemlich grossen Grube des füntten Bauchringes leicht zu erkennen.

Bei der unbedeutenden Var. a sind die ersten drei Fühlerglieder unten und die Knie mehr oder weniger hell roth.

Auf' kurzem Alpengrase an den Berglehnen bei Mattmark am Nordabhange des Monte Rosa ron Herm r. Kiesenwetter entdeckt. aber auch in den Tiroler Alpen und am Gross-Glockner.

b. Fliigeldecken kahl, nur am Seitenrande hinter der Mitte sparsam und äusserst fein bewimpert.

* Beine einfarbig rothgelb.

5. I. xanthopoda: Oblongus, connexiusculus, niger, nitidissimus, antennarum basi pedibusque totis rufo-flaris, fronte et prothorace rie jerspicue elytrisque subtiliter punctulatis; tarsis sat brevibus. - Long. $4-5,5 \mathrm{~mm}$.

II as: antemis comporis longitudine, capite cum oculis prominulis mothorace paulo augustione.

Chrysomela xanthopoda Schrank Enum. Ius. (1781) 93.

? Coccinella rufipes Scop. Ent. Carn. (1763) 73. - Panz. Fium. Gelm. 32. 5 (Crioceris).

Crioceris rufiues Duftschm. Faun. A. III. 232. - Joann. MIon. 141 (Lup.). - Rertb. Faun. A. II. 492.

Luperus pallipes Bach Käferfauna III. 135.

Das Männchen länger, das Weibchen kïrer eiförmig, ziemlich plump gebaut, mässig gewölbt, rein und tief schwarz, stark glänzend, die Mandibeln und Maxillartaster, die ersten vier Fïhlerglieder und die Beine einfarbig röthlichgelb. Die Stim ist umbehart, glatt und selbst bei starker Vergrösserung kaum sichtbar punktirt, wie das Halsschild. Ietzteres ist $u m$ die Hälfte breiter als lang, am al)gestutzten Vrorderrande ungefahr eben so breit als am gerundeten Hinterrande, die seiten schwach gerundet, der vordere Borstenkegel ziemlich gross, ron oben sichtbar, der hintere etwas kleiner. Flügeldecken auf der immeren Hälfte fein und verloschen, auf der äusseren kaum bemerkbar punktirt. Die Tarsen sind riemlich kurz, ihr erstes Glied an den Hinterbeinen wenig oder kam lïnger als die beiden folgenden zusammen. 


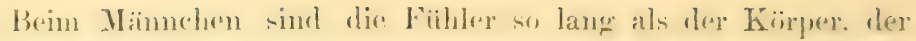

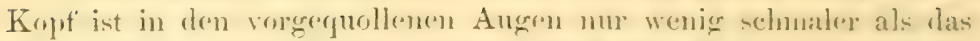

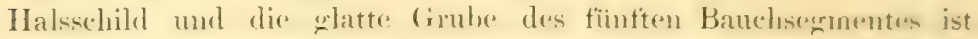
Eross, ticf, fast gleichbreit. und steigt nach den Vorderrande des Ringes hin allmählich an. - Penis ku\%, mäissig dick. vorn etwas zusammengedrïckt und eine Spur verengt, an Ende nach unten gekrimnnt, nit zwei divergirenden, rückwäits gerichteten schmalen und scharfen Spitzen.

In den meisten Provinzen ()esterreichs, namentlich in Kärnthen, (rörz und Krain häufig. Lngarn. Serbien. Wohludscha.

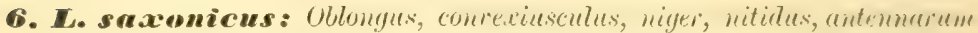
busi pedibusque totis rujo-testuceis, elytris leriter sed eridenter viridirel coeruleo-micantibus; fronte supra sulcum transerersum et protharace subtilissime elytrisque sat fortiter punctatis, tresis brerilus. - Long. $4-5,5 \mathrm{~mm}$.

Mas: untemis hand corporis longitudine, copite cum oculis prominulis prothorace aequali, asticulo primo tarsom anteriorum dilatato.

Cryptocephalus (Crioceris) suconicus Gmel. Ed. Linn. XIII. p. 1723. Crioceris rufipes Fabr. Mant. Ins. I. (1787) 89.

Lup. unthopolu Kiesw. Berl. ent. Zeit. 1861.393; 1. с. 1873. 1. 26 et 28. - Seidl. F. balt. 492. (?)

Mit dem vorigen nahe verwandt. eben so plump gebaut und von derselben Grösse, aber in folgenden Stücken abweichend: Die Farbe der ersten vier bis fünf Fühlerglieder und der Beine ist weniger gelb, sondern mehr roth, die Stirn und das Halssehild sind sehr fein, mässig dicht punktirt, die Fliigeldecken besitzen stets einen deutlichen blanen oder grünen schimmer und sind riel weniger glänzend, da sie gleichmässig ziemlich dicht und kräftig punktirt sind, weitlïufiger und etwas schwïcher als bei nigripes. Die Punkte sind scharf' und ziemlich tief eingestochen, ihre Zwischenräume unter stärkerer Vergrösserung mit einzelnen äusserst feinen Pünktchen besetzt.

Das Männchen hat stärker vorgequollene Augen und ladurch einen etwas breiteren Kopf, der mindestens die Halsschildbreite erreicht, die Fühler sind kürer und endigen weit ror der Spitze der Fliigeldecken, die Grube des fünten Banchringes ist nach rorn merklich rerschmälert, die beiden Spitzen des Penis sind kurz, ziemlich breit, nur schwach nach rückwärts gebogen.

Bis jetzt nur am Elbufer bei Dresden auf Weiden stellenweise häufig gefunden; auch bei Dessau.

Die vorliegende Art ist die wirkliche Crior, rufipes des Fabricius (Hubitat in stuonine frinticibus!) ant welche alle späteren Peschreiber 
Bezmen nehmen, ohne sie geselien zu haben; mu Kiesenwetter kannte

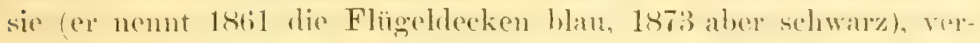

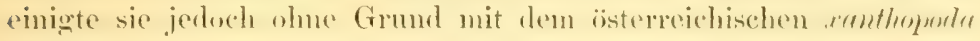
Schrank.
Beine rothgelb, Sehenkel theilweise schwarz.
+ Halsschild in beiden Geschlechtern schwarz.

7. W. Iongicornis: Niger, nitidus, antennurum articulis f primis perlibustue rufo-testaceis, femoribus basi nigris, prothorace subtilissime elytrisque sat crebre tenuiter at mofundius punctatis. - Long. 4-5 mm.

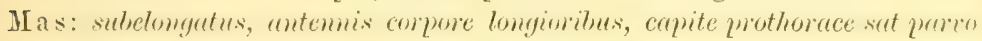
latione.

Femina: oblonga, antemis conpore brenioribus, capite prothorace angustione

Ptinus longicornis Fabr. Spec. Ins. I. 1781. p. $72(\hat{o})$. - Kiesw.

Berl. ent. Zeit. 1873. 26 et 29 (Luperus). - Seidl. Faun. balt. 493

? Coccinella rufipes Scop. Ent. Carn. 73.

Galleruca rufipes Gyllh. Ins. Suec. III. 518. - Küst. Käf. Eur.

14. 96 pars (Lup.). - Kiesw. 1. c. 1861. 393. - Thoms, Skand.

Col. VIII 160. - Bach Käferfauna III. 13 ว.

Luperus betulime Joann. Mon. 143.

Var. a. Margine postico protoracis testaceo.

Dem I. exthopoda sehr ähnlich, aber das Halsschild kleiner, die Flügeldecken kräftiger punktirt und die Beine nicht cinfarbig rothgelb. Rein und tief schwarz, glänzend, das Halsschild mehr pechschwarz, die Leiste des Hinterrandes zuweilen (Var. a) gelh. die exsten vier Fühlerglieder und die Beine röthlichgell, cine kleine, rerwaschene Makel auf der Unterseite der Vorderschenkel, dicht an den Hïften, und ein Ring am Grunde der Mittelschenkel hraun oder pechschwarz, die Basalhälfte der Hinterschenkel schwarz. Halsschild ror der Witte am breitesten, nach rom etwas schueller als nach hinten gerundet-verengt, weitläufig und änsserst f’ein punktulirt, die Piuktchen, besonders die auf der Mitte der Scheibe, nu bei starker Vergrösserung sichtbar. Flügeldecken mässig tein murl dicht dentlich punktirt, die I'unkte scharf eingestochen, mit breiteren fast glatten Zwischenräumen.

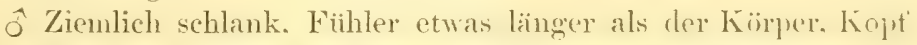
mit den grossen Angen lreitex als das Malsschild, dieses ziemlich klein, seitlich schwach gerundet. Fliigeldecken tiast parallel: ant dem letzten Bauchringe eine ziemlich grosse und tiefie (ivnlux.

q Langlich-eitömig. Fiihler viel kü̈zer als der Kinrper, Konft schmaler als das Halsschild, dieses ron nomaler (iriisse, an den seiten stärker gerundet. Flïgeldecken nach hinten erweitert. 


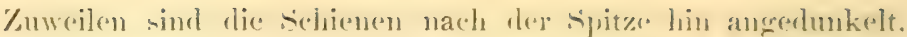

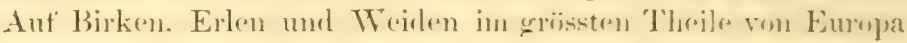
nicht selten.

Letp. rlinionsis Bellier (Amn. d. Fr. 1870. 27) aus der Lomgegend rom Digne im siidöstlichen Frankreich, ist nach unatuscefärbten Stiicken anfgrestellt (Entierement d'un brun fonce), mol musis nach der oberflächlichen Beschreibung mit der vorliegenden Art vereingt werden. Küster hat. da er die Flïgeldecken bläulichschwarz nennt, auch das j der folugenden Art mit seinem rufipes verbunden.

$\dagger \dagger$ Halsschild des Männchens dunkelbraun oder schwarz. des Weibchens roth.

8. I. miger: $\hat{o}$ Elongutus, niger, nitidus, capite cum uculis jomimulis mothorace rix latione, antennis corpore longionitnes nigris, reticulis mimis inferne testaceis, prothorace piceo vel nigro, sultilius punctulato, laterilus. minus rotundato, elytris leviter aeneo-micautibus, crebre minus subtiliter punctatis, pedibus anticis maxima parte, posterioribus geniculis testacti. - Long. 4-4,5 min.

I Oblongu, antemis corpore lnevionibus, articulis primis testactin, prothorace rufo-testucen, lateribus rotumlutis, elytris migris, pedibus tertaceis, femoribus basi nigris.

Goeze Ent. Beitr. I. 1777. p. 321. ㅇ․ - Kiesw. Berl, ent. Zeit, 1873. 26. 27. - Seidl. F. balt. 493.

Luperus ulmarius Fourcr. Ent. Par. I. 1785. p. 89. 우.

, Maerkeli Motsch. Bull. Mose. 18500. 368.

" rufipes Goeze 1. c. 322. §̧. - Küst. Käf. Eur, 14. 96 (pars).

" betutimes Fourer. 1. c. 90.

, dispar Redtb. Faun. A. II. 492.

Das Männchen ist dem der vorigen Art ähmlich. aber kleiner und viel schlanker, mit längeren Fibhlern und noch krättiger punktirten Flïgeldecken, gestreckt, schwarz, glänzend. Fopł nit den grossen, vorgequollenen Augen so breit als das Halsichild, Fülller bedeutend länger als der Körper, dunkel, die drei ersten Glieder unterseits röthlichgelb. Halsschild schwarz oder pechbram, etwas breiter als lang, an den Seiten wenig gerundet, oben cusserst fein punktulirt. Flïgeldecken bei ausgehärteten ${ }^{1}$, Exemplaren schwarz, metallisch grum angehaucht, dicht und mässig fein, deutlich punktirt. Die Vorderbeine sind röthlichgelb. mit dunklex Basalhältte der

1) Die Fld. frischer Stïcke sind bei dieser und den anderen Arten in der Regel feiner punktirt, mitunter fast glatt, oft mit mdeutlichen und sehr flachen furchenartigen Längsvertiefungen rersehen. 
Schenkel, die hinteren Brine sind dunkel, nu die Spitze der. Schenkel und der Grund der Schienen röthlich.

Das Weibehen libst sich vom of des I. flaipes nul hei grossen Aufinerksamkeit merscheiden; es ist kleiner und auf den Fligeldecken olchehmässiger und stioker punktirt; länglich-citömig, schwarz, die ersten drei oder vier Glieder der kuxzen Fühler, die Beine, mit Ausnahme der schenkelbasis, und das Halsschild galblichroth. S'elten sind die schienen nach dex spitze hin angedunkelt wie heim $\hat{j}$.

Auf Llmen und anderem Gestrïnch in den bergigen Gegenden Dentschlands, sowie in Mittel- und Siideuropa nicht selten, scheint aber in der norddeutsehen Tiefebene nicht mehr rorzukommen.

L. Maerlieli wurde von Motschulsky unzeifelhaft nach weihlichen Stiicken aus dex Umgebung ron Wehlen in der sächsischen Schweiz beschrieben; die dabei erwähnten Männchen existirten wahrscheinlich nu in der Einbildung des genannten Autors.

$\uparrow+\dagger$ Halsschild in beiden Geschlechtern roth.

9. L. carniolicus: Oblongus, niger, nitidus, antennarm basi, mothorace luteribus leniter rotumlato pedibusque rufo-testaceis, femonum basi nigris; elytris parcius punctatis - Long. 3,5-4 mm.

II as: copite cum veulis prothorace rix latione, antemis conpore longionibus, tibiis apice tarsisque infuscatis.

Kiesw. Berl. ent, Zeit. 1861. 393. ô.-Joann. Mon. 146.

Die Art stimmt zwar in der Färbung ganz mit fluripes überein. ist aber durch die Punktirung der Fliigeldecken mit der rorhergehenden näher verwandt, verhältnissmässig kleiner als beide. Länglich-eifömig, mässig gewölbt, schwarz, glänzend, die ersteu Fiihlerglieder, Halsschild und Beine röthlich gelb, die Basalhältte der vorderen und der grösste Theil der beiden Hinterschenkel schwarz, Schienen nach der Spitze hin mehr oder weniger angedunkelt, namentlich beim Männchen. Das Halsschild hat fast gradlinige, nur ummerklich gerumlete s'eiten, die Punkte der tief schwarzen Flïgeldecken sind ron gleicher Grösse und stehen weitläntiger als bei niger, ihre Zwischenräume sind eben und glatt.

Das Männchen weicht in der Kiirperform wenig vom WVeihchen ab. nur ist der Kopt durch die kugeligen Angen, welche jedoch nicht gan\% so stark wie die von flacipes heranstreten, hreiter: dis Fithler sind länger als der Körper, die Grube aut dem letzten Bauchringe gross und tief.

-In den Alpen von Kärnthen und Krain. 


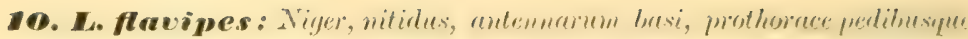

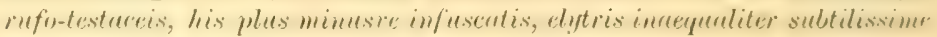
punctatis, obsolete rugulosis. - Long. 3,8-5 $\mathrm{mm}$.

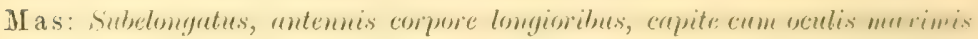
prothorace latiore.

Linn. Syst. Nat. ed. XII. 601. - Schrank Enum. 94 (r\%).rimela). - Panz. Faun. Germ. 32.4. - Duft. Faun. A. III. 233 (Ćrioceris), 一 Gyllh. Ins. Suec. III. 517 (Galleruca). Kiesw. Berl, ent. Zeit. 1861. 393; 1. c. 1873. 29. - Joann. Mon. 144. - Thoms. Skand. Col. VIII. 161. - Redtb. Faun. A. II. 493. - Seidl. F. balt. 493.

Luperus megalophthalmus Joann. MIon. 147. - Desbr. Ann. Fr. 1872. 431 .

Lang-eifümig, schwarz, glänzend, die crsten Fiihlerglieder und die Beine röthlichgelb, die Basis dex Torderschenkel, die Basalhälfte der Mittelschenkel und der grösste Theil der Hinterschenkel schwarz. Halsschild hell rothgelb. kaum punktirt. ror der Mitte am breitesten, nach hinten etwas mehr als nach rorn gemudetverengt. Flügeldecken fein und seicht ungleichnässirr punktirt und in der Nähe der Naht verlosehen quer gerumzelt, die vereinzelten Punkte in den Lwischenräumen lıall, so stark als die ubrigen.

Bein schlankeren Männchen überragen die Fühler weniustens mit den zwei letzten Gliedern die spitze der Fliigeldecken und es sind an ihmen die ersten beiden Gilieder unterseits und die Basis des dritten Gliedes hell gefärbt; der Kopt ist in den grossen, kugeligen Angen breiter als das Halsschild, die Grube auf dem letzten Bauchringe reicht tast his zum Vorderrande. und die Tarsen und Schienen sind mehr oder weniger angedunkelt.

Beim Teibchen sind gewöhnlich die drei oder vier ersten Fühlerglieder nebst schienen und 'Tarsen einfarbig rothgell.

Auf Erlen, Birken und Weiden ïber den grössten 'Theil rom Enropa und der nördlichen Hälfte von Asien lris Nikolajewsk (Koltze) verbreitet.

1. L. viridipennis: Oblongus, niger, nitidus, antemurum bus:, mu-

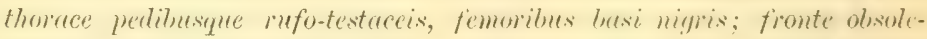

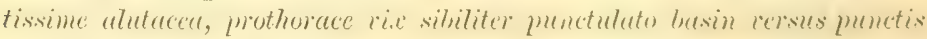

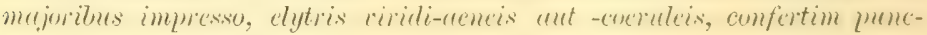
tatis. - Long. $3,5-5 \mathrm{~mm}$.

Mas: tarsis anticis articulo primo dilatato.

Germar Ins. spec. nov. 1824. p. 597. - Küst. Käf. Eur. 14.97.

- Kiesw. Berl. ent Zeit. 1861. 393. - Joann. Mon. 1ว̆4.

- Redtb Faun. A. II. 492. 
(inoceris comelesens Duft. Faun. Austr. III. 18:5. p. 23:3. - Bach Käferf. III. 136.

Luperus levicis Motsch. Mélang. hiol. Ac. Petr. 1859. 1. 23t. -Joann. Mon. 149.

Luperus Garieli Aubé Ann. d. Fr. 1862. 74. - Joann. Mon. 153. Var. a. varicollis: Disco prothoracis brumeo.

An dem rothen, eigenthümlich punktirten Malsschilde in Verbindung mit den blauen oder grimen, krättig punktirten Flitgeldecken leicht kemntlich. Länglich-eitörmig, mässig gewölbt, schwarz, die ersten Fühlerghieder, die Beine, mit Ausnahme der Fehenkelhasis, und das Halsschild röthlichgelh, Fliigeldecken griinlich blau nder metallisch grün, zuweilen mit Bronzeschimmer. Kopf wit schwarzer oder messinggelb angelaufener, unter starker Vergrösserung sehr tein gewirkter Stirn. Halsschild äusserst fein punktulirt, in der hinteren Hälfte, wenigstens jederseits ror den. Hinterecken. untermischt mit grösseren. mehr oder weniger deutlichen Punkten, welche untel einer scharfen Lıpe wie Grübchen aussehen. Flügeldecken ziemlich dicht und wenig fein punktirt. Die Beine sind beim $\hat{\jmath}$, im Gegensatze zu den vorhergehenden Arten, gewöhnlich heller getärbt als beim 우, die Vorderschenkel unterseits in geringer Ausdelmung' g'ebräunt oder einfarbig rothgelb, Mittelschenkel nur an der Basis schwärzlich, Hinterschenkel im ersten Drittel schwarz; beim $q$ sind alle schenkel an der Basis oder fast bis zur. Spitze schwarz, häufig auch die Schienen, mit Ausnahme der Basis, und die Tarsen dunkel.

Das Jännchen ist wenig schlanker wie das Weibchen, mit längeren Fühlern, die ziemlich bis zur Spitze der Fliigeldecken reichen, die Augen sind nur ummerklich grösser, dagegen ist das erste Glied der Vordertarsen deutlich erweitert, die Grube auf dem letzten Bauchringe lang und tief. - Penis gleich breit, voln schmell und gradlinig in eine breite, ausgerandete Spitze verengt, an der Stelle, wo die Verengerung anfängt, steht am Hinterrande jederseits ein rechtwinkeliges, nach hinten gerichtetes Zähnchen.

In den Gebirgsgegenden Deutschlands besonders auf Erlen häufig. Frankreich, Siideuropa, Ungarn. Sibirien bis Nikolajewsk (Koltze).

Stiicke mit einfarbig gelben Beinen, die Gredler (Kät. Tir. 434. Aumerk.) anführt, sowie solche mit einfarbig schwarzem Halsschilde, welche nach Joannis (Mon. 153) in siidöstlichsten Frankreich bei Barcelonette vorkommen sollen, sind mir unlrekamnt; in Deutschland, besonders in Steiermark (Kahr), findet sich sparsan (2ine Form (Var. a), bei der die scheihe des Halsschildes, mit Ausnahme der Ränder. braun ist.

VI. 4. 


\section{Lochmaea.}

We ise, Deutsche ent. Zeitschr, 1883, p. 316.

Corpus supra fere glabrum, subtus parce pubescens. Acetabula antica aperta.

Tibiae muticae, unguiculi dentati.

Fine durch die fast kahle Oherseite und die eigenthünliche (ieschlechtsauszeichmung von Gralevucella wohl unterschierlene Gattung, welche in der Färbung und auch habituell an fialeruca erinnert, von der sie jedoch durch die offenen Hüftpfamnen der Vorderbeine abweicht.

Kopf klein, breiter als lang. Stirn punktirt, in jedem Punkte ein äusserst feines Härchen, uiber der Fühlerwurzel zwei dreieckige Beulen; das Koptschild klein, abschüssig, vorn mit einem flachen Querstreifen, die Mandibeln kurz und breit. vierzähnig, die Zähne stumpf, die beiden mittleren ziemlich gleich lang. Fühler heim Männchen schlank, länger als der halbe Körper, ihr drittes Glied länger als das erste; beim Weibchen kürer und etwas dicker, das dritte Glied mit dem ersten ungefähr gleich lang, das vierte his zehnte Glied unter sich in beiden Geschlechtern ron gleicher Länge. Halsschild mit undeutlichen oder sehx kleinen Borstenkegeln, aut der Scheibe eine vorn und hinten stärker vertiefte Wittelrime und eine weite Grube jederseits. Sichildchen dreieckig, oder an der Spitze abgestutzt, in der Mitte kahl, oder ganz behart (cratregi). Flïgeldecken nach hinten verbreitert, mässig oder stark gewälbt. unregelmässig kräftig punktirt, kahl, nu an der Spitze sparsam bewimpert, oder in jedem Punkte ein zartes Härchen, welches kaum aus demselben herausragt; die Naht erhöht, der abgesetzte Sitenrand verdickt. indem dicht iiber der feinen seitemrandlinie eine sehr schmale, glatte Längswulst in der Regel bis zur abgerundeten Nahtecke fortläuft. Die Seitenstücke der. Vorderlurust endigen hinter den Hiiften in eine Spitze, welche ein stück den etwas auf'gebogenen Hinterrand der Gelenkhöhlen überragt, ohne sich mit dem sehr schmalen Prosternalfortsatze zu rerbinden: die Mittelhust ist zwischen den Hüiten in eine schmale Platte verlängert, welche nach hinten abtallt und vollkommen verdeckt, oder, bei cratreni, ansteigend und sichtbar ist; erster Hinterleibsring über die Mitte gemessen nur so lang als der füntte. Beine, besonders die sichienen, stärker als in der Gattung Galerucella.

Das Männchen zeichnet sich durch die leicht gekrimmten Hinterschienen, das erweiterte erste Tarsenglied und die Bildung der beiden letzten Hinterleibssegmente aus. Es fallen nämlich die seiten des vierten segmentes plützlich zu einem keilförmigen, glatten 
Querstreifen ab. dessen Spitze nach innen gerichtet ist, der fünfte Ring ist abschüssig. in der Mitte mit einer durchgehenden tiefen Lïngscrube, deren Ränder leistenförmig aufstehen und vorn hufeisenförmig zusammengekrimmt sind. - Der Penis ist mehrfach sebogen, entweder an der spit\%e unsymmetrisch gebaut oder zweimal erweitert.

Man findet die drei bekannten, über Europa und die nördliche Hälfte von Asien verbreiteten Arten auf Gebüschen und am Rancle von Sümpfen auf niederen Pflanzen. Ueber ihre Entwicklung ist uur das Wenige bekannt, was Ratzeburg in den Forstins. 2. Aufl. p. 244. t. 20. f. 5 von $L$. capreae anfiihrt. Die Larven derselben firessen an Birken und Sahlweiden (Salix caprea L.) und richten dureh das vollstïndige Skeletiren der Blätter zuweilen beträchtlichen schaden an; sie sind den Larven von Melasoma populi ähnlich, kleiner, eine Spur flacher, weiss oder gelblichweiss, schwarz gefleckt. Die beiden schwarzen Querflecke jedes Segmentes sind ziemlich weit getrennt und fliessen auf den letzten Ringen nicht $\mathrm{zu}$ einem Flecke zusammen. Für die Larve von $L$. crataegi halte ich die, welche man in den vertrockneten Früchten von Crataegus zuweilen antrifft. Sic ist zusammengekrimmt, gelblichweiss, der Kopf, die Beine und das Aftersegment braun.

\section{A. Halsschild an den Seiten winkelig erweitert.}

1. L. capreae: Oblonga, convexiuscula, nigra, prothorace elytrisque testaceo-favis, antennis basi, genubus, tibiis tarsisque plus minusve testaceis; fronte evidenter alutacea, crebre subrugoso-punctata, tuberculis facialibus postice subdepressis th minus discretis; prothonace nitidulo, linea media "blreviata et utrinque foreula fuscu vel nigna impresso, sat crebre fortiter punctato; elytris nitilulis, sat crebre fortiter punctatis. - Long. 4-6 mm. II as: segmentis rentrulibus 2-4 medio longe pilosis, tarsis praesertim posticis articulo primo dilatato.

Linn. Syst. Nat. ed. X. 376. - Ratzeb. Forstins. I. 244. t 20. f. 5 (Chrysomela). - Scop. Ent. Carn. 83 (Tenebrio). Oliv. Ent. VI. 638. t. 1. f. 4. - Duft. Faun. Austr. II. 221 (Galleruca). - Thoms. Skand. Col. VIII. 151 (Galenuca). — Schrank Faun. boic. 557. - Küst. Käf. Eur. 1. 67. Redtb. Faun. A. II.487. - Seidl. F. balt. 491 (Adimonia). Adimonia polygonata Laich. Verz. Tyrol. Ins. I. 193.

Var. a. Prothorace elytrisque sordide brunneis.

Var. b. scutellata: Prothosace elytrisque saturate rufo-ochraceis, antennis fere totis pedibusque plerumque nigris.

- Adimonia scutellata Chevrl. Rev. zool. 1840. 17. - Joann. Mon. 75.

Var. c. luctuosa: Piothorace testaceo-flaro, plerumque brunneo rel nigromaculato, elytris plus minusve nigris. 


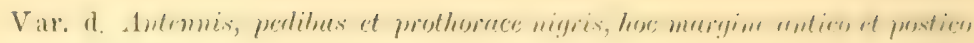
flavescente.

Var. e. pallidipennis: Ut in b, sed prothorace toto nigro.

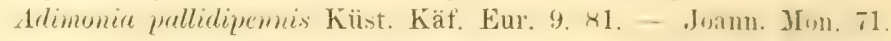

Länglich-foifömign, mässieg gewijlht. schwar\%. Halsschilıt 1111 Flizgeldecken blass brïunliclogelb. Kopf klein, tivf sclawa\%. mit röthlichen Mandibehn, wie das Halsschild zerstrout und selu frin behaart, zwischen den Fïhlern mit einer seichten Isängrsinne. di. sich darüber meist grubenförnig erweitert und restioft nud ant des. dicht, schwach-runzelig punktirten Stirn allmählich verflacht his \%un Scheitel hinzieht. Die Stirnhöcker sind ziemlich klein. qurr, etwas feiner gewirkt als die matte Stim. welten ganz gratt, im linteren Theile niedergedrückt und schlecht begrenzt. Fiihler so lang if oder lünger ( $\hat{o})$ als der halbe Körper. Glied 3 über doppelt so lang als 2 , die ersten vier oder fiinf Crliefler röthlichgelh, dlas erste olbenseits schwärzlich. die folgenden nicht selten mit angedunkelter Sritze. Halsschild fast nu halb so lang als hreit, vorn ziemlich grarle abgeschnitten. schmaler als hinten, die seiten in der Mitte winkelig erweitert; oben wenig gewölbt, schwach glänzend, mässig dicht. stark und tief punktirt, meben, mit einer heiderseits abgekiuzten. oft unterbrochenen und rorn grubig erweiterten Wittelrinne und einer ziemlich weiten Langsgrube jederseits, welche nach der Masis hin in einen seichten Eindruck ibergeht. Die vertietten stellen des Halsschildes sind gebräunt oder schwarz. schildchen kaum sichtbar gewirkt, glänzend, vorn sparsam beharrt, an den Rändern dicht gewimpert, länglich dreieckig, an der spitze abgermulet, schwarz, oder hinten in verschiedener Ausdehnung rïthlichgelb. hier auch bisweilen mit kurzer, feiner Längsrinne. Flügeldecken an der Basis etwas breiter als der Grund des Halsschildes, mit abgerundeten Schulterecken, nach hinten sanft verbreitert. gleichmässign ziemlich dicht, stark und tief punktirt, die sichulterbeule fast glatt. hoch, innen deutlich begrenzt, ein schmaler Naht- und seitensaum verdickt und dadurch etwas erhöht. Unterseite schwary, fein punktirt und behaart, die Spitze der Schenkel, die Schienen und Tarsen wenig lebhaft bräunlichgelh, häutig̨ sind die Tarsen sowie die Innenseite der Schienen dunkel.

Das Mämmchen besitzt in der Mitte des zweiten bis vierten Bauchringes lange, aufrechte Härchen, dic auf dem zweiten und dritten Ringe etwas zahlreicher und biischelförmig zusammengeneigt sind; ausserdem ist das erste Tarsenglied merklich erweitert.

Der Penis ist etwas länger als der Hinterleib, bis zur unsymmetrischen Spitze allmählich schwach verbreitert, kurz ror der spitze ist die linke Seite ausgebuchtet, die rechte tritt als ein grosser, bogen- 
fömmig begrenztej Lappen nach aussen, so dass die kurce, schmal dreieckige, gerimnte Endspitze mach links grerichtet ist. Ant der sehr grossen Oeffinmog liegt eine schmale, gebogene, scharf' zugespitzte Klappe. welche sich vom in die Rimme der Endspitze legt. Ausserdem ist der schiefe Vorderrand anf der rechten Seite noch mit einem aufstehenden, etwas nach aussen gelogenen Homhaken versehen.

In der Fïhumg kommen hauptsïchlich fünf Abänderungen vor: a. Halsschild und Flügeldecken sind schmutzign gelbbraun, bei lebenden Stücken (mit Ausnahme der helleren Ränder) lebhaft rostroth angelaufen.

h. Tief schwarz, Halsschild und Flügeliecken lebhaft und gesättigt riithlich-ockergelb, das erste Fiihlerglied an der Spitze, einige der folgenden Glieder an der Basis röthlich, nach Joannis auch der Grund der Schienen.

‘. Halsschild einfarbig bräunlich-gelb oder in den Vertiefungen braun bis schwarz, Flügeldecken mehr oder weniger schwarz, hald jede einzelne auf der sicheibe, bald beide mit einer grossen. gemeinschaftlichen Makel.

d. Fühler, Beine und die Scheibe des Halsschildes schwarz, so dass aut letzterem nur ein Saum am Vorder- und Hinterrande bräunlich-gelb bleibt.

↔. Körper tief schwarz. Mandibeln röthlich, Flügeldecken hell bräunlich-gelb.

In Bezug auf die Skulptur verdienen noch solche Exemplare einer besonderen Erwähnung, bei denen das vordere Drittel des Halsschildes und die Mitte der Sicheibe fast glatt oder nur mit verdinzelnen Punkten besetzt ist; sie sind ron suturatis am leichtesten durch die schwarzen Wangen zu trennen.

Von Mai bis Juli auf Weiden, namentlich Sal. craprer I. nicht selten, in Norddeutschland auf Birken in Torfsimpfen häufig. Gauz Europa. Asien bis Japan. Die auffallige Var. e ist bisher nur aus der T'ürkei und aus dem Kankasus (Leder) bekannt, die Var. b. clie der cratregi recht ähnlich gefärbt ist, findet sich im nördlichen Spanien, hauptsächlich in der Provinz Galicien.

2. L. suturalis: Oblonga, concexiusculu, nigra, prothoiace elytrisque testacen-flaris, yenis, antennis basi, genubus tibiisque plus minusve testraceis; firmte sultilissime alutaceu, parce punctata, tuberallis facialibus politis, postice bene discretis, prothorace nitido, linea media ablreviata t utrinque foreola fuscu rel nigra impresso, parce punctato, elytris sat nitidis, crebre minus fortiter punctatis, suturn plerumque infuscata. Long. 5--6 mm. 
Thoms. Skand. Col. VIII. 151. - Seidl. F. balt. thl (Galerucra)

- Kraatz Berl. Zeit. 1867. 386. - Redtb. F. Austr. II. 488 (Adimonia).

Galleruca caprese Gyllh. Ins. Sinec. III. 504. - Joann. JIon. Tx (Adimon.).

Var. a. Prothorace elytrisque fusco-brunneis.

Var. b. Prothorace maculis is nigerrimis, aut liberis aut in fresciom nndulatam transversam comatis.

Var. c. nigrita: Nigra, gemubus marginituesque prothoprecis pteremene. testaceis.

Wer vorigen sehr nahe verwandt, beinahe von gleicher Forn und Eärbung, aber in der Grösse weniger variirend. An Kopte sind ausser den Mandibeln noch der Vorderrand des Kopfschiliten (oder dieses ganz) und die Seiten vor den Angen. ron der Fühlerwurel an nach aussen rïthlichgelb, die Stirn ist mässig dicht. aber kaum runzelig punktirt, eine spur glänzender, ihre Mittelrinn hinter den ziemlich grossen, glatten, scharf begrenzten Schwielen weniger grubenförmig erweitert und rertieft; die Fühler schlanker. ihr erstes Glied bedeutend länger. Das Halsschild ist glänzender. besonders in der vorderen Hälfte sparsamer punktirt, dagegen sind die Punkte der Fliigeldecken kaum halb so gross und tief, aber viel mehr zusammengedrängt als bei caprene: die Naht der Flügeldecken ist auf der inneren Fläche in der Regel gehräunt.

Beim Männchen ist das erste Tarsenglied namentlich an den Hinterbeinen stark erweitert, die Haarbiischel des zweiten und dritten Bauchringes sind ziemlich gross und dicht. - Der Penis ist am Ende (Seitenansicht) wie die Kufe eines Schlittens aufgebogen, so dass hier auf der Unterseite eine tiefe Aushöhlung entsteht, vorn mit scharfen Ecken schief abgestutzt. In der linken Ecke liegt die Rinne füir den Ductus, die ganze Spitze ist weniger unsymmetrisch als bei camreae, die linke Seite derselben ist niedrig, die rechte hoch.

Wie bei der vorigen kommen anch bei dieser Art nicht selten Stücke vor (Var. a), welche auf Halssch. und Fld. statt der normalen bräunlichgelben, eine mehr oder weniger röthlichbraune, in Lehen beinahe rostrothe Grundfarbe besitzen; letztere wird allmählich durch Schwarz verdrängt, indem zunächst (Var. b) die drei in einer Querreihe vor der Mitte des Halssch. stehenden, tief schwarzen. aber selten scharf begrenzten Makeln zu einer Querbinde mit welligen Rändern vereint, später (Var.c) die scheibe des Halssch. bis dicht an die Ränder und die Fld. gänzlich daron iiberzogen werden. an den Beinen bleibt gewöhnlich die spitze der schenkel und die Basis der Schienen, wenigstens aber die letztere, röthlich-gelbbraun. An Sumpfpflanzen, auch auf Birken und Weiden in simpten 
durch ganz Europa verbreitet, in Dentschland noch häufiger als die vorige Art. Sie ist in der zweiten Hillte des Juli entwickelt.

Da Gyllenhal a. a. O. die Flïgeldecken seiner cumere: confertissime rage punctata, sutura calloque (?) humerali plerumque brunneis nennt. so lässt sich seine Beschreibung und die nur mit unwesentlichen Zuthaten versehene Uebersetzung derselben ron Joannis 1. c. mit Sicherheit auf die vorliegende Art beziehen.

\section{B. Halsschild mit gerundeten Seiten.}

3. L. crataegi: Breviter-oblonga, convexa, supra sanguinea, fortiter sulmugoso-punctata, subtus (ano excepto) nigra; prothorace linea media postice ablneviuta foreolaque utrinque impresso, lateribus rotunduto, elytris pone basin leviter transversim depressis. - Long. 4-5 mm.

Mas: scutello et impressionibus prothoracis nigricantibus, elytris medio linealis 2 nigris abbreriatis, interiore parva, pedibus nigris, tibiis basi testaceis, posticis interne basin versus sinuatis, tarsis articulo mimo modice dilatato.

Femina: mothorace elytrisque immaculatis, pedibus rufis.

Forst. Nov. Spec. Ins. (1771) 28 (Chrys.). - Marsh. Ent. Brit. I. 228 (Crioceris).

Gallenea sanguinea Fabr. Syst. Ent. (1750) 119. - Oliv. Ent. VI

634. t. 3. f. 41. - Payk. Faun. Suec. II. 94. - Gyllh. Ins.

Suec. III. 505 (우). - Duft. Faun. A. III. 222 (오), - Joann.

Mon. 76 (q). - Thoms. Skand. Col. VIII. 150 (Galeruca). -

Rossi Faun. Etr. I. 105 (Crioc.) - Küst. Käf. Eur. 1. 66

(亏ै). - Kraatz Berl. ent. Zeitschr. 1867.387. - Redtb. Faun.

A. II. 487. - Seidl. F. balt. 491 (Adimonia).

Galleruca tibialis Duft. 1. c. 224 ઈิ.

", femoralis Duft. 1. c. $225 \hat{\jmath}$.

? " pallida Joann. 1. c. $77 \hat{o}$.

Var. a. ô Prothorace elytrisque immaculatis, scutello rufo.

Var. b. ô Capite, prothorace pedibusque fere totis nigris.

Galleruca binotata Duft. 1. c. 222.

Var. c. 우 Prothorace nigro-maculato, scutello nigricante.

Galleruca crataegi Duft. 1. c. 223.

Var.d. ㅇ Elytro singulo lineolis 2 ablreviatis nigris.

Bedeutend kürzer und gewölbter als die rorigen Arten, durch kurze Fühler und Tarsen, das ganz behaarte schildchen und die Bildung des Halssch, sehr abweichend; oben blutroth oder ziegelroth, dicht, stark und tief, etwas runzelig punktirt, unten schwarz, fein punktirt, der letzte Bauchring ganz. oder in der Mitte, und der vierte, oft auch noch der dritte hing in der mittleren Hälte roth. Die Stirn mit wenig tiefer, auf dem Scheitel erlïschender Mittel- 


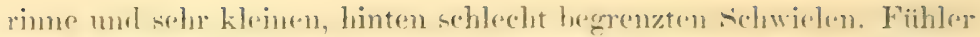

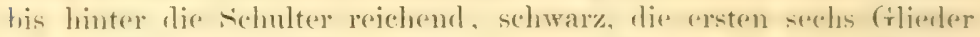
an der basis heim $f$ in grisserer Auzdelmung als bein jorthhranu, Glied :3 etwas länger (f), orlex doppelt su lang ij als 2. Halsscl. kurz, stark quer. an rlen seiten kam winkeligr. sourkern gerundet erweitert. eine weite Grule jedersents anf dex sicheibe und eine Mittelrime in der vorleren Hältte schwach rerticeft. Fld. ungrefahe im ersten Viertel an der Naht mit einem gemeinschattichen schwachen Quereindrucke, welcher die Wuzclgenend zwischen der Taht und der Vertiefung an der Imnenseite des schulterhückers sanft emporhebt.

Das Männchen ist kürzer, ohen in ler Regrel dunkler roth frefärbt als das Weibchen, die Eindrïcke des Halssch, das Schildchen, zwei Striche anf jeder Fld. (der innere kur, makeltïmig, in änsseren Ende des gemeinschaftlichen Quereindruckes. der äussere lang, hinter der Schulter, das mittlere Drittel der Länge einnehmend) und die Beine schwar, mit röthlicher Basis der schienen. Das erste Tarsenglied ist breiter als beim Weibchen, und die Hinterschienen sind an der Innenseite vor der spitze ausgeschweift. wodurch sie stärker gebogen erscheinen. wie bei den anderen Arten. - Der Penis ist so lang als der Hinterleib, sehr schlank, in vorderen Viertel und an der Spitze sanft gerundet erweitert, zuletzt so rerengt, dass er der Spitze einer herzförmigen Figur ähnlich ist. Beim ₹ sind Halssch., Schildchen Fld. und Beine einfarbig roth.

Die geringfügigen Farbenvarietäten richten sich nach dem Geschlechte. Zwei betreffen das Mämnchen, nämlich a. Schildchen roth, Halssch. und Fld. einfarbig, b. Kopt, Halssch. (mit Ausnahme ron einem Querflecke jederseits an der Basis) und Beine fast ganz schwarz; zwei das Weibchen: c. Halssch. nit dumklen Makeln, schildehen dunkel, oder d. Fld. wenigstens mit dem äusseren, oft auch noch mit dem inmeren schwarzen striche des $\hat{o}$. Bei dieser Abänderung kamn das Halssch. eine dunkle Mittelstrieme und noch einige dunkle Makehn besitzen, oder das Schildchen dunkel sein.

Auf Gebischen, namentlich bliihendem ('ratruens I Mespitus), in dessen Fruchtknoten die Larve lebt, nicht selten.

\section{Gralerncella.}

Croteh, Proe. Ac. Philad. 1873. p. 5̆.

Corpus dense pubescens. Acetabula antica aperta.

Tibiue margine exteriore glatsue, "ysice muticue, unguiculi ant dente parvo acuto instructi aut bifidi. 
Kïrper lainglich his lang-oval, dicht mit sehr kurzen and feinen anliegenden Härehen hekleidet. Kopt ziemlich his zum Iinterande

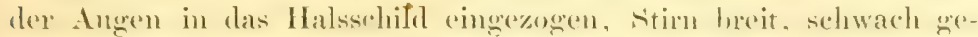

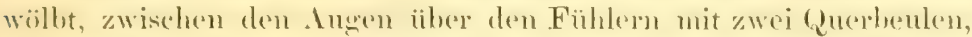
welehe oben chreh rine gade, oder aus zwei schwachen bogen bestehende Rime heerenzt und dureh eine auf dem Koptischilde hegimnende, zwischen der Fïhlerwurzel nund den Benden stärker vertiefte and bis zum seleitel allmählich verlïschende Mittelrime getremut werelen. Angen oval, an den seiten des Koptes fast grade herablanfend. so dass die Innemrinder riemlich parallel sind. nur mässig gewïlbt und vorspringend, fein gekörnt. Fiihler ungefähr von halber Kïrperlïnge oder wenig länger, ihre Basen von einander so writ wie von den Angen abstehend, dicht iiber der Linie eincefïigt, welche den Linterrand der Augen rerbinden wiirde. das Wruzelglied ist das stärkste, nach der Spitze hỉn allmählich verdickt. etwa dreimal so lang als breit; das zweite Glied ist das kiirzeste, ein Drittel so lang als das erste, Glied 3 etwa so lang als 1. die folgenden kürzer, unter sich ziemlich gleich lang, oder his ztm zehnten alluählich etwas an Länge abnehmend. das Endglied so lang oder fast so lang als Glied 3, zugespitzt. Kopfschild schmal. stumptirinkelig, nach rorn steil zu dem flachen Querstreiten abtallend, Oberlippe viereckig oder quer, gerundet-abgestutzt; Mandibehn kräftig, vierzähnig, der obere Zahn ist von der Oberlipe bedeckt, breit, stumpt, der folgende ist der längste und wie die beiden anderen, allmählich kürzer werdenden Zälno spitz. Maxillartaster kurz, das zweite und dritte Glied bei ribumi anfigetrieben, hei den übrigen Arten nur mässig dick, Fndglied kegeltömig zugespitzt; ähnlich sind auch die Lippentaster gebildet. Halsschild yu(2) viereckis, in der Nähe der Mitte am breitesten, die Seiten sermudet oder winkelig erweitert, der Torderand grade abseschinten, ler Hinterrand ror dem Schildeben und nahe den Hinterecken mehr oder weniger tief' bogenfömig ausgerandet, die Eckborsten stehen anf kleinen Kegeh. Die Obertlache ist wenig gewölbt, punktirt, mit einer Mittelrinne und einer Grube jederseits. Schilrlehen ziemlich gross, beinaho viereckig, nach hinten verengt, an der suitze ausgerandet, alogestutzt oder ahgerundet, meist der Länge nach eingedriickt. Flügeldecken an der Wruzel breiter als das Halsschild, hinter den schultern ziemlich sleich breit oler allmählich leicht erweitert, in letzten Viertel gerundet-verengt, jede einzelne an der Nahtecke abgermulet oder in eine kleme Spitze ausgezogen, die Obertärohe nurgelmässign punktirt. mit dentlicher Schulterbeule, einem oder zwei seichten Langsistreifen auf der iuneren Hälfte, zwischen denen dam die Naht und zwei Länoslinien leicht 
in die Höhe getholen werrlen, und einem tiefieren Länogseindrucke iiber dem etwas ausgebreiteten beitenrande. Vorderbrust zwirchen den zapfentrimiz voragenden Vorderhiiften in eine glejeh hohe, schmale fiante verlängert, an welche die seitenstücke mit ihrer Spyitze lange nicht heranreichen; sie fallen viehnehr hinter den Höften schell zu dem aufgehogenen, aber niedrigen liande der Gelenkhöhlen al, so dass diese hinten offen bleiben, ${ }^{\mathrm{i}}$ ) und die Hiiften sich an die Mittelbrust legen müssen. Diese ist kurz, ihr mittlerer Theil wenig breit, dann sind die Huiften noch deutlich getremnt, oder sehr sehmal. Der Hinterleib hat etwa die halbe Körperlänge. sein erster king ist etwas länger als einer der folgenden. Die Beine sind wenig stark, die schienen haben am Aussenrande einen mubhaarten Streifen, der mit zwei seichten Rimen versehen ist. und sind an der dicht uud fein beborsteten spitze unledornt; an den 'Tarsen ist bald das erste, bald das zweite Gilied am längsten, das dritte am breitesten, an der spitze eingeschnitten. mit zwei grossen, gerundeten Lappen. die Klauen haben einen kleinen, scharfen Zahn oder sind gespalten.

Beim Männchen ist der fünfte Bauchring etwas kürzer als beim Weibchen, am Hinterrande mehr oder weniger aufgebogen und in der Mitte desselben mit einer Grube besetzt, deren Ränder (mit Ausschluss des Hinterrandes) steil abtallen und dichter und länger als die übrigen 'Theile des Ringes behaart sind. Die Grube ist bei viburni ziemlich halbkreisförmig, bei den anderen Arten mehr dreieckig; an ihrer Stelle haben die Weibchen einen Ausschnitt oder eine Ausrandung. Ist der Hinterleib schwarz gefärbt, so erstreckt sich die gelbe Zeichnung der spitze beim $\hat{0}$ immer ither eine grössere Fläche als beim 우, wo sie in der Regel nur auf einen Saum am After beschränkt ist. - Der Penis ist sehr einfach gebaut, eine gerade oder nicht stark gebogene Röhre mit lang-ovaler Oeftuung. die bei einigen Arten schief zur Längsachse liegt; er ist fast gleich breit oder rerengt sich nach der abgerundeten, abgestutzten oder scharfen Spitze hin.

Die Galerucellen sind über die ganze Erde rerbreitet, jedoch hauptsächlich in Amerika zu Hause; es sind verschossen gefärlbte. oben einfarbige oder mit rerwaschenen braunen bis schwarzen (selten metallisch-grinen) Zeichnungen versehene 'Thiere, von denen bis jetzt ungefähr 40 Arten bekannt sind. ${ }^{2}$ ) sie leben stets in Menge bei einander auf Blättern, die sie unregehnässig durchlöchem;

1) Chapuis betrachtet die Höhlen (Genera XI. 1. 222) für geschlossen.

$\Rightarrow$ Der Mïnchener Katalog zählt allerdings l: Arten auf. dieselben gehören aber mehreren Gattungen an. 
einige Arten finden ihre Nahrung in einer bestimmten P'flanzengattung, z. B. riburni in den Viburnum-Arten, andere lelen an Gewächsen ans den verschiedensten Familien, \%. 13. mymphacue an Nymphaeaceen, Potameen, P'olygoneen, ()enothereen ('T'rapa) und Hydrocharideen. Man findet ihre stark gerundeten Fier in Mai bis in den Juni an der Lnterseite der durch den Frass kenntich gemachten Blätter in Häufchen bis zu 20 stiick angekleht, ${ }^{1}$ ) die Larven sind Anfang Juli ausgewachsen, in der zweiten IIälfte desselben erscheinen schon die Käfer.

Die Larven dex Gal. mmphacae, ron Degeer (Mem. V. 405. t. 10. f. 3-6) und Westwood (Introd. I. 382. f. 46) bekannt gemacht. ist nach meinen Beobachtungen $9 \mathrm{~mm}$. lang, oberseits schwarz, Oberlippe, Kopt'schild, Vorderrand der Stim und eine feine Querlinie über demselben, welche fast die Gestalt einer Klammer hat, eine Mittellinie der 'Thoraxringe und die Nähte der iibrigen Ringe nebst der ganzen Unterseite dottergelb. Maxillartaster gross, konisch, Glied 1 lang und dick, 2 eben so stark, aber kurz, beide gelb, 3 so lang als 2, aber nur halb so dick und wie das vierte, eine kleine Spitze vorstellende Glied dunkel gefärbt. Fühler klein, viergliederig, konisch, hinter ihnen je eine Ocelle. Die Abdominalringe an dex Seite mit schwachen Tuberkeln. Setzt man die Larven mit den Seerosenblättern, auf' denen sie fressen, in den letzten Tagen des Juni in ein Gefäss mit Wasser, so bemerkt man, dass sie sich nach kurzer Zeit vom Blatte entfernen und, frei im Wasser schwimmend, zur Puppe verwandeln. Es platzt ihnen die Haut auf dem Kopfe und den drei Brustringen in der Mitte der Länge nach auf, und aus den Spalte drängt sich unter zuckenden Bewegungen die dottergelbe, $6 \mathrm{~mm}$. lange und $33 \mathrm{~mm}$. breite Puppe, die sich im Terlauf einiger Stunden tief schwarz färbt; nur die Brust und der bleiben etwas gelblich, die Hinterleibssegmente besitzen an den Seiten einige lange, schwärzliche Borsten In 8 bis 9 Tagen schliuptt der Käfer aus.

Ueber die Verwüstungen, die $\boldsymbol{r}_{\text {r. }}$ xunthomelaena an den Ulmen im Parke ron Laxenburg verursachte, berichtet Leineweber in den Verh. d. zool. hot. Ges. Wien 1856 p. 74 und 1858 p. 29. Die Eier sassen an der Unterseite der Blätter oft zu 3 bis 5 Häufchen dicht neben einander; die Larven hatten Mitte Juni alle Blätter skeletirt,

1) Eine sehr befremdliche IIittheilung macht Ratzeburg (Forstins. 2. Aufl. p. 244), worach die Gr. riburni, nach einer Beobachtung Hartig's, ihre Eier zur Ueberwinterung in Löcher legen soll, welche sie im Herbste in die jumgen Triebe des Schneeballes frisst und znletzt mit den Nagespähnchen verkleht. 


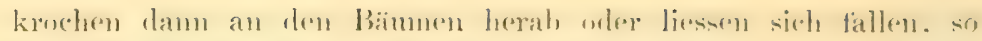

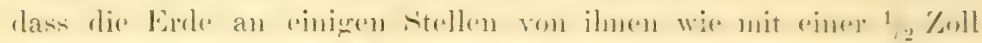

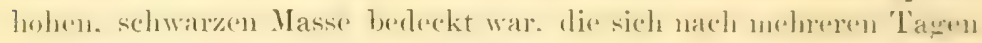

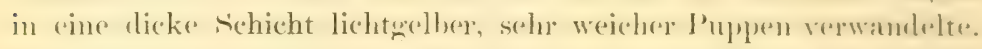
Fon den eleen entwiekelten Kiffern wurlen dive Bläter des zweiten Triebes zerfressen. Eine eingehende Beschreibung der Entwicklung griebt Heeger (sitzungstore. Wien. Ac. 185s. 100\%, t. 5).

Die Larven von $G$. viburni und lineola sind einander sehr :Hholich, hell gefärbt. nit dunklen T'uberkeln. Erstere, won Bouché Nat. Ins. 1834 p. 205), Kawall (Corresp. nat. Ver. Riga 18.53 p. 601 und Kaltenbach (Pflanzenfeintle p. 299) heschrieluen, ist wenigr iiber 8 mm. lang, vorn etwas mehr als hinten verengt, gellhichweiss, dej kleine Kopft. mit Ansnahme Res Mundes und einer klanmerfïmigen Querlinie der Stim, das Analsegment und die Beine schwar\%. Stirn durch eine Mittelrime in zwei leicht gewiollote Hälften getheilt, auf jeder eine Ocelle dicht ïher den Fühler, ron ó Borstenkïrnchen ungeben; Prothorax etwas breiter als der Kont: dunkel. die Ränder md eine Mittellinie hell, ein weiter Eindruck jederseits groh punktirt, die gerumdeten Seiten mit Borsten besetzt. Im den folgenden 10 Leibesringen hat jeder zwei Qnerreihen ron 4 bis 5 schwarzen Tuberkeln, nämlich eine breite, strichförmige Mitteltuberkel aut dem Meso- und Metathorax durch eine helle Mittellinie hallirt) und eine (beide Brustringe) oder zwei punktfïrmige reitentuberkeln, ansserdem ist eine grosse, sichelförmige Beule an den seiten der beiden 'Thoraxringe und der sehwach zitzenförmig ansgezugene mittlere Theil jedes Bauchringes schwarz und mit 1. 2 oder 3 dumklen Börstchen besetzt. Auf der Lnterseite lat jedes Bauchsegment nahe dem Vorderrande eine schwarze Quermakel und hinter dieser vier kleinere Makeln, die mittelsten punktförmig, die seitlichen länglich.

Die anf Weiden, Erlen und Haselstauden üherall gremeine Larve der lineoln unterseheidet sich wesentlich durch den grösseren Kopf. mit gleichmässig gewöll,ter stim, und die viel hreiteren, überhaupt grösseren Thoraxringe, welche nicht, wie bei vilumi sehmaler, sondern breiter sind als die Bauchringe; letztere nehmen nach hinten allmählich an Breite etwas ab. sind an der seite spitz und scharf zitzenförmig ansgezogen und besitzen kleinere. meln' zusanmengedrängte Tuberkeln.

Anch die Larve von $G$. calmariensis $L$. scheint nach der Beschreihung von Comelins (Atett. ent. Zeit. 18tiz. 21:3) ähnlich geebaut und gezeichnet zu sein. 


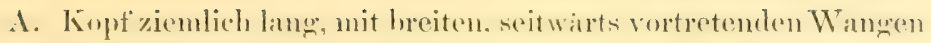
und starke'n, langen Mamlibeln. Sichenkel verhaltnissmaissien stark, die beiden hinteren otwas dicker als die äbrigen. sul,genus Pyrrhalta Joannis. Trirrhabda Auctor.

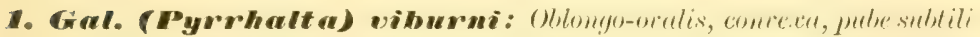
anero-grisen densisime restitu, crebre subtilissimeque punctutu, suboprea,

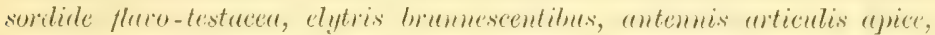

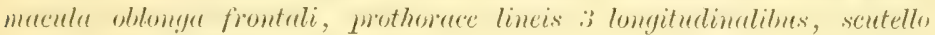
callorque hemereli elytrorum nigris, suture "price rotumdate. - Long. $4,5-6,5 \mathrm{~mm}$.

I as: segmento 5:0 ventrali profunde semicirculariter impresso.

Femina: segmento ultimo ventrali leviter canaliculato apice subtriangulariter. emarginato.

Payk. Faun. Suec. II. 89. - Gyllh. Ins. Suec. III. 507. Duft. Faum. A. III. 226. - Joann. Mon. 82 (Galleruca). Marsh. Ent. Brit. I. 224 (Crioceris). - Thoms. Skand. Col. VIII. 153. - Redtb. Faun. A. II. 488. - s'eidl. F. balt. 491 (Galeruca).

Var.a. Elytris leviter viridi-micantibus.

Var. b. Elytris vitta nigra submarginali postice abbreviata.

Etwas breiter, zugleich höher gewölbt, oben viel dichter und feiner punktirt und behaart, unterseits heller gefärbt als eine der tolgenden Arten. Länglich-eiförmig; schmutzig hellgelb mit bräunlicher Beimischung, die Fld. stärker gebräunt, die sipitze der einzeluen Fühlerglieder, eine längliche Stirmmakel, die Mittellinie und die seiten des Halssch., das Schildchen und der Schulterhöcker der Fld. schwärzlich. Die Oberseite ziemlich matt seidenglänzend, sehr dicht mit zarten und langen goldgelblich schimmernden Härchen besetzt, die nur über dem Seitenrande und auf einer kleinen Stelle der Scheibe ror dem Abfalle zur spitze so nach hinten gerichtet sind, wie bei den ibrigen Arten, sonst eine schiefe Richtung nach aussen und hinten besitzen. Unterseite sparsamer behaart, glänzender. Kopf gross, in den etwas gewölbten Augen so breit als das Halssch. am Vorderrande, unterhalb der Augen kaum verschnälert, mit einer kurzen Mittelrime zwischen den flachen, schlecht begrenzten Stirnhöckern; Wangen und Unterkopf tast glatt, die grosse, ebene Stim dicht, sehr fein punktirt. Fïhler die Mitte der Fld. erreichend ( $q$ ) oder iberragend $(\hat{o})$, Glied 1 ziemlich dick, 2 kur. 3 doplelt so lang als dieses und etwas länger als 1, die folgenden Glieder etwas kürzer, wenig nder kaum an Länge abnehmend. Halssch. quer viereckig, doppelt so breit als lang, nur an den in der Mitte leicht winkelig erweiterten seiten undeutlich serandet, die vorderen Borstenkegel gross. weit vorstehend, die hinteren klein, die Ober- 


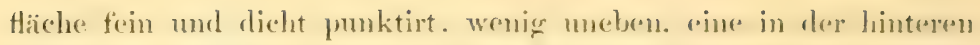

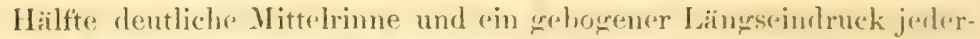
seits schwach vertieft. Fld. sehr dicht und fein, fast runzelig jumktirt. am Nahtwinkel rollkommen aberemete mit einer leichten V'ertirefung. fie von der schulter schräg nach hinten und immen zieht und riner schwach aufgetriehenen, breiten Langslinie hinter der Witte, der Naht näher als dem Scitenrande. Ine Epipleuren sind breit, scharf gerandet, verengen sich von dex Mitte ab alhnählich und endigen ein Stück vor der Sjutze, wo sich die innere Randlinie init der äusseren vereinigt.

Beim Männchen hat der letzte Bauchring eine bis zum Vorlerrande reichende, tiefe, halbkreisförmige Grube, deren Vorder- und Seitenrand senkrecht abfällt, der tiefliegende Hinterrand ist in der Witte schwach bogig ansgeschnitten. - Penis mässig breit, rorm allmählich gerundet-rerengt, mit einer schmalen, leicht abgestutzten Spitze. Das letzte Segment des Weibchens ist mit einer feinen Mittelrinne versehen, in der Mitte am schmalsten, jederseits davon bildet der Hinterrand einen flachen Bogen und reicht lange nicht an die Afterdecke, so dass ein Querschlitz offen bleibt. aus dem eine grosse und besonders breite, zungenförmige Platte hervortritt, deren Hinterrand in ler Mitte leicht ausgeschnitten ist.

Bisweilen sind die Fld. sehr dunkel und schimmern wrinlich (Var. a), oder sie besitzen eine schmale. schwarze Längsbinde dicht iber dem breiten Seitenrande, von der schulter bis hinter die Mitte (Var. b).

Auf dem Schmeeball, Viburnum opulus, in Nort- und besonders Mitteleuropa häufig, in den Alpen auch auf Tib. lantana, in Sïdeuropa zuweilen auf Lorbeergesträuch (vielleicht Til. tinus I..?, Dieck, Berl. ent. Zeit. 1870. 150.)

Die vorliegende Art wird von Horn zu der amerikanischen Gattung Trimhabda gebracht, ist aber davon nicht nur habituell, sondern anch durch die offenen vorderen Hüftpfamnen durchaus verschieden.

B. Kopf kurz, mit schmalen, vertieften Wangen und ziemlich kurzen Mandibeln. Schenkel wenig stark. Galerneclla in sper.

a. Epipleuren abgekürzt, ihre innere Randlinie ist bis zum Ende scharf und rerbindet sich ein stiick ror der spitze mit der äusseren.

* Spitzenrand der Fld. ausgebuchtet, so dass der Nahtwinkel in eine Spitze ausgezogen erscheint. Mittelhüiten deutlich getrennt.

2. Gal. nymphaeae: Oblonga, leviter contexa, nigra, capite antice, prothorace (maculis 2 vel 3 exceptis), elytrorum limbo laterali pedibusque. 
rufo-testaceis, femoribus interdum infuscutis; mothorace basi enidenter. marginato utrimaue simuto, lateribus pone medium simuato-angustato, supra fere laeri, nitido, foreis ¿ latis subrugoso-punctatis et parce pubescentilus impresso; elytris subtiliter griseo-pubescentilus, crelne sat fortiter punctutis, lexiter transuersim biimpressis, singulo lineis \& lomgitulinalibus subconvexis, interdum testaceis. - Long. 6-8 mm.

Linn. Syst Nat. ed. X. 376 (Chrysom:) - Marsh. Ent. Brit.

I. 224 (Crioceris). - Oliv. Ent. VI. 643. t. 3.f. 31. - Payk.

Faun. Suec. II. 92. - Gryllh. Ins. Suec. IIT. 509. - Duft.

Faun. A. III. 227. - Küst. Käf. Eur. 3. 77. - Joann.

Mon. 86 (Galleruca). - Thoms. Skand. Col. VIII. 156. -

Redtb. Faun. A. II. 489. - Seidl. F. balt. 491 (Galemuca).

Var. a. aquatica: Minor, elytris griseo-testaceis, margine flavescentibus, angulo suturali acuto plerumque minus prominulo.

Fourer. Ent. Par. I. 103.

Gallenuca sagittariae Joann. MLon. 92. - Thoms. 1. c. 157. - Redtb.

1. e. 489. - Bach Käferf. III. 133.

Eine unserer grössten Arten, durch das in der Mitte fast spiegelglatte Halssch. und die etwas unebenen, am Nahtwinkel in eine Spitze ausgezogenen Fld. leicht kenntlich. Länglich elliptisch, hinten etwas breiter als vorn, ziemlich flach, schwarz, der Vorderkopf, die erhöhten Stellen des Halssch., ein Saum am Seitenrande der Fld., die Seiten der Vorderbrust, After und Beine dunkelröthlich-gelbbraun, Schenkel und Knie zuweilen angedunkelt. Kopt mässig gross, mit einer tiefen Mittelrinne zwischen den Fiihlern und den glänzenden, länglichen, wenig gewölbten Stirnbeulen; Stirn dicht und fein punktirt und behaart, matt, ein schwacher Mittelkiel meist angedeutet. Fühler ungefähr das erste Viertel der Fld. erreichend, die einzelnen Glieder am Grunde mehr oder weniger röthlich, nur die letzten Glieder einfarbig schwarz, Glied 3 etwa so lang als das erste, die folgenden nelımen allmählich an Länge ab. Halssch. überall, doch vorn am schwächsten gerandet, die Seiten von der Vorderecke bis vor die Mitte fast gradlinig erweitert, dahinter buchtig, bald bogenförmig, bald winkelig verengt, der Hinterrand in den Ecken jederseits tief ausgerandet, so dass die hinteren Borstenkegel ein Stück vor der Basis der Fld. stehen. Die Oberfläche ist uneben, beinahe spiegelglatt, nur zwei grosse und tiefe Quergruben sind dicht und stark, fast runzelig punktirt, sparsam behaart und ziemlich matt. Beide Gruben werden durch einen breiten Mittelstreifen des Halssch., der aus zwei hinter einander liegenden seichten Eindrücken besteht, getremnt, liegen dem Vorderrande viel näher als der Basis und reichen anssen bis an die Randlinie. Fld. fast gleich breit, hinten gemeinschaftlich abgerundet. aber jede an der Naht in eine kurze, dreieckige, scharfe Spitze 


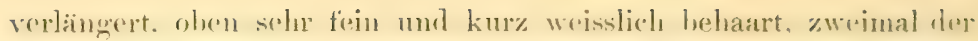

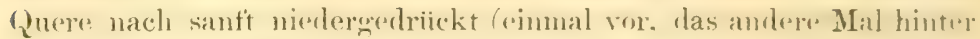
der Mitt(2), ziemlich stark ungleichuässign punktirt, nämlich ant dem vorleren umd imeren 'Thrile jeder Fld. weitläufiger und stäkre als nach den seiten und der spitze zu. Jerle Fld. hat zwoi schwarh

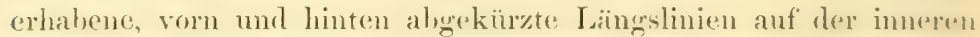
Hälfte, die Epripleuren sind zienlich hreit, wach hinten nur schwach verengt. L'nterseite sehr dicht, fein, querrunzelig punktirt, weisslich seidenschimmernd behart.

Das Mänmchen lässt sich durch die hreitere und tiefere dreieckige Grube am Hinterrande des fünften Bauchringes nicht immer sicher vom Weibchen tremen. - Der Penis ist schlank, nach rorn unmerklich verbreitert und am Ende wieder ganz allmählich in eine scharfe Spitze verschmälert.

Bei frischen Atiicken sind die Fld. einfarbig schmutzig gelhhraun, es färbt sich zuerst die Schulterbeule. spüter geht auch die Scheibe alhuählich durch rothbraun und pechbraun in ein nicht tiefes schwarz iiber, wobei die beiden erhabenen Längslinien jecler Fld., besonders die ïussere, noch lange gelblich bleiben. Eine kleine Form (Var. a), bei welcher der Nahtwinkel of nu in eine sehr kurze, unscheimbare sipitze vorgezogen ist, behält gewöhnlich gelbe bis rothbräunliche, an den Seiten hellere Fld.

Aut den schwimmenden Blättern von TVasserpflanzen, besonder: auf Nymphace und Niuhar-Arten, häufig, anch an Lfergewächsen an Gräben, Flüssen und Seen.

** Spitzenrand der Fld. ohne Ausbuchtung, Nahtwinkel ahgerundet, Mittelhüften fast zusammenstossend.

3. Cal. sagittariae: Oblongu, comieriuscula, obsure fluiv-testucu. antennis (basi pleramque excepto), macula firont is et prothoracis, scutello. pectore abdomineque nigris; prothorace basi evidenter marginato utrinum. simuato, lateribus pone medium fortiter simuato-angustuto, fere lieri, nitido, foreis : latis, profundis, fortiter subruguso munctutis at evidenter pubescentilus instructo, elytris sat dense griseo-puluescentilus, crelure punctutis, singulo lineis z subconereis obsoletissimis, ungulo suturali rotundato. - Long. $4-5 \mathrm{~mm}$.

Mas: segmento 5: o ventiali profunde triangulariter impresso.

Femina: segmento ultimo ventrali apice minus profunde inciso. Gyllh. Ins. Suec. III. 511.

Var. a. grisescens: Prothoracis disco pedibusque nigris.

Joann. Mon. 98.

ben hellen stäcken ron (i. calmuriensis bei obertä̈chlicher betrachtumg ähnlicher als der vorigen Art. jedoch nur mit dieser 
arhe verwandt und von ihr hauptsächlich in folgenden Punkten verschieden: Kaum halb so gross, schlanker, hinten stärker abgerundet, oberseits ziemlich einfartog schmutzig gelbbram, oder nur die Scheibe der Fld. durch eine röthliche Beimischung stärker gebräunt als die Ränder und die ganze spitze. Fithler dunkler gefärbt und viel schlanker, die letzten Glieder weniger verkiirzt, das erste Glied unterseits und einige der folgenden Glieder nur an der Basis röthlich. Die Stimhöcker sind kürzer und gerundeter, hinten fiefer begrenzt, ziemlich gewölbt, Stirn mit mässig grosser schwärzlicher Makel, etwas weitläufiger punktirt, weniger matt. Halssch. schmaler, die beiden Gruben auf der Scheibe tiefer, stärker punktirt und dichter behaart, auch weniger quer, sondern mehr länglich-oval, der sie trennende glatte Mittelstreifen ist in der Mitte seln stark verengt, die hinteren Borstenkegel sind noch weiter nach vorn gerückt. Auf den Fld. ist höchstens der hintere Quereindruck ror dem Abfalle zur Spitze angedentet, die beiden abgekürzten, erhabenen Iängslinien sind nur wenig bemerkbar, die Punktirung ist durchgängig dichter und feiner, die Behaarung etwas länger, heller und viel gedrängter, der Nahtwinkel endlich vollkommen abgerundet, also weder spitz-, noch rechtwinkelig, die Mittelhüften berühren sich beinahe.

Das Männchen hat eine tiefe, dreieckige Grube auf dem letzten Bauchringe, welche ziemlich bis zum Vorderrande reicht, das Weibchen mur einen kleinen, kurzen Ausschnitt. - Der Penis ist in der vorderen Hälfte allmählich geradlinig verschmälert.

Nicht immer ist das Halsseh. einfarbig, sondern öfter auf dem breiten glatten Mittelstreifen sowie in den Gruben, selten auf der ganzen Scheibe schwärzlich, mit hellen Rändern; auch die Fühler werden einfarbig schwarz, dann ist an den Beinen die Aussenhältte der Schenkel oder noch ein Theil der Schienen angedunkelt; die Var. a ist nach einem dunklen, schwarzbeinigen Stücke von Sicilien beschrieben.

Im Frühlinge und im August auf Sumpfpflanzen, hauptsächlich Iysimachia vulgaris $I$. nicht selten, im sommer zuweilen auch auf Hydrocharis morsus rance $I_{\text {..; }}$ vereinzelt in Südeuropa.

Sieht man von der Angabe bei Gyllenhal: ,Elytra apice minus rcuminatu" ab, die noch eine Zuspitzung des Nahtwinkels vorauszusetzen scheint, aber insofern ron geringer Berleutung ist, als Gyllh, bei den übrigen Arten, ausser nymphaeac, lie Nahtbildung nicht bericksichtigte, so passt seine Beschreibung um anf die vorliegende Art, die weder Thomson, noch Rertenbacher und Joannis bekannt war. Letzterer gab deshalb unter sagittariat p. 92 nur eine Uebersetzung der Gyllh. Beschreibung, fïhrte aber die dunkle Abänderung p. 98 als neue Art auf, was aus der Alittheilung iiber die Halsschildbildung unzweifelhaft herrorgeht.

VI. 4. 


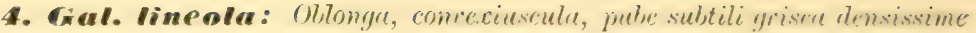

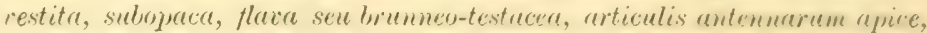
restice, macula media prothoracis, scutello, mess- ct metrestemes alshomineque (ano exceptos) nigris; prothorace basi haud marginatos, latcrilues. rotundato-ditatato, supra linen media ablneriata foreisque : lat i.s, minus.s 1"rofundis impresso, elytris sat crelne et fortiter punctatis, anguls suturali subrecto, rotundato. - Long. 5-6 $\mathrm{mm}$.

II as: segmento ultimo centrali aprice profunde triangulariter impressors.

Femina: Segmento ultimo apice leviter inciso.

Fabr. Spec. Ins. I. (1781) 149. - O 1. Ent. VI. 644.t. 3. f. 52 . Payk. Faun. Suec. II. 90. - Gyllh. Ins. Suec. III. 512. Duft. Faun. A. III. 228. - Küst. Käf. Eur. 3. 78. Joann. Mon. 83 (Galleruca). - Thoms. Skand. Col. VIII. 154. - Redtb. Faun. A. II. 489. - Seidl, F. balt. 492. (Galeruca).

Adimonia verna Laich. Verz. Tyrol. Ins. (1781) 194.

Var. a. Elytris callo humerali nigro.

Var. b. Elytris vitta indeterminata brunnea vel nigra.

Die gleichmässig dicht behaarte Oberseite. germotete Fieiten des Halssch., dessen Scheibe nu mit flachen Gruben versehen ist, dentlich alogekürzte Epipleuren und die fast rechtwinkeligren, aher an der äussersten spritze doch abgerundeten Nahtecken der Fld. machen diese Art leicht kenntlich.

Lang elliptisch, mässig gewölbt, sehr dicht und fein weisslichsxau seidenschimmernd behaart, ziemlich matt, citronengelh oder röthlich gelbbraun, die einzelnen Fiihlerglieder an der spitze. die Stim iiber den Häckern, oder wenigstens eine oder mehrere Makeh aut' derselben, eine breite, etwas makelförmige Mittellinie des Halssch., das Schildchen, Mittel- und Hinterbrust, sowie der Bauch. mit Ausnahme der spitze, schwarz. Fühler ziemlich dick, die Mitte der Fld. kaum erreichend, Glied 3 kürzer als 1, und $u m$ die Hältte länger als 2, \pm bis 7 unter sich ziemlich gleichlang, jerles wenig länger als 2, von den Gliedern 8 his 10 jerles einzelne sn lang als 2. Kopf mit feiner und kurzer Mittelimme zwischen den queren. wenig gewölbten, glänzenden Stirnhöckern, ïber diesen undeutich. aber dicht punktirt. Halssch. in der Mitte am hreitesten, beiderseits fast gleichmaissig germetet-verengt, mit grossen Borstenkegeln, von denen die hinteren dicht an der Basis der Fld. liegen. olven seln sehwach gewölbt, nu an dem leicht verdickten Vorderante sprarsam, sonst gleichmässig dicht hehart, undeutlich grol, punktirt, eine abgekiuzte Mittelrinne und eine seln weite Grube jederseits. rerhälnnissmässig schwach rertiett. Fld. heinahe gleichhrit, längs der erhabenen, heller gefübten Naht mehr oler weniger eingredrückt. ziemlich dicht und stark punktirt, nach den seiten und der spitze 
hin dichter und feiner; Epipleuren vorn breit. von der Witte der Hinterbrust an alhuählich verengt, die innere Randlinie erhahen, vor der Spitze dicht an die :unssere geriickt, aber nur selten scharf und deutlich mit ihr verbunden.

§. Letzter Bauchring mit einer dreieckigen, stark behaarten Grube, die zu ihrer tiefen, rimnenförmigen Mitte allmählich abfällt. Penis unsymmetrisch, die lang orale Oeffnung liegt in grader Richtung mit dem Basaltheile der Rïhre ganz auf der rechten Seite, wïhrend auf der linken ein breiter Randstreifen iibrig bleibt, vor der Oeffnumg ist die allmählich verengte, am Ende scharfe Spitze leicht nach links, zuletzt plötzlich nach rechts gebogen. Das 우 besitzt einen kleinen dreieckigen Aussehnitt in der Mitte des Hinterrandes am fünften Bauchringe.

In Deutschland kommt die Form mit einfarbigen Fld, weit sparsamer vor als die Var. a, bei der die Schulterbeule dunkel oder schwarz ist; ebenfalls häufig, aber nur an Erlen und Haseln, tritt die Var. b auf, mit einer braunen bis schwarzen Längsbinde nahe dem Seitenrande jerler Fld., von der Basis an der Schulter bis vor die Spitze. innen undeutlicher als aussen begrenzt und zuweilen so verbreitert, dass die Scheibe, mit Ausnahme der Ränder, schwarz ist.

Auf Weidengebüsch, besonders Salix viminalis L., und an Erlen und Haseln in ganz Europa gemein.

Die an Weiden lebenden Exemplarc haben eine gesättigt rothgelbe Gunndfarbe, am Bauche sind in der Regel die zwei letzten, oft auch der Hinterrand, oder noch die Seiten der beiden vorhergehenden Ringe roth; bei den Thieren, die sich von Erlen- und Haselnussblättern genährt haben, ist die Farbe der Oberseite und Beine viel blasser, ziemlich grangelb, die Unterseite dumkler, so dass am Bauche gewöhnlich nur ein Saum am After hell bleibt.

b. Die Epipleuren der Fld. reichen bis zur Spitze.

* Augen gross. Fld. auf der Unterseite glänzend glatt, tief schwarz, Epipleuren schmal, hinter der Mitte allmählich auf die Unterseite der Fld. umgehogen, ihre innere Randlinie nirgends scharf; Nahtwinkel abgerundet.

5. Gal. xanthomelaena: $\left.{ }^{1}\right)$ Oblonga, conrexiuscula, undique subtitissime minus rense griseo-pubescens, surdide testaceo-allida, antennis superne piceis, tuberculis politis fucialibus, macula frontati, muculis

1) Eben so grosse Angen, ähnlich gebillete Epiplenren und unterseits schwarze Fld. hat nur noch:

Gal. subcoerulescens Weise (Deutsch. ent. Zeit. 1884. 159) ron Amasia, wahrscheinlich in ganz Kleinasien verbreitet. Eiförmig, schmutzig 


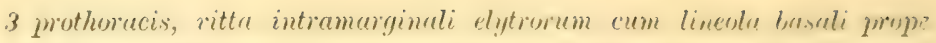
scutellum, metasterno abdominerue nigris; sculis magnis, craprite prothoraceque sat crebre punctatis, subnitidis, hoc basi haud marginuts, laterilus: rotundato, supra lineu media foreisque 2 latis, minu. profundis impresss, elytri.s confertim subruguloso-punctatis. - Long. $6-8 \mathrm{~mm}$.

II as: segmento 5: o rentruli fortiter triunguluriter imprexisy.

Femina: segmento 5:0 ventrali apice profunde exciso.

Schrank Enum. 78 (Chrysum.). - Dutt. Fium. A. III. 25. $\mathrm{K}$ üst. Käf. Eur. 9. 82, - Fa irm. Gen. Col. Eur. VI. t. 68. f. 326. (Galleruca). - Thoms. Skand. Col. VHI. 154. Redtb. Faun. A. II. 488 (Galeruca).

Gallence calmariensis Fabr. Syst. Ent. 119. - Payk. Faun. Suec. II. 90. - Gyllh. Ins. Suec. III. 508. - Thunb. Nov. Act. T. 93 (Crioceris).

Galleruca cratcegi Bach Käferfauna III. 133. - Joann. MIon. 84. - Seidl. F. balt. 492.

Var. a. Lineola basati elytrorum deficiente.

Eine an der Farbe und Zeichnung des Körpers und den dicht querrunzelig punktirten Fld. sehr kenntliche Art. Länglich, flach gewölbt, fein, aber nicht dicht gelblich-grau behaart. verschossen bräunlich oder gelblich weiss, die Fühlerglieder oberseits pechbraun oder schwarz, die glänzenden Stirnhöcker, eine Längsmakel der Stirn, drei oder vier kleine Makeln des Halssch., woron eine oder zwei auf der Mittellinie und eine jederseits nahe dem seitenrande liegen, eine Längsbinde nahe dem Seitenrande der Fld. und eine kurze Längslinie an der Basis nahe dem Schildchen. die Hinterbrust und der Bauch (letzterer theilweise, oder bis auf den After) schwarz. Der Kopf klein, dem ron G. ribumi ähnlicher gebaut, als bei einer der iibrigen Arten, indem der winkelige, hoch auf-

gelbbraun, ziemlich glänzend, sparsam behaart und punktirt, nur die Fld., ohne das Schildchen, dunkelbraun, mit starkem blanem Schimmer, dicht punktulirt und weisslich behaart. - L. 4,5 mm.

Da bei dieser Art die Nahtecke der Fld. in eine ziemlich grosse Spitze verlängèrt ist, so bildet sie einen guten Lebergang zur folgenden Gruppe.

Gal. maculicollis Hotsch. (Etud. ent. 2. 1853. p. 49) aus dem nördlichen China und vom Amur, ist gleichfalls mit canthomelaena rerwandt, aber etwas grösser und gewölbter, oben matt rothbraun, Oberlippe, die flachen Stiruhöcker, eine grosse orale Scheitelmakel, drei ovale Längsmakeln des Halssch. (eine in der Mitte und eine jederseits neben dem roth gesäumten Seitenrande), Schildchen und die Schulterbeule jeder Fld. schwarz. Halssch. mit zwei unmerklichen Eindriicken, Fld, äusserst dicht, mässig stark aber tief punktirt, auf der Unterseite roth. Fiihler, Beine, Hinterbrust und Bauch zum grössten Theile schwarz. - L. 8-9 mm. 
gebogene Vorderrand der Stim steil zu dem fast dreieckigen Kopfschilde abfillt; eine feine Mittelrinne lïuft von der höchsten Stelle des Vorderrandes zwischen dex Fühlerwurzel und den ovalen Stirnhöckern hindurch bis auf den Scheitel, der ziemlich dicht und mässig stark punktirt ist. Das IIalsseh. ist vorn wenig schmaler als hinten, an den Seiten nicht stark, aber fast gleichmässig gerundet, wenig kräftiger als der Kopf punktirt, ziemlich glänzend, mit einer breiten Mittelrinne, die oft nur aus zwei hinter einander liegenden kleinen Eindriicken besteht, und einer weiten, hinten mehr als vorn vertieften Quergrube jederseits. Die Fld. sind fast parallel, im letzten Viertel allmählich gerundet-verengt, jede an der fast rechtwinkeligen Nahtecke abgerundet, oben äusserst dicht querrunzelig punktirt, öfter mit der Spur von zwei erhabenen Längslinien. Auf der imneren von diesen liegt am Grunde die kurze, schlecht begrenzte schwarze Längslinie, die äussere begrenzt gewöhnlich die schwarze Längsbinde scharf auf ihrer Innenseite.

Beim Männchen ist der letzte Bauchring in der Mitte der Länge nach breit und tief dreieckig eingedriickt und lang und dicht behaart, beim Weibchen schmal, aber tief ausgeschnitten. - Der Penis ist rorn breit, schnell gerundet-verengt und in der Mitte in eine kleine stumpfe Spitze vorgezogen.

$\mathrm{Zu}$ der unbedentenden Abänderung a gehören die Stücke ohne eine kurze schwarze Basallinie auf den Fld.

Auf jungen Ulmen (Ulmus campestris L.) und auf Weiden im Frühlinge in Südeuropa häufig, im nördlichen Deutschland wenig, im mittleren und suidlichen mehr verbreitet und stellenweise in Menge.

* A Augen klein. Unterseite der Fld. wie die Oberseite gefärbt. Epipleuren breit, ihre innere Randlinie scharf erhaben, der äusseren fast parallel laufend, dicht vor der Spitze plützlich abbrechend; Nahtwinkel in eine kleine, deutliche. Spitze verlängert.

6. Cal. calmariensis: Oblonga, conrexiuscula, pube subtili pallida dense restita, flara, elytris ferrugineis, vertice, linea media pothoracis, scutello, vitta lata intramarginali elytrom, pectore abdomineque (ano excepto) nigris; antemis nigris, basi rufis; prothorace linea media foreisque 2 latis, sat profundis instructo, elytris profunde subocellato-punctatis.

- Long. 4-5 $\mathrm{mm}$.

II as: segmento ultimo ventrali apice profunde et late triungulturiter impresso. Femina: segmento ultimo apice sut profunde triungulariter inciso.

Linn. Syst. Nat. ed. XII. 600 (Chrysm.). - Ol. Ent. VI. 632. t. 3. f. 37. - Duft. Faun. A. III. 229. - Seidl. F. balt. 492 (Galleruca), - Marsh. Ent. Brit. I. 227 (Crioceris). 
Var. a. Elytris ommino flaris aut testaceis, calls humerali jlerumque infuscato.

Galleruca lythri Gyllh. Ins. Suec. III. 513.

Gallenea calmariensis Joamn. IIon. \$1. - Thoms. Skand. Col. VIII. 155. - Redtb. Faun. A. II. 489.

Diese und die folgenden Arten unterscheiden sich durch die Punktirung der Fld., eigentliumlich gebaute Epipleuren und den in eine Spitze auslaufenden Nahtwinkel der Fld. wesentlich ron den vorigen Arten, auch von den gleichfalls mit einer Spitze versehenen nymphaeae und subcoerulescens. Während bei diesen nämlich die Spitze durch eine Biegung des Hinterrandes gebildet wird, nur nach hinten gerichtet, ziemlich wagerecht und dentlich dreieckig ist. läuft hier der Hinterrand bis an die obere Randlinie der Naht, und die mehr nach unten als nach hinten gerichtete, fast senkrecht stehende, kaum dreieckige Spitze entsteht dadurch, dass sich die untere Randlinie unter der oberen etwas nach hinten rerlängert; mit andern Worten: bei nympluaeae und subcoemulescens ist die Spitze eine Verlängerung der Oberfläche der Fld, hier eine Fortsetzung der schmalen Nahtfläche.

Länglich, flach gewölbt, fein und dicht weisslichgrau behaart. bei guten Exemplaren auf den Fld. wie bereift. im Leben schmutzig citronen-, auf den Fld. mehr orangengelb, nach dem Tode ockerfarben, der Scheitel ganz, oder eine Makel auf demselben, eine breite Mittellinie des Halssch., das Schildchen, eine an der Schulter beginnende, nach hinten etwas rerbreiterte, aussen scharf, innen schlecht begrenzte Längsbinde der Fld., welche hinter der Mitte allmählich verblasst, die Mittel- und Hinterbrust sowie der Bauch, mit Ausnahme des Afters (meist f), oder des ganzen letzten Bauchringes schwarz. Fühler mässig lang, schwarz, die ersten Gliecler röthlich, die letzten öfter nur pechbraun, die Mittelrinne der Stirn zwischen den ziemlich flachen, hinten durch eine seichte Querlinie begrenzten Höckern tief, nach dem Scheitel zu allmählich rertlacht. Halssch. etwa in der Mitte am breitesten, nach rorn wenig mehr als nach hinten verengt, mit gerundeten Seiten und leicht vortretenden Borstenkegeln, an der Basis undeutlich gerandet, die Oberseite, mit Ausnahme des glänzenden, sparsam punktirten, wulstigen Vorderrandes, ziemlich matt, dicht punktirt und behaart, eine breite, abgekürzte Mittelrime und eine grosse Grube jederseits ziemlich stark vertieft. Fld. nach hinten ummerklich erweitert, tast parallel, hinten gemeinschaftlich abgerundet, die Nahtkante spitz und ziemlich stark vortretend; oben dicht und rerhältnissmässig grob punktirt, die Punkte tief eingestochen, ihr Grund hell durchscheinend. 
Brim Mïnnchen ist der letzte Bauchring mit einer tiefen, dreieckigen, über die Mitte nach vorn reichenden Grube versehen, deren. hohe seitenränder abstehend behart sind, beim Woibchen tiest dreieckig, nicht ganz bis zur Mitte auseschnitten, die Seiten des Ausschnitte's kaum stärker behaart, als der iibrige 'Theil des Segmentes. - Der Penis ist schmal, vorn gleichbreit, am Ende breit abgerundet.

Die hellsten, in der Regel noch nicht rollständig ausgetairbten Stücke (Var. a) haben auf den Fld. kaum eine Andeutung der Längsbinde, aber gewöhnlich ist bei ihnen die schulterbeule schwärzlich.

Aut Iythrum salicaria $I_{\text {. an }}$ Gräben und auf feuchten Wiesen stellenweise häufig in ganz Europa.

7. Gal. pusilla: Oblonga, comexiuscula, pube subtilissima, pallida sat dense restita, flaco-testacea, vertice, scutello, callo humevali elytrorum, pectore segmentisque 3 primis abdominalibus nigris, antennis nigris, basi rufis; mothorace linea media foveisque 2 latis et profundis impressu, elytris crebre punctatis. - Long. 3,5-4,5 mm.

Ias: segmento ultimo rentrali apice sat profunde et late triangulariter impresso.

Femina: segmento ultimo ventrali apice leviter emarginato.

Duft. Faun. Austr. III. 230.

Galleruca teriella Joann. Mon. 93.

Var. a. Callo humerali elytrorum haud nigro.

Var. b. Elytris umbra longitudinali nigrescente.

Durchschnittlich kleiner, aber ebenso gestreckt als die vorige Art und rom ihx nux in folgenden Punkten sicher rerschieden: Die Farbe des Kïrpers ist in der Regel weniger rothgelb, sondern mehr hellbraum, auf dem Halssch. fehlt die schwarze Mittellinie ganz oder ist nur ausnahmsweise allein oder mit den Gruben etwas angedunkelt, die Schulterbeule der Fld. ist schwärzlich oder schwarz, auf der Unterseite sind die beiden letzten Segmente hell gelblichbraun, die Behaarung der Oberseite ist feiner und kiirzer, die der Unterseite, besonders des Bauches, entschieden dichter. Die Fühler sind dünner, die Mittelrime des Halssch. ist schmaler und seichter, die Seitengruben sind tiefer, die Punktirung der Fld, ist dicht, aber merklich feiner.

Letzter Bauchring des Männchens mit einem wenig tiefen, his iiber die Mitte nach rom reichenden dreieckigen Eindrucke, dessen etwas aufstehende Seitenränder behart sind; bein Weibchen nur in der Mitte des Hinterrandes schwach gerundet-ausgeschnitten. - 
Penis dem von sngittariae ähnlich, in der vorderen II:ilfter, allmählich gradlinig verschmälert, scharf zugespitzt.

Zuweilen fehlt die schwarze Schultermakel der Fld. (Var. a), grler letztere besitzen hinter der schwarzen Schulterbeule einen nirgends scharf begrenzten, vorn schmalen. hinten breiteren Längsschatten (Var. b).

Auf verschiedenen Pflanzen, hesonders auf Stacluys prlustris $I$. und Veronica-Arten am Rande von Gräben und sumpfigen Gewässern in ganz Europa ebenso häufig als die vorige Art, von mir besonders im Winter aus trockenen Carex-Büschen auf dem Fise gesieht. Caucasus (Leder).

Diese Art ist nicht schwierig, an der Geschlechtsauszeichnung sogar stets mit Sicherheit zu erkennen; sie wurde von Duftschnid genau beschrieben, aber von den späteren Autoren nicht anerkannt, sondern meist mit der folgenden, trotz ihrer geringen Aehnlichkeit. verbunden. Da die G. tenella Joannis auf den zwei oder drei letztert Bauchringen gelblichbraun sein soll, so ist sie olne Frage nach Stiicken der pusilla beschrieben worden, während die wirkliche G. tenella $I$. unter der Var. B bei Joannis zu suchen ist.

8. Gal. temellax: Oblungo-oralis, concexiuscula, flara seu testaceu, elytro singulo in disco rufo-brumeo, vertice, pectore abdomineque nigris, ano testaceo; antennis apicem rersus interdum leviter infuscatis, prothorace subglabro, linea media foveisque 2 latis, mofundis, fortius parce punctatis et parce pubescentibus impresso, clytris crebre punctatis. - Long. $3,2-4 \mathrm{~mm}$.

I as: segmento ultimo ventrali apice leviter triangulariter impresso.

Femina: segmento ultimo apice fere integro.

Linn. Faun. Suec. ed. 2. 171 (Chrysom.). - Oliv. Ent. VI. 645. t. 4. f. 53. - Gyllh. Ins. Suec. III. 5̆14. - Duft. Faun. A. III. 228. - Thoms. Skand. Col. VIII. 156. - Redtb. Faun. A. II, 489. - Seidl. F. balt. 492 (Galleruca).

Galleruca tenella var. B, Joannis Mon. 94.

Galeruca minima Weidenbach 12. Ber. Naturhist. Ver. Augsb. 1859. 84.

Var. a. Lineola media mothoracis calloque humerali elytrom infuscatis aut nigris.

Var. b. Eadem, sed elytris vitta intramarginali nigra.

Unsere kleinste Art, kaum schmaler, aber merklich kiirzer als die vorige Art, in der Punktirung der Fld. mit ihr ziemlich über-

1) Da die $\widehat{o}$ bein Tode oft die rordere Hälfte des Penis heransstrecken, so habe ich denselben hier und bei einigen anderen Arten nicht erst herausgenommen, weil ohnehin an der Basalhälfte kein wichtiges Unterscheidungsmerkmal $\mathrm{zu}$ finden ist. 
einstimmend, aber durch das fist kahle, nur sehr sparsim behaarte Halssch. und die hellen Fiihler leicht von ihr und calmariensis zu trennen.

Länglich-eifömig, schwach grewölbt, selb oder gelblichbraum, die scheibe jeder Fld. bei gut ausgefärbten sitücken rothbraun, der Scheitel, die Mittel- und Hinterbrust, sowie „ler Bauch, mit Ausnahme des Afters oder des ganzen letzten Segmentes, schwarz; Schildchen schwärzlich, die mässig langen Fiihler nach der spitze hin bisweilen leicht angedunkelt. Kopf mit tiefer Mittelrime zwischen den ziemlich flachen, hinten von einer seichten Querlinie begrenzten Stimhöckern, iiber diesen dicht und fein punktirt. Halssch. in der Mitte der gerundeten Seiten am breitesten, nach voru wenig mehr als nach hinten verengt, die vorderen Borstenkegel deutlicher hervortretend als die hinteren, an der Basis undeutlich gerandet, mit einer flachen Mittelrinne und einer grossen Grube jederseits, sparsam, grob punktirt, bei schwacher Vergrösserung fast kahl, bei starker Vergrösserung sieht man auf und neben der Mittelrinne zahlreiche, auf den iibrigen Theilen nur vereinzelte Härchen. Fld. dicht und gewöhnlich etwas feiner als das Halssch. punktirt, ziemlich sparsam und sehr fein behaart, die Spitze des Nahtwinkels klein.

Beim Männchen ist der letzte Bauchring nicht tief dreieckig eingedrickt, beim ㅇ in der Mitte am Hinterrande kaum merklich ausgeschnitten. - Der Penis verengert sich vorn allmählich in eine ziemlich schmale, abgerundete Spitze.

Sticke mit einer dunklen Mittellinie des Halssch. und dunkler Schulterbeule (Var. a), oder schwarzer Längsbinde der Fld. (Var. b) kommen nur vereinzelt vor.

Auf feuchten Wiesen und an Gräben auf den Blättern von Spiraea ulmarin $I_{\text {. }}$ im Frühlinge und im Juli gemein.

\section{Diorhabda.}

Weise. Deutsche entomol. Zeitschr. 1883 p. 316.

Corpus supra parce subtilissimeque pubescens.

Acetabula antica occhesa.

Tibiae muticae; tarsi angusti, articulo tertio profunde inciso, lobis subacutis, articulo quarto praecedentibus simul sumtis longitudine cequali; unguiculi longi sed tenues, dentati.

Körper ziemlich weich, mehr oder weniger gestreckt, schwach oder mässig gewölbt, rothbraun bis hell gelbbraum, oben sprarsam oder nicht besonders dicht, sehr fein, unten deutlicher und länger behaart. Kopf klein, besonders der 'Theil vor den Angen kurz, 
Oberlipe schmal. Maxillartaster miisig langr und dick. Glierd 2 mol is

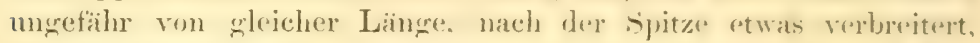
Gilies 4 länger als 3 , allnählich mugespitzt: Konfichlild über dem ziemlich tief liegenden (Querstreiten lreit dreieckig. wenig gewiolht. nach der spitze zu mit einer verschieden tiefon Längsrimne, die sich iiber der Fühlerwurzel stark vertieft und dic stimbenlen deutlich trennt, hierauf nach und nach verflacht und his aut den grrossen. queren, kräftig punktirten s'cheitel fortgesetzt ist. Fiilıler kurz. höchstens halb so lang als der Körpere in einer Linie mit dem Lnterrande der Angen eingrefiigt, (ilied 1 mässig lang und stark. 2 klein, 3 und 4 ungefähr gleichlang oder 3 länger. jedes einzelne kürzer als Glied 1, die folgenden kürzer als 4, entweder unter sich von gleicher Stärke und Länge, oder allmählich etwas rerdickt, aber an Länge abnehmend. das Endglied ziemlich lang. einfach zugespitzt, oder kurz, mit dentlich abgesetzter spitze. Angen weit getrennt, oval, ziemlich flach, fein gekïrnt. schräg nach unten und aussen laufend. Halsschild quer, am Vorderrande sanft ausgeschweift, am Hinterrande in der Mitte ziemlich grade oder leicht ausgerandet, jederseits davon schräg oder winkelig nach rorn gebogen, die Seiten gerundet, die Ecken stumpfwinkelig, etwas abgerundet, mit undentlicher Borstenpore und feiner Borste; die Oberfläche mit mehr oder weniger deutlichen Vertietungen, nämlich einer rom und hinten tieferen Mittelrinne und einer weiten Grube jederseits. Schildchen breit dreieckig, seine seiten gebogen, die spitze meist abgerundet. Fliigeldecken etwa viermal so lang als das Halssch., dicht und ziemlich fein punktirt, mit zwei bis rier bald kaum bemerkbaren, bald deutlichen leistenförmigen oder durch kleine Höckerchen gebildeten Rippen, Epipleuren ziemlich schmal, bald hinter der Mitte erlöschend. Das Prosternum bildet eine kleine, dreieckige Spitze, welche sich nur an die Hüften legt, aber nicht zwischen ihmen hindurch geht, die Gelenkhïhlen stehen also mit einander in Verbindung, sind jedoch hinten durch einen mäswig breiten Streifen der Epimeren rollständig geschlossen. Die Hinterbrust fällt in starker Wölbung in die Gelenkhöhlen der Mittelbeine ab, ohne durch eine Randleiste begrenzt zu werden, und die Mittelhiiften stossen zusammen. An den Beinen sind die schenkel fast glatt, sparsam fein behaart, die Schienen diinn, an der Spitze mit einem Borstenkranze, aber unbedornt, Tarsen schlank, gleichbreit. ihr erstes Glied etwas lïnger als eins der folgenden, das zweite so lang als das dritte, dieses breit und tief ansgerandet, mit zwei schmalen und ziemlich spitzen Lappen. das Klanenglied so lang als die drei vorhergehenden zusammen, die Klauen lang. gezähnt.

Das einzige ïussere Geschlechtsmerkmal besteht darin, dass 
beim Männchen der letzte Bauchring an Hinterrande alogestutzt. und mit einer dreieckigen, in der Mitte der Länge nach sehr vertieften crube versehen, heim Weibehen eben und am Finterande leicht abgerumdet ist.

Die Gattung enthailt bis jetat nur wenige Arten, welche den Galerucellen ïhneln, aher durch die geschlossenen vorderen frelenkhöhlen, das schmale dritte 'Tarsenglied und das sehr lange Klauenglied bedeutend abweichen.

1. Diorh. elongata: Elongato-ovata, sordide flava, allicans aut rufescens, sat nitida, macula frontali, antennis, genubus, tibiis apice tarsisque nigricantibus, fronte prothoraceque minus crebre punctutis, hoc lateribus parce longeque ciliatis, elyti is dense subtiliter punctatis, plerumque costulis 3 anyustis; unguiculis dente minutissimo armatis. - Long. $5,5-8 \mathrm{~mm}$.

Brullé Expéd. sc. Morée IIT. 271. t. 44. f. 10 (Galeruca). Joann. Mon, 83.

Galeruca sublineata Luc. Explor. Alg. Ent. 1849. p. 542. t. 44. f. 8.

Tar. a. carinata: Prothorace femoribusque nigro-maculatis, elytris interdum infuscatis, pectore abdomineque plus minusve nigris.

Falderm. Nouv. Mém. Mosc. 1837. V. 329.

Gal. costalis MIuls. Mém. Ac. Lyon II. 1852. p. 16; Opuse. I. 17t;.

Gal. carimulata Desbr. Abeille VII. 1870. p. 134.

Gestreckt, sehr lang eiförmig oder elliptisch, verschossen bräunlichgelb, selten hell gelblichweiss, häufiger röthlichbraun, glänzend, eine rerwaschene Makel auf der Stirn, oder auch eine schmale, in der Mitte verengte Quermakel des Scheitels, die Fühler, besonders oberseits, die Knie, Spitze der Schienen und die Tarsen dunkel. braun bis schwärzlich. Stimhöcker flach, schlecht begrenzt, die Stirn über ihmen mässig dicht und ziemlich stark punktirt. Fühler nach der Śpitze zu nicht verdickt, Glied 2 kurz, 3 länger als 4, die folgenden wenig kürzer als 4, unter sich von gleicher Länge, jedes deutlich länger als breit. Halssch. meben, weitläntig in sehr veränderlicher Stärke punktirt, die Mittellinic beiderseits etwas vertieft, die Grube jederseits mehr oder weniger gross und tief, der Seitenrand sparsam lang bewimpert. Fld. dicht und ziemlich f'ein punktirt, über dem breit abgesetzten, aher wenig aufgehogenen Seitenrande mit einem breiten, vertieften Streifen, welcher innen von einer schmalen und hohen Längsippe begrenzt wird. die dem Seitemrande parallel ron der Schulterbenle bis ror die Spitze läuft; auf der imneren Hälfte sind mitunter zwei hreitere, aber sehr niedrige Rippen zu hemerken, welche aus kleinen Längs- 
höckerchen gebildet werden. Die schlanken Klanen hahen in der Mitte (inen sehr kleinen, wenig abstehenden Zahn. ${ }^{1}$ )

Die Art ist in der Grösse, Skulptur und Earbe sehr veränterlich. Es färben sich allmählich die vertieften Stellen des Halssch., die Hinterbrust und die Seiten des Banches schwarz, die Schenkel exhalten schwarze Striche oder Lïngsmakehn, und auf jeder Fld. treten zuweilen zwei brame Längswische hervor; die Punktirung des Halssch. ist bald feiner, bald stärker als die des Kopfes, die Seitenrippe der Fld. oft nur schwach entwickelt.

Auf Aeckern an der ganzen Küste des mittelländischen Meeres nicht selten. Oesterreichisches Küstenland bei Triest. Sarepta.

Die D. carinulata Desbr., nach einem Ex. von Sarepta beschrieben, zeichnet sich durch ein stark punktirtes Halssch. aus, ist aber von carinata Fald. nicht zu trennen.

1) Die übrigen beiden Arten sind oherseits sehr kurz und fein behaart, sie haben dickere Klanen, mit einem längeren, weit abstehenden Zahne, die Fühler sind kïrzer, ihre einzelnen Glieder vom füinften an kaum länger als breit, oder breiter, die Seitenrippe der Fld. fehlt, oder ist nebst drei anderen, in gleichen Abständen von einander befindlichen Längslinien, die aus einer Reihe grösserer Punkte, mit etwas breiteren, glatten, böckerförmigen Zwischenräumen bestehen, nur angedeutet. Es sind:

1. D. persica Fald. Nouv. Jém. Mísc. V. 1837. p. 331; Joann. Mon. $87=$ sareptana Stier]. Bull. Mosc. 1863. I.V. 501; Joann. Mon. 95̆ = damascena Joann. Mon. 96). Gestreckt, einfarbig gelbbraun (unausgefärbt) oder rothbraun, Fühler, eine Stijnmakel, Mittelrime des Halssch., Schildchen, Brust und Banch mehr oder weniger schwarz. Stim dicht runzelig punktirt, die Beulen niedrig oder mässig hoch. Halssch. etwa doppelt so breit wie lang, an den Seiten gerundet, weitläufiger, die Fld. änsserst dicht punktirt. - L. 4,5-6 mm. Sarepta, Caspisches Meer. Syrien.

2. D. Fischeri Fald. (1. c. 334; Joann. 90). Etwas kïrzer und breiter als die vorige, gelbbraum, eine Längsbinde des Halssch., Schildchen. Naht und Unterseite mit Ausnahme der Beine schwarz. Stirnhücker sehr hoch, Halssch. fast dreimal so breit als lang, an den Seiten sehr stark, etwàs winkelig erweitert. - L. 4,5-5,5 mm. Caucasus.

Aendert ab: subnigra Ws. (Beitr. Kank. Käf. 335) Kiopf, mit Ansnahme der Stirn, oder nur 'der Benlen, Fühler, eine breite Längsbinde ïber die Mitte des Halssch., die sich oft moch jederseits am Basalrande ansdehnt, eine breite, gemeinschaftliche Längsbinde ter Fld. und eine ähnliche am Seitemrande jeder einzelnen, sowie die Lnterseite mit den Beinen schwarz. 


\section{Galeruca.}

Geoffroy, Hist. Ins. I. 1762 p. 251.

Adimonia Laichart. Verzeichn. Tyrol. Ins, 1781 p. 190.

Corpus suma purce subtilissimeque pubescens, interdum fere glabmum. Acetabula antica postice occhusa.

Tibiae intermediae calcari distincto.

Tursi sat lati subtus pulvillati, articulo tertio latissimo, aprice leviter inciso, lobis rotundatis, quarto pimo parum longiore, unguiculi validi, dentati.

Körper plump gebaut, ziemlich hart, gelbbraun bis tief schwarz, wenig glänzend, mässig gewölbt, vorn schmal, nach rückwärts stark erweitert, die grösste Breite gewöhnlich hinter der Mitte, hinten schnell gerundet-verengt, oben stark punktirt und sparsam und fein, oder kaum bemerkbar, unten deutlicher behaart. Kopf geneigt, fast dreieckig, meist bis zum Hinterrande der ziemlich kleinen, breit elliptischen, mässig gewölbten Augen in das Halssch. eingezogen; Maxillartaster klein und wenig dick, Glied 2 und 3 schwach rerkehrt-kegelförmig; das Endglied so lang als das vorhergehende, nach und nach etwas zugespitzt; Mandibeln kurz und breit, dreizähnig, der untere Zahn kürzer als die beiden oberen; Oberlippe schmal, quer, vorn mehr oder weniger ausgerandet; Kopfschild iiber dem niedergedriickten Streifen steil zu einer dicken, hohen, winkeligen Kante ansteigend, hinter welcher sofort die grossen und tiefen Gruben um die Fühlerwurzel beginnen; zwischen denselben ist die Stirn nur schmal, grösstentheils von einer Längsrimne eingenommen, die sich nach oben allmählich vertieft und von einer wenig deutlichen Querrinne durchsetzt, hierauf flacher wird und auf dem Scheitel endet. Die Stimbeulen sind selten scharf ausgeprägt, weil sich die grobe und runzelige Punktirung der Stirn auf dieselben ausdehnt. Fühler kräftig, fadenförmig, bei zwei Arten perlschnurförmig, ungefähr halb so lang als der Körper, das erste Glied das längste, nach der. Spitze verdickt, das zweite das kleinste, Glied 3 wenig kürzer als 1 und in der Regel fast doppelt so lang als 2, 4 etwas kiirzer als 3, die folgenden eben so lang oder nur unmerklich küizer und diunner, das siebente oben in eine mehr oder weniger deutliche Spitze ausgezogen, die sich auf das achte Glied legt, Endglied mit leicht abgesetzter Spitze. Halsschild doppelt so lang als breit, oder breiter, am Vorderrande abgestutzt oder in sanftem Bogen ausgeschnitten und schmaler als am Hinterrande, hier bei einigen Arten ziemlich grade, oder nur vor dem Schildchen, bei der Mehrzahl dagegen auch noch an den Ecken schwach ausgeschweift, dic Seitenränder in eine Leiste erhöht, hinter der Mitte im Bogen oder 


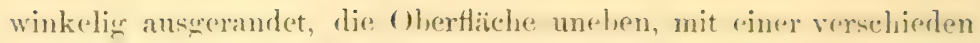
breiten und tiefen Vittelrime nud einem writen Eindrucke jederseits. Flügreldecken am Grunde wenig hreiter als die basis des

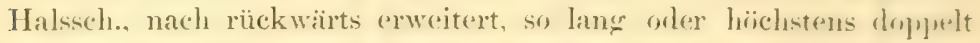
so lang als breit, am Nahtwinkel schwach einzeln alyerundet, in der vorderen Hälfte etwas zusannmengedriickt, der 'ieitenrand leistenförmigr aufgehogen; leei den meisten Arten ist die Naht verdickt, ausserden treten auf jeder Fld. vier Längsrippen. zuweilen auch fünf Nebenrippen (costulae) aus der starken. unregelmäisigen (selten gereihten) Punktirung heraus. Die erste Rippe liegt ein ziemliches stiick von der Naht ab und ist hinten gewöhnlich mit der vierten verbunden, die unterhalb der Schulterbeule beginnt und dem seitenrande parallel läuft, zwischen beiden befinden sich die zweite und dritte Rippe, letztere ist in der Regel die schwächste. Die erste Nebenrippe liegt zwischen der Naht und der ersten Rippe. die fünfte zwischen Rippe 4 und dem Seitenrande. Prosternum dreieckig. in eine schmale von den Hüften rerdeckte Leiste verlängert; Gelenkhöhlen geschlossen; Mesosternum ebenfalls schmal dreieckir; Pleuren der Hinterbrust breit, nach hinten verschmälert und stumpt zugespitzt. Beine stark, Schienen stets krättiger punktirt als die Schenkel, kurz beborstet, nach der Spitze verhreitert. an Ende mit einem Borstenkranze, die Mittelschienen ausserdem noch mit einem kurzen, stets deutlichen Enddorne versehen. der nux bei melanoceplata sehr klein, bei mefa auch noch an den Hinterschienen vorhanden ist. Die Aussenseite der Schienen hat zwei Rinnen, dazwischen einen Längskiel. Tarsen mit einer dichten, bei wenigen Arten durch eine kahle Mittellinie ganz oder theilweise halbirten Filzsohle, das erste Glied an den Hinterfïssen so lang als die beiden folgenden zusammen und kaum länger als das vierte, das dritte Glied herzförmig, breiter als die rorhergehenden, Klanen in der Mitte scharf gezähnt.

Beim Männchen ist der letzte Bauchring hinten abgestutzt oder in schwachem Bogen ansgerandet. oft dem breiten Theile einer herzförmigen Figur ähnlich, mit einem tiefen, dreieckigen Gribchen in der Mitte an Hinterrande. Der Penis hat einen sehr einförmigen Ban; er heginnt mit einem dieken, knieförmig gebogenen Theile. der schmell zu der geraden. flach gedrickten vorderen Hälfte abtaillt, welche grösstentheils von der Oeftinung eingenommen wird, mnd nur an Ende in sanfter Rundung verengt, zugleich in eine kurze, abgerundete Spitze verlängert ist.

Die Arten leben rorzugsweise in trocknen, somigen Gegenden (wenige anf feuchten Wiesen) an rerschiedenen Ptlanzen in der Nähe des Erdbodens; sie sind hauptsächlich in der Lingebung des 
Mittelländischen Meeres zu Mause und verbreiten sich von hier aus in almehmender '/ahl bis in's nördliche Enropa und durch sibirien bis zum stillen Oceane; möglich, dass anch noch einige aus Nordamerika beschiehene Irten zur Gattumg gehören. Ueber die Entwicklung liegen nur unvollständige Nachrichten vor, und zwar von Hornumg (Bericht nat. Ver. Harzes 1847 p. 4), Fuss (Mittheil. Siehb. Ver. Naturw. 1856 p. 106) und Kaltenbach (Pflanzenfeinde 344 und 773) über tonaceti, ron Kaltenbach (1. c. 374) iiber pomonae und von Boheman (Oefrers. Vetensk. Foerh. 1852 p. 8) üher laticollis. Die Larven treten zuweilen in solcher Menge auf, dass sie neben den sparsam berasten Stellen trockener Gegenden handbreite Flecke vollständig bedecken und alle in der Nähe befindlichen saftreichen Pflanzen, z. B. Taraxucum officinale, bis auf die Wurzel verzehren, andere, wie Achillea millefolium, Centaurea jacea, Artemisia campestris, Cerastium arcense ete. ihrer sämmtlichen Blätter berauben. sie sind erwachsen etwa ${ }^{1 / 3}$ länger, aber kaum breiter als der Käter, beiderseits verengt, matt pechschwarz, der Banch heller, zuweilen schmutzig grün; Kopt klein, glänzend, sparsam lang behart, Taster und Fithler kegelförmig, hinter dem Fühler eine grosse Ocelle. Jedes Segment trägt auf dem Rücken zwei Querreihen von je 8 glänzend schwarzen, mit langen Haaren besetzten Warzen, ${ }^{1}$ ) von denen die seitlichen niedrig, die mittleren ziemlich lang und beinahe stäbchenförmig, zugleich etwas nach hinten geneigt sind. Diese Warzen bilden bei tanaceti in der Mitte durchaus regelmässige Längsreihen. bei pomonce und interveptre nicht; sie sind kurz und dick bei tanaceti, etwas länger, aber kaum halb so dick bei pomonae, doppelt so lang und fast eben so dick (wie dic der trunceti) bei intermotr. Die Verpuppung geschieht in der Erde. Die Puppe ist gelb, hic und da mit schwarzen Börstehen versehen, von denen vier, die an leistenformigen Hinterrande jedes Segmentes stehen, Längsreihen bilden. Einige Arten erlangen ihre vollkommene Ausfirbung schnell, andere sehr langsam, die ersten, z. B. die mit truaceti verwandten, bilden deshalb keine, die letzten, wozu besonders pomonae gehïrt, zahlreiche Farbenahänderungen, von denen die hellen und dunklen Fromen immer als verschiedene Arten betrachtet worden sind. Verkriippelungen und Misshildungen finden sich namentlich am Halsschilde häufig.

1) Das darlurch hervorgernfene eigenthiimliche Aussehen der Larren war Geoffroy jedenfalls bekamt (eine Abbildung findet sich schon im ersten Jerian-Bande) und wohl die Veranlassung zu dem Gattungsmamen. den man von galea der Helm und erucn die Ranpe herleiten kamm. 
Eine Bearbeitung der Gattung lieferte bisher nur Joannis (Abeille 1866); in derselben ist leinler das Hanptgewicht auf die Farbe und den sehr variablen Limriss des Halsschildes gelegt, die Arten sind olme Rücksicht auf ihre Verwandtschaft zusammengestellt und ohne Angabe der wesentlichsten Lnterschiede beschrieben. so dass das sichere Wiedererkennen der zahlreich neu aufgestellten, selbst mit Hilfe der ungenauen Thoraxbilder auf Tafel 2, ummöglich ist. Ich lasse deshalb hier eine Uebersicht iiher die Arten aus der paläarctischen Zone folgen, in der die ausserdeutschen Arten mit kurzen Beschreibungen versehen sind.

I. Fühler dick, fardenförmig, Naxillartaster schwach, Beine mässig stark, Mittelschienen an der Spitze mit einem deutlichen Enddorne.

1. Die Rinne, welche den Seitenrand der Fld. absetzt, zieht sich um die flachen Schultern herum bis über die Mitte zwischen Schulter und Schildchen nach innen, der abgesetzte Seitenrand ist deshalb in der Basalhälfte jeder Fld. deutlich und besonders vor der Schulter hoch aufgebogen (wenig hoch bei IIacchoi und incisicollis). Körper stets einfarbig tief schwarz. . . 2.

11. Die Rinne am Seitenrande der Fld. endigt an der Schulter, daher ist der aufgebogene Seitenrand daselbt niedrig und erlischt an den Hinterecken des Halsschildes . . . . . . 6.

2. Ungeflügelt. Körper ziemlich flach. Epipleuren der Fld. sehr breit, nach hinten schnell rerengt. Mittelhüften durch die verhältniissmässig breiten Zipfel der Hinter- und Mittelbrust deutlich getrennt, Hinterbrust sehr kurz, so dass die Mittel- und Hinterhüften dicht hintereinander stehen. Halsseh. flach, nach voru wenig mehr als nach hinten verengt, Seiten gerundet, Basis in einem weiten Bogen ausgerandet. Fld, in beiden Greschlechtern den Hinterleib nicht bedeckend, etwas dichter als das Halssch. und wie dieses nux mässig stark (selten grob) punktirt, ohne merkliche Rippen. Bauch sparsam weisslieh behaart. L. 7-12 mm. Pyrenäen . monticola Kiesenw.

21. Geflügelt. Körper mässig gewölbt. Halssch. nur ror dem Schildchen leicht ausgerandet. Epipleuren der Fld. mässig. breit, nach hinten allmählich verengt. Yittelhütten ziemlich zusammenstossend. Bauch sehr fein dunkel behaart . . 3.

3. Hinterbrust ziemlich kurz, in der vorderen Hälfte ohne Mittelrimne, vor dem spitzen, zwischen die Hinterhuiften rorgezogenen Zipfel des ersten Bauchringes stark ansteigend. Den griissten Stücken ron tanaceti ähnlich, noch tiefer schwarz und 
durchweg glïnzender, die Zwischenrïume der tief eingestochenen, starken Punkte der Fld, zu schmalen und scharfen, oft mit einander verbundenen glänzenden Längslinien verschmolzen, zwischen denen zwei schmale Rippen auf der inneren Hälfte mehr hervortreten. Halssch. im vorderen Drittel stark verengt und zusammengedrückt. I. 10-13 mm. Sicilien sir an a Reiche.

3. Hinterbrust mässig lang, uit feiner, aber deutlicher Mittelrime; der zwischen die Hiiften vorspringende Zipfel des ersten Bauchringes kurz, breit und stumpf.

4. Halssch. nach rorn stark rerengt, an den Vorderecken deutlich nach unten gebogen und zusammengedrückt, aufgebogener Seitenrand der Fld. breit, diese nebst dem Halssch. ziemlich stark punktirt; Zwischenräume der Punkte auf den Fld. sparsam und sehr fein gerunzelt, in der äusseren Hälfte ziemlich flach, in der inneren öfter zu Längslinien vereint. - L. 6-12 mm. Ganz Europa . . . . . . . . . . tanaceti L.

$4^{1}$. Halssch. nach vorn nur wenig mehr als nach hinten verengt, aufgebogener Seitenrand der Fld. schmal.

5. Kopf und Halssch. grob, aber nur mässig dicht, Fld. dicht und selr grob punktirt; auf der inneren Hälfte derselben fliessen zwei oder mehrere Punkte zu unregehmässigen Längs- und Quergruben zusammen, ihre Zwischenräume zu hohen und starken Runzeln. - L. 9-11 mm. Portugal. Santiago in Galicien Macchoi Joann. ${ }^{1}$ )

51. Kopf und Halssch. mässig dicht, Fld. sehr dicht, gleichmässig und stark punktirt, mit 3 oder vier leichten Rippen. - L. 4-9 mm. Daurien. Amur. ... . incisicollis Motsch.

6. Halssch. mit einem tiefen, halbovalen Ausschnitte hinter den hornförmigen Vorderecken. Gestreckt, schwarz, fast matt, Kopf und Halssch. runzelig punktirt und sparsamer als die Lnterseite weisslich behaart, Fld. kahl, äusserst dicht und gleichmässig, aber ziemlich fein punktirt, ohne Spuren von Rippen, nebst dem Halssch. lelmmgelb, gelblich, bis kaffeebraun. oft die Scheibe des Halssch. und der Fld. dunkler als die Ränder, oder (var. tenebricosa) einfarbig schwarzbraun bis schwarz. - L. 8-11 mm. Suidspanien, Portugal, Tanger.

Haagi Joann.

61. Halssch. ohne einen tiefen Ausschnitt hinter den Vorderecken 7 .

1) Dieser Art scheint mach der Beschreibung G. Miegi Perez (Anals. Soc. esp. 1874. 151. t. 3. f. 6) von Vergara in den baskischen Provinzen sehr nahe zu stehen, aber jede Fld. besitzt 8 etwas unregelmässige Punktreihen, aus verschieden grossen, grubenartigen Punkten gebildet.

VI, 4. 
7. Fld. sprarsan und sehe grol, jumktirt, viel stiorkel als Kopt und Halssel. Einfarhige schwar, zienulich matt, oder die Flrl. dunkel röthlichlram, jede mit vier hohen, scharfen, glänzenden Riplen. - I. 8,5-12 mm. Sardinien. Spanien. Nordatika, an Gurpherlium-Arten . . . . . . . . . sardoa Gené.

7'. Fld. dicht und wenig stärker, oder schwächer junktirt als $\mathrm{K}$ out und Halssch.

8. Schienen mehu oder weniger zusammengedrickt, an der Basis schmal, vor der Spitze schnell exweitert, der Aussemand daher stark gehogen, am Ende scharf und spitzig vortretend. sypitze der Vorderschienen in einen breiten Ziptel vorgezogen. linter dem das erste Tarsenglied weit oben eingefïgt ist, letzteres ist deshalb heweglicher und schlanker wie hei den übrigen Arten, gewöhlich wagerecht nach hinten geschlagen, selten nach unten gerichtet. Die Sohle der 'Tarsen, wenigstens des el'sten Gliedes, mit kahler Mittelrinne

81. Schienen nach der Spitze hin wenig und mehr allnählig verbreitert, der Aussenrand schwach gebogen und an der spitze kaum oder sehr stumpf rortretend, das erste 'Tarsenglied ist nur wenig iiber der breiten Spitze der Vorderschienen eingefügt . . . . . . . . . . . . . . 14

9. Fld. ohne Rippen, oder nur mit niedrigen. schmalen und wenishervortretenden. Tief schwarz (frische Stiicke mehr oder weniwer röthlich pechbraun), mässig glänzend, Halssch. und Fld. zienlich dicht und stark punktirt, letztere kahl. Die ganze Fusssohle halbirt. - L. 7-10 mm. Von den Pyrenäen durch ganz ípanien bis Nordafrika verbreitet. Sicilien . . angusta Kü̈ster.

91. Fld. mit kräftigen Rippen, die dritte derselben in der Regel etwas schwächer als die uibrigen . . . . . . . . 10.

10. Die Rippen der Fld. durch rerschiedene breite, punktirte Zwischenräume unterbrochen, so dass von ihnex und den etwa vorhandenen Nebenrippen gewöhnlich mu cine Anzahl länڤlicher Körner übrig bleiben. Schwar, Halssch. und Fld. welhbram. Scheibe des ersteren und die Iängskiorner der letzteren pechbraun. - L. 6-8,5 mm. Ganz Europa. interrupta (0).

10. Rippen der Fld. nicht unterbrochen. öter jedoch in die beirlen äusseren einige Punkte eingestochen . . . . . . . 11.

1]. Tahtecke dev Fld. deutlich stumptwinkelig. da der untere Xaht-

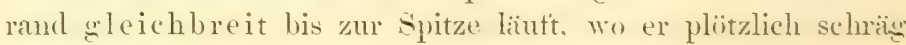
abgeschnitten ist. Schlank, schwarz, Halssch. und Fld. blass selbbram, sänzend. stark und tiet punktirt. die scheibe des ersteren und vier scharte und broite. aber nicht besonder: 
hohe Längsrippen der letzteren pechschwarz. - L. 8-10 mm. Erzerum . . . . . . . armeniaca n. sp.

11. Nahtecke der Fld. ahgerundet, der untere Nahtrand ist weit vor der Spitze allmählich verschmälert . . . . . . 12.

12. Körper einfarbig tief schwar/, bei sehr frischen stiicken pechbraun, 2 Flecke auf der Stirn röthlich . . . . . . . 13.

121. Körper schwarz, die Ränder des Halssch. und die Fld. gelbbraun bis braun, letztere mit pechschwarzen Rippen, oder die Oberseite pechschwarz, selten einfarbig, meist die Seiten der Fll. und ifter auch des Halssch. hellbraun gesäiumt. - L. 6-9,5 mm. Schweiz, Oesterreich, Schlesien, südliches Europa, Caucasus, Armenien, Syrien . . . circumdata Duft. ${ }^{1}$ )

13. Epipleuren der Fld. sehr breit nach hinten allmählich und wenig verengt, vorn ungefähr doppelt so breit als die Basis ron den Episternen der Hinterbrust. Kurz und ziemlich stark gewölbt, kohlschwarz, glanzlos, Kopf und Halssch. grob runzelig, Fld. grob und tief punktirt, dicht quer gestrichelt, mit 4 hohen und scharfen glänzenden Rippen und 2 bis 3 feinen Nebenrippen. Brust und Bauch ziemlich stark und sehr dicht quer gestrichelt, matt. - L. 7,5-10 mm. Südspanien. Algier.

barbara Er.

131. Epipleuren der Fld. mässig breit, vorn wenig breiter als das Seitenstiick der Hinterbrust, diese und der Bauch wenig dicht quer gestrichelt, mässig oder stark glänzend. Ziemlich gestreckt und wenig gewölbt, oben etwas glänzend, Halssch. und Fld. stark punktirt, die Rippen breit, aber nur mässig scharf und hoch, die vierte gewöhnlich die höchste. - L. 7-10 mm. Algier Goudoti Joann.

14. Schultern schwach entwickelt, so dass die aufgebogene Leiste am Seitenrande der Fld. (bei der Ansicht von oben) neben und vor ihnen sichtbar bleibt . . . . . . . . . 15.

141. Schultern stark entwickelt, die aufgebogene Randleiste der Fld. neben und vor ihnen vèrdeckt. . . . . . . . 25.

15. Der Eindruck, der den Seitenrand des Halssch. absetzt, ist in der vorderen Hälfte wenig tiefer und breiter als hinten, er hebt die gewöhnlich stumpfwinkeligen, abgerundeten Vorderecken nur leicht, den Vorderrand gar nicht in die Höhe 16.

1) $G$. lobata Joann., nach einem $\hat{\sigma}$ ans Konstantinopel beschrieben, gehört wohl sicher in diese Abtheilung, da die Schienen, ,assez dilatées a l'extrémité" genannt sind; vielleicht lässt sie sich von circundutu durch die grossen, regelmässig gerundeten Vorderecken des Halssch, dessen Seiten stärker erweitert sein sollen, unterscheiden. 
151. Der Eindruck am Seitenrande des Halssch. verbreitert und vertieft sich in der vorderen Hailfte sehr stark. rimnenfirmig. und hel,t die scharfen, dickrandigen Vorderecken und eineu Theil des Vorderrandes bis hinter jedes Auge authillig hoch empor

16. Kurz und plump gelsant, unten schwarz, oben hell rothloran. Kopf, Scheibe des Halssch., die Naht und rie ziemlich hohen. breiten Rippen der Fld. dunkelhraun oder pechschwarz. Oberseite änsserst dicht, grob, aher nicht hesonders tief punktirt: Halssch. doppelt so hreit als lang, hinten fast gleichlıeit, im vorderen Drittel stark verengt. - L. 7,5-10 mm. Uestliche Hälfte von Sibirien . . . . . . Sedakovi Joann.

16. Sehr gestreckt, schwarz, Fld. gelbl,raun, Kopf und Halssch. dicht und stark runzelig punktirt, letzteres wenig- länger als an der Basis oder Spitze breit, nach rorn und hinten fast gleichmässig verengt, Hinterecken abgerundet. Fld. tast regelmässig oval, beiderseits ziemlich gleichmässig verengt, dicht und stark punktirt, mit schmalen, scharf begrenzten, mässig starken Rippen. Bauch matt, sehr dicht quer liniirt. - L. 8-10,5 mm. Aendert ab: Var. aterrima, Körper einfarbig tief schwarz. Corsica

17. Oberseite dentlich und verhältnissmässig lang und stark weisslichgrau, etwas abstehend behaart; tief'schwarz, wenig glänzend, grob runzelig punktirt, die vier Rippen der Fld. kaum bemerkbar, oder nebst den ersten beiden Nebenrippen schwach ansgeprägt. - L. 9-12 mm. Mittel- und Siidspanien

artemisiae Rosh.

17'. Behaarung der Oberseite fein, wenig dicht, meist kaum bemerkbar .

18. Jedes Härchen der Fld. mindestens doppelt so lang, als der Punkt, in dem es steht, mit der Spitze in den dahinter liegenden Punkt hinein gebogen . . . . . . . . . . 19.

181. Härchen der Fld. äusserst fein, kurz, bei gewöhnlicher Vergrösserung kaum sichtbar, jedes einzelne kürzer. oder nur so lang, als der Punkt, in dem es steht . . . . . . 20.

19. Behaarung der Fld. röthlichgran. Halssch. kurz, hinten mit ziemlich parallelen Seiten, im rorderen Irittel gerundet- oder gradlinig-verengt, die Vorderecken stumpfirinkelig, kaum nach aussen vortretend. Schwarz, die ganze (Oberseite oder nur die Fld. kaffeebraun, etwas glänzend; Kopf und Halssch. dicht und stark runzelig-, Fld. weniger dicht, stark punktirt, ohne oder mit 1 bis 4 sehr leichten Rippen, wovon die innere höher ist als die übrigen. - L. 8-10 mm. . . Reichei Joann. 
19². Beharung der Fld. weisslichgrau. Malsseh. hinter der Mitte ausgerandet, vorn mehr oder weniger bogig verengt, die Vorderecken in der Regel seharf und spitz, wenigstens rechtwinklig. Schwarz oder pechbraun, matt, oben äusserst dicht gewirkt; Kopf' und Halssch. stark runzelig-, Fld. dicht und grob punktirt, die beiden ersten Rippen meist deutlich ansgeprïgt. - $\mathrm{L}$. 7,5-11 mm. Dalmatien, Griechenland, Creta littoralis Fabr.

20. Cnterseite nebst den Beinen dunkel und anliegend behaart, wie bei trnareti . . . . . . . . . . . . . . . 21.

$20^{1}$. Unterseite und Schenkel mit weisslichén. schwach abstebenden Härchen ziemlich dicht besetzt .

22.

21. In Farbe und Gestalt an die am stärksten punktirten Stiicke ron tanareti erimnernd und so wie diese glänzend, aber das Halssch. vorn bedentend breiter, an den Seiten zweimal gebuchtet. die Vorderecken scharf rechtwinkelig oder sehr spitz und in diesem Falle nach aussen gerichtet. Auf den Fld. ist keine, oder die erste Nebenrippe und die erste und vierte Rippe schwach ausgeprägt. - L. 8-9 mm. Stidfrankreich. Albas in Galicien (Heyden) . . . . . . luctuosa Joann.

21․ Den dunkelsten, vielrippigen und flacheren Stücken der pomonae ähnlich, aber der Seitenrand der Fld, auffällig breit abgesetzt. Schwarz. unausgefärbt dunkel pechbram, ziemlich matt, stark punktirt, Fld. mit mässigen Rippen und 2 bis 4 eben so lıohen Nebenrippen. - L. 8-10 mm. Westalpen. Nizza.

abbreviata Joann.

22. Fühler nur mässig stark. - L. 7-11 mm. Europa, Caucasus, Sibirien . . . . . . . . pomonae Scop.

$22^{1}$. Fühler stark . . . . . . . . . . . . . 23.

23. Halssch. kurz, mehr als doppelt so breit wie lang, am Hinterrande leicht dreimal gebuchtet, am Vorderrande hinter den Augen ziemlich grade. Unterseite schwarz, Kopf, Halssch. und Schildchen rothbraun bis schwarz, stark runzelig punktirt. Fld. gelbbraun bis rostroth, imnen grob und dicht, aussen feiner punktirt, mit 4 nur måssig scharf begrenzten, nicht hohen Rippen, von denen die dritte schwach ist. - L. 10-14 mm. Griechenland, Türkei . . . . . fuliginosa Joann. ${ }^{1}$ ) 231. Halssch. länger, kaum doppelt so breit als lang, am Hinterrande tief dreimal gebuchtet, am Vorderrande hinter den Angen dem Kopfe genau angeschmiegt, und deshalb dort steil abfallend, so dass zwischen dieser Stelle und den aufgebogenen.

1) Das einzige $\hat{o}$ in der Sammlung Chevrolat's, welches Joamis kannte, hat angeblich in Griechenland und im Caucasus gelebt. 


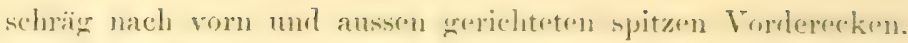
hei der Ansicht von oben, seheinbar rine kleine. winkelize Ausbuchtung entsteht . . . . . . . . . 24

24. Schwarz, Oherseite sehr groh rmzelig-punktirt. Flsl. nnit thohen. von einzelnen Punkten angegriffenen orler unterbrochenen, also nicht scharf begrenzten lippen, die Zwischenrüume der Punkte bilkden hohe Runzeln, die sich oft zu einigen geschlängelten Nelonrippen rereinen. Aendert ab): die Fld., seltener die ganze Oberseite dunkel rïthlichbram his gelblichbram. - L. 10-15nm. Syrien. Kleinasien, Armenien . . orientulis ()esculat.

241. Schwar\%, Fld. kaffeebraum bis riithlich gelbbram. tief. aher weniger runzelig punktirt als bei orientalis, won der das 'Thier wohl nur eine Localrasse ist. - L. 10-12 mm. Caucasus. Siidrussland . . . . . . spectabilis Falderm.

25. Ziemlich lang-oval, Halssch. verhältnissmässig flach, Vorrlerecken abgemulet. Schwar\%, Halssch. und Fld. gell, - L 6-9 mm. Europa. Sibirien . . . . laticollis Sahlb.

251. Breit-oral, rorn stark rerschmälert, Halssch. an den seiten. namentlich rom, stark ahwärts gewölbt, Vorderecken schart winkelig vortretend. Schwarz, die ganze Oberseite gelb, oder auch der Kopf braun bis schwarz. Fld. mit leichten Rippen. - L. 5,5-8 mm. Mitteleuropa. Sibirien . . Dahli Joann.

II. Die vier Hinterschienen mit dentlichem Enddorne. Fühler perlschnuförmig, Schienen sehr breit. Schwarz, die ersten Fühlerglieder und die Oberseite roth. - L. 4,5-6 mm. Südliche Provinzen Oesterreichs, griechische Halbinsel, Krim. rufa Germar.

III. Mittelschienen mit undentlichem Enddorne. Kante des Knpfschildes in der Witte durch die Stirnfurche unterbrochen. Lngefliigelt, flach gedrückt, schwarz, das mit zwei schrïgen Quergruben rersehene Halssch. und die dicht und fein punktirten Fld. roth. - L. $3,5-5$ mm. Mittel- und siideuropa melanocephala Ponza.

I. Fühler fadenförmig, Maxillartaster schwach, Mittelschienen mit einem deutlichen Enddorne: Galeruca in spec.

A. Randleiste an den Schultern der Fld. hoch autgebogen und am Vorderrande weit nach innen rerlängert. Lnterseite dunkel behaart.

1. Gal. Ianaceti: Nigru, nitidula, suhtus pilis obscure griseis parce restita, supra fere glabra, crebre et profunde junctata, prothorace antrorsum subcompresso, lateribus leviter iel haud simato, apice truncato, 
angulis obtusis, sulnotundutis, sulco marginali antice profundius immesso, elytris contis dorsalibus vix conspicuis. - Long. 6-10 mm.

Linné Syst. Nat. el. X. 1758. p. 369 ((7rysom.). - F abr. Syst. ent. 103. - Oliv. Ent. VI. 618. t. 1. f. 1. - Payk. Faun. Suec. II. 86. - Gyllh. Ins. Suec. III. 502, - Duft. Faun. A. III. 219 (Gallemea). - Laichart. Verz. Tyrol. Ins. I. 191. - K ïst. Käf. Eur. 2.64. - Joann. Mon. 29. - Thoms. Skand. Col. VIII. 145. - Redtb. Famn. A. 486. - Seidl. F. balt. 490 (Adimonia).

Tenebrio tristis Scop. Ent. Carn. 1763 p. 83.

Adimonia declivis Joann. Mon. 49.

" Bomouloiri Joann. Mon. 65.

" cicatricosa Cherrol. Abeille 1872. Nouv, et faits N.32. p, 131.

Var.a. Supra fortissime punctata.

Var. b. Costis dorsalibus elytrorum bene conspicuis.

Var.c. Majon: - Long: 8-12 mm.

Adim. gibbosa Reiche Ann. Fr. 1858 p. 41. - Joann. Mon. 44.

Einfarbig tief schwarz, etwas glänzend, zuweilen ziemlich matt, oben nur auf Kopf und Halssch. mit äusserst kurzen und feinen Härchen in den Punkten, unten überall gleichmässig aber weitläufig mit ziemlich langen, fast anliegenden, feinen dunkelbraunen Haaren besetzt, die bei seitwärts einfallendem Lichte nie weiss glänzen, wie bei den folgenden Arten. Halssch. doppelt so breit als lang, an der Basis nur vor dem Schildchen in einem weiten und sehr flachen Bogen ausgerandet, die Hinterecken wenig grösser als rechtwinkelig, leicht oder stark abgerundet, die Seiten daror bis zum ersten Drittel beinahe parallel oder wenig erweitert, zuweilen schwach ausgeschweift, im ersten Drittel gerundet-verengt, die Vorderecken rollkommen abgerundet bis scharf stumpfwinkelig, die Basis fast grade abgestutzt. Oberseite linten schwach, rom stärker gewölbt und öfter so zusammengedrückt, dass die Vorderecken bei der Ansicht ron oben ziemlich rerdeckt werden; die Rimne, welche den Seitenrand absetzt, rertieft und verbreitert sich vor der Mitte erheblich und hebt den Rand der Vorderecken bis hinter jedes Auge hoch empor; die breite, aber sehr flache Mittelfurche ist nebst einem mehr oder weniger niedergedrückten Streifen ror der Basis dicht punktirt, mit schmalen Zwischenräumen, auf den übrigen Theilen des Halssch., besonders in der grossen, schwachen Grube jederseits, stehen die Punkte weitläufiger, so dass ihre Zwischenräume verschieden breite, glatte Flächen bilden. Fld. an der Basis wenig breiter als das Halssch., hinter den schultern etwas zusammengedriickt, rückwärts in verschiedenem Grade erweitert, dichter als das Halssch., nach hinten und aussen zu auch etwas feiner als dieses runzelig punktirt, meist mit schwachen 
Spuren der nomalen Rippen 1,2 und 4, oder auch nuch der ersten heiden Yobenrippen, Zwischenräune der P'unkte weitläufig und selur fein quer gestrichelt; der Spitzenrand nicht verdickt. Die Rinne, welche den aufgebogenen Seitenrand ahsetzt, beginnt schmal an der hinteren Aussenecke und verbreitert und vertieft sich inmer melir bis zum ersten Viertel, von wo aus sie wieder etwas verschmälert ist, aber tief um die Schulter herumzieht und den Basalrand deutlich in die Höhe hebt.

Von den geringen Abänderungen sind anzufiilnen: a. Halssch. und Fld. sehr grob und etwas weitläufiger punktirt als hei der gewöhnlichen Form, daher auch in der Regel etwas glänzender; b. die Rippen, oder noch die ersten Nebenrippen der Fld. sint schmal und niedrig, aber ziemlich scharf begrenzt und sehr deutlich; c. Körper auffällig gross, an G. sicula erinnernd.

Auf trockenen, sandigen Grasplätzen in ganz Europa häufig; die Var. a. hauptsächlich am Südabhange der Alpen, Var. c. in Griechenland.

Nur ganz frische Exemplare, die nach dem Tode unregelmässig zusammentrockuen, haben diister braune Fld., sind aber auf keinen Fall als Varietäten zu betrachten, obgleich Joamnis nach einem solchen, welches sich jetzt in der v. Heyden'schen Sammlung befindet, sogar eine Art. die G. declivis, aufstellte. Dass Gyllenhal unter seiner Var. b. ,thorace elytrisque griseis" nicht ähnliche Stiicke, sondern die G. laticollis beschrieben hat, ist bereits von Thomson nachgewiesen, aber noch immer nicht berücksichtigt worden.

Thomson und Seidlitz nennen die Seitenstiicke der Hinterbrust kahl, aber sie haben die dunkle Behaarung derselben nur ïbersehen.

Von Ad. Bonvouloiri Joamn. aus Sarepta und cicatricosa Cherr. ans Galicien, die ich nach den ziemlich inhaltlosen Beschreibungen hierher ziehe, miissen erst wirkliche Unterschiede gebracht werden, ehe sie als Arten anzusehen sind, gibbosa Reiche ist, nach dem Mrateriale aller mir zngänglichen Sammlungen, sicher nur eine grosse Form ron tanaceti.

B. Randleiste der Fligeldecken vor der Schulter niedrig. erlöschend. Unterseite weisslich behaart.

a. Schienen dünn, vor der Spitze schnell erweitert.

2. Gal. interrupta: Ollongo-oruta, picen, subopuca, subtus pilis breribus albicantibus, supm pilis brexissimis parce cestitu, crebre et profunde punctate, antennis articulo tertio secundo duplo Tongiori, prothorace ralde transcerso, luteribus leviter bisinuatis, anyulis subrotumlatis, sulco marginali antrorsum. haud profundiore, marginilus clytrisque obscure testaceis, his costis dorsalibus et interdum costulis :2 mimis distinctis, piceis, interruptis. - Long. 6-8,5 mm. 
Oliv. Ent. VI. 620.t. 2. f. 18. - Illig. Mag. 1.423. - Gyllh. Ins. Suec. III. 718 (Gulleruca). - Joann. Mon. 57. Thoms. Skand. Col. VIII. 149. - Redtb. Faun. A. II. 487. Seidl. F. balt, 490 .

Lang-eifömig, pechschwarz, ziemlich matt, Unterseite und Schenkel nicht dicht, aber deutlich gelblichweiss behaart, auf der Oberseite ist jeder Punkt des Koptes und Halssch. mit einem kuren und feinen, jeder Punkt der Fld. mit einem äusserst kuren, schwer sichtbaren Härchen besetzt. An den tief schwarzen Fuihlern ist Glied 3 reichlich doppelt so lang als 2, die vicr vorletzten Glieder sind kurz, kaum länger als breit. Halssch. braun oder pechbraun, an den Rändern tast immer heller als in der Mitte, mehr als doppelt so breit wie lang, an der Basis dreimal schwach gebuchtet, die Hinterecken bald vollkommen abgerundet, bald scharf stumpfwinkelig, die Seiten bis zur Mitte etwas erweitert und ausgebuchtet, vor der Mitte ziemlich gradlinig, oder leicht ausgeschweift-verengt, der Vorderrand grade abgestutzt oder hinter jedem Auge ausgerandet, in letzterem Falle treten die stumpfen Vorderecken etwas vor; der Eindruck längs des Seitenrandes ist vor der Mitte zwar etwas verbreitert und vertieft, aber er wird nicht rinnenförmig und hebt den Rand und die Vorderecken nur umbedentend empor. Die Scheibe ist hinten wenig, vorn mässig gewölbt, dicht runzelig punktirt, mit breiter Mittelfurche und einer schwächeren, grossen, länglichen Grube jederseits; Schildchen schwarzbraun. Fld. rückwärts wenig erweitert, schmutzig gelbbraun, an den Seiten meist heller, dicht, tief und etwas stärker als das Halssch. punktirt, mit dicht und fein gelumzelten, matten Zwischemäumen und pechschwarzen, glänzenden Haupt- und einigen Nebenrippen. Dieselben werden durch mehr oder weniger breite, punktirte und hell gefärbte Zwischenräume unregelmässig unterbrochen und in einzelne kiirzere oder längere K̈̈̈rner aufgelöst; die Schultern sind ziemlich stark entwickelt und verdecken beinahe die schmale, wenig hohe und an den Hinterecken des Halssch. erlöschende Leiste des Seitemrandes bei der Ansicht von oben. Die Schienen sind zusammengedrückt, ziemlich schmal, vor der Spitze schnell erweitert, mit gebogenem Aussenrande, das erste Tarsenglied ist weit über der vorgezogenen, gerundeten Spitze der Vorderschienen eingefügt und besitzt beim f an allen, beim $\hat{o}$ oft nur an den Hinterbeinen eine glatte Längslinie auf der filzigen Unterseite. Der Bauch ist verschieden dicht quer gestichelt, glänzend oder fast matt.

Die Art variurt in der Farbe nur wenig, denn dic dunkelsten Stïcke bleiben auf den Fld. immer noch braun; veränderlicher ist die Körperform, da neben den gestreckten, ganz unabhängig vom 
Geschlechte. atuch sehr kure und wach hinten stark erweriterte Stücke vorkommen, die an pomonae erimuern: selten ist das Halmoch. an den seiten gleichnässig gerundet. orler von der Mitte ans bejolerseits fast gradlinig verengt: zuweilen sind rinzelne Riplen der Flil.. besonders die erste oder vierte, nicht unterbrochen.

In sandigen Gegenden in ganz Europa zuweilen sehr häufiz.

3. Carl. circumatata: Oblongo-orata, nigre, suboprece, sultutus pitis: brevibus allicantibus, suma pilis brevissimis parce restita (in coljnte et 1mothorace plerumque eridentiore), crelne et mimus profunde punctata. antennis articulo $3: 02: 0$ longiore, mothorace transierso, laterilus interdum luridis pone mertium leniter sinuris, angulis subrotundutis. sulco marginali antrorsum haud profuntiore, elytris piceis, lateribus dilutioribus, costis dorsalibus distinctis. - Long. 6-9,5 $\mathrm{mm}$.

Duft. Faun. Austr. III, 219 (Galleruca), - Joann. JIon. 53. Redtb. Faun. A. II. 486 (Adimonia).

Adim. florentina Redtb. 1. c. ed. 1. 522. - Küst. Käf. Eur. 18. 85. Adim. circumcincta Manmh. Bull. Jose. 1814. 199. - Joanu. JIon. 60. Trar. a, oelandica: Nigra, capite prothoraceque saepius nitidulis, elytris piceis aut nigris.

Bohem. Vetensk. Ac. Foerhandl. 1849. 239. - Joann. Mon. 51. - Thoms. Skand. Ccl. VIII. 147 (Adim.).

Ad. hungarica Friv. Adatok 1876 p. 340.

Var. b. jucunda: Prothorace elytrisque testacein, illo maculis tribus, plerumque in maculam magnam centralem confluentibus, nigris notato, elytris costis fuscis.

Falderm. Nouv. Mém. Mose. 1837. V. 328, - Joann. Mon. 55. - Heyd. Berl. ent. Zeitschr. 1867. 382. - Redtb. Faun. A. II. 487 .

$\mathrm{V}$ ar, c. Elytris costulis 2-5 distinctis.

$\mathrm{V}$ ar. d. sicelidis: Breviter-ohorata, elytris fortius profundeque punctutis, costis 4 sat crassis.

Der vorigen äusserst nahe rerwandt, wahrscheinlich nur eine Localrasse derselben, und daher auch durch folgende Punkte nicht immer mit absoluter Sicherheit zu unterscheiden: An den Fühlern ist das zweite Glied gewöhnlich etwas länger, das dritte deshalb kaum doppelt so lang, bei einzelnen Exemplaren kaum $1_{1 / 2}^{1 / 2}$ mal so lang als das zweite, die vier vorletzten Glieder sind deutlich länger als breit; auf den Fld. ist die Punktirmng weniger tief, die Rippen (mit Ansnahme der schwachen dritten) sind in der Regel nebst den etwa vorhandenen Nebenrippen nicht unterbrochen, und die Schultern verdecken weniger den aufgebogenen Seitenrand.

Das Thier ist sehr veränderlich. Bei der ron Duftschmid beschriebenen, rerhältnissmässig kleinen Form aus der Lmgebung 
von Wien ist die Oherseite schwarz oder dunkellnann, ein schmaler Saum am Seitenrande des Malssch. und cin breiterer an dom des. Fld., oft bis in die Nïhe der vierten Riple reichend, gell)- his rothbraun. Kopt' und Halsseh. sind sehr dicht rumzelig-punktirt, ziemlich matt, mit wenigen oder keinen loreiteren, gliunzenden Zwischenriumen, Fld. etwas stärker, aber weniger dicht punktirt, Zwischenriume f'ein gerunzelt, matt, die erste, zweite und vierte Rippe mässig hoch, schart begrenzt, die dritte fehlend oder durch kiirzere oder längere Könchen angedentet, zuweilen ist auch die erste und zweite Nebenrippe in der vorderen Iälfte hemerkbar. Bauch mehr oder weniger dicht quer gestrichelt oder gerumzelt. Das Halsseh. kanm auch einfarbig braun his sehwarz werden und der helle, gelbliche Saum der Fld. auf eine feine Jinie beschränkt sein, welche an Aussemrande der Epipleuren fortliuft und ron oben wenig oder kaum, ron unten deutlich sichtbar ist; zu gleicher Zeit hebt sich mitunter eine grosse Makel auf der Schulterbeule, oder ein hellerer Saum an der Basis oder an der Naht ziemlich unbestimmt aus der dunkleren Färbung heraus.

Eine ähnliche Form (Var. a), aber einfarbig schwarz oder mit pechschwarzen, am Rande kaum helleren Fld., ist gewöhnlich aut Kopf und Halssch. weitläufiger punktirt und durch die zahlreichen breiteren, glatten Räume zwischen den Punkten zugleich glänzender, auf den Fld. feimer, in einzelnen Fällen bedeutend feiner als das Malssch. punktirt und dann mit ziemlich schwachen Rippen. Sie erinnert an angusta Küst.

Bei harten, jedoch wohl noch nicht vollständig ausgefardoten Exemplaren (Var. b) ist der Kopf schwärzlich, öfter mit röthlichem Scheitel, Halssch. und Fld. sind gelbbram, die Mittelrinne und die beiden Gruben auf ersterem schwarz, die Rippen der Fld. braum. Nach und nach fliesst die Zeichnung des Halssch. zu einem grossen Ścheibenflecke zusammen, der sich zuletzt bis auf den Vorderund Hinterrand ausdehnt und nur die Seiten frei lässt.

Zwischen den Hauptrippen der Fld. treten (Var. c) 2 bis 5 Tebenrippen auf, von denen die erste, oder die beiden imneren oft so stark und hoch sind, wie die erste Hauptrippe; die dritte und vierte Nebenrippe, welche die dritte Hauptrippe umgeben, sind wie diese oft undeutlich und schwach, aus Könchen zusammengesetzt. oft aber scharf begrenzt und nicht muterbrochen. Stiicke mit 4 bis 5 Nebenrippen sind immer gross und hreit, plump gebaut, oben hell gefärbt, wie jucnndr, oder dunkel, wie rirumdata oder oplandica, sie kommen hauptsächlich in Wallis bei sitten und in Kärnthen bei Klagenfurt vor.

Die auftälligste Form (Var. r) tritt in sürllichen Italien und 


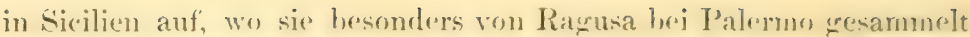
wurte. Sie ist der prmonne sehr ähnlich, nach hintron stark erweitert, sewöllt. anf den Fld. sroh punktirt, alle 4 Ripuen granz. hreit und hoch, gewïhnlich auch die erste Nebenripue dentlich auspreprärt.

Auf sonnigen Anhöhen mit fruchtharem linden im ersten Frïhlinge und im Herbste zerstreut durch ganz Europa, hesonders laäutig in Italien, Cancasus. Syrien; die Var. a namentlich bei sarepta. scheint in der norddentschen Tiefebene, wo intermptra vorkommt. zu fehlen.

Die oben angegebene Synonymie balte ich fü̈r so sicher, dass ich nicht erst eine genanere Begründung nöthig erachte; nur für circumcincte Hannh., die nach einem Stiick ron Kasantholm in Fimnland beschrieben wurde, bleibt es zweifelhaft, ob sie hier, oder bei der folgenden Art unterzubringen ist; die Worte: das Halsschild , rentice parum emarginatus, angulis ralde productis, lobatis, reflexis, apice rotundatis" und "margine laterali elerato-reflece, pracsertim antict" lassen auf pomonae schliessen, bei welcher jedoch eine ähnliche Färbung (K̈̈rper schwarz, die Naht und ein hreiter Seitensaum der Fld. gelbbraum) noch nicht beobachtet wurde.

b. Schienen nach der Spitze hin allmählich erweitert.

* Schultern schwach entwickelt. die Randleiste der Fld. ist neben und vor ihnen nicht verdeckt.

4. Gal. pomonae: Nigre, subopacu, subtus pitis righilis allidis sat dense, supra pilis brerisimis et tenuissimis parce restita, furtius subregoso-punctuta, prothorace brumeo, calde transcrerso, lateribus bisinutis, angulis anticis dentato-productis, sulco murginali antice profundius imfresso; elytris testaceis, costis dorsulibus costulapue prima sat elerutis subnitidis. - Long: 7-11 mm.

Scopoli Ent. Carn. 1763 p. 83 (Tenebrio).

(Wrysomele mesticu Sehaller Abhandl. Hall. Ges. 1783 p. 27t. -

Fabr. Mant. I. 74. - Payk. Faun. Suec. II. 87. - Rossi Faun. Etr. I. 75. - Gyllh. Ins. Suee. III. 503. - Duft. Faun.

A. III. 220. - Steph. Illustr. Brit. IV. 288 (Galleruca). Kiist. Käf. Eur. 2. 65. - Joann. Mon. 33. - Redtb. Faun.

A. II. 486. - Seidl. F. balt. 490 (Adimonia).

Adim. tanaceti var, $y$ et $d$ 'Laichart. Verz. Tyrol. Ins. 192.

Adim. dispar Joann. Mon. 34.

Adim. rufescens Joann. Mon. 34.

?Adim. Aubei Joann. Hon. 70.

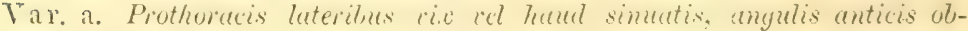
tusiusculis.

Var. b. alpestris: Prothorace plerumque ut in a, elytris costis 4 et costulis $2-5$ valde eleratis. 
Vax. c. Prothorace elytrisque migro-piceis.

? Adim. Gredleri Joann. Mou. 41.

Var. d. unthracina: Ommino saturate nigra, subopeca anet subnitidn costis (interdum etiam costulis ¿ wimis) elytrorum deratis, distinctis, vel vix conspicuis.

Adim rustica Thoms. Skand. Col. VIII. 148.

Adim. littorulis Joann. М[on. 26.

Mit tunrecti weniy verwandt und wegen der scharfen Vorderecken des Halssch., der vor den Schultern niedrigen Randleiste der Fld. und der weisslichen Beharmug der Unterseite niemals zu rerwechseln, eben so bestimint von den vorigen Arten durch die auffällig vertictte Rimne am Seitenrande des Halssch. ${ }^{2}$ ) und die breiteren, nach der Spitze alhuählicher erweiterten, viel rauheren Schienen rerschieden.

Breit eiförmig, gewölbt, schwarz, ziemlich matt, Halssch. einfarbig gelbbraun, oder dunkelbraun, meist mit helleren Rändern, oder in den Vertiefungen schwärzlich, nebst dem Kopfe deutlicher als die gelbbraunen Fld., aber sehr kurz und fein behaart. Halssch. mehr als doppelt so breit wie lang, an der Basis dreimal gebuchtet. am Vorderrande merklich schmaler als am Hinterrande, abgestutzt oder ausgerandet; die Seiten hinter der Mitte mit einem ziemlich tiefen Ausschnitte, davor zuerst etwas gerundet-erweitert, dann stärker verengt und ausgeschweift, so dass die scharfen Vorderecken sehwach nach aussen vortreten, die Hinterecken sind ziemlich scharf, rechtoder stumpfwinkelig. Oberfläche wenig: gewölbt, grob runzelig punktirt, Vorder- und Hinterrand zuweilen etwas wulstig verdickt, die Mittelfurche und die Grube jederseits mässig tief, die Rinne am Seitenrande in der hinteren Hälfte schmal und flach, oft undeutlich, in der vorderen breiter, sehr tief. Sie zieht sich ain Vorderrande noch ein Stiick bis hinter jedes Auge nach imnen und hebt den Raud besonders in den Ecken stark empor. Fld. regelmässiger und weniger runzelig punktirt als das Halssch., mit dicht und fein gerunzelten, fast quer gestrichelten, matten Zwischenräumen und ziemlich starken, glänzenden, zuweilen dunkler gefärbten Rippen. Ton diesen ist die erste oder das erste Paar am stärksten; die Punkte, die sich in den beiden immeren Zwischenstreifen befinden, sind entweder ganz verworren oder zu vier, mitunter sehr regelmässigen Reihen geordnet und damn tritt gewöhnlich zur 'Trennung von je zwei Reihen eine Tebenrippe anf, die meln oder weniger hoch, aber niedriger und schmaler als eine der immeren Hauptrippen

1) Um diese Rimne richtig zu erkemnen, ist das Thier schräg rou vorn zu betrachten. 


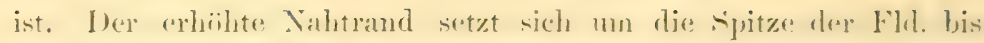

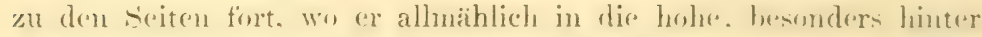

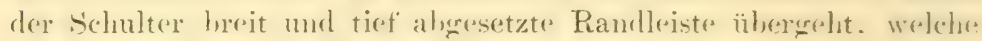
an Vorderande. nalue bei den Hinterecken des Halsich. enulet. Unterseite mässig dicht und ziemlich steif, weisslich lwhart, ver-

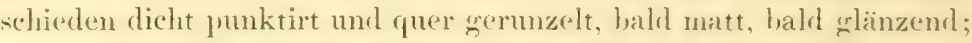
schienen vor der spitze schwach erweitert, mit wenig gelugenem Aussenrande und stumpfer Aussenecke; 'Tarsen mit ganzer Filzsolile, das erste Glied an den Vorderbeinen dicht ïher der kurz vorgezngenen dreieckigren spitze der Schienen eingefiigt.

Die veränderlichste Art der ganzen Gattung. Der Kürper wird einerseits gross, breit, stark gewijlbt, mit der grijssten Breite an irgend einem Punkte zwischen der Mitte und dem letzten Fünftel der Fld, andererseits gestreckt, mehr parallel, weniger gewiilbt, dazwischen finden sich ansser einer Inenge von Lebergangsstuten auch solche Formen, die bei grosser Breite weniger gewiilbt. nder bei verhältnissmässig gestrecktem Baue stärker grewälbt sind. Ias Halssch. kam nicht nur den Ausschnitt hinter der Mitte, sondern anch die bogenfömige Ausrandung hinter den Vorderecken einbuissen (Var. a), es ist dann an den Seiten bis vor die Mitte ziemlich parallel oder ummerklich verbreitert. im vorderen Drittel gleichmässig verengt, die Vorderecken sind stumpfwinkelig. weder nach ausien, noch nach vorn vortretend, wenn der Vorderrand abgestutzt. oder mehr rechtwinkelig und etwas vorgezogen, wem derselbe ausgerandet ist. Die Fld. sind an der spitze gemeinschaftlich breit abgerundet, jede einzelue mit mehr oder weniger stark remundeter Nahtecke, bis zu welcher der untere Nahtrand geradlinig verläutt ${ }^{1}$ ): die Rippen sind zuweilen eben so dicht gerunzelt und matt wie die Zwischenstreifen. Bei der Var. b, die hauptsächlich in den südlichen Alpen der Schweiz rorkommt und selır oft die zur Var. a gehörige Halsschildbildung autweist. sind 2 bis 5 Tehemrippen rorhanden. welche ziemlich dieselbe stärke erreichen. wie die daucben liegenden Hauptrippen und auch so scharf begrenzt sind wie diese. Zuweilen bleiben nur die beiden ersten Haupt- und Vebenrippen sichtbar, während die äusseren fehlen.

Vereinzelt finden sich stücke mit schwarzem. höchstens an den

1) Gal. cratica Joann. (Mon. 69) aus den Pyrenäen, die in ler Grösse. Farhe und Skulptur ganz mit pomonue übereinstimmt, besitzt ein nach rorn weniger rerengtes Halssch. und sebr stark einzeln abgerundete Fld Dieselben entfernen sich auf dem Abtalle zur Spitze weit rou einander und dex untere Nabtrand folgt der Rundung ziemlich bis zum hintersten Punkte. 
Rändern hellerem Halssch. und eintarbig genbbranen bis braunen Fld., oder ant letzteren ist ein schlecht begrenzter xam an Seitenrande melst den Epipleuren, oder ein sitreifen an der Naht, selten ein melu oder weniger grosser 'Theil aut' der' hinteren Hälfte schwäizlich; in der Regel nimmt jedoch die dumklere Firhung anf Halsseh. und Fld. gleichmässig zu, bis die Oberseite cinfarbig pechbraun oder schwarz, selbst tief schwarz wird. Die pechschwarze Form (Var. c) ist in einigen Gegenden, z B. bei Sarepta von Becker häutiger, an der Ostseekuiste (in Pommern von H. Tium) und an verschiedenen Punkten Oesterreichs einzeln gesammelt worden; sie hesitzt oben mur einen geringen Glanz oder ist durch eine dichte und feine Querrunzelung selır matt und stumpf und dann der G ${ }_{x}$. littoralis aus Dahmatien täuschend ähnlich. Die glänzendere, tief schwarze Form (Var. d) aus den Pyrenäen, der Schweiz. vom Lntersberge bei Salzburg (Ludy) und aus dem Ampezzothale in Siidtirol (Kauffmamm) crimmert lebhaft an $G$. tanaceti, namentlich wenn bei ihr die Rippen der Fld. erlöschen.

Auf trocknen Grasplätzen nicht selten. Ganz Europa. Sibirien.

Die Richtigkeit der angegebenen Synonymie liess sich nux in Bezug anf Aubei und Gredleri Joann. nicht sicher feststellen; erstere ist nach Stiicken aus der Sammlung von Aubé beschrieben, die in Südfrankreich bei Fréjus gefangen worden sind, letztere wahrscheinlich nach einem durchschnittlich fein punktirten, ron Gredler in Tirol gesammelten Exemplare.

* Schultern stark entwickelt, die Randleiste der Flügeldecken neben und vor ihmen vollständig verdeckt.

5. Cal. Inticollis: Ohovatu, nigra, nitidulu, prothorace elytrisque testaceo-flatis, illo transierso-qualrato, apice quam basi parum angustiore, ungulis anticis obtusis, sulnotundutis, supre minus contexo, sat crebre punctato, elytris fortius punctatis; fronte profunde impressa. - Long. 6-9 $\mathrm{mm}$.

Sahlberg Ins. Femn. II 218. - Joann. Mon. 94. - Seidl. F. balt. 491. pars.

Adim. fontinalis Bohem. Act. Holm. 1851. p. 93; Oefers. Vet.

Ak. Förh. 1852. 8. - Thoms. Skand. Col. VIII. 146. -

Kraatz Berl. ent. Zeit, 1873, 198.

Adim. flava Küist. Käf. Eur. 28, 86, - Joann. Mon. 72.

Galleruca tanaceti var. b. Gyllh. Ins. Snec. III. 502.

Aclim. confinis Gebler Bull. Josc. 1848. III. 12. - Joann. M[0n. 35.

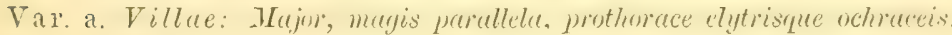

Comolli Col. Nov. Norocom. 1837. 46. - K iist. I. c. 1.64.-

Joann. Mon. 62, - Redtb. Faun. A. II. 488 (Adim.). 
Grösser, namentlich breiter als die ähnliche Lochmacu crupreae. schwar\%. Ifalssch. und Fld. brïunliclogell, oder rein hellgell, nach dem 'Tode mehr oder weniger gehräunt. Kople schwar, atwas glänzend, stark und wenig dicht punktirt und nebst dem Halssch. einzeln, kaum bemerkhar hehaart. Die Stirnrinne erweitert sich oben, zwischen den Augen zu einer weiten Grube, deren Vorderrand yon der Querrinne gebildet wird, welche die stimbeulen dentlich begrenzt. Fühler sehr schlank, schwar\%, Glied 2 zuweilen röthlich. Halssch. mehr als doppelt so hreit wie lang, an der Spitze wenig schmaler als an der Basis, die Seiten bald ziemlich grade, bald in der Nähe der Mitte etwas erweitert, gewiohnlich mit zwei äusserst schwachen, oft undeutlichen Ausbuchtungen, dic vordere liegt hinter den stumpfen und etwas alggerundeten Vorderecken, die andere, etwas tiefere, hinter der Yitte; Scheibe wenig gewölbt, stark, mässig dicht punktirt, mit mehr oder weniger zahlreichen breiten, glatten und glänzenden Zwischenräumen, die Mittelfurche und die beiden Gruben weit und flach, in der Regel dunkler gefärbt als die übrigen Theile. Fld. nach rïckwärts allmällich und mässig erweitert, dicht hinter der Mitte am breitesten, daun wieder verengt und an der Spitze einzeln abgerundet; kahl, dichter und stärker als das Halssch. punktirt, ohne Rippen, oder nur mit Spuren derselben, die durch unregelmässige Längshöcker hervorgerufen werden; der Seitenrand schmal abgesetzt und wenig anfgebogen. Unterseite und Beine fein weisslich behaart.

Die Art ist in Grösse und Körperform, sowie im Tone der gelben Färbung auf Halssch. und Fld. veränderlich; besondere Erwähnung verdient die Form a, von der südlichen Abdachung der Mittelalpen, auch aus Oberitalien und Dalmatien, welche durchschnittlich bedeutend grösser, namentlich länger als die nördlicher lebende Form und oberseits mehr rostroth als gelbbraun gefarbs ist.

Ueber das nördliche und mittlere Europa und Sibirien rerbreitet, auf feuchten Wiesen im Juli hauptsächlich in der norddeutschen 'Tiefebene nicht selten, an den Alpenbächen gem aut' Aconitum napellus.

Joamnis hat von dem Thiere drei Beschreibungen unter Adimoniu und eine unter Galleruca geliefert, die in der Hauptsache röllig übereinstimmen, da in ihmen anch nicht ein annähernd branchbares Unterscheidungsmerkmal angegeben ist; nach meinem Mrateriale ist insbesondere die Zusammengehörigkeit ron flara Küst. aus Kasan und confinis Gebl. vom Altai mit laticollis zweifellos. In Sibirien rariirt die Art ziemlich in derselben Richtung wie in Europa, indem Stiicke ans der Ebene kleiner. hiurzer und etwas gewölbter sind als die von den südlichen Randgebirgen. 
6. Gol. Dahli: Breviter-obovatu, subtus nigra, supra testaceo-flara, niticlula, prothorace upice quam basi exidenter angustiore, antrorsum subcompresso, luteribus leviter bisinuato, angulis anticis subproductis, supra conrees, crebre punctato, elytris fortius punctatis, costis dorsalibus sat distinctis; fronte modice impressa. - Long. 5,5-8 $\mathrm{mm}$.

Joann. Mon. 36. - Heyd. Berl. ent. Zeitschr. 1867. $382 .-$

Kratz Berl. ent. Z. 1873. 198. - Redtb. Faun. A. II. 487 (Adimonia).

Ad. laticollis Seidl. F. balt. 491. pars.

$\mathrm{V}$ ar. a. Capite ferrugineo, piceo vel nigro.

Von der vorigen nur in folgenden Stiicken verschieden: Der Körper nach hinten melr erweitert, der Kopf dichter punktirt, weniger glänzend, die Stimeindricke seichter und die Beulen undeutlicher; das $\mathrm{H}$ alssch. nach vorn stärker verengt und zusammengedrückt, daher gewölbter, an den Seiten mit zwei kleinen, aber deutlichen bogenförmigen Ausschnitten, der erste hinter den scharfen Vorderecken, die oft in eine kleine, nach aussen vorspringende Spitze verlängert sind, der andere dicht hinter der Mitte, die Scheibe dichter punktirt. Fld. in der vorderen Hälfte an den Seiten stärker zusammengedriickt, hinten deutlicher erweitert, der abgesetzte Seitenrand durchgehends breiter, die Punktirung ist gröber und es treten in der Regel zwei bis drei Rippen $(1,2,4)$ merklich hervor. Oft ist der Kopf mit Ausnahme eines Saumes um die Augen röthlichgelb, aber diese Färbung verdunkelt sich bis zu rostroth und beschränkt sich bei vielen Stïcken nur auf die Stim iiber der Querlinie, fehlt bei anderen gänzlich (Var.a).

In Mitteleuropa seltener als die vorige; bei Berlin im Juni zuweilen zahlreich im Finkenkruge. Sibirien bis zum Amur.

II. Beine kurz und stark, Schienen sehr breit, an den vier Hinterbeinen mit einem Enddorne, Tarsenglieder kurz, breit, Fühler perlschnurförmig. Subgenus: Emarhopa.

7. Gal. rufa: Nigra, supra mufa, antennis moniliformibus basi mus, capite prothoraceque profunde punctatis, elytris crebre subrugoso-pnenctatis, costis dorsalibus 3 angustis sat obsoletis; tibiis latissimis. - Long. 4,5-6 $\mathrm{mm}$.

Germar Ins. spec. nov. 1824. p. 603. - Duft. Faun. A. III. 1825. 223. - Küst. Käf. Eur. 1. 65 (Nachdruck). - Joanu. Mon. 74 (Adimonia). - Redtb. Faun. A. II. 487.

Ad. reticulata Küst. 1. c. 1. 65 (Erster Druck).

Var.a. Capite prothoracisque disco nigricantibus.

Eiförmig, mässig gewölbt, oben roth, schwach glänzend, unten schwarz. Kopf und Halssch. ziemlich dicht und stark punktirt,

VI. 4 . 


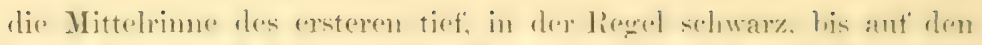

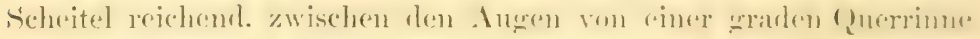

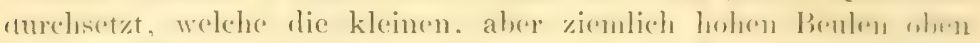

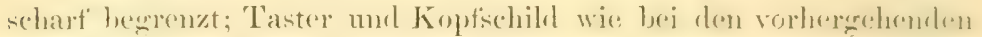
Arten. Fiihler kurz, dick, nur das arste. Iritte mul letzte (islied merklieh, die ïhrigen kaum oder unberdentenrl lïnger als hreit. nit schmaler Basis, der ganze Fïhler daher perlschnurfoimnig: schwarz. die ersten beiden und die Basis der drei his vier froterenden Glieder. selten auch das Endylied roth. Halssch. doppelt sis lreit als laug. linter der Mitte an hreitesten, von hier nach riickwiirts wenig. nach vorn mehr verengt, die seiten leicht gerundet, gleichnnässigr schmal gerandet, Vorderecken wenig rorgezogen und abgerumetet. Hinterecken stumpfwinkelig, Scheihe nit seichter, breiter Mittelrinne und einer ähnlichen Grube jederseits. Sichildchen roth. punktirt. Fld. mit stark entwickelten Schnltern, welche die fin bewimperte Randleiste rerlecken. nach hinten schwach verhreitert. viel feiner und dichter als das Halssch., runzelig-punktirt, gewiihnlich mit den drei schmalen, undeutlichen Längsrippen 1. 2 und $t$. Beine kiirzer und stärker als bei den ülnrigen Arten. Schenkel dick. Schienen an der Spitze fast $1 / 3$ in breit als lang. der Yittelkiel an ihrer Aussenkante hoch, jederseits rom einer sehr undeutliehen Rimne begrenzt, der Endilorn an den vier hinteren schienen ku1z. dick: erstes Tarsenglied mit schmaler, stielfömniger Basis, zweites so lang̈ und breit wie der breite Theil des ersten Gliedes. drittes wenilänger und breiter als das zweite, an der spitze ausgerandet. Kklanenglied dick, Klanen mit scharfem, schräg nach innen gerichteten Zahne.

Die geringen $A$ bänderungen bestehen darin. dass entweder der Kolf und die scheibe des Halssch. schwärzlichbram wird (Tar. a). oder auf den Fld. einige unregelmässige schwärzliche Tüipfelchen auftreten.

In Oesterreich, nach Brancsik auf'Gesträuch ziemlich selten. häutiger im südöstlichen Europa: U'ngarn, griechische Halbinsel. Südrussland.

III. Taster dick, Fühler perlsehnurfürmig. Mittelrimne der Stirn bis an den Vorderrand des Kopf'schildes rerlängert, Enddorn der Mittelschienen äusserst klein, vordere Tarsen breit. Körper ungeflügelt. Subgenus Haptoscelis.

४. Gal. melanocephala: Aptera, depresiusculu, nigra, prothorace "lytrisque rutis, illo profunde biimpresso, parce punctato, his apice sulttruncatis, dense subtititerque punctritis. - Long. 3,5-5 mm. 
Ponza Mém. Ac. Turin 1805 p. 57. t. 1. lin. 2. n. 3.

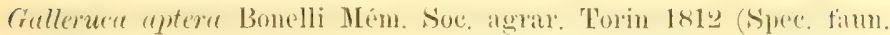
subalp.) p. 168. t. 3. f. 13. - Bach Fauna III. 131. - Joann. ILon. 73. - Seidl, F. balt. 491.

(ral. haemetiden Germ. Ins. spees. nov. b03.-- I) nt't. Famm. A. IIT. 224. - Redtb. Faun. A. II. 487.

Lnepefligerelt, oben kahl, zart gewirkt, 1unten zerstreut, fein, weisslich behatart, sehr flach, schwar/, Halssch. und Fld. roth. Kopt klein, der Mund bedentend nach rickwärts gerichtet, Maxillartaster dick. Glied 2 ziemlich birnentörmig, $3 \mathrm{kur}$, etwas breiter als 2 , 4 :m Grunde ziemlich so breit als das rorhergehende, kegreltommig. Fiihler (twas länger als bei der rorigen, die einzelnen Glieder weniger germulet. Glied 1 dick, 2 kurz, 3 und die folgenden unentühr ron gleicher Länge. Das Koptschild ist schmal-dreieckig: stark ansteigend, die beiden oberen seiten, die bei den anderen Arten eine hohe, stumptivinkelige Kante bilden, stossen hier nicht zusammen, sondern sind durch die breite Mittelfurche der Stiru getremnt; in dieser läuft eine feine, zwischen den Augen von einer mehr oder weniger deutlichen Querlinie durchsetzte Rimne bis zum Scheitel, die Stirn ist weitläufig und grob, aber nicht tief punktir wie das Halssch. Letzteres quer, vor der Mitte an breitesten, nach rorn eben so stark als nach hinten rerengt, Ecken stumpf, Scheibe flach. mit undeutlicher Mittelrinne, eine schräg nach vorn und aussen gerichtete grosse Grube jederseits, sowie ein Gribchen an der Basis, nahe jeder Hinterecke, tief. Schildchen schwarz, dreieckig, mit abgermdeter spitze, oder ziemlich halboval. Fld. nach hinten erweitert, an Ende abgestutzt, die Aussen- und Innenecke jeder einzelnen daselbst abgerundet, Epipleuren bewimpert, hinter der Mitte senkrecht stehend oder zım Theil auf die fein und dicht punktirte Oherfläche gebogen, in ter Mitte des Hinterrandes allmählich erläschend. Beine mässig stark, Schienen nach der Spitze zu wenig rerbreitert, mit undeuthichem Mittelkiele an der Aussen kante, der Enddorn der Mittelschienen schwer zu bemerken, die Tarsenglieder der vorderen Beine breit, an den Hinterbeinen gestreckt.

An verschiedenen Punkten Mitteleuropa's selten. In Frankreich besonders in Anjou; Oesterreich, Oberitalien, Provinz Preussen bei Königsberg, Ungarn, Donaustaaten. 


\section{Sermyla.}

Chapuis, Genera Col. XI. 1875 p. 224.

Corpus supra glabrum.

I'ulpi maxillares articulo penultimo apicem versus sat inflates quan secundo fere duplo latiore, ultimo brevi.

Acetabula antica occlusa.

Hetustermu processu anticn Ineri, triangulari, marginato, depress's. Tibiae posteriores calcuri distincts; tarsi lati, articuls grarts primes breviore, unguiculi validi, appendiculati.

Körper rothbraun, mit metallisch blangrimen Fliigeldecken, oben kahl, unten fein, auf dem Bauche etwas abstehend hehaart. Ko flt ziemlich gross, Augen wenig länger als breit, fast halbkugelig. Oberlippe gross, ausgerandet, Mandibeln kräftig, vierähnig, die beiden mittleren Zähne länger als die übrigen; an den Maxillartastern ist das dritte Glied nach der Spitze kugelig aufgetriehen. das letzte kurz, kegelförmig. Kopfschild breit-dreieckig. etwas tiefer als der vordere Querstreifen, hinten ron einer winkeligen, hohen Kante begrenzt, welche sich auf der Stirn bis zwischen die Fühlerwurzel zieht; dariiber beginnt eine kurze, tiefe Längsfurche, die in Verbindung mit einer aus zwei leichten Bogen bestehenden Querfurche die grossen Stimhöcker begrenzt. Fühler etwas länger als der halbe Körper, Glied 1 lang, nach der spitze ganz allmählich verdickt, 2 sehr kurz, ว̉ etwas länger als 2, 4 das läng'ste, 5 und die folgenden unter sich fast gleichlang, länger als 3. aber kürzer als 4. Halsschild quer viereckig, Vorder- und Hinterrand ziemlich parallel, ungerandet, die Seiten vor der Mitte deutlich oder kaum erweitert, breit gerandet, Ecken stumpt, abgerundet, die vorderen oft etwas nach aussen vortretend. Scheibe leicht gewölht, mit einer grossen und tiefen Grube jederseits. Fliigeldecken an der Basis wenig breiter als der Grund des Halsschildes, nach riickwärts etwas erweitert, wenig gewölbt, verworen punktirt, Epipleuren mässig breit, nach und nach verengt, die Spitze lange nicht erreichend. Prosternum vor den Hüften dreieckig, zwischen denselben zu einer sehr schmalen Scheidewand ansteigend, die sich hinter ihnen in eine dreiecke Fläche erweitert. An diese legen sich die Zipfel der Seitenstïcke und schliessen die Gelenkhöhlen. Die Hinterbrust ist rorn gerandet und sendet einen knrzen, dreieckigen. tiefliegenden Fortsatz zwischen die Mittelhiiften. Schienen am Aussenrande gewölbt, die vier hinteren mit einem deutlichen Fnddorne; erstes Tarsenglied beinahe so lang als dic beiden folgenden zusammen, das vierte kürzer, mit starken, am Grunde scharf' zahnartig erweiterten Klauen.

Beim Männchen ist das erste Tarsenglied unmerklich erweitert, 
der Hinterrand des letzten Banchringes zweimal seicht ausgofomehtet; das Weibehen besitzt an der sipitze der Lerescheide zwei lange und dünne hornige Stiele.

Die Gattung wurde bis in die neneste Zeit mit Agelestica verbumlen, von der sic wesentlich verschieden ist, aber anch die Vereinigumg mit Agelase Motsch. ist unhalthar, da diese Gattung durch die Bildume der Fiihlex, des Halssch. und des Meso- und Metasternum sebr abweicht. Es ist nur eine Art hekannt, ïber deren ('rste Stände H. Dr. Buddebero (Jahrb. Nassau. Ver. 1884 1. 101) ausführliche Mittheilumgen macht. Die Eier, welche $1 \mathrm{~mm}$ lang, leblaft gelb gefärbt und mit flachen Gruben besetzt sind, zwischen denen die Eihülle rerdickt ist, werden schon im Herloste, oft bis zn mehreren hundert Stück von einem Thiere, an Gralinm mollugo nnelegt, die Larve entwickelt sich im April und Mai des folgenden Jahres. Dieselbe ist ausgewachsen $10 \mathrm{~mm}$ lang, mässig gewïlbt, gelblich weiss, braun gescheckt, Kopf pechbraun, an den Seiten heller, mit einer klammerförmigen weissen Querlinie auf der Stim, Oberkiefer vierzähnig, Maxillartaster viergliederig, die unteren Glieder kurz, breit, das obere kegelförmig, länger als breit; hinter dem kleinen, kegelförmigen Fiihler keine Ocelle. Prothorax dunkelbraun, die Ränder und die Mittellinie heller, nneben, mit einigen grolien Punkten und einem kurzen Längsstriche jederseits an der Basis. Meso- und Metathorax mit je zwei Querreihen vou vier lraumen Tuberkeln, die mittleren beiden quer, die äussere rund. Auf jedem Riickemringe sind drei Querreihen brauner Warzenflecke; in der Mitte dicht hinter dem Vorderrande liegt ein gewöhnlich halbirter Querstrich, dahinter hefinden sich zwei Querflecke und jeclerseits ein Punkt, dahinter endlich ein Querfleck in der Mitte und jederseits ron diesem zwei Punkte. Ausserdem bemerkt man an den seiten auf der Wölbung nach unten noch zwei hinter einander stehende Punkte und die gewöhnlicle sichelförmige Seitentuberkel, auf der Unterseite einige Reihen grauer Flecken. In der Jugend ist die Larve dunkler, zuerst grau, mit einem grïnlichen Längsstreif iber den Riicken, später heller, Kopt, Prothorax und 'Tuberkeln der übrigen Leibesringe schwarz. Die Puppe erreicht die Lüinge des Käfers und ist mit einzelnen abstehenden brïunlichen Haaren besetzt, Kopf, Brust, Beine und Fligel goldgell, der Hinterleib hell bräunlichgelb, jederseits mit 5 sehwarzen Stigmen, am After zwei kurze, alstehende, am Fude hakig gelogene Spitzen.

1. Serm. Halensis: Obocata, rufo-testucea, untemis scutclloque nigris, rertice elytrisque sat crelne punctutis coerulon-ciridi-aeneis. - Long. $5,5-7 \mathrm{~mm}$. 
Linné Syst. Nat. ed. XII. 589. - Sehrank Enum. I. 79 (Chrysomela). - Herbst Arch. 7. 164. t. 45. f. 5. - Duft. Faun. A. III. 232 (Crioceris). - Steph. Illustr. Brit. IV. 286 (Adimonia). - K üst. Käf. Eur. 3. 79. - Joann. Mon. 109. - Redtb. Faun. A. II. 491. - Seidl. F. balt. 49: (Agelastica).

Galleruca nigricomis Fabr. Syst. Ent. 119. - Oliv. Ent. VI. 639. t. 1. f. 7 .

Var. a. Elytris viridi-aeneis, interdum aurichalceo micantibus.

Var. b. cuprina: Elytris cupreo-aeneis.

Hell röthlich gelbbraun, glänzend, Fühler, Angen mol sichildchen schwarz. Spitze der Schienen und 'Tarsen in ler Iiegel sclwwärzlich. (in Quertleck auf dem Scheitel und dio Fld. metallisch hlaugriu. Jas Halssch. ist in der Mitte ziemlich shlatt, nach den Sciten zu und besonders in den heiden tiefen Gruben dentlich junktirt, znweilen wird eine hreite, aber flache Jittelrime sichthar. Schildchen dreieckig, hinten abgertundet, fast glatt. Fld. mässig dicht, ziemlich stark punktirt.

Die Farthe der Scheitelmakel und der Fld. wird a. lehhaft metallisch grim. ohne blane Beimischung, aber oft mit Messingschimmer; b. lehhaft kuptermoth oder metallisch tenemoth.

In Mitteleuropa auf Galium-Arten stellenweise häufig.

\section{Euluperus.}

Corpus sublungatum suma fore glabrum, elytris pitis nommullis crectis. Antennae tenues, filiformes, articulo secundo tertio haud breviore. Acetabula antice occlusa.

Tibiae subcylindricae, apice calcari distincto.

Körper weich, gestreckt, mässig gewölbt, stahlblau oler metallisch griinlichblau. "glänzend, oben kahl, nur auf' dem Kiopfe und den Flïgeldecken mit einzelnen autstehenden feinen Härchen. Ǩn $\mathrm{f}^{\prime}$ klein, Oberlippe rorn durch einen Quereindruck ansgerander. Mandiheln stark, mit fünf stumpfen Zähnen, von denen der mittlere (ler längste ist; Maxillartaster klein, Glied 2 und 3 rerkehrt keggelförmig, 3 etwas stïrker als 2, das Endglied an der Basis so lreit wie das rorhergehende, kegelförmig. Kopfschild hinter dem breiten Querstreifen kurz dreieckig, schnell zu einer hohen Kante ansteigend, welche sich zwischen den Fühlem zu einem breiten Kiele ausbildet. Derselbe ist von zwei feinen Rimen begrenzt, die sich zwischen den Augen vereinigen und eine tiefe Grube bilden. in die anch eine mehr oder weniger tiefe, die stirnbeulen oben begrenzende Querrinne eimmündet; darüber ist die stim einzeln punktirt und 


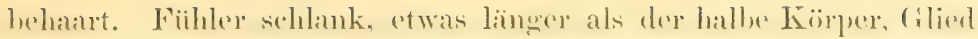

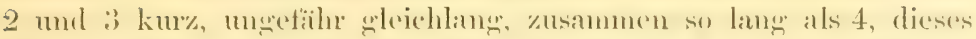

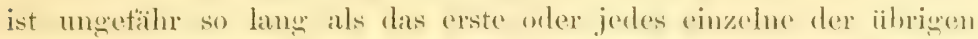
filieder vom fünften an. Ilalssehild quer viereckig, am cirundes

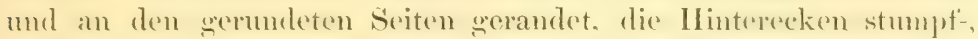

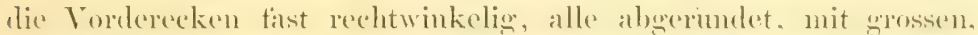
Hachen borstemporen, olen wenig sowilht, ziendich dicht, meist doppelt punktirt. Schildehen Areicekig. an der spitze abgerumbet. Fliigroldecken etwas loreiter als das Inalsschild, ziemlich gleichhreit, in lotzten Viertel schwach verengt, hinten leicht einzelu abererundet. anf dem Abtalle zur spitze mit einzelnen anfrechten Härchen; dicht punktirt, Fpipleuren schmal, sparsam bewimpert, von der Mitte der Hinterbrust an ziemlich stark verengt, im letzten Viertel follend. Das Prosternum bildet zwischen den Hiiften eine holle, schmale scheidewand, hinter ihnen fällt es wieder ab, rerbreitert sich und erreicht die Seitenstïcke, so dass die Hiiftpramnen vollständig geschlossen werden; zwischen die Mittelhüften tritt ein schmaler Ziptel der Mittel- und Hinterbrust. Die Unterseite und die schenkel sind weitläufig fein punktirt und behaart, sehr tein sewirkt. Beine schlank, Schienen eylindrisch, an der spitze mit deutlichen Enddorne; exstes Tarsenglied länger als die beiden folgenden zusammen, Klauen mit einem grossen Zahne an Grunde.

Beim Mämnchen ist der Bauch in der Mitte der Länge nach entweder flach gedrickt, selbst schwach vertieft, und mit längeren Haaren besetzt, oder dicht gekörnt, der Hinterrand des letzten Ringes ist in der Mitte abgestutzt oder in schwachem Bogen vorgezogen, daror mit einem tiefen Eindrucke rersehen, welcher nach rorn allmählich ansteigt, an den Seiten aber zu einer dicken Längsbeule emporgehoben ist.

Die wenigen Arten dieser Gattung, die in südöstlichen Europa und dem angrenzenden Asien einheimisch sind, wurden bisher zu Luperus, und zwar zur Ćnlumicrus-Gruppe gerechnet, mit der sie habituell grosse Aehnlichkeit haben, aber durch die geschlossenen Gelenkhöhlen, die Punktirung und die Geschlechtsauszeichumng abweichen.

1. Eul. xanthopus: Subjarallelus, minus comerus, supra chalybaens, nitidus, antemnis aprem rersus infuscatis pedibusque fleris, femorum basi nigra; prothorace elytrisque dense subtilissime punctulatis. - Long. 4,5-5 $\mathrm{mm}$.

Ias: subtus niger, metastemo chalybaeo, rentre in medio yramuluto-punctato, opaco, segmento ultimo apicem rersus late et profunde impresso, lateribus impressionis prasertion postice tuberculuto-eleratis. 


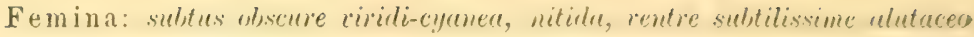
et parce punctulato.

Duf't. Faun. Austr. III. 234 (('rioceris). - Joann. JIun. 130. Redtb. Faun. A. II. 492 (Luperus).

Lup. violaceus Harold Col. Heft. 15.

, rufipes Ratzeb. Forstins. 245.

" Chevrolati Joann. Mon. 128.

" fossulatus Joann. Mon. 131.

Gestreckt, ziemlich parallel, wenig gewïlht, lebliaft und gläuzend stahlblau, auf Kopf und Halssch. ïter nit grünlichem schimmer, Fiihlex und Beine grösstentheils gelb. Erstere sind verhälnissmässig kräftig gebaut, bei frischen Stücken einfarbig gell, orler die spitz: der letzten Glieder schwärzlich, bei vollkommen ausgefärbten sind die vier letzten Glieder schwarz und die drei vorhergehenden etwas gebräunt; das zweite Glied ist wenig aber deutlich kiirzer als das dritte. Halssch. am Vorderrande so breit als der Kopf in den Augen, iiber den Vorderecken stark abtallend, dic Ecken daher von oben nicht sichtbar; äusserst fein punktulirt, dazwischen mit einzelnen grösseren Punkten, welche ror der Basis stärker werden und ziemlich dicht stehen. Fld. stärker und dichter punktirt als das Halssch., in den Zwischenrämmen mit mehr oder weniger zahlreichen feineren Piinktchen. Diese treten bei frischen Stiucken wenig hervor, bei ausgehärteten erreichen sie fast die Stärke der iibrigen Punkte und schwächen den Glanz der Fld. etwas ab. Die Beine sind gelb, Vorderschenkel in der Basalhälfte, die übrigen über die Hälfte oder bis in die Nähe der Knie schwarz, oft mit blauem oder griinem Schimmer.

Beim Männcheu sind die Seiten der Mittel- mol Hinterbrust und der Bauch schwarz, letzterer ist längs der Mitte auf einem breiten Streifen dicht körnig punktirt, matt, das letzte Segment in der Regel so lang als die drei rorhergehenden zusammen, der grubenförmige Eindruck auf demselben beginnt bald hinter dem Vorderrande und rertieft sich allmählich stark nach hinten. Die Unterseite des Weibchens ist dunkel metallisch grimblau, glänzend, der Bauch äusserst fein und nicht besonders dicht gewirkt. sparsam punktulixt.

Bei Wien (Duftschm.); Ungarn, Siidrussland, Kaukasus.

Nach der Tradition ist die rorliegende Art, welche friiher besonders durch Steven und Parreyss aus der Krim in den Sammlumgen rerbreitet wurde, die wirkliche ('rioc. xanthopa Duft, auch geht aus deren Diagnose hervor, dass Duftschm, nicht die zweite, in Dalmatien häufige Art ror sich gehabt haben kann, da er die Schenkel nicht schwarz, sondern nur ,f cmorum busi nigra" nemnt; dagegen ist ihx Vorkommen in Oesterreich 
nicht verbüret. Schmiltberger (Ratzeb. Forstins. 245) soll sie zwar auf Obstbämmen, namentlich Apfelbämmen gefunden haben, deren Blätter von ihr zerfiessen wurden, und Redtenbacher wie Joamis geben ebenfalls als Vaterland Oesterreich an, aber die Herren Ganglbaner und Miller theilten mir mit, dass ihnen noch kein zuverlässig ïsterreichisches Stück vor Augen gekommen wäre.

Erwähnenswerth scheinen mir zwei Formen, welche sich nach der Ansicht eines reichlichen Materiales vielleicht als Arten herausstellen, hier aber nur als örtliche Abänderungen betrachtet sind.

a. Var. rirescens. Halssch, und Fld, oder wenigstens die letzeren blangriun, durchgängig stärker punktirt, die vier ersten Fühlerglieder, die äusserste Spitze der Schenkel an allen Beinen, sowie die Schienen und das erste Tarsenglied rüthlichgelb. Glied 2 und 3 der Fühler ziemlich gleichlang: - L. 4-6 mm. Kurusch (Faust).

b. Var. fuscipes. Beine pechbraun oder schwarz, Schenkel grïnlich glänzend, die Spitze der Vorderschenkel, die Vorderschienen und die Basis der vier hinteren Schienen in geringer Ausdehmung gelbbraun; die ganze Oberseite kräftig doppelt punktirt, bläulich metallgrün, oder Kopf und Halssch. stärker in Blan übergehend. Gestalt und Farbe der Fiihler wie bei der vorigen Varietät. L. 4-6 mm. Kankasus: Swanetien (Leder, Reitter), Plateau von Gudaur (Schneider, Beitr. Kauk. Käferf. 338 als nigripes var.? aufgezählt).

Eine zweite emropäische Art ist Eul. cyaneus Joann. Mon. 129, wozu als $\hat{\jmath}$ der nach einem sehr frischen Stücke beschriebene Lup. costulis Joann. Mon. 134 gehört. Sie ist dem canthopus sehr ähnlich, aber die Fïhler sind bedeutend feiner, Glied 2 und 3, die ungefähr gleiche Länge haben, gestreckter, die ersten fünf Glieder rothgelb, die Vorderecken des Halssch. treten schärfer und weiter nach aussen vor und sind von oben sichtbar, die dunkel stahlblane Oberseite ist feiner und verloschener, die grülichblane Unterseite dagegen etwas stärker punktirt, die Schenkel sind bis nahe an die Spitze schwarz. Beim Männchen sind in der Regel die hinteren Schienen mehr oder weniger weit gebräunt oder geschwärzt, auf dem Bauche ist höchstens die Hitte der beiden letzten Segmente gekörnt und die Grube am Hinterrande des fünften Ringes nur kurz und mässig tief. - L. $3,5-5 \mathrm{~mm}$. In Dalmatien und der Herzegowina (Reitter) nicht selten.

Herr Kauffmann in Wien fing bei Zara ein $\hat{\jmath}$, welches mit einem ㅇ von Lup. aetolicus in Copula ist.

Fiir eine Form (Var. major) von cycneus halte ich einige, mir aus den Sammlungen der Herren Hiller und Kanffmann vorliegende weibliche Stücke, welche H. Merkl in der Türkei gesammelt hat. Sie sind länger, bedentend breiter und gewölbter als Dalmatiner Exemplare, ibr Halssch. ist rorn mehr verengt, die Vorderecken desselben treten nicht nach aussen vor und sind bei der Ansicht ron oben rerdeckt, die Torderschenkel nur in der Basalhälfte schwarz. - L. 5,5-6 mm. 


\section{Zweite Unterabtheilung: Halticae.}

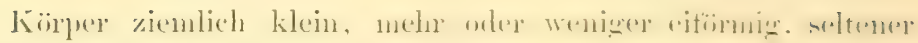

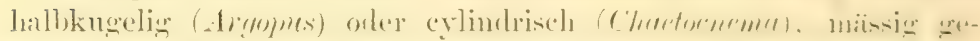

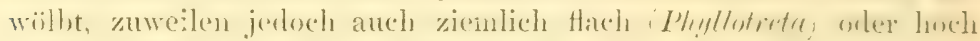

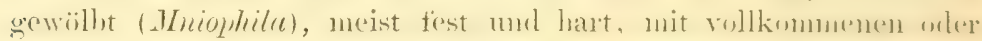

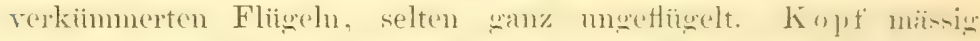
oross, schmaler oder nur so breit als der Torderrand des IIalsschildes und in dieses bis zum Hinterrande der Augen oder winzlich (I)ibolia) eingezogen, der Mund gerade nach muten, orler in

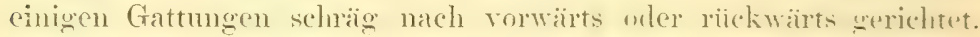

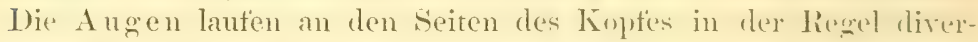
girend nach unten. sie sind regehnäsig alliptisch, oval oder sehwath

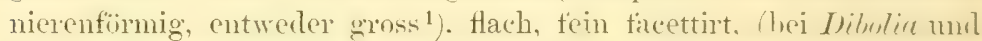
den wenigen exotischen Gattmengen nit vollständig cinzidhbarem Kopfe), oder kleiner, sols facettirt, nach hinten und ausisen gewijlbt. Im letzteren Falle befindet sich hinter ihnen, zur Autualnue der Vorderrandkante des Halsschildes, eine verschieden tiete Rinne, die sich auf die Stirn bis über die Fülnlerwurzel vellingeret und hei den meisten Gattungen nahe jedem Auge mit einer Borstenpore besetzt ist. oder dicht nehen einer solehen hinzieht. Diese heiden Rimen des Koptes lanfen entweder cin kleines stitck ouler bis über die Fiihlerwurzel ummittelbar am Inmemande der Angen fint und gehen dann in eine gerade. bogentörmige oder gebuclitete Querrime zwischen den Augen iiber. so dass sie eine einzige. bogenfömige oder zwei- bis viemal gebrochene Rime bilken; orler sie entfernen sich allmählich rom inneren Rande der Augen. stossen auf der Stirn in einem Punkte zusammen oder durchschmeiden sich daselbst und bilden einen melw oder weniger scharten Winkel. Leber oder unter ihmen liegen meist immer zwei benlen ituberuluc frontules, schmal ofler breit, rund. oval oder seln esestreckt, ringsum, an ein oder mehrecen Seiten oder nirerents schart begrenzt. Zwischen den Fiihlern ist die Nim a. ziemlich weichbreit, bald schmal, in einen Längskiel (cavinn fucrulis) autopetriehen. der sich über dem steil abtallenden, sehr kurmen und breiten. dreieckigen

1) Bei der amerikanischen Gattung. Mergistops stossen die Augen auf dem Scheitel beinahe oder vollständig zusammen. 


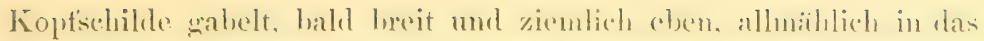
Koptsichild ähergehend; oler h. math nuten oder nach when hin

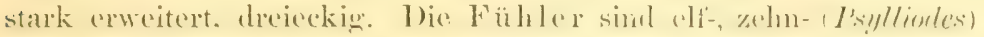

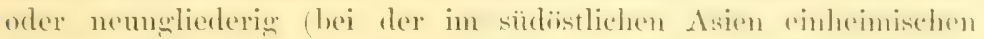

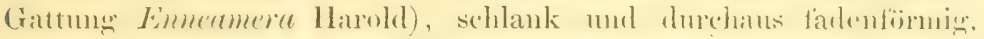
wler nach der spitze allmählich etwas verbreited. orler mullich mit

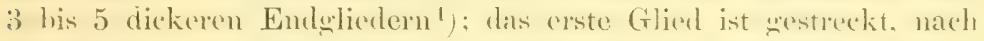
der spitze zu wenig oder stark rerdickt und dort oft broiter als dir. folgenden, in der Ruhe wirt es in sine Vortichung nuterhalb dere Angen eingelent: das zweite Gilied ist gewöhnlieh das kleinste, zuweilen jedoch shen so gross als das dritte, selten länger, dic folgenden Glieder sind mehr oder weniger gestreckt, das Eudwlied oft mit scharter, deutlich absesetzter spitze. Die Insertionsitelle der Fiiluler hefindet sich etwas über der Linie, welehe den muteren. Rand der dugen verhinden wiirde, merklich höher hei Longitusus, viel tieter hei Iithonoma: die Fühlerwurehn haben wuter sich und ron den Augen ungefähr den gleichen Abstand, aber sie rïcken näher aneinander in der Gattung Dibolid, weiter auseinander bei Manture Orestir ate. lesonders weit bei Psylliodes, wo sie rlicht an inneren Angentande stehen nud ziemlich durch die sanze stimbreite getremut werden. Das Koptsehild ist von der stim weder durch einen Eindruck. noch durch eine Linie getrennt ninl fäll zu seinen vordersten 'Theile, dem gerade abgestutzten, flachen und mehr oder weniger hewimperten Querstreifen allmählich orler plützlich ab: nur in der Gattung Argopms ist der dicke Vorderrand der Stirn tief, hufeisenfömig ausgeschniten, wodurch jederseits eine verschieden lange, behaarte suitze entsteht, unter welcher der Querstreiten des Koptischilies ebentalls in eine (von oben verteckte) spitze rerlingert ist. Die ()herlippe ist horniy, quer-viereckig, vorn gerade oder hogentïmig alowestutzt, hantig ausgerandet, mit einer Quereihe ron grubenfömigen. mit je ('incm Vimperhärehen hesetzten Punkten in orler vor der Mitte. Die Mandibeln sind stark, liurz und breit, tïintzähnis.. dex mittelste, die spitze bildende Zahn und der darmuter befindliche sind meist immer sichtbar. während ron den drei übrigen, kürzeren Zähnen die ersten beiden unter der Oberliple, der füntte unter den 'Tastern rersteckt sind; vierzähnige Kimbacken benitzt Haltira, schlanke, zweizähnige Plectroselis. I)as Halsschild ist quer viereckig, an der Basis so breit oder wenion schmaler als die Flïgeldecken, denselben genau angepasst und fin, häufiger nicht gerandet. in den Hinterecken

1) Bei einigen exotischen Gattungen gesägt. 
mit rinere grossen Borstenpore, die nur hei Mrenteren mulentlich wirk oder fehlt; die seiten convergiren gradlinigr oder gerumbet nach vorn, haben einen abgesetzten und mehr orler wenigere antgetugenen Rand und treten in der Xiahe der Vorderecken oder in diesen selhst winkelig oder zahnartig vor, je nachdem olie Borstenpore in oder hinter den Ecken, in der Seitenkante onler über derselben eingestochen ist; der Vordermand ist in leichtem Bogen ansseschnitten oder ahgestutzt, meist ungerandet. Die Oherfläche. ge wöhnlich in der vorderen Hailfte stärker queriileer gewijllt als in der hinteren, ist verworren punktirt und be: einem Theile der Arten ohne Eindriicke oder Vertiefungen, leei drun andern a mit einem tiefen, aussen oft scharfkantign hegrenzten strichelchen jederseits an der Basis z. B. bei Hruture, oder b. auch noch an Vorderrande (Pordanica), c. mit einem moln oder weniger tiefen Quereindrucke vor dem Hinterrande, welcher an den Seiten allmählich erlöschend, umleutlich grubenförmig vertieft (Incttirn), oder d. jederseits von einem Längsstrichelchen begrenzt ist (Crepuddoderr). Schildchen klein. dreieckig. Flügeldecken hinter den sichultem erweitert, hicrauf entweder ziemlich gleichbreit, fast parallel wler schwach gerundet, oder nach hinten verbreitert. ror der spitze wieder verengt, an derselben gemeinschaftlich oder einzeln ahgerundet, ausnahmsweise abgestutyt und in leichtem Bogen ausgerandet (Awhenocoela), oben rerworren punktirt bei den Arten mit offenen Gelenkhöhlen, gereiht- oder gestreift-punktirt bei den Arten mit geschlossenen Gruben der Vorderhüften. Die Obertlïche ist kahl, selten aut dem Abfalle zur spitze einzeln behart. in der Gattung Epitrix aber haben die '/wischenräume der Punktstreifen regelmässige Reihen feiner Hürchen. Die Epipleuren sind ziemlich breit und verjiungen sich allmählich bis in die Tähe der Spritze oder bis an den hinteren Aussenwinkel der Fld., bei Lomgitarsus reichen sie nur bis hinter die Nitte und bei Irbolia verschwinden sie noch früher; ihre Fläche ist ziemlich eben. glatt, oder mit einer Punktreihe besetzt, oft bewimpert, hald schüäg nach unten und innen gerichtet. bald wagerecht, selten nach imnen zu vertiett. Zi: grösseren Befestigung der Flügeldecken bleilut die untere Nahtkante bis zur Spitze ron der oberen entfernt und die riemlich breite. leistentörmige, senkrecht nach unten serrelitete innere Nahttlïche greift in je eine Längsfurche oder Gruhe ant der Afterdecke ein.

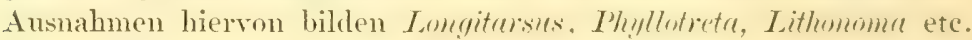
Die Vorderbrust kann nur in zwei Gattmengen. Apteropedu und I libulia, den Yund aufnehmen, indem sie gross. stark gewolbt und in der Witte des Vorderrandes etwas vorgezngen ist. bei den ührigen ist sie rorn ansgeschnitten, schliesst sich an die kehle an und liisst. 
den Mund weit frei. Dex mittlere Theil, das eigentliche Prosternum, hildet zwischen den Vorderhiiften eine vorscheden hreite I'latte, welche gewöhnlich in der Mitte rersehmälert, hinter den ILiften

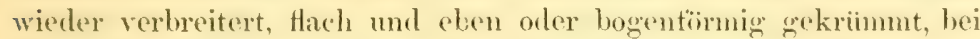
Orestia der Lange nach vertieft und mit ihren riekwairts divergirenden leistenfömigen seitenaindern höher als die Ifüften ist. Hinten fällt sie ab und legt sich in ein oder melurere fruben oder eine Querrinme der Mittelhrust fest ein, vorn goht sie alhuahlich in die Epistermen iber, welche quer-viereckig sind wie bei den Chrysomelinen. Eine Naht, die ron der Aussenecke der IÜftgrube schräg nach dem Vorderande liuft, tremnt sie von dem grossen Epimerum. Dasselbe ist im vorderen 'Theile hoch und mehr oder weniger gewölbt, hinten zur Einlagerumg der Vorderschenkel vertieft und verlängert sich hinter den Hiiften in eine schmale und lange. dreieckige Spitze, ohne das Prosternum zu erreichen, oder in einen schmalen Streifen, welcher sich an das Prosternum legt und die Hïften schliesst. Die Mittelbrust ist kurz, der mittlere Theil quer- bis länglich-viercekig, nach vorn abfallend, öfter ganz verdeckt; die Seiteustuicke sind deutlich und ziemlich gross, durch dicke Nähte getrennt. Das Metasternum ragt mit einem Fortsatze wenig oder weit zwischen die Mittelhüften hinein, bei mehreren Gattungen (Orestia, Mniophila etc.) berührt es das Prosternum und verdeckt dann das Mesosternum vollständig; die Seitenstiicke sind nur bei Mniophila nicht deutlich getrennt, bei Hipmuriphila Modeeri dicht behaart. Die Hüften liegen quer, ihre Pfannen sind eiförmig, innen gerundet, aussen zugespitzt. Die vier Vorderbeine sind ron normaler Bildung ${ }^{1}$ ), mit spindelförmigen, nicht dicken Schenkeln und schlanken Schienen, die Schenkel der Hinterbeine dagegen verlängert und keulenförmig rerdickt, entweder linsen- oder eiförmig, an der Basis am breitesten, oder mehr spindelförmig; der Hinter- oder Innenrand zur Aufnahme der Schienen gerinnt, selten nur abgeplattet. Die Hinterschienen sind länger als die übrigen, wie diese auf dem Rücken gerundet, flach gedrückt, rinnenförmig ausgehöhlt oder (Haltica) mit einem feinen Mittelkiele versehen; die Ränder der Riickenfläche sind einfach, oder mit Körnchen, Haaren, Börstchen oder dornartigen Zähnnchen besetzt, mehrfach ausgeschnitten (Psylliodes), oder nur der Aussemrand in der Spitzenhälfte bogenförmig ausgerandet (Iithonoma, Plectroscelis). Am Ende der Hintersehienen befindet sich ein einfacher, nur bei Dibolia sehr breiter und in zwei Spitzen verlängerter

1) Psilapha flara Clark aus Neu-Granada hat nach der Spitze stark erweiterte Vorderschenkel und -Schienen. 


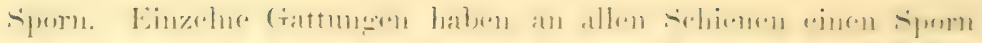

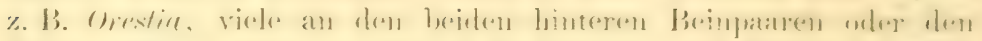

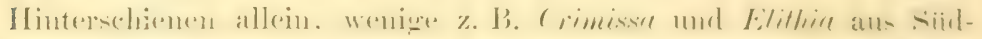

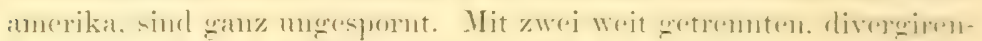

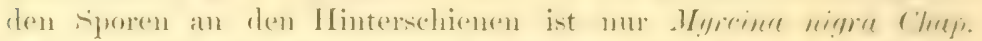

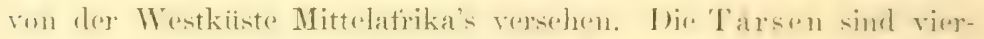

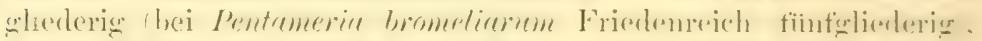

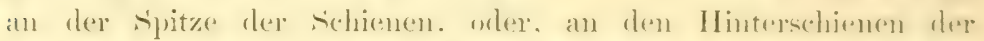

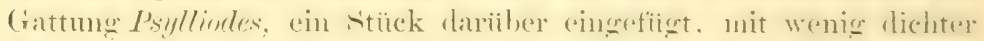
Filzsohle, einzelne Glieder oft nur bewimpert \%. B. das erste filied der Hintertarsen bei vielen I'sylliodes-Arten. orler schuppentionnier

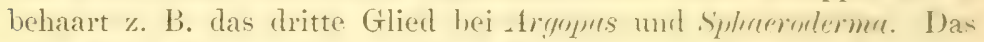
erste cilied ist länger als eins der tolgenden. sn lang als diese zusammen und of länger als die halbe schiene an den Hinterleinen

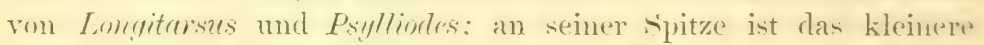
zweite Glied in einer (irmbe orler in einer Rimne mit lohen seitenkanten (Psylliorles) befestigt. das dritte ist zwoilapprig orler ziemliclı herztömig. breiter und sowïhnlich anch längere als das zweite lwi Psylliorles und Iongitarses viel kürzer!. Das Klauenglied (rweitert sich aus schnaler Bawis etwas nach rom. ist schlank niler mässig breit, in odex vor der Mitte des dritten Gliedes befestignt

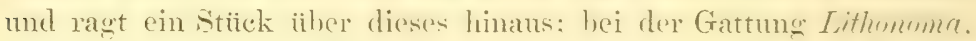
die als letzter Ausläufer einer untangreichen tropischen Gruplue in die eurouäische Fauna hineinreicht, ist der Basaltheil des Klanengliedes an den Hinterbeinen sehr dïnn, dex treie, voragende Theil dagegen blasentiomig verdickt. Die Klanen sind schwach unt kurz, mit einem zahnfïmigen Anhängsel am (rrmute. selten einfach. Der Bauch besteht aus tünf Pingren, ron denen in der Plertroscelis-Gruppe die beirlen ersten rerwachsen sind. der erste und der letzte ist lang, jeder der drei mittleren kurz.

Aenssere mind recht bedentende Geschlechtsmerkmale finlen sich namentlich bei den Arten, wo die Männchen durch erreiterte Fiillerchlieder, oder das breite, öfter beinahe scheibentimuige urste Tarsenglied, cigenthümlich gebaute schienen. oder durch Tertiefungen auf dem letzten Bauchringe ausgerzeichnet sind. In den meisten Fïllen wind ibberhaupt die Bildung des füinften segmentes zur Unterscheidung beider Geschlechter ausreichen, sein Hinterrand ist nämlich beim Weibchen einfach, alogerumlet oder stumpt zugespitzt, beim ILämchen beiderseits leicht auscerandet oder weschweift. wodureh der mittlere Theil in einen kleinen, gerundeten, etwas niedergedrickten oder vertieften Lappen vorgezogen und der. ganze Rand abgestutzt erscheint. - Der Penis bildet eine hornige. gebogene oder gerade Röhre. mit weiter Oeftinum und rerschieden 


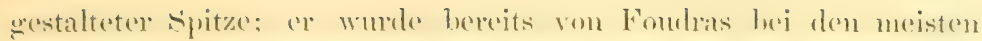

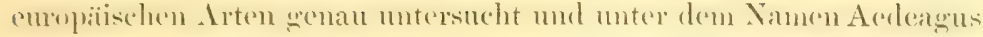

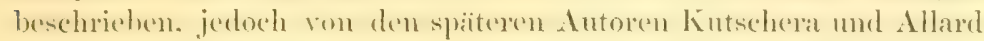

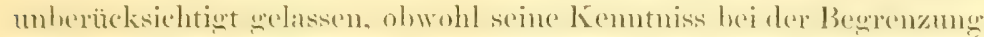

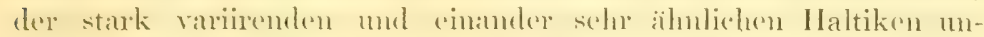

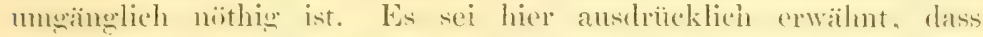
Fondras den l'enis sterts von unten betrachtet und daher immere dise seite desselben hesehrioben hat, ant der die t)effinmeg nicht liegt.

Lnsere Kemutniss ron der Entwicklung ist sehn gering und theilwoise moch ungenan: mit sicherheit geht aus den bisherigen Benbachtungen ungetih Folendes hervor: Die Eier werden von den übrrwinterten Insekten in Friblinge an den Stengel oder dic Blitter der Nährptlanze relegt ${ }^{1}$, sie kleben in mehr oder weniger grossen Häufchen nehen einander, sind regelmässig elliptisch, meist matt. weisslich, gelb oder roth, und dicht mit regelmässigen oder umregelmässigen schwachen V'ertiefungen besetzt, deren /wischenrïume zu feinen leistenfömigen händern aufgebngen sind. Die Laven werden mehr als doppelt so lang wie der Kïfer, sind gestreckt, linear oder heiderseits verschmilert, halbwalzig (unten flach) wler ziemlich cylindrisch, abstehend sparsam behart. Wor Kopf ist klein, gerundet-dreieckig, hornig. Mandibeln schmal oder mässien breit, rorn mit mehreren scharfen Zähnen; Maxillartaster gross. conisch, vieroliederig; Füilıler von älnlicher Form, aber kürzer, dreiglierlerig, hinter ihnen gewöhnlich keine (Ucelle²). Der Prothorax ist länger mul etwas härter als einer der folgenden Ringe. jederseits in der rerschiedensten Form eingedrickt, wïhrend die iibrigen segmente eine oder mehrere Querfurchen besitzen, das Analsegment ist meist in der Mitte grubig vertieft. Von den 9 Stigmenpaaren steht das erste auf dem Mesothorax, die andem befinden sich an den seiten der ersten 8 Riickenringe. An den kurzen Beinen ist die Schiene etwa so lang als der richenkel, die. Klaue einfach. Die Larren leben hald aut' der L'nter- oder (Oberseite der Blätter, die sie skeletiren (Irultira), benagen oder miniren (Phyllutretre), bald im oberen 'Theile der Wrurzel oder der stengel. hasis i Longiturses, Porlanvicre) ihre Terpuppung geschieht in der

1) Dass Pudugrica fuscipes die Eier in die Erde lege, wie Fundras (Altis. p. 34t) mitheilt, beruht wohl nur ant einer ungenïgenden Beobachtiung:

2) In dieser Hinsicht sind oft die Arten einer Gattung rerschierden: so hat z. B. die Larve von Haltica coryli deutliche Ocellen, die von oleracea nicht. 


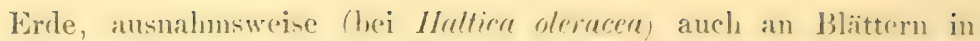
ähnlicher Art wie hei den Crexinellen. Die Puppen sind etwa von der Iänge und Gestalt des Käfirs, weisslich oder gelblich, einzoln behaart, die Fiihler bogenfömign un die vorderen beiden Beinparte gelegt, an After hefinden sich gewöhnlich zwei spitzen.

Eine andere Entwicklung diurte sich bei den Orestien heransstellen, dem man findet diese Thiere in den gelirgigen Gegenden nur in dichten Wäldem unter Laub und Fichtemnadeln an Stellen. denen die niedere Vegetation fehlt, und es ist nicht unwahrscheinlich, dass sie sich dort ron Schimmelpilzen ernähreu.

Das vollkommene Insekt schlüpft im Juni und Juli, oder noch später aus, und deshalb ist der Hochsommer bis in den Herbst die ergiebigste Zeit zum Sammeh der Haltiken, olwohl manche Arten, namentlich die an sumpfigen, im Sommer schwer zugänglichen Orten lebenden, z. B. Phyllotreta ochripes, zahlreich in ihrem Winterlager in den abgestorbenen Grasbüscheln auf dem Eise zu fangen sind. Aus der grïndlichen Zusammenstellung von Futterpflanzen, die H. Bargagli im Bull. ent. Soc. Ital. X. 187 s fasc. 1 und 2 für die meisten europäischen Arten lieferte ${ }^{1}$ ), ergiebt sich, dass Cruciferen, Boragineen, Compositen, Labiaten und Malvaceen die hauptsächlichste Nahrung fiir diese Thiere lilden und dass einzelne Gattungen, z. B. Podagrica, nur auf eine Pflanzenfamilie angewiesen sind.

Die in Europa und auch in dem hier behandelten Gebiete zahlreich vertretenen Arten nähern sich im Körperbaue und der Lebensweise den Chrysomelinen; es sind träge Thiere, die gewöhnlich auf' der Unterseite der Blätter sitzen und sich bei der Beriihrung fallen lassen, oder in der Regel durch einen Sprung zu retten versuchen. Bei ihrem lang'samen Marsche treten sie mit allen Tarsen auf, indem sie nicht nur die vorderen, sondern auch die Hinterschienen als Stiitze gebrauchen, oder sie haben dabei die Hinterschienen stets in die Schenkelrinne eingelegt und treten nur mit den beiden mittleren Fussgliedern der Hinterbeine auf (Psyllindes); ihre Sprungfähigkeit ist gering (Orestia, Hypnophila, Sphaeroderma), mässig, bei der Mehrzahl der Arten, in einigen Gattungen, besonders Psylliodes und Longitarsus, sehr bedeutend, oft wird sie durch eine gleichzeitige Flugthẳtigkeit unterstützt.

Wenn der Bau der Hinterbeine und die dadurch bedingte eigenthimliche Art der Fortbewegung durch einen Sprung, als der

1) Darin werden anch einige Pflanzen genannt, die ron den Thieren entschieden nicht der Nahrung wegen, sondern nur zum rorübergehenden Aufenthalte aufgesucht worden sind. 
hauptsächlichste, weil leicht in die Angen fallende Unterschied von der vorigen Unterabtheilung anzusehen ist, so besitzen die Haltiken noch eine lieihe anderer. schon in ihrer Charakteristik besprochener Merkmale, welche eine Verwechselung mit den Galeruken ausschliessen: Ihr Kirper ist weniger lose, vielmehr in allen seinen Theilen f'ester zusammengefügt, das Halsschild mit den Flïgeldecken, die Vorderbrust mit der Mittelbrust, die Fld. mit dem Rücken des Hinterleibes enger verbunden, die Fiihler sind durchschnittlich kiirzer, die Vorder- und Mittelhuiften niedriger, tiefer in die Pfannen eingesenkt, immer deutlich und mässig breit von einander getrennt, der Bauch ist härter, beim Weibchen nur wenig dehnbar, woraus auf eine verschiedene 'Trächtigkeitsdauer oder auf eine andere Entwicklung der Eier geschlossen werden darf.

Die wenigen Arten, welche Linné kannte, wurden von ihm in der Syst. Nat. ed. X. 1758 und der Faun. Svec. ed. II. 1761 zur Gattung Chrysomela gestellt und durch den Beinamen saltatoriae von den iibrigen gesondert, Geoffroy grüindete darauf (Hist. d. Ins. 1762) die Gattung Altica, welcher Name, von Olivier, Paykull, Gyllenhal, Illiger, Duftschmid etc. in demselben Sinne gebraucht, durch die allmähliche Abtrennung von Gattungen ein etwas unsicherer Begriff wurde, so dass ihn Allard in der Monographie 1866 nicht mehr anwendet, obgleich er unbedingt erhalten bleiben und auf Graptodera All. bezogen werden muss. Einen ersten, zugleich wohlgelungenen Versuch zur Eintheilung machte Paykull, Faun. Srecica II. 1799, indem er die Arten nach der verworrenen oder gereihten Punktirung der Flügeldecken trennte; die Verfasser der Entomologischen Hefte II. (Hoffmann, Koch, Linz und Müller) nahmen zwar denselben an (1803, späterhin auch Gyllenhal und Duftschmid), aber er wurde nach und nach durch die Arbeit Illiger's (Magazin für Insektenkunde VI., 1807 p. 51) verdrängt, in der wir die Haltiken in 9 sogenannte Familien (Halticae physapodes, oedipodes, caesae, sulcicolles, saltatrices, striatae, longitarses, cryptocephalae und altitarses ${ }^{1}$ ) zerlegt finden, von denen Latreille (Cuvier règn.

1) Klauenglied blasenförmig verdickt, Fld. verworren- (physapodes) oder gereiht-punktirt (oedipodes). Klanenglied einfach. Halssch. mit Querfurche, Fld. gereiht- (caesce) oder verworren-punktirt (sulcicolles). Halsseh. ohne Querfurche, Hintertarsen in der Mitte der Schiene (altitarses) oder an der Spitze eingefügt. Kopf ganz einziehbar, Hinterschienendorn zweizinkig (cryptocephalae). Kopf vorragend, Hinterschienendorn einfach, erstes Hintertarsenglied so lang oder länger als die halbe Schiene (longitarses), oder kürzer. Fld, verworren- (saltatrices) oder gereiht-punktirt (striatae).

VI. 4. 
animal. ed. 2 V., 1829) vier, Oedionyshes, Lomgitorsus, Inibrtia und Pssyllindes als Gattungen feststellte. Die fast gleichzeitig mit einander erschienenen Monographicen von Foudras (Ann. Froc. Linn. Lyon 1860(1), Allard (Ann. d. Fr. 1860), auch die spätere in der Abeille III., 1866 und 67) und Kutschera (Wiener ent. Monatsschr. 1859 bis 1864) waren systematisch ziemlich bedeutungslos, weil sie entweder Illiger's Eintheilung folgen, oder die Grattungen willkürlich neben einander gereiht vorführen; erst Thomson gelang. 1866 (Skandinav. Coleoptera VIII. 164 u. 213), die möglichst natürliche und sichere Gliederung der Haltiken in eine Gruppe mit offenen und eine mit geschlossenen Hüftpfannen der Vorderbeine. womit die frühere Eintheilung von Paykull nahezu übereinstimmt. rla die erste Gruppe vorzugsweise verworren-punktirte, die zweite gereiht-punktirte Fliigeldecken aufweist. In neuerer Zeit hat C'hapuis (Genera XI. p. 20) seine Abtheilung Halticides im Sinne Thomson's gegliedert und auch Herr v. Harold spricht sich (Coleopt. Hefte 14. 2) für eine Zerlegung nach der Beschaffenheit der Hüftpfannen aus, doch greifen beide Autoren dabei wieder auf Illiger zurück, insofern sie zunächst die Arten mit aufgetriebenem Klanengliede denen mit einfachem gegenüberstellen und erst dann die Sonderung nach den offenen oder geschlossenen Pfamnen vornehmen. Für die europäische Fauna. die nur eine Gattung der Physayodes hesitzt. ist dieses Niitzlichkeitsprinzip nicht angebracht; es stellt sich eine Uebersicht der Gattungen am einfachsten folgendermassen heraus:

1. Gelenkhöhlen der Vorderhüften hinten geschlossen. Halsschild fast immer mit einem Längsfältchen jederseits an der Basis oder einer Querfurche, Fliigeldecken gereiht- oder gestreift-punktirt 2.

1 $^{1}$. Hüftpfannen der Vorderbeine hinten offen. Halsschild nur bei der Gattung Haltica mit einer einfachen, bei Hermaenphaga jederseits durch ein Längsstrichelchen begrenzten Querfurche. sonst ohne Eindriicke, Fliigeldecken in der Regel verworren punktirt .

2. Fïhler zehngliederig. Hintertarsen ein Stück iiber der spitze der Schiene eingefügt. . . . . . Psylliodes Latr.

21. Fühler eltgliederig. Tarsen an der Spitze der schienen befestigt

3. Mittel- und Hinterschienen am Aussemande hinter der Mitte ausgeschnitten und lang bewimpert; die ersten beiden Bauchringe verwachsen. . . . . . . Chaetocnema Steph.

1) Dies ist die bedeutendste Arbeit, obwohl sie durch den plützlichen Tod des Verfassers unvollendet blieb. 
$3^{1}$. Schienen an Aussenrande nicht ausgeschnitten. Bauchringe frei . . . . . . . . . . . . . . 4.

4. Hinterbrust weit zwischen die Mittelhüften vorgezogen, das Mesosternum bedeckend. Dies ist fast senkrecht, wenigstens steil abfallend und unter der Verlängerung des Metasternum zur Aufnahme des Prosternum quer ausgehöhlt .

5.

$4^{1}$. Die Hinterbrust nicht weit zwischen die Mittelhiiften vorgezogen, Mesosternum deutlich, eine viereckige, nach vorn mehr oder weniger geneigte Fläche

5. Prosternum mit zwei hohen Kielen, welche bald hinter dem Vorderrande beginnen und leicht divergirend nach hinten laufen, wo sie den hohen, abgestutzten oder ausgerandeten Fortsatz scharf begrenzen. . . . . . . Orestia Germ.

5'. Prosternum ohne dentliche Kiellinien, hinter den Hüften allmählich abfallend

6. Auf dem Halsschilde befindet sich ein schwacher Quereindruck vor der Basis, jederseits von einer Längsfalte begrenzt

Hippuriphila Foudr.

61. Halssehild nur mit einem Längsstriche jederseits am Grunde

Hypnophila Foudr.

7. Borsten in den Ecken des Halsschildes und deren Poren klein, die hinteren undeutlich oder fehlend. Stirn ohne Benlen, zwischen den Fühlern breit und eben, Stirnlinie scharf, zweimal gebrochen, Fühler mit 5 breiten Endgliedern Mantura Steph.

71. Borsten und Poren des Halsschildes deutlich. Stirn mit zwei mehr oder weniger scharf hervortretenden Beulen und Linien, die sich in der Regel x-förmig durchschneiden . . . . . 8.

8. Halsschild über den Vorderecken schwach wulstartig gewölbt, die Randleiste des Seitenrandes zieht um die Vorderecken herum bis hinter jedes Auge, wo sie plötzlich in einer Grube oder einem Schrägeindrucke erlischt. Flügeldecken in unregelmässigen einfachen oder doppelten Reihen punktirt

Podagrica Foudr.

81. Halsschild zu den Vorderecken in gleichmässiger Wölbung abfallend, im Vorderrande hinter jedem Auge keine Grube, Falte oder Ausrandung. Fliigeldecken gestreift-, sehr selten nur gereiht-punktirt . . . . . . . . . . . 9.

9. Flügeldecken reihenweise behart. . . Epitrix Foudr.

$9^{1}$. Fliigeldecken kahl (nur bei Derocrep. serbica Kutseh. mit einigen Härchen vor der Spitze) .

10. Letztes Glied der Maxillartaster kaum so lang als das vorletzte, kurz und dick, conisch, vorn scharf zugespitzt.

11. 
10). Letztes Maxillartaster-(ilied schlank, länger als das vorletzte. nach der Basis etwas verengt, voru allmählich zugespitzt 13.

11. Stimhöcker gewölht, im hinteren Theile nicht getrennt. I be Grube um die Fühlerwurzel hat einen leistentiomigen. hohen Rand. Halssch. mit einem Quereindrucke ror der Basis, welcher jederseits durch ein tiefes Längsstrichelchen hegrenzt ist. dan den Hinterrand unterbricht . . . Crepidodera Cherr.

11'. Stirnhöcker mehr oder weniger flach, von einander getrennt 12.

12. Stirnhöcker gross, ringsum deutlich hegrenzt. Halssch. mit einer Querfurche vor der Basis, welche jederseits durch ein tiefes Längsstrichelchen algekürzt ist. Letzteres verbindet sich hinten mit der Randlinie des Halssch., zwischen dieser und der Querfurche eine Querwulst . . . . Derocrepis Ws.

121. Stirnhöcker klein, undeutlich, flach, schlecht begrenzt. Halssch. ziemlich gleichmässig gewölbt oder vor der Basis mit einem leichten Eindrucke, der sich, ein Stück von den Seiten entfernt, nach hinten biegt und mit der Randlinie an der Basis verbindet . . . . . . . Ochrosis Foudr.

13. Halsschild an der Basis ungerandet, vor derselben mit einer jederseits erweiterten und rertieften Querrinne. Flïgeldecken an der Spitze abgestutzt . . . Arrhenocoela Foudr. ${ }^{2}$ )

$13^{1}$. Halsschild an der Basis gerandet, vor derselhen mit einem rertieften Quereindrucke, welcher jederseits in ein auf der Basis stehendes Längsstrichelchen übergeht. Flügeldecken hinten gerundet. . . . . . . . Chalcoides Foudr.

14. Klauenglied der Hinterbeine blasenförmig aufgetrieben

Lithonoma Rosenh. ${ }^{2}$ )

141. Klauenglied der Hinterbeine nicht verdickt

1) Hierher nur eine Art, Arrh. lineata Rossi. Röthlichgelb, Kopf. Querrinne des Halssch., Naht der Fld. und die ganze Unterseite rostroth. Fld. stark punktirt-gestreift, einfarbig (meist $\hat{o}$ ), oder ein Strich auf flem dritten Zwischenraume an der Basis, ein öfter fehlender Punkt auf der Schulter, sowie der fünfte und siebente Zwischenstreifen hinter dem ersten Drittel jeder Fld. ganz oder theilweise schwarz. Beim $\hat{o}$ ist das erste Tarsenglied stark verbreitert, der letzte Bauchring mit einer grossen, ovalen Grube versehen. - L. 4-5 mm. Italien, südliches Frankreich. Spanien, Nordafrika auf Erica scoparia $L$.

2) Körper oval, ziemlich flach, ungefliigelt; Fühler kräftig, fast perlschnurförmig; Halssch. quer viereckig, vorn und hinten abgestutzt, an den Seiten gerundet und breit gerandet. Riicken des letzten Bauchringes ohne Rinne; Hinterschenkel sehr gross, von der Gestalt eines Apfelkernes, der Aussenrand auf dem Rüicken der vier Hinterschienen ein Stïck vor 
15. Der Fortsatz der Hinterbrust bedeckt das Mesosternum, indem er sich an die spitze des P'rosternum anlegt. Hinterbrust ohne Nähte für die Seitenstiicke. Fühler mit dreigliedriger Keule

$$
\text { Mniophila Steph. }
$$

151. Mesosternum sichtbar. Hinterbrust mit deutlich begrenzten Seitenstücken

16. Kopt in das Halsschild einziehbar. Angen fein facettirt. End-

der Spitze mit einem Zahne; zweites Tarsenglied klein. Beim $\hat{j}$ ist das erste Tarsenglied an den vorderen Beinen stark erweitert.

Auf der Pyrenäen-Halbinsel und dem gegenüberliegenden Küstenstriche Nordafrika's 3 Arten:

1. Lith. cinct. Fabr. Oberseite glänzend, in verschiedener Stärke mässig dicht punktirt. Metallisch blaugrün oder blau, Mnnd, Fühler und Beine schwarz, ein Saum an den Seiten des Halssch., sowie eine Quermakel in der Mitte des Vorder- und Hinterrandes, ein Saum am Seitennnd Hinterrande der Fld. und vier schräge Makeln auf denselben (1, 1, die vordere im ersten Drittel, die hintere in $2 / 3$ der Länge), näher der Yaht als dem Seitenrande, nach der Mitte der Naht gerichtet, weisslichgelb bis hellbraun. - L. 3,5-6 mm. Siidlichstes Frankreich, Spanien, Portugal.

Aendert ab: a. Grundfarbe der Oberseite metallisch-violett; b. lusitanica: Makel 1 jeder Fld. bis an die Naht verlängert und hier mehr oder weniger breit mit 2 verbunden; c. dor salis: Makeln fehlend; d. Fld. mit 3 Längsvertiefungen, welche eine Schrägbeule auf Makel 1 und 2 Längsrippen emporheben, deren äussere die Verlängerung der Schulterbeule ist.

2. Lith. limbata Fabr. Oberseite ziemlich matt, änsserst dicht runzelig-punktirt. Farbe und Zeichnung der vorigen, aber die Makel am Vorder- und Hinterrande des Halsseh. ist mehr bindeuförmig, zuweilen bis an die Seiten verlängert, jede Fld. ansser dem Seitensaume mit einer gelbbraunen Längsbinde anf der inneren Hälfte, an der Basis beginnend, dahinter wenig der Naht zu gebogen, auf dem Abfalle zur Spitze nach anssen gekrïmmt und oft mit dem Seitensaume verbunden. Zwischen ihr und dem Seitenrande mitunter ein gelber Längsstrich. Die Schnlterbenle verlängert sich rippenförmig nach hinten. - L. 4-7 mm. Im Mär'z und April an Quellen (Rosh.) und auf Brachfeldern (Lederer) in Andalnsien. Tanger.

Aendert $a b$ : Jede Fld. mit 2 bis 3 breiten Längstertiefungen (die innere liegt an der Naht), zwischen denen 2 bis :3, oft sehr deutliche Rippen steheu.

3. L. Furieri Fairm. (Ann. Fr. 1880). 30). Vielleicht nur eine Form von limbuta; in der Körperform unl Punktirung mit ihn ganz übereinstimmend, aber die Oberseite einfarhig, dunkel metallisch kornblumenblau oder blangrüin, jede Fld. mit 3 Rippen. - L. 5 mm. Malaga. Marnceo. 
dorn der Hinterschienen breit, nach der Spitze hin erweitert und an derselben tief gerundet- oder dreieckig ansceschnitten

Dibolia Latr.

16. Kopf nur bis zum Hinterrande der Augen einziehbar, diese grob facettirt, Enddorn der Hinterschienen einfach, zugespitzt 17.

17. Vorderlrust zur vollständigen Aufnahme des Mundes eingerichtet Apteropeda Redtb.

17. Mund frei, in das Prosternum nicht einziehbar . . . . 18.

18. Kopfschild sehr tief ausgebuchtet, seine Vorderecken spitz. oft etwas aufstehend. . . . . . Argopus Fischer.

181. Kopfschild am Vorderrande abgestutzt . . . . . . 19.

19. Prosternum an der Basis bogenförmig ausgerandet. Körper länglich-halbkugelig . . . . . Sphaeroderma Steph.

191. Prosternum an der Basis abgestutzt oder germotet. Kürper mehr oder weniger gestreckt . . . . . . 20.

20. Flügeldecken regelmässig punktirt-gestreift Batophila Foudr.

201. Flügeldecken verworren-punktirt oder nur mit Spuren von Punktreihen . . . . . . . . . . . . 21.

21. Halsschild mit einer Querfurche ror der Basis . . . 22.

$21^{1}$. Halsschild ohne Querfurche oder Längsfältchen . . . . 23.

22. Die Querfurche des Halsschildes jederseits durch eine Längsfalte abgekürzt . . . . Hermaeophaga Foudr.

221. Dieselbe ist nicht abgekürzt. . . . . Haltica Greoffr.

23. Eckborsten des Halsschildes so lang oder beinahe so lang als dasselbe. Erstes Glied der Hintertarsen sehr schlank. so lang als die halbe Schiene, fast stielrund, mit schmaler, verhältnissmässig lang abstehend behaarter Sohle, schräg nach innen an die Schiene zurückgeschlagen, zweites Glied durch ein ScharnierGelenk mit dem ersten verbunden. Der Enddorn der Hintertibien stelit am Innemrande. Afterdecke ohne Mittelrinne

\section{Longitarsus Latr.}

231. Eckborsten des Halssch. kurz, etwa $1 / 3$ so lang als dasselbe. Erstes Glied der Hintertarsen normal, mehr oder weniger gestreckt, kürzer als die halbe Schiene, mit breiter. dicht bürstenartig behaarter Sohle, an der Spitze kein scharniergelenk 24.

24. Enddorn der Hinterschienen in der Mitte des spitzenrandes befestigt. Afterdecke ohne Mittelrinne Phyllotreta Foudr.

241. Enddorn der Hinterschienen an der Aussenseite des Spitzenrandes. Afterdecke mit einer Mittelrime zur Aufnahme der Nahtecke jeder Fld. . . . . . Aphthona Chevr. 


\title{
Podagriea.
}

\author{
Foudras, Altisides p. 337. \\ Haltica Kutschera. Nisotra Baly.
}

Acetabula antica occlusa; mesosternum conspicuum.

Palpi maxillares articulo ultimo elongato.

Irothorax upice utrinque subpulvinutus, basi plica apiceque impressione pare utrinque impressias, forea setigera in angulis antici.s acutis sita.

Elytra antrorsum subseriatim vel subgeminatim punctata.

Körper kurz- oder lang-eiförmig, mässig gewölbt, bei den einheimischen Arten ziemlich ïbereinstimmend gefärbt, nämlich: Fühlerbasis. Kopt, Halsschild, Vorderbrust und oft auch die Beine roth, Flïg'eldecken blau orler grünlichblau, bis dunkel broncefarbig variirend. die iibrigen 'Theile schwarz. Kopf abgerundet-rlreieckig, hinter den Augen stark verengt, daher nicht ganz bis zum Hinterrande derselben in das Halsschild eingezogen, Stiun breit, wenig uneben, die Höcker schmal und undeutlich, ron sehr feinen Linien begrenzt, und durch einen punktförmigen Eindruck geschieden, der breite, nicht kielartig gewölbte, sondern flache Raum zwischen den Fühlern erweitert sich nach unten in ein breites Dreieck und fällt ziemlich steil zu dem Querstreifen des Kopfschildes ab; die Furche unter den Augen, zur Einlagerung für das erste Fiihlerglied, ist nur nach aussen gerichtet. Oberlippe quer, vorn ausgerandet, Mandibeln fünfzähnig; die beiden oberen und der äusserste Zahn klein, verdeckt, die beiden dazwischen liegenden lang, scharf zugespitzt; Maxillartaster schlank, das letzte Glied schmaler, aber bedeutend länger als das vorletzte, nach der Basis zu etwas verengt, nach rorn allmählich zugespitzt. Fühler von halber Körperlänge, zwischen den Augen und diesen mehr genähert als sich selbst eingefügt, Glied 1 lang, mässig angeschwollen, 2 bis 5 schlank, unter diesen das dritte das längste, die folgenden merklich dicker, unter sich und mit dem zweiten etwa gleichlang, Endglied verlängert, scharf zugespitzt. Augen kleiu, oval, mässig gewölbt, körnig facettirt. Halsschild quer, an der Basis wenig, an den Seiten stärker gerundet, nach vorn mehr als nach hinten verengt, am Vorderrande abgestutzt und so breit als der Kopf in den Augen, die Ecken scharf, weil in ihmen die Borstenpore steht; die Oberfläche ist schwach gewölbt, fällt aber iiber den seiten und besonders über den Vorderecken steiler ab, wodureh sie daselbst leicht kissenartig gewölbt erscheint; sie ist an der Basis und den Seiten scharf und deutlich gerandet, die Randleiste setzt sich ron der vorderen Borstenpore aus noch ein Stiick am Vorderrande bis hinter jedes Auge fort, wo sie in 
riner Grube orler einem bald mehr, bald weniger ausgeprägrten bchrügrindrucke endet, der nach hinten und innen gerichtet ist. ausserdem steht jederseits auf der Basis ein kurzes Längsstrichelchen (bei einigen exotischen Arten auf einen Punkt reducirt) mit lorhem, scharfkantigen Aussenrande, zu welchem hin sich die Randlinie vom Schildchen aus etwas vertieft. Die I'unktirung ist mehr ork $\mathrm{r}$ weniger dicht, fein oder mässiğ stark, ïber dem S'eitenrand: (نine starke Punktreihe, die Eckborsten kurz und sehr f'ein. Schildchen klein, dreieckig oder halboval. Flügeldecken au firunde wenig breiter als das Halsschild, nach rückwärts etwas erweitert, in oder hinter der Mitte am breitesten, hinten allmählich verengt und gremeinschaftlich abgerundet, mit fast rechteckigem Nahtwinkel. um den sich die Rinne, welche den feinen Seitenrand absetzt, herum und noch ein stückchen an der Naht aufwärts zieht; die Nichulterbeule ist klein, innen durch einen seichten Eindruck abgesetzt, Epipleuren breit, von der Mitte ab alluählich verschmälert. bis zur Spitze reichend. Die Punktirung ist verhältnissmässig fiein und seicht, in der vorderen Hälfte mehr oder weniger gereiht, in der hinteren verworen. Das Prosternum ist ziemlich breit und eben, fällt hinter den Hüften etwas ab und schliesst durch einen breiten Streifen die Ptammen; das Mesosternum ist sichtbar, quer-viereckig. hinten bogenförmig ausgerandet und leistenförmig erhöht, genau an den abgerundeten und hochgerandeten Ziptel der Hinterbrust grelegt, der sich ungefähr bis in die Mitte zwischen die Mittelhütten zieht. Die Beine sind mässig stark, Hinterschenkel spindelförmig, Schienen zur Spitze hin allmählich erweitert, mit leicht gewölbtem und ron einem feinen Mittelkiele durchsetzten Rücken; die Spitze ist schräg abgestutzt und bildet eine runde Fläche, deren Rand mit kurzen, feinen Dörnchen besetzt ist und einen stärkeren Enddorn trägt. unmittelbar über diesem ist das erste Tarsenglied eingefügt. I)ie Klauen haben am Grunde einen grossen Zahn.

Beim Männchen ist das erste Tarsenglied erweitert, der Hinterrand des letzten Banchringes jederseits abgestutzt, in der Mitte in einen kurzen, aber breiten Zipfel verlängert, der gewöhnlich von einer Querrimme eingenommen wird. - Der Y'enis ist sehr einfach gebaut, wenig länger als die vier letzten Bauchringe zusammen, gleichbreit, schwach gebogen, an der spitze kurz abgerundet, oben mit langer, weiter Ueffnung und vor derselben mit einer f'einen Rimne für den Ductus, auf der Unterseite ein rinnenförmiger Längseindruck.

Die Gattung ist durch das schlanke letzte Tasterglied, die Bildung der Stirn, die Stellung der vorderen Borstenpore ummittelbar in den Torderecken des Halsschildes, die kissenartige Wülbung 
desselben an den Seiten und iiber den Ecken, d'n Eindruck jedorseits an Vorderrande hintex den Augen, weleher keiner anderen Gattung zukommt, sowie die P'unktirung der Fliigeldecken vortrefflich begrenzt. Sie ist über die alte Welt in einer Ifenge iiberaus ähnlicher Arten verbreitet, von denen bis jetzt einige 30 als Podagrica und Nisotra $\left.{ }^{1}\right)$ beschrieben worden sind. I) typische Färbung derselben, Kopt', Halssch. und Beine roth, Fld. blan, andert so weit ab, dass die Oberseite blan und die Beine schwary werden, z. B. bei tristicula ('hevr. aus Syrien, oder der ganze Körper wird (bei einigen atrikanischen Arten) einfarbig rothgelb his žlbbraun. Die Thiere, deren Sprungtähigkeit ziemlich gering ist, leben gesellig auf den Blättem von Malvaceen, die sie allmählich durchlöcherı und skeletiren; ihre Eier werden dagegen an die Basis des stengels odter in die Nähe derselben gelegt, sie sind oval, gell, und viel kürzer als die von $H$. oleracea (Foudr. Mon. 344). Die auskriechenden Larven nagen nach den Beobachtumgen Heeger's (Sitzungsber. Ak. Wiss. Wien 1858 p. 106. t. 3, Pod. fuscicomis) an der Rinde des Wurzelhalses, beissen sich später durch die holzige Masse bis in das Mark, welches sie theilweise ausfressen, und iuberwintern in der dadurch entstandenen Höhlung. Ende März oder Anfang April gehen sie heraus in die Erde, um sich dort zu verpuppen, ihre Lebensweise ist also der der Longitarsus-Larven sehr ähnlich. Der Körper ist lang, madenförmig, beiderseits etwas verschmälert, gelb, glänzend, glatt, an den Seiten mit einzelnen abstehenden Haaren besetzt; der Kopf länglich, auf dem Scheitel dreieckig ausgekerbt, Fühler und Taster sehr klein, durchscheinend, Mandibeln braun, Ocellen fehlend, Beine kurz, letzter Bauchring: (bei fuscipes) ron oben zusammengedrückt, punktirt, hinten in einen abgerundeten Vorsprung verlängert, dessen Rand sechs Härchen trägt. Die Puppe ist gelb, wenig grösser als das vollkommene Insekt, ler Kopf besitzt vier brame Härchen, je eins am Innenrande der dunklen Augen und zwei in der Mitte der Stirn, der Hinterleib ist gewölbt, mit drei Längsvertiefungen und endet in zwei konische Spitzen.

1. Poalagr. fuscipes: Oblonga, sat convexa, nitida, antennarum basi, capite prothoraceque rufis, hoc disperse inaequaliter punctulato, extrorsum fortius declixi, margine postico ante scutellum minus elevato plerumque trincato et subdilatato, elytris aut nigro-coevuleis aut niolaceis, subregulariter striato-punctutis, punctis serierum sut remote impressis. Long. 3,5-4 $\mathrm{mm}$.

1) Nisotra lässt sich nicht eimmal als Untergattung halten, sondern ist mit Podagrica identisch. 
Fabx. Syot. Eut. 1775 p. 114. - Oliv. Ent. VI. 704. t. 93. f. b4 - Illig. Mag. IV. 158. - Gyllh. Ins. Suec. IU, 560. Duft. Faun. A. III. 276. - Kutsch. Wien. Monat. 1860. 195; Mon. 106. 1) - Redtb. Faum. A. II. 498 (Haltica). Seid1. F. balt. 495. - Thoms. Skand. Col. VIII. 214.

Var. a. metallescens: Elytris nigro-aeneis vel -aurichalceis. Altice fuscipes Panz. Faun. Germ. 21. 11. - Koch Ent. Heft. II. 10. - Foudr. Mon, 343. - A11. Ann. Fr. 1860. 540; MIon. 267.

Altica nitidula Laich. Verz. Tirol. Ins. 200.

Var. b. Foudrasi: Prothorace nigro.

Halt. fuscipes Steph. Man. 293?

Var. c. Immatura; pedibus anterioribus tibiesque prosticis plus minusre rufescentibus.

Durch das an den Seiten schwach gerundete Halssch.. die feinen, einfachen P'unktreihen der Fld. und die dunklen Beine kenntlich; länglich-eiförmig, mässig gewölht, schwarz, glänzend. Kopf, mit Ausnahme des pechbraunen II undes, die vier oder fïnt ersten Fühlerglieder und das Halssch. roth, Fld. dunkelblau oder violett, selten mit griulichem Anfluge. Scheitel gewölbt, Stim zwischen den Fiihlern breit, eben, ziemlich stark punktirt, oben jederseits in eine nach dem Auge ziehende Leiste verlängert und in der Mitte ohme bestimmte Grenze in eine kurze und tiefe, grubenförmige Furche abfallend, welche die sehr schmalen, doch deutlichen Stirnhöcker trennt. Halssch. doppelt so breit als lang, an den Seiten und voru so stark abwärts gewölbt, dass die entsprechenden Ränder bei der Ansicht ron oben rerdeckt werden und die Seiten in den hinteren zwei Dritteln fast parallel erscheinen; bei seitlicher Ansicht ist das Halssch. jedoch ror der Mitte am breitesten, mach hinten allmählich, nach rorn stärker gerundet-verengt; die scheibe zerstreut und fein doppelt punktirt, einzelne Punkte viel stärker als die übrigen, eine breite Mittellinie glatt. Die Basis ist vor dem Schildchen abgestutzt oder ausgerandet, die Randleiste daselbst etwas verbreitert aber weniger in die Höhe gehohen, als an den Seiten, weil der Quereindruck in der Mitte sehr seicht, nach dem ziemlich langen und tiefen Läugsstrichelchen hin merklich rer-

1) Die Arbeit von Kutschera in der Wiener entomol. Monatschrift 1860-1865 ist auch in einem Bande mit besonderer Paginirung erschienen. und ich werde in der Folge, jedoch ohne Verbindlichkeit, auch die Seitenzahlen des Abdruckes in Klammern angeben, ron Foudras ist nur der Band der Coléoptères de France citirt, der die Altisides entbält, ron Allard nux die letzte Arbeit, in der Abeille III. 
breitert und rertieft ist; am Vorderrande stehen in dem kurzen Schrägeindrucke hinter jedem Auge 2 his 4 staikere Punkte. Fld. mit ziemlich regelmässigen und feinen einfachen Punktreihen, welche erst aut' dem Abfalle zur Spitze schwächer werden und sich verwirren, die ' $/$ wischenstreiten sehr fein punktirt. Beine schwarz, Knie und Tarsen zuweilen pechbraun, bei firschen stücken (Var.c.) sind die vorderen Beine und die Hintersehienen grösstentheils röthlichbraun.

Die Färbung ändert ab:

a. Fld. dunkel erzoriin, oft mit starkem Messingschimmer,

b. das Halssch. einfarbig schwarz.

Auf Malven an Dorfstrassen und auf trocknen Hügeln in ganz Deutschland und dem grössten Theile ron Europa ziemlich selten.

Stephens nennt ,head and thorax black", wofür wohl aber red zu lesen sein dürfte.

2. Podagr. malvae: Oblonga, sat convexa, nigra, nitida, antennarum basi, capite, prothorace pedibusque rufis, occipite femoribusque posticis nigro-aeneis; prothorace sat crebre aequaliter punctulato, postice evidenter rotundato-angustato, elytris cyaneis aut coeruleo-virescentibus striatopunctatis, pnonctis serierum crebre impressis, retrosum geminatis. Long. $3-3,5 \mathrm{~mm}$.

Illig. Mag. VI. 63. - Redtb. Faun. A. ed. 1. 530; ed. 3. II. 498. - Seidl. F. balt. 496 (Haltica). - Foudr. Mon. 339. - Allard Mon. 268.

Var. a. Femoribus anterioribus medio piceis.

Var. b. aenescens: Elytris nigro-aeneis, plerumque aurichalceis.

Haltica malrae Duft. Faum. A. III. 286. - Kutseh. Wien. MLonat. 1860. 196 (106).

Var. c. Immatura; capite pedibusque omnino rufis. $\left.{ }^{1}\right)$

Durchschnittlich kleiner und besonders nach vorn hin schmaler als die rorige, das Halssch. dichter und etwas stärker punktirt, an den Seiten gerundeter, nach hinten deutlich rerengt, die Punkte in den Reihen der Fld. dichter, ein Stiick hinter der Basis verdoppelt.

Lang-eiförmig, mässig gewölbt, glänzend, schwarz, Kopf roth, Oberlippe und Mundtheile pechbram, Stirn zwischen den Fiihlern

1) Es ist zwar falsch, unausgefärbte Thiere als Varietäten zu betrachten, aber da bei vielen Haltiken Fiihler und Beine zuletzt ilure Normalfärbung anzunehmen scheinen, während die übrigen Körpertheile dieselbe längst vollständig besitzen, so könnten dergleichen frische Stiicke leicht als ausgehärtet und $z \mathbf{u}$ verwandten Arten gehörig angesehen werden. wenn nicht ausdrücklich auf sie hingewiesen würde. 
gewölbter als boi fiescipes, punktirt, oben zu einer tirefen, bogenfïrmigen Querrinne al,fallond, über der die heiden undeutlichen simhöcker liegen, welche weit vou einander entfernt sind; ler Raum ron diesen bis zum Scheitel ist schwach zewiilht, schwarzgrüu, sehr fein punktirt. Halssch. roth. fast doppelt so lreit als lang, gleichmässig und riemlich dicht und fin punktirt, an der Basis und den stark gerundeten Seiten mmerklich schwarz gesäumt; vor der Mitte am breitesten, nach vorn nur mberleutend mehr als nach hinten verengt, die Randleiste an der Basis iiberall von wleicher Breite, die Querlinie davor auch vor dem richildchen tief und schart, am Längsstriche jederseits etwas verbreitert. Fld. dunkelblau, oft mit violettem oder grünem schimmer, ihre Punktreihen starker als bei fuscipes, die Punkte in denselben gedrängter, nur an der Basis einfach, bald hinter derselben verdoppelt, von der Mitte an abgeschwächt. aut dem Abfalle zur Spitze verworen. Beine bräunlichroth, Hinterschenkel bram bis schwarz, griinlich schimmernd. bei den dunkelsten Stiucken (Var. a) auch die Mitte der rorderen Schenkel pechschwarz.

Häufig sind die Fld. schwarzgrün, messinggelb glänzend (Var. b); firsch entwickelte Exemplare haben Kopt und Beine einfarbig roth.

In Mittel- und süilemopa anf Jalraceen nicht selten.

Von dieser Art sind schwierig und ohme rechte Sicherheit zu tremnen:

1. Pod. saracena Reiche (Ann. Fr. 1858. 52). Beine in der Regel pechbraun, Knie und Basis der Schenkel röthlich, Halssch. und Fld. etwas kräftiger punktirt, Schulterbeule stärker entwickelt, Randlinie an der Basis des Halssch. einfach, am Längsstriche jederseits nicht erweitert oder vertieft. - Bei Damaskus und an der Küste ron Srrien häufig.

2. Pod. semirufa Küst. (Käf. Eur. 9. 86). Bedentend gestreckter und flacher als malcue, Kopf, Halssch. und Beine einfarbig gelblich-roth, oder ersterer mu mit einem grünlichen Anfluge, Seiten des Halssch. noch stärker gerundet, Fld. blau, grün, violett. - L. 3-4 mm. Dalmatien, Italien (bei San Remo, Dr. Schneider; bei Rom, Strasser), Corsica, Sardinien häufig.

3. Porl. intermedia Kutsch. (Wien. Monatschr. 1860). 197 (108). Kleiner als die rorige, Kopf, Halssch. und Beine roth. Fld. schwarzblan oder schwarzgrim, Punktreihen derselben regelmässiger, Zwischenstreiten glänzender und glatter. - L. 2,5-3,5 mm. Griechenland.

4. Pod. tristicula Chevr. (Amn. Fr. 1860.543). Kurz-eiformig, schwarz, Glied 2-4 der Fühler röthlich, Oberseite dunkelblan oder grünlich. Halssch. gewölbt, dicht und ziemlich stark junktirt, Punktreihen der Fld. kräftig, bald hinter der Basis rerloppelt. Bei frischen Stitchen ist das Halssch. dunkelroth, blau angelaufen. - L. $\stackrel{2}{-5-3}-3,5 \mathrm{~mm}$. In Syrien, z. B. bei Haifa (Simon) häufig. 


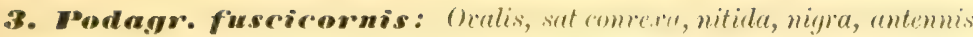
extronsum fuscis capite, mothorace pedilusique rufis, mothorace fonditer transverso, sublaeri, pone medium evidenter rotunduto-angustato, striolis

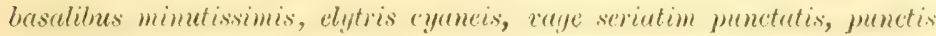
serierum geminatis. - Long. 3,5-4 mm.

Linn. Syst. Nat. ed. 12. 595 (Chrys.). - Koch Ent. Heft. II. 51. - Illig. Mag. VI. 127. - Gyllh. Ins. Suec. III. 520. - Duft. Fam. A. III. 265. - Steph. Ill. Brit. IV. 300; Man. 293. - Schilling Ber. Schles. Ges. 1846. 91. Kutseh. Wien, Monatsch. 1860, 199 (110). - Redtb. Faun. A. II. 498, - Seidl. F. balt. 496 (Haltica). - K üst. Käf. Eur. 8. 100. - Foudr. Mon. 340. - All. Mon. 270.

Galleruce refipes Payk. Fn. Suec. II. 97. - Panz. Faun. Germ. 21. 10. - Oliv. Ent. VI. 703. t. 93. f. 63 (Halt.). - Rossi Faun. Etr. I. 90. - Marsh. Ent. Brit. I, 198 (Chrys.).

Var. a. meridionalis: Major, elytris plerumque coeruleo-virescentibus punctis profundioribus. - Long. 4-7 mm.

Var. b. Elytris violaceis.

Etwas grösser, in der Mitte breiter als die vorhergehende, an den sehr kurzen Längsstrichelchen des Halssch. und den undeutlichen, verdoppelten Punktreihen der Fld. kenntlich. Eiförmig, mässig gewölbt, glänzend, schwarz, Kopf, Halssch. und Beine roth, Fld. dunkelblau. Die ersten vier oder fünf Fiihlerglieder röthlichgelb, die folgenden dunkel, entweder nach und nach von roth in pechbraum übergehend oder einfarbig schwärzlich, Oberlippe pechschwarz, vorn gelb gesäumt, oder einfarbig roth bis blassgelb; Stiru zwischen den Fühlern punktirt, oben, nebst den undentlichen Stirnhöckern schlecht begrenzt, Scheitel fast glatt. Halssch. doppelt so breit als lang, in oder vor der Mitte am breitesten, an den Seiten ziemlich stark gerundet, oben äusserst fein und erloschen pruktirt; die Randlinie an der Basis überall von gleicher 'Tiefe. und an dem sehr kurzen und schwachen Längsstriche jederseits nicht erweitert, der Eindruck hinter jedem Auge seicht, aber in der Regel länger als bei den vorigen Arten. Fld. mit neun erloschenen doppelten Punktreihen, aus denen sich die schmalen und flachen $Z$ wischenstreifen so wenig herausheben, dass man dieselben leicht iibersieht und dic Punktirung fïr verworren hïlt.

Von der kleinen, in Norddeutschland und Schweden einheimischen Form weicht die siiddeutsche und iiber ganz Siideuropa rerbreitete Var. a durch auffällige Grösse und die etwas tiefer eingestochenen Punkte der Fld. ab. Letztere sind vorherrschend hlaugrün, seltener dunkel-violett (Var. b) gefärbt.

Auf Malven und besonders an Althaea rosea Car: in Gärten nicht selten. Verwandt sind: 
1. Ped. rhrysomelime Waltl 'Reis. Span. 83) aus dern siidlichen spanien und Nordafrika. Ganz von der Grösse. Gestalt und Farbe der Var. a von fiescirmuis, jedoch durch die Fld.. welche noch etwas stärker und deutlicher punktirt sind, sowie den Ban des Halssch. erheblich verschieden. Dasselhe ist bei gleicher Länge viel schmaler, nicht ganz um die Halfte breiter als lang, bald hinter den Vorderecken am hreitesten und ron hier allmählich in sehr schwachem Bogen nach rückwärts verengt.

2. Por. discedens Boield. (Ann. Fr. 1859. 475. t. 8. f. 9). Breiteiförmig, stark gewölbt, mässig glänzend, schwarz, die vier ersten Fühlerglieder, Kopf und Halssch. roth, Fld. blaugriun, Beine schwarz, Schienen und Tarsen oft nur röthlich-braun. Halssch. dicht und ziemlich stark punktirt, zuweilen gerunzelt. Fld. mit verhältnissmässig groben Doppelreihen, die im ersten Drittel von einander getrennt, dahinter mehr rerworren sind. L. 3,5-4,5 mm. Siidlichstes Frankreich, Italien, Dalmatien. In Ungarn bei Komorn (v. Hopffigarten). daher vielleicht anch noch in Oesterreich aufzufinden.

3. Pod. Menetriesi Fald. (Nour. Mém. Mose. V. 399). Ton der vorigen nur durch den sehr kurzen und mehr gerundeten Körper abweichend. Die Beine sind dunkelroth oder pechbraun. - Im Kaukasus (bei Katharinenfeld, Leder).

\section{Derocrepis.}

Acetabula antica occlusa, mesosternum conspicuum.

Palpi maxillares articulo uttimo brevi, conico.

Tubercula frontalia distincta, subconiexa, ocata, evidenter discreta; clypeus trigonus.

Prothorar marginatus, ante basin sulco transterso, utrinque plicu terminato, fovea setigera antica pone angulos anticos sita.

Elytra pone humeros transtersim deplanata, punctato-striata; stria prima pone medium profunde impressa, sulciformi.

Die Gattung, welche bisher mit Crepidudera rerbunden wurde. weicht von dieser wesentlich in folgenden stïcken ab: Der Körper. ist schlanker, länglich-oval oder sehr gestreckt, beiderseits gleichmässig verschmälert, an den seiten weniger germudet, ungefliigelt. Der Stirnkiel ist hoch, nach oben hin nicht verbreitert, läuft unten durch das vertiefte, mit einem aufgebogenen Vorder- und Hinterrande versehene, also deutlich abgesetzte Koptschild, welches bald die Form eines kurzen und sehr hreiten Dreieckes. bald die eines Querstreifens hat, und endet, durchaus einfach, oder erweitert und in zwei divergirende Leisten gespalten, iiber dem pergamentartigen 
Querstreifen, welcher auf der Oberlippe liegt. 1)ie Fühler sind einander genähert und von den Augen weiter entfernt eingefiigt, der ()berrand ihrer (relenkhöhlen kaum hemerkbar erhöht. Die Stirnhöcker liegen schräg, sind gross, ziemlich oval, etwas gewölbt, ringsum scharf begrenzt und durch die Stimlinien. die sich zwischen ihnen $\mathrm{x}$-förmig durchschneiden, auch deutlich geschieden. Das Halsschild ist nach hinten fast so stark rerengt wie nach rorm, wenig quer, bei serbicr etwa so lang als breit, ringsum gerandet; es besitzt an der Stelle des Quereindruckes eine breite, tiefe Querfurche, welche jederseits in einen starken Längsstrich iibergeht, der den Basalrand nicht unterbricht, sondern sich vor demselben mit der Randlinie verbindet. Dadurch wird ein gewölbter Querstreifen vor der Basis des Halssch. umschlossen, der sich bei keiner andern Gattung wieder findet. Die starke Punktreihe am Seitenrande setzt sich in der rertieften Linie des Vorderrandes bis hinter die Augen fort. Das Schildchen ist breit-dreieckig. Auf den Flïgeldecken zeigt sich oft ein Eindruck hinter der Schulter, der den Raum zwischen dieser und dem Schildchen etwas in die Höhe hebt; die erste Punktreihe nähert sich hinter der Mitte der Naht und rertieft sich furchenartig bis zur Spitze; die Epipleuren sind äusserst fein und kurz bewimpert, hinten zwar sehr schmal, erreichen aber beinahe die Nahtecke. Die Schienen verbreitern sich aus schmaler Basis ganz bedeutend nach der Spitze hin.

Beim Männchen ist das erste Tarsenglied besonders an den vorderen Beinen erweitert, der letzte Bauchring hinter der Mitte quer rertieft, ausserdem mit einer schwachen Mittelrinne versehen, am Hinterrande in einen ziemlich grossen Lappen vorgezogen. der jederseits vertieft, in der Mitte schwach gekielt ist. - Penis eine gebogene, dreiseitige Röhre, mit scharfen Kanten, die obere sehr hoch und schmal, vorn schnell zu der bogenförmig in die Höhe gekrümmten Klappe abfallend, welche in der Ruhe die kurze Oeffinung zur Hältte schliesst; die breite Lnterseite ist rimnenförmig ausgehöhlt, besitzt an der Oeffinung jederseits ein sehr kleines, nach hinten gerichtetes Zähnchen und ist rorn in eine oder mehrere Spitzen verlängert.

Ton den drei emropäischen Arten ist die eine weit verbreitet. die zweite scheint nur dem Alyengebiete, die dritte dem siidisstlichen Europa anzugehören; sie leben an Waldrändern auf Lapilionaceen, besonders Lathyrus-, Vicin- und P'isum-Arten, doch ist ihre Entnicklung noch unbekamnt. In den entom. Heften und rom Bach (Käferfauna III. 138) wird angegehene dass sich I). rufiures aut Malven und Althaea rosea aufhalten soll. es dürfte hier aber eine Verwechselung mit der Lebensweise einer Itudagrira vorliegen. 
7. Der. rufipes: Oblonga, comrex, nitida, eropite, antennis, prothomace fere lnevi lateritus aequalitor rotundato perditusque mfis, pectore alsdomineque nigris, elytris apice rotundats-angustatis nigro-coeruteis, cyaneis.s vel coeruleo-virescentibus, sat fortiter punctato-striatis, punctis serierum. crebris. - Long. 2,8-3,5 mm.

Linné Syst. Nat. ed. X. 373; Faun. Suec. 545. - Scopol. Ent. Carn. 69. - Rossi Faún. Etr. I. 90 (Chrysomela). Ent. Heft. II. 11. - Illig. Mag. VI. 114. - Gyllh. Ins. Suec. III. 558. - Duft. Faun. A. III. 271. - Steph. Ill. Brit. IV. 304; Manual 294. - Schilling Ber. Schles. Ges. 1846. 91. - Kntsch. Wien. Monatsch. 72 (75). - Redtb. Faum. A. II. 496 - Seidl. F. balt. 494 (Haltica) - K ïst. Käf. Eur. 9. 85. - Allard Mon. 187. - Foudr. Mon. 323. - Thoms. Skand. Col. VIII. 217 (Crepidodera).

Gulleruca micomis Fabr. Ent. Syst. I. 2. 32; Syst. El. I. 464 (Crioceris). - Payk. Faun. Suec. II. 108 (Gal.). - Marsh. Ent. Brit. I. 199 (Chrys.). — Panz. Faun. Germ. 21. 12 (Altica).

Var. a. Elytris viridi-aeneis vel nigris.

$\mathrm{V}$ ar. b. Antennis extrorsum infuscatis.

Var. c. obscura: Ut in b, sed vertice prothoraceque rufo-piceis, femoribus posticis interdum nigris.

Lang-eiförmig, stark gewölbt, glänzend; Fühler, Kopf, Halssch., Vorderbrust und Beine roth, Mittel- und Hinterbrust, sowie der Bauch schwarz, der After zuweilen röthlich, Fld. dunkelblau, kornblumenblau oder bläulich griin. Scheitel glatt, mit zwei bis vier Punkten an der Stirnlinie in der Nähe jedes Auges. Fühler beim of so lang, beim ô länger als der halbe Körper, Glied 1 dick, 2 bedeutend schwächer, kürzer als 3 , dieses so lang als 4 oder merklich kürzer und nebst dem noch längeren fünften Gliede mit verhältnissmässig dünner Basis und schwach knotig verdickter Spitze. Halssch. um die Hälfte breiter als lang, glatt oder weitläufig und verloschen punktirt, nach rorn etwas mehr als nach hinten verengt, die grösste Breite in oder dicht hinter der Mitte. die Seiten bilden einen flachen, regelmässigen Bogen. Fld, an der Wurzel wenig breiter als das Halssch., mit germudeten Schultern heraustretend, nach rückwärts bis über die Mitte leicht erweitert. sodann allmählich verengt, hinten gemeinschaftlich abgerundet oder ein wenig abgestutzt; kräftig punktirt-gestreift, die Punkte in den Streifen dicht gedrängt, stark, nach der Spitze feiner und etwas weitläufiger, die ersten fünf Reihen (und die abgekürzte am Schildchen) beginnen an der Basis und sind in dem Quereindrucke der Fld. leicht gebogen, die folgenden vier entspringen hinter der mässig grossen. glatten sichulterbeule, welche imnen ron dem rertieften fünften Punktstreifen begrenzt wird. Fliigel verkümmert, 
kaum so lang als die Fld., mit zwoi starken, nach hinten diverzrirenden Iängsadom, dio eine nahe dem Anssenmule, die andere weiter einwärts.

Der Penis des $\hat{j}$ ist vor der (Oeffinmog wenig verengt, breit abgerundet.

Hie wichtigsten Farbenabänderungen sind folgende:

a. Fld. dunkel metallisch-yriin, ohme blane Beinischung, oder beinahe rein schwarz;

b. Fïhler nach der sitze mehr oder weniger angerlunkelt, schwärzlich; ausserdem

c. der Scheitel und das Halssch, röthlich-pechbraun, die Hinterschenkel bisweilen schwarz.

Auf Waldwiesen rom Mai bis Juli an Vicia sepinm und Lathymes remus, nach Kaltenbach auch an den jungen Blättern aufgehender Bohnen und Erbsen, im ganzen Gebiete nicht selten, nördlich bis s'chweden (am Kinnekulle von mir zahlreich gefangen), siidlich bis Oberitalien und Dalmatien verbreitet.

2. Der. sodalis: Oblonga, comrexa, nitida, capite, antennis, prothorace parce punctulato, lateribus pone medium vix rotundato perlibusque rufi., pectore abdomineque nignis, elytris apice subtruncatis nigro-viridi-aeneis: vel -coeruleis, sat fortiter punctato-striatis, punctis serierum minus crebris, - Long. $3-4 \mathrm{~mm}$.

Kutsch. Wien, ent. Monatschr. 1860. 73 (76). - All. Ann. Fr. 1861. 308; Mon. 187 (Crepidod.).

Var. a. Vertice et femoribus posticis infuscatis.

Der vorigen täuschend ähulich, gewöhmlich etwas grösser nnd ein wenig breiter, die Fld, vorherrschend dunkel metallisch-griu getärbt, eine spur glänzender. Die Fühler sind in der Regel kräftiger, (ilied 2 wenig schmaler als 1, verkehrt eiförmig, 3, 4 und 5 nach der śpitze allmählich verdickt, aber in der Länge ebenso variabel wie hei rufipes, in den meisten Fällen ist 3 am kiirzesten, 5 an längsten. I)as Halssch. ist weitläufig und sehr fein punktirt, nach vorn gerundet-, nach hinten ziemlich gradlinigverengt, so dass die seiten keinen regulmässigen Bogen bilden; bei einzelnen stiicken sind dieselhen ror den Hinterecken sanft ausgreschweift, auch erscheinen sie an der breitesten Stelle. vor der Mitte, etwas winkelig. Die P'unktstreifen der Fld. sind unregelmässiger, die Streifen sellost Hacher, am Grunde und in dem Quereindrucke mehr gebogen, die Punkte in ihnen meist grösser und stärker, viel weitläutiger und noch weniger genau hinter einander gestellt; der (quereindruck ist tiefire und der Raum davor, zwischen

VI. 4. 


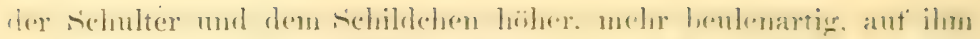

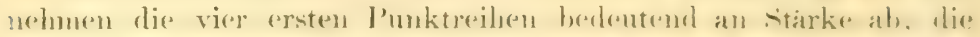
Zwischenstreifen sind zimlich flach und breit. Xach hinten sind

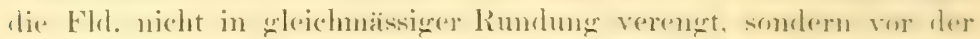

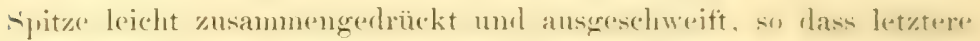
otwas nach hinten answezogen und al,egestutyt erscheint.

Der Penis hat an Ende zwei hreite syitzen. die durch rinen grossen, halbovalen Ausschnitt getrennt sind.

()he Zweifel rarïrt die Farbung in dersellen Weise wie hei den anderen Arten, dass nämlich zuletzt Kopt. Halssch. und Hinterschenkel pechschwarz werlen, aber es sind mir his jetzt nur Exemplare hekannt (Var. a), die einen dunklen scheitel und einen grosim, schwärzlichen Wisch auf der Oherseite der schenkel bewitzen.

In Tirol (Reitter) namentlich in der Lmgegend von Bozen ron H. Ludy zahlreich gesammelt. auch in der Lombardei (Kutschera) und Toskana (v. Bruck).

Eine dritte europäische Art ist: I)es. serbicu Kutsch. (Wien. tut. Monatschr. 1860. 73, Mon. 76; stranguluta All. Anñ. Fr. 1860. 1il. IIon. 188): Sat elongata, concexa, nitida, nigro picen, one antennis pediluasique

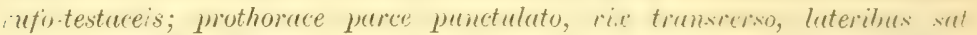
fortiter rotumlatis, elytris plerimque riridi- rel cyanen-micuntibus, fortins: (afucem ressus subtilius) punctuto-striatis, interstitios striarum antransum ungustissimis, eleratis. Femina: elytris pone medium purre subtilisimerue pubescentibus. - Long. 2,5-3,3 mm. Serbien. Konstantinopel

Variat a. bicolor: C'apite prothoraceque rutis, dytris couruleis, cyancis ant virescentibus, interdum margine busali et laterali epripleurisque rufescentibus;

b. caucusica: Elytris subtiliter punctatu-striatis, interstitiis striuium untrorsum sat latis, haud concexis. Derbent (Faust), im Kankasus weit verbreitet (Leder, Schneider, Beitr. Kank. Käferfauna 334, hier ron Allard als Crep. serlica aufgeführt).

Die Art ist durch die schlanke Körperform mo das lange nach hinten so stark als mach rorn verengte Halssch. sehr ausgezeichnet. bein Mäninchen sind die Fld. wenig länger als Kopt und Halssch. zusimmen und nur an der. Spitze der Epiplemen bewimpert, beim Weibchen viet länger, auf dem Abfalle zu Spitze äusserst fein. sparsam hehaart.

\section{Crepidodera.}

Chevrol. JiOn bign. Dict. Hist. nat. IV. 1844 p. 324. Foudras MLon. 521.

Acetabula antica occlusa; mesosternum conspicuum.

Palpi maxillares articulo ultimo brevi, conico.

Tuberculu frontalia distincta, conced, postice cunnatu, haul sejunt:- 


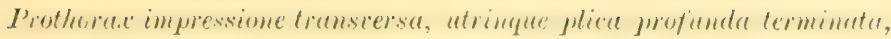
margine postice utrinque intermple, firea setigera untice pune anyulos anticos sita.

Elytra saepe punctato-striata, modo seriatim punctata.

Kïrper eiformig, hinten gewöhnlich retwas ansgezogen, mässign

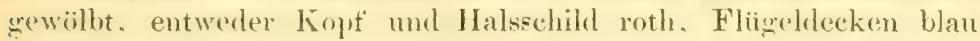
bis schwar\%. oder die ganze ()berseite blauschwarz, rostroth, gecllobram bis röthlich gelb. Kopt dreieckiy, bis zum Hinterrande der Atgen in das Halsichild eingetïgt, stirn mässig breit, uneben, dir Höcker gewölbt, in oberen Theile mit einander verbunden und vom scheitel kam oder mur durch eine seichte Vertiefing gretremnt, im unteren 'Theile wn der ziemlich tiefen Stimlinie begrenzt, welche aus zwei Bogen besteht, die sich in der Mitte winkelig verpinigen und lie Höcker bis ungefähr zux Mitte seheiden. Daher "rhalten beide Beulen eine amähernd herzförmige Gestalt. Der Raum zwischen den Fühlem ist kielartig gewölbt, nach unten verschmälert, voru allmählich zu dem Querstreifen des Kopfschildes abfallend. Die Vertiefung zur Einlagerung des ersten Fühlergliedes ist sehr gross. reicht vom Auge bis an den Stirnkiel und bedingt eine viel grössere Beweglichkeit der Fiihlerwurzel, als bei den beiden rorigen Gattungen, namentlich bei Podagrica. Oberlippe gross, quer. vorn leicht ausgerandet, Maudibeln fünfzähnig. der dritte und vierte Zahn gross und lang, die übrigen klein; Maxillartaster kurz, Glied 2 und besonders 3 nach der Spitze hin angeschwollen, 4 kaum so lang als das dritte, aus breitem Grunde schmell und fast gradlinig verengt, kegelförmig. Fühler kräittig, halb so lang als der Körper oder etwas länger, nach aussen schwach verdickt, unter sich weiter als von den Augen eingefügt, die obere Kante ihrer Pfannen hoch, leistentörnig; Glied 1 ziemlich lang und stark, 2 gewöhnlich das kiirzeste. 3 etwas länger, dem vierten gleich. 5) und die folgenden länger als 4, das Endglied verlängert. scharf zugespitzt. Augen gross, grobkörnio facettirt. Halsschild mässig oder wenig breiter als lang, am Hinterrande abgestutzt oder schwach gerundet, jederseits leicht ausgebuchtet und vom Längsstriche bis zu den spitzen Hinterecken fein gerandet, die Seiten mehr oder weniger gerundet, vorn mehr als hinten eingezogen, scharf gerandet; die Randleiste verbreitert sich nach vorn allmählich und springt hinter den stumpfen oder abgerundeten Vorderecken winkelig nach aussen, weil hier die Borstenpore eingedrückt ist. Uie Oberfläche ist der Quere nach weniger als der Länge nach gewölbt. fällt aber zu den Vorderecken gleichmässig ab. ein Stück vor dem Hinterrande befindet sich ein Quereindruck, welcher jederseits von einem tiefen und breiten Längsstriche abgekürzt wird, 
der den Grundrand vollständigr unterbricht; über dem Seitenranile: steht eine stärkere Punktreihe, die vorn, ungefähr an dror Borstenprore. hourenförmig nach innen zieht und allmählich erlischt. I)io Eokborsten sind fein und mässig lang. Sehildchen hallonal. Fliignaldecken am Grunde breiter als der Hinterram des IJalsschildes. bis zur Mitte wenig erweitert. dahinter nach und nach rement. hinten gemeinschaftlich ahgerundet und einzeh schwach algestutzt.

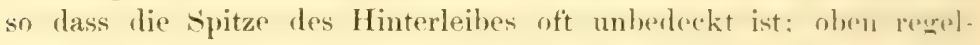
mässig punktirt-gestreift, oder in Reihen punktirt, die J'unkte dicht vor der Spitze verworren. Jie Seitenmullinie ist am Fude fein. oder hört ein Stück vor der etwas gewölbten sipitze aut, elrens.n erreichen die kahlen Epipleuren dieselhe nicht, die Schulterhenle? ist dentlich. innen von einem Eindrucke abgesetzt. durch den dip füinfte l'unktreihe läuft. Das I'rosternum ist wenig breit, der Länge nach vertieft, die ziemlich parallelen Seiten schwach leistentörmin erhöht; es fällt nach hinten zu einem mässig breiten Querstreiten ah, der sich an die Epimeren legt und die Hïfptamnen schliesst. das Mesosternum ist kur\%, hinten stark ansteigend und ausgerandet, in die Ausrandung legt sich der gerundete Zipfel der Hinterbrust. der sich bis in die Mitte zwischen die Mittelhitten rorschieht. Beine mässig stark, Hinterschenkel spindelformig, Schienen nach. der Spitze schwach verdickt, mit leicht gewiilbtem Riicken, an Ende schief abgestutzt, der Enddorn kurz und fein. Klauen an Grunde zahnartig erweitert.

$\hat{\sigma}$ Fliigeldecken glänzend, erstes 'Tarsenglied sehr gross. letzter Bauchring schmal, stark querüber gewïlbt, oft mit einer feinen Längsrimme, der Hinterrand abgestutzt und in der Mitte in eir kurzes und breites Läppehen ausgedehnt. - Der Penis ist verhältnissmässig lang und stark, wenig oder kaum gebogen, nach rorn allmählich und sehr schwach erweitert, an Ende corundet-rerengt und gewöhnlich in eine kleine spitze verlangert. f Glanz der Fliigeldecken durch eine kaum sichthare ('hagrinimung abgeschwächt. letzter Bauchring abgerundet.

Die Arten sind iiber Europra und die niordliche Hälte ron Asien verbreitet; sie leben entweder in der Ehene, hauptsiachlich auf fruchtbaren Wiesen, wo sie nach der ersten Henernte massenhaft auftreten, orler sind dem Gebirwe eigen. mul dort an fouchten oder sumptigen stellen ebentalls zahlreich zu fincen. Frstere siml oberseits einfarbig roth- oder celbbraun, letztere dunkelblau oder zweitarbig, die häufigste ron diesen, ( $r$. femmrata, findet sich nicht nux in allen Gebirgsgegenden Mitteleuropa's, sondern auch in Altai und in Lappland. Leber ihre Entwicklung ist noch nichts reriftentlicht worden, Die Taven scheinen sich in Pflanzenwurzeln 
und den unteren Stengeltheilen aufzuhalten. Eine sehr gestreckte. gelbliche Larve, Kopt und Beine braiunlich, in Cirsinm- und Ianunculus-Arten, halte ich für die von $\mathrm{Cr}$. ferruginea.

A. Der Inmenrand des Langsstrichelchens ist dicht an der Basis des Halsschildes ziemlich seharfkantig, etwas in die Höhe gehoben und mindestens so hoch als der Aussenrand.

a. Halsschild roth, Flügeldecken blau, grün odex schwar\%.

1. Crep. Peimolemi: Oblongo-ovata, convexiuscula, nitidu, nigra,

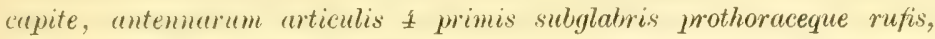
hoc sulluevi vel olsolete punctuto, postice minus angustato, lateribus sulvotundatis, impressione transversa profunda, elytris subparallelis, laete cyaneis, profunde punctato-striatis, punctis striarum crebris; humeris prominulis. - Long. 4-4,5 $\mathrm{mm}$.

Kutschera Wien. Monatsch, 1860. 131 (92). - All. Mon. 190. - Redtb. Faun. A. II. 502.

$\mathrm{Var}$. a. Immutura; antennis apicem versus leviter infuscatis-tibiis (praesertim anterioribus) tarsisque rufescentibus.

Var. b. \& Elytris minus nitidis, sericeo-micantibus.

Var. c. superba: Elytris laete coeruleo-viridibus aut nigro-aeneis, aurichalceo micantibus.

$\mathrm{V}$ ar. d. moesta: Elytris nigris, interdum subviolaceis.

Die grösste, am lebhaftesten gefärbte Art in dieser Abtheilung, durch die grosse, stark abgesetzte Schulterbeule und die dichte Punktirung in den Streifen der fast gleichbreiten, hinten schmell verengten Fld. ausgezeichnet. Länglich-eiförmig, nur mässig gewölbt, glänzend, schwarz, die vier ersten, wenig behaarten Fühlersrlieder, der Kopf, mit Ausschluss des pechbraunen Mundes, und das Halssch. roth, Fld. licht kornblumenblau. Halssch. etwas breiter als lang, beiderseits wenig verengt, an der Basis daher fast so breit als an der Spitze, die Seiten schwach gerundet, zweimal ausuebuchtet, das eine Mal seicht und undeutlich vor den Hinterecken, das andre Mal deutlich, an der vorderen Borstenpore. die ein stiick hinter den abgerundeten, wulstartig verdickten Vorderecken eingestochen ist und den Seitenrand hier winkelig nach aussen drückt; die Oberfläche ist vor dem sehr tiefen und sparsam grob punktirten Quereindrucke gewölbt, bald fast glatt, bald sehr fein und ziemlich dicht punktirt. Fld, in den Schultern breiter als das Halssch., dahinter kaum erweitert, mit ziemlich parallelen Seiten, erst im letzten Viertel verengt, oben flach gewölbt, verhäiltnissmässig tief gestreift und in den Streifen dicht, mässig stark, aber tief punktirt, auf der Wölbung nach der Spitze zu allmählich 


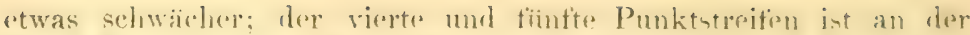
Basis furchenartig und hebt die grosse, glatte schulterbenle huch empor; die imneren Zwischenstreifen siml breit, besonders diclut

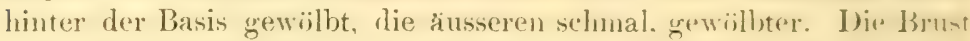
ist zerstrent, der Bauch nach ruickwärts allnählich dichter un! feiner punktirt, seine rier letzten segmente mehr od wernigrer deutlich gewirkt, zart behaart.

Bei frischen stücken (Var. a) sind die vorderen schienen unl alle Tarsen rothbraun, die vier ersten Fühlerglieder rothgelh, dic iibrigen bräunlichroth, an der Spitze nur angerlunkelt.

Auf den Fld. wird bei einzehen Weibehen der Glanz durch eine äusserst dichte Chagrinirung mehr als gewöhnljelı abgeschwächt und in einen seidenartigen Schimmer rerwandelt (Var. ly; ihre Farbe geht nicht selten in ein lebhattes Blan- oder schwarzgriun, mit Messingglanz (Var. c). oder in Sichwar\%, mit riolettem Anfluge, oder ein reines Schwarz iiber (Var. d), welches bei den Stiicken, die zugleich der Var. b angehören, am tiefisten ist.

In ganzen Alpenzuge rerbreitet und waluscheinlich dort rom Juli his zum Beginue des Winters in der Lnoehung ron Quellem nicht seltener als die übrigen Arten, aber hisher wonig beachtet. Aus der Wehncke'schen Sammlung besitze ich auch ein als melunostoma hestimmtes Stiick, das aus den Pyrenäen stammen soll.

2. Crep. femorata: Oblongu-orata, coniein, nitida, nigra, antemnis tibiis tarsisque rufo-testaceis, capite prothoraceque rufis, hoc sublacri, gibboso, postice evidenter angustato, lateribus rotundutis, impressime transversa profunda, elytris nigro coeruleis aut-cyanescentibus, punctatostriatis, punctis striarum fortibus, subremotis, apicem rersus evmescentibus; humeris sat prominulis. - Long. 3-4 min.

Gy 11 h. Ins, Suec. III. 554. - Steph. Ill. Brit. IV. 304; Man 294.

- Kutsch. Wien. Monat. 1860. 130 (90). - Redtb. Faun.

A. II. 497. - Seidl. F. balt. 494 (Halt.). - Kiist, Käf.

Eur. 9. 87. -- Foudr. Mon. 326. -- A 11. MIon. 189 et 487.

Haltica femoralis Duft. Faun. A. III. 271.

Var. a, infuscipes: Antemarum urticulis ultimis tibiinque plus minusie infuscatis.

Foudr. 1. c. 326 .

Var. b. aeneipennis: Elytris nigro-aeneis.

Eine weit verbreitete, häufige Art; an den einfarbigren hellen Fülılern, dem stark gewölbten, etwas herztörmigen Halssch. ${ }^{2}$ ) und

1) A ehnlich gebaut ist das Halsschild nur noch bei Crep. transsylranica Fuss (Verh. Siebenbürg. Ver. Hermannst 1864. 147. - Miller, Verh: 


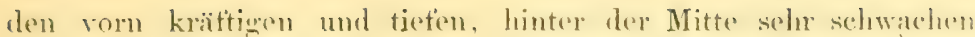

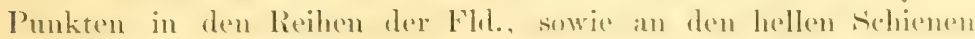
leicht kenutlich.

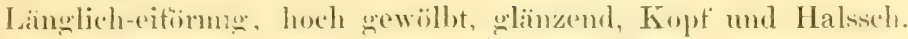
roth. Flıl. schwarzhlau, Fühler, schienen und Tarsen röthlich getelh. hram. Ilalssch. etwas breiter als lang, vor dex Mitte gremumbeterweitert, hinter derselben wieder fast phen so stark rerenet und vor den Hinterecken ausgeschweitt. so dass es dasellst wie ringeschürt erscheint und entfernt an eine Herzform erimert; di* scheibe ist vor dem tiefen. sparsam grob punktirten Quereindruek" beinahe kugelig wewlbt, glatt oder ziemlich dicht und äusserst fein punktulirt. Fld. an den Schultern so breit als das Halssch., in dentlicher Rundung bis zur Mitte erweitert, dahinter zuerst wenig. damn stärker verengt, Hach gestreift und in den Streifen stark und tief, aber nicht dicht punktirt; hinter der Mitte werden streifen und Punkte fein und rerschwinden beinahe, wenn man sie nur unter schwacher Verörösserung betrachtet. Zwischenstreiten beim Männehen schmal, ziemlich eben, kaum sichtbar punktulirt, beim Weibchen etwas breiter, äusserst fein gewirkt, leicht erhöht, die vier äusseren in beiden Geschlechtern deutlich gewölbt.

Von Aländerungen führt schon Foudras die seltene Var. a aut, bei welcher die letzten Fühlerglieder und die Schienen, namentlich die der Hinterbeine in rerschiedenem Grade angedunkelt sind; ausserem ist mir nur noch die Var. b, mit schwarzen, mehr messingfarbig als grün glänzenden Fld. bekannt.

Auf sumpfigen Wiesen, auch in der Nähe von Quellen und auf Lichtungen in feuchten Wäldern durch die Gebirgsgegenden Dentschlands und Mitteleuropa's verbreitet und im Juli und August an rerschiedenen Pflanzen häufig; Lappland, Altai. In der sächsischen Schweiz fand sich das Thier Fnde Juli in Copula auf Galeopsis tetrahit, deren Blätter ron ihm in Gesellschaft der Chrs. fastuosa zerfressen wurden.

3. Crep. melanopus: Oblongo-ovata, convexa, nitida, nigra, antenmis basi rufescentibus, capite prothraceque rufis, hoc obsolete minus dense punctato, concexo, postice sat angustato, lateribus leniter rotundatis, impessione transersa profunda, elytris laete cyaneis, punctato-striatis,

zool. bot. Ges. Wien 1867. 31) aus den Transsylvanischen Alpen. Kleiner und bedentend kürzer als femorata, tiefschwarz, der Kopf, das sehr dentlich punktirte Halsschild, Fiihler und Beine einfarbig roth. I. $2,5-3,5 \mathrm{~mm}$. 


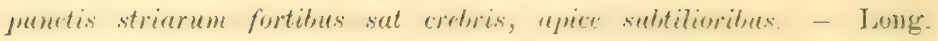
$3,5-4 \mathrm{~mm}$.

Kutsch. Wien. Monatsch. 1860. 139 (91). - A 11. Mon. I69.

$\mathrm{V}$ ax. a. Immatura; antennis, titiarum basi tarsisque fuscis.

Der vorigen äusserst nahe verwandt. jedoch etwas länglicher, das Halssch. eine spur kiirzer. flacher, dentlich aleer weitlinitizer punktulirt. kaum herzförnig. die Seiten vol der Mitte nur sanft gerundet, nach hinten mehr gradlinig verengt. vor den Hinterecke'n granz ummerklich eingeschnürt. Die Fld. sind lebhaft kornhlumenblau, dunkler als bei Peirolevii, aber viel heller als hei femuratu, ihre Punktreihen stehen in mässig tiefen Streifen, welche hinter der Mitte zwar etwas schwächer werden, doch fast his zur spitze dentlich bleiben, die Punkte in denselben sind wohl nicht zahlreicher aber grösser, grübchenartig, daher näher an einander gerückt, bis zum Ende der Streifen sichtbar; die inneren Zwischenstreifen etwas. die äusseren stark gewölht. An den Fühlem sind die ersten vier Glieder röthlich. jedes einzelne oberseits zuweilen angredunkelt, die folgenden Glieder schwarzbraun; dieselbe Farbe besitzen auch die Schienen und 'Tarsen. Letztere werden bei noch nicht ganz harten Stiicken (Var. a), nebst der Schienenwurzel und der oberen Hälfte der Fühler heller, röthlichbraun.

Zuerst in den Pyrenäen von v. Kiesenwetter und Perris. spaiter auch in den Westalpen, der Schweiz und Tyrol aufgefunden: ich erhielt z. B. ein Exemplar als femorata zugesandt, welches auf' dem Stilfser Joche gesammelt worden ist.

4. Crep. frigida: Oblongo-orata, concexiuscula, nitida, nigra, antemis (apice infuscatis), prothorace, tibiis tarsisque rufis, capite femorihusque piceis; prothorace breviusculo, sat concevo, obsolete minus dense muctulato, postice subangustato, lateribus pullo iotundatis, impressione transnersu sut profunda, elytris nigro-aeneis aut -coerulescentibus, subtiliter punctato-striutis, punctis striarum sat remotis, apicem rersus subtilinibus. - Long. 2,5-3,2 $\mathrm{mm}$.

Kleiner, noch schlanker und namentlich flacher als C'r. melanopus, durch die verhältnissmässig fein punktirten Fld. und den dunklen Kopf sehr abweichend. Länglich-eiförmig, fast elliptisch, beiderseits ziemlich gleichmässig verengt, schwach gewölbt, glänzend. schwarz, Kopf pechbraun, zwischen den Fühlern in der Mitte der Stirn gewöhnlich etwas heller, Fïhler röthlich gelbbram, die tünf letzten Glieder schwarzlich angelauten. Halsseh. roth (am Vorderrande schimmert oft der schwarze Scheitel durch), etwa um die Hailfte breiter als lang, vorn kaum schmaler als hinten, die seiten 
exscheinen sehr schwach gerundet, da sie hinter der vorderen Borstenpore und vor den llinterecken sanft ausceschweift sind, die Oberfläche ist mässig gewölbt, verloschen und nicht dicht punktirt, der Quereindruck vor der Basis ziemlich tief. Fld. in den Schultem otwas breiter als das Halssch., an den Seiten wenig gerundet, bedeutend feiner als hei den vorigen Arten punktirt; in der vorderen Hälfte stehen die Punkte in seichten Streifen. hinter der Mitte bilden sie nur sehr feine Reihen, die bis vor die Spitzo sichtbar bleiben, die /wischenstreifen sind unbedentend gewölbt. Beine pechbraum, s'chienen und Tarsen briumlichroth.

In den Mittelalpen an Stilfser Joche und im Wallis auf der Gemmi beim Bade Leuk.

5. Crep. Mhatica: Ovata, conera, migra, nitida, antennis (interdum aprice leviter infuscatis), perlibus, capite (ore excepto) prothoraceque rufis, hoc sat crebre minus subtiliter punctulato, lateribus subrotundatis, impressione transcersa mofunda, elytris subtiliter punctato-striatis, punctis striarum crebris, apicem versus subtilioribus. - Long. 3,2-4 mm.

Kntsch. Wien. Monatsch. 1860, 133 (95). - Redtb. Faun. A. II. 502 (Halt.). - A Il. Mon. 191.

Die vorliegende und folgende, sowie eine nahe verwandte, in Deutschland bis jetzt noch nicht beobachtete Art ${ }^{1}$ ) zeichnen sich durch einen etwas abweichenden Bau des Körpers aus, welcher hauptsächlich durch die weniger deutliche Trennung des Halssch. von den Fld. bedingt wird. Während bei den vorhergehenden, mit $C r$. femorata verwandten Thieren das Halssch. nach hinten beinahe so stark als nach vorn verengt ist, und die Fld, an den Sichultern weit über die Basis des Halssch. heraustreten, wodurch vor ihnen ein tiefer Ausschnitt im Körperumrisse entsteht, liegt lier die stärkste Verschmälerung in der vorderen Hälfte des Halssch, die Fld. verengern sich allmählich etwas mehr nach den Schultern hin, diese haben nur eine sehr niedrige Beule, sind weniger eckig: stärker abgerundet. der Ausschnitt vor ihmen ist unbedentender, und der Körper erscheint deshalb fester zusammengefügt, gẻdrungener.

1) Crep. corpulentu Kutsch. (1. c. 132 [93]). Durchschnittlich grösser, mamentlich von breiterem Ban, aber ganz ähnlich gefärbt wie rhaetica, Halssch. sehr fein, oft kaum bemerkbar punktulirt, Punkte in den Reihen ler Fld. viel weit]äufiger gestellt. Hinterschenkel schwarz. - L. 3,8 bis $4,3 \mathrm{~mm}$. Siebenbürgen, Südungarn. Croatien, nördliches Italien.

Bei einzelnen Stücken haven die Fld, einen grünlichen oder bläulichen Anflug. 


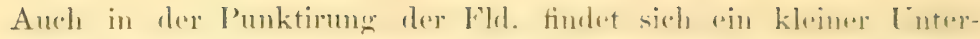
schied, da dir J'unktreihen anf den kurzen. zur Banis alifallemulen

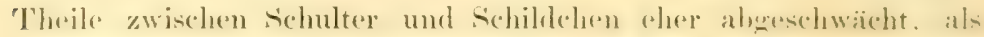
verstärkt und vertieft sind, wie bei den vorigen Arten.

Eifömie, gewiolht, stark glänzend, schwatz. Kopt. Halsicht..

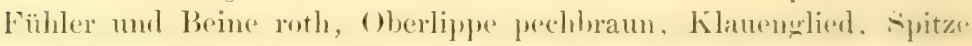
der Fühler und ein Streifen am Hinterrande des Halsich. zuwirilen angedunkelt. Halssch. etwas breiter als lang, in der. Witte an hreitesten, ziemlich dicht und sehr deutlich punktirt, der (pnereindruck tief, nahe dem Iängsstrich jeslerseits erweitert mul nach hinten gebogen. Fld. tief' schwarz, die Eppipleuren oler cin feiner Saum an der spitze zuweilen rothlsaun, in den Reilren mit glexichmässig tief eingestochenen und dicht neben einander stehenden Punkten, welche bedentend feinex als bei femorutre sind. ant den Alfalle etwas schwacher werden, aber his hinten dentlich bleibun.

West- und Mittelalpen. In 'Timol am Brenner unt sitiltser' Joche.

6. Crep. melanostoma: Orata, conrexiuscula, nigra, nitida, capite (ore excepto), antennis, prothorace pedibusque rufis, femoribus posticis saepe infuscatis; prothorace subtilissime punctulato, impressione transversa minus profunda, elytris aeneo-vel coeruleo-micantibus subtiliter: munctato-striatis, punctis striarum subremotis, apicem revius eranescentibus. - Long. 2,8-3,5 $\mathrm{mm}$.

Redtb. Faun. A. ed. 1. 529; ed 2. 935; ed. 3. II. 497. - Kutsch. Wien. Monatsch. 1860, 133 (94 Halt.). - All. Mon. 191.

Kiirzer, weniger gewolbt als die rorige, hesonders die Wribchen breit-eiförmig, Kopf, Halssch., Fühler und Beine roth, Hinterschenkel in der Mitte dunkel, zuweilen auch die Fiihler an der spitze gebräunt, Mund, Brust und Bauch sehwarz, Fld. sehr dunkel metallisch griü, schwach messingfarben oder bläulich. Halssch. in der Mitte am breitesten, fein und nicht immer deutlich punktulirt, ror dem graden, wenig tiefen Quereindrucke nur mässig gewiilht. Fld. mit regelmässigen, beim ô feinen, beim f etwas stiulieren. vor der Spitze verschwindenden Punktreihen, in denen die Punkte bald durch engere, bald durch weite Zwischemäume getrennt sind.

Auf Cullma vulgaris I. (Haidekraut) in den Ostalpen.

b. Oberseite blau, Kopf und Halsschild etwas dunkler als die Fld., oder schwarz.

\%. Crep. cyanescens: Oblongo-ovata, convexa, nitida, nigra, supra coerulea vel cyanea, antennis, tilitis tarsisque mifo-bumeis; prothurace 
conrexo, subtiliter punctulo, postice subungustato, impressime transwersen

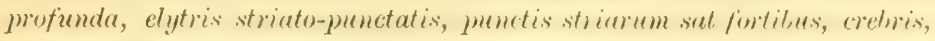
upice subtilioribus, interstitiis comrexiusculis. - Iong. 33,5 + mm.

Duft. Faun. A. III, 274. - Kutsch. Wien. Monatsch. 1860. 134 (96). - Redtb. Faun. A. II. 497 (Halt.). - Kiist. Käf. Eur. 28. 88. - Foudr. Mon. 325. - A 11. Mon. 192.

Hullien alpicola Schmidt Haiding. Ber. TI. 1850). 1xt; Jahreshett Ver. Krain. Landes-Mus. 1856. 29.

Var. a. Immature; femoribus rufo-piceis, antennis, tibies tarsisque dilutioribus, interdum testaceis.

Var. b. Supra coeruleo-rirescens.

Dex ( $r$. frmoratı in Grösse und Gestalt ähnlich, aher das Halssch. etwas flacher, stärker punktirt, hinten weniger verengt, die Punkte in den Reihen der Fld feiner und dichter, lis zur spitzo bemerkbar.

Länglich-eiförnig. gewölbt, glänzend, schwarz, die Oherseite blau oder schwärzlich blau, auf Kopf und Halssch etwas dumkler als auf den Fld., Fithler, Schienen und Tarsen röthlichloraun. Halssch. hreiter als lang, vor der Mitte gerundet-erweitert, hinter derselben verengt und nahe den Hinterecken wenig oder nicht ausgeschweift, die scheibe vor dem tiefen Quereindrucke gewölbt, ziemlich dicht und deutlich punktirt, an den Seiten fast g.latt. Fld. in den vichultern so breit als das Halssch., mit mässiger Schulterbeule, die Hachen Streifen tief und ziemlich stark und dicht punktirt, hinter der Mitte werden Streifeu und Punkte etwas feiner. aber sie bleiben bis zur Spitze sichtbar. Zwischenstreifen leicht gewölbt, beim Männchen schmal, äusserst fein punktulirt, beim Weibchen breiter, sehr fein und dicht gewirkt.

Frisch entwickelte Exemplare haben hellere, rïthlich gelbbrame Fiihler, Schienen und Tarsen und pechbräunliche Schenkel (Var. a), ausgehärtete sind bisweilen auf der Oberseite, namentlich auf den Fld. bläulich metallisch-griin (Var. b).

An Bächen aut Aconitum murllus und den Feratmom-Arten in ganzen Alpen- und Karpathenzuge verbreitet.

Lnhekamnt blieb mir die Halt. simplicipes Kutsch. (Wien. Monat. 1860. 137 (99): „Oblongonrata, concexa, nitida; supra viridirenea, antennis perlibusque pireis; femoribus posticis non incrassatis: thorace mimntissime sparsim punctulato, postice sulen obsoleto transversim impresso; clytris striato-pmetatis, apire sublacribus, stries exterioribus subregularibus. - Long. $2,8 \mathrm{~mm}$.

Durch erzgrïne Färbung, äusserst schwachen Quereindruck des Halssch., etwas unregrelmässige äussere I'unktreihen der Fld. und 


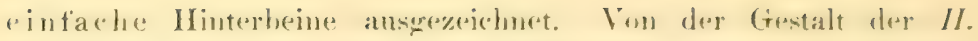
myanescens, aber etwas kleiner und schmäler.

Nach einem Weibchen beschrieben, welches H. Miller anf einee Alpe in Steiermark gefangen hat.

8. Crep. cyanipennis: Oblongo-aiata, comeriuscula, nitidu, ningra, untennis tibiisque basi rufescentibus, jothorare conchausculo, subtiliter functulato, jostice subangustato, impressione transiersat sat jofundr, elytris nigro-coeruleis aut-cyaneis, strinto-punctutis, junctis striarum subtiliorihns, subremotis, apice eranescentilus, interstitis planiusculis. Long. $3 \mathrm{~mm}$.

Kutsch. Wien. Monatsch, 1860. 135 (97). - Redtb. II. 502 (Halt.). - All. Non. 193.

In der (iriosse. (iestalt und Punktirumy an meisten an C'r. frigida erimmend, der Farbe nach mehr mit der vorigen verwandt und rom dieser leicht durch folgende Punkte zu unterscheiden: der Kïper ist bedeutend kleiner, etwas schlanker. weniger gewijlht, durchgängig feiner punktirt, eine spur matter, tief schwarz, nur die Fld. wenig lebhaft schwarzblan. Fiihler kürzer und bedeutend dicker, schwärzlich, die spitze des ersten Gliedes und die folgenden bis zum siebenten Gliede einfarbig rothbram. Halssch. sehr tein frunktulirt; Fld. nit ziemlich weitläufig punktirten Reihen, die feiner als bei cyrnescens sind und vor der spitze verschwinden, ihre Zwischemäume sind breit, beim Jännchen ausserst fein gewirkt und sparsam, verloschen punktirt, beim of etwas stärker sewirkt. Beine schwarz, Basis und Spitze der schienen, oft anch die 'Tarsen rothbraun.

In den Alpen bis jetzt am Monte Viso und Monte Rosa, sowie in Kärnthen aufgefunden.

B. Ier Innemand der beiden Iängsstrichelchen aut dem Halssch. ist niedrig und verlosehen.

9. Crep. transwersa: Oblomg-ocatu, comeca, fermyineu-testacen, nitida, prothorace laevi prope linea mmediam subtiliter ot in impressione transversa sat profunda paullo fortius punctuto, laterilus sat late marginato posticeque sensim, sed evidenter angustato, elytris substriato-punctatis, interstitiis sat angustis. - Long. 4-5 mm.

Mas: angustion, prothorace vix trunser:so, serielus elytronum fere simplicibus, segmento ultimo ventrali apice profunde transitrsim impresso.

Femina: latior, seriebus elytrorum geminatis.

Marsh. Ent. Brit. I. 203 (Chrys.) - Gyllh. Ins. Suec. III. 553. - Kutsch. Wien. Monatsch. 1860. 117 (88). - Redtb. 
Faun. A. II. 497 (Halt.), - Küst. Käf. Eur. 9. 83. Foudr. Mon. 331. - All. Mon. 185.

Halt. impressa Duft. Faun. A. III. 270. -- Seidl. F. balt. 494.

Halt. exoleta Panz. Faun. Germ. 21. 14, - Koch Ent. Heft. II. 17 (pars).

Halt. ferruginea Steph. Ill. Brit IV. 302; Man. 294.

Lang eiförmig, gewïlht. hell rostroth, glänzend, Fühlex, Beines und die Spitze der Fld. gewibhlich etwas hlasser, Brust und Banch dunkler. Fühler schlank, merklich linger und diunner als bei den vorigen Arten. Halsseh. vor der Mitte am hreitesten, nach hinten allmählich, doch beinahe eben so stark als nach vorn verengt, mit gerundeten seiten, die hinter der vorderen Borstenpore etwas stairker als dicht vor den Hinterecken ausgeschweift sind. Der Seitenrand bildet eine ziemlich breite und dicke Kante, die von einer tiefen und breiten, verhältnissmässig weit nach innen gerüickten Rinne abgesetzt wird, an deren Imnenseite die starke Punktreihe steht. Diese hat in der Mitte ein oder mehrere Punkte neben sich; rorn biegt sie hinter dem Auge einwärts und verlängert sich ein Stück auf die Scheibe so, dass die letzten Punkte genau aut das Längsstrichelchen zu gerichtet sind. Im Uebrigen ist die Scheibe an den Seiten glatt und nur im mittleren 'Theile punktirt; die stärksten Punkte stehen in und neben dem riemlich tiefen Quereindrucke und vor demselben in der Nähe der Mittellinie, von dieser aus verfeinern sie sich seitwärts und nach dem Vorderrande hin. Die Fld. haben unregelmässige Punktreihen, aus hinterund nebeneinander stehenden Punkten zusammengesetzt, welche nach hinten schwächer werden und vor der einzeln leicht abgestutzten Spitze erlöschen. Die Zwischenstreifen sind ziemlich schmal.

Das Männchen ist auffällig gestreckt, scin Halssch. (mit gerundeten Seiten) fast quadratisch. wenig breiter als lang und fast so breit als die Fld., die Punkte in den Reihen der Fld. kräftig, nicht ganz regelmässig hinter einander gestellt, indem einzelne bahl nach rechts, bald nach links von rer graden Linie abweichen, aber selten verdoppelt sind; Zwischenstreifen glatt. Letzter Bauchring mit feiner Mittelrime, welche am abgestutzten Hinterrande in einen ziemlich grossen und tiefen Quereinduck entet. Penis so lang als der Hinterleih, gerade, nach der ()offinmug hin äusserst schwach erweitert, fast gleichbreit, vorn germotererengt und in eine kurze, breite Spitze ausgezogen.

Das Weibchen ist bedeutend breiter; sein Halssch. un diu Hälte breiter als lang, aher schmaler als die Flil., diese sind fein 


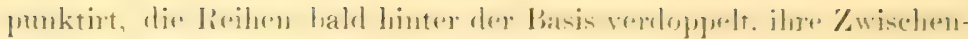
streifen äusserst dicht und fein gewirkt.

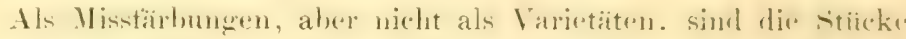
anzusetem, bei denen einzehe Kärperstellen dunkel gefarth simbl. \%. 13. das Halssch. an Hinterrande, an Quereindrucke. coder in der

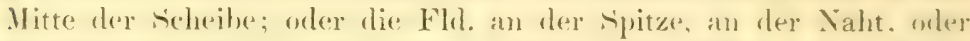
den heitenrande. Bach erwahnt (Fann. III. 1:38) ein von Rogen in Schlesien gefangenes Exemplar, das im hinteren Drittel der Fld. und an der Naht noch etwas weiter schwarz ist.

Auf C'irsinm-Arten und L'mbelliferen, hauptsächlich an P'restinueren satice auf fruchtbaren Wiesen, an Weg- und (irabenrïndern in ganz Mitteleuropa häufig.

Ob $H$. fermaine Steph. auf die vorliegende Art bezogen werden darf, scheint zweifelhaft, da sie , dull red" genamnt wird, dagegen ist. exoleta Panz. sicher nach einem $\hat{o}$ abgebildet und deshalb nicht zu ferruginea zu stellen.

10. Crep. impressa: Oratu, conreca, mfo-custanea, nitirla, inothurace subtilissime obsoleteque punctulato, impressione transiersa profundu evidenter punctatu, lateribus unguste marginats posticeque iix angustato, elytris sultiliter lineato-punctatis, lineis plerumque geminutis, interstitis latis. - Long. 4-5 mm.

II s: minor, seymento ultimo ventrati apice leviter impresso.

Fabr. Syst. El. I. $496^{\circ}$ (Galleruca). - Illig. Mag. VI. 57 et 109. Kutsch. Wien. Monat. 1860, 119 (88), -- Redtb. Faun. A. II. 497 (Halt.). - Foudr. Mon. 329. - All. Mon. 184.

Crepid. rufa Küst. Käf. Eur. 15. 91.

, marginicollis Küst. 1. c. 92.

Den Weibchen der vorigen Art ähnlich, aber in folgendent Stiicken von ihnen verschieden: Die Färbung des Kïrpers ist hell kastanienbraun, oberseits stärker, beim $\hat{j}$ fast lackartig glänzend: das Halssch. in der Mitte am breitesten, rïckwärts kaum, wenicrstens nicht bedeutend verengt, überall gleichmässig, äusserst f’ein und verloschen punktirt, bei schwacher Vergrosserung fast glatt, mur im Quereindrucke, der hier stets tiefer als bei den ähnlichen Arten ist, mit einzehen, oder einer umegehmässigen Querreihe ron stärkeren Punkten versehen, vor denen noch ein bis drei ähnliche Punkte jederseits neben der Mittellinic stehen. Die sicheibe ist verhältnissmässig stark gewölbt. die aufgebogene Kante am seitenrande schmal, scharf, nicht verdickt, weil die absetzende Rinne unmittelbar neben ih hinläuft. Fld. durchweg feiner und insofern regelmässiger punktirt, als die einfachen oder verdoppelten Reihen 
durch breitere \%wischenräume weiter von einander gretrennt und schärter abegerenzt werden, anch die l'unkte in ilnen erhehlich dichter neben cinandere gestellt sind. Jede cinzelne. Fld. ist hinten, ummittelbar nelen der Saht undentlich abgestutat, der Winkel. an welchem die Abstutzung beginnt, mehr verrundet.

beite Geschlechter weichen im Kïperbau nur in goringen Grade ab. Bein kleineren Mämohen ist das Ilalsich. wenig breiter als lang, viel schmaler als die Fld, an den seiten sehr schwach geremdet, die I'unktreihen der Fld. sind einfach, gewöhnlich nu aut der inneren und hinteren Hälte jeder Decke verdoppelt, dic Zwischenstroifen eben, watt. oder einzeln fein punktirt; der letzte Bauchring hreiter als hei transersu, in der Mitte des absestutzten Hinterandes leicht rertieft. - Penis klein, kürzer als der Hinterleih, an der Oetfinme deutlich erweitert, davor wieder in allmahlicher loundung verengt und in eine scharfe spritze ausgezongen. Auf' Tritten an der Kiiste des mittelländischen Weeres nicht selten. Aus unserem Gebiete sind mir nur Stücke bekannt. die von H. Prot. Schreiber bei Görz gesammelt wurden; sie zeichnen sich durch eine krättige Punktirung der Fld. vor den südeuropäischen und nordafrikanischen Exemplaren aus.

Nahe verwandt ist:

1. ('r. pregrina Harold (laerigata Foudr Mon. 331). Ganz wie impressu, weniger gestreckt und auf den Fld. ansserordentlich fein punktirt, die Reihen sebr unregehmässig. - Das Thier ist nach einem co aus der Umgegend von Bona beschrieben, mir ist nicht bekannt, ob es seither wieder aufgetunden ist, da die Angaben vom Vorkommen in Spanien und Sicilien wohl anf einer Verwechselung nit Hermuenphaga ruficollis Luc. beruhen dürften.

2. ( $i$. wiscuritarsis Motwch. (Bull. Mosc. 1859. 489) vom Amur; ledentend grösser. durchweg feiner puntirt, Punktreihen der Fld. schwer zu erkennen, die letzten sechs Fïhlerglieder, Tarsen, Spitze der Hinterschenkel und die Hinterschienen braun orler schwärzlich L. $5-6 \mathrm{~mm}$.

11. Crep. ferruginea: Oratu, convex, ferrugineo-testaceu, nitidu,

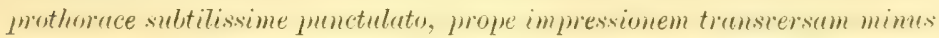
profundam exidentius punctato, laterilues anguste marginuto posticerpue subangustato, elytris punctato-striatis. -- Long. 3-4 mm.

II as: cuguestion, striis el, trorum regulariter punctutis, segmento ullimo ventrali apice evidenter transversim impresso.

Scop. Ent. Carn. 70. - Schrank Enum. 1533 (Chrysom.). Illig. Mag. VI. 104. - Schill. Ber. Schles. Ges, 1846. 91. - Kutsch. Wien, Monat. 1860. 119. (89). - Redtb. 
Faun. A. II. 497 (Halt.). - Foudr. Mon. 332. - A 11. ILon. 186 .

Gialleruca pxoletu Fabr. Syst. Ent. 115. - Payk. Faun. Suec. II 108. - Oliv. Ent VI. 700. t. 3. f. 57. - Koch Ent. Hft. II 17 (pars). - Gyllh. Ins. Suec. III. 551. - Duft. Faun. A III. 270. - Zett. Faun. Lapp. 224, - Seidl. F. balt, 494 (Halt.) - K iist. Käf. Eur. 984.

Mordella flaca Limn. Faun. Snec. ert. 1. 535. - Steph. Iil. Brit IV. 303; Jan. 294 (Halt.); et var. similis Steph. 1. c.

Halt. crassicomis Fald. Nouv. Mém. M[ose. V. 34: - All. MLon. 4*6; Schneid. u. Leder Beitr. Kank. 339.

Durch die feine Randleiste des Halsseh. mit der vorigen verwandt, in der Körperfarbe mehr an trinscersa erinnemd. von beiten durch geringe (irösse, kurzes Halssch. und die regelmässigen starken und fast einfachen Punktreihen der Fld. abweichend.

Eiförmig, hinten stärker verengt als vorn, oft kurz zugespityt. gewölbt, hell rostroth, glänzend. Halssch. um die Hälfte breiter als lang, vor der Mitte am breitesten. nach der Basis etwas weniger als nach der spitze rerschmälert, an den Seiten gerundet und in eine schmale Leiste aufgebogen. welche hinter der vorderen Borstenpore in leichtem Bogen nach aussen tritt; die (1)erfläche ist sehr fein punktirt. in dem schwachen Quereindrucke, sowie auf einem grösseren Raume davor mit stïrkeren Punkten hesetzt. Die Fli. haben beinahe regelmässige. an der sipitze rerschwindende Punktreihen, welche, wenigstens vor der Vitte. in deutlichen Streifen stehen und durch gewölbte Zwischenräume getrennt werden.

Das Männchen ist gewöhnlich kleiner und etwas gestreckter als das Weibchen, selten ganz übereinstimmend gebaut, die P'unktreihen der Fld. sind meist regelmässiger, namentlich die imneren, welche beim Weibchen häufig durch überzählige oder verschobene Punkte gestört sind; der letate Banchring hat einen deutlichen Quereindruck auf dem Zipfel, in den der abgestutzte Hinterrand in der Mitte verlängert ist. - Penis klein, vor der (leftnung unmerklich zusammengedrickt, an Ende in allmählicher Rundung zu einer dreieckigen spitze verengt, welche an der Basis stärker als bei impressu nach unten gebogen ist.

Die Art ändert in der Form der einzelnen Körpertheile, in der Stärke und regehmässigen Anordnumg der Punkte auf den Fhl. sowie in der Färbung etwas, jedoch nicht auttällig ab: trische stiucke, besonders solche, die durch schlechte Behandlung in den sammelflaschen gelitten haben, sind mehr oler weniger pechbramn. Auf trocknen Grasplätzen gemein.

('rep). crussicornis Fald., aus T'ranskankasien, wird zwar von 
Allard als Art zu halten gesucht, aber ich halbe keinen stichlialtigen Unterschied an ihe autfiuden können. ('r. marginicollis Küst. darf' wegen dere angegebenen Fiarbung (tief rostroth, fast hell blutroth) nicht zu fermeninen. sondern nur zu impressu gestellt werden.

\section{Dehrosis.}

Foudras, Altisides p. 302.

Acetabula antica occlusa, mesostermum conspicuum.

Palpi maxillares articulo ultimo brevi, conico.

Tubercula frontalia obsoleta, discreta, trigona.

Prothorax in basi et lateribus margimutus, integer vel impressione obsoleta transiersa, utrinque basin versus inflexa; forea setigera antica pone angulos anticos sita.

Elytra punctato-striata, apice sublaevia.

Der Gattung C'repidoder sehr nahe verwandt und hauptsächlich durch die Bildung des Kopfes und Halssch. verschieden. Auf ersterem sind die stimbeulen klein, dreieckig, ziemlich flach, wenig hervortretend, aber deutlich von einander getrennt, die Linien, die sie begrenzen fein und seicht; die Stimlinie läuft zuerst rom Hinterrande jedes Auges schräg nach imnen und biegt sich dann uiber der Fühlerwurzel so, dass sie im mittleren Theile eine fast gerade Querlinie bildet, welche die Höcker oben begrenzt; ron ihrer Mitte laufen zwei divergirende Linien nach unten, die den breiten, nach vorn allmählich abfallenden und etwas verschmälerten Längskiel einschliessen. Derselbe ist zuletzt wieder leicht verbreitert und geht ohme bestimmte Grenze in das Kopfschild iiber. An den Fiihlern sind die Glieder 2 bis 4 ziemlich kurz, unter sich von gleicher Länge. 5 gestreckt, noch etwas länger als 6, die folgenden dicker, allmählich verbreitert. Das gleichmässig punktirte $\mathrm{H}$ alssch. hesitzt an der Basis und den Seiten eine foine, aber deutliche Randleiste, vor dem Grunde keinen, oder einen schwachen Quereindruck, welcher sich seitlich etwas vertieft, nach hinten hiegt und mit der. Randlinie an der Basis rerbindet; der dadurch umschlossene Raum ist ziemlich eben. Die Fliigeldecken sind rom nicht besonders stark. hinter der Mitte sehr fein und verlnsehen punktirt-gestreift. Das erste 'Tarsenglied ist an den beiden vorleren Beinparen schwach erweitert, so dass es monetialn diu Breite des dritten ciliedess erreicht $(\hat{j})$, während es beim of bedentend schmaler bleibt, ebonso ist bei diesem der Hinterrand des letaten Banchringes gerumletvorgezogen, beim ô aloer aligestutzt und in der Mitte in einen ungebogenen Querzipfel verlängert.

VI. 4. 


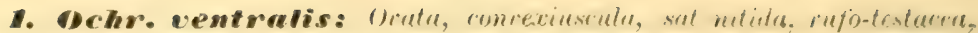

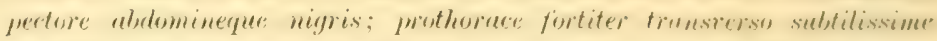
puncluto, lateribus rix rotundato, impressione tirenstersen subtili, utringue plicu bassali eridenter terminutu, elytris flaco-testacein, strinto-punetulis, apice fere laevibus. - Long. 2-2,5 $\mathrm{mm}$.

Illig. Mag. VI, 5s et 111. - Kutsch. Wirn. Mronat.142(10i3).

- Redtb. II. 498 (Halt.). - All. Mon. 182 (r'rep.). Foudr. Mon. 305.

Crep. abdominalis Kiist. Käf, Eur. 15., 93.

Var. a. Vertice brunneo.

Var. b. Supra castanea.

Halt. nigviventris Bach Stett. ent. Zeit. 1856. 245.

Fast rom Ansehen eines Lathridius, eiförnige, schwach gewrilbt, ziemlich glänzend, röthlich gelhbram, die Fld. etwas heller. Yittelund Hinterbrust, sowie der Bauch schwarz. Halssch. dopyelt so breit als lang, wenig gewoilbt, nit fast graden seiten, wie die stim äher den Beulen sehr fein und wenig deutlich punktirt, zwischen den Punkten zart gerrirkt. Der Quereindruek ist in der Mitte flach und undeutlich, rertieft sich jederseits etwas und liegt nach hintebis zum Grundrande. wo er grubenförmig wird und aussen ron einer hohen, scharfen Kante begrenzt ist. Fld. in den schräir unl etwas winkelig heraustretenden Schultern hedeutend loreiter als das Halssch., an den seiten schwach gerundet, mit der yrössten Brite in der Nähe der Mitte, die Punkte in den Reihen fein und wenig tief. auf dem Abfalle zur Spitze allmählich erlïschemil. ebenso in dem Raume zwischen der grossen und hohen schulterbenle und dem Schildchen.

Bei einzelnen Stiicken ist der Scheitel mehr oder weniger dunkelbram (Var. a), oder das Halssch, an der Basis und den Seiten fein schwarz gesäum, auch sind zuweilen die fünt dickeren Endglieder der Fiihler gebräunt, oder die I'unkte auf den Fld. sind durchscheinend und sehen dunkler als gewiilmlich aus: selten ist die ganze Oberseite kastanienbraun (Var. b).

In Thüringen, schlesien. Baiern und (lesterreich im Vorgebirge. anf sodumm dulcumara ziemlich selten, in südeuropa häutigex.

Ungemein nahe verwandt sind:

1. Orhr. Kräperi: Oralis, sut comeru, testacen-rufu, elytris pullide testaceis, antennis aprem rewas leviter infusentis: cupite prothoraceque subtiliter punctatis, hoc hasi impressione trasterse utrinque plicu profunda terminuta, elytris sulititer punctuto-strintis, pone medium laeribus. - Long. 2,2 mm. Creta (Krïper).

Oberseits dex $O$. centrulis ähnlich gefärbt. jedoch breiter als diese gehaut md hiemach der $O$. rulricunda näher rerwandt. ron beiden 
durch die einfarbig rothe Enterseite, stärke Punktirung des Konfex und Halssch, den tieferen, an den Seiten stiinker vertieften (Quereindruck vor der Basis des letzteren mo die anf der hinteren Hailfte mpunktirten Fld. verschieden. Allard befindet sich, falls er dienelbe Art aus dem Kaukisus mol Syrien vor sich grehabt hat, im Trrthume. wemn er sie für eine Var. von rentralis hält (Beitr. Kauk. Käf. 3+0: .Ablumen semper flarum (?) et nunquam nigrum ut in (rep). ventr. Europue. Haer iretas siyrum quoque hubitat"), demn Kopf, Halssch. und namentlich die Vorderbrust sind intensiver roth gefärbt als bei der schwarzbauchigen ventralis.

2. Ochr. rubicunda Perris (Ann. Fr. 1864. 302; corsica All. Mon. 18t66. 184). Etwas kräftiger gebant als ventralis, die Farbe ähnlich vertheilt, aber die Oberseite lebhaft bräunlich roth, bei den dunkelsten Stücken das Halssch. am Seiten- und Hinterrande und die Fld. an der Naht und am Seitenrande schwarz gesäumt, die Punkte in den Reihen der Fld. feiner, viel weitläufiger gestellt. - Auf Corsica.

3. Ochr. pisana All. (Amm. Fr. 1861.308; Mon. 183). Körper schwarz, mur die Fïhler und Beine roth. Halssch. etwas länger und nach vorn stärker verengt als bei ventralis. - Im Juli auf Hyoscyamus allus bei Pisa und Livorno (Bargagli).

2. Dehr. salicamiae: Ovalis, comexa, sat nitida, rufo-testacea, pectore ablumineque nigris, prothorace transierso, sultilissime punctato, lateribus. rotundato, elytris flaco-testreceis, sutwa leriter infuscatu, striato-punctatis, apice fere laevibus. - Long. 2-2,5 mm.

Payk. Faun. Suec. III. 453 (Galleruca). - Gyllh. Ins. Suec. III. 554. - Steph. IIl. Brit. IV. 303; Man. 294. - Kutsch. Wien. Monat, 1860, 140 (102). - Redtb. Faun. A. II. 498. - Seidl. F. balt. 495 (Halt.). - All. Mon. 183 (Crep.). Foudr. Mon. 304. - Thoms. Skand. Col. VIII. 224.

Haltica striatella Illig. Mag. VI. 159.

Var. a. Immatura; pectore abdomineque rufo-piceis.

Var. b. picicollis: Capite prothoraceque brunneis aut piceis.

Gedrumgener gebaut und stärker gewölbt als die vorige, an dem schmaleren Halssch. olne Quereindruck, und den kiurzeren Fld. leicht zu unterscheiden. Eiförmig, gewölbt, ziemlich glänzend, röthlich gelbbraun, die Fld. etwas heller, häufic mit bräunlicher Naht, Mittel- und Hinterbrust, sowie der Bauch schwarz. Halssch. kaum doppelt so breit wie lang, an den seiten schwach, aber deutlich gerundet, oben gewölbt, fein punktirt, durchaus ohme Quereindruck, oder nur mit der spur einer Quervertiefumg, die aber dicht vor dem Hinterrande liegt und beiderseits nicht grubenförmig erweitert ist. Fld. in den bogenförmig heranstretenden schultern hreiter als das Halssch., mit gerundeten Seiten, namentlich bein $q$. 


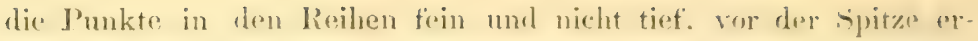
liischend, die sehulterbeule klein mol nur mässig hoch.

Bei frischen Stiicken ist Brust und Banch röthlich pechluanu, das letate Bauchsegment ïfter noch hellor: die dunkelstre Form (Var. b) ist anf Kont und IIalssch., orlere anf letyterem allein. hramu

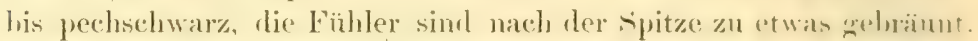
Grosse, verhälnissmäsiy stark punktirte Exrmplare, hei domen die P’unkte auf den Flıl. nicht selten hräunlich durehsehimmerm. haluen fein und deutlich punktirte Zwischenstreifen.

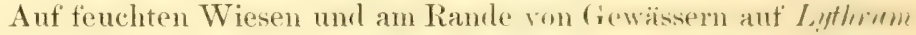
salicaria in Mitteleuropa häufig: sparsamer in noirdlichen und siirllichen Europa.

Dic Halt. striatella Ill. wurde lange Zeit fül eine besondere Art gehalten, weil Illiger ihr Halssch. ,wenig breiter als lang" nannte, sie ist aber mit salicariue identisch, was aus dem Vergleiche mit der Be. schreibung von rentrulis Ill. hervorgeht (in der das Halssch. nur ..,breiter als lang" angegeben ist) und ausserdem durch ein typisches Stiick auf dem Berliner Museum bestätigt wird.

Crep. nitidicolles Hotsch. (Schenck Reis. Il. 1860. 233. t. 11. 1. 21) von Amur sieht ganz wie srlicariae aus, das Halssch. ist feiner punktirt, an den Seiteu weniger gerundet, die Fld etwas stälker punktirt.

\section{Epitrix.}

Foudras, Altisides p. 308 .

Acetabula antica occlusa, mesosternum conspicuum.

Iinea frontalis angulata, profunda; tubercula frontalia mulla

Prothora.x punctatus laterilnes ciliatis, impressione transocrsa arentri. utrinque plica terminata; scutellum parvum.

Elytra punctato-striata, interstitiis uniseriatim punctetix et pilesis:

Kopf klein. dreicekig, mit breiter stim, mäsige grosisen, lany walen und nicht besonders gewölhten Angen. einem schmalen, hohen und scharten stimkiele und einer kleinen, vorn answerandeten Oberlippe. Die Stimlinie ist tief und bildet einen Minkel, dessen Scheitelpunkt an der spitze des stirnkieles liegt. iiher ihr. nicht weit von den Augen entfernt, befinden sich jederseits einiwn Borstenporen, während der übrige Theil der stirn tein gewirkt ist; unter ihr breitet sich ant jeder Seite his zum Auwe und der Fühlerwurzel ein kleiner, unebener, mit groben l'unkten versehener Raum aus, dessen Imnenecke kaum als Stimhöcker hetrachtet werden kann. Der Kiel ist zwischen den Fühlern am hïchsten, fallt nach oben wenig. nach unten mehr ab und ereht hier in das kurze, breit 
dreieckige Kopfischild iiber, welches olen nicht scharf begrenzt ist. Mandibehn kräftig, tüntzailnnig. die 'aiihne sehr spitz, der dritte und vierte von ihnen am längsten. Naxillartaster kurz, iln letztes (xlied diim, allmählich zugespitzt. Fühler kiirzer als der halle Körper, (ilied 1 diek, 2 etwas kleiner, 3 bis 6 viel dimner, 3 und 4 kur\%, 5 und 6 etwas lïnger als 2 . die folgenden merklich lïnger und hreiter. Halssch. quer, stark punktirt, nach vorn etwas verengt zund zusammengedrïckt, an Hinterrande jederseits ausgebuchtet und stark gegen das schildchen vorgezogen. an den seiten fein gerandet, die Randlinie änsserst fein gekerbt und deutlich bewimpert, die vordere Borstenpore bald hinter den abgerundeten und verdickten Vorderecken, oder an Ende des ersten Drittels eingestochen, nit langer Borste; der Quereindruck läuft dem Basalrande parallel. so dass er in der Mitte dem s'childchen zugebogen ist, auf jeder Seite ist er stärker vertieft und dureh ein Längsfältchen abgekürzt; Schildchen klein. Flügeldecken wenig breiter als die Basis des Halssch., bis zur Spitze regelmässig gestreift punktirt, die abgekiirzte Punktreihe an der Naht sehr lang, bis zur Mitte, oder bis zum zweiten Drittel reichend, die Zwischenstreifen mit einer feinen Junktreihe, welche in jedem Punkte ein nach rückwärts gerichtetes greises Härchen trägt; Epipleuren breit, am zweiten Bauchringe schmell auf einen schmalen streifen verengt, der bis kurz vor die Spitze sichtbar bleibt. Anf der Unterseite ist die Vorderbrust nebst den Seitenstücken der Hinterbrust grob und dicht, der Bauch fein, die Hinterbrust sparsam punktirt.

Das Mämnchen zeichnet sich durch das etwas erweiterte erste Tarsenglied an den vorderen Beinen und den glinzenderen Bauch ans, dessen letztes Segment an Hinterrande ahgestutzt ist. - Der Penis bildet eine flache, von oben zusammengedriickte Röhre, mit langer Oeffinung, die von einer Klappe vollständig bedeckt wird; ler etwas vorgezogene Unterrand ist in mässiger Rundung verengt und in eine kurze Spitze verlängert.

Die Gattung ist mit Chalcoules verwandt, aber durch die Kopfbildung, die Bewimperung der Halsschildseiten, den gebogenen Querrindruck. die Behaarung der Flügeldecken und die weit vor der Spitze verengten Epipleuren verschieden; sie enthält eine Menge iiberaus ähnlicher kleiner Arten, die ausschliesslich auf Soluneen lehen und ïber Europa, Afrika und namentlich Amerika, die eigentliche Heimath ihrer Nöhrpflanzen, verbreitet sind. Ihr Körper ist entweder einfarbig schwar\%. gewöhnlich mit gelbbramen Fiihlem und Beinen, oder gelbbraun gefleckt bis einfarbig rithlichgelb. 


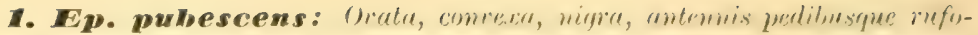
testaceis, femeribus posticis nigris; prothorace sat crebre juenetroto sulstilissimeques alutuces, minus mitirlo, seta antira lomge pone anguelos colles-

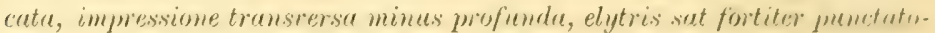
striatis, epipleuris fere glabris. - Long. 1,5-2 mm.

Koch Ent. Heft. II. 37. - Illig. Mag. VI. 112. - Panz. Faun. Germ. 99. 6. - Duft. Faun. A. III. 275. - Gyllh. Ins. Suec. III. 555. - Schilling Ber. Schles. Ges, 1846. 91. - Kutsch. Wien. Monat. 1860. 114 (84). - Redtb. Faun. A. II. 496. - Seidl. F. balt. 495 (Halt.). - K üst. Käf. Eur. 28. 89. - All. Mon. 198 (Crep.). - Foudr. Mon. 310. Thoms. Skand. Col. VIII. 223.

Var. ferruginea: Supra ferruginea, limbo suturali et marginali elytronum nigricante.

Breit und plump gebaut, ziemlich gleichbreit, beiderseits wleichmässig, sehr kurz abgerundet, gewölht. tief schwarz. Fühler und Beine röthlich gelbbraun, jene bisweilen nach der sipitze hin angedunkelt, diese mit braunen oder schwarzen Hinterschenkeln, selten alle Schenkel schwärzlich. Halssch. doppelt so hreit als lang, hinten wenig, vorn stärker verschmälert. mit tast regelnässị gerumdeten Seiten, deren aufgebogene Leiste wenig dicht, kurz und fein bewimpert und beinalue ganzrandig ist; die vordere Borstenpore steht weit hinter den kaum rerdickten Vorderecken, ungetähr in $1 / 3$ der Länge, und drängt den Seitenrand nicht winkelig nach aussen, die andere befindet sich in den stumpten Hinterecken. Die Oberfläche ist ziemlich dicht und tief, ror dem Schildehen oft sparsamer punktirt (die Punkte ïberall ron gleicher Grösse), mit sehr fein gewirkten Zwischenäumen, ziemlich matt, der Quereindruck deutlich, aber wenig tief. die Scheibe vor demselben stark gewïlbt. Fld. kräftig punktirt-gestreift, die abgekiirzte Punktreihe endet ungefähr in der Mitte, die Zwischenstreifen sind schmal, etwas gewölbt und glänzend, mit einer äusserst teinen Punktreihe mnd kurzen. niedergedrückten Härchen. I) Epipleuren hahen eine grobe Punktreihe längs der hohen Innenkante, sind aber sonst kaum deutlich punktirt, unmerklich behaart. - Penis des ô unterseits leicht gewölbt, am Vorderrande mit kleiner, stumpfer spitze.

Eine auffallige Form (Var. a) ist oberseits rostroth oder dunkel rothbraun, auf dem Halssch. in der Regel heller als aut den Fld.. diese besitzen einen schwärlichen Sarm an der Naht und am Seitemrande.

Auf Solamum dulcamara gemein. 
2. Ep. atropae: Oratu, concesinsculu, nigno, nitidulu, unlemnis: pedibusque testuceis, femoribus posticis nigris, anterioribus interlum infuscutis; prothorace crebre punctato, interstitios luevibus, seta anticu jucta angulos collocata, impressione transiversa olsoletisisima, elytris minus fortiter punctuto-striatis apice testuceis, epliplentis enidenter punrtatis et pilosis. - Long: 1,5-2 mm.

Foudr. Mon. 311. - Al1. Mon. 199 (Crep.). - Redtb. Faun

A. II. 496. - Gerh. Deutsch. ent. Zeit. 1878, 210 (Halt.).

Haltice pulescens var. Koch. Ent. Heft. II. 37. - Intt. Faun. A.

III. 275. - Küst. Käf. Eur. 28. 89 (Crep.).

Var. nigritula: Elytris nigris.

? Halt atropae Kutsch. Wien. Monat. 1860. 116 (85).

Tar. f-maculatu: Elytris maculis duabus testaceis, altera baseos, alter" apicis.

Durch den nach rorn merklich verschmälerten Körper, die verhältnissmässig lang beharte Oberseite, das glänzende, sehr abweichend gebaute Halssch., die längere Punktreihe an der Naht der Fld., endlich in den meisten Fällen schon durch die Färbung von der vorigen leicht zu trennen.

Eiföming, mit der grössten Breite hinter der Mitte, ron hier nach rorn allmählich, nach rüickwärts schnell verengt, mässig gewölbt, schwarz, ziemlich glänzend, Fühler, Beine und die Fld. vor der Spitze hell bräunlichgelb, Hinterschenkel schwarz, zuweilen auch die vorderen Schenkel dunkel. Halssch. etwas vor der Basis doppelt so breit als lang, im Bogen nach vorn verschmälert, die Leiste am seitenrande deutlich gekerbt und ziemlich lang bewimpert, bald hinter den rerdickten Vorderecken durch die Borstenpore winkelig nach aussen gedrückt, die Hinterecken sehr stumpf, fast abgerundet; die Oberfläche dicht und ziemlich tief, nach den Seiten hin etwas stärker als in der Mitte punktirt, mit sehr schmalen, glatten und glänzenden Kwischenräumen. Der Quereindruck ist sehr flach und erloschen, auch die vertiefte Stelle an jeder Seite nebst dem begrenzenden Längsfältchen undentlich, die Scheibe daror wenig gewölbt. Fld. nur mässig tief und stark punktirtgestreift, die abgekiirzte Punktreihe an der Naht bis zum letzten Drittel der Länge reichend, die Zwischenräume schmal, weniger hervortretend als bei pubescens, seicht quer gerunzelt, mit je einer Reihe längerer, aufgerichteter, greiser Härchen besetzt. auch die Epipleuren punktirt und behaart. Wie gelbbraune Färbung an der Spitze nimmt ungefähr ein Drittel jeder Fld. ein und bildet, da Naht- und Seitenrand in der Regel schwarz bleiben, eine grosse, verwaschene Makel, die sich allmählich verkleinern und endlich vollständig erlöschen kamn (Var.a). In entgegengesetzten Falle 
tritt ausiser der. Sitzenmakel noch cin welbhrauner Fleck an der fichulter auf, welcher sich oft so vergrössert, dass die Fld. bräunlichzell, werden, und die schwarze Grundfarbe ant einen siann an der Naht und an Seitenrande, sowie eine zackige Querlinje üher die Mitte heschränkt bleibt (Var. b). - Bein $\hat{j}$ ist der Penis unterseits schwach gerinnt, die spitze am Vorterrande fein und sehr scharf.

In den Wäldern der Vorberge und des nierderen Crehirges ant Atropa belladonna ziemlich häufig, die Var. a selten.

X. Ep. intermedia: ()blongo-viatu, minus concen, migre, sumu leviter aneo-micans, sat nitida, antennis pedibusque testaceis, femoribus posticis nigris, anterioribus plus minusre nigricantilus; prothorace crebre punctato, interstitiis laevibus, seta antica jucta angulos collocata, imyressione transversa sat obsoleta, etytris profunde punctuto-striatis, interstitiis convexiusculis. - Long. 1,5-2 mm.

Foudr. Mon. 311. - A 11. Mon. 199 (Crep.). - v. Heyd. Berl. ent. Zeit. 1867. 382.

? Halt, atropae Kutsch, 1. c. 116 (85).

Diese Art stimmt mit der vorigen in der Behaarung des Kïrpers und in der Bildung der Seitenränder des Halssch. vïllig iiberein, ist aber bedeutend schlanker gebaut, vorn und hinten fast gleichmässig verengt, beinahe elliptisch, auffillig flach, schwarz, ziemlich glänzend, oben mit deutlichem, in's Grünliche spielenden Metallschimmer. Halssch. an der Spitze breiter als bei atropae, in schwachem Bogen nach vorn verschmälert, die antgebogene Leiste am Seitenrande gekerbt, ziemlich lang bewimpert, hinter den rerdickten Vorderecken, wo die Borstenpore eingestochen ist, winkelignach aussen gebogen, Hinterecken stumpf, schwach abgerundet, Quereindrnck ziemlich flach, deutlicher wie bei utropae, seichter als bei pubescens, die Scheibe davor etwas gewölbt, überall gleichmässig sehr dicht und ziemlich stark punktirt. mit glatten Zwischenräumen. Fld. tief punktirt-gestreift, die Punkte in den Reihen viel dichter gestellt und schärfer eingestochen, wie bei der vorigen, Zwischenstreifen schmal, namentlich auf dem Abfalle zur Spitze gewölbt, mit einer regelmässigen feinen Punkt- und Haarreihe. Fühler und Beine sind hell röthlichgelb, die vier vorderen schenkel, Hüften und spitze derselben ansgenommen, pechschwarz, Hinterschenkel einfarbig schwarz, oft metallisch glänzend. - Der Penis hat unterseits eine tiefe Mittelrinne. am Vorderrande ein stumpfes. Zähnchen. 
Im Herbste aut solumum nigrum L. bis jetzt nur bei Erlangen setunden, aussorlem in Frankreich und siideuropa his Griechenland (v. Oertzen) verbreitet.

Wahrscheinlich hat Kutschera die vorliegende Art unter seiner $H$. utrupae mit beschrieben, da er diese, nach riickwärt mehr (als bei mbescens) verschmälert" nennt und von einem, ,stärkeren Metallglanze" ler Oberseite spricht. Die einfarbig schwarzen Stiicke von atropat sind so selten, dass sie Foudras und Allard ganz unbekannt blieben, ausserdem ist bei ihnen von einem metallischen Schimmer eben so wenig zu bemerken, wie bei den tänschend änlichen Exemplaren der $E$. pubescens.

\section{Chalcoides.}

Foudras, Altisides p. 312.

Acetabula antica occlusa, mesosternum conspicuum.

Palpi maxillares articulo ultimo subelongato.

Tubercula frontalia angusta, obliqua, sulci frontales decussati.

1'rothorac punctatus, impressione transversa utrinque plica terminata, fovea setigera antica juxta angulos sita.

Elytra metallica punctato-striata.

Kopf kurz dreieckig, mit grossen, ovalen, gewölbten Augen, lie Stirn zwischen ihnen ziemlich breit; die Linien sind scharf einžeschnitten. laufen vom Hinterrande der Augen zuerst schwach nach innen, biegen damn winkelig um und durchschneiden sich, nachdem sie ein Stück fast wagerecht gezogen sind. $x$-förmig in der Mitte. Nicht weit ron dem höchsten Punkte jedes Auges ist ein grosser Borstenpunkt eingestochen, von welchem ein tiefer Längseindruck nach unten zu den Stirulinien läuft; unter diesen liegrt zunächst über jeder Fühlerwurzel eine kleine, dreiekige Beule und in der Mitte der Stirnkiel, welcher zwischen den Fühlern am breitesten und höchsten, nach unten und oben verschmälert und abgeflacht, beinahe länglich-rautenförmig ist. Das kurze. undeutliche Koptsehild ist abschüssig, die Oberlippe quer, an der Basis mit einer Reihe von groben Punkten, vorn abgestutzt, Mandibehn kräftig, fünfzähnig, der dritte Zahn am längsten. Maxillartaster kurz und dümn, das vorletzte Glied nach der spitze allmählich verbreitert, das Endglied am Grunde mässig dick, davor zuerst erweitert, dam nach und nach zugespitzt. Fiihler so lang als der lıalbe Körper, Glied 1 gestreckt, 2 klein, die folgenden Glieder bedeutend oder wenig kürzer als 1, bald unter sich von gleicher Länge, oder Glied 4 das kürzeste. und 5 das längste, 6 stets kleiner 
als die rinschliessenten, die übrigen otwas hreirer und wenig langer als 5. II alsoch. punktirt, quer. nach worn stärker als nach hinten verengt. an der spitze ungeramlet. abgestutzt. an der Basis joder-

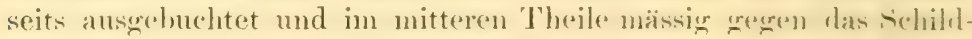
chen vorgezogen, an den Seiten gerumlet, nit foriner, glatter mol kahler Leiste, die von einer breiten Rinne abgesetzt wird. In dieser betindet sich eine starke P'unktreihe. welche rom etwan nach innen biegt. Die Eckhorsten sind kurz und stelien in grossen I'oren. die eine in den rechtwinkeligen Hinterecken. die andre im äusseren 'Theile der abgestutzten Vorderecken. Der Quereindruck ist entwerlex gradlinig und tief, oder Hach, leicht grebugen, jedoch nicht ganz dem Hinterrande parallel; er wird ant jeder seite durch einen tiefen Längsstrich algekiurzt. der einen hohen, scharfen Aussemrand hat und hinten mit der Randlinie verbunden ist, die den Basalrand schwach in die Höhe hebt. Schildchen halboval. Flügeldecken wenig breiter als die Basis des Halsschildes, oral. his zur spitze regelmässig gestreift- oder gereilıt-punktirt, ihre abgekiurzte Punktreihe an der Naht nimmt ungefähr ein Viertel der Länge ein. dic 'Zwischenstreifen sind sehr fein punktirt, bei nitiduln ausserdem noch mit einer unregehmässigen starken Punktreihe rersehen. Epipleuren mässig breit, hinter der Mitte nach und nach rerengt. bis dicht vor die Spitze reichend. Das Prosternum faillt zum Vorderrande etwas, nach hinten viel stärker ab und ist mehr oder weniger dicht punktirt, die Seitenstiicke, sowie Mittel- und Hinterlorust sind fast glatt, die Bauchsegmente fein und sparsam punktulirt.

Man erkennt das Männchen an dem abgestutzten und ungeschlagenen Hinterrande des letzten Bauchringes; der Penis bildet eine kleine, von oben flach gedrückte, wenig gebogene Röhre, deren grosse Oeffung von der abgerundeten oder allmählich verengten Spitze weit entfernt bleibt.

Die Käfer leben auf́ den Blättern ron Weiden und Pappeln es sind, trotz ihrer geringen Grösse, sehr bekamnte Tlhiere. weil sie überall häufig vorkommen und durch die lebhaft metallische Färbung ihrer Oberseite die Aufmerksamkeit jedes Sammlers auf sich lenken. Linné kannte zwei derselben, Chrysom. nitidula und helxines: davon wurde die erste, deren Farbe nur wenig variirt in der Folge stets richtig wieder erkannt, die andre aber allmählich zum Inbegriff der übrigen Arten gemacht, bis Foudras diese nach der verschiedenen Form des Penis ein für alle Mal feststellte. Von den bis jetzt beschriebenen acht Arten kommen sechs in Deutschland vor; zu einer schnellen Orientirung über dieselben dürfte die folgende Tabelle ausreichen: 
1. Zwischenstreiten der Fld. stark und nehr orler weniger gereihtpunktirt . . . . . . . . . nitidula $\mathrm{I}$.

11. Kwischenstreiten ler Fld. äusserst fein punktirt. . . . 2.

2. Halsseh. tein und einfach punktirt, mit tiefer (2ureturehe. Fühler ganz röthlichgelb, oder die vies letzten filisher schwarzlich. Gebirge Mitteleuropa's . . . . metallica Duft.

21. Halssch. deutlich doppelt punktirt, nit wenig tiefer orler wam\% flacher Querfurche . . . . . . . . . . 3 .

3. Fühler eintarbig röthlichgelb oder nach der spitze allmählich leicht gebräunt . . . . . . . . . . . . 4 . . . . . . . . . .

$3^{1}$. Die ersten Fühlerglieder röthlichgelb, die iibrigen schwarz 5.

4. Die starken Punkte des Halssch. sind gross, aber Hach. Körper mässig gross . . . . . . . . . cyanea Marsch.

$4^{1}$. Die starken l'unkte des Halssch. gross und tief. Körper klein . . . . . . . . . leluines I.

5. An den Fiihlern sind die vier ersten Glieder röthlichgelb. Halssch. und Fld. ziemlich übereinstimmend gefärbt. chloris Foudr.

5 Die fünf ersten Fühlerglieder röthlichgelb. Halssch. und Fld. von sehr verschiedener Farbe . . . aurata Marsh.

1. Chalc. mitidula: Oblongo-elliptice, sat comere, nitide, antennis fuscis busi pedibusque rufo-testaceis, pectore, abdomine femoribusque posticis nigris, capite prothoraceque crelre punctato niridi-aureis, elytris nigro-coeruleis, violaceis aut coeruleo-vivescentibus, striato-punctatis, interstitis fere uniseriatim punctatis et parce punctulatis, angulo suturali mucronato. - Long. $3-4,3 \mathrm{~mm}$.

Linné Syst. Nat. ed. X. 373; Faun. Snec. 542 (Chrysom.). Payk. Faum. Suec. II. 105 (Galleruca). - Oliv. Ent. VI. 713. t. 5. f. 80. - Koeh Ent. Hft. II. 13. - Illig. Mag. VI. 113. - Gyllh. Ins. Suec. III. 561. - Duft. Faun. A. III. 2:2. - Steph. Ill. Brit. IV.305; Man. 294. - Ratzeb. Forstins. ed. 2.243. - Schilling Ber. Schles. Ges. 1846. 91.

- Kut $s \mathrm{ch}$. Wien. Monatsch. 1860.75 (78). - Redtb. Faun.

A. II. 496. - Seidl. F. balt. 494 (Halt.). - All. MLon. 194. Thoms. Skand, Col. VIII. 217 (Crepid.). - Foudr. Mon. 314.

Var. a. Capite prothoraceque aureo-cupreis.

Von den folgenden Arten durch den beiderseits fast gleichmässig verschmälerten und abgexundeten Körper, feinere Punktirung, die gereihten starken Punkte in den \%wischenstreifen der Fld. und die deutliche Ausrandung an der spitze der Fld., wodurch die Nahtecke zahntömmig rorgezogen wird, sehr verschieden. Langelliptisch, mässig gewölht, gläuzend, Kopf und Halssch. goldgrün, oder (Var. a) lebhatt goldig kupterroth, Fld. dunkelblau, veilchen- 
blan oder bangrün. Tonterseite schwar\% die beine. nit Ausnahne der donklen Ilinterschenkel, und die Fiihler rö̈thlich gelhbrann. letztere nach der spitze hin angedunkelt, die Endglieder hrann mder schwärlich. Halssch. un die Hälfte herester als lang, nach vorn molur als nach hinten verengt, die gröjste breite vor der Mitte, an den seiten gerundet, vor den Hinterecken leicht geschweift. dicht und ziemlieh goleichmässig punktirt, der Quereindruck zir-mlich grade, mässig tief, furchenartic, in der Mitte wenirg. an den seiten nicht verbreitert, das Längsstrichelchen reicht vorn weit iiher denselben hinaus. Fld. in den Schultern etwas breiter als das Halssch., an den Seiten schwach gerundet, hinten in gemeinschattlichem Bogen verengt, jede einzelne aber leicht ausgerandet, so dass die Nahtecke eine kurze spitze bildet; oben mit wenig starken. bis linten hin gleichmässigen Punktreihen, in denen nicht alle Punkte grenau hinter einander stehen, sondern einzelne ein wenig nach rechts oder links abweichend eingestochen sind. Die Reihen heben sich nur wenig heraus, weil die Zwischenstreifen ziemlich dicht doppelt junktirt sind; einige P’unkte nämlich sind gross, fast so stark als die der Reihen und mehr oder weniger regelmässig zu einer Reihe geordnet, die in den breiten \%wischenstreifen. 2, 4 und 6. lang und deutlich, aus viclen Punkten zusammengesetzt ist, in den cchmalen, 1. 3, 5 ete. nur aus einzehen Punkten hesteht; zwischen diesen befinden sich feine Pünktchen.

Der Penis ist so lang als der Hinterleib. schwach gethogen. an iler Geffnung jederseits weit und Hach eingeschnürt. die lange. allmählich verengte Spitze in starkem Bogen aufwärts gekrimmt.

In den Gebirgsgegenden Deutschlands und Mitteleuropa's !auf Salix cineren und den zarten Trieben von Popmelns tremuln stellenweise nicht selten, sparsamer in der norddentschen 'T'iefebene. England. Schweden.

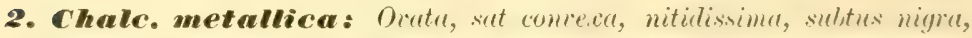
antemis pedibusque rufo-testuceis, illis articulis $t$ ultimis plerumque infuscretis, his femoribus posticis nigrin, supure luete riridis, unichulceo micuns; prothorace subtilius aequaliter punctuto, sulco transereso profunde impresso, elytris punctuto-striatis, punctis striurum sat creluris, interstitiis latis, subtilissime punctulatis - Long. 3-4,2 mm.

Duft. Faum. A. III. 273. - Seidl. Faun. balt. 495 (Halt.).

Haltica helxines var. Kutsch. Mon. 83.

Haltica aurata var. Redtb. Faun. A. II. 496.

Var. a. sapphirina: Sume coeruleu aut cyuner tote, rel prothorace viridi-coeruleo.

Var. b. aeruginosu: suma obsure aenea aut brunneo-neruginosu.

Var. c. cuprea: Supra aurichalceo-cuprea: 
Wenig kleiner als die vorige und die am nächsten verwandto folgende Art, von dieser dureh das gleichmässig und fein ymuktirte, stark elänzende Malssch., welches zugleich in der Gattung den tiefsten Quereindruck lesitzt, auf den resten Blick sicher zu unterseheiden.

Eiförmig, mässign sewölht, stark glänzend, die Oherseite lehhaft grün mit Goldschimmer, die Unterseite schwar\%, nur die Hinterbrust wie die (Oherseite getähth, Beine, mit Ausmahme der dunklent Hintersehenkel, und Fïhler ribhlichbraun, an letzteren in der Regel die vier Endglieder schwarzlich. Halsseh. um die Hälte breiter als lamg: nach rorn kaum oder schwach verengt, die Seiten fast parallel, nu in lex Mitte santt gerundet, vor den Hinterecken und hinter der vorderen Borstempore leicht ausgeschweift; die Scheibe mässig dicht, flach und fein punktirt, alle Punkte rom gleicher (rrösse. ihre / wischenräume glatt, der Quereindruck ziemlich grade, sehr tief, furchenartig, mit einer starken Punktreihe, die sich an den seiten verwirrt. Fld. regehmässig punktirt-gestreitt, die Punkte ziemlich stark und nur mässig dicht, Zwischenstreifen breit, ziemlich eben, äusserst fein punktulirt.

Die Oberseite kann eintarbig goldig-griin genannt werden, denn das Halssch. besitzt gewöhnlich nur einen sehr geringen Zusatz ron Messingrelb mehr als die Fld., diese Fäbung rerändert sich :

a. inden das Gelb durch Blan verdrängt wird, in bläulich-grüu bis lebhatt hell oder dunkel blau, entweder aut'den Fld. allein oder "auf der ganzen Oberseite;

b. durch Abnahme von gelb und Zunahme ron kupterroth, in ein dunkles und trübes Griu mit kupferigem oder braumem Metallschimmer; endlich

c. durch den Ersatz ron griun durch kupterroth, in ein mehr oder weniger goldiges starkes Feuerroth.

Auf Weiden an den Baichen im schlesischen Gehirge, hauptsächlich am Glatzer sichnceherge, und in den Alpen ziemlich selten.

3. Chalc. cyanea: Oratu, sat comeren nitidissima, subtus nigra, antemis pedibusque rufo-testaceis, illis interdum apicem rersus leviter in-

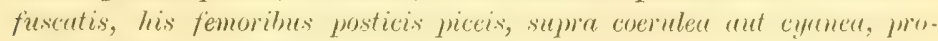
thorace interdum viridi-micante rage inuequaliterque punctuto, lateritnes:

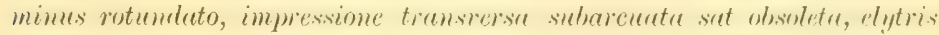
punctutestriatis, punctis striarum (rebris, interstities latis, subtilinsime punctatis. - Long. 3-4,5 mm.

Marsh. Ent. Brit, 1802. p. 196 (Chysom.). - Duft. Faun. A III. 274. - Steph. Ill. Brit. IV. 306; Man. 295 (Halt.). 
Haltica yaudens Steph. 1. c.

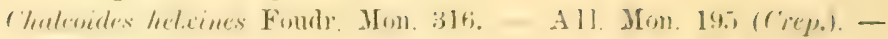

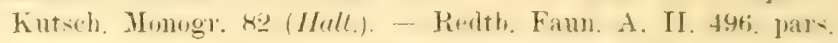

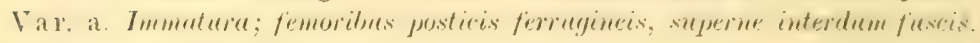
Var. b. laeta: Supra saturate viridi-aenea.

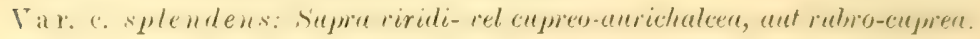

Die groisste Art, an dem flachen, geolongenen Quereindrucke des Halssch., welches aut der sicheibe umglejchnässign, seicht uml etwas runzelig punktirt ist, zu erkennen.

Breit eiformig, namentlich das Wreibchen, mässig gewölbt. stark glainzend, Oberseite hell oder dunkel blan. Halssch. hisweilen grünlich blau oder grün, Fühler und Beine röthlich gell, raum, bei frischen Stioken ( Var. a) einfarbig, oder die Hinterschenkel oberseits braun angelaufen, bei ausgehärteten nit schwarzen Hinterschenkeln, oft anch die letzten Fiihlerglieder gebräunt. Halssch. beinahe doppelt so breit als lang, hinten ziemlich gleichbreit, vorn in mässigem Bogen verengt, die Seiten nicht, oder mur hinter der vorderen Borstenpore ausgeschweift. Die scheile ist durch eine runzelige doppelte Punktirung etwas rauh, letztere besteht aus unregelmässig und im ganzen weitläufig gestellten zieulich grossen, aber flachen Punkten, zwischen renen viel feinere Punkte eingestrent sind; der Quereindruck ist schwach, etwas nach hinten gebogen. seitlich nur mässig rertiett, das begrenzende Längsfältchen nicht hesonders hoch. Fld. in den regehmässigen Reihen mit starken und tiefen. dicht hinter einander stehenden Punkten. Zwischenstreifen breit, eben oder wenig gewölbt, sehr fein punktirt.

Der Penis ist kürzer als der Hinterleib, schwach gebogen. ein Stiick vor der Spitze jederseits in sehr flachem Bogen ausgerandet. vorn gerundet-abgestutzi und mit einem kleinen Ausschnitte in der Mitte, so dass der Vorderrand leicht zweilappig wird.

Es treten folgende Farbenabänderungen auf:

b. Die blane Oberseite wird durch Zutritt von Grün zunächst griulichblau, damn bläulichgriin, endlich gesättigt griin. ohne blauen Schimmer, und geht allmählich,

c. unter Beimisehung von Messingeelb, in ein reines und lehhattes Goldgriin, zu dem sich später ein leichter Kupferglanz gesellt, oder ein gesättigtes Kupferroth über.

In ganz Mitteleuropa häufig. jedoch die rein grime Form seltener als die blaue und goldfarbige.

Die vorliegende Art wird mit Unrecht von Kintschera. Fondras um Allard auf ( $h r$. heldines $\mathrm{L}$. bezogen, denn Limné kamn dieselbe nicht beschrieben haben, da sie in Schweden fehlt. was mit Sicherheit ans den 
zuverlässigen Angaben bei Gyllenhal und Thomsom hervoregeht. Bei dem Vergleiche der alten Autoren komte ich nu eine Beschreihng finden. die sich mit Wahrscheinlichkeit auf unsere Art anwenden lässt, es ist die von cyuned Marsh.: allerdings bleibt, wegen des Aushuckes ,thorax minutely punctured", noch der Zweifel, ob Marsham nicht die II. metrallica Duft. vor sich gehabt hat Findet sich diese in England, so würde sie umberlingt mit cyuncu Marsh. zu bezeichnen sein, und fïr die vorstehende Art kömte der Name meiner Var. c, für die blame Form cyonen Duft. eintreten.

4. Chalc. heldxines: Ueutu, sut comexa, nitida, subtus migra, antemis pedibusque rufo-testucis, illis plerumque upicem versus leriter infuscutis, his femoribus posticis apice satpius macula picen notatis, supra lacte cirili-aenea iel-an ichalcer, obsolete coeruleo-limbata; prothorace laterilns rotundatis ante husin subsinuatis, fortius inaequaliter punctat), impressione transrerse sat profunda, elytris punctatu-striatis, punctis striarum sat crebris, interstitiis angustis, subconexis, subtilissime punctulatis. - Long. 2,2-3,3 mm.

Linné Syst. Nat. ed. X. 373 (Chrys.). - Panz. Faun. Germ. 21. 6. - Koch Ent. Heft II. 15. - Gyllb. Ins. Suec. III. 562. - Duft. Faun. A. III. 272. - Steph. Ill. Brit. IV. 305̃ ; Man. 294. - Seidl. F. balt. 495 (Halt.). - Thoms. Skand. Col. VIII. 219 (Crepid.).

Chalcoides smaragdina Foudr. Mon. 319. - All. Mon. 197.

Haltica versicolor var. e. Kutsch. Wien. Monat, 1860. 78 (80).

Var. a. picicurnis: Antennis pedibusque plus mimusve infuscatis, piceis. Var. b. fulvicornis: Supra fusco-, rubro- vel aureo-cuprea, interdum etiam leviter viridi-vel coeruleo-micans.

Galleruca fulvicornis Fabr. Ent Syst. I. 2. 30.

Var. c. jucundu: Sinpre coeruleu rel cyunea tota, aut capite prothoraceque viridi-coerultis vel -aeneis.

Lnugetähr halb so gross wie die vorige und von ihr durch das grob umd tief punktirte. hinten merklich zusammengezogene Halssch.. den tieferen Quereindruck desselhen, engere Zwischenstreifen der Fld. etc. zu unterscheiden.

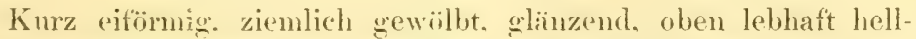
griin oder goldig grïn. eintarhig, bis anf die fem blau gesäumten Siren des Halssch. und der Fld.. unten schwar\%, wie bei den übrigen Arten mit griin oder blau glänzender Hinterbrust. Fiihler und Beine röthlich gelbbraun, erstere oft nach der sipitze hin dunkel angelauten, letztere meist nit einer pechbriunlichen Makel aut dem liaicken der Hinterschenkel, die sich iiber die Spitzenhälte derselben ausdehnen kann. Halssch. fast rloppelt so breit als lang. vor der Mitte am breitesten. nach rom in starker Rundung bis 
zur winkelig vorterenden Erweiterung an der Burstenjores nach hinten weit schwächer verengt und vor der Basis sanft ancsgeschweift. die sicheibe ziemlich dicht, groh, und tief, dazwischen fein punktirt.

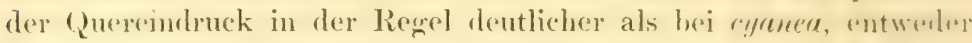

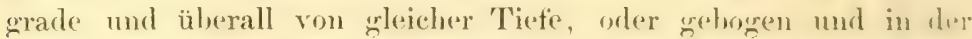
Mitte erweitert nnd stirker vertieft. Fld. mit kräftigen und tiefen. regelmässigen Punktreihen und schuralen, etwas gewijh,ten Zwischen. räumen, die sehr fein punktulirt sind.

1)er Penis ist mässig gebogen, gleichbreit, an Vorderande abgerundet, die spitze etwas in die Höhe gebogen.

Die grüne Färbung der Oberseite ist viel lichter als bei den entsprechenden Varietäten der zwei vorangehenden Arten und steht dem Maigrin am nächsten; sie verwandelt sich, je nachdem lioth in grösserer oder geringerer Menge zugesetzt ist, in ein dunkelbraunes, gesättigtes und reines, oder ein goldiges Kupferroth, welches zuweilen noch grün oder bläulich angelaufen ist (Var. b).

Uebergänge zu dex hiilsschen Var. c kenne ich nicht. Bei derselben sind die Fld. gesättigt himmelblau, dunkel kornblumenblau oder schwarz-violett, während das Halssch. in der Regel sehr hell griulichblau, seltener lebhaft metallisch grỉn, in wenigen Fällen endlich mit den Fld. übereinstimmend blan gefärbt ist.

Am bemerkenswerthesten erscheint mir die Var. a, mit hell oder dunkelpechbraunen Fühlern und Beinen.

In ganz Europa auf Weiden- und Pappel-Grebüsch gemein: anch durch Sibirien bis zum Amur (Koltze) verbreitet.

Spanische Exemplare, die mir von H. Jartinez y Saez aus der L'mgegend von Madrid eingesandt, wurden, zeichnen sich durch einen schlanken. an $C h$. chloris erimnernden Körperbatu aus, sind aber wohl nicht specifisch verschieden.

('halc. aureola Foudr. (Mon. 320). die seither nur im siidlichen Frankreich, im Dép. Lozère gefunden wurde, scheint der helcines sehr nahe zu stehen, ist oben rein goldgelb, unten goldiggriun. mit einfarhiy röthlichgelben Fühlern und Beinen. - L. 2,5 mm.

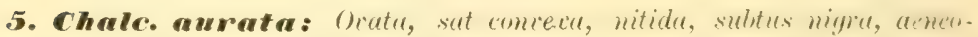
vel coeruleo-micans, antemnis fuscis, articulis 5 pimis pedibusque fermginein, femoribus posticis nigrix; cupite prothoraceque ante-cupreis ant ignitis, hoc increqualiter junctuto, lateribus rotundutis ante basin subsimatis, impressione transterse sat protunda, elytris cyaneis ant rindaceis, functuto-striatis, punctix striarum crebris, interstitios latiusculis suthtilissime punctulatis. - Long. 2,5-3,5 mm.

Marsh. Ent. Brit. 1802. p. 195 (Chrys.). - Redtb. Faum. A. II. 496. - Seidl. F. balt. 495 (Halt.). - All. Mon. 196 
(Crep.). - Thoms. Skand. Col. VIII. 221. - Foudr. Mon. 317.

Haltica versicolor Kutsch. Wien, Monat. 1860. 77 (79).

Haltica helxines Ratzeb. Forstins, ed. 2. 243.

Var. a. Prothorace viridi-aurichulceo.

Var. b. Elytris coeruleo-viridibus.

Var. c. pulchella: Elytris obscure aut laete viridibus, obsolete viridiaureis vel brunneo-aurichalceis.

Halt. pulchella Steph. IIl. Brit. V. 423. - Man. 295.

Var. d. nigricoxis: Femoribus anterioribus piceis; tibiis interdum infuscatis.

('repidod. nigricoxis All. Beitr. Kauk. Käf. 1878. p. 340.

Etwas grösser, namentlich länglicher als die vorhergehende, die sechs letzten Fühlerglieder stets dunkel, die Oberseite beständig. zweifarbig, das Halssch. viel weitläufiger und etwas feiner, die Reihen der Fld. dagegen dichter punktirt.

Eiförmig, mässig gewölbt, glänzend, unterseits schwarz, grün oder bläulich angelaufen, oben auf Kopf und Halssch. goldig kupferroth oder feuerroth, auf den Fld. dunkel kornblumen- oder veilchenblau; die Fühler schwärzlich, das sechste Glied gewöhnlich heller, die fünf ersten Glieder und die Beine hell rostroth, Hinterschenkel schwarz mit Metallschimmer. Halssch. um die Hälfte breiter als lang, vorn mässig verengt, an den Seiten gerundet und vor der Basis, sowie hinter der vorderen Borstenpore ausgeschweift, die Scheibe wenig dicht, aber ziemlich stark und tief, dazwischen fein punktirt, der Quereindruck grade, kräftig. Fld. regelmässig punktirtgestreift, die Punkte tief und dicht neben einander eingestochen, Zwischenstreifen leicht gewölbt, etwas breiter als bei helxines, sehr fein punktulirt.

Der Penis ist wenig gebogen, gleichbreit, an der Spitze in flachem Bogen abgerundet.

Es sind folgende Farbenabänderungen beobachtet worden:

a. Auf dem goldig- oder gesättigt feuerrothen Halssch., welches bei einzelnen Stücken durch einen violetten Schimmer sehr verdunkelt ist, verschwindet allmählich die Kupferfarbe ganz und es wird zuletzt blass messinggelb mit grünem Anfluge;

b. die Fld. erhalten einen grünen Glanz; sie werden später lebhaft bläulich grün, oder

c. rein dunkel- bis hellgriin, endlich verschossen gold- oder messinggelb mit grüner oder brauner Beimischung. Jedoch scheint die Oberseite niemals einfarbig zu werden, weíl auf dem Halssch. eine ausgesprochen blaue, aut den Fld. eine kupferrothe Färbung nicht vorkommt; ja selbst in dem Falle, wo ein grünlich-goldiges VI. 4. 
Halssch. mit : zhnlichen Fld. zusammentritt. sind letztere urm mehrere Töne tiefer gefärbt.

d. An den Beinen sind alle Schenkel pechschwarz, oft auch die Sichienen angedunkelt, wenigstens nicht immer so hell roth wie bei der Normalform.

In ganz Europa gemein; die Varietäten a und d seltener.

Aus der dürftigen Beschreibung von nigricaxis All., worin diese Art nur mit der unähnlichen chloris verglichen ist. scheint hervorzugehen, dass Allard ein dunkelbeiniges Stïck von aurat im Kaukasus keine Seltenheit ist.

6. Chalc. chloris: Oblonga, minus comexa, nitida, subtus nigra, aeneo- vel coeruleo-micans, antennis nigris, articulis \pm primis pedibusque rufo-testaceis, femoribus posticis nigris, supra obscure viridi-aurichalcea, prothorace cupreo micante sat fortiter inaequaliterque punctato, lateribus paullo rotundato, impressione transversa sat profunda, elytris junctatostriatis, punctis serierum creberimis, interstitiis angustis, subtilissime punctulatis. - Long. 2,5-3,5 $\mathrm{mm}$.

Foudr: Mon. 318. - Redtb. Faun. A. II. 502 (Halt.). Seidl. F. balt. 494 - A 11. Mon. 196 (Crep.). - Thoms. Skand. Col. VIII. 218.

Var.a. Elytris aut obscure aeneis aut saturate viridibus.

Var. b. Foudrasi: Suma viridi-cocrulea, aut laete coerulea, tota, rel prothorace plerumque viridi-aenea aut-aurichalcea.

Von allen vorhergehenden Arten durch schlanke Körperform und geringe Wölbung abweichend; überhaupt nur mit $C$ h. helxines zu verwechseln, welcher sie in der Grösse und Gesanmtfärbung am ähnlichsten wird, aber von ihr durch die schwarzen Hinterschenkel und die Fühler, an denen nur vier Glieder rothgelb sind, sicher zu trennen.

Lang eiförmig, wenig gewölbt, oft etwas flach gedrückt, glänzend. Unterseite und Hinterschenkel schwarz, die Brust stärker, der Hinterleib sehr schwach matallisch grün oder blau schimmernd, Fühler schwarz, ihre vier ersten Glieder und die Beine (mit Ausnahme der Hinterschenkel) röthlich gelbbraun. Halssch. wenig quer, in seltenen Fällen etwas kiirzer und nicht ganz um die Hälfte breiter als lang, an den Seiten fast gleichmässig schwach gerundet. die Scheibe ziemlich dicht und stark, dazwischen einzeln sehr tein punktirt, verschossen goldig kupferroth. Fld. griin messingfarbig, ihre regehmässigen Reihen mässig stark und tief, durchschnittlich feiner als bei helxines, aber sehr dicht punktirt, so dass sich die schmalen, fein und deutlich punktulirten Zwischenstreifen gut herausheben. 
Der Penis ist gebogen, vorn gradlinig verengt und scharf zugespitzt.

Die Farbe der Art ist in Allgemeinen als weniger lebhaft zu bezeichmen und ihre Abinderungen bewegen sich nur in engen Grenzen:

a. Fld. verschossen bräunlich-, schwärzlich-, oder gesättigt metallgrün, Halssch. in der Regel heller, mehr oder weniger messingschimmernd, nur selten mit kupfrigem Anfluge.

b. I)ie Oberseite nicht besonders tief grünlich blau oder rein hellblau, einfarbig, oder das Halssch. von grün bis grünlichmessinggelb variirend.

In Mitteleuropa und in Sibirien bis zum Amur (Koltze) stellenweise häufig, besonders auf den ausgedehnten Weidengebüschen am Ufer oder auf den Sandbänken grösserer Flüsse und Ströme. Bei uns namentlich an der Oder und Elbe verbreitet; im südlichen Schweden auf Pappeln. Italien.

\section{Hippuriphila.}

Foudras, Altisides p. 306.

Acetabula antica occlusa.

Prothorax margine basali fere immarginato utrinque subintermupto, ante basin impressione obsoleta, transversa, utrinque plica terminata.

Prosternum haud bicarinatum, mesosternum occultum.

Kopf ziemlich lang-dreieckig, mit breiter Stirn, auf welcher die Stirnlinien in der Mitte einen gleichmässigen, schwachen Bogen oder einen nach oben gerichteten Winkel bilden; im ersten Falle sind die Beulen darüber undeutlich oder vollständig fehlend, im andern deutlich, oben abgeflacht und verbunden, unten getrennt. Der Stirnkiel ist breit, nach dem Munde zu verschmälert, und geht ohne bestimmte Grenze in das Kopfschild über, von dem selbst der niedergedriickte Querstreifen kaum abgesetzt und sichtbar ist. Mundtheile wie in den vorhergehenden Gattungen; an den Fühlem sind die letzten fünf Glieder wenig oder bedeutend breiter als die iibrigen. Halssch. quer, vorn mehr oder weniger verengt und zusammengedrückt, die flache Rinne, welche den Seitenrand schmal absetzt, zieht sich um die verdickten Vorderecken herum und ein Stïck am aufgebogenen Vorderrande nach innen, wo sie allmählich erlischt (Modeeri), oder sie biegt unmittelbar neben den Vordexecken unter den etwas vorgezogenen Vorderrand, der ihre Verlängerung nach innen bedeckt (nigritula); der Hinterrand ist in 
der Mitte gegen das Schildchen erweitert, mit einer äusserst feinen Randleiste oder ohne dieselbe, die Scheibe mässig gewïll,t, punktirt. ihr Quereindruck seicht, nicht rinnenfiormig, jederseits von einem tiefen Längsstriche begrenzt, dessen scharfer Aussenrand weit üher den Eindruck nach rom reicht. Eckporen ziemlich gross und tief mit kurzen Borsten, die eine in den Hinterecken, die andere balil hinter den Vorderecken am seitenrande. welcher nicht nach aussen gedrückt wird. Schildchen klein. Flügeldecken in regelmässigen Reihen punktirt, welche auf dem Abfalle zur spitze schwächer werden, oder ganz erlöschen. Die Vorderbrust ist zwischen den Hüften ziemlich breit, stark punktirt, fällt hinten etwas ab und erweitert sich zu einem Streifen, der mit den Seitenstiicken rerbunden ist und die Pfannen schliesst. Sein Hinterrand liegt sn weit auf der Mittelbrust, dass er von der Verlängerung der Hinterbrust verdeckt wird, welche zwischen den Mittelhiiften einen gerundeten, dickrandigen Vorsprung bildet. Hinterhüften durch einen weiten Zwischenraum ron einander getrennt. Beine mässig stark. Hinterschenkel spindelförmig, Enddorn der Hinterschienen kurz. fein, Zahn an der Basis der Klauen schwach.

Beim Mämnchen ist das erste Tarsenglied an den beiden vorderen Beinpaaren erweitert und so hreit als das dritte Glied, der letzte Bauchring an der Spitze abgestutzt.

Die Gattung wurde auf Chrysomela Modeeri L. begründet, die nicht nur einen auffälligen Körperbau besitzt, sondern auch durch ihre, den Donacien ähnliche Lebensweise an Wasserpflanzen, worauf schon die dichte Behaarung auf dem grössten Theile der Unterseite hindeutet, von den übrigen verwandten Arten sehr abweicht; insbesondere ist ihre Vereinigung mit C'repidodera nicht zu rechtfertigen. Die zweite Art. nigritula Gyllh., hat eine nicht unbedentende habituelle Aehnlichkeit mit (rep. cyanescens und cyanipennis, weicht aber von diesen in Wirklichkeit viel mehr als von Orestia $\mathrm{ab}$, und ich betrachte sie daher als den passendsten Uebergang zu der letzgenannten Gattung, da ihre Hinterbrust zwischen den Mittelhüften noch weiter vorgezogen ist als bei Modceri.

Ueber die Entwickelung ist noch nichts bekannt.

a. Stirnhöcker über der fast graden Stirnlinie undeutlich oder fehlend.

1. Hipp. Irodeeri: Breviter-ovata, comica, nitida, nigru-aenea, antennis fuscis, basi pedibusque testaceo-rufis, femoribus posticis infuscatis; mothorace punctato apice compresso-angustato, elytris sat fortiter, postice subtilius striato-punctatis, apice flavo-testaceis, pleuris meso-et metasterni abdominisque lateribus argenteo-sericeis. - Long. 2-2,5 $\mathrm{mm}$. 
Linné Faun. Snec. 167; Syst. Nat. ed. XII. 594. - Marsh. Ent. Brit. I. 194 (Chrys.), - Oliv. Ent. VI. 724. t. 5. f. 98. - Koch Ent. Hft. II. 47. - Illig. Mag. VI. 112. Gyllh. Ins. Suec. III. 580. - Duft. Faun. A. III. 276. Steph. Ill. Brit. IV. 304; Man. 294. - Kutsch. Wien. Monat. 1860. 139 (100). - Schilling Ber. Schles. Ges. 1846. 91. - Redtb. Faun. A. II. 497. - Seidl. F. balt. 495 (Halt.). - Küst. Käf. Eur. 8. 94. - All. Mon. 198 (Crep.). Foudr. Mon. 306. - Thoms. Sk. Col. VIII. 222.

Var. a. Immatura; elytris flaro-testaceis, basi interne suturaque aeneis. Var. b. bimaculata: Elytris mucula determinata testacea ante apicem. Altica Modeeri Panz. Faun. Germ. 21. 7.

Var. c. Supra picea, plerumque metallico-, interdum cupreo-splendens, elytris apice flavo-testaceis.

Var. d. chalybaea: Ut in c, sed laete chalybaea.

Breit eiförmig, beiderseits stark verengt und hinten in eine sehr kurze, gemeinschaftliche Spitze ausgezogen, gewölbt, schwarz, mit grünlichem Messingglanze, die Spitze der Fld. mit Ausnahme der Naht verwaschen hell bräunlichgelb, die sechs ersten Fühlerglieder und die Beine röthlich gelbbraun, die übrigen Fühlerglieder, Mundtheile und Hinterschenkel, letztere wenigstens in der Spitzenhälfte stark gebräunt, oft pechbraun. Auf der Unterseite sind die Seitenstücke der Mittel- und Hinterbrust und ein breiter Streifen am Rande des Bauches dicht weisslich seidenschimmernd, die mittleren Theile des Bauches sparsamer behaart. Halssch. hinten doppelt so breit als lang und bis zur Mitte ziemlich gleichbreit, davor in starkem Bogen verschmälert und deutlich zusammengedrückt, mässig dicht, fein punktirt, mit glatten und glänzenden, oder gewirkten und weniger glänzenden Zwischenräumen. Das Längsstrichelchen ist tief und breit, besonders am Grunde, wo es von einer schmalen Kante des Basalrandes begrenzt wird. Die Fld. treten bis zur hohen Schulterbeule schräg nach aussen, haben etwas gerundete Seiten und mässig starke Punktreihen, die auf dem Abfalle zur Spitze fast erlöschen, ihre Zwischenstreifen sind kaum bemerkbar punktirt und gerunzelt, unter schwacher Vergrösserung glatt.

In der Skulptur und Farbe sehr veränderlich. Die Punkte des Halssch. sind bald sehr fein und flach, undeutlich, weit getrennt, bald tief und deutlich, näher an einander gerückt, die der Fld. entweder fein, einfache, nicht vertiefte Reihen bildend, oder kräftig, in deutliche Streifen gestellt, deren Zwischenräume schwach gewölbt sind. Die Färbung ändert $a b$ :

a. Fld. bräunlichgelb, ein gemeinschaftlicher Fleck an der Basis von einer schulterbeule zur anderı, der sich nach rückwärts 
allmählich verschmälert und im letzten Drittel ant die Valıt beschränkt ist, pechschwarz, metallisch grün oder gell, ylänz'nd. an den Rändern verwaschen und durch Braun in die helle Farbe ühergehend, die Epipleuren. oder noch ein itreition darüber gleichfalls dunkel. Hierzu gehören nur frische stiuckr.

Allmählich dehnt sich die dunkel-metallische Färbung sn weit aus, dass auf dem hinteren I)rittel jeder Fld. (sime schiefliegende, ovale Makel gelb bleilst, welche den Spitzenrand vollständig einnimmt und vorn sehr verschwommen ist (Normalfärbung).

b. Zuletzt zeigt sich auf jeder Fld. nur noch eine kleine. schart begrenzte Makel ron runder oder dreieckiger Form, ein Stïck vor der Spitze.

c. Die Hauptfarbe der Oberseite ist pechschwarz, ohne jeden Metallschimmer, oder mehr pechbraun. metallisch oder kupterig glänzend; endlich

d. lebhaft stahlblau, mit gelber Spitze der Fld.

Auf nassen Wiesen und am Lfer von Gewaissern häutig in ganz Europa; die Abänderungen b und d selten.

b. Die Höcker über der in der Mitte winkelig gebogenen Stirnlinie deutlich.

2. Hipp. nigmitula: Ocalis, conrexa, nigra, subtus parce pubescens, supra nigro-coerulea, nitida, antemis, tibiis tarsisque piceis, prothorace subtilissime punctato, elytris antice sat fortiter striato-punctatis, apice laevibus. - Long. 2,2-2,8 mm.

Gyllh. Ins. Suec. III. 557. - Bach Fauna III. 139, - K utsch.

Wien. Monat. 1860, 136 (98), - Redtb. Faun. A. II. 497.Seidl. F. balt. 494 (Halt.). - Foudr. Mon. 328. - All. Mon. 193 (Crep.). - Thoms. Skand. Col. VIII. 222.

Halt. ovulum Duft. Faun. A. III. 274.

Halt. impressa Waltl. Isis 1839. 226.

Eiförmig, hinten stärker verengt als vorn, gewölbt, unten schwarz, sparsam hehaart, auf den Seitenstiicken der Hinterbrust etwas dichter, oben schwarzllau, glänzend, Fiihler, schienen und 'Tarsen pechbram, oft röthlichbram, Schenkel pechschwarz. Halssch. an den Seiten schwach gerundet, nach vorn nur wenig verengt, über den Vorderecken etwas zusammengedriickt, die Scheibe grewölht. gleichmässig sehr fein punktirt, in dem seichten Quereindrucke etwas stärker, auf einem steil abfallenden Streifen über den Seiten ziemlich glatt. Das Längsstrichelchen jederseits ist schart' und tiff und unterbricht mehr oder weniger den Hinterand. Die Fld. sind 
an der Basis etwas breiter als der Grund des Halssch., in oder vor der Mitte am breitesten, mit schwacher schulterbeule und starken, hinter der Mitte allmählich ganz erlöschendeu Punktreihen, in denen die Punkte ziemlich weitläufig eingestochen sind.

Auf jungem Laubholze im Vorgebirge nichț häufig. oft auch unter abgefallenem Laube an Waldrändern. Sächsische Schweiz, Schlesien, baierische und österreichische Alpen; ausserdem in Finnland und bei Stockholm.

\section{Orestia.}

Germa r, Fauna Insect. Europ. 23. 1849 p. 17.

Acetabula antica occlusa.

Prothorax margine basali immarginato utrinque plice profunda interrupto, saepe ante basin impressione transversa instructus.

Prosternum bicarinatum, processu retrorsum dilatato apice subemarginato; mesosternum occultum.

Körper bei den meisten Arten ungeflügelt, dunkelbraun, bei wenigen gefliigelt, hellbraun oder schwarzblau, stark glänzend. Kopf ziemlich klein, dreieckig, mit breiter, glatter und gewölbter Stirn, auf welcher sich die Stirnlinien in der Mitte zu einem schwachen Bogen vereinigen, von dem eine mehr oder weniger lange Mittelrime aufwärts zieht. Neben derselben liegen die flachen oder mässig gewölbten Stirnhöcker, welche grosse Aehnlichkeit mit denen der Gattung Crepidodera besitzen, oben höchst selten durch einen leichten, bogenförmigen Eindruck begrenzt sind, vielmehr in der Regel unmerklich in den Scheitel übergehen. Der Stirnkiel ist oben breit und wenig gewölbt, er verschmälert sich schnell nach unten zu und geht allmählich in das flache, nirgends scharf begrenzte Kopfschild über, dessen niedergedrückter Querstreifen kurz und undeutlich ist. Die Oberlippe ist fast so lang als breit, vorn leicht ausgerandet, nebst dem Kopfschilde mit langen, starren, gelblichen Haaren versehen; Mandibeln klein, mit fünf Zähnchen, der obere und untere derselben sehr kurz, beinahe hinter dem. folgenden verborgen, der mittelste ragt entweder weit vor und ist zugleich etwas grösser als die beiden ihn umgebenden, order mit dem zweiten ron gleicher Grösse und Länge. Glied 1 der Maxillartaster sehr kurz, 2 gestreckt, nach der spitze verbreitert, 3 so lang, aber dicker als 2, 4 conisch, kürzer als das vorhergehende. Fühler ziemlich nahe an den Augen eingefügt, so lang oder kürzer als der halbe Kürper, dick, das erste Glied eiförmig, die drei folgenden kurz, unter sich ziemlich gleich- 
gross, die übrigen etwas länger und stärker, Endglied schief abgeschnitten und zugespitzt. Halssch. glatt oder nur fein punktirt, quer, bei einigen Arten stark, bei anderen kaum nach vorn verengt, nur an den Seiten gerandet. Die Kandlinie biegt an der vorderen Borstenpore, die den Ecken bald nahe, bald entfernter eingefuigt ist, nach innen, vertieft sich und endet hinter dem Auge, indem sie den Vorderrand unterbricht; die Randleiste theilt sich an den Hinterecken und umschliesst die grosse Borstenpore, welche in dieser Gattung auf die Oberfäche, neben die Ecken an den Hinterrand gerückt ist. Ein Theil der Arten hat jederseits einen ziemlich langen und tiefen Längsstrich, an dem der bogenförmige Basalrand ausgeschweift und unterbrochen ist, der andere Theil ausserdem noch einen graden oder gebogenen Quereindruck. Letzterer scheint in einer gewissen Wechselbeziehung zu dem Umfange des Halssch, zu stehen, denn je tiefer er ausgeprägt ist. desto weniger verengt sich das Halssch. nach vorn (relpincl), und umgekehrt, je flacher er wird, desto grösser ist die Verschmälerung ( (urcuata), am bedeutendsten also bei den Arten, denen der Eindruck fehlt (apennina). Das Schildchen ist klein, dreieckig, glatt. Flügeldecken entweder ron gleicher Breite, an den Seiten parallel, hinten schnell verengt, an der Basis zum Hinterrande des Halssch. merklich abfallend, mit deutlicher Schulterbeule (geflügelte Arten), oder im ersten Drittel am breitesten, rückwärts allmählich verengt und am Ende oft etwas ausgezogen, die Seiten weniger gerundet, wenn das Halssch. der Art vorn nicht verschmälert, stärker gerundet, wenn dasselbe vorn bedeutend verengt ist, oben mehr oder weniger gewölbt, ohne Schulterbeule (ungeflügelte Arten). Die Scheibe ist regelmässig gereiht-, seltener gestreift-punktirt, nach den Seiten und zur Spitze hin viel feiner als auf dem inneren und vorderen Theile, jedoch bleibt hier ein Streifen an der Basis immer glatt. Die Epipleuren sind breit und eben, werden hinter der Mitte schmaler und endigen ein Stück vor der Spitze, die von hier bis zur Nahtecke in verschiedenem Grade ausgerandet ist. Prosternum ziemlich breit, rückwärts erweitert, der Länge nach vertieft und an jeder Seite mit einem hohen Kiele versehen, am Ende abgestutzt oder bogenförmig ausgeschnitten. Metasternum bis vor die Mittelhüften verlängert, mit der Spitze in die Ausrandung der Vorderbrust eingelegt, daher das Mesosternum vollständig bedeckt. Von den fünf Bauchsegmenten ist das erste und letzte lang, die mittleren sind kurz, das Pygidium hat eine lange und tiefe Doppelrinne zur Einlagerung der Nahtkante der Fld. Hiiften niedrig, die der Vorderbeine eiförmig und etwas gewölbt, kaum so hoch als die Seiten des Prosternum, die vier hinteren wenig über die 
Pfannen erhöht. Beine ziemlich schlank, die Hinterschenkel in der Regel nur etwas dicker, bei wenigen Arten viel dicker als die übrigen, an allen Schienen ein deutlicher Enddorn, Klauen zart, am Grunde in einen kleinen, aber scharfen Zahn erweitert.

Das Männchen lässt sich vom Weibchen leicht durch das erweiterte erste 'Tarsenglied an den vier Vorderbeinen und die Bildung des letzten Bauchringes unterscheiden. Dieser ist längs der Mitte flach gedrickt oder mit einer feinen Rinne versehen, am Hinterrande in einen eckigen Querzipfel verlängert, welcher von den schmalen, abgestutzten Seitentheilen durch einen Einschnitt getrennt wird. Der Penis ist eine meist mit vielen Leisten und Rinnen versehene Röhre, die an der Oeffnung in der Regel erweitert und eigenthümlich gebaut, vor derselben in eine Spitze ausgezogen ist; die Scheide des + endet in zwei weit von einander getrennte, feine, nadelförmige Zipfel, welche am Ende lang bewimpert sind.

$\mathrm{Zu}$ der Gattung gehören bis jetzt 18 Arten, welche hauptsächlich in den Wäldern der Karpathen, Alpen und Pyrenäen ${ }^{1}$ ) zwischen moderndem Laube und unter Fichtennadeln leben, auch unter Steine und in faulendes $\mathrm{Holz}$ kriechen, wenige hat man von Pflanzen gestreift, darunter die in Spanien weit verbreitete Or.punctipennis. Nur wenn die für eine Haltica auffällige Lebensweise einzig in's Auge gefasst wird, lässt es sich vielleicht erklären, dass die Gattung anfänglich keinen bestimmten Platz im Systeme erhalten konnte, denn Germar stellte sie zu den Erotyliden, Redtenbacher (Faun. A. ed. 1. 199) zu den Cryptophagiden und Gerstäcker zu den Eumolpiden (Monogr. d. Endomych. 32). Obwohl nun Erichson (Bericht 1845. p. 76) und Kraatz (Berl. Zeit. 1858. 392) dieselbe zu den Haltiken verwiesen und Kutschera sie sogar in seiner Gattung Haltica unterbrachte, wurde sie in neuerer Zeit von Chapuis (Genera XII. 72-76) in einer weitschweifigen Auseinandersetzung, welche die unglaublichsten Fehler aufweist, zu einer Mittelform zwischen den Erotyliden und Endomychiden gestempelt, von Herrn v. Harold endlich wieder für eine echte Erotylide angesprochen (Brl. ent. Zeit. 1884. 131). Da die Orestien aber durch die Bildung der Fühler und sämmtlicher Mundwerkzeuge, des Kopfschildes und der Stirn, des Halssch., der Fld. und Beine, sowie des Hinterleibes, und in der Geschlechtsauszeichnung so gut wie gar keine Aehnlichkeit mit den Erotyliden oder Endomychiden haben, vielmehr im Baue aller Körpertheile auf's Genaueste mit den Haltiken über-

1) Auch aus Nordafrika sind zwei, vom Kaukasus, dem asiatischen Olymp, und aus Syrien je eine Art bekannt geworden. 
einstimmen und insbesondere von den blauen Cirepidudero-Arten. cymenipennis etc., die von Chapuis und $\mathrm{v}$. Harold doch unbestenklich zu Julticu gerechnet werden, nur schwierig zu trennen siml, su wäre eine Losreissung von diesen und eine Vereinigung mit jentu einfach unnatürlich.

Lnsere Kenntniss der Arten, von denen die meisten als Seltenheiten gelten, enthehrt der geniigenden Sicherheit, und ich kann in der folgenden Tabelle, die sich theilweise auf eine Libersicht stuitzt, welche von H. Reitter in den Yerh. d. zool. but. Gres. Wien 1879 p. 54 veröffentlicht wurde, nur einzelne (iesichtspunkte angeben, die für cine spätere bestimmte Begrenzung aller Arten förderlich sein dürften.

1. Körper gefligelt, an den Seiten fast parallel, oben hell rothbraun, wie polirt glänzend, oder schwarzhlau. Fld. mit deutlicher Schulterbeule und bis zum Abfalle nach der Spitze hin bemerkbaren Punktreihen, daron ist die abgekürte Reihe an der Naht lang, bis zum ersten Drittel oder fast bis zur Mitte reichend. Der hintere Nahtwinkel leicht abgerundet. Halssch. mit Quereindruck: Subgenus Pyladia. . . . . . . 2.

$1^{1}$. Körper ungetlügelt, beiderseits gleichmässig oder nur nach hinten stark verschmälert, an den Seiten mehr oder weniger gerundet, oben dunkelbraun. oder die Fld. pechschwarz, hlau oder violett, Kopf und Halssch. bräunlichroth. Fld. ohne Schulterbeule, abgekürte Punktreihe kurz; der spitzenrand abgestutzt oder ausgerandet: Orestia in spec.. . . . . . 5.

2. Oberseite hell rothbraun . . . . . . . . . . . . . 3.

21. Uberseite bläulich-schwarz. Quereindruck des Halssch. sehr tief, furchenartig, Körper auffällig schlank, flach . . . . 4 .

3. Klein und schlank. Hinterschenkel schwach rerdickt, Punkte in den Reihen der Fld. flach, nicht dicht gestellt, Quereindruck des Halsseh. tief. -- I. 1, \$-2 mm. Syrien: Haifa (Reitter. Simon) . . . . . . . . . Brulleriei All.

31. Grösser, fast länglich-viereckig, Hinterschenkel stark verdickt, Punkte in den Reihen der Fld. tief eingestochen, dicht gestellt. oft dunkel umsäumt. - L. 2,5-3 mm. Corsica, sïdliche Hälfte von Spanien, Portugal (Reitter), Algier. punctipennis Luc.

4. Fiihler und Beine rostroth, Halsseh. undeutlich punktirt, die inneren Punktreihen auf den blauen Fld. bedeutend tiefer als die äusseren, mit schmalen, leicht gewölbten Zwischenräumen. L. $2 \mathrm{~mm}$. Algier (Abeille VII. 33) . . Pommereani Perris 4² Fühler und Beine pechbraun, Schienen etwas heller, Tarsen und 'Taster rothgelb. Halssch, deutlich punktirt, alle Punkt- 
reihen auf den fast schwarzen, nur leicht bläulich angehauchten Fld. ungefähr von gleicher Stärke, mit ziemlich ebenen Zwischenräumen. - L. 2,5 mm. Andalusien: sierra Cordoba. (I)eutsch. ent. Z. 1882, 48)

5. Halssch. mit einem Quereindrucke sierrana Heyd.

51 . Halssch, ohne spur eines Quereindruckes.

6. Kopt und Halssch. roth, letzteres mit gebogenem Quereindrucke, Fld. schwarzblau oder schwarzviolett

$6^{1}$ Oberseite einfarbig dunkelbraun

7. Gewölbt, breit elliptisch, Seiten des Halssch. grarlliniy nach der vorderen Borstenpore hin conrergirend. Fld. schwarzblau, nur die vier immeren Punktreihen sichtbar. - L. 3 mm. Algier: Bona, Edough

Leprieuri All.

71. Flach, gestreckt, Seiten des Halssch. gerundet. Fld. schwarzviolett, mit sechs oder sieben sehr feinen Punktreihen. L. $2 \mathrm{~mm}$. Dalmatien (ex Allard; ausser dem beschriebenen $\hat{\sigma}$ existirt kein weiteres Exemplar)..... Kraatzi All.

8. Halssch an der vorderen Borstenpore breiter, eben so breit oder wenig schmaler als in den Hinterecken, Längsstrichelchen mit dem Seitenrande divergirend, Körper mehr oder weniger gestreckt, länglich-eifömuig, mit schwach gerundeten Seiten 9 .

81. Halssch. an der vorderen Borstenpore bedeutend schmaler als in den Hinterecken, Längsstrichelchen mit dem seitenranrle ziemlich parallel, Quereindruck stark gebogen, hïrper kirz, breit-eiförmig, hinten stark verengt .. . . . . . . 14

9. Halssch. fein und dicht, aber tief punktirt, hinter der vorderen Borstenpore stark gerundet-erweitert, nach hinten verengt, deshalb eine Spur herzförnig; alle Punktreihen der Fld. deutlich. L. 2,8 mm. 'Transsylvan. Alpen (ex Reitter) puncticollis Reitt.

91. Halssch. sehr fein, nur unter starker Vergrösserung deutlich punktirt, zwischen den Hinterecken und der vorderen Pore nicht oder sehr schwach gerundet-erweitert . . . . . 10 .

10. Halssch. an den Torderecken kaum zusammengedrickt, fast regelmässig vicreckig, über die Mitte beinahe so lang als breit, der Quereindruck ziemlich grade, nur im mittleren Theile meist erweitert und unmerklich nach hinten gebogen, alle Punktreihen der Fld. deutlich. - L. 2, $,-3,2 \mathrm{~mm}$. Croatien Kärnthen, Steiermark . . . . . . . . Hampei Miller.

Dieser Art scheint nach der Beschreibung Or. olympira Friv. (Termeszetr. 1884 p. 7) rom asiat. Olymp am näichsten zu stehen

10'. Halssch. bedeutend breiter als lang, über den Vorderecken mehr oder weniger zusammengedrückt . 
11. Tie drei inneren Punktreitıen der Fld. deutlich, die folgenden kurz, undeutlich. Quereindruck des Halssch. grade, sparsam punktirt. - L. 2. 2-3 mm. Ostalpen. . alpinn Germ.

11. T)ie sechs inneren Punktreihen der Fld. deutlich, die drei äusseren schwach

12. Quereindruck des Halssch. grade, ohne Spur von Punkten. Reihen der Fld. sehr fein. Sichlanker und flacher als alpina. - L. 2,5 mm. Türkei (Merkl) . . . . . Merkli Ws.

121. Quereindruck des Halssch. bogenförmig, sparsam punktirt, Punktreihen der Fld. kräftig, die inneren in leichte Streifen gestellt

13. Seiten des Halssch. von den Hinterecken bis zur vorderen Eckpore gradlinig, schwach verengt. - L. 2,8-3,3 mm. Am Surampasse im Caucasus von Leder entdeckt. caucrsica Reitt.

13. Seiten des Halssch. schwach, aber deutlich gerundet. L. 3-3,8 mm. Krain........ carniolica Ws.

14. Der Rand an der Spitze der Fld. leicht abgestutzt, die Nahtecke daselbst stumpfwinkelig, nicht vorgezogen; Halssch. zur vorderen Eckpore beinahe gradlinig verengt, äusserst fein punktirt, nur die inneren Punktreihen der Fld. deutlich. L. 2-2,6 mm. Südungarn, Krain. . . . A Abei All.

Nach der Beschreibung lässt sich Or. andalusirca All. (Abeille V. 1869.476) aus Andalusien von dieser Art nur durch den sehr flachen (très-ocale et déprimée) Körper unterscheiden.

141. Spitzenrand der Fld. bogenförmig ausgeschnitten. die Nahtecke spitz vorgezogen. Halssch. zur vorderen Pore gerundet-verengt, fein, in und hinter dem Quereindrucke stärker punktirt, Punktreihen der Fld. fein, deutlich. - L. 2,2-2,8 mm. In den Karpathen von der Tatra bis Siebenbürgen. arcuata Mill.

Von dieser Art ist Or. carpathica Reitt. (Verh. zool. bot. Ges. Wien 1879. 55) aus der C'zerna hora in L'ngarn durch das nach vorn stärker verschmälerte, an den Seiten nicht gerundete Halssch. verschieden. welches einen fast graden Quereindruck besitzt.

15. Körper langgestreckt, ziemlich flach, Halssch. nach vorn sehr wenig verengt. - Siidungarn (ex Reitter) . Paveli Friv.

15². Körper kurz, gedrungen, eiförmig, gewölbt . . . . . 16.

16. Alle Punktreihen der Fld. sichtbar, aus grossen. aber flachen und ziemlich entfernten Punkten grebildet. Oberseite dunkel rothbraun, Halssch. fast gradlinig nach der vorderen Pore verengt. - L. 2-2, $\mathbf{m m}$. Pyrenäen . Pandellei All.

Sehr nahe verwandt scheint zu sein Ur. Flectra Gredl. aus Tirol. 
16'. Nur dis vier inneren P'unktreihen der Fld. sichtbar, aus grossen, sehr flachen und weit entfernten l'unkten gebildet, die iibrigen ganz fehlend. Oberseite bei nicht ausgefürbten Stücken riothlich braun, bei ausgehärteten ist das Halssch. roth, Fld. pechschwarz. Halssch. von den Hinterecken bis zur vorderen Pore stark in grader Linie verengt. - L. 2,2-3 mm. Oberitalien: I Aucea (Keitter)

apennina W. $\left.{ }^{1}\right)$

1. Or. II ampei: Oblonga, sat convexa, nitida, castanea, antennis pedibusque pallidioribus; tuberculis frontalibus discretis, wrothorace subtilissime punctulato minus transverso, apice quam basi fere latiore, lateribus vix rotundatis, impressione transversa sat profunda, subrecta, sporsim munctata, elytris interne punctato-substriatis, extrorsum striato-punctatis, postice sublaevilus, apice subsinuato-truncatis, femoribus posticis vix incrassatis. - Long. 2,5-3,2 mm.

Ililler Verh. zool. bot. Gesellsch. Wien 1868. 32. - Reitt. 1. c. 1879.55 .

Der Käfer ist an dem verhältnissmässig langen Halssch., welches vorn fast breiter als an der Basis und überhaupt regelmässiger viereckig erscheint als bei den iibrigen Arten, nicht schwer zu erkennen.

Gestreckt, an den Seiten wenig gerundet, hinter der Mitte verengt, mässig gewölbt, glänzend kastanienbraun, Fühler und Beine rostroth. Stirnhöcker ziemlich flach, durch eine Längsrimne getrennt, oben nur undeutlich von einem schwachen Eindrucke begrenzt. Halssch. viereckig, tast so lang als breit, an der Basis in starkem Bogen gegen das Schildchen vorgezogen, die Seiten fast parallel, entweder ron den Hinterecken aus allmählich und äusserst schwach erweitert, ein Stück ror der Mitte wieder ebenso. verengt, oder bei einzelnen Exemplaren vor den Hinterecken eine Spur stärker als hinter der vorderen Eckpore, jedoch an beiden Stellen sanft ausgeschweift, an den wulstigen Vorderecken stark verengt und über den abgestutzten Vorderrand vorgezogen, oben wenig gewölbt und vorn kaum mehr als hinten zusammengedrückt, der breit abgesetzte Seitenrand daher, bei der Betrachtung ron

1) Or. apennina: Breviter-ovalis, sat convexa, nitida, antemis, capite, prothorace pedibusque ferrugineis, elytris nigro-piceis; prothorace laevi antrorsum fortius angustato, lateribus rectis, impressione transversa mullu, elytris striato-punctatis, extrorsum posticeque laevibus, apice obsolete singulatim rotundatis; femoribus posticis leviter incrassatis. - Long. 2,2-3 mm. Lucca. 
ohen. in seiner granzen Lünge sichthar; aut der stheibe ziemlich weitliutig und sehr fein grunktulirt, nit stärkeren l'unkten im Quereindrucke. Dieser ist ziemlich tief. in der Mitte breiter als an den seiten, nur unbedeutend gekrümmt. und trifit die starke Längstalte jederseits wenig hinter ihrer Mitte. Fld. olne Sclulterheule. von der Basis bis zum ersten Drittel etwas erweitert, dahinter allmählich verengt, an der Spitze abgestutzt und in schwachem Bogren ausgerandet, die Nahtecke rechtwinkelig, nach unten ungebogen und in die breite und tiefe Rinne der Afterdecke eingelegt; die Oberseite mit mässig starken Punktreihen, von denen die drei inneren in seichten Streifen stehen. Im vorderen Theile der Fld. sind alle Reihen sichtbar, die zwei oder drei ersten werden hinter der Mitte, die ibrigen schon vor derselben fein und undeutlich. Die Hinterschenkel sind nur unbedeutend dicker als die vorderen.

Unter feuchtem Laube in den Wäldern der Ostalpen. Kärnthen (Dahl), Steiermark und Croatien.

2. Or. carmiolica: Oblongo-ocalis, sat convexa, nitida, rufo-picea, prothorace subtilissime punctulato transierso, apice quam basi parum angustiore, lateribus leviter rotundatis, impressione transcersa sat profinda, subarcuata, sparsim punctata, elytris interne punctato-striatis, extrorsum striato-punctatis, postice sublaevibus, apice truncatis; femoribus posticis modice incrassatis. - Long. $3-3,8 \mathrm{~mm}$.

Die grösste Art, durch die Punktirung der Fld. mit der vorigen, im Habitus, insbesondere im Baue des Halssch. mehr mit der folgenden verwandt; lang-eiförmig, an den Seiten etwas gerundet. hinter der Mitte verengt, mässig gewölbt, glänzend röthlich-pechbraun, die Fühler an der Spitze etwas heller, die Taster, Spitze der Schienen und die Tarsen an allen Beinen rostroth. Halssch. um die Hälfte breiter als lang, an der Basis in schwachem Bogen gegen das Schildchen vorgezogen, an den Seiten leicht gerundet, mit der grössten Breite hinter der Mitte, von hier aus nach den Hinterecken mässig und schmell, nach vorn allmählich und in einem fast gleichmässigen Bogen bis zur äussersten Spitze in den wulstig verdickten Vorderecken verengt, die über den abgestutzten Vorderrand vorgezogen sind. Die Oberfläche ist kissenartig gewölbt, vorn bedeutend mehr als hinten zusammengedrückt, ziemlich weitläutig und äusserst fein punktirt, mit stärkeren Punkten im Quereindrucke. Dieser ist ziemlich tief, überall ron gleicher Breite, bogenförmig, und trifft die sehr starke Längstalte ein Stïckchen vor ihrer Basis. Dadurch scheint die Falte erheblich länger als bei der vorigen und folgenden Art; während bei diesen etwa die 
Hailfte der Falte vor dem Quereindrucke liegt, sind hier zwei Drittel äber denselhen hinaus verlängert. Fld. im ersten I)rittel am breitesten, dahinter allmählich verengt, an der Spitze abgestutzt, die Tahtecke stumptwinkelig, ahgerumlet, nach unten wenig umgebogen; die ścheibe mit ziemlich starken l'unktreihen, von denen die inmeren in streifen stehen und his hinter die Mitte, die iunsseren kaum bis zur Mitte deutlich bleiben, dam sehr fein werlen und sich ror der Spitze in zerstreute, äusserst feine Pünktchen auflösen. Die Hinterschenkel sind mässig verdickt.

Der Penis ist auf jeder Seite der Länge nach eingedrückt, beide Eindricke sind unten flach und gehen allmählich in die Rundung der Lnterseite ïber, oben tief', mit leistenartig aufgebogenem Rande; sie nähern sich nach vorn einander immer mehr und verschwinden an der Oeffumng. Ihre beiden Randleisten umschliessen auf der Oberseite einen schwach vertieften, lang dreieckigen Raum, stossen an der urossen, länglich-ovalen Oeffinung zusammen, umranden diese und endigen vor ihr in einer breiten, scharf abgestutzten Spitze, welche mit der Schnauze eines Töpfehens Aehnlichkeit hat. Die Oeftnung ist mit einer pergamentartigen Klappe bedeckt, an deren Vorderrande sich ein horniger, grosser und breiter, löffelförmiger Anhang erhebt, welcher mit dem abgerundeten freien Ende wagerecht nach hinten gerichtet ist, am festgewachsenen vorderen Ende zwei Spitzen besitzt. Auf der Unterseite befindet sich eine Längsvertiefung, von zwei mässig hohen Leisten begrenzt, welche an der Basis weit von einander abstehen, nach vorn convergiren, unterhalb der Oeffuung wieder bogenförmig auseinander laufen und zugleich sehr hoch, diimmandig und scharf werden.

Unter feuchtem Laube bei Laak in Krain (Ludy).

3. Or. alpina: Oblongo-ocalis, sut concexu, nitida, rufo-pricea, antenmis pedibusque dilutioribus, prothorace vix sibiliter punctulato transierso, apice quam basi parum angustiore, lateribus eridenter rotundatis, impressione transrersa profunda, subsulciformi, recta, sparsim punctata instructo, elytris subtiliter striato-punctatis, extrorsum pasticeque sublatritus, apice simuatis, angulo suturali acuto, femoribus posticis leviter incrassatis. - Long. 2,2-3 mm.

(term. Ins. spec nor. 622 (Lycoperdina); Faum. Ins. Eur. fase. 23. 17. - Redtb. Faun. A. ed. 1. 199; ed. 2.373. - Guér. Thoms. Arch. I. 276. t. 13. f. 30. - A 1l. Mon. 201 (Orestia). Kutsch. Wien. Monat. 1860. 138 (100). - Redtb. l. c. ed. 3. II. 497 (Haltica).

Aehnlich gebaut wie die vorige, aber kleiner und etwas breiter, an den schwachen Punktreihen der Fld., von denen die inneren 
schon von der Mitte ab, die äusseren überhaupt undeutlich sind, zu erkemnen. Länglich-eitörmig, mit mässig gerundeten seiten, ziemlich gewïlbt, glainzend rïthlich-pechbraun, Fiihler und Beine rostroth. Halssch. un die Hälfte breiter als lang. an der Basis in schwachem Bogen gegen das schildchen vorgezogen, an den Seiten deutlich gerundet, mit der grössten Breite in der Mitte. von hier beiderseits gleichmässig verengt, der Vorderrand abgestutzt, mit etwas vorgezogenen Ecken. I)ie Oberfläche kissenartig gewïlbt. vorn mehr als hinten zusammengedrückt, wenig dicht und äusserst fein, undeutlich punktirt, mit stärkeren Punkten im Quereindrucke. Letzterer ist tief, fast rinnenförmig, grade, und trifft die starke Längsfalte jederseits wenig hinter ihrer Mitte. Von den feinen Punktreihen der Fld. sind die drei inneren bis zur Mitte deutlich. die folgenden, namentlich die fünfte bis siebente scblecht und meist nur bei stärkerer Vergrösserung sichtbar, so dass die äussere und die hintere Hälfte der Fld. glatt aussieht. Die Hinterschenkel sind leicht verdickt. Der Penis ist dem der vorigen Art ähnlich. aber an den Seiten gerundet, oben rinnenartig vertieft, mit leistenförmigen Rändern, welche bis zur grossen, ovalen Oeffnung beinahe parallel laufen, hierauf letztere ungrenzen und davor allmählich in die eckige, breite, am Vorderrande leicht ausgekerbte Spitze übergehen. Die Klappe der Oeffnung ist vorn in die Höhe gebogen und mit einem Höcker versehen, auf dem ein horniges, schmal dreieckiges Anhängsel befestigt ist, welches wagerecht nach hinten gebogen ist. Die erhöhten Ränder der Unterseite werden vorn, unterhalb der Oeffnung, plötzlich höher, ziehen dann in gleicher Höhe weiter und fallen vor der Spitze des Penis eben so schnell wieder ab.

In feuchtem Laube der Gebirgswälder von Steiermark und Krain selten.

Die Abbildung der Art in Thomson's Archiv ist höchst ungenau. Das Halssch. hat dort weder Basalfältchen noch einen Quereindruck, die Punktreihen der Fld. sind falsch, am Hinterleibe des $q$ ragt ein fremdartiger Körper hervor etc.

4. Or. Aubei: Ovalis, convexa, nitida, ferruginea; tuberculis frontalibus haud discretis, prothorace subtilissime punctulato, antrorsum fortius angustato, lateribus fere rectis, impressione transiersa arcuata mimus profunda, elytris subtiliter striato-punctatis, extrorsum posticeque sublaevibus, apice subtruncatis, femoribus posticis incrassatis - Long. 2-2,6 mm.

Allard Ann. d. France 1860. 70; Mon. 201. - Redt. Faun. A. II. 502. - Reitt. Verh. zool. bot. Ges. Wien 1879. 55.

Breiter, gewölbter und beiderseits viel mehr verengt als die vorhergehenden, eiförmig, glänzend, dunkel rostroth, Fïhler und 
Beine nicht oder wenig heller. Stimbeulen sehr flach, nur vorn durch einen kurzen und flachen Eindruck getrennt, oben verbunden und allmählich in die Scheitelfläche iibergehend. Halssch. an der gerundeten Basis am breitesten, hier etwa um die Hälfte breiter als lang, bis zur vorderen Pore stark und beinahe gradlinig verengt, oben mässig gewöllbt, äusserst fein punktirt. Der Quereindruck ist gebogen, wenig tief', die Längsfältchen verhältnissmässig kurz, mit dem Seitenrande fast parallel lautend. Fld. an der Basis erweitert, bald hinter derselben am breitesten, nach hinten allmählich verengt, die Spitze schräg abgestutzt, mit stumpfwinkeliger Nahtecke. Von den feinen Punktreihen sind die drei oder vier inneren von der Mitte $a b$, die äusseren überall undeutlich. Hinterschenkel spindelförmig, etwa doppelt so breit als die vorderen.

Der Penis besitzt oben eine tiefe und breite Längsrinne, die sich vorn allmählich erweitert und in die grosse, ovale Oeffnung übergeht, deren Vorderrand in eine schnabelförmige, abgerundete Spitze verlängert ist; die pergamenthäutige Klappe der Oeffnung ist einfach. Auf der Unterseite befindet sich ein sehr schwacher Längseindruck.

In Krain und im südlichen Ungarn bei Mehadia (Reitter) unter Laub.

5. Or. Electra: Fusiformi-ovalis, retrorsum angustata, convexa, nitidula, fusco-picea, antennis pedibusque pallidioribus, thorace transversim. haud impresso, utrimque sulcato, elytris lineato-punctatis, punctis apicem versus evanescentibus. - Long. 2,3 mm.

Gredler Col. Hft. III. 1868. p. 78. - Redtb. Faun. A. II. 503. - Reitt. Verh. zool. bot. Ges. Wien. 1879. 54.

Stark gewölbt, verkehrt ei-, fast spindelförmig (von Olibrusartigem Aussehen), blass pechbraun, Fiihler und Beine heller rostfarben. Halssch. kurz, an den Seiten leicht gerundet und nach vorn etwas verengt, die Scheibe sehr fein und zerstreut punktirt, ohne Quereindruck. Fld. nach der verschmälerten Spitze zu allmählich lichter gefärbt, mit distanten Punktreihen, die bis zur Mitte aus weit abstehenden und kräftigen, vor der Spitze aber verschwindenden Punkten bestehen und jeder Spur von Streifung entbehren.

Bei Valsugana und in Judicarien in Tirol an Alpenquellen auf Holzklümpchen träge sitzend vom Förster Gobanz gefunden(Gredler).

Die mir unbekannte Art ist nach der vorstehend wieder gegebenen Diagnose und Beschreibung, aus welcher nur einige unwesentliche Punkte wegblieben, mit Or. Pandellei All. äusserst nahe 
verwandt und kiinnte sich viflleicht durch stärk (are. I'mnktirung des Halssch. und etwas grössere Rundung seiner Geiten unterscheiden lassen.

\section{Hypnophila.}

Foudras, Ann. Soc. Linn. Lyon VI. 1859. p. 146: Altisides p. 282. Minota Kutschera Wien. Ent. Monatsch. 1859. p. 141.

Acetrubula antica occlusa.

Prothorax utrinque plica basali.

Prosternum haud carinatum, mesosternum occultum.

Körper fast elliptisch, halbkugelig gewölbt, ungeflügelt, pechbraun oder schwarz, die Oberseite mehr oder weniger stark grünlich metallschimmernd, Fühler und Beine hell rostroth, Hinterschenkel oft dunkler. Kopf klein, stark geneigt, von oben durch den Vorderrand des Halsschildes verdeckt, mit breiter Stirn; der obere Theil derselben ist schwach gewölbt und besitzt über der bogenförnigen, tiefen Stirnlinie zwei grosse, flache, schlecht begrenzte Beulen, häufiger jedoch kaum eine Spur derselben. Auf dem unteren Theile liegt zunächst über jeder Fühlerwurzel eine schiefe, hohe Leiste (von Kutschera für das Stirnhöckerchen angesehen) zwischen der grossen Fühlerpfanne und der Stirnlinie, sodann in der Mitte der Längskiel. Dieser hat fast die Form eines gleichschenkligen Dreiecks, dessen Grundlinie an der Stirnrinne liegt, ist flach gedriickt und fällt an den Seiten und der Spitze steil ab, davor ist das Kopfschild eben, so dass für das erste Fühlerglied ein sehr grosser Raum bleibt, auf dem es sich hin und her bewegen kann. Die Oberlippe ist vorn gerundet-abgestutzt, mit einem kleinen Ausschnitt in der Mitte. Fühler ziemlich nahe an den grobgekörnten Augen eingefügt, am dritten Gliede, welches eine schiefe Spitze hat, leicht gekniet, Glied 1 lang und dick, 2 bis 6 dünn, die folgenden verbreitert, 2 bis $4 \mathrm{kurz}$, unter sich beinahe ron gleicher Länge, 5 wenig kürzer oder so lang als die beiden rorhergehenden zusammen, 6 so gross als 2, die folgenden etwas länger, das Endglied schief zugespitzt. Halssch. nach vorn stark verschmälert und zusammengedrückt, die Seiten von oben nicht sichtbar, an der Basis in schwacher Rundung, an der Spitze dagegen fast gradlinig abgestutzt, mit den Flügeldecken in einer Flucht gewölbt, fein punktirt und äusserst fein gerunzelt, am Grunde jederseits ein Längsstrich. Die Borstenporen sind ziemlich gross, in der scharfen Hinterecke und ein mehr oder weniger grosses Stiick hinter der verdickten Vorderecke eingestochen, mit je einer feinen, mässig 
langen Borste. Flï geldecke u an der Basis so breit als das Halssch, bis zum ersten Drittel erweitert, dann verengt, hinten gemeinschaftlich stumpf zugespitzt, ohne Schulterhöcker, regelmässig in sehr schwachen Streifen punktirt, ihre Epipleuren breit, eben, nach der Spitze allmählich rerengt, neben der hohen Kante des Immenrandes steht eine Punktreihe. Das Prosternum erweitert sich zwischen den Hiiften nach rückwärts ganz bedeutend und schliesst die Pfannen von hinten, es ist längs der Mitte vertieft, und an den Seiten etwas aufgebogen, aber nicht gekielt wie bei Orestia; der Hinterrand, der sich auf der Mittelbrust einlagert, wird von einem breiten, gerundeten, weit vorgezogenen Zipfel der Hinterbrust überragt und verdeckt. Hüften gross, niedrig, die vorderen etwas gewölbt; Beine kurz und kräftig. Hinterschenkel verdickt, Schienen mit äussert kleinem Enddorne, Klauen am Grunde zahnartig erweitert.

Beim Männchen ist das erste Tarsenglied der vier Vorderbeine breiter als die übrigen, der letzte Bauchring am Hinterrande leicht bogenförmig ausgeschnitten; der Penis so lang als der Hinterleib, ein Stück vor der Basis schwach gekniet, davor grade, mit grosser Oeffnung, welche eine Klappe in der Ruhe schliesst, vorn allmählich verengt und zugespitzt.

Die beiden bis jetzt bekannten Arten leben auf feuchten Gebirgswiesen, wo sie namentlich gegen Abend vom Grase abgestreift und leicht aus dem Käscher gefangen werden können, da sie nur kurze und matte Sprünge auszuführen vermögen. Dass sie auf Moos leben sollen, wie man aus ihrem Namen "Moosfreundin" und aus den Angaben bei Foudras zu schliessen berechtigt wäre, ist durchaus unverbürgt, denn im feuchten Moose (Foudras nennt besonders Hypnum loreum und triquetrum L.) findet man nur die Stïcke, die sich bei einer Beunruhigung fallen liessen oder durch einen Sprung zu retten versuchten. Nach ihrem Habitus, welcher ausserordentlich an die Apteropeda-Arten erinnert, wurden sie früher zwischen diese Gattung und Mniophila gestellt, sind aber mit beiden kaum verwandt und lassen sich durch die tief ausgeschnittene, zur Aufnahme des Mundes also nicht eingerichtete Vorderbrust schon bei oberflächlicher Betrachtung unterscheiden; sie gehören vielmehr zur Crepidodera-Gruppe, worauf bereits Kutschera (Mon. 425) hinwies.

1. Hypn. obesa: Oblongo-hemisphaerica, nitida, nigro-aenea, subtus picea, antennis (articulo 5:0 4:0 sesqui longiore) pedibusque ferrugineis, femoribus infuscatis, posticis interdum aeneo-micantibus, prothorace subtilissime punctato, plica basali brevi, elytris striato-punctatis, punctis serierum sat crebris. - Long. 2,2-3,2 mm. 
Waltl Isis 1839. 225 (Halt.). - All. Ann. Fr. 1860. 552 ( Balanom.); Mon. 293. - Kutsch. Wien. Monat. 1864. 45; (425). - Red tb. Faun. A. ed. 3. II. 518.

Balanomon pha caricis Maerkel Stett. Zeit. 1847. 86. - Küst. Käf. Eur. 28. 100 (Apterop.). - Rerth. 1. c. ed. 2. 950. - Foudr. Mon. 283.

Var. a. Supra brunneo-aurichalcea.

Var. b. Immatura, supra picea, leviter vel haud aeneo-micans, elytris: apicem versus rufescentibus.

$\mathrm{V}$ ar. c. Antennis sat gracilibus, articulo 5:0 4:0 duplo longiore.

Länglich - halbkugelig, beiderseits stark verschmälert, oben glänzend, metallisch griinlich schwarz, unten mehr pechschwarz, Fỉhler und Beine hell rostroth, Schenkel angedunkelt, zuweilen die Hinterschenkel schwarzgrün. Halssch. bald sehr fein, flach und undeutlich punktirt, mit dicht gewirkten Zwischenräumen, bald deutlich, tief und weniger fein punktirt, mit glatten Zwischenräumen, das Strichelchen an der Basis jederseits ist mässig tief, und nimmt höchstens das hintere Viertel der Länge ein. Fld. mit regelmässigen, ziemlich starken, vor der Spitze abgeschwächten und verworrenen Punktreihen und äussert fein punktirten Zwischenräumen. Die Reihen sind bei frischen Stiicken fein. nicht rertieft, bei ausgehärteten stärker, in schwache Streifen gestellt, welche die Zwischenräume schwach emporheben.

Der Penis ist an der Oeffnung allmählich verengt, am Ende mit einer kurzen, abgestutzten Spitze, auf der Unterseite der Länge nach vertieft, fast ausgehöhlt, mit scharfen, hoch aufgebogenen Seitenrändern, die ein Stück vor der knieförmigen Biegung erweitert sind. Nach der Spitze hin verflacht sich die Aushöhlung und in demselben Masse werden die Ränder niedriger.

Das Thier wariirt in der Form mehr als in der Färbung. Die grössten und zugleich breitesten Stücke, welche der Apteropedo graminis Koch ähnlich werden, kommen besonders in Krain vor und sehen wesentlich anders aus als die kleine und auffällig schmale Form, die man in den Sümpfen des Altvater- und Riesengebirges antrifft, lassen sich aber specifisch nicht von dieser unterscheiden. Die Farbe der Oberseite ist zuweilen bräunlich-messinggelb, ohne griune Beimischung (Var.a), bei frischen Exemplaren (Var. b) pechschwarz, ohne Metallschimmer, oder grünlich uiberflogen, die Spitze der Fld. rothbraun, Beine einfarbig hell rostroth.

Im Allgemeinen sind die Fühler ziemlich kräftig, Glied 2 bis 5 wenig schmaler als die folgenden, 2 oft länger als 3 oder 4 , Glied 5 um die Hälfte länger als 4; bisweilen aber werden die Fiihler schlank, Glied 3 bis 5 viel schmaler als die übrigen, 5 be- 
sonders gestreckt und wenigstens doppelt so lang als das vorhergehende (Var. c).

Auf Gebirgswiesen von den Alpen bis zum Harze im Juli hïufig. Nach Preller auch in Holstein gefangen.

Die äusserst ähnliche zweite Art, Hypn impuncticollis All. (Ann. Fr. 1860. 552; Mon. 294) aus den Pyrenäen und den sïlfranzösischen Gebirgen ist oben pechschwarz, mit röthlicher Flügeldeckenspitze und schwachem Metallschimmer, Fühler und Beine einfarbig rothgelb. Das Halssch. vorn breiter, Basalstrichelchen desselben länger, das letzte Drittel der Länge eimnehmend, in der Mitte mehr vertieft und verbreitert als an beiden Enden, die Reihen der Fld, viel weitläufiger punktirt.

\section{Mantura.}

Stephens, Illustr. Brit. IV. 1831. p. 323.

Balanomorpha Chevrol. D'Orbign. Dict. Hist. nat. II. 1842. p. 426.

Acetabula antica occlusa.

Frons lata, carina faciali tuberculisque nullis.

Prothorae basi coleopteris haud angustion, plica basali utrinque instructus; foveae setigerae posticae saepius nullae.

Mesasternum conspicum; tibiae omnes calcari distincto, unguiculi fere simplici.

Körper geflïgelt, langgestreekt, unten ziemlich flach, oben gewölbt, beinahe halbeylindrisch, vorn etwas kürzer abgerundet als hinten, überall äusserst fein und dicht gewirkt, so dass der Glanz erheblich abgeschwächt wird. Kopf fast senkrecht nach unten gerichtet, mit kleinen, munden, gewölbten Augen und sehr breiter Stirn. Der Scheitel ist gewölbt und fällt zu der tiefen Stirnlinie $a b$, welche ïber der Fühlerwurzel winkelig gebrochen in eine bogenförmige Querrinne übergeht und hier jederseits einen kurzen Strich nach unten sendet; der Raum zwischen den Fühlern ist breit, mehr oder weniger flach gedrückt, aber nicht kielartig gewölbt (am höchsten noch bei obtusata), und verläuft gleichmässig bis zur Oberlippe. Diese ist quer, vorn leicht ausgerandet. Mandibeln fünfzähnig, der mittelste Zahn am weitesten vorgestreckt; Maxillartaster kurz, cylindrisch, ihr Endglied allmählich zugespitzt, bedeutend länger als das vorletzte. Fühler kürzer als der halbe Körper, Glied 1 lang und dick, 2 bis $6 \mathrm{kurz}$, dünn, die folgenden merklich verbreitert und von den vorhergehenden abgesetzt. Halssch. quer, am Grunde so breit als die Flügeldecken und mit diesen in einer Flucht gewölbt, an der Basis und Spitze abgestutzt, an den Seiten gerundet, vorn verengt und schwach zusammengedrückt. wie der 
Kopf kräftig punktirt, mit einem tiefen Längstältchen beiderseits am Grunde, welches sich oft als Randlinie noch ein stick an der Basis einwärts zieht, vor dem Schildchen aber erlischt. Fon den kleinen Eckporen, deren Borste äusserst fein und kurz, meist kaum bemerkbar ist, sind nur die beiden vorderen deutlich, ummittellbar hinter den Vorderecken eingestochen, die beiden hinteren fehlen oder stehen in der Seitenrandleiste in den Hinterecken zienlich versteckt. Schildchen klein, kurz dreieckig, doppelt so breit als lang. Flügeldecken an den Seiten wenig erweitert, vor der Mitte am breitesten, hinten gemeinschaftlich abgerundet, gestreift-punktirt; die abgekürzte Punktreihe ist vorn mehr oder weniger weit verdoppelt und reicht über die Mitte hinaus, die Schulterheule ist deutlich, jedoch klein, da sich auf ihrer Innenseite noch die sechste Punktreihe befindet, die bei den meisten ïbrigen Gattungen erst hinter der Beule entspringt. Epipleuren schmal, kurz vor der Spitze erlöschend; diese ist leicht umgebogen und mit der Nahtecke in eine breite und tiefe Rinne der Afterdecke eingelegt. Prosternum eben, hinter den Hüften schwach abfallend, und in einen breiten Streifen ausgezogen, der die Pfannen schliesst; Mesosternum und Fortsatz des Metasternum kurz. Hintersehenkel verdickt, lang oval, Schienen gerade oder die vorderen leicht gekrümmt, nach der Spitze allmählich erweitert, auf dem Riicken gerinnt, alle Schienen mit einem Enddorne, woron der an den Hinterschienen viel kräftiger als an den vorderen ist, Klauen einfach oder am Grunde etwas verdickt.

Beim Männchen ist das erste Tarsenglied aller Beine ungefähr doppelt so breit als beim Weibehen, der Hinterrand des letzten Bauchringes läuft an jeder Seite schräg nach vorn und innen und ist sodann im mitleren Theile abgestutzt. - Penis kürzer als der Bauch, schlank, gleichbreit, schwach gebogen, vorn abgerundet.

Die Arten leben auf verschiedenen Pflanzen, und sind am Habitus leicht zu erkennen, welcher entfernt an einige EucnemidenFormen erinnert; ausserdem bieten die breite, gleichmässig gewölbte Stirn, auf der Längskiel und Beulen fehlen, die Fühlerbildung, die ausserordentlich feinen, kurzen Eckborsten, sowie die kleinen, undeutlichen oder ganz fehlenden Poren in den Hinterecken des Halssch. weitere brauchbare Unterscheidungsmerkmale. In näherer Verwandtsehaft steht die Gattung nur zu Chaetocnema. der sie in Farbe, Punktirung, Körperform und Bildung der Stirn ähnlich ist; sie umfasst sieben europäische Arten:

1. Halssch. an der Basis ohne Längsfältchen. Schwarz, Fühler, mit Ausnahme des ersten und der verdickten letzten Glieder, sowie Schienen und Tarsen rostroth. Oberseite hell messing- 
glänzend. Stim einzeln, Halssch. grob und etwas weitlïutig, an den seiten runzelig, in der Mitte teiner punktirt. - I. 2 mm. Dalmatien (Verh. Wien. 1\$80. 2) . . cylindrica Miller. 11. An der Basis des Halssch. jederseits ein Lingstältchen . . 2.

2. Aeusserer Zwischenraum der Fld. in der vorderen Hälfte mit einer unregelmässigen, starken Punktreihe. Tief blau oder lehhaft metallisch grün, auch mit Messing-oder Kupferehsimmer, Halssch an den Seiten und vor der Basis grob, sonst (wie die Stirn) fein punktirt, mit sehr feinen Pïnktehen in den Zwischenriumen. Fld. mässig stark punktirt-gestreift, Zwischenstreifen stärker und weitläufiger gewirkt als bei den iibrigen Arten. - L. 2-2,3 $\mathrm{mm}$. England, Frankreich (aeraria Foudr.) . Mathewsi Curtis.

Aendert ab: (var. bicolor) Kopf und Halssch. blau oder schwarz, Fld. grün, messinggelb oder kupferig; oder (var. aeraria Kutsch.) Kopf und Halssch. grün, messingrgelb oder kupferig, Fld. blau.

Von dieser Art trennt Allard noch ein Thier aus Algier (II. nitens All. Mon. 501) durch etwas plumperen Körperbau, die ausserordentlich glänzende bronce-kupferige Oberseite und die stärkere, aber weitläufigere Punktirung des Halssch.

21. Aeusserer Zwischenraum der Fld. olne Punkte . . . . . 3.

3. Körper röthlichgelb, oben oft metalliseh griin angehaucht, Scheitel, Bauch und Hinterschenkel in der Regel rothbraun, Kopf und Halsseh. grob runzelig punktirt, mit eingemengten feinen Pünktchen, Längsfalten breit und sehr tief, Fld. kräftigpunktirt-gestreift. - L. 1,6-2 mm. Von Frankreich durch Spanien (z. B. bei Algeciras, Simon) bis Algier verbreitet lutea All.

$3^{1}$. Körper dunkel metallisch gefärbt . . . . . . . . . . 4 .

4. Querlinie der Stirn tief. Körper schwarz, oben unmerklich grün schimmernd. L. 2,3-2,9 mm. Ganz Europa und Sibirien obtusata Gyllh.

$4^{1}$. Querlinie der Stirn flach. 5.

5. Oberseite einfarbig dunkelblau. - L. 2,5 mm. Aachen, Paris ambigua Kutsch.

5?. Fld. mit heller Spitze oder fast ganz rostroth 6.

6. Die Längsfalten des weitläufig punktirten Halssch. reichen fast bis zur Mitte nach vorn. Oberseite dunkelblau, blaugrün oder dunkel metallisch grün, das hintere Viertel oder Drittel jeder Fld. rostroth. - L 2,3-3 mm. Ganz Europa. Sibirien rustica L.

6. Die Längsfalten des dicht punktirten Halssch. kurz. Oberseite trübe grünlich-messingfarbig, die Fld. nach der Spitze hin röthlich durchschimmernd. - L. 1,8-2,8 mm. Europa. Algier 


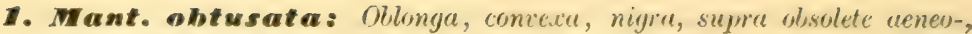
rarius crevelen-micans, minus nitida, antennarum articulis sex primis pedibusque ferrugineis, femoribus posticis aeneo-nigris, anterioribus interdum fuscis; linea frontali profunda, mothorace sat cretre in medirs sulsliliter punctato, plica laterali minus profunda, elyftris striato-punetatis. - Long. 2,3-2,8 $\mathrm{mm}$.

Gyllh. Ins. Suec. III. 579. - Kutsch. Wien. Monat. 1862. 52 (174). - Redtb. Faun. A. II. 502. - Bach Käferf. III. 147. - Seidl. F. balt. 495 (Halt.). - Foudr. Mon. 274. A 11. Mon. 289. - Thoms. Skand. Col. VIII. 226 (Bahum.). - Steph. Ill. Brit. IV. 323; MLan. 299.

Var. a. Immatura; pedibus ferrugineis totis.

Durch dunkle Färbung, geringen Glanz der Oberseite und die tiefe Querlinie der Stirn ausgezeichnet. Schmal eifrimior. hinten etwas stärker verengt als vorn, gewölbt, schwarz, mit einem Stich in's Grünliche oder Bläuliche, fettig glänzend, die sechs ersten Fühlerglieder und die Beine hell rostroth, die vier vorderen Schenkel und das erste Fühlerglied gewöhnlich mehr gebräunt, selten pechbraun, Hinterschenkel schwarz metallisch. Stirn zerstreut punktirt, mit furchenartiger Querlinie, unter welcher der breite Raum zwischen den Fühlern leicht gewölbt und höher als bei den übrigen Arten ist. Halssch. um die Hälfte breiter als lang, in der Mitte am breitesten, mit gerundeten Seiten, nach hiuten wenig, nach rorn stark verengt und zusammengedrückt, wie der Kopf deutlich gewirkt, mässig dicht punktirt, in der Mitte feiner als an den Seiten. Die Längsfältchen wenig lang und tief. Fld. etwas schwächer gewirkt wie das Halssch., glänzender, ziemlich fein punktirt-gestreift, die Punktstreifen in der hinteren Hälfte oft schwach und erloschen.

Bei frischen Stiucken sind die Beine einfarbig gelblich rostroth.

Auf sonnigen, trockenen Grasplätzen, auf Rainen und Dämmen nicht selten.

2. Mant. ambiguat: Oblonga, modice concexu, obscure cyanea, parum nitida, antennis dimidio basali, tibiis tarsisque ferrugineis, femoribus 4 anterioribus piceis, posticis cyaneo-nigris; linea frontali minus profunda, prothorace crebre profunde punctato, plica laterali profunda, elytris fortiter ac profunde striato-punctatis. - Long. 2,5 mm.

Kutsch. Wien. Monat. 1862. 52 (174), - Redtb. Faun. A. II. 503 (Halt.). - All. Mon. 289 (Balanom.).

Eine mir unbekannte Art, welche Kutschera folgendermassen beschreibt:

Der $M$. obtusatu auf den ersten Aublick gleichend, namentlich hinsichtlich der einfarbig dunkelblanen Oberseite, aber von breiterem 
und stumpterem Umriss, anderer Wölbung und Rumdung des Ilalssch. und durch tiefere und stärkere P'unktirung desselben und der Fld. abweichend. Wenig glïnzend, mässig gewölbt; Oberseite einfarbig dunkelblau, Unterseite sehwäxzlich; untere Fühlerhälfte, śchienen und 'Iarsen rostroth, Vorderschenkel, Klauenglied und Wurzel des ersten Fühlergliedes pechbraun, Hinterschenkel schwar», mit bläulichem Erzschimmer. Scheitel mässig stark punktirt, Quereindruck rer Stirn seicht. Halsseh. fast zweimal so breit als lang, matt grlänzend, ziemlich dicht mit gröberen und tiefen Punkten hesetzt, welche längs der Vitte des Rückens etwas feiner und weitläufiger sind und einen mehr oder weniger deutlichen glatten Längsstreifen ïbrig lassen; die beiden Längsfältchen sehr tief. Fld. etwa um die Hältte länger als breit, an der Spitze riemlich stumpf gerundet, mit tiefen und groben I'unktstreifen, deren erster an der Naht etwas unregelmässig, und mit glatten fast ebenen Zwischenräumen.

Bei Aachen und nach Allard auch bei Paris.

3. VIant. chrysanthemi: Oblonga, convexa, fusco-aeneu, subnitida, antennis articulis 6 primis pedibusque ferrugineis, femoribus posticis aeneo-piceis; linea frontali sat obsoleta, prothorace plus minusve crebre punctato, plica laterali profunda, sed brevi, elytris striato-punctatis, apicem versus ferrugineo pellucidis. - Long. 1,8-2,8 mm.

Koch Ent. Hft. II. 45. - Illig. Mag. VI. 160. - Gyllh. Ins. Suec. III. 578, - Kutseh. Wien. Monat. 1862. 51 (173). Redtb. Fam. A. II. 502. - Bach Käferf. III. 147. Seidl. F. balt. 495 (Halt.), - Foudr. Mon, 273. - All. Mon. 288. - Thoms. Skand. Col. VIII. 226 (Balanom.). Steph. Ill. Brit. IV. 324; Man. 299.

$\mathrm{Var}$ a. Immatura; elytris dilutius subaeneo-ferrugineis, sutura interdum obscuriore.

Balanomorpha chrysanthemi var. Crotchi All. Mon. 501.

Kleiner, etwas gewölbter und glänzender als obtusata, schmal elliptisch, dunkel grülich broncefarben, die Fld. braun durchschimmernd, namentlich vor der Spitze, die sechs ersten Fühlerglieder und die Beine rostroth, Hinterschenkel, oft auch die Mittelschenkel pechbraun, metallisch glänzend. Stirn mässig dicht punktirt, mit flacher Querlinie, unter welcher der Raum zwischen den Fïhlern durchaus eben ist. Halssch. nach hinten wenig, nach vorn stark verengt und zusanmengedrickt, an den seiten gerundet, die Vorderecken nur wenig vom Halse und den Augen abstehend. Die Oberfläche in der Regel eben so tein, selten stärker gewirkt als Kopf und Fld., ziemlich dicht punktirt, längs der Mitte etwas weitläufiger 
und feiner als an den Seiten; das Längsfailtchen jederseits kurz und tief. Fld. mässig stark punktirt-gestreift.

Den Fld. noch nicht ganz ausgehärteter sitiicke fehlt der broncefarbene Ueberzug oft fast gan\%, sie sind röthlichlıraun, an der Naht gewöhnlieh angedunkelt.

In sommer aut Chrysanthemem leucanthemum L. überall häutig.

4. Mant. rustica: Oblonga, sat comexa, nitidula, subtus aeneo-nigra. antennis articulis 6 primis peditusque ferrugineis, femoribus posticis nigris, coeruleo-vel aeneo-micantilus, capite prothoraceque viridi-aeneis, illo linea frontali parum profunde impressa, hoc sat furtiter minus crelore punctato, plica laterali profunda et longa, elytris obscure coeruleis, ipire ferrugineis, striato-punctatis. - Long. 2,3-3 mm.

Linné Syst. Nat. ed. 12. 595 (Chysom.). - Illig. JIag. VI. 159. - Schilling Ber. Schles. Ges. 1846. 92. - Kutsch. Wien. Monat. 1862. 49. - Redtb. Faun. A. II. 502. Bach Käferf. III. 146. - Seidl, F. balt. 495 (Halt.). Foudr. Mon. 271. - All. Mon. 288, - Thoms. Skand. Col. VIII. 225 (Balanom.).

Galleruca semiaenea Fabr. Ent. Syst. I. 2.30. - Payk. Faun. Suec. II. 109. - Harsh. Ent. Brit. I. 194 (Chrysom.). - Ko ch Eut. Hft. II. 43. - Gyllh. Ins. Suec. III. 577. - Duft. Faun. A. III. 277 (Halt.) - Steph. Ill. Brit. IV. 323; Man. 299.

Var. a. Elytris coeruleo-aeneis, apice ferrugineis.

V ar. b. Supra nigro-coerulea, elytris apice ferrugineis.

Var. c. suturalis: Elytris ferrugineis, limbo suturali postice eranescente viridi-aeneo aut coeruleo.

Durchschnittlich grösser und flacher als die vorhergehenden, beiderseits fast gleichmässig verengt, sehr lang elliptisch, unten schwarz metallisch, die sechs ersten Fïhlerolieder und die Beine hell rostroth, Hinterschenkel pechbram oder schwarz, bläulich oder erzgrün angelaufen, öfter auch das erste Fïhlerglied und die vorderen Schenkel gebräunt. Kopf und Halsschild dunkelgriu, bisweilen messinggelb oder kupferig schimmernd. Stim zerstreut punktirt, mit wenig tiefer Querlinie, unter welcher der Raum zwischen den Fühlern ziemlich eben ist. Halssch. um die Hälfte breiter als lang, von der Mitte aus beiderseits fast gradlinig, nach hinten wenig, nach vorn stärker verengt, hier zugleich etwas zusammengedrïckt, jedoch viel schwächer als bei den vorigen Arten, die Vorderecken umschliessen daher den Hals nicht so genau, wie bei diesen, sondern stehen von den Augen weiter ab. Die Oberfläche ist äusserst fein und undeutlich gewirkt, zerstreut punktirt, die Punkte zwischen dem langen und tiefen Iä̈ngsfältchen und dem Seitenrande sind 
öfter zu unordentlichen Längsreihen geordnet. Fld. dunkelblau, an der Spitze in grösserer oder geringerer Ausdehnung rostroth, mässig stark punktirt gestreift.

Die Färbung ist veränderlich:

a. Bisweilen sind die Fld. mit Ausnahme der Spitze bläulich metallgriin oder grün, mit leichtem Messingschimmer, wie das Halssch., oder

b. die Oberseite ist schwarzblau, mit rostrother Spitze der Fld, endlich

c. die Fld. sind rostroth, der Seitenrand und ein mehr oder weniger breiter und rerwaschener Saum an der Naht sehwarzgrün oder dunkelblau. Letzterer ist meist nach rïckwärts verschmälert und endet in zwei Drittel der Länge.

Auf sandigen, feuchten Orten hauptsächlich an Ampfer-Arten ziemlich häufig.

\section{Chaetocnema.}

Stephens, Illustrations of Brit. Ent. IV. 1831. p. 325.

Plectroscelis Redtb. Faun. Austr. ed. 1. 1849. p. 539.

Acetabula antica occlusa.

Tibiae posteriores externe infra medium abmupte emarginatue et dense ciliatae.

Abdomen segmentis 2 primis connatis.

Elytra aut regulariter aut antrorsum prope suturam irregulariter punctato-striata.

Körper eiförmig, länglich-elliptisch, oder fast walzenförmig, mehr oder weniger gewölbt, meist wenig lebhaft metallisch gefärbt, selten unvollkommen oder nicht geflügelt. Kopf geneigt, der Mund nach unten oder nach riickwärts gerichtet, Scheitel breit, gewölbt, ganz oder theilweise punktirt. Die Stimlinien laufen rom oberen Innenrande der Augen schräg nach innen und unten bis zur Fiihlerwurzel, wo sie bei einzelnen Arten in mässiger Rundung, bei anderen unter einem Winkel in eine Querlinie uibergehen, welche im ersteren Falle grade oder nach unten gebogen, im andern bedeutend nach oben zu gebogen ist. Von beiden Enden dieser Linie zieht sich jederseits zwischen die Fühlerwurzel eine Rimne; dieselbe ist entweder breit und tief und hebt den Zwischenraum kielartig empor (Exorhina), oder kurz und undeutlich, so dass der Raum zwisehen den Fühlern ziemlich eben bleibt (Chactocnema). Das Koptsehild ist absehuissig, in der ersten Gruppe dentlich begrenzt, quer, schmal dreieckig, in der zweiten nur undentlich von der Stirn geschieden. 
Die ()herlippe ist quer viereckig, an den Ecken abgerundet. leicht neswollht, in oder vor der Mitte mit einer Qurreihe von starken Punkten, am Vorderrande abwiirts gebogen und oft seicht ausgrehuchtet (z. B. bei semicoendea), oder die Lippe ist der Quere nach vertieft und an der Basis mit eines Reihe gruhentrimniger Punkte besetzt, ihr Vorderrand algestutzt und mehr oder weniger leistenförmig aufgebogen (aridula). Die Mandibeln endigen in zwei grosse und spitze Zähne, von denen der äussere länger als ler innere ist, oft befindet sich auch noch ein kleines, undeutliches Zähnchen auf jeder Seite; Waxillartaster kurz und dünn, Glied 2 und 3 rerkehrt kegelförmig, 4 konisch. Fülıler elfgliedrig. fadenförmig, kaum so lang als der halbe Körper, Glied 3 bis 6 sehr schlank, die fünf letzten Glieder etwas verdickt. Augen oval, bald flach, fein facettirt, bald gewölbt, stärker facettirt. Halssch. quer, schmaler oder ziemlich so breit als die Fld., an der Basis leicht gerundet, an der spitze grade abgeschitten, nur nach vorn, oder auch noch schwächer nach rückwärts verengt, mit fast gradlinigen oder gerundeten Seiten; die Oberfläche querüber gewölbt, mehr oder weniger dicht punktirt, selten mit einem kurzen Längsstrichelchen oder einem Schrägeindrucke jederseits am Grunde. Von den Eckporen ist die vordere gross, ein Stïck hinter der Ecke eingestochen. die hintere kleiner, in der Seitenkante jeder Hinterecke, die Borsten fein und ziemlich kurz. Schildchen klein, gerundet dreieckig. Flügeldecken länglich eiförmig, hinten etwas rerschmälert und an der Spitze beinahe regelmässig gemeinschaftlich abgerundet, die Spitze selbst umgebogen und in die Rinne der Afterdecke eingelegt, welche ein Stückchen unbedeckt bleibt. Die Oberfläche ist mit neun ganzen und einem abgekürzten Punktstreifen an der Naht versehen, oder in Reihen punktirt, welche sich in der vorderen Hälfte nahe der Naht meist verwirren; Epipleuren ziemlich breit, rückwärts allmählich verengt. wenig vor der Spitze erlöschend. Prosternum mit hohem (semicoemulea) oder tief liegendem Vorderrande (aridella), zwischen den Hüften ziemlich schmal, dahinter stark abwärts gewölbt, verbreitert und mit den Seitenstücken verbunden, so dass die Pfamen geschlossen werden; Mittelbrust kurz, quer; Hinterbrust zwischen die Hittelhüften mehr oder weniger weit vorgezogen, ziemlich glatt oder stark punktirt. Bauch gewölbt, erstes und zweites segment verwachsen, mit sichtbarer Naht, zusammen so lang als die übrigen Ringe. Beine kräftig, mässig lang, Hinterschenkel stark verdickt, sehr breit spindelförmig, Vorderschienen einfach, an der Aussenseite leicht gewölbt, Mittelund Hinterschienen aus dünner Basis allmählich verbreitert, auf 
dem Riicken schief abgeflacht oder vertieft, indem die äussere Seitenkante höher als die innere ist, hinter der Mitte bis zur spitze ausgeschnitten und schwach rinnenf"ormig auswehöhlt. Diese Ausbuchtung dient zur Aufnahme des ersten Tarsengliedes, sie beginnt plötzlich und scharf meist hinter einem breiten Kahne, in den die Aussenkante des Rüickens ansteigt (die Innenkante nicht) und ist an beiden Rändern mit weisslichen Wimperhaaren besetzt. Letztere stehen auf dem Aussenrande äusserst gedrängt neben einander und sind beinahe ron gleicher Länge, nur die ersten an der Basis bedeutend länger als die übrigen und öfter büschelförmig zusammen gebogen, die Härchen des Innenrandes sind weitläufiger gestellt, in der Mitte am längsten, beiderseits allmählich verkürzt. Am Ende der Hinterschienen befindet sich ein starker, aufwärts gebogener Dorn. Die Länge des ersten Tarsengliedes ist ungefähr dem Viertel oder 1)rittel der Schiene gleich, das zweite Glied ist kaum halb so lang, das dritte zweilappig, Klauen am Grunde zahnförmig erweitert.

Beim Männchen ist das erste Tarsenglied an den vorderen Beimpaaren stark verbreitert, die Ausrandung auf dem Rücken der Schiene, namentlich an den Mittelschienen tiefer als beim Weibchen, der Hinterrand des letzten Bauchringes nicht abgerundet, sondern ziemlich gleichmässig, oder nur auf beiden Seiten abgestutzt und in der Mitte in einen mehr oder weniger grossen Zipfel rorgezogen, endlich weicht die Skulptur der Flügeldecken in der Stärke, der Verbindung der Punktstreifen vor der Spitze und zuweilen auch in dem Ersatze ron Runzeln durch Punkte in den Zwischenstreifen von der des Weibchens ab. Der Penis ist einfach gebaut, eine flach gedrückte Röhre mit langer Oeffnung, am Ende zugespitzt, abgerundet, oder in einen kurzen Fortsatz verlängert.

Die Gattung ist durch die ausgerandeten Mittel- und Hinterschienen und die grossen, mit einander verwachsenen beiden ersten Bauchsegmente von allen übrigen verschieden; sie wird sich in Zukunft wohl als eine der umfangreichsten herausstellen, denn von den vielen, über alle Erdtheile verbreiteten Arten ist bis jetzt nur ein geringer Theil, wenig iiber 130 Arten, beschrieben worden, wovon auf Deutschland noch nicht 20, auf Europa und Sibirien gegen 30 entfallen. Dieselben leben auf verschiedenen niederen Pflanzen, einige nur an trockenen, andere an feuchten Orten, wenige auf' Weidenbiischen, doch ist ihre Entwicklung noch unbekannt.

Stephens stellte zuerst die ihm vorliegenden Arten aridella, Sahlbergi, aridula und concinna zu einer Gattung zusammen, allein seine Benennung Chaetocnema gelangte zunächst nicht zur Annahme. 
weil sie von dem spaiter') durch ('hevrolat in ('at. 1)ej. cingutührten und durch Redtenbacher 1849 berrindeten Nimen I'lertroscelis verdrängt wurde. Derselbe ist mit Chatornema vollkommen identisch und daher weder als Gattungs- noch Gruppenbezeichnung branchbar. Eine Zerlegung in zwei Gattungen, welche Foudras und Thomson hauptsächlich durch die verschiedene Bildung der Oberlippe und Stirm zu rechtfertigen versuchten, lisst sich, schon bei der Berïcksichtigung der europäischen Arten, nicht schart genug durchfïhren, weil sich die Lnterschiede ziemlich verwischen. wie ein Vergleich der Oberlippe von $C h$. major mit procerula. oder der Stirnbildung von conducta oder Coyei mit irgend einer echten Chatocnema zur Geniige zeigt. Das einzige, noch einigermassen stichhaltige Merkmal, die in der Mitte glatte Hinterbrust bei den Thieren der ersten Gruppe im Gegensatze zu der stark und dicht punktirten Hinterbrust der zweiten, dürfte für die Begrenzung von Gruppen, aber nicht von Gattungen ausreichend sein.

\section{Uebersicht der Chaetocnema-Arten:}

1. Vorderkopf mit mehr oder weniger hohem Längskiele, einem dentlichen, quer dreieckigen, abschüssigen Kopfschilde und einer Rinne zur Einlagerung des ersten Fühlergliedes unter jedem Auge. Metasternum glatt oder vereinzelt punktirt. Körper mässig gewölbt. Subgenus: Exorhina . . . . 2.

$1^{1}$. Vorderkopf breit, eben, ohne Kiel, Fühlerrinne oder ein deutlich begrenztes Kopfschild. Körper gewölbt, fast walzenförmig. Subg.: Chaetocnema in spec. . . . . . . . . . . 14.

2. Oberseite einfarbig schwarz, blau, grün oder messingfarbig 3 .

21. Fld. grösstentheils hellgelb oder gelblich braun . . . . 11.

3. Hals breit, der Kopf daher nicht ganz bis zum Hinterrande, der flachen Augen in das Halssch. eingezogen, die Schläfen und die grob punktirten Wangen hinter ihnen sichtbar. Körper lang-elliptisch . . . . . . . . . . . . . . 4 .

$3^{1}$. Hals schmal, der Kopf bis zum Hinterrande der mehr oder weniger gewölbten Augen eingezogen, hinter diesen weder Schläfen noch Wangen sichtbar . . . . . . . . 7.

1) Allard citirt (Mon. 272) mit Unrecht Latreille als Autor von Plectroscelis, da an dem von ihm angegebenen Orte (Règn. Anim. V. 139 et 519) von Haltiken keine Rede ist und Latr. die hier besprochenen Arten nur in einer Note (l. c. V. 154) erwähnt, ohne sie zu benennen. 
4. Halsschild an der Basis jederseits mit einem tiefen Längrsstrichelchen, welehes mit der Randlinie an der Basis verbunden ist, die den Hinterrand scharf und ziemlich breit leistenfrirmig in die Höhe hebt . . . . . . . . . . . . . . . 5.

4². Halssch. ohne spur von Längsstrichelchen, an dei Basis sehr fein gerandet

5. Scheitel mit einem Querstreifen ron wenigen starken P'unkten, Halssch. ungleichmässig, wenig dicht punktirt, in den Vorderecken nicht erweitert; Oberseite griin, blau oder schwarz. L. 2,7-4 mm. Siidwestliches Viertel von Europa. Algier

chlorophana Duft.

51. Scheitel ohne grobe Punkte, Halssch. gleichmässig sehr dicht punktirt, an den Vorderecken erweitert und schwach napfförmig vertieft. Zwischenstreifen der Fld. deutlich punktirt. Oberseite dunkel und wenig lebhaft grünlich-blau. L. 3-4,5 mm. Frankreich, Spanien . . . . . . major Duval.

6. Scheitel mit einem Querstreifen von zahlreichen starken Punkten, Halsschild gleichmässig sehr dicht punktirt, mit glänzenden Zwischenräumen, in den Vorderecken nicht erweitert, Zwischenstreifen der Fld. fein querrunzelig. Oberseite grün, bald bläulich, bald messinggelb oder kupferig schimmernd. L. 3-4 mm. Griechenland, Türkei, Südrussland, Kaukasus, Kleinasien, Syrien . . . . . . . . Coyei All.

Die Farbe der Oberseite ändert ab (Var. metallica) in metallisch braun, oft mit einer leichten kupferigen oder messinggelben Beimischung, jedoch ohne grünen Schimmer.

61. Stirn zerstreut punktirt, neben jedem Auge dichter; Halssch. gleichmässig sehr dicht punktirt, mit deutlich gewirkten, ziemlich matten Zwischenräumen, in den Vorderecken nicht erweitert. Zwischenstreifen der Fld. fein und deutlich punktirt. Oberseite dunkel bräunlich metallisch. - L. $2 \mathrm{~mm}$. Oesterreich. Ungarn. Tïrkei . . . . . . Scheffleri Kutsch.

7. Halssch. in der Mitte glatt, nach den Seiten zu sehr fein punktirt. Schwarz, Fühler mit Ausnahme der dunklen Spitze, Knie, Schienen und Tarsen rostroth. Fld, fein punktirtgestreift. - L. 1,5mm. Südliches Schweden laevicollis Thoms.

$7^{1}$. Halssch gleichmässig und deutlich punktirt . . . . . . 8.

8. Halssch. in der Randlinie am Grunde zu beiden Seiten des Schildchens mit 3 bis 6 starken Punkten, vor der Basis jederseits mit einem mehr oder weniger tiefen Schrägeindrucke, welcher den Raum bis zu den Hinterecken etwas wulstartig in die Höhe hebt . . . . . . . . . . . 9.

81. Halssch. ohne Eindriicke oder stärkere Punkte an der Basis 10. 
9. Stirn mit einem Querstreifen von zahlreichen groben P'unkten. Vorderbeine in der Regel einfarbig rostroth. - L. 2-3 mm. Mittel- und Siideuropa . . . . semicoerulea Koch. 91. Stirn neben jedem Auge mit 3 bis 6 groben Punkten. Vorderschenkel stets schwarz. - L. 1, $,-2,6 \mathrm{~mm}$. (tanz Europa unl Sibirien . . . . . . . . . concinna Marsh.

10. Stirn auf jeder Seite mit ungefähr 10 Punkten, die beinahe einen Querstreifen bilden. Halssch. gewölbt, dicht punktirt, Zwischenräume kaum so gross als die Punkte. Oberseite braunerzfarbig, gleichmässig glänzend, Fld. tief punktirt-gestreift. L. 1,5-2,2 mm. Oesterreich. Siideuropa . . tibialis Illig. 101. Stirn neben jedem Auge mit 2 bis 5 Punkten, Halssch. wenig gewölbt, mässig dicht punktirt, Zwischenräume doppelt so gross als die Punkte. Oberseite grün-, seltener braunerzfarbig, Kopt und Halssch. sehr deutlich gewirkt, mit mattem seidenartigen Schimmer, Fld. glänzend, nur mässig tief punktirt-gestreift, Zwischenstreifen sparsam, äusserst fein punktirt. - L. $2 \mathrm{~mm}$. Krim, Astrachan, Kaukasus. . . breviuscula Fald.

11. Körper breit eiförmig, mässig gewölbt, Fld. mit starker Schulterbeule .

11'. Körper lang eiförmig, flach, Fld. mit sehr schwacher Schulterbeule . . . . . . . . . . . . . 13.

12. Kopf und Halsseh. deutlich punktirt, metallisch grün mit leichtem Messingglanze; Naht der Fld. bis zum ersten Punktstreifen, die Schulterbeule und der äuserste Zwischenstreifen am Seitenrande schwarz metallisch. - L. 1,5-2,5 mm. Oesterreich. Südeuropa . . . . . . . . . . conducta Motsch.

121. Kopf und Halssch. undeutlich punktirt, glänzend broncegriin, seltener schwarz metallisch, eben so ein Saum an der Naht der Fld., der bis zum zweiten Punktstreifen reicht und vor der Mitte allmählich bis zur Schulter verbreitert ist, die schulterbeule und die drei äusseren Zwischenstreifen. Auf jeder Fld. bleibt eine gebogene weisslichgelbe Längsstrieme iibrig, die in der vorderen Hälfte nur schmal, in der hinteren ziemlich breit ist. - L. 1,5-2 mm. Suidungarn (Merkl), Griechenland (Kutschera), Mersina . . . . . orientalis Baud.

13. Stirn so dicht punktirt und gewirkt wie das Halssch., beide wenig glänzend, schwach goldig-grün, Fld. hell bräunlich-gelb. ein schmaler Saum an der Naht und am seitenrande schwarz. -- L. 1,7-2,3 mm. Südwestliches Europa depressa Boield. 131. Stirn mit wenigen Punkten, dentlicher gewirkt und matter als das Halssch., Fld. hell gelbbram, eine verwaschene, sehr breite 
gemeinschaftliche Querbinde schwairzlich. - Is. 1, - 2,5 1 mm. Derbent . . . . . . . . . nebulosa Ws. ${ }^{1}$ )

14. Körper schlank, fast gleichbreit, unvollkommen gefligelt, Fld. regelmässign punktirt-gestreift, in den Schultern nicht heraustretend und ohne merkliche Beule . . . . . . 15 .

14'. Körper länglich eiförmigr, in der Regel geflügelt, Fld. breiter als das Halssch., in den Schultern vorspringend, mit deutlicher Schulterbeule, an der Basis und Naht verworren-punktirt, iiber dem Aussenrande und hinter dex Mitte (selten iiberall gleichmässig) gestreift-punktirt . . . . . . . . . . 17.

15. Fld. sehr tief punktirt-gestreift, mit schmalen, fast kielförmigen Zwischenstreifen, die äusseren Punktreihen laufen iiber die Schulter fort bis zur Basis. Oberseite dunkel metallisch gruin bis grinlichblau, Kopf und Halssch. dicht und fein punktirt. L $2 \mathrm{~mm}$. Alpen, Französisches Bergland, Pyrenäen

angustula Rosh.

15 ${ }^{1}$ Fld. mässig tief punktirt getreift, mit breiteren $\mathrm{Zwischenräumen,}$ von denen höchstens die über dem Seitenrande liegenden etwas gewölbt sind. Die 6. bis 8. Punktreihe ist hinter der Schulter abgekiirzt, so dass auf dieser ein glatter Raum entsteht, Kopf und Halssch. mässig dicht, fein punktirt . . . . . . 16.

16. Stirn sparsam und äusserst fein punktirt. Schwarz, mit

1) Chaetocnema nebulosa: Elongato-elliptica, depressiuscula, nigra, subritida, antennis apice fuscis, tibris tarsisque testaceis; capite prothoraceque viridi-aeneis, alutaceis, illo carina faciali elevata, fronte utrinque punctis nonnullis impressa; prothorace antrorsum angustato, crebre evidenter punctato; elytris testaceis, fascia media communi lata, infuscata, suturam versus dilatata instructis, profunde punctato-striatis, interstitiis angustis convexis. - Long. 1,8-2,5 mm. Russia merid.

Am nächsten mit Ch. depressa Boield. verwandt, aber beiderseits stärker verschmälert, die Punktstreifen der Fld, viel tiefer, mit grösseren Punkten besetzt, so dass die Zwischenstreifen äusserst schmal werden, ausserdem an den wenigen Punkten der Stirn sofort zu unterscheiden.

Auf den gelbbraunen Fld, befindet sich eine etwas dunklere, sehr verwaschene gemeinschaftliche Querbinde, welche mit ihrem grösseren Theile von der Mitte liegt und sich nach der Naht hin so verbreitert, dass sie in der einen Spitze das Schildchen, in der anderen das letzte Viertel der Länge erreicht; dadurch wird die hellere Grundfarbe anf 4 grosse. längliche, jedoch sehr unbestimmte Makeln reducirt, wovon die eine an der Basis um die Schulter herum. die andere auf dem hinteren Drittel ser Fld. liegt, deren Seitenrand wie bei depressa schwärzlich ist.

In der Umgegend von Derbent von $\mathrm{H}$. Faust gesammelt.

VI. 4. 
schwachem hliulichen oder qrïnlichen Anfluge. I. 1, $4-2,4 \mathrm{~mm}$. Frankreich, Deutschland, (Hesterreich. Griechenland

compressa Letzn.

16. Ntirn deutlich punktirt. Kopf und Halssch. schwarz mit Metallschimmer, Fld. blau oder blaugriun. zuweilen (Var. aenescens) die Oberseite einfarbig braun broncefarben. - $\mathrm{I}, 2,4-2,5 \mathrm{~mm}$. Uesterreich, Sülfrankreich, Spanien, Algier procerula Rosh.

17. Kopf iiber der Querlinie der stim bedeutend feiner punktirt als unterhalb derselben, Punktirung des Halsschildes mehr oder weniger dicht und fein

17 $7^{1}$ Kopf über der Querlinie der Stirn so stark oder nur unmerklich schwächer punktirt als unterhalb derselben, Halssch. stark und sehr dicht punktirt, gewirkt, wenig glänzend . . . 24.

18. Fld. an Stelle der sechs inneren Punktreihen, sehr dicht. fein, verworren und schwach runzelig punktirt, die äusseren Streifen, sowie die inneren hinter der Mitte fein und wenig tief. Kurz eiförmig, schwarz, mit einem bläulichen, grünlichen oder broncefarbenen Schimmer, Fühler pechschwarz, ihre 5 bis 6 ersten Glieder, die Schienen und Tarsen röthlich gelb. - L. 2,3-3 mm. Suideuropa ... . . . . . . arenacea All.

$18^{1}$. Fld, bald in ziemlich regelmässigen Reihen, bald vor der Mitte melr oder weniger weit verworren punktirt, mit deutlichen, oft breiten Zwischenräumen der Punkte . . . . 19.

19. Oberlippe verhältnissmässig gross, an Vorder- und Seitenrande rostroth, breit aufgebogen. Kurz eiförmig, stark gewölbt, Kopf, Halssch. und Schildehen schwarz, mit starkem dunkelgrimen Messingglanze, Fld. dunkelblau, viel weniger glänzend. punktirtgestreift, vor der Mitte mit überzähligen Punkten neben den Reihen. - L. 2,5-3 mm. Schlesien. Oesterreich, Ungarn, Suideuropa . . . . . . . meridionalis Foudr.

19². Oberlippe von gewöhnlicher Grösse. einfarbig schwarz . 20.

20. Die Punktreihe der Oberlippe bildet einen starken Bogen, der nach dem Kopfschilde zu gerichtet ist. Kurz eiförmig, hoch gewölbt, oben dunkelblau oder schwarzgrün, mit messinggelbem Anfluge, stärker glänzend als alle verwandten Arten. Fld. verworren, wenig dicht, aber kräftig punktirt, iiber dem Aussenrande und hinter der Mitte mit Punktstreifen und breiten, merklich gewölbten Zwischenräumen. - L. 2,5-3 mm. Schweden, Mitteleuropa. . . . . . . . confusa Bohem.

201. Punktreihe der Oberlippe grade . . . . . . . . . 21.

21. Oherseite dunkelblau, selten mit grünlichem Schimmer, Halssch. bisweilen schwarz. . . . . . . . . . . . . 22.

$21^{1}$. Oberseite schwarz exzfarbig oder grün mit Bronceschimmer 23. 
22. Lainglich oval, Fld. auf dem Ruicken grösstentheils verworren punktirt. - L. 2,2-3,2 mm. Mitteleuropa. Sibirien

Mannerheimi Gyllh.

2:1. Gestreckt, sehr lang oval, die starken Punktreihen der Fld. nur ganz vorn neben der Naht verworren. - L. '2-2,5 mu. England, schlesien. Oesterreich . subcoerulea Kutsch.

23. Länglich oval. Oberseite schwarz, mit geringem grüinlichen oder Iräunlichen Bronceschimmer. Taster und die ersten Fühlergrlieder dunkel rostroth. In Gestalt and Grösse der Mannerheimi am ähulichsten. - I. 2,5-3 mm. Ganz Europa

aridula Gyllh.

231. Kurz oral, Oberseite mehr oder weniger dunkel broncegrün, die ersten Fühlerglieder und Taster röthlichgelb; der hortensis tïuschend ähnlich. - L. 1,6-2,5 mm. Mitteleuropa a rida Foudr.

24. Die Taster und ersten Fiihlerglieder einfarbig röthlichgelb, die vorderen Beine in der Regel ziemlich ganz rostroth. Oberseite erzgrün, Fld. weit verworren punktirt oder ziemlich regelmässig punktirt-gestreift. - L. 1, - $2,8 \mathrm{~mm}$. Europa, Sibirien

hortensis Fourcr.

24. Taster und die ersten Fühlerglieder dunkel rothbraun, Schenkel schwarz, Schienen und Tarsen rostroth . . . . . . 25 .

25. Käfer schwarzblau, bläulichgrün oder violett, Fld. fettig glänzend, die Punktreihen vorn verdoppelt. - Ganz Europa

Sahlbergi Gyllh.

251. Käfer erzfarbig oder kupferig, Fld, glänzend, regelmässig punktirt-gestreift. - I. 1, $\mathrm{mm}$. Schlesien, Alpen aerosa Letzn.

I. Frons carina faciali plus minusve elevata et linea utrinque impressa bene discreta, scrobiculo antennati obliquo clypeoque triangulari sat distinctis; metastermm fere laeve. (Plectroscelis Foudr.) Exorhina Ws.

A. Collum latum, oculi parum convexi.

1. Charet. chlorophana: Elongato-elliptica, modice convexa, subtius nigro-aenea, supra laete aeneo-vividis obsolete alutacea, sat nitida, antennarum basi interdum etiam tibiis tarsisque obscure ferrugineis, femoribus cyanescentibus; fronte punct is nonnullis impressa, prothorace brevi, apicem versus angustato, sat crebre inaequaliterque punctato, basi evidenter marginato et utrinque striola breci impresso, elytris striato-punctatis, interstitiis planis. - Long. 2,7-4 $\mathrm{mm}$.

II as: interstitiis elytrorum leviter rugulosis è parce punctulatis, tarsis anterioribus articulo primo sat dilatato.

Duft. Faun. A. III. 286 (Halt.). - Redtb. Faun. A. ed. I. 539; ed. 3. II. 511. - Bach Käferf. III. 160. - Foudr. 
Ion. 98. - Kutsch. Wien. Jonat. 18h4.319(326). - All. IIon. 275.

Halt. dentipes Oliv. Ent. VI. (1808) 711. t. 4. f. 78.

Var. a. Antennarum basi tibiis tarsisque rufo-testaceis.

Var. b. laeta: Supra aurichalcea, aureo-cuprea vel fuscu aencu

Tar. c. amoena: Supra laete coerulea, cyanea aut violnceu totu, interinm capite prothoraceque aeneo-viridibus.

Var. d. Kolbei: Supra nigra.

Gefligelt. Länglich-elliptisch. mässig gewiilht, unten schwarz metallisch, Śchenkel schwarzblau orler erzfarbigr, śchienen und T'arsen pechschwarz, dunkel rostroth orler (Var. a) röthlich gell)braun. Oberseite lebhaft grïn mit Messingschimmer, oder dunkler grün. meist mit bläulichem Anfluge. Fühler verhältnissmäissig lang und kräftig, pechschwarz, die ersten vier oder fünf Glieder theilweise oder ganz dunkel rostroth, bei der Var. a. röthlich gelbbraun. Kopf gross, nicht ganz bis zum Hinterrande der wenig gewölloten Augen in das Halssch. eingezogen, Stirn verloschen gewirkt, mit mehr oder weniger zahlreichen starken Punkten auf einem streiten zwischen dem Oberrande der Augen, einer tiefen stirnlinie und schmalem Kiele zwischen den Fühlern. Halssch. kurz, dopuelt so breit als lang, nach vorn wenig verengt, mit schr schwach gerundeten, fast graden Seiten, ziemlich stark querïber gewïll,t, namentlich in der vorderen Hälfte, ungleichmässig und wenig dicht punktirt. In den Zwischenräumen, von denen einzelne breit, andere schmal sind, stehen feine Punkte, zugleich ist ihr Grund verloschen gewirkt und schwach gerunzelt. An der gerandeten Basis befindet sich jederseits ein kurzes, tiefes Längsstrichelchen. Fld. regelmässig und stark punktirt-gestreift, Zwischenräume eben, schwach gewirkt und kaum merklich punktulirt ( $q$ ), oder fein punktirt und gerunzelt $(\hat{\sigma})$; die Schulterbeule klein, nicht vorspringend.

Beim Männchen ist das erste Tarsenglied an den vorderen Beinen etwas erweitert und so breit als das dritte, der letzte Bauchring bedeutend kuirzer als beim Weibchen, am Hinterrande dicht und lang weisslich bewimpert, abgestutzt und in der Mitte unbedeutend vorgezogen. - Penis beinahe so lang als der Hinterleib. gebogen, oben gewölbt, unten rinnentörmig ausgrehöhlt, vorn in schwacher Rundung allmählich in eine feine, am Ende abgestutzte Spitze verengt.

Die Farbe der Oberseite geht, inden Griin allmählich verdrängt wird, bei der Abänderung b. in ein reines Messinggelb. ein goldiges Kupferroth oder ein metallisches Braun, bei der Var. c. in himmelbis kornblumenblau und violett uiber; die auffällige Var. d. ist oben tief schwarz. 
Bei Kassel (Bach); in der Ungegend von Wien wurde das Thier hauptsächlich von $\mathbf{H}$. Kolbe in der Brühl bei Mïdling in Menge auf einer Agrostis-Art gesammelt, die Var.d. war selten. Aussertem in Italien, Nüdfrankreich, Spanien, Algier.

2. Chaet. Schefflemi: Elongato-elliptica, modice convexa, nigro-ceneu, supra olscure aenea, antemurum basi tibiis tarsisque formgineis, fronte munctis nonmullis impressa prothoraceque alutaceis, subsericeo micantibus, hoc transererso, antrorsum angustato, dense subtiliter punctato, elytris sat niticlis, regulariter substriato-punctatis, interstitiis evidenter punctulatis.

- Long. $2 \mathrm{~mm}$.

Kutsch. Wien. Monat. 1864. 315 (321). - All. Mon. 275. Redtb. Faun. A. II. 510.

Bedentend kleiner und schlanker als die vorige, beiderseits stärker verengt und zusammengedrückt, der Ch. hortensis am ähnlichsten gefärlbt. Geflïgelt, lang elliptisch, mässig gewölbt, unten schwarz metallisch. oben trïbe, mehr bräunlich als grün erzfarbig, Kopf und Halssch. dicht gewirkt, matt seidenschimmernd, Fld. glïnzend. Fühler etwa halb so lang als der Körper, die ersten vier bis sechs Glieder (wie die Schienen und Tarsen) dunkel rostroth, die iibrigen pechschwarz, eben so das Wurzelglied in der Basalhälfte. Kopf klein, kaum bis zum Hinterrande der grossen, ziemlich flachen Augen in das Halssch. eingezogen, Stirn sparsam grob punktirt, in der Nähe der Augen etwas dichter, Kiel schmal grewïlbt, glatt, glänzend. Halssch. um die Hälfte breiter als lang, nach vorn rerengt, mit fast graden Seiten, oben stark querüber gewölbt, beinahe gleichmässig dicht und ziemlich fein punktirt. ohne Eindrücke oder stärkere Punkte vor der sehr schmalen und undeutlichen Leiste am Basalrande. Fld. mit regelmässigen, wenig starken Punktreiluen, von welchen nur die beiden inneren und die :iusseren in schwachen Streifen stehen; ihre Zwischenräume sind sehr fein. aber tief und deutlich punktirt, Schulterbeule klein.

Diese, von Kutschera nach einem $f$ aus Niederösterreich (Scheffler) beschriebene Art, ist nenerdings von $\mathrm{H}$. Merkl in einigen Stiicken in der Türkei aufgefunden worden.

\section{B. Collum angustum, oculi convexi.}

a. Elytra aut coerulea aut aenea.

* Prothorax ante basin utrinque impressione olliqua instructus, linea marginali in basi utrinque profindius impressa et fortius punctata.

3. Chart. semicoerulea: Subovalis, modice convexa, nigru, capite prothoraceque aeneis, aurichalceis aut obscure cupreis, elytris coeruleis 
interdum viridi-micantibus, antennarum basi peditusque formuineis, femoribus josticis nigris; vertice punctato, prothorace transterso, unte medium angustato, lateribus subrotundato, crebre punctato, elytris striutojunctriss, tuberculo humerali prominuls. - Long. 2-3 $\mathrm{mm}$.

Mas: tarsis anterioribus articulo mimo magno, interstities elytrorum sulstilius et fere biseriatim punctulatis.

Femina: interstitis elytrom alutaceis.

Koch Ent. Hft. II. 40. -- Illig. Mag. VI. 15\%. - Duft. Faun.

A. III. 277 (Haltica). - Redtb. Faun. A. ed. 1.539; ed. 3.

II. 510. - Küst. Käf. Eur. 28. 94. - Bach Käferf. III. 159. - Foudr. Mon. 99. - All. Mon. 277. - Kntsch.

Wien. ALonat. 1864.312 (318). - Se idl. F. balt. 50n (Plectrose.).

Var. a. femoralis: Femoribus anterionibus nigris, tarsis plerumque infuscatis Var. b. saliceti: Elytris aurichalceis, cupreis, aeneis aut aeneo-nigris

Kürzer und viel breiter gebaut als die rorigen Arten, ziemlich eiförmig, mässig gewölbt, schwarz, Kopf und Halssch. metallisch grïn, messing- oder kupferfarbig, Fld. dunkelblau oder blaugrüin, selten schwach violett. Fühler schwärzlich, die ersten fünf oder sechs Glieder und die Beine, mit Ausnahme der schwarzen Hinterschenkel, rostroth. K opf klein, mit schmalem. etwas gewölbtem Stirnkiele und kleinem Munde. auf der Stirn fein gewirkt, neben den Augen und auf dem Scheitel punktirt. so dass ein grosser. länglicher Raum iber der Stirnlinie ron Punkten trei bleibt. Halssch. um die Hälfte breiter als lang, hinter der Mitte am breitesten, nach rückwärts wenig und gerundet. nach rorn stärker und melur gradlinig rerengt, die Vorderecken etwas rorgezngen und nach aussen gedrückt, recht- oder spitzwinkelig, vor der Borstenpore meist grubig vertieft, die Oberseite schwach gewölbt, äusserst fein lederartig gerunzelt und gleichmässig dicht punktirt, in der Mitte feiner als an den Seiten. Wenig ror der Basis befindet sich jederseits ein weiter Schrägeindruck, welcher den Raum über dem Seitenrande, namentlich im hinteren Theile leicht in die Höhe hebt. die Randlinie der Basis vertieft sich zu beiden Seiten des Sichildehens ungefähr bis hinter den Schrägeindruck und ist mit 3 bis 7 starken Punkten besetzt. Fld. am Grunde etwas breiter als das Halssch., mit grosser, deutlich rorspringender Schulterbeule, starken Punktstreifen und flachen oder gewölbten Zwischenräumen. Bei vieleu Exemplaren wird durch einen Quereindruck hinter der Basis der Raum zwischen dem sehr tiefen vierten und fïnften Punktstreifen und dem Schildehen beulenartig aufgetrieben. Gefligelt.

$\widehat{\sigma}$ Erstes 'Tarsenglied der vier Vorderbeine verlängert und ziemlich stark erweitert, letzter Bauchring auf einem breiten Längsstreifen über die Mitte ziemlich glatt, am Hinterrande abgestutzt, Zwischenstreiten der Fld, mit je zwei unregelmässigen Reihen 
ïusserst feiner I'unkte, beim of dagegen sehr fein grewirkt. Penis so lang als die vier letzten Bauchringe zusammen, in den ersten zwei Dritteh gleichbreit, daror allmählich in eine scharfe Spitze verengt, der verschmälerte 'Theil, von der seite betrachtet, schwach wellig gehogen: die Oeffnumg nimmt viel melur als die vordere Hälfte ein.

Die Farbe der vorderen schenkel verändert sich zuweilen in dunkel rostroth bis pechbraun und geht zuletzt in ein ziemlich reines oder metallisches Schwarz üher (Var. a), die der Fld. wird nicht selten messinggelb, kupferig; spangriin- oder erztarbig-schwarz (Var. b).

Auf Weidengebüschen an sandigen Flussuferm in Mittel- und Südeuropa nicht selten, in der Mark besonders an der Oder und Elbe. Die Abänderung a tritt in Süddentschland nur vereinzelt unter der gelbbeinigen Hauptform auf, scheint aber in einzelnen G'egenden Siideuropa's ausschliesslich vorzukommen z. B. bei Rom, wo sie ron $H$. Strasser aus München gesammelt wurde.

4. Chaet. concinna: Subovalis, modice convexa, aeneo-nigra, nitida, supra plerumque leviter viridi-, aurichalce-vel cupreo-micans, antennarum basi, tibiis tarsisque fusco-ferrugineis, fronte postice utrinque punctis nonnullis impressa, prothorace brevi, apicem versus angustato, lateribus rotundato, in disco crebre et concinne punctato, elytris punctato-striatis, tuberculo humerali subprominulo. - Long. 1,8-2,6 mm.

II as: tarsis anterioribus articulo primo valde dilatato, elytris vage punctatostriatis interstitiis subtilius punctulatis.

Femina: elytris profunde punctato-striatis, interstitiis obsolete alutaceis.

II a rsh. Ent. Brit. I. 1802. p. 196 (Chrys.). - Steph. Ill. Brit.

IV. 327: Man. 302. - Kutseh. Wien. Monat. 1864.313. -

Thoms. Skand. Col. VIII. 229. - Redtb. Faun. A. II.510.

- Seidl. F. balt. 500 (Plectrosc.).

Haltica dentipes Koch Ent. Hft. II. 1803. p. 38. t. 3. f. 1. - Illig. Mag. VI. 162. - Duft. Faun. A. III. 278, - Gyllh. Ins. Suec.

III. 573. - Redtb. 1. c. ed. 1. 450 (Plectrosc.). - Küst. Käf.

Eur. 28. 95. - Bach Käferf. III. 160. - Foudr. Mon. 101. -

A 11. Mon. 277.

Den dunklen Stücken der Var. saliceti von der vorhergehenden Art ähnlich, aber noch kürzer als diese, ziemlich eiförmig, schwarz metallisch, oben dunkel grünlich- oder bräunlich erzfarben, seltener schwach kupferig oder broncefarbig, glänzend, die ersten fünf Fühlerglieder nebst den schlanken Schienen und Tarsen rothbraun, theilweise noch dunkler. Kopf klein, mit schmalem Stirnkiele und äusserst fein gewirkter Stirn, auf welcher sieh neben jedem Auge ein Punkthåufehen befindet. Halssch, kurz, doppelt so 
treit als langr, nach vorn in leichtem Bogren verenet. mit kaum vorgezorenen, stumpt-alggerundeten Vorderecken; ziemlich stark queriiber gewïlbt, gleichmässig fein und sehr dicht, doch etwas stürker als bei semicoeruler punktirt. Die Randlinie an der Basis ist ehenfalls auf jeder Seite des Schildchens vertieft und mit einigen groben Punkten besetzt, aher der Schrägeindruck jederseits sehr schwach, oft erloschen. Fld. am Grunde etwas breiter als ilas Halssch., die schulterbeule deutlich, aber wenig vorspringend, die Punktstreifen regelmässig und stark. Gefliigelt.

$\widehat{\jmath}$ Erstes Tarsenglied der vier Vorderheine breit, letzter Bauchring vorn sparsam punktirt, glänzend, hinten sehr dicht punktirt, matt, am Hinterrande abgestutzt und in der Yitte in einen kleinen niedergedriickten Zipfel verlängert, die Punktreihen der Fld. stehen in kaum merklichen Streifen und werden aus starken, jedoch wenig dichten Punkten gebildet, hinten vereinigt sich in der Regel der dritte und vierte Streifen, die Zwischenräume sind eben, fein punktulirt. - Penis sehr schlank, schwach gebogen, eylindrisch, von oben etwas zusammengedriickt, vorn schnell verengt und in eine äusserst kurze und undeutliche, abgerundete spitze verlängert.

우 Erstes Tarsenglied schmal, letzter Banchring dicht punktirt, hinten abgerundet, die deutlichen Streifen der Fld.. von denen sich hinten meist der vierte mit dem fünften verbindet. sind stark und dicht punktirt, ihre Zwischenstreifen mehr oder weniger gewölbt und verloschen gewirkt.

Auf trocknen Grasplätzen, Rainen und Wiesen, auch an Hecken und Gebüschen in Deutschland, wie überhaupt in Europa und Sibirien gemein.

Chaet. picipes Steph (1. c. 327) scheint das Männchen dieser Art, und $C h$. saltitans Steph. ein fein punktirtes $\hat{o}$ von $C h$. semicoerulea Koch zu sein.

b. Prothorax linea marginali in basi obsoleta, ante basin hand impressus.

5. Charet. tibialis: Ovalis, modice convexa, nigr $\alpha$, supru aenea aut obscure aurichalcea, subnitida, antennis pedilusque piceis, illis basi, his genubus tarsisque rufo-testaceis, femoribus posterioribus nigro-creneis, fronte utrinque punctis numerosis impressa prothoraceque subtilissime coriaceis, hoc brevi, apicem versus angustato, creberime et subtiliter punctato, elytris punctato-striatis, interstitiis leviter squamoso-rugulosis. Long. 1,5-2,2 $\mathrm{mm}$.

Mas: tarsis anterioribus articulo primo modice dilatato.

Illig. Mag. VI. 64 et 162 (Halt.). - Foudr. Mon. 103. All. Mon. 278. - Kutsch. Wien. Monat. 18064. 315 (321).

- Redtb. Faun. A. II. 510. 
ber vorigen Art sehr ähnlich, aber durchselmittlich etwas kleiner, heller cryfarbig, weniger glänzend, dic Basis der Fiihler, Knie und 'l'arsen lichter grefärbt, Halssch. und Fld. zu cinem fast regelmässigen Ovale vereint, welches vor den Schultern nicht durch einen Ausschnitt gestört wirel wie bei concinnu. Halssch. foiner und dichter punktirt, an der Basis gleichnässign queriber gewölht, also ohne merklich vertiefte und mit stiikeren Prunkten hestetzte hamullinie an der Basis und ohne einen Sehrägenulruck jederseits vor derselben.

Eifömig, schwach gewölbt, schwarz, oben griinlich- orler bräunlich-erzfarbig. oft mit blassem Messingschimmer, Fiihler bis zum fünften oder sechsten Gliede röthlichgelb, die folgenden Glieder rothbram bis pechschwarz. An den Beinen sind Knie und 'Tarsen rüthlich gelbbraun. der grösste Theil aller Schienen und die Vorderschenkel pechbrau, Mittel- und Hinterschenkel schwarz erzfarbig. Kopt klein, wie das Halssch. fein lederartig gerunzelt, der Kiel zwischen den Fühlern mässig breit, wenig gewölbt, die Stim mit zahlreichen Punkten besetzt, die den scheitel und einen nach unten verbreiterten Raum iiber der Querlinie frei lassen. Halssch fast doppelt so breit wie lang, nach vorn in sehr schwachem Bogen verengt, gleichmässig äusserst dicht und fein punktirt. Fld. am Grunde so breit als das Halssch., mit kleiner und schwacher s'chulterbeule, ziemlich feinen Punktstreifen und äusserst fein schuppenförmig-gerunzelten Zwischenstreifen; es verbinden sich aut' dem Abfalle zur Spitze in der Regel der vierte und fuinfte Punktstreiten mit einander. Geflügelt.

Beim Mämnchen ist das erste Tarsenglied der vorderen Beine erweitert. - Penis noch schlanker als der von concinna, vorn abgerundet.

Auf somigen Grasplätzen im ganzen Alpengebiete zerstreut, häufiger in Südeuropa. Algier, Kaukasus.

Chaet. brevinscula Fald. ist zwar der vorliegenden Art sehr nahe verwandt, aber stets sicher durch die sparsam punktirte Stiru und das viel mattere, weitläufiger und noch f'einer punktirte Halssch. zu unterscheiden. Die Unterseite ist schwarz, die Uberseite dunkel metallisch-grün, die fünf ersten Fïhlerglieder, sowie Schienen und 'Tarsen röthlich gelbbraun. Aut den Fld. verbindet sich gewöhnlich der fünfte und sechste Punktstreif.

Elytra flavo-testacea seu straminea.

6. Chaet. conducta: Ovali-subcylindrica, sat concexa, subtus nigra, antennarum basi tibiis tarsisque testuceis, capite prothuraceque aeneo- 
vel aurichalces-riridibus, ills carina faciali lata, deplanutu, frente punetata linca medin laeri, hoc breri, "picem rersus parum angustato, subtilissime coriacen, sat crebre et subtilius punctuto, elytris stramineis, profunde punctato-striatis, callo humerali subprominulo limboque suturali et laterali nigris. - Long. 1,6-2,5 mm.

Motsch. Bull. Mosc. 1838. 180. t. 3. f. d. D. Hult.). - Foull r Mon. 104. - A 11. Mon. 278. - Kutsch. Wien. Monat. 1864. 320 (326). - Redtb. Faun. A. II. 511 (Plectrosc.).

Bedeutend kleiner, etwas gerlungener gebaut und grewiilhter als $C h$. chlorophana, beiderseits wenig rerschmälert. annähernl cylindrisch, jedoch dazu nicht stark genug gewïlbt. Kopt und Halssch. dunkel metallisch-griin, oft mit Messingschimmer. Flu. strohgelb, ein Saum an der Naht und am Seitenrande. sowie die Schulterbeule schwarz. Der Nahtsaum dehnt sich his zum ersten Punktstreifen aus, der Seitensaum nimnt ror der Mitte ungetähr den äussersten Zwischenstreifen ein, ist dahinter auf die Kante und die Epipleuren beschränkt und setzt sich um die Spitze hermm his an die Naht fort. Die Fühler sind röthlich gelbbraun, ihre vier oder fiunf letzten Glieder bald wenig, bald stark gebräunt. Lnterseite schwarz, die Spitze der vorderen sichenkel, alle Schienen und Tarsen röthlich-gelbbraun. Kopf und Halssch. fein lederartig gerunzelt, seidenglänzend, Stirn zwischen den Fuihlern breit, nicht gekielt, sondern ziemlich eben, oberhalb der Querlinie mässig dicht punktirt, nur auf einem Längsstreifen über die Mitte ohne Punkte. Halssch. fast doppelt so lang als breit, mit leicht gerundeten Seiten, nach rorn schwach rerengt aber bedeutend zusammengedrickt, ziemlich dicht und fein, nach den Seiten zu kräftiger punktirt, mit einer starken Punktreihe in der Randlinie am Grunde, Schildchen dreieckig, an der Spitze abgerundet. Fld. etwas breiter als das Halssch., hinten kurz abgerundet, tief punktirt-gestreift. mit leicht gewölbten, äusserst fein punktulirten Zwischenräumen: die Schulterbeule ist ziemlich gross und tritt etwas nach aussen vor. Geflügelt.

Das Männchen besitzt ein schwach erweitertes erstes Tarsenglied. - Der Penis ist sehr wenig gekrïmmt, fast cylindrisch, im letzten Drittel allmählich in eine scharfe wellig gebogene spitze verengt.

Im Alpengebiete in der Schweiz, dem siddichen Tirol (Manuel). bei Görz (Ludy) und Wien auf' sumpfigen Wiesen und am Rande von Gräben und Bäehen im Mai und Juni selten, häufiger in Südeuropa, von Spanien und Südfrankreich bis siddrussland und in den Kaukasus. Nördliches Afrika. Syrien (Simon). 
Kutschera erwähnt 1. c. 321 (327) eine Form aus Griechenland, welche sich durch bedeutendere Grösse, stark verbreiterten Naht- und Seitensaun der Fld. und fast ganz röthliche vordere schenkel auszeichnen soll; dieselbe gehört aber wohl zu der aus Syrien beschriebenen C $\%$ orientalis Banduer, die in Europa bis in den Banat verbreitet ist, wo sie von H. Merkl bei Resicza gesammelt wurde.

Die Ansicht Bauduer's (Ann. Fr. 1874. 162), dass die von Foudras und Allard beschriebene $C h$. conducta nicht mit der Motschulsky'sehen Art aus dem Kaukasus identisch sei, entbehrt jeden Grundes, deun die Stiicke, welche z. B. Leder bei Elisabetthal fand, unterscheirlen sich von österreichischeu und französischen nicht, mithin ist der für letztere a. a. O. auf eine vage Vermuthung hin vorgeschlagene Name Foudrasi Baud. zuriickzuweisen.

7. Charet. depressa: Subaptera, oblongo-ovuta, depresisiuscula, subtus nigra, antennarum basi, tibiis tarsisque testaceis, femoribus subaeneis, capite prothoraceque aeneo-viridibus, illo carina faciali angusta, convexiuscula, fronte crebre punctata, hoc transverso, apicem versus angustato, subtilissime coriaceo, crebre et concinne punctato, elytris flavo-testaceis, prof unde punctato-striatis, callo humerali mullo, margine laterali suturaque nigris. - Long. 1,7-2,3 $\mathrm{mm}$.

Boield. Ann. Fr. 1859. 482.

Plectroscelis chrysicollis Foudr. Mon. 105. - All. MLon. 678. Kutsch. Wien. Monat. 1864. 316 (322).

Die flachste Art unter den Exorhinen, durch den Bau der Stirn und die dichte Punktirung derselben von allen übrigren abweichend. Lang eiförmig, sehr flach gewölbt, Kopf und Halssch. dunkel metallisch grïn, Fld. bräunlichgelb mit einem schmalen, schwarzen Naht- und Seitemrandsaume, Unterseite schwarz, die ersten füinf oder sechs Fühlerglieder, Schienen und Tarsen röthlich gelbbraun, schenkel (namentlich die hinteren) nit matallischen. Schimmer. Kopf länglich, die Stimlinien laufen schräg nach innen und erlöschen zwischen den Fïhlern, ohne durch eine Querlinie verbunden zu sein, der ziemlich hohe, aber nicht breite Längskiel geht oben allmählich in die lange, dreieckige Stirn über, welche äusserst fein lederartig gerunzelt und gleichmässig dicht punktirt ist, wie bei den meisten echten Chactocnema-Arten. Halsseh. beinahe um die Hälfte breiter als lang, vor der Basis am breitesten, nach hinten wenig, nach vorn etwas mehr verengt, schwach gewölbt, wenig zusammengedrickt, wie der Kopf gewirkt und noch etwas dichter punktirt, an den Seiten eben so stark als derselbe, in der Mitte etwas feiner. Die Punkte in der zarten Randlinie an der Basis sind nicht stärker als die auf' dem übrigen 'Theile der Scheibe. Schildchen kurz und breit dreieckig. Fld. auf dem Rücken flach 
gredritckt, an (irmole so breit als das Halssch., in den schultern nicht heraustretend und ohme Beule. tief punktirt-gestreift, mit schnalen. gewiolbten, kaum sichthar punktirten und gerunzelten Zwischenstreifen. Der schwar\%e Nahtsaum ist iiherall von gleicher Breite und endet im ersten P'unktstreifen, nahe der Basis jedrch schon in der alygekuirzten Punktreihe, der Seitensaum ist auf die Epipleuren und den aufgebogenen Rand äber denselben heschränkt.

Beim Mimnchen ist das erste 'Tarsenglied schwach erweitert; dex Penis gebogen, unten rinnenförmig vertieft, vorn in eine scharfe, etwas wellige Spitze verschmälert.

Auf trockenen Grasplätzen bei Triest (Kutschera), in Tirol und am siidfusse der Alpen selten; gemein im südtranzösischen Berglande. Pyrenäen.

II. Frons curina faciuli lute, deplanata, scrobiculo antennali clypeoque hand discretis, metastermm penctatum. Chaetocnema in spec.

A. Prothorax coleopteris reguluriter punctato-striatis iel-substriatis haud angustior.

8. Charet.procerula: Subaptera, sat elongata, subcylindrica, nitidiuscula, nigra, antennarum basi, tibiarum apice tarsisque rufescentibus, capite prothoraceque alsscure aeneis aut aurichalceis, minus dense, subtiliter punctatis, elytris nigro-coeruleis, saepe viridi-micantibus, regulariter punctato-substriatis, interstitiis vix sitiliter coriaceis, callo humerali deplanato laevi. - Long. 2,4-2,8 $\mathrm{mm}$.

Rosenh. Thiere Andalus. 344. - All. Mon. 279. - Kutseh.

Wien. Monat. 1864. 337 (328). - Redtb. Faun. A. II. 511. (Plectroscelis).

Chaetocn. compressa Fondr. Mon. 109.

Var. a. Capite prothoraceque plumbeo-nigris.

Var. b. aenescens: Supra tota aurichalcen.

Unvollkommen geflügelt, sehr lang gestreckt, fast cylindrisch, aber nur mässig gewölht, etwas glänzend, schwarz, die vier ersten Fïhlerglieder, die spitze der Schienen und die 'Tarsen röthlich. Kopf und Halssch. mit einem meist schwachen metallisch grinen oder messingfarbigen Schimmer, F'ld. schwarzblau, griinlichblau oder hlaugrün. Kopf gross, bis vor die Fühlerwurzel gewölbt, darunter his zum Vorderrande des Koptschildes stark abfallend und vertieft, die Oberlippe wieder etwas nach vorn gerichtet; Stirn breit, äusserst fein lederartig gerunzelt und wenig dicht, sehr fein punktirt, ein kleiner Raum über der bogenförnigen Querlinie, gwöhnlich ohne I'mukte. Der Stimkiel lildet eine breite, ebene, wenigstens nicht 
der Quere nach gewölhte Fläche, die mit einigen rmoben Punkten in der Mitte und an den Seiten besetzt ist; die Oherlippe ist sehr breit und kurz, an Vorderrande abgestutzt. Halssch. fast um dir Hailfte breiter als lang, vor der Mitte am breitesten, beiderseits gerundet-verengt, jedoch nach hinten allmählicher als nach vorn, so dass Basis und spitze ziemlich dieselbe Breite besitzen; es ist vorn merklich zusammengedrückt und gewölbt, oben äusserst fein gewirkt und mässig dicht punktirt. Die Punkte sind entweder unter sich gleichgross und ungefähr so fein als die des Halssch., oder sie werden nach dem seiten- und Hinterrande zu etwas stärker. Fld. lang oval, bis zur Mitte schwach erweitert und hier ungefähr so breit wie das Halssch. an der breitesten Stelle, hinten etwas zugespitzt, auf dem Rücken flach gewölbt, kräftig in regelmässigen Reihen punktirt, ron denen die inneren in sehr schwachen, die äusseren in stärkeren Streiten stehen, welche die kaum bemerkbar gewirkten Zwischenstreifen entsprechend in die Höhe heben. Die Schulterbeule wird nur durch einen glatten Raum angedeutet, hinter dem die Punktstreifen 6 bis 9 abgekürzt sind.

Beim Männchen ist das erste 'Tarsenglied leicht erweitert, der Hinterrand des letzten Bauchringes abgestutzt und in der Mitte in einen schmalen, vertieften Zipfel verlängert, der Penis endlich winkelig gebogen, in der Basalhälfte gerinnt, in der vorderen Hälfte allmählich zu einer abgerundeten Spitze verengt.

Die häufigste Form (Var. a) ist auf dem Kopfe und Halssch. schwarz mit Bleischimmer; bei der hübschen Abänderung b, welche bis jetzt nur aus Spanien und Algier bekannt geworden ist, wird die Oberseite einfarbig, bald heller, bald dunkler broncefarben.

Auf Wiesen im Mai und Juni selten. In der Mark bei Eberswalde, Schlesien, in Oesterreich weit verbreitet. Corfu (Erber), Frankreich, Spanien, Algier.

9. Chaet. compressa: Subaptera, oblongo-subcylindrica, plumbeonigra, supra interdum leviter coeruleo-seu viridi-micans, subtilissime coriaceu, minus nitida, antennarum articulis primis inferne tarsisque fuscis; fronte parce obsoleteque punctulata, mothorace minus dense subtiliter, basin et latera versus paullo fintius punctato, elytris punctatosubstriatis, callo humerali deplanato, laevi. - Long. 1,8-2,4 $\mathrm{mm}$

Letzn. Bericht Arb. Schles. Ges, 1846.85 (Halt.). - A 11. MIon.

279. - Kutsch. Wien. Monat. 1864. 338 (329). - Redtb.

Faun. A. II. 511.

Chaetocn. tarda Foudr. Mon. 112.

Bei ziemlich gleicher Breite etwas kürzer als die vorige, vorn stärker verengt und gewölbt, oberseits weniger glänzend, mit 
dunkleren Fühlern und leeinen. Lnvollkommen greflïgelt. gestreckt, fast cylindrisch, nach der Mitte hin etwas erweitert, hleifarbig schwarz, oben zuweilen bläulich oder grinlich angehaucht, zart, jednch deutlich lederartic germuelt, fettig grlänzend. die ersten drei order vier Fiihlerchlieder und die 'Tarsen auf der Lnterseite rothbraun. bisweilen auch noch die Schienen. Kopf wie bei der vorhergehenden grebaut, aber die Vorderecken der Oberlippe vorgezogen, so dass zwischen ihnen ein deutlicher Ausschnitt entsteht, die Stirn ist mit Ausnahme eines Längrsstreifens über die Mitte sprarsam, äusserst fein und verloschen punktirt, der Längskiel zwischen den Fiihlern nur mit wenigen kräftigen Punkten an den Seiten besetzt. Halssch. um die Hälfte breiter als lang, in oder hinter der Mitte am breitesten. nach vorn etwas mehr als nach hinten gerundet-verengt, zusammengedrückt, stark querïber gewölbt, auf der Scheibe mässig dicht und sehr fein, nahe dem Seiten- und Hinterrande stärker und deutlicher punktirt, die Vorderecken fest an den Kopf gelegt. Fld. långlichoval, bis zur Mitte mässig erweitert und hier eine Spur breiter wie das Halssch. an seiner breitesten Stelle, hinten gerundet- und etwas stumpfer zugespitzt als bei procerulu, auf dem Rücken mässig gewölbt, kräftig in regelmässigen Reihen punktirt, welche innen in leichten, aussen in stärkeren Streifen stehen. Die Schulterbeule ist durch einen glatten Raum angedeutet, hinter dem die vier :̈usseren Punktstreifen beginnen.

Das erste Tarsenglied des Männchens ist mässig erweitert. der Penis stark gebogen, unten gerinnt, im vorderen Drittel allmählich und sehr wenig, am Ende plötzlich und schnell verengt und in der Mitte in eine äusserst kurze Spitze vorgezogen.

An trockenen Dämmen und Wiesenstreifen am Ufer grösserer Flüsse, sowie auf den Küsteninseln der Nordsee. Sylt, Norderney, fast im ganzen Elb- und Oderthale, Oesterreich, Griechenland (Allard), Frankreich. Nach H. Schilsky's Beobachtungen lebt das Thier ausschliesslich auf Carduus nutans L.

Was Bach (Käferf. III. 160) unter Plectr. compressa und turda verstanden hat, lässt sich nicht mit Gewissheit nachweisen: möglich, dass seine compressa $=$ procerula Rosh. und seine tarda $=$ compressa Letzn. ist, oder dass beide nur nach etwas abweichenden Stücken der letztgenamnten Art beschrieben wurden.

10. Chaet. angustula: Subaptera, breviter subcylindrica, subtus aeneo-nigra, supra obscure viridi-dened, antennarum basi, palpis, titiis tarsisque rufo-testaceis, capite prothoraceque crebre subtiliter punctatis, elytris profunde punctato-striatis interstitiis convecis, striis exterioribus in humeris vix abbreviatis. - Long. $2 \mathrm{~mm}$. 
Rosenh. Beitr. Faun. Ins. Eur. 1847.62. - All. Mon. 280. Kutsch. Wien. Monat. 1864. 338 (329). - Red tb. Faun. A. II. 511 (Plectrose.). - Foudr. MLon. 111.

Plectroscelis balunomoryha Boield. Ann. Fr. 1859. 481. t. 8. f. 12. Var. a. alpicola: Supra aut viridi-aut plumbeo-coerulea.

Noch etwas kïrzer als die vorhergehende, durch die lebhaftere Farbe des Körpers, der Fiihler una Beine, die kaum gewölbte Stirn, welche nebst dem Halssch. dichter und stärker punktirt ist, endlich durch die weit tieferen, an der Schulter kaum abgekiirzten Punktstreifen der Fld. von ihr und procerula leicht zu trennen.

Unvollkommen gefliigelt, gestreckt, fast cylindrisch, unten schwarz. mehr oder weniger metallisch glänzend, oben dunkelgrün, bronceschimmernd, bald tast glatt, ziemlich glänzend, bald durch eine sehr feine Runzelung etwas matter, seidenglänzend, namentlich ant dem Kopte und Halsschilde; die ersten fünf bis sechs Fühlerglieder, Taster, Schienen und Tarsen röthlich gelb Kopf mässig gross, die Stim iiber der Querlinie gewölbt, fein aber deutlich und dicht punktirt, darunter bis zum Vorderrande des Kopfschildes flach gedriickt, eben, stark und sehr dicht punktirt; Oberlippe vorn in leichter Rundung abgestutzt. Halssch. um ein Drittel breiter als lang, stark zusammengedrückt und gewölbt, vor der Mitte am breitesten, beiderseits schwach gerundet-verengt, jedoch nach hinten allmählicher als nach rorn; bei der Ansicht von oben scheint es, als ob die grösste Breite hinter der Mitte läge und die Seiten nach vorn stärker, nach rückwärts weniger eingezogen wären. Die Scheibe ist deutlich und dicht, an den Seiten etwas stärker, als in der Vitte punktirt. Fld. länglich oval, hinten ziemlich breit abgerundet, regrelmässig, tief und stark punktirt-gestreift, mit gewölbten, ïber dem Seitemrande zuweilen kielförmigen Zwischenrïumen, Schulterbeule kaum angedentet, da der sechste bis neunte Punktstreif vorn nicht abgekürzt ist.

Das Männchen erkennt man am breiteren Halssch., dem erweiterten ersten 'Tarsengliede und an dem abgestutzten und in der Mitte vertieften Hinterrande des letzten Banchsegmentes. - Der Penis ist etwas gebogen, unten gerinnt, vorn abgerundet. mit einer kleinen, abgesetzten und gerundeten Spitze.

Eine beachtenswerthe Abänderung (Var. a), welche sich in der Färbung den vorigen Arten nähert, ist auf der Oberseite griunlich blau oder dunkelblau, mit einem blassen, bleifarbigen S̈chimmer; sie findet sich im südlichen Tirol (Manuel).

Auf Wiesen in den Alpen von Krain bis in die Schweiz. Siidfranzösisches Bergland, Pyrenäien. Foudras sammelte das Thier unter Moos und in Pflanzenbüscheln rorzugsweise am Nordabliange der Berge. 


\section{B. Prothorax coleopteris angustion.}

* Fromes sulititer, carina facialis fortius punetatu.

1. Chot. rhombea: Suboralis, antice josticeque fortius angustatu, morlice comrexa, nigra, supma obscure eurichalcea, subtilissime coriucra, sat nitida, antennis apicem versus infuscatis pedibusque rufo-fermunine is,

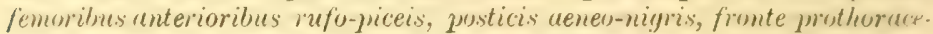
que antrorsum angustato mimus dense subtiliter junctatis, elytris regulariter punctato-substriatis, callo humerali parum promimels, pectore in lateribus laevi. - Long. 2,2 mm.

In der Grisse und Gestalt der C $\%$. tibialis älınlich, indessen nach rückwärts stärker verengt, beinahe länglich-rautenförmig, die Seiten in der Mitte nicht eckig, sondern abgerundet. Geflügelt, mässig grewölbt, unten schwarz, oben mehr oder weniger lironcefarbig, seltener schwach bleifarben oder kupferig schimmernd. äusserst fein gewirkt, zienlich glinzend. Fïhler und Beine röthlich gelbbraun oder hell rostroth, an ersteren die tiunf Endglieder angedunkelt, an letzteren die vier Vorderschenkel röthlich pechbram, zuweilen metallisch grün iiberflogen, die Hinterschenkel schwarz erztarbig. Kopf klein, dreieckig, unterhalb der Stirnlinie dicht und stark, über derselben weitläufig und sehr fein punktirt. Halssch. etwa un die Hälfte breiter als lang, nach vorn allmählich mässig verengt, mit wenig gerundeten Seiten, schwach zusammengedrückt und gewölbt, eben so weitlaiufig und tein, oder nur nach den Seiten hin etwas stäiker punktirt als der Kopf. Fld. an der Basis kaum breiter wie der Grund des Halssch., bis zum ersten Drittel gerundeterweitert, dahinter allmählich stark verengt, mit durchaus regelmässigen Punktreihen, welche aus mässig dichtstehenden. vorn grossen und ziemlich tiefen, hinter der Mitte viel feineren und seichteren Punkten gebildet werden. Die Punktreihen befinden sich vor der Mitte in schwachen Streifen und heben auch nur dort die Zwischenräume etwas empor; die Schulterbeule ist ziemlich gross, wenig gewïllot und leicht rortretend. Hinterbrust im mittleren Theile punktirt, aussen nebst den Seitentheilen aller Brustringe nur gewirkt, ohne Punkte, der Bauch an den Seiten der beiden letzten segmente dicht, sonst sehr vereinzelt punktirt.

Beim Männchen ist das erste 'Tarsenglied an den vorderen Beinen mässig erweitert. In Sachsen (Rosenhauer). Syrien (Simon).

Die Art, die ich als aerosa Letzn. erhielt, worauf sie sich jedoch nach den Beschreibungen ron Letzner, Foudras und Kutschera nicht beziehen lasst, ist durch die umpunktirten seiten der Brust und die sparsame P'unktirung des Banches sehr ausgezeichnet und hierin mit den Arten der ersten Gruppe verwandt, von denen sie jedoch durch den aufgebogenen Vorderrand der Oberlippe, sowie durch den breiten, ebenen Raum zwischen den Fühlern abweicht. 
12. Char. mevidionalis: Oblongu-oralis, subcylindrica, niyru aenea, cupite, prothurate, scutello femoribusque posticis iridi-aeneis vel aurichalceis, nitidis, elytris obscure virili-coenuleis aut cyaneis, maryinibus labri mayni, antennis basi, tibies tarsisque ferngineis; prothorace sat brevi, luteribus rotunduto, sut crebre subtiliter punctulato; clytris callo humerali purum prominulo sat profunde punctuto-striatis, striis internis basin versus ivegularibus; pleuris meso-et metastemi segmenlisque ventralibus posticis 4 latera versus subtiliter punctulatis, alutaceis et dense argenteo-pilosis. - Long. 2,5-3 mm.

Ias: articulo mimo antennarum crassiusculo tarsorumque valde dilatato. Foudr. MLn. 116. - All. Ann. Fr. 1859. Bull. 105; Mon. 286 (Plectr.) - Kutsch. Wien. Monat. 1864. 347 (338). Redtb. Faun. A. II. 511.

Plectrosc. obesa Boield. Ann. Fr. 1859. 480. t. 8. f. 11.

Var. a. unicolor: Supra aut omnino obscure coerulea, interdum viridimicans, aut aurichalcea.

Chaetoc. insolita Rey Opuscul. entom. 1875. 18.

Durch die grosse, rothgesäumte Oberlippe, das grüne oder messingfarbene Halssch. in Verbindung mit blauen Fld., vor allen Dingen aber durch die weiss behaarten Seiten der Brust und des Bauches ausgezeichnet und nicht leicht mit einer der folgenden ähulichen Arten zu verwechseln.

In der Regel unvollkommen geflïgelt, länglich-eiförmig, beiderseits wenig verschmälert, fast cylindrisch, erzfarbig schwarz, Kopf, Halssch., Schildchen und Schenkel (namentlich die Hinterschenkel) metallisch gxiun bis messingfarbig, glänzend, Fld. dunkel grïnlichblau oder rein blau, weniger glänzend. Oberlippe gross, pechschwarz, Vorder- und Seitenrand hoch aufgebogen, rostroth; Fühler pechschmarz, die exsten 3 bis 5 Glieder unterseits und an der Spitze rostroth. Stirn und Halssch. äusserst dicht und zart gewirkt, jedoch beim Weibchen viel deutlicher als beim Männchen, und mässig dicht, fein punktirt, ror dem Hinterrande und an den Seiten des Halssch. stärker. Letzteres ist wenig (ô) oder um die Harlfte breiter als lang, stark zusammengedrickt, mit gerundeten Seiten, nach vorn etwas mehr als riickwärts verengt. Fld. an der Basis wenig breiter als das Halssch., bis zur Mitte leicht erweitert, dahinter ähnlich verengt und an der Spitze breit abgerundet, viel deutlicher als das Halssch. gewirkt, fast regelmässig, ziemlich tief und stark punktirt-gestreift, es werden jedoch die 4 oder 5 inneren Punktreihen auf dem vorderen Drittel durch daneben tretende Punkte verdoppelt und mehr oder weniger gestört. Die kleine, glatte Schulterbeule tritt kaum iiber die Rundung der Schulter hinaus. Die Seitenstiicke der Mittel- und Hinterbrust sind sehr dicht und fein punktrit, und nebst einem breiten Streifen an der

VI. 5 . 


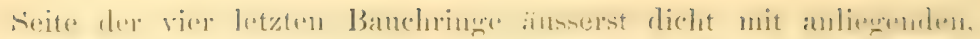

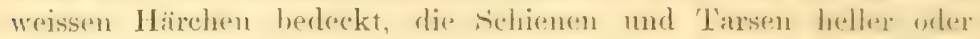
dunkler rostroth.

$\hat{3}$. Achlanker, shlinzender und durchwerg feiner junktirt als das Weibchen, das Basalghlied der Fühler verdickt. "rotes Tarnonglied an den vorderen Beinen breit herzförmig.

Die Farbe des Halssch. geht zuweilen in blangriin oder blau über, so dass die ganze Oberseite, zuletzt einfarlig blau ist, orler die Fld. nehmen die broncegelbe Farbe des Halssch. an (Var. a).

Auf feuchten und sumpfigen Wiesen, hauptsiachlich an Gräben und Bächen. Schlesien in Altrater bei Lindewiese, Baiern, () sterreich, besonders hei Wien; an vielen Punkten von Lngarn mol dem siidlichen Frankreich, ausserdem in sïdeuropa von Andalusien bis Samara (Faust) verbreitet. Algier.

13. Chaet. confusa: Subovalis, convexu, olscure cyanea vel nigroviridis, nitida, antennarum busi pedibusque fermeineis, femoribus anterioribus superne, posticis totis aeneis, fronte prothoraceque crebre subtiliter punctulatis, hoc treri, lateribus rotundatis: elytris apice outuse rotundatis, dorso antice confuse, postice bistrutim punctatis, e.terne punctuto-striatis, callo humerali sulprominulo. - Long. 2,5-3 mm.

Bohem. Oefvers. Ak. Förhandl. XV. 185̆1. 234 (Plectr.). A 11. Mon. 282. - Kutsch. Wien. Monat. 1864. 341 (335) Redtb. Faun. A. II. 512. - Seidl. F. balt. 500. - Thoms. Skand. Col. VIII. 232 (Chaet.). - Leesb. Tijdschr. Ent. 24. 192 .

Etwas breiter, höher gewölbt, an den Seiten gerundeter, aber nach vorn stïrker verengt als die vorhergehende, fast eifömig: metallisch dunkelblau oder schwarzgrim, oft mit messingtarbenem Anfluge, itberall äusserst zart aber wenig dicht lederartig germuelt. Oberlippe und Fühler pechschwarz, die 4 bis 6 Basalglieder der letzteren, Taster, Schienen uud Tarsen hell rostroth, hei frischen Stücken auch noch die untere Hälfte der vier Vorderschenkel. Oberlippe mässig gross, hinter dem aufgebogenen Vorderrande rimnenförmig vertieft, im oberen Theile mit sechs tiefen Grübchen, welche eine nach dem Koptschilde zu gebogene Querreihe bilden, die bei der vorigen und folgenden Art viel schwächer, umregelmässiger und fast grade ist. Stirn ibber der Querrime wenig dicht und sehr fein punktirt; Halssch. quer, hinter der Witte am breitesten, an den Seiten gerundet, oben dichter und etwas stärker als die Stirn punktirt, besonders nach dem Seiten- und Hinterande zu. Fld. an der Basis nur wenig breiter als das Halssch., an den 


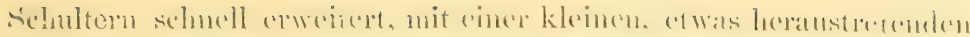
Benle, hinten hreit ahgerumdet, aut der s'ohribu mässig stark und fist verworem punktirt. Jie sechs inneren J'unktreilsen nimlich sind bis zur Mitte kaum zu unterschedele, erst dahinter treten sie dentlich hervor, und zwar die drei noben der Nalit als I)opurelerihen, die anderen als einfiache Reihen, und werden nebst den drei fast regohmissigen Reihen üher dem Seitemrande dureh breite, schwach gewiilhte Zwisehenstreifen esescheden. Seitenstiike der Mittel- und Hinterhrust kraititig punktirt, sparsim und fein behaart. Fast immer unvollkommen geflügelt.

Aut sumptigen Wiesen sclten, aber wohl vielfach iibersehen. Mark Brandeubure, Frankfurt a. Main (v. Heyden); ausserdem in England, Frankreich und dem siidlichen Schweden.

1. Charet. Mannerheimi: Oblongo-ovata, connexa, nigra, coeruleomicans, nitidula, sumu vividi-coeruler aut coerulea, latwo antennisque piceis, his articulix primis inforne, tibiis tarsisque fermuineis, fronte prothoraceque crebre subtiliter punctutis, hoc sat brexi, luteribus leniter rotundatis, ante busin utrinque obsolete transiersim depresso, elytris callo Tumerali mominulo, externe et ante apicem striato-punctatis, interne confertim vage punctatis, ventre minus crelve punctato, segmento ultimo in medio impunctato, polito. - Long. 2,2-3,2 $\mathrm{mm}$.

II as: tursis articulo primo valde dilatato, maryine postico segmenti ultimi bisimuatu, segmentis mediis latera versus evidenter alutaceis, haud punctatis.

Gyllh. Ins. Suec. IV. App. 664. - Motsch. Bull. Mose. 1845. I. 108 (Halt.). - Steph. Ill. Brit. IV. 323; Man. 299 (Mantura). - Redtb. Faun. A. II. 511. - Bach Käferf. III. 160. - A 11. Mon. 281. - Kutsch. Wien. Monat. 1864. 341 (331). - Seidl. F. balt. 500 (Plectrose.). - Foudr. Mon. 115. - Leesberg, Tijdschr. Ent. 24. 191.

Var, a. Nigro-cyanea aut violacea.

Var. b. fallax: Supra obscure aenea.

Mit der rorigen Art nahe verwandt, aber bedentend schlanker, auf den Fld. feiner punktirt, Fühlerluasis, Schienen und Füsse dunkler. Geflügelt, länglich-eifümig, tist eylindrisch, heiderseits etwas rerengt, wenig leblaft grüulich hlan odes blau, auf Kopt: Halssch. nud Unterseite gewöhnlich viel dunkler; dicht und ausserst fein gewirkt, mässig glänzent, ()herlippe und Fühler pechschwarz, die drei bis tünf Basalglieler der letzteren bei frischen Stücken fast ganz, bei ausgehairteten nur auf der Unterseite rostrotl, cbenso die Taster, Schienen und Fïsser, mit Ausnahme des dunkleren 
Klanemgliedes. Kopt ziemlich klein, unterhalb der stimlinic fin eben, dicht und grobly punktirt. über der stirnrime bis zun sicheitel sanft gewïllt und fein punktirt. Halssch. nu die Hälfte breiter als lang, heiderseits gleichnässig leicht verengt, an den seiten santi gerundet, ziemlich stark zusanmengerlriickt und queriiber gewijllt. anf der scheibe dicht und fein, an den Seiten und besonders in den schwachen Quereindrucke vor den Hinterrande stärker junktirt. Fld. an cler Basis merklich breiter als das Halssch., mit vorspringender glatter, deutlich ahgesetzter Schulterbeule, dahinter wenig und fast gradlinig erweitert, nahe der Mitte, selten weiter nach hinten am breitesten, die spitze mässig breit abgerundet. Leber dem Seitenrande befinden sich gewöhnlich vier ziemlich krättige und regelnnässige Punktstreifen, auf dem Rücken sind die Punkte vorn beinahe verworren, treten aber von der Mitte ab deutlich in doppelte Reihen zusammen, welche nach hinten regehnïssiger und tiefer werden und vor der Spitze selbst einfach sind. Die Seiten der Vorderbrust, die Hinterbrust und der erste Banchring sind stark, die Seitenstiicke der Mittel- und Hinterbrust, nebst den iibrigen Bauchringen feiner punktirt, sparsam und äusserst fein behaart, ein Streifen am Hinterrande des 2. lis 4. Segmentes, sowie ein mehr oder weniger grosser Fleck in der Mitte des letzten Ringes olnne Punkte, beinahe spiegelglatt.

Häufig ist der Körper dunkelblau oder violett (Var. a), seltener die Oberseite verschossen und dunkel metallisch grün, ähnlich wie bei der $C h$. aridula, die Unterseite blau (Var. b).

Beim Männchen ist das erste Tarsenglied stark erweitert, ein breiter Streifen an der Seite der drei mittleren Bauchringe dicht gewirkt, matt, kaum punktirt, und der Hinterrand des letzten Ringes beiderseits ein wenig ausgebuchtet. - Penis vorn abgerundet und in der Mitte in einen scharf abgesetzten kurzen Zipfel verlängert, der vorn grade ab- gestutzt ist.

Auf nassen Wiesen in Mitteleuropa, und besonders im nördlichen und mittleren Deutschland nirgends selten.

15. Chaet. subcoerulea: Sat elongata, convexiuscula, coeruleonigra, nitidula, untennarum basi inferne, tibiis tarsisque ferruineis, plus minusve infuscatis; vertice subtilissime prothoraceque subtiliter punctatis, hoc breviusculo, lateribus leniter rotundatis, elytris striutopunctatis, striis dorsalibus antice sat irregularibus, callo humeruli subprominulo; segmento ultimo rentrali in medio alutaceo et parce punctuto. Long: 2-2,5 $\mathrm{mm}$.

Mas: tarsis anterioribus articulo primo dilatato 
Kutsch. Wien. Monat. 1864. 346 (337). - All. Mon. 283 (Plectr.). - Rey, Opusc. ent. 16. 1875. 17.

Chatocn. Sahlbergi var. a Foudr. Mon. 118.

Chatocn. punctulate Rey, 1. e. 18.

Jie Art lässt sich nur bei flüchtiger Betrachtung mit der rorigen oder Ch. Sahlbergi verwechseln; sie ist dunkler gefärbt und schlanker als beide, und unterscheidet sich von der ersteren durch geringe Griisse und die stärkere Punktirung der Fld., des Metasternmm ind ersten Bauchringes, von der letzteren durch die feine Skulptur des ganzen Körpers, namentlich der Stirn.

Gefliigelt, langgestreckt, rïckwärts viel mehr als nach vorn verengt, ziemlich gewölbt, schwarzblau, bisweilen auf Kopf und Halssch. mit griinlichem Anfluge, mässig glänzend, die ersten Fühlerglieder unterseits, Taster, Schienen am Knie und auf der Unterseite, sowie die Tarsen (wenigstens unten) rostroth. Stirn iiber der Querlinie, welche tiefer und in der Mitte breiter wie die von Mannerheimi ist, verloschen und äusserst fein punktirt, bald ziemlich glatt und glänzend, bald deutlich gewirkt, matt. Halssch. quer, in der Nitte am breitesten, beiderseits gleichmässig in sanfter Rundung verengt, auf der Scheibe fein, nach den Seiten und der Basis hin etwas stärker punktirt, mit fast glatten und glänzenden Zwischenräumen, selten dicht gewirkt und matt. Fld, am Grunde kaum breiter als das Halssch., mit kleiner, glatter Schulterbeule, bis zur Mitte in schwacher Rundung allmählich erweitert, dahinter nach und nach verengt, hinten sehr schmal abgerundet; kräftig in Reihen punktirt, von denen die drei bis fünf inneren im ersten Drittel oder noch näher an der Basis durch daneben tretende Punkte gestört werden, aber in der Regel deutlich von einander zu unterscheiden sind, weil die leicht gewölbten Zwischenstreifen fast die Basis erreichen. Die Mitte der Hinterbrust und der erste Banchring sind stark und dicht runzelig punktirt, Seitenstücke der Brust und die iibrigen Banchsegmente feiner, letztere auch weitläufiger punktirt, besonders die Mitte des Analringes.

ऽ. Erstes Glied der vier Vordertarsen erweitert, aber nicht ganz so breit als das dritte, letzter Banchring schmal, gewölbt, der Hinterrand in der Mitte vorgezogen. - Penis vorn allmählich verengt und in einen kurzen, vorn abgestutzten und erweiterten Zipfel ausgezogen.

In den Gebirgsgegenden Deutschlands weit verbreitet, mit den Flïssen oft in die Ebene hinabgeführt. Harz, Thüringen, Schlesien. Baiern, Elsass, Oesterreich bis nach Tirol, Steiermark und Triest, Frankreich. England. 


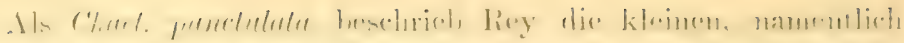

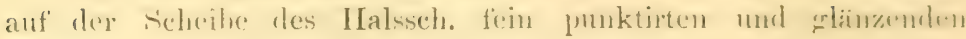
Stiucke.

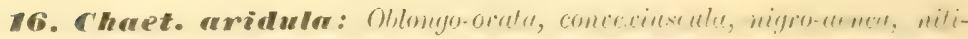

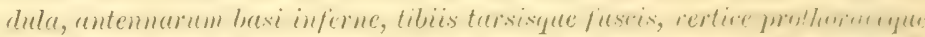

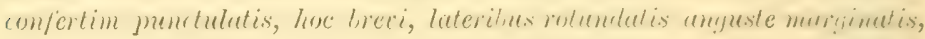
elytris punctuto-strintis, striis internis suldilioribus, antice deplimalis of

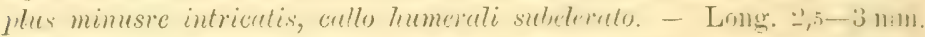

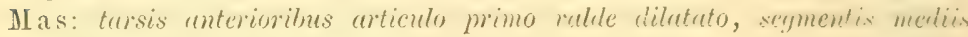
abdominalibus latera versus obsolete punctatis

Gyllh. Ins. Suec. IV. App. 663 (Haltica). - Kutsch. Wien. Monat. 1864. 342 (332). - All. Mon. 281. - Redtb. Faun. A. II. 511. - Bach, Käferf. III. 161. - Seidl. F. balt. 500 (Plectr.). - Steph. Ill. Brit. IV. 326; Man. 302. Foudr. Mon. 119. - Thoms. Skand. Col. VIII. 232. Leesberg, Tijdschr. Ent. 24. 193.

Var.a. Supra aeneo-viridis.

Ziemlich von der Grösse und Gestalt der Ch. Munnerheimi. die Fld. jedoch an den Seiten mehr gerundet und in den Schultern stärker verengt, der letzte Bauchring ziemlich dicht punktirt. Geflïgclt; länglich-eiförmig; mässig gewälbt, sehr dunkel erzfarlig̨, mit hraunem oder messingfarbenem Schimmex, ziemlich glänzend, Fühler schwarz. die ersten Glieder auf' der Lnterseite. oder das zweite bis sechste Glied mit Ausnahme der Spitze, nebst Schienen und Tarsen rostroth, die untere Hälfte der Schienen oft angedunkelt, oder ihr Riicken erzfarbig. Mittlerer Theil der Stirminne flach, unleutlich begrenzt, Stirn und Halssch. sehr fein gewirkt und dieht und fein punktulirt. Letzteres ist $u m$ die Hälfte breiter als lang, nach rorn wenig mehr als nach hinten verschmälert, mit schwach germuleten und sehr schmal gerandeten Seiten. Fld. an der Basis kaun breiter als das Halssch., mit kleiner, ziemlich niedriger und schwach abgesetzter Schulterbeule, bis zur Mitte allmählich erweitert. dahintèr stärker in eine ziemlich schmal abgermulete spitze verengt. oben wenig stark in Reihen punktirt. 1)ic vier äusseren Roihen sind regehnëssig und befinden sich in leicht vertietten Streifen, die inneren nehmen nach der Basis lin an Stärke ah. Sint his zur Vitte einfach. daror verdoppelt und mehr oder weniger in einander gewirt. Brust und Bauch cinzeh behaart, ziemlich dicht punktirt.

ふ. Erstes Tarsenglied an den Vorderbeinen sehr hreit herzförmig; an den Mittelbeinen etwas schmaler; die Seiten der drei mittleren Banchringe motentlich punktirt. Penis dem ron Lermer- 
heimi ähnlich, aber vorn in schwacher limulung verengt und in einen längeren viereckigen Zipfel ausgezogen.

Von Farbenabinderungen ist mir nur die Var. a. mit dunkelgrimer ()herseite bekannt; weit mehr variirt dis J'unktirung der Fld., indem die inneren l'unktreihen entweder his zur Basis nur mit wengen iiberzahligen l'unkten versehen, also ziomlich regelmässig (meist $\hat{j}$ ) oder in der Basalhälfte des Riickens vollstïndig verworen sind (meist f); das IIalssch. ist mitunter merklich tiefer als gewiilnlich punktirt, stirker gewirkt, f'ast matt.

Am Grase aut sommigen, trocknen Plätzen, an Weg- und Waldrändern in sanz Deutsehland und Mitteleuropa häufig.

Thomson hat unzweifelhaft die vorliegende Art als aridula beschrieben, er nemut sic jedoch im Gegensatze zu Sahlbergi und aridella mngeflïgelt und bezieht auch ariduli Kutsch. mur fraglich darauf, es mïssten also, wemu seine Angabe nicht auf ungenügender Beobachtumg beruht, ungeflitgelte Stücke rorkommen, was nicht ohne Weiteres zu bestreiten ist, da dies Thier eine wenig entwickelte Schulterbenle hat. Exemplare, die ich bei Lidliöping, jedenfalls in der Nähe des Gyllenhal'schen Originalfundortes sammelte, sind vollkommen geflïgelt.

17. Chaev. arida: Elongato-elliptica, convexiuscula, sat nitida, nigroacnea aurichalceo micans, antennam basi, tibiis tarsisque fermineis; labro transversim deplanato, vertice subtiliter punctulato, prothorace breriusculv antrorsum angustato et fortiter compresso, lateribus minus anguste maryinatis; confertim subtiliter punctato, elytris punctato-striatis, striis internis basin versus imegulariter duplicatis, callo humerali subprominuto. - Long. 1,6-2,5 mm.

Mas: tarsis anterioribus articulo primo elongato et dilatato.

Foudr. Mon. 122. - All. Ann. Fr. 1860. 573 (Plectr.). Kutsch. Wien. Monat. 1864. 345 (336).

Var. a. Obscure vividi-aenea.

Var. b. aestiva: Antennarum basi, palpis, tibiis tarsisque plus minusve infuscatis.

Die kleinste Art in dieser Gruppe, der vorigen in der Körperfarbe, der Ch. hortensis mehr im Baue ähnlich, jedoch merklich schlanker als diese. Unvollkommen geflügelt, lang und fast regelmässig elliptisch, mässig gewölbt, ziemlich glänzend, sehr dunkel hräunlich erzfarbig, mit Messingschimmer, die ersten 5 bis 6 Fühlermieder, 'Taster, Schienen und Füsse rostroth, bei frischen Stücken auch die Basis oder die Unterseite der vordereu Schenkel bräunlich. Oberlippe quer vertieft, Stirnlinien flach und undeutlich, Stirn und Scheitel fein punktulirt, mehr oder weniger gewirkt. Halssel. ziemlich schmal, an der Basis $n$ m ein I)rittel breiter als lang, nach 
hinten wenis, nach rom hedentend verengt, sark queriiber we willn mol in rler vorderen IHälfte manmmengerlriickt, nit mäsig hrejter Seitemrandleiste. Die Oherflache ist in verseliedenem Grarle gewirkt. dicht punktirt, die Punkte sind num in dre Yähe des Vorderrandes fein und seicht, nehmen nach dem seiten- und Hinterrande hin erhehlich an Grïsse und Tiefe zu und sind hier viel stärker als hei aridula, aber feiner als bei hortensis. Fld. am Grunde so breit wie. das Halssch., dahinter schwach erweitert, in oder vor der. Mitte am breitesten, linten schmal abgerundet; die Schulterbeule klein und niedrig. Von den leicht vertieften und nur wenig stark punktirten Reihen der Fld. sind die c̈usseren regelmässig, die inneren vor der Mitte durch einige daneben tretende Punkte gestört, sie bleiben also meist viel regelmässiger wie die der hortensis.

๙. Erstes Tarsenglied an den vier Vorderleinen verlängert und nur mässig erweitert, ungefähr doppelt so lang als breit. Penis vorn allmählich in eine äusserst schwach abgesetzte kurze und ziemlich breite Spitze verengt, welche scharf abgestutzt ist.

Die Färbung verändert sich wenig, indem die Oberseite nur metallisch dunkelgrün wird (Var. a), oder die Taster, die Basalglieder der Fühler (wenigstens auf der Oberseite) und die Schienen und Tarsen auf dem Rücken in verschiedenem Grade angedunkelt, zuletzt schwärzlich sind (Var.b).

Auf fruchtbaren Wiesen vom Juli bis in den Herbst nicht selten und wahrscheinlich ïber ganz Mitteleuropa verbreitet. Die Stammform scheint mehr in Mittel- und Süddeutschland (Baiern, Oesterreich) vorzukommen, während alle meine Stücke ron Berlin nnd verschiedenen Punkten der Mark, sowie aus Schlesien, zur Var. b. gehören.

\section{** Frons mode punctata.}

18. Chaet. Sahbergi: Oblongo-ovati, conrexa, coerulco-rirescens, antemanm basi, tibiis tarsisque obscure fermeineis, capite prothoraceque opacis vel nitidulis crebre punctatis, elytris nitidioribus sat fortiter punctato-striatis, interstitiis sat latis, striis primis basin rersus ireguluriter duplicatis; tarsis angustis. - Long. 2-2,5 $\mathrm{mm}$.

IIas: tursis anterioribus articulo primo calde dilatato, segmentis mediis latera versus evidenter alutaceis et impunctatis.

Gyllh. Ins. Suec. IV. App. 662 (Halt). - Redtb. Faun. A. II. 512. - Bach, Käferf. III. 161 (Plectr.). - Steph. Ill. Brit. IV. 326; Man. 302. - Thoms. Skand. Col. VIII. 231. Gullevuc. aridellae var. Payk. Faum. Suec. II. 111. - Koch Ent. Hft. II. 41 (Halt.). - Gyllh. 1. c. III. 575. - Küst. Käf. Eur. 9. 89 (Plectr.). 
Tlectroscelis Faimarei Fairm. Ann. Fr. 1852. 6:10. t. 11. IV. f. 1 Plectr. Saltheryi var. insolitu All. Amm. Fr. 1860. 570. - Kutsch.

Wien. Monat. 1864. 349. - Foudr. Mon. 118 (Chaet.).

Var. a. cyanescens: Vigro-coerulea, -cyanea ant-riolacea, minus nitida, striis elytrorum sat irregularibus.

('haetocnema Sahlbergi Foudr. Mon. 118 - Tsesherg, Tijaschr.

Ent. 24. 191. - A11. M[ou. 284 (Plectr.), - Kutsch. 1. c. 349 (339). - Seidl. F. balt. 500.

Var. b. Obscure aeneo-viridis.

Durchgehends stäker punktirt als die blauen Arten der vorigen Gruppe. Geflïgelt, länglich-eiförmig, §ॄеwölbt, dunkel bläulich-griin, Fld. ziemlich stark, Kopf und Halssch. weniger glänzend, oft ganz matt. Fühler schwarz, die ersten Glieder mterseits nebst den Schienen und Tarsen dunkel rostroth. Kopf gewirkt, tief und dicht punktirt, Stimlinie in der Mitte grubig vertieft. Halssch. stark querüber gewölbt und noch kräftiger punktirt und gewirkt als der Kopf; Schildchen glatt. Fld. an der Basis wenig breiter als das Halssch., mit groben Punktreihen, von denen die inneren nach dem Grunde zu mehr oder weniger verdoppelt, jedoch in den meisten Fällen bis zur Basis deutlich zu unterscheiden sind; die Zwischenstreifen verhältnissmässig breit, äusserst fein und verloschen gewirkt, glänzend, die inneren flach, die äusseren gewölbt. Schulterbeule flach und niedrig. Hinterbrust sehr grob, Seitenstiicke fein und dicht runzelig, Bauch mässig stark und nicht dicht punktirt. Tarsen schmal, Klanenglied sehr schlank.

Beim $\hat{\sigma}$ ist das erste Tarsenglied an den vier Vorderbeinen sehr verbreitert, herzförmig, ein Streifen an der Seite der mittleren Bauchringe dicht gewirkt, ohne Punkte; der Penis nach vorn allmählich in eine kurze, breit abgestutzte Spitze verengt.

Zuweilen ist der Körper schwarzblau, kornblumenblau oder violett, die Fld. sind weniger glänzend, oft ziemlich matt, ihre Punktreihen in der Regel verworrener, schlechter begrenzt und aus den merklich gewirkten, unregelmässigen und schmalen Zwischenstreifen weniger deutlich heraustretend (Var. a). Von dieser Abänderung kommen, jedoch selten, auch dunkel metallisch grüne Stiucke vor, ohne jeden blauen Schimmer (Var. b).

An Carex-Arten auf sumpfigen Wiesen in Nord- und Mittelcuropa häufig. Das Thier ist. wie alle nahe verwandten Arten, Mitte Juli entwickelt; die ron Gyllenhal beschiehene Form habe ich bis jetzt nu in den Torfsümpfen der norddentschen Tiefebene in steter Begleitung von Vaccinium oxycoccos angetroffen.

Von Plectroscelis Fairmairei existirt keine Beschreibung; sondern nur die Abbildung ron Boiellieu, nach welcher sie zur echten Sahlbergi Gyllh. 


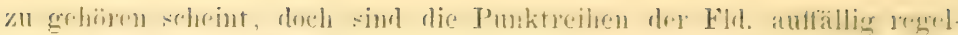
mäsigg gezeichnet. Fairmaire bozieht sie a. a. 9 . chenfalls auf dic rorliegende Art, Allard (Mon, 286) auf hortensis.

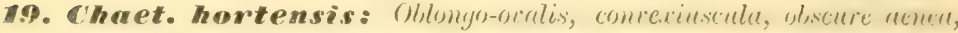

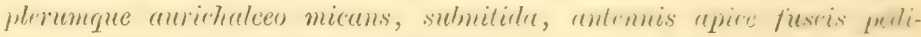

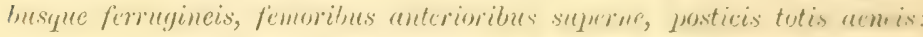

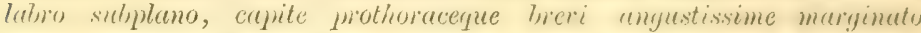
welie et profunde punctutis, elytris striato-punctutis, stries dorsulibus antice irregulariter cheplicutis et plus minusec intricatis, cullo humerali elevato tarsis angustis. - Long. 1,8-2,8 $\mathrm{mm}$.

II as: tursis anterioribus articulo primo valde dilututo, ablomine serjmentis mealiis latera versus alutaceis, haud punctatis.

Fourcr. Ent. Par. I. 1875. 98. - Leesberg, Tijdschr. Ent. 24. 192 .

7lulticu aridella Ill. Mag. VI. 162. - (yllh. Ins. Suec. IV. All'. 662. - Schilling Bericht 1846. 93. - Redtb. Faun. A. II. 512 (Plectr.). - Bach, Käferf. III. 161. - Kutsch. Wien. Monat. 1864. 350 (340), - All. Mon. 285. - Seidl. F. balt. 500. - Steph. Ill. Brit. IV. 326; Man. 302 (Chact.). - Foudr. Mon. 121. - Thoms. Skand. Col. VIII. 231. -

Cralleruca aridella (exclus. var.) Payk. Faum. Suec. II. 111. Koch. Ent. Hft. II. 41. t. 3. f. 2 (Halt.), - Oliv. Ent. V. 714. t. 5. f. 81 . - Gyllh. 1. c. III. 575. - Duft. Faun. A. III. 287. - Kiist. Käf. Eur. 9. 89 (Plectr.).

Plectroscelis scabricollis All. Ann. Fr. 1860. 569; Mon, 283. Kutsch. 1. c. 352 (343). - Rey, Opuscul. ent, 16. 1875. 20 (Chaet.).

Var. a. Supra obscure cuprea.

Va 1. b. Aurichalceo-viridis seu aeruginosa.

Sehr leicht an der grob punktirten Stirn, der hellen Fiihlerwurzel und den röthlichen Vordersehenkeln zu erkennen.

Geflügelt, länglich eiförmig, ziemlich gewölbt, dunkel erztarlig, mit bräunlich-messingfarbenem Glanze, 'Taster, Fühler, mit Ausnahme der 4 bis 5 letzten pechbramen Glieder. und die Beine rostroth, die vier Vorderschenkel bei ausgehärteten Stiicken auf' dem Riicken in verschiedener Ausdehmung metallisch griun angelaufen und deshalb von schwärzlichem Aussehen, aber stets roth durchscheinend, die Hinterschenkel vollkommen erzarbig. Kopf und Ilalssch. dicht und stark punktirt, gewirkt, wenig glänzend, der vordere Querstreifen dex Oberlippe ziemlich eben, Stirnlinien meisî schwach und undeuthich. Halsseh. kurz, beim ô beinahe um die Hälfte, beim $\&$ fast doppelt so breit als lang; mehr oder weniger sewoilbt, an den Seiten leicht gerundet und mit einer sehr schmal 


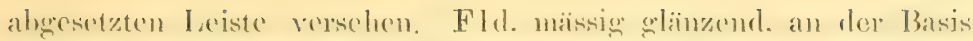
deutlich hroiter als das Ilalssch., mit ciner kleinen, etwas vorspringenden sichulterbenle, an der spitze mässign breit abgerundet; die ()herflähe in der liowel etwas schwächer als hei Sahlbergi junktirt-gestroift, dic äusseren drei l’unktroihen recolmässign, die

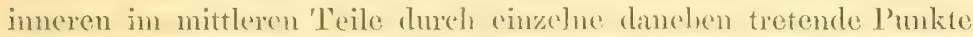
scostivt, in vorderen l)ritel verdoppelt und molu oder weniger in cinameler gewint, balel his zur Basis erkennbar, bald schon dicht vor der Mitte nicht mehr zn unterscheiden. 'Larsen schmal.

$\hat{\jmath}$. Erstes 'Tauscherlied der vorderen Beine herzformig, die drei mittleren Banchinge an der Neite nur gewirkt. - Penis voru schmell, beinalıe sradlinig verengt und in eine schwach abgesetzte, kurze und am Ende grade abgestutzte Spitze verlängert.

1)ie Farbe rerindert sich a. in ein dunkles, kupferiges Braun, b. in Grïn mit Messingschimmer oder ein dunkles und wenig glänzendes Spangrïn.

An sommigen, trocknen Grasplätzen in Europa und Sibirien; in Deutschland gemein.

Allard nemut mit Unrecht alle Schenkel gleichgefärbt (toutes les cuisses sont bronztes) und beschreibt die Stiicke mit rostfarbenen Vorderschenkeln, welche zugleich auf dem Rücken der Fld. recht verwor'ren punktirt sind als sculricollis; die Autoren von Paykull bis Kïster rechneten Ch. Sahlbergi sicher, aridula wahrscheinlich als Var. zu aridella.

20. Chaet. cerosa: Suboralis, comexiuscula, obscuve brumeo-acnea, interdum subcupre-micans, antennarum busi, tibiis tarsisque ubscure ferrugineis; capite prothoraceque alutuceis, nitidulis, confertim punctatis, elytris nitilis, fortius punctato-striatis, stria suturali antice duplicata, callo Inumerali prominulo; tarsis latiusculis. - Long. 1,8-2,2 $\mathrm{mm}$.

Mas: articulo primo tarsorum anteriorum paullo dilatato.

Letzuer, Arb. Schles. Ges. 1846. 84 (Plectr.). - Redtb. Faun. A. II. 511. - Bach, Käferf. III. 159. - All. Mon. 280. - Kutsch. Wien. Monat. 1864. 531 (342). - Foudr. Ion. 114 (Chaet.).

Plcctroscelis punctatissima Graëlls, Mém. Map. geol. zool. 1853. 96. t. 5. f. 8 .

Etwas kürzer als die rorige, und von ihr durch die glänzenden, stark mud regelmässig punktirten Fld., sowie die breiteren Tarsen sicher zu unterscheiden. Gefliigelt, zicmlich eiförmig, rïkwärts etwas mehr als voru verengt, mässig gewölht, Oberseite metallisch braun, zuweilen kupfrig, Unterseite und Beine viel dunkler. Fiihler pechschwarz, dic 5 ersten Glieder derselben, Schienen und Füsse rostroth. ziemlich stark angednukelt. Kopf dicht punktirt, हैewirkt, 
wenige glänzend, Stimlinien schwach und mudentlich. Il alssch. um dic: Inalfte breiter als lang, nach vorn etwas verengt und an den Vorderecken zusammengedriickt, ol,en gewirkt, nur schwach glänzend. seln dicht punktirt, die Punkte werden nach der Seite und dem IInterrande zu allmählich immer stärker. Fld. am Grunde bedeutend breiter als das Halssch., mit einer kleinen und hrohen Śchulterbeule; regelmässig und stark punktirt-gestreift, die Zwischenstreifen leicht gewölbt, kaum gewirkt, glänzend. die abgekiirzte Punktreihe an der Naht im vorderen Theile unregelnn̈̈ssig oder verloppelt. Hinterbrust und erster Bauchringrgob punktirt. glänzend. Seitenstiicke der Mittel- und Hinterbrust nebst den iibrigen Bauchringen fein punktirt, dicht gewirkt, ziemlich matt. Tarsen an den vier Vorderbeinen kurz, das zweite und dritte Glied etwas breiter als lang, das erste beim $q$ schmaler, beim $\hat{\sigma}$ fast so breit als das dritte.

Die Farbe der Oberseite erhält zuweilen einen geringen Zusatz von Grün.

Auf fruchtbaren Grasplätzen selten, weil wenig beachtet. Bei Saalfeld in Ostpreussen und am Dammteiche bei Königsberg (Czwalina), Berlin, noch Anfang Oktober, Schlesien, Wien, Italien. Frankreich, Spanien.

\section{Psylliodes.}

Latreille, Cuv, règn. anim. ed, 2. V. 1829. p. 154.

Macrocnema Stephens, Ill. Brit. IV. 317.

Acetabula antica occlusa; mesostemum oblongo-quadratum.

Tibiae posticae compressae, dorso canaliculatae. Metatarsus longus, subtus ciliatus, dorso ante apicem tibiarum insertus.

Antennae decem-articulatae, basi late distantes, juxta marginom oculorum insertae.

Prothorax simplex, rarius in basi utrinque plica obsoleta breii instructus.

Körper eiförmig, gewölbt, dunkel metallisch grün oder blaı, seltener schwarz, pechbraun oder röthlichgelb gefärbt, glänzend. bei dem grösseren Theile der Arten geflügelt. Kopf klein, etwas rorgestreckt oder geneigt, nach unten verschmälert, dreieckig; Augen kurz elliptisch oder rund, innen wenig, hinten und aussen stärker gewölbt, die Stirn zwischen ihnen bald länglich, mit parallelen Seiten, bald breit, nach unten etwas rerengt. Die Stirnlinien sind ค. vollständig, scharf und tief eingegraben, durchschneiden sich iiber 
der Fïhlerwurzel x-fömmig und bergrenzen die dreieckigen stirnhöcker deutlich (Ps.attenutala); b. unvollstindig; als tiefe Rimne am Innenrande der Augen zur Fühlerwurzel herablaufeud, zwischen den Angen aber verloschen, oder noch durch ein Grübchen im Durchkreuzungspunkte der normalen Linien angedeutet (I's. chrysocephala); endlich c. vollständig verwischt (I's. cucullata). Fiihler hart am Angenrande eingefiigt, zehngliederig, fadenförmig, die fünf letzten Glieder umbedentend breiter als die vorhergehenden; Stirnkiel gewölbt und nach unten versehnälert, oder flach und beinahe gleichbreit, seitlich in eine Vertiefung abfallend, die sich unter jedes Auge rieht und zur Einlagerung des ersten Fühlergliedes dient. Koptsehild kurz, quer, Oberlippe mit einer Querreihe von vier bis sechs Punkten, am Vorderrande abgestutzt oder gerundet, in der Mitte ausgerandet; Mandibeln ziemlich breit, mit fünf Zähnen, von denen der mittlere wenig grösser ist als die seitlichen ( $P$ s. dulcamarae), oder stark zusammengedrüickt, der Mittelzahn lang, die Seitenzälne äusserst kurz (Ps. cucullata); drittes Glied der kleinen Maxillartaster rerkehrt kegelförmig, das Endglied vorn scharf zugespitzt, ron wechselnder Länge. Halssch. breiter als lang, nach vorn allmählich zusammengedrückt und in gerader Linie oder gerundetverengt, queriiber gewölbt, meist deutlich punktirt und gewirkt, mit einem starken Punkte oder einem kurzen Längsstrichelchen jederseits an der Basis; Eckborsten ziemlich lang, Poren gross, die eine liegt ein Stiick hinter den Vorderecken und driickt den fein bewimperten Seitenrand oft winkelig nach aussen, die andere befiudet sich in den stumpfen Hinterecken. Schildchen klein, dreieckig. Fliigeldecken gestreift - punktirt, Epipleuren allmählich verengt fast bis an die Spitze reichend, fein und sparsam behaart, in letzten Viertel meist deutlich kurz bewimpert. Vorderbrust dicht punktirt, zwischen den Hüften am höchsten, nach hinten immer selı stark, nach vorn oft kaum bemerkbar, oft ebenfalls stark abwärts gewölbt, im ersten Falle werden die Hüften noch durch einen mässig breiten, ziemlich ebenen Querstreifen von der Kehle getrennt (Arten mit vorgestrecktem Kopfe), im andern Falle nicht, so dass sich hier der Mund unmittelbar an die Hüften legen kann (Arten mit stark geneigtem Kopfe). Der Fortsatz des Prosternums verbreitert sich hinter den Hüften bis zu den Seitenstiicken und schliesst die Gelenkhöhlen; ${ }^{1}$ ) das Mesosternum ist in der Regel zwischen den Hiiften schmal, länglich-viereckig, die Hinterbrust fein und zerstrent punktirt. Bauch fast dachfürmig, in der Mitte stark erhöht, namentlich auf

1) Dieselben werden von Chapnis als offen angegeben. 


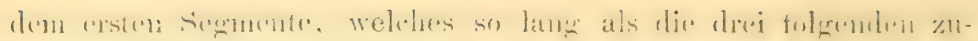

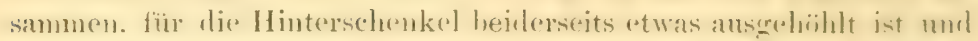
an der basis mit einem kumon, drexeckigen Furtsatze in cinen Ausschnitt der Hinterbrust eingreift; die Rinere sind nach der Mitte zu melu orler weniger diclit punktirt. und joder l'mukt triart win

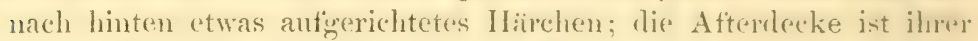
ganzen Länge nach mit einer tiefen Mittulrimes zur Anlinalinu der nuteren Nahtkante versehen. Hinterschenkel selur stark. eitumigr. Hinterschienen mu bei wenigen Arten in der ganzen Anstehnung zusammengedrickt, bei den meisten nur von Grunde his \%ur Einlenkumgsstelle der 'Tarsen, dahinter vou nornaler Breite; der vorlere 'Theil hat zwei Randleisten, die äussere länft unutorhochen von der Basis his zur Spitze und setzt sich um dieselhe herun anf der Immenseite der Schienen (als abgekiirzte Innenrandleiste) noch lis zur Basis der Tarsen fort, die innere ist gewöhnlich höher. steigt in grösserer als geringerer Entfermung von der Einfügungsstelle der Tarsen allmählich oder plötzlich an und tällt dahinter ('ntwerler schnell in den breiteren, löffeltömmig vertieften 'Theil der sehienen ab, oder zieht sich, nummehr zur Mittelleiste geworden und nach und nach abfallend, his zur Spitze. Tor dem höchsten Theile befindet sich ein rerschieden tiefer und scharter Ansschnitt. an welchem die Leiste jederscits zahnförmig antsteigt. Da diese Zühne bei der. Unterseheidung der Arten eine nicht mwesentliche Rolle spielen, indem ihre Bildung oft allein hinreicht, eine Art mit sicherieit zu erkemmen, so nemne ich den ror dem Ausschnitte befindlichen den ersten (dens primus carimulce), den dahinter liegenden, der zum Schntze des Tarsengelenkes dient, den zweiten Leistenzahn. Das erste 'Tarsenglied, der Metatarsus, ist melir oder weniger. weit von der Spitze der sichienen, an welcher ein starker, nach aussen gerichteter Enddorn steht, in einer Rimne neben dem zweiten Zähnchen und dem hohen Endzipfel der abgekürzten Innenrandleiste cingelenkt; es ist ungefähr halb so lang als die schiene, etwas zusammengedriickt, nach der Spitze leicht erweitert und auf der Sohle mit abstehenden Härehen ron rerschichener Lïnge besetzt: das zweite Glied ist fast immer hall, so lang als das criste und mit ihm durch ein Scharniergelenk rerbunden, das dritte sehr ku\%, zweilappig, Klanenglied schlank, Klauen kur und fein, am Grunde zahnförmig erweitert. ${ }^{1}$ )

Lebend verbergen die Psyllioden ihre Hinterschienen in einer Vertiefung unter dem Innemande der schenkel, schlagen den

1) Chapnis nemnt in seiner anftallend Hiichtigen Behandlung der Gattung: (Genera XI. 140) die Klawen einfach. 


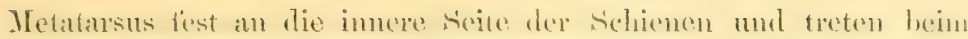
Gange nur mit dem zweiten und dritten 'Tassengliede aut', die deshalb allein eine dicht beharte Sohle besitzen.

Das Mänuchen reichnet sich durch das erwoiterte arste Glies? der Vordertarsen und den abgestutaten llinterrand des letaten lianchringes ans; der l'enis ist sehr einfach gebaut, fast so lang als rler Hinterleih), schwach gekrimmt, oben gewölbt, unten rimmenfiirnig vertieft, an der spitze abgerumlet oder zugespitzt, ibrigens bei den verwandten Arten sehr wenig verschieden.

Die Gattung lässt sich an den zehngliedrigen Fühlem und dem entfernt ron der spitze der Hinterschienen eingefïgten Metatarsis ohue Schwierigkeit erkemen; sie enthält bis jetzt ungefähr 80 sebr ähnliche, doch der Mehrzahl nach gut zu unterscheidende Arten, welche an der Lnterseite der Blätter hauptsächlich auf Cruciferen mnd Solaneen gesellig leben und in der nördlichen gemässigten Zone, namentlich in Europa und Asien zu Hause sind. Bis jetzt wurden eingehende Beobachtungen über ihre Lebensweise und Entwicklung nur bei den drei häufigsten Arten angestellt, nämlich iiber die ron Ps. chrysocephala durch Taschenberg. (Schädliche Thiere, 1865, 69-72. t. 2. f. 1), Perris (Amu. Fr. 1876. 182 ), Omerod (Entomologist, 1878. 217-220) und Wttewaal (Landbouw-Courant. 1859; Abdruck in Sn. v. Vollenhoren, Gelede dieren 1859. 238); iiber Ps. napi durch Goureau, Ann. Fr. 1864. 668; und über Ps. dulcamarae, ebenfalls durch Groureau, 1. c. 1866. 169. Aus denselben ergiebt sich Folgendes: Die Eier werden im Friihlinge einzelı an den Stengel oder die Blattstiele der Tährpflanzen geklebt und liefern schon nach wenigen Tagen die Laven, welche fleischig; doch ziemlich fest, sehr gestreckt, fadenförmig orler cylindrisch, aber an beiden Enden schnell verengt, der Hauptsache nach weiss gefärbt und in ein bis zwei Monaten vïllig ausgewachsen ungefähr ein Viertel länger sind als der Käfex. Thr Kopf ist hornig: vorn flach gedriickt, mit kurzen, konischen, dreigliedrigen Fühlern, das letzte Segment ist länger als eins der vorhergehenden und endet in zwei kleine, aufgerichtete Spitzen oder zwei nach unten gekrümmte Irïkchen. Die Larren fressen im Innern des Blattstieles oder des Stengels, seltener auch im W wrzelstocke, einen Gang, der seine grösste Länge, etwa drei Centimeter, erreicht, wem er in dem Stengel oter jn den Stielen gradlinig nach unten verläuft, jedoch viel kïrzer zu sein pflegt, wenn er umbiegt, oder aus Seitentrieben oder Blattstielen in den Haupttriel, oder den Stengel übergeht. Eine Pflanze beherbergt gewïhnlich ohne wesentlichen Nachtheil mehrere Larven. da die Gänge, die bald iiber einander liegen, bald neben einander herlanten und nur duch diime /wischenwïnde geschierlen werden, 


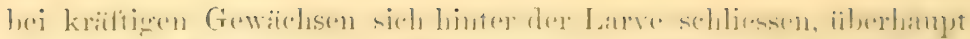
viel zn klein sind, 1 m das Wachsthum der I'flanze erhelflich leeinträchtigen oder unterdriicken zu kïmen; daher kommen Fialle. in denen die Psyllioden. \%. B. rlmysorepterle aut liajsfeddern, natuhatten Schaden aurichten, ïnsserst selten vor. Die Larven sind verschierten gezeichnet; 1. chrysorephala: weiss, Koplif, rin Saum ann Vorderrande des P'rothorax, zwei Querlinien in der. Mitte und neben jeder ein Punkt auf dem Meso- und Hetathorax, zwei Querlinien, aus je 6 kleinen Punkten gebildet, auf jerlem der 8 Baucluringe. das letzte Segment, die Unterseite des Prothorax und die Beine hraun. Die Zeichnung ist an jungen Larven dentlich, an ausgewachsenen verloschen und rerliert sich bei der dufluewahrung in Spiritus ganz; 2. napi: weiss, Kopf, ein undeutliches šchildchen anf dem Prothorax und die Spitze der Beine schwarz; 3. dulcamarae: weiss, Kopf bräunlich mit schwarzen Mandibehn, Beine hraun gefleckt, auf der Oberseite des letzten Segmentes eine schildförmige, tiefschwarze Platte, deren Seiten- und Hinterrand erhaben ist.

Die Verpuppung geschieht in der Erde, im Juli erscheint das vollkommene Insekt.

Die erste Uebersicht der europäischen Arten ron Foudras (Mon. 38.) war lediglich auf die Färbung basirt und wurde bald durch die von Kutschera verdrängt, welche besonders die Stellung des Kopfes und die Bildung der Hinterschienen in Betracht zog; ich habe letztere in der nachfolgenden Tabelle so weit als mïglich zu benutzen versucht.

1. Oberlippe sehr kurz und breit, hinter dem abgestutzten und aufgebogenen Vorderrande vertieft; Kopf unterhalb der Augen äusserst kurz, ohne Fühlerrinne, Seiten des Halssel. ziemlich parallel, Fld. auf dem Abfalle zur Spitze sparsam behaart. Hinterschienen so stark zusammengedrückt, dass der Rücken linienförmig erscheint, Metatarsus in der Mitte derselben eingefügt, so lang als die halbe Schiene und kaum länger als das zweite Glied. Subgenus Semicnema Ws.

Hierher nur eine Art: Gestreckt, fast gleich breit, oben schwarzblau, kräftig punktirt. - L. 3,2 mm. Wien 1. Reitteri W's.

$1^{1}$. Oberlippe höchstens doppelt so breit als lang, am Vorderrande abschiissig, Kopf unter jedem Ange mit deutlicher Fühlerrimne, Halssch. nach vorn rerengt, Fld. kahl. Hinterschienen mässig zusammengedrückt, Metatarsus zwischen der Mitte und Spitze derselben eingefügt, viel länger als das zweite Glied . . 2.

2. Die Stirn geht durch eine punktirte weite und sehr flache Vertiefung fast unmerklich in den Augenrand über. Mandibeln 
stark zusammengedrickt, scheinbar droizilnion, Seitenzähnchen klein und undentlich. Kopfschild dureh eine tiefe Bogenlinie aligesetzt Metatarsus apleiumnt. Spindelförmige, unvollkommen gotliggralte Arten. Subgenus Marrocnema Ws. . . 3.

2t. Die stirn ist durch eine scharfe und tiefe Rimns von den Augen geschieden. Mandibeln wenig zusammengedrückt, mit 5 dentlichen '/aihnen. Metatarsus gerade, gleichbreit. Kopfschild vertieft, bandförmig Psylliodes. i.sp. . . . . . 5.

3. Fld. an der Sipitze abgestutzt, mit stumptivinkeliger Nahtecke. Metatarsus in der Mitte am höchsten, nach der Spitze hin merklich rerengt. Erzgrün, Malssch. dicht und tief punktirt, matt oder wenig glänzend. - L. 2-3 mm. Ganz Europa und Sibiren . . . . . . . . . 2. cucullata 1 . . . .

3'. Fld. an der Spitze gerundet-rerengt, mit spitzwinkeliger Nahtecke. Metatarsus nach der Spitze hin unmerklich oder nicht verschmälert . . . . . . . . . . . . . . 4.

4. Erzgrün, Halssch. zerstreut und verloschen punktirt, glänzend.L. 2-2,3 mm. In den Pyrenäen, besonders bei Cauterets

petasata Foudr.

41. Dunkel erzfarbig-braum, Halssch. und Fld. kräftig punktirt. L. 3-3,5 mm. Sierra de Gerez .. . . Heydeni Ws. ${ }^{1}$ )

5. Ungefliigelt, Schulterbeule der Fld. fehlend oder sehr schwach entwickelt und nicht vortretend. . . . . . . . 6 .

5'. Tollkommen geflügelt (nur bei Ps. napi kommt eine ungeflügelte Form ror), Schulterbeule der Fld. deutlich rortretend. . 12.

6. Stim bis ror die Fühlerwurzel in gleichmässigem Bogen gewiilbt. mit hohem Kiele; Prosternum ror den Hiiften breit und zienlich eben, der Mund also von den Hiiften weit getrennt. Kurz und sehr regelmässig oral, schwarz mit blanem oder grituem Metallschimmer, Fühler, Schienen und Tarsen rothgelb, alle Schenkel schwarz. - L. 2,5-3,2 mm. Karpathen, Ostalpen . . . . . . . . 7. subaenea Kutseh.

61 . Scheitel mehr oder weniger gewölbt, aber die Stirn bis zum Kopfschilde flach gedriickt; ror den Hüften mehr oder weniger abschiissig, so dass sich der Mund an die Hüften legen kamn 7.

7. Schwarz, ohne wesentliche metallische Beimischung . . 8.

1) Psyll. Heydeni: Elongato-ovatr, convexa, acnea, nitida, antennis apice infuscatis pedibusque testaceo-rufis, femoribus posticis aeneis, mothorice antrorsum compresso, sat welre punctuto, interstitiis sultilissime alutaceis, elytris sat fortiter punctuto-striatis, interstitiis munctulatis, angulo suturali acuto. Metrsterno haud dilatat». - Long: 3-3,5 mm. Sierra de Gerez (von Heyden).

VI. 5. 
71. Braun his schwarz, bei ausgefärbten stüken mehr, bei trischen weniger metallisch-grün . . . . . . . . . . . 9.

8. I ainglich-oder lang-rsal, rein und tief schwarz, Vorderbrust nach dem Halse zu nicht abschiissig, letaterer von den Hiiften durch einen schmalen und ziemlich ebenen Querstreifen getrenut. Halsseh. dicht gewirkt und deutlich punktirt, Fld. mit schwachen Punktreihen, die aus grossen, flachen I'unkten gebildet sind. L. 2-2,5 mm. Tatra, Karpathen, Transsylranische Alpen

$$
\text { Frivaldszkyi Ws. }{ }^{1} \text { ) }
$$

81. Kurz-oval, mit der Spur eines metallischen Anfluges, Vorderbrust abschüssig, der Mund an die Hüften anlegloar, Halssch. äusserst fein gewirkt und verloschen punktirt, Fld. mit ziemlich starken und tiefen Punktstreifen. - L, 2,5-3 mm. Mittel- und Ostalpen . . . . . . . . . 6. glabra Duft.

9. Beide Leistenzähme hoch, der erste sehr spitz, der zweite mit breiter, nach hinten übergeneigter spitze. - L. 2,5-3 mm. Tirol, Sïdeuropa, Nordafrika, Syrien. . 4. inflata Reiche.

91. Beide Leistenzähne niedrig und klein . . . . . . . 10.

10. Hinterschienen ziemlich schlank, der erste Zahn spitz aufstehend, der zweite stumpfwinkelig. - L. 2,5 mm. Kärnthen, Istrien . . . . . . . . Kiesenevetteri Kutsch.

101. Hinterschienen kurz und breit . . . . . . . . . 11.

11. Der erste Leistenzahn stumpfwinkelig, der zweite abgerundet, zwischen beiden ein ziemlich tiefer bogenförmiger Ausschnitt. Eiförmig, erzbraun, mit grünlichem Glanze, Fühler und Beine rostroth, Hinterschenkel erzfarbig, oft die Vorderschenkel zum grössten Theile schwärzlich. Halssch. fein und mässig dicht, nach den Seiten stärker punktirt, glänzend, Fld. punktirtgestreift, mit breiten, glänzenden, äusserst fein punktirten Zwischenstreifen. - I. 2,8-3,3 mm. Asturien, Portugal

Gougeleti All.

11'. Der erste Leistenzahn undeutlich oder fehlend, hinter ihm entreder eine selur sanfte oder keine Ausbuchtung, der zweite Zahn hat die Form eines kleinen Kreisabschnittes. Elliptisch, bläulich-erzgruin, Fühler und Beine mit Ausnahme der Hinter-

1) Psyll. Frivaldszkyi: Oblongo-ovata, convexa, saturate nigra, nitidd, antennis pedibusque ferrugineis, femoribus posticis plerumque piceis; fronte punctata, prothorace ninus transierso, antrorsum rotundato-angustato, supra ralde convexo, evidenter alutaceo et punctato, subsericeo-micante, elytris concinne striato-punctatis, interstiis planis, prosterno ante coxas haud declivi. - Long. 2-2,5 mm. 
schenkel hell rostroth, Halssch. dicht punktirt. wenig wänzend, Fld. punktirt-gestreift, mit mässig breiten, ziemlich gläinzenden, deutlich punktirten $/ 4$ wischenstreifen. - I. 2,5-3,5 mu. Alpen, Süieuropa

5. gibbosa All.

12. Hinterschienen schlank, am Unterrande wenig gekrimmt, vor der Spitze löffelförmig ausgehöhlt, die äussere und die abgekürzte immere Seitemandleiste dicht und regelnüssig kammartig bedornt; Hinterschenkel mässig breit . . . . . . . . 13.

12. Hinterschienen kurz, am Unterrande stark gebogen, vor der Spitze meist rimuenförmig vertieft, mit sparsam, unregelmässig und kurz bedornten Seiten; Hintersehenkel sehr breit. . 33.

13. Stimlinien scharf und tief $\mathrm{x}$-förmig eingeschnitten, Stimhöcker dreieckig, deutlich begrenzt, Stirn bis zum Scheitel lederartig g'ewirkt, aber nicht punktirt. Gestreckt, erzgrïn, Fld. oft mit röthlicher Spitze, ihre Punktstreifen stark, Zwischenstreifen deutlich punktirt. - L. 2,3-3 mm. Mittel- und Südeuropa, ganz Sibirien... . . . . 9. attenuata Koch.

131. Die Stirnlinien zwischen den Augen und die Stirnhöcker sind sehr undeutlich oder fehlen . . . . . . . . . 14.

14. Halssch. an der vorderen Borstenpore kaum nach aussen gedrückt, die Seiten daher in schwacher Rundung ziemlich gleichmässig nach vorn verengt . . . . . . . . . 15.

141. Halssch. an der vorderen Borstenpore winkelig nach aussen tretend, davor stark und fast in grader Linie verengt . . 16.

15. Oberlippe rothgelb. Zwischenstreifen der Fld. deutlich punktirt. Lang-oral, griinlich blau, Unterkopf röthlich gelbbraun. Aendert ab: a. Halssch. roth, b. Halssch. dunkel erzfarbig, Fld. gelbbraun, c. Oberseite gelbbraun. - I. 3-4,8 mm. Europa, Sibirien . . . . . . . . . 11. chrysocephala L.

$15^{1}$ Oberlippe schwarz. Zwischenstreifen der starken Punktreihen auf den Fld. vereinzelt und äusserst fein punktirt. Glänzend dunkelblau, oval, wenig gewölbt, Fïhlerwurzel und Beine, mit Ausnahme der Hinterschenkel, rothgelb. - L. $3-3,5 \mathrm{~mm}$. Sicilien, Algeciras .... . . . . . ticollis Kutsch.

16. Oberseite, oder wenigstens die Fld. blau, griin oder erzfarbig 17.

161. Oberseite hell bräunlich- oder röthlichgelb . . . . . 30.

17. Augen verhältnissmässig klein, rund, Stinn quer, nach unten etwas verengt. Oval, schwarz mit leichtem Bronceschimmer, Oberlippe und Unterkopf dunkel rostroth. - L. 2,5-3 mm. Alpen, Apenninen ....... 8. latifrons Ws.

17. Augen gross, länglich, Stim ziemlich schmal, so lang, oder länger als breit

18. 
18. Ine liandsanmu der Angren arweitert sich zwischen der Angenlime mol der Vertiefung un die Fiihlerhasis in eine dreieckige. leicht gewiolhte, glatte Flaiche. Beide Leistenzähne klein, aher brech und selur spitz. Bram erzfarbig, I Jalssch. kräftig und die: Zwischenstreifen der Fld. dentlich punktirt. - L 2,5--.;mm. Mitteleuropa . . . . . . 10. cupreata Duft.

18'. Der Randsaum der Augen erweitert sich üher der Fiihlerwurzel nicht

19. Kopf und Halssch, einfarbig roth, letzteres mneilen schwarz. Fld. blan, hlaugrün oder grïu. - L. 3,3-4 mm. Hauptsächlich in Mitteleuropa....... . 12. cyanoptera Ill.

191. Kopf entweder schwarz, oder wie die Fld. getärlot. . . 20.

20. Die Rinue neken dem Innenrande jedes Auges läuft ununterbrochen bis zur Fühlerwurzel nach unten . . . . . . 21.

201. Die Augenrimne ist durch eine schräge Querleiste, welche ron denı änsseren Theile der linienförmigen Stirnhöcker gebildet wird, eingeengt und ron der Tertiefung um die Fühlerbasis mehr oder weniger vollkommen geschieden. . . . . 27.

21. Halssch, und Fld. stark gewölbt . . . . . . 22.

$21^{1} . \quad " \quad$ sehwach gewölbt . . . . . . 24.

22. Körper oval, wenig gestreckt, Punkte in den Reihen der Fld. stark, weitläufig gestellt. Oberseite schwarzblau bis grün, Beine röthlichgelb, Hinterschenkel schwarz. - L. 2-3,s mm. Im grössten Theile von Europa . . . . . . . 13. napi Fabr.

221. Körper gestreckt, lang oval, Vorderschenkel stets angedunkelt 23.

23. Oberseite veilchenblau, auf Kopf und Halssch. blau. Punktstreifen der Fld. mässig stark, gedrängt punktirt, Zwischenstreifen leicht gewölbt. - L. $3 \mathrm{~mm}$. Wien . 14. picipes Rdtb.

$23^{1}$. Blänlich- oder grïnlich-schwarz, namentlich auf Kopf und Halssch. stark glänzend, Punktstreifen der Fld. fein. mässig dicht punktirt. Zwischenstreifen eben. - L. 2,s-3,3 mm. Cephalonia, Parnass. . . . . . Milleri Kutsch.

24. Halssch. im Verhältniss zu den Fld. auffällig schmal, von den Hinterecken bis zur rorderen Borstenpore unmerklich rerengt, wenig breiter als lang. Länglich-oval, ziemlich Hach, oben gewirkt, matt seidenartig gläuzend, korublumenblau oder heller blau, oft mit grünlichem Schimmer, Fühler und Beine pechschwarz, die ersten 2 Fiihlerglieder rostroth, die Hinterschenkel ocler alle Schenkel bläulich schwarz. Halssch. dicht und fein punktirt, Fld. an den sichultern stark heraustretend, in den nicht tiefen Streifen dicht mit mässig grossen Punkten besetzt. Vorderbrust ror den Hüften sehr lang, Hinterschienen schlank, 
der Metatarsus kur\% ver der Spitze eingelenkt. 1. 2,5 mm. Südspanien . . . . . . coerulea Ws. ${ }^{1}$ )

241. Halssch. an der Basis wenig schmaler als die Fld., bis zur vorderen Burstenpore deutlich verengt . . . . . . . 25.

25. Scheibe des Halssch. dicht und fein, aber tief punktirt. Dunkel broncegrün oder lmann, Punktstreifen der Fld. scharf' ansgeprägt. - L. 2, $-3,5 \mathrm{~mm}$. Südwestliches Viertel von Europa

16. obscura Duft.

251. Scheibe des Halssch. verloschen punktirt . . . . . 26.

26. Oberseite blau oder hlaugriin, Punktreihen der Fld. mässig stark, auf der hinteren Hälfte nur wenig abgeschwächt, Zwischenstreifen äusserst fein gewirkt und in der Regel deutlich punktulirt, Fühlerwurzel und der grösste Theil der Beine röthlich gelbbraun. - L. 3-4 mm. Mittel- und Siideuropa

15. thlaspis Foudr.

261. Oberseite verschossen metallisch brann, grün oder blau, Punktreihen der Fld. fein, anf der hinteren Hälfte sehr schwach, Zwischenstreifen fein gewirkt und sehr undeutlich punktulirt. Fühlerwurzel und der grösste Theil der Beine hell bräunlichgelb. - L. 2,5-3,2 mm. Nittel- und Südeuropa, Nordafrika, Syrien . . . . . . . . . 17. cuprea Koch.

27. Die Stirnhöcker verbinden sich vollständig mit dem Augenrande. Punktstreifen der Fld. hinten kaum merklich abgeschwächt, die Punkte in ihnen äusserst gedrängt; Zwischenstreifen dicht und deutlich punktirt. Dunkelgrün oder blau. - I. 3,5-4 mm. Suideuropa. In Mitteleuropa bis Mainz . 18. fusiformis Ill. 27․ Die Stirnhöcker, von denen meist nur die äusserste Spitze scharf ausgeprägt ist, erlöschen dicht neben dem Augenrande. Punktstreifen der Fld. allmählich nach hinten abgeschwächt 28.

28. Kurz eiförmig, Halssch. dicht gewirkt, nur an den Seiten bemerkbar punktirt, Zwischenstreifen der Fld. fein gewirkt. Dunkelgrün oder kupferig. - L. 2,5 mm. Südfrankreich, Oesterreich . . . . . . . . . . . 21. aerer Foudr. 281. Lang eiförmig, Halssch. deutlich punktirt . . . . . 29.

1) Ps, coerulea: Oblongo-ovata, depressiuscula, nigra, antennis articulis 2 primis ferrugineis, supra coerulea aut cyunea, sublitissime alutacea, sericeo-micans, fronte lateribus sulparallelis parce subtiliter punctata, prothorace vix transverso antice leviter angustato, rebre subtiliter punctuto, elytris prothorace evidenter latioribus, punctato-striatis, interstitiis punctulatis, callo humerali prominulo; prosterno ante coxas lato, tibie posticis gracilibus, metatarso paullo ante apicem inserto. - Long. '2,5 $\mathrm{mm}$. Hispania meridionalis. 
29. Stark fewrilht, dunkelgriin, durchgängreg tein punktirt. - I. 2,5-3 mm. Witteleuropa . . . 20. instabilis Frudr.

291. Mässig gewölbt, lehhaft grün orler braun metallicch, durchwex kräftig punktirt. - L. 3-3,5 mun. Mittel- und sïrleurora

19. pyritosa Kutsch.

30. Stirn deutlich gewirkt, ohne Punkte. Kopf, Naht der Flı., Brust, Bauch und Hinterschenkel pechschwarz bis rothlraum, letztere am Unterrande winkelig erweitert. - I. 2,3-3,3 mm. Europa . . . . . . . . 22. affinis Payk.

301. Stirn punktirt, Hinterschenkel normal 31.

31. Beide Leistenzähnchen klein und niedrig, das letzte Drittel der Hinterschienen wenig breiter als der vortere Theil. Taht und Spitze der Fld, zuweilen auch der Aussenrand, nebst Kopf und Halssch. schwarz. - L. $3-3,5 \mathrm{~mm}$. Oesterreich, Siideuropa, Syrien . . . . . . . . 23. circumdata Redtb.

31'. Beide Leistenzähne hoch, letztes Drittel der Hinterschienen auffällig breit .

32. Brust schwarz, Punktreihen der Fld. fein. Breit eiförmig. Kopf und Halssch. rothbraun mit grünem Metallschimmer, Fld. blass gelbbraun. - L. $3 \mathrm{~mm}$. Am Meeresstrande in Südfrankreich, Spanien, Algier . . . . . pallidipennis Rosh.

321. Kopf, Halssch. und Brust rothbraun, oft nit schwachem griinen Metallschimmer, Punktreihen der gelbbraunen Fld. kräftig. L. 3--4 mm. Am Meeresufer um Mittel- und Siideuropa

24. marcida Ill.

33. Halssch. doppelt punktirt . . . . . . . . . . 34.

$33^{1}$. $\%$ einfach $\%$, an der Basis jederseits mit einem Längsgriibchen und am Vorderrande, jederseits hinter dem Auge, mit einer Randleiste . . . . . . . . . . 35.

34. Stirnlinien seicht, zwischen Fühlerwurzel und Auge keine Grube, Seitenrand des Halssch. an der vorderen Borstenpore winkelig nach aussen tretend, Reibefläche des ersten Bauchringes quer gerieft, nicht punktirt. Oberseite schwarzblau, Beine dunkel, Punktstreifen der Fld. fein. - L. 3,5-4 mm. Europa

25. dulcamarae Koch.

341. Stimlinien tief, über der Fühlerwurzel eine Grube, Seiten des Halssch. gleichmässig nach vorn convergirend, an der vorderen Borstenpore nicht winkelig nach aussen tretend. Reibefläche des ersten Bauchringes punktirt, Punktstreifen der Fld. stark. L. 3-4 mm. Europa, Sibirien. . . . 26. hyoscyami L.

35. Innere Randleiste der Hinterschienen normal, der erste Zahn niedrig, der zweite auffallend hoch und stark, die abgekürzte Innemrandleiste selr hoch, tief ausgeschnitten, der vordere 
'Theil zahnfömig. Glänzend röthlich gelbbraun, Flrl. hlasser. I. 2,5-3,5 mm. Siidfrankreich, Spanien, Italien

puncticollis Rosh.

35\%. Die innere Randleiste der Hinterschienen steigt allmählich bis zur Metatarsalbasis an, fällt dahinter wieder ah und endet kurz vor dem Enddorne, die Leistenzähnehen fehlen

36.

3:- Metatarsus ungefähu in der Mitte der Schiene eingefügt. Hell röthlichgelb, Stirn glatt, Halssch. fein, Fld. stark punktirt, mit sehr fein punktirten Zwischenstreifen. Vordere Borstenpore des Halsseh. in $1 / 3$ der Länge eingestochen. - L. 3-3,6 mm. Andalusien, Algier, Sicilien . . . . . algirica All.

$36^{1}$. Metatarsus etwa in $2 / 3$ der Schiene, vordere Borstenpore des Halssch. näher an den Vorderecken, etwa in $1 / 4$ der Länge eingefügt . . . . . . . . . . . . . . . 37 .

37. Stirn zwischen den Augen doppelt punktirt. Hell rostroth. L. 2,5-3 mm. Mittel- und Südeuropa . . 27. luteola Mïll.

37'. Stirn glatt . . . . . . . . . . . . . . . 38

38. Punktstreifen der Fld. tief, nur dicht vor der Spitze abgeschwächt, mit sehr schmalen, leicht gewölbten, äusserst fein punktirten Zwischenstreifen . . . . . . . . . 39.

381. Punktstreifen der Fld. mässig tief, nach hinten allmählich abgeschwächt, Zwischenstreifen eben . . . . . . . 40 .

39. Länglich-oval, die Fld, an den Seiten fast parallel, Halssch. nach vorn mässig verengt und zusammengedrückt, fein punktirt mit glatten oder einzeln und äusserst fein punktulirten Zwischenräumen. Schwarz, mit schwachem Erzglanze, Taster, Fiihler (nach der Spitze hin angedunkelt), und Beine hell rostroth, Hinterschenkel schwarz, am Unterrande und der Spitze roth. Fld. bei frischen Stücken braun bis gelbbraun, mit Erzschimmer. L. 2,5-3 mm. Mittel und Südspanien obscuroacnea Rosh. 391. Kurz-oval, an den Seiten gerundet, Halssch. nach vorn stark verengt und zusammengedrüickt, dicht und mässig fein, aber nicht tief punktirt, mit äusserst fein gewirkten Zwischenräumen; schwarzblau, Taster, Fühler, Schienen und Tarsen röthlichgelb. I. 2,5 mm. Auf Castanea vesca im westlichen Creta cretica W s. ${ }^{1}$ )

1) Psyll. cretica: Breviter ovalis, sat convexa, coeruleo-nigra, nitida, ralpis, antennis, tibiis tarsisque testaceis, fronte laevi, tuberculis frontalibus minus distinctis, triangularibus, foveola separatis, prothorace antrorsum fortiter compresso-angustato, crebre parum profunde punctato, interstitiis obsoletissime alutaceis, elytris lateribus sat rotundatis, profunde punctatostriatis, interstitiis angustis, leviter convexis, subtilissime punctulatis. mm Creta (Reitter). 


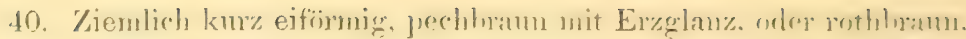
Halssch. fein punktirt, init glatten orler unnerklich gew wirkten Zwischenräumen, Schulterbenle der Flrl. wenigr antwickelt. Zwischenstreifen sehr fein punktirt. - L. 2,5-3 unu. Mitte]europa . . . . . . . . . 28 picina Marsh. 401. Länglich-eiförmig, schwarz-er\%farbig. grimulich oter bläulich schimmernd. Halssch, dicht punktirt mit gewirkten Zwischenräumen, Schulterbeule der Fld. ziemlich stark entwickelt. Zwischenstreifen fein punktirt. - L. $3 \mathrm{~mm}$. Italien, sicilient. Syrien .......... . laevifrons Kutsch.

A. Labrum transversim lineare, margine antico elecato. Caynet antimum brevissimum scrobiculo antennali mullo. Tibiat. posticae graciles, valde compressat: metutarsus in medio insertus articulo :2: o longitudine aequalis. Subgenus Scmicnema.

1. Psyll. Reitteri: Alata, subparallela concexiuscula, subtus nigru, supra aneo-coerulea, nitida, antemis jiceis, basi testaceis, pedibus ferrujineis, dorso femorum posticom infuscato: fionte ata, antice polita, postice alutucea et subremote subtiliterque punctata, sulcis vocularibus nullis. Prothorace antrorsum haud angustato sed purum compresso, sut fortiter punctato, linea mediu laeri, elytris apice rotundato-truncatis, profunde punctato-striatis, interstitiis fere uniseriatim punctulatis. Long. $3,3 \mathrm{~mm}$.

Vom Ansehen einer Chactocnema, gestreckt, fast gleichbreit, mässig gewölbt, glänzend schwarzblau, mit einem Stich ins Grüne, Brust und Bauch schwarz. Kopf gross, etwas breiter als lang: Stirn quer, schwach gewölbt, ziemlich weitläufig fein, aber tief punktirt. im oberen Theile gewirkt, zwischen den Füblem glatt, seitlich sanft bis zum Rande der Augen abfallend; letztere sind gross. rund, mässig gewölbt, ziemlich grob facettirt. Dicht unterhalb der Fiihlerwurzel und Augen fällt die Stirn plötzlich zu dem rostrothen bandförmigen Streifen des Kopfschildes ab, so dass für die Fühlerfurche kein Raum bleibt. Die Oberlippe ist ungefähr viermal so breit als lang, rostroth, vorn der Quere nach rinnenförmig vertieft, ihr abgestutzter Vorderrand aufgebogen. Fühler halb so lang als der Körper, die ersten drei Glieder bräunlichgelb, die drei folgenden rothbram. die übrigen pechbram. Halssch. un die Hälfte breiter als lang und etwas breiter als der Kopf, nach rorn wenig zusammengedrückt und kaum verengt, die Seiten leicht gerundet und hinter der vorderen Borsteupore. welche nahe an den Vorderecken liegt. 
sowie vor den Hinterecken simft ausgebuchtro, oben mäsigg dicht, tief und fein, nach dem Seiten- und Hintervande zu allmählich immer stärker punktirt, mit breiter glatter Mittellinie. sehildchen quer, dreieckig, glatt. Fld. etwas breiter als das IIalssch., in den A'chultern schnell heraustretend, dahinter unbodeutend exweitert, ziemlich parallel, an der Spitze gerundet-alogestutzt, mit stumpfwinkeliger Nalıtecke; Schulterbeule mässig entwickelt, glatt, Punktstreifen vertieft und stark und tief, äusserst dicht punktirt, die schmalen Zwischenstreifen mit je einer nicht ganz regelmässigen und sehr feimen Punktreihe. Beine hell rostroth, der Rücken der Hinterschenkel schwärzlich, Hinterschienen vollständig zusammengedriickt, der Metatarsus in der Mitte eingefitgt, fast halb so lang als die Schiene und kaum länger als das zweite Tarsenglied.

Ein stiick dieser anffälligen Art wnrde von Herrn Reitter in der Umgegend Wien's gefangen.

B. Mandibulae valde compressae, dentibus lateralibus mimutissimis. Caput mutans, carina faciali lata deplanata, sulcis ocularibus mullis, clypeo linea arcuata profunda separato. Corpus subapterum. - Subgenus Macrocnema Ws.

2. Psyll. cucullata: Elongato-ovata, convexa, obscure aeneo-viridis, sat nitida, antemis apicem versus infuscatis pedilusque testaceo-rufis, femoribus posticis aeneis, anterioribus saepe firscis; fronte alutacea ct obsolete parceque punctulato, wrothorace antrorsum compresso-angustato, confertim punctato, elytris punctato-striutis, interstitiis vage rugulosis et punctulatis, angulo suturali obtuso. Metatarso in medio dilatato. Long. 2-3 $\mathrm{mm}$.

Illig. Mag. VI. 73 et 172 (Halt.). - Kiist. Käf. Eur. 28. 9. Bach, Käferf. III. 157. - Foudr. Mon. 62. - Kutsch. Wien. Mon. 1864. 422 (392). - All. Mon. 480. - Redtb. Faun. A. II. 515. - Seidl. F. balt. 501. - Thoms. Skand. Col. VIII. 241. - Leesberg, Tijdschr. Ent. 24. 185.

Haltica spergulae Gyllh. Ins. Suec. 111.571.

Halt. spergulae var. angustata Waltl, Isis 1835. 82.

V ar. a. Nigro-aenea, coeruleo-micans.

Cylindrisch, beiderseits verengt, dunkel grïnlich erzfarbig, die Basis der schwärzlichen Fühler und die Beine (mit Ausnahme der Hinterschenkel) rostroth, die Vorderschenkel oft stark gebräunt. Kopf senkrecht, rom Vorderrande des Halssch. verdeckt, Stirn breit, mit mässig gewölbtem Scheitel, fein gewirkt und vereinzelt und verloschen punktirt; Höckerchen undeutlich, durch eine Grube geschieden, ohen nicht oder nur sehr schwach von einer Linie be- 
grenzt, welche fast grarle zu den Augen läuft und hier in pinen weiten Eindruck ühergelıt; Stirnkiel breit, flach gedrückt, vorn in eine tiefe Bogenlinie abfallend, die das grosse Kropfschild begrenzt. ILalssch. nach vorn gleichmässig und stark zusammengedriickt und verengt, wenig breiter als lang, fein gewirkt und dicht und tief punktirt, fettig glänzend. Fld. an der Basis so breit als der Hinterrand des Halssch., im ersten Viertel ctwas erweitert, dahinter wieder allmählich verengt, an der Spitze schwach einzeln abgestutzt. mit stumpfwinkeliger Nahtecke; die Schulterbeule niedrig, nur bei den grösseren Exemplaren deutlich abgesetzt, Punktstreifen fein (q) oder mässig stark ( $\hat{\sigma})$, nicht besonders scharf begrenzt, bis zur Spitze wenig abgeschwächt; Zwischenstreifen glänzend, verloschen gerunzelt und punktirt.

Vorderbrust vor den Hüften abschüssig, so dass der Mund an letztere gelegt werden kann; Hinterschienen ziemlich schlank, ihre Höcker niedrig, abgerundet, durch eine sanfte Ausbuchtung geschieden, Metatarsus in der Mitte am höchsten, beiderseits allmählich verschmälert.

Die griine Farbe der Oberseite hat nicht selten einen blauen Schimmer (Var, a.)

An Spergula arensis und anderen Pflanzen auf trockneren Wiesen, Waldsäumen, besonder's in jungen, grasigen Schonungen gemein.

C. Mandibulae plerumque evidenter 5-dentatae. Caput sulcis ocularibus distinctis, clypeo transiersim lineare. Metatarsus medio haud dilatatus. Psylliodes in spec.

* Corpus subapterum, callo humerali nullo.

3. Esyll. Kiesenwetteri: Oblongo-ovata, comexa, nigro-aenea, nitida antennis apicem versus leviter infuscatis pedibusque ferrugineis, femoribus anterioribus infuscatis, posticis piceis; fronte minus dense punctata, prothorace transverso antrorsum compresso-angustato, crebre punctato, elytris sat profunde punctato-striatis, interstitiis punctulatis; dente primo carinulae parvo, acuto. - Long. 2,5 mm.

Kutsch. Wien. Monat. 1864. 425 (395) Anmerkung. - Redtb. Faun. A. II. 516.

Psylliodes petasata Kutsch. 1, c. 423 (393).

Var. a. Obscure aeneo-coerulea.

Var. b. Immatura, elytris brunneis, aeneo-micantibus.

Den kleineren Stïcken der vorigen Art ähnlich, aber verhältnissmässig breiter, beiderseits weniger verengt, glänzender, der Kopf stärker punktirt, der Metatarsus von gleicher Dicke. 
Lang eiförmig, etwas cylindrisch, griulich schwarz mit Bronceschimmer, glänzend, Fühler röthlich gelhbraun, die letzten füinf Glieder gebräint, Beine rostroth, die vier Vorderschenkel, mit Ausnahme der Basis und Spitze, schwärzlich, Hinterschenkel pechschwarz, auch die Schienen bisweilen angerlunkelt. Kopf senkrecht, Stirn wenig gewïlbt, an den Seiten von einer tiefen, nach der Fiihlerwurzel ziehenden Rimne begrenzt, anf dem Scheitel fein, nach unten allmählich stärker und zuletzt über dem Grübchen zwischen den Fühlern runzelig punktirt, so dass die schmalen, glatten Höckerchen nirgends deutlich begrenzt sind. Stirnkiel breit, flach, glatt, dreieckig, vorn plötzlich zu dem bandförmigen Kopfschilde abfallend; Oberlippe und Taster pechbram. Halssch. breiter als lang, nach vorn ziemlich stark zusammengedriickt und verengt, äusserst fein gewirkt (bei frischen Stüeken stärker), dicht punktirt, auf der Scheibe feiner als an den Seiten. Die Fld. bilden mit dem Halssch. ein regelmässiges Oval, dessen grösste Breite in der Mitte oder etwas dahinter liegt, sie sind hinten ziemlich schnell gerundet-verengt, zuletzt abgestutzt, mit stumpfwinkeliger Nahtecke; die Schulterbenle undeutlich, Punktstreifen mässig stark, schärfer als bei cucullatı ausgeprägt, Zwischenstreifen stärker glänzend, unmerklich gerunzelt und fein punktulirt. Vorderbrust vor den Hüften abschüssig; Hinterschienen ziemlich schlank, mit kleinen Zähnen, der erste spitz, aufstehend, der zweite stumpfwinkelig.

Zuweilen schimmert die Oberseite blau (Var. a), bei frischen Exemplaren sind die Fld. braun, mit erzgrünem Anfluge.

In Kärnthen (Kahr) und bei Pola in Istrien (Stussiner).

4. Psyll. infiata: Ovata, convexa, aeneo-nigra, nitida, capite antice, antennis pedibusque testaceis, femoribus posticis piceis; fronte prothoraceque subtiliter punctatis, hoc transverso, antrorsum compresso-angustato, elytris minus fortiter punctato-striatis, interstitiis punctulatis, tibiis posticis sat latis, dentibus carinulae altis. - Long. 2,5-3 mm.

Reiche Ann. Fr. 1858. 50. - All. Mon, 484.

Var. a. Capite nigro-aeneo, labro clypeoque piceis, femoribus anterioribus infuscatis.

$\mathrm{V}$ ar. b. Immatura, elytris brunneis aut piceis, interdum aeneo-micantibus.

Durch die feine Skulptur der Oberseite und die kräftigen Zähne der Schienenleiste ausgezeichnet. Eiförmig, nach vorn etwas mehr als hinten verengt, gewölbt, schwarz-erzfarbig, glänzend; der Kopf unterhalb der Fuihler, diese selbst und die Beine röthlich gelbbraun, Hinterschienen pechbraun. Kopf wie bei der vorigen Axt gebaut, 
auf dem hrichsten Theile rer Stim soln fein. nach unten stwas stärker punktirt. Halssch. zienlich um die Hälfte breiter als lang, vorwïrts zissammengedrïckt und verengt, nit schwach gerundeten Seiten; fein und mässig dicht punktirt, an den Seiten etwas stirike. als in der Mitte. Fld. am Grumbe von der Breite des Halssch., his zur Mitte gleichmässig erweitert und dahinter abenso verengt, an der Spitze gerundet-ahgestutzt, regelmässig, weder besonders tief noch stark punktirt-gestreift, mit ebenen, mehr oder weniger deutlicl, punktulirten 'Zwischenstreifen. Vorderbrust abschiissig. Hinterschienen ziemlich kurz, der erste Leistenzahn klein, aber aufistehend und sehr spitz, der zweite hoch, hinten meist in schwachem Bogen ausgeschnitten, so dass die schmale, etwas abgerundete Spitze leicht nach hinten überhängt.

Von dieser Art scheinen vollständig ausgefärbte dunkle Exemplare selten vorzukommen, bei denen der Kopf his zum Kopfschilde einfarbig schwarzgrïn und nur das letztere nebst der Oberlippe pechbraun ist ( $\mathrm{Var}^{\circ}$ a); in den Sammlungen sind umreife Stiicke mit braunen Fld. (Var. b) vorzugsweise vertreten.

Im sürllichen Tirol (Nanuel) und in der Limgebung des mittelländischen Meeres ron Spanien und Marocco bis Syrien.

Sollte das Thier bestimmt ans Transcancasien nachgewiesen werdeu, so dïrfte darauf die $P_{s}$. callinote Fald. Fann. Transe. II. 348 (1837) zu beziehen sein, welche wohl nach Stiicken, die zur Var. a gehören, beschrieben worden ist.

5. Psyll.gibbosa: Oblongo-ovatu, convera, nigro-aenea, coeruleo-micans, sat nitida, capite antice ferrugineo, antennis apicem versus infuscatis pedibusque rufo-testaceis, femoribus posticis piceis; fronte alutacea subtiliterque punctata, mothorace transierso, apice compresso, alutacco, crebre punctato, elytris sat profunde punctato-striatis, interstitiis punctulatis tibiis posticis sat brevibus, dentibus corinulae haud discretis. Long: 2,5-3,5 mm.

All. Ann. Fr. 1860, 820; Mon. 484. - Kutsch. Wien. IIonat. 1864. 425 (395). - Redtb. Faum. A. II. 515.

Psyll. sicula Stierl. Mittheil. Schweiz. Ent. Ges. II. 1866. 228.

Psyll. ventricosa Rottb. Berl. ent. Zeit. 1871. 246.

Var. a. Supra haud coeruleo micans.

Etwas küuzer und im Verhältnisse breiter als mucullata. länglicheiförmig, beiderseits stark verengt, gewölbt, dunkel erzfarbig, mit blauem Schimmer, oder (Var. a) schwarz erzfarbig, ähnlich wie bei cucullata; der Kopf unter der Querlinie zwischen den Fühlern rostroth, die an der Spitze leicht gebräunten Fühler und die Beine röthlich 
gelbbraun, Hinterschenkel grösstentheiłs pechschwar\%. Kopf senkrecht, der Mund nicht selten etwas vorgestreckt und der gewölbte Scheitel oft über den Vorderrand des Halssch. vortretend, Stirn ziemlich flach, äusserst fein gewirkt, mässig dicht, fein punktirt, mit tiefer Augenrime jederseits; Stiruhöckerchen undentlich, nirgends scharf begrenzt. Halssch. um die Hälfte breiter als lang, gewölbt, aber nur nahe den Vorderecken stärker zusammengedrückt und verengt, fein gewirkt, dicht und kräftig punktirt. Fld. an der Basis so breit als der Grund des Halssch., bis zum ersten Drittel erweitert, dahinter znerst allmählich, im letzten Drittel stärker verengt, kräftig punktirt-gestreift, in den Zwischenstreifen punktulirt. Vorderbrust vor den Hiiften mässig abfallend, mit einem schmalen Querstreifen zwischen dem Halse und den Pfannen; Hinterschienen ziemlich kurz, am Unterrande deutlich gekrümmt, die Längsleiste derselben steigt allmählich an und besitzt vor der höchsten Stelle eine so schwache Ausbuchtung wie bei keiner der vorigen Arten, wodurch die Zähnchen sehr undeutlich werden, das erste derselben ist niedrig, das zweite bildet einen regelmässigen Bogen.

Diese Art ist in der Grösse, namentlich in der Breite sehr veränderlich, indessen an den schlecht ausgeprägten Zähnchen auf der Leiste der Hinterschienen stets sicher zu erkemnen; sie bildet im Verein mit Gougeleti, glabra und Frivaldszkyi, bei denen die Hüften rom Halse stufenweise weiter abgerückt sind, den Uebergang zu den Arten mit breitem und flachem Querstreifen der Vorderbrust und vorgestrektem Kopfe.

Auf Disteln in Tirol, Görz (Schreiber) und Krain. In Südeuropa besonders in Italien von Venedig (Czwalina) bis Sicilien häufig.

6. Psyll.glabra: Breviter-ovata, sat convexa, nigra, vix aeneo micans, nitida, antennis pedibusque ferugineis, femoribus posticis plerumque piceis aut nigris, fronte evidenter punctata, prothorace transverso antrorsum morlice angustato, obsolete alutaceo et subtiliter punctato, elytris sat fortiter punctato-striatis, interstitiis subconrexis, sublaevibus, dentilu.. carimulae obsoletis, prosterno declivi. - Long: 2,5-2,8 mm.

Duft. Faun. A. III. 282 (Halt.). - Kutsch. Wien. MIonat. 1864. 420 (390). - A 11. Mon. 479. - Redtb. Fann. A. ed. 3. II. 514 .

Psyll. alpina Redtb. 1. c. ed. 1. 538; ed. 2. 925. - Bach Käferf. III. 156. - Foudr. Mon. 51. - A11. Ann. Fr. 1860. 823.

Var. a. Prothorace haud alutaceo.

Var, b. Femoribus anterioribus infuscatis. 
Ku\% eifïmig, ziemlich gewïllst, glainzend. schwar, snit einem leichten, kaum bemerkbaren Metallschimmer, Fühler und Beine hell rostroth, Hinterschenkel bei ausgereiften Stücken pechloaun his schwarz, selten (Var. b) auch die worderen Schenkel geschwärzt. Kopf senkrecht, Stirn fein und tief, nach unten zu meist stäker als auf dem Scheitel punktirt, mit undeutlichen Stimlinien und Höckern, die durch eine Grube getrennt sind; der Stimkiel ist in der Regel etwas schmaler und gewiolbter wie bei den vorhergehenden Arten. Halssch. um die Hälfte breiter als lang, nach rorn schwach zusammengedrückt, mässig verengt, nämlich bis zur vorderen Borstempore, an welcher der Seitenrand schwach nach aussen gedrückt ist, gradlinig und sehr schwach, vor der Pore bedeutend stärker. Die Oberfläche ist gewölbt, durchaus glatt (Var. a) oder äusserst fein lederartig gewirkt, in beiden Fällen fein und seicht punktirt. Fld. an der Basis so breit als das Halssch., bis zur Mitte erweitert, hinten schmal abgerundet und etwas abgestutzt, mit starken und tiefen, hinter der Mitte allmählich schwächer werdenden Punktstreifen und leicht gewölbten, einzeln und verloschen punktulinten, daher fast glatten Zwischenstreifen. Vorderbrust abschüssig; Hinterschienen ziemlich kurz, die Leistenzähnchen undeutlich und ähnlich wie die dex rorigen Art gebildet.

In den Mittel- und Ostalpen auf feuchten, schattigen Stellen, an denen man das Thier gewöhnlich aus Moos siebt.

7. Psyll. subaeneat: Subelliptica, sat convexa, nigro-aenea, sericeomicans, antennis (rarius apicem versus infuscatis), tibiis tarsisque ferrugineis, femoribus anterioribus piceis; capite inclinato, carina faciali sat acute elenata, fronte convexa prothoraceque alutaceis vageque punctatis, hoc transverso, antice fortiter rotundatim angustato, elytris punctatostriatis, interstitiis obsolete punctulatis, prosterno planiusculo. - Long. $2,5-3,2 \mathrm{~mm}$.

Kutsch. Wien. Monat. 1864. 407. (377). - All. Mon. 466. Redtb. Faun. A. II. 514.

Var. a. Tibiis infuscatis.

Var. b. Olivacea.

Fast regelmässig elliptisch, beiderseits jedoch stark rerengt, mässig gewöllbt, schwarz-erzfarbig, fein gewirkt, seidenartig glänzend, Fiihler, Schienen und Füsse rostroth, erstere nur selten nach der Spitze zu gebräunt; die vier Vorderschenkel mit Ausnahme der Spitze schwärzlich, öfter (Var. a) auch die Schienen angedunkelt. Kopf etwas rorgestreckt, die Stirn gleichmässig der Länge nach gewölbt, mit der höchsten Stelle an dem flachen Gribchen, welches 
iiber der Fühlerwurzel liegt und die verwischten Höckerchen trennt; der Stirnkiel ziemlich hoch, nach unten zugespitzt. Halssch. breit, vorn leicht zusammengerlrückt, aber in starker Rundung verengt, nur mässig gewölbt, fein und verloschen punktirt; so dass sich die Punkte aus der feinen Granulirung des Grundes, wenigstens auf der Mitte der Scheibe, kaum herausheben. Am Hinterrande ist oft cine S:elle vor dem dritten bis fünften Punktstreifen der Fld. jederseits niedergedrückt und mit einigen starken Punkten besetzt. Fld. im vorderen Drittel ziemlich stark, dahinter allmählich immer schwächer punktirt-gestreift, vor der Spitze fast glatt, Zwischenstreifen rerloschen punktulirt. Vorderbrust fast eben, mit einem breiten Querstreifen vor den Hüften, die Hinterschenkel sind an der Basis mehr verschmälert und die Hinterschienen eine Spur länger als bei den vorigen Arten, das erste Leistenzähnchen klein, aufstehend, spitz, das zweite wenig höher, stumpf, zwischen beiden ein tiefer Ausschnitt.

Die Farbe der Oberseite erhält zuweilen eine bläuliche Beimischung, oft sind auch Kopf und Halssch. dunkler als die Fld. und fast schwarz, endlich (Var. b) ist der Körper metallisch olivengrün.

In den Ostalpen, den Transsylvanischen Alpen und Karpathen, nördlich bis zur Theissquelle in der Czerna hora.

\section{** Corpus alatum, callo humerali prominulo. \\ + Tibice posticae margine infero leviter curvatae, marginibus superioribus apicem versus dense denticulatae.}

8. Psyll. Latifrons: Subovata, sat convexa, piceo-aut nigro-aenea, nitida, capite antice plus minusve, antennarum picearum basi pedibusque ferrugineis, femoribus anterioribus infuscatis, posticis piceis aut nigroaeneis; fronte lata, subtiliter minus crebre punctata, prothorace transverso crebre punctato, elytris striato-punctatis, interstitiis parce punctulatis; prosterno subdeclivi, - Long. 2,5-3 $\mathrm{mm}$.

Psyll. picipes Foudr. Mon. 49. - All. Ann. Fr. 1860. 828. -

Kutsch. Wien. Monat. 1864. 406 (376), - Bach. 1. c. III. 156.

Psyll. rufilabris All. Mon 465.

Var. a. Supra coeruleo micans.

In der Körperform, der Bildung des Kopfes und der Fühler, sowie in der Skulptur den vorigen Arten, namentlich Ps. gibbosa ähnlich, aber an der kräftig entwickelten Schulterbeule leicht zu unterscheiden; die Form der Hinterschienen nähert sich mehr der von Ps. napi. 


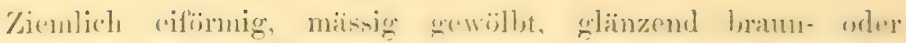

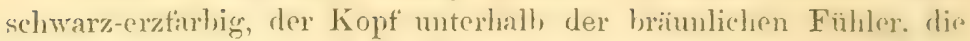
Basis der letzteren und dio Brine dumkel dostronth, die vorderen

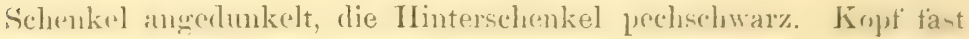
senkrecht. Stim breit. quer, loicht gowijlbt, änscerst fein gowirkt und riemlich weitläufig, fein, nach unten stwas stäker pmuktirt, mit undentlichen Höckern, die dureh ein Gribchrn gestrenut sinr, und einen breiten, flachgedrickten. glatten Kiele. Die Augen sind verhältnissmässig klein mol engen die Stirn nach rlen Fiihlerı zu etwas ein. Halssch. um die Hïlfte lıeiter als lang, grwäht, an den Vorderecken zusammengedriickt. nach voln in leichtem Bogen verschmillert, welcher durch den an der vorderen Pore heraustretenden Seitenrand etwas unterbrochen wird: es ist dicht und deutlich fein punktirt, in den schmalen Zwischenrämen zart gewirkt. Fll. an der Basis so breit als das Halssch., dahinter zuerst schnell, damn bis zur Mitte wenig erweitert, mit glatter. Schulterbeule und nicht besonders tiefen Punktstreifen, die aus dicht hinter einander gestellten kräftigen Punkten gebildet werden. Die Zwischenstreifen sind fein punktulirt. Die Vorderbrust bildet vor den Hüften eine Kante, ror der sie steil abfällt, die Hinterschenkel sind breit, Schienen ziemlich schlank, mit niedrigen Zähnen, welche ein sanfter Ausschnitt trennt.

Die Farbe der Oberseite erhält zureilen, namentlich auf den Fld, einen bläulichen Schimmer (Var. a); am Kopfe bleiben bei sehr dunklen Stücken nur die Oberlippe und der Mund rostroth. bei frischen dehnt sich die rothe Färbung bis in die Nähe des Scheitels aus, und wird auch auf den Epipleuren, der Brust und dem Bauche in verschiedenem Grade bemerkbar.

Auf Biscutella laevigata $I_{\text {. }}$ in den niederen Thälern an siidfusse der Alpen von der Rhonemindung (Nimes) bis in die Wiener Gegend. Tirol, Kärnthen, Steiermark, Italien.

Auf die vorliegende Art sind wahrscheinlich die Beschreibungen der Ps. picipes von Foudras, Allard und Kutschera zu beziehen, dagegen hat weder Ps. picipes Redtb., noch milabris Koch, oder Allardi Bach, mit derselben etwas zu thun. Die Kemutniss der Art scheint bei Allard unsicher gewesen zu sein, denn derselbe geht mit Stillschweigen darïber ninweg, dass er in der Ifonographie die ron ihm noch 1860, Ann. Fr. p. 806 und 828 getrennten Arten rufilaturis und picipes, ron denen die eine als laug, spindelförmig, die andere als kurz, eiförmig hingestellt ist, plützlich vereinigt mol damit Unterschiede im Körperumriss. die bei seinen Beschreibungen stets die Hauptrolle spielen, als nebensächlich ansieht. Ausserdem wurden ron ihm, in einer Sendung rom 25. December 1860 an H. Dr. Kraatz, ein kleines Stück von chrysocephula als rufilabris und ein ähnliches Exemplar der $P$ s. napi als picipes determinirt. 
9. Psyll. affenmata: Elmugato-viata, concexiusulu, acneo-virilis, sat nitida, antennis pulibusque fermuineis; capite parvo, fronte angusia, alutacen, lineis binis decussatis mofunde impressu, prothorace antronsum angustato, suberebre punctato, elytris striato-punctatis, apice mescentibus, interstitiis evidenter punctulatis. - Long. 2,3-3 mm.

K och, Ent. Heft. II. 34. t. 2. f. 10 (Halt.). - Illig. Mag. VI. 173. - Duft. Faun. A. III, 284. - Küst. Käf. Eur. 28. 90 (Psyll.). - Bach, Käferf. III. 155. - Foudr. Mon. 55. All. Mon. 458. - Kutsch. Wien. Monat. 1864. 399 (369).

- Redtb. Fam. A. II. 513. - Leesberg, Tijdschr. Ent. 24. 181 .

Macrocnema apicalis Steph. Ill. Brit. IV. 321; Man. 301.

$\mathrm{V}$ ar. a. Antennis apicem versus pedibusque plus minusve piceis.

Var. b. picicornis: Elytris unicoloribus.

Macrocnema picicornis Steph. l. c.

Psyll, attenuata var, picicornis Foudr., All., Kutsch. 1. c.

Psyll. attenuata var. vicina Redtb. 1. c. 513.

Die tiefen Linien auf der gewirkten, aber nicht punktirten Stirn und die röthliche Spitze der Fld. machen diese Art sehr kenntlich. Lang-eiförmig, mässig gewölbt, dunkelgrün mit Messingschimmer, ziemlich glänzend, Fühler und Beine dunkel rostroth, die ersteren nach der Spitze etwas gebräunt, namentlich die fünf letzten Glieder, welche erheblich breiter als die vorhergehenden sind; Hinterschenkel pechbraun. Kopf klein, etwas vorgestreckt, nebst dem Halssch. deutlich gewirkt, mit tiefen Stirnlinien, die sich $\mathrm{x}$-förmig durchschneiden. Halssch. etwas breiter als lang, nach vorn in schwachem Bogen verengt, der an der vorderen Pore unbedeutend gestört ist, oben mässig gewölbt, dicht punktirt. Fld. ungefähr dreimal so lang als breit, in den Schultern etwas erweitert, mit kleiner Schulterbeule, ziemlich stark und tief punktirtgestreift und in den Zwischenstreifen deutlich punktulirt, auf dem letzten Drittel gelb- bis rothbraun, mit grünlichem Messingschimmer überflogen. Vorderbrust beinahe eben, Hinterschienen schlank, die innere Leiste allmählich nach hinten ansteigend, das erste Zähnchen wenig erhölıt, dahinter plötzlich tief ausgeschnitten, das zweite Zähnchen grösser, gerundet.

Bei der unbedeutenden Abänderung a. sind die Fühler nach der Spitze hin und die vier Vorderschenkel pechbraun, mitunter auch die Schienen angedunkelt; bei b. die Fld. einfarbig grün.

Auf Hanf und Hopfen in Mittel- und Süddeutschland zuweilen in lästiger Menge; übrigens über den grössten Theil ron Mittelund Südeuropa bis in's östliche Sibiren verbreitet.

VI. 5. 


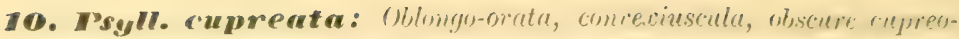
aenea, nitida, antenmis brasi ferragineis femoribusque unteriorilus piccis, tibiis tarsisque olscure ferrugineis; firmte angusta subtiliter junctula, margine interno oculonum supra antennas triangulariter dilatato, mothanace sulnuguloso-punctato, elytris striats-punctatis, interstiticis punctulatis; dentibus carinulae acutis. - Long. 2,5-3 mm.

Duftschm. Faun. A. III. 282 (Hallica). - All. M[on. 4:5. Kutsch. Wien. MLnat. 1864. 397 (367). - Redtb. Famn. A. II. 513. - Leesberg, Tijdschr. Ent. 24. 182.

Var. a. Immatura; pedibus omnino ferrugineis.

Durch den exweiterten Augensaum und die kleinen, aber spitzen Zähne auf der Leiste der Hinterschienen ron allen Arten alweichend. Länglich-eiförmig, mässig gewöllbt, dunkel kuptrig-erzfarben, glänzend, Fühler und Beine pechlraun, die Basis der ersteren sowie die Kuie, Schienen und Füsse rostroth. Stirn schmal, mit fast parallelen Päudern, auf dem Scheitel gewirkt, darunter bis zu den undeutlichen Stirnlinien hin allmählich immer stärker punktirt, Augen am Vorderrande nicht gerundet, wie bei den iibrigen Arten, sondern über der Fühlerwurzel grade abgeschnitten oder sanft ausgerandet, ihr Saum daher an dieser Stelle in eine dreieckige, leicht gewölbte, glatte Fläche erweitert. Halssclı. um die Hälfte breiter als lang, nach vorn etwas verengt und zusammengedriickt, die Seiten gerundet, an der vorderen Pore winkelig hexaustretend; oben mässig gewölbt, dicht und etwas runzelig punktirt, mit fein gewirkten Zwischenräumen. Fld. ziemlich stark, aber nicht tief punktirtgestreift, die Punktreihen hinter der Mitte bedeutend abgeschwächt, Zwischenstreifen sehr fein punktulirt. Hinterschienen schlank, die Leiste des Aussenrandes in den vorderen zwei Dritteln mit vier bis sechs Zähnchen versehen, die beiden Zähne der imneren Leiste klein, aber hoch und spitz, der Metatarsus kurz vor der spitze der Schienen*) eingefügt.

Im Frïhlinge und Ende August, wo das Thier entwickelt ist, auf Kohläckern und in der Umgebung von Gemüsegärten in ganz Deutschland und Mitteleuropa stellenweise nicht selten.

1. Psyll. chrysocephala: Oblongo-ovata, convexiuscula, obscure coerulea aut virdi-coevulea, nitida, antennis gracilibus piceis basi, fucie pedilusque fervugineis, femoribus posticis nigro-aeneis, fronte aeneo-

*) Eine ähnliche Bildung der Hinterschienen besitzt mur woch Ps, coerulea. 
infuscatu crelse punctulutu, prothorace antrorsum fure reyuluriler rotundatim angustato, crebre punctato, elytris tenuiter punctato-striatis, interstitiis dense punctulatis. - Long. $3-4,8 \mathrm{~mm}$.

Linné Syst. Nat. ed. 10. 372 (Chrysomela). - Scop. Ent. Carn. 69. - Oliv. Enc. IV. 111 (Halt.). - Koch Ent. Heft. II. 31. t. 2. f. 8. - Illig. Mag. VI. 174, - Gyllh. Ins. Suec. III. 568. - Duft. Faun. A. III. 279. - Steph. Ill. Brit. IV. 319; Man. 300 (Macrocn.). - Bach Käferf. III. 157. (Psyll.). - Foudr. Mon. 47. - All. Mon. 441. Kutsch. Wien. Mon. 1864. 385 (355). - Thoms. Skand. Col. VIII. 237. - Redtb. Faun. A. II, 513. - Seidl. F. balt. 501. - Leesberg Tijdschr. Ent. 24. 177.

Var. minor.

Psyll. mefilabris All. Ann. Fr. 1860. 806.

Psyll. Allardi Bach, Käferf. III. Nachträge 355.

Var, a. Pedibus plus minusve infuscatis.

Chrysomela erythrocephala Linn. 1. c. 573. - W aterh. Trans.

Ent. Soc. 3. Ser. I. 23.

Var. b. Immatura, fronte plerumque infuscata, prothorace piceo aut nigro, saepe aeneo-micante, elytris sordide testaceis, femoribus posticis apicem versus infuscatis.

Macrocnema nigricollis var. sordida Steph. 1. c. 320 et 300.

Var. c. Immatura, luride brunnea aut testacea, pectore interdum piceo.

Var. d. peregrina: Breviter ovata, obscure coeruleo-nigra, capite concolore, labro ferrugineo, antennis pedibusque maxima parte piceis.

Var. e. Eadem, sed capite prothoraceque rufis, antennis pedibusque rufotestaceis, femoribus posticis piceis.

Var. f. catinensis: Omnino ut in chrysocephala, sed magis elongata, elytris fortiter punctato-striatis.

R ottenb. Berl. Zeitschr. 1871. 245.

Var. g. collaris: Eadem, capite prothoraceque rufis, fronte plerumque aeneo-infuscata.

Haltica cyanoptera var. I11. 1. c. 175. - All. 1. c. 442.

Haltica elongata Gyllh. 1. c. 570 (pars).

Psylliod. chrysocephala var. cyanoptera Foudr. Mon. 47. - Leesberg 1. c. 177.

Var. b. Eadem, sed elytris aeneo-viridibus.

Var. i. anglica: Ut in b, sed prothorace nigro-aeneo, elytris pallide testaceis, paullo profundius punctato-striatis.

Fabr. Syst. Ent. 114. - Oliv. Ent. VI. 708. t. 4. f. 73 (Halt.). - Var. Leesb. 1. c.

Chysomela nigricollis Marsh. Ent. Brit. I. 205. - Steph. 1. c. (Macrocn.). - Foudr. Mon. 73 (Psyll.). - All. Mon. 440. Kutsch. l. c. 384 (35̆4). - Rye Ent. Monthl. Mag. VI. 88. Fairm. Gen. Col. IV. t. 71. f. 340. - Redtb. 1. c. 515. 


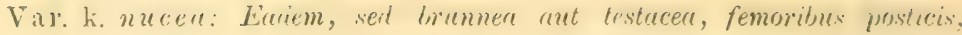
pectore abdomineque plus minusve nigricantibus.

I11. 1. c. 175 (Halt.). - Foudr. Mon. 77. (Psyll.). - A 11. Mon. 459. - Kutsch. 1. c. 400 (370). - Redtb. 1. c. 515. - Leesberg 1. c. 184

Psylliod. Kunzei Foudr. Mon. 75. - All. Mon. 460. -- Kutsch. 1. c. 401 . - Redtb. 1. c. 515 .

Unsere grösste Art; an dem rostrothen Gesichte, den fast gleichmässig gerundeten Seiten des Halssch. und den breiten, dicht punktulirten Zwischenstreifen der Fld. kemntlich. Lünglich-eifürmig, das $\hat{o}$ schlanker als das + , mässig gewïlbt, schwarzblau oder grïnlichblau, glänzend, das Halssch. entweder dunkler als die Fld., oder erzgrün. Kopf rostroth, die schmale Stirn iiber den undeutlichen Höckerchen dicht und fein punktirt, oberwärts allmählich dunkler gefärbt, so dass der Scheitel in der Regel pechschwarz ist, mit grïnem Metallglanze. Fiihler wenigstens so lang als die Hälfte des Körpers, an der Basis hell rostroth, nach der Spitze wenig verdickt, schlank, gebräunt his pechschwarz, Halssch. klein, breiter als lang, nach vorn stark zusammengedrückt und rerengt, an den Seiten ziemlich gleichmässig gerundet und neben der vorderen Borstenpore nicht oder nur sanft heraustretend; die Oberfläche gewölbt, dicht, fein und flach punktirt. Fld, am Grunde wenig breiter als das Halssch., bis zum ersten Drittel erweitert, dahinter in leichtem, vor der Spitze etwas stärkerem Bogen verengt, nit feinen Punktstreifen und breiten, ebenen, deutlich und dicht punktulirten Zwischenstreifen. Pro- und Mesosternum rothbraun, Beine hell rostroth, Hinterschenkel schwarz erzfarbig, die vier Vorderschenkel öfter gebräunt, oder (Var. a) die Beine pechbraun, Knie und Tarsen röthlich. Die innere Leiste der Hinterschienen ist hoch, der erste Zahn spitz, der zweite gross, abgerundet, Metatarsus in $3 / 4$ der Schienenlänge eingefügt.

Diese weit verbreitete und häufige Art ist so erheblichen $\mathrm{Ab}$ änderungen unterworfen, dass ich, um ein richtiges Bild derselben zu geben, mich gezwungen sehe, hier auch die ausserdeutschen Varietäten zu berücksichtigen. Es treten drei Hauptformen auf:

1. Körper mässig gestreckt, Fld. fein punktirt-gestreift. Hierzu gehört die eigentliche Ps. chrysocephala nebst den Farbenvarietäten $\mathrm{a}, \mathrm{b}$ und $\mathrm{c}$, von denen die zwei letzten hauptsächlich auf mangelhaft ausgefärbte oder umreife Stiicke begründet sind. Bei diesen ist das Halssch, pech- oder tiefschwarz, meist metalliseh grün überzogen, die Stirn angedunkelt, Brust und Bauch sind schwärzlich, die Fld, ver- 
schossen rïhlich gelhbram, zuweilen hliulich orler sroinlich angehaucht, die spitze der Hinterschenkel ist schwärzlich (Var. b. sordida steph.); oder die Oherseite ist einfarbig. schmutzix hellbraun bis röthlichgelb, die Brust zuweilen pechschwarz, Var c). Vorherrschend in Mittel- mol Nordeuropa und Sibirien.

2. Kïrper kurz eitörmig, nicht ganz so breit als bei Ps. dulcamarac, die Fld. t'ein punktirt-gestreift. Oberseite schwarzblau, am Kopfe meist nur die Oberlippe röthlich, die Fühler und Beine zum grössten Theile pechbraun bis schwarz (Var. peregrina); oder Kopf und Halssch. sind roth, Fühler und Beine, mit Ausnahme der dunklen Hinterschenkel rothgelb (Var. e). In Syrien z. B. bei Haifa (Simon.)

3. Körper gestreckt, länglich- bis sehr lang eiförmig, Fld. stark punktirt-gestreift, mindestens deutlicher und tiefer als bei chrysocephala. Nach meinem Materiale bildet diese Form, welche namentlich in der Nähe des Meeres vorkommt, drei locale Farbenabänderungen:

a. im südlichen Frankreich, in Spanien, Süditalien und Sicilien die Varietäten $\mathrm{f}$ bis $\mathrm{h}$, wovon $\mathrm{f}$ (catinensis) in der Färbung mit chrysocephala völlig, g (collaris) mit Ps. cyanoptera und der oben angeführten Abänderung e beinahe übereinstimmt, und nur durch die dunkle Stirn abweicht; h ist eine collaris, bei der die Fld. lebhaft broncegriin sind;

b. an der Nordseekiiste, vom südlichen England bis Hamburg, die Varietät anglica, wie chrysocephala gefärbt, aber die Fld. blass röthlich gelbbraun, bisweilen mit dunkler Naht und einem verwaschenen, erzfarbigen Saume an der Spitze oder den Seiten; endlich

c. in Siidfrankreich, Spanien und Italien die Varietät nucea, fast einfarbig hellbraun oder röthlichgelb, Brust, Bauch und Hinterschenkel mehr oder weniger schwarz.

Auf Cruciferen, namentlich am Meerrettig (Cochlearia armoracia L.), an Raps und den Kohlarten häufig.

Die Ps. catinensis hat Rottenberg nach einem Exemplar beschrieben, welches wie chrysocephala aussieht, ein zweites, welches in der Beschreibung erwähnt wird, und das mir H. Letzner in Breslau giitigst zur Ansicht sandte, ist nicht vollständig ausgefärbt (Halssch. schwarz, Fld. pechbrauu, an der Naht, den Seiten und ror der Spitze heller, Beine rostroth, der Rücken der Hinterschenkel dunkel) und steht so in der Hitte zwischen chrysocephala und anglica. 


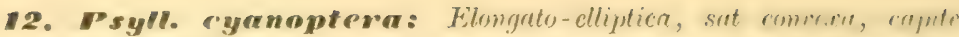
prothoraceque dense punctatis, rufis, elytris cyancis, fortiter muitatostriatis, antennarum basi dilute-peilibusque fusco-forrugineis, portore, abdomine femoribusque posticis nigris. - Long. 3,3-4 mun.

I11. Mag. VI. 77 et 175 (Varietas exclusa). - All. Mon. 442. - Kutsch. Wien. MIonat 1864. 387 (357). - Rerltb. Faun. A. II. 513. - Seidl. F. balt. 501. - Thoms. Skand. Col. VIII. 238.

Haltica elongata Gyllh. Ins. Suec. III. 5770 (pars).

Var. a. Immatura; pedibus anterioribus ferrugineis.

Var. b. Elytris coeruleo-viridibus aut aeneis.

Var. c. tricolor: Prothorace nigro.

Var. d. Eadem, sed elytris aurichalceo-viridibus.

Durchschnittlich kleiner als die vorige und deren Abänderungen e, g und h, mit rothem Halssch., sehr ähnlich. aber die Fühler kürzer und dicker, nebst dem Vorderkörper und den Beinen dunkler gefärbt, der Kopf einfarbig roth, auf der Stirn ohne Metallschimmer, und die Seiten des Halssch. an der vorderen Pore winkelig erweitert.

Sehr lang elliptisch, ziemlich gewölbt und mässig glänzend. Kopf und Halssch. dunkelroth, Fühler kurz, die ersten vier Glieder stärker als bei chrysocephala, die folgenden merklich rerdickt, wenig länger als breit, Glied 1. und 2 rostroth, 3 und 4 pechbraun, die iibrigen schwarz. Halssch. bis zur vorderen Pore fast gradlinig verengt, neben derselben winkelig nach aussen tretend, davor stark verschmälert, oben gewölbt, dicht, mässig fein nnd tief punktirt. Fld. gesättigt blau mit grünlichem Schimmer, selten blaugrïn oder erzfarbig (Var. b), kräftig punktirt-gestreift, mit dicht und deutlich punktulirten Zwischenstreifen. Unterseite schwarz, die Vorderbrust ganz oder nur an den Seiten roth, Beine selu dunkel roth, beinahe pechbraun, an den Gelenken heller, Hinterschenkel schwarz; frische Stücke haben hell rostrothe Beine mit dunklen Hinterschenkeln (Var. a).

Am Halssch. ist sowohl bei dieser Art, als auch bei den obengenannten Varietäten der vorigen ein Saum am Hinterrande und die aufgebogene Leiste des Seitenrandes, die von den Hinterecken bis zu der vorderen Pore reicht, schwarz gefürbt; möglich, dass sich diese Farbe allmählich ausbreitet, ich kenne jedoch nur Stiicke. bei denen sie das Halssch. gänzlich einnimmt. Diese Abänderung (Var. tricolor) ist durch die eigenthümliche Farbenzusammenstellung. Kopf roth, Halssch. tief schwarz. Fld. blau, grünlich blan oder noch häufiger grün mit Bronceschimmer (Var. d), sehr auffällig.

Auf Cruciferen: an verschiedenen Kohlarten, rorzüglich aber an Sisymbrium sophic L. seltener als die vorige. 
Die Art, wolehe im westlichen und südlichen Europa sehr selten zu scin scheint, dagegen östlich bis nach Tukestan und Westsibirien, nördlich his Mittelschweden verbreitet ist. wurde seit der ersten Beschreihung durch Illiger bis zur letzten von Allard mit der siideuropäischen Form von chrysucchlula vermengt, demn eine Varietät, hei welcher ,der Hinterkopf dunkel metalliseh iiberlanfen ist" (Illig.), kommt davon nicht vor, es lässt sich vielmehr der Mangel jeden metallischen Schimmers auf Kopf und Halssch, als ein gutes Unterscheidungsmerkmal von chrysocephalu betrachten.

13. Psyll. napi: Alata, ovata, convexa, nigro-coerulen, nitida, antennis piceis busi, pedibus anterioribus, tibiis tarsisque posticis testuceis, prothorace sat compresso, subpulvinato, subtiliter punctato, impressione obsoleta obliqua utrinque longitudinuliter instructo, elytris punctatostriatis, punctis striarum subremotis, interstitiis subseriatim punctulatis. - Long. 2-3,8 $\mathrm{mm}$.

Fabr. Ent. Syst. I. 2. 29 (Galeruca); Syst. Et. 1. 176 (Ghrysom.). - Panzer, Faun. Germ. 21. 3 (Altica). - Koch, Ent. Hft. II. 30 (Halt.). - Gyllh. Ins. Suec. III. 568. - Duft. Faun. A. III. 280. - Steph. Ill. Brit. IV. 318; Man. 300 (Macrocn.). - Foudr. Mon. 44 (Psyll.). - All. Mon. 445. - Kutsch. Wien. Monat. 1864. 389 (359). - Redtb. Faun. A. II. 513. - Seidl F. balt. 501. - Thoms. Skand. Col. VIII. 237.

Haltica rapae IIl. Mag. VI. 174. - Steph. 1. c. - Redtb. I. c. ed. 1. 539 (Psyll.). - Küst. Käf. Eur. 2. 68. - Leesberg, Tijdschr. Ent. 24, 179.

Psyll. ecalcarata Redtb. 1. c. ed. 1.537.

Var. a. Obscure cienea.

Var. b. Femoribus anterioribus infuscatis.

Var. c. flavicornis: Robustion, aptera aut subaptera, nigro-aenea leviter aurichalceo micans, antennis testaceis, apicem versus rarius infuscatis.

Weise, Deutsch. Ent. Zeitschr. 1883. 219.

Var. d. Eadem, sed femoribus anterioribus infuscatis.

Var. e. asturiensis: Ut in c, sed brevior, coerulea, antennis apicem versus piceis, prothorace plerumque parce punctulato.

Unter den vorhergehenden Arten nur der chrysocephala ähnlich, aber viel kürzer und gewölbter, hinten breiter gebaut als diese. Eiförmig, glänzend schwarzblau, bisweilen Kopf und Halssch., seltener die ganze Oberseite mit griinlichem Schimmer, die vorderen Beine, sowie Hinterschienen und -Tarsen röthlich gelb. Fühler schlank, aber wenig länger als die Hälfte des Körpers, Glied 1 bis 3 , oder noch 4, blass gelbbraun, 5 und 6 braun, die folgenden pechschwarz. Kopf klein, Stirn äusserst fein gewirkt und mit Ausnahme des Scheitels zerstreut, fein punktirt, mit undeutlichen 
Linien mol Iföckern. Halssch. un die Hailfte lreitar als lang. nach vorn ziemlich stark zusammengerlrickt. droch nur in rinem flachen Bogen verengt, der durch die winkelirg heraustretenten Seiten an der rorderen Pore unterbrochen wird. ohen stark mul fast kissenartig gewölbt (dicht vor dem Schildchen an schwächsten), fein und mässig dicht punktirt, in den Zwischenräumen leicht gewirkt. Vor der Hinterrandleiste befindet sich ein Quereindruck, weleher vor der dritten und vierten Punktreihe der Fld. an tiefsten und mit starken Punkten besetzt ist, ebenso zieht sich ein in der Mitte meist grubenartig vertiefter Längseindruck ein Stück ïher dem Aussenrande nach jedem Auge hin. Fld. an der Basis in starker Rundung heraustretend und in den Schultern viel hneiter als das Halsseh., bis zur. Mitte erweitert, dahinter wieder in gleichmässigem Bogen verengt, ihre Punktstreifen ziemlich flach, aber mit groben und tiefen, ziemlich entfernt stehenden Punkten besetzt, die hinter der Mitte allmählich schwächer werlen; die Zwischenstreifen sind leicht gewölbt und sparsam und verloschen, fast reihenweise punktulirt. Die kleine, glänzende Schulterbeule wird innen von der vertieften fünften Punktreihe abgesetzt. Die Vorderbrust bildet eine schmale Querwulst, die gleichmässig nach dem Halse und den Vorderhüften abfällt. Die Hinterschienen sind schlank, die beiden Zähne der Leiste niedrig, der erste spitz, der zweite stumpf. Fliigel vollständig entwickelt.

Die Oberseite ist zuweilen dunkel broncegrïn (Var. a), selten sind die Vorderschenkel geschwärzt (Var. b.); bei sehr frischen Stïcken ist die Punktirung der Fld. auffallend fein, die Punktreihen sind nur im vorderen Drittel deutlich, hinter der Mitte erloschen.

Von dieser Art kommen zwei gänzlich ungeflügelte, oder mit Flügelstummeln versehene Gebirgsformen vor, bei denen die Schulterbeule schwächer entwickelt und die Basis der Fld. in dem Raume zwischen Schulter und Schildchen ziemlich eben ist. wenigstens nicht in dem Masse wie bei napi nach dem Hinterrande des Halssch zu abfällt. Die eine (v. flavicomis) ist durchschnittlich grösser und breiter als napi, auf dem Halssch. dichter, auf den Fld. in der Regel feiner punktirt, etwas glänzender, hunkel broncegrün. ohne blauen Schimmer, die Fühler einfarbig hell gelbbraun. seltener die fünf letzten Glieder rostroth; ausnahmsweise auch die vorderen Schenkel angedunkelt. Die andere (v. asturiensis) ist verhältnissmässig klein, kurz, hinten stark abwärts gewölbt, lebhaft gesättigt blau, selten mit grünem Anfluge, Halsseh. gewöhnlich sparsam und sehr fein punktirt, Fühler wie bei napi.

Auf Cruciferen, besonders an Nasturtium officinale R. Br. und Cardamine amara L. am Ufer schattiger Bäche im ganzen Gebiete, 
wie üherhanpt im gxiossten 'Theile von Europa hänfig. Ile Van. c auf Lumaria rectivice L. im Glatzer Gebirge und Altvater, dic Var. e im asturischen Gebirge (Getschmann).

Illigers Aenterung des Namens in rapue ist zuriickzuweisen, weil napi Fabr. nach der Bewchreibung einen schwarzen Kopf hesitzen soll. also nicht anf chrysosephala bezogen werden darf, mol die Abhilhung von nani Panzer, deren iihertriebene Grössemangabe den einzigen Anlass zu der leichtfertigen Aenderung gegeben hat, nur die vorliegende Art, und zwar unverkeunbar darstellt.

14. Psyll. picipes: Oblongo-ovata, conrexa, nigro-cyanea, nitida antennis apicem versus infuscatis pedibusque ferrugineis, femoribus anterioritus fuscis, posticis aeneo-nigris; prothorace subtransverso, antrorsum compresso, sat crebre subtilius punctato, elytris punctato-striatis, punctis striarum creberimis, interstitiis subconvexis parce subseriatim punctulatis. - Long. $3 \mathrm{~mm}$.

Redtb. Faun. A. ed, 1. 538; ed. 3. II. 514.

Viel schlanker als die vorige, an den Seiten weniger gerundet, beiderseits stärker verengt, die Punktstreifen der Fld. feiner, aber viel schärfer begrenzt, die Punkte in ihnen äusserst dicht aneinander gereiht. Länglich-eiförmig, sehr dunkel kornblımenblau, auf Kopf und Halssch. etwas heller blau, stark glïnzend. Fühler (nach der Spitze gebräunt) und Beine rostroth, die vorderen Schenkel in der Mitte dunkelbraun, Hinterschenkel schwarz erzfarbig. Stirn glänzend, kaum bemerkbar gewirkt und sparsam, sehr fein punktirt, mit schwachen Stimlinien, die sich x-förmig durchschneiden. Halssch. klein, wenig breiter als lang, nach vorn zusammengedrückt und verengt, oben stark querüber gewölbt, etwas deutlicher als der Kopf gewirkt und punktirt, glänzend. Fld. an der Basis kaum breiter als das Halssch., bis zur Mitte wenig, aber gleichmässig verbreitert, dahinter ebenso verengt, mit kleiner Schulterbeule und mässig tiefen Punktstreifen, in denen die kleinen Punkte tief und scharf eingestochen, sehr dicht hinter einander stehen und erst auf dem Abfalle zur Spitze merklich abgeschwächt sind; die Zwischenstreifen schmal, leicht gewölbt, sparsam und sehr fein, fast gereiht punktirt.

Bei Reichenau am Wiener Schneeberge gefangen.

Da Redtenbacher das Thier ei- oder kurzeiförmig nennt und mit aerea und subaenea in Vergleich stellt, kann man dasselbe leicht für breiter halten, als es ist. Es hat, nach dem einzigen bekannten Stiicke, welches ich aus dem Wiener HInseum durch die Freundlichkeit des Herrn Ganglbauer zur Ansicht erhalten habe, genau die Körperform von Ps. Milleri Kutsch. orler von einer schlanken fusiformis. Wenu Foudras 


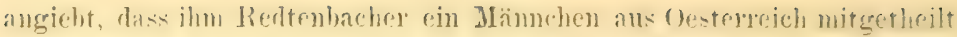
habe, sn muss hierbei cine Verwechselung unit lutifrons vorgekommen scin. da $\mathrm{er}$ die Alt sonst nicht, woir bronie arec un reflet verdatre" und das Halsch. rloppelt so breit als lang leschreiben kïnnte; auch hutschera hat aus denselben Grinden picipes Rerltb. nicht vor sich gehabt.

15. Psyer. thlaspis: Oblonyo-oruta, sat concexa, nigio-coerulea, alutacea, sat nitida, antennis apicem iersus fuscis perlibusque rufu-testaceis, femoribus anterioribus plerumque infuscatis, posticis aenco-nigris; fronte prothoraceque sat crebre et vage punctatis, hoc transverso antrorsum anyustato, elytris punctato-striatis, punctis striarum crebris, upicem attingentibus, interstitiis dense punctulatis. - Long. 3-4 mm.

Foudr. Mon. 42. - All. MLon. 449. - Kutsch. Wien. JIonat.

1864. 391 (361). - Rejtb. Faun. A. ed. 3. II. 5̌13. Leesberg, Tijdschr. Ent. 24. 179.

Psyll. fusiformis Redtb. 1. c. ed. 1. 538; ed. 2. 946.

Psyll. cuprea var. 3 Kutsch. 1. c. 394.

Var. a. Capite prothoraceque coeruleo-viridibus.

Var. b. Supra coenuleo-viridis.

Var. c. Prothorace cupreo.

Psyll. thlaspis var a. Foudr. l. c.

Var. d. Prothorace sat fortiter ruguloso-punctato.

Var. e. Femoribus posticis rufis, macula dorsali nigrescente.

Der Ps. napi sehr ähnlich, aber etwas schlanker, weniger gewölbt, auf dem Halssch. matter, die Punkte in den Streifen der Fld. dichter gestellt; viel näher noch mit den beiden folgenden Arten verwandt, von denen sie durch die stärkere Punktirung der Streifen und Zwischenstreifen auf den Fld. und den kleineren Schulterhöcker vielleicht nicht specifisch abweicht.

Länglich-eiförmig, ziemlich gewölbt, dunkelblau, gleichmässig, oder auf dem Halssch. stärker als auf Kopf und Fld. gewirkt, mässig glänzend, Beine und Fühler rötllich gelb, letztere rom vierten Gliede an allmählich immer stärker gebräunt, die vorderen Schenkel oft angedunkelt, auch die Schienen zuweilen gebräunt, die Hinterschenkel erzfarbig schwarz. Stim mit Ausnahme des Scheitels mehr oder weniger fein punktirt, mit undentlichen Linien und Höckern. Halssch. wenigstens um die Hälfte breiter als lang, bis zur vorderen Pore mässig und fast gradlinig, davor stärker verengt, queriiber gewölbt, ziemlich dicht, fein und seicht punktirt, die Punkte auf der Scheibe verloschen, an den Seiten deutlicher. Fld. an der Basis leicht heraustretend, bis zur Mitte schwach erweitert, dahinter ahnlich verengt, mit mässig tiefen Punktstreifen, welche aus sehr genäherten. vor der Spitze wenig abgeschwächten 
Pnnkten gehililet werden und die breiten. dich punktulinten Zwischenstreifen ziemlich scharf begrenzen. Die Sehulterbenle ist klein und flach, wenig abgesetzt.

Bisweilen ist der Kopf und das Halssch. (Var. a) oder die ganze Oberseite (Var. b) bläulich metallgriin, oder das Halssch. zicmlich kräftig runzelig punktirt (Var. d), oder die Hinterschenkel sind roth, mit einer schwärzlichen Makel auf' dem Rücken nahe der Spitze (Var. e); nach Foudras sollen auch Stücke mit kupferigem oder broncefarbenem Halssch. (Var. c) vorkommen.

Auf Cruciferen z. B. Isatis tinctoria L. im Sauerthale (v. Heyden), bei Magdeburg (Breddin), in Oesterreich und Ungarn; häufiger in Sïdfrankreich (nach Foudras auf Lepidium compestre L.) und im siidlichen Europa.

16. Psyll. obscura: Oblongo-ovata, subconvexa, aeneo-nigra, subcupreo micans, antennis apicem versus infuscatis pedibusque ferrugineis, femoribus anterioribus saepe infuscatis, posticis aeneo-nigris; prothorace transierso, antrorsum angustato, evidenter aluaceo, crebervime subtiliter, sed mofunde punctato, interstitiis parce punctulatis, elytris nitidis, evidenter sed tenuiter punctato-striatis, punctis striarum creberrimis apicem attingentilus, interstitis, planis, obsoletissime alutuceis et punctulatis. - Long. 2,8-3,5 mm.

Duft. Faun. Aust. III. 281.

Var. a. Viridi-aenea.

Psyll. herbacea Foudr. Mon. 23. - A11. Mon. 451.

Psyll. cupronitens A1l. Ann. Fr. 1860. 815. —Leesb. Tijdschr. 24. 183.

Von der vorhergehenden Art nur in folgenden Punkten abweichend: die Farbe der Oberseite ist in der Regel erzfarbig schwarz, mit kupferigem Bronceschimmer, etwas blasser als bei cupreata, seltener (Var. a) metallisch grün; das Halssch. ist dichter, zwar fein, aber auch auf der Scheibe tief und deutlich punktirt, in den schmalen Zwischenräumen gewirkt und mit einzelnen Pünktchen besetzt, matt seidenschimmernd; die Fld. sind glänzend, mit grösserer Schulterbeule, hinter dieser etwas mehr zusammengedrïckt und an der Basis zum Hinterrande des Halssch. stärker abwärts gewölbt, auf dem Rücken viel feiner punktirt-gestreift, die Zwischenstreifen äusserst zart gewirkt und kaum hemerkbar punktulirt.

Auf Cruciferen in der Rheinprovinz und in Oesterreich, Frankreich, Spanien, Balearen, Italien.

Es ist versucht worden, die $P$ s. cupronitens Förster auf diese Art zu beziehen, dem steht jedoch die Diagnose: ,elytris profunde punctato-striatis" und Beschreibung: ,,von der Grösse der chrysocephala, aber etwas breiter, die Stirn mit flachem Dreieck" durchaus entgegen. 


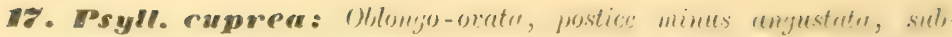
converr, olscure rividi-uenert, cupreo-micuns, sut nitidu, antennis fuscis lase podibusque testaceis, femoribus antcrioriluses suepe infuscatis, prosticis renco-nigris, fionte prothonacerpe sat crelse olsolete punctutis, elytris sulntiliter punctato-striatis, punctis striarum crelnis pone medium sensim obsoletioribus, interstitiis plenis subtilissime ulutuceis, vic punctulatis. - Long. 2,5-3,2 mm.

Koch, Ent. Hft. II. 28. t. 2. f. 7 (Halt.) - I11. Mag. VI. 172. - Duft. Famn. A. III. 281. - Redtb. Fann. A. ed. 1. 537; ed. 3. II. 513 (Psyll.). - Fondr. MIon. 56. - A11. Mon. 4533.

- Kutsch. Wien, Monat, 1864. 394 (exclns. var. 3). Leesberg, Tijdschr. Ent. 24. 183.

Psyll. Foudrasi Bach, Käferf. ШI. 355.

Vax. a. Viridi-aurichalcea.

V a r. b. Nigro-aenea.

Var.c. Viridi-, sordide-, vel nigro-coerulea.

Durchschnittlich kürzer und namentlich, hinten breiter gebaut als die vorige, länglich-eiförmig, flach gewölbt, dunkel erzgriin, mit bräınlichem Kupferschimmer, sehr fein und dicht gewirkt, mässig und etwas seidenartig glänzend, die Beine und die drei ersten Fïhlerglieder hell röthlich- oder brüunlich-gelb, die folgenden Fïhlerghieder allmählich melı gebräunt, die vorderen Schenkel oft in der Mitte angedunkelt, dic Hinterschenkel erzfarbig schwarz. Stirn fein gewirkt, mit Ausnahme des richeitels mässig dicht, fein punktirt, Stirnlinien in der Mitte durch Punktreihen angedentet, $\Lambda$-förmig. Halssch. wenigstens um die Hälfte breiter als lang, bis zux vorderen Pore mässig, davor stärker verengt, auf der Scheibe ziemlich dicht, fein und verloschen punktirt. Fld. an der Basis gerundet heraustretend und in den Schultern merklich breiter als das Halssch., bis zur Nitte oder darïber hinaus schwach erweitert, hinten ziemlich kurz abgerundet, mit feinen und seichten Punktstreifen, die auf dem Abfalle fast erlöschen. und mit ebenen, kaum sichtbar punktulirten Zwischenstreifen.

Die Farbe der Oberseite verändert sich, indem die kupferige Beimischung verschwindet, in ein etwas verschossenes Grün mit Bronceschimmer (Var. a), oder ein schwärzliches Erzgrïn (Var. b), endlich durch Zutritt von Blau in grinlichblau, verschossen blau oder schwarzblau (Var. c).

Auf Cruciferen z. B. Sisymbrium officinale bei Königsberg in Pr. (Czwalina) und Berlin, in Schlesien (Letzner), am Rhein und in Oesterreich (nach Kutschera an Paparer rhoeus) zuweilen nicht selten; über Mittel- und Siideuropa verbreitet; Nordafrika, Syrien.

Wie bei allen Arten variirt anch hier die Skulptur der Oberseite nicht unbeträchtlich, und es ist zweifelhaft, ob bei reichem Materiale der 
Kïrpexumiss anseichen wird, die Art vou obscura zu tremen. Kutschera hat sich durch die etwas ibertriebene Schilderumg bei Foudras, welcher "uprea als "breviter orata" und herbacea als "oblongo-oucula" hinstellte, zu der Ansicht verleiten lassen, dass er miter cuprea eine andere Art als Foudras beschrieben habe. Dies ist nicht der Fall, sondern die cuprea Foudr.. All., Kutsch. und Koch ist ein und dasselbe Thier.

18. Psyll. fusiformis: Elongato-elliptica, subconvexa, aeneo-coerulea, tenuiter alutacea, sut nitida, antennis piceis basi pedibusque ferrugineis, femoribus posticis upice macula nigra notatis; canalicula oculari inter-rupta, prothorace crebre punctato, elytris sat profunde punctato-striatis, interstitiis dense punctulatis. - Long. 3,5-4 $\mathrm{mm}$.

Illig: MIag. VI. 77 et 174 (Halt.). - A 11. Anm. Fr. 1860. 813; Jion. 450 (Psyll.). - Kutsch. Wien. Monat. 1864, 392 (362). - Redtb. Faun. A. ed. 3. II, 515.

Psyll. luteipes Kïst. Käf. Eur. 17. 96.

Var. a. Nigro-aenea.

Var. b. Immatura; spadicea, aeneo-micans.

Diese und die drei nachstehenden Arten bilden eine gut begrenzte Gruppe, an der unterbrochenen Rinne kemntlich, die sich auf der Stirn neben dem Innenrande jedes Auges befindet. Dieselbe läuft bei den vorhergehenden Arten in ziemlich gleicher Tiefe und Breite bis zur Vertiefung um die Fühlerwurzel nach unten, bei den folgenden tritt dagegen die Spitze der linealisehen Stirnhöekerchen hinein und trenut sie mehr oder weniger vollkommen, jedoch immer deutlich, von der Vertiefung um die Fühlerbasis.

Die vorliegende ist durch ihre Grösse, die lebhaft rostrothen Beine, an denen nur der Rücken der Hinterschenkel eine schwärzliche Makel hat, sowie durch die kräftige Punktirung der Fld. ausgezeichnet; sie ist lang-elliptisch, mässig gewölbt, metallisch grünlich blau, selten schwarz erzfarbig (Var. a), oder (unreif) rothbraun, mit starkem Erzglanze (Var. b), fein gewirkt, ziemlich glänzend. Fühler schlank, Glied 1 lis 4 gelblich-roth, die folgenden gebräunt, die letzten pechbraun. Stirn mit Ausnahme des Scheitels fein punktirt, ihre Linien rerloschen und nur in der Mitte bemerkbar, die Höcker bilken eine von unten scharf begrenzte Kante, die schräg bis zum Augenrande läuft und die Angenrinne völlig schliesst. Halsseh. kaum um die Hälfte breiter als lang, nach vorn mässig verengt, bald in gleichmässigen Bogen, der an der vorderen Pore kaum unterbrochen wird, bald bis zu dieser und ebenso davor gradlinig; oben gewölbt, dicht punktirt. Fld. bis zum ersten Drittel erweitert, die Schulterbeule kriiftig, wenig heraustretend, Punktstreifen 
ziemlich siak. ans gerdröingten I'unkten gelildet und bis zur spitze nicht alogeschwächt, Zwischenstreifen lureit, dicht und dentlich punktulirt. Ifinterschienen merklich dicker als bei naji. jedoch mit åhnlichen Leistenzähnchen.

An Rheine, in 'Tirol und Istrien selten. Italien bis sicilien. südliches Frankreich, Spanien, Nordafrika.

Illiger hat, da er von sehr kleinen Exemplaren spricht. mit dieser Art zugleich die folgende beschrieben. gerade so wie er cucullata mit Heydeni und cyanoptera nit den Tarietäten von chrysocephola vermengt hat, die ein rothes Halssch besitzen.

Psyll. luridipennis Kutsch. (1. c. 393), nach einem wahrscheinlich umreifen Stücke von der Insel Lundy (England) beschrieben, scheint hinter der Mitte breiter gebant, auf Kopf und Halssch. stärker, in den Zwischenstreifen der Fld. feiner punktirt zu sein. Mit welcher Art sie verwandt oder identisch sei, lässt sich ans der Beschreibung nicht erkennen.

19. Psyll-pyritosa: Oblongo-ovata, subconvexr, cupreo-aenea, nitida, antennis piceis basi pedibusque rufo-testaceis, femoribus posticis ueneonigris, anterioribus plerumque infuscutis; fronte subtiliter punctata, canalicula aculari sulinterrupta, prothnrace crelre muloso-punctato, elytris striato-punctatis, striis postice subtilioribus, interstitiis plus minusve punctulatis. - Long. 2,5-3,5 mm.

Kutsch. Wien. Monat. 1864. 396 (366). - Al1. M[on. 454. Redtb. Faun. A. II. 515.

Var. a. Nigro-aenea, plenumque aurichalceo micans.

Var. b. Immatura; elytris spadiceis, aeneo-micantibus.

Der Ps. cuprea und obscura zwar sehr ähnlich, aber an der Stirnbildung auf den ersten Blick zu unterscheiden, eine Terwechselung mit der vorigen ist schon wegen der dunklen Hinterschenkel ausgeschlossen.

Länglich-eiförmig, mässig gewölbt, dunkel braun-erzfarbig, glänzend, Fühler dunkelbraum, mit hellen Basalgliedern, Beine röthlichgelb, Vorderschenkel meist angedunkelt, Hinterschenkel erzfarbig schwarz. Stirn wie bei fusiformis, aber die Angenrinne nicht vollständig unterbrochen, indem die f'eine, kielförmige Spitze der Stirnhöckerchen in dieselbe hinein und ein Stiickchen darin nach oben läuft, wobei auf jeder Seite eine schmale Rinne übrig bleibt. Halssch. kurz, ungefähr doppelt so breit wie lang, nach vorn mässig rerengt, oben gewölbt, sehr dicht runzelig punktirt, mit schmalen, gewirkten Zwischenrïumen. Fld. in deu Schultem etwas breiter als das Halssch., an den Seiten schwach gerundet, mit ziemlich feinen, gedrängt punktirten Streifen, welche sich ron 
den dicht punktulirten '/wischenstreifen rerhialtnissmiassig schwach abheben und hinter der Yitte teiner werden. Dis Schulterbeule ist niedrig und klein.

Die Oberseite wird dunkel metallisch griin, oft mit lehhaftem Bronceschimmer (Var, a), bei nicht vïllig ansgefïirbten Exemplaren sind die Fld. rothbrium, nit grün metallischem Anfluge (Var. b).

In Berg- und Gehirgsgegenden selten. Thüringen (bei Weimar), Erzgebirge, Schlesien, Oesterreich. Auf Veglia (Stussiner), Italien bis Sicilien. Griechenland.

20. Psyte. instabilis: Oblongo-ovata, convexa, nigra, reneo-micans, nitida, antennis piceis basi pedibusque rufo-testaceis, femoribus anterioribus fuscis, posticis aeneo-nigris; fronte vage punctulata, canalicula oculari subinterrupta, prothorace subtiliter et vage ruguloso-punctato, elytris striato-punctatis, striis postice evanescentibus, interstitiis obsolete punctulatis. - Long. 2,5-3 mm.

Foudr. Mon. 59. - A 11. Mon. 456. - Kutsch. Wien. Monat. 1864. 398 (368). - Redtb. Faun. A. II. 513. - Leesb. Tijdschr. 24, 181.

V ar. a. Nigra coeruleo-micans aut nigra.

Der vorigen äusserst nahe verwandt und von ihr durch folgende Punkte zu unterscheiden: der Körper ist kuirzer und gewölbter, rorherrschend metallisch grünlich-schwarz, selten (Var. a) dunkel bläulich oder ziemlich rein schwarz, Kopf und Halssch. sind verlosehener punktirt, glänzender, die Punktstreifen der Fld. tiefer, viel schärfer begrenzt, mit äusserst fein punktulirten, deutlicher heraustretenden Zwischenstreifen; die Beine sind stets dunkler gefärbt, indem die vier Vorderschenkel pechbraun, öfter auch die Sehienen angedunkelt sind.

Hauptsächlich auf Kalkboden an Erysimum-Arten, Sinapis Cheiranthus, Iberis pinnata und anderen Cruciferen in Schlesien, Böhmen, Oesterreich, besonders in den Ostalpen, am Rheine stellenweise zahlreich. Holland, Frankreich.

21. Psyul aerea: Breviter ovata, convexa, aenea, interdum cupreomicans, antennis piceis basi pedibusque ferrugineis, femoribus anterioribus fuscis posticis aeneo-nigris; fronte parce vageque punctulato, canalicula oculari subinterrupta, mothorace evidenter alutaceo, obsoletissime punctato, elytris sat profunde punctato-striatis, striis apice deletis, interstitiis leviter convexis, alutaceis, vix punctulatis. - Long. $2,5 \mathrm{~mm}$.

Foudr. Mon. 53. - All. Mon. 467. - Kutseh. Wien, Monat. 1864. 408 (378). 


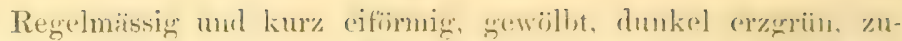
weilen mit Kupferschimmer, Fühler pechschwarz. ihre drei ersten Glieder, Schienen und Füsse rostroth, Vorderschenkel pechbraun, Hinterschenkel schwarz, Schienen l,isweilen angedunkelt. Stim fein gewirkt, olne Punkte. oder sparsam und sehr fein punktirt, mit deutlichen Stimlinien und linealischen Hïckern, deren Spitze in die Augenrinne läuft und dieselbe theilweise unterbricht. $\mathrm{Halssch}$. doppelt so breit als lang, nach rorn verengt und etwas zusammengedrückt, mässig gewölbt, fein gewirkt und verloschen punktirt. mit mattem Glanze. Fld. an der Basis so breit als das Halssch., bis zum ersten Drittel gerundet-erweitert, in der Mitte fast parallel, im letzten Drittel verengt, mit kleiner und niedriger Schulterbeule, nicht besonders starken Punktstreifen und glänzenden, äusserst fein gewirkten aber kaum punktulirten Zwischenstreifen.

Bei Wien, selten. Südfrankreich.

22. Psyul. affimis: Oblongo-ovata, convexiuscula, nigra, antennis, prothorace confertim punctato pedibusque (femoribus posticis exceptis) ferrugineis, elytris testaceis, sutura nigra, sat profunde punctato-striatis, interstitiis parce subtilissime punctulatis, fronte impunctata, femoribus posticis margine inferiore subangulatim dilatatis. - Long. $2,3-3,3 \mathrm{~mm}$.

Payk. Faun. Snec. II. 1799 1. 109 (Galleruca). - Koch, Ent. Hft. II. 35 (Halt.) - Oliv. Ent. V. 719. t. 5. f. 90. Gyllh. Ins. Suec. III. 553; IV. 660. - Duft. Faun. A. III. 285. - Küst. Käf. Eur. 28. 93 (Psyll.). -- Foudr. Mon. 68. - All. Mon. 462. - Kutsch. Wien. Monat. 1864. 403 (373). - Redtb. Faun. II. 514. - Thoms. Skand. Col. VIII, 239. - Seidl. F, balt 501. - Leesb. Tijdschr. Ent. 24. 184.

Altica atricilla Panz. Faun. Germ. 21. 8.

Haltica exoleta I11. Mag. VI. 78 et, 176.

Var. a. Femoribus anterioribus fuscis.

Var. b. Capite ferrugineo vertice infuscato.

Var.c. Immatura; supra tota testacea, perlibus ferrugineis, femoribus posticis apice infuscatis.

An der umpunktirten Stirn und den winkelig erweiterten Hinterschenkeln zu erkennen. Lang-eifürmig bis eiförmig, mässig gewölbt, Fuihler, Halssch. und Beine rostroth, Fld. gelbbraun, die Naht derselben bis zum ersten Punktstreifen, sowie Kopf. Brust und Bauch sehwarz, Hinterschenkel rothbraun bis pechschwarz. Stirn schmal, wie bei napi gebaut, mit undeutlichen Linien und Hückerchen, äusserst fein gewirkt und, ausser zwei bis drei grösseren 
Punkten neben der Borstenpore an der Anwenrime, ohme l'unkte.

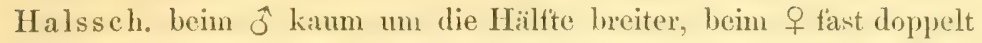
so breit wie lans, nach vorn wenig in sehr flachem Bogen verengt, der dureh die Erwciterumg an der vorderen Pore kaum unterbrochen wird, oben mässign wewölbt, mehr oder weniger dicht und verhältnissmässig stark punktirt, der Hinterrand und die Leiste des seitenrandes bis zur vorderen Pore schwärzlich. Fld. am Grunde in starker Rundung heraustretend, bald hinter den Schultern am breitesten, mit kleiner śchulterbeule, ziemlich tiefen und starken, im letzten Drittel erheblich abgeschwächten Punktstreifen und glänzenden, mehr oder weniger fein, fast reihig punktulirten Zwischenstreifen. Prosteruun leicht gewölbt, vor den Hüften in einen kleinen Höcker erhöht; Hinterschenkel sehr breit, die äussere Kante der śchienenrimme zweimal flach ausgeschnitten, dazwischen in eine stumpfe Ecke rorgezogen; Hinterschienen an der Basis gebog'en, ihre Leistenzähmchen klein, der erste spitz, der zweite abgerundet.

Die Verschiedeuheiten in der Skulptur und Farbe fallen wenig in's Gewicht. Häufig sind die vorderen Schenkel geschwärzt (Var.a), oder der Kopf ist rostroth mit dunklem Scheitel (Var. b), endlich die Oberseite röthlich gelb, auf den Fld. wenig blasser als auf Kopt' und Halssch, Hinterschenkel rostroth, an der Spitze schwärzlich (Var.c); Stuicke aus Siiddeutschland, Oesterreich und Südeuropa sind durchschnittilich grösser und kräftiger, auf dem Halssch. zugleich viel dichter punktirt als die aus der norddeutschen Ebene, auch besitzt ihre Oberseite in der Regel einen gesättigteren Farbenton. Auf Solaneen z. B. an Sol. dulcamara gemein.

23. Psyוt. circumalata: Oblongo-ovata, convexiuscula, picea vel nigra, antennis pedilusque (fenoribus posticis exceptis) ferrugineis, fronte subtilissime prothoraceque subtiliter punctatis, elytris testaceis, sutura, apice epipleurisque piceis vel nigris, dorso punctato-striatis, interstitiis obsolete punctulatis. - Long: 3--3,5 mm.

Wilh. Redtb. Quaed. Gen. et spec. Col. 27 (Halt.). - Redtb. Faun. A. ed. 1. 536; ed. 3. II. 513 (Psyll.), - Foudr. Mon. 70. - Kutsch. Wien. Monat. 1864. 405 (375). - All. Mon. 464.

Var. a. Femoribus anterioribus infuscatis.

Var. b. Capite prothoraceque ferrugineis.

Var. c. integra: Eaden, sed elytris testaceo-flavis, sutwa apiceque infuscatis, ferrugineis, piceis, ant nigris, femoribus posticis saepe rufescentibus.

Var. d. Fronte protoraceque minus subtiliter punctatis.

VI. ว. 
Der L's. affinis nahe vorwandt. aleer etwas länger nnd schnaler. die Stirn punktirt. die Spitze der Fld. in den meisten Fälten dunkel, die Hinterschenkel ron normalem Bau. nicht winkelig erweitert.

Sehr lang eifömig, mässig gewiilbt. pechbraun oder schwar\%. die Fïhler und Beine, mit Ausnalme der Hinterschenkel rostroth, die vorderen Schenkel zuweilen schwiirzlich (Var. a), Fld. golıbram, ihre Naht, ein meh oder weniger yrosses stiick an der sjitze und die Fpipleuren, letztere wenigstens hinter der Mitte, pechlraun bis schwax, Kopf, Halssch, und die an den Rändern verwaschene rlunkle Zeichnung der Fld. häufig mit metallisch grünen Anflugre. Stirn :iusserst fein gewirkt und punktirt. II alssch. kaum um dif Hiilte breiter bis doppelt so lreit als lang: ziemlich dicht, fein und nicht tief punktirt. Fld. am Grunde in sanftem Bogen heraustretend, bald hinter den Schultern am breitesten, nit kleiner Schulterbeule, wemig tiefen, vor der Spitze erlöschenden Punktstreifen und undeutlich punktulirten Zwischenstreifeu.

Die angegebene Fïrbung bildet die Ausnahme, denn die der affinis ahnlichsten Abänderungen b. mit rostrothem Kopfe und Halssch., an ersterem noch mitunter der Scheitel dunkel, oder c. mit hell bräunlichgelben Fld., deren Naht und spitze schwarz, pechbraun oder bei frischen Stiicken rostroth, mindestens leicht gebräunt ist, treten vorherrschend auf. Es giebt auch Exemplare, bei denen der Kopf einfarhig rostrotb. das Halssch. schwarz, am Seitenrande braun ist; die Var. d., deren Stirn und Halssch, dichter und stärker punktirt ist, findet sich nur im südlichsten Europa.

Auf Solaneen in Oesterreich, ron Tirol (Gredler) bis Wien, selten. Suideuropa, Nordafrika, Syrien, Kaukasus.

Ps. Lethierryi All. (Mon. 463) aus Tunis und Bona, und die mit ihr identische Ps. sicand Rey (Opuse. ent. 1875. 11) aus Sicilien sind mit circumdata äusserst nahe verwandt und von deren Var. c. vielleicht dadurch zu unterscheiden, dass bei ihnen nur die Naht mehr oder weniger weit dunkel gesäumt, die Spitze der Fld. dagegen stets hell gefärbt ist.

21. Isyll. marcida: Orata, ferruinea, leviter aeneo-micans, fronte prothoraceque subrugoso-punctatis, elytris flaro-testaceis, sat profunde punctato-striatis, interstitis crebre punctulatis, femoribus posticis apice macula obscura, tibiis posticis ante apicem ralde dilatatis. - Long: 3-4 mm.

Illig. Mag. VI. 175 (Halt.). - Steph. Ill. Brit IV. 320; Man. 300 (Macrocn.). - Redtb. Faun. A. II. 515 (Psyll.). Kutsch. Wien. Monat. 1864. 402 (372). - All. Mon. 461. - Seidl. F. balt. 501. - Leesb. Tijdschr. Ent. 24. 184. 
Psyll. operosa Foudr. Mon. 76.

Var. a. Capite aeneo-piceo, pectore, femoribus posticis abdomineque piceis. Vax. b. Immatura, testacea tota.

Eine dureh die Form der Linterschienen und die Färbung ausgezeichnete Art. Eiförmig. rostroth, Fld. bräunlich gelb. Kopt, Halsch. und Ilinterschenkel, öfter anch die Brust mit bläulichem oder grünlichem Metallschimmer. Stirn ziemlich breit, auf dem Scheitel gewirkt. darunter dicht und kräftig punktirt, schwach gerunzelt, die Stirnlinien fein, Höckerchen linienförmig, mit der Spitze in die Angenurime reichend. Halsseh. kurz, mehr als doppelt so breit wie lang, nach rorn stark verengt und zusammengedriickt, dicht und kräftig punktirt und namentlich an den Seiten gerunzelt. Fld. am Grunde in schwacher Rundung heraustretend, bis zum ersten Drittel erweitert, mit niedriger Schulterbenle, ziemlich tiefen, stark und gedrängt punktirten Streifen, die vor der spitze etwas abgeschwächt sind, und breiten, dicht und sehr fein punktulirten Zwischenstreifen. Hinterschienen vorn stark zusammengedrückt, mit hohen Leistenzähnchen, von denen der erste sehr spitz, der zweite abgerundet ist, neben diesem plötzlich sehr verbreitert und bis zur Spitze gleichbreit, tief löffelförmig ausgehöhlt, die Ränder hier mit braunen, ziemlich hohen Zähnchen dicht besetzt, kammförmig, Enddorn schwarz.

Vollkommen ausgefärbt besitzt das Thier einen pechbraunen, lebhaft metallisch grün oder bläulich glänzenden Kopf, auch die Hinterbrust, der Bauch und eine Makel auf dem Rücken der Hinterschenkel sind pechbraun (Var. a); unreif ist es beinahe einfarbig hell bräunlich gelb.

Auf Cruciferen, nämlich Crambe und Cakile maritima an den Küsten der Ost- und Nordsee häufig, ebenso am Strande in Holland, England, Frankreich, Spanien, Italien, Nordafrika.

* Tibiae posticae margine infero fortiter curvatae, marginibus superioribus apicem versus parce et obsolete denticulatae.

25. Psyll. dulcamarae: Ovalis, convexiuscula, nigro-coerulea aut cyanea, antennis basi rufis pedibusque piceo-nigris, femoribus posticis coeruleis, tuberculis frontalibus antice subdiscretis, prothorace antrorsum fortiter compresso et angulatim angustato, elytris subtiliter punctatostriatis, interstitiis, punctulatis. - Long. 3,5-4 mm.

Koch, Ent. Hft. II. 24. t. 2. f. 5 (Haltica). - Ill. Mag. VI, 173. - Gyllh. Ins. Suec, III. 565. - Duft. Faum. Austr. III. 279. - Schilling, Ber. Schles. Ges. 1846. 93. - 
Steph. Ill. Brit. IV. 3̇18; Man. 299 (Macrocn.). - Foudr. Mon. 34 (Psyll.). - kutsch. Wien. Monat. 1864. 410(354).

- All. Mon. 471. - Thoms. Skand. Col. VIII. 234. Redtb. Faun. A. II. 514. - Seidl. F. balt. 501. - Leesl. Tijdschr. Ent. 24, 180 .

Var. a. Obscure coeruleo-viridis.

Yas. b. Pedibus anterioritus tibiesque pusticis rufo-testareis iel ferrugineis.

Die nun folgende Grupue weicht von den vorhergehenden gerflïgelten Arten dureh die Bildung der Hinterschienen ab. an welchen die beiden liäuder des Riickens nach der Spitze hin cntwerler ganz ungezähnelt. oder mit ungleichen Dörnchen sparsam losetzt sind. wïhrend der Unterrand einen ziemlich starken Bogen bildet. Die beiden Zähne der Imnenrandleiste findet man nur bei einer Art (functirollis Rosh.) entwickelt, bei den iibrigen sind sie undeutlich oder fehlen. Die Fühler sind verlailtnissmässig kurz und dick. Bei zwei Arten ist der Metatarsus an der Spitze schnell erweitert und das Hasssch. doppelt punktirt, indem zwischen den feinen Punkten zahlreiche tiefe, gribchenartige P'unkte unregelmässig eingestreut sind, bei den iibrigen nicht. Zu ersteren gehört die vorliegende Art. Dieselhe ist eiförmig, ziemlich gewölbt. schwarzblau, glänzend. Fühler pechschwarz. die drei ersten Glieder roth, Beine fast schwarz, Gelenke und Tarsen röthlich, Hinterschenkel mit blauem Schimmer. Stirn breit, weitläufig und fein punktirt, mit glatten, queren, bandförmigen Hückern, welche oben in der Regel scharf, unten mdentlich begrenzt, in der Mitte durch eine Grube getrennt werden und an den Seiten allmählich in eine grob punktirte Erweiterung des Augenrandsammes iibergehen. Zuweilen sind die Linien nur durch Punktreihen angedentet. Der Nasenkiel ist breit und flach. Halssch. doppelt so breit als lang, nach rorn bis zur Erweiterung an der Pore wenig, davor stärker verengt. merklich zusammengedrïckt und gewölbt, doppelt punktirt, mit glatter Mittellinie in der hinteren Iralfte. Fild. an der Basis gerundet heraustretend und bald hinter der Schulter am breitesten. fein punktirtgestreift, die Zwisehenstreifen dicht und fein punktulirt, die Schulterbeule klein und niedrig. Bauch kriaftig punktirt, auf der Reibeflïche der Hintersehenkel nur gewirkt und fein quer gerieft. Der Penis ist vorn in eine Spitze verengt.

Die Farbe der Oberseite verändert sich durch Hinzutritt ron Grün allmählich in Dunkelgriin mit bläulichem schimmer (Var. a), selten sind die vorderen Beine und die Schienen und Tarsen an den Hinterbeinen röthlichgelb oder rostroth ( Tar. b).

Auf Solamm dulcamara L. rom Juli his in deu Herbst in Mitteleuropa gemein. sparsam im nördlichen und siidlichen Europa. 


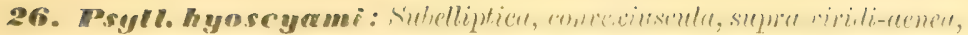

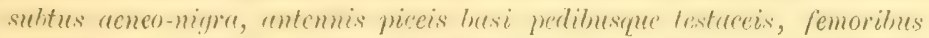

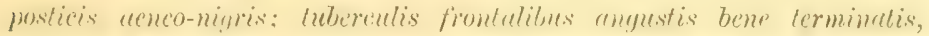
mothmace antrorsum sensim compresso-ungustuln, elytris fortiter pun-

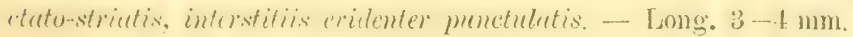

Limué, Syst. Nat. efl. 10. 372 (1/rysmele). - Marsh. Ent. Brit. I. 193, - Payk. Faun. Suec. II. 104 (Galleruca), - Oliv. Ent. V. 709. t. 4. f. 75 (Halt.). - Koeh, Ent. Hft. II. 27. t. 2. f. 6. - Ill. Mag. VI. 173. - Gyllh. Ins. Suec. III. 566. - Duft. Faun. A. III. 279. -- Steph. Ill. Brit. IV. 318; Man. 300 (Macrocn.). - Foudx. Mon. 52 (Psyll.). Kutsch. Wien. Monat. 1864. 413 (383). - All. Mon. 473. - Thoms. Skand. Col. VIII. 236. - Redtb. Faun. A. 514 Seidl. F. balt. 501. - Leesb. Tijdschr. Ent. 24. 181.

Var. a. cupronitens: Supra leviter cupreo-micans.

Ps. cupronitens Först. Verh. Nat. Ver. Rheinl. 1849. 27.

Var. b. coerulescens: Supra viridi-coerulea vel coerulea.

Var. c. Antennis testaceis apicem versus vix infuscatis.

Va1. d. Femoribus anterioribus infuscatis aut piceis.

Vir. e. chalcomera: Oralis, postice attenuata, supra cyanea vel coerulea, subtus aeneo-nigru, antenumum basi, geniculis, tibiis tarsisque obscure fermujincis, rurins testaceis, femoribus anterioribus piceis; prothorace untrorsum fortiter compiesso et rotundatim angustato, elytris plerimque minus profunde punctato-striatis.

Haltica chalcomera Ill. Mag. VI. 75 et 173. - Steph. 1. c. 318; Man. 300 (Macrocn.). - Foudr. Mon. 41 (Psyll.). - Kutsch. 1. c. 412. - All. Mon. 472. - Thoms. 1. c. 235. - Redtb. 1. c. 516. - Seid1. 1. c. 501. - Leesb. 180.

Vax. f. Capite prothoruceque virescentibus, interchm viridi-aeneis.

Haltica brunnipes Duft. 1. c. 280.

Var. g. Supra coeruleo-viridis.

Var. h. cardui: Supra saturate fusco-aenea.

Die zweite Art mit doppelter Punktirung des Halssch., von der vorigen durch die schärfer begrenzten Stirnhöcker, ein Grübchen iiber der Fühlerwurzel, die an der vorderen Borstempore nicht winkelig erweiterten Sciten des Halsschildes, durchweg kräftigere. s'kulptur der Oberseite und die ziemlich gleichmässig̨c Punktirmng: ¿les Bauches ahweichend. Lang-elliptisch, beirlerseits gleichmässio gerundet-verengt, ziemlich gewölbt, oben dunkel metallisch-grün, unten schwarz, mit Erzschimmer; Fühler pechbraun, ihre drei oder vier ersten Glieder und dic Beine, mit Ausnahme der Hinterschenkel, hell bräunlich gelb oder rothgelb, die Hiuterschienen und -Tarsen dunkler. Stirn weitläufig punktirt. mit quer bandförmigen oder dreieckigen Höckern, welche von tiefen Linien ungrenst und in 


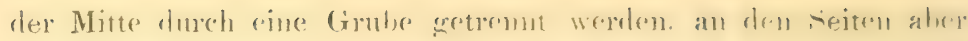
durch einen feinen Kiel mit dem Augenrande vertumeles sind. J)arunter hefindet sich ein tiefes Griihchen iiber der Fiihlerwurm. Halssch. rloppelt so breit als lang, merklich zewrilbt. nach vom

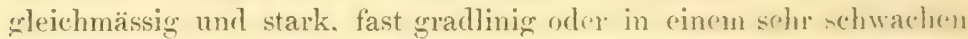
Bogen verengt. welcher an der vortern Borstenprore nicht unterbrochen wird. FId. an der Basis gemundet-heraustretrind. hieranf bis zur Mitte wenig erweitert, die Seiten daher zienlich parallel. hinten fast gemeinschaftlich abgerundet. die śchulterbeule etwas grösser als bei dulcamarre, die Punktstreifen melır oder wenigrer stark und tief, die Zwischenstreifen dicht und fein junktulirt. Zuweilen sind die Fld. Hald hinter der Schulter am breitesten und verengen sich dahinter, zuerst allmählich und sradlinig, nahe der Spitze stärker. Bauch nicht besonders dicht. aber kräftig junktirt, auf der Reibefäche der Hinterschenkel wenig schwächer als aut den übrigen 'Theilen. nahe den Seiten gerunzelt. Der Penis ist vorn abgerundet.

Bei den angeführten Varietäten wird a. die Oberseite kupfrig schimmernd, oder b. grïnlichblau, blass- oder dunkelblau; c. die Farhe der Fühler sehr hell, zuletzt fast einfarlic röthlichgelh, nach der Spitze etwas getrïbt, oder d. die der vier Vorderschenkel allmählich in Braun- bis Pechschwarz verdunkelt.

Die eben beschriebene Form kommt nur an Hyoscyumus niger L.. in Südeuropa auch an $H$. albus L. vor, eine andere (chalcomera) lebt hauptsächlich auf Carduus mutans L. und erleidet durch diese veränderte Lebensweise einige Abweichungen im Körperbau. in der Farbe und Punktirung. Das Thier ist merklich kürzer, das Halssch. an den Seiten gerundet, an der Spitze stärker zusammengedrückt, so dass die Vorderecken bei der Ansicht von oben mehr verdeckt werden, die Fld. sind etwas bauchiger, ihre Punktstreifen in der Regel schlechter begrenzt und seichter, die Punkte in ihmen grösser, aber flacher, eine Spur weitläufiger gestellt. auch tritt dic feine Punktirung der Zwischenstreifen weniger hervor. Die Oberseite ist einfarbig dunkelblau, seltener auf dem Kopfe und Halssch. allein (Var.f.) oder gänzlich metallisch-grün. mit blauen Schimmer (Var. g), orler gesättigt braun erzfarbig (Var. h), die L'nterseite schwarz, mehr oder weniger bronceglänzend. Fiihler und die vier Vorderschenkel pechschwarz, die Basis der ersteren und die spitze der letzteren, nebst Schienen und Tarsen dunkel rostroth. seltener röthlichgelb.

In Deutschland, wic im grössten Theile ron Europa, Klcinasien, dem Kaukasus und Sibirien stellenweise nicht selten.

Obgleich diese Art nur mit dulcamarae näher verwandt ist. 
wurde sie rom dron ältesten Autroren, ja noch vour Fourlans, zam Vergleiche mit den iibrigen. ganz unilinlichen Arten lıcrangezogen.

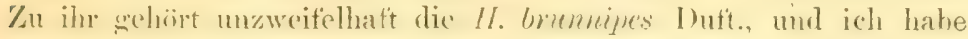

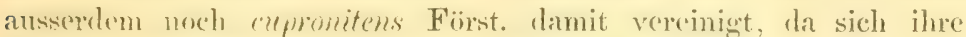
Beschreibung aut keine andere Art anwenden lässt.

b. I'votharm.r aequaliter punctatus, basi utrinque striola brevi instructus.

27. Psyil. Cuteota: Subllipica, minus concexa, nitida, ferruginea, pectore alslomineque piceis, labro, antemis apicem versus femoribusque justicis in lurso infuscutis; oculis oldonus, fronte latu, parce punctutu, interstilies punctulatis, tuberculis frontalibus angustis bene terminatis, prothorace subtilisime punctato, elytris sut profunde punctato-striatis. Long. 2,5-3 $\mathrm{mm}$.

IIill. Zool. Daus. Prodr. 84 (Altica). - Foudr. MLn. 78 (Psyll.).

- Kutsch. Wien. Mon, 1864.417. - A I1. Mon. 476. - Redtb.

Faun. A. II. 515. - Lees b. Tijdschr. Ent. 24. 185.

Haltica nana Duft. Faun. A. III. 285.

Macrocnema pallida Steph. Ill. Brit. IV. 321; Man. 301.

Psyll. propinqua Redtb. 1. c. ed. 1. 536; ed 2. 944.

Lanc-elliptisch, wenig gewölbt, hell rostroth, die Fld. bald etwas dunkler, bald blasser als das Halssch., zuweilen an der Naht gebräunt. Hinterbrust und Bauch pechschwarz, Oberlippe, die Fühler nach der Spitze hin und der Riicken der Hinterschenkel schwärzlich. Stirn breit, wach unten etwas verengt, glatt und glänzend, zwischen ren länglichen Augen mit zerstreuten, äusserst feinen Pünktchen und eingemengten grösseren Punkten, welche oft nur auf einen dreieckigen Raum über den Stimlinien beschränkt bleiben. Letztere sind fein, aber ziemlich tief und begrenzen die Stirnböcker deutlich, diese sind bandförmig, in der Mitte durch ein Grübchen getrennt und laufen seitlich in gleicher Breite und Höhe bis an den Augenrand. Halssch. fast doppelt so breit als lang, bis zur vorderen Pore, an welcher die Seiten etwas heraustreten, mässig, davor stärker verengt, hinten weniger als vorn gewölbt, ziemlich dicht, fein punktirt, glänzend, mit einem kurzen Längsstrich jederseits an der Basis. Fld. am Grunde in starker Rundung heraustretend und exwas breiter als das Halssch., dahinter bis zur Mitte wenig erweitert, mit kräftiger Schulterbeule, ziemlich starken, rückwärts abgeschwächten Punktstreifen und verloschen punktulirten Zwischenstreifen. Leiste der Hinterschienen olne Zähnchen, bis zur Tarsalbasis ansteigend. dahinted allmählich abtallend. 


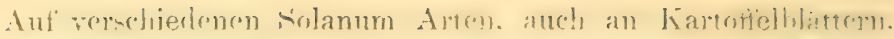
in Dentschland und Oesterreich zostrout, iiberhaupt im griinten Theile von Mittel- und Südeuropa einheimisch.

28. T"syll. picina: Subelliptica, comceinscula, nitisla, nis,ro-jicen, suepe aene-micans, fucie, antennis upicem rersus infuscutis pertibusque fermuineis, femoribus posticis purtim niymo-picein, oculis sulbrotundatis, fronte sat lata laeci, medio aut deplanata aut longitudinaliter impressu, plerumque foreolis nommullis instructa, tuberculis frontalibus unyustis, modice discretis, prothorace sultilissime junctato, elytris punctato-striatis. - Long. 2,5-3 mm.

Marsh. Ent. Brit. 1. 206 (Chrysomela), - Steph. Ill. Brit. IV. 322: Man. 301 (Macrocn.). - Kutsch. Wien. Monat. 1864. 415 (Psyll.). - All. Mon. 475. - Redtb. Faun. A. ed 3. II. 514. - Leesb. Tijdschr. Ent. 24. 185.

Haltice rufilabris Koch, Ent. Hft. II. 33. t. 2. f. 9. - Schilling. Ber. Schles. Ges. 1846. 93. - Redtb. 1. c. ed. 2. 946.

Psyll. picea Redtb. 1. c. ed. 1. ว36; ed. 2. 946. - Kïst. Käf. Eur. 28. 92. - Foudr. Mon. 6ó.

Vax.a. melanophthalma: Rufo-picer varius ceneo-micans, castenea vel ferruginea,

Halt. melanophthalma Duft. Faun. A. III. 284: - Redtb. 1. c. ed. 1. 536. - All. Ann. Fr. 1860. 826.

Halt. rufopicea Letzn. Arb. Schles. Ges. 1848, 83.

Der vorigen ähnlich. stärker gewölbt, an den Seiten melr gerundet, lang-elliptisch, mässig gewölbt, glänzend. pechschwarz oder schwarz, in der Regel mit Metallschimmer, der Kopt unterhalb der Fïhler, diese selbst und die Beine röthlich gelbbrann, die dicken Endglieder der Fühler leicht gebräunt. die Hinterschenkel, mit Ausnahme eines breiten Saumes um die Spitze und am Unterande. pechschwarz. Stirn ziemlich breit, nach unten stark verengt, grlatt und glänzend, in der Mitte der Länge nach flach gedrückt, oder mit einer Vertiefung oder mehreren Eindrïcken rersehen, die Stirnlinien fein, Höckerchen flach, quer, durch eine Grube getremnt. nach aussen allmählich verengt und mit der schmalen Syitze in den erweiterten Augenrand ïbergehend; die Angen gerundet. etwas gewölbt. Halssch. wie bei luteola grebaut, aber nur um die Hälfte hreiter als lang und nach rorn oft in einem flachen Bogen rerschmälert, der an der vorderen Pore kaum unterbrochen ist, die Scheibe ziemlich dicht, fein punktirt. Fld. an der Basis so breit als das Halssch., bis zur Witte etwas erweitert, mit kleiner Schulter- 
boule. mässig starken. röickwärts ahgenchwächten l'unktstreiten und erloschen punktulirten Zwischenstreifen.

Hänfiger als diese villien ausgefarbte Form tritt die Var. a auf, welche entweder rïhlich pechbraun. mit odex ohne Frasehimmer, oder hell kastanienbraum bis rostroth ist und in den meisten Fällen schon durch die gleichfarbige Unterseite von luteolu sich unterscheiden lässt.

Vom Juli bis in ren Spätherbst an Cirsium quatustre Scop., nach Kutschera auch an I.ythrum salicaria L., in Mitteleuropa nirgends selten.

\section{Haltica.}

Ge offroy, Hist. Ins. I. 1762. p. 244.

Graptodera Chevrol. D'Orbign. Dict. Hist. Nat, IV, 1845. 307.

Acetabula antica aperta; coxae fere aequilate distantes; tibiae dorso carina media instructae, posticae calcari distincto.

Palpi maxillares articulo ultimo parvo, conico.

Prothorax ante basin impiessione sulciformi transversa; pone angulos anticos utrinque serie angulata e punctis multis majoribus formatu impressus.

Corpus alatum, oblongum, coeruteum vel aeneum.

Körper gefliigelt, läng’er oder kürzer eiförmig, mässig gewölbt, metallisch grïn, broncefarbig, blaugrün oder blau, lederartig gewirkt und glänzend, Taster, Fühler und Tarsen schwarz, die ersten Fühlerglieder mit metallisch grünem Anfluge, das erste bisweilen mit röthlicher Spitze. Kopf klein, Stirn kurz, leicht gewölbt, mit undentlichen Linien, die als breite, punktirte Vertiefung vom oberen Augenrande schwach gebogen nach der Mitte ziehen, so dass zwischen ihnen, den gewölbten Augen und der Fühlerwurel ein grosser dreieckiger Raum entsteht, welcher zu den Augen ansteigt. Höcker gross, gewölbt, meist deutlich umgrenzt; Nasenkiel hoch und lang, oben in einer Spitze zwischen den Höckern endigend, unten zum aufgebogenen Rande des Kopfschildes abfallend. Oberlippe breiter als lang, mit einer Querreihe von vier bis sechs Punkten, oder beiderscits zahlreich punktirt, rorn ausgerandet. Mandibeln kurz und breit, gleichmässig gebogen, entwerler vierzähnig, die beiden mittleren Zähne gross, spitz oder stumpt. an der linken Mandibel gewöhnlich stumpfer als an der rechten, dic seitlichen klein und spitz (oleracea), oder dreizähnig, der innere Zahn am längsten, der äussere sehr kur\%. of undeutlich. zuweilen fehlend. 
Kimlartentaster kur\% das drite Glied nach der spitze allmäblich roweitert, das Fndglier kleiner. konisch. Eiihler unter sich weiter "ntfernt als wom den Augen eingefitgt. schlank, farlenförmigr, atwa-

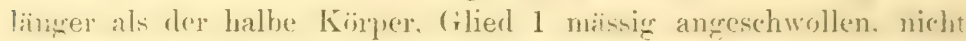
granz on lang als die beiden frolgenden zusammen. 2 kur\% dir. iihrigen gestreckt, wenig in der Liinge verschieden, nur 4.5 und 7 in der Regel etwas lünger als eins der andern Gilieder. Halssch. ruer, an der Basis schwach grerundet, fein grerandet und auf jerler Seite des schildchens sauft ansgebuchtet. an den Seiten breiter gerandet, hald fast gradlinis nach rorn rerengt, bald gerundet und nach hinten gewöhnlich schwächer als nach vorn verschmälext; die Rinne am Seitenrande biegt an den verdickten Vorderecken nach innen und endet, indem sie den ahgestutzten Vorderrand durchietzr. hinter jedem Auge. Die Oberfläche fällt nach morn wenir. nach den seiten und besonders nach den Vorderecken hin stärkex ab: sie besitzt 1. ein Stück vor der Basis eine grade oder jederseits gehngene Querfurche. welche an den Seiten allmählich erlischt, in einen gruhentörmigen Eindruck iibergeht, oder sich mit der Vertiefung neben dem Seitenrande rerhindet: 2.. auf der vorderen Hälfte jederseits eine winkelige Punktreilie, the aus zahlreichen, unregelmässig neben einander gestellten groben Punkten besteht, über den Vorderecken zuerst schräg nach innen läuft, vor der Mitte plötzlich nach aussen biegt und in grader Richtung nach dem seitenrande zieht; 3 . einen grossen und tiefen Punkt jederseits in der Mitte der Scheibe, welcher aber für die Unterscheidung der Arten ohne Belangr ist, da er oft auf der einen seite alloin, oft aut' beiden Seiten fehlt. Von den Eckporen, die eine feine Borste tragen. steht die eine aut einem Kegel in den Hinterecken. die andere am Fnde der wulstartigen Verdickung der Vorderecken. Was Schildchen ist dreieckig, mit abgerundeter Spitze, und tällt vorn in cinen rom Halssch. hedeckten, tiefen, beharten Quereindruck ab. Die Flïgeldecken treten an der Basis iiber den Grund des Halsschildes heraus, erweitern sich noch etwas bis hinter die Mitte und sind damn in einem grossen, gemeinschaftlichen Bogen abgerundet, auf' ter Naht, dicht vor der Spitze eingedrickt, oben verworren punktirt, mit Spuren von Längsrippen, die zwischen unregehmässig verdoppelten Punktreihen stehen und auf der Oberseite schwächer als auf der schwarzen. älig glänzenden Unterseite ansgeprägt sind. Die Epipleuren haben neben der Hinterbrust eine sehr lange und flache bogenförmige Ausrandung, verschmälern sich dahinter allmählich, so dass sie zwischen der hinteren Aussen- und Nahtecke linienförmig werden, und sind im letzten Viertel fein und kurz bewimpert. Prosterum ziemlich breit, hinter die Hiiften verlängert und auf die Nittelbrust 


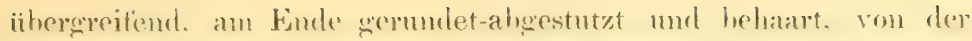
Spitze der Seitenstiicke weit entfernt, so dass die Hiittpfannen offen bleiben. Beine ziemlich lang, Hinterschenkel schwach vordickt, spindelfömis. Schienen an den Seiten mit stamen, gellhlich grauen Haaren besetzt, auf' dem lïucken kahl, mit einer Mittelleiste, an dre Spitze der Hinterschinen ein kurzer Dorn. Das deitte 'l'arsenglied ist zweilappig, etwas breiter als die vorhergehenten, die Klauen sind krätig, an der Basis mit einer grossen, zahnartigen Erweiterung. Das Pygidium besitat eine breite und tiefe Mittelrinne zum Finlegen der Nahtkante.

Beim Männchen sind die Fühler gestreckt und merklich länger als beim 우, das erste Tarsenglied ist, namentlich an den vier Vorderbeinen, verbreitert, hei cinigen exotischen Arten ziemlich so breit als lang. scheibenförmig, der letzte Bauchring ist auf einem Längsstreifen in der Mitte glatt, flach gedrückt oder vertieft, die Mitte des Hinterrandes bogenförmig vorgezogen. - Der Penis bildet eine von oben zusammengedrickte Röhre, welche auf der Oberseite eine lange, quer geriefte oder gestrichelte Vertiefung besitzt, die vorn in der langen, glatten Klappe am tief'sten ist; die Unterseite wird durch zwei schwache Eindricke, oder Rinnen, oder Leisten in drei Längsstreifen getheilt, die bei einigen Arten gewölbt, bei anderen vertieft' sind und von denen der mittlere meist glatt, die beiden äusseren meist schräg gerieft sind. Der Vorderrand ist vollkommen abgerundet (olerrcea), gradlinig verengt, oder gerundet-abgestutzt und in der Mitte in eine kurze und breite Spitze verlängert.

Die Larven leben auf den Blättern verschiedener Pflanzen. die sie zuletzt vollständig skeletiren, indem sie das Parenchym sowohl von der Ober-als Unterseite abfiessen. Völlig ausgewachsen sind sie um die Hälfte länger als $\mathrm{der}$ Käfer, hinten etwas mehr verschmälert als vorn, ziemlich cylindrisch, mit flacherer, wachsgelber Unterseite und bräunlich gelber Oberseite, welche durch äusserst feine und dicht gestellte Körnchen matt und im Verein mit grösseren, schwarzen, glänzenden Tuberkeln verdunkelt wird, beim Aublicke mit blossem Auge ungefähr zimmtbraun erscheint. Der Kopf und Prothoras, die Anusdecke und Beine sind schwarz. Kopf ziemlich klein, gerundet-dreieckig, glatt, glänzend, sparsam mit aufstehenden Borstenhärchen besetzt, eine weite, aus vier Eindrücken zusammengesetzte Grube auf ler Witte der Stirn und eine bis auf den scheitel reichende Mittelrinne stark vertieft. Fühler klein, droigliederig, Glied 1 dick, 2 kurz und breit, eylindrisch, mit seharfem Rande. der unten in ein Dörnchen verlängert ist, 3 sehr schmal, kegelförmig; über dem Fühler steht eine Ocelle, die wahrscheinlich nur bei oleracea fehlt. Mandiheln zwei- bis vierzähnig, Maxillartaster. 


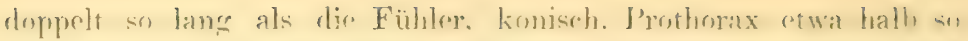
lang als breit. an den firiten grermolet. mit rimigen sparsam und

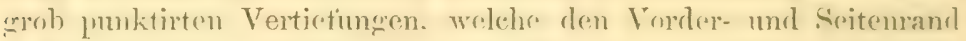
mud gewïhlich noch einen Questreifen hinter der Witte wulstatior (mporhelsen, alle erhöhten Theile sind mit riner Reile vom Burstruhïrchen besetzt. Die folgenden Ringe sind unter sich ähnlich. durch rine Querlinie in zwei Streifen setheilt, von denen jeder sine breite. strichfoinige, an beiden Enden crhöhtes und mit cinem Borstenhärchen rersehene Wittelbeule mul zwei (auf Meso- und Metathorax virsclimolzen). mit einer Borste besetrte punktförmige Seitenlienlen besitzt, wozu noch auf jedem Rückenringe eine Tuberkel an den Enden der Querlinie hinzutritt. Mer Anus ist mit einer grossen halbovalen Platte bedeckt.

Bis jetzt wurde nur die Larve ron $H$. nterace ${ }^{1}$ ) dureh (ormelius (Stettin. Zeit. 1864. 98; Taschenberg; Schidl.Thiere 1865. 74. t. 2. f.6, und die einer andern Art, vielleicht H. Iythri, durch Perris (Ann. Fr. 1876. 214) beschriehen, die zahlreichen anderweiten Mittheilungen iiber Larven sind entweder zu oberflächlich oder durch die zweifelhafte, ja falsche Bestimmung der Art zwecklos.

Die Larve geht im Juli in die Erde und verwandelt sich dicht unter der Oberfläche in eine hellbräunlich gelbe Puppe, deren Kopt, Thorax und Riicken mit einzclnen Tuberkeln besetzt ist, ron denen jede ein langes, starkes Haar trägt. Zuerst färben sich die Augen, Fühler und Taster und schimmern dunkel durch. - Nach einigen Wochen erscheinen die Käfer, fressen bis Ende September und iiberwintern unter Laub und Moos, sie sind daher in den letzten warmen Herbsttagen, oder im Siebicht und Anspülicht zu Ende des Winters, hauptsächlich aber bei der Copula Anfang Mai zu fangen. Aus dem Umstande, dass die Männchen verhältuissmässig selten vorkommen, darf wohl auf deren kurze Lebensdauer geschlossen werden.

Zur Gattung Ilaltica, die über die ganze Erde rerbreitet ist. rechnet man gegenwärtig ungefähr hundert ansehnliche Arten. von denen die Mehrzahl auf Gebiischen, der Rest an krïftigen. perennirenden Pflanzen lebt und an denselben nicht merheblichen Schaden anrichtet, wenn die Witterung ihrer Entwicklung giinstig ist. Die Feststellung der Arten nach äusseren Kennzeichen wird durch die überraschende Wandelbarkeit aller Mrerkmale so sehr wie in keiner anderen Gattung erschwert, in den meisten Fiallen unmöxlich gemacht, so dass mit Sicherheit überhaupt nur die Männchen bestimmt werden können, deren Penisform innerhalb der Gattung:

1) Nicht von lythri, wie Perris a. a, O. annimmt. 
recht versehieden ist, immerhalb jecter Art aber ziemlich constant beibt. Hiernach stellt sich eine Uebersicht der europaiischen Arten augenblicklich folgendermassen heraus:

A. Der glatte Mittelstreifen aứ der Unterseite des P'enis ist undeutlich. von den Seitenstreifen schlecht abgesetzt, \%wischen der Nitte und dem letsten Viertel auf eine schmale, flache und glatte Rinne besehränkt, hierauf bis zum Vorderrande in starker Rundung ('rweitert, bedeutend vertieft, schräg gerieft, das letzte Viertel daher löffelförmig. . . . . . pusilla Dft.

Der glatte Mittelstreif der Unterseite ist deutlich begrenzt und ammähernd so breit, oder breiter als der Längsstreif an jeder Seite.

B. Vorderrand abgerundet . . . . . . .oleracea L.

C. Vorderrand jederseits gradlinig oder dureh einen hogenförmigen Ausschnitt in eine grosse, breite dreieckige und beinahe ebent spitze vorgezogen; der dicke Vorderrandsaum auf der Oberseite ohne Mittelrinne.

a. Der Mittelstreifen bildet eine sehr tiefe Rinne, welche anf jeder Seite zu einem hohen und sehr scharfen Längskiele ansteigt

$a^{1}$. Der Mittelstreifen ist kielförmig oder leicht querüber gewölbt und wenigstens in der vorderen Hälfte von den Seitenstreifen durch eine schwache Rinne geschieden . c.

b. Diese Längskiele sind parallel . . . palustris Ws.

$\mathrm{l}^{1}$. Dieselben divergiren allmählich stark von der Mitte nach dem Vorderrande hin . . . . carduorum Guer.

c. Aussenecken des Vorderrandes deutlich, gerundet-stumptwinkelig, Spitze breit und kurz dreieckig, oft jederseits sanft ausgeschweift . . . . . tamaricis Schrank.

$c^{1}$. Aussenecken vollkommen abgerundet, die Spitze bildet ein ziemlich gleichseitiges Dreieck . . carinthiaca Ws.

D. Vorderrand gerundet-algestutzt und in der Mitte plötzlich in eine kleine und selır kurze, gewülbte, oberseits vertiefte Spitze verlïngert; Vorderrandsaum auf der Oberseite mit einer mehr oder weniger tiefen Mittelrinne.

a. Der breite, glatte Vittelstreifen der Unterseite ist gleichmässig schwach queriiber gewöllht und fällt beiderscits in eine wenig scharfe und tiefe Längsrime $a b$, welche die Seitenstreifen deutlich absetzt. Letztere sind ebenfalls schwach gewölbt, seicht und spärlich schräg gerieft, im vorderen Drittel glatt und olne Längsvertiefung . . b.

$a^{1}$. Der Mittelstreifen ist vertieft, oft noch mit einem Mittelkiele versehen. mul steigt in den ersten drei Vierteln all- 


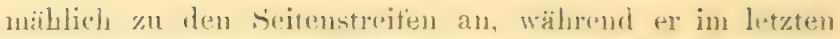
Viertel beiderseits won einer Iängsleistr sclarf begrenzt ist, neben der sich ant den seitenstreifen eine lange Grube hinzieht

b. Die Seitenstreifen sind rom, etwa in drei Virertel der Länge verbreitert und ler Mittelstreifen ist dasellyst verengt . . . . . . . quercetorum Foudr. b1. Seiten- und Mittelstreifen sind iberall riemlich gleich breit ericeti All.

c. Der Mittelstreifen ist in drei Viertel der Läuge stark verengt, davor unter cinem stumpten Winkel lis zur spitze gradlinig und stark verbreitert, im letzten Viertel beilfïrmig, selur stark rertieft, olme Rimme nehen der hohen Leiste der Seitenstreifen . . . . . saliceti Ws.

$c^{1}$. Der Mittelstreifen verengt sich alluählich in sehr sehwacher Rundung von der Basis bis zum letzten Viertel unbedentend und erweitert sich ähnlich daror; er hat im letzten Viertel jederseits eine ticfe Rinne neben der Leiste der Seitenstreifen . . . . . . . . . . . d.

d. Seitenstreifen glatt, höchstens mit einigen ganz undeutlichen Kerben am äussersten Rande der Längsgrube . . fruticola

Ws.

$d^{1}$. Seitenstreifen im mittleren Drittel schräg gerieft . . . e.

e. Die breite, rinnenförmige Vertiefung der Oberseite glatt oder mit einzelnen, weit abstehenden Querriefen, Seitenstreifen der Unterseite ziemlich weitläufig gerieft . lythri

Aub.

$e^{1}$. Der allmähliche Abfall zur Oeffnung auf der Oberseite und die Seitenstreifen der Unterseite dicht und stark gerieft . . . . . . . ampelophaga Guer.

\section{Bestimmung's - Tabelle.}

1. Mandibeln dreizähnig, die Zähne nach unten allmählich an Länge abnehmend, der unterste Zahn zuweilen verkümmert. Stimhöckerchen meist scharf begrenzt, grösser als die ringförmige Leiste um die Fühlerwurzel. Grössere Arten ron 4 bis $6 \mathrm{~mm}$ Länge, ausgenommen die kleine carinthiaca . 2.

1. Mandibeln rierzähnig, die beiden mittleren Zähme lang und ziemlich gross, die beiden äusseren weit davon entfernt, der immere von diesen breit, der äussere schmal. Stirnhöckerchen schlecht begrenzt, kaum so gross als die ringförmige Leiste $\mathrm{um}$ die Fiihlerwurzel. Kleine Arten von $3,2-4,5$ mm Länge 9. 
2. Halsseh. schmal. an der Basis etwa halb so breit als die Fld. in den Schultern, mit breit abgesetztem Scitenrande, welcher bei der Ansicht von oben bis zu den Vorderecken sichtbar bleibt. Stirnhëckerchen schnal, lanzettlich oder lang dreieckig, schief' zu einander gestellt. Fld. verloschen punktirt L. 4,5-5,2 mm. Mitteleuropa - . 5 tamaricis Schrank.

$2^{1}$. Halssch, an der Basis fast so breit oder merklich schmaler als die Fld. in den tehulteru. mitschmal abgesetztem Seitenrande, welcher bei der Ansicht ron oben in der vorderen Hälfte, wenigstens in der Nïhe der Vorderecken verdeckt ist. Stirnhöckerchen dreieckig. grade neben einander gestellt, oder rundlich . 3.

3. Fld. mit den Halsschilde in einer Flucht gewölbt, an der Basis wenig breiter als das Halssch., mit einem sehr schwachen, gerundeten und kaum heraustretenden Schulterwinkel und undeutlicher Schulterbeule . . . . . . . . . 4.

$3^{1}$. Fld. an der Basis merklich ansteigend und breiter als der Grund des Halsschildes, mit dentlichem Schulterwinkel und Schulterhöcker . . . . . . . . . . . . 5.

4. Die Fld. erweitern sich nach hinten allmählich und erreichen ihre grösste Breite hinter der Mitte; drittes Fühlerglied wenig länger und schmaler als das zweite. Vorherrschend dunkelblau, fein punktulirt, oft mit Spuren von Längsrippen auf den Fld. L. 4,5-6 mm. Mitteleuropa . . . . .4 lythri Aub.

$4^{1}$. Fld. in den mittleren zwei Dritteln ziemlich parallel; drittes Fühlerglied doppelt so lang und merklich schmaler als das zweite. Gestreckt, rorherrschend grün, auf den Fld. kräftig punktirt und gewirkt - L. 4,5-5,5 mm. Südeuropa ericeti All.

5. Vorderecken des Halsseh. vor der Pore erweitert und verdickt, von den Augen abstehend . . . . . . . . . 6.

51. Vorderecken des Halssch. mit den Seiten in ziemlich gleichmässigem Bogen verengt, kaum erweitert oder verdickt, den Augen nahe

6. Vorderecken des Halssch, rorgezogen, ziemlich spitzwinkelig: Grün bis grünlich blau, Fld kräftig punktirt. - L. 4,5-5 $\mathrm{mm}$. Frankreich, Tirol, Südeuropa - . . 3 ampelophaga Guer.

61. Vorderecken des Halssch, nicht vorgezogen . . . . . 7.

7. Grün, Fld. kräftig punktirt. - L. 4-5,5 mm. Mitteleuropa

1. quevcetorum Foudr.

71. Grünlich blan, Fld. fein punktirt. - L. $4 \mathrm{~mm}$. Kärnthen

6. carinthiaca Ws.

8. Fld. hinter dem ersten Viertel der Jünge niedergedrïckt, dè Raum davor etwas wulstartig gewölbt. Blaugrün oder grün, 
sele plump gevant, Fhl. fin punktirt. - I. 5-6 mm. Witteldeutschland . . . . . . . . 2 suliceti WTs.

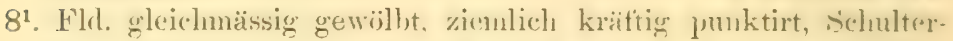
beule hroch, imen nur von einem kurzen und schwachen Eindrucke alygesetzt. Grün lis blan, mässigg grestreckt. vorn selnnaler als hinten. - I. 4,3-5 mm. Mitttel- und Siideuropa. . . . . . . . . 7 fruticola Ws.

9. Stimlinie klammerfömig, ziemlich in sleicher Tiefe vom oberen Augenrande bis zwisclen die stirnluöcker laufend, letztere oben flach, deutlich begrenzt, unten gewöll,t. Kurz eifürmig, dunkelblau oder griin, Fld. mit ziemlich grossen aber flachen Punkten. L. 3,5-4,2 mm. Baiern, Oesterreich, Südeuropa

8 carduorum Guer.

91. Stimlinien undeutlich, Höckerchen flach, oben und an den Seiten durch zahlreiche verworrene Punkte schlecht begrenzt . . . . . . . . . . . . . 10 . .

10. Fld. auf der vorderen Hälfte des Rückens kriaftig gereihtpunktirt und nebst dem Kopfe und Halssch. dicht gewirkt, seidenartig glänzend, Naht vor der Spitze grubenförmig vertieft. Vorherrschend grïn, ziemlich gestreckt. - L. 3, $0-4,2 \mathrm{~mm}$. Ganz Europa . . . . . . . . 10 oleracea L.

101. Fld. in der Regel ohne Grube ror der Spitze, auf dem Rücken verworren und mehr oder neniger verloschen punktirt, nebst dem Halssch. wenig dicht und äusserst zart gewirkt, glänzend 11.

11. Fld. mit ziemlich grossen, aber seichten Punkten, an den Schultern merklich heraustretend. Dunkelblau, selten mit grüulichem Schimmer. - L. 3,5-4,2 mm. Norddeutschland

9 palustris Ws.

11․ Fld. mit kleinen, äusserst seichten Punkten, an den Schultern wenig heraustretend und die Basis des Halsschildes überragent. Dunkelblau oder -grün. - L. 3-4 mn. Alpen, Togesen

11. pusilla Duft.

1. Halt. quercetorum: Ol,ongo-ornta, parum concexa, vividi-denea, interdum coeruleo micans, nitida, tuberculis frontalibus magnis, postice linea transversa bene discretis, prothorace subtilissime punctato, conrexo, lateribus paullo rotundatis, angulis unticis subcallosis, rotundatis, sulco ante basin modice impresso, elytris incequaliter punctatis, supra marginem lateralem plicatis. - Long. 4-5,5 $\mathrm{mm}$.

Fondr. Mon. 293. -- Leesb. Tijdschr. Ent. 25. 146. t. 11. f.4. Haltica erucae 01. Ent. VI. 705. t. 4. f. 67. - Aubé, Ann. Fr. 1843. 9. - Kutsch. Wien. Mon. 1860. 76 (62). - Bach, Käferf. III. 137. - Redtb. Faun. A. II. 495. - Seidl. F. balt, 493. - A11. Mon. 211 (Groptod.). 


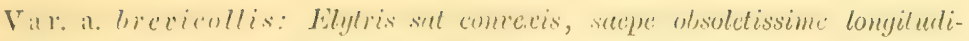
naliter sulcatis, plica laterali nulla.

Halt. brevicollis F oudr. Mon. 296.

Graptod. coryli All. Ann. Fr. 1860, 77; Mon. 213.

Hult. olcrece Ratz. For'stins. 242. t. 20. f. 8. - Bach, Käferf. III. 137.

Halt. ampelophaga Leesb. 1. c. 148.

Var. b. Viridi-aurichalcea vel cuprea.

Var. c. azurescens: Supra obscure coerulea.

Länglich eitörmig, wenig gewölbt, rein metallisch grün, zuweilen mit blanem Schimmer, glänzend, der Mund, der grösste Theil der Fïhler und die Tarsen schwarz. Mandibehn mit zwei grossen und stumpfen Zähnen und einem kleinen, verkümmerten, oft nur durch eiue kleine Erweiterung angedeuteten Zahne an der Seite. Stirnhöcker gross, quer, dreieckig oder rund, in der Regel ringsum scharf begrenzt, durch eine tiefe, öfter bis auf den Scheitel verlängerte Rime von einander und dureh eine grade, seltener aus zwei Bogen bestehende Querrinne von dem oberen Theile der Stirn geschieden, welcher, wie die Höcker selbst kaun lederartig genetzt ist und stark glänzt. Der Nasenkiel ist schmal und scharf, bisweilen aber zwischen den Fihlern rerbreitert und abgeflacht und ragt mit der Spitze mehr oder weniger weit zwischen die Höcker hinein. Das dritte Fuihlerglied ist etwas sehmaler und fast doppelt so lang als das zweite. Halssch. beim ô $\mathrm{um}$ die Hälfte, beim 우 doppelt so breit als lang, vor der Mitte am breitesten, nach hinten allmählich, nach rorn etwas schneller, im Ganzen jedoch wenig und nur in leichter Rundung verengt, ror den stumpfirinkeligen Hinterecken oft sanft ansgeschweift, die Vorderecken ror der Pore wulstartig verdickt, leicht nach aussen tretend, rorn abgermudet. Die Oberfläche stark querüber gewölbt, so dass der schmal abgesetzte Seitenrand bei der Ansicht ron oben rerdeckt wird, f'in punktirt, kaum gewirkt, glänzend, die winkelige Punktreihe jederseits deutlich, die Querrinne mässig tief. Fld. in den Schultern breiter als die Basis des Halsschildes, rückwärts etwas erweitert, im letzten Drittel gerundetverengt. mit schwach einzeln ahgerundeter Nahtecke; auf dem Rücken wenig gewölbt und allmählich in einen Längseindruck abfallend, welcher parallel mit dem scitenrande von der Imnenseite des Schulterhöckers bis anf den Abfall zur Spitze läuft, in der vorderen Hälfte aber nicht selten alogeküirzt ist. Sein Aussenrand ist hoch, vor der Spitze zuweilen rippenartig. Die Fld. sind ziemlich dicht und deutlich punktirt, nit feineren Punkten in den weitläufig und verloschen gewirkten Zwischenräumen, weniger glänzend als

VI. 5. 


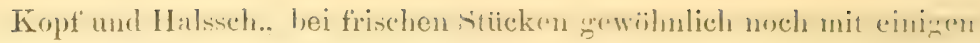
schwachen Längsfurchen versehen.

Das $\hat{j}$ hat das erste Tarsenglied wenig crweitert und auf dem letzten Bauchringe einen Einrluck orler eine glatte, flache Mittelrinne, die vor dem Hinterrande verbreitert und vertieft ist. Penis nicht ganz so lang als der Hinterleil, nach der Spitze hin umbedeutend erweitert, rorn gerundet-abgestutyt, mit einer kleinen bogenförmigen Spitze in der Nitte; die drei Längsstreifen der Luter-. seite sind leicht querüber gewiill,t, der glatte Mittelstreifen ist in drei Viertel seiner Länge am schmalsten. davor erweitert, in letzten Viertel durch eine Rimne von den S'citenstreiten getrennt, welche nahe der Mitte schräg gerieft, vorn jednch nicht rertieft sind.

Bei der auffälligen, wahrscheinlich durch die abreichende Nahrung bedingten Form a. fehlt die Längstalte iiber den Seiten der Fld. gänzlich; letztere erscheinen wesentlich höher, weil die Vertiefung neben der Falte ausgefiillt und die Wölbung nicht unterbrochen ist.

Farbenabänderungen kommen bei quercetorum sparsamer als bei der Form brevicollis vor; es sind die Var. b, welche bald aut' Kopf und Halssch., oder auf einigen, schwach erhabenen Längsstreifen der Fld. allein, bald auf der ganzen Oberseite einfarbig grün ist, mit starkem Messing-oder Kupferschimmer; und Var. c. mit grïnlich blauer oder dunkelblauer Oberseite. Diese Varietät wird der $H$. lythri Aub. namentlich in solchen Exemplaren täuschend ähnlich, die in den Schultern schmal gebaut sind, lässt sich aber in den meisten Fällen dưch längere Vorderecken, die rom Vorderrande entfernter eingestochene Borstenpore des Halssch. und kräftigere Punktirung der Fld. unterscheiden.

In Bezug auf die rariable Skulptur ist besonders auf solche Stuicke hinzuweisen, deren Halssch. dicht und fein, etwas runzelig. punktirt, dentlich gewirkt und wenig glänzend ist.

Auf jungen Eichen in Mitteleuropa bis in den Caucasus sehr zerstreut, weit häufiger (namentlich in der norddeutschen Tiefebene gemein) die Var. a. auf Haselnussgebüschen im Friilılinge und Herbste.

Die Längsfalte der Fld. lässt sich bei dieser Art nicht als specifisches Merkmal verwenden, da sie eine ganz verschiedene Länge besitzt, zuletzt also verschwinden muss.

In derselben Weise variirt H. bicarinata Kutsch. 1. c. 77 (63) aus Syrien (Beirut, Lenthner), deren Längsfalte bald von der Schulter bis vor die Spitze reicht, bald nur hinten deutlich ausgeprägt, oft nicht $z \mathfrak{n}$ 


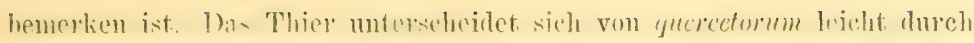
schlanken Bau, bedentend feimere Punktirung und das viereckige, an den Seiten ziemlich parallele, gleichmässig quer iiber gewïlbte Halssch., dessen Seiten bis zu den Vorderecken von oben sichtbar. sind. Der Fundort Kaukasus ist zu streichen.

2. IIalt. saliceti: Oblongo-ovata, parum convexa, viridi-cenea, plerumque coeruleo-micins, nitida, tuberculis frontalibus magni.s, postice linea transversa bine discretis, prothorace lato, minus conceco, crebre sultilissime punctuto, luteribus rotundatis, angulis anticis haud callosis, ollique trunctatis, sulco ante basin modice, latera versus pro/undius impresso, clytris inaequaliter punctulatis, saepe longitudinaliter subsulcatis, callo humerali magno. - Long. 5-6 mm.

Den grössten und flachsten Exemplaren der vorigen Art sehr ähnlich, aber vorn bedeutend breiter gebaut, ziemlich lang viereckig, beiderseits beinahe gleichmässig breit abgerundet, an den Seiten ziemlich parallel. Das Halssch. ist in beiden Geschlechtern doppelt so breit wie lang, die Seiten stärker gerundet, in den Vorderecken kaum verdickt und uach aussen tretend, vor der Pore gewöhnlich schräg abgestutzt, die Oberfläche weniger gewölbt, so dass der breiter abgesetzte Seitenrand bei der Ansicht von oben bis vor die Mitte sichtbar bleibt, dicht und fein punktirt, schwach gewirkt, mit etwas seidenartigem Glanze. Die winkelige Punktreihe ist deutlich, die Querfurche seicht, jederseits in einem weiten und tiefen grubenförmigen Eindrucke endigend. Auf den Fld. ist die Punktirung in der Regel flacher und tritt aus dem schärfer gewirkten Grunde weniger hervor, die Schulterbeule ist lang und hoch, innen durch einen langen Eindruck abgesetzt, welcher sich ungefähr in ein Viertel der Länge mit einer Vertiefung an der Naht verbindet und den Raum davor bis zur Basis etwas in die Höhe hebt. Der übrige Theil der Scheibe ist von mehreren äusserst schwachen Längsstreifen durchzogen.

Beim Männchen ist das erste Tarsenglied wenig erweitert, die Mitte des letzten Bauchringes glatt, hinten allmählich vertieft; der Penis etwas breiter wie bei quercetorum, vorn gerundet-abgestutzt, gleichfalls mit einer kleinen, bogenförmigen Spitze in der Mitte; auf der Unterseite sind die Seitenstreifen stark gerieft, neben der tiefen Längsgrube vor der Spitze winkelig erweitert, mit hohem, leistenförmigen Innemrande, der Mittelstreifen verengt sich bogeuförmig von der Mitte bis zum letzten Viertel, erweitert sich davor gradlinig bis zum Vorderrande und ist vor der höchsten Wölbuug, die in dem eingeengten Theile liegt, auffällig vertieft. 


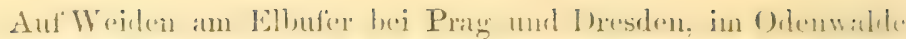
bei Diehurg (Dr. Flach) und jedenfalls in den Bergogegenden Mitteldeutschlands weiter verbreitet.

3. Iralt. ampelophaga: Olongo-uratu, sut concexa, rividi-reneu, interdum coerulen micans, nitida, tuberculis frontalibus magnis, jmstice linea biarcuata bene discretis, proflurace sat conveav, crelore puntulato, lateribus paullo rotunlatis, angulis anticis eridenter callusis, plerumque acutiusculis et prominulis, elytris crebre inaequaliterque punctatis, tuberculo humerali distincto. - Long: 4,5-5 mm.

Guer. Rev. zool. 1858. 415., - All. Mon, 213. (Graptod.).

Haltica consobrina Foudr. Mon. 291.

Var. a. Coevulea, interdum leviter viridi micans.

Graptodera hispana All. Abeille V. 477.

Var. b. Aurichalcea.

Diese Art nähert sich in der Körperform, Farbe und Skulptur der gewölbten Form von quercetorum (v. brexicollis) oft so sehr, dass ilhe sichere Unterscheidung schwierig wird, besonders wenn einzelne Exemplare ohne genane Angabe des Fundortes und der Nahrungspflanze vorliegen; eine Verwechselung mit saliceti, welche breiter und thacher, auf den Fld. verloschener und feiner punktirt ist, dürfte ausgeschlossen sein.

Länglich eiförmig, mässig gewölbt, metallisch grün, selten blau (Var. a), oder messinggelb (Var. b), glänzend. Mandibeln mit drei ziemlich langen, sehmalen und spitzen Zähnen, von denen der innere am weitesten, der äussere am wenigsten rorgestreckt ist. Stirnhöcker gross, quer, rund oder dreieckig, durch die spitze des Nasenkieles getrennt und von der Stirn durch eine ans zwei Bogen bestehende Rinne geschieden, über welcher der winkelige Raum in der Mitte gewölbt ist. Halssch. ungefähr um die Hälfte breiter als lang, an den Seiten wenig $(\hat{o})$ oder stärker ( $q$ ) gerundet, ror den Hinterecken und hinter der vorderen Borstenpore sanft ausgescluweift, die Vorderecken verdickt, ziemlich grade nach vorn lanfend und in den meisten Fällen ausgezogen und etwas zugespitzt, nicht verrundet, wie bei brevicollis. Die Oberfläche ist mässig queriiber gewölbt und auf dem schwach gewirkten Grunde dicht und fein punktirt. Fld. stärker gewirkt, krättig punktirt, mit einzelnen sehr feinen Punkten in den Zwischenräumen; die Schulterbeule dentlich.

ô Erstes Tarsenglied ziemlich so breit als das dritte, die Mitte des letzten Bauchringes glatt, flach goedrückt, mit ganzer Mittelrinne. Penis vor der Mitte ummerklich verbreitert, vorn gerundet-abgestutzt und in der Mitte in eine kleine, bogenförmige Spitze verlängert, 


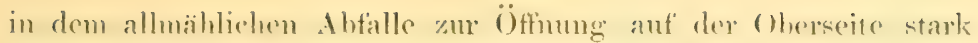
quer serieft, der glatte, tieflicgende Mittelstreifen der Unterseite rerengt sich in seln schwacher Rundung bis zum lotzten Vicrtel, "rwertert sich ähnlich davor und besitzt in letzten Viertel cine Mittelrime, sowic rine tiefere Rinne jederseits, die seitenstreiten sind stark schrịg weriett, vorn glatt, mit einer tiefen Längsgrube.

Auf Wrinblättem in 'Tirol, besonders in der Ungelung von Buzen; Siilfiankreich, wanz Südeuropa, Algier, Syrien. Das Vorkommen in England (Allard) ist nnwahrscheinlich.

Hult. criceti A Il. A.m. Fr. 1859. Bull. 166; Mon. 212) ist den schlinken Stiicken der vorliegenden Art ïberans äbnlich und nur unsicher durch den sehr gestreckten, oben in einer Flucht mit dem Halssch. gewölbten, mehr gleichbreiten Körper, schmale Schultern, welche kaum ïber die Basis des Halssch, heranstreten, und die undeutliche Schulterbenle zu nuterscheiden; der Penis erinnert aber, da die Seitenstreifen der Tnterseite keine Grube besitzen, mehr an den von quercetorum. Das Thier lebt auf Ericu tetralix L. in Frankreich, Spanien (Seidlitz) und Griechenland (Krïper).

4. Wratt. Iythri: Oblonyo-ovata, convexiuscula, nigro-cyanea aut violacea, interdum rividi micans, alutacea, nitidiuscula, tuberculis frontalibus sat magnis, postice linea transversa saepe biarcuata bene discretis, prothorace convexo, crebre punctulato, angulis anticis minimis, subcallosis, elytris subtiliter punctatis apicem versus dilatatis. - Long. 4,5-6 $\mathrm{mm}$.

Aubé, Ann. Fr. 1843. 8. - Kutseh. Wien. Monat. 1860. 9 (58). - Foudr. Mon. 292. - Redtb. Faun. A. II. 496. Thoms. Skand. Col. VIIr. 207. - Leesberg, Tijdschr. Ent. 25. 149. - All. Mon. 214 (Graptod.).

Halt. erucae Duft. Fam. Austr. III. 251.

Halt. indigacea Steph. Ill. Brit. IV. 307; Man. 295.

Var. a. Elytris obsolete longitudinaliter sulcatis, aut costulis 2 vel 3 sat acute elevatis, interdum intermutis instructis.

Var. b. aenescens: coeruleo-vel aeneo-viridis.

I ang eiförmig, vorn schmal, bis hinter die Mitte fast gleichmässig schwach erweitert, hinten breit abgerundet (q) oder allmählich verengt und etwas ausgezogen (ठ̋). flach gewölbt, dunkel kornblumen- oder veilchenblax, fein gewirkt, nur mässig glänzend. Wandibeln dreizähnig, die beiden inneren Zähne gross, breit, ziemlich spitz, der äussere sehr kurz, schmal und spitz. Fïhler kräftig, Glied 3 wenig länger und kaum schmaler als 2. Stirnhöckerchen kleiner als bei den vorigen Arten, insbesondere von der Fühlerwurzel weiter entfernt. am Innenrande am höchsten und durch eine tiefe und sehr 


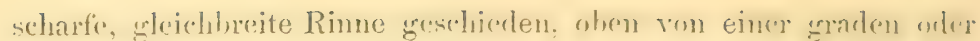

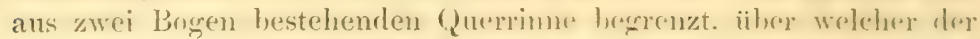

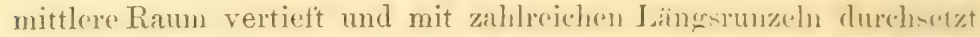
ist. Halssch. etwa um die Hälfte breiter als langr an den Seitrol vor den recht- oder spitzwinkeligen IJinterecken leicht geschweift, vor der Mitte etwas gerundet, nach vorm verengt, die vordere Borstenpore so dicht linter dem Vorderrande eingefiigt wie hei keiner anderen Art, weshalb die rerdickten Vorderecken sehr klein erscheinen. Die Scheibe ist dicht, fein und verloschen punktirt. auch die winkelige Punktreihe jederseits undeutlich, der Quereindruck seicht, an den Enden etwas tiefer. Fld. in den Schultern wenig über die Basis des Halssch. vortretend, neben dem Schildchen kaum ansteigend, daher mit dem Halssch. in einer Flucht gewölht, mit schwacher Schulterbeule und feinen, mässig dichten Punkten, welche sich von der lederartigen Runzelung schwach ablieben.

๙. Erstes Tarsenglied erweitert, fast so breit als das dritte, die Mitte des letzten Banchringes sparsam puuktirt und behaart, flach gedriickt, an der Spitze vertieft. - Penis rorn gerundet-abgestutzt und in der Mitte in eine kleine, bogenförmige Spitze ausgezogen, oben der Länge nach stark rinnenförmig vertieft, glatt, oder verlosehen und sparsam quer gerieft, der glatte, ziemlich flache Mittelstreifen der Unterseite verengt sich in sehr schwacher Rundung bis zum letzten Viertel, erweitert sich kaum davor und besitzt im letzten Viertel eine breite Mittelfurche, sowie cine tiefe, nach vorn rerengte und verflachte Rinne jederseits; die Seitenstreifen sind ziemlich weitläufig schräg gerieft, vorn glatt und mit einer langen Grube versehen.

Oft bemerkt man auf den Fld. zahlreiche breite, aber sehr schwache Längsfurchen, von denen die äusseren, welche neben und hinter der Schulter entspringen und den Seiten ziemlich parallel laufen, gewöhnlich tiefer als die inneren sind; mitunter vereinigen sich mehrere dieser Furchen und heben dann zwei bis drei schmale, vielfach leicht unterbrochene Längsrippen empor, die ziemlich genau im ersten, zweiten und dritten Viertel der Breite liegen und sowohl vorn als hinten verkuirzt sind (Var. a).

Die Farbe geht durch eine allmähliche Zunahme von Grün. zunächst auf dem Kopfe und Halsschilde, später auch auf den Fld. in griinlichblau, blaugriin und (Var. b) ein mehr oder weniger lebhaftes metallisches Grïn ïber, jedoch sind Stücke mit einfarbig grüner Oberseite recht selten.

Auf Birkengesträuch, nach Aubé auf Lythrum salicaria L., in Mitteleuropa sehr zerstreut. Männchen wurden in letzter Zeit besonders von H. Konow in der Kalkhorst bei Fïrstenberg in Mecklb. gesammelt. 


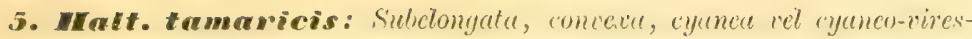
cens, slutuce, obsolete punctata, scrico-micuns, tuberculis frontalibus clongutis, oblique digestis, prothorace parvo, concexo, antrorsum vix angustato, laterilnes param rotundatis late marginutis, angulis antiris haud callosis, sulco ante basin profunde impresso, elytris basi prothorace multo latioribus, aprice rotundato-productis, humeris prominulis. Long: 4,5-5,2 $\mathrm{mm}$.

Schrank, Fuessli Neu Mag. II. 1785. 318. - Leesb. Tijdschr.

Ent. 25. 147.

Galleruca erucae Fabr. Ent. Syst. I. 2. 28. - Steph. Ill. Brit. IV. 307; Man. 295 (Halt.).

Halt. oleracea var. eyanea Ill. Mag. VI, 116.

Halt. consobrina Duft. Faun. A. III. 252. - Kutsch. Wien

Monat. 1860, 11 (60). - Redtb. Faun. A. II. 495. -

Seidl. F. balt. 494.

Hult. hippophaës A ubé, Ann. Fr. 1843. 8. - Foudr. Mon. 290.

- A 11. Mon. 216 (Grapt.).

Galleruca articulata Beck, Beitr. baier. Ins. 17. t. 4. f. 21.

Var. a. Elytris subtiliter sed evidenter punctatis, sat nitidis.

Var. b. Supra violacea.

Var. c. Omnino aeneo-viridis.

Etwas schlanker als die vorigen und an den schmalen Stirnhöckerchen, dem kleinen, mit tiefer Querfurche versehenen und an den Seiten verhältnissmässig breit gerandeten Halsschilde, sowie an den fein und verloschen punktulirten Fld., deren Schultern weit iiber die Basis des Halssch. vortreten, leicht zu erkennen.

Lang eiförmig, gewölbt, dunkel kornblumenblau oder heller rriunlichblau, sehr dicht und fein lederartig gewirkt, matt seidenartic glänzend. Mandibeln mit drei kurzen und breiten, ziemlich stumpfen Zähnen. Fühler kräftig, Glied 3 um die Hälfte länger und kaum schmaler als 2. Stirnhöckerchen länglich, schief gestellt, oben von einer aus zwei Bogen gebildeten Rinne begrenzt, in der Mitte durch eine kurze Furche geschieden in welche der ziemlich breite, oben schnell verengte Nasenkiel hineinragt. Halssch. um die Hälfte breiter als lang, an der Spitze ziemlich so breit wie an तer Basis, die Seiten wenig gerundet, mit breit abgesetztem und schwach aufgebogenem Rande, welcher vor der vorderen Pore weder verdickt ist noch heraustritt. Die Scheibe ist vor der tiefen Querfurche gewölbt, dicht, äusserst fein und verloschen punktirt. Fld. in den wagerecht vorspringenden Schultern fast doppelt so breit als die Basis des Halssch., an den Seiten wenig gerundet, beinahe gleichbreit, hinten allmählich abgerundet, vorn etwas ansteigend, auf dem Abfalle vor der Spitze leicht quer vertieft; mit einer stark erhabenen, innen deutlich abgesetzten Schulterbeule und dicht ge- 


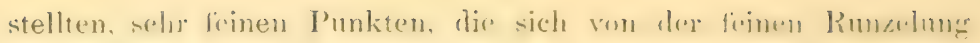
des Grundes wenig abheben.

Das Minnchen zeichnet sich durch das stark crweitrepte arste

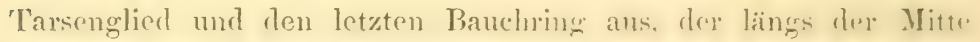
s.latt, an der. Basis und Spitze verticht, odter nit riner seichtem Xittehinne versehen ist. - Der l'enis verenget sich vorn mit abgermulet-stumptwinkeliger Ecke jorlersoits yrarlinig orter in sanftem Bogen und bildet so eine grosse, Wreit dreieckige Splitze, die Oberseite ist fast der ganzen Lünge nach muldenfïrnigr vertieft; schwach quer gerieft, der glatte Mittelstreifen and der Lunterseite kielförmig, am Ende oft mit feiner Iittelrinne, von den Seitenstreifen durch eine gleichmässig tiefe orler in der Mitte abgeflachte Furche getrennt.

Zu beachten sind hauptsächlich folgende Varietïten:

a. Die Fld. sind weit stärker und deutlicher punktirt. gewöhnlich auch glänzender, da die Runzelung des Grundes an Stärke abnimmt;

b. die Oberseite ist gesättigt violett, die Unterseite mehr grüulich blau;

c. der ganze Körper lebhaft metallisch grün. Diese Form macht einen recht fremdartigen Eindruck, wenn die Fld. wie bei der Var. a glänzend sind.

Auf Myricaria germanicn Dest. und Hippophrë rhamnoides L. in den Giessbächen der Alpen und Karpatben. mit den Flüssen in die Ebene steigend (Baicrn, Oesterreich), ausserdem an der Ostseeküste von Holstein bis Preussen, namentlich in Pommern bei Kolberg, Köslin (Lüllwwitz, Mietz) und Stolp ('Timm häutig. Holland, England, Schweden.

6. Hatt. carinthiaca: Oblongo-orata, convexiuscula, viriti-aenea, leviter coeruleo-micans, subtilissime alutacen, subsericeo-micans, tuberculis frontalibus magnis, triangularibus, postice lineu transiersa bene discretis, prothorace sat parvo et brevi, concexo, lateribus paullo rotundatis, angulis anticis parvis, subcallosis, elytris ubique tenuiter ct crebre punctatis, sutura antice elevata. - Long. $4 \mathrm{~mm}$.

Var. a. Supra cyanea.

Haltica spec. Kutsch. Wien. Monat. 1860. 18. Anmerkung.

Von den kleinen Exemplaren der II. olcracen durch grosse. oben deutlich begrenzte Stirnhöcker, rom sechsten Gliede an mehr verdickte Fuihler, das kïrzere, in den Vorderecken nach aussen tretende Halssch. und die bis zu Spitze gleichmïssig fein punktirten 
Fld. schwierig zu unterscheiden, mit oben so zeringer vieherheit von II. pessilla zu tremnen, welche im Ialsisch. und den Schultern gewöhnlich bedentend sehmaler gebaut ist; trotzdem eine grute Art, welche duch die Bildumg der Mandibehn und des Penis weit von beiden genannten Arten abweicht

Limglich eifoimig. zicmlich gewïlht, metallisch griin, nach Blau hinüberspielend, dicht und äusserst fein gewirkt, mit seidenartigem Glanze. Mindibeln dreizälmigr, die Zïhne klein, schmal, ziemlich stumpf, durch breite Korben getrennt. der imnere nur wenig länger als die äusseren. Fühler länger als der hallhe Körper, ihre scehs letzten Glieder merklich breiter als die vorhergehenden. Stimhöcker gross, quer, dreieckig, durch die lange Spitze des Nasenkieles getrennt, oben ziemlich scharf' und gradlinig begrenzt. Halssch. verhältnissmässig klein und kiurz, wenig ïber die Hälfte breiter wie lang, die Seiten vor den Hinterecken leicht geschweift, in der Mitte gerundet-erweitert und nach rom bis zur rorderen Borstenpore etwas rerschmälert, an dieser heraustretend, die Vorderecken klein, gerundet, etwas verdickt. Die Oberfläche vor der nicht tiefen, beiderseits in eine weite Grube auslaufenden Querfurche gewölht, fein gewirkt und rerloschen, etwas runzelig punktirt, ron der winkeligen Punktreilhe ist nur der äussere Theil der Schenkel durch einige tiefe Punkte angedeutet. Fld. in den wagerecht vorspringenden Schultern bedeutend breiter als die Basis des Halsschildes, an den Seiten fast parallel, hinten in allmählicher Rundung verengt und glejchmässig zur Spitze abwärts gewölbt, mit vorragender Schulterbeule und stark erhabener Naht im ersten Viertel der Länge. Die Punktirung ist feiner und dichter als bei oleracea, weil die Pünktchen der Zwischenräume ziemlich dieselbe Grösse besitzen wie die übrigen Punkte, die Reihe an der Naht ist hinten verworren und undeutlich, vorn regelmässig und stark, und liegt hier in eimem vertieften Streifen.

ऊ Erstes Tarsenglied stark erweitert, letzter Bauchring in der Mitte gewirkt, nicht punktirt, an der Spitze ein Quereindruck. Penis vorn gradlinig verschmälert und vor den völlig abgerundeten Ecken in eine viel längere, dreicckige Spitze ausgezogen als bei der rorigen Art, unterseits in der Basalhälfte glatt und in einer Flucht sanft queriber gewölbt, in der Spitzenhälfte mit den gewöhnlichen drei Längsstreifen. Der mittlere derselben hat wonig aufstehende und schlecht abgesetzte parallele Ränder und wird durch zwei schwache Längslcisten in drei wenig vertiefte gleiche Streifehen getheilt, die Seitenstreifen sind ror der Mitte sehwach gerieft und besitzen ror der Spitze eine Vertiefung, deren Aussemrand etwas aufgebogen ist. 
Yon Il. Liegel in zwei mämnlichen Exemplaten in dex Longelung vom (inesan bei Hinmelherg in Kïrntlien aufgefunden und dort jerlenfalls weiter verbreitet, da die von Kutschera a. a. (). erwiahnten stiicke aus Kärnthen" unzweifelhaft zur vorliegenden Art gehören.

\%. Halt. fruticola: Oblongo-arata, sat concexa, coeruled-rividi-aenea, tuberculis frontalibus triangularitus, postice transiersim discretis, prothorace breri, obsolete alutaceo et subtilissime punctuto, lateribus parum rotundatis; angulis anticis parris, vic callosis, sulco transterso tenuiter impresso, elytris crelre et profunde punctatis, subtiliter aluturcis, subsericco-micantibus, callo humerali parro, prominulo. - Long. 4,3-5 mm.

Den am stärksten punktirten und zugleich glänzendsten Stiicken von tamaricis ähnlich, jedoch ausser der skulptur an dem breiteren Halssch. zu unterscheiden, dessen Querfurche fein und wenig tief eingedrückt ist.

Lang elliptisch, fast von demselben Baue als die kleinere oleracea, ziemlich gewölbt, bläulich metallisch grïn, glänzend, auf den Fld. etwas seidenschimmernd. Stirnhöckerchen ziemlich gross. dreieckig, glatt, durch die Spitze des schmalen und scharfen Nasenkieles getrennt und von der Stirn durch eine feine. in der Regel durch eingestochene Punkte verwischte Querrinne geschieden, welche an der Spitze der Höckerchen, in der Nähe dex grossen Borstenpore, verbreitert und vertieft, am Oberrande der Augen wieder rerflacht ist. Halssch. etwa um die Hälfte breiter als lang, an den Seiten gleichmässig aber schwach gerundet und olme merkliche Ecke an der vorderen Borstenpore, vor dieser wenig rerdickt; oben ziemlich stark gewölbt, gewöhnlich kaum sichtbar gewirkt, fein punktulirt, mit schmaler und nicht tiefer Querfurche, welche hald in der Mitte, bald an den Seiten am tiefsten ist. Fld. an der Basis in starkem Bogen heraustretend und in den Schultern etwas breiter als der Grund des Halssehildes, bis hinter die Mitte sehr wenig erweitert, beinahe parallel, zuletzt allmählich rerengt und abgerundet, oben gewölbt, verhältnissmässig stark und dicht punktirt, mit gewirkten, sparsam und fein punktulirten Zwischenräumen; die Schulterbeule klein, doch deutlich abgesetzt.

ô. Erstes Tarsenglied der vorderen Beine erweitert, letzter Bauchring mit einer unpunktirten Mittellinie und rertieftem Mittelzipfel. - Penis dem von lythri ähnlich, gleichbreit, glatt, vorn gerundet-abgestutzt und in eine kleine Spitze ausgezogen, oben fast 
der ganzen Länge nach rimenfoimig vortieft; der Mittelstroifon der Tnterseite ist nu vor der Mitte jeclerseits von einer schwach nach immen gebogenen Leiste begrenzt. neben der die Längsurube der Seitenstreifen liegt.

Vereinzelt bei Berlin, in Oesterreich, dem Wallis, in Siebenbürgen, Balkan, Italien, besonders bei Rom, nördliches Spanien, wahrscheinlich bisher mit tamaricis oder oleracer verwechselt.

8. Malt. carduorum: Subovalis, convexiuscula, obscure coerulea ant cyanen, nitidiuscula, tuberculis frontalibus postice deplanatis, linea arcute aliscretis, antice convexis, prothorace sat magno, fortiter trunsver:o, concexo, obsolete punctulato, angulis anticis purvis, ablique truncatis, sulco transverso modice impresso, elytris crebre ct sat yrosse, sed parum profunde punctutis, callo humerali magno, prominulo. - Long. $3,5-4,2 \mathrm{~mm}$.

Guer. Rev. Zool. 1858. 415. - All. Mon. 215. - Rey, Opusc. 1875. 38.

Var. a. Obscure viridi-aenea.

Von der Länge der $H$. oleracen, aber bedeutend breiter, gerundeter, verhältnissmässig plump gebaut, fast eiförmig, gewölbt, dunkelblau, mässig glänzend. Mandibeln vierzähnig, der innere Zahn gross, fast rechtwinkelig, mit scharfer, etwas ansgezogener Spitze, von den unter sich beinahe gleichlangen beiden Mittelzähnen etwas weiter entfernt als der äussere, kleine und sehr spitze Zahn. Stirnhöckerchen kleiner als die ringförmige Leiste um die Fühlerwurzel, rundlich, unten gewölbt, sehr tief umgrenzt und durch die breite Spitze des Nasenkieles getrennt, oben flacher, von der Stirn durch eine aus zwei Bogen gebildete Rinne geschieden, welche nach aussen, zwischen den Höckern und dem oberen Augenrande auffällig verbreitert und vertieft ist, namentlich in der Nähe der grossen Borstenpore. Halssch. gross, ungefähr doppelt so breit als lang, an den Seiten gerundet, vorn zusammengedriickt und etwas verengt, mit kleinen. schwach verdickten, schräg abgestutzten (selten mit den Seiten in gleichem Bogen abgerundeten) Vorderecken; die Oberfläche vor der måssig tiefen Querfurche gewölbt, dicht mit feinen und sehr rerloschenen Pünktchen besetzt, die in der Umgebung der starken winkeligen Punktreihe jederseits deutlicher werden. Fld. an der Basis in starkem Bogen heraustretend und in den Schultern breiter als der Grund des Halsschildes, an den Seiten mässig gerundet, hinten wenig vorgezogen oder breit abgerundet, äusserst fein gewirkt und mit ziemlich grossen aber flachen, hinter der Mitte allmählich erlöschenden Punkten besetzt, von denen die vorderen etwa 


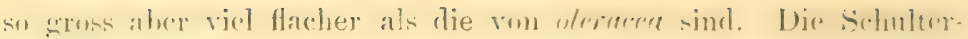
benle ist gewiolbt, vortretend. innen und hinten dentlich alyesenty.

Das Männchen erkemt man an ersten Tarengliedle. wroldes an den vier vorderen Beinen stark erweitert ist. sowie an dem vor der Spitze vertieften und anf einem breiten Streifen längs der Mittr glatten letzten Bauchringe. - Der Penis ist vom plitzlich gradliniy

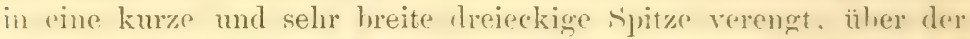
Klappe ant" der Oberseite seicht eingedrickt und quer grerieft; anf der Unterseite bildet der Mittelstreifen in den vorderen zwei I)ritteln cine anfangs schmale und scichte, von der Mitte aus allnailhlich his zum Vorlerrande verbreiterte und vertiefte Rimne, welche durch einen schr hohen und vor der Mitte anch scharfen Längrkicl jederseits von den Seitenstreifen geschieden wird, die der Längre nach vertieft, nahe der Basis schräg gerieft sind.

Die Farbe der Oberseite wird bisweilen dureh einen Zusatz von Roth in kornblumenblau bis vinlett rerwandelt. oder geht unter Znnahme von Grün allmählich in grüinlich-blan, bläulich-grün, oder ein dunkles, aber reines metallisches Grün über (Var, a).

In den Alpen von Baiem und Oesterreich (Tirol, Kärnthen, Krain, Steiermark, Istrien) weit verbreitet. in Südeuropa von Frankreich und Spanien (Seidlitz) bis Griechenland (Krüper); nach Guérin auf Disteln.

D. Halt. palustris: Subovalis, convexiuscula, nigro-cocrulea aut -cyaner nitidula, tulserculis frontalibus deplanatis, postice depressione vel linea punctata terminutis, mothorace sat (omexo, obsolete punctulato, angulis anticis vix callosis, sulrotundatis, sulco transverso parum profunde impresso, elytris crebre sat jirosse et parum profunile punctatis, callo humerali parvo, subprominulo. - Long. 3,8-4,2 mm.

Var. a, Coeruleo-viridis.

In der Gestalt, Grösse, Skulptur und Farbe mit der vorigen ziemlich übereinstimmend, ummerklich schlanker, hauptsächlich durch die in der unteren Hälfte flachen Stirnhöcker, ein schmalexes Halssch. und niedrigere, imnen und hinten undeutlich abgesetzte Schulterbeule verschieden.

Beinahe eiförmig, mässigg gewölbt, dunkclblau, sehr selten bläulich grï (Var. a), mehr oder weniger glänzend. Mandibeln wie bei carduorum, Stimhïeker Hach, durch die breite Spitze des Nasenkieles getrennt, von der Fühlerwurzel durch einen weiten und tiefen Eindruck geschieden, der oft srün oder messinggelb spefärbt ist, oben und an den Seiten dureh eine punktirte Vertiefung 


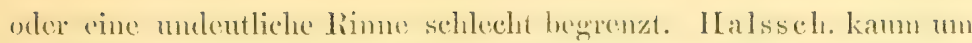
die Ilithte breiter als lang, mit sanft gerundeten seiten und kaum verdickten Vorderecken, welche sich mit den seiten in gleichmässigem Bogen verengen, oben queriiber gewölbt, dicht und rerloschen punktulirt, mit mässig tiefer Querfurche. Fld. an der Basis in schwachem Bogen heranstretend und in den Schultern etwas breiter als dex Gromd des Lalsschildes, an den Seiten leicht gerumlet, linten lïnger oder kiirzer abgerundet, kaum sichtbar gewirkt und mit ziemlich grossen, aber schr Hachen, iiber dem Aussenrande feineren Punkten versehen. Die Schulterbeule ist gewölbt, jerloch nirgends deutlich abgesetzt.

Beim Mämnchen ist das erste Tarsenglied verbreitert und der letzte Bauchring auf einer sehr schmalen Linie längs der Mitte unpunktirt und kahl; der Penis ähnelt dem der vorigen Art, nu ist der tiefe, rinmenförmige Mittelstreifen auf der Unterseite sehr breit, beginnt schon an der Basis und ist bis zur Mitte in einem unmerklichen Bogen verengt, davor ähnlich erweitert, also ziemlich von gleicher Breite, ebenso reicht die hohe Längsleiste, die ihn jederseits einfasst, von der Basis bis zum Vorderrande.

Auf sumpfigen Wiesen, besonders in den Torfmooren der norddentschen Tiefebene. Bei Berlin in manchen Jahren zahlreich im Anspülicht zwischen dem Gefängnisse Plötzensee und dem Forsthause Königsdamm.

10. Malt. oleracea: Sat elongata, convexa, vividi-aenea, subtiliter alutacea, subsericeo-micans, tuberculis frontalibus parvis, deplanatis, postice depressione punctata vix discretis, prothorace obsolete punctulato, sat convexo, lateribus vix rotundatis, angulis anticis obtusiusculis, sulco transverso profunde impresso, elytris antice minus crebre sed profunde subseriatim-, postice obsoletius punctatis, sutura ante apicem saepe foveolata. - Long. 3,5-4,2 mm.

Linn. Syst. Nat. ed. 10. 372 (Chrysom.) - Scop. Ent. Carn. 69. - Marsh. Ent. Brit. 192. - Panz. Faum. Germ. 21. 1 (Halt.). - Duft. Faun, Austr. III. 252. - Steph. IIl. Brit. IV. 306; Man. 295. - A ubé, Ann. Fr. 1843. 8. - Kutsch. Wien. Monat. 1860. 16 (64). - Foudr. Mon. 295. - Redtb. Faun. A. II. 496. - Thoms. Skand. Col. VIII. 206. Leesb. Tijdschr. Ent. 25. 147. - A 11. Mon. 218 (Graptod.). Graptod. pusilla A 11. Mon. 219. - Rey, Opuse. 1875. 41.

Graptod. potentillae A 1l. Ann. Fr. 1859. Bull. 166.

Var. a. nobilis: Supra aurichalcea aut cuprea.

? Graptodera. splendens Rey, Opusc. 1875. 40.

Var. b. lugubris: coerulea aut cyanea. 


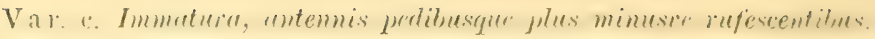

Var. d. Prothorace hetud alutaceo parce subilissimeque punctulats, fere prolito. Graptodera longicollis A 11. Mon. 217. - Rey, Opusc. 1875. 39.

Var. e. Elytris subtiliter punctatis.

Var. f. Elytris obsolete longitudinaliter sulcatis.

Schlanker gebant, etwas höher gewölbt und auf den Fld, weitläufiger, tiefer und deutlicher punktirt als die beiden worhergehenden Arten, sehr lang elliptisch, beiderseits gleichniësig verengt, orler vorn schmaler als hinten, oberseits metallisch grün, zuweilen blïulich schimmernd, unterseits dunkler, blaugruin, fein gewirkt, mit mattem seidenartigen Glanze. Mandibeln vierzähnig, der innere Zahn etwas kleiner und spitzer wie bei den rorigen. Stirnhöckerchen klein, flach, wie die Stirn gewirkt, durch die breite Spitze des Nasenkieles und eine kurze, oft noch ein Stiick auf die Stirn verlängerte Rinne geschieden, aussen von zahlreichen Punkten. oben von einem Eindrucke oder einer vertieften Punktreihe schlecht begrenzt. Halssch. ungefähr um die Hälfte breiter als lang, an den Seiten bis zur vorderen Pore fast parallel oder ror der Mitte in sanfter Rundung rerengt, neben der Pore etwas nach aussen gedrückt, so dass die wenig verdickten Vorderecken beinahe schief abgestutzt erscheinen. Die Scheibe vor der tiefen und ziemlich graden Querfurche nur mässig gewölbt, dicht und zart gewirkt und selr fein punktulirt, ziemlich matt. Fld. an der Basis in starkem Bogen heranstretend und etwas breiter als der Grund des Halsschildes, mit einer kleinen, hohen und deutlich abgesetzten Schulterbeule, an den seiten sehr schwach gerundet, hinten allmählich verengt und abgerundet, dio Oberfläche gewölbt, zart gewirkt, in der vorderen Hülfte deutlich und tief gereiht punktirt, wenigstens mit einigen Reihen schräg nach hinten und innen rom Schulterhöcker, hinter der Mitte allmählich schwächer rerworren punktirt, oft mit einem Eindrucke auf der Naht vor der Spitze.

Das Männchen besitzt an den vier Vorderbeinen ein erweitertes erstes Tarsenglied, auf dem letzten Bauchringe eine Quergrube ror dem Hinterrande und zuweilen auch noch eine seichte, rorn erlöschende, nicht punktirte Mittelrinne. - Der Penis ist in der Mitte etwas verengt, vorn abgerundet, oben mit einer auffallend langen Klappe versehen, welche die Öffnung in der Ruhe schliesst, unten, ähnlich wie bei palustris mit einem tiefen Mittelstreifen, welcher von zwei hohen Längskielen eingefasst und in vorderen Drittel erweitert ist, die Seitenstreifen sind ebenfalls rimenfömig rertieft, mit hoch aufgebogener Leiste am Aussenrande, welche nahe dem Vorderrande schnell abfällt. 


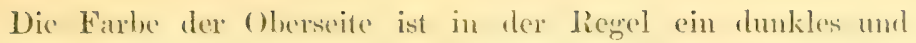
wenig lebhattes Metallgrün, welches mitunter einen schwärzlichen Ton, ïhnlich wie bei pusilla, oder cinen blanen Schimmer ammiumt mo einerseits in ein schönes Messinggelb, oder ein kupfriges Braun (Var. a), andrerseits in ein mehr oder weniger dunkles Blan uibergeht (Var. b); frische, oben meist olivengrüne Stücke haben hisweilen rostrothe oler pechbranne Fühler und Beine (Var.c).

Der Tasenkiol ist zwischen den Wühlern ziemlich breit, oben stumpf zugespitzt, unten schmal und scharf, oder er hildet eine gleichmässig schmale und hohe Leiste; die Stirnhöcker sind nicht selten glatt, spiegelblank, gewölbt, ringssm deutlich begrenzt. Auf' dem Halsschilde kann die lederartige Runzelung des Grundes gänzlich verschwinden und die feine Punktirung so abnehmen, dass sie selbst unter starker Vergrösserung kaum noch bemerkbar bleibt (Var. d), auch die Tiefe der Querfurche ist variabel. Die Fld. endlich, deren Punkte auf der vorderen Hälfte nicht grösser, aber tiefer als bei carduorum und palustris, und etwas feiner als bei brevicollis und amphelophaga zu sein pflegen, sind zuweilen (Var. e) kaum gereiht- und so fein punktirt wie die von pusilla, andrerseits (Var. f') mit unregelmässigen Doppelreihen versehen, die in schwachen Längsfurchen stehen und durch leicht gewölbte Zwischenstreifen getrennt sind. Von der Vertiefung auf der Naht felllt oft jede Spur.

Auf Oenothera biennis, Epilobium- und Brassica-Arten, sowie an rerschiedenen anderen Pflanzen in ganz Europa gemein. Die Angaben iiber das Vorkommen an Weiden, Haselnuss- und Eichengebüschen beruhen hauptsächlich auf einer Verwechselung mit anderen Arten.

Bei vielen älteren Autoren, selbst in den Ent. Hft. II. $\tilde{5} 4$, bei Illiger, Mag. VI. 166 und Gyllenhal, Ins. S. III. 521 sind unter olerecea alle Arten zusammengefasst, weshalb die Citate oben nicht angefuihrt wurden; Allard hat die bereits von Foudras benutzte Untersuchung des Penis nicht berücksichtigt und so ein falsches Bild der Art erhalten, zu welcher er nur die ungemein seltenen Exemplare rechnete, deren Halssch. „fast doppelt so breit als lang" ist. Seine Grapt. longicollis ist die typische oleracea mit ziemlich schmalem (und blankem) Halsschilde und pusilla All. eine dunkle, etwas feiner als gewöhnlich punktirte Form, während die eigentliche pusilla Duft als helianthemi und montance All. auftritt.

11. IIalt. pusilla: Oblongo-ovata, convexa, obscure viriti-aenea, nitida, tuberculis frontalibus paris, postice linea vel depressione punctata rix discretis, prothorace obsolete punctulato, lateribus paullo rotundato, antice angustato, angulis anticis obtusiusculis, sulco transverso leviter impresso, 


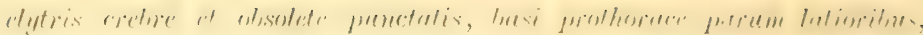

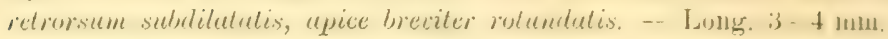

Duftschm. Faun. Aust. III. 253. -

H. cognata Kutsch. Wien. IIonat. 186jo. 17 (bff). - Redtb. Fatum. A. II. 495 .

Grapt. hetianthemi A11. Anu. Fr. 185.9. Bull. 166; JLon. 217.

Var. montana: Nigro-coerulea vel-cyanea.

Halt. montance Foudr. Mon. 295. - A11. Jon. 219 (Grapt.).

Eine Halt. lythri im Kleinen, in den Schultern riel enger, hinten etwas broiter gebaut als oleracen und durch die Oberseite, welche mit einer feinen und verloschenen Punktirung einen verhältnissmässig starken Glanz verbindet. von ihr und den iibrigen Arten ausgezeichuet; noch mehr dentet die Form dus Penis aut eine röllige Isolirung innerhalb der Gattung lim.

Iänglich eiförmig, ziemlich stark gewölbt, hinten oft etwas buckelig; dunkel metallisch griin, oft bläılich schimmernd, kaum bemerkbar gewirkt, glänzend. Mandibeln vierzähnig, der innere Zahn rechteckig mit ausgezogener Spitze. ron dem tolgenden weit abstehend, dieser gross und spitz. vorgestreckt, der dritte merklich kürzer, der vierte klein. Stirnhöcker fast kreisrund oder quer und ziemlich rautentörmig, mässig gewölbt, durch eine limne getrennt, in welche die Spitze des lanzettlichen Nasenkieles wenig hineinragt, an den Seiten durch einen punktirten Eindruck, oben durch eine punktirte Linie nicht scharf begrenzt. Halssch. um die Hälfte breiter als lang, in schwacher Rundung nach roru etwas verengt und zusammengedrückt, mit leicht rerdickten. gerundetabgestutzten Vorderecken, auf der Ṡcheibe mässig gewölht. dicht und äusserst fein punktulirt; die Querfurche in der Regel flacher als bei oleracea. Fld. an der Basis in sehr schwachem Bogen heraustretend und in den Schultern wenig oder kaum breiter als der Grund des Halssch., mit einer sehr kleinen, schlecht abgesetzten Schulterbeule, dahinter allmïhlich leicht verbreitert, im letzten Drittel verengt und ziemlich breit abgerundet, auf der scheibe dicht und verloschen, neben der Naht etwas deutlicher punktirt.

Beim Männchen ist das erste Tarsenglied erweitert, der letzte Bauchring in der mittleren Hälfte flach gedrickt, mpunktirt, nach hinten abfallend. Der Penis rerbreitert sich allmählich ron der Basis aus, ist vorn mit abgerumdeten Ecken fast gradlinig in eine grosse Spitze verengt, oben der Länge nach rerticft und über der Klappe quer gerieft, unterseits schrig gerieft, im letzten Viertel löffelförmig ausgehöhlt, der schmale Mittelstreifen von den Seitentheilen schlecht gesondert, vor der Mitte etwas verengt und vertieft. 
Die einzige bemerkenswerthe Abäuderung (Var. montuna) ist tunkelblau.

Von den Pyrenäen (im Dep. Landes nach Perris auf Ilelianthemum quttatum) durch Siidfrunkreich und in den Alpen vom Mt. Viso bis zum Schneeberge bei Wien rerbreitet, besonders häufig in Käruthen z. B. bei Gnesau (Liegel). Vogesen (Puton).

\section{Hermaeophaga.}

Foudras, Altisides 1860. p. 299.

Linozosta Allard, Ann. d. Fr. 1860. p. 72.

Acetabula antica aperta; coxae sensim latius distantes; tibiae dorso subteretes, posticae calcari distincto.

Palpi maxillares articulo ultimo elongato, apice acuminato.

Sulci frontales sensim convergentes usque ad antennas basin continuati.

Prothorax ante basin impressione sulciformi transversa, plica utrinque terminata.

Körper eiförmig, bei zwei Arten schwarzblau, bei einer gelbbraun, glänzend. K opf kurz, dreieckig, mit mässigen, wenig gewölbten Augen und breiter Stirn, auf welcher die scharf eingeschnittenen Linien, deren Aussenrand leistenförmig erhöht ist, vom Hinterrande der Augen ziemlich gradlinig zur Fühlerbasis laufen und die grossen, leicht gewölbten, durch eine Rinne getreunten und nur unten deutlich begrenzten Stirnhöcker, sowie den breiten, ebenen Nasenkiel einschliessen. Letzterer erweitert sich nach unten und fällt plötzlich zu dem schmalen, quer dreieckigen Kopfschilde ab. Die Fïhler sind ungefähr so lang als der halbe Körper, nach aussen etwas verdickt, weit von einander getrennt noch unterhalb der Linie eingefügt, welche den Unterrand der Augen verbinden wïrde; Mandibeln dreizähnig (mercurialis), der Mittelzahn viel grösser als die seitlichen; Endglied der Maxillartaster schlank, länger wie eins der vorhergehenden Glieder. Halsschild quer, an den Seiten gerundet, oben mässig gewölbt, äusserst fein punktirt, fast glatt, ror der Basis mit einem rinnenförmigen Quereindrucke, welcher beiderseits durch ein tiefes, gebogenes oder grades, aussen scharf begrenztes Längsstrichelchen abgekürzt wird. Fliigeldecken in den Schultern breiter als der Grund des Halsschildes, bis zur Mitte erweitert, hinten fast gemeinschaftlich abgerundet, mit breiten, allmählich verengten und ror der Spitze verschwindenden Epipleuren; auf dem Rücken fein, verworren punktirt, mit zahlieichen sehr feinen Punkten in den Zwischenräumen. Aus der Punktirung

VI. 5. 
hehen sich wine ahwekiil\%ts: Punktreihe an ichildchen nud vier dopleste J'unktreihen mehr oder woniger deutlich heraus, letztere schliessen je einen schmalen, fast glatten Zwischenstreifen ein. Prosternum hinter den IIüften erweitert und abgerundet, din stiick

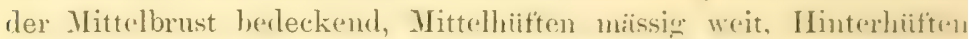
weit ron einander getrent; Brust verloschen, Banch zerstrout mul ziemlich kräftig in unregelmässigen Querreihen punktirt, Jygidiun mit zwei dicht neheneinander liegenden flachen Mittehinmen, zur Aufnalme der Nahtecke der Fliigeldecken. Beine kur\% und kräftig, der Rücken der Schienen gewölbt, Hinterschenkel spindelförmig, Tarsen kiirzer als die Schienen, Glied 1 lang. 2 und 3 zusammen so lang als 1, 3 kurz, an der Spitze gerundet-abgestutzt. kaum breiter als die vorhergehenlen ${ }^{1}$ ), Klauenglied schlank, Klanen sehr zart, mit einem unscheinbaren zahnförmigen Anhange an der Basis.

Beim Männchen ist das erste Tarsenglied erweitert, der Hinterrand des fünften Bauchringes an den Seiten abgestutzt, in der Mitte in einen fast halbkreisförmigen Zipfel ausgezogen; der Penis bildet eine von oben zusammengedrückte, vorn in cine dreieckige Spitze verschmälerte Röhre, die auf einem breiten Mittelstreifen sowohl von oben als unten muldenförmig vertieft und durchscheinend ist.

Von den wenigen Arten dieser Gattung gehören drei der europäischen Fauna an; sie stehen weder zu Haltica noch zu den folgenden Gattungen in naher Verwandtschaft und erinnern im Körperbau, besonders in der Bildung des Kopfes und Halsschildes ungemein an Crepidodeva. Ueber ihre Entwicklung an den Nährpflanzen, rerschiedenen Mercurialis-Arten, ist noch nichts bekannt.

1. Schwarzblau. Längsstrichelchen an der Basis des Halsseh. grubenförmig, mit gebogenem Aussenrande, Fïhler, Taster und Beine dick: Hermaeophaga i. spec. . . . . . . . 2.

$1^{1}$. Längsstrichelchen an der Basis des Halssch. grade, Taster. Fühler und Beine schlank. . . . Subgenus Orthocrepis. Hierher nur eine Art: Gestreckt, gelbbraun, Kopf, Halssch., Hinterbrust und Bauch mehr rothbraun, Fühler vom fünften Gliede an schwärzlich, Naht nnd Epipleuren der Fld. oft gebräunt. - L. 3-3,5 mm. Am Strande in Südspanien und Sicilien; Nordküste von Afrika, Syrien ruficollis Luc.

1) Ein auffällig breites drittes Tarsenglied hat die Gattung Phygasic Dej. i. litt.: Acetabula antica aperta. Pulpi maxillares articulo penultimo crasso, ultimo brevi, conico. Sulci oculares breves. Prothorax ante basin impressione transversa utrinque plica terminata instructo. Tursi urticulo tertio latissimo. Typus Phyg. helrola Dalm. Sierra Leone. Ashante. 


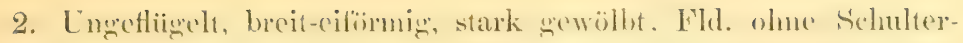
beule. - 1. 2,5-3,2 mm. Mittel- und Siideuropa, Schweden mercurialis $\mathbf{E}$.

2'. Getlïgelt, lïnglich-eifömig, mäissig gewïlbt, Fld, mit s'chulterbeule. - 1. 2,5-3,5 mm. Suidwestliches Viertel ron Luropa cicatrix III.

1. Herm. mercurialis: Subaptera, breviter ovalis, gibboso-conceru, nigm, nitide sun) coeruleo-micans, antennam basi tarsisque obscure fermuineis, prothorace fortiter trensererso angulis anticis subrotundatis, elytris subtilissime punctatis, callo humerali mullo. - Long: 2,5-3,2 mm.

Fabr. Ent. Syst. I. 2. 33 (Galleruca). - I1l, Mag. VI. 117 (Halt.). - Oliv. Ent. VI. 721. t. 5. f.93. - Gyllh. Ins. Suec. III. 523. - Schilling, Bericht Breslau 1846. 91. Kutsch. Wien. Monat. 1860, 67 (70). - Redtb. Faun. A. II. 495. - Seidl. F. balt. 494. - Foudr. Mon. 301 (Herm.). - All. Mon. 207. - Thoms, Skand. Col. VWI. 205. - Leesberg, Tijdschr. Ent. 25. 145.

Breit-eiförmig, buckelig-gewölbt, schwarz, glänzend, die Oberseite oder wenigstens die Fld. schwarzblau, der Mund, das erste Fühlerglied an der Spitze, die folgenden drei bis vier Glieder ganz und die Tarsen dunkel rostroth. Halssch. ungefähr doppelt so breit als lang, an der spitze wenig sehmaler als an der Basis, die Seiten in der Nitte leicht germnlet, an der vorderen Borstenpore allmäblich und unbedeutend nach aussen gedrückt, mit abgerundeten Vorderecken, oben äusserst fein und verloschen punktirt, ziemlich glatt. Fld. olne deutliche Schulterbeule, sehr fein doppelt punktirt, mit einigen schlecht hervortretenden parigen Punktreihen auf der vorderen Hälfte. Flügel sehr kurz, verkümmert.

In schattigen Wäldern auf Mercurialis perennis und in Gärten an $\boldsymbol{I}$. anmu L. im Frihlinge und Herbste stellenweise häufig.

2. Herna. cicatrix: Alata, ollongo-ovalis, convexa, nitida, supra cyanea, capite prothoraceque interdum viridi-micantibus, subtus coeruleonigra, antemarum basi obscure ferrugineo, mothorace transverso, angulis anticis oblique truncatis, elytris subtiliter punctatis, tuberculo humerali sat prominulo. - Long. 2,8-3,5 mm.

I11. Mag. VI. 59 et 116 (Halt.). - Kutsch. Wien. Monat. 1860. 66 (69). - Redtb. 1. c. II. - Foudr. Mon. 300 (Herm.). - All. Mon. 208. 
Gefliigelt, länglich-eiförnig, an den Seiten fast parallel, etwas lebbatter gefärbt und stärker punktirt, aber viel weniger gewiilht als die vorige, nit schlankeren Fühlem und Beinen. Dunkell,lan, glänzend, unten zicmlich schwa\%, Kopf und Halssch. oft mit griuen Schimmer; die exsten vier oder fiinf Fülılerglieder dunkel rostroth. Halssch. um die Hälfte lreiter als lang. Die seiten an der vorderen Pore dentlich in schwachem Winkel nach aussen gedrückt, davor gradlinig und schmell rerengt, fast schräg abgestuzt. Fld. mit erhabener, innen durch einen Längseindruck ahgesetzter schulterbeule, und feiner doppelter Punktirung. Die stärkeren Punkte bilden neben den vier nornalen, leicht gewölbten Längsstreifen, von denen wenigstens die beiden inneren sichtbar sind, ziemlich regelmässige Reihen.

Auf Mercurialis perennis und anmu L. bei Hagenan im Elsass (Wencker); häufiger in Frankreich und auf der Pyrenäen-Halbinsel auch an $M$. tomentosa $\mathrm{L}$.

\section{Batophila.}

Foudras, Altisides p. 266.

Acetabula antica aperta.

Corpus apterum, nigrum vel aeneum.

Prothorax ante basin fere immarginatum sine impressione vel plica. Tibiae posticae in dorso antice subcarinatae, postice deplanatae. Elytra punctato-striata.

Körper ungeflïgelt, länglich-oval, gewölbt, schwarz oder metallisch griin, mit rostrothen Fiihlern und Beinen. Kopf mit breiter Stirn, welche leicht gewölbt, fein gewirkt und jederseits mit grösseren Punkten besetzt ist, Furchen, Höckerchen und Nasenkiel schlecht ausgeprägt, erstere oft kaum angedeutet; Fühler ungefăhır halb so lang als der Körper, die einzelnen Glieder verhältnissmässig kurz und kräftig, die letzten fünf etwas verdickt. Halssch. breiter als lang, querüber gewölbt, an den Seiten deutlich, an der Basis und Spitze nicht gerandet, oder mit einer feinen Leiste jederseits an der Basis; die vordere Borstenpore liegt ein Stiick hinter den Vorderecken, die hintere in den Hinterecken, der Riicken ist deutlich punktirt, ohne Quereindruck oder Längsstrichelchen; Schildchen klein, quer, dreieckig, mit abgerundeter spitze. Flii geldecken eiförmig, regelmässig und ziemlich stark punktirt gestreift, in den fast ebenen oder gewölbten Zwischenstreifen äusserst undeutlich einreihig punktirt, 
Schulterheule fehlend, Epipleuren breit, von der Mitte der Hinterbrust an allmählich verengt, vor der Spitze endigend. Prosternum dicht runzelig punktirt, hinter den Huiften in einen erweiterten, abwärts gewölbten und am Ende gerundet-abgestutzten Fortsatz verlängert. welcher den griissten Theil des Mesosternmm bedeckt, von den Seitenstiicken entfernt bleibt und die Pfannen offen lässt. Mittelmol ITinterhiiften ziemlich weit getrennt, Metasternum sehr kurz, mit einem hoch gerandeten Fortsatze, der zwischen die Mittelhuiften reicht. Hinterschenkel stark angeschwollen, Schienen zur Spitze hin allmählich verbreitert, der Riicken vorn mit einer schwachen Längsleiste, im letzten Fünftel eben. Enddorn der Hinterschienen deutlich, Metatarsus etwa zwei Fünftel so lang als die Schiene und so lang als die folgenden zwei Glieder zusammen, Glied 3 zweilappig, Klauen sehr fein, am Grunde winkelig erweitert.

Beim Männchen ist das erste Tarsenglied an den vorderen Beinen etwas verbreitert und der Hinterrand des letzten Bauchringes in der Mitte in einen bogenförmigen, vertieften Zipfel verlängert, der Penis gebogen, vorn abgerundet, unten mit einer ganzen (aerata) oder in der Basalhälfte fehlenden Mittelrinne (rubi).

Die Gattung enthält nur zwei oder drei Arten, welche auf Rubus- (Brom- und Himbeer-) Blättern leben, habituell an die kleinen Chaetocnema-Arten erinnern und von den übrigen Gattungen in dieser Abtheilung durch die regelmässig punktirt-gestreiften Flïgeldecken gut zu unterscheiden sind.

1. Bat. rubi: Orata, valde convexa, nigra, nitida, elytris saepe aeneomicantibus, antennis pedibusque ferrugineis, femoribus posticis plerumque infuscatis; fronte utrinque punctis nonnullis obsoletis impressa, prothoruce transverso, crebre subtiliter punctato, elytris humeris vix prominulis, punctato striatis. -- Long. 1,5-2 mm.

Paykull, Faun. Suec. II. 112 (Galleruca). - Fabr. Syst. El. I. 468 (Crioceris). - Koch, Ent. Hft. II. 43 (Halt.). Illig. Mag. VI. 160. - Gyllh. Ins. Suec. III. 581. Steph. IIl. Brit. IV. 301; Man. 293. - Zett. Faun. Lapp. 225. - Schilling, Ber. Schles. Ges. 1846. 92. - Redtb. Faun. A. II. 495. - Bach, Käferf. III. 146. - Kutsch. Wien. Monat. 1861, 25 (144), - Seid1. F. balt. 495. Foudr. Mon. 268 (Bat.). - All. Mon, 272. - Thoms. Skand. Col. VIII. 227. - Leesb. Tijdschr. Ent. 24. 193. t. 16. f. 6 .

Chrysomela striatula Marh. Ent. Brit. I. 205. - Steph. 1. c. (Halt.). Haltica pallidicornis Walt1, Isis 1839. 225. 


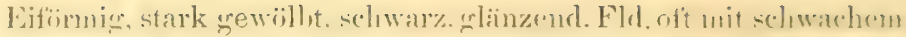
Erzschinmer, Fühler und Beinc rostroth, die füuf Endylieder der Fühler wenig. die Ilinterschenkel stärker sebräunt. Strirn üher der Fiahlerwurzel neben jedem Auge mit rinigen Punkten, ron denen die inneren schr verloschen sind, so dass rler mittlere, nur gewirkte 'Theil der Stirn riemlich breit erscheint. Halssch. um ein Vientel bis um die Hälfte lreiter als lang, an den Seiten gerundet. bisweilen mit vortretender Ecke an der vorderen Pore, in den Vorderecken wenig schmaler oder eben so breit als an der Basis, die Olerfläche bald weitläufig und fein punktirt, mit hreiten, grlatten und grlänzenden Zwischenräumen, bald dicht und etwas stärker punktirt, mit lederatịn gewirkten und matten Zwischenräumen, von der Mitte bis zum Vorderrande merklich abwärts gewölbt. Die Fld. bilden mit dem Halssch. ein regelmässiges Oval. indem sie sich hinter der Basis bis zur Mitte allmählich in sanfter Rundung erweitern und in den Schultern kaun nach aussen treten; sie sind entweder fein punktirt-gestreift, mit breiten, ebenen Zwischenstreifen, oder tief und stark muktirt-gestreift. mit schmalen und gewölbten Zwischenstreifen, auf denen stets die äusserst feine, verloschene Punktreihe bei stärkerer Vergrösserung: sichtbar wird.

Auf Himbeer- und Brombeergesträuch in mittleren und nördlichen Europa nicht selten.

2. Bat. aerata: Oblonga, convexa, nigra, supra viriti-aurichalcen, nitida, antennis pedibusque ferrugineis; fronte utrinque punctis numerosis profundis, sublineatim disposit is impressa, mothorace subtransverso, crebre punctato, elytris humeris sat prominulis, punctato-striutis. Long. 1,5-2 mm.

Mar'sh. Ent. Brit. I. 204 (Chysomela). - Steph. Ill. Brit. IV. 301; Man. 293 (Halt.). - Kutsch. Wien. Monat. 1861. -66 (144). - Redtb. Faum. A. II. õ02. - Foudr. MLon. 267 (Bat.). - A11, Mon. 271.

Batophila Bertolinii Gredl. Käf. Tir. 438. - Weise, Deutsch. ent. Zeit. 1886. 249.

Var. a. fullax: Brevior, nigra, supra viridi-aeneo micans.

Etwas länger, schmaler und flacher als die vorige, das Halssch. gestreckter, rückwärts mehr verengt. die Fld. in den Schultern am breitesten, an den Seiten weniger gerundet, die Stirnbildung endlich sehr verschieden.

Jänglich-eiförmig, gewölbt, oben griinlich-messingfarben, unten schwarz, Fiihler und Beine rostroth, die fünf Endglieder der ersteren und die Hinterschenkel bisweilen leicht gehräunt. Stirn jederseits 
mit zahlreichen, zienulich kräftion Punkten, welche zwischen den Angen und einem schwachen Lïngseindrucke iiher der Fühlerwural ziemlich gerhängt stehen, ausserdem cine, in der Vitte unterbrochene Querreihe am Anfimge des scheitels bilden, und den mittleren, nur gowirkten Thril dex stim auf einen Lïngstreifen einengen. II alsseh. "twal so lang als breit, oder un cin Viertel breiter, vor der Mitte am breitesten, von hier nach hinten stailker als nach vorn verengt, die Oberfliche dicht und mässig stark punktirt, mit scbmalen lederartiy gewirkten Zwischenräumen, in der Mitte oft mit einem verlosehenen Quereindrucke, aber vor derselben bis zum Vorderrande kaum abwitrts gewölbt. Die Fld. treten an der Basis in starkerer Rundung heraus, so dass sie verkehrt eiförmig sind, oder für sich ein Oval bilden, welches in der Nïhe der Schultern am breitesten, bis zum letzten Drittel sehr schwach und fast gradlinig verengt, dahinter stärker verschmälert ist; sie sind ziemlich tief und stark punktirt-gestreift, mit schmalen, gewölbten Zwischenstreifen, auf denen die f'eine Punktreihe auch bei starker Vergrösserung schwer zu bemerken ist.

Auf Brombeeren in den Alpen von Baiern, Tirol und Krain. England, häufig in Frankreich (nach Rey an Rubus tomentosus: Borkh.) und ganz Südeuropa, Algier, Kaukasus.

Gegenïber den Angaben vou Foudras, Kutschera etc. muss hervorgehoben werden, dass die Skulptur des Halssch. bei der vorliegenden Art in der Regel kräftiger und die Streifung der Fld. tiefer ist als bei rubi, so dass die Beschreibung der Chrys, aevata Marsh. daranf schlecht passt.

Eine gedrungene und dunkle, oberseits mit ziemlich schwachem griinen Metallschimmer versehenen Form (Var. a), welche sich der B. rubi in Körperbau und der Färbung nähert, kommt im Kaukasus bei Borshom, Achalzich und Elisabetthal (Schneider u. Leder) vor, und dürfte auch noch in den Alpen aufgefunden werden; fraglich bleibt nur, ob davon die mir unbekannte B. pyrenaea All. (Mon. 271), im Depart. Hautes-Pyrenées von Bonrouloir entdeckt, wesentlich abweicht. Sie besitzt nach der Beschreibung Grösse und Gestalt der aerata, ist aber schwarz-broncefarbig, mit pechfarbenen Fühlern und Beinen, nur die Basis der ersteren und die Schienen heller, das Halssch. am Grunde breiter als an der Spitze.

Bat. graeca All. (Wien. ent. Zeit, 1884 p. 248) - rostroth, Halssch. stark glänzend, kaum bemerkbar metallisch grün angehaucht, Fld. dunkel grïnlich blan - gehürt, nach dem typischen Exemplare in Reitter's Sammlung, nicht hierher, sondern bildet eine Gattung neben Derocrepis, die in der Körperfarbe und der sparsamen Behaarmng der Fld. vor der Spitze mit Derocr. serbica Kutsch. ïbereinstimmt, durch die fehlende Querfurche des Halssch. und die Schienenbildung abweicht. Ich nenne dieselbe Aeschrocnemis: Acetabula antica occlusa. Prothorax sat mag- 


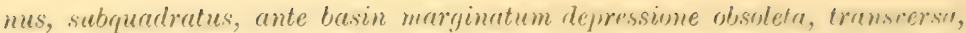
crebrius punctata instructus. Tibiae pone medium valde dilutatne, fere clacatae, calcari distincto. Elytra striato-punctata apice purce pilosa, strin prima haud sulciformi.

\section{Phyllotreta.}

Foudras, Astisides 1860 p. 230.

Acetabula antica aperta.

Frons punctata lineis et tuberculis obsoletis.

Prothorax angutis posticis obtusis, vix discretis.

Pygidium haud canaliculatum.

Tibiae posticae dorso subcarinato, apice breviter canaliculato calcriri brevi.

Körper geflügelt, bald eiförmig und mässig gewölbt, bald gestreckt, ziemlich parallel und wenig gewölbt oder flach, einfarbig dunkel gefärbt oder schwarz, mit einer gelben Längsbinde auf jeder Fld, welche oft verkleinert und in zwei Makeln aufgelöst ist, zuweilen aber die Fld. mit Ausnahme der Ränder einnimmt. Kopf klein, Stirn breit, flach oder wenig gewölbt, zwischen den Fühlern am höchsten, durch eine rinnenförmige Vertiefung, welche vom Hinterrande der Augen bis zur Fïhlerwurzel zieht, bedeutend eingeengt, mehr oder weniger deutlich gewirkt und gleichmässig, oder auf einem Längs- oder Querstreifen zwischen den Augen, wenigstens aber neben denselben punktirt und einzeln behaart. Die Höckerchen fehlen oder sind durch eine flache Schwiele angedeutet, welche eine feine Mittelrinne besitzt und unten unmerklich in den schnell verengten, hohen, bogenförmigen Nasenkiel übergeht. an den sich das abschüssige, dreieckige Kopfschild anschliesst. Augen wenig oder mässig gewölbt, Fühler weit von denselben eingefügt, schlank, meist länger als der halbe Körper, das erste Glied verlängert, doppelt so lang als der Querdurchmesser des Auges, die letzten fuinf Glieder etwas verbreitert. Oberlippe quer-viereckig, Mandibeln fünfzähnig. Halssch. quer, bei einigen Arten ziemlich quadratisch, an der Basis leicht gerundet, vor dem Schildehen abgestutzt und jederseits daron schwach ausgebuchtet, an der Spitze abgestutzt, hinten wenig, nach vorn zu allmählich stärker querüber gewölbt, mit herabgebogenen Vorderecken; hinter diesen ist der Seitenrand bis zur vorderen Pore wenig verdickt und kaum nach aussen gedrückt, die hintere Pore steht in einer kleinen Ausrandung dicht vor oder in den Hinterecken. Letztere sind stumpfwinkelig und schlecht hegrenzt. Schildchen 
klein, halboval. Fliigeldecken in den Schultern etwas hreiter als das Halssch., an den Seiten gerundet oder fast parallel, hinten gemeinschaftlich abgerumdet, seltener abgestutzt und einzeln abgerundet, oben verworren orler in umegehmässigen Linien punktirt. Prosternum bald dentlich bandförmig, mit einem Mittelkiele, hinter den Hüften verbreitert und in einen wenig oder mässig abfallenden Fortsatz verlängert, bald zwischen den Hüften stark verengt. linienförmig, hinten abschüssig, nicht verbreitert und auf die Mittelbrust verlängert, stets von den Seitenstiicken getrennt, so dass die Hüftenpfannen offen bleiben; das Mesosternum ist lang viereckig und in der Breite von der des Prosternum abhängig; Pygidium leicht gewölbt, an den Seiten zuweilen vertieft, ohne Mittelrinne. Beine ziemlich schlank, Schienen grade, auf dem Rücken mit stumpfer Längskante und einer Rinne zur Aufnahme des ersten Tarsengliedes an der Spitze; Hinterschenkel mässig angeschwollen, Hinterschienen mit einem Enddorne, welcher in der Mitte des Spitzenrandes befestigt und nach aussen gebogen ist.

Das Männchen ist am erweiterten ersten Tarsengliede der vorderen Beine und an dem letzten Bauchringe zu erkennen, welcher längs der Mitte eingedrückt oder rinnenförmig vertieft und in der Mitte des Hinterrandes in einen grossen, bogenförmigen Vorsprung: verlängert ist, der sich in der Ruhe in den herausstehenden Hemicyclus einlagert; ausserdem tritt bei vielen Arten noch ein auffälliges Merkmal, nämlich die Erweiterung des 3., 4 oder 5. Fühlergliedes, oder mehrerer derselben hinzu, deren Stärke individuell schwaukt, je nachdem ein Thier kräftiger oder schwächer entwickelt ist. Diese breiteren Fühlerglieder zeichnen sich meist durch stärkeren Glanz der Oberseite und eine quer gestrichelte oder mit Gribchen oder Körnern besetzte Unterseite aus; das dritte ist seitlich in eine Spitze verlängert, entweder nur innen (bei Foudrasi) oder beiderseits (antennata), das viexte und füinfte bilden ein schmales Rechteck (oder das vierte bei antennata ein grosses, unregelmässiges Viereck) mit leicht gewölbter Ober- und sanft ausgehöhlter Unterseite. Der Penis ist fast so lang als der Bauch, mässig von oben zusammengedrückt, am Ende ausgerandet, gerundet oder zugespitzt.

Beim Weibchen ist der letzte Bauchring dichter und stärker punktirt und behaart als die vorhergehenden, am Hinterrande abgerundet, nur achripes (vielleicht auch das mir unbekannte 오 von flavoguttata) besitzt auf demselben eine Eigrube, wie die Cryptocephalen.

Die Gattung ist durch den Bau und die Punktimung des Kopfes. die Form der Halsschild-Hinterecken, des Pygidium und der Hinterschienen, sowie die eigenthümliche Geschlechtsauszeichnung vorzüglich 


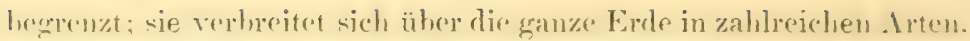
rmu denen bis jetzt erst ungefähr 80 beschrichen wurden, darmuter fin I rittel aus Europra. Dieselben lehen hauptsiichlich an den Blätem von Cruciferen, an welche sie in April oder Mai ihre Eier allegen: lie Larven. nach Foudras Blattminirer, die das Parenchym zwischen der ()l,er- und Lnterhant ausfressen, sind in Juli ausgewachsen, gehen zur Verpuppung in die Erde und liefern nach etwa 1ttizriger liuhe das vollkommene Insekt, welches in Grashüscheln und zwischen ahgestorbenen Wasserpflanzen, in Moose und unter Laub, besonder: germ aber in den Ritzen von Baumstämmen überwintert, wie ohen (rwähnt erst spät im Friblinge seine Schlupfwinkel verlässt und bei massenhaftem Auftreten erheblichen Schaden anrichtet. Bekamnt ist nur die Larve von $P h$. nemorum ${ }^{1}$ ): griunlich gelb, Knpt' klein und schmal, braun, Vorder-Seitenrand und Mittellinie gelh, die folgenden Segmente mit kleinen braunen. schwach erhabenen ' $\mathrm{Tu}$ berkeln, wovon auf den beiden Thoraxringen je sechs (zwei quere in der Mitte, eine punktförmige und eine mondförmige jederseits davon) und auf den übrigen Ringen eine grössere Anzahl stehen und hier je zwei unregelmässige Querreihen hilden. Der Anus ist mit einer glatten, hellbraunen Platte bedeckt.

Die einander sehr ähnlichen Arten wurden anfänglich in wenige Chrysomela-, Galemea-, oder Haltica-species zusammengefasst und erst von Kutsehera und Foudras sicher auseinander gehalten. Nach der Penisform gliedern sich dieselben folgendermassen:

Die Klappe, welche die Oeffnung des Penis schliesst. endet a. in einen hornigen. breiten, abgerundeten Ziptel, der weit iiber den abgestutzten Vorderrand hinausragt, nemorum. oder reicht nicht bis zum Vorderrande. Dieser ist b. stumpf abgerundet, parallela und vilis, oder c. gerundet, mit einem schwachen. herzförmigen Ausschnitte, daher leicht zweilappig, flacoguttata, oder besitzt d. drei kurze Spitzen, die mittlere etwas länger als die seitlichen, zwischen ihmen zwei bogenförmige Ausschnitte, ochrifres. e. zwei lange, scharfe, etwas nach imnen gekrümmte Spitzen, dazwischen einen halbkreisförmigen Ausschnit, armoraciae, f. zwei dreieckige, vorn sehr scharfe Spitzen, zwischen ihmen einen tief dreieckigen Ausschnitt, procera, g. zwei breite und sehr kurze Spitzen, dazwischen einen bogenförmigen Ausschnitt, exclamationis, h. eine Spitze. Dann ist die Oberseite entweder glatt und die ganze Röhre beinahe grade, cariipennis. cruciferae und consobrina,

1) Le Keux, Trans, ent. Soc. 1837. 24. t. IV. f. 1-8. - Foudr. IIon. 261. - Tasch enberg, Schädl. Thiere 73. t. 2. f. 3. 4. 
i. ziemlich gohogen, ni,fripes. k. stark gekrïmms, "ulonuatu; oder sic ist dicht quer gestrichelt und l. von einer tiefen und breiten Rimne eingenommen, "era. diademata, m. jederseits mit oner

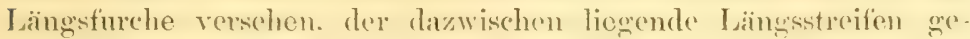
wiolbt, simuatu. flexuosa und undulatu, endlich n. ziemlich sleichmässig und schwach queriiler sewölbt, tetrostigma, vittu$l a$ und $a t r a$.

Bei Berücksichtigun der äusseren Merkmale ergiebt sich folgende Bestimmungstabelle:

1. Fld. grösstentheils gell oder schwarz mit gelber Lüingshinde oder gelben Flecken . . . . . . . . . . 2.

1'. Fld. einfarbig schwarz, blan oder griin . . . . . . . 19.

2. Kopt, mit Ausnahme der metallisch grimen Stirn iiber den Höekern, und das Halsseh. rostroth. - L. 2-2,5 mm. Derbent ruficollis W. ${ }^{1}$ ).

21. Kopf und Halssch. einfarbig schwarz oder dunkel metalliseh grün . . . . . . . . . . . . . . 3 . .

3. Fld. nebst Epipleuren bräunlich-gelb, ein gleichbreiter, vor der Spitze gerundet-abgekiirzter Nahtsaum, eine kleine Schultermakel an der Basis und eine grössere ovale oder rechteckige Längsmakel dahinter, ungefähr in der Mitte der Fld., weder Nathsaum noch Seitenrand berührend, schwarz. Länglich-oval, wenig gewölbt, schwarz, Fïhler und Beine röthlich gelb, erstere nach aussen und die Spitze der Hinterschenkel auf dem Rücken mehr oder weniger angedunkelt (bimaculata All. Ann. Fr. 1859. Bull. 100; biguttata Foudr. Mon. 251); zuveilen sind die Fiihler rom sechste» Gliede an schwarz, die Vorderschenkel ziemlich bis zur Spitze und die Hinterschenkel auf dem Ruicken schwärzlich. - L. 1,8-2,5 mm. Siidfrankreich, Spanien, Algier, Sicilien, Sardinien (Käf. Eur. 17. 95. 1849.) rugifrons Küst.

:1. Epipleuren und ein Saum an der Naht, am Seiten- und Spitzenrande der Fld. schwarz . . . . . . . . . 4.

4. Der schwarze Seitensaum der Fld. erweitert sich an der Basis nicht und lässt den Schulterhöcker völlig frei . . . . 5.

1) Phyll. ruficollis: Oblonga, subparallela, subdepressa, nigra, capite (fronte viridi-aenea excepta) prothoraceque dilute fermuineis, hoc leviter aeneo micante, antennis piceis articulis 5 primis pedibusque testuceis, femoribus posticis nigris; fionte inter oculos, prothoruce elytrisque crebre subtiliterque sed evilenter punctatis, his piceis, epripleuris antice maculisque 4 oblique digestis /lanescentibus: prima magna, oblongu, in basi, secunda purva, unte apicem. Antennarum articulo 5:0 longissimo, tarsis gracilibus. - Long. 2-2,5 mm. Derbent. (Faust.). 
41. Iorselhe 'rweitert sich an der Basis makelförmig und hedeckt die Schulterbenle theilweise orler gänzlich .

5. Eiförmig, an den Seiten gerundet, grewiolbt. Kopf und Halssch. schwarz, Fld. weisslichrelb, ein schmaler Aussen- und ein hreiterer gemeinschaftlicher, beilerseits verengter Nahtsaum schwarz. - L. 3-3,5 mm. Mitteleuropa 1. armoraciae Koch.

51 . Gestreckt, an den Seiten ziemlich parallel, flach, Kopf und Halssch. metallisch griin, stark punktirt, Fld. weisslich-gelh, ein nicht breiter, beiderseits verengter Naht- und ein schmaler Seitensaum schwar\%, mit grünem Anfluge. - L. 2,5 mm. Kaukasus (Reitter) . . . . . . . . . . . sisymbrii Ws. ${ }^{1}$ )

6. Gestreckt, flach, Fld. an den Seiten fast parallel, fein, äusserst dicht punktirt, ohne Spuren von Reihen . . . . . 7.

61. Oval oder länglich-oval, gewölbt, selten gestreckt, flach, und die Fld. an den Seiten ziemlich parallel, dann aber in deutlichen Reihen punktirt

7. Die schwarze Schultermakel ist verlängert und bildet hinten einen sehr spitzen Winkel. Die schwarze, gemeinschaftliche Nahtstrieme breit, mit beinahe parallelen Rändern, linten gerundet-verengt, der dunkle Aussensaum schmal, innen gradlinig begrenzt, mit dem Seitenrande nicht gleichlaufend, neben der Schulter fast unterbrochen. $\hat{\sigma}$ Glied 4 und 5 der Fühler schwach verlängert und verbreitert, 6 klein. - L. 2,8 mm. Frankreich, Spanien, Algier . . . parallela Boield.

71. Die schwarze Schultermakel ist klein, recht- oder stumpfwinklig, und nimmt nur die vordere Hälfte der Schulterbeule ein . . . . . . . . . . 8 .

8. Der Nahtsaum von der Basis der Fld. bis hinter die Mitte allmählich erweitert, hinten gerundet-verengt, Seitensaum sehr schmal, sein Innenraud mit den Seiten gleichlaufend. Kopf und Halsseh, metallisch grüin, mässig stark punktirt; fünftes Fühlerglied in beiden Geschlechtern rerlängert. - L. 2-2,8 mm. Griechenland (ex Kutsch.) . . . . latevittata Kutsch.

81. Nahtsaum ein Stiick hinter der Basis der Fld. schnell erweitert, hinten sehr schwach verengt, Seitensaum mässig breit, an den

1) Phyll. sisymbrii: Subelongata, depressa, nitida, nigra, antennis apicem versus infuscatis, genubus, tibiis tarsisque testaceis, capite prothoraceque aeneo-viridibus, crebre sat fortiter punctatis, elytris albido-flavis, confertim subtiliter punctatis, vitta communi suturali, utrinque angustata, et limbo angusto laterali subaeneo-nigris, sutura elecata. Antennarum artirulis 4,5 et 6 subaequalibus. - Long. 2,5 mm. Elisabetthal (Leder). 
Schultern verschmälert. Fünftes Fiuhlerglied verlängert und beim $\hat{\jmath}$ verdickt. - L. 1,8-2,3 $\mathrm{mm}$. Elsass, 'Tirol, Görz, Siideuropa, Nordafrika . . . . 7. variipennis Boield.

9. Die gelbe Firbung jeder Fld. ist auf eine ziemlich schmale, fast gleich breite, aussen nicht, oder in einem sehr langen und schwachen Bogen ausgerandete Lüngsbindo beschränkt, die niemals in zwei Makeln aufgelöst ist. . . . . . . . 10.

91. Dieselbe nimmt eine mehr oder weniger breite Längsbinde ein, welche aussen durch einen tiefen Bogen stark ausgebuchtet und zuletzt in zwei Makeln aufgelöst ist . . . . . 14.

10. Stirn auf einem Querstreifen über den Höckern punktirt, an den Seiten und auf dem Scheitel nur gewirkt. - L. 2-2,8 mm. Europa, Sibirien bis zum Amur . . 9. undulata Kutsch.

101. Stirn und Scheitel gleichmässig, oder letzterer wenigstens in der Mitte punktirt . . . . . . . . . . . 11.

11. Der Innenrand der Längsbinde ist gerade, von der fünften Punktreihe begrenzt, hinten der Naht zugebogen. - L. 1,8 bis $2,3 \mathrm{~mm}$. Im grössten Theile von Europa - 8 vittula Redtb.

11․ Innenrand der Längsbinde zweimal sanft ausgeschweift, daher am Anfange und Ende mehr oder weniger der Naht zugebogen

12. Fühler vom vierten Gliede an schwarz. - L. $3-3,5 \mathrm{~mm}$. Europa, Westsibirien . . . . 10. nemorum L.

121. Fühler vom fünften odex sechsten Gliede an pechbraun . 13. 13. Regelmässig lang elliptisch, ziemlich gewölbt, die gelbe Längsbinde der Fld. schmal, an der Schulter kaum ausgerandet. L. $2 \mathrm{~mm}$. Italien . . . . . . . Seidlit $\approx i \mathrm{Ws.}^{1}$ ) 131. Fld. in den Schultern viel breiter als das Halssch., an den Seiten fast parallel, wenig gewölbt, Längsbinde an der Schulterbeule deutlich ausgerandet. - L. $2 \mathrm{~mm}$. Griechische Inseln, Smyrna . . . . . . . . . . vilis $\mathrm{Ws.}^{2}$ )

1) Phyllotr. Seidlitzi: Elongato-elliptica, convexiuscula, saturate nigra, nitida, supra undique confertim punctata, antennis piceis, articulis 4 vel 5 basalibus, femorum et tibiarum apice tarsisque testaceis, elytris apice rotundatis, singulo vitta media angusta, lenissime bisinuata, flaro-albida. - Long. $2 \mathrm{~mm}$. Rom (Seidlitz). P. vittulae similis, corpore convexo, saturate nigro, subtiliter punctato, vitta elytronum angustiore pone callum humeralem haud excisa facillime distinguenda.

$\left.{ }^{2}\right)$ Phyll. vilis: Oblonga, subparallela, minus convexa, nigra, antennarum basi, femorum apice, tibiis (in medio plerumque infuscatis) tarsisque testaceis, fronte subtilius prothoraceque crebre punctatis, hoc alutaceo, minus nitilo, elytris creberrime subseriatim punctatis, nitidis, vitta flavo-albida 


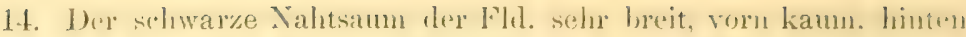
nur wenig der Naht genähert, daher fast gradlinigr becrrenzt. I. 2,5-3 1 m. Im grijsten Theile von Europa 5. flexuosu Ill. 14. Derselbe ist bogenfömig begrenzt, hejderseits dentlich verngt 15 ).

15. Dex schwarze Nahtsaum der Fld. arweitert sich ein stück hinter der Basis winkelig and rerengt sich ahulich vor der spitze, sein mittlerer 'Theil bildet eine rechteckige Figur. - L. 2 $2,5 \mathrm{~mm}$. Europa, ganz Sibirien . . . 6. simata steph.

15. Derselhe ist vorn alluählich, hinten etwas schneller rersclmälert und hat eine lang ovile oder lanzettliche For'm 16.

16. Fühler mit Ausmahme der drei ersten Glierler und der grö̈ste Theil der Beine schwarz; füinftes Fïhlerglied wenig läner als das sechste. - L. 2, $5-3,5 \mathrm{~mm}$. Europa 4. tetrastigma C'rm.

16․ Der grössere Theil der Beine, oft auch der Fühler gelb, selten so dunkel wie bei tetrastigm ; füntes Fühlerglied ungefähr. doppelt so lang als das sechste . . . . . . . . 17.

17. Der vorlere Theil der gelben Läugsbinde, die in der Regel nicht unterbrochen ist, dehnt sich bis in die Nähe des Seitenrandes aus. \& mit einer Eigrube auf dem letzten Bauchringe. L. 2,5-3 mm. Europa . . . . . . 3. ochripes Curt.

17'. Der vordere Theil der Binde, die fast immer in zwei Makeln aufgelöst ist, bleibt rom Seitemrande weit entfernt . . . 18.

18. Fünftes (zuweilen auch das vierte) Fühlerglied des Männchens wenig verdickt. Lang eiförnig, wenigstens die vier ersten Fühlerglieder, die Basalhälfte der śchienen und die Tarsen röthlich gelb, jede Fld. mit zwei goldgelben Makeln, die vordere länglich-riereckig, die hintere mehr oval. - L. 2,5 $\mathrm{mm}$. Griechenland . . . . . . flaroquttata Kutsch.

181. Fünftes Fühlerglied des $\hat{o}$ stark erweitert; $f$ olne Eigrube. Auf jeder Fld. zwei dreieckige oder mondförmige. selten rexbundene Makeln. - L. 1,5-2 mm. Europa

2. exclamationis Thumb.

19. Die hintere Borstenpore stelit in einer kleinen Ausbuchtung: des Seitenrandes dicht ror den Hinterecken des Halssch.,

interne leniter bisinuata, externe latissime ct in callo humerali breviter emarginata ornatis. II as: antennis articulo quarto parum elonguto et dilatato, 5:o et 6:0 longitudine aequalitus. - Long. $2 \mathrm{~mm}$. Enböa. Smyrna.

Ph. undulata affinis, sed minor, subtilius et in elytris crebrius punctata, fronte omnino punctulata, prothorace evidenter alutaceo, mims nitido, vitta elytron pone humeros magis dilatata; bene distinctus. - Penis purum compressus, supra politus, apertura sat breri, upice rotundatus. 
Prosternum zwischen den Ilitten stank verengt, vorn dreieckig, hinten linientïrmig, Mesosterum doppelt so lang als breit 20. 191. Die hintere Borstenpore steht in den Hinterecken, Prostemum zwischen den Ifüften mäissig verengt, bandförnigg, dentlich sichtbar, Mesosternum wenig länger als breit . . . . . 24. 20. Stirn zwischen den Augen gleichmässig punktirt . . . 21. $20^{1}$. Stirn mit wenigen P'unkten nahe der Borstenpore neben jeden Auge, in der Mitte nicht punktirt . . . . . . . 22.

21. Stim auf eincm breiten Querstreiten zwischen den Angen dicht und grob punktirt. Broncebraun, oft mit griulichem oder kupferfarbigem Schimmer, Halssch. und Fld. dicht und fein punktirt, gewirkt, mit mattem Seidenglanze, Fühler (nach der Spitze etwas angedunkelt), Schienen und Tarsen rostroth. L. $2,5-3 \mathrm{~mm}$. Suidfrankreich, Suideuropa, Nordafrika, Syrien, Derbent . . . . . . . . corrugata Reiche. 21'. Stim zerstreut und verloschen punktirt, die Punkte in der Regel in 6 bis 8 Längsreihen geordnet. Blan oder metallisch griu, Unterseite, Fïhler und Beine schwarz. - I. 2,2-2,s mm. Europa . . , . . . . . . 17. nigripes Fabr.

22. Halssch. über den stark gerundeten Seiten etwas wulstartig gewölbt, oben zerstreut und fein punktirt, mit glatten, wie polirten Zwischenräumen, viel glänzender als die äusserst dicht und runzelig punktirten Fld. Metallisch bläulich grün, die ersten 4 Fibhlerglieder und die Schienen mehr oder weniger rostroth, Tarsen röthlich gelb. ô 3. und 4. Fühlerglied etwas rerdickt, ersteres dreieckig, mit einer leistenförmigen Kante auf der Unterseite, doppelt so lang als 2, letzteres gestreckt, länger als $3 .-$ L. $3 \mathrm{~mm}$. Neapel, Sicilien nitidicollis Ws. ${ }^{1}$ ) 221. Halssch. in der Regel ziemlich quadratisch, an den Seiten wenig gerundet, fast eben so dicht punktirt und gewirkt und eben so matt als die Fld . . . . . . . . . . . . . . 23. 23. Fühler schlank, in beiden Geschlechtern ziemlich überein-

1) Phyll. nitidicollis: Elongata, sat depressa, subtus aeneo-nigra, supra viridi-aenea, antennis crassiusculis articulis 4 primis tibiisque ferrugineis, tarsis testaceis, fronte laeii sat lata, lineis profumlis et punctis paucis utrinque impressa, prothorace subtransverso, convexiusculo, lateribus rotundato, subtiliter punctulato, haud alutaceo, nitido; elytris coerulescentibus, alutaceis, sericeo-micantibus, confertissime subtiliter punctatis. II as: antennarum articulo 2:0 parvo, 3:o et $1: 0$ parum incrassutis, illo trianyuluri 2: o duplo longiore, hoc oblongo praecelente evidenter longiore; segmento ultimo ventrali apice fovea triangulari sat magna, sed parum profunda impresso. - Long. $3 \mathrm{~mm}$. Neapolis, Sicilia. 
stimnend gebaut, Glied 2 und 3 kurz, jedes aber länger als breit; Stim zwischen den Augen schmaler als der Querdurchmesser eines Auges. Braun erzfarbig, bronce- oder blau-griin. Fühler schwarz, oder (Var. rufitursis All.) die vier ersten Glieder rostroth. - L. $2-3 \mathrm{~mm}$. Mittel- und siideuropa, Nordafrika, Kleinasien . . . . 19. procera Redtb.

23'. Fühler kräftig, Glied 2 und 3 sehr kurz, kaum so lang als breit, beim ô Glied 3 quer dreieckig, 4 sehr gross, ziemlich beilförmig, 5 dick, cylindrisch. Stirn zwischen den Augeu breiter als der Querdurchmesser eines Auges. Schwarz erzfarbig, oder Kopf und Halssch. mit Bronceschimmer, Fld. schwarzgrün oder kupferig. - L. 2,5-3 mm. Mittel- und Suideuropa, Nordafrika . . . . 18. nodicornis Marsh.

24. Fühler einfarbig schwarz. Körper schwarz, die Fld. gewöhnlich mit grünem oder bläulichem Schimmer, äusserst dicht, fein runzelig punktirt. Beim ô das 3., 4. und 5. Fühlerglied erweitert. L. 1,8-2,5 mm. Westdeutschland, Frankreich, Spanien

16. consobrina Curt.

241. Die Basalglieder der Fühler röthlichgelb, gelbbraun oder düster rostroth

25. Stim nur auf einem vertieften Querstreifen zwischen den Augen punktirt. Oberseite rein schwarz. - L. $1, x-2,5 \mathrm{~mm}$. Mitteleuropa . . . . . . . 15. diademata Foudr.

251. Stirn und Seheitel punktirt . . . . . . . . . 26

26. Stimlinien schmal und scharf, gradlinig bis zur Fühlerwurzel convergirend, der Raum dariiber gleichmässig, dicht, selır fein punktirt. Schwarz, fettig glänzend, Halssch. wenig, Fld. deutlich stärker und weitläufiger als der Kopf, jedoch fein punktirt. $\hat{o}$ Unterseite des dritten Fühlergliedes nach der Spitze hin stark dreieckig erweitert. - L. 1,5-1,s mm. Südfrankreich . . . . . . . . . Foudrasi Bris.

261. Stirnlinien besonders neben den Augen durch Punkte verbreitert und schlecht begrenzt, der scheitel nur in der Mitte punktirt, an den Seiten gewirkt . . . . . . 27.

27. Die ersten vier oder fünf Fïhlerglieder einfarbig röthlich gelb, Stirn und Mitte des Scheitels weitlïufig und seln fein punktirt. Rein schwarz, oder oberseits bläulich oder broncefarben schimmernd, die Spitze der vier Vorderschenkel und die Schienen und Tarsen hell rostroth, oder die Schienen in der Spitzenhälfte schwärzlich. ô Fiihlerglied 4 sehr kurz, f’ast breiter als lang, 5 verlängert und rerdickt. - L. 1,8-2,5 mm. Mittel- und Südeuropa . . . 14. crassicornis All. 27. Das zweite und dritte Fühlerglied nebst der Spitze des ersten 
und dex Basis des vierten Gliedes röthlich gell, oder rostroth, Beine grösstentheils schwarz . . . . . . . . . 28. 28. Fld. fein, sehr dicht, verworren punktirt. Schwarz, oberseits häufig blau oder broncefarben schimmernd, Fïhler in beiden Geschlechtern gleich. - L. 1,8-2,3 mm. Holland, Frankreich, Baiern, Oesterreich, Südeuropa . . . . . 13. a erea All. 28'. Fld, kraiftig, mässig dicht und mehr oder weniger gereihtpunktirt . . . . . . . . . . . . . . 29.

29. Dunkel metallisch blau oder grün, Halssch. mässig zusammengedrückt, besonders in der hinteren Hälfte schwach gewölbt, ungefähr so stark als die Fld. punktirt. - L. 2,3-3 inm. Mittel- und Südeuropa . . . . 12. cruciferae Goeze. 291. Schwarz, Halssch. stark zusammengedriickt, querüber gewölbt, schwächer als die Fld. punktirt. - L. 2-2,8 mm. Europa 11. atra $\mathrm{E}$.

A. Flügeldecken gelb, oder gelb gezeichnet.

1. Phylı. armoraciae: Ovalis, convexa, nigra, nitida, antennarum articulis 3 primis, tibiis tarsisque rufo-testaceis, fronte subtilissime, prothorace elytrisque concinne punctatis, his testaceo-flavis, limbo laterali angusto suturalique latiore, utrinque angustato, nigris. - Long. 3-3,5 mm. Ias: antennis articulo 4:0 subincrassato 5:0 longiore.

Femina: antennarum articulis 4 et 5 aequalibus.

Koch, Ent. Hft. II. 75. t. 3. f. 6 (Haltica). - Illig. Mag. VI. 150. - Duft. Faun. A. III, 254. - Gyllh. Ins. Suec. IV. App. 654. - Schilling;, Ber. Schles. Ges. 1846. 92. - Kutsch. Wien. Monat. 1860. 203 (115). - Redtb. Faun. A. II. 498. - Bach, Käferf. III. 140. - Seidl. F. balt. 496. - Foudr. Mon. 234. (Phyllotr.) - All. Mon. 257. - Leesberg, Tijdschr. Ent. 24. 204 (Aphthona).

Chrysomela nemorum Fabr. Spec. Ins. I. 136; Mant. Ins. 1. 78; Ent. Syst. 115 (Altica).

Var. a. Tibiis infuscatis.

Haltica vittata Steph. Ill. Brit. IV. 297; Man. 292.

Eiförmig, gewölbt, oben lackartig glänzend, schwarz, die drei ersten Fïhlerglieder, die Spitze der vier Vorderschenkel, die Schienen (nur bei der seltenen Var. a schwärzlich) und Tarsen röthlich gelbbraun, Fld. weissgelb, nach dem Tode bräunlich-gelb, ihre Epipleuren und ein Saum an den Seiten und der Naht schwarz. Der Seitensaum ist schmal, beginnt hinter der Schulter und verbindet sich um die Spitze herum mit dem Nahtsaume. Dieser ist etwas breiter und im ersten und letzten Viertel der Fld. merklich verengt. Stirn zer-

VI. 5 . 
streut und :iusserst fein, Halssch. und Fll. dicht und fein punktirt: drittes Fühlerglied etwas länger als das zweite, das vierte bein $\hat{j}$ schwach verdickt und etwas länger als das fünfte, hein $q$ ungrefuhr so lang als Glied 5. Penis an Ende jederseits in eine lange und scharfe, etwas nach innen gekrïnnte Spitze ausgezogen, dazwischen halbkreisförmig ausgeschnitten,

In Mitteleuropa auf Cochlearia armoracia L. sehr zerstreut.

2. Phyıl. exclamationis: Ovalis, comvexa, nigra, nitida, antemis, articulo 5:0 elongato, $6: 0$ brevissimo, basi testaceis, tibiis tarsisque plus minusve ferrugineis, clytris concinne punctatis, marulis, 2 fluco-testaceis, altera basali, altera lunata ante apicem, cornatis. - Long. 1,5-2 $1 m m$. Mas: antennarum articulo 5: 0 valde dilatato.

Thunb. Act. Nov. Ups. IV. 1784. 14. - Leesberg, Tijdschr. Ent, 24. 207 (Aphth.).

Haltica brassicae Illig. Mag. VI. 149. - Steph. Ill. Brit. IV. 296; Man. 291. - Schilling, Ber. Schles. Ges. 1846. 92. - Kutsch. Wien. Monat. 1860. 297 (120). - Red tb. Faun. A. II. 499. - Bach, Käferf. III. 142. - Seidl. F. balt. 497. - All. Mon. 263 (Phyll.). - Tho ms. Skand. Col. VU. 190. Gallerucu 4-pustulata Payk. Faun. Suec. II. 99. - Koch. Ent. Hft. II. 73. t. 3. f. 5 (Halt.). - Gyllh. Ins. Suec. II. 533. - Duft. Faun. A. III. 260. - K iist. Käf. Eur. 8. 95 (Phyll.). - Foudr. Mon. 249.

Var. a. Antennis ferugineis, articulis 4primis, tibiis tarsisque testaceis. Var. b. Tibiis tarsisque aut pedibus testaceis, femoribus posticis in dorso nigricantibus.

Var. c. vibex: Plerumque ut in a et $b$, sed maculis elytrorum dilatatis intus connexis.

Kaum halb so gross als die vorige, eiförmig, gewölbt, schwarz, glänzend, die ersten vier Fühlerglieder röthlich gelbbraun, an den vorderen Beinen meist die Knie und die Spitze der Schienen, an den Hinterbeinen der grösste Theil der Schienen rostroth, die Tarsen pechbraun, auf jeder Fld. zwei bräunlich gelbe Makeln, eine an der Basis, bald dreieckig, mit oder ohne Ausschnitt auf der Schulterbeule, bald schmal, streifenförmig, die andre vor der Spitze, mondförmig. Stirn zerstreut und äusserst fein, Halssch. etwas stärker punktirt; Fld. an den Seiten gerundet, vorn dicht und ziemlich kräftig, hinter der Mitte und nach aussen hin allmählich immer schwächer punktirt. Das zweite bis vierte Fühlerglied ungefähr von gleicher Länge, Glied 5 verlängert, beim ô stark verbreitert, Glied 6 selu kurz. Penis vorn gerundet-verengt, mit einem kleinen halbkreisförmigen Ausschnitte in der Mitte. 
Zuweilen sind die Fühler rostruth, mit hellerer Basis, beim $\hat{\jmath}$ bleibt jeduch wenigstens Glied 5 dunkel (Var. a), oder es sind die Schienen und 'T'arsen, dann die Spitzen der Vorderschenkel, zuletzt die Beine, mit Ausuahme der schwärzlichen Spitze dex Iinterschenkel rüthlich-gelb (Var.b); endlich vereinigen sich die beiden hellen Makeln jeder Fld. zu einer Längsbinde, welche an der basis und Spitze der Naht zugebogen, auf der Schulter winkelig, und in der Mitte des Aussenrandes tief bogenfömig ausgeschnitten ist. Diese seltene Abiandermy c, mit einer Zeichnung der Fld., die bei den folgenden Arten normal auftritt, umfasst in der Regel die Varietäten a und b. Bisweilen sind die Fld. auf der immeren Hälfte in deutlichen Reihen punktirt.

Auf Nasturtium und anderen im Wasser wachsenden Cruciferen in ganz Europa häufig:

3. Phyıl. ochripes: Subovalis, convexa, nigra, nitida, antennis, articulo quinto valde elongato, sexto brevi, fuscis, basi pedibusque testaceis, femoribus posticis nigris; fronte prothoraceque concimne punctatis, elytiris anterius minus fortiter, postice subtilius punctatis, flavis, plaga communi suturati utrinque angustata limboque laterali angusto (in tuberculo humerali angulatim et in medio arcuatim dilatato) nigris. - Long. 2,5-3 mm. Mas: antennis articulo quinto dilatato, nigro.

Femina: segmento ultimo ventrali apice fovea sat magna profunde impressa.

Curtis, Brit. Ent. 14, 630 (Halt.). - Steph. Man. 291. Kutsch. Wien. Monat, 1860. 298 (121). - Seidl, F. balt. 496. - All. Mon. 259 (Phyllotr.). - Thoms. Skand. Col. VIII. 193. - Leesb. Tijdschr. 24. 206. t. 16. f. 9. 우 (Aphthona).

Haltica excisa Redtb. Faun. A. ed. 1.532; ed. 3. II. 499. - Bach, Käferf. ПI. 141. - All. Ann. Fr. 1860. 384. - Foudr. Mon. 242 (Phyllotr.).

Var. a. Femoribus posticis testaceis in dorso apicem versus nigricantibus. Var. b. Femoribus anterioribus plus minusve infuscatis.

Var. c. Pedibus piceis, genubus paullo dilutioribus.

Var. d. cruciata: Elytris nigris, singulo maculis 2 flavis ornatis, altera ante, altera pone medium.

Eiförmig, aber an den Seiten etwas weniger gerundet als die vorhergehenden, gewölbt, schwarz, glänzend, Fühler dunkelbraun, die ersten drei ( $₫$ ) oder vier (q) Glieder und die Beine rüthlichgelb, Hinterschenkel schwarz; Fld. hell schwefelgelb, ein gemeinschaftlicher breiter Nahtsaum, der sich an der Basis und spitze etwas verengt, und ein schmaler Seitensaum, welcher am Grunde winkelig und in der Mitte bogenförmig erweitert, neben der Schulter oft nur 
nuf die Seitenkante heschränkt ist, schwarz. Stirn sehr finin. Hal-ich. namentlich nach dem Hinterrande zu rtwas stürker junktirt. Fld. in del vorderen Hälfte mässig stark und in wenig deutlichen Reihen, dahinter und nale den seiten feiner und verworrener punktirt. Das zweite bis vierte Fiihlerglied ungefähr rom gleicher Länge, Glicrl 5 doppelt so lang als 4, stets dunkler gefärbt als die iibrigen Glieder und beim Männchen verbreitert, Glied 6 etwas kïrzer als 4 . Penis am Vorderrande mit zwei hogenfömigen Ausschnitten, durch welche drei Zähmchen gebildet werden, won denen das mittlere etwas länger und spitzer ist als die seitlichen.

Die Färbung ist veränderlich:

An den Fühlern werden die fünf oder sechs äusseren Glieder nicht selten rostroth, mit schwärzlicher Spitze jedes einzelnen Gliedes. oder einfarbig hell rostroth; dann ist das fünfte Glied. häufig auch das vierte und sechste, pechbraun bis rothbraun; an den Beinen der hellsten Stücke bleibt nur ein Wisch auf dem Rücken der Hinterschenkel, nahe der Spitze schwärzlich (Var. a), bei Stücken mit dunklen Fühlern und Fld. bräunen sich zunächst die Mittelschenkel in der Basalhälfte, dann die Vorderschenkel (Var. b), endlich auch Schienen und Tarsen, so dass die Beine zuletzt pechschwarz sind, mit etwas helleren Knieen (Var.c); auf den Fld. dehnt sich die bogenförmige Erweiterung des schwarzen seitensaumes allmählich nach innen bis zum Nahtsaume aus, ${ }^{1}$ ) und es bleiben auf jeder Fld. zwei grosse, gelbe Makeln übrig (Var. d).

Am Rande von Gewässern und in Sümpfen, hauptsächlich an Cardamine amara L. und Nasturtium amphibium R. Br. in Mitteleuropa nicht selten. Südliches Schweden, Sïdeuropa, Kaukasus.

Phyllotr. caucasica Harold, Col. Hft. 16. 1879. 231, nach einem von Leder gesammelten Exemplare aus dem Kaukasus beschrieben, gehört, wenn dasselbe ein $\rho$ war, zur rorliegenden Art, sollte es aber wirklich ein $\hat{o}$ gewesen sein, als helle Form, mit ganzer Längsbinde auf den Fld., zu flavoguttata Kutsch.

Halt. horticola Richter, Suppl. Faun. Ins. Eur. I. 8. von Güttingen und Breslau ist vielleicht nach Stücken der ochripes beschrieben worden, doch will die Bezeichnung ,capite et thorax obscuro-aeneis, vix punctatis, elytra laevia" und die Abbildung, bei welcher der zweite dunkle Fleck an der Seite der Fld. zu klein, auch der Spitze der Fld. zu nahe angegeben ist, nicht recht zutreffen.

1) Eine Unterbrechung der gelben Zeichnung jeder Fld. findet bei ochripes und den folgenden Arten nicht nur beim Männchen statt, wie Kutschera angiebt, sondern ist vom Geschlechte durchaus unabhängig. 


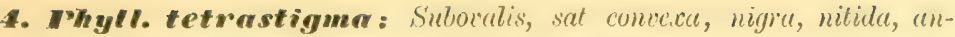
tennis tibiisque basi testaceis vel fermaineis, fronte prothoraceque vage punctutis, clytris anterius sut crebre subseriution, postice subtiliter punctatis, sinumlo maculis binis, oblique digestis, testaceis ornata. - Long. $2,8-3,5 \mathrm{~mm}$.

Comolli, Col. Nov. Novocom. 1837. 47. (Halt.) - Seidl. F. balt. 497. - Foudr. Mon. 246 (Phyll.) - Leesb. Tijdschr. 24. 207 (Aphthona).

Haltica flexuosa var. 3 I11. Mag. VI. 148.

Haltica flexuosa Duft. Fam. A. III. 263. pars. - Redtb. Faun. A. II. 499 (secunda).

Var. dilatutı: Elytris vittı media lata, testacea, interne leviter sed evidenter curvata, externe sinu medio profundo instructa.

Phyllotreta dilatata Thoms. Skand. Col. VIII. 192.

Haltica tetrastigma Kutsch. Wien. Monat. 1860. 204 (116).

Ungefähr so lang, aber in der vorderen Hälfte nicht ganz so breit als "rmoracicue, ziemlich eiförmig, mässig gewölbt, schwarz, glänzend, die ersten zwei oder drei Fühlerglieder und die Basis der Schienen röthlich gelbbraum bis dunkel rostroth, oft das erste Fühlexglied und die Spitze des dritten geschwärzt. Die Stirn auf einem Querstreifen zwischen den Augen verloschen, das Halssch. etwas stärker aber nur mässig dicht punktirt, mit äusserst fein und undeutlich gewirkten Zwischenräumen. Fld. nicht dicht und wenig stark in deutlichen, wenn auch unregelmässigen Reihen punktirt, die hinter der Mitte allmählich schwächer werden; der Streifen zwischen der vierten und fünften, sowie der achten und neunten Punktreihe ist hier, wie bei den übrigen Arten mit ähnlicher Punktirung bisweilen schärfer begrenzt, breiter, und besonders im vorderen Drittel leicht gewölbt. Auf jeder Fld. befinden sich zwei grosse röthlich- oder weisslich-gelbe Makeln, die vordere ist breit, beilförmig: oder unregelmässig dreieckig, mit der Spitze nach hinten und innen und mit einem stumpfwinkeligen Ausschnitte der Grundlinie auf der Schulterbeule; die andere, hinter der Mitte, ist etwas kleiner, mehr oder weniger mondförmig, vorn abgestutzt oder ausgerandet. Der Innenrand beider Makeln bildet eine beinahe regelmässige, flache und in der Mitte unterbrochene Bogenlinie, welche vollständig wird, sobald sich die Flecke vergrössern und durch einen Strich oder Streifen vereinigen. Zuletzt (Var.a) sind die Fld., ähnlich wie bei ochripes, gelb, ein lang ovaler, fast lanzettlicher gemeinschaftlicher Nahtsaum und ein sehr schmaler Seitensaum schwarz, letzterer auf der Schulter winkelig, in der Mitte bogenförmig erweitert; neben der Schulter in seltenen Fällen nur auf die Randleiste beschränkt. Die Fühler sind bei beiden Geschlechtern gleich. - Penis schlank, 
mit paralleten seiten. vorn gresundet-verengt und in der Mitte in eine ziemlich stark nach unten grakrïmmte spitze verlängert, von der Basis bis zum Ende der Klappe gleichmässier schwach querüher gewölbt.

In Gräben und an feuchten Orten auf Trasturtium offirinule R. Br., Cardamine amara L. und anderen Cruciferen in Mitteleuropa häufig.

5. Phyll. Rexuosa: Suboralis, comcriuscula, nigru, nitida, antennarum tibiarumque basi obscure ferrugineis, dytris anterius sut crebie subseriatim, jostice subtilius munctatis, singulo vitta media luteo-testuce:, interne fere recta, externe sinu medio profundo semiocato instructa. Long. 2,5-3 mm.

I11. Sehneid. Mag. V. 601. - Kutsch. Wien. JLnat. 1860. 205 (117). - Redtb. Faun. A. II, 499 (primá). - Seidl. F. balt. 496 (Halt.). - All. Mon. 262 (Phyll.) - Leesb. Tijdschr. Ent. 24. 206 (Aphth.).

Phyll. fullax All. Ann. Fr. 1860. 834 et 1861. 330. - Rey, Opuse. 1875. 36.

Phyll. tetrastigma Thoms. Skand. Col. VIII. 191.

Var. a. fenestrata: Elytro singulo maculis binis trigonis testaceis.

Etwas kürzer und flacher als die vorige, mit dunkleren Fühlern und Beinen, an dem langen Ausschnitte auf der Aussenseite der gelben Längsbinde und dem sehr breiten gemeinschaftlichen schwarzen Nahtsaume der Fld. kenntlich, welcher gleichbreit oder nach vorn sehr wenig und fast gradlinig verengt ist.

Länglich-eiförmig, etwas gewölbt, glänzend schwarz, die ersten drei Fühlerglieder oder wenigstens das zweite Glied dunkel rostroth, die Basis der Schienen pechbraun. Die Stirn auf einem Querstreifen ïber den undeutlichen Höckerchen und das Halssch. fein und mässig. dicht punktirt. Fld. mit theilweise gereihten Punkten ziemlich dicht besetzt, welche hinter der Mitte allmählich immer schwächer werden; iiber jede Fld. zieht sich ein röthlich-gelber Längsstreifen, dessen Innenrand ziemlich gradlinig, der Aussenrand an der Schulter abgeschrägt, in đer Mitte lang und tief, halb eiförmig ausgeschnitten ist. Der Längsstreifen besteht also aus einem lang dreieckigen Theile vor der Mitte, welcher durch eine schmale Linie mit einem kleineren, mehr mondförmigen Theile hinter der Mitte verbunden ist, liegt von der Naht weit entfernt und nähert sich dieser vorn nur unmerklich, hinten deutlicher. Nicht selten ist er in der Mitte sehr breit unterbrochen und in zwei kleine Makeln aufgelöst (Var. a), von denen die vordere einen der Naht parallelen Innenrand besitzt, also nicht 
schrig zu derselhen crestellt ist wie bei tetrustigma. I)ie Fiihler sind in heiden Geschlechtern gleich. Der Ponis älnelt dem der vorigen Art. ist aber im letzten Viertel etwas schmaler und in sanfter Rundung verengt, mit einer kleinen plötzlich nach unten gebogenen Spitze, die Wölbumg iiber der Klappe fällt jederseits in eine Längsvertiefung ab.

Anf Nasturtim und anderen Cruciferen am Rande sumpfiger Gewässer im grössten Theile von Europa, in Norddeutschland häufig.

6. Irhyוl. simuata: Oblongo-ovalis, subdepressa, nigra, sat nitida, antemnis tibiisque basi ferrugineis, fronte, prothorace crebre subrugoso-elytrisque subseriatim punctatis, his singulo vitta media albido-flava, antice posticeque suturam angulatim approximata, externe profunde excisa, plaga communi suturali nigra utrinque subito constricto. - Long. $2-2,5 \mathrm{~mm}$.

Mas: antennarum articulis 4 et 5 ditatatis.

Redtb. Faun. A. ed. 1. 532; ed. 3. II. 499 (Halt.). - Kutsch.

Wien. Monat. 1860. 300 (123). - Foudr. Mon. 244 (Phyll.).

- All. Mon. 259. - Thoms. Skand. Col. VIII. 196. Leesb. Tijdschr. Ent. 24, 206 (Aphthona).

Var. monticola: Vitta flava elytrorum latissima, externe simu medio parvo, parum profundo, vage terminato instructa.

Var. discedens: Vitta flava elytrorum late interrupta.

Durch den rechteckigen, beiderseits stark verengten schwarzen Nahtsaum der Fld. sehr ausgezeichnet, merklich kleiner, schmaler und flacher als die vorhergehende Art. Lang eiförmig, wenig gewölbt, schwarz, mässig glänzend, die ersten zwei Fühlerglieder, oder das zweite allein, und die Basis der Schienen hell rostroth, eine Längsbinde auf jeder Fld. schwefelgelb, seltener bräunlich gelb. Der Anssenrand dieser Binde ist auf der Schulter winkelig-, in der Mitte kurz, halbkreisförmig ausgeschnitten und der Innenrand sowohl vorn als hinten unter einem stumpfen Winkel bedeutend nach innen gebogen, so dass auf der Naht ein gemeinschaftlicher breiter Saum schwarz bleibt, welcher ungefähr die Form eines sehr langen, beiderseits schnell verengten und auf der Naht schmal ausgezogenen Rechteckes hat. Die Stirn ist mit Ausnahme des Scheitels fein und dicht, das Halssch. etwas stärker und oft runzelig punktirt, die Punkte der Fld. sind dicht, kräftig, in mehr oder weniger dentliche Reihen geordnet, und werden hinter der Mitte, namentlich an den Seiten allmählich feiner. Das fünfte Fühlerglied ist sehr lang, beim $\widetilde{ }$ nach der Spitze stark erweitert, mit bogenförmiger Unterseite, etwa 
um die II iilfte lingere als das vierte. welches heim $\hat{j}$ verdickt int. Glied 6i kurz, etwas länger (q) oder nicht cranz so langr als hreit ( $\hat{j}$ ).

Ausser einer unbedeutenden Varirtät mit einfarliog schwarzen Fiihlern treten zwei wesentliche Aländeruneren auf:

a. Iie gello Längsbinde der Fld. rehnt sich über den gröisten T'heil der Fld. aus und lässt einen schmalen Seitensaun, der am Grunde winkelig, in der Mitte kurz und sehr flach borenfirmigr crweitert, hier zugleich in der Regel schlecht hegrenzt ist, sowie einen mässig breiten, vorn winkeligr, hinter der Mitte allmählich bis dicht an die Naht verengten Nahtsaum frei.

b. Die gelbe Längsbinde löst sich in zwei kleine Makeln aut: von denen die erste in einer schräg nach innen gerichteten Spitze hinter der Schulter endet, die andere länglich, schwach mondförmig ist.

Auf den verschiedensten Cruciferen in ganz Europa häufig; Nordafrika, Syrien, Sibirien bis Wladiwostok (Koltze); die Var, a in Kärnthen und Krain.

\%. Phyll. variopennis: Subclongata, depressa, nigra, nitidiuscula, supra confertim punctulata, caprite prothoracerue obscure viridi aeneis, antennarum basi, femorum anteriorum apree, tibiis tarsisque testaceis, tibiis posticis infuscatis, clytris allido-fluris, vitta communi suturali basi constricta et limbo laterali in humero angulatim dilatato nigris, plerumque leviter coerulescentibus. - Long. 1,8-2,3 mm.

Mas: antennarum articulo 5: o incrassato.

Boield. Ann. Fr. 1859. 477. t. 8. f. 10. - All. l. c. 1860.385; Mon. 264. - Kutseh. Wien. Monat. 1860. 50 (129).

Phyllotreta varians Foudr. Mon. 248.

Var. a. Limbo laterali elytrorum medio arcuatim dilatato.

Var. guttata: Elytris guttis oblongis 4 flavis, 1,1 collocatis.

In der Grösse, Gestalt und Farbe am meisten an Ph. vittula erinnernd, aber durch die feine und dichte, kaum gereihte Punktirung der Fld. leicht davon zu unterscheiden. Ziemlich gestreckt, flach. schwarz, mässig glänzend, die vier $(\hat{o})$ oder fünf (ㅇ) ersten Fühlerglieder, die Spitze der vier vorderen Schenkel, nebst Schienen und Tarsen röthlichgelb, Hinterschienen, oft auch die Mittelschienen in der Spitzenhälfte geschwärzt. Kopf und Halssch. dunkel metallischoder bläulich grïn, letzteres dicht und etwas stärker als die Stirn punktirt. Fld. blassgelb, ein gemeinschaftlicher Nahtsaum, der vor der Mitte in schwachem Bogen um die Hälfte rerengt ist, ferner ein Saum am Seitenrande, nahe der Schulter verschmälert, auf derselben winkelig erweitert, sowie ein feiner Saum an der Basis schwarz oder bläulichschwarz. Die gelbe Grundfarbe bildet also auf jeder Fld. 
eine Iängsbinde, wolche hedeutend mohr als das mittlere I rittel der Breite einnimmt, hinten ziemlich gleichbreit, im ersten Viertel aber erweitert ist. In den Fiihlern ist das fiinfte Glied verlängert, beim of nicht verdickt und nicht ganz so lang, beim $\hat{\jmath}$ verdickt und etwas länger als Glied 4 und 6 zusammen. Der Penis ist grade, grlatt, vorn in eine kurze Spitze verengt.

Weim die dunkle Zeichnung auf den Fld. zunimmt, so verbreitert sich der Nahtsaum allmählich hinter dem ersten I)rittel und der Seitensaum kurz, halbkreisfömig in der Mitte (Var. a), zuletzt vereinigen sich beide und lösen die gelbe Längsbinde in zwei ovale Makeln auf, die eine gross, schräg nach hinten und aussen gerichtet, an der Basis, die andre klein, der Naht parallel, vor der Spitze.

Vereinzelt in der Umgebung ron Strassburg, Bozen und Görz, in ganz Südleuropa nicht selten. Nach Foudras auf Diplotaxis muralis und tenuifolia $\mathrm{L}$.

8. Phyll. vittula: Subelongata, depressa, nigra, antennis apicem versus nigris tibiisque basi testaceis, fronte prothoraceque dense punctatis minus nitidis, leviter viridi -vel coeruleo micantibus, elytris sat crebe seriatim punctutis, nitidis, vitta media sat angusta flava, fere recta, in humero excisa. - Long. 1,8-2,3 $\mathrm{mm}$.

Redtb. Faun. A. ed. 1. 531; ed. 3. II, 498 (Halt.), - Kutsch. Wien. Monat. 1860. 304 (127). - Seidl. F. balt. 496. - Foudr. Mon. 237 (Phyll.). - All. Mon. 261. - Thoms. Skand. Col. VIII. 197. - Leesb. Tijdschr Ent. 24. 205 (Aphth.).

Diese und die beiden folgenden Arten weichen von den vorhergehenden (mit Ausschluss von armoraciae, die einen Vergleich nicht nöthig macht) wesentlich dadurch ab, dass die gelbe Farbe der Fld. auf eine Längsbinde beschränkt ist, welche in der Mitte des Aussenrandes niemals einen tiefen Ausschnitt besitzt und beim Ueberhandnehmen der schwarzen Färbung zwar verengt, aber nicht unterbrochen wird.

Die vorliegende ist an dem kleinen, gestreckten und flachen Körper, grüinlich- oder bläulich-schimmernden Halssch. und an den hinten breit abgerundeten Fld. kenntlich, schwarz, die ersten vier Fühlerglieder röthlichgelb, die beiden folgenden braun, die Basis der Schienen röthlichbraun. Stirn fein, Halssch. dichter und stärker punktirt, letzteres auf den sehr schmalen Zwischenräumen gewirkt, wenig glänzend. Fld. mässig dicht gereiht punktirt, schwarz, glänzend, in den Schultern kaum heraustretend, hinter der niedrigen 


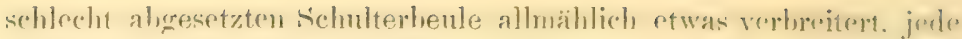
mit einem gelben Iängsstreifen, welcher wom der Breite etwas nelır als das unittere Drittel eimnimut, dem Aussenrande näher als der Naht liegt und letzterer am Ende zugobogen ist; innen wirl er ron der fünten Punktreihe hegrenzt und ist an der Basis des Anssenrandes winkelig ausgeschnitten, hierauf in sehr flachem Bogen his zur Abrundung der Fld. ausgerandlet und sehlecht hegrenzt. Fühler bei beiden Geschlechtern gleich. die fünf letzten (ilieder jednch beim $\hat{3}$ etwas mohr verbreitert als beim $q$. Penis schlank. gleichbreit. vorn in mässiger Rundung zu einer scharfen. nach unten gekrümmten Spitze verengt, oben schwach gewölbt, quer gestreift, plïtzlich zu der Vertiefung an der Oeffnung abfallend.

In ganz Deutschland wie im grössten Theile ron Europa auf den verschiedensten Cruciferen gemein.

9. Phyll. undulata: Otlongo-oralis, minus conrexa, nigra, nitida, antemis tibiisque basi ferrugineis, fronte antice punctulata, protharace aeneo dense punctato, elytris subseriatim punctatis, ritta media fara, interne fere recta basi et apice suturam versus inflexa, externe leniter sinuata. - Long. 2-2,8 $\mathrm{mm}$.

Mas: antennarum articulo 4:0 et 5:0 paullo incrassato.

Kutsch. Wien. 1860. 301 (124). - Seidl. F. balt. 496 (Halt.).

- A11. Mon. 261. (Phyll.). - Thoms. Skand. Col. VII. 195. - Leesb. Tijdschr. 24. 205 (Aphth.).

Halt. nemorum Panz. Fauı. Germ. 21. - Koch, Ent. Hft. II. 70 (pars).

Phyll. flexuosa Foudr. Mon. 238.

Var. bilineata: Vitta flava elytrorum angusta, fere recta.

Grösser und gewölbter als die rorige, glänzend schwarz, auf der Oberseite mit einem wenig in die Angen fallenden Messingschimmer, die ersten Fühlerglieder und die Basis der Schienen rostroth. Stirn auf einem Querstreifen zwischen den undentlichen Höckerchen und einer Linie, welche den Oberrand der Augen verbinden würde, fein und dicht punktirt, auf dem Scheitel nur gewirkt. Halssch. ziemlich dicht und kräftig punktirt, in den Zwischenräumen glänzend; Fld. gereiht-punktirt, an den Schultern gerundet heraustretend und etwas breiter als der Grund des Halssch., mit hoher, innen dentlich abgesetzter, glatter Schulterbeule. Ueber die Mitte jeder einzelnen zieht sich eine weisslich- bis bräunlich-gelbe längsbinde, deren Aussenrand an der Schulter meist hogenförmig (selten winkelig-) ansgeschnitten und in der Mitte sehr breit und seicht ausgerandet ist, während sich der ziemlich grade, von der füinften 
oder sechsten l'unktrihe begrenzte Immemand vorn und hinten der Naht allmählich nähert; ihre grösste Breite liegrt also dicht hinter der Schulterbeule, wo sie winkelig nach aussen tritt, und hinter der Mitte, kurz vor dem Abfalle zur Spitze. I)er breite, gemeinschaftliche, schwarze Nahtsaum hat cine gewisse $̈$ hnlichkeit mit dem von simuatr, aber er ist beiderseits weniger stark und nicht winkelig, sondern in leichtem Bogen verengt.

Beim Männchen ist das 4. Fühlerglied wenig, das 5. etwas mehr verdickt, der Penis in der vorderen Hälfte allmählich und unherlentend verschmälert, vorn abgerundet und in eine breite und ziemlich lange, in rechtem Winkel nach unten gebogene scharfe Spitze ausgezogen.

Frische Stiicke haben hell rostrothe Schienen und röthliche Tarsen. Nicht selten dehnt sich die schwarze Farbe der Fld. aus und verengt die Lïngsbinde auf einen schmalen, ibberall gleichbreiten, zuletzt linienförmigen Streifen, welcher sich zwar vor der Spitze, aber nicht an der Basis der Naht nähert und am Aussenrande weder auf der Schulter, noch dahinter ausgerandet ist (Var. a).

Unsere häufig'ste Art; über Europa und Sibirien bis Wladiwostok (Koltze) verbreitet.

10. Phyll. nemorum: Oblongo-ovalis, convexiuscula, nigra, nitida, antennarum articulis 3 primis, tibiis tarsisque testaceis, fronte punctatu, mothorace aeneo fortiter punctato, elytris subseriatim punctatis, vitta media sat lata, leniter biarcuata albido-flava. - Long. 3-3,5 mm.

II as: antennarum articulo 4:0 fortius, 5: o modice incrassato, 6:o brevi. Linn. Syst. Nat. ed. 10. 373; ed. 12. 595; erl. 13. 1695; Faum. Suec. 543 (Chrysomela). - Scop. Ent. Carn. 69. - Fabr. Ent. Syst. II. 34 (Galleruca). - Duft. Faun. A. III. 262 (Halt.). - Gyllh. Ins. Suec. III. 530. - Steph. III. Brit. IV. 296; Man. 291. - Kutsch. Wien. Monat. 1860. 303 (125). - Redtb. Faun. A. II. 499. - Seidl. F. balt. 496. - Küst. Käf. Eur. 8. 96 (Phyll.). - Foudr. Mon. 240. A11. Mon. 260. - Thoms. Skand. Col. VIII. 194. - Leesb. Tijdschr. 24. 204 (Aphthon.).

Halt, nasturtii Panz. Faun. Germ. 21. 9.

$\mathrm{V}$ ar. a, Pedibus nigris.

Var. b. Prothorace parce punctato.

Va1. c. Elytris subtilius punctatis.

Nächst Phyll. armoracirıe und tetrastigma die grösste Art, jedoch erheblich flacher und schlanker als beide; durch den punktirten Scheitel, hellere Fühlerwurzel und Schienen und die wellige Längsbinde auf den Fld. von der ähnlichen undulata, durch die Penisform endlich von allen übrigen Arten abweichend. 
Lang pifoirmigr, mässigr crewiilht, schwar, gränzend. Kroft und Ialsseh. mit l) laugriunem oder hroncefarbenom Metallschimmer, die

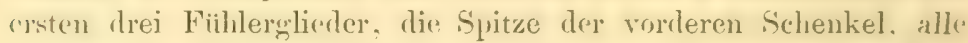
Sehinuen und Tarsen röthlichgelb. Stirn moln oder weniger dicht punktirt, auf einer Stelle über den Augen jederseits nur grwirkt. II alssch. mässig dicht und stark, die Fld. etwas feiner und in Reihen punktirt, jede mit einer blassgelben Längsbinde, welche im ersten Viertel etwas mehr, dahinter etwas weniger als das mittlere Trittel der Breite eimnimmt, heinahe parallele Ränder hesitzt, in rrsten und letzten Viertel sehr sanft nach aussen, in der Mitte ähnlich nach innen gebogen, hinten der Nalıt zugebogen ist und schwach wellenförmig aussieht. In der Niahe der Schulter ist nie eine winkelige Ausrandung oder eine plïtzliche Erweiterung nach aussen bemerkbar. Die Fühler sind vom vierten Gliede an tief schwarz, so dass sich ihre helle und dunkle Färbung schärfer als bei den vorigen Arten sondert, Glied 4 bis 6 beim $q$ gestreckt, unter sich ziemlich von gleicher Länge, oben dicht behaart und matt wie die Endglieder, beim ô oberseits fast kahl, glänzend. Glied 1 stark verdickt, beinahe so lang als 2 und 3 zusammen, 5 kürzer und weniger verdickt, 6 sehr kurz. Penis rorn bogenfömig ausgerandet und abgestutzt, die Klappe, mit der die Öffnung in der Ruhe zugedeckt ist, über den Vorderrand verlängert und in einen gerundet-erweiterten, vorn bogenförmig-abgestutzten Querzipfel auslaufend.

Von Abänderungen sind zu erwähnen:

a. Die Schienen und Tarsen werden allmählich dunkel, zuletzt schwarz, auch an den Fühlern ist oft Glied 1 auf der Oberseite, oder mit Ausnahme der Spitze schwarz und Glied 2 und 3 bräunlich rostroth;

b. das Halssch. ist sehr sparsam, oder

c. die Fld. sind auffallend fein punktirt.

An trocknen und feuchten Lokalitäten auf den verschiedensten Cruciferen in Europa und Westsibirien ziemlich häutig.

B. Flügeldecken einfarbig schwarz, griin oder blau.

a. Prosternum zwischen den Hiiften nur mässig verengt, bandförmig; die hintere Borstenpore des Halssch. steht in den Hinterecken.

11. Phyll. atra: Subelongata, depressiuscula, nigra, sat nitida, antennis busi ferrugineis, geniculis tursisque fuscis, fronte prothoraceque crebre punctulatis, hoc transversim convexo, antrorsum anyustato, elytris crebre subseriatim punctatis. -- Long. 2-2,8 $\mathrm{mm}$. 
Fabr. Syst Ent. 1775. 115 (Allica). - Payk. Faum. Suce. II. 100) (Gulleruca). - Koch, Ent. Hit. II. 63 (Halt.). - Gy H h. Ins. Suec. III 529. - Duft. Faun. A. III. 268, - Kutsch. Wien. Monat. 1861, 14 (133). - Bach, Käferf. III. 143. Redtb. Faum. A. II. 499. - Seidl. F. balt, 496. - Foudr. Mon. 254 (Phyll.). - All. Mon. 253. - Thoms. Skand. Col. VIII. 198.

Chrysomela aterrima Schrank, Faum. boic. 1798. 561. - Leesb. Tijdschr. Ent. 24. 203 (Aphth.).

Chrys. punctuluta Mar'sh. Ent. Brit. 200. - Steph. Ill. Brit. IV. 298; Man. 292 (Halt.).

Haltica melaena I11. Mag. VI. 60 et 154. 155 (pars). - Schilling, Bericht Schles. Ges. 1846. 92.

Phyll. obscurella Foudr. Mon. 233. 우.

Var. a. Antennis et tibiis basi nigro-piceis.

V ar. b. Supra obsolete aenescens.

Gestreckt, ziemlich flach, rein schwarz, zuweilen (Var. b) anf dem Kopfe und Halssch. oder der ganzen Oberseite metallisch angehaucht, mässig glänzend, Knie und Tarsen röthlich, das erste Fühlerglied unterseits und an der Spitze, das zweite und dritte gä̈nzlich rostroth, bisweilen Glied 2 und 3 oben dunkel, oder alle Basalglieder pechbraun (Var.a). Stirn und Mitte des Scheitels sparsam oder dicht und mehr oder weniger stark punktirt. Halsseh. um die Hälfte breiter als lang, mit gerundeten Seiten nach vorn verengt und zusammengedrückt, oben querüber gewölbt, dicht punktirt und sehr fein, aber wenig dicht gewirkt, die aufgebogene Iseiste am Seitenrande schmal abgesetzt, bei der Ansicht von oben in der hinteren Hälfte meist von der Wölbung verdeckt. Fld. breiter als das Halssch., dabei tiefer als dieses und in Reihen punktirt, welche rorn, namentlich in der Nähe der Naht von Querrunzeln durchsetzt sind, hinter der Mitte allmåhlich immer feiner werden und sich verwirren.

Fiihler in beiden Geschlechtern gleich. Letzter Bauchring des Männchens mit kleinem, schwach vertieftem Mittelzipfel; Penis vorn in sehr schwacher Rundung, oder fast gradlinig in eine scharfe, etwas nach unten gekrümmte Spitze verengt, die mittleren beiden Viertel der Oberseite quer gestreift.

Auf Kohlarten, Merrettig und anderen Cruciferen in Deutschland und Europa gemein.

Altica atra F., die der Beschreibung: ,atra, nitida" entgegen nicht anf Longitarsus parvulus Payk. bezog'en werden darf, ist unbedingt die vorliegende Art, zumal Fabricius selbst die Gall. atra Payk, damit jilentificirt. 


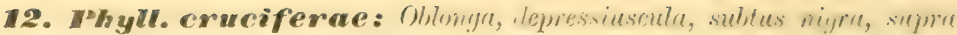

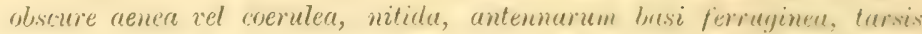
piceis; fronte prothorareque crebre punctatis, hor: antice comjuressir-ungustato, elylris crelse sulseriatim menctatis. - Long. 2,3-3 mm.

Groze, Ent. Beytr. I. 312 (('/rysm.). - Leesb. Tijdschr. 24 203 (Aphth.).

Ifalt. obscurelle I11. MIag. VI. 154. - Steph. Ill. Brit IV. sgs: Man. 292. - Kutsch. Wien. Mon. 18ti1. 16 (134). - Seidl. F. balt. 496 .

Halt, nigroaenea Marsh. Ent. Brit. 197. - Steph. 1. c. Halt. poeciloceras Com. Col. Nor. 48. - All. Mon. 253 (Phyll.).

Phyll. colorea Foudr. Mon. 258.

Halt.punctipennis IV eidenba ch, Bericht 12. Naturf. Vers. 1859. 85. Var. a. Supra olivaceo-vel brunneo-aurichalcea.

In der Regel etwas grösser und breiter als die vorige, oben dunkel metallisch grün oder blau, glänzend, die ersten drei selten vier) Fühlerglieder, mit Ausnahme der Basalhälfte des ersten, hell rostroth bis rothbraun, letztere Farbe besitzen auch die Tarsen. Stim und Halssch. dicht punktirt, dieses ungefähır doppelt so breit als lang, von den Hinterecken bis zur Mitte gleichbreit oder sehr schwach erweitert, davor verengt und zusammengedrückt, die Scheibe in der hinteren Hälfte sehr wenig, vorn deutlich querüber gewölbt, die Leiste am Seitenrande mässig breit abgesetzt und bei der Ansicht von oben bis zu den Hinterecken sichtbar. Fld. gewühnlich so stark als das Halssch., zuweilen aber etwas feiner punktirt, die Punkte in der vorderen Hälfte, besonders nahe der Naht gereiht, der Nahtwinkel mehr abgerundet wie bei atra.

Penis vorn gerundet-verengt und in der Mitte in eine kleine, kurze und scharfe, nach unten gebogene Spitze verlängert, auf der Oberseite glatt.

Die Färbung variirt: Halssch. metallisch grün, Fld. blan, und umgekehrt; oder (Var. a) das Halssch. allein, oder die ganze Oberseite olivengriin oder braun mit Messingschimmer.

Auf den verschiedensten Cruciferen in Mittel- und Südeuropa, jedoch weniger häufig als atra.

133. Phyll. areare: Oblonga, depressiuscula, subtus nigra, suma aeneonigra, sat nitida, antemis busi fermuineis, geniculis tursisque piceis, prothorace elytrisque subtilissime punctulatis. - Long. 1,8-2,3 mm.

All. Ann. Fr. 1859. Bull. 100.

Phyllotr. punctulata Foudr. Mon. 255. - A 11. Mon. 254. - K utsch. 
Wien. Monat. 1861. 18 (136. Halt.). - Redtb. Faun. A. II. 499. - Leesb. Tijdschr. 24. 202 (Aphth.).

Var. a. Nigra vel coeruleo-nigra.

In der Grösse mit vittulu, in der skulptur mit lepidii am meisten übereinstimment, viel feiner und seichter punktirt als die beiden vorhergehenden Arten, ziemlich gestreckt, Hach, unten schwarz, oben etwas erzfarloig, fettig glänzend, die drei Basalglieder der Fühler rostroth, das erste nnd vierte Glied in der Wurzelhälfte gebräunt; Knie und Tarsen pechbraun. Stirn und die Mitte des Scheitels nebst dem Halssch. dicht und sehr fein punktirt; Fld. etwas breiter als das Halssch., an den seiten wenig gerundet, hinten breit gerundetabgestutzt, dicht und selor fein und flach verworren punktirt, in der vorderen Hälfte nahe der Naht leicht gerunzelt.

Die Fühler sind in beiden Geschlechtern ziemlich übereinstimmend gebaut, Glied 3 und 4 dünn, 5, 6 und 7 etwas verlängert und verdickt, die folgenden vier merklich dicker als die vorhergehenden. Penis mässig gebogen, in der Basalhälfte schwach querüber gewölbt und quer gestreift, in der vorderen Hälfte allmählich und sehr wenig verengt, rimmenförmig vertieft, mit aufgebogenem Vorderrande der Klappe, am Ende schnell gerundet-verengt und in eine sehr kleine, vorgestreckte Spitze ausgezogen.

Die Farbe der Oberseite ist in seltenen Fällen rein schwarz, häufiger mit einem deutlichen blauen Schimmer, wenigstens auf den Fld. (Var, a).

Auf Cruciferen, nach Kutschera an jungen Kohlrüben, in Baiern, Böhmen und Oesterreich selten und bisher nur an wenigen Stellen aufgefunden; hauptsächlich in Sïdeuropa verbreitet.

Chrysom. punctulata Marsh. muss nach der Beschreibung auf den Fld. stärker punktirt sein als cruciferce (nigroaenea Marsh.) und ist daher auf keinen Fall zur vorliegenden Art zu rechnen, selbst wenn diese wirklich noch in England vorkäme. An und für sich wäre es schon unbegreiflich, wie Marsham dazu gekommen sein sollte, eine seltene, vorzugsweise südeuropäische Art zu beschreiben und die in England gemeine atra nicht.

14. Phyll. crassicomis: Oblonga, convexiuscula, nigra, supra interdum leviter aeneo aut violaceo-micans, antennarum articulis 4, 5 vel 6 primis rufotestaceis, femoribus anterioribus apice, tibiis tarsisque ferrugineis, tibiis apicem versus saepe infuscatis, fronte parce obsulete punctulata, prothorace subtilissime elytrisque apice breviter rotundatis subtititer punctatis, punctis interdum subseriatis. - Long. 1,8-2,5 mm. Mas: antennarum articulo 4:0 brevissimo, 5:0 incrassato.

A11. Mon. 255. ڤิ. 
Nieht ganz so flach als die vorige und an rere hellen Fiihlerwurzel und schenkelbasis, sowis an dem ziemlich langen fïnften Fiihlergliede, welches von zwei sehr kurzen Gliedern eingeschlussen ist, leicht $z u$ erkennen. Länglich cifïmmig, mässig gewïlbt, schwar\%. oben zuweilen broncefarben oder bäulich angehaucht, rienlich glänzend, die ersten vier bis sechs Fühlerglieder einfarbig rïthlichgelb, die Spitze der vier vorderen śchenkel nelst śchicnen und Tarsen rostroth, bei dunklen Stïcken sind die Schienen nach der Spitze hin gebräunt. Stirn und die Mitte des Scheitels sparsam und äusserst fein punktirt; Halssch. fast doppelt so breit als lang, an den Seiten wenig gerundet, nach vorn verengt, oben gewölbt, dicht und sehr fein punktirt. Fld. an der Spitze breit abgerundet, mit stumpfer Nahtecke, auf dem Riicken weniger dicht, aber etwas stärker und tiefer als das Halssch. punktirt, nahe der Naht zuweilen mit Spuren von Reihen. Die Punktirung ist bedeutend feiner und verworrener wie die von atra und stärker als die ron aerea.

$\hat{o}$. Glied 4 der Fühler sehr klein, kaum so lang als breit, 5 rerdickt, fast dreimal so lang als 4, 6 kurz, halb so lang und bedeutend schmaler als 5, die folgenden unter sich gleichbreit, wenig dicker als 5. Beim 우 ist Glied 5 länger als 4 und 6 .

Weit verbreitet, aber wohl rielfach übersehen und mit der folgenden verwechselt. Baiern, Krain, Kroatien, Siidfrankreich, Florenz, Sarepta, Astrachan.

15. Hyll. diademata: Ollonga, convexiuscula, nigra, nitidula, antennarum basi ferruginea, geniculis tarsisque piceis, fronte inter oculos depressa et punctatr, prothorace confertim subtilissime elytrisque subtiliter. punctatis, his apice subseparatim rotundatis. - Long. 1,8-2,5 mm.

Mas: segmento ultimo ventrali linea media et apice forea magna profunda impresso.

Foudr. Mon. 257. - A 1l. Mon. 254. - Kutsch. Wien. Monat. 1861. 17 (135. Halt.). - Redtb. Faun. A. II. 500, - Lees b. Tijdschr. 24. 204 (Aphth.).

Durchschnittlich kleiner und breiter als atra, auf den Fld. feiner und weniger deutlich gereiht punktirt, mit durchaus unpunktirtem Scheitel. Länglich eiförmig, mässig gewölbt, schwarz, fettig glänzend, die Spitze des ersten Fühlergliedes, das zweite und dritte, sowie oft noch die Basis des vierten Gliedes dunkel rostroth, Kniee und Tarsen pechbraun. Stirn mit deutlichen, durch eine Rimne getrennten Höckerchen, darüber auf einem Querstreifen zwischen den Augen niedergedrückt und punktirt, der ganze 


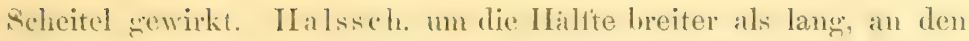
Seiten etwas gerumdet, nach vorn verengt, oben sche dicht und fein, etwats runzelig-punktist, in mittleren 'Theile rienlich flach, an den Ściten abwärts grewölbt. Fld. an der Basis etwas ansteigend, nahe dem schildehen niedergerliückt, linten nicht besonders breit, einzeln abgerundet, mit serumbt-stumptivinkeliger Nahtecke, etwas weitlüufiger aber stärker als das Halssch. punktirt, die Punkte in der vorkeren Hailfte undentlich gereiht.

Fühler in beiden Geschlechtern gleich, Glied 4 und 6 unter sich gleich lang, jedes etwas länger als 3, 5 länger als 4 . ô Letzter Bauchring auf einem Längsstreifen in der Mitte glatt, mit feiner Mittelrime, der Mittelziptel am Hinterrande gross, fast so ling als das übrige Segment, zu ciner sehr grossen Grube vertieft. Penis mässig' gebogen, in den vorderen zwei Dritteln unmerklich rerschmählert und auf der Oberseite mit einer breiten Rimme versehen, welche in der Mitte etwas eingeengt ist; vorn gerundet-rexengt and in eine grosse, scharfe, nach unten gebogene Spitze ausgezogen.

In ganz Deutschland und Mitteleuropa stellenweise nicht selten.

16. Phyll. consobrina: Subclongata, depressiuscula, nigra, supra, plerumque aenescens vel coerulescens, confertissime subtiliter subruguloso punctata. - Long. 1,8-2,5 mm.

Mas: antennarum articulis 3:0, 4:0 et 5:0 incrassatis.

Curtis, Brit. Ent. XIV. t. 630 (Halt.). - Steph. Han. 291. Halt. melaena I1l. Mag. VI. 60 (pars).

Phyll. meluena Foudr. Mon. 259. - All. Mon. 256. - Kutsch.

Vien. Monat. 1861. 23. (141. Halt.). - Redtb. Faun. A. II. 503. - Leesb. Tijdschr. 24, 202 (Aphth.).

Halt. dispar Newm. Zoologist 1846. 517.

Sowohl mit Pl. cerea als mit nigripes leicht zu verwechseln, jedoch tiefer und etwas kräftig'er punktirt als beide, von ersterer ausserdem durch einfarbige Fiihler und die überall gleichmässig punktirte Stirn, von letzterer durch die in den Hinterecken eingefiigte Borstenpore des Halssch. und breiteres Prosternum zu unterscheiden.

Mehr oder weniger gestreckt, flach, schwarz, auf der Oberseite gewöhnlich metallisch grün, noch häutiger blau, wenig glänzend, Fühler und Beine schwarz, die Kniee und Tarsen, bei frischen Exemplaren auch die ersten drei Fiihlerglieder pechbraun. Stirn und Sclieitel dicht punktirt; Halssch. fast doppelt so breit als

VI. 5. 
lang, nach vorn verengt, die soiten gemundet, an der vorlerent Borstenpore etwas nach aussen gedriickt, oben mässig gewwill, und ein. wenig stärker als der Kopf punktirt. Die Leiste des sirejtenrandes biegt in den Hinterecken nach innen und unschlilesst die Borstenpore. Fld. wenig breiter als das Halssch., mit zienulich parallelen Seiten, hinten breit gerundet-alygestutat, olsen Hach. äusserst dicht mit sehr f'einen, scharfen und tiefen P'unkten besetzt und verloschen gerunzelt.

An den Fuihlern des $q$ sind die Glieder 2, 3, 4 und 6 ungefähr von gleicher Länge, dagegen ist 5 bedeutend länger als eins der genannten; beim ơ bilden die Glieder 3 his 5 eine grmeinschaftliche, durch die Nähte wenig unterbrochene Erweiterung, Glierl 3 ist koniseh, nach der Spitze verbreitert, kaum länger als 2. 4 länger als 3, 5 länger als 4. - Penis rom in eine sehr kurze Spitze verengt, mit einer tiefen, löffelförmigen Rinne auf der vorleren Hälfte der Oberseite.

Vereinzelt in Baden, dem Elsass und der Rheinprovinz, im westlichen Europa, England, Holland, Frankreich und der Pyrenäen-Halbinsel stellenweise nicht selten.

Diese Art kann als melaena Ill. nicht weitergeführt werden, da Illiger wiederholt erklärt, dass er darunter nur $P$ h. atra Payk. rerstanden habe (l. c. p. 61 "Ich musste den Paykullischen Namen (atra) ändern" und p. 155. „Die Galleruca atra Payk. haben wir schon vorher unter den Namen melaena aufgefïhrt"), es tritt demnach der näclistälteste Tame ron Curtis in seine Rechte. Derselbe collidirt, da er bisher nie angewandt wurde, mit Halt. consobrina Dft. nicht.

b. Prosternum zwischen den Hüften stark rerengt, linienfürmig; die hintere Borstenpore steht in einer Ausbuchtung dicht ror deu Hinterecken des Halsschildes.

17. Phyll. nigripes: Subelongata, depressiuscula, nigra, supra riritliaenea, confertim subtilissime punctata. - Long. 2,2--2,8 mm.

Fabr. Syst. Ent. 113 (Altica). - Goeze, Ent. Beytr. I. 314 (Chrys.). - Panz. Faun. Germ. 21. 5 (Halt.). - Seidl. F. balt. 496. - All. Mon. 256 (Phyll.). - Leesb. Tijdschr 24. 201 (Aphth.).

Halt. lepidii K och, Ent. Heft. II. 64. - Ill. MIag. VI. 15t. Gyllh. Ins. Suec. III. 527. - Duft. Faun. Austr. III. 269. - Steph. Ill. Brit. IV. 297; Man. 292. - Bach, Käferf. III. 143. - Kutsch. Wien. Monat. 1861. 18 (137). - Redtb. Faum. A. II. ธ00. - Küst. Käf. Eur. 8. 97 (Phyll.). Foudr. MIon. 261. - Thoms. Skand, Col. VIII. 198. 
Var. a. Supra obscure coerulea aut violacea.

Chrysom. lens Thunb. Nov. Act. Upsill IV. 1784. 13. - Gyll. l. c.

Var. b. Immatura, rufo-testacen aut bruma totu, suma plerumque leviter aeneo-micans.

Ziemlich gestreckt und Hach, schwarz, oben metallisch grïn, oft bläulich schimmernd, oder Kopt und Halssch. mit kupferigem Anfluge, Knie und 'Tarsen, ausuahmsweise anch das zweite und dritte Fühlerglied pechbraun. Stim zerstrent und rerlosehen in etwa sechs bis acht umegelmässigen Längsreihen punktirt. Halssch. um die Hältte breiter als laug, nach rorn verschmälert, dicht und sehr fein punktirt. $\mathrm{k}$ ld. an der Basis kaum heraustretend, an den seiten flach gerundet, hinten schwach einzeln abgerundet, ähnlich wie das Halsseh. punktirt.

Die Fühler sind in beiden Geschlechtern gleich, Glied 2 und 3 kurz, 4 um die Hälfte länger als 3, 5 noch etwas länger. Penis schwach gebogen, vorn gerundet-verengt und zugespitzt, oben glatt, mit einer Längsvertiefung im vorderen Drittel.

Die grüne Form wird durch ummerkliche Uebergänge mit der oberseits dunkelblauen oder violetten Var. a verbunden; sehr frische stiicke sind einfarbig röthlich gelbbraun bis rothbraun, auf der Oberseite metallisch grün angehaucht (Var. b).

In Deutschland und dem grössten Theile von Europa gemein auf den verschiedensten Cruciferen.

Die zuerst ron Koch geäusserten Zweifel, dass Fabricius unter nigripes ein anderes als das rorliegende Thier verstanden habe, sind grumflos, zunächst, weil die alten Antoren mit Vorliebe jede grüne Haltica mit hyoscyami L. rerglichen, und dann, weil schon Goeze, Beytr. I. 1777 p. 312) die von Fabr. mit Unrecht unter nigripes citirte Art Ge offr. I. 246. 5, welche wahrscheinlich eine Hermaeophaga vorstellen soll, von nigripes abtrennt und als Chr. nigra ovalis beschreibt.

20. Phyll. modicomis: Elongata, depressa, cupreo-nigra, sericeomicans, antennis basi ferrugineis tibiisque nigris, genubus tarsisque rufopiceis; fronte sat lata, punctis pancis utrinque impressa, lineis profundis, antemis crassinsculis, articulo $2: 0$ et $3: 0$ brevissimis, prothorace elytrisque confertissime subtiliter punctatis, - Long: 2,5-3 mm.

II as: antemarum articulo 3:0 triangulariter, 4:o fortissime 5:oque parum dilatato et compresso, sermento ultimo ventrali apicem rersus depresso.

II arsh. Ent. Brit. I. 204 (Chrysomel $t$ ). - A 11. Amn. Fr. 1860.

371. - Leesb. Tijdschr. 24. 202. t. 16. f. 8 (Aphth.).

Halt. antemate Hofm. Ent. Hft. II. 67. t. 3. f. 4. - Panz. Fam. Germ, 99. 5. - Ill. Mag. VI. 153. - Oliv. Ent. VI. 714. t. 5. f. 82, - Duft. Faun, A. IIT. 269. - Steph. Ill. Brit. IV. 
295; Min. 291. - Bach, Kaferf. III. 143. - Kutsil. Wien. HLonat. 1861. 21 (134). - Tedtb. Faun. A. II. ju(s. - Fulldr. Mon. 264. (Phyll.). - A 1l. Mon. 252.

ㅇ. Halt. procera Bach, 1. c. Anmerk.

Var. a. Elytris coeruleo- aut nigro-cueneis.

Gestreckt, flach, kupferig schwar\%, die Fld. zuweilen bläulichoder schwäzlich - exzfarbig (Var. a), seirlenartig gläuzend. Fïhler lang und ziemlich krättig, pechschwarz, die sjpitze des ersten Gliedes und die beiden folgenden Gilieder rostroth, letztere kaum so lang als breit. Stim breiter als der Querelurehuesser eines Anges, iusserst fein gewirkt, jederseits mit einer tieten Rime, wrlele oben, neben den Augen, verbreitert und mit nuehr oder weniger \%ilhlreichen Punkten besetzt, hierauf verengt, iiber der Fülılerwurzel endlich wieder verbeitert und vertieft ist. If alssch. ziemlich ruuadratisch, wenig breiter als lang, an den Seiten sanft gerundet und nach vorn und hinten fast gleichmässig, aber schwach verschmälert. dicht und sehr fein punktirt. Fld. in den schultern breiter als die Basis des Halssch., hinten gerundet-abgestutzt, mit abgerundeter Nahtecke, die Spitze des Pygidium nicht bedeckend; wenig stärker als das Halssch., dicht und verworren punktirt.

Beim ô vertieft sich der letzte Bauchring unbedeutend aut dem kurzen Mittelzipfel des Hinterrandes, tas dritte Fühlerglied ist nach unten dreieckig erweitert und ungetahr doppelt so breit als lang, das vierte bildet ein grosses unregelmässiges Viereck, welches sich aus schmaler Basis nach der Spitze stark rerbreitert und eine convexgebogene obere und eine concav-gebogene untere Längsseite besitzt; es ist flach gedrückt, mit gewölbter Aussen- und ausgehöhlter Immenfäche. Glied 5 ist länglich, so breit als Glied 3 an der śpitze, ebenfalls flach gedrückt, aber nicht halb so breit als das vierte. Penis stark gekrümmt, gleichbreit, vorn in eine scharfe spitze verengt.

Auf Reseda lutea, luteola und odorata L. auf' Acckern und somnigen Abhängen im nördlichen Deutschland sehr zerstreut (in der Mark namentlich im Odergebiete), häufiger in Mittel- und Sïddeutschland und Oesterreich. Von England und Algier bis Siidrussland verbreitet.

19. Phyll. procera: Elongata, depressa, obscure aenea, sericeo micans, antennis, tibris tarsisque nigris, fronte sat angusta, punctis paucis utrinque impressa, lineis obsoletis, antennis sut gracitibus, articulo $2: 0$ et 3:0 elongato, prothorace elytrisque confertissime punctulatis. - Long. $2-3 \mathrm{~mm}$. 
I as: antennarum articulo $5: 0$ leviler dilatuto, segmento ultimo rentrati apice foveola parva impresso.

Redtb. Fam. 1. ed. 1. 530; ed. 3. II. 500 (IIcalt.). - Kutseh. Wien. Monat, 1861. 20 (138). - Foudr. Mon. 263 (Phyll.). - A11. Mon. 256. - Leesb. Tijdschr. 24. 201 (Aphth.).

Halt. melaena Steph. Ill. Brit. VI. 154; Man. 292.

Var. a. Aurichalcea vel cupred.

Var. 1). Antennumem basi, geniculis tarsisque plus minusre ferrugineis.

$\mathrm{V}$ ar. c. Ut in b, sed viridi-denea, viridi-coerulea vel coerulea.

Ihyll. rufitursis A 11. Ann. Fr. 1859 Bull. 100; 1860. 373; Mon. 252.

Etwas schmaler und flacher als die vorige, noch feiner punktirt, deutlicher wirkt, daher matter seidenglänzend, gestreckt, sehr flach, wenig leblatt brüunlich oder grimlich exzarben mit Bronceschimmer. Fiihler schlank, schwarz, Glied 2 und 3 kurz, etwas länger als breit, \pm so lang als die beiden vorhergehenden zusammen, 5 eben so lang oler wenig kiurzer. Stirn viel schmaler als bei nodicornis, kaum so breit als der Querdurchmesser eines Auges, mit schwacher und schlecht begrenzter Linie jederseits, sowie einigen vorloschenen Punkten in der Nähe der Augen. Halssch. breiter als lang, nach rorn verengt, äusserst dicht und fein punktirt. Fld, in den Schultern merklich breiter als die Basis des Halssch., nach hinten eine Spur erweitert, ähnlich wie das Halssch. punktirt.

Die Fülller sind in beiden Geschlechtern ziemlich übereinstimmend gebaut, nur beim ô etwas stärker als beim 오, und ihr fünftes Glied bei kräftigen Mämuchen dentlich, bei schwachen kaum verlickt. Penis gebogen, rorn gerundet-verengt und durch einen schmalen, aber ticten dreieckigen Ausschnitt in zwei scharfe Spitzen getheilt.

Die Farbe verindert sich oft in ein unattes Messinggelb oder Kupferbraun (Var.a), seltener in metallisch grün, grünlich blau oder blau. Die Fiihler bleiben nicht immer einfarbig schwarz, sondern es wird die Spitze des ersten Gliedes und das zweite, dritte und vierte Glied mehr oder weniger deutlich rostroth, zu gleicher Zeit nehmen auch dic Knie und Tarsen eine röthliche Färbung an (Var. b). Nach solchen Stücken aus Algier, die dunkelblau oder kupferigbroncefarben, auf dem Halssch. weitläufiger und schr verloschen junktirt, iiberhaupt auf der Oberseite weniger bemerkbar gewirkt und etwas glänzender sind als die Normalform, beschrieb Allard Ph. rufitarsis. Dieselbe kommt auch in Syrien vor.

Auf Reseda-Arten in Mittel- und Süddeutschland seltener als rie vorige, in Südeuropa, Nordafrika und Syrien sehr verbreitet und häufig. 


\section{Aphthona.}

Chevrolat, D'Orbign. Dict. Hist. nat. II. 1842 p. 5.

Acetabula antica aperta.

Frons impunctata lineis et tuberculis sat rlistinctis instructe.

Prothorae suepe sulco obsoletissimo, utrineue longitudinaliter impressio, angulis posticis discretis, acutiuscutis.

Pygidium plerumque canaliculatum.

Tibiae ommes calcari brevi distincto, posticue dorso deplanato rel canaliculato, lateribus carinato-elevatis.

Körper in der Regel geflügelt, eiförmig, gewölbt. grelbbraun oder dunkelblau bis violett, seltener metallisch-griin oder ziemlich schwarz, mit theilweise oder gänzlich rothen bis röthlich-gelhen Fühlern und Beinen. ${ }^{1}$ ) Kopf klein, gerundet dreieckig, mit breiter. glatter und gewölbter Stirn, die oben neben jedem Auge eine Borstenpore trägt und unten zu den schrägen oder klammerförmigen, mehr oder weniger tiefen Stirnlinien abfällt. Letztere bilden die obere Grenze der dreieckigen oder länglichen, leicht gewölbten Stirnhöcker, durchschneiden sich x-förmig zwischen diesen und schliessen die Spitze des Tasenkieles ein. Dieser ist bei einigen Arten breit und flach, nach unten erweitert, bei anderen schmal, sehr hoch und scharf, nach unten allmählich verengt und fällt hier plötzlich zu dem querliegenden. vertieften Kopfschilde ab. Oberlippe gross, vorn leicht ausgerandet, Mandibeln schmal, fünfzähnig; die drei mittleren Zähne lang, scharf zugespitzt, die beiden seitlichen klein, kurz und undeutlich. Augen mässig gewölbt, Fühler mehr oder weniger weit von denselben eingefügt, ziemlich kräftig, fadenförmig, länger als der halbe Körper, Glied 1 verlängert und verdickt, 3 und 4 kurz und schmal, die fünf Endglieder erweitert. Halssch. breiter als lang, an der Basis bogenförmig, an der Spitze grade abgestutzt, die Seiten an der vorderen Borstenpore, die ein Stiick hinter den Vorderecken eingestochen ist, oft winkelig heraustretend, davor verdickt, gradlinig verengt und zart bewimpert, die hintere Borstenpore auf einem kleinen Kegel in den stumpfwinkeligen Hinterecken eingefiigt; die Borsten sind halb so lang als das Halssch. oder wenig länger. Die Oberfläche ist querüber gewölbt, in der Mitte schwächer als an den Seiten, so dass sich hier ein schwacher Längswulst bildet, der bei einigen Arten kaum, oder nur durch einige undeutliche Vertiefungen,

1) Auffällig gefärbt ist $A$ phth. pulcherrima All. (Mon. 489) aus Algier: der ganze Körper einfarbig roth, nur die Fld. lebhaft blau. Sie erimnert in der Grösse, Gestalt und Farbe an Podagrica semirufa Kü̈st. 
bei anderen durch einen rinnenfirmigen Eindruck, der mit dem Seitenrande parallel läutt. von der Scheibe esechieden wirl; diese ist sparsim, doch vor der Basis meist deutlich punktirt, nach den Vordereck'n hin mul üher den Seiten glatt, in der limne des Seitenrandes mit einer Punktreihe, welche an der vorderen Borstenpore nach immen liegt. Schildchen dreieckig, mit abgerundeter Spitze. Flügeldecken hei den peflïgelten Arten oder Formen am Grunde sturk heranstretend und in den Schultem breiter als die Basis des Halsschildes. mit entwickelter Schulterbeule, bei den ungeflügelten Arten an Grunde in sanfter Rundung heraustretend, kaum breiter als das Halsschild und ohne merklichen Schulterhöcker; hinten breit gemeinschaftlich algerundet, bei einigen Arten schwach abgestutzt oder cinzehn abgerundet, vor der Spitze in der Regel mit einer gemeinschaftlichen Vertiefung auf der Naht, in welcher der Nahtstreifen dentlich ausgeprägt ist. Der Riicken ist verworren punktirt, oder mit unregelmässigen Punktreihen namentlich in der vorderen Hälfte rersehen; Epipleuren mässig breit, nach hinten allmählich rerengt, von der Abrundung bis zum Nahtwinkel linienförmig, zart bewimpert. Prosternum zwischen den Hüften verengt, dahinter in einen kurzen, abgestutzten und bewimperten Fortsatz verbreitert, welcher wenig über den Vorderrand der Mittelbrust hinweg reicht, aber von den Seitenstiicken der Vorderbrust sehr weit entfernt blcibt, so dass die grossen, queren Hüftpfannen weit geöffnet sind. Mesosternum länglich viereckig, etwas breiter als das Prosternum. Pygidium querüber gewölbt, in den vorderen zwei Dritteln mit einer tiefen und breiten, oft scharfrandigen Mittelrinne, in welche die Spitze der unteren Nahtkante eingelegt werden kann. Diese Rinne ist bei A. Erichsoni schmal, bei coerulea verloschen und fehlt bei lacertosa und herbigrada oft gänzlich. Beine ziemlich kurz und kräftig, Hinterschenkel mit beinahe grader Innenseite und bogenförmiger Aussenseite, im ersten Drittel am breitesten, nach der Spitze stark rerengt; Schienen grade oder wenig gekrümmt, zur Spitze hin allmählich verbreitert, auf dem Rücken abgeplattet oder leicht gewölbt, an den Seiten bewimpert, die Hinterschienen öfter vertieft mit leistenförmigen Rändern. Die vier Vorderschienen besitzen einen kleinen Enddorn unter der Basis des ersten Tarsengliedes, die Hinterschienen einen längeren oben an der Aussenseite der Spitze. Die Tarsen sind ziemlich breit, mit gleichmässiger Filzsohle, ihr erstes Glied ist an den Hinterbeinen ungefähr ein Drittel so lang als die Schiene, Glied 2 halb so lang als 1, 3 zweilappig, 4 etwas länger als 3, mit feinen, am Grunde eckig erweiterten Klauen.

Das Männchen zeichnet sich durch schlankeren Bau, namentlich ein schmaleres Halssch., das schwach erweiterte erste Tarsenglied 


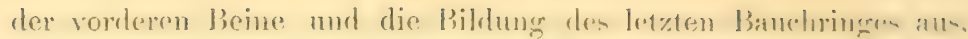
welcher vor dem abosestutzten oder in der. Vitte gerundet-vorgezonenen Ifinterrande mit einer Vortiefungr versehen ist, derent seiten uft heulenartigr verdickt find. Hor Penis ist in der Regrel herlentend

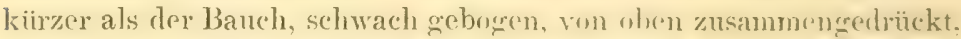
oft gerinnt, bald in der Mitte am breitesten und nach leiden Seiten hin verengt (Erichsomi), oder in der Mitte weit und stark eingeschnürt (picipes), bald won gleicher Breite. vorn a. dreieckig ansgeschnitten (cyparissiae), b. mit alogermuleten Ecken plïtzlich breit und gradlinig abgestutzt (cenustula, Albertinae, sicclidis. orata Foudr.), c. gerundet-algestutzt und in der Mittre in eine stumpfe Spitze ansgezogen (pallida, nigriceps, suturella), d. in einem ziemlich oder vollkommen regelmässigen Bogen abgerundet (lacertosa, heibigrada, atrovirens, Czwalinae, coerulea, abdominalis) und ausserdem noch e. in eine kurze und breite, abgesetzte Spitze rerlïngert (pscuedacori, janthina), f. gleichmässig und allmählich (flariceps) oder schnell, ziemlich gradlinig verengt (semicyanea, melancholica, cyanclla, pygmaea, euphorbiae), endlich g. in eine gerinnte, am Ende etwas rerdickte Spitze ausgezogen (lutescens). Die Klappe, welche die Öffnung in der Ruhe schliesst, ist gewöhnlich vorn abgestutzt.

Aus der Reihe der Gattungen mit geöffneten vorderen Gelenkhöhlen hebt sich die vorliegende durch den Habitus, den Bau des Kopfes, des Halsschildes und der Hinterbeine scharf heraus; sie ist nur mit Longitarsus näher verwandt und leicht zu verwechseln, obwohl die tief umgrenzten Stirnhöeker, die kïrzeren Borstenporen des Halsschildes, die grade Riickenfläche der Hinterschienen, der an der Aussenseite derselben eingefügte Enddorn, sowie der kurze Metatarsus, welcher mit einer gleichmässigen Filzsohle versehen ist und an der Spitze kein Scharnirgelenk besitzt, sichere Unterscheidungsmerkmale darbieten. Gegenwärtig umfasst sie etwa 130 kleine, ungemein ähnliche Arten, von denen vielleicht 35 auf Eurour entfallen; die Meluzahl derselben lebt auf den Blättern von Eųihorbiaceen und Irideen, ${ }^{1}$ ) aber ihre Entwickelung ist unbekannt. Im Allgemeinen haben sie durch wenig bestechende Eigenschaften, namentlich ihre geringe Grösse und schlichte Färbung, bei wenigen Entomologen ein reges Interesse erweckt und sind in den Sammlungen schlecht vertreten, da die besseren Arten, obgleich weit verbreitet, doch nur lokal und zwar an solchen Orten rorkommen, die, wie Sümpfe oder sehr sterile Plätze, von erfahrenen Sammlern

1) Irrthïmlich ist die Angabe Nördlingers (Kaltenbach, Pflanzenfeinde p. 691.): $H$. coerulea frisst die Nadeln der Kiefer! 
selten besucht werden. Hiern gesellt sich die schwierigkeit ihrer sicheren Deterniuation, hervorgerufen einestheils durch unklare Synonymie, die besonders in der verkehten Auffassung von exphorbiue Schr., hilaris steph. und psenducori Marsh. zu 'Tage tritt, anderntheils durch meniigende Beschreibungen, wolehe, wie dicjenigen von Allard und Rey, weder die merlässlichen Anwaben iiber die Gestalt des Penis, noch Verwleiche mit den in Wirklichkeit nahe verwandten Arten, ja zum Theil sogar unwahrscheinliche Farbenbezeichnungen enthalten, denn ein schwarzes, oder gar tiefschwarzes Colorit des Körpers, ohme blaue Beimischung, findet man bei den europäischen Arten höehst selten, während Foudras vier und Allard in seiner syuoptischen Uebersicht nicht weniger als sieben noir nennt.

\section{Bestimmungs - Tabelle.}

1. Oberseite hell rostroth, röthlich gelbbraun bis blassgelb . 2 . 1'. " grïn, blan, violett, selten kupfrig oder schwarz . 10.

2. Die Stirnlimien laufen von den Augen zur Fühlerwurzel und sind über den Höckerchen erloschen, letztere daher sehr undeutlich. Röthlich-gelb, die Fld. oft sehr blass, äusserst dicht punktirt, mit einem feinen, schwarzen Nahtsaume. - L. 2,2 bis 2,6 mm. Europa. . . . . . . 6. lutescens Gyllh.

$2^{1}$. Die Stirnlinien sind scharf, laufen iiber den Höckerchen fort und durchschneiden sich zwischen diesen. Fld. mässig oder wenig dicht punktirt . . . . . . . . . 3 .

3. Fld. einfarbig . . . . . . . . . . . 4.

$3^{1}$. Fld. an der Naht mehr oder weniger breit schwarz gesäumt. Kopf schwarz . . . . . . . . . . . . . . . . 9.

4. Nasenkiel breit, von dreieckigem oder glockenförmigem Umrisse. Grössere Arten . . . . . . . . . . . . . 5.

41. Nasenkiel schmal, kommaförmig. Kleine Arten . . . . 6.

5. Halsseh. stark quer, zusammengedrückt, an den Seiten gleichmässig gerundet, die Seitenrandlinie bei der Ansicht von oben kaum bis zur Mitte nach vorn sichtbar. Hell rostroth, Fld. blassgelb, Brust und Bauch dunkel. Penis an der Spitze dreieckig ausgeschnitten. - 3-4 mm. Mittel- und Südeuropa

1. cyparissiae Koch.

$5^{1}$. Halssch. wenig breiter als lang, kaum zusammengedrückt, an den Seiten sehr schwach gerundet, die Seitenrandlinie fast bis zu den Vorderecken sichthar. Lebhaft rostroth, Fiihler an der Spitze gebräunt. Penis mit abgerundeter Spitze. - L. 2,5 bis $3,8 \mathrm{~mm}$. Süifrankreich, Pyrenäen-Halbinsel, Algier. Italien? 


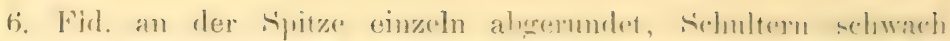

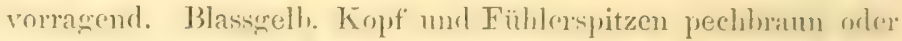
dunkel. Brust unt Banch sclwwar\%. L. 1,5-2 mrn. Mittelund Süddeutschland . . . . . . 4. pallida Bach.

6i. Flel. an der spitze breit und fast gemeinsclatitlich alyerementet. Schultern vorragend

7. Malssch. in der Basalhälfte sehr fein. jerloch tiof und hei stärkerer Vergrösserung dentlich punktirt. Fld. erlainzend. ant der vorderen Hälfte wenig diclit, ziemlich kriftig in Reihen punktirt. Brust und Banch schwarz. - L. 2-2,3 mm. Bercrsexenden in Deutschland, ()esterreich. Italien, Frankreich

2 abdominalis Duft.

71. Halssch. selbst unter starker Vergrösserung glatt nder ätsserst flach und verloschen punktirt . . . . . . . . 8.

8. Strohgelb, Kopf, Brust und Bauch mstroth, letztere oft angerlunkelt. Fld. mit ziemlich parallelen Seiten. - I. 1,s bis 2,3 mm. Oesterreich, Südeuropa . . . 3. flaviceps All.

81. Oberseite, Brust und Bauch einfarhig blass röthlichgelh, stark glänzend, Fühler und Beine mstroth. Fld. an den Seiten gerundet. - L. $2 \mathrm{~mm}$. Lyon. . . . . variolosa Foudr.

9. Der schwarze Nahtsaum ist im ersten und letzten Viertel sehr verengt oder fehlt dort ganz. - L. 1, t-2 mm. Oesterreich. Suideuropa, Algier . . . . . 5. nigriceps Redtb. $\left.{ }^{1}\right)$ 91. Nahtsaum breit, nur vor der Spitze etwas verschmälert. L. $2 \mathrm{~mm}$. Creta. . . . . . decorata Kutsch.

10. Nasenkiel breit und flach. . . . . . . . . 11. 101. $\%$ schmal, hoch und scharf . . . . . . . 13.

11. Stirnhöcker durch eine grosse und sehr tiefe Grube getrennt; innere Leiste auf dem Riicken der Hinterschienen bis zur Basis scharf erhaben. Ungefliigelt, gestreckt, dunkel metallisch grün,

1) In diese Gruppe noch eine kleinasiatisch-syrische Art: Aphth. suturella: Oralis, convexa, pallide testacea, nitida, antennis apicem rersus leriter infuscatis, capite fermuineo, ore, limbo suturali elytrorum utrinque angustato et abbreviato, pectore ubdomineque piceis aut nigris; prothorace lacvi, elytris obsoletissime punctulatis, sublaeribus. - Long. 2 mm. Smyrna (Krïper), Haifa (Simon).

Sowohl pallida als nigriceps sehr nahe rerwand, feiner punktirt als heide, von ersterer durch den in der Jitte breiten, beiderseits rerschmïlerten und abgekïrzten dunklen Nahtsaum der Fld., vou letzterer durch den hell rostfarbigen Kopf leicht an tremmen. Penis wie der ron pallida, aber schlanker, die Spitze des Vorderrandes viel kürzer und breiter, undeutlich abgesetzt. 
oft blänlich. Fibhlep und Beine rithlichgelh, erstere an der Spitze dunkel. Hinterschenkel mit schwarzem Rü̈cken. Schultesbeule fehlend. -- L. 2,5-3,5 mm. Wien. Ungarn, Serhien

20. lacertosa Rosh.

11'. Stimhö̈ker durch feine Linien undeutlich getremt, innere Randleiste der Hinterschienen nur vor der spitze hoch ansteigend .

12. Die Stirnlinien versehwinden oben, neben den Augen, so dass der Hinterrand derselben unmittelbar in den Hals übergeht. Lïnglich eiförmig, dunkelblau, selten metalliseh griin oder kupferig, Fühlerbasis und Beine röthlich gelb. Hinterschenkel mit schwarzer Spitzenmakel, Klauenglied dunkel. Fld. sehr dicht verworren und etwas rmzelig punktirt. Zuweilen ungeflügelt. - L. 2-3,5 mm. Europa. . 13, coerulea Payk.

121. Die Stimlinien laufen bis hinter die Augen und setzen am Hinterrande derselben einen erhabenen, glatten Saum ab. Kurz eiförmig, schwarzblau, Fuihlerbasis rothbraun, Beine, mit Ausnahme der angedunkelten Tarsen einfarbig lebhaft bräunlich roth. - L. 1,5-2,5 mm. Norddentschland, nördliches Europa 11. Erichsoni Zett.

13. Schultern winkelig heraustretend, mit deutlicher Beule, bedeutend breiter als die Basis des Halsschildes. Körper gefliigelt ${ }^{1}$ ) . . . . . . . . . . . . . . . 14

131. Schultern vollkommen abgerundet, ohne Beule. Körper ungefliigelt oder mit Flügelstummeln versehen . . . . . 24

14. Fld. bis zur Spitze dicht gestreift-punktirt. Länglich-oval, wenig gewölbt, oben glänzend broncegrün, unten pechschwarz, Fühler und Beine braun, an ersteren Glied 2-4 heller. - L. 2,5 mm. Ronda in Andalusien (ex Allard) . . . Heydeni All.

141. Fld. verworren oder in unregelmässigen Reihen punktirt 15.

15. Die Stimlinie läuft als tiefe Furche von den Augen zur Fühlerwurzel, ist jedoch über und zwischen den undeutlichen Höckerchen erloschen. Dunkel metallisch griin, selten blan, Fiillerwurzel und Beine, mit Ausnahme der dunklen Hinterschenkel hell röthlich oder bräunlich gelb, Halssch. in der Regel fein. Fld. etwas stärker verworren und schwach runzelig

1) Bei der mir unbekannten A. delicatula Fondr. (MIon. 373) sollen einzelne 우 nur mit Fliigelstummeln rersehen sein. Die Art ist der orata sehr ähnlich, kleiner, noch gewölbter. Stimhöckerchen sehr kurz, Fld. feiner punktirt, mit dentlicherer Schulterbeule. Lyon: Mont-Cindre, im September. 


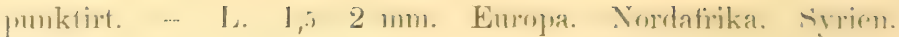
Sibirien (hilaris Auctor.) . . . . 14. euphorbiae Schr.

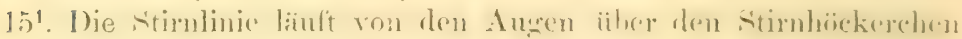
fort bis zwischen dio letzteren und aremut diese dentlich. 16.

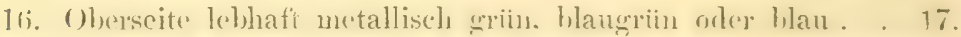
16.1. Oherseite schwawhlau, -violett. orler sehr diunkel und schwach metallisch . . . . . . . . . . . . . 18.

17. Stimhöcker gross, lïnslich-oval, scharfirandiær. iiherall ron ciner sehr ticfen Rinne nmgrenzt, Fld. zicmlich stark und tiof punktirt. Ziemlich breit eifirmigs, sewölht, motallisch griin. selten mit blïulicher Beimischung. unterseits dumkler, dio 5 his 6 crsten Fiihlerglieder uml die Beine vïthlich gell. Hinturschenkel einfarbig schwar\%. - L. 3-3, 1 mm. Danzi心, Samara

12. Czwalinae Ws.

Dieser Art scheint A. viridula All. M[on. 491.) von Saida in Syrien ähmlich zu sein, ihre Fühler und Beine sind aher schwarz, die drei Basalglieder der ersteren, Kniegelenke und Tarsenbasis röthlich. - L. $3,5 \mathrm{~mm}$.

17'. Stimhöcker klein, dreieckiæ, nur oben ticf umrandet, Fld. mässic dicht, gross und flach, daher ziemlich narhig punktirt. Eiförmig, schön gruinlichblau, oder blau, metalliseh, die an der Spitze gebräunten oder greschwärzten Fiihler und die Beine hell rostroth, Hintersehenkel schwarzblau. - L. 2,5-3 $\mathrm{mm}$. Sicilien . . . . . . . . . sicelidis $\mathrm{W}^{1}{ }^{1}$ )

18. Der grösste Theil der Fühler und die vier Vorderbeine einfarbig röthlichgelb oder blass gelbbraun . . . . . 19.

18. ${ }^{1}$ Wenigstens die Basalhälfte der vier Vorderschenkel dunkel, pechbraun oder schwarz . . . . . . . . . . 21.

19. Fld. dunkel violett. in der vorderen Hälfte, wenigstens hinter den Schultern scharf in weitläufigen und etwas unregelmässigen Reihen punktirt, mit ebenen Zwischenrïumen, Hinterschenkel leicht gebräunt. - I. 1,b-2 mm. Mittel- und siideuropa

10. cyanella Redtb.

1) Aphth. sicelidis: Oblongo-oralis, convexa, late viridi-coerulea rel cocrulea, nitida, subtus obscuru, antemis grucilibus apicem rersus infuscatis pedibusque dilute forrugineis, femoribus anteriorilus rarius litura purva et obsoleta brumnea notatis, posticis coeruleo-nigits, tubercutis frontalibus modice concexis et discretis, carinu faciali acuta, elytris cvidenter rarioloso-punctatis, pone humeros ralde prominulos leviter transiersim depressis. - Long. 2,5-3 mm. Sicilia (Kläger, Reitter). Der A. cenustula. Kutsch. verwaudt, fast doppelt so gross, lebhaft gefürbt, Fühler viel schlanker, Fld. bedentend stärker punktirt. Penis auf der Unterseite mit einem schwachen Längskiele. 
191. Fld. ohme violetten sehimmer, riemlich dicht punktirt. . 20.

20. Oberseite sehwil\%, die Fld. blan oder grün schinmernd, fein punktirt, mit etwas linebenen, gewälbten Zwischenriumen, Hintersehenkel schwärzlich. - L. 1,5-2 mm. Europa

9. pygmaea Kutsch.

$20^{1}$. Kopt und Halssch. dunkel metallisch griun, letzteres mit blau'n Schimmer, Fld. dunkelblat, ziemlich gross, aloer sehr Hach narbig punktirt, Hinterselienkel sehwar\% - L. 2-2,5 mm. Asturien, Portugal . . . . . melancholica Ws. ${ }^{1}$ )

21. ILalsseh. deutlich, Fld. (wenigstens in der vorderen IIïlte) grob) und etwas gereiht punktirt. Dunkel komblumenblau, selten mit grinlichem śchimmer, die zwei oder drei ersten Glieder der dunklen Fühler, die spitzen der vorderen Selıenkel und alle schienen röthlich gelbbraun, Tarsen dunkel. - L. 3,5-4 mm. Vallombrosa bei Florenz . . . . punctatissima $\mathrm{Ws}{ }^{2}$ ) 21'. Halssch. glatt oder äusserst fein punktulirt, Fld. fein punktirt 22. 22. Die vier Vorderschenkel pechschwarz, ihre Spitze nebst den Schienen röthlichgelb. Schwarzblau, zuweilen mit grünlichem Anfluge, Fld. verlosehen punktirt, abgekuirzte Punktreihe schwach und undeutlich, die Naht daneben nicht emporgehoben.

1) Aphth. melancholica: Ovalis, convexa, nigra, nitida, antennis apicem versus infuscatis pedibusque testaceis, fomoribus posticis nigris, capite aeneo tuberculis frontalibus bene discretis, carina faciali acuta, prothorace elytrisque coeruleo-micuntilus, illo subvirescente, subtilissime alutuceo et punctulato, his obsolete varioloso punctutis, callo humerali prominulo. Long: 2-2,5 mm. Asturien (Getschmann) nördliches Portugal. (Halt. violacea Ill. Mag. VI. 62 et 156 var. 2). Der A. venustula Kutsch. änsserst ähnlich, die Oberseite eine Spur lebhafter gefärbt, Stirulinien mud Höckerchen viel schärfer ausgeprägt, Fld. etwas weitläufiger, grösser aber flacher punktirt, die vier Vorderbeine einfarbig hell röthlichgelb. Penis vorn in eine schmale und scharfe Spitze ausgezogen, oben in der vor(eren Hälfte löffelförmig ausgehöhlt, unten gleichmässig' schwach g'ewölbt.

2) Aphth. punctatissima: Alata, ovalis, sat convexa, nigro-cyanea, interdum subirescens, nitida, untennarum articulis 2 vel 3 primis, femoribus anterioribus apice, tibiis tarsisque rufo-testaceis, his gracilibus, tuberculis frontalibus subtrigonis bene discretis, carina faciali alta, prothorace lateribus vix rotundato, crebre subtiliter punctato, elytris anterius fortiter subseriatim, postice subtilius punctatis, callo humerali mominulo. HLas: tarsis intermediis articulo primo dilatato. - Long. 3,5-4 mm. Vallombrosib (Czwalina). Von der äusserst ähulichen, aber unrollkommen geflügelten A. semicyanea All. durch das an den Seiten ziemlich gradlinige Halssch., winkelig heraustretende und mit einer hohen Benle versehene Schultern, dumkle Vorderschenkel und ror Allem durch die schlanken Tarsen verschieden. 
- L. 1, - 2,3 mm. Mitteleurna, Datuatien. Nonditalien

8. venustula Kutsch.

Bedentend klemer ist A. puraticentris Rey (Upuscules 16. 4tj) von Hyères.

221. Fühler und Beine pechlnaun, die Wrurzol der ersteren sowie die Knie heller, selten anch Schienen und 'Tarsen rostroth. Dje abgekiirzte P'unktreihe der Fld. ist deutlich, rertieft, und helst deshalb die Naht empor . . . . . . . . . 23.

23. Schwarzblau. - L. 2-2,8 mm. Mitteleuropa

7. pseudacori Marsh.

23. ${ }^{1}$ Glïnzend schwarz, Fli. mit wenig bemerkbarem bläulichen Anfluge. - L. 2-2,5 mm. Kaukasus . . picipes W s. ${ }^{1}$ )

Hier ist noch einzureihen: 1. A. carbonaria Rosh. 'Thier. And. 337, von Port Real, tiefscliwarz, stark glänzend, Fülılerbasis und Beine rothgell, alle Sehenkel an der Basis schwärzlich, Halssch. dicht und zart, Fld. dicht und ziemlich stark punktirt, die Punkte vor der Mitte neben der Naht etwas gereiht. Mir unbekannt. 2. A. junt7ina All. Mon. $24 \overline{7}$ aus Algier und Marocco, mit dunkel violetten Fld., sonst pseredacori täuschend ähnlich. Penis auf der Lnterseite mit einer feinen Mittelrinne.

24. Fühler und Beine schwarz, die Spitze des ersten Fiihlergliedes und die drei folgenden Glieder, sowie die Kniegelenke und die Tarsen röthlichbraun. Regelmässig cifürmig, hinter der Mitte am breitesten, hoch gewölbt, schön dunkelblau, stark glänzend, Halssch. und Fld. äusserst fein punktulirt, fast glatt. A. Erichsoni sehr ähnlich, eine spur lebhatter gefärbt, die Fild. in den Schultern eng'er, dahinter weniger gerundet. - L. 1, bis 2,2 mm. Corsica. . . . . . . . Perrisi All.

1) Aphth. picipes: Ovalis, subconvexa, nigna, elytris leviter coemulescentibus, antemis ferrugineis apicem versus infuscatis, gemubus, tibiarum. apice tarsisque ferrugineis, fronte vix sibititer alutucea, fere polita, tuberculis paris, discretis, carina fuciuli acuta, prothorace transierso, purce subtilissimeque punculato, nitidissimo, latcribus subrotundatis, antice minus compresso et angustato, clytris subtiliter punctatis, nitilis. - Long: 2-2,5 mm. (A. gracilis All., Schneid. u. Lerler, Beitr. Kankis, p. 3+1). Im Kankasus und Georgien verbreitet. - Penis in der Mitte weit und stark eingeschnürt, der breite Vordertheil anf der Unterseite mit einer grossen lang-ovalen Grube, welche jederseits von einer feinen Längsrimne begleitet ist.

Da meine Stücke anf Kopf und Halssch. nicht eine Spur grïnen Schimmers besitzen, vermag ich sie nicht auf die mir mbekannte $A$. gracilis Fald. aus dem Kaukasus zu beziehen. 
Hierher wahrscheinlich noch: 1. A. Reitteri All. (Wien. ent. Zeit. 1884. 248) vom Kankasus, linnglich eiförmig, sehr stark gewölbt und wlïnzend, dunkelblan (?), IIalssch, an den seiten stark gerundet, last glatt, Fld. für sich ein hoch gewöllotes Oval bildend, verloschen punktirt. - I. 2,: mm. 2. A. hispana All. (Мon. 232), linglich oval, wenig gewölbt, tiefschway, glanzen, Ifalssch. sehr fein, lld. in der vorderen Inälfte fein und etwas gereilit punktirt, hinten fist glatt. - I, 1,5 mm. Nach einem of aus spanien (!) beschrieben. 3. A. aener All. (Mon. 233), lang oval, wenig gewïlbt, schwarz, Halssch. ohne sichtbare Punktirung, Fld. bronceschimmernd, ziemlich stark punktirt, mit einigen Reihen an der Naht. - L. 1,6 mm. Landes.

241․ Die ganzen Fühler, oder wenigstens ilıre Basalhälfte, nebst dem grïssten Theile der Beine lebhaft rostroth bis hell gelbbraun 25.

25. Ilalsch. beiderseits verengt, mit verhältnissmässig stark gerundeten seiten, Fld, grob und tief punktixt. Eiförmig, gewölbt, dunkelblan, oft mit metallisch grüiner Beimischung, Fühlerbasis und Beine rostroth, Hintersehenkel dunkel. - L. :3-4 mm. Siidfrankreich, Krain, Croatien, Dalmatien, Sicilien

15. semicyanea All.

25. Seiten des Halsschildes wenig gerundet, von oben gesehen ziemlich parallel, Fld. fein punktirt . . . . . . 26.

26. Halsseh. fast so lang als breit, Fld. an der Spitze schmell verengt, beinahe gerundet abgestutzt. Gestreckt, mässig gewölbt, metallisch griun oder blau, die an der spitze gebräunten Fühler und die Beine röthlichgelb, Hinterschenkel auf dem Rücken dunkler, Halsseh. sehr feiu, Fld. etwas stärker runzelig punktirt. - L. 1,6-2,3 mm. Gebirgsgegenden Mitteleuropas

19. herbigrada Curt.

Hierher vielleicht noch: A. sardea All. (Mon. 490) aus Sardinien, von herbigrada nur durch die in der vorderen Hälfte gereiht punktirten Fld. zu trennen, und A. subovata All. (Mon.236) aus Algier, sehr gestreckt und flach, tiefsehwarz, Fïhler und Beine hell rostroth, Hitte der Schenkel pechbraun. - L. 1,5 mm.

$26^{1}$. Ialssch. wenigstens um die Hälfte breiter als lang, Fld. hinten allmählich gerundet verengt . . . . . . . . . 27.

27. Oberseite lebhaft metallisch grün oder blau, Fühler und Beine hell bräunlichgelb, Endglieder der Fiihler und das Klanenglied der Beine gebräunt, Hinterschenkel schwarz, metallisch. Halssch. an der Basis sehr fein, Fld. in der vorderen Halfte dentlich, verworren oder gereilit punktirt, hinten fast glatt. Grösse, Körperform und skulptur der A. oxata; Penis im vorderen Drittel verbreitert, oben mit tiefer und breiter Mittelrinne, die 


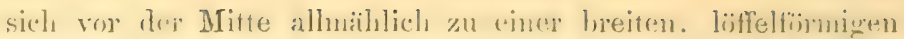

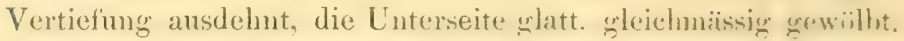
- L. 2-2,5 1nm. Reynosa in Cantalurischen Gebirge, Asturion. Albertinae All.

$27^{1}$. Oberseite schwarz nit gruinem, blanem orler violetten schimmer; Fiihler und Beine röthlichgelly, erstere an der spitze zuwesilen dunkel. Hinterschenkel, oft anch die Basis der vorderen Schenkel schwärzlich . . . . . . . . . . . 28.

28. Die Fld. treten in den schultern in starkem Bogen heraus, sind an den Seiten regelmïssig gerundet und bilden für sich ein Oral, welches viel breiter ist als das Halssch. . . . . 29.

281. Die Fld. treten in den Schultem kaum iiher die Basis des Ifalssch, hinaus, erweitern sich allnählich bis in die Mitte oder linter dieselbe und bilden mit dem Halsseh. ein (Grall $\left.{ }^{1}\right)$. 30.

29. Fühler kurz und kräftig, die einzelnen Glieder, mit Ausnahme des ersten und letzten, kaum oder wenig länger als breit. Länglich-oval, schwarz, grünlich oder blau schimmernd. Fld. dicht und ziemlich gross, aber nicht tief punktirt. - L. 1,3-1, $8 \mathrm{~mm}$. Rheinprovinz, Thïringen, Oesterreich. Schweiz, Frankreich

18. atrovirens Först.

291. Fühler schlank, ihre einzelnen Glieder riel länger als breit. Oval, wenig lebhaft dunkelblau. Fld. kurz, bauchig, fein punktirt. vor der Mitte in Reihen. - $\mathrm{L}, 1,8-2,8$ mm. Siidliches Frankreich, Oesterreich, Italien, Serbien . . 16. ovata Foudr.

30. Regelmässig elliptisch, gewölbt, schwarz, Fld. violett schimmernd, an der Basis in Reihen punktirt. - L. $2 \mathrm{~mm}$. Krain

17. Stussineri Ws.

30². Länglich-oval, wenig gewölbt, schwarz, blau oder blaugrün schimmernd, Fühler lang und kräftig, Fld. dicht mit grossen, ziemlich flachen Punkten besetzt, gerunzelt. - L. 1,5-1, s mm. Südfrankreich (punctigera Rey, Opuse. 16. 48). atratula All.

A. Oberseite gelbbraun.

1) In diese Gruppe gehört noch eine auffällige syrische Art: A. microcephala: Aptera, breviter ovalis, comexa, niticlissima, nigra, antennis pedibusque rufo-testaceis, femoribus posticis infuscratis, pectore prothoraceque saepe brunneis aut piceis, hoc transwerso, lateribus vic rotundato, subtiliter punctulato aut laeri, elytris oblongo-hemisphuericis, subtiliter basin versus subseriatim punctatis. - Long. 1,5-2 mm. Haifa (Simon). 
1. Aphth. cyparissiae: Suborulis, comera, testacea, nitila, atennarum apice infuscato, ore, scutello lituraque apicali femorum posticarum piceis, pectore abdomineque nigris; prothoruce subtilissime elytrisque sat crebre subtititer punctatis. - Long. 3-4 mm.

Koch, Ent. Hft. II. 80. t. 3. f. 8. a. (Halt.). - Oliv. Ent. VI. 719. t. 5. f. 89. - I11. Mag. VI. 152. - Duft. Faun. Austr. III. 256. - Steph. Ill. Brit. IV. 299; Man. 292. - Schilling', Ber. Schles. Ges. 1846. 92. - Bach, Käferf. III. 140. - Kutseh. Wien. 1861. 235 (148). - Redtb. Faun. A. II. 500. - Seidl. F. balt. 497. - Foudr. Mon. 358 (Aphth.). - A.11. Mon. 225. - Leesb. Tijdschr. 24. 197. t. 16. f. 7. Aphth. nigriscutis Foudr. Mon. 375.

Aphth. nigriventris All. Ann. Fr. 1860. 390; Mon. 224.

Var. a. Supra flavo-rel albido-testacea, praesertim in elytris.

Haltica tabida Duft. 1. c. 256.

Var. b. Prothorace elytrisque sublaevibus.

Var. c. Immatura; testacea, pectore abdomineque aut rufescentibus aut infuscatis.

Unsere grösste Art; mehr cylindrisch als eiförmig, gewölbt, stark glänzend, röthlich gelbbraun, Kopf und Halssch. dunkler als die Fld., das Halssch. oft mit durchscheinenden, verwaschenen rostrothen Flecken, von denen man zwei neben einander auf der vorderen Hälfte und je einen vor dem Hinterrande nahe den Ecken bemerkt, Mund, Schildchen und ein Wisch in der Spitzenhälfte auf dem Ruicken der Hinterschenkel pechschwarz, das Prosternum und die hinteren Theile der Vorderbrust, die Mittel- und Hinterbrust nebst dem Bauche schwarz. Stirnlinien tief, Höckerchen scharf umgrenzt, gewölbt, imnen zugespitzt, aussen mehr gerundet, Nasenkiel breit, oben gewölbt, unten verbreitert und etwas abgeflacht. Halssch. fast doppelt so breit wie lang, stark querüber gewölbt und nach rorn etwas zusammengedriickt, so dass der abgesetzte Seitenrand in der vorderen Hälfte von der Wölbung verdeckt wird; ziemlich dicht und sehr fein punktirt, mit einer meist deutlichen Längsvertiefung ïber dem glatten Seitenstreifen. Fld. in den Schultern etwas breiter als die Basis des Halssch., an den Seiten wenig gerundet, mässig dicht und fein punktirt, mit einzeln punktulirten Zwischenräumen, die Schulterbeule klein, erhaben, glatt. Rinne auf dem Pygidium breit, jederseits von einer tiefen Furche begrenzt, die rückwärts flacher wird und hinter der Mitte erlischt. Geflügelt.

Beim Männchen ist der letzte Bauchring am Hinterrande abschüssig, grade abgestutzt und in der Mitte in einen viereckigen, queren, nach unten geschlagenen Lappen verlängert, davor mit

VI. 5 . 


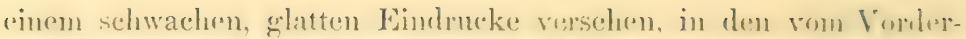
rande her ene feine Mittelrime länt. Der Penis ist durel dell drejeckigen Antsschnitt an Vorderrande leicht rom den der anderen Arten zu unterscheiden, er laiuft in zwei stumpfe spitzen aus. von denen die rechte bedentend griosser ist als die linke.

Völlig' ausgefïirbt ist das 'Thier auf' dex ()herseite, oder wenigstens auf den Fld. oft blass brämulich-gell, oder hellgelb. Mund, Schildchen, Brust und Bauch tief schwarz, der Anus zuweilen gellybraun (Var. a), oft zugleich auf dem Halssch. spiegelglatt, anf' den Fld. sehr fein und undeutlich punktirt (Var. bj; frische stücke sind dagegen röthlich gelbbraun, die Fld. blass, oft durchscheinend, Brust und Bauch rostroth oder angedunkelt, Beine einfarbig oder aut den Hintersehenkeln ein dunkler Rückenfleck.

Auf trocknen, unfruchtbaren Plïtzen in Mittel- und Siideuropa an Euphorbia cyparissias namentlich im Juli häufig.

Foudras und Allard haben unter cyparissae nur die mansgefärbten Exemplare beschrieben und die ausgereiften als hesondere Art betrachtet.

2. Aphth. abdominalis: Oulongo-ovalis, convexiuscula, nitida, rufotestacea, elytris testaceis, pectore abdomineque nigris, antemis apiccm versus infuscatis, ore femoribusque posticis superne piceis; prothorace ante basin subtiliter, sed exidenter punctato, elytris basi minus crelre subseriatim-, apice obsolete punctatis. - Long. 2-2,3 mm.

Duft. Faun. Austr. II. 262 (Halt.). - Kutsch. Wien. 1861. 238 (150). - Redtb. Fann. A. II. 500. - Bach, Käferf. III. 335. - Foudr. Mon. 362 (Aphth.). - All. Ann. Fr. 1860. 390; Mon. 224.

Aphth. albinea Thoms. Skand. Col. VIII. 182. nota.

Var. a. Fronte scutelloque fuscis.

Var. b. Immatura; femoribus posticis rufo-testaceis.

Kaum halb so gross als die vorige, länglich-eiförmig, mässig' gewölbt, glänzend, Kopf, Halssch., Schildchen, Vorderbrust (mit Ausnahme des Fortsatzes zwischen den Hüften) und die Hinterschenkel hell rostroth, die Fühler, deren fünf Endglieder dunkel sind, sowie Fld. und Beine bräunlich gelb, Mund und Rücken der Hinterschenkel pechbraun, Mittel- und Hinterbrust nebst dem Bauche schwarz. Stirnlinien tief, Höckerchen klein, länglich, aussen schlecht umgrenzt, Nasenkiel ziemlich sehmal und gewölbt. Halssch. um die Hïlfte breiter als lang, schwach gewölbt, vorn etwas zusammengedriickt, mit wenig gerundeten Seiten, auf der vorderen Hälfte der Scheibe fast glatt, auf der hinteren dicht, sehr fein, aber tief und 
deutlich pumktir. Fld. in den sichultern etwas breiter als die Basis des Halssch., an den Seiten mässig gerundet; wenig dicht in unregelmässigen Reihen funktirt, die hinter der Mitte schwächer werden, sich v'rwiren und ror der Spitze ziemlich verlöschen. Schulterbenle klein, erhaben, glatt. Rime des Pyoidium breit und tief, mit steilen Rändern, ungefähr bis zum letzten Viertel reichend. Geflügelt.

Der letzte Bauchring des $\hat{o}$ ist auf einem breiten Längsstreifen in der Mitte niedergedrückt, fein gewirkt, kaum punktirt. - Penis mit ausgehöhlter Ober- und Unterseite, vorn allmählich abgerundet.

Bei der umberlentenden Var. a ist die Stirn und das Schildchen dunkel rothbraun, bei b, welche die nicht völlig ausgefärbten Stücke umfasst, fehlt der schwärzliche Wisch auf dem Rücken der Hinterschenkel.

In den Gebirgsgegenden von Deutschland (nördlich bis Schlesien, den Harz und Thüringen) und Oesterreich weit verbreitet, aber bisher nur vereinzelt gefangen. Nördliches Italien, Frankreich.

3. Aphth. flaviceps: Oblongo-ovalis, convexiuscula, testace-flava, nitida, antemis apicem versus infuscatis, capite, scutello, pectore abdomineque ferrugineis, ore, lateribus metasterni basique adominis plerumque fuscis, prothorace laevi, elytris subtilissime punctatis. - Long. $1,8-2,3 \mathrm{~mm}$.

All. Ann. Fr. 1859. Bull. 100; 1. e. 1860.392; Mon. 226. Kutsch. Wien. 1861. 238 (150. Halt.). - Redtb. Faun. A. II. 500. - Bach, Käferf. III. 335.

Aphthona straminea Foudr. Mon. 363.

Var. a. Prothorace elytrisque pallide-testaceis, his sublaevibus.

Var. b. Femoribus posticis superne infuscatis.

In der Regel kleiner und schlanker als die vorige, oben mehr gelblich gefärbt, durch das glatte Halssch. und die dichter und feiner, kaum in Reihen punktirten Fld. leicht zu unterscheiden.

Länglich-eiförmig, mässig gewölbt, glänzend, gesättigt strohgelb, Kopf, Schildchen, Brust und Bauch rostroth, der Mund, die Seiten der Hinterbrust und die ersten Bauchringe meist dunkler, mehr oder weniger kastanienbraun, die Fühler vom fünften Gliede ab gebräunt. Stirnlinien tief, Höckerchen klein, länglich oder dreieckig, scharf umgrenzt, Nasenkiel schmal, gewölbt. Halssch. um die Hälfte breiter, bis doppelt so breit als lang, schwach gewölbt und rom leicht zusammengedrückt, mit sanft gerundeten Seiten; auf der Scheibe glatt, oder in der Mitte derselben mit zahlreichen Pünktchen, die 
nur bei starker Vergrijsserumg sichthar werken. F'hl. in de'n Selunltern breiter als die Basis des Halsich., an den seiten schwach gerumdet, hinten alhuählich und fast geneinschaftlich abgerundet. an der Xaht und dem Seitenrande oft cine spur grelraiunt; dicht und sehr fein. doch deutlich punktirt, wor der Spitze heinale glatt. Schulterlouke klein, erhaben, nach aussen ctwas vortretent. Rime des I'yuidium durch einen kuren und seichten Eindruck angerlentet; Banch sparsann punktirt und behaart. Geflügelt.

Beim ô ist der letzte Bauchring an den Seiten punktirt, im mittleren Drittel flach gedrückt, an Hinterrande ahwärts grewoiltht, in der Mitte desselben in einen kurzen, bogenfümmigen (Querziptel verlängert. - Penis oben schwach gewölbt, in der vorderen Hälfte ausgehöhlt, diese Vertiefung beiderseits verengt, unten mit einem undeutlichen breiten Längseindrucke vor der Mitte, vorn allmählich in eine nicht scharfe Spitze verengt.

Zuweilen ist die Oberseite mit Ausnahme des Kopfes sehr blassoder weisslich-gelb, und die Punktirung der Fld. beinahe erloschen (Var. a), oder die Hinterschenkel sind auf dem Rücken dunkel, besonders nahe an der Spitze (Var. b); dagegen sind mir Exemplare, die nach Kutschera's Beschreibung auf Brust und Bauch schwarz sein sollen, unbekannt.

In Oesterreich nördlich bis Wien, nach W'ahnschaffe (Verzeichniss. 401, auch bei Magdeburg); Südfrankreich; häufiger in Südeuropa von Portugal bis Griechenland, Syrien (bei Haifa, Simon).

Dieser Art scheint nach der Beschreibung Aphth. variolosa Foudr. (Mon. 364) äusserst ähnlich zu sein, durch die hellere Unterseite, stärkeren Glanz der Oberseite (britlant gélatineux) und die gerundeten Seiten der Fld. abzuweichen. Der Penis ist oben fein gerinnt, an der Spitze abgerundet, erweitert, ansgehöhlt, und besitzt unten eine mässig tiefe, in der Mitte verengte Längsrimne. Das Thier kommt im Herbste auf Triften bei Lyon vor. Stïcke, die ich als rariolosa ans Oesterreich, Spanien und Sardinien (Dieck, Berl, ent. Z. 1870. 157 и. 180.) erhielt; gehören zu flaviceps.

4. Aphth. pallida ; Oralis, sat conrexa, nitida, pallide-testacea, capite et antennarum apice piceis aut fuscis, pectore abdomineque nigris: prothorace fere laevi, elytris subtilissime punctatis, apice subseparatim rotundatis, callo humerali vix prominulo. - Long. 1,5-2 $\mathrm{mm}$.

Bach, Käferf. III. 141. (Hult.). - Kntseh. Wien. 1861. 241 (153). - All. Ann. Fr. 1860. 391; Mon. 225 (Aphth.) Lees b. Tijdschr. 24. 198.

Haltica placida Kutsch. l. c. 1864.472 (442). - All. Mon. 488. Var. a. Prothorace evidenter punctato. 
$\mathrm{Var}$. b. ('ap)ite testaceo, ore fronteque fuscir, jectorc ablomincque interdum piceis.

Vax. c. Immatura; testuceu, ore, fronte, pectore abdomineque concoloribus vel infuscatis.

Dureh den dunklen Kopf', schmale Schultern, niedrige Schulterbeule und die an der spitze einzeh abgerundeten Fld. ausgezeichnet und de'n vorherehenenten, durehschnittlich grösseren Arten habituell vicl weniger ähnulich als der tolgenden. Eiförmig, die ô etwas schlimker. ziemlich gewöllot, blass röthlich gelbbraun, die Fld. durchscheinend, meist weisslich gelb, die Fühler nach der Spitze hin und der Kopf pech-oder rothbram, Mittel- und Hinterbrust nebst dem Banche schwarz. Stim unter scharfer Vergrösserung fein genetzt, stirnlinien tief', Höckerchen länglich oder schmal dreieckig, scharf umgrenzt, Nasenkiel schmal und hoch. Halssch. um die Hälfte breiter als lang, nach vorn etwas verengt, mit sanft gerundeten Seiten, leicht queriber gewölbt, fast glatt. Fld. am Grunde in schwachem Bogen heraustretend und wenig breiter als die Basis des Halssch., an den Seiten gerundet, hinten allmählich verengt und schwach, dnch deutlich einzeln abgerundet; mässig dicht, sehr fein und seicht punktirt, vor der Spitze fast glatt. Schulterbeule klein, niedrig, innen kaum abgesetzt. Rinne des Pygidium kurz und schmal, scharfiandig; Bauch dicht punktirt und weisslich behaart. Geflügelt.

Das letzte Bauchsegment des $\hat{\sigma}$ ist auf einem breiten Längsstreifen in der Mitte vertieft, ausserdem mit einer ganzen Längsrinne versehen und am Hinterrande in einen sehr kurzen und breiten bogenförmigen Mittelzipfel verlängert. - Penis an der Basis schnell crweitert, hierauf parallel, vorn gerundet-verengt und in der Mitte in eine ziemlich schmale, sehr kurze Spitze ansgezogen, die Oberseite im ersten Viertel schwach querüber gewölbt, in den übrigen drei Vierteln ausgehöhlt, diese Vertiefung durch eine Erweiterung des hohen Seitenrandes ungefähr am Beginn des letzten Viertels eingeschmiirt, die Lnterseite wird ziemlich ganz von einer nach vorn etwas verbreiterten und abgeflachten Längsrinne eingenommen, deren Ränder scharfkantig sind.

Nicht selten ist das Halssch. sehr fein aber deutlich punktirt (Var. a); bei weniger ausgefärbten Exemplaren ist der Kopf im mittleren Theile, von den Höckerchen bis zur Oberlippe röthlich gelb, Brust und Bauch nft pechbraun (Var. b), bei sehr frischen der Körper ziemlich einfarbig röthlich-gelbbraun, Mrund, Stirn, Brust und Hinterleib meist etwas angedunkelt (Var. c).

In Mittel- und Siiddeutschland und in Oesterreich sehr zerstreut, 
nördlich noch in Schlesien, 'Thiiringen, hei Aschaffernbury (1)r. Flach) und Erankfurt a. M. heohachtet; nach Kellner auf Germinm protense L.

Kutschera hat von der Art zwei Diagnosen gegeben, die mur in unwesentlichen Stücken von einander abweichen und sich auf cin und datselbe Thier beziehen.

5. Aphth. nigriceps: Ovalis, sat conrexa, pallidle testacea, nitirla, antennis apicem rersus infuscatis, capite, scutello, limbo suturali clytrurum utrinque sensim angustato, pectore abdomineque nigris; prothorace sublaeri, elytris obsolete punctulatis. - Long. 1,5-2 mm.

W. Redtb. Quaed. Gen. Spec. Col. 27 (Longitarsus). - Redtb. Faun A. ed. 1. 533. - Bach, Käferf. III. 151. - Kutsch. Wien. 1861. 240 (152. Haltica) - Redtb. 1. c. ed. 3 II. 501. - All. Mon, 228 (Aphth.)

Aphthona sicula Foudr. Mon. 365.

Var. a. Femoribus posticis superne infuscatis.

Var. b. Elytris limbo suturali angusto utrinque abbreviato.

Var. c. Immatura, capite antico ferrugineo, scutello suturaque leviter infuscatis, pectore abdomineque fuscis, piceis aut nigris.

Der vorigen ausserordentlich nahe verwandt, aber von ihr durch etwas breitere Schultern, die dunkle Naht und den nicht abgerundeten Nahtwinkel an der Spitze der Fld. leicht zu unterscheiden. Eiförmig, ziemlich gewölbt, hell gelbbraun, glänzend, die Fühler vom fünften oder sechsten Gliede an gebräunt, der Kopf, das Schildehen, ein in der Mitte mässig breiter, beiderseits allmählich verengter Nahtsaum, Brust und Bauch schwarz, zuweilen auch die Hinterschenkel auf dem Rücken angedunkelt (Var.a). Stirnlinien scharf und mässig tief, Höckerchen dreieckig, ringsum deutlich begrenzt, Nasenkiel schmal und ziemlich hoch. Halsseh. beinahe doppelt so breit als lang, nach vorn in schwachem Bogen verengt und etwas zusammengedrückt, fast glatt. Fld. in den Schultern winkelig heraustretend und merklich breiter als die Basis des Halssch., an den Seiten gexundet, hinten fast gemeinschaftlich abgerundet, mit ziemlich rechtem Nahtwinkel; auf der Scheibe dicht, sehr fein und verloschen punktulirt. Die Schulterbeule kräftig, etwas vortretend. Rimne des Pygidium breit und ziemlich kurz, Banch dicht punktirt, das letzte Segment dichter und feiner als die vorhergehenden. Geflügelt.

ô Letzter Bauchring mit einer grossen, querovalen Grube. deren. eine Hälfte auf dem Segmente, die andre auf dem bogenförmigen Zipfel liegt, in welchen die Mitte des Hinterrandes verlängert ist. Penis wie bei pallida, jedoch nach vorn eine Spur erweitert und dicht vor dem Vorderrande am breitesten, dieser ist grade abgestutzt. 
mit gerundeten Aussenecken, in der Mitte mit einer kurzen und breiten, etwas aufgebogenen Spitze, die Aushöhlung der Oberseite am Begimn des letzten Viertels wenig eingeschuirt, der Vorderrand auf der Unterseite jederseits in eimen kleinen, autistehenden, zahnförmigen Zipfel verlängert.

Gewiihnlich zieht sich der schwarze Nahtsaum auf' den Fld. rom bis zur Basis, hinten bis kurz vor die Spitze, bei weniger dunklen Stiicken ist er beiderseits weit abgekiirzt (Var b) und bei mnausgefärbten nur durch eine 'Trübung der Nahtmitte angerleutet. Zugleich ist hier das Schildchen ziemlich hell, der Kopf unterhalb der Stimhöeker rostroth. Brust und Bauch theilweise oder gainzlich rothbraun, pechbraun oder schwarz (Var. c).

Nach Redtenbacher in Oesterreich, "selten", mir nur aus Südfrankreich, ganz Siideuropa und Algier bekannt; Bargagli nennt als Futterpflanze (?) Citrus aurantium L.

6. Aphth. Intescens: Subovatis, convexiuscula, flavo-testacea, nitida, capite ferminineo, antennis apicem versus fuscis, ore, femoribus posticis upicc, pectore ubdomineque nigris, tuberculis frontalibus obsoletis, linea

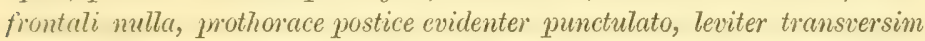
impresso, lateribus rotundatis, elytris sutura medio nigra crebervime subtilius punctatis. - Long. 2,2-2,6 mm.

Gyllh. Ins. Suec. III. 546 (Haltica). - Bach, Käferf. III. 140. - Kutsch. Wien. 1861. 239 (151). - Redtb. Faun. A. II. 501. - Seidl. F. balt. 497. - Steph. Ill. Brit. IV. 310; Man. 296 (Thyamis). - Foudr. Mon. 361 (Aphth.). A 11. Mon. 227. - Thoms. Skand. Col. VIII. 199. - Leesb. Tijdschr. 24. 197.

Longitarsus lutescens Redtb. 1. c. ed. 1. 533. - Bach, 1. c. 151. V ar. a. Fronte fusca.

Var. b. Prothorace densissime subrugoso-punctulato.

Var. c. Immatura; tota testacea.

Die Art steht nach der Penisform isolirt in der Gattung da und lässt sich an den schlecht ausgeprägten Stimhöckern, über denen die Stirnlinie fehlt, und an den dicht punktirten Fld. anf den ersten Blick erkennen; die Färbung und der leichte Quereindruck vor der Halsschildbasis erinnern an Ochrosis salicariae, welche mit ihr an derselben Pflanze lebt.

Länglich eiförmig, mässig gewölbt, glïnzend, hell gelbbraun, die Fld. etwas blasser als das Halssch., oft durchscheinend, auf der Naht fein schwarz gesäumat, der Kopf rostroth, Fühler vom fünften Gliede an dunkel, Mund, Spitze der Hinterschenkel, Brust und 


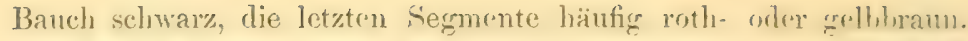
Stimlinie nur am oberen Rande der Augen deutlich. darunter in einen weiten und tiefen Eindruck übergehend, wrlcher zur Fiihlerwurzel länft, Höckerchen wenig gewiollst. verloschen umgrenzt mul schlecht von einander geschieden, Nasenkiel schmal, mässig scharf. Halssch. wenigstens um die Hälfte breiter als lang, vor den Hinterwinkeln sanft ausgeschweift. vor der Mitte gerundet-verengt, die scheibe im vorderen Theile fast slatt, im hinteren fein und meist deutlich punktulirt, vor der Basis mit einem äusserst schwachen Quereindrucke, welcher auf beiden Seiten durch cine weite Vertiefung oder ein Grübchen abgekürzt ist. Fld. in den sichultern bedeutend breiter als das Halssch., mit starker schulterlseule. dahinter wenig erweitert, am Ende fast gemeinschaftlich algerundet, fein und äusserst dicht punktirt, die engen Zwischenräume oft etwas gerunzelt, der Nahtsaum schmal, iiberall gleich lreit. beiderseits abgekuirzt. Pygidium an der Spitze ausgerandet, Rimne breit, flach, mit feinen, leistenartigen Rändern. vor der Spitze erlöschend, (ङ) , oder tief, mit hohen Rändern, bis zur Spitze reichend (f), Banch wenig dicht punktirt. Geflïgelt.

$\hat{o}$ Letztes Hinterleibssegment in der Mitte des Hinterrandes rechteckig erweitert, davor eingedrückt. - Penis vorn in allmählicher Rundung etwas schief rerengt, indem der Bogen auf der rechten Seite (von der Spitze aus betrachtet) erheblich grösser als der auf der linken ist, hierauf in eine mässig lange, mit einer Rinne versehene Spitze ausgezogen, die am Ende verdickt und etwas rerbreitert ist.

Von Abänderungen sind zu erwähnen:

a. Die Stirn wird über den Höckerchen nach und nach dunkler, so dass der Scheitel nicht selten pechschwarz ist.

b. Das Halssch. überall deutlich und sehr dicht punktirt, häufig gerunzelt.

c. Der Körper fast einfarbig röthlich gelbhraun, die Endglieder der Fühler meist, seltener auch die Naht gehräunt.

Auf feuchten Wiesen an Lythrim salicaria in ganz Deutschland und im grössten Theile von Europa häufig.

B. Oberseite griin, blau, violett bis ziemlich schwarz.

a. Schultern vorragend, mit mehr oder weniger starker Beule. Körper geflügelt.

7. Aphth. pseudacomi: Ovalis, conrexiuscula, nigra, supra obscurc coerulea, antennarum basi, genubus tarsisque rufescentibus, fronte ubsoletissime alutacea tuberculis externe parum discretis, prothorace subtiliter punctulato, elytris sat crebre punctutis. - Long. 2-2, $8 \mathrm{~mm}$. 
MIarsh. Ent. Brit. I. 1:4 (Chrysomela). - Steph. Ill. Brit. IV. 300: Man, 293 (Ialt.). - Bach, Käferf. III. 145. - Redtb. Faun. A. II. 501. - Foudr. Mon. 369 (Aphth.).

Halt. violuce Koch, Ent. Htt. II. 56. - Ill. MLag. VI. 156 exchs. var. 2. - Duft. Faun. A. III. 267. - Kutsch. Wien. 1861. 247 (160). - Seidl. F. balt. 497. - All. Ann. Fr. 1860. 403; Mon. 238 (Aphth.). - Leesb. Tijdschr. 24. 201.

Var. a. Immatura; untemarum. basi, tibies tarsisque fermuincis ant rufotestaceis, epipleuris elytron piceis.

Haltica sublaevis Bohem. Vet. Ak. Förh. 1831. 233. - All. I. c. 1860. 400.

Aphth, violaced Thoms. Skand, Col. VIII. 201.

Var. b. Prothorace crebre et evidentius punctato, plenumque longitudinaliter ruguloso.

Etwas breit eiförmig und nur mässig gewölbt, schwarz, Oberseite und Hinterschenkel dunkelblau, Fiihlerbasis, Knie und Fuisse mehr oder weniger röthlich. Stirn äusserst fein gewirkt, bei den $\widehat{\jmath}$ öfter glatt, die Borstenpore jederseits durch eine Gruppe von härchentragenden Punkten ersetzt, die in der Nähe der Augen in einer Vertiefung stehen; unter dieser beginnen die tiefen Stirnlinien, ziehen sich in sehr schwachem Bogen nach innen und durchschneiden sich $\mathrm{x}$-förmig, sodass die dreieckigen Höcker scharf getrennt und begrenzt sind. Nur aussen gehen dieselben in einen weiten, flachen Eindruck iiber, welcher sie von dem Streifen an den Augen schlecht absondert. Nasenkiel ziemlich schmal und hoch. Halssch. um die Hälfte breiter als lang, etwas kissenartig gewölbt, vor der Mitte leicht gerundet verengt und zusammengedrïckt, auf der Scheibe äusserst tein punktulirt. Fld. in den Schultern breiter als das Halssch., bis zur Mitte allmählich erweitert, dabinter ähnlich verengt, schwach querüber gewölbt, mässig dicht, fein und verworren punktirt, in der vorderen Hälfte zuweilen mit Spuren von Reihen; die Schulterbeule klein, niedrig, wenig vorspringend. Rinne des Pygidium breit und tief, hinter der Mitte erlöschend, Bauch fein punktulirt. Gefliggelt.

$\hat{\sigma}$ Letztes Hinterleibssegment mit glatter Mittellinie, hinter der Mitte vertieft, am Hinterrande in einen quer-viereckigen Zipfel verlängert. - Der Penis endigt in eine kurze, abgestutzte Spitze, welche auf der Mitte des bogenförmigen Vorderrandes steht; seine Oberseite ist leicht gewölbt, von einer feinen Mittelrinne durchzogen und am Ende länglich-löffelförmig ausgehöhlt, die Unterseite besitzt in der Basalhälfte zwei breite und tiefe Längsrinnen, welche von einer scharfen Leiste an den seiten begrenzt und durch eine ähnliche Mittelleiste geschieden werden. Letztere gabelt sich in der 


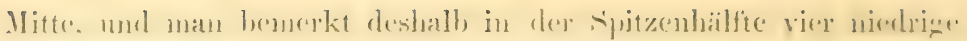
Längsleisten, dazwischen drei flache Rinnen.

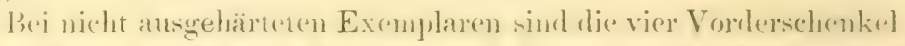

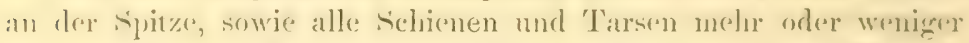
hell rostroth, die Epipleuren der Fld, rïthlich pechloram (Var. a): läufige ist das Halssch. dicht und dentlich punktirt, oft lïngsrunzelizr (Var. b).

Anf Emphorbia prelustris L, und Iris pseudaromes L. in Mitteleuropa zerstreut.

Nach Ansicht der Type Marsham's bezog Allard rie Clerys. pseudicori auf coeruleu, dem widerspricht jedoch in allen Punkten die Beschreibung, nach der wir uns allein zu richten hahen, da sic nicht ggefälscht werden kaun, wie ein Typ.

8. Aphth. venustula: Breviter oralis, conrexa, subtus nigra, supru nigro-coerulea, nitidissima, antemis dimidio basali, fomoribus anterioritus apice, tibiis tarsisque testuceis, tuberalis frontalitus parum conrcxis, modice discretis, mothorace sublacri, elytris absolete rariolosomunctatis, pone humeros prominulos leviter transcersim depressis. Loug: 1,8-2,3 $\mathrm{mm}$.

Kutsch. Wien. 1861. 244. (15̆6. Hultica). - Redtb. Faun. A II. 501. - Bach, Käferf. III. 335. - Leesb. Tijdschr. 24. 200.

Aphthona euphorbiae A11. Ann. Fr. 1860. 400; Mon. 236. Aphth. cyanella Foudr. Mon. 370.

Var. a. Immatura; femoribus anterioribus testaceis basi infuscatis.

Etwas schmaler und beträchtlich kürzer als die vorige. mit höheren, stärker heraustretenden Schultern. helleren Fühlern und Beinen, feinerer Punktirung und einem dunkleren, aber weniger gesättigten Blau der Oberseite. Kurz eiförmig, gewölbt, schwarz, oben von einem blassen Blau überdeckt, welches bisweilen cinen grünlichen Schimmer annimmt, stark glänzend, Fïhler und Beine röthlich gelbbraun, die fünf Endglieder der ersteren mehr oder weniger dunkel, die vier Vorderschenkel, mit Ausnahme der Spitze, und die Hintersehenkel schwarz, bei frischen Stiieken oft nur die Basis der vorderen Schenkel angedunkelt (Var. a). Stiru glatt odler äusserst fein gewirkt, Stirnlinien winkelig gebogen. vom oberen Angenrande his zur Borstenpore sehr tief und breit. weiter nach innen flach oder ziemlich erloschen, die länglichen, weuig gewölbten Ḧ̈ckerchen meist nur aussen tief umgrenzt, unter sich und ron der Stirn schwach und oft undeutlich getrennt, Nasenkiel hoch und schmal. Halssch. wenigstens um die Hälte breiter als lang, vorn etwas verengt und 
zusammengedrückt, bald shlatt, bakl mit weitlatufigen, nur unter starker Vergrössermug sichtbaren l’inktchen auf der Mitte der Scheibe, namentlich in deren Basalhälfte. Fld. an der Basis gradlinig heraustreteud und in den sehultern viel breiter als das Ilalssch., bis hinter die Mitte umbedeutend erweitert, fist parallel, an Ende kurz und breit abgerundet, an der Basis etwas ansteigend und hinter dem ersten Viertel wieder quer niedergedriickt, so dass der duw wehen liegende Raum rom grossen und hohen schulterhöcker, welcher inmen kaum abgesetzt ist, bis in die Nähe der Naht leicht beulenartig erhöht ist. Die Punkte der Fld. sind fein und flach, und treten überhaupt nu in dem breiten Quereindrucke hinter der Schulter, sowie in der Nähe der Naht deutlicher hervor; letztere ist vorn vertieft, die abgekürzte Punktreihe daneben erloschen, höchst selten mässig ausgeprägt oder durch eine seichte Furche ersetzt. Rinne des Pygidium sehr flach und kurz, Bauch zerstreut und fein punktirt, auf dem Analringe viel dichter. Geflïgelt.

$\widehat{o}$ Letztes Hinterleibssegment mit einer glatten, riickwärts etwas verbreiterten Mittelrinne, der Zipfel des Hinterrandes in den Hemicyclus eingebogen. - Penis von der Basis bis zur Oeffnung gleichbreit, davor sanft erweitert, jedoch bald wieder auf die ursprüngliche Breite verengt und grade abgestutzt, oben mit einer im ersten Drittel beginnenden breiten und tiefen Rinne, die sich nach vorn verbreitert und vertieft und in die ziemlich runde löffelförmige Aushöhlung an der Oeffnung übergeht; unten gleichmässig und schwach gewölbt, mit einem seichten Quereindrucke am Vorderrande

Ueber ganz Mitteleuropa verbreitet und namentlich in den Mitteldeutschen Berggegenden und den Alpen- und Karpathenländern an Euphorbia-Arten nicht selten, im nördlichen Theile bis jetzt nu vereinzelt bei Berlin, in Hannover und Holland beobachtet. Dalmatien, Oberitalien.

9. Aphth. pygmaea: Ovalis, convexa, nigra, nitida, antennis apicem versus infuscatis pedibusque testaceis aut flavescentibus, femoribus posticis fuscis, tuberculis frontalibus bene discretis, prothorace punctulato, elytris coeruleo- aut viridi-nigris, subtiliter punctatis, punctis basin et suturam versus interdum subseriatis, callo humerali prominulo. - Long. $1,5-2 \mathrm{~mm}$.

Kutsch. Wien. Monat. 1861. 246. (158. Haltica). - Redtb. Faun. A. II. 501. - All. Ann. Fr. 1861. 232; Mon. 231 (Aphth.).

Aphthona atracoerulea Thoms. Skand. Col. VIII. 202.

Var. nigella: Elytris leviter vel vix coerulescentibus, subtitius menctatis, lateribus rotundatis. 
Haltica nigella Kutsch. 1. c. 247 (159). - A II. Jon, 238.

Aphthona euphorbiae Foudr. Mon. 371.

? Aphth. orientalis Rey, Opuscules 16. 49.

Var. b. Prothorace obsolete longitudinaliter mguloso.

I urchschnittlich kleiner und schlanker als die vorhergehende. oherseits viel dunkler geffärlot, auf dem Halssch. und den Fld, deutlicher punktirt, die Stirnhiicker breiter, when dureh cine tiefe Rinne begrenzt, die vorderen Beine einfarbig.

Eifömmig, gewölbt, sehwarz, glänzend, rlie Fld, bläulich. seltener griinlich schimmernd, Fühler und Beine gellhhraun orler blasswell. die fünf Endglieder der ersteren meln oder weniger angedunkelt. die Hintersehenkel bräunlich schwarz. Stirn glatt, oder verloschen gewirkt, Stimlinien tief, rimnentörmig, fast grade. Höckerchen klein. dreieckig, ringsum scharf begrenzt, Nasenkiel hoch und schmal. Halssch. kurz, um die Hülfte loreiter, bis doppelt so breit als lang. an den Seiten gerundet, voru etwas verengt und zusammengedriickt, mässig dicht und äusserst fein punktirt, die Pünktchen tief eingestochen, bisweilen (Var.h) durch zahlreiche schwache Längsrunzeln rerbunden. Fld. an der Basis im Bogen heraustretend und in den Schultern breiter als das Halsseh., mit schwach serundeten seiten, am Grunde nicht beulenartig gewölbt, vor der Mitte mässig dicht, ziemlich fein und tief punktirt, mit leicht gewölbten Zwischenräumen. neben der grossen, gewölbten Schulterbeule und neben der Nalıt einige unregelmässige Reihen; hinter der Mitte, hesonders in der äusseren Hälfte mit verloschenen Punkten. Rime des Pygidium schmal und flach, Bauch mässig dicht punktulirt.

Beim $\delta$ ist das letzte Hinterleibssegment in der Mitte flach gedriickt, am. Hinterrande in einen sehr breiten und kurzen rechteckigen Zipfel verlängert. - Penis fast grade, die Seiten parallel, vorn gradlinig in eine stumpfe Spitze verengt, oben mit einer verlosehenen Mittelrinne und einer gerundet-rautenförmigen Aushöhlung an der Oeffnung, unten in den ersten zwei Dritteln muldenförmig vertieft, so dass die Seiten nur als schmale Leisten aufstehen, der Glanz der Vertiefung durch feine Runzeln abgeschwächt; das Spitzendrittel glänzend, schwach gewölbt, mit einer sehr feinen, nach vorn verengten Mittelrinne, die vor der Spitze erlischt.

Die Art variirt etwas in Körperumriss, dem Farbentone und der Skulptur; bei der nördlichen, im allgemeinen schlankeren und (namentlich auf den Fld.) kräftig punktirten Form tritt die blaue oder griine Färbung der Fld. zwar schwach, doch verhältnissmässig deutlich hervor, anch nimmt das Halssch. bisweilen einen metallischgriunlichen Anflug an, die siidliche Form (nigclla), welche in Krain. 
Istrien und (roatien, sowie in sam\% siblemopa aultritt, besitot breitere, an don seiten mchrermetere Fld., die durchschnittlich sche fein punktirt und in so geringem Giade blan geffïbt sind, dass sie leicht füir schwar gehalten werchen kïmnen. Beide Eommen sind durch ummerkliche Uebergänge verbmden und nach der Penisbildung sicher identisch.

An verschichenen Étphorbia-Arten im grössten Theile von Europa nicht häufig.

$H$. atrocoenule Steph. bleibt zweifelhaft, da die Angaben der Diagnose , erery thickly punctured, especially on the thorax, above deep-blue or greenish" sich un anf die vorliegente Art, auf keinen Fall aber aut die folgeude beziehen kümnen, für welche einzig die Worte ,legs entrely pale testaceous" zu sprechen scheinen.

10. Aphth. cyanella: Ovalis, convexa, nigra, nitida, antennis apicem versus infuscatis pedilusque rufo-testaceis, femoribus posticis fuscescentibus, mothorace sublaevi, elytris obscure violaceis, antice subseriatim punctatis, postice fere laevibus, callo humerali prominulo. - Long. $1,6-2 \mathrm{~mm}$.

Redtb. Faun. A. ed. 1. 531. (Haltica); ed. 3. II. 501. - Bach, Käferf. II, 144. - Kutsch. Wien. 1861. 245 (157).

Aphth. atrocoerulea All. Ann. Fr. 1860. 398; Mon. 237. - Leesb. Tijdschr. 24. 199.

Var. a. Femoribus anterioribus medio leviter infuscatis.

Der vorigen sehr nahe rerwandt und äusserst ähnlich, jedoch darin unterschieden, dass die Fuihlerbasis und die Beine etwas dunkler, mehx röthlichgelb gefärbt, die Hinterschenkel nur leicht gebräunt, die Fld. tief violett, dabei weitläufiger und in der vorderen Hälfte durchgängig regelmässiger gereiht punktirt sind, mit ebenen Zwischenräumen. Auf dem Halssch. bemerkt man nur bei scharfer Vergrösserung einzelne Piinktchen in der Basalhälfte, die Seiten desselben treten an der vorderen Borstempore etwas stärker, zahnartig heraus.

Beim $\hat{\sigma}$ ist der Penis kaum halb so breit wie der von pygmaea, ebenfalls ziemlich grade und an den Seiten parallel, vorn grerundet verengt, oben mit einer unmerklichen breiten Längsvertiefung, welche an der Oeffnung etwas stärker wird, unten glatt, mit einem sanften Längseindrucke in und vor der Mitte.

Bei einzelnen stiicken ist der mittlere Theil der vier Vorderschenkel eine Spur gebräunt.

Auf Euphorbia esulu. L. und verwandten Arten in Deutschland und Mittel- und Südenropa weit verbreitet, jedoch ziemlich selten. 


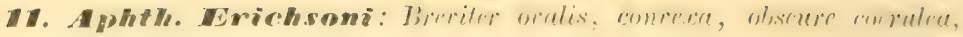

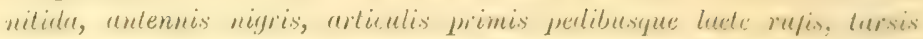

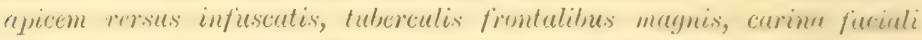

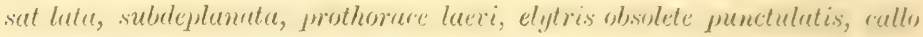
humerali parvo, parum prominulo. - Long. 1,8-2,5 mm.

Zetterst. Ins. Lap1. 18:38. 202 (Halt.). - Kutsch. Wien. 18 ti1. 291 (168). - Redtb. Faun. A. II. 503, - Seidl. F. balt. 497. - All. Ann. Fr. 1860. 408; Mon. 239 (Aphthona). Thoms. Skand. Col. VIII. 200.

Ilalt. curvifions Bach, Kifferf. III. 144. - Kutsch. 1. c. 2.12 (169). Var. a. Tuberculo humerali elytrorm magno, prominulo.

Durch den bauchigen Körper, die Bildung des Knpfes und lebhaft rothe Beine sehr ausgezeichnet: breit eiförnig, gewölbt, dunkel- oder schwarzblan, glänzend, die ersten drei Fühlerglieder rostroth bis hell röthlichgelb, die folgenden pechlram oder schwarz, namentlich die füuf letzten, merklich verlängerten und verdickten Glieder. Beine einfarbig hellroth, nur die Tarsen gebräunt. Stirnlinien tief, von der Borstenpore aus bogenförmig bis zwischen die grossen, eiförmigen Höckerchen laufend, wo sie sich in einem Grübchen durchschneiden und nach unten, mehr oder weniger abgeflacht und verbreitert, fortsetzen, so dass die Höckerchen meist undentlich vom Nasenkiele getrennt sind. Letzterer ist ziemlich breit und kurz, flach, oder wenig gewïlbt, abwärts rerschmålert. Halssch. 1 m die Hälfte breiter, bis doppelt so breit als lang, querüber gewölbt, glatt oder mmerklich gewirkt, von den Hinterecken bis zur vorderen Borstenpore gleichbreit oder etwas rerbreitert, die Seiten bald gradlinig, bald gerundet, vor der Pore, welche den Vorderecken nahe eingestochen ist, schräg abgestutzt. Fld. an der Basis in starkem Bogen heraustretend und in den Schultern viel breiter als das Halssch., mit gerundeten Seiten und flacher, kaum abgesetzter Schulterbeule, stark gewölbt, verloschen und undeutlich punktulirt. Rinne des Pygidium tief, aber sebr kurz, Metasternum mit aufstehenden, Seitenstiicke der Hinterbrust mit anliegenden weissen Härchen versehen. Geflügelt.

ô Letzter Bauchring auf der Mittellinie nicht punktirt, hinten vertieft und in einen bogenförmigen Zipfel rerlängert. -- Penis in der Mitte am breitesten, beiderseits etwas verengt, vorn gerundet abgestutzt, oben der Länge nach rimenförmig vertieft, vor der abgestutzten Klappe ausgeböhlt.

Von den geringen Abänderungen der Art ist rielleicht nur die seltene Var. a. erwilhmenswerth, welche ein schmales Halssch. und hohe, innen abgesetzte Schulterbeulen besitzt.

In den Torfsümpfen Norddentschlands verbreitet, aber nicht 


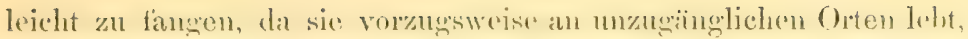

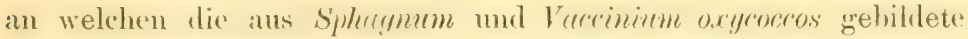
Sumptilecke den simmlex nicht mehr trägt. Nördliches buropa.

12. Aphth. Cowadinae: Oralis, convexiuscula, viridi-nenca, nitida, antenuis nigris busi pedilneque testaceis, femoribus posticis nigris, lineis frontalibus profumle impressis, carina faciali acute, prothorace besin versus subtiliter punctulato, elytris sat crebre punctatis, cullo humerali prominulo. - Log. $3-3,8 \mathrm{~mm}$.

Var. a. Viridi-coerulea.

Var. b. Prothorace evidenter punctato.

Eine der grössten Arten dieser Gruppe, am meisten A. coemule ähnlich, aber durch stärkeren Glanz, viel weitläufigere Punktirung, den ganz verschiedenen Bau der Stirn, höhere Schultern und einfarbig schwarze Hinterschenkel ohne Weiteres zu unterscheiden.

Ziemlich breit eiförmig, mässig gewölbt, oberseits metallisch grüin, selten grünlichblau (Var.a), glänzend, unterseits schwarz mit grünem Schimmer, die ersten fünf oder sechs Fühlerglieder röthlichgelb, die folgenden pechschwarz, Beine röthlichgelb, Hinterschenkel mit Ausnahme der Trochanteren schwarz. Stirn zart gerunzelt oder glatt, mit tiefen Stirnlinien, Höckerehen lünglich-oval, gewölbt, scharf umgrenzt, Nasenkiel hoch und schmal. Halssch. um die Hälfte breiter als lang, schwach queriber gewölbt, nach vorn wenig verengt und zusammengedrüickt, die Seiten gerundet; auf der Scheibe mässig dicht und sehr fein punktirt, in der vorderen Hälfte meist ganz verloschen, in der hinteren deutlicher. Zuweilen ist auch die Scheibe gleichmässig und so stark punktirt, dass sich die Punkte bei schwächster Vergrösserung wahrnehmen lassen. Schildchen schwarz. Fld. in den Schultern etwas breiter als das Halssch., nach hinten allmählich erweitert und in zwei Drittel der Länge am breitesten, ziemlich dicht punktirt, hinter der Mitte wenig: schwächer als davor, mit etwas gewölbten, glatten Zwischenräumen. Rinne des Pygidium breit, flach, stumpf gerandet, in der Mitte erlïschend, Bauch dicht und fein punktirt. Gefliigelt.

ô Der letzte Banchring besitzt eine dreieckige Grube ror dem kleinen, bogenförmigen Mittelzipfel, welcher mit einer Mittelrinue rersehen und in den Hemicyclus eingebogen ist. - Penis schlank, an den Seiten parallel, vorn breit abgerundet, oben sehr lang lïffelfömig ausgehöhlt; auf der Unterseite läuft eine flache Mittelrime von der Mitte bis zum Vorderrande. 


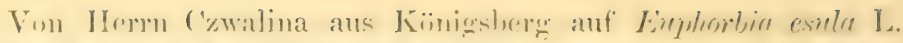
bei ()liva, in der Nahe Danzig's entrleckt, ausserelen nur nuch hei Samara von H. Faust gesammelt.

13. Aphth. coerulea: Suboratis, comreciuscula, saturate coerulea, nitidula, subtus obscura, antemis piceis basi perlibustue testarcis, femoribus posticis apice tarsisque articulo ultimo nigris, lineis frontulibus extrorsum deletis, tuberculis sat olsoletis, carina faciali deplanata, prothorace punctulato, crebervime sutruguloso-punctatis, interstitiis punctulatis, callo humerali parvo. - Long. 2-3,5 mm.

Fourcr. Ent. Par. 100 (Halt.) - Olir. Encyclop. IV. 108; Ent. VI. 711. t. 4. f. 47. - Koch, Ent. Hft. II. 55. Illig. Mag. VI. 155. - Gyllh. Ins. Suec. III. 524. - Duft. Famn. A. III. 266. - Step h. Ill. Brit. IV. 300; JIan. 293. - Bach, Käferf. UI, 145. - Kutsch. Wien. 1861. 242 (154). - Seidl. F. balt. 497. - Payk. Faun. Suec. II. 97 (Galleruca). - Kiist. Käf. Eur, 8.98 (Aphth.) - Foudr. Hon. 367. - All. Mon. 228. - Th oms. Skand. Col. VIII. 200. Aphth. nonstriata Leesb. Tijdschr. 24, 198.

Var. a. Cyanea aut violacea.

Var. b. aenescens: Viridi-aenea vel obscure aureo-cuprea.

Altica hyoscyami Panz. Faun. Germ. 21, 4.

Var. c. asthmatica: Minor, subaptera aut aptera, humeris vix prominulis tuberculo obsoleto.

Unsere bekannteste Art, durch geringen Glanz, gewölbte Seitenstücke der Stirn und flache Augen sehr ansgezeichnet; ziemlich eifürmig, mässig gewölbt, oben gesättigt blan, unten schwärzlich, schwach glänzend, die ersten zwei oder drei Fühlerglieder hell röthlich gelb, die folgenden drei rothbram, die iibrigen pechsehwarz. Beine röthlich gelb, das Klauenglied sowie die Spitzenhälfte der Hinterschenkel schwarz. Stirn ansserordentlich fein gewirkt und punktirt, oben gleichmässig bis an den Augenrand gewölbt. die Stirnlinien verloschen, nur nahe der Borstenpore allmählich zu cinem rinnenförmigen Grübchen vertieft, von dem eine nach und nach verfachte Rinne zur Fïhlerwurel zieht. Die ziemlich gewölbten Höckerchen sind deshalb schlecht begrenzt und ron einander getrennt, und heben sich nur an der ätsseren Spitze schärfer ab; der Nasenkiel ist breit und Hach. Halssch. um die Hälfte breiter bis doppelt so breit als lang, an den Seiten mehr oder weniger gerundet, rorn etwas zusammengedriickt, kaum sichtbar gewirkt und ziemlich dicht und fein punktulirt, mit der Spur einer erhabenen glatten Mittellinie, wenigstens ror dem Schildchen. 
Fld. länglich-eiförmig, in den Schultern etwas breiter als die Basis des Halssch., schwach gerundet, hinter der Mitte am breitesten, sehr dicht runzelig punktirt, mit ungeführ halb so stark punktulirten, :usserst schmalen Zwischenräumen; die Puukte in der Basalhälfte oft etwas gereiht, die Schulterbenle klein, gewölbt, heraustretend. Rinne des Pygidium breit, hoch gerandet, vor der Spitze erlöschend. Geflügelt.

ô Letzter Bauchring vor dem kleinen Mittelzipfel niedergedrückt. - Penis mässig gebogen, vorn allmählich gerundetverengt, oben mit breiter Mittelfurche, die in die Aushöhlung an der Oeffnung übergeht, auf der vorderen Hälfte der Unterseite mit einer Vertiefung, welche durch einen Mittelkiel in zwei breite Rinnen getheilt wird.

Die Farbe der Oberseite verdunkelt sich oft bis zu einem tiefen Kornblumen- und Veilchenblau (Var. a), oder geht unter allmählicher Zunahme von Griin in ein lebhaft metallisches Gritin oder dunkles Messinggelb mit kupferigem Schimmer (Var. b) über. Wichtiger ist die in Krain und Görz lebende Var. c, die in der Grösse wesentlich hinter der Stammform zurück bleibt, nur mit Flügelstummeln versehen oder ungefliigelt ist und durch ihre schmal gebauten Schultern, deren Beule wenig entwickelt, klein und niedrig ist, eine entfernte Aehnlichkeit mit $A$. herbigrada Curt. besitzt.

Auf Iris pseudacorus L. in ganz Deutschland und dem grössten Theile von Europa häufig.

Die Beschreibung von Chrysomela nonstriata Goeze (Ent. Beytr. 312.): "coerulea, elytris punctis sparsis, tibiis ferrugineis" lässt sich auf verschiedene blane Haltiken z. B. Longitarsus echii $\mathrm{K} 0 \mathrm{ch}$. Aphth. pseudacori etc. beziehen, nur nicht auf die vorliegende Art. Die von Koch l. c. 56 angefiihrte dritte Abänderung, ,deren Füsse mehr auf's Bräunliche ziehen und deren Vorderschenkel in der Mitte dunkel sind" ist venustula Kutsch.

14. Aphth, exphorhiae: Oblongo-ovalis, convexiuscula, sum.a nigroaenea, nitida, subtus nigra, antennarum basi pedibusque testaceis, femoribus posticis nigris, fronte subtilissime alutacea sulcis ocularibus profundis, lineis tuberculisque frontalibus obsoletissimis, carina faciali acuta, prothorace elytrisque subtiliter subruguloso-punctatis, his callo humerali prominulo. - Long. 1,5-2 $\mathrm{mm}$.

Sehrank, Enum. 1781. p. 83 (Chrysomela). - Fabr. Ent. Syst. I. 2. 34; Syst. El. I. 467 (Crioceris). - Payk. Faun. Suec. 2. 101 (Galleruca). - Koch, Ent. Hft. II, 58 (Halt.). Gyllh. Ins. Suec. III. 525, - Duft. Faun. A. III. 267. Steph. Ill. Brit. IV. 299; Man. 292. - Schilling, Ber. Schles. Ges. 1846. 92. - Ba ch, Käferf. II. 144 (pars).

VI. 5. 
Aphthona hilaris All. Ann. Fr. 1860. 399; Jon. 242. - Thoms. Skand. Col. VIII. 203. - Leesb. Tijdschr. 24. 199. - Kutsch. Wien. 1861. 243 (15็5) Halt. - Redtb. Faun. A. II. 501. Bach, 1. c. 335. - Seidl. F. balt. 497.

Aphthona virescens Foudr. Mon, 375.

Var. a. Immatura, supra brunnea, femoribus posticis ferrugineis.

Var. b. cyanescens: Supra viridi-coerulea, nigro-coerulea aut cyanea. Var. c. Fronte prothoraceque politis.

Eine der häufigsten Arten, an der tiefen Augenrinne, der dunkel erzgrünen Oberseite und der runzeligen Punktirung auf Halssch. und Fld. kenntlich. Länglich eiförmig, mässig gewölbt, schwarz, oben mehr oder weniger metallisch grün, glänzend. Fühler zienlich schlank, röthlichgelb, die fünf letzten Glieder verbreitert, je nach dem Grade der Ausfärbung rostroth, pechbraun oder schwarz, Beine röthlichgelb, die Hinterschenkel bei den ausgehärteten Stücken einfarbig schwarz. Stirn sehr fein quer gestrichelt, mit ziemlich oder völlig erloschenen Stirnlinien und Höckerchen, seitwärts in eine tiefe und scharfe Rinne abfallend, welche sich vom Hinterrande der Augen bis zur Fühlerwurzel hinzieht; Nasenkiel hoch und schmal. Halssch. fast doppelt so breit als lang (beim $\hat{\sigma}$ hier, wie bei den übrigen Arten, etwas schmaler), an den Seiten schwach, gerundet, vor der Mitte verengt, dicht und sehr fein punktulirt, meist mit zahlreichen feinen Längsrunzeln in der Basalhälfte. Fld. am Grunde stark heraustretend und in den Schultern viel breiter als das Halssch., rïckwärts leicht erweitert, hinter der Mitte am breitesten, am Ende fast gemeinschaftlich abgerundet, ziemlich dicht und ungefähr doppelt so stark als das Halssch. punktirt, die Zwischenräume glatt, etwas gewölbt, so dass die Punkte, besonders in der Basalhälfte, durch seichte, runzelartige Vertiefungen verbunden sind. Pygidialrinne kurz, Bauch vorn sparsam, auf den beiden letzten Ringen dichter punktirt. Geflügelt.

ô Letztes Bauchsegment mit breiter, unpunktirter Mittelrime und einer tiefen Grube vor dem Mittelzipfel. - Penis breit, vorm gradlinig in eine stumpfe, wenig schmale Spitze verengt, die Oberseite fast ganz von einer rinnenförmigen Vertiefung eingenommen, Unterseite ziemlich eben.

Unreife Stücke sind auf der Oberseite braun, zuweilen metallisch grün angehaucht, Hinterschenkel rostroth (Var. a), ausgefärbte durch eine allmähliche Zunahme von Blau, oberseits metallisch grinlichblau, oder schwarzblau, selten dunkel und gesättigt blau (Var. b); die Scheibe des Halsschildes verliert anfangs die feinen Längsrunzeln, nach und nach auch die Pünktchen und ist zuletzt also (Var. c) spiegelglatt. 
Anf fruchtbaren Wiesen, an Waldrändern, auf trocknen Plätzen an Euphorbia 'yparissias, auf' Aeckern an den 13lïttern von Runkelrüben (Beta vulgaris I.) und an bliihendem Lein (Limum usitatissimum L.), in der Ebene wie im Gebirge in Deutschland und Oesterreich, iiberhaupt in Europa (den höchsten Norden vielleicht ausgeschlossen) gemein. Norlafrika, Syrien, Sibiricu.

Schrank's Beschreibung von Chr. euphorticue lässt sich nux auf diese Art anwenden, insbesondere charakterisiren die Worte: „atra, minime aes aurumve inclinans" ihre Farbe so vortrefflich, dass die älteren Autoren ausnahmslos den Schrank'schen Namen richtig gebrauchten, die neueren kehrten sich weder an die Tradition noch an die vorangehenden klaren Beschreibungen, sondern bezogen euphorbiae willkürlich auf blau e Arten, Foudras auf pygmaea, Redtenbacher und Kntschera auf ovata, Allard auf venustula, letzterer führte überdies noch den Namen hilaris ein, welcher um so sicherer zurückzuweisen ist, da Stephens einmal seinen Longitarsus hilaris (p. 298.) ,very black" nennt und dann unsere Art (p. 292) kenntlich als Halt. euphorbiae beschreibt.

b. Schultern vollkommen abgerundet. Körper ungeflïgelt.

15. Aphth. semicyonea: Aptera vel subaptera, ovata, convexa, cyanea, nitida, antennarum basi pedibusque ferrugineis, femoribus posticis nigricantibus, tarsis sat validis, tuberculis frontalibus angustis, modice discretis, carina faciali alta, prothorace lateribus rotundato, vage punctato, ante basin utrinque subimpresso, elytris ovatis, anterius fortiter subseriatim, postice subtilius punctatis. - Long. 3-4 mm.

All. Ann. Fr. 1859. Bull. 101; Mon. 229. - Kutseh. Wien. 1861. 290 (167).

Var. a. Prothorace crebre evidenter punctato, rarius obsolete longitudinaliter ruguloso.

Var. b. Obscure coeruleo-viridis.

Eine ansehnliche, durch Körperform und starke Punktirung ausgezeichnete Art, dem Longitarsus Linnei sehr ähnlich; eiförmig, gewölbt, dunkel kornblumenblau, glänzend, Fühlerbasis und Beine, mit Ausnahme der dunklen Hinterschenkel, rostroth. Fühler kräftig, Glied 2 bis 5 wenig schmaler als die folgenden; Stimlinien und Höckerchen mässig scharf ausgeprägt, Nasenkiel ziemlich schmal, hoch, oben oft etwas flach gedrückt. Halssch. um die Hälfte breiter als lang, vor der Mitte stärker zusammengedruickt als dahinter, an den Seiten gerundet und rom bedeutend, hinten schwächer verengt, die Scheibe beinahe kissenartig gewölbt, mässig dicht und rerloschen punktirt, nahe den Hinterecken beiderseits mit einem leichten Quereindrucke, welcher seitlich in den Längseindruck neben 
dem glatten Randstreifen iibergeht. Fld. mit dem Halssch. in einer Flucht gewölbt, am Girunde bogenförmig heraustretend und etwas hreiter als die Basis des Halssch., oval, mit der grössten Breite linter der Mitte, am Ende fast gemeinschaftlich abgerundet; stark nnd ziemlich dicht in unregelmässigen Reihen punktirt, die Punkte auf dem Abfalle zur Spitze gewöhnlich verloschen, die sehr niedrige und kleine Schulterbeule imnen durch eine unregehässige vertiefte Punktreihe abgesetzt. Beine kurz und kräftig, Schienen nach der Spitze bedeutend erweitert, erstes Tarsenglied wenig schmaler als das dritte, Bauch fein punktirt, Pygidialrinne breit, scharfrandig. Ungeflügelt oder mit kurzen Flügeln, die nicht die Spitze der Fld. erreichen.

§. Letztes Hinterleibssegment auf der Mittellinie glatt, am Hinterrande jederseits mit einem kleinen Ausschnitte, dazwischen in einen breiten, aber kurzen Zipfel verlängert, der in den Hemicyclus eingebogen ist. - Penis ziemlich schlank, gleichbreit, vorn allmählich und fast gradlinig verengt, über der abgestutzten Klappe der Länge nach sanft eingedrückt, die Unterseite vertieft und mit einem scharfen Mittelkiele versehen, der ein Stiick vor der Spitze allmählich erlischt.

Die wichtigsten Abänderungen sind:

a. Das Halssch. ist ziemlich stark und tief punktirt, zuweilen nur wenig schwächer als die Fld., anch kann der Glanz desselben noch durch seichte Längsrunzeln abgeschwächt sein;

b. Die Oberseite ist dunkel metallisch grün, mit bläulichem Schimmer.

In Südfrankreich bei Hyères und Frejus entdeckt, später in Croatien bei Fiume von Stussiner und Reitter in Menge gefangen, Dalmatien, Sicilien auf einer Iris (Rottenberg). Aus der Wehucke'schen Sammlung erhielt ich auch ein Stiick aus Krain, ohne nähere Fundortsangabe.

16. Aphth. ovata: Subovalis, convexa, coeruleo-nigra, nitida, antennis apicem versus leviter infuscatis pedibusque testaceis, femoribus posticis nigricantibus, tuberculis frontalibus angustis, discretis, carina faciali acuta, prothorace transverso, subquadrato, sublaeri, elytris sat amplis, absolete sed basin vertus evidentius et seriatim punctatis. - Long. 1,8 bis $2,8 \mathrm{~mm}$.

Foudr. Mon. 372. - All. Ann. Fr. 1860. 40t; Mon. 231.

Haltica euphorbiae Redtb. Faun. A. ed. 1. 531; ed. 3. II. 5̃01.- 
Kutsch. Wien. 1861. 249 (161). - Leesb. Tijdschr. 24. 200 (Aphth.).

Var. a. Femoribus anterioribus dimidio basali fuscis.

Var. b. Prothorace erebre subruguloso-punctulato.

In der Earbe der Oberseite an A. pseudacori erinnernd, noch dunkler als diese, und durch die etwas bauchigen Fld, welche im VerhäItnisse zu dem schmalen Vorderleibe sehr breit erscheinen, ausgezeichnet. Fast eiförmig, gewölbt, schwarz, mit einem deutlichen blassblauen Schimmer, der sich entweder uiberall gleichmässig oder auf den Fld. allein zeigt, während dann Kopf und Halssch. metallisch grün überflogen oder rein schwarz sind. Fühler und Beine bräunlich gelb, die Endglieder der ersteren etwas dunkler, das Klauenglied und die Hinterschenkel schwärzlich, seltener auch die vier Vorderschenkel in der Basalhälfte angedunkelt (Var. a) Die Stirnlinien und die schmalen Höckerchen mässig scharf ausgeprägt, Nasenkiel schmal, Fiihler schlank, nach der Spitze wenig verdickt, Glied 2 etwas, die folgenden viel länger als breit. Halssch. $\mathrm{um}$ die Hälfte breiter als lang, an der vorderen Borstenpore am breitesten, hinter derselben zuerst sanft ausgebuchtet, dann schwach gerundet-erweitert, endlich wieder etwas verengt, die Seiten im Ganzen ziemlich parallel, die Scheibe mässig gewölbt, mit äusserst feinen Pünktchen bestreut, nahe den Hinterecken jederseits ein leichter Quereindruck. Fld. am Grunde bogenförmig heraustretend und in den Schultern breiter als die Basis des Halsschildes, an den Seiten mehr (q) oder weniger ( $\hat{\sigma})$ gerundet, hinten gemeinschaftlich abgerundet, ziemlich stark gewölbt, im vorderen Drittel fein, aber sehr deutlich und namentlich nahe der Naht gereiht-punktirt, dahinter nehmen die Punkte allmählich an Stärke ab und verwirren sich, eine Schulterbeule fehlt. Rinne des Pygidium ziemlich lang und breit, scharf gerandet, Bauch zerstreut punktulirt, Tarsen schlank.

๙. Letzter Bauchring etwas gewölbt, vor dem kurzen, bogenförmigen Mittelzipfel des Hinterrandes vertieft. - Penis in der Nähe der Oeffnung jederseits kaum bemerkbar ausgesehweift, vorn gerundet-verengt und in der Mitte abgestutzt, oben mit einer feinen Mittelrinne, unten in den vorderen zwei Dritteln vertieft, mit einem schmalen, hohen und scharfen Mittelkiele.

Zuweilen ist das Halssch. dicht punktulirt und mit zahlreichen kurzen und feinen Längsrunzeln versehen (Var. b).

Im Alpengebiete vom südlichen Frankreich bis Croatien und Serbien auf Euphorbia cyparissias L. stellenweise häufig, vereinzelt rielleicht auch noch in den Gebirgsgegenden Mitteldeutschlands. 
Diese Art wurle zuerst von Rertenbacher unterschieden, jerloch unter der falschen Bezeichnung euphorbiae $\mathrm{Fabl}$, so dass der spätere Name ocata Foudr. eintreten muss; auch die Angaben bei Redtenbacher ,sehr gemein" und bei Kutschera ,in ganz Europa gemein" sind irrig und haben leider die ungerechtfertigte Aufnahme der Art in zahlreiche Localfaunen veranlasst.

17. Aphth. Stussineri: Elliptica, conrexa, nigra, nitida, antennis upice ferrugineis pedibusque testaceis, femoribus anterioribus basi fuscis, posticis nigricantibus, tuberculis frontalibus angustis, discretis, carina faciali sat acuta, prothorace transverso, subtiliter punctulato, interdum ruguloso, elytris prothorace parum latioribus, violaceo micantibus, obsolete, basi distinctius substriato-punctatis. - Long. $2 \mathrm{~mm}$.

Der vorhergehenden nahe rerwandt, aber von anderem L'mriss, verschiedener Farbe, Skulptur und Fühlerbildung. Regelmässig länglich elliptisch, in der Mitte am breitesten und nach beiden Seiten in gleichmässigem Bogen verschmälert, hoch gewölbt, glänzend schwarz, die Fld. violett schimmernd, Fühler und Beine bräunlich gelb, die Endglieder der ersteren rostroth, die vier vorderen Schenkel in der Basalhälfte oder noch darüber hinaus schwärzlich, Hinterschenkel ziemlich schwarz. Stirn wie bei ovata gebaut; an den Fühlern ist das dritte Glied sehr klein, viel kürzer als das zweite oder vierte Glied. Halsseh. gross, doppelt so breit als lang, mit gewölbten Seiten, welche die Randlinie und den Zahn an der vorderen Borstenpore bei der Ansicht von oben verdecken, die Scheibe sehr fein punktulirt, zuweilen längsrunzelig. Fld. am Grunde so breit als die Basis des Halssch., dahinter ganz allmählich und sehr schwach erweitert, sodann ähnlich verengt, im Ganzen wenig breiter als das Halssch., hinten sehr undeutlich, vor der Mitte stärker punktirt. mit deutlichen vertieften Punktreihen und etwas gewölbten Zwischenstreifen im vorderen Drittel, ohne Schulterbeule.

Von H. Stussiner bei Laibach bisher nur in einigen weiblichen Exemplaren aus Laub gesiebt.

18. Aphth. atrovirens: Oblongo-ovalis, subconvexa, nigra, supra viridi-coeruleo-micans, nitida, antemis sat validis apice infuscatis pedibusque ferrugineis, femoribus posticis fuscis, tuberculis frontalibus modice discretis, carina faciali acuta, prothorace transierso sublaevi, elytris subtiliter subruguloso punctatis. - Long, 1,3-1,8 mm.

Fölster, Verh. Preuss. Theinl. 1849. Nachtr. I. 37 (Halt.) Kutsch. Wien. 1861. 286 (163). - Redtb. Faun. A. II. 
502. - All. Ann. Fr. 1860. 406; Mon. 232 (Aphth.) - Leesb. Tijdschr. 24. 198.

Aphthona tantilla Foudr. Mon. 374.

Gleichfalls mit $A$. ovuta nahe verwandt und derselben ähnlicher als der vorigen Art, indessen etwas kleiner, schmaler, weniger gewölbt, mit kräftigen Fühlern, weniger hellen Beinen und deutlicher, dichter Punktirung der Fld. Länglich-eiförmig, mäissig gewölbt, schwarz, die Oberseite grünlich-blau schimmernd, glänzend, Fühler und Beine röthlichbraun, erstere in der Spitzenhälfte dunkel, Hinterschenkel schwärzlich. Stirn sehr fein quer gestrichelt, Höckerchen glatt, glänzend, wenig scharf umgrenzt und von einander getrennt, Nasenkiel schmal und hoch. Fühler etwas länger als der halbe Körper, das dritte bis sechste Glied merklich dicker als bei den vorigen Arten, die folgenden Glieder erweitert, nur das erste und letzte Glied erheblich länger als breit. Halssch. im Bau mit dem von ovata iibereinstimmend, quer viereckig, fast doppelt so breit als lang, bald glatt, bald mit feinen Pünktchen bestreut, oder noch sparsam und äusserst zart gerunzelt. Fld. am Grunde bogenförmig heraustretend und in den Schultern breiter als das Halssch., dahinter sanft gerundet; mässig gewölbt, bis auf den Abfall zur Spitze fast in gleicher Stärke punktirt, die Punkte fein, verhältnissmässig kräftig, mit sehr schmalen Zwischenräumen, welche einzelne Pünktchen besitzen und theilweise zu kurzen, aber sehr schwachen Schrägrunzeln vereinigt sind. Bauch kräftig punktirt, Rinne des Pygidium breit, in der Mitte erlöschend.

Beim Männchen besitzt der letzte Hinterleibsring eine glatte Mittellinie; der Penis ist vorn abgerundet, mit einer feinen Mittelrinne auf der Ober- und Unterseite.

Im Alpengebiete und den Berggegenden Mitteldeutschlands, nördlich bis Schlesien, Thüringen, Aachen, namentlich auf Kalkboden im Herbste. Frankreich.

19. Aphth. herbigrada: Oblonga, subconvexa, nigra, supra viridiaenea, interdum obscure aurichalcea aut coerulescens, sat nitida, antennis elongatis pedibusque testaceis, illis femoribusque posticis apicem versus infuscatis, tuberculis frontalibus parvis bene discretis, carina faciali acuta, prothorace subquadrato, subtilissime ruguloso-punctulato, elytris apice rotundato-subtruncatis, ruguloso punctulatis. - Long. 1,6-2,3 mm.

Curtis, Brit. Entom. 14. fol. 630 (Halt.). - Steph. Man. 293. - Bach, Käferf. III. 145. - Kutsch. Wien. 1861. 287 (164). - Foudr. Mon. 376 (Aphth.) - All. Mon. 235. - Leesb. Tijdschr. 24. 199. 
Haltica campanulae W. Redtb. Quaed. gen. et. spec. Col. Austr. 1842. 28. - Redtb. Faun. A. II. 502.

Var. a. Prothorace fere laevi.

Aphthona laevicollis Rey, Opusc. ent. 1875. 53.

Var. b. dimidiata: Capite prothoraceque cupreis.

Rey, 1. c. 54 .

? Apththona rossulate A 11. Ann. Fr. 1859. Bull. 101.

In der Farbe und Skulptur einer gestreckten A. euphorticue am ähnlichsten, aber durch die deutlichen Stirnhö̈ker und die schmalen, beuleulosen Schultern leicht zu unterscheiden.

Sehr lang eiförmig, mässig gewölbt, unten schwarz, oben metallisch grün, oft dunkel broncefarben-, seltener bläulich-schimmernd, ziemlich glänzend, Fïhler und Beine bräunlichgelb, erstere nebst den Hinterschenkeln an der Spitze melır oder weniger angedunkelt. Scheitel äusserst fein quer gestrichelt, oft noch punktulirt, Höckerchen klein, gewölbt, ringsum deutlich abgesetzt, Nasenkiel schmal und hoch. Halsseh. viereckig, nur wenig breiter als lang, und an den Seiten eine Spur gerundet, meist mit einem bogenförmigen, weiten, aber schlecht bemerkbaren Quereindrucke. welcher von einer Vorderecke zur andern zieht und sich nach der Mitte hin allmählich immer weiter vom Vorderrande entfernt. Der Raum vor diesem Eindrucke ist ziemlich glatt, der dahinter liegende sehr fein und etwas runzelig punktirt; besonders nahe der Basis. Fld. am Grunde kaum breiter als der Hinterrand des Halssch., ohne Schulterbeule, bis hinter die Mitte nach und nach erweitert, ziemlich dicht und runzelig punktirt. Rinne des kräftig punktirten Pygidium fehlend oder durch zwei Punktreihen angedentet, die eine glatte Mittellinie einschliessen.

ô Letzter Bauchring vor dem Mittelzipfel vertieft, glatt und glänzend; Penis vorn gerundet, oben mit tiefer und breiter Mittelfurche, unten mit zwei Längsrinnen.

Wie bei den iibrigen Arten so kommen auch bei dieser Stücke mit beinahe glattem, spiegelblankem Halssch. vor (Var. a); auffälliger ist die hübsche Var. b, bei welcher die Fld. normal, Kopf und Halssch. dagegen lebhaft kupferig gefärbt sind, mitunter auch noch einen bläulichen Anflug besitzen.

Vorherrschend auf Kalkboden, in den mitteleuropäischen Gebirgsgegenden im Herbste stellenweise nicht selten.

Nach der Diagnose vermag ich die von Allard 1859 beschriebene, später verleugnete $A$. fossulata nicht von der Var. b zu trennen. 
20. Aphth. lacertosa: Subcylindrica, modice convexa, obscure viridiaenea, nitida, antennis pedibusque crassiusculis rufo-testaceis, illis apicem versus et peditus posticis superne infuscatis; tuberculis frontalibus fovea profunda separatis, carina faciali lata, prothorace elytrisque subtiliter subruguloso punctatis, his apice rotunlato-truncatis. - Long. 2,5-3,5 mm.

Rosenh. Beitr. Ins. Eur. 60 (Haltica). - Kutsch. Wien. 1861. 388 (165). - Redtb. Faun. A. ed. 3. II. 501. - Foudr. Mon. 366 (Aphth.). - All. Mon. 234.

Haltica divaricata Redtb. 1. c. ed. 1.531. - Bach, Käferf. III. 146.

V ax. a. Prothorace vix punctato, subpolito.

V ar. b. Prothorace crebre ruguloso-punctato, minus nitido.

Var. c. Supra obscure viridi-coerulea.

Von den vorhergehenden Arten durch den cylindrischen Körper und die tiefe Grube zwischen den Stirnhöckern abweichend, am nächsten vielleicht mit der gelben $A$. cyparissiae verwandt. - Gestreckt, cylindrisch, aber nur mässig gewölbt, oben dunkel erzfarbig grün, glänzend, unten schwarz, metallisch, Fühler und Beine röthlich gelbbraun, erstere nach der Spitze hin, sowie der Rücken der Hinterschenkel angedunkelt. Stirn glatt oder äusserst fein quer runzelig, Stirnlinien tief, zwischen den Höckerchen eine breite und sehr tiefe Grube bildend, in welche die bogenförmige Spitze des breiten und hohen, oben abgeflachten Nasenkieles abfällt. Fühler kräftig und lang. Halssch. um die Hälfte breiter als lang, ziemlich stark querüber gewölbt, an den Seiten wenig gerundet, vorn etwas verengt, auf der Scheibe dicht und fein, schwach runzelig punktirt, nach aussen vom Längseindrucke fast glatt. Fld. am Grunde so breit als das Halssch,, ohne Schulterbeule, bis zur Mitte sehr wenig erweitert, dahinter ähnlich verengt, an der Spitze mit gerundeten Ecken abgestutzt; in der Regel etwas stärker als das Halssch., verworren und schwach runzelig punktirt, oft mit Spuren seichter Längsfurchen. Pygidium dicht gewirkt und sparsam punktulirt, ohne Rinne, Bauch ebenfalls dicht gewirkt, mit einzelnen Punkten.

ô. Letztes Bauchsegment auf einem Längsstreifen in der Mitte eingedrückt, glatt und glänzend; Penis gebogen, vorn mit mässiger Rundung in eine unscheinbare Spitze verengt, oben mit einer schmalen, tiefen, vorn verbreiterten Mittelrinne, auf der Unterseite leicht gewölbt, unter der Oeffnung schwach eingedrïckt.

Nicht selten ist die Punktirung des Halssch. nur noch in der Nähe der Basis bemerkbar, der iibrige Theil erscheint spiegelglatt (Var. a), umgekehrt nimmt die Skulptur so weit zu, dass das Halssch. stärker als die Fld, sehr dicht runzelig punktirt und wenig 
glänzend ist (Var. b), zuweilen (Var, c) erhält die Farbe der Oberseite einen blauen Schimmer.

Auf Kalkboden in der Umgebung der Uonau von Wien his nach Serbien; die Angabe von Kutschera, auch in Schlesien (Glatz)" bedarf der Bestätigung.

\section{Longitarsus.}

Latreille, Cuvier, règn. animal. ed. 2. V. 1829. p. 155.

Thyamis Stephens 1839. Teinodactyla Cherrolat 1842.

Acetabula antica aperta.

Frons impunctata, saepe subtiliter alutacea vel transversim strigosa, lineis et tuberculis obsoletissimis aut nullis.

Elytra postice ciliata, apice subsingulatim rotundata.

Pygidium haud canaliculatum.

Tibiae posticae calcari distincto, dorso inclinatae, extrorsum assurgentes, margine externo carinato-elevato, denticulato; metatarsus tibiarum apici insertus, valde elongatus, tibiam dimidiam sacpissime superans.

Körper vorherrschend geflïgelt, mehr oder weniger eiförmig und gewölbt, gelbbraun, bräunlich-roth, pechbraun, schwarz, selten metallisch grün, broncefarben oder blau, mit wenigstens theilweise röthlichen bis bräunlich gelben Fühlern und Beinen. Kopf klein, ziemlich dreieckig, mit breiter und etwas gewölbter Stirn, welche jederseits in eine rinnenförmige Vertiefung, vom inneren Augenrande bis zur Fühlerwurzel reichend, abfällt und mit ein oder mehreren Borstenporen versehen, in der Regel nicht punktirt, aber äusserst fein gewirkt oder quer gestrichelt ist. Sie besitzt nur bei wenigen Arten sehr feine, grade Stirnlinien, die sich von der Augenrinne unterhalb der Borstenpore trennen, iiber dem Nasenkiele durchschneiden und so die kleinen, linealischen, kaum gewölbten Stirnhöckerchen schwach umgrenzen. Die Augen sind ziemlich gross, grobkörnig facettirt und im Ganzen mässig gewölbt, aussen etwas stärker als innen. Der Nasenkiel ist schmal, meist scharf, oben und unten abfallend, daher leicht gebogen, er erlischt in dem verdickten vorderen Theile des Kopfschildes, welches sich plötzlich zu dem flachen Querstreifen vertieft, der die Basis der gerundet abgestutzten und schwach ausgerandeten Oberlippe bedeckt. Mandibeln fünfzähnig, der mittelste Zahn am weitesten vorstehend. Fülller schlank, länger als der halbe Körper, entweder durchaus 
fadenförmis, oder die fünf oder sechs letzten Glieder verbreitert, elfgliedrig, Glied 1 aus schmaler Basis allmählich erweitert, keulenförmig, 2 kurz, 3 so lang oder länger als 2 , die folgenden gestreckt, ungefähr so lang als 2 und 3 zusammen, Fndglied mit etwas abgesetzter Spitze. Halssch. quer-viereckig, auf der Scheibe wenig gewölbt, aber an den Seiten stark abfallend, und an der Spitze etwas zusammengedriickt, die Basis sehr fein gerandet und in der Mitte sanft, an den Seiten stärker gerundet, vorn gerade abgeschnitten; der Seitenrand mit einer abgesetzten Leiste, welche an der vorderen Borstenpore etwas erweitert und von hier bis zu den Vorderecken verdickt, hinter der Borstenpore ausgesehweift, vor den Hinterecken wieder leicht eingezogen und iiberall kurz und fein bewimpert ist. Die hintere Borstenpore befindet sich auf einem Kegel, einem vorspringenden Zähnchen oder einer Erweiterung der Randleiste in den Hinterecken, die vordere am Ende des ersten Drittels oder Viertels, stets von den Vorderecken entfernt; die Borsten sind ziemlich so lang als das Halsschild, oder länger. Oft zeigt sich auf dem Halsschilde jederseits ein schwacher Längseindruck, der einen Streifen bis zur Seitenrandlinie, von der vorderen Pore bis nahe an den Hinterrand, mehr oder weniger wulstartig in die Höhe drückt. Schildehen klein, dreieckig, mit stumpfer Spitze. Flügeldecken an der Basis entweder winkelig heraustretend, mit einer deutlichen, glatten, wenn auch niemals sehr hohen Schulterbeule (geflügelte Formen), oder am Grunde so breit als das Halsschild, dahinter allmählich erweitert, mit völlig verrundeten Schultern und ohne Beule (unvollkommen oder ungeflügelte Formen); mehr oder weniger eiförmig, hinten gleichmässig abgerundet oder abgestutzt, die Nahtecke rund oder stumpfwinkelig, daher die Spitze des Pygidium gewöhnlich unbedeckt. Die Scheibe ist in verschiedenem Grade gewölbt, bald verworren, bald reihig punktirt, bei einigen Arten durchscheinend und dann mit drei bis fünf dunkel durchschimmernden Längsstreifen auf der inneren Hälfte versehen. Die untere Nahtkante verbindet sich vor der Spitze mit der oberen, so dass eine Rinne zum Einlegen derselben auf dem Pygidium nicht nöthig ist. Die Epipleuren sind mässig geneigt und von der Seite sichtbar, vorn ziemlich breit, hinter dem ersten Drittel allmählich verengt, vom Beginn der Abrundung der Fld. aus auf einen ziemlich schmalen Streifen beschränkt, welcher nahe der Spitze erlischt. Sie sind vorn meist etwas gewölbt, glatt, mit einer Punktreihe neben dem inneren Rande, hinten bewimpert, ihr Aussenrand wird durch die scharfe Randleiste der Fld. gebildet, izber welcher ein tiefer Punktstreifen eingegraben ist. Prosternum zwischen den etwas vorstehenden Hüften sehr schmal, leistenförmig gerandet, 
dahinter in einen abgestutzten Fortsatz erweitert, welcher in eine Vertiefung der Mittelbrust eingreift und von den Seitenstücken entfernt bleiht, weshalb die Gelenkhöhlen hinten geöffnet sind; die Mittelhüften stehen bei einigen Arten z. B. verbasci, lnevis etc. ehenfalls nahe an einander, bei andern, z. B. melanocephalus. sind sie weiter getrennt. Hinterbrust hreit, wenigstens im mittleren Theile weisslich behaart, oft quer gerunzelt, vor den Hinterhüften der Länge nach eingedrückt, vorn und an den Seiten von einem Punktstreifen umzogen, die Seitenstücke bei vielen Arten vertieft und punktirt. Bauch nach der Mitte ansteigend, das erste Segment länger als eins der übrigen, zur Aufnahme der Hinterschenkel vertieft oder ausgehöhlt, in der Mitte fast kielförmig. Hinterschenkel stark, sehr lang eiförmig oder einem schmalenA pfelkern ähulich, vorn breit, mit der inneren Ecke befestigt, unter dem Innenrande mit einer Rinne zum Einlegen der Schienen. Diese sind schlank, grade oder leicht gebogen, etwas zusammengedrückt, entweder nur nahe der Spitze schnell, oder von der Basis aus ganz allmählich (zuletzt etwas stärker) erweitert, dreikantig. Von den beiden oberen Kanten ist die äussere hoch, leistenförmig, vorn sparsam und fein gezähnelt, im letzten Viertel dicht mit kurzen Dörnchen von gleicher Länge kammartig besetzt. Die innere Kante liegt viel tiefer, weil der glatte, bald ebene, bald vertiefte oder etwas gewölbte Rücken nach innen bedeutend abfällt, und ist bei den meisten Arten stumpf und undeutlich, durch eine Haarreihe markirt, nur an der Spitze mehr oder weniger hoch aufsteigend und hier ebenfalls kammartig bedornt. Die dritte Kante, auf der Unterseite, ist breit und etwas abgerundet, über ihrer Spitze ist in einer Grube der schwach gekrümmte Enddorn und über diesem der Metatarsus eigelenkt. Dieser reicht ungefähr bis zur Mitte der Schiene oder darüber hinaus, und besitzt eine aus Härchen von verschiedener Länge gebildete, höchstens an der Basis filzige oder sammetartige Sohle und an der Spitze einen Ausschnitt, in welchem das zweite Tarsenglied befestigt ist. Letzteres erreicht kaum die halbe Länge des Metatarsus, das dritte Glied ist noch kürzer, schwach herzförmig, das Klanenglied schlank, mit kleinen, sehr gekrümmten, am Grunde zahnartig verdickten Klauen.

Die Longitarsen machen ihre Hinterschienen nur zum Sprunge frei, sonst legen sie dieselben fest in die Schenkelrinne, schlagen den Metatarsus in schräger Richtung auf die innere Seite der Schienen zurück, bringen das zweite Tarsenglied in eine rechtwinklige Lage zum ersten und treten bei ihrem schnellen, jedoch ungeschickten Marsche nur mit der Spitze des zweiten und mit dem dritten Gliede der Hintertarsen auf. 
Das Männchen zeichnet sich durch den kleineren, schlanker gebanten Körper, längere Fühler und grösseren Glanz der Oberseite aus und ist an dem erweiterten ersten Tarsengliede der vier Vorderbeine, sowie an dem schmalen letzten Banchringe, welcher bald der Länge nach, bald grubenförmig eingedrückt und an Hinterrande ausgeschnitten, abgestutzt oder in einen Mittelzipfel verlängert ist, mit Sicherheit zu erkennen. Der Hemicyelus ist ziemlich gross, wenigstens theilweise sichtbar; der Penis bildet eine sehr flach gedrückte Röhre, mit grosser Oeffnung, welche in der Ruhe von einer vorn meist abgestutzten Klappe fast ganz geschlossen wird; er ist oben oft der Länge nach eingedrückt oder rinnenförmig vertieft, unten ausgehöhlt, rorn ausgerandet, abgerundet oder zugespitzt, bei einigen Arten auffällig klein, bei anderen ungemein lang.

Die Gattung nähert sich durch das schmale Prosternum den Galeruken, erinnert in der Bildung der Hinterbeine ausserordentlich an Psylliodes, und ist habituell mit Aphthona so nahe verwandt, dass die sichere Gattungsbestimmung bei Thieren mit verklebten Hinterbeinen oft nicht ohne Schwierigkeit ist, wofür die Thatsache, dass mehrere Aphthona-Arten als Longitarsus beschrieben worden sind, den besten Beweis liefert. Die Arten leben hauptsächlich au Compositen, den unter sich verwandten Convolvulaceen, Boragineen, Scrophulariaceen und Labiaten, sowie an Plantagineen, in der Regel an zweijälurigen oder perennirenden Gewächsen, die eine ziemliche Widerstandsfähigkeit besitzen und nicht leicht am Frasse der Larven und Käfer zu Grunde gehen, weshalb wohl von einem erheblichen Schaden, den Longitarsus-Arten verursacht hätten, bisher nichts bekannt geworden ist. Ueber die ersten Stände liegen nur wenige sichere Nachrichten vor, nämlich von Rupertsberger (Verh. zool. bot. Ver. Wien 1872. 20) iuber L. huridus, und von Buddeberg (Jahrb. Nass. Ver. f. Natur. 1885. 103) iiber L. echii und (l. c. 1886. 105-108) über exoletus und melanocephatus. Die Eier sind sehr lang elliptisch, gelb oder roth, dicht mit erhaben gerandeten schwachen Vertiefungen besetzt, die Larven sehr gestreckt, walzenförmig, weiss, nicht dicht, aber ziemlich lang, abstehend weiss behaart, namentlich an den Seiten. Kopf klein, glatt, bei exoletıs gerundet viereckig, hell graubraun, auf der Mittellinie und an den Ränderu dunkler, bei melanocephalus rundlich, schwarzbraun, neben der dunkleren Mittellinie jederseits eine schräge weisse Linie, vom ausgekerbten Hinterrande bis zu den Vorderecken laufend, bei echii endlich gewölbt, in der Jugend schwarz, später bräunlich, zwei in der Mitte des Scheitels beginnende, schräg zum Vorderrande ziehende und hier erweiterte Linien, weiss. Mandibehn vierzähnig, der zweite Zahn von aussen am längsten. Brustringe entweder wie die Hinter- 
leilsringe gestaltet, nach hinten an Breite zunchmend und an Länge fast grleich, oder der Prothorax bei melanorephalus mit mehreren kleinen, graubraunen Flecken, bei echii dagegen länger als die übrigen, vor dem Ininterrande jederseits mit einer flachen Quervertiefing. an Hinterrande grau, mit weissen Längslinien. Der Analring ist in einen abgrundeten Vorsprung erweitert (exoletus), oder an kinde bram, mit zwei kurzen nach vorn gekrümrnten schwarzen sjpitzen (melanocephalus), oder verschmälert, mit einigen seichten Längsfurchen vor dem schwach erhabenen Hinterrande, welcher zwei aufgerichtete schwarze Spitzchen trägt (echii). Die Puppe besitzt ungefähr die Grösse und Gestalt des Käfers, ist weiss, gelblich oder gelb, glatt, mit einigen abstehenden bräunlichen Härchen auf' Kopff, Halsschild, den Rändern und Seiten der Hinterleibsringe, sowie Ije zwei) auf jedem Knie. Es bräunen sich zuerst die Augen und Kiefer, später die Hinterschenkel, falls dieselben überhaupt bei dem Käfer dunkel sind.

Aus der Erscheinungszeit des vollkommenen Thieres lässt sich im Allgemeinen ein Schluss auf die Entwickelungszeiten ziehen: Die Mehrzahl aller Arten, die im Hochsommer oder Herbste auftreten, z. B. L. melanocephalus, pratensis, luridus, brumeus, tabidus etc., legt ihre Eier im ersten Frühlinge, ihre Larven sind ungefähr. im Juli entwickelt, gehen zur Verpuppung in die Erde und der Käfer erscheint Ende Juli, oder im August bis September. Eine Ausnahme hiervon beobachtete Buddeberg an $L$. echii, welcher Anfang August völlig entwickelt ist, aber bis zum nächsten Frühjahre in der Erde bleiben soll. Bei einem kleineren Theile der Arten, wozu z. B. exoletus gehört, werden die Eier erst im Juni gelegt, die Larve überwintert, verpuppt sich beim Eintritt des milderen Wetters und verwandelt sich frühestens im April zum vollkommenen Insekt.

Die Eier werden an Wurzelblättern oder an der Stengelbasis befestigt, die Larven dringen in die Wurzel ein und fressen dicht unter der Rinde einen abwärtsfithrenden Gang, durch den sie auch zuletzt die Wurzel verlassen; nach Rupertsberger sollen die Larren des $L$. luridus den mittleren Stengeltheil von Alectorolophus major Rchb. (einer einjährigen Pflanze!), ron 2 Zoll hoch ïber der Erde bis zu den ersten Aesten bewohnen und sich rom Stengelmarke nähren. Soviel steht fest, dass Larven und Käfer durchaus nicht auf eine Pflanzenart angewiesen sind, denn man findet den Käfer in einer Gegend auf diesem, in einer andern auf jenem Gewächse, z. B. obliteratus an Thymus serpyllum und Salcia pratensis, L. anchusue an Echium, Anehusa, Cynoglossum. Symphytum, L. mbiginosus an Euputorium und Convolvulus, L. aeruginosus ebenfalls an Eupa- 
torium, aber noch häufiger an Symphytum ete. Der Käfer frisst runde Löcher vou verschiedener Grösse, so dass die Blätter der Nährpflanze zuletzt siebartig durchlöchert sind.

Von der umfangreichen (xattung wurden bisher ungefähr 300 Arten beschrieben; dawon fällt die kleinere Fialfte auf Luropa und Nordafrika, die grössere auf Asien, Nord- und Sudlamerika, ein sehr geringer Theil gehört dem südlichen Afrika an. Ubwohl die Arten in der Körperform und Skulptur, theilweise auch in der Färbung variiren, lassen sie sich doch gut auseinander halten, aber ihre natïrliche Gruppirung bietet uniiberwindliche Schwierigkeiten, weil die brauchbarsten Unterschiede, welche die Bildung der Stirn, der Schultern und Hinterschienen aufweist, in der Artenreihe sich allmählich verwischen und überhaupt nicht ein Merkmal existirt, nach welchem die Gattung in zwei Theile zu zerlegen wäre. Aus diesem Grunde empfiehlt es sich, die durch Foudras und Kutschera befolgte und seither eingebürgerte Anordnung nach der Hauptfarbe des Körpers beizubehalten, wenn auch nach derselben die nicht ganz ausgefärbten Individuen schwierig, und nur bei genauester Artkenntniss unterzubringen sind.

Die Gründe, welche Foudras und Allard bestimmten, den ältesten Namen der Gattung mit einem späteren (Teinodactyla oder Thyamis) zu vertauschen, dürfen, weil sie auf Willkür beruhen, nicht gebilligt werden, da kein Autor gezwungen werden kann, seinen Gattungsnamen unbedingt der griechischen Sprache zu entlehnen, so wünschenswerth dies auch an und für sich erscheinen mag, und weil ferner jeder Autor das Genus seiner Gattung nach eigenem, freiem Ermessen bestimmt. Dass Latreille grade die kräftigsten Springer unter unseren Haltiken, die Longitarsen (und jedenfalls auch Psylliodes!) nicht schablonenmässig zu Femininis herabwürdigte, sondern als Masculina angesehen wissen wollte, legt ein glänzendes Zeugniss von seiner simnigen Naturbetrachtung und von der wahren Kenntniss der nunmehr zu behandelnden Thiere ab.

1. Long. echii: : Alatus vel subapterus, subellipticus, convexus, coeruleovirescenti-aeneus, nitidus, antennarum basi, tibiis tarsisque ferrugineis; fronte vage punctulata et rugulosa, utrinque impressione punctata instructa, prothorace punctato, elytris sat fortiter punctatis, angulo suturali subrotundato, tibiis posticis compressis, apice dilatatis, carina exteriore dorsali subintegra. - Long. 2,6-4 mm.

Koch, Ent. Hft. II. 52. t. 3. f. 3 (Halt.), - Oliv. Ent, VI 709. t. 4. f. 74. - Illig. Mag. VI. 171. - Steph. Ill. Brit. IV. 424; Man. 301 (Macrocnema), - Küst. Käf. Eur. 2. 2 (Teinodactyla), - Foudr. Mon, 130. - All. Man. 328 (Thyamis). - Kutsch. Wien. 1862. 105 (Longit.). - Redtb. 
Faun. A. II. 504, - Bach, Käferf. III. 148. - Seidl. F. balt. 497 .

Var. a. tibialis: Viridis, saepe brunneo-, cuprer-, rel aurichalceo micans. Halt. tibialis Duft. Faun. A. III. 258.

Var. b. coerulescens: Supra plus minusre coeruleus aut riolaceus.

Var. c. nigrescens: Supra nigra.

Var. d. peregrinus: Saturate brunneo-metallicus, nitidissimus, elytris apice breviter-rotundatis, punctis apicem versus evanescentibus.

Var. e. Prothorace subtilissime punctato, subpolito.

Thyamis dimidiata All. Mon. 329.

Eine ansehnliche, in der Gattung einzeln stehende Art, bei der die Augenrinne durch einen weiten, dicht punktirten Eindruck ersetzt, die Hinterbrust auch an den Seiten stark punktirt und der Ruicken der Hinterschienen sehr schmal und mit einer Innenrandleiste versehen ist. Ziemlich gestreckt, lang elliptisch, gewölbt, bläulich metallisch grün, glänzend. Fühler pechschwarz, die Unterseite, oder mux die Basis und Spitze des ersten Gliedes, das zweite und dritte Glied grösstentheils oder gänzlich, und die Basis der drei folgenden Glieder rostroth bis gelblraun. Letztere Färbung besitzen auch die Beine, nur sind die rorderen Schenkel mit Ausnahme der Spitze schwärzlich und die Hinterschenkel einfarbig schwarz mit Metallschimmer. Stirn breit, äusserst fein punktirt und quer gerunzelt, an den Seiten breit eingedrüickt und kräftig punktirt. Höckerchen undeutlich, lanzettlich, oben zuweilen von einer feinen Linie begrenzt, Nasenkiel schmal und scharf, selten zwischen den Fiihlern verbreitert. Halss ch, um die Hälfte breiter als lang, ziemlich dicht, nach den Seiten stärker als in der Mitte und in dem Längseindrucke jederseits runzelig punktirt, auf dem Streifen über dem Seitenrande fast glatt. Fld. in den Schultern wenig breiter als das Halssch., mit einer lang'en, flachen, innen und hinten schwach abgesetzten Beule, dahinter wenig erweitert, in der hinteren Hälfte allmählich gerundet-verengt, die Nahtecke stumpf, leicht abgeruudet, die Scheibe verworren und stark punktirt, auf dem sanften Abfalle zur. Spitze in der Regel etwas feiner. Hinterbrust ziemlich gleichmässig grob runzelig punktirt, weisslich behaart. Hinterschienen nach innen gekrimmt, stark zusammengedrückt, an der Spitze schnell verbreitert, der Rücken mit einer feinen, aber scharfen Innenrandleiste, welche an der Einlagel'ungsstelle des Metatarsus verschwindet; Enddorn lang. Die Flügel sind beim ô nur mässig, beim \& noch weniger entwickelt, klein und schmal.

$ٌ$. Erstes 'Tarsenglied an den vier Vorderbeinen etwas rerbreitert, letztes Bauchsegment von einem feinen, gauzen oder rorn abgekiirzten Läugskiele durchzogen, an Hinterrande mit einem bogenförmigen, dicht punktirten, in den Hemicyelus abtallenden 
Mittelzipfel, ror welchem die Leiste des Hinterrandes winkelig oder gerundet nach vorn gebogen ist. Penis so lang als die drei letzten Bauchringe zusammen, schlank, gekrümmt, oben ziemlich flach gewölbt, mit kurzer Oeffnung und Klappe, vor dieser ziemlich schnell gerundet-verengt, an der Spitze ein kleiner, dreieckiger Ausschnitt, auf der Unterseite eine mässig breite und tiefe Mittelfurche.

Besondere Beachtung verdienen die mannigfaltigen Farbenabänderungen, weil die Art in den meisten Handbüchern namentlich durch die Farbe von der folgenden unterschieden wurde. Bei der ersten Reihe verschwindet die blaue Beimischung völlig, so dass die Oberseite rein grün, oder braun, kupferig bis messinggelb schimmernd ist (Var. a); bei einer andern erlischt der grüne Zusatz zunächst auf den Fld., später auf der ganzen Oberseite, oder kann anch durch Roth ersetzt sein, das Thier ist dann dunkelblau bis violett gefärbt (Var. b); selten wird die Oberseite tief schwarz (Var. c). Die Var. d endlich, kaffeebraun, messing- oder goldgelb überflogen, zeichnet sich durch sehr starken Glanz, nur im letzten Drittel verengte und an der Spitze breitere Fld. aus, deren Punkte vor der Spitze fast erlöschen; sie ist mir bisher nur aus der Umgegend von Rom (Strasser) und San Remo bekannt geworden.

Häufig ist das Halsseh., besonders in der Mitte der Scheibe, ïusserst fein punktirt, beinahe spiegelglatt (Var. e).

Im Frühlinge auf Echium, Anchusa, Cynoglossum und anderen Boragineen in Norddeutschland nur an wenigen Punkten (bis Königsberg), verbreiteter in Mittel- und Süddeutschland und Südeuropa. England. Algier.

2. Long. Linnaei: Alatus, ovalis, convexus, coeruleus, nitidus, antennarum basi pedibusque rufo-testaceis, femoribus posticis subaeneo-nigris; fronte vage rugulosa, sulcis ocularibus profunde impressis, prothorace subtiliter punctato, elytris sat fortiter, postice subtilius punctatis, tibiis posticis modice compressis, apicem versus parum dilatatis, carina don'sali interiore sacpe subintergra, exteriore longe ante apicem elevata. - Long. 2,5-4 mm.

Duft. Faun. Austr. III. 265 (Halt.). - Redtb. Faun. A. ed. 1. 535 ; ed. 3. II. 504 (Longit.). - Bach, Käferf. IIT. 148. - Kutsch. Wien. 1862. 104 (184): - Foudr. Mon. 128 (Teinodact.). - A11. Mon. 310 (Thyamis).

Var, a. amoenus: Laete aeneo-viridis, interdum leviter coerulco micans. Var. b. fallax: Nigno aenea, interdum obscure arichalcen rel cuprea, nitidissima.

VI. 5. 
Ganz vom Ansehen einer Aphth. semicyanea, bei gleicher Länge etwas breiter und an den Seiten gerundeter als der vorige, aber durch die Augenrinnen, stärkere Hinterschienen und hellere Vorderbeine leicht davon zu trennen. Eiförmig, gewölbt, oben schön dunkelblau, öfter Kopf und Halssch., seltener die ganze Oberseite violett, oder die Fld. grünlich schimmernd, glänzend, Unterseite schwarzblau; die vier ersten Fühlerglieder und die Beine röthlich gelbbraun, Hinterschenkel erzfarbig schwarz. Stirn verloschen querrunzelig, jederseits mit tiefer Augenrinne, welche bis über die Fühlerwurzel läuft und die undeutlichen, flachen Höckerchen unten begrenzt. Nasenkiel gleichmässig schmal und scharf, oder oben allmählich verbreitert und etwas flach gedrückt. Halssch. wenig oder um die Hälfte breiter als lang, mit feinen, nahe dem Hinterrande und dem Längseindrucke jederseits stärkeren Punkten mässig dicht besetzt. Fld. in den gerundet heraustretenden. Schultern breiter als das Halssch., mit einer etwas vorspringenden, mässig hohen, glatten Beule, dahinter gleichmässig gerundet, oben stark punktirt, hinter der Mitte etwas feiner als vor derselben. Hinterbrust runzelig punktirt und fein weisslich behaart, an den Seiten glatt. Hinterschienen grade, rorn wenig zusammengedruickt, hinter der Mitte nach und nach bis zur Spitze verbreitert, der Rücken abfallend, seine Innenrandleiste in der Regel deutlich, fein und scharf, an der Einlagerungsstelle des Metatarsus unterbrochen, die äussere Leiste vorn niedrig, mit kleinen Zähnen und langen Wimperhaaren besetzt, ein Stiick vor der Spitze schnell erhöht und von hier aus kammförmig gezähnt; Enddorn lang. Die Flügel sind gross.

§. Erstes Tarsenglied an den vier Vorderbeinen leicht rerbreitert, Aftersegment mit glatter, zuweilen vertiefter Mittellinie und einem weiten Quereindrucke vor dem Hinterrande; letzterer ist hinter der graden, oder in der Mitte etwas nach vorn gebogenen Randleiste noch in einen kleinen, abschüssigen Zipfel verlängert. Penis fast so lang als der Hinterleib, schlank, von der Mitte bis zum letzten Viertel jederseits kaum bemerkbar ausgeschweift, vorn gerundet-verengt, mit einer wenig abgesetzten kurzen und stumpfen Spitze; die Oeffnung nebst der sie schliessenden, an der Basis rinnenförmig vertieften Klappe halb so lang als die Röhre, diese unterseits ausgehöhlt.

Bisweilen wird die Oberseite lebhaft metallisch grün, anfangs noch mit blauem Schimmer, zuletzt ohne denselben (Var, a), bei einer in Italien bis Sicilien und in Südungarn (Banat, Merkl) rorkommenden Form (Var. b) dagegen sehr dunkel metallisch grïn zuweilen düster bräunlich-messingfarbig oder kupferig, stark glänzend. 
Der Nasenkiel ist hier stets nach oben verbreitert, die Fld. sind hinter der Mitte gewöhnlich sehr fein punktirt und am Ende etwas breiter abgerundet, dic Beine endlich nicht ganz so hell gefäirbt wie bei der Stammform.

Vom Mai bis Anfang Juli auf Symphytum tuberosum L. in Oesterreich, südlich der Donau, stellenweise häufig. Banat, Südrussland, Dalmatien, Italien, Siidfrankreich.

3. Long. fuscorenews: Alatus, oblongus, minus convexus, aeneus, nitidulus, antennarum basi pedibusque ferrugineis, plus minusve infuscatis, femoribus posticis aeneis; prothorace alutaceo confertim punctulato, elytris creberime ruguloso-punctatis, subdeplanatis, lateribus declivibus, apice rotundato-truncatis, callo humerali prominulo, metasterno alutaceo, latera versus haud punctato, tibiis posticis carina dorsali interiore nulla. - Long. 2-2,3 mm.

Redtb. Faun. A. ed. 1. 535; ed. 3. II. 504. - Bach, Käferf. III. 148. - Kutsch. Wien. 1862. 106 (186).

Diese Art bildet mit den beiden folgenden und einigen, der weiteren europäischen Fauna angehörenden Arten eine kleine Gruppe, welche sich durch ziemlich flache, an der Spitze abgestutzte und an den Seiten plötzlich abfallende und zusammengedrückte Fld. auszeichnet, deren Seitenrandlinie und -Leiste sehr foin und weit vor der Spitze abgekürzt, bei der Ansicht von oben überhaupt verdeckt ist.

Die vorliegende ist gestreckt, von den Schultern bis zum letzten Drittel ziemlich parallel, davor und dahinter gleichmässig verengt, wenig gewölbt, schwarz, mit ziemlich starker metallisch brauner, dunkel messing-oder kupferfarbener Beimischung, mässig glänzend. Die ersten fünf Fühlerglieder sehr dunkel rostroth, die folgenden merklich verbreitert, pechschwarz, Beine ebenfalls rothbraun, Hinterschenkel schwarz metallisch, die vorderen Schenkel und die Schienen bei ausgefärbten Exemplaren grösstentheils schwärzlich. Stirn äusserst zart gewirkt, Höckerchen glatt, schmal und lang, oben undeutlich oder durch eine feine Linie begrenzt, Nasenkiel ziemlich scharf. Halssch. um ein Drittel breiter als lang, mässig gewölbt, dicht und deutlich punktirt, in den Zwischenräumen gewirkt, auf dem Streifen über dem Seitenrande glatter. Fld. winkelig heraustretend und in den Schultern viel breiter als der Grund des Halssch., dahinter sanft gerundet, vor der Spitze verengt und an derselben gerundet-abgestutzt, auf dem Rücken abgeflacht, bis zur feinen Kante des Seitenrandes gleichmässig und zuusserst dicht runzelig punktirt, also ohne glatten Längsstreifen und die denselben 
innen begrenzende fast regelmässige Punktreihe, welche man bei den meisten übrigen Arten bemerkt. Die Zwischenrüume der Punkte sind kleiner als diese selbst, die Schulterbenle ist vorspringend, fein punktirt, innen durch eine Vertiefung abgesetzt; die obere Randlinie der Naht biegt vor der Spitze etwas auf die Fld. herauf, wodurch der untere Nahtrand als glatter Streifen sichtbar wird. Hinterbrust an den Seiten verloschen gewirkt, olne Punkte; Hinterschienen kurz, bis zur Spitze allmählich erweitert, mit breitem, abschüssigem Rüicken und mässig langem Enddorne. Flügel vollkommen.

Nach Kutschera hat das Männchen in der Mitte des letzten Bauchringes einen ziemlich tiefen Längseindruck.

Im Frühlinge auf Brachen, wiisten Grasplätzen und Raineu (vielleicht auf Echium? Kutsch.) bei Wien selten. Serbien (Getschmann).

1. Long. aeneus: Alatus, oblongus, subconiexus, aeneus, sut nitidus, antennis apicem versus leviter infuscatis pedibusque laete ferrugineis, femoribus posticis obscuris, aeneo-micantibus; prothorace mimus dense punctulato, elytris crebre punctatis, subdeplanatis, lateribus declivibus, apice rotundato-truneatis, callo humerali sat prominulo, metasterno latera versus parce punctato et piloso. - Long. 1,8-2,5 mm.

Kutseh. Wien. Mon. 1862. 107 (187).

Var. a. involucer: apterus, nitidus, humeris hand prominulis, callo humerali fere nullo.

Teinodactyla fuscoaenea Foudr. Mon. 132.

Dem vorigen sehr ähnlich, glänzender, eine Spur gewölbter und an den Seiten mehr gerundet, Fühler und Beine fast ganz hell gefärbt, Halssch. und Fld. auf glattem Grunde bedentend weitlïufiger punktirt, die Seiten der Hinterbrust endlich mit Punkten und Härchen besetzt.

Gestreckt, schwach gewölbt, dunkel erzfarbig, glïnzend, Fiihler und Beine hell rostroth, die ersteren mach der Spitze zu etwas gebräunt, letztere mit braunen, metallisch glănzenden Hinterschenkeln. Stirn sehr fein quer gerumzelt, Höckerchen glatt, schmal, oben von einer seichten Linie begrenzt, Nasenkiel ziemlich scharf. Halssch. um ein Drittel breiter als lang, stark queriiber gewölbt und glänzend, mässig dicht, fein punktirt, die Punkte an den Seiten stärker als in der Mitte und oft durch schwache Runzeln verbunlen. Fld. am Grunde bogentörmig heraustretend und in den Schultem etwas breiter als das Halssch., dahinter gleichmässig. gerundet, an der Spitze breit, gerundet-abgestutzt, auf dem vorderen 
Theile des Rückens wenig, hinten deutlicher abgeflacht, dicht punktirt, mit ebenen, glänzenden Zwischenräumen, welche viel grösser sind als die Punkte. Letztere werden auf dem flacheren Theile der Fld., ungefähr von der Mitte bis vor die Spitze merklich feiner als vor der Mitte und an der Spitze, und reichen in der linteren Hälfte ebenfalls bis an die schwache Leiste des Seitenrandes, bilden davor aber eine Reihe neben derselben. Die Schulterbeule ist ziemlich gross, vorspringend, beinahe glatt, innen leicht abgesetzt. Seiten der Hinterbrust wenig dicht punktirt und weisslich behaart; Hinterschienen kurz, etwas schwächer wie die von fuscoaeners, mit mässig langem Enddorn. Flügel vollkommen entwickelt.

Beim Männchen ist das erste Tarsenglied der vier vorderen Beine erweitert und ziemlich so breit als Glied 3, Analsegment vor der Mitte des leistenförmig aufgebogenen Hinterrandes spiegelglatt. Penis schlank, vorn abgerundet, mit kurzer Oeffnung und Klappe, unten rinnenförmig ausgehöhlt, die Rinne vor der Mitte verbreitert.

Auf Echium vulgare L. bei Triest; iiberhaupt an der Küste des mittelländischen Meeres von Spanien bis Syrien stellenweise häufig.

In Südeuropa tritt neben der geflügelten Form noch die flügellose Var. a zahlreich auf, welche sehr stark glänzt, durchweg weitläufiger und feiner punktirt ist und einen schwachen, oft kaum bemerkbaren Schulterhöcker, sowie etwas breitere, länger bedornte Hinterschienen besitzt.

5. Hong. anchusaie: Apterus, oblongus, subconvexus, niger, nitidus, antennarum basi, genubus, tibiis tarsisque ferrugineis aut rufo-testaceis, prothorace alutaceo et vage punctato, elytris subtiliter punctatis, punctis ante apicem rotundato-truncatum et alutaceum evanescentibus, tuberculo humerali nullo. - Long. 1,2-3 mm.

Payk. Faun. Suec. II. 101 (Galleruca). - Koch, Ent. Hft. II. 62 (Halt.). - Ill. Mag. VI. 170. - Gyllh. Ins. Suec. III. 536. - Schilling, Ber. Bresl 1846. 93. - Steph. Ill. Brit. IV. 316; Man. 298 (Thyamis). - All. Mon. 374. Foudr. Mon. 136 (Teinod.). - Redtb. Faun. A. ed. 1. 536; ed. 3. II. 504 (Longit.). - B a ch, Käferf. III. 149. - Kutsch. Wien. 1862. 219 (193). - Seidl. F. balt, 498. - Leesb. Tijdschr. 25. 162.

Haltica gagathina Duft. Faun. A. III. 267. Altica atra Laich. Verz. Tir. Ins. 202.

? Chrysomela pulex Schrank Enum. Ins. Austr. 85.

Var. a. Tibiis infuscatis. 
Var. b. punctatissimus: Alatus, elytris magis deplanatis callo humerali prominulo, subpolito.

Teinodact. punctatissima Foudr. Mon. 138.

Eine unserer häufigen Arten, ähnlich, aber in den Schultern schmaler gebaut als die beiden vorhergehenden und wegen der nicht metallischen Färbung kaum mit ihnen zu verwechseln. Gestreckt, mässig gewölbt, tief schwarz, glänzend, die ersten vier Fühlerglieder, die Wurzel und Spitze der vier Vordersehenkel, alle Schienen und Tarsen rostroth bis hell röthlich gelbbraun, das fünfte und sechste Fiihlerglied röthlich, das erste Glied oft an der Wurzel, seltener (Var. a) auch die Schienen mehr oder weniger stark angedunkelt, zuweilen pechschwarz. Stirn äusserst fein quer gerunzelt oder gewirkt, Höckerchen nur durch eine längliche, glatte Erhöhung angedeutet, Nasenkiel ziemlich breit und stumpf. Hals sch. um ein Drittel (o) bis um die Hälfte (q) breiter als lang, der Quere nach stark gewölbt, an den Seiten gerundet und neben der vorderen Borstenpore eckig heraustretend, auf der Scheibe mehr oder weniger stark lederartig gerunzelt, bald glänzend (vorherrschend $\widehat{\sigma}$ ), bald seidenartig schimmernd, oder selbst matt, mässig dicht, aber sehr flach und verloschen punktirt. Fld. an der Basis in schwachem Bogen heraustretend und in den Schultern wenig breiter als das Halssch, an den Seiten etwas gerundet, hinten breit bogenförmigabgestutzt, auf dem Ruicken in der vorderen Hälfte gewölbt, hinten mehr flach gedrückt, ziemlich dicht und tief, fein punktirt, die Punkte hinter der Mitte abgeschwächt und vor der Spitze auf einem in veränderlicher Stärke gewirkten Streifen oft völlig exlöschend; die Seitenrandleiste sehr fein, Schulterbeule kaum angedeutet. Seiten der Hinterbrust glatt oder gewirkt, aber nicht punktirt und behaart. Hinterschienen kurz und ziemlich kräftig, ihr Rücken nach innen gerundet-abfallend, Enddorn kurz. Flügel verkïmmert, äusserst kurz und schmal.

๙. Das erste Tarsenglied an den vorderen Beinen erweitert, letzter Bauchring auf einem breiten Längsstreifen in der Mitte glatt, vor dem Hinterrande quer eingedrückt, letzterer in der Mitte ohne Randleiste und in einen abschiissigen, bogenförmigen Zipfel verlängert. Penis so lang als der Hinterleib, schlank, an der breiten, aber ziemlich kurzen Oeffnung sanft erweitert, sodann in eine sehr scharfe Spitze gerundet-verengt.

Bei der auffälligen Var. b ist der Nasenkiel sehr breit, die Fld. sind an der Basis weniger gewölbt, durchgängig etwas stärker und dichter punktirt und weniger glänzend als bei der Hauptform, mit breiten Schultern und einer hohen, ziemlich glatten, heraus- 
tretenden und inmen durch eine Vertiefung abgesetzten Schulterbeule.

Auf Symphytum, Echium, Anchusa und anderen Boragineen an Dämmen und Flussufern im grössten Theile von Europa häufig; die Var. b in der Schweiz, Oesterreich, Dalmatien, Ungarn und Croatien (Apfelbeck).

Mit dieser Art nahe verwandt, den kleinsten Exemplaren derselben sehr ähnlich ist Long. Bonnairei All. aus Corsica, aber stärker glänzend, viel feiner punktirt, der Rüicken der Fid. bis zur Spitze höher gewölbt und an dieser nicht gewirkt. Die Beine sind pechschwarz, die vier Vorderschienen und alle Tarsen röthlich.

6. Long. pinguis: Apterus, oblongo-ovatus, valde convexus, niger nitidus, antennarum basi, genubus, tibiis tarsisque ferrugineis aut testaceis, prothorace vage alutaceo et subtiliter punctato, elytris ovalibus, crebre profundeque punctatis, apice rotundato subtruncatis, tuberculo humerali nullo. - Long. 1,8-2,5 mm.

? Haltica atra Ill. Mag. VI. 170.

Var. a. Prothorace fere polito.

Vom vorhergehenden durch etwas grösseren Glanz und weit stärkere Wölbung und Punktirung der Fld., welche für sich ein Oval bilden, in den Schultern stark gerundet-heraustreten, vor der Mitte am breitesten und dahinter merklich verengt sind, sicher zu unterscheiden.

Länglich eiförmig, hoch gewölbt, rein und tief schwarz, glänzend, die ersten vier Fühlerglieder, die Wurzel und Spitze der vorderen Schenkel, alle Schienen und Tarsen hell rostroth bis bräunlich gelb, das fünfte und sechste Fühlerglied rothbraun. Stirn äusserst fein gewirkt, Höckerchen länglich, glatt, oben durch einen verloschenen Eindruck oder eine feine Linie von der Stirn geschieden, Nasenkiel ziemlich schmal. Halssch, um ein Drittel breiter als lang, der Quere nach stark gewölbt und alle Ecken nach unten gedrückt, von der winkelig nach aussen tretenden vorderen Borstenpore bis zu den Hinterecken allmählich leicht verengt, seltener etwas gerundet, auf' der Scheibe äusserst fein gewirkt, mässig dicht, fein und nicht besonders tief punktirt, bisweilen (Var. a) fast spiegelglatt. Fld, an der Basis in starkem Bogen heraustretend und in den Schultern bedeutend breiter als der Grund des Halssch, an den Seiten gerundet, aber schon von der Mitte ab verschmälert, hinten ziemlich breit bogenförmig-abgestutzt, mit stumpfwinkliger, in der Regel scharfer Nahtecke; auf dem Rücken gewölbt und nach dem Seitenranke stark, jedoch in einem viel regelmässigeren Bogen ab- 
fallend wie bei anchusae, gleichmässig dicht, tief und kräfti punktirt, mit schmalen und glatten Zwischenräunen, welche stellen weise wenig hervortretende Schrägrunzeln bilden. Die Seitenrandleiste ist mässig breit, die S'chulterbeule fehlt gänzlich. Hinterschienen zusammengedriickt, ziemlich dünn, Enddorn kurz. Ungeflïgelt.

Das Männchen erkennt man, abgesehen von seiner geringen Grösse, an den verlängerten Fühlern, welche mindestens zwei Drittel so lang sind als der Körper, sowie am letzten Bauchringe, der in der Mitte eine ovale, tiefe, im Grunde rinnenförmig verengte Grube besitzt. Dieselbe reicht von der Nähe des Vorderrandes bis auf den bogenförmigen Mittelzipfel. Penis kräftig, dem von puruulus ähnlich, an den Seiten sehr lang und sanft ausgeschweift, vorn breit abgerundet, mit einer unscheinbaren, stumpfen, deutlich abgesetzten Spitze, die Oeffnung breit und ziemlich kurz. Auf der Unterseite befindet sich eine scharfrandige, muldenförmige Rinne, welche ungefähr das mittlere Drittel der Breite einnimmt und nahe der Spitze erweitert ist.

Bei Roveredo im südlichen Tirol; ausserdem bei Riva und Lugano. Serbien, Griechenland, Syrien. Vielleicht bis in's nördliche Deutschland verbreitet, da die Beschreibung von Halt. atra Illiger, nach einem in der Umgegend von Braunschweig gefangenen Stücke entworfen, wahrscheinlich auf den vorliegenden Käfer bezogen werden muss.

\%. Long. absinthii: Apterus, oblongus, sat convexus, subtilissime alutaceus, nitidulus, niger, vix virescens aut coerulcscens, antennarum basi pedibusque brunneo-rufis, femoribus obscurioritus; fronte tuberculis nullis, prothorace crebre punctulato, elytris dense et subtiliter subrugolosopunctatis, apice fere singulatim rotundatis, callo humerali haud discreto, tibiis posticis sat gracilibus. - Long. 1,4-1,8 $\mathrm{mm}$.

Kutsch. Wien. Monat. 1862. 217 (191). - Bach, Käferf. III.

336. - Seidl. F. balt. 498. - All. Mon. 326 (Thyamis.).

Long. niger Bach l. c. III. 149.

? Long. absinthii Thoms. Skand. Col. VII. 168.

Var. a. Antennis apicem versus leviter infuscatis pedibusque testaceis, femoribus posticis superne brunneis.

Den beiden vorigen nahe verwandt, und kleinen Stücken des L. anchusae ähnlich, aber etwas schlanker, nicht ganz so tief schwarz gefärbt und weniger glänzend, die Fld. in gleichmässigem Bogen zu den Seiten abfallend und an der Spitze schmaler abgerundet; nach dem Habitus noch leichter mit der folgenden Art zu ver 
wechseln, die Stirn jedoch olne eigentliche Stirnlinien, nur mit einer Augenrimne jederseits, die Fld. tiefer, aber feiner, ungefähr doppelt so dicht punktirt und die Hinterschenkel heller gefärbt.

Gestreckt, mässig gewölbt, schwarz, zuweilen mit einer sehr geringen, kaum bemerkbaren Beimischung von Griin oder Blan, mässig glänzend, Fỉhler und Beine bräunlich roth, erstere vom fünften oder sechsten Gliede an verbreitert und nebst einem grösseren oder geringeren Theile der Schenkel, namentlich der Hinterschenkel dunkler, oft pechbraun. Stirn äusserst fein grewirkt, mit eincr scharfen, rom oberen Rande der Augen zur Fühlerwurzel zichenden Rimne jederseits, welche grade oder schwach nach aussen gebogen sein kann. Höckerchen völlig verwischt, selten durch eine längliche glatte Erhöhung angedeutet, Nasenkiel ziemlich schmal. Halssch. um ein Drittel breiter als lang, quer gewölbt, körnig gewirkt und fein, wenig tief punktirt, matt seidenartig glänzend. Fld. in schwachem Bogen heraustretend und in den Schultern wenig breiter als die Basis des Halsch., an den Seiten leicht gerundet hinten verengt und mässig breit, fast einzeln abgerundet, auf dem Rücken nicht bedeutend, aber ziemlich gleichmässig gewölbt, dicht und tief, fein punktirt, mit sehr schmalen Zwischenräumen, welche zu langen und schwachen Schrägrunzeln verbunden und undeutlich gewirkt sind. Seiten der Hinterbrust lederartig gerunzelt, Hinterschienen ziemlich dünn, zusammengedrückt, ohne Innenrandleiste, ihr Enddorn kurz. Flügel verkümmert.

Beim Männchen ist das erste Tarsenglied an den vorderen Beinen bedeutend erweitert, der letzte Bauchring in der Mitte des Hinterrandes in einen kleinen, halbkreisförmigen Zipfel verlängert, welcher in den Hemicyclus eingelagert und grösstentheils von einem tiefen Grübchen eingenommen ist.

Bei einzelnen Stiicken wird das Halssch. pechbraun, am Vorderrande schmal röthlich gesåumt, auch schimmert der Hinterrand der Fld. so weit rothbraun durch, als er über den zusammengezogenen Analring hinausragt; zuweilen sind die Fühler und Beine hell röthlich gelbbraun, erstere nach der Spitze hin und die Hinterschenkel auf dem Rücken rothbraun (Var a).

In den Berggegenden Deutschlands, am Rheine, in Thüringen, Schlesien und in Oesterreich auf Artemisia absinthium selten, ausserdem noch in England (Allard), Ungarn (v. Hopffgarten) und vielleicht auch in Schweden; zuerst von $H$. Bach bei Boppard gefunden und als niger Koch beschrieben und versandt.

Fraglich bleibt es, ob absinthii Thoms. ,oben stahlblau schimmernd. mit einer röthlichen Makel an der Schulter und vor der Spitze der Fld.," hierher gehört. 
8. Iong.obliteratus: Apterus, oblongus, convexus, nitidulus, niger, subreneo-micans, antennarum basi pedibusque (femoribus posticis excrptis) testaceis, fronte alutacea tuberculis angustis bene discretis, prothorace subliliter subruguloso-punctato, elytris sat crebre, mimus subtiliter serl vage seriatim punctatis, humeris rotundatis. Long. $1-1,8 \mathrm{~mm}$.

Tcinodactyla obliterata Rosh. Beitr. Ins. Eur. 1847. 61.Al1. Ann. Fr. 1860. 96; Mon. 325 (Thyamis).

Long. obliteratus Kutsch. Wien. 1862. 216 (190). - Redtb. Faun. A. ed. II. 504. - Bach, Käferf. III. 336.

Long. consociatus Först. Verb. Preuss. Rheinl. V1. Nachtr. I. 38. - Redtb. 1. c. ed. 2. 943. - Bach, 1. c. 149.

Teinodact. pulex Foudr. Mon. 139. - Leesb. Tijdschr. ¿5. 161 (Long.).

Var. a. meridionalis: Alatus, elytris tuberculo humerali prominulo.

Var. b. Femoribus anterioribus infuscatis.

Var. c. Prothorace parce punctulato, nitido.

Var. d. Immaturus, brunneus, leviter deneo-micans.

Die kleinste metallisch gefärbte Art, an den tiefen und geraden Stirnlinien sofort zu erkennen. Sehr lang und schmal eiförmig. gewölbt, fettig glänzend, schwarz mit metallisch grünem Anfluge; die nach der Spitze hin gebräunten oder geschwärzten Fülller und die Beine röthlich gelbbraun, Hinterschenkel erzfarbig schwarz, die Spitze ihres Innenrandes nebst dem grössten Theile der verdeckten inneren Fläche rostroth. Stirn äusserst fein gewirkt, jederseits mit einer scharf eingeschnittenen Rinne, welche vom oberen Rande der Augen durchaus oder fast gradlinig bis zur Spitze des Nasenkieles läuft und die schmalen, linienförmigen Höckerchen deutlich von der Stirn trennt. Halsseh. etwa um die Hälfte breiter als lang, quer gewölbt, an den Seiten ziemlich gerade, nur neben der vorderen Borstenpore wenig und stumpfwinkelig nach aussen gedrückt, auf der Seheibe ziemlich dicht, fein, aber sehr flach und verloschen punktirt, die Punkte in die Länge gezogen, ihre Zwischenräume längsgestrichelt und hie und da $\mathrm{zu}$ undeutlichen Runzeln vereint; der Streifen iiber den Seiten ist fast glatt und wird meist durch einen Eindruck von der Scheibe abgesetzt. Fld. in schwachem Bogen heraustretend und in den völlig beulenlosen Schultern etwas breitcr als die Basis des Halssch., an den Seiten mehr oder weniger gerundet, hinten verengt und beinahe gemeinschaftlich abgerundet; mit sehr stumpfer, verrundeter Nahtecke; auf dem Rücken gewölbt, mässig dicht in Reihen punktirt, welche theilweise, namentlich nahe der Naht, der Basis und dem Seitenrande in seichten Furchen stehen. Die Punkte sind grösser als die des Halssch., sehr flach, ihre Zwischenräume verloschen gewirkt, etwas oder riel breiter als 
die Punkte. Seiten der Hinterbrust beinahe spiegelglatt, Hinterschienen dünn, mit langem Enddorne. Ungefligelt.

ô Erstes Tarsenglied der vorteren Beine wenig erweitert, letzter Bauchring vor dem kleinen, halbkreisförmigen Mittelzipfel abgeflacht, oder der Quere nach eingedrïckt; Penis leicht gebogen, schlank, gleich breit, vorn gleichmässig und ziemlich schnell verengt, auf der Oberscite nimmt die von einer Klajpe bedeckte Oeffnung mehr als die Hälfte der Länge ein, die Unterseite ist flach muldenförmig vertieft.

Die wichtigste Abänderung (Var. a) hat vollkommen entwickelte Flügel und an der Basis winkelig heraustretende, breite Schultern, mit einer grossen und hohen, vorstehenden, nicht punktirten Schulterbeule, hinter der die Fld. kaum gerundet sind; weniger bedeutend sind die Varietäten $b$, deren vier Vorderschenkel mehr oder weniger weit angedunkelt sind, oder e, mit ziemlich glattem, kaum gewirkten und gerunzelten, sondern nur äusserst fein punktulirten Halssch., und d, die frischen Stuicke umfassend, welche in verschiedenem Grade braun gefärbt und mit einem leichten Erzschimmer versehen sind.

Im Frühlinge und Herbste an den Wurzelblättern von Salvia pratensis auf Kalkboden, am Rheine, in Thüringen (nördlich noch bei Magdeburg, Breddin) und in Oesterreich, hier auch an Thymus serpyllum. Ausserdem in England, Frankreich, Ungarn, Russland und ganz Südeuropa. Die Var. a erhielt ich aus Madrid von H. Martinez und aus Syrien (von Haifa, Simon). An der Salbei wird das Thier durchschnittlich grösser als am Thymian.

Obgleich bereits $\mathrm{K} n \mathrm{tschera}$ darauf hinwies, dass die Beschreibung von L. pulex Schrank und Marsham, schwerlich die vorliegende Art erkenmen lasse", führte H. v. Harold neuerdings diesen Namen ohne weitere Prüfung ein. Die Worte "Atra, nitens, antennis tibiisque rufis. - Long. $3 / 4\left(1^{1 / 4}\right)$ lin. Oblonga, tota nigra, nitens, thorace elytrisque subtilissime at irregulariter punctatis" lassen sich vielleicht dem $I$. anchusae anpassen, auf keinen Fall aber dem obliteratus.

9. Iong. niger: Alatus, ovalis, convexus, niger, nitidus, antennis apice fuscis pedibusque pallide flavis, femoribus posticis piceis aut nigris, tibiis posticis compressis basi infuscatis; mothorace subtiliter punctulato, elytris crebre subseriatim punctatis, antrorsum subrugulosis, apice fice conjunctim rotundatis, callo humerali sublaevi. - Long. 2,3-3 mm.

Haltica nigra Koch, Ent. Heft. II. 57. - Ill. Mag. VI. 171. - Gyllh. Ins. Suec, IV. App. 655. - Foudr. Mon. 135. (Teinod.). - All. Mon. 312 (Thyamis).

Long. niger Redtb. Faun. A. ed. 1. 536; ed. 3. II. 504. - Kutseh. 
Wien. Monat. 1862. 220 (194). - Thoms. Skanrl. Col. VIII. 166. - Seidl. F. balt. 498, - Leesb. Tijdschr. 25. 161.

Longit, elongatus Bach, Käferf. III. 147. - Kraatz, Berl. Zeitschr. 1868. 304.

Var. a. Immaturus; tibiis posticis flacis, epipleuris, interdum etiam prothorace latera versus piceo-rufis.

Var. b. Pedibus ferrugineis aut leviter infuscatis.

Länger oder küirzer eiförmig, gewölbt, tiefschwarz, glänzend. die Fühler, mit Ausnahme der dunklen Endglieder, und die Beine blass bräunlichgelb, Hinterschenkel schwarz oder pechbraun, Hinterschienen mehr rostroth und in der Basalhälfte angedunkelt. Stirn äusseist fein und dicht gewirkt, ohne Spur von Linien oder Höckern, die Augenrinnen jederseits mässig tief, der Nasenkiel schmal. Halssch. um die Hälfte breiter oder doppelt so breit als lang, mit gerundeten Seiten, stark querüber gewölbt, fein punktulirt, die Punkte seicht und in die Länge gezogen, die Zwischenräume bald ziemlich glatt, glänzend, bald gewirkt, der Länge nach gestrichelt, oder verlosehen gerunzelt, seidenartig glänzend; der Streifen über dem Seitenrande stets glatter als die Scheibe und von dieser durch ein oder mehrere Grübchen, oder einen Längseindruck geschieden. Fld. an der Basis in sehr sehwachem Bogen heraustretend und in den Schultern wenig breiter als das Halssch., an den Seiten gleichmässig gerundet, hinten beinahe gemeinschaftlich abgerundet, mit stumpfer Nahtecke, der Rücken gewölbt, nach der starken Seitenrandleiste mässig abfallend, dicht in unregelmässigen Reihen punktirt, wovon sich ungefähr 16 bis 17 unterscheiden lassen. Die äusserste Reihe läuft in der Regel vorn dem Seitenrande parallel. beschreibt in der Mitte einen kleinen, nach innen gerichteten Bogen und nähert sich dahinter den Seiten, oder erlischt. Die Zwischenräume der Punkte sind weitläufig gewirkt, ohne dadurch viel an Glanz einzubüssen, und bilden in der vorderen Hälfte sehr schwache Schrägrunzeln, die Schulterbeule ist ziemlich lang, niedrig, fast glatt, nur hinten deutlich abgesetzt. Seiten der Hinterbrust äusserst fein gewirkt, Hinterschienen stark zusammengedrückt, leicht nach innen gekrümmt, an der Spitze erweitert, auf der Leiste des Aussenrandes mit kräftigen Zähnchen. Geflïgelt.

Beim Männchen ist das erste Tarsenglied an den Vorderbeinen sehr stark, an den Mittelbeinen schwächer erweitert, der letzte Bauchring besitzt eine glatte Mittellinie und einen leistenförmig aufgebogenen Hinterrand, welcher vor dem grubig vertieften Mittelzipfel dreieckig ausgeschnitten ist. - Penis klein, mässig breit, mit parallalen Seiten, vorn beiderseits fast gradlinig verschmälert, so 
dass die Spitze ungefähı cin gleichschenkliges Dreieck bildet; die Unterseite ist muldenförmig ausgehöhlt.

Nicht völlig ausgehärtete Stiicke besitzen hellgelbe Hinterschienen, rothbrame Epipleuren und zuweilen noch pechbraune Seiten des Halsschildes, bei cingetrocknetem IIinterleibe schimmert. die Spitze der Fld., soweit sie von unten nicht bedeckt wird, rothbraun durch (Var. a); die Beine sehr dunkler Exemplare sind zum grössten Theile rostroth, oder xöthlich gelbbraun und stellenweise angedunkelt (Var. b).

Auf feuchten Grasplätzen in den Berggegenden Deutschlands, sowie Mittel- und Südeuropa's zerstreut. Schweden.

10. Long. rectilineatus: Alatus, ovalis, convexus, niger, subtilissime alutaceus sat nitilus, antennis (apicem ver'sus fuscis), genubus, tibiis tarsisque ferrugineis, prothorace subtiliter punctulato, elytris antice sat crebre subseriatim, postice subtilius punctatis, apice fere conjunctim rotundatis, tuberculo humerali prominulo. - Long. 1,6--2,2 mm.

Teinodactyla rectilineata Foudr. Mon. 138. - All. Mon. 409 (Thyamis).

Longit. rectilineatus Kutsch. Wien. Monat. 1862. 221 (195).

Ganz rom Ansehen der vorigen Art, aber etwas kleiner, mit breiteren Schultern, weniger dicht punktirten Fld. und dunkleren Vorderschenkeln: Eiförmig, gewölbt, tiefschwarz, äusserst fein gewirkt, ziemlich glänzend, die Fühler mit Ausnahme der dunklen Endglieder, die Schienen und T'arsen, sowie die Basis und Spitze der vier Vorderschenkel hell rostroth. Stirnhöckerchen undeutlich, etwas glänzender als der übrige Theil der Stirn und zuweilen oben durch eine feine Linie begrenzt. Fld. an der Basis winkelig. heraustretend und in den Schultern bedentend breiter als das Halssch., mit einer hohen, vorspringenden, glatten Schulterbeule, welche innen und hinten schwach abgesetzt ist; die Seiten mässig gerundet, der Rüicken ziemlich dicht in Reihen punktirt, von denen sich ungefähr 12 bis 13 unterscheiden lassen. Hinter der Mitte verwirren sich die Punkte völlig, und werden allmählich feiner, besonders seichter, so dass sie auf dem Abfalle zur Spitze, ausgenommen vielleicht aut einer mehr oder weniger grossen Stelle an der Nahtecke, ziemlich erlöschen. Alles Uebrige wie bei $L$. niger.

Nach Foudras soll der letzte Bauchring des Männchens mit einem kleinen, linienförmigen Längseindrucke versehen und an Hinterrande abgerundet, der Penis vorn allmählich zugespitzt sein.

In Oesterreich, der Schweiz und Siidfrankreich. Mir liegen nur einige Weibchen aus der Umgegend rou Budapest ror. 
11. Cong. parvulus: Alatus, subovalis, comrexus, piceo-niger, subtilissime alutaceus, subsericeo-, sed vix aeneo-micans, antennarum basi pedibusque testaceis, femoribus posticis superne, anterioribus in medis infuscalis; prothorace vage sulbruguloso-elytrisque subtiliter obsolete punctatis, his apice fere singulatim rotundatis, tuberculo humerali subprominulo. - Long. $1-1,8 \mathrm{~mm}$.

Galleruca parvula Payk. Faun. Suec. II. 102. - Koch, Ent. Hft. II. 59 (Halt.). - Gyllh. Ins. Suec. III. 526. - Duft. Faun. A. III. 268. - Steph. Ill. Brit. IV. 316; Man. 298 (Thyamis). - All. Mon. 413. - Foudr. Mon. 146 (Teinod.).

Longitarsus parvulus Redtb. Faun. A. ed. 1. 535; ed. 3. II. 504. - Bach, Käferf. III. 149. - Kutsch. Wien. 1862. 223. (197). -- Thoms. Skand. Col. VIII. 167. - Seidl. F. balt. 498. Haltica pumila Ill. Mag. VI. 170.

Longit. ater Leesb. Tijdschr. 25. 162.

Var. a. Immaturus, rufo-piceus.

Var. b. Supra evidenter punctatus.

Var. c. concinnus: Apterus, elytris basi angustis postice dilatatis, tuber culo humerali nullo.

Einer kleinen Aphthona ungemein ähnlich; unter den vorhergehenden Arten nur mit obliteratus und absinthii zu rerwechseln, von ersterem aber durch die fehlenden Stirnlinien und den kurzen Enddorn der Hinterschienen, ron letzterem durch weit schlankere, in den Endgliedern wenig erweiterte Fühler, ein breiteres Halssch. und die verloschene Punktirung der Fld. abweichend.

Länglich eiförmig, die Männchen an den Seiten wenig, die Weibchen mehr gerundet, ziemlich stark gewölbt, auf der Oberseite fast gleichmässig äusserst dicht und fein gewirkt, seidenartig oder fettig, selten noch stärker glänzend, pechschwarz, zuweilen mit einem leichten metallischen Anfluge. Die ersten vier bis sechs Fühlerglieder und die Beine röthlich bis blass gelbbrann, die Hinterschenkel rostroth, ihr Rücken, sowie die Mitte der vier Vorderschenkel mehr oder weniger angedunkelt. Stimhückerchen erloschen, Nasenkiel schmal und scharf, oben etwas verbreitert. Halsseh. kurz, etwa doppelt so breit als lang, mit gerundeten Seiten, äusserst undeutlich längsrunzelig punktirt, auf dem Längsstreifen an den Seiten, der imen durch einen Eindruck abgesetzt wird, beinahe glatt. Fld. in starkem Bogen heraustretend und in den Schultern merklich breiter als das Halssch., an der Spitze sehr schwach einzeln abgerundet, auf dem Rücken mässig dicht, sehr fein und besonders seicht punktirt, die Punkte in der vorderen Hälfte etwas gereiht. Seiten der Hinterbrust glatt, Hinterschienen riemlich kurz und dünn, auf der Seitenleiste des Rückens undentlich grezähnelt, mit kurzem Enddorne. Vollkommen geflügelt. 
o Erstes Tarsenglied an den vorderen Beinen mässig erweitert, letzter Bauchring mit einer glatten, zuweilen vertieften Mittellinie und verhältnissmässig grossem, bogenförmigem Mittelzipfel, der in den Hemicyelus abfällt. - Penis so lang als der Hinterleib, in der Mitte jederseits weit und sanft ausgeschweift, rom in breiter Rundung verengt und in eine kleine, scharfe Spitze ansgezogen; die Oeffnung kurz, eiförmig, die Unterseite ausgekehilt, an der Spitze eben.

Bei der nicht ausgereiften, röthlich pechbraunen Var. a ist die Oberseite metallisch angehaucht, die Spitze der Fld. meist noch heller gefärbt als der übrige Theil; die Skulptur nimmt soweit zu, dass sowohl die länglichen, runzeligen P'unkte des Halssch., als auch die feinen Punkte der Fld. aus der Netzelung des Grundes deutlich hervortreten (Var. b). Eine bisher unbeachtete flügellose Form ${ }^{1}$ ), die Var. c, erinnert im Körperbau an L. obliteratus, die Fld. erweitern sich von den engen, wenig über den Grund des Halssch. vortretenden Schultern bis hinter die Mitte, sind hinten etwas breiter abgermidet und besitzen von der Schulterbeule keine Spur.

Vom Juni bis in den Herbst an Wegen und Waldrändern in Deutschland, wie in grössten Theile von Europa gemein, am häufigsten auf blïhendem Flachs, Linum usitatissimum L., die Var. c in Krain und in der Ungegend von Sarajewo (Apfelbeck).

12. Long, nigermimus: Alatus, breviter ovalis, convexus, nitidus, niger, prothorace subtititer elytrisque crebre punctatis, his apice conjunctim rotundatis, tuberculo humerali discreto, metatarso et tibiis posticis compressis, his calcari sat longo instructis. - Long. 1,5-2,2 mm. Haltica nigerrima Gyllh. Ins. Suec. IV. App. 656. - Kutsch. Wien. Monat. 1864. 277 (298), -- A.1l. MIon. 321 (Thyamis).

Longit. nigerrimus Thoms. Skand. Col. VIII. 166. - Seidl. F. balt. 498 .

Dem folgenden so ähnlich, dass man leicht versucht sein könnte, beide für eine Art zu halten, jedoch durehschnittlich kleiner, einfarbig, mit stärkerer Schulterbeule, weniger abgerundeter Nahtecke und lïngerem Dorn der Hinterschienen, iiberhaupt dureh die Penisform sehr verschieden.

1) Da es nicht unwabrscheinlich ist, dass von den meisten g'eflïg'elten Longitarsen auch eine ungefligelte Form existirt, und umgekehrt, so diirfte das seither zur Unterscheidung von Arten und Gruppen rorwiegend benutzte Merkmal der Schulterbillung erheblich an Werth verlieren. 
Kur\% eiförmig, hochgewölbt, tiefschwarz, glänzend, bei frischen Stiicken die ersten Fühlerglieder an der Spitze oder ganz, und die vier vorderen Beine pechbraun, mit röthlichen Knien. Fühler dünn, Glied 1 kurz und dick, 2 etwas kugeliy, die tolgenden schlank, 3 und 4 von gleicher Länge, die fünf Endglierler anch hein $\vec{\jmath}$ wenig verdickt. Stirn ummerklich gewirkt, oft mit einem punktoder winkelförmigen Eindrucke zwischen den verwischten Hïckern, Nasenkiel nach oben verbreitert. Halssch. um die Hälite breiter als lang, an den Seiten stark abwärts gewölbt, die Scheibe auf glattem Grunde vor der Mitte sparsam, dahinter dicht und fein punktirt und hier zuweilen etwas runzelig. Fld. mit gleichmässig gerundeteu Seiten, überall ziemlich kräftig punktirt, die Schulterbenle vorspringend, glatt, innen und hinten von einem stärker punktirten Eindrucke emporgehoben, die Nahtecke schwach abgerundet. Hinterschenkel bis zur Spitze der Fld. reichend, Enddorn der Hinterschienen, die nebst dem Metatarsus ganz ähnlich gebaut sind wie bei holsaticus, ziemlich lang. Vollkommen geflügelt.

$\hat{o}$ Die drei ersten Tarsenglieder an den vorderen Beinen ron gleicher Breite, der letzte Bauchring etwas aufgetrieben, mit feiner Mittelrimme, sein leistenförmig aufgebogener Hinterrand aus zwei schwachen Bogen gebildet und der Mittelziptel grubentörmig ausggehöhlt. Penis kurz und breit, in den mittleren beiden Vierteln der Länge unbedentend, in Endviertel ziemlich schnell verengt, so dass letzteres etwa ein gleichseitiges Dreieck bildet; die Oeffinung gross, elliptisch, die Unterseite ausgekehlt.

Vom Juli an auf feuchten Wiesen in Gesellschaft von Dibolia occultans. Ueber das nördliche Deutschland verbreitet und zu Ende des Winters oft zahlreich im Anspülicht ron Torfsümpfen. Bei Le Mans in Frankreich, England, Schweden.

Vielleicht hat Stephens seine Thyamis atricornis nach einem frischen Stïcke dieser Art aufgestellt, nur lässt sich damit die Angabe „elytiat very obscurely punctured" schlecht vereinigen.

13. Long. holsaticus: Alatus, breviter ovalis, concexus, nitidus, niger, antennarum basi, pedibus anterioritus tarsisque posticis mescentilus, prothorace subtiliter punctato, elytris crebre punctatis ante apicem subconjunctim rotundatum macula determinata rufa signatis, tuberculo humerali parvo, metatarso et tibiis posticis compressis, his calcari brevi. - Long. 1,8-2,5 mm.

('hrysomela holsatica L. Syst. Nat. ed. 10. 373. - Fabr. Syst. Ent. 115. Altica. - Payk. Faun. Suec. II, 99. Galleruca. Koch, Ent. II. 60 (Halt.). - Ill. Mag. VI. 169. - Gyllh. Ins. Suec. III. 534. - Dnft. Faun. A. III. 264. - Schilling, 
Ber. Breslau 1846. 93. - Steph. Ill. Brit. IV. 317; Man. 298. Thyamis. - All. Mron. 320. - Küst. Käf. Eur. 8. 99. Teinodactyla. - Foudr. Mon. 141.

Longit. holsaticus Redtb. Faum. A. ed. 1. 535; ed. 3. II. 504.

- Bach, Käferf. III. 150. - Kutsch. Wien. 1862. 225. (199).

- Thoms. Skand. Col. VIII. 169. - Seidl. F. balt. 498. Leesb. Tijdschr. 25. 162.

Var. a. Pedibus anterioribus infuscatis.

Var. b. Pedibus rufo-testaceis, femoribus posticis piceis.

Var. c. Prothorace subruguloso punctato, alutaceo, minus nitido.

Var. d. pulicarius: Macula elytrom parva, transversa, trigona vel subcordata.

Chriysomela pulicaria L. 1. c. ed. 12. 595. - Thunb. Act. Upsal.

V. 113. Haltica. - Gyllh. l. c.

Var. e. discoideus: Ut in b, sed elytris laete testaceo-flavis, limbo suturali basin versus dilatato maculaque elongata intramarginali nigris, punctis elytrorum saepe in fundo obscuris.

Durch den Körperbau und die rothe Makel vor der Spitze der Fld. kenntlich, kurz eiförmig, hochgewölbt, schwarz, glänzend, die Fühlerwurzel nebst den vier Vorderbeinen und den Hintertarsen rostroth, hinter der Mitte jeder Fld. eine grosse, rothgelbe Makel, welche von der Spitze etwas weiter entfernt bleibt als von der Naht und dem Seitenrande und nicht immer scharf begrenzt ist. Fühler dünn, nur die beiden Basalglieder kräftig, die folgenden gestreckt. Stirn äusserst fein und dicht lederartig gerunzelt, Höckerchen glatt, erloschen, weder von dem ziemlich schmalen Nasenkiele noch von der Stirn deutlich geschieden. Halssch. um die Hälfte breiter als lang, uiber den etwas gerundeten Seiten stark abfallend; ziemlich dicht, fein punktirt, nahe der Basis bisweilen längsrunzelig, die Zwischenräume meist glatt. Fld. in starkem Bogen heraustretend und in den Schultern merklich breiter als das Halssch., bis zur Mitte oder hinter dieselbe erweitert, am Ende fast gemeinschaftlich abgerundet, mit stumpfer Nahtecke; die Oberfläche dicht und ziemlich kräftig punktirt, die Punkte auf der vorderen Hälfte an einzelnen Stellen gereiht, auf dem hell gefärbten Theile hinter der Mitte oft abgeschwächt. Seiten der Hinterbrust fast glatt, Seitenstücke derselben schwach gerunzelt; Hinterschienen leicht nach innen gekrümmt, zusammengedrückt, innere Rückenleiste fehlend, äussere deutlich gezähnelt, Enddorn kurz. Metatarsus länger als die halbe Schiene, ebenfalls zusammengedriickt, mit schmaler Sohle. Vollkommen geflügelt.

Beim Mäunchen ist das erste Tarsenglied der vorderen Beine wenig erweitert, der Hinterrand des letzten Bauchringes fein gerandet, sehr weit und flach dreieckig ausgeschnitten, der Mittel-

VI. 5. 
zipfel grubig vertieft. - Penis von der Basis bis neben die Oeffinung eine Spur verbreitert, vor der breitesten. Stelle allnählich und fast geradlinig verengt, die ziemlich scharfe Spitze leicht aufwärts gebogen. Von Abänderungen sind zu erwähnen:

a. Die Beine werden fast so dunkel wie die der vorigen Art, es bleibt jedoch die Spitze der Schenkel und ein Theil der Schienen und Tarsen an den vorderen Beinen röthlich, oder

b. die Beine sind röthlich gelbbraun und nur die Hinterschenkel pechschwarz.

c. Das Halssch. ist dicht und etwas runzelig punktirt, mit gewirkten, weniger glänzenden Zwischenräimen.

d. Die Makel der Fld. verengt sich auf einen kleinen, bald queren, bald dreieckigen, zuweilen am Vorderrande ausgebuchteten und fast herzförmigen Fleck. oder dehnt sich

e. bis zum Vorderrande aus. Bei dieser Varietït sind die Fld. lebhaft bräunlichgelb, ein mässig breiter Nahtsaum, der sich vor der Mitte allmählich so erweitert, dass er die Basis der Fld. von einer Hinterecke des Halsschildes zur anderen einnimmt, sowie ein Seitensaum schwarz. Letzterer ist anfangs auf die Randleiste beschränkt, hinter der Schulterbeule makelförmig bis zur zweiten äusseren Punktreihe nach innen erweitert, bald hinter der Mitte wieder auf die Seitenkante verengt und an der Spitze abermals rerbreitert. Die Farbe der Scheibe, auf welcher die Punkte oft dunkel sind, geht durch rothbraun in den schwarzen Saum über.

Auf sumpfigen Wiesen im mittleren und nördlichen Europa häufig, namentlich im Anspülicht im ersten Frühjahre; die Var. e bei Sarepta und Samara. Soll nach Stephens auf Pedicularis palustris leben.

14. Long. quadriguttatus: Alatus, oblongo ovalis, converiusculus, niger, leviter aeneo micans, nitidus, antennam basi pedibusque ferrugineis, femoribus posticis nigris; elytris subtiliter punctatis, macula humerali alteraque majore ante apicem separatim rotundatum ferrugineis, tuberculo humerali parum prominulo, pedibus posticis longis, tibiis apicem versus sensim dilatatis. - Long. 2,5-3,3 $\mathrm{mm}$.

Chrysomela 4-guttata Pontopp. Nat. Dan. 1765. 203. t. 16.

Long. 4-guttatus Leesb. Tijdschr. 25. 163.

Altica 4-pustulata Fabr. Syst. Ent. 114. - Oliv. Encycl. IV. 109;

Ent. VI. 715. t. 5. f. 83. - Panz. Faun. Germ. 88. 2. Illig. Mag: VI. 168. - Steph. Ill. Brit. VI. 168; Man. 295

(Thyamis 4-punctulata).

Longitarsus 4-pustulatus Redtb. Faum. A. ed. 1. 5ั35̆ : ed. 3. II. 
504. - Bach, Käferf. III. 150. - Kutsch. Wien. 1862. 227

(201). - Th om s. Skand. Col. VIII. 170. - Seidl. F. balt. 498. Chrysomela 4-notata Gmel. Ed. Lim. I. 4. p. 1697. - D nft. Faun. A. III. 259 (Halt).

Hultica 1-maculata Koch, Ent. Hft. II. App. 128. - Foudr. Mon. 142 (Teinod.).

Longitarsus 4-maculatus Weidenb. Bericht. 12. Nat. Vers. Augsburg 1859. 85.

Chrysomela cynoglossi Mar'sh. Ent. Brit. I. 205.

Var. a. Femoribus anterioribus basi infuscatis.

Var. b. binotatus: Macula apicali aut humerali elytrorum deficiente. Var. c. immaculatus: Elytris nigris.

Var. d. vittatus: Maculis elytrorum longitudinaliter confluentibus.

Grösser, namentlich länger, in den Schultern schmaler gebaut als die beiden vorigen Arten; länglich eiförmig, ziemlich gewölbt, schwarz, wenigstens auf dem Kopfe und Halssch. metallisch angehaucht, die Basalhälfte der Fühler und die Beine mit Ausnahme der schwarzen Hinterschenkel hell rostroth. Fühler etwa drei Viertel so lang als der Körper, kräftig, Glied 2 und 3 kurz, in der Form wenig verschieden. Stirn fast glatt, Höckerchen dreieckig oder lang-oval und aussen zugespitzt, oben durch eine sehr feine Linie begrenzt, Nasenkiel zwischen den Fühlern verbreitert und abgeflacht. Halssch. bald wenig, bald um die Hälfte breiter als lang, an den Seiten leicht gerundet, auf der Seheibe mässig dicht und sehr fein punktirt, nach dem Hinterrande zu etwas dichter und stärker, mit glatten und glänzenden Zwischenräumen, seltener etwas runzelig punktirt, mit sehr fein gewirkten Zwischenräumen. Fld. an der Basis stumpfwinkelig heraustretend und in den Schultern breiter als das Halssch., bis zur Mitte in schwacher Rundung erweitert, dahinter ähnlich verengt, am Ende einzeln abgerundet; sie sind ziemlich dicht, seicht und fein punktirt, die Punkte unmittelbar an der Basis, neben der Naht im vorderen Drittel und an der Spitze etwas stärker und tiefer wie auf den ïbrigen Theilen, die Schulterbeule ziemlich klein, nur vorn deutlich abfallend. Jede Fld. besitzt zwei längliche, rothe Makeln, welche von der Grundfarbe wenig abstechen und an den Rändern verwaschen sind; sie liegen hinter einander, die kleinere auf und hinter der Schulter, die grössere hinter der Mitte, und bleiben von der Naht viel weiter entfernt als vom Seitenrande. Die Hinterbeine sind lang, ihre Schenkel reichen bis zum Hinterrande der Fld., ihre Schienen sind nach der Spitze allmählich verbreitert und sehr schwach nach innen gekriimmt, besonders dann, wenn die Innenrandleiste des Riickens in der vorderen Hälfte scharf ausgeprägt ist; der Enddorn ziemlich kurz. Geflügelt. 
Das kleine und schlanke Männchen zeichnet sich durch den geraden Hinterrand des letzten Bauchrings aus, hinter dessen Randleiste der kleine, bogenförmige Mittelzipfel in den Hemicyclus abfällt. - Penis schlank, mässig gekriimmt, ein Stück vor der Oeffnung schnell in eine dreieckige, stumpfe Spitze verschmälert, die Oberseite mit einer Rinne, welehe plötzlich in die weite Vertiefung der Klappe übergeht, Unterseite schwach gerinnt.

Die Färbung ist veränderlich: Einerseits verdunkelt sich der Farbenton der Beine bis Rothbraun, an der Basis der vorderen Schenkel bis Pechschwarz (Var. a), andrerseits kann die Nebenfarbe der Fld. verdrängt oder übermässig ausgebreitet sein. Im ersten Falle erlöschen die Schulter- oder Spitzenmakeln allein (Var. b), oder alle vier gleichzeitig (Var. c), im andern Falle fliessen die Makeln jeder Fld., anfangs nur innen, zuletzt völlig zusammen und bilden einen Scheibenfleck, der einen mehr oder weniger breiten Naht- und Spitzensaum und die Kante des Seitenrandes freilässt. Auf Cynoglossum officinale, vielleicht auch an Salvia pratensis, im Juni und Juli in Deutschland, wie in Mittel- und Südeuropa und im siidlichen Schweden stellenweise nicht selten; die Abänderungen $\mathrm{b}$ bis d kommen, scharf ausgeprägt, sehr sparsam vor, zu b und c gehören vorzugsweise Männchen.

15. Iong. apicalis: Apterus, ovalis, sat convexus, nigro-aeneus, subnitidus, antennarum basi, maculu apicali elytrorum pedibusque ferrugineis aut testaceis, femoribus posticis superne infuscatis; prothorace convexo, subtiliter punctato, interstitiis laevibus, nitidis, aut alutaceis, elytris confuse vel subseriatim punctatis, punctis apicem versus evanescentibus, tuberculo humerali parro, pedibus posticis sat longis. - Long. 2-3,5 mm.

Haltica apicalis Beck, Beitr. baier. Ins. 18. t. 5. f. 23. - All. Mon. 311. Thyamis. - Kutsch. Wien. 1862. 224 (198) Longitarsus. - Thoms. Skand. Col. VIII. 169. - Seidl. F. balt. 498. - Leesb. Tijdschr. 25. 163.

Halt. analis Duft. Faun. Austr. III. 264. - Redtb. Faun. A. II. 505. Longitarsus. - Bach, Käferf. III. 149. - Foudr. Mon. 144. Teinod.

Halt. praticola Sa hlb. Bull. Mosc. 1834, 279.

Halt. Fischeri Zett. Ins. Lapp. 223.

Var. a. Immaturus, lateribus prothoracis et elytrorum, pectore abdomineque brunneis, femoribus posticis brunneo-rufis.

Var. b. Elytris evidenter alutaceis, subopacis.

Var.c. Alatus.

Var. d. 4-maculatus: Coleopteris maculis 4 testaceis, adjecta nempe parva humerali. 
An der dunkel metallischen, etwas olivengruinen Färbung, und an der hellen Schrägmakel der Fld., welche oft einen breiten Saum am Hinterrande bildet, gut zu erkennen, habituell mehr mit der folgenden, wie mit der vorhergehenden Art verwandt. Eiförmig, die Weibchen oft sehr breit gebaut, mässig gewölbt, schwarz, oberseits mit einem trüben grünlichen oder bräunlichen Metallschimmer, mehr oder weniger glänzend, die Basalhälfte der Fühler, das hintere Viertel der Fld., oder wenigstens eine saumförmige Makel an der Spitze derselben, so wie die Beine lebhaft rostroth bis bräunlich gelb, Hinterschenkel rothbraun, auf dem Rücken schwärzlich. Stirn zart gewirkt, Höckerchen völlig erloschen oder durch eine längliche und glatte, oben von einer feinen Linie begrenzte Erhöhung angedentet, Nasenkiel mässig scharf. Halssch. um die Hälfte breiter als lang, sehr stark querüber gewölbt und nach vorn etwas zusammengedrückt, mit breiter Leiste des Seitenrandes, ziemlich fein und seicht punktirt (in der hinteren Hälfte dichter als in der vorderen), zuweilen runzelig, die Zwischenräume entweder fast glatt, glänzend, oder fein gewirkt und seidenartig schimmernd. Fld. an der Basis im Bogen heraustretend und in den Schultern breiter als das Halssch., bis zur Mitte wenig ( $\widehat{\jmath})$, oder bedeutend erweitert (q), dahinter stärker verengt, am Ende fast gemeinschaftlich abgerundet, auf dem Rücken schwach, an den Seiten dagegen stark gewölbt; ihre Punkte sind in der vorderen Hälfte kräftig, gereiht oder verworren, werden dahinter feiner und verlöschen nahe der Spitze. Die Schulterbeule ist glatt, niedrig, innen durch einige etwas vertiefte Punktreihen abgesetzt. Hinterbeine etwas kürzer als bei 4-guttatus, die Schenkel derselben erreichen nicht den Hinterrand der Fld., die Schienen sind wenig zusammengedrückt, leicht nach innen gekrïmmt, ohne Leiste auf dem inneren Rande des Rückens, Enddorn kurz und stark. Flügelstummel sehr klein.

๖. Erstes Tarsenglied an den vorderen Beinen mässig verbreitert, letzter Bauchring mit einer glatten erhabenen oder vertieften, selbst grubenförmigen Mittellinie, am Hinterrande gerundetabgestutzt und hinter der Randlinie noch in einen breiten, aber kurzen Zipfel ausgezogen, der in den Hemicyclus abfällt. - Penis etwa so lang als der Hinterleib, ziemlich schlank, neben dem Ende der Oeffnung sanft erweitert, davor in schwachem Bogen verengt und in eine kleine, scharfe Spitze verlängert, auf der Unterseite mit einer sehr breiten Rinne.

Frische Stücke sind häufig an den Seiten des Halsschildes und der Fld, auf der Brust und dem Bauche dunkel rothbraun, auch fehlt meist der schwärzliche Wisch am Ruicken der Hinterschenkel (Var. a); zuweilen nimmt die lederartige Runzelung der Fld., 
welche in der Regel kanm zu bemerken ist, so weit zul, dass die Punktirung erheblich abgeschwächt wird und die Fld. gleichrnässig matt und stumpf aussehen (Var. b). Die Form c, mit völligr entwickelten Flügeln, kommt im nördlichen Europa vor und dürte auch noch bei uns aufgefunden werden, ist jedoch äusserlich schwieriger als bei andern Arten zu unterscheiden, weil ihre Schultern nicht wesentlich stärker entwickelt sind wie die der ungefligelten Form. Auf den Fld. zeigt sich bisweilen ausser der Spitzenmakel, die am Vorderrande stets, am Innenrande lıäufig verwaschen ist und einen Saum an der Naht freilässt, noch ein kleinerer röthlich gelber Fleck an der Schulter (Var. d).

Im Sommer und Herbst auf sumpfigen Grasplätzen am L'fer von Gebirgsgewässern, angeblich auf Chaerophyllum hirsutum $L$. In den Alpen, den Karpathen und den mitteldeutschen Gebirgen nördlich bis zum Harze nicht selten; Samara (Faust), nördliches Europa, Westsibirien.

16. Long. Brunneus: Apterus, ovalis, convexiusculus, rufo-brunneus, sat nitidus, antennarum basi, elytrorum apice pedibusque dilutioribus, femoribus posticis apice infuscatis; prothorace subtiliter punctato, elytris humeris rotundatis basi sat profunde, pone medium obsoletissime punctatis, margine postico pilis longis 12-13 ciliatis, tuberculo humerali obsoleto vel nullo. - Long. 2-3 mm.

Haltica brunnea Duft. Faun. Austr. III. 260. - Steph. Ill. Brit. IV. 314; Man. 297. Thyamis.

Teinodactyla castanea Foudr. Mon. 150. - All. Mon. 378. Thyamis. Longitarsus castaneus Kutsch. Wien. Monat. 1863. 162 (213). Redtb. Faun. A. II. 505̃. - Thoms. Skand. Col. VIII. 187. - Seid1. F. balt 498. - Leesb. Tijdschr. 25. 165.

Var. a. picinus: Subtus nigricans, supra aut omnino piceo-niger, aut prothorace rufescente, capite elytrisque piceis, his interdum macula apicali testacea ornatis.

V a r. b. Immaturus, laete fermgineus aut rufo-testaceus, capite disco prothoracis plus minusve, plerumque etiam sutura elytrorum fuscescentibus.

Var. c. laevicollis: Prothorace vix vel haud punctato.

Var. d. robustus: Alatus, lateribus elytrorum parum rotundatis, humeris prominulis tuberculo magno.

Etwas kleiner, besonders kürzer, im Halssch. breiter als die vorige Art, mit ähnlicher, aber feinerer Skulptur der Fld., sehr kenntlich durch die lange Bewimperung am Hinterrande der Flügeldecken. Eiförmig, mässig gewölbt, ziemlich glänzend, gesättigt rothbraun, auf der Unterseite dunkler als auf der Oberseite, die Fühler mit Ausnahme der leicht erweiterten Endglieder, die Spitze der Fld. und die Beine hell rostroth, der Mund und der äussere Theil des 
Rückens an den Hinterschenkeln schwärølich. Stim äusserst dicht und fein gewirkt, Höckerchen fehlend oder durch eine ziemlich grosse, längliche und glatte Erhöhung angedeutet, welche in der Mitte ohne Unterbrechung in deu schmalen, oben stumpfen, unten scharfen Nasenkiel übergeht. Halssch. fast doppelt so breit als lang, mässig gewölbt, an den Seiten gerundet, nach hinten melu als nach rorn verengt, mit schmaler, an der vorderen Borstenpore heraustretenden und davor merklich verdickten Randleiste, auf der Scheibe kaum bemerkbar gewirkt und mëssig dicht, fein punktulirt. Fld. an der Basis im Bogen nach aussen tretend und in den Schultern breiter als das Halssch., die Seiten in den mittleren beiden Vierteln ziemlich parallel $(\hat{0})$, oder gerundet und meist von der Mitte ab verengt (ㅇ), hinten beinahe gemeinschaftlich abgerundet, mit stumpfer oder verrundeter Nahtecke; auf dem Rücken ziemlich schwach, an den Seiten stärker abwärts gewölbt, in der vorderen Hälfte kräftiger als das Halssch., fein aber ziemlich tief punktirt, die Punkte verworren oder undeutlich gereiht, hinter der Mitte so abgeschwächt, dass sie sich aus der feinen, lederartigen Runzelung, welche den Fld. oft einen deutlichen Seidenschimmer verleiht, nur bei starker Vergrösserung abheben. Die Schulterbeule fehlt, oder bildet eine sanfte, ziemlich glatte Erhöhung; die weisslichen Wimperhärchen der Epipleuren an der Spitze der Fld. sind länger als bei den übrigen Arten, die ersten neun oder zehn nach hinten gerichtet und mit der Spitze nach innen, die beiden folgenden nach aussen gekrümmt, das letzte, welches in einer Pore an der Naht, ein Stiick über dem vorletzten, neben der Nahtecke eingefügten Härchen steht, ist wie dieses sehr lang, jedoch grade aufgerichtet. Hinterbeine ziemlich kurz, ihre Schenkelspitze bleibt vom Hinterrande der Fld. entfernt, die Schienen sind mässig zusammengedrückt und nach der Spitze allmählich schwach verbreitert, mit kurzem Enddorne. Ungeflïgelt.

§. Das erste Tarsenglied an den vier Vorderbeinen sehr gross, letzter Bauchring etwas gewölbt, mit einer feinen, erhabenen Mittellinie, am Hinterrande jederseits sanft ausgeschweift. - Penis leicht gebogen, flach, an den Seiten parallel, vor der Oeffnung jederseits gradlinig in eine lang dreieckige, scharfe Spitze verengt.

Die wichtigsten Abänderungen sind:

a. Unterseite schwärzlich, Oberseite pechschwarz, entweder einfarbig oder das Halssch. noch gesättigt rothbraun bis rostroth, an der Spitze der Fld. zuweilen eine mehr oder weniger grosse, röthlich- oder bräunlich-gelbe (nicht etwa nur durchscheinende) Yakel, welche der von apicalis ähnlich einen breiten Saum am Aussenrande bildet und innen allmählich 
in die dunkle Färbung übergeht. Gleichzeitig kamn ein kleinerer heller Fleck an der Sichulter auftreten und die Oberseite einen kaum bemerkbaren metallischen Anflug annehmen.

b. Sehr frische Stiicke sind hell rostroth oder blass röthlich gelbbraun, Kopf, Halssch. (theilweise oder ganz) und in den meisten Fällen auch die Nahtkante der Fld. angedunkelt.

c. Das Halssch. ist genau so fein und dicht gewirki wie die Stirn, oft mit einem leichten Seidenschimmer versehen, aber kaum punktirt.

d. Vollkommen geflügelt, Schultern sehr breit, mit grosser und hoher Beule, hinter welcher die Seiten auch beim $q$ wenig oder kaum gerundet sind. Durch die Erhöhung der Schultern erscheint die Basalhälfte der Fld. noch flacher wie bei der ungefliugelten Form.

Vom Juli ab auf feuchten, sumpfigen Wiesen in der Ebene nnd an Gebirgsbächen in Deutschland nirgends selten, doch vielfach verkannt und übersehen; im grössten Theile von Europa und Sibirien einheimisch. Die Varietäten c, aus Dalmatien, Reitter, und d, von Lille im nördl. Frankreich, dürften sicher noch in unserm Gebiete aufgefunden werden.

Die Beschreibung der Halt. brunnea Duft, in welcher die feine Punktirung der Fld. besonders hervorgehoben wird, weist so bestimmt auf die vorliegende Art, dass die durch Redtenbacher und Foudras, ja wider besseres Wissen sogar von Kutschera eingeführte Nomenclatur verlassen werden muss. Es fällt L. brunneus der genannten Autoren und castaneus Duft. mit luridus Scop. zusammen.

17. Long. fulgens: Alatus, ovalis, convexus, piceus, vix aeneo-micans, nitidissimus, prothorace et humeris rufescentibus, antennarum basi, elytrorum apice pedibusque ferrugineis vel rufo-testaceis, femoribus posticis piceis; prothorace subtiliter punctato, elytris concinne subseriatim punctatis, interstitiis politis, callo humerali prominulo. - Long. 1,8 bis $2,8 \mathrm{~mm}$.

Foudr. Mon. 149. Teinodactyla. - A 11. Mon. 382. Thyamis. Kutsch. Wien. Monat. 1863. 153 (204) Longitarsus. Redtb. Faun. A. II. 505. - Leesb. Tijdschr. 25. 164.

Var. a. exhaustus: Apterus, tuberculo humerali parvo, parum discreto, interdum nullo.

Var. b. Capite prothoraceque evidenter alutaceis, subsericeo micantibus.

Var, c. tristis: Supra omnino piceus, elytris sat fortiter et crebre haud seriatim punctatis.

Diese Art lässt sich mit der dunklen Varietät der vorigen, sowie mit den fast schwarzen Formen von luridus leicht verwechseln, weicht aber von ersterer durch die hinter der Mitte deutlich 
punktirten und an der Spitze kurz bewimperten Fld., von beiden ausserdem durch die spiegelglatten, auffrillig glïnzenden Zwischenräume der Fld. ab; selrr dunkle Stücke der Var. c eriunern besonders an $L$. niger, der jedoch anf den Fld. runzelig punktirt und weniger glänzend ist, und durch die schlanken, gebogenen Hinterschienen sicher unterschieden werden kann.

Eiförmig, gewölbt, pechbraun, oben sehr stark und beinahe wie metallisch glänzend, das Halssch. und die Schultern röthlich, die Basalhälfte der Fiihler, Spitze der Fld. und die Beine rostroth bis röthlichgelb, Hinterschenkel pechbraun, Tarsen an der Spitze dunkel. Stirn äusserst schwach gewirkt, glänzend, Höckerchen undeutlich, meist durch eine feine und kurze Rinne über dem Nasenkiele geschieden; Fühler bis zum letzten Drittel der Fld. reichend, ziemlich kräftig, Glied 2 so lang, doch etwas dicker als 3, die fünf Endglieder verbreitert. Halssch. um die Hälfte breiter als lang, beim 우 noch breiter, ziemlich stark gewölbt, auf der Mitte der Scheibe sehr fein, nach den Rändern zu etwas stärker punktirt, in den Zwischenräumen und auf dem Längsstreifen über den Seiten fast glatt. Fld. an der Basis winkelig heraustretend und in den Schultern viel breiter als das Halssch., mit hoher Beule, dahinter wenig erweitert, von der Mitte ab sehr schwach verengt, am Ende breit und fast einzeln abgerundet, mit stumpfer Nahtecke; auf dem Rücken gewölbt, mässig dicht, tief, bald ziemlich fein, bald kräftiger in Reihen punktirt, die Punkte auf dem Abfalle zur Spitze abgeschwächt und verwirrt, ihre Zwischenräume auch unter starker Vergrösserung glatt. Die Hinterschenkel erreichen nicht die Spitze der Fld., die Hinterschienen sind grade, mässig zusammengedrickt, bis zur Spitze allmählich verbreitert; ihr Rücken fällt wenig und in sanfter Wölbung nach innen $a b$ und ist auf der Kante des Aussenrandes sparsam und fein gezähnelt, der Enddorn kurz. Brust und Bauch gewirkt. Vollkommen geflügelt.

๙. Erstes Tarsenglied an den vorderen Beinen erweitert, letzter Bauchring mit unpunktirter oder rinnenförmiger Mittellinie, welche am Hinterrande plötzlich in eine runde, glatte Grube abfällt. Diese nimmt den Mittelzipfel und einen geringen Theil vom Segmente selbst ein. Penis, ziemlich dick, neben der Oeffnung sanft erweitert, mit breit abgerundetem Vorderrande, in dessen Mitte eine stumpfe Spitze angedeutet ist. Auf der Oberseite befindet sich eine feine Mittelrinne, welche allmählich zu der langen, eiförmigen, tief liegenden Klappe übergeht, auf der Unterseite eine muldenförmige Vertiefung.

Die Art tritt vorzugsweise in der ungeflügelten Form a auf, welche kaum stärker gewölbt als die geflügelte, in den Schultern 
aher viel enger gebaut ist. Wenn dieselbe noch eine niedrige. ctwas vortretende and innen von einer weiten und seichten Vertiefung ahgesetzte Schulterbeule hat, ist die Basis merklich breiter als das Halssch, und die Schultern erscheinen viel höher als bei tmenneus, zuweilen jedoch verschwindet die Beule ganz und die Fld. erweitern sich vom Grunde aus in einem äusserst schwachen Bogen. Bei dieser Form a ist bisweilen die stiru und das Halssch. dentlich gewirkt, seidenschimmernd, letzteres stärker, oft runzelig punktirt (Var. b), oder die Oberseite einfarbig pechschwarz; Fll. dicht und kräftig punktirt, ohne spur von Reihen, mit sehr schmalen. glatten Zwischenräumen (Var. c).

Vom Juli ab auf feuchten Wiesen wahrscheinlich in ganz Deutschland, die gefligelte Form bis jetzt allerdings erst aus Oesterreich und Steiermark durch Kutschera nachgewiesen (ansserdem bei Lyon und in Holland), die ungeflügelte bei Eberswalde in der Nähe von Berlin, bei Mainz und München und in Schlesien aufgefunden, sonst noch in Serbien, und die Var. c bei Sarepta (Becker) und Derbent (Faust).

18. Long-gravidulus: Apterus, ovalis, valde convexus, rufo-brunneus, nitidulus, antennis pedibusque pallidioribus; prothorace vaye subtiliter punctato, elytris subellipticis sat crebre vageque punctatis, interdum fere rugulosis, basi evidenter marginatis, apice brevissime ciliatis, tuberculo humerali nullo. - Long. 1,8-2,5 mm.

Kutsch. Wien. Monat. 1863. 166 (217). - Redtb. Faun. A. II. 505 .

Thyamis gravidula All. Mon. 338.

Teinodactyla brunnea A11. Ann. Fr. 1860. 12 (pars).

Var. a. Supra nitidus.

Durch bedeutende Wölbung und ziemlich bauchige Fld. ausgezeichnet, von festem, gedrungenem Ansehen, welches besonders durch den innigen Anschluss des Halsschildes an den Rüicken bedingt ist, und hierdurch dem $L$. pinguis am ähnlichsten; ziemlich kurz eiförmig oder elliptisch, stark gewölbt, auf Kopf und Halssch. deutlich, auf den Fld. äusserst fein und dicht gewirkt, fettig glänzend, bald gesättigt und dunkel-, bald hell und lebhaft rothbraun, die Fühler und Beine stets blasser, Brust und Bauch dunkler gefärbt als die Oberseite. Stirnhöckerchen undeutlich, zuweilen etwas heller und glänzender als der ïbrige Theil der Stirn, Nasenkiel ziemlich scharf. Fühler bis zum letzten Drittel der Fld. reichend, Glied 2 verdickt, 4 bei 7 schlank, viel länger als die rier Endglieder. Halssch. um die Hälfte breiter als lang, der Quere nach stark gewölbt und vorn etwas zusammengedrückt, von der vorderen 
Borstenpore, die den Seitenrand winkelig nach aussen driickt, his vor die Hinterecken in leichter Rundung verengt, mässig rlicht, fein und selı flach punktirt, der Längsstroifen über den Sciten beinahe glatt. Fld. elliptisch, an den Seiten gleichmässig gerunrlet, hinten schmal, fast einzeln abgerundet, mit kurzen Wimperhärchen und stumpfwinkliger, fast verundeter Nahtecke; auf dem Rücken gewölbt, ziemlich dicht und flach runzelig-punktirt, die Punkte in der vorderen Hälfte noch verhältnissmässig gross und deutlich, hinter der Mitte verloschen. Die Schultern fallen in gleichmässiger Wölbung zur Kante des Seitenrandes ab, die sich bogenförmig nach innen, bis in die Nähe des Schildchens, in gleicher Höhe mit der feinen Leiste am Hinterrande des Halssch. fortsetzt und durch einen Quereindruck an der Basis der Fld. emporgehoben wird. Hinterbeine kräftig, ihre Schienen wenig zusammengedrückt, mit ziemlich breitem Rücken, dessen Aussenrand sparsam und fein gezähnelt ist; Enddorn kurz. Ungeflïgelt.

§. Erstes Tarsenglied an den vorderen Beinen erweitert, letzter Bauchring auf einem Längsstreifen in der Mitte glatt, mit einer Mittelrinne, welche sich am Hinterrande zu einer kleinen, ebenfalls glatten Grube ausweitet. Dieselbe nimmt kaum ein Drittel des bogenförmigen Mittelzipfels ein. - Penis fast grade, noch breiter wie bei der vorigen Art .und dadurch verschieden, dass der Vorderrand in der Mitte in eine deutlich abgesetzte kleine Spitze vorgezogen und die Oeffnung von der abgestutzten Klappe nur zux Hälfte bedeckt ist.

Bei der einzigen nennenswerthen Abänderung a wird die Oberseite ziemlich stark glänzend.

In den Alpen vom stidlichen Frankreich bis Croatien (bei Agram, Apfelbeck) und in den Transsylvanischen Alpen einheimisch, nach Letzner auch auf dem Altvater in Schlesion.

19. Long. mubellus: Apterus, oblongo-ovalis, convexus, obscure rufobrunneus vel fuscus, fere opccus, antennarum basi pedibusque dilutioribus, femoribus posticis apice infuscatis; capite sat magno, prothorace subquadrato, obsolete punctulato, elytris oblongis, subtilissime punctatis, tuberculo humerali obsoleto. - Long. 2-2,5 mm.

Teinodactyla rubella Foudr. Mon. 156. - All. Mon. 337. Thyamis.

Longitarsus languidus Kutsch. Wien. Monat. 1863. 163 (214). Redtb. Faun. A. II. 505.

Teinod. brunnea A 11. Ann. Fr. 1860. 129 (pars).

Var. a. Immaturus; luridus, antennis apicem versus, capite femoribusque posticis fuscis. 
Von schlankerer Gestalt als die vorhergehenden, mit geringerern Glanze und feinerer, einförmiger Punktirung, besonders am Baue des Vorderkörpers, welcher im Verhältniss zu den Fld. sehr breit rrscheint, leicht zu erkennen. Lang eiförmig, das Männchen oft unit wenig gerundeten, fast parallelen Seiten, gewölbt, gleichmässig äusserst dicht und fein gewirkt, matt seidenschimmernd, dunkel rothbraun, die untere Hälfte der Fuihler, die Beine, zuweilen auch Schulter und Spitze der Fld. heller, rostroth, die Hinterschenkel nach dem Knie hin angedunkelt. Fühler ziemlich kräftig, bis zum letzten Drittel der Fld. reichend, die oberen acht Glieder ungefähr von gleicher Länge und die letzten fünf oder sechs etwas erweitert, namentlich beim $\hat{\delta}$. Kopf verhältnissmässig gross, mit glatten, lang eiförmigen, undeutlich begrenzten Stirnhöckerchen und einem breiten, stumpfen Nasenkiele. Halssch. quer viereckig, wenigstens um ein Drittel breiter als lang, an den Seiten stärker als auf dem Rücken gewölbt, die Wölbung aber nicht nach vorn zusammengedrückt wie bei den vorigen Arten; die Oberfläche ziemlich dicht, sehr fein und seicht punktirt, auf dem Längsstreifen über den Seiten nur gewirkt. Fld. gestreckt, in den Schultern wenig breiter als das Halssch., bis zur Mitte sehr schwach erweitert, an der Spitze einzeln abgerundet und kurz bewimpert, ähnlich wie das Halssch. punktirt, die Punkte aber vor der Mitte etwas schärfer eingestochen und stellenweise gereiht. Im ersten Viertel befindet sich ein Längseindruck neben der Schulter welcher diese, sowie den Raum gegen das Schildchen hin sanft emporhebt. Die Hinterschenkel sind ziemlich schlank, länger als die Schienen, diese schwach zusammengedrückt, mit kurzem Enddorne. Ungeflügelt.

Beim $\hat{\sigma}$ ist das erste Tarsenglied an den vorderen Beinen bedeutend erweitert und der letzte Bauchring auf dem Mittelzipfel grubenförmig eingedrückt.

Unreife Exemplare sind schmutzig gelbbraun, annähernd lehmgelb, die obere Hälfte der Fühler, der Kopf und die Hinterschenkel mehr oder weniger dunkel braun (Var. a).

Im Sommer auf Waldwiesen bei Mauer und Mödling südlich von Wien. Kärnthen.

20. Iong. Iurialus: Apterus, oblongo-ovalis, convexiusculus, fuscorufus, subtilissime alutaceus, sat nitidus, pectore abdomineque nigris, antennis breviusculis basi pedibusque ferrugineis, femoribus posticis interdum superne infuscatis; prothorace subtiliter ruguloso-punctato, clytris sat fortiter, basin versus subseriatim, apice subtilius punctatis, lateribus rotundatis, tuberculo humerali vix discreto vel nullo. - Long. $1,5-2,5 \mathrm{~mm}$. 
Chrysomela lurida Scop. Ent. Carn. 70. f. 219. - Rossi, Faun Etr. I. 89. - Oliv. Ent. VI. 112. Altica. - Illig. Mag. VI. 165. Haltica. - Steph. Ill. Brit. IV. 314; Man. 297. Thyamis. Longit. luridus Bach, Käferf. III. 153.

Longit. brunneus Redtb. Faun. A. el. 1. 534; ed. 3. II. 505. Kutsch. Wien. 1863. 158 (209). - Seidl. F. balt. 498. Le es b.Tijdschr.25.165. - Foudr. Mon. 152. Tein. - A 11. Mon.333. Haltica castanea Duft. Faun. A. III. 260. - Steph. 1. c. Haltica pratensis Koch, Ent. Hft. II. 88.

Var. a. Prothorace haud ruguloso-punctato, interstitiis laeviusculis, nitidis. Var. b. Apterus, elytris tuberculo humerali prominulo.

Var. c. Immaturus; capite prothorace pectoreque rufescentibus, antennis plus minusve, elytris et pedibus testaceis, femoribus posticis abdomineque fuscescentibus.

V a r. d. Prothorace rufo vel piceo, elytris totis ferrugineis, aut fusco olumbratis. Var. e. nigricans: Supra piceo-niger aut piceus, saepe prothorace rufo, aut humeris apiceque elytrorum rufescentibus.

Haltica lurida Gyllh. Ins, Suec. III. 537.

Longit, luridus Tho ms. Skand. Col. VIII. 189.

Var. f. cognatus: Alatus, supra rufo-brunneus, elytris dilutioribus, sutura margineque laterali plerumque obumbratis, lateribus minus rotundatis, tuberculo humerali prominulo.

Teinodactyla lurida Foudr. Mon. 158. - All. Mon. 380. Thyamis. Long. luridus Kutsch. Wien. Monat. 1863. 156 (207). - Redtb.

1. c. II. 505. - Seidl. 1. c. 498. - Leesb. 1. c. 164.

Var.g. 4-signatus: Nigro-piceus, saepe macula humerali et apicali elytrorum rufescentibus.

Haltica 4-signata Duft. 1. c. 259. - All. Mon. 383. Thyamis.

Longit. 4-signatus Kutsch. 1. c. 155 (206). - Redtb. ed. 3. II. 505.

Eine unserer häufigsten und veränderlichsten Arten, hauptsächlich an der kräftigen, etwas runzeligen und auf den Fld. gereihten Punktirung zu erkennen, in den hellen Formen weniger gleichmässig und rein gefärbt als brunneus und gravidulus. Länglich eiförmig, mehr oder weniger gewölbt, dunkelbraun, mit wenig hervortretendem Roth, nur mässig dicht aber sehr fein gewirkt, ziemlich glänzend, Brust und Bauch schwarz, die untere Hälfte der Fühler nebst den Beinen blass rostroth, an letzteren die Hinterschenkel dunkel, mit schwärzlichem Wisch an der Spitze des Rückens. Fühler beim $q$ ungefähr halb so lang als der Körper, beim $\hat{\sigma}$ länger, ihre sechs letzten Glicder merklich verbreitert. Stirnhöckerchen fehlend, oder durch eine linienförmige oder längliche Erhöhung: angedeutet. Halssch. wenigstens um die Hïlfte breiter als lang; querüber gewölbt, und die Wölbung nach voru etwas zusammengedrückt und verengt, deutlich und dicht rumzelig punktirt, die Zwischenräume nicht besonders dicht lederartig gerunzelt, der Lüngs- 
streifen üler den Seiten ziemlich glatt, von der Scheilue meist durch einen deutlichen Eindruck geschieden. Fld. an der Basis in schwachem Bogen heraustretend und in den schultern breiter als das Halssch., bis zur. Mitte gerundet-erweitert, dahinter ähnlich verengt, an der Spitze sehr schwach einzeln abgerundet und kurz bewimpert, auf der vorderen Hälfte des Riickens etwas abgeflacht, linten und an den Seiten stark abfallend, mit grossen und ziemlich tiefen Punkten besetzt, welche vor der Mitte meln oder weniger gereiht, hinter derselben verwirt und an der Spitze abgeschwächt sind. Die erste Punktreihe vertieft sich nach hinten und helst dadurch den Zwischenraum an der Naht, welcher mit einer äusserst feinen und dichten überzähligen Punktreilıe besetzt ist, besonders auf dem Abfalle zur Spitze empor. Die Hinterschenkel sind dick, wenig länger als die Schienen, diese zusammengedrückt, mit schmalem Riicken, welcher vorn etwas gewölbt, hinten sehr abschïssig und an der Aussenkante fein gezähnelt ist. Enddorn kurz. Ungefliigelt.

o. Erstes Tarsenglied an den vorderen Beinen erweitert, das letzte Segment mit einer grossen, glatten Grube, die nach der Mittellinie allmählich abfällt, nahe dem Vorderrande beginnt, nach hinten sich verbreitert und an aufgebogenen Hinterrande des kurzen Mittelzipfels endet. - Penis ziemlich breit, vor der Mitte jederseits msgeschweift oder weit eingeschnürt, sodam in starker Rundung verengt, die äusserste Spitze sehr stumpf, kurz, kaum abgesetzt, die Oberseite ist gewölbt, ohne Mittelrinne, nur die Klappe im vorderen Theile vertieft, die Unterseite bis zum Ende der Einschnürung: scharf gerandet und muldenförmig ausgehöhlt, an der Spitze ziemlich eben.

Es sind folgende Abänderungen zu unterscheiden:

a. Das Halsch. ist mässig dicht punktirt, nicht gerunzelt, mit glatten und glänzenden Zwischenräumen.

b. Schulterbeule der Fld. dentlich, klein, gewöllbt, fast glatt, über den Seitenrand heranstretend, die Flügel fehlen oder sind kurz und sehmal.

c. Frisch entwickelt ist das Thier sehr hell gefärbt, nämlich der grösste Theil der Fühler, die Fld. und Beine blass bräunlich gelb, Kopf, Halssch. und Brust dunkler, etwa bräunlich roth, die Endglieder der Fiihler, die Hinterschenkel und der Bauch angedunkelt, zuweilen schwärzlich. In der Folge wird

d. der Farbenton der Fld. gesättigter, neigt mehr nach Roth und unterscheidet sich dann unwesentlich ron dem des Halsschildes, oder es verdunkelt sich der Naht- und Seitenrand der Fld, gewöhmlich auch die Stirn, das Schildehen und auf dem Halsseh, ein feiner Saum am Hinterrande nebst der 
Seitenrandleiste, selten dio gauze Scheibe. Bei weiterer Trübung entsteht die Normalfärbumg, zuletzt die Varietät

e. pechbraun bis fast schwarz, selten ganz einfarbig, das Halssch. in der Regel bräunlichroth, rothbraun, oder wenigstens etwas mehr mit Roth versetzt als die Fld. Auf diesen hïufig noch ein kleiner, unbestimmter Fleck an der Schulter und die Spitze in grösserer oder geringerer Ausdehnung röthlich. Die Spitze kamm selbst bräunlich gelb werden oder mit einer ungefähr makelförmigen blassgelben Zeichnung versehen sein, die an den Rändern verwaschen ist und durch Rothbraun allmählich in die dunkle Farbe der Scheibe übergeht.

f. Die geflügelte Form ist weniger gewölbt als die flügellose und ihre Fld, haben in Folge der breiten Schultern einen mehr viereckigen als ovalen Umriss. In der Färbung ähnelt sie der Var. d, Kopf dunkel, Halssch. heller rothbram, Fld. gelblichbraun, bei frischen Stücken einfarbig, bei ausgehärteten mit braunem oder schwärzlichem Naht- und Seitenrandsaume, Brust und Bauch je nach dem Grade der Ausfärbung braun bis schwarz, Fühler dunkel, in der unteren Hälfte nebst den Beinen rostroth, Hinterschenkel gebräunt, an der Spitze pechschwarz. Die Schulterbeule ist etwas stärker entwickelt wie bei der Var.b.

Anfangs beschränkt sich die dunkle Farbe der Fld., wie schon erwähnt, auf einen verschieden breiten, unbestimmten Saum an der Naht, welcher das Schildehen mit umfasst und auf dem Abfalle zur Spitze endet, sowie auf einen ähnlichen Saum am Seitenrande, der hinter der Schulterbeule verbreitert und am Beginn des letzten Viertels abgekürzt ist; sie breitet sich dann

g. allmählich aus, bis beide Säume, ungefähr im ersten Drittel der Länge, in einander fliessen und zuletzt die Scheibe völlig bedecken; sehr lange bleibt jedoch noch die Schulterbeule und eine verwaschene Makel frei, deren hellster Theil ein Stiick vor der Spitze liegt. Bei dieser Farbenänderung ist das Halssch. entweder rostroth, oder nebst dem Kopfe pechschwarz.

Von Ende Juli bis in den Herbst auf fruchtbaren, etwas feuchten Wiesen und im Anspülicht zu Beginn des Frühlings in ganz Deutschland und Europa häufig, wahrscheinlich an Alectorolophus inajor; die geflügelte Form kommt nicht mehr nördlich vom 55. Parallelkreise vor und ist im iibrigen Europa ohne Ausnahme viel seltener als die ungeflügelte, die dunklen Varietäten e und $g$, namentlich die letztere, sind selten.

Chrys. lurida Scop. muss, der herrschenden Ansicht entgegen, auf die ungefliugelte Form bezogen werden, weil die erste ausführliche unl sichere Beschreibung durch Gyllenhal nur diese bericksichtigte, und weil sie 
ferner die vorherrschende ist. Wie es Kutschera möglich war, beide Formen als Arten zu betrachten, lässt sich um so weniger begreifen, als derselbe rloch flïgellose Formen anderer Arten, die sich ausser dem abweichenden Habitus noch durch eine auffälige Zeichnung unterscheiden (z. B. seine Var. von lateripunctatus, der ich den Namen personatus gebe) ohne Weiteres mit der geflïgelten Form verbunden hat. Dass die Flrl. der Var. cognatus in der Regel heller erscheinen müssen wie bei dem eigentlichen luridus beruht wohl anf einer Täuschung des Auges, da bei der ersten die weissen Flügel durchschimmern, bei letzterem den dunkle Hinterleib; andere Angaben, z. B. über eine wesentlich verschiedene Bildung des Analringes beim $\hat{\sigma}$, oder des Penis, endlich die Mittheilung Redtenbachers, dass luvidus nur subalpin lebe, kann ich nicht bestätigen.

21. Long. pallidicormis: Apterus, oblongo-ovalis, convexus, nitidus, obscure castaneus aut fusco-piceus, elytron um humeris apiceque dilutioribus, antennis longis totis pedibusque pallide testaceis, femoribus posticis fuscescentibus; prothorace obsolete ruguloso-punctato, elytris apice singulatim rotundatis, subtiliter confuse ruguloso-punctatis. - Long. 2,3 mm. Kutsch. Wien. Monat, 1863. 164 (215). - Redtb. Faun. A. II. 505. - All. Mon. 335. Thyamis.

Der Var. e des rorigen ähulich, indessen durch einfarbige, längere Fithler und blasse Beine, die feinere verworrene Punktirung: der Fld. und deren stärker abgerundete Spitze verschieden. Länglich eiförmig, stark gewölbt, dunkel kastanien- oder pechbraun. glänzend, die Fld. nach dem Seitenrande hin, namentlich an der Schulter und Spitze in gelbbraun iibergehend, Fïhler und Beine blass gelbbraun, nur die Hinterschenkel braun, mit schwirzlichem Rücken. Stirn äusserst fein gewirkt, Hückerchen ziemlich deutlich, rom Scheitel durch einen fein querrumzeligen Eindruck geschieden, Nasenkiel schnal. Fühler sehr schlank, bis zum letzten Viertel der Fld. reichend, die Endglieder kaum rerdickt, Glied 2 so lang als 3. Halssch. etwa um die Hälfte breiter als lang, stark queriiber gewölbt, äusserst fein gewirkt und auf der scheibe gleichmässig fein punktirt, melur oder weniger runzelig, der glatte Längsstreifen uber den Seiten wenig abgesetzt. Fld. an der Basis schmal, ohne Schulterbeule, bis zur Mitte gerundet-erweitert, dahinter ähnlich verengt, an der Spitze ziemlich breit und stark einzeln abgerundet; verworren und fein runzelig-punktirt, die Punkte an der Basis etwas stärker als die des Halssch. nach den Seiten und der Spitze hin feiner und verloschener. Enddorn der Hinterschienen kurz. Ungeflügelt.

Beim $\hat{o}$ ist das erste Tarsenglied der vorderen Beine wenig exweitert, loppelt so lang als breit, das letzte Banclisegment vor dem bogenfömigen Mittelzipfel seicht eingedrickt.

Nach Kutschera in Oesterreich ob der Enns. 
22. Long. minasculas: Apterus, oblongo-opalis, conceniusculus, subtiliter alutaceus fere serice-micans, picen-rufus, antennurum basi pedibusque formaineis, fronte tuberculis mullis, prothorace punctulato, elytris crebre punctatis apice subsingulatim rotumulis, callo humerali mullo. Long: $1,2-1,6 \mathrm{~mm}$.

Teinod. minuscula Foudr.J[on. 154. - A11. MIon. 345 (Thyumis). Long. minusculus Kutseh. Wien. Monat. 1863. 160 (211). Redtb. Faun. A. II. 505.

Var. a. Elytris, pectore abdomineque piceo-nigris.

Vom Ansehen eimes sehr kleinen L. luridus, jedoch von diesem durch feinere und viel dichtere Punktirung sicher zu unterscheiden. Lang eiförmig, mehr oder weniger gewölbt, ziemlich dunkel braınroth, die ersten drei bis sechs Fiihlerglieder und die Beine rostroth. Stirn sehr fein gewirkt, ohme bemerkbare Höckerchen, aber mit tiefer Seitenrinue. Halsseh. um die Hälfte breiter als lang, an den Seiten stark abfallend, deutlich körnig gewirkt und fein punktulirt, sehr matt seidenartig glänzend; die Punkte oft zahlreich, gut bemerkbar, oft sehr sparsam und in der Runzelung verschwindend. Fld. in den Schultern kaum breiter als das IIalssch., ohne Beule, an den Seiten schwach gerundet, hinten schmal, fast einzelu abgerundet und sehr kurz bewimpert, auf dem Rïcken dicht, stellenweise runzlig punktirt und etwas feiner wie das Halssch. gewirkt, seidenartig glänzend. Hinterschienen schlank, ohne Innenrandleiste, ihr Enddorn kurz. Ungefliigelt.

ô Erstes 'Tarsenglied an den vorderen Beinen mässig' erweitert. letzter Bauchring auf einem Längsstreifen in der Mitte, welcher sich mach hinten etwas rertieft, beinahe glatt, der Mittelzipfel grubenförmig ausgehöhlt. - Penis vor der Oeffnung allmählich in eine scharfe Spitze verengt.

Bei dunklen, wahrscheinlich vollkommen ausgefärbten Exemplaren (Var, a.) wird die rothe Farbe auf dem Halssch. wenig, auf den Fld, der Brust und dem Bauche bisweilen völlig verdrängt und hier durch ein tiefes Pechschwarz ersetzt. Diese Stücke kömnten leicht zu $L$. absinthii, namentlich zu dessen Var. a. gestellt werlen, bei welcher die Farbe des Halssch. auch einen röthlichen Ton hat, weichen aber durch schwächeren Glanz, noch weniger angedeutete Schultern und den Mangel jeglichen metallischen Schimmers auf der Oberseite ab, welcher bei absinthii die Aehnlichkeit mit obliteratus bedingt.

Im Frühlinge auf Turitis glabra L. in Bergoggenden: Kreuznach, Thuiringen, Wien, Kïnthen, Krain. Herzegowina, Lyon und Paris.

VI. 6. 
23. Long. dorsalis: Alatus, bllongus, subconecus, niger, sat nitidus, antennis crassiusculis artıculis primis tarsisque fuscis, tuberculis frontalibus angustis, modice discretis, prothorace vage punctulats, flairstestaceo, elytris confertim subtilissime punctatis, limbo laterali lato flavo. - Long. 1,8 -2,5 mm.

Fabr. Ent. Syst. 1. 2. 31 (Galleruca); Syst. El. 1. 465. Crinceris. - Oliv. Ent. VI. 717. t. 5. f. 87. Altica. - Koch, Ent. Hft. II. 79. t. 3. f. 7. - Ill. Mag. VI. 169. - Ste jh. Ill. Brit. IV. 315; Man. 298. Thyamis. - All. MIon. 375. -- Foudr. Mon. 169. Teinod. - Bach, Käferf. III. 150. Longit. Kutsch. Wien. Honat. 1863. 299 (2:7). - Redtb. Faun. A. II. 508. - Leesb. Tijdschr. 25. 166.

Var. a. Prothorace plus minusve infuscato.

In der Körperform entfernt an $L$. anchusae erinnernd, durch den breiten hellen Seitensaum der Fld. sehr ausgezeichnet. Länglich, mässig gewölbt und glänzend, schwarz, die ersten Fỉhlerglieder und die Tarsen rothbraun, Halssch. und Vorderbrust hell röthlichgelb, ein breiter, innen scharf begrenzter Saum um dic Seiten der Fld, weisslichgelb. Auf den Decken bleibt ein grosser, gemeinschaftlicher Rïckenfleck ron der schwarzen Grundfarbe übrig, dessen Seiten dem Seitenrande ziemlich parallel laufen, sich aber in der hinteren Rundung merklich der Spitze nähern. Stirn dicht gewirkt, die niedrigen, lanzettlichen Höckerchen durch eine undeutliche Rinne von derselben getrennt. Fühler lang und kräftig. vom sechsten Gliede an etwas verbreitert. Halssch. fast doppelt so breit als lang, an den Seiten gerundet, nach rorn wenig mehr als nach hinten verengt und neben der vorderen Borstenpore kaum heraustretend, oben gewirkt und rerloschen punktulirt. Fld. in den Schultern wenig breiter als die Basis des Halssch., dahinter sanft gerundet, am Ende einzeln abgerundet, auf dem Rücken schwach gewölbt, dicht und fein punktirt. Geflügelt.

Beim $\hat{\sigma}$ ist das erste Tarsenglied wenig erweitert, der letzte Bauchring mit einer durchgehendeu glatten Längsgrube versehen, welche im Grunde rinnenförmig rertieft und nach hinten etwas verbreitert ist.

Zuweilen sind die Fühler und Schienen grösstentheils dunkel rothbraun, oder, Var. a, die Scheibe des Halssch, ist angedunkelt.

Auf Senecio erucifolius L. im westlichen Deutschland bei Erlangen, Regensburg und in der Rheinpfalz (bei Kaiserslautern): Westeuropa, Algier. 
21. Tong. stragurlatus: Alutus, oblonfus, subunrecus, niger, sut

nitidus, antenmis gracilimes basi pedibusque dilute fermaineis, femoribus posticis plerumque infurectis, tuberculis fromlulibus obsoletis, yrothorace vage elytrisque evidente' subtitissime punctatis, his limbo laterali lato flavo. - Long. 1,8-2,5 mm.

Teinoluctyla stragulata Foudr. Mon. 170. - Kutsch. Wien. Monat. 1863. 297 (225) Longitars. - All. Mon. 376.

Teinod. circumsepta A 11. Ann. Fr. 1860. 105.

Var. a. Limbo laterali elytrorum ante medium dilatato.

Var. b. sellatus: Elytris nigris, humeris apiceque flavis.

Vom vorhergehenden nur durch dïnne Fühler, ein längeres, schwarz gefärbtes Halssch., dunkle Vorderbrust, helle Fühler und Beine, sowie durch die Veränderlichkeit des hellen Satmes un die Seiten der Fld, abweichend.

Länglich, mässig gewölbt, ziemlich glänzend, schwarz, Fühler und Beine röthlich gelbbraun, erstere in der oberen Hälfte, sowie die Schenkel dunkler, die Hinterschenkel zuweilen pechbraun, ein breiter Seitensaum der Fld. weisslicbgelb. Fühler schlank, nach der Spitze kaum erweitert. Halssch. um die Hälfte breiter als lang, an den Seiten gerundet, nach vorn zusammengedruickt und mehr als nach hinten rerengt, neben der vorderen Borstempore kaum heraustretend, auf dem Rücken gewirkt und verloschen, selten deutlich punktirt. Fld, in den Schultern wenig breiter als die Basis des Halssch., mit deutlicher Beule, dahinter schwach gerundet, auf dem Riicken dicht und fein punktirt. Geflügelt.

$\hat{o}$ Erstes Tarsenglied sehr wenig erweitert, letzter Bauchring mit einer grossen und tiefen eiförmigen Längsgrube.

Das Halssch. ist zuweilen verwaschen röthlichbraun gesäumt, mamentlich am Basalrande und an den Seiten nahe den Vorderecken; auf den Fld, ist der gemeinschaftliche schrarze Rückenfleck häufig ror der Mitte verengt und mit unregelmässigen, dem Seitenrande nicht parallelen Räudern versehen (Var. a.). Oder der Fleck dehnt sich soweit aus, dass von dem hellen Seitensaume nur eine veränderliche Makel auf der Sehulter und eine ähnliche an der Spitze übrig bleibt (Var. b). Bei den Uebergangsstücken zu dieser Abänderung, welche mit einzelnen Formen von L. lateralis Ähnlichkeit haben, tritt zuerst ein schmaler, dunkler Saum in der Mitte des Seitenrandes auf, der in der Folge die Epipleuren mit umfasst und endlich mit der Erweiterung des Dorsalfleckes sich verbindet.

Am Rheine bei Mainz. Frankreich, nördlich bis Romen, Spanien, Algier, Sardinien, Sicilien. 
2.5. Long. Catemipunotatus: Alutus, oblong oratis conicen: rufies ith picens, nitidus, capite tuberculis frontulibus nullis prothriraceque leriter aeneo-micantibus, hose rugulose-puncluluto, elytris stramincis, relsere sat sulfiliter punctatis, limbo sulurali et marginali rufo-piccis junctoque subhumerali nigro, antenni: peditusque testuceis, femoribus posticis infuscatis. - Long. 1,5-2,2 mm.

Rosenh. Thier. Andal. 339. - Kutsch. Wien. M[unat. 1863. 300 (228). - Redtb. Faun. A. II. 505. - All. Mon. 409. Thyamis.

Teinod. signata Reiche Ann. Fr. 1858. 49.

Teinod. biguttata Foudr. Mon. 172.

Var. a. personatus: Ovalis, apterus, callo humerati nullo, limbo suturali elytrorum ante medium angulatim dilatato.

Durch den grossen, schwarzen Punkt linter der schulter jeder Fld. ansgezeichnet. Länglich eiförmig, gewölbt, glänzend, rothbraun bis pechschwarz, das Halssch. meist etwas heller als der Kopt und wie dieser metallisch griin angeflogen, die Fld. hell strolıgelb. ein mässig breiter, vorn rerschmalerter Nahtsaum. ein ähulicher Seitensaum, beide hinten abgekürst, und eine runde Iakel hinter der Schulter, mit dem Seitensaume in der Regel zusammenhängend, rothbraun bis schwarz, metallisch angehaucht. Fühler und Beine röthlichgelb, erstere nach der Spitze etwas angedunkelt, die Hinterschenkel am Ende schwärzlich, besonders auf dem Rücken. Fühler schlank, länger als der halbe Körper, Stirn fein gewirkt. Halssch. um ein Drittel oder um die Hälfte breiter wie lang; an den Seiten stark abfallend, diese wenig gerundet, hinter der vorderen Borstenpore sanft ausgeschweift, die Scheibe gewirkt, bald fein, bald stärker, etwas runzelig punktirt, ein grösserer Raum an den Seiten, von der Mitte bis zu den Hinterecken glatt. Fld. an der Basis schnell heranstretend und in den Schultern breiter als das Halssch., mit kleiner und niedriger Beule, dahinter wenig erweitert, an der Spitze mit abgerundeter Nabtecke, aní dem Riicken dicht und mässig fein, stets kräftiger als das Halssch punktirt, in der vorderen Hälfte zuweilen mit deutlichen Reihen. Enddorn der Hinterschienen kurz und fein. Geflügelt.

Bei der Form mit rerkümmerten Flügeln (Var. a.) sind die Decken mehr gewölbt, an den Seiten stärker gerundet und falleu auf der Schulter gleichmässig ab, ohne eine merkliche Beule zu bilden; ihre Punktirung ist iiberall rerworren, der dunkle Nahtsaum erweitert sich schnell vor der Mlitte, so dass er beinahe die dancben liegende Makel beriihrt, und verengt sich allmählich bis drei Viertel der Länge, ron wo aus die Naht sehr schmal dunkel eingefasst ist. 


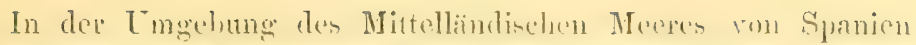
und Marocen bis Syrien; in Deutschland wurde bisher nur dic Var. a bei Wien beobachtet. Letztere knmmt anch in Ungarn vor, wo sie LI. Viertl an I'ulmonaria in ersten Fribllinge bei Fünflirehen sammelte. und in Oberitalien an Rubus (I)r. Flach).

26. Eong. nasturtio: Alatus, oblongo-ovatus, convexinsculus, niger, nitidus, antennarum busi pedibusque testaceis aut ferrugineis, femoribus. posticis nigris, elytris confertim punctatis, pullide testaceis, sat nitidis. sutura nigra, limbo laterali fusco. - Long. 1,5-2 mm.

II s: tibiis posticis apicem versus dilatatis, margine inferiore subcurvato, segmento ultimo ventrali apice biimpresso, carinula vel tuberculo parvo instructo.

Fabr. Ent. Syst. T. 2. 31 (Galleruca); Syst. EI. 1. 465 (Crioceris) Steph. Ill. Brit. IV. 311: Man, 296 (Thyamis). - All. Mon 390. - Gyll. Ins. Suec III 160 (Haltica). - Foudr. Mon. 160 (Teinod). - Redtb. Fauu. A. II. 506 (Longit.). Kutsch. Wien. Monat 1863. 302 (230). - Bach Käferf. III 152. - Thoms. Skand. Col. VIII 176. - Seidl. F. balt. 499. - Leesb. Tijdschr. Ent. 25. 167.

Galleruca atricilla var. c. Payk. Faun. Suec. II. 103. - var. 1. Illig. Mag. VI. 166 (Halt.).

Halt pratensis var. b. Koch Ent. Hft. II. 88. t. 3. fig. 9. Duft. Faun. A. III. 258.

Longit. circumscriptus Bach 1. c. 150.

Var. a, auctumnalis: Brachypterus vel apteris, convexus, elytris suepe pellucidis callo humerali parvo aut nullo.

Var. b. Pedibus plus minusve infuscatis.

Var. c. Fronte prothoraceque subaeneo-micantibus.

Var. d. Prothorace rufo-piceo.

Var. e. Lateribus elytrorum vix infuscatis.

Eine der kleineren Arten. kenntlich arn-Kontraste zwischen dem schwarzen Vorderkörper und den sehr hellen Fld, die mit einem ganzen schwarzen Nahtsaume versehen sind, welcher sich in der Regel $1 \mathrm{~m}$ die Spitze herum fortsetzt. Länglich eiförmig, etwas gewölbt. schwarz, die Wurzel der Fühler und die Beine röthlich gelbbram bis rostroth, Hinterschenkel schwarz, Fld. weisslich gelbbraun, ein schmaler, mässig scharf begrenzter Sam an der Naht schwarz. Letzterer erweitert sich oft rom, nahe dem Schildchen zu einem dreieckigen Flecke, während er hinten in cinen rerwaschenen, schwärzlichen oder lräiunlichen Saum um den Sipitzenund Seitenrand ïbergeht; anch die Epipleuren sind schwarz oder

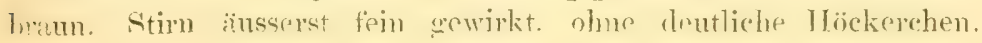


Halssch. kimm mu die Hälfte l,reiter als lang, an den Seitren selur schwach germolet, auf der Scheile: lederartig gemonzelt und nothr orler weniger dicht, jedoch nicht tief' punktirt, zuweilen sehr fein und moleutlich punktirt, die Zwisclienräune fast glatt. Fld. in den sichultern breiter als das ILalssch., mit kleiner, deutlicher, vormagender Beule, an den Seiten sanft geruntet, hinten schwach einzch abgerundet und sehr ku\% bewimpert; auf dem Riicken, ron rer Basis bis zur spitze, fast gleichnässig diclit, ziemlich fein und lach punktirt. Hinterheine ziemlich kurz, nit wenig gebogenen zusammengedrückten und an der Spitze erweiterten Schienen, deren Enddom mässig lang ist. Vollkommen gefligelt.

$\hat{j}$ Erstes Tarsenglied an den vorderen Beinen wenig erweitert, Unterrand der Hinterschienen gebogen, letzter Bauchring hinter der Mitte mit einer grossen, glatten Quergrube, welche durch einen Höcker oder einen breiten, hinten plötzlich abgeflachten Mittelkiel in zwei Theile geschieden wird. - Penis grade, die Seiten in der Mitte weit und sanft ausgeschweift, rorn ziemlich schnell gerundetrerengt und in eine sehr kleine, scharfe, wenig abgesetzte Spitze ausgezogen.

Bei der unrollkommenen, gefliggelten Form a. sind die Fld. durchscheinend, in der Regel mehr gewölbt, am Grunde nur wenig breiter als das Halssch., ohne Schulterbeule, oder nur mit einem niedrigen und flachen, kaum heraustretendeu Höcker.

Die Farbe der Fld. verdunkelt sich mitunter in röthlich-gelbbraun, kann auch durch Ausdelnung des dunklen Naht- und Seitensaumes bis auf einen Längswisch in der Mitte eingeengt sein; ausserdem findet man noch folgende leichte Abänderungen: Die vier Vorderbeine sind nebst den Hinterschienen angedunkelt (Var. b): Kopf und Halssch. haben einen metallischen Schimmer (Var.c). oder das Halssch. ist pechbraun Var.d), der dunkle Saum am Seiten- und Spitzenrande der Fld. endlich kaum noch hemerkbar (Var. e).

Im Sommer rereinzelt, im Herbste, besonders Anfany Oktober auf Brachäckern, und kurz berasten Wege- und Waldrïndern häutig; in Norddeutschland die ungefliggelte Form, in Mittel- und Sürdeutschland die gefliigelte vorherrschend. Foudras nennt als Futterpflanze Echium. Thoms on Nasturtium und andere Wassergewächse.

27. Long. suturalis: Alatus, oblungo-oralis, comeriusculus, niger, nitiulus, antennarum basi pedibusque testaceis aut fermuineis, femoribus posticis piceis, cupite prothoraceque aenein, elytris sat crebre subseriatim, postice olsoletius punctatis, patlide testaceis, limbo suturali postice 
angustato et abbreviato aene-nigro, margine laterali infuscato, callo humerali magno, prominulo, - Long, 1,8-3 mm.

II as: tarsis anterioribus articulo mimo dilatato, seymento ultimo ventrali vix emarginato, linea media laevi instructo.

If arseh, Ent. Brit. I. 201 (Chrysomela). - Steph. Ill. Brit. IV. 311; Man. 296 (Thyamis). - Al1. Mon. 391. - Kutsch. Wien. Monat. 1863. 303 (231) Longit. - Redtb. Faun. A. II. 508. - Leesb. Tijdschr. Ent. 25. 167.

Teinodact. nigricollis Foudr. Mon. 161.

Thyamis aeneicollis Fald. Nouv. Mèm. Mose. 346.

L. senecionis, Bach, Käferf. 3. 150 et 341 .

Var. a. Prothorace aeneo-piceo aut brunneo.

Var. b. rubenticollis: Minor, capite prothoraceque ferrugineis, vix vel haud aeneo-micantibus, elytris pallide testaceis, paulo subtiliter et crebrius punctatis, limbo suturali piceo angustissimo. - Long. 1,5-2,8 mm.

A 11. Ann. Fr. 1860. 118; Mon. 392.

Mit der vorigen nahe verwandt, aber Kopt und Halssch. deutlich erzfarbig glänzend, Fld. stärker und weitläufiger punktirt, auf der inneren Hälfte in Reihen, ihr dunkler Nahtsaum nach hinten verschmälert und vor der Spitze abgekürzt, der Spitzenrand also nie dunkel gesäumt, der letzte Bauchring des ô ohne Grube und Höcker.

Lang-eiförmig, mässig gewölbt, glänzend schwarz, Kopf und Halssch. grïnlich metallschimmernd, bisweilen pechschwarz oder braun (Var, a), die Wurzel der Fühler und die Beine röthlich gelbbraun bis rostroth, Hinterschenkel pechschwarz, innen rothbraun, Fld. weisslich gelbbraun, ein Saum an der Naht, vorn wenig breiter als das Schildchen, nach hinten allmählich verengt und vor der Spitze erlöschend, schwarz, erzglänzend, die Epipleuren und ein unbestimmter Saum darüber, welcher hinter der Mitte erlischt, bräunlich oder schwärzlich. Stirn äusserst fein gewirkt, mit sehr schmalen, verloschenen Höckerchen. Halssch, kaum um die Hälfte breiter als lang, an den Seiten schwach gerundet, auf der Scheibe sehr fein lederartig gerumzelt und mehr oder weniger dicht punktirt, stark glänzend, selten runzelig-punktirt und ziemlich matt. Fld. in den Schultern viel breiter als das Halssch., mit stark vorragender Beule, dahinter sanft gerundet, am Ende äusserst fein und kurz bewimpert und g'emeinschaftlich rerengt, mit abgerundetem Nahtwinkel; die Scheibe mässig dicht punktirt. Die Punkte sind an den Seiten und hinter der Mitte fein, seicht und verworren, ror der Mitte werden sie nach der Naht hin immer stärker und tiefer und bilden unregelmässige Reihen. Hinterbeine ziemlich lang, mit wenig gebogenen, zusammengedrückten, an der Spitze erweiterten Schienen und kurzem Enddorne. Vollkommen gefliggelt. 
j Erstres Tarsenglied an den vorderen Beinen erweitert, letzter Banchring dicht punktirt, eine feine unscheinbare, oft vertiefte Mittellinie glatt. der. Interrand mit einer Leiste rersehen. die ror dor Gruhe des Mittelzipfels kurz dreieckig ansgerandet ist. - Penis voln unbedeutend geloogen, so dass die Spitze anfwirts gerichtet ist. dicht iiber der Oeffnung jederseits leicht eingeschniurt, vor dersclben schnell gerunder verengt und in eine kurze, etwas abgesetzte Spitze ausgezogen.

Die ungeflügelte Form ist mir noch nicht bekannt geworden. es ist aber nach der Beschreibung zu vermuthen, dass Thyamis papaveris All (Mon. 394) dieselbe sein wird. Bei einer durchschnittlich kleineren Var. (b), welche in Spanien (Seidlitz), Algier und Maroceo auftritt, ist das Halssch. stets rostroth, stark, aber kaum metallisch glänzend, die Fld. sind eine Spur feiner und dichter punktirt, ohne dunkle Färbung am Seitenrande, der Nahtsaum pechbraun, sehr sehmal.

Ende Juni auf Aeckern an Adonis-Arten und an Wegränderı in den Vorbergen Mittel- und Süddeutschlands stellenweise.

28. Eong. atricillus: Alatus, oblongo-oralis, concexus, niger, nitidus, antennis fuscis basi pedibusque testaceis, femoribus posticis superne piceis, mothoruce rufo-brunnen, aeneo-micante, elytris sordide testaceis, sat crebre, apicem versus subtilius punctatis, sutura fusca, callo humerali parvo, vix prominulo. - Long. $1,8-3 \mathrm{~mm}$.

Mas: tursis anterioribus articulo primo dilatato, segmento ultimo vertrati integro, linea media laevi instructo.

Linn. Faun. Suec. 537 ((hrysom.). - Fabr. Ent. Syst. 1. 2. 31 (Galleruca); Syst. El. 1. 465 (Crioceris). - Gyllh. Ins. Suec. III. 540 (Haltica). - Koch Ent. Hft. II. 86. - Duft. Fauv. A. III. 256. - Schilling, Bericht Breslau 1846. 93. A11. Mon. 329 (Thyamis). - Redtb. Fann. A. II. 506. Longit. - Kntsch. Wien. Jlonat. 1864. 33 (248). - Bach. Käferf. III. 152 et 338. - Seid1. F. balt. 499. - Leesb. Tijdschr. Ent. 25. 168.

Halt. suturalis Duft. 1. c. 261.

Thyamis fuscicollis Steph. Ih. Brit. IV. 309; Man. 296.

Var. a. decliris: Brachipterus, rel apterus, callo humerali nullo.

Teinod. fuscicollis Foudr. Mon, 175.

Var. b. Capite rufo-brunneo.

Var. c. sutura cimcolore, pectore abdomineque interdum pice-forrugineis. Tar. 1. similis: Capite mothoraceque aeneo-nigris, margine laterali elytrorum saepe infuscato vel nigro.

Thyamis atricilla Steph. 1. c. 309 et 296 
Iler voricen drt ausserst wahe stehend, etwas hreiter gelout. gewölbter, auf dem Halssch. durchchnittlich heller, auf den Fld. triber getarbt, letztere verworen punktirt, der Nahtsam sehr schmal und unbestimmt, Schulterhöcker nicrlrig. Länglich-eiförmig. zienlich stark gewölht, schwary, glänzend. Fühler dunkelbraun, ihre Basis und die Beine röthlich-gelb, der Rücken der Hinterschenkel pechschwarz. Halssch. rothbraun, wie der Kopf stets metallisch gläuzend. Stirn äusserst fein gewirkt, ohne deutliche Höckerchen; Halssch. wenigstens um die Hälfte breiter als lang, an den Seiten gerundet, auf der Scheibe gewirkt und dicht runzlig punktirt, seltener fein punktirt und mit ebenen, fast spiegelglatten Zwischenräumen. Fld. in den Schultern nu wenig breiter als das Halssch., mit niedriger, kaum vorstehender Beule, an den Seiten gerundet, am Ende fein und kurz bewimpert, gemeinschaftlich verengt, am Nahtwinkel etwas abgerundet; die Scheibe ziemlich dicht punktirt, an den Seiten und vor der Spitze feiner als nach der Naht hin. Selten sind die Punkte auf der vorderen Innenhälfte der Fld. gereiht. Hinterbeine und Geschlechtsunterschiede wie bei der vorigen Art, der feine leistenförmige Hinterrand des Analringes vor dem Mittelzipfel in der Regel nicht ausgeschnitten, der Penis vorn weniger schnell verengt.

Die unvollkommen gefliggelte Form (Var, a), bei welcher die Fld. an der Basis kaum über das Halssch. hinaustreten, sondern mit diesem ein langes Oval bilden, ist auf den Fld. durchschnittlich dunkler gefärbt als die geflügelte, da die Decken bei noch nicht ausgehärteten Exemplaren den schwarzen Rücken der Bauchringe durchschimmern lassen; bei älteren Stücken ist die Mitte der Fld. zuweilen angedunkelt, nur die Basis und Spitze hell. Frische Exemplare besitzen eimen glänzend rothbraunen Kopf. wonig dunkler als das Halsseh. (Var. b), auch kamn der Nahtsaum auf den Fld. fehlen, dann sind Brust und Bauch meist röthlich pechbraun Var c). Die dunkelste Abänderung (Var. d) gleicht der suturalis, indem Kopf und Halssch. schwarz, erzfarbig glänzend, und auf den Fld. ausser dem Nahtsaume noch die Epipleuren und ein Saum darüber dunkel gefärbt sind.

Das Thier ist im Herbste entwickelt und dawn aut fenchten Wiesen und in ausgetrockneten Gräben sehr häufig; in Dentsehland herrscht die unvollkommen geflügelte Form vor.

29. Long. suturellus: Subajterus, fere orulis, concexus, piceus, nitidus, antemarum basi pedibusque testrceo-rufis, femoribus posticis apicem versus nignirantibus. Irothorace saepe rufo-maculato, aut ommino 
rufo-trunnet), fortiter transersim conreco, sublueri, elytris sat crebre rageque punctulis, testaceo-rufis, lateribus sat rotundatis, margine prostico breviter ciliatis, sutura piceo-limbata. - Long. 1,8-2,8 mm.

II as: tarsis anterioribus articulo primo dilatato, seymento ultimo rentrali late impresso, impressione sulco medio instructa.

Halt. suturella Duftsehm. Faun. A. 3. 262.

Teinodact. melanocephala Kiesw. Stett. Z. 1347. 85. - Foudr. Mon. 163.

Teinod. thoraciea A ll. Ann. Fr. 1860. 107; J Jon. 393 (Thyamis), Long. thoracicus Kutsch. Wien. Monat. 1863. 310 (238). -

Bach, Käferf. 3. 342. -- Redtb. Faun. A. 2. 506. Seidl. F. balt. ed. 2. 722; transs. 813.

Var. a. Alatus, callo humerali sat prominulo.

Var. b. Prothorace evidenter alutaceo et punctato, minus nitido.

Var. c. Pedibus plus minusve infuscatis.

Var. d. Prothorace elytrisque brunneo-rufis.

Var. e. Immaturus, prothorace rufo-testaceo, elytris stramineis, sutura concolore aut brunneo-vel piceo-limbata.

Var. f. paludosus: Alatus, niger, antemis gracilibus basi testaceis, tibiis anterioribus interdum rufescentibus, elytris testaceo-flacis, sutura late nigro-limbata.

Long. suturellus Leesb. Tijdschr. 25. 167.

Var. g. Elytris limbo laterali infuscato.

Var. h. Immaturus, prothorace piceo, interdum rufo-maculato, tibris tarsisque ferrugineis.

Var. i. Ut in f, subapterus.

Var. k. macer: minor, praecipue angustior, alatus, niger, fronte sacpius piceo-rufa, antennarum basi prothoraceque ferrugineis, pedibus elytrisque testaceis, his sutura sat anguste, sed determinate nigro-limbata, limbo utrinque angustato, saepe abbreviato, femoribus posticis interdum apice infuscatis.

Var. l. Antennis testaceis, articulis ultimis vix infuscatis.

Verhältnissmässig dunkel gefärbt, und an der starken Wölbung. dem Glanze und der verloschenen Punktirung, den krärtigen und langen Fühlern, sowie an den Hinterschienen zu erkennen, an denen, ähnlich wie bei den zwei folgenden Arten. die innere Rückenleiste verhältnissmässig wenig niedriger liegt, als die äussere. Ziemlich eiförmig, gewölbt, pechschwarz, glänzend, Fühlerwurzel und Beine hell rostroth, der Rücken der Hinterschenkel an der Spitze schwärzlich. Halsseh. oft mit zwei oder drei $(2,1)$, wenig bestimmten rothen Flecken ror dem Schildchen, oder rothbraun, einfarbig, zuweilen noch mit einer schwarzen Längsmakel ïber den Seiten; Fld. röthlich gelbbraun, ein mässig breiter, schlecht begrenzter Saum an der Naht pechschwarz. Stirn kaum sichtbar gewirkt. mit undeutlichen Höckerchen. Fühler fast bis zum letzten 
Drittel der Fll. reichend, filjed 2 und $3 \mathrm{kur}$, moter sich etwa gleich lang, Glied 4 und 5 gestreckt, jedes cinzelne fast so lang als 2 und 3 zusammen. Halssch. um die Hiilfte breiter als lang, stark queriiber gewölbt, an den Seiten gerundet, auf der Scheibe äusserst foin gewirkt und schwach punktulixt, glänzend, selten deutlich gewirkt und punktirt, matt seidenschimmernd (Var. b). Fld. an der Basis gerundet-hexaustretend und in den Schultern etwas breiter als das Halssch., mit niedriger und kleiner Beule, bis hinter die Mitte verbreitert, an der Spitze breit abgerundet, zart und kurz bewimpert, mit verrundeter Nahtecke; die Scheibe ziemlich dicht, fein und flach punktirt. Hinterbeine mässig lang, ihre Schienen gerade, nach der Spitze allmählich erweitert und auf dem Rïcken sehr schwach nach innen abfallend; Enddorn kurz.

Beim $\hat{\sigma}$ ist das erste Tarsenglied der vorderen Beine erweitert, und der letzte Bauchring eingedrïckt. Der Eindruck beginnt in ein Viertel der Länge, erweitert und vertieft sich nach hinten und ist von einer Mittelrinne durchzogen, welche ebenfalls nach hinten stärker wird; er ist in der Regel flach, indem die Seiten allmählich in die Ebene des Segmentes iibergehen, zuweilen jedoch grubenförmig, wenn der Vorderrand von einer Kante begrenzt ist, die manchmal neben der Mittelrinne jederseits zu einem Höckerchen ansteigt. - Penis gleichbreit, vorn abgerundet, mit einer kurzen und breiten, wenig abgesetzten Spitze in der Mitte; unten schwach ausgehöhlt, am Ende mit drei feinen und seichten Rinnen, deren mittelste am breitesten ist.

Die vollkommen gefligelte Form a, welche vereinzelt auftritt, weicht durch etwas breitere Schultern und die höhere Beule derselben im Ganzen so wenig ab, dass ihre Trennung nur in den Fällen möglich ist, wenn die Fld. durchschimmernd sind, oder klaffen. Von Farbenabänderungen kommen vor, die Var. c, bei der die Beine, namentlich die vorderen Schenkel bald mehr, bald weniger angedunkelt sind; Var. d, oberseits einfarbig rothbraun, oder nur die Naht der Fld. schwärzlich, mit den hellen Stiicken des L. brunneus Duft, zu verwechseln, das Halssch, aber kleiner, neben der vorderen Borstempore weniger erweitert und die Fld. an der Spitze kurz bewimpert; endlich die Var. e, welche die frischen Exemplare umfasst, Kopf dunkelbraun, Halssch. gelblichroth, zuweilen mit zwei oder vier dunklen Makeln, Fld. strohgelb, mit dunkel gesäumter Naht, oder einfarbig, dann an pellucidus erinnernd.

Von der vorstehenden, in den Hauptvarietäten kenntlich gemachten Form des Gebirges weicht die der Ebene merklich ab. Sie ist vorherrschend gefligelt, hat schlankere Fühler, deren 


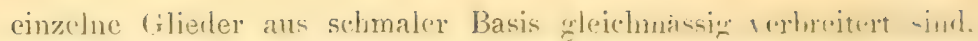

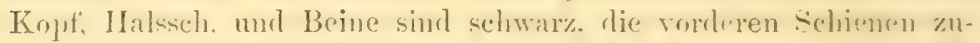
weikn röthlich, dis Flel. blass brïunlich golb, olne rothe Brimischung, aber mit rinem hreitren, ziemlich scharf hererenzten schwarzen Nahtsaume (Var. f'lledosne), der sich lisweilen, etwas verblasst, $u$ m die Spitze herumzielit und als Seitonsaum bis unter die Schulter fortsetzt (Var. g). Nicht völlig ausgelıärtete Stücke (Var. h) haloen bald ein pechbraunes, bald ein roth geflecktes orler röthliches Halssch. und rostrothe Schienen und Tarsen: unvollkommen geflügelte bilden die Var. i.

Im südlichen Europa von Krain und Görz bis Spanien, Sicilien und Griechenland, ist das Thier klein, schlank, schwarz, Stirn of rö̈thlich, Fühlerwurzel und Halssch. rostroth, Beine und Fld. lubhaft hräunlich gelb, Hinterschenkel selten mit einem schwarzen Wisch am Ende des Rückens, Nahtsamm schmal, schwarz. in der Regel beiderseits abgekürt. Von dieser Form (Var. macor) kommen auch Exemplare mit röthlichgelben Fïhlern vor, deren Endglieder kaum dunkler sind.

Im Juli auf Senecio nemorensis L. in Gebirgsgegenden laäufig. die Varietäten $f$ bis i Anfang Mai auf Senecio paludosus $L$. in sumpfigen Gegenden Torddeutschlands weit verbreitet (g und i selten), von $\mathrm{H}$. Hahn bei Magdeburg auch auf Angelica-Sprösslingen und Scrophularia vernalis gefunden.

Long. senecionis Hotsch., Bull. Hosc. 1851. 4. 599, ist unbeschrieben.

30. Long. piciceps: Alatus, oblongus, minus contexus, piceo-niger, nitidus, antennarum basi pedibusque tentaceis, femoribus prsticis superne piceis, prothorace subquadrato, convexiusculo, rufo testaceo, punctulato, elytris subparallelis, crebre subtiliter punctatis, pallide testaceis, margine postico breviter ciliatis, sutura nigro limbata Long. 2-2,5mm.

Mas: segmento ultimo ventrali canaliculato.

Steph. I1]. Brit. 4. 309; Man. 296 (Thyamis). - Foudr. Mon. 166 (Teinod.). - Kutsch. Wien. Monat. 1863. 308 (236 Longitars). - Thoms. Skand. Col. 8. 177. - Leesb. Tijdschr. 25. 166. - Seidl. F. balt. ed. 2. 722 ; transs. 813.

Long. atricapillus Redtb. Faun. A. ed. 1.534. - Bach, Käfert. 3. 152.

Thyamis picipes All. Mon. 385. - Redtb. 1. c. ed. 3. 2. 506.

Thyamis senecionis Bris. Ann. Fr. 1873. Bull. 218.

Var. a. Femoribus anterioribus tibiisque posticis basi infuscatis.

Den schlanken Exemplaren der rorigen Art, die ein röthliches Halssch. besitzen, sehr ähnlich, aber gestreckter, auf dem Rüicken mehr abgeflacht, die Fld. tiefer punktirt. an den seiten beinahe parallel. Gestreckt. schwach gewölbt, Kopf, Prosternum. Brust und 
Bauch pechschwarz, chenso der Riicken, oder die Aussenseite der Hinterschenkel, Ialsseh, röthlich gelbbraun, Fühlerwuryl und Beine etwas heller, Fld. blassgelb, ein schmaler, an der Spitzo gewöhnlich abgekiuzter Nahtsaum schwarz. II alssch. ungefilux cin Drittel breiter als lang: an den Seiten wenig gerundet, anf der Scheibe äusserst fein punktulirt, ziemlich flach, zum Seitenrande nur mässig abfallend. Fld. an der Basis stark heraustretend und in den Schultern viel brcier als das Halssch.. mit niedriger Beule, hinter dieser unbedeutend erweitert, ziemlich parallel, die Spitze gemeinschaftlich abgerundet, kurz bewimpert, mit verrundeter Nahtecke; auf dem Rücken dicht und fein punktirt. Geflügelt.

ô Letzter Bauchring mit durchgehender, hinten oft grubenförmiger Mittelrinne. - Penis jederseits weit und sehr sanft ausgeschweift, vorn mit gerundeten Ecken gradlinig verengt, so dass die Spitze etwa ein gleichseitiges Dreieck bildet, die Unterseite f’ach ausgehöhlt.

Nicht immer bleibt sich die Breite des Halssch. gleich. Es kommen Stücke ror, bei denen das Halssch. so lang als breit, ziemlich quadratisch ist; sie zeichnen sich ausserdem durch etwas längere Fühler und Hinterbeine aus. Bei dem entgegengesetzten Extreme ist das Halssch. quer, um die Hälfte breiter als lang, die Fühler überragen wenig die Hälfte des Körpers und die Hinterbeine sind von normaler Länge. Selten ist die Basis der vorderen Schenkel und der Hinterschienen gebräunt (Var. a).

In August und September auf Inula britannica L. und SenecioArten, in Deutschland bisher nur in Gebirgsgegenden beobachtet, z. B. in Schlesien (Riesengebirge und Altvater), Sachsen, Thüringen, am Rheine (Niederwald-Denkmal, Koltze); bei Wien. Foudras traf die Art im Mai auf sumpfigen Wiesen bei Lyon, Allard gemein auf Senecio viscosus bei Paris an. Hier wurde die Form mit breiterem Halssch. von Brisont bei St. Germain gefangen; sie findet sich vereinzelt in Holland, England, Schweden und Südeuropa.

31. Iong. gracibis: Alatus, oblongus, minus convexus, testaceus, antennis, apicem iersus, capite, pectore abdomineque fuscis, elytris albidis, obsoletissime punctulatis. - Long. 1,8-2,5 mm.

Kutsch. Wien. Monat. 1864. 275 (297). - All. MLon. 407.

Var. a. Immaturus, crpite, pectore abdomineque formyineis, antennurum apice infuscato, elytris pellucidis.

Var. b. Elytris limbo suturali postice longe abbreviate nigro, pectore abdomineque nigris.

Thyamis Poweri All. Mon. 408. 
In Croisse, Gestalt und Farlus an Aphthonu reblominulis Duft. erimmernt, von den ähnlichen gestreckten Longitusus-Arten durch die sehr flache, kam sichthare Punktirumo der Fld. vonn dem hierin ïhnlichen $I$. pratensis durch viel längre Fuhler abweichend. Gestreckt, das o länglich-eiförmier. das $\hat{\jmath}$ an den Suiten fast parallel. wenig gewölbt, glänzend, bräunlich gelh, die Fiiller (oft schon rom fiunften oder sechsten Gliede an), der Kopf; die Brust und der Bauch schwärzlich braun, die Fld. weisslich gelb. Stirn kaum growirkt, mit ziemlich grossen. uubestimmten Höckerchen: Fühles ctwas kiirzer als der Körper, Glied 2 und 3 ziemlich kurz. etwa vom gleicher Liinge, die mittleren Glieder wohl viermal so lang als hreit. Halssch. um die Hälfte breiter oder doppelt so loreit als lang. fast glatt, an den Seiten stark abfallend. diese gerundet. Fld. in den Schultern stark heraustretend und breiter als das Halssch., mit niedriger Beule, hinten ziemlich hreit alogerundet, kurz bewimpert, mit verrundeter Nahtecke, beim 'ó etwas kiurzer als der Hinterleib; auf dem Rücken sehr fein, äusserst flach und verloschen punktirt, die Punkte gewöhnlich nur auf der immeren Hälfte unter stärkerer Vergrösserung sichtbar, oder wenn sie dunkel durchscheinen. Beine einfarbig, röthlich gelbbraun, die dicken Hinterschenkel auf dem Rücken zuweilen rostroth, die beiden letzten Tarsenglieder oft angedunkelt; der Dorn der Hinterschienen kurz. Geflügelt.

$\hat{o}$ Erstes 'Tarsenglied an den vorderen Beinen erweitert, letzter' Bauchring mit feiner Mittelrinne, die sich hinten in eine Grube erweitert. - Penis vor der Mitte einer Spur erweitert. vorn in eine scharfe Spitze gerundet-verengt; die Unterseite ausgehöhlt.

Bei unreifen Stücken, wonach Kutschera die Art beschrieben haben mag, ist der Kopf, die Brust und der Hinterleib bell rothbraun, die Fiihler sind zuweilen nur an der Spitze angedunkelt, die Fld. weisslichgelb, durchseheinend. Ausgehärtete Exemplare haben bald einfarbig weissliche Fld, bald einen schwärzlichen Nahtsaum, welcher sich hinter der Mitte rerschmälert und weit vor der spitze endet: Brust und Bauch sind bei ihnen oft tief schwarz.

Nordwestliches Europa. Im Anspülicht der Nahe bei Kreuznach. Auf Tussilago farfara L. bei St. Germain in der Nähe ron Paris (Brisont de Barneville), England.

32. Long. Longiseta: Alatus, oblongus, sat convexus, nitidus, piceus, fronte rufo-brunuea, antennarum basi, prothorace elytris pedibusque testaceo-flaits, femoribus posticis apice nigris, limbo suturali elytrorum sat lato, antice longe abbreviato, nigro; mrothorace transwerso evidenter. 
punctato, clytris crebre punctutis, lateribus paullo rotundatis, margine postico ciliatis, ritiis \& primis longissimis, - Long. 1,5-2,2 min.

Weise, Deutsch. Zeitschr. 1889. 420.

? Teinod. nigriceps Foudr. Mon. 173.

Var. a. Subaptera, callo humerati nullo.

Var. b. Immaturus, limbo suturali elytrorum angustissimo, pectore ab)domineque rufo-brunneis.

Viel schlanker als die ähmlich gefärbte Aphtona nigriceps $\mathrm{R}$ edtb., an der kräftigen Punktirung der Oberseite, dem vorn abgekurzten schwarzen Nahtsaume und den beiden ersten, auffällig langen Wimperhärchen am hinteren Nahtwinkel der Fld. sofort zu erkennen.

Gestreckt und mässig gewölbt, mehr oder weniger glänzend, pechschwarz, der Kopf, mit Ausnalime des Mundes, rothbraun, Beine, Fühlerbasis, Halssch. und Fld. strohgelb, zuweilen mehr gebräunt, das Halssch. rostroth angehaucht; das Schildchen und ein Saum an der Naht schwarz. Letzterer beginnt schmal in ein Drittel der Länge, ist in der Mitte am breitesten, hinten wieder verschmälert und abgekürzt. Auch der Rücken der Hinterschenkel ist in der Spitzenhälfte schwarz, die beiden letzten Tarsenglieder sind angedunkelt. Fühler etwas länger als die Hälfte des Körpers; Stirn äusserst fein gewirkt, Hockerchen klein, oval oder länglichdreieckig, nirgends deutlich begrenzt, aber durch ihre Wölbung und den Glanz hervortretend. Halssch. wenigstens um die Hälfte breiter als lang, stark queriber gewölbt, an den Seiten leicht gerundet, auf der Scheibe dicht und deutlich punktirt, oft runzelig, seltener fast glatt. Fld. an der Basis in flachem Bogen heraustretend und in den Schultern etwas breiter als das Halssch., mit flacher, aber merklich heraustretender Beule; bis zur Mitte sehr schwach erweitert, hinten schmal abgerundet, mit verrundeter Nahtecke; auf dem Rücken dicht, ziemlich kräftig, verworren punktirt. Die Punkte sind neben der Naht zuweilen gereiht, etwas stärker als bei $L$. atricillıs, stehen dichter als bei diesen und sind nach hinten weniger abgeschwächt. Das erste Wimperhärchen am Nahtwinkel ist aufgerichtet, so lang als der Metatarsus und das folgende Tarsenglied zusammen, das zweite Härchen ist ein wenig kïrzer, gebogen nach hinten gerichtet. Hinterschienendorn kurz.

$\hat{\sigma}$ Die fünf letzten Fühlerglieder verdickt, erstes Tarsenglied an den vier Vorderbeinen leicht erweitert, der letzte Bauchring mit einer seichten, ziemlich glatten, nach hinten verbreiterten und vertieften Mittelrinne.

Diese Art scheint vorherrscheud gefligelt zu sein; bei der Form mit verkümmerten Flügeln (Var.a) ist die längliche, innen schwach abgesetzte schulterbeule völlig geschwunden und die 
Schultern fallen in gleichmissiger Wölumg zur Randlinic al, Nicht ganz ansgereifte Stücke crinnern in ler Fïrbung an I. melanocephalus, ilre Nahtkante ist in eler Mitte dumkel, Brust und Bauch (namentlich der letztere) sind rïthlichbraun, die Hinterschenkel haben einen kleinen dunklen Fleck an der Spitze (Var. b).

In Schlesien und in den Alpen: München (Daniel). Salzburg (Wehncke), Karawancken (Knauth). Auch in der Schweiz und den Westalpen.

Die T. nigriceps Foudr, welche von Allard und Kutschera stillschweigend übergangen worden ist, künnte nach der Färbung der Fld. hierber gebören, die Punktirung und die Farbe der Beine scheinen mehr auf gracilis Kutsch, hinzudenten.

33. Long. vidums: Subapterus, ovalis, convexus, nitidulus, piceus, antennis sat brevibus basi, prothorace, elytris pedilusque testaceis, femribus posticis infuscatis, prothorace fortiter transeerso, convexo, ruguloso-punclulato, elytris prothorace paullo latioribus, crebre punctutis, apice breviter ciliatis; pallidis, limbo suturali angustissimo, utrinque abbreviato, nigro. - Long. 1,8-2,3 mm.

Mas: segmento ultimo ventrali linea media impresso, tarsis anterioribus articulo primo leviter dilatato.

Thyamis vidua A 1l. Mon. 340.

? Thyamis subquadrata All. Mon. 414.

Var. a. Immaturus, subtus ferrugineus, sutura elytrorum vic vel haud nigro-limbata.

Den hellen, unausgefärbten Stücken von L. suturellus ähnlich, durch breiten Kopf, ein sehr kurzes Halssch. und die deutliche Punktirung der Fld. verschieden.

Eiförmig, gewölbt, ziemlich glänzend, pechbraun, die untere Hälfte der Fühler, das Halssch. und die Beine rötllich grelbbraum, Hinterschenkel angedunkelt, Fld. blassgelb, ein f'einer Saum an der Naht schwarz. Stirn kaum bemerkbar oder sehr deutlich gewirkt, mit undeutlichen Höckerchen; Fühler ziemlich kư, wenig über die Mitte der Fld. reichend, Glied 2 und 3 klein, 4 wenig länger als 3. H alssch. doppelt so breit als lang, an der Seite stark abfallend, dicht und sehr fein längsrunzelig punktirt, gewirkt, matt, seltener nu hinter der Mitte mit länglichen Punkten bedeckt, oder fast glatt; Schildchen braun. Fld. an der Basis gerundetheraustretend und in den schultern etwas breiter als das Halssch., wit niedriger Beule, bis zur Mitte schwach erweitert, dahinter ähnlich revengt, an der Spitze hreit abgerundet. kurz bewimpert. 
mit rerrundeter Nahtecke; die selneibe verworren und dicht, fein. aber tief punktirt mit zart gewirkten \%wischenriumen. Hinterboine mässig lang, ihre Schienen grade, auf dem lïicken stark nach imen abfallend, Endeloru klein. Unvollkommen geflügelt.

$\hat{o}$ Letzter Banchring mit f'einer Mittelrime. die in einen Gribchen des Mittriziptels endet; erstes Tarsenglied an den vorderen Beinen schwach erweitert, - Penis schlank, ror der Mitte eine spur verengt, vorn allmählich in eine stumpfe Spitze verschmälert, welche etwas aufwärts gekrimmt, unterseits rimnenförmig ausgehöhlt ist. Diese Aushöhlung setzt sich, bald auf eine Furche rerengt, bis zur Basis fort; auch auf der Oberseite der Röhre befindet sich, in der vorleren, flachen Hälfte eine Rimne, welche schmal beginnt und sich bis zur Oeffnung immer mehr verbreitert.

Der schwarze Nahtsaum der Fld. ist beiderseits verengt und abgekiurzt, er wird oft sehr undeutlich, besonders bei frisch entwickelten Thieren, deren Unterseite rostroth gefärbt ist, auf der Brust gewöhnlich dunkler als auf dem Bauche. Bisweilen ist die Tahtkante der Fld. vor dem Saume bräunlich angelaufen.

In Gebirgsgegenden: Riesengebirge, Minchen, Tirol, Görz, Mehadia.

34. Long. curtus: Alalus, breviter ovalis, convexus, sat nitidus, nigro-piceus, antennarum basi, mothorace, elytris pedibusque testaceis, scutello, sutura elytrorum femoribusque posticis infuscatis, prothorace parvo, transverso, crebre subtiliter ruguloso-punctato, elytris latiusculis, humeris valde mominulis, apice late subsingulatim rotundatis brevissimeque ciliatis, minus profunde et crebre punctatis. - Long. 1,8-2,4 mm.

II as: tarsis anterioribus articulo primo dilatato, segmento ultimo ventrali medio deplanato, aut apicem versus impresso.

Teinod. curta A11. Ann. Fr. 1860. 832; Mon. 410 (Thyamis).

L. curtus Kutsch. Wien. Monat. 1864. 41. 256. - Bach, Käferf. 3. 344. - Redtb. Faun. A. 2. 507. - Seidl. Faun. transs. 813. Teinod. pratensis A11. Ann. Fr. 1860. 137.

Var. a. Immaturus, capite fusco, sutura elytrorum leviter rel haud infuscata, pectore abdomineque plus minusve ferrugineis.

Var. b. Prothorace infuscato.

Var. c. monticola: apterus, elytris basin iersus ungustutis callo humerali nullo.

Kutsch. 1. c. 46. (259). - Bach, 1. c. 344. - Redtb. 1. c. 506. - Seidl.1. c. - All. Mon. 372 Thyamis.

Diese Art zeichnet sich durch breite, kurze und gewölbte Fld. aus, gegen die der Torderkörper klein und schmal erscheint; sie hat grosse Aehnlichkeit mit der rorigren. dis aber melur gleichbreit

VI. 6. 
gebaut und f'ciner und dichter punktirt ist, auch lässt sie sich leicht mit frischen, hellen Stücken von luridus verwechseln, die aber längere, weniger gewölhte Fld, und einen rostrothen, nie schwarzen Kopf besitzen.

Ziemlich kurz-eiförmig, gewölbt, mässig glänzend, pechschwarz, die ersten 3 bis 5 Fithlerglieder, das Halssch. und die Beine röthlich gelbbraun, das Halssch. oft rostroth und die Fld, blassgelb. Schildchen, Nahtkante der Fld. und die Hinterschenkel schwärzlich. Stirn äusserst fein gewirkt, mit undeutlichen glänzenden Höckerchen: Fühler merklich länger als die Hälfte des Körpers, namentlich beim $\hat{\jmath}$, Glied 2 und 3 kurz, 4 nicht ganz so lang als beide zusarnmen. Halssch. stark querüber gewölbt, um die Hälfte breiter wie lang, dicht und fein, meist etwas runzelig punktirt. Fld. an der Basis in starker Rundung heraustretend und in den Schultern viel breiter als das Halssch., mit grosser und ziemlich hoher Beule. dahinter fast parallel, am Ende schwach einzeln abgerundet und sehr kurz bewimpert; ron der Mitte an nach hinten stark abwärts gewölbt, mässig dicht narbig punktirt.

Die Punkte sind in der Regel rerworren, ziemlich gross, nicht tief, bis zur Mitte sehr deutlich, hinter derselben verloschen, die Zwischenräume zart gewirkt. Hinterbeine ziemlich kurz, ibre Schienen grade, auf dem Rücken stark nach innen abfallend, Enddorn klein. Geflügelt.

$\hat{o}$ Letzter Bauchring in der Mitte abgeflacht, oder vor dem Hinterrande eingedrückt, das erste Tarsenglied der vorderen Beine erweitert, breiter als bei viduus. - Penis ziemlich grade, gleichbreit, vor der Oeffnung in eine mässig lange, flache und scharfe Spitze verengt, unten breit gerinnt, oben in der vorderen Hälfte eingedrückt.

Bei mangelhaft ausgefärbten Stücken ist der Kopf braun, die Nahtkante der Fld. rostroth angelaufen, oder mit den Fld. gleichfarbig, die Unterseite mehr oder weniger rostfarben. (Var. a); einen Ueberschuss an Farbe bemerkt man zuweilen auf dem Halsschilde, welches am Vorderrande oder auf der Scheibe angedunkelt ist (Var. b). Einen fremdartigen Eindruck macht die ungefliigelte Form c, bei der sich die Fld. aus schmaler Basis bis in oder hinter dis Mitte verbreitern und an den beulenlosen Schultern gleichmässig: abfallen.

Die gefliigelte Form lebt nach Allard auf Echium rulgare L. und ist in den bergigen Gegenden Deutschlands, wie in ganz Mitteleuropa ziemlich verbreitet, die fligellose kommt unter der gefiügelten nördlich noch bei Weimar vor. 
35. Long. melanocephalus: Alutus, oblongu-voutis, sat convexus, niger, nithlus, antennarum basi, prothorace subtiliter punstuto pedibusque fermuineis, femoribus tibiisque posticis piceis, fronte sulco laterali ah oculis parum remoto, elytris testaceis ronfertim, ante apicem subacuminatum fere rugubso-punctatis, margine postico breviter ciliatis, suture nigna; tibiis posticis loniter curvatis. - Long. $2-3 \mathrm{~mm}$.

Ias: tarsis anterioribus articulo primo vulde dilutato, segmento ultimo ventrali apice emarginato, linea media laevi.

Chrysom. melanocephala Deg. Ins. 5. 348. - Gyllh. Ins. Suec. 3. 545 (Halt.). Zett. Ius. Lapp. 223. - A 11. Mon. 313 (Thyamis).

Longit. melanocephalus Bach, Käferf. 3. 153. - Kutsch. Wien. Monat. 1864. 35 (250). - Redtb. Faun. A. 2. 507. - Thoms. Skand. Col. 8. 173. - Lees b. Tijdschr. 25. 171. - Seidl. F. balt. 722 ; transs. 813 .

Haltica atricapilla Dft. Faun. A. 3. 257. - Foudr. Mon. 176 (Teinod.)

Long. atricapillus Bach, 1. c. 152. - Thoms. 1. c. 174. Leesb. 1. c. 171.

Chrysom. atricilla Marsb. Ent. Brit. 1. 200.

Var. a. Prothorace piceo.

Var. b. nigrinus: Niger, antennarum basi ferrugineo, elytris piceis latera versus rufescentibus.

Var. c. Elytris haud pellucidis, stramineis.

$\mathrm{V}$ ar. d. Fronte ferruginea.

Var. e. Tibiis posticis rufo-testaceis.

Var. f. Immaturus, testaceus, capite, pectore, abdomine femoribusque posticis plus minusve ferrugineis, his superne antennisque apicem versus infuscatis, sutura elytrorum brunnea aut concolore.

Var. g. atriceps: Minor, praesertim brevior, elytris paullo fortius sed minus crelve punctatis, stramineis, callo humerali sat prominulo.

Kutsch. 1. c. 38 (253). - Redtb. 1. c.507. - A11. Mon. 317. Teinodactyla atricilla Foudr. Mon. 164.

Eine der gemeinsten Arten, durch den schmalen dreieckigen Raum zwischen Fühlerwurzel und Auge, die verhältnissmässig: kräftige Punktirung der Fld, auf dem Abfalle zur Spitze, die zusammengedrückten und leicht gebogenen Hinterschienen und das grosse erste Tarsenglied des ô ausgezeichnet.

Länglich-oval, ziemlich gewölbt, Kopf, obere Fühlerhälfte, Brust, Bauch und Hinterbeine pechschwarz, Fühlerbasis, Halssch., die vier vorderen Beine und die Hintertarsen rostroth, Fld, röthlich gelbbraun, vor der Spitze blass, weil die zusammengefalteten Flügel nicht bis hierher reichen; die Naht schwärzlich gesäumt. Stirn verhältnissmässig schnal, jederseits \%u ciner gebogenen Riune abfallend, welche sich weniger rom Auge entfernt, als bei den ver- 
wandten Arten, so dass zwischen Auge und Fihlerwurzel nur ein schmaler Raum ïbrig bleibt; Höckerchen unhestimmt. Fühler etwas länger, als der halbe Körper, Glied 2 ungefälı so lang als 3 . Halssch. fast doplelt so hreit als lang, stark der Quere nach gewölbt, an den Seiten etwas gerundet, auf der Scheibe rlicht und fein, oft runzelig punktirt, selten fast glatt. Fld. an der Basis winkelig heraustretend und in den Schultern bedrutend breiter als das Halssch., mit flacher. wenig vortretender Beule. bis zur Mitte beim $\hat{o}$ kaum, beim $q$ merklich erweitert. hinter derselten in schwacher Rundung zu einer gemeinschaftlichen kuren und sehr stumpfen Spitze rerengt, deren Nahtwinkel al,gerundet sind. Des Ruicken ist dicht und deutlich, bald stärker, bald schwächer punktirt. die Punkte sind völlig rerworren, oder bilden zahlreiche. wenig in die Augen fallende Reihen, werden zwar an der Seite und hinter der Mitte etwas feiner, nehmen aber nahe der Spitze wieder an Stärke zu, und sind hier durch sehr schmale, runzelige Zwischenräume getrennt. Hinterbeine kräftig, ziemlich kurz, ihre Schienen zusammengedrückt, leicht nach innen gebogen, mit mässig langem Enddorn.

ô Erstes Tarsenglied an den vorderen Beinen selır stark erweitert, letztes Bauchsegment mit einer glatten, oft vertieften Mittellinie versehen, der Mittelzipfel grubenförmig, vor demselben ein mehr oder weniger tiefer Ausschnitt in der erhabenen Leiste des Hinterrandes. - Penis ungefähr von gleicher Breite, vorn gradlinig in eine mässig breite Spitze rerengt, welche grade abgestutzt ist. Auf der Oberseite befindet sich in der Basalhälfte ein hoher und ziemlich scharfer Mittelkiel, welcher, nach rorn verbreitert und verflacht, allmählich in die Klappe iibergeht.

Von den zahlreichen Abänderungen verdienen vielleicht die folgenden beachtet $\mathrm{zu}$ werden:

a. Das Halssch. ist braun oder pechschwarz, auf der Naht der Fld. gewöhnlich ein deutlicher schwarzer Saum;

b. der Körper tief schwarz, nur die Basis der Fühler rostroth, die Fld. pechschwarz, nach aussen und zur Spitze hin allmählich in eine röthliche Farbe iibergehend;

c. die Fld. sind hart, nicht durchscheinend. lebhaft und hell strohgelb ${ }^{1}$ ), kräftig punktirt;

1) Die Aushärtung der hellen Longitarsus-Arten geht langsam ror sich, und die Mehrzahl derselben wird gefangen, ehe sie den Zustand völliger Festigkeit erlangt hat, daher sind ihre Fld. durchscheinend, so dass man die Flïgel oder deren Stummel, öfter sogar die Lage der Rïckenringe wahrnehmen kann, ohne die Decken zu sperren. Bei gänzlich ansgereiften, wohl mindestens ein halbes Jahr alten Indi- 
d. die Stirn, oder der Kopt' mit Arsnahme des Mundes, ist rothbraun oder rostroth;

e. Schienen und 'Tarsen der Hinterbeine rithlich-gelbbraun;

t. Oberseite brämlichgell, Kopf, Brust, Bauch und Hinterschenkel mehr oder weniger rostroth, Rücken der letzteren, :ahnlich wie die obere Hälfte der Fülller, angedunkelt, Naht bräunlich gesäumt, oder mit den Fld. gleichfarbig;

g. Körper klein, oval, die Fld. in der Regel fest und undurchsichtig, hell strohgelb wie bei der Var. b, aber etwas weitläufiger punktirt, mit hoher, dentlich heraustretender Schulterbeule, hinten weniger ausgezngen, breiter abgerundet.

Im Juli entwickelt und bis in den Herbst auf fruchtbaren Wiesen, sowie zu Ende des Winters in Anspiilicht gemein; die Varietäten $a$ und $b$ selten, $f$ unter der Hauptform vereinzelt in den Alpen z. B. Kärnthen (Liegel), Erzherzogthum Oesterreich, Steiermark, Kroatien (Apfelbeck).

Dieses veränderliche Thier schied Foudras in zwei Arten, die von Thomson durch recht hinfällige Gründe zu halten versucht wurden, auch die Meinung von Kutschera bestätigt sich nicht, dass die kleinen Stiicke aus den Alpen eine besondere Art bildeten.

36. Long. Longïpennis: Apterus, oblongus, convexus, testaceus, sat nitidus, capite rufo-ferrugineo, antennis apicem versus suturaque elytrorum infuscatis, pectore, abdomine, femoribusque posticis superne nigris, prothorace brevi ruguloso-punctato, elytris oblongis, apice late fere singulatim rotundatis, sat fortiter punctatis, callo humerali nullo, tibiis inferne subcurvatis apice dilatatis, articulo primo tarsorum anteriorum elongato. - Long. 2-3 mm.

II as: segmento ultimo ventrali medio polito, deplanato, canaliculato.

Kutsch. Wien. Monat. 1863. 306 (234). - Redtb. Faun. A. 2. 506. - Bach, Käferf. 3. 337.

Long. femoralis Redtb. I. c. ed. 1.545; ed. 2. 941. - Bach, 1. c. 151 .

Var. a. Capite piceo, prothorace saepe ferrugineo.

Var. b. Immaturus, sutura elytrorum concolore, abdomine plus minusve rufescente.

viduen ist dies nicht möglich, da ihre Fld. allmählich eine dicke Schicht Farbestoff angesetzt haben und nudurchsichtig geworden sind. Zugleich verlieren dabei oft die Zwischenräume der Punkte ihre ursprïnglichen feinen Runzeln und werden fast spiegelglatt. Die völlige Ausfärbung der Fld. fällt nicht immer mit der dunkelsten Färbung des Kopfes, der Unterseite und Beine zusammen, denn es finden sich auch Stücke, bei denen die genannten Theile ihre anfängliche helle Farbe behalten. 
Eime antfilliw schlanke Art. welche sich an don krittig funktirten und hinten bycit abgermuleten Fld. leicht wied erk erknen lïst. Gestreckt, beiderseits wenig verschmälert, grewiilht, rijthlich gelbbraun. die Fld. zuweilen weisslichgelb. der Kopf rothluaun. die Fiuhler nach der Spitze hin und die Naht angedunkelt. Oberlippe. Mittel- und Hinterbrust, Bauch und der grösste 'Theil der Hinterschenkel schwarz oder pechschwarz. Stirn mit undeutlichen, unten breiten, oben zugespitzten Höckerchen, welche oft durch eine Rimus geschieden sind. Fiihler schlank. Halssch. kurz, fast doppelt sı breit als lang. stark und etwas kissenartig gewölbt. runzelig punktirt. Fld. wenig breiter als das Halssch. in der Mitte beinahe parallel. an den Schultern und vor der Spitze sehr schwach hogig verengt. hinten ungefähr so breit als rorn und einzeln in einem breiten und flachen Bogen abgerundet. so dass das Pygidium meist unbedeckt ist: auf dem Rücken ziemlich stark punktirt. Die Punkte stehen mässig dicht, sind verworren, oder mregelmässig gereiht, auf der rorderen Hälfte stärker als die des Halsschildes, hinter der Mitte nach und nach abgeschwächt. Hinterbeine mässig lang. Schenkel gross und stark. Schienen kurz, rorn etwas zusammengedrickt, an der Spitze stärker rerdickt. der Rücken mässig g'eneigt, an der Basis oft mit kurzer Innemrandleiste, der Aussenrand sparsam und schwach gezähnelt, die Unterseite sanft gebog'en, namentlich in der Nähe der Spitze. Enddorn kurz. das erste Tarsenglied an den vorderen Beinen gestreckt, nicht ganz so lang als die folgenden zusammen.

Beim $\hat{o}$ ist das mittlere Viertel des letzten Bauchringes spiegelslatt, leicht vertiet't, mit einer Längsrimne versehen, die in eimem Gribchen des grossen Mittelzipfels eudet. das stark punktirte Pygidium ist gerade abgestutzt, beim of dagegen in eine breite. stumpf-abgerundete spitze rerlängert. - Penis ziemlich breit. an der Oeffnung rertieft, vorn abgerundet. unten breit rimnenförmig ausgehöhlt.

Zuweilen ist dex Kopf pechschwarz (Var.a), bei frischen Stiicken die Naht mit den Fld. gleichfarbig und der Bauch mehr oder weniger röthlichbraun (Var. b).

Aut' Convolvulus arvensis L. an steinigen Abhängen und auf Rainen im Gebirge. Riesengebirge. Glatz. Wien, Steiermark. Kroatien: Vellebit (Reitter).

Die befremdliche Mittheilung Kutschera's, dass das $\hat{o}$ bei dieser Art und nigrocillus Motsch. „weit kiirzere und mehr eifömige Fld." zeigen soll, beruht auf Irrthum, dasselbe ist, wie in der wanzen Gattung, schlanker gebaut als das of. Der Long. femoralis 
Foudr. kaun nicht hierher gehören, da er einen vorn zugespitzten Penis besitzen soll.

37. Long. Iateralis: Alatus vel subapterus, oblongo-ovalis, convexus, piceus aut niger, pedibus, antennarum basi, jrothorace elytrisque testaceis, his subseriatim punctatis, limbo suturali vittaque laterali saepe intermpta nigris, femoribus posticis plerumque piceis, tibiis posticis leviter curcatis, carina interiore dorsali subintegra. - Long. $2-3 \mathrm{~mm}$.

I as: segmento ultimo ventrali longitudinaliter impresso, maryine postico aut evidenter aut vix emarginato.

Illig. Mag. 6. 68 et 168. Halt. - Duft Faun. A. 3. 254. Foudr. Mon. 178. Teinod, - A11. Mon. 395. Thyamis. Kutsch. Wien. Monat. 1863. 317 (245). Longit. - Redtb. Faun. A. 2. 506. - Seid1. F. balt. 722 ; transs. 813.

Long. longipes Bach, Käferf. 3. 153.

Var. a. Capite, prothorace pedibusque plus minusve nigris.

Vax. b. Vitta laterali clytrorum integra postice cum limbo suturali conjuncta.

Var.c. domesticus: elytris testaceis, sutura nigra.

Var. d. patruelis: Ut in e, sed humeris elytrorum magis prominulis. A11. Mon. 398.

Var. e. Elytris unicoloribus, testaceis.

Var.f. Immaturus, capite, pectore abdomineque ferrugineis, prothorace elytrisque testaceis.

Von der Grösse des melanocephalus, die Fld. aber etwas kürzer, in den Schultern enger, an den Seiten mehr gerundet, auf der Scheibe stärker punktirt, die Fühler und Hinterbeine bedeutend länger und stärker.

Länglich eiförmig, fast elliptisch, gewölbt. Stim gewirkt, mit kaum angedeuteten Höckerchen, Nasenkiel schmal, scharf, Fühler viel länger als der halbe Körper, ziemlich stark, namentlich die 5 letzten Glieder. HaIssch. kaum um die Hälfte breiter als lang: sclten breiter, stark queriiber gewölbt, vorn zusammengedrïckt, mit fast parallelen Seiten, deutlich und ziemlich dicht, bald stärker. bald schwächer punktirt, die Zwischenräume gewirkt oder glatt. Fld, an der Basis in sanftem Bogen heraustretend, mit niedriger Schulterbeule, bis zur Mitte gleichmässig schwach erweitert, dahinter ähnlich verengt, an der Spitze schmal, fast gremeinschaftlich abgerundet. kurz bewimpert, mit verrundeter Nahtecke; der Rücken ahnlich wie bei $L$. echii. nur feiner punktirt, die Punkte vorn gereiht, hinter der Witte abgeschwächt. die Zwischenräume zart gewirkt. Hinterbeine lang und kräftig, ihre Schienen einwärts gebogen, am Ende erweitert, mit vollständiger Leiste am Inmenrande des Rückens, ier Enddorn ziemlich lang. Die unvollkommen geflügelte Form 


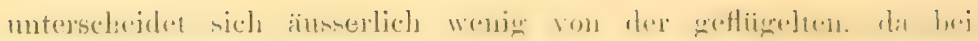
beiden die Schulterbeule klein und niedrig ist.

o Frstes Tarsenglied an den vorderen Beinen kanu remeiturt. lotzter Bauchring yleichnässign junktirt, orler mit einem ghlaten Lingsstreifen in der Witte: anf letzteren kanu orler deutlich vertieft, die Vertiefung Hach oder rinnenfömig. gan\% wder mur an IInterrande hemerkhar, letzteres vor dre frrube des Mittelziptrels stumpfiwinkelig ausgerandet oder ziemlich grarlinig. - Penis schlank. an der Basis dick, dicht davor etwas verengt, sorlamn parallel bis zur Oeftinung, ror dieser aufwairts gekrimmt und schmell in einr wagerechte, verhältnissmässig lange und dimme Spitze ausgrezogen.

Die Färbung der Art ist sehr reränderlich. Bei frischen Stück'n (Var. f) sind Kopf und Unterseite rostroth. Beine und Fülıler heller. letztere mit gebräunter Spitze, das Halssch. röthlich. dis Fld. gellıbraun. Allmählich färbt sich der Kopf. dic Brust, der Bauch und der Rücken der Hinterschenkel dunkel. his pechhram oder schwarz. und auf dem Halsschilde zeigen sich einige sehr verwaschene Flecke. Diese fliessen gewöhnlich zu einer unbestimmten M-förmigen Zeichnung zusammen. aus der dann zwei lıelle Makeln vor dem schildchen deutlich herrortreten. oder sie dehuen sich iiber das ganze Halssch. aus (Var. a: mit dem feinpunktirten suturellus leicht zu rerwechseln). Auch die Hinterschienen und Torderbeine. mit Ansmahme der Knies und der Tarsen, kömnen schwärzlich werden Die Fld. bleiben entweder einfarbig gelbbram (Var.e), oder erhalten einen dunklen bis schwarzen Nalitsaum, welcher ziemlich rou gleicher Breite, oder vorn verengt, linten oft abgekiirzt ist (rax. domesticus): später zeigt sich über der Seitenrandlinie ein schwarzer Punkt. oder. cine nach immen gebogene Makel hinter der schulter und ein Strich in zwei Drittel der Länge, seltener noch ein Piuktchen auf der schulterbeule und ein Fleck ror der Spitze. Dieselben rereinigen sich zuletzt in einen schwarzen Seitensaum (7ateralis), der ausnahmsweise grade rerläuft, in der Regel jedoch hinter der Schulter nach innen biegt und einen yrossen Bogen bis zur Jitte beschreibt. damn am Seitenrande entlang zieht und zuweilen um die Spitze herum sich mit dem Nahtsaume rerbindet (Tar. h). Die dunkelsten Stiicke, bei denen der äussere, rom Bogen des sicitensaumes umschlossene 'Theil der Fld. hinter' der Schulter' bis zum Rande schwarz ist, haben eine entfernte Aehnlichkeit mit rem kleineren lateripunctatus.

Von der Färbung der Fld ist die des Koptes und Halsschildes. der Fiihler und Beine nicht immer abhängig. So tindet man Exemplare mit sehr ausgedehnter schwarzer Zeichnung der Fld.. hei denen die Fiihler fast einfarbig rostroth. oder der Kopt roth- 
brann. orter tie Reine gleichmässig rïthlichgell, sind. und umgekehr Stiieke, mit gelbbraunen, hörhstens an der Naht dunklen Fld., hei denen die Fiihler sehr weit, Kopf und Halssch. gainzlich, und die Beine fast ganz schwarz gefärbt sind.

Den $I$. patruclis All. vermag ich nur als eine kraiftig entwickelte Varietït anzuschen, deren Fld, an der Basis stäker als gewöhnlich heraustreten, daher finst gleichbreit, auf dem Rüeken ctwas feiner punktirt und mit einem feinen schwarzen Nahtsaume versehen sind.

Auf Verbascum-Arten, namentlich $V$. nigrum $L$. an somigen Waldrändern und durch Felsen geschiitzten Orten des Vorgebirges. namentlich auf Kalkboden häufig, Ende Juli entwickelt. In MittelEuropa ist die Tar. c und e rorherrschend, a und d selten, die eigentliche lateralis und ihre Var, b, welche iiber ganz Südeuropa verbreitet sind, äusserst selten.

I. suturatus Foudr., Mon. 180, aus Frankreich und Spanien, lässt sich nicht durch die Hinterleibsbildung des $\hat{\sigma}$ von der vorliegenden Art unterscheiden. duirfte aber nicht zu ihr gehören, wenn sich die Angabe bestätigt, das der Penis, ,ripice obtuse lanceolatus, inflexus" ist.

38. Long. verbasci: Alatus, ovalis, concens, subtus piceus, pedibus anterioribus, antennis (apicem nersus saepe infuscatis), capite prothoraceque rufo-testaceis, hoc transverso, sublaevi, elytris pallide testaceis subtiliter obsoleteque junctulatis, sutura infuscata aut niyro-limbata, tibiis posticis leviter curvatis, crina interione dorsali subintegro. Long. 2,5-4 $\mathrm{mm}$

II s: segmento ultimo ientrali linea mediu laevi, vel antice subcarinat" postice impressa instructo.

Panz. Faum. germ. 21. 17 (Haltica).-Hoffm. Ent. Hft. 2.84. - Duft. Faun. A. 3. 255. - All. Mon. 309 (Thyamis). Kutsch. Wien. MLonat. 1863. 312 (240 Longitars.), - Bach, Käferf. 3. 151. - Redtb. Faun. A, 2, 506.

Long. tabidus Waterd. Trans. ent. Soc. 1861. 27. -- Leesb. Tijdschr. 25. 168.

Chrysom. dorsalis Rossi, Faun. Etr. Mantissa 1792. 32.

Chrysom thapsi Marsh. Ent. Brit. 202.

Halt. borealis Zett. Ins. Lapp. 1840. 233.

Var. a. Pedibus posticis fermyineis.

$\mathrm{Var}$. b. Elytris maculis 2 nigris marginalibus, liberis aut comatis.

Crioceris sisymbrii Fabr. Syst. El, 1. 465.

Yar. c. oulgaris: Ferugineus, labro nigro, antennarum apice et femorum posticorum dorso interdum infuscatis, elytris testuceis suturn saepe ferruginea. 
Haltire eerbusci Ill. Mag. 6. 167. - riyllh. Ins. Suec. :3. 543. - Thoms. Skand. Col. 8. 172. Longit.

Vas. 1. Oblongo-ovalis, sat convexus, alatus vel subapterus.

Teinodact. verbasci Foudr. Mon. 182.

Var. e. elongatus: $L^{\top} t$ in $d$, sed ferrugineus, pectore interdum fusco, prothorace elytrisque hand pellucidis flavo-albidis, nitidissimis.

Long. pallens Kutsch. 1. c. 315 (243).

Fbenfalls eine unserer häufigen Arten und unter den hell gefärbten die grösste. Ziemlich breit eiförmig', gewölbt, unten pechschwarz, die vier Vorderbeine, der grösste Theil der Fiihler, Kopf und Halssch. röthlich gelbbraun, die Fld. hell gelbbraun, mit dunkel oder schwarz gesäumter Naht. Stirn glatt, mit undeutlichen Höckerchen, der Scheitel sparsam und sehr fein schräg gestrichelt, Nasenkiel breit und ziemlich stumpf. Fühler länger als der halbe Körper, ziemlich stark, die fünt' letzten Glieder etwas rerbreitert. Halssch. beinahe doppelt so breit als lang, stark querüber gewölbt an den Seiten schwach gerundet, oben glatt. oder sehr fein und verloschen punktirt. Fld. in den Schultern breiter als das Halssch, mit kleiner, wenig heraustretender Beule, an den Seiten gerundet, hinten schmal abgerundet, sehr kurz und sparsam bewimpert, mit verrundeter Nahtecke, der Rïcken etwas durchscheinend, dicht, fein und seicht punktirt, die Punkte in der Regel nur nahe der Naht in der vorderen Hälfte deutlich. Hinterbeine lang und kräftig, ihre Schienen zusammengedrüickt, nach innen gekrümmt, am Ende erweitert, auf dem Rücken mit einer scharfen Leiste am Innenrande, der Enddorn lang und stark.

$\hat{o}$ Letzter Bauchring viel kïrzer als beim 오, zienlich eben. in der Mitte eine glatte Längslinie. auf der zuweilen vorn ein feiner Kiel, hinten ein Eindruck herrortritt. der Mittelziptel durch eine leistenförnige, stumpfwinkelige Naht getrennt, mit deutlicher Mittelrinne. - Penis gerade, parallel, neben der Oeffnung sanft erweitert. davor schnell gerundet-rerengt. so dass eine kurz-dreieckige stumpfe Spitze entsteht.

Bisweilen sind die Hinterschienen allein; oder die Hinterbeine gänzlich rostroth (Var, a); oder dicht iiber dem Seitenrande jeder Fld, befindet sich ein schwarzer Punkt hinter der Schulter, sowie eine Längsmakel hinter der Mitte, beide zuletzt in einen gleichbreiten schwarzen Saum vereint (sisymbrii). Diese Form, bei welcher der Scheitel oft schwarz und der Nahtsaum sehr breit. scharf begrenzt, vorn verengt, hinten g'erundet-abgekürzt ist, gehört nebst dem typischen verbasci Panz. Suideuropa an und ist in Deutschland nur vereinzelt zu findeu. Hier tritt die hell gofärbte Var, c auf, dem L, tabidus F, ähnlich: Fld, blassgelb, die Naht fein 
rostroth gesänme, Fühler, mit Ausnahme der Spitze. Kopt', Halssch. und Beine röthlich gelbbram, die Hintersehenkel auf dem Riicken zuweilen angedunkelt, Brust und Bauch hell oder dunkel rothbraun, Oberlippe und Spitze der 'Taster schwarz. Frische Stiicke dieser Var. sind an den sehr durchscheinenden Fld. zu erkennen.

Zwischen der breiten, gewölbten Form lebt bei uns einzeln, in Oesterreich und dem siidlichen Europa zahlreicher, eine schlanke, weniger gewölbte, in den Schultern schmale Form (Var. d), meist wie Var. c gefärbt, oder Halssch. und Fld. gelblich-weiss, letztere hart, undurchsichtig, äusserst fein punktirt und stark glänzend (Var. e). Von ihr kommen auch Exemplare mit kurzen Flügelstummeln, ohne Schulterbeule vor.

Auf dem Halssch. bilden sich manchmal einige verschwommene dunkle Flecke, doch wird dasselbe nie völlig schwarz, wio bei lateralis, ebenso wenig der Kopf, und es ist auch noch kein Fall bekannt, dass dex schwarze Seitensaum der Fld. hinter der Schulter einen Bogen beschreibt. Dagegen erwähnt Gyllenhal, Ins. Suec. 4. 657, ein Exemplar aus dem südlichen Schweden, bei dem sich die beiden schwarzen Makeln über dem Seitenrande der Fld. nach innen ausgedehnt haben. wodurch auf jeder Decke zwei schwarzbraune Querbinden entstehen, die weder Naht noch Seitenrand berïhren.

Auf Verbascum thapsus L. und namentlich thapsiforme schrad. vom Juli bis in den Herbst häufig.

Long. agilis Rye, Monthl. Mag. 1868. 133, sieht, wach dem mir vorliegenden Stiicke aus England (Sharp), wie die Var. e von verbasci aus, ist aber etwas kürzer, breiter, stärker gerundet und gewölbt, die Punkte der Fld. sind anch nur auf der inneren Vorderhälfte sichtbar, eben so flach, aber grösser, weitläufiger gestellt, der Enddorn der Hinterschienen nur halb so lang als bei verbasci.

39. Long. Foudrasi: Alatus, oblongo-ovatus, convexus, stramineus, capite. pectore abdomineque ferrugineis, ore, anternis femoribusque posticis apice plus minusve infuscatis; prothorace transverso voge punctulato, elytris subellipticis vix punctulatis, tibiis posticis leviter curvatis, carina interiore dorsali subintegro. - Long. 2,7-3,5 mm.

Mas: segmento 5: o ventrali in medio et apice deplanato utrinque subcalloso.

Teinod. pallens Foudr. Mon. 211. - All. Mon. 318. Thyamis.

Var. a. Apterus.

Var. b. Pectore abdomineque fuscis.

Var. c. Elytris subseriatim punctulatis.

Der ungefiügelten Form von exoletus in der Körperform und Farbe der Oberseite am ähnlichsten, aber durch das breite Halssch. 
viel feime junktirte Fld. und die Leiste der. Hinterschienen leicht \%n unterscheiden: cinem gestreckten ierbresci sehr nahe verwandt. jedoch in den Schultern schmal gebaut.

Lang riförmig, gewölbt, strolgell, glïnzend, Kopf; Mittel- und IIinterbrust, Bauch und Hinterschenkel rostroth, der. Irund und die obere Hälfte der Fühler mehr oder weniger schwärzlich, ijfter auch der Riicken der Hinterschenkel. Stirn glatt, mit undeutlichen Höckerchen. der Nasenkiel schmal. scharf. Fühler um ein Irittel kiirzer als der Körper. Halssch. ungefaibr doppelt so hreit als lang, stark querüber gewölbt, fast glatt, oder mit narbigen Piinktchen, die auf der rorderen Iinlfte in der Regel sehr undeutlich sind. Fld, vom im Bogen heraustretend und in den Schultern wenig breiter als das Halssch., mit schwacher Benle, nach hinten etwas erweitert, am Ende schmal abgerundet, äusserst kurz bewimpert, auf der Scheibe kaum sichtbar punktirt. Hinterbeine wie beim vorigen.

o Letzter Bauchring in der Mitte glatt, Hach gedrickt, oft mit dunkler Mittellinie, jederseits in eine Beule erhöht, die hinten ron einem ebenfalls flachen Streifen an Hinterrande des Segmentes begrenzt wird. - Penis noch schlanker als der ron lateralis, gleich breit, unten mit muldenförmiger Mittelrinne: welche die Hälfte der Breite einnimmt, vor der Oeffnung jederseits gradlinig in eine scharfe Spitze verengt.

Die ungefliugelte Form a weicht wenig ab: sie ist in den Schultern nur so breit als das Halssch. Manchmal sind auf den Fld. unter mässiger Vergrösserung Punkte zu bemerken. welche durchschimmern und in Reihen geordnet sind (Var. c): auf der Unterseite können die Mittel- und Hinterbrust nebst dem Bauche schwärzlich braun werden (Var. b).

In Frankreich auf Verbaseum-Arten und Scrophularia canina L. von Foudras, bei Venedig ron Czwalina, bei Nassau auf Ballota nigra L. von Buddeberg gefangen.

Foudras bezog diese Art irrthïmlich auf Thyamis pallens Steph. (Ill. brit. 4. 313; Man. 297), welche zu den kleinsten Arten der Gattung. gehören muss.

10. Long. Iycopi: Alutus, oblongo-oculis, subconiexus, testacens, nitidus, antennis apicem rersus, capite, pectore, abdomine femoribusque posticis superne niyro-piccis, fronte sulcis oculuribus mullis, tuberculis angustis bene discretis, prothorace transverso subtiliter punctuto, elytris evidentius antice subseriatim punctatis, sutura fusca. tibiis posticis calcari longiusculo instructis. - Long. 1,5-2 mm.

II as: tarsis anterioribus articulo primo leviter dilatato. 
Foudr. Mon. 193 (Teinodact.). - A 11. M[on. 387. (Thyamis). Kutseh. Wien. Monat. 1864. 39 (254. Longitars.) - Bach, Käfert. 3. 343. - Redtb. Faun. A. 2. 506. - L eesb. Tijdschr. 25. 170. - Seidl. F. balt. 723 ; transs. 813.

Var. a, Prothorace fermgineo, infuseato vel piceo-nigro, chytris lateribus fuscescentibus, sutura nigra.

$\mathrm{V}$ ar. b. Abdomine apice rufo-testaceo.

Var. c. Elytris pellucidis. flavo-albidis, sutura plerumque concolore.

Var. d. fulviventris: latior, minus convexus, dilute testuceus, antennis apice infuscatis, capite, pectore femoribusque posticis ferrugincis, elytris subparallelis saepe seriatim munctatis, callo humerali prominulo.

Longit. juncicola K utsch. Wien. Monat. 1864. 51 (266).

Var. e. Apterus, elytris interdum crebrius punctatis.

In Grösse und Habitus mit nasturtii ibereinstimmend, den kleinsten hellen Stücken der geflügelten Form von luridus zum Verwechseln ähnlich, aber durch den längeren Enddorn der Hinterschienen und die fehlende Seitenrinne der Stirn sicher zu unterscheiden.

Länglich eiförmig; mässig gewölbt, Kopf, Spitze der Fühler, Brust, Bauch und der Rüicken der Hinterschenkel pechschwarz, die ibrigen Theile röthlich gelbbram, das Halssch. und die Hinterschenkel in der Regel dunkler als die Fühlerwurzel, Beine und Fld, letztere mit brauner oder schwarzer Naht. Stirn sehr fein körnig-gewirkt, Höckerchen schmal und deutlich, oben durch eine Rinne begrenzt, welche ron der Spitze des Nasenkieles gradlinig: zum oberen Angenrande läuft, aussen mit dem ziemlich ebenen, dreieckigen Raume zwischen Auge und Fühlerwurzel verbunden. Fühler merklich länger als die Hälfte des Körpers, Glied 2 und 3 klein, die 5 Englieder erweitert. Halssch. quer, an den Seiten stark abfallend und etwas gerundet, fein punktirt, of 't gerunzelt, mit glatten oder gewirkten Zwischenräumen. Fld. an der Basis gerundet heraustretend und in den Schultern etwas breiter als das Halssch . mit ziemlich hoher Beule, bis hinter die Mitte wenig erweitert, am Ende gemeinschaftlich abgerundet, sehx kurz bewimpert, mit rermundeter Nahtecke; der Rücken deutlich punktirt, weitläufig'er wie bei nasturtii. Die Punkte sind durchaus verworren, oder aut der rorderen Hälfte, nahe der Naht, unregelmässig-, oft sogar (Var.d) fast regelmässig gereiht. Hinterschienen leicht gebogen, ihr Ruicken fällt stark nach imnen ab, der Fundorn ist verhältnissuässig lang. Flïgel gross, weisslich.

$\hat{o}$ Erstes Tarsenglied an den rorderen Beinen etwas verbreitert. letzter Bauchring in der Jitte fast glatt, cben orler cingedrückt. 
auf' dem Anhängsel ein Gribschen. - L'enis in der nittleren IIälftr unmerklich verengt, wor der ()effinung fast pradlinig in eine stumple spitze verschmïlert, oben mit einem Xittelkiele, welcher in der Nitte zu der schmalen, vorn erweiterten und algerundeten Klappe abfällt, die Unterseite ist muldenförmig ausgchiöhlt. \& Bauch häufig angeschwollen, die spitze unbeleckt, nach unten gekrümmt.

Die Abänderungen im Umriss und in der Fïrbung sind mannigfaltig. Bald ist das Thier sehr schlank, die Fld, in den Schultern eng, wach hinten erweitert, mit kleiner. hoher Schulterbeule (geflügelte Form) oder ohne Schulterhöcker (Var.e); bald treten die Fld. an der Basis stairker, winkelig herans und sind in den Schultern bedeutend breiter als das Halssch,, mit rortretender Beule und fast parallelen Seiten, dann erhält die Art einige Aehmlichkeit nit curtus (Var.d), ist aber bedeutend länger.

Bei Zunahme der schwarzen Färbung bildet sich eine Zeichnung, die der des nasturtii ähnlich wird: Kopf, Halssch., Schildchen, ein Nahtsaum und ein unbestimmter Saum am Seitenrande der Fld. nebst den Epipleuren pechsehwarz (Var. a); nimmt die schwarze Färbung ab, so wird die Spitze des Bauches röthlich gelbbraun (Var.b), oder die Fld. sind einfarbig gelblich weiss, sehr durchscheinend (Var.c). Die breiter gebaute, flachere Var.d ist rolherrschend hell gefärbt, blass bräunlich gelb, nur die Spitze der Fühler gebräunt, Kopf, Brust und Hinterschenkel sind rostroth.

An feuchten Orten, nach Foudras auf Lycopus europaeus L. und Mentha-Arten in Deutschland, wabrscheinlich mlt Aussehluss der norddeutschen Tiefebene, zerstrent, über Mittel- und namentlich Suideuropa verbreitet. Caucasus, Armenien. Syrien. Im Sïden die Var. d vorherrschend.

1. Long. abdominalis: Alatus, ovalis, concerus, testaceus, nitidus. antennis apicem versus, capite, pectore, abdomine femoribusque posticis apice nigro-piceis; fronte sulcis ocularibus nullis, tuberculis angustis bene discretis, prothorace brevi, transverso, subtiliter saepe rugulosopunctato, elytris humeris valde prominulis crebre seriatim punctatis, sutura fusca, tibiis posticis calcari brevi. - Long. 1,8-2,2 mm.

Mas: segmento ultimo ventrali linea laevi instructo.

All. Ann. Fr. 1860. 119; Mon. 411. - Rey, Opuscules 1875. 25.

Var. a. Immaturus, capite, pectore abdomineque rufo-brunneis.

Den breiten Stücken der vorigen Art täuschend ähnlich, aber durch folgende Punkte bestimmt verschieden: Das Halssch. ist mindestens doppelt so breit als lang, in den Vorderecken stärker winkelig erweitert; die Fld. treten an der Basis stark heraus. sind an den Seiten leicht germulet. ungefähr doppelt so lang als breit, 
stärker und tiefer punktirt; ilie schwarze Färbung der Hinterschenkel erstreckt sich wenigstens üher die Spitzenhälfte; dor Hinterschienendorn ist nur halb so lang:

Beim of hat der letzte Baucluing einen glatten Längsstreifen, der hinten oft ein wenig verbreitert und vertieft ist, der breite und gewölbte, bogenförmige Mittelzipfel eine Rinne. - Der Penis gleicht dem von ochroleucus, ist vor der Mitte jederseits tief ausgeschweift, vorn breit im Bogen abgerundet.

Auf den ersten Anblick kann man das Thier mit curtus verwechseln, aber bei diesem ist die Stirn abweichend gebaut, das Halssch. kleiner, die Fld. sind flacher und weniger dicht und bestimmt punktirt.

Auf Glechoma hederacea L, bei Paris (Allard), in Ungarn bei Fünfkirchen (Maggi). Aus unserem Gebiete besitze ich nur zwei Exemplare von Wien (Wehncke).

42. Long. membranaceus: Apterus, ovatus, convexus, pallide testaceus, capite, pectore, abdomine femoribusque posticis ferrugineis, labro piceo, antennarum apice infuscato, fronte sulcis ocularibus nullis, tuberculis angustis bene discretis, prothorace parvo, transverso, punctulato, elytris ovatis, punctatis, punctis suturam versus seriatis, postice obsoletioribus, tibiis posticis calcari longiusculo. - Long. 1,5-2 $\mathrm{mm}$.

Mas: segmento 5: o ventrali medio deplanato.

Teinod. membranacea Foudr. Mon. 222. - All. Mon. 346. Thyamis.

Long. membranaceus Kutsch. Wien. Monat. 1864. 156 (282). Redtb. Faun. A. 2.509. - Leesb. Tijdschr, 55. 176.

Teinod. teucrii A11. Ann. Fr. 1860. 139.

Var. a. Abdomine fusco apice ferrugineo.

Var. b. Prothorace elytrisque subtilius punctatis.

Long. helvolus Kutsch. 1. c. 269 (290). - Redtb. 1. c. $508 .-$ Bach, Käferf. 3. 348.

Von den beiden vorigen durch die an der Basis sehr sehmalen, nach hinten verbreiterten Fld, abweichend, der Hinterschienendorn so lang wie der von lycopi. Eiförmig, gewölbt, blass röthlich gelbbraun, Kopf, Brust, Bauch nnd Hinterschenkel rostroth. Oberlippe pechschwarz, die Fühler nach der Spitze àngedunkelt. Stirn und Fühler wie bei lycopi; Halssch. klein, kurz, fast doppelt so breit als lang; deutlich, meist etwas runzelig punktirt, an den Seiten gerundet, oder ron dem eckigen Vorsprunge an der vorderen Borstenpore bis zum Hinterrande allmählich sanft verengt. Fld. gewölbt, mehr oder weniger durchscheinend, in den abgerundeten und beulenlosen Schultern schmal, wenig breiter als das Halsseh., bis hinter die Mitte erweitert. am Ende einzeln abgerundet, aut 
dem Riicken etwas stiirker als das Halssch. pmuktirt. Die I'unkte sind in dex vordement Hiilfte ziemlieht gaross und Hach, schlecelat bergrenzt, und werlen nach hinten feiner, nahe der Naht bilden sie oft mehrere Reihen. Hinterschienen kurz, düm, innen stark al,fallend, ihr Enddorn eine spur kiirzer als bei lycopi.

ô Letzter Bauchring auf einem Längsstreifen in der Mittr glatt. flach gedriickt, Hinterrand leistenfïrmig anfistehend und wor dem grubig rertieften Mittelziptel winkelig grolngen. - Penis schwach gekrimmt, gleichbreit, ror der Oeffnung gerundet-verengt und in eine ziemlich scharfe Spitze ausgezogen.

Die Oberseite ist selten rein und hell gefärbt, häufig ziemlich dunkel und rostroth angelaufen, die Lnterseite ausgehärteter Stücke wenigstens auf dem Banche schwarzbraun, mit heller Spitze (Var. a). Diese Form darf mit dem grösseren, auf den Fld. gelb gefärbten juncicola nicht verwechselt werden.

Bisweilen ist das Halssch. stark glänzend und wenig dicht punktulirt, auch die Punkte der Fld. sind feiner als gewöhnlich. A uf diese Stiicke ist helvolus Kutsch. zu beziehen, den der Autor nicht von membranacens unterscheidet, weil er annahm. dass die letztgenannte Art bei Wien fehlt.

Auf Teucrium-Arten, hauptsächlich 'T', scorodonia L, im Torgebirge auf Kalkboden stellenweise: Magdeburg (Breddin), Thüringen bei Jena und auf dem Kyffhäuser, an Rheine bei Dürkheim (Eppelsheim), in Oesterreich: Böhmen, Wien. Frankreich, Holland. England.

43. Long. nanus: Apterus, ovatus, conrexiusculus, pallide ferrugineus, nitidus, labro infuscato, fronte sulcis ocularibus mullis, tuberculis angustis bene discretis, wothorace parvo, transverso, punctulato, elytris ovatis, brunne-flavis, vage subtilissimeque punctatis, punctis interdum seriatis, postice evanescentibus, tibiis posticis calcari brcri. - Long. 1,4-1,8 mm. Mas: segmento 5: o ventrali linea laevi.

Tein. nana Foudr. Mon. 223. - All. Mon. 347. Thyamis.

Long. vitreus Kutsch. Wien. MLuat. 1864. 270 (292). - Redtb. Faun. A. 2. 508. - Bach, Käferf. 3. 348. - Seidl. F. balt. 724 ; transs. 815 .

Var. a. Metasterno abdomineque fuscis, ano ferrugineo.

Etwas kleiner und flacher als die vorhergehende Art, ähnlich gefärbt, die Fühler an der Spitze nicht angedunkelt, die Fld. bei ausgehärteten Exemplaren kaum durchscheinend, heller; bräunlich gelb gefärbt, mit feiner, rerloschener, meist nur in der rorderen Hälfte wahrnehmbarer Punktirung; der Enddorn der Hinterschienen endlich sehr klein. In der Farbe und Punktimng erinnert das Thier anch an succineus. 
Beim $\hat{o}$ ist der letzte Banchring gheichmässig gewölbt, oder in der Mitte undeutlich flach gedriickt, mit glatter Lïngslinie. - Penis rerhältnissmässig stark, rorn mit siufter Rundung in cine scharte, aufwärts gekrümmte Spitze verschmälert.

Die Var. a umfasst dunkle Stiicke, bei denen Brust und Hinterleib rothbraun his schwarzbraun werden. After um Pygidium bleiben rostroth.

Bei Wien (Kutschera, Scheffler). Finflkirchen (Viertl) und Lyon (Foudras); in 'Thiiringen und am Rheine auf Kalkhoden jedenfalls noch aufzufinden.

Die Synonymie von vitreus, helvolus etc. ist hier nach der Penisform bestimmt und deshalb sicherer als die von Allard gegebene, der seinerzeit die Arten aufs Gerathewohl unterbrachte.

Unbekannt blieb mir L. brevicollis Kutsch., Wien. Monat. 1864. 271 (293), welcher sich von namus durch geringere Wölbung und mit Runzelı untermischte Punktirung der Fld. zu unterscheiden scheint. Kutschera beschreibt denselben folgendermassen:

E. Hrevicullis: „Ovatus, depressiusculus, subnitidus, albidus vel pallide flavesceus, capite, pectore, abdomine femoribusque posticis rufo-ferrugineis, labro apice infuscato, antennis extrorsum fuscescentibus; fronte encarpis distinctis; thorace brevissimo, longitudine plus duplo latiore, laevi vel obsolete ruguloso-punctulato; elytris ovatis, postice latiusculis, humeri.s vis prominulis obtuse, apice singulutim rotundatis, distincte et sat dense ruguloso-punctulatis, punctis basin versus subseriatis. Tibiarum posticarum spinula apicali brevi. Apterus, Long. 1/2 lin., lat. 1/5 lin. Mas: abdominis segmento ultimo integro.

Eine leicht kenntliche Art, ausgezeichnet vor den Vorhergehenden durch flachere, nach rückwärts deutlich verbreiterte Gestalt, weissgelbe Färbung des Halssch. und der Fld, schmalere Schultern, deutlichere und dichtere mit Runzeln gemengte Punktirung etc. - Eiförmig, mässig glänzend, flach gewölbt. Kopf rostroth, gewöhnlich mit etwas dunklerem Scheitel und schwärzlicher Spitze der Oberlippe; Halssch., Fld., die Fühler, bis auf die bräunliche Spitze, dann die Vorderbeine, Hinterschienen und Tarsen weisslich gelb, Brust und Banch, die Hinterschenkel, alle Klauen und der Hinterschienendorn rostroth. Kielung der Stim oberhalb stumpfer, nach unten schärfer; Höckerchen sehr deutlich, lanzettförmig, durch schart eingeschnittene Linien abgesetzt, Scheitel äusserst fein granulirt und fein querrunzelig. Fühler wenig länger als der halbe Körper, ihr zweites Glied deutlich länger als das dritte. Halssch. äusserst kur\%, beim ô mindestens doppelt so breit als lang, beim 우 noch breiter, flach gewölbt, mit durchscheinendem Vorderrande, an den Seiten kaum gerundet. mit deutlich rorVI. 6. 
springender. ctwa pin Dritel des Seitenrandes einnehmemler Vir. dickung hinter den Vorderecken: es ist bei vielen Individuen beinahe: glatt, bei andern nur äusserst fein zerstreut punktirt, mit eingemengten feinen Runzeln; die Schwiele an soitenrande undeutlich. Fld. won den schmalen, kaum üher die Basis des Ifalssch. vorspringenden Schultern rückwärts his auf zwei Lrittel der Länge erweitert und an der spitze einzeln abgerundet. mit sebr stmupfen Nabtwinkeln; sie sind schwach gewillth und besonders nach der Spitze hin flach, ihre Punktirung f'ein und seicht. aher ziemlich dicht und bis an die Spitze deutlich, die Zwischenräume in mehr oder weniger deutliche Runzeln zusammen gezogen; die Punkte erscheinen auf der Vorderhälfte meln oder weniger deutlich gereiht, uach der Spitze hin verworren; Kerbstreifen am Seitenrande mässig stark. Ungeflügelt. Bauchsegmente kaum punktirt, beinahe glatt, beim $\vec{\jmath}$ ist das letzte ohne Eindruck oder Ausschnitt, und das erste Vordertarsenglied etwas erweitert; Hinterschienendorn kurz.

Oesterreich, auf den Abhängen des Geisberges bei Bertholdsdorf von Scheffler und mir im Herbste gesammelt."

Von Allard ist eine sehr ähnliche, vielleicht identische Art aus „Frankreich" unter dem Namen liliputrna (Mon. 384) beschrieben worden.

4. Hong. tantalus: Alatus, oblongo-oralis, subconvexus, testaccus, nitidus, antennis sat brevibus apicem rersus, pectore, aldomine femoribusque posticis nigro-piceis, fronte sulcis ocularibus distinctis, tuberculis nullis, prothorace transverso crebre sultiliter rugoso-punctulato elytris minus crebre evidentius, apicem versus obsolete punctatis, sutura interdum leviter infuscata. - Long. 1,3-2 mm.

II as: abdomine segmento ultimo medio deplanato, polito.

Teinod. tantula Foudr. Mon. 195. - All. Mon. 371.

Teinod. brunniceps All. Ann. Fr. 1860. 138.

Long. lycopi Thoms. Skand. Col. 8. 179?

Var. a. Apterus, humeris angustis.

Long. minimus Kutsch. Wien. Monat. 1864. 144 (270), - Bacb, Käferf. 3 346. - R edtb. Faun. A. 2. 507.

Var. b. Femoribus posticis ferrugineis.

Var. c. Abdomine apicem versus rufescente.

Einem ziemlich hell gefärbten lycopi ähnlich, aber die Stirn olme deutliche Höckerchen. mit Seiteurimnen, Fühler und Hinterschienendorn kürzer, Punkte der Fld. nach hinten mehr abgeschwïcht; auch mit pratensis leicht zu rerwechseln. die Fld. hinten schmal abgerundet und stärker, doppelt so weitläufig punktirt wie bei diesem. 
Lang eiförmig und mässign gewiolht, röthlich gुelhhraun, glänzend, der Kopf rostroth, selten noch dunkler, Brust, Bauch und Hinterschenkel pechsehwarz, die Nahtkante der Fld, ötter gecoüunt. Stiru äusserst zart gewirkt, jederseits in einu schart:. Rimme über der Fiblerwurzel abfallend. Fülıler kaum his zur Mitte der Fld. reichend, vou vierten Gliede ah gehriunt. Halssch. wenigstens um die Hälfte breiter als lang, vorn stïrker als hinten der Quere nach gewölbt, dicht und fein rumzelig punktirt und in den 'wischenräumen gewirkt. Fld, an der Basis gerundet heraustretend, in den Schultern etwas breiter als das Halssch., mit schwacher Beule, bis zur Mitte wenig erweitert, an der Spitze sehr fein und kurz bewimpert, gemeinschaftlich abgerundet, mit leicht verrundeter Nahtecke; auf dem Rücken deutlich und mässig dicht punktirt, die Punkte hald verworren, bald deutlich gereiht, hinter der Mitte verloscheu, die $\mathrm{Zwischenräume} \mathrm{sehx} \mathrm{fein} \mathrm{gewirkt.} \mathrm{Himterbeine} \mathrm{ziemlich} \mathrm{lang;}$ ihre Schienen fast gerade, auf dem Rücken stark nach innen abfallend, Enddorn klein. Flïgel vollkommen.

ô Erstes Tarsenglied leicht erweitert, letzter Bauchring auf einem ebenen Längsstreifen in der Mitte glatt, das Anhängsel mit einer tiefen Grube. - Penis dem von pratensis ähnlich, doch viel schlanker, jederseits weit und sehr sanft ausgeschweift, vorn ziemlich schnell in eine stumpfe Spitze gerundet-verengt, unten ausgehöhlt.

Von Abänderungen sind zu nemnen die Var.a. Ungeflüg'elt, Schultern schmal, olne merkliche Beule; Var. b. Hinterschenkel einfarbig hell rostroth: Var. c. Bauch rothbraun, namentlich in der Nähe des Afters.

Im Herbste auf trockenen Triften in Gebirgsgegenden, bei Wien, in Kärnthen, Tirol, schweiz, Frankreich, Siideuropa.

Da T. tantula Foudr. dentlich begrenzte Stirnhöckerchen haben soll, bin ich im Zweifel, ob der Name auf das vorliegende Thier anzuwenden ist, aber die Beschreibung des Penis passt auf keine andere Art. L. lycopi Thoms, rechne ich hierher, weil er ausdrücklich mit nicht abgesetzten Stirnhöckerchen beschrieben wird, und von minimus Kutsch. liegen mir Exemplare aus Oesterreich und Spanien vor, die mit der Beschreibung ïbereinstimmen.

45. Long. pratensis: Alutus vel subapterus, oblongo-ovalis, minus convexus, nitidulus, pallide testaceus, dense subtilissimeque punctatus, antennis sat brevibus apicem versus, fronte, scutello, pectore abdomineque nigro-fuscis, femoribus posticis interdum infuscatis, fronte linea laterali profunda, tuberculis mullis, prothorace transverso, elytris apice singulatim sat late rotundatis, tibiis posticis calcari brevi. - Long. 1,2 bis $2,2 \mathrm{~mm}$. 
X[as: segmento ultimo rentrali forer profunda instructo.

Femina: segmento ult. centrali medio longitudinaliter impresso.

Panz. Faun. germ. 21. 16.

Haltica pusilla Gyll. Ins. Snec. 3. 549. - steph. Ill. Bi.t. 4 313; Man. 297 Thyamis. - All. Mon. 369.

Long. pusillus Kutsch. Wien. Mronat. 1864. 141 (267. - Redtb. Faun. A. 2. 507. - Bach, Käferf. 3. 154. - Seidl. F. balt. 723; transs. 814. - Lees b. Tijdschr, 25. 172.

Var. a. Major, sat convexus, elytris evidentius punctatis.

Teinod medicaginis All. Ann. Fr. 1860. 124; Mon. 366 Thyamis. Kutsch. 1. c. 143 (269). - Bach, 1. c. 345 . - Redtb. I. c. 507. - Leesb. 1. c. 172.

Teinod. Reichei All. 1. c. 1860. 132: IIon. 366. - Kutsch. 1. c. 145 (271).

Var. b. Prothorace elytrisque rufo-testaceis.

Thyamis scutellaris Rey, Opusc. 1875. 27.

Var. c. Immaturus, capite fermineo, abdominis apice saepe mufescente.

Var. d. Capite nigro.

Var. e. Sutura antice vel tota ferruginea aut picea.

Var. f." collaris: Prothorace fusco maculato rel omnino piceo aut nigro, femoribus posticis plerumque fuscis.

S te ph. Ill. Brit. 4. 313; Man. 297.

Var.g. Ut in $f$, sed elytris sutura limboque postico infuscatis.

Thyamis funerea Rey, l. c. 28.

Var. h. 9 Segmento ultimo ventrali vix impresso.

Durchschmittlich kleiner als der in Körperform und Skulptur ähnliche L.nasturtii $\mathrm{F}$., länglich, mässig gewölbt, schwach glänzend, der Mund, die obere Hälfte der Fïhler, die Stirn, das Schildchen und der grösste Theil der Unterseite pechschwarz, die übrigen Theile gelbbraun, das Halssch., die Hinterschenkel und namentlich das Gesicht mehr röthlich, die Fld. sehr blaśs. Stirn breit, zart gewirkt. mit tiefer Rinne jederseits, ohne deutliche Höckerchen; Füihler kurz. anch beim $\hat{o}$ wenig iber die Mitte der Fld. reichend, die mittleren Glieder kaum dreimal so lang als breit. Halssch. ungefähr doppelt so breit als lang; in der Mitte der S'cheibe ziemlich flach, an den Seiten, namentlich vor der Mitte stark abfallend, die Seiten wenig gerundet, der Rücken sehr fein und dicht punktirt, oft runzelig, seltener fast glatt, die Zwischenräume meist äusserst fein gewirkt. Fld. an der Basis winkelig heraustretend und in den Schultern breiter als das Halssch., mit rorspringender Beule, bis zur Mitte wenig erweitert, an der Spitze kurz bewimpert und ziemlich breit abgerundet, mit völlig verrundeter Nahtecke, so dass das Pygidium bei ausgehärteten Stiicken umbedeckt ist, auf dem Riicken bald sehr wenig grewölbt und an den Seiten stark abfallend. bald gleichmässig 
querïber sewölbt. dicht unl sehr fein junktirt. Die P'unkte sind verworen oder vorn gereiht, zuweilen so flach, dass sie erst unter starker Vergrössemug bomerkbar werden, oft deutlich, tief eingestochen, nach der spitye meist feiner, die Zwischenräume äusserst fein gewirkt. Hinterbeine kurz, ihre Schicnen leicht gebogen, nach der Spitzc allmïhlich erweitert, auf' dem Riicken stark abgeschrägt, Enddorn klein. Flügel vollkommen oder verkïrzt

ô Erstes Tarsenglied der vier Vorderbeine wenig erweitert, letzter Bauchring mit einer weiten und tiefen Längsgrube, an die sich ein Grübchen auf dem bogenförmigen Mittelzipfel schliesst. - Penis gross, fast gleich breit, vorn schwach gerundet-rerengt, so dass vor der Oeffnung ein kurzer dreicckiger, etwas aufgebogener Fortsatz entsteht, die Unterseite ausgehöhlt die Oberseite von der Mitte bis zur Oeffnung rertieft; die Basis gewölbt oder mit feiner Mittelrinne.

f Letzter Bauchring mit einer schmalen, elliptischen Längsgrube, die nur selten fehlt (Var. h). Grosse, auf den Fld. kräftiger punktirte Stücke (Var.a) sind von Kutschera als medicaginis beschrieben worden und es ist wahrscheinlich, dass auch die gleichnamige Art Allard's hierzu gerechnet werden muss, obgleich sie tief begrenzte Stirnhöckerchen haben soll; von ihr wüsste ich Reichei All. nicht zu unterscheiden.

Sonst ändert die Art noch mannigfach ab: Das Halssch. und die Fld. werden röthlich gelbbraun, oder das Halssch. ist rostroth, (Var. b); bei frischen Exemplaren ist der Kopf rothbraun, die Spitze des Bauches meistens röthlich gelb, Fld. sehr durchscheinend (Var. c). Zuletzt wird der Kopf einfarbig schwarz (Var.d), oder die Naht der Fld. im rorderen Drittel, selten bis zur Spitze rostroth bis schwärzlich (Var. e). Das Halssch. dunkel gefleckt, oft einfarbig pechbraun bis schwarz (Tar, f), ausserdem noch ein Saum an der Naht und am Hinterrande der Fld. dunkel (Var. g). Die Hinterschenkel sind bei den hellen Varitäten in der Regel röthlich-gelbbraun, bei den dunklen mehr oder weniger geschwärzt.

In der Ebene an Plantago lanceolata und media L. auf Wiesen, in Berggegenden auf trockenen Abhängen gemein, an Salzstellen und an der Meeresküste auf Plantago maritima L. Im Juli entwickelt.

Altica pratensis Panz. ist bisher auf 6 verschiedene Longitarsen bezogen worden, obgleich die Beschreibung und die von Sturm dazu gegebene Abbildung eines of nur auf die vorliegende Art passen. Foudras beschreibt die Penisform ungenau, die Aushöhlung der Unterseite bildet eine mehr oder weniger breite Rinne mit hoben und scharfen Rändem, frwcitert sich vorn, und ist im mittleren Theile nicht immer verengt. 


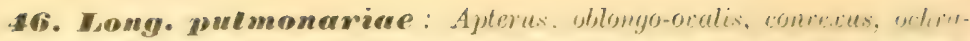
ceus, nitidissimus, ceppite ferrugineo, femoribus posticis interdum superme injuscatis, labro, mesosterno, postpectore abdominerpe nigris, prothorare subquadrato basi subtiliter punctulato, elytris sort rebre minus profunde. postice obsoletius punctatis, apice rolundatis, callo humerali reglanato, articulo primo tarsorum anteriorum elongato. - Long. 2-2,5mm.

IIas: segmento ultimo ventrali subtiliter canaliculato, ajice leriter omarginato.

Teinod. pratensis A11. Ann. Fr. 1860. 832; Mon. 316 Thyamis.

Teinod. femoralis Foudr. Mon. 188.

$\mathrm{V}$ ar. a. Immaturus, ventre rufo-brumeo, apice pygritioque piceis rel nigris. Var. b. Alatus.

Die vorliegende und folgende Art gehören zu einer Gruppe. die sich durch ein langes Halssch., schmalen Kopf mit langem Untergesichte und das verlängerte erste 'Tarsenglied an den Vorderheinen auszeichnet und ron den gelben Arten in der Regel durch den tief schwarzen Bauch sofort zu unterscheiden ist.

Lang (ô) oder länglich-eiförmig (), gewölbt, hell ockergelb. nach dem Tode schmutzig gelbbraun ${ }^{1}$ ). stark, glasartig glănzend. Kopf rostroth, auch das Halssch. oft röthlich, die Oberlippe oder der Unterkopf, die Mittel- und Hinterbrust nebst dem Bauche schwarz, die Hinterschenkel auf dem Riicken, nahe der Spitze nicht selten angedunkelt. Bei frischen Stücken ist der Bauch rothbraun. das letzte Segment und das Pygidium aber pechbraun oder schwarz (Var. a). Fühler fast so lang als der Körper. einfarbig gelbbraun. oder die letzten zwei oder drei Glieder an der Spitze leicht gebräunt. Stirn mit schmal dreieckigen, nur durch stärkeren Glanz hervorgehobenen Höckerchen. Halssch. stark queriiber gewölbt. von oben betrachtet wenig breiter als lang, beim $\hat{o}$ zuweilen so lang als breit, glatt, oder mit verloschenen Pünktchen, die nahe der Basis deutlicher werden. Schildchen gebräunt. Fld. in den Schultern breiter als das Halssch. mit flacher. imnen nicht aboesetzter und aussen wenig rortretender Benle, dahinter kitum $(\hat{0})$. oler bis hinter die Mitte (q) erweitert, am Ende in mässig breitem Bogen verengt und an der Nahtecke gerundet; auf' dem Rücken ziemlich dicht punktirt. Die Punkte sind mässig gross und tief, nach den Seiten hin und vor der Spitze allmählich rerfeinert, die Zwischenräune fast glatt. in der Basallaälfte hie und da gewölbt

1) Man klagt darïber, dass die Farben der Cassiden, Coccinellen etc. verbleichen; dieselben werden bei den gelben Longitursen gleichfalls nach dem Tode sehr rerändert, aber hier dunkler, unrein, so dass die bedentenden Abstufungen, welche die Arten lebend zeigen. für die Enterscheidung nicht mehr zu benutzen sind 
und zu seln schwachen Runzeln vereint. Hinterheine lang, ihre Schienen fast grade, mach der spitze allmählich verbreitert, der Riicken stark nach immen geneigent, mit dicht gezihneltem Aussenrande, ohme Immenrandleiste; Euddorn mässig' lang, das crste 'Tarsenglied an den vorderen Beinen gestreckt unt ungeführ so lang als die folgenden drei Glieder zusammen.

o Letzter Banchring mehr oder weniger dicht punktirt, oft runzelig, in der Mitte eine seichte Längsrinne, am Hinterrande ein kleiner, winkeliger Ausschnitt. - Penis fast so lang als der Hinterleib, vor der Basis am breitesten, von hier bis neben die Oeffnung gleichmässig, äusserst schwach verengt, davor fast gradlinig in eine mässig scharfe, ebene Spitze verschmälert, welche kaum oder viel weniger als bei exoletus nach oben gebogen ist; die Unterseite ist in der Basalhälfte Hach, eben, vor der Mitte befindet sich eine Rinne, die sich schnell nach vorn verbreitert.

Die rollkommen gefligelte Form b weicht im Bau wenig von der ungeflügelten ab und ist nur sicher zu erkennen, wenn die Fld. klaffen oder durchscheinend sind.

Im Juni und Juli an sehx schattigen Stellen im Webicht, einem Laubwalde bei Weimar, auf den Blättern von Pulmonaria officinalis L. Auch in Frankreich.

Foudras hat seinen pratensis und femoralis nicht scharf auseinander gehalten, und es ist nicht möglich, aus der Beschreibung einen sicheren Schluss zu ziehen; da er aber pratensis die häufige, in ganz Europa vorkommende Art nennt, ist sein femoralis, der nur bei Lyon gefangen wurde, sicher auf die vorliegende Art zu beziehen. Damit stimmt auch die Angabe über die Penisform überein, wenn der sinnentstellende Fehler: "usque ad basin" progressim attennatus in usque "ad apicem" berichtigt wird.

4\%. Long. exoletus: Alatus, oblongo-ovalis, convexus, nitidus, testaceus, capite ferrugineo, antennis apicem versus infuscatis, pectore, abdomine femoribusque posticis apice nigris, prothorace subquadrato vix vel evidenter punctulato, saepe ruguloso, elytris subtilites punctatis, apice fere conjunctim rotundatis, callo humerali mominulo, articulo primo tarsorum anteriorum elongato. - Long. 2,3-3 mm.

II as: segmento ultimo ventrali crebre punctato, obsolete canaliculato, aut carinato, apice leviter emarginato.

Chrysomela exoleta L. Syst. Nat. ed. 10. 373 - Waterh. Trans Ent. Soc. 1861. 23. - Leesb. Tijdschr. 25. 173. Longitars.

Chrys. femoralis MI arsh. Ent. Brit. 1. 201. - Gyllh. Ins. Suec. 4. 675. Haltica.-Steph. Ill. Brit. 4. 309; MIan. 296. Thyamis. - A 11. Mon, 356. - Kutseh. Wien. Monat. 1864. 47. (262) Longit. - Thoms. Skand. Col. 8. 183. - Redtb. Faun. A. 2. 507. - Seidl. F. balt. 723 ; transs. 814. 
Long. pratensis Foudr. Mon. 186.

Long. Zoppardiensis Bach, Käferf. 3. 152.

Var. a. Immaturus, abdomine rufescente.

Va1. b. arctulus: Apterus, elytris ollongis, humeris angustis callo nullo. Vax. c. Major, alatus rel subupterus, mothorare, elytris, pedibusque an. terioribus plerumque stramineis. - Long. $3-3,8 \mathrm{~mm}$.

Tar. d. rufulus: Omnino ut in e, sed cajpite, pectors, abdomine pedibusque posticis ferrugineis, his interdum unicoloribus.

Teinod. rufula Foudr. Mon. 205. - A 11. Mon. 357. Thyamis.

Long. vufulus Kutsch. Wien. Monat. 1864. 147 (273). - Redtl. 1. c. 509 .

Weniger schlank als der vorhergehende. feiner punktirt. schwächer glänzend, mit dunkleren Fühlern und Hinterschenkeln: unausgefürbten Stücken des melanocephalus in der Gestalt und in der Farbe der Oberseite ähnlich. Lang-oval, an den Seiten wenig gerundet, gewölbt, glänzend röthlich-gelbbraun, die Fld. oft weisslich gelb und nicht durchscheinend. Der Kopf rothbraun, Fühler vom 4. oder 5. Gliede an nebst dem Schildchen angedunkelt, Oberlippe. Mittel- und Hinterbrust, Bauch und ein Wisch auf dem Rücken der Hinterschenkel nahe der Spitze schwarz. Stirn mit undeutlichen. schmal dreieckigen Höckerchen, welche oben nur selten ron einem rinnenförmigen Eindrucke begrenzt werden. Halssch. wenig breiter als lang, queriiber gewölbt, bald verloschen und ïusserst fein, hald deutlich und etwas runzelig punktirt, namentlich in der hinteren Hälfte. Fld. in den Schultern bedeutend breiter als das Halssch. mit vortretender Beule, dahinter etwas erweitert, an der spitze und am Nahtwinkel schmal abgerundet, so dass höchsteus die Spitze des I'ygidium unbedeckt bleibt; auf dem Rücken gleichmässig dicht und fein verworren punktirt, die \%wischenräume gewirkt. Beine wie bei der vorigen Art gebaut, nur der Dorn der Hinterschienen eine Spur länger.

ô Letzter Bauchring dicht punktirt, mit seichter Längsrinne oder schwachem Längskiele, am Hinterraude, vor dem tiefliegenden. grubig vertieften Mittelzipfel schwach winkelig ausgeschnitten. Penis so lang als der Hinterleib, nahe der Mitte unmerklich ausgeschweift, vorn flach, vor der Oeftinung jederseits in sanftem Bogen verengt, die Spitze sehr stumpf, etwas nach oben gekrümmt: auf der Unterseite eine Rinne mit ziemlich scharfen Rïndern, die sich vor der Mitte allmählich verbreitert und vertieft.

Bei frischen Stücken ist nur die Hinterbrust schwarz. der Bauch mehr oder weniger röthlich-braun (Var. a). Neben der Form, hei welcher die Flügel länger. oder unbedeutend kürzer sind als die Dccken, tritt stellenweise eine umgettigelte Abändering aut 
(Var. b), die in Körperform an longinennis erimnert. Ihre Fld sind in den Schultern schmal, ohne Boule, bis hinter die Mitte leicht verbreitert, und bilden mit dem Hilssch. cin unencinsames langes Oval.

Auf Echium vulgare und Cynoglossum officinale I., nach Bach anch ant' Convolvulus sepium L., in der norddeutschen Tiefebene selten, in den Bergyegenden Mitteleuropas besonders auf Kaikhoden sehr häufig. die Var. b bei Prag (Fleischer) und Magdeburg (Hahn).

In Südeuropa und dem Kaukasus (Reitter), im siidlichen Frankreich, auf dem Mt. Baldo (Halbherr), in Krain (Stussiner), Ungarn und Rumänien wird die Art viel grösser als bei uns und ist dann sehr leicht mit $L$. tabidus zu verwechseln. welcher aber durch das breitere Halssch. und kurze Tarsenglieder sicher abweicht. Bei ausgehärteten Stiicken kann nun die Brust, der Bauch und die Spitze der Hinterschenkel schwarz werden, wie bei unserer Form (Var.c) meistens verdukeln sich diese Theile aber nur bis rostroth (Var. d). Die Fld, sind zuweilen sehr fein punktirt und auf dem Ruicken abgeflacht.

48. Long-pectoralis: Alatus, ovalis, convexus, rufo-testaceus, sat nitidus, capite ferrugineo, ore, mesosterno postpectoreque niyris, fenoribus posticis apice infuscatis, prothorace subtransverso, antice sat angustato, obsolete ruguloso-punctulato, elytris pallide testuceis, confertim subtiliter punctatis. - Long. 2-2,5 $\mathrm{mm}$.

Foudr. Mon. 196. Teinod. - A 11. Mon. 319. Thyamis. - Kutsch. Wien. Monatsh. 1864. 50 (265) Longit. - Redtb. Faun. A. 2. 507 .

Bedeutend kiirzer als die rorige Art, besonders hinten breiter gebaut und breit abgerundet, von ihr ausserdem durch folgende Punkte abweichend: Das Halssch, ist mehr als ein Drittel breiter wie lang; rorn stärker zusammengedriickt und rerengt; die Fld. sind sehr dicht, fein punktirt; auf der Unterseite ist nur das Wittelbruststiick und die Hinterbrust schwarz, während der Bauch nebst dem Pygidium, die Seiten der Mittelbrust und die Vorderbrust, Beine, Fühler und Halssch. röthlich gelbbraun sind. Der Kopt ist rostroth, mit schwarzem Munde und Kopfschilde, die letzten Fiihlerglieder und die Hinterschenkel auf dem Riicken, nahe der Spitze. angedunkelt. Die Fld. sind hell gelb, das erste 'Trusenglied an den vorderen Beinen etwas weniger gestreckt.

In der Geschlechtsauszeichnung und Penisform scheint die Art ziemlich mit exoletus übereinzustimmen.

Nach Kutschera in Oesterreich und Steiermark wahrscheinlich anch an Echium, nach Fondras anf 'Triften im suidlichen Frank- 


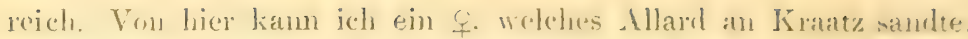
vergleichen. Dasselbe sicht genan wie ein fein punktirtes of der

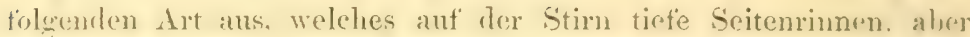
keine dentlichen IHäcker besitzt. Da juncirolı stets sicher zn erkennen ist, so dürfte sich hiernach anch pectoralis gut bestimmen lassen, wenn er wieder gefunden wird.

19. Long. juncicola: Alatus, onalis, comerus, testaceus, nitidus, anteminis sat longis apice fuscis, labro, postpectore abdomineque nigris, seymento ultimo pygidioque testaceis, fronte rlutacea, sulci.s oculuribus mullis, tuberculis rengustis bone discretis, prothorace transwerso sat parw, clytris sat fortiter llerumque seriatim junctatis, callo humerali sul)prominulo. - Long. 1,6-2,5 mm.

Mas: segmento ultimo ventrali fovea vaga impresso.

Foudr. Mon. 189. Teinod. - A 11. Mon. 384. Thyamis.

Var. a. Fronte picea vel capite omnino nigricante.

Long. substriatus Kutsch. Wien. Monat. 1864. 43. (258). Redtb. Faun. A. 2. 507. - Bach, Käferf. 3. 343. - Leesb. Tijdschr. 25. 169.

Var. b. Abdomine toto nigro.

Haltica pratensis Gyll. Ins. Snec. 3. 539. - Thoms. Skand.

Col. 8. 183. Long.

Var.c. Abdomine ferrugineo.

Var. d. Elytrorum lateribus subparallelis, sutura fusca.

? Long. seriatus Kuts ch. 1. c. 154 (280).

Var. e. Waterhousei: Apterus, callo humerali fere nullo.

Kutsch. 1. c. 274 (295).

Vom Ansehen eines I. curtus, mit breiten, gewölbten Fld, und kleinem Vorderkörper. die Stirn wie bei dem kleineren und flachen tycopi gebaut.

Eiförmig, gewölbt, von vorn bis hinter die Mitte allmählich ansteigend, dahinter schnell abfallend, röthlich gelbbraun, ziemlich stark glänzend, die Fld. hellgelh. zuweilen mi bräunlicher Nahtkante. Oberlippe, Hinterbrust und Bauch schwarz. Vorder- und Mittelbrust, sowie der letzte Banchring und das Pygidium rïthlich gelbbraun. Hinterschenkel rostroth, selten an der Spitze angedunkelt. Stirn sehr fein körnig gewirkt, Höckerchen schmal, bis neben die Augen dentlich, oben durch eine grade Rimue begrenzt, die zum oberen Augenrande läutt. Fühler hedentend länger als die Hälfte des Körpers, ihre erweiterten Glieder schwärzlich. Halssch. quer. nach den Seiten stark abfallend und hier deutlich gerundet. auf der Scheibe meist dicht und runzelig punktirt, seltener mit weitläufigen, sehr feinen Punkten. und stark glänzenden Zwischenräumen. Fld, in schwacher Rundung heraustretend und in den 
Schultern "twas hreiter als das Halssch., mit sehwacher Reule, his hinter die Mitte leicht crweitert, am Ende breit ahgermdet (f), beim ô mehr parallel. Der Ritcken ist ziemlich stark verworren, oder in Reihen punktirt, die Punkte hinter der Witte allmählich abgeschwächt.

$\hat{\sigma}$ Letzter Banchring mit glatter Mittellinie und einem schwachen. of't kaum bemerkbaren Eindrucke. der Mittelziptel grubig vertieft. - Penis rorn in eine mässig lange Spitze verschnälert. deren Seitem leicht ausgeschweift sind.

Mitunter färbt sich der Kopf' vom Seheitel bis zu den Höckerchen, nder gänzlich pechschwarz (Var. a), auch die Spitze des Hinterleibes kann schwärzlich werden (Var. b), oder der ganze Bauch rothbraun (Var, c); die Fld. erhalten in seltenen Fällen einen feinen, dunklen Nahtsaum, oder sind (bei frischen Stücken nach dem Tode) einfarbig hell rostroth.

Die Körperform verändert sich dadurch, dass die schultem und ihre Beule stärker als gewöhnlich heraustreten, wodurch die Fld. auch beim 올 mehr oder weniger parallel aussehen (Var.d), oder die Schultern sind eng und fallen gleichmässig ab, bei der ungeflügelten Form e.

Auf feuchten Wiesen bei Berlin, Glatz, Weimar; Paderborn (Eppelsheim). Das Thier ist über ganz Dentsehland und den grössten Theil ron Europa verbreitet, aber bisher immer nur in einzelnen Stiicken g'efangen worden.

Kutschera hat diese Art nicht erkanut; aus seinen Beschreibungen geht hervor: juncicola Kutsch, dessen Beschreibung lediglich eine Uebersetzung aus Foudras ist, = lycopi var., substriatus und Waterhousei Kutsch. = juncicola (geflïgelte und ungeflügelte Eorm), wahrscheinlich auch seriatus, von dem ich allerdings noch kein Exemplar mit heller Brust gesehen habe.

50. Long. ballotane: Subajterus, fere ellipticus, concexus, subtilissine alutaceus, minus nitidus, crebre concinneque punctatus, testaceus, mothorace brevi elytrisque albidis, capite fermgineo, antenis apice femoribusque posticis infuscatis, ore, pectore abdomineque nigris, tibiis postici.s. leviter curvatis calcari magno. - Long. 1,6-2,2 min.

Marsh. Ent. Brit. 1. 205. Chrysom. - Steph. Ill. Brit. 4. 312: Man. 297. Thyamis. - All. Mon. 323. - Foudr. Mon. 191. Teinod. - Kutsch. Wien. Monat. 1864.46 (261). Longit. Redtb. Faum. A. 2. 507. - Bach, Käferf. 3. 345. - Seidl.

F. transs. 813. - Leesb. Tijdschr. 25. 172.

Var. a. Capite plus minusie piceo, sutura chytronum rufescente.

Var. b. Pectore abdomineque testaceis aut ferrugineis.

Var. c. Elytris seriatim punctatis.

Var. d. Alatus, minus conrexus, callo humerali sat prominulo. 


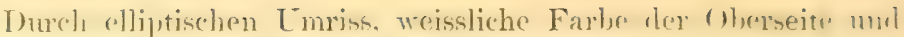
verhailtnissmässig langen Fnddorn der Hintersthienen ansgezerichnet. in der Kärperform dem grösser'n und viel stiirker punktirtrn lateralis ähnlich.

Ziemlich sestreckt, lang rlliptisch, hinten wenig breiter als rorn, oben mässig gewölbt, gellhlich weiss, äusserst tein gewirkt. fettig glänzend. Kopf heller oder dunkler rothbraun. die Fühler und Hinterschenkel an der Spitze geschwärzt. Mund, Brust unr Hinterleib schwarz, letzterer oft noch mit röthlicher syitze. Stirn äusserst fein körnig gerumzult, mit kleinen und flachen Höckerchen. die aussen bis zur tiefen Seitenrimne laufen und oben ron einer feinen Linie begrenzt werden. Fühler länger als die Hältte des Körpers. Halssch. doppelt so breit als lang. an den Seiten gerundet, vorn etwas zusammengedriickt, oben gewölbt, dicht und fein punktirt, meist gerunzelt. Fld. bis zur Witte in sanftem Bogen erweitert, dahinter ähnlich verengt, fast gleichuässig dicht und deutlich, stärker als das Halssch punktirt; die Punkte scharf eingestochen, auf dem Rücken in verworrene, oder (T'ar. c) fast regelmässige Reihen geordnet, über dem Seiten- und Hinterrande gewöhnlich etwas abgeschwächt. Schulterbenle fehlend oder wenig: bemerkbar, innen kaum abgesetzt; Härchen am spitzenrande sehr kurz. Hinterschienen leicht nach innen gekrümmt, auf dem Rücken oft eine wenig in die Augen fallende feine und kurze Längsleiste an der Basis des Innenrandes, der Enddorn lang und stark.

$\hat{o}$ Letzter Bauchring in der Mitte eben oder vertieft, zuweilen mit einem kleinen Längskiele vor dem Mittelzipfel; dieser klein, halbkreisförmig, voln durch den aufgebogenen und stumpfwinkelig: ausgeschnittenen Hinterrand des Segments begrenzt. - Penis schlank, ziemlich von gleicher Breite, vor der Oeffnung gradlinig in eine mässig lange, oben verdickte und rorn abgestumptte Spitze verengt, unten der Länge nach ausgehöhlt.

Das Thier ist im Käscher nicht leicht zu sehen, woil die Farbe der Oberseite wenig ron der der granen Leinewand absticht; im Juli und August fängt man nur umreife Exemplare. deren Lnterseite anfangs röthlich gelbbraun ist und nach und nach dunkel rothbraun wird (Var. b). Ende September und im Oktober. sowie im folgenden Frühlinge herrschen die Stiicke mit schwarzer Unterseite vor, deren dunkelste einen pechschwarzen Kopf und eine röthliche Naht haben (Var, a), bisweilen anch ein rostrothes Halssch. und röthlich gelbbrame Fld. Unsere mittelemopäische Form ist durchschnittlich viel kleiner als die siideuropäische und cnthält nur selten vollkommen geflügelte Thiere (Var. d), welche an den ściten mehr parallel, auf dem Rücken flacher erscheinen 
und durch die stärker lickanstretenden Schultern einen fremdartigen Umriss bekommen.

An somnigen Heckeu, Dortstrassen und Mauem alter Kirchhöte auf Ballota nigra und Marrubium vulgare L. in ganz Deutschland; über Mittel- und siideuropa von Spanien bis in den Kankasus verbreitet.

Da Fondras selbst augiebt. dass die unvollkommen geflïgelte Form in Sïdfrankreich (wie überall) vorherrschend ist, so mnss die Beschreibung auch von dieser ausgehen, ferner, weil die geflïgelten $\widehat{\sigma}$ zu den grössten Seltenheiten gehören.

51. Long. rubiginosus: Apterus, oblongo-ovatus, convexus, nitidus, pallide testaceus, capite, pectore abdomineque ferrugineis, antennis corpore vix brevioribus, prothorace transverso evidenter punctato, elytris humeris rotundatis crebre sat fortiter punctatis, punctis suturam versus subseriatis, tibiis posticis calcari brevi. - Long. $2-3 \mathrm{~mm}$.

Mas: segmento ultimo ventrali fovea laevi profunde impresso.

Teinod. rubiginosa Foudr. Mon. 204.

Long. rubiginosus Kutsch. Wien. Monat. 1864. 157 (283). Redtb. Faun. A. 2. 508.

Tein. flavicornis A11. Ann. Fr. 1860, 136; Jon. 350 Thyamis. Leesb. Tijdschr. 25. 175. - Seidl. F. balt. 723; transs. 814.

Var. a. profugus: Alatus, humeris prominulis callo discreto, antennis brevioribus.

Var. b. fumigatus: Capite prothoraceque ferrugineis, aut plus minusve piceis, sutura elytrorum fusca, pectore abdomineque fuscis vel piceis. Var.c. Prothorace elytrisque subtilius punctatis.

Etwas grösser, doppelt so stark und tungleichmässiger punktirt als der vorige, durch die Punktirung dem luridus ähnlich, aber an den langen, hellen Fühlern sicher zu unterscheiden.

Länglich eiförmig;, gewölbt, glänzend und hell braungelb, Kopf; Brust, Bauch und Hinterschenkel dunkler, rothbraun. Stirn glatt, oder äusserst zart gewirkt, Höckerchen kurz, eiförmig, mit der Spitze in die tiefe Seitenrinne abfallend, oben nicht oder sehr fein begrenzt. Fühler ungefähr so lang als der Körper, stärker wie bei aernginosus, einfarbig, oder die letzten Glieder bei dunkel gefärbten Stücken leicht gebräunt. Halssch. um die Hälfte breiter als lang, an den Seiten gerundet, auf der Sicheibe dicht und ziemlich kräftig runzelig-punktirt, bisweilen jedoch feiner und sparsam punktirt, mit breiten, glatten Zwischenräumen. Fld. vval, mit flach abgerundeten, beulenlosen Schultern, bis zur Mitte schwach, (ઠ) oder mässig erweitert (q), dahinter ähnlich verengt, an der Spitze einzeln abgerundet und kurz bewimpert; dicht und stark punktirt, die Punkte neben der Naht gereiht, ilne Zwischenräume 
gewïhnlich unregelmässig gewijlbt. Hinterschienendorn fein unrl kurz, Flïgel verkümmert oder fehlend.

o Letzter Bauchring mit einer tiefen, eifömigen, glatten Gruhre, die im Grunde rimenformig rerengt ist. - T'enis gerade. von der Basis lois vor die Mitte jederseits fast unmerklich ausgeschweift, damn allmählich schwach erweitert und neben der Oetrinung an breitesten, daror schnell germotetrerengt mol in cine solir kurze. breite und stumpfe Spitze vorgezogen.

Bei der gefligelten Form a. treten die Fld. an der Basis stark heraus und sind in den Schultern hedentend breiter als dlas Halssch.. nit deutlicher, hoher Beule, die Fühler sind merklich kuirzer.

Die Art ist nicht immer hell getärbt, und crinnert in den dunkelsten Stücken einigermassen an atricillus. Der Kopt wird pechbraun, unterhalb der Fühler oft schwarz, das Halssch. rothbraun, an den Seiten pechschwarz, die Naht der Fld. ist dunkel gesäumt und die ganze Brust nehst dem Banche schwärzlich (Var. b). Auch die Punktirung der Fld. variirt; sie wird bisweilen so fein wie bei pellucidus (Var. c.), mitunter aber sehr stark. auf dem grössten Theile des Rüickens gereiht, dam stehen manchmal einige Reihen in deutlichen Streifen.

An Gräben, Sümpfen, feuchten Waldrändern auf' Conrolrulus sepium L. in der norddeutschen Tiefebene häufig rom Juli bis in den Herbst; in Mittel- und Süddeutschland, wie überhaupt in Mitteleuropa wenig seltener. Im Berglande auch auf ziemlich trocknen Abhängen und Feldern, die mit Futterpflanzen z. B. Medicago sativa $\mathrm{L}$. bestellt sind, in Gesellschaft ron $L$. aeruginosus. und pellucidns. Foudras bezeichnet als Futterptanze Eupatorium cannabinum L.

52. Long. fermugineus: Apterus, oblongo-ovatus, convexus, nitidus, laete ferrugineus, labro fusco, antennis apice infuscatis pedibusque dilutioribus, fronte sulcis ocularibus nullis, tuberculis angustis sat discretis, prothorace transverso evidenter punctato, elytris humeris rotundatis crebre sat fortiter punctatis, punctis suturam rersus subseriatis, tibiis posticis calcari valido. - Long. 2-2,5 mm.

Mas: segmento 5: o ventrali impressione media laevi.

Teinod. ferruginea Foudr. IFou. 216. -- A11. MIon. 349 Thyamis. Long. ferrugineus Kutsch. Wien. Jonat. 1864. 155 (281). Redtb. Faun, A. 2. 508. - Seidl. F. balt. 723 ; transs. 814

Der vorigen Art sehr nahe rerwandt und ähnlich, jedoch in der Regel kleiner, eine Spur gewölbter. lebhaft und glänzend rostroth, die Fïhler (deren fünf Endglieder angedunkelt sind), die rier Vorderbeine und die Hinterschienen und Tarsen röthlich gelb. Auf 
der sim fehlen die Seiteminnen, die Häkerchen treten nicht ganz so scharf' als bei lyropi hervor und sind an der Basis etwas breiter, laufen aber aussen auch bis neben die ilngen und sind oben durch eine ziemlich serade Linie fein, doch deutlich begrenzt. I)ic Punktirung der Fle. ist meist etwas Hacher wie dic ron moiginosus, und der Enddorn der Winterschienen ist stark, grebogen, viel linger als die Schienen vor der Spitze breit sind.

Beim ô hat das letzte Banchsegment in der Mitte einen breiten, glatten Längseindruck, welcher sich nach hinten verflacht. - Der Penis ist vor der Oeffinung in eine lange, scharfe Spitze verengt.

Bei Wien vou Kutschera und Scheftler, bei Lyon von Foudras gesammelt. Ich besitze nur $2 \hat{\jmath}$, eims aus śpanien, das andre aus dem Kankasus (Leder, Reitter) und glaube, dass die Angaben uiber das Trorkommen der Art in Deutschland auf einer Verwechselung mit der vorigen Art beruhen dürften.

53. Long. pellucidus: Alatus vel subapterus, oblongo-ovatus, convexiusculus, pallide testaceus, nitidus, capite, pectorc abdomineque ferrugineis, labro piceo, antennis corpore brevioribus apice vix infuscatis, prothorace transverso punctulato, elytris sat crebre subseriatim punctatis, apice breviter ciliatis, humeris prominulis. - Long. 1,8-2,8 $\mathrm{mm}$.

II a : segmento 5: o ventrali impressione laevigata postice profundiove instructo.

Teinod. pellucida Foudr. Mon. 210. - A11. Mon. 403. Thyamis

Long. pellucidus Kutsch. Wien. Monat. 1864. 152 (278). Redtb. Faun. A. 2.508. - Leesb. Tijdschr. 25. 174. - Seidl. F. balt. 723 ; transs. 814 .

Var. a. Supra ferrugineus, femoribus posticis apice leviter infuscatis.

Var. b. nigriventris: Pectore abdomineque fuscis vel piceis.

Long. pellucidus Thoms. Skand. Col. 8. 184.

$\mathrm{Var}$. c. Ut in b, sed prothorace, sutura margineque laterati clytrom infuscatis.

Var. d. Elytris obsolete punctulatis, sublaevibus.

An den blassen, durchscheinenden, auf dem Rücken abgeflachten und in wenig dichten Reihen punktirten Fld. kemntlich. Lang: eiförmig, nur mässig gewölbt, Kopf, Unterseite und Hinterschenkel rostroth, Fühler, Beine und Halssch. röthlich gelbbram, Fld. weisslich gelb, Oberlippe schwärzlich. Stim fast glatt, oder umregelmässig zart gewirkt, mit undeutlichen Höckerchen. Fühler um ein Drittel kürzer als der Körper, die letzten Glieder schr wenig gebräunt. Halssch. quer, mindestens um dic Hälfte breiter als lang: fein punktirt, oft längsrumzelig. Fld. an der Basis winkelig heraustretend und in den Schultern breiter als das Halssch., mit niedriger und kleiner Beule. dahinter kaum oder wenig erweitert, am Ende 
schwach rinzeln algerundet. anf hen Rürken fein. alver nur mïssig: diclut junktirt. Die Punkte sind vor der Mitte gereiht, aussen und linten verworen und alggeschwächt: der Suitzenrand ist ziemlich dicht und kurz bewimpert, die beirlen wrsten Hirchen sind kürzer als das zweite Hintertarsenglierl. Enddorn kurz: Fliigel pollkommen ausgebildet oder verkümmert.

ô Letzter Bauchring mit cinem glatten Längseindrucke, dè hinten plötzlich in die tiefe Grube des Mittelzipfels abfällt. Penis gebogen, an der Geffunng sanft erweitert, löffelfr̈rmig. der Vorderrand abgerundet, in der Mitte in eine unscheinbare spitze verlängert.

Da die Schultern dieser Art stets rorgezogen und nit einer Beule versehen sind, so weicht die röllig geflïgelte Form äusserlich wenig ron der unvollkommen geflügelten al. Hinsichtlich der Färbung sind zwei Varietäten zu beachten. Die eine (a) ist oherseits gleichmässig röthlich gelb bis rostroth und hat an der Spitze der Hinterschenkel zuweilen einen dunklen $W$ isch; die andere ist entweder auf Brust und Bauch allein (Var. b) oder auch an den Seiten des Halssch. dunkelbraun bis pechschwarz, und Taht und Aussenrand der Fld. sind braun angelaufen. Die Fld. sind bald stärker als gewöhnlich, bald schwächer punktirt, manchmal fast glatt (Var. d).

Vom Juli ab auf Stoppelfeldern an Convolvulus arrensis L.. häufig in Mittel- und Südeuropa, zuweilen auch an Paparer argemone und rhoeas L. In Thïringen lebte das Thier massenhaft auf Medicago satira, nach Allard bei Paris auf Kleefeldern und Mentha rotundifolia L., nach Kutschera bei Tien anf Inula britannica L.

54. Long. succineus: Apterus, oblongo-ovatus, convexus, nitidus, pallide testaceus, capite, pectore abdomineque fermgineis, antennis longis, articulo ultimo apice infuscato, prothorace transverso punctulato, elytris subpellucidis basi vage subtilissimeque punctatis, apice sat breviter ciliatis, humeris rotundatis. Long. 1,5-2,5 mm.

II s: segmento ultimo ventrali linea media laevi impresso.

Teinod. succinea Foudr. Mon. 218.

Teinod. laevis All. Ann. Fr. 1860. 121; Mron. 351. Thyamis, Kntsch. Wien. MLonats. 1864. 162 (288) Longit. - Redtb. Faun. A. 2. 508. - Leesb. Tijdschr. 25. 176. - Seid1. F balt. 724 ; transs. 815 .

Halt. pratensis var. c. Gyllh. Ins. Suec, 3. 539.

Var. a. perfectus: Alatus, humeris prominulis.

Var. b. Prothorace elytrisque haud pellucidis flavo-allidis.

Var. c. Supra mfo-testaceus, femoribus posticis apice nigris. 
Var. d. Pectore abdomineque fuscescentibus.

Var. e. Prothorace crebre ruguloso-punctulato.

Var. f. Elytris antice evidenter punctutis.

Var. g. Elytris laevibus.

$\mathrm{V}$ ar. h. Elytris alutaceis, minus nitidis.

Die häufigste Art der Gattung, kürzer gebaut, höher gewölbt und durchschnittlich viel feiner punktirt als die vorige. Länglich eiförmig stark gewölbt, blass bräunlich gelb, Kopf, Brust, Bauch und Hinterschenkel rostroth, letztere zuweilen auf dem Rücken angedunkelt. Stirn fast glatt, mit tiefen Seitenrinnen und undeutlichen Höckern. Fühler beim ô so lang als der Körper, beim 우 etwas kuirzer. die Spitze des letzten Gliedes schwärzlich. Halssch. klein, quer, um die Hälfte breiter als lang, stark querïber gewölbt, fein punktulirt, die Puinktchen oft durch Längsrisse verbunden; die Zwischenräume gewirkt, matt, oder glatt und glänzend. Fld, ziemlich elliptisch, an den Schultern schmal, sehr flach abgerundet, in oder hinter der Mitte am breitesten, an der Spitze einzeln abg'erundet und deutlich bewimpert, die ersten beiden Härchen fast so lang als das zweite Glied der Hintertarsen. Die Scheibe ist in der vorderen Hälfte, namentlich nach der Naht hin sehr fein und verloschen, aber stärker als das Halssch. punktirt, selten ganz glatt (Var. g), oder sehr deutlich fein und tief punktirt (Var. f). Auf jeder Decke sind meist 3 bis 5 dunkle, durchscheinende Längslinien zu bemerken, zwischen denen sich hellere, mit weisslich gelbem Farbstoffe versehene undurchsichtige Z $Z$ wischenstreifen befinden. Der Enddorn der Hinterschienen ist kurz, die Flügel fehlen.

ô Letzter. Bauchring mit feiner, glatter Mittelrinne, die hinten in eine grosse Grube des Mittelzipfels abfällt. - Penis in den beiden mittleren Vierteln jederseits sehr sanft ausgeschweift, vorn breit abgerundet, in der Mitte des Vorderrandes eine äusserst kleine Spitze.

Die geflügelte Form a, welche die früheren Monographen der Gattung zu pellucidus gestellt haben müssen, hat starke, vortretende Schultern mit verschieden hoher Beule; die übrigen Varietäten sind weniger auffällig. Bei b ist die Oberseite gelblich weiss, nicht durchscheinend, bei c röthlich gelb oder gesättigt ockergelb, und die Hinterschenkel besitzen oft eine lange schwarze Makel auf dem Rücken, bei d sind Brust und Banch schwärzlich braun, auf den Fld. zuweilen dic Naht gebräunt, bei e ist das Halssch. stärker als gewöhnlich, dicht runzelig punktirt, und bei h die Oberseite, besonders auf den Fld. deutlich zart gewirkt, wit einem matten Hauche überflogen.

VI. 6. 
In sandigen Gegenden ter Ehome auf Artemisia campestris L. und an trocknen Abhängen des Vorgebirges an Euphorbia cyparisuias L. und anderen Pflanzen gemein, ebenso in iihrigen Europa, mit Ausschluss des hohen Nordens. Allard nennt als Futterptlanze Artemisia absinthium L.

55. Cong. aeruginosus: Apterus, ocalis, nitidissimus, pallide testaceus, labro infuscato, antennis tenuissimis, longissimis, prothorace transverso obsolete ruguloso-punctulato, elytris minus crebre cage curislosopunctatis apice sat longe ciliatis, humeris rotundatis. - Long. 1,5-2,9 mm.

IIas: minor, subparallelus, segmento 5: o ventrali suleo medio obsolets apice in foveam dilatato.

Femina: Major, postice plus minusve ampliata.

Teinod. aeruginos a Foudr. Mon. 203. - All. Mon. 353. Thyamis.

Long. aeruginosus $\mathrm{Kutsch}$. Wien. Monat. 1864. 161 (287). Redtb. Faun. A. 2. 508, - Seidl. F. balt. 724; transs, 815 .

Var. a. luctator: alatus, antennis brevioribus, elytris subparallelis humeri. prominulis.

Var. b. Laete ferrugineus.

Var. c. Pectore abdomineque ferrugineis, saepe infuscatis.

Mit keiner anderen Art zu verwechseln, durch einfarbige, sehr blasse, zarte und lange Fühler, helle Oberseite und durchsichtige sehr verloschen narbig punktirte Fld. ausgezeichnet. Blass gelbbraun, im Leben hellgelb, mit starkem Glanze, die Oberlippe und das Endglied der Maxillartaster gesehwärzt, Brust und Bauch zuweilen rostroth, selbst schwärzlich (Var. c), oder das ganze Thier lebhaft rothbraun (Var. b). Stirn glatt, mit breiten, undeutlichen Höckerchen und kurzen, wenig scharfen Seitenrimnen. Fühler so lang (q) oder länger ( $\hat{\sigma})$ als der Körper, nur die beiden Basalglieder verdickt, die ïbrigen cylindrisch, sehr dümn, ziemlich ron gleicher Stärke. Halsch. quer, glatt, mit feinen Längsrunzeln. seltener mit deutlichen Pünktchen. Fld. an der Basis im Bogen heraustretend, ohme merkliche Beulen, nur mässig dicht und fein, aber sehr flach und verloschen pockemnarbig punktirt, an der Spitze ziemlich lang bewimpert, die beiden ersten Härchen so lang als das zweite Glied der Hintertarsen. Enddorn kurz. Flïgel fehlen oder sind nur kurze Stummel.

o Halb so gross als das $q$, beinahe gleichbreit, erstes Glied an den vorderen Beinen verbreitert, letzter Bauchring mit einer breiten und flachen Mittelrinne, die in einer mehr oder weniger grossen Grube des Mittelzipfels endet. - Penis schwach gebogen, vorn in eine stumpfe Spitze verengt.

Beim of sind die Fld. bis hinter die Mitte erweitert, oft banchig gewölbt und am Ende sehr breit abgerundet. 
Die geflügelte Form, zu der etwa 5 Procent aller Individuen gehören, enthält vorwiegend $\&$, nit verkiiryten Fïhlern und eckigen Fld., die in den Schultern stark heraustreten und viel breiter als das Halssch. sind.

Auf feuchten Wiesen, an Gräben und k'lussuferm auf Symphytum officinale L. rom Juli bis in den Herbst in ganz Deutschland, sowohl in der Ebene, wie im Vorgebirge nicht selten. Foudras fand die Art angeblich auf Eupatorium cannabinum L.

56. Long. tabidas: Alatus, oblongo-ovatus, convexus, dilute ochraceus, labro, palpis antennisque apice infuscatis, prothorace transverso, obsolete punctulato, elytris subopacis, vage subtiliter punctatis, tibiis posticis brevibus, articulis 2 primis tarsorum posticorum late compressis. Long. 2,5-3,5 $\mathrm{mm}$.

I as: segmento ultimo ventrali fovea laevi impresso.

Altica tabida Fabr. Syst. Ent. 1775. 115. - Panz. Faun. germ. 21. 15. - Ill. Mag. 6. 166. - Gyllh. Ins. suec. 3. 542. Steph. Ill. Brit. 4. 308; Man. 295. Thyamis. - A 11. Mon. 402. Foudr. Mon. 201. Teinod.

Long. tabidus Kutsch. Wien. Monat. 1864. 148 (275). - Bach, Käferf. 3. 153. - Redtb. Faun. A. 2.507. - Seidl. F. balt. 723 ; transs. 814.

Thyamis jacobaeae Waterh. Cat. Brit. Col. 1858. 94. - Leesb. Tijdschr. 25. 174.

Halt. laevis Duft. Faun. A. 3. 261.

Var. a. Elytris nitidis.

Etwas kleiner als die gestreckte Form von verbasci, länglicheiförmig, gewölbt, hell ockergelb, Brust und Banch zuweilen rostroth, die Spitze der Oberlippe, der Taster und Fühler schwärzlich, die Fld. matt iiberhaucht, seltener glatt und glänzend (Var, a). Stirn kaum gewirkt, mit kurzen, ovalen, höchst selten deutlich umgrenzten Höckern, Nasenkiel meist breit und flach. Halssch. quer, um die Hälfte breiter als lang, rorn etwas zusammengedruickt, oben äusserst fein, verloschen punktirt, glänzend. Fld. in den Schultern bedeutend breiter als das Halssch., mit kleiner, vorspringender Beule, bis in oder hinter die Mitte sanft erweitert, dahinter stärker verengt, schwach einzeln abgerundet und äusserst kurz bewimpert; auf dem Riicken sehr fein und verloschen punktirt, die Punkte nur nahe der Basis neben der Nalit bemerkbar, oder wem sie dunkel durchscheinen. Hinterschienen verhältnissmässig kurz, ebenso der Metatarsus und das folgende 'Tarsenglied, welche nach der Śpitze merklich erweitert sind und, von der Seite geschen, einen viel grösseren Querdurchmesser besitzen als die übrigen Arten. Enddorn sehr kurz, Flügel vollkommen. 


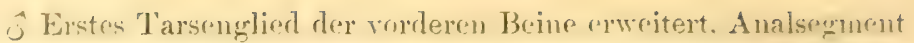
mit cinex walen, glatten Gruhe die sich auf' den Mittelzipfel ausidehnt. - Penis gleichbreit, unten flach auscrekchlt, vorn jederseits grarllinig verengt, so dass vor der. Oeftinung eine scharfe, dreieckige Spitze liegt.

Im Spätsommer auf Triesen an senecio jacobaca L. von dem das Thier am lichsten die Wurzelblätter frisst. wrodurch dieselhen siebartig durchlöchert werden.

58. Long. ochroleucus: Alatus, oblongo-ovatus, concexinsculus, testaceus, ore maculaque apicali femorum josticorum nigris, antennis tarsisque apice fuscis, prothorace transverso sublaeri, elytris strmineis crebre subtilissimeque punctatis. - Long. 2-3 mm.

Mas: abdominis segmento 5: o fovea sulciformi impresso.

Chrysom. ochroleuca Marsh. Ent. brit. 1. 202. - Gyllh. Ins. suec. 4. 658. Halt. - Steph. Ill. brit. 4. 311; Mou. 296. Thyamis. - All. Mon. 405. - Foudr. Mon. 208. - Teinod. Long. ochroleucus Kutsch. Wien. MLn. 1864. 146 (272). Redb. Fam. A. 2. 507. - Bach, Käferf. 3. 153. - Thoms. Skand. Col. 8. 181. - Leesb. Tijdschr. 25. 173. - Seidl. F. balt. 723 ; transs. 814 .

Var. a. Immaturus, femoribus posticis apice infuscatis rel unicoloribus. $\mathrm{Var}$ b. Pleuris metasterni abdominisque basi in medio piccis.

Eine sehr hell gefärbte Art, welche durch die schwarze Spitze der Hinterschenkel auffällig ist. Wie die vorige gebaut. aber kleiner, etwas flacher, blass röthlich gelbbraum, das Halssch. hellgelb, die Fld. gelblich weiss, Oberlippe und Taster. sowie eine ziemlich grosse und scharf begrenzte Makel in der Spitzenhälfte der Hinterschenkel schwarz; die sechs äusseren Fühlerglieder und die beiden letzten Tarsenglieder schwärzlich. Stirn mit Seitemrinnen uncl kleinen, undeutlichen, oben durch eine Linie begrenzten Höckerchen. Fühler ein Viertel kürzer als der Körper. Halssch, quer. an den Seiten stark abfallend, glänzend und fast glatt, oder zart gewirkt und äusserst fein punktirt. Fld. an der Basis winkelig heraustretend, mit vorspringender Schulterbeule, bis zur. Mitte etwas erweitert, an der Spitze sehr schwach einzeln abgerundet und kurz bewimpert, auf dem Rücken dicht und sehr fein verworren punktirt. Hinterschienendorn ziemlich kurz, Flügel rollkommen entwickelt.

ô Letzter Bauchring mit einer ovalen, nach hinten verbreiterten und vertieften Iuängsgrube, deren Seiten ziemlich steil zur Mittılrime abfallen. - Penis ror der Mitte jederseits bogenförmig ausgeschweift. so dass die spitze für sich ungefähr eine kurze Ellipse bildet, deren Vorderrand in der Mitte sich in eine kleine, kurze Spitze verlängert. 
Bei frischen Stiicken sind die IInterschenkel an der Spitze nur angedunkelt, selbst einfiulig rostroth (Var. a), bei ausgehärteten ist zuweilen die Mitte des Banches an der Basis nehst den Seitenstücken der Hinterbrust pechschwar, wïhrend die Seiten der Mittelbrust hellgelb bleiben (Var. b).

In Deutschland und Mitteleuropa, sowie in südlichen schweden nur an wenigen Orten gefangen, häufiger in Südeuropa und der Nordafrikanischen Küste. Aus Dentsehland sah ich lis jetzt nur 1 Stiick, welches H, von Heyden im unteren Saarthale sammelte. Miller klopfte die Art zahlreich von Fichten auf Cephalonia, Leesberg. bei Maastricht von Weiden.

\section{Bestimmungs-Tabelle.}

A. Fld. rerwachsen und an der hinteren Nahtecke nicht klaffend, mehr oder weniger behaart. Kaukasische Arten vom Habitus des L. rubellus. Subgenus Testergus.

1. Eiförmig, der Batophila rubi ähnlich, schwarz, sehr schwach metallisch grün angehaucht, Fühler und Beine rostroth, Halssch. und Fld, fein punktirt, letztere im hinteren Drittel sparsam und äusserst zart behaart. L. 1,6-2 mm. Cireassien, Swanetien (Wien. ent. Z. 1889. 3) . . . . . . . Lederi Ws.

1'. Lang eiförmig, schwarz, mit erzfarbigem Schimmer, Fiihler und Beine rostroth, Fld. kräftig punktirt, fein und wenig dicht weisslich, seidenschimmernd behaart. L. $2-2,5 \mathrm{~mm}$. Swanetien, Armenische Gebirge. (Wien. ent. Z. 1890. 114) pubescens Ws.

B. Fld. nicht verwachsen, nur die Kante des Seitenrandes hinter: der Mitte bewimpert . . . . Longitarsus i. sp.

1. Oberseite einfarbig blau, metallisch blaugrün, grün, messingfarbig bis kupfrig braun, oder tief schwarz .

$1^{1}$. Oberseite schwarz, zuweilen metallisch angehaucht, mit hellen Makeln, ganz oder theilweise pechbraun, rothbraun, gelbbraun bis weisslichgelb . . . . . . . . . 20.

2. Stirn an den Seiten vertieft und dicht punktirt, ohne scharfe Rinne, Hinterbrust in der Mitte stark germuzelt und lang behaart, Seitenstücke grol) punktirt, Rücken der Hinterschienen mit deutlicher Innenrandleiste. Elliptisch, blan, grün, messingfarbig oder kuptrig hraun, Beine gellbraun, Schenkel dunkel, Fld. stark punktirt. - L. 2, $6-4 \mathrm{~mm}$. Im grö̈ssten Theile ron Mitteleuropa, Siideuropa, Nordafrika . . 1. echii Koch.

$2^{1}$. Stirn mit tiefer und scharfer Seitenrinne. . . . . . . 3 . 3. Hinterschienen kräftig, mit breitem Rücken. die äussere Leiste 
desselhen unregelmässig bedomt, mit langen Wimperlaar(u. ler lintere, kammförmig hedornte Theil lang, an der Basin ylïtzlich ansteigend und hïher als dex davor liegende Theil. Oberseite blau, metallisch griin bis dunkel kupferig bram, Beine, mit Ausnahme der Hinterschenkel, gelbhraun, selten die Torderschenkel dunkel, Fld. stark punktirt. - I. 2,5-4 mm. Oesterreich südlich der Donau, Ungarn, Serbien, Süidfrankreich, Italien, Griechenland, Kaukasus, Armenien

2. Linnaei Duft.

$3^{\natural}$. Hinterschienen dünn, mit sehr abschüssigem Rücken, der kamnförmig gezähnte Theil am Aussenrande derselben ron dem vorderen Theile kaum abgesetzt.

4. Körper auffällig kurz und breit, hoch gewölbt, einfarbig schwarz, bei frischen Stücken Füblerwurzel und die Beine pechschwarz. L. 1,5-2,2 mm. Norddeutschland, Fraukreich, Schweden

12. nigerrimus Gyllh.

$4^{1}$ Körper mehr oder weniger gestreckt, wenigstens Fühlerbasis und Schienen röthlich gelbbraun . . . . . . . . . 5.

5. Fld. schief- oder ausgerandet-abgestutzt, das grosse Pygidium oder auch noch der davor liegende Ring umbedeckt . . 6.

51. Fld. an der Spitze gerundet-abgestutzt oder einzeln bis gemeinschaftich abgerundet . . . . . . . . . 9.

6. Fld. hinten in gemeinschaftlichem Bogen ausgerandet. Gestreckt, hoch gewölbt, schwarz, die Oberseite, namentlich die Fld. metallisch grün schimmernd, kräftig punktirt; Fühlerwurzel und Beine rothgelb, Stirnhöckerchen lanzettlich, scharf begrenzt. - L. $2 \mathrm{~mm}$. Syrien (Wien. Z. 1890. 115)

emarginatus Ws.

$6^{1}$. Fld. hinten einzeln schief abgestutzt, Stirnhöckerchen undeutlich 7 .

7. Oberseite dunkel messingfarben oder kupferig. - L. 1,6-2 mm. Dalmatien, Jonische Inseln. (Wien. Monat. 1862. 108 (188).

cuprinus Kutsch.

Dieser Art sehr äbnlich, vielleicht mit ihr synonym ist L. multipunctatus All. Mon. 331 aus Algier.

71. Oberseite tiefschwarz

8. Glänzend, hoch gewölbt, beiderseits verschnälert, Halssch. und Fld. ziemlich fein punktirt. Hinterschienendorn klein.- L. $2 \mathrm{~mm}$. Griechenland, (Wien. Z. 1890. 115) . . truncatellus Ws.

81. Mässig gewölbt, Kopf und Halssch, glänzend, wenig schmaler als die Fld., diese gewirkt, matt-seidenglänzend, dicht und sehr fein punktulirt, Hinterschienendorn gross und stark. - L. 2,2 mm. Araxesthal (1. c. 116) . . . . . . brachypterus Ws.

9. Die Stirnlinien sind deutlich, grade, laufen rom oberen Augenrande zur Spitze des Nasenkieles und durchsehneiden sich hier 
x-fïmig. Achwar, mit erimlichem Anfluge, Halssch. mol Fld. schwach punktirt, ersteres runzolig, letztere in Reilen. I. 1-1, mm. Mittel- mul Südeurna. Nordafika, Syrien

8. obliteratus Rosh.

91. Stimlinien gobogen, undentlich oder fehlend. . . . . 10.

10. Fll. an den Seiten, namentlich von der Mittel-oder Hinterbrust aus bis zur hinteren dussenecke zusimmengedrückt und fist senkrecht abfallend, mit sehr feiner Seitenandlinie und Randleiste, welche weit vor der Spitze erlischt . . . . 11. 101. Fld. an den Seiten in gleichmässigem Bogen abfallend, dio Linie über der Randleiste stark und tief . . . . . . 15.

11. Oberseite dunkel, bräunlich erzfarbig . . . . . . . 12

11‥ Oberseite schwarz . . . . . . . . . . . . . 14.

12. Fld. an der Basis kaum breiter als das Halssch, mit abschüssigen Schultern und kaum bemerkbarer Beule, gleichmässig stark punktirt. - L. 1,8-2 mm. Dalmatien, Südeuropa. (ex Kutsch. Wien. Monat. 1862. 109 (189); mediterraneus All. Mon. 332.). . . . . . . . . corynthius Reiche.

12'. Fld. an der Basis breiter als das Halssch., mit vorspringenden Schultern

13. Hinterbrust fast kahl, Fld. sehr dicht runzelig punktirt, die obere Randlinie der Naht vor der spitze auf die Fld. heraufgebogen, Fiihler und Beine dunkel rostroth. ô Letzter Bauchring mit feiner Mittelrinne, deren Umgebung glatt ist. Penis ziemlich breit, rorn gerundet-abgestutzt, in der Mitte des Vorderrandes eine kleine Spitze. - L. 2-3 mm. Schlesien im Friihlinge auf Lithospermum arvense $L$. bei Liegnitz, (Gerhardt), Oesterreich, Serbien. . 3. fuscoaeneus Redtb.

13². Hinterbrust aufstehend behaart, Fld. mässig dicht punktirt, die obere Randlinie der Naht vor der Spitze kaum von der unteren entfernt, Fibler und Beine grösstentheils hell rostroth. - L 1,,$-2.5 \mathrm{~mm}$. Rheinpfalz (Eppelsheim), Triest. Südeuropa

4. aeneus Kutsch.

14. Oberseite äusserst fein und dicht gewirkt, ziemlich glänzend, Fld. mässig dicht und fein punktirt, die Punkte hinter der Mitte abgeschwächt und auf einem Querstreifen an der Spitze oft erlöschend. - L. 1,2-3 mm. Im grössten Theile von Europa

5. anchusae Payk.

142. Oberseite kaun gewirkt, stark glänzend, Fld, seln fein punktirt, - L. 1,5-2 mm. Corsica . . . . Bonnairei All.

15. Oberseite dunkel erzfarlig, die ïbrigen Theile des Körpers schwarz, das erste Fühlerglied und die folgenden drei oder vier Glieder, die Kniee. Spitze der Schienen und Tarsen roth- 
hram. Halssch. und Fld, sehr dicht punktirt. letztere mit stark heraustretenden Schultern. L. 2 mm. Sarepta, Kaukasus violentus Ws. ${ }^{1}$ )

15'. ()herseite rein schwar\%, oder mit kaum merklichem metallischen Anfluge .

16. Oberseite äusserst dicht und fein gewirkt und seln fein, flach und verloschen punktirt. - L. 1-1,8 mm. Europa

\section{1. parvulus Payk.}

161. Fld. deutlich und tief punktirt

17. Schultern der Fld. abgerundet, ohne spur einer Beule. 18.

171. Fld. in den Schultern heraustretend, mit hoher, glatter Beule 19.

18. Gestreckt und ziemlich flach, mässig glänzend, schwarz, Fld. mit kaum bemerkbarem griinen Schimmer, sehr dicht und ziemlich fein punktirt. ô Penis fast so lang als der Bauch, neben der Oeffnung in sanftem Bogen erweitert, sodann beinahe gradlinig in eine schmale, abgestutzte Spitze verengt. I. 1,4-1,8 mm. Berggegenden Mitteldeutschlands, England, Schweden, Ungarn . . . . 7. absinthii Kutsch.

181. Oval, hochgewölbt, glänzend schwarz, Fld. für sich ein Oval bildend, dicht und sehr kräftig punktirt. -- L. 1,8-2,5 mm. Schweiz, Tirol, Serbien, Griechenland, Syrien 6. pinguis Ws.

19. Die Fld. dicht punktirt, mit ungefähr 16 mregelmässigen Punktreihen. Glänzend schwarz, Fühlerbasis und Beine röthlichgelb, Hinterschenkel schwarz, in seltenen Fällen auch die vorderen Schenkel angedunkelt. - L. 2,3-3 mm. Mittel- und Suideuropa, Schweden . . . . . 9. niger Koch.

19. Fld. mässig dicht in ungefähr 13 bis 14 ziemlich deutlichen Reihen punktirt. Schwarz, mässig glänzend, Fühler (an der Spitze angedunkelt) und Beine brämnlich gelb, Torderschenkel, mit Ausnahme der Spitze, und die Hinterschenkel gewöhnlich pechschwarz. Penis vorn viel länger zugespitzt als bei miyer. L. 1,6-2,2 mm. Frankreich, Oesterreich, Ungarn, Süideuropa. Kaukasus

10. rectilineatus Foudr.

1) Long. violentus: Oblongo-oratus, minus conexus, subtus niger, antemnarum basi, genubus tibiis apjec tarsisque rufo-brunneis, supra obscure aeneus, nitidus, prothosace elytrisque crebrime sat subtiliter punctatis, humeris valde prominulis. - Loug. $2 \mathrm{~mm}$. Sarepta (Cl. Mï̈ller), Kaukasus, Armenisches Gebirge (Reitter).

Nahe mit asperifoliarum Ws. (Deutsch. Z. 185\%. 334) ans Turkestan verwandt, aber die Metallfarbe der Oberseite ist nicht messing gelb, Fühler und Beine sind dunkel, die Fld. viel dichter, leicht runzelig, nirgends gereiht-punktirt, in den Schultern breiter und mit stärkerer Beule. Beim $\hat{j}$ ist der Banch in der Jitte glatt, der letzte Ring daselhst flach gedrückt, das erste Tarsenglied etwas erweitert. 
20. Fld. sehwar\%, oder dunkel exztarben, mit rothen oder gelhen Makeln

201. Fld, pechsehway, hram oder gelb, einfarbig odex mit dunkler Zeichnung

23.

21. Körper kur\% und breit, gewïll,t, Fld, tief schwar\%, vor der Spitze eine gelthlich-rothe Makel, die sich in seltenen Fällen über den grössten Theil der Fld, ausdehnt. - L, 1,5-2,5 mm. Mittel und Nordeuropa, Sibirien (Baikalsee, Leder)

13. holsaticus L.

21․ Körper länglich-eitörmig, nur mässig gewöllt . . . . 22.

22. Fld. fein punktirt, schwarz, ohne wesentlichen Metallschimmer, jede mit zwei hellen Makeln (eine an der Schulter, die andre vor der Spitze), die zuweilen der Länge nach zusammen fliessen, selten theilweise oder gänzlich verschwinden. - L. 2,5-3,3 mm. Mittel- und Siideuropa, Schweden . 14. 4-guttatus Pont.

$22^{1}$. Fld. rorn stark punktirt, in der Regel mit olivengrinem Metallschimmer, eine Schrägmakel in der Spitze, selten auch ein Fleck an der Schulter gelbbraun. - L. 2-3,5 mm Gebirge Mitteleuropa's, Nordeuropa . . . 15. apicalis Beck.

23. Körper pechschwarz, braun oder rothbraun, Schulter und Spitze der Fld. zuweilen heller, Fühler kräftig . . . . . 24.

$23^{1}$. Fld. theilweise orler gänzlich röthlich-gelbbraun, roth bis gelb 32 .

24. Spitzenrand der Fld, sehr lang bewimpert, die letzten Härchen über der Nahtecke länger als der halbe Metatarsus. L. $2-3 \mathrm{~mm}$. Europa . . . . . 16. brunneus Dft.

$24^{1}$. Derselbe ist kurz oder sehr kurz bewimpert . . . . . 25.

25. Die Härchen anf dem Spitzenrande der Fld. nehmen nach der Spitze lin an Länge zu, die drei letzten an der Nahtecke sind fast so lang als ein Viertel des Metatarsus. - L. 1,8-2,5 mm. Alpen (gravidulus Kutsch.) . . . . 18, rubellus Foudr.

251. Dieselben sind sehr kurz und fast ron gleicher Länge . 26.

26. Fühler einfarbig hell bräunlich gelb . . . . . . 27.

261. Fühler nach der Spitze hin angedunkelt . . . . . . 29.

27. Körper kurz, Fld. an den Seiten auffällig gerundet, Halssch. fast glatt.

28.

271. Körper länglich, Fld, an den Seiten mässig gerundet, Halssch. gewirkt und fein punktirt, Fühler sehr lang. - L. 2,3 mm. Erzherzogth. Oesterreich, Steiermark (Eppelsheim)

21. pallidicornis Kutsch.

28. Rostroth, Fld. deutlich und ziemlich tief pnnktirt.- L. 1,5-2 mm. Siidfrankreich, Pyrenäen (Mon. 155). . gibbosus Foudr.

281. Pechschwarz, Naht oft röthlich gesäunt. Fld. undeutlich. wenig fein, aber sehr flach punktirt, nur ein vertietter, äusserst schmaler 
(Euretreifen an der Basis mit stäkeren tirfen I'mktran hesetz. - L. 1,5 mm. Frankreich, Pyrenäen (Mon. 147)

ventricosus Foudr.

29. Halssch. und Fld. änsserst fein verworren junktirt. L. $2-2,5$ mm. Kärnthen, Wien (mbella All. Ws. 95.5)

19. languidus Kutseh.

291. Halsseh. und Fld., namentlich dic letzteren, deutlich und tiet punktirt

30. Zwischenräume der Punkte glatt, stark glänzend. - I. 1, $-2, \varsigma \mathrm{mm}$. Mitteleuropa . . . . . . 17. fulgens Kutsch. ${ }^{1}$ )

301. Zwischenräume der Punkte äusserst fein und in der Regel dicht gewirkt, seidenartig glänzend . . . . . . . . 31.

31. Fld. kräftig und in der vorderen Hälfte gereiht-punktirt, die Zwischenräume meist grösser als die Punkte. - L . 1,5-2.5 mm. Europa . . . . . . . . . 20. luridus Scop.

311. Fld. dicht, fein und stellenweise runzelig punktirt. L. 1,2-1.6 mm. Berggegenden Mitteleuropas

22. minusculus Foudr.

32. Fld. schwarz, mit einem breiten hęllen Seitensaume, der höchst selten in der Mitte unterbrochen ist . . . . . . . 33.

321 . Fld. hell, oft mit dunkler Zeichnung . . . . . . . 34.

33. Halssch. hell, höchstens die Mitte der Scheibe angedunkelt. L. 1,8-2,5 mm. Rheinpfalz, westliches Europa 23. dorsalis F.

$33^{1}$. Halssch. schwarz. - L. 1, $-2,5 \mathrm{~mm}$. Mainz, siidwestliches Europa. . . . . . . . 24. stragulatus Foudr.

34. Stirn ziemlich dentlich gewirkt, ohne scharfe Seitenrimnen, mit lanzettlichen Höckerchen, dieaussen bis neben die Augen reichen und oben von einer graden Rinne begrenzt sind . . . 35.

341. Stirn mit deutlichen Seitenrinnen und undeutlichen Höckerchen. Bei einigen Arten sind letztere gut umgrenzt, aber breit, oval, aussen spitz und nur bis zur Seitenrinne reichend. . . 39.

35. Enddorn der Hintersehienen ziemlich lang, länger als der Querdurchmesser der Schienen vor der Spitze . . . . . 36.

351․ Enddorn kurz . . . . . . . . . . . . . 37.

36. Gestreckt, Fld. in den Schultern mehr oder weniger vortretend. dicht und meist in Reihen punktirt, I'unkte scharf eingestochen, Hinterschenkel an der Spitze dunkel. - L. 1,5-2 mm. Mittelund Südeuropa, Kankasus . . . . 40. lycopi Foudr.

1) Long. Bedeli Lhayon, Anales Soc. Espan. Madrid 1887. 392., scheint dem fulgens Kutsch. sehr ähnlich. Er ist glänzend pechschwarz, Fithlerbasis, Beine und Bauch rostroth, auf den Fld, ein rothgoldener Fleck, ähnlich wie bei holsuticus, aber bis ror die Mitte reichend. 
361. Eifömig, Fld, in den Schultem schmal, nach hinten verhereitert. mässig fein, flach punktirt, Hinterschenkel einfarlig rostroth. L. 1,5-2 mm. Mitteleuropa. . 42. membranacens Foudr.

37. Fld. in den Schultern mehr oder weniger vortretend und breiter als das Halssch. . . . . . . . . . . . . . 38.

$37^{\prime}$. Fld. in den Schultern sehmal, nach hinten verloreitert, fein und verloschen punktirt, hinten fast glatt. - L. 1,4-1,8 mm. Ungarn, Wien, Lyon . . . . . . . . 43 nanus Foudr.

Hierher noch L. brezicollis Kutsch. Wien. Oberseite Hach, weissgelb, Fld. dicht runzelig-punktirt; Grösse und Körperform des nanus.

Ausserdem scheinen in diese Gruple zwei unbekannte Arten aus dem sïdlichen Frankreich zu gehören: cerinus Foudr. ILon. 219 und ordinatus Foudr. 221. Nach der Bestimmungstabelle des Autor's haben beide ovale Stirnhöckerchen, nach der Beschreibung lanzettliche. Ich wiisste nicht, wodurch sich ordinatus von der südeuropäischen, unterseits hellen Form des lycopi unterscheiden sollte. Er ist, nebst cerimus nicht aus Deutschland nachgewiesen, da die Angaben (Berl. Zeit. 1867. 382) auf falschen Bestimmungen Allard's beruhen.

38. Fld. gelb, selten mit dunkler Naht, stark punktirt, hinten schnell abfallend, Bauch schwarz, das letzte Segment und Pygidium hell. - L. 1,6-2,5 mm. Im grössten Theile von Europa

49. juncicola Foudr.

38 . Fld. meist mit dunkler Naht, fein gereiht-punktirt, hinten allmählich abfallend; Bauch schwarz. - L. 1,8-2,2 mm. Ungarn, Wien, Frankreich. . . . . 41. abdominalis All.

39. Hinterschienen schlank, gebogen, mit einer sehr deutlichen hohen und langen Leiste am inneren Rande des Riickens und einem starken und langen Enddorn. Letzterer ist nur bei agitis kiuzer als der Querdurchmesser der Schienen vor der Spitze 40.

$39^{1}$. Hinterschienen ohne Imnenrandleiste, oder es ist von ihr nur der Anfang nahe der Basis vorhanden, aber niedrig', schwer zu bemerken z. B. bei pellucidus, succineus, ballotae, ferrugineus 46 .

40. Fld, fein punktirt und in den Zwischenräumen sehr dicht und deutlich gewirkt, matt. Rostroth, Halssch. und Fld. lehmgelb. - L. 2,8-3,4 mm. Corsica. (Mon. 385) . rudipennis All.

$40^{1}$. Fld, glänzend . . . . . . . . . . . . 41.

41. Fld, fein, meist verworren punktirt . . . . . . . . 42.

41 . Fld. kräftig, mässig dicht, gereiht punktirt . . . . . . 45.

42. Halssch. viereckig, wenig breiter als lang. Fld. in der Regel flach und verloschen punktirt, mit Spuren rou Reihen. Kopí, Halssch., ein breiter Nahtsaum und ein Längsfleck auf der Aussenhälfte der Fld. pechschwarz, letzterer oft so ausgedehnt, 
daws e' unit dem Nahtsamme zusammenfliesst. Dam Wheihen ein basalsaun und einige kleine, sehr verwaschene Makehu iilecr dem Seitenrande und nahe der Naht linter der Mitte lell. - L. 1, i- 2.5 mn. (orsica, Sarrlinien. Neapel. (Mon. 49.5 ) nebulosus All.

421. Halssch. fast doppelt so breit als lang. Grijssere Arten . 43.

43. Punkte der Fld. fein und äusserst flach, nur damn gni zu bemerken, wenn sie dunkel durchscheinen. Hinterhrust mit durchgehender Mittelrime. ô Aftersegment durch einen Lüngseindruck in der Hitte und einen Quereindruck am Hinterrande jederseits beulenfïming aufgetrieben. Rostroth, Halssch. und Fld. strolgelb, Fühler und Hinterschenkel nach der Spitze hin angedunkelt. - L. 2,7-3,5 mm. Nassau. Südeuropa

39. Foudrasi Ws.

Aehnlich ist Long. gracilicornis Rey, Opuscules 1875. 34 aus Südfrankreich und Sicilien.

431. Punkte der Fld. narbig vertieft, Hinterbrust am Ende mit einer Grube zwischen den Hüften. Aftersegment des $\hat{\sigma}$ fast gleichmässig gewölbt . . . . . . . . . . . . . . . 44.

44. Körper breit- oder länglich-eiförmig, gewölbt, Fld. ziemlich dicht punktirt, Enddorn der Hinterschienen sehr lang: Rostroth, Halssch. und Fld. blassgelb, letztere an der Naht und am Seitenrande zuweilen schwarz gezeichnet. - L. 2,5- $4 \mathrm{~mm}$. Europa . . . . . . . . . . 38, verbasci Panz.

441. Sehr kurz-eiförmig, hoch gewölbt, Fld. weitläufiger punktirt, Enddorn kurz. - L. 2,5-3 mm. England . a gilis Rye.

45. Fld. in den Schnltern schmal, etwas breiter als das Halssch. mässig dicht, stark punktirt. Kopf', Cnterseite und Hinterschenkel meist schwarz, Fld. gelbbraun. die Naht und ein hinter der Schulter bogenförmiger Seitensaum schwarz, letzterer oft unterbrochen oder fehlend. - L. 2-3 mm. Mittel- und Südeuropa . . . . . . . . . 37. lateralis Ill.

Hierher gehört auch der mir unbekannte $L$. suturatus Foudr.

451. Fld. in den Schultern bedentend breiter als das Halssch., dicht punktirt, nebst dem Halssch. strohgelb, Naht, Kopf und L'nterseite rostroth, Spitze der Hinterschenkel zuweilen dunkel. L. 2,8-3,5 mm. Südfrankreich. Spanien. Rom, Dalmatien. (Mon. 213)

crassicornis Foudr.

4h. Fld. mit einem mehr oder weniger breiten schwarzen Nahtsaume, welcher oft auf die Xahtkante beschränkt ist: letztere zuweilen nur braun . . . . . . . . . . . . . 47

$46^{1}$. Fld, durchaus einfarbig. hell gefärbt. . . . . . . 59. 
47. Ausser dem Nahtsaume hesitzen die Fld. unch am Ścitenrande schwarze oder dunkle Zeichnungen . . . . . . . . 48.

47'. Nur die Naht dunkel . . . . . . . . . . . . 50.

48. Die S'eitenzeichnung besteht aus cinem dmolen Randsaume, mit der eine grosse, runde, schwarze Makel hinter der Schulter zusammenhängt; dieselbe ist scharf begrenzt und dehnt sich immen bis uahe an den Nahtsaum aus, - L. 1,5-2,2 mu. Wien, Ungarn, Ungebung des Mittelländischen Meeres.

25. lateripunctatus Rosh.

481. Die Seitenzeichnumg besteht aus einem dunklen Randsaume 49.

Nach der Zeichnung witrde lycopi, eine Var. von juncicolı, nebulosus, lateralis und eine sehr dunkle Var. ron verbasci hier zu suchen sein.

49. Der schwarze Nahtsaum der Fld. setzt sich um die Spitze herum als dunkler Seitensaum fort. - L. 1,5-2 mm. Europa.

26. nasturtii Fabr.

491. Der schwarze, erzglänzende Nahtsaum endet vor der Spitze, am Seitemande sind die Ejipleuren und ein unbestimmter Saum dariiber, vor der Mitte, schwärzlich. - 1,8-3 mm. Berggegenden in Mittel- und Südeuropa . 27. suturalis Marsh.

50. Kopf und Halssch. dunkel, roth bis schwarz, metallisch glänzend. Schultern wenig rorspringend. - L. 1,8-3 mm. Europa, Nordafrika . . . . . . . . . 28, atricillus L. .

$50^{1}$. Halssch. ohne metallischen Schimmer . . . . . . . 51.

51. Hinterschienen mit gebogener Unterseite, vor der Spitze stark verdickt . . . . . . . . . . . . . . 52.

51․ Hinterschienen gerade, schlank, nach der Spitze allmählich schwach verbreitert . . . . . . . . . . . 53.

52. Fld, am Ende gemeinschaftlich gerundet-abgestutzt, der Spitzenwinkel an der Naht deutlich. Kopf und ein ziemlich breiter Nahtsaum schwarz. - L. 2-2,3 mm. Südfrankreich, Suideuropa. (subterlucens Foudr. Mon. 168). . . nigrocillus Motsch.

521. Fld. am Ende breit einzeln abgerundet. Kopf rothbraun bis pechschwarz, die Naht der Fld. nur gebräunt nder angedunkelt. - L. 2-3mm. Sudeten, Alpen . 36. longipennis Kutsch.

53. Die beiden ersten Wimperhärchen am Nahtwinkel der Fld. auffullig lang. Fld. gelb, kräftig punktirt, ihr schwarzer Naht-

1) Den grössten Stücken des atricillus ähnlich ist Long. distingucndus Rye aus England, aber weniger regelmässig oval, Fiihler stärker, die schwarze Farbe der 6 Endglieder von der hellen Farbe der Basis scharf abgesetzt, Kopf und Halssch. ohne Metallschimmer, Fld. in den Schultern mehr heraustretend, vorn oft gereiht punktirt, Hintertarsen uud Enddorn länger. Auf Senecio jacobaea L. (Ent. Monthl. Mag. 1872. 157. 


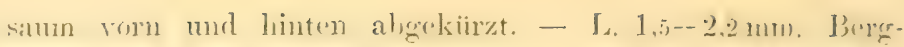
gegenden Mitteleuropas. . . . . . 32. Longisetu Ws.

$53^{1}$. spitzenmend der Fld. kur bewimpert.

54. Fld. hinten allmählich verengt und etwas ausserogron, auf den Abfalle zur Spitze eben so kriftig als an der IBasis. mejist runzelig-punktirt. Stimrinnen wenig rom Augr entfernt. L. 2-3 mm. Europa . . . 35. melanocephalus Deg.

$54{ }^{1}$. Fld. hinten mehr oder weniger breit alogerundet. mit rerrundetem Nahtwinkel, schwächer als an der Basis punktirt. Die Stimrinnen entfernen sich nach unten bedeutend vom Auge . . . . . . . . . . . . . . . . . . 55.

55. Körper ziemlich breit-eiförmig, gewölbt . . . . . . . 56.

$55^{1}$. Körper gestreckt, måssig gewölbt . . . . . . . . 58.

56. Fld. fein und sehr flach verloschen punktirt; Kopf, Halssch. und ein breiter Nahtsaum der Fld. bei ausgefärbten Sticken schwarz. - L. 1,8-2,s mm. Europa . . 29. suturellus Dft.

$56{ }^{1}$. Fld deutlich punktirt . . . . . . . . . 57.

57. Fld. höchstens mit dunkler Nahtkante, ziemlich dicht, narbig punktirt; Fühler wenig iiber die Mitte der Fld. reichend. L. 1,8-2,4 mm. Berggegenden Mittel- und Süddeutschlands. Frankreich. . . . . . . . . 34. curtus All.

Fühler so lang als der Körper. Fld. grob punktirt: rubiginosus var.

571. Fld. mit einem abgekürzten schwarzen Nahtsaume, dicht, fein. verhältnissmässig tief und scharf punktirt. - L. 1,8-2,3 mm. Berggegenden Mittel-Europa's . . . 33. viduus All.

Sehr ähnlich scheint zu sein L. sternalis Rey, Opusc. 1875. 29 aus Suidfrankreich.

58. Hinterschenkel auf dem Rücken schwarz, Fld. sehr fein, doch deutlich punktirt. - L. 2-2.8mm. Im grüssten Theile ron Europa . . . . . . . . . . 30. piciceps Foudr.

581. Beine einfarbig röthlich gelbbraun, Fld. kaum deutlich punktirt. - L. 1,8-2,5 mm. Am Rheine. Frankreich, England

31. gracilis Kutsch.

59. Fld. hell blutroth, die ïbrigen Körpertheile gelblich roth. L. 3-3,5 mm. Frankreich, Pyrenäen-Halbinsel . vutilus Ill. $59^{1}$. Fld, rostroth, gelb bis gelblich-weiss . . . . . . . 60.

60. Fiilıler hell gelb, äusserst diunn und zart, schlank, die einzelnen Glieder rom vierten an wohl sechsmal so lang als breit, die füunf Endglieder nach der Spitze ummerklich erweitert. Das ganze Thier sieht sehr hell, glïnzend, zart und zerhrechlich aus. - L. 1, $1-2.8 \mathrm{~mm}$. Mittel- und sideuropa. 
$60^{1}$. Fiihler normal, bald stärker, bahl schwiacher, die fïnf Endgolieder doutlich rerbereitert, hördistens viemal so lang als breit . . . . . . . . . . 61. 61.

61. Brust und Banch (wenigstens die (rstere) bei ansgereiften Stiicken schwarz .

61․ Brust und Bauch röthlich gelblorum bis rostroth. Linige hierher gehörende Arten z. B. pellucidus bilden lä̈ufiger, succineus und mliginosus seltener Varietaiten mit schwarzer Unterseite. 69.

62. Halssch. stark querüber gewölbt, von oben gesehen quadratisch, wenig breiter als lang; Kopf hell rothbraun . . . . . 63.

$62^{1}$. Halssch. kurz, viel breiter als lang, Kopf in der Regel dunkel 65.

63. Hinterleib tief schwarz, bei frischen Stücken wenigstens noch das Pygidium.

631. Brust schwarz, Bauch und Pygidium gelbbraun. - L. 2 bis 2,5 mm. Oesterreich, Frankreich . . 48. pectoralis Foudr.

Durch ein breiteres Halssch. scheint sich I. livens Rey, Opuse. 1875. 31, aus Frankreich zu unterscheiden.

64. Fühler einfarbig gelbbraun oder nur die 3 letzten Glieder an der Spitze leicht gebräunt, Fld. stark glänzend, kräftig punktirt, mit schwach heraustretenden Schultern, Hinterschenkel auf dem Rücken nahe der Spitze selten angedunkelt. - L. 2-2,5 $\mathrm{mm}$. Deutschland, Frankreich . . . . 46. putmonariae Ws.

64․ำ Fiihler nach der Spitze dunkel, Fld. mässig glänzend, fein punktirt, in den Schultern stark heraustretend (gefligelte Form), Hinterschenkel meist auf dem Riicken schwarz. - L. 2,3-3 mm. Nitteleuropa . . . . . . . . . 47. exoletus L.

65. Enddorn der Hinterschienen länger als die grösste Breite der Schiene vor der Spitze. Halssch. und Fld. weisslich, zwischen der Punktirung äusserst fein gewirkt, fettig glänzend. L. 1,6--2,2 mm. Mittel- und Suideuropa, Syrien, Nordafrika

50. ballotae Marsh.

651. Enddorn kurz, nicht so lang wie die Hiuterschienen ror der Spitze breit sind . . . . . . . . . . . 66.

66. Fld. röthlich gelbbraun, mässig dicht, deutlich, meist gereiht punktirt, linten ziemlich schmal abgerundet. - L. 1,3-2 mm. Alpen, Südeuropa . . . . . 44. tantulus Foudr.

$66^{1}$. Fld. hellgelb oder blass gelbbram, dicht punktirt, hinten ziemlich breit einzeln abgerundet, dic Spitze des Hinterleibes gewöhnlich unbedeckt

67. Fld. bis zur Spitze fast gleichmässig sehr dicht und deutlich, mässig fein punktirt. Gestreckt, einem kleinen und schlanken ochroleucus täuschend ähnlich, die Fld. mehr gelb gefeärot, Mittel- und Hinterbrust, oft noch die Basis des Bauchess schwaw. 
Ilinterschenkel rostroth, selten mit dunkler Makel vor der Spitze. - L. 2-2,5 mm. Südeuropa. Kaukasus.

albineus Foudr.

Bei vielen Stücken dieser Art ist lie Brust rothbraun, der Banch noch heller; wom ibnen soll sich $I$. ranescens Foudr. (Mon. 215) ron Lyon, durch dentlichere nnd regehnässigere Punktirmg unterscheiden. Auch L. paleacers Rey Opusc. 1875. 32) von Lyon muss sehr ähnlich sein.

$67^{1}$. Fld. sehr fein, oft undeutlich punktirt, ror der Spitze ziemlich glatt

68. Fühller lang, wenig kürzer als der Körper. gracilis Kutsch. 681. Fühler kurz, beim $\hat{o}$ wenig ïber die Mitte der Fld, reichend. - L. 1,2-2,2 mm. Europa . . . 45. pratensis Panz.

69. Metatarsus kurz, wie bei den iibrigen Arten ron der Seite flach gedrückt, aber nebst dem folgenden Tarsengliede mit viel grösserem Querdurchmesser. Fld. in der Regel ron einem matten Hauche bedeckt. Oberseite ockergelb. - L, 2,5-3,5 mm. Mitteleuropa, Schweden . . . . . 56. tabidus F.

691. Metatarsus und das folgende Tarsenglied schlank . . . 70.

70. Halssch. von oben betrachtet quadratisch, ziemlich so lang als breit. Strohgelb, Kopf, Brust und Banch rostroth, Fld. fein punktirt. - L. 3-3,8 mm. Krain, Südeuropa, Kankasus

exoletus v. rufulus Foudr.

701. Halssch. quer .

71. Enddorn der Hinterschienen lang und stark. Hell rostroth. stark glänzend, Fld. kräftig punktirt, fast so stark wie bei mbiginosus. - L. 2-2,5 mm. Oesterreich, Südeuropa, Kaukasus

52. ferrugineus Foudr.

$71^{1}$. Hinterschienendorn kurz

72.

72. Fld. grob punktirt. -- L. $2-3 \mathrm{~mm}$. Mitteleuropa

51. rubiginosus Foudr.

$72^{1}$. Flügeld. fein punktirt

73. Halssch. und Fld. sehr blass, letztere gelblich weiss. Hinterschenkel mit tiefschwarzer Spitze. L. 2-3 mm. Südeuropa, zerstreut in Mitteleuropa und dem siidlichen Schweden

57. ochroleucus Marsh.

731. Hinterschenkel rostroth, selten an der Spitze angedunkelt, diese Färbung aber wenig abstechend

74. Fld. auf dem Rücken etwas abgeflacht, in der Regel mit vorspringenden Schultern. - L. $1.8-2,8 \mathrm{~mm}$. Im grössten 'Theile von Europa . . . . . . . 53, pellucidus Foudr.

Dieser Art scheint sehr nahe zu stehen L. australis Rey. Opuse. 1875. 23. Languedoc, Dauphiné. 
741. Fld. gleichmässig ziemlich stark gewölht, mit ahgerundeten Schultern (letztere treten nu bei dex seltenen gefligelten Form winkelig heraus) . . . . . . . . . . . 75 .

75. Halssch, klein, meist um die Hälfte breiter als lang, Fld. sehr hell bräunlichgelb, f'cin punktirt, glänzend. Penis neben der Oeffnung schwach erweitert, am Vorderande breit ahgerundet, mit einem sehr kleinen Spitzchen in der Mitte. - L. 1,5-2,5 mm. Europa . . . . . . . 54. succineus Foudr.

Nach der Beschreibung muss I. obsoletus Rey, Opuse. 1875. 26 aus Frankreich nahe verwandt sein.

$75^{1}$, Halssch. gross, doppelt so breit als lang, Fld. gelblich weiss, gewirkt, mit einem matten Hauche iiberzogen, oder nur mässig glänzend, dem vorigen täuschend ähnlich, aber der Penis vorn fast gradlinig in eine kurze, sehr breite, scharfe, dreieckige Spitze verengt. - L. 2-2,5 mm. Südfrankreich, Corsica. (Mon. 207) candidulus Foudr.

\section{Dibolia.}

Latreille, Cuv. Regn. animal. ed. 2, V. 155.

\section{Acetabula antica aperta.}

Caput retractum scrobibus latis instructum; frons foveis binis setigeris; oculi magni, subreniformes, vix convexi.

Prothorax transversus, angulis fovea setigera instructus, anticis subcallosis, interne sulco profundo terminatis; elytra epipleuris angustis, brevibus.

Prosternum magnum. Tibiae posticae calcari lato, apice dilatato triangulariter emarginato armatae, dorso excavatae, marginibus elevatis et denticulatis; metutarsus tibiarum apici insertus, basi plus minusve tenuis, nudus.

Körper meist geflïg'elt, regelmässig eiförmig, oder lang' elliptisch, ohne rortretende Schultern, oben in einer Flucht gewölbt. Kopf in das Halsschild zurïckgezogen, mit senkrechter, ziemlich ebener Stirn, auf welcher jederseits eine grosse, scharfrandige Borsteupore ïber der Fühlerwurzel liegt. Die Höckerchen sind gross, ziemlich flach, gerundet, durch eime schmale, wenigstens angedeutete Rinne getrennt, aussen kaum, oben nur bei einigen Arten, unten stets scharf begrenzt. Augen am Inmenrande weit und sanft ausgeschweift, leicht nierenförmig, fein facettirt, nicht gewölbt, nach unten dirergirend. Fïhler höchstens halb so lang als der Körper, elfgliedrig, das erste Glied mässig rerdickt, keulenförmig, in eine weite Riune zwischen dem Ange und dem unterwärts rerbreiterten Tasenkiele eingelegt, Glied 3 an diunsten, die VI. 6. 
folgenden, namentlich die letzten 6 Glierler stärker. Mandibeln fünfzähnig, der dritte Zahn am weitesten vorgestreckt, Taster kurz, diinn. Halsschild viel breiter als lang, der Quere nach stark gewiilbt, oft zusammengedrückt und cylindrisch. nach vorn verengt, die Hinterecken umfassen ein wenig die Schultern. Von den Randlinien ist die an der Basis fein, nur in der Mitte zu bemerken. die des Vorderrandes in der Mitte erloschen, nach den Seiten allmählich vertieft, die neben dem aufgebogenen seitenrande endlich ist tief, biegt hinter den wulstig verdickten Vorderecken nach innen und durchsetzt den Vorderrand. Flügeldecken fast immer in mehr oder weniger regelmässigen Reihen punktirt, mit schwacher Schulterbeule, ihre Seiten im ersten Drittel bogenförmig verlängert und nur hier mit Epipleuren versehen. Vorderbrust zur Aufnahme des Mundes gewölbt, zwischen den Hïften bandförmig, dahinter wieder etwas verbreitert, abgestutzt. Bauch nach der Mitte ansteigend, der erste Ring der längste. Hinterschenkel sehr stark, vorn gerundet-abgestutzt, an der inneren Ecke befestigt, unter dem Innenrande eine gebogene Rinne zum Einlegen der Schienen. Diese sind kurz, zusammengedrückt, nach der Spitze rerbreitert, auf dem Rücken ausgekehlt, mit scharfen Kanten, welche nach dem Ende hin mit Zähnchen bewehrt sind. Enddorn lang und breit, an der Spitze erweitert und dreieckig ausgeschnitten. Über dem Dorne ist der Metatarsus befestigt, welcher fast halb so lang: als die Schiene und an der Basis kahl ist, so dass die Filzsohle iiber derselben, bei einigen Arten sogar erst kurz vor der Mitte beginnt. Klauen an der Basis fein gezähnt.

Das Männchen lässt sich leicht erkennen, da es klein, besonders schlank, bei vielen Arten auf den Flügeldecken stärker und regelmässiger punktirt und glänzender ist als das Weibchen. Ausserdem ist der Hinterrand des letzten Bauchringes beiderseits oder auch noch in der Mitte ausgerandet, und das erste Tarsenglied an den 4 Vorderbeinen verbreitert, wenigstens so breit als Glied 3, bei einigen Arten sogar breiter, fast herzförmig ${ }^{1}$ ). Der Penis ist eine gekrümmte Röhre.

Diese Gattung, an welche sich nach dem Baue der Vorderbrust Apteropeda lehnt, ist durch den gegabeiten Enddorn der Hinterschienen von allen einheimischen Gattungen ausgezeichnet und

1) Auf diese Geschlechtsauszeichnung gründete Motschulsky eine Gattung Petalopus (Bull. Mosc. 1845. 107) ron welcher sogar behauptet wird, dass die Tarsen der vorderen Beine stark herzförmig ertreitert seien! 
bildet mit Negistops ${ }^{1}$ ) eine natiirliche kleine Gruppe. Es sind etwa 20 Arten aus Europa und Nordafrika, Asien und Nordamerika beschrieben, die hauptsiichlich auf Lahliaten an geschiitzten, nach Siiden geneigten Orten leben. Die kntwicklung wurde mit Sicherheit nur von D. femoralis beobachtet (IIeeger, Sitzmogsber. Ac. Wien. 1858100 t. 1), denn die anderweite Wittheilung von Frauenfeld (Verhandl. zool. bot. Ver. 1864. 692) iiher eine in Salvia silvestris minirende Larve von $D$. rugulosa Redtb., dürfte sich kaum auf diese, ausschliesslich an Stachys gefundene Art beziehen, gehört vielleicht zu Schillingi. Nach Heeger 1. c. sind die Eier von femoralis weiss, fast durchsichtig und walzenförmig, werden Ende Mai oder Anfang Juli einzeln an je ein Blatt von Salvia austriaca oder silvestris in eine Rippenachse auf der Unterseite gelegt (von einem f insgesammt 30 bis 40 Stück) und liefern je nach der Witterung, in 5 bis 14 Tagen die Larven. Dieselben sind weiss, fast durchsichtig, ziemlich flach, bandförmig, um $1 / 3$ länger als der Käfer, beinahe gleichbreit, die einzelnen Ringe wenig von einander abg'eschnïrt, und von gleicher Länge. Kopf rund, dunkel, viel schmäler als der Leib, oben ziemlich gewölbt; Oberlippe und Oberkiefer gelbbraun, letztere fast kegelförmig, fünfzähnig; Fühler 2gliedrig, Glied 1 breit, ringförmig, gelbbraun, darauf stehen zwei sehr kleine Kegel, ein grösserer, kahl, am Innenrande, ein kleinerer, behaart, am Aussenrande; Ocellen sehr klein, wenig gewölbt, nur eine jederseits über dem Fühler. Scheibe des ersten Brustringes von eimem braunen Hornplättchen bedeckt, das durch eine helle Längslinie halbirt wird, dahinter stehen 8 blasse Haarwärzchen in einer Querreihe. Die beiden anderen Brustringe, sowie die Bauchsegmente tragen in der Mitte eine Querreihe von 4 ähnlichen Wärzchen, die 8 Bauchringe ausserdem in der Mitte des Seitenrandes ein feines Zäpfchen; der Analring endlich ist einfach, hinten breit abgerundet und mit einigen Härchen gefranzt. Die Beine sind zusammengedrückt, die Hüfte von ihnen durch eine schwarze Hornleiste abgesondert, die Klaue klein. Nach kurzer Zeit beisst sich die Larve in das Blatt ein, frisst darin eine Höhlung aus, deren Decken nach und nach trocken werden und sich braun färben, ist, ohne sich gehäutet zu haben, in 14 bis 20 Tagen aus-

1) Megistops Boh. Resa Eugen. 1859. 186 Augen auf der Stim zusammenstossend, Halssch. vorm und an der Basis ohne Randlinie, Vorderbrust flach, zur Aufuahme des IIundes nicht eingerichtet, Klanen einfuch. Zahlreiche Arten in Mittel- und Südamerika.

Paradibolia Baly, Trans. ent. Soc. 1875. 31, mit einer Art, indica Baly l. $c$, hat oben fast zusammenstossende Augen, weicht aber sonst. nach der Diagnose nicht von Dibolia ab. 
gewachson, und geht dann, nachdem sie sich rler Exerenente viillig entledigt hat, in die Erde. Hier verfertigt sie sich, ungrefibr 3 bis 4 Zoll unter der Futterpflanze, ein Tönnchen, rerwandelt sich darin nach 3 bis 5 Tagen zu einer blass gelblich-weiswen, beinahe eiförnnigen Nymphe und nach 10 his 12 Tagen, (Mitte onder Ende Juli) zum Käfer. Diese Entwicklungszeit ron ungefähr 2 Monaten stimmt mit derjenigen der iibrigen I libolien und fast allar IIalticiden überein, deshall, kann die Angabe Heeger's, I. femoralis bilde im August noch eine zweite Generation, deren Larven zur Ueberwinterung in die Erde gehen, im April zur Nymphe. Ende Mai zum Käfer entwickelt sein sollen, so lange nicht anerkannt werden, bis sie neuere Beobachtungen bestätigen.

Unsere einheimischen Arten sind nur nach untergeordneten Merkmalen z. B. der reränderlichen Punktirung unterschieden und ohne Berücksichtigung der Verwandtschaft neben einander gestellt worden, liessen sich daher nur fraglich bestimmen; vielleicht ändert sich dies zum Theil mit Hilfe der folgenden Uebersicht:

1. Die innere Kante der Hintersehienen steigt allmällich an und bildet am Ende einen mässig scharfen Winkel. Metatarsus in der Basalhälfte sehr schlank, nackt, die obere Hälfte breit, mit starker Filzsohle. Grössere Arten, die an Salvia leben . 2.

11. Die innere Kante der Hinterschienen bildet am Ende einen plötzlich ansteigenden seharfen Zahn. Metatarsus aus mässig: breiter Basis nach der Spitze wenig und allmählich verbreitert. die Filzsohle nur dicht an der Basis fehlend. Kleinere Arten . . . . . . . . . . . . . . . . . 3.

2. Nasenkiel breit, gleichmässig schwach gewölbt. Wulst in den Vorderecken des Halssch. kurz und breit, dreieckig, die Pore weit nach innen geriickt, fast ebenso weit rom Seiten- wie rom Vorderrande abstehend. Stirnporen dicht über den Fühlerwurzeln, diese weiter ron einander als ron der Pore entfernt. Oberseite dunkelbroncefarben, Fld. in Reihen punktirt, Zwischenräume dicht lederartig gewirkt. L. 3-t,2 mm. Mittelund Südeuropa . . . . . . 1. Schillingi Letzn.

21. Nasenkiel schmal, dachförmig. Wulst in den Vorderecken des Halssch. schmal, lang, Pore dicht neben dem Seitemrande, weit vom Vorderrande eingefiigt. Stimporen doppelt so weit ron den Fühlerwurzeln entfernt als diese unter sich. Oberseite metallisch, grün, bläulich oder braun, Fld. rerworren und stark punktirt, selten mit einzelnen Reihen, Zwischenräume schmal, fast glatt. L. 3-4,2 mm.

a) Höchstens der After roth gesäumt. Gebirge Mittel-Europas. Siideuropa .

2. femoralis Redtb. 
1.) Die letzten drei Banchringe roth. Śpanien, Alyier (Mon. 420) . . . . . . . v, erythrogaster All.

3. Fühlerfurche lang, oben von ciner hohen. geraden Leiste begrenzt, die vom wberen Rande der Fühlergrube ausgeht und in eine tiefe, den unteren Rand der Augen berihrende Rinne abfällt

31. Fiihlerfurche kurz, oben von einem katum aufstehenden, bogenförmigen Rande begrenzt, welcher von der unteren Ecke der Fuihlergrube ausgeht und oben keine tiefe Randlinie besitzt 13 .

4. Körper auffällig schlank. Stirnporen durch eine gerade, scharfe Rimne verbunden, auf der die ähnliche Rinne zwischen den Höckerch€n senkrecht steht . . . . . . . . . 5 .

$4^{1}$. Körper an den Seiten gerundet, oval, Stirnporen frei oder undeutlich durch einen bogenförmigen Eindruck verbunden, Stirnhöcker durch eine Grube oder eine feine Linie schlecht getrennt

5. Halssch. verhältnissmässig lang, fein punktirt, mit spitzen, etwas rorgezogenen Vorderecken. Fld. beim $q$ dicht und sehr fein gewirkt. - L. 2,5-3,5 mm. Deutschland, Oesterreich, Frankreich, Spanien . . . . . . 3. timida Ill.

51. Halssch. kurz, dicht runzelig punktirt, mit kleinen, ziemlich stumpfen, kaum vortretenden Vorderecken. - L. 2,2-3 mm. Ungarn, Türkei, Syrien . . . . . orientalis Ws.

6. Stirnporen dicht neben dem Augenrande. Zwischenstreifen der Fld. fein, gereiht oder verworren punktirt und sehr dicht und äusserst fein punktulirt . . . . . . . . . . . 7 .

61. Stirnporen wenigstens um ihren Durchmesser vom Augenrande entfernt. Zwischenstreifen der Fld, punktirt und netzförmig gerunzelt .

7. Tiefschwarz, Fiihler. Schenkelspitzen und Schienen der vorderen Beine, sowie alle Tarsen röthlich gelb-braun, die 9 Hauptreihen der Fld. scharf hervortretend. - I. 2,8-3,5 mm. Central-Europa.

4. Försteri Bach.

$7^{1}$. Dunkelblau, Hauptreihen der Fld. fein punktirt und wenig hervorgehoben. Fühler und Beine wie bei der vorigen Art gefärbt, oder die 6 Endglieder der Fühler dunkel und die Beine mit Ausuahme der Hinterschenkel rostroth. - L. 2,6-3 mm. Mittel- und Südrussland

russica $\mathrm{Ws.}^{1}$ )

1) Dib. russica: Subovalis, convexa, nigro-coerulea, antennis (apicem versus saepe infuscatis), pedibus anterioribus tibiis tarsisque posticis ferrugineis, femoribus anterioribus medio interdum piceis; fronte crebre punctulata, foveis juxta marginem oculorum impressis, prothorace minus crebre punctato, elytris subtiliter seriatim punctatis, interstitiis latis subtilissime punctulatis 
8. Wulst in den Vorderecken des Halssel. kurz und breit, dreieckig. Die vier Vorderbeine nebst den Schienen und Tarsen der Hinterbeine röthlich gelbhraun, ()berseite schwarz, diclit und riemlich stark punktirt, die Punkte der Fld, kaum gereiht. - L. 2, - - $3 \mathrm{~mm}$. Lngarn, Siebenbürgen. carpathica ITs. $\left.{ }^{1}\right)$

81. Wulst in den Vorderecken des Halssch. schmal, hï̈chstens lang-dreieckig

9. Fld. schwarz. - L. 2,3-3,5 mm. Mitteleuropa.

5. depressiuscula Letzn.

$9^{1}$. Fld. erzfarbig .

10. Nasenkiel breit, stumpf. Penis unten jederseits mit einer sehr grossen und tiefen Grube. - L. 2,5-3,5 mm. Mitteleuropa.

6. rugulosa Redtb.

101. Nasenkiel schmal, scharf. Seiten des Penis auf der Lnterseite flach, oder leicht muldenförmig vertieft .

11. Halssch, und die vordere Hälfte der Fld, dicht und kräftig runzelig punktirt. - Mittelstreifen auf der Lnterseite des Penis ansgehöhlt, in der Mitte stark verengt. - L. 3,5 mm. Caucasus: Meskisches Gebirge (Leder, Reitter). Bull. Mosc. 1845. 107. metallica Motsch. ${ }^{2}$ )

11․ Halssch, weitläufig punktirt 3

et uniseriatim subtilissimeque punctatis, - Long. 2,6-3 mm. Minsk, Sarepta.

Von zwei anderen blauen Arten ist die eine, D. maura All. Mon. 431 aus Algier, nach Allard's Beschreibung der depressiuscula sehr ähnlich, etwas kleiner, feiner punktirt (L. $2 \mathrm{~mm}$.), die andre, D. Cherrolati All. l. c. 432 ans Suidrussland, Syrien und Algerien, auf den Fld. ungleichmässig verworren punktirt, die Punkte nur in der hinteren Hälfte und an den Seiten gereiht. L. 2,6 mm.

1) Dib. carpathica: Oblongo-ocalis, conrexiuscula, nigra, nitidu, untennis apicem versus infuscatis pedilusque testaceis, femoribus posticis nigris; fronte purce subtiliter punctata, tuberculis sat discretis, carinu faciuli angusta, antice fere truncata, prothorace confertissime profunde punctato, angulis anticis late callosis, elytris confertim punctatis, punctis hinc inde seriatis. - Long. 2,8-3 mm. Marmarosch, Hermannstadt.

Einer grossen occultans sehr ähnlich, nach demselben Plane, aber durchweg stärker punktirt, an den hellen Fühlern und Beinen, dem gradlinig zum Kopfschilde abfalleuden Nasenkiele und dem breit dreieckigen Wulste in den Vorderecken des Halssch. sofort zu erkennen. Die Oberseite hat einen leichten blauen Anflug:

2) Hit dieser Art muss D. phoeniciu All. Mon, 424 ans Syrien wahe verwandt sein, aber sie besitzt pechbraume Schienen und Tarsen. D. puTudina Fondr. Mon. 90, die anch hierher gehört, ist mach All. Mon. 426 nu. 2,1 mu, lang, anf den Fld. feiner wie auf dem Halssch. punktirt. 
12. Punkte des Halsseh. grob. Mittelstreifen des Penis nur an der Basis vertieft, sonst eben. - L. 2,8-3,2 mm. Berggegenden Mitteleuropas . . . . . 7. cynoglossi Koch. 121. Punkte des Halssch. sehr fein. - I. 2,6-3 mm. Frankreich, Italien. Mon. 422 . . . . . . . Pelleti All.

13. Erstes Fühlerglied dunkel, Nasenkiel vorn ausgerandet, Fld. schwarz, wie das Halsseh. kräftig punktirt. - L. 2,2-2,8 mm. In grössten Theile von Eropa. . . 8, occultans Koch.

131. Erstes Fiihlerglied hell, Nasenkiel vorn gerade, Oberseite erzfarbig, verloschen punktirt. - L. 1,8-2,5 mm. Berggegenden in Mitteleuropa. . . . . 9. cryptocephala Koch.

Erste Gruppe: Innenrand der Hinterschienen allmählich ansteigend, Metatarsus nur in der oberen Hälfte mit einer Filzsohle.

1. Dib. Schillingi: Nigro-aenea, antennis pedibusque ferrugineis, femoribus posticis nigro-aeneis; carina faciali lata, minus convexa, foveis frontalibus antennarum basi approximatis, prothorace crebre subtiliter punctato, nitido, angulis anticis late callosis, elytris sat crebre subtiliter punctatis, punctis majoribus subseriatis. - Long. 3-4,2 mm. Mas: elytris nitidis, tarsis anterioribus articulo primo valde dilatato. Femina: elytris alutaceis, sericeo-micantibus, lineis elevatis nonnullis. Letzner, Uebersicht Arb. Schles. Gesellsch. 1846. 82. - Bach. Käferf. ПII. 162. - Ku tsch. Wien, Monat. 1864. 438 (408). - All. Mon. 424. - Redtb. Faun. A. II. 517. - Seidl. Fn. balt. ed. 2. 724 ; Fn. transs. 815.

Dibol. punctillata Foudr. Mon. 84.

Dunkel bräunlich, seltener grünlich broncefarben, Fühler und Beine, ausgenommen die Hinterschenkel, hell rostroth, die obere Hälfte der Fühler und die Hinterschienen zuweilen angedunkelt. Scheitel dicht, Stirn sparsamer sehr fein punktirt, mit noch feineren Punkten und kurzen Runzeln in den Zwischenräumen; Stirnporen näher der Fühlerwurzel eingestochen als bei den ähnlichen Arten, meist durch einen seichten Quereindruck verbunden, die Höckerchen durch eine scharfe Rinne getrennt. Nasenkiel breit, wenig gewölbt, oben in der Regel ohne Rinne neben der Fühlerwurzel. Halssch. glänzend, dicht und fein punktirt, in den Zwischenräumen punktirt, runzelig, selten glatt, an den Seiten gerundet, der Wulst in den Vorderecken kurz und breit, dreieckig, die Borstenpore weit nach innen gerückt und fast eben so weit vom Seiten-, wie vom Vorderrande abstehend. Fld. fein und ziemlich dicht punktirt, die Punkte entweder wenig in der Grösse verschieden, verworren, oder ungleich, dann treten die grösseren zu 9, mehr oder weniger in die Augen fallenden Reihen zusammen. 
of Fld. molentlich gewirkt, glänzend. arstes Tarsenglied an den Vorlerterinen schr stark, an den Yittelbeinen etwas schwicher erweitert. - Penis vorn allnälilich in eine scharfe Spitze verenet, die Seiten in rler vorderen IIälfte fein kömig junktirt und grerunzelt.

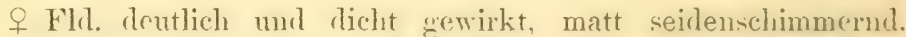
die Streifen zwischen den rertieften Punktreihen namentlich nahe der Naht gewölbt.

Auf den Wurzelb]ättern von Salvia-Arten, hesonders an s. pratensis L. rom Juli ab im ganzen Gelicte zicmlich häufig. Ueher Suideuropa und den grössten Theil ron Mitteleuropa verbreitet.

2. Dih. femoratis: Nigra, suma obscure iridi-aenea, interdum coevulescens, sat nitida, antennis apicem versus infuscatis pedibu:que ferrugineis, femoribus posticis aeneo-nigris, ano ferrugineo limbato; carina faciali sat angusta, convexa, foreis frontalibus antennarum basi longe separatis, prothorace angulis anticis angaste callosis elytrisque fortiter. punctatis. - Long. 3-4,2 $\mathrm{mm}$.

Mas: Articulo primo tarsorum anteriorum dilatato.

Redt b. Faum. A. 540; ed. 3. II. 516. - Bach, Käferf. III. 161. -

K utsch. Wien. Jionat. 1864. 434 (404). - Foudr 3Ion. 83. All. Mon. 420. - Leesb. Tijdschr. 24, 188. - Seidl. Fn. transs. 815 .

Haltica aerata Dalm. Analecta ent. 81.

Var, a. Femoribus anterioribus plus minusve infuscatis.

Var. b. Punctis elytrorum hine inde seriatis.

Dib. aurichalcea Först. Verhandl. nat. Ver. Rheinl. 1849, 1. Nachtr. 37.

Var.c. peregrina: Supra fusco-vel nigro-aenea.

Durch Stirn- und Halsschildbildung von der vorigen sehr verschieden. Unten schwarz, mur der After gewöhnlich roth gesäumt, oben dunkel metallisch grün, zuweilen nach blau hinïberspielend, dicht und stark punktirt, mässig glänzend, die Fubler (nach der Spitze angedunkelt) und Beine hell rostroth, Hinterschenkel schwarz metallisch. Stirn bald dicht, bald spärlich punktirt, Poren weit rou der Fühlerwurzel entfernt, in der Regel trei, Hückerchen undeutlich begrenzt und getrennt. Nasenkiel oben schmal. dachförmig: durch eine Rinne jederseits ron der Leiste um die Fiihlerwurzel geschieden. Halssch, in ien Vorderecken mit sclmalem und langem Wulste, auf dem die Borstenpore nahe dem Seitenrande eingestochen ist. Fld. in den Zwischemräumen glatt, mit einzelnen ieinen Punkten, bei beiden Geschlechtern durch den Glanz kaum zu unterscheiden.

$\hat{o}$ Erstes Tarsenglied der vorderen Beine mässjg erweitert. 
wenig. breiter als das dritte Glied. - Penis schlank, glatt, vorn allmählich zugespitzt.

Iäutig sind die vorderen Schenkel in rler Mitte gebräunt, seltener bis in die Nähe der Spitze geschwinzt (Var. a), oder die Punkte auf' den Fld. sind in Reihen geordnct, zwischen denen man beim of sogar einzelne leicht erhabene $/ /$ wischenstreifen antrifft (Var. b.), endlich kamn die Oberseite bram-broncefarben, älnnlich wio bei 1). Schillingi, oder schwarz werden mit metallischem Schimmer (Var, c).

In Gebirgsgegenden anf Salvia pratensis, silvestris T. und austriaca Jacq. stellenweise: am Rheine, Harz, Thüringen, Baiern, Oesterreich, Suideuropa, Nordafrika.

Zweite Gruppe: Imnenrand der Hinterschienen am Ende schnell zu einem scharfen Zahne ansteigend, Metatarsus nur dicht an der Basis kahl.

a. Seitenrand der Fiihlerfurche lang, wenig gebogen.

3. Dib. timida: ') Oblonga, convexiuscula, obscure brunneo-vel cupreoaurichalcea, subtus nigra, antennarum basi, genubus, tibiarum apice tarsisque ferrugineis; fronte vage ruguloso-punctulata, tuberculis pro-

1) In Oesterreich diirfte noch aufgefunden werden: Dib. orientalis: oblonga, convexiuscula, nigro-aenea vel obscure brunne-aurichalcea, nitida, subtus nigra, antennarum basi, tibiis tarsisque ferrugineis, plus minusve infuscatis; fronte subtiliter ruguloso-punctata, tuberculis sat discretis, prothorace brevi, crebre nugoso-punctato, antice rotundato-angustato, angulis anticis obtusiusculis, elytris subtilissime punctatis, punctis majoribus seriatis. - Long. 2,2-3mm. Hungaria mer., Turcia (Merkl), Syria: Haifa (Simon).

Variat u. Supra aeneo-viridis; b. cyanescens: Supra nigno-cyanea.

Durchscbnittlich kleiner als die täuschend ähnliche timida; die Rinne zwischen den Stirnporen und Höckerchen fein, das Halssch, kurz, an den Seiten, besonder's ror'n, gerundet, die Vorderecken klein, ziemlich stumpf, die Scheibe dicht runzelig punktirt. so dass die Zwischenräume kaum so gross als die Punkte selbst sind. Skulptur der Fld. bei beiden Geschlechteru gleich. Der Penis weicht nux dadurch ab, dass die Spitze nicht gradlinige, sondern in der oberen Hälfte sanft ausgeschweifte Seiten hat und rol'n etwas umgebogen ist. Die Ebene rer Unterscite verengt sich nach vorn fast allmählich aut einen Streifen, der jederseits zu einer scharfen Pandleiste ansteigt, neben welcher, nach aussen, eine grosse, lange und tiefe Grube liegt, an derselben Stelle, wo sich bei dem Peuis von timida die beulenförmige Verdicknng befindet.

Ich wiurde dies Thier füir D. phoenicia All. (Mon. 424) aus Syrien halten, wenn sie der Autor mit timida rerglichen hätte. 
funde disretis, jrothorace minus brexi, sat crelse subtiliter punctato, antrorsum sensim angustato, angulis anticis acutis, elytris subtilissime Junctatis, punctis majoribus seriatis. - Long. 2,5-3,5 mm.

Ias: elytris vage reticulatis, nitidis, articulo 1: o tarsorum anteriorum sat fortiter dilatato.

Femina: elytris alutaceis, leviter sericeo- micantibus.

Illig. Mag. VI. 71 et 172 (Haltica). - Foudr. Mon. 85 (Dib.). - All. Mon. 425. - Kutse h. Wien. Monat. 1864. 439 (409). Redtb. Faun. A. II. 517. - Se idl. Fn. transs. 815.

D. eryngii Bach, Käferf. III. 163.

Var. a. Supra obscure viridi-aenea.

Eine sehr schlanke, metallisch gefärbte Art mit dunklen Fühlern und Beinen. Lang-eiförmig, gewölbt, doch auf dem Riicken deutlich abgeflacht, braun erzfarbig, mitunter kupfrig, selbst metallisch grün (Var. a.), unten schwarz, die 4 bis 5 ersten Fühlerglieder, Kniee, Schienenspitzen und Tarsen dunkel rostroth, das erste Fühlerglied (oft auch die folgenden) auf der Oberseite angedunkelt. Stirn selir fein und verloschen punktirt und gerunzelt, die Höckerchen scharf geschieden und oben von einer tiefen, graden Querrinne begrenzt, welche die Poren verbindet. Halssch. verhältnissmässig lang, vor der Basis etwas gerundet, sodann fast gradlinig nach rorn verengt, die Vorderecken spitz vortretend; auf der Scheibe fein und wenig tief punktirt, die Zwischenräume viel grösser als die Punkte und äusserst verloschen punktulirt oder gewirkt, fast glatt, glänzend. Fld. bald eben so stark, bald feiner als das Halssch. punktirt; die Punkte ron ungleicher Grösse, die stärkeren in nicht ganz regelmässige Längsreihen geordnet, die feineren in den Zwischenstreifen. Vorderbrust vor den Hiiften länger und viel flacher als bei den iibrigen Arten.

ô Fld. glänzend, äusserst fein, aber sehr weitläufig netzartig gerunzelt, indem die geschlängelte Mittellinie jedes Zwischenstreifens durch Querlinien, eine zwischen je zwei Punkten einer Reihe, mit ben benachbarten verbunden ist. Das erste Tarsenglied der vorderen Beine ziemlich stark erweitert. - Penis dunkelbraun, rorn gradlinig in eine mässig lange, helle, etwas abgerundete Spitze rerengt; die Unterseite bildet an der Basis eine Ebene, welche sich bis zur Spitze hinzieht, aber von der Mitte ab durch eine beulenartige Verdickung der Seiten ungefähr auf die Hälfte der Breite verengt wird und im vorderen Viertel nur einen schmalen, mit einer Längsrinne versehenen Streifen bildet. Eine gebogene, vom Seitenrande schräg nach innen und rorn ziehende Rinne begrenzt die Verdickung in der hinteren Hälfte.

ㅇ Fld. äusserst dicht und fein gewirkt, etwas matt, seidenschimmernd. 
Auf Eryngium campestre I. in Berggegenden, von der Rheinprovinz bis Thüringen (nördlich noch bei Magdehurg, Hahn) und in Oesterreich weit verbreitet. Frankreich, Spanien, Algier.

4. Dib. Färsteri: Subovalis, convecta, nigra, nitida, femoribus apice et tibiis anterioribus tarsisque rufo-testaceis, fronte parce punctata foveis juxta marginem oculorum insculptis, prothorace sat dense punctato, clytris seriatim punctatis, interstitiis latis creberrime subtilissimeque punctulatis et parce subtiliter punctatis. Long. 2,8-3,5 $\mathrm{mm}$.

II as: tarsis anterioribus articulo primo leviter dilatato.

Bach, Käferf. III. 163. - All. Mon. 428. - Kutsch. Wien. Monat. 1864. 436. (406). - Red tb. Faum. A. II. 516. Leesb. Tijdschr. 24. 187. - Seidl. Faun. balt. ed. 2. 724; Faun. transs. 815.

D. buglossi Foudr. Mon. 86.

Var. a. Pedibus anterioribus testaceis, femoribus medio paullo infuscatis.

Var. b. Antennis apicem versus infuscatis.

Var. c. Capite prothoraceque leviter aurichalceo micantibus.

? Dib. Foudrasi Rey, Opuse. ent. 16. 15.

Durch die glänzend schwarze Oberseite, helle Fühler und Beine, die scharf begrenzten Punkte des Halssch. und die deutlich hervortretenden, von einander entfernten Punktreihen der Fld. ausgezeichnet, in Ganzen etwas plumper gebaut als die folgenden Arten.

Fast eiförmig, an den Seiten gleichmässig' gerundet und in der Mitte am breitesten (meist +), oder dicht hinter den Schultern am breitesten, ron hier bis zum letzten Viertel unmerklich verengt, mit ziemlich parallelen Seiten (meist $\hat{0}$ ), tiefsehwarz, glänzend, Kopf und Halssch. zuweilen messinggelb angehaucht (Var. c.), Fühler und Beine röthlich gelbbraun, an jenen ausnahmsweise die drei oder vier letzten Glieder angedunkelt (Var. h); an diesen die rier Vorderschenkel mit Ausnahme der Trochanteren und der Spitze, sowie die Hinterschenkel gänzlich schwarz, Hinterschienen pechbraun. Bei einzelnen, vielleicht frischen Exemplaren ist die Mitte der vorderen Schenkel nur schwach gebräunt (Var. a). Stirn weitläufig und sehr fein punktirt, diese Punkte um die Poren. welche dicht neben dem Rande der Augen liegen, fast kreisförmig: gestellt; Höckerchen schlecht begrenzt, Nasenkiel sehr schmai, scharf. Halssch. kurz, nach vorn mässig verengt, ziemlich dicht, an den Seiten stärker als in der Mitte punktirt, die Punkte kräftig, tief, scharf begrenzt, ihre Zwischenräume glatt, glänzend $(\widehat{o})$, oder äusserst fein und dicht punktulirt (f). Fld. mit 9 leicht bemerkbaren, rorn ziemlich starken, hinten abgeschwächten Punktreihen, ron denen die äusseren einander paarig genähert sind. Die Zwischen- 
streifen ainsurest dicht und fein punktulirt, funserdron mit einer Anzalıl rom Punkten verschen. welche kaum laalh so stark sind als die der Reihen und eine schr unregelnieissige Reihe bilden.

$\hat{j}$ Erstes Tarsenglierl an den vorleren beinen fast so loreit als das dritte. - Jenis dick, bein Beainn der langen ()efnung am loreitesten, hierauf grallinig und schwach verengt, zuletzt plötzlich in eine breit dreieckige slitze verschmälert. Auf der Lnterseite hemerkt man einen muldenförmigen Mittelstreifen, welcher im rorderen Theile eine feine Mittelleiste besitzt und durch die scharfkantigen, sanft nach innen gebrgenen Ränder in der Mitte merklich eingeengt ist. Auf jeder Seite desselben liegt ein lanzettlicher, ausgehöhlter Seitenstreifen.

In den Berggegenden') Mitteleuropa's zerstreut. Von Schlesien durch Thüringen bis zum Rheine und nach Frankreich, sowie in den Alpenländern und durch Ungarn, Transsylranien bis zum Balkan rerbreitet. H. Gerhardt fand das Thier auf Betonica officinalis L.

5. Dib. depressiuscula: Suboculis, convexiusculu aut conrece, nigra, antennarum et tiliarum basi tarsisque ferrugineis, fronte rugulosopunctulata, foveis margine oculonum sat longe separatis, prothorace sat crebre ruguloso-punctato, elytris substriatim punctatis, interstitiis angustis subtilissime reticulatis. - Long. 2,3-3,5 $\mathrm{mm}$.

Mas: elytris nitidis, articulo primo tarsorum anteriorum sat dialato.

Femina: elytris leviter sericeo-micantibus.

Letzner, Uebersicht Arb. Schles. Ges. 1846. 83. - Bach, Käferf. III. 163. - A 1l. Mon. 429. - Kutsch. Wien. Monat. 1864. 437 (407). - Redtb. Faun. A. II. 516. - Seidl. F. balt. ed. $2.724 ;$ F. transs. 815 .

D. laevicollis Foudr. Mon. 89 .

V ar. a. Prothorace creberrime ruguloso-punctato, interstitiis punctulatis.

$\mathrm{V}$ ar. b. Prothorace vage punctulato, fere laevi.

Var. c. Elytris cvidenter reticulatis, punctis minutissimis seriatis.

Var. d. Antennis, femoribus apice et tibiis anterioribus, tibiis posticis in basi tarsisque rufo-testaceis, elytris seriatim punctatis, interstitiis latis subtiliter punctatis, vix reticulatis.

Var. e. Capite prothoraceque leviter aurichalceo micantibus.

Var. f. Antennarum articulo primo piceo.

1) Die Angabe, dass die Art in der Ebene, z. B. noch bei Berlin rorkommen soll, beruht wohl anf einer Verwechselung mit depressiuscula. Ob huglossi Foudr, wirklich zu unserer Art gehört, lässt sich, da der Penis undeutlich beschrieben ist, nicht meln? feststellen. Jedenfalls ist mir ein unvollkommen gefligeltes Stück noch nicht zu Gesicht gekommen. 
Die zweite schwarze Art, an den selu dunklen Füblen nund Beinen zu erkennen, aber in den Varietiten leicht mit dex vorigen und dunklen stioken der folgenden zu verwechseln.

Ziemlich eitörmig, rorn in der Regel mehr verengt als Fürsteri. schwarz, ziemlich glïnzend, die ersten 5 orler 6 fühlerghoder, die äusserste Basis der Sichienen und die Tarsen rostroth. Stirn fein und seicht punktulirt, gewöhnlich lïngsrumzelig, die Poren weiter als un ihren 1)urchmesser rom Augenrande entfernt, Höekerehen schlecht begrenzt, Nasenkiel schmal und ziemlich seharf. Halsseh. nach vorn stark verengt, zicmlich dicht punktirt, die Punkte fein, wenig tief, etwas in die Länge g'ezogen, ihre Zwischenräume äusserst fein längsrunzelig, beim $q$ in diesen Runzeln oft noch dicht punktulirt. Fld. mit zahlreichen mässig feinen Punktreihen besetzt, ron denen die 9 Hauptreihen zwar fast regelmässig sind, sich aber aus den nur wenig feineren Punkten in den Zwischenstreifen schlecht abhoben.

ô Erstes Tarsenglied an den vorderen Beinen so breit als das dritte Glied. - Penis von gleicher Breite, vorn gerundet-vereng't und in eine kleine, etwas abgesetzte scharfe Spitze ausgezogen. Auf der Unterseite befindet sich ein sehr sanft ausgehöhlter Mittelstreifen, der durch die etwas kantigen, stark nach innen gebogenen Ränder in der Mitte bedeutend verengt wird. Jederseits davon liegt ein lanzettlicher, flacher Seitenstreifen.

Skulptur und Farbe variiren erheblich:

a. Das Halsseh. ist dicht und kräftig runzelig punktirt wie bei der in Norddeutschland vorherrschenden Form von rugulosa, in den Zwischenräumen dicht punktulirt.

b. Halssch. fast glatt, sehr weitläufig, seicht und fein punktirt, die Zwischenräume spiegelnd.

c. Fld. dicht und sehr deutlich maschig gerunzelt, mit äusserst feinen Punktreihen, deren Punkte kaum stärker sind als die Runzeln.

d. Fühler röthlich gelbbraun, ebenso die Spitze der Schenkel und die Schienen an den 4 Vorderbeinen nebst allen Tarsen; die Basis der Hinterschienen dunkler, mehr rothbraun. Diese Varietät wird dex 1). Försteri schr ähnlich, wenn das Halssch. kräftig punktirt ist und die Hauptreihen der Punkte auf den Fld. sich ron den Nebenreihen deutlich abheben.

e. Kopf und Halssch. mit metallischem Anfluge.

f. Sehr oft ist das erste Fiihlerglied pechschwarz, wie bei occultans, an der Spitze röthlich.

Au sonnigen Hecken auf Ballota nigra L. in ganz Deutsch- 
land und Oesterreich. Von Frankreich bis an die Wrolga ausgebreitet.

6. Dib. rugulosa: Oblongo-ovalis, convexiuscula aut convexa, aenea, antennis (apicem versus infuscatis) genubus, tibiis trusisque rufo-testaceis, tibiis posticis fuscis, fronte rugoso-punctulatu, linea transtersa obsoleta, carina faciali sat lata, prothorace subtiliter punctato, nitido, lateribus paullo rotundatis, angulis anticis evidenter callosis, acutiusculis, elytris creberrime reticulatis, punctis minutissimis seriatis, sericeomicantibus. - Long. 2,5-3,5 $\mathrm{mm}$.

Redtb. Faun. A. 541; ed. 3. II. 517. - Bach, Käferf. III. 161. - Foudr. Mon. 87. - All. Mon. 421. - Kutsch. Wien. Monat. 1864. 440 (410). - Leesb. Tijdschr. 24. 188. -- Seidl. F. balt. ed. 2724 ; F. transs. 816.

Var. a. Tibiis posticis testaceis.

Var. b. Antennarum articulo primo infuscato.

Var. c. Prothorace confertim ruguloso- punctato, subopaco.

Var. d. Prothorace sat dense profundeque punctato, interstitiis subpolitis.

$\mathrm{V}$ ar. e. Elytris evidenter seriatim punctatis, vage reticulatis, sat nitidis.

Var. f. Elytris substriato-punctatis, interstitiis convexiusculis.

Länglich-eiförmig, mehr oder weniger gewölbt, dunkel grünlichmessingfarben, ungefähr wie Schillingi gefärbt, die Fühler mit Ausnahme der gebräunten Endglieder, die Spitze der vier Vorderschenkel, die Schienen und Tarsen röthlich gelbbraun oder rostroth, Hinterschienen dunkel rothbraun. Stirn ziemlich glatt, oder sehr fein runzelig punktirt, die Poren weiter als um ihren Durchmesser vom Rande der Augen entfernt, bald frei, bald durch eine gerade oder bogige Querlinie verbunden, welche die Höckerchen in der Regel schlecht absetzt; Nasenkiel breit und stumpf, im oberen Theile eben und meist ohne Rinne neben der Fühlerwurzel. Halssch. glänzend, sehr fein punktirt, in den $\mathrm{Z}$ wischemräunen verloschen punktulirt, an den Seiten wenig gerundet, der Tulst in den etwas vorgezogenen und zugespitzten Vorderecken lang, dreieckig. Fld. äusserst dicht und fein netzförmig gerunzelt, seidenglänzend, mit gereihten Punkten, welche wenig stärker sind als die Runzeln und deshalb nur undeutlich hervortreten.

$\hat{o}$ Fld. weitlänfiger und schwächer gerunzelt als beim $q$, glänzender, das erste Tarsenglied der vorderen Beine fast so breit als das dritte Glied. - Penis ziemlich schlank, an den Seiten parallel, vorn allmählich gerundet-verengt und in eine kurze, jederseits durch einen sanften Bogen abgesetzte Spitze verlängert. Die Unterseite hat einen schmalen Mittelstreifen, welcher sich nach der Basis und Spitze hin stark erweitert und vertieft und im mittlereu Theile jederseits von einer grossen und sehr tiefen länglichen Grube begrenzt ist. 
Die metallische Färbung der Oberseite ist ziemlich beständig, kann aber zuweilen durch Abnahme der messinggelben Beimischung auf den Fld. so sehr verdunkelt werden, dass sie zur Unterscheidung vou depressiuscula kaum mehr brauchhar ist. In einzelnen Fällen sind die Hinterschienen eben so hell wie die Vorderschienen (Var. a), oder die Fühler durchgehends sehr dunkel gefarirbt, ihr erstes Glied mehr oder weniger schwärzlich (Var. b).

Bei der Betrachtung der Skulptur ergeben sich folgende Abänderungen:

c. Halssch, matt, sehr dicht punktirt, die Punkte durch Längsrunzeln verbunden, in den Zwischenräumen zahlreiche Pünktchen, ebenfalls durch Runzeln zusammenhängend;

d. Halssch. wie bei cynoglossi mässig dicht und stark, besonders tief punktirt, die Zwischenräume fast glatt;

e. Fld. glänzend, verloschen netzartig gerunzelt, mit deutlich heraustretenden Punktreihen;

f. Fld. in vertieften Reihen punktirt, deren Zwischenstreifen sanft gewölbt sind.

An warmen, nach Süden geneigten Abhängen auf Stachys recta L. in Deutschland, Oesterreich und in Mitteleuropa stellenweise sehr häufig.

7. Dib. cynoglossi: Oblongo-ovalis, convexiuscula, nigro-aenea, nitida, antennis (apicem versus infuscatis), genubus, tibiis tarsisque rufo-testaceis, tibiis posticis fuscis, fronte ruguloso-punctulato, linea transversa obsoleta, carina faciali angusta, prothorace sat dense punctato, lateribus rotundatis, angulis anticis minime callosis, obtusiusculis, elytris subseriatim punctatis, interstitiis vage reticulatis, parce subtiliter punctatis. Long. $2,8-3,2 \mathrm{~mm}$.

Halt. cynoglossi Koch, Ent. Hft. II. 20. t. 2, f. 2. - Ill. Mag. VI. 172. - Duft. Faun. A. III. 283. - R edtb. Faun. A.II. 517 (Dibol.). - B a ch, Käferf. III. 162. - Foudr. Mon. 91. - All. Mon. 427. - Kuts ch. Wien. Monat. 1864. 441 (411). - Leesb. Tijdschr. 24. 187 - Seidl. F. balt. ed. 2. $724 ;$ F. transs. 816.

Der vorigen äusserst ähnlich, oberseits stets glänzend, grünlich schwarz, mit geringem Messingschimmer, der Nasenkiel schmal und scharf, das Halssch. an den Seiten stark gerundet, mit sehr kleinem und schmalem Wulst in den stumpfen Vorderecken, auf der Scheibe ziemlich dicht, kräftig punktirt, in den Zwischenräumen glatt oder fein gerunzelt. Fld. in ziemlich deutlichen Reihen punktirt, deren Punkte vorn nur wenig feiner als die des Halssch., hinter der Mitte abgeschwächt sind, Zwischenstreifen breit, weitläufig und flach 
netyfirmingerunzelt und mit Punkten hesetzt, die etwas kleinen sind als die der Reihen.

ù Erstes Tarsenglied drer vorteren Beine ziemlich so hreit als das dritte Glied. - Penis dem ron depressiustula sehr ähnlich, kurz, nach der spitze hin kaum merklich verbreitert, wrom schnell gerundet-rerengt, zu einer äusserst kurzen. stumpfen und breiten. wenig deutlichen Spitze in der Mitte des Vorderrandes alisgragenen. Auf der Lnterseite befindet sich ein fast ebener, in der. Mitte leicht rerengter Mittelstreifen, welcher jederseits steil zu den lanzettlichen Seitenstreifen abfällt.

Auf Cynoglossum officinale L. in Berggegenden Mitteleuropa's sehr zerstreut.

b. Seitenrand der Fühlerfurche kurz, gebogen.

8. Dib. occultans: Oblongo-ovalis, convexiuscula, nigra, nitidula, capite prothoraceque aeneo-micantibus, antennarum basi (articulo primo excepto) tarisque obscure ferrugineis; carina faciali angusta antice triangulariter excisa, prothorace crebre punctato, elytris confertim subseriatim punctatis. - Long. 2-2,8 mm.

Halt. occultans Koch, Ent. Hft. II. 23. t. 2. f. 4. - Ill. Mag. VI. 71 et. 171. - Gyllh. In. Suec. III. 572. - Redtb. Faun. A. II. 516 (Dibolia). - Bach, Käferf. III. 163. Foudr. Mon. 88, - All. Mon. 430. - Kutsch. Wien. Monat. 1864. 435 (405). - Thoms. Skand. Col. VIII. 211. - Leesb. Tijdschr. 24. 188. t. 16. f. 3. - Seidl. F. balt. ed. 2. 724 ; transs. 815.

Var. a. Antennis ferrugineis, apice vix infuscatis, articulo primo basi brunneo.

Var. b. Antennis omnino nigro-piceis.

Var. c. Elytris leviter aeneo-micantibus.

An der dichten und ziemlich starken Punktirung auf den schwarzen Fld., sehr dunklen Fühlern und Beinen und an der Form des Nasenkieles leicht zu erkennen. Länglich-eiförmig, mässig gewölbt, schwarz, ziemlich glänzend, Kopf und Halssch. erzfarbig, die Spitze des ersten Fühlergliedes nebst den drei folgenden Gliedern rostroth, das Kniegelenk der Beine und die Tarsen oft röthlich. Stirn zerstreut punktulirt, mit schlecht begrenzten Höckerchen. Nasenkiel schmal, scharf, vorn breit dreieckig ansgerandet. Halssch. nach vorn verengt und zusammengedriickt, der Trulst in den Vorderecken klein, schmal, Scheibe mässig dicht und stark punktirt. Fld. in den mittleren zwei Dritteln fast parallel, dicht mit kräftigen I'unktreihen besetzt, von denen die neun Hauptreihen fast regel- 
mïssig sind. aber ans den glejelyosisen orler wong kleineron P'unkten der /wischenstreiten wenis herrorstechen.

$\hat{o}$ Erstes 'I'arsenglied an den vorderen Drinen grö̈sser und breiter als das dritte Glied. - Penis neben dex (heffmmg jederseits sanft ausgeschweift, vorn fast gradlinig verengt.

Die Art variirt nur wenig:

a. Fibler hell rostroth, nach der Śpitze unbedeutend dunkler, das erste Clied an der Basis leicht gebräunt. Vorherrschend im südlichen Europa.

b. Fiihler pechschwarz, das zweite bis vierte Glied kaum heller als die ibrigen.

c. Fld. mit erzfarbigem Anfluge.

Auf feuchten, fruchtbaren Wiesen und an grasigen Flussufern, vielleicht an Mentha-Arten oder Lanium album, nicht selten. Von Spanien und Griechenland bis England und Südschweden verbreitet.

9. Dib. cryptocephala: Oblongo-ovalis, convexa, renea, nitidula, antennis, tibiis tarsisque testaceis, fronte obsolete punctulata, tuberculis bene discretis, prothorace elytrisque sat crebre subtiliter et vage punctatis.

- Long. 1,8-2,5 $\mathrm{mm}$.

Halt. cryptocephala Koch, Ent. Hft. II. 22. t. 2. f. 3. - Ill. Nag. VI. 171. - Redtb. Faun. A. II. 517 (Dibolia). Bach, Käferf. III. 162. - Foudr. Mon. 92. - All. Mon. 423. - Kutseh. Wien. Monat. 1864. 442 (412), - Seidl. F. balt. $724 ;$ F. transs. 816 .

Var. a. Antennis apice tibiisque plus mimusve infuscatis.

Var. b. Prothorace subtilissime punctato, elytris evidenter seriatim punctatis, interstitiis latis, subtilius subseriatim punctatis.

Unsere kleinste Art; metalliseh griun oder bronzefarbig, bald mehr, bald weniger glänzend, Fühler, Schienen und Tarsen röthlich gelbbraun, die Hinterschienen oft angedunkelt. Stirn fein punktirt, die Poren durch eine gerade Querturche verbunden, welche die Höckerchen deutlich begrenzt, Nasenkiel ziemlich schmal, vorn grade abgestutzt. Halssch. an den Seiten gerundet, mit sehr kleinem Wulste in den Vorderecken; auf der Scheibe ziemlich dicht, fein und seicht punktirt. Fld, in den Schultern nur so breit wie das Halssch, und ohne Beule, dahinter sanft gerundet, wenig stärker als das Halssch. punktirt, die Punkte in der rorderen Hälfte theilweise gereiht.

ô Erstes Tarsenglied an den vorderen Beinen grösser und etwas breiter als das dritte Glied. - Penis sehr einfach gebaut, stark gebogen, rorn gerundet-zugespitzt, miten schwach queriiber gewölbt und auf cinem Iängsstreiten in der Mitte flach gedrückt. Zuweilen sind die Fühler an der Spitze nebst den vorderen VI. 6. 
Schienen angerlunkelt (Var. a) orler das Halssch. ist änssent fein

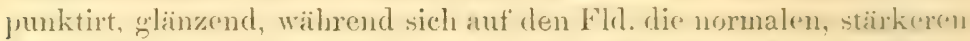
J'unktreihen aus den feinen, gereihten Prunkten der Zwisclucnstreifen deutlich herausheben.

Auf sommigen Abhängen in Nittel- und süddeutschland und Oesterreich nicht selten, in Norddeutschland bei Danzig ('zwalina). Frankreich, Russland. Nach Kutschera auf Adonis vernalis I.

\section{Apteropeda.}

Cheorolat, D'Orbign. Dict. Hist. nat. II. 1842 p. 43.

Acetabula antica aperta.

Corpus subhemisphacricum vel ellipticum, apterum, surra pitis vitr perspicuis parce vestitum.

Prosternum processu labiali instructum; mesosternum occultum.

Tibiae breivusculae, posticae dorso deplanato rel subcanalicululn, apice calcari brevi, crassiusculo instructae, unguiculi mutici.

Körper fast halbkugelig oder elliptisch, ungeflügelt, mehr oder weniger metallisch gefärbt, glänzend, oben mit äusserst kurzen und teinen, kaum bemerkbaren Härchen sparsam besetzt, unten zerstreut behaart. Kopf geneigt, klein, mit gewölbten, grob facettirten Augen, welche die Stim nach unten einengen. Hier liegen dicht über dem leistenartigen Rande der Fiihlerpfammen die grossen und glatten, queren Stimhöcker, welche durch eine Mittelrimne getrennt und oben von einer graden Rime begrenzt werden. Tasenkiel kurz, unten in die hohen Kanten des quer dreieckigen Koptschildes übergehend; Oberlippe breit, rorn gerundet-ahgestutzt, oder sanf't ausgeschweift. Fühler kräftig, nach aussen schwach rerdickt, namentlich die 5 letzten Glieder. Halssch. kurz, gewölbt. nach rorn verschmälert, punktirt, die Borsteuporen gross. mit langen Borsten, die vordere steht in oder hinter dem ersten Drittel nelen der stark aufgebogenen Kante des Seitenrandes, die andere in den Hinterecken. Flïgeldecken regehnässig punktirt-gestreift. in den Zwischenstreifen punktulirt. Vorderbrust rorn gewölbt, mit einem kurzen und breiten Fortsatze zur Aufnahme des Mundes, Prosternum zwischen den Hiiften der Länge nach vertieft. am Ende alogestutzt oder ansgeschweift, die Vorderhüften linten offen. Hinterbrust kurz, in einen breiten Zipfel zwischen die Mittelhiiften vorgezogen. welcher das Prosternum beriihrt und das Mesosternum rerdeckt. Seitenstücke dureh dicke Nähte begrenzt. Bauch ziemlich dachförmig. Beine kräftig, IIinterschenkel stark rerdickt. Hinterschienen mit kräftigem Enddorne, auf dem Rüicken abgeschrägt, eben oder 
leicht rinnenförmig, die äussere Kante hïher als die innere und mit Zähnchen bewehrt. Tarsen an der Spitze der Schienen eingeftigt, das crste Glied so lang als die folgenden zusammen, Klauen einfach.

Das Männehen erkemnt man an dem erweiterten ersten Tarsengliede der Vorderbeine, dem in der Mitte abgestutzten Hinterrande des letzten Bauchringes, ausserdem noch bei einer Art an den Hinterschienen, bei einer andern an einem Eindrucke des Aftersegmentes. Der Penis besteht aus einer verschieden gestalteten Röhre.

Unsere drei einheimischen Arten sind ziemlich träge Thiere, leben an Pflanzen auf fenchten Grasplätzen sehattiger Berg- und Gebirgswïlder und sind im Juli entwickelt. Sic lassen sich am Bau der Stirn und der Vorderbrust sicher erkeunen, von der einzigen habituell ähnlichen Gattung Iypnophila dureh die fehlenden Basalstrichelchen des Halsschildes auf den ersten Blick unterscheiden. Die Larven von orbiculata miniren nach Kaltenbach (Pflanzenfeinde 373) die Blätter von Plantago-, Digitalis-, und Teucrium-Arten; sie ähneln in der Gestalt denen von Sphaeroderma testaceum F.

1. Augenrinne seicht, Augen etwa um ihren Längsdurchmesser von einander getrennt, Stirn breit, ziemlich flach, Aussenrand der Hinterschienen äusserst fein gezähnelt, $\hat{\sigma}$ Mitte des letzten Bauchringes mit einer grossen, glatten, unebenen Grube, deren Seiten verdickt und länger behaart sind. - L. 2,5-3 $\mathrm{mm}$. Alpen, Pyrenäen, Hamburg . . . . . splendida All.

11. Augenrinne tief, Augen kaum um die Hälfte ihres Längsdurchmessers von einander getrennt, Stirn schmal, ziemlich gewölbt, Aussenrand der Hinterschienen in der Regel deutlich gezähnelt . . . . . . . . . . . . . . . . . . 2.

2. Körper gestreckt, lang elliptisch, oben dunkel, mit grünlichem oder bräimlichem Bronceschimmer, Enddorn der Hinterschienen lang und stark. -- L. 3,5 mm. Portugal. (Mag. VI. 65).

ovulum Illig.

2. Körper ziemlich halbkugelig, Enddorn der Hinterschienen kurz 3.

3. Vorderecken des Halssch. abgerundet; schwarz, mit schwachem grünen oder blanen Metallschimmer. ô Untere Kante der Hinterschienen winkelig gebogen. - L. 2,7-3,5 mm. Gebirgsländer Mitteleuropa's . . . . . . globosa Illig. $3^{1}$. Vorderecken des Halssch. spitz, rorgezogen. Grün, riolett, blau, messingfarben. - I. 2,5-3 mm. Bergläuder Mitteleuropa's. orbiculata Marsh.

A. Stim schmal, Augen gross, ihre Facetten in 10-12 Schrïgreihen geordnet. 
1. Apt. globosa: Nigro-aenea, ore, antemnis pedibustue ferrugine is, femoribus posticis aener-nigris, lineis fronlalibus fere aequaliter immessis, prothorace angulis anticis subrotumdatis, i.s. prominulis, elytris strirto-punctatis interstitis leriter conrecis, punctulatis. - Iong. 2, bis $3,5 \mathrm{~mm}$.

Mas: tibiis posticis inferne angulatis, obsolete denticulatis, segmentos 5: 0 ventrali depressione lata nitida instructo.

Haltica globosa Illig. Schneid. Neu. Mag. I. 1794. 602. Panz. Faun. germ. 25. 13. - Steph. Ill. Brit. IV. 329; Man. 303 (Sinhueroderma). - A 1l. Mon. 292 (Apterop.). -- Kutsch. Wien. IIonat. 1864. 451 (421), - Redtb. Faun. A. ed. 3. II 518. - Leesb. Tijdschr. 25. 155. t. 11. f. 8. - Seidl. F. transs. 816. - W s. D. Z. 1883. 253.

Halt. conglomerata I1l. Mag. VI. 164. Küst. Käf. Eur. 28. 99 (Apterop.). - Bach. Käferf. III. 165.

Halt. globus Duft. Faun. A. III. 288.

Apterop. majuscula Foudr. Mon. 281.

A pt. nigro-aenea We id en b. Bericht Naturf. T'ers. A ugsluurg 1859. 85. $\mathrm{V}$ ar. a. Supra nigro-coerulea.

Halbkugelig; aber nach vorn und hinten allmählich stark verschmälert und etwas zugespitzt, sehr dunkel metallisch griu, zuweilen schwarzblau (Var. a), stark glänzend, \und, Fühler und Beine mit Ausnahme der Hinterschenkel rostroth. Stirn dicht punktirt, Höckerschen durch eine Rime getrennt, die feiner oder höchstens so stark ist als die Querrinne über ihmen, Nasenkiel zwischen den Fuihlern breit, darunter sehr schmal und scharf. Fünftes Fühlerglied merklich länger als die benachbarten. Halssch. nach vorn rerengt und zusammengedrückt, bald mässig dicht, fein punktirt, glänzend, bald dicht und kräftig punktirt, matt, in den Zwischenräumen mehr oder weniger deutlich gewirkt, an den Seiten schwach gerundet, die Vorderecken breit und stumpf, sehr wenig vortretend. Fld. in verïnderlicher Stärke punktirt-gestreift, Punkte an der Spitze rerworren, Zwischenstreifen fast glatt oder neitlïnfig. und fein punktirt. Hinterschienen am Aussemrande in der Regcel kräftig gezähnelt.

Beim $\hat{\sigma}$ ist der untere Rand der Hinterschienen in der Mitte winkelig gekrümmt und in einen Zahn rorgezogen. hinter dem sich, auf die Spitze zu, eine Reihe sehr kleiner Doppelzähnchen befindet; die Nitte des letzten Banchringes ist flach gedriickt, rereinzelt punktirt, glänzend. - Penis kurz und ziemlich dick, wenig gebogen, am Beginn der Oeffnung erweitert, hierauf fast gleichbreit his zum Vorderrande. welcher gerundet-alogestutzt ist und in seiner Nitte eine kleine Spitze trägt. Die Cnterseite ist mässig tief ausgrebiihlt, the Oberseite ist ror der Mitte abschiissig und bildet dort 


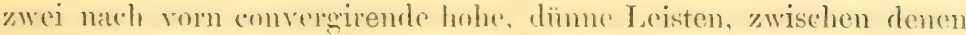
sich die milssig enosse ()effumog für den ductus, dawor eine hreite

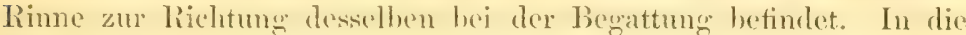
Oeftinung ragt von oben ein vorn ausgerandeter Katpfen hinein.

Auf schattigen, fenchten (irasplätzen in den Berggegenden Deutschlands und ()esterreichs, sowie Mitteleuropa's nicht selten.

2. Apt. osbiculata: Viridi-ueneu, antennis pedibusque (femorilus posticis exceptis) rufo-testaceis aut brumeo-rufis, tuherculis frontalibus linea profundn separatis, mothorace angulis anticis acutis, jrominulis, clytris sat fortiter striato-punctatis interstitiis evidenter punctulatis. Long 2,5-3 $\mathrm{mm}$.

IIas: tibiis posticis inferne leviter rotundato-dilatatis.

Chrypsomela orbiculata Marsh. Ent. Brit. I. (1802) 200. Foudr. Mon. 279 (Apterop.). - Kutsch. Wien. Mon. 1864. 449. (419), - Redtb. Faun. A. II. 517. - Leesb. Tijdschr. 25. 155. - Seidl. F. transs. 816.

Sphaeroderma orbiculatum Steph. Ill. Brit. IV. 329; Man. 302. Haltica graminis Koch Ent. Heft. 2. (1803) 47. - Duft. Faum. A. III. 288.

Altica ciliata 0l. (1808) Ent. V. 710. t.4. f. 76. - Bach, Käferf. III. 165 (Apterop.). - All. Mon. 291.

Halt. hederae Illig. Mag. VI. 164 (1807).

Var.a. Elytris subtiliter obsoleteque striato-punctatis.

Var. b. aurichalcea: Supra brunneo-vel cupreo-aurichalcea.

Var.c. coerulans: Supra saturate coerulea aut violacea.

Kleiner und schlanker, beiderseits weniger verengt, immer lebhafter gefärbt als die vorige, breit-eiförmig, lebhaft metallisch griun, stark glänzend, unten dunkler, oft schwarz; Fïhler und Beine röthlich gelbbraun bis rothbraun, dic Spitze der Filhler und die vier Torderschenkel oft angedunkelt, die Hinterschenkel ähnlich der Oberseite gefärbt. Stim dicht und kräftig punktirt, Höckcrehen durch eine Rimme getrennt, die breiter und tiefer ist als die Querrinne ïber ihnen, Nasenkiel nach unten allmählich verengt und kaum scharf hegrenzt; 5. Fiilılerglied ummerklich länger als die einschliessenden. Halssch. nach voru gerundet-verengt, weitläutig und fein, oder dicht und kräftig punktirt, in den Zwischenräumen meist gewirkt, die Vorderecken spitzwinkelig, rorgezogen, die Rimne, welche sie von der Scheibe soudert, sehr breit und tief. Fld. stark gestreift-punktirt, in den /wischenstreifen moist deutlicher als bei der vorigen punktulirt. Hinterschienen am Aussenrande fein gezähnelt, selten fast glatt

ô. Hinterschienen in dor Spitzenhälfte etwas erweitert und am unteren Rande stärker gelongen wie heim q. - Penis ziemlich 
schlank, flach, gelogen, nach worn alhmählich, äusserst schwarl, verengt, an Ente plätzlich und schmell verschmälert, in eine kurze. abgerundete Spitze auslaufend.

Zuweilen werden die Punktreihen auf den Fld. sehr fein und helen sich ron der Punktirung der Zwischenstreifen wenig al, (Var.a); die F'arbe der Oberseite rerëindert sich in messingrelb, nach braun oder kufferroth himneigend (Var. b), oder in ein gesättigtes Blau oder Violett.

Häufig auf schattigen feuchten Grasplätzen in Wäldern der Berggegenden Mitteleuropas.

B. Stim breit, Augen mässig gross, ihre Facetten in 8 Schrägyreihen gestellt.

3. Apt. splendida: Nigra, obsolete coeruleorel cividi-coeruleo micans, antennis pedibusque (femoribus posticis exceptis) testaceis, rufis, aut brunneis, tuberculis frontalibus linea profundu separatis, prothorace angulis anticis coutiusculis, parum prominulis, elytris striato-punctatis, tibiis posticis vage denticulatis. - Long. $2,5-3 \mathrm{~mm}$.

Mas: segmento ultimo ventrali longitudinaliter late: minus profunde impresso, lateribus impressionis subcallosis et pilosis.

All. JIon. 292, - Kutsch. Wien. IIon. 1864. 452 (422), Redtb. Faum. A. II. 517. - Seidl. Fn. transs. 816.

Apt. globosa Foudr. Mon. 278.

Apt. ciliata Redtb. Faun. A. ed. 1. 542; ed. 2, 950. - Küst. Käf. Eur. 28. 98.

Mit globosa in der Körperform, Skulptur und der dunklen Farbe mehr übereinstimmend wie mit der rorigen, von beiden durch den Bau der Stirn abweichend. Die Augen sind an der inneren Seite etwas verkleinert und es bildet sich ein grösserer, dreieckiger, glatter Raum zwischen Ange und Stirnhöcker, wodurch die Stirn verbreitert wird. Dieselbe ist ausserdem weniger gewölbt. fällt also zur Augenrinne schwächer ab und diese erscheint flacher. Die Höckerchen sind durch eine nach unten erweiterte und vertiefte Rime geschieden, der Nasenkiel ist unterhalb der Fiihlerwurzel zu einer kumen, niedrigen Leiste zusammengepresst.

Halbkugelig, beiderseits etwas zngespitzt, schwarz, mit blanem oder bläulich griinem Schimmer, stark glänzend. Fühler und Beine hell bräunlich gelb, röthlich oder braun. Hinterschenkel schwarz, die vier vorderen Schenkel und die Hinterschienen oft geschwïrzt. Halssch. nach rom in schwacher Rundung rerengt, mässig dicht und fein punktirt, die Vorderecken ziemlich spitz, wenig rorgezogen. Fld. gestreift-punktirt, in den Zwischenstreifen sparsam junktulirt. Hinterschienen am Aussenrande ïusserst fein. undeutlich gezähnelt. 
$\hat{j}$ Letzter Banchring anf emem lneiten Laingsstreifen in der Mitte glatt und rertioft. Diose Vertiefme ist meben, sie fällt hesonders zu zwei. durch rinen Quereindruck rephundenen Gruben in der Mitte ab, welehe nelen den fast walstartigen, dichter behatarten seiten liegen. -- P'enis ku\% und dick, nach rorn etwas crweitert, unten mit oinem hohen, nach der Spitze verengten Mittelkicle, der jederseits durel eine tiefe Längsgrube hegrenzt ist. I)ie Oberseite ist muldenförmig und fällt fast senkrecht zu der grossen Oethinung al). Diese hat einen annähernd herzförmigen Umfang and wirt durch eine zangenförmige Klappe geschlossen, durch deren Mitte der ductus heraustreten kann.

In den Alpen sehr selten, aber bisher wohl uibersehen: Wien, Bozen (Ludy), Miunchen (Strasser), auch bei Hamburg (Koltze) und nach Letzner in Schlesien. Pyrenaeen.

\section{Mniophila.}

Stephens, Illustrat. of Brit. Ent. IV. 1834. 330.

Acetabula antica aperta.

Corpus subglobosum, apterum, supra pilis vix perspicuis parce vestitum.

Labrum semicirculariter emarginatum.

Antennae articulis 3 ultimis clavam formantibus.

Prosternum mocessu apice triangulariter emarginato; mesosternum occultum, metasternum magnum episternis haud distinctis.

Tibicle sat tenuae, subcompressae, posticae in dorso teretes, apice calcari temuissimo instructae; metatarsus brevis; unguiculi mutici.

Körper klein, annähernd kugelig, ungeflïgelt, oben rereinzelt mit äusserst feinen und kurzen Härchen besetzt, die auf dem Halsschilde und den Flïgeldecken selbst bei starker Vergrösserung schwer sichtbar werden. Kopf stark geneigt, fein und dicht lederartig gerunzelt, mit kleinen, gewölbten, grob facettirten Augen, deren Innenrand in flachem Bogen ausgerandet ist. In einiger Entfernung von ihnen befindet sich ein tiefer Eindruck neben der Fühlerpfanne; die Stimlinien sind scicht, zuweilen verlosehen, durchschneiden sich x-förmig, oder bestehen aus zwei sich beriihrenden Bogen, so dass die flachen, wenig deutlichen Stimböckerchen eime dreieckige Form erhalten. Der Nasenkiel ist flach, zwisehen den Fühlern breit, darunter schnell rerengt und fällt hier in eine weite Vertiefung ab, worin sich das erste Fühlerglied einlegen und bewegen kann. Die schmale Oherlippe ist rorn tief, bogenfürmig arsgerandet. Fiilller halh so lang als der Körper, nach einem 


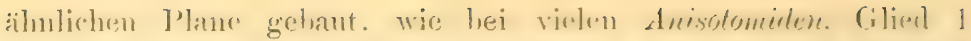

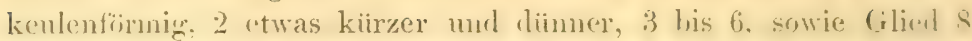
kur\% und diim, 7 fast so gross als 2, die drei Endylierler dicker als 7 , eine schwache Kenle lijdend. If alsschild linter den Angen und vor der sichulter jederseits sanft ansyeschweift, die vordere Borstenpore gross, die hintere klein. die Borsten sellost sehr fein und kurz. Fliigeldecken an har Basis gerundet-hrranstretend und die Hinterecken des Halsschildes bedeckend, wor der Mitte am breitesten, dahinter allmählich in eine gemeinschaftliche, abgerundete Spitze verengt, über welche die Nahtkante jecler Decke in Form eines scharf zugespitzten Zähnchens verlängert und in die tiefe Rinne des Pygidium eingefugt ist; aut der Scheibe fein rerworren oder in Reihen punktirt, die Epipleuren breit, im letzten Drittel schnell verengt. Prosternum zwischen den Huiften mit undeutlichem Mittelkiele und leistenförmigen Seitenrändern, hinten dreieckig ansgeschnitten, so dass der Fortsatz in zwei Spitzen endet, die von den Seitentheilen entfernt bleiben, aber das Metasternum ziemlich berühren. Letzteres verlängert sich in einen breiten, abgerundeten Zipfel zwischen den Mittelhiiften. An der Hinterbrust fehlt die Naht, welche bei den iibrigen Halticiden die Seitenstuicke absondert. Beine kurz, Hinterschenkel rerdickt, Hinterschienen seitlich zusammengedriickt, mit schmalem Ruicken und sehr feinem Enddorne. Metatarsus kaum so lang als die beiden folgenden Glieder zusammen, Klauen einfach.

Aeussere Geschlechtsmerkmale sind schlecht ansgeprägt: Das erste Tarsenglied ist beim $\hat{\sigma}$ an den vorderen Beinen eine spu hreiter als beim $q$ und das Pygidium gerundet-abgestutzt, weniger verschmälert, der letzte Bauchring endlich ror dem leistenförmigen Hinterrande niedergedriickt. Sicherer lassen sich beide Geschlechter durch die innere Einrichtung des Afters unterscheiden, welchen die Thiere beim Tode fast immer aufsperren. Ist die Oeftinung leer, oder nur mit den beiden langen, gelben Zipfehn der Legescheide besetzt, so hat man ein f ror sich; wird die Oettinung dagegen von dem grossen und breiten. mit einer Mittelrinne rersehenen, pergamentartigen Hemicyclus ansgefitillt, welcher die Penisspitze birgt, so liegt ein $\hat{o}$ vor. Der Penis bildet eine von oben flach gedriickte, hogenförmige Röhre, rerschmälert sich ror der Oeffnung etwas und ist am Ende germulet-abgestutzt.

Es giebt nu eine Art. Die Larve derselben will Kaltenbach (Pflanzenfeinde 497) in den Blättem ron Plantago lanceoluta und medin, Teucrium scorodonia und Digitalis purpurea minirend gefunden haben. Er macht folgende Angaben: Die Mine ist oberseitig, hreit, etwas geschlängelt und rerhältnissmässig kurz. Die 


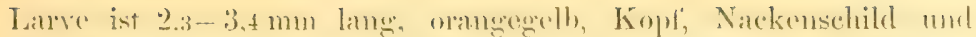
IFïse sehwarz; olen ziendich flach, kahl, runzelig, an den Ściten wulstig. I de Verwandlumg zur Nimphe erlobst in der Erde, nach 3 Wochen erscheint der Kïfer.

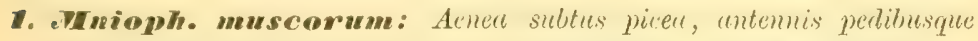
ferrugineis, lineis frontalibus fore semicircularibus, fromie prothoraceque ubsolcte alutaceis, elytris serintim penctulatis. - Long. 1-1,5mm.

Koch, Ent. Heft. II. 48, t. 2. f. 12. Haltica. - Illig. Mag. VI. 165. - Duft. Faun. A. III, 289. - Steph. Ill. Brit. IV. 330; Man. 303. Mnioph. - Bach, Käferf. II. 166. - Foudr. Mou. 285. - All. Mon. 295. - Kutseh. Wien. Monat. 1864. 459 (429). - Redtb. Faun. A. II. 518. - Leesb. Tijdscirr. 1882. 154. t. 11. f. 7. - Seidl. F. balt. ed. 2. 725; F. transs. 816. - Gerhardt, Zeitschr. Ent. Breslau 1891. 30.

Var. a. Immatura, supra rufo-picea, vix nel haud rene-micuns.

$\mathrm{Var}$. b. Lineis frontalibus saepe litteram $x$ formantibus, elytris confuse punctulatis.

Mn. Wroblewskii Wankowicz, Ann. Fr. 1880 Bull. 118. Weise, Dentsch. ent. Zeitschr. 1883. 252. - Gerhardt, 1. c. 30 .

Einer Alexia ähnlich, oben schwarz, mit metallisch grimem Schimmer, unten pech- bis rothbraun, Fühler und Beine rostroth. Die Stimlinien bilden zwei Bogen, von denen der nach unten offene grösser und viel mehr vertieft ist, als der nach oben geöffnete, zugleich läuft dieser gewöhnlich etwas in den unteren hinein. Halssch. äusserst fein lederartig gerunzelt, of noch erloschen punktirt. Fld. mit 9 mehr oder weniger regelmässigen Reihen von flachen Punkten, die vor der Spitze erlöschen.

Frische Stïcke sind oberseits röthlich pechbraun, wenig oder kaum metallisch angehaucht (Var. a); zu der unbedentenden Abänderung b. sind dic Exemplare zu rechnen, deren Fld. vorherschend verworren punktirt sind und bei denen sich die Stirnlinien gradlinig, x-fömig durchschneiden. Mitunter lassen sich weder Stirnlinien noch Höckerchen erkennen.

In Noose an starken Buchen und Ahornstämmen in den Bergogegenden Mitteleuropa's häutig, in Norddeutschland auch in Holstein, Pommern und Preussen. Südliches Schweden.

\section{Argopus.}

Fischer, Entomographia Imp. Ross. II. 1824. 182.

Corpus hemisphuericum rel ocutum, alatum, fermgineum, nitidum. 
Labrum margine antico dense ciliatum.

I'ulpi macillures crassiusculi, artirulos altimu breri, oldus amian. Clypeus excavatus.

Antennae filiformes, articulo 4: o elongato 3: o longiore.

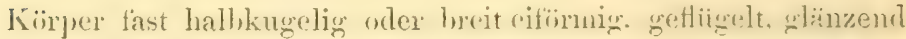
rostroth. Ko lif sonkrecht, dreieckig: bis zum Hinterrande der müssig gewölhten, körnig-facettirten Augen in das Halschild ringezogen; Stirnlinien aus zwei flachen brgen hestehenrl. die sich ein Stiick iiler der Fühlerbasis durehschneiden und dis grossen, fast dreieckigen Stirnhöcker rom scheitel und her Spitze des Nasenkicles alssondern. Letzterer ist hreit. mehr oder weniger grewijlbt, oft dachförmig und geht allmählich in das Kopfischild über: welches rorn ausgehöhlt ist, so dass der flache, bandförmige Querstreiten sehr tief liegt. Die Aushühlung ist a. dreieckig, mit graden. scharfkantigen hohen Seiten, dann endet das Koptischild jederseits in cinen gxossen, flachen, angedriickten und rom abgerundeten Lappen neben der Basis der Mandibeln; oder b. gerundet. mit stumpfen Seiten, damn läuft das Kopfschild jederseits in eine dicke, leicht aufgerichtete Spitze aus. Oberlippe am Vorderrande diclit und kurz bewimpert, in der Mitte desselben ausgeschweift. Mandibehn an der Spitze schwarz, fünfzähnig, der mittelste Zahn am weitesten vorgestreckt. Maxillartaster ziemlich dick, manentlich das vorletzte Glied, das letzte ist kurz, kegelförmig. Fühler schlank, fast von Körperlänge, Ctlied 2 und $3 \mathrm{kurz}$, zusammen so lang oder wenig länger als 4, dieses mit den ïbrigen ungefähr ron gleicher Lünge. Halsschild doppelt so breit als lang, nach rorn stark verschmälert und etwas zusammengedrückt, an der Basis in einen kleinen Zipfel gegen das Schildchen rorspringend, die Eckborsten mässig lang; die rordere Borstenpore ist gross, aut einer Terdickung der Vorderecken eingestochen, die hintere klein, anf der Seitenkante in den Hinterecken. Scheibe mässig gewölbt. ungleichmässig und wenig dicht punktirt (nur hei wenigen Arten gleichmässig, daun aber dichter und feiner punktirt), über dem Seitemande und diesem parallel ein Längseinduck. Flügeldecken an Grunde wenig breiter als das Halsschild, im ersten Drittel, oder bis zur Miite bogenförmig erweitert, dahinter :̈hnlich rerengt. gemeinschaftlich abgerundet, mit gerumlet-abgestutzter Nahtecke: auf dem Rüeken gewölbt, verworren und fein, oder kräftig und theilweise gereihtjunktirt. Epipleuren hinter der Mitte allmählichrerengt. Prosternum vor den Huiften sehr schmal, leistentörmig, zwischen ihnen melur oder weniger breit, der Fortsatz linten gerade oder in sanftem Bogen ausgerandet. Beine kräftig, Hintersehenkel nur mäisig verdickt. alle Schenkel mit einer Rinne zur Aufnahme ler sichienen 
verselen, letztere an der Wurzel gekrümunt, anf dem Riicken gewölbt und in einen Nittelkiel ansteigend, oder zur Einlagermng der 'Tarsen vertieft. An der spitze der Hinterschienen ein rinfacher Enddorn, über dem die Tarsen befestignt sind, Klauen gespreizt, am Grunde in einen grossen, gemeinschattlichen, eckigen Anhang verbreitet.

Beim Minnchen tritt der Hinterrand des letzten Batuchringes in der Mitte in cinem bogenförmigen, vertieften Zipfel gegen das Prgidium vor, die Fiihler sind etwas verlängert und das erste 'Tarsenglied aller Beine ist deutlich erweitert, ziemlich so breit als das dritte Glied. Der Penis bildet eine einfache Röhre.

Die Entwicklung ist nur von unserer einheimischen Art, A. Ahrensi Germ., durch Heeger (Sitzungsber. Ac. Wiss. Wien 1858. 29. 109-112. t. 4) beobachtet worden: Ende April oder Anfang Mai kommen die Käfer zum Vorschein und benagen die Blätter versehiedener Clematis-Arten an der Oberseite. Das Weibchen legt während 6 bis 10 Tagen 40 bis 50 gelblichweisse, glatte Eier einzeln an die Unterseite der Blätter; nach 8 bis 12 Tagen entwickeln sich die gelblichweissen Larven, beissen sich in das Blatt ein und miniren dasselbe meist gänzlich. In der Regel lebt in einem Blatte nur eine Larve; ist dasselbe ausgefressen, oder zerreist die Epidermis zufällig, so sucht die Larve ein frisches auf. Sie häutet sich im Blatte dreimal. Ausgewachsen ist sie $9 \mathrm{~mm}$ lang und kaum $2,3 \mathrm{~mm}$ breit, fast gleichbreit, flacher, aber von ähnlichem Bane wie die von Dibolia; die Ringe sind quer, deutlich von einander abgeschü̈rt, unter sich ziemlich gleich lang, nur der Prothoraxund Analring kleiner, einem Kreisabschnitte ähnlich. Ersterer ist auf dem Rücken hornig, gelbbraun, mit blasser Mittellinie; jeder der iibrigen 10 Ringe besitzt eine Querfurche in der Mitte. Der Kopf ist klein, rund, hellgelb, Kopfschild braun, quer, sein Vorderrand abgerundet und in der Mitte gekerbt. Mandibeln mit drei grossen Zühnen, Fühler breit kegelförmig, dreigliedrig; dicht hinter jedem Auge liegt eine kleine, schwarze, wenig erhabene Ocelle. I) ie Beine sind kurz und dick, die Schenkel und Schienen fast walzenförmig, die Klane ist brann, konisch, an der Spitze mit einem hakenförmigen Dorne bewehrt.

In günstigen Jalıren, wo der Käfer zalılreich auftritt, findet man nicht selten mehrere Larren in einem Blatte und zugleich dis verschiedensten Entwicklungsstadien unter einander. Franenfeld berichtet (Verh. zool. bot. Tereins, Wien 1864. 686), dass er die Larven nur in Blättern ron ('lematis recta $\mathrm{I}$. angetroften habe und dass dieselben bei Nahrungsmangel die ihnen leicht erreichbaren Blätter von $\mathrm{Cl}$. vitalba $\mathrm{L}$. durchaus verschmähten. 


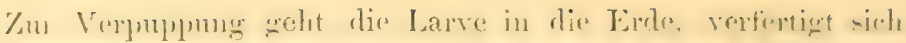
rin Jijnnchen und reswandelt sich darin nach 6 bis 8 'Tagen zute

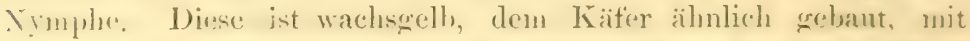
froiliegenden Beinen, unter deren Sohenkelspitzen der grösste Theil der Fiihler liegt.

Die Gattung verbreitet sich aut einem sitreifen von der J'yenäen Ifalbinsel und Ilggier durch das mittlere und südliche Europa in 4 Arten. und durch Wittelasien lis Japan in 12 Arten $^{1}$ ). hald vom Halitus einer Coccinella, bald (inem Phaerlon ähnlich, mit geriugem Sprungremögen. Foudras lrachte sie (Mon. 345 u. 348) in zwei (tattungen: 1. Argopus: Supra minus arebe sat fortiter punctatis, clypeus triangulariter excavatus. lobis rotundatis, depressis, tibiae in dorso carina elevata instructae: 2. Iicherosis: Sulpra crebe subtiliter punctatis, clypews rotundatim excavatus, lobis dentiformibus suberectis, tibice (plerumque) in dorso sulcatae: allein die Unterschiede in der Punktirung und der Bildung der Beine büssen durch Zwischenformen aus Asien ihren Werth ein, und man darf augenblicklich nur noch die verschiedene Form des Kopfischildes berücksichtigen. Da die Ausrandung desselben zuletzt ganz unbedeutend wird ( $~$. B. beim $q$ des $A$, orientalis Baly) bleibt es eine Frage der Zeit, entweder Sphcceroderma Steph. als Ahtheilumg von Argopus anzusehen, oder eine Reihe neuer, kleinerer Gattungen zu errichten.

Von den uns zunächst interessirenden Arten gab Schaufuss eine Lebersicht (Nunquam ot. II. 423), die unbrauchbar werden musste, weil er von den besprochenen sechs Arten nur zwei besass.

A. Koptschild gerundet-ansgehöhlt, mit stumpfen Rändern, rorn jederseits in eine etwas aufstehende und nach innen gerichtete Spitze verlängert, Fiihlerglied 2 und 3 seln kurz, gleichlang.

Subgenus Dicherosis Foudr.

1. Körper nebst Fühlern einfarbig rothgelb, Halssch. und Fld. fein punktirt, mit wenig feineren Punkten in den Zwischen-

1) Vielleicht werden mit Unrecht anch mehrere Species aus Afriki und Sïdamerika zur Gattung gerechnet; noch weniger gehören dazu die Arten aus Malacca. Sumatra etc., welche ein oder mehrere weisslich gelbe Endglieder der Fühler besitzen. Sie unterscheiden sich auf den ersten Blick Aurch die weit getrennte Fïhlerwurzel, den auffällig grossen, oben breiten nach unten gradlinig und sehr stark erweiterten Nasenkiel, welcher ungefähr die Form eines gleichseitigen Dreiecks hat, sanft gewölbt. ist und unten plötzlich zu dem ebenen Querstreifen des Kopfschildes al)fällt. Von den Borstemporen ist die vordere auf einem Vorsprunge etwas ror der Hitte des Seitemrandes eingestochen, welcher von hier aus bis zu den Vorderecken cylinderfömig verdickt ist, die hintere steht auf einem Kegel in den Hinterecken. Ich lege diesen Arten den Namen Dimar bei. 
räumen. Die vier Vordersehienen ant' dem hiicken rimnenatipy vertieft, uber der Basis winkelig gebogen . . . . . . 2 .

1'. Körper und die drei ersten riuhlergheder rothgelb, dio übrigen Fïhlerglieder nebst Schienen und 'Tasen pechschwar\%. IFalssch. und Fld, kräiftig punktirt, mit viel feineren Pinktchen in den Zwischenrïumen, die vier Vorderschienen auf den Rücken gewölbt, mit stumpfem Längskiel, iiber der Basis nicht winkelig. gebogen, die Zähme des Kopfsehildes verhältnissmässig. lang, gritfelförmig. - L.4,2 mm. Wladiwostok (Wiegm. Arch.1887.208).

intermedius $\mathrm{W}_{\mathrm{s}}$.

2. Länglich-rund, Halssch, vorn in einem weiten; fast gleichmässigen Bogen ausgeschnitten, mehr wie doppelt so breit, als in der Mitte lang. - L. 3,5-4,8 mm. Central-Europa.

Ahrensi Germ.

21. Rund, Vorderrand des Halssch. neben den Augen tief ausgeschnitten, kaum doppelt so breit als in der Mitte lang. Oberseite kaum halb so stark punktirt, wie bei Altrensi. - L.4,5 mm. Spanien, Südfrankreich. (Mon, 246) . . . . brevis All.

B. Kopfschild dachförmig, dreieckig ausgehöhlt, mit scharfen Rändern, rorn jederseits in einen angedrickten, gerundeten Lappen rerlängert, Fühler dunkel mit heller Basis, das dritte Glied oft länger als das zweite, aber kürzer als das vierte. Schienen schlank, auf dem Rücken mit feinem Mittelkiele.

Argopus in spec.

1. Körper mit Ausnahme der dumklen Fühlerspitze gelblichroth 2. 11. Wenigstens noch Schienen und Tarsen schwarz . . . . 3.

2. Torderecken des Halssch. spitz, nach aussen tretend. Kopfschild sehr tief dreieckig ausgeschnitten, Fld. ziemlich dicht und stark verworren punktirt, über den Seiten mit einigen Punktreihen.-I. 5 mm. Amur'(Schrenck, Reis. Am.235. t.9. f. 24) unicolor Motsch.

$2^{1}$. Vorderecken des Halssch, abgerundet Kopfschild schwach ausgeschnitten, Fld. sehr stark in weitläufigen und fast regelmässigen Reihen punktirt. -- L. 3,7-4 mm. Amur (Wiegur. Arch. 1887. 206 . . . . . . . substriatus T's.

3. Beine einfarbig schwarz . . . . . . . . . . . . 4.

31. Nur die Schienen und Tarsen dunkel, pechbraun oder schwarz. Oberseite zerstreut und ziemlich kräftig punktirt, über den Seiten der Fld, einige Punktreihen. - I. 4 mm. Sarepta, Turkestan, Westsibirien (Mém. Mose. 1823. 125). 


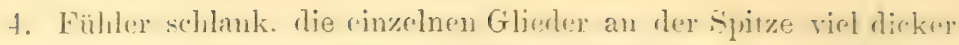

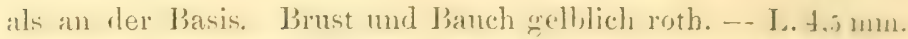
Kan-son, sze-tchuan (Horae 23. 64t2) . . . nigripes W.

41. Unterseite schwarz, nur die Seiten der Vorterlmast roth. L. 3,5-5 $\mathrm{mm}$. An der unteren Donan von Lngam his siidrussland. Kaukasus (discolor Bielz, Verh. Sichb. 1852. 16. punctrtus Schauf. Nunqu. ot. II. 424. ${ }^{1}$ ) - Entonnog. Ross. II. 1824. 182. t. 47. f. 3.) . . . . . . bicolor Fisch.

1. Argop. Ahrensi: Ocali-hemisphaericus, mufo-testaceus, nitidus, prothorace fortiter transwerso, apice late emarginato elytrisque subtiliter punctatis. - Long. $3,5-4,8 \mathrm{~mm}$.

Germ. Reis. Dalmat. 1817. 206. t. 10. f. 6 (Hultica). - Seidl. F. transs. 817; F. balt. ed. 2. 725 .

Halt, hemisphaeriea Duft. Fann. A. III, 1825. 253. - Foudr. Mon. 348 (Dicheros).

Argop. hemisphaericus Redtb. Fam. A. II. 519. - Bach, Käferf. III. 164. - Kutsch. Tien. Monat. 1864. 468 (438). A 11. Mon. 246.

Länglich halbkugelig, röthlich gelbbraun, glänzend, Halssch. und Fld. ziemlich dicht, fein punktirt, diese Punktirung aus grösseren und kleineren Pünktchen zusammengesetzt. Halssch. über dem Seitenrande mit einem schwachen Längswulst, welcher von der Scheibe durch einen mehr oder weniger deutlichen Eindruck al,gesetzt wird, der hinter dem Auge meist in einem Gribchen endet. Die grösseren Punkte der Fld. ordnen sich oft zu acht wenig dentlichen Punktreihen, ron denen je zwei einander genähert sind.

Der Penis ist gleichbreit, unten schwächer als oben rinnenförmig vertieft, vorn allmählig in eine stumpfe spitze rerengt, mit grosser und langer Oeffnumg, die in der Ruhe durch eine rorn abgestutzte Klappe fast zur Hälfte geschlossen wird.

An Clematis recta L. in Deutschland und Oesterreich sehr' zerstreut.

\section{Sphaeroderma.}

Stephens, Illustrat. of. Brit. Ent. IV. 1834. 328.

Palpi maxillares sat tenues, articulo ultimo elongato penultimo haud breviore, apice acuto.

Clypeus deplanatus.

Antennae filiformes, articulo 4: o 3: o longitudine aequali.

1) Die Art kommt nicht mit schwarzem Schildchen ror, wie Fischer mul Kutschera angeben; Bielz und Schanfuss haben sich dadurch täuschen lassen und die Art nochmals beschrieben. 
Die Untersehiede von der vorigen Gittung bestehen nur in den schlankeren Maxillartastem, deren letztes filied lang, schart zugespitzt. kaum kiirzer als das vorletzte ist, in dem niedrigen, rorn nicht ansgerandeten oder ausgehöhten Kopfschilde und in dem kuren vierten Fuhlergliede, welehes nur so gross als das dritte und viel kuirzer als das fünfte Glied ist.

Bekamnt ist die 6-7 mm. lange Larve von Sph. testuccum durch die kurze Beschreibung von Kaltenbach (Pflanzenfeinde 373) und die ansfiulnrliche ron Perris (Ann. Fr. 1876. 177); sie kann mit der im Körperban ähnlichen von Argop. Ahrensi nicht leicht rerwechselt werden, weil sie auf dem Riicken mehr oder weniger braun gefleckt ist. Der Prothorax ist röthlich, mit zwei dunkleren Längsbinden in der Mitte, die beiden anderen Brustringe mit 8 oder 10 braunen Punkten: 2 oder 4 in einer Querreihe nahe dem Vorderrande, die beideu mittleren genïhert und auf dem Mesothorax quer, und 6 in einer älnnlichen Reihe dahinter, die beiden mittleren weiter ron einander entfernt als von den übrigen. Ausserdem bemerkt man zuweilen auf jedem der folgenden 8 Rückemringe 6 braune Punkte, 4 in einem nach vor $n$ offenen Bogen und einen jederseits unter dem zitzenförmigen Wulste am Seitenrande.

Der Kopf ist nach Perris sehr klein, fast viereckig, röthlich, mit dunkleren Linien, Mandibeln sehr klein und ziemlich schlank, vielleicht ohne Zähne und nur am Ende zugespitzt. Fühler dick, konisch, verhältnissmässig lang, viergliederig; dahinter jederseits eine ziemlich grosse, wenig erhabene Ocelle. Stigmen sind nem Paare vorhanden, das erste auf dem Mesothorax, liegt tiefer als die übrigen, die sich auf den ersten 8 Hinterleibsringen, vor dem Seitenwnlste derselben befinden. Beine sehr weit getrennt, kurz, oben braun, mit einer feinen Klane, die unten cine blasenförnige Membran besitzt.

Diese Larve minirt die Blätter verschiedener Cirsium-, Cynaraund Carduns-Arten, indem sie einen ziemlich kurzen, geschlängelten, mregelmässigen Gang gräbt. Ausgewachsen durchbohrt sie die Oberhant, lässt sich zur Erde fallen und dringt in dieselbe ein, um sich zur Nymphe zu verwandehn. Diese besitzt einige steife Hürehen auf der Stirn, dem Rücken und Umkreis des Prothorax, auf dem Meso- und Metathorax, an Hinterrande der Bauchringe und an den Knicen; hinten endigt sie in zwei konische Warzen, deren scharfe röthliche Spitze etwas hornig ist.

Von einigen dreissig zur Zeit beschniebenen Arten koumen zwei in Europa vor: 


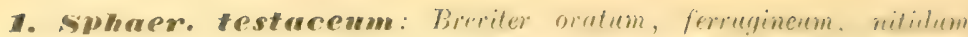

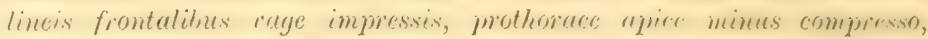
lateritus prorum rotudatis, angulis antiris acutiusculis, risero subtilito. punctato, elytris sat crebre punctatis. - Long. 3-4 mm.

Mas: tarsis articulo primo magno, fortiter dilatato.

Altica testacea Fabr. Ent. Syst. 114. - Panz. Famm. Fierm. 21. 13. - Koch, Ent. Hft. II 50 (Halt.). - $111 \mathrm{in.} \mathrm{Mag.} \mathrm{VI}$ 157. - Duft. Faun. A. III. 253. - Bach, Käferf. III. 164, (Sphacrod). - Küst. Käf. Eur. 9. 90 (Argopus).

Altica voluta Laich. Verz. Tyrol. 196.

Halt. cardui Gyllh. Ins. Snec. III. 551; IT. 659. - K ïst. I c.

28. 97 (Arg.) - Bach, 1. c. 164. Sphaerod. - Redtb. Faun,

A. II. 518, - Foudr. Mon. 352. - Kutsch. Wien. Monat. 1864. 463 (433). - All. MLon. 248. - Thoms. Skaud. Col. VIII. 210. - Seidl. F. trans. 817 ; F. balt. ed. 2. 725 . Leesb. Trjdschr. 1882. 153. t. 11. f. 6 .

Var. a. Prothorace elytrisque subtiliter obsoleteque punctulatis.

Kurz eiförmig, rostroth, glänzend. Nasenkiel rhombisch, oben durch schwache oder erloschene Linien ron den Höckern getrennt. Halssch. um die Hälfte breiter als lang, nach rom mässig verengt und zusammengedrickt, die Seiten wenig gerundet und bei der Ansicht von oben bemerkbar; auf der Scheibe fein, aber deutlich punktirt, die Torderecken nach aussen gebogen, ziemlich spitz, am Ende abgerumdet. Fld. länglich, an den Seiten schwach gerundet und ron ein Drittel der Länge an nach hinten rerengt: etwas weitläufiger und stärkel als das Halssch. punktirt, dic Punkte zwischen Schulter und Naht, iiber dem Seitemrande und ror der Spitze oft in Reihen geordnet.

Bisweilen ist die Punktirumg des Halssch und der Fld. sehr fein und selbst bei starker Tergrösserung schlecht hemerkbar (Var. a).

ô Erstes Tarsenglied gross, so lang als die beiden folgenden Glieder zusammen und so breit als das dritte Glied. - Penis an der Oeffnung leicht erweitert, hierauf allmïhlich und schwach gerundet in eine nicht scharfe spitze rerengt, die Oeftumng gross, ron einer ziemlich elliptischen, gelbbramen, ebenen Klappe geschlossen, deren Vorderrand jederscits aufigebogen ist.

Auf Wiesen, Triften und Brachäckern an Cirsium lanceolatum und oleraceum Scop., sowie an Cardums-Arten gemein.

Diese Art wurde 1755 von Fabricius unrolliommen beschrieben und erst 1794 durch die Panzer'sche Abbildung festgestellt. Leider hat Gyllenhal 1808 die testacea Panz. nicht unter diesem Tamen, sondern als cardui s. weitelgefuihrt, die folgende Art für testacea Panz. gehalten und so den Grund zu der bisherigen falschen Synonymie gelegt. 
2. Sphaer. rubidum: Oblongo-hemisphaericum, firugineum vel castaneum, nitichm, lineis frontalibus profunde impressis, yrothoruce apice valde compresso, lateribus angulisque anticis rolundatis, risco subtilissime punctato, elytris sat crebre subtiliter junctatis. - Long. 3-4 mm. Mas: tarsis articulo primo sat magno, dilatato.

Argop. rubidus Graëlls Memor. Map. geol. Esp. 1858. 97. t. 5 . f. 9 .

Sphaer. rubidum All MIon. 248. - Kutsch. Wien. Monat. 1868. 464 (434).

Var. a. Minus, saepe magis rotundum. - Long. 2,8-3,8 mm.

Halt. testacea Gyll. Ins. Suec. III. 550.

Sphaer. testaceum Redtb. Faun. A. II. 518. - Foudr. Mon. 352. - A 11. Mon. 248. - Kutsch. 1. c. 463 (433). - Thoms. 1. c. 210. - Seidl. 1. c. 816 et 725.- Leesb. 1. c. 153.

Der vorigen Art sehr ähnlich, aber in folgenden Stiicken verschieden; der Körper ist an den Seiten stärker gerundet, oben durchschnittlich feiner punktirt, meist dunkler, bis lebhaft kastanienbrau gefärbt. Nasenkiel nach unten verbreitet, dreieckig, von den Stirnhöckern durch tiefe, deutliche Linien getrennt; die Stirn ist zwischen den Augen etwas schmaler. Das Halssch. ist doppelt so breit als lang, nach vorn stark verengt und zusammengedrückt, so dass die gerundeten Seiten bei der Ansicht von oben verdeckt werden, die Vorderecken sind kurz, abgerundet. Fühler und Beine weniger dick.

Bei den Männchen ist das erste Tarsenglied fast so breit als das dritte, aber kiirzer als Glied 2 und 3 zusammen. - Penis gleichbreit, vorn allmählich verengt, oben schwach muldenförmig. vertieft, die Oeffnung lang, zur Hälfte von einer halbovalen, an der Spitze verdickten uud gebräunten Klappe bedeckt, auf welcher zwei Längseindrücke sichtbar sind, die ein Mittelkiel trennt.

Im suidlichen Europa häufig; stellenweise auch in den Berggegenden Mittel- und Siiddentschlands und in Oesterreich, Ungarn ete, hier aber vorherrschend in der kleineren, namentlich kürzeren Form a. Aus Norddeutschland kenne ich die Art nicht. 


\section{Vierte Abtheilung: CRYPTOSTOMA.}

Chapuis, Genera des Coloopt. XI. 250.

Caput valde inclinatum, ore infero.

Antennae "pproximatae fronti plerumque alte insertae.

Coxae anticae transversae.

Tarsi articulo penultimo bilobo ultimum recipiente.

Kopf cylindrisch, mit schräg abgeschnittener Vorderfläche, auf' welcher die Stirn vorstehend, der Mund dagegen weit zurückgezogen, nach hinten gerichtet ist; auf dem am weitesten rorgestreckten Theile sind die Fuihler dicht neben einander zwischen den grossen, länglichen, genäherten Augen eingefügt. Mund sehr gross, rund oder oval, mit starken Mandibeln und langen, gerade nach rorn, oder selbst etwas nach oben gerichteten Tastern. Halsschild quer, selten so lang als breit, oder länger, in wenigen Fällen mit Eckporen und Eckborsten; Schildchen deutlich, in einer Ebene mit den Flügeldecken. Diese sind in der Regel so breit, oder breiter als das Halsschild, auf die verschiedenste Art punktirt, etwas länger als der Hinterleib. Das Prosternum ist zwischen den Hüften mässig breit, dahinter erweitert, mit den Seitenstiicken der Vorderbrust verbunden und schliesst so die stark in die Quere ausgedehnten Hüften hinten vollständig ein. Beine verhältnissmässig kurz, das erste Tarsenglied dreieckig, das zweite an der Spitze ausgerandet, herzförmig, oft zweilappig, das dritte tief gespalten, das vierte von den Lappen des vorhergehenden eingeschlossen und nur selten länger als diese; Klauen stark gekrümmt.

Die Larven sind Blattminirer (ITispini) oder leben frei an den Pflanzen (Crassidini), ihr Körper besteht, ausser dem Kopfe, aus 11. Ringen, an denen sich 8 Stigmenpaare befinden.

Nach dem Körperbaue gliedert sich diese Abtheilung in zwei natürliche Gruppen:

A. Kopf nebst den Mundtheilen frei. Halsschild viereckig. Epipleuren der Flügeldecken normal. Hispini.

13. Kopf in das Halsschild eingezogen und fast immer ron einer dachförmigen Verlängermg desselben bedeckt, die Mundtheile im Prosternum verborgen. Halsschild einem Kreissegmente ähnlich, meist ohne Vorderecken. Epipleuren der Flïgeldecken dachförmig rerbreitert.

Cassidini. 


\section{Erste Gruppe: HISPINI.}

Chapuis, Genera XI. 251.

Caput liberum, oculi prominuli.

Prothorax subquadratus, angulis anticis distinctis.

Körper länglich bis sehr gestreckt, flach, oder nicht hesonders stark gewölbt, oft mit 'Zïlmehen oder Dornen besetzt, namentlich am Rande des Halssehildes oder der Fliigeldecken. Kopf klein, meist bis zum Hinterrande der Augen in das Halsschild eingesenkt, rer obere Theil bildet mit dem unteren Stücke der Stirn cinen rechten oder spitzen Winkel und besitzt oft ein Gribchen, eine Längsrinne (5 Längsrinnen bei Pentispa Chap. aus Nord- und Mittel-Amerika), oder eine Querverticfung, welche die Grenzen der bei den Halticiden so gut ausgeprägten Stirnhöckerchen andenten. Die Oberlippe ist zuweilen weit hinauf zwischen die Augen geriickt, die übrigen Mundtheile, welche sich hauptsächlich dadurch von denen der Galemuciden unterscheiden ${ }^{1}$ ), dass sich sämmtliche Zähne der Mandibeln am inneren Rande befinden, liegen frei, nur bei der südamerikanischen Gattung Amplipalpa Harold werden sie theilweise durch den erweiterten Vorderrand des Prosternum bedeckt. Die Fiihler, welche von dem lebenden Thiere meist gerade rorgestreckt werden wie bei Orthocerus oder Brontes, sind verschieden gebildet, fadenförmig, schnurförmig, keulenförmig, zusammengedruickt, gesägt, gekänmmt (O)tocladiscus Thoms, aus Cayenne), meist 11-gliederig, doch verringert sich diese Zahl, indem zwei oder mehrere Glieder so verschmelzen, dass höchstens die Nähte sichtbar bleiben, auf 10 Glieder bei Leucispa Chap. Australien, 9 bei Platypria Guér. Senegal, 8 bei Microrhopala Baly Nord-. Octotoma Suffr. Mittel- und Uroplata Baly Siidamerika, 7 bei Plrysocoryna Chap. Brasilien, und variirt in der siidamerikanischen Gattung Acanthispa Baly zwischen 7 und 3 Gliedern. Das Halsschild ist gewöhnlich schmaler als die Flügeldecken, viereckig, quer oder gestreckt, an den Seiten schmal und oft scharf gerandet, selten ungerandet (Eurispa, Leucispa), oder die Scheibe flach gedriickt, wie mit einem Schilde beleg't, welches stellenweise oder gänzlich vom Hinterrande entfernt bleibt, wodurch dort mehrere Randlinien und Ecken entstehen (Hispa, Alumms). Die Flïgeldecken sind in wenigen Gattungen unregelnässig verworren punktirt, bei der Mehrzahl derselben besitzen sie 8, 10, oder mehr Punktreihen oder

1) Die Gattung Chaeridiona Baly ans Ostindien zeichnet sich jedoch durch den völligen Mangel der Lippentaster von allen Chrysomeliden aus. 
Panktstrcifen und viclfach noch Läingsrippen. Von den 5 Ringen de's Ilinterleibes sind die beiden ersten verwachsen, die Beine sind oft kurz und dick, und einzelne Schienenpaare grekrimmt, die drei ersten 'Tarsenglieder mit einer Filzsolle versehen. Das vierte Fussglied ist nur bei Loucispa Odewahni Baly, welche in Körperform und Farbe cinen Lixus ähnelt, nicht frei, sondern mit den Lappen des dritten Glicdes verbunden und ohne Klauen. Letztere sind bei Mlonochimus fast bis zur Spitze verwachsen, in den übrigen Gattungen frei und einfach (bei drescus ein Anhängsel am Grunde.)

Geschlechtsunterschiede lassen sich äusserlich schlecht wahrnehmen, abgesehen von einigen Arescus-Arten, bei denen sie in erweiterten Schultern des $\hat{o}$, einer innen ausgehöhlten hohen Längsrippe in der Basalhälfte jeder Flügeldecke, sowie einem löffelförmigen Anhange an der Spitze derselben bestehen. Der Penis bildet eine flach gedrückte Röhre.

Die Larven, welche erst von 4 Arten bekaunt sind, machen ihre Verwandlung in Blättern perennirender Pflanzen durch; sie haben einen länglichen, flachen Körper.

$\mathrm{Zu}$ den Hispinen gehören ungefähr 700 vorzugsweise durch Baly (Catal. Hispid. 1858) und Chapius (Annales Soc. Belgique 1876 u. 77) beschriebene Arten aus der heissen Zone. Ton der Mannigfaltigkeit ihrer Formen, Farben und Zeichnungen geben die wenigen Arten, die bis in unsere europäische Fauna hinein reichen, keinen Begriff. Letztere vertheilen sich auf folgende Gattungen :

1. Seiten des Halssch. und der Fld. bedornt. Beine ziemlich schlank. Eckborsten des Halssch. auf cylinderförmigen Höckern eingefügt . . . . . . . . . . . . . . . 2.

1'. Seiten des Halssch, und der Fld. einfach, glatt, durch eine eingegrabene oder punktirte Linie scharf abgesetzt. Beine kurz, dick. Eckborsten des Halssch. in Poren eingefügt.

Leptispa Baly ${ }^{1}$.

1) Hierher eine sehr schlanke Art aus Corsica, Unteritalien und Sicilien, L. filiformis Germ. (Faun. Ins. Eur. 22. 10). Oben dunkel metallisch grün oder blau, Halssch. ungleichmässig stark punktirt, Fld. mit 10 regelmässigen Punktreihen. Der obere Theil der Stirn lang, mit Mittelrinne, vorn in eine beiderseits abgermndete Querkante auslaufend, unter welcher die Fühler eingefügt sind. - L. $5 \mathrm{~mm}$.

Verwandt ist die Gattung Callispa Baly, welche wohl noch am Amur anfoefunden werden dürfte; die Fühler sind in einer grossen Grube jederseits eingefügt, diese Gruben durch eine schmale Leiste getrenut, in welche die Stirn verengt ist. In den meisten Sammlungen befindet sich Call. Bowringi Baly (Cat. Hispid. 5) von Hongkong. Eiförmig, ziemlich Hach, schwarz, Tarsen und Bauch gelb, Oberseite schön blau oder riolett, Halsseh. kräftig punktirt, Fld mit $11^{1}{ }_{2}$ Punktstreifen. - L. 6-7 mm. 
2. Die 6 Basalglieder der Fïhler zusammengedrückt, bisweilen fast vierkantig, das erste mit langem Dorne. Unterseite des vierten Tarsenglieles an der Spitze nicht erweitert. . . 3.

2! Fühlerglieder ziemlich walzentörmig, olıne Dorn. Ausschnitt der Schienen flach, geradlinig oder winkelig. Unterseite des vierten 'Tarsengliedes an der Spitze jederseits zahnförnig' erweitert . . . . . . . . . . . Hispa L.

3. Klauen frei. Aussehnitt der Schienen tief, hogenförmig, oben von einem vortretenden spitzen Zahne begrenzt.

\section{Hispella Chap.}

31. Klauen verwachsen, oder nur an der äussersten Spitze getremnt. Ausschnitt der Schienen stumpfwinkelig, oben olıne zahnförmige Grenze . . . . . . . . Monochirus Chap.)

\section{Hispa.}

Linné, Systema Nat. ed. 12.603.

Antennae 11-articulatae, subteretes.

Pedes sat elongati, nitidi, femora muticu, tibiae apice mediocriter emarginatae, tarsis articulis 3 primis aequaliter pulvillatis, articulo ultimo intus utrinque dentato-producto.

Der Körper behaart, rostroth oder schwarz, zuweilen bläulich schimmernd, am Rande des Halsschildes und auf den Flügeldecken mit Dornen bewehrt. Oberlippe quer, vorn in breitem Bogen ausgerandet; Mandibeln mit sehr stumpfen, gerundeten oder eckigen Zähnen, deren Anzahl variirt; Taster sehr schlank. Auf dem oberen Theile der Stirn eine Mittelrinne und neben jedem Auge eine dicht mit Härchen besetzte Furche. Die Fühler beinahe cylindrisch. unbedeutend zusammengedrickt, der Querdurchschnitt eines Gliedes mehr kreisrund als oval, die ersten 7 Glieder etwas glänzend, mit langgestreckten Punkten oder mit Rimnen versehen, in denen einzelne Härchen sitzen, die 5 Endglieder leicht verdickt, dicht behaart, matt. Halsschild wenig breiter als lang, die Scheibe

1) Vom Ansehen der Hisp. atra. Dorn des ersten Fühlergliedes einfach, Fld. nur am Seitenrande mit einem Kranze spitzer Dornen, die am abgerundeten Hinterrande allmählich länger werden. L. $5 \mathrm{~mm}$. Smyrna, Armenien, Kaukasus, Kirghisensteppe. Mon. inermis Zoubk. Bull. Mosc. 1833. 337; caucasicus Heyden Beitr. Kauk. 343.

Dorn des ersten Fühlergliedes in der Basalhälfte mit mehreren kleinen Zähnchen, die geraden Zwischenstreifen der Fld. mit je einer Reihe nach rückwärts gerichteter Dörnchen besetzt. - L. $5,8-6,3 \mathrm{~mm}$. Mongolei. M. Potanini Ws. Horae 1889. 486. 
mit einem flachen, matten sichilds helegt, welches eine glatte Mittelrime, oder Mittellinie und vor dem aufgebogenen Hinterrande einen Guereindruck lesitzt, an Vorder- und Seitenrande mit Dornem versehen ist. Diese entspringen oft zu zwei, drei bis sechs aus einer gemeinsamen sticl- oder leistenfömigen Basis. Sehr eigenthiimlich sind die Eckborsten auf cylinderförmigen, nach aussen gerichteten IHöckern eingefiigt. Flügreldecken mit 10 stellenweise abgekürzten oder durch Ḧ̈cker, Dornen ete. unterbrochenen Reihen von groben Punkten. Beine ziemlich schlank, Schenkel einfach (bei wenigen Arten z. B. armata Gnér. aus Mittelafrika bedornt), Schienen an der Spitze schief ausgerandet, damit sich das erste Fussglied einlagern kann, die drei ersten Tarsenglieder unten mit dichter Haarbekleidung, das vierte an der Spitze jederseits in einen Zahn erweitert, an den sich die rorgestreckten Klanten legen.

Die Ifispa-Arten, von denen einige 70 bekannt sind, verbreiten sich iiber Afrika und Asien bis nach den Philippinen und Sundainseln; auf ihre Entwicklung kann nur aus den Beobachtungen geschlossen werden, welche Perris iiber testacea L., die einzige Art, welche nach Europa bineinreicht, veröffentlicht hat (Mém. Liége 1855. 260. t. 5. f. 89-92). Danach findet die Begattung im Juli statt, und die Weibchen legen bald darauf ihre Eier, die erst im April des nächsten Jahres auszukommen scheinen. Man trifft die kleinen Larven dam an den frisch ausgeschlagenen Blättchen von Cistus salvifolius L., in die sie leicht einzudringen vermögen. Die Larve frisst zwischen der Ober- und Unterseite eine Höhlung, welche zuletzt etwa drei Viertheile des Blattes ausmacht, dann durehbricht sie die Epidermis, wandert auf das am Stengel gegeniiberstehende Blatt, dringt hier, nahe der Mittelrippe, den Kopf nach der Basis gewandt, ins Innere und schreitet in einer Art Röhre, die sich vorn unregelmässig erweitert, allmählich bis an den Grund des Blattes vor, wo derselbe an den Stiel geheftet ist. Hier erfolgt die Verwandlung zur Puppe.

Die Larve ist ziemlich breit und flach, spatelförmig, oben und unten mit kleinen, braunen Körnchen besetzt, und hat 6 sehr kurze Beine, die am Ende eine schwärzliche Klaue tragen. Kopf klein, glänzend, rothgelb, eben, mit einer Mittehrime und jederseits 4 Ocellen; Mandibeln dreieckig, einfach; Maxillartaster konisch, in der Mitte eingeschnürt, Lippentaster fehlen. Fühler viergliedrig. Glied 1 kurz, 2 und 3 kngelig, letzteres mit einem Härchen an der Aussenseite, 4 kurz und sehr schmal. Brustringe nach hinteu verbreitert, Prothorax oben theilweise hornig, Meso- und Metathorax kiirzer. mit einer Querfurche, an den Seiten zu einem höckerigen 
Wulste ansteigend; unten betinden sich zwei kreisrunde, stärker gehöckerte Querwiilste Der Ilinterleib bildet 8 Segmente, die vier ersten allmiihlich mehr verbreitert als die Brustringe, dic folgenden verengt, das sicbente mit einer Querfalte, das achte gross, seleinbar aus zwei 'Theilen bestehend, der hintere Theil von einem rothgelhen Hormplättchen bedeckt. Das crste Stigmenpar tritt zwischen Pround Mesothorax herans, die sieben übrigen Paare liegen auf den 7 ersten Batchringen.

ד. Ir. testacea: Rufo-testacea, supra pilosa, antennis, spinis, episternis meso- et metasterni tarsisque articulo ultimo in apice piceis, prothorace subquadrato luteribus antice in lobum 6-spinosum productis. - Long. $4,2-5,5 \mathrm{~mm}$.

Linné, Syst. Nat. ed, 12. 603. - Fabr. Syst. Ent. 71.-Illig. Mag. 3. 169. - Rossi Faun. Etr. 1. 52. - Fairm. Gen. Col. Eur. t. 72. f. 345, - - Küst. Käf. Eur. 12. 100.

Var. a. Antemis apicem versus vel ommino testaceis, spinis basi rufescentibus.

Röthlich gelbbraun bis dunkel rothbraun, Fühler, Dornen des Halssch. und der Fld., Episternen der Mittel- und Hinterbrust, sowie die Spitze des vierten Tarsengliedes pechschwarz; die Fïhler zuweilen mit 5 rothen Endgliedern und rothem ersten Gliede, oder gänzlich roth, an der Spitze heller als am Grunde, auch die Dornen an der Basis röthlich (Var, a). Augenrinne mit weisslichen, glänzenden Haaren besetzt. Halssch. fast so lang als breit, dicht runzelig punktirt, mit zahlreichen niederliegenden hellen Härchen, matt, in der Mittelrinne glatt und kahl, die Seiten vor der Mitte in einen grossen, unregelmässigen, kahlen Vorsprung erweitert, welcher 6 leicht gekriimmte Dornen trägt. Von diesen steht einer innen und ist nach vorn gerichtet, die übrigen sind aussen befestigt, der letzte ist kürzer als die anderen. Fld, an der Basis viel breiter als das Halssch., hinter den Schultern etwas zusammengedrückt, am Ende kurz gemeinschaftlich abgerundet; der Aussenrand mit einem Kranze fast wagerecht abstehender Dornen bewehrt, der sich um die Schulter herum auf den Basalrand fortsetzt und an der Naht hinter dem Schildchen endet. Die Dornen sind verschieden lang: an der Naht kurz, am Vorderrande länger, von der Schulter bis hinter die Mitte am längsten (doch wechselt hier gewöhnlich ein längerer und dickerer Dorn mit einem kiirzeren und schwächeren ab), dahinter wieder kürzer, unter sich gleich, etwa so lang wie die vor der Schulter. Die Oberfläche der Fld, ist wenig dicht aufstehend behaart und hat zehn Punktstreifen, deren schmale, s.änzende Zwischenstreifen mit einzehen Dornen versehen sind. 
In den mugraden Zwischenstreifen findet man nierrige und schwache. in den geraden hohe und starke Dornen. Die Zähnchen an der Unterseite des Klanengliedes reichen etwas über die Mitte der Klanen hinweg.

Ueber Nordafrika und ganz Suideuropa verbreitet, aher anch in Tirol bei 'Trient von H. Schreiher gefangen und nach Grimmer in Steiermark.

\section{Hispella.}

Chapu is, Genera des Coleopt. XI. 334.

Antennae 11-articulatae, compressae, articulo primo unispinoso, sequentibus 5 fere ancipitibus, angulo superiore spinosis, articulis 5 ultimis minus compressis.

Pedes sat validi, opaci; femora inferne spinis minimis, tibiae apice profunde arcuatim emarginatae, tarsi articulo tertio apice pulvillato, ultimo intus haud producto; unguiculi longitudine inaequali.

Mandibeln am Innenrande mit zahlreichen spitzen Zähnen, von denen die beiden ersten grösser als die übrigen sind. An den Fühlern ist das Basalglied dick, oben zusammengedrückt und in einen langen, gebogenen Dorn ausgezogen, die folgenden fünf Glieder sind an den Seiten zu einer feinen Leiste zusammengepresst, daher fast zweischneidig; die obere Leiste geht an der Spitze in einen Dorn über, der am zweiten Gliede noch ziemlich lang, an den folgenden allmählich rerkürzt und mehr zahnförmig ist, die fünf Endglieder sind wenig zusammengedriickt, dicht behaart. Die Beine ziemlich kräftig, dicht lederartig gerunzelt, matt, Schenkel auf der Unterseite mit vielen sehr kurzen, höckerartigen Dörnchen versehen, Schienen dreikantig, die Aussenkante scharf, über der Mitte in einen Zahn erweitert, vor dem sich ein bogenförmiger Ausschnitt bis zur Spitze erstreckt. Die Solıle des dritten Tarsengliedes ist an der Basis kahl, auf jedem Lappen zeigt sich ein ovaler, dicht mit Haaren bekleideter Fleck, das Klauenglied ist an der Spitze einfach und die Klanen liegen rom Grunde an frei, die innere derselben ist kürzer als die äussere.

Diese Gattung enthält nur wenige schwarze Arten; wollte man sie mit Chapuis als Untergattung von Hispa betrachten, so muisste mbedingt auch Monochirus dazu gezogen werden, obwohl er in den Genera XI. 330 als Typus einer eigenen (natiirlich unhaltbaren) Gruppe angesehen wurde. In der Klauenbildung vermittelt Hispella. den Uebergang von Monochirus zu Hispa; letzteren Namen beanpsruche ich ausdriicklich fiur die umfangreichere Gattung. 
7. W. atra: Atra, prothorace opaco, apice utrinque bispinoso, spinis basi conjunctis, lateribus rotundato trispinoso, spinis anterioribus basi conjunctis, elytris obsolete chalybaeo-vel metallico-resplendentibus, multispinosis. - Long. 3-4 mm.

Linné Syst. Nat. ed. 12. 603. - Fabr. Syst. Ent. 71.-Payk. Fn. Suec. II. 151. - Rossi Faun. Etr. 1. 52. - Gyll. Ins. - Suec. III. 449. - Panz. Faun. Germ. 96. 8. - Luc. Expl. Alg. Ent. 515. t. 44. f. 3. - Küst. Käf. Eur. 3. 76. Thoms. Skand. Col. VIII. 317. - Redtb. Faun. A. ed. 3. II. 519. - Bach, Käferf. III. 72. - Seidl. F. balt. ed. 2. 703; F. transs. 789.

H. aptera Motsch. - Schrenck Reise II. 218.

? H. minuta Balbi Contribuz. Faun. dEur. 1892. 11.

Tief schwarz, matt, nur der Bauch auf einem Längsstreifen in der Mitte glänzend, und die Fld. mit einem wenig in die Augen fallenden verwaschen stahlblanen oder metallischen Anfluge. Stirn uiber den Fühlern ziemlich eben, fein und dicht gerunzelt, durch eine Querriune hinter den Augen vom Halse getrennt, und durch eine Mittelrinne in zwei grosse Flächen getheilt. Halssch. quer, flach, dicht und fein gerunzelt, mit 10 Dornen: zwei jederseits am Vorderrande, rechtwinkelig zu einander gestellt und an der Basis verwachsen, drei andere auf dem gerundeten Seitenrande, nach aussen gerichtet, die beiden ersten ebenfalls am Grunde zusammen gewachsen. Fld. viel breiter als das Halssch., mit ziemlich parallelen Seiten, hinten gemeinschaftlich abgerundet, von einem Kranze dicht stehender Dornen umgeben, welche hinten etwas kürzer werden, am Vorderrande nach vorn gerichtet, sonst wagerecht abstehend sind. Die Scheibe der Fld. ist äusserst zart gewirkt, in zehn wenig regelmässigen Reihen stark punktirt (die 7. und 8. Reihe fehlt vor der Mitte) und mit vielen Dornen versehen. Diese stehen auf dem 1. und 2. Zwischenstreifen namentlich vor der Mitte vereinzelt, auf dem 4. und 6. Zwischenstreifen, welche schwach kielförmig sind dicht neben einander. Die Dornenreihe des sechsten Streifens reicht bis zur Mitte und setzt sich dann auf dem achten Streifen fort.

Im Sommer auf trocknen Grasplätzen nicht selten. Nordafrika, Europa, Kleinasien, Turkestan.

\section{Zweite Gruppe: CASSIDINI.}

Chapuis, Genera XI. 341.

Caput occultum, oculi vix prominuli.

Prothorax angulis anticis mullis, lateribus epipleurisque elytrorum valde dilatatis, protectum plus minusve translucidum formantibus. 


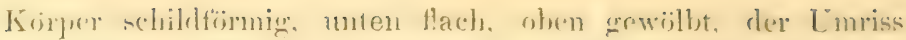

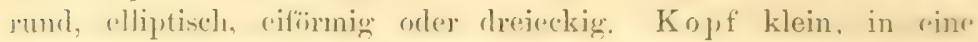
Riihre des Ilakschildes eingroogen. von oben selten sichthar, anch rie Mundtheile groisstentheils vom Prosternum herleckt. Stirn mit einer Mittelrinne und meist deutlichen Ilïckerchen iiher der Fiihlere wurzel, darunter ein in der Regel grosses Koptschild; Augen lain rich. fein facettirt, nach unten divergirend: Olerliple quer, alsgerandet. Wandibeln bei den europüischen Arten sechszihnig, 2 grosse Zähno vorn. 2 kleinere auf jeder Seite; Maxillartaster viergliederig. (ilierl 1 klein, 2 schlank, $3 \mathrm{kurz}, 4$ das längste, rorm zugespitzt, nur in der brasilianischen Gattung Platyanchenia, welche unseren SilphuArten ähnelt, angeschwollen und rom abgestutzt; Lippentaster dreigliederig. Fïhler meist mit fünf dickeren Endgliedern. Halssclı. an den Seiten dachförmig rerlängert, einem Kreissegmente ähnlich, olne Vorderecken (scheinbare treten in den Gattungen auf, bei denen der Vorderrand ausgeschnitten und die Fühlerwurzel, oder noch ein Theil der Stirn von oben sichtbar wird z. B. Prioptera, wirkliche, mit Fckpore und Borste versehene, nu bei Porphyraspiss). Die Basis des Halssch. ist gerundet, oder jederseits ausgeschweift, selten fast gradlinig, und hat in der Mitte einen gegen das Schildchen vorgezogenen Lappen. Letzteres klein, vorn gerade abgestutzt, dreieckig; selten vorn zugespitzt, dann rautenförmig (bei Batonota). Fliigeldecken genau an das Halsschild schliessend, am Seitenrande mehr oder weniger dachförmig verlängert, hinten gemeinschaftlich abgerundet, selten zugespitzt oder abgestutzt; der Basalrand selı oft dicht gezähnelt und, bei bell gefärbten Arten dunkel oder schwarz gesäumt, die Scheibe rerworren oder gereiht-punktirt. bald gleichmässig gewölbt, bald zu einem gemeinschattlichen Höcker. ein Stzick hinter dem Schildchen aufsteigend, vor welchem dam ein dreicckiger, gleichmässig abfallender Raum gebildet wird, der oft noch seitwärts rom Schildchen muldenfömig vertieft ist. Abweichend sind die Flügeldecken gebant bei Batonota, wo statt des Höckers ein langer, anfrechter Dorn jerlerseits an der Naht auftritt und die Schultern spitz, dreieckig vorspringen, ferner bei einigen Desmonota, die einen Höcker in der Mitte jeder Fld.. etwas rou der Naht entfernt, besitzen, sowie bei Tauroma Hope (alle drei aus Siidamerika), deren Schultern in Gestalt eines langen. dreikantigen Stabes wagerecht nach aussen treten. Prosternum zur Aufnahme des Mundes vorn erhöht, mitunter auch lappenförmig: erweitert, zwischen den Huiften stets breit und deutlich. dahinter in cinen Fortsatz erweitert, welcher sich mit den Seitenstiicken rerbindet und hinten in das kurze Mesosternum ringreift. Mittelhiiften mehr oder weniger weit getremnt, Hinterbrust gross, ilne 
Seitenstücke schlank, parallel, oclep in ter Mitte cingeengt. vorn oft mit einem Zipfel in die Giplemen lautend. Banch selur schwach oder kaum gewölbt, mit fünf' Rinesen. Brine kur\%. untex den Flel. verborgen, Schenkel ziemlich dümn, eintach, Śchiencn grarle, nach vorn allmählich verdickt und an der sipize ansegerandet, das arste Fussglied theilweise eingelagert; 'Tarsen breit, unten mit dichter Haarbiuste, Glied 1 meist klein, 2 an der spitze ansgerandet, 3 tief gespalten, 4 ron den Lappen des dritten anfgenommen und selten länger oder kürzer als diese, einfach, nư in der Gattung. Calaspider aus Siidamevika vor den Lappen des dritten Gliedes plötzlich erweitert, abgestutzt. Klauen mehr oder weniger weit gespreizt (bei Batonota einander beriihrend), entweder einfich, oder mit einem runden oder spitzen Anhäng'sel am Grunde, zuweilen kammförmig gezähnt.

Die Entwicklung vollzieht sich frei auf der Nährpflanze. Die länglichen Eier werden in kleinen Häufchen an ein Blatt geklebt und mit Excrementen eingehüllt, damit sie nicht übermässig austrocknen; auch die Larve bedeckt sich aus demselben Grunde ${ }^{1}$ ) mit einem dicken Kothdache, welches nicht, wie bei den Larven der Criocerinen, direkt auf dem Riicken liegt, sondern iiber demselben auf einer zweizinkigen Gabel getragen wird und auf und ab bewegt, selbst nach hinten geschlagen werden kann. Die Gabel befindet sich am letzten Abdominalringe, wolchen das Thier so weit in die Höhe hebt, dass die Zinken wagerecht nach vorn stehen. Der After ist dann gleichfalls nach vorn gebogen und die Kothballen schieben sich auf vorwärts gerichtete Dörnchen an der Basis der Zinken, wo sie festgehalten, durch die nachfolgenden Ballen weiter geschoben und endlich, in Verbindung mit den alten Larvenhäuten, zu einem meist schwärzlich gefärbten Dache von veränderlicher Form zusammengeklebt werden, unter den die Larve zuletzt fast ganz versteckt ist. Die Puppe hat eine zarte Oberhaut, die bei der Mehrzahl der Cassiden an den Seiten der einzelnen Bauchringe in verschieden geformte zahnfömige Anhängsel ausläuft, und ist mit dem Ende in der Spitze der Larrenhaut bebefestigt, welche am Blatte kleben bleibt²).

1) Nicht zum Schntze gegen Feinde, wie rielfach, anch noch ron Chapius (Genera XI. 349) angegeben wird.

$\left.{ }^{2}\right)$ Die Beohachtung von Comelins (Stett.Z. 1847. 348), , has man, (C. nebulosu ansgenommen, niemals Puppen oder deren Ueberreste auf der' Futterpflanze antrifft," kann ich nicht hestätigen; ich habc rielmeln" lebende Puppen und deren Häute von den verschiedensten Alten oft zu Tausenden an die Blätter der Nährpflinze geklebt angetroffen. Ebenso muss hier eine falsche Beobachtung Suffrians, die auch von Chapuis, 
I) Cussiden lilden eine abgreschlossene Gruppe, die ansere leichten Anklängen an die Itispiden keinen L'ehergang zu anderen Ahtheilungen der C'hrysomeliden aufweist; sie setzt sich gegenwirtigr aus etwa 1800 Arten der heissen Zone, von denen zwei Drittheile, und zugleich die grössten und prïchtigsten 'Thiere. auf' Mittel- und Südamerika, die übrigen fast zu gleichen Theilen auf Afrika und Asien entfallen, und aus ungefähr 200 Arten in den gemässigten Zonen zusammen, wovon Europa etwa 60 beherbergen mag. Fast alle sind durch lebhafte, bald kräftig, bald zart aufgetragene Farben. oder eigenthümliche Zeichnungen der Oberseite bemerkenswerth. Ein Theil ist gesättigt roth, oder roth und schwarz, auch rothbraun gefärbt und im Leben dann selten mit metallischem Goldschimmer iiberzogen; ein anderer hat kupferige, goldige, grüne, blaue, braune, helle oder dunkle, glänzende oder matte, sehr dauerhafte Metallfarben; ein dritter und zwar der umfangreichste Theil, bei welchem cine blattgrüne, gelbe oder gelbbraune Farbe vorherrscht, ist im Leben auf der Oberfläche, oder einzelnen Theilen derselben ron einem bläulichen Silber-, oder grünlichen bis kupferigen Goldglanze bedeckt, welcher nach dem Tode durch das Austrocknen der Epidermis völlig verschwindet. Hierbei verbleichen allmählich auch die Grundfarben, bei den sehr dicken und harten Decken langsam, bei diunnen oder weichen schneller. Will man die ursprüngliche Färbung lange erhalten, so müssen die Thiere in Spiritus aufbewahrt werden; grüne Thiere verbleichen erst nach vielen Jahren. wenn sie in Schnupftaback getötet wurden.

So leicht es sein mag, eine Casside als solche zu erkennen, so schwierig wird die Zusammenstellung der Arten in natürliche Gattungen, da die in Betracht zu ziehenden Körpertheile sehr gleichmässig gebaut sind. Die jetzigen Gattungen, welche theils von Hope Ann. nat. Hist. III. 1838. 94 und Coleopt. Man. III. 1840. 153), theils ron Boheman in einer umfangreichen, aber der kritischen Schärfe entbehrenden Monographie (I. 1850, II. 1854. III. 1855 IV. 1862) aufgestellt, auch ron Chapuis (Genera XI. 335)

Genera XI. 350, nachgeschrieben wird, berichtigt werden. Suffrian erzählt (Stett. Z. 1844. 218), dass die Puppen ,etwa auf der MIitte des zweiten oder dritten Bauchringes mit einem Tröpfchen einer gelben, zähen Feuchtigkeit festgeklebt waren". Die mir bekaunten Puppen, auch die von Suffr. besprochene der azurea, welche ich nebst Larren durch die Freundlichkeit des Herrn Direktor Dr. Buddeberg von Nassau erhielt, sind frei, nur der Anus steckt in der festgeklebten letzten Larrenhaut, in welcher er durch eine Gabel festgehalten wird, die in der Gabel der Larvenhaut sitzt. Berührt man eine Puppe, 'so richtet sie sich ihrer ganzen Länge nach in die Höhe. 
näher begründet wurden, variiren in den trennenden Merkmalen (der heutige Begriff ('assidı z. B. enthält Repräsentanten von vielen anderen Gattungen), so dass ein zukiinftiger Monograph die Genera entweder schr verringern, oder ganz bedeutend vermehren muss.

Für uns dürften nur die folgenden von Interesse sein:

1. Klauen gänzlich, wenigstens an der Basis kammförmig gezälınt, drittes Fühlerglied viel länger als das zweite.

Aspidomorpha Hope ${ }^{1}$ )

1'. Klauen am Grunde mit einem zahnartigen Angängsel oder ohne Auszeichnung . . . . . . . . . . . . . . 2.

2. Fiihler schlank, bis an die Hinterbrust reichend.

Coptocycla Boh. ${ }^{2}$ )

$2^{1}$. Fühler kaum die Basis der Vorderbrust überragend . . . 3.

3. Vorder- und Mittelhüften einander fast berührend, Seitenstiucke der Vorderbrust in eine linienförmige, niedrige Leiste verengt, welche die Pfannen unvollkommen schliesst, Hinterrand des Metasternum in der Mitte mit zwei feinen Zähnchen, Halssch. nach rorn sehr steil abfallend, der Vorderrand bildet einen schwachen, der Hinterrand einen auffällig tiefen Bogen.

Chelysida Fairm. ${ }^{3}$ )

$3^{1}$. Vorder- und Mittelhuiften deutlich durch einen ebenen, bandförmigen Streifen der Seitenstücke getrennt, welcher die Vorderpfannen vollkommen schliesst; Hinterrand des Metasternum in der Mitte winkelig ausgeschnitten . . . . . . . . 4.

4. Drittes Fühlerglied kürzer als das zweite, Körper seitlich zusammengedrückt, in den Schultern, welche als grosse Beulen heraustreten, am breitesten, dahinter verschmälert, zehnte Punktreihe der Fld. nicht erkennbar. . . . Ischyronota Ws. $\left.{ }^{4}\right)$

1) Die Gattung umfasst etwa 250 Arten, nur eine kommt noch am Amur vor, Asp. difformis Motsch. (Kraatz, Deutsch. Zeitschr. 1879. 270).

2) Von 400 Arten ebenfalls eine am Amur: Copt. a murens is Kraatz (1. c. 141).

$\left.{ }^{3}\right)$ In der Umgebung des mittelländischen Meeres 2 Arten, die sich durch hohe Wölbung auszeichnen: Ch. deflexicollis Boh. (Mon, 4. 333) Schulterbeule klein, kaum abgesetzt, Fld. fein und ziemlich verworren punktirt. - L. 3-4mm. Unteritalien, Sicilien, Südfrankreich. - Chel. vagepunctata Desbr. Schulterbeule gross, hoch, vortretend, Fld. mit flachen und grossen, theilweise gereihten Punkten. - L. 3-4 mm. Oran. Mogador. (Fritsch,, v. Heyden).

$\left.{ }^{4}\right)$ Blassgrïne Arten, die nach dem Tode auf dem Halssch, und der Unterseite bald in ein helles Gelbbraun verbleichen:

1. Basalrand der Fld. schwarz gesäumt, regelmässig und stark gezähnelt 2.

11. Basalrand der Fld, bräunlich, unregelmässig und sehr undentlich gezähnelt 
41. Urittes Füblerglied so lang od(re liingrer als das zweite. zohnte l'unktreilue der Flil. stets deutlich, meist aus sellu grolien Punkten gebildet . . . . . . . . . . . 5 .

5. Klanenglierl in den Lappen des dritten 'Tarsengliedes verborgen. Cassida L.

51. Klanenglied sehr lang und stark. donpelt bis dreitach sn lang als das dritte 'Tarsenglied (Horae 23. 647) ('hividula Ws.')

\section{Cassida.}

Linné, Syst. Nat. ed. 10 (1758) 362.

Antennae breviusculce, articulo $3: 0: \therefore:$ o longiore, articulis 5 ultimis dilatatis, inferne subdeplanatis.

Metasternum magnum, episternis distinctis.

2. Schulterbeule klein. Gläuzend, Fld. sehr grob, fast reihenweise punktirt. - L 4,5 mm. Araxesthal (D. Z. 1890 175) elexuta Reitt.

$2^{1}$. Schulterbeule gross, hoch, stark vortretend . . . . . . 3.

3. Jatt, Fld mit grossen, flachen Nabelpunkten. - L. 5-5,5 mm. Algier (D. Z. 1889. 288) . . . . . Brisouti Reitt.

$3^{1}$. Glänzend, Fld. mässig stark und tief, grösstentheils in Reiben punktirt. -- L. 5 mm. Turkestan. (D. Z. 1890. 367). Wahrscheinlich mit elevata sehr nahe verwandt . . . . . nitidula Ws.

4. Schulterbeule klein, wenig vortretend, Fld. einfarbig, jede mit 3 hinter der Mitte dentlichen Punktstreifen an der Naht. Kopf gelbbraun oder (var. araxicolu Reitt. D.Z. 1889. 288) schwarz. - L. 4-5 mm. Sarepta, Astrachan, Araxes. (1. c. 288) C. salsolae Desbr. Mon. 43. Jakow lew iReitt.

41. Schulterbeule gross, stark rortretend, Fld neben der Naht mehr oder weniger in Reihen punktirt, an der Selnulter und Spitze röthlich. L. 4,5-5,5 mm. Astrachan, Kirghisensteppe. Turemenien. (Bull. Mosc. 1833. 305) . . . . . . . . desertorum Gebl. C. niticula Desbr. MLon. (1891) 44 rou Algier ist wahrscheinlich mit Brisouti Reitt. identisch.

1) 1. Klanenglied dreimal so lang als die Lappen des dritten Tarsengliedes und etwas länger als die ersten drei Glieder zusammen. Gelbbraun, dicht mit weisslichen, sehr kurzen, schuppenförmigen Börstchen besetzt, Halssch. dicht und fein längsrunzelig punktirt, mit stumpfen, weit vor der Schulterecke liegenden Ecken, Fld. stark punktirt, jede mit drei Längsrippen, die durch eine Anzahl kleiner Querrippen verbunden sind - L 5,2-6 mm. (Verh. Brünn 1889. 42) Araxes, Turkmenien . . . . . suberosa Ws.

Aendert ab: Pechschwarz, ein zweilappiger Fensterfleck am Vorderrande des Halssch, ein breiter Seitensaum ron der Basis bis hinter die Mitte der Fll., der hintere Kinoten der ersten Rippe und die Beine theilweise gelbbram. (Färbung an atrata erimnernd) D. Z. 1891. 35. Turkestin. Duirfte mit $C$. apicalis (Tebl. Bull. Petr. III. 1845. 105 zusammenfallen . . . . v. discoidalis Reitt. 
Die Fülller sind 11-gliedrig, Glied 3 so lang, oder in der Regel lïnger als 2, die 5 Endglieder verbreitert, anliegend dicht behaart, unten etwas abgeflacht und fast immer heller gefärbt als oben. Beim 'Tode werden die Fiihler an die Seiten der Vorderbrust gelegt (in einzelnen Fällen sogar in wirkliche Rimene) und reichen dann mit dem letzten Gliede über die Basis derselben hinweg. Die Oberlippe hat einen kleinen winkeligen oder viereckigen Aussehnitt am Vorderrande. Das Halsschild ist quer, bald einem Kreissegmente, bald einem schiefen Ovale ähnlich, dessen hinterer Bogen riel flacher als der vordere ist; die Vorderecken fehlen stets, es entstehen jedoch bei lineola vier andere deutliche Ecken (zwei an den Seiten, zwei am Grunde), bei den iibrigen Arten zwei an der Basis, die aber nur bei einer kleinen Anzabl ron Arten (canaliculata, fastuosa, murraea, atrata, seladonia, lineola und denticollis) den Namen Hinterecken rerdienen, der Kürze wegen trotzdem blos als "Ecken" zu bezeichnen sind. In allen anderen Fällen müssen die wahren Hinterecken in Uebereinstimmung mit den anderen Chrysomeliden vor der Schulter, in dem hinteren Vereinigungspunkte der Halsschild. und Brustfläche gesucht werden und sind entweder ganz verrundet (bei viridis, nebulosa, subferruginea, flaveola etc.), oder durch ein Zähnchen kenntlich, welches ich den Basalzahn nennen will. Derselbe ist unter der Kante der Flïgeldecken rerborgen und wird bei abgebogenem Halsschilde sichtbar, selteu ziemlich frei z. B. bei denticollis. Die Lage dieses Zahnes lässt sich bei allen Arten erkennen, da der Basalrand des Halssch. und der Fld. von einem Zahne zum anderen schwarz gesäumt, auf den Fld. ausserdem noch melır oder weniger deutlich gekerbt oder gezähnelt ist. Flügeldecken ungefähn ron der Breite des Halsschildes, vor der Schulter melu oder weniger tief ausgerandet, wovon die Grösse des Aussenwinkels abhängt, auf der Scheibe verworren, gereiht, oder gestreift-punktirt, die 9. und 10. Punktreihe immer vorhanden. Letztere ist gewöhnlich aus sehr groben Punkten zusammengesetzt und giebt die Grenze der Fld. an, da sie genau auf derselben Stelle entlang läuft, wo sich bei

2. Klaneng'lied doppelt so lang als die Lappen des dritten Tarsengliedes. Körperbau an seladonia Gyll. erinnernd, grïn, Halssch. und Beine verblasst, brämulich gelb, Brust und Hitte des Bauches dunkel. Fld. wenig stark und tief punktirt, jetle mit 3 etwas erhabenen Längslinien. - L.5,5-6mm. Turkestan. (Horae 23.647) Semenowi Ws.

3. Klanenglied nicht ganz doppelt so lang als die Lappen des dritten Tarsengliedes. Vom Ansehen der C. murraca L., oben rothbrau, mit schwarzen Punkten anf den Fld, unten schway. - L . 7,5-8,5 mm. Turkmenien, Sibirien. (Bull. Mose. 1833. 306) 11-not at a Febler 
anderen Küfern die Randlinie befindet. Zur festen Verbindung der heiden Haupttheile des Körpers dient nicht nur der rhombische Fortsatz des Prostermum, sondern auch ein zahnörmiger Vorsprung an der Basis der Vorderbrust jederseits, welcher auf die Mittelbrust, dicht neben den Epimeren, hinüberreicht. Die Hinterbrust ist durch eine dicke Naht von den Seitenstücken getrennt. Jeder vertiefte Punkt der Oberseite trägt ein halb aufgerichtetes, schuppenförmiges, oder nach der Spitze verdicktes, wasserhelles Härchen, ebenso ist jeder Zwischenstreif der Fld. mit einer weitläufigen Reihe solcher Härchen besetzt. Dieselben sind indessen bei den meisten Arten so fein und kurz, dass sie nur unter stärkerer Vergrösserung und an sauber gehaltenen Exemplaren sichtbar werden; mit blossem Auge kann man sie vielleicht nur bei vilex wahrnehmen. Diese Härchen, sowie die überaus empfindlichen grünen Farben lassen sich, wie schon in der Gruppeneintheilung erwähnt, dadurch gut erhalten, dass die Thiere in Sclinupftaback (Grand Cardinal) getödtet werden.

Die Männchen zeichnen sich im Allgemeinen durch ein breiteres Halsschild aus; der Penis ist eine stark gebogene, mehr oder weniger von oben zusammengedrückte Röhre mit kleiner Oeffnung für den Duktus, vorn abgerundet, leicht abgestutzt oder zugespitzt, bei den einzelnen Arten wenig verschieden.

Der Körper der Larven ist lang eiförmig, hinten stärker rerschmälert als vorn, grïn, ror der Verpuppung bra:m oder schwärzlich, ziemlich flach, an den Seiten mit einem Kranze von 32 wagerecht abstehenden dornähnlichen Verlängerungen umgeben, woron jede wieder zahlreiche Dörnchen trägt. Diese Bewaffung, sowie die Anordnung der Dornen ruft eine entfernte Aehnlichkeit mit ausgebildeten Hispa-Arten hervor. Um den Prothorax stehen 8 Dornen, davon entspringen 2 jederseits am Vorderrande fast aus gemeinsamer Basis, die übrigen sind frei; am Meso- und Metathorax sitzen je 2, an den 8 Bauchringen je ein Dorn auf jeder Seite. Die Form und Lage ron Kopf und Prothorax, die Richtung der Stirn und des Mundes, sowie die Bildung der Oberlippe stimmen mit der des Käfers iiberein. Der Kopf hat eine sehr dïnne, pergamentartige Schale, Mandibeln 6-zähnig ${ }^{1}$ ), ein grosser Zahn an der Spitze, zwei kleine darüber, zwei grössere und ein kleiner darunter; Taster konisch, die Maxillartaster mit 4, die Lippentaster mit 3 Gliedern, Fühler ebenfalls 3-gliederig, Glied 1 gross, fleischig, halbkreisförmig, 2 kurz, schmal, cylindrisch, 3 bildet

1) Nicht 3-4-zähnig, Chapius, Genera XI. 348 . 
eine kleine, kaum bemerkhare Spitze. Ocellen ${ }^{1}$ ) auf jeder Seite 5, 4 davon in einer Schräigreihe, die unterste, neben dem Fühler, besteht oft aus 2 dentlich getrennten Ocellen und ist ron den drei anderen weiter entfernt als diese unter sich, hinter der dritten Ocelle (von oben gerechnet) liegt die fünfte. Der I'rothorax ist mit zerstreuten sehr kleinen IIöckerchen oder Borstenkegeln besetzt, ron denen einige, ein Stiick ror dem Hinterrande, eine deutliche Querreihe bilden. Diese beschreibt in der Mitte einen nach vorn gerichteten Bogen und geht jederseits in eine grosse, kreisförmige Fläche über, welche aus unregelmässigen, meist dunkel gefärbten Gruben besteht. Die Stigmen sind gross, kegelförmig, das erste Paar liegt in den Ecken des Prothorax, die uibrigen 7 Paare befinden sich an den Seiten der ersten 7 Hinterleibsringe. Beine kurz und dick, sparsam und lang behaart, Schenkel walzenförmig, Schienen bei einigen Arten (z. B. subferruginea) wenig, bei andern z. B. azurea) viel kürzer und dünner, am Ende mit einer braunen, hornigen Klaue bewehrt.

Die Puppe ist kürzer als die Larve und wenig länger als der Käfer, dunkel gefärbt. Das Halsschild hat ungefähr die Form wie beim Männchen von lineola, die Seiten erweitern sich also vor der Basis gradlinig in eine mehr oder weniger scharfe Ecke und bilden davor einen regelmässigen Bogen; ihr Rand ist mit 30 bis 60 wagerecht abstehenden Dornen von verschiedener Länge und Stärke besetzt. Von den grösseren Dornen stehen bei vielen Arten 6 in der Mitte des Vorderrandes und eben so viele jederseits auf dem verengten Theile vor der Basis, der letzte derselben ist besonders gross, zwei- bis vierspitzig. Bei wenigen Arten z. B. bei nebulosa sind die Dornen fast gleichlang. Die beiden hinteren Thoraxringe und die Hinterleibssegmente sind viel schmaler als der Prothorax in seiner grössten Breite, es wird jedoch jeder der ersten 6 Rückenringe (die nicht von der alten Larvenhaut eingeschlossen sind) durch einen häutigen Fortsatz auf jeder Seite verbreitert. Diese Fortsätze sind lang dreieckig, scharf zugespitzt und an den beiden Rändern mit Dörnchen versehen; sie färben sich vor dem Ausschlüpfen des Käfers meist weisslich. Die der beiden ersten Ringe sind am grössten, mit der Spitze nach vorn gerichtet, die beiden folgenden kleiner, fast wagerecht abstehend, die beiden letzten klein, nach hinten gerichtet. Dicht neben diesen Fortsätzen liegen die Stigmen, von denen 6 Paare sichtbar sind: die ersten

1) Nicht 4 (Chapius 1.c.), dagegen kann man 6 angeben, wenn in der Nähe des Fühlers 2 Ocellen dicht neben einander liegen.

VI. 6. 
4 Paare hilden hohe, schrïg nach aussen gerichtete Cylinder. dlie beiden hinteren Paare sind niedrig.

Schon nach einer Woche, meist im Juli, schlüpft der Käfer aus. Er ist sehr weich, einfarbig schmutzig weiss oder blasserelb (viridis), härtet sich in Verlanfe einiger 'Tage. ist aher erst nach mehreren Wochen nothdiurftig ausgefarbt, was man am besten darans erkennt, dass der helle, zweitheilige Fleck, den alle frisclien Stiicke auf dem Halsschilde vor dem Schildchen besitzen. verschwunden ist. Die völlige Ausfärbung tritt bei den meisten Arten gegen den Herbst oder im nächsten Frühjahre ein; dann ist die Oberseite, wenigstens auf einzelnen Stellen, mit eineun prïclitigen grünen, goldigen, kupferrothen oder silberweissen Metallschimmer oder Perlmutterglanze überzogen, der nur C. fastuosa, muraea, atrata, rubiginosa und thoracica fehlt. Bei rielen grünen Arten ändert die Grundfarbe des Hochzeitskleides und die metallische Nebenfarbe desselben nach einzelnen Individuen ab von maigriun bis dunkelgrün oder blaugrün, nirgends, oder an einzelnen Stellen, oder auf dem grössten Theile der Oherseite mit Metallfarben, kupferroth, goldgelb bis silberweiss, verziert.

\section{Bestimmungstabelle.}

A. Drittes Fühlerglied unmerklich kürzer oder nur so lang als das zweite; der Vorderrand der Vorderbrust fällt jederseits neben dem Auge plötzlich ab und bildet eine Ecke, Fühler in tiefe, neben den Augen fortlaufende Furchen eingelegt. Oberseite schmutzig rostroth, Fld, verworren punktirt, jede mit 4 Längsrippen . . . . . Subgenus Hypocassida.

1. Zähnchen am Basalrande der Fld. ron gleicher Grösse. L. 4,5 bis $6 \mathrm{~mm}$. Europa . . . . 1. subferruginea Schrank.

$1^{1}$. Basis der Fld, vor der Schulter sehr tief ausgebuchtet und hier mit einigen grossen Zähnchen besetzt, die riel grösser sind als die nahe dem Schildchen. - L. 5-6 mm. Siideuropa. (Stett. Z. 1844. 276) . . . . . meridionalis Suffr.

A ${ }^{1}$. Drittes Fühlerglied merklich länger als das zweite. Vorderrand der Vorderbrust neben den Augen allmählich abfallend.

B. Klauen an der Basis in ein zahnartiges Anhängsel erweitert.

Subgenus Odontionycha.

1. Seitenrand des Halssch. rerdickt, durch einen grob punktirten tiefen Eindruck emporgehoben und von der fein punktirten, kissenartig gewölbten Scheibe getrennt. Grundrand der Fld. vor der Schulterbeule tief ausgerandet und grob gezähnt. 
Klauenzahu sehr klein. Nelen den Augen eine Fïhlerrime. I. 4,5-6 mm. (Pilemostoma 1)eshr.) . . 2. fastuosa Schall.

11. Soitenraud des Halssch. einläch, meist dünn, hö̈hstens dureh (inen weiten Findruck in die Hïhe goholen. Grundrand der Fld. gleichmässig gebogen oder vor der Schulterbeule seicht ausgerandet und foin gezilhnt. Fiihlerfiuche undeutlich . 2.

2. Körper mach hinten allmählich vereng"t, leicht dreickign; Fld. reworren punktirt, ihr Basaldreieck ist deutlich abgesetzt und bildet eine abschiissige Ebene, die mit der Seheibe des Halssch. in einer Flucht abtällt

2 Körper hinten breit abgerundet, elliptisch oder rund; Fld. olnne deutlich abgesetzte dreieckige Fläche an der Basis

3. Brust und Bauch schwarz, letzterer gelb gesäumt. L. $7-9 \mathrm{~mm}$. 4. viridis $I$.

31. Brust und Bauch gelbbraun. Fld. eine Spur stärker punktirt, sonst wie vorige (vielleicht nur Var. derselben). Spanien, Portugal (Ann. Fr. 1852. 92) . . . . nigriceps Fairm.

4. Fld. jederseits hinter dem Schildchen mit einem Lindrucke, der hinten von einer Querleiste begrenzt ist, welche die beiden ersten Punktreihen unterbricht, Zwischenräume spiegelglatt 6 .

41. Fld, ohne Querleiste, Zwischenräume lederartig gewirkt . 5.

5. Fld. sehr dicht gleichmässig punktirt, ihr Seitendach abschüssig. L. $4,5-5,2 \mathrm{~mm}$. . . . . . 5. hemisphaerica Herbst. 51. Fld. ungleichmässig gereiht-punktirt, ihr Seitendach ähnlich wie das des Halssch. aufgebogen. L. 9-10,5 mm.

3. canaliculata Laich.

6. Umfang fast kreisuund, Seitendach der Fld. selor breit, flach. Bräunlichgelb, Schenkelbasis, Kopf, Brust und Bauch schwarz, letzterer gelb gerandet. - L. $5 \mathrm{~mm}$. Caucasus (Mem. Mosc. 5. 325. t. 12. f. 3) . . . . . . . . bella Fald.

61. Umfang breit eiförmig, seitendach der Fld. breit, ziemlich abschüssig. Wie vorige gefärbt, Beine in der Regel einfarbig' gelb, Fld. mit 5 kirschrothen Makeln, je zwei an der Basis und eine gemeinschaftliche in der. Mitte. - L. 5-6,5 mm. Türkei, Griechenland, Kleinasien (D. Z. 1884. 159). . . brevis IV s.

C. Klauen einfach.

1. Klauenglied klein, schmal, wicht ganz so lang als die Lappen des dritten Tarsengliedes, dessen Wimperkranz von den kleinen, wenig gespreizten Klauen nicht iiberragt wird; Kopfschild dreieckig, ron tiefen und breiten Furchen begrenzt, mit einer vorn abgekürzten Mittehime (Mionycha W's.) . . . . . 2.

11. Klanenglied so lang oder lïnger als die Lappen des dritten 
Tarsengliedes, Klanen gross, gespreizt, den Wimperhesatz des dritten Gliedes üherragend.

2. Bauch grün (gelb). Körper hinten höher gewöllbt und steiler abfallend als vorn. Ecken des HaIssch. stumpfwinkelig. - I. 3 bis $4,5 \mathrm{~mm}$. Europa. . . . 8. margaritacea Schall.

$2^{1}$. Bauch wenigstens längs der Mitte schwarz, oder dunkler als am Rande

3. Ecken des Halssch. breit algerundet, Fld. stark gestreift-punktirt, die Punktreihen so breit oder breiter als die Zwischenstreifen. - L. 5-7 mm. Mitteleuropa. . . . 6. azurea F.

$3^{1}$. Ecken des Halssch. stumpfwinkelig, die Spitze abgerundet, Punktreihen der Fld. riel schmaler als die Zwischenstreifen. - L. 4,8-5,5 mm. . . . . . . 7. splendidula Suffr.

4. Umriss annähernd quadratisch, Dach der Fld. mit einem grossen, innen gerundeten Fensterflecke, hinter dem Schildchen jederseits eine grosse, tiefe Grube, die hinten zu einer höckerartigen Querleiste ansteigt. (Schenkel an der Basis schwärzlich)

Subgenus Deloyala Redtb.

a. Oberseite rothbraun, oft auch der Kopf; Halssch. grösstentheils bräunlich gelb. - L. 4,5-5.5mm. Türkei, Griechenland, Kleinasien (Bull. Petr. I. 1836. 151.)

seraphina Ménétr.

b. Oberseite schwarz, Vorderrand des Halssch, ron einem gut begrenzten, in der Mitte verengten Fensterflecke eingenommen. L. $6,5 \mathrm{~mm}$. Caucasus, Armenien (Bull. Mosc. 1838. 182) . . . . . .. . hablitziae Motsch.

$4^{1}$. Umriss rund oder länglich, Seitendach der Fld, ohne Fensterfleck

5. Seitendach der Fld. mehr oder weniger flach ausgebreitet, die Wölbung der Fld. nicht gleichmässig fortsetzend. Brust so hoch als der Rand der Fld, letztere an der Basis oft gezähnt.

Cassida in spec. 6.

51. Seitendach der Fld. steil abfallend, Brust niedrig, nicht so hoch als der Rand der Fld., letztere an der Basis meist ungezähnt.

Cassidula 35.

6. Der Basalzahn des Halssch. bildet die Ecken desselben, Grundrand der Fld. gänzlich gezähnt

61. Der Basalzahn des Halssch liegt innen, ron den Ecken entfernt, oder fehlt; Grundrand der Fld. nur theilweise, zuweilen kaum gezähnt .

7. Beine einfarbig schwarz (bei ganz frischen Ex. zuweilen die Schienen röthlich)

$7^{1}$. Beine gelb (grün) 
8. Halssch, vor den Ecken gerundet-erweitert, am Vorderrande mit einem zweitheiligen Fensterflecke, die Oberseite sonst schwarz. L. 6-8 mm. Osteuropa . . . . 11. atrata F.

81. Halssch, vor den Ecken verschmïlert, ohne Fensterfleck. Oberseite rothbraun oler grün, die Fld. meist schwarz gefleckt. L. 6-8,5 mm. Europa . . . . . . 9. murraea L.

9. Fld. mit starken Längsrippen und einigen schwarzen Strichen, Seiten des Halsseh. vor den Hinterecken beim $\hat{\sigma}$ stark und gradlinig-, beim of sehr schwach und leicht gerundet-erweitert. - L. 6,5-8 mm. Suidöstliches Europa.

10. lineola Creutz.

91. Fld. ohne schwarze Zeichnung, mit niedrigen Rippen oder ganz verworren punktirt; Seiten des Halssch. vor den Ecken mehr oder weniger gerundet-erweitert . . . . . . . 10.

10. Fld. wenig gewölbt, verhältnissmässig fein, verworren punktirt, vor der Schulter tief ausgerandet und stark gezähnelt, Halssch. vor der Basis in breiter Rundung erweitert. - L. 5,5-7 mm. Europa . . . . . . . 12. seladonia Gyllh.

101. Fld. mässig gewölbt, kräftig gereiht-punktirt, der zweite und vierte Zwischenstreif deutlich, breit, etwas gewölbt. Basalrand gleichmässig gezähnelt, jederseits leicht ausgerandet. Seiten des Halssch. vor der Basis in eine Ecke erweitert, welche beim $\hat{o}$ breiter als beim 우 abgerundet ist. - L. $5-7 \mathrm{~mm}$. Europa.

13. denticollis Suffi.

11. Fld. regelmässig punktirt-gestreift. Kopf fast ohne Ausnahme gelb . . . . . . . . . . . . 12.

11'. Fld. verworren punktirt, oder die Punkte theilweise gereiht 14.

12. Mittelhüften weit getrennt, die Randleiste des Mesosternum zwischen den Hüften länger als eine der schrägen Seitenleisten vor den Mittelhüften. Basalrand der Fld. schwarz, deutlich gezähnt, die Leiste des Seitenrandes in der Mitte verdickt. -L. 5-7 mm. Europa . . . . . . 24 nebulosa L.

121. Mittelhüften nahe an einander stehend, Basalrand der Fld. gleichfarbig, nicht oder undeutlich gezähnelt, die Leiste des Seitenrandes überall von gleicher Stärke . . . . . 13.

13. Kopf glatt, oder sehr sparsam und fein punktirt, Brust und Bauch gröstentheils schwarz, Zwischenstreifen der Fld. schmal, nicht ganz regelmässig. - L. 4,5-6 mm. Europa.

25 flaveola Thunb.

131. Kopf tief und stark punktirt, die ganze Unterseite gelblich braun, Zwischenstreifen der Fld. fast iiberall so breit als die Punktstreifen und sehr regelmässig, über der Leiste des Seiten- 
daches eine deutliche Punktreihe. - L. 4-5 mm. Tord. deutschland. Ungarn, Russland. Sihirien 26 berolinensis suffi.

14. Fld. grün (gelb), auf dem Ntreifen an der Yaht lis zur crsten Rippe jederscits einfarbig luram, häufiger bis zur Spitze bran gefleckt, ansserdem gewöhnlich noch mit einem braunen Punkte in der Mitte, dicht iiber den beiden äusseren. grroben Punktreihen. - L. 5-8,5 mm. Europa . . . . . 23 vibex L.

141. Der Streifen an der Naht hinter der Mitte mit der Scheibe der Fld. gleichfarbig . . . . . . . . . . 15

15. Stirn schmal, ein nach der Fühlerwurzel leicht verengtes Rechteck bildend. Körper ziemlich flach, Oberseite grün (gelh, hellbraun), Fld, ohne scharfe Rippen, Schenkel gewöhnlich schwarz . . . . . . . . . . . . . 16 .

15. Die Stirn ist breit und bildet zwischen den Augen ein nach hinten leicht verengtes Quadrat. Körper mehr oder weniger gewölbt, Schenkel bei der Mehrzahl der Arten gelb . . 23.

16. Prosternum hinter den Hiiften plötzlich abfallend, der Fortsatz tief liegend. Basis der Fld. (ron einer Schulter zur andern) mit 6 kleinen, tiefen, in der Regel dunklen Griibchen. Lang elliptisch, Ecken des Halssch. breit abgerundet, Fld. verloschen gereiht-punktirt. - L. 5 mm. Italien, Südtrankreich, PyrenäenHalbinsel (Stett. Z. 184t. 140) . . . . hexastigma Suffr.

16 ${ }^{1}$. Prosternum fast in einer Flucht verlaufend, der Fortsatz nur sanft abfallend. Basis der Fld, höchstens mit flachen Eindrücken

17. Stim doppelt so lang als breit. Gestalt der canaliculata Laich., Oberseite einfarbig griin (gelb), ziemlich matt, Fld. rerworren sehr dicht und flach punktirt, auf der inmeren Hälfte leicht querrunzelig, Schulterbeule innen kaum abgesetzt. - L. 11 mm. Andalusien. oranensis Desbr. Mon. 39? (Wien, Z. 1891. 205).

angustifrons Ws.

171. Stirn kaum um die Hälfte länger als breit . . . . . 18

18. Halssch, einfarbig . . . . . . . . . . 19

181. Halssch. mit einer breiten blutrothen (braunen) Querbinde an der Basis

19. Basis der Fld, vor der Schulter tief ausgeschweift. kräftig gezähnelt, Härchen der Fld. sehr deutlich. Vom Habitus einer grossen rubiginosa, oben griin (gelb), ziemlich matt, Fld. rerworren, mässig dicht und stark punktirt, oft runzelig. das Basaldreieck rothbraun. Beine einfarbig gelb; Basis der Schenkel zuweilen schwarz. - L. 8-9 mm. Andalusien, Algier. corrosa Desbr. Mon. 39? (Berl. Z. 1874. 103) . humeralis Kraatz. 
19'. Basis der Fld. vor der Schulter grade oder sanft ansgeschweift, undeutlich gezähnelt; Härchen der Fld. kaum bemerkbar 20.

20. Körper lang elliptisch, auffïllig flach. Basis der Fld. sanft geschwungen, die Sehulterecken und der ïnssere 'Theil der Halsschildbasis schrïg vorgezogen, Ecken des Halssch. scharf, spitz- oder rechtwinkelig. Oberseite griin (gelb), Fld. selır dicht gereiht-punktirt, Schenkel mit Ansuahme der Spitze schwarz. - L. 5,5-6 mm. Suideuropa, Nordafrika. C. prasina Boh. Mon. 2. 381; Desbr. Mon. 21. (Expl. Alg. 513)

\section{algirica Luc.}

201. Körper mässig gewölbt; Basis der Fld. kaum geschwungen, fast gradlinig, die Scheibe derselben sehr unregelmässig gereihtpunktirt .

21. Stirn dicht punktirt und sehr fein körnig gerunzelt, matt, Fld. hinten breit abgerundet. Oberseite griin (gelb), Basaldreieck der Fld, braun, hinten mit einem gemeinschaftlichen schwarzen Flecke endigend. - L. 6-8 mm. Europa 20 rubiginos a Müll.

211. Stirn weitläufig punktirt, zwischen den Punkten glatt, glänzend, Fld. hinten allmählicher verengt, etwas ausgezogen. Oberseite griu (gelb). L. 7-9 mm. Vielleicht nur eine Form von rubiginosa (Stett. Z. 1844. 139). . . . . . . . deflorata Suffr.

22. Basis der Fld. in tiefem Bogen ausgerandet, Halssch. kurz und sehr breit, die Ecken desselben stumpf, weit vor dem Schildchen liegend, Fld. hinter der Mitte abgeflacht, mit sehr breit abgesetztem Seitendache, dicht und ziemlich fein punktirt, Beine einfarbig gelb. - L. 6-7mm. Mitteleuropa, Schweden, Finland.

21 thoracica Panz.

221. Basis der Fld. in sehr flachem Bogen ansgerandet, Halssch. mässig lang, Ecken spitz, wenig weit vor dem Schildchen liegend, Fld, vor der Spitze ziemlich steil abfallend, mit schmalem Seitendache, mïssig dicht, stark, gereiht-punktirt, Schenkel mit Ausnahme der Spitze schwarz. - L. 5,5-6 mm. Deutschland, Oesterreich, Ungarn

22 tincta Ws.

23. Basis der Fld. in tiefem Bogen ausgerandet, die Schulterecken spitzwinkelig; vorgezogen, weit ror dem Schildchen liegend 24.

231. Basis der Fld. sanft ausgerandet oder fast gerade, Schulterecken stumpf, wenig weit vor dem Schildchen liegend . 25.

24. Seiten der Fld. bis zur Mitte etwas erweitert, Oberseite grün (gelb), Fld. mit zwei blutrothen Flecken jederseits neben dem Schildchen, Beine nebst Trochanteren gelb. - L. 5,5-6 $\mathrm{mm}$. Mitteleuropa .

15 stigmatica Suffr. 241. Seiten der Fld. bis zur Mitte parallel, Scheibe der Fld. hellroth, 
Schenkel mit Ausnahme der Spitze schwarz. - L. 4,5-5.31mm. Steiermark, Ungarn . . . . . . 16 rosea Boh.

25. Brust, Bauch und Beine einfarbig grün (gelblıraun oder rostroth) . . . . . . . . . . 26.

251. Brust und Bauch grösstentheils schwarz . . . . . . 29.

26. Kopf grün (gelbbraun) . . . . . . . . . 27.

261. Kopf schwarz . . . . . . . . . . . . 28.

27. Breit-eiförmig, Halssch. stark, kissenartig gewöllıt, das Dach sehr vertieft; Fld. stark punktirt, unehen, grün, mit drei oder vier Längsrippen, von denen die erste an der Basis, sowie in ein und zwei Drittel der Länge, die zweite vorn, die dritte dicht hinter der Mitte verbreitert und gelblich gefärbt ist. Zwei Flecke jederseits neben dem Sehildchen blutroth. - L. 5,5-6 $\mathrm{mm}$. Mittel- und Südspanien. C. artemisiae Bris. Ann. Fr. 1880. 234. Bull. 24 (Mon. 4. 306) . . . . . corallina Boh.

$27^{1}$. Schlank, Halssch. mässig gewölbt, Fld. ziemlich stark punktirt, mit drei Längsrippen, ihr Dach und ein Saum an der Basis und Naht rostroth, die Scheibe grün. - I. 4,5-5 mm. Caucasus, Armenisches Gebirge . . . . . . Reitteri Ws.

28. Zwischenräume der Fld. fast glatt, glänzend. Breit elliptisch, hochgewölbt, oben griun (gelb), glasartig durchscheinend, Halssch. dicht, runzelig-, Fld. viel stärker, mässig dicht gereihtpunktirt, jede mit 3 Längsrippen. - L. $8 \mathrm{~mm}$. Cuença (Wien. Z. 1891. 205) . . . . . . . hyalina Ws.

281. Zwischenräume der Fld, gewirkt, ziemiich matt . . 29.

29. Ecken des Halssch. in ziemlich breitem Bogen $(\hat{o})$, oder nur an der Spitze abgerundet. Körperform, Farbe der Oberseite und Skulptur wie bei der nahe verwandten denticollis. - L 6,5-8 mm. Sarepta (Horae 1873. 126) . sareptana Kraatz.

291. Ecken des Halssch. spitz. Der C. sanguinolenta ähnlich. L. $5 \mathrm{~mm}$. Sarepta. (1. c. 127) . . . . flaviventris $\mathrm{Kr}$.

30. Beine, sammt den vier Vorderhüften hellgelb, Unterseite ziemlich dicht behaart, schwach seidenglänzend, Hinterbrust dicht quergestrichelt, in der Regel metallisch. Körper sehr flach, oben verschossen grün (gelb) $=$ depressa Suffr. Stett. Z. 1844. 141; oder die Fld. mit je zwei schmalen, rothen Querfleckchen an der Basis, die durch eine gelbgrüne Schwiele getrennt werden. Fld, ganz unregelmässig punktirt (= sordida Bris. A. 1860. 348) oder mit gereihten Punkten und zwei schmalen Längsrippen auf der inneren Hälfte. Hinterecken des Halssch. recht- oder spitzwinkelig, leicht abgerundet. L. 5-6,5 mm. Frankreich, Südeuropa, Nordafrika (Bohemani Bris. 1. c.). . . . . . . . . inquinata Brull. 
30. ${ }^{1}$ Körper mehr oder weniger gewölbt, alle Hüften schwarz, nur iln Anhang oft gelb, Unterseite sparsam behaart, Brust nie metalliseh

31. Fld. grob verworren punktirt, ohne deutliche Längsstreifen; grün, ein Fleck ron einer Schulter zux andern, der sich nach hinten allmählich verengt und hinter der Mitte endet, roth. L. $6 \mathrm{~mm}$. Deutschand . . . . . 14. rufovirens Suffr.

$31^{1}$. Wenigstens der zweite und vierte $Z$ wischenstreifen auf den Fld. deutlich

32. Basalrand der Fld. gleichmässig und kräftig gezähnelt, die Schulterecke mit verrundeter Spitze, Ecken des Halssch. deutlich, stumpfwinkelig. Gestreckt, grünlich-(weiss- oder bräunlich-) gelb, stark glänzend, Fld. kräftig und tief in ziemlich regelmässigen Reihen punktirt, der zweite und vierte Zwischenstreifen schmal, kaum gewölbt. - L. 5,5-6 mm. Rhilo-Dagh in Bulgarien (Wien, Z. 1891. 205) . . . . rhilensis Ws.

$32^{1}$. Dieser Rand, namentlich vor der Schulter, schwach und undeutlich gezähnelt

33. Der zweite Zwischenranm der Fld. wenig erhöht, nahe der Basis meist undeutlich, so dass der wenig vertiefte rothe (braune) Raum im Basaldreiecke jederseits eine Fläche bildet. - L. 6-7 mm. Mittel- und Nordeuropa . 19. sanguinosa Suffr.

$33^{1}$. Der zweite Zwischenraum der Fld. vor der Mitte rippenförmig, der vertiefte Raum im Basaldreiecke jederseits dadurch in zwei Gruben getheilt, eine kleine an der Schulter, eine grössere, langgestreckte neben dem Schildchen . . . . . . 34.

34. Breit-eiförmig, Ecken des Halssch. spitz, Basaldreieck der Fld. mit 4 rothen Flecken. L. 5-6 mm. Mitteleuropa.

18. prasina Ill.

341. Eiförmig, Ecken des Halssch. stumpfwinkelig, Scheibe der Fld. grösstentheils roth. - L. 4,5-5,5 mm. Mitteleuropa.

17. sanguinolenta Müll.

35. Geflügelt, oben kahl, Halssch. fast glatt oder mässig dicht punktirt, wenigstens die dritte und vierte Punktreihe der Fld. durch überzählige Punkte mehr oder weniger gestört . . 36 .

351. Ungeflügelt, Halssch. stark und äusserst dicht runzelig-punktirt, Fld, ohne merklichen Schulterhöcker, zerstreut mit aufgerichteten, schuppenförmigen Härchen besetzt, mit 10 regelmässigen Reihen grosser Nabelpunkte, deren Zwischenstreifen schmal und von gleicher Breite sind. Oberseite matt grün, Unterseite einfarbig gelbbraun

36. Körper nach hinten viel mehr als nach vorn verengt, ähnlich wio bei viridis, von vorn bis zu einem starken Querhöcker, 
welcher die heiden ersten Punktreihen der Fld. in ein Viertel ihrer Läinge unterbricht, fast in einer Flucht ansteigend, dalinter allmailhlich in schwacher Woilthung abfallend. F'uilılerpfannen gross. lis an die s'eitenleiste der Auren reichend. Lnterseite einfarbig blass gelbbram. Oherseite griin, mit einigen verwaschenen und blassrothen, seltener scharfen und blutrothen Makeln im Basaldreiecke und längs der Nalıt . . . . 37.

361. Körper lïnglich, oben gleichmiissig gewrilbt, Fiihlerpfannen vron den Augen getremnt, die ersten Punktreihen der Fld. an der Naht nicht unterbrochen, die zweite und dritte Reihe durch einen breiten, in Leben goldgrüneu Zwischenstreif gretrennt, Brust und Bauch grösstentheils schwarz . . . . . . 38.

37. Oberseite stark lackartig glänzend, Punktreihen der Fld, beinahe regelmëssig. - L. $4.5-5 \mathrm{~mm}$. Tiflis, Araxesthal (Wien. Z. 1889.260) . . . . . . . saucia Ws.

$37^{1}$. Oberseite mässig glänzend, Fld. verworren punktirt, nur die drei ersten, starken und tiefen Reihen an der Naht, sowie die äusseren Reiheu in der Nähe der Schulter deutlich und regelmässig. - L. 6-6,5 mm. Turemenien . . turcmenica Ws.

38. Kopfschild von tiefen Rinnen begrenzt, die sich schon ein Stiick vor der Fühlerwurzel zu einer Mittelrinne vereinigen, welche zwischen den Fühlem hindurch bis anf den Scheitel läuft. Schenkel schwarz. - L. 3,5-5,5 mm. Europa

27. nobilis L.

381. Stirnlinieu erst an der Fühlerwurzel zusammenstossend, wenn sie nicht vorher erlöschen. Beine einfarbig gelb . . . 39.

39. Kopf schwarz, Stirn länger als breit, dicht punktirt. ziemlich eben, mit schwachen Stirnlinien.-L. 5-6,5 mm. Mittel- und Südeuropa . . . . . . . 28. vittata Villers.

391. Stirn gelb, breiter als lang, grob punktirt, Kopfschild tiefer als die Seitentheile liegend, Stirnfurchen tief, Halssch. ziemlich stark punktirt, sonst der nobilis ähnlich. - L. 4,5-5 mm. Astrachan, Sibirien (Mon. 2. 428). . . . parvula Boh.

40. Mässig gewölbt, Punkte in den Reihen der Fld. gleichmässig und äusserst dicht hinter einander gestellt. - L. 4,5-5 mm. Frankreich, Spanien, Italien, Dalmatien, Elsass C. mollis, pupillata Boh. (Reis. Span. 82) . . . . . pusilla Waltl.

401. Stark gewölbt, Punkte in den Reihen der Fld. ungleichmässig hinter einander gestellt, die Entfernung der Punkte untereinander oft grösser als diese. Eine kleine Makel zwischen den beiden ersten Punkten der 3. und 4. Reihe, sowie der Streifen zwischen der 8. und 9. Reihe im zweiten Viertel der Länge in der Regel schwarzbraun - L, 4,5 mm. Ostpyrenäen 
I. Antennae in sulcis sternalibus receptae, articulo $2: 0$ obtongoovati, quam 3:0 fere longiore.

1. Cass. subfemuginea: Onalis, formgincu, subopaca, pectore abdomineque nigris, mothorace subelliptico, clytris basi prothorase latioribus, humeris productis, disco costatis, crebre punctutis. - Long. 4,5 bis $6 \mathrm{~mm}$.

Sehrank, Beytriige 1776. 62; Enum. 49. - Seidl. F. balt. ed. 2. 701 ; transs. 787.

C. ferruginea F. Spec. Ins. 1. 1781. 108. - Illig. Käf. Preuss. 482. - Suffr. Stett. Z. 1844. 274. - Boh. Mon. 2. 453. Redtb. Faun. A. 2. 523. - Bach, Käferf. 3. 77. - Desbroch. Mon. 27.

C. fusca Laich. Verz. Tyr. 112.

Var. a. Femoribus basi nigris.

Var. b. sobrina: Elytris fuscis, nigro irroratis.

Var. c. Junior, supra testacea, elytris saepe fusco-irroratis.

Eiförmig, schmutzig rostroth, ziemlich matt, Mund, Brust und Bauch schwarz, letzterer hell gesäumt. Halssch. etwas schmaler als die Fld, mit völlig verrundeten Ecken, einem querliegenden Ovale ähnlich; am Vorderrande über der Stirn aufgebogen, die Scheibe gewölbt, fein und dicht, meist rumzelig punktirt. Fld. an der Basis ausgerandet, mit starker Schulterbeule und vorgezogenen Schulterecken; im Basaldreiecke ansteigend und in dem Querhöcker, welcher die beiden ersten Punktreihen mehr oder weniger deutlich unterbricht, am höchsten, dahinter in gleichmässiger Wölbung abfallend; dicht punktirt (nu die beiden ersten Reihen hinter dem Querhöcker und die neunte Reihe regelmässig) mit 2 bis 4 feinen Längsrippen, die in den graden Zwischenstreifen stehen, die beiden immeren am höchsten. Seitendach vor der Spitze schmal und mit einigen tiefen, meist dunkel gefärbten Grübchen besetzt. Fühler in tiefe Rinnen eingelegt, die neben den Augen fortlaufen, bis zu den Hüften schmal, von einer ziemlich hohen und scharfen Aussenkante begrenzt, dahinter allmählich erweitert und verflacht sind; Glied 3 ist eine Spur kürzer als 2, Glied 7 etwas, die folgenden stark verbreitert. Vorder- und Mittelhüiften sehr weit getremnt.

Frische Stücke sind bräunlich-gelb, Brust und Mitte des Bauches schwärzlich, auf den Fld, zahlreiche braune Pünktchen neben den Rippen und auf der hinteren Hälfte des Seitendaches. Später wird die Oberseite rostroth, auf den Fld. oft dunkel gesprenkelt, beim lebenden Thiere zuletzt mit einem schwachen Goldglanze überzogen, der auf dem Halssch., Schildchen und den breiteren Zwischenräumen der Fld, einen kupferigen Schimmer annimmt. Die Schenkel sind in der Basalhälfte zuweilen schwarz (Var,a), 
die Fld, ohne das Dach, schwärzlich braun, mit dunkleren Sprenkeln (Var. b).

In sandigen G'genden an Convolvulus arvensis L. häufig; bei Berlin Mitte Juli entwickelt. Europa, Nordafrika, Syrien, Turkestan, Sibirien.

II. Antennarum articulo 2:0 3:0 breciore. Lnguiculi appendiculati.

\section{A. Antennae in sulcis sternalibus receptae.}

2. Cass. fastuosa: Subelliptica, convexiuscula, nigra, supra saturate lateritia, nitida, nigro-maculata, maculis in lineas 3 longiturlinales collocatis, protecto angusto crebre punctuto, margine laterali crasso, reflexo; prothorace semicirculari angulis acutis, coleopteris subtiliter striato-punctatis, basi utrinque profunde emarginatis fortiusque crenulatis. Long. 4,5-6 $\mathrm{mm}$.

Schaller, Abhandl. Hall. Ges. 1783. 259. - Seidl. F. balt. ed. 2. 701 ; transs. 788.

C. vittata F. Supplem. Ent. Syst. 1798. 81. - Herbst Käf. 8. 353. - Suffr. Stett. Z. 1844. 98. - Boh. Mon. 2. 360. Redtb. Faun. A. ed. 2.2.521. - Bach, Käferf. 3.73. - Desbroch. Mon. 14.

Var. a. nigrina: Supra nigra, maculis nonnullis parvis rufescentibus.

C. vittata var. A hr. Neue Schrift. Ges. Halle I. 2. t. 2. f. 6.

Var. b. delicatula: Supra lucida, maculis paucis nigris notata.

Var. c. Junior, supra testaceo-viridis, plus minusve migro-maculata.

Vorn und hinten breit abgerundet, an den Seiten fast parallel, lang elliptisch, mässig gewölbt, schwarz, Fühlerbasis und Klauen röthlich, die Oberseite gesättigt ziegehroth, glänzend, mit drei Längsreihen schwarzer Makeln. In der Mittelreihe liegen: eine kleine Makel dicht hinter dem Vorderrande des Halssch,, eine grössere, herzförmige, vor dem Schildchen und 4 Makeln an der Taht der Fld., zu einer zackigen oder fast gleichbreiten Nahtbinde vereint,

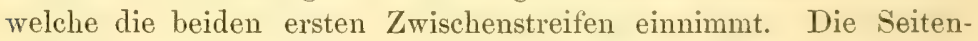
reihen werden gebildet: aus einer Längsmakel am Rande des Halssch. hinter der Mitte, meist mit einem Basalpunkte vor der Schulter verbunden, und aus 4 Makeln auf den Fld. Die erste derselben rundlich, in dem Eindrucke ror der Schulterbeule, Makel 2, von der Schulter bis hinter die Mitte reichend, lang dreieckig, die Grundlinie auf der neunten, die Spitze an der vierten Punktreihe, Makel 3 klein, oft fehlend, hinter der Mitte zwischen der 2. und 4. Punktreihe, Makel 4 endlich quer oder länglich, vor der Spitze, aussen von der neunten, innen von der 2. oder 
3. Punktreihe begrenzt. Halssch. halbkreisförmig, mit spitzen Ecken, die durch den Basalzahn gebildet werden; die Scheibe gewölbt, fein punktirt, das Dach muldenförmig, dicht und stark punktirt, der aufgebogene Rand nach hinten verdickt. Fld. jederseits vor der schulter grob gezähnelt und tief ausgerandet, so dass die Schulterecke rorgezogen erscheint, auf der Scheibe f'ein und in regehmässigen Reihen, auf dem muldenförmigen Dache stärker und runzelig-punktirt. Filhlerfurche an der Aussenseite weniger scharfkantig begrenzt, als bei der vorigen Art. Vorder- und Mittelhüften weit getrennt. Zahn der Klauen klein und spitz.

Bei frischen Stiicken ist die Grundfarbe der Oberseite gelblich griin (Var. c). Selten sind die schwarzen Makeln verkleinert, theilweise erloschen, dass zuletzt auf dem Halssch. nur zwei Fleckchen neben den Ecken und auf den Fld. Makel 1 und 2 an der Schulter, nebst einem schmalen, zackigen Nahtsaume übrig bleiben (Var. b); oder die Makeln dehnen sich aus (Var. a), die Oberseite wird schwarz, ein zweilappiger Fleck am Vorderrande des Halssch. vor dem Kopfe (und ein sichelförmiger Längsstrich jederseits auf der Scheibe), sowie das Dach der Fld, roth. Häufiger bleiben Reste der Grundfarbe auf der Scheibe der Fld. übrig in einem Fleckchen nahe der Schulter und einem anderen in der Mitte.

Auf feuchten Wiesen, am Rande von Tümpeln und Torfstichen zerstreut, in Norddeutschland bei Ueberschwemmungen im Frühlinge oft zahlreich. Mitteleuropa, Krim, Sarepta, Westsibirien.

\section{B. Antennae haud totae receptae.}

3. Cass. canaliculata: Elliptica, convexiuscula, brunneo-rufa, minus nitida, capite, pectore, abdomine (marginibus exceptis) femoribusque nigris, protecto lato margine laterali reflexo, prothorace crebre subtiliter punctato, sublunato, angulorum apice rotundato, elytris subseriatim punctatis, fusco-sparsis, interstitiis 2 et 4 leviter convexis. Long. $9-10,5 \mathrm{~mm}$.

Laichh. Verz. Tyrol. Ins. 1781. 109. - Seidl. F. transs. 788.

C. austriaca F. Ent. Syst. 1. 1792. 293. - Herbst, Käf. 8. 254. - Suffr. Stett. Z. 1844. 95. - Boh. Mon. 2. 357. Bach, Käferf. 3. 73. - Redtb. Faun. A. 2. 521.

C. speciosa Brahm, Ins. Kalend. 1790. 74; Naturforsch. 29. 166. t. 3. f. 22 .

C. austriaca var. illyrica Boh. l. c.

Var. a. Junior, supra viridi-testacea, flavo-testacea vel ferruginea, elytris plus minusve brunneo-sparsis.

C. austriaca var. graminis Suffr. 1. c. 97.

C. austriaca var, immutabilis Boh. 1. c. 
Unsere grösste Art, elliptisch, nur miissigr gewoilht. dunkel lräimlich roth, wenig glainzend, Konff. Brust, bauteh folme den seitemrand) und dis Schenkel, nit Aisnahne der spitze und der T'rochanteren. schwar\%; das seitendach loreit, flach, nuit hoch autgebogenem soitenrande. II alssch. rinem Keiscemente ahlulich. auf der Scheibe dicht, ziemlich fein runzelig-pnuktirt. die Mittellinie hinten vertieft, vorn kielfömnig, der Basalzalm sehe stumpt: undeutlich, die Ecken eine spur weiter nach aussen tretend. spitzwinkelig, abgerundet. Fld, an der Basis fein gezihmelt, jederseits sanft ausgeschweift, fast gerade, die Scheihe sehr unregrelmässig gereiht-punktirt, der 2, und 4. Zwischenstreif gewijlbt. Fïller dünn, die vier ersten Glieder in eine kurze limne nelsen den Angen einleg'bar, die fünf' Endglieder dunkel, wenig erweitert. Vorder- und Mittelhuiften weit getremnt, Klanenzahn ziemlich klein und stumpf.

Die Oberseite ist verlosehen dunkel gesprenkelt, namentlich auf den Fld, wo eine Anzahl der Punkte von dunklen Rändern umgeben ist, die sich stellenweise zu kleinen Flecken vereinigen: auf dem Halssch. bemerkt man gewöhnlich nur einen dunklen Strich auf' der Mittellinie vor dem śchildchen und vier schwärzliche Punkte, zwei in der Mitte und zwei dahinter, diese weiter rou einander abstehend als die vorderen.

Anfangs ist das Thier, ähnlich wie murraea, oberseits grünlichoder bräunlich-gelb, oder hell rostroth, mehr oder weniger dunkel gesprenkelt; völlig ausgehïrtet dagegen im Leben mit einem prächtigen Goldglanze iiberzogen, welcher auch bläulich oder grün schimmern kann, und auf den dunklen Stellen, sowie auf dem Seitendache fehlt.

An Salvia pratensis L. stellenweise in den mitteldentschen Berggegenden (nördlich bei Mainz, Erfurt, Halle) und in den Alpenländern. Ungarn, Transsylvanien, Tïrkei. Soll auch an Artemisia absynthium L. leben.

4. Cass. vimidis: Subovalis, postice angustata, supra viridis, minus nitida, subtus nigra, limbo ventrali pedibusque testaceis, prothorace fere elliptico, sublaevi, elytris in basi leniter assurgentilus, apicem rersus sensim dectivibus, crebre punctatis, - Long. 7-9 mm.

Linué, Faun. Suec. 152. - Fabr. Syst. ent. 88. - Illig. Käf. Preuss. 480. - Herbst, Käf. 8. 209. - Desbroch. Mon. 16.

C. equestris F. Mant, 1. 62. - Panz. Faun. germ. 96.5. - Gyllh. Ins. Suec. 3, 436. - Suffr. Stett, Z, 1844. 89. - Boh. Mon. 2. 474. - Bach, Käferf. 3. 73. - Redtb. Faun. A. 2.521.- 
Thoms. Skand. Col. 8. 320. - Seidl. F. balt. ed. 2. 701; transs. 787.

Var. a. Lateribus pectoris ventrisque late testuceo-limbatis.

Von den grösseren griuen Arten sogleich durch die rerworren punktirten, nach hinten allmïhlich verengten, etwas dreicekigen Fld. zu unterscheiden.

Oben grasgrün, äusserst dicht und fein gewirkt, wenig glïnzend, unten schwarz, die Beine und ein Saum des Bauches grülich(brämulich-) gelb. Halssch. schmaler als die Fld., mit völlig verrundeten Ecken, einem querliegenden Ovale ähnlich, die Scheibe schwach gewölbt, undeutlich-, das Dach deutlicher punktirt. Fld. am Grunde undeutlich gezähnelt, seicht ausgerandet und in den Schulterecken etwas vorgezogen, im Basaldreiecke mit dem Halssch. in einer Flucht ansteigend, dahinter allmählich abfallend, überall gleichmässig; dicht punktirt, nur die 9. und 10. Punktreihe vorhanden. Vorder- und Mittelhüften mässig weit getrennt, Klauenzahn gross, stumpf.

Oft sind die Seitenstïcke der Mittelbrust, oder noch ein Saum an der Aussenseite der Vorderhüften, seltener auch die Seitenstücke der Hinterbrust hell gefärbt. Reife Stücke haben im Leben einen silberweissen Streifen auf der Basalkante der Fld, von einer Schulter zur andern.

An feuchten Orten auf Labiaten z. B. Mentha aquatica und rotundifolia L., Lycopus, Salvia pratensis und glutinosa L., aber auch an Compositen z. B. Cirsium arvense und oleraceum L. gemein. Ueber Europa und Sibirien verbreitet.

5. Cass. hemisphrerica: Subrotunda, convexa, dilute viridis, sat nitida, capite lineis clypei sulciformibus pectoreque nigris, prothorace sublunato angulis obtusiusculis, parce punctulato, elytris confertim punctatis. - Long. 4,5-5,2 mm.

Herbst, Käf. 8. 226. t. 129. f. 9. - Gyllh. Ins. Suec. 4. 645. - Suffr. Stett. Z. 1844. 92. - Boh. Mon. 2.484.-Thoms. Skand. Col. 8. 324. - Redtb. Faun. A. 2. 521. - Seidl. F. balt. ed. 2, 703; transs. 789. - Desbroch. Mon. 32.

C. Cori Fairm. Ann. Fr. 1880, 244.

Var. a. nigriventris: Abomine nigro limbo pallido.

v. Heyden, Verz. Käf. Nassau's 1877. 310.

Länglich-rund, gewölbt, gelblich grün (bis bräunlich-gelb verbleichend), ziemlich glänzend, Kopf und Brust schwarz. Ersterer sparsam punktirt, die Kopfschildlinien grade, breit und tief, furchenartig, an der Fühlerwurzel nur noch durch die hohen Ränder der Mittellinie getremut, welche sich mehr oder weniger weit nach vorn 
verlängert. Halssch mondförmig. die Ecken stumpfwinkelig. hrim ô ziemlich scharf, beim $q$ abgerundet, die scheibe gewölbt, deutlich gewirkt, zerstreut punktirt, das Dach wenig niedergedriickt, mit durchscheinender Netzzeichnung. Fld. mit steil abfallendem Seitendache, am Grunde mässig ausgerandet, ungezíhtht, in den Schulterecken etwas vorgezogen und beim of daselhst breiter als das Halssch.; überall gleichmässig, dicht und ziemlich tief, oder sehr dicht und tief punktirt, nur die 9. und 10. Punktreihe rorhanden, zuweilen jedoch der zweite Zwischenstreifen und die 4. und 5. Reihe angedeutet. Die Punkte sind genabelt, mit einem nach rorn gekrümmten äusserst kurzen Härchen in dem helleren Mittelpunkte. Vorder- und Mittelhüften ziemlich weit getrennt, Beine kurz, Klauenzahn klein.

Bei reifen Exemplaren ist die Oberseite, mit Ausnahme des Daches, im Leben silberglänzend, bald bläulich, bald grünlich schimmernd. Die einzige bemerkenswerthe Abänderung (Var. a.) zeichnet sich durch den schwarzen Hinterleib aus, der an den Seiten hell gesäumt ist.

Auf Rainen. Triften, trocknen Waldwiesen in ganz Deutschland und im grössten Theile von Europa nicht selten; nach Letzner an Silene Behen L.

III. Tarsorum articulo 4:0 parvo 3:0 sat breviore, unguicuti simplici parum divaricati; clypeus triangularis, sulcis profundis terminatus.

6. Cass. azurea: Breviter elliptica, convexa, testacea, capite, pectore abdomineque nigris, prothorace subelliptico, punctulato, elytris obsolete sanguineo-lituratis, sat fortiter striato-punctatis. Long. $5-7 \mathrm{~mm}$.

Fabr. Syst. El. 1. 389.

C. lucida Suffr. Stett. Z. 1844. 215. - Bob. Mon. 2. 412. Redtb. Faun. A. 2. 523.-Bach, Käferf. 3. 75. - Dcsbroch. Mon. 30.

C. ornata Seidl. F. balt, ed. 2. 702 ; transs. 788 .

Var. a. ornata: Femoribus basi plus minusve nigris.

Creutzer, Ent. Versuche 118. t. 2. f. 22.

C. azurea Suffr. 1. c. 213 . - Boh. I. c. 411 - Redtb. 1. c. 522. - Bach, l. c. - Desbr. Mon. 29.

Var. b. Fronte ferruginea.

Diese Art bildet im Vereine mit den beiden folgenden eine Gruppe, welche in der Stirnbildung der vorigen Art nahe steht, an dem breit gerundeten und gewölbten Körper und den glänzenden, regelmässig gestreift punktirten Fld. leicht zu erkennen ist. Das Klauenglied ist klein, schmaler und nicht ganz so lang, als die 
Lappen des dritten Tarsengliedes, über deren Wimpereinfassung die schwachen, wenig gespreizten Klanen nicht hinausragen; das dritte Glied der einfarbig gelben Fühler ist oft kuř, wenig länger als das vorhergehende.

Die C. azurea ist sehr breit elliptisch, von der Seite betrachtet in einem fast gleichmässigen Bogen gewölbt, bräunlich gelb, Kopf, Brust und Bauch schwarz, letzterer schmal hell gesäumt. Halssch. mit völlig verrundeten Ecken, einem querliegenden Ovale ähnlich, zerstreut und fein, meist undeutlich punktirt, das Dach vertieft, am Rande etwas aufgebogen. Fld. am Grunde ausgerandet, ungezähnelt, in den Schulterecken etwas vorgezogen und so breit, oder breiter als das Halssch,, der Rüicken hinter der Schulter zusammengedrïckt, regelmässig und stark gestreift-punktirt, die zweite Punktreihe vor der Mitte nach innen gebogen, der zwoite Zwischenstreif dadurch verbreitert, die übrigen höchstens so breit als die Reihen. Die Punkte sind entweder allein verschossen blutroth gefärbt, oder noch einzelne Stellen neben ihnen, die sich zu grossen, unbestimmten Wischen (an den Seiten über der 10. Punktreihe, neben dem Schildchen und in der Mitte an der Naht) ausdehnen, oder den Rüicken völlig überziehen können. Das Dach ist hell, durchscheinend. und fällt allmählich ab, es hat eine ziemlich dicke Seitenleiste. Die Beine sind einfarbig bräunlich-gelb, häufiger die Schenkel über den Trochanteren angedunkelt, zuletzt in der Basalhälfte, oder daribber hinaus schwarz, (Var. a). Mittelhüften näher an einander gestellt als die Vorderhüften.

Im Leben glänzt das Halssch. des reifen Thieres bald bläulich silberweiss, bald lebhaft metallisch grün, oder goldig, mit Kupferschimmer; die Fld. sind weinroth, mit bläulichem Perlmutterglanze überzogen. Frische Stiicke sind oberseits bräunlich gelb.

In den Bergländern von Mittel- und Süddeutschland und in Oesterreich auf Silene Behen I. (inflata Smith) stellenweise. Frankreich, Ungarn.

Die Art führt den Namen azurea F. (1801), da ornata Creutz. (1799) wegen C. ornatr F. Ent. Syst. Suppl. 81 (1798) ungiltig ist, was bereits Suffr. angiebt. Letzterer hat aber mit Unrecht die allerdings unbedeutende Abäuderung mit schwarzen Schenkeln auf azurea F. bezogen, von der ausdrücklich ,pedibus pallidis" verlangt werden.

7. Cass. splendidula: Fere hemisphaerica, testacea, nitida, capite, pectore abdomineque (limbo laterali lato excesto) nigris, prothorace sublunato, angulis obtusiusculis, subtiliter punctuluto, elytris obsolete sanguineo-lituratis, concinne striato-punctatis. - Long: 4,8-5,5 $\mathrm{mm}$.

Suffr. Stett. Zeit. Juni 1844. 223.

Var. a. Junior, elytris testaceis.

VI. 6. 
C. subreticulata Suffr. 1. c. Juli 1844, 244. - Boh. Iron. 2. 436. - Redtb. Faun. A. 2. 522. - Seidl. F. balt. ed. 2. -03; transs. 789. - Desbroch. Mon, 30.

Var. b. ventralis: Subtus ferminea, capite nigro, limbo lato ventrali testaceo.

Aehnlich, nur heller und zarter gefärbt als die vorige, der Körper viel kürzer, fast lialbkugelig, nach rorn alhnählich und fast in einer Ebene, hinten in starker und breiter Wijlbung abfallend. Das Halssch. mit deutlichen stumpfen Ecken, deren Spitze allein abgerundet ist. Die Fld. bedeutend feiner gestreiftpunktirt, ihre glatten Zwischenstreifen viel breiter als die Punktreihen, namentlich auf der inmeren Hälfte; der Rücken uneben. mit einem grossen und starken Eindrucke neben dem Schildchen, welcher die Naht auffällig in die Höhe hebt und hinten von einem Querhöcker begrenzt wird, der die erste Punktreihe unterbricht. Diese ist hinter dem Höcker furchenartig rertieft und hebt gleichfalls die Naht empor; der Eindruck hinter der Schulter, welcher die Fld. zusammendriickt, verlängert sich nach innen und rertieft sich in der Nähe des Querhöckers. Das Seitendach fällt steil ab. Der Bauch ist breit gelb gesäumt, die Seitenstücke der Hinterbrust in der hinteren Hälfte, sowie die Seiten der Mittel- und Vorderbrust ebenfalls gelb.

Anfangs ist die Oberseite hell bräunlich-gelb (Var. a), dann wird die Naht, vorzüglich hinter dem Schildchen, und ein Längsschatten uiber der 8. Punktreihe röthlich, zuletzt ist der Rücken bis zur 8. Punktreihe hell kirschroth, ein unregelmässiger Längsfleck von der Basis bis auf den Querhöcker, und eine ähnliche Quermakel auf dem Abfalle zur Spitze blassgelb, im Leben goldgrïn metallisch glänzend. Die Fld. können auch einfarbig kirschroth werden, das Dach nur eine Spur heller, der Querhöcker und der zweite Zwischenstreif metallisch glänzend. Wemn bei diesen völlig ausgefärbten Exemplaren nur der Kopf schwarz, Brust und Bauch hell (rostroth an den Rändern lichter) gefärbt ist, entsteht die seltene Var. b.

In den Alpen, besonders in Kärnthen und Steiermark, Tirol und Krain selten. Frankreich, Schweiz, Dalmatien und Sicilien.

Mit dieser Art ist C. concha Solsky, Horae 1872. 264 rom Amur (bei Pochrofka und Wladiwostok, Koltze) nabe verwandt, nur 3,5-4 mm. lang und fast ebenso breit, die Fld. mit ähnlichen, nur tieferen Eindrïcken, daher viel unebener, das Seitendach breit, schwach abfallend.

8. Cass. margarifacea: Breviter ovalis aut subrotunda, convera, postice subgibbosa, dilute viridis (testacea), capite jectoreque nigris, 
prothorace sublunato, subtiliter punctulato, angulis obtusis, elytris striato-punctatis. - Long. 3-4,5 mm.

Schaller, Abh. Hall. Ges. 1783. 259. - Fabr. Ent. Syst. 1. 297; Syst. El. 1. 397. - Suffr. Stett. Z. 1844. 241. Boh. Mon. 2. 432. - Redtb. Faun. A. 2. 522. - Bach, Käferf. 3. 76. - Seidl. F. balt. 703; transs. 789. - Desbroch. Mon. 31 .

Var. a. melanocephala: Subtus pallida, capite nigro.

Suffr. 1. c. 243.

Var. b. nigrescens: Protecto suturaque elytrorum nigricantibus.

Unsere kleinste Art, entweder eiförmig, bedeutend länger als breit, oder stark gerundet; der Rücken in der vorderen Hälfte allmählich ansteigend, in der hinteren fast buckelig gewölbt. Hellgrün, in bräunlich gelb verbleichend, mehr oder weniger glänzend, Kopf und Brust schwarz. Halssch. fast halbmondförmig, mit stumpfen Ecken, zerstreut und fein punktulirt, auf dem Dache stärker als auf der Scheihe. Fld, vorn ausgerandet, ungezähnelt, in den Schultern vorgezogen, der Rücken in der Nähe des Schildchens und hinter der Schulter sehr sanft eingedrückt, wenig uneben, regelmässig gestreift-punktirt, die Punkte von veränderlicher Stärke. Die erste Punktreihe hinter dem Schildchen nicht unterbrochen, oder ihre Punkte daselbst nur durch einen glatten grösseren Raum getrennt, dahinter mässig vertieft, so dass die Nahtkante leicht emporgehoben wird. Die Zwischenstreifen sind glatt, wenigstens die fünf inneren breiter als die Punktreihen.

Auf der Unterseite sind Beine und Bauch stets hell, grün- oder bräunlich-gelb (der Bauch bisweileu röthlich gelbbraun), aber auch die Brust nimmt allmählich dieselbe Farbe an, zunächst an den Seiten, später gänzlich, der Kopf bleibt allein schwarz (Var. a). Bei der seltenen Var b. ist die Nahtkante und das Dach der Fld, oder des ganzen Körpers schwärzlich. Im Leben schimmert die Oberseite reifer Thiere in einem lebhaften griinen und goldigkupferrothen Metallglanze.

Obwohl die Untersehiede von splendidula, geringe Grösse, ein gestreckterer Körper, etwas schärfere Ecken des Halssch., wenig unebene Fld. mit niedriger Nahtkante und der stets gelbe Bauch. verhältnissmässig unbedeutend sind, dürften doch beide Thiere specifisch verschieden sein.

Auf sonnigen Abhängen und auf trocknen, unkultivirten Orten häufig in Mitteleuropa an Helichrysum arenarium, Centaurea scabiosa und paniculata I., ausserdem in Gärten auf Antennaria margaritaceum beobachtet. 
IV. Tarsorum urticulo 4:0 3:0 aequali, unguiculi diraricuti, simplici. Elytra protecto plus minusve explanato.

A. Dentes basales prothoracis ante angulos humerales elytrorum siti.

9. Cass. murrarea: Subelliptica, sat comexa, nigra, supra rufa, prothorace semicirculari, coleopteris basi evidenter crenulat's utrinque vic sinuato, striato-punctatis, maculis nigris series 3 longitudinalss formantibus. - Long. 6-8,5 mm.

Linné, Syst. Nat. ed. 12. 575. - Fabr. Syst. El. 1. 390. Illig. Käf. Preuss. 476. - Herbst, Käf. 8. 240. - Suffr. Stett. Z. 1844. 101. - Boh. Mon. 2. 358. - Redtb. Faur. A. 2. 521. - Thoms. Skand. Col. 8. 319. - Seidl. F. balt. ed. 2. 701; transs. 787. - Desbr. Mon. 15.

Var. a. dorsalis: Elytris nigris, protecto maculisque nomullis paris rufis.

Var. b. immaculata: Supra ferrugineo-rufa, elytris punctis nomnullis nigris, aut immaculatis.

Desbroch. Mon. 16.

Var. c. Junior, supra viridi-testacea, elytris nigro-maculatis.

C. maculata Linn. 1. c. - Illig. 1. c.

Länglich-elliptisch, an den Seiten mässig () oder wenig gerundet, fast parallel ( $\hat{)})$, schwarz, oben gleichmässig, ziemlich schwach gewölbt, ziegelroth, fettig glänzend, die Fld. schwarz gefleckt. Halssch. vor den rom Basalzahne gebildeten Ecken halbkreisförmig; auf der Scheibe sanft gewölbt, das Dach etwas rertieft und am Rande aufgebogen; dicht und äusserst fein lederartig gerunzelt und zerstreut und rerloschen punktulirt. Schildchen dunkel. Fld. an der Basis fast gradlinig, mit seho deutlich gezähueltem Rande, der Rücken regelmässig gestreift punktirt, die Zwischenstreifen zart gerunzelt, breit, eben, selten gewölbt und der 2. und 4. dann kielförmig. Die schwarzen Makeln sind klein, umegelmässig, in drei Längsreihen geordnet, die eine, gemeinschaftlich an der Naht, besteht aus 5 bis 7 Punktpaaren, die sich bis zur zweiten Punktreilue ausdehnen und zuweilen in einen zackigen Nahtsaum zusammen fliessen; die andre Längreihe befindet sich zwischen der 3. und 8. Punktreihe jeder Fld. und enthält 5 bis 7 Flecke: zwei kleine in dem Eindrucke ror der Schulter, ein grosser, oft in viele Punkte zerrissener Schrïgfleck hinter der Schulterbeule, ein oder zwei Punkte in der Mitte und zwei oder drei Punkte dahinter. Diese Makeln kömnen röllig rerschwinden (Var. b), oder sich ansdehnen, zusammenfliessen und die Fld. bis zur 9. Punktreihe so iiberziehen, dass höchstens einige kleine Flecke (am Schildchen, auf dem zweiten ' Zwischenstreifen, in dem Hachen Eindrucke hinter der Schulter und ror der Spitze) roth bleiben (Var, a). Die Basis 
der Fiihler ist in eine kurze, flache Rinne eingelegt, das zweite bis sechste Fühlerglied rïthlich. Kopfschild ron feinen, undeutlichen Linien bergrenzt, Vorder- uml Mittelhiiften weit wetrennt.

l3ei trisch entwickelten Stiocken, die Limné als hesondere Art betrachtete. ist die (irmulfarbe der Oberseite hellgriin, nach dem Tode bleichgelb, wird später bräunlich griin (bräunlich gelh), znletzt leuchtend ziegelroth (bräunlich roth).

Auf Inula Helenium, britamnica und salicina $\mathrm{I}_{\text {.., }}$ und Pulicaria diysenterica L. in ganz Deutschland und Oesterreich zerstreut, lıäufiger in Gebirgsgegenden. Auch an Mentha, Verbascum thapsus L. und Distelarten beobachtet. Europa, Sibirien.

10. Cass. Iineolas: Ovalis, convexiuscula, subtus fermginea, capite, interdum etiam pectore abdomineque nigris, supra viridis (testacea vel ferruginea), prothorace ante basin impressa, subtiliter, motecto fortius punctato, elytris basi truncato, subcrenulato, striato-punctatis, interstitiis alternis subcostatis, lineolis nonnullis nigris. - Long. 6,5-8 mm.

Creutzer, Ent. Vers. 1799. 119. t. 2. f. 23 (ô). - Suffr. Stett. Z. 1844. 210. - Boh. Mon, 2. 450.

II as: prothorace ante angulos fortius dilatato, latissimo, lateribus angulatis.

C. russica Herbst, Käf. 8. 1799. 232. t. 131. f. 1 .

C. lineola Seidl. F. balt. ed. 2. 702 ; transs. 789.

C. sibirica Desbr. Mon. 42.

Femina: prothorace elytrorum latitudine semicirculari.

C. signata Herbst, 1. c. 234.f. 2.

C. lineola Redtb. Faun. A. 2.523. - Desbr. Mon. 42.

C. sibirica Gebl. Bull. Mosc. 1833. 306. - Kraatz, Berl. Z. 1874. 97.

Das $q$ der vorigen Art ähnlich, aber durch helle Beine sofort zu unterscheiden, das ô von allen einheimischen Arten durch den Bau des Halssch. abweichend, dessen Seiten sich hinter der Mitte plötzlich gradlinig verengen.

ô Verkehrt-eiförmig, mässig gewölbt, grün, in den Sammlungen bis gelbbraun und rostroth verbleichend, unten rostfarbig, der Kopf' und selten auch Brust und Bauch schwarz, letzterer hell gesäumt. Halssch. breiter als die Basis der Fld., vorn einen sehr flachen Bogen bildend, welcher bis hinter die Mitte reicht, sodann plötzlich unter einem stumpfen Winkel nach imen gebogen und bis zu dem grossen Basalzahne in den Ecken gradlinig rerengt. Die Scheibe ist kissenartig gewölbt, dicht und ziemlich fein punktirt, vor dem Schildchen mit einem grubenförmigen Eindrucke, der sich jederseits bis auf das niedergedrückte, stärker punktirte Seitendach verlängert. Fld. vor der Mitte fast parallel, dahinter in allmählicher Rundung: rerengt, ziemlich stark gestreift-punktirt, die 3. und 4., 8, und 9. 
Reihe verworren, der 2., 4. und 6. Zwischenstreif kielfïrmirg, das Seitendach schmal, mit dickem Rande. Auf der Scheibe stelen einige schwarze Striche, von denen die beiden längeren, einer am Anfange des dritten Kieles anf der Schulter, der andre in der Mitte des zweiten Kieles, die beständigsten sind, während die kürzeren, melır punktförmigen (zwei bis vier an der Naht hinter dem ersten Drittel, einer am Ende des zweiten Kieles und zwei binter der Mitte zwischen der 8. und 9. I'unktreihe) oft undeutlich werden und verschwinden. Vorder- und Mittelhiiften durch einen schmalen Zwischenraum getrennt.

‥ Halssch. schmal, halbkreisförmig, dicht ror dem Basalzahne in den Ecken eine Spur erweitert, die Seiten der Fld. schwach gerundet.

Bei dem lebenden geschlechtsreifen Thiere ist der erste und zweite Längskiel der Fld., letzterer mit Ausschluss der schwarzen Stellen, lebhaft metallisch grün silberweiss oder goldig glänzend.

Auf Artemisia eampestris I. stellenweise. Von der Schweiz und den Rheingegenden durch Deutschland, Oesterreich und Russland bis Sibirien verbreitet.

11. Cass. atrata: Sat lata, subparallela, conrexiuscula, nigra, oleaceomicans, prothorace magno, crebre punctato, fere semicirculari, ante angulos rotundatim dilatato, protecto antice macula bil ba pellucida, ferruginea, coleopteris basi crenato, utrinque sinuato, sat fortiter punctatis, plus minusve costatis; interstitiis parce transversim rugosis, antennarum basi ferrugineo. - Long. $6-8 \mathrm{~mm}$.

Fabr. Mantissa Ins. 1. 1787. 62; Syst. El. 1. 390. - Suffr. Stett. Z. 1844. 282. - Boh. Mon. 2. 470. - Redtb. Faun. A. 2. 521. - Seidl. F. balt. 701 ; transs. 787.

Var. a. Junior, disco prothoracis elytrorumque rufo-piceo, tibiis interdum ferrugineis.

Kaum doppelt so lang als breit, annähernd rechteckig, rorn und hinten in breitem Bogen abgerundet, mässig gewölbt, hinter der Mitte am höchsten; schwarz, fettig glänzend, Glied 2 bis 6 der Fühler röthlich, ein zweilappiger Fensterfleck am Vorderrande des Halsschilddaches blassgelb bis rostroth. Halssch. gross, ror den Ecken gerundet-erweitert, einem Halbkreise ähulich, das Dach ziemlich breit, flach, stärker als die Scheibe punktirt, diese sanft gewölbt, mit einem Eindrucke vor dem Schildchen, zuweilen noch mit einer kurzen Längsrinne jederseits. Fld. kaum doppelt so lang als das Halssch., an der Basis jederseits nahe der Schulter ausgerandet und stark gezähnelt, die Schulterecke vorgezogen, abgerundet, das Seitendach mässig breit, mit aufgebogenem schmalem 
Rande; der Rücken uneben, unrenchüssig gereilit-punktirt, die graden Zwischenstreifen kielförmig, an verschiedenen Stellen knotenartig verdickt und dureh Querrippen unter sich und mit der Naht verbunden. Alle diese Erhöhungen sind niemals scharf ausgeprägt, zuweilen fast abgeschliften, und nehmen nach aussen hin an Stärke ab. Fihler schlank, Glied 3 melır als doppelt so lang wie 2, Prosternum breit, Mesosternum schmal.

Bei frisch entwickelten Exemplaren ist die Scheibe des Falssch. dunkel rothbram, die der Fld, pechbraun, namentlich auf den Erhöhungen, die Schienen sind mehr odler weniger rostroth.

Auf Salvia glutinosa und pratensis L. in Baiern, Thüringen, Schlesien und Oesterreich sehr zerstreut. Ungarn, Serbien, Griechenland, Krim.

12. Cass. selodonia: Subelliptica, minus convexa, nitidula, prasina (testacea), capite, pectore abdomineque nigris, prothorace semicirculari ante angulos rotundatim dilatato, elytris crebre punctatis, basi plerumque sanguineis utrinque sinu profundo fortius crenato. - Long. 5,5 bis $7 \mathrm{~mm}$.

Gyllh. Ins. Suec. 4. 644. - Thoms. Skand. Col. 8. 323. Kraatz, Berl. Z. 1874. 86. - Desbroch. Mon. 23.

C. rotundicollis Bris. Ann. Fr. 1860. 348.

Var. a. Immatura, elytris unicoloribus, lateribus pectoris ventrisque late testaceo-limbatis.

Var. b. filaginis: Pectore abdomineque viridi-testaceis vel ferrugineis, hine inde infuscatis, elytris basi sanguineo-maculatis.

Perris, Ann. Fr. 1855. Bull. 79.

Kleiner und etwas schmaler als die vorige, an den Seiten eine Spur gerundeter, elliptisch, wenig gewölbt, griin, nach gelbbrau verbleichend, Kopf, Brust und Bauch schwarz, letzterer hell gesäumt, wenigstens mit einem hellen Flecke an den Seiten der einzelnen Segmente. Halssch. vor den Ecken gerundet-erweitert, halbkreisförmig, dicht punktirt, auf dem Seitendache stärker als auf der Scheibe, diese oft mit einem Eindrucke vor dem Schildchen. Fld. an der Basis jederseits nahe der Schulter tief ausgerandet und stark gezähnelt, die Schulterecke etwas vorgezogen und völlig verrundet, das Seitendach mässig breit, mit feiner Randleiste; der Rücken schwach gewölbt, mehr oder weniger dicht verworren punktirt, nur die 10. Punktreihe regelmässig;, der 2., 4. und 6. Zwischenstreif bisweilen als glatte Längslinie bemerkbar.

Die Oberseite ist einfarbig griun, bei reifen Thieren an der Basis der Fld. wässerig blutroth gesäumt; dieser Saum schmal, hinten verwaschen begrenzt, häufig durch eine gross?, glatte, helle 
Beule (den Anfang des 2. Zwischenstreifens) nahı dem Schildehen unterbrochen und in vier kleine Makeln aufigelisst. Auf ier Lnterseite sind die seitentheile der Brust, namentlich der Mittellorust, und der Bauch hell gefärbt, die Mitte der Banchringe bald mohr, bald weniger geschwirzt; es kommen jedoch auch Exemplare mit blass-grünlicher Lnterseite vor. (nur der Kopf schwarz), bei welchen sich die helle Farbe üherhaupt nur bis rostroth verdunkelt, hï̈lsstens einige kleine, veränderliche Flecke auf der Brust schwärzlich werden (Var. b).

Diese Art erinnert in der Farbe und Punktirung einigermassen an die noch flachere siideuropäische inquinata Brull., ist aber nur mit denticollis zu verwechseln, welche indessen auf den ersten Blick an den gewölbten graden $\mathrm{Zwischenstreifen} \mathrm{der} \mathrm{Fld.} \mathrm{und} \mathrm{den} \mathrm{regel-}$ mässigen Punktreihen an der Naht zu unterscheiden ist.

In Sandgegenden auf Filago-Arten (arrensis, gallica) wahl'scheinlich in ganz Dentschland, aber bis jetzt nur bei Mainz, in Schlesien, bei Berlin und Königsberg gesammelt; iiber den grössten Theil von Europa verbreitet.

13. Cass.denticottis: Ovalis, convexiuscula, viridis, parum nitida, subtus nigra, antennarum basi, pedibus limloque rentrali pallidis, prothorace fere semicirculari ante angulos subrotundatim dilatato, elytris basi crenulato utrinque leviter sinuatis, intus sanguineis, dorso sat fortiter substriato-punctatis, interstitiis alternis convexiusculis. - Long. $5-7 \mathrm{~mm}$.

Mas: Prothorace lato, angulo laterali late rotundato.

Femina: Prothorace angustiore, angulo laterali parum rotundato.

Suffr. Stett. Z. 1844. 186. - Boh. Mon. 2. 371. - Thoms. Skand. Col. 8. 322. - Redtb. Faun. A. 2.522. - Kraatz Berl. Z. 1874. 88. - Letzner, Bericht Schles. Ges. 1879. 5. - Seidl. F. balt. ed. 2. 702 ; transs. 788. - Desbroch. Mon. 22.

Var. a. Immatura, elytris unicoloribus, viridibus.

Var. b. fuscicollis: Prothorace ferminineo, elytris viridibus.

Eine unserer häufigsten Arten, eirund, mässig gewölbt, grün, ziemlich matt ${ }^{1}$ ), ein Basalsaum der Fld. blutroth, die Unterseite schwarz, Fühlerbasis, Beine und Seiten des Banches hell (grünlich) gelb. Halssch. bald gleichmässig, bald nur auf der Scheibe gewölbt und das Dach dann niedergedrüickt, letzteres stärker als die Scheibe punktirt. oft gerunzelt. Fld. an der Basis dentlich gezälnnelt, jederseits

1) Die grünen Arten sind im ausgefärbten Zustande mehr oder weniger matt, unreife Stïcke werden dagegen stark glänzend, besonders wenn sie durch Benzin, Chloroform, Aether etc. getödtet wurden. 
Ieicht auswerandet, mit breit algerundeten und sehr wenig rorgezogenen Schulterecken. das Dach mïssiy hreit, mit feiner Randleiste. Der Riicken gewölbt, nicht dicht, aher zicmlich stark gereiht-punktirt, die 3. und 4., 8. und 9. Reihe unregelmäissig, die graden Zwischenstreiten gewöllot, besonders die beiden inneren deutlich herrortretend. Der rothe Basalsam wird oft durch das helle Vorderende des zweiten Zwischenstreif's unterhrochen; er rieht sich entweder in gleicher Breite mu das Schildehen herum von einer Schulter zur andern, oder bildet ein niedriges, stumpfwinkeliges Dreieck, dessen Spitze ein Stiick hinter dem Schildchen liegt; die Nahtkante ist gelblich.

Beide Geschlechter sind durch den Bau des Halssch. sehr verschieden. Beim $\hat{o}$ ist dasselbe breit, ziemlich halbkreisförmig, vor der Basis schnell, gradlinig exweitert, so dass die Seiten daselbst einen dentlichen stumpfen, aber abgerundeten Winkel bilden; beim $q$ ist es etwas schmaler, und die Seiten bilden einen viel kleineren Winkel, welcher über die Schulterecken kaum hinaustritt und dicht vor denselben liegt. Hierdurch erhält das Halssch. fast die Form, wie sie in der folgenden Gruppe auftritt, da man die Ecken des Seitenrandes leicht für die Hinterecken halten kann.

Unreife Stiicke sind auf den Fld. einfarbig grïn (gelbbraun), bei ausgehärteten lässt im Leben die äussere Schicht der Oberseite (ohne das Dach) ein mattes Metallgrün hindurch schimmern, hie und da mit kupferigen Pïnktchen untermischt, der etwas verdickte, glatte Hinterrand des Halssch., der breite Theil des zweiten Zwischenstreifens und bei einzelnen Exemplaren auch die Schulterbeule sind lebhaft metallisch grün oder goldig gefärbt. Eine auffällige Varietät (b) hat lebhaft grüne Fld. und ein rostrothes Halssch.

Auf grasigen Wegrändem und Rainen an Achillea millefolium L. gemein. Im grössten Theile von Europa.

B. Dentes basales prothoracis intra augulos humerales elytrorum siti.

14. Cass. rufovimens: Subelliptica, minus comiexa, prasina, parum nitida, subtus nigra, antennarum basi, limbo ventrali pedibusque pallidis, femoribus medio saepe brunnea-annulatis, prothorace semicirculari anyulis obtusis, subrotundatis, elytris fortius punctatis, basi crenulato utrinque leviter sinuato plaga magna communi, subtriangulari, sanyuinea. Long. $6 \mathrm{~mm}$.

Suffr. Stett. Z. 1844. 144. - Boh. Mon. 2. 386. - Redtb. Faun. A. 2.522. - Bach, Käferf. 3. 75.

C. denticollis var. Desbroch. Mon. 23, et. 41. Var. a. Junior, elytris prasinis (testaceis), immaculatis. 
Bei ren Arten dieser Gruppe liegrt der Basalzahn des Malssch. cin Sitiick innerhalh, der Schulterecken und ist bedentend kleiner als bei den vorhergehenden Arten, oft kaum noch zu benerken. selbst vïllig vernumlet, so dass die eigentlichen Hinterecken sehr undeutlich werden und rerschwinden. Der Ausdruck .,Ecken" bezeichnet in den folgenden Beschreihungen nur noch den Winkel, unter dem der gradlinige oder brgenförmige Hinterrand mit dem Bogen des Vorderrandes an der breitesten Stelle des Halssch. zilsammenstösst.

Die vorliegende Art hat den Habitus der C.seladonia, ist aber nicht ganz so flach, viel stärker punktirt, ziemlich elliptisch, hellgriin, Kopf, Brust und Bauch, mit Ausnahme eines Randsaumes, schwarz, die Beine bräunlich gelb, um die Mitte der Schenkel oft ein dunkler Ring. Halsseh. fast wie beim of von denticollis gebaut, halbkreisförmig; die Ecken stumpfwinkelig, schwach abgerundet, dicht ror der Schulterecke liegend. Fld. an der Wurzel jederseits in weitern Bogen ausgerandet und fein gezähnelt, die Schulterecken sehr wenig vorgezogen, mit stumpfer oder abgerundeter Spitze, der Rüicken an den Seiten ansteigend, aber in der Mitte ziemlich flach gedriickt, verworren und stark punktirt, die Punkte an einigen Stellen in kurze Reihen geordnet, so dass zuweilen ein Theil des zweiten und vierten völlig ebenen Zwischenstreifs sichtbar wird. Die Färbung der Fld. ist wie bei sanguinolenta: ein wässerig-blutrother Scheibenfleck, der die Basis von einer Schulter zur andern einnimmt, zieht sich, allmählich verschmälert und rerblasst, bis hinter die Mitte, wo er in der grünen Färbung rerschwindet.

Unreife Thiere sind oberseits einfarbig griin, in den Sammlungen gelbbraun, bei ausgehärteten ist der Scheibenfleck im Leben dunkel blutroth mit Perlmutterglanz.

In Nord- und Mitteldeutschland sehr selten, wahrscheinlich auf Achillea.

15. Cass. stigmatica: Ovata, concexa, rividis, nitidula, subtus nigra, pedibus limboque ventrali pallidis, prothorace sat parro, subelliptico, punctulato, elytris basi emarginatis, evidenter cremulatis, sanguineomaculatis, angulo humerali productis, disco substriato punctatis, interstitiis secundo antice, quarto postice fortius elevatis. - Long. $5,5-6 \mathrm{~mm}$.

Suffr. Stett. Z. 1844. 206. - Boh. Hon. 2.385. - Redtb. Faun. A. 2. 522. - Bach, Käferf. 3. 74. - Kraatz, Berl. Z. 1874. 88 .

C. sanguinolenta var. Desbroch. Mon. 24.

Var. a. Junior, elytris immaculatis. 
Dureh die Bildung des Halssch, und den tiefen bogenförmigen Aussehnitt an der Wurzel der H'll. sehr ausgezeichnet. Eirund, gewölbt, griin, schwach glänzent, Unterseite sehwarz, der grösste Theil der Fülller, die Beine und ein Saum des Bauches hell, bräunlich-gelb. Halssch. verhältnissmässig klein, einem querliegenden Ovale ähnlich, dessen hinterer Bogen etwas flacher als der vordere ist, die Ecken liegen weit vor dem Schildchen und sind breit, abgerundet stumpfiwinkelig. Fld, beim 우 bis zur Mitte merklich erweitert, beim ô mehr parallel, dahinter in allmählicher Rundung verengt, an der Basis tief bogenförmig ausgerandet und deutlich gezähnelt, die Schulterecken vorgezogen, spitzwinkelig, mit abgerundeter Spitze. Der Rücken ist gewölbt, ziemlich dicht und etwas unregelmässig gereiht-punktirt, die graden $\mathrm{Zwischen-}$ streifen gewölbt, der zweite vor, der vierte hinter der Mitte verbreitert und durch weite Längsvertiefungen, die an ibrem Aussenrande hinziehen, stark emporgehoben, rippenförmig. An der Basis befinden sich vier kleine, blutrothe Makeln, die eine rundlich, quer oder aus zwei Punkten zusammengesetzt, in einer Grube vor dem hohen Schulterhöcker, die andre strichförmig, neben dem Schildchen; bei unreifen Stücken fehlen dieselben.

Im Leben ist die Scheibe des Halssch. nahe der Basis nebst den Erhöhungen an der Wurzel der Fld, perlmutterglänzend.

Auf Achillea millefolium L. in den Berggegenden Mittel- und Süddeutschlands stellenweise. Oesterreich, Ungarn, Kroatien, Dalmatien, Sarepta.

16. Cass. rosea: Subelliptica, convexa, prasina, subtus nigra, antennarum basi, genubus, tibiis tarsisque testaceis, prothorace sublunato, angulis obtusiusculis, elytris basi emarginatis, crenulatis, angulo humerali productis, dorso sanguineis, fortiter substriato-punctatis, interstitiis secundo et quarto subelevatis. - Long. 4,5-5,3 mm.

Boh. Mon. 2. 387. - Redtb. Faun. A. 2. 523.

C. denticollis var. Desbroch. Mon. 23. et. 41.

Var. a. Immatura, supra prasina (testacea).

Var. b. Tibiis tarsisque infuscatis.

Mässig gestreckt, an den Seiten fast parallel, vorn und hinten breit abgerundet, gewölbt, hellgriin, wenig glänzend, Kopf, Brust und Bauch schwarz, ein schmaler Saum an den Seiten des letzteren, Glied 2 bis 6 der Fühler und die Beine bräunlich gelb, die Schenkel mit Ausnahme der Spitze und der Trochanteren schwarz. Halssch. mondförmig, der Hinterrand zwischen den Schultern fast grade, sodann auf jeder Seite deutlich nach vorn und aussen gebogen, so dass die schmalen, stumpfwinkeligen und an der Spitze leicht 
gerundeten Ecken zienlich weit vor dem seliildchen liegen. Fld. an der Jasis fast grade, nur die Schulterecken vorgrezngen. der Rïcken dicht und stark gereilhtpunktirt, ohne stirkore Vertietimgron. daher kaum uneben, der zweite Zwischenstreif hreit. der vierte schmal, beide etwas gewijlbt. I) ie scheile wirl ron einer wässerig blutrothen Makel herleckt, welche sich üher die niedrige schnlterbeule hin his zur neunten P'unktreihe ausdehnt. auf den Alifalle zur Spitze in einem mässig breiten grünen Saume über dem hellen Seitendache verliert. Bisweilen reicht die rothe Makel nur rom einer Schulter zur andern, verschmälert sich nach hinten und endet in $2 / 3$ der Länge, sie hat dann dieselbe dreieckige Form wie bei sanguinolenta.

Unreife Stiicke hahen einfarbig hellgxüne Fld, die nach dem Tode eine gelbbraune Farbe annehmen; zuweilen ist der grösste Theil der Schienen und Tarsen pechschwarz (Tar. b).

Diese hübsche Art ist an den schwarzen Schenkeln. die schon das unreife Thier besitzt, sicher zu erkennen. Mit denticollis hat sie nichts zu thum, da die fast verrundeten Basalzähne des Halssch. weit innerhalb der Schulterecken liegen; eher wäre eine Verwechselung mit der etwas breiter gebauten sangrinolentr möglich, welche indessen durch den schwach gebogenen Hinterrand und die wenig vorgezogenen Ecken des Halssch., den undeutlicher gezähnelten Basalrand der Fld, stärkere Vertiefungen vor der Schulterbeule und neben dem Schildchen und die meist kielförmigen graden Zwischenstreifen abweicht.

In Steiermark. Anch bei Kaschan in Ungarn von mir auf Achillea millefolium L. gefangen.

17. Cass. sanguinolenta: Ovatr, convexa, prasina, subtus nigra, epimeris mesosterni, limbo ventrali pedibusque pallidis, prothorace sublunato, angulis fere rectis, elytris basi vage cremulato parum emarginatis, humeris vix productis, dorso plaga magna postice evanescente sanguinea ornatis, substriato-punctatis, interstitiis alternis elevatis, protecto minus explanato. Long. 4,5-5,5 $\mathrm{mm}$.

Müller, Zool. Dan. Prodr. 1776. 65. - Illig. Kär. Preuss. 482. - Payk. Faun, 2.46. - Herbst, Käf. 8. 229. - Fabr. Syst. El. 1. 389. - Gyllh. Ins. 3. 441. - Suffr. Stett. Z. 1844. 208. - Boh. Mon. 2. 388, - Bach, Käferf. 3. 74. Thoms. Skand. Col. 8. 322. - Kraatz, Berl. Z. 1874. 90. Seidl. F. balt. 702; transs. 788. - Desbroch. Mon. 24 (pars).

Var. a. Elytris basi emarginatis, humeris sat productis.

Var. b. Angulis prothoracis apice rotundatis.

Var. c. Elytris fortius striato-punctatis.

$\mathrm{V}$ ar. d. Junior, elytris unicoloribus, prasinis. 
Ziemlich breit eiförmig, gewölbt, hellgriin, Kopf, Brust und Bauch schwarz, die ersten sechs Fühlerglieder, Epimeren der Mittelbrust und ein Samu an den Seiten des Bauches hell. If alssch. beim ô viel breiter als beim f, mondförmig, am Ilinterrande jederseits, ungeffihr von der Mitte der Flügeldeckenbasis an, sehr sanft nach rorn und aussen gebogen, so dass die rechtwinkeligen Ecken sehr wenig (o) oder nicht weit $(\hat{\sigma})$ vor dem Schildchen liegen, der Vorderrand ist gleichmässig gerunlet, häufiger ror dem Kopfo etwas ausgezogen. Fld. an der Basis fast grade, sehr schwach und undeutlich gezithnelt, in den Schultern wenig vorgezogen, das Dach ziemlich steil abfallend; der Rücken beinahe regelmässig gereihtpunktirt, nur die dritte und vierte Reihe häufig vor der Mitte durch danebentretende Punkte gestört, der zweite und vierte $Z$ wischenstreif breit, wenigstens der erstere hoch gewölbt, kielförmig, namentlich in der vorderen Hälfte.

Lange Zeit bleibt das Thier auf der Oberseite einfarbig hellgrün, dann bildet sich ein rosenrother Wisch an der Basis der Fld., von einer Schulter zur andern, welcher etwa in $1 / 4$ der Länge erlischt; später färben sich die beiden Längskiele roth und zuletzt der ganze, von ihnen eingeschlossene Raum. Es entsteht so ein gemeinschaftlicher Scheibenfleck, welcher auf dem Abfalle zur Spitze allmählich in die griine Farbe iibergeht, aussen aber vom zweiten Längskiele begrenzt wird, über den er manchmal vor der Mitte, ungefähr bis zur 6. Punktreihe, hinaustritt. Die Farbe dieses Fleckes verdunkelt sich bei der V'ergrösserung bis zu einem wässerigen blutroth, im Leben bläulich schimmernd, die Schulterbeule, sowie der Anfang der ersten Längsrippe sind dann perlmuttergiänzend.

Wenn die Fld. an der Basis in leichten Bogen ausgerandet (Var. a.) und anch die Ecken des Halssch. an der Spitze abgerundet sind (Var. b.) erhält das Thier eine entfernte Aehnlichkeit mit stigmatica.

Die Punkte der Fld. sind verhältnissmässig fein, es kommen aber auch rereinzelt Stücke mit einer weit stärkeren Punktirung vor, der von denticollis ähnlich (Var. c.)

Auf Achillea millefolium L. Ende Juli in Mitteleuropa häufig. Schweden.

18. Cass. prasina: Freviter oratis, convexiuscula, prasina, subnitida, subtus nigra, pedibus limboque ventrali pallidis; mothorace semicirculari, angutis acutiusculis, elytris basi vage cremulato vii emarginatis, sanguineo-muculatis, dorso substriato-punctutis, interstitiis alternis elevatis, protecto modice explanato - Long. 5-6 $\mathrm{mm}$.

Illig. Käf. Preuss. 481. 
C. chloris Suffr. Stett. 7. 1844. 188. - Boh. Jon. 2. 384. Redtb. Faun. A. 2. 523. - Kraatz, Berl. Z. 1874. 92. Letzner, Bericht 1879. 5.

Var. a. Junior, elytris immaculatis.

Mit der vorigen Art leicht zu verwechseln, aber durchschnittlich grösser und breiter. Das Halssch. ist einem Halbkreise ähnlich und bildet am Hinterrande einen fast gleichmässigen, sehr schwachen Bogen, mit einem deutlichen Basalzahne jederseits, die Hinterecken sind spitzwinkelig, mit scharfer Spitze und liegen in einer Linie, die dicht vor dem Schildchen hinziehen würde. Die Fld. fallen hinter der Nitte schnell ab, ihr Seitendach ist weniger abschüssig, flach ausgebreitet, der Rücken in der Regel feiner punktirt, niemals mit einer grösseren gemeinschaftlichen Makel, oder einem Wische versehen. Dafür treten an der Basis 4 kirschrothe Flecke auf, der eine, quer, in der Grube vor dem Schulterhücker, der andre am Seitenrande des Schildchens, strichförmig, zuweilen rergrössert, oval, die ganze Vertiefung am Schildchen überziehend. Durch diese Zeichnung wird die Art auch der C. stigmatica ähnlich, die sich jedoch leicht durch den völlig abweichenden Bau des Halssch, und die vorgezogenen Schulterecken trennen lässt.

Auf Achillea millefolium L. in Mitteleuropa zerstreut. Dalmatien, Türkei.

Illiger hat diese Art a. a. O. so genau beschrieben und von sanguinolenta unterschieden, dass jeder Zweifel ausgeschlossen ist; Suffrian scheint aber die Käf. Preuss. nicht gelesen zu haben und zog den Namen prasina Ill. zu sanguinolenta, nach einem Stücke, welches er nicht einmal gesehen hat?

19. Cass. sanguinosa: Breviter ovalis, convexiuscula, viridis, subtus nigra, pedibus limboque ventrali pallidis, femoribus basi plerumque infuscatis; fronte sat lata, prothorace fere semicirculari, crebre punctulato, angulis acutiusculis, elytris basi evidenter crenulato macula brevi subtriangulari ferruginea vel sanguinea notato, vix emarginatis, dorso crebre punctatis, punctis hine inde seriatis, interstitiis secundo et quarto subelevatis, protecto sat declivi. - Long. 6-7 $\mathrm{mm}$.

Suffr. Stett. Z. 1844. 105. - Boh. Mon. 2. 369. - Thoms. Skand. Col. 8. 321. - Redtb. Faun. A. 2. 522. - Des. broch. Mon. 20.

C. prasina Herbst, Käf. 8. 221.

C. languida Cornel. Stett. Z. 1851. 88. - Boh. 1. c. 383.

Var. a. Femoribus ad medium usque piceis aut nigris.

Diese und die folgende Art unterscheiden sich ron den vorhergehenden kleineren grünen Arteu, namentlich von prasina, 
welche ein ähnlich gebautes Halssch. hat, durch die unregelmåssigere Punktirung der Fld. Die ersten beiden Punktreihen an der Naht sind durch eingestrente Punkte mehr oder weniger verwirt, der zweite Längskiel nähert sich hinten viel weniger dem ersten, der Raum zwischen beiden ist riel breiter, hinten bereits mit 3- bis 4-fachen verworrenen Punktreihen besetzt, und die 5. bis 9. Punktreihe ist in der Regel nur dicht hinter dem Schulterhöcker regelmässig.

C. sanguinosa ist breit-eiförmig, mässig gewölbt, grün, nach dem 'Tode leicht in bräunlich-gelb verbleichend, Kopf', Brust und Bauch schwarz, letzterer an den Seiten schmal hell gesäumt, die Schenkel an der Basis mit einem bräunlichen Schatten, selten ganz einfarbig, das erste Fühlerglied und die erweiterten Glieder oberseits dunkel. Stirn (wie bei den vorigen Arten) zwischen den Augen mindestens so breit als lang, dicht punktirt, in der Mitte oft etwas rertieft, das Kopfschild gross, dreieckig, die Grenzlinien grade, fein oder undeutlich, zwischen der Fühlerwurzel fast zusammenstossend. Halsseh. beinahe halbkreisförmig, beim $\hat{o} \mathrm{oft}$ breiter als der Grund der Fld., dicht und fein punktirt, oft gerunzelt, die Ecken scharf und spitz. Fld. an der Basis deutlich gezähnelt, fast grade, nur die Schultern etwas vorgezogen, das Seitendach ziemlich steil abfallend, mässig breit, der Rücken über demselben schnell ansteigend, hinter der Schulterbeule etwas zusammengedrïckt; dicht punktirt, der 2. und 4. Zwischenstreif aus der Punktirung herausgehoben, schwach kielförmig. Die Nahtkante bräunlich-gelb bis rothbraun, ein Saum an der Basis, von einer Schulter um das Schildchen herum zur andern, oft durch den hellgefärbten Anfang des ersten Längskieles jederseits unterbrochen, rostfarbig oder lebhaft blutroth. Dieser Saum ist nicht selten verbreitert und bildet dann ein kurzes und sehr breites Dreieck, dessen Spitze sich ein Stück hinter dem Schildchen befindet. Bei lebenden, gesehlechtsreifen Thieren bemerkt man auf der Schulterbeule und dem Schildchen zuweilen einen schwachen Perlmutterglanz; häufig sind die Schenkel rom Grunde bis zur Mitte pechbraun oder schwarz (Var. a).

Auf Tanacetum vulgare L. an Ufern und Wegen stellenweise in ganz Mitteleuropa. Schweden.

C. languida Corn. hat zwar Kraatz, Berl. Z. 1874. 93, nach typischen Stiicken auf chloris bezogen, aber Coruelius muss falsche Typen eingesandt haben, da sie mit seiner Beschreibung nicht übereinstimmten, welche nur auf sanguinosa zutrifft.

20. Cass. rubiginosa: Breviter ovalis, minus convexa, viridis, opaca, subtus nigra, limbo ventrali anguste, femoribus apice, tibiis tarsisque pallidis, fronte angusta, alutacea, punctata, prothorace sublunato, 
crebre punctulato, angulis acutiusculis, elytris busi iage crenulato macula transversa, subtriangulari fermeninen, apice jicere cel nigra. notatis, dorso crebre punctatis, punctis hinc inde seriatis, interstitiis secund et quarto interdum subelevatis, protecto fortius explanato. - Long. 6 bis $8 \mathrm{~mm}$.

IIiller, Zool. Dan. 65 - Illig. Käf. Preuss. 479. - Herbst, Käf. 8. 223. - Suffr. Stett. Z. 1844. 135. - Bulı. J[on. 2. 373. - Thoms. Skand. Col. 8. 320. - Redtb. Faun. A. 2. 521. - Seidl. F. balt. 702; transs. 788. - Desbroch. Mon. 17.

C. vibex Harold, Catalog. 3659 .

C. viridis F. Ent. Syst. 1. 291. - Syst El. 1. 387.

C. alpina Bremi, Stett. Z. 1856. 197.

Var. a. fuliginosa: nigra, protecto ferrugineo-translucido.

C. nigra Suffr. 1. c. 142.

Var. b. Oblongo-ovalis, elytris antice parallelis.

Var. c. graeca: Subrotunda, depressiuscula, creberrime punctata.

Kraatz, Berl. Zeit. 1874. 104.

Breit-eiförmig, wenig gewölbt, oben griin, matt, unten schwarz, die dünnen Fühlerglieder, die Schenkelspitzen, Schienen, Tarsen und ein schmaler Saun an den Seiten des Bauches hell. Stirn zwischen den Augen bedeutend länger als breit, äusserst fein körnig gerunzelt, matt, punktirt, Kopfschild ron zarten Linien begrenzt, die bald gradlinig, bald gebogen zur Fühlerwurzel laufen.

Halssch. kurz, mondförmig, dicht und feiu punktirt, oft runzelig, mit spitzen Ecken. Fld. kaum breiter als das Halssch., an der Basis schwach und undeutlich gezähnelt, fast grade, in deu Schultern wenig vorgezogen, das Seitendach breit, allmählich abfallend, der Rücken über demselben langsam ansteigend, hinter der Schulter unmerklich zusammengedriickt, dicht punktirt, der 2. und 4. Zwischenstreif aus der Punktirung herausgehoben, flach, seltener gewölbt. Ein vorziigliches Merkmal, woran sich die Art in den meisten Fällen schnell erkennen lässt, bietet die eigenthümliche Zeichnung am Vorderrande der Fld. Es liegt dort zwischen den Schultern ein rostrother, selten kirschrother Saum. welcher an der Basis vier bis sechs dunkle Punkte besitzt (zwei in dem Eindrucke vor der Schulter und einen oft fehlenden, dicht an Schildchen), sich hinter dem Schildchen an der Naht etwas verlängert und in einer pechbraunen oder schwarzen Makel endet. Diese Makel liegt am Ende des Basaldreieckes, wo sich die rorn schmale Nahtkante erweitert, ist stets dunkler gefärbt als der übrige Theil und liäufig schon bei frischen Stiicken vorhanden.

Die sehr seltene Varietät a ist einfarbig schwarz, nur das 
Seitendach rothbraun, durchschimmernd, und die Schienen und Tarsen zuweilen röthlich; ebentalls selten ist die Var. b., die sich durch den gestreckten K̈̈rper, von der Schulter bis zur Mitte parallele, dahinter allmïhlich verengte und etwas ausgezogene Fld. und deren schmaleres Dach auszeichnet.

Auffàllig breite und kurze, an clen Seiten stark gerundete, auf' dem Rücken flache Exemplare, deren Fld. dichter und feiner als gewöhnlich punktirt sind, bilden die Var. c, die im südlichen Krain, in Istrien und Dalmatien bis Griechenland vorherrscht.

Gemein auf Carduus nutans L., Cirsium-, Sonchus-, Onopordonund Lappa-Arten, sowie auf Tranacetum. Europa.

Als eine Form kömnte sich bei reicherem Mrateriale herausstellen: C. incompta Ws. Dentsch. Z. 1887. 334, von Armenien bis Turkestan verbreitet. Sie ist den längeren, an den Seiten fast parallelen, aber hinten breit abgerundeten Exemplaren von rubiginosa ähnlich, sehr flach, oben einfarbig grün, das Halssch. gross, die Fld. gleichmässig dicht, fein und tief punktirt, die Beine einfarbig gelb, oder die Schenkel an den Trochanteren schwärzlich. Einzelne Stiicke aus dem Araxesthale (Reitter) haben die Schenkel bis zur Mitte schwarz.

21. C'ass. thoracica: Breviter-ovalis, minus convexa, subtus nigra, antennis, pedibus limboque ventrali pallidis, fronte angusta, prothorace brevi, subelliptico angulis obtusiusculis, sat rotundatis, crebre punctulato, ferrugineo-rufo, limbo lato basali sanguineo, coleopteris viridibus, basi vage crenulato profunde emarginatis, macula sublyratu sanguinea notatis, dorso postice sensim declivibus, crebre subtiliter punctatis, punctis hinc inde seriatis, interstitio secundo antice subconvexo, protecto lato, fortius explanato. - Long: $6-7 \mathrm{~mm}$.

Panz. Faun. germ. 1796. 38. 24. - Illig. Käf. Prenss. 478. - Fabr. Syst. El. 1. 388. - Gyll. Ins. Suec. 3. 439. Steph. Ill. Brit. 4. 366; Man. 286. - Suffr. Stett. Z. 1844. 142. - Boh. Mon. 2. 376. - Redtb. Faun. A. 2.522 (pars). Thoms. Skand. Col. 8. 322.

C. ferruginea Harold. Col. Heft. 6. 64. - Seidl. F. balt. 702; transs. 789.

Vax. a. Junior, prothorace viridi-testaceo, limbo lato basali brunneo.

Der vorhergehenden nahe verwandt, ihren kurzen und breiten Stücken ähnlich, in der Form und Farbe des Halssch, und der Basalmakel auf den Fld. sehr abweichend.

Breit-eiförmig, vorn allmählich in einer fast ebenen Fläche ansteigend, und hinter dem Schildchen am höchsten, dahinter in sanfter Wölbung abfallend, das Seitendach ziemlich flach, breiter als bei den übrigen Arten, namentlich vor der Spitze. I) Sic Stirn ist schmal, fein punktirt, matt, mit feinen, graden Linien. Halssch. kurz und

VI. 6 . 
selır breit, einem querliegenden ()vale ähnlich, dessen rorderer Bogen wenig grösser als der hintere ist, die Ecken stumpfwinkelig. abgerundet, weit vor dem Schildchen; die Farbe der Ober- und Unterseite hell rostroth, durchscheinend, ein breiter Saum an Hinterrande dunkel blutroth, nicht durchscheinend. Der Saum läuft rom Seitenrande aus der Basis parallel nach innen, ist rorn nicht scharf begrenzt, vor dem Schildchen auf einem unbestimmten. oft zweilappigen Flecke heller gefärbt, davor verdunkelt und bis auf den Raum uiber dem Kopfe verbreitert. Fld, an der Basis verloschen gezähnelt und in weitem Bogen ausgerandet, grün, ziemlich matt, dicht und verhältnissmässig fein, rerworren punktirt, nur die beiden ersten und einige der äusseren Reihen in der Nähe der Schulter zu unterscheiden, der zweite Zwischenstreif ror der Mitte etwas gewölbt; am Vorderrande ein gemeinschaftlicher, blutrother (nach dem Tode oft pechbrauner) Fleck, lyrafürmig, oder dem oberen Theile einer Vase ähnlich. Derselbe nimmt das Basaldreieck ein, erweitert sich aber rorn jederseits in einen gerundeten Zipfel, der auf die Schulterbeule tritt, geht hinten, auf dem schmalen und hohen, gröber punktirten Querstreifen, der das Dreieck abschliesst und die ersten beiden Punktreihen unterbricht, in ein helles Rostroth iiber und bildet dahinter einen grossen, ruudlichen dunklen Fleck zwischen den Längsrippen. Oft ist ein Streifen an jeder Seite des Schildchens heller gefärbt. Die Zeichnung der C. mbiginosa ist kleiner, steigt nicht auf die Schulterbeule hinauf und endet schon in der Spitze des Basaldreieckes. Auf der Unterseite sind Kopf, Brust und Banch schwarz, die Fïhler und Beine einfarbig hellgrün (bräunlich gelb), ebenso ein Saum an den Seiten des Bauches.

Das Halssch. frisch entwickelter Stücke ist vorn, auf den durchscheinenden Stellen gelblich-grim, auf den undurchsichtigen dunkelbraun (Var. a).

An Lappa-Arten stellenweise in Mitteleuropa, aber bisher nur vereinzelt gefangen.

Nach Angaben von Redtenbacher und Desbrochers soll die Art auch mit schwarzen Sçenkeln vorkommen, vielleicht liegt eine Verwechselung mit der folgenden vor.

Der verschollene Name C. ferruginea Goeze, Ent. Beytr. 1. 233, erst. von Harold und Seidlitz fälschlich auf thoracica bezogen, darf nicht mehr gebraucht werden, da ans der Beschreibung: "Viridis, thorace ferrugineo", keine bestimmte Art zu erkennen ist; vielleicht hat Goeze eine Varietät von denticollis, stigmatica oder sanguinosa vor sich gehabt.

22. Cass. tincta: Ovalis, aequaliter convexa, subtus nigra, antennarum basi, femorum apice, tibiis, tarsis limboque ventrali pallidis; fronte sut angusta, prothorace fere semicirculari angulis acutiusculis, crebre punctu- 
lato, fermuineo-rufo, postice obscure sanguinco-limbato, clytris basi crenulato vix emarginatis, macule tringuluri obsene sanguineu notatis, sat regulariter striato-puntatis, interstitio secundo antice convexo, protecto subdeclivi. - Long. 5,5-6 num.

Weise, Wien. ent. Z. 1891. 205.

? C. thoracica Desbr. Mon. 19. - Redtb. Fam. A. 2. 522 (pars).

Eiförmig; g:leichmässig gewölbt, unten schwarz, Fiihler, mit Ausnahme der erweiterten Glieder die Spitze der Schenkel, Schienen, Tarsen und ein Saum an den Seiten des Bauches hell gefärbt. Halssch. fast halbkreisförmig, ähulich wie das von sanguinosa, der Hinterrand sehr wenig gebogen, der Vorderrand gleichmässig: gerundet oder vor dem Kopfe ausgezogen (dann ist das Halssch. mehr dreieckig), die Ecken scharf, spitz, die Scheibe wenig gewölbt, dicht und fein runzelig-punktirt, rostroth, ein Saum am Hinterrande, welcher iberall gleichbreit, bedeutend schmaler als bei thoracica und rorn noch schlechter begrenzt ist, blutroth. Fld. an der Basis wenig ausgerandet, ziemlich deutlich gezähnelt, das Seitendach mässig breit und abschüissig, der Rücken gewölbt, kräftig; gereiht-punktirt, ähnlich, aber stärker als bei sanguinolent $\iota$; zwischen der dritten und vierten Reile vor der Mitte eine ïberzählige Punktreihe, der zweite Zwischenstreif, vorn gewölbt. Die Farbe ist griun, die Nahtkante und eine grosse, gemeinschaftliche Basalmakel blutroth. Diese Makel ist entweder gleichmässig dunkel gefärbt, oder schliesst einige hellere Stellen ein (z. B. den Anfang des zweiten $\mathrm{Z}$ wischenstreifs, oder noch einen Fleck jederseits am Schildchen); sie bedeckt das Basaldreieck und verlängert sich dahinter bis nahe zur Mitte in einen, besonders dunkel gefärbten Strich, welcher, bis zur zweiten Punktreihe ausgedehnt, neben der Naht herläuft. Diese Zeichmung ist dem oberen Theile eines Weinglases ähnlich und unterscheidet sich von der bei thoracica auftretenden dadurch, dass sie rorn kaum auf die Schulterbeule hinaufreicht, und hinten nicht makelförmig endet.

In Thiuringen (Wehncke) und Oesterreich (Reitter); Ungarn.

23. Cass. vihex: Ovalis, convexiuscula, testuceo-viridis, setulis brevissimis obsita, subtus nigra, antennarum basi, femorum apice tibiis tar. sisque pallidis, prothorace sublunato, crebre punctulato, angulis obtusiusculis, elytris substriato-punctatis, basi crenuluto leniter emarginatis, puncto medio juxta marginem brunneo, macula basali triangulari limboque suturali brunneo-variegatis. Long. 5-8,5 mm.

Linné, Syst. Nat. ed. 12. 575. - Fabr. Syst. Ent. 89. Schrank, Enumer. 48. - Scriba, Beiträge 1.80.t.8.f.1. - Illig, Käf. Preuss. 477. - Gyllh Ins. Suec. 3. 440. Suffr. Stett. Z. 1844. 146. - Thoms. Skand. Col. 8. 321. 
- Redtb. Faun. A. 2. 521. - Seid. F. balt. 702; transs. 789. - Desbroch. Mon, 19.

C. liriophora Kirby, Trans. Linn. Soc. III. 1797. 8.

Var. a. pannonica: Pedibus totis flavis.

Suffr. I. c. 147.

V ar. b. Elytris puncto medio nullo.

V ar. c. Ut in $b$, sed sutura concolore.

Var. d. discoidea: prothorace fermgineo, elytris viridibus singulo late ferrugineo-cincto.

C. vibex Herbst, Käf. 8. 218, t. 129, f. 5.

Var. e. Supra ferruginea, sutura elytrorum brunnea.

$\mathrm{V}$ ar. f. Angulis prothoracis sat rotundatis.

V ar. g. Elytris basi profunde emarginatis, humeris fortius productis.

Var. h. elongata: Angusta, subparallela.

An der Zeichnung der Fld. leicht kenntlich, welche sich nur mit der ron muraea rergleichen lässt, obwohl aie Makeln schlecht begrenzt und viel heller sind als bei dieser, und ron der äusseren Längsreihe blos der mittelste Punkt iibrig' geblieben ist.

Eifömig, mässig gewölbt, vorn allmählich ansteigend, hinten schnell abfallend, oben schmutzig gelbg'iin, im Leben schön bläulich grün, gesättigt blattgriin, oder maigriin, oder das Halssch. zuweilen auch die Fld. goldig kupferroth angehaucht, mit sehr kurzen. weissen Börstchen besetzt, unten schwarz, die ersten sechs oder sieben Fühlerglieder, Schenkelspitzen, Schienen und Tarsen hellgrün (bläulich gelb). Stirn zwischen den Augen so breit als lang, oder wenig schmaler, punktirt, dicht gewirkt, fast matt, mit verloschenen Linien. Halssch. ziemlich kurz. mondförmig, dicht und fein runzelig. punktirt, die Ecken stumpfwinkelig, mässig schart. Fld. etwas schmaler ( $\hat{\sigma})$, orler so breit als das Halssch. (q), an der Basis sanft ausgerandet und mehr oder weniger deutlich gezähnelt, das Seitendach ziemlich breit, der Rücken gereiht-punktirt, die beiden ersten Reihen stärker und tiefer als die iibrigen, die 3. und 4. Reihe ror der Mitte und die 7. bis 9. Reihe durch einen breiten, mit vielen Punkten besetzten Raum getrennt, der zweite Zwischenstreif gewölbt, kielförmig. In der Mitte jeder Fld. steht eine kleine, dunkelbraune Makel zwischen der 7. und 8. Punktreihe, ausserdem ist das Basaldreieck dunkelbraun, oft mit helleren Stellen, und der Raum an der Naht zwischen den Längsrippen beider Fld. dunkelbraun gefleckt. Diese Flecke sind selır unregelmässig. aus Längsstrichen und Makeln znsammengesetzt, welche bisweilen ineinander fliessen und einen breiten, regelmässigen Nahtsaum bilden, der sich vor der Spitze auf die Nahtkante verengt.

Die Art ist sehr veränderlich. Bei der Betrachtung der Farbe 
ergeben sich fünf Varietiten: a. Die Schenkel sind nur an den Trochanteren sehwarz, oder die Beine cinfarbig gelb; b. der dunkle Punkt jeder Fld, fehlt, ausserdem c. auch noch dic dunkle Zeiehnung an der Naht hinter dem Basaldreiecke; d. das Halssch., das Seitendach der Fld., ihr Basaldreieck und ein gleichnaissiger, nicht durch helle Stellen unterbrochener Nahtsamm, bis zur dritten Punktreihe jederseits reichend, hell rostroth, die scheibe jeder Fld. lebhaft griin; e. Oberseite rostroth, mit dunkelbrauner Zeichnung auf' den Fld.

Eine abweichende Form besitzen die Varietïten f. Ecken des Halssch. ziemlich breit, abgerundet; g. Basis der Fld. tief ausgerandet und die Schulterecken weit rorgezogen; h. sehr schlank, die Fld. an den Seiten fast parallel, im letzten Drittel allmählich gerundet-verengt.

Auf Cirsium arvense und palustre L., zuweilen auch an Tanacetum, gemein. Nordafrika, Europa, Westasien. Die Var. a lebt in Sandgegenden auf Centaurea paniculata L.; die Var. c. und d. sind sehr selten, g. wurde bei Laak in Krain von $H$. Ludy, $h$. bei Sarepta von H. Becker gefangen.

Nahe verwandt ist C. fusco-rufa Motsch., Bull. Mose. 1866. 1. 178, vom Amur (Wladiwostok, Koltze) und aus Japan. Bei ihr ist die Oberseite gleichmässig dunkel rostroth, nur das Dach heller, die Unterseite einfarbig schwarz, die Fld. haben einige Längsrippen.

24. Cass. nebulosa: Ovalis, convexiuscula, dilute ferruginea, minus nitida, subtus nigra, fronte, pedibus limboque ventrali testaceis, femoribus plerumque infuscatis, prothorace subelliptico, crebre punctulato, elytris nigro sparsis basi crenulato prothorace latioritus, humeris fortiter productis, dorso fortius punctato-striatis, interstitiis angustissimis, protecto sat angusto margine laterali reflexo, medio incrassato, metasterno processu inter coxas intermedias lato. - Long. 5-7 $\mathrm{mm}$.

Linné, Faun. Suec. 1761. 152. - Gyllh. Ins. Suee. 3. 442. Illig. Käf. Pr. 483. - Suffr. Stett. Z. 1844. 277. - Boh. Mon. 2. 451. - Thoms. Skand. Col. 8. 318. - Redtb. Faun. A. 2. 523. - Seidl. F. balt. 701; transs. 788. Desbroch. Mon. 25.

C. affinis Fabr. Syst. Ent. 88.

Var. a. Junior, supra pallida, viridi-flavescens, elytris nigro-sparsis.

C. maculata Fabr. 1. c. 1775.88.

C. tigrina Deg. Mem. 5. 1775. 168.

Var. b. Pedibus testaceis.

Var. c. Fronte infuscata, rarius nigra.

Var. d. Prothorace postice macula transversa, obsoleta, fusca.

Var. e. nigra: Supra picea, protecto fusco.

Herbst, Käf. 8. 258. - Kraatz, Berl. Z. 1874. 95. 
Eiförmig. mässig gewölbt, hell rostroth oder lederfarthig. wenig glïnzend, die Fld., sowie ihr Seitendach hinter der Mitte, unregrelmiissig schwarz gefleckt, Lnterseite schwar\%, der Kopf, die Beine und ein Saum an den Seiten des Bauches bräunlich gelb, Schenkel mehr oder weniger angerlunkelt. Stirn fein und zerstreut punktirt, mit schwachen Linien. Halssch, etwas schmaler als die Flil, mit völlig verrundeten Ecken, einem querliegenden Orale ähnlich, dessen vorderer Bogen viel grösser als der hintere ist. dicht, runzelig punktirt. Fld, an der Basis fein schwarz gesäumt und deutlich gezähnelt, die Schulterecken rund, stark rorgezogen, das Seitendach ziemlich schmal, mit aufgebogener und in der Mitte verdickter Randleiste ${ }^{1}$ ); der Rücken regelmässig und grob punktirt-gestreift, die Punkte quer, durch feine Leisten getrennt, die Zwischenstreifen selur schmal, kielförmig, nur der zweite breit, höher als die übrigen, das Basaldreieck hinten ron einer Querleiste geschlossen, welche die beiden ersten Punktstreifen unterbricht. Hinterbrust in einen breiten Fortsatz zwischen die Mittelhüften verlängert, so dass die Mittelbrust nur eine schmale Querkante bildet.

Diese Art ist im Körperbau recht beständig, ändert aber in der Farbe verschiedentlich ab. Das frische Thier ist oberseits sehr blass, auf dem Halssch. weisslich-, auf den Fld. mehr grïnlich-gelb, letztere schwarz gesprenkelt (Var. $\left.\mathrm{a}^{2}\right)$, nach und nach zeigt sich ein schwacher, röthlicher Anflug, welcher bei der Geschlechtsreife in ein helles Rostroth iibergeht und im Leben von einem wenig lebhaften Perlmutterglanze bedeckt ist. Die Beine sind beim of röthlich-gelb, ein Streifen auf' dem Rücken der Schenkel schwärzlich, beim $\hat{\sigma}$ in der Regel viel duukler, die Schenkel fast bis zur Spitze, oft auch der Rücken der Schienen schwarz; es kommen aber männliche Stücke mit einfarbig gelben Beinen selten, weibliche häufig vor (Var.b). Auch die Stirn wird zuweilen dunkel, selbst schwarz (Var. c); auf der Scheibe des Halssch. bildet sich öfter eine braunrothe, sehr verschwommene Quermakel vor dem Hinterrande (Var. d); endlich kann die Oberseite schwarzbraun, selbst tief schwarz und glanzlos werden, nur das Dach röthlich durchschimmernd (Var. e).

Auf Chenopodiaceen (Chenopodium, Beta und Atriplex) gemein, an Runkelrüben bisweilen sehr schädlich.

1) Diese Erweitermng des Raudes erwähnt auch Herbst bei C. nigra p. 259 .

$\left.{ }^{2}\right)$ Ein schlechtes Licht auf die Logik mancher Entomologen, welche gegen die Benennung von Varietäten ins Feld zogen, wirft die Thatsache, dass sie selbst für die Jugendfärbung der C. nebulosa den Namen affinis F., oder tigrina Deg. anwandten. 
25. Cass. flaveola: Ellipticu, converiuscula, testucea, antennis apice infuscatis, pectore abdomineque nigris, hoc pallide limbato, fronte sublaevi, prothorace subelliptico, disco alulaceo, elytris basi vix crenuatis, humeris leniter productis, dorso punctuto-striatis, interstitiis angustis, inaequatibus, metasterno processu inter coxus intermedias angusto. Long. 4,5-6 mm.

T'humberg, Ins. Suec. 8. 1794. 103. - Seidl. F. balt. 701; transs. 788

C. obsoleta Illig. Käf. Preuss, 484. - Gyllh. Ins. Suec. 3. 444. - Suffr. Stett. Z. 1844. 272. - Boh. Mon. 2,455. - Thoms. Skand. Col. 8. 319. - Redtb. Faun. A. 2. 523. - Desbroch. Mon. 26.

Var. a. Immatura, albida, elytris interdum brunneo-variegatis, pectore abdomineque fuscescentibus.

Var. b. littoralis: Dilute ochracea, pectore abdomineque medio nigricantibus.

Var. c. Elystris fusco-nebulosis vel fuscis, punctis plurimis testaceis, prothorace postice rarius infuscato.

C. ferruginea Fabr. Syst. Ent. 89.

Var. d. dorsalis: Elytris plus minusve nigris, aut corpore nigro, protecto rufo-translucido.

Desbroch. Mon. 27. (15. Septemb. 1891).

C. flaveola var. atrata Gerh. Zeit. Entom. Breslau, Octob. 1891. 28.

Mässig breit, an den Seiten fast parallel, vorn und hinten breit abgerundet, nicht stark gewölbt, hell, aber wenig lebhaft gelblichbraun, die verdickten Fühlerglieder, die Brust und der Bauch schwarz, letzterer gelb gerandet. Stirn glatt, selten mit einigen deutlichen Punkten, die Linien schwach, oft erloschen. Halssch. wie bei nebulosa geformt, die Scheibe zart gewirkt, nur auf dem Abhange an den Seiten fein punktirt, das Dach narbig, mit durchscheinender Netzzeichnung. Fld. am Basalrande hell, kaum gezähnelt, jederseits etwas ausgeschweift, wodurch die Schulterecken schwach vortreten, das Seitendach schmal, mit feiner und niedriger Randleiste; der Rüicken regelmässig punktirt-gestreift. Die Punkte reichen theilweise auf die Zwischenstreifen, so dass diese schlecht begrenzt und nicht überall von gleicher Breite sind. Die Punktirung ist veränderlich. Meist stehen in den Streifen starke und tiefe, etwas quergezogene Punkte, welche schmale, theilweis gewölbte oder rippenförmige Zwischenstreifen übrig lassen, seltener sind die Punkte fein, rund, nur gereiht und kaum in Streifen gestellt, die Zwischenstreifen breiter und fast eben. Das Basaldreieck wird hinten undeutlich begrenzt und die erste und zweite Punktreihe kaum unterbrochen. Die Mittelhüften sind durch einen schmalen Fortsatz der Hinterbrust und einen ähnlichen Zipfel des Metasternum getrennt. 
Längere Zeit nach dem Ausschliipfen hleibt das Thier weisslicl, auf den Fld. zuweilen mit verloschenen hraunen Sprenkeln zwischen der Naht und der 6. P'unktreihe, Brust und Bauch dunkelbraun; damn nimmt die Oberseite eine gelblichgrane Fürbung an. die sich zuletzt in ein schmutziges Braun verwandelt, wie es ein helles Tabackblatt besitzt. Im Leben bemerkt man auf dem IIalssch. schwachen, auf den Fld. lebhaften Goldschimmer.

Unter den Abänderungen sind zu beachten:

b. Hell ockergelb, Brust und Bauch in der Mitte schwärzlich, seltener tiefschwarz, der Bauch dann breit gelh gesäumt und die Füllerkeule dunkel. Auf Honkenya peploides L. am Seestrande.

c. Schmutzig hellbraun, Scheibe der Fld. mit verloschenen, bindenähnlichen dunklen Flecken, oder die Fld. bis auf den Abhang vor der Spitze dunkelbraun, mit vielen kleinen, unregelmässigen helleren Makeln, die wenig ins Auge fallen. Vor dem Hinterrande des Halssch. manchmal ein dunkler Querfleck.

d. Fld. in den vorderen zwei Dritteln oder der ganze Körper pechbraun bis schwarz, nur das Seitendach röthlich durchscheinend.

Auf Alsineen, besonders Stellaria holostea und graminea L., Spergula arvensis L. etc. häufig.

26. Cass.berolimensis : Elliptica, convexiuscula, testaceo-brunnea,pectore abdomineque medio ferrugineis, fronte sat fortiter punctata, prothorace semicirculari, angulis late rotundatis, disco evidenter punctulato, elytris basi vix crenulatis, punctato-striatis, interstitiis sat angustis, aequalibus. - Long. 4-5 mm.

Suffr. Stett. Z. 1844. 270. - Boh. IIon. 2. 458. - Krattz, Berl. Z. 1874. 94. - Redtb. Faun. A. 2. 524.

C. obsoleta Herbst, Käf. 8. 248.

Var. a. daurica: Elytris maculis nonnullis parvis, fuscis.

Boh. Mon. 2. 457. - Kraatz, 1. c. 1879. 269.

Durchschnittlich kleiner, etwas dunkler gefärbt als die vorige und von ihr leicht durch folgende Punkte zu unterscheiden: Der Kopf ist kräftig punktirt, mit deutlichen Stirnlinien neben dem Augenrande. Das Halssch. ist auf der Scheibe fein, am Hinterrande und namentlich auf dem Dache stärker punktirt, halbkreisförmig, mit abgerundeten Ecken, welche riel kleiner als bei flaveola sind und näher an der Schulter liegen. Die Fld, haben sehr regelmässige Punkt- und Zwischenstreifen, die Punkte sind rund, genau hintereinander gestellt und greifen die $\mathrm{Z}$ wischenstreifen nicht 
an; das Seitendach fällt stärker ab, und die Aussonkante wird durch eine regelmiissige und sehr deutliche P'unktreihe algesetzt. Die Unterseite ist gelblich bram, Brust und Banch nach der Mitte hin etwas dunkler, rostroth. In Leben schimmert die ()berseite mattgoldig, besonders anf' der Schulter und dem 2. und 4. Zwischenstreif vor der Mitte.

Die einzige, umbedentende Varictät, daurica Boh., ist mir aus Russland, dem Caucasus und Sibirien bekannt, wixd aber in Deutschland sicher anfgefunden werden. Bei ihr sind die Fld. mit einigen dunkelbraunen, ziemlich unbestimmten Flecken versehen z. B. ein Punkt ror dem Schulterhöcker, eine Makel in der Grube, worin die 3. und 4. Punktreihe an der Basis entspringt, ein Strich auf der Nahtkante hinter dem Basaldreieck, je ein Punkt auf dem 3. und 7. Zwischenstreif hinter der Mitte, ein ähnlicher an der Vereinigung der 3. und 4. Punktreihe $\mathrm{u}$. s. w.

Die Lebensweise der Art ist unbekannt; es sind bis jetzt einzelne überwinterte Stücke im Anspülicht bei Berlin, Stettin und in Mecklenburg gefangen worden.

\section{Elytra protecto fortiter declivi.}

28. Cass. nobilis: Oblongo-ovalis, convexa, pallide testacea, subtus nigra, limbo ventrali pedibusque pallidis, femoribus ultra medium nigris; capite punctato, clypeo parvo, triangulari, sulcis profundis ante antennas conjunctis terminato, prothorace angulis obtusis, rotundatis, elytris basi haud crenulato subtruncatis, humeris productis, disco punctato-striatis, interstitio $2: 0$ subconvexo, $3: 0$ punctato-Long. $3,5-5,5 \mathrm{~mm}$.

Linné, Faun. Suec. 1761. 153. - Fabr. Syst. Ent. 90; Syst. El. 1. 396. - Illig. Käf. Pr. 485. - Gyllh. Ins. Suec. 3. 445. - Suffr. Stett. Z. 1844. 245. - Boh. Mon. 2. 423. Thoms. Skand. Col. 8. 323. - Redtb. Faun. A. 2. 523, Desbr. Mon. 35.

C. pulchella Panz. Faun. germ. 39. 15. - Illig. 1. c. 486.

C. laevis Herbst, Käf. 8. 250.

C. urticae Brahm, Naturforsch. 29. 170. t. 3. f. 23.

Var. a. Prothorace ubique evidenter punctato.

Var. b. Junior, supra pallide-virescens, aut unicolor, aut elytris punctis et lineis fuscis, indeterminatis, sparsis.

C. viridula Payk. Faun. 2. 49. - Gyllh. 1. c. 447. - Suffr. 1. c. 249 .

Var. c. rosea: Elytris modo vitta media rosea (ochracea), nunc totis roseis (ochraceis), interstitio secundo protectoque albicantibus.

Illig. Käf. Preuss. 486.

V ar. d. Elytris vitta suturali abbreviata lineisque duabus in singulo fuscis. Var. e. Supra badia.

Var. f. obscura: Subtus saepe nigra, unicolor, supra testacea, protecto, sutura lineolisque elytrorum nigricantibus. 
Merklich schlanker als die vorhergehenden Arten, an den Seiten steiler abfallend und das Dach der Fld. so weit nach unten verlängert, dass die Brust im Sitzen nicht mehr die Lnterlage berühren kann, ubrigens durch die Bildung des Kopfschildes ron allen Arten abweichend.

Länglich-eirund, gewölbt, blass bräunlich-gelh, unten schwarz. die Fühler, das letzte Drittel der Schenkel, die Schienen, Tarsen und ein Saum an den Seiten des Banches hell gefärbt. Stirn dicht prunktirt, mit kleinem, dreieckigem Kopfschilde, wn tiefen und graden Rinnen begrenzt, die sich weit vor der Fühlerwurzel zu einer auf den Scheitel laufenden Mittelrinne vereinigen. Halssch. einem querliegenden Ovale ähnlich, der Vorderrand bogenförmig, der Hinterrand fast gradlinig, jederseits stark nach vorn und aussen gebogen, so dass die stumpfwinkeligen, abgerundeten Ecken weit vor dem Schildchen liegen und von den Schulterecken getrennt sind, die Scheibe dicht und zart gewirkt, das Dach mit durchscheinender Netzzeichnung. Fld. an der Basis ungezähnelt, gradlinig, die Schulterecken schräg vorgezogen, auf dem Riicken regelmässig gestreift-punktirt, der zweite Zwischenstreif breiter als die übrigen, leicht gewölbt, der dritte mit einer Punktreihe, die wenigstens hinter der Mitte nie fehlt, selten durch eine Menge rerworrener Punkte ersetzt ist. Die Mittelhüften sind wenig getrennt.

Die Skulptur der Fld. ist in der Stärke veränderlich, wie bei den meisten Arten; auf dem Halssch, bemerkt man oft feine Punkte vor dem Hinterrande, selten ist die ganze Fläche sehr deutlich, fein und tief punktirt (Var. a).

Die Farbe der frischen Stücke ist blassgrün, nach dem Tode gewöhnlich, weisslich, Kopf, Mitte der Brust und des Bauches, so. wie die Basalhälfte der Schenkel schwärzlich, die Fld. zuweilen mit hellbraunen, unbestimmten Makeln (auf' der Schulter, auf dem grössten Theile des ersten, der Mitte des zweiten und der Basis des dritten Zwischenstreifs). Die weitere Ausfärbung geht in rerschiedener Art vor sich: 1., Auf der Scheibe jeder Fld, erscheint ein rosenrother Längswisch, der sich allmählich über die Fld. verbreitet und dann nur von dem perlmutterfarbenen zweiten $Z$ wischenstreif unterbrochen ist. Nach dem Tode erlischt die rothe Farbe, und die Fld. werden einfarbig strohgelb, oder sie verwandelt sich in ein röthliches Ockergelb, der metallische Zwischenstreif wird nebst dem Dache weisslich (Var. c). 2., Die Oberseite erhält nach und nach einen braunen Ton (nach dem Tode lederbraun), der zweite Zwischenstreif, die Schulter, oft auch der 6. und 8. Zwischenstreif hinter der Mitte lebhaft goldgrün oder perlmutterfarbig, ein gemeinschaftlicher Saum an der Naht, der dritte Zwischenstreif vorn und 
der siehente hinter der Mitte schwarhlnaun. Bei den Exemplaren der Sammlung rerschwindet die metallische Zeichntmg, zuweilen erhält sich aber die sehwaybrame, wem auch etwas verblasst, und es entsteht damn die Var. d. Hïchst selten wird die Oberseite gleichmässig verschossen kastanienbraun (Var. e), orlex lederbraun, das Dach, die Schulterbeule und zum 'Theil anch die inmeren vier Zwischenstreifen der Fld. pechschwarz, die Unterseite nebst den Beinen einfarbig schwarz (Var. f).

Iuf Kleefeldern (Buddeberg), oder an Spergula arvensis (v. Heyden) und Chenopodium-Arten (Letzner) häutig.

28. Cass, vittata: Oblongo-ovalis, convexa, pallide viresceus (testucea), capite, pectore abdominisque medio nigris, fronte punctata, clypeo magno, lineis inter antennas conjunctis terminato, mothorace angulis obtusiusculis, elytris basi haud cremulato, subtruncatis, humeris moductis, dorso subtiliter striato-punctatis, interstitio 2:0 lato, 3:0 crebre punctato. Long: $5-6,5 \mathrm{~mm}$.

Villers, Edit. Linn. 1789. 1. 93.

C. oblonga Illig. Käf. Preuss, 485. - Suffr. Stett. Z. 1844. 252. - Boh. Mon. 2. 422, - Redtb. Faun. A. 2. 522. Desbroch. Mon. 36.

Var. a. Immatura, pallide flava, capite nigro, pectore abdomineque medio infuscatis, elytris rarius longitudinaliter ferrugineo-nebulosis. Var. b. Femoribus basi nigris.

Aehnlich gebaut wie nobilis, aber etwas grösser, auf den Fld. fein und weniger regelmässig punktirt, das Dach des Halssch. schmaler, die Beine hell, in der Bildung der Stirn sehr abweichend. Dieselbe ist dicht punktirt, mit feinen, oder mässig starken, graden Linien, die erst zwischen der Fühlerwurzel zusammenstossen und so ein grosses Kopfschild einschliessen. Das Halssch. ist mondförmig, verloschen punktirt. der Hinterrand in der Mitte gradinig, an den Seiten schräg nach vorn und aussen gebogen, mit beinahe stumpfwinkeligen, schwach abgerundeten Ecken, die unmittelbar an den Schulterecken und mässig weit vor dem Schildchen liegen. Fld. fein gereiht-punktirt, der zweite und dritte Zwischenstreif breit, eben, letzterer dicht punktirt.

Anfänglich ist das 'Thier weissgelb; bald färbt sich der Kopf' schwarz, und die Mitte der Brust und des Bauches schwärzlich, auf den Fld, bilden sich mitunter viele veränderliche rostrothe Längsfleckchen von der Schulter bis vor die Spitze und zwischen der 4. Punktreihe und dem Seitendache. Später wird die Brust und der Bauch tief schwarz (letzterer behält aber einen sehr breiten, scharf begrenzten hellen Seitensaum), die Oberseite blassgrün (gelbbraun), 
das Inch bräunlich. und auf jeder Fld. liegt im Leben eine breite. metallisch griine Iängshinde, welche den Raum zwischen der 2. his 5. (oder 7.) Punktreihe eimnimmt, am Innenrande der Saht parallel läuft, am Aussenrande hinter der Schulter brgenfürnig ausgebuchtet ist.

An den Beinen wird häufig die Basis der Schenkel nehen den Trochanteren, oder das ganze Basaldrittel schwarz (Var. h).

Auf Disteln und an Spergula arrensis ( $v$. Heyden) oder Lrtica dioica (Suffrian) ziemlich häufig in Mittel- und Südeuropa. 


\section{Nachträge und Berichtigungen.}

S. 6. Orsodacna lineola. Var. h. croatica: Cyaneo-nigra, capite antice vel omnino, thorace pedibusque rufis aut rufo-tcstaceis, femoribus interdum infuscatis. Die Fld., sowie die Brust oder die Unterseite bläulich schwarz, der Kopf nebst Fühlern, Halssch., Beine (und oft der Bauch) roth oder rothgelb. Krain, Croatien, Banat. (Deutsche Z. 1883. 251).

Ors. mespili Lac. dürfte besser unter meiner Var. a citirt werden.

S. 18. Donacia dentata. Grüne Stiicke nannte Westhof, Käf. Westph. 253, chrysochlora, violette autumnalis, schwarze, mit einem Stich ins Violette diabolus.

S. 23. Donacia sparganii. Die Varietäten sind so zu ändern: Var. a. Supra laete viridis vel auro-cuprea.

Var. b. coelestis: Supra coerulea, cyanea aut violacea.

S. 24. Donacia limbata. Die Varietät b nannte Westhof, Käf. Westphal. 255 unicolor.

S. 28. Donacia thalassina. Stücke, deren Oberseite intensiv purpurroth ist bezeichnet Westhof, 1. c. als Var. porphyrogenita.

Von D. thalassina, impressa, platysterna brevicornis und brevitarsis gab Thomson neuerdings Diagnosen in den Ann. d. France 1884. Bull. 148.

S. 36. Donacia fennica. In den Horae 26. p. 412-437 (1892) befindet sich eine ,Analytische Uebersicht der bekannten Donaciaund Plateumaris-Arten der alten Welt" von G. Jacobsohn, worin fennica Payk. als eigene Art angesprochen wird:

a. Spitze der Fld. grade abgestutzt und stark abgerundet, Halssch. feiner und sparsamer punktirt, Hinterschenkel die Spitze der Fld. lange nicht erreichend, Beine meist dunkel. Deutschland, Oesterreich. (Halsseh. und Fld. röthlich gelbbraun $\mathrm{v}$. arundinis Ahr.) Malinowskyi Ahr.

b. Spitze der Fld. schräg nach innen abgestuzt und schwach abgerundet, Halssch. stärker und dichter punktirt, Hinterschenkel die Spitze der Fld. fast erreichend, besonders beim $\hat{0}$, Beine pechbraun. Halssch. und Fld. kastanienbraun. Schweden, Finnland, Sibirien. fennica Payk.

$\mathrm{Ob}$ diese Unterschiede stichhaltig sind, wird sich erst heransstellen, wenn ein ausreichendes nordisches Material vorhanden ist.

S. 38. Donacia semicuprea. Die lebhaft gefärbten Exemplare belegte Westhof, Käf. Westph. 259, mit dem Namen iris, die ober- 
seits einfarbig metallschwarzen, mit dem Namen tenebrans: J. vulgaris mit einfarbigen Fld. bildet die Var. concolor Westh. 1. c. 260 .

S. 40. INonacia simplex. Oberseite dunkelblau $=\mathrm{r}$. pulchervima Humm. Lssais 7.32, oder dunkel purpurroth = sunguinea Westh. 1. c. 259.

S. 45. Plateumaris sericea var. $\mathrm{e}=$ tenebricosa und luctuosa Westh. 1. c. 256.

S. 59. Als Autor der heutigen Gattung Lema ist nicht Fabr., Supplem. Ent. Syst. 90, sondern Lacordaire, Mon. 303, zu betrachten.

S. 72. Crioceris tibialis. Dieselbe bildet zwei bemerkenswerthe Varietäten:

a. Elytris minus fortiter punctato-striatis, interstitiis rix concexis.

b. Tibiis anticis basi nigris.

S. 75. Crioceris 5-punctata bildet zuweilen eine Varietät thoracica: Prothorace punctis 2 nigris, saepe in litteram $Y$ confluentibus.

S. 77. Crioceris decorata Moraw. = bicruciata Sahlb.

S. 79. Zu Crioceris asparagi. Herr Oberst Gabriel iiberliess mir ein bei Neisse gefangenes Stück der Var. f., bei dem die hinteren beiden hellen Makeln jeder Fld, völlig zusammengeflossen sind und zwei kleine dunkle Punkte einschliessen.

S. 97. Von Labidostomis pallidipennis kommt eine Abänderung mit dunkel gelbbraunen Schienen und Tarsen vor.

S. 101. Macrolenes ruficollis: Fabricius hat, Syst. Ent. 109, unter dem Namen ruficollis einen echten Ciryptocephalus von St. Helena beschrieben mit ,antennis filiformibus, longitudine corporis", der sich bei ihm später in die heutige ('yytra verwandelte. Es tritt dafür die Clytra dentipes Oliv. Ent. VI. 1808. 857 ein, weil alle älteren Benennungen ungiltig sind.

Sehr dunkle Stiicke bilden die Var. e. confluens: Maculis elytrom confluentibus, pedibus saepe fuscis. Die beiden Basalmakeln jeder Fld. sind in einen grossen Fleck rereint, welcher zuletzt durch einen Längsstreif mit den beiden hinteren Makeln in Verbindung tritt, die in eine Querbinde zusammenfliessen.

S. 111. Lachna ea hirta lässt sich durch den rorn sehr schmal abgesetzten Seitenrand des Halssch. rom täuschend ähnlichen 오 der vicina unterscheiden, bei dem der Seitenrand bis rorn breit abgesezt ist.

S. 113. Unsere Clytra-Arten können so hell gefärbt sein, dass die hintere schwarze Zeichnung jeder Fld. rerschwindet. Diese Form habe ich bei (l. quadripunctata als Var. dissimitis, bei appendicina als Var. arida und bei laeriuscula als Var. anti- 
stita bezeichnet (Horae 23.563); bei nigrocincta hat sie $\mathbf{H}$. von Heyden Var. deficiens genannt (D. Z. 1891. 368).

Sind die beiden hinteren schwarzen Makeln zu einer beiden Decken gemeinsamen Querbinde zusammengeflossen, so hat man bei C?. laeviuscula die Tar. connexa Schilsky, D. Z. 1888. 325, bei atraphaxidis die Var. conjuncta Heyd. D. Z. 1891. 368.

S. 119. Von Gynandrophthalma salicina wurde bei Neisse (Gabriel) ein Ex. gefangen, welches auf der Scheibe des Halssch. einen grossen pechschwarzen Fleck besitzt, dessen Ränder verwaschen und jederseits mit einer kleinen Makel verbunden sind.

S. 125. Gynandrophthalma tibialis ist von H. Maggi bei Fünfkirchen angetroffen worden and könnte nördlich bis Oesterreich vordringen.

S. 132. Coptocephala unifasciata bildet eine Abänderung; welche auf den Fld. wie rubicunda gezeichnet ist, Var. fallax Ws., Zeitschr. Entom. Breslau 1887. 56, Elytris maculis duabus nigro-aeneis, prima ollonga humerali altera majori transversa infra medium.

S. 155. Cryptocephalus variegatus var. b. Strasseri Ws. Deutsch. Zeitschr. 1889. 416, Elytris testaceis, unicoloribus.

S. 156. Cryptoc. distinguendus var. d ist noch beizufiugen: rarius in fasciis binis confluentibus.

S. 166. Cryptoc. bipunctatus Var, a und b, Fld. einfarbig roth, oder mit schwarzem Schulterpunkt=var. cautus; unter der Var. e ist 4 -notatus H. Schäff, t. 22. f. 135, paradoxus Suffr. Mon. 3. 35, unter der Var.g clericus Seidl. Faun. transs. 763 anzufuihren.

S. 174. Cryptoc. gamma westlich schon bis Siebenbuirgen ( $v$. Méhely) nachgewiesen.

S. 183. Crypt. sericeus v. intrusus muss den älteren Namen zambanellus Mars. führen.

S. 186. Die Var. b. des Crypt. aureolus nannte Schilsky, Deutsch. Z. 1888, 322, coerulescens, blaue globicollis H. von Heyden, 1. c. 1891, 368, cyaneomicans.

S. 189. Die bis jetzt nur in einzelner. Stücken aus den Alpen und aus Schweden bekannte blaue Varietät von Crypt. hypochoeridis mag den Namen cyanescens führen.

S. 190. Crypt. virens Suffr. sammelte H. Miller bei Mödling; südlich von Wien, und bei Neusiedl.

Der Käfer ist plumper gebaut, wenig breiter, aber merklich kürzer als der äusserst ähnliche violaceus Laich, lebhafter gefärbt auf Kopf und Halssch. meist goldig metallisch-griin, auf den Fld. bläulich-grün bis blau. Stim und Kopfschild sind sparsam und sehr 
kur\%, bei violaceus dagegen lang und dicht hehaart, so dass bei ersterem die Grenze zwischen Koyfsehild und Oberlippe stets deutlich. bei letzterem undeutlich, ja bei wohlerhaltenen Exemplaren durch die weisslichen Härchen vollständig verdeckt ist. Uas erste Fülılerglied ist goldgriin, das dritte doppelt so lang (hei viol. kaum $1 / 2$ mal so lang) als das zweite. Das Halssch. ist kürzer und kugeliger, vorn viel weniger zusammengedrückt, auch in vielen Fällen f'einer und weitläufiger punktirt als bei viol., während die Fld. weniger dicht, aber mit viel grösseren, bedeutend flacheren und schlechter begrenzten Punkten besetzt sind, welche sich nie zu recht deutlichen Querrunzeln verbinden, wie bei der ähulichen Art. Die Lnterseite ist durchweg feiner und kürzer behaart.

Der letzte Bauchring des ô besitzt einen schwachen Quereindruck in der vorderen Hälfte und steigt zum Hinterrande stark an (virens), oder ist in der Mitte der Luänge nach flach gedrückt, zum Hinterrande kaum, wohl aber am Vorderrande zu einer kräftigen Querleiste ansteigend (violaceus). Bei ersterem ist der Penis bis zur Oeffnung allmählich schwach erweitert. an derselben jederseits stark, fast abgestutzt-verengt, mit einer abgesetzten dreieckigen Spitze; bei letzterem an der Oeffnung nach und nach in eine breite, leicht wellig gebogene Spitze verschmälert.

Das of hat auf dem letzten Bauchringe eine flache Eigrube und einen abgestutzten Hinterrand (vivens), oder eine tiefe Grube und einen in der Mitte dreieckig ausgeschnittenen Hinterrand (violaceus).

S. 212. Crypt. princeps Rottb. scheint nur eine Varietät von stragula Rossi zu sein.

S. 214. Bei Crypt. flavipes fehlt noch die Var. i. obscuripes: Pedibus posticis totis intermediisque maxima parte nigris.

S. 220. Die Var. b. ron C'rypt. ocellatus bildet eine eigene Art, die dem ganzen Karpathenzuge angehört; sie wurde ron Frivaldszky, Termeszetrajzi Fizetek 1883, 15 als ('r. carpathicus beschrieben und weicht ron ocellatus durch schlankeren Körperban, einfarbig schwarze Stirn und schwarze Schenkel ab, ist auch oberseits in der Regel stärker punktirt.

S. 234. Bei Crypt.signaticollis ist die Geschlechtsauszeichnung anzufügen: $\hat{o}$ Letzter Bauchring mit einer grossen, nach hinten verbreiterten Grube, an den Seiten derselben dicht abstehend und ziemlich lang behaart.

Crypt. elegantulus ist bei Thorn, macellus bei Pillau gefangen (Deutsch. Z. 1885, 256).

S. 242. Crypt. pusillus var. d. viduns: Das Halsseh. tief schwarz, ein Saum am Vorder- und Seiteurande weisslich. ein grosser Fleck in den Vorderecken und ein schmaler, mondförmiger, 
in der Mitte oft unterbrochener Querfleck auf der hinteren Hälfte gelblichroth. D. Z. 1889. 218.

S. 256. Der in der Anmerkung erwïhnte Pachybrachys ist nicht glycyrrhizae Ol., sondern nigropunctatus Suffr. Beide unterscheiden sich so (D. Z. 1892. 413):

Fld. mit unregelmässigen Punktreihen, im vorderen Theile der Innenhälfte ganz verworren punktixt, Unterseite dicht silberweiss behaart. - L. 4-4,5 mm. Persien, Mesopotamien, Tiflis, Araxesthal, Armenien, Syrien. (Mon. 9. 152). nigropunctatus Suffr.

FId. regelmässig punktirt-gestreift, höchstens mit einigen überzähligen Punkten nahe dem Schildchen, Unterseite undicht silberweiss behaart. -- L. 2,5--3 mm. Bagdad, Araxesthal (Ent. 6. 838). glycyrrhizae $\mathrm{Ol}$.

S. 264. Pach. picus sammelte H. Buddeberg auf Eichen bei Nassau.

S. 273. Bei Stylosomus ilicicola ist das Halssch. bald etwas weitläufiger punktirt, mit glänzenden $Z$ wischenräumen, bald dichter punktirt, matt, etwas runzelig. Jetztere Form ist von Abeille, Ann. Fr. 1877 Bull. 49, als rugithorax beschrieben. Die Art lässt sich leicht an dem Ansschnitte in den Hinterecken des Halssch. erkennen.

S. 290. Grösseres Material veranlasste eine nenerliche Durchsicht der Gattung Colaspidea, nach welcher sie in drei Gattungen aufzulösen ist.

Corpus alatum, pubescens. Elytra subparallela callo humerali prominulo. Metathorax pleuris dense abbido villosis, unguiculi apice bifidi.

Colaspina Ws.

Hierher eine Art Colaspina Saportae Gren., Catal. Col. France 1863. 119, aus der Provence.

Corpus apterum, pubescens. Elylra lateribus rotundata, callo humerali nullo. Metathorax pleuris parce pubescentibus vel glabris, unguiculi bifldi.

Colaspidea Lap.

Hierher die übrigen drei p. 291 genannten Arten.

Corpus oblongum, convexum, apterum, supra nitidum, glabrum. Prothorax sat magnus, transversus, marginatus, lateribus rotundatus, angulis dentato-prominulis. Elytra epipleuris distinctis confuse seriatimve punctata. Episternum prothoracis margine antico interno parum elevatum et a margine antico prosterni vix separatum; sulci antennales nulli. Pedes robusti, tibiae validae apicem versus sensim dilatatae, vix emarginatae. Unguiculi basi dentati.

Colaspinella Ws.

$\mathrm{Zu}$ dieser Gattung gehört, ausser einer noch unbeschriebenen Art von Persien, die Colaspidea grandis Friv., Termeszetr. Fiiz. 1880. 264, welehe ron Merkl auf dem asiatischen Olym], im vorigen IV. 6 . 
Sommer auch bei Constantinopel gefunden wurde und in der europriischen 'Türkei jedenfalls weiter verbreitet ist.

S. 337. Die Var. h. von Timarcha metallica $=$ splendens Matzek, Uebers. Arb. Schles. Ges. 1842. 154.

S. 362. Chrysomela olivacea oberseits rein schwarz $=$ Var. umbratilis Ws. Deutsch. Z. 1887. 185.

S. 369. Die sehr auffällige Var. C'ameranoi Piolti, Atti Ac. Torin. 15. 378, ron Clerys. haemoptera, bei welcher die Oberseite tief schwarz und mit einem leichten Bronzeschimmer belegt ist, sammelt H. Merkl in der Türkei. Genau dieselbe Farbe hat Chrys. turca Fairm., welche nicht eine Var. von vernalis ist, wie p. 365 angegeben, sondern gute Art, und durch sehr grosse und tiefe, grubenförmige Punkte der Fld. abweicht.

S. 387. Chrys. carnifex Var. c. Fonowi Ts., Veutsch. Z. 1889. 127, Fld. roth, mit eimem verwaschenen schwärzlich metallischen Nahtsaume.

S. 396. Die typische Chrys. fuliginosa kommt rereinzelt noch nördlich bis Thüringen vor.

S. 414. Unter Chrys. cerealis ist einzureihen die Var. k. Capite prothoraceque piceis, elytris rufo-brumeis, margine laterali leviter viridi-aeneo resplendentibus.

S. 418. Chrys. asclepiadis ist nur eine Varietät ron Chr. aurichalcea Mannh. (Gebler), Ws. Wiegmann's Archiv 1887. 181 bis 186, und kommt auch in Thüringen vor.

S. 420. Von Chrys. coerulans beschrieb Fleischer, Wien. Zeit. 1892. 142, eine sehr ausgezeichnete Var. olivaceanigra aus Böhmen. Dieselbe ist schwarz, mit grünem oder bräunlichem Metallglanze.

S. 441. Eine kleine Form von Orina tristis wurde in Finnland entdeckt, wonach auch die Einleitung p. 436 zu berichtigen ist.

S. 451. Orina nigrina Suffr. ist eine schlanke, stark punktirte schwarze oder dunkelblaue Form ron alpestris aus den Pyrenäen; die schwarze, breite Form der gloriosa aus den Alpen ist als Var. atramentaria $W_{\mathrm{S}}$. Deutsch, Z. 1891, 37t, anzufïhren.

S. 465. Schwarze Stiicke der Or. viridis, mit rerhältnissmässig stark punktirten Fld, sammelte Puton in den Vogesen.

S. 468. Or. virgulata rar. e. Papei Ws., Deutsch. 7. $18 \$ 7$. 364, Obsolete aurichalcea, fusco-nenea, riridis rel cyanen, elytris subopacis marginibus interdum nitidis. Am Susten Passe.

S. 473. () r. plagiata ist auf dem westlichsten Ausläufer der Karpathen, der Lissa hora, in unserem Gebiete entdeckt worden. 
Die Var. a. mit cinfarbig rothen Fld. muss den Namen distinctissima Ulannwski, Societas ent. 1886. 22., erhalten, die dunkelste Form, Tar. b., Elytris piceis margine luterali rufis, den Namen dorsalis W's. Deutsch. \%. 1887. 186. Ausserdem ist mir noch eine eigenthümliche Var. c. bekannt geworden, bei welchex die Fld. normal gefärbt sind, aber der Vorderkopf, die Fühler und Beine sind roth, an der Aussenseite der Schenkel, nahe der Basis, eine schwarze Makel.

Am Zirbitz Kogel in Steiermark ist neuerdings aufgefunden:

14a. Or. commutata: Brevis, convexa, nigra, nitida, prothorace elytrisque rufis, illo transverso, "pice sat 1nofunde emarginato quam basi parum angustiore, lateribus paullo rotundatis, interdum subrectis, angulis rectiusculis, supra parum convexo, obsoletissime alutaceo, inctequaliter punctato, callo laterali lato, impressione sat profunda antice foveolato-dilatata terminato; elytris sat fortiter munloso-punctatis, interstitiis politis. - Long. 7,5-9 mill.

Mas: Segmento ultimo abdominis medio leviter impresso, apice truncato, utrinque sinuato, articulo primo tarsorum sat fortiter dilatato.

Suffr. Stett, ent. Zeit. 1861, 435. - Weise, Dentsch. Z. 1891,375 .

Habituell der Or. intricata älnlich, mit Ludovicae Muls. am nächsten verwandt, jedoch kürzer, gewölbter und viel glänzender als diese, der Körper vorn verschmälert, Seiten des Halssch. wenig gerundet und die Punktirung der Fld. kräftiger. Von melanocephala durch bedeutenderen Glanz der Oberseite, ein an den Seiten ziemlich paralleles Halssch. und die feinere Punktirung der Fld, von der einfarbigen plagiata endlich durch ein breites Halssch. mit deutlich abgesetztem Seitenwulste und die runzelige Punktirung: der Fld, zu unterscheiden.

Kurz oval, hinten stark gewölbt, glänzend, schwarz, der After roth gesäumt, Halssch. und Fld. gesättigt bräunlich roth. Kopf und Halssch. äusserst fein geschuppt und unregelmässig mit stärkeren und schwächeren, im Ganzen feinen Punkten besetzt. Halssch. mehr als doppelt so breit wie lang, an den Seiten sehr wenig gerundet, fast parallel, nur nahe den Vorderecken deutlich verengt; die Oberfläche wenig gewölbt, mit einem ziemlich tiefen, aber weiten, hinten fast rinnenförmigen, vor der Mitte grubenförmigen Längseindrucke jederseits, welcher den breiten, mässig gewölbten Seitenwulst deutlich absetzt. Die Ecken sind rechtwinkelig. Fld. an der Basis etwas breiter als das Halssch., nach hinten mehr oder weniger erweitert, dicht und ziemlich stark runzelig-punktirt, wenig stärker als bei plagiuta und etwa halb so kräftig als bei melanocephala. mit glatten, innen ebenen, nach aussen zu gewölbten Zwischenräumen, 
J):as of hat einen seichten Eindruck in der Mitte des letzten Bauchringes, dessen Hinterrand jerlerseits ausgebuchtet, dazwischen alggestutzt ist; das erste Tarsenglied ist ziemlich loreit. - Penis dem ron Indoricae und plagiatu ähnlich, jedoch rom in eine grosse, breite, abgerundete Spitze vorgezogen, der ()berrand des ductus wird durch einen dreieckigen Ausschnitt in zwei breite, gerundete Läppchen getheilt.

S. 476. Or. cacaliae var k. bohemica Ws., Deutsch. Z. 1889. 127, Saturate viridi-aenea vel aurichalcea. callo laterali prothoracis elytrisque auro-aut rubro-cupreis, his limbo angusto suturali ryaneovivideque ornato vittaque obsoletr snblaterali viridi-tinctis.

Unterseite und Beine gesaittigt griin, zuweilen goldig, (r)benso die Scheibe des Halsschildes, die verdickten Seiten des letzteren und die Fld. lebhaft goldig-kupferroth, fenerroth oder dunkel und bräunlich kupferig: Die Naht ist blan gesäumt, aussen in Griun übergehend, oft noch eine wischartige Längsbinde über dem Seitenrande hinter dem Schulterhöcker grïn. Zuweilen ist das Halssch.. bis auf einen griinen Saum an der Basis, kupferroth. Auf dem Böhmer-Walde.

S. 487. Or. frigida var. cupreata Ws., D. Z. 1887. 36t, Supra cupreo-brunnea vel viridi-cuprea.

S. 491. Die Varietäten von Phytodecta viminalis sind ron Gradl, Katter, Ent. Nachr. 1882. 329 und ron H. v. Heyden, 1. c. 1883. 53 benannt worden; ebenso die ron nivosa, aber die Namen von Gradl sind hier ungiltig, weil falsch auf affinis bezogen. Exemplare der nivosa mit einfarbig rothem Halsseh., Fld, normal gefärbt, oder fast einfarbig schwarz, bilden die Tar. f. ruficollis Ws. D. Z. 1891. 160.

S. 496. Phyt. flavicornis: Meine Angaben beziehen sich auf Ka ufmanni Mill., die Suffrian'sche Art lernte ich erst neuerdings aus einigen Exemplaren keunen, welche Herr Oberst Gabriel in Saarlouis einsandte.

3. Phytod. flavicornis: Breviter ovalis, convexiuscula, nigra, nitida, antennis (apice infuscatis), tibiis, tursis limboque anali testaceis, elytris rufis, semper immaculatis. Prothorace nigro, brexi, luteribus antice rotundatim-angustato, angulis anticis latis, rotundatis, disco obsolete inaequaliter punctulato latera versus fortiter punctato, interstitiis laeris. Elytris discretim punctato striatis, interstitiis sat crebre subtiliter punctatis. - Long. $4,5-6 \mathrm{~mm}$.

Suffr. Mon. 215.

Chrysom. tibialis var, lurida Duft. Faun. A. 3. 202.

Var. a. Prothorace utrinque macula apicali rufa.

Der Chrysomela lurida ähnlich, in der Färbung auch an rimimulis rar. bicolor $\mathrm{Kr}$. exinnernd, aber viel kleiner, kürzer und etwas 
flacher als diese. Sehwar, oberseits stark glinzend, mit cinfartig ziegelrothen orler lebhaft rothbraunen Fld., die Fiihler, mit Ausnahme der fünf' letzten angedunkelten Glieder, die Schienen, 'Tarsen und ein Saum an der. Spitze des letzten Bauchringes röthlich gelbbraun. Halssch. kurz, rorn stark abfallend, die Seiten riemlich parallel, vor der Mitte gerundet-verengt, so dass vorn breite, abgerundete Ecken entstehen, oben glänzend schwarz, in der Witte fast glatt, mit ungleich grossen, feinen und verloschenen Pünktchen besetzt, an den Seiten grob punktirt. Fld. mit ziemlich kräftigen, nach aussen wenig stärkeren Punktstreifen, deren Punkte scharf begrenzt, gleichmässig dicht hinter einander gestellt sind, die fünfte Reihe neben der grossen Schulterbeule seh" vertieft, Zwischenstreifen glänzend, mässig dicht und tief punktirt, die Punkte nicht ausgerissen, viel feiner als die der Streifen, die äusseren Zwischenstreifen, namentlich beim $\hat{o}$, in der vorderen Hälfte schmal und einreihig punktirt.

Penis am Ende der Oeffnung leicht verengt, hierauf in eine lange und breite, fast parallele, vorn gerade-abgestutzte Spitze ausgezogen. An der verengten Stelle biegen die Seitenränder nach innen auf die Fläche hinauf und erweitern sich zu zwei sanft ansteigenden Längsplättchen, welche in der Mitte zusammenstossen und eine lange, dachförmige Röhre bilden, durch welche der duetus läuft.

Bisweilen bildet sich jederseits in den Vorderecken des Halssch. eine grosse, rothe, schlecht begrenzte Makel (Var. a); Suffrian erwähnt ausserdem. dass die Fld. pechbraun oder schwärzlich werden, Schulterbeule, Basis und Aussenrand etwas heller.

Die Art scheint dem niederen Gebirge anzugehören und weit in's Vorland hinab zu steigen, ist aber in den Sammlungen sparsam vertreten. Sichere Fundorte sind: Schlesien (Letzner), Erfurt und Gotha (Kellner), Westphalen (bei Meschede, Schultze), Rheinprovinz, im Schwarzwalde bei Buhlbach (Simon), München. Nach Suffrian auch in der Schweiz, Tirol, Galizien.

3a. Whytod. Kaufmenni: Breviter ovalis, convexiuscula, nigra, sat nitida, antennis (apice infuscatis), tibiis, tursis limboque anali testuceis, elytris obscure lestaceo-rufis, semper immaculatis. Prothorace brevi lateribus parum rotundato, angulis anticis sat angustis, obtusis, disco rufo, macula basali magna bidentata, apicem fere attingente, nigra; subtiliter sed evidenter latera versus fortius punctato, interstitiis ahttaceis. Elytris interne tenuiter, extrorsum fortius profundeque punctatostriatis, interstitiis crebre evidenter subruguloso-punctutis. - Long. 5 bis $6,5 \mathrm{~mm}$.

Miller, Verh. zool. bot. Ges. Wien 1880. 7.

Phyt. flavicornis Ws. Ins. Deutsch. 6. 496; Deutscb. Z. 1886. t. 1. f. 34 . 
Var. a. Prothorace nigro utrinque macula apicaii rufa.

Var. b. seminigra: Prothorace omnino nigro.

Var, c. Elytris nigricantibus.

Durchschnittlich grösser als die vorige, wenigrer gränzend, die Fld. in der Regel trüber gefärbt. Ialsch, vorn sauft abfallend, an den Seiten wenig gerundet, vor der Mitte schwach verengt, die Vorderecken stumpfwinkelig, viel kleiner als bei flavicornis; es ist uiberall fein gewirkt, auf dem Mittelfelde mit ungleich grossen, tiefen und deutlichen Pünktchen dicht besetzt. oft nnit unpunktirter Mittellinie; die Farbe ist roth, eine grosse, quere Basalmakel schwarz. Diese reicht anfangs an der Basis fast ron einer Ecke zur andern, und setzt sich nach vorn, stark und geradlinig verschmälert, ungefähr bis in die Mitte der Scheibe fort, wo ihr Vorderrand durch einen tiefeu, dreieckigen Ausschnitt in zwei breite Spitzen getheilt wird. Sie rergrössert sich, ohne wesentlich ihre Form zu verändern, am Grunde bis in die Hinterecken, an der Spitze bis zum Vorderrande, später iiber den grössten Theil der Scheibe, von der nur ein schmaler, in den Vorderecken makelförmig erweiterter Saum roth bleibt. (Var. a), zuletzt ist das Halssch. einfarbig schwarz (Var. b). Fld. braunroth oder (Var. c) pechbraun, selbst schwärzlich, die Schulter und der Aussenrand zuweilen etwas lichter, die Punktstreifen nahe der Naht sind ziemlich seicht und fein, die äusseren durchgängig stärker vertieft und kräftiger pruktirt, der fünfte Streifen neben der kleinen und niedrigen Schulterbeule mässig oder schwach eingedrückt. Die Punkte sind nicht gleichmässig hinter einander gestellt und greifen oft auf die dicht und etwas runzelig punktirten Zwischenstreifen über.

Penis vor der Oeffnung ausgerandet-abgestutzt, hierauf in eine schmal beginnende stielförmige Spitze ausgezogen, welche allmählich sanft verbreitert und am Ende abgestutzt ist; oberseits hat sie eine Rinne zur Einlagerung des ductus, unten einen hohen Mittelkiel. Auf Weiden an der Grenze des Baumwuchses in den Mittelund Ostalpen, Ende Juni.

S. 510. Phytod. pallida rar. nigripennis Ws, Deutsch. Z. 1887. 364; Saturate nigra, capite prothorace scutelloque laete testaceomis, antennis prosterno pedibusque phus minusve testaceis.

Da sich durch neuerdings eingegangenes Material die Ansichten iiber einige Arten geändert haben, gebe ich hier eine kurze Uebersicht der Gattung Phytodecta.

1. Seiten der Mandibeln ausgehöhlt, so dass sich das Endglied der Maxillartaster einlegen kamn, alle Schienen an der Spitze stark zahnartig verbreitert. Halsschild nur mit einer Borstenpore jederseits in den Hinterecken . . . Phytodecta i. sp. 2. 
1. Seiten der Mandibehn Hach gedriickt, das letyte 'Tasterghlied neben der Fühlerwurel nur angelegt, Halssch, in allen Ecken mit einer Borstenpore

spartiophila Chevrol. 12.

2. Halssch. von den Hinterecken aus nach vorn stark und in gleichmässigem Bogen verengt, an der Spitze fist nur halb so breit als an der Basis, Zwischenstreifen der Fld. spiegelglatt oder mit vereinzelten, äusserst feinen Punkten. Das erste 'Tarsenglied beim ô sehr schwach erweitert, letzter Bauchring in der Mitte grade abgestutzt .

$2^{1}$. Halssch, hinten parallel oder von der Basis aus leicht erweitert, erst vor der Mitte mehr oder weniger stark verengt, das erste Tarsenglied des ô gross und breit . . . . . . . . 4.

3. Schwarz, stark glänzend, Fühlerbasis, IIalsseh. und Fld. (ohne das Schildchen) gelblich roth, Nahtkante vor der Spitze gewöhnlich angedunkelt. - Penis von der Mitte der Oeffnung aus schnell gerundet-verengt, hierauf in eine stiltörmige, oben mit einer Rinne versehene Spitze ausgezogen, welche bis kurz ror das Ende sanft erweitert und mehr als halb so lang wie der breite Theil des Penis ist. - L. 4-6,5 mm. Amur. (Etud. ent. 9. 1860.41) . . . . . . . . fulva Motsch.

$3^{1}$. Schwarz, oben stark glänzend, Fühlerbasis, Klanen und die Ränder der Hinterleibsringe röthlich-gelbbraun, Fld. lebhaft braunroth, etwa hell kastanienbraun. - Penis neben der kurzen Oeffinung fast gradlinig verengt, sodann in eine schmale, schnabelförmige Spitze verlängert, welche bald vor der Basis etwas erweitert, dann allmählich bis zum Ende verengt, oben mit einer Rinne für den ductus versehen ist. - L. $5 \mathrm{~mm}$. Japan. (Ann. nat. hist. 1862. 28). . . . rubripennis Baly.

4. Zwischenstreifen der Fld. glänzend, fein, aber dentlich und tief punktirt, mit sparsamen, verlosehenen Querrissen. Glied 7 bis 10 der Fiihler breit, jedes einzelne breiter als lang . 5 . 41. Zwischenstreifen der Fld. sehr fein, flach und meist undeutlich punktirt, sehr dicht mit feinen Rissen versehen und mässig glänzend ( $\hat{)}$ ), oder dicht lederartig gerunzelt, seidenartig glänzend bis matt (o). Die einzelnen Fühlerglieder 7 bis 10 so lang als breit, in der Regel länger. . . . . . . . 9.

5. Fld. stets einfarbig, rothbraun, selten schwärzlich braun . 6.

51 . Fld. schwarz gefleckt, nur in einzelnen Varietäten einfarbig hell gefärbt . . . . . . . . . . . . 8.

6. Schenkel, Kopf und Halssch. (letzteres mindestens in der Basalhälfte) schwarz . . . . . . . . . . . . 7.

6². Röthlich gelbbraun, die erweiterten Fühlerglieder, die Brust und der Bauch, zuweilen auch der Scheitel pechschwarz; Fld. 
tief punktirt-gestreift. - I. 5.5-6,5 mm. Sibirien, 'Transbaikalien (Leder, Reitter) . . . . . . sibirica Ws. ${ }^{1}$ )

7. Vorderecken des Halssch. hreit, abgerundet; tïnfte Punktreihe der Fld. nahe der Basis sehr vertieft und die grrosse schulterbeule dadureh stark emporgehohen, alle Punktreihen der Fld. regelmässig, die immeren wenig schwächer als die zuusseren, P'unkte in den 'Zwischenstreifen scharf begrenzt, Halssch. in der Regel einfarbig schwarz. - L. 5-6 mm. Berggegenden Mitteleuropas . . . . . . flavicornis Suffi.

71. Vorderecken des Halsseh. schmal, ziemlich spitz: I'unkte in den Reihen und Zwischenstreifen der Fld. schlecht begrenzt, in kurze Risse übergehend, Halssch. und Fld. stärker punktirt als bei der vorigen, von rauherem Ansehen, die äusseren Punktreihen der Fld. bedeutend gröber als die inneren, die fünfte neben der kleinen und ziemlich niedrigen Schulterbeule mässig oder schwach vertieft. Halssch. gewöhnlich roth, mit zwei grossen. zusammengeflossenen schwarzen Makeln an der Basis. - L. 5-6,5 mm. Mittel- und Ostalpen . Kaufmanni Mill.

8. Nahtecke der Fld., oder die Epipleuren an der Spitze angedunkelt, oder schwarz, die füntte Makel der Fld. lang, den Seiten parallel, strich- oder wischförmig, Kopfschild dicht punktirt, Kopf, zwei Basalmakeln des Halssch., 5 Makeln auf jeder Fld., Unterseite und Beine schwarz. Die Zeichnung sehr variabel, zuletzt die Oberseite einfarbig rothgelb oder schwarz. Der ductus läuft durch zwei dachförmig zusammen geneigte Spitzen, die durch eine sehr tiefe Einschnürung rom Penis ab-

1) Phyt. sibirica: Ovalis, convexiuscula, testaceo-rufa, nitida, antennis articulis 5 ultimis, pectore, abdomine, interdum etiam rertice piceis; mrothorace transverso, ante medium sat fortiter rotundato-ungustato, angulis anticis obtuse productis, disco inciequaliter yunctulato latera versus fortius punctato, elytris profunde punctato-striatis, interstitis sat crebre sub. tiliterque punctatis. - Long. 5,5-6,5 mm. Sibiria.

Durch helle Farbe der Oberseite und Beine sehr ausgezeichnet, durchschnittlich grösser als fulva, aber kleiner und etwas schlanker als viminalis und rufipes. Beim $\hat{\sigma}$ ist der Hinterrand des letzten Bauchringes in der Mitte ausgeschweift, das erste Tarsenglied breit, der Penis ist dem von flavicornis am ähnlichsten, vor der Oeffuung schnell gerundetverengt, mit sehr kurzer, schmaler, ausgerandeter Spitze. Die Seiten gehen neben der Oeffnung in einen aufstehenden, gebogenen, rorn abgerundeten Längsstreifen über, dessen Oberseite vertieft ist. Beide Streifen berihren sich an der Spitze, und es entsteht dort eine kurze, dachförmige Röhre, durch die der ductus heraustritt. Auf der Unterseite befindet sich in vorderen Theile eine lang-rantenförmige Vertiefung. 
gesetzt werden. - L. 5,5-7 mm. Europa, Sibirien bis zur Amur-Mündung . . . . . . . . . . . viminalis L.

Bei uns ist die Art von der folgenden leicht dureh die schwarzen Beine zu unterscheiden, am Amur knmmt sie jedoch häufig mit einfarbig rothgelben Beinen vor:

a. Der ganze Körper gelblich roth, einfarbig, oder ein Querstreifen auf dem Scheitel, das Schildchen und ein sehr kleiner Theil der Schienenbasis schwärlich, Brust und Mitte des Bauches oft bis rothbraun verdunkelt. (Deutsch. Z. 1879. 139)

จ. rufa Kraatz.

b. Stirn iiber dem Kopfschilde, Schildchen und die 5 Normalmakeln jeder Fld. sehwarz, Brust und Bauch grösstentheils pechschwarz. (Wiegmann's Archiv 1887. 186).

v. collaris Ws.

c. Wie vorige, das Halssch. aber mit zwei freien oder zusammengeflossenen schwarzen Makeln an der Basis, die Makeln der Fld. bisweilen ausgedehnt und theilweise vereinigt. Der europäischen Var. Baaderi ähnlich, aber die Beine roth.

v. pallidipes Ws.

Diese drei sibirischen Varietäten sind merklich grösser als unsere Formen, kräftiger punktirt, mit breiterem, an den Seiten stärker gerundetem Halssch.

$8^{1}$. Nahtecke der Fld. roth, Kopfschild sparsam punktirt. Roth, die Stirn iiber dem Kopfschilde, zwei Basalmakeln des Halssch. und 5 Makeln jeder Fld., Brust und Bauch schwarz; die Makel 5 auf den Fld. scharf begrenzt, rund oder quer; die Zeichnung der Oberseite nur so weit variirend, dass Makel 4 und 5 der Fld. verschwindet. Der ductus läuft durch eine sehr lange Röhre, die am Ende leicht verdickt und wellig gebogen ist. - L. 5,5-7,5 mm. Mittel- und Nordeuropa, Sibirien, Japan . . . . . . . . . . . . . rufipes Deg.

9. Kleine Art; Halssch, an den Seiten sehr wenig gebogen und rorn allmählich verengt, Schienen und 'Tarsen hell. -- L. 4,5 bis $5,5 \mathrm{~mm}$. Hochalpen . . . . . nivosa Suffr.

91. Grössere Arten, Halssch, vor der Mitte stark verengt . . 10.

10. Klauenzahn klein und sehr spitz. Fünfte Makel der Fld. gross, ähnlich wie bei viminalis, lang, dem Seitenrande parallel, oft bis an die Naht vor der Spitze verlängert. Halssch. mit zwei freien oder vereinigten schwarzen Basalnakeln. L. 6,5-7 mm. Transbaikalien (Leder), Amur (Kraatz, Deutsch. Z. 1879. 135).

gracilicornis $\mathrm{Kr}$.

101. Klauenzahn gross, fast rechtwinkelig. Fünfte Makel der Fld. klein, rund oder quier, ron der Spitze weit entfernt . . 11. 
11. Halssch. vom germeter-verengt, mit stmupten Ecken, aut du. Sicheihe etwas feiner als die Stirn punktirt, an den Seiten mit sehr zahlreichen groben I'unkten, eine grosse, eckige Makel an den Seiten gewöhnlich roth, Schienen mehr oder wenigrer hell gefürbt. - L. 6-7mm. Gebirgsrgegenden Mittel-Europa's, Nordeuropa, Sibirien . . . . linnaeana Sehrank.

11'. Halssch. vorn fast gradlinig rerschnälert, mit ziemlich spitzen Vorderecken, nebst den Beinen schwarz, aut der Scheibe rlatt. an den Seiten sparsam grob punktirt, diese Punkte nur an der Basis dicht gestellt und zu Längssunzeln vereinigt. Vitte der Stim ziemlich glatt. - L. 5,5-6,5 $\mathrm{mm}$. Norwegen, Lappland. affinis Schönh.

12. Endglied der Taster beilförmig. Halssch. der Quere nach stark gewölbt, mit fein punktirter Scheibe. Vorderschienen schwach. Hinterschienen auffällig stark zahnartig erweitert . . . 13.

121. Endglied der Taster birnenförmig, Halssch. der Quere nach wenig gewölbt, grob punktirt, Vorderschienen einfach, die übrigen schwach zahnartig erweitert . . . . . . 15.

13. Fld. dicht punktirt, die Punkte entweder verworren, oder theilweise gereiht, häufig in Doppelreihen gestellt. - L. 5-8,5 mm. Südfrankreich, Spanien Portugal . . . variabilis Oliv. Wenn Ph. Mannerheimi Stãl. (Kraatz, D. Z. 1879. 137) in die vorliegende Gattung gehört, müsste sie nach der Punktirung der Fld. hier untergebracht werden. Sie ist kleiner und schmaler als olivacea, blass bräunlich gelb, Fld, mit metallisch griinem Nahtsaume.

131. Fld. gestreift-punktirt . . . . . . . . . . . 14

14. Halssch. auch an den Seiten fein punktirt, Zwischenstreifen der Fld. dicht punktirt. - L. 5-7mm. Berggegenden MittelEuropa's, Siideuropa, Kleinasien, Syrien, Nordafrika.

fornicata Brüggem.

141. Halssch. an den Seiten grob-, Zwischenstreifen der Fld. sparsam und verloschen punktirt. - L. 3-5,5 mm. Europa.

olivacea Forst.

Hier ist auch $P h$. Weisei Reitt. (Deutsch. Z. 1886. 71) ans Portugal einzureihen, sowie die sehr kurze und gewölbte, rorherrschend schwarz gefärbte $\mathrm{Ph}$. caraganae Gebl. (Chrys. Sib. rar. 1823. 131) aus Westsibirien.

15. Epipleuren der Fld, vor der stumpfen Spitze gewölbt, innen ohne Randleiste, die fünf Endglieder der Fühler gestreckt. L. 5-6,5 mm. Mittel- und Nordeuropa. . 5-punctata F. 151. Epipleuren vor der etwas ansgezogenen Spitze eben, mit deut- 
licher Innenrandleiste; die Endglieder der Fühler ziemlich kurz. -- L. 5- $7 \mathrm{~mm}$. Bergliinder Mitteleuropa's, Nordeuropa. pallida $\mathrm{L}$.

S. 517. Phyllod. viennensis muss den. Namen tibialis Suffr. erhalten, weil die Schrank'sche viennensis = Colaphus sophiae ist.

S. 536. Nachdem ich ein Stück des Scleroph. orbicularis, ron Herrn Stussiner bei Janerburg in Krain gesammelt, erhalten habe, scheint es mir richtig, in der Gattung drei Arten zu unterscheiden (Deutsch. Z. 1891. 158), die darin iibereinstimmen, dass das Halsschild sehr weitläufig punktirt ist und die Zwischenstreifen der groben Punktreihen auf den Fld. je eine leicht geschlängelte, sehr fein eingeritzte Mittellinie besitzen, von welcher Querrisse zwischen je zwei Punkten einer Reihe hindurch zu den benachbarten Mittellinien laufen. Die wesentlichsten Unterschiede sind folgende:

1. Körper sehr breit eiförmig, mit deutlichem Ausschnitte zwischen Halssch. und Schulter, dicht hinter den Schultern am breitesten, von hier bis zum letzten Drittel mit ziemlich parallelen Seiten sehr schwach verengt, dahinter in mässigem Bogen in eine gemeinschaftliche stumpfe Spitze verengt; Halssch. doppelt so breit als lang, Prosternum ebenso grob punktirt wie das $\mathrm{Me}$ tasternum. Schenkel wenig verdickt

1 $^{1}$ Körper fast halbkugelig ohne wesentlichen Ausschnitt zwischen den Hinterecken des Halssch, und der Schulter, in der Mitte der Fld. am breitesten und hier wenig schmaler als lang, Halssch. etwa dreimal so breit wie lang, Prosternum ohne dentliche Punkte, Schenkel dick, Schienen stark gekrümmt, im Basaldrittel schmal, dahinter breit. Krain, Selkethal im Harze (Suffr.).

orbicularis Suff.

2. Beine schlank, mit geraden Schienen, pechbraun, die Schienenspitze, Tarsen und Fühler bräunlichroth. Vorderecken des Halssch. spitz, kaum an die Augen gedrückt. Penis vor der Oeffnung deutlich, aber allmählich verengt, an der mässig breiten Spitze gerundet-abgestutzt. Karpathisches Waldgebirge, Siebenbürgen, Banat. (Phaed. carniolicus var. Fuss. Verh. Siebbürg. Ver. 1861, 169) . . . . . carpathicns Ws.

Sind die Seiten des Halssch. gerundet, so ist dies die Chrysom. Kenderesyi Kiesw.

$2^{1}$. Beine mässig schlank, mit leicht gebogenen, nach der Spitze verbreiterten Schienen, wie die Fühler schwarz, Tarsen zuweilen pechbraun. Vorderecken des Halssch. rechtwinkelig, oft abgerundet, an die Augen gedrückt. Penis dicht vor der 
Spitze am breitesten, hierauf kurz verengt, dis spitze brwit, bogenfiomig ausgerandet. In den $A$ lpen und Karpathen, sowie den Mittedeutschen Gehirgen häutign . arniolicus Germ. S. 541. Pleaedon pyritosus. Den Symonymen ist anzufügen: Altica "lnaminis Panz. Faun. Germ. 61. 4. - Illig. Mag. fi. 164.

S. 545. Phacd. cochlearine. Als symonym beizufïgen: Altica erucae Panz. 1. c. 21.2.

S. 563. Melasoma pounli var. l,. Janareki Reitt. Wien. Z. 1892. 240. Vigro-reerulea, nitida, elytris totis nigris.

S. 574. Aulacophora abdominalis Fabr. Der Gattungsname ist in Rhaphidopalpa Rosenh. und der Name der Art in foreicoll is Luc. Explor. Alg. 1849. 542. t.44. f. 9. - Küst. Kät. Eur. 28 (1854) 100 abzuändern. In der Gattung Rhaphidop. haben die ô lang behaarte Schultern.

Unsere europäische Art komnt nur in der Lmgebung des Mittelländischen Meeres vor. (Vergl. Ws. Deutsch. Z. 1892. 393.)

S. 575. Bei der Gattung Luperus ist das erste Glied der Hintertarsen wenig gestreckt, ungefähr so lang als die beiden folgenden Glieder, bei Luperodes Motsch. sehr schlank, wenigstens so lang als die drei folgenden zusammen.

S. 613. Lochmaea suturalis lebt hauptsächlich auf Calluna vulgaris $L$. am Rande von Kiefernwäldern, und man findet sie unter den Heidekrantbüschen zahlreich im ersten Frühlinge.

S. 624. Galerucella sagittariae lebt weniger an Lysimachia vulgaris als an $\mathrm{L}$. thyrsiflora $\mathrm{L}$., deren Blätter von ihr im August oft vollständig zerfressen sind.

S. 635. Diorhabda elongata. Die Gal. sublineata ist nicht als Synonym, sondern als Var. a. aufzufassen: Elytris flacescentibus, singulo vittis duabus antice abbreviatis, postice conjunctis, fuscis.

Die G. carinata bildet die Var. b.

S. 636. Einfarbig gelbbraune Stiicke ron Diorh. persica wurden als Galeruca turcica Stierl. Mittheil. Schweiz. 2. 1866. 226 beschrieben.

S. 698. 5a. Crepidodera norica: Oblongo-ovata, conrevu, nigra, nitida, antennis, pedibus, capite prothoraceque rufis, hoc sublueri, lateribus rotundatis, impressione transversa profunda, uniseriatim punctata, elytris sat fortiter parum profunde punctato-striatis, punctis striarum sat crebris, pone medium evanescentibus. - Long. 2,8-3,3 mm.

Weise, Deutsch. Z. 1890. 30.

In der Färbung am meisten an $C r$, rhatica Kutsch, erinnerud, aber durch das fast glatte, an den Seiten stark gerundete Halssch., welches wie das ron femorata gebaut ist, sofort ron ihr und den iibrigen rothbeinigen Arten zu unterscheiden. 
Vom Habitus einer kleinen femorata, nur in den Schultem etwas mehr verengt, gewïlht. Kopff, Taster und Fiihler, Halsseh., Vorderbrust und Beine roth, dic iibrigen Theile der Brust, der Finterleib und die Fld. tief schwarz, glimzend, die Oberlippe angedunkelt. Halsseh. etwas breiter als lang, in der Mitte am breitesten, von hier aus beiderseits ziemlich gleichmässig gerundetverengt, die Hinterecken wieder etwas nach aussen gerichtet. Die Scheibe gewölbt, glatt oder mit sehr feinen Pünktchen besetzt, die erst bei stïrkerer Vergrösserung sichtbar werden; in dem tiefen Quereindrucke befindet sich eine Reihe stärkerer Punkte. Fld. in den Schultern wenig breiter als die Basis des Halssch., bis zur Mitte etwas erweitert, dahinter stark verengt; sehr flach gestreift und in den Streifen mässig stark und wenig tief punktirt, die Zwischenstreifen eben. Hinter der Mitte verschwinden Streifen und Punkte, so dass sie bei schwacher Vergrösserung kaum noch bemerkt werden können.

In den Karawanken nördlich bis Villach und Klagenfurt, stidlich bis Krainburg und Laibach verbreitet.

S. 699. Haltica simplicipes Kutsch. findet sich in Steiermark (Dr. Knauth). Nach dem Baue der Fühler. des Halsschildes und der Mittelbrust gehört das Thier in die Gattung Hippuriphila, in die nächste Verwandtschaft mit H. nigritula, von welcher dasselbe durch gestreckteren, etwas flacheren Körper, die Farbe, breite Mittelbrust, Punktirung der Fld. und äusserst feine Behaarung eines Theiles der Oberseite abreicht. Die Diagnose lautet:

Iripp. simplicipes: Aptera, oblongo-ovata, nigro-aenea, sat convexa, nitidissima, antennis pedibusque nigro-piceis, prothorace tenuissime punctato, latera versus fere laevi sed parce, subtilissimeque pubescente, elytris antice sat fortiter punctato-striatis, apice sublaevibus, interstitiis parce tenuissime punctulatis, apicem et latera versus subtilissime vix sibiliter. pubescentibus. - Long. 2,8-3 mm. Styria: Zirbitz Kogel.

Vom Ansehen einer Mantura chrysanthemi, aber grösser und glänzender, in der Farbe und in der Punktirung der Fld. an Chrysom. marginata $L$. erinnernd, ungeflügelt, gestreckt, lang eiförmig, ziemlich gewölbt, fast spiegelnd, schwarz, mit starkem Metallschimmer, welcher weder zu Grün noch Messinggelb besonders hinneigt, Fühler und Beine pechschwarz. Stirnhöeker gross, mässig. scharf, fein umgrenzt, die Stirn darüber einzehn punktirt und behaart. Halssch. etwas breiter als lang, in der Mitte sehr f'ein, nach hinten an Stärke zunehmend punktirt, auf einem breiten Streifen an den Seiten ziemlich glatt, äusserst fein behart. Fld, ïber den Seiten und auf dem Abfalle zur Spitze ebenfalls mit äusserst zarten Härcheu besetzt, stark punktirt-gestreift; dic Punkte bilden nicht ganz regel- 
miissige Reihen, welche vor der Spitze verschwinden, und stchen in molentlichen Lëngsfurchen. deren hreite und gewillbte Zwischenstreifen ̈̈usserst fein punktirt sind. Das Prosternum ist breit, grob punktirt, die Mittelbrust unsichtbar, von der Hinterbrust bedeckt, welche sich in einem selır breiten Zipfel nach vorn bis zum ProsternalFortsatze rerlängert. Die Hinterschenkel sind schwach rerdickt und ungefähr so breit wie die von nigritula.

S. 700. Crepidod. cyrnipennis wurde bei München ron H. Korb gefangen.

S. 717. Chalcoides metallica findet sich auch bei Altenburg (Krause) an Populus tremula und Salix caprea L. Für C'halc. cyanea tritt der Name meiner Var. c. splendens ein, während cyanea Marsh. zu helxines zu stellen ist.

S. 743. An die Spitze der deutschen Arten ist zu stellen:

MIatura Mrathewsi: Subylindrica, aenco-nigra, antennarum basi, tibiis tarsisque fermuineis, supra obscure liridi-aenea, minus nitida, fronte sat plana, obsolete punctata, inferne linea transversa parum profunda terminata, prothorace magno crebre punctato, plica laterali profunda, elytris striato-punctatis, interstitio externo antice uniseriatim punctato. - Long. 2-2,3 $\mathrm{mm}$.

Curt is, Brit. Ent. 10. 1833. t. 435. Cardiapus. - Steph. III. Brit. 4. 424. Man. 301. - All. Ion. 289. Balanomorpha. Kutsch. Wien. Monat. 1862. 54. (176). - Weise, Ins. Deutschl. 6. 743. Mantura.

Balanomorpha aeraria Foudr. Mon, 275.

Var. a. Supra aurichalcea vel cuprea.

Var. b. bicolor (Ws. l. c.): Capite prothoraceque nigro-coeruleis aut nigris, elytris aeneis, aurichalceis vel cupreis.

Var. c. aeraria: Capite prothoraceque aeneis, aurichalceis aut cupreis, elytris coerulescentibus.

Kutsch. l. e.

Durch die breite und flache Stirn und das grosse, rorn stark gewölbte Halssch. von den übrigen Arten abweichend, am nächsteu noch mit cylindrica Mill. rerwandt. kleiner und schlanker als obtusata.

Fast cylindrisch, unten schwarz, mit Metallschimmer, oben dunkel erzgrün, fein gewirkt, schwach glänzend, das zweite bis fünfte Fuihlerglied, Schienen und Tarsen hell rostroth. Stirn oben ungleichmässig und rerloschen, unterhalb der seichten Querfurche stärker punktirt. Halssch. nach der Mitte des Vorderrandes etwas rorgezogen, über die Mittellinie also riel länger als an den Seiten. ron oben betrachtet fast halbkugelig, dicht und tief punktirt, auf dem hinteren Theile der Scheibe gewöhnlich etwas weitläufiger und feiner als vorn und an den Seiten. Die Lüngstailtehen sind 
tief. Fld. miissig stark punktirt-gestreift, der breite äussere Zwischenstreifen in dex vorder'n Hälftr mit einer unregelmässigen starken Punktreihe, ron der zuweilen nur noch wenige Punkte vorhanden sind.

Die Oberseite kann lebhat't griu, messingzelb oder kupferig werden (Var. a), oder der Kopf und namentlich das Malssch. sind dunkelblau bis schwarz (Var. b), endlich die Fld. blau, Kopf und Halssch. grün bis kupferig gefärbt (Var, c).

Diese bisher aus Frankreich und England bekannte Art lebt Anfang Juli am Raude einer etwas feuchten Wiesenfläche bei Jena, am Waldwege zwischen dem Forstthume und Vollradisrorta.

S. 751. Chaetocnema chlorophana ist anch in den östlichen Ländern des Mittelmeeres verbreitet.

S. 835. Haltica saliceti. Diese Art scheint nicht ausschliesslich auf eine Nahrungspflanze (Salix-Arten) angewiesen zu sein, sondern lebt, wie oleracea, an verschiedenen Pflanzen. Sie wurde 1888 in Menge auf den Blättern von Eichenschösslingen in der Pirschhaide bei Potsdam von Herrn Pape aufgefunden. In der ersten Hälfte des Juni waren die bezeichneten Blätter zum grossen 'Theile zerfressen, ung'efähr siebartig' oder netzförmig' durchlöchert. Das Thier frisst die Blattsubstanz von der Oberseite aus ab, so dass nux die zarten Rippen und ein verschieden breiter Rand der Blattmasse, der sich in der Folge gelbbraun färbt, übrig bleiben; es beginnt stets an der Basis eines Blattes und schreitet allmählich nach der Spitze hin fort.

Am 10. Juni (vielleicht ausnahmsweise spät, da das Frihjahr 1888 trocken und kalt war) hatten die Weibchen ihre Eier abgelegt. Letztere sind hellgelb, $1 \mathrm{~mm}$. lang und ungefäh $2^{1} / 2$ mal so lang: als breit, beinahe cylindrisch, aber jederseits eine Spur verschmälert und an den Enden abgerundet. Die Oberfäche ist unter starker Vergrösserung dicht, aber sehr undentlich gerunzelt und wie mit einem matten, weisslichen Reife überzogen, kaum glänzend. Die Eier waren mit der Längsseite an die Unterseite der Eicheublätter geklebt, entweder in einer Reihe neben einander oder in einem Häufchen von zwei bis drei Reihen, jedes Häufchen enthielt 8 bis 12 Stück und befand sich stets in der Nähe des Blattrandes, niemals an der Hauptrippe.

Die weitere Entwickelung konnte leider noch nicht beobachtet werden. Deutsch. Z. 1889. 112.

S. 846. Haltica longicollis All. Mon. 217. Nach Exemplaren aus den Ost-Pyrenïen, die ich durch H. Brisont de Barueville erhielt, ist das Thier eine gute Art, viel kleiner als die ähnlich gebaute lythri oder ericeti. Das Halssch. ist tast glatt, selnr 
glïnzend, mit scharfer Querfurche, so hreit oder nur wenir schmaler als die Fld. und an den Seiten schwach germudet. Die Stimhïicker sind gross, dreieckig. durch eine Rinne über dem Nasenkiele getremnt. Der Penis ist rorn schwach in eine kurze und sehr breite Spitze verengt, welche völlig abgerundet ist, die Lnterseite ist glatt. ohne Querriefen, steigt in der Mitte zu einer schwachen Luingserhöhung an, die vor der Spitze wieder abfällt, und die sehr kleinen und kurzen Seitenstreifen bilden eine schmal lanzettliche, beiderseits zugespitzte vertiefte glatte Fläehe. Aus der Penisbildung geht herror, dass die Art mit keiner der uibrigen verwandt ist.

S. 900. Aphthona pallida ist an Geranium pratense L. bei Weimar häufig, darunter sind zahlreiche Stücke, welche einen deutlichen, scharf begrenzten, in der Mitte rerbreiterten und hinten abgekürten schwarzen Nahtsaum auf den Fld, haben: Apht. pallida var. geranii. Diese Abänderung ist genan wie Aphth. nigriceps Redtb. gefärbt, so dass als leicht bemerkbare äussere Lnterschiede von dieser nur noch die schmalen Schultern mit kleiner Beule und die kräftigere Punktirung der Fld., welche hinten am Nahtwinkel stärker abgerundet sind, übrig bleiben. D. Z. 1891. 379.

S. 902. Aphthona nigriceps. Häufig behalten ausgereifte. mit einem breiten schwarzen Nahtsaum versehene Stücke die Kopffärbung der Var. c bei, d. h. unterhalb der Fühlerwurzel bleibt ein mehr oder weniger ausgedehnter Fleck rostroth.

S. 904. Aphthona pseudacori wurde im Juni auf sumpfigen Wiesen in der Nähe des Wildparkes bei Potsdam ron Hrn. Pape mehrfach in Copula gefangen. Sie lebte auf den unteren Blättern von Euphorbia palustris L.; das Klopfen der Büsche über einem Schirme war resultatlos und man erhielt das Thier nur durch Käschern.

Von Larven und deren Frassstellen fand sich an den Pflanzen keine Spur, so dafs ihr Aufenthalt an der Wurzel, ähnlich wie es Buddeberg (Jahrb. Nass. Vereins f. Naturk. 1888, 17) ron Aphth. cyparissiae schildert wahrscheinlich wird. Bei allen Stiicken sind die Fühler und Beine ziemlich einfarbig schwarz, höchstens die Basis der ersteren und die Schienen dunkel rostroth. Die der Art eigenthümliche dunkle, bläulich-schwarze Farbe der Oberseite rariirt aufserordentlich selten. Unter den vielen Stiicken fanden sich nur wenige welche die Varietät discolor: Supra nigra, obscure ciridiaeneo micans bilden, bei welcher die Oberseite gleichmässig sehr dunkel metallisch grün ist, ohne Spur eines blanen Schimmers. D. Z. 1889. 112.

S. 913. Hinter A. coerulea ist einzureihen:

$13 a$. Aphthona metallica: Alata oblongo-aralis, sat contectu, viridiaurichalceu, interdum cupreo-micans, nitida, antennarum basi pedibusque 
testaceis, femoritus posticis nigro-ueneis, rentre nigro; fronte subtilissime alutacea, sulcis ocularimes sat profundis, tuberculis frontalibus. angustis, obsuletis, carina faciali acuta; prothorace subtiliter punctato, elytris erebre punctatis, interstities punctulutis, callo humerali pravo. Long. 1.8-2.2 mill.

Weise, Deutsch, Z. 1889. 415.

Var. a: Subaptera.

Kleiner, aber ahnlich gebaut wie Aphth. coevulea Fourer., in der Färbung mit dereu Var. acnescens Ws. abereinstimmend, dureh deutliche Augenrimnen, sehr schmale Stirnhöcker und weniger dichte Punktirung der Fld. abweichend; grosse stiicke ron A phth. enphorbice Schrank sind flacher weniger lebhaft getärbt, wit breiten Schultern und heraustretender Schulterbeule.

Länglich-eiförmig, ziemlich gewölbt, dunkelgrün, mit starken Messing- oder Kupferschimmer, gläuzend, der Bauch schwarz, die ersten 6 bis 7 Fühlerglieder und die Beine röthlich gelbbraun die letzten 4 oder 5 Fühlerglieder schwärzlich, die Hinterschenkel metallisch dunkelgrün, seltener die vier vorderen Schenkel anf dem Ruicken leicht angedunkelt. Stirn äusserst fein gewirkt, seitwärts in die scharfe und ziemlich tiefe Augerinne abfallend, die Höckerchen lanzettlich, oben ron einer verloschenen Linie begrenzt, der Nasenkiel schmal. Halssch. um die Hälfte breiter als lang (beim $q$ noch breiter), an den Seiteu mässig gerundet oben fein punktirt, stark glänzend. Fld. in den Schultern wenig breiter als das Halssch., mit kleiner kaum heraustretender Schulterbeule, hinter der Mitte am breitesten, dicht und ziemlich kräftig punktirt, mit einzeln punktulirten Zwischenräumen.

$\hat{o}$. Letzter Bauchring auf und vor dem kleinen Mittelzipfel vertieft. - Penis sehr schlank, gleichbreit, neben der kleinen Oeffnung allmählich in eine mässig scharfe Spitze verengt, die Oberseite ziemlich flach, eben, nur nahe der Oeffnung vertieft, die Unterseite mit einer ganzen Längsfurche.

Bei Darmstadt von Hrn. Heyer auf Euphorbia (esula L.?) gefangen (Breddin), auch ron Hm. Oberpfarer Scriba (Wimpfen) zahlreich auf Limum in der Bergstrasse nahe bei Alsbach gekäschert.

S. 918. Aphthona atrovirens findet sich bei Weimar (U. Z. 1892. 411) auf Euporbia cyparissias L. gesellschaftlich mit abdominalis und pygmaea, nebst der kleinen Form des Longitarus oblievatus Rosenh. Man kamn die schlanke, kleine, ungeflügelte Art leicht an der wenig̨ lebhaften rothbraunen Farbe der ersten 5 bis 6 Fiblerglieder, der. rorderen Beine und der Hinterschienen, von den ähmlichen deutsehen Arten unterscheiden.

Die rom Förster zuerst beschriebene Form, deren Oberseite VI. 6. 
dunkel schwarzgrün, wit bläulichem Schimmer ist, fehlt: es komuen aber zwei andere Färbungen vor. Die eine (Var, a), welche in Thüringen vorherrsehend ist, hesitzt keine Spur von grünem Schimmer, sondern ist oberseits schwar\%, mit sehr geringer bläulicher Beimischung, die auf Kopf und Halssch, noch mehr als auf den Flld. hervortritt. Diese schwarze Form wird der eluenso kleinen, gleichfalls ungellügelten Aplitho atratula All. Mon. 235 aus Siirlfrankreich äusserst ähnlich, ist aher dunkler, weniger blau gefuirbt, stärker gewölbt, namentlich auf dem Halssch., welches ausserdem durch deutlich gerundete Seiten erheblich ałweicht. Wahrscheinlich ist es, dass Aphth. punctigera Rey, Opusc. 1875, 48, nicht, wie der Autor rermuthet, zu atratula All. gehört, sondern auf die Var. a von atrovirens bezogen werden muss, da Rey das Halssch. seiner Art zum Unterschiede ron atratula ,verloschener punktirt und an den Seiten stärker gerundet" angiebt.

Die zweite Form (var. aeneipennis: capite prothoraceque aeneo-nigris, elytris aeneis) kommt vereinzelt ror. Bei ihr sind Kopf und Halsseh. schwarz, mit Metallschimmer, die Fld. metallisch grïn, zuweilen mit bräunlichem oder messingfarbenen Anfluge.

Der Penis dieser Art, von mir Ins. D. 919 unvollständig beschrieben, ist ziemlich schlank, wenig gebogen, rorn in eine breit abgerundete Spitze verengt; auf der Unterseite befindet sich eine weite, rimnenförnige Vertiefung, auf der Oberseite eine feine Mittelrinne, welche rorn plötzlich zu einer grossen und tiefen, oralen Grube abfällt, in der sich die Oeffnung befindet.

S. 919. Aphth. herbigrada ist an Cistus helianthemum L. bei Jena sehr häufig. Redtenbacher giebt das Thier auf Campanula rotundifolia lebend an, es scheint mir jedoch zweifellhaft, dass es sich dort nähren könnte; denu die Wurzelblïtter vertrocknen und die Stengelblätter gewähren für eine Menge von Thieren zu wenig Nahrung.

Unter der bekannten, schlank gebauten Form lebte eine anffällige, kurz-eiförmige Varietät, die ich gibbula nenne. Bei derselben erweitern sich die Fld, ron der Basis aus gleichmässig nach hinten, erreichen die grösste Breite weit hinter der Mitte und runden sich hierauf schnell (jede einzeln) in einem weiten Bogen ab. Die Fld. sind hinten beinahe doppelt so breit wie bei der normalen Form, so dass man beim ersten Anblick des Thieres glaubt, eine verschiedene Art vor sich zu haben. D. Z, 1891. 379.

s. 1049. Hinter der Gattung IIniophila findet seine Stellung:

\section{Cardax.}

Corpus fere ellipticum, apterum.

Antennae 11-articulatae, articulis 5 ultimis crassioribus. 
Prothorax lateribus subparallelus, ante basin impressione obsoleta transversa instructus.

Elytra substriato-punctata.

Mesosternum lineare, metasternum episternis haud distinctis.

Tibiae posticae apice calcari nullo.

Körper ziemlich klein, fast elliptisch, ungefliigelt, nur auf dem Bauche mit vereinzelten Härchen besetzt. Kopf geneigt, fast glatt, mit kleinen, ovalen, gewölbten, ziemlich grob facettirten Augen. Von der Mitte derselben läuft eine hohe. bogenförmige Leiste jederseits zwischen der Fühlerwurzel hindurch bis zur Basis der Mandibeln und umschliesst so eine sehr grosse, tiefe Crube, in welcher sich das erste Fïhlerglied bewegen kann. Die Stirn ist breit, wenig gewölbt oder beinahe eben, mit einem punktförmigen Grübchen in der Mitte; rom Nasenkiele durch eine Querfurche getrennt. Der Kiel ist breit, eben, nach unten erweitert, uiber der Oberlippe quer vertieft. Taster schlank, Fühler kaum halb so lang als der Körper, kräftig, Glied 1 etwas länger und dicker als die folgenden, diese bis zum sechsten Gliede unter sich ziemlich von gleicher Stärke und Länge, die fünf Endglieder etwas länger und dicker. Halsschild quer-riereckig, nach den Seiten abfallend, letztere mit abgesetzter Randleiste, welche an der vorderen Borstenpore winkelig nach aussen tritt und von hier bis zu den Vorderecken verdickt ist. Vor der Basis befindet sich ein sehr flacher, stärker punktirter, bogenförmiger Quereindruck, der sich an den Seiten mehr vertieft und allmählich dem Hinterrande nähert, den er in den stumpfen, niedergedruickten Hinterecken erreicht. Die Flügeldecken treten an der Basis in starker Rundung heraus und bilden für sich ein breites Oral, welches hinten schmal, gemeinschaftlich abgerundet ist; sie sind vorn regelmässig in Reihen punktirt, die in leicht vertieften Streifen stehen, hinter der Mitte und ïber dem Aussenrande glatt, nicht punktirt. Epipleuren breit, hinter der Mitte schnell rerengt. Prosternum zwischen den Huiften ziemlich ebeu, stärker punktirt; Mesosternum abschüssig, so dass nur eine Querleiste zwischen den Mittelhüften sichtbar ist. Letztere werden ausserdem durch einen breiten, vorn gerade abgestutzten Zipfel des Metasternum getrennt, welches ohne sichtbare Naht in die Seitenstiicke übergeht. Beine kurz, Hinterschenkel mässig verdickt, Hinterschienen seitlich zusammengedrückt, mit schmalem Rüicken, am Ende schnell erweitert, ohne Enddorn. Klanen am Grunde fein gezähnt.

Das einzige Stück, welches von dieser interessanten IIaltica gefangen wurde, scheint offene Vorderhüftpfannen zu besitzen und ein Männchen zu sein, dessen erstes Tarsenglied namentlich an den 
Hinterbeinen stark erweitert ist. Jedenfalls lebt das Thier alunlich wie Mniophila.

1. Cardax Stussineri: Picea, nitidn, capite, antennis (apicem rersus dilutioribus) prothoraceque rufo-ferrugineis, hoc sat dense punctulato, pedibus testaceis, elytris ante medium subtiliter substriato-jundatis. Long. 1,8 $\mathrm{mm}$.

Einer breiten Atomaria ähnlich, pechschwarz. stark glänzend, Kopf und Halssch, bräunlich roth, Fühler rostroth, nach der spitze allmählich heller, die Beine lebhaft rothgelb. Das Halssch. ist rom fast glatt, nach hinten allmählich stärker punktirt, die stärksten Punkte in dem bogenförmigen Eindrucke, besonders an den Seiten. Schildchen dreieckig, glatt. Fld, mit etwa 8 Punktreihen vor der Mitte, die nach aussen und hinten allmählich feiner werden.

Meinem Freunde Stussiner in Laibach gewidmet, der die Art in Istrien, wahrscheinlich mit Hilfe des Siebes gefangen hat. 


\section{Druekfehler.}

S. 38 Reihe 12 v. o. lies tibiisque statt libiisque.

" 64 " 1 v. o. ist Crioceris cyanella zu streichen.

" 72 " 6 v. u. lies abdominisque statt abdomisque.

" 121 " 2 v. o. lies sulcata statt sulcato.

" 123 " 19 v. o. lies viridana.

" 138 " 1 v. o. lies Schienen statt Schenkel.

" 170 " 7 v. 0. Stchukini "Stschukini.

" 170 " 20 ซ. 0.107 " 170.

"171 11 v. 0. conjuncto " conjunctum.

" 206 " 8 v. 0. 465 " 165.

" 229 " 2 v. u. fehlt hinter "Spitze" das Wort "oft".

" 231 " 13 o. o. tessellatus statt tesselatus.

" 239 " 13 v. о. metasterno " metasternum.

" 262 " 9 v. o. tessellatus " tesselatus.

" 269 " 8 v. u. prothoracis " prothoracio.

" 269 " 6 จ. u. pedibusque ” pedibusqus.

" 278 " 6 v. u. lies Bull. p. 11 statt 43. 10.

" 279 " 5 จ. u. lies graeca Lef. = rubripes Schauf.

" $285 " 16$ v. 0 . lies tessellatus statt tesselatus.

" 300 " 11 ซ. o lies Klauen " Tarsen.

" 304 " 8 v. u. lies rufifrons statt rugifrons.

" 368 Fehlt Reibe 11: a. Halsschild ohne Eckporen und Borsten.

405 Reihe 13 v. u. lies nicht statt dicht.

" 411 " 2 v u. lies Fairm. " Reiche.

" 428 Die Varietäten sind mit b, c, d, e, nicht a, b, c, d zu bezeichnen.

446 Reihe 5 v. u. lies 174 statt 181.

" 540 " 4 v. o. fehlt hinter Ungefliigelt die Angabe: Sternoplatys Motsch., Schrenk Reis. Amur 2. 220.

" 573 Reihe 16 v. u. lies Wiegm. statt Wiechm.

"585 " 20 v. u. lies quadrimaculata statt 4-punctata.

” 594 » 6 v. u. lies Graecia statt Graecea.

" 599 " 22 v. u. lies transverso statt transversus.

602 " 19 v. и. lies Vaccinium myrtillus.

"602 " 18 v. u. lies das statt des.

" 683 " 20 v. 0. retrorsum statt retrosum.

" 715 " 13 ซ. 0. lies Marsh. statt Marsch.

" 719 " 15 จ. 0. lies punctato statt punctata.

"785 " 9 จ. u. fehit hinter dem Worte gedrückt: „Prosterum“.

" 823 " 8 v. o. lies luteola statt luteota.

" 912 " 8 v. o. muss vor creberrime das Wort elytris stehen.

" 914 " 21 v. o. ist hinter schwach das Komma zu streichen.

"936 » 1 v. o. lies kräftig statt kräfti. 


\section{REGISTER.}

Acanthispa 1059.

Acanthodon lineatum 504.

Adimonia Aubei 652.

Bonvouloiri 647.

capreae 611.

cicatricosa 647 .

circumeineta 650 .

circumdata 650 .

coufinis 655 .

Dahli 657.

declivis 647 .

dispar 652.

flava 655 .

florentina 650

fontinalis 655 .

gibbosa 647.

Gredleri 653.

halensis 661 .

hungarica 650 .

laticollis 657 .

littoralis 653.

oelandica 650 .

pallidipennis 612

polygonata 611 .

reticulata 657 .

rufa 657.

rufescens 652 .

rustica 652 .

sanguinea 615 .

scutellata 611.

suturalis 613 .

tanaceti 646.

verna 626.

Villae 655

violacea 580.

Adoxus 293.

epilobii 295.

obseurus 295.

vitis 295.

Aeschrocnemis graeca 855.

Agelasa nigriceps 578 .

Agelastica alni 580 . coerulea 580.

halensis 661 .

Alpaeixena 343.
Altica atra 877. 933.

atricilla 816.

brassicae 600 .

ciliata 1045.

dorsalis 962 .

erucae 1132.

fuscipes 682 .

graminis 1132 .

luteola 823.

nitidula 682.

ruficornis 688 .

tabida 1011.

testacea 1056.

voluta 1056

Ambrostoma 413.

Amplipalpa 1059.

Anopachys asclepiadis 418.

Aphthona 886.

abdominalis 898 .

aenea 895 .

aeneipennis 1138 .

aenescens 912.

Albertinae 896.

albinea 898.

armoraciae 865 .

asthmatica 912.

atratula 896, 1138.

atrocoerulea 907.909.

atrovirens 918.

1137.

carbonaria 894.

coerulea 912.

cruciferae 878.

c yanella 906. 909.

cyanescens 914.

cyparissiae 897.

Czwalinae 911.

decorata 890.

delicatula 891 .

diademata 880 .

dimidiata 920 .

discolor 1136.

Erichsoni 910.

euphorbiae 913.

906. 908, 916

flaviceps 899 .
A phthona fossulata

920.

geranii 1136.

gibbula 1138.

herbigrada

1138.

Heydeni 891.

hilaris 914.

hispana 895.

hyoscyami 912.

janthina 894.

lacertosa 921 .

laevicollis 920 .

laevigata 889 .

lutescens 903 .

melaena 881.

melancholica 893.

metallica 1136.

microcephala 896 .

nigella 907.

nigriceps 902.1136.

nigriscutis 897.

nigriventris 897.

nonstriata 912 .

orientalis 908 .

ovata 916.

pallida 900. 1136.

Perrisi 894

picipes 894 .

procera 885 .

pseudacori 904 .

1136.

pulcherrima 886.

punctatissima 893 .

punctigera 896. 1138.

punctulata 878 .

pygmaea 907.

Reitteri 895.

sardea 895.

semicyanea 915.

sicelidis 892 .

sicula 902.

sinuata 871 .

straminea 899.

Stussineri 918 .

sublaevis 905 .

subovata 895 . 
A phthona suturella 890.

tantilla 919. tetrastigma 869 . variolosa 890. 900 . venustula 906. violace 905 . virescens 914. vittula 873.

Apteropeda 1042. aurichalcea 1045. caricis 740 .

ciliata 1045. 1046. coerulans 1045 . conglomerata 1044 globosa 1044. 1046. majuscula 1044. nigro-aenea 1044. orbiculata 1045 . ovulum 1043. splendida 1046. Arescus 1060.

Argopus 1049.

Ahrensi 1054.

bicolor 1054 .

brevis 1053 .

discolor 1054 .

hemisphaericus 1054 . intermedius 1053 . nigripes 1054 . nigritarsis 1053. orientalis 1052. punetatus 1054. rubidus 1057. substriatus 1053. testaceus 1056. unicolor 1053.

Arima brachyptera 574. brevipennis 574 . cincta 574. marginata 574.

Arrhenocoela lineata 676.

Aspidomorpha difformis 1069.

Attelabus lilii 69 .

Aulacophora 574. 1132. abdominalis 574 . foveicollis 574 . nigriventris 574 . signata 575.

Balanomorpha ambigua 744.

caricis 740 .

chrysanthemi 745.

Crotchi 745.

Mathewsi 1134.

obesa 739.

obtusata 744 .
Balanom, rustica 746.

Barathraea cerealis 106. straminipennis 106. tripunctata 106.

Batonota 1066.

Batophila 852. a erata 854 .

Bertolinii 854. fallax 854. pyrenaea 855 . rubi 853.

Bedelia angustata 278. insignis 278.

Bittotaenia salviae 409 .

Bromius obscurus 295. vitis 295.

Buprestis biguttata 168. lunata 249.

8-punctata 150 sexpunctata 107. unifasciata 132.

Byrrbus concolor 282.

Calaspidea 1067.

Calliope Fausti 280.

Callispa Bowringi 1060.

Calomicrus circumfusus 600.

Calyptorrhina 123.

Camptosomata 81.

Cardax 1138. Stussineri 1140.

Cardiapus Mathewsi 1134.

Cassida 1070 . affinis 1109 . algirica 1079. alpina 1104. angustifrons 1078. artemisiae 1080 . atrata 1094. 1111. austriaca 1085. azurea 1088. bella 1075 . berolinensis 1112. Bohemani 1080. brevis 1075 . canaliculata 1085 chloris 1102. concha 1090 corallina 1080. Cori 1087 corrosa 1078. daurica 1112. deflorata 1079. delicatula 1084 denticollis 1096 . discoidea 1108. dorsalis 1092. 1111. elongata 1108.
Cassida equestris 1086.

fastuos a 1084 . ferruginea 1083. 1105.

1111.

filaginis 1095.

flaveola 1111

flaviventris 1080 .

fuliginosa 1104.

fusca 1083.

fuscicollis 1096 .

graeca 1104.

graminis 1085 .

hablitziae 1076 .

hemisphaerica 1087.

hexastigma 1078.

humeralis 1078.

hyalina 1080.

illyrica 1085.

incompta 1105.

inquinata 1080.

immaculata 1092.

immutabilis $\mathbf{1 0 8 5}$.

laevis 1113.

languida 1102.

Jineola 1093.

liriophora 1108.

littoralis 1111.

lucida 1088.

maculata 1092. 1109.

margaritacea 1090.

melanocephala 1091

meridionalis 1074 .

mollis 1082.

murraea 1092.

nebulosa 1109.

nigra 1104. 1109.

nigrescens 1091 .

nigriceps 1075 .

nigrina 1084.

nigriventris 1087.

nobilis 1113 .

oblonga 1115.

obscura 1113.

obsoleta 1111. 1112.

oranensis 1078 .

ornata 1088.

pannonica 1108.

parvula 1082.

prasina 1101. 1102. 1079.

pulchella 1113. pupillata 1082.

pusilla 1032.

pyrenaea 1082.

Reitteri 1080.

rhilensis 1081 . 
Cassida rosea 1099. 1113.

rotundicollis 1095 .

rubiginosa 1103.

xufovirens 1097.

russica 1093.

sanguinolenta

1100.

s anguinosa 1102 .

sareptana 1080.

saucia 1082.

seladonia 1095.

seraphina 1076.

sibirica 1093.

signata 1093.

sobrina 1083.

sordida 1080.

speciosa 1085.

splendidula 1089.

stigmatica 1098.

subferruginea

1083

subreticulata 1090.

thoracica 1105.

1107.

tigrina 1109.

tincta 1106.

turcmenica 1082.

urticae 1113.

ventralis 1090 .

vibex 1104. 1107.

1108.

viridis 1086. 1104.

viridula 1113.

vittata 1115, 1084.

Cassidini 1065.

Cassidula 1076.

nobilis 1082.

parvula 1082.

pusilla 1082.

pyrenaea 1082.

saucia 1082.

turcmenica 1082.

vittata 1082.

Ceralces 299.

Chaeridiona 1059.

Chaetocera vugatissima 514.

Chaetocnema 747. aenescens 764 .

aerosa 779 .

aestiva 775 .

alpicola 767.

amoena 756.

angustula 766 .

arenacea 754 .

arida 775 .

aridula 774 .

breviuscula 752.761 .
Chaetocnema chlorophana 755. 1135. compressa 765. 764. concinna 759.

conducta 761 .

confusa 770 .

Coyei 751.

cyanescens 777.

de pressa 763.

fallax 771 .

femoralis 758 .

Foudrasi 763.

hortensis 778 .

insolita 769. 777.

Kolbei 756.

laeta 756 .

laevicollis 751 .

major 751 .

Ml a nnerheimi 771.

meridionalis 769 .

metallica 751 .

nebulosa 753 .

orientalis 752. 763 .

procerula 764.

punctulata 772.

r hombea 768 .

Sahlbergi 776 .

saliceti 758 .

Scheffleri 757.

semicoerulea 757.

subcoerulea 772.

tarda 765 .

tibialis 760 .

unicolor 769 .

Chalcoidea marginata 391.

Chaleoides 713 . aeruginosa 716 . aurata 720 .

aureola 720 .

chloris 722.

cuprea 716.

cyanea 717.

Foudrasi 722.

fulvicornis 719 .

helxines 719 .

jucunda 719.

laeta 718.

metallica 716.1134.

nigricoxis 721 .

nitidula 715 .

picicornis 719 .

pulchella 721.

sapphirina 716.

splendens 718 .

Chelysida deflexicollis 1069.

vagepunctata 1069 .
Chilotoma bucephala 129.

erythrostoma 129.

musciform is 129 .

Reyi 128.

Chiridula apicalis 1070 discoidalis 1070 .

Semenowi 1071.

suberosa 1070.

11-notata 1071.

Chlamydini 82.

Chloropterus bimaculatus 278.

stigmaticollis 278.

versicolor 278.

Chrysochares asiatica 278.

Chrysochus pretiosus 297.

chinensis 298.

Chrysolina staphylea 380.

Chrysomela 339.

adonidis 310 .

aegrota 503.

aenea 554.

aerata 854 .

aerea 363 .

aethiops 387. 429 .

affinis 373.500 .

ahena 350 .

alcyonea 468 .

alni 580.

alternans 413.

alternata 405 .

ambigua 407.

americana 411.

amethystina 554.

analis 393 .

Anderschi 444.

angelica 420 .

angusticollis 333 .

armeniaca 389.

armoraciae 550 .

artemisiae 424.

asclepiadis 418 .

1122.

asparagi 77 .

aterrima 877.

atra 343. 362.

atricilla 968. 979.

atrovirens 370 .

aucta 525 .

auraria 427.

aurata 720 .

aurichalcea 418.

aurita 121.

aurocuprea 426 .

aurulenta 444. 
Chrysomela Baaderi 491.

baetica 373 .

ballotae 1003 .

Banksi 379

beccabung:ae 533 .

betulae 554 .

bicolor 411. 365 .

bifrons 461 .

bigorrensis 366 .

bilineata 230 .

bipunctata 166 .

bivittata 417 .

Blanchei 362.

blanda 426.

brunsvicensis 401.

bucephala 129 .

cacaliae 444. 475 .

calcarata 492.

caliginosa 373.

calmariensis 629 .

Cameranoi 369. 1122.

cantabrica 366.

capreae 611.

carbonaria 366.

carnifex 386. 385.

carniolica 536.

carpathica 350 .

cancasica 352. 426.

centaura 429.

centaurei 429

cerealis 413. 1122.

chalcites 399 .

chalcitis 400 .

chloris 426.

chlorizans 379 .

chloromaura 431. 433.

chrysocephala 802.

cinctella 391.

cinctipennis 390 .

circumducta 390 .

cochleariae 547.

coerulans 420 .

coerulea 347.

coeruleolineata 476 .

coeruleoviolacea 554 .

coerulescens 387 .

concinna 759.

confossa 395 .

confusa 372 .

consularis 411.

convergens 481.

corcyrica 403.

coriacea 366. 395.

coriaria 333 .

coryli 147

crassicollis 361 .

crassimargo 357. 359.
Chrysom ela crassipes 333.

crataegi 615.

cretica 365

cribellata 369.427.

cribrosa 346.

croatica 426 .

cruciferae 878.

cuprea 380.

cupreopunctata 369.

cuprina 403. 409. 414. curvilinea 389.

cyanea 717.

cyaneo-aurata 414.

cynoglossi 947.

Dabli 353.357.

daurica 381.

decempunctata 491 .

decora 462.

depressa 387.

did y ma ta 408 .

dierythra 392 .

diluta 370 .

discipennis 377 .

dispar 508. 510.

dolorosa 411.

dorsalis 313. 395. 985.

duplicata 402 .

egena 525.

elevata 418.

elongata 485.

ericae 414

erythrocephala 803.

erythromera 396.

erythropus 305.

Escheri 560.

exoleta 999.

fallaciosa 401 .

fastuosa 422 .

femoralis 371.999.

ferruginea 703 .

fimbrial is 344 .

Findeli 375.

flavicans 506 .

flavicornis 496 .

flavipes 608 .

florea 365 .

fossulata 366 .

fridrichsdalensis 491 .

fucata 406.

fulgens 413 .

fulgida 424. 426 .

fuliginosa 394 . 1122.

fulminans 426 .

fulvipes 495 .

fuscicornis 554. 685 .

fuscoaenea 480.481.

galeopsidis 423 .
Chrysomela gallega

431.

galii 394.

gallica 365.

Gaubili 382.

gemellata 405. 406 .

geminata 403.

gibba 339.

glacialis 391.

globipennis 349 .

globosa 363. 339.

gloriosa 450. 476 .

g oettingens is 374 . 333.

Graëllsi 390.

graminicola 542.

graminis 424. 426 .

grammica 546.

grossa 431.

gypsophilae 382.

haemoptera 368 .

374. 414441.

halensis 661 .

hannoverana 528.

helopioides 344 .

helxines 718 .

h e m is ph a e ric a 360 .

herbacea 426 .

Heri 365.

Hobsoni 398.

Hochhuthi 375.

holsatica 944.

hottentotta 368 .

hungarica 345 .

hyacinthina 369 .

hyoscyami 821 .

hyperici 406.429 .

hyrcana 389.

ignita 426. 465 .

jllita 432.

incerta 365 .

indigena 405 .

interstincta 386 .

intricata 446. 444.

islandica 350 .

italica 365 .

juncorum 481.

Kenderesyi 536.

Kiesenwetteri 413.

Konowi 1122.

laeta 360. 372.

lamina 398.

laminula 414.

laevicollis 398 .

laevigata 322 .

laevipennis 433 .

Lederi 381.

lens 883.

lepida 379. 395. 
Chrysomela lesinae 411.

lichenis 349 .

limbata 375 .

limbifera 375 .

linnaeana 498.

litura 506.

liturata 457.

livonica 414.

lomata 393.

longimana 96.

lucida 433.

lucidicollis 382 .

luctuosa 441.

lurida 378. 957.

lusitanica 583.

luteocincta 392.

mactata 371.

marcasitica 354 .

marginalis 385 .

marginata 389.

marginella 528.

Megerlei 413. 414.

melanaria 414.

melanocephala 470 . 979.

melanostigma 382.

menthae 353 .

menthastri 426 .

merdigera 69.

meridionalis 396 .

metallica 337. 353.

mixta 413. 414.

Modeeri 725.

mollnginis 345.394.

monticola 461. 487.

moraviaca 350.

morio 399.

musciformis 129.

napi $80 \%$.

nemorum 865. 875

nigerrima 350 .

nigriceps 471 .

nigricollis 803 .

nigrina 450 .

nigripes 491. 882.

nigropunctata 411 .

nitens 194

nitida 194.

nitidula 715 .

nivalis 465 .

nivosa 500.

nobilis 443 .

nodicornis 883 .

nymphaeae 622 .

oblonga 420.

obscura 295.

obscurella 347.

ochrolenca 1012.
Chrysomela octovittata 414

oleracea 845 .

olivacea 362.506.

olivacenigra 1122.

Olivieri 365 .

opaca 394.

opulenta 353.

orbicularis 536 .

orbiculata 1045.

oricalcia 398.

orientalis 366 .

ornata 414.

padi 510.

pallida 510.

palustris 426 .

parvula 547.

pelagica 347.

Peirolerii 470.

peregrina 397.

phalerata 450.457.

phellandrii 531.

picina 824.

plagiata 473 .

polita 430.

polonica 374.

polygoni 308 .

porphyrea 352.

prasina 393.

pratensis 429 .

pretiosa 297.

privigna 407.

provincialis 387 .

pseudacori 904.

pulex 933.

pulicaria 945.

punctulata 877.

purpurascens 357 .

pyrenaica 366.

pyritosa 540 .

quadricollis 350 .

quadrigem in a 404

quadriguttata 946.

quadriimpressa 413.

quadrimaculata 585

132.

quadrinotata 947.

quadripunctata 113.

5-punctata 508.

ranunculi 528.

raphani 307.

recticollis 426

Reitteri 378.

relucens 417.

resplendens 426 .

Rossia 370.

Rossii 370.

rubrocuprea 380 .

rufa 352.
Chry $80 \mathrm{mela}$ ruficandis 556 .

ruficollis 308.

rufilabris 352 .

rufipes 305. 495. 685.

688.

r u fo a enea 400.

rufofemorata 373.

rufomarginata 282.

rugicollis 426 .

rugipennis 366. 395 .

rugosa 333 .

rugulosa 443.

rustica 652.746.

sabulicola 543 .

sacra 312.

Sahlbergi 369.

salisburgensis 178 .

salviae 409.

sanguinolenta

384. 370 .

sardea 426.

schach 393.

Schneideri 349.

Schotti 396.

scopolina 134.

sculptipennis 409.

semiaenea 746.

senecionis 476 .

sericea 183.

sexnotata 504.

sexpunctata 151.495

505.

solitaria 391.

songorica 391.

sophiae 305.

Sparshalli 382.

spartii 504.

speciosa 423. 480 .

speciosissima 480 .

splendidula 475 .

splendorifera 420 .

squalida 353.

stachydis 382 .

staphylea 380 .

striatula 853.

Sturmi 374.

subaenea 366 .

subfastuosa 420.

subferruginea 381.

subincrassata 355 .

subseriata 387.

subseriepunctata 402 .

Suffiriani 430.

sulcata 391.

sumptuosa 476.

superba 450.

suturalis 967 .

syriaca 408. 
Chrysomela tagana 347.

Tagenii 372.

tanaceti 646 .

teuebricosa 321.

tenella 632.

thapsi 985.

tibialis 498.517.

transversa 700.

triandrae 498 .

tridentata 89 .

tristis 441.476 .

turca 365. 1122.

turgida 355 .

tussilaginis 476 .

unicolor 369.

variabilis 503 .

varians 428 .

variolosa 382 .

varipes 373 .

venefica 369 .

ventricosa 422 .

venusta 450.

vernalis 365 .

viminalis 491 .

violacea 414. 420 .

554.

violaceonigra 331.

virgulata 468 .

viridana 426.

viridis 359. 465 .

viridula 307.

vitellinae 514. 554 .

vittigera 458 .

vulgatissima 514.

xanthomelaena 627 .

xanthopoda 603. 604 .

Chrysomelini 298.

Chrysomorpha cerealis 413.

Clytra 112.

aleppensis 117 . antistita 1118 .

appendicina 114. arida 1118

atraphaxidis 117.

bucephala 129 .

chalybaea 131.

conjuncta 1119.

connexa 1119.

deficiens 1119 .

dissimilis 1118 .

dissimilithorax 116

elata 117.

flavicollis 119 .

globulosa 117.

humeralis 91.

japonica 118.

laeviuscula 115.
Clytra lucida 93. macropus 103. maculifrons 117. nigrocincta 117. novempunctata 117 . ovata 117.

pallidipennis 97.

quadripunctata 113

quadrisignata 113.

rubicunda 135 .

salicariae 101

tetrastigma 116.

valerianae 116.

xanthaspis 122 .

Clytrini 82.

Coccinella 10-punctata 491.

haemorrhoidalis 492.

liturata 457.

rufipes 603.605 .

signata 491.

Colaphodes hottentotta 368.

Colaphoptera hemisphaerica 360 .

Colaphosoma goettingensis 374.

Colaphus 303 .

apicalis 305 .

Höfti 305.

pulchellus 305 .

sophiae 305.

tibialis 305 .

Colaspidea 290. globosa 291. grossa 293.

metallica 291.

nitida 293.

oblonga 292.

Saportae 291. 1121. sphaeroides 293.

Colaspidema atrum 304. barbarum 304.

Dufouri 304.

maculicolle 304 .

plagiatum 304.

rufifrons 304.

signatipenne 304.

sophiae 305 .

Colaspina Saportae 1121.

Colaspinella grandis 1121.

Coptocephala 130.

apicalis 137 .

bistrimaculata 136 .

bistrinotata 138 .

chalybaea 131 .
Coptocephala cyanocephala 137.

fallax 1119 .

femoralis 132 .

floralis 135. 138.

fossulata 137 .

Gebleri 137.

Küsteri 134.

maculiceps 132 .

melanocephala 134.

plagiocepbala 134.

quadrimaculata 132.

quinquenotata 137.

rubicunda 135.

scopolina 133.

tetradyma 136 .

unicolor 131.

unifasciata 132.

Coptocycla amurensis 1069.

Corynodes 297.

Crepidodera 690.

abdominalis 706 .

aeneipennis 694 .

atropae 711.

aurata 720.

chloris 722 .

corpulenta 697.

c yanescens 698 .

cyanipennis 700 .

1134.

femorata 694.

ferruginea 703.

frigida 696 .

helxines 718 .

impressa 702.

infuscipes 694 .

intermedia 712.

laevigata 703.

marginicollis 702 .

melanopus 695 .

melanostoma 698.

Modeeri 725.

moesta 693.

nigricoxis 721 .

nigritula 726.

nigriventris 706 .

nitidula 715 .

norica 1132.

obscuritarsis 703 .

Peirolerii 693.

peregrina 703 .

pubescens 710 .

rhaetica 697.

rufa 702 .

rufipes 688 .

salicariae 707.

simplicipes 699 .

1133. 
Crepidodera sodalis 689.

superba 693.

transsylvanica 694.

transversa 700. ventralis 706 .

Crimissa 670.

Criocerini 54.

Crioceris 67.

adusta 587.

alpina 72 .

asparagi 77. 1118 .

atricilla 968

bicruciata 75 .

bimaculata 585 .

brunnea 70 .

calmariensis 629 .

cantharoides 5 .

campestris 77. 78, 79

chlorotica 4.

circumfusa 600 .

coerulescens 609.

collaris 71 .

cornuta 70.

crataegi 615 .

Dahli 77

decorata 77. 1118.

dodecastigma 72.

dorsalis 962 .

duodecimpunctata 72.

euphorbiae 913.

Faldermanni 70 .

flavipes 608 .

glabrata 5.

halensis 661.

Iaeviuscula 69 .

lilii 69

liliorum 69.

macilenta 79 .

maculipes 78 .

merdigera 70

nasturtii 965 .

nymphaeae 623.

paracenthesis 76 .

pinicola 601.

pupillata 77.

4-maculata 585.

14-punctata 74.

quinquepunctata 75.

rubi 853 .

ruficornis 688 .

rufipes 70.603 .604 .

sanguinea 615 .

similis 70

sisymbrii 985 .

stercoraria 69 .

Suffriani 70.

suturalis 76 .
Crioceris thoracica 1118.

tibialis 72. 1118.

viburni 621 .

violacea 533.

xanthopus 663 .

Crosita altaica 343 .

Cryptocephalini 138.

Cryptocephalus 140. abietinus 146.

abietis 206.

aeneus 284.

aethiops 212.

affinis 121 .

albolineatus 157.

alboscutellatus 239 .

alpinus 214.

amoenus 233.

androgyne 200.

anticus 169. 227

apicalis 176. 212.

apricus 235 .

arenarius 235.

armeniacus 230 .

arquatus 225.

astracanicus 173.

asturiensis 188 .

aureolus 186 .

axillaris 155 .

baeticus 178 .

barbareae 208

Beckeri 170. 174.

bebulae nanae 208 .

bidens 169. 183.

bigut ta tus 168.216.

bignttulus 201.

bilineatus 229 .

bimaculatus 161 .

bipunctatus 166 .

bipustulatus 168 .

bisbipustulatus 161 .

Bischoffi 158.

bisignatus 212 .

bistripunctatus 164 .

bivittatus 225 .

blandulus 235

Boehmi 175.

bohemius 175 .

bothnicus 208 .

brachialis 241 .

callifer 209.

carinthiacus 144.

carpathicus 1120.

cautus 1119 .

celtibericus 229 .

centrimaculatus 228.

chrysocephalus 196.

chrysopus 216.
Cryptocephalus cicatricosus 162. clericus 1119.

coerulescens 200. 1119.

cneruleus 183. 199.

coloratus 171 .

concinnus 201.

confusus 195.

concolor 188

connexus 234.

cordiger 148.

coronatus 169.

coryli 147.

crassus 226.

creticus 211.

cribratus 153 .

cristatus 188.

cristula 189.

cruciatus 225.

curvilinea 204.

cyaneomicans 1119.

cyanescens 1119.

cyaneus 119.

cyanipes 182.

cynarae 203.

Czwalinae 216.

dauricus 170. 178.

$10-$ maculatus 207.

10 -punctatus 207.

digrammus 222.

discicollis 243 .

dispar 166.

distinguendus

156. 1119.

12-plagiatus 204.

12-punctatus 204. duplicatus 188. eburatus 176.

elegantulus 231. 1120.

elongatus 191.

ergenensis 174.

erosus 144

etruscus 162.

excisus 144.

exiguus 223.

exilis 222 .

Fabricii 209.

fallax 241 .

fasciatus 146 .

Fansti 236.

flavescens 209.

flavicollis 170 .

flavifrons 194.

flavilabris 199. 200.

flavipes 213.

flavoguttatus 176.

flexmosus 175 . 
Cryptocephalus floralis 170 .

florentinus 144. floribundus 146 . frenatus 209. frontalis 217. fulcratus 199 . fulvicollis 237 . fulvus 236. furcatus 214. gaditanus 228. gamma 174, 1119. geminus 220 . globicollis 186 . gracilis 243. Graëllsi 228. gravidus 226. Grohmanni 202. Gyllenhali 152. haemorrhoidalis 180 . halophilus 170.172. hieroglyphicus 248. hirticollis 162. hirtifrons 228 .

histrio 249.

Hüibneri 216.

humeralis 156. 178.

hypochoeridis 188. janthinus 197. ilicis 162.

immaculatus 243 .

imperialis 164 . 163.

inexpectus 192.

infirmior 161 .

informis 144.

inops 204.

insignis 196.

interruptofasciatus 225.

interruptus 154.

intrusus 183. 1119.

jucundus 231.

Kowarzi 211.

Koyi 227.

Kulibini 193.

labiatus 221 .

laetus 178 .

laevicollis 159 .

laevigatus 206.

lateralis 177.

lignosus 260.

limbellus 174 .

limbifer 216.

lineellus 240 .

lineola 167.

livens 199.

lividimanus 146.

longicornis 222.
Cryptocephalus

Loreyi 142.

luridicollis 240 .

Insitanicus 146.

ma cellus 238. 1120.

maculicollis 226 .

major 142.

Manueli 164.

marginatus 202.

marginellus 192 . 243.

Mariae 224.

Martinezi 227.

Marshami 243.

maurus 211.

Mayeti 238.

minutus 237. 242.

modestus 194.

moestus 230, 208.

Moraei 224.

mutatus 178.

mystacatus 218.

negligens 229 .

nigrescens 214.

nigribuccis 211.

nigridorsum 239.

nigritarsis 170 .

nigrocoerulens 199.

nitens 194. 199.

nitidulus 193.

nitidus 194.

obscuripes 1120 .

obscurus 295.

ocellatns 219.

o chroleucus 240.

ochropezus 219.

ochrostoma 193.

octoguttatus 227.

octomaculatus 204.

octonotatus 204 .

o ctopunctatus

149.

ocularis 222.

omissus 227.

oneratus 227.

oranensis 244 .

orientalis 233.

ornatus 208.

palliatus 202.

pallifrons 196.

paradoxus 1119.

parvulus 198.

Pelleti 200.

Perrieri 157.

Perrisi 162.

pexicollis 162 .

pictus 152.

Pilleri 171.

pilosts 178.
Cryptocephalus

pini 205.

pistaciae 215

planifrons 239.

plantaris 240.

podager 206.

politus 238.

populi 241.

pratorum 183.

pretiosus 297.

primarius 162.

princeps 212. 1120.

pulchellus 235.

pumilio 195.

punctiger 195.

pusillus 242

pygmaeus 233 .

pyrenaeus 224.

quadriguttatus 211.

4-notatus 162. 1119.

4-punctatus 146.

4 -pustulatus 212.

14 -maculatus 169.

querceti 221.

5 -punctatus 203.

Ramburi 193.

ramosus 170 .

regalis 178 .

Reitteri 172.

rhaeticus 212 .

Rossii 228.

rubellus 154.

rubi 173.

ruficollis 101.

rufilabris 201.

rufipes 244.

rufolimbatus 163 .

rugicollis 178.

rugulipennis 189 .

saliceti 219

salicis 165 .

salisburgensis 178 .

sanguinolentus 167.

sareptanus 174.

saxonicus 604.

scapularis 217.

scenicus 207.

Schäfferi 179 .

seminiger 209.

separandus 152.

sericeus 183. 186.

188.

sesquistriatus 174.

sexmaculatus 162.

165.

sexnotatus 178.

sexpunctatus 151 .

sexpustulatus 226 . 
Cryptocephalus signaticollis 234. 1120. signatifrons 214. signatus 153. 224. similis 212.

Simoni 205. sinuatus 146 . smaragdinus 190. solutus 207. Spitzyi 230. Stchukini 170. Stierlini 147. stragula 2:6. stramineus 204. Strasseri 1119. strigosus 232. subconnexus 235. succinctus 234. Suffriani 157. 170. sulphureus 206. tamaricis 173. 272. Tappesi 169. temesiensis 147. tenebricosus 226 . terminatus 202. tessellatus 231 . testaceus 204. tetraspilus 193 . Thomsoni 167. thoracicus 151. tibialis 191. tricolor 144. trilineatus 209. trimaculatus 165 . tristigma 162 tristis 249, 266. tureicus 215. unicolor 180. variabilis 150 . varieg a tus 155.156. verrucosus 178 . verticalis 242 . viduus 1120 . viennensis 159 . villosulus 182. violaceus 190. 199. virens 190. 1119. virgatus 178. vitis 147. 295. vittatus 228. vittiger 225 . vittula 233. Wagneri 178. Wasastjernae 223.

Wehnckei 179. Wydleri 213. 214. ypsilon 174.

zambanellus 184 . Cryptostoma 1058.
Cyaniris thoracica 122. virens 124

Cyclica 275.

Cyrtonus 342.

Deloyala hablitziae 1076.

seraphina 1076.

Derocrepis 686. bicolor 690 . cattcasica 690. obscura 688. rufipes 688 . serbica 690. sodalis 689 . strangulata 690 .

Desmonota 1066.

Dia nitida 292. oblonga 292. proxima 292.

Dibolia 1025. aurichalcea 1032. buglossi 1035. carpathica 1030. Chevrolati 1030. cryptocephala 1041.

cyanescens 1033. cynoglossi 1039. depressiuseula 1036.

eryngii 1034 erythrogaster 1029. femoralis 1032. Försteri 1035. Foudrasi 1035. laevicollis 1036 . maura 1030. metallica 1030. occultans 1040. orientalis 1029. 1033 . paludina 1030 .

Pelleti 1031. peregrina 1032. phoenicia 1030. punctillata 1031. rugulosa 1038. russica 1029. Scbillingi 1031. timid a 1033 .

Dicherosis 1052. Ahrensi 1053. brevis 1053 . hemisphaericus 1054 . intermedius 1053.

\section{Dimax 1052.}

Diorhabda 633. carinata 635. 1132. damascena 636 . elongata 635 .
Diorhabda Fischeri 636.

persica 636. sareptana 636. sublineata 635. 1132 . subnigra 636. tureica 1132.

Disopus abietis 206.

Dlochrysa 343. virgata 425 . auraria 425 .

Donacia 14. andalusiaca 31 . angustata 18. antiqua 32. apricans 32 . appendiculata 33 . aquatica 22 . arundinis 36.1117 . aurea 26. autumnalis 1117 . bicolora 26 . bidens 21. brevicornis 29. 31 . 32.

chrysochlora 1117. ciucta 21. cinerea 41. clavipes 21. 34 . coelestis 1117 . collaris 26 . crassipes 17. diabolus 1117. dentata 18. dentipes 22. fennica 36. 1117. glabrata 35 . gracilis 32 . hydrochaeridis 42 . hydrocharis 42 . impressa 31. 27. iris 1117.

Kraatzi 38. lateralis 24 . lemnae 24. limbata 24 . linearis 41 . Malinowskyi 36. 1117. menyanthidis 35 . moerens 38. mutica 35 . obscura 27. phellandrii 18. platysterna 29. polita 20 . porphyrogenita 1117. pulcherrima 1118. reticulata 33 . sagittariae 26 . 
Donacia sanguinea 1118.

semicuprea 38. simplex 40 . simplicifrons 32 sparganii 23. spinosa 17. striata 17. tenebrans 1118. tersata 42 . tha a s sina 28.1117 . tomentosa 43 . typhae 40. unicolor 1117. versicolorea 20. vittata 25 . จulgaris 39 .

Donaciini 7. Doryphora 299. Elithia 670.

Emarbopa rufa 657 . Emmetrus 538. Enipeus 276. Enneamera 667. Eutomoscelis 309. adonidis 310 . berytensis 312 . rumicis 313. s a cra 312. suturalis 312.

Epitrix 708. atropae 711. ferruginea 710 . intermedia 712 . nigritula 711 . pubescens 710 . 4-maculata 711.

Euluperus 662. cyaneus 665 . fuscipes 665 . major 665 . virescens 665 . xanthopus 663 .

Eumolpini 276.

Eumolpus obscurus 295. pretiosus 297. vitis 295.

Eupoda 1.

Eurispa 1059.

Exorhina 750.

Galeruca (Galleruca) 637.

abbreviata 654 . affinis 816. alni 580 . alpestris 652 . anchusae 933. angusta 642 . anthracina 653 .
Galeruea aptera 659. armeninca 643.

artemisiae 644 . articulata 839 . aterrima 644. atra 877. atricilla 968. barbara 643 .

binotata 615 . calcarata 492. calmariensis 628.629 . capreae 611. 614. carinulata 635 . circumdata 650 . coerulea 912. corsica 644. costalis 635 . crataegi 615. 628 . Dahli 657. dorsalis 962 . elongata 635 . erratica 654 . erucae 839. euphorbiae 913. exoleta 704. femoralis 615 . flavipes 608 . fuliginosa 645 . fulvicornis 719 . Goudoti 643.

Haagi 641. haematidea 659 . holsatica 944. impressa 702. incisicollis 641 . interrupta 648. jucunda 650 . laticollis 655 . lineola 626. lobata 643 .

luctuosa 645 . lusitanica 583 . lythri 630 .

Macchoi 641. melanocephala 658.

melanura 5. mercurialis 851 . Miegi 641. minima 632. monticola 640 . napi 807. nasturtii 965 nemorum 875. nigricornis 662 . nitidula 715 . nymphaeae 623. oelandica 650 . orientalis 646 .
Galeruca pallida 615. parvula 942. pinicola 601 . pomonae 652. 4-maculata 585. Reichei 644. rubi 853. rufa 657 . rufipes 605.685 . rustica 652. sagittariae 623 . salicariae 707. sanguinea 615 . sardoa 642.

Sedakovi 644. semiaenea 746 . sicana 641 . sicelidis 650 . spectabilis 646 . sublineata 635 . suturalis 613 . tanaceti 646. tenebricosa 641. tenella 631. 632 . tibialis 615 . turcica 1132. viburni 621. Villae 655 . violacea 577. xanthomelaena 627.

Galerucae 569.

Galerucella 616. aquatica 623. calmariensis 629. grisescens 624. lineola 626 . maculicollis 628 . nymphaeae 622 . pusilla 631. sagittariae 624. 1132.

subcoerulescens 627 . tenella 632. viburni 621. xanthomelaena 627.

Galerucida bifasciata 578.

Galerucini 567.

Gastroidea 306. alpina 307. pennina 307. po]yg oni 308 . viridula 307.

Gastrophysa polygoni 308. raphani 307. viridula 307.

Gavirga 299. 
Gonioctena dispar 508. pallida 510 . salicis 498. sexpunctata 505 . viminalis 491 .

Graptodera ampelophaga 836. coryli 833. erucae 832. helianthemi 848 . hippophaës 839 . hispana 836. longicollis 846 . lythri 837. montana 848. oleracea 845 . potentillae 845 . pusilla 845 . splendens 845 .

Gynandrophthalma 117. affinis 121 . amabilis 125 . aurita 121 . baetica 123 . banatica 123. bioculata 127. brevicornis 126 . chloris 123. collaris 128. concolor 125. coptocephaloides 126 . cyanea 119. djebelina 124. diversipes 120. ferulae 127. flavicollis 119. graeca 127. 128. gratiosa 125. hellenica 125. hypocrita 125. judaica 128. limbata 126. liturata 128. manicata 128. Menetriesi 125. nigritarsis 126 . Raffrayi 126. Reyi 128. rufimana 127. salicina 119. 1119. scutellaris 126. thoracica 127. tibialis 125. 1119 . viridana 123 . xanthaspis 122 .

Haemonia 10. appendiculata 11. baltica 13 .
Haemonia Cherrolati 12.

Curtisi 13. equiseti 12.

flavicollis 12 .

Gyllenhali 13.

incisa 13.

lineata 12.

mosellae 12.

rugipennis 13 .

rmppiae 13.

Sablbergi 13.

Schioedtei 13.

zosterae 13.

Haltica 825 .

abdominalis 898 .

aenescens 837.

aerata 854. 1032.

affinis 816 .

Ahrensi 1054

alpicola 699.

alpina 735 .

ambigua 744.

a mpelophaga 836 . 833.

analis 948 .

anchusae 933.

anglica 803.

antennata 883 .

apicalis 948 .

armoraciae 865.

aridella 778 .

aridula 774 .

atra 935 .

atricapilla 979 .

atricilla 968.

atropae 711.

atrovirens 918

attenuata 801 .

aurata 720 .

azurescens 833 .

bicarinata 834 .

borealis 985 .

brassicae 866 .

brevicollis 833 .

brunnea 950 .

brunnipes 821 .

campanulae 920.

cardui 1056.

carduorum 843.

carinthiaca 840 .

castanea 957.

chalcomera 821.

chloris 722 .

chlorophana 755.

chrysanthemi 745 .

chrysocephala 802.

cicatrix 851 .

coerulea 912. cogmati 849.

colorea 878 .

compressa 765 .

conducta 761 .

conglomerata 1044 .

consobrina 836. 839 . 881.

crassicornis 704 .

cryptocephala 1041.

cucullata 793.

cuprea 812.

cupreata 802

curvifrous 910.

cyanea 717. 839 .

cyanella 909.

cyanescens 698 .

cyanoptera 803 .

cynoglossi 1039.

cyparissiae 897.

dentipes 756. 759 .

diademata 880.

dispar 881.

divaricata 921.

dorsalis 962.

dulcamarae 819 .

echii 927.

elongata 803.806 .

ericeti 831.

Erichsoni 910.

erucae 832. 837. 839.

euphorbiae 916.

excisa 867.

exoleta 701. 704. 816 .

femoralis 644. 999 .

femorata 694.

ferruginea 701. 703 .

Fischeri 948.

Haviceps 899 .

fruticola 842 .

fuscicornis 685 .

fuscipes 681 .

fusiformis 813 .

gagathina 933 .

gaudens 718 .

glabra 797.

globosa 1044.

globus 1044.

graminis 1045 .

hederae 1045.

helxines 718. 721 .

hemisphaerica 1054 .

herbigrada 919.

hilaris 914

hippophaës 839.

holsatica 944 .

hyoscyami 821 .

indigacea 837.

impressa 701. 702. 
Haltica lacertosa 921. lateralis 983 .

lepidii 882.

Linnaei 929.

Iongicollis 1135 .

lugubris 845.

lurida 957.

lutescens 903

lythri 837.

malvae 683.

MIaunerheimi 771.

marcida 818.

melaena 877.

melanocephala 979.

melanophthalma 824.

melanostoma 698.

mercurialis 851 .

metallica 716 .

Modeeri 725.

montana 848.

muscorum 1049.

nana 823.

napi 807.

nasturtii 875. 965.

nemorum 874.

nigerrima 943 .

nigra 939.

nigriceps 902.

nigripes 882 .

nigritula 726 .

nigroaenea 878.

nitidula 715 .

nobilis 845 .

nucea 804.

obesa 739.

obtusata 744 .

occultans 1040 .

ochripes 867.

ochroleuca 1012.

oleracea 845.833.

ovulum 726.

pallida 900 .

pallidicornis 853 .

palustris 844 .

parvula 942.

placida 900.

poeciloceras 878 .

pratensis 957. 1002 .

praticola 948.

procera 884.

pseudacori 904.

pubescens 710 .

pulchella 721.

pulicaria 945.

pumila 942.

punctipennis 878 .

pusilla 847. 996.

quadrimaculata 947.

4-notata 947.
Haltica 4-pustulata 866. 946.

4-signata 957.

quercetorum 832.

rapae 807.

rhaetica 697.

rubi 853.

rufilabris 824 .

rufipes 685.688 .

rufopicea 824 .

rustica 746 .

Sahlbergi 776.

salicariae 707.

saliceti 835. 1135.

semicoerulea 757.

sinuata 871.

spartii 600.

spergulae 793 .

striatella 707.

suturalis 968.

suturella 970.

tabida 897.

tamaricis 839 .

testacea 1056.

tibialis $760,928$.

timida 1033.

transversa 700 .

undulata 874.

ventralis 706 .

venustula 906 .

verbasci 985

versicolor 721 .

violacea 905 .

vittata 865 .

vittula 873.

Halticae 666. altitarses 673 .

caesae 673.

cryptocephalae 673 .

oedipodes 673 .

physapodes 673.

saltatrices 673 .

striatae 673.

sulcicolles 673 .

Haptoscelis melanocephala 658.

Helodes beccabungae 533.

phellandrii 531.

violacea 533 .

Hermaeophaga 849 .

cicatrix 851 .

mercurialis 851 .

ruficollis 850 .

Himera 276.

Hippuripbila 723.

bimaculata 725 .

chalybaea 725 .

Modeeri 724.
Hippuriphila nigritula 726. simplicipes 1133.

Hispa aptera 1065. atra 1065.

minuta 1065 .

testacea 1063.

Hispella aptera 1065 . atra 1065 .

minuta 1065.

Hispini 1059 .

Homalopus 142.

Hoplosoma lamina 398.

Hylaspes 570 .

Hydrothassa aucta 525.

calthae 528.

flavocincta 527.

glabra 525.

hannoverana 528.

marginella 527.

potentillae 528 .

Hy pnophila 738. impuncticollis 741 . obesa 739.

Hypocassida meridionalis 1074.

subferruginea 1074.

Ischyronota 1069 .

Labidomera 300.

Labidostomis 85 .

armeniaca 90

asiatica 90 .

axillaris 94.

Beckeri 93.

bigemina 87 .

bipunctata 90 .

brevipennis 92 .

cavifrons 90.

centromaculata 95 .

chalybeicornis 97 .

cyanicornis 99.

dalmatina 96.

Damryi 95.

decipiens 91.

distinguenda 97.

diversifrous 91 .

Ghilianii 95.

Guerini 99.

hebraea 90 .

hispanica 95 .

hordei 99.

humeralis 90 .

hybrida 87.

Kindermanni 91.

laticollis 94 .

Lejeuni 9599.

Leithneri 89.

lepida 99. 
Labidostomis limbata 90 .

lineola 91.

longimana 95 . longipennis 97. lucaniformis 86 . lucida 92. lusitanica 87. maculipennis 91. maruccana 86 . meridionalis 87 . metallica 93. pallidipennis 97 . 1118.

Pelissieri 99. pilicollis 97. propinqua 90. quadrinotata 87. 95. rubripennis 86 . rugicollis 93 . rufa 90 sareptana 94. senicula 93. sibirica 99 . speculifrons 91. syriaca 95. taxicornis 86 . tibialis 87.

tridentata 89.99. trifoveolata 99. uralensis 93.

Lachnaea 106. brachialis 107 . cylindrica 110. glabricollis 107 . hirta 111. 1118. hirtipes 111. italica 108. longipes 107. macrodactyla 111. orientalis 111. palmata 111. pararloxa 110. puncticollis 109. sexpunctata 107. Suffriani 111. tripunctata 111. tristigma 110. variolosa 110. vicina 110

Lamprosoma 279. africanum 281 concolor 282

L e m a 59. asparagi 77 . atrata 65. campestris 79 . cyanella 61.64. cyanipennis 66 .
Is ma dodecastigma 72 . Duftschmidi 65. Erichsoni 62. flavipes 65. fulvicollis 4 . gallaeciana 64 . Hoffmannseggi 65. lichenis 63 . Lipperti 62. melanopa 65. obscura 64. puncticollis 61 . rufocyanea 66 . rugicollis 61 septentrion is 63 .

Leptispa filifor'mis 1060 .

Leptosonyx costipennis 576.

hirtus 577. nigrolineatus 577. silphoides 576.

Leucispa Odewahni 1060.

Lina aenea 554 . collaris 560 . cuprea 555. lapponica 557. populi 563. tremulae 564. 566 vigintipunctata 558 .

Linaeidea aenea 553

Linozosta 849.

Lithonoma cincta 677 dorsalis 677 .

Favieri 677.

limbata 677. Jusitanica 677.

Lochmaea capreae 611.

crataegi 615.

luctuosa 611.

nigrita 614 pallidipennis 612 . scutellata 611. suturalis 613. 1132.

Longitarsus 922. abdominalis 990 . absinthii 936 . aeneus 932 . a eruginosus 1010. agilis 987 .

albineus 1024 .

amoeuns 929.

analis 948 .

anchusae 933.

apicalis 948 .

aretulus 1000 .

ater 942

atricapillus 972. 979.
Long it arsus atriceps 979.

atricillus 968 . auctumnalis 965 . australis 1024 . ballotae 1003. Bedeli 1018.

Bonnairei 935. 1015. boppardiensis 1000 . brachypterus 1014. brevicollis 993 . brunneus 950. 957. candidulus 1025. canescens 1024. castaneus 950 . cerinus 1019. circumscriptus 965 . coerulescens 928. cognatus 957. collaris 996 . concinnus 942 . consociatus 938. corynthius 1015. crassicornis 1020 . cuprinus 1014. curtus 977. declivis 968.

discoideus 945 . distinguendus 1021 . domesticus 983 . dorsalis 962. echii 927. elongatus 940. emarginatus 1014. exhaustus 952. exoletus 999. fallax 929 .

femoralis 981. 999. fer'ugineus 1006. Foudrasi 987. fulgens 952 . fulviventris 989 . fumigatus 1005 fuscoaeneus 931 . gibbosus 1017. gracilicornis 1020 . gracilis 973. gravidulus 954. helvolus 991. holsaticus 944 . jacobaeae 1011. involucer 932 juncicola 1002. 989. laevicolis 950 . laevis 1008. 1011. languidus 955 . lateralis 983 . lateripunctatus 964. 
Longitarsus Lederi 1013.

Linnaei 929 .

livens 1023 .

longipennis 981 .

longipes 983 .

longiseta 974 .

luctator 1010.

Iuridus 956.

Iutescens 903.

Iусорі 988. 994.

macer 970 .

merlicaginis 996 .

mediter'raneus 1015 .

melanocephalus

979.

membran ace us $\$ 991$.

meridionalis 938 .

minimus 994.

minusculus 961 .

monticola 977.

nanus 992.

nasturtii 965 .

nebulosus 1020 .

niger 936. 939.

nigerrimus 943 .

nigrescens 928 .

nigricans 957.

nigriceps 902 .

nig'rinus 979.

nigriventris 1007.

nigrocillus 1021.

obliteratus 938.

ochroleucus 1012.

ordinatus 1019.

paleaceus 1024.

pallens 986. 987.

pallidicornis 960 .

paludosus 970 .

parvulus 942.

patruelis 983.

pectoralis 1001.

pellucidus 1007.

peregrinus 928.

perfectus 1008 .

personatus 964.

piciceps 972.

picinus 950.

pinguis 935 .

Poweri 973.

pratensis 995. 977.

profugus 1005.

pubescens 1013.

pulicarius 945.

pulmonariae 998.

punctatissimus 934.

pusillus 996.

quadriguttatus

946.
Longitarsus 4-mactlatus 948.

4-pustulatus 946.

4-signatus 957.

rectilineatus 941.

Reichei 996.

robustus 950

rubellus 955 .

rubenticollis 967.

rubiginosus 1005.

rudipennis 1019.

rufulus 1000.

rutilus 1022 .

scutellaris 996.

sellatus 963 .

senecionis 967. 972.

seriatus 1002 .

similis 968 .

sternalis 1022.

stragulatus 963 .

substriatus 1002.

subterlucens 1021.

succineus 1008.

suturalis 966.

suturatus 985. 1020.

suturellus 969.

tabidus 1011. 985.

tantulus 994.

thoracicus 970 .

tibialis 928 .

tristis 952.

truncatellus 1014

ventricosus 1018.

verbasci 985 .

viduus 976.

violentus 1016 .

vitreus 992

vulgaris 985 .

Waterhousei 1002.

Luperodes 575. 1132.

dubius 575 .

nigripennis 575 .

praeustus 575 .

4-guttatus 575 .

Luperus 589.

abdominalis 596 .

aetolicus 597.

altaicus 593.

amoenus 595.

armeniacus 597 .

betulinus 605.606 .

Biraghii 599.

carniolicus 607 .

cancasicus 599.

Chevrolati 664

circumfusus 600 .

costalis 665 .

diniensis 606 .

discolor 598.
Luperus dispar 606.

fallax 592 .

flavipennis 593 .

flavipes 608.

flavus 593.

floralis 597.

fossulatus 664 .

foveolatus 593.

Garieli 609.

geniculatus 602.

gularis 602.

Kiesenwetteri 594.

laevis 598.

laricis 609 .

lividus 593.

longicornis 605 .

luteicollis 583 .

lydius 594.

maculicornis 598 .

Maerkeli 606.

megalophthalmus 608.

minutus 593.

mixtus 598.

niger 606.

nigripes 602.

nigritarsis 592.

nigrofasciatus

600.

orientalis 595.

oxypterus 594.

pallipes 603 .

pinicola 601.

pygmaeus 596.

pyrenaeus 596.

Revelierei 595.

Rottenbergi 594.

rufipes 603. 605. 606 . 664.

rugifrons 595.

saxonicus 604 .

setulosus 592.

silvestris 601 .

sordidus 592.

sulphuripes 596 .

ulmarius 606.

varicollis 609 .

violaceus 664 .

viridipennis 608.

xanthopoda 603 .

Lycoperdina alpina 735 .

Macetes 276.

Macrocnema 785.

apicalis 801 .

cucullata 793 .

dulcamarae 819.

echii 927.

hyoseyami 821.

marcida 818.

nigricollis 803 . 
Iacrocuema pallida 823.

picicornis 801.

picina 824. sordida 803.

Macrolenes Bellieri 101.

confluens 1118 .

dentipes 1118.

ruficollis 101. 1118.

Macrolina 20-punctata 559.

Malacosoma 581.

collaris 583 .

cyanoptera 583.

flavipes 583.

Gaudioni 583.

lepida 583.

lusitanica 583.

luteicollis 583 .

thoracica 583.

triumphans 583 .

Mantura 741 .

aeraria 743 .

a mbigua 744 .

bicolor 743 .

chrysanthemi 745.

Crotchi 745 .

cylindrica 743 .

lutea 743 .

Mannerheimi 771.

Mathewsi 743.1134.

nitens 743 .

obtusata 744 .

rustica 746.

suturalis 746 .

Marseulia dilativentris 573.

Megalopini 82.

Megascelini 82.

Megistops 666.

Melas oma 551 .

a enea 554 .

alpina 560 .

altaica 557.

bulgharensis 557 .

collaris 560 .

cuprea 555.

curvilinea 557.

daurica 561.

geniculata 560 .

haemorrhoidalis 554 .

Janaceki 1132.

lapp onica 556.

lineatopunctata 560 .

longicollis 564 .

populi 563.

pustulata 559 .

saliceti 565 .
Mel a soma salicis 561 . thoracica 560.

tremulae 564. 566 . vigintipunetata 558.

Melitonoma Simoni 112.

Microrhopala 1059.

Minota 738.

Mionycha azurea 1076. margaritacea 1076. splendidula 1076.

Mniophila 1047. muscorum 1049. Wroblewskii 1049.

Nonochirus caucacisus 1061.

inermis 1061.

Potanini 1061.

Monolepta dubia 576. erythrocephala 576.

Mordella flava 704.

Myrcina nigra 670.

Nisotra 681.

Ochrosis corsica 707. Krüperi 706. picicollis 707 . pisana 707. rubicunda 707. salicariae 707. ventralis 706 .

Octocladiscus 1059.

Octotoma 1059.

Odontionycha bella 1075.

brevis 1075 .

canaliculata 1075 . fastuosa 1075.

hemisphaerica 1075 .

nigriceps 1075 .

viridis 1075.

Oomorpha Rossii 370.

Oomorphus concolor 282. unicolor 282.

Orestia 727. alpina 735 . andalusiaca 732 . apennina 733 . arcuata 732 . Aubei 736. Brulleriei 730. carpathica 732. caucasica 732. electra 737. Hampei 733 . Kraatzi 731. Leprieuri 731.

- Merkli 732. olympica 731 .
Orestia Pandellei 732.

Paveli 732.

Pommereaui 730. puncticollis 731 . punctipennis 730 . sierrana 731.

Orina 434. aenescens 462 . aerosa 461 . alcyonea 468 . alpestris 446 . amethystina 444. Anderschi 444. atramentaria 1122. aurata 462. aurulenta 444. balcanica 455 . bannatica 447 . basilea 465 . bicolora 447 . bifrons 461.459 . bohemica 1124. cacaliae 475. 444. candens 468. carpathica 481. coeruleolineata 476 . commutata 474 . 1123.

convergens 481 . cupreata 1124. cuprina 441. cyanea 485 . cyanescens 462 . cyanipennis 476 . decora 462. discolor 451 . distinctissima 1123. dorsalis 1123. elegans 440. elongata 485 . excellens 451. Fairmairei 475. fontinalis 447 . fraudulenta 476 . frigida 487 .

fuscoaenea 480.481. glacialis 459 . gloriosa 450.455 . haemoptera 441.

Heeri 465. ignita 465. intricata 444. juncorum 481.

Kiesenwetteri 487.

Letzneri 480.

liturata 457. luctuosa 441. Ludovicae 470. lugubris 465 . 
Orina macera 476 .

melancholica 472.

melanocephala 470 .

Merkli 466.

mirifica 465 .

moesta 447.

monticola 461. 487.

nigrescens 480 .

nigriceps 470 . 471 .

nigrina 450, 1122.

nivalis 465 .

nobilis 443 .

nubigena 476 .

nubila 450 .

olivacea 447.

Papei 1122.

Peirolerii 471. 473.

phalerata 450.457.

plagiata 473 .

polymorpha 447.

praefica 468 .

pretiosa 450 .

punctatissima 446 .

pyrenaica 481 .

rhaetica 487 .

rivularis 446 .

rugulos a 443.

Schummeli 480.

seminigra 444

senecionis 476 .

serena 468

silesiaca 481 .

smaragdina 441.

speciosa 447.450 .451 .

speciosissima 480 .

splendidula 475.

Stussineri 461.

sulcata 465 .

sumptuosa 476.

superba 450

tenebrosa 441.

transsylvanica 466 .

tristicula 476.

tris $\mathrm{t}$ is 441.443 .476$. 1122 .

troglodytes 481 .

tussilaginis 476 .

umbrosa 447.

variabilis 455 .

venusta 450 .

virgo 450 .

virgulata 468.

viridescens 480 .

viridis 465 .

violacea 480.

vittigera 458.

Orsodacna cerasi 4. chlorotica 5.
Orsodacna coerulescens 6 .

croatica 1117.

glabrata 5.

humeralis 6 .

limbata 5 .

lineola 6.5 .

marginella 6

mespili 6. 1117.

nematoides 6 ,

nigriceps 6 .

nigricollis 6 .

Orsodacnidae 4.

Otiocephala forcipifera 124.

opaca 124.

Warioni 124.

Pachnephorus 282. arenarius 284. 286. aspericollis 289 .

baeticus 287.

Brucki 288.

canus 285.

chalybaeus 289 .

corinthius 288.

cylindricus 288.

globosus 293.

hipponensis 288.

hispidulus 289.

impressus 287.

laevicollis 289 .

lepidopterus 284.

pilosus 284.

robustus 288.

ruficornis 285 .

rugaticollis 289 .

sabulosus 286.

tessellatus 285.

villosus 287. 286.

Pachybrachys 245.

aethiops 262.

albicans 248 .

anoguttatus 255 .

ater 264.

azureus 269.

baeticus 269

bisignatus 262 .

cinctus 265 .

erycinus 254.

fimbriolatus 265 . 267.

flexuosus 254.

fulvipes 268.255 .

ictericus 249 .

israelita 256.

italicus 249.

Kraatzi 255.

gallicus 253.

glycyrrhizae 256.1121.
Pachybrachys haliciensis 258.

Hellwigi 254.

hieroglyphicus 248.

hip pophaës 260 .

histrio 262. 264.

laetificus 256 .

lignosus 260.

limbatus 264.

lineolatus 254.

lngubris 248.

maculatus 264

mendax 268.

nigropunctatus 1121.

pallidulus 254.

piceus 252.

picus 264. 1121.

pradensis 268.

probus 267.

pteromelas 255. 266.

regius 269.

riguus 255.

rufimanus 258 .

scipticollis 248. 256.

scriptidorsum 248.

scriptus 254.

simius 256.

Suffriani 251.

suturalis 252.

tauricus 262.

terminalis 251 .

tessellatus 262.

testaceus 255 .

tristis 266.

vermicularis 256 .

viennensis 256 .

viridissimus 269 .

Pales vlema 279.

Pallasia absinthii 577. violacea 577.

Pallena 276.

Paradibolia 1027.

Paralina indica 299.

Paropis sorbi 508.

Pentameria bromeliarum 670.

Pentispa 1059.

Petalopus 1026.

Phaedon 538.

armoraciae 547.

betulae 547 .

carniolicus 536 .

caucasicus 543 .

cochleariae 545.

1132.

conciunus 547.

Fausti 540.

foreolatus 536 . 
Phaedon galeopsis 543. 545 .

gramicus 544. 543. 545.

hederae 540. 546.

laevigatus 543 .

neglectus 546 .

nbesus 546.

obscurus 540

omissus 545.

orbicularis 542 .

pyritosus 541.1132.

salicinus 547.

$\mathrm{seg} n$ is 540 .

tumidulus 545 .

violaceus 543 .

Phalacrus maritimus 282.

Phratora 511.

altaica 521

angusticollis 519 .

brevicollis 519 .

coerulescens 515 .

Fairmairei 519 .

funesta 519 .

latipennis 519 .

longula 515.

obtusicollis 515 .

vitellinae 519 .

vulgatissima 514.

Phygasia helvola 850.

Phy 11 obrotica 584 . adusta 587.

bisignata 587.

elegans 587.

froutalis 587 .

munda 585 .

4 - $m$ a cul a ta 585.

4-punctata 585.

sibirica 587.

signata 587.

Phyllodecta 511.

restiva 515 .

atrovirens 522.

cavifrons 521.

coerulea 517.

Cormelii 517.

inhonesta 514.

laticollis 520 .

major 519.

nigrica 519.

obscura 515.

tibialis 517 .

viennensis 517, 1131

vitellinae 518.

vulgatis sima 514.

Phyllotreta 856.

a erea 878.

antennata 883 .
Phyllotreta armoraciae 865 .

atra 876.

biguttata 859

bilineata 874 .

bimaculata 859 .

brassicae 866 .

cancasica 868 .

consobrina 881 .

corrugata 863.

crassicornis 879 .

cruciata 867

cruciferae 878.

diademata 880 .

dilatata 869 .

discedens 871.

excisa 867.

exclamation is 866 .

fallax 870 .

fenestrata 870 .

flavoguttata 862.

flexuosa 870.874.

Fondrasi 864.

guttata 872 .

horticola 868 .

latevittatr 860 .

lepidii 882.

melaena 881. 885.

monticola 871.

nemorum 875.

$n$ igripes 882 .

nitidicollis 863 .

nodicornis 883 .

obscurella 877. 878.

ochripes 867.

parallela 860.

procera 884.

punctulata 878 .

4-pustulata 866.

ruficollis 859 .

rugifrons 859 .

rufitarsis 885 .

Seidlitzi 861.

sinuata 871 .

sisymbrii 860 .

tetrastigma 869 . 870.

undulata 874 .

varians 872 .

variipenuis 872 .

vibex 866 .

vilis 861 .

vittula 873 .

Physocoryna 1059.

Phytodecta 488.

aegrota 503 .

affinis 500. 1130.

Baaderi 491.

bicolor 491.
Phytodecta borealis 510.

calcarata 492.

caraganae 1130.

cincta 492.

collaris 1129.

decastigma 498.

decempunctata 491 .

decipiens 510.

dispar 508.

Eppelsheimi 501.

flavicans 506 .

flavicollis 508 .

flavicornis 496 . 1124.

fornicata 503. 1130 .

frontalis 510 .

fulva 1127.

funesta 501 .

gracilicornis 1129.

Grandini 504.

innotata 505 .

Ka ufmanni 496 . 1125.

Kraatzi 498.

linnaeana 498. 1130.

litura 506.

Mannerheimi 1130

munda 491.

nigricans 507 .

nigricollis 498 .

nigripennis 1126.

nivosa 500. 1129 .

obscura 509.

olivacea 506. 1130.

orientalis 498 .

pallida 510. 1131.

pallidipes 1129 .

personata 501.

picea 505 .

5 -punctata 508. 1130.

rubripeunis 1127.

rufa 1129.

ruficollis 1124 .

rufipes 495. 1129.

rufula 501.

salicis 498 .

satanas 498 .

seminigra 1126.

sexnotata 504.

sexpunctata 495.

sibirica 1128.

sorbi 508 .

spartii 504 .

tibialis 498 .

triandrae 498.

unicolor 508. 
$\mathrm{Phytodecta} \mathrm{variabilis}$ 503. 1130.

viminalis 491. 1124.

Weisei 1130.

Pilemostoma fastuosa 1075.

Plagiodera clavicor$n$ is 551 .

salicis 550 .

versicolora 550 .

Plateumaris 44.

aenea 45 .

affinis 53 .

armata 45.

assimilis 50 .

braccata 49 .

comari 47.

consimilis 50 .

discolox 47.50. 53. festucae 45 .

geniculata 47.

Lacordairei 47.

laevicollis 45 .

micans 45 .

nigra 49.

nymphaeae 45 .

pallipes 53 .

palustris 47.49 .

planicollis 51 .

proteus 47.

rustica 51.

sericea 45 .

sibirica 45.

variabilis 50 .

violacea 45 .

Platyauchenia 1066.

Platypria 1059.

Plectroscelis aerosa 779.

angustata 766 .

arida 775 .

aridella 778 .

axidula 774 .

chrysicollis 763 .

concinna 759 .

conducta 761 .

confusa 770 .

dentipes 759 .

Fairmairei 777.

Mannerheimi 771.

meridionalis 769 .

obesa 769 .

procerula 764 .

punctatissima 779 .

Sahlbergi 776.

seabricollis 778 .

semicoerulea 757.

subcoerulea 772 .

Podagrica 679

aenescens 683 .
Podag rica chrysonelina 686

discedens 686 .

Fondrasi 682.

fuscicornis 685 .

fuscipes 681 .

intermedia 684 .

malvae 683 .

Menetriesi 686.

meridionalis 685 .

metallescens 682 .

saracena 684.

semirufa 684.

tristicula 684.

Porphyraspis 1066.

Prasocuris 529.

atra 533.

chalybaea 534 .

cicutae 532.

distincta 531.

hispanica 534.

junci 533 .

litigiosa 534.

marginicollis 531 .

phellandrii 531.

sii 532.

suturella 531.

vicina 534

Prioptera 1066.

Psendocolaspis brunnipes 279

carbonaria 279

cylindrica 279.

graeca 279.

Heydeni 279.

Psilapha flava 669.

Psylliodes 780.

a erea 815 .

affinis 816 .

algirica 791.

Allardi 803.

alpina 797.

auglica 803.

asturiensis 807 .

attenuata 801.

callinota 796.

cardui 821.

catinensis 803 .

chalcomera 821.

chrysocephala 802 .

circumdata 817.

coerulea 789 .

coerulescens 821.

collaris 803.

cretica 791.

cucullata 793.

cuprea 812.

cupreata 802.

cuprouitens 811. 821 .
Psylliodes cyanoptera 806.

dulcamarae 819.

ecalcarata 807.

flavicornis 807 .

Foudrasi 812.

Frivaldszkyi 786.

fusiformis 813.810 .

gibbosa 796.

glabra 797.

Gougeleti 786 .

herbacea 811.

Heydeni 785.

hyoseyami 821 .

inflata 795 .

instabilis 815 .

integra 817.

Kiesenwetteri 794.

Kunzei 804.

laevifrons 791.

laticollis 787 .

latifrous 799 .

luridipennis 814.

luteipes 813.

luteola 822.

marcida 818.

melanophthalma 824 .

Milleri 788.

napi 807.

nigricollis 803 .

nucea 804.

obscura 811.

obscuroaenea 791.

operosa 819.

pallidipennis 790 .

peregrina 803.

petasata 785. 794.

picea 824 .

picicornis 801 .

picina 824.

picipes 809.

propinqua 823.

puncticollis 791 .

pyritosa 814 .

rapae 807.

Reitteri 792.

rufilabris 799. 803 .

sicula 796.

subaenea 798 .

thlaspis 810 .

tricolor 806 .

ventricosa 796 .

vicina 801.

Ptinus longicornis 605.

Pyladia 730.

Py r'h a l t a vibuini 621.

Ruacbus 3

Sagrini 2 . 
Sclerophaedon 534. 'Teinodactyla atricilla carniolicus 536. 1132.

carpathicus 537. 1131. foveolatus 536 .

Kenderesyi 536. 1131. obscurus 536.

orbicularis 537. 1131.

transsylvanicus 537.

Semicnema 784.

Reitteri 792.

Sermyla cuprina 662. halensis 661 .

Spartiophila litura 506 . sexpunctata 505.

Sphaerocharini 82.

$\mathrm{Sph}$ aeroderma 1054 . cardui 1056.

globosum 1044 orbiculatum 1045. rubidum 1057. testaceum 1056. 1057.

Spilopyra 277.

Stenomela 300.

Stichoptera sanguinolenta 384.

Stichosoma Banksi 379.

Stylosomus 270.

bipartitus 272 .

biplagiatus 272 .

bituberculatus 273 .

constrictus 273.

cruciatus 272

cylindricus 272.

depilis 274.

ericeti 273.

erythrocephalns 271.

flavus 271.

ilicicola 273. 1121. macer 271.

minutissimus 274 .

niloticus 271.

rugithorax 1121.

tamaricis 271.

Syagrus 283.

Syneta betulae 54 .

Taeniosticha lurida 378.

Tauroma 1066

Tenebrio capreae 611 pomonae 652 . tristis 647 .

'Testergus Lederi 1013. pubescens 1013.

Teinodactyla 922 . aeruginosa 1010. analis 948 .

anchusae 933.
979

ballotae 1003 .

biguttata 964.

brunnea 954.955.

brunniceps 994 .

castanea 950

circumsepta 963.

curta 977.

dorsalis 962 .

ecbii 927.

femoralis 998 .

ferruginea 1006.

flavicornis 1005 .

fuscicollis 968 .

fuscoaenea 932.

holsatica 944

juncicola 1002.

laevis 1008 .

lateralis 983 .

Linnaei 929.

lurida 957.

lycopi 988.

medicaginis 996.

melanocephala 970.

membranacea 991.

minuscula 961.

nana 992.

nasturtii 965 .

nigra 939.

nigriceps 975.

nigricollis 967 .

obliterata 938.

ochrolenca 1012.

parvula 942.

pectoralis 1001 .

pellucida 1007.

piciceps 972 .

pratensis 998. 1000.

pulex 938.

puuctatissima 934.

4-maculata 947.

Reichei 996.

rectilineata 941.

rubella 955 .

rufula 1000

rnbiginosa 1005.

signata 964.

stragulata 963 .

succinea 1008.

tabida 1011.

tantula 994

teucrii 991.

thoracica 970.

Thelyterotarsus 246

Fausti 247.

Thyamis 922 .

abdominalis 990 .

absinthii 936.
Thyamis aeneicollis 967.

aeruginosa 1010.

anchusae 933.

apicalis 948.

atriceps 979.

atricilla 968 .

ballotae 1003 .

brunnea 950 .

castanea 950.

collaris 996.

curta 977.

dimidiata 928.

dorsalis 962 .

echii 927.

femoralis 999 .

ferruginea 1006.

flavicornis 1005 .

fulgens 952.

funerea 996.

fuscicollis 968 .

gravidula 954 .

holsatica 944

jacobaeae 1011.

juncicola 1002.

laevis 1008.

lateralis 983.

lateripunctatus 964 .

Linnaei 929.

lurirla 957

Intescens 903.

lycopi 988.

medicaginis 996 .

membranacea 991.

minuscula 961

monticola 977.

nana $992^{\circ}$

nasturtii 965.

nigerrima 943 .

nigra 939.

obliterata 938.

ochroleuca 1012.

pallens 987.

pallidicornis 960 .

parvula 942.

patruelis 983 .

pectoralis 1001 .

pellucida 1007 .

piciceps 972 .

picipes 972 .

Poweri 973

pratensis 998.

pusilla 996.

4-punctulata 946.

rectilinenta 941 .

rubella 955 .

rufula 1000 .

scutellaris 996.

subquadrata 976 .

suturalis 967 . 
Thyamis tabida 1011. thoracica 970. verbasci 985 . vidua 976 .

Timarcha 314. aerea 333 .

amethystipes 326 . angulicollis 322 . angusticollis 322. apricaria 320 . armeniaca 336. asturiensis 337 . balearica 318 . brachydera 326. Brulerii 319. calceata 319. Camoensi 322. chalcosoma 322. chloropus 337. coarcticollis 320 . corallipes 328 . coriaria 333. corinthia 336. crassaticollis 326 . cyanescens 332 . Ehlersi 319. elliptica 332. endora 328. erosa 319. fallax 319 . gallica 333. generosa 327. geniculata 331.337. gibba 338. globata 335 . globipennis 333 . globosa 336. 339. Gougeleti 337. gravis 322. Henoni 326. Heydeni 321. hispanica 319. Hummeli 336. iberica 322 . immarginata 337.
Timarch a insignis328. insparsa 320. intermedia 324. interstitialis 332 italica 324

Kiesenwetteri 318. laevigata 326. 333. laevisterna 319.

Lomnicki 335. lugens 319. marginicollis 320 . maritima 331 . maroccana 325. melitensis 318 . metallica 336 . montana 329. monticola 332 . nicaeensis 324 . oblongula 336 . Olivieri 336. parnassia 332. parvicollis 320 . Paulinoi 320. pimelioides 326 . Piochardi 319. pratensis 329 . punctatella 327. punica 327. recticollis 333 . rufipes 326 . rugipennis 319 . rugosa 326. rugosula 333 . rugulosa 334. sardea 329. scabra 325 . scabripennis 325 . scortea 336.

Seidlitzi 320. semipolita 322. sericea 319. sphaeroptera 337. sicelidis 329 . sinuatocollis 331 . splendens 1122.
Timarcha splendida 321.

strangulata 331 .

subcyanea 322.

sublaevis 329 .

tenebricosa 321. tenuicornis 319 . tingitana 320 . trapezicollis 337 . turbida 327. validicornis 322. venosula 325 . ventricosa 327 . vermiculata 319 . violaceonigra 331.

Tituboea 102 . arabica 106. biguttata 105 . dispar 105. fasciata 105 . filitarsis 106 . Illigeri 104. laticollis 105 macropus 103. nigriventris 106 . octopunctata 105. octosignata 105. Olivieri 106. parviceps 104. Paykulli 105. Perrisi 106. sexmaculata 104. sexpunctata 106. 13-punctata 106.

Trirrhabda 621.

Uroplata 1059.

Zeugophora 55. australis 58 . fla aicollis 58 . frontalis 56 . rufotestacea 58 . scutellaris 56 . subspinosa 57 . Turneri 57.

Zeugotaenia limbata375. 


$$
17+3=4
$$






\section{,}





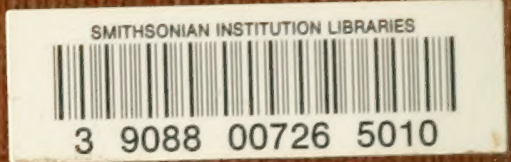

BHL 